
SOUTHERN BRANCH, DIVERSITY OF CALIFORNIA LIBRARY,

LOS ANGELES, CALIF. 



BIBLIOGRAPHY OF UNITED STATES PUBLIC DOCUMENTS

Department List No. 1.

\title{
LIST OF PUBLICATIONS
}

OF THE

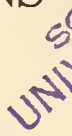

1862-1902

WITH ANALYTICAL INDEX

\section{AGRICULTURE DEPARTMENT}

\author{
WITH ANALYTICAL INDEX
}

Prepared in the Office of the

SUPERINTENDENT OF DOCUMENTS

GOVERNMENT PRINTING OFFICE

\section{WASHINGTON}

GOVERNMENT PRINTING OFFICE

1904 



\section{CONTEN'TS}

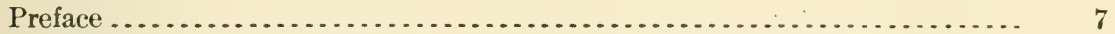

Classification explained.................................. 8

Tables........................................................ 19

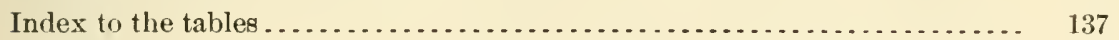

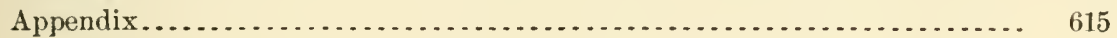

\section{ABBREVIA'TIONS}

(Circ.).... Single-sheet publication, unnumbered. Cong..... Congress.

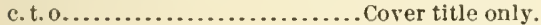
D. C ..................... District of Columbia.

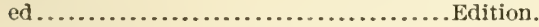
H. ex. doe ...........Ifouse executive document, H. mis. doe ...... House miscellaneous document.

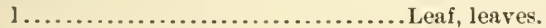

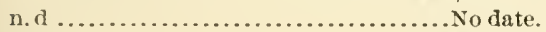

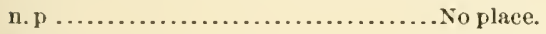
n.t.p .......................... No title-page. p., pp............................. Page, pages. pt., pts ........................... Part, parts. pl ............................ Plate, plates. por.................................. Portrait.

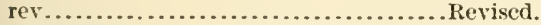
S. ex. doc........... Senate exeeutive doeument.
S. mis. doc...... Senate miscellaneous document. Serial no....... Serial numbe's first assigned to bound volumes of Congressional documents in Document Checklist, $2 \mathrm{~d}$ ed., 1895 , and continued in doctument indexes of 55 th and subsequent Congresses. U.S . . . . . . . . . . . . . . . . . . . . . . . . United States. v ........................ Volume, volumes.

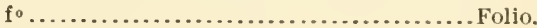

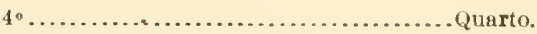

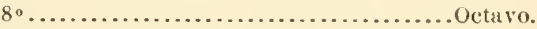

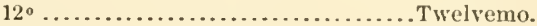

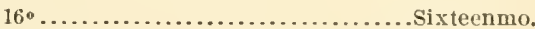
$24^{\circ} \ldots \ldots \ldots \ldots \ldots \ldots \ldots \ldots \ldots \ldots \ldots$. Twenty-fourmo. $32^{\circ} \ldots \ldots \ldots \ldots \ldots \ldots \ldots \ldots \ldots . \ldots \ldots . . \ldots \ldots$ Thirty-twomo. 



\section{ENTRODUC'TION}

This List of Publications of the Agriculture Department, 1862-1902, with analytical index, is the first of the series of contributions toward a Bibliography of United States public documents, which will deal with the publications of all the Executive Departments and other independent publishing offices of the Govermment. Separate lists of the publications of each of these Departments and offices will be issned from time to time as completed, and will be supplied to State and Territorial libraries, designated depositories, and other libraries as far as the limited edition will admit. Librarians are invited to point out errors and to make suggestions for consideration prior to the consolidation of the complete work.

I desire to express my sincere thank for the assistance rendered by Mr. George William Hill, Chief of the Publications Division, and Mr. Robert B. Handy, assistant in charge of the document section, Agriculture Department.

L. C. Ferreis, Superintendent of Documents.

Octolsk: 13, 1903. 



\section{PREF ACE}

Though next to the youngest of the Executive Departments of the United States Gorernment, and its work haring been for years impeded by lack of interest on the part of Congress, the publications of the Agriculture Department rank second to none in number and usefulness.

From a doubtful experiment, with an annual report as its only publication, the Department has developed into a great publishing office, the output of which is eagerly sought by those engaged in agricultural inquiry.

The constant changes in the personnel of the various divisions composing the Department, the growing need and gradual extension of investigations, necessitated in a degree, and at least satisfactorily explain, the otherwise incomprehensible peculiarities and confused methods which characterize the publications of the various bureaus and offices and of the Department as a whole.

\section{FORMEIR IISTS.}

As early as 1867 a general index was made to the annual reports from 1862 to that date (A1.1:S67, p. 473), and a still more elaborate index, 1837-1876 (including the agricultural reports made through the Patent Office from 1837-1861), was issued in 1879 (A1.8:14), with a supplement bringing the work down to 1855 , printed in 1856 ( $1.8: 42)$; but it was not until 1894 that a list of the miscellaneons publication appeared (A1.s:55), and that included only the publications for the five years from 1859 to 1893 , being simply a consolidated reprint of the lists which had been a feature of the annual reports of the Secretary for those years.

In 1896 another index to the annual reports, 1837-1893, was printed (A21.3:1), in the preface to which the former attempts to index the reports are characterized as "so unsatisfactory for the purpose for which they were designed as to have fallen into almost complete dis- 
use." While it is not doubted that this index was of great service, it still left the problem of the miscollaneons publications unsolved, and it was therefore gratifying when, toward the latter end of the same year, the first list inchuling these publications wats issued.

This checklist, inchuding all the publications from $18+1$ to . In 80 , 1595 (A17.3: :9), and giving a decimal classification for the convenience of those who wished to " keep their files of Goremment publications apart from their general collection of books," served to emplasize the necessity for a complete catalogue of the publications therein enumerated, and formed a working basis in collecting the set of publieations of the Agriculture Department in the library of the office of the Superintendent of Documents, which is now the most complete set of such publications in existence.

In 1898 an author index to all the publications of the Department, 18t1-1897. was printed (A21.3:4). Much valuable information was necessarily omitted from this work on account of the limitations of a strictly "author index," which debarred some important publications that failed to bear their anthor's names.

The latest attempt to supply the much-needed reference list was a "List by titles from 1940 to Jume, 1901," issned in 1902 (A21.3:6). It was but an elaboration of the checklist of 1896, and while more complete, presented the matter in an equally awkward form for quick reference use.

It is hoped that the present list, combining both methods used by its predecessors, the checklist and the index forms, will prove a satisfactory reference work and lead the searcher quickly to the desired publication.

\section{CLASSIFICATION EXPIAANED.}

With the establishment of the oflice of the Superintendent of Documents, by the provisions of the printing act of Ianuary 12, 1895, a new era in the history of public documents was inaugurated. Not only did the office at once undertake the tasks of cataloguing and indexing imposed upon it by law, but in its establishment as a great clearing house for the publications of the Government it became necessary to keep a file of the publications for reference use. In the beginning no definite idea could be formed of the extent of such a collection, and no one dreamed of the magnitude of the work undertaken when it was decided to collect and classify a library strictly governmental in character.

As it was seen to be impossible to arrange such a large and uncertain collection of special publications by either the "decimal" or "expansive" systen of library classification in general use, a governmental author arrangement was adopted, corresponding in the main 
to the chassification applied by Miss Adelaide R. Hasse to the publica tions of the Agriculture Department in a list issued hy the Department in 1895 .

It was soon found that this rassification, howerer adequate for a single Department, was not eapable of meeting the needs of a great library of Government literature, and a new classification became a necessity.

It was no simple mattel to devise a system of classification elastic enough to meet the needs of such a mass of nurelated matter as necessarily forms a lihrary of United States public documents, nor to foresee, thougl aided by the fruits of the former experience, the many ineonsistencies and incongruities against which to guard. Decimal, alphabetical, numerical, chronologieal, author, subject, and serial methods of elasifieation were experimented with, until at last the present system, a combination of various schemes, was decided upon as the most simple and usuble, and its application to the Library has proven satisfactory in every way.

But if the task of applying an acceptable system to the books was hard, that of explaining it concisely and lucidly is certainly more difficult. In giving the following explanation of the method of classification for United States public docmments, as it is now used in the Public Documents Liblary, which contains the largest collection of such publications, the hope is entertained that many of the large libraries may be led to use the scheme, thus insuring uniformity of classification, and making the lists of the various Departments, of which this work is the first, a direct index to the publications on their shelves.

The classification is by governmental authors: First, by Departments or independent publishing offices; second, by bureus, offices, or divisions of such Departments or independent publishing offices.

\section{Department symbol.}

The first letter of the distinctive word in the title of each of the nine Executive Departments is used to designate the Department, and is written as the first term in the "classification number," as follows:

$A=$ Agriculture I)epartment.

$\mathrm{C}=$ Commerce and Iabor Department.

$\mathrm{I}=$ Interior Department.

$J=$ Justice Department.

$\mathrm{N}=$ Nary Department.

$P^{\prime}=$ Post-Office Department.

$S=$ State Department.

'T' = 'reasury Department.

$W^{r}=W_{\text {ar Department. }}$ 
In order that no conflict should an ise between the Executive Departments notation and that of any of the independent publishing offices, two letters are nsed in all other notations, as follows:

CS = Civil Service Commission.

$\mathrm{DC}=$ District of Columbia.

$\mathrm{FC}=$ Fish Commission.

FS $=$ Freedman's Savings and Trust Company.

GN = Geographic Names Board.

$\mathrm{GP}=$ Government Printing Oflice.

$\mathrm{IC}=$ Interstate Commerce Commission.

$J_{u}=$ Judiciary (United States courts, ete.).

La = Labor Department.

$\mathrm{LC}=$ Library of Congress.

$\mathrm{NA}=$ National Academy of Seiences.

$\mathrm{NH}=$ National Hone for Disabled Volunteer Soldiers.

$\mathrm{Pr}=$ President of United States.

SI = Smithsonian Institution.

These two lists grive the complete letter symbols, and the arrangement on the shelves is strictly alphabetical taking them as a whole. Of course, the publications of the Fish Commission and the Labor Department have since the 1st day of July, 1903, been elassified among the publications of the Commerce and Labor Department, of which they are now bureaus, but their publications as separate publishing offices are left under the old classification.

\section{Bureau, office, or division symbol.}

A symbol having been supplied for the Departments and independent publishing offices, one for each of the bureaus, offices, and divisions of such Departments or publishing offices was next considered.

The figure 1 following the Department or independent publishing office symbol was fixed upon to represent the Secretary of the Department or the chief executive officer of any of the independent publishing offices, and is always used for such, thus-

A1 = Agriculture Department, Secretary's office.

W1 $=$ War Department, Secretary's office.

GP1 = Government Printing Office, Public Printer's office.

Beginning with figure 2 , the numbers are applied in numerical order to the various publishing bureaus, offices, and divisions, these having been arranged alphabetically when the classification was applied; new offices to be added at the end of the list of a Department and assigned the next number.

This of course does not provide for an alphabetical arrangement of the bureaus, offices, etc., in the future, but does furnish a distinctive symbol for each without limit. 
A point is placed after this second symbol to separate the Department and bureau notation from the rest of the "classification number."

Examples:

A1. = Agriculture Department, Secretary's Office.

A2. = Agriculture Department, Aecounts and Disbursements Division.

A3. = Agriculture Department, Agrostology Division.

A4. = Agriculture Department, Animal Industry Bureau.

T1. = Treasury Department, Secretary's Office.

T2. = Treasury Department, Appointments Division.

T3. = Treasury Department, Auditor for 'Treasury Department (First Auditor.)

T4. = Treasury Department, Auditor for War Department (Second Auditor.)

\section{Series symbol.}

Next to be considered was a symbol for the numerous series of publieations which emanate from these various publishing offices. As substantially every Government publishing office issues an annual report, this annual report is considered to be the most important serier in the publications of every office, and figure 1 was therefore designated as the symbol for "annual reports," and written as the third term in a "classification number," following the point.

In like manner an arbitrary symbol, figure 2, is assigned to the numerous publications of a miscellaneous character which are not numbered or volumed in any series. Such sporadic issues have been called "general publications," and their symbol, figure 2 , is written as the third term in a "classification number".

A majority of the publishing offices issue their publications numbered in series called "bulletins" or "circulars" or both; the terms being applied without any regularity as to size or character of the works thus numbered. The figure 3 for "bulletins" and the figure 4 for "cireulars" have been permanently assigned to these classes, to be written as the third term in a "classification number."

We now have figures $1,2,3$, and 4 , when written after the point as the third term in a "classification number," permanently assigned as symbols, as follows:

$$
\begin{aligned}
& .1=\text { Annual reports. } \\
& .2=\text { General publications. } \\
& .3=\text { Bulletins. } \\
& .4=\text { Circulars. }
\end{aligned}
$$

From this point the varions series are arranged alphabetically as far as possible, assigned the numbers following indefinitely, and all 
new series as they come to hand are given the next number to be applied to a series, under the office from which they emanate.

Should an oftice fail to issue any of the four classes of publications here described, the numbers are left blank, and the numbering of such series as they may issue begins with figure 5 .

Following the series symbol a colon is used to separate the series figure or figures from the clatacter's nsed as individual "book 1 munbers" to follow.

Examples:

A1. = Agriculture Department, Secretary's Office.

A1.1: = Agriculture Department, Secretary's Office, annual reports.

A1.2: = Agriculture Drpartment, Secretary's Gffice, general publications.

A1.3: = Agriculture Department, Secretury's Office, bulletins.

A1.4: = Agriculture Department, Seeretary's Ollice, circulars.

A1.5: = Agriculture Department, Śceretary's Office, miscellaneous circulars.

A1.6: = Agriculture Department, Secretary's Office, special reports.

N6. = Nary Department, Hyclrographic Office.

N6.1: = Nary Department, Hydrographic Oftice, annual reports. N6.2: = Nary Department, Hydrographic Oftice, general publications.

N6.3: = Navy Department, Hydrographic Office, bulletins.

N6.4: = Nary Department, Hydrographic Office, circular's.

N6.5: = Nary Department, Hydrographic Office, catalogues and lists.

N6.6: = Nary Department, Hydrographic Office, corrections and additions.

N6.7: = Nary Department, Hydrographic Oftice [practical papers].

\section{Borl: number.}

An individual "book number" is all that is now needed to complete the classification. The symbols for this purpose are written after the colon as the fourth term in the "classification number." In the case of annual or periodical publications the date is used as the book number; for a rolumed series the rolume number is used, and in a numbered series the number. The works classified as "general pub)lications" heing without any of these distinctive features, it is foumel advisable to arrange them in alphabetical order molor the most significant words of their titles, or under their subjects. and the Cutter Author 'Table symbols for such words are used as "hook numbers." 
Examples:

A1.1:901 = Agriculture Dept., Seey's Office, annual report, 1901.

A1.1:902 = Same, 1902 .

A1.2: = Agriculture Dept., Secy's Office, general publications. 11.2:Ant $=$ Angora. Notice of receipt of letter from Minister Terrell, relating to agriculture in Angora. November 1, $1893 . \quad$ (Cire.)

A1.2:LtS $=$ Leave of absence not allowed to employees outside of Washington. October 21, 1896. (Circ.)

N6.8: = Nary Department, Hydrographic Office, publications (numbered).

N6.s:3 $=$ [No. 3.] List of reported dangers to navigation in Pacitic Ocean, whose positions are doubtful, or not found on charts in general use. 1866. $191 \mathrm{pp}$.

Nt.s:40 $=$ No. 40. Steam lanes across Atlantic; [by M. F. Maury.] 1872. $19 \mathrm{pp} .3 \mathrm{pl}$.

T14.5: = Treasury Department, Second Comptroller, decisions, digest of.

T14.5:1 = Volume 1. Compiled by George Chipman. 1852.

T14.5:2 = Volume 2, 1869-1884; compiled by R. J. Mitchell. 1885. $433 \mathrm{pp}$.

\section{Superior letters and figures.}

Two other very useful features of the classification need some explanation, namely, the use of the superior letter a $\left({ }^{a}\right)$, and the superior figures $\left({ }^{1-9}\right)$.

The superior letter always designates excerpts from the publication bearing the same notation withont the ${ }^{(")}$. The name adopted for these excerpts is "separates," and they are always designated by the superior ("). These "separates" are arranged in classes by themselves, immediately following the series from which they are taken. In cases where the separates are from an annual report series it has often been found necessary to miake two classes. The personal report of the ehief, which usually appears in pamphlet form without the accompanying document, is arranged and hook-numbered by dates. The other class, scientific reports accompanying the report of the chief, is arranged alphabetically on the same plan as the "general publications."

Examples:

A1.1:901 = Agriculure Department, Secretary's Oflice, anmual report, 1901.

A $1.1^{\text {* }: 901}=$ Agriculture Department, Secretary's Oflice, anmual report, 1901 (sepanate). 
Examples-Continued.

N14.5:s85 = Nary Department, Naval Observatory, Astronomieal and Meteorological Observations, 1885.

N14.5 $: \mathrm{A} .8$ = Same (separate). Astrophotographic Congress, International, ete.; by A. G. Winterhalter. 1889. (Reprint of Appendix 1, Astronomical and Meteorological Observations, 1855.)

The superior figures are nsed to differentiate between two publications which may of necessity he assigned the same symbol in the alphahetical classification, and also to distinguish between the various editions of the same serial or numbered publication.

Examples:

A1.2: = Agriculture Dept., Secy's Office, general publications. A1.2: $\operatorname{Ag}^{1}=$ Agricultural colleges. List of delegates and visitors to tenth annual convention of Association of American Agricultural Colleges and Experiment Stations, 1896 . n. t. p. 3 pp.

A1.2: $\mathrm{AgS}^{2}=$ Agrieulture Department. [Letter as to work and needs of Department of Agriculture; by William G. Le Duc.] February 27, 1880. n. t. p. 15 pp.

I16.5: = Interior Department, Education Bureau, Circulars of Information.

I16.5:575 $=1875$, No. 1. Proceedings of Department of Superintendence of National Educational Association, Washington, D. C., January 27 and $28,1875.1875 .114 \mathrm{pp} .1 \mathrm{pl}$.

I16.5: $: 575^{2}=1875$, No. 2. Education in Japan; [by William E. Griftis and David Murray.] 1875. 64 pp.

N6.8: = Navy Department, Hydrographic Office, publications (numbered).

N6.8:9(1) $=$ No. 90. Development of great circle sailing; by G. W. Littlehales. 1859.53 pp. 5 pl. 1 map.

N6.8:90 $=$ Same, 2 d ed. 1559.63 pp. 7 pl. 2 maps.

It will be seen that the system here presented is expansive enough to cover any number of departments, offices, series, or books, and that, too, in as concise a form as possible. A long or intricate classification number is not only hard to apply to a book, but it is difficult to remember in consulting the shelves, and it should therefore be as short and simple as possible. Certainly the numbers or symbols in the method herein described express a great deal in a limited space, and it is hard to conceive of at shorter method of expressing such a phrase ats "Interior Department, Geological and Geographical Survey 
of the Territories (Hayden), Final reports, Volume 9," than by the accurate notation I18.5:!), which, when analyzed, exhibits a clear statement of the entire phrase: (I) Interior Department; (18) Geological and Geographieal Survey of the Territories (Hayden); (.5) Final reports; (:9) Volume $9:=\mathrm{I} 18.5: 9$.

\section{TIIE TABLES.}

The Tables in this work are elaborated from the card shelf list used in this Library. All the necessary bibliographical information is appended to the entry of a publication or series, and no time or effort has been spared in the attempt to make these Tables present an accurate and complete list of all the publications of the Department from 1862 , including all 1902 imprints.

When a publication was also issued as a Congressional document the Congressional reference is inserted after the entry for such publication in the Tables. In a few instances a single paper in a volume has been so issued, and in those cases it has been necessary to insert the Congressional reference in the Index.

Those publications which cmanated from the Department, but which were issued only as Congressional documents, are listed chronologically in the Appendix to this work.

The titles in the Tables are exact copies of the title-pages of the publications with the omission of unnecessary articles. In case of "general publications" or other series which are classified alphabetically the subject words are introduced as headings and the title follows as it appears on the publication.

In counting the maps, plates, charts, ete., in a volume the total number has been stated as "plates," except in cases where the character" of the illustration was plainly determined by numbering.

When the word circular "(circ.)" appears at the end of an entry it indicates a one-page publication of uncertain size.

THE INDEX.

The Index, which forms the most important as well as the larger part of this work, has been carefully compiled with a view to quick reference to any special author, subject, or title. In dealing with a collection of publications differing so widely in their subject-matter, and for the most part of a scientific character, it has been found difficult to determine the best form of entry in many instances for papers with meaningless or strictly technical headings, especially when a reading of the paper by one unacquainted with the subject treated has proved equally unsatisfactory in suggesting a suitable title. The re are doubtless omissions on account of these nondescript titles, which, to save time, have been used for the Index entries. Only where titles 
were found perfectly meaningless, as "A few facts from Florida" or "A popular" experiment," las the article been read, the reason for" whish is clearly indicated by the statement that a complete collection of the publiations of the Department includes abont 3,500 books, paumphicts, and circulars of from 1 to 1,500 pagres each, some of which contain fifty or more distinct papers.

The Index entries to the volumes listed are in many cases greatly abhroviated, as the full titlo and all information concerning the publication can he obtained from the entry in the Tables, but in the ease of analytical references the full title as giren in the document has been entered, in order to convey as much information as possible.

In analyzing the annual reports of the chicfs of the various bureaus or offices, only paper's distinct from the main report, or which, if included, have an individual anthor, are brought out in the Index, the various subheads in the reports not being noted.

When a date does not appear in an entry in the Index it indicates that there is more than one edition or print of the article indexed, except in cases of undated publications, where a date could not be given, or of annual report analyticals, where the date appears as the book number.

\section{CONCLUSION.}

The greatest drawback to systematic elassification and ready reference was the vast number of miscellaneous unnumbered publications. An endearor has been '..... ' this list to classify in distinct series, as fal as possible, this mowieldy mass, and to that end numbers have been assigned and series formed and named, or they were numbered in either the series " bulletins" or "circulars" when these series were not already filled.

There is no well-defined definition for either " bulletin " or "circular" as applied to public documents, as dritnessed by the fact that the series of numbered "circulars" in the Surgeon-General's office, War Department, contains both large (juarto volumes and one-page letters, while the circulars of other offices are single sheets of many varying sizes, and of some of the seientific hureaus of the Agriculture Department are small pamphlets. In assigning numbers in this list, however, the series of "hulletins" have been filled with the more important pamphlet publications, and the series "circulars," made up of the ephemeral or smaller works, generally of one-page letters.

'The mmecessiry nultiplication of numbers on the title pages, especially of the publications of the Agriculture Department, is a subject which does not lend itself to easy explanation, if indeed there is any reason in it, and no account, therefore, has been taken in this list of the various "whole numbers" of the divisions, nor" the "serial num- 
bers" of certain classes of literature, which form a confused jumble of unintelligible characters on the title-pages of so many of the Department's pamphlets.

If the publications of each publishing oflice could be confined within the two series "bulletins" and "circulars," for which provision is made under each office in the classification; or if, in cuse of continued issues, they could be given a series title and series number of their own, such series title and series number to appear on the titlepage (not on the cover or in the back title) of each publication, much of the confusion and oft-complained-of "multiplication of numbering" would be done away with.

Another great hoon to librarians would be the adoption by the Department of a "whole number," to be assigned to all publications of the Department, nomatter by which bureau issued, serially in the order of issuc, printed in small type in an inconspicuous place on the title-page, or at the heading of an article, and applied without reservation to everything issued which the Department considers a "publication." 'This "whole number," however, not to supersede the series numbers of the publishing bureaus, but to take the place of all other title-page numbers.

In compiling lists of the publications of the Departments, crerything issued by a Department, except circular letters and cards and notices of a purely office character, should be listed; and ret it is found in many instances almost impossible to determine what the Department considers a "publication." hatiig" numbered issues being of but a temporary character, while an unnumbered card or circular may be of importance, and if discarded would be regarded as a serious omisision.

"Whole numbers" are now used by many of the publishing offices to designate a certain class of litereture, but to be of practical value the number must be applied by the Department, and should appear on everything iscued which it consider's " "publication." Librarians could then easily keep track of the publications and be sure when they had them all, whereas now no one knows what constitutes a complete set of the publications of any of the great Departments.

A carefully assorted and beautifully bound collection of many of the publications of the Department, which proved of grat value in compiling this list, is safely entombed in a vault in the gronnds of the Department; its library has a fair representation of the publications; while most of the scientific bureans retain files of at least the last editions of their works; but in no one place, nor in all combined, does the Department possess anything like a complete file of its valuable litenture. 'This, however, is not surprising, for in all the well- 
equipped libraries of the various Departments it is most discouraging to note the dearth of publications of the Departments themselves, a fact which should certainly be remedied.

Every bureau and office in the Department has been visited and private files searched in the endeavor to make this list complete, and it is hoped it will prove a satisfactory substitute for a catalogue of the Department's publications.

\section{Public Documents Library,}

Wilitam Lanander Post.

October 12, 1903. 


\section{TABLES}

For a full explanation of the classification used in these Tables, see pp. 8-15, without a careful perusal of which the best results can not be obtained in using this list. 



\section{A. AGRICULTURE DEPAR'TMENT}

[By an appropriation for the eollection of agricultural statistics, Mareh 3, 1839, an agricultural section was established in the Patent Office. The section continued until May 15, 1862, when it was made a separate Department, though it was not until February 9, 18s9, that it was raised to the dignity of a Cabinet office.]

Classifleatlon no.

\section{A. SECIETARY}

\section{1: Innual reports}

[The annual report on agriculture began in 1837 with a two-page statement in the report of Henry L. Ellsworth, Commissioner of Patents. From that date to 1861 it formed a part of the report of the Commissioner of Patents, making a separate volume after 1849.

In 1862 the Department of Agriculture was established and its anuual report was uniformly issued up to 1893 . Beginning with the report for 1894, in accordance with paragraph 2 , section 73 , of the printing act of January 12,1895 , the report has been prepared in two volumes, one containing the Secretary's report and the purely executive reports of the several ehiefs of bureaus, divisions, and offiees; the other, known as the Yearbook (A1.10:), embracing the Secretary's report and a collection of special articles on agricultural science.

The title of the head of the Department was Commissioner of Agriculture until 1889, when he became Seeretary of Agriculture and a member of the Cabinet.

References to the various reports and seientific papers contained in this series of annual reports will be found under their proper headings in the Index to this work.

For further information see notes uuder A1.1 $a$ :]

Commissioner of Agriculture

1862 (Newton), 632 pl., $52 \mathrm{pl}$.

Same, 37 th Cong., 3 d sess., H. ex. doc. 78; serial no. 1168.

86i'3

1863 (Newton), 698 pl., 48 pl.

Same, 3stll Cong., 1st sess. In H. ex. doc. v. 5; serial no. 1184. 1864 (Newton), 676 pp., $48 \mathrm{pl}$.

Same, 38th Cong., 2 d sess., H. ex. doe. 68; serial no. 1228. 1865 (Newton), iv +608 pp., $32 \mathrm{pl}$.

Same, 39th Cong., 1st sess., H. ex. doc. 136; serial no. 1266. 1866 (Newton), 656 pp., 36 pl.

Same, 39th Cong., 2d sess., H. ex. doc. 107; serial no. 1297.

1867 (Stokes; Capron), $\mathrm{xix}+512$ pp., 37 pl.

Same, 40th Cong., 2 d sess. In H. ex. doc. v. 21 ; serial no. 1347. 1868 (Capron), [4]+671 pp., 19 pl.

Same, toth Cong., 3 d sess., H. ex. doc. nnnumbered; serial no. 1383. 1869 (Capron), 702 vI., $38 \mathrm{pl}$.

Same, 4lst Cong., 2il sess., II. ex. doc. unnumbered; serial no. 1428. 1870 (Capron), 685 pp., 33 pl.

Same, 41 st Cong., 31 sess., H. ex. dor. numumbered; serial no. 1461. 1871 (Watts), [4] +524 pl., 29 pl.

Same, f2ul Cong., 2d sess., II. ex. doe. [327]; serial no. 1522.

Same, without accompanying documents. 421 Cong., 21 sess., H. cx. doc. 1, 1) 145; serial no. 1502 .

1872 (Watts), 524 pp., 12 pl. (Not issued in Congressional set.)

1873 (Watts), 496 pl), I pl. [Erroneonsly assigned serial no. 1616, but never issued in Congressional set. 7

1874 (Watts), 463 pl., 9 pl.

Same, $43 d$ Cong., 2d sess., 11. ex. doe. unnumbered; serial no. 1652. 1875 (Watts), 536 pp., 61 pl. (Xut issued in Congressional net.) 


\section{Tables}

('lassinca. tlon no.

1.1:

876

877

878

879

880)

$881-2$

s.83

884

8.5

ssti

857

888

889

890

591

892

$\checkmark 893$

894

895

896

897

898

899

900

901

902

1.1 $1:$

A 1. 1 $a$ :

\section{A1. SECIR'TIRY-continued}

\section{Anual reporto-Continned}

1576 (Watts), $447 \mathrm{pp}, 15 \mathrm{pl}$. (Not issuel in Congressional set.)

1877 (Le Inc), 592+[1] pl., 54 pl. (Not issued in Congressional set.)

Sip for supplemental report, $1877, A 1.2: A n 7^{-1}$

1878 (I.e 1)ne), $608+[1] \mathrm{pp} ., 59 \mathrm{pl}$. (Not issued in Congressional set.)

1879 (Le Duc), 621 pp., 67 pl. (Not issued in (ongressional set.)

1880 (Le Due), 672 pp., 136 pl.

Same, preliminary report, 46 th Cong., $3 d$ sess., S. ex, doc. 27; serial no. $19+1$

1881 and 188.2 (Loring), 704 py., 85 pl.

same, 47th Cong., 1st ses.., H. ex. der. [228]; serial no. 2034.

1853 (Loring), $496 \mathrm{pl}$., $54 \mathrm{pl}$.

Sinne, 47th Cong., 2t sess., II, ex. dor. 109; serial no. 2114.

$188+$ (Loring), 581 pp., $71 \mathrm{pl}$.

Same, 4sth Cong., 1st sess., H. ex. dw. 178; serial no. 2212.

1885) (Colnuan), 640 pp., 45 pl.

Same, 48th Cong, 2d sess., H. ex. loe. 269; serial no. 2309.

1856 (Colman), 719 pp., 72 pl.

Same, 49th Cong., 1st sess., H. ex. (loc. 378; serial no. 2405.

1887 (Colman), 724 pp., 70 pl., 1 map.

Same, 49 th Cong., 2 d sess., H. ex. loc. 201; serial no. 2487.

1888 (Colman), 708 pp., 69 jl., 1 map.

Same, 50th Cong., 1st sess., II. ex. doe. 470; serial no. 2564.

SECRETARY OF AGRICULTURE

1889 (Rusk), 560 pp., $44 \mathrm{pl}$.

Same, 51st Cong., 1st sess., H. ex. doc. 1, pt. 7 ; serial no. 2732.

1890 (Rusk), 612 pp., $50 \mathrm{pl}$.

Same, 51st Cong., 2 d sess., H. ex. doc. 1, pt. 6 ; serial no. $28+7$.

1891 (Rusk), 653 pp., 59 pl., 1 map.

Same, 52d Cong., Ist sess., II. ex. doc. 1, pt. 6; serial no. 2940.

1892 (Rusk), 656 pp., 71 pl.

Same, 52 d Cong., 2 d sess., H. ex. doc. 1, pt. 6; serial no. 3095.

1893 (Morton), 608 pp., 29 pl.

Same, 53d Cong., 2 d sess., H. ex. doe. 1, pt. 6; serial no. 3216.

1894 (Morton), $120 \mathrm{pp}$.

Same, 53d Cong., 3d sess., H. ex. doc. 1, pt. 6; serial no, 3310.

1895 (Morton), 266 pp., l chart.

Same, 54th Cong., 1st sess., H. doe. 6; serial no 3390 .

1896 (Morton), li $+269 \mathrm{pp}$.

Same, 54 th Cong., $2 d$ sess., H. doc. 6 ; serial no. 3496 .

1897 (Wilson), liv $+226 \mathrm{pp}$.

Same, 55th Cong., 21 sess., H. doc. 6; serial no 3651.

1898 (Wilson), lxiii $+212 \mathrm{pp}$.

Same, 55th Cong., 3d sess., H. doe. 6; serial no. 3768.

1899 (Wilson), $1 \mathrm{xx}+266 \mathrm{pp}$.

Same, 56th Cong., 1st sess., If. doe. 6; serial no. 3929.

1900 (Wilson), lxxviii +297 pp.

Same, 56th Cong., 2d sess., H. doe. 6; serial no. 4116 .

1901 (Wilson), cxv+34t pp.

Same, 57th Cong., 1st sess. II. doc. 6; serial no. 4301.

1902 (Wilson), exxiv +402 pp.

Same, 57 th Cong.. $2 d$ sess., H. doc. 6 ; serial no. 4466.

See also, for another print of personal report of Secretary, 1902, 11.8:73

\section{Anmual reporis (separates; Secretary's report)}

[The personal report of the Seeretary is issued separately in pamphlet form in arvante of the inain volmme; is also the first paper in the learbok (A1.10:); and sometimes appears as a broadside, or as a pamphlet printed on one side of the page only, for the use of the press.]

Annual reports (seprarates; miscellaneous)

[Only a small number of the seientific papers aceompanying the report of the secretary are known to have been printed separately. References to all the scientific papers will be found muder their proper headings in the index to this work.] 


\section{A.1:2 General publications}

Ag8 ${ }^{1}$ Agricnltural Colleges. list of delegates and visitors to 10 th annual convention of Association of American Agrieultural Colleges and Experiment Stations. 1896 . n. t. p. $3 \mathrm{pp}$.

Ags". Agriculture Department. [Letter as to work and needs of Deprartment of Agriculture; by William G. Le Duc.] Feh. 27, 1880. n.t.p. $15 \mathrm{pp}$.

$\operatorname{Ag} 8^{3}$

Agriculture Department. Notice of its various functions. 1893. (Circ.)

Ant

$\operatorname{An} 5^{1}$

Angora. Notice of receipt of letter from Minister Terrell relating to Agrieulture in Angora. Nov. 1, 1893. (Cire.)

Animal Industry Bureau. Proposed lill sulmitted for consideration and revision, offering amendments to act of May 29, 1884, establishing Bureau of Animal Industry, with view of more effectual control of eontagions diseases. n. t. p. n. d. 12 pp. $4^{\circ}$

An $^{2}$ Animal Industry Bureau. [Letter of J. M. Rusk relative to establishment of Burean of Animal Industry, etc.] $\Lambda$ pr. 12, 1890. $8 \mathrm{pp}$.

$A n 7^{1}$ Annual report of Commissioner of Agriculture (supplemental) to President. Nov., 1877. 19 pp.

$\operatorname{An} 7^{2}$

$A_{1} 4^{1}$

Apt ${ }^{2}$

Same, also transmitting special Department reports no. 1 [11.6:1] and nо. $3[\mathrm{~A} 1.6: 3] 19+32+26 \mathrm{pp}$.

Apparatus for sale. Jan. 24, 1896. (Cire.)

Appalachian region. Message from Iresident of U. S., transmitting report of Secretary of Agriculture [James Wilson, in collaboration with Department of the Interior], in relation to forests, rivers, and mountains of southern Appalachian region. 1902. 210 pp. 78 $[80]$ pl. large $8^{\circ}$

Same, 57 th Cong., 1.t sess., S. doc. 84; serial no. 4229.

$\mathrm{Ap}_{\mathrm{p}} \mathrm{6}^{1}$

A $6^{2}$

$\mathrm{B} 39^{1}$

B39 ${ }^{2}$

Bi39 3

B39 ${ }^{4}$

$1339)^{5}$

$\mathrm{C} 29^{\mathrm{r}}$

$\mathrm{C} 29^{2}$

$\mathrm{C} 29^{3}$

$\mathrm{C} 29^{4}$

$\mathrm{C} 29^{5}$

(C29) ${ }^{6}$

$\mathrm{C} 49^{1}$

$\left(49^{2}\right.$

$\mathrm{C} 49^{3}$

$\mathrm{C} 49^{4}$

Appointment clerk, report of. Dec. 1, 1901. n. t. p. 5 pp.

Same; revised. Dec. 1, 1901 . n. t. p. 7 pp.

Beet sugar. Sperial report on beet-sugar industry in U. S. [in 1897]. 1898. 240 pp. 2 maps.

Same, 55th Cong., 2d sess., H. doc. 396; serial no. 3691.

Same, separate, pp. iv.+161-233; Beet-sugar industry in U. S. [in 1897], report of special agent Charles F. Saylor.

Same, separate, pp. 135-140, 160; Analyses of sugar beets grown in various States; by $H$. W. Wiley.

lieet sugar. Progress of beet-sugar industry in U. S. in 1898. 1899. $162 \mathrm{pp}$

Same, 55th Cong., 3rl sess., H. doc. 267; serial no. 3812.

Beet sugar. Progress of beet-sugar industry in U. S. in 1899; with a supplementary report on cane-sugar industry of Hawaiian Islands. $1900.200 \mathrm{pp} .4$ maps.

Same, 56th Cong., 1st sess., H. doc. 699; serial no. 3985.

See also A1.8:69.

Cattle. Reports on diseases of cattle in U. S., made to Commissioner of Agriculture, with accompanying documents. $1869.190 \mathrm{pp}$. 1 pl.

Cattle. Report of Commissioner of Agriculture on diseases of cattle in U. S. 1871 . [4] +205 pp. 14 pl. $4^{\circ}$

Cattle. Corresponlence with S. W. Allerton concerning exportation of Canadian cattle from port of Boston, Mass. Der. 28, 1896. 11. t. 1. $11 \mathrm{pp}$.

Same. (Broaklide.)

(attle. Results of examinations of fluids of cliseased cattle, with reference to presence of eryptogamic growth. 1871. 12 pl). $4^{\circ}$ *

Cattle. Contagions pleuro-pneumonia or lung plague of cattle; where and to what extent it exists. $1870.17 \mathrm{pp}$.

Civil service. Letter relative to elassified service. Dee. 16, 1895. (Cire.)

Same. Dee. 1, 1896. (Cire.)

Civil serviec. Civil scrvice in [Agriculture] Department. Fob. 29, 1896. II. t. p. 2 pp.

Same. Nay 14, 1896. n. t. 13. 2 pp.

* No copy found. 
A 1.2:

(7)

C76

D]4.

Ex6 ${ }^{1}$

$1 \times 6^{2}$

F76

H7s

H89

In 7

L48

N84

P53

P69

P94

P96 $^{1}$

$\mathrm{P} 96^{2}$

$196^{3}$

$\mathrm{P}^{2} 6^{4}$

$\mathrm{P} 96^{5}$

$\mathrm{PO}^{6}$

${ }^{2} 96^{7}$

$\mathrm{P}^{\circ}{ }^{8}$

R13

R89

Sei $1^{\prime}$

Sci $1^{2}$

Sei I ${ }^{3}$

Sei $1^{4}$

Sei $1^{5}$

Sci ${ }^{6}$

Sei $1^{7}$

Gencral publications-Continued

Colman, N. J. Report in response to infuiries of select committee of Senate appointed to inquire into and examine the methods of business of the Exerntive Departments. 1888. n. t. p. $106 \mathrm{pl}$.

Convention. Proceedings of National Agrieultural Convention held at Washington, Feb. 15-17, 1872. 1872. $84 \mathrm{pp}$.

Same, $42 d$ Cong., $2 d$ sess., S. mis. doc. 164; serial no. 1526.

Dairy. Lxport of dairy products of U. S., 1821-1890. [1890.] (Cire.) *

Expenditures. [Relative to restriction of expenditures in Department.] Apr. 6, $1896 . \quad$ (Cire.)

Experiments. Protest against proposed legislation restrieting experiments of Department. [With enpy of Senate bill 1063.] May 25, 1897. n. t. p. $8+2$ ] 1 .

Flax and Hemp Commission. Report of Flax and Hemp Commission [J. K. Moorhead, Jno. A. Warder, and Chas. Jackson], appointed under act of Congress of Fel,. 25, 186\%. n. p. [1865.] "16 p]. (Cover title only.)

Same, 38th Cong., 2d sess., S. ex. doc. 35; serial no. 1209.

IIorses. Market for American horses in foreign countries. 1898. $94 \mathrm{pl}$. $6 \mathrm{pl}$.

Hungarian brome grass. Notice of eircular [no. 1, Botany Division] on Hungarian brome grass. June, 1894. (Circ.) *

Inspectors. General orders to inspectors [relative to humane treatment of animals]. Nay 13, 1896 . (Circ.)

Leave of absence not allowed to employees outside of Washington. Out. 21, 1896. (Circ.)

Notice of receipt of communications on various subjects. July 7, 1893. (Cire.) $*$

Philarlelphia, Pa. Report of participation of Department of Agriculture in International Exhibition of 1876 ; by William Samders. 1884. *

Plants. ('atalogue of U.S. plants in Department of Agriculture. [186-.] $27 \mathrm{pl}$. (Cover title only.)

Promotions. Regulations governing promotions, etc., in Department of Agriculture. Dec. 1, 1896. n. t. 1) 3 pl.

Publications. General order [relative to] distribution of publications. Jan. 10, 1896. (Circ.)

Same, Farmers' bulletins. Oct. 15, $1895 . \quad+\mathrm{pp}$.

Same, Farmers' bulletins. Feb. 25, 1896. 4 pp.

Same, Farmers' bulletins. May 16, 1896. $4 \mathrm{pp}$.

Same, Farmers' bulletins. July 1, 1896. 4 pp.

Same, Farmers' bulletins. Mar. 15, 1897. 4 p. $4^{\circ}$

Same, Farmers' bulletins. June 30, 1897. 4 pp. $4^{\circ}$

Publications. Instructions relating to purchase of publications. Jan. 22, 1896. (Circ.)

Railroad and transportation companies. Circular to railroad and transportation companies relative to prevention of exportation of diseased cattle. Feb. 24, 1890. (Cire.) *

Rusk, Jeremiah M. Annual reports, with selected correspondence, relating to export trade of $T$. S. in live stock and meat p,roducts, of Jeremialı M. Rusk, 1889-92. 1893. $40+52+59+64+33$ pp.

See also for correspondence $A 1.8: 53$.

Scientific work in Department. liecommendation for appointment of director in (hief of seientific work. Feb. 15, 1896 . n. t. p. 3 l)?.

Scientific work in Department. ()pinions of scientific men and otlers with regarl to proposition for a director in chief of seientific: bureaus. 1.t ed. [1896.] n. t p. 3 lp.

Same. 21 ed. [1896.] n. t. p. 8 pp.

Same. 3d ed. [1896.] n.t. p. $16 \mathrm{pp}$.

Same, additional opinions. [1896.] n.t. p. 4 pp.

Same, alditional resolutions. [1896.] n. t. 1. t pp.

Same, with report of Senate Committee on Agriculture and Forestry. [1896.] n.t. 1. 12 1'p.

* No copy foumd. 
A 1.2:

$\operatorname{ses}^{1}$

Lie $3^{2}$

Se: ${ }^{3}$

Se. ${ }^{4}$

Se. ${ }^{5}$

Sie: ${ }^{6}$

Se:3i

$\operatorname{sen}^{\mathrm{x}}$

Shis

Sol

Sp:3

S113

T69 I

T $69^{2}$

$\checkmark 67$

W69

1 1.3:

I1.1:

Genemal puldications-Continued

seed. Relative to status and diseontinuance of distribution of seed. July 2.5, 1895. (Circ.)

Seed. Opinions of the press coneerning fres-seed distribution. n. 1. n. t. p. $12 \mathrm{pp}$.

Seed. Statement of secretary at joint meeting of Senate and House Committees of Agrieulture [relative to] free-seed distribution. Jan. 15, 1896. n. t. p. 8 pl.

Scerl. Proposils for furnishing seed. Mar. 18, 1896. (Slip.)

Seerl. Statement in regard to award of seed contract. Apr. 16, 1896. 11. t. 1. $8 \mathrm{pp}$.

Secrl. Prohibiting use of Government seed invelopes by numthorized parties. May 2, $1896 . \quad$ (Cire.)

Seed. Cost of seed ilistribution. Jan. 30, 1897. n. t. p. $3 \mathrm{pp}$.

Secel. Brief instructions in regard to sowing seeds and raising young plants of forest trees. n. d. $5 \mathrm{pp}$.

Sheep hushandry in U. S. Grigin and growth of sheep husbandry in U. S., with some remarks on angora fleere. 1880. [1]+133 pp. 4 pl.

Same, 45th Cong., id sess., S. ex. doe. 25; serial no. 1828.

Societies. List of agrienltural and horticultural societies in U.S. 1869. *

Specifications of workmanship and materials required in ereetion and completion of new bnililing for accommodation of Department of Agrieulture in Washington, D. C.; prepared by Cluss \& Kammerhueber. $1867.26+2 \mathrm{pp}$.

Sugarhouse machinery for sale July 1,1895 . n. t. p. 8 pp. $4^{\circ}$

Traveling expenses. Allowances for traveling expenses. Oct. 1, 1889. $8 \mathrm{pp}$.

Same. July 1, $1893.11 \mathrm{pp}$.

Vienna. Notice relating to International Exhibition, Vienna, 1894. Nov. 27, 1893. (Cire.)

Wilson, James. Speech by James Wilson, Secretary of Agrieulture, delivered July 7, 1902, at Sehool of Agrieulture, Cohmbus, Ohio. July 17, 1902. n.t. p. 6 pp.

Wools. Peport upon examination of wools and other mimal fibers; by William Me Murtrie. $1886.613 \mathrm{pp}$. $72 \mathrm{pl} .4^{\circ}$

Same, 49th Cong., 1st sess., H. mis. doe. 392. Serial no. 2426.

\section{Bulletins}

None issued.

\section{Circular's}

[No. 1.] Statement in regarl to awarl of seed contract. Apr. 16, 1896. n. t. p. 8 pp.

[No. 2.] Vivinection in District of Columbia. May 16, 1896. n. t. p. 8 pp. No. 3. Address on progress of Southern agriculture; by Charles Wr. Dabney. June 1, 1896 . n. t. \%. $12 \mathrm{pp}$.

No. 4. [Letter of protest and appeal to persons interested in animal inchustry, aceompanying a draft of Senate bill 1552, 5th Cong., 1st sess., entitled " $\mathrm{A}_{\mathrm{n}}$ act for the further prevention of rrnelty to animals in District of Cohmolia." ] June 5, 1896. 11. t. p. 3 " pp.

No. 5. Civil service in Department of Agrienlture. Jume 20, 1896. n. t. P. 4 pl.

No. 6. Number, status, and compensation of employous in Department of Agriculture, July 1, 1897. Jan. 20, 1898. n. t. j. 4 pl).

No. 7. Possible influence of inportation of Hawaiian sugar on beet-singatr production in United States. Jan. 17, 1898. n. t. p. 4 pl.

No. 8. [Cooperative work in grass and forage plant investigations with State experiment stations; ly T. A. Williams.] Nov. 20, 1900. n. t. P. $1+\mathrm{pp}$.

Same, revised. [1901.] n.t. p. li pp.

No. 9. [Collection and distribution of urass soed: field work; by C. I. Shear.] Dec. 10, 1900. 11. t. p. 11 pp.

* No copy found. 
A 1.5:

1.6:

\section{Miscellanegus einceularo}

No. 1. Castor-oil plant. n. d. n. t. p. + pp.

No. 2. Mississibli liver floud. Apr. 12, 1897. n. t. p. 6 pp.

No. 3. Mississippi liver tlood, 21 report. Apr. 22, 1897. n. t. 1. 4 pp.

\section{Nipecial reperts}

No. 1. Condition and prosperts of eane-sugal industry in U.S. 187 . 41 plo.

tien also $\ 1.2: \mathrm{\perp n}^{2}$

Yo. 2. Condition of (rops, etc. 187\%. (In $127.9: 15$.

No. 3. Thea virilis or Cluinese tea-plant, aucl practicability of its culture and manufacture in L.R. Alwo some remarks on altivation of Coffee ylant. 1877. $26 \mathrm{\mu l}$.

See also $\mathrm{A} 1.2: \mathrm{An} 7^{2}$

Nu. 4. Cultivation of fig, and method of preparing the fruit for commerce; also report on iniportance of cultivation of flate palı. $1878.17 \mathrm{pl}$.

No. 5. Condition of crops, June 1, 1878. (In A27.9:16.)

No. 6. Condition of ('rops, July 1, 1878. (In A27.9:16.)

No. 7. Condition of erops, Aug. 1, 1878. (In A27.9:16.)

No. 8. Condition of crops, Sept. 1, 1878. (1n A27.9:16.)

To. 9. Condition of (rops, Dec. 1, 1878. (In 127.9:16.)

No. 10. Condition of erops, and live stock, Jan., 1879. (In A27.9:17.)

No. 11. The silk-worm; being brief manual of instruction for production of silk. [By C. V. Riley.] 1879. \$1 pl.

Same; by C. T. Riley, 2l edition. 18s2. $37 \mathrm{pp}$.

Same, 3il edition.*

Same, 4th edition. 1883. $37 \mathrm{pp}$.

Same, 5th elition. 1884. $37 \mathrm{lp.}$

No. 12. Invest gation of diseases of swine, and infections and contagions diseases incident to other classes of tomesticated animals. 1879. $292 \mathrm{pp} . \quad 17 \mathrm{p}, \mathrm{l}$.

No. 13. Condition of crops and live stock, Apr., 1879. (In A27.9:17.)

No. 14. Condition of props and live stock, June, 1879. (In 127.9:17.)

No. 15. Condition of erops, July 1, 1879. (In A27.9:17.)

No. 16. Condition of crops, Aug. 1, 1879. (In A27.9:17.)

No. 17. Coudition of crops, Sept. 1, 1879. (In 127.9:17.)

No. 18. Tea-culture as a probable American industry; by William Saunders. Read before New York Horticultural Society, at its meeting, Oct. 7 , 1879. 1879. $21 \mathrm{pp}$.

No. 19. Condition of erops, Nov. 1, 1879. (In A27.9:17.)

No. 20. Condition uf (rops, Dec. 1, 1879. (In 127.9:17.)

No. 21. Number and prices of farm animals, Jan. 1, 1880. (In 127.9:18.)

No. 22. Contagions diseases of domesticated animals; continuation of investigation by Department of Agriculture. 1880.268 pl). $15 \mathrm{pl}$. 1 map.

No. 23. Condition of erops, Apr., 1880. (In A27.9:18.)

No. 24. Condition of crops, June and July, 1880. (In A27.9:18.)

No. 25. Condition of crops, Aug., 1880 . (In A27.9:18.)

No. 26. Culture of sumac in Sicily, and its preparation for market in Europe and I. S.; by William MeMurtrie. $1880.32 \mathrm{pp} .8 \mathrm{pl}$.

No. 27. Condition of erops, Sept., 1850. (In A27.9:18.)

No. 28. Culture of sugar beet and manufacture of sugar therefrom in France and U. S.; By William Mc.Nurtrie. 1880.294 p. 32 p. 4 maps.

[Extensively quoter] in Bulletin No. 26, Chemistry Bureau. See A 8.3:26.]

No. 29. Condition of erops, Nov. 1, 1880. (In A27.9:18.)

No. 30. Condition of erous, Dec. 1, 1850. (In A27.9:18.)

No. 31. Contagious plenro-pneumonia; 3 l report of Charles I'. Lyman. 1881. 20 川. 7 pl.

No. 32. Condition of (rops and live stock, Apr., 1881. (In A27.9:19.)

No. 3i. Analytical work done on sorghum and cornstalks hy Chemical division, July-Dec., Is80; by Peter ('ollier. 1881. 101 pl. 27 pl.

Yo. 34. Contagious diseases of domesticated animals. 1881. 391 pl. 51 pl.

* No copy found. 


\section{Spccial reporta-Continuerl}

No. 35. Inserts injurious to sugrar (ane; l)y J. Ilenry Comstock. 1881. $11 \mathrm{pp}$.

No. 36. lieport upon statistics of grape culture and wine production in U. S. for 1880; by William IIellmtric. 1881. 104 pl).

No. 37. Condition of erops, June-July, 1881. ( $\ln$ 127.9:19.)

No. 38. Condition of erops, Aug. 1, 1851. (In A27.9:19.)

No. 39. Condition of erops, Sept. 1, 18s1. (In A27.9:19.)

Yo. 40. Condition and needs of spring wheat culture in Northwest; by C. C. Andrews. 1882. $99 \mathrm{pp}$.

No. 41. Report upon estinated prorluetion of cereals of I. S., for year 1881 . [Febrnary, 188\%.] 188\%. (In A27.9:20.)

No. 42. Condition of winter grain, ete., A pr., 1882. (In 127.9:20.)

No. 43. Condition of winter grain, ete., May, 1882. (In A27.9:20.)

No. 4t. Acreage and condition of cotton, etc., June, 1ss2. (In A27.9:20.)

No. 45. Area and condition of corn, ete., July, 1882. (In A27.9:20.)

No. 46. Courlition of corn and cotton, ete., Aug., 1852. (In A27.9:20.)

No. 47. Climate, soil, and agricultural capabilities of Sonth Carolina and Georgia; by J. C. Hemphill. 1882 . $65 \mathrm{pp}$.

48 No. 48. Silos and ensilage; a-record of practical tests in several States and Canada. 1882. $70 \mathrm{pl}$.

No. 49. Condition of com and cotton, ete., Sept., 1882. (In A27.9:20.)

No. 50. 1)issemination of Texas ferer of cattle, and how to control it. 1882. $14 \mathrm{mp}$.

No. 51. Yield and ruality of small grain, ete. 188\%. (In A27.9:20.)

To. 52. Yield per acre of cotton, com, potatoes, ete. Nov., 1882. A $27.9: 20$.)

No. 53. Product and price of principal crops of 1882. 1882. A $27.9: 20$.

No. 54. Adllress of Geo. B. Loring [on sorghum sugar industry] before Mississippi Valley Cane-(rrowers' Association, St. Louis, Mo., Dec. 14, 1882. 1883. $19 \mathrm{pp}$.

No. 55. Cirange: its origin, progress, and educational purposes, hy I. Wyatt Aiken; read before a convention called ly Commissioner of Agriculture Jannary 23, 1883, to consider subject of agricultural education. 1883 . is pp.

No. 56. Numbers and values of farm animals, Feb., 1883. (In A27.9:21.)

No. 57. Distribution, etc., of com and wheat, Mar., 1883. (In A27.9:21.)

To. 58. Area and condition of winter wheat, etc., Apr., 1883. (In A27.9:21.)

No. 59. Condition of winter grain, ete., May, 18s3. (In A27.9:21.)

No. 60. Acreage of spring grain and cotton, etc, June, 1883. $\Lambda 27.9: 21$.)

No. 61. Area of corn, potatoes, and tobaceo, ete, July, 1883. 127.9:21.)

62 No. 62. Olservations on soils and produets of Florida; hy William Saunders. $1883.30 \mathrm{pp}$.

63. No. 63. Grasses of U. S.; beng a synopsis of tribes and genera, with descriptions of genera, and list of species; by Geo. Vasey. 18s:. ti pp.

No. 64. Condition of erops, ete, Ang., 1883. (In A 27.9:2.'1.)

No. 65. Condition of "rops, Sept., 1883. (In A27.9:21.)

[Series discontiuued. Statistienl matter of like character published wfter this date in Statistieal report, Statisties division. 127.9 :]

\section{A1.7: Miscellancous special peports}

1 No. 1. Address of (ien. 13. Loring before Ameriean Forestry Congress,

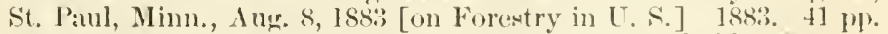

2 No. 2. I'rocecelings of [21] convention of agriculturists, hede at Ihepartment of Agrieulture, Jan. 23-29), 1883. 1883. $245 \mathrm{pl}$.

3 No. 3. Mississippi: itsclimate, soil, problutions, and agricultural capaloili. ties; by $\Lambda$. B. llurt. 188t. $89 \mathrm{pp}$.

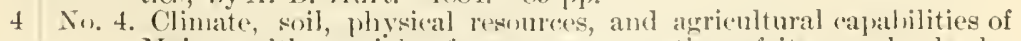
Iane, with sperial reference to ocenpation of its new lames; by Samuel L. Boarlman, 1884. bil 1)? 
Miscellaneous special reports-Continued

No. 5. Proper value and management of (iovernment timber lands, and distribution of North American forest trees, being papers read at U. S. Department of Agriculture, May 7-8, 1S84. Is84. 47 pl).

No. 6. Address of (ieo. B. Loring at National Comvention of CattleBreeders, Chicago, IH1., Nov. 13, Isst [on the cattle industry]; also report of veterinary inspectors of $\mathrm{New}$ York. 1884. $21 \mathrm{ll}$.

No. T. Tide marshes of I $^{*}$ S., by D. M. Nesbit; with contributions from U. S. Coast Survey, S. I. Boarlman, Elchiclese Morse, aud uthers. 1855. $259 \mathrm{pp}$

No. 8. Cotton in Empire of Brazil; antiquity, methods, and extent of its cultivation, with statisties of exportation and lome consumption; by John C. Branner. 1885. 79 pl.

No. 9. Proceedings of eonvention of delegates from agrienltural colleges and experiment stations, held at Department of Agriculture, July 8 and 9,1885 . 1885.196 pp.

No. 10. Descriptive catalogne of manufactures from native wools as shown in exhibit of U.s. Department of Agriculture at Worlcl's Industrial and Cotton Exposition at New Orleans, Ia.; lyy Charles Richards Dodge. 1886. $84 \mathrm{pp}$.

[Series discontinued.]

\section{A 1.*: [Department] reports}

[Nos. 1-58 were issued, 1862-1898, without numbers. A list of titles and assigned numbers for this series was printed on cover pages 3 and 4 of No. h9, which was the first to bear a number. A reprint of No. 5s, in 1901, bore the number, though the old imprint date, 1898, was retained.]

[No. 1.] Circular from Commissioner of Agriculture on present agricultural, mineral, and manufacturing conditions and resources of U. S.; [by [saac Newton]. 1862. 8 pl.

[No. 2.] Catalogue of plants, bulbs, tubers, etc., for distribution from I.S. propagating garlen, with report on object and aims of garlen; by William Saunters. 1862. 8 pp.

[Said to be the first publieatios issued by the Department of Agriculture.]

[No. 3.] Chemical analysis of grapes; by Charles M. Wetherill. 1862. $6 \mathrm{pp} . *$

[No. 4.] List of agricultural, hortieultural, and pomological societies and farmers' elubs, etc., on books of Department of Agriculture, July 1, 1870, ete. 1870 . +7 l).

[No. 5.] I ist of agricultural colleges and farmers' clubs and agricultural, horticultural, and pomological societies on books of Department of Agriculture, June 1, 1872, with name of jresident and secretary of each. 1872. $66 \mathrm{pp}$.

6 [Yo.6.] Descriptive catalogne of plants in exntic collection of the Department of Agriculture; by William Saunders. 1872. 51 Wp.

[No. 7.] Department of Agriculture: its history and objects; by James M. Swank. 1872. 64 1). $12^{\circ}$.

8 [No. 8.] Culture and manufaeture of ramie and jute in U. S.; by Emile Lefranc: 1873.19 pl.

[No. 9.] Eucalyptus globulus from a botanic, economic, and medical point of view, embracing its introduction, culture, and nses; translated from the French of J. E. Planchon. 1875. 20 ll. $1 \mathrm{pl}$.

[No. 10.] Planter's guide for eultivating and curing tobaceo, with information and instruction ronceming the Shelton tobacco-hanger; prepared by Shelton Tobacen-Curing Co., of Asheville, N. C. 1876. 24 pl.

[No. 11.] Catalogue of forest trees of U. S. which msually attain height of 16 feet or more, with notes and brief descriptions of more important species, illustrating collection of forest-tree section on exhibition by Department of Agrieulture at Centemnial Exhibition, Philadelphia; by George Vasey. 1876. 38 pl?.

[No. 12.] List of agricultural societies and farmers' clubs establisherl to promote the agricultural, horticultural, and pomological interests of the farmer on books of Department, July 4, 1876, with list of agricultural colleges. $1876.63 \mathrm{Pp}$.

* No cony found. 
[Department] reports-Continuer]

[No. 1.i.] Statement of appropriations and expenditures of the Department, 1839 to 1877 , inclusive. 1877. $18 \mathrm{pp}$.

[No. 14.] (ieneral index of agrinaltural reports of Patent Oflice, 1837-1861, and of Department of Agriculture, 1862-1876. 1879. 225 pp.

Se for supplement, 1877-1885, A1.8:42.

[No. 15.] Cireular letter from Commissioner of Agriculture relative to mannfacture of maize and sorglum sngars. 1879. $21 \mathrm{pp}$.

[No. 16.] Letter of Commissioner of Agriculture to Jno. W. Johnston, chaiman of Senate Committee on Agriculture, on sorghum sugar [loy W. G. LeDuc]. 1880. 42 pl. 33.pls. 1 folled table.

[No. 17.] Address of Geo. B. Loring and other proceedings of Cotton Convention hed in Atlanta, Ga., Nov. 2, 1881. 1881. 35 pp.

[No. 18.] Fertilizers. Cooperative experimenting as means of sturlying effects of fertilizers and feeding capacities of plants; by W. 0 . Atwater. 1882. $33 \mathrm{pl}$.

[No. 19.] Artesian wells upon Great Plains; being report of geological commission appointed to examine a portion of Great Plains east of Rocky Mountains, and report upon localities deemed favorable for making experinental horings [by C. $A$. White and Samuel Aughey ]. 1882. 38 pp. 1 map.

[Xo, 20.] Climatic: and agricultural features, and agricultural practices and needs of arid regions of Pacific slope, with notes on Arizona and New Mexico; by E. W. Hilgard, T. C. Jones, and R. W. Furnas. 1882. 182 pl.

[No. 21.] Florida: its climate, soil, productions, and agricultural capabilities [papers by Genrge B. Carse and James H. Foss]. 1882. 98 pp.

[No. 22.] l'roceedings of convention of agriculturists held in Department of Agriculture, Jin. 10-18 [1882]. 1882. 204 pp.

[No. 23.] Area and product of cereals grown in 1879 as returned by census of $1880 . \quad 1883.97 \mathrm{pP}$.

[No. 24.] Culture of date; by W. G. Klee. 1883. $25 \mathrm{pp}$.
[No. 25.] Necessity of agricultural education. Address before convention of presiclents and professors of ayricultural colleges, etc.; by Augustine J. Smith, Jan. 23, 188:3. 1883.15 pp. *

[No. 26.] Encouragenent to sorghum and beet sugar industry. 1883. 64 pl.

[No. 27.] Investigation of sorghum as sugar-prolucing plant; [by] Peter Collier. $1883.68 \mathrm{pH} .1 \mathrm{pl} .3$ tables.

[No. 28.] Preliminary report on forestry of Mississippi Valley, [by F. P. Baker]; 'Tree planting on plains, [by Rolsert W. Furnas]. 1883. $45 \mathrm{p}$.

[No. 29.] Proceedings of national convention of cattle breeders and others, called in Chicago, Nov., 1883, to consider subject of contagious diseases of domestie animals. $1883.85 \mathrm{pp}$.

[No. 30.] Report on jute culture and importance of the industry; by S. Waterhouse. 188\%. $21 \mathrm{pp}$.

[Yo. 31.] Results of field experiments with various fertilizers; hy W. O. Atwater. 1853. 18:3 1'\%. '2 folded tables.

[No. 32.] Agricultura] grasses and forage plants of U. S., by Geo. Vasey; alse the chemical composition of grasses, by Clifford Richardson. 1884. $14.4 \mathrm{Pr} .120 \mathrm{pl}$. 32 rev.] Agrienltural grassey and forage plants of TT.S., and such with an anpentix on chemical composition of grasses, by Clifford Ridhardson, and glossiry of ternss used in describing grasses. New revised and enlarged edition. $188 \% .148 \mathrm{pl}$. $114 \mathrm{pl}$.

[Xis. 33.] Report of proceeding of national convention of cattle lireeders and otliers, Chicange, Nov. [1884]. 1884. 21 P]. *

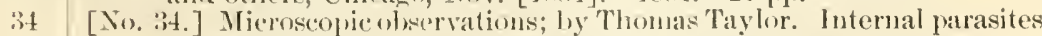
in domestie fowls. and butter and fats. 1884. $7 \mathrm{pp} .1 \mathrm{pl}$.

35) [No. 35.] Soils and productsof southwestem lonisiana, including parishes of Saint Lambry, Lafayette, Vermilion, Saint Martins, Iberia, and Saint Mary; [l,y li. k. Rapley]. 1884. $40 \mathrm{pp}$. 


\section{[Deparianent] reporis-Continuerl}

[No. 36.] Organization amd manarement of seven agricultural sehools in Germany, Belgimn, and England; by A. S. Welch. 1885. 107 Pl).

[Ni. 37.] Address of Norman J. Colman, Commissioner of Agriculture, before convention of anricultural colleges and experiment stations, Washington, D. ( .., July 8, 1885. 1885. $17 \mathrm{pP}$.

[No. 38.] Addresses of Norman J. Colman and D. E. Salmon, before third national convention of stockmen, Chicago, Nov., 1885. 1885. $29 \mathrm{PI}$.

[Nu. 39.] Directory of dlepartments, boards, societies, colleges, and other organizations in interest of agrieulture, hortieulture, stock raising, dairying, bee keeping, fish culture, and kindred industries. $\mathbf{1 8 8 5}$. $88 \mathrm{pl}$.

[No. 40.] Report of exlibits illustrating agrieultural statistics at World's Industrial and Cotton Exposition, New Orleans, La.; by J. R. Dodge. $1885.42 \mathrm{pp} .27$ diagrams.

[No. 41.] Report on condition of dairying in principal dairy States for seasm of 1885 . $1886.35 \mathrm{pp}$.

[No. 42.] Supplement to general index of agricultural reports, 1877 to 1885. 1886. $113 \mathrm{pr}$.

Se'e for general index A1.S:14.

[No. 43.] Addresses of Norman J. Colman and D. E. Salmon, before national cattle growers' convention, Kansas City, Mo., Oct. 31 and Nov. 1 and 2, 1887. 1887. $11 \mathrm{pl}$.

[No. 44.] Rules and regulations of U. S. Department of Agriculture for suppression and extirpation of all contagious, infections, and communicable diseases among domestic animals of U. S.; [by Norman J. Colman]. 1887. n. t. ए. 7 IP.

[No. 45.] Association of American Agrieultural Colleges and Experiment Stations convention held in Washington, D. C., Oct., 1887. Report of eommittee on station work. W. O. Atwater, S. W. Johnson, Geo. II. Cook, committee. 1888. $32 \mathrm{pl}$.

[No. 46.] Hog cholera: its history, nature, and treatment as determined by inquiries and investigations of Bureau of Animal Industry; [by D. E. Salmon]. 1889.197 pp. $16 \mathrm{pl}$.

[No. 47.] Catalogue of economic plants in collection of Department of Agriculture; by William Saunders. 1891. $42 \mu \mathrm{p}$.

[No. 48.] Papers on horticultural and kindred subjects; by William Saunders. Reprinted from reports of Department of Agriculture, 18631889. 1891. 124 pp.

[No.49.] Report on use of maize (Indian corn) in Furope and on possibilities of its extension; 1. Introduction of maize into Europe, by Charles J. Murplyy; 2. Food value of maize, hy II. W. TViley; 3. Indian eorn industry in United States, by B. IT. Snow. 1891. 36 pp.

Same, in French (with omission of article by Charles J. Murphy). 1892. 22 pp.

Same, in German (with omission of article by Charles J. Murplıy, and adclition of recipe for "Murply-frod"). 1892. $23 \mathrm{pp}$.

Same, in Scandiuavian (with omission of article by Charles J. Murpluy). 18:2. $22 \mathrm{pp}$.

Sande, in Spanish (witl omission of article by Charles J. Murphy). 1892. $24 \mathrm{pp}$.

[No. 50.] Progress report on dairy industry of Demmark; ly C. C. Georgeson. [1893.] $14 \mathrm{pl}$.

[No. 51.] Stumlies of parasitic and predaceous insocts in New Zealand, Australia, and arljacent islandls; ly $\mathrm{A}$. Kinebele. $1893.39 \mathrm{pp}$.

[No. 5:.] Indian corn (or maize) in manufacture of heer; by Rohert Wahl. 1893. 21 pl.

Same, German. 1893. 22 pl.

[No. 53.] Felected corresponclence relating to export trakle in live stock and meat products; [by J. M. Rusk. 1893.] 33 j'p.

Sice also A1,2:R89. 
[Departinent] reporis-Continned

[No. 54.] Suggestions regarding cooking of foud; ly Ecward Atkinson; with introuluetory statements regarling untritive value of common foorl materials; liv Ellen H. Richares. 1894. 31 pp.

[No. 55.] List of publications of U. s. Department of Agriculture, 1889-93, inclusive. 189:. $42 \mathrm{p}$ 'p.

[No. 56.] Arbor day; its history and olservance; by N. H. Egleston. 1896. $80 \mathrm{yp}$.

[No.57.] Proceedings of National convention for suppression of insect pests and plant diseases by legislation, held at Washington, D. C., Iar. 5 and 6, 1897; edited by B. T. Galloway. 1897. 31 pp.

[No. 58.] Cultivation of tobaceo in Sumatra; by Emile Mulder. 1898. 39 pl. 1 pl.

Same. 1898 [1901]. 39 \% $1 \mathrm{pl}$

No. 59. Curing and fermentation of cigar-leaf tolaceo; by Oscar Loew. 1899. $3 \pm$ lp.

No. 60. Temperature changes in fermenting piles of cigar-leaf tolsceo; by Milton Whitney and Thos. H. Means. 1899. $28 \mathrm{pl}$.

No. 61. Tea culture: the experiment in South Carolina; by Charles U. Shepard. 1899. 27 pp. 9 pl.

No. 62. Cultivation of cigar-leaf tobaceo in Florida; by Marcus L. Floyd. 1899. 31 pp. 8 j,l.

No. 63. Work of agricultural experiment stations on tobacco; ahstraeted by J. I. Schulte, with introduction and commentsby Milton Whitney. 1900. $48 \mathrm{pl}$.

No. 64. Field operations of Division of Soils, 1899, by Milton Whitney; with aceompanying papers by Thomas H. Means, Frank I). Gardner, Clarence II. Dorsey, Frank K. Cameron, Lyman J. Briggs. 1900. 198 ㄴ. 29 pl.

Same. IIaps. 11 maps in cloth folder (octavo).

Same, with maps, 56 th Cong., 1st sess., II. 1oc. 399; serial no. 3985.

[For subsequent erlitions sce A26.5:]

No. 65. Physiologieal sturlies of Commectient leaf tobaceo; by Oscar luew. 1900. 57 il).

No. 66. Sheep and wool, a review of progress of $A$ merican sheep husbandry; by .I. R. Hodge. 1900. $6: 3$ I).

No. 67. Foreien markets for Anerican agrienltural products; testimony of Frank II. Hitchenck before Industrial Commission. 1901. 5:; 1 ).

No. tis. ('atalase, a new enzym of general occurrence, with special reference to tolaceo plant; by Oscar loew. 1901. $47 \mathrm{PP}$.

No. 69). P'rogress of heet-sugar industry in U. S. in 1900. 1901. 178 jp. Sre also $11.2:$ :339 and 1 1.8:72.

No. 70. Exhaustion and abandonment of soils; textimony of Milton Whituey hefore Industrial Commission. 1901. $45 \mathrm{pl}$.

No. 71 . Sone mutnal relations hetween alkali soils and vegetation; ly Thomas H. Kiamey aul Frank K. Cameron. I902. 78 p]).

No. 72. Progress of beet-sugar industry in U. S. in $1901.1902 .106 \mathrm{pl}$. $15 \mathrm{pl}$.

Same, 57th Cong., 1st sess., S. dox. 316; serial no. 42.11.

the alsos $\triangle 1.2: 13: 39$ and $11.8: 69$.

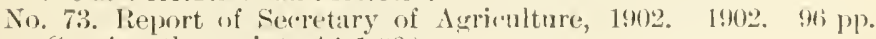
See who other prints ${ }^{\circ} \mathrm{A} 1.1: 902$.

\section{Daruncrs" Holletisas}

No. 1. What and why of agrieultural experiment stations, I8S4. It: pp. No. 2. Work of agricinltural (xperiment stations. 1890. $16 \mathrm{pp}$.

No. 3. Culture of sugar bect; ly II. W. Wiley. 18!1. 24 WP.

No. 4. Fungons discases of grape and their treatment; loy R. T. (ialloway. 1891. 12 p).

No. 5. 'Treatment of smuts of oats and wheat. 1892. 8 pl. $1 \mathrm{pl}$

Fo. 6. Tobacen, instructions for its enltivation and curing; ly Joln 11 . listes. [89\%. 8 y 


\section{Farmers" bulletins-('ontinued}

To. 7. Spraying fruits for insert pests and fungous diseases, with sperial (ons sileration of subject in its relation to public health. 1892. $20 \mathrm{pp}$.

No. 7 [partial reprint]. Spraying for fungons diseases of apple, pear, and other fruits. 1895. 14 \%). cholera; by D. F. Salinon, 18!2. 40
ch.

No. 9. Milk fermentations and their relations to dairying. 1892. 24 Pp.

No. 10. Russian thistle and other troublesone weals in wheat region of Minnesota and North and South Dakota. 1893. $16 \mathrm{pp} .2 \mathrm{pl}$.

No. 11. Rape plant, its history, ('ulture, and uses; by Thomas Shaw. 1893. $20 \mathrm{pp}$.

No. 12. Nostrums for increasing yield of hutter; ły Harvey W. Wiley. 1893. $16 \mathrm{pp}$.

No. 13. Cranberry culture; by William Samders. 1894. 16 pp.

No. 14. Fertilizers for eotton; by J. M. MeBryde. 1894. 32 pl.

No. 15. Some destructive potato diseases, what they areaurl how to prevent them; by L. T. Galloway. 1894. $8 \mathrm{pP}$.

No. 16. Leguminous plants for green nanuring and feeding; by $\mathrm{F} . \mathrm{W}$. Allen. 1894. 24 PP.

No. 17. Peach yellows and peach rosette; by Erwin F. Smith. 1894. $20 \mathrm{pp}$.

No. 18. Forage plants for the South; hy S. M. Tracy. 1894. 30 pl. Same, with list of Farmers' bulletins. 1897. $31 \mathrm{pp}$.

No. 19. Important inspecticides, directions for their preparation and use; by (. I. Marlatt. 1894. 20 I').

Same, rev. ed. 1895. '23 pr.

Same, [reprint, 1897]. 24 pp.

Same, 31 rev. ed. 1897.32 p.

Same, th rev. ed. 1898. $32 \mathrm{Pp}$.

No. 20. Washed soils: how to prevent and reelain them. 1894. 22 pp.

No. 21. Barnyard manure; Jy IV. H. Beal. 18!4. 32 pl.

No. 22. Feeding of farm animals; by E. II. Nllen. 1895. 32 Pl.

Same, rev. 1897. 32 Pl.

Same, rev. erl. 1901. $14 \mathrm{pp}$.

No. 23. Foorls: nutritive value and cost; by W. O. Atwater. 1894. 32 pp.

No. 24. Hog cholera and swine plague; by D. F. Salmon. 1894. 16 pp.

No. 25. Peanuts: culture and uses; by R. B. llandy. 1895. 24 II). Same [new ed.] 1896.24 Pp.

No. 26. Sweet potatoes, culture and uses; ly J. F. Dugrar. 1895. 30 pp. Same [reprinted]. 1897. $30 \mathrm{pp}$.

Same, revised. 1900. $32 \mathrm{pp}$.

No. 27. Flax for seed and fiber in U. S.; by Chas. Richarts Dorlge. 1895. $16 \mathrm{pp}$

No. 28. Weeds, and how to kill them; by Jyster II. Dewey. 1895. :31 pl. Same, [reprint, 1898]. With list of Farmers bulletins. $32 \mathrm{pp}$.

Same, revised eflition. $190^{\circ}$. 31 1 1 \%.

No. 29. Sonring of milk and other changes in milk prodnets. $1895.23 \mathrm{pl}$.

No. 30. Grape diseases on I'acific coast; ly Newtun B. Pierce. 1895. 15 PP.

No. 31. Alfalfa, ol lueern; [hy] Jared G. Smith. 1895. 23 Pl.

Same, reved. 1898. 23 jp.

Same, [rev. el.] 1899. 24 pp.

No. 32. Silos and silage; by Charles S. Pluml. 1695. 31 pp.

No. 33. Peach growing for market; hy Erwin F. Sulth. 18:5. 24 pp. Same [21 ed.] 18:5 [1897]. 24 pp.

No. 34. Meats: composition and cooking; hy Chas. T. Woods. 1896. $29 \mathrm{pp}$.

To. 35. Potato culture; by J. F. Dugarar. 1896. 23 Pr.

No. 36. Cotton seed and its prosluets. 1896. $16 \mathrm{pl}$.

No. 37. Kafir com, characteristics, culture, and uses; wy (‥ ( C Georgeson. 1896. 12 pp.

$37^{2}$ Same, [reprint, different illustrations, 1. I2 extendes]]. 1896 [1897]. 12 1). 
A 1.9: Farmers bulledins - Continued

No. 38. Spraying for fruit diseases; by B. T. (ialloway.

No. 39. Onion culture; by R. L. Watts. 189k. :31 pi).

1896. 12 P .

No. 40. Farm drainage; by (. G. Elliott. 1896. 24 pl.

Same, rev. 1899. 24 pp.

No. 41. Fowls: care and feeding; by (i. C. Watson. 1896. 24 pp.

No. 42. Facts abont nilk; hy R. A. Pearson. $1896.29 \mathrm{pp}$.

No. 43. Sewage disposal on farm, and protection of drinking water; by Theohald smith. 1896. $20 \mathrm{pp}$.

No. 44. Commercial fertilizers, composition and use; by Edward B. Voorhees. $1896.24 \mathrm{pp}$.

Same, [2d print, with changes]. Sept. 1896. $24 \mathrm{pp}$.

No. 45. Some inseets injurious to stored grain; by F. H. Chittenden. 1896. $24 \mathrm{pp}$.

Same, rev. ed. 1897. 24 pp.

No. 46. Irrigation in humid elimater; ly F. H. King. 1896. $27 \mathrm{pp}$.

Yo. 4i. Insects affecting cotton plant; by L. O. Howard. Reprinterl, with revision by author, from Bulletin 33, Office of Experinent Stations. 1897. $32 \mathrm{pp}$.

No. 48. Manuring of cotton; condensed from article by H. C. White, in Bulletin no. 33 of Office of Experiment Stations. 1897. $16 \mathrm{pp}$.

No. 49. Slseep feeding; by John A. Craig. 1897. 24 pp.

No. 50 . Sorghum as a forage crop; by Thomas A. Williams. $1897,20 \mathrm{pp}$. Same, rev. 1899. $20 \mathrm{pp}$.

No. 51. Standard varieties of chickens; by George E. Howarl. 1897. 48 pp. Same, [2t ed.] res: 1897. t8 pp.

Same, [3rl ed.] rer. 1899. $48 \mathrm{pp}$.

No. 52. Sugar beet, culture, seed development, manufacture, and statisties; by H. W. Wiley. 1897. 48 pp.

Same, rer. 1899. $48 \mathrm{pp}$.

Same, 21 rev. er. [statistical matter revised]; by G. L. Spencer. 1901. $48 \mathrm{pP}$.

No. 53. How to grow mushroms; by William Falconer. 1897. $20 \mathrm{pp}$.

No. 54. Some common birds in their relation to agriculture; hy F. E. L. Beal. 1897. $40 \mathrm{pp}$.

Same, rev. 1898. $40 \mathrm{pp}$.

No. 55. Dairy herd, its formation and management; hy Henry k. Alvorl. Reprinted, with revision by author, from Y'arbook for 1894. 1897. $24 \mathrm{pp}$.

No. 56. Experiment station work, 1. 1897. $31 \mathrm{pp}$. See also. A 10.11:1.

No. 57. Butter making on the farm; by C. P. (ioodrich. 1897. $15 \mathrm{pp}$. Same, 21 print. 1897 [1898]. $16 \mathrm{pp}$.

No. 58. Soy bean as a forage erop, by Thomas A. Williams; with appendix on soy beans as food for man, by C. F. Langworthy. 1897. $24 \mathrm{pp}$. Same, rev. 1897. $24 \mathrm{pp}$.

Same, rev. 1899. 24 pp.

No. 59. Bee keeping; by Frank Benton. 1897. $32 \mathrm{pp}$.

Yo. 60. Methods of curing tobacco; by Milton Whitney. 1897. $16 \mathrm{pp}$. Same, rev. eil. $1898.16 \mathrm{pp}$.

Same, 2d rev. ed. 1902. $24 \mathrm{pp}$.

No. 61. Asparagus culture; by R. B. Handy. 1897. $40 \mathrm{pp}$.

To. 62. Marketing farm produce; by George (i. Hill. 1897. 28 pp.

No. 63. Care of milk on farm; hy R. A. Pearson. 1897. $40 \mathrm{pp}$.

No. 64. Ducks and geese, standard breeds and management; by George E. Howard. 1897. 48 pp.

No. 65. Experiment station work, 2. 1898. $32 \mathrm{pp}$. See also A10.11:1.

No. 66. Meadows and pastures, formation and cultivation in Middle Eastern States; by Jared (i. Smith. 1897. 2t pp.

Same, rev. ed. 1899. 28 1.p.

No. 67. Forestry for lamers; by B. E. Fernow. (Reprinted from Yearbooks of De(partment of A griculture for 1894 and 1895.) 1898. 48 pI). 
A 1.9: Farmers' bullins-Continued

No. 68. Black rot of eablage; by Erwin F. Smith. 1898. 22 pl.

No. 69. Experiment station work, 3. 1898. 32 pp. See also A 10.11:1.

Yo. 70. Principal insect enemies of grape; ly C. I. Marlatt. 1898. $23 \mathrm{pp}$.

No. 71. Some essentials in beef prorluction; by Charles F. Curtiss. 1895. $24 \mathrm{pp}$.

No. 72. Cattle ranges of the Sonthwest, history of exhaustion of pasturage and suggestions for its restoration; by H. L. Bentley. 1898. 32 pp.

No. 73. Experiment station work, 4. 1898. $32 \mathrm{pp}$. See also $110.11: 1$.

No. 74. Milk as food. 1898. $39 \mathrm{pp}$.

No. 75. Grain smuts; how they are caused and how to prevent them; by iValter T. Swingle. $1898.20 \mathrm{pp}$.

No. 76. Tomato growing; by Fdward B. Voorhees. 1898.30 pp.

No. 77. Liming of soils; by H. J. Wheeler. 1898. $19 \mathrm{pp}$. Same. rev. $1899.19 \mathrm{pp}$.

No. 78. Experiment station work, 5. 1898. $32 \mathrm{pp}$. See also A10.11:1.

No. 79. Experiment station work, 6. 1898. 28 pp. See also A 10.11:1.

No. 80 . Peach twig-borer, an important enemy of stone fruits; by C. L. Marlatt. $1898.16 \mathrm{pp}$.

No. 81. Corn eulture in South; by S. MI. Tracy. 1898. 24 pp.

No. 82. Culture of tobacco; by Otto Carl Butterweck. 1898.24 pp.

No. 83. Tobacco soils; by Milton Whitney. 1898. 23 pp.

No. 84. Experiment station work, 7. 1898. 32 pp. See also A10.11:1.

No. 85. Fish as food; by C. F. Langworthy. $1898.30 \mathrm{pp}$.

No. 86. Thirty poisonous plants of U. S.; by V. K. Chesnut. 1S98. 32 pp.

No. 87. Experiment station work, 8. 1899. $32 \mathrm{pp}$. See also A10.11:1.

No. 88. Alkali lands; by Milton Whitney and Thomas II. Means. 1899. $23 \mathrm{pp}$.

No. 89. Cowpeas; by Jared G. Smith. 1899.16 pp.

No. 90. Manufacture of sorghum sirup; by A. A. Denton. 1899. 32 pp. No. 91. Potato diseases and their treatment; by B. T. Galloway. 1899. $12 \mathrm{pp}$.

No. 92. Experiment station work, 9, 1899. 30 pp. See also A10.11:1.

No. 93. Sugar as food; by Mary Himman Abel. 1899. 27 pp.

No. 94. Tegetable garden; by Charles H. Greathouse. 1899. 24 pp.

No. 95. Good roads for farmers; by Maurice O. Eldridge. $1899 . \quad 47$ p. Same, [2d ed.] 1900. 47 pp.

No. 96. Raising sheep for mutton; by Charles F. Curtiss. 1899. 48 pp.

No. 97. Experiment station work, 10. $1899.32 \mathrm{pp}$. See also A 10.11:1.

No. 98. Suggestions to southern farmers. $1899.48 \mathrm{pp}$.

No. 99. Three inseet enemies of shade trees; ly I. O. Howard. (Reprinted with some annotations by the author from Yearbook of Department of Agriculture for 1895.) $1899.30 \mathrm{pp}$.

No. 100. Hog raising in the South; by S. M. Tracy. $1899.40 \mathrm{pp}$.

No. 101. Millets; by Thomas $\Lambda$. Williams. $1899.28 \mathrm{pp}$.

No. 102. Southern forage plants; compiled from publications of Division of Agrostoloury, by F. Lamson-Scribner. 1899. 48 pp:

No. 103. Experiment station work, 11. 1899. $32 \mathrm{pp}$. See also A10.11:1.

No. 104. Notes on frost; by F. B. Garriott. 1899. 24 pp.

No. 105. Experiment station work, 12. $1899.32 \mathrm{pp}$. See rilso A10.11:1.

Yo. 106. Breeds of dairy cattle; by Henry 1:. Alvord. (Reprinted from report of Bureau of Animal Industry for 1898.) 1899. 48 pp. 
A1.9:

Farmers' bulletins-Continued

No. 107. Experiment station work, 13. 1899. $32 \mathrm{pp}$. See also A10.11:1.

No. 108. Saltbushes; by P. Beveridge Kennedy. 1900. 20 pp.

No. 109. Farmers' reading courses; by L. H. Bailey. (Abridgment of bull. 72, exp. stations). $1900.20 \mathrm{pp}$.

No. 110. Rice culture in U. S.; by S. A. Knapp. 1900. 28 pp.

No. 111. Farmer's interest in good seed; by A. J. Pieters. 1900. $24 \mathrm{pp}$.

No. 112. Bread and principles of bread making; by Helen W. Atwater. 1900. $39 \mathrm{pp}$.

No. 113. Apple and how to grow it; by G. B. Brackett. $1900.32 \mathrm{pp}$.

No. 114. Experiment station work, 14. 1900. $28 \mathrm{pp}$. See also A10.11:1.

No. 115. Hop culture in California; by Daniel Flint. 1900.28 pp.

No. 116. Irrigation in fruit growing; by E. J. Wickson. $1900.48 \mathrm{pp}$.

No. 117. Sheep, hogs, and horses in Pacific Northwest; 1 . Sheep husbandry, by James Withcombe; 2 . Hog raising, by Hiram T. French; 3. Horse industry, by S. B. Nelson. 1900. 28 pp.

No. 118. Grape growing in South [by] S. M. Tracy. 1900. 32 pp.

No. 119. Experiment station work, 15. 1900 . $31 \mathrm{pp}$. See also A10.11:1.

No. 120. Principal insects affecting tobacco plant; by L. O. Howard.

(Reprinted, with slight revision by the author, from Yearbook of

Department of Agriculture for 1898.) $1900.32 \mathrm{pp}$.

No. 121. Beans, peas, and other legumes as food; by Mary Himman Abel. 1900. $32 \mathrm{pp}$.

No. 122. Experiment station work, 16. 1900. 32 pp. See also A10.11:1.

No. 123. Red clover seed: information for purchasers; by A. J. Pieters. 1901. $11 \mathrm{pp}$.

No. 124. Experiment station work, 17. 1901. $32 \mathrm{pp}$. See also A10.11:1.

No. 125. Protection of food products from injurious temperatures; by H. E. Williams. $1901.26 \mathrm{pp}$.

No. 126. Practical suggestions for farm buildings; by George G. Hill. 1901. $48 \mathrm{pp}$.

No. 127. Important insecticides: directions for their preparation and use; revision of Farmers' Bulletin no. 19; by C. L. Marlatt. 1901. $42 \mathrm{pp}$.

No. 128. Eggs and their uses as food; by C. F. Langworthy. 1901.32 pp. Same, revised edition. 1901. $32 \mathrm{pp}$.

No. 129. Sweet potatoes; by D. M. Nesbit. $1901.40 \mathrm{pp}$.

Same [revised]. $1902.40 \mathrm{pp}$.

No. 130. Mexican cotton-boll weevil; by Frederick W. Mally. 1901. $30 \mathrm{pp}$.

No. 131. Household tests for detection of oleomargarine and renovated butter; by G. E. Patrick. 1901. $11 \mathrm{pp}$.

No. 132. Principal insect enemies of growing wheat; by C. L. Marlatt. 1901. $40 \mathrm{pp}$.

No. 133. Experiment station work, 18. 1901. $32 \mathrm{pp}$.

See also A10.11:1.

No. 134. Tree planting on rural school grounds; by Wm. L. Hall. 1901. $38 \mathrm{pp}$.

No. 135. Sorghum sirup manufacture; by A. A. Denton. $1901.40 \mathrm{pp}$.

No. 136. Earth roads; by Maurice O. Elilritge. 1902. $24 \mathrm{pp}$.

No. 137. Angora goat; by George Fayette Thompson. 1901. $48 \mathrm{pp}$.

To. 138. Irrigation in field and garden; by E. J. Wickson. 1901. $40 \mathrm{pp}$.

No. 139. Emmer; a grain for semiarid regions; by Mark Alfred Carleton. 1901. $16 \mathrm{pp}$.

No. 140. Pineapple growing; by Peter II. Rolfs. 1901. 48 pp.

No. 141. Poultry raising on farm; by D. F. Salmon. 1901. $16 \mathrm{pp}$.

No. 142. Principles of nutrition and nutritive value of food; by W. O. Atwater. 1902. $48 \mathrm{pp}$. 
A 1.9:

143

14

145

146

147

148

150

151

152

153

154

155

156

157

158

160

161

A 1. 10:

894

89.5

896

897

898

$899^{1}$

$899^{2}$

900

A 1. 10

\section{Farmers'bulletius-Continued}

No. 143. Conformation of beef and dairy cattle; by Andrew M. Soule. 1902. $44 \mathrm{pl}$.

No. 14t. Experiment station work, 19. 1901. $32 \mathrm{pp}$.

Sece ralso A10.11:1.

No. 145. Carbon bisulphid as an insecticide; by W. E. Hinds. 1902. $28 \mathrm{pl}$.

To. 146. Insecticides and fungicides: chemical composition and effectiveness of rertain preparations; ly .J. K. IIaywood. $1902.16 \mathrm{pp}$.

No. 147. Winter forage crops for the South; by Carleton R. Ball. 1902. $36 \mathrm{pp}$.

No. 148. Celery culture; by W. R. Beattie. 1902. $32 \mathrm{pp}$.

To. 149. Experiment station work, 20. $1902.32 \mathrm{pp.}$

Sié also A 10.11:1.

No. 150. Clearing new land; by Franklin Williams, jr. 1902. 24 pp.

No. 151. Dairving in the South; by S. M. Tracy. 1902. $48 \mathrm{pp}$.

No. 152. Seabies in cattle; by Richard W. Hickman. 1902. $24 \mathrm{pp}$.

No. 153. Orchard enemies in Yacific Northwest; by C. V. Piper. 1902. $39 \mathrm{pp}$.

No. 154. Home fruit garden, preparation and eare; by L. C. Corbett. 1902. $20 \mathrm{pp}$.

No. 155. How insects affect health in rural distriets; by L. O. Howard. 1902. $20 \mathrm{pp}$.

No. 156. Home vineyard, with special reference to northern conditions; by IV. H. Ragan. 1902. $24 \mathrm{np}$.

No. 157. Propagation of plants; by L. C. Corbett. 1902. 24 pp.

No. 158. How to build small irrigation ditches; by C. T. Johnston and J. D. Stannard. 1902. $28 \mathrm{pp}$.

No. 159. Not yet issued.

No. 160. Game laws for 1902; summary of provisions relating to seasons, shipment, sale, and licenses; by T. S. Palmer and H. W. Olds. $1902.56 \mathrm{pp}$.

No. 161. Practical suggestions for fruit growers; by H. P. Gould. 1902. $28 \mathrm{pp}$.

\section{Yearbook}

[Since 1894 the Yearbook has been issued as second part of the report of the Secretary of $\mathrm{Agrieulture}$ including, besides the report of the Secretary, scientific reports of division ehiefs and miseellaneous papers on agricultural science.] 1894,608 pp., 7 pl.

Same, 53d Cong., $3 \mathrm{~d}$ sess., H. ex. 1loc. 355 ; serial no. 3326. 1895,656 pp., $10 \mathrm{pl}$.

Same, 5tth Cong., 1st sess., H. loc. 380; serial no. 3441 . 1896,686 pp., $6 \mathrm{pl}$.

Same, 5th Cong., 2 d sess., H. «loc. 6, pt. 2; serial no. 3496. 1897,792 pp., 41 ji.

Same, 55th Cong., 2d sess., II. doc. 454; serial no. 3693. 1898, 768 pp., 42 pl.

Sane, 5nth Cong., 3d sess., H. doc. 293 ; serial no. 3824.

1899, 880 pp., 64 pl.

Same, printed on heavier paper and lettererl on back "Special edition Paris Exposition, 1900."

Same, 56th Cong., 1st sess., H. loc. 588; serial no. 3996. 1900, 888 pp., 87 pl., 1 por.

Same, 56th Cong., 21 sess., H. doc. 519 ; serial no. 4179 . $1901,8+6$ pp., 90 pl., 1 por.

Same, 57 th Cong., 1st sess., H. doc. 661 ; serial no. 4385.

\section{Vearbook (separates)}

[The Secretary's report and most of the articles on seientifie subjects contained in the Yearbook are printed separately.] 


\section{A2. ICCOUNTS AND DISBURSEMENTS DIVISION}

A2.1: Annual reports

8931893 (Evans), pp. iii +411-416. (Also in A1.1:893, p. 411.)

$894 \quad 1894$ (Evans), pp. iii +189-194. (Also in A1.1:894, p. 189.)

8951895 (Evans), pp. ïi +245-264. (Also in A1.1:895, p. 245.)

8961896 (Evans), pp. iii $+71-82$. (Also in A1.1:896, p. 71.)

8971897 (Evans), pp. iii +93-110. (Also in A1.1:897, p. 93.)

8981898 (Evans), pp. iii $+8 \overline{7}-102$. (Also in A1.1:898, p. 87.)

8991899 (Evans), pp. iii +215-233. (Also in A1.1:899, p. 215.)

9001900 (Evans), pp. iii +233-263. (Also in A1.1:900, p. 233.)

9011901 (Evans), pp. iii + 253-269. (Also in A1.1:901, p. 253.)

9021902 (Evans), pp. iii +219-233. (Also in A1.1:902, p. 219.)

\section{A2.2: General publications}

[Publications which originated in this Division, but which were published in a numbered series of the Secretary's office, or some other division of the Department, are entered only where such numbering places them, with referenees under the proper headings in the index to this work. Pnblications of the Division issued only as Congressional documents are noted in chronological order in the Appendix to this work.]

Ap6 Appropriations. Use of annual appropriations. [Decision of Comptroller of Treasury, Apr. 18, 1900] reprinted for use of disbursing officer, Agriculture Department. n. t. p. 4 pp.

F49 Financial transactions. Regulations governing financial transactions with U.S. Department of Agriculture, with extracts from Revised Statutes, decisions of the Comptrollers, etc. $1894.42 \mathrm{pp} .1$ folded table.

F52 ${ }^{1}$ Fiscal regulations of U. S. Department of Agriculture, with extracts from Revised Statutes, decisions of courts, rulings of the Comptrollers, opinions of Attorneys-General, etc. $1898.45 \mathrm{pp} .1$ folded table.

F52 ${ }^{2}$

Same. Revised edition, 1901. 49 pp. 1 folded table.

A2.3: Bulletins

None issued.

A2.4: Circulars

None issued.

\section{A3. AGROSTOLOGY DIVISION}

[For historieal sketeh of Division, see Yearbook, 1897, p. 160 (A1.10:897). The Division was merged into Bureau of Plant Industry July 1, 1901. Sce A19.1

\section{A3.1: Anmual reporis}

1895 (Scribner). (In A1.1:895, p. 165).

8961896 (Scribner), pp. iii +103-108. (Also in A1.1:896, p. 103.)

8971897 (Scribner), PH. [i] +161-166. (Also in A1.1:897, p. 161.)

8981898 (Scribner), pp. iii + 145-152. (Also in A1.1:898, p. 145.)

8991899 (Scribner), pp. iii +113-117. (Also in A1.1:899, p. 113.)

9001900 (Scribner), pp. iii +83-90. (Also in A1.1:900, p. 83.)

1901 (Scribner). This final report of the Division was made through the chief of the Bureau of Plant Industry, forming part of his ammual report for 1901. See A1.1:901, p. 67; also A19.1:901, p. 67.]

\section{A3.2: General publicalions}

[Publications which originated in this Division, bnt which were pub]ished in $\Omega$ numbered series of Secretary's oflice, or some other division of the Depurtment, are entered only where sneh numbering blaces them, with references undur the proper headings in the index to this work. Publications of the Dirision issued only as Congressional documents are nuted in chronological order in the A ppendix to this work.]

\section{A:3.3: Hullotius}

1 No. 1. (irasses and forage plants of the Sontheastern States; by 'Thomas 1I. Keamey, jr. 1895. $28 \mathrm{pP}$. 
A3.:3:

A3.4:

\section{Bulletins-Continued}

No. 2. Forlder and forage plants exclusive of grasses; by Jared G. Smith. 1896. $58 \mathrm{pp}$.

Same. Revised ed. 1900.86 pp. 2 pl.

No. 3. Useful and ornamental grasses; by F. Lamson-Scribner. 1896. $119 \mathrm{pp}$.

No. 4. Studies on American grasses; by F. Lamson-Scribner, Jared G. Smitl, and Theo. Holm. 1897. 43 pp. 5 pl.

No. 5. Grasses and forage plants of Rocky Mountain region; by P. A. Rydberg and C. L. Shear. 1897. $48 \mathrm{pp}$.

No. 6. Grasses and forage plants of the Dakotas; by Thomas A. Williams. 1897. $47 \mathrm{pp}$.

No. 7. American grasses; by F. Lamson-Scribner. 1897. 331 pp.

No. 7. American grasses, 1. Rev. ed. 1898. 331 pp.

Same, 3d ed. 1900.319 pp.

No. 8. Studies on American grasses; by F. Lamson-Scribner and Miss E. L. Ogden. 1897. 23 pp. 9 pl.

No. 9. Grasses and forage plants of Iowa, Nebraska, and Colorado; by $\mathbf{L}$. H. Pammel. 1897. $47 \mathrm{pp}$.

No. 10. Grasses and forage plants of central Texas; by H. L. Bentley. 1898. $38 \mathrm{pp}$.

No. 11. Studies on American grasses; by Thomas H. Kearney, jr., and F. Lamson-Scribner. $1898.62 \mathrm{pp} .17 \mathrm{pl}$.

No. 12. Grasses and forage plants and forage conditions of eastern Rocky Mountain region; by Thomas A. Williams. 1898. $78 \mathrm{pp}$.

No. 13. Red Desert of Wyoming and its forage resources; by Aven Nelson. $1898.72 \mathrm{pp} .5 \mathrm{pl}$.

No. 14. Economic grasses; by F. Lamson-Scribner. $1898.85 \mathrm{pp} .3 \mathrm{pl}$. Same, rev. 1900 . 85 pp. 3 pl.

No. 15. Forage plants and forage resources of Gulf States; by S. M. Traoy. 1898. $55 \mathrm{pp}$.

No. 16. Grazing problems in Southwest and how to meet them; by Jared G. Smith. $1899.47 \mathrm{pp}$.

No. 17. American grasses, 2; by F. Lamson-Scribner. 1899. 349 pp. Same, rev. ed. 1901. $349 \mathrm{pp}$.

No. 18. Studies on American grasses; synopsis of genus sitanion; by J. G. Smith. 1899.21 pp. 4 pl.

No. 19. Structure of caryopsis of grasses, with reference to morphology and classification; by P. Beveridge Kennedy. 1899.44 pp. 8 pl. Same, revised. 1900.44 pp. 8 pl.

No. 20. American grasses, 3; by F. Lamson-Scribner. 1900.197 pp. Same, rev. ed. 1900.197 pp.

No. 21. Studies on American grasses; North American species of chætochloa; by F. Lamson-Scribner and Elmer D. Merrill. $1900.44 \mathrm{pp}$. No. 22. Cooperative experiments with grasses and forage plants; by $\mathbf{P}$. Beveridge Kennedy. $1900.86 \mathrm{pp} .13 \mathrm{pl}$.

No. 23. Studies on American grasses: a revision of North American species of bromus occurring north of Mexico; by Cornelius L. Shear. $1900.66 \mathrm{pp}$.

No. 24. Studies on American grasses; by F. Lamson-Scribner, Elmer D. Merrill, and Carleton R. Ball. 1900. $55 \mathrm{pp}$.

No. 25. Field work of Division of Agrostology; review and summary of work done since organization of division, July 1, 1895; by Cornelius L. Shear, 1901.67 pp. 28 pls. 8 maps.

\section{Cireulars}

No. 1. Note on experimental grass gardens; by Jared G. Smith. Aug. 6, 1895. n. t. p. 4 pp.

No. 2. Hairy vetch, sand vetch, or Russian vetch; by F. Lamson-Scribner. Oct. 1, 1895 . n. t. p. 4 pp.

No. 3. Saltbushes; by Jared G. Smith. Mar. 13, 1896. n. t. p. 4 pp.

No. 4. Renewing of worn-out native prairie pastures; by Thomas A. Williams. Nov, 2,1896 . n. t. p. 4 pp. 
Circulars-Continued

Same, revised. Nor. 15,1897 . n. t. p. 4 pp.

No. 5. Cowpeas; by Jared G. Smith. Nov. 26, 1897. n. t. p. 10 pp.

Same, rev. ed. Mar. 25, 1898 . n. t. p. 11 pp.

No. 6. Cultivated retches; by Jared G. Smith. Feb. 25, 1898. n. t. p. $7 \mathrm{pp}$.

Same, rev. ed. Apr. 15, 1898 . n. t. p. 8 pp.

No. 7. Gram, chick-pea, or Idaho pea; by Jared (i. Snith. Nov. 18, 1898. n. t. p. 4 pl).

No. 8. Experiments in range improvements; by Jared (i. Smith. Dec. 27,1898 . n. t. p. 5 pp.

No. 9. New species of North American grasses; by F. Lamson-Scribner. Feb. 15, 1899 . n. t. p. 7 pp.

No. 10. Poa fendleriana and its allies; by Thomas A. Williams. Apr. 15, 1899. n. t. p. $6 \mathrm{pp}$.

No. 11. Flat pea; by F. Lamson-Scribner. A pr. 28,1899 . n. t. 1. 6 pp.

No. 12. Rape as a forage plant; by Thomas A. Williams. May 5, 1899. n. t. p. 6 pp.

No. 13. Florida beggar weed, also known as Beggar weed, Florida clover, Giant Beggar weed; by Jared G. Smith. May 6, 1899 . n. t. p. 5 pp.

No. 14. Velvet bean; by Jared G. Smith. May 13, 1899 . n. t. p. $5 \mathrm{pp}$.

No. 15. Recent additions to systematic agrostology. July 14,1899. n.t.p. $10 \mathrm{pp}$.

No. 16. New species of North American grasses; by F. Lamson-Scribner. July 1, 1899. n. t. p. 6 pp.

No. 17. Crimson clover; by Thomas A. Williams. Aug. 19, 1899. n. t. p. $6 \mathrm{pp}$.

No. 18. Smooth brome-grass; by P. Beveridge Kennedy. Dec. 1, 1899. n. t. p. $9 \mathrm{pp}$.

No. 19. New or little known Mexican grasses; by F. Lamson-Scribner. Dee. 19,1899 . n. t. p. 4 pp.

No. 20. Experiments with forage plants in Ontario; by P. Beveridge Kennedy. Dec. 15,1899 . n. t. p. 3 pp.

No. 21. Cooperative range grass and forage plant experiments at Highmore, South Dakota; by F. Lamson-Scribner. Dec. 20, 1899. n. t. p. $10 \mathrm{pp}$.

No. 22. Grass and forage plant investigations on the Pacific Coast; by F. Lamson-Scribner. Dec. 22, 1899 . n. t. p. 7 pl.

No. 23. Progress of experiments in forage crops and range improvement at Abilene, Texas; by H. L. Bentley. Dec. 30,1899 . n. t. p. 20 pp.

No. 24. Cowpeas and corn for silage and fodder; by W. Gettys. Fel,. 26, 1900. n. t. p. $10 \mathrm{pp}$.

No. 25. Turkestan alfalfa; by P. Beveridge Kennedy. Apr. 9, 1900. n. t. p. $20 \mathrm{pp}$.

Same, rev. [Aug. 1900.] n. t. p. 20 pp.

No. 26. Reseue grass; by Cornelius 1 . Shear. Nay 21,1900 . n.t.p. 4 pp. No. 27. Agrostological notes: Grasses of herbarium of Dr. H. IIullenberg, by F. Lamson-Scribner and Elmer D. Merrill; Two new species of Eatonia, ete. Dec. 4, 1900. n. t. P. 10 pl.

io. 28. (irasses and fodder plants on Potomac flats; by C. R. Ball. Dec. 13, 1900. n. t. p. is pl.

No. 29. Grasses in Elliott's "Sketch of Botany of Sonth Carolina and Cieorgia"; by F". Lamson-Scribner. [1901.] 11. t. p. $12 \mathrm{pp}$.

No. 30. New or little known grasses; by F. Lamson-Síribner. Mar. 8, 1901. n. t. p. 8 pre.

No. 31. Bermula grass; by A. S. Hitcheock. Mar.21, 1901. 'n.t. p. 6pp.

No. 32. Some Arizona grasses; hy Elmer 1). Merrill. Apr. 22, 1901. in. t. 1. 10 pp.

No. 33. Range grass and forage plant experiments at Highmore, S. Dak., report of progress; by F. Lamson-Scribner. April 2, 1901. n.t.p. $5 \mathrm{pl}$. 
Tables

Classifleatlon w1.

A.1:

34

\section{A3. IGROATOLORY IDISIOX-Continued}

Circulars-Continned

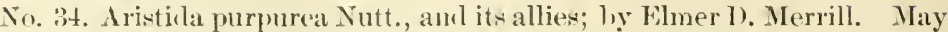
24, 1901. n. t. p. 8 pp.

No. 35. Agrostological notes; by F. Lamson-Scribner and Elmer 1). Nerrill. June 18,1901 . n. t. p. $6 \mathrm{pp}$.

No. 36. List of publications of Division of Agrostology; l,y F. LamsonSerilner. June 12, 1901. n. t. p. 8 pp.

\section{A. ANIMAL, INIDESTRY IBUTEAT}

[For historienl sketch of Bureau, sce Yearbook, 1897 (A1.10:897), ]. 236.]

A.1:

884

885

886

$887-S$

$889-90$

$891-2$

$893-4$

$895-6$

897

898

899

900

901

\section{Annual reports}

[The "also" references are to an abbreviated report of the chief withont accompanying documents. From 1877 to 1883 reports on contagions disenses of domestic animals aecompanied the annual reports of the seeretary. The report for 1881 and 1882 is designated in the running heading as a report of the Veterinary division, though that division was not formally organized until 1883 . Referenees to these reports will be found under "Domestic animals" and "Veterinary division" in the index to this work.]

1884 , 1st (Salmon), 512 pl., 19 pl. (Also in A1.1:884, p. 181.)

Same, 4Sth ('ong., 21 sess., It. mis. doc. 25; serial no. 2311.

$1885,2 d$ (Salmon), 662 pl., 11 pl. (Also in A1.1:885, p. 431.)

Same, 4Sth Cong., 21 sess., H. mis. doc. 36; serial no. 2311.

1886, $3 \mathrm{l}$ (Salmon), $456 \mathrm{pl}$., 17 pl. (Al.o in A1.1:886, p. 593.)

Same, 49th Cong., 21 sess., H. mis. doc. 156; serial no. 2493.

1887 and 1888,4 th and 5 th (Salmon), 510 pp., $25 \mathrm{pl}$. (1887, also in A1.1: 887, p. 457; 1888 , also in A1.1:888, p. 145.)

Same, 50th Cong., 2l sess., H. mis. dor. 139; serial no. 2665.

1889 and $1890,6 \mathrm{th}$ and $7 \mathrm{th}$ (Salmon), 503 jp., 1 j.l. (1889, also in $\mathrm{A1.1}$ : 889$, p. $49 ; 1890$, also in $A 1.1: 890$, p. 75.$)$

Same, 51 st Cong., 1st sess., H. mis. doc. 270; serial no. 2801.

1890 and 1892, 8th and 9th (Salmon), 428 pp., 19 pl. (1891, also in 11.1 : 891, p. $83 ; 1892$, also in $A 1.1: 892$, p. 85 .)

Same, 521 Cong., 2d sess., 11. mis. duc. 120; serial no. 3138.

1893 and 1894,10 th and $11 \mathrm{th}$ (Salmon), $127 \mathrm{pp}$. (1893, also in A1.1:893, p. $123 ; 1894$, also in $\mathrm{A} 1.1: 894$, p. 103 .)

Same, 54 th Cong., 1st sess., II. (loc. 205; serial no. 3420.

1895 and 1896,12 th and 13 th (Salmon), 362 pp., 38 pl. (1895, also in A1.1: 895 , p. 97 ; 1896 , also in A1.1:896, p. 1.)

Same, 5tth Cong., 2d sess., H. hoc: 291 ; serial no. 3537.

1897,14 th (Salmon), 727 pls., 6 pl. (Also in A 1.1:897, p. 185.)

Same, 5.5th Cong., 21 kess., H. doe. 578; serial 1103680.

1898, 15th (Salmon), 647 pl., 25 pl., 1 map. (Also in A1.1:898,p. 179.)

Same, 55th Cong., 31 sess., II. dloe. 307 ; serial no. 3831.

1899 , 16th (Salmon), $790 \mathrm{pl}$. $41 \mathrm{pl}$. (Also in A 1.1:899, p. 243.)

Same, 56th Cong., 1st sess., H. doc. 7 i5; s srial no. 4019.

1900,17 th (Salmon), 642 pp., 98 pl. (Also in A 1.1:900, p. 211.)

Same, 56th Cong., 21 sess., 1I. doe. 549; serial 110. 4201.

1901, 18th (Salmon), 706 p)., 117 pl. (Ilso in A1.1:901, 1. 15.)

Same, 57 th Cong., 1st sess., H, doc. 682; serial no. 4387 .

[The Bureau also made an annual report to Congress of its employees, expenditures, and work, etc., no luureal edition of which was issued. Following are the references to these reports as they appear in the Congressional set.]

1887, 50tlı Cong., 1st sess., S. ex. lloe. 69; serial no. 2510.

1888, 50th Cong., 21 sess., II. mis. duc. 62; serial no. 2654.

1889, 51st Cong., 1.t sess., s. ex. doc. 2t; serial no. 268:.

1890, 51st Cong., $2 \mathrm{l}$ sess., S. ex. doc. 8; serial 110. 2818.

1891, 521 Cong., 1st sess., S. ex. doc. 11; serial no. 2892.

1892, 521 Cong., 21 sess., S. ex. 1loc. 20 ; serial no. 3056.

1894, 53d Cong., 31 sess., S. ex. Aoc. 27 ; serial no. 3275.

1895, 54th Cong., 1st sess., II. doc. 96; serial no. 3414 .

1896, 5tth Cong., 2ul sess., S. dor. 45; serial no. 3469.

1897, 55th Cong., 2d sess., II. dixe. 22.7; serial no. 3680.

1899, 56th Cong., 1st sess., s. dox. 100; serial no. 3550.

1900, 56th Cong., 2 d sess., '. doc. 96; serial no. 4033. 
A4.1": Annual reeports (separates, reports of chicf)

[The personal rejort of the chiof is issued separately in pamphlet form.]

Anumal reports (misecellaneous separates)

The more important of the seientific pitpers accompanying the reports of the ehief are issuer separalely in pamphlet form. References to all the seientifie papers will be found nnder their proper headings in the index to this work.]

\section{Gencral publicalions}

[Publications whieh originated in this Burean, but which were published in a numbered series of the Secretary's office, or some other division of the Department, are entererl only where such numbering plaees them, with referenees under the proper headings in the Index to this work. Publications of the Bureau issted only as Congressional documents are noted in ehronologieal order in the Appendix to this work.]

1n.5

Animals. Contagions diseases of domesticated animals; investigations ] y Department of Agriculture, 1883-1884. 1884. 368 pp., $17 \mathrm{pl}$.

B399

Beef supply of U. S., and export tracle in animals and meat jroducts; by D. E. Salmon. Arvance sheets from annual report [of Secretary] 1889. 1890. $15 \mathrm{pl}$. (Special bulletin.)

C29 Cattlemen. Proceerlings of interstate convention of (attlemen, held at Fort Wortl, Texas, March 11-13, 1890. 1890. 102 pl). (Speeial bulletin.)

C29 ${ }^{2}$ Cattle. Special rejort on diseases of cattle and rattle feeding; lyy Drs. IIurray, Atkinson, Harbaugh, Łowe, Jaw, Dickson, Trumbower, Smith, and Professor llenry. 1892. $496 \mathrm{pl}$. $4 \mathrm{pl}$.

Same, $52 \mathrm{~d}$ Cong., 21 sess., H. inis. doe. 106; serial no. 2125.

C29: Same, reprint, 1896 . 496 jp. $4 t$ pl.

101t Dairy. Fifty dairy rules; reprinted from Famers' bulletin 63. (Placarl.)

Fts Filled cheese. [Notice of passage of filled-cheese bill.] Jume 10, 1896. (Cire.)

[To aecompany Circular 11 (A4.4:11.)]

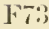

Foot-and-mouth disease. Instructions concerning inspection for foot-andmouth disease. Dec. 3,1902 . n. t. p. 3 pp.

F8: Fowl tholera. Rejort on prevention of fowl cholera; Jy D. F. Salmon.; Feb. 23, 1881. 11. t. 1. 2 pp. t $^{\circ}$.

IITS IIorse. Special report on diseases of the horse; by Drs. Mieliener, Law, Harbaugl, Trumbower, Liautard, Holcombe, Huiclekoper, and Dickson. 1890. $560 \mathrm{pl}$. $44 \mathrm{pl}$.

l't2 Pork. Instructions for mieroseopists in examination of pork for trichina. June 26, 1896. n. t. P. 21.

Sht Sheep. Animal parasites of sheep; by Cooper Curtice. 1890. 22.2 pr. $36 \mathrm{pl}$.

Sht ${ }^{2}$ Sheep. Special report on histrory and present condition of shecp industry of U. S.; by Ezra A. Camman, II. A. Heath, and John IInto. 1892. 1,000 pl). 96 j,l.

Same, 52d Cong., 2d sess., I1. mis. doe. 105, serial no. 3124.

Swh Swine plague. Special report on cause and prevention of swine plagne, results of experiments comblueted by Theolabls Smith. 1891. 166 [P. $12 \mathrm{pl}$.

\section{8: IBulletius:}

1 No. 1. Investigations into nature, (ausation, and juevention of Texas or southern cattle fever; by Thoobald Smith and F. L. Kilborne. 1893. 301 pp. $10 \mathrm{\mu l}$.

No. 2. Investigations relating to treatment of lumpy jaw or actinomycosis in cattle; by D. E. Salinon. 1893.90 pl) \& pl.

No. 2. Miscellaneons investigations concerning infoctions and parasitie: diseases of domesticated animals; conduceted by F. I. Kilborne, Veranus A. Noore, J. C. Sehroeter, Theolald Sulth, and C. IV'. Stiles. 189\%. 86 [']. 3 pl.

No. 4. Revision of the ardult costorles of cattle, sheep, and alliol animals;

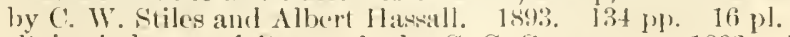




\section{Tables}

Classiflcatlou no.

1. . B:

\section{A. INIMAY, INDUSTRY IBUREAU-Continued}

\section{Barlerins-Continued}

No. 6. Additional investigations concerning infections swine diseases; [articles] by Theobald Smith and Veranus A. Moore. 1894. $117 \mathrm{pp}$.

No. 7. Investigations concerning bovine tuberculosis, with speeial reference to diagnosis and prevention. 1894. 178 p). $6 \mathrm{pl}$.

No. 8. Investigations concerning infectious diseases among poultry; [articles] by Theobald Smith and Teranus A. Noore. 1895. 90 p. $6 \mathrm{pl}$.

No. 9. Rules and regulations governing operations of Bureau of Animal Industry; also acts of Congress under which they are made. 1895. $46 \mathrm{pp}$.

No. 10. Cornstalk disease and rabies in cattle; [articles] by Veranus A. Moore and E. A. de Schweinitz. 1896. 92 pp. 2 pl.

No. 11. Statistics of the dairy; compiled from U. S. Census, 1890, and other reliable sources by Henry E. Alvord. $1896.53 \mathrm{pp}$.

No. 12. Tapeworms of poultry; report [by] Ch. Wardell Stiles [and] Bibliography, [by] Albert Hassall. 1896.88 pp. 22 pl.

No. 13. Tuberculosis investigations; [articles] by E. A. de Schweinitz, Marion Dorset, and E. C. Schroeder. 1896. 27 pp. 2 pl.

To. 14. Dairying in California; by F. J. Wickson. $1896.31 \mathrm{pp}$.

No. 15. Cheese industry of State of New York; by B. D. Gilbert. 1896. $54 \mathrm{pp}$.

No. 16. Dairy industry in Nebraska, South Dakota, and Nortl Dakota; by John H. Monrad. 1896. 21 pp.

No. 17. Dairy schools; by R. A. Pearson. 1896. 35 pp. 4 pl.

No. 18. Dairy industry in Missouri and Kansas; by Levi Chubbuck. 1897. $23 \mathrm{pp}$.

No. 19. Inspection of meats for animal parasites; [articles by] Ch. Wardell Stiles and Albert Hassall. 1898.161 pp.

Same, 55th Cong., $2 \mathrm{~d}$ sess., H. doc. 338 ; serial no. 3680.

No. 20. Milk supply of Boston and other New England cities; by George M. Whittaker. 1898. 37 pl. 3 pl.

No. 21. Sheep scab: its nature and treatment; by D. E. Salmon and Ch. IVardell Stiles. 1898.64 pp. 6 pl.

Same, revised. $1900.64 \mathrm{pl} .6 \mathrm{pl}$.

No. 22. Proceedings of second annual meeting of association of experiment station veterinarians, held at Omaha, Nebr., Sept. 8, 1898. 1895. $29 \mathrm{pp}$.

No. 23. Serum treatment of swine plague and hog cholera; by E. A. de Schweinitz, with collaboration of Marion Dorset and E. C. Schroeder. 1899. $18 \mathrm{pp}$.

Same, by E. A. de Schweinitz, with collaboration of Marion Dorset. 1899. 18 l').

No. 24. Notes upon rlairying in California and export of California butter to Orient; by R. A. Pearson. 1900. $29 \mathrm{pp}$. 4 pl.

No. 25. Rabies. Report of committee on Public Health of Medical Society of District of Columbia. 1900. $29 \mathrm{pp}$.

No. 26. National and State dairy laws; compiled and abstracted by R. A. Pearson. 1900. $100 \mathrm{pp}$.

No. 27. Information concerning Angora goat; by George Fayette Thompson. 1901. 94 pp. 17 pls.

No. 28. Legislation with reference to bovine tuberculosis, being digest of laws now in force, and transcript of laws, rules and regulations, and proclamations for the several States and Territories; [compiled] by D. E. Sahnon. 1901. $173 \mathrm{pp}$.

No. 29. American breeds of fowls; 1. Plymouth Rock; by T. F. MeGrew. 1901. 32 pp. 6 pl.

No. 30. Trichinosis in Germany, Parts 1-3, [articles] by Ch. Wardell Stiles; pt. 4, Bibliography, hy Albert Hassall, 1901. 211 pp.

No. 31. American breeds of fowls; 2. Wyandotte; by T. F. MeGrew. 1901. $30 \mathrm{pp} .10 \mathrm{pl}$.

No. 32. Tuberculin test of imported cattle; by D. E. Salmon. 1901. 22 pp. 
Bulletins-Continued

No. 33. Relation of bovine tuberculous to public health; by D. E. Salmon. 1901. 36 PI).

No. 34. American breeks of beef eattle, with remarks on jedigrees; by George M. Rommel. 1902. 34 p). 23 иl.

No. 35. Fleven miscellaneous papers on animal parasites. 1902. $61 \mathrm{pp}$. 5 pls.

No. 36. Apoplectiform septicemia in chickens. Preliminary report on a highly fatal disease caused by nompyogenic strepococcus; by Victor A. Nörgaard and John R. Mohler. 1902.24 pp. 4 pl.

No. 37. Market classes of horses; by George M. Rommel. 1902. 32 pp. $12 \mathrm{pl}$.

No. 38. Not issued 1902

No. 39. Index catalogue of medical and veterinary zoology, pt. 1. Authors: A to Azevedo; by Ch. Wardell Stiles and Albert Hassall. 1902. $46 \mathrm{pp}$.

No. 40. Description and treatment of scabies in cattle; by Richard W. Hickman, 1902. 23 pp. 1 pl.

[Identical with A1.9:152.]

No. 41. Mexico as a market for pure-bred beef cattle from U. S.; by D. E. Sałmon. 1902. 28 pp. 1 map.

No. 42. Emergency report on surra, by D. E. Sahmon and Ch. Wardell Stiles; with bibliography of surra and allied try panosomatic diseases, by Albert Hassall. $1902 . \quad 152$ pp. $16 \mathrm{pl}$.

No. 43. State and Territorial laws relating to contagious and infectious diseases of animals, 1901. 1902. 72 pp.

\section{Circulars}

[No. 1. Directions for sterilization of milk.] Dec. 19, 1893. (Circ.) Same, $2 d$ ed. July 24, 1894 . (Circ.)

No. 1. Same. [3d ed.] Dec. 19, 1893 [1896]. (Circ.)

No. 1. Directions for pastemrization of milk; revised Nov. 15, 1897. (Circ.) No. 2. Wheat as a food for growing and fattening animals; by D. E. Salmon. n. d. n.t. p. 4 pp.

No. 3. Nodular treniasis in towls; by Veranus A. Moore. Aug. 28, 1895. n. t. ?) 4 pp.

No. 4. Crossing improved breerls of swine with the common hogs of Florida; by Robt. W. Furnas. Dec. 28, 1895. n. t. p. 3 pp.

No. 5. Direct transmission of infections entero-luepatitis in turkeys; by Veranus A. Moore. Mar. 11, 1896. n. t. p. 8 Ir.

No. 6. Black quarter; by D. E. Salmon. n. d. n. t. p. 4 p.

No. 7. Actinom y cosis, or lumpy jaw; by D. E. Salmon. n. d. n.t. p. 4 pp.

No. 8. Injuries to cattle from swallowing pointed objects, by Theobald Smith and Charles F. Dawson. n. d. n. t. p. 4 p).

No. 9. Checklist of animal parasites of chickens; by Alhert Hassall. Mar. 25, 1896, with allendum, Apr. 10, 1896. is. t. I\% 7 Pl).

No. 10. List of State dairy commissioners and associations of dairymen in the U. S. and Canada, 1896; by Henıy 1. Nlvord. Mlar. 30, 1896. 11. t. p. 6 pl.

No. 11. How to select good cheese; lyy Henry F. Alord. Apr. 20, 1896. n. t. p. 11 p.

[For notice to accompany, sce $\Lambda 1.2$ :F48.]

No. 12. Checklist of animal parasites of turkers; by Allert llassall. Apr. 29), 1896 . 11. t. p. 3 \%).

No. 13. Checklist of animal parasites of ducks; by Albert Hassall. May 14, 1896 . n. t. 1 . 7 pp.

No. 14. Checklist of animal parasites of geese; loy Albert Ilassall. June 15, $18 \%$. n. t. p. 5 pl.

No. 15. Checklist of animal parasites of pigeons; hy Albert Massall. July 21, 1896. n.t. p. 4 !).

No. 16. Correspondence defining "filled cheene." sept. 1, 1896. n. t. p. 2 pl. 
A.1.1:

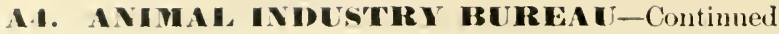

C'inculars-c'ontinued

No. 17. Hxports of animals and their products; by 1). E. Salmon. Jan. 21, 18:7. 11. t. p. 3 pl.

No. 18. List of oflicials and associations connected with clairy interests in U. S. and Canada for 1897; by Henry E. Alvord. Apr. 10, 1897. 3. t. ]. 8 pl.

No. 19. Factory cheese and how it is male; by G. Merry. n. d. n. t. p. 8 pl).

No. 20. Preventive vaccination against blackleg; by D. E. Salmon. n. t. p. 2 p.

No. 21. Directions for use of blackleg vaccine; by [Victor F. Nörgaard]. Aug. 3, 1897. 11. t. p. 8 pp.

[No. 23, 24 rerision, is issued under identical title.]

No. 22. List of oflicials connected with dairy interests, 1898; by Henry E. Alvord. Mar. 1, 1898. n. t. p. 8 pp.

No. 23. Blackleg: its nature, (ause, and prevention; Wy Victor A. Nörgaard. Mar. 12,1898 . n. t. p. 12 pp.

Same, rev. ed. Feb. 11, 1899 . n. t. l. 15 pl.

Same, 21 revision. Apr. 21, 1900 . n. t. p. 8 pp.

[Title changed to "Directions for use of blackleg vaceine"; identical with A4.4:21.]

No. 24. Colored spots in cheese; by R. A. Pearson. July 22, 1898 . n. t. p. $7 \mathrm{pp}$.

No. 25. State standarls for dairy products. 1898. Oct.31,1898. (Circ.)

Same, revised. Mar. 1, 1902 . n. t. p. 3 pp.

No. 26. Otticials, associations, and educational institutions connected with dairy interests of U.S. for year 1899; by Henry E. Alvord. Mar. 1, 1899. 12. t. P. 8 pp.

No. 27. Scales of points in use in U. S. for judging dairy breeds of cattle; reprinted from 15th annual report of Bureau of Animal Industry. 1899. $16 \mathrm{pl}$.

Same, revised. May 8,1900 . n. t. p. 16 pp.

No. 28. Letters relating to distribution of vaccine. [1900.] n.t. p. 9 pp.

No. 29. Officials, associations, and educational institutions connected with dairy interests for 1900; by Henry E. Alvord. Feb. 24, 1900. n.t.p. $10 \mathrm{pp}$.

No. 30. Rabies in District of Columbia; by D. E. Salmon. Apr. 30, 1900. n. t. $\% .15 \mathrm{pp}$.

No. 31. Blackleg, its nature, cause, and prevention; ly Victor A. Nörgaard. June 5, 1900 . n. t. p. $22 \mathrm{pp}$.

same, revised. Nov. 10, 1900. n. t. p. 23 pp.

No. 32. Imperial German meat inspection law. Feb. 15, 1901. n. t. p. 19 pp.

No. 33. Officials, associations, ancl educational institutions connected with dairy interests of U. S., 1901; by Henry E. Alvord. Feb. 23, 1901. n. t. p. 8 pp.

No. 34. Notes on parasites, 55-57; by Ch. Wardell Stiles and Albert Hassall. Mar. 26, 1901. n. t. p. 4 pp.

No. 35. Treatment of roundworms in sheep, goats, and cattle; hy Ch. Wardell stiles. Juty 24, 1901. n. t. p. 8 pl.

No. 36. Ofticials, associations, anıl educational institutions connected with dairy interests of L. S., 1902; by Henry E. Alvord. Mar. 1, 1902. 11. t. p. 8 pp.

No. 37 . Prelininary report on Argentina as a market for pure-bred cattle from U. S.; liy D. E. Salmon. Apr. 26, 1902. n. t. p. 4 pp.

No. 38. Foot-and-mouth disease, warning to all owners of cattle, sheep, and swine; by I). F. Salmon. Dec. 4, 1902. n. t. p. 3 pl.

\section{B. A. I. Oralers (signed by Secretiry of Agriculture)}

[From July ], 18s5, to Feb. 19, 1897, ninety circular orders were issued without numbers. The full text of these orders is given in the $141 \mathrm{~h}$ unnual report of the Burean of Animal luhistry, 1897, beginning at p. 324 (A4.1:897).]

No. 1. Exportation of beef. Mar. 9, 1897. (Cire.)

No. 2. Mlodifying quarantine line for California. Mar. 19, 1897. (Circ.) 
A.5:

H. A. I. Orders-Continued

Same, amended. July $17,189 \bar{\tau}$. (Cire.)

So. 3. Modifying quarantine line for Oklahona. (Amendment.) Apr. 26, 1897. (Circ.)

No. 4. Concerning cattle transportation. May 17, 18\%7. (Amenrment to orler dated Jan. 27,1897 .) (Cire.)

No. 5. Transportation of sheep affected with scalies. June 18, 1897.

No. 6. Placing counties in Texas in quarantine. Jnly 6, 1897. (Circ.)

Same, amended. July 13, i897. (Circ.)

No. 7. Placing counties in Tennessee in ruarantine. Ang. 16, 1897. (Cire.)

No. 8. Concerning cattle transportation, 1898. Dec. 15, 1897. Nos. 9-14. [supplementary quarantine regulations, 1898.] Dec. $16,1897$. n. t. p. 9 pp.

No. 15. Cattle transportation, feeding stations at Fort Worth, Tex., and Salisbury, N. C. Jan. 3, 1898. (Amendment to no. 8.) (Cire.)

No. 16. Cattle transportation, suspending no. 8. Jan. 22, 1898. (Circ.)

No. 17. Cattle transportation, amendment to no. 8. Mar. 4, 1898. (Circ.)

No. 18. Modifying quarantine line for California; supersedes and revokes no. 9. Mar. 25, 1898 . (Cire.)

No. 19. Safe transport of cattle to foreign countries. May 11, 1898. (Amendment to section 18 of order dated Feb. 18, 1895.) (Circ.)

No. 20. Placing certain counties in Texas in quarantine (additional to no. 10). Aug. 17,1898 . (Circ.)

No. 21. Releasing cattle in counties of Union, Towns, and part of Rabm, Ga., from restrictions. Sept. 7, 1898. (Circ.)

No. 22. Placing counties in Texas in quarantine (additional to no. 10). Sept. 30, 1898. (Cire.)

No. 23. Modifying no. 8. Oct. 12, 1898 . (Cire.)

No. 24. Concerning cattle transportation. Dec. 19, 1898. n. t. p. $4 \mathrm{pp}$.

Nos. 25-29. Supplementary quarantine regulations, 1899. Dee. 20, 1898. n. t. p. 6 pp.

No. 30. Placing certain counties in Texas in quarantine (additional to no. 25). Jan 9, 1899. (Cire.)

No. 31. Concerning cattle transportation (amendment to no. 24). Jan. 9,1899 . (Cire.)

No. 32. Concerning cattle transportation (amendment to no. 24). Mar. 8, 1899. (Circ.)

No. 33. Rules and regulations for inspection of live stock, etc. Mar. 15, 1899. n. t. p. 9 pp.

Same, with general instructions to inspectors, etc. Mar. 15, 16, 1899. n. t. p. $17 \mathrm{pp} .16^{\circ}$. [Title on cover $\mathrm{M}$ [eat] $\mathrm{I}$ [nspection] rules and regulations and instructions.]

No. 33. Amendment no. 2. June 21, 1902. (Cire.)

[For amendment no. 1, see A4.5:78.]

No. 34. Concerning cattle transportation (amendment to no. 29). Mar. 25, 1899. (Circ.)

No. 35. Inspection and safe transport of animals to foreign countries. May 1, 1899 . n. t. p. $11 \mu \mathrm{p}$.

Same, modifications and extension. Sept. 11, 1899. (Circ.)

No. 36. Placing certain counties in Texas in quarantine (additional to no. 25 and no. 30). June 27, 1899 . (Circ.)

No. 37. Providing for return to non-infected district of eattle exhibited at State fair, Raleigh, North Carolina (supplementary to no. 24). July 18, 1899. (Cire.)

No. 38. Dipping of sheep affeeted with scabies. July 20, 1899. (Cire.)

No. 39. Inspection and certification of graded cattle for Cuba. July 21, 1899. 3 pp. (half title.)

No. 40. Revocation of no 39. July 28, 1899. (Cire.)

No. 41. Releasing cattle in counties of Union, Towns, and part of Rabun, Ga., from restrictions of no. 24. A ug. 1, 1899. (Circ.)

No. 42. Placing Washita County, Okla., in quarantine (additional to no. 26). Aug. 4, 1899. (Circ.) 
A. 1.5:

13. A. I. Orders-Continued

No. 43. l'roviding for return to noninfected district of cattle exhibited at State fair, Sacramento, Cal. (supplementary to no. 24). Aug. 28, 1899. (Circ.)

No. 44. l'roviding additional ports of export for Canadian (attle in bond. Ang. 28, $1899 . \quad$ (Cire.)

No. 45. Modifying quarantine line for California (amendment to no. 24). Ang. 30, 1899. (Circ.)

No. 4t. Superseding no. 35. Oct. 4, 1899. n. t. p. 11 pp.

Same, amendment no. 1. Nor. 18, 1901. (Cire)

No. 47 . Concerning cattle transportation (amendment to no. 24). Oet.21, 1899. (Circ.)

No. 48. Concerning movement of animals from districts in which rabies exists. Dec. 11, 1899. (Circ.)

No. 49. Concerning cattle transportation. Dec. 16,1899 . n. t. p. 4 pp. (Also in $A+.5: 49-55$. )

No. 49. Concerning cattle transportation. Dec. 16, 1899. Nos. 50-55. Supplementary quarantine regulations. 1900 . Dec. 19, 1899. n.t.p. $10 \mathrm{pP}$.

No. 56. Inspection and quarantine of horses, neat cattle, sheep, and other ruminants, and swine, imported. Dec. 28, 1899 . n. t. p. 10 pp.

Same, Amendment no. 1. See A 4.5:58.

Same, Amendment no. 2. See A 4.5:64.

Same, Amendment no. 3. See A4.5:77.

Same, Amendment no. 4. See A 4.5:79.

Same, Amendment no. 5. [Cattle may be tested in Europe or Canada.] May 21, 1901. (Cire.)

Same, Amendment no. 6. Oct. 4,1901 . (Circ.)

Same, Amendment no. 7. Oct. 16, 1901. (Cire.)

Same, Amendment 120. 8. Nov. 23, 1901. (Circ.)

Same, Amendment no. 9. Mar. 22, 1902. (Circ.)

Same, Amendment no. 10. May 7, 1902. (Circ.)

Same, Amendment no. 11. Ang. 20, 1902. (Circ.)

Same, Amendment no. 12. Oct. 25, 1902. (Circ.)

Same, Amendment no. 13. Dec. 15, 1902. (Circ.)

No. 57. Cattle transportation (amendment to no. 49). (Circ.) Jan. 20, 1900.

No. 58. Inspection and quarantine of horses and other ruminants and swine importerl into T. S. Modification of no. 56. Jan. 27, 1900. (Circ.)

No. 59. Releasing certain cattle in California from restrictions imposed by Order 49. Feb. 26, 1900. (Circ.)

No. 60. Providing for return to noninfected district of cattle exhiloited at State fair at Raleigh, N. C. A )r. 6, 1900. (Circ.)

No. 61. Exportation of cattle and sheep in ressels carrying hides from foreign countries. Apr. 23, 1900 . (Circ.)

No. 62. Cattle transportation (amendment to no. 49). May 11, 1900. (Circ.)

No. 63. Cattle transportation (amendment to no. 49). Jlay 16, 1900 . (Cire.)

No. 64. Inspection and quarantine of horses and other ruminants and swine, imported into U. S. (amendment to no. 56). June 1, 1900. (Cire.)

No. 65. Providing for importation of Canadian cattle for exhibition purposes at Pan-American Exposition, Buffalo, N. Y. June 15, 1900. (Circ.)

No. 66. Regulations concerning cattle transportation (amendment to no. 49). July 13,1900 . (Cire.)

No. 67. Providing for importation of Canadian cattle, sheep, and swine for exhibition purposes at International Livestock Exposition, Chicago, Ill. July 13, 1900 . (Cir(:)

No. 68. Revoking no. 63. Aug. 13, 1900. (Circ.)

No. 69. Supplemental to nos. 55 and 59. Aug. 18, 1900. (Circ.)

No. 70. Supplementary to no. 49 . Ang. 20, 1900. (Circ.)

No. 71. Revoking no. 66. Aug. 23, 1900. (Circ.) 
A 1.5:

A4. ANIMAL.INDUSTRY IUREAU-Continuerl

\section{I3. A. I. Orders-Continued}

No. 72. Amendment to nos. 49 and 51. Aug. 29, 1900. (Cire.)

No. 73. Providing for exhibition of uninspected cattle at frolden (iate Fair (supplemental to nos. 55 and 59). Sept. 8, 1900. (Circ.)

No. 74. Amendment to nos. 49 and 51. Sept. 17, 1900. (Circ.)

No. 75. Amendment to nos. 49 and 50. Sept. 26, 1900. (Circ.)

No. 76. Amendment to no. 49. Oct. 9, 1900. (Circ.)

No. 77. Inspection and quarantine of horses and other ruminants, and swine, imported (amendment to no. 56). Oct. 20, 1900. (Cire.)

No. 78. Inspection of live stock and products (amendment to no. 33). O t. $22,1900 . \quad$ (Cire.)

No. 79. Inspection and quarantine of horses and other ruminants, and swine, imported (amendment to no. 56). Nov. 10, 1900. (Circ.)

No. 80. Regulations concerning cattle transportation; Nos. 81-87, supplementary quarantine regulations (amendments nos. 1-7). Dec. 10-14, 1900. n. t. p. 12 pp.

See for amendment no. 8, A4.5:88; for amendment no. 9, A4.5:89.

Same, Amendment no. 10. Jan. 31, 1901. (Cire.)

Same, Amendment no. 11. Feb. 5, 1901. (Circ.)

Same, Amendment no. 12. Apr. 18, 1901. (Cire.)

Same, Amendment no. 13. Apr. 20, 1901. (Circ.)

Same, Amendment no. 14. July 13, 1901. (Cire.)

Same, Amendment no. 15. Aug. 21, 1901. (Circ.)

Same, Amendment no. 16. Oct. 3, 1901. (Cire.)

Same, Amendment no. 17. Oct. 15, 1901. (Circ.)

Same, Amendment no. 18. Oct. 22, 1901. (Circ.)

No. 88. Amendment to no. 80. Dec. 22, 1900. (Cire.)

No. 89. Amendment to no. 80. Dee. 22, 1900. (Cire.)

No. 90. Importation of Canadian cattle, sheep, and swine for exhibition at Chicago. Sept. 12, 1901. (Cire.)

No. 91. Rules and regulations for inspection and marking dairy products for export. Oct. 30, 1901. n. t. p. 3 pp.

No. 92. Prohibiting landing of animals from Philippine Islands. Dec. 13, 1901. (Circ.)

No. 93. Regulations concerning cattle transportation. Jan. 10, 1902. (Contains amendments $1-8$ to no. 93 , and changes in quarantine line for 1902.) n.t. p. $16 \mathrm{pp}$.

Same, Amendment no. 9, Jan. 23, 1902. (Circ.)

Same, Amendment no. 10. Feb. 13, 1902. (Cire.)

Same, Amendment no. 11. Mar. 1, 1902. (Circ.)

Same, Amendment no. 12. Mar. 14, 1902. (Circ.)

Same, Amendment no. 13. Apr. 16, 1902. " (Cire.)

Same, Amendment no. 14. June 28, 1902. (Circ.)

Same, Amendment no. 15. July 30, 1902. (Circ.)

Same, Amendment 110. 16. July 30, 1902. (Cire.)

Same, Amendment no. 17. Sept. 10, 1902. (Cire.)

Same, Amendment no. 18. Oct. 10, 1902. (Circ.)

Same, Amendment no. 19. Oct. 22, 1902. (Circ.)

No. 94. Rules and regulations in regard to "renovated butter," and information concerning "adulterated butter." June 21, 1902. n. t. p. $12 \mathrm{pp}$.

No. 95. Importation of Canarlian animals for exhibition at State fair, Syracuse, N. Y. June 26, 1902. (Cire.)

No. 96. Importation of Canadian cattle, sheep, and swine for exhibition at International Live-stock Exhibition, Chicago. July 16, 1902. (Cire.)

No. 97. Fxtracts from existing laws, with rules and regulations as therein provided, prescribed for inspection and certification of renovated butter and other dairy products for export. Oct. 1, 1902. n. t. p. $6 \mathrm{pp}$.

[Printed "No. 96," ehanged with rubber stamp to "No. 97."]

No. 98. Rules and regulations prescribed in regard to " renovated butter," in accordance with act of Congress approved Nay 9, 1902, and information concerning "adulterated butter." Nov. 1, 1902. n. t. p. $16 \mathrm{pp}$. 
A.1. : :

$99^{\mathrm{I}}$

$99^{2}$

$90^{3}$

$999^{4}$

100

10)1

A.1.6:

891

892

893

894

895

896

897

S.9.

899

900

901

\section{A. IVIMAI. INIUS'TRY IBUIREIU-Continued}

\section{I. I. Order-Continued}

No. 99. Quarantine of cattle, sheep, and other ruminants, and swine in New England States. Nov. 27, 1902. (Circ.)

Same, Amendment no. 1. Nov. 29, 1902. (Circ.)

Same, Amendment no. 2. Dec. 13, 1902. (Cire)

same, Amendment no. 3. Dec. 22, 1902. (Circ.)

No. 100. Prohibition of exportation of eattle, sheep, and other rminints, and swine from port of Boston. Nov. 27, 1902. (Circ.)

No. 101 Concerning cattle transportation. Dec. 26, 1902. (Contains amendments nos. 1-9.) n. t. p. 15 pp.

\section{Map of distriets infected with splenctic fever}

1s91, Feb. 5.

1892, Feb. 26.

1893, Feb. 15.

1894, Feb. 5.

1895, Feb. 5 .

1896, June.

1897 , Feb.

1898, Jan. 1.

1899, Jan. 1.

1900, Jan. 1.

1901, Jan. (in 5 sections).

\section{A.5. HBIOLOGICAL, SURVEY}

[Former] known as Division of Ornithology and Mammalogy or Economic Ornithology and Mammology. For historical sketch of Division, see Yearbook, 1897 (A1.10:897), p. 115.]

\section{A.5.1: Annual reports}

ORNITHOLOGIST

8861886 (Merriam), [1]+227-258 pl. 1 map. (Also in A 1.1:856, p. 2.27.)

8871887 (Merriam), jii $+399-456$ ii pp. 1 pl. (Also in A1.1:887, p. 399.)

ORTITIOLOGIST ANI MAMALOGIST

8881888 (Nerriam), iii $+477-536$ pp. 1 pl. (Also in A1.1:Sss, p. 47.)

8891889 (Meriam), [1] +363-376 pp. 2 pl. (Also in A1.1:\$89, p. 36..)

8901890 (Merriam), iii $277-285 \mathrm{pp}$. (Also in A1.1:590, p. 27..)

$\$ 911891$ (Merriam), [1]+267-271 pp. (Also in $11.1: 891$, p. 267.)

8921892 (Merriam), [1] +181-200 pp., 5 pl. (Also in A1.1:892, p. 181.)

8931893 (Ierriam), iii + 227-234 pp., 1 map. (Also in A1.1:893, ए. 227.)

1894 (Merriam). (In A1.1:894, P. 227.)

1895 (Merriam). (In A 1.1:895, p. 175.)

8961896 (IIerriam), iit+23-25 pp. (Also in A1.1:896, 1. 23.)

Division of Biological StRYey

8971897 (Merriam), ii $+15-20$ p). (Also in Al.1:897, 1. 15.)

Acting Chief, Division of Biologichl sirvey

8981898 (Palmer), iii $+37-42$ pl. (Also in A 1.1:898, p. 37.)

8991899 (Palmer), iii $+59-70 \mathrm{pp}$. (Also in A 1.1:899, p. 59.)

9001900 (Palmer), ii + 35-48 pp. (Also in A1.1:900, p. 35.)

9011901 (Palmer), iii-151-162 pp. (Also in A1.1:901, p. 151.)

Chlef of Biologlcal Rirver

9021902 (Merriam), iii +209-218 pp. (Also in A1.1:902, p. 209.)

A5.2. Teneral publication.

[Publications which originated in this division, but which were published in a num bered series of the siccretury's office, or some other division of the Department, are entered only where such numbering places them, with references under the proper headings in the index 10 this work. Publications of this division issued only as Congressional documents are noted in chronological order in the appendix to this work.

\section{A.5.3: Bulletius}

1 No. 1. English sparrow (Pascer (Homesticus) in North America, especially in its relation to agriculture: by Walter B. Parrows. 1889.405 p). 1 maj.

2 No. 2. Birlunigration in Mississinni Valley, 1884 and 1885 ; Jy W. W. Cooke. Edited and revised by C. Hart Merriam. 1888. 313 pP. 1 map. 
A T. 0 :3:

A.7. :

\section{Bulletins-Continued}

No. 3. Hawks and owls of U.S. in their relation to agriculture; by $A$. K. Fisher. $1893.210 \mathrm{pp} .26 \mathrm{pl}$.

No. 4. Prairie ground squirrels, or spermuphiles, of Mississippi Valley; by Vermon Bailey. $1893.64 \mathrm{Pl} .5$ pl.

No. 5. Porket sophlers of U. S.; by Vermon Bailey. 1895. $47 \mathrm{pp} .2 \mathrm{pl}$.

No. 15. Common crow of U. S.; [articles] by Walter B. Barrows and E. A. S.hwarz. 1895. $98 \mathrm{pp} .1 \mathrm{pl}$.

No. 7. Preliminary report on food of woolpeckers, by F. E. L. Beal;

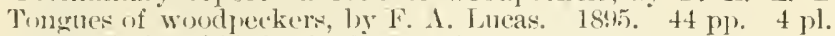

In. 8. Jack rabbits of U. S.; by 'T. S. Palmer. 1896. 84 pl. $7 \mathrm{pl}$. Same, revicel ed. 1897. $881 \% .7$ pl.

xo. 9. Cuckoos and shrikes in their relation to agriculture; Food of (uckoos, by F. E. I. Beal, [and] Foorl of shrikes, ly Sylvester D. Judel. $1898.26 \mathrm{pp} .1 \mathrm{pt}$.

No. 10. Life zones and crop zones of C. S.; by C. Hart Merrian. 1898. $79 \mathrm{pp} .1$ inap.

Xo. 11. (ieographic distribution of cereals in North Anerica; ly C. S. Plumt. 1898. 24 pl'. $]$ nap.

No. 12. Legislation for protection of birls other than game ljirds; by T. S. Palmer. 1900. $94 \mathrm{pP} .2 \mathrm{pl}$.

Same, reviserl ed., 1902. $143 \mathrm{pp} .+\mathrm{pl}$.

No. 13. Fool of boloolink, l, lackbirds, and grackles; by F. E. L. Beal. 1900. 77 pp. 1 pl.

No. 14. Laws regulating transportation and sale of game; by T. S. P'almer and II. WV. Olds. $1900.89 \mathrm{pp}$. 9 pl. 1 folder table.

No. 15. Relation of sparrows to agriculture; by Sylvester D. Jukl. 1901. $98 \mathrm{pp} .4 \mathrm{pl}$.

No. 16. Digest of game laws for 1901; by T. S. Palmer and H. W. Olds. 1901. $152 \mathrm{pp} .8 \mathrm{pls} .2$ folder tables.

No. 17. Birds of a Maryland farm, a local study of economie ornithology; by sylvester D. Jurld. $1902.116 \mathrm{pp} .17 \mathrm{fl}$.

\section{iBulleting (separates)}

[A few of the more important papers contained in the Bulletins have been issued separately. Referenees to all the papers will be found under their proper headings in the index to this work.]

\section{Circulats}

No. 1. On food habits of bircls. Ont of print.*

Same, 2tl ellition. Uet. 12,1886 . n. t. p. [3] pr.

No. 2. On linglish sparrow. July 20, 1886. (Cire.)

Yo, 3. On economic relations of mammals. July $2 \bar{\tau}, 18 s 6 . \quad n . t . p$. [3] $\mathrm{p}$.

No. 4. [Leaflet relating to collection of birds' stumatehs. Nov., 18s6.] (Cire.)

No. 5. To rice growers. n. «. (Cire.)

Fo. 6. Arknowledgment of receipt of moledule on kinglish sparrow. (Hat of print.*

Sime, 21 colition. n, a. (Circ.)

No. 7. Topostmasters in relation to Englishsparrow. Nov. 8, 1886. (Cire.)

No. 8. On geograthical distrilution and migration of Nortl Anerican birels for 1887 . Feb. 2:?, 1887 . n. t. 1) [t] pp.

No. 9. On gophers. July :30, 1888. (Circ.)

No. 10. On killeleer plover. Jan. 15, 1899. (Circe)

No. 11. Brief directions for meanurement of small mannals, and preparation of musem skins; ly (. Hart Merriam. 188s. 4 jp. l pl.

No. 12. Directions for collecting the stomach of lircls. $\Lambda_{\text {pr. }} 25,1891$. n. t. p. [3] pp.

Fo. 13. [For acknowledging reneipt of North Ameriann Fama.] n. il. (Cire)

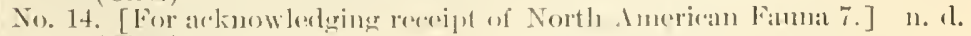
(Cire)

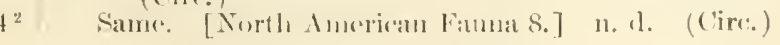

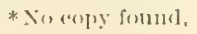


A 5.4:

\section{A5.5: North Ameriean fauma}

1 No. 1. Revision of North American pocket mice; by C. Hart Merriam. 1889. vii $+36 \mathrm{pp} . \quad 4 \mathrm{pl}$.

2 No. 2. Descriptions of fourteen new species and one new genus of North American mammals; by C. Hart Merriam. 1889 . v+52 pp. 8 pl.

Circulars-Continued

No. 15. [For acknowlerleing receipt of North American Fanna 10.] Jan. 1896. (Cire.)

No. 16. [For acknowledging receipt of North America Fanna 11.] July, 1896 (Circ.)

No. 17. Bird day in the schools. July 2, 1896. n. t. p. 4 pp.

Same, reprint with additions. 1n. t. I. \& pp.

No. 18. [For acknowledging receint of North American Fauna 12.] n. d. (Cire.)

No. 19. In relation to bounties on mammals and birds. n. d. (Cire.)

No. 20. Distribution and sale of publications. Oct. 20, 1896. n. t. p. $2 \mathrm{PP}$.

To. 21. Geographic distribution of North American cereals. Jan. 4, 1897 (Cire.)

No. 22. Geographic distribution of North American cereals. Mar. 1, 1897 (Cire.)

No. 23. [For acknowlerking receipt of North American Fauna 13.] Oct., 1897. (Circ.)

No. 24. [For acknowledging receipt of North American Fanna 14.] May 1, 1899. (Cire.)

No. 25. [For acknowledging receipt of North American Fauna 15.] Aug 10, 1899. (Cire.)

No. 26. [For acknowledging receipt of North American Fauna 16.] Oct. 3I, 1899. (Cire.)

No. 27. [For acknowledging receipt of North American Fauna 17.] May 31 [June 6], 1900. (Cire.)

No. 28. Directory of State officials and organizations concerned with protection of birds and game. July 10, 1900. n. t. p. 8 pp.

No. 29. Protection and importation of birls under act of Congress approved May 25,1900 . July 13,1900 . n. t. p. 6 pp.

No. 30. Wild animals and birds which may be imported without permits. Sept. 13, 1900. (Circ.)

No. 31. Information concerning game: Seasons, shipment, and sale; by T. S. Palmer and H. W. Olds. Oct. 25, 1900. n. t. p. 20 pp.

No. 32. Directions for destruction of prairie dogs; by C. Hart Merriam. Feb. 21, 1901. n. t. p. 2 pp.

No. 33. Protection of birds and game, directory of State ofticials and organizations for 1901; by T. S. Palmer. Apr. 18, 1901. n. t. p. $10 \mathrm{pp}$.

No. 34. Laws for protection of birds and game in District of Columbia; by T. S. Palmer. Oct. 25,1901 . n. t. p. 8 pp.

No. 35. Directory of State officials and organizations concerned with protection of birds and game, 1902; by T. S. Palmer. Apr. 15, 1902. n. t. p. $10 \mathrm{pp}$.

No. 36. Importation of reptiles into Hawaii, order for prevention of. [Amendment to circular no. 30] Jay 22, 1902. (Circ.)

No. 37. Regulations for importation of eggs of game birds for propagation. June 9, 1902. n. t. p. 2 pp.

No. 38. Interstate commerce in birds and game. Aug. 23, 1902. n. t. p. $3 \mathrm{pp}$. Results of a biological survey of San Francisco mountain region and desert of the Little Colorado, Arizona; [articles] by C. Hart Merriam and Leonhard Stejneger. 1890. vii+136 pp. 14 leaves 14 pl. 5 maps.

No. 4. Descriptions of twenty-six new species of North American mammals; by C. H. Merriain. $1890 . \quad v+60$ pp. 3 pl. 1 table. 


\section{A5.5: | North American famna-Continued}

No. 5. Results of a biological reconnaissance of south central Idaho; [articles] by C. II. Merriam and Leonhard Stejneger; Descriptions of new genus and two new species of North Anerican mammals, by C. Hart Merriam, 1891. vii +128 pp. 4 pl.

No. 6. Death Valley expedition, pt. 1. Not publisherl.

No. 7. Death Valley expedition, a biological survey of parts of California, Nevada, Arizona, and Utah, pt. 2; [reports by] A. K. Fisher [and others]. $1893.402 \mathrm{pp} .19 \mathrm{pl}$.

No. 8. Monographic revision of the pocket gophers, family Geomyidx, exclusive of species of Thomomys; by C. Hart Mlerriam. 1895.258 pp. $23 \mathrm{pl}$.

No. 9. Not published.

No. 10. Revision of shrews of American genera Blarina and Notiosorex, by C. Hart Merriam; Long-tailed shrews of eastern U. S., by Gerrit S. Miller, jr.; Synopsis of American shrews of genus Sorex, by C. Hart Merriam. 1895. $124 \mathrm{pp} .12 \mathrm{pl}$.

No. 11. Synopsis of weasels of North Ameriea; [by] C. Hart Merriam. 1896. 44 pp. $6 \mathrm{pl}$.

No. 12. Genera and subgenera of voles and lemmings; by Gerrit S. Miller, jr. $1896.84 \mathrm{pp} .3 \mathrm{pl}$.

No. 13. Revision of North American bats of family Vespertilionidæ; by Gerrit S. Niller, jr. $1897.140 \mathrm{pp} .3 \mathrm{pl}$.

No. 14. Natural history of Tres Marias Islands, Mexico; General account of islands, with reports on mammals and birds, by E. W. Nelson; Reptiles, by Leonhard Stejneger; Crustacea, by Mary J. Rathbun; Plants, by J. N. Rose; Bibliography, by E. W. Nelson. 1899. 97 pp. 1 pl.

No. 15. Revision of jumping mice of genus Zapus; by Edward A. Preble. 1899. 42 pp. 1 pl.

No. 16. Results of biological survey of Mt. Shasta, Cal.; ly C. Hart Merriam. 1899. 179 pp. 5 pl.

No. 17. Revision of American voles of genus Microtus; by Vernon Bailey. 1900. 88 pp. 5 pl.

No. 18. Revision of pocket mice of genus Perognathus; by Wilfred H. Osgood. $1900.72 \mathrm{pp} .4 \mathrm{pl}$.

No. 19. Results of a biological reconnoissance of Yukon River region; General account of region [and] annotated list of mammals, by Wilfred H. Osgood; Annotated list of birds, [by] Louis B. Bishop. 1900. $100 \mathrm{pp} .7 \mathrm{pl}$.

No. 20. Revision of skunks of genus Chincha; by Arthur H. Howell. 1901. $62 \mathrm{pp} .8 \mathrm{pl}$.

No. 21. Natural history of Queen Charlotte Islands, British Columbia; natural history of Cook Inlet region, Alaska; by Wilfred H. Osgood. 1901. $87 \mathrm{pp} .7 \mathrm{pl}$.

No. 22. Biological investigation of Hudson Bay region; by Edwari $\Lambda$. Preble. $1902.140 \mathrm{pp} .14 \mathrm{pl}$.

North American fauna (separates)

[A few of the more important papers contained in the North Ameriean Faung have been issued separately. References to all the papers will be found under their proper headings in the index to this work.]

\section{A6. HO'TANY DIVISION}

[Merged into Bureaı of Plant Industry, July 1, 1901, see A 19. For historieal sketeh of Division, sce Yearbook 1897 (A1.10:897), p. 90.]

\section{A6.1: Annual reports}

1869 (Parry) (In A1.1:869, p. 91.)

1870 (Parry) (In A1.1:870, p. 108.)

1871 No report made.

1872 (Vasey) (In A1.1:872, p. 159.)

1873 No report made.

1874 (Vasey) (In A1.1:874, p. 156.) 
A (i. 1:

\section{Anmual repon's-Continnel}

1875 No report made.

1876 (Vasty) (In A1.1:876, P. 7i:.)

1877 jo rejort made.

1878 [Xo resular annual report appears, hut a "lieport of the Botanist and (Chemist on grasise anel folate plants, by Georuge Vasey and Peter Collier," appears in the Serretary's report for 1878, p1. 157194. See A 1.1:878].

1879 (Vasey). (In A1.1:879, 1. 349.)

1880 (Vasey). (In A1.1:880, 1. 375.)

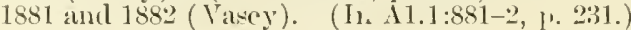

1883 (Vasey). (In 11.1:853, p. 83.)

$185 t$ (Vasey). (In $11.1: 85 t, 1 \% 123$.

1885 ( Vasey). (In A $1.1: 8.85$, p. 63.)

1886 (Vasey), [1] +69-93 pp. 21 pls. ( Mlso in $11.1: 886,1.69$.

1887 (Vasey). (In A1.1:857, 1. 301.)

888

SS?

890

1888 (Vasey), [1] + 305-32+ P'P. 13 pils. (Also in A1.1:885, ए. 305.)

1889 (Vasey), [1] $+377-396$ pए. 11 pls. (Also in A1.1:859, 1. 377.)

1890 (Vasey), [1]+375-392 pr. 8 pls. (Also in A1.1:890, 1\% 375.)

1891 (Vasey), [1] +341-358 pp. 10 pls. (Also in A1.1:891, p. 341.)

1892 (Vasey), [1] +201-214. 9 pls. (Also in A1.1:892, 1. 201.)

1893 (Coville), iii +235-24t p). (Also in A1.1:893, p. 235.)

$189+$ (Coville), iii $+161-166$ p). (Also in A1.1:894, p. 161.)

1895 (Coville), iii $+159-16+\mathrm{Pl}$. (Also in A1.1:895, P. 159.)

1896 (Coville), iii $+95-102$ pl. (Also in A1.1:896, P. 95.)

1897 (Coville), ii $+167-172$ Pp. (Also in A $1.1: 897$, P. 167.)

1898 (Coville), iii $+153-158 \mathrm{pl}$. (Also in A1.1:898, p. 153.)

1899 (Coville), iii + 53-57 ए). (Also in A1.1:899, ए.53.)

1900 (Coville), iii-91-101 pl. (Also in $\mathrm{N} 1.1: 900$, p. 91.)

1901 (Coville). [This final report of the Division was made through the chief of the Bureau of Plant Industry, forming part of his annual report for 1901. (See $A 1.1: 901,1.62$; also $A 19.1: 901, \mathrm{P} .67)$.

A6.1 $"$ : Anmual reporis (separates)

[A few of the more important papers eontained in the annual reports 1 ave been issued separately. References to all the papers will be found under their proper headings in the index to this work.]

A 6.2:

\section{Gencral pablicatioms}

[Publications which originated in this Dirision but which were published in a num. bered series of the Seeretary's office, or some other division of the Department, are entered only where such numbering places them, with references under the proper headings in the Index to this work. Publications of the Division issuerl only as Congressional doeuments are noted in chronologieal order in the Appendix to this work.]

B 65

Botanical Exchange Club. Rules for Botanical Exchange (lnJ); by George Vasey. n. d. (circ.)

G76 Grasses of U. S. Descriptive catalogue of grasses of U. S., including especially grass collections at New Orleans Exposition made by U.S. Departuent of Agriculture and State exhibits of grasses, with notes on such species as are nore or less employed in agriculture or deserving of trial and cultivation; by Geo. Tasey. 1885. Washington, Gibson Bros. 1S85. $110 \mathrm{pp}$.

[Pulished as report of Agrienlture Department at World's Industrial and Cotton Centennial. "sail to bave been printed at Gibson Bros. to save expense. Paid for from Exposition funds."-(Written note on t. p. of copy in file of Agrieulture Department, Publieations Division.)]

Int Instructions to botanical collectors; by Geo. Vasey. n. d. (Circ.)

N82 ${ }^{2}$ North American grasses. Illustrations of North Imerican grasses, vol. 1. Grasses of the Sonthwest; plates and deweriptions of grasses of desert region of wostern 'Trxas, New Mexire, Arizona, and southern California; by creo. Vascy. 1891. vii $+[2]+7+[2] \mathrm{pl} .49 \mathrm{l} .50 \mathrm{pl}$. and $7+[2] \mathrm{pl}$. 49 1. 50 p). Large $8^{\circ}$. (Reissue of Botany Bulletin no. 12. pts. $1,2$. 
16.2:

N8.2

P69

A6.:3:

\section{Gencral publications-Continneal}

North Americam grasses. Grasses of the Paeitie slope, inelueling Alaska and arljarent islands; plates and lescriptions of grassess of California, Oregon, Waslington, and the northwestern coast, inclurling $A$ laska; by Geo. Vasey. 1893. viii [4] pp. 98 $1.100 \mathrm{pl}$. large $\mathrm{s}^{\circ}$.

[Reissue of Botany Bulletin no. 13, pts. 1, 2.]

P'lant breeding and seed selection; w Fresterick V. Coville. June 22, 1898. n. t. 1. 2 pr.

\section{Bulletins}

No. 1. Investigation of grasses of arid districts of Kansas, Nebraska, and Colorarlo; by fieorge Vasey. $1886.19 \mathrm{pl} .13 \mathrm{pl}$.

To. 2. Fungus diseases of grape vine; by Frank Lamson-Seribner. 1886. $136 \mathrm{pp} .7 \mathrm{pl}$.

No. 3. Grasses of the South, report on rertain grasses am forage plants for cultivation in sonth and sonthwest; by George Vasey. 1887. $63 \mathrm{pH} .16 \mathrm{pl}$.

No. 4. Desiderata of herlarimm for North America north of Mexico. Ranunculacese to Rosacese, inclusive; by Geo. Vasey.

(Distributed among botanists with the purpose of obtaining specimens.) 1887. 15 wp.

No. 5. Experiments made in 1897 in treatment of downy mildew and black-rot of grapevine with chapter on apparatus for applying remedies for these liseases; ly F. Lamson-Scribner. 1888. $113 \mathrm{pp}$. 1 table.

[No. 6. Grasses of arid districts.] Investigation of grasses of atriol chistricts of Texas, New Mexico, Arizona, Nevala, and Utah, in 18s7. 1888. $61 \mathrm{pp} .30 \mathrm{pl}$.

[The Department and Division designation and the bulletin number and series titles as braeketed above appear only on the eover.]

No. 7. Black rot [of grape vine]; by F. Lamson-ficrilner and Pierre Viala. 1888. 29 pl. 1 pl.

No. 8. Record of some work of division, incluling extracts from correspondence and other communications; [articles] prepared by (reorge Vasey and B. T. Galloway. 1889. 67 pl.

No. 9. Peach vellows, a preliminary renort; by Erwin F. Smith. 1888. $25+1 \mathrm{pl} .46 \mathrm{pl}$.

No. 10. Experinents made in 1888 in treatment of downy mildew and black lost of grape vine. 1889 . $61 \mathrm{lp} .2$ pl.

No. 11. Experiments made in 1889 in treatment of iungous direases of plants; prepared hy I3. T. Galloway. $1890 . \quad 119 \mathrm{pp} . \quad 7 \mathrm{pl}$.

[1'lates numbered to eight, but plate 1 is page 26.]

No. 12. Grasses of the Sonthwest; plates and descriptions of granses of desert region of western Texas, New Mexico, Arizona, and sonthern California; by Greo. Vasey. Pt. 1, $1890.7+-[2] \mathrm{lp} .49 \mathrm{l} .50 \mathrm{pl}$. large $8^{\circ}$.

Same, pit. 2. 1891. $7+[4]$ pp. 49 ]. $50 \mathrm{pl}$. large $8^{\circ}$. (Title-page and table of contents for vol. 1, Illnstrations of North Aneriean Grasses, appended to this part.)

[Bulletin no. 12, , ts. 1, 2, also issued as vol. 1, Illustrations of North American (irasses. See 16.2:N8.2.1.]

No. 13. Grasses of Pacifie Slope, including Alaska and arljacent islands; plates and deseriptions of grasses of California, Oreegon, Washington, and the northwestern coast, inchuding Alaska; by Geo. Vasey, Pt. 1. 1892. $7+[2]$ pp. 4? 1.50 pl. large $8^{\circ}$.

Same, pt. 2. 1893. $7+[2] \mathrm{Pp} .491 .50 \mathrm{pl}$. large $8^{\circ}$. (Title-page and table of contents for vol. 2, Illustrations of North Ameriean Grisses, appended to this part.)

[Bulletin no. 13, pts. 1, 2, also issued ats wo]. 2, Illustrations of North American Giasses Sre $\mathrm{A} 6.2: \mathrm{NS}^{2} \%$.]

No. 14. Hex cassine, aboriginal North Anerican tea, its history, distribution, and use anong native North Inerican Indians; by E. II. Hale. 1891. 22 pp. $1 \mathrm{pl}$. 
16.:3:

A 6.1:

\section{IBulledins-continued}

No. 15. Russian thistle, its history as a weed in U. S., with an aceount of means avilable for its cradication; by Lyster Hoxie Dewey. 1894. $32 \mathrm{pl} . \quad 3 \mathrm{pl} .2$ maps.

No. 16. American ginseng, its commercial history, protection, and eultivation; by George V. Nash. 1895. $22 \mathrm{pp}$.

Same, revised and extended by Mauriee G. Kains. 1898. 32 pp.

Same, [with prefatory note by Frederick V. Coville]. 1902. $32 \mathrm{pp}$.

No. 17. Legislation against weeds; by Lyster H. Dewey. 1896.60 pp.

No. 18. Water hyacinth, and its relation to navigation in Florida; by Herbert J. Webber. $1897.20 \mathrm{pp} . \quad \mathrm{I}$ pl.

No. 19. Chicory growing as addition to resources of American farmer; by Maurice G. Kains. $1898.52 \mathrm{pp}$.

No. 20. Principal poisonous plants of United States; by Y. K. Chesnut. 1898. $60 \mathrm{pp}$.

No. 21. Vanilla culture, as practiced in Seychelles Islands; hy S. J. Galbraith. $1898.24 \mathrm{pp} .1 \mathrm{pl}$.

No. 22. Present status of rice culture in United States; by S. A. Knapp. 1899. 56 pp. 3 pl.

No. 23. Russian cereals adapted for eultivation in United States; by Mark Alfred Carleton. 1900. $42 \mathrm{pp} .2 \mathrm{pl}$.

No. 24. Germination of seeds as affected by certain chemical fertilizers; by Gilbert II. Hicks. 1900.15 pp. 2 pl.

No. 25. Shade in coffee culture; by O. F. Cook. 1901. 79 pp. 16 pl.

No. 26. Stock-poisoning plants of Montana, preliminary report; by V. K. Chesnut and E. Y. Wilcox. 1901. 150 pp. 37 pl.

Same, 56th Cong., 2 d sess., S. doc. 160 ; serial no. 4039.

No. 27. Seeds of commercial saltbushes; by G. N. Collins. 1901. 28 p.p. 8 pl.

No. 28. Chayote, a tropical vegetable; by O. F. Cook. 1901.31 pp. 8 pl. No. 29. Seed coats of certain species of genus Brassica; by A. J. Pieters and Vera K. Charles. 1901. 19 pp. 1 pl.

\section{Circulars}

No. 1. II ungarian brome grass; by F. Lamson-Scribner. May 23, 1894. I1. t. p. 4 pp.

No. 2. Nut grass; by L. H. Dewey. Oct. 16,1894 . n. t. p. 4 pp.

No. 3. Russian thistle; by L. H. Dewey. [Jan. 4, 1895.] n. t. p. 8 pp. Same, rev. ed. Nov. 20, 1895 . n. t. p. 8 pp.

No. 4. Flat pea; by F. Lamson-Scribner. Feb. 27,1895 . n. t. p. 7 pp.

No. 5. Giant knotweed, or sachaline; by F. Lamson-Scribner. Feb. 26, 1895. n. t. p. 4 pp.

No. 6. Standards of the purity and vitality of agricultural seeds; by Gilbert H. Hicks. May 9, 1896. n. t. p. 4 pp.

No. 7. Tumbling mustard, by Lyster H. Dewey. June 5, 1896 . n. t. p. $8 \mathrm{pp}$.

Same, 2d ed. June 5, $1896 . \quad$ n. t. p. 8 pp.

No. 8. Crimson clover hair balls; by Frederick V. Coville. June 15, 1896. n.t.p. 4 pp.

No. 9. Wild garlic; by Lyster H. Dewey. Feh. 15, 1897 . n. t. p. 8 pp. Same, revisell. June 2, 1900 . n. t. p. 8 pp.

No. 10. Three new weeds of mustard family; by Lyster H. Dewey. Apr. 30, 1897. n. t. p. 6 pp.

No. 11. Vitality of seed treated with carbon bisulphid; by Gilbert $H$. Hicks and John C. Dabney. n. d. n. t. p. 5 pp.

No. 12. Camphor tree; by Lyster H. Dewey. Aug. 12, 1897. n. t. p. $7 \mathrm{pp}$.

Same, revised. Sept. 21, 1897. n. t. 1. 8 pp.

No. 13. Observations on recent cases of mushroom poisoning in District of Columbia; by Frederick Y. Coville. Dec. 1, 1897. n. t. p. $21 \mathrm{pp}$.

Same, rev. ed. Jan. 4, 1898 . n. t. p. 24 pp.

Same, 3d ed. May 15, 1899 . n. t. p. 24 pp. 
A6.) : Cireulars-Continued

No. 14. Dodders infesting clover and alfalia; ly I,yster II. Dewey. Apr. 25, 1898 . n. t. p. 7 pl.

No. 15. Horke-radis!; ly M. G. Kains. May 20, 1898. n.t. p. 8 pp.

No. 16. Section of seed and plant introduction; ly O. F. Cook. Jan. 25, 1899. n. t. p. $6 \mathrm{pp}$.

To. 17. Notes on plant products of Philippine Islands; by Frank II. Hitcheock. May 15,1899 . n. t. p. 8 pr.

$18^{1}$ No. 18. Crimson cloverseerl; by A. J. Pieters. Aug. 5, 1899. n.t. p. 4 pl. Same, revised. July 20, 1900 . n. t. p. 7 pp.

No. 19. IIop cultivation in Bohemia; ly David G. Fairchild. Oct. 10, 1899. n. t. p. 6 pp.

No. 20. Horse-radish culture in Bohenia; Jy DavidG. Fairchild. Dec. 15, 1899. n. t. P. 3 pp.

To. 21. Yans in IVest Indies; hy David G. Fairchild. Dec. 6, 1899. 1. t. p. + pp.

No. 2*. Bur, or globe, artichokes; by Walter T. Swingle and Davia G. Fairchild. Dee. 11, 1899. נ]. t. [. 6 pl.

No. 23. Lebhek or siris tree; ly David G. Fairchild. Feb. 3, 1900. s. t. p. 4 pl.

To. 24. Red clover seed; hy Arrian J. Pieters. Mar. 6, 1900. n. t. p. 5 pl).

No. 25. Seed of bearkless brome grass; hy A. J. Pieters. Mar. 10, 1900. n. t. ए. 5 pl.

No. 26. Egyptian cotton in U. S.; hy Lyster H. Dewey. Mar. 16, 1900. 11. t. 1.9 9 p.

No. 27. Canada thistle; by Lyster II. Dewey. May 15, 1900. n. t. p. $1+\mathrm{pl}$.

Same, revised. 1901. 11. t. p. 14 p.

No. 28. Rubber cultivation for Porto Rico; by O. F. Cook. June 22, 1900. n. t. p. $12 \mathrm{pp}$.

No. 29. Chicory growing; by Maurice G. Kains. Oct. 30, 1900. n. t. p. $12 \mathrm{pp}$.

No. 30. List of publications of Division of Botany; by Frederick $Y$. Coville. May 17, 1901. 11. t. p. 10 p.

\section{Contributions fron U. S. national loerbarium}

[The U. S. National Herbarium, founded by the Smithsonian Institution, was transferred to the Agrienlture Department in 1868, and returned to the eustody of the Smithsonian Institution, July 1, 1896. The Agriculture Department, however, continued to publish this series of botanieal reports until July 1,1902 , when, in pursuance of an act of Congress, the National Museum assumed the responsibility of the publieation.]

Y. 1. Reports on collections and miscellaneous papers. 1890-1895. Contents:

No. 1. List of plants collected by Edward I'almer in 1888 in Sonth Carolina, by ieorge Vasey and J.N. Rose; List of plants collected by Edwurd Palmer at Lagoon Y Iead, Cedros Island, San Benito Island, Guadalupe Island, Ilead of Gulf of California, by George Vasey and J. N. Rose. $1 \times 90$. vii +28 pp.

No. 2. Colleetion of plants made by G. C. Nealley in region of Rio Grande in Tuxas. from Brazos Santiago to El Paso County; by Joln M. Coulter. 1890 . iii $+29-65 \mathrm{PP}$ Ni). S. List of plants collected by Edward Pulmer in 1890 in Lower California and western Mexico, at La l'az, San Pedro, Martin Island, Raza Island, Santa Rosalia, and Santa Agueda, Guaymas; ly George Vasey ank J. N. Rose. $1890 . \quad y i+63-90$ pp. $1 \mathrm{pl}$.

No. 4. List of plants eollected by Edward Palmer in 1890 in western Mexico and A rizoma, at Alamos and [in] Arizona; ly J. N. Rose. 1891. vii $+91-127 \mathrm{pp} .10$ pl. No. 6. List of plants eolleeted by Edwaril f'almer in 1890 on Curmen island, by J. N. Rose; I ist of plants colleeted by U. S. S. Albatross in 1887-91 along westeri coast of A ineriea, [artieles] by J. N. Rose, D. C. Eaton, J. W. Eekfeldt, and A. W. Evans; Revision of North Anerienn speeies of Hoffmanseggin, by 1\%. M. Fisher; Systematie and alphaluetie index of new speeies of North A merican phanerogams and pteridophytes, published in 1891, by Josepline $A$. Clirk. 1892, $x+129-188$ I.P. 5 pl.

No. 6. List of plants eolleeted by C. S. Sheldon and M. A. Carleton in Indian Territory in 1891, by J. M. Tfolzinger; Oiservations un mative plants of Oklahoma Territory and adjacent districts, by M. A. (arleton, 1892. ix +15y-232 p). 2 j,l.

No. 7. Systematic and alphabetir inilex to new speeies of North American phanerogams und pteridophytes pablished in 1592; by Josephine A. Clnrk. 1893. iii + $233-261+$ iii jp. 


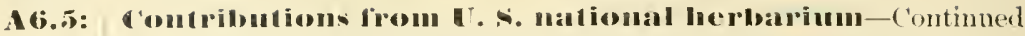

1 V. 1. Reports on collections amd miscellaneons japers-continued Contents-Continued

No. 8. Notes on some l'aeific (onst grasses, by George Vasey; Deseriptions of new or noteworthy grastes from $\tau^{*}$. S., by George Vasey; Descriptions of new grasses from Nexico. by Goorge Vasey; Jeseriptions of new plants from Texas and Colorado, by .J. is Holzinger; List of plants new to Florida, by J. M. Holzinger; Descriptions of three new plants, by I. N. Rose; List of liehens from Californin and Mexico, collected by Eilwarl l'almer from 1858 to 1892, by J. W. Eekfeldt. 1893. $\mathrm{iii}+265-292+\mathrm{ii}$ jp. 5 11.

Vo. 9. Report on collection of ylants made in States of Sonora and Colima, Mexico by Edward Palmer, in $1 \times 90$ and 1891 ; by $J$. N. Rose. 1895 . y+293-434 pp. $13 \mathrm{pl}$. [Title page and tables of (ontents and illustrations for volume 1, appended to this number. viti pp.]

V. 2. Botany of western Texas, a mannal of phanerogams and pteridophytes of western Texas; by John M. Coulter. 1891-94. contents:

No. 1. Hanual of phanerogams and pteridophytes of western Texas; Polypetalæ, by John M. Coulter. 1891. v+152+iv Tip. 1 pl.

No.2. Same, Gamopetalæe; by John .I. Conlter. 1892. $x+153-345$ pp. $2 \mathrm{pl}$.

No. 3. Same, Apetalæ, Ionoenyledome, Pteridophyta, by John Mf. Coulter. 1894 $r+347-585$ pp. (1 sheet following p. 430 .) [Title page alid table of contents for rolume, issued with this part. y $\mu$ w.]

[Volume 2 was reprinted by the Smitbsonian Institution, 1902, uncler title "Botany of western Texas."]

V. 3. Reports on collections, revisions of groups, and miscellaneous papers. $1892-1896$.

Contents:

Yo. 1. Monograph of grasses of U'. S. and British Amerien; by George Vasey. 1892. $\mathrm{xiv}+89 \mathrm{pp}$.

No.2. Preliminary revision of North Ameriean speeies of eactus, anhalonium, and lophophora; by John M. Coulter. 1891. iii +91-132+ii pp.

No. 3. Flora of sand hills of Nebraska; by P. A. Ryiberg. 1895. v+133-203 pp. $2 \mathrm{pl}$.

No.\%. Report on eollection of plants made by J. H. Sandberg and assistants in northern Idaho in 1892; by John M. Holzinger. 189.5. $\mathrm{v}+20.5-287+\mathrm{v}$ pl. $2 \mathrm{pl}$.

No. 5. Report on Mexican umbellifere, mostly from State of Oaxach, recently colleeted by C. G. l'ringle and t: W. Nelwon, by John N. Coulter and J. N. Rose: Descriptions on plants, mostly new, from Mexleo and U. S., by J. N. Rose. 1895. $\mathrm{v}+289-323+\mathrm{ii}$ pp. $12 \mathrm{pl}$.

No. 6. Botany of Yakutat Bay, Alaska, by Frederiek Yernon Coville; with field report, by Frederick Funstun. 1895. jii+325-353+ji pp.

No. 7. Preliminary revision of North American species of eehinocaetus, eereus, and opmntia: by John .1. Coulter. 1896. iii $+355-162+$ iv pp.

No. 8. Flora of Black Hills of South Dakota; by P. A. Rydberg. 1896. V+463$536+$ iv pD. 4 pl.

No. 9. Flora of sonthwestern Kansas, report on eollection of plants made by C. H. Thompson in 1893 , by A. S. Hiteheock; Crepis oecirlentalix, and its allies, by Frederick V. Coville; I'lants from Big Horn Mountains of Wroming, by J. N. Rose; Leibergia, a new genus of nmbellifere from Columbia River region, by John M. Coulter and J. N. Rose; Roseanthus, a new genus of eueurbitacex from Acapuleo, Nexieo, by Alfred Cogniaux. 1896. v+537-612 1\%, 8 I,]. [Title page and table of eontents for volmme issued with this part. vii pp.]

V. 4. Botany of Death Valley expedition; Report on botany of expedition sent out in 1891 by U. S. Department of Agriculture to make biological survey of region of Death Valley, California, by Frederick Vernon Coville. 1893. viii +363 pp. 22 pl. 1 map.

V. 5. Systematic, economic, and ecological investigations. 1897-1901. Contents:

No. 1. General report on butanieal survey of Cour d'Alene Mountains in Idaho during summer of 1895 ; by Joln B. Leiberg. $189 \overline{\%}$. $\mathrm{v}+55 \mathrm{pp}$. $1 \mathrm{pl}$.

No. 2. Plants used by Klamath Indians of Oregon; by Frederick V. Coville. 1897. $r+5 i-108+$ ii pp.

No. 3. Studies of Mexiean and Central Ameriean plants; by J. N. Rose. 1897. vii $+109-144+1$ pp. 16 [ll.

No. 4. Studies of Mlexiean and Central Ameriean plants-No. 2; ly . . N. Rose: Two new speeies of jlunt from northwestern U.S., by L. F. Henderson; II esperigenia, a new genus of unbellifore from lount Rainier, by J. I Conlter and J.N. Rose; Three new speeies of trudeveuntia from IT.S., by J. N. Rose; 'Treleasen, a new genus of eommelenacere, by J. N. Rose; Notes ou useful plants of Mexieo, by I. X. Rose. 1 199 . viii $145-259+$ viii jp. $17 \mathrm{pl}$

No. 5. Plant eovering of Oeracoke Islind, a study in the ecology of the North Carolina strand of vegetation; by Thomas If. Kearney, jr. 1900. ir+261319 H.p.

No. 6 . Report on totanieal survey of Dismal Swamp region; ly thomas $H$. Kearner. 1901. $\mathrm{x}+321-585+\mathrm{x}$ pr. $12 \mathrm{pl} .2$ maps. [Title page and table of contents for volume, issued with this part. $\mathrm{x}$ pp. I 


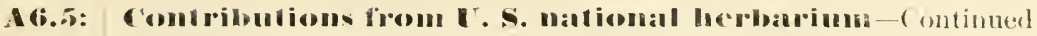

(i) V. i. Plant life of Alahama; distribution, modes of assoriation, ann adaptations of flora of A labama, with systenatice "atalogne of plants

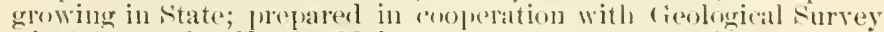
of Mlahanı; by Charles Molır. 1901. y2] l'p. I:3 pl.

V. T. Systematic and geographic botany and aboriginal uses of fuants. $1900-1902$. ('ontents:

No. 1. Monograph of North Ameriean umbellifera; by John M. Coulter and J. $\mathrm{X}$. Ruse. 1900, $256+$ vil

No. 2. Origin and distribution of Cocon palm: by 0. F. Cook. $1901 . v+257-293 \mathrm{pp}$.

Ai. S. Plants used hy Indians of Mendoeino County, Californin; by V. K. Chesnut. 1902. ri+29i-108+vii IP. 11. 10-21. [Title lage and contents for volume, 1900-1902. [p. 1-8, 409-42.]

A 6.5": C'onfributions from T. A. national berbarimu (separates)

[. few of the more important papers eontained in the varions numbers of this series are issued separately in pamphlet form. Refereneess to all the papers contained in this series will be fonnd under the proper headings in the index to this work.]

\section{M6.ti: Inventories}

1 No. 1. Foreign seeds and plants imported by section of seed and plant introduction, numbers $1-1000$. n. 1 . " 81 l'l).

2 No. 2. Foreign seeds and plants imported by section of seed and plant introduction, numbers 1001-1900. [July 5, 1899.] $94 \mathrm{pp}$.

3 To. 3. Seeds of sacelarine sorghums distributed hy soction of seed and plant introduction. [Ap 10, 18\%9.] 14 1'\%.

4 No. t. Cereals and forage plants collected in Russia hy M. A. Carleton for section of seed and plant introduction. [Ap. 15, 1899.] \& lph.

5 No. 5. Foreign seeds and plants imported by Department of Agriculture and for distribution through the section of seed and plant introduction. Numbers 1901-2700. Nov. 3, 18\%9. 62 p1.

6 So. 6. Foreigu seeds and plants collected in Austria, Italy, and Egypt by Barbour Lathrop and David G. Fairchild for section of seed and plant introduction. [Jan. 30, 1900.] 15 p.p.

7 So. 7. Foreign seeds and plants imported by Department of Agriculture; numbers 2701-:;400. Aug. 18, 1900. 86 pl.

8 To. 8. Seeds and plants imported for distribution in coöperation with agricultural experiment stations; numbers 3401-4350. Jan. 1, 1901. $106 \mathrm{pp}$.

\section{A 7. CHEMIS'TI Y HULEAT}

[Formerly Chemistry Iivision; (hanged] to Burean July 1, 1901. For historienl sketeh of Division, sce leurbook 1897 (A1.10:897), p. 76.]

\section{A7.1: Anmual reports}

1862 (Wetherill). ( $(\mathrm{n}$ A1.1:86i2, p. 508.)

1863 no report printed.

186t (Erni). (In A1.1:86t, p. 514.)

1865 (Lmi). (I $11.1: 865$, \%. 46.)

1866 Antisell). (In A1.1:866, 1). 45.)

1867 Antivell). (In $11.1: 867,1 \% 31$.

1868 (Antisell). (In A 1.1:868, 1).59.)

1869) (Antikell). (In A1.1:869, p. 65.)

1870 (Antisell). (In $\Lambda 1.1: 870,1.91$.

1871 (Brown). (In A1.1:871, ए. 89.)

1872 (Brown). (In A1.1:872, 1. 138.)

187:3 (M.Murtrie). $\quad(\ln$ A1.1:873, p. 170.)

1874 (Ic)lurtrie). (In $11.1: 874,1 \% 14$.

187.5 (Me:Mutrie). (111 A1.1:875, p. 141.)

1876 (NeNhrtrie). (111 A1.1:876, p. 46.)

1877 (Me.IIurtrie). (In $\wedge 1.1: 877$, p. 65.)

1878 (Collier). (In A1.1:878, p. 95.)

1879 (Collier). (In A 1.1:879, P. 35.) 
A.1: Anumal reports-Continued

1880 (Collier). (In A1.1:880, p. 37.)

1881 and 1852 (Collier). ( 1 n A 1.1:881-2, p. 379.)

1883 (Richardson). (In A1.1:883, p. 197.)

1884 (Wiley). (In A1.1:884, p. 19.)

1885 (Wiley). (In A1.1:885, p. 109.)

1886 (Wiley). (In A1.1:886, p. 277.)

1887 (Wiley). (1n A 1.1:887, D. 181.)

1888 (Wiley). (In A1.1:888, D. 221.)

889

890

891

892

893

\$96

897

898

899

900

901

902

A7.2:

Oi5

P96 ${ }^{1}$

$\mathrm{P} 96^{2}$

$196^{3}$

A 7.83:

1889 (Wiley), [1] +135-190 pp. (Also in A1.1:889, p. 135.)

1890 (Wiley), iii -133-192 pp. (Also in $\Lambda 1.1: 890$, p. 133.)

1891 (Wiley), [3] +143-190 pp. (Also in A1.1:891, p. 143.)

1892 (Wiley), iii + 123-152 pp. (Also in A1.1:892, p. 123.)

1893 (Wiley), iv +169-198 pp. (Also in A1.1:893, p. 169.)

1894 (Wiley). (In A1.1:894, p. 151.)

1895 (Wiley). (In A1.1:895, p. 145.)

1896 (Wiley), iii +9-14 pp. (Also in A1.1:896, p. 9.)

1897 (Wiley), $\mathrm{ii}+5 \mathrm{pp}$. (Also in A1.1:897, p. 1.)

1898 (Wiley), iii $+7-15$ pp. (Also in A1.1:898, p. 7.)

1899 (Wiley), iii $+25-42$ pp. (Also in $A 1.1: 899, \mathrm{p} .25$.)

1900 (Wiley), $\mathrm{ii}+17-26 \mathrm{pp}$. (Also in A1.1:900, p, 17.)

1901 (Wiley), $\mathrm{ii}+95-111$ pp. (Also in A1.1:901, p. 95.)

1902 (Wiley), $\mathrm{ii}+137-154$ pp. (Also in A1.1:902, p. 137.)

\section{General publications}

[Publications which originated in this Bureau, but which were published in a numbered series of the Secretary's oflice, or some other division of the Department, are entered only where such numbering places them, with references under the proper headings in the index to this work. Publications of this Bureau, issued only as Congressional documents, are noted in ehronological order in the Appendix to this work ]

Beet sugar industry. See A 1.2: B39.

Oils and fats. Methods for analysis of edible oils and fats, not including lairy products; by L. M. Tolman. [1901.] n. t. p. 15 pp.

Publications of Division of Chemistry. Dec. 20, 1899. n. t. p. 4 pp.

Same. May 1, 1901. n. t. p. 4 pl.

Same. Aug. 1, 1902. n. t. P. 6 pp.

\section{Bullelins}

No. 1. Investigation of composition of American wheat and corn; [by] Clifford Richardson. 1883.69 pp. 1 folled table.

[For errata to this Bulletin, sce A7.3:1, p. 98.]

No. 2. Diffusion, its application to sugar cane and record of experiments with sorghum in 1883; [1)y] H. W. Wiley. 1884. 36 pp. 2 pl.

No. 3. Northern sugar industry; a record of jts progress during season of 1883; [hy] H. W. Wiley. 188t. $118+2$ pp. 4 pl. 11 charts.

No. 4. Investigation of composition of American wheat and corn, $2 \mathrm{~d}$ report; [by] Clifford Richardson. 1884. 98 pp.

[Errata to Bulletin No. 1 on page 98.]

No. 5. Sugar industry of United States, cane sugar, beet sugar, sorghum sugar, maple sugar; by Harvey W. Wiley. 1885.224 pp. 16 pl. $1 \mathrm{map}$.

No. 6. Experiments with diffusion and carbonatation at Ottawa, Kansas, eampaign of 1885; by Harvey W. Wiley. $1885.20 \mathrm{pp}$.

No. 7. Methods of analysis of commercial tertilizers; proceedings [2d annual convention] Association of Official Agricultural Chemists, Sept. 1, 2, 1885 [edited by Chas. W. Dabney, jr.]. 1885. 49 pp.

No. 8. Methods and machinery for application of diffusion to extraction of sugar from sugar cane and sorghum, and for use of lime and carbonic and sulphurous acids in purifying the diffusion juices; [by] Harvey W. Wiley. 1886. 8i) pp. $22 \mathrm{pl}$.

No. 9. Third report on chemical composition and physical properties of American cereals, wheat, oats, barley, and rye; by Clifford Richardson. 1856. $82 \mathrm{pp}$. 
17.3:

10

\section{Bulletins-Continued}

No. 10. Principles and methods of soil analysis; [by] Edgar Richards. 1886. $66 \mathrm{pp}$.

No. 11. Experiments in manufacture of sugar at Magnolia Station, Lawrence, La., season of 1885-6. 2 d report; by Givilford L. Spencer. 1886. 26 pp. 1 pl.

No. 12. Methods of analysis of eommereial fertilizers; proceedings $3 \mathrm{~d}$ annual convention of Association of Official Agrieultural Chemists, Aug. 26, 27, 1886. $1886.59 \mathrm{pp}$.

No. 13. Foods and food adulterants; pt. 1. Dairy products. 1887. $128+$ iv pp. 12 pl.

Same, pt. 2. Spices and condiments; by Clifford Richardson. 1887. [1] $+129-259 \mathrm{pp} . \quad 16 \mathrm{pl}$.

Same, pt. 3. Fermented alcoholic beverages, malt liquors, wine, and cicler; by C. A. Crampton. 1887. [1]+261-399 pp.

Same, pt. 4. Lard and lard arlulterations; by H. W. Wiley. 1889. $[1]+403-554 \mathrm{pp} . \quad 10 \mathrm{pl}$.

Same, pt. 5. Baking powders; by C. A. Crampton. 1889. [1]+557$627 \mathrm{pp}$.

Same, pt. 6. Sngar, molasses and sirup, confections, honey, and beeswax, made under direction of H. W. Wiley, with collaboration of I1. A. Ituston, II. H. Nicholson, W. B. Rising, M. A. Scovell, S. P. Sharples, W. C. Stubbs, Shippen Wallace, F. G. Weichmann, H. A. Weber, and K. P. MeElroy. 1892. [1] $+631-874+\mathrm{ix}$ pp.

Same, pt. 7. Tea, coffee, and cocoa preparations; by Guilford I. Spencer with collaboration of Ervine E. Ewell. 1892. vii $+875-1014-$ vi pp. $9 \mathrm{pl}$.

Same, pt. 8. Camed vegetables; by K. P. McElroy with collaboration of W. D. Bigelow. 1893. vi+1015-1167+xii pp.

Same, pt. 9. Cereals and cereal products made under direction of $H . W$. Wiley, with collaboration of K. P. McElroy, IV. H. Krug, T. C. Treseot, W. D. Bigelow, and others. $1898 . \quad$ vii $+1169-1374 \mathrm{pp} .7 \mathrm{pl}$.

Same, pt. 10. Preserved meats; by W. D. Bigelow, with collaboration of Edward Mackay Chance, L. S. Munson, L. M. Tolman, and others. 1902. ix $+1375-1517 \mathrm{pp}$.

No. 14. Experiments at Fort Scott, Kansas, in manufacture of sugar from sorghum and sugar eanes in 1886; by $\mathrm{H}$. W. Wiley. 1887. $64 \mathrm{pp}$.

No. 15. Experiments in manufacture of sugar at Nagnolia Station, Lawrence, Lonisiana, season of 1886-87; 3d rp., by Guilford L. spencer. 1887. $35 \mathrm{pp}$.

No. 16. Methods of analysis of commereial fertilizers, feerling stuffs, and dairy products, adopted at 4 th annual convention of Association of Official Agrieultural Chemists, Aug. 16-18, 1887; edited by Clifford Richardson. $1887.80 \mathrm{pp} .4 \mathrm{pl}$.

No. 17. Experiments in manufacture of sugar from sorghum and sugar canes at Fort Scott, Kansas, Rio Grande, N. J., and Lawrence, La. 1888. $118 \mathrm{pp} .6 \mathrm{pl}$.

No. 18. Sugar-produeing plants; analyses made under direction of chemist; sorghum [at] Fort Scott, Kans., Rio Grande, N. J.; sugar cane [at Magnolia Station] Lawrence, La.; with study of data collected on sorghum and sugar eane. $1888.132 \mathrm{pp}$.

No. 19. Methods of analysis of commereial fertilizers, cattle foods, dairy products, sugar, and fermenter liquors, adopted at fifth anmual convention Association of Oflicial Agrienltural Chemists, held Aug. 9, 10, 1888; edited by Clifford Riehardson. 1888. 96 pp.

No. 20. Record of experiments in manufacture of sugar from sorghum at Rio Grande, N. J.; Kenner, La.; Conway Snrings, Donglass, and Sterling, Ks., 1888; by H. W. Wiley. 1889. $162 \mathrm{pp}$.

No. 21. Experiments in manufacture of sugar by diffusion at Magnolia Station, Lawrence, La., season of 1888-89; by Guilford L. Spencer. $1889.67 \mathrm{pl}$.

No. 22. Reeord of experiments at Des lignes sugar experiment station, Baldwin, La., season of 1888; by C. A. Crampton. 1859. 36 pp. 
A \%.:3: | IBullediu-Continuer

2:) No. 23. Experiments at sumar experiuent station on Calumet Plantation, Pattersonville, lal., [1888]; by Hubert Fdson. 1889. $42 \mathrm{pp}$.

24 No. 24. Proceedings 6 th anmmal ronvention Association of Official Agrieultural Chemists, Sept. 10-12, 1889, nethods of analysis of commercial fertilizers, cattle fuods, dairy products, and fermented liquors; edited hy Harvey W. Wiley. 1890. $235 \mathrm{pp}$.

No. 25. Popular treatise on extent and character of food adulterations; by Alex. J. Wedlerburn. 1890. $61 \mathrm{pp}$.

Vi. 26. Record of experiments in production of sugar from sorghum in 1889, at Cơlar Falls, Iowa; Rio (irande, N. J.; Morrisville, Va.; Kemner, La.; College Station, Md.; and Conway Springs, Attica, Medicine Lodge, Ness City, Iiberal, Arkalon, Meade, Minneola, and Sterling, Kans.; by II. W'. Wiley. 1890. 112 \%. 1 folded table.

Nı. 27. Sugar-beet industry; culture of sugar beet and manufaeture of beet sugar; ly H. W. Wiley. 1890. 262 JP. 12 jl.

Ni. 28. Proceedinus of $7 \mathrm{th}$ annual convention of Association of Official Agricultural Chemists, Ang. 28-30, 1890; methods of analysis of commercial fertilizers, foods, and feeding stuffs, dairy products, fermented liquors, and sugars; edited by Harvey W. Wiley. 1890. $238 \mathrm{PP}$.

No. 29. Record of experiments with sorghum in 1890 ; ly Harvey W. Wiley. 1891. 125 pp. 1 folded table.

No. 30. Exjeriments with sugar beets in 1890; by Harvey W. Wiley. 1891. $93 \mathrm{pp}$.

No. 31. Proeeedings of 8th annual eonvention of Association of Official Agricultural Chemists, Ang. 13-15, 1891; methods of analysis of commercial fertilizers, foods and feeding stuffs, dairy products, fermented liquors, and sugars; edited by Harvey W. Wiley. 1891. 253 pl'.

No. 32. Special report on extent and character of food adulterations, including State and other laws relating to foods and beverages; by Alex. J. Wedderburn. 1892. $17+\mathrm{pI}$.

No. 33. Experiments with sugar beets in 1891; by Harvey W. Wiley, with collaboration of Walter Maxwell, W. A. Henry, and others. 1892. $158 \mathrm{pp}$.

No. 34. Record of experiments with sorghum in 1891; by Harvey WV. Wiley, with collaboration of G. L. Spencer, A. A. Denton, and Wibray J. Thompson. $1892.132 \mathrm{pp}$.

No. 35. Proceedings of 9 th annual convention of Association of Official Agricultural Chemists, Aug. 25-27, 1892; edited by Harvey IV. Wiley. 1892. vi $+243+v i i-x v i i$.

No. 36. Hxperiments with sugar beets in 1892 ; by Harvey W. Wiley, with collaboration of Walter Maxwell. 1893. $74 \mathrm{Hp}$.

No. 37. Recorl of experiments with sorghum in 1892 ; by Harvey W. Wiley, with collaboration of A. A. Denton, Glen O'Brien, C. I. Himan, Wibray J. Tlompson, J. L. Fuelling, and Oma Carr. 1893. $100 \mathrm{pp}$.

No. 38. Proceedings of 10 th annual convention of Association of Official Agrieultural Chemists, Chicago, Ill., Aug. 24-26, 1893; edited by Harvey W. Wiley. 1893. vi+218+vii-xiv pp.

No. 39. Experiments with sugar beets in 1893; by Harvey W. Wiley, with eollaboration of Walter Maxwell. $1894.59 \mathrm{pp}$.

No. 40. Record of experiments with sorghum in 1893; by Harvey W. Wiley, with collaboration of Ona Carr and C. I. Hinman. 1894. $38 \mathrm{l} \mathrm{p}$.

No. 41. Extent and character of food and drug adulteration; by Alex. J. Wedderburn. 1894. $64 \mathrm{pl}$.

No. 42. Compilation of pharmacy and drug laws of the several states and territories; l,y Alex. J. Wedderburn. 1894. $152 \mathrm{pp}$.

No. 43. Proceedings of 11 th annual eonvention of Association of Official Agricultural Chemists, Aug. 23-25, 1894; edited by Harvey W. Wiley. 1894. $403 \mathrm{pp}$. 
A7.3: 44

Bulletins-Continued

No. 4t. Sweet cassava; its culture, properties, and uses; ly Harvey W. W'iley. 1894. $16 \mathrm{pp} .2 \mathrm{pl}$.

No. 45. Analyses of cereals collecterl at World's Columbian Exposition, and comparisons with other data; ly Harvey W. Wiley. 1895. $57 \mathrm{pp}$.

No. 46. Nlethols of analysis adopted loy Association of ()fficial Agricultural Chemists, Sept. 5- $\overline{7}$, 1895; edited by Harvey W. Wiley, with collaboration of L. L. Yan Slyke and W. D. Bigelow. 1895. 84 pp.

See velso A7.4:4.

No. 46, rev. ed. Nlethods of analysis adopted by Association of Official Agricultural Chemists, Nov. 11, 12, 14, 1898; edited by Harvey IT. Wiley. $1899.86 \mathrm{pp}$.

No. 47. Proceedings of 12 th annual convention of Association of Official Agricultural Chemists, Sept. 5-7, 1895; edited by Harvey W. Wiley. 1895. $172 \mathrm{pp}$.

No. 48. Zine in evaporated apples; by Harvey W. Wiley. $1896.38 \mathrm{pp}$.

No. 49. Proceedings 13th anmual convention Assoriation of Official Agricultural Chemists, Nov. 6, 7, 9, 1896; edited by 11. W. Wiley. 1897. $127 \mathrm{pp}$.

Same, [another print; letter of transmittal and list of illustrations omitted]. $127 \mathrm{pp}$.

See also A7.4:2 and 7 7.4:4.

No. 50. Composition of maize (Indian corn), includiug grain, meal, stalks, pith, fodder, and colss; compiled by H. W. Wiley. 189s. $31 \mathrm{pp}$.

See also for French abstract of this Bull., A 7.4:6.

No. 51. Proceedings of 14 th annual convention of Association of Official Agricultural Chemists, Oct. 26-28, 1897; edited by Harvey W. Wiley. 1898. $169 \mathrm{pp}$.

See also A7.4:4.

No. 52. Experiments with sugar beets in 1897 ; by Harvey W. Wiley. 1898. 165 pp. 2 maps.

Same, revised. 1899.165 pp. 2 maps.

No. 53. Chemical composition of carcasses of pigs; by Harvey IT. Wiley, with collaboration of E. E. Ewell, W. H. Krug, T. C. Trescot, and others. 1898. $80 \mathrm{pp}$.

No. 54. Investigation of analytical methods for distinguishing between nitrogen of proteids and that of simpler amids or amido-acids, by J. W. Mallet; with chapter on Separation of flesh bases from proteill matters by means of bromin, by H. W. Wiley. 1898. $30 \mathrm{pl}$.

No. 55. Fertilizing value of street sweepings; by Ervin E. Ewell. 1898. $19 \mathrm{pl}$.

No. 56. Proceedings of 15 th annual convention of Association of Official Agricultural Chemists, Washington, D. C., Nov. 11, 12, 14, 1898; editerl by Harvey W. Wiley. 1899. $140 \mathrm{pp}$.

No. 57. Proceedings of 16th annual convention of Association of Official Agricultural Chemists, San Francisco, July 5-7, 1899; edited by Harvey W. Wiley. $1899.130 \mathrm{pp}$.

No. 58. Manufacture of starch from potatoes and cassava; by llarrey W. Wiley. $1900.48 \mathrm{pp} .8 \mathrm{pl}$.

No. 59. Composition of American wines; by W. D. Bigelow. 1900. $76 \mathrm{pp}$. No. 60. Sunflower plant, its cultivation, composition amul uses; by Ilarvey W. Wiley. 1901. 31 pp. 1 pl.

No. 61. Pure-food laws of European conntries affecting American exports; by W. D. Bigelow. 1901. $39 \mathrm{pp}$.

No. 62. Proceedings of 17 th annual convention Assoriation of Oflicial Agricultural Chemists, Washington, Nov. 16, 17, 19, 1900; edited by H. W. Wiley, 1901. $16.3 \mathrm{pp} .2 \mathrm{pl}$.

No. 63. Exhibit of Burean at Pan-American Exposition, Buffalo, N. Y., 1901; by E. E. Ewell, W. D. Bigelow, and Logan Waller Page. 1901. 29 pp. 4 pl.

No. 64. Influence of environment upon comprosition of sugall beet; by Harvey W. Wiley. 1901. $32 \mathrm{lp}$. 


\section{Tables}

Classifles. tlon 110.

17.3 :

bis

66

67

68

$69^{1}$

$69^{2}$

$69^{3}$

$69^{4}$

$69^{5}$

70

А 7.:3 $\%$

A.. C: Cireular:

1

\section{BBullerins-Continued}

No. 6in. Provisional methods for analysis of foods adopted by Association of Oflicial Agricultural Chemists, Nov. 14-16, 1901; editerl by H. W. Wiley, with collaburation of W. D. Bigelow. 1902. $169 \mathrm{pp}$.

No. 66. Fruits and fruit products, chemical and microscopical examination; [Pt. 1], by I. S. Mumson [and] L. M. Tolman; [Pt. 2, by] Burton J. Howard. 1902. $114 \mathrm{pp} .12 \mathrm{jl}$.

No. 67. Proceedings of 18 th annual convention of Association of Official Agricultural Chemists, held at Washington, D. C., Nov. 14-16, 1901; edited by Harvey W. Wiley. 1902. 184 I'p. 1 por.

No. 68. Chemical composition of insecticides and fungicides, with an account of methods of analysis employed; by J. K. Haywood, in cooperation with Division of Entomology. 1902. 62 Pp.

No. 69. P't. 1. Foods and food control, [no.] 1; by W. D. Bigelow. 1902. $\mathrm{vi}+93 \mathrm{pp}$.

Same, It. 2, [no.] 2. 1902. vi+95-187 pp.

Same, Pt. 3, [no.] 3. 1902. vi $189-272$ Pp.

Same, Pt. 4, [no.] 4. 1902. vi $+273-372$ Pp.

Same, Pt. 5, [no.] 5. 1902. vi $+373-461 \mathrm{pp}$.

No. 70 . Manufacture of table sirups from sugar cane; by H. W. Wiley. 1902. $32 \mathrm{pp} .10 \mathrm{pl}$.

\section{IBullelius (separates)}

[A few of the papers contained in the Bulletins were issued separately in pamphlet form. Referenees to all the papers will be found under their proper headings in the index to this work.]

No. 1. Mannfacture of sorghm sirup; hy G. L. Spencer. July 15, 1894. n. t. p. 3 pl).

No. 2. Changes in and additions to methods of analysis arlopted at 13th annual meeting of Association of Ofincial Agricultural Chemists. Dec. $12,1896$. n. t. p. 6 lp.

No. 3. Needed reforms in fertilizer inspection; by H. J. Wheeler, H. P. Armsby, C. D. Woods, H. W. Wiley. July 8, 1897. n. t. p. 3 pp. Same, revised. n. d. n. t. p. 4 pp.

Same, 2 d rev. ed. Mar. 20, 1902 . n. t. P. 4 pp.

No. 4 (to accompany bulletin 46). Changes in and additions to methods of analysis adopterl at $13 \mathrm{th}$ and 14 th annual meetings Association of Official Agrieultural Chemists. Dee. 11, 1897. n. t. p. $10 \mathrm{pp}$.

No. 5. Chemical examination of eanned meats; by H. W. Wiley. Jan. 18, 1899. n. t. p. 7 pp.

No. 6. Composition chimique du maïs et de ses produits; par MI. H. W. Wiley. June 22, 1900. (French abstract of Chem. Bull. 50, Composition of maize; by H. W. Wiley.) July 21, 1900. $15 \mathrm{pp}$.

No. 7. Outline of work on foods and feeding stuffs for 1901; by William H. Krug. Apr. 29, 1901 . n. t. p. 3 pp.

Same, revised ed. Apr. 18, 1902. (Title changerl to "Amended methods adopted at 18th annual convention of Association of Official Agricultural Chemists.") n. t. p. 3 pp.

No. 8. Official method for analysis of tanning materials. Nov. 19, 1901. n. t. p. 2 pp.

Same, Dee. 18, 1902 . n. t. p. 2 pp.

No. 9. l'lan for eooperating in study of available plant food; by C. C. Moore. Jan. 3, 1902. n. t. p. 8 plp.

No. 10. Methods for analysis of insecticides and fungieides; by J. K. Haywood. Mar. 7, 1902. n. t. p. S pp.

\section{A*. ENTOMOLOGICAL COMMISEION}

[Formerly under Interior Department, sce I 26.]

\section{A.1: Inmual reports}

1st annual report on Rocky Mfountain locust. Issued as a publication of the Geological and Geographical Survey of the Territories (Hayden).

See I26.1:1. 
A8.3:

A 8.4:

\section{Circulars}

[None issued under Agriculture Derartment. Twelve circulars issued under Interior Department. See I26:1].

\section{A9. ENTOMILOCE DIVISION}

[For historical sketch of Division, sce Yearbook 1897 (A1.10:897), p. 84.]

\section{A9.1: Annual reports}

REPORT OF ENTONOLOGIST

1863 (Glover). (In A1.1:863, p. 561.)

186+ (Glover). (In A1.1:864, P. 540.)

1865 (Glover). (In A1.1:865, p. 33.)

1866 (Glover). (In A1.1:866, p. 27.)

1867 (Glover). (In A 1.1:867, ग. 58.)

1868 (Glover). Title: Foorls and habits of beetles. (In A1.1:868, 1. 7s.)

1869 (Glover). (In A1.1:869, p. 60.)

Report of ENtonologist axi ('Trator OF M USEUN

1870 (Glover). (In A 1.1:870, p. 65.)

1871 (Glover). (In A1.1:871, p. 69.)

1872 (Glover). (In A l.1:872, p. 112.)

1873 [Glover]. (In A1.1:873, p. 152.)

1874 (Glover). (In A1.1:874, 1.122 .)

RePORT UF ExTOMOLOGIST

1875 (Glover). (In A1.1:875, p. 11t.)

REPORT OF ENTOMOLOGist ANI CURATOR of MUSEum

1876 (Glover). (In A 1.1:876, p. 17.)

1877 (Glover). (In $A 1.1: 877,1.89$.

1878 (none issued).

REPORT OF FNTOMOLOGIST

1879 (Riley), from June, 1878, to Mar. 1, 1879. 52+[1] pp. 7 pl. (Also in $A 1.1: 878$, p. 207 .)

1880 (Comstock), submitted June 30, 1880. (In A1.1:879, p. 185.)

8811881 (Comstock), submitted June 15, 1881. iv+235-373+iv pl. 224 pl. (Also in $\mathrm{A} 1.1: 880, \mathrm{\mu} .235$.) 
19.1: Inmaal reports-Continued

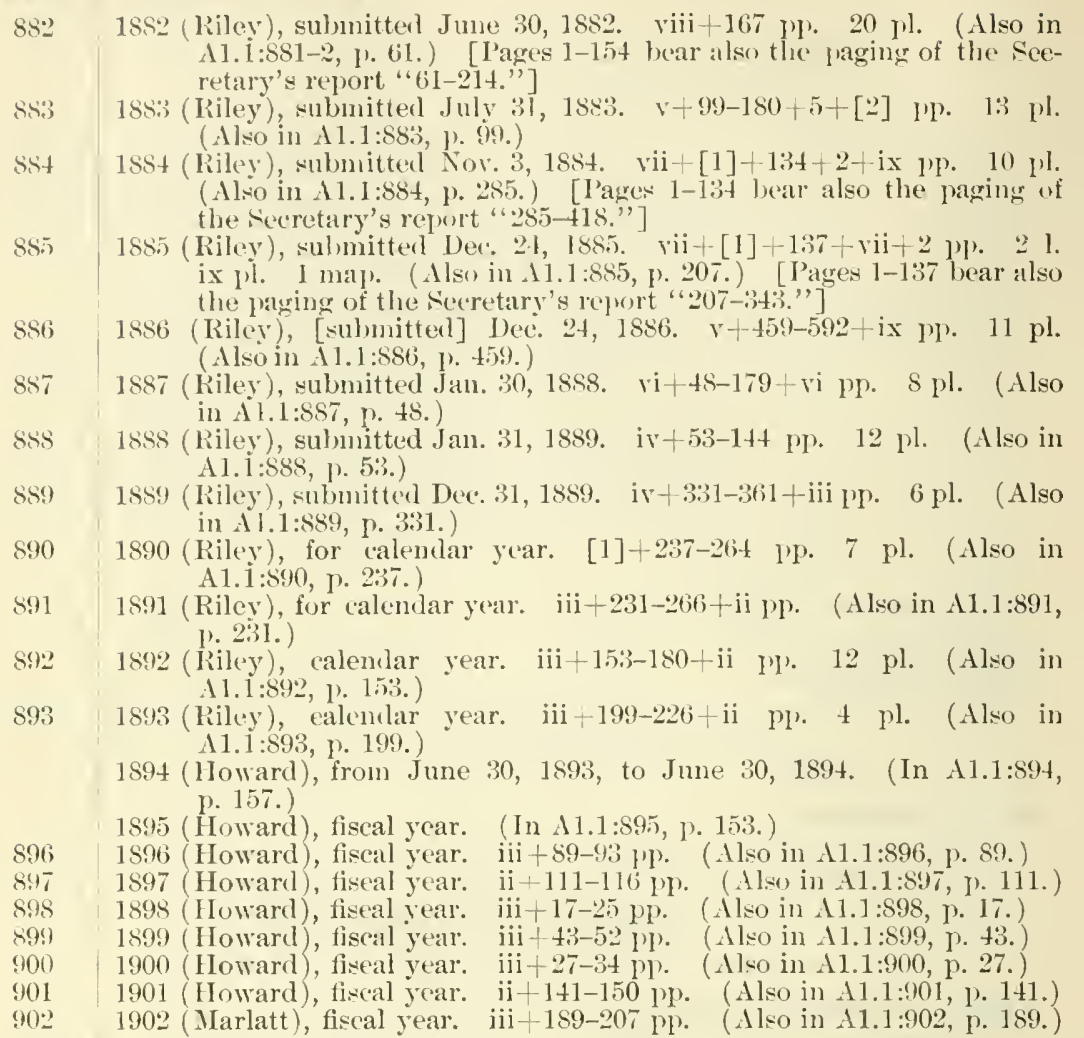

B4t $7^{1-3}$ Bibliograply of nore important contributions to American conomic ('ntomology; prepared by Sammel lfenshaw. L'ts. 1-3, more important writings of Benjamin Danu Walsh and Charles Valentine Riley. 1890. [1] +45t pp.

Contents:

[Publications which originated in this Division, but which were published in a numbered series of the Secretary's Otliee, or some other division of the Department. are entered only where such numbering places them, with references under the proper headings in the Index to this work. Publications of the Division, issned only as Congresional doeuments, a re noted in chronologieal order in the Appendix to this work.]

l't. 1. More important writings of Benjamin Dann Walsh. $1859.50 \mathrm{pp}$.

Pt.2. Hore important joint wrilings of B. D. Walsh and C. V. Riley. 1ss9. pp. 51-96. Pt. 3. Jore important writings ol Charles Valentine Riley. 1889. pp. 97-371.

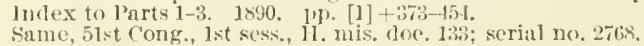

$34^{+}$Same. I't. 4. More important writings of (iovermment and State entomologists, and of other contributors to literature of Anericau Economie Entomology. A-K. $1895.167 \mathrm{pp}$.

l3475 Same. T't. 5. L-\%. 189\%. $179 \%$ \%.

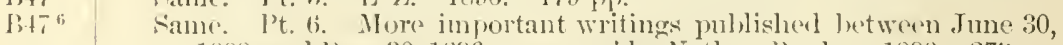
1888, and bec. 30, 1896; prepared hy Xathan banks. 1898. $273 \mathrm{pp}$.

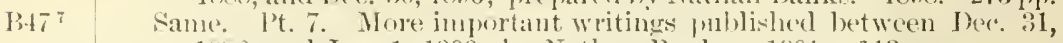
1596, ankl Jan. 1, 1900; by Nathan Panks. 1901. $113 \mu$ \%.

C82 Cotton inserets. Report upon cotton insects; by J. Henry Comstock. 1879. $\mathrm{r}+511 \mathrm{pL} .: \mathrm{pl}$. 


\section{2: Gencral pablications-Continued}

N.2 New Orleans Expusition. Catalogue of exhibit of economic entomology at New Orleans World's Inlustrial and Cotton Centennial Expowtion, 18st-5. 188. $9 \%$ pI.

Or 1 Orange. lepert on insects affecting the orange and other plants of eitrus family, with practical suggestions for their control or extermination; by H. (i. Hubbard. 18s5. 227 pp. $14 \mathrm{pl}$.

Same, 4 Sth Cong., 21 sess., H. mis. doc. 40 ; rerial no. 2326 .

[Periodical eicada, or seventeen-year locust; by C. V. Riley.] May, 1894. n. t. p. [3] pp. $4^{\circ}$

A9.3: Bulletins (old series)

$1^{1}$ No. 1. Reports of experiments, chiefly with kerosene, upon insects injurously affecting orange tree and eotton plant. $1883.62 \mathrm{pp}$.

$1^{2} \quad$ Same, $2 \mathrm{l}$ edition. $1883.62 \mathrm{pp}$.

$2^{1}$ No. 2. Reports and observations on Rocky $\mathbf{M}$ ountain locust and chinch bug, with extracts from correspondence of the Division on miscellaneous insects. $1853.36 \mathrm{pp}$.

Same, $2 \mathrm{l}$ edition. $1883.36 \mathrm{pp}$.

No.3. Reports of ubservations and experimentsin practical work of the Division, marle uncler direction of the Entomologist. $1883.75 \mathrm{pp} .3 \mathrm{pl}$.

No. t. Reports of observations and experiments in practical work of the Division, made muler direction of the Entomologist, with extracts from correspondence on miscellaneous insects. $1884.102 \mathrm{pp}$.

No. 5. Descriptions of North American chalcidide, from collections of Department of Agriculture and C. V. Riley, with biological notes. [1st paper], with list of described North American speeies of this family; by 1. . O. Howard. $1885.47 \mathrm{pp}$.

$6^{1}$ No. 6. Imported elm leaf beetle; its habits and natural history, and means of counteracting its injuries. $1885.20 \mathrm{pp} . \quad 1 \mathrm{pl}$.

$6^{2} \quad$ Same, 2d ed. 1891. 21 pp. 1 pl.

INo. 7. Pediculi and mallophaga affecting man and lower animals; by Herbert Osborn. 1891. $5 t^{i} \mathrm{pp}$.

No. 8. Periodical cicarla; an account of Cicada septemdecim ancl its tredecin race, with chronology of broods known; by Charles V. Riley.* Same, 2d edition. 1885. $46 \mathrm{pp}$.

No. 9. Mulberry silk-worm; being a manual of instructions in silk culture; by C. Y. Kiley. 6th rev. ed. 1886 . vii $+65 \mathrm{pl}$. 2 pl.

Same, 7 th rev. ed. 1888 . vii $+65 \mathrm{pp}$. $2 \mathrm{pl}$. [For editions 1 to 5 , see A1.6:11.]

No. 10. Our shade trees and their insect defoliators, being a consideration of four most injurions species which affect trees of the Capital, with means of destroying them; by C. V. Riley. 1887. $199 \mathrm{PJ}$.

No. 11. Reports of experiments with varions insecticile substances, chiefly upon insects affecting garden crojs. $1886.34 \mathrm{pp}$.

No. 12. Miscellaneons notes on work of Division of Entomology for season of 1885.1886 . th $\mathrm{lp}, 1 \mathrm{pl}$.

No. 13. Reports of obervations and experiments in practical work of the Division, marle under direction of the Entomologist. 1887. $78 \mathrm{pp}$.

No. 14. Reports of observations and experinents in pratical work of the Division. 1887. [Adlitional to 20. 13.] (i2 [N. 1 pl.

No. 15. Icerya or fluted soale, otherwise known as cottony cushion-sale. 1887. $40 \mathrm{pp}$.

No. 16. Entomological writings of Alphens spring Packard; by Samuel Henshaw. 1887. $49 \mathrm{pP}$.

No. 17. Chinch bug; general summary of its history, habits, enemies, and of remedies and preventives to be nsed ayainst it; by $I_{\text {s. }} \mathrm{O}$. Howard. 1888. [1] $48 \mathrm{pp}$.

No. 18. Life and entomologieal work of Townend Glover; by Charles Richards Dodge. 1888. $68 \mathrm{pl} .2 \mathrm{pl}$.

19 No. 19. Enumeration of pulblished synopser, catalognes, and lists of Nortl American insects, with other information intencled to assist the student of American entomology. 1888. $77 \mathrm{pp}$. 


\section{A). ENTOVOLOGX DIVISEON-Continued}

A9.3: IBulletins (old series) - Continued

20 To. 20. Root-knot disease of peach, wrange, and other plants in Florida, ilue to work of anguillula; by J. ('. Neal. $1889.31 \mathrm{pp} .21 \mathrm{pl}$.

$21^{1}$ To. 21. Report of trip to Anstralia to investigate natural enemies of fluted scale; by Albert Koebele. 1890. 32 pp.

$21^{2}$ simes, reve eil. 1890 . 320 pp.

22.2 No. 22. Reports of observations and experiments in practical work of the [ivision, made under diretion of the Entomologist. $1890.110 \mathrm{pp}$.

2:) No. 2\%. Reports of observations and experiments in practical work of the Division, under direction of the Entomologist. 1891. $83 \mathrm{pp}$.

24 No. 24. Boll worm of cotton, report of progress in snpplementary investigation of this insect; by F. W. Mally. 1891. $50 \mathrm{pp}$.

25) No. 25. Destructive locusts, a popular consideration of a few of the more injurious locusts (or "grasshoppers") of U. S., with best means of destroying them; by C. I. Riley. 1891. 62 pl. $12 \mathrm{pl}$. 1 map.

No. 26. Reports of observations and experiments in practical work of the Division, marle under direction of the Entomologist. $1892.95 \mathrm{pp}$.

To. 27. Reports on damage by destructive locusts during 1891. 1892. $6+1 p$.

No. 28. More destructive locusts of America north of Mexico; by Lawrence Bruner. 1893. $40 \mathrm{pp}$.

No. 29. Boll worm of cotton; by F. W. Mally. 1893. $73 \mathrm{pl} .2 \mathrm{pl}$.

No. 30. Reports of observations and experiments in practical work of the Division, made umler direction of the Entomologist. 1893. $67 \mathrm{pp}$.

No. 31. Catalogue of exhibit of economic entomology at World's Columbian Exposition, Chieago, Ill., 1893. 1893. 121 pp.

No. 32. Reports of observations and experiments in practical work of the Division, made under direction of the Entomologist. 1894. $59 \mathrm{pp}$.

No. 33. Legislation against injurious insects, compilation of laws and regulations in United States and British Columbia; by L. O. Howard. 1895. $46 \mathrm{pl}$.

\section{A9.1: Cireulars (first series)}

[NoTE.-This series is described as " a miscellancous and indifferent series, hardly worthy to be entitled to the dignity of being considered publications." The whole number exceeded 40 , nearly all being circular letters, and of which Nos, 1 , 18 , and 22 are the only ones known to exist.]

1 No. 1 c. [Relating to silk worm eggs.] n. d. (Circ.)

18 No. 18. [Establishment of branch of economic ornithology.] July 1, 1885. (Circ.)

22 No. 22. [Bee culture.] July 28, 1885. (Cire.)

\section{A.5: Circulars, wecond series}

1 No. 1. Condensed information concerning some of the more important insecticirles. May, 1891. $7 \mathrm{pp}$.

$2^{1}$ Yo. 2. Hop plant-lonse, and the remedies to be used against it. June, 1891. $7 \mathrm{pp} . \quad 1 \mathrm{pl}$.

\section{$2^{2} \quad$ Same, [new elt. Aug. 1899.] 7 pp. 1 pl.}

No. 3. Important enemy to fruit trees; San Jose scale, its appearance in Eastern U. S.; measures to be taken to prevent its spreal and to destroy it; by L. O. Howard. April 4, 1S93. n. t. p. $10 \mathrm{pp}$.

No. 4. Army worm, circular relative to; by L. O. Howard. June 16, 1894. n. t. p. 5 pp.

No. 5. Carpet beetle or "Buffalo moth"; hy L. O. Howard. Sept. 8, 1894. u. t. p. \& pp.

To. 6. Mexican cotton-boll weevil; by L. O. Howard. April 2, 1895. n. t. \%. $5 \mathrm{pp}$.

same, [Spanish ed.] $6 \mathrm{pH}$.

[For revision, see A9.5:14.]

No. 7. Pear-tree puylla; by C. L. Marlatt. May 1, 1895 . n. t. p. 8 pp.

No. 8. Imported elim leaf-beetle; by C. I. Marlatt. May 23,1895 . n.t. p. + pll.

9 No. 9. Canker-worms; by D. W. Coquillett. May 24, 1895. n. t. p. + pli). 
A9.5: | Circulars, secend series-Continued

No. 10. Ilarlexuin cabbage bug, or Calico lack; hy L. (). Howare. May 24,1895 . n. t. 1 . 2 ' 1 p.

No. 11. Rose-chafer; by F. H. Chittenden. Iay 21, 18\%. n.t. 1) 4 pp.

No. 12. Hessian fly; by C. I. Marlatt. July 26, 1895. 11. t. p. 4 pp. Same, rev. ed. Apr. 13, 1900. n. t. 1." 4 pl.

No. 13. Mosquitoes and fleas; by L. O. Howard. Feh. 1, 1896. n. t. p. 4 PP.

same, rev. ell. Nov. 15, 1897. n. t. p. 5 pp.

No. 14. (Revision of No. 6.) Mexican cotton-boll wevil; by L. O. Howard. Feb. 12, 1896. n. t. p. 8 pp.

Same, [Spanish edition.] 11. t. p. S pp.

[For revision, see A9.5:18.]

Yo. 15. General work against insects which defoliate shade trees in cities and towns; by L. (). Howard. Mar. 6, 1896. n. t. P. 4 \%p.

[In advanee, from article "Shade-tree insect problem in Eastern U. S.," published in Yearbook for 1895.]

No. 16. Larger corn stalk-borer; by L. O. IIoward. Ang. 13, 1896. n. t. p. $3 \mathrm{pp}$.

No. 17. Peach-tree borer; by C. L. Marlatt. Sept. 30, 1896. ก. t. p. $4 \mathrm{pl}$.

No. 18. Mexican cotton-boll weevil. Revision of No. 14. Feb. 4, 1897. n. t. p. 8 pp.

Same. [Spanish edition.] n.t. p. 10 pp.

Same. [German edition.] n. t. p. 11 pp.

No. 19. Clover mite; by C. L. Marlatt. Mar. 5, 1897. n. t. p. $\quad$ t pp.

Same, 2d ed. July 19, 1897. n. t. p. 4 pp.

No. 20. Woolly aphis of apple; by (C. L. Marlatt. Mar. 15, 1897. n. t. p. $6 \mathrm{pp}$.

No. 21. Strawberry weevil; by F. H. Chittenden. Mar. 18, 1897. n. t. p. $7 \mathrm{pp}$.

No. 22. Periodical cicada in 1897; by E. A. Sehwarz. May 1, 1897. n. t. p. 4 pp.

No. 23. Buffalo tree-hopper; by C. L. Marlatt. May 10, 1897. n. t. p. $4 \mathrm{pp}$.

No. 24. Two-lined chestnut borer; by F. H. Chittenden. July 14, 1897. n. t. p. 8 pp.

No. 25. Ox warble; by C. L. Narlatt. July 19, 1897. n. t. p. 10 pp.

No. 26. Pear slug; by C. L. Marlatt. Aug. 28, 1897. n. t. p. 7 pp.

No. 27. Mexiean cotton-boll weevil in 1897; by L. O. Howard. Dec. 31, 1897. n. t. p. 7 pP.

No. 28. Box-elder plant-bug; by I. O. Howard. Jan. 8, 1898. 1]. t. p. 3 pp.

No. 29. Fruit-tree bark-beetle; ly F. H. Chittenden. Mar. 25, 1898. n. t. p. 8 pp.

No. 30. P'eriodical cicaula in 1898; by E. A. Selıwarz. Apr. 1, 1898. n. t. p. 3 p'p.

No. 31. Striperl cucumber beetle; by F. H. Chittenden. Apr. 26, 1898. n. t. p. 7 Pp.

No. 32. larger apple-tree borers; by F. II. Chittenden. July 1, 1898. 11. t. p. 12 p!

Same, revised exition. Ang. 30, 1902. n. t. \%. 12 pp.

No. 33. Remedial work against Irexican cotton-boll weevil; by L. O. Howard. July 1, 1898. n. t. p. 6 jp.

No. 34. House ants; by C. L. Marlatt. July 6, 1898. n. t. p. 4 p).

No. 35. House flies; by 1. O. Howard. July 11, 1898. 11. t. p. 8 pl.

No. 36. True clothes noths; by C. L. Marlatt. July 18, 1898 . n. t. p. 8 pp.

No. 37. Use of hydrocyanie aeirl gas for fumigating greenhouses and coli? frames; by Albert F. Woods and P. H. Dorsett. Jan. 10, 1899. n. t. ए. 10 p.

Same, corrected print. [Compare page 8.] .Jan. 10, 1899. 11. t. 1. $10 \mathrm{pp}$. 


\section{E.TOMOLOGI DVIISION-Continuer}

I9.5:

25

\section{Circalars, sceomal serics-Continued}

No. 3s. squash-vine borer; by F. 11. Chittematen. Apr. 22, 1899. n. t. p. 6 pl.

Fo. 39. Common squash bur; ly F. 11. Chittenden. Apr. 27, 1899. n. t. 1). 5 pl.

No. 40. How to distinguish different mosquitoes of North Ameriea; by L. O. Howarl [with symontinal table of mosquitoes; by D. W. Coquillett]. Feb. 20, 1940. n. t. 1. T Pr.

Same [ [1901], "d print. 11. t. p. 8 pl).

No. 41. Regulations of foreign wovernuments regarding importation of American plants, trees, and fruits; by L. O. Howard. Aug. 2t, 1900. 11. t. p. 4 pp.

No. 42. How to control Sin Jose scale; by C. 1. Marlatt. Oet. 22, 1900. n. t. 1.6 llp. $^{2}$

same, revised. Hav 17, 1902.

No. 43. Destructive green pea louse; by F. II. Chittenden. May 23, 1901. n. t. p. $8 \mathrm{pl}$.

No. 44. P'eriodical cicada in 1902; Jy W. D. Hunter. Mar. 13, 1902. n. t. p. + p.

No. 45. New nomenclature for broorls of periorlical cicada; by C. I. Marlatt. May 1, 1902. 12. t. p. 8 pp.

No. 46. Hydrocyanic-acil gas against household invects; by L. O. Howard. May 22, 1902. 11. t. p. + p.p.

No. 47. The bedbug; Ly C. L. Marlatt. June 15, 1902. n. t. p. 8 pp.

No. 48. Honse centiperle; ly C. L. Marlatt. June 10, 1902. n.t. p. 4 pp. No. 49. Silver fish; by (. . L. Marlatt. June 20, 1902. 4 pl.

No. 50. White ant; by C. I. Marlatt. June 30,1902 . n. t. p. S pp.

No. 51. Cockroaches; by C. L. Marlatt. June 23, 1902. n. t. p. 15 pp.

\section{Bulletius, new series}

No. 1. Honeybee, a manual of instruction in apiculture; by Frank Benton. 1895. $118 \mathrm{pp} .12 \mathrm{pl}$.

Same, rev. ed. 1896.118 pp. $12 \mathrm{pl}$.

Same, 3d ed. 1899. 118 pp. 12 pl.

Same, 5tth Cong., 1nt sess., II. Ioc. 359 ; serial no. 3435 .

No. 2. Proceedings of 7 th annual meeting of Association of Economic Entomologists [Springfield, Mass., 1895]. 1895. 100 pp.

No. 3. San Jose seale, ity occurrences in U. S., with full account of its life history and remedies to be used against it; by L. O. Howard and C. L. Marlatt. 1896. $80 \mathrm{pp}$.

No. 4. Principal houseliold insects of U. S., by L. O. Iloward and C. L, Marlatt; with chapter on inseets affecting dry vegetable foods, by F. H. Chittenden. 1896. $130 \mathrm{pp}$.

Same, revised edition. 1896 [1899]. $131 \mathrm{pp}$.

No. $\bar{~}$. Insects affecting domestic animals, an aceount of species of importance in North America, with mention of related forms occurring on other animals; by Herbert Osborn. $1896.302 \mathrm{pp} .5 \mathrm{pl}$.

No. 6. Proceclings of 8 th annual meeting Association of Feonomic Entomologists. 18.96. $100 \mathrm{pp}$.

No. 7. Some niscellaneous results of work of I,ivision of Entomology [1]. $1897.87 \mathrm{pP}$.

No. 8. Some little known insects affecting stored vegetable produets: a collection of articles detailing certain original olservations made upon insects of this class; by F. 11. Chittenden. 1897. $45 \mathrm{pp}$.

No. 9. Proceedings 9th annual meeting of Association of Feonomie Entomologists. 1897. $87 \mathrm{pl}$.

No. 10. Some miscellaneous results of work of Division of Entomology [2]. 1598. $99 \mathrm{pp}$.

No. 11. Gipsy moth in America, a summary account of introduction and spread of Porthetrial dispar in Massachusetts and of efforts made to repress and exterminate it; by L. O. Howard. $1897.39 \mathrm{pp}$.

To. 12. San Jose seale, 1896-97; by L. O. Howard. 1898. 31 pp. 
19.6:

\section{Bulletins, new series-Continuel}

No. 13. Recent laws against injurions inserts in Forth America, with laws relative to fonl hrool; compiled hy L. O. Iloward. 1898. 6s p.

No. 14. Periodical ciodadi, an aceount of Cicadat septendecin, its natural enemies and means of furerenting its injur, with summary of distribution of different brools; by (: I. ilarlatt. 1S9s. $14 \mathrm{pp}$. 1 leaf. 4 ll.

No. 15. Chinch bug, its probable origin and cliffusion, its habits and development, natmal checks and remedial and preventive measures, with nention of habits of an allied European species; by F. II. Welster. 1898. 8:2 l丷.

To. 16. Hessian fly in Tnited States; by Herbert Osborn. 1898. 5s pp. i) pl.

No. 17. Proceelings 10th annual nnceting Association of Economic Entomologrists. 1898. $104 \mathrm{pp}$.

No. 18. Some miscellaneous results of work of Division of Entomology, 3. 1898. $101 \mathrm{pp}$.

No. 19. Some insects injurions to garden and orehard erops; by F. H. Chittenden. 1899. $99 \mathrm{pp}$.

No. 20. Proceedings 11th annual meeting Association of Economic Entomologists. $1899.111 \mathrm{pp}$.

No. 21. Preliminary report on insect enemies of forests in northwest, an aceount of results gained from a reconnoissance trip made in spring and early summer of 1899 ; by A. D. Hopkins. 1899. $27 \mathrm{pp}$.

No. 22. Some miscellaneous results of work of Division of Entomology, 4. 1900. $109 \mathrm{pp}$.

To. 23. Some insects injurious to garlen crops; hy F. H. Chittenden. 1900. $92 \mathrm{pp}$.

No. 24. List of works on North Americun entomology; ompilesl by Nathan Banks. $1900.95 \mathrm{pl}$.

No. 25. Notes on mosquitoes of [C. S., giving some account of their strueture and biologr, with remarks on remedies; by L. O. Howard. 1900. 70 pp.

No. 26. Proceerlings 12th annual meeting Association of Feonomic Fintomologists. $1900.102 \mathrm{pp} .2 \mathrm{pl}$.

To. 27. Some insects injurious to riolet, rove, and other omamental plants; by F. H. (hittenclen. 1901. 114 pr. 4 pl.

Same, revieed ell. 1901. $114 \mathrm{pp} .4 \mathrm{pl}$.

No. 28. Insert enemies of spruce in northeast, a popmlar account of results of special investigations, with recommentations for preventing losses; ly A. D). Topkins. 1901. 80 pl. 16 p.1.

Ar. 29. Fall army worm and variegated entworm; by F. H. Chittenden. 1:01. $64 \mathrm{pp}$.

No. :30. Some nincellaneous results of work of bivision of Fintomology, 5. $1901.98 \mathrm{pp} .2 \mathrm{pl}$.

No. 31. Proceenlings of 13th annual meeting of Association of Eeonomic Entomologists [1901]. 1902. 103\% $1 \%$. $21 \%$.

Fi). 32. Insect enemies of pine in Plack IIills forest Reserve, an acrount of results of special investigations, with rerommendations for preventing losses; by A. D. Hopkins. 1902. $24 \mathrm{pp} .7 \mathrm{pl}$.

To. 33. Sone insects injurions to vegetable (rops; hy F. Jl. Chittenten. 1902. $117 \mathrm{PP}$.

No. :H. Principal insects liable to he distributerl on nursery stock; hy Nathan lianks. 1902. $46 \mathrm{pp}$.

No. 35. Report orf corlling-moth investigations in northwest during 1:401; by C. B. Simpon. 1902. 29 TH. 5 pl.

No. 36. An index to Bulletins Nos. 1-30 (new series 1s:36-1901) of l)ivision of Entomology; compiled by Natlam lianks. 19(1)2. (it pp.

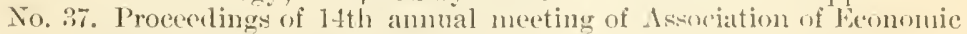
Entomologints. $1902.125 \mathrm{pl} \% 1 \mathrm{pl}$.

No. 38. Some miscellaneons rewlt of work of llivision of Entomology, 6. 1902. 110 10. 2 211. 


\section{6i": IBulletins, new series (separates)}

[A few of the more important papers contained in the bulletins were issned separately. Referenees to all the papers will be found under their proper headings in the Index to $1 \mathrm{~b}$ is work.]

\section{7: Inscet life}

[In indexing these volumes for this work the "notes" were all disregarded.]

Y. 1. Periodical bulletin, Julv, lsss, to Jnne, 1s89. [Nos. 1-12.]

To. 1. July, 1-32 pp.

No. 2. Aug., $2+33-62 \mathrm{pp}$.

So. 3. Sept., [2]+63-92 pr.

To. 4. Oct., $2+9.3-122$ pp.

No. 5. Nov, $[2]+123-162 \mathrm{pp}$.

No. 6. Dec., $2+16.3-200 \mathrm{pp}$.

So. 7. Jan., $2+201-230$ pp.

No. s. Feb., ii $2: 31-260$ pl.

To. 9. Mar., ii $+261-295$ pr.

No. 11. Apr., ii +247-326 pl.

To. 11. May, ii-327-357 pl.

To. 12. June, $2+359-385$. [Title page, table of contents, and index for vol. 1 issued with this number. xxxii pp.]

V. 2. Periodical lulletin, July, 1889, to June, 1590. [12 numbers in 10.]

No. 1. July, 2-:30 lp.

No. 2. Ang., ii $+31-60 \mathrm{pp}$.

To. 3. Sept., $\mathrm{ii}+\mathbf{6 1 - 9 0} \mathrm{j}$.

No. 4. O(t., ii $91-123 \mathrm{pr}$.

No. 5. Nov., ii-125-162 pp.

To. 6. Dec., ii-163-197 pl.

Nos. 7 and 8. Jan. and Feb., ii-199-26: pp.

No. 9. Mar., $\mathrm{ii}+263-292 \mathrm{pp}$.

No. 10. Apr., ii $1298-333$ pl.

Tos. 11 and 12. May and Jume, ii -..835-390 pp.

[Title page, table of contents, and index issued with no. 1 of vol. 3.]

3 T. 3. Periodical bulletin, Iugust, 1890, to August, 1891. [12 numbers in 8.]

No. 1. Aug., ii +41 pp. [Title page, tal)le of tontents, and index for vol. 2 issued with this number, viii $+391-115$ p. $]$

No. 2. Sept., ii $+41-87$ pp.

No. 3. Nov., ii $+89-129 \mathrm{pp}$.

No. 4. Nov., ii $+131-178 \mathrm{pp}$.

No. 5. Jan., ii $179-250 \mathrm{pP}$.

No. 6. Mar., ii 251-30t pp.

Nos. 7 and 8. Apr., ii $+305-357 \mathrm{pl}$.

Tos. 9 and 10. June, ii $-359-432 \mathrm{pp}$.

Nos. 11 and 12. Aug., $\mathrm{ii}-433-519 \mathrm{pp}$. [Title page and table of contents for vol. 3 issued with this number, viii pr.]

V. 4. Periodical bulletin, October, 1S!1, to August, 1S\%2. [12 numbers in 6.$]$

Nos. 1 and 2. Oct., iv $+8 t i p j$.

Nos. 3 and t. Nor., iy-87-162 pl.

Nos. 5 and 6. Dec., iii $-163-230 \mathrm{pl}$.

Nos. 7 and 8. April, ii $+231-292$ wp

Nos. 9 and 10. Jume, $\mathrm{ii}+293-52 \mathrm{pp}$.*

Tos. 11 and 12. Aug., iii $+353-141$ ly. ['Title page and table of contents for vol. 4 issued with this number, viii pp. ]

V. 5. Periodical bulletin, September, 189:- ใo July, 1893. [Nos. 1-5.]

No. 1. Sept., $\mathrm{iii}+62 \mathrm{pp}$.

No. 2. Nov., iii $+63-146 \mathrm{Pl}$.

No. 9. Jan., iii $+1+7-212$ pl.

No. 4. Apr., iii $+213-288$ pp.

No. 5. July, iii-289-402 yp. [Title patge and table of contents for rol. 5 issuer with this number, vii ly.]

* The unbound serial numbers of this issue could not be found. As bound in the volumes the lettered pages are omitted. and could not therefore be verified. 
A.9.7: Insect life-Continued

6 V. 6. Periodical bulletin, November, 1893, to Anguat [September], 1894. [Nos. 1-5.]

No. 1. Nov, iii +58 pr.*

No. 2. Dec, iii $59-206 \mathrm{pp} . *{ }^{*}$

No. 3. Feb., iii $+20 \bar{i}-282$ pp.*

No. 4. May, iii $+283-3+6$ pw.*

No. 5. Sept., iii $+347-405$ pp.* [Title page and table of contents for volume 6 issued with this number, vii pP. ]

V. . Periodical bulletin, September, 1S.4, to July, 1895. [Nos. 1-5.]

No. 1. Sept., $\mathrm{iii}+5 t \mathrm{pp}$.

No. 2. Oct., $\mathrm{iii}+55-215$ pp.**

To. 3. Dee, $\mathrm{iii}+21 \bar{\tau}-280 \mathrm{pr}$ * $^{*}$

No. 4. Mar., ii $+281-360 \mathrm{pu}$ **

No. 5. July, iii $+361-448$ J.** [Title page and table of contents for vol. 7 issued with this number, $r$ pp.]

[V. S] General index to the seven volnmes of Insect Life, 1888-1895. 1897. $145 \mathrm{pp}$.

[Diseontinued. The class of matter formerly used in this series is continued in Bulletins, new series (A9.6:) and Technical series (A9.8:)]

A9.7": Insect life (separates)

A few of the mor important artieles were issued separately in pamphlet form. References to all the articles will be found under their proper headings in the index to this work.1

\section{A9. - : Technical series}

1 No. 1. Revision of Aphelinina of North America, a subtamily of hymenopterous parasites of family Chaleilicle; by L. O. Howarl. 1895. $4+\mathrm{pp}$.

No. 2. Grass and urain joint-worm flies and their allies, a consideration of some. North American phytophagie Enrytominas; by L. O. Howard. 1896. $24 \mathrm{pp}$.

No. 3. Revision of Nematine of North Ameriea, a subfamily of leaf-feerting hymenoptera of family Tenthredinide; by C. L. Narlatt. 1896. 135 pp. 1 pl.

No. 4. Some Mexicm and Japanese injurions insects liable to be introduced into United States. 1896. $56 \mathrm{pp}$.

No. 5. Study in inseet parasitism, consicleration of parasites of whitemarked tussock moth, with aceount of their habits, and interrelations, with deseriptions of new species; by L. O. Howard. 1897. 57 pp.

No. 6. San Jose seale and its nearest allies; ly T. D. A. Cockerell. 1897. $31 \mathrm{pp}$.

No. 7. Revision of Tachinida of America north of Nexico, a family of parasitic two-winged insects; by D. IV. Coquillett. 1897. 154t $149-156 \mathrm{pP}$.

[Corrected index issued Dec. 1897.]

No. 8. Contributions toward a monograph of the American Aleurodidir, by A. L. Quaintance; Red spiders of U. S. (Tetranychus and Stignixus), by Nathan Banks. 1900.79 pp. 8 pl.

No. 9. Life history of two speries of plant-liee inlabiting both witch-hazel and birch; by Theo. I'ergande. 1901. $44 \mathrm{l}$.

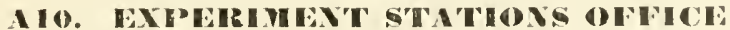

[For historient sketeh of Oftice, sor Yearbouk, 1 k97 (A1.10:k97), p. 135.]

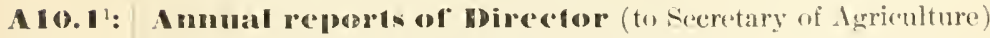

1888 ( Atwater). (In $\Lambda 1.1: 888$, p. 537.)

8.8! 1889 ( Atwater), [1] + 485-54t+iv 1). (Aleo in $11.1: 889$, \%. 485.)

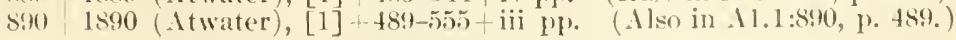

* The unbound serial numbers of these issues eould not be fonud. As bound in the volumes the lettered pages are omitted, and conld not therefore be verified. 
M10.1 I Amual reports of Dircetor (to Secretary of Agriculture)-Continuerl.

S91

892

893

894

895

896

897

898

899

900

901

902

A 10. 12:

A 10.2:

Ab 2

C1s

$\mathrm{C}+3^{1}$

$\mathrm{C}+3^{2}$

C4. $)^{3}$

$\mathrm{C}_{4} 3^{4}$

F7. 1

$173^{2}$

1891 (11:1ric), [1]-503-5.s + ii pp. Map. (Also in $11.1: 891$, p. 503.)

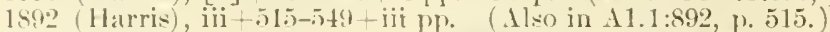

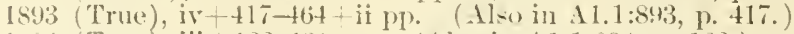

1894 (True), iii $+123-131$ p1. (11-o in $11.1: 894$, p. 123.)

159.5 (True), iii $+131-143$ lv). (Al=o in $11.1: \$ 95$, p. 131.)

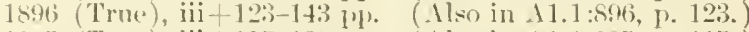

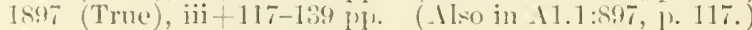

1898 (True), iii $+103-126$ pr. (Also in Al.1:s 98, p. 103.)

18.19 (Trtie), iii-119-153 pr. (.11:0 in A1.1:894, 1. 119.)

1900 (True), ii $+16.5-210$ l1). (Al:o in A $1.1: 900$, p. 165.)

1901 (True), iiit 175-293) pl. (Alvo in $11.1: 901.1 \%$ 175.)

1902 (True), iii $+241-30+1$ ' $)$ (Also in 11.1:902, 1. 241.)

Anumal reports of Otlice of Experinent Stations (to Con(rress)

[By lorovision of the act establishing experiment stations in connection with the agricultural colleges in the variuns states and territories, approved Mar. 2, 1857 the stations wore required to send to the governors of their respective states or territories, for transmission to the seeretary of Agrieulture, on or hefore February 1st of earh year, a statement of their reeeiptsand expenditures, with an ontline of the work atcomplisherl.

It was not, however, until the approval of the Agrieultural appropriation are of Aug. 8, 1894, that provision was made for sending to Congress an anuual report lased upon these returns. The report for the fiscal year 1895 , the one called for in the aet, was laid before the Senate A pr. 7, 1s96, and referred to the Committee on Printing, who reporter a eoneurrent resolution providing for its publication as a doeument, with 2,000 additional copies for the use of the Agrieulture Department. The resolution passed the Senate but did not receive the sanction of the House, and the report therefore was never printed.

The seeond report, 1896, ('alled for by Congress, Was printed as S. 1,ue. 137, 5tth Cong. 2dl sess.; serial no, 3470 .

The third report, 1897 , was printed as $H$. doe. 205, 55th Cong., $2 d$ sess.; serial no. 3tifi, and ulso as Bulletín 10.50, Experiment Stations Uttiee.

The fourth report, 1898 , was printed as H. doe. 121, 55th Cong., 3d sess.; serial no. 3768 , and ulso as Bulletin 110, 61, Experiment statious Offiee.

The fifth report, 1899 , was printed as $H$. doe. 500 , 56 th Cong., 1st sess.; serial no. 3929 and also as Bull tin no. 83, Experiment Statims Oftice.

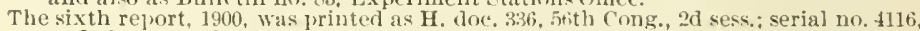
and also as Bulletin no. 93, Fxperiment stations offiee.

The seventh report, 1901 , the first to be published as an "anuual report of the offiee of Experiment Stations," was also printed as 1f. dove. 334, 57th Cong., 1st sess.; serial no. 4301.

Future reports will be issued in eonformity with this latter method and will inelude, besides the receipts and expenditures, reports of the Alaska, Hawaii, and Porto Rieo Experiment stations, whieh are under the direet supervision of the Oftice: reports on Investigations on irrigation and on the nutrition of man, and on Agrieultural Education and the Farmers' Institutes.]

1901 (True), 489 pp. $41 \mathrm{pl}$.

Same, 57th Cong., 1st sess., II. doc. 334; serial 110. 4301.

\section{Fencral pablicalious}

fublieations which originated in this Office, but which were publisher in a numbered series of the secretary"s Oftice or some other division of the Department, are entered only where such numbering plaees them, with references under the proper headings in the Index to this work. P'ublications of this Office issued only as Congressional documents are noted in clironologieal order in the Appendix to this work.]

Abbreviations used in Experiment Station Record. n. t. p. n. d. 16 pp.

Card index of agrioultural literature. Terms of sale of carl index of agricultural literature. n. d. n. t. P. [: $\left.{ }^{\prime}\right]$ p.

[Chicago, Ill., World's Colmmbian Exposition, Collective Collere and Station exhibit.] n. t. I'. May 12, 1892. [4] [p. $4^{\circ}$

Sane. Address by arlvisory board. Nov. 19, 1892. (Cire.)

Same. [letter to iccomlany adliess.] Fov. 23, 18.2. (Cire.)

Same. Extract from annnal adelress of Yew Orleans convention. Nos, 1892. (Cire.)

Food and nutrition of man. List of publixations on ford and nutrition of man. [May, 1898.] n. t. 1. 4 4 p.

Same, reve [July, 1s98.] n. t. p. 4 PP. 
110.2

$\mathrm{F} 73^{3}$

F7? 4

$\mathrm{F} 73^{5}$

F $73^{6}$

F73 ${ }^{7}$

$\ln 2$

Ir 7

$\mathrm{Ir}^{-2}$

$\mathrm{Ir}^{-3}$

Ir $7^{4}$

P8:

St2

A 10.3:

\section{General pundicanions-Continued}

Food and nutrition of man. List of jublications on food and nutrition of man, rev. [July, 1S99.] n. t. p. is pl.

Same, rev. [Mar. 1900.] 11. t. 1\% 6 pp.

sume, rev. [Dec. 1900.] 11. t. 1'. T I'W.

Same, rev. [O(t. 1901.] 11. t. p. 8 pp.

Same, rev. Nov. 5, 1902. 11. t. p. " pl.

Index to "Fxperiment Station ITork." [Announcement regarding.] May 7 , 1898. ((ire.)

Irrigation. List of jublicationsof ()thee on Irrigation. n. t. I) n. d. 2pl). Sante, rev [1901.] n. t. p. \& ll].

Same, rev. [1901.] n. t. P. 5 P.

Same, rev. Oct. 15,1902 . n. t. p. 7 pl).

Porto Rico. Mescage from Presirlent of U. S., transmitting report on investigations of agricultural resources and capabilities of Porto Rico, with special reference to establishment of an agricultural experiment station in that island, [by Seaman A. Knapl.] 1901. 32 pl). 7 pl.

Same, 5 thth Cong., $2 \mathrm{~d}$ sess., H. doc. 171 ; serial no. 4117 .

Station publications. List of station publications lacking in library of office of Experiment Stations. Nov. 1, 1892. n. t. 1. + pp.

\section{Bullerins}

To. 1. Organization of Agricultural Fxperiment Stations in T. S. 1889. 8: pl.

No. 2. Digest of annual reports of Experiment Stations in I. S., 1888, pt. 1. $1889.258 \mathrm{pp}$.

Sime, pt. 2. 1891. 173 pp.

No. 3. Report of meeting of horticulturists of Acricultural Experiment Stations, at Columbus, Ohio, June 13, 14, 18s9; hy A. Tr. Harris. 185\%. $12 \mathrm{pp}$.

Fo. 4. List of horticulturists of Agricultural Experiment Stations in U. S., with outline of work in horticulture at the several stations; by $\mathrm{W} . \mathrm{B}$. Alwood. 1889.27 lj.

No. 5. Organization lists of Agricultural Experiment Stations and agricultural schools and colleges in T. S. 1890. 67 pl.

To. 6. List of botanists of Agricultural Experiment Stations in U. ..., with ontline of work in botany at the several stations. 1890. 23 jp.

No. 7. Proceerlings of 5 th annual convention Association of American Agricultural Colleges and Experiment Stations, Washington, D. C., Aug. 12-18, 1891; ellited by 1. IT. Harric and H. E. Alvord. 189:' 113 p.

No. 8. Six lectures on investigations at Rothamster Fxperimental Station, delivered uniler provisions of laves Agricultural trust by Riolet. Warington, hefore Association of American Agricultural Collegess and Experiment Stations at Washington, I. C.. Ang. 12-18, 1s91. 1892. $113 \mathrm{pm} .11 \mathrm{pl}$.

No. 9. Fermentations of millk; by II. W. Comn. 1892. 75 pp.

No. 10. Meteorological work for agricultural institntions; [by] Mark 11 . IJarrington. 18:)2. 2:3 pp.

No. 11. Compilation of analyses of Aneriean feerling stutfs; by li. H. Jenkins and $\AA$. L. Winton. 1892. 155 Pl.

o. 12. Organization lists of Agrieultural Experinent Stations and agricultural schools amel colleges in [T. S. 1892. 78 pp.

No. 1:3. Organization lists of Agroultual Txperiment stations and agri-

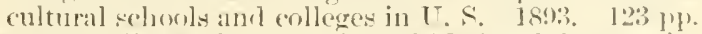

No. 14. Proceceling of convention of Sational l.earue for Cioml Roads, hed, at Waslrington, 1). C., Jan. 17, 18, 1893, and hearing hy Committee on Agriculture of llomese of Representatives January 19, 1893. 18.3. 101 \%).

Ni. 15). ilandlook of experiment station work: a popular digest of pul. lieations of the acricultural experiment stations in I. . . 1893. 411 以).

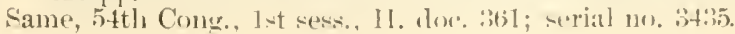


110.3:

IBulletins-Continued

Fo. 16. Proceslings bth annual convention of Association of American Arricultural Colleges and Experiment Stations, New Orleans, La.,

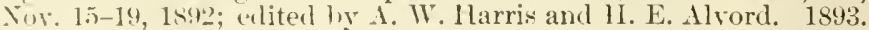
176 川\%.

No. 17. Surgetions for extablishment of fool laboratories in connection with agricultural "xperiment stations of U. S.; [by Edward Atkinson]. $1893.20 \mathrm{pp}$.

Fo. 18. Contribution to investigation of assimilation of free atmospheric nitrogen hy white and blark mustard; by J. l'. Lotsy. 1894. $19 \mathrm{pp.}$

Yo. 19. Organization lists of arrinitural experiment stations and agricultural schools and colleges in I. S. 1894. $99 \mathrm{pP}$.

No. 20. Proceedings of 7 th ammal convention of Association of American Agricultural Colleges and Experiment Stations, Chicago, Ill., Oct. 17-19,1893; eliterl ly A. C. True and II. E. Aliord. 1894. $100 \mathrm{pl}$.

No. 21. Methods and results of investigations on chemistry and economy of food; by W. (1. Atwater. 1895. 202) yp.

To. 22. Agricultural investigations at hothamsted, England, during 50 vears; six lectures delivered under provisions of Lawes agricultural trust; hy sir Joseph Ilenry (iillert. 1895. 316 pl. 3 pl.

To. 23. Oruanization lists of arricultural experiment stations and institutions with courses in agrienlture in $\mathrm{l}^{\circ}$. . . 1895. Ss pp.

No. 24. Proceedings stł ammal convention of Association of American Ayricultural Colleges and Experiment Stations, Washington, D. C., Nov. 13-15, 1894; edited by A. C. True and H. H. Goodell. 1895. 98 pp.

No. 25. Dairy hacteriologry; by II. W. Conn. 1595. $40 \mathrm{pp}$.

Yo. 26. Agricultural experimentstations, their objects andwork; by A. C. True. 1895. 16 [リ).

To. 27 . Orunization lists of agricultural experiment stations and institution having courses in agriculture in $\mathrm{L} . \mathrm{S}$. 1896. $93 \mathrm{pp}$

No. 28. Chemical composition of American food materials; $\mathrm{w}$ W. $\mathrm{O}$. Atwater and Chas. D. Woods. 1896. 47 pp.

Same, rev. enl.; by W. O. Atwater and A. P. Bryant. 1899. 87 pp.

No. 29. Dietary studies at Tniversity of Tennessee in 1895; by Chas. E. Wait, with comments by W. O. Atwater and Chas. D. Woods. 1896. $45 \mathrm{pp}$.

No. 30. Proceedings of 9th annual convention of Association of American Agricultural Colleges and Experiment Stations, Denver, Colo., July 16-18, 1895; edited by 1. C. True and H. H. Goodell. 1896. 100 pp.

No. 31. Dietary studies at University of Missouri in 1895 and data relating to bread and meat consumption in Missouri; by H. B. Gibson, S. Calvert, and 5). W. May, with comments by W. O. Atwater and Chas. D. Wooks. 1896.24 pp.

No. 32. Dietary studies at P'urdue University, Lafayette, Ind., in 1895; by Winthrop E. Stone, with comments by W. O. Atwater and Chas. D. Woorls. 1896. 28 1'\%.

No. 33. Cottou plant: its history, botany, chemistry, culture, enemies, and uses; [Repurt] with introduction by Charles IV. Dabney. 1896. 4833 jp. $11 . \pm$ il.

Same, 54 th Cong., 2d sess., H. dre. 267 ; serial no. 3536.

See also $\mathbf{A} 1.9: 47$ and $\mathbf{1} 1.9: 48$.

5o. 34. Carbohylrates of wheat, maize, flour, and bread, and action of enzynic ferments upon starches of different origin; by Winthrop E. Stone. 1s.6. $44 \mathrm{pp}$.

[Withdrawn .lan., 1s9s; reisued Jan., 1899; again withdrawn June 24, 1899.]

No. 35. Foorl and mutrition investigations in New Jersey in 1895 and 1896; br Eilwart B. Voorlsees. 18!6. $40 \mathrm{pp}$.

No. 36. "Notes nu irrigation in Commecticut and New Jerser; by C. S. Phelps and Elward B. Voorhees. 1897. 64 \%.

No. 37. Dietary studies at Maine State College in 1895; by Whitman $\mathbf{H}$. Jordan. 1897. 57 , 1 n. 


\section{A10. EXPERIMENT S'TATION OFFICE-Continued}

\section{Bulledins-Continued}

No. 38. Dietary studies with reference to foor of negro in Alabama, in 189.5 and 1896 , conducted with cooperation of Tuskegee Normal and Industrial Institute and the Igrienltural and Mechanical College of Alabama; reported by W. O. Atwater and Chas. D. Woods. 1897. 69 pl. 2 pl.

No. 39. Organization lists of agricultural experiment stations and institutions with courses in agriculture in $\mathrm{C} . \mathrm{S} . \quad 1897.96 \mathrm{pp}$.

No. 40. Dietary studies in New Mexico in 1895; by Arthur Goss. 1897. $23 \mathrm{pp}$.

same. $1899.23 \mathrm{pp}$.

No. 41. Proceedings of 10 th annual convention of Association of American Agricultural Colleges and Experiment Stations, Washington, D. C., Nor. 10-12, 1896; edited by A. C. True and H. H. croodell. 1897. $120 \mathrm{pp}$.

No. 42. Cotton culture in Egypt; by George P. Foarlen. 1897. 3t pl.

No. 43. Losses in boiling vegetables and compusition and digestibility of potatoes and eggr; [articles] hy H. Snyeler and Almah J. Frisby and $\mathrm{A}$. P. Bryant. 1897. $31 \mathrm{pr}$.

No. 44. Report of preliminary investigations on metabolism of nitrogen and carbon in lumman organism, with respiration calorimeter of special construction; by W. O. Atwater, C. D. Woords, and F. G. Benedict. 1897. tit pp.

No. 45 . Digest of metabolism experiments in which the balance of income and outgo was determined; by $\mathbb{W}$. (). Atwater and C. F. Langworthy. .897. $4.34 \mathrm{pl}$.

Same, rev. el. 1s9s, $4: 34 \mathrm{pp}$.

No. 46. Dietary studies in Yew York ('ity in 1895 and 1896 ; by $\mathrm{W}$. O. Atwater and Chas. D. Woods. 1s98. $117 \mathrm{pp}$.

No. 47 . Organization list of anricultural experiment stations and institutions with courses in agriculture in $\mathrm{C}$. . . . 1898. \% $\mathrm{pP}$.

No. 48. Report to Congress on arriculture in Alaska, includling reports by Walter 11. Evans, Benton Killin, and Sheldon Jackson. 1898. iv $+36 \mathrm{pp} .223 \mathrm{pl}$.

Same, 55 th Cong., 21 sess., H. dnc. 160 ; serial no. 3667 .

No. 49. Proceedings of 11 th annual convention of Association of American Agricultural Colleges anel Experiment Stations, IInneapolis, July 13-15, 1897; eslited by A. C. True and II. H. Goodell. 1898. 100 pp.

No. 50. Work and expentitures of agrieultural experiment stations for 1897; Wy A. C. True. 1898. vi +97 ll. $6 \mathrm{pl}$.

Same, 55tli Cong., 2d sess., H. doc. 205; serial no. 3667.

No. 51. Statistics of land-grant colleges and agricultural experiment stations in I'. S. for year ending June 30, 1897. [Compiled by Miss S. L. Sommers.] $1898.39 \mathrm{pp}$.

No. 52. Nutrition investigations in Pittsburg, Pa., 1894-96; by Isabel Bevier. 1898. $48 \mathrm{pp}$.

No. 53. Nutrition investigations at University of Tennessee in 1896 and 1897; by Chas. E. Wait. 1898. $46 \mathrm{pl}$.

No. 54. Nutrition investigations in New Mexico in 1897; by Arthur Goss. 1898. $20 \mathrm{pP} .1 \mathrm{pl}$.

No, 55. Dietary sturlies in Chicago, 1845 and 1896 , conducted with cooperation of Jane Arldams and Caroline L. Innt, of Hull Honse; reported by W. $\mathrm{O}$. Atwater and $\mathrm{A}$. P'. Bryant. 1898. $76 \mathrm{pp}$.

No. 56. Historyand present status of instruction in cooking in publie schools of New York City, 1899; reported by (Mrs.) Lotiee E. Hogall, with introduction by $\mathrm{A}$. C. True. $1899.70 \mathrm{pl}$. $12 \mathrm{pl}$

[Withdrawn.]

To. 57. Varicties of corn; by E. L. Sturtevant. 1899. 108 1\%p.

To. 58. Water rights on ilissouri River and tribntaries, by Elwond Ilead; with papers on water laws of Colorarlo, by John E. Fiekl, and of Nebraska, by J. M. Wilson. 1899. $80 \mathrm{lp}$. 3 pl.

Xo. 59. Organization lists of arricultural colleges and experinent stations in U. S., with lint of agricultural experiment stations in foreign countries. 1899. 15 pl. 
No. 60. Alstract of laws for acquiring titles to water from Missouri River

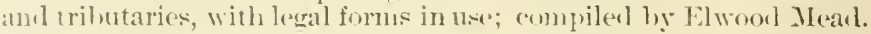
18.49. 75 \%).

No. 1i1. Report of work and expenditures of agricultural experiment sta-

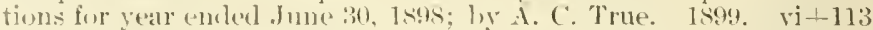
l). $14,1.1$.

Sanes, 55th Cong. : 1 sess. H. doc. 121; serial 110. 37tis.

No. 62. Sexond report to Congress on auriculture in Ilaska, including re-

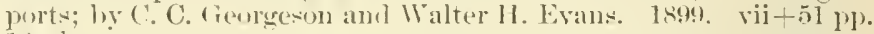
12 pl.

Same, 55th Cong., 31 sess., I1. doe. 169; serial no. 376s.

No. 63. Hescription of a new respiration alorineter and experinents on (onservation of (b) Rosa. 1s.99. 94 jp). \& j). (slip of corrections for page s6.)

No. 64. Statistics of land-grant colleges and experinent stations in C. S. for year encling June 30, 189s; [compiled by Miss s. L. Sommers]. 189.\%. 89 ]').

No. 65. Proceedings of 12 th ammal ennvention of Association of American Agricultural Colleges and Experiment stations, Washington, D. C., Nor. 15-17, 1898; edited Wy A. C. Trute, W. H. Peal, and H. H. Gootlell. 1599. $138 \mathrm{pl}$.

No. 66. Plysiolosical effect of creatin and "reatinin, and their valne as nutrients; by J. II. Mallet. 1s.99. 24 pl.

No. 67. Studies on breal and bread making; [articles] hy Harry snyder and 1. A. Voorlees. 1899. 51 j'l. 2 pl.

No. 68. Description of some Chinese vegetable fond materials and their nutritive and "conomic value; by Walter ('. Blastale. 1899. 48 p). 8 p.l.

No. 69. Lxperiments on metalulism of matter and energy in human body; by $W^{2}$. (). Atwater and F. (r. Benediut, with collaboration of A. WT. Sinith and A. I'. Bryant. 18:19. 112 yr.

Nin. 70. Water-right problems of Bear River; [artioles] hy Clarence $T$. Johnston and Joseph A. Breckons. 1899. 40 pl. i pl.

Ni. 71. Dietary sturlies of nesroes in eastern Tirginia in 1897 and 1898 ; [articles] by 11. R. Frissell and Isabel Jevier. 18:4. 45 p. $3 \mathrm{pl}$.

Vu. 72. Farmers' realling commes; by L. H. Bailey. 1899. 36 1'p.

‘) No. 73. Irrigation in Rocky Momntain States: by J. C. Tlrich. 1899. 64 [1]. 10 y.].

No. it. Orqanization lists of agricultural colleges and experiment stations in $1 . .$. , with list of agrieultural experinent stations in foreign (*)untries. 1900. 12: l Pp.

Vo. 75. I)ictary stulies of university boat rews; ly $\mathbb{W}$. O. Atwater and A. P'. Birvant. $1900.72 \mathrm{pl}$.

Yo. 76. Proceerlings of 13th ammual envention of Assnciation of American Aerioultural ('olleges and Experiment Stations, san Francisco, Cal., July 5-7, 1899; erlited by A. C.True, IV. H. Heal, and II. H. Goodell. 1900. 112 Ip.

No. T7. Digestibility of American feelling stufis; hy Whitman II. Jorlan and linuk H. Hall. 1400. 100 1)

No. 78. Statisties of land-grant colleges aml agricultural experiment sta-

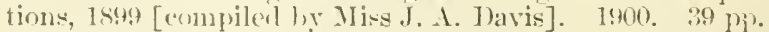

No. 79. Farners' institutes, history aml status in IT. S. and Canala; by 1. I1. liailey. 1900. it pp.

Yo. so. [History ame] present status of] Agricultural experiment stations in I. S.; lyy A. (. True and V. A. Clark. Paris Exposition, 1900, prepared to acempany experiment station exhilit. 1900. 636 pp. 15.3 pl. nuap.

Same, 5fith Cung., 2l ses., II. doe, 507; serial no. 4170.

No. 81. Tite wi water in irrixation in 11 yoming and its relation to ownership and distrilutjon ot natural supply: hy 1. C. Buffum. 1900.

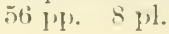




\section{ENPERIMEVT STATIONS OFFICE-Continuel}

\section{IBullerins-Continued}

No. 82. Agricultural investigations in Alaska, 1849); hy C. C. Cieorgewon.

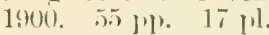

Sinne, 5tith congr., 1st sess, II. doc. 31t; serial nu. 3929.

Yo. 83. Work and expenditures of arricultural experiment stations for

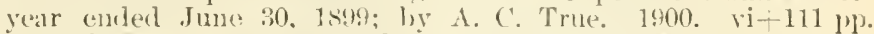

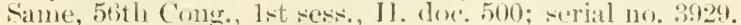

No. 8t. Nutrition investimations at california asrioultural experiment station, 1896-1895; Jy M. L. Jaffa. 1900. 39! pu.

No. 85. Investigations on digestibility and mutritive value of bread; by Chas. D. Woods and L. H. Merrill. 1900. 51 lp.

No. 86. Use of water in irrigatim; report of investigations made in 1899 under supervision of Elwool Mead and C. T. Johnston, including reports by sperial agents and observors W. II. Reed, W. H. Code, W. Irving, O. V. P. Stout, Thomas berry, S. Fortier, R. C. Gemmell, (i. L. Swendsen, and J). W. Ross. 1900. 253 pp. 50 pl.

Same, 56th Cong., 2il secse., H. llec. 466; rerial no. 4117.

No. 87. Irrigation in New Jerey; liy Whard J3. Voorhees. 1900. 40 pp.

No. 88. Organization liwts of anricultural colleges and experiment station. in U.S., witl list of acricultural experiment stations in foreign countries. 1901. 134 pp.

No. 89. Experiments on effect of muscular work upon digestibility of fool and metalolism of nitrogen, condneted at [niversity of Tennessee, 1897 to 1899 ; by Chas. E. Wait. 1901. $77 \mathrm{pp}$.

No. 90. Irrigation in Ifawaii; by Walter Maxwell. 1900. 4s pp. $6 \mathrm{pl}$.

No. 91. Nutrition investigations at Eniversity of Illinois, North Dakota Agricultural College, and Lake Erie Collecre, Ohio, 1896-1900; ly H. S. Grindley, J. I. Sammis, E. F. Ladd, lsabel lsevier, anil Elizabeth C. Sprague. 1900. 42 w.

No. 92. Reservoir system of Cache la Poudre Valley; hy l. s. Nettleton. 1901. 48 [P. $14 \mathrm{pl}$

No. 93. Work and expenditures of asrieultural experiment stations for year ended June 30, 1900; by A. C. True. 1901. 181 JP. \& fl.

Same, 56th Cong., 2d ses., 1I. doc, 336; serial no, 4116.

No. 94. Fourth report on aurionltural investigations in Alaska, 1900; by C. C. Georgeson, 1901. $8: 3 \mathrm{pP} .24 \mathrm{pl}$.

Same, 5tith Cong., 2d sess., H. doc. 335; serial no. 4117

No. 95. Report on agricultural resources and (apabilities of Jlawaii; by Wm. C. Stubbs. 1901. $100 \mathrm{pr} .28 \mathrm{pl}$.

Same, 56tl Cong., 2d ses., 11. doc. 36s; serial no. 4117

No. 9t3. Irrigation laws of northwest territories of (anada, and of Wyoming, with discussions by J. S. Dennis, Fred Bond, and J. M. Wilsoll. 1901. 90 W. 6 pil.

No. 97. Statisticy of land-grant colleges and agricultural experiment stations in U. S., for year endel June 30, 1900 [compiled loy Miso Marie T. Spethmam ]. 1901. $37 \mathrm{\mu \%}$

No. 98. Liffect of severe and prolonged musenlar work on food consumprtion, digestion, and metabolisn, l, 11 . O. Atwater and 11 . Sherman; and Mechanical work and effreiency of bieyclers, Jy R. (․ Carpenter. 1901. 67 \%.

No. 99. Proceedlings of $14 t t_{1}$ anmual eonvention of Association of American Agrieultural Colleges and Experiment Stations, Nor. 13-15, 1900; edited by A. C. True, W. I1. Beal, and H. H. Goodell. 1901. 192 pp. : 11.

No, 100. lieport of irrigation investigations in California mule direction of Elwool Mead, assisted by William E. smythe, Marsden Manson, J. II. Wilson, Claarles D. Marx, Frank Soulé, C. F, Grunsky, Edward II. Boggs, and Jannes D. Schuyler. 1!01. 411 lif. $29 \mathrm{pl} .4^{\circ}$

Same, 57th Cong. 1st sess., S. doe. 356 ; serial 110.4246.

[Preliminary report, 73 pp., transmitted to Congress, Jun. 24, 1901. (56-2, S. doc. 105, serial no. 4033.)] 
I10.8:

$11) 1$

$10: 2$

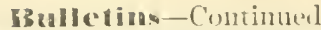

No. 101. Studies on ]real and brearl making at Lniversity of Minnesota, 1899 anıl 1900; by Harry snyder. 1901. (6.) pl. 3 pl.

No. 10:2. Experiments on loses in conking meat, 1898-1900; by H. S. (irindlev, with (onperation of 11. JeCormack ami 11. C. Porter. 1901. $64 \mathrm{pr}$.

No. 103. Evolution of reaping mathines; by Merritt Finley Miller. 1902. 43 1). 9 pl.

No. 104. Report of irrigation investigations for 1900; nnrler supervision of Elwood Mead, including reports by special agents and observers WV. M. Rered, W. H. Code, 1. J. M.Clatehie, W. Irving, J. M. Wilson, R. C. Gemmell, G. L. Swentsen, O. V. P. Stout, W. H. Fairfield, I). W. Ross, (1. 1. Waller, S. Fortier, and J. C. Nagle. 1902. 334 pl. 25 pl. 3 maps.

No. 105. Irrigation in $\mathrm{U}$. S.; testimony of Elwool Meat hefore Industrial Commission, June 11 and 12, 1901. Reprinterl from report of $\mathrm{I}^{\mathrm{T}} \mathrm{S}$. S. Tndustrial Commission on agrieulture and agricultural labor. 1901. $47 \mathrm{pp} .12 \mathrm{pl}$.

No. 106. Resnlts of investigations on Rothansted soils, being lectures delivered mder provisions of Lawes agricultural trust, by Bernard Dyer, before Association of American Agricultural Colleges and Experiment Stations at New Haven and Jiddletown, Conn., Nov, 1900. 1902. $180 \mathrm{pp}$.

No. 107. Nutrition investigations among iruitarians and Chinese at California Agricultural Experiment Station, 1899-1901; by M. E. Jaffa. 1901. 43 pp. 1 ,1.

Fo. 108. Irrigation practice among fruit growers on Pacific coast; by E.J. Wickion. 1902. $5 \pm$ pp. 10 pl.

To. 109. Experiments on metabolism of matter and energy in human body, 1898-1900; by W. O. Atwater and F. (i. Benedict, with conperation of A. P. Bryant, A. W. Smith, and J. F. Snell. 1902. 147 pp.

No. 110. Proceedings of 6 th annual meeting of American Association of Farmers' Institute Workers, Buffalo, Sept. 18 and 19, 1901; edited by A. C. 'True, D. J. Crosby, and G. C. Creelman. 1902. 55 pp.

So. 111. Organization lists of agricultural colleges and experiment stations in U.S., with list of agricultural experiment stations in foreign countries. 1902. $130 \mathrm{pp}$.

No. 112. Agricultural experiment stations in foreign countries; by A. C. True and D. J. Crosby. 1902. $230 \mathrm{pl}$.

No. 113. Irrigation of rice in C.S.; [articles] by Frank Bond and George H. Keeney. 1902. $77 \mathrm{pl}$. $29 \mathrm{pl}$.

No. 114. Statistics of land-grant colleges and agricultural experiment stations in U. S. for year ender Jume 30, 1901 [compiled by Miss Marie T. Spethmanin]. 1902. $39 \mathrm{pp}$.

\o. 115. Proceedings of 15 th annual convention of Association of American Agricultural Colleges and Experiment Stations, held at Wash. ington, D. C., Nov. 12-14, 1901; erlited by A. C. True, W. H. Beal, anil H. H. Goorlell. 1902. 13t l'p.

Fo. 116. Dietary stulles in New York ('ity in 1896 and 1897 ; by W. 0.

Atwater and $\Lambda$. P. Bryant. 1902 . \&3 pl.
To. 117. Experiments on effect of muscular work upon digestibility of food and metaloolism of nitrogen, conducted at Lniversity of Tennessee, 1899-1900; by Chas. E. Wait. 1902. 43 pp.

ฟo. 118. Irrigation from Big Thompson River; by John E. Field. 1902. 75) $19.6 \mathrm{pl}$.

No. 119. Report of irrigation investigations for 1901, containing Summary of results, by R. P. Teetle, and Reports by IV. M. Reed, W. H. Code, A. J. McClatchie, E. W. Hilgard, W. Irving, A. E. Chandler, O. L. Waller, D. IV. Ross, Samuel Fortier, A. P. Stover, O. V. P. Stout, H. J. Waters, F. H. King, E. B. Voorhees, and J. C. Nagle. 1902. 401 pp. 64 pl. 


\section{3: E3alletins-Cuntinnert}

120 No. 120. Proceulings of 7 th ammal meeting of American Association of Farmers' Institute Workers, held at Washington, D. C., June 2426, 1902; edited by 1. C. True, D. I. Crosby, and C. C. Creelman. $1902.119 \mathrm{Pl}$.

121 To. 12]. Experiments on metabolism of nitrogen. sulphur, and phosphorus in the human organism; by II. C. Sherman. Conducterl in cooperation with Columbia University. 1902. $4 \overrightarrow{\mathrm{pp}}$.

\section{A10 3 $a$ : Bulletins (separates)}

[A few of the more important articles contained in the Bulletins were issuerl separately in pamphlet form. References to all the articles will be found under their proper headings in the index to this work].

\section{A 10.4: Circulars}

1 To. 1. List of agricultural experiment stations in T. S., with addresses. Feb. 1, 1889 . n. p. n. d. 7 pp.

To. 2. [In regaril to meeting of those interesterl in use of fertilizers. Jan. 31,1889 . n. t. p. [3] pp.

3 To. 3. [Extract from proceedings of Knoxville Convention.] Feb. 6, 1889. n. t. p. [3] pp.

4 No. 4. Memorandum for station reports. Feb. 12, 1889 . n. p.n.d. 4 pp.

To. 5. [Call for meeting of experiment stations for discussion.] Feb. 25, 1889. (Cire.)

6 No. 6. List of originators of fruits, vegetables, ete., in U. S., with addresses and names of specialists. Mar. $8,1889 . \quad 7 \mathrm{l}$. $\mathrm{f}^{\circ}$

[Mimeographed; never printed.] •

To. 7. Cooperative field experiments with fertilizers. Mar., 18s?. n. p. n. d. $39 \mathrm{pp}$.

No. 8. Explanations and directions for soil tests with fertilizers. Mar. 1859. n. p. n. d. 11 pp.

To. 9. Memorandum for report on farmers institutes in United States. n. d. 41. blank.

No. 10. [Horticulturists' circular, schedule of questions. List of horticulturists and botanists of Fxperiment Stations in U. ...] June 27 , 1889. 7 1. $\mathrm{f}^{\circ}$

[Mimeographed; never printed.]

No. 11. Rules for naming vegetables. Report of Committee of Experiment-Station Horticulturists. Sept., 1889. n. p. n. d. [3] pp.

No. 12. Regarding library and publications of Office of Experiment Stations. July, 1889. 3 pp. n. p. n. d. (c. t. o.)

No. 13. [Calling attention to meeting of American agricultural colleges and experiment stations. Oct. 16,1889 . n. t. p. [3] pp.

To. 14. [Calling attention to meeting of official economic entomologists.] Oct. 28,1889 . n. t. p. [3] pp.

15 No. 15. Inquiries regarding investigations in botany at agricultural colleges and experiment stations. Ja11., 1890. n. p. n. d. [4] p].

No. 16. [Relating to publications of Office.] n. d. n. t. ?. [3] pp.

No. 17. Jetter to manufacturers of spray machinery. n. d. n. t. p. [3] pp.

No. 18. List of originators of fruits and vegetables in United States, with adrlresses and names of specialties. n. p. 11. d. 12 pp.

No. 19. Experiments with fertilizers on fruits and vegetables, to study feerling capacities of plants and variations due to action of fertilizers. Mar., 1891. n. t. p. 4 pp.

20 To. 20. Organization list of agricultural experiment stations in U. S. June, 1891. n. p. n. d. 21 pp.

21 To. 21. Fifth annual convention of Association of American Agricultural Colleges and Experiment Stations; delegates and visitors registererl. Aug. 13, 1891. 11. 1. 11. d. [4] pl.

22 No. 22. [Letter relative to] subjeet index of literature of agrieultural experiment stations and kindred institutions. Nov., 1891. n. t. p. [3] pp. 


\section{Circulars-Continued}

No. 23. Key to subject index of literature of agricultural experiment stations, and kincled institutions. Dec., 1593. n. p. 11. d. [3] pp. $12^{\circ}$.

Same, revised. Apr. 25, 1902. [3] Pl. so.

No. 24. Address list of atgricultural experiment stations. [Dec., 1893.] (Circ.)

No. 25. Report on canaigre. Iny 15, 1894. n. t. p. 4 pp.

Same, rer. Nor. 20, 1s5\%. n. t. ए. 4 pl.

No. 26. Address list of agricultural colleges and experiment stations. n. 1. 11. t. p. + pl.

No. 27. Statisties of apricultural colleges and experiment stations, 1894. May 16, 1895. 11. t. p. 18 pp.

No. 2s. Report on broom corn. Jan. \&, 1896.

Same, rev. Nov. 20, 1897. n. t. p. 4 l'P.

Same, rev. Oct. 3, 1900. n. t. p. 4 pp.

No. 29. Work and expenditures of agricultural experiment stations. Mar. 10, 1896. 4 P'.

[Also printed as appendix to Annual report of Director, 1496. See A10.1:896, p. 141; and also for other prints, efe A 10.3:59, p. 96, and A 10.3:74, p. 101.]

No. 30. Permanent elements in experiment station work; by A. C. True. May 26,1896 . n. t. p. 4 pp.

No. 31. Some books on agriculture and agricultural science, published 1893-96; [compiled by F. H. Hall]. Nov. 2, 1896 . n. t. p. 176 pp., interleaved.

No. 32. Report of committee on methoris of teaching agriculture. Dec. 8, 1896. n. t. p. 20 p. ${ }^{\circ}$

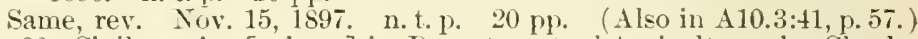
No. 33. Civil service [reform] in Deprartment of Agriculture; by Charles W. Dabney, jr. Jan. 26, 1897 . n. t. p. 10 pp.

No. 34. Rules and apparatus for seed testing. Fel). 17, 1897. n. t. p. 9 pp.

No. 35. Statistics of land-grant colleges and agricultural experiment :tations, 1896. Apr. 1, 1897. n. t. p. $18 \mathrm{pp}$.

No. 36. Constitution of Association of American A tricultural Colleges and Experiment stations. [1897.] n. t. 1\% 4 \%p.

No. 37. Second report of committee on methods of teaching agriculture. July 24, 1597. n. t. p. 4 pp.

Same, rev. Nov. 15,1897 . n. t. p. 4 pp.

No. 38. Some hooks on agriculture and sciences related to agriculture; published 1896-98. July 1, 1898 . 45 pl.

No. 39. Third rejort of committee on methods of teaching agriculture. Nov. 21, 1898 . n. t. P. 7 pp.

No. 40. Land-grant and other colleges and national dlefense; by Charles W. Dabney, jr. n. d. n. t. p. $15 \mathrm{pp}$.

No. 41. Fourth report of committee on methods of teaching agriculture. Sept. 28, 1899. n. t. p. 7 pp.

No. 42. German common school with a garden; hy C. B. Smith. Oct. 28, 1899. n. t. \%. ‘ pl.

No. 43. [Report on] Fuod; Nutrients; Food economy. Oct. 31, 1899. n. t. p. $6 \mathrm{pp}$.

Same, reviserl. Jume 20, 1900. n. t. p. 6 pl.

No. 4t. Agriculture experiment stations in U. S.; [ [ y A. C. True. June 8, 1900.] n. p. 1. d. 8 pp.

Same, revised, 1901. $11 \mathrm{pp}$.

No. 45. Fith report of Comnittee on methods of teaching agriculture. Jan. 5, 1901. n. t. p. 8 pp.

No. 46. Functions and uses of fool; by C. F. Langworthy. Apr. 5, 1901. n. t. p. $10 \mathrm{pp}$.

No. 47 . [Outline of general plan of] card index of experiment station literature; by A. C. True. Apr. 19, 1902. 11. t. p. 2 pp.

No. 48. What the Department of Agriculture is doing for Irrigation; by Elwood Mearl. Oct. 14, 1902. n. t. p. 4 p.

No. 49. Secondary courses in agriculture. Oct. 17, 1902. n. t. p. 10 pp. 
110. EXPERIMENT ATATIONS OFFICE-Continuel

\section{Miscellancous Intletins}

To. 1. Proceedings of 2 \& annual convention of Asociation of American Agricultural Colleges and Experiment stations, Knoxville, Temn. . H11. 1-3, 1889; edited ly A. II. Harris and II. E. Alvorl. 1889. 1.20

No. 2. Proceedings of 34 annual convention of Association of American Agricultmal Colleges and lixperiment Stations, Washington, D. C. Nox. 12-15, 1889; editerl by A. W. Harris and H. L. AFord. 1890. $142 \mathrm{pP}$.

No. 3. Proceedings of th annual convention of Assoriation of American Agricultural Colleges and Experiment Station, Champaign, Ill. Nor. 11-13, 1890; edited by A. W. Harris and I. E. Alvord. 1891. $156 \mathrm{pl}$.

[Serjes disenntinued.]

\section{Experiment station record}

[In the first three volumes of the Record the abstracts of the statinn reports were grouped by stations, arranged alphabetically by states. Beginning with Vol. 4 an arrangement by topies was aropted, each topic being edited by the dexurtment's expert in that lins. The various topics usually treated in agricultura publications are all represented. With bit few exceptions each number also contained a paper by some noted authority on a particular subject.]

V. 1. September, 1889-July, 1890. 1890. iii $+35 \mathrm{~s} \mathrm{pp}$.

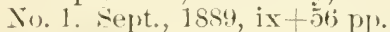

No. 2. Nor., 1889, -5i-115 pp.*

Yo. 3. Jan., $1890,+117-174 \mathrm{pl}^{*}$ *

No. 4. Mar., $1890, \quad+175-243 \mathrm{HP}^{*}{ }^{*}$

No. ‥ May, $1890,+245-307 \mathrm{pl}$.*

Yo. 6. July, 18:0, +309-358 pr.* [Title-page and table of contents for vol. 1, issued with this number. iii pp.]

V. 2. Augunt, 1890-July, 1891. 1891. xxxii +853 pp.

No. 1. lug., $1890, \mathrm{ir}+40 \mathrm{pl}$.

No. 2. Рерt., $1890,+41-8 \mathrm{~s} p 1 . *$

No. 3. Oct., $1890, \mathrm{is}+89-138 \mathrm{pp}$.

No. t. Tor., 1890, v-139-184 pl.

No. 5. llec., 18\%0, vi $185-2641$ 1'.

No. 6. Jan., 1s:1, v $265-308$ pr.

No. T. F(d), 1s!1, vi-309-384 pl.

No. 8. Mar., 1891, vii $+385-168$ pp.

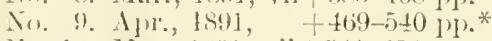

No. 11. Mlay, 1891, vii 541-624 1p.

No. 11. Junc, 1891, vii $+625-698 \mathrm{pp}$.

No. 12. July, 1891, vi $+699-853$ II1\%. [Title-page and table of contents for rol. "2, issued with this number. xxxii plr.]

3. August, 1491-July, 1892. 1892. xxxviii $+1059 \mathrm{pH}$.

No. 1. Aug., $1891, \mathrm{vi}+72 \mathrm{pP}$.

No. 2. Sept., 1891, vi 73-138 एp.

To. 3. (o). 1 , 1891 , vi $1: 39-206111$.

No. 4. Nov, I891, vi $207-27+141$.

Xo. 5. Dere, 1891, vii $275-364$ HP.

To. 6. Ja11., 1892, viit $365-43811 \%$

No. T. F(b), 1892, vi $+439-506$ j).

No. S. Mar., $1892,1+507-584 \mathrm{pp}$.

No. 9. Apr., 1892, vii $+585-6641 \mathrm{pl}$.

Yo. 10. Ma!, 1892, vii $+66.5-758$ 11\%.

No. 11. Jane, 1892, vii $+759-840$ 1p.

No. I2. July, ] 892, vii $8+1-970$ p 1 .

[No. 13.] Index. 1). 979-1059. [Title-palge and table of contents fur vol. :3, issuent with this number. xxxiii lp.]

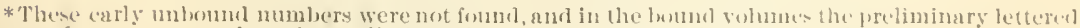
pages of eontents, etr., have been climinated. The pagination given is therefore not entirely inmplete. 
No. 1. Alug., 184:2, vii 110 pl.

No. 2. Sept., 1892, vii - 111-230 pн.

No. 3. O(t., 1s92, vi $+231-322 \mathrm{pl}$.

No. t. Nov., 1892, vi $+323-3144$ 1'1.

No. 万. Dec., 1892, $\mathrm{v}+395-45+\mathrm{pl}$.

No. 6. Jan., 1893, vi $+45.5-524$ l'p. (Errata slip.)

No. 7. Fel., 1893, vi $+525-624$ I'?.

No. 8. Mar., 1893, vi $+625-70011 \%$.

No. 9. Apr., 1893, vii $701-790$ ]"?.

No. 10. Mlay, 189:, vii $+791-878 \mathrm{pp}$.

Yo. 11. June, 1893, vii +879-994 p'p.

To. 12. July, 189:, [1] $+995-1086$ pl. [Title-pare and table of contents for vol. $t$, issued with this number. xxx pp.]

$5 \quad$ ᄂ. 5. 1893-1894. 1845. xxxiv $+1227 \mathrm{pp}$.

†o. 1. 1893 , viii +138 pl.

No. 2. 1893 , viii $-139-268$ J'

No. 3. 1893 , vii $+269-358$ Pl).

No. 4. 1894, vi $+359-452$ pp.

No. 5. 1894 , vi $+453-5+6$ pp.

Ti. t. 1894 , viii $+5+7-666 \mathrm{Pl}$.

No. 7. 1894, vi+667-74t pl).

No. 8. 1894 , vi $745-830$ lu.

No. 9. 1894, vii $+831-940 \mathrm{pp}$.

No. 10. 1894, vii $941-1040$ pl.

No. 11. 1894, v+1041-1106 p'.

To. 12. 1894, pp. 1107-1227. (Cover title only.) [Title-page and table of eontents for vol. 5, issued with this number. xxxiv pp.]

(i) Y.6. 1894-1895. 1896. xii+1194 l'l.

To. 1. 1894 , vi +88 pl. (Cover title only.)

No. 2. 1894, vi+89-17t Pp. (Cover title only.)

No. 3. $1894, \mathrm{v}+175-254 \mathrm{pl}$. (Cover title only.)

No. 4. 1895, vi $255-348$ pl. (Cover title only.)

No. 5. 1895, viii +34!-488 jp. (Cover title only.)

To. 6. 1895, vii $+489-584$ pp. (Cover title only.)

No. 7. 1895, vi $+585-678$ p. (Cover title only.)

No. \&. $1895, v+679-758$ p). (Cover title only.)

No. 9. 1895, vi $-759-850$ pp. (Cover title only.)

No. 10. 1895, vi $+851-944$ pP. (Cover title ouly.)

No. 11. 1895, vi $+945-1082$ pl. (Cover title only.)

No. 12. 1895, 1). 1033-1134. (Cover title only.) [Title-page and table of contents for vol. 6 , issued with this number. xii lp.]

7 ᄂ. 7. 189.7-1896. 1897. $\mathrm{xii}+1092 \mathrm{pl}$.

So. 1. 1895, $\mathrm{r}+\mathrm{7}+\mathrm{p}$. (Cover title only.)

No. 2. 1895, vii $75-166$ pp. (Cover title only.)

No. 3. $1895, \mathrm{vi}+167-260 \mathrm{Hp}$. (Cover title only.)

No. 4. 1895, v-261-342 lp. (Cover title only.)

No. 5. $1896, \mathrm{r}+343-434 \mathrm{pm}$. (Cover title only.)

No. 6. $1896, \mathrm{vi}+435-534$ pp. (Cover title only.)

No. 7. $18 ! 6, \mathrm{v}+535-632 \mathrm{pp}$. (Cover title only.)

No. 8. $1896, v+633-722 \mathrm{ll}$. (Cover title on]y.)

No. \%. 1896, v $+723-814$ w. (Cover title only.)

No. 10. 1896, vi $815-901$ pp. (Cover title only.)

No. 11. 1896, vi-903-996 $\mu$. (Cover title only.)

So. 12. 1896, Pए. 997-1092. (Cover title only.) [Title-page and table of contents for vol. 7 , issued with this number. xii $)$.]

s V. S. 1896-1897. 1897. xiv+1128 pp.

o. 1. 1896 , vi +94 l'r. (Cover title only.)

So. 2. 1896 , vii $-95-176 \mathrm{pu}$. (Cover title only.)

No. 3. 1896, vi $+177-268$ Pl). (Cover title only.)

No. 4. $189 \overline{7}$, vii $+269-35+$ H). (Cover title only.)

No. 5. 1897, vi-355-44t Pr. (Cover title only.) 
Classifleation no.

\section{A10. EXPERIMENT STATIONS OERICE-Continued}

A 10.6: Experiment stalion record-Continued

8 V. 8. 1896-1897-Continuerl

So. 6. 1897 , vi $445-538 \mathrm{pp}$. (Cover title only.)

No. 7. 1897, vi $534-638$ l'1. (Cover title onli.)

No. ร. 1897, r $-639-738 \mathrm{pp}$. (Cover title only.)

Xo. 9. 18\%, vii $+339-838$ plp. (Cover title only.)

No. 10. 1897, v+839-938 pp. (Cover title only.)

ํ. 11. 1897, vi+93i-1086 p). (Cover title only.)

Lis. 12. 1897, pp. 1037-1128. (Corer title only.) [Title-page and table of contents for vol. 8 , iswerl with this number. xivpe.]

V. 9. 1897-1898. 1898. $x v i+1198 \mathrm{pp}$.

No. 1. $189 \%, \mathrm{ir}+100 \mathrm{pp}$. (Cover title only.)

No. 2. 1897, vi $101-200 \mathrm{pp}$. (Cover title only.)

No. 3. 1897, vi 201-300 1p. (Cover title only.)

No. 4. 1897 , vii-301-400 pp. (Cover title only.)

No. 5. $1898, \mathrm{v}+401-500 \mathrm{pp}$. (Cover title only.)

No. 6. $1898, \mathrm{v}+501-600 \mathrm{pp}$. (('over title only.)

No. 7. 1898, vi $+601-700$ pl. (Cover title only.)

No. 8. $1898, \mathrm{vi}+701-800 \mathrm{pl}$. (Cover title only.)

No. 9. 1898, vii $+801-900$ pr. (Corer title only.)

No. 10. $1898, \mathrm{r}-901-1000 \mathrm{pm}$. (Cover title only.)

Yo. 11. $1898, v+1001-1100 \mathrm{jl}$. (Cover title only.)

No. 12. 1898, pp. 1101-119\%. (Cover title only.) [Title-page and table of contents for rol. 9, issued with this number. xri pp.]

T. 10. 1898. 1899. 1899. xvi $1208 \mathrm{pl}$.

No. 1. $1898, \mathrm{y}+100 \mathrm{pp}$. (Cover title only.)

No. 2. 1898, ri -101-200 pl. z pl. (Cover title only.)

No. 3. 189s, vi -201-300 pl. (Corer title only.)

No. 4. 1898 , viii-301-400 pl. (Cover title only.)

No. 5. $1899, \mathrm{vi}+401-500 \mathrm{pl}$. ((over title only)

Yo. 6. 1899, vi -501-600 pp. (Cover title only.)

No. 7. 1899, vii + $301-700 \mathrm{ll}$. (Cover title only.)

No. 8. 1899 , vi $701-800$ pp. (Cover title only.)

No. 9. $1899, \mathrm{r}+801-900 \mathrm{pP}$. (Cover title only.)

No. 10. 1894, vi $-901-1000$ pr. (Corer tithe only.)

No. 11. 18:49, vi 1001-1100 pr. (Cover title only.)

No. 12. 1899, W. 1101-1208. (Cover title only.) [Title-page and talule of contents for vol. 10, iswerl with this number. xvi pp.]

11 V. 11. 1899-1900. 1900. xvi $+1208 \mathrm{pp}$.

No. 1. 1849 , vi 100 1'ए (Cover title only.)

No. 2. 18:19, vii 101-200 Hip. (Cover title only.)

No. 3. 1899, rii +201-300 1)1. (Cover title only.)

No. 4. 18999 , vii $-301-400 \mathrm{pl}$. (Cover title only.)

No. 5. 1899, vi $+401-500$ H'P. (Cover title only.)

No. 6. $1900, x+501-600$ pl?. (Cover title only.)

No. 7. $1900, \mathrm{v}+601-700$ pl. (Coser title only.)

Fo. 8. $1900, \mathrm{v}+701-800 \mathrm{ll}$. (Cover title only.)

No. 9. 1900 , vi $+801-900 \mathrm{pp}$. (Cover title only.)

No. 10, 1900, vi $+901-1000$ pr. (Cover title only.)

No. 11. 1900, vii +1001-1100 pp. (Cuver title only.)

No. 12. 1900, 1\%. 1101-1208. (Cuver title only.) [Title-page and table of contents for vol. 11, issued with this inmber. xil lp.]

V. 12. 1900-1901. 1901. $\mathrm{xvi}+1189 \mathrm{pp}$.

No. 1. $1900, \mathrm{ri}+100$ \%). (Cover title only.)

No. 2. $1900, \mathrm{vi}+101-200$ ) l. (Cover title only.)

No. :. 1900 , viii $+201-300 \mathrm{pl}$. (Cover title only.)

No. 4. 1900, ri $301-400$ ll. (Cover title only.)

No. 5. 1901, vi-401-500 plp. (Cover title m1

No. 6. 1901, vi-501-600 pp. (Cover title nnly.)

No. 7. 1901, vi-601-700 lu). (Cover titleonly.)

No. S. 1901, vi $+701-800$ ps. (Cover titleonly.)

No. 9. 1901, vii $+801-900$ 1\%. (Cover tille only.)

No. 10. 1901, vii-901-1000 1pp. (Cover title unly.) 
T:ubles

l'Iusillcathom no.

110.6:

10.6i:

110.8:

10.6:

10.9:

A 10.10:

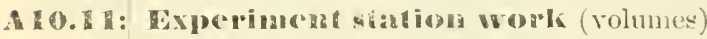

1 Vol. 1. Experiment station work, rol. 1, inchuding lexperiment station work 1-XX (Farmers' bulletins 56, 65, 69, 73, 78, 79, 84, 87, 92, 97, $103,105,107,114,119,122,124,133,144,149) .1902 . \mathrm{xir}+$

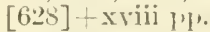

[Title-]wye, table of contents, inflex, and glossary for this yolume were issued as a panphlet of $\mathrm{xi}+\mathrm{xvii}$ pages in orler that the 20 numbers of Experiment station work which har been issued as Farmers bulleting (A1.9:) might be brouglit together. As arach bullotin bears its own paging, the reforenees in the imlex are somewlat awkwal; but in future provision will be made for the volumes by isuing an extra elition of the Farmers' bulletins which contain the numbers of Experiment station work, without the bulletin numbers and with continuwus paging.] 


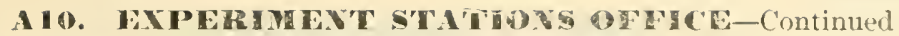

\section{A 10.12: Porte Haco agricultural cxpcrincur station hulletin}

No. 1 not issined 190:2.

21 To. 2. The changa, or mole cricket, in Portu Rien; by O. W. Barrett. 1902. $20 \mathrm{pp}$.

Same. In Spanish. (lad changa, o'grillotalpa en Puerto Rico.) 1902. $20 \mathrm{pl}$.

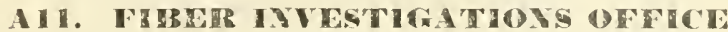

[Fiber investigatious were begun by the Division of Statisties in 18\%9, and in 1890 a Section of Fiber Investigations was ereated in the Division. January 1, 1×91, the Section was made independent. under the name Office of Fiber Investigations, and so contimed unil Jume 30, 149s, when its work was assigned to the Division of Botant. For historical sketeh of Office, sce Yearbook, 1897 ( $11.10: 897)$, p. 22.24.]

\section{A1.1: Anumal peportis}

890

891

892

899

896

897

A 1.2:

A1.8:

A11.8:

A1.5:

ANNUAL REPORT I"PON FIBER INVESTIGATIONS

1890 (Dodge), [1] +451-470 pp. (Also in A1.1:890, p. 451.)

1891 (Dodge), [1] $+417-438$ pp. 2 pl. (Also in A1.1:891, p. 41\%.)

1892 (Dodge), [1] +359-376 pp. $6 \mathrm{pl}$. (Also in A 1.1:842, p. 359.)

1893 (Dorlge), iii $567-581$ pp. 1 pl. (Also in A1.1:893, p. 567.)

1894 (Dorlge). (In A1.1:894, p. 197.)

1895 (Dodge). (In A1.1:895, P. 187.)

REPORT OF SPECIAL $A$ (iENT OF OFFICE OF FIBER INVESTIGATIONS

1896 (Domges), [1]+27-25 pp. (Al>0 in A1.1:896, p. 27.)

1597 (I)odge), $\mathrm{iii}+21-24 \mathrm{pp}$. (Also in A1.1:S97, p. 21.)

\section{General pablizations:}

[Publications which originated in this office but which were publisherl in a numbered series of the secretary"s office, or some other alivison of the Department, alle cutered onty where such numbering places them, with references under the proper headings in the index to this work. Publications of the uffice issered only as Congresuional doeuments are noted in chronological order in tle Appendix to this work.]

\section{Henlletins}

None issmed.

\section{Circolares}

Tone issued.

\section{neporto}

No. 1. Report on flax, hemp, ramie, and jute, with considerations upon dax and hemp eulture in Enrope, report on ramie machine trials of 1889 in Paris, and present status of fiber industries of U. S.; by Charlew Richatrds Dodge. 24l ed. 1842. $104 \mathrm{pp}$.

[For 1st exlition we A27.8:1.]

No. 2. Recent facts regarding ramie industry in America, with brief statements relating to manufacture in Europe, etc.; by Charles lichards Hodge. 189\%. $16 \mathrm{\mu l}$.

[Reprinterl from Rip. of Statistician, May, 1891.]

: No. 3. Sisal hemp culture in Uniterl States [Florida], with statements relating to industry in Yncatan and Bahama Jslands, and brief considerations upon question of machinery for extracting fiber; by Charles Richards Dodge. Is91. 59) p. 8 pl.

No. t. Flax culture for fiber in $T$. S., inchulinespecial reports on flax culture in Irelankl, Belyimm, and Anstria, with statements relative to the industry in Ruswia; ly Charles Richards Dorlge. 1892. 931 p. 2 pl.

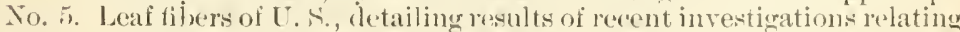
to Florida sival liemp, the falke sival hemp plant of Florila, and other fiber-problucing agaves, bowstring hemp, pineapple fiber, New Ingland flax, and bear grass; by Chas. Riteluards Dodge. 1893. $73 \mathrm{pr} .10 \mathrm{pl}$.

No. 6. Tneultivatel hast tiber of U. K., including history of previons experiments with plants or fibers, and brief statements relating to allied species that am promburl commercially in the old world; by

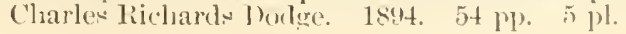




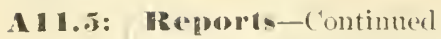

7 So. $\%$. Cultivation of ramir in I'. .., with statements concerning practice in foreign enntries, cost of (nItivation and percentages of yield, the machine question, and preparation of fiber for manufacture; by Chass. Richards Dodge. 18\%5. 6:3 pr. 5 pl.

To. S. Culture of hemp and jute in $[\mathrm{T}$. S... with statements conceming practice in foreign countries, jreparation of fiber for market, and renark on the nachine question; by Chas. Richards Dodge. 1896. $4: 3$ pr. :3 pl.

To. 9. Descriptive eatalogue of useful fiber plants of workl, including structural and economic classitications of fibers; by Chas. Richards Dodlge. 1897. $361 \mathrm{pl}$. 13 pl.

10 No. 10. Flax culture for seed and fiber in Europe and Imerica; by Charles Richarels Doulge. Ists. 80 Pp. 4 pll.

11 No. 11. Culture of hemp in Europe, including suecial consular report on growth of hemp in ltaly; by Charles Richards Dodge. $1898.29 \mathrm{pp}$.

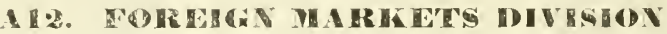

[Formerlysetion of Foreign Markete. For historical sketeh of Division, see Yearbook, 1897 (A1.10:297), 1., 270.]

\subsection{1: Inmeill reports}

s.95 1898 (IItchcock), jii +16.3-166 pp. (Also in A1.1:898, p. 163.)

s99 1899 (Hitcheock), iii + 235-241 pl. (Also in A1.1:899, 1. 235.)

4001900 (Hitcheock), iii $+265-272 \mathrm{pP}$. (Also in A1.1:900, [1. 265.)

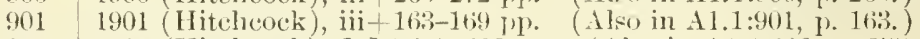

902 1902 (Hitchcock), [1]+377-382 PT. (Also in A1.1:902, p. 37T.)

\section{2: General pabliceations}

[Publieations which originated in this Division but which were unblished in a numbered series of the secretary's oflice, or some other division of the Department, are entered only wheresuch numbering places them, with referenees under the proper headings in the intex to this work. Publications of the Division issuet only as congressional doeuments are noted in ehr. nologieal order in the Appendix to this work.]

\section{A 2.3: Bullerint:}

No. 1. World's markets for American products: (ireat Britain and Ireland. 1895. $93 \mathrm{pP}$.

No. 2. Morld's markets for American products: (ierman Empire. 1895. $91 \mathrm{lp} .1 \mathrm{ll}$.

No. 3. World's markets for Anerican products: France. 1895. 74 ?).

No. 4. World's markets for Imerion products: Canala. 1895. 67 jip.

So. 5. World's markets for American products: Netherlands. 1895. $76 \mathrm{pl}$.

No. 6. Worlul's markets for American proulucts: Belgium. 1895. 90 pp. †o. 7. Worlıl's market, for American products: Norway. 1896. 68 pr. Sante, revised edition. 1898. 68 pu.

No. 8. Worll's markets for American products: Sweden. 1896. 92 pl.. Same, revised. 1898. 9:3 pl).

No. 9. Trate of Lemmark; by Frank H. Hiteheock. 1900. 88 pp. 1 p. No. 10. Our foreign trade in agrieultural pudnets during five fiscal years, 189:-97; by Frank H1. Hitchenck. 1898. 38 pp.

11 To. 11. Spain's foreign trake; by Frank H. Hitcleork. 1s.98. $47 \mathrm{pr}$.

1: $\quad$ To. 12. Onr trale with Span, 1888-97; Wy Frank H. Hitrhcock. 1898. 47 , 1 .

13 No. 13. Tracle of Puerto Rico; by Fank H. Hitcheock. 1898. St pl.

14 No. 14. Trate of l'lilipuine islands; by Frank 11. Ifitchcock. 1898. 160 [P. 1 , 1.

15 No. 15. Ony foreign trate in acricultural products, 18yt-98; by Frank H. Hitclicock. 1599. 4.5 pl. 


\section{Bulletins-Continuert}

No. 16. Distribution of agricultmal exports of ['. .., 1s:4-9s; by Fank H. Hitcheock. $1899.153 \mathrm{pl}$.

No. 17. Sources oi agricultural imports of [. S., 18:4-189s; by Frank II. Hitelscock. 1990. 118 $1 \%$.

Yo. 1s. Our trade with Jatran, (hina, and llongkong, 1ss!s-1s!n?; by Frank 11. Hitcheock. $1900.168 \mathrm{pl}$.

No. 19. Gur foreign trade in agricultural uroulucts, $1890-1899$; W Frank H. Hitcheock. 1900. ti2 lp.

No, 20. Agricultural exports of $\mathrm{T}$. S., Jy comntries, 1895-1899; by Frank II. Hitehcock. $1900.88 \mathrm{mp}$

Yo. 21. Agricultural imports of U. S., He comntries, 1895-1899; by Frank H. Hitcheock. $1900.7 \pm \mathrm{pp}$.

No. 22. Our trade with Scandinavia, 1891-1900; hy Frank 11. IIteheock. 1901. 124 个中.

No. 23. Our foreign trasle in agrimultural prolucts, 1891-1900; by Frank II. Hitcheock. 1900. $61 \mathrm{IP}$.

No. 24. Sources of agricultural imports of Ut. S., 189t-1900; Jy Frank U. Hitchcock. 1901. 1:0 1リ.

To. 25. Distribution of agrieultural exports of $\mathrm{I}^{\top} . \mathbf{s}, 189+1900$; by Frank H. Hitcheock. 1901. $182 \mathrm{pI}$.

No. 26. Agricnltural imports of the United Kinglom, 1s:\%-1900; by Frank II. Ilitcheork. 1902. 2207 p.

No. 27. Our foreign trade in agricultural products, 1892-1901; ly Frank H. Hitcheock. 1902. $67 \mathrm{pp}$.

No. 28. Sonres of auricultural inports of U. S., 1897-1901; by Frank H. Hitcheock. 1902. 132 pp.

No. 29. Distrihution of agricultural exports of U.S., 189i-1901; by Frank H. Hitchcock. 1902. $202 \mathrm{pp}$.

\section{Cirevulars}

No. 1. Peaches and other fruits in England. June 1, 189.5. 11. t. p. $2+$ [1] pl.

No. 2. American dried apples in German Empire. n. t. p. n. d. 4 pp. Same, $2 d$ series [edition]. n. t. p. $3+[1] \mu p$.

To. 3. Imports aml exports for 1893 and 1894 . Ang. 19, 1895. n. t. p. $+\mathrm{pp}$.

No. 4. Example for American farmers and dairymen. n. t. p. n. a. $3 \mathrm{pp}$.

No. 5. Treaty of Shimonoseki between China and Japan of April 17, 1895, and our possibilities of trale with those ronntries. (A.t. 16, 1895 . 11.t.1. 7 pl.

Yo. 6. Imports and exports for 1 s9:3, 1894, and 1895. n. d. n.t. p. $6 \mathrm{pl}$.

No. 7. Extension of markets for American feed stuffs. n. d. n. t. p. $8 \mathrm{pH}$.

To. 8. Manchester district of England as market for American wrohluets. il. d. I. t. p. 8 (l).

Xo. 9. Imports and exports for $18933,1894,189.5$, and 1896 . n. d. n. t. p. $8 \mathrm{pl}$.

To. 10. Conrse of wheat production and exportation in I'nited States, Canara, Argentina, Iruguaty, Rinsia, and Britich India, 1880-96. Oet. 2:3, 18:96. n. t. p. 8 ili.

No. 11. Agricultural products inported and exported by l'nited States, 1892-96. J:11. 9, 1897. 11. t. 1. 8 pए.

Yo. 12. Sonres of principal agrionltural imports of United States during

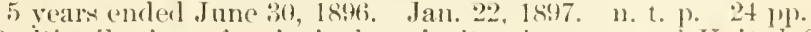

No. 13. Distribution of unincipal agricultural exports of [nited States

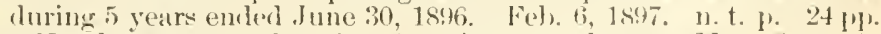
No. 14. Iamburg as market for Imerican products. Max."2, 1897. 1. t. \%. 10 pl.

No. 15. Exports of rotton from Egypt. May 12, 1897. 11. 1. p. 7 p). [Reprinter] from Bull. 2, Experiment stutions ()tlice.]

o. 16. Our trale with Cula fron 1887 to 1897 . June 19, 1897. n. t. p. 30 $\mathrm{pN}$ 


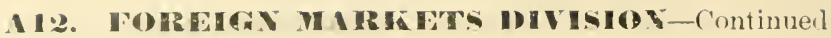

\subsection{1: Cirendalrs-Continued}

17 To. 17. [nited states wheat for Fastern Lsia. June 2.2, 1897. 11. t. p. $8 \mathrm{pl}$.

151 No. 18. Ilawailan commerce, irom 1887 to 1897. July 10, 1897. n. t. p. 37 l P.

1s"2 Same, revised. May 12, 1898. n. t. 1. 37 pp.

19 No, 1!. Sustria-Hungary as factor in world's grain trade; Recent use of American wheat in that comntry. O)et. 5, 1897. n. t. p. 23 pp.

20 No. 20. Agricultural imports and exports, 1893-97. Jan. 22, 1898. n.t.p. 1.5 1.'.

21 To. 21. Inricultural imports and exports, 1894-98. Apr. 24, 1899. 11. t. 1). 16 [P.

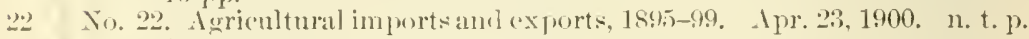
1 li $p$ 'l).

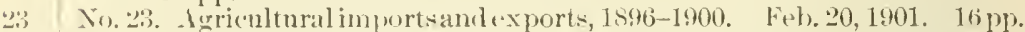

24 No. 24. Agrienltural imports and exports, 1897-1901. Apr. 10, 1902. n. t. J). 16 I'p.

\section{1 3. FOIRESTIEY IBITEEMY}

[Formerly bivision of Forestry. For historien] skuteh, see Vearbook 1897 (A1.10:597), p. 143.]

A 1:3.1:

$\sin 0$

SST

sis

Sis.

$\$ 90$

891

892

899

896

837

898

899

800

901

902

A 1 3.2:

Bis

FTi

1. $1 \%$

165

\section{Amenal reports}

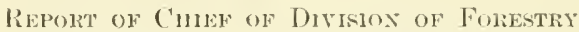

188:; (Egleston). (In 11.1:88:, 1. 4t4.)

1884 (Eigleston). (In 11.1:s84, p. 137.)

1885 (Eyleston). (In A1.1:885, 3). 183.)

1886 (Fernuw), [1]+149-226 pr. $1 \mathrm{pl}$. (1 lso in $11.1: 886, \mathrm{p} .149$.

1857 (Fernow), [1]-156 pp. (Abstract (p). 605-616. 1 map.)

In $11.1: 887,1,605$.

1888 (Fernow), iv $597-641 \mathrm{pl} .1 \mathrm{pl}$. (Alwo in $11.1: 888, \mathrm{p} .597$.)

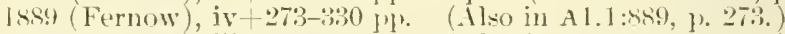

1890 (Fernow), iii $+193-236 \mathrm{pm}$. (Ako in $11.1: 590, \mathrm{p} .193$.

1891 (Fernow), [1]+191-229 pp. \& pl. (1lwo in 11.1:891, p. 191.)

1892 (Fernow), iii + 293-358 pl. opl. (Also in $11.1: 892$, p. 29.3.)

1893 (Fernow), iv +303-363 pp. 3 pl. (Also in $11.1: 893$, J. 303.)

1894 (Fernow). (In 11.1:894, p. 133.)

I 895 (Fernow). (In A1.1:895, p. 149.)

1896 (Fernow), iii $+83-\$ 8$ pp. (1lso in A1.1:\$96. p. 8.8.)

1897 (Fermow), ii $+141-146 \mathrm{pp}$. (Also in $A 1.1: \$ 97.1 \% 141$.

1898 (Pinchot), iii +169-173 N. (Also in 11.1:898, p. 169.)

REPURT OF FoRESTER.

1899 (Pinchot), iii +93-100 pr. (Also in A1.1:599, p. 63.)

1900 (P'inchot), iii + 103-110 pp. (Alko in A 1.1:900, \%. 103.)

1901 (Pinchot), iii + 325-339 pl. (Also in $11.1: 901$, p. 325.)

1902 (Pinchot), iv $+109-136$ fN. (Also in $11.1: 902, \mathrm{p} .109$.

\section{Gicucral publications}

[Publientions wheh originated in this Burenu, but which were published in a numbered series of the secrelary's nftice, or some other division of the Department. are cutercil only where such numbering places them, with references under the proper headings in the morex to this work. Publicatius of the Burean isened only as Congresuional documents are noted in ehronologieal order in the Appendix (1) this work.]

lig trees of ('alifornia. 1900. $30 \mathrm{pp} . \quad 17 \mathrm{pl}$.

[.1ko i-suled us Bulletin no. 28. sige 113.3:2s.]

Forest growth. Letter to Secretary of Acriculture regarding forest growth ant timber consmuption; by B. E. Fernow. Apr. 5, 1893 . n. t. p. :1).

l.mmber and wool trale. Lettur from acent of Forestry Division requesting information as to extent of lumber and woorl trale. July, 18.53. $f^{\circ}$ sheet.*

l'ines. Instructions for collextion of test pieces of pines for timber inrestigations. [1892.] n. t. .1. + pr].

* $\mathrm{Xos}$ eopy. forma. 
R13 Railroads. Alphabetical list of land-grant and bond-aided railroads in U. S. (Extract from Army creneral orters, no. 140, and supplement. ) $1902 .+11 \%$.

Statement of B. E. Fernow, Chief of Division of Forestry, Acriculture Dejartment, before Honse Committer on Acriculture. Feb. 16, 1845. n. t. p. 4 pl).

Trees of Washington, D. C.; compliments of Forestry Division, C. B. sudworth, lotanist, B. F. Fernow, chief. [Ylash., Bell Bros., 1891.] [16] p. [2] maps. oblong $24^{\circ}$ pap.*

\section{3.:3: IBuiletirs.}

No. 1. Relation of railroads to forest supplies and forestry; with appendices on structure of some timber ties, their behavior, and cause of their deray in roarl-berl; on wood preservation; on metal ties; and on use of spark arresters. 1887. 149 ple. 19 pl.

Io. 2. Forest conlitions of Rocky Hountains, and other papers; with majs showing location of forest areas on liocky IIomtain range. 1S8\%. $252+[1]$ Pl. 1 pl. 2 folled tables. 1 map. Same. 21 erlition. $1889 . *$

To. 3. Prelininary rejort on use of netal track on railways as substitute for woden ties, by E. F. Russell Tratman; to which is atder a report of experiments in wood seasoning by Chicago, Burlington and (quincy Railuad Company, and other notes; compiled by B. E. Fermow. 1859. 7? l'?.

No. 4. Substitution of metal for wood in railroad ties, lyy E. I. Russell Tratman; with liscussion on practicable economies in use of wood for lailway purpuse, by B. E. Fernow. 1890. \$36 p. 31 pl.

[For supplemental mattcr, se Bill. 9.]

To. 5. What is forestry? Jy B. E. Fernow. 1891. 52 pl.

To. 6. Timber physics: pt. 1, Preliminary report: Need of investigation; Scope and historicul development of science of "Timber Thysics"; ormanization and methods ot timber examinations in Division of Forestry; compiled by 13. E. Fernow. 1892. iii $+5 i+\mathrm{iv}$ pl. 6 pl. $4^{\circ}$ [For pt. 2, see Bull. s.]

To. 7. Forest Influences: (1) Introduction and summary of conclusions, by B. E. Fermow; (2) Review of forest meteorological oiservations, a stmely preliminary to discussion of relation of forests to climate, by M. IV. Harrington; (3) Relation of forests to watry supplies, by B. F. Fermow; (4) Totes on sanitary simnificatue of forests, ly B. I. Fernow. Aplendires: (1) Determination of true amount of precipitation and its baring on theories of forest influences, by Clevelant Albe; (2) Analyis of rainfall with relation to surface conditions, by (reorge E. Ciurtis. 1893. $197 \mathrm{pp}$.

No. \&. Timber plysis: pt. 2, P'rocress report: Results of inrestigations on long-leaf pine (Pinns palustris). 1893. vii 92 pl. 12 pl. $4^{\circ}$

[For p.t. 1, ser Bulletin 6.]

No. 4. Ure of netal railroad ties and preservative processes and metal tirplates for woolen ties; ly F. E. Rusidl Tratman. Suphlementary to [linlletin no. 4] report on substitution of netal for wool in rail-

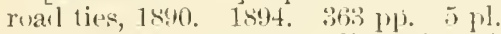

No. 10. Timber, an elementary discusion of eharateristies and profertits of wood; hy Filibert Roth. 1895. Ss pl?.

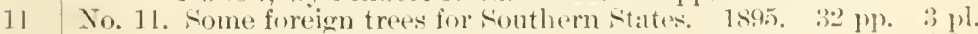

121 No. 12. Fonomical designing of timber trestle Jridges; hy . I. L. Johnsin. 18:16. 57 \%).

$12^{2} \quad$ simut, $1902.57 \mathrm{pl}$.

$13^{1}$ To. 13. Timber pines of southern Tnited States, hy Charles Mohr; with discussion of structure of their wousl. We Fililest Roth. Bs!n. 160 1). 27 , $1.44^{\circ}$.

$13^{2}$ same, rer. ed. 1897. 176 j).

* No enty fomml. 
1:3.:3:

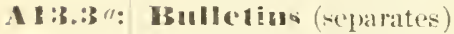

[Inscut ("nemies of white pinc, hy F. II. chittenten, isstent as separate from Bullein no. 22, is the only seprerate of which wo have any recorr.]

\section{1:3.1: Cỏrculak}

$1 \quad[$ Yo. 1.] Request to educator for (on seration. $1880 .+\mathrm{pl}$.*

2 [To. 2.] To educational men. 1ss. (Cire.)

\section{* No (*opy formel.}

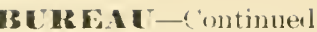

Bullerius-c'untimuer

\section{sulworth, 189\%. viii-419 pl.}

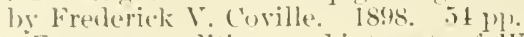
with a lisension ly B. E. Eernow. 1s9s. 7 (i p). 1 pl.

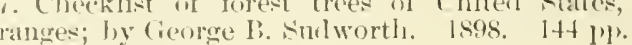

Experimental treo plantinx in the plains; ly Charles 1 . Keffer. 1898. (4t ply. 5 pll.

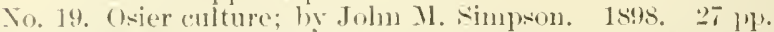
l). 2 pl.

Datrid (i. Fairchild. $1898.241 \%$. tenden: Woud of white nime, he Filibert Roth. 1899. is. $1+$ pl. $4^{\circ}$

No. 23. Dot isiterl 1902.

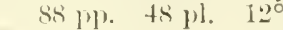

Sane, 56tl ('ong., 1st sess., H. cloc. 727; serial no. 4007. lip. tis $11.12^{\circ}$ 1899. ts \%). 9 j).

7. Practical trea planting in uperation; hy .J. IV. Tonrney. 1900. 27 l'p. $+1,1$.

Same, 5tith cong., 1st. sess., F. renc. 398; serial 110.3877.

see also $1132: 2$ : lits.

lings; by Geo. 13. Snlworth. 1900. ti:; pp. 6 pl. homer and kucenes. Bruce; preceded ly diseussion of conservative hmbering and water supply by Frederick H. Newell. 1901. 64 pl. 11 jl. + maps.

dotes on red "edar; by Charles Mohr. 1901. 37 pp. 3 j1. (rick F. (Hnsterl. 1902. 4S jl). $10 \mathrm{pl}$. large $8^{\circ}$

No. 33. Western hemlock; hy lidward T. Allen. 1902. 55 pl. 13 pl. F. Fox. 1902. 59 py. 20 j. large $8^{\circ}$

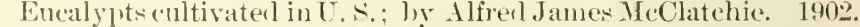

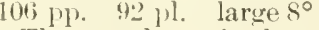
1902. $1.4 \mathrm{~s}$ ). $1 \mathrm{pl} .16^{\circ}$

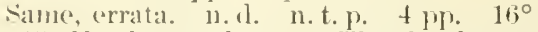

arty catalua. 1. The harly catalpa in commereial plantations, lyy William L. Hall; "2. Diseases of hardy catalpa, by Herman von fillenk. 190:2. 58 pp. $31 \mathrm{pl}$. large $8^{\circ}$ 
133.4: Circulars-Continued

3 [No. 3.] Increasing durability of tumber; information to wood consumers; by Xorman J. Colman. 188. [4] Il).

[No. 4.] For information of railroad managers [chestnut oak for ties; by Jorman J. Colman]. Dec., 18s7. 11. t. 1). "3 1\%. $4^{\circ}$

No. 5. Arbor day planting in Eastern States. n. 1. n. t. \%. [4] pp. $4^{\circ}$

Xo. 6. Instructions for growing tree seedlings. 11. A. 11. t. p. [4] pp. $4^{\circ}$

To. 7. Government timber tests; by B. E. Fermow. 11. 1. n. t. p. [t] up.

To. S. Strength of "boxed" or "turpentine" timber"; by B. E. Fernow. n. 11. 11. t. p. $3 \mathrm{pp}$.

No. 9. Effect of turpentine gathering on timber of pine; by B. E. Fernow. n. d. (Circ.)

No. 10. Sugrestions to lumbermen of $\mathrm{U} . \mathrm{S}$. in behalf of more rational forest numagement; by B. L. Fermow. n. d. 11. t. p. s pp.

No. 11. Farts and figures regarding our forest resources, briefly stated ; by B. E. Fernow. Feh. 10, 1896 . n. t. p. 8 pp.

No. 12. Sonthern pine; mechanical and physical properties [investigations of J. B. Jolneon and Filihert Roth]; by B. E. Fernow. Mar. 6, 1896. n. t. \% 12 1\%. t $^{\circ}$

To. 13. Forest fire legi-lation in United State; by B. E. Fernow. Mar. 16, 1896. 11. t. p. \& pl).

No. 14. Is protection against forest fires practicable? by B. E. Fernow. n. d. n. t. \%. 4 pp.

No. 15. Summary of mechanical tests on $: 32$ species of American wools; by P. E. Fernow. 11. d. n. t. p. 12 p. to $^{\circ}$

In. 16. Age of trees and time of blazing determined by ammal rings; by B. E. Fernow: Alig. 18, 1897 . n. t. \%. $11 \mathrm{pp}$.

No. 17. Recent legislation on State forestry commissions aml forest reserves; by B. E. Fernow n. d. n. t. p. $15 \mathrm{pl}$.

Same, reviseil. Dec. 15,1897 . 11. t. p. $16 \mathrm{pl}$.

No. 18. Progress in timber physics; by B. H. Fermow. Jan. 2, 1898. 1. t. p. $20 \mathrm{pp} .4^{\circ}$

No. 19. Progress in timber physics; hy Filibert Roth. May 25, 1898. n. t. P. 24 pए. $4^{\circ}$

To. 20. Increasing durability of timber; by I3. E. Fernow. May 25, 1898. n. t. p. 5 Pp.

No. 21. Practical assistance to farmers, lumbermen, and others in handling forest lands; by Gifford Pinchot. Get. 8, 1s9s. n. t. p. $5 \mathrm{pp}$.

2.1 No. 22. Practiral assistance to tree planters; by (iifford Pinchot. July 8 , 1899. n. t. P. $11 \mathrm{pp}$.

202 Same, rev. (d. Fel, 15, 1901. 11. t. p. 12 pp.

2:) To. 23. Suggestions to prospective forest students; ly Gifforl Pinchot. Jan. 15, 1902. n. t. p. 5 pp.

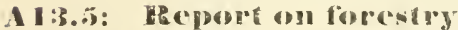

[Vols. 1 and 2 werc published prior to the establishment of the Forestry Division, but are clitsified here in order to bring all the volumes together, as vols. is and 4 were prepareal und transmitted by the chief of the Forestry 1)ivision.]

1 [ [ . l.] $1878 ;$ by Franklin P. Hongh. 650 pl.

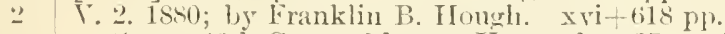

Same, thith Cong., 2d sees., H. ex. dor. 37: serial no, 1922.2.

[V. 3.] 188\%; hy Franklin B. IIongh. xii -318 pe.

Same, tith Cong., 1st sesis, 11, mis, doc. ns; serial no. 204ti.

\section{Precos bulledins (circ.)}

[Notes on work and publications relative to forestry, insled for nse of press.]

No. 1. F(b), :, 1900 .

No. 2. Feb. 17, 1900.

No. 3. Mar. :, 1900.

No. 4. Mar. $23,1900$.

No, 5. Apr. 9,1900 .

6 No. 6. Nlay 2, 1900. 
A13.1i: Mpeso bullerins-Continned

i Xo. 7. June 6,1900 .

s' No. \&. July $7,1900$.

s" To. S. New York supu., July 7, 1900.

(1) ㄱ. 4. Am. 11, 19100.

10 No. 10. Yor. 15, 1900 .

11 Io. 11. Feb. T, 1901.

1.2 ํ. 12. Var. 7,1901 .

13 No. 13. Apr. 8, 1901.

1t No. 1t. July s, 3901 .

15 No. 15. Oct. 30,1901 .

16 No. 16. Jan. 11, 190:.

17 No. 17. July $16,1902$.

1s No. 18, Aug. 12, 1902.

19 No. 19. Ang. 12, 1902 .

20 No. 20. Sept. 5, 1902.

21 No. 21. Fept. 30, 1902.

No, 2.2. Sept. 30, 190)2.

No. 2:3. Nor. 14, 1902.

It No. 2t. Inamage by recent forest fires. n. d.

25 No. 25. Dec. 10,1902 .

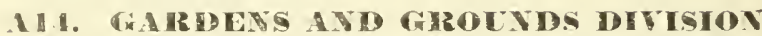

[Mergen] inte 13uresu of Plant Industry July 1, 1901, see A19. For historical sketch of Division, see Fearbook, 1897 (11.10:\$97, p. 180.]

\subsection{1: | Ammial reparta}

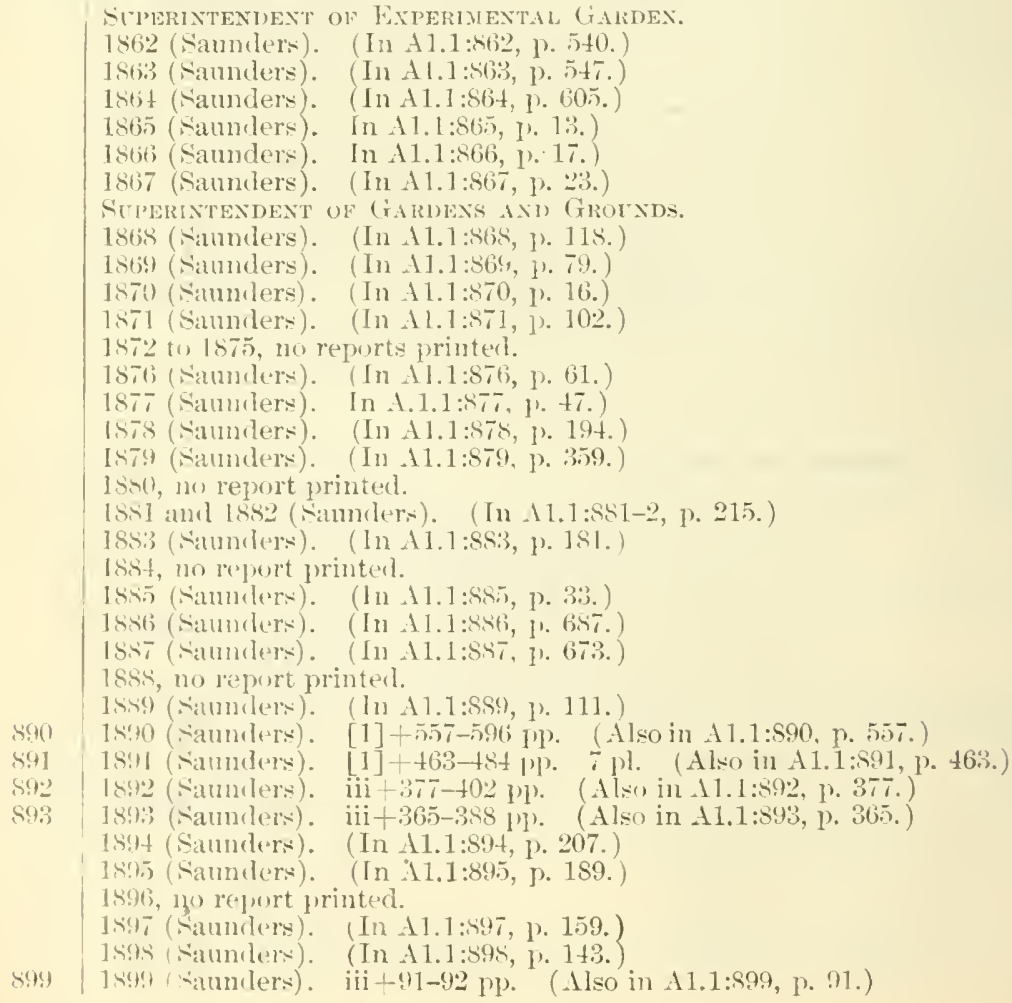


Tables

Classificalion $11 \%$.

1.1.1:

900

\section{2: Gencral pablications}

Tone isisued.

\section{1.:3: IRULlerimas}

1.1.1:

Tone issued.

\section{Circular's}

No. 1. An experiment in tea culture; leport on tea gardens of I) r. ( U. Shepard, Pinehurst, S. C., l,y William Samolers. [1s97.] n.t. p. 101 ip.

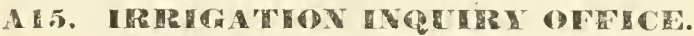

[Discontinuel June 30, 189t.]

\section{A.5.1: Mnumal report:}

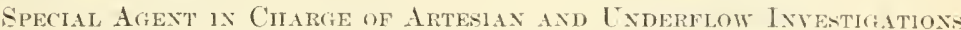
ANU OF IRIGATION IXrLIRY.

890

841

\section{0 (Hinton). [1]+ti1-15s ]p.}

1891 (Finton) [1]-439-1.50 ]). map.

1892, no report printed.

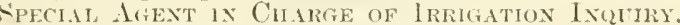

1893 (Irish). (In A1.1:\$93, p. 593.)

CHIEF OF OFFICE OF IRRIGATIUN INQUIRY.

1894 (Irish). (In A 1.1:894, p. 219.)

1895 (Irish). (In A 1.1:895, p. 18\%.)

\section{2: Crencerai poublications}

[Publications which originated in this Oflice, but which were mblished in a num. bered series of the Secretary's Otfiee, or some other division of the Dejartment, are entered only where such numbering places them, with references under the proper headings in the index to this work. Publications of the office issued only as Congressional domments are noted in ehronologieal order in the fonendix to this work.]

Artesian wells. IReport on prelininary investigation to determinc proper location of artesian wells within area of ninety-seventh meridian, and east of foothills of Roxky Momntains; [by Richarrl J. Hinton, and others]. 18:70. $398 \mathrm{IP} .15 \mathrm{pl}$.

Same, 5lat Cong., 1st sess., N. ex. cloc. 22:2 serial no. 2689.

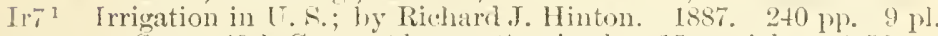

Same, 49th Cone., 2u sess., S. mis. ıloc. 15; surial no. 2450.

$I_{1} 7^{2}$ Irrigation. [Report on irrigation.] (52d Cong., 1st sess., R. ex. doc. t1, in 4 parts.) 189:3. (No serial title-page; \pm pts. homml in one vol.)

Contenis:

l't. 1. Irrigation and eultivation of soil thereby, with physul dnta, ennditions, and

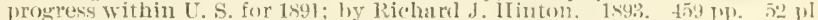

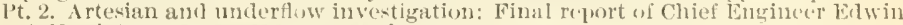
S. Xettleton. 1893. 116 ip. 29 pl.

p'. 3. Final geological reports of artesian und underflow investigation betwen $97 \mathrm{th}$ meridian of longiture and foothills of Rox $\mathrm{ky}$. Iountains; by Robert Hat: 1 s93. $209 \mathrm{pp} .4 \mathrm{lpl}$.

Pt. 4. Final report on misl-plains division of artexian and underflow investigation between 97 th meridian of longitude west of creenwiold and forthills of Rocky Monntains, hy .J. W. Grexory; and special rejort on eertain artesian conclitions in State of Sontl Dakota: by Fresl F. B. (ontin. 1893. (il F]'s spl,

Prift Progress report on irrigation in U. S. for 1890, hy R. J. Ilinton. l't. 1. 1891. 337 pp. 5 pl.

Py42 Same, 1t. 2. P'ogress report of artesian and underflow investinatium between nincty-seventh dogree of west longitule and foothills of Rocky Monntains; by E. S. Nettleton. 1891. 14 j). 12 majs (callerl appendixes).

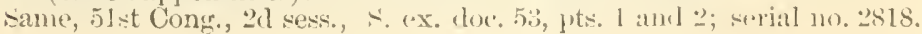




\section{Bulletina}

No, 1. Mlstract of law of the several States and Territories on irrigation and water rights; tompiled by (). A. Critehett. $1893.180 \mathrm{pp}$.

11.3.1:

\section{Circulares}

Some iscmenl.

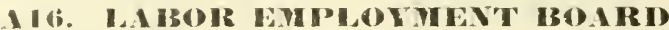

\section{I.1: Intual reparts}

None issmerl.

\section{2: Cuncral pablications.}

In $\bar{\imath}$ Instrutions to applicants for appointment to position of mere unskillerl laborer in I. . . Department of Agriculture, at Washington, D. C.., July 18, 1902. n. t. p. 3 pp.

Lati liegulations governing appointment to position of mere unskilled laborer under Department of Agriculture in D. C., July 2, 1902 . n. t. p. $t \mathrm{pp}$.

\section{3: HBullerins}

Fone issued.

\section{Al6.i: Circulars}

Tone irsted.

\section{A17. I.IEIR ARI}

[For historical sketch of Library ser Yearbook, 1897 (A1.10:597), p. 220.]

\section{A7.1: Annual meporin}

1894 (Cutter) (In A1.1: 894, p. 203.)

1895 to 1897 , no reports printed.

1901 (Clark) $\mathrm{iii}+171-173 \mathrm{pp}$. (Also in $\mathrm{Al} .1: 901,1$ 1. 171.)

\section{A 18.2: Gineral publicatians}

\section{3: Mulletins}

The Librart issues printed Catalogue cards (anthor and subject analyticals) for the fublications of the Department, its endeavor being to fully eatalogue such publications. These cards are supplied to libraries by the Department.

1 No. 1. Accessions to Department Library, [Jan,-Mlar.] 1894. Apr., 1894. n. t. [1. 12 1 \%. $4^{\circ}$

$\because$ So. 2 l'eriodicals and society publisations, currently [1894] received at Deprartment Library, June, 1894. n. t. p. 8 pp. $4^{\circ}$

3 No. 3. Arcessions to Department Lilorary, April-June, 1894. Ang., 1894 n. t. 1. $11 \mathrm{pP} .4^{\circ}$

4 No. 4. Areestions to Department Librars, July-Oet., 1894. Dee., 1894. n. t. 1. 9 pp. $4^{\circ}$

5 No. 5. Aerewions to Department Library, Noy-Dee, 1894. Feb., 1895. 1. t. p. 7 pp. to $^{\circ}$

6) To. 6. Aeressions to Department Library, Jan.-Mar., 1895. May, 1895. 11 t. 1. 12 1) t $^{\circ}$

7 No. 7. Arresions to Department Library, Apr.-Jume, 1845. Aug., 1895. 11. t. 1. $11 \mathrm{pP} .4^{\circ}$

\& Vo. 8. Airesions to Department Library, July-Sept., 1895. Nox., 1895. 11. 1. 1. $11 \mathrm{~Np}$ 4 $^{\circ}$

4) No. 4. List of pufilications of $\mathrm{V}$. S. Department of Agriculture from $18+1$ to Jtne 30, 1895, inclusive: [compiled by Adelaide R. Hasse]. 1896. $76 \mathrm{pp}$. 
1 1 \%.3:

EBulletin:-Continuml

No. 10. Aeressions to Department library, Get.-Der., 1s?5. Feb., 1896. 11. t. 1). 14 ?]). $t^{\circ}$

No. 11. Acerssims to Departnent Library, Jan--Mar., 1896. May, 1 s96. 11. t. 1). 15 l'). to

No, 12. Accessions to Department Library, Apr.-Jume, 1896. Ing., 1896. 11. t. 1) 14 yp. $t^{\circ}$

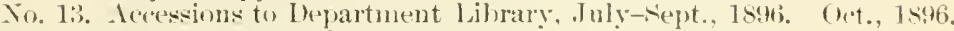
n. t. p. 10 pe. $4^{\circ}$

No. 14. Acressions to Department Library, ().t.-Les:, 1s96. Feb., 1s97. 11. t. 1). 13 pp. $t^{\circ}$

No. 15. Aceessions to Department Library, Jan.-Mar., 1897. May, 1897. n. t. p. 15 l'l\%. t $^{\circ}$

Vi. 16. References to literature of sugar beet exclusive of works in foreign languages; compiled ly Claribel R. Barnett. June, 1897. n. t. p. 9 pl. $4^{\circ}$

['Title and contents supplied for binding nos, 1-s, 10-16.]

No. 17. Aecessions to Department Library, Apr.-June, 1897. Aug. 1897. 12. t. 11. 26 leaves.

No. 18. Bibliograply of poultry; compilerl by Fuma B. Ilawks. Oct. 1897. n. t. j. 32: leaves.

No. 19. Arcessions to Department Lilnary, July-Seje, 1897. Nor., 1897. n. t. p. 25 leaves.

Nu. 20. Reference list of jublications relating to elible and poisonous mushrooms; rompiled by Josephine A. Clark. Jan. 1898. $16 \mathrm{pp}$.

To. 21. Accessions to Department library, Oct.-1)er., 1897. Feb. 1s95. n. t. p. 2:3 leaves.

No. 22. Areessions to Jepartment Library, Jan.-Mar., 189s. Apr., 1898. n. t. p. 88 pl).

No. 23. Areessions to Department Library, Alr.-Jnne, 189s. Ang., 1sise n. t. p. $25 \mathrm{pl}$.

To. 24. List of publications relating to forestry in I tepartment Library. 1898. 93 leaves.

No. 25. Accessions to Department Library, Julv-Sent., 1898. Nox., 1s98. 11. t. p. 16 leaves.

No. 26. Afeessions to Department Lihrary, oct.-Der., 1s.8. Feb., 1899. n. t. 1. 24 leaves.

5i). 27. Areessions to Department Lilirary, Jan.-Mar., 189.. Apr., 1899. n. t. p. 20 leaves.

To. "s. Aceossions to Department Jibrary, A pr.--June, 1899. July, Is99. n. t. 1. 2:3 leaves.

No. 29. Leessions to Department library, July-fent., 1899. Nov., 1899. н. t. p. 2l leaves.

Se. 30. Accessions to Department Library, (tet.-lece, 1899. Feb., 1900. 28 leaves.

No. 31. Acressions to Department Libruy, Jan.-Mar., 1900. May, 1900. 11. t. p. 25 leaves.

Vo. 92. Aceessions to Department Library, Apr.-June, 1900. Ang., 1900. 11. t. 1'. $2: 3$ leaves.

No. 33. Ireessions to Department Lilorary, July-Sept., 1900. Nov., 1900. n. t. I. 1!) leaves.

So. 3t. Aceessions to Department library, (net.-Deee, 1900. Foth., 1901. n. t. p. 28 leaver.

No. 35. Aceessions to Department Library, Jan.-Mar., 1901. Apr., I:401. 3. t. p. 29 leaves.

No, i6. Accessions to Tepartment I ibrary, Apr.-June, 1901. 1901. n. t. p. 24 loaves.

7 No. 37. Catalogue of periodicals and other sorial publications, exclusive of [T.S. Ciovermment publications, in Library of Department of Agriculture. 1901. 362 3 p.

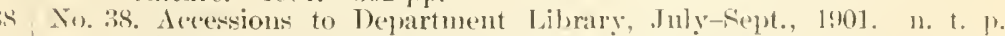
35 1).

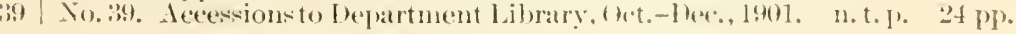


I17.3:

40

$11 \% .1:$

A17.5:

2. Jan., 1902. $37 \mathrm{Pl}$. $51 \mathrm{Pl}$.

\section{Circulars}

None issued.

\section{IBullatins-Continned}

No. 40. Areessons to Jepartment Library, Jan.-1Iar, , 1902. 1902. 6i pp. No. 41. List of references to publications relating to irrigation and land drainatge; conpiled hy Ellen A. Hedrick. 1902. $181 \mathrm{pp}$.

No. 42. Catalogne of publicutions relating to botany in library of $\mathrm{U}$. S. Departusent of Agriculture. 1902. 242 1 pp.

No. 43. Accessions to I) partment Library, April-Jume, 190:. 190\%.

No. 4t. Accessions to Department Library, July-Sept., 1902. 1902.

\section{List of duplieates offered ate cxchanges}

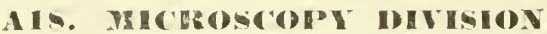

[Division organized in 1‥5: abolished in 1895.]

\section{A5.1: Innual reportw}

Microscopic INTESTIGATIOSS: RePnRT OF Mitcroscoplst 1872 (Taylor). (In Al.1.5.2, [\% Iss.) 1873 ('Taylor). (In Al.1:sis, p. 18:3.) $187 t$ (Taylor). (In A1.1:8it, p. 161.) 1875 (Taylor). (In A1.1:875, P. 187.) 1876 ('Taylor). (In A1.1:\$76, p. 74.) 1877 to 1854 , no reports printed.

Report of Microncopist (Microscopy Divisiox)

1885 (Taylor). (In A1.1:885, p. 8\%.)

1886 (Taylor). (In $11.1: 886$, p. 139.) 1887 (Taylor). (In A1.1:8.87, p. 617.) 1888 (Taylor). (In A1.1:888, p. 559.)

8891889 (Taylor), [1]+191-200 pp. 1: pl. (Also in A1.1:889, p. 191.)

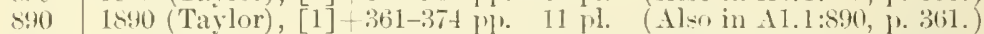

S91 1891 (Taylor), [1] + 405-416 W\%. 9 pl. (Al.o in A1.1:891, 1. 405.)

89.2 1s92 (Taylor), [1]+281-292 ए巾. 9 pl. (Also in A1.1:892, p. 281.)

(MIIEF of Division OF Microaroly

69:3 1893 (Taylor), iii - 297-302 p). T jo. (Also in A1.1:893, p. 297.) 1894 (Taylor). (In A1.1:844, 1. 195.)

\section{A la.e: Rencial publicadisons}

Ft4 Fibrine and hacteria; ly T. Taylor. n. d. 5 pp.*

Ins Mierotone. Letter of ('. P'. J yman to Dr. Thomas Taylor on the work of his microtome. Sept. 30, 1881.*

Ni6 Naphthaline as an insecticide, etc, its effect on seeds, plants, and animals; Jy T. Taylor. 1853. 6 pp.

\section{3: Ibulledius}

None issued.

\section{1: Circulises}

None issured.

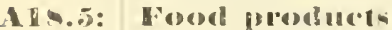

$1^{1}$ No. I. Twelve edilute mushronms of U. S., with dirertions for their identification and their preparation as fool; by Thomas Taylor. (Reprinted from report (ommisioner of Igrienlture for 18\&5.) 1893. 20 il. 1 1\%.

1. Sanc, [reprinted with addition of article on mushrom industry (Falconer).] 1894. 20 Pl. $1 \mathrm{fll}$.

* so erivy found. 


\section{Food products-Continued}

21 No. 2. Eight edible and twelve poisonons mush romms of $T$. S., with directions for eulture and eulinary preparation of the edible species; by Thomas Taylor. (Reprinted from report of -ecretary of Agriculture, 1890 , pu. 366-373, with appendix: List of edible fungi of U.S.) 1891. 16 pI. 5 pl.

Same, 21 rev. el. [24 etl. rev.]. 1893. 23 jp. 6 pl.

No. 3. Improved methork of distingujshing hetween pure and fictitions lard [and] Four edible mushrooms of U. S.; by Thomas Taylor. (Reprinted, with revision, from report of Secretary of Agriculture for 1891.) 1893. 22 pp. $6 \mathrm{pl}$.

\section{A19. PLAVE IVIDSTIEY METREAU}

[The Bureau of P'lant Industry was organized July 1, 1901, by the consolidation of the following divisions of the Department, viz: Agrostology Division, see A3; Botany Division, see Af; Gardens. and Grounds Division, see A14; Pomology Division, see 120, Seetl and Phant Introduction, see A23; seed Division, sre A24: Vegetable Physiology and Pathology Division, ste A2s. Also Arlington Experimental Farm and Tea [nvestigations and Experiments Oftice.]

\section{1: | Ansual reports}

9011901 (Galloway), iij-49-94 II). (Also in A1.1:901, 1). 43.)

902 1902 (Galloway), iv $+47-108$ pp. (Also in 11.1:902, p. 108.)

\section{A 19.2: Gencrall publicatians}

F7t Furage crop seed. Plan of clistributing forage crop seed and cultural directions for crops distributed. [1902.] 1 n. t. P. $8 \mathrm{Pl} .16^{\circ}$

P963 Publications. List of publieations of Otfice of Crass and Forage Plant Investigations and Division of Agrostology; by IV. J. Spillman. 1902. $12 \mathrm{pl}$.

T5̆5 Tobacen seel. Plan of distributing tobaceo seed and cultural directions for different types of tobacco distributerl. [1902.] $11 . \mathrm{t} . \mathrm{p} . \quad 15 \mathrm{pp}$. $160^{\circ}$

\section{A 19.3: Bonllerins (large $8^{\circ}$ )}

$1^{I}$ No. 1. Relation of lime and magnesia to plant growth; 1, Liming of soils from pliysologi(al stamlpoint, hy ()ear Loew; 2, Experimental stndy of relation of lime and magnesia to plant growtl, by D. WW. May. 1901. 53 \%1. : $\mathrm{pl}$. Sime, corrertel. 1901. 5:3 p. $3 \mathrm{pl}$.

No. 2. Spernatogenesis and feeundation of zania; by llerbert J. Webher. 1901. 100 ple. $7 \mathrm{pl}$.

To. 3. Macaroni wheats; by Mark Alfred Carleton. 1901. 62 PD. 11 pl.

No. t. Ranger improvement in Arizona; by David cirittiths. 1901. BII IP. it pl.

No. 5. Seerls and plantw imported, inventory no. "4, numbers 4351-5̃ono. 1902.79101.

See for inventories 1-8, \7.6:1-8.

No. 6. List of American varieties of peppers; by $\mathbb{W}$. W: Tracy, jr. I902:. 19 \%).

No. 7. Algerian durum wheats, chassitied list, with dewriptions; by (arl S. Scotield. 1902. 48 pr. is pl.

$8 \quad$ No. s. Collection of economie and other fmur prepared for clistribution; loy Flora W. I'atterson. I!:0\%. :31 ly).

No. 9. North Amerian species of Spartina; ly Ehmer 1). Merrill. 1!102. 16 ㅆ.

No. 10. Records of seed distribution and conperative experiments with

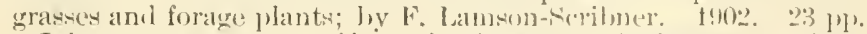

11 No. 11. Johneon grass, report of investiuations numle during : ly Carleton R. Ball. 1902. 204 Hp. 1 pl.

12 No. 12. Stock ranges of northwestern Californiar, notes on grasses amel forage plants and range conditions; be Juenh Burtt I)ary. 1902. $81 \mathrm{pp} .8 \mathrm{pl} .3$ maps. 
A19.3:

$119.8 \%$ :

R31

19.1 :

19.5:

\section{Bullesino-continuerl}

Yo. $1 \%$. Fipriments in range improvement in Central Texas; by $11 . \mathrm{L}$. Bentley. 1902. $72 \mathrm{pp} .2 \mathrm{pt}$.

Yo. 1t. Decay of timber and methods of preventing it; by Hermann von Sehrenk. 1902. 96 pp. 18 pl.

To. 15. Forage conditions on northern border of Great Basin, being report upon investigations made during July and August, 1901, in region between Winnemncca, Ner., and Ontario, Oregon; by Dari.l Griffiths. $1902.60 \mathrm{pp} .16 \mathrm{pl}$. 1 map.

No. 16. Preliminary study of germination of spores of Agariens campestris and other hasidionycetous fungi; by Margaret C. Ferguson. 1902. 43 il. 3 pl.

No. 17 . Some diseases of the cowpea; 1 , Wilt disease and its control. by IV. A. Orton; 2, ('owpea resistant to root-knot, by Herbert $\dot{J}$. Webber and W. A. Orton. 1902. $38 \mathrm{pp} .6 \mathrm{pl}$.

No. 18. Observations on mosaic disease of tohacco; by Albert F. Woods. May $15,1902.24 \mathrm{pp} .6 \mathrm{pl}$.

No. 19. Kentucky bhuegrass seed, harvesting, euring, and cleaning; by A. J. Pieters and Edgar Brown. 1902. 19 pp. $6 \mathrm{pl}$.

No. 20. Manufacture of semolina and macaroni; by Robert P. Skinner. 1902. 31 pp. 5 pl.

No. 21. Not issued 1902.

No. 22. Injurious effects of premature pollination, with general notes on artificial pollination and setting of fruit without pollination; by Charles P. Hartley. 1902. $48 \mathrm{pp} .4 \mathrm{pl}$.

No. 23. Berseem, the great forage and soiling (rop of Nile Valley; by David G. Fairchill. 190\%. $20 \mathrm{pp} .14 \mathrm{pl}$.

No. 24. Manufacture and preservation of unfermenterl grape must; by George C. Husmann. 1902. $19 \mathrm{pp} .1 \mathrm{pl}$.

No. 25. Not isilled 1902; see for arlvance issue A19.3 $\tau$ :R31.

No. 26. Spanish almonds and their introduction into America; lir David G. Fairchild. 1902.16 pp. 8 pl.

Nos. 27-29, not issued 1902.

No. 30. Budding the pecan: by George W. Oliver. 1902. $20 \mathrm{pp} .8 \mathrm{pl}$. No. 31. Cultivated forage crops of Northwestern States; by A. S. Hitcheock. 1902. $28 \mathrm{pl}$. $7 \mathrm{pl}$.

ubullerins (sejarates)

Rescue grass. Seeds of resene grass and chess; by F. H. Hilhnan. 1902. $[1]+4 \mathrm{pp}$.

[Adrance issue of portion of Bulletin no. 25.]

\section{Circulars}

None issued.

\section{Novelties and specialties, Distribution of $\left(16^{\circ}\right)$}

Section I. n. t. p. 4 pp.

Section 2. n.t. 1. 4 pp.

Section 3. n. t. p. 4 pp.

Section 4. n. t. p. 4 pl.

Section 5. 11. t. p. 4 pp.

Section 5 ${ }^{a}$. n. t. p. 4 pp.

Section 6. n. t. p. $4 \mathrm{pp}$.

Section $6{ }^{a}$. n. t. p. 4 pp.

\section{A 20. POMOLOGY DIVISION}

[Merged into Bureau of Plant Industry, July 1, 1901, see A19. For historical sketch of Division, see learbook, 1897 (A1.10:897), p. 111.]

\section{A20.1: Annual reparts}

REPORT OF POMOLOGLT

1886 (Van Deman). (In A1.1:886, p. 259.)

8871887 (Van Deman), [1]+6:7-65: pp. 9 pl.

1888 (Van Deman). (In A1.1:888, P. 565.)

(Also in A1.1:887, p. 627.) 
A20.1: Innual reports-Continued

sis

$\$ 90$

891

s. 2

893

8.14

(3).

$8: 96$

8.7

898

899

900

901

\section{2: Gencral publications}

[Publications which originated in this Division, but which were published in a numbered series of the secretary's office or some other division of the Department, are entered only where such numbering places them, witl references under the proper headings in the index to this work. Publications of the bivision iswed only as Congressional documents are noted in chronologieal order in the Apendix to this work.]

Nut culture in U. S., embracing native and introduced species; [compilerl by W. P. Corsa]. 1896. $144 \mathrm{pp} .16 \mathrm{pl}$. large $\mathrm{S}^{\circ}$

IIt

No. 1. Report on condition of tropical and semitropical fruits in United States in 1887, prepared under direction of Commissioner of Agriculture; Tropical and semitropical fruits in Floricla and Gnlf States, by P. IV. Reasoner; Tropical and semitropical fruits of California, Arizona, and New Mexico, by W. G. Klee. 18s8. 149 ly. 3 pl.

Sime, [2l ed.]. 1891. 149 Pl.

No. 2. Adaptation of Russian and other fruits to extreme northern por. tions of [nited States; [ly T. T. Lyon]. 1888. tit pp.

To. 3. Classification aud generic synopsis of wild grapes of North America; by T. T. Munson. 1890. 14 lp.

No. 4. Relative merit of varjons stocks for orange, with notes on mal di goma and mutual influence of stock and scion; [compiled by William R. King]. 1891. 21 jp.

No. 5. Fig culture; edible figs, their culture and curing, by Gustar Fisen; Fig culture in Gulf States, by Frank S. Farle. 1897. 32 1).

No. ti. Catalogne of fruits retommended for cultivation in varions sections of U. S., ly American Pomological Society; revised by committee of society, T. T. Lyon, chairman. 1897. 39 pp.

No. 7. Fruit industry and sulstitution of domestio for foreign-orown fruits, witl historical and descriptive notes on ten varieties of apple suitable for export trade; by William A. Taylor. 1898. vii $+305-362$ jl. 5 jl.

[Reprint from Yenrbook for 1897.]

No. 8. Revised catalogne of fruits recommended for cultivation in various sections of $U$. F. and British provinces, by Anerican l'omolowieal Society; revised by committee of society, WT. H. Ragan, chairman. 1899. 63 р) 1 p. 1.

No. 9. Fin, its history, culture, and curing, with deseriptive catalogue of known valieties of figs; by (iustav fisen. 1901. $317 \mathrm{pl}$. $16 \mathrm{pl}$.

No. 10. P'rmes and prume conlmre in Western Wurope, with sperial reference to existing conditions in Pacife Northwest; by Edward h. Lake. 1901. 23 pl. 10 pl. 


\section{Tilbles}

I Iam) tloll $11 \%$.

\section{1: Circular}

[lieprinted from Report of l'omologist for 1894.]

fo. 1. Nut culture; ly II. M. Engle. August 18, 1896 . 11. t. p. 4 pp.

No. 2. P'rme culture in P'acific Northwest; by F. R. Lake. n. 1. n. t. p. 7 l).

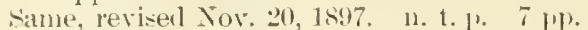

No. 3. Noter on peach culture; by J. II. Hale. n. d. n. t. 1. 10 pp.

Sime, revined Nox. 20, 1897. [Erronenusly numbered 40.] 11. t. p. $8 \mathrm{pP}$.

same [with correct mumber.] n. t. F. is ly.

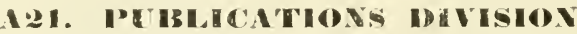

[Formerly Division of Recoris and Editing.]

\section{1: Anurial peports}

REPorT of EDITUR

1868 (Doulge). (In A1.1:868, P. 190.)

1869 (I)orlge). (In Al.I:869, p. 157.)

1870 (Dodge). ( $\ln$ A $1.1: 870$, P. 153.)

1871 (Dorlge). (In A1.1: $871,1.123$.

1872 to 1888 no reports printed.

1889 Report of Secretary relative to establishment and work of the division. 3 lp. (1lso in A 1.1:889, p. 10.)

Report of ChIEF of Division of Records aNd EDITINg

890

S.41

$8(1) 2$

8.93

$8: 14$

89.5

$890^{\circ}$

897

805

849

900

901

902

A21.2:

Axs

Atti

[3:17

(4) :

( $44^{2}$

Fo..2 1

1:20."

F. 2023

F.2.24

F.:25

$\mathrm{P}^{3} \mathrm{6}$

$\left.P^{3}\right) 6^{2}$

1890 (Hill), [1] $+4: 37-477 \%$ (Also in $\ 1.1: 890, \mathrm{p} .437$.

1891 (Hill), [1] + $489-498$ p. (Also in A1.1:891, P. 489.)

1892 (Hill), [1] $+497-508$ pl). (Also in A $1.1: 892$, p. 497.)

1893 (Hill), iii $+395-408$ pl). (Also in $\Lambda 1.1: 893$, \%. 395.)

1894 (IIill), iii $+171-184$ jp. (Also in A1.1:894, 1. 171.)

REPORT OF CIIEF OF DIVISION OF PUBLICATIONS

1895 (Hill), iii $+221-244 \mathrm{Pl}$. ( 11 so in Al.1:895, ए. 221.)

1896 (IIill), iv $+29-76$ p). (Also in $11.1: 896,1.29)$.

1897 (Hill), iv+25-91 Pp. (Also in A1.1:897, ए. 25).

1895 (Hill), iv +4is-86 pl. (Also in Al.1:898, I. 43 ).

REPORT OF EDITOR

1899 (1Fill), iv +161-211 pl. (Also in 11.1:899, p. 161.)

1900 (Mill), iii $+113-164$ pl). (Also in $11.1: 900$, p. 113.)

1901 (Hill), iii-271-324 j). (Also in 11.1:901, p. 271.)

1902 (Hill), iii +317-376 l'l. (Also in 11.1:902, p. 317.)

\section{Genceral pobalicarioms}

Agrioulture Department. Department of Agrioulture and its work; by George William Ilill. Aug. 6, 1898. n. t. p. 12 lip.

Atlanta, (ra. Organization of $T$. S. Department of Agrimulture and list of its exhibits at Cotton statesanel hotemational Exposition, Atlanta, (ia., Sept. 8, 1895, to Jan. 1, $1896.1895 .14 \mathrm{pP} .4 \mathrm{pl}$. $16^{\circ}$

butter making. Report on recently patented process of butter making; liy I. E. Falmon. Nov. 20 , is?7. n. t. $\mathrm{p} .3 \mathrm{pl}$.

(Circulats issued loy the various divisions of the Department of Agrieulture to Nov. 1, 18:77. n. p. n. (l. 11 p).

Circulars of information [issued by the various divisions of Agrienlture Department]. n. 1. 11. t. p. 6 pp.

Farmers bulletins [arailable for distribution]. July 10, 1s96. n. t. p. \pm Pl\%.

$$
\begin{aligned}
& \text { Fame. Oet. 7, 1896. n. t. 1'. } 4 \text { p). } \\
& \text { Same. Feb. 1, 1897. n. t. p. } 4 \text { lly. } 4^{\circ} \\
& \text { Same. Apr. 1, 1897. 11. t. p. } 3+[1] \text { pl. } 4^{\circ}
\end{aligned}
$$

P'ublication work as affected ly law of Jan. 12, 18,.). Jan. 18, 1897.

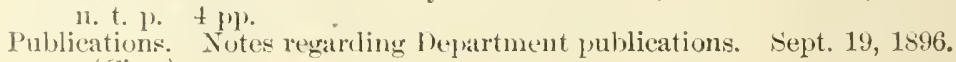
(Circ.) 
(lasisification 11 \%.

2:4.2:

$\mathrm{I}^{3}(1) \mathrm{i}^{3}$

R2?)

\subsection{3:}

A.21.1:

A.1.5:

\section{A21. PIBLICATIOXS DIVISIOX-Continuted}

\section{Gancral publicationa-Continued}

Publications availalle. Special list of publications available 1 pr. 10, 18.99 , for distribution to correspondents and others rendering service to the Department. n. 1. n. t. p. 10 pp.

Reprints. [list of] Congressional reprints for sale by Supt. of Documents. April 30,1897 . 11. t. p. $2 \mathrm{pl}$.

\section{Bulletins}

[No. 1.] Index to annual leports of $[$. . . Department of Agriculture, 18.37 to 1893; [compiled hy Georce 1. Thompson]. 1896. 25:2 pl.

No. 1. Same, [reprint, 1899]. $252 \mathrm{pP}$.

No. 2. Synoptical index of reports of Statistician, 1 sto to $1594 ;$ by Geo. F. Thiompson. 1897. $258 \mathrm{pp}$.

No. 3. Historical sketch of C. S. Department of Agriculture, its objects and present organization; compiled lyy Charles 11. Greathouse. 1898. $74 \mathrm{pP}$. $3 \mathrm{pl}$.

Same. Revised edition. 1898. it pl. 3 pl.

No. 4. Index to anthors, with titles of their publications, in documents of U. S. Department of Agriculture, 1841 to 1847 ; by Geo. F. Thompson. 1898. $303 \mathrm{pp}$.

No. 5. Index to literature relating to animal industry in publications of Department of Agriculture, 1837 to 1898; by George Fayette Thompson. 1900. $676 \mathrm{pp}$.

No. 6. List by titles of publications of $\mathrm{C}$. S. Department of Agriculture from 1840 to Jume, 1901, inclusive; compiled and compared with originals by R. L. Mandy and Minna A. Cannon. 1902. $216 \mathrm{pl}$.

No. 7. Index to yearbooks of $\dot{C}$. S. Department of Agriculture, 1894-1900; prepared by Charles H. (ireathouse. 1902. 196 \%l.

\section{Circulars}

No. 1. Organization of Dept. of Agriculture, 1901-1902. Oet. 23, 1901. n. t. p. $20 \mathrm{pp}$.

\section{list of bullelins and cireulars avalable for frec distribu-} ion. [Publication] no. 247.

Corrected to Nov. 1, 1897. 15 pp.

[Revised.] Corrected to O.t. 1, 1898. 18 pu.

3i ed. Corrected to Jnme 1, 1899. 20 pp.

the ed. Corrected to July 1, 1899. 20 pp.

5th ed. Corrected to Apr. 1, 1900. $21 \mathrm{pp}$.

6tli er. Correcterl to O(.t. 15, $1900.24 \mathrm{pp}$.

ith ed. Corrected to Jan. 1, 1902. 24 pp.

\section{Manthy list ot publications}

[Note.-Issued as a olle-page circular of variols sizes up to March, 1896, when it became a pamphlet of from 3 to 8 pages, without title page, in which form it is still issued.]

1892. Jan.-Dec.

1893. Jan,-I Iec.

1894. Jall.-Der.

1895. Jan.-Dec:

1896. Jan.-Dec: [2d ell of Nov., Jan., and Fet).]

1897. Jan.-I)ec.

1898. Jan.-Dec. [20l enl. of Aug. and sent.]

1899. Jan.-I )ec.

1900. Jall.-Dec.

1901. Ja11.-Dec.

1902. Ja11.-Dec.

\section{Prens notices}

[Synoptical notices of publications which are to uppear. Distribnted in large numbers to the press for cony.] 
Doseruncuts. [Publication no, 179.]

$1^{1}$
$1^{2}$
2
3
4
5
6
7
5
9

[1st exl.] Fel, 19, 1Siti. 15 ply.

same, supl. Aug. :3, 1s96. [Erroneonsly called "Ciremlar" 179.]

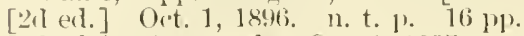

[3] exl.] ('orrected to Oc.t. 1, 1897. n. p. 11. d. 2s p]).

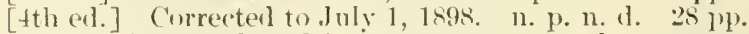

5therl. Correrted to Feb. 1, 1899. n. 1. n. 1. :33 1.].

bith ed. Correcterl to F(b. 1, 1900. n. 1) n. d. $37 \mathrm{pl}$.

7th erl. ('orrecterl to July 1, 1900. n. 1. n. d. 36 pl).

sth ed. Corrected to Ang. 1, 1901. n. 1\%. n. 1. 40 ply.

th ed. Corrected to Aug. 1, 1402. 1902. 45 P\%.

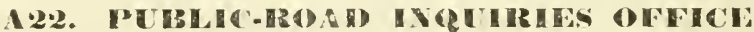

[Formerly oftice of Road Inquiry. For historienl sketeh of the Oftiee, sef Yearbook, 1897 (A1.]0:897).

\section{A22. I: Anmual reports}

$$
\text { 1. 17.5.] }
$$

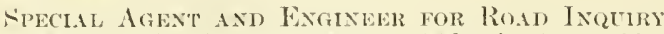

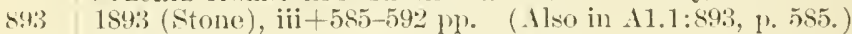

1894 (Stone). (In A1.1:S!1t, p. 217.)

1895 (Strune). (In A 1.1:895, P. 195.)

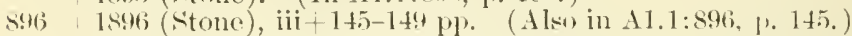

I) IRECTOR OF ORFICE OF RoAl) INCLTIRY

8971897 (Ntone), iii $+173-175 \mathrm{pl}$. (Alwo in A1.1:897, 1. 173.)

s.9 1898 (Dodge), iii + 159-162 11). (Also in A 1.1:898, 1. 15!.)

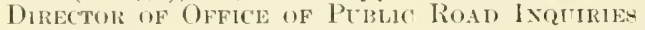

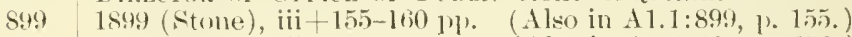

9001900 (Dolge), ii +279-291 pp. (Also in A1.1:900, 1. 279.)

ReIORT aF OFFI('E OF PIBLIC RoAl) INQTIRIES

901 1901 (Dorlge), iii-235-252 pp. (Al=0 in A1.1:901, 1. 235.)

9021902 (Jorlge), iii-305-316 llp. (Also in A 1.1:902, 1. 305.)

\subsection{2: Genceal publications}

[Publications which originated in this Office, but were published in a numbered series of the Secretary's office, or some other divisiom of the Department, are entered only where such numbering places them, with references under the proper loradings in the indes to this work. Publications of the oftice issued nnly as Congresional documents are noted in chronological order in the Appendix to this work.]

Agrs 1

Agricultural colleges. [Letter regarding comperation of Roarl Inquiry Office with agricultural colleges and experiment stations in disseminating information upon best methods of road-making; by lioy stone.] Hec. 1, 18:6. 11. t. P. :3 pp.

$\operatorname{Ag} 8^{2}$ Same, [reprint. 189\%.] 11. t. \%. 3 pr.

1386 Buffalo, $N$. Y. [Letter of invitation inclosing eall for an International Ciood Roals Congress, to be hell at Buffalo, X. Y., Sept. 16-21, 1901.] A119. 5, 1901. 2 1.

Cos ${ }^{1}$ Charlottesille, Va. [Letter of invitation to attend Jefferson Memorial and lnterstate Gond Robls Convention to be held at Charlottesville, Va., A pr. 2-4, 190:2] Nhar. 3, 1902. (Cire.)

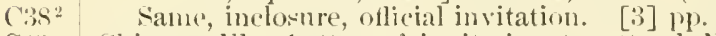

C4: Chicago, Ill. Letter of invitation to attenel National Good Rokls and Irrigation inngresses, to be helil at Chicago, Ill., Nov. 19-24, 1900. Oct. 25,1900 . (Cire.)

Eds Eduction. Correspondene with Commissioner of Eabeation. June 2, 1896. (Cire.)

I.11 Laboratory for physical and hemieal examination of road materials. 11. d. (Cire.)

Lin6 ${ }^{1}$ Letter to accompany Cirenlar No. 17. Tune 1, 1896. n. 1. (Cire.)

L.56 ${ }^{2}$ Letter to acompany correspondence and documents. June 12, 1896 , 11. 1. (Cire.)

No1 National Roarl Parlianent. [Notiee of meeting of National loarl Parliament.] Sept. ]5, 184s. (Circ.)

Py6 $^{1}$ Publications of Otfice of Rual Inquiry. [1896.] (Cire.) 
1.2.2:

$\mathrm{PQ6}^{2}$

$199 j^{3}$

$\mathrm{PQ6}^{4}$

$\mathrm{P}^{6} 6^{5}$

$\mathrm{P} 96^{6}$

[:i:3]

1 :2.:3:

1.2.

PV IBI I C'-RROAI

IVREHIES

OE. ICE-Continuerl

\section{Gencral fablicatioms-Continued}

Publications of Office of Road Inuniry. [1897.] n. t. p. 6 1'p** Sime, and adrlenda. $[1899$.$] n. t. p. 6 \mathrm{pp}$.

Same. [1 1 s49.] n. t. F. 7 pr.

Same, corrected to dpr. 2, 1900. n. t. p. $8 \mathrm{pp}$.

Same, rorrected to Sept., 1901. s pp.

[Resmmption of oflice and greneral inquiries.] Fel). ti, 1899. (Cire)

\section{EBulletiprs}

No. 1. State laws relating to management of roals, enacted in 1858-93; compiled by Roy Stone. 1894. $95 \mathrm{pp}$.

No. 2. Proceedings of Minnesota Ciood Roads Convention, helel at St. .Paul, Yimn., Jan. 25, 26, $1894.1894 .16 \mathrm{pp}$.

No. 3. Improvement of road system of (ieorgia; by 0. H. Sheffield. 1894. $31 \mathrm{pl}$.

No. 4. Roarl-making materials in Arkansas; by John C. Branner. 1894. 11 1 p.

No. 5. Information regarding mal materials and transportation rates in certain states west of Mississippi River; fumished by officials of various railway companies. $1894.2 \pm \mathrm{pp}$.

Yo. 6. Information regarding roads, road materials, and freight rates in certain States north of Ohio River; furnished by officials of varions railway companies. $1894.30 \mathrm{pp}$.

No. 7. Information regarling ruads and roal-making materials in certain Eastern and Southern States; furnished by officials of varions railway companies. $1894.29 \mathrm{pp}$.

No. 8. Earth roads, hints on their eonstruction and repair; eompiled by Roy Stone. 1894. $20 \mathrm{pp}$.

No. 9. Ntate aid to road building in New Jersey; by Edward Burrongh. 1894. $20 \mathrm{FP}$.

No. 10. Proceedings of National Road Conference, Asbury Park, July 5,6 , 1594. 1894. $63 \mathrm{\mu p}$.

No. 11. Proceelings of V'irginia Good Roads Convention, Richmomu, Va., Oct. 18, 1894. 1895. $62 \mathrm{pp}$.

No. 12. Wide tires, laws of certain, States relating to their use, and other pertinent information; compilerl by Roy Stone. $1895.16 \mathrm{Pp}$.

No. 13. Kentuck $\mathrm{y}$ highways, history of old and new systems; by M. H. Crump. 1895. 24 mp.

No. 14. Good roads, extracts from messages of governors; compiled by Roy Stone. $1895.24 \mathrm{pp}$.

No. 15. Proceedings of Good Roads Convention of Texas, Honston, Tex., Feb. $19,1895.1895 .24 \mathrm{pr}$.

No. 16. Notes on employment of convicts in connection with road builsing; compiled by Roy Stone. $1895.15 \mathrm{pp}$.

sane, revised erlition. 1898.21 p.

No. 17. Historical and technieal papers on road building in [nited states. 1895. 52 $1 \%$.

No. 18. State law's relating to management of roads enacted in 1894-1895; compiled by Roy Stone. $1895.86 \mathrm{Hp}$.

[Continuation of Bull. 1.]

Same, Supplement. 1895. $v+87-124 \mathrm{pp}$.

No. 19. Progress of roal construction in Lnited States; reports by delegates to National Roakl Parliament, Atlanta, (ia., Oct. 17-19, 1895. 1897. $47 \mathrm{pl}$.

No. 20. Traction test:; by samuel T. Neely. 1896. 22.2p. 2pl.

No. 21. Proceedings of International Gond Roads Congress, held at Buffalo, N. Y., Fept. 16-21, 1901. 1901. 100 pp.

No. 22. I'roecedings of $3 d$ Annual Good Roats Convention of Poards of Supervisors of State of New York, held at Albany, N. Y., Jan. 28

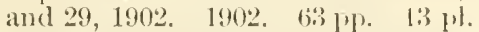

No. 2:?. Rual eonventions in Southern states and object-lesson roads constructed nuder supervicion of ()flice of l'ublic Road Inquiries, with cooperation of Sonthern Railway. 1902. 89 pp. 11 pl.

$$
\text { * No moly former. }
$$


A:2.:3:

\section{Bulledins-cintinnel}

No. 24. Not issuen 190:2.

No. 25. Proceedings of Jefferson Memorial and Interstate (rood Roada Convention, held at Charlottesville, Va., Apr. "2-1, 1902. 1902. $60 \mathrm{pl} .5 \mathrm{pl}$.

\section{Circulars}

No. 1. Circular letter to the governors of States and Territories requenting conperation with Otlice of Roal Inquiry.*

No. 2. Sane, to the seeretarie's of state.*

No. 3. Same, to the members of Congress.*

No. 4. Same, to the State geologists.*

No. 5. Same, to the railroad presidents.*

No. ti. (ieneral circular of inquiry.*

No. 7. Request for information, ete.*

No. S. Sanle**

No. 9. Cireular relating to roal conferenee at Asbury Park, X. J.*

No. 10. Circular of a temporary character. [Copy not preserved by oftice. ]*

11 No. 11. Sane.*

12 No. 12. Circular adilressed to the statistical correspondents of the ontice.*

No. 13. List of Publications of the ()ffice of Road Inquiry.*

No. 14. Addresses on roal improvement; lw Ruy Stone. 1894. n. t. p. $15 \mathrm{Pl}$.

No. 15. Aet to provide for construction of roals by Iocal assessment, county and State airl, paswed by New York Assembly. Oct. 31, 1894. 1. t. P. 3 PI.

No. 16. Ifighway taxation, comparative results of labor and money systems. Nov. 9, 1894. n. t. p. 5 pl.

[For revision, see no. 24.]

No. 17. Urigin and wrork of Darlington Road leagne. Sept. 25, 1895. $6 \mathrm{pp}$.

No. 18. Report of Committee on Legislation adopted by state Good Roads Convention, Richmom, Va., Oet. 10, 11, ]s95. Oct. 29, 1895. 6 pp. same, Nor. 10, 1895. 6 pr.

No. 19. Traftie of comntry roais. Apr. 4, 1896. 4 pp.

No. 20. Comments on iystems of maintaining country marls. May 1 , $1896 . \div \mathrm{PP}$.

[For revinion, sep revized enl. no. 24.]

N1. 21. Metherls of (onstrueting macadamized roals. Jnne 6, 1896. 12 pp. No. 22. [Appeal for urganization of state and local road-injoroment societies]; by C. A. Locke. June 25, 1896. :3 $1 \%$.

No. 22. Money value of good roals to farmers; by II. C. Iatta. July 15 , 1896. 4 pp.

No. 24. Highway repairing. $18.66 .12 \mathrm{pp}$.

To. 24. Revision of nos. 16, 20, 24, Highway maintenance and repairs. Dec. $15,1897.16 \mathrm{pl}$.

No. 25. Brick paving for country roaks. Dec. 16, 1896. T pl).

No. 26. Going in debt for good roads; address of Jndge Thayer. Jan. 16, 189\%. 6 ily.

No. 27. Cost of hauling farm prolucts to market or to shipping points in European comtries; reports from consuls. Feb. 5, 1897. 12 pl'.

5o. 28. Adrlresses on rual improvenent in Maine, New Jork, North Carnlina, aml Illinois; by Roy Stone. Mar. 2, 1897. 26 l'p.

No. 29. Forces which operate to destroy roals, with notes on road stones and problems therewith comnected; ly C. L. Whittle. Mar. 13, 1897. $1+\mathrm{pp} .4 \mathrm{pl}$.

No. 30. Repairs of maearlan roarls; Hy 1\%. (i. Marrison. Mar. 1, 1895. $14 \mathrm{pl}$.

No. 31. Yust farmer pay for gool roads? hyotto Dorner. [1. 1.] 40 pp. $16^{\circ}$

[This number was duplisated by assigning it to "state aid to rond building in Minnesota," but a new elition of that circular was issued bearing its proper number, which is no. 32].

\section{* No copy found.}


Tables

1.20.1:

Circulars-Continued

32 ${ }^{2}$ [No, 32.] State airl to roarl builling in Minnesota; by A. B. Choate. July 23 , 1898.12 "l.

[Erroneously numbered 31.]

$32^{2}$ No. 32. Same, [reprint with correct number]. 12 jp.

33) No. 33. Road improvement in governors' messages. May 1, 1899. It pp.

34 Yo. 34. Social, commereial, and eeonomic phases of road subject; lyy $\mathrm{W}$. H.

Moore. Mar. 29, 1!100. \& Pl'.

3.) No. 35. [Higbie-A rmstrong road improvementact]. Way 16,1900. 1.5 pp. $36^{\text {I }}$ Jo. 36 . List of national, state, and local roal associations and kindred organizations in U. S. Jan. 20, 1902. n. t. p. 13 1'p.

$36^{2}$. Same, revised. Jay 1, 190.2. 11. t. P. 14 l' 1.

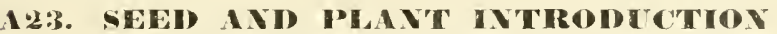

[separated from livision of Botany and made independent publishing office about Jan. 1, 1901 Jersed into Plant Industry Bureau July 1, 1901. See A19.]

\section{A:3.1: | Anmual neporto}

None issued.

\section{2:3.2: Gencial publicalious}

Tone issued.

\section{2:3.3: Bulletins}

None issued.

\section{2:3.1: Circulars}

1 To. 1. Best horse-radish varieties of Europe, and methorls of cultivation; by David G. Fairchild. Dec. 24, 1900. n. t. 1). 8 pp.

No. 2. Cultivation of Znaim cucumbers; by David G. Fairchild. Jan. 10, 1901. 8 pp.

\section{Inventories}

See A6.6:1-8.

See for Inventory no. 9, A19.8:5.

\section{A2. SEEID DIVISION}

[Mergenl into Bureau of Plant 1ndustry, July 1, 1901. See A19.]

\section{A2.1.1: Annual reports}

1868 (Dean). (In A1.1:Stis, p. 125.)

1869 No report issided.

1870 (1)an). (In A1.1:870, P. 155.)

1871 (Dean). (In 11.1:871, 1. 125.)

1872 (Dean). (In A 1.1:87:, p. 407.)

1873 (Dean). (In 11.1:873, p. 210.)

1874 (I)ean). (In A 1.1:874, p. 179.)

1875 (Dean). (In A 1.1:875, 1). 359.)

1876 to 1878 , no rejort issued.

1879 (Dean). (In A 1.1:879, ]. 484.)

1850 to 1884 , no report issued.

1885 (King). (In Al.1:885, 1).47.)

18s6 (King). ( In $11.1: 8 \$ 6$, p. 47.)

1887 ( King). ( In A1.1:887, 1). 65i:.)

1858 ( ling). (In A 1.1:888, p. 64:3.)

$18 \times 9$ (Jongley). (In 11.1:659, p. 47..)

18.10 (l'eck). (In 11.1:890, 1). 425.)

18:11 (Peck). (In A 1.1:S91, 1\%. 451.)

18:2 (l'eck). (In A 1.1:892, 1). 471.)

893

1893 (Fegan) (calendar year) $\mathrm{ii}+389-392 \mathrm{pp}$.

(Also in 11.1:\$98, p. 389.)

1894 (Fegan). (In A1.1:894, 1. 187.) 
A2.1.1: Innual reports-Continued

s.9t

1895 (Fegan ) July, 1s94-(K0t. 1895. (In A1.1:s95, 1. 201.)

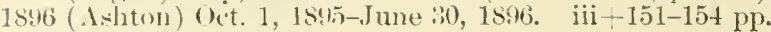

(.1150 in $11.1: \$ 96$, p. 151.$)$

$18.7-1900$ none issued.

A.2.2: Cienceral publications

None irsued.

A21.3: IBulletins

None issued.

A2.1.1: Cireulanes

None isined.

A2..万: Special areut for secd distribuliou, ammul reports of

s94 1894 (Harmken), [1]+211-213 pp. (Also in 11.1:8\%4, p.211.)

1895 (Haruden). (In A1.1:895, p. 213.)

8961896 (Hamden), [1] $155-237 \mathrm{pl} \%$ (Al-o in $11.1: 896,1 \%$ 155.)

1897 (Harnden). (In 11.1:897, p. 181.)

1898 (Brigham). (In 11.1:89s, p. 1.)

1899 (Brigham). (In $11.1: 899$, p. 3.)

1900 (Brigham). (In A1.1:900, p. 7.)

\section{WLK SEC'TION}

[Discontinued June 30, 1891. By order of Oct. 28, 1889, this section was severes from the Division of Enfomolngy, with which it had been connected since the beginning of the period of regular appropriations made by Congress in 1SE4.]

\section{A25.1: Anumal repor1s}

8891889 (Walker), [1] $+453-476 \mathrm{pp.}$ (Also in 11.1:88!!, p. 453.)

8901890 (Walker), [1] $+265-276 \mathrm{pp} ., 6 \mathrm{pl}$. (Also in A1.1:890, p. 265.)

A.5.2: Giencral publications:

None issued.

A25.3: IBullelins

1 No. 1. How to raise silkworms, a brief manual of instructions abridged from Bulletin no. 9 of Division of Entomology; by Philip Watker. 1890. $16 \mathrm{pp}$.

\subsection{1: Circoulars}

None issued.

\section{A26. SOILA IBHIEII}

[Formerly Dirision of soils. For historicul sketch of Bureul, sr Yearbook, 1897 (A1.10:897), P. 122.]

\section{A26.1: Amumal reports}

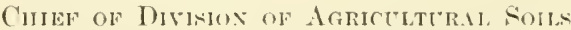

1894 (Whitney). (In \1.1:89.1, 1. 199.)

1895 (Whitney). (In A1.1:\$95, 1. 179.)

$896^{\circ}$

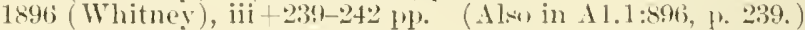

CHIEF of DIVTSION OF NOLL

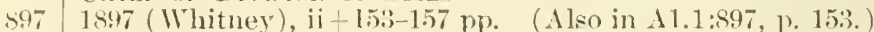

8981898 (Whitney), iii $+133-142 \mathrm{pp}$. (Nlso in A1.1:898, p. 133.)

89981899 (Whitney), iii-101-111 pp. (Also in A1.1:899, p. 101.)

9001900 (Whitney), iii-67-8:; 以). (Alvo in A1.1:900, p. (65.)

9011901 (Whitney), iii - 113-140 pp. (Also in A1.1:901, p. 113.)

[Though the title-page of the 1901 report rearks "Division of Soils" the heading of the letter of transmittal reals correctly "Bureau of soils." ]

Chief of Bure.ti of Solls

9021902 (Whitney), iv+155-18s pp. (Also in A1.1:902, p. 155.) 


\section{2: | Fenceal publicaliems}

Ft5 Field parties. Instructions to field parties and rescriptions of soil types. Field ieason 190\%. n. (l. Tip pl.

T5.)

Tobaceo. Catalouse of C'onmecticut shade-errown tolaceo, fumatra ancl Havana seel wrappers, grown unler lirection of Department of Agriculture duriner seasun of 1901, and packesl in Sumatra aml Cnhan packages, to be sold at pulblic anction May 1, 1902, at llartford, Comn., for acount of growers who have coofuerated with Department. 1902. 26 \% t $^{\circ}$

Types. List of soil types established ly. Division of soils in 1899 ancl 1900, with brief lescription. Mar. 1, 1901. 11. t. 1\% 11 yl.

\section{A26.3: Hulletins:}

No. 1. Soil moisture, a record of amount of water contained in soils, luring May, 1895.16 H'p.

2 No. 2. Śane, June, 1895. lij pp.

3 No. 3. Same, July, 1895. 2:3 pl'.

4 No. t. Iethods of mechanical analysis of soils and of determination of amount of moisture in soils in field. 1896. 24 1 p.

No. 5. Texture of sone important soil formations. $1896.23 \mathrm{pp} . \quad 35 \mathrm{pl}$.

No. 17. An electrical methor of deternining moisture content of arable soils; by Nilton Whitney, Frank D. Cardner, and Lrman J. Brigge. 1897. 26 in?.

No. .. An electrical methot of determining temperature of soils; hy Milton Whitney and Lyman J. Briggs. $1897.15 \mathrm{pp}$.

So. R. An electrical method of determining soluble salt content of soils, witl, some results of investiuations on effect of water and soluble salts on electrical resistance of soils: by Hilton Whitney and Thos. H. Means. 1897. 30 p).

No. 9. Soil moisture: record of amount of water contained in soils cluring crop season of 1896 ; hy Milton Whitney and Ralph $\mathrm{S}$. Hosmer. 1897. $23 \mathrm{pl}$.

No. 10. Mechanics of soil moisture; hy Lyman .J. Briggs. 1897. If PP.

No. 11. Tolvacco soils of Cnited States, a preliminary report upon soils

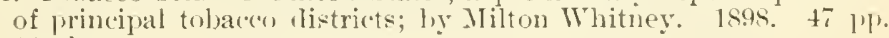
1:) pl.

No. 12. Electrical methon of moisture determination in suils, results and morlifications in 1897 ; hy Frank D. Garlner. 1898.24 p). \$ pl.

1:5 No. 13. Preliminary report on soils of Floricla; by Milton Whituey. 1898. 31 1). 6 pl.

14 Tu. 14. Alkali soils of Yellowstone Valloy, from prelininary investigation of soils near lillings, MIont.; by Milton Whitney and Thos. 11. Means. 1898. :3! 1). 17 1)].

No. 15. Electrical instrmuents for determining moistme, trmperature, and soluble salt content of soils; by Lyman.J. Brigrgs: 1899. 35. $1 \%$.

16 To. 16. ('atalogue of lirst 4,000 samples in soil mollection of l)ivision af Soils; ly Milton Whitney. Bs(x). 145 1']'.

17 No. 17. Soil solutions, their natmre and functions, and relasifieation of alkali lankls; loy Frank K. Canteron. 1901. 39 I'l.

18 To. 18. Solution studies of salts oreurring in alkali soils; [articles] loy Frank K. Cameron, Jyman J. Brigers, amel Itherton coidell. 190i. Sin 1 '1.

Vo. 19. Capillary studles and filtration of ray irom soil solutions; [articles]

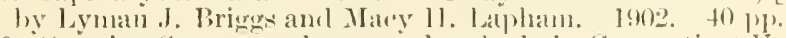

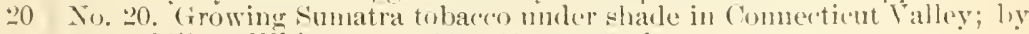
Milton Whitney. 1902. $31 \mathrm{\mu l} .7 \mathrm{pl}$

\section{A26.1: Circulatos}

1 So. 1. Amonncement [of functions of Division]; ly Milton Whituey. Mar. :30, 18:14. 11. t. p. :

2 No. 2. Instructions for taking samples of soll for mosismedeterminations; by Milton Whituey. Apr. 26, 1s.14. 14. t. p. :3 pl.

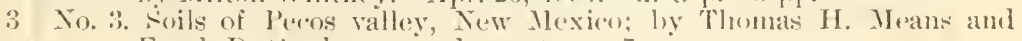
Frauk D. Cardner. in. 1. 11. t. 1. 7 11\%. 
126.1: C'ircular's-('ontinuerl

A.26..5:

$500^{1}$

$900^{2}$

(30)1

$901^{2}$

1.6.5\%:

Ni. 4. Soils of Salt Lake ralley, Utah; by Frank I). Gardner and John stewart. n. 1. n. t. p. 11 lp.

No. 5. Bulk fermentation of Connecticut tolneco; by Marrus L. Floyt. n. 九l. 11. t. p. 10 pp.

No. 6. Instructions for determining in field the salt content of alkali water: and soils; ly Milton Whitney. Mar. 7, 1900. 12. t. P. 9 P1.

Vo. 7. Description of soil map of ('onnecticut valley. June 29, 1900. n. t. P. 4 Pl.

No. 8. Reclamation of salt marsh lands; ly Thos. 11. Mleans. Ang. 3, 1901. n. t. p. $10 \mathrm{pp}$.

No. 9. Soil survey aronnl Lmperial, Cal.; by Thomas H. Means and J. Garnett IJolmes. Jan. 10, 1902. n. t. p. 20 pp.

\section{Niclal aberalions of bivision of soils (annnal)}

1899. [1:st.] Siep Al.s:64.

1900. 2d. $47+\mathrm{pp} .51 \mathrm{pl}$.

Same. 24 maps in $8^{\circ}$ folder.

same, including maps. 56th Cong., 2d sess., H. doc. 526; serial no. 4181.

1901. 31. 647 pp. $96 \mathrm{pl}$.

Same. 31 maps in $8^{\circ}$ folder.

same, including maps. 57th Cong., 1st sess., H. doe. 65̃ō; serial no. 4384.

\section{Field opperallons of Division of soifs (sefarates.)}

[Each of the papers contained in the report is issued separately, with maps belonging thereto.]

\section{A27. STATETICA IDIVISION}

For historieal sketeh of Jivision, see Jearbook, 1497 (A1.10:^97), p. 25\%.

\section{A27.1: Ininas meports}

REPORT OF ACiRICULTURAL STATISTICS

1863 (Bollman). (In A1.1:863, p. 579.)

1864 (Bollman). (In A1.1:864, 1. 564.)

REPORT OF STATHTICIAN

1865 (Dodge). (In A1.1:865, p. 54.)

1866 (Dorlge). (In A1.1:866, p. 51.)

1867 (Dorlge). (In Al.1:867, p. 77.)

1868 (Dorlge). (In A1.1:868, p. 16.$)$

1869 (borlge). (In A1.1:869, p. 20.

1870 (Derlge). (In A1.1:870, 1. 24.)

1871 (Iodlge). (In A1.1:871, p. 13.)

187.2 (I)orlge). (In $11.1: 872$, 1. 9.)

1873 [Dodge]. (In A1.1:873, p. 15.)

$187 t$ (Dodge). ( In $A 1.1: 874$, p. 15.)

1875 (Dorlge). $(\ln$ A 1.1:875, 1. 17.)

1876 (1)odge). (In A1.1:876, 1. 87.)

187 (I)odge). (In A1.1:87\%, 1. 149.)

1878 (Worthington). (In $11.1: 878$, p. 257.)

1879 (Worthington). (In A 1.1:879, p. 127.)

1880 (Worthington). (In A1.1:880, p. 185.)

1881 and 1882 (Dodge). (In A1.1:881-2, p. 57.

188.3 (1)odge). (In A1.1:883, p. 251.)

1884 (Dodge). (In A1.1:Ss4, 1. 419.)

1885 (1)odge). (In A1.1:885, p. 345.)

1886 (Dodlge). (In A 1.1:886, p. 3.39.)

1887 (Dodge). (In A1.1:887, p. 523.)

1s8s (Dorlge). (In A 1.1:8s8, p. 405.)

1889 (Dorlge), [1]+201-27:2 pp. (Also in A1.1:889, p. 201.)

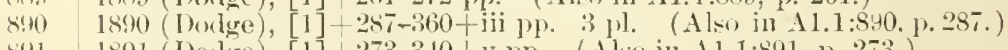

s.91 1891 (Dorlge), [1] $273-340+\mathrm{vp}$. (Also in A1.1:891, p. 273.)

89.2 1 1892 (Dodge), iii $+403-470+\mathrm{ii}$ p. (Also in A1.1:89.2, p. 403.) 


\section{1: Anumal reports-Continned}

Report of Śtatistician-Continued

$89 \%$

1893 (Robinson), $\mathrm{iij}+465-566+$ iv pl

1894 (Robinson). (1n A1.1:894, p. 11:.

895

896

$\$ 97$

898

1895 (Robinson), iii-111-129 pr. (Also in \$1.1:\$95, 1. 111.)

1896 (Robinson), iii + 115-122 ply. (Also in $11.1: \$ ! 6,1 \% 115$.

1897 (Hyde), ii $219-22+1$ p. (Also in $\$ 1.1: 897,1.219$.

1898 (Hyde), iii $175-178$ p. (Also in $11.1: 895$, \%. 175.)

1899 (Hyde), iii +263-266 pp. (Also in $11.1: 899$, p. 263.)

900

1900 (Hyde), 293-297 j). 11. t. 1). (Also in A1.1:900, p. 293.)

9011901 (Hyde), 341-34t pl). n. t. p. (Also in $11.1: 401, \mathrm{p} .3+1$. )

1902 (Hyde). (In A1.1:902, p. 401.)

\section{2\%.z: Gencral publications}

Ags

Agrieultural statistics. American centennial album of agrieuitural statistice, including maps, charts, diagrams, illnstrations of industrial colleges, and specimens of breeds of farm animals; compiled by J. R. Dorlge, Washington. 1876. 46 1. oblong large $8^{\circ}$

C.33) Cereals. Production and distribution of cereals of [T. S.; by J. R. Dorlge. 1879. 14 Pl).

[Extract from report of Joseph Nimmo, jr.., (hiel of Bureau of Statistics. Treasury Department, on Internal commerce of $\mathrm{U}$. S., published Dee. 1, 1579.]

Css 1 Crop correspondents. Manual of instruetions to crop correspondents; by Henry A. Robinson. 18\%5. 28 pr.

$\operatorname{Css}^{2}$ same, revised and corrected. 1896. 2: 191 .

$\left(756^{-1}\right.$ Ciraphics. Album of agricultural graphics of $\mathrm{C}$. S.; [by J. R. Dodge]. Is90. [6] \%). $10 \mathrm{pl}$. 12 ! inches $\mathrm{x} 185$ inches.

$676^{2}$

In:

P96

$-t 2^{1}$

St? $)^{2}$

A27.ib:

A.27..1:

Sanie; by J.R. Dodge. 1891. [6] \%. 10 pl. $12 \frac{5}{8}$ inches $x 181$ inches. Industrial Colleges: The nature of education to be given in them; their several kinds of instruction comsilered, by Lewis Bolluran; to which is arled a communication of general plan of collexe building, with necessary aids to instruction in each department of education, by Richard Owen. [186t.] to pl.

Publications. [Letter relating to publications.] By llenry A. Robinson. July 15, 1895. (Cire.)

Statistics. Album of agricultural statistics of U. S.; [by J. R. Dodge]. 18s!. \& Pp. 16 1). $4^{\circ}$

Same; by J. R. Dorlge. 1891. 8 plp. 16 pl. $4^{\circ}$

\section{IbHIllin:}

vee 127.8 :

\section{Cigerustro}

No. 1. Acreace, prouluction, and value of farm crojs in U. ..., 18titi to 1s95, with other data as to cotton and wool. July 24, 1896. 11. t. p. 8 Pl.

No. 2. IT heat erop of worlel. Ine. 7, 1896 . 11. t. p. 2 1'p.

[Reprinted from statistieian's report, Jaroh, 1k96.]

No. 3. Famers' interest in finance. 1)er. 4, 18:4\% 11. t. 1\% $15 \mathrm{py}$.

No. 4. Cotton (:rop of 1895 ; by Janes L. Watkins. Dex. 4, 18.96. n. t. p. $15 \mathrm{pl}$.

No. 5. Ser $127.9: 35$.

No. ti. See $127.9: 35$.

No. 7. Sier A27.9:35).

No. 8. kip A:7.9::35.

No.9. Cotton erop of $1897-98$; by James 1. Watkins. Yoy. 14, 1895. n. t. p. $[6 \mathrm{p} \mathrm{pl}$.

\o. 10. Jirazos river, 'Texas, flool of June-July, lsag); its (effects upon acriculture of submerged region; by E. S. Holnew, jr. Aug. 19, 18.19. 11. t. 1\%. 8 pl.

No. 11. World's grain crops in 18:49. Oct. 5, 1894. 4. t. !. s' w.

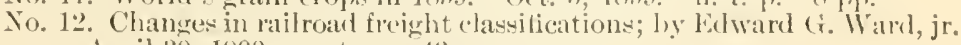
April 30, 1900. 11. t. 1. 43 1). 
12\%.1: Circular-continued

13 No. 13. List of free employment agencies for use of farmers; by Max IVest. June 28,1900 . 42 12 .

No. 14. Fstimates of Russian crops; by li. T. Peters. Fel. 5, 1901. n. t. l". 11 Pl'.

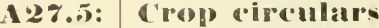

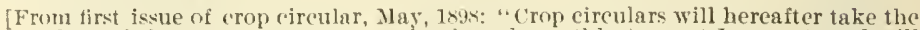
place of the crop rejorts, new series, issued monthly (except January), and will comsist of the information contained in the telegraphie reports of the 10 th of each month, with such ulclitions as will culnanee its value to the farmers and as the circular form will permit. Special crop reportw will not be abandoned, but their issne will depend upon the seasonableness and importance of the subject and not upon a fixed date."]

895

1s.t. May, 3 pr.

Jume, 4 \%).

July, 4 pl.

Aug., $+\mathrm{pp}$.

sept., 4 pr.

()et., 8 pl).

Nov., 4 Pl.

8949

18.9. May, $4 \mathrm{pp}$.

lune, $t \mathrm{pP}$.

July, 8 pp.

Aug., 4 l'p.

Sept., 4 Hiv.

Oct., + Pl).

Nov. 4 lop.

$\$ 00$

1900. Apr., 4 (y).

[1)iseontinued.]

\section{Cropreponer $4^{\circ}$}

[Announcement (v, 1, no, 1, May, 1899): "This publication is issued for the benefit of the erop correspondents of the Division of Statisties, and as a convenient means of communieation between them and the statisticinn. It will be selut every monthly correspondent regularly enrolled so long as he continues to supply the Statistician with the information asked for. and an earnest effort will be made to make it interesting, instructive, and helpful to him in his work. This is not designed for general distribution and will not be mailed to any but actual and active crop correspondents."'l

V. 1. No. 1, May, 1899. 1. t. 1. 4 pp.

No. 2, Jume, 1899. n. t. 1. + 4 p.

No. 3, July, 1s99. n. t. p. \& pp.

No. 4, Aug., 1899 . n. t. p. 4 pp.

No. 5, Sept., 1899. n. t. p. 4 pp.

No. 6, Oct., 1899. n. t. p. 4 pp.

No. 7 , Tov., 1899. n. t. p. 4 pp.

No. 8, Dec., 1899. n. t. p. 4 pp.

To. 9, Jan., 1900 . n. t. p. 4 pp.

No. 10, Feb., 1900. n. t. ए. 4 pl.

No. 11, Mar., 1900. n. t. p. 4 pp.

No. 12, Apr., 1900. n. t. p. 4 pp.

I. 2. No. 1, May, 1900 . n. t. 1) 8 pp.

广o. 2 , June, 1900 . n. t. p. 8 pl.

No. :, July, 1900. n. t. p. 8 pp.

No. t, Aug., 1900 . n. t. p. 8 pp.

Same, suplement. n.t. p. 4 pl.

No. 5, Sept., 1900 . 11. t. p. 8 pp.

No. 6, Oct., 1900. n. t. p. 8 pp.

No. 7, Nov., 1900. n. t. p. 8 p).

To. 8, Dec., 1900. n. t. 1. \& pp.

No. 9, Jan., 190I. n. t. p. 8 pp.

No. 10, Feb., 1901. n. t. p. 8 pp.

No. ]1, Mar., 1901. 11. t. p. 8 pp.

No. 12, Аpr., 1901. n. t. p. 8 pp.

3 Y. 3. Yo. 1, May, 1901. n. t. p. 8 ?p.

No. 2, June, 1901. n. t. 1. 8 pp. 
C'rop reporter-Cintinued

1. 3. \i. 3, July, 1901. n. t. I. s pp.

No. 4. Au世., 1901. n. t. p. s plp.

No. 5, Fept., 1901. 11. t. 1'. s' lip.

No. 6, Oct., 1901. n. t. p. \& pp.

No. 7, \ov., 1901. n. t. 1. s plp.

No. 8, Dec., 1901, n. t. p. s' pr.

No. 9, Jan., 1902. n. t. 1. 8 [ग\%.

No. 10, Feb., 1902. n. t. p. \& pp.

Fo. 11, Mar., 1902. n.t. J) s ill.

No. 12 , Apr., 1902. 3. t. P. 8 fp.

V. 4. \о. 1, May, 1902. n. t. [. 8 pl.

No. 2, June, 1902. n. t. p. 8 pl).

No. 3, July, 1902. n. t. l. 8 Pl.

No. 4, Aug., $190^{\circ}$. n. t. ए. 8 pP.

No. 5, sept., 1902. n. t. p. 8 pl.

Fo. 6, Oct., 1902 . n. t. 1\% 8 pp.

No. 7, Nor., 1902. n. t. p. 8 Pp.

No. 8, Dec., 1902. n. t. p. s pp.

127.7:

Dec.

189.2. Feb.

Mar.

Apr.

May.

June.

July.

Auge.

Sejt.

Oct.

Nor.

Dece.

Fel.

Mar.

Apr.

May.

Jinie.

July.

Aug.

(Synopsis of Statistical Report no. 71.)

(Symopsis of Statistical Report no. 72.)

(Synopsis of Statistical Report no. 73.)

(Synopsis of Statistical Reprort no. 7t.)

(Syuopsis of statistical Report no. 75.)

(Synopsis of Statistical Report no. 76.)

(Synopsis of Statistical Rejort no. 77.)

(Synopsis of Statistical Report no. 78 .)

(Synopsis of Statistical Report no. 79. )

Synopsis of Statistical Report no. so.

(Synopsis of Statistical Report no. 81.)

(Synopsis of Statistical Report no. 82.)

(Symopsis of Statistical Report no. 83.)

(Synopsis of Statistical Report no. 84.)

(Synopis of Statistical Report no. 85.)

(Svmolnis of Statistical Report no. 86.)

(Synopsis of statistical lieport no. 87.)

(Symopsis of statistical Report no. 88.)

(Simopic of Statistical Report no. 89.)

(Synopsic of Statistical lieport no. 90.)

(Synopis of Statistical Report no. 91.)

(Sinopsis of Statistical Report no. 92.)

(Sinopsis of Statistical Report no. 93.)

(Synopsis of Statistical Reprort no. 94.)

(Sinopsis of Statistical Report no. 95.)

(Symopis of Statistical Report no. 96.)

(Synopsis of Statistieal Rejort no. 97.)

(Sinopsis of August Crop Report.)

(Synopsis of September Crop Report.)

(Sinopsis of (October Crup Rejort.)

(Synopsis of November Crop Report.)

(Synopsis of December Crop Report.)

(Synopsis of December Crop Report.)

(Synopsis of Statistical Report no. 101.)

(Symopsis of Statistic“al Report no. 102.)

(Symopsis of statistical Report no. 103.)

(Synopsis of Statistical Report no. 104.)

(Synopsis of statistical Report no. 105.)

(Symopsis of Statistieal Report no. 106.)

(Synopsis of Statistical Report no. 107.) 
Table.

Clacisificta* tlon 110.

1.27.7:

893

$s 94$

1894. Fet.

tor.

May.

June.

July.

Alig.

Sept.

Det.

Nor.

189. Jaแ.

Fel.

Mar.

Apr.

May.

June.

July.

Aug.

Sept.

ict.

Nov.

Dec.

1896. Mar.

Apr.

llay.

127. S'TITISTIS DIVISIOV-C'ontinued

[Discontinued.

\section{A27. V: Viscellancous series, balletin}

["The word "Bulletin", was adied to the series litle beginning with no. 9.]

1 To. 1. Report on flax, hemp, ramie, and jute, with ronsiderations upon flax and hemp culture in Enrole, report on ramie nachine trials of 1889 in Paris, and present status of fiber industries in $\mathrm{C}$. S.; by Charles Richards Dodge. [1st erl.] 1890. 104 pl.

see, for 2 d ed., A11.5:1.

2 So. 2. Report on agriculture of Sonth America, with maps and latest statistics of trade; by Almont Barnes. 1892. $189 \mathrm{pp}$.

3 To. 3. Coöjerative credit associations in certain European countries, and their relation to agricultural interests; by Fiward T. Peters. 1892. 117 Pp.

4 No. 4. Wages of farm labor in Cnited States, lesults of nine statistical investigations from 1866 to 1892 , with extensive inquiries concerning wages from 1840 to $1865.699^{\circ}$. $69 \mathrm{H \mu}$.

5 To. 5. Production and distribution of principal agricultural products of world. 1893. 205 pp.

6 To. 6. Rice: its cultivation, production, and distribution in I. S. and foreign countries, by Amory Austin; with chapter wn Rice soils of Gouth Carolina, hy Milton Whitney. 1893. $89 \mathrm{yp}$.

7 No.7. An agricultural survey of Wyoming; by John W. IIort. 1s92. 72 pp.

8 To. s. Recent features of our iorein trade; by Edward T. Peters. 1894. $2+\mathrm{pl}^{3}$

9 Xo. 9. Production and price of cotton for 100 years; hy . Jues 1. Watkins. 18:5. $20 \mathrm{pl}$.

See, for abstract, $12 \pi .8 \%: C 82$

10 No. 10. Railway charges for transportation of wool. 1s96. $30 \mathrm{PP}$.

11 So. 11. Number and value of fim animals of U.S., and animal prouluets, Is80-1896. 1896. $63 \mathrm{PP}$.

12 Jo. 12. Freight charges for ocean transportation of prouncts of agriculture, Oct. 1, 1895-Oct. 1, 1896. 1896. 53 pp. 
No. 13. Fertilizer industry; review of statistics of froduction and consumption, with abstract of State laws for analysis and sale; by John Hyde. $1898.27 \mathrm{pp}$.

No. 14. Of what service are statistics to the farmer? by John Hyde. 1898. $\mathrm{iii}+258-270 \mathrm{pp}$.

[lieprint from Yearbook, 1s97, p. 258. sese A1.10:1897.]

No. 15. Changes in rates of charge for railway and other transportation services; by H. T. Newcomb. 1898. $80 \mathrm{pp}$.

Same, revised, 1901. 86 j].

No. 16. Cost of cotton production; by James L. Watkins. 1899. 99 pp.

No. 17. Cotton crop of 1898-99; by James L. Watkins. 1900. 32 pp.

No. 18. Course of prices of farm implements and machinery for series of years; by qeorge K. Holmes. 1901. $31 \mathrm{pP}$.

To. 19. Cotton crop of 1899-1900; by James L. Watkins. 1901. $46 \mathrm{pp}$.

To. 20. Wheat growing and general agricultural comlitions in Pacifir coist region of U. S.; by Ellwin S. Holmes, jr. 1901. It pp. \& pl. 1 map.

No. 21. Rates of charge for transporting garden truck, with notes on growth of inclustry; by Edwarl (r. Warl, jr., and Edwin S. Holmes, jr. $1901.86 \mathrm{pp}$.

No. 22. Wages of farm labor in U. S.; reult of eleven stat istical investigations, 1866-1899. 1901. $47 \mathrm{pp}$.

No. 23. Statistice on fruit industry of California; by Edwin S. Holmes, jr. 1901. $11 \mathrm{pl}$.

\section{A27.8": Viscellancous serico, loullelin (sejarates)}

[A bstraet of Mise, series, Bull. No. 9. See A27, א:9.]

\section{A27.9: Stalisticall reports}

[Contains reports on condition of erops, and speeial subjects of interest to farmers, Issued as "Monthly" or "Bi-monthly Report" of Department from May, 1863, to December, 1876 , when the series was discontimued and the issue of the statistieal matter was transferred to the series of "special reports" (A1.6:) and there appeared under various numbers, not always collsecutive, from Jan., 1877, to sept. 1883. Another change was made in october, 18,83 , when "New Series, Report no. 1." appeared containing the crop statistics. This last serits was continued, conseritively numbered, np to 110. 155, December, 1897. No. 156 was issued A pril 20, 1899. From May, 1898, to April, 1900, the statisties were issued in a "Crop cireular" (A27.5). Beginning with May, 1900, they were merged into the "Crop Reporter" (A27.6:) which is now being issued. A "Synoptieal index" of this series was issued by the Department in 1897 ( $121.3: 2)$, but as it did not give a table of the various reports of the Statistieian, indexed under the eomprobensive title "Reports of the Gtatistieian," it ean not be definitely determined whether the rosent collation includes all or more than the index. All reports of the Statistician relative to erops ant farm animals have, however, been included. 'The volume numbers are assigned to the yearly groups of reports to farilitate listing and reference.]

[Y.o. 1.] Nonthly report on conclition of crops, Nay and June, 1863, n. t. 1\% $16 \mathrm{pp}$.

[No. 2.] Same, July, 1863, n. t. p. 19 yp.

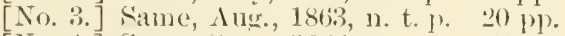

[No. 4.] Siame, Sept., 18ti3, 11. t. 1. $41 \mathrm{pp}$.

[No. 5.] Same, Oct., 1863, n. t. 1. 20 pl.

[No.6.] Same, Nov., 1863, 1. t. 1). is pl.

$2 \mid$ T. 2.] 1864 .

Same, Dee. (None iswued.)

[No. 1.] Bi-monthly report of Agricultural Tepartment, Jan. and Feb., 1864. 72 川\%.

[No. 2.] Same, Mar. and Apr., 1864. $96 \mathrm{pp}$.

[No. :. ] Same, Apr. and May, 1864. 38 p]'.

[No.4.] Same, Jume and Inly, 1864. 23 pp.

Same, Lus. (Nome issued.)

[No. 5.] Same, Sept. and ().t., 1864. 56 jp.

[No.6.] Same, Nov. and Dee., 1s64. 59 Pए. 
127.9: Gtatistical reports-Contimuel

$\because \quad[\mathrm{V} . .3] .18(6)$

[No. 1.] Thonthly report of Agrienltural Department, Jan., 1865. $50 \mathrm{pl}$.

[No. 2.] Same, Feb., 1865. ts pr.

[No. 3.] Same, Mar., 1865. 41 pl.

[No. 4.] Same, Apr.-May, 186.). 86 pp.

[No. 5.] Fame, June-July, ]865. 60 lp.

[No. i). Same, Aug., 1865. it pl\%.

[No. 7.] Sane, Sept., 1865. 5l pl).

[No. 8.] Same, Get., 1865. 46 lp.

[No. 9.] Same, Nov., 1865. 53 jp.

[No. 10.] Same, Dec., 1865. 43 pp.

$+\left[\mathrm{V}^{\mathrm{t}} \mathrm{t}.\right] 1866^{\circ}$.

Ionthly report of Department of Agriculture for year $1866 ; \mathrm{J} . \mathrm{R}$. Dorlge, ellitor. 186\%. vii-457 pr.

Contents:

Jan., 50 pp.; Feb., pp, 51-122; Yar., pp. 123-169; Apr., pp. 171-22s; Jay (unne issued): June, pp. 229-276; July, Jp. 277-324; Alug. (none issued); Sept., I1). 325371; Oe1., l'p. 373-10s; Nov, ani Dee., pp. 409-45i.

i) $[\mathrm{V} .5]$.1867 .

Monthly reports of l)epartment of Agriculture for year 1867 ; J. R. Dodge, ellitur. 1868. $\mathrm{xi}+397 \mathrm{\mu p}$.

(ontents:

Jan., ts pp.: Feb.. 49-io; Mar., pp. s1-127: Apr., pl. 129-1s6; May-June, pp. 1sт-2:33; Ju1y, pl. 235-270; Aug.-Sept., IP. 271-311; (let., pp. 313-352; Nov.-Dee. I IP.
353-39\%.

(i) [V.6.] 1868.

Monthly reports of Department of Igriculture for year 1868 ; edited by J. R. Dorlge. 18tis. xi- 483 I'l',

Contents:

Jan., 55 PI.: Feb., wp. 57-107; Mar., 109-169; A pr., Pp. 171-834; Nhay-June, pp. 23ä-307: July, pp. 309-339: Aug.-Sept., Wp. 341-343; Oet., PP. 385-120: Nur.-Dec., pp. 421-1s3.

$[1.7]$.

MLnthly reports of Department of Agriculture for vear 186 ; ; elited by J. R. Dodge. 1869. xii +419 'J. Contents:

Jau., 40 pp.: Feb, pp. 41-82; Nlar.-A pr. pp. 83-185; Hay-June, pp. 18i-262: Jul PP. 263-314; Aug.-Sept., Ip. 263-326; Ocl., pp. 327-3at; Nov.-Dec., pp. 327-414.

Noте. - Starred pages in index refer to those pages duplitated in Ang.-Sept.. and Nov, - lee. numbers.

[Y. S.] 1870

Ionthly reports of l lepartment of Agriculture for year 1870 ; edited by j. R. Dorlge. 1si]. xiii +498 pl. Contents:

Jan., 64 pp.; Feb., Pp. 6ö-110; Jar.-Apr., pp. 111-1\$7; May-June, pp. 189-260: July, pp. 2ti1-305: Aug.-Sept., pp. 309-3\$5; Oct., pp. 357-454; Nor.-Dec., Pp. 455-198.

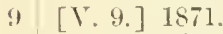

Monthly reports of Dejartment of Agriculture for year 1871. 1872. xivi51\% (').

contents.

Jan., 52 נp.: Feb., pp. 53-92: SIar.-Apr., pp. 93-165: May-June, pp. I69-230; July, Pp. 231-291: Aug.-Sept., lp. 293-376: Oet., pp. 377-130; Xov.-Dec., pp. 131-517.

[V. 10.] 1872.

Monthly reports of Tepartment of Agriculture for year 1872.1873. xiv 528 ('). Contents:

Jan., is pl,: Feb., Pp. 19-102; Ylar.-Apr., 1p. 10:-169; Yay-June, Pp. 171-246; July,

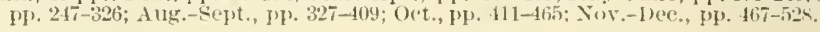

11 [V. 11.] 1873.

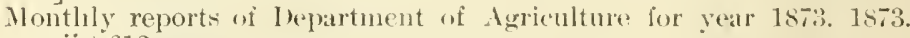
xii 618 'l.

Contents:

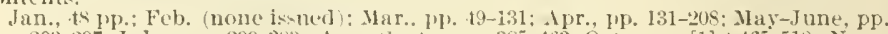
209-297; July, pp. 299-3k3; Ang.-Sept., pl. 385-463; Oct., pp. [1] +465-51s; Nov.Dee., IP. $i i+519-61$. 
[Y. 1\%. 1874 .

Monthly reports of bepartmint of Agriculture for year 1874. 1875. $\mathrm{xi}+5+5 \mathrm{pl}$.

Contents:

Jan,, 70 pp.: Feb.-Mar., Ip. 71-173; A pr.-May, pp. 175-242; June, pp. 243-2\$5; July, pp. 2ni-335; A ug.-Sept., pp. 339-400; Oct., pp. 401-459; Nov.-Dec., pp. 461-545.

$13 \quad[\mathrm{~V} .13] 1575$.

Monthly reports of Department of Agriculture for vatr 1875. 1876. $\mathrm{xiii}+5: 32 \mathrm{PP}$.

\section{Contents:}

Jan., 63 pp.; Feb.-Mar.. pp. 65-146; Apr., pp. [1] +147-186; May-June, pn. 187-257, 3 pl.; fuly, pp. 259-329, 1 pl.; Ang.-Sept., 1P. 331-111; Oet., pp.413-471; Nor.-Dec., pI. $473-532$.

$14 \quad[\mathrm{Y} .14]$.

Ionthly reports of Department of Agriculture for vear 1s76. 1877. xi -511 pl.

Contents:

Jan.-Feb., 74 pp. 2 pl.; Mar.-Apr., pp. 75-129, 1 pl.; Mar-June, pp. [1] +131-214, 10 pl.; July, pp. 215-291; Aug.-Sept., 1,p. 293-379, 1 pl.; Oct., pp. 381-139, 2 pl.; Nov.-Dec. pp. 411-511.

[Numbers in that part of the Statistical Series designated as "Special Reports" whiel are missing here will be found in the series of speeial Reports under the secretary's Office (A1.6.) All of the special Reports which are properly in the Statistical series are, howerer, found here, those in A1.6 being special reports on miscellaneous subjects.]

$15 \quad[\mathrm{~V} .15] 1877$.

Special report no. 2. Report upon condition of crops; also, statement of international wheat supply, and our wheat exports, with foreign crops and prices. $1877.35 \mathrm{pp}$.

$16 \quad[\mathrm{~T} .16] 1878$.

Sirecial reports no. 5. Report upon condition of crojs, June 1, 1878. 1878. $10 \mathrm{pl}$.

Special reports no. 6. Same, July 1, 1878. 1878. $17 \mathrm{pH.}$

Special rejorts no. 7. Same, Ang. 1, 1878. 1878. 26 11.

Special reports no. 8. Same, Sept. 1, 187s. 1878. 22 U).

$17 \quad[\mathrm{r} .17$.$] is 79$

Syecial report no 10 . Report upon conclition wi crops and livestork, January, 1879. 1879. ¿21 pю.

Special report no. 13, April, 1879. 1879. 26 p.

Sperial report no. 14. Same. June 1, 1879. 1879. 2.2 pp.

special rejort no. 15. Report upon condition of crops, July 1, 1879. 1879. 24 $21 \%$.

Special report no. 16. Same, Aue. 1, 1879. 1879. 25 1'l.

Siecial report no. 17. Same, Sept. 1, 1879. 1879. 25 pl.

Sipecial repolt no. 19. Same, Nov. 1, 1879. 1879. 21 H\}.

Special report no. 20. Same, Dec. 1, 1879. 1879. 15 pp.

18 [T. 18.] 1880 .

Special report no 21. Report upon number and prices of farn animals, Jan. 1, 1880. 1880. 27 pp.

Special report no. 23. Report upon eondition of erops and live stork, April, 1880. 1880. 22 "l).

special report no. 24. Report upon condition of erops, June and July, 1880. 1880. 31 lp.

Special report 110. 25. Same, Aug. 1, 1880.1880. 2y pp.

Sprecial report no. 27. Same, Nept. 1, 1880. 1880. 31 pl).

Sipecial report no. "2). Same, Nov. 1, 1880. 1880. 19) भा.

special report no. 30. Same, Dec. 1, 1880. 18s0. 1? Pl.

[Г. 1!.] 1881 .

Special report no. 32. Lieport upon condition of crops and live stock, A pril, 1881. 1881. 22 y).

Special report no. :37. Report upon condition of erops, June and July, 1881. 1881. 24 11 .

Special report no. 38 . Same, Aug. 1, 1881. 1881. „21 1).

Special report 110. 39. Same, sept. 1, 1881. 1881. $30 \mathrm{pr}$. 
[V. 20] 1882 .

Special report no. 41 . lieport upon estimated prorluction of cereals of U. S., for year 1881. [Fehruary, 1852.] $1852.8 \mathrm{pl}$.

special report no. 4\%. Condition of winter grain and numbers and comlition of farm animals of [L. S., April, 1882. 1882. $82 \mathrm{pp}$.

Special report no. 43. Condition of winter grain; progress of cutton and corn planting; rate of wages and labor; and results of tile draining, May, 1882. 188:. 20 l'l.

Special report 110, 4t. Acreage and condition of cotton; condition of all cereals; and area of spring grain, June, 1s82. 18s2. $15 \mathrm{pl}$.

Special report 110. 45. Area and condition of corn; condition of cotton, and of small grains, sorghum, tobaceo, ete, July, 1882. 1882. $33 \mathrm{pp}$.

Special report no. 46. Condition of corn and cotton, of spring wheat, fruits, etc.; also freight rates of transportation companies, August, 1882. 1882. $54 \mathrm{pp}$.

Special report no. 49. Condition of corn and cotton, of potatoes, fruits, etc.; also freight rates of trankportation companies, Sceptember, 1882. 1882. $48 \mathrm{pp}$.

Special report no. 51. Yield and quality of small grain; condition of corn and cotton, of potatoes, tobace, ete., also freight rates of transportation companies, October, $1882 . \quad 1882.58 \mathrm{pp}$.

Special report 110. 52. Field per acre of cotton, corn, potatoes, and other field crops, with comparative product of fruits; also local freight rates of transportation companies, November, 1882. 1882. $109 \mathrm{Pp}$.

Special report no. 53. Product and price of principal crops of 1882; also freight rates of transportation companies, including changes of winter tariff, December, 188:. $1882.79 \mathrm{pp}$.

Special report no. 56. Numbers and values of farm animals; product and quality of cotton; and comparative values of American and European farm inplements; also rates of transportation in Enrope and U. S., February, 1883. 1883. 74 pp.

Special report no. 57." Distribution and consumption of corn and wheat, and rates of transportation of farm products, March, 1883. 1883. $39 \mathrm{pp}$.

Special report 110.58. Area and condition of winter wheat, and condition of farm animals; alio spring rates of transportation of farm products, April, $1883.1883 .46 \mathrm{pp}$.

Special report no. 59. Condition of winter grain; progress of cotton planting, ancl estimates of cereals of 1882, with freight rates of transportation companies, Мay, 1883. 1883. $65 \mathrm{p} \mathrm{p}$.

Special report no. 60. Acreage of spring grain and cutton; condition of winter wheat, and Eumpean grain prospects, with freight rates of transportation companies, June, 1s83. 1583. $56 \mathrm{pp}$.

Special report no, 61. Area of corn, potatoes, and tobaceo, and condition of growing erops in U. S. and Enrope, with report on rates of transportation, July, 1883 . 1883. t8 pp.

Special report nu, 64. Report on condition of erops, "American competition," and freiglut rates of transportation empanies, August, 1883. 1883. $80 \mathrm{pl}$.

Special report no. (5i. Report on condition of crops and on freight rates of transportation companies, September, 1853. $1883.55 \mathrm{pp}$.

New series, report no. 1. Condition of crops, yield of grain per acre, and freight rates of tiansportation companics, October, 1883. 1883. 28 ip.

New series, report no. 2. Yield of crops per acre; progress of sorghum growing; crops of Europe; and freight rates of transportation companies, November, $188 \%$. 1883. $59 \mathrm{pp}$.

New series, report no.3. ('rops of year; cereal production in Europe; and freight rates of transportation companies, December, 1883. 18s3. $7 \pm \mathrm{pp}$. 
Statistical reports-Continued

$\left[V^{*}, 20\right] 1884$.

New series, report no. 4. Number and value of farm animals; certain causes affecting wages of farm labor; and freiglit rates of transportation companies, February, 1s84. 18st. 56 yp.

New series, report no. 5. Distribution and consumption of corn and wheat, and rates of transportation of farm products, March, 1884. 1884. 4t Pp.

New series, report no. 6. Area of winter grain; condition of farm animals; and freight rates of transportation companies, April, 1884. 1854. 4s $1 \%$.

New series, report no. 7. Condition of winter grain; progress of cotton planting; and estimates of cereals of $183 \%$, with freight rates of transportation companies, May, 1884. 1884. $36 \mathrm{pp}$.

New series, report no. 8. Acreage of spring grain and cotton; condition of winter wheat; Emropean grain prosperts. with freight rates of transportation companies, June, 185t. 1884.39 p.

New series, report no. 9. Area of corn, potatoes, and tobacco; condition of growing crops, and rates of transportation, July, 1884. 1884. $59 \mathrm{pl}$.

New series, report no. 10. Condition of growing crops and rates of transportation, August, 1884. 1884. $36 \mathrm{pp}$.

New series, report no. 11. Condition of crops; wheat in India; and freiglet rates of transportation companies, September, 1884. 1884. $87 \mathrm{pl}$.

New series, report no, 12. Condition of crops; yield of grain per acre; and freight rates of transportation companies, October, 1884. 1884. 44 pl.

New series, report no. 13. Yield of crops per acre; agriculture in Mexico; and freight rates of transportation companies, Fovember, 1884. 1884. 94 pp.

New series, report no. 14. Crops of year, and freight rates of transportation companies, December, $1884.1885 .60 \mathrm{pl}$. (nos. 15-25, new series) [Jan.-Dec., 1885]; by J. R. Dodge, Statistician, Washington, D. C. 1885.

Contents:

ludex. v pp.

New series, report no. 15 . Numbers and values of farm animals; cotton crop and its distribution: and freight rates of transportation companies. Jan. and Feb., 1885. 1855 . $64 \mathrm{pp}$.

New series, report no. 16. Distribution and eonsumption of corn and wheat; consumption of cereals in Europe; and freight rates of transportation eompanies. Mar., 1885. 1885. $47 \mathrm{pp}$.

New series, report 110.17. Area of winter grain; condition of farm animals; and freight rates of transportation companies. Apr., 1885. $1885.80 \mathrm{pp}$.

New series, report no. 18. Condition of vinter grain; progress of eotton planting; wages of farm labor; also, freight rates of transportation companies. Hay, ins. 1885. $60 \mathrm{\mu p}$.

New series, report no. 19. Acreage of spring grain and cotton: eondition of winter wheat; European grain prospects; with freight rates of Iransportation compunies. June, 1885 . 1885. $56 \mathrm{FP}$.

New series, report no. 20. Area of eorn, potatoes, and tobaceo; rondition of growing ('rojs; and rates of transportation. July, 18s5. 1885. 64 pp.

New series, report 160. 21. Condition of growing erops; international dairy statisties; and rutes of transportation. Ang., 1855. 1855. $70 \mathrm{pp}$.

New series, report no. 22. Condition of crops in Ameriea and Europe; und freight rates of transportation companies, Sept, 1885. 1885, $58 \mathrm{lp.}$

New series, report no. 23. Condition of croys; yield of grain per aere; and freight rates of transportation companies. Oet., 1885. 1אк5. $55 \mathrm{pp}$.

New series, report no. 21. Yjuld of crops jer ucre; und freiglit rates of trusportation compunies. Nov, $1885 ., 1885.51 \mathrm{pp}$.

New series, report un. 25. Crops of the year; and freight rates of transportation (ompanies. Dec., 18\%5. $1885.55 \mathrm{pl}$.

[Y.24.] Reports of Burean of Statistics of Department of Agriculture, (nos. 26-36) [Jan.-Dec., 1886]; by J. R. Jodge. 1886. 580 pl. (omtents:

New series, report no. 26. Numbers und values of furm animuls; cotton erop and its distribution; and freight rates of transportution companies. Jun. and Feb., 1886. 1856. [1]. 1-56.

New series, remrt no, 27. Distribution and eonsumption of ern and wheat; production of European whent; and freight rates of transportation compunies. Mar., 1856. 1856. pp. 57-10s. 
A2\%.s): Shatistical reponts-Continuer

24 [Y. 24.] Reports of Burean of Statistics of Department of Agriculture, etc.-Continued

contents-Continued

New series, report no. 2k. Irea of winter grain; eondition of farm animals; and freight rates of transportation companies. Apr., 1886. 1886. pp. 109-170.

New series, report no. 29. Condition of winter grain: progress of cotton planting: and freight rates of transportation companies. Hay, 1886. 1586. pp. 171-21\%.

New series, report no. 30 . Acrenge of spring wheat and cotton; condition of winter grain; world's supply of whent; with freight rates of transportation companies. June, 18\$6. 18s6. pp. 219-263.

New series, report no. 31. Area of corn, potatoes, and tobacco; condition of growing crops; and freight rates of transportation compunies. July, 1886. 1886. pp. 26.508.

New series, report no. 32. Condition of growing erops: and freiglit rates of transportation companies. Ang., 1856. 1886. Pp.309-360.

New series, report no. 33 . Condition of erops in America and Europe; and freight rates of transportation companies. Sept., 1886. 14.46. pp. 361-119.

New series, report no. 34. Condition of crops; yieh of gram per acre; and freight rates of transportation companies. Oct., 1886. 18\$6. एp. 121-460.

New series, report no. 35. Yield of crops per acre; and freght rates of transportation companies. Nov., 1846. 1.886. pp. 461-532.

New series, report no. 36 . Crops of the year; and freight rates of transportation eompanies. Dee., 184t. 1s8ti. Up, 533-580.

25 [Y. 25.] Reports of Bureau of Statistics of Department of Acriculture, (nos. $37-47$ ) [Jan.-Iec., 1887]; by J. R. Dodge. 1888. 7+662 II). Contents:

Index. $7 \mathrm{pl}$.

New series, report no. 37. Numbers and values of farm animals; eotton erop and its distribution; and freight rates of transportation companies. Jan. and Feb., 1847. 1857. up. $1-56$.

New seriss, report no. 3x. Distribution and eonsumption of eorn and wheat; wheat product of the world; and freight rates of transportation companies. Mar., 1887. 1887. pp. 57-100.

New series, report no. 39. (ondition of winter grain; eondition of farm animals; and freight rates of transportation companies. A pr., 1887. 1887. pp. 101-16-1.

New series, report no. 40. Condition of winter grain; progress of cotton planting; and freight rates of transportation companies. May, 1887. 1887. Jp. 165-21\%.

New series, report no. 41. Acreage of wheat and cotton; condition of eereal crops: with freight rates of transportation companies. June, 1487. 1587. pp. 239-27.

New series, report no. 42. Area of corn, potatoes, and tobaceo; condition of growing crops: and freight rates of transportation rompanies. July, 1887. 1887. pp. $279-326$.

New series, report no. 43. Condition of growing crops: and freight rates of transportation companies. Aug., 1887. 1887. PI. $327-406$.

New series, report no. 44. Condition of erops in Amerien and Eurnpe; and freight rates of transportation companies. Sept., 1887. 18\$7. pp. 407-470.

New series, report no.45. Condition of erops; yicld of grain per acre; labor and priees in Jlexico; and freight rates of transportation eompanies. Oct., 1887. 1887. pp. $471-558$

New series, report in, 46 . Yield of crops per acre: and freight rates of transportation companies. Nov., 1887. 1837. pp. 559-614.

New series, report no. 47. Crops of the year; and freight rates of transportation companies, Dec, 1887.1887 . pp. $615-662$. (nos. 48-58) [Jan.-Dec., 1888]; by J. R. Dodge. 1889. $7+592 \mathrm{PP}$. Contents:

Index. $7 \mathrm{pp}$.

New series, report no, 48 . Numbers and values of farm animals; and freight rates of transportation companies, Jan. and Feb., 1888. 1888. pl. 1-64.

New series, report no. 49. Distribution and consumption of corn nud wheat; and freight rates of transportation companies. Mar., 185s. 1848. pp. 65-96.

New series, report 110, 50. Condition of winter grain; condition of farm animals: and freight rates of transportation companies. Apr., 1588. 1888. [1]. 97-15\%.

New series, report no. 51. Condition of winter grain; progress of cotton planting; wages of farm labor; silso freight rates of trunsportation compunies. May, 1sss. 18s4. JP. 153-200.

New series, report no, 52. Acreage of wheat and cotton; condition of cereal crons: with freight rates of transportation companies. June, 18s8. 1848. pp. 201-259.

New series, report no. 53. Area of corn, potatoes, and tobreco; condition of growing erons; and freight rates of transportation companies. July, 1888. 1888. pD. $261-323$.

New series, report no. $5 \mathrm{t}$. Condition of growing crops; and freight rates of transportation companies, Aug., 1888. 1888. pH. 325-380.

New series, report no. 55 . Condition of crops in America and Europe; and freight rates of iransportation (companies. Sept., 1888. 1858. pp. 381-144.

New series, report no. 56. (ondition of crops: yield of grain per acre; and freight rates of transportation eompanies. Oet., 188\%. 148\%. pp. 415-500.

New series, report no. 57. Vield of erops per acre; and freight rates of transportation companies. Nov., 1688. 1848. pH. 501-55i.

New series, report no. 5 ., Crows of the yenr; and freight rates of transportation companies. Dee., 15\%8. 1685. PP. 553-592. 
[1.27.] Reports of Burean of Statisties of Department of Agriculture (nos. 59-69) [Jan.-Dec., 1889]. 1890. $7+5+8 \mathrm{pl}$.

Contents:

Index. $7 \mathrm{pp}$.

New series, report no. 59. Numbers and values of firm animals; and freight rates of transportation (ompanies. Jan. and Feb., 1899. 1889. p\%, 1-48.

New series, report no. 60 . Distribution and consumption of eorn and whent; und freight rates of transportation eompnnies. Mar., 1859. 1889. pp. 49-84.

New series, report 110. 61. Condition of winter grain; condition of farm animals; and freight rates of transportation companies. Apr., 1889. 18s9. pp. 89-136.

New series, report 110. 62. Condition of winter grain; progress of cotton ylanting; also, freight rates of transportation companies. May, 1889. 1889. pp. 137-189.

New series, report no. 63. Acreage of wheat and cotton; condition of cereal crops; and freight rates of transportation companies. June, 18s9. 1s49. pp. 189-236.

New serifs, report no. 64. Area of enrn, potatoes, and tobacco; condition of growing crops; and freight rates of trunsportation companies. July, 1889. 1889. pp. $237-276$.

New scries, report no. 65. Condition of growing erops; and freight rates of transportation eompanies. Aug., 1889. 1859. pp. 277-332.

New series, report no. 66. Condition of erops in America and Europe; and freight rates of transportation companies. Sept., 1889. 1889. pp. 333-39\%.

New suries, report 110.67. Condition of erops; yield of grain per acere; anm freight rates of transportution companies. Oct., 1889 . 1889. pp. 393-135.

New series, report no. $6 \mathrm{~s}$. Yield of crops per acre; and freight rates of transportation companies. Nov. 1889. 1889. Pp. 437-18.4.

New series, report no. 69. Crops of the year; and freight rates of transportation comprnies. Dee., 1889. 1589. pp. $485-5$ t. 9.

[V. 28.] Reports of Bureau of Statistics of Department of Agriculture (nos. 70-80) [Jan.-Dec., 1890]. 1891. viii+652 pl. Contents:

Index. viii pp.

New series, report no. 70. Numbers and values of farm animals; and freight rates of transportation companies. Jan. and Feb., 1890. 1890. pp. 1-64.

New series, report no. 71. Distribution and consumption of corn nut wheat; and freight rates of trinsportation companies. Mar., 1890. 1890. pn. 65-116.

New series, report no. 72 . Condition of winter grain; condition of farm animals and freight rates of transportation companies. Apr., 1890. 1890. pp. 117-174.

New series, report no. 73. Condition of winter grain: progress of cotton planting; wages of farm labor; also, freight rates of transportation companies. Nay, 1890 . 1890. 1P. 175-230.

New series, report no. 74 . Acreage of wheat and cotton; fondition of cereal crops and freight rates of transportation companies. June, 1890. 1×90. Pl). 231-310.

New series, report no. 75. A rea of eorn, potatoes, and tobacco; condition of growing erops; and freight rates of transportation companies. July, 3890. 1890. pl.,311-374.

New series, report 110.76. Condition of growing crops; and freight rates of trans portation companies. Aug., 1890. 1890. pp. 375-430.

New series, report no. 77. Condition of erops in America and Enrope; and freight rates of transportation companies. Sept., 1890. 1890. Hp. 431-494.

New series, report no. 78 . Condition of erops: yield of grain per arte; and freight rates of transportation eompanies. Oet., $1 \times 90$. 1890. 19. 495-542.

New series, report no. 79. Yichl of erops per acre; and freight rates of transportation eompanies, Nov, 1890. 1890. pp. 543-590.

New series, report 11\%.80. Crops of the year; and freight rates of transportation complanies. DCe., 1890. 1891. pp. 591-652.

29 [S. 29.] Reports of Bureau of Statistics of Department of Agrienlture (nos. 81-91) [Jan.-Dec., 1891]. 9+698 PI.

Contents:

index. $9 \mathrm{pp}$.

New series, report no, 81 . Numbers and values of farm aninuls: and freight rates of transportation companies. Jan. and Feb, 1891, 1891. '1), 1-56.

New series, report no. 82. Distribution and consumption of corn and whent; and freight rates of transportation companies. Mar., 1891. 1891. pp. 57-104.

New series, report no. $\times 3$. Condition of winter grain: condition of farm animals and freight rates of trumsportation companies. Apr., 1891. 1891, op. 105-158.

New series, report 10.8. Condition of winter grain: provress of poton planting: nlso, freight rates of transportation companies. May, 1891. 1891. Pp. 159-2\%8.

New series, report 110. 85. Aerenge of whent und cotton; condition of erent rrops: and freight rates of transportation eommaies. dune, 1891. 1891. 1P. 239-302.

New series, report 110, 86 . A ren of corn, potutoes, anr tobacen; condition of growing 'rops; and freight rntes of trunsportation companies. July, 1891. 1891. pp. $303-37.4$.

New series, report no. 87. Condition of growing crops: nut freight rates of tunsportation companies. Ang., 1891. 1891. JP. 375-437.

New series, report 110. 88 . Condition of crops in America und burope; and freight rates of transportation eompanies. Scpt., 1891. 1491. lip. $+399-518$.

New series, report no. 89 . Cendition of crops; yeld of grinin per acre; and freight rates of transportation companies. Ort., 1891. 1891. (p). 519-590.

New series, report no. 90 . lield of erops per nere: nud frejoht rutes of transportation compankes, Nov., 1s91. 1s91. 1)6. 591-634.

New series, report no. 91. ('rops of the yenr; and freight rutes of trunsportution companies. Dee., 1591. 1892. [Pp. 635-698. 
[Y.30.] heports of Bureau of Statistics of Dopartment of Agriculture

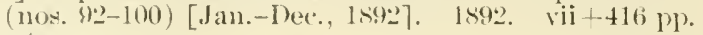

$$
\text { ('ontents: }
$$

Index, vii pp.

New series, report 110, 92, Numbers and values of farm animals: and freight rates

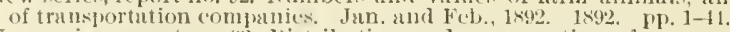

New scries, report no. 93. Distribution and consumption of corn and whent; and

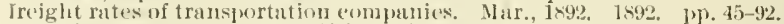

New series, report no, 9. Condition of winter grain: condition of firm animals; and freiglit rates of transpurtation companies. Apr., 1892. 1892. fp, 93-147.

New series, report uo. 95. Condition of winter grain; progress of cotton planting: also freight rates of transportution compunies. May, 1892. 1692. JP. 149-196.

New series, report no. 96. Acreage of whent and "otton; ("ondition of cereal crops; and freiglit rates of transportation companies. Junc, 1892. 1592. pp. 197-2 14.

New series, report 110.97 . Aren of corn, jotutoes, und tobaceo; and condition of growing ('rols. July, 1892. 1892. 13). 245-272.

special report of Stativician, July, 1s92; foreign crop reports and miscellaneous information; freight rates of transportation eompanies, 189:. DI. 273-296.

New series, report 110. 98. Report of the Statisticinin, Aug., 1892. Primary prices of farm products; foreign trade in agrieultural products: European erop prospects for Ang.; consular notes on foreign agrienlture; freight rates of transportation (ompanies. 1892. 1). 297-327.

[New series, refort 110, 94A.] Condition of growing "rops, Aug., 1892. 1592. 16 pp. New veries, report no. 98B.] Siame, sept., 1892. 1892. $20 \mathrm{flp}$.

New series, regrort 110.98C.] Condition of growing (rops and yield of grain per acre. Oet., 1592. 1892. 23 y.

New series, report no. 99. keport of Statistician, Sept, and Oct., 1892. Farm prices in two centuries: rumie mizehine trials in New orleans: Indiau wheat crop of 1892; notes of domestiv and foreign trade and industry; Europeun crop report for Sejt.; freight rates of trunsportation companies. 1892. pp. 329-376.

[New series, report no, $99 \AA$. .] Yield of erops per acre; and produet compared with last year. Nor, 1892. 1892. lif jp.

New series, report no. 100. Report of Statistician. Nov. and bee., 1492. Agricultural production and distribution of world; tests of averages of eondition; addresy of Statistician at annual meeting of $P$ [atrons] of II [usbindry]; reeiprocity and agrieultural exports; Eurowean crop report for bec., 1s92; and Ireight rates of trunsportation companies. 1892. Ji). 377-116.

[New series, rejort no. 100A.] Crops of the yeir, Dee, 1892. 1893. 28 p]'.

[V. 31.] Reports of Bureau of Statistics of Department of Agriculture (nos. 101-111) [Jan.-Dee., 1893]. 1894. x+521 I'p. Contents:

Index. $x p$

New series, report no. 101. Report of Statistician, Jan. and Feb., 1893. Agriculture in France; Hungarian milling: canning industry; tobaceo experiments in Texas: Europen crop revort for Feb. farm inimais of the world; frcight rates of transportation companies. $1893, \mathrm{pp}, 1-71$.

[New series, report no. 1011.] Number and value of furm animals; and cotton distribution. Jan.-Feb., 1893. 1893. $20 \mathrm{pp}$.

New series, report no, 102. Report of Statistician, Nar. 1893. Agriculture in Alaskit; foreign official crop extimates: Eumean crop report; wheat crop of the world; ireight rates of transportation companies. 1893. 1小. 73-95.

[New series, report no. 102A.] Distribution and consumption of corn and wheat, Nar., 1893. 1893. 16 pp.

New suries, report no, 103. lieport of Statisticiun, Aur. 1893, 1893. [Contents: Coudition of winter gruin; notes eoncerning wheat; condition of farm animals; European crop report for March, 1893; transportation rates.] pD. 97-140.

New series, report no. 104. Rejort of Statistician, May, 1893. 1893. [Contents: Condition of winter grain: mowing lands and pastures; progress of cotton planting; suring flowing; changes in crop areas: temperature and rainfall; notes from reports of State agents; the cotton ('rop of India for 1892-93; European crop report for May, 1893; transportation rates.] p1) 14I-17x.

New series, report 110. 105. Report of Statistician, June, 1893. 1893. [Contents: Crop report for Jume; agriculture in the Cameasus: the enstoms tariff in llartinique: agrienltural produce statisties of the United Kingdom; transportation rates.] 1p. 179-2:21.

New series, report no. 106. Report of Statistician, July, 1893. 1493. [Contents: Crop report for July; statintics of Ontario; foreign imjurt duties on wheat: notes on foreignagrieulture; use of maize of United States in Nexico; transportation rates.] pp. 223-270.

New series, rejort no. 107. Report of Statistician, Ang., 1893. 1893. [Contents: Crop report for lug.; noles on foreign ugrienlture: wheat crop of India for 1893; production of corn in New sonth Wales; domestic and transatlantie freight rates.] 19. $271-3222$.

N'w series, report no, 10s. Report of Statistician, Sept., 1893, 1893. [Contents: Agrieultural returns of Great Brituin; Ontario crop roport: (rops in Germany; notes Irom United States eonsmlar oflicers in sothend. Frince, Germany, Belgium, Corhin-bhina, and (ontario; domestie and transat lantic freight rates.] pp. 323-369.

New series, report 110, 109. Remurt of stativticiun, oet. 1893. 1893. [Contents: Notes from reports of state agents; imports of hay into United states; cereal crops of Franec and Italy for 1N93: production, commerce, and ensumption of wine in italy; corn as feed for horses in Germany: reports from enmsular officers relating to crons in frermany. Seotland. New Brunswick, and ontario: domestic and transatlantie freight rates.] PP. $371-11$. 
A27.9: Statistical reporrs-continued

31 [Y. 31.] Reports of Bureau of Statistics of Department of Agriculture, etr.-Contintled

contents-Contiuued

Sew series, relort mo. 110. Report of Statistician, Noy, 1s93, 1493, [Contents: Notes frou reports of State agents; jmports of Americun wheat flour into Europe; bon

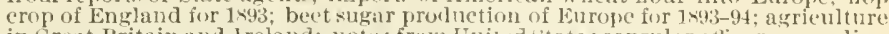
in Great Britain and I reland; notes from [nitedstates eonsular otlieers regarding

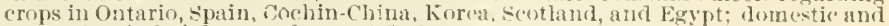
transatantic freight rates.] pp. 415-lis.

New series, report 110. 111. Report on the r.rops of the rear. Hee., 1493. 1894. pp. $459-521$.

[V. 32.] Reports of Bureau of Statistics of Deprartment of Agriculture (nos. 112-122) [Jan.-1)ec.] 1894. 1895. xiii 778 r.

Contents:

Index. xiil pp.

Tew series, report 110, 112. Report of Statistieian, Jan.-Feb., 1894. Repurt on farm animals; notes from reports of State agents: the eot ton erop: agrietrlture in china: the sugar crop of the world; Germany as in importer of Ameriean agrientural products: the canning industry; notes on foreign agrieulture; domestic and transatlantic freight rates. 189l. lop. 1-6s.

New series, report 110. 113. Report of Statistician, Mar., 1894. Distribution am consumption of eorn and wheat; supsly and distribution of wheat for twentyfive years; wheat erop of the world; wholesalc prices of principal agrienltural products in all sections of U. S.; expense of latising wheat and corn; proluction of honey and beeswax: ponltry and eggs: dairy products; ofticial statisties of foreign crops; the world's wool supply; notes from U. S. consular officers and European agents; domestic and transatlantic freight rates, 1,991. 1p. 69-156.

New series, report no. 114. Report of Statistician, Apr., 1\$94. Condition oi winter grain; wheat production in census vears since 1s69; farm animals, condition and losses; increase and decrease in number and value of farm unimals, 18s0-1890; agricultural developments in Bosnia and Herzegovina; health of the people; cotton erop of India for 1893-94; reports of $(T$. S. consular officer's; trunsportation rates, 1894. pp. 157-218.

New series, report no. 115. Report of statistician, May, 1894. Temperature and rainfall; condition of winter grain; changes in crop area; world's supply and consumption of eotton; fruit-crop prospects it the U. S., Nay 1, 1894; agriealtural production of Nexico for 1899 and 1892; agrieultural statisties of [rugua : Austrian cereal crops for 1893; Jupanese cerenl erops for 1893; European (rof) report; notes from U. S. consuliar ofticers: transportation rates. pp. 219-294.

New series, report no. 116. Report of Statistician, June, 1894. Crop report for June; tariff rates on principal cereals and flour in European countries; notes on foreign agriculture; notes from U.S. consular officers; climate of Nexieo; Nexican railways; transportation rates, 1894. pp. 295-394.

New series, report no. 117. Report of Statistician, July, 1894. Crop report for July; notes on foreign agrieulture; reports of $\mathbf{U}^{+}$. S. consular officers; transportatiosi rates. 1891. pp. 395-114.

New series, report no. 118. Report of Stutistician. Angust, 1894. Crop report for August; notes on foreign agriculture; production and consumption of rice in U. S.; commerce between U.S. and IIexjeo for years 1873, 1878, 1883, 1888, and 1898 ; transiortation rates. 1894. pp. 445-536.

New series, report 110. 119. Rewort of Statistician, Sept. 189t. Crop report for Sept.; stork hogs; notes from reporta of State agents; table showing eondition of crops sept. 1, 1894; urban population in south; notes on foreign agrieulture; transportation rates, 1891 . pp. 537-601.

New series, report no. 120. Report of Statistician, Oct., 189t. Crop report for o.t.: notes from reports of State agents; table showing vield per aere and eondition by States, Oet. 1, 1894; rice production in $1 T$. S.; hotes on foreign agrioulture; transportation rates. 1894. 112. 605-660.

New series, report no. 121. Report of Statistieian, Nov., 1894. Nov. erop report notes from reports of State agents; table showing estimnted vield per acre of fertain erops Nov. 1, 1891; notes on foreign ngrieulture; transportation rates. 1894. PP. $661-702$.

New series, report no. 122. Report of Statistician, Dee., 1894. Crops of the year; crop review: prineinal ('rops of 1894: furm prices and market quotutions: agrieultural exports and imports; ofliejal statisties of forejgu crops: transportation rutes. 1891. pl, 703-778. (nos. 123-133) [Ja11,-Dec., 1895]. 1896. v. p. contents:

New series, report no. 123. Report of Statistician, Jan.-leb., 1895. Farm animals; rotton crop; live stoek in Grent l3rituin and Irelant: cotton erop of Indiu for

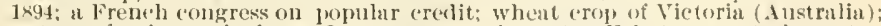
noteson foreign agriculture; Jan. transportation rates; Feb, transportation rates. 1895. P1\%. T-58.

New serres, report no. 124. Report of Statistieinn, Mar., 1s95. loistribution nud consumption of wheat in U. S.; consumption of wheat per rapjta in $\mathbb{T}_{\text {. }} S_{\text {. }}$ whent crop of world; prices of whent since $1 \times 65$; wholesale prices of principul agriculture products, etc:; report of European agent; transportution rules. 1895. $p 1$, ii $+59-106$. 
[V.34.] Reports of Division of Statistics of Department of Agriculture Contents:

(nos. 13t-14t) [Jan.-Dec.] 1896, 1897. r. ए.

Index, $6 \mathrm{pp}$

New series, report no. 134. Prices and numbers of farm animals: rejort of European agent. n.t. p. 8 pl.

New serjes, report no. 135. ('rop report for Mareh, 1896. 11. t. 1) $16 \mathrm{pp.}$

New series, report no. 135. Same, summary of eotton report for Mareh, 1 s96. n. t. P. 4 pl.

New serjes, report no. 136. Crop report for April, 1896. n. t. p. 7 yp

New series, rejort no. 137. Crop report for May, 1896. n. t. p. 8 pp.

New series, report no. 13к. Crop report for June, 1s96. 11. t. p. 4 pp.

New series, report no, 139. (rop report for July, 1896. n. t. p. \& pp.

New series, report no. 110. Crop report for August, 1896. n. t. p. \& $p p$.

New series, report no. 111. Crop report for September, 1896. n. t. Is. 7 yp.

New series, report no. 142. Crop report for October, 1896 . n. t. P. 7 ll.

New series, report no. 143. Crop report for November, 1896 . n. 1. p. $4 \mathrm{pp}$.

New series, report no. 144. Crop report for December, 1896. 11. t. 1. $16 \mathrm{jp}$.

[V.35.] Publications of Division of Statistics of Department of Agriculture, Reports nos. 145 to 155 ; Circulars nos. 5-8. 1898. v. 1 . contents:

Index. vii pp.

New series, report no. 145. (rop report for Jan.-Feb., 1\&97. n. t. p. 7 pl.

New series, reinort 110. 146. Crop report for Mareh, 1s97. 11. t. 1 . 4 pp.

New serias, rewort no. 147. Crop report for April, 1897. 11. t. 1. \& pp.

New series, report no. 148. Crop, report for May, 1897. n. t. 1. 4 [p?.

New series, report no. 149. ('rop report for June, 1897, n. t. 3'. 4 iv).

New series, report no. 150. Crup leport for July, 1897. n. t. p. 8 lp.

New series, report 110, 151. Crof report for August, 1897. n. t. 1. 7 pp.

New series, report no. 152. Crop report for September, 1897. 11. t. 1\%. 4 pp.

New series, report no. 153. ('rol report for Oetober, 1597. n. t. J. I Ip].

New series, report no. 154. Crop report for November, 1.97. 11. t. p. 4 pp.

New series, report 110, 155, ('rop report for Deeember, 1897 . n. t. p. $30 \mathrm{mp}$

Circular No. 5. Local taxation as affecting farms, 1897. 16 pI.

Cireular No. 6. Cereal crops of 1\$96. 11. t. P. $12 \mathrm{pp}$.

Cirenlar No. 7. Cotton crop of $1 \times 96$. n. t. p. 4 pr.

Circular No. 8. Cotton erops of 1896-97. 11. t. p. $11 \mathrm{pp}$

36 [V. 36] No. 156. Report on condition of winter grain on April 1, 1899 , and losses of farm animals during year ending Mar. 31, 18.19, with statistics of foreign (rops. n. t. p). $38 \mathrm{pp}$.

[1)iseontinued.]

\section{A.27.9": Slatisticat peperis (separates)}

F94 Fruit-('rol' prospects in I. S. May 1, 1894. n. t. P. Pp. 251-253.

[Reprinted from New series, report no. 115 of statistician.] 
[Formerly Division of Vegetable Pathology. Merged into Bureau of Plant Industry July 1, 1901. Sce A19. For historical sketeh of Division see Yearbook $1897(\Lambda 1.10: 897), \mathrm{i}, 99$.

Classiflatlonl $\mathrm{no}$.

A.28.1:

886

887

888

889

890

891

892

893

896

897

898

899

900

A28.2:

A20.:

\section{Annual reports}

REPORT OF TIE MIYCOLOGIST

1886 (Scribner) [1]+95-138 pp. 8 pl. 3 maps. 1 diagram. (Also in A1.1:886, p. 95.)

Report of Cinfef of Section of Vegetable Pathology

1887 (Seribner), 323-397 pp. $17 \mathrm{pl}$. (Also in $A 1.1: 857,1.323$. )

1888 (Galloway), iv-325-404+iii wp. 19 pl. 1 map. (Also in A1.1:8s8, p. 325.)

1889 (Galloway), [1]+397-432 pp. $2 \mathrm{pl} . \quad$ (Also in A1.1:889, P. 397.)

Repolit of Chief of Division of Vegetable Pathology

1890 (Galloway), [1] +393-408 pp. 5 pl. (Also in A1.1:890, p. 393.)

1891 (Galloway), [1] $+359-378$ pp. 3 pl. (Also in A1.1:891, p. 359.)

1892 (Galloway), [1]+215-246 pp. 4 pl. (Also in A1.1:892, p. 215.)

1893 (Galloway), iii $+245-276 \mathrm{pu}$. (Also in A1.1:893, p. 245.)

1894 (Galloway). (In A1.1:894, p. 143.)

Report of Chief of Division of Vegetable Pitysiology and Pathology 1895 (Galloway). (In A1.1:895, p. 169.)

1896 (Galloway), iii + 15-22 pp. (Also in A1.1:896, p. 15.)

1897 (Galloway), iii + 7-13 pP. (Also in A1.1:897, p. 7.)

1898 (Woods), iii +27-36 pp. (Also in A1.1:898, p. 27.)

1899 (Galloway), iii +71-83 pp. (Also in A1.1:899, p. 71.)

1900 (Galloway), ii $+49-58 \mathrm{p}$. (Also in A1.1:900, 1.49. )

1901 (Woods). [This final report of the dirision was made through the chief of the Bureau of I'lant Industry, forming part of his annual report for 1901. (See A1.1:901, p. 46; also A19.1:901, p. 46.)]

\section{Gencral publications}

None issued.

\section{roulletins}

No. 1. Additional evidenee on communicability of peach yellows and peach rosette; by Erwin F. Smith. 1891. 65 pu. 39 pl.

No. 2. California vine clisease, preliminary report of investigations; by Newton B. Pierce. 1892. 222 pp. 25 fil. 2 eharts.

No. 3. Experiments marle in 1891 in treatment of plant diseases; by B. T. Galloway. $1892 . \quad 76+[1]$ pp. $\&$ pl.

No. 4. Experiments with fertilizers for prevention and cure of peach yellows, 1889-92; by Erwin F. Snith. 1893. $197 \mathrm{FP} .33$ pl.

No. 5. Pollination of pear flowers; by Merton B. Waite. 1894. $110 \mathrm{pp}$. $12 \mathrm{pl}$.

Same, [2d erlition.] 1895. 110 pp. 12 pl.

No. 6. Bordeaux mixture as a fungicicle; by D. C. Fairchild. 1894. $55 \mathrm{pp}$.

No. 7. Effect of spraying with fungicides on growth of nursery stock; by B. T. Galloway. $1894.41 \mathrm{pp}$.

No. 8. Principal diseases of citrus fruits in Florida; by Walter T. Swingle and Herbert J. Webber. 1896. $42 \mathrm{pl}$. 8 pl.

No. 9. Bordeanx mixture, its rhemistry, physical properties, and toxic effects on fungi and algae; by Walter T. Swinghe. 1896. $37 \mathrm{pr}$.

No. 10. Copper sulphate and germination, treatment of seed with copper sulphates to prevent attacks of fungi; by Walter H. Evans. 1sith. $24 \mathrm{pl}$.

No. 11. Legal enactments for restriction of plant diseases, compilation of laws of U. S. and Canada; by Erwin F. Smith. 1896. 45 Pp.

No. 12. Bacterial disease of tomato, eggplant, and Irisll potato; by Erwin F. Sulth. $1896.28 \mathrm{pl} .2 \mathrm{pl}$.

No. 13. Sooty mold of orange and its treatment; by Herlert J. Webber. 1897. $44 \mathrm{pp} .5 \mathrm{pl}$.

No. 14. Bermuda lily disease, freliminary report of investigations; by Albert F. Woods. 1897 . $15 \mathrm{HP}$. 
('lassiflou= tlon 110.

1.24.:3:

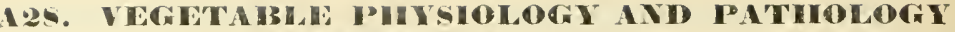

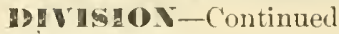

\section{BBulledius-Continural}

To. 15. Some elible and poisonoms fungi; by W. G. Farlow. 1898. iii $+4.3-770$ Pl. 10 pl.

[Reprinted from Yearbsuk, 1097.]

No. 16. Cereal rusts of United states, a physiological investigation; by Mark Alfreil carleton. 1899. $74 \mathrm{pP} .4 \mathrm{pl}$.

Vo. 17. Wilt disease of cotton, watermelon, and cowpea; by Jrwin F. smitl. 1890. 72 1\%. $10 \mathrm{pl}$.

No. 1s. Physiological rôle uf mineral nutrients; ly oscar Loew. 1899. (i) $\mathrm{pP}$.

No. 19. Stigmonose: a clisease of earnations and other pink-; by dlbert $\mathbf{F}$. Woods. 1!100. 30 p). 3 pl.

No. 20. P'each leaf curl, its nature and treatment; by Newton B. Pierce. 1900. 204 pp. 30 leaves. $30 \mathrm{pl}$.

No. 21. Two diseases of red cedar, cansed by Polyporus juniperinns n. sp. and Polyporus carneus nees; preliminary report; by II ermann von sichrenk. 1900.202 y. 7 pl.

No. 22. Nenia, or immerliate effect of pollen, in maize; by Ilerbert J. Webber. 1900. 44 Pr. 4 Jl.

No. 23. Spot disease of violet (Alternaria viole n. ep.) ; by I'. H. Dorsett. 1900. $16 \mathrm{pl}$. 7 ,l.

No. 24. Basis for improvement of American wheats; by Mark Alfred Carleton. 1900. 87 lp. 11 pl.

To. 25. Some discases of New England conifers, prelininary report; by Hermani von Sichrenk. 1900. $56 \mathrm{pJ} .15 \mathrm{pl}$.

No. 26. Wakker's hyacintl germ Pseudomanas hyacinthi (Wakker); by Erwin F. Sinith. 1901. 45 pl. 1 pl.

Same, 56th Cong., 1st sess., H. doc. 694; serial no. 4000.

No. 27. Wilt disease of cotton and its control; by W. A. Orton. 1900. 16 pp. 4 pl.

No. 28. Cultural cluaracters of Pseudomonas hyacinthi, Ps. campestris, Ps. phaseola, and Ps. stewarti, four one-flagellate yellow bacteria parasitic on plants; by Erwin F. Smith. $1901.153 \mathrm{pp}$.

No. 29. Plant breeding; by ivillet M. Hays. $1901.72 \mathrm{pp} .6 \mathrm{pl}$.

\section{Circular's}

[To. 1.] Treatment of downy grape mildew and black-rot [of grape]. [May, 1886.] n. t. p. $3 \mathrm{pp}$.

[No. 2. (irapevine mildew and black-rot.] May 11, 18s6. n. t. p. 3 pp.

No. 3. Treatment of clowny mildew and black-rot of grape; by Norman J. Colman. April, iss7. 2 pl. $4^{\circ}$.

No. 4. Treatment of potato and tomato for lolight and rot; by F. LamsonScribner. July 2, 1887. [3] Pp. $4^{\circ}$.

No. 5. Fungicides, or remedies for plant diseases; by F. Lamson-Scribner. Apr. 25, 1888. n. t. p. 10 pp.

No. 6. Treatment of hlack-rot of grape; by B. T. Galloway. n. d. 11. t. p. 3 pl).

No. 7. Grape-vine diseases; by B. T. Galloway. n. d. n. t. p. [4] pp.

No. 8. Experiuents in treatment of pear leaf-blight and apple powdery millew; [by 13. T. Galloway]. n. 1). [1889] 11 pp.

No. 9. Root-rot of cotton, circular of inquiry; by J. M. Rusk. n. d. n. t. p. [t] PI.

No. 10. Treatment of nursery stock for leaf-blight and powrlery mildew; by B. T. Cralloway. 1891. 8 Ip.

1 No. 11. [(2uestions regarding black-rot, lowny mildew, and anthracnose of grape; by Edwin Willits.] n. d. (Cire.)

No. 12. [(2uestions asked and specimens of straw and stubble of wheat, oats, rye, and barley solicited; by J. M. Rusk.] n. d. (Cire.)

No. 13. [Jetter of inquiry relative to leaf curl of peach trees; by Edwin

Willits.] Nov. $25,18 \% 3$. [3] Hp. $4^{\circ}$
No. 14. [Letter of inquiry relative to grain rusts, requesting specimens of rusted wheat, oats, rye, and harley; by Chas. W. Dabney.] Feb. 23, 1894. (Circ.) 
Clasingetthon ino.

12m.4:

15

16

17

16

1.24.5:

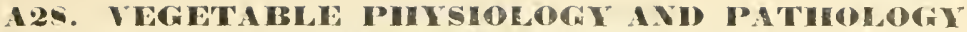 IVISION-Contiuned}

C'ircul:ur:-Continned

No. 15. Treatment for sooty moll of orange; by H. J. Webler. Jan. 2, 189.5. n. t. p. 4 pp.

No. 16. Danger of introluring a Central American coffee discase into Hawaii; by Walter T. Swingle. July 26, 1898. 4 lip.

No. 17. New spraying devices; by B. T. Galkoway. April s, ks.9. n. t. 1). $+1 \mathrm{p}$.

No. 18. New wheat industry for semi-arid west; by Mark . lired carleton. June 28, 1901. 11. t. p. \& pp.

\section{Dournal of myeatory}

[Devoter to study of fungi, especially in their relation to plant diseases.]

V. 1-4. (Not Government publications.)

(2UARTERLY BULLETIN.

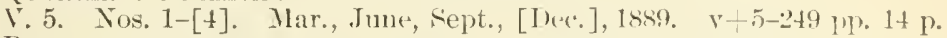

Periodical bUlletix.

V.6. Tos. 1-4. May, Sept., 1890; Jan., Apr., 1891. iv - 207 pp. 18 pl.

T. 7. Nos. 1-4. Sejt., 1891; May, 1892; May, 1893; Aug., 1894. V+ iii +48 1). $35 \mathrm{pl}$.

[Discontinued.]

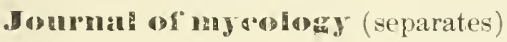

[A few of the more important papers eontcined in the rolumes were iscled separately.]

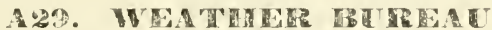

[For historical sketeh of Bure:u, ser Yearbook, 1s97 ( $\mathrm{A1.10:897),} \mathrm{P.} \mathrm{59.]}$

\section{A29.1: Annual reports}

[From 1891 to 1895 the report wa4 in two parts, the actministrative, which was printer as part of the Annmal Report of the Seeretary of Agrieulture, and also iscued separately in pamphlet form, and the "Neteorologieal data" a continution of the series issued by t Signal onice, War Dept., bonnd in quarto eloth volnmes. Beginning with 1896 , he two were combiner in one volume, an abbrutition of the administrative portion also appearing in the seeretary's report and in a separate [mimphlet, $\left.8^{\circ}\right]$

1891 [I't. 1]. Sprecial report of Chief of Weather Burean to Secretary of Agriculture, [July to Oct.] 1891. 1891. $26 \mathrm{pl}$.

1891 [l't. 2]. [Administrative] rejort of Chief of IVeather Bureau for

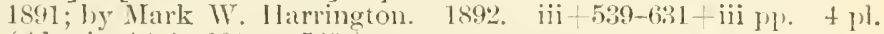
(Al:o in 11.1: 891, 1. 5:39.)

1891 [Pt. :3]. Report of Chief of Weather Bureau, 1891-92. [Metrorolog-

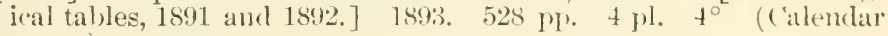
vears.)

Same, 521 Cong. 2d sess., II. mis rloe. 107, serial no. 3126.

1892. [Administrative] report of Chief of Weather Bureau for 189.; by Mark W. Harrington. 1893. iv+551-626+ii j). (Calendar year.) ( Also in 11.1 : si.2, 1. 551.)

[For meteorological tables, 1892 (calentar year), se $129.1: 8913$. ]

$89: 3^{1}$

$8: 13^{2}$

894

189:3 [Pt. 1]. [Administrative] report of Chice of Weather Bureati for

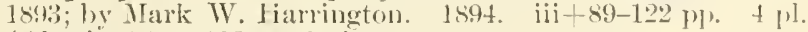

( 11 so in $11.1: 893, \mathrm{~T}$. 89. )

1893 [Pt. 2]. Report of Chief of Weather Bureau, 189:). [Metwonlowical tables, 1893 (calenclar year).] 1994. 319 pl. $4^{\circ}$

1894. Report of Chief of Weatlier Bureau, 189t. [Mnteorological tables, 1894 (calendar year).] 1895. 288 \%). $4^{\circ}$

Same, $53 \mathrm{~d}$ Cong., $3 \mathrm{~d}$ sess., H. mis. doc. 88; serial no. 3:3;:3.

[For administrutive report (fiscal year) see $11.1: \$ 94,1 \%, 77$.

1895. Report of Chief of Weather Inreau for 1895, hy Willis 1. Moore. 1895. iii $65-96 \mathrm{PI}$. (Also in Al.1:895, p. (i5.)

[For meteorologieal tubles, ls9is (calendair yeur), sce A29.1:\$96.] 


\section{Tableo}

Clansitic ("il tion 110.

129. 1:

Sati

\section{A29.2:}

Al 1

Ir4

$1 \mathrm{t} 6^{1}$

$A t 6^{2}$

1373

C:3s

('4)

\section{29. WENTHEIR IBETREA-Continued}

\section{Anmual reports-Continued}

1896. Report of Chief of Weather Bureau. 1895-96 (fiscal year). [With meteorological tables, 1895 (calendar year).] $1845 . \quad x+266 \mathrm{pp}$. 8 cliarts. $4^{\circ}$

Same, 54th Cong., 1st sess., H. doe. 428; surial no. 3453.

[The administrative portion of the repor, rearranged, is also in .11.1:596, p. 243.]

1897. Report of Chief of Weather Burean, 1896-97 (fiscal year). [With meteorological tables, 1896 (calendar vear).] $189 \% . \quad x+431 \mathrm{pp}$. $22+11$ charts. 1 il pl. 2 il.

Same, 55 th Cong., 21 sess., H. doc. 166 ; serial no. 3670.

[Administrative portion of report, also in A1.1:897, p. 199.]

1898. Report of Chice of Weather Bureau, 1897-98 (fiscal year). [With meteorological tables, 1897 (calendar year).] $1899.338 \mathrm{pl} . \quad 7 \mathrm{pl}$. 21 charts. 9 dliagrans.

Same, 55th Cong., 3d sess., H. 'loc. 270; serial no. 3820.

[Administrative portion of report, also in A1.1:898, p. 20s.]

1899. Report of Chief of Weather Bureau, 1898-99, vol. 1 (fiscal year). [With meteorological tables, 1898 (calendar year).] 1900. $\mathrm{v}+247 \mathrm{lp} . \quad 4^{\circ}$

Same, vol. 2. [Reyort on international clond olservations, May 1, 1896, to July 1, 1897; prepared by Frank 11. Bigelow.] 1900. 787 pl. 79 charts. $4^{\circ}$

Same, 56th Cong., 1st sess., II. doc. 660, pts. 1 and 2; serial nos. 3998 and] 3999.

[Administrative portion of report, also in A1.1:899, p. 9.]

1900. Report of Chief of Weather Bnrean, 1899-1900 (fiscal year). [With meteorological tables, 1899 (calendar year).] 1901. $436 \mathrm{pp} .4^{\circ}$

Same, 56th Cong., 2 d sess., H. doc. 517; serial no. 417 .

[Administrative portion of report, also in A1.1:900, p. 7.]

1901. Report of Chief of Weather Burean, 1900-1901 (fiscal year), voi. 1. [With meteorological tables, 1900 (calendar year).] 1901. $318 \mathrm{pp} .4^{\circ}$

Same, 57th Cong., 1st sess., H. doc. 19, pts. 1 and 2; serial nos. 4319 and 4320.

[Administrative portion of report, also in A1.1:901, p. 3.]

Same, v. 2. [Report on barometry of U. S., Canada, and West Indies; by Frank II. Bigelow. ] 1902. [1]+1005 pp. 222 charts.

1902. Report of Chief of Weather Bureau, 1901-1902 (fiscal year). [With meteorological tables, 1901 (calendar year).] 1902. $\mathrm{x} \times \mathrm{vii}+342 \mathrm{l}$ \%. 5 charts.

Same, 57th Cong., $2 d$ stris., H. doc. 19 ; serial no. 4485.

[Administrative portion of report, also in A1.1:902, p. 3.]

\section{Anuual reporis (separates)}

[The various series of tables, designated as "parts" in the volumes, are also issued separately.]

\section{Concral publications}

Alaska. The climate of Alaska; by Willis L. Monre. 1897. $2 \mathrm{l} .4^{\circ}$

Arid regions. Some climatic features of arid regions; communicated to National Irrigation Congress at its 5th annual session, Phoenix, Ariz., Dee. 15-17, 1896; hy Willis L. Moore. 1896. 19 pp. 3 charts. Atmospheric circulation in tropical cyclones, as shown by movements of clonds; by H. B. Boyer. [1896.] $17 \mathrm{pp} .17 \mathrm{pl}$.

Atmospheric survey. I. S. daily atmospheric survey; by IT. I. Moore. 1897. n. t. 1. 6 pp.

Brazos River flood bulletin. July 15, 1889. (Map.)

Charts showing daily river stages in feet. $1892.19 \times 24 \mathrm{in}$.

Cipher code of wind signal orders, amending instructions to special display men. Nor., 1892. $10 \mathrm{pp}$. 
Clastforation no.

A.29.2:

$\mathrm{Ctil}^{1}$

(ii $)^{2}$

$(6) 2$

(6):

( $(1)$

$\left(1 ; 2^{1}\right.$

C4:?

C:19

D14

[5)]

$\mathrm{Fit}$

$\mathrm{F}+2$

Fy+4

GS1 ${ }^{1}$

[is $]^{2}$

$\mathrm{Cist}^{3}$

(is ${ }^{4}$

(is $1^{5}$

GS1

Gist ${ }^{7}$

G $81^{8}$

H94

Ins

1.15

Lfi:

L $62^{2}$

L(i) ${ }^{3}$

$1: 7$

181

PII

P19

P.) 1

$\mathrm{POI}^{1}$

\section{Genceal publicanions Continued}

Climate and Ilealth (monthly perioulical). [Amnouncing discontinuance of mblication of Climate and Health.] June 2:), 1896. (Cire.)

('limatic charts of $\mathrm{I}^{5}$. S., 1900. [26 charts bound.]

[Each chart was originally issued separately.]

Cloud forms. Description of elond forms. 11. 1. (Chart.)

Same, 2l edition. 11. d.

Same, 3 l edition. n. d.

Same, fth exlition. n. 1 .

Current chart of Great Lakes. 1892. Proballe currents of Great lakes [deducel from bottle paper olservations]. 189:. 24x:34 in. (Chart.)

Cyclones. Development and movement of eyclones, as shown in morning and evening weather maps Apr. 2-6, 1892; jrepared loy C. F. Marvin. 1893. [18] $1 \%$. Oblong 1. $8^{\circ}$

Dakotas. Certain climatic features of two Dakotas; by Joln P. Finley. 1S93. $206 \mathrm{pl} .89 \mathrm{pl} .4^{\circ}$

Same, 52d Cong., 1st sess., S. ex. doc. 157; serial no. 2893.

Dew-point. Tables for obtaining temperature of lew-point, relative humidity, ete. [From instructions to voluntary olservers. 1892. In 129.12:V88.] 1897. pp. 66-98. (c. t. o.)

Forecaster and newspaper; Jy Harrey Maitland Watts. 1901. $22 \mathrm{pl}$.

Frost. Injury and nethods of protection from frost; by W. H. Hammon. 1896. 12 l'p. (For revised ed., see A29.3:23.)

Fruits. Protection of fruits, vegetables, and other food products, from injury by heat or cold luring transportation; by Mark IV. llarrington. Aug. 22, 1894. 11. t. \%. 7 j).

Great Lakes. Display of wind signals on Great Lakes. 1895. (Circular of information.) 13 pl. 1 pl.

Same. 1896.18 pl. 1 pl.

Great Lakes. Wreck chart of Great Lakes. 1886-91. (Broarlside.)

Same. 1856-93. (Broaidside.)

Great Lakes. Wrecks which occurred on Great Lakes Dee. 17, 1885, to Nov. 15, 1893. 1894. 22 pr.

Great Lakes. Wrecks and casualties on Great Lakes rluring 1895, 1896, 1897; by Norman B. Conger. 1898. 23 pp.

Great Lakes. Wreck and casualty chart of Great Lakes. 1894. (Broadside. )

Great Lakes. Section map of Great Lakes. [1892.] ('hart $19 \times 2+$ inches, Hurricane of Aug. 13-16, 1901, on Louisiana and Mlississiyji coasts. Sipcial report on. [1901.] n.t.p. (i p).

[International symbols recommended for use ] y Metenrological Congress, Munich, 18.2; by Mark W. Harrington.] Jan. 1, 1894. 11.t. 1. 5 pl.

lake levels. Yariations in lake levels and atmospheric precipitation; by Alfred J. Henry. $1899.8 \mathrm{pl}$.

lightning. l'rotection from lightning; by Alexander Medolie. 1894. (Circular of information.) $20 \mathrm{pp} .11 \mathrm{pl}$.

Same. 21 edition. 1894. 21 p. 6 pl.

Same. 3d edition. 1894. 21 lip. $1 \mathrm{p}$ pl.

See, for 4th ed., A 29.8:15.

Vebraska. Departures form normal temperature and rainfall with erop) yiclds in Nebraska; by H. 11. C. Dunwoorly. 1s9t6. 20 jer. to

Forth Pacific coast weather map. Wxplanation of North laceific coast weather map; by Willis L. Moore. 4 ll). $16^{\circ}$

Pacific slope. Weather forecasting and weather tyjes on North l'acilic slope; by B. S. Pague and S. M. Blandford, Portland, ()rog. Is:97. $29+[1]$.

I'an-American Fxposition weather maps; with special color-printed "nvelope. [1:001.] (Broarkide.)

Jaris. Responses to programme of ipuestions proposed for discussion at Paris International Meteorological (Congress, sopt., 18\%(6. 1896. $29 \mathrm{pl}$.

Precipitation. Details of precipitation (rain and melted snow) at stations in Nebraska and Sonth Dakota. Mar, 6, 1894. 33 pp.* 
A 2!).2:

1391"

$1991^{3}$

I.45

lis: ${ }^{1}$

R $1: 3^{2}$

R5: 1

R5.22

Sa2

Si:2 1

Si:2

$\mathrm{S}_{11} 7^{1}$

$\mathrm{S}_{11} 7^{2}$

T11

T:34

$T+3^{1}$

$\mathrm{T}+3^{2}$

$1 \mathrm{~V} 37^{1}$

$1 V^{2}: 7^{2}$

$1157^{3}$

WI:-4

$11: 7^{5}$

$11: 37^{6}$

$1137^{7}$

A29.:3:

\section{A29. WVATIIRT IBITEAU-continues}

\section{Gemeral pablicationa-C'ontinuerl}

Precipitation. Tables of daily precipitation at siecial river and rainfall stations of U. S. Weather Bureau, for 1893, 1894, 1895. 1900). $[2] \div 256$ )

Precipitation. Table showing depth of precipitation corresponding to given weights. [18:2.] ("aril. 120.

lsychometric tables for oldtaining rapor pressure, relative humbidy, and temperature of dew-point; prepared by C. F. Marvin. 1900. st pl.

liainfall chart. Lines of equal time of water travel at Cairo, Ill. [I892.] $22 \times 28$ in.

Rainfall laws, deduced from twenty years' observations; by Ciustavus Hinrichs. Weather Bureau, 189\%. 94 ए).

River and flood service. Chart of river and flood service. 1897.

River and flood service (nlats, showing area covered by water of Mississipui River in April, I897. 1897 *

St. Marys Falls Canal. Relation of certain atmospheric changes to changes in water level in St. Marys Falls Canal. 1sot. n. t. p. 2 Pl. $4^{\circ}$

Simal Service. Statement of expenrlitures of Signal Service and IT eather Bureau. 1893. :3 Pl.

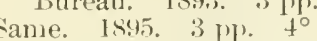

Sunsline. Table of monthly amounts of possible sunshine for hours eucling shortly after sumise (and) sunset. 1894. '2 j'p. 'arcl.

Sunshine table 1. Local time of sumrise and sunset for north latitules, from $25^{\circ}$ to 4$)^{\circ}$, inclusive. 2 pre card.

Tables for rividing by $672,720,744,56,60,62$. Recorls Division, Weatler Bureau. 1893. $15 \mathrm{pl}$.

Thermometer scales. Comprarison of themometer scales. [18:2.] "ard. Thunlerstorm observations. [Circular of instructions.] [1892.] 2 Ip. Same. [1893.] 2 pl.

Wrather Bureau. [Its history and work.] 1901. $15 \mathrm{pP} .24^{\circ}$

[For distribution at Pan-American Exposition.]

Weather chart.. Explanation of weather charts. (Gingle sheet.) [1892.] $\mathrm{f}^{\circ}$

Weather code, Dec. 1, $1892 . \quad 1892.93 \mathrm{pP} .4^{\circ}$

Same, Dec. 1, 1896. 1896. $116 \mathrm{pp} .4^{\circ}$

same, Mar. 1, 1902. 1902. 93 jl'. $4^{\circ}$

IV eathej map. Explanation of weather map; ly IVillis L. Moore. $3 \mathrm{pp}$. $16^{\circ}$

Weather malp, Ther. 13-16, 189\%. [ [ Wall map, $52 \times 56 \mathrm{~m}.] \quad 1894$.

\section{Boulletions}

No. 1. Notes on climate and meteorology of Death Valley, California; by Mark 11 . Harrington. 1892. $50 \mathrm{pl}$.

No. 2. Notes on new method for discussion of magnetic observations; by Frank H. ligelow. 18:2. 40 pp. 1 pl.

No. 3. Relations of soil to climate; by $1 \%$. Wilgarl. $1892.59 \mathrm{pp}$.

No. 4. Sone physical properties of soils in their relation to moisture and (a)p distribution; by Milton Whitney. 1892. $90 \mathrm{pl}$

No. 5. (lbselvations and expreriments on fluctuations in level and rate of movement of ground water on Wisconsin Agricultural Experiment Station farm, and at Whitewater, Wis.; by Franklin H. Kúing. 18.9.2. 75 PI\% 6 pl.

No. 6. Dinmal variation of barometric pressure; by Frank $\mathrm{Y}$. Cole. 1892. $323 \mathrm{pm}$.

No. T. Repurt of tirst annual meeting of American dssociation of state We'athrer fervices. 1893. $497 \%$.

No. 8. Climatology of cotton plant; by P. H. Mell. 1893. 68 pp. 1 pl.

Fo. . Forecasting of thmulerstorms during smmmer of $1593 ;$ by N. B. Conger. 1893. 54 pl). (i p)].

No. 10. Climate of Chicago; ly llemry A. Hazen. 1893, 137 pp. 4 pl. * No copy found. 
129.:3:

$11^{1}$

\section{A29.8\%: BBullediun (separates)}

[Some of the articles in the Bulletins are issued sepurately.]

\section{A29.1: Circular.}

None issued. 
A29.5: IBulletins (lettererl)

A. Snmmary of international meteorological obserrations; by II. II. C. Dunwoorly. 18:3. 10 leaves. 53 pl. eleph $\mathrm{f}^{\circ}$

13 $^{1}$ B. Currents of Great Lakes, as ilednced from movements of bottle papers, during seasons of 1892 and 1893 ; ly Mark W. Harrington. 1894. 6 leaves. $6 \mathrm{pl}$. eleph. $\mathrm{f}^{\circ}$

$\mathrm{B}^{2} \quad$ Sante, revised cdition. $1895.14 \mathrm{pl} . \quad 6 \mathrm{pl}$. eleph. $\mathrm{f}^{\circ}$

(C1 C. Rainfall and snow of United States, compiled to end 1891, with annual, seasonal, monthly, and other warts; l,y Mark W. IIarrington. 1894. $80 \mathrm{pp} .4^{\circ}$.

$\mathrm{C}^{2}$ Sane, Atlas. 1894. 25 pl. eleph.f ${ }^{\circ}$

D I. Rainfall of ['nited States, with anmmal, seasonal, anrl other charts; by Alfred J. Henry. $1897.58 \mathrm{pp} .15 \mathrm{pl}$.

E E. Floods of Mississippi River; by Park Morrill. 1s:7. vi+79 p. $58 \mathrm{pl} .4^{\circ}$

F F. Vertical gradients of temperature, humidity, and wind direction. Preliminary report on kite olservations of 1898 ; by H. C. Frankenfield. $1899.71 \mathrm{pp} .7 \mathrm{pl} .4^{\circ}$

(i. Atmospheric radiation, a research conducted at Allegheny Observatory and at Providence, R. I.; submitted to Chief of Weather Bureau by Frank W. Tery. 1900. $134 \mathrm{Pl} .4^{\circ}$

H. West Indian hurricanes; by E. B. Garriott. 1900. iii +69 pp. 7 charts. $4^{\circ}$

1. Eclipse, meteorology, and allied problems; by Frank II. Bigelow. 1902. $166 \mathrm{PP} .43$ eharts. $4^{\circ}$

J. Wind velocity and fluctuations of water level on Lake lirie; loy Alfred J. Henry. 1902. $22 \mathrm{pp} .25 \mathrm{pl}$.

\section{A29.6:}

\section{Fond bly weather review}

[Vols. 1-18 and nos. 1-6 of vol. 19 issued by Signal Service, War Department, W42.20: The chart numbers are given as they appear on the publications, regardless of the fact that they are printed on both sides of a page.]

V. 19. [1891] n. t. p.

No. 7. July. pp. 155-179. + eh. 1 pl.

No. 8. Aug. pp. 181-207. $4 \mathrm{ch} .1 \mathrm{pl}$.

No. 9. Sept. I'p. 209-232+ix. 4 ch. 1 pl.

No. 10. Uet. pp. 233-258. $5 \mathrm{ch} .1 \mathrm{pl}$.

No. 11. Noy. pp. 259-287. $7 \mathrm{ch}$.

No. 12. Dec. PP. $289-330+\mathrm{x} .13 \mathrm{ch}$.

T. 20. [1892] n. t. p.

No. 1. Jan. pp. 1-31. $7 \mathrm{ch}$.

No. 2. Feb. pl. 33-59. 7 ch.

No. 3. Mar. pp. 61-87. $7 \mathrm{ch}$.

No. 4. Apr. pl. 89-116. $5 \mathrm{eh}$.

No. 5. May, pp. 117-147. $5 \mathrm{eh}$.

No. 6. June Pए. 149-178. $4 \mathrm{ch}$

No. 7. July. pp. 179-206. 4 ch.

No. 8. Aug. pp. 207-234. $4 \mathrm{ch}$.

No. 9. Sept. pr. 235-260. 4 ch.

No. 10. O(t. pp. 261-2s8. 5 ch.

No. 11. Nov. pp. 289-318. $6 \mathrm{ch}$.

No. 12. Dec. pp. $319-346+10.7$ ch.

V. 21. 1893. Washington, D. C., Weather Bureau. 1894.

No. 1. Jan. pp. 1-30. $9 \mathrm{ch}$.

No. 2. Feb. pl. 31-60. 8 eh.

No. 3. Mar. pp. 61-90. $6 \mathrm{ch}$.

No. 4. Apr. pp. 91-122. $6 \mathrm{ch}$.

No. 5. May. pp. 123-152. $6 \mathrm{ch}$.

No. 6. Jume. PP. 153-178. $5 \mathrm{ch}$.

No. 7. July. pp. 179-204. 5 ch.

No. 8. Aug. pp. 205-240. 5 eh.

No. 9. Sept. PP. 241-267. 6 ch.

No. 10. (Oet. 269-307. 6 cl.

No. 11. Nov. 309-342. $7 \mathrm{ch}$. 


\section{Monthly weather reviest-continued}

21 V. 21. 1893. Washington, D. C., Weather Burean. 1894-Continued No. 1:. Dec. 343-376. $7 \mathrm{ch}$.

To. 13. Annual Summary. 1). $37 T-390+v i .7 \mathrm{ch}$.

T. 22. 1894. Washington: Weather Bureau. 1895.

No. 1. Jan. pp. 1-45. $6 \mathrm{ch}$.

No. 2. Fel. Pr. 47-97. ti ch.

No. 3. Nar. PI. 99-147. $8 \mathrm{ch}$.

No. 4. Apr. Pp. 149-191. $5 \mathrm{ch}$.

No. 5. May. PP. 193-234. $4 \mathrm{ch}$.

No. 6. June. Pp. 235-272. $4 \mathrm{ch}$.

No. 7. July. pp. 273-310. $4 \mathrm{ch}$.

No. 8. Aug. pp. 311-350. 4 ch.

No. 9. Sept. pp. 351-392. $6 \mathrm{ch}$.

No. 10. Oct. pp. $393-439$. $6 \mathrm{ch}$.

No. 11. Nov. pp. $441-485$. $7 \mathrm{ch}$.

No. 12. Dec. P1). 487-533. $7 \mathrm{ch}$.

No. 13. Annual Summary. pp. 535-547+vii. $3 \mathrm{ch}$,

V. 23. 1895. Washington: Weather Bureau. 1896.

To. 1. Jan. pp. 1-45. $32 \mathrm{ch}$.

No. 2. Feb. pp. $47-80.7 \mathrm{ch}$.

To. 3. Mar. pp. $81-116.9 \mathrm{ch}$.

No. 4. Apr. pp. 117-155. $6 \mathrm{ch}$

广o. 5. May. Pp. 157-197. $8 \mathrm{ch}$.

No. 6. June. pp. 199-239. $5 \mathrm{ch}$.

No T. July. pp. 241-282. $6 \mathrm{ch}$.

No 8. Aug. pp. $283-324.5 \mathrm{ch}$.

No. 9. Sept. pp. $325-364.6 \mathrm{ch}$.

No. 10. Oct. pl. $365-407.6 \mathrm{ch}$.

No. 11. Nov. pp. 409-4ts. 8 eh.

No. 12. Dec. Pp. $449-487.1$ pl. $7 \mathrm{ch}$.

No. 13. Innual Summary. pl. 489-501+vii. 5 ch.

V. 24. 1896. Washington: Weather Burean. 1897.

To. 1. Jan. pl. 1-38. $7 \mathrm{ch}$.

To. 2. Feb. pp. 39-68. $7 \mathrm{ch}$.

No. 3. Mar. Pl. 69-103. $9 \mathrm{ch}$.

No. 4. Apr. Pl. 105-14t. 9 ch.

No. 5. May. Pp. 145-190. 12 ch.

No. 6. Jume. p). 191-228. $6 \mathrm{ch}$.

No. 7. July. pp. 229-280. 8 ch.

No. 8. Aug. P1). 2S1-314. $4 \mathrm{ch}$.

No. 9. Sept. 1). $315-358.6 \mathrm{ch}$.

No. 10. Oet. pl). 359-395. $5 \mathrm{ch}$.

No. 11. Nov. [p. 397-442. $9 \mathrm{ch}$.

No. 12. Dec. Pr. 443-485. 6 ch.

No. 13. Annual Summary. P1. $487-496+$ vi. $5 \mathrm{ch}$.

V. 25.1897. Washington: Weather Bureau. 1898.

No. 1. Jan. 1). 1-42. 7 ch.

No. 2. Feb. ju. 4i3-84. $7 \mathrm{ch}$.

No. 3. Mar. IJ). 85-121. 6 ih.

No. 1. Apr. 1). 123-188. $6 \mathrm{ch}$.

No. 5. May. H). 189-234. 5 ch.

No. 6. June. pr. 2:35-283. $5 \mathrm{ch}$.

No. 7. July. [1]. 285-3:38. $5 \mathrm{ch}$.

No. 8. Aug. ple. $339-379.6 \mathrm{ch}$.

No. 9. Sept. pp. 38I-424. 8 ch.

No. 10. (1) [1. $425-470.6 \mathrm{ch}$.

No. 11. Nor. pp. 471-516+[1]. $9 \mathrm{ch}$.

No. 12. Dec. pp. 519-568. $7 \mathrm{ch}$.

To. 13. Annual Summary. pl. $569-579+7.5 \mathrm{ch}$.

V. 26. 1898. Washinerton: IVeather Bureau. 1899.

No. 1. Jan. p). 1-43. 13) ch.

No. 2. Feb. pp. 45-8!. 10 (ch.

No. 3. Mar. 1'). 91-137. 13 ch. 
V. 26. 1898. Washington: Weather Bureau. 1899-Continued No. 4. Apr. pp. 139-193. \& ch.

No. 5. May. Pp. 195-240. 12 ch.

No. 6. June. pp. 2t1-290. 7 ch.

No. 7. July. pp. 291-341. 12 ch.

No. 8. Aug. pr. $343-390.7 \mathrm{ch}$.

No. 9. Sept. pp. 391-137. 17 a.

No. 10. Oet. II'. 439-492. 11 eh.

No. 11. Nov. Yp. 493-525. $12 \mathrm{ch}$.

No. 12. Dee. pl. 527-591. 12 ch.

No. 13. Annual Summary. pł. 593-605+x. 5 ch.

V. 27. 1899. Washington: Weather Bureau. 1900.

No. 1. Jan. JW. 1-40. $9 \mathrm{ch}$.

No. 2. Feb. pp. $41-87.6 \mathrm{pl} .13 \mathrm{ch}$.

No. 3. Mar. pl. 89-138. $13 \mathrm{ch}$.

No. 4. Apr. I'P. 139-186. $11 \mathrm{ch}$.

No. 5. Mlay. 1p. 187-241. 6 pl. 8 ch.

No. 6. June. P.. 243-28.5. $9 \mathrm{ch}$.

No. 7. July. pp. 287-341. 3 pl. 8 ch.

No. 8. Aug. pp. $343-393.2 \mathrm{pl} .12 \mathrm{ch}$.

No. 9. Sept. pp. 395-448. 11 ch.

No. 10. Oet. jp. 449-502. 1 pl. $9 \mathrm{ch}$.

No. 11. Nov. PP. 503-533. $9 \mathrm{ch}$.

No. 12. Dec. pp. 535-575. $10 \mathrm{ch}$

No. 13. Amnual summary. pr. $5 \overline{7}-597+\mathrm{ix}$. 5 $\mathrm{ch}$.

Y. 28. 1900. Washington: Weather Bureau. 1901.

No. 1. Jan. pp. $1-49.10 \mathrm{ch}$.

No. 2. Feb. pp. 51-93. $1 \mathrm{pl} .11 \mathrm{ch}$.

No. 3. Mar. pp. 95-139. 10 ('h.

No. 4. Apr. pp. 141-191. 9 ch.

No. 5. Nay. pp. 193-238. \& ch.

No. 6. June. pp. 239-278. 8 ch.

No. 7. July. pp. 279-320. 3 pl. 8 ch.

No. 8. Aug. pp. 321-370. $8 \mathrm{ch}$.

No. 9. Sept. pp. 371-424. 13 ch.

No. 10. Oet. pp. $425-476.10 \mathrm{ch}$.

No. 11. Nov. pp. $47-525.2 \mathrm{pl} .10 \mathrm{ch}$.

No. 12. Dee. pp. 527-583. 1 pl. 10 ch.

No. 13. Annual summary. pp. $585-599+\mathrm{x} . \quad 7 \mathrm{ch}$.

Y. 29. 1901. Washington: Weather Bureau. 1902.

No. 1. Jan. pp. 1-47. 10 ch. 2 pl.

No. 2. Feb. pp. 49-97. $13 \mathrm{ch} .5 \mathrm{pl}$.

No. 3. Mar. pp. 99-143. 9 ch. 1 pl.

No. 4. Apr. pp. 145-199. $9 \mathrm{ch}$.

No. 5. May. pp. 201-241. 10 ch. 4 pl.

No. 6. June. pp. 243-289. 4 pl.

No. 7. July. pp. 291-339. 1 l. 9 ch. 1 pl.

No. S. Aug. pp. 341-397. s ch. 3 pl.

No. 9. Sept. pp. 399-145. $10 \mathrm{ch}$.

No. 10. Oct. pp. $447-487.9 \mathrm{ch} .1$ pl.

No. 11. Nov. Pl. 489-533. 13 ch.

No. 12. Dec. pp. 535-589. $10 \mathrm{ch}$.

No. 13. Amual Summary, 1901. pp. $591-613+\mathrm{ix} .7 \mathrm{ch}$.

No. 1. Jan. pp. 1-59 $10 \mathrm{ch}$.

No. 2. Fel. ID. 61-10s. $10 \mathrm{ch}$.

No. 3. Mar. Pp. 109-156. 9 ch.

No. 4. Apr. pp. 157-243. 12 eh.

No. 5. May. pp. 245-292. 8 ch. 1 pl.

No. 6. June. Pp. 29:3-340. 8 ch.

No. 7. July. pu. 341-392. 8 ch.

No. 8. Aug. Ip. 393-482. 8 ch.

No. 9. Sept. pp. 483-472. sh.

No. 10. Oct. Pp. $473-510$. s ch. 


\section{A29.6: Momilly wealher review (separates)}

[Some of the more important articles in the Reriew were issued suparately in pimphlet form.]

\section{Climate and crop bulletin (broadside)}

[The Climate and Crop Bulletin is issued weekly from April to Scptember during the season of planting, cultivating, and harvesting of erops, and monthly from October to March. The title "Climate and Crop Bulletin" was adopted February, 1896, the bnlletin haviug been previously issued under the title "Weather-Crop Bulletin." This publication deals with the general weather and crop conditions of the United States, while bulletins showing more detailed information for the several States are issued from the central stations of 43 climate and crop centers. A Climate and Crop Bulletin of the cotton region, dealing more particularly with the weather conditions affecting the cotton crop, is published weekly at New Orleans from about May 1 to the latter part of October. Cotton Region Bulletins containing temperature and rainfall observations reported by telegraph from about 150 stations in the Southern States are issued daily from 12 district centers in the cotton belt from April 16 to Oetober 31 . Corn and Wheat Region Bulletins, identical in character with the preeding, are issued daily from 9 district centers in the corn and wheat belt from April 1 to September 30 . Fruit and Wheat Bulletins, also identical, are issued from San Francisco during June, July, and August.]

Weather-crop bulletin.

[Nos. 1-21 issued by Signal Ottice, U. S. A.]

891

892

$\$ 9: 3$

894

895

$596^{1}$

$896^{2}$

897

898

899

900

901

902

A29.8:

\section{A29.9: Cold wave bulletin (broadside)}

A.29.10:

1891. Nos. 22-39.

1892. Nos. 1-33.

1893. Nos. 1-32.

1894. Nos. 1-32.

1895. Nos. 1-32.

1896. No. 1.

Climate and crop bulletin.

1896. Nos. 2-32.

1897. Nos. 1-32.

1898. Nos. 1-31.

1899. Nos. 1-31.

1900. Nos. 1-32.

1901. Nos. 1-32.

1902. Nos. 1-30.

\section{climate and Health}

1895. V. 1, nos. 1-6. July-Dec. 1895.

No. 1. July. Pp. 1-25. $20 \mathrm{ch}$.

No. 2. Aug. pp. 27-58. $25 \mathrm{ch}$.

No. 3. Sept. pp. 59-82. $20 \mathrm{ch}$.

No. 4. Oct. pl. 83-107. $20 \mathrm{ch}$.

No. 5. Nov. pp. 109-145. $24 \mathrm{ch}$.

No. 6. Dec. pp. 147-174. $12 \mathrm{ch}$.

1896. v. 2, nos. 1-3. Jan.-Nar. 1896.

No. 1. Jan. 1-35. $14 \mathrm{ch}$.

No. 2. Fel, 37-64. $12 \mathrm{ch}$.

No. 3. Mar. 65-92, 12 ch. 1 diagram.

[Diseontinued Mar. 28, 1896.]

\section{Daily river stages}

[Contains reports of "systematic investigation to ascertain the relationships and applicability of climatic and weather conditions to sanitary science." Issued monthly, July, 1895, to Mareh, 1896, and then discontinued.]

No. 1. Colıl wave of Jan. 2-5, 1896. Jan. 8, 1896. (Chart.)

Pts. 1-3. Issued by Signal Office, War Department.

Ht. 4. Principal rivers of U.S., 1890-92; by Thomas Russell. Ixvii. $4^{\circ}$ Same, with gauge reatings. lxvii $+439 \mathrm{pp} .10$ charts. $4^{\circ}$

Pt. 5. Principal rivers of U. S., 1893-95; by Park Morrill. Jxii pl. $4^{\circ}$ Same, with gauge reallings. $1 x i i+555 \mathrm{pl}$. $4^{\circ}$

Pt. 6. Principal rivers of U. S., 1896-99; by H. C. Frankenfield. 1900. $446 \mathrm{pl} .4^{\circ}$ 


\section{A29.11: Instrument Room (or Division) circulars}

$A^{1}$ A. Instructions for obtaining and transcribing records from recording instruments. Washington, Weather Bureau. $1892.12 \mathrm{pp}$.

$A^{2}$ Same, rev. ed.; by C. F. Marvin. 1894. $40 \mathrm{pp}$.

$A^{3} \quad$ A. Instructions for obtaining and tabulating records from recording instruments; by C. F. Marvin. 1898. 31 pp.

$\mathrm{B}^{1}$ B. Directions for use of maximum and minimum thermometers. Washington, Weather Bureau. 1892. $11 \mathrm{pp}$.

$\mathrm{B}^{2} \quad$ B. Instructions for use of maximum and minimum thermometers, rev. ed. $1895.16 \mathrm{pl}$.

$\mathrm{C}^{1}$ C. Instructions for use of rain-gauge. Washington, Weather Bureau, 1892. 8 pp.

$\mathrm{C}^{2} \quad$ Same, rev. ed. $1895.11 \mathrm{pp}$.

$D^{1}$ D. Anemometry, a circular of general information respecting theory and operation of typical instruments for indicating, measuring, and automatically recording wind movement and direction, etc.; prepared by C. F. Marvin. Washington, Weather Bureau. 1893. $40 \mathrm{pP}$.

$\mathrm{D}^{2} \quad$ Same. $1900.67 \mathrm{pl} . \quad 1 \mathrm{pl}$.

$\mathrm{E}^{1} \quad$ E. Instructions for using Marvin's weighing rain and snow gauge [by C. F. Marvin]. $1893.16 \mathrm{pp}$.

$\mathrm{E}^{2}$ E. Measurement of precipitation; by C. F. Marvin. $1899.28 \mathrm{pp}$.

$\mathrm{F}^{1} \quad \mathrm{~F}$. Barometers and measurement of atmospheric pressure; by C. F. Marvin. 1894. $74 \mathrm{pp}$.

$\mathrm{F}^{2} \quad$ Same, $2 \mathrm{~d}$ edition. 1901. $94 \mathrm{pp}$.

$\mathrm{G}^{1}$ G. Instructions for use of combined maximum and minimum soil thermometers; by C. F. Marvin and Milton Whitney. 1894. $8 \mathrm{pp}$.

$\mathrm{G}^{2} \quad \mathrm{G}$. Instructions for care and management of sunshine recorders; by C. F. Marvin. 1896. $18 \mathrm{pl}$.

$\mathrm{G}^{3} \quad$ Same, 2d ed. 1901. $19 \mathrm{pp}$.

H H. Instructions for use of maximum and minimum radiation thermometers; by C. F. JIarvin and Milton Whitney. 1894. $10 \mathrm{pp}$.

[No circulars I or $J$ will be issued.]

$\mathrm{K}$ K. Instructions for aerial observers; by C. F. Marvin. 1898. $33 \mathrm{pp}$. $3 \mathrm{pl}$.

A29.12: Instructions (unnumbered)

An3 Aneroid barograph. Instructions for use of aneroid barograph on Great Lakes. Washington, Weather Bureau. 1897. $7 \mathrm{pl}$.

C81 Corn. Instructions governing corn, wheat, cotton, sugar, and rice region service; by James Berry. Washington, Weather Bureau. 1897. $9 \mathrm{pp.} 1$ table.

C82 ${ }^{1}$ Cotton region. Instructions to observers and code for enciphering reports at cotton region and sugar and rice stations of Weather Bureau. Washington, D. C., Weather Burean. 1892. 27 pp.

\section{C82 ${ }^{2}$ Same. 1895. 39 pp.}

D6 $3^{1}$ Displaymen. Instructions to special displaymen. Washington, D. C., Weather Bureau. $1892.13 \mathrm{pp} .12^{\circ}$.

D63 ${ }^{2}$ Displaymen. Instructions to wind-signal displaymen. Washington, Weather Bureau. $1896.11 \mathrm{pp} .1 \mathrm{pl}$.

$\mathrm{Ob} 7$ Observers. Instructions for observers. 1895. $82 \mathrm{pp}$.

R13 Rainfall observers. Instructions to special rainfall observers. Washington, D. C., Weather Bureau. 1893. 22 pp.

R52 ${ }^{1}$ River observers. Instructions for special river observers; by Thomas Kussell. Washington, D. C., Weather Bureau. 1892. $54 \mathrm{pp}$.

R522 River observers. Instructions for special river observers. $1894.49 \mathrm{pp}$.

$\mathrm{R}^{2} 2^{3}$ River observers. Instructions to special river and rainfall observers. 1902. $48 \mathrm{pp}$.

Se1 ${ }^{1}$ Seacoast telegraph lines. Instrnctions to operators on United States seacoast telegraph lines; by E. L. Bugbee. 1892. $24 \mathrm{pp}$.

$\mathrm{Se}^{2}$ Seacoast telegraph lines. Instructions to operators on seacoast telegraph lines; by J. H. Robinson. Washington, Weather Bureau. 1897. 26 pp. 1 pl.

Sunshine recorder. Instructions for using glass electrical sunshine recorder, pattern, 1893 . n. t. l. [189:. 4 pp. 
29. 12: Instructions (unmmbered)-Continued

Vs8 1 Voluntary observers. Instructions for voluntary observers; by T. liussell. 189.2. 100 p.

$\mathrm{VSS}^{2}$ Voluntary observers. Instructions for voluntary observers. Washington, Weather Bureau. 1897. $22 \mathrm{pp} .1 \mathrm{pl}$.

$18 s^{3}$ Same, Washington, Weather Bureau. 1899. $23 \mathrm{pp} 1 \mathrm{pl}$.

$\mathrm{ISS}^{4}$ Same, $2 \mathrm{I}$ edition, comprising circulars $\mathrm{B}$ and C, instrument room. 1901. 28 pp. 1 pl.

\section{A29. I:3: Veteorological chart of the Great hakes $(20 \times 25$ in. $)$}

897

898

899

900

$101^{1}$

$901^{2}$

902

A29.1.8:

897

898

1897. ()et.-Dec.

1898. Apr.-Dec. and Summary for vear.

1899. Nay-Dec.; Summary for 1899 ; V. 2 , no. 9; by A. J. Henry and N. B. Conger. 1899. 28 pp. 12 charts. $4^{\circ}$

1900. May-Dec. Nos. 1-8; Summary for season; by A. J. Henry and N. B. Conger. V. 3, no. 9 [erronenusly printed 10]. $23 \mathrm{pp} .14 \mathrm{ch} .4^{\circ}$

1901. No. 1. [Nomonthly date, received June 21, 1901.] 28 pp. 4 ch. $4^{\circ}$ To. 2. Summary for season [no monthly date, received Jan. 30, 1902]. - 32 pp. 8 ch. $4^{\circ}$

1902. No. 1. $26 \mathrm{pl} .1 \mathrm{pl} .4^{\circ}$

\section{River and flood service}

Monthly report (reprinted from Monthly Weather Review).

1897. Sept., 11 pp. 1 pl.

Oct., 11 pp. 1 pl.

Nov., 13 pp. $1 \mathrm{pl}$.

Dee., 13 pp. 1 pl.

1898. Jan., 18 pp. 1 pl.

Fels., 14 pp. $1 \mathrm{pl}$.

Mar., 19 pp. $1 \mathrm{pl}$.

Apr., 30 pp. 1 pl.

May, 14 pp. 1 pl.

June, 14 pp. 1 pl.

July, 13 pp. 1 pl.

Aug., 15 pp. $1 \mathrm{pl}$.

Sept., $15 \%$ p. 1 pl.

Oct., 16 pp. 1 pl.

[Discontinued.]

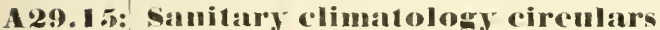

No. 1. [Asking cooperation of physicians, boards of health, ete.] Jan. 2, 1895. (Circ.)

No. 2. [To ofticials of United States weather bureans on methorks of keeping statistics, etc.] Jan. 2, 1895. (Circ.)

3 No. 3. [To publishers of periodicals, newspapers, ete.] Jan. 2, 1895. (Cire.)

4 No. 4. Information relative to investigation of influence of climate on health. [1895.] 7 pp.

[Series diseontinued.]

\section{A29.16: Snow :and ice bulletin}

[Issne begun Feb., 1892. Issued in weekly numbers from early in December to latter part of Marcli. First title, "lepth of Snow on Groma,", lised to Mar. 30, 1896; changed to "Snow and Ice Chart" and eontinued under that name until Feb. 21, 1899, when the present title was snbstituted. Shows area covered by snow, its depth, and the thickness of ice in rivers and harbors.]

\section{A29.17: Storm bulletin}

LAKE STORM BLLLETIN,

893 1893, nos. 1-5.

$894^{1} 1894$, no. 1 .

STORYH IULLETIN.

$894^{2} \quad 1894$, nos. 2,3 .

8951895, nos. $1-3$.

8961896, nos. $1-5$.

$897 \quad 1897$ (none issued). 


\subsection{7: Storm bulledin-Continued}

898

899

900

129. $18:$

Storm bulletin-Continued

1898 , no. 1 .

1899, no. 1 .

1900, no. 1.

\section{Weatlev map (broadside)}

[This publication, issued at the Weather Bureau in Washington, is the only Government publication issued every day in the year. Sundays and holidays included.

At 94 stations of the Wiather Bureau smaller weather maps are issucd daily, except Sundays and holidays. At 18 of the less important stations bulletins, containing practically the same meteorological data that appear on the weather maps, are issucd.

To an extent permitted by the cditions, the maps and bulletins are furnished free of charge to business and commercial exchanges, corporations, firms, individnals, and educational institutions that will display them for the benefit of the public or use them for educational purposes.]

[Issued by Signal Office, tri-flaily from Jan. 1, 1871, 7:35 a. m., to June 30, 1888; semidaily, July 1, 1858, to June $30,1891$.

891 1891, July 1-Dec. 31.

892 1892, Jan. 1-Dec. 31.

893 1893, Jan. 1-Dec. 31.

894 1894, Jan. 1-Dee. 31.

$895^{1}$ 1895, Jan. 1-Sept. 30.

Daily.

$895^{2}$ 1895, Oct. 1-Dec. 31

896 1896, Jan. 1-Dec. 31.

897 1897, Jan. 1-Dec. 31.

898 1898, Jan. 1-Dec. 31.

899 1899, Jan. 1-Dec. 31.

900 1900, Jan. 1-Dec. 31.

901 1901, Jan. 1-Dec. 31.

902 1902, Jan. 1-Dec. 31.

A29.19: Special river bulletins (circulars) $4^{\circ}$

897 1897. Mar. 15-19, 28-31; Apr. 1-29. 


\section{INDEX TO TIIE TABLES}

When the consulter finds in this index an entry which interests him, let him note the reference figures or "classification number" opposite such entry, then turn to the sime figures in the "Tables" which form the first part of this work. These will easily be found, because they are arranged in numerical order from 1 to the end. Haring turned in the Tables to the figures of the index entry, there will be found a complete statement of the number, series, bureau, ete., by which the publication indexed is known, and also its exact title and history.

For a full explanation of the "classification numbers" used as reference figures in this index, see pp. 8-15, without a careful perusal of which the best results can not be obtained in using this index. 

Abattoirs. Sice Cattle markets and abattoirs.

Ab]re, Cleveland:

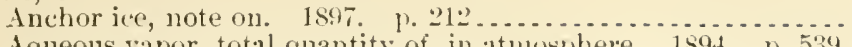
Aqueous vapor, total quantity of, in atmosphere. 1894. p. 539. A tmospheric refractions at surface of water. 1896. p. $371 \ldots \ldots$
Marine nephoscope and its usefulness to navigator. 1894 . p. 161 . Meteorological notes, month]y, Any., Is93, to Oct., 1902. [The "Notes" are entered under individual titles in index] . . . . . .

Metereological work of U. S. Signal Service, 1870 to 1891 . 1895.

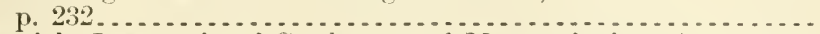

Munich, International Conference of Meteorologists, Aug., 1891. p. 626 . same, p. 626 . . . . . . . . .

Precipitation, true anount of, determination of, and its bearing on theories of forest influence. 1893. p. 175.

Rainfall, charting of, note on. 1902. p. 214 . . . . . . . . . .

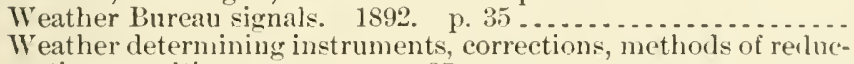
tion, resulting accuracy. p. $37 \ldots \ldots \ldots$

Weather forecasts, long-ringe, physical basis of. 1901. p. 551 .

See also, as joint author, De Riemer, Alicia - Richards, (ieorge W.; as translator, Bergholz, Paul.

Abbot, Charles G. Sun-spot cycle, relation of, to meteorology. 1902. p. $178 \ldots$.

Abbot, Henry Larcom:

Chavres River-

discharges of, ratio of, to rainfall. 1900. p. 541. upper, rainfall and clrainage in. 1900. p. 243.

Climatology of Isthmus of Panama, inclucling temperature, winds, larometric pressure, and precipitation, 1899 pp. 198, 302 ...

Heat, our killing. 1901. p. $371 \ldots \ldots \ldots . . . . . . . . . . .$.

Meteorology of Panama-

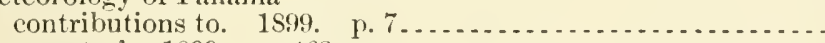

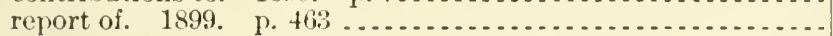

Abbott, James WT. Roads, mountain. p. $183 \ldots \ldots \ldots$

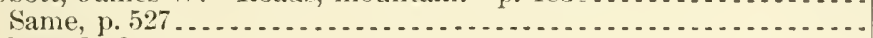

Abbott, 1. S.:

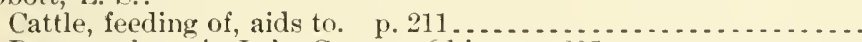

Potato culture in Lake County, Ohio. p. $295 .$.

Abbreviations used in Experiment Station Record . . . . . . . . . . Abel, (Mrs.) Mary Hinnan:

Beans, peas, and other legumes as food. 1900

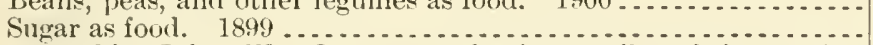
Abercrombie, John IV. Common schools as affected by roads.

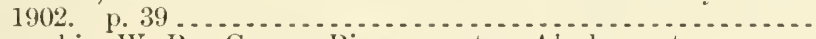

Abercrombie, W. R. Copper River country, Alaska, notes on. p.

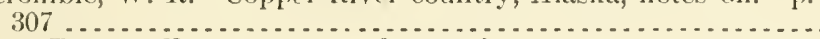

Abilene, Texas. Forage crops and range improvement at, progress of experiments (Bentley).

Abortion. See Cows-Mares.

Abutilon avicennce, cultivation of, in New Jersey (Waterhouse).

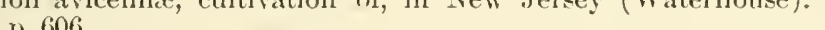

Acapuleo, Mexico:

Grasses collected by Dr. E. Palmer in vicinity of (Scribner).

Roseanthus, a new genus of cucurbitacese from (Cogniaux).

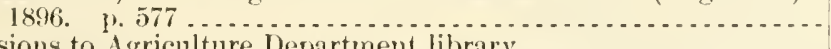

Accessions to Agriculture Department library . . . . . . . . . . . . . . Accounts and Disbursements Division, Agriculture Department . . . . . Acetylene gas, substitution of, for oil in storm-warning lanterns

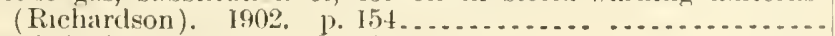
Acid and alkali solutions, standardization of:

1892 (Parsous). p. 80

1893 (Jenter). p. 43.

1894 (Miller). W. 145

A $29.6: 25$

$129.6: 22$

$129.6: 24$

$+29.3: 11^{1}$

129.6:

129.8:11"

A 1.1:891

A29.1:891 2

A 13.3:7

A29.6:30

A29.3:7

129.1:S91 ${ }^{3}$

$+29.6: 29$

A29.6:30

A $29.6: 27$

+29.6:28

A29.6:27

A29.6:29

A29.6:28

A29.6:27

A1.10:900

d1.10:901

A $1.1: 866$

A1.1:865

A10.2: $1 \mathrm{~b} 2$

A 1.9:121

A1.9:93

122.8:23

A 10.12:901

A3.4:23

A3.3:4

A6.5:3

A 17.3:

12.

129.3:31

17.8:35

17.3:38

A7.3:43

Acid soils. See Solls. 
Acom insects, primary and secondary (Murtfelıtt). 1894. p. 31s ..' 19.7:6

Aromomycosis. Sé Lumpy-jaw.

Acworth, 1. E. Old records of cold weather in March in Maryland, $18-3+94$

\section{Adams. F. (i.:} p. 126

$A: 9: 6: 2 \cdot 2$

Aericulture in common schook. 1885. p. 174

forghmm culture in Kansas, history of. 1884. p. 71.

Wham (Mrs.) L. B. Home life, training, and ambitions of farmers' boy.s. 1. 307

Adam, Iane. See Atwater, Wilbur Olin, and Bryant, Arthur Peyton.

Ailirondacks, practical forestry in (iraves). 1 sy9..............

Alulterated butter. See Renovated butter.

Aegeriidir. See Moths.

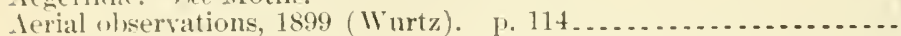
same (Noyes). p. 117 . . .

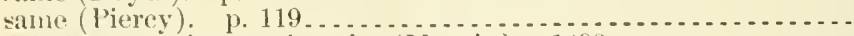

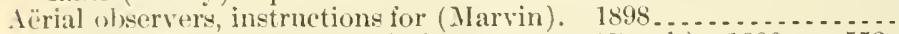

Aërial voyages by balloons and kites, notes on (Rotch). 1900. p. 553. vee rlso Balloons.

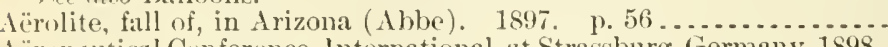

Ä̈ronatutical Conference, International, at Strassburg, Germany, 1898,

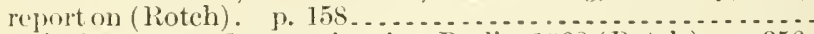

Aëronatical Congress, International, at Berlin, 1902 (Rotch); p. 356 . Aërontuties, international committee on, personnel of (Abbe). 1896.

Aërophysical observatory, equipment of (ICAdie). 1896. Afrien, south:

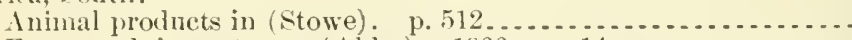

Frost work in, notes on (Abbe). 1900. p. 14...............

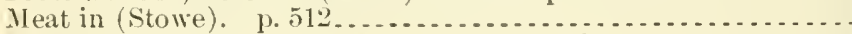

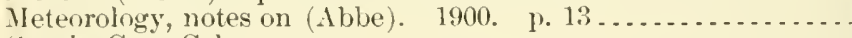
sie cilso Cape Colony.

Agamorlistomnm ophthalmobim. See Flnke-worms.

Agaric's, North American, report on (Macadam). 1889. p. 58, 135. . See also IIushrooms.

Agaricus campestris and other basidiomycetous fungi, spores of, preliminary study of germination of (Ferguson). 1902 ......... . Agaves:

Fiber-producing (Dodge). 1893. p. 34 . . . . . . . . . . . . . . . . (ieographic and vertical distribution of, in deserts and desert
ranges of southern California, southern Nevada, northwestern

Arizona, and southwestern Utah (Merriam). 1893. p. 345. Age, determination of, by teeth in domestic animals. 1898 . p.667. Agonolerus pallepes injurions to corn, note on. 1886 . p. 44 .... Agricultural Academy. See Poppelsdorf, Pruscia.

Agricultural and climatie features of arid regions of Pacific slope, ete.

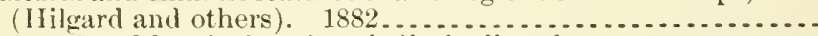
Agricultural and horticultural periodicals, list of:

1867. p. 404.

1868. p. 608

Agricultural and horticultural societies and clubs, complete list. p.

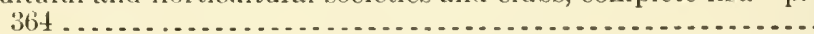

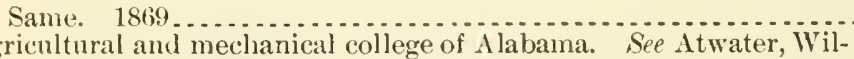

Agricultural and mechanical college of $A$ lab
bur Olin, and Woods, Chas. Dayton.

Agricultural and mechanical colleges:

Relation of-

to Department of Interior, 1893 (Holcombe). p. 114

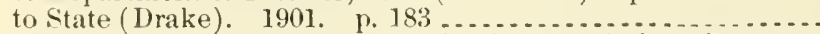
Agricultural associations and farmers institutes, relations between (Die). 1902. p. 44 .

Agricultural associations in Belgim (De Vuyst). 1898 p. 3 ..... Acricultural books, recent, review of:

1868 . p. 555 .

1869. D. 487

1871. p. 410

A 1.1:863

A13.3:26

129.3:24

129.3:24

A29.3:24

A29.11:K

A29.6:28

129.6:25

A29.6:26

A 29.6:30

A29.6:24

A $29.6: 24$

A4.1:898

A 29.6:28

A 4. 1:900

A29.6:28

A28.5:5

A19.3:16

A11.5:5

A5.5:7

A 1.10:898

A9.3:12

A 1.8:20

A 1.1:86

A 1.1:868

A 1.1:870

A1.1:867

A1.2:Sol

A 10.3:16

A 10.3:99

A 10.3:110

A 10.6:9

11.1:868

A1.1:869

A1.1:871 
Agricultuxal botany. Sife Botany.

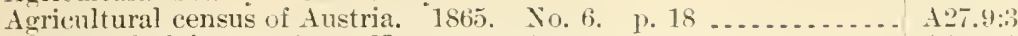

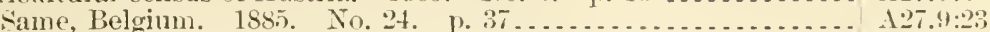

Agricultural chemical analysis, apparatus nsed in, some new forms

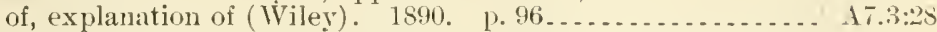

Agricultural chemistry:

Estimation and importance to, of ash ronstituents of plants (Tol-

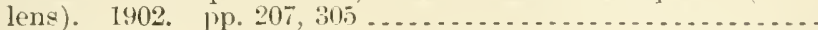

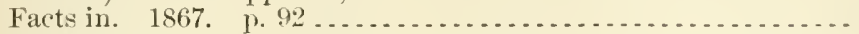

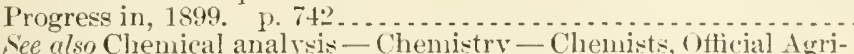

See also Chemical analysis- Chem of - Fertilizers - Manures-Soils.
cultural, Association -

Agricultural Chemists, Official, Assuciation of. See Chemists, Official Agricultural, Association of.

Agricultural climatology station at Juvisy, physical and meteorological researches at, principally on solar rays (Flammarion). 1899. p. $103,20 \%$

Agricultural college, what [it] ought to be, paper on (Maurice). 1855. 108 . 108 .

Agricultural colleges (land-grant colleges):

Agricultural departments of, requirements for admission to, and

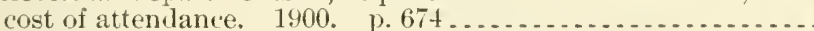

American, some types of ('True). 1898. p. 63...............

Attitude of, toward university extension (Toorhees). 1895 . p. 49

Collective exhibit of, at IVorl's's Colmmbian Exposition, 1893 (dlvord). p. 103 .

Education at, general drift of (Patterson). 1901. j. 99

Forest experiment stations in connection witl (Fgleston). 1885. p. 153

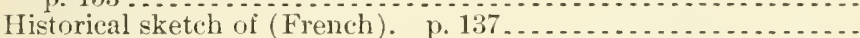

How may university extension work be best conducted by? (Roberts). 1898. p. 55 . . . . . . . . . . . . . . . . . . . .

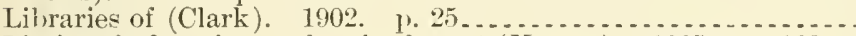

Limits of education under the law at (Knapp). 1885. p. 163...

List of, 1872 same. 18,6

Manual labor in (Einery). 1891. p. 106

Military instruction in, report of committee on (Atherton).

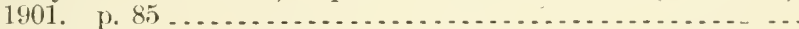

National defense and (Dabney). 1899. p. $64 \ldots \ldots \ldots \ldots . . .6$.

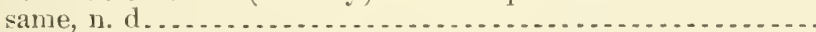

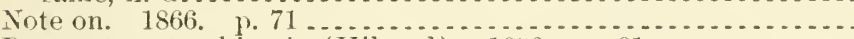

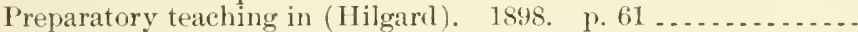

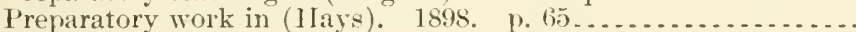

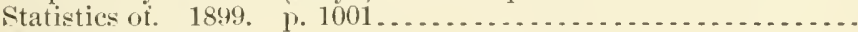

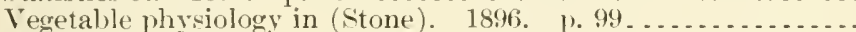

What can they do to nourish a learty sentiment for rural life (I)avenport). $1896 . \quad$ p. 82.

What merhanical work shall we give to students of our?

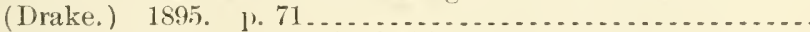

What should be tauglit in? (Fairchild). $1896.10 .69 \ldots \ldots .$.

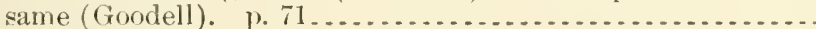
same (Waters). p. 73

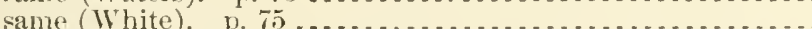

Work of, some general considerations regarding (Ellis). 1899.

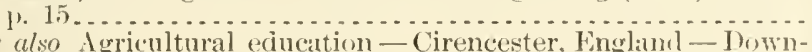

Siee also Agricultural education-Cirencester, Fnglaml-Inwn-
ton, England-Illinois, [niversity of - Kansas State Agri cultural Collegre - l'oppelsdort, I'russia - Purdue Lniversity School of Acriculture.

Agricultural colleges and experiment stations:

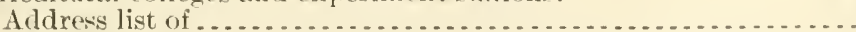

Relation to farm('rs' institutes (Hutchinson). $190 \%$ p. $3.3 . .$.

Road making at, letter relative to cooperation of road-inquiry

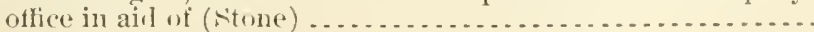

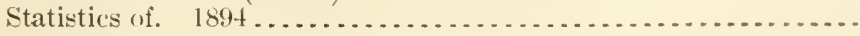

111). $6: 13$

A $27.99: 5$

11.10:\$99

$\$ 10.6: 10$

$11.10: 900$

1 $1.10: 895$ A10.3:24

A10.3:16

110.3:99

A $1.7: 9$

A 1.1:565

A10.3: 49

A $10.3: 115$

A $1.7: 9$

A1.8:5

A1.8:12

A 10.3:7

A10.3:99

A 10.3:65

A 10. 4: 40

A27.9:4

A 10.3: 49

A 10.3: 49

A 10.6: 0

A10.3:41

A 10.3:41

1]0.3:-24

110.3:-41

i $10.3: \$ 1$

110.3:41

110.3: 41

$110.3: 6.5$

110. $4: 26^{3}$

110.3:110

1:20.2: 1 ges

110.4:27 
Agricultural colleges and experiment stations-Continued

Statistices of-

$1 \mathrm{sect}$

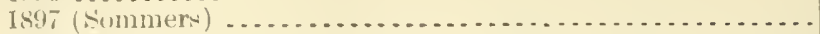

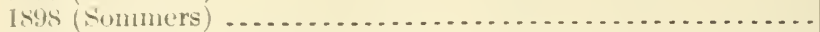

1899 (Davis) . . . . . . . . . . . . . . . . . . . . . . . . .

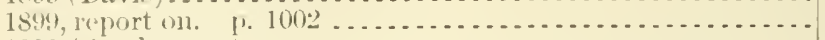

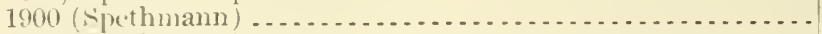

1901 (Spethmann) . E. . . . . . . . . . . . . . . . . . . . . . . . . tion of:

[] st anmul] convention, July $8,9,1855$, proceedings of

[1 ammual convention, Jan., issit, circular urving attenlance at ... same, procedings of; elitel by $A$. $I I$. Harris and $H$. E. Alvoril. 1889

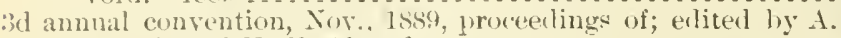

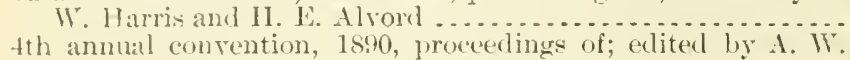
llaris and H. E. Alrorl

5th annual convention, 1891 , proceedings of edited by $\mathrm{A}$.

Harris and H. F. Alvord.

stme, delecrates and visitor registered

A $10.4: 35$

A 10.3:51

A $10.3: 64$

A 10.3:78

1 $10.6: 10$

A 10.3:97

A10.3:114

11.7:9

1 10.4:13

\10.5:1

1 10.5:2

110.5:3

110.3: 7

A 10.4:21

bith ammal convention, $189^{\circ}$, procerlings of; edited by $A$. $W$.

llarris and H. E. Alvord. same, report on. p. 397.

7 th annual convention, 1893 , proceelings of; edited $\hat{y}_{\mathrm{A}} \mathrm{A}$.

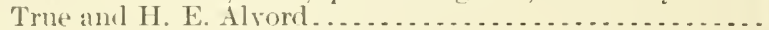
same, repurt on. p. 272.

sth annual convention, $189 t$, proceedings of ; edited by A. C.

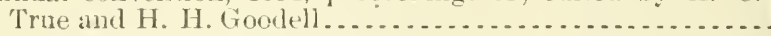

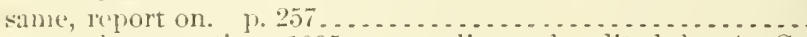

9th annual convention, 1895, proceedings of ; edited by 1 . C.

True and II. H. Cioodell.

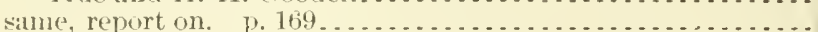

10 th innmal convention, 1896 , list of delegates and visitors to. $1890^{\circ}$

same, proceedings of ; edited by $\mathrm{A}$. C. True and II. H. Goodell.

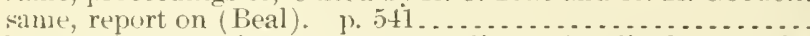

11 th aumal convention, 1897 , proceedings of ; edited by $\mathrm{A}$. C.

True and H. H. croodell same, report on (Beal). p. 303.

12 th annual convention, 1898 , proceedings of edited by $\mathrm{A}$. $\mathrm{C}$.

True, IV. II. Beal, and H. H. (roodell. same, report on (Beal). p. 704 .

l3th annual convention, 1899 , proceelings of ; edited by $\mathrm{A}$. C.

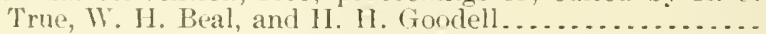

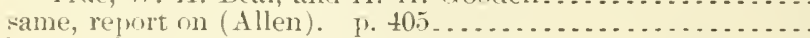
Itth anmul convention, 1900, proceedings of ; edited ly $\mathrm{A}$. C.

True, W. II. Beal, and II. II. Gooklell................

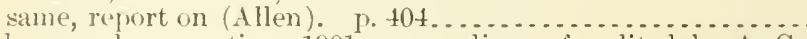
15th annual convention, 1901, proceedings of; adited by A. C.

'True, II. H. Beal, and H. H. Goodell. ............... . . . same, report on. p. 507 .

16 th annmal convention, 1902, report on (Crosby). p. 313

Constitution of. 1897 .

Report of executive committer-

Jan., 1889. ग. 23

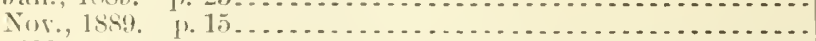

1890. э. 19 .

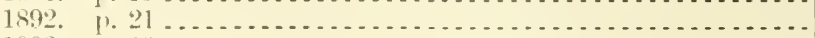

1893. 1. 19

1894. 1. 15

189.5. (1). 5.

18.6. ए. 11

1897. I\% 11

189. [\%. 13

1S99. p. 11

A 10.:3:16

A 10.6:4

A 10.2:20

A 10.6:5

A 10.3:2t

A 10.6:6

A $10.3: 30$

A 10.6:7

11.2: $\operatorname{dg} 8^{I}$

A 10.3:41

110.6:8

\10.3: 49

A 10.6:9

1 10.3:65

$+10.6: 10$

$110.3: 76$

A10.6:11

A10.3:99

$+10.6: 12$

A10.3:115

$+10.6: 13$

A10.6:14

110.t:36

1 $10.5: 1$

A $10.5: 2$

A $10.5: 3$

A $10.3: 16$

A 10.3:20

A 10.3:24

A 10.3:30

A 10.3: 11

A 10.3: 49

A 10.3:65

A 10.3:76 
Agriculiural Colleges and Experiment Stations, ste.-Continuer

Report of executive committee-Continmer

1900. p. 11

1901. p. 19

Classiffration no.

See also Agricultural Congress, National - Agriculture and Chemistry Section - Agriculture Section - Agriculturists, conventions of, 188:2 and 1883 - Botany section-Chemistry Section - College Work Section - Entomology Section - Horticultureand Botany Section - Horticulture Section-Mechanic Arts Section.

Agricultural colleges and morlel farms, letter on (NcChosney).

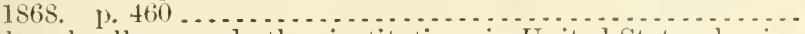

Agricultural colleges and other institutions in United States, having courses in agriculture:

Directory of. 1855

List of-

1895. p. 557

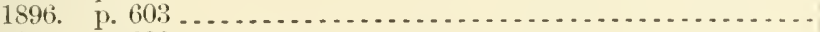

1897 . p. 622

1898. 1. 597

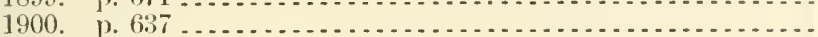

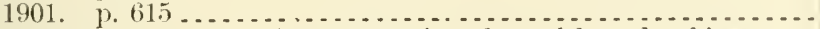

Organization, list of, with courses of study and boards of instruction-

18s9. 1. 24

1890. P. 37

June, 1892.

A pril, 1893.

Jan., 1894.

Jan., 1895.

Jan., 1896.

Feb., 1897.

Jan., 1898.

Jan., 1899.

Jan., 1900.

Jan., 1901.

Var, 1902. 1. 11

Agricultural Congress, National, procecdings of:

[1st] annual meeting, Wanhington, I. C., Fel). 15-17, 1872.

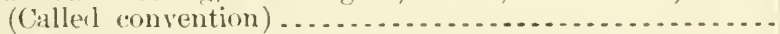

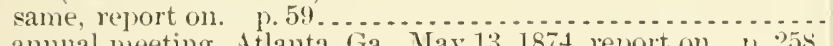

3 amual neeting, Atlanta, Ga., May 13, 1874, report on. 1. 25.

5 th annual meeting, Philarlelphia, Pa., Sept. 12-14, 187t, rejort ol1. 11. $40^{\circ}$

Agrieultural education:

Adrless on (Hamilton). 1896. p. 48.

Adrances in (Hays). 1893. p. 132

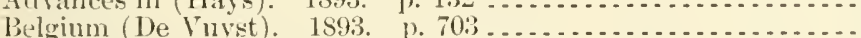

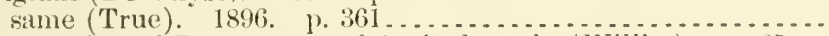

Cooperation of Department of Agriculture in (Villits). 1. 65...

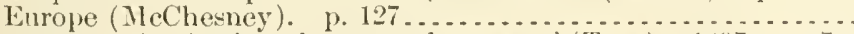

European institutions for, some features of (True). 1897. 1.7.

Evolution of (Fairchill). 1898 . p. $32 \ldots$.

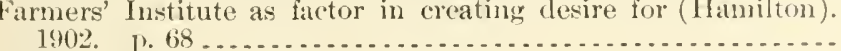

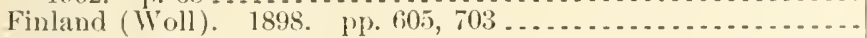

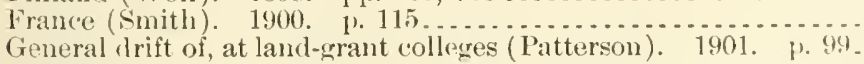

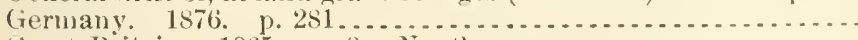

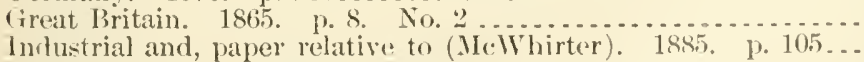

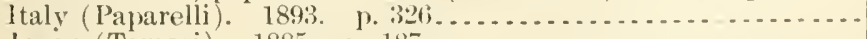

Limaits of, momer the law, at agricultural eolleges (Kmapp). 1885. 1) 163 
Agrienltural ednation-c'ontinued

Veecesity of (smith). lssi.

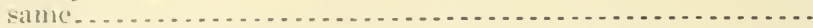

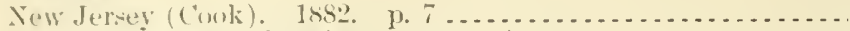

Vurth Carolina (llolmes). 1853. p. 8t ..................

Popular, for farmer in Lnited states (True). 1897. ए. 279....

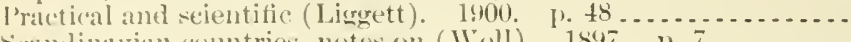

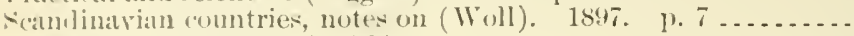
same. 1sis. [р. 605,703

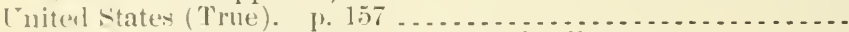

we ulso Agricultural collecres-Inilustrial colleges.

Aericultural engineer (Magruder), 1900 . ए. $103 \ldots \ldots \ldots \ldots \ldots . . . . .$.

Arricultural exhihition. See Hamburg.

fericultural experiment station as eflueator of farmer (Caldwell).

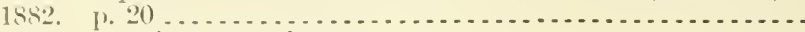

Ierricultural experiment stations:

Ibstratcts of reports off. 1859-1902.

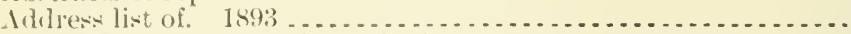

Arlvertising in publications of (True). 1898. p. $41 \ldots \ldots . . .$.

Igricultural conditions in U. S. as related to (Snith). 1900.

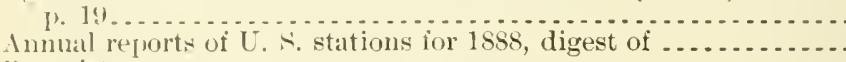

Botanists at-

functions of (Stone) 1901. 1. 138................... list of, witl outline of work in botany. $1890 \ldots \ldots \ldots . . . . . .$.

Binletins of-

present and prospective (Ingersoll). 1893. Ir. 138

what is mission wi? (Goorlell). 1895. p. 69...........

Collective exhibit at laris exposition, 1900

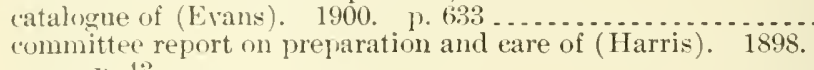

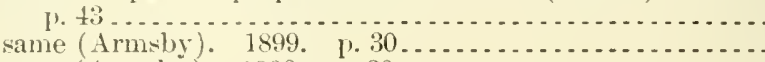

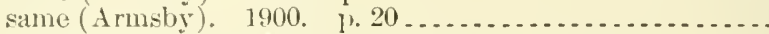

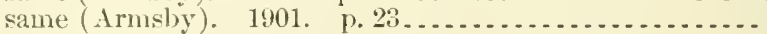

Coöperative exhibit at World's Columbian Expositioncommittee report on (Armsby). 1892. p. 2t_...........

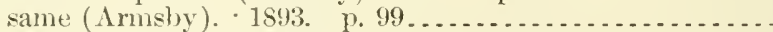

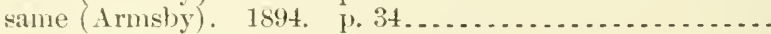

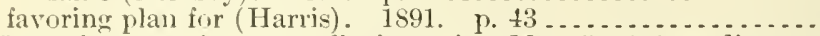
('oöperative experiments, call of meeting, Mar. 5, 1889, to discuss. ('oöperative work letween Agriculture Department and (Bryan). 1901. ए. 59

Coöjrerition with-

farmer's organizations in experiment work (Jenkins). 1895.

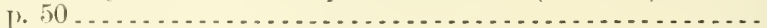

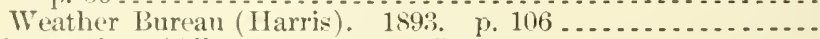

Dairy work at (Allen). 1897. p. $359 \ldots \ldots \ldots \ldots$

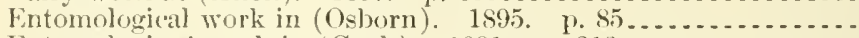

Entomologists' work in (Cook). 1891. p. 212 .............

Establishment and growth of, in U.S. (True). 1889 p. $73 \ldots$

Farmers' institute as promoter of closer intimacy between farmers and. 1902. p. 78 .

Food laboratories in connection with, suggestions for establishment of. 1893

Foreign-

list of, Jan., $1899 . \quad$ p. 63.

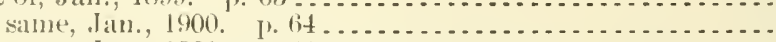

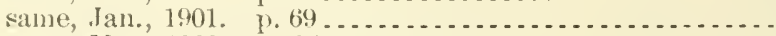

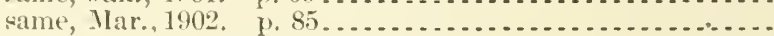

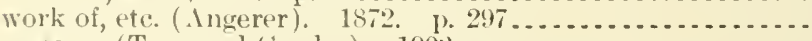

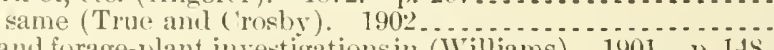

Grassand forage-plant investigationsin (Williams). 1901. 1). 148 .

(irowth and purpose in America, addresson (Jordan). 1901. 1. 42.

IIistorical and statistical report of, in U.S. (True). 1899. p.513.

History and present status of, in U. S., report prepared for Paris

Exposition, 1900 (True and Clark). 1900

11.7:2

A1. $8: 25$

A1.8::2:2

A1. $7: 2$

A 1.10:897

A 10.3:76

1 10.4:32

A10.6:!

A1.10:899

A10.3:76

A1. S:2:2

A 10.6:

A $10.4: 24$

A10.3:49

A10.3:80

A $10.3: 21$

A 10.3:99

A10.3:6

A10.3:16

A10.3:2t

+10.3:80

A 10.3: 49

\10.3:65

1 10.3:76

A10.3:99

A10.3:

+10.3:16

A10.3:20

A10.5:3

110.4:5

110.3:99

A10.3:24

1 $10.3: 16$

A10.6:8

A10.3:2t

19.7:3

A10.3:1

A 10.3:120

110.3:17

A 10.3:59

A $10.3: 74$

A 10.3:88

\10.3:11

$+27.4: 10$

A 10.3:112

A 10.3:99

A10.3:99

A1.10:899

A10.3:80 
list of, with ontline of work in horticulture at the several stat-

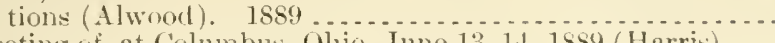
meeting of, at Columbus, Olio, June 13, 14, 18s9) (Harris) ....

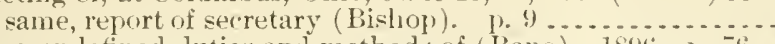

some undefined duties and methods of (Rane). 1896.1 .
How ean they reach and interest the farmers? (Roberts). 1859 . 1. $30 \ldots$ litrature of. Se Agricultural literature.

Inspection of agricultural materials by, in U.S. (Allen and others).

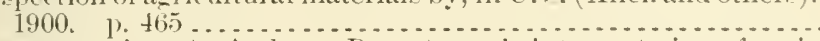

Law governing, Agriculture Department's interpretation of vari-

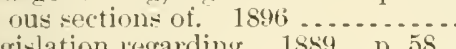

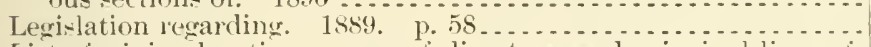

List of, giving location, names of clirectors, and principal lines of work-

1894. ए. 526

1895. P. 5.58

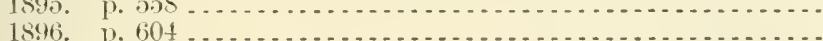

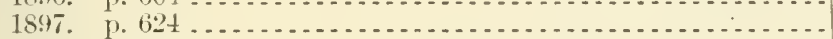

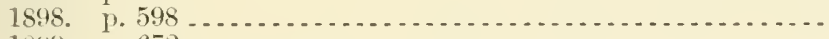

1899. 1) $672 \ldots \ldots$

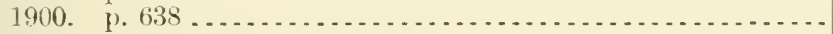

List of, showing organization, with names of governing loarls and station staff-

1889 (preliminary list)

1889 p. 28 .

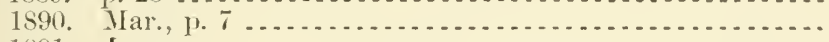

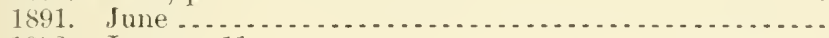

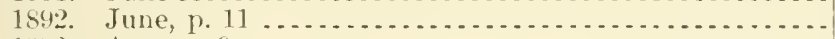

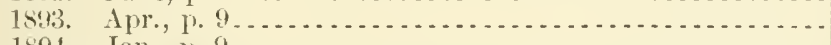

1894. Jan.,

1895. Jan., p. т............................

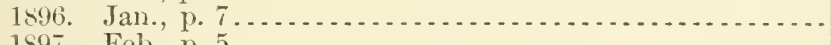

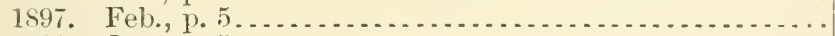

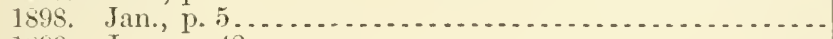

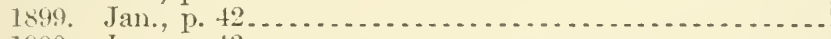

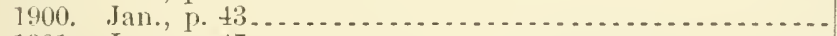

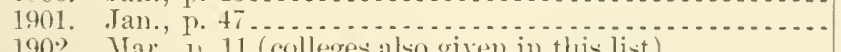

1902. IIar, 1) 11 (colleges also given in this list) ............

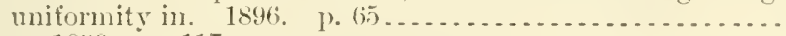
same, 18.19. p. 117

Officers of, how can we increase attenclance of, at om ammal

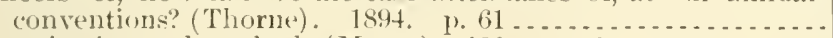

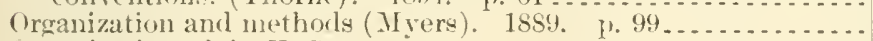

Oreanization of, in $\mathrm{T}^{\mathrm{T}}$. S.-

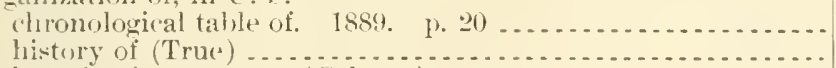

introduction to report (Colman). 1859 p. $5 \ldots \ldots \ldots$

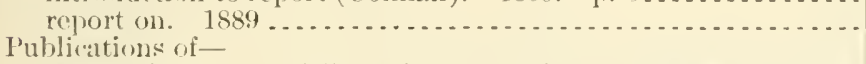

lacking in library of Fxperiment Stations office, Agriculture

Department, list of, Nov. $1,1812 \ldots . . . . . . . . . . . .$.

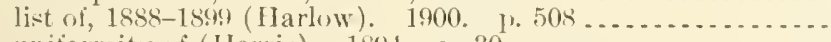

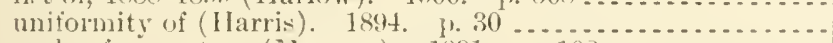

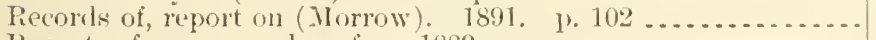

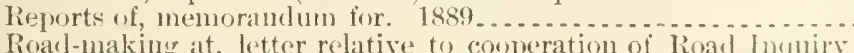

Roarl-making at, letter relative to conperation of hoal Infuiry
Oflice in aid of (Stonse)

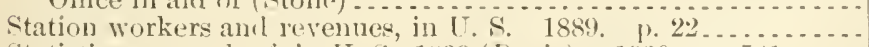

Statistic.s, general, of, in U. S., 1899 (Davis). 1900. 1. $501 \ldots .$. See also Agricultural colleges and experiment stations.

A10.3:4

1 $10.3: 3$

A $10.3: 3$

A $10.3: 30$

A 10.5:1

A 10.3:80

110.4:29

110.3:1

A $1.10: 894$

A $1.10: 895$

A1.10:596

A1.10:597

A1.10:59S

A $1.10: 599$

A $1.10: 900$

A1.10:901

A10. $4: 1$

A 10.3:1

A10.3:5

A 10.4:20

A10.3:12

A 10.3.13

A 10.3:19

A10.3:23

A 10.3:27

A 10.3::39

$+10.3: 47$

A10.3:59

A 10.3:74

A 10.3:88

\$10.3:111

A 10.3:41

110.3:65

1 10.3:20

A10.5:1

A 10.8:1

A10.4:4t

A 10.8:1

A 10.3:1

110.2:- -2

A $110.3: 80$

A $10.3: 20$

A 10.5::;

110.4:4

A:2.2.2:Aus

110.:3:1

A 10.3:80 
Agrienltural experiment stations-Continued

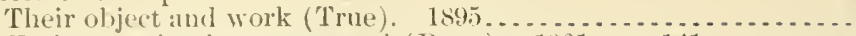

Variety testing in, progress of (Rame), 1901. p. 141.........

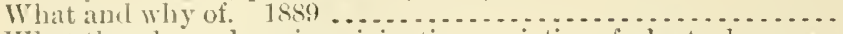

What they lrave done in originating varieties of plants, by cross-

Work and expetediture of, annual statement of, to Congress

1897

(True) -

1898 . . . . . . . . . .

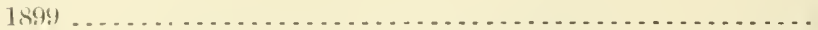

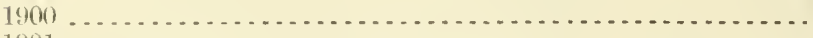

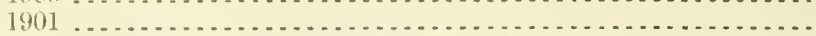

Sie chlso Explanatory note under $110.1^{2}$ :

Trork of-

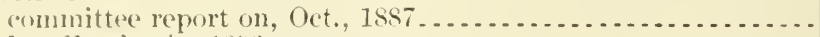

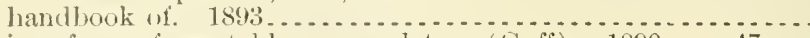
in reform of vegetable nomenclature (Goff). 1890, p. 47..

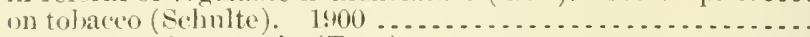

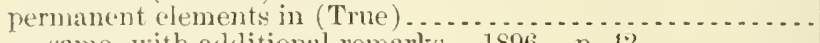
same, with additional remarks. 1896 . p. $42 . . . . . . .$. slunt reports on va rions subjects. $1890 \ldots \ldots$. . . . . . . . . . See also Experiment station work.

See clso Agricultural colleges and experiment stations - Alaska Belgium - Bernburg Agricultural Experiment Station - Connecticut - Darmstadt - Europe - Experiment Stations Office-German Agricultural Experiment Station - Ghent Grignon Agricultural Experiment Station-Halle - HawaiiIIolland - Hungary - Italy - New York State Experinent Station - Philipines - Porto Rico - Rothamsted Experimental Station - Switzerland - Veterinarians - Wyoming Experiment Station.

Agricultural experiment work:

Copperation of agricultural experiment stations with farmers' organizations in (Jenkins). 1895 . p. $50 \ldots \ldots . . . . . . . . .$.

Establishment of official methods of (Gulley). 1893. p. 147...

Relation of teaching to (Morrow). 1891. p 67 .............

See also Agricultural experiment stations, and references thereunder-Field experimentation -- Plat experimenting.

Agricultural exports:

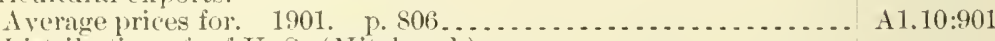

Listribution of, of U. S. (Hitelheork) $1892-1896^{\circ}$

$1894-9 \mathrm{~S}$

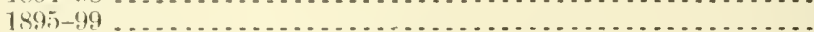

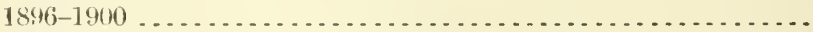

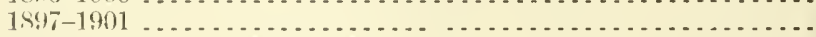

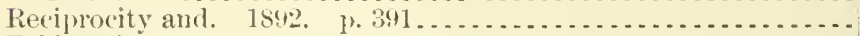

Tables of-

$1826-62 . \quad 1.599$

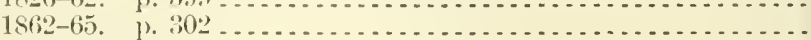

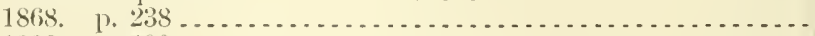

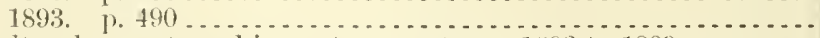

Agricultural exports and imports, reports on, 1593 to $1899 \ldots \ldots . . .$.

Igrienltural expositions, results of, in l'russia. 1871. p. $456 \ldots . .$.

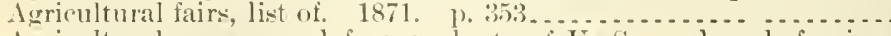

Agricultural grasses and forage plants of $\mathrm{I}$. S., and such foreign

kinds as have been introfluced (Vasey) .................

Acricultural hylraulics (Charpentier de Cossigny). 1891. pt. 1. p. 349

Agricultural implentents:

Ancient and molern machines and. p. $392 \ldots . . . . . . . . .$.

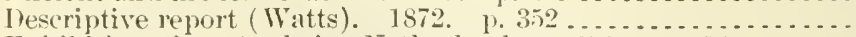

Fxhibition of, at A rnhein, Netherlands. 1870 . 1. $154 . . . .$.

International statisties of. 1885. No. 23. p. 15 ............

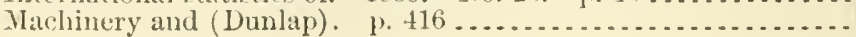

A10.3:24

A10.3:16

A10.3: 7

A 12.4:13

A12.3:16

A 12.3:20

A12.3:25

A12.3:2?

A27.9:30

A1.1:86:

A $27.9: 4$

A 27.9:7

A27.9:31

A12.4:

A27.9:10

A 27.9:9

A1.8:32

A 15.2: $\operatorname{Ir}^{-2}$

A 1.1:\$70

A $27.9: 10$

A27.9:8

A27.9:23

A1.1:863 
Agricultural imports:

Average prices for. 1901. p. 806

Great Britain. 1868-69. p. 143....................... A27.9:8

Note on. 1866. 1. 18.........................................

Sollre's of, of U. S.-

$1842-96$ (Hitcheork)

A $12.4: 12$

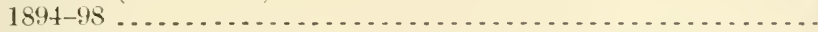

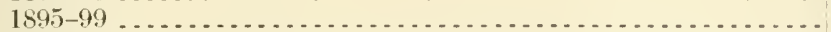

$1896-1900$. . . . . . . . . . . . . . . . . . . . . . . . . .

$1897-1901$

A12.3:17

A12.3:21

A12.3:24

A12.3:28

Tables of -

1868-19. p. 299

A $27.9: 7$

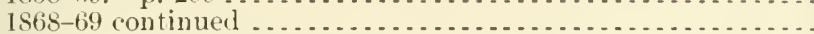

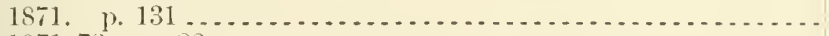

$1871-72$. p. 28 . . . . .

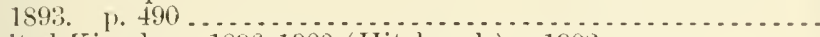

Uniterl Kinglom, 1896-1900 (Hitcheock). 1902 .............

Agricultural imports and exports, reports on, 1893 to 1899

Agricultural institutions, meteorological work for (Harrington).

Agrieultural institutions founded on Congressional grant of 1862 , what work is legitimate to? (Peabody). 1882. p. 42 . ...... Agricultural libraries:

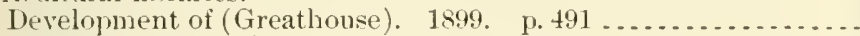

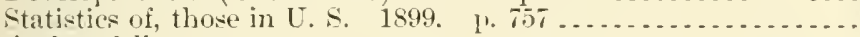
Agricoultural literature:

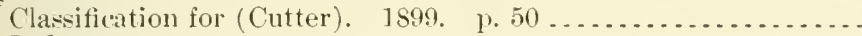

Index to-

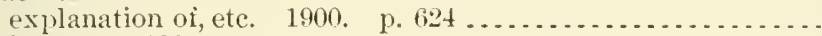

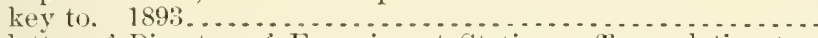

letter of Director of Experiment Stations office, relative to. 1891

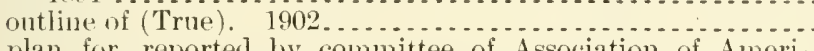

127.9:8

A27.9:9

A27.9:11

A27.9:31

A $12.3: 26$

A12.4:

A $10.3: 10$

A1.8:22

A1.10:899

11.10:899

A10.3:65

A10.3:80

A $10.4: 2: 3$

A $10.4: 22$

A $10.4: 47$

plan for, reporter by committee of Association of Ameri-
can Agricultural Colleges and Experiment Stations.

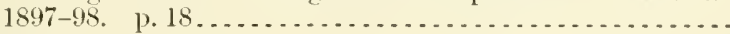

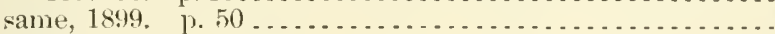

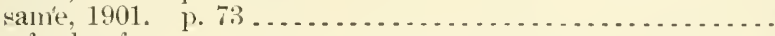

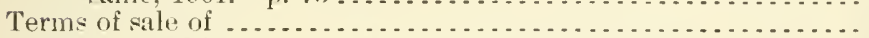

A10.3:49

A 10.3:65

A10.3:99

A 10.2:C18

Agricultural machinery. See Agricultural implements.

Agricultural materials, inspection of, by Agricultural experiment stations in U.S. 1900 . (Allen anl others.) p. $465 . . . . .$. Agricultural meteorology. Sie Meteorology.

Aorricultural musemm. See Agriculture department-Berlin.

Agricultural nomenclature. See Asricultural experiment stations, nomenclature userl in publications of.

Agricultural officials of foreign conntries, list of:

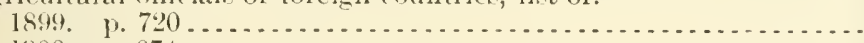

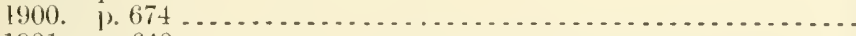

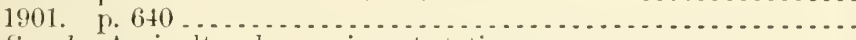

Sie also Agricultural experiment stations.

Agricultural ornithology (. Michener). p. $287 \ldots \ldots \ldots \ldots \ldots \ldots \ldots \ldots . . . \ldots 1.1: 863$

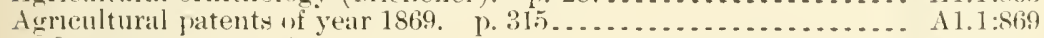

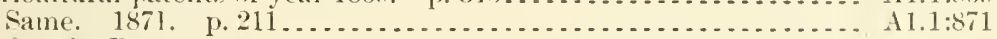

See ulso Patents.

Agricultural pests. Sie Caterpillars - Fung1 - Insects - Weerls.

Agricultural products:

Ameriean-

foreign markets for, testimony before Industrial Commission

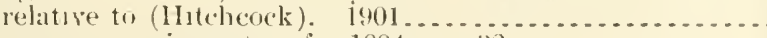

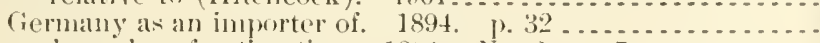

Anmual, morles of estimating. 1864. No. 2. j. T............

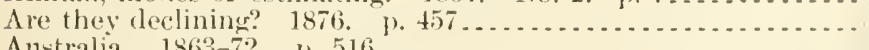

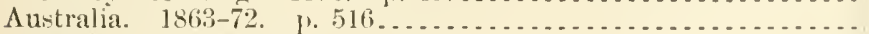

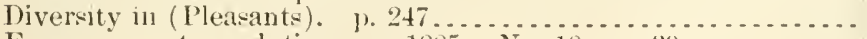

Diversity in (Pleasants). p. $247 \ldots \ldots \ldots \ldots \ldots \ldots \ldots \ldots \ldots . . .11 .1: 867$

A $1.8: 67$

A:27.9:3:2

1.7.9:2:2

A $27.9: 14$

A $27.9: 10$

A.7.9:2:3 
Agricultural froduets-Continued

lixperts of $\rightarrow$

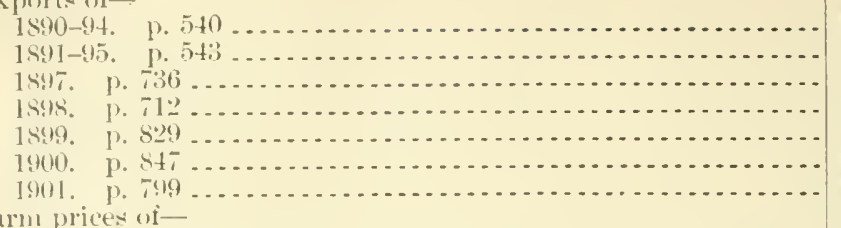

Farm prices oi-

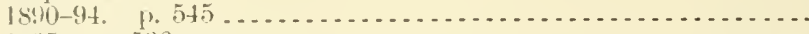

1.895. p. $5: 36$

1894-98. ค. 692

1890-99, 1) 793 .

For Anerican consumption (Dorge). 1884. No. 11, p. 41; 110.

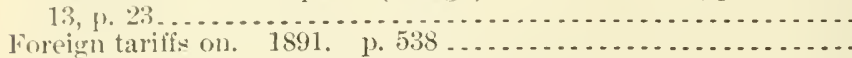

Foreign trale in-

1892. 1. 308

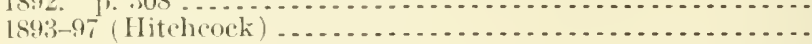

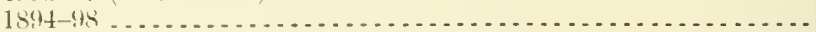

$1890-99$

$1891-1900$

1892-1901

Imports of-

1591-94.

1891-95.

1897.

p. 543

1.. 5 ts

1898.

70.7

1 1899. p. 829

1900 . p. 840

1901. 1. 792

A1.10:894

A1.10:895

A1.10:897

A $1.10: 898$

A1.10:899

A1.10:900

11.10:901

A1.10:894

A1.10:895

A1.10:898

A1.10:899

A $27.9: 2 \cdot 2$

A27.9:29

A $27.9: 30$

A 12.3:10

A12.3:15

A 12.3:19

A 12.3:23

A 12.3:27

A1.10:894

A1.10:895

A $1.10: 897$

A1.10:898

A1.10:899

A 1.10:900

A 1.10:901

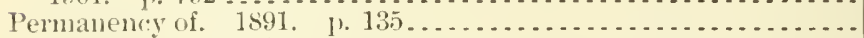

Prives and (Ilohmes). 1897. p. 577

A $27.9: 29$

Principal, of worli, production and distribution of. $1893 . \ldots . .$.

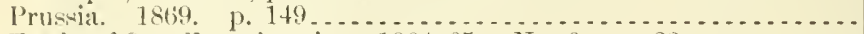

Trade of San Francisco in. 1864-65. No. 6. p. 28..........

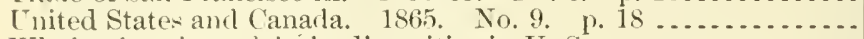

Wholesale prices of, in leading cities in U. S.-

$1890-1894$.

1895. p. 583

18!99. p. $7(9 !)$

1900. p. 8293

$1901.0 .773-20$

Ser clso Anerican products - Crops - Farm products.

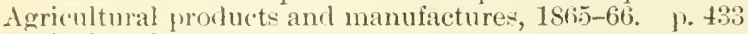

Agrienlturial resources:

Alaskil (Dall). 1. 170

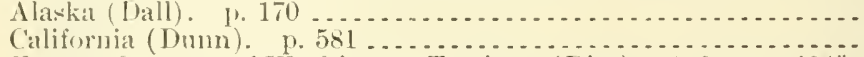

Wastern Oregon and Washington Territory (Ritz). 1869. p. $384^{*}$.

Jeflerson Comty, Colorado (Berthour). 1869. p. 381*......

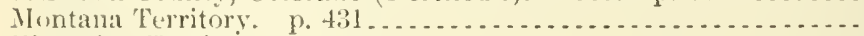

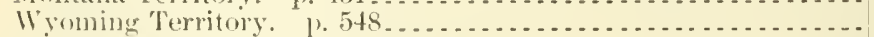

Agrincultural resources and capabilities:

Hawaii (stubbs). 1901.

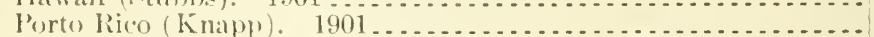

A $1.10: 897$

A27.8:5

A27.9:7

A27.9:3

A $27.9: 8$

A $1.10: 894$

A $1.10: 895$

A $1.10: 899$

A $1.10: 900$

A1.10:901

$127.9: 4$

A $1.1: 868$

A 1.1:866

127.9:7

A27.9:7

A1.1:871

A. $1: 1: 870$

A10.3:95

A 10.2:PS:3

Agriaultural schools. See Agricultural colleges - Telch, A. S.

Agrieultural seience:

Pioneer in; Elmund Ruffin (Cutter). 1895. p. 493.

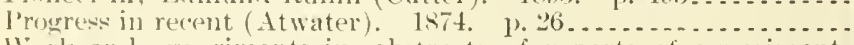

Work and experiments in, abstricts of reports of experiment stations on, $1889-1902$

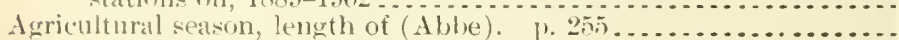

Agricultural seeds. See Seeds.

Agricultural societies:

Foreign, exchanges with. p. 256

A $1.10: 895$

A27.9:12

A10.6:

A $29.6: 27$

A1.1:869

* By a misprent, this page number appears twice. 
Agriculture-Continued

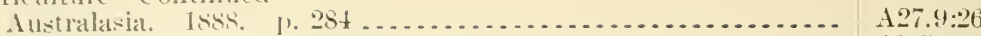

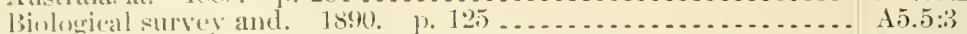

birls, sone (omimos, in their relation to (Beal) ........... $11.9: 54$

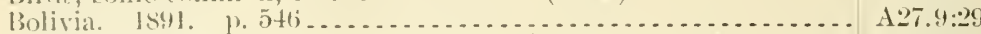

Bosnia and IIerzenovina, development of. 1594. p. 197 ....... A27.9:32

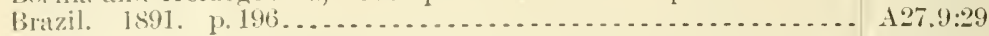

Cillifornial-

notes on. 1872. 1. 199.

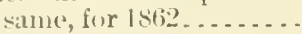

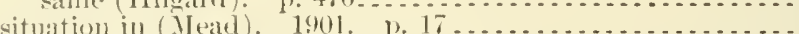

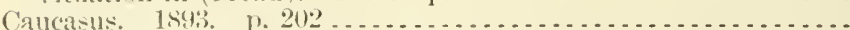

('entemnial of Anerican lndependence, relation to. p. 288..... ('hemistry in its relation to progress of (Wiley). 1899. p. 201.

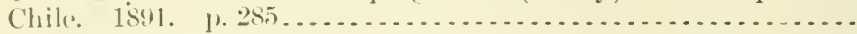

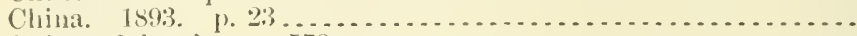

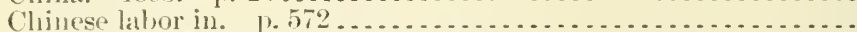

Colleges of. See Agricultural collecres.

Colorarlo, notes on (Tliomas). 1869. pp. $284,379 *$

A27.9:10

A1.1:86:2

A $1.1: 878$

A 10.3:100

A $27.9: 31$

A1.1:871

A1. $\mathrm{i} 0: 899$

A $27.9: 29$

A27.9:32

11.1:870

Common schouls. 1868. p. $92 \ldots \ldots \ldots \ldots \ldots \ldots$

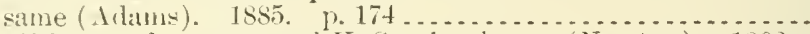

Conditions and resoures of $I^{-}$. S., circular on (Newton). 1862.

('onditions in $\mathrm{T}$. S., greneral, as relatel to work of agricultural experiment stations (smith). 1900. p. 19 .....................

Contributions of, to international commerce. 1891. p. $77 \ldots .$.

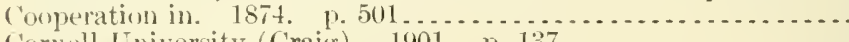

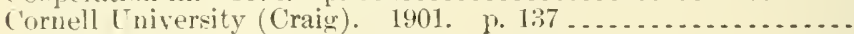

Correspondence courses in (Craig). 1902. p. 50 . . . . . . . . .

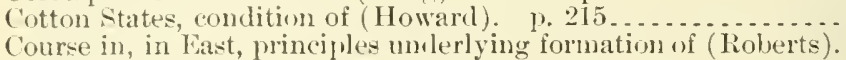
1900. 11. 65. same, in South (Coates). 1900 . p. 59

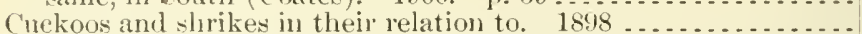

Departments of, in land-grant colleges, requirements for admission to and cost of attendance. 1900 . 1). 674

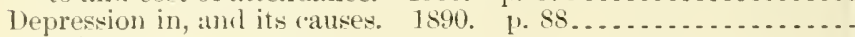

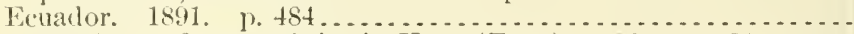

Elneation and researeh in, in U. S. (True). 1894. 1). $81 \ldots . .$.

Erlucation in. See Agrimultural colleges and experiment stations - Agricultural erlucation.

Elucational forces in U. S. relating to cooperation of Department

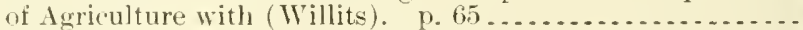

English sparrow in its relation to (Barrows). 1889 . . . . . . . . .

Estimation and importance of asl constituents of plants to (Tollens). 1902. p1\%.207, 305

Experinent, its conception and methods of procedure (Bolley). 1898. 1. 47

lixperimental, at meteorolugical stations (Abbe). 1902 p. 410.

Fucts in, current-

1868. 1. $4: 35$

1.66\% (2. 408

1870. \%. 4:3

1871. 1. 208

$1873 . \quad$ 0. 272

1874.26 .26

127.9:-

A27.9:6

A $1.7: 9$

1.1.8:1

A $10.3: 80$

A $27.9: 29$

A27.9:12

A 10.3:99

A 10.3:110

A1.1:574

A10.3:76

A10.3:76

A5.3:9

A1.10:900

A27.9:28

A.7.9:29

A1.10:894

A1.1:891

A5. : : 1

110.6:1:

A $27.9: 21$

A $10.3: 49$

A $29.6: 30$

A1.1:868

A 1.1:869

A 1.1:870

A 1.1:871

A1.1:5:\%

11.1::7:3

A $1.1 .87+$

Sire alvo Farm facts and experiments.

Foreign-

investigations in, abstracts of reports of anrieultural experiment stations on, 1889-1902.

110.6:

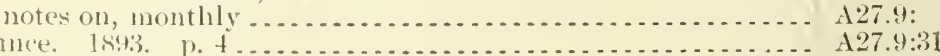

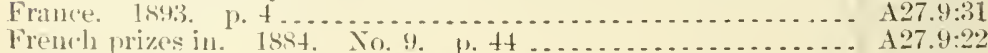

French publications relating to, notes from recent. p. ti2 6 ..... A $1.1: 869$

* By a misprint, this page number appears twice. 
andex

Agrienlture-Continued

French schools of. 1874. p. 212................ A27.9:12

Georgia, climate, soil, and,(Hemphill ). 1852 .............. A1.6:47

(ierman, letter on (Kipy)art). 1865. No. 6. p.6.......... A27.9:3

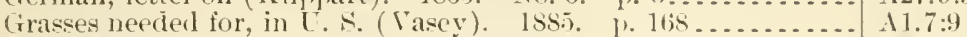

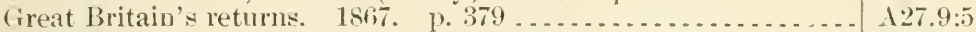

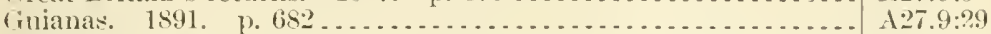

Hawks and owls in their relation to (Fisher). 1893.......... A5.3:3

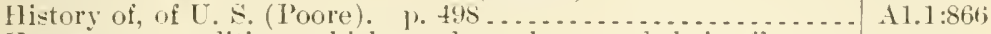

Hot waver; conditions which produce them, and their effect on

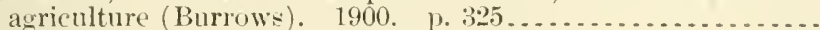

Hundred years progress in (Flint). p. $275 \ldots . . . . . . . . .$.

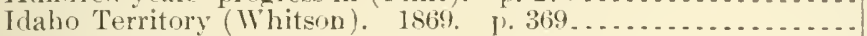

Improvement in. $1874 . \quad$ b. 99 . . . . . . . . . . . . . . . . .

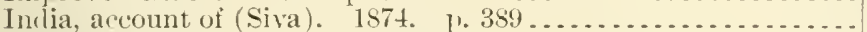

Industries, other, in their relation to-

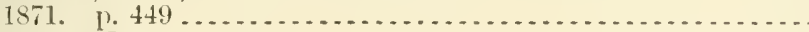

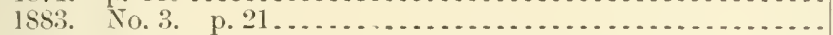

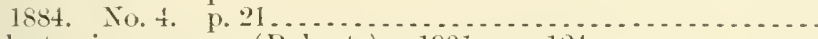

Inclustry in, our new (Roberts). 1901 . p. $124 \ldots \ldots \ldots . . . . . .$.
Investigations in. See Agricultural experiment stations, and references thereunder.

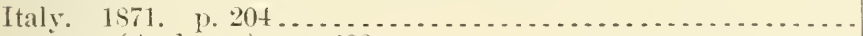
same (Andrews). 1. $283 \ldots \ldots \ldots \ldots$

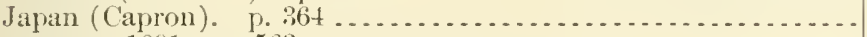
same, 1891. p. 563

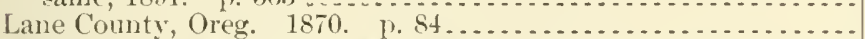

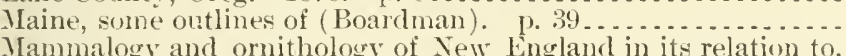

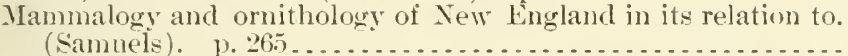

Meteorolngist, work of, for benefit of (Bigelow). 1899. 11. $71 .$.

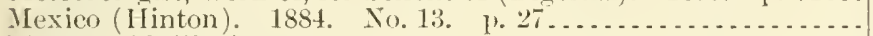

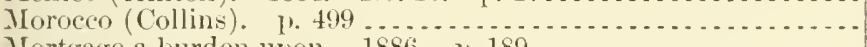

Mortgage a burden upon. 1886. 1. 189......................

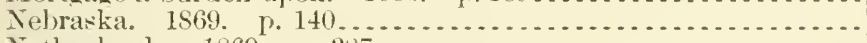

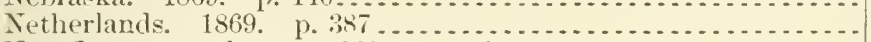

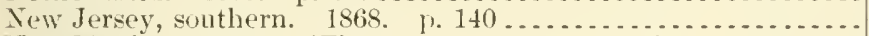

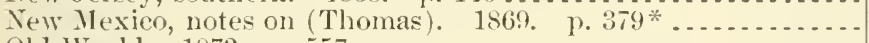

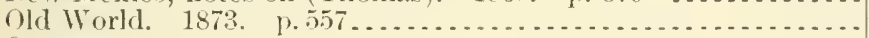

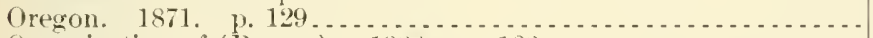

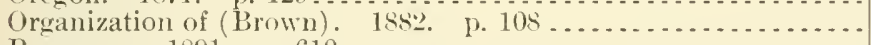

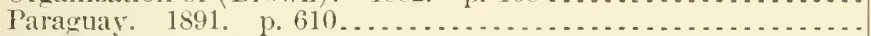

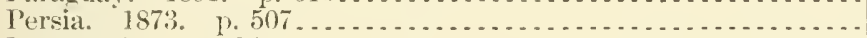

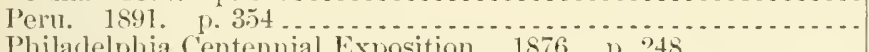

Plant physiology in relation to (Woods). 1901. p. 127....... A10.3:99

Portugal. 1871. 1. 141 ............................. 127.9:9

Iotash and its functions in (Wiley). 1896. p. $107 \ldots \ldots . . . . . .11 .10: 896$

Practical-

nitrogen assimilation in its application to. $1897 . p$ p. $906 \ldots . . .410 .6: 7$

scientific work of Department of Agriculture in its relations

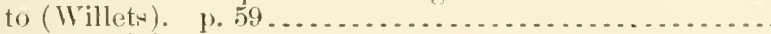

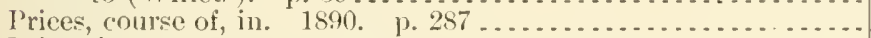

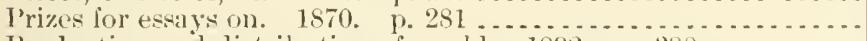

Production and distribution of world. $1892 . \quad \% 380 \ldots . . . . . .$.

l'roducts of, freight charges for vcean transportation of, (let. 1. 1895 -Oet. 1, 1896 .

Profesors of, what shall they teach? (Harwood). 1893. I. 139.

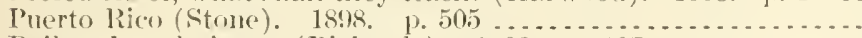

Railmads, relation to (Richards). $1902 . \mathrm{p} .107 \ldots \ldots \ldots \ldots \ldots .$.

Rural schools (Powell). 1902. p. 109...................

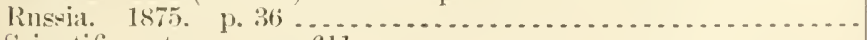

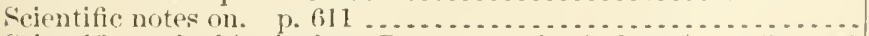

Secentific work of Agrienltmre Department in (1)alnney). 18\%5. 1. (6.)

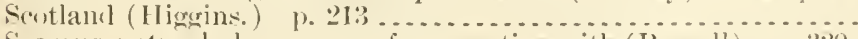

$11.10: 900$

11.1:8:2

127.9:12

A $27.9: 12$

1.1:871

$127.9: 21$

$127.9: 2.2$

A 10.3:99

A $27.9: 9$

A1.1:876

A1.1:878

$27.9: 29$

+1.1:862

A1.1:86:3

$11.10: 899$

127.9:24

A 27.9:7

1.
1.9.7 9.6

127.9:7

$27.9: 11$

11.8:22

A $27.9: 29$

A $27.9: 11$

$127.9: 29$

A10.n.7

A1.1:890

A27.9:28

127.9:8

A $27.9: 30$

$127,8: 12$

\$10.3:16

11.10:8 89

A10.3:1:20

1 10.3:120)

1.2. (9:1:3

11.1:870

1 10.3:24

14.1 :898

Seasons, natural phenomena of, connection with (Ruscell). p. 3:9. . 11.1:864

\footnotetext{
* By a misprint, this page number appears twice.
} 
Agriculture-Continnes

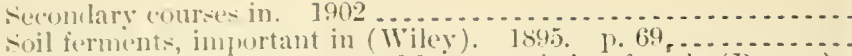
sonth America, with maths and latest statisties of trade (Barnes).

1892

South Carolina, climate, soil, and (Hemphili). 1s82..........

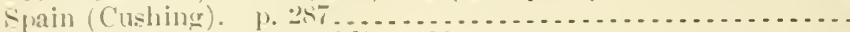

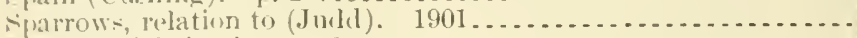
State oflicials in charge of-

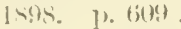

1syg 1) list

19(1), 1), (it1 ...

1901. [1. ti20

- tate rejorts of-

1stit. p. $33: 3$.

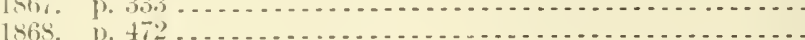

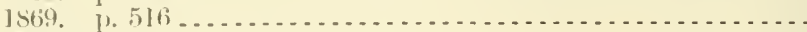

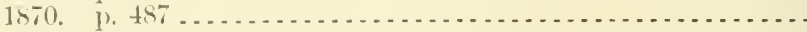

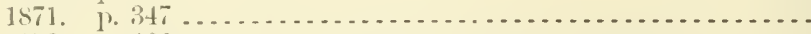

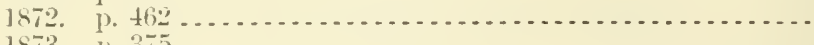

1873. [1. 375.

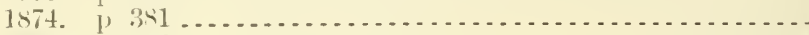

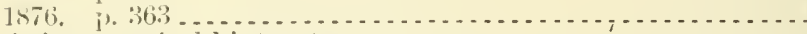

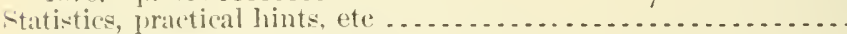
vie ulso Igricultural statistics.

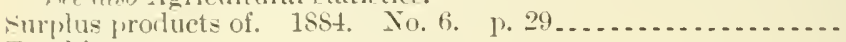
Te:aching-

how may farmers' organizations hasten, in public shools

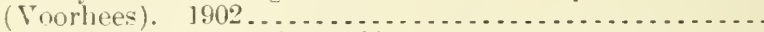

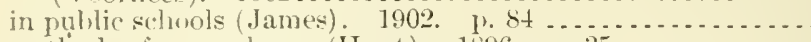

methods of, remarkson (Hunt). 1896. p. $35 \ldots . . . . . . .$.

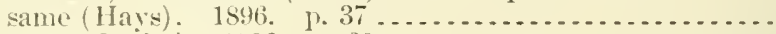

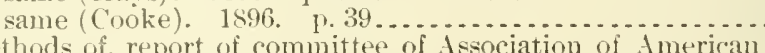

methods of, report of committee of Association of Am
Agrienltural Colleges and Experiment Stations-

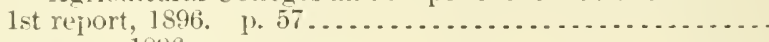

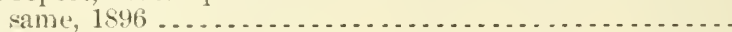

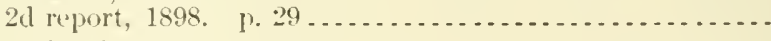

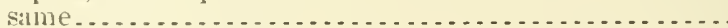

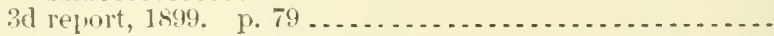
same.

4th rejort, 1900 , р. 37 .

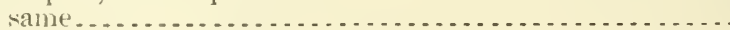

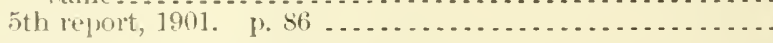

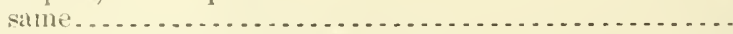

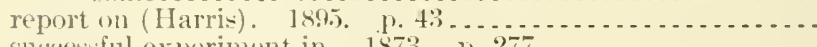
successul experiment in. 1873. 1. 277

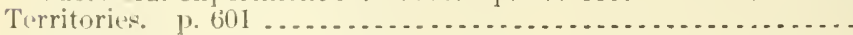

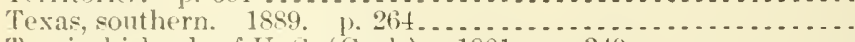

Tropical istands of U.S. (Cook). 1901, p. 349 ............

Tuspan, Hexico (Johnson). 187t. p. 498.

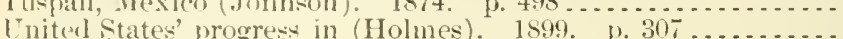

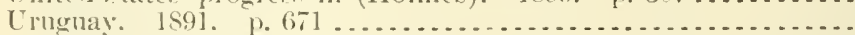

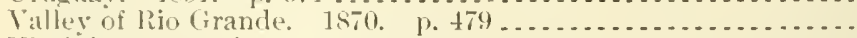

Yiruinia, status of. 18\%0. ['. 267.

Washington Territory, statistice of (Simmons). 1869, p. $370 \ldots$

Western Anerica, condition of. 1871 . ए. $329 \ldots \ldots \ldots \ldots \ldots \ldots$.

Sipe rlso Alaka - American products - Animals, domestic -

Barns - Biees - Potany - Butter - Cattle - Cereal crops Chese - Coffes - Corn - Cotton - Cow - Crops - Dairy lomestic science - I)rainage - Ensilage - Farmer - Farming - Farms - Fertilizers - Field crops - Flax - ForestryFruit-ciarlening - Grain - Grape - Crass - Greenhouses Irrigation - Maize - Manures - Milk - Pacific coast - I'oultry - Soils - Southern agriculture - Sugar - Tobacco Trees - Vecetables - Wheat - Wool - Yukon Valley lieadings beginning with Agricultural.

A 10.4:49

A $1.10: 895$

127.8:2

A1.6:47

A1.1:576

\5. 3:15

A1.10:898

A1.10:899

A1.10:900

A. $10: 901$

A1.1:S67

A1.1:S68

A1.1:869

A1.1:870

A 1.1:871

A 1.1:872

A1.1:873

A $1.1: 874$

A 1.1:57 6

A 27.9 :

A27.9:22

A 10.3:120

A $10.3: 120$

A 10.3:30

A 10.3:30

A 10.3:30

A $10.3: 41$

110.4:32

A 10.3:49

A 10.4:37

A 10.3:65

A 10.4:39

A 10.3:76

A 10.4: 41

A 10.3:99

A 10.4:45

A 10.3:24

A27.9:11

A 1.1:869

A27.9:27

A 1. 10:901

A27.9:12

A $1.10: 899$

A27.9:29

127.9:8

A $1.1: 870$

A.27.9:7

127.9:9 
Agriculture, Assistant Secretary of, duties of, special report on (Wi)-

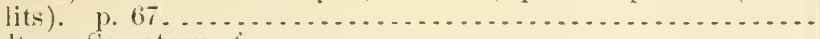
Agriculture, Secretary of ...............................

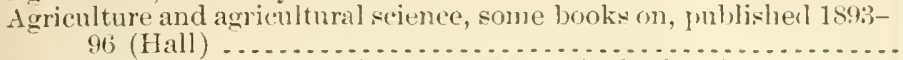

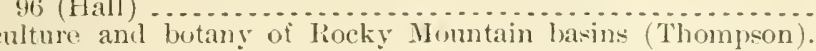

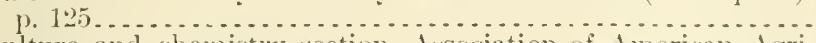

Agriculture and chemistry section, $A$ ssociation of American Agricultural Colleges and lixperiment Stations, leport of:

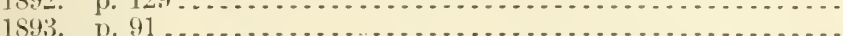

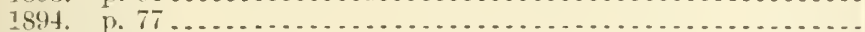

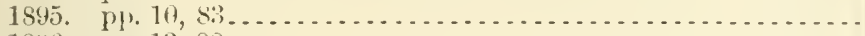

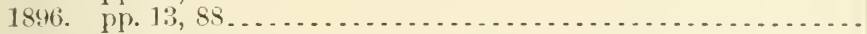

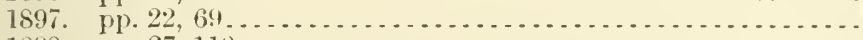

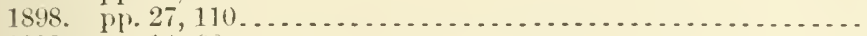

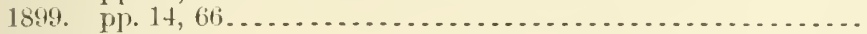

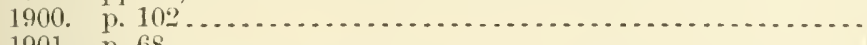

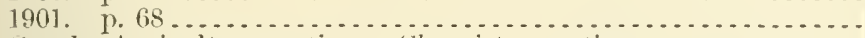

Sipe also Agriculture section - Chemistry sertion.

Agriculture and Forestry, Exposition of. See Belgimm - Vienna.

Agriculture and industries, ideal dejartment of (Tisserand). 1896. 1. $5+3$.

Agriculture and related sciences, some books on, published $1896-98$, list of.

Agriculture and rual economy, imerican works on. p. $597 \ldots . .$.

Agriculture Committee, Jlouse of Representatives:

Hearings by, on subject of good roads. $1893 . \quad$ p. s5. . . . . . . .

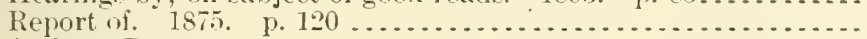
Agriculture Department:

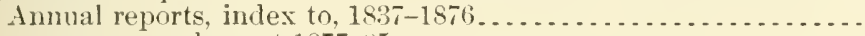

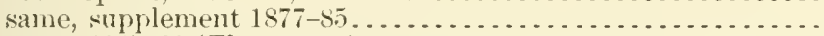
same, 1837-93 (Thompson) . . . . . . . . . . . . . . . . . . .

Appropriations and expenditures, 1839 to $187 \%$, statement of.... Appropriations for ficcal years1896 and 1897 . p. 6.59.

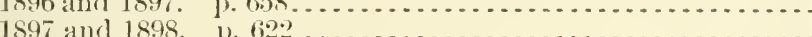

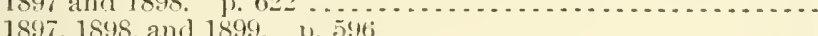

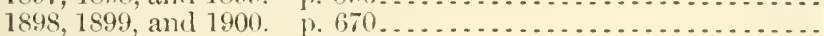

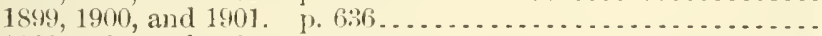

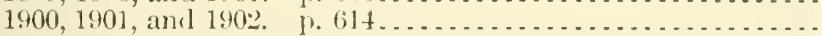

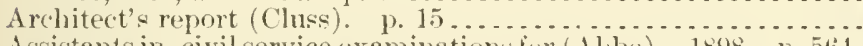
Assistants in, civil service cxaminations for (Albe). 1s98. p. 564 .

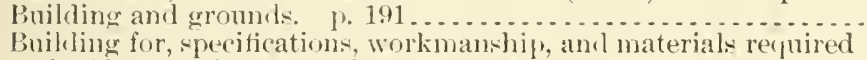
in (Cluss and Kammerineber). 1867.................

Bulletins and circulars of, avalable for free distribntion, circo.

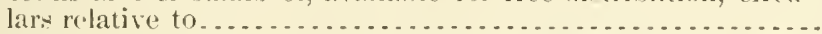

Bureatu of Information amd lixclatuges in, arlidess fivoring coration of (Woorlliull). 1855. Y. 19..

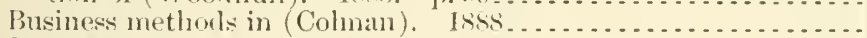

Circulars issued hy various divisions of . . . . . . . . . . . . . .

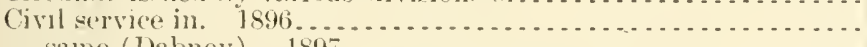
same (Dabney). 1897

Consular correspondenee of (Dorlge). I1. 487 . . . . . . . . . .

Cooperation of, with erlueational fores in United states relating to acriculture (Willits). 1. 65).

Cooprative work betwern experiment stations and, rejort of

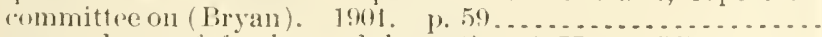

Correspondence of foreign and domestic. 1877. 1.527......

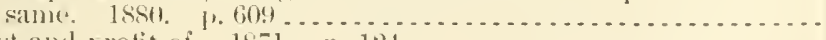

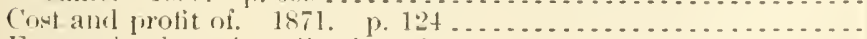

Economice plants in collestion of, catalogue of (samulers) . . . . .

Eniployees ofnumber, status, and (ompensation; July $1,1847 \ldots . . . . .$.

clansiticatlon no.

11.1:542

11.

110.4:31

1 $1.1: \$ 66$

1 $10.3: 16$

A 10.:3:20

1 ] $10.3: 24$

A 10.3:30

A $10.3: 41$

A $10.3: 49$

A 10.8:65

1 $10.3: 76$

A 10.8:99:

$+10.3: 115$

11.10:896

110.4:38

A1.1:568

110.8:14

A27.91:13

A1.8:14

A 1.8:42

A21.3:1

A 1.8:13

A $1.10: 896$

A $1.10: 8.17$

11.10:898

A $1.10: 899$

\$1.10:900

A1.10:901

A] $1: 868$

A:9.6:26

A1.1:869

A 1.2.5 1):3

121.5:

A $1.7: 9$

A 1.2:C71

A21.2:(4)

1 1. $4: 5$

$110.4: 28: 3$

11.1:564

A $1.1: \$ \$ 1$

1 10.3:999

A $1.1 .8 \%$

A $1.1: 580$

1:7.9:9

1] $8: 47$

1 $1.4: 6$ 
Agriculture Inepartment-Continuel

limployecs of-Continued

ontside of Wathington, leave of absence not allowed to, letter

relative to . . . . . . . . . . . . . . . . . . . . . . . . . . .

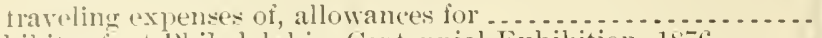

Exhibits of, at l'hiladelphia, Centennial Exhibition, 18,ti-

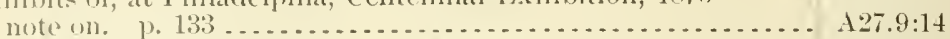

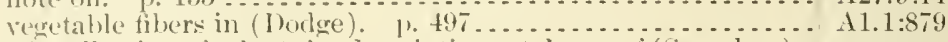

fixoticeollection of, plants in, descriptive catalogue of (Samblers). $1,7: 2$.

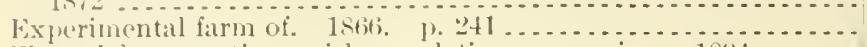

Financial transactions witl, regulations governing. $1894 . . . .$.

Fiscal regulations of . . . . . . . . . . . . . . . . . . . . . . . .

Funetions of, notice as to rarious . . . . . .

(irass and forage-plant inrestigations in (Williams). 1901. 1. 148..

Iistorical sketch of, its objects and present oryanization (Greathouse)

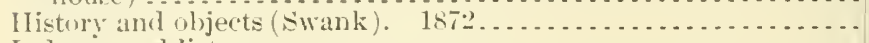

Indexes and lists-

amnial l'eports, $1837-1876$.

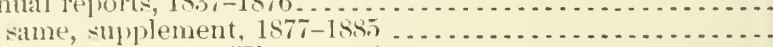

same, 1837-1893 (Thompsin) .......................

general inclex for reports on agriculture, $1847-1866.1 \%+73 \ldots$ sane, anthors, with titles of their publications, 15 11-1897

(Thompson) ... . . . . . . . . . . . . . . . . . . . . . . sane, list by titles, 1840 to June, 1901. (Handy and Cannon) ................................

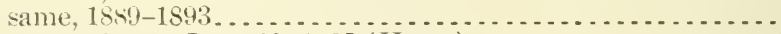
same, 1841 to June 30,1895 (Hasse) Sie also Animal industry.

Letter as to work and needs (Le Dute). 18s0..

Library of-

botauy publications in, catalogue of. 1902.

pallications of .

Iuseum of, donations to-

1862-63. p. 615 .

1867. p. 470 .

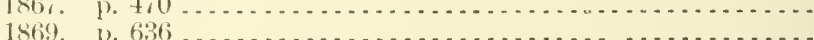

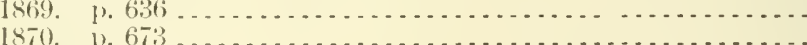

18,.) 1. 67.3.

1873. 1). 447 .

Intual interests and relations of farmer and, farmers institute as molium for developing (Trie). 1902. 1. 102 ..........

Sotice of receipt of communications on various subjects. 1893.

Nutrition investigations of, development of (True and Milner). 18:9. p. 403

Organization of18\%5. 1). $52: 3$

sime, with list of exhibits at Cotton States and Interna-

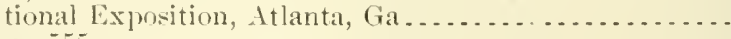

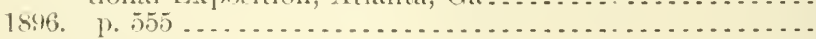

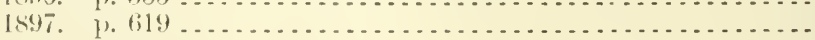

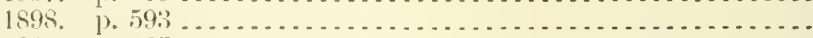

1899. p. 667 .

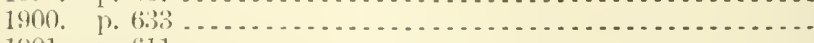

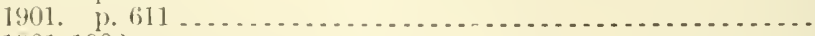

$1901-1902$
Osciniclat and Agromyzide reared at, halits of (copuillett).
ls9s.

Philadelphia Centennial Exhibition, 1876 , participation in (Samnlers) . . . . . . . . . . . . . . . . . . . . .

I'romotions, ete, regulations gowerning. Pec. $1,1896 \ldots . . . . .$.

l'ublication work of, as affected by law. $1897 \ldots \ldots \ldots \ldots \ldots .$.

l'ublications ofalstracts of, $1889-1902$. arrangerl hy hureaus and offices, with their barions series....

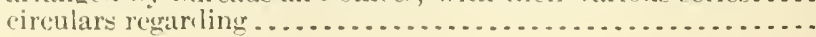

A1.2: L 48

A1.2:T69

11.8:6

127.9:4

A.2.:F49

A:.2:F52

11.2:Agr 4

A10.3:99

A21.3:3 1

A $1.8: 7$

A 1.8:14

A 1.8:42

121.3:1

11.1:867

A21.3:4

A21.3:6

A1. $8: 55$

A17.3:9

A1.2: $\operatorname{lgg}^{3}$

117.3:42

A17.

A1.1:862

A $1.1: 86 \pi$

11.1:869

A $1.1: 870$

1 1.1:872

A1.1:873

A10.3:120

A 1.2:184

A1.10:899

11.10:845

A21.2:At6

11.10:896

A1. $10: 897$

A $1.10: 898$

A $1.10: 899$

A 1.10:900

A 1.10:901

A21.4:1

ג9.6:10

A 1.2:1'53

A 1.2:P94

A21.2:P96 ${ }^{1}$

A 10.6:

A 1-A 29

A21.2:P96 ${ }^{2}$ 
Publieations of-Contiuued

distribution of, orders relative to.

indexes. See Agriculture Department, indexes ani lists.

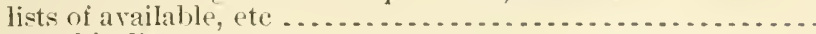

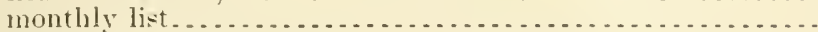

notes regarding, list, ett.-

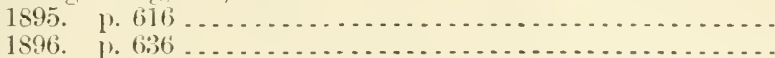

1897. [. 627

1898. 1\%, 601

1899. 1) 676 .

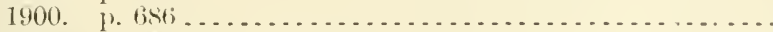

1901. [. 683

price lists of

special list of those available for distribution to correspond-

ents and others rendering service to Department ..........

Relation of, to famers' institutes (True). 1902. p. 22........

Relation of Weather Bureau to (Calvert). 1899. p. $54 . . . . . . .$.

Scientific aids and assistants of, note on. 1899. pp. 213,548...

scientific work of-

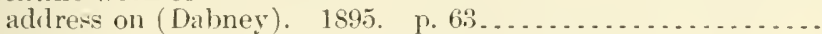

in its relation to practical agriculture (Willets). p. $59 \ldots . .$.

seed and plant introduction work since 1897 (Smith) 1901 . p. 145.

Feed tests. See Seeds.

Sketch of. 1871. p. 257.

Student assistants in. 1901.

Tolaceo culture (Thitney). 1901. p. 108.

Unskilled laborer in, instructions to applicants for appointment as. 1902

same, regulations governing appointments. $1902 \ldots \ldots \ldots \ldots$.

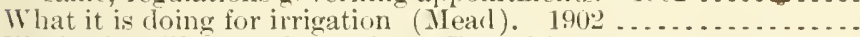

IVork of, as illustrated at Atlanta Exposition. 1895. \%. 503..... Agriculture Department and Cotton Exchange reports. 1886 . p. 496. Agriculture Department and its work (Hill). 1898 . . . . . . . . . . . Agriculture section, Association of American Agricultural Colleges and Experiment stations, report of:

1890.

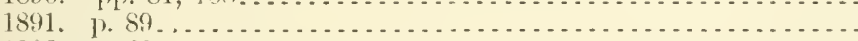

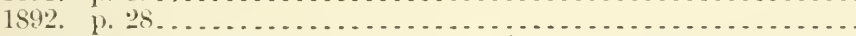

tie also Agrioulture and chemistry section.

Agriculturist, work of signal Fervice Bureau for (Birkheimer). 1882. p. 110 ............

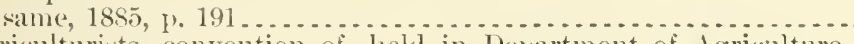

Agriculturists, convention of, lield in Dejartment of Agriculture, proceerlings of, Jan. 10-18, 1882. 1882 ..................

same, second convention, proceelings of, Jan. 23-29, 1883.1883. Agrilus, food plants and injury of, North American species of (Chit-

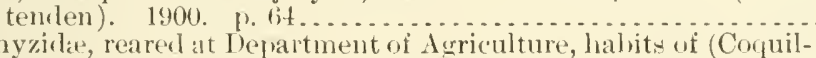

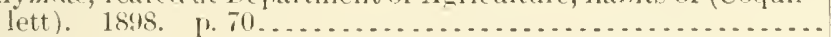

Agrommic: Institute, National, of France 1876. p. $490 \ldots . . . . .$. Agropyrom, native and introrluced species of (Scribner and smith).

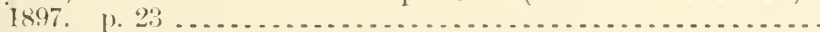

Agrostological notes, circular . . . . . . . . . . . . . . . . . . . . . Agrostology:

Ecomolnic and scientitic, progress of (Scribner), 1899. p. 347 ..

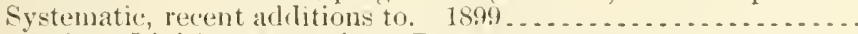

Agrostology Division, Agriculture Department ... . . . . . . . . . . .

Fiell work of; review and summary of work done since organization of division, July 1, 1895 (Shear). $1901 \ldots \ldots \ldots \ldots \ldots \ldots$.

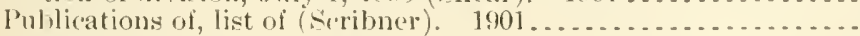
same (Epillman). 1902

Work wf, for farmer (Aribner). 18\%7. p. 160 .

Aiguillon, France, blark rot of crapevine, treatment of, experiments made at, in 1858 (Prillieux). iss9. p. $49 \ldots . . . . .16 .3: 10$

A10.3:99 
Aiken, 1). 11 vatt. Tirnge, its origin, progress, and eiucational pur-

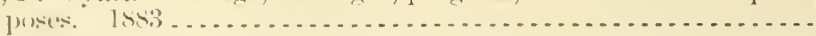

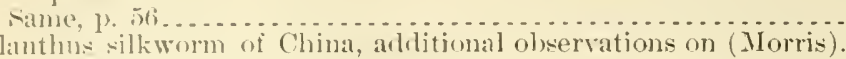

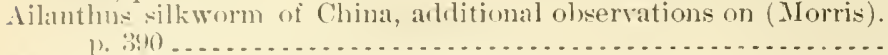
Iir:

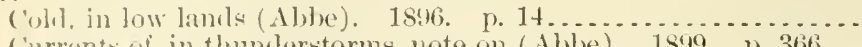

(iurronts if, in thmolerstoms, note on (Abbe). 1899. p. 366 ..

Expluration of, with kites, prouress at Blue IIill Ohservatory,

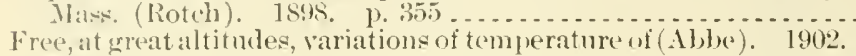

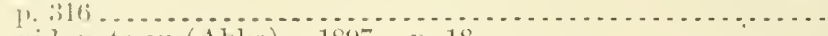

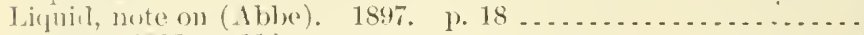
sante; 1899, p. 110 . . . . . . . . . . . . . . . . . . . . . . .

Temperature of, monthly notes on, July, 1891-Oet., $1902 \ldots . . . .$.

[pper, chemical compusition of, notes on (Abbe). 1897. P. iil.

Warm, attending low areas (Ibbe). 1894. p. $464 \ldots . . . . . .$. See clso Atrial observations-Atmosphere - Ballooning-Barometer- Meteorology.

Aitken, A. P. Fiber letermination in Seotland. 1894. p. 172....

Aitken, John. Atmospheric lust observations. 1896. p. 734 .... Alabana:

Cattle trate and dairy interests of (Perry). p. 385. . . . . . . . .

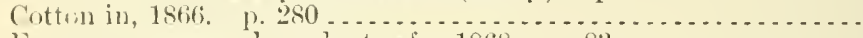

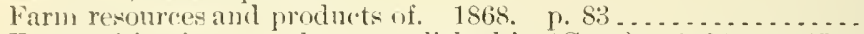

Farmers' institute work accomplished in (Cary), 1902. 1) 15 ..

Negro in, dietary studies with reference to food of, in 1895 and 1896 (1twater and Woods)

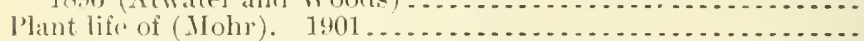

Roat improvement in, extract from governor's message (John-

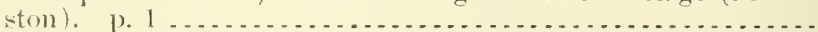

Sep ulso. Jefferion Cominty.

Alamame (ounty, North Carolina, soil survey of (Coffey and Hearn).

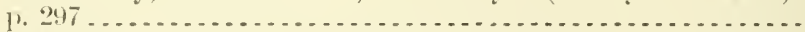

Alamos, Mexico, plants collected by Edward Palmer at, in 1890 , list Alaska:

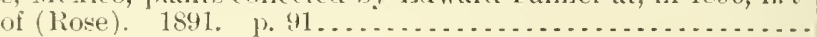

Ierricultural eapabilities of, investigation of1.t report, 1897 . al report $1808=$ 31 1.

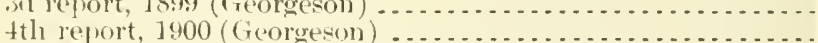

Irricnltural experiments in (Cieorgeson). 1898. p. $515 \ldots . .$. sime, p. 7 ..................................

Acricultural nutlook of coalst region of (Evans). 1897. 1. $553 \ldots$

A erricultural resources of (Dall). 1. $170 \ldots \ldots \ldots . . . . . . . . .$.

Aericulture in -

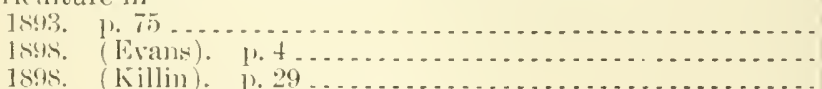

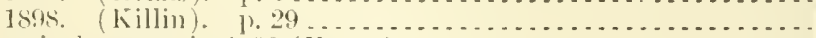

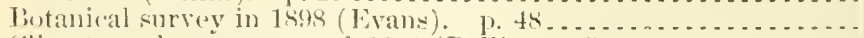

Climate and erop report of, 1898 (Dall). 1) $548 \ldots \ldots \ldots \ldots \ldots \ldots$

Climate of (1] (3)

189\%. 1. 248.

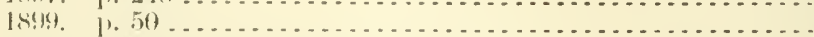

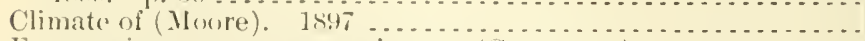

Famers in, ponoer, suggestions to (Goorgeson), 1902 . . . . .

Farmers' institnte work ac'(omplished in (True). 1902. 1. 33 ..

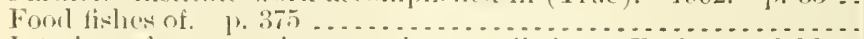

Interior of, recommoistance along trail from Eagle to Valdez

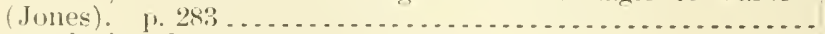

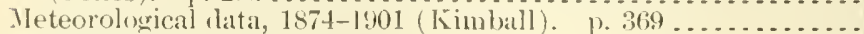

Metenrological observations in-

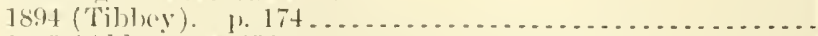

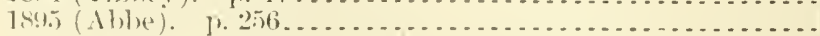

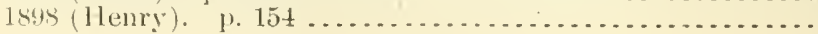

A1.6:55

A1.7:2

A 1. 1:862

A:99.6:24

A $29.6: 27$

A $29.6: 26$

A29.6:30

A29.6:25

A $29.6: 27$

A29.6:

129.6:25

A29.6:20

17.3:4:

A29.::5:113

14.1:85:

A27.9:4

A27.9:6

A $10.3: 120$

A10.3:38

16.5:6

A22.4:33

A $26.5: 901^{1}$

16.5:1

A 10.3:48

110.3:6?

110.3:82

1 10.3:94

11.10:898

A10.3:62

11.10:89\%

A1.1:S68

127.9:31

110.3:48

A10.3:48

A $10.3: 62$

129.6:26

\29.6:25

A10.3:62

A29.2:A11

A 10.10:1

A 10.3:120

A 1.1:870

110. $1^{2}: 901$

A29.6:30

A29.6:22

А $29.6: 23$

A $29.6: 26$ 

same (Abbe). 1899. p. 5!)

see also Circle City - Cook inlet region-Copper River countryDyea - Eagle - Kenai experiment station - Jome, Cape-St. Michael - Tanana Valley - Yakutat Bay - Yukon Valley.

Alaska agrienltural experiment stations:

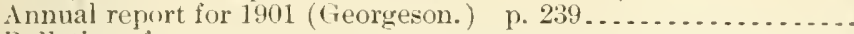
Bulletins of.

$110.1^{2}:(101$ 110.10:

Alaska and northwestern coast, grasses of, plates and descriptions of (Vacey.) 189:

Same

Elin leaf-beetle in (Lintner). 1895. p. 50

Tornado at, Jareh 26, 1895. Report of (Sims). "Albatross," I. S. S, plants collected by in $1887-91$ along

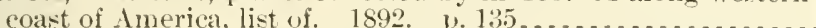

Albert, Prince of Moncco. Meteorological observatories, creation of, on islands connected by cable with a continent. 1894. p. 158.

Albumen, determination of, in cow's milk (Vanslyke). 1894. p. 188. Albuminoid nitrogen, determination of, error in present ofticial

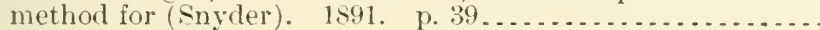

Albuminoiks in milk, estimation of (Sebelien). 1889. 1. 169 ..... Alcohol:

Sulphurous acid in manufacture of (MeNhrtrie). 1873. p. 32... Use of, in mannfacture of sugar (Gilbee). 1891. 1. $8 \ldots \ldots . .$. Withdrawal of, from lond for scientific purposes (Richards).

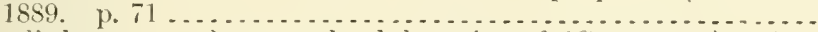

129.6:2 $1 ;$ A29.6:27

16.2:Ns:2 A $6.3: 13$

19.6:2)

1:9.6:2:3

(6.5):1

$129.3: 11^{1}$

1 $7.3: 48$

A $7.3: 31$

A $7.8: 2 t$

127.9:11

17.3:34

A7.3:24

Alcoholic beverages, fermented, adulteration of (Crampton.) 1887. p. 2633.

Sice also Licjuors.

Aldrich, J. M.:

Insects of Nortlidahn, notes on. 1894, p. 201

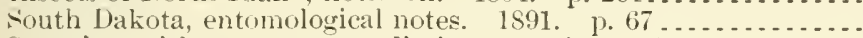
Spraying without pump, preliminary notice. 1894, p. 114...

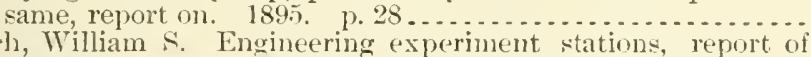

Aldrich, William S. Engineering experiment stations, report of
eommittee on, before Convention of American Agricultural Colleges and Experinent Stations. 1896. p. 116......... A $10.3: 41$

Aletia. Nie Cotton worm.

Aleurodidie, Ameriean, contributions toward a monngrapl of.

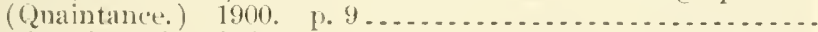
See rlso Alevmos citri.

Alexanier, Edward Porter:

Hurricanes, destructive forces of, and conditions of safety and

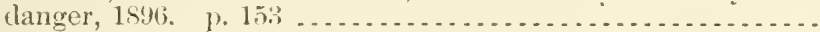

Storm waves of South Carolinal and Texas. 1900. p. 381 .....

Alexander, William II.:

Basseterre, Nt. Kitts, W. I. Floorl of Jan., 18s0, at. b. 196.....

Climatology of Antigua, IV. I. 1901, 1. 165..............

Climatology of st. Kitts-

1899. 1..5x?

.

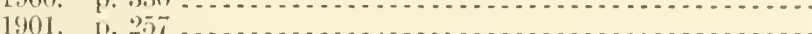

Hurricanes, especially those of Porto Rieo and St. Kitts. $1902 .$.

Ratintal! -

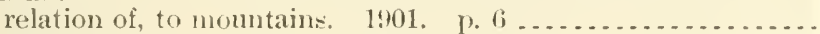

St. Kitts, W. I. I900, p. 4\$7 . . . . .

Reforestation and rainfall in Lecwarl klands. 1901. p. $254 . .$.

st. Kitts, W. L., adelitional observations of hurricane. 1899. p. 409 ... . . . . . . . . . . . . . . . . . . . . . . . .

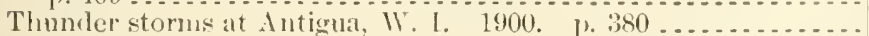
Aleyroules citri:

Fungons parasite on. P'reliminary untice of (Webher). 1891.

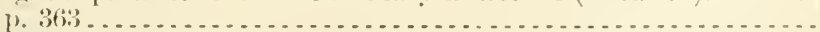

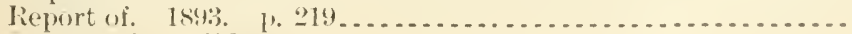
sec also Aleurodidie. 
Alfalia or lucern:

1.s a fertilizer. 1901

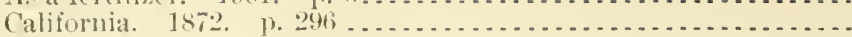

Cultivation of (Henderson). p. 566....................

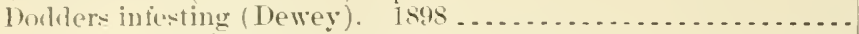

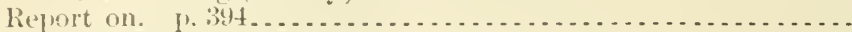

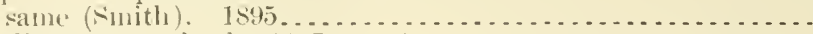

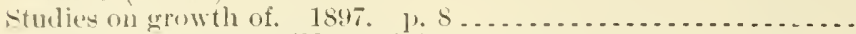

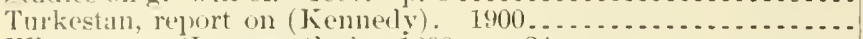

When to rut (Langworthy). is99. [. 24..............

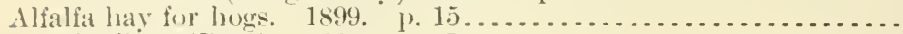

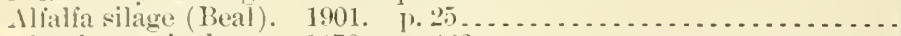

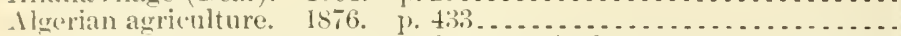

Algerian durum wheats, classifiel list, with ileseriptions (Fotield). 1402

ilerior, Africa, irrigation by artesian wells in. 1891. [it. 1. p. 369. Ilkali:

Black. Sie Sodium earhonate.

lnfluence of, on germination and growth of plants. p.8......

Irrigation and, recent invertigations by Wyoming Experiment Sta-

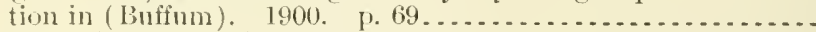

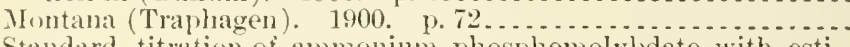

Standard, titration of ammonimm phosphomolybdate with, estimation of phosphoric acid in soils by double precipitation with molylylic solution and (Williams). 1895. p. $82 \ldots . .$. sie also Ammonia.

Alkali lands:

(lassification of (Cameron). 1901

(Higin, value, and reclamation of (Hilgard). 1895. p. 103.... lieport on (Whitney and Means). 1899..................

Alkali soils:

Certain components of, effect upon seedling plants (Kearney and

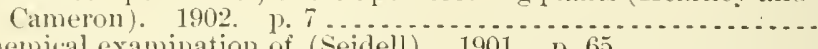
Chemical examination of (Seidell). 1901. p. 65............. Forage plants for cultivation on (Smith). 1898. p. $535 \ldots . . . .$. Ilechanical analysis, necessary modifications in (Briggs). 1900.

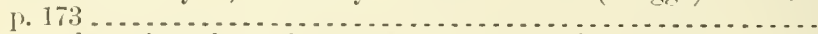

I'lants adapterl to, thronghout western portion of U.S. 1899 . p. 6 . Salt content of, instructions for determining in field (Whitney).. Salts in, distribution of (Hilgard). 1896. p. 66.............

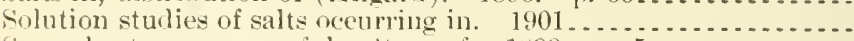
Sugar beets on, suecessful culture of. 1899. p. $5 \ldots . . . . . . . .$.

Alkali soils and vegetation, some mutual relations between (Fearney and Cameron). 1902

Alkali soils and waters in California (Ililgard). $1885-89 . \quad$ p. 297.

Alkali solntions. See Acid and alkali solutions.

Alkalies in soil analysis, separation of, by official method (Hopkins).

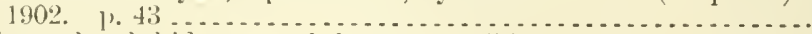

Alkaline polysul, hides, nse of, for grape millew 1885 . p. $67 . \ldots$.

Mllegan Cominty, Mich., soil survey of (Fiplin and Rice). 1.93....

Allegheny Oliservatory, research at, on atmospheric radiation (Very). 1900.

Allen, L. Quasia and other hoj substitutes in beer, improved

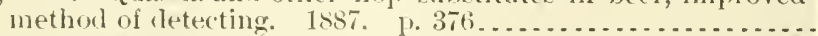

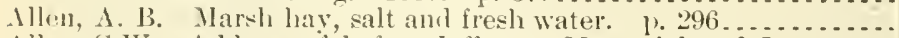

Allen, C.IV. Aduress of before lefferson Memorial and Interstate Good Roads Convention. Apr., 1902. p. $13 \ldots . . . . . . . .$.

Allen, Edward T. Western helulock. 1902..................... dlen, Edwin Wist:

Agricultura] Colleges and lixperinent Stations, American, thirteenth annual convention of Association of, 1899 , report on. 1900 . P. 40 .

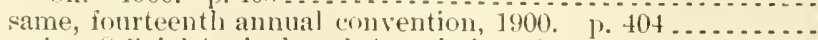

(hemists, ()thial Agricultural, Association of, convention of, 1899 ,

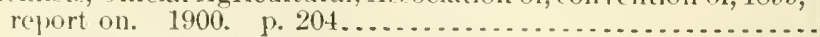
Cotton-seerl meal, effect of, on quality of butter. 1900 . 1. 24 ... Cows, protitabie and unprofitable, statenent of. 1900 . I). 21 ...

A1.1:884

16.4:14

A1. 1:875

A1.9:31

A1.9:56

A $3.4: 25$

A1.9:105

A 1.9:97

1 1.9:124

A:7.9:1t

A19.3:7

1 $15.2: \mathrm{Ir}^{2}$

$+1.9: 97$

110.3:76

A 10.3:76

A7.3:47

A26.3:17

A1. 10:895

A1.9:88

A1.8:71

A26.3:15

A $1.10: 898$

A1.8:64

A 1.9:97

A26. $4: 6$

A 10.3:30

A26.3:18

A 1.9:92

A1.8: 71

A 15.2:P94 ${ }^{1}$

A7.3:67

A6.3:2

A26.5:901 1

A $29.5: G$

A $7.3: 13^{3}$

A $1.1: 8,6$

A22.3:25

113.3:33

A 10.6:11

A 10.6:12

A 10.6:11

A 1.9:119

A1.9:114 
Allen, Edwin West-Continued

Cream, pasteurized, commercial butter cultures used in conneetion

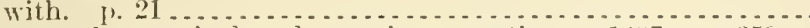

Dairy work at agricultural experiment stations. 1897. 1\%. $359 \ldots$

Dairying, review of recent work on. 1895. 1']. $443,1043 \ldots \ldots .$.

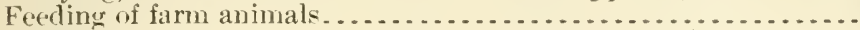

Feeding stuffs, eontrol of, needs and requirements of. 1897. p.

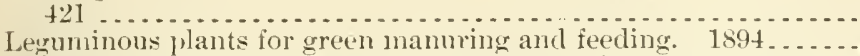

Milch cows, light rersus heay grain feeding for. 1900 . p. 25 -

Iilk and cream, ropy, examination as to cause of. 1899 . 1. 26.

Allen, Edwin West, Beal, Walter Ienry, and Wilcox, Earley Vernon. Agricultural materials, inspection of, by agricultural experiment stations. 1900 . p. 46.5

Allen, Henry L. Temperatures obtained by kites at Bergen Point,

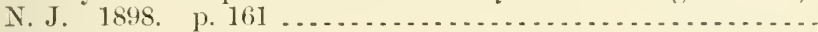

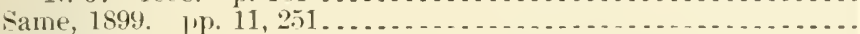

Allen, Lewis F.:

Cattle-

native, improvement of.

short-horned breed of, considered with reference to beef and

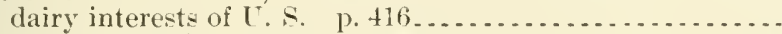
live stock, Ameriean. 1876. p. 403

A 1.1:866

A1.1:875 A $27.9: 14$

Allen, Robert G.:

Clinate and crop correspondents, Weather Bureau, how many are required? 1902 . 1. $195 \ldots \ldots \ldots \ldots$

Lightning, destruction by, in State of New York, Aug., 1898. p. 357

Weather observers, voluntary, book for record of instruments

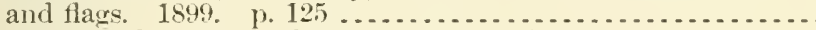

Allen, Townsend. The Cyclone, a poem. 1902. p. 270 ........

Allen, W. M. Food preservatives, provisional method for analysis of. $1902 . \quad$ P. 107 .

Allerton, Samuel Waters. Correspondence with, relative to exportation of Canadian cattle from Boston, Mass.

A $29.3: 31$

A $29.6: 26$

A $29.3: 24$

A $29.6: 30$

A 7.3:65

A $1.2: \mathrm{C}: 29^{3}$

Allierl national agricultural societies of America, othicers of. 1900. p. 643 3.

Same, 1901 P. 637 . . . . . . . . . . . . .

Allingham, William. Ocean storms, forecasting, and hest methods of making forecasts available to commerce. 1894, p. 150...

Allorhina, white grub of, note on (Townsend). 1891. p. 25.....

Almanaes and Weather Bureau, notes on (Abhe), 1898. p. 21 ....

Almond disease raused by Cereospora circumscissa, remedies for

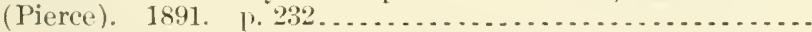

Almond in southwest [tal and southeast Nevada (Judd). p. $55 . .$.

Almond trees, disease of (Pierce). 1891. p.66...............

Almonds, earth. See Cluufa-spanish almonds.

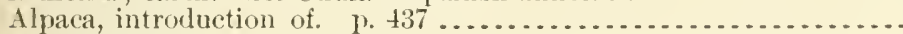

Alsike clover:

Description of, translated by J. Arrhenins. p. $355^{\circ} \ldots . . . . . . .$.

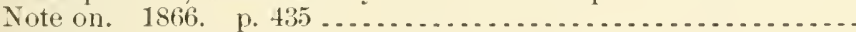

Alumina:

Determination of, in phosphates, methods of (IreDonnell). 1897.

Estimation of, in mineral plosphates (Kehmann). 1897 . p. $61 .$.

Aluminic phospluate, high grarle, action of ammonic citrate on (Huston). 1890.0 .170

Alumimm, ehloride of, nse of, against Peronospora of graperine, first results of (Conles and Deperais). 1s90. 1. $94 \ldots . . . .$.

Aluminum scales. See Themometers.

Alvarado, Cal. :

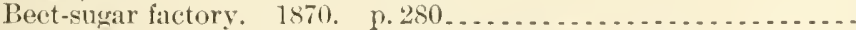

Standaril Sugar Refinery, report on (Fumas), 18.i, p. 91 ....

Alvorl, C. T. Maple sugir, manufacture of. p. $394 \ldots . . . . . .$.

Alvord, IIenry Elijah:

Address of, as president of Association of American Agrienltural Colleges and Experiment Stations, at ninth annual eonverltion. 1S96. 1. 20

\1.10:900

A1.10:901

A29.3:111

A9. $7: 4$

$129.6: 26$

A28.5:7

A20.1:595

A28.5:7

A1.1:875

A 1.1:565

A27.9:4

A7.3:51

A7.3:51

A7.3:28

16.3:11

127.9:8

11.8::20

A1.1:56:

110.3:30 
Alvorl, Ienry Elijah-Continued

Agricultural colleges, collective exhibit at World's Columbian Exposition, report on. 1893. p.103..........................

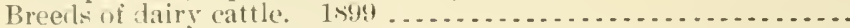
Butter, experimental exports of. 1897. p. $\$ 3$

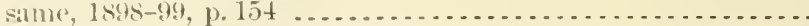
Cattle markets and abattoirs in Europe. p. 279

Cheese-

grood, how to select. $1890^{2}$ mannfacture and consumption of. 1845 .

A 10.3:16

A1.9:106

A $4.1: 898$

At.1:899

A 4. 1:901

Creameries or butter factories; advantages, location, organiza-

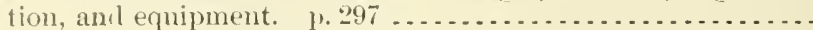

Dairy-

by-prorlucts of, utilization of. 1897. p. $509 \ldots \ldots \ldots \ldots . . . . . . .$.

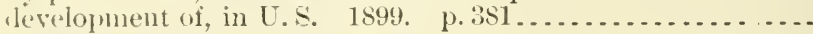

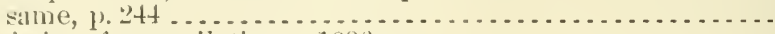

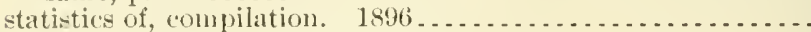

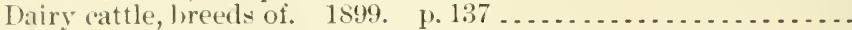
Dairy herd; formation and management. 1894. p. $295 \ldots \ldots \ldots$.

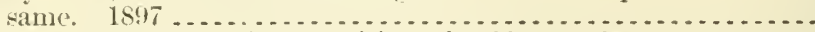

Dairy prorlucts at Paris Exposition of 1900. p. 194_............

Darying, officials and associations connected with, in U. S. and

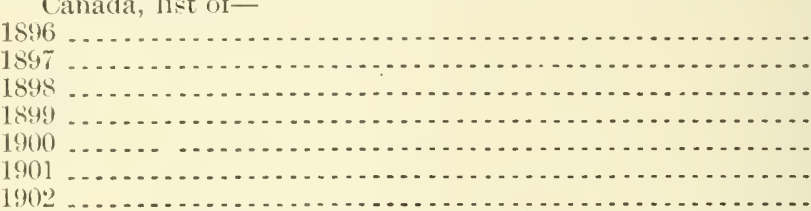

Eggw, trial shipments of, to England. p. $321 \ldots \ldots . . . . . . .$.

Meats and meat products at Paris Exposition of 1900. P. 223....

Se also, as editor, Agricultural Colleges and Experiment Stations,

American Awsociation of, proceedings of.

Alwood, William B:

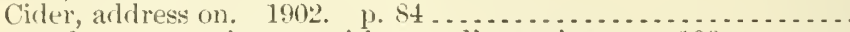

Hop louse, experiments with remedies against. p. 102........ same, p. $10^{2}$.

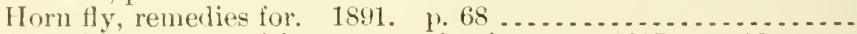

Inserticiles, tests with, upon garilen insects. 1887. p. 38 .....

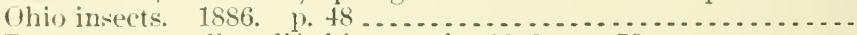
Protoparce carolina, life history of. 1898. p. $72 \ldots . . . . . . .$. san Jose scale; is cooperation for control of practicable? 1896.

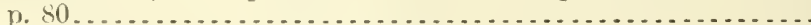
Spray manhery, standard fittiugs for. 1891 . p. $58 . . . . . . .$. Woolly aphis of apple, life history of, notes on. 1898, p. 70 ..

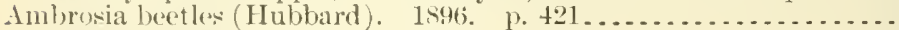
Sane (Hubbard), 1897. p. America:

(avalry horses in (Morris). p. 15!).

Flax culture for seed and fiber in (Dorlge). $1895 . . .6 . . . . . .6$. Leather, production of (Bailey). p. $19 \ldots \ldots \ldots \ldots \ldots \ldots \ldots$.

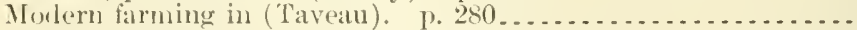

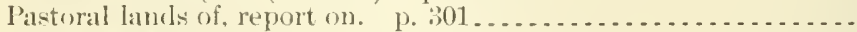
Trichiniasis in, extent of (Salmon). p. 455

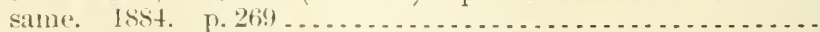

Western coast of, plants collected by $u$. S. S. Albatross along,

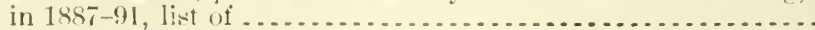

A $4.4: 11$ A 1.10:895

A 4.1:895-6.

A1.10:897

A1.10:899

A 4. 1:899

A4.3:11

A 4.1:898

A 1.10:894

A 1.9:55

A $4.1: 900$

A1. $10: 900$

A 4. 4:10

A $4.4: 18$

A 4.4:22

A $4.4: 26$

A $4.4: 29$

A $4.4: 33$

At. $4: 36$

At.1:889

A $4.1: 900$

A 7.3:67

A1.1:858

A9.1:88S

A9.7:4

A9.3:13

A 9.3:13

A9.6:17

A9.6:6

A9.7:4

A9.6:17

A1.10:896

A9.6:7

A 1.1:863

A11.5:10

At.1:857-8

A1.1:874

A1.1:870

A. $4.1: 884$

A4.2:An5

American Asrociation for Arlvancenent of Science. See EntomoIorical ('lul).

American Association of Farmers' Institute Workers. See Farmers' Institute Worker.

American Asweiation of state Weather services. Sce State Weather Services.

A6.5:1 
American breeds of fowls:

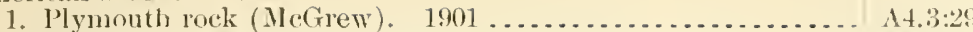

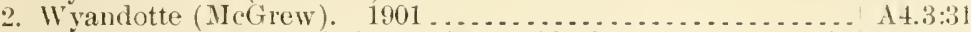

American Jairymen's Association, Utica, N. Y., Jun. 1871, notice of.

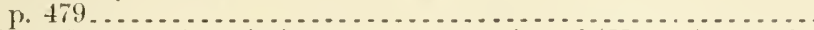

American Forestry Association, summer neeting of (I Inry). 1902.

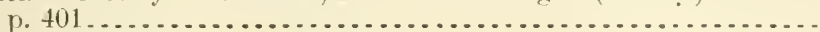

$127.9: 8$

A $29.6: 30$

American grasses:

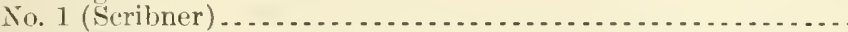

No. 2 (seribner)

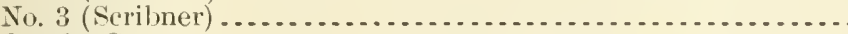
See also Grasses.

American Institute Farmers' Club, report on. p. 416

American Ponological Society:

Catalogue of fruits recommended for cultivation in various sections of U.S. 1897 .

same, including British provinces. 1899

History and progress (Wilder). ए. $149 \ldots \ldots \ldots \ldots$

Richmonfl, Va., thirteenth session. 1871. p. $328 \ldots \ldots \ldots \ldots \ldots$.

American prolucts:

Hamburg as a market for. 1897

Manchester district of Englanrl as a market for .............

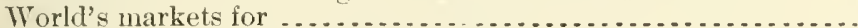

American troops returning from the East:

Cestorle, arlult (Diplogonoporms grandis) of man which may occur in (Stiles and Tayler). 1902. p. 43 .................... . .

Egyptian and Japanese strongyle (Strongylus subtilis) which may

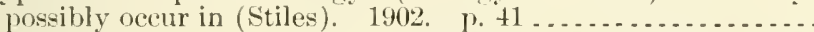

Larval cestode of man which may possibly occur in (Stiles and

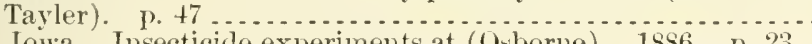

Ames, Iowa. Insecticide experiments at (G.sborne). 1856. p. 23. Sep also Iowa College of Agriculture and Mechanic Arts.

Amids, or amido-acisls, nitrogen of, investigation of analy tical methods for rlistinguishing between, and proteils (Mallet). $1898 \ldots$.

A mity ranal in Colorado, futy of water under (Berry). 1900. P. 159.

Ammonia, results in mixed fertilizers varialle (Williams). 1901. 1). 28.

Ammonium citrate:

Action of-

on basic slag (Huston and Jones). 1896. p. 68 ........... on high-grade aluminic phosphate (Huston). 1890. 1. 170 . Neutrality in solution, indicator for letection of (Richardson). 1886. p. 21 See also Pliosphoric acid.

Ammonium nitrate, use of, in retermination of phosphoric acial

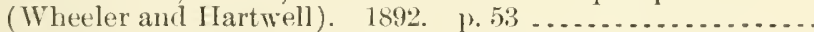
Ammonium phosphomolybrlate:

\section{New reaction with (Rioss). 1894. p. 97}

Report on estination of phosplioric acid by titration of yellow

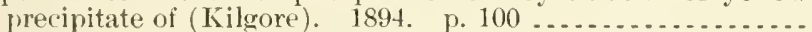

Titration of, with stanclarr alkali, estimation of phosphoric ac.id in soils by donble precipitation with molybrlic solution and (Williams). 1845. p. 82

Ammonimm sulplate, nitrification of, in different soils ( IV ithers and

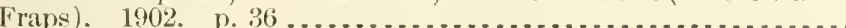

Amoss, William I.:

Adllress of, as presirlent of American Association of Farmers' Institute Workers, at seventl annual meeting. $1900^{\circ}$. p. 14.

Farmers' institute work ar'complisherl in Marylind. 1902. p. 25. Question box at farmers' institutes. 1902. p. 49 ........... Amoy, China, rainfall of, $1897-1902$ (Fesler). j. $486 \ldots \ldots . . . . .$.

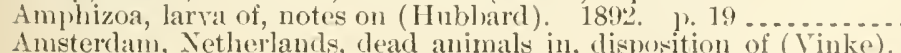

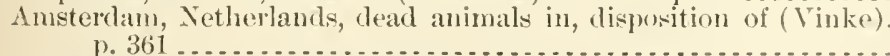
Analysis. See Chemical analysis.

Anarsia lineatella zell. Notes on (Cordley). 1897. 1. $71 \ldots \ldots .$.

A27.9:9

A 12.4:14

A $12.4: 8$

A12.3:

$14.3: 35$

A4.3:35

A9.3:11

A7.3:54

A $10.3: 86$

A7.3:62

A 7.3:49

A7.3:28

A 7.3:12

A7.3:35

A 7.3:43

A7.3:43

A7.3:47

A 10.3:120

A 10.3:120

1 10.3:110

1:9.6:30

19.7:5

14.1:899

1! $6: 9$ 
Anchor ice. Sice lce.

Anchylostomianis. See Hookworm tisease.

Anderson, E. II.:

Aletia, reports on. 18s0-82. App., p. 37

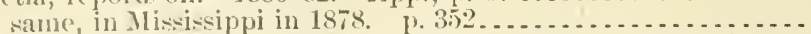

Cotton worm in sonth Texas in spring and early summer of 1883.

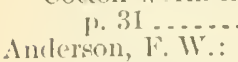

Frysiphese of Montana, preliminary list of. 1889 , p. 188 ..... A28.5:5

Fingi, few common, of Montana, bricf notes on. 1889 . p. $30.428 .5: 5$ [Frroneonsly attributed to "W. F. Anlerson" in book] ...... A28.5:5

Fungi of Helena, Mont., supplementary notes on. 1889. p. 82.- A28.5:5

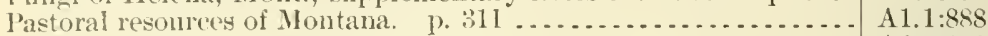
same, p. 311 ....................................

Urelinese and notilaginese, notes on certain. 1891. p. 121 . . ... Interson, F. W., and Kelsey, F. D. Erysiphe:e upon phytoptus dis-

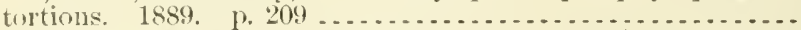

Anderson, J. T. Moisture and other extract, experiments in determination of. 1890. P. 93 . . . . . . . . . . . . . . . .

Anlerson, W. B. Skim milk as fool for young chickens. 1. 47t. See also, as joint author, Plumb, Charles Sumner.

Andrew, John A. Industrial classes, elucation of. 1864. No. 1,

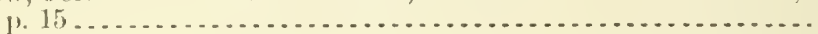

Andrews, C. C.:

Address of, before Minnesota Good Roads Convention. Jan.,

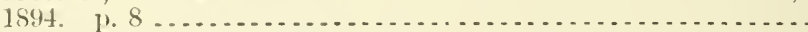

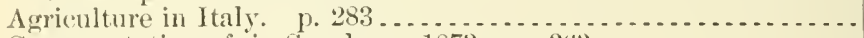

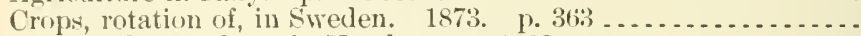

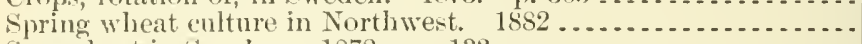

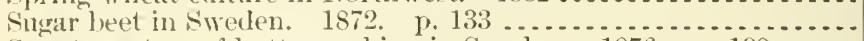

Swartz system of butter-making in Sweden. 1876, p. $198 \ldots \ldots$. Anemometer:

Local anemometric peculiarities (Abbe). 1900. p. 155 . . . . . .

Pressure, prize for (Abbe). 1902. p. 130.....................

Relative merits of anemometers in general use (Dines). 1896.

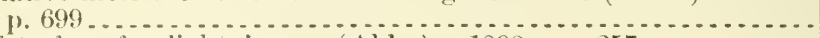

Safety fuse for lightning on (Abbe). 1898. p. 257...........

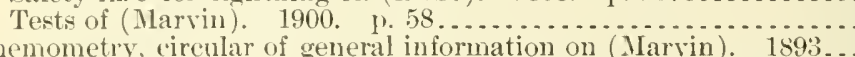

Anemometry, circular of general information on (Marvin). 1893...
Aneroid, new style of (Ablue). 1898. p. $566 \ldots . . . . . . . . . .$.

Aneroid lrarograph on (ireat Lakes, instructions for use of, $1897 \ldots$

Aneroid barometers, report on (Marvin). 1898. p. 410..........

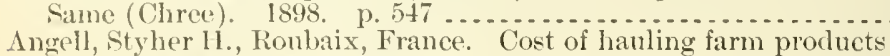

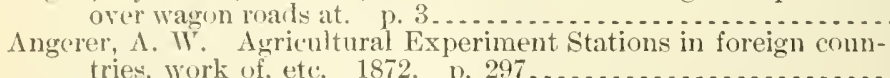
tries, work of, etc. 1872 . p. 297

See also, as translator, Salviate, E. de.

Angleworms and warm rains, note on (Abbe), 1899. p. 474 .....

Angrom, Tulkey, agrieulture in. Notice of receipt of letter from Minister Terrell relative to

Alugora goat:

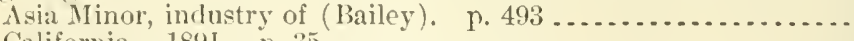

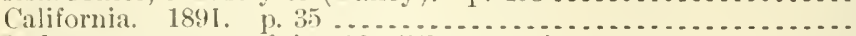

Industry, progress of, in 1901 (Thompson). p. $457 \ldots \ldots \ldots \ldots .$.

Information concerning (Thompson), p. $281 \ldots \ldots \ldots \ldots \ldots \ldots . .$.

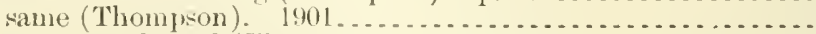

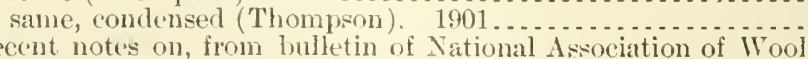

Recent notes on, from bulletin of National Association of Wool
Nanufacturers, 18,8 , p. 126

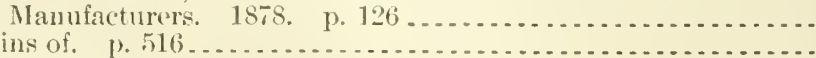

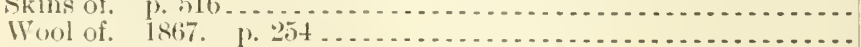

Angura Goat Brecders' Convention, Feb., 1872, report on. p. $153 \ldots$ Angot, $A$ lfred:

Cloud photography. $1896 . \quad 1 \% .769$.

Rainfall and eluats of rainfall. 1902. p. 237 . . . . . . . . . . . A6.1:8.8 A $28.5: 6$

A28.5:5

17.3::8

A4.1:899

A27.9:3

A 22.3:2

A 1.1:876

A 27.9:11

A $1.6: 40$

$127.9: 10$

A27.9:14

A $29.6: 28$

A29.6:30

A 29.3:11 3

$129.6: 26$ A29.6:28

A29.11:D

A $29.6: 26$

A $29.12: \mathrm{An} 3$

A29.6:26

129.6:26

122.4:27

$127.9: 10$

A29.6:27

11.2: $\mathrm{An} 4$

A 4.1:901

A27.9:29

A $4.1: 901$

A $4.1: 900$

A $4.3: 27$

A 1.9:13\%

A1.2:Sh3

A 4.1:900

A.2.9:5

A $27.9: 10$

A29.3:113

A $29.6: 30$

Angoumois grain motl or "Fly weevil" (Howard) 1893. p. 325. A9.7:5 
Angström, Knut, on atmospheric absorption, notes on (Abhe). 1901.

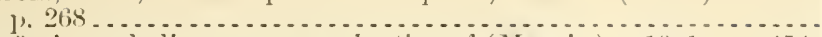

Angströn's pyrheliometer, examination of (Marvin). 19(1. 1'. 45t.

Anguillula. See Root-knot disease, ett.

Angruilula aceti, infection in human bladiler, (ase of (stiles amul Frankland). 1902 , P. 35

sice also Aphelenchus olesistus.

Anhalonium, North American species of, preliminary revision of

(Coulter). Is92. p. $91 \ldots \ldots \ldots \ldots \ldots \ldots$
Animal, what is live weight of? (Patterson). 1893, p. 150....... Animal body:

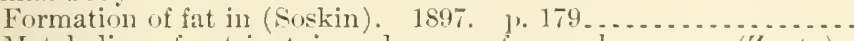

Metabolism of nutrients in and souree of museular enery! ('/untz). $189 \overline{-}$ 1. 538

Inimal breeding, progress in (Hays). 1901. p. 217............

C'lan-lficatlon no.

A $24.6: 29$

1.29.6:2!)

$14,3: 35$

16.5:3

A10.:3:16

$\$ 10.6: 8$

110.6:7

Animal diseases. Sé Diseases of animals.

Animal fibers. Sce Wrool.

Animal husbandry in central West (Morrow). 1882. 1. 62......

Animal industry:

Administrative work of Federal fimermment in relation to

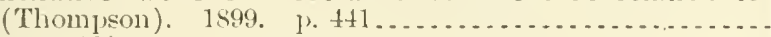

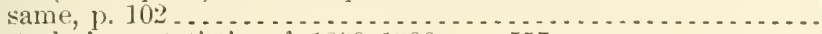

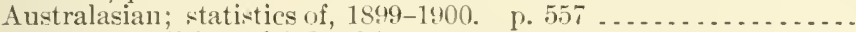

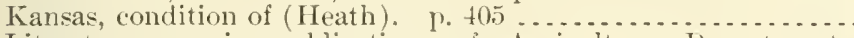

Literature on, in publications of Agriculture Iejartuent,

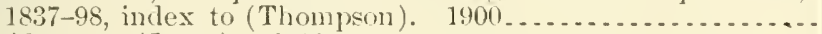

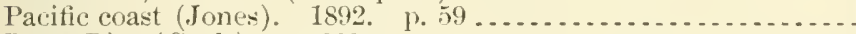

Portu Rico (Cook). p. $663 \ldots$
United States with especial reference to breeding of cattle,

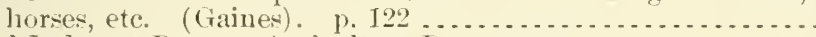

Animal Industry Bureau, Agriculture Department:

Act for establishment of. p. 473 . same, proposed amendments to . . . . . . . . . . . . . . . . .

Bill injuriously affecting work of, with letter of protest and apjeal

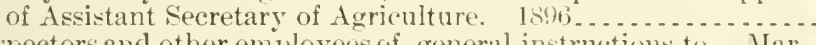

Inspectors and other employees of, generil instructions to. Mar.

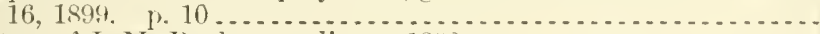

Letter of J. M. Rusk regarding. $1890 \ldots \ldots+\ldots$

Papers accompanying exhibit of at l'aris Exposition of $185 \%$.

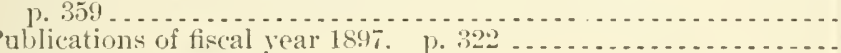

Rules and regulations-

1895

1897. 324

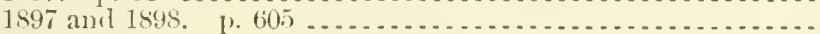

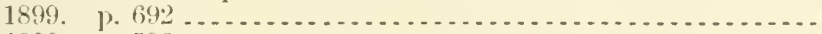

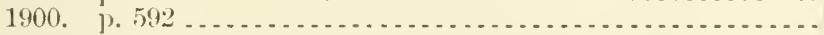

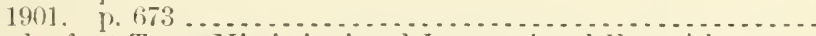

Work of, at Trans-Mississippi anrl Intemutional Exposition. p.

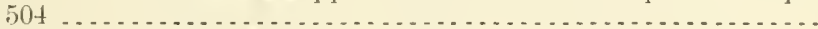

Work of, for farmer (Silmon). 1897. p. $286 \ldots . . . . . . .$.

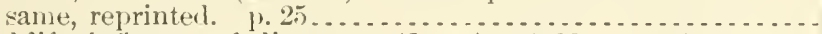

Animal life, influence of climate on (Dean). 1902. 1. $107 \ldots \ldots .$.

Animal parasites:

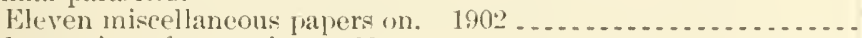

Inspection of meats for. 1898.

Fotes on (Stiles and liassall) -

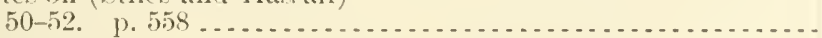

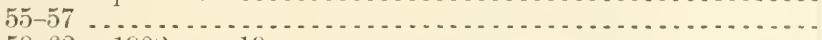

58-62. $1902 . \quad$ p. 19.

See also Chirkens - Ducks - Geese - Darasites - i'jgeons sheep-Turkeys.

Animal products:

Cape of Gool Hope, exports aud imports of. p. 5:9 . . . . . . . . 14.1:899

South dirica (Stowe). 1.512 ............................ At.898

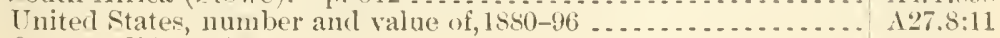

See also Hides - Meats.

$14.1: 899$

A21.3:5

11. $8: 20$

14.1:899

$11.7: 2$

At.

14.1:884

11.2: $\ln 5^{1}$

A1. $4: 4$

$-14.5: 3::^{2}$

11.2: An $5^{2}$

14.1:887-8

1f.1:897

1+.:3:9

14.1:897

14.1:898

A $4.1: 599$

1 $4.1: 900$

14.1:901

(4.1:599)

1 $1.10: 597$

14.1:597

1.9.3::31

14.3:35

14.3:19

14.1:899

14.4:34

$14.3: 35$ 


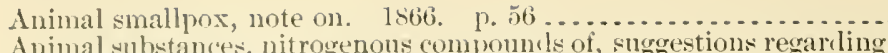
Animal substancer, nit rogenous componnds of, suggestions regarling
nomenclature of (Atwater). 1899 . p. $118 \ldots \ldots \ldots \ldots \ldots \ldots .$. Animals: nomenclature of (Atwater). 1899. p. $118 \ldots \ldots \ldots \ldots \ldots \ldots \ldots$ A10.3:65

('ruelty to, prevention of, in D. C., lill relative to, ete. $18 \%$....

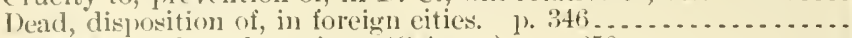
Discared, food produets from (Salmon). p) $250 \ldots \ldots \ldots \ldots \ldots .$. 1)iscases of. Sice Diseases of animals.

lifect of naphthaline on (Taylor). 1883.

Excretion of metabolizel nitrogen by (langwortiy). 1597. p. 817

lixport trade in 1859 p. 69 .

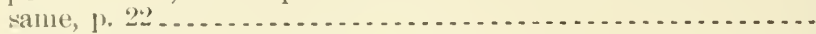

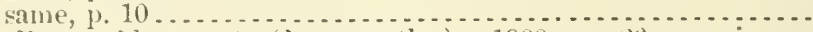

Feeding inoldy com to (Langworthy). 1900. 1. 26.......... Fecding of-

abstracts of reports of Agricultural Experiment Stations on,

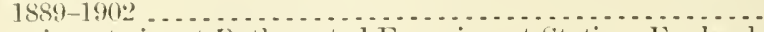
experiments in, at Rothamsted Experiment Sitation, England, lecture on (ilbert.) 1893. 1.231 ... . . . . . . . . . . . use of condimental feeding stufis in. 1898. p. $25 \ldots . . . .$.

Feeding stuffs for, composition, etc.-

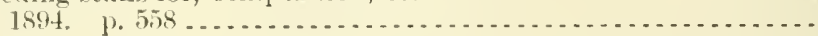

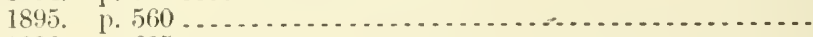

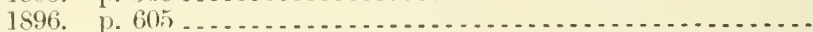

Food for-

cutting and cooking (Stewart). P. 396.................

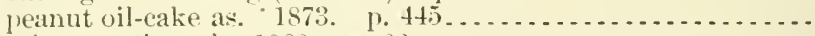

Free importation of. 1868 . $\mathrm{P} .62 \ldots \ldots \ldots \ldots$ Geographic distribution of, in North America (Merriam). p. 203 . Humane treatment of, general order to inspectors. . . . . . . . . . . Imported, inspection and quarantine ot. p. 85 . . . . . . . . . . . same, 1. 73

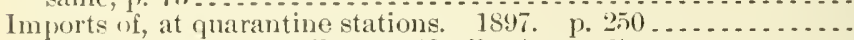

"Loco" plant and its effect on (Stalker). p. $271 \ldots . . . . . . .$.

Lower, pedienli and mallophaga affecting man and (Osborn). 1891.

Hovements of, from districts in which rabies exists, order con('erning. 1899.

Number of, to be used in feeding experiments (Gulley). 1891.

I'hysieal conditions surrounding, in expermental feeding, espeeially as relative to stalls and mangers (Henry). 1891, 1.92.

Quarantine of. See Cattle orders.

slaughtered for food, necessity for inspecting (Salmon). 1889.

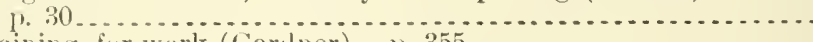

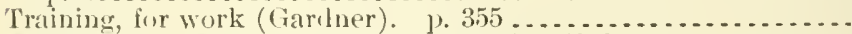

Wheat as a food for growing and fattening (Salmon) . .........

See also Alpaca - Angora goats - Arvicolinie - Bandicoots Baty - Blarina - Brecling - Buffalo - Cashmere goat Cattle - Diseases of eattle - Evotomys - Farm animals (rophers - Grasshopper mouse - Ground squirrels - Gininea pigs - IIsperomys - Jack rabbits - Jumping mice - Kangaroo rats - Lemmings - Mammals - Merino ram - Musk ox - Pika - Pocket gophers - Pocket mice - Prairie dogs Rabhits-liats - Rocky Momtain goat-Shrews-SkunksSpluirrels - Voles - Weasels - Zebroids - Zoology - and hearlings betginning witl Animal.

Animals, domestic:

Age of, determination by teetb. 18:8. p. 667

Feeding standards for (Külnn). 1893. p. 6...............

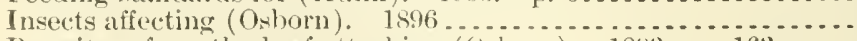
Parasites of, methods of attacking (Oslom). 1893. p. 163..... Temperature, pulse, and respiration of, 1900. 1). 740 ......... Upper air passages of, pathogenic and toxicogenic bacteria in (Moore). 1893. p. 38.

See also Cattle - Dogs - Farm animals - Goats - Hogs Horses - Lambs - Mules - Pigs - Sheep - Swine.

11. $4: 4$

A $4.1: 899$

A4.1:901

118.2: 16

A $10.6: 7$

A 1.1:88.7

A $4.1: 889-90$

A $4.2: 339$

A 1.9:7:202

A 10.6 :

A $10.3: 2: 2$

A1.9:73

A1.10:894

A 1.10:895

A 1.10:896

A 1.1:865

A $27.9: 11$

A 27.9:6

A $1.10: 894$

A 1. $2: \ln 7^{-2}$

A 1.1:590

A4. $1: 889-90$

At. 1:597

At. I:886

A9.3:7

A $4.5: 48$

A 10.3:7

A 10.3:7

A 7.3:25

A 1.1:866

A $4.4: 2$

A1. 10:898

A10.6:4

A9.6:5

A9.7:6

A1.10:900

A4.3:3 
Animals, noxious:

Danger of introducing (Palmer). 1898. 1 $187 . \ldots . . . . . . . . .$.

Externination of, hy bounties (Palmer). 1846. p. 5.5........ Statistics of. 1888. p. 366.

Animals, wilk, which may he imported without permits. 1900 . . . A5.4:30

Animals and animal prodinets:

Exports of (Salnon). 1897 .......................... At.4:17

Great Britain (May). 1898. 1. 440.................... At.1:s98

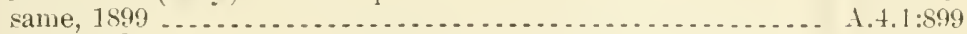

Imports and exports of-

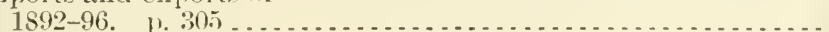

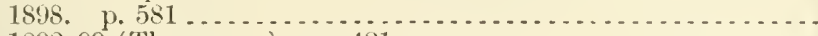

1892-99 (Thompson). p. 421 ...........................

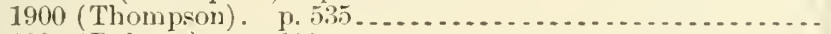

1901 (Roherts). !) $611 \ldots \ldots \ldots$

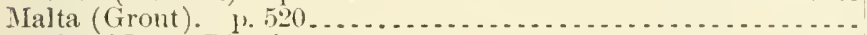

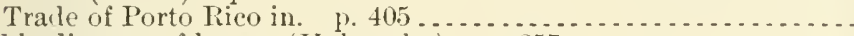

Ankle diseases of horses (Holcombe). p. 357 . . . . . . . . . . . . .

Antarctic, fresh light on (Abbe). 1902. p. $31 \ldots \ldots . . . . . . . .$.

Anthomyia angustifrons, a ligniyorous insect. 1886 . p. $38 . . . . .$.

Anthracite coal, production of, in Pennsylvania. 1820-72. 1.36...

Anthracnose. See Cotton - Grape.

Anthrax or charbon:

California cattle (Bowhill). p. 443.

same, further investigation (Chandler). p. $450 \ldots \ldots . . . . . .$.

Cattle in the Nortliwest (McLean). 1881. 1.311 .............

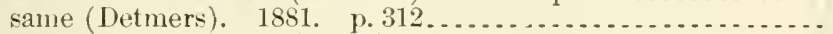

Delaware, combating in (Neale). p. $190 \ldots \ldots . . . . . . . . . .$.

Dreaded diseases, one of the most. p. 23 ..................

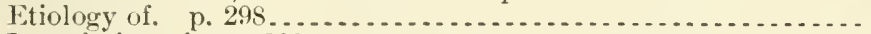

Inoculation of. p. $209 \ldots \ldots \ldots \ldots$

Lonisiana, ontbreak in, 1896 (MeQueen). p. 176 ............

Lower Mississippi Valley, outbreak in. p. 166 ..............

New Jersey cattle (Hunt). p. 359 . . . . . . . . . . . same (Law). 1881. 1. 312 . . . . . . . . . . . . . . . . . . .

New Mexico, outbreak of (McLean), 1881. p. $317 \ldots \ldots . . . . .$.

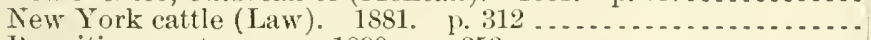

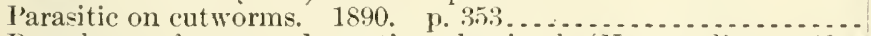

Prevalence of, among domesticated animals (Norgaard). P. $40 .$.

Western Mississippi outbreak. p. 379

Antigua, W. I.:

Climate of, seasonal variations in, 1890-1900 (Kimluall). ․ 168 . Climatolngy of (Alexander). 1901. p. 165 ..................

Thunderstorms at (Alexander). 1900 . p. $380 \ldots \ldots \ldots \ldots . .$.

Antisell, Thomas:

Cinchona, cultivation of, in United States. p. $454 \ldots \ldots . . . . .$.

Sewage deposit, value of, of city of Washington. 1869. p. 228. See also, for reports as Chemist, Chemistry Bureau, Agriculture Department, 1866-1870

Antitoxic serum, treatment of experimental tuberculosis with (I)

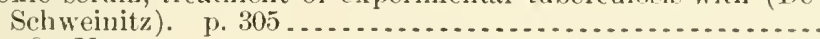

$14.1: 897$

14.1:898

A $4.1: 899$

A $4.1: 900$

A 4.1:901

A 4.1:898

A4.1:899

A4.2:1178

A29.6:30

A9.3:12

127.9:11

A $1.1: 88 \div-8$

A $1.1: 887-8$

A $1.6: 34$

A 1.6:34

A $4.1: 89 \vec{r}$

A1.9:79

A1.6:34

A 1.6:2:2

14.1:897

A $4.1: 897$

11.1:881-2

A $1.6: 3+$

A1.6:34

A $1.6: 34$

A9.7:2

A $4.1: 89:-1$

1 4:1:889-90

A29.6:29

129.6:29

129.6:28

A 1.1:866

A27.9:7

A7.1:

A4.1:598

A6.5:2

A9.7:6

A9.8:1

A9.6:26

Aphididar:

Apetalie of western Texas, deseription of (Conlter). 1894. p. 347.

Aphelenchus olesistus, a nematoid worm, canse of leaf sickness in

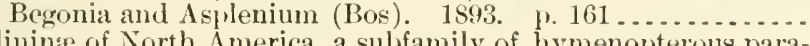

A helinine of North America, a subfamily of hymenopterous para-
sites of family Chalcidide, revision of (Howart). 1895 .

A phelinus fuscipennis, an important parasite upon San Josíscale in eastern United States (Jolnson1). 1900 . p. $73 \ldots . . . . . .$.

Certain little known, fifth contribution to a knowledge of (Weal).

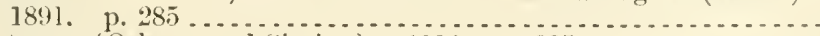

Fotes on (Oshorm and Sirrine). $189 \%$ p. $235 \ldots \ldots \ldots$ Aphis:

Some questions relating to (Smith), 1891, p. $226 \ldots \ldots \ldots \ldots . .49 .7: 3$

Apple, pear, and quince (Sanderson). 1902. p.123.......... A10.3:115 
Aphis-Continued

Corn-root, stmminary history of (Fories). 1891. p. 233 . .......

Now specics of, injurions to phums and peaches in Georgia, pre-

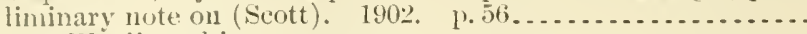

Stee also Woolly aphis.

Aphthe, epizootic, of stock, nature, causes, treatment, etc., of. pilso Foot-and-mouth disease.

See ulso Foot-and-mouth disease.
hithous ferer. See Foot-and-nouth disease of cattle.

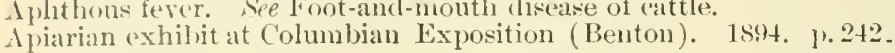
Apiculture:

Experiments in-

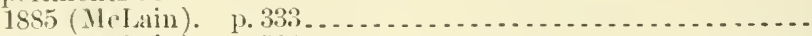

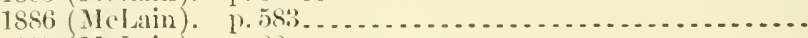

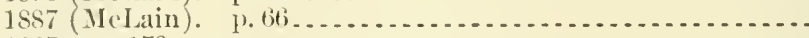

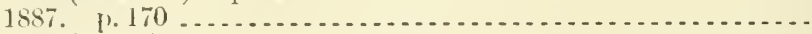

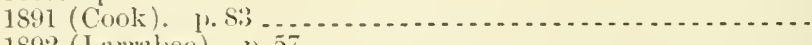

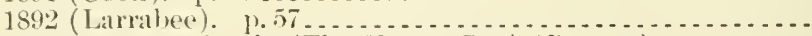

Manual of instruction in (The Iloney Bee) (Benton) ..........

See also Beers.

Apoplectiform septicemia. See Chickens.

Appalachian forests, southern, by river basins, leseription of (Ayres

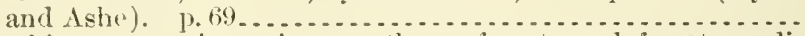

Appalachian momtain region, southern, forests and forest condi-

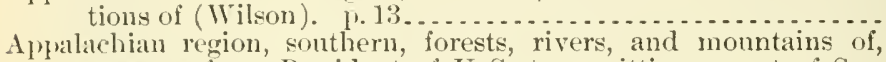
message from President of U.S., transmitting report of See-

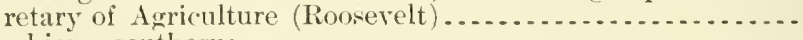

Appalachians, southern:

Area of heavy rainfall in (Hawkins). 1897. p. $442 \ldots . . . . . .$.

Climate of (Henry). p. 143 ..................................

Forest reserve in, proposed, present status of movement ior, memorials, reports, and extracts from press. p. $155 \ldots \ldots . .$.

Forests and forest conditions in (Ayres and Ashe). p. 45.......

Hydrography of (Pressey and II yers). p. 123 .................

Lumbering in, now and inder Govermment ownership and super-

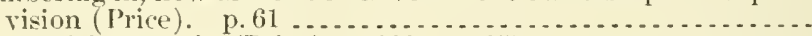

Practieal forestry in (Price). 1900. p. 357 .................

Topography and geology of (Keith). P. 111 ....................

Trees of (Ashe and Ayres). 1.93 . . . . . . . . . .

$\Lambda$ pparatus for sale by Agrienlture Department. Jan. $24,1896$.

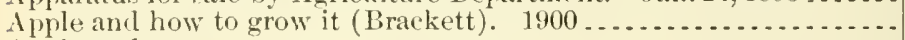

Apple scab:

Remedirs for, experiments with (Taft). p. $30 \ldots \ldots \ldots \ldots \ldots . . . . . . .$.

Treatment of, experiments-

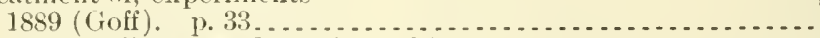

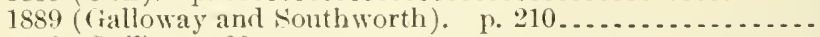

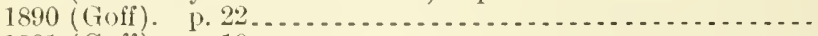

1891 (Goff). p. $19 \ldots \ldots \ldots \ldots$

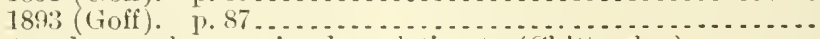

Apple-tree borers, larger, circular relating to (Chittenden) ...........

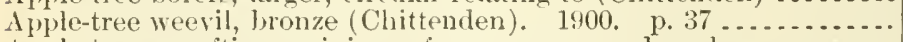

$\Lambda$ pple trees, grafting, opinions of nurserymen and apple growers re-

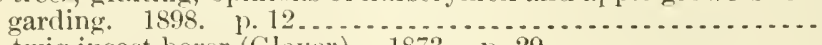

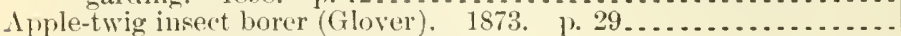
Apples:

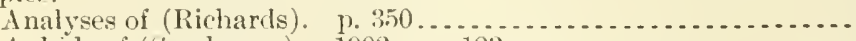

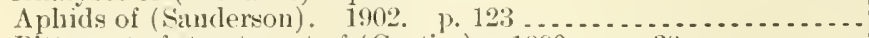

Bitter rot of, treatment of (Curtiss). 1890 , j. $38 \ldots \ldots \ldots \ldots$.

Commercial orchlarding (Brackett). 1901. p. 593.............

Description of leading popular varieties. p. 163 .............

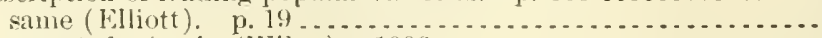

Evaporated, zine in (Wiley). 1896 . . . . .

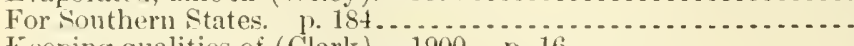

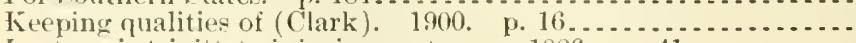

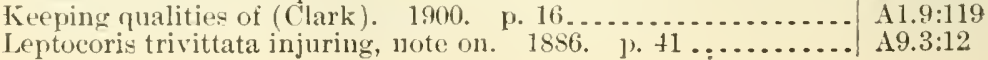

A1.1:885

A1.1:886

A9.3:13

A $1.1: 887$

A $9.3: 26$

A9.3:30

A9.6:1

A1.2: $\mathrm{Ap}^{2}{ }^{2}$

11.2:Ap4

A1.2:Apt ${ }^{2}$

A29.6:25

A $1.2: \mathrm{Apt}^{2}$

A1.2: $\mathrm{Apt}^{2}$

A $1.2: \mathrm{Apt}^{2}$

$\mathrm{A} 1.2: \mathrm{AP}_{\mathrm{P}} 4^{2}$

A1.2:Apt²

A $1.10: 900$

A $1.2: \mathrm{Apt}^{2}$

A1.2: Apt $^{2}$

A1.2: $\mathrm{Apt}^{1}$

A 1.9:113

A6.3:11

A 28.5:5

A28.5:5

A6.3:11

A 28.5:6

A 10.3:16

A 9.5:32

19.6:22

A1.9:79

A27.9:11

A1.1:886

A $10.3: 115$

A6.3:11

A1.10:901

A1.1:862

A 1.1:863

A7.3:48

A 1.1:869 
Apples-Continued

Low-urade, use of, by evaporation and manufacture of cirler.

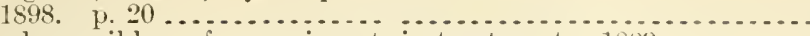

Powdery millew of, experiments in treatment. $1889 \ldots \ldots . . .$.

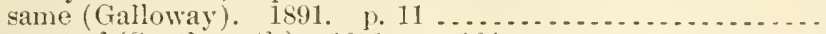

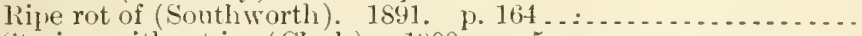

Storing, without ice (Clark). 1900 . p. 5 ...................

Ten varieties of, suitable for export trade (Taylor). 18:s. p. 3.00.

see also Dritor apples- 1 oolly aphis.

Appleyard, T.J. Iddress of, before National Roarl Conference, July",

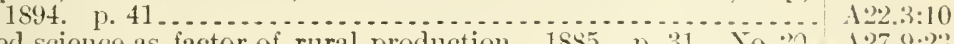

Applied science as factor of rural production. 1855. p. 31. No.20. 127.9:2:"

Appointment clerk, Agriculture Department:

Report of-

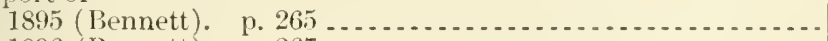

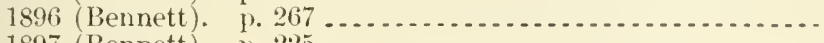

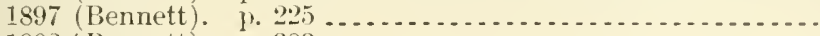

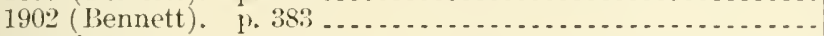

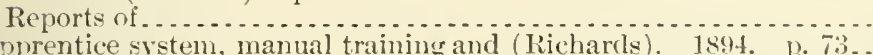
Apprentice system, manual training and (Richards). 1894. 1). 73. .
Appropriations, annual, use of, decision of Comptroller of Treasury, A pr. 18, 1900

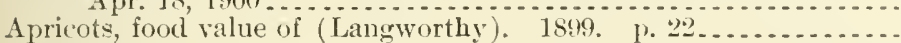
April:

No ehanges in climate of (Ablue). 1899. 1. $158 \ldots . . . . . . . .$.

Weather condition for, statement of average (Garriott). P. 162..

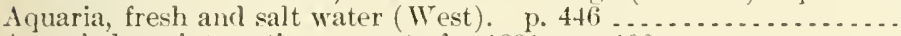

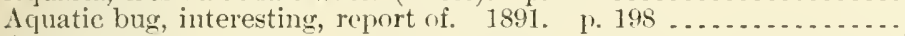

Aqueous vapor:

Relative qualities of, in atmosphere, determination of, by means of absorption lines of the spectrum. 1896 ..............

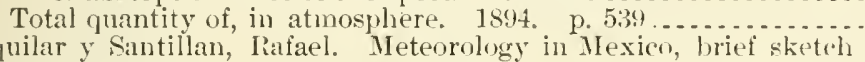

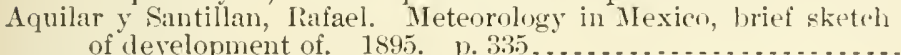

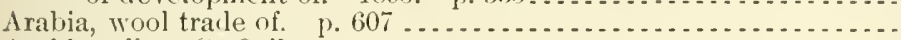
Arable soils. See Soils.

Arbor day:

History and olservance (Egleston). 1896.

Observance of, by schools (Northrop).

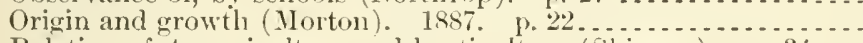

Relation of, to agriculture and lorticulture (shinner). p. $34 \ldots$

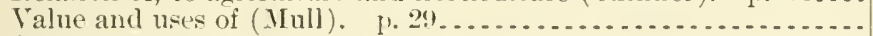

See also Forestry.

Arbor day for the commonwealth (Higbee). 1, 28 _........... Arbor day planting in Gastern States . . . . . . . . . . . . . . . . . . Arborescent flora of $[T$. S., nomenclature of (Sudworth). 1897 ... Archibald, E. Donglas:

Droughts, famines, and forecasts in India. 1900, p. 246.......

Report of, on kites, note on (Abbe). 1897. 1. $164 . . . . . .$.

Arctic and antaretic meteorolugical observers, notes on ( $\mathrm{A}$ bie).

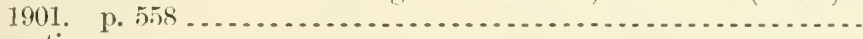
Argentina:

As a market for pure-lored cattle from L. S. (Salmon), $\quad 1902 \ldots$

Cattle and cattle products of, some statistics of, 1899 , 1. $515 \ldots$

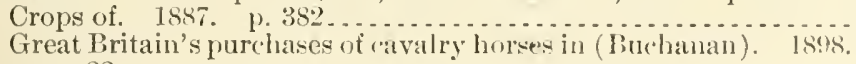

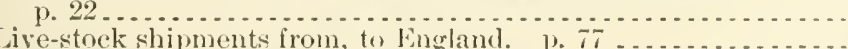

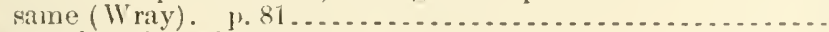

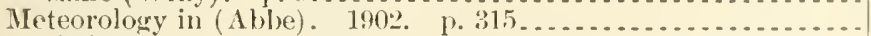

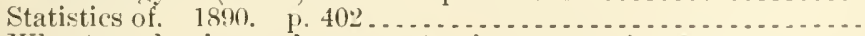

Wheat production and exportation in, (ourse of, $1880-1896 \ldots$

See also Buenos Ayres-Corlora.

Argyresthia, notes on, with descriptions of new species (Walsing-

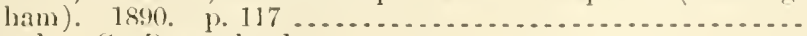

A1. 1: 895

A 1.1:896

A 1. 1:897

1 1.1:902

A 1.2: A p 61

A $10.3: 20$

12. $2: \mathrm{Ap}^{6}$

A $1.9: 105$

129.6:27

A29.6:29

A 1.1:86+

A9.7:4

A29.3:16

A29.6:22

$129.3: 11^{2}$

A. 1:901

A $1.8: 56$

A $1.8: 56$

A $1.8: 56$

A 1.8:56

1 1.8:56

A 1.8:56

A $13.4: 5$

A 13.3:14

1 $29.6: 28$

1:29.6:25

129). $6: 28$

14.4:37

A $4.1: 899$

$127.9: 25$

1 1.2:1178

A $4.1: 895-13$

14. $1: 895-6$

129.6:30

$127.9: 28$

$112.1: 10$

A $1.7: 3$ 
Aril regrions:

Colorato-

grassey of, investigation of (Vasey). 1886.

possibilities of reclamation of, ly ntilizing underlying waters

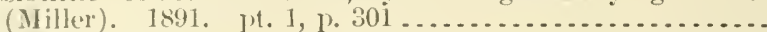

Kansas-

grasses of, investigation of (Vasey). $1886 \ldots \ldots . . . . . . . . .$. possibilities of reclamation of, by utilizing underlying waters

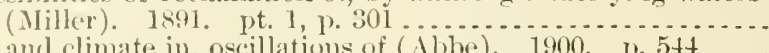

Lakes and climate in, oscillations of (Abbe). 1900. P. $54+\ldots .$.
Pacife slopre, climatic and agricultural features of, ete. (Hilgard

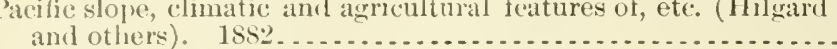

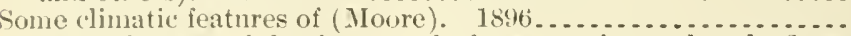

Waterworks east of, having supply from artesian and underflow

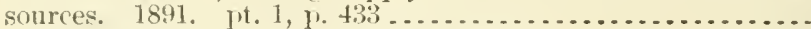
See also Destitute regions - Semiarid regions.

Aristila purpurea nutt., and its allies (Merrill). 1901 ............ Arizona:

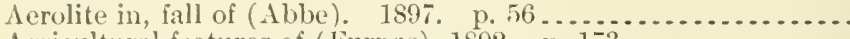

Agricultural features of (Furnas), 1892. p. $173 \ldots \ldots \ldots \ldots \ldots . .$.

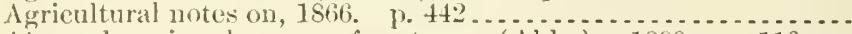

Atinosphere in, elearness of, notes on (Abbe). 1899 . p. 110...

Birls observed in parts of, by Death Valley Expedition of 1891,

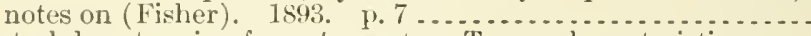

Central desert region from, to westem Texas, characteristic vege-

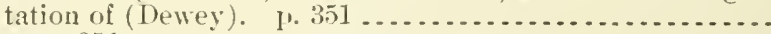

same, p. 351 . . .

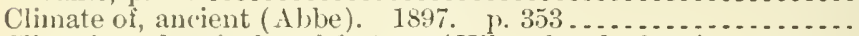

Climatic and anrienltural features (Hilgard and others). 1882....

Fintomological notes from (Cockerell), 1902, p. 107.........

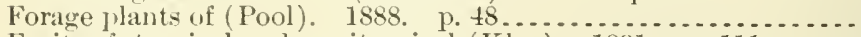

Fruits of, tropical and semitropical (Klee). 1891. p. 111_.....

Grasses of (Merrill), 1901 ................................

(irasses of arid districts of, investigation of (Tracy). 18ss. p. 5. .

(irasses of desert region of, plates and descriptions of (Vasey).

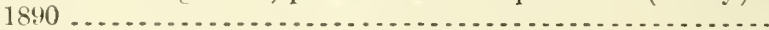

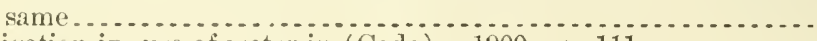

Irrigation in, use of water in (Code). 1900 . p. $111 \ldots . . .6 . .$. See also Arizona Experiment Station farm.

Locnsts, injurious and other (Townsend). 1893. p. 28.......

Northwestern-

cactuses, yuccas, and agave in deserts and desert ranges of, geograplic and vertical distribution (Merriam). $1893 . \quad \mathrm{p}$.

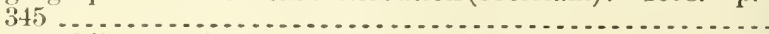
spermophile, new, from, description of (Merriam). 1893. p. 17. trees and shrubs in dleserts and desert ranges of, distribution

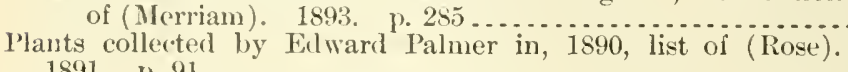

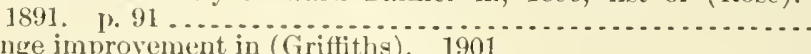

Range improvement in (Griffiths). 1901 . . . . . . . . . . . . . . .

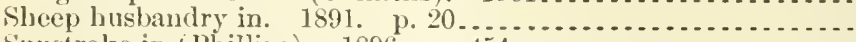

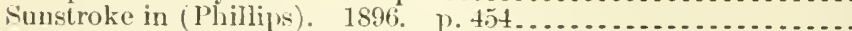

See also Flagstaff - Little Colorado River, Desert of - Lower Colorado River-Phoenix - San Francisco Mountain region Salt River Valley.

Arizona and Japan, winds of (Abbe). 1895. p. $255 \ldots \ldots \ldots \ldots . . . .$. Arizona Experiment Station farm, irrigation at, 1901 (IIcClatehie).

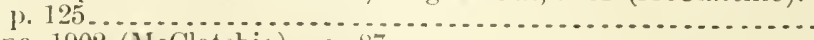
same, 1902 (McClatchie). p. 87 ...............................

Arkalon, Kansas, sorghum sugar experiments at, 1889 (Wiley) ..... Arkansas:

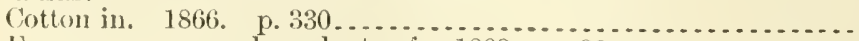

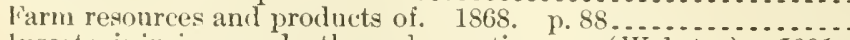

lnsects, injurious and other, qbervations on (Webster). Is91.

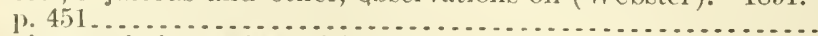

Moving cattle into Missour from two northern tiers of counties in, Mar. 8, 1899

A6.3:1

A15.2:Ir $7^{2}$

A6.3:1

A $15.2: \operatorname{lr} 7^{2}$

A29.6:28

A $1.8: 20$

A29.2:Art

A $15.2: \operatorname{Ir}^{-2}$

A3.4:34

A29.6:25

A ].8:20

A 27.9:4

A $29.6: 27$

A5.5:7

A 1. 1:891

A6.1:891

A $29.6: 25$

A 1.8:20

19.6:37

A6.3:6

A 20.3:1

A $3.4: 32$

A6.3:6

A6.2: $\mathrm{N}^{2} 2^{1}$

A6.3:12

A 10.3:86

A9.7:6

A5.5:7

A5.5:2

A5.5:7

A6.5:1

A 19.3:4

A27.9:29

A29.6:24

A29.6:23

A10.3:10t

A 10.3:119

A 7.3:26

A27.9:4

A27.9:6

A9.7:3

A4.5:32 
Endex

Arkansas-Continued

Roarl-making materials in (Branner). 1894.................

Southwestem, climate of, $1840-67$. 1. 4:9.

Tornadoes in (Emery). 1900. p. 499

see calso Fort Smith - Pine Bluff.

Arkansas Experiment Station, Fayetterille, laboratory notes from. 1890. p. 134

Arkansas Valley, Colorado, irrigation in (Stover). 1902. 1. 2sĭ...

Arkansas Valley, mpper, description of. 1870. p. $150 \ldots . . . . . .$. Armour, Philip Danforth. Ttilization of packing-house offal. 1900 . p. 514 .

Armsby, Henry Prentiss:

Address as president of Association of American Agricultural Colleges and Experiment Stations, at 13th annual (onvention. 1900. p. 21

Agricultural experiment stations, collective exhilit at Paris Fxjosition, report of committee on-

1899, ? .30

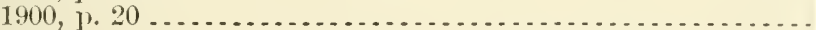

1901, P. 23

$12: 2.3: 4$

A.27.9:8

129.6:28

A7.3:24

A 10.3:119

$127.9: 8$

$14.1: 900$

A $10 . \therefore: 76$

A10.3:65

A $10.3: 76$

1 10.3:99

Agricultural experiment stations, cooperative exhilit at Worli's Columbian Exposition, 1893, report of committee on-

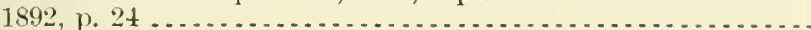

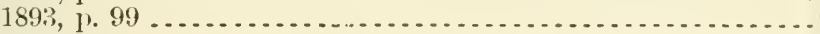

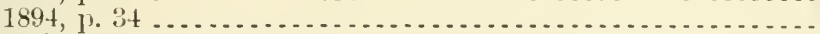

Digestion experiment-

is a digestion experiment fallacions? 1891. 1.89..........

recent work abroad. 1891, p. $132 \ldots . . \ldots \ldots . . . . . . . . . . .$.

See also, as joint author, Wheeler Honer Jay.

Army horses, German, requirements for (Kuhn). 1895. p. 31 ....

Amy Medical Department, connection of, with development of meteorology in U. S. (Smart). 1895. p. $207 \ldots . . . . . .$. A rmir worm:

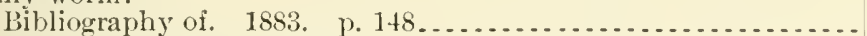

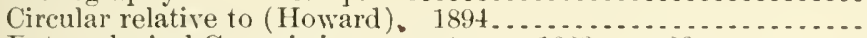

Entomological Commission, report on. 1883. p. $89 \ldots \ldots \ldots \ldots$.

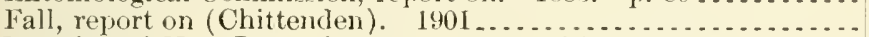

Invasion of New Jersey in 1880, account of (Lockwooll). I. 101.

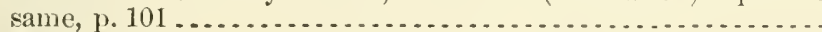
same, p. 139

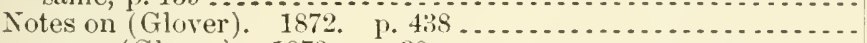
same (Glover). 1873. p. $30 \ldots \ldots \ldots \ldots \ldots \ldots$

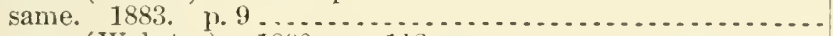

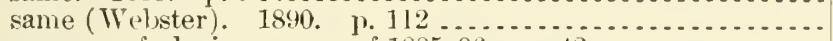

Occurrence of, during season of $1885-86$. p. $42 \ldots . . . . . . . . .$.

Outbreak of, and some other insects affeeting grain in Maryland (Ashmead). 1890. p. 53.

Almheim, Netherlands, exhibition of agricultural implements at.

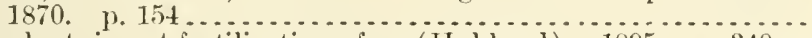
A roid plant, insect fertilization of an (Hubbard). 1895. p. $340 \ldots$ Aroostook County, Maine, farming in. 1869. p. $149 \ldots \ldots . . . .$. Arrhenius, J. See, as translator, Alsike clover.

Arsenate of lead:

Improvenent in mamnfacture of (Kirkland). 1899. ए. 102.... Preparation and use of (Kirkland) 1897. p. $46 \ldots . . . . . . .$. Arsenic, soluble, in arsenical insecticides (Haywood). 1902. ए. 51. Arsenical insecticides:

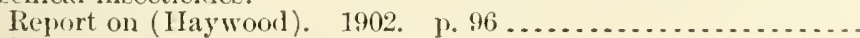

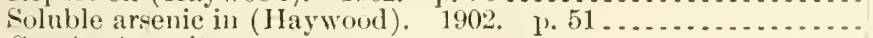

See also Arsenites.

1 $10.3: 20$

A10.5::

1 $10.5: 3$

A 1.2:H78

A29.3:11

AS.1:3

A. $9.5: 4$

A $8.1: 3$

A $9.6: 29$

1 1.1:881, 882

A9.1:85:

A $5.1: 3$

A27.9:10

A27.9:11

A9.3:3

A9.7:3

A9.3:12

19.7:3

A $27.9: \mathrm{S}$

A9.7:7

A $27.9: 5$

19.6:20

A9.6:4

19.6:3:

17.3:65

19.6:37

$19.7: 2$

Arsenical spraving of fruit trees while in blossom (lintuer). Is:?:?. 1). 181

19. $7: 6$

A rsenicals, new and old, comparative tests with, on foliage and with

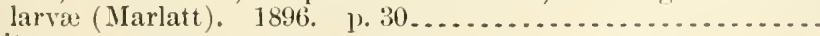
A rwenites:

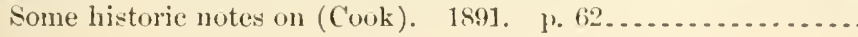

19.1i:0

A.1.7:t 
Arsenites-C'ontinued

Ppraying with, rs. hees (Welster). 1892. p. 121

A9.7:5

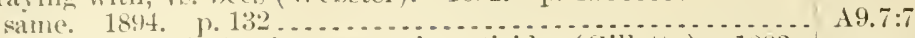

Arsenitus and arsenical mixtures as insecticides (cillette). 1s.93. Ash:

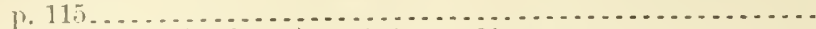

Art, seieme versis (Roberts). 189s. p. 69. . . . . . . . . . . . . . .

Artace punctistriga, some observations mpon (Morgan). 1901. p. 1 s.2. . . . . . . . . . . . . . . . . . .

Artesian and nuderflow investigation: Between nimety-seventh degree of west longitude and foothils

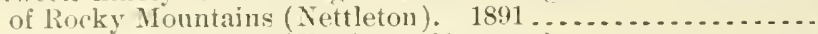
Final geological reports (Ilay). 1893. pt. 3 ............... Final repurt of ehief engineer (Nettleton). 1893. pt.2....... Progress report (Hay). 1891, p. 137 ..................... Progress report on central division of (ireat Plains (iregory).

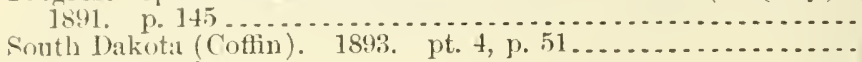
Sie also Irrigation.

Artesian and mulerflow investigations and irrigation inquiry, reports of special agent in charge. . . . . . . . . . . . . . . . . . . . . .

Artesian and mulerground waters in Texas, eastern New Nexico, and Inclian Territory, west of ninety-seventh meridian (IIIl). 1893. yt. 3, p. 41 ... . . . . . . . . . . . . . . . . . .

Artesian basins in eastern Colorado and New Mexico, geological

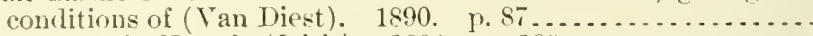

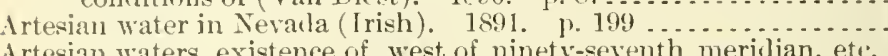

Artesian waters, existence of, west of ninet $y$-seventh merilian, ete. (Dumble). $1890 . \quad$ p. 99.

Artesian well investigations:

Colorato field work (Carpenter). 1890. p. 173............. Field agents' report for middle division (Gregory). 1890. p. 145.

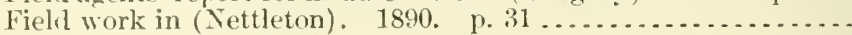

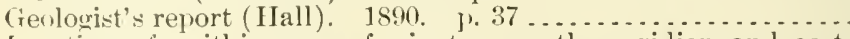
location of, within area of ninety-seventh merilian and east of foothills of Rocky Mountains, to determine (Hinton and

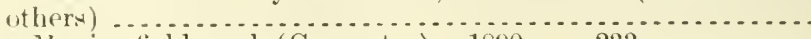

New Mexico field work (Carpenter). 1890. 1) 233............ Sorth and South Dakota field work (Culver). 1890. p. 55 ..... North Dakota field work (Inderhill). 1890. p. 105. . . . . . . South Dakota field work (Coffin). 1890. p. 125 ............

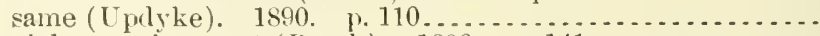
Special expert's report (Beach). 1890 . p. $141 \ldots . . . . . . . . .$. Texas field work (Roesler). 1890, p. 243 .................. Artesian well near Fort Lyon, Colo. (White and Aughey). 1?. 26... Artesian wells:

Irrigation by, in Algiers. 1891. pt. 1, p. 369

$\mathrm{U}_{\mathrm{P}}$ n $\mathrm{nreat}$ plains; report of Cieological Commision (White and Anghey). 1882

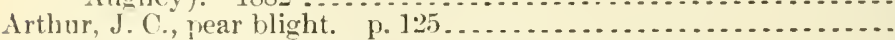

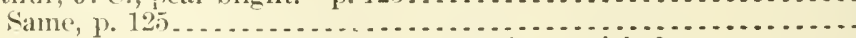

Artichokes. See bur artichokes - Jerusalem artichokes.

Arts. See Industries and arts.

Arvicolinie, description of new genus (Plienacomys) and four new

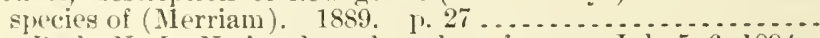

Asbury Park, N. J., National good roal conference, July 5, 6, 1894. .

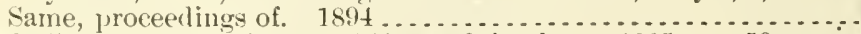

Aschaffenburg, Bavaria, Royal Forest School at 1885 , p. 50 .....

Asli, committee on, report of, at Association of Official Agrienltural

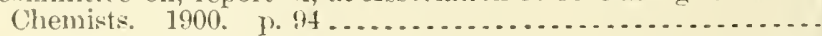

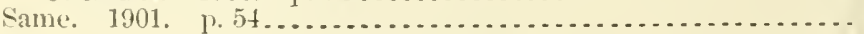

19.7:6

$+10.3: 49$

$\$ 10.3: 99$

A 15.2:P94 ${ }^{2}$

A15.2:1r"

A15.2: $\operatorname{lr} 7$

A 15.2:P94

A15. 2:P94 ${ }^{\mathrm{I}}$

A15.2: Ir $^{-2}$

A 15. 1:

A 15.2:Ir ${ }^{-2}$

A 15.2:Ar A 15.2:P(4)

A15.2:Ar

A15.2:Ar 7

A15.2: Ar 7

A15.2:Ar 7

A15.2:Ar7

A15.2:Ar 7

A 15.2:Ar 7

A 15.2:Ar7

A $15.2: \mathrm{Ar} 7$

A 15.2: Ar 7

A 15.2:Ar7

A $15.2:$ Ar 7

A15.2:Ar7

A1.1:881-2

A 15.2: $\operatorname{Ir}^{-2}$

A1.8:19

11.1:886

+28.1:886

A5.5:2

A $22.4: 9$

A $22.3: 10$

A $1.8: 36$

A 7.3:62

A $7.3: 67$

Composition of, of wheat grain and wheat straw grown at Rothamsted in different seasons and by different manures (Lawes and Gilbert). p. 85

Fstimation and importanee to agricultural ehemistry and agri(nlture of ash constitnents of plants (Tollens). 1902. Pp.207, 305
A $7.3: 4$

A $10.6: 1: 3$ 
Ash-Continued

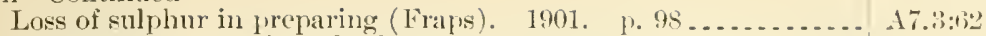

See also Ashes - Soils and ash.

Ashburner, Charles E., jr.:

Highways, their construction and maintenance. 1895. p. \$2 _. . 122.3:11

Macadamized roards, report on. 1895. H. 31 .............. A22.3:17

Ashby, Newton B.:

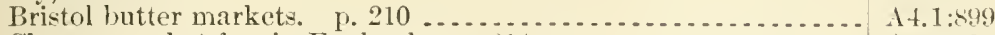

Cheese, market for, in England. p. 214................... A t.1:899

Hamburg butter and cheese markets. 1. 2020 . . . . . . . . . . . . . A4.1:\$99

Hamburg trade in eggs. p. 345.......................... A4.1:899

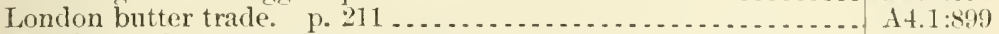

Manchester butter market. p. 201 . ......................... A . . . . (899

Paris butter and cheese markets. p. 220 ..................... At.1:899

Paris market for eggs. p. 336 ........................... A $4.1: 899$

Poultry dressed in foreign citties. p. 330.................... $14.1: 899$

Ponltry markets of Paris. p. 341 .......................... 14.1:\$99

See also, as translator, Scelle, Ch.

Asheraft, Charles E., jr. Lightning from a clondless sky. 1900.

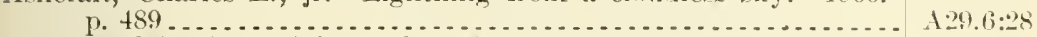

Ashe, W. Wr. See, as joint author, A yres, Horace B.

Ashe, W. Wr., and Ayres, Horace B. Trees of Southern AppaAshes:

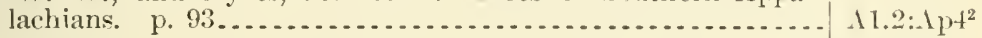

Are they an economical fertilizer at present prices? 1897. p. 24. 11.9:65

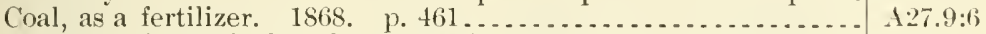

Supply of, for agricultural purposes (Fleirchman). 1884. No.9.

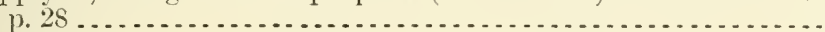
See also Ash.

Asheville, N. C. See Shelton Toharo-Curing Co.

Ashley, Alexander McC.:

Seasonal forecasts, long range, for Pacifie Coast States. 1901. p.

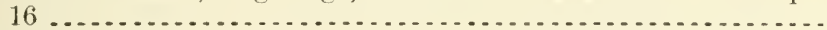

Short bingraphy of (Abbe). 1901. p. 17:3 ...................

Ashmead, Willian Harris:

Army worm and some other insects affecting grain in Maryland,

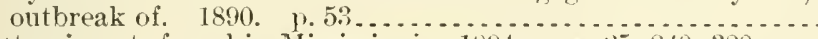
Cotton insects found in Mississippi, 1594 pl. $25,240,320 \ldots$ Encyrtid with six-l,ranched antennæ. 1891. 1. 455.......... Insects injurious to garlen crops in Florida. 1887. p.9...... Spider parasite, new. 1894. p. 259

Ashton, A. J. See, for report as chief of Seeel l)ivision, Aurricultural Asia:

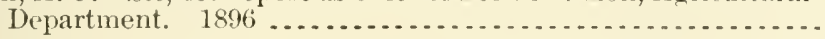

Climatology of southem and westem (Dallas). 1896. H. 672...

Eastern, United states wheat for. $1897 . \ldots$ relationshi betwen

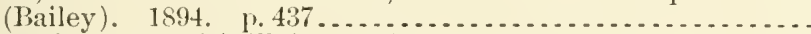

Magnetic survey of (Tillo). 1895. p. 465 ...................

Asia Minor, angora goat industry of (Bailey). 1. 493.............

Asiatic ladybird, importation and present status of, preliminary le-

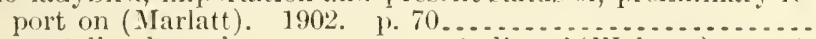

Asopia costalis, clover hay-worm, some studies of (Webster). 1 sil.

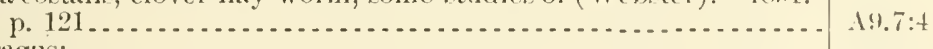

\section{Asparagus:}

Culture of (1Iandy). 1897

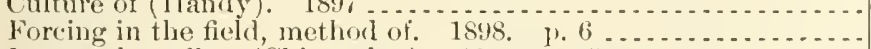

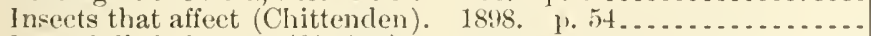

Pest of, little-known (Sirrine). 1901. 1, $177 \ldots \ldots \ldots \ldots \ldots \ldots$.

Power sprayer for (Sirrine). 1901. p. $377 \ldots \ldots \ldots \ldots$

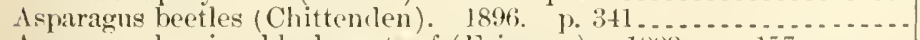

Asparagus berries, black spots of (Faiman). 1889. p. $157 \ldots \ldots$.

Aspicliotus ostrexeformis, account of (Marlatt). 1899. 1.76 ......

Asplenium. See $A$ phelenchus olesistus.

Isplenium, leaf sickness in, aphelenchus olesistus (anse of (Bos).

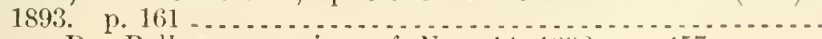


Associations, Tee Tames of associations.

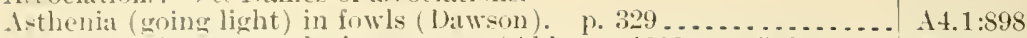

1-tronomy for meteorologist, nute on (Abbe). 1898. p. 562..... A29.6:26

A.tronomi. Sie Anrora-I - Ievelins-Leonids at Havre, Mont.Lunar nainbow - Meterr - Moon - I’arhelion - Stars - Sum.

A.strophysical Observatory of Smithsonian Institution, annals of

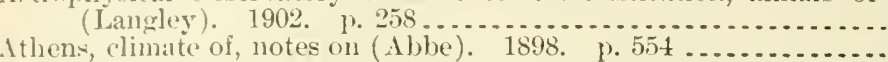
Itherton, Georize Washington:

Adelress of, its president of Association of Ameriean Agrienltural Collegresand Experiment stations at seeond annual conven-

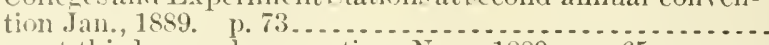
same, at third annual convention, Nov., 1889 . p. $65 \ldots . . . . .$.

I and-grant rolleges, military instruction in, report of committee

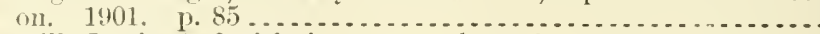

Morrill, Justin S., legislative career of. 1001. p. $60 \ldots \ldots \ldots$ Atkinson, Ellward:

Cooking of food, suggestions regarding. $1894 \ldots \ldots \ldots \ldots \ldots \ldots \ldots . . .6$.

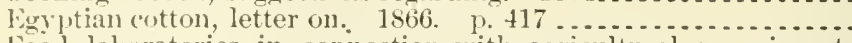

food laboratories in connection with agricultural experiment stations of $\mathrm{U}$. S., suggestions for establishment of. $1893 .$.

Atkinson, George Francis:

Anthracnose of cotton. 1891. p. 173 . . . . . . . . . . . . . . . .

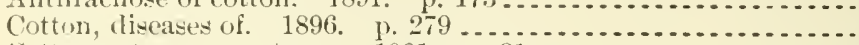

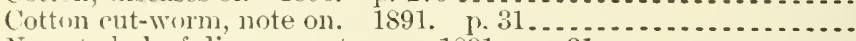

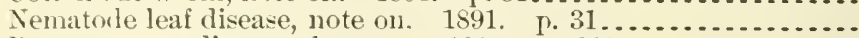

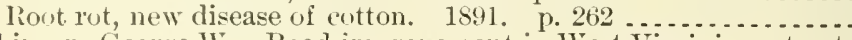

Atkinson, George $\mathbb{W}$. Roal improvement in West Virginia, extraet

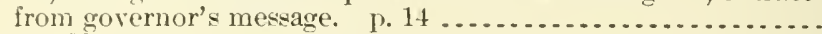

Atkinson, I. T.:

Cattle, bones of, diseases and aceidents to. 1892. p. 281 .......

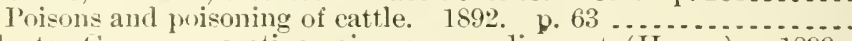

Atlanta, (ia., comparative rain gage readings at (Henry). 1899.

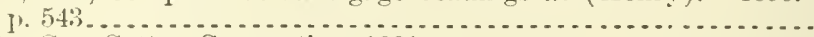

Atlanta, Ga., Cotton Convention, 1881:

Adilress before, relative to eotton worn (Riley). p. 153.

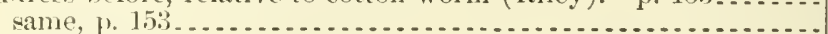

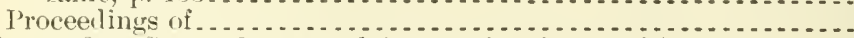

Atlanta, Ga., Cotton States and International Exposition, 1895:

Organization of Dept. and list of jts exhiljits at. $1895 \ldots . . . .$.

Work of Agriculture Dept. illustrated at (Wait). 1895. p. 503 .

Atlanta, Ga., National Road Parliament, Oet. 17-19, 1895, reports by delegates to

Atlanta, Ga., Southern Interstate Fair, cattle exhibited at, order regariing. Anc. 20, 1900

Atlantic, north:

Meteorology, monthly notes on, Jan., 1894-June, 1895.

Storms, monthly notes on, July, 1891-Dee., 1893

Atluntic and ciulf coasts. Are present [storm] warnings and displays by flag and lantern best that can be devised for? (Smith).

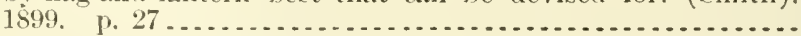

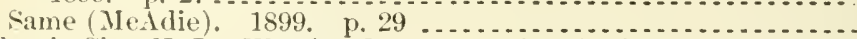

Atlantic: City, N.J. Weather Bureau at, electric signal apparatus at

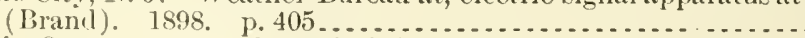

Atlantic Ocean, storms of, tropical, in September, 1895 (Garriott).

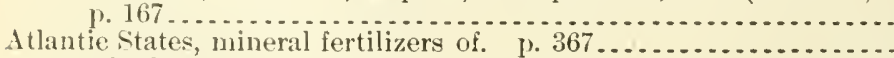

see also States and Territories.

Atlas, elimatological, of Russian Empire (Abbe), 1900, p. 343 ....

Atmidometry, some experiments in (Stevens), 1902, p. 129..... Atmosphere:

Aqueous vapor inrelative quantities of, determination of, by means of absorption lines of spectrum (Jewell). 1896............... . . .

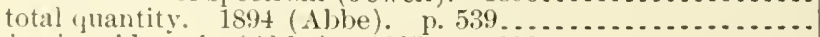

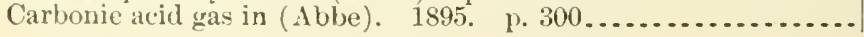


Atmosphere-Continued

Circulation of, in tropical and expatorial regions (Roteh). 1902.

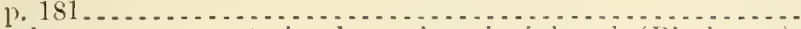

Circulatory movements in, dynamic prineiple of (Bjerkmaes).

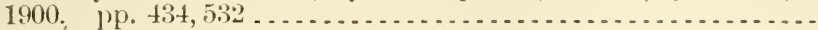

Clearness of, in Arizuna (Abbe). 1899. p. 110 ...........

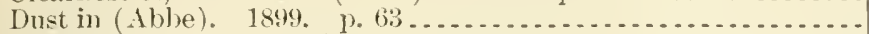

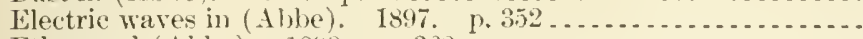

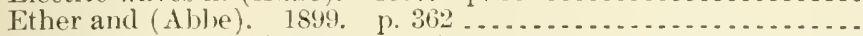

Flux and reflux of (De Lamanon). 1898. [. 463............

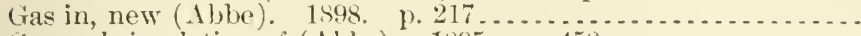

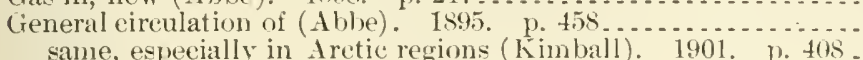
same, espeeially in Aretic regions ( $\mathrm{K}$ imball). 1901. P. $40 \mathrm{~s}$.
same, original memoirs on (Brillouin). 1902. p. 300 ......

Humidity in-

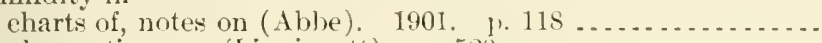

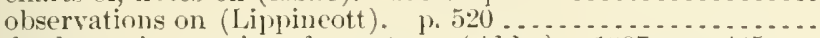

Hydrodynamic equations for, note on (Able). 1897, p. $445 .$.

Line integrals in (Bigelow). 1900. p. $535 \ldots . . . . . . . . . . . . .$.

IIovement of, new methor of observing direction of (Clough).

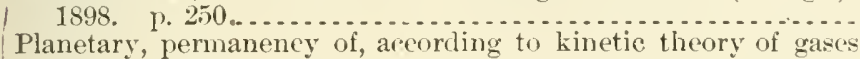

Planetary, permaneney of, aceording to kinetic theory of gases

Statics and kinematies of, studies on, in U. S. (Bigelow). 190:2.

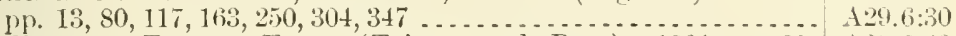

Studies on, at Trappes, France (Teisserenc de Bort). 1901. p. 20. A $29.6: 29$

Systematic exploration of, by means of kites, methoul for (Rotch). $190^{\circ}$. P. $66^{\circ}$

Temperature of, average (Abbe). 1898. p. $415 \ldots \ldots \ldots \ldots \ldots$

Tides in, notes on (Abbe). 1900. 1. 109..................

Upper, study of -

by means of balloons (Kremser). 1896. p. 725.

l,y means of cloud observations (Vettin). $1896 . \quad$ p. $758 \ldots . .$. fron observations on mountain stations (Hann). 1896. 1).75t.

Weight or mass of, notes on (Abbe). I899. 1.58 ........... See also Air - Aqueous vapor - Autumn haze - Parogram - Bar-
ograph - Meteorology - and headings beginning Atmospheric.

Atmospheric absorption. See Angstrom, Knut.

Atmospheric air, ionisation of, report on (Wilson). 1901. 1. 159..

Atmospherie changes, relation of, to changes of water level in st.

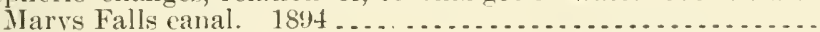

Atmospherie circulation:

In tropical cyclones, as shown by movements of clouds (Bnyer).

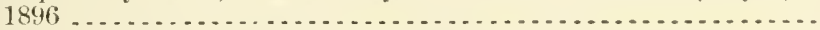

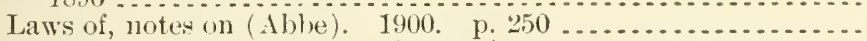
Atmospheric disturhances, local (Ilenry). 1898. p. $539 \ldots \ldots \ldots$. Atmospherie dust. S'ee Dust.

Atmospheric electricity:

Brillowin's theory (Abe). 1897. P. $446 \ldots \ldots \ldots \ldots \ldots \ldots \ldots$

Early experiments in (West). 1896. p. $333 \ldots \ldots \ldots \ldots \ldots \ldots$.

Methods and instruments of precision for study of (Chamvean).

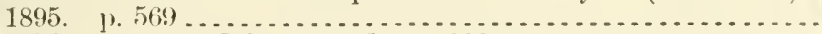

Monthly notes on, July, 1891-Ort., 1902 .................

Origin, variations, and perturbations (Brillouin) 1897. p. $440 \ldots$

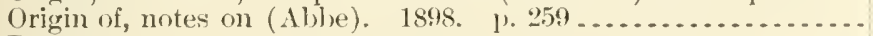

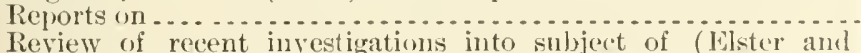

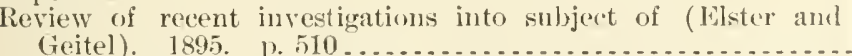

Some experimentsin (Mc Aclie). 1891. p. $171 \ldots \ldots \ldots \ldots \ldots$

Atmospheric moisture, eondensation of (Barus). p. 526 ........

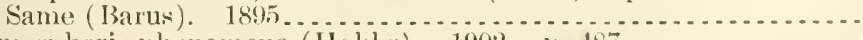

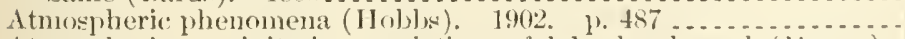

Atmospheric precipitation, variations of lake levels and (Ilenry). 1899

See rlso Precipitation.

Atmospherie pressine:

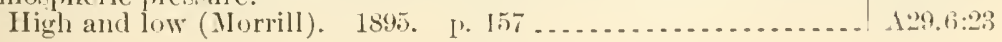

129.2: $216^{1}$

129.6:2:8

$1: 9.6: 26$

A $29.6: 25$

129.6:24

129.3:112

112.6:

129.6:25

129.6:26

1.9.6:

$129.3: 11^{2}$

A:9.6:19

1:9.1:851 3

$129.3: 12$

$1: 9.6: 30$

129.2:1.15 
Atmospheric pressure-Contimned

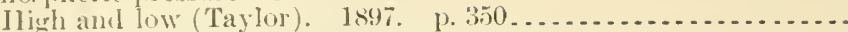

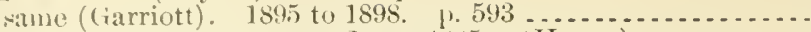
silne, monthly report on, Jume, 1895. (Hazen) ........... same (Bigelow). July-Oct., 1895..................... same (Hazen). Nov, 1895-Nov., 1899...................... stme (Frankenfield). Dec. $1899-\Lambda$ pr., 1900.

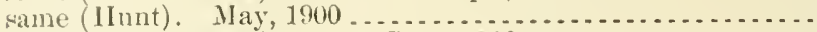

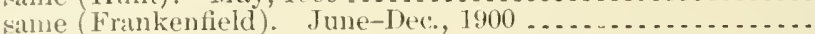
sane Jan.-May, 1901 . . . . . . . . . . . . . . . . . . . . . . . . silue (IIunt). June-1ug., 1901 .....................

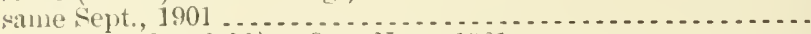

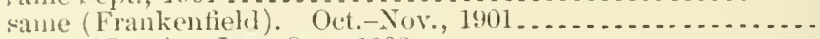

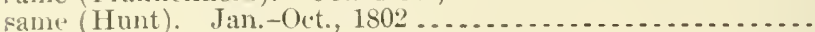

Low-

effect of, in determining weather conditions in upper Missis-

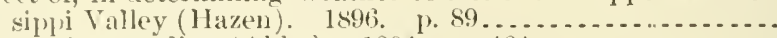

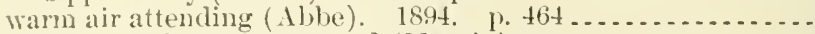
Ieasurement of barometers and (Marvin) ................

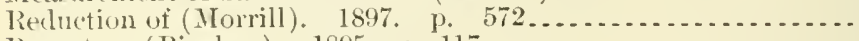

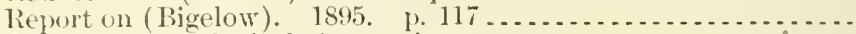
see also Mteteorological observations.

Atmosplueric ratiation:

Research conclucted, at Allegheny observatory and at Providence, R. I. (Very). 1900.

Very's memoir on, review of (Dorsey). 1900. p. $394 \ldots . . . .$. se also Electrodynamic radiation.

Atmospheric refractions at surface of water (Abbe). 1896 . p.371_.. Atmospheric rolls, horizontal, report on (Proctor). 1896. p.367... Atmospheric survey, United States daily (Moore). 1897 ......... Atmospherictemperatures during July (Phillips). 1895. p. 253.... Atmosplieric vapor, note on (Abbe). 1897. p. 208............

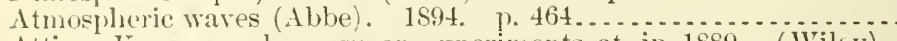
Attica, Kans., sorghum sugar experiments at, in 1889. (Wilty).

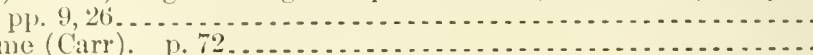
sime (Carr). p. Helen Woodari. Bread and principles of brad making. 1900

Atwater, Wilbur Olin:

Agricultural experiment stations in Furope. p. 517

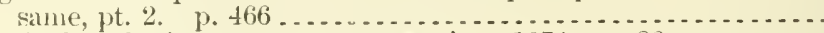
Agricultural seience, recent progress in. is 7 t. p. $26 \ldots . . . . . .$.

Connecticut Experiment Station, arkluess on. 1901. 1.51....

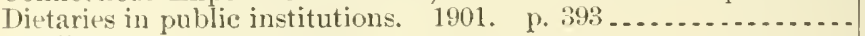

Fertilizers-

cooperative experimenting as a means of studying effects of fertilizers and feeding capacities of plants. 1882 ........ effects of, and feeding capacities of plants, cooperative experim(enting as a means of studying. 1882. p. 27 various, results of field experiments with. $1883 \ldots . . . . . . .$.

Food, chemistry and economy of, methods and results of inves-

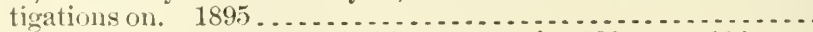
Foorl and body material, available energy of. 1901. p. 112 ....

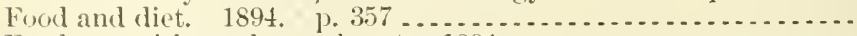

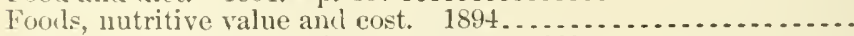
Holland experiment stations. 1895. p. 669.................

Nitrogenous compounds of animal and vegetable substances, suggestions regarding nomenclature of. 1899. p. $118 \ldots \ldots . . .$.

Tutrition, frinciples of, and nutritive value of food. $1901 \ldots . .$.

Sie also, for reports as chief of Experiment Stations Office, 18851890

Atwater, Wibur Olin, and Benedict, Francis $G$. Jetabolism of matter and energy in human body, experiments on; with cooperation of 1 . W. Simith and Arthur Peyton Bryant. 1899.

129.6:25

A 29.6:26

A $29.6: 23$

A29.6:23

A29.6:

A29.6:

A29.6:28

A29.6:28

A29.6:29

A29.6:29

A29.6:29

А $29.6: 29$

A29.6:30

A29.6:23

A 29.6:22

A $29.11: \mathrm{F}$

A29.6:25

A 29.623

A 29.5:G

A $29.6: 28$

A 29.6:24

A29.6:2t

129.2: t $6^{2}$

A 29.6:23

A29.6:25

A $29.6: 2: 2$

A $7.3: 26$

1 7.3:26

A $1.9: 112$

A1.1:875

A 27.9:14

A 27.9:12

A 10.3:99

A1.10:901

11.8:15

11.8:22

11.8:31

A 10.3:21

\10.3:99

11.10:594

A 1.9:2:

A $10.6: 5$

A 10.3:65

A $1.9: 1+2$

A10.1:

1 10.3:69

Atwater, Wilhur Olin, Benerlict, Francis G., Bryant, Arthur Peyton, sinith, A. W., and Snell, J. F. Metabolism of matter and (encrgy in luman body, experiments on, 1898-1900. $1902 \ldots$ 
Atwater, Wilbur Olin, and Bryant, Arthur Peyton:

Chemical composition of American food materials. 1899 . . . . . .

Dietary studies in Chicago, Ill., in 1895 and 1896 , conducted with cooperation of Jane Addams and Caroline L. Ifunt, of Hull

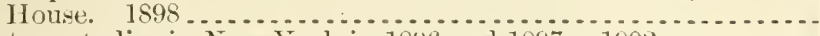

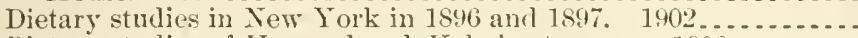

Dietary studies of Harrard and Yale hoat (rews. $1900 . . . . . .$.

Atwater, IVilbur Olin, Johnson, S. W., and Cook, Geo. H. Agricultural experiment station work, report of committee on, to convention of Association of American Agricultural Colleges and Experiment Stations, Washington, D. C., Oct., 18s7 ....

Atwater, Wilbur (Olin, and Langworthy, Charles Ford. Metabolism experiments in which the balance of income and outgo was determined, digest of

Atwater, Willum Olin, and Rosa, Edward Bennett. Respiration calorimeter, new, description of, and experiments on conservation of energy in human body. 1899.

Atwater, Wilhur Olin, and Sherman, H. C. Muscular work, severe and prolonged, effect of, on food consmmption, digestion, and

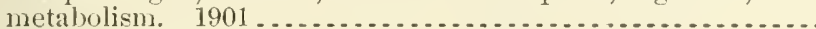

Atwater, Wilbur Olin, and Woods, Charles Dayton:

Chemical composition of American food materials. 1896

Dietary studies-

New York City in 1895 and 1896

Purlue University, Lafayette, Ind University of Missouri, comments on. 1896. 1. $21 \ldots . . . .$. University of Tennessee, comments on. p. 33 .................. with reference to food of negro in Alabama in 1895 and 1896 , conducted with cooperation of Tuskegee Normal and Industrial Institute and the Agricultural and Mechanical College

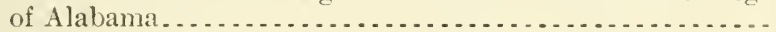

Atwater, Wilbur Olin, Woods, Cluales Dayton, and Benedict, Francis G. Metabolism of nitrogen and carbon in human organism, with respiration calorimeter of special construction, report of

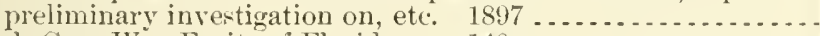

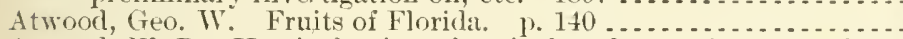
Atrood, W. B. Horticulturists of agricultural experiment stations in $\mathrm{L}$. S., list of, with outlines of work in horticulture at the

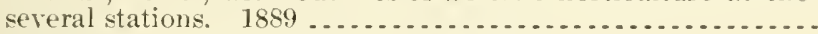

Aughey, Samuel. Nee, as joint author, White, C. $\mathrm{A}$.

August weather (Moore). $1900 . \quad$ p. 343

Augusta, Ga., Congress of Cotton States, Oct., 1870, address before (Capron). 1. 473

A ugusta, Ga., tornado at, Jar. 20,1895 (Fisher) inrora:

Altitucle of (Abbe). 1902. p. 314.

Anomalous and sporadic, notes on (Abbe) 1898.260.

Cosmical relations manifested in simultaneous disturbances of, sun, and terrestrial magnetic field (Lemströn). 1895. p. 492.

Florida, note on (Ab)e). 1900. p. 294...................

Moon and, report on (Mazen). 1898. p. 108 ...............

Note on, of Aug. 19-20, 1894 (Abbe). 1. 328 ..............

Relater conditions and international cipher corle for correspone!-

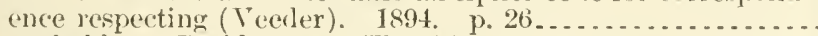

Remarkable, at Braidentown, Fla., Nov. 18, 1899 (Ten Broeck). p. 582

Soutl Carolina anıl Kentucky (Ajbe)

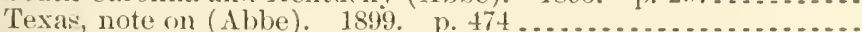

Willets Joint, N. Y., recorl of. $1870-85$ ( $\mathrm{i}$ bbe) j. $253 \ldots . .$. A urora australis of April 20, 1897 ('ampbell-Hepworth). 1) $204 \ldots .$.

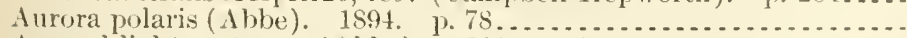

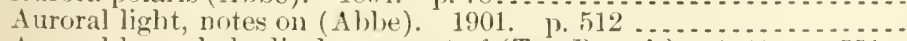
Auroral-lunar halo display, report of (Ten Proeck). j90i. 1. 551. Auroral observations on 21 Wellmamn expedition marle in neighborhood of Franz Josef Iand, 1 s:8-9! (Baldwin). \%. 107 ......

Austin, Amory. Rice; its cultivation, production, and distribution in U. S. and foreign comntries. 1893
A $10.3: 28^{2}$

$110.3: 55$

A10.3:116

110.3:75

A 1.8:4.

A10.3:45

1] $] 0.3: 6: 3$

A 10.3:95

A $10.3: 2 \mathrm{~s}^{1}$

A $10.3: 46^{\circ}$

A 10.3:32

A 10.3:31

A 10.3:29

A]0.3:38

A 10.3:44

A 1.1:867

A 10.3:4

129.6:28

A $27.9: 8$

A $29.6: 23$

A29.6:30)

A29.6:26

129.8:11\% A 29.6:28

A $29.6: 26$

A $29.6: 2: 2$

A:9.8:11

129.6:27

129.6::2:

129.6:27

A $29.6: 2: 23$

129.6::25

A:9.6:2:2:

A29.6::2?

A:9.6:29

129.6:29?

A27.8:6 
Anstralasia:

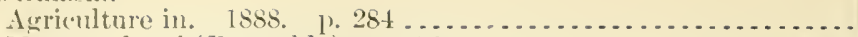

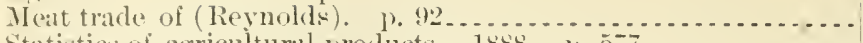

Statisties of agrienltural products. 1s8s. 1. 577 . . . . . . . .

Statistiss of animal industry of, 1899-1900. p. 55i ............

Seeralso liji Islands-Malay A rehipelago-New Zealand-Queen Australia:

Charlotte Islands - Tasmania.

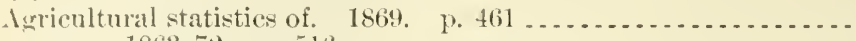

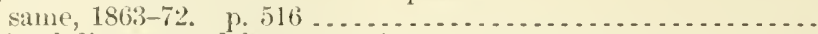

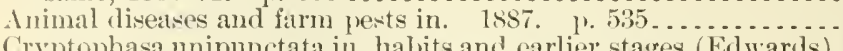

Cryptophasa unipunctata in, habits and carlier stages (Edwards).

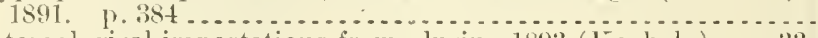

Entomolugical importations from, during 1893 (Koebele). p. 33. linserts of -

notes on some injurious and beneficial (Webster). 1889. p.

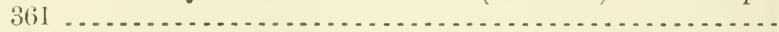
Iarasitic and predaceous, studies on (Koebele). 1s!3 ....... sent by Albert Koebele to Ellwood Cooper and B. II. Lelong,

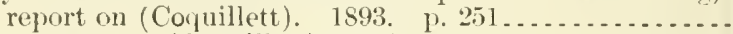
same, status of (Conuillett). 1893. p. $24 \ldots \ldots \ldots \ldots$ ste also dustralian ladylird - Fluted scale-Red and black scale.

Irrigation in; recent investigation, legislation, and administration by colonies of Victoria and New Sonth Wales(Hinton). 1891. l. $2: 35$

Live-stock shipments from, to England p. $77_{\ldots} \ldots \ldots$

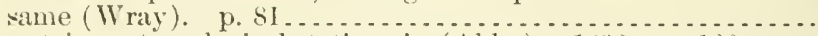

IIountain meteorological stations in (Abbe). 1898, p. 166.....

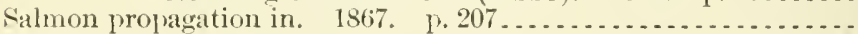
Texas fever in. p. 85 . . . . .

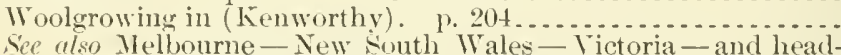
ings beginning Australian.

Australian hymenopterous parasite. Ser Fluted scale.

Australian ladybirs, imported (Coquillett). 1889 . ․ 70 . . ......

A ustralian lamellicorns, new genus and two new species of (Sharp).

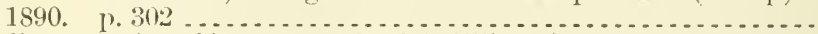

Anstralian parasite of icerya purchasi (Williston). 1888, p. 21 ...Anstralian report on American irrigation, 188t-85 (Deakin). p. 19\%. Australian scymmus estahlished and described in California (Riley). 1892. 1) 127 ...

Australian weather guide, notes on (dbbe) 1898.

Australian wheat statistics. 1883-84. p. 38. No. 11 ...........

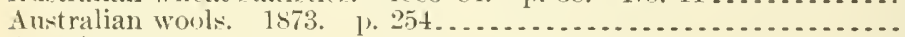

Austria:

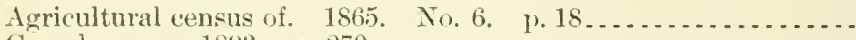

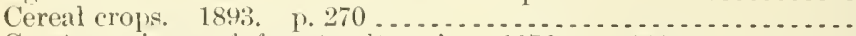

Coant provinces of, forest culture in. 1873. p. 141 ..........

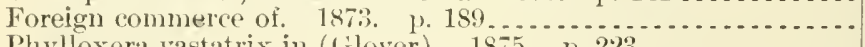

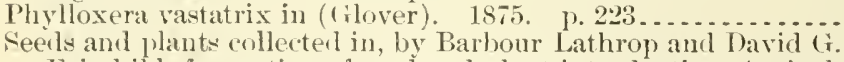
Fairchild, for section of seed and plant introduction, Agricul-

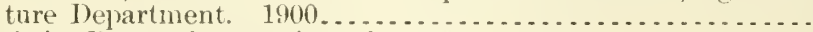

Statisties 13ureau in, ereation of. 1873. p. 188.............. Wines, becrs, ete, analysis of, methots proposed for arloption for

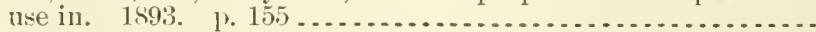
Sce ulso Vienna.

Austria-Hungary:

As a factor in world's grain trade; recent use of American wheat

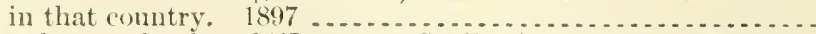

('ereal crops of, value of (Nemmam-Spallert). 1883. No.64. p.66.

(limate of, references to sonrces of information relative to (Hann).

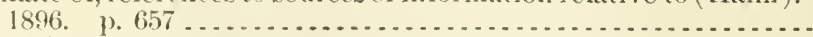

Crops in. 1876. p. $33 \ldots \ldots \ldots$

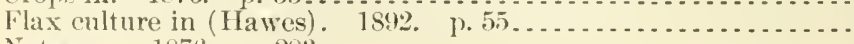

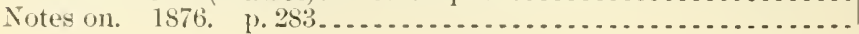


Austria-IInngary-Continnerl

People's Janks of. 1891.

Classifleatlon no.

See also Austria - Inungary - Bosnia.

Autumn haze, notes on (Abbe). 1901. 1. 37t . . . . . . . . . . . . .

Avalanches, their formation and prevention (Femow). 1888. p.236.

Axes, coorlinate, stanclard system of, for magnetic and meteorological observations and computations (Bigelow). 1897. P. 201.

Axima, North American, and its habits (Howard). 1890, 1. 365 ..

Ayres, Horace B. See, as joint anthor, Ashe, IV. IV.

Ayres, Horace B., and Aske, $\mathrm{IV}^{\mathrm{T}} \mathrm{W}$.:

Appalachian forests, southern, description of, by river basins. 1.69.

Forests and forest conditions in southern Appalachians. 1). $45 .$.

Ayrshire cattle, characteristies of (Howard). p.193............

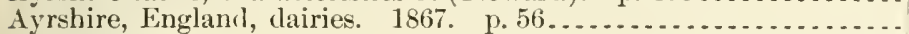

Azores:

Irrigation in, as presented in Census Bulletin No. 35, Feb. 27, 1891.

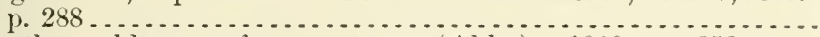

Weather cablegrams from, notes on (Abbe). 1900. 1. 258..... See also I'onta Delgata.

Aztec names and their pronunciation (Abbe). 1900, 1.549......

Babcock, S. MI.:

Address of, as presiclent of Association of Official Agricultural Chemists, at tenth annual convention. 1893. p. 3 .......

Butter, variations in compusition of. 1856. p. $25 \ldots \ldots \ldots . . .$.

Babcoek method for testing milk. See Bartlett, James MomroeVan Slyke, Lincoln Lucius - Winton, Andrew Lincoln.

Babinet, Jacques:

Floods in water courses, best means of finding rules for prealict-

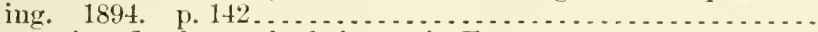

Forecasting floods, netlods in use in France. 1894. 1.94 ....

Bachelor of science, four-yeur course, what studiesshould be embracerl

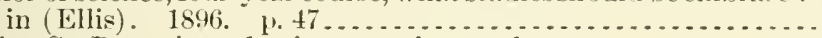

Bacilli. See Bacteria and references thereuniler.

Bacon, euring of, p. 87

Sie also Hog-Pork.

Bacot, Williani s. Adilress of, before National Roarl Conferencer,

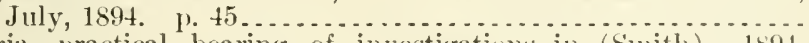

Bacteria, practical bearing of investigations in (Sinith). 1894.

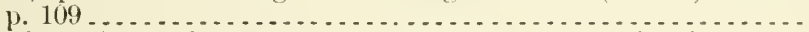

See clso Animals, domestic - references moler Bacterial diseases Clieese - Mare - Milk - Pig - Swine plague bacteria - Tuberculosis hacillus.

Bacteria and fibrine (Taylor) .

Bacterial diseases. Ser Bovine tuberculosis - Cabbage - Egg plant Fowl cholera - Glanders-Hog cholera - Irish yotatoPlants - Swine plague - Tubereulosis.

Bacterial flora of foremilk, relation of cheese-curd inflation to

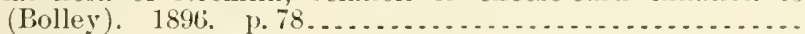

Bacterial produets, in restigation of effects of, in prevention of animal

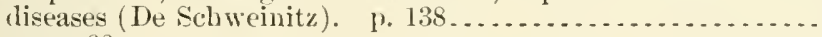

Same, p. $66 \ldots \ldots \ldots \ldots \ldots \ldots$

Bacteriology, dairy (Comn). $1895 \ldots \ldots \ldots$

Baden-Barlen, Germany, Seventh International Veterinary Comgress, Aug. 7-12, 1899 (Norgaard). p. 5.84 ... . . . . . . . . . . . .

Baguio, Philippine Islands, climate of (Stretsou). 1902. 1. $478 \ldots .$.

Baguios of l'hilippines, note on (Abbe). 1599. 1. $470 \ldots . . . . .$. Bahana Islands:

Cotton plant in, insects living on or injurions to (Schwarz).

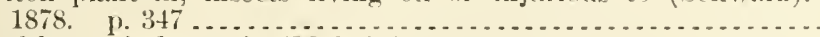

Sisal hemp industry in (MeLain). 1891. p. 52 . $\ldots \ldots \ldots \ldots . . .6$ Baier, Julius. St. Lomis tolnado, low pressure in. 18!)t. 1?.3:2... Bailey, G. Is. Geology of South Dakota west of Mistomi hiver and of II yoming east of forthills of Rocky Mountains. $18 \% 0$.

Bailey, luase II. Leather production of America, report ateompanying exhibit of Animal Industry Iurcau at Paris Expo-

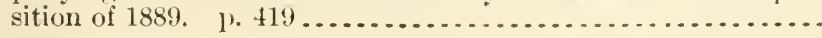

$1: 7.9: 29$

129.6:29

113.3:2

129.6:25

19.7:2

A1.2: A p $4^{2}$

11.2: $\mathrm{ppt}^{2}$

A 1.1:86:3

A $27.9: 5$

115.2: $\mathrm{P9}^{1}$

129.6:28

129.6:28

A $7.3: 38$

A 7.3:16

A29.3:11 1

1 $29.3: 11^{1}$

110.3:30

14. I:S97

$122.3: 10$

$1+.3: 6$

A1S.2:F+1

110.3:30

A1.1:8:11

1.1:891-"2

A 10.3:25

A $4.1: 6999$

1.29.6:30

1:9.6:27

19.2:C8:

1 $11.5: 3$

129.6:24

115.2:117

$1+.1: 88 \pi-8$

$114-0 t-12$ 
Builey, Jannes s. Cossinle, North American, with farts in life history of cossus centereneis. ISS3. 1. fi................

Bailey, Liberty Hycle:

Climatology and horticnlture, some interrelations of. 1895.

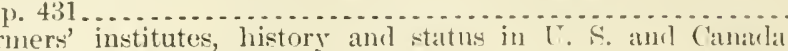

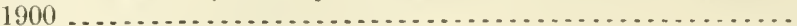

Farmers' reading courses. 1899. same (abridgm(nt). 1900

Fruits-

Anerican and Eastern Asian, sketch of relationship betwe'n.

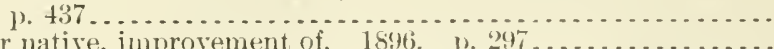

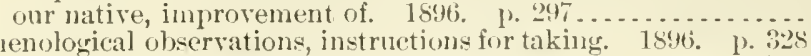

Baley, S. S. Highway improvement, slall famers have aid for, from wealth of nation? 1901. ए. 63.

19.3:3

$1: 39.3: 11^{2}$

$110.3: 79$

$110.3: 72$

A 1.9:109

11.10:894

11.10:896

129.6:24

$122.3: 21$

Bailey, Vernon

Mainmals and birds, results of trip, throngh parts of Minnesuta and Dakota for purpose of investigating fool habits and

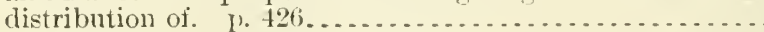
same, 1 . 426

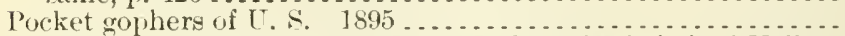

Prairie ground squirrels, or spermophiles, of Mississiphi Valley. 1893

Spernophiles and pocket gophers of Jiscisippi Valley. 1. 185.

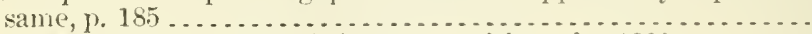

Voles, American, of genus Microtus, revision of. 1900 ... . . . . . Bailey, Willard C. Angora goat industry of Asia Minor. 1. 493 ... Bainbriclge-Hoff, W11. See Hloff.

latirl, Spencer Fullerton. Origin of dometic turkey. 1. 28S.....

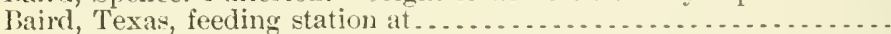
Baker, F. I':

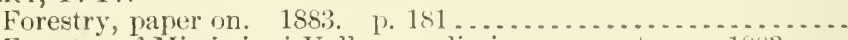

Forestry of Ilississippi Valley, preliminary report on. $18 \$ 3 . . .$.

Forests, timber-culture, etc., conclition of, in southem and Western Situtes. 1884. p. 105

Lumber and wood trade in eertain states. $1854.198 \ldots . .$.

States, forest condition of. 1884. p. $181 \ldots \ldots \ldots \ldots \ldots \ldots \ldots$.

Timber lands of $\mathrm{T}$. S., value and management of. 1884. 1. 17

Baker, Geo. S. Cattle tick and tuberrulosis in New Sonth Wales.

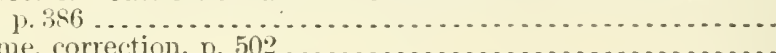

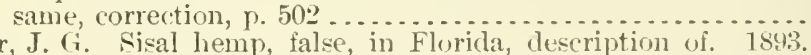

Baker, J. G. Sisal hemp, false, in Florida, description of. 1893.

Baker, R. Cattle, best ireeds of, allanted for creneral farmer of

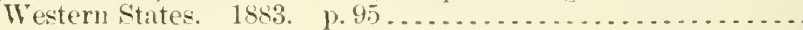

Baker, Willian E. Seeds, experiments nitl. $1870.0 .25 \ldots . .$.

Bakersfield, California, feeding station at ....................... Baking powlers:

Adulteration of (Crampton). 1889. p. $555 \ldots \ldots \ldots \ldots . . . . .$.

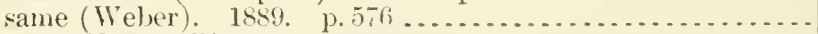
same (Cornwall). 1859. p.583.....................

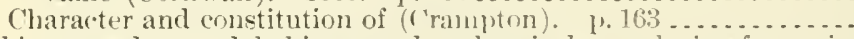

Baking powders and luking-powler chemicals, analysis of, provi-

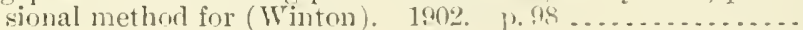

Balel, Edwin Swift. Evaporation underoround, report on. 1901.

Baklwin, livelyn B.:

Auroral observations on 2d Wellmann expedition nade in neighborhood of Franz Josef Land, 1898-99. p. $107 \ldots . . . . . . . .$.

Meteorologieal work, outline of scope and eharacter of, in Franz Josef Land, 1898-99. 1901. p. 351

Baldwin, Lat. See Des Lignes Sugar Experiment'Station.

Ball, Carleton Roy:

Grasses and fodiler plants of Potomar flats. 1900

11.1:887

A5. $1: 887$

A5.3:5

A5.3:4

11.1:892

\5.1:892

\$5.5:17

14.1:901

11.1:866

14.5:57

1 1.7:2

$11.8: 28$

\13.5:4

113.5:4

1 13.5:4

11.7:5

A $4.1: 89.8$

+4. $1: 899$

A11.5:5

11.7:2

A27.9:8

A $4.5: 57$

A7.3:13

A $7.3: 13^{5}$

A 7.8:135

17.1:589

A7.3:65

1:29.6:29

A $29.6: 29$

A 29.1:900

A3. 4:28

Johusonl grass, investigations made turing season of 1901. I902 . A 19.3:11 
Ball, Carleton Roy-Continued

Winter forage crops for South.

See also, as joint author, Scribner, Frank Lamson.

Ball, E. D. Lntomology, economic, simple form of accessions

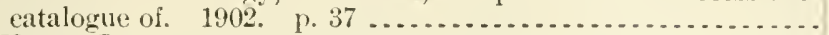

Ball, Hector L.

Climate and crop report, season of 1898, laska section. p. $548 .$.

Tornado at Eaglesmere, P'a., June 27, 1842. p. 309 ............

Weather Bureau service in Alaska. 1898. p. $254 \ldots \ldots . . . . .$.

Balloon ascensions:

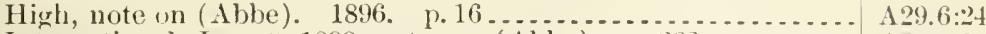

International, June s, 1898 , notes on ( $\mathrm{Ab}$ be). p. $262 \ldots \ldots \ldots . . . . . . .429 .6: 26$

Meteorological, at Strassburg, Germany (Rotch), 1901. p. 298 . A29.6:29

Report of-

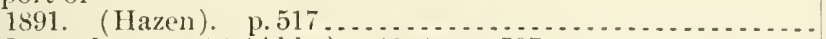

December 4, 1894 (Abbe). 1894. p.507..............

Nov. 14, 1896 (Assmann) p. $457 \ldots \ldots \ldots$

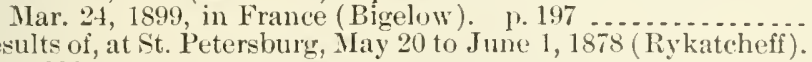

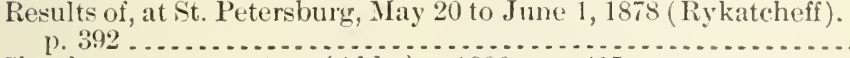

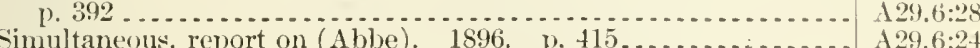

Balloon voyages:

Barometer needed in, notes on (Abbe). 1900. p. $552 \ldots \ldots . .$.

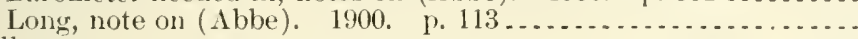

Balloons:

Aerial voyages by, notes on (Rotch). 1900. p. 553

Altitudes attained by, photographic apparatus for measuring (Cailletet). 1897. p. 443

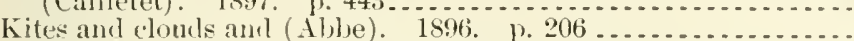

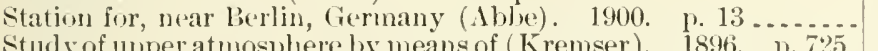

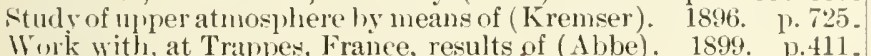

A29.1:89: $\mathrm{L}^{3}$

$129.6: 22$

A29.6:24

$129.6: 27$

A $29.6: 24$

A $29.6: 28$

A29.6:28

A29.6:28

129.6:25

A29.6:24

A $29.6: 28$

A29.3:11:

A $29.6: 27$

ree ulow Balloon aseensions - Balloon voyages.

Baltimore, MIl.:

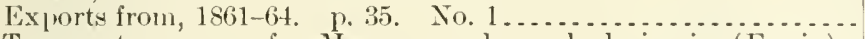

Temperature curve for May, normal, marked rise in (Fassig).

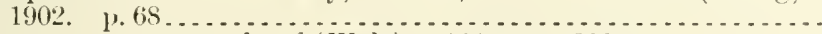

Temperatures at, sturly of (Walz). 1899 p. $293 \ldots \ldots \ldots \ldots .$.

Temperatures for, hourly (Kimball), 1902. p. $131 \ldots \ldots \ldots . .$.

Baltimore oriole ancl meadow lark (Beal), 1595, p. 419.........

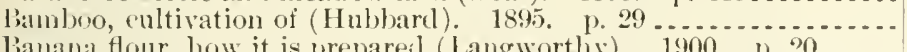

Banana flour, how it is prepareal (Langworthy). 1900 . P. $20 . .$.
bananas, partially digesterl, spurious parasitism due to (Stiles and

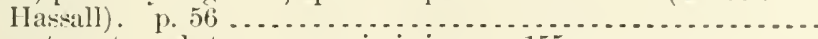

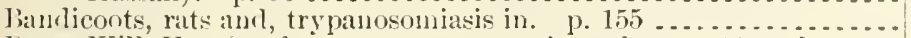

Bane, Will H. See, for reports as superintenclent, 1893 and 1894, Document and folling roum, Agriculture Department.

Bang, B. Tuberculosis in clomestic animals, preventive neasures

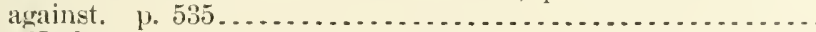

Batnk, Nathan:

Eutomolngy, Ameriean economie, bibliography of more important writings published on, between June 30,1858 , and

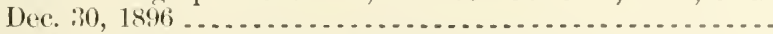
sane, between Dec. 31, 1896, anm Jan. 1, $1900 \ldots \ldots$. . . . . .

Entomology, North Ameriean, list of works on, $1900 \ldots . . . . . .$.

Index to Bulletins nos. 1-30 (new series, 1896-1901) of Jhivision of Entomology. 1902.

A27.9:3

A29.3:31

A $29.6: 27$

A $29.6: 30$

A1.10:895

|13.3:11

11.9:119

A $4.3: 35$

14.1:901

A. $1: 899$

A9.2:B+7

A $9.2: 13+7$

19.6:-24

A $9.6: 36$

19.6:34

19.8:8 Banks:

mery stock, principal insects liable to be distributed on. 1902

Peoples', Austria-Hungary. 1891. p. $491 \ldots \ldots \ldots \ldots \ldots \ldots$.

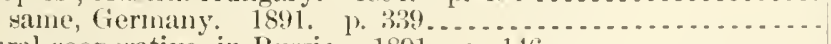

Rural cooperative, in Russia. 1891. p. 146.............. 127.9:29

Báreena, Mariamo:

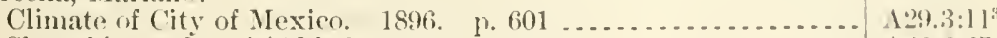

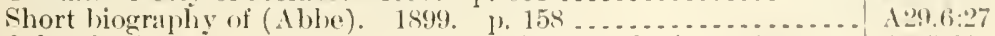

liark-beetle, fruit-tree, circular relative to (Clittenden). $1898 \ldots . . .1$ A9.5:29 
Barley:

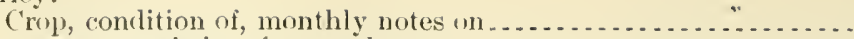
same, statistics of, anmual...........................

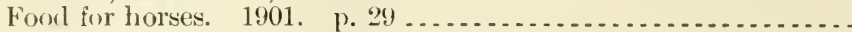
Rusted, request for specimens of (Dabney). $1894 . . . \ldots . . . . . .$.

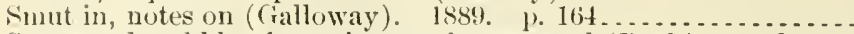
Straw and stubble of, specimens of, requested (Rusk), 11, 1l.... Wide drilling and tilling of. 1870 , p. 485 ................. See also Cereals - Crops-Farm products.

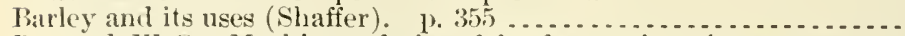

Barnard, W.S. Machinery designed for destruction of cotton worm,

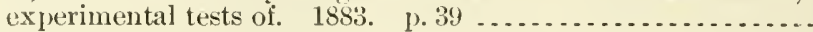

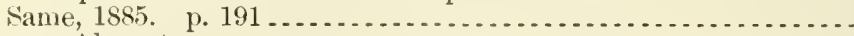
Barnes, Almont:

Agrieulture of Sonth America, report on, with maps and latest

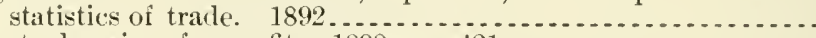
Goats, keeping, for profit. 1898. p. $421 \ldots \ldots \ldots \ldots$

\section{Barnes, John A.:}

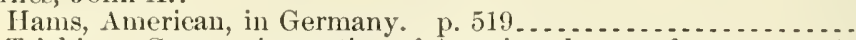

Trichine: German inspection of Ameriean hog products. 1\%.516.

Barnett, Claribel Rnth. Sugar beet, references to literature of, exclusive of works in foreign languages. $1887 \ldots \ldots . . . . . .$.

Barns, Pennsylvania, description of (Watts). p. $289 \ldots \ldots \ldots \ldots$. Bamyard manure:

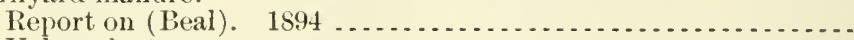

Value of, etc.-

1895. p. 570

1896. p. 616 .

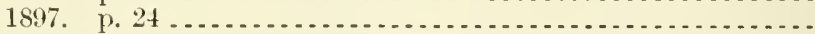

Barogram near hurricane center, report on ( $\mathrm{Ab}, \mathrm{e})$. $1896 . \mathrm{p.} 336$. Barograph enre, winter, from south Pacific Ocean (Warl). 1897.

Barograph on ships1. $484 \ldots \ldots \ldots \ldots$ 1898 (Abbe).

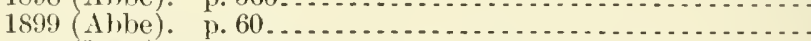

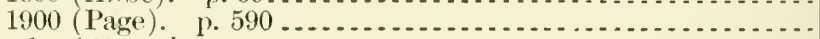
See also Atmosphere.

Barwick, James Arthur. Electrie storms of California. 1897. ए. 539. . Barometer:

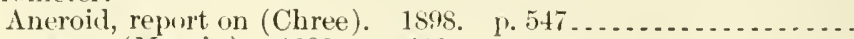

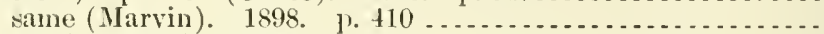

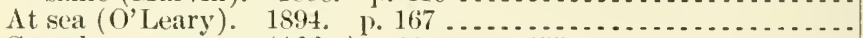

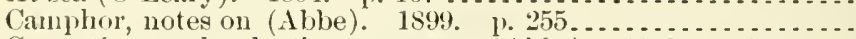
Corrections and reluctions, notes on (Abbe). 1899. p. $548 . .$. Diurnal variation of, notes on (Abbe). 1899. p. 314.......... History of-

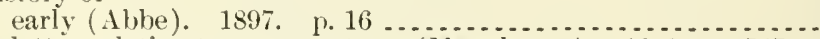
letter relative to, comments on (Monchamp). 1899. p. 547 .. notes on (Abbe). 1899. p. 546........................

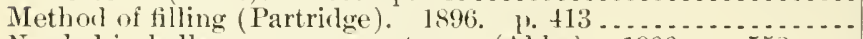
Needed in balloon voyages, notes on (Able). 1900 p. p52.... Popular substitute for (Abbe). 1895 . p. 299 ................ Rearlingsconverted into standart pressures (Abbe). 1898. 1. $314 \ldots$ metric and English, erroneous conversion of (Marvin). 1898.

Reduction of -

to sea level (Hazen). 1894. p. 538

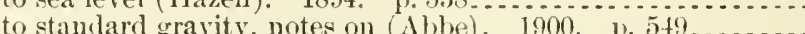

Userl at sea, notes on (Abbe). 1901. p. $459 \ldots \ldots \ldots \ldots$.

Used in determining climatology of st. Kitts, comparison of

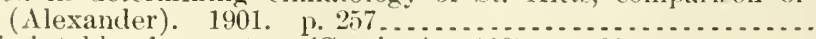
Wind, table of, report on (Garriott). 1897. p. $204 \ldots \ldots \ldots \ldots .$. See also Thermoscope.

Baroneters and measurement of atmospherie pressure (Marvin) .. Barometric pressure:

Diurnal variation of (Cole). 189: . 
Barometric pressure-Centinued

Hourly results from self-registers for recording (Ahbe). 1897.

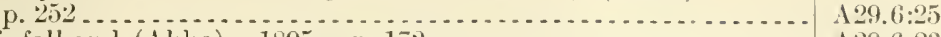

Rainfall and (Ahbe). 1895. p. 172.................... 129.6:23

Reduction of, to sea level (1lorrill). 18!6. p. 492 .......... $129.6: 23$

Relations between strength and direction of ocean enrrents and

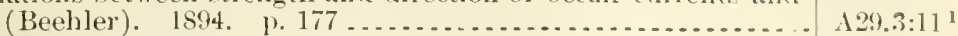

See ulso Clinatie charts - Seiches.

Barometric stantarel of Costa Rica, comparison with (Able). 1902.

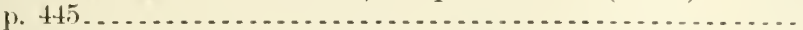

Barometric troughs of platean region, repurt on (IIazen), 18\%5.

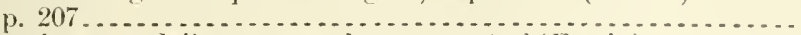

Barometric wave, daily, westward movenent of (Fassig). 1901. 1\%

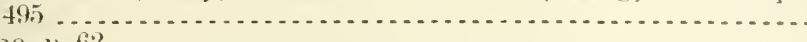

same, 1.62 . Barometry of $\mathrm{T}$. S., Camala, and West Indies, report on (Bigelow). $190^{\circ}$

Barrett, O. W. Changa or mole ericket in Forto Rico. 1902..... Barringer, P. J. Address of, before Jefferson Mlemorial and Interstate crool Roals Convention, A pr., 1902. p. 1t . . . . . . . . .

Barrows, Walter Bralford:

Crow, common, of U.S. 1895. p. 9 ...................

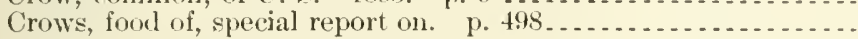
same, p. 498 .

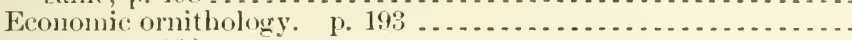

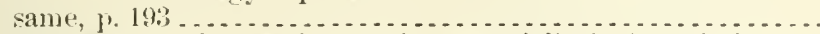

English sparrow in North America, especially in its relation to aqriculture. 1889.

Kingbirl, or bee martin, food haljits of. p. 233 ..............

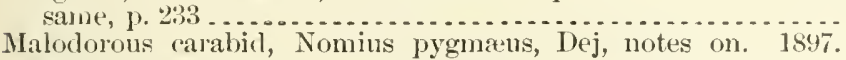
p. 49 . . . . . . . . . . . . . .

San Jose seale, present status of, in Michigan, 1897 . p. $27 \ldots \ldots$

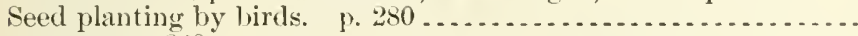

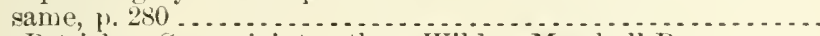

Barry, Patrick. See, as joint author, Wilder, Marshall P.

Bartholomew's physical atlas, note on (Kimball). 1902. p. 29 ...

Bartlett, James Mhonroe. Milk and cream testing, modification of Babeock method and apparatus for. 1896 . p. $104 \ldots . . . . .$.

See also, as joint authur, Huston, Henry Augustus.

Bartlett, Levi. Wheat growing in New llampshire. p. $96 . . . . .$. Parus, (arl:

Atmospheric moisture, report on condensation of. p. 526 .....

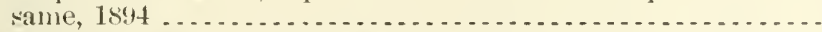

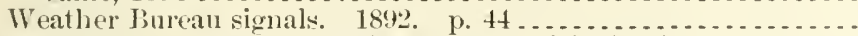

Basic phosphatic slags, mechanical analysis of (Wiley). 1896. p. 78 . Basic slag:

Action of ammomium citrate and eitrie acid on (Inston and

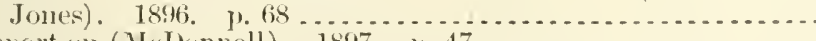

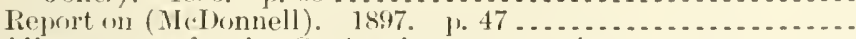
Basiliomycetous fungi. Se Agarious campestris.

Bassetere, St. Kitse, W. I., flood of Jan., 1880, at (Alexander)

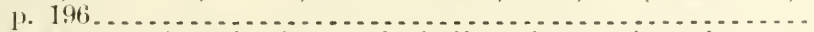

Bast fibers, unenltivated, of U. S., including history of previons experiments with plants and fibers, and brief statements relating to allied species produced commercially in the old workl (Dodge). - 189.4

Bate, Ilenry $\mathrm{C}$. Weather forecasts, what clases are most benefited by? are they just what are neeled? are they properly dis-

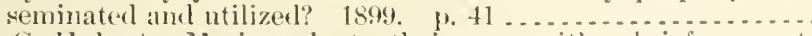

Bates, G. Hubert. Marine plants, their uses, with a briof acount of curing of Irish moss. p. 42 ?

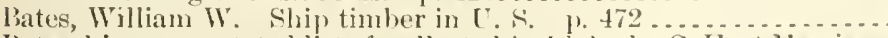

Batrachians, annotated list of, collected in ldaho lyy C. Hart Merriam and party, 1890 (Stejneger). p. 109.

See also Frogrs - Reptiles and hat rachians.

A29.6:30

A29.6:2:3

129.6:29

129.3:31

A:9.1:901 2

$\$ 10.12: 2$

A22.3:25

15.3:6

A1.1:688

A5.1:888

A 1.1:892

15.1:892

A5.3:1

A 1.1:843

A5. 1:893

A $9.6: 9$

A9.6:9

A 1.1:890

A5.1:890

A.9.6:30

A 7.3:49

A1.1:81;2

A 29.1:8:11 ${ }^{3}$

A $29.3: 1: 2$

A29.3:7

A7.3:49

A 7.3:4!!

A7.3:5

1:99.6:27

A 11.5:6

A2:3:3:24

Al.1:Stio

11. $1: 866$

A.5.5:5 
Bats:

Excrement, use of (McMurtrie). 1873. p. $580 \ldots \ldots \ldots \ldots \ldots \ldots . . .427 .9: 11$

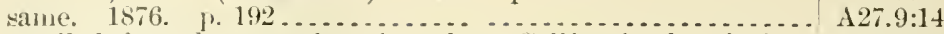

Free-tailer, from desert region of southern California, description of new species of (Merriam). 1889. p. $23 \ldots . . . . . . .$. same, from Lower Coloralo River, Arizona (Merriam). 1884.

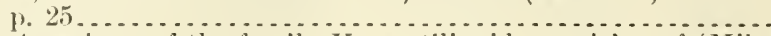

North American, of the fanily Vespertilioniclac, revision of (III-

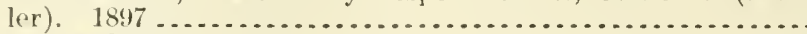
Síe rilio Molossun.

Battey, Arthur H. Work of press for good roads. 1901. J. 89... Same. 1902. p. 55................................ Battle, Herbert Bemerton:

Fertilizer sumples-

bottlerl, loss of moisture in, when closed with cork. 1891.

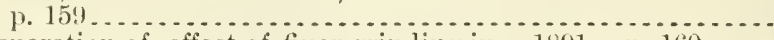
preparation of, effeet of finer grinding in. 1891. p. 160 ....

Baturoni, (i. September norther on Mexiean coast. 1892. p. 252.

Baner, (. E. Is Texas a wine land"? 1868. 1. 451 ............ Bauer, Jacob W.:

Meteorological observations, should not a book for permanent reeord of, be furnished to section eenters and volmutary stations? 1899. p. 12I ..............................

Meteorologieal reports of volnntary olservers, monthly, ('xamination of; is it desirable to report back to volmutary observer errors and irregularities discovered in his report? $190^{\circ}$. p.

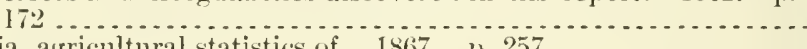

Bavaria, agricultural statistic's of. 1867. 1. $257 \ldots \ldots \ldots \ldots$ see also Aschaffenburg.

Bayonne, N. J.:

Burning of Standard Oil Company's plant at, July 5, 6, and 7,

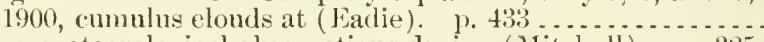
same, meteorological observations during (Mitchell). p. 325.

Kite corps at, records by (Alken). 1899. pl). 11, 251 ........

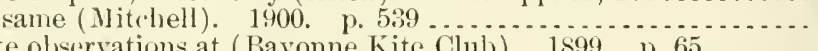

Kite olsservations at (Bayonne Kite Cluh). 1899. p.65.......

Beach, Horace. Artesian well investigation, special experts' report. 1890. p. 141

Beach, S. A. Horticultural work at State Agricultural Exporiment Station, Geneva, N. Y., methorls of keeping recorils of. 1898.

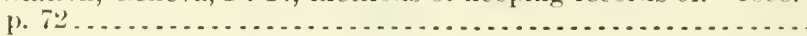

Beal, Foster Ellenborough Lascelles:

Birls, some common, in their relation to agrieulture . . . . . . . .

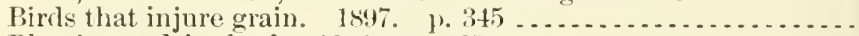

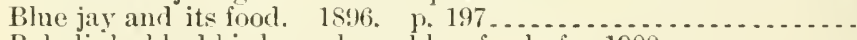

Bobolink, blackbirds, and graekles, food of, $1900 \ldots \ldots \ldots \ldots \ldots$.

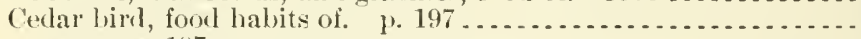
same, p. 197 . . . . . . . . . . . . . . . .

Crow blacklirks anıl their food. 1894, p. $233 \ldots \ldots \ldots \ldots$

Cuckous, fond of. $1898 \ldots \ldots \ldots \ldots \ldots$

Meartow lark and Baltimore oriole. 1895, p. $419 \ldots \ldots \ldots . . .6$

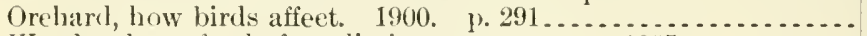

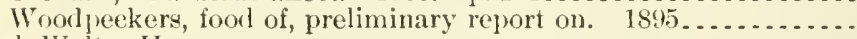
Beal, Walter Henry:

Agricultural Colleges and Experiment Stations, American, tenth annual convention of Assoeiation of, 1896 p. p. $541 \ldots . .$. sane, eleventh annual convention, 1897. p. $303 \ldots \ldots \ldots \ldots$ same, twelth annual convention, 18:8. p. 704 ...........

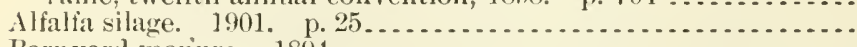

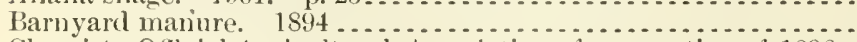

Chemists, Offieial Igricultural, $\Lambda$ ssociation of, convention of, 1896 ,

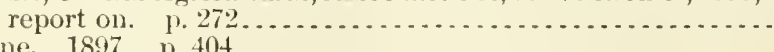

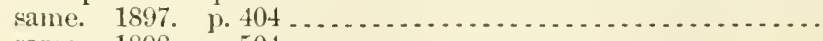

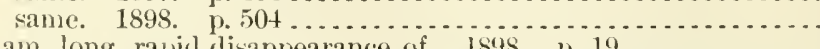

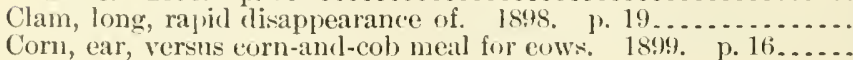

122.3:21 $120.3: 20$

A 7.3:31

17.3:31

А29.6:20

$127.9: 6$

129.3:24

A29.3:31 A $27.9: 5$

A29.6:28

A29.6:28

129.6:27

129.6:28

129.6:28

A15. 2: $\mathrm{Ar} 7$

A 10.8:49

11.9:54

11.10:897

II. 10:896

A5.3:13

A1.1:892

A5. $1: 892$

11.10:894

A5.3:9

11. 10:895

11. $10: 900$

15.3:7

A10.6:8

A 10.6:9

A 10.6:10

A 1.9:124

11.9:21

A 10.6:8

A 10.6:9

\10.6:10

A 1.9:10:3

A 1.9:107 
Beal, Walter Henry-Continned

Cornstalks, waste in feeling.

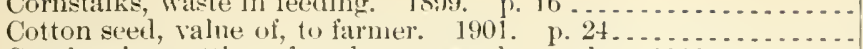

Cranberries, rotting of, and a proposed remedy. 1900 . p. $9 \ldots$.

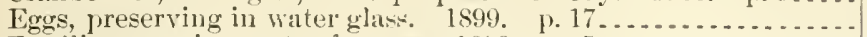

Fertilizer requirements of crops. 1899. p. 5....................

(irapevines, girdling or ringing, operation of. 1899 . p. 17....

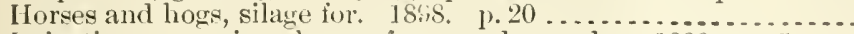

Irrigation, excessive, danger from, and remedy. 1899. p.5

Lime, fertilizing value of different forms of. 1901. p. 12.......

Mutton sheep, establishing flock of. 1900. p. $23 \ldots \ldots \ldots \ldots \ldots$

Oxeye daisy, beantiful flower and pernicions weed. p. $15 \ldots . .$.

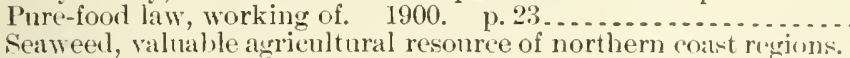

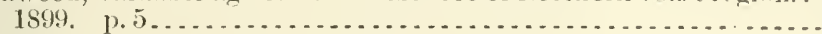

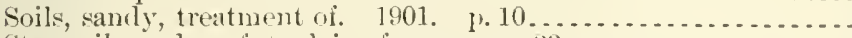

Stave silo, value of, to dairy farmer. 1\%.28 . . . . . . . . . . . . .

Unfermented grape juice, preparation of. 1900. p. 27 ........

Water, distilled, for drinking purposes. 1901. 1, $5 \ldots \ldots \ldots .$.

See also, as editor of proceedings, igricultural Colleges and Experiment Stations, American, Association of; as joint autbor, Allen, Edwin West-McBryde, J. Bolton-May, David W. - Sinith, C. B.

Beal, Walter Henry, and smitl, C. B. Liming grass lands. 1900.

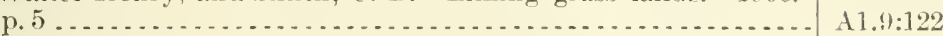

Beals, Elward A.:

Chicago weather forerast cistriet, monthly report of, June, July,

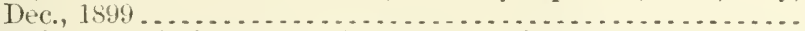

Electricity, static, in Weather Burean work, importance of. $18 \%$. p. 39 . . . . . . . . . . . . . . . . . . .

Oregon weather and Bering Sea ice, notes on, 1890-99. p. 201..

Portland, Oreg., weather lorecast distriet, monthly report of,

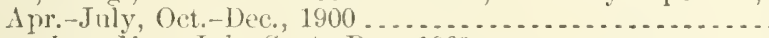
same, Jan., Mar.-July, Sept.-Dec., 1901 ................... same, Jan.-()et., 1902 .

press, commercial bodies, and seientitic organizations, relations of weather oflieials with, how promoted. 1899 . p. $69 \ldots \ldots$.

Bean, J. F. Road question, a farmer's views on. 1901. P. $67 . \ldots$. Pean-leaf beetle, report on (Chittenden). 1597. p.6t.......... Bean weeril:

Nomenclature and oviposition of. 18:22. 1. 27 ............

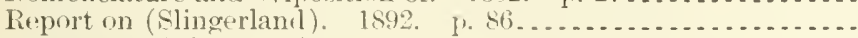

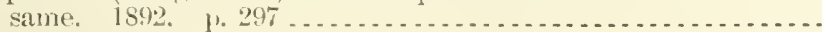

Bealls:

Plister beetles, note on great damage by. 1886. p. $37 \ldots \ldots . .$. Gray hair-streak louterfly and its lanage to. 1895. p. $354 \ldots .$. Insects injurions to (Chittenden). 18!8. 1) $233 \ldots \ldots . . . . .$.

Pole, forcing of, under glass (Clark). 1898, p. $13 . . . . . . . . .$. Sop rlso Crops-Velvet bean.

Beans, peas, and other legumes as form (Ahel.) $1900 \ldots . . . . . . . .$. Bear-grass, results of recent investigations relating to (I)orlge). 1 sil3. Bear River:

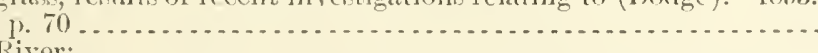

Interstate water rights in (Breckons). 1899. B. 26 .......... Irrigation of valley of, in Utah, 1901 (Stover). 1902. 1) 24:3...

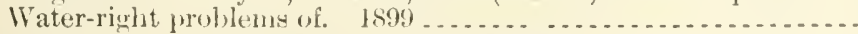
Water supply of, and its liversion (Johnston). 1899. p.9....

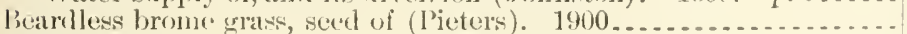
Beattie, Wr. R.:

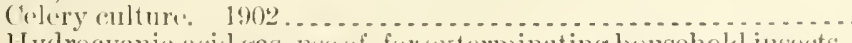
II ydrocyanic-atcid gas, useof, for exterminating household inseds. 1902 . p. 8()$.

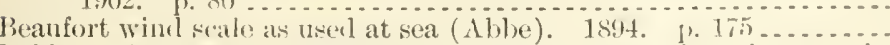
liebher, W. J. van. Weather service, present condition of; propesitions for ils improvement. 1s94. p. $34 \ldots . . . . . . . . . . .$.

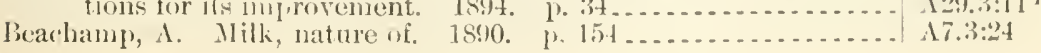




\section{Index}

Beekwith, M. H.:

Corn crambid, alsstract of notes on. 1891. p. 42

Insecticiles, use of, practical notes on. 1891. p. 269

19.7:4

A $9.7: 3$

Bedbugs:

Circular on (Marlatt). 1902.

Report on (Riley). 1889. P. 104 same (Marlatt). 1896. p. 32

A 9.5:47

A9.7:2

A9.6:4

Bedford area, Virginia, soil survey of (Jinomey and others). p. 239 ..

Bedle, Benjanin R. Sheftield, England, cost of hauling farm products over wagon roads at. $1,3 \ldots . . . \ldots \ldots . . . . . . . . . .$.

Piee disease. See Foul brood.

line keepers' associations, national, sectional, and State, list of, with officers:

1899. 1. 708

1900 . 1. 662

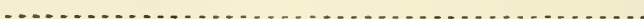

Bee-keeping:

Comlition of industry, ete., 1889. p. 224.

Directory of departments, boards, sorieties, colleges, and other organizations in juterest of. 1885.

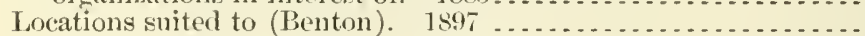

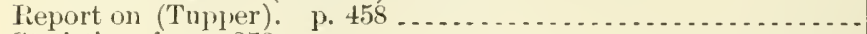

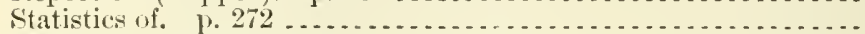

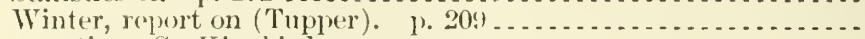

Bee martin. See Kinglird.

Beech trees, discase of. 1873 . p. 502.

Beef:

American and European, comparative composition of (Woods).

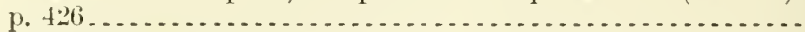

Breeding and feeding of, and supply of market therewith (Beverly).

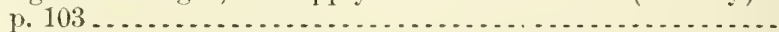

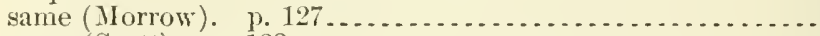

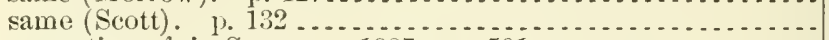

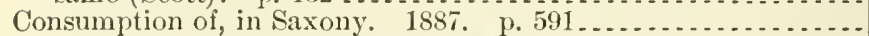

Exportation of, orler regarding. Mar. 9, 1897

Production of, some essentials in (Curtiss). p. 48

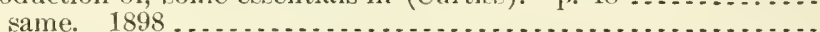

Report encerning 6.25 protein factor as applied to (Goss). 1899.

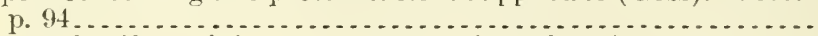

Steer and heifer, opinions as to comparative value of. $1898 . \quad$ p. 27. Supply of--

American, address on, before 31 national convention of stockmen, Chicago, Nor. 1885 (Colman) ...

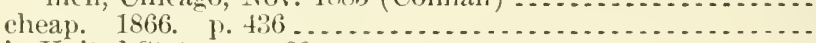

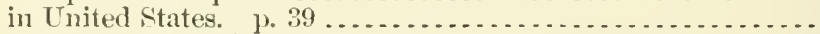

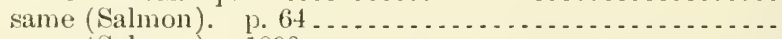

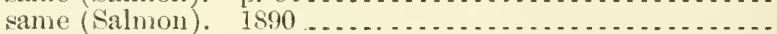

See also Cilttle.

Beef and beef cattle of the West (Corbett). p. $326 \ldots \ldots \ldots \ldots \ldots$
Beef and clairy cattle, conformation of (Soule). $1902 \ldots \ldots \ldots \ldots$

Beehler, WV. II. :

Barometrie pressure and strength and direction of ocean currents,

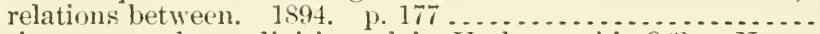

Marine meteorology, division of, in Hydrographie Othce, Navy Beer: Department, origin and work of. 1895. p. $221 \ldots \ldots \ldots \ldots$.

American, composition of, and substances used in adulteration

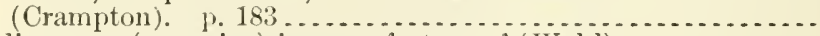

Indian corn (or maize) in manufacture of (Wahl)
Quassia and other hop substitutes in, improved method of detectBees:

ing (Allen). 188\%, p. $376 \ldots \ldots \ldots \ldots \ldots \ldots \ldots \ldots$.

Culture of, circular relating to. 1885 .

Great value of, to fruit and seed growers (Benton). 1892. p. 254 .

Hive, wheel bugs destroying, note on. 1886 . p. 44 ..........

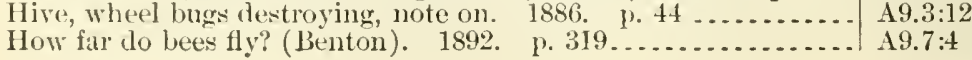




\section{Index}

Bees-Contimued

Latuglom nonswaming device (Benton). 1893. j).230

l'robluetion of loney and wax, statisties. 1901. p. 784 . . . . .

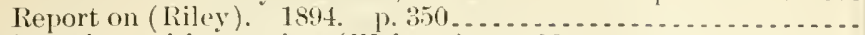

Spraying, with arsenites (Welster). 1892. p. 121 .........

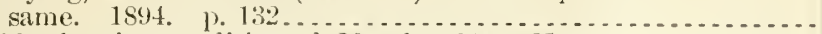

Table showing condition of, March, 1864. No. 2. p. 35. $2 . .$.
See also Apiarian exhibit-Apiculture - Bee keeping - Foml Beeswax: brood - IIoneybee - Italian honeybee.

Adulteration of (Wiley and others). 1892. 1.633...........

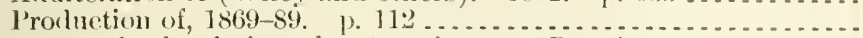

Beet, growth of, relation of meteorology to (Davy). 1879. 1) 284. Sep also Sugar beets.

Beet and beet-root sicar (Cull). 1873. p. 366 .

Beet insects, motes on (Brmer). 1891. I1. 229.................

Beet-juices, analysis of, with table for ealeulation of analyses (Cram)-

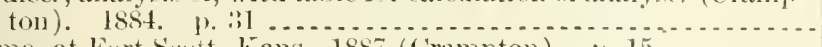

Same, at Fort sent, lians., 1887 (crampton). 1. 15........

Beet-leaf pegomyia, report of (Iloward). 1895, p. 379........

Beet-sugar:

Chemical memoramda on (Brown), 1872, 1. 218 ...........

Encouragement of sorghum industry and. $1883 \ldots \ldots \ldots$

Europe (Gemnert). 1. 158...........

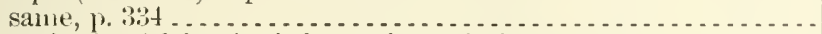

Factories in (alifomia, information relative to. 1870. 1. 357... same, $1887,1.452$

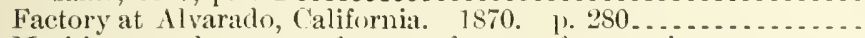

Machinery and processes for manufacture of, recent improvements

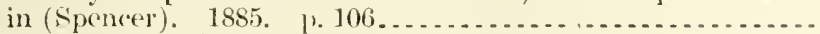

Maine (Blackwell). 188\%. p. 26. No. $61 \ldots \ldots$

Manufacture of-

culture of sugar beet and (IViley). 1890..................

France and Germany, progress of. 1866. p. 179.........

German zollverein. 1s70, 1\% 42 ....................

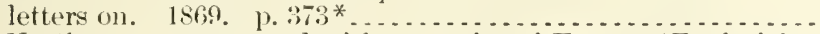

Nortliwest as compared with countries of Europe (Freilericksen). $1879 . \quad$ p. 275

progress in. 1872. p. $14 \ldots \ldots \ldots \ldots$

report on (Irulse). 1870. p. 147

sucess of. 1871. 1) 195.........

use of resiclues from, in eattle feeding (Spencer). 1sis. p.

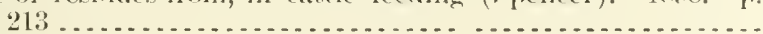

Notes on. 18tir. No.6. p. $23 \ldots \ldots \ldots \ldots$

Production of-

note on (Caprom). 1868. 1. 5!).

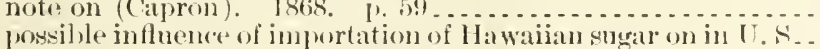

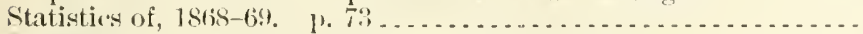

See also Beet and bret-ruot sugar-Sugar beets.

Beet-sugar industry in U. S.:

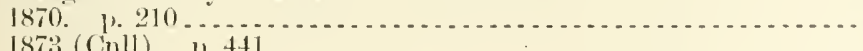
1878 (Cull). 1. 441.
1897 (Saylor). p. 161.
sante.
1897 (Wiley). p. 11
-
1898 (Wiley)

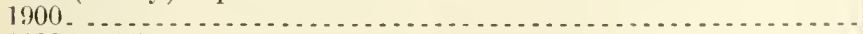

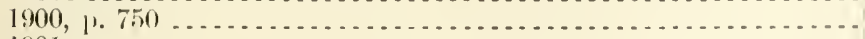

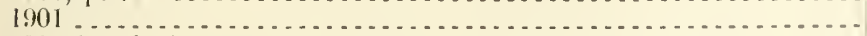
1901 (Kaylor). 1.487 . . .
Certain imported, distrilution of (Chittemlen). 1895. 1'. 32:65..

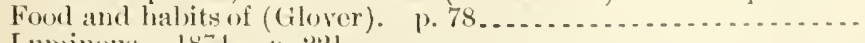
Luminoms, 1874. 1.221 $\ldots \ldots \ldots$
A $1.1: 870$
$1: 7,9: 11$
A1.2:(B.39 1
1 1.2: $\mathrm{B} 339^{2}$
A $1.2:(3: 3)^{\circ}$
1 $1.2: 13: 39^{4}$
11.2:1339 *
A $1.8: 69$
A $1.10: 900$
A I.s:7:
1 1. $10: 901$
A9.7:7
A.1:Bris
127.9:1")
1:7.9:9

Bentles:

17.3:13 6

127. 11.32

11.6:28

1:27.9:11

19.7:")

17..9:15

A7.3:17

19.7:7

1ะร.9:10

11.8:26

1 $1.1: 868$

A 1.1:869

A27.9:8

1:27.9:25

127.9:5

17.8:5

127.9:21

A $7.3: 27$

127.9):4

A 27.9:8

A 27.9:7

11.6:29

A27.9:10

A27.9:8

A $27.9: 9$

1 $1.10: 598$

127.9:3

$127.9: 6$

11.4:7

$127.9: 8$

* liy a misprint, this Inga number appars twice. 
Bectles-Continued

See also Agmoulerus pallepes - Agrilus - Allorhina - Ambrosia beetles - Amplizoa - Aspanagns beetles - Australian lamellicorns - bark betle - Bean leat-beetles - Blister beetles Bruchns-Carabid malorlorous-Carpet beetle-Cicindela limbata - Clover-loat bectle-Cocinellidie - Coleoptera Colorado potato betle-Cottonwond beetle-Cuemmber beetles - Cureulio - Curculiomilae - Dermestida - Diabrotica somor-Diabrotica 12-punctata-Elsuria quadrimaenlata - Iilm leaf-beetle- Fig eater-Flea beetle-Graptodera foliacea - Hornia - IIorse-rarlish flea-beetle - Hylesinus serirens - Hyperaspis simnata - Lachmosterna - Lachnosterna fusea - Lady-bird - Lamellicorns - languria - Leaf - mining locmst-beetle-Leonia Rileyi - Lucust bectle-Mexican cottonboll weeril - Novins cardinalis - l'ea weevil - Pea and hean weevils - Pine bark-beetle - Plum curculio - Plum gouger Poplar gonioctena - Potato long - Potato-bug weevil - Redlegged fiea-beetle - Rhinoceros beetle-Rose-loug - Rose chafer - Rose leaf-beetle - Rove beetle-Scolytidre Scolytids-Scymnus-Spruce bark-beetle-Strawberry leaf-flea beetle-Strawberry weevil - Sugar-cane beetle - Tan-bark beetle-Tobacco Hea-beetle-Tobacco-stalk weevil-Twig girller.

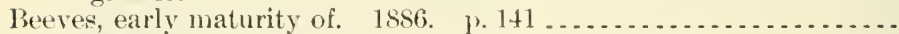
S'e also Cuttle.

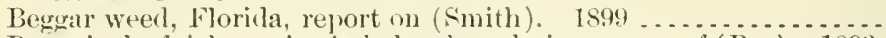

Begonia, leaf sickness in, Aphelenolms olesistus canse of (Bos). 1893 .

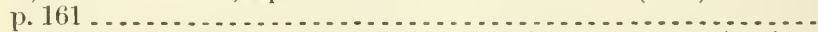

Behr, IIerman, and Klee, W. C., California, plants worth trying in. 1892. ए. 141

Belden, W. S. Climate and cropsections, Weather Burean, publications of, necensity for binding and otherwise preserving. 1902. 1. 177

Belfast, Ireland, British Association, 1900. Address on meteorology

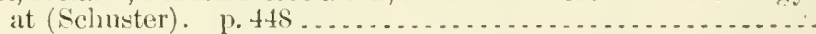

Belgian Exposition of Agrienlture and Forestry, 31, 1869, advance motice of p. 235 . . . . . . . . . . . .

Belgian State Laboratories, official methods of analyses of fertilizing Belgium: and feeding stuffs adopted by. 1899. p. 304 ..........................

Agricultural associations in (De V'uyst). 189s. p. 3.......... Agricultural census of. 1865. 1). 37. No. 24 .............. Agricultural education and research in (True). 1896. ए. $361 \ldots$ Agricultural education in (De Vuyst). 1893. p. $703 . . . . . .$. Agricultural experiment stations in (Petermann). 1895. 1 . 5.50

Agricultural sehools in, organization and management of (Wel.h).

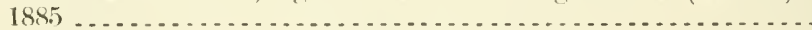

Agrienliure of. $1873.10 .562 \ldots \ldots \ldots \ldots$

American horses in (Storer). 1897. p. 24 . . . . . . . . . . . .

Cost of hauling farm produrts over waen roaks in (Rooscrelt).

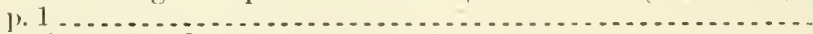

Crops in 1890 and 1889 , $1843 \ldots \ldots \ldots$

Dead animals in, disposition of (Roosevelt). p. 354 .........

Flax culture in (Wallace). 1892. J. $47 \ldots \ldots \ldots \ldots$

Horse breeding in (Winslow). 11.503 ... . . . . . . . . . .

Markets for $\Lambda$ merican products in. $1895 \ldots \ldots$

Meteorulogy in, history of, notes on (Alibe). 1901. [1.66) ....

Poultry raising in (Lincoln). p. $506 \ldots . . .6$.

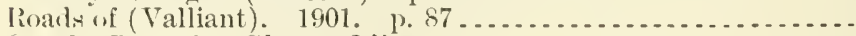

Sire also Brussels-Ghent-licige.

billevoye, M. A. Monomorimm pharaonis, olservations on. 1890.

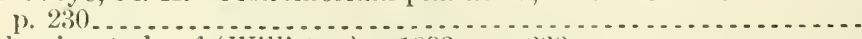

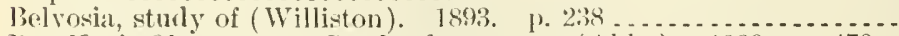

ben Nevi, Observatory, Seotland, notes on (Ablee). 1899. p. $470 \ldots$

Benedict, Francis $G$. See, as joiut author, Itwater, Wilbur Olin. 
Bengal, India:

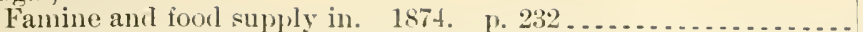

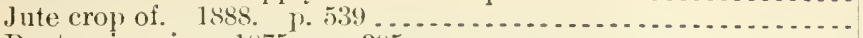

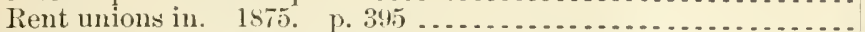

Bennett, A. W. Flowers, fertilization of 1873. p. $586 \ldots \ldots \ldots$. Bennett, Frank, jr. Sie, as joint author, Smith, Willian (i.

Bennett, Joseph 13. See, for reports as appoint ment elerk, 1895-1902, Appointment clerk, Agrieulture Department.

Bennett, Thomas:

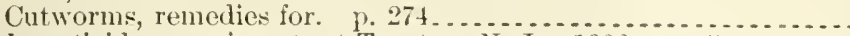

Inseeticide experiments at Trenton, N. J. 1886, p. 27 ........

Bentley, Henry Lewis:

Cattle ranges of Southwest, history of exhaustion of pasturage and suguestions for its restoration, 1 sas.

Forage erops and range improvements, progress of experiments

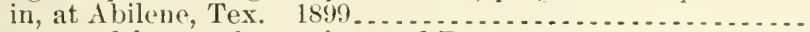

Grasses anel forage plants of eentral Texas. 1898 . .............

Range improvement in central Texas, experiments in. $1902 \ldots .$. Brintley, Wr. A. Snow crystals, twenty years' study of. 1901.

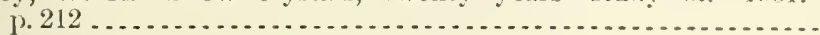

Benton, Frank:

Apiarian exhibit at Columbian Exposition, 1894. p. $242 \ldots \ldots$.

Bee keeping. 1897 . . . . . . . . . . . . . . . . . . . . . . . . . . .

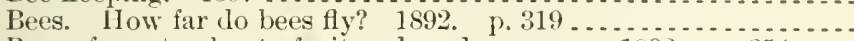

Bees of great value to fruit and seed growers. 1892 , p. $254 . \ldots$.

Honey bee, a manual of instruction in apiculture . . . . . . . . . . .

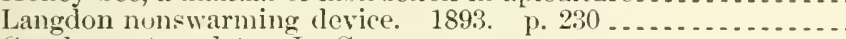
See also, as translator, Le Cocq.

Berg, Walter $G$. Timber trestle briclges, economical designing of, notes on report of $\mathrm{A}$. L. Johnson. p. $34 \ldots . . . \ldots \ldots \ldots . . . . .$.

Bergami, Francis. See Kilgore, Benjamin Wesley.

Bergen Point, N. J. Temperatures obtained by kites at (Allen).

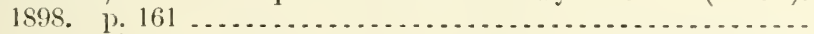

Bergholz, Panl. Typhoons of Orient; origin, paths, and liniting zones of, translated by Cleveland Abje. 1899. p. $402 \ldots . .$.

Bergroth, E. Water bug found by J. L. Zabriskie, note on. 1892.

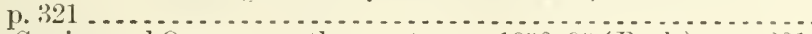

Bering Sea ice and Oregon weather, notes on, 1890-99 (Beals). 1.201

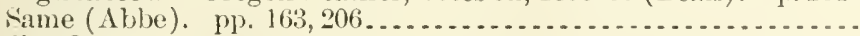

Berlin, Germany:

Cost of lauling farm products over wagon roads at (De Kay). p.t. Deat animals in, disposition of (Mason). p. 349 ............. Kite and balloon station near, note on (Abbe). 1900. p. 13...

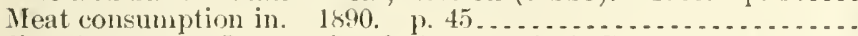

Perlin, Germany, International Aeronantical Congress at, 190\%,

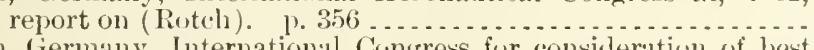

Berlin, Germany, International Congress for eonsideration of hest methods for ehecking or curing Tubereulosis, May 24-27, 1899 (De Selıweinitz). J. 126

Berlin, Germany, International Geographical Congress, ] s.99, notes on (Abbe). p. 470 .

Berlin, Germany, Royal Agricultural Museum, description of. 1874.

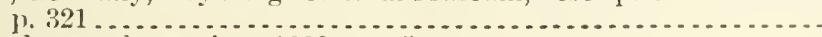

Bermuda, peach pest in. 1890 . p. 5 . Bermuda grass:

Circular on (Hiteheock). 1901.

Monephoral licinta damaging, note on. 1886, p. $34 \ldots . . . . . .$.

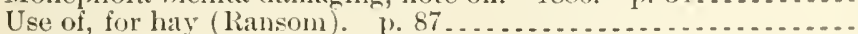

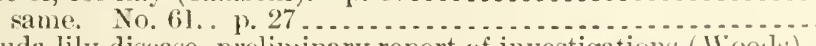

Bermuda lily disease, prelininary report of investigations (ivoorls). 1897

Bernburg Agricultural Hxperiment Station, samilalures at, methods

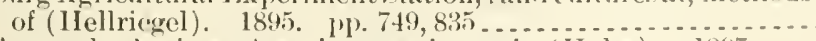

Berolinense lierbarium, Ameriran panicums in (Holm). 189\% \%.

17
Berries. ries - Elderberry - Mulberries - Strawberries. 
Perry, James:

Jiliress as chairman section of climate and crop service before serond (onvention of Weather I3mrean officials leclil at Milwaukee, Wis., A11g. 27, 28, 29, 1901. 1902. 1. 184.

Amrican Issociation of State Weather Services, 2 d annul convention of, proceelings of, with reference to former conven-

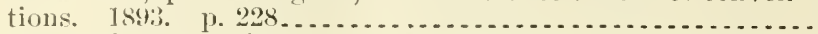

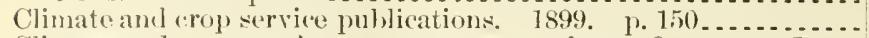

Clinate and ('rip) service reports, extracts from, Oct., 1895-Dec. 1902

Corn, wheat, cotton, sugar, and rice region, Weather Burean service, instructions roveruing 1897

Weather foreasts, metlorls employed in distrihution of 1901.

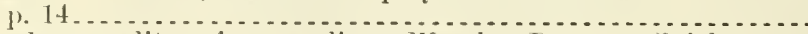

See ulso, as editor of proceedings, IV eathor Burean officials, ('onventions.

Berry, James E. State weather services, reports of, A pr., May, Sept.,

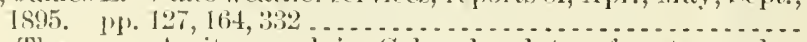

Berry, Thomas. Amity (anal in Coloralo, inty of water under.

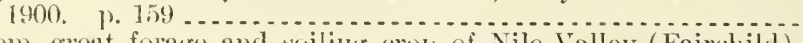

Berseem, great forage and soiling (rop of Nile Valley (Fairchild).

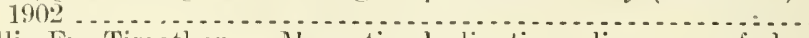

Bertel]i, Fr. Timotheus. Magnetic declination, discovery of, by

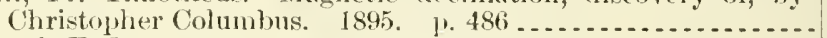

Bertlıomel, E. L.:

Agricultural resources of Jefferson Comnty, Colorado. 1569. p.

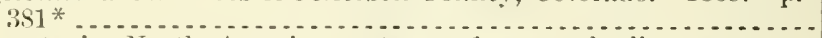

Loensts in North America, extracts from early literature on.

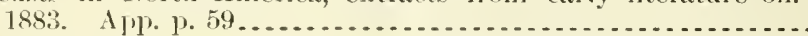

Besana, Charles:

Butter and atriticial butter, methods of distinguishing. 1889.

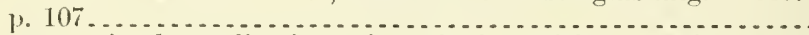

Butters, mixed, application of methods Reichert, Meissl, and

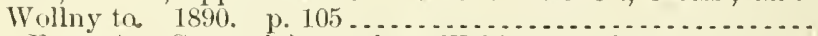

Bessey, Ernst A. See, as joint author, Webber, Herbert John.

Besson, louis. Meteorology, optical, circunthorizontal arc in. 1902.

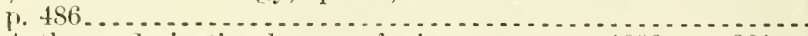

Betts, Arthur. Irrigation by $11 \mathrm{se}$ of wire, report on, 1899 , p. $301 .$.

Pentelspacher, Gustave. Canarlian-Britisl rattle tralle, decrease in. 1). 515 .

Beverages. See Cider-Coffee-Fermenterl alcoholic beveragesliquors - Tea.

Beverly, Robert. Beof, hreerling and feeding of, and supply of mar-

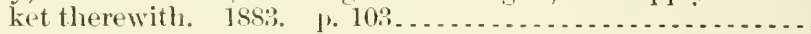

Bevier, Isabel:

Negroes, dietary studies among, in eastern Virginia, in 1898.

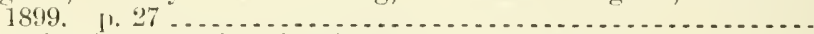

Nutrition investigations in Pittsiurg, Pa., $1894-96 . . .2 . . . . .$.

Bevicr, Isabel, and Spragne, Elizabeth C. Dietary stndy at Iake Erie College, P'ainesville, Ohio. 1901. p, $27 \ldots \ldots . . . . .$.

Biarr, L. True ash in cane-sugar manufactory products incinerated with sul phuric acid. 1891. p. $77 \ldots \ldots . . .2 \ldots$

Bibio albipennis as an injurions insect, note on. 1886 , p. $36 \ldots \ldots .$. Bicarbonate of soda in milk, detection of (Pade). 1889. I\%. 170 ... Bicyciers, mechanieal work aud efficiency of (Carpenter). 1901.

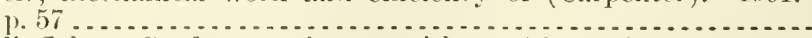

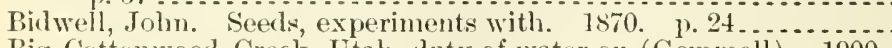

Big Cottonwood Creek, Utah, dnty of water on (Gemmell). 1900.

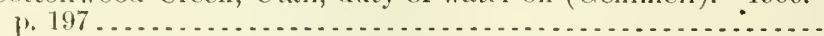

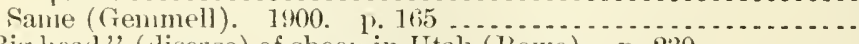

"Big head" (disease) of sheep) in Utah (liowe). p. $230 \ldots \ldots \ldots . . .$. Big florn llountains of Wyo:ning, plants from (Rose). 1896 . p. 567. Bige Thompson River, irrigation from (Field). 1902...............

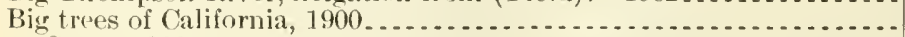

Salle, 1900 
Bigelow, Frank Hagar:

Atmospliere-

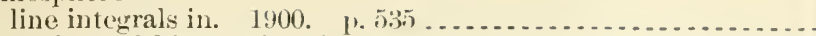

staties and kinematics of, in $\mathrm{C}$. S., studies on. 1402. 111. 13,

80, 117, 163, 250, 304,347 ... . . . . . . . . . . . . . . .

Atmosplieric pressure-

high and low, monthly notes on, July-Oet., 1S:5 ..........

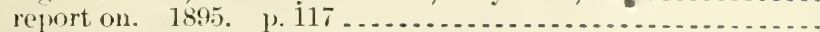

Balloon ascensions on IIarch 24, 1899, in France, p. 197......

Piarometry of $\mathrm{L}$. S., Canada, and West Indies. $1902 \ldots . . . . .$.

Chicago weather furecast district, monthly report of, .July, 1900. .

Cloud observations--

international, of Weather Bureau. 1899. p. $404 \ldots \ldots . . . .$. international, some results of, for I..S. 1899. p. . . . . . . . made in cooperation with scheme of International Clourl

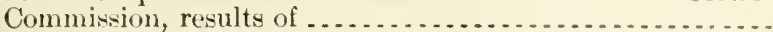

Coorlinate axes, standard system of, for magnetic and meteorological observations and computations. 1897. p. 201

Cyclones, hurricanes, and tornadoes. 1898. p. $525 \ldots \ldots \ldots \ldots$.

Eclipse meteorology and allied problems. 1902 . . . . . . . . . .

Hann's (Julius) neteorology. 1902 . p. $298 \ldots \ldots$
Magnetic observations, notes on new methor for, riscussion of. 1892

Meteorological observations made to determine probable state of sky at several stations along patl of total eclipse of sun,

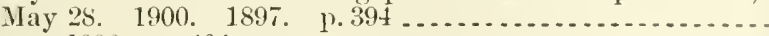

Same. 1898. p. $404 \ldots \ldots . .$.
Meteurologist, work of, for benefit of agriculture, commerce, and

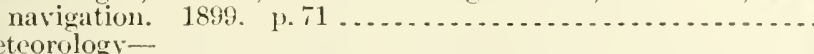

Meteorology-

higher, in Weather Bureau. 190:2. 1'. 19 _...

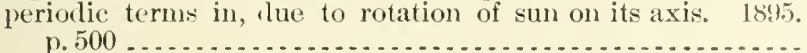

Meteorology and magnetism, montlly rejort on, March, 1895-

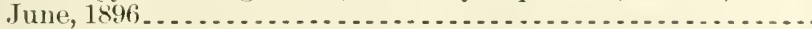

Mexico, National IIcteorological Congress of, 1st, 1900, digest of report of. 1\%.311

Solar and terrestrial nagnetism in their relations to meteorulugy. 1898

Solar magnetism, report on relations of to terrestial magnetism and meteorulogy. p. is

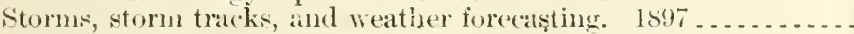

Sun sprots and weather, commection between. 1895.- p. $91 \ldots . . .$.

Temperature-

comparison of, with magnetic horizontal foree. 1894. $111 .+15$,

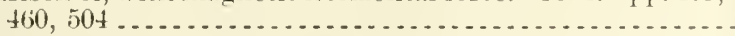

same. $1895.96 \ldots$ diumal range of, variation of, with latitude and locality. 1902.

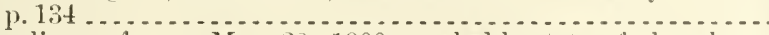

Total eclipse of sun, May 28, 1900 , probable state of sky along

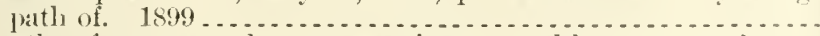

Weather forerasts and storm wamings, montlily notes on, JuneAug., 1898.

Bigelow, Willari Dell:

Food preservatives, use and abuse of. 1900. 1. $551 \ldots \ldots \ldots \ldots .$.

Fouls and foorl control. 1902

ional nethorls for analysis

Liptors, fermenterl and distilled, provisional methorls for analysis

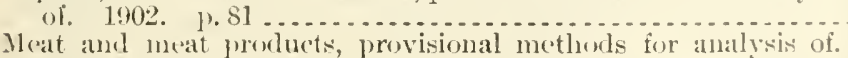
1902.

Preserved meats, adulterations of, report on, witl (a)lialonation of Elwarr Mackay Chauee, I. S. Mumson, I. M. Tolman, amd others. 190:2. 1). 1375.

Pure-food laws of Furopean countries affecting Amoriean exports. 1901

Wines, American, composition of. 1900 
Bigelow, Millarrl Dell-Continued

See illow, als collaborator, Mc.Elroy, Karl P. - Wiley, Harvey

IVashinston; as joint anthor, Ewell, Erwin Elgar; as joint editur, Chemical analysis, methods of.

Bigelow, Willad Dell, and Swectsor, William S. Fond andulteration, mothuls for determination of. 1897. p. 117 ............

Billings, John Shatw, and Curtis, Edward. Fluids of diseased cattle with reference to presence of ('ryptogamic growths. 1869.

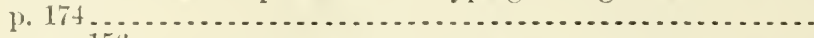

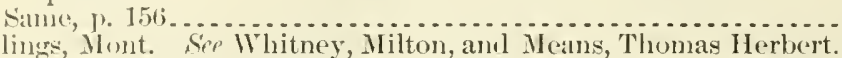
Billings, Mont. Sep Whitney, Milton, and Means, Thomas Merbert.
Bingliam, Joseplı II. Adelress of, before Mmerican Association of Farmers' Institute lVorkers, at seventl annual meeting. $190^{\circ}$.

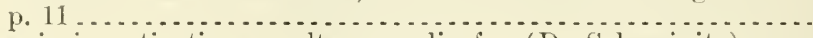

Biochemic investigations, culture merlia for (De Schwoinitz). P. 145 comic laboratory, investigations conducted by, in 1892 (I)

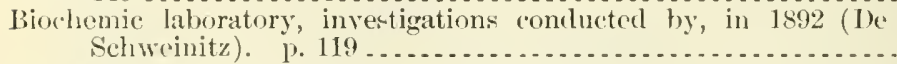

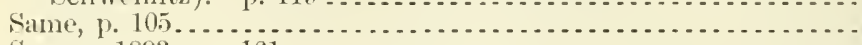

Same. 1893. p. $161 \ldots \ldots \ldots$

Biologic notes on New Mexico insects (Townsend). 1892. p. $37 .$.

Biological and dairy buileling, at New York State Experiment Station,

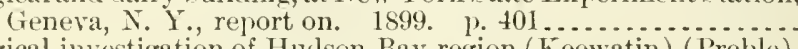

Biological investigation of Hudson Bay region (Keewatin) (Preble). 1902

Biological reconnoissance of soutl central Idaho (Ierriam). 1891 ...

Biological reconnoissance of $Y$ ukon River region. 1900 ..........

Biological Survey Division, Agriculture Department:

Publications of

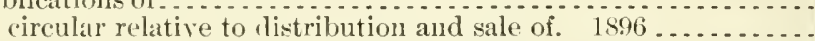

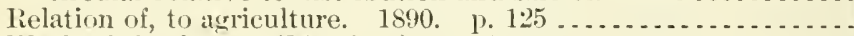

Work of, for farmer (Merriam). 1897. [1. $115 \ldots \ldots \ldots \ldots \ldots \ldots$

Biological Survey:

Hount Shasta, Cal., results of (Merriam). 1900 ..............
San Francisco mountain region and desert of little Colorado River, Arizona, results of (Merriam). $1890 \ldots . . . . . . . . .$. Biology. See Metabolism.

Bircll:

Coccirl on, new (Huhbard and Pergande). 1898. p. 13....... Oceurrence of Bucenlatrix canadensisella on, in Rhole Fiand

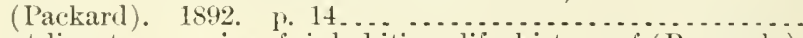
Plant-lice, two species of, inhabiting, life history of (Pergande).

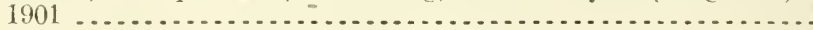

Birch trecs, destructive borer enemy of (Chittonden). 1sss. p. 44. Bird, William $\mathrm{X}$. 1). Ergotism among cattle in Kansas. 1. 317... Birl day in the schools. . . . . . . . . . . . . . . . . . . . . . . . . . Bird-lice. See Mallophaga.

Bird migration in Mississippi Valley in 1884 and 1855 (Cooke). 1888. Bircls:

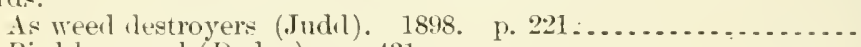

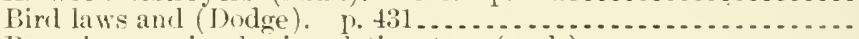

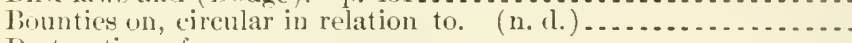
Destruction of-

cotton worms by (Redfield). 1883. No.65. p. 25........

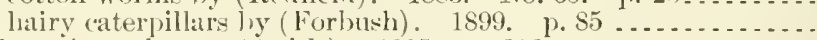
Effect of weather on (smith). 1895. p. 212............... Farm, value of, on (Camuels). p. 201 ... . . . . . . . . . . . . Food halsits and distribution of, in parts of Minnesota and Dakuta

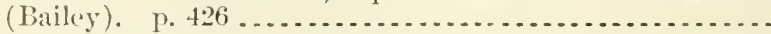

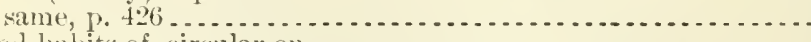
Foorl liabits of, circular on . Four common, of farm and garden (Judd). 1895. p. 405 ....

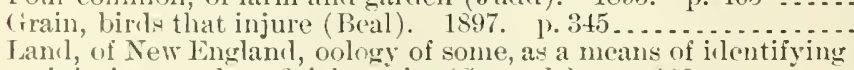
injurions or beneficial speries (Samuels). p. 3A6......... Legistation for protection of birds other than wasse (Palmer)....

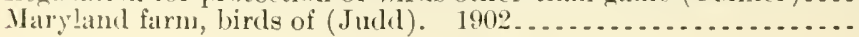


Iulberries, birds which feer on (Merriam). 1. $285 \ldots . . . . . .11 .1: 890$

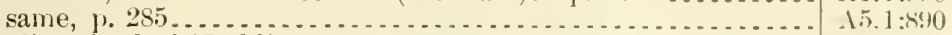

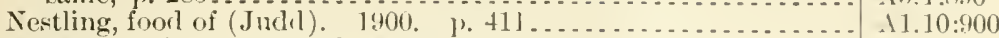

North American, geographical distribution ancl nuigration of, circular on. 1887 .

Noxious, danger of introducing (Palmer) 1898 . J

Observed in southern ('alifomial, sonthern Nevarla, and parts of Arizoni, and Utah, notes on, being report on ornithology of Death 1 alley expedition of 1891 (Fisher). 1893. 1. $7 .$.

Orchard, how lirds affect (Peal). $1900 . \quad$ p. $291 \ldots \ldots . . . . .$.

Permits, birds which may be imported without. 1900 . . . . . . . .

Poisoning, experiments in (Fisher). p. 423................

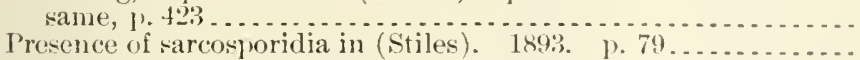

Protection and importation of, under act of Congress approveri Nay 25,1900

Protection of-

Directory of State officials and organizations for 1:901 (I'alnere) same. 1902 .

Laws for, in District of Columbia. $190 \mathrm{~L}$

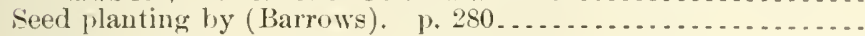
same, p. 280

Some common, in their relation to agriculture (Beal) . . . . .

Song, effect of ajlyroaching storms upon (Limney). 1898. p.354.

Stomachs of, directions for collecting. 1891 ................ same.

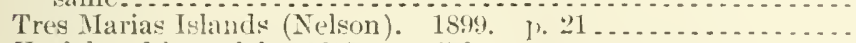

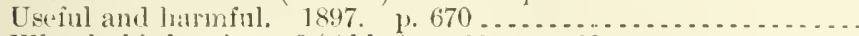

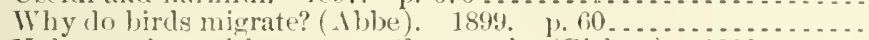

Yukon regirn, with notes on other species (Bishop). 1900. 1.47.

See rlso Baltimore oriole - Blarkhirds - Bhne jay - Bololink-Carrion cows-Cerlar bird-Crow blackbirls-('rowsCuckons - English sparrow-Eurolean tree sprum- faune birk-Cirackles - Cirodjeak - llouse suarrow - Killdeer pher - Kinobird - Marsh hawk - Ml earlow lark - triole. Ornithology - fwl - Pheasants-I'igeons-Sparrow - Sparrow hawk - Iroodpecker:

Birds and ganse:

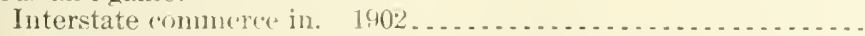

National and state rrganizations for protertion of -

1899. 1. 713

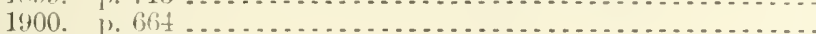

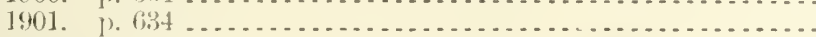

State uflicials and organizations concerned in protection of, rirestory of. 1900

State oflicials concerned with jotertion of, list of -

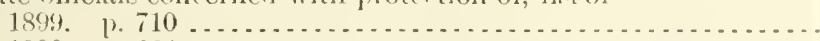
1900. 1. 661

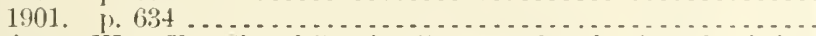

A.5. $4: 8$

11.10:898

$15.5: 7$

$11.10: 900$

A. $.4: 30$

A].1:887

$15.1: 887$

A $4.3: 3$

A. $4: 29$

Ais. $4: 3 ; 3$

15.4:35

15. 4:34

$11.1: 890$

A.5.1:890

1 1.9:54

1 $29.6: 26$

15. $4: 4$

A5.4:12

A5.5:14

A1.10:8:17

A29.ti:27

15.5:19

15. $4: 38$

A 1.10:899

$11.30: 900$

11.10:901

15. $4: 28$

11.10:899

11.10:900

11.10::0101

Birkheimer, Wn. F. Signal Service Burean, sketch of work of, for agriculturist. $1882 . \quad$ p. 110

Same, 1885. 1) 191.

Bishop, Louis Bennett. Yukon region, birks of, with notes on other

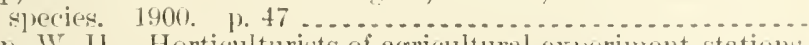

Bishop, W. Il. Horticulturists of agrionluiral exjeriment stations, secretary's report of meeting at (columbus, ohio, lune 13, 14,

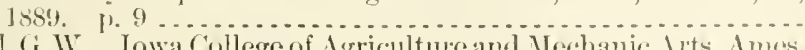

13isell, (i.W. Iowa College of Agricultureand Mechanic Arts, Ames, Iowa, slopwork instructions at. 1894. p. 6i).............

$11.8: 2: 2$

A1.7:!

$15.5: 19$

$110 .: 3: 3$

1 $10.8: 20$

Bisulphid. See Carloon bisulphid.

Bitter rot. Sire Apple.

Bitting, Arrill Wayne:

Indiana, hog cholera and swine plague in. p. $199 \ldots . . . . . . .$.

Veterinarian, experiment station, and foral veterimarians in the State, lecirability of conperation between. Is:s, p. 231... sallere, 1). 420 
Bitting, Arvill Watye-Continued

Veterinarians, laboratory reenrls for. 1s9s. p. 18

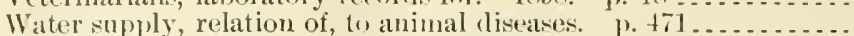

Bixhy, William llerbert. Word-reosote ail. 1857. p. 99 Sillile. Reprint. p. 282.

A $4.3: 22$

14.]:899

A 13.3:1

\13.3:9

Bjerknes, V. Atmospliere, circulatory movements in, ivnamic: prin-

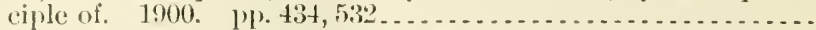

Black, Samuel E., short biography of (Abbe). 1898. p. 217 .....

Black alkali. See sorlium varbonate.

Blatck tlies. Sce Buffalo guats.

Blitck-heal sheep. See Somali.

Black Hills, South Dakota:

Evotomys from, description of (Merrian). 1890. 1) $119 \ldots \ldots .$.

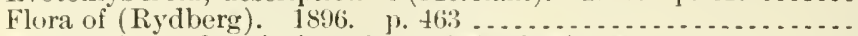
Marmot from, description of new (Merrian). 18s!) p. $7 \ldots \ldots$

Black Iills Forest Reserve, insect enemies of pine in (Hopkins). 1902

Black knot of plum and cherry trees (Peck). p. 175. . . . . . . . .

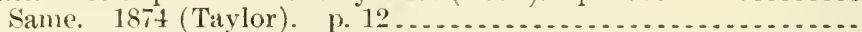

Black-quarter. See Blackley.

Black River thaw, note on (Abbe). 1900. p. 114..............

Black rot. See Cabbage - Crape - Sweet potato.

Black scale:

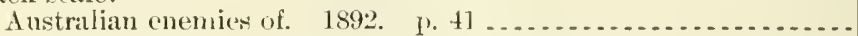

Of California-

found in South Carolina, note on. 1886, p. $36 \ldots \ldots \ldots \ldots . .$.

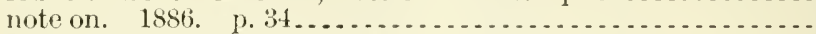

Black spot of asparagus berries (Faimman). 1889 , p. $157 \ldots \ldots$

Blacklerry, lecanium infesting, eonsidered irlentical with L. fitchii (Cockerell). 1894. p. 29.........................

Blackberry borers, notes on (Smith). 189$]$ p. 27.2.
Blackberry rust, perennial mycelium of fungus of (Newcombe).

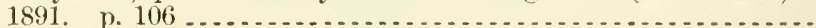

Blackbirls:

Depredations of, in northern Iowa and southem Minnesota in fall

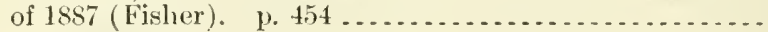

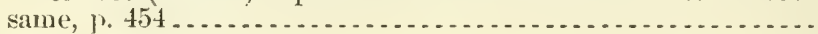

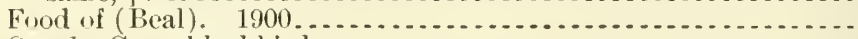

See rlso Crow blackbird.

Blackleg or black-quarter:

Among cattle, letter on (Watts). 1874. p. 157.

Nature, eause, and prevention (Nörgaard). 1s9s $\ldots \ldots \ldots$

Preventive vaceination against (Nörgaard). $1897 \ldots \ldots \ldots \ldots \ldots$

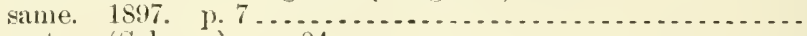

Report on (Salmon). p. $84 \ldots \ldots \ldots \ldots \ldots \ldots$

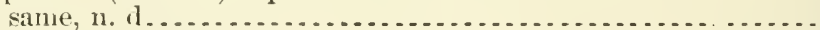

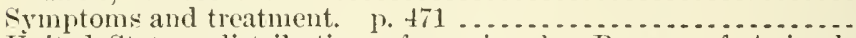
United States; distribution of vaceine by Bureatu of Animal Industry (Nörgaard). p, 27 .................... same, abstract; "Blacklegr: its nature, cause, and prevention";

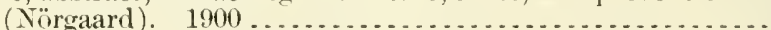

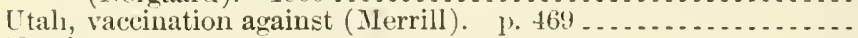
Vactine-

directions for use of (Nörgaaril). 1897.

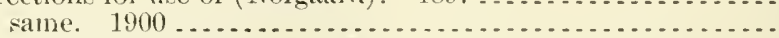
distribution of. 1899 p. $582 \ldots \ldots \ldots$

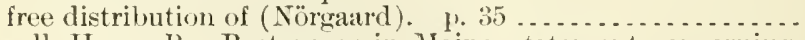

Blarkwell, Henry B. Beet sugar in Maine, statement concerning.

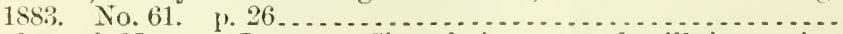

Blackwood, Norman Jerone. Shanglıa, neat and milk inspection

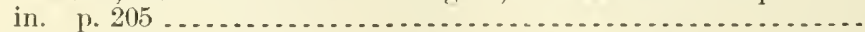

Blarlifer, human, vinegar eel infection in, case of (Stiles and Frank-

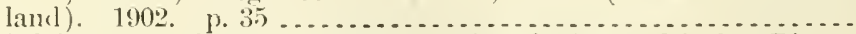

Blaislell, F. F. Coleoptera, some species of, observed in San Diero Connty, Cal., notes on habits of. 1892. p. $33 . \ldots . \ldots . . .$.

B'ake, F. L. Cloud observations at Toronto. 1897. p. 19........

129.6:28

1 $29.6: 26$

A $5.5: 5$

A6.5:3

A5.5:2

19.6:32

1 $1.1: 872$

A $27.9: 12$

129.6:28

A $9.7: 5$

19.3:12

A9.3:12

128.5:5

A9.7:7

19.7:4

$128.5: 6$

11.1:887

15.1:887

15.3:13

127.9:12

14.4:23

14.4:20

1.4:21

14. ]:89:3-4

14.4:6

14.1:887-8

1-1.1:898

14.4:31

14.1:899

14.4:21

$14.4: 23^{3}$

14.1:899

14.1:900

A27.9:21

14.1:898

At.3:35

19.7:5

A29.6:25 
Blandford, Samuel M.:

Climate of Jlaho, some features of. 1901. 1. 19.............

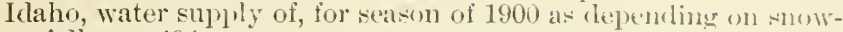
fall. p. 494.

See also, as joint antlior, Pague, Bomers.

Blandford, W. F. H. Scolytidie and their fuorl phants, notes (1I.

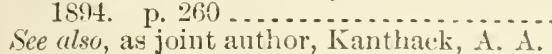

Blarina, American genera, revision of shrews of (Merriam). 1s95. 1. 5 .

Blasclale, Walter C. Chinese regetable foor materials, descrijotion of, and their nutritive and economic ralue. 18.19

Blastophaga psenes, first introduction of, into California (lisin). 1891. p. 128.

Bleclynder, A. H. Rheea fiber, information concerning. 1850.

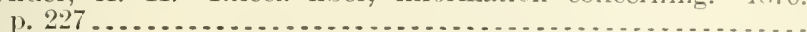

Blight, George. Ginenon system of selecting ('attle, value of. $188 \%$.

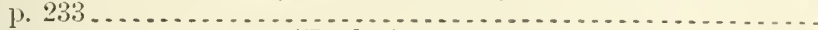

Blight, pear-tree, report on (Taylor). 1872 . p. $225 . . . . . . . .$.

Blister beetles, great damage to beans by, note on. 1886. p. $37 \ldots$

Blister mite, pear-leaf, report on (Slingerland). 1892. p. 104..... Blizzard:

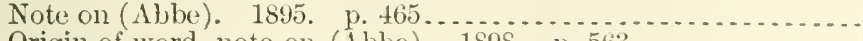

Origin of word, note on (Abbe). 1898, 1) $563 \ldots \ldots \ldots \ldots$

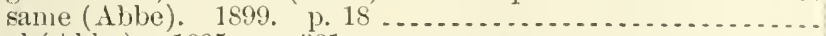
sand (.lblue). 1895. p. 381

B]odget, Lorin:

Forest cultivation on plains, general discussion of. p. 316......

Short liography of (Ahbe), 1901. 1) 174 ...............

Blom, Jules:

Boots and shoes, Amorican, in Demmark. 1. 521.... . . . . . .

Iorse ineat, Anerieam, in Denmatrk. ๒. 50,

Blood and serum injections in connection with Texas ferer investi-

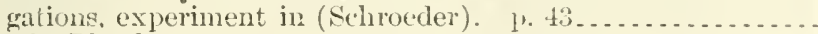
See cilso Blood serum.

Blood horse, essay on (Jackson). 1852. p. 50.

Blood louse, observations on cycle of sexual development of ( $\mathrm{Hok}$ -

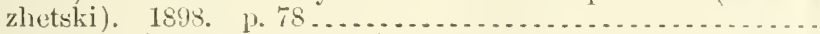

Blood poisoning (malignant edema) in slieepand lambs in New / land (Gilruth). 1). 233

Blond serum, experiments with, as a preventive and cure for lixas fever (Robert). 1'. 482

see cilso Iiloorl and serum.

Blood-ressels distrases:

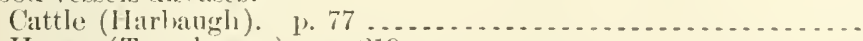

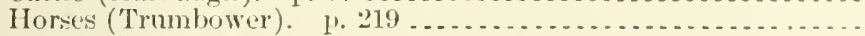

Blount, $A$. F.:

Cereals, improvement of. 1882. p. 104

Wheats, oricrin and treatment. $\mathrm{p}, 550)$

Blue IIIl meteorological olservatory, Milton, MIass.:

Clourl observations and measurements at (Ritch), 18:?. 1\%. 1:. same (Clayton). 1897. T. 135 . . . . . . . . . . . . . . . . .

Exploration of air with kites at, progress in (liotch). 1sis. p.

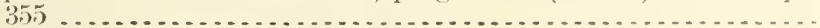

Kite, high, ascension at (F(rgusson) 1896. 1). $327 \ldots \ldots \ldots \ldots$

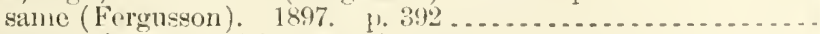

Kite experiments at ( lergusson). 1896. p. 32: . . . . . . . . .

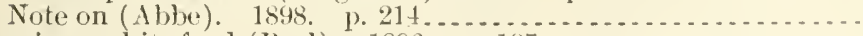

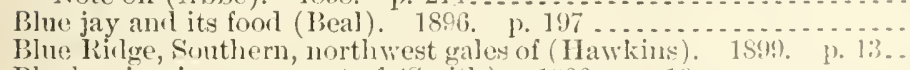

Blweberries, improvement of (Smith). 1900. 1\% 18 . . . . . . . .

Bluegrass seed, Kentucky, harvesting, curing, and clcaning (Pioters

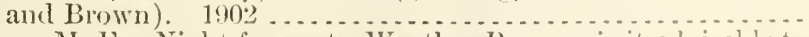

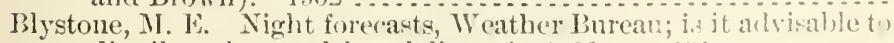
distribute by rural free delivery? 1902. p. 1!1 . . . . . . . . .

Blythe, $W^{T}$. T. Weather forecasts, distribution of, methods of sasing time in. 1902. 1. 203 .

i10.:3:is

$127.91: 5$

$11.7: 2$

A: $1.91: 10$

A $9.3: 1: 2$

19.7:5

129.6:2:3

129.6:26

A $29.6: 27$

A29.6:2:)

A1.1:57:

A29.6:29)

14.1:К? 19

$.1+1: 100$

14.1:s9:!

A1.8:2:2

$19.4: 18$

A. $1: 1901$

$14.1: 598$

1+.2):( 289$)$

$1+.2: 117$

11.8:20)

11. 1:121-2

1.29.6:25:5

129.11:25

129. $6:: 26$

1:99.6:24

$129.61: 25$

129). $6: 2:-1$

129.6:20 6

11.10:891;

$129.6: 27$

11.9:119

(19.):3:1!)

1:99.:1::;1

1:99:3::1

$114-0+-13$ 
Bo:monan, Samuel L.:

Climate, soil, physical resources, and agrienltural apabilities of Iaine, with special reference to oceupation of its new lambls. 1884

Corn caning in Maine. 1886 . p. 554 .

A $1.7: 4$

A:27.9:24

Maine, agriculture of, some ontlines of. 1\%.39 ............ $11.1: 86^{6}$

Nova Scotia and New Brunswick, tidal lands and rlikerl narsies

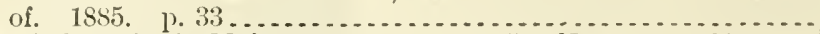

Starch factories in Maine, report on. 1885. No. 19. 1\%.23.....

Boardman, Samuel P'. Sheep hushandry in the IVest. I. 286.....

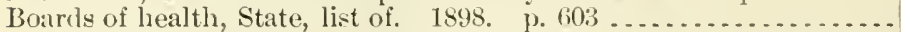

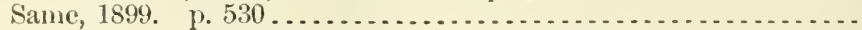

Boards of trade that publish commercial news, list of:

1899. p. 758

1900. p. 752

Boat crews. See Harvard and Yale boat crews.

Bobolink, food of (Beal). 1900.

Bïdiker, T. German Empire, statistical menoir of. 1874. p. 266 .

Boly material, available energy of (Atwater). 1901. p. 112......

Boerner, Charles G. Short biography of. 1900. p. 22..........

Boggs, Elward M. Water rights on Los Angeles River, Cal., study of. 1901. p. 327

Bohemia:

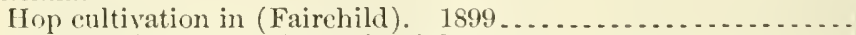

II orse-radish culture in (Fairchild). 1899

$11.7: 7$

+27.9:23

A 1.1:862

A $4.1: 898$

1. $1: 899$

A1.10:599

ג1.10:900

11.10:901

A5.3:13

127.9:12

110.3:99

129.6:28

110.3:100

A6.4:19

16.4:20

A26.5:901

Boise area, 1daho, soil survey of (Jensen and (Jisilusen). 1). 421 ..

Boise Valley, Idaho, duty of water as related to irrigation prol)-

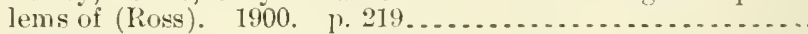

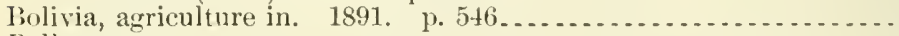

Boll worm:

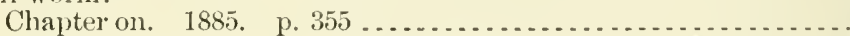

Injuring corn in Califormia (Coquillett). 1859. 1.331.......

Injuring tomatoes, experiments on (Tracy). 1. 141 .......... same, p. 141 . . . . . . . . . . . . . . . . . . . . . . . . .

Mississippi, observations on (Mullen). 1893. p. $240 \ldots . . . .$.

Report upon (Johnson)-

1880. p. 150 .

1880. p. 150

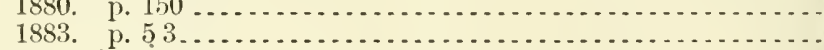

1 10.3:86

A 27.9:29

18.1:4

A9.7:1

A1.1:S58

A9.1:888

A9.7:5

A1.1:881-2

A9.1:S5:

19.3:1

Boll worm of cotton:

Progress in supplementary investigation of (Mally)-

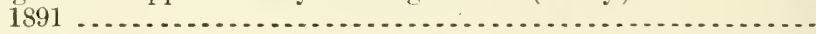

1892. p. 45 .

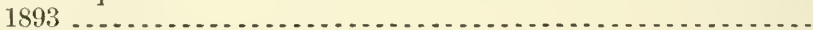

Report on. 1879. p. $285 \ldots \ldots \ldots$

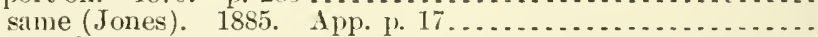
see also Cotton insects.

Bolley, Henry L.:

Cheese-curd inflation; its relation to bacterial flora of foremilk. 1896. p. 78

kxperiment, its conception, and methods of procedure. 1898.

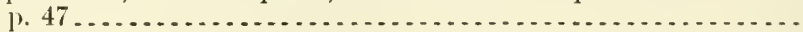

Bollman, Lewis:

Hop plant, cultivation of. p. 97.

Industrial colleges; nature of education to be given in them; their several kinds of instruction, etc. $186 \pm$

Silk cultivation, condition of, etc. p. 304

ITheat plant, report on.

A $9.3: 24$

A9.3:26

19.3:29

A9.2:C82

A $8.1: 4$

A 10.3:30

A 10.3: 49

A1.1:864

A27.2:In2

A1.1:872

A1.1:862

A1.1:862

See also, for reports as statistician, Agriculture Department, 1863 and $186+$

Bolton, B. Meade. Swine, epidemic diseases among. p. $135 . . . .$.

Bombyeide, list of, taken by electric lamps at Poughkeepsie, N. Y. (Dyar). 1891.

A27.1:

A $4.1: 889-90$

Siee also Moths.

A9.7:3 
Bond, Fdward A.:

Address of welcome at International Good Roals Congress, held at Buffalo, N. Y., Sept. 16-21, 1901. p. 9 ..............

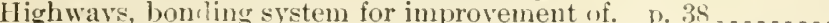

State aid to roud ruads in New York 100 .

Bond, Frank. Irrigation of rice on uplands of Lonisiana and Texas. 1902. p. $11 \ldots \ldots \ldots \ldots \ldots \ldots$

Bond, Fred, and Wilson, James Maxwell. Irrigation system of

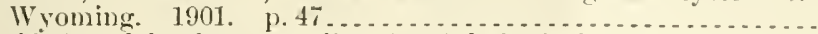

Bond-icled and land-grant railrouls, alphabetionl list of, in U.S.

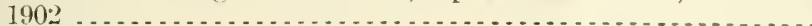

Bone fertilizers. See Fertilizers.

Bones:

Diseases and accidents to, of eattle (Atkinson). p. 281 ......... Used as fertilizers, new process for dissolving. 1866. p. $3337 \ldots$

Bones and bone ash, export of, from Urugnay (Swalm). p. $519 \ldots .$.

Bonsteel, Jay Allan:

Soil survey of Kent County, M[d. p. 173 same, St. Marys County, M«l. p. 125

See also, as joint author, Dorsey, Clarence Wilbur.

Bonsteel, Jay Allan, and Burke, R. T. Avon. Soil survey of Calvert

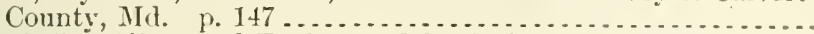

Bonsteel, Jay Allan, and Taylor, F. W. Soil survey of Salem area,

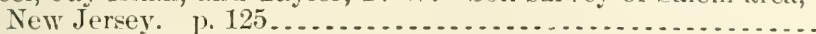

Bonsteel, Jay Allan, and party:

Soil survey of Prince George County, Md. p. 173.............

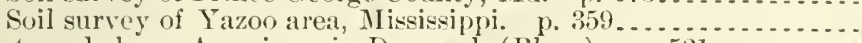

Boots and shoes, Anerican, in Denmark (Blom). p. 521.........

Borax as a preservative of butter, letter relating to (Crosby). p.576.

Bordeaux mixture:

Chemistry, physical properties, and toxic effects on fungi and

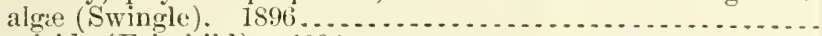

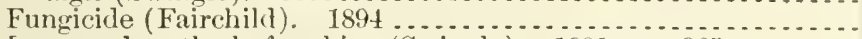

Improved method of making (Swingle). 1891. p. $365 \ldots \ldots .$.

Börgen, C. Polar experlitions, international, 1882-83. 1895. 1.

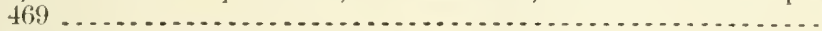

Borstel, E. von. Date, cultivation of. 1883 p. p. $25, \ldots \ldots \ldots$

Bus, J. Ritzema:

Aphelencluns olesistus, a nematoid worm, canse of leaf sickness in Begonlia and Asplenium. 1893. p. 161 ....................

Phytomyza attinis as cauve of decay in clematis. 1893. p. $92 .$.

Bosnia and Herzegovina, Austria-Hungary, agricultural development in. 1894 . p. 197

Bosse, Eugene. Flax culture in the Northwest, investigation of, in 1891. 1892. p. 40 .

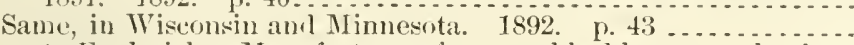

Bossert, Frederick. Manufacture of grape, blackluerry, amil other fruit wines, on Gall's methor, with few remarks on cultivation of grapevine in Germany, France, and U. S. p. 156.

Boston, Mass.:

Cattle, sheep, and other ruminants, and swine, prohibition of

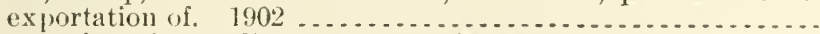

Exportation of Canadian eattle from (Allerton) ..............

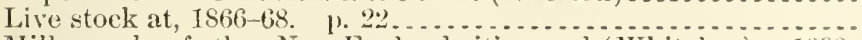

Milk supply of other New England cities, and (Whitaker). 1s98,

Precipitation at, 1889-91. p. 108.

Weather forecast district, report of, monthly, Jnly, Oct.-l)ec., 1901 (Snith) . . . . . . . . . . . . . . . . . . . . . . .

Bot: - same, Jan.-Oct., 1902 (Smith)

14.2:C292

127.9:4

A 4.1:900

A $26.5: 900^{1}$

A26.5:900 1

A26.5:900

A26.5:901 ${ }^{1}$

A26.5:901

A $26.5: 901^{1}$

A4.1:899.

A 1.1:878

A28.3:9

A28.3:6

A28.5:7

A29.3:1 $11^{2}$

A1.8:24

A9.7:6

A9.7:6

A27.9:32

111.5:4

A1].5:t

A $1.1: 863$

A $4.5: 100$

A1.2:(2: $3^{3}$

127.9:7

A 4.3:20

A29.6:2:1)

1:29.6:29

129.6:30

Cottontail. Further notes on, with breeding and identification of

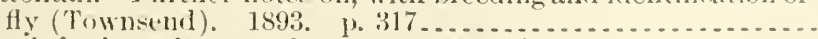

Man-infesting, alsetract of paper on (Matas). 188s. 1\%.6.....

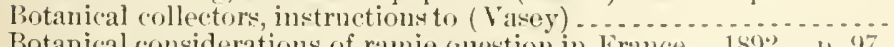

Botanical considerations of runie question in France. 1892. 1\%.97.

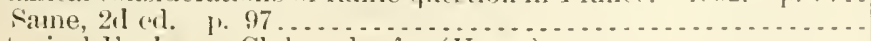

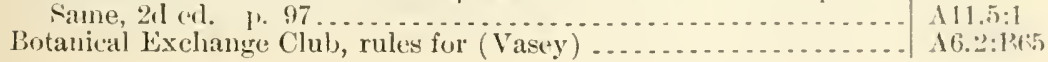

$19.7: 5$

$19.7: 1$

16.2:In7

A27.8:1 
Botanical explorations in East Tennesse (l'arry). 1870. 1. 221 ..

Botanical history of sorghmm (l'eck). p. 299.................. A1.1:865

Botanieal instruction, importance of mycoplasey in a conses of

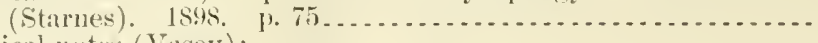

Botanical uotes (Vasey):

1872. 1) 20.22, $313,381,446,505$

1873. PP. $34,115,171,247,354,503,585$.

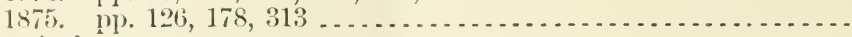

liotanical survey:

Alaska, $1898^{\circ}$ (Evans). p. $48 .$.

Dismal Swany region (Kearney). 1901. 1).321

А $27.9: 10$

A $27.9: 11$

$127.9: 12$

А $27.9: 13$

$110.3: 6: 2$

Jotanists at agricultural experiment stations in I. S.:

Function of (Stune). 1901. 1. 138.....................

List of, with ontline of work in botany at the several stations.

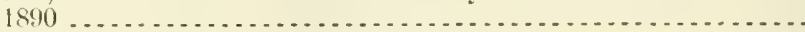

Butainy:

Mlistracts of reports of agricultural experiuent stations on. $1889-1902$

Arricultural, review of publications on, issucel in Fance luring

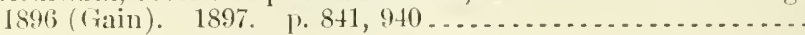

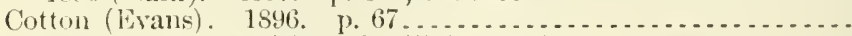

Death Valley Fxpedition (Coville). 1893.

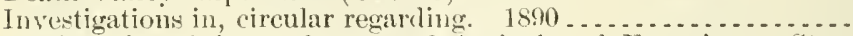

Outline of work in, at the several Agricultural Fxperiment Stations. 1890

Publications on, in Agriculture Department library. 1902.

Text-looks on (Coville). 1899. 1. 15t_..................

Takutat Bay, Alaska (Coville and Funston). 1895. D. 325 .... Ser ulso Agriculture - Plants - learlings beginning Botanical.

Hotauy and agriculture of Rocky Mountain basins (Thompson). p. 125

Jutany committee of Association of American Agricultural Colleges and Experiment stations, report of. 1890 , p. $128 \ldots . . . .$.

botany Jivision, Agriculfure Department:

Couperative branch stations in Sonth, report of superintendent.

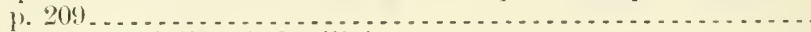

Pulblications of, list of (Coville) . . . . . . . . . . . . . . . . . .

Recort of some work of, including extracts from correspondence aml other commmitations (Vasey). 1889. p. 7..........

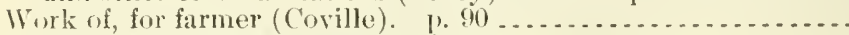

See also Teretable P'athology sertion.

Botan section, Association of Anerican Agricultural Colleges am Experiment stations, report of:

1890. p. 128

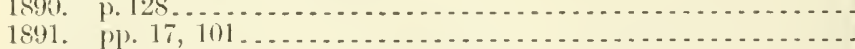

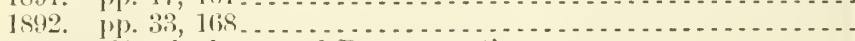

Sere also llorticulture amel Botany section.

Bollly, emascoulating, report on. Iss?. 1). 214

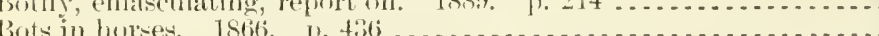

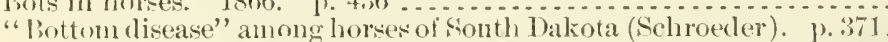

Boncart, Robert. Milk, analysis of, with view to determining its

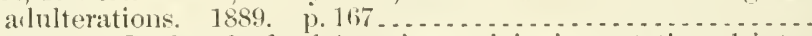

Inuley, —. Pork, salted, of American origin, importation of, into

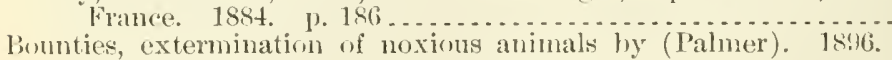

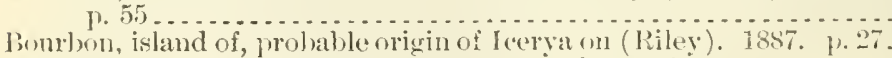

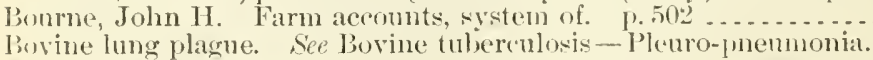
bovine tuberculosis:

barillus, virulence of, for monkeys (Schweinitz and Schroeler).

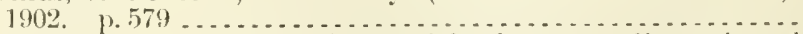

livestigations concerning, with special reference to diannosis and

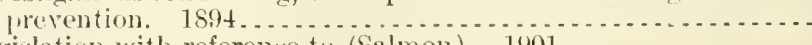

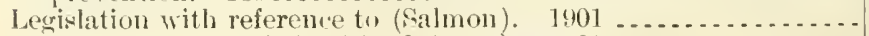

Relatiun of, to public health (Salmon). $1901 \ldots . . . . . . . . . .$.

16.5:5

A 10.3:99

A10.3:6

110.6:

110.6:8

110.3:33

16.5:4

1 10.4:15

A 10.3:6

A 17.3:42

A29.6:27

A6.5:3

A 1.1:86io

A 10.5:3

A6.

11. 1:892

A6.4:30

A6.3:8

\1.10:897

$+10.5: 3$

A 10.3:7

A 10.3:16

19.7:1

$127.9: 4$

14.1:8!1-2

17.:2::24

A $1.3: 30$

\1.10:896

\9.3:15

11.1:865 
Bovine tubereulosis-Continued

Soldiers' Home herd of to cattle, clinical notes on (Kilborne and

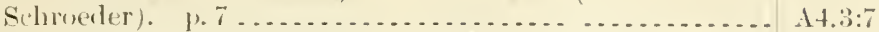
same, patbological notes (smith). 1).26 ............. 14.3:7

studies in, with sucrial reforence to prevention (smith). 1894. 1. 88

See chlso l'lenso-puenumonia-Tuberculosis.

Bovines, contagious pleuro-pmenmonia and infections ]ronco-[mon-

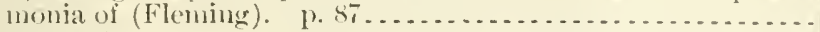

Salmes, 1). 14

see clsis Cittle.

Bowhill, Thomas:

Anthrax and Somthern wattle fever among California cattle. 1.. $44: 3$

Califoruia cattle, mortality anung, antojsies to letermint of. P. 453.

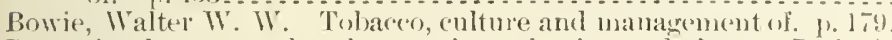

Bowktring hemp, results of recent investigations relating to (Dorlge). $1893.1 \% .52$.

Boxerl or turpentine timber:

Field report on (Roth). 1893.

Strength of (Fernow) .

Box-eliter plant buc circular relative

Boyer, H. B.:

Atmospheric circulation in tropical cyclones, as slown by move-

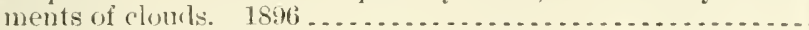

Weather foreeasts and public. 1902 . p. $151 \ldots \ldots . . . . . . . .$.

Wind lirection, some observations of, at different altitudes around

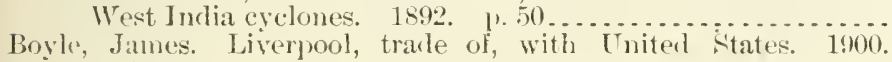

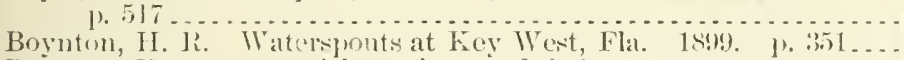

Buynton, Henry. Fianish merinos and their management. j. 1:46. Bozarth, John. Son _. 1111 sugar experinuts at Cedar Falls, Iowa.

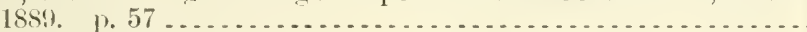

Brackett, Gustarus Bensml:

Apple, and bow to grow it. 1900.

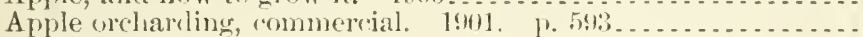

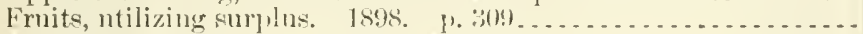

Pomology Division, lerricultum. I)epartment, work of, fon harner.

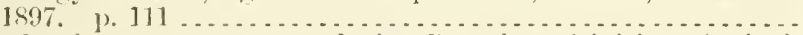

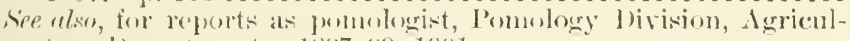

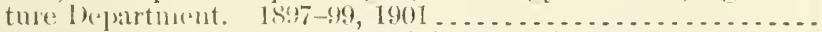

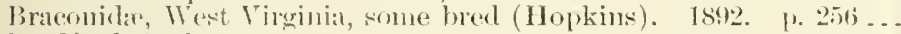
Liralford, 1.. J.:

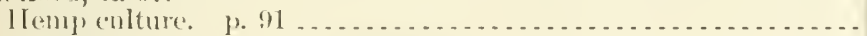

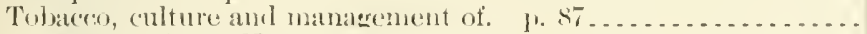

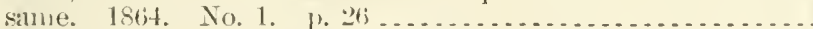
bialley, J. N.:

Cattle interests west of Mississip pi River. p. $424 \ldots . . . . . . .$.

swine and fowl industry of Missomri and ammual lose by disease. 1. 418

braiclentown, Fla., renuakable aurora at, Nov. 18, 1899 (T'en

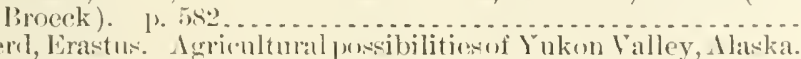

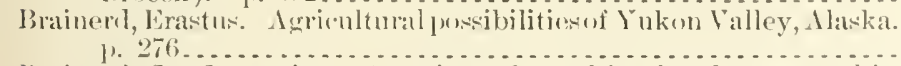

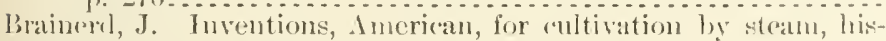

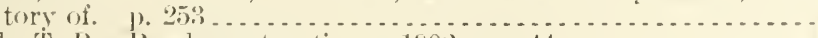

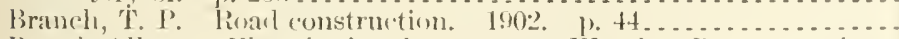

Branl, Albert. Electric signal aplaratus, Weather Burcan station,

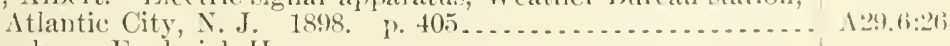

Brandenburg, Frerkerick II.:

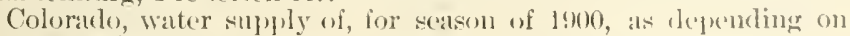
snowfall. r. 4933 .

Denver weather foreast district, momthly reports of, July, fept.Der:, 1901 same, Jan.-(het., 19()$_{2}^{2}$

A $1.1: 6: 91$

$14.1: \$, 11-2$

$1+1: 58.4-8$

At.1:\$S7-4

A1.1: stit

A $11.5: 5$

113.3:8

1 13.4:8

19.5:28

$129.2: \mathrm{tt}^{1}$

129.3:31

$12 ! 1.6: 20$

14.1:899

$1: 9.6: 27$

11.1:S64

17.8:26

11.9:11:

11.10:001

11.10:89s

$11.10: 8 \div 9$

1:2) (1:

19.7:4

11.1:56\%?

11.1:56\%

A:7.9:2

A $4.1: 88.5$

$14.1: 885$

129.6::27

$110.1^{2}:(101$

$11.1: 864$

$122.3: 2: 3$

1:9!.6:2:-8

129.6:2:24)

199.6::30 
Brandenburg, Frederick II.-Continuel

Northers, colll waves, and heavy snows, possibility of giving warnings of, to stock-raising interests 45 hours in adrance. 1899. p. 33.

Weather and live-stock inlustry, rejort on. 1900 . p. $589 \ldots . .$.

Weather types, corresponding, facilities for systematic study of.

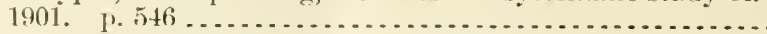
same. 1902. p. 136 .

Brandles, California wines and (Hilgard). 1852. p. 109........ Branuer, John ('asper:

Cotton caterpillars in Brazil. 1885. App. p. 49.

Cotton in Empire of Brazil. 1885.

Insects injurions to cotton, orange, and sugar cane in lirazil, preliminary report of ubservations upon. 18st. p. $63 \ldots \ldots .$.

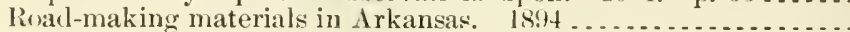

Brassica, seed coats of certain species of (I'icters and Charles). 19()1. Brazil:

Agriculture in. 1891.

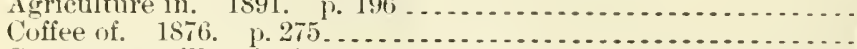

Cotton caterpillars in (Branner). 1885. App. p. $49 \ldots \ldots \ldots \ldots$

Cotton in; antiquity, methods, and extent of cultivation, etc. (Branner). 1885

lnsects injurious to cotton, orange, and sugar cane in, preliminary report of olservations upon (Branner). 1884. p. 63.

Statistics of, $1876 . \quad$ p. 482

Brazos River, Tex.:

Flood bulletin. July 15, 1899. map....................

Flood of June-July, 1899

effects upon agriculture of submerged region (Holmes) . special report on, with notes of previous overflows of river (Cline). 1). 295

Valley of, floods in, April 27 to May 17, 1900 , special report on; also freshets in other streams (Cline). p. 198

Brazos Santiago. See Rio Grande region, Tex.

Bread:

Carbohydrates of (Stone). 1896.

Digestibility and nutritive value of, report of investigations on

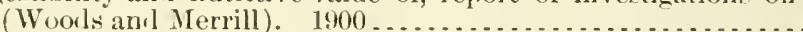

Brearl and meat consmmption in Missouri, data relating to (Gibson and others).

Bread making:

At University of Minnesota, studies on, in 1897 and 1898 (Sny-

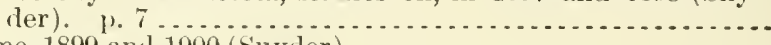

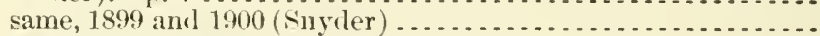

Experiments ill, 1883. No. 3. p. $30 \ldots \ldots \ldots \ldots$

Losses in (Tourhees). 1894\% 1. $37 \ldots \ldots \ldots \ldots \ldots$

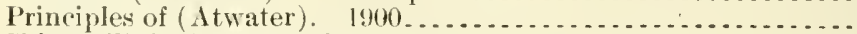

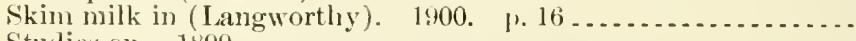
Studies on. 1899

Breadstuffs:

American, foreign markets for. 1863. p. 4. No.4..........

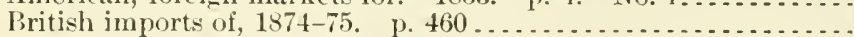

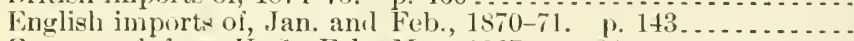

Exports of, from U. S., Feb.-May, 1867. p. 24S..........

Imports of, into Great Britain, 1863-64. No. 1. p. 39 ........

Brrekons, Joseph Allison. Bear River, intrrstate water rights in.

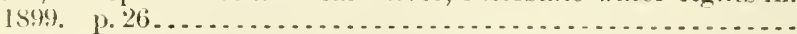

Breel, Daniel. Insect destruction, recent inventions for. p. $323 .$. Broet, (Miss) S. Wvelyn. Teaching domestic science in mual dis-

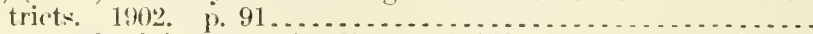

Breeder, work of, in improving live stock (Clay). 1 kist. p. 627...

Breeders, State associations of, list of. 1900 , p. $653 . . .2 . . .$.

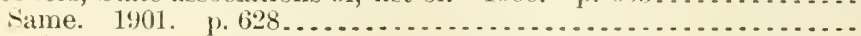
Breerling:

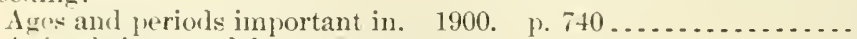

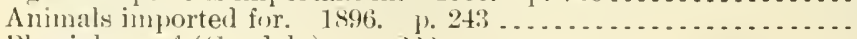

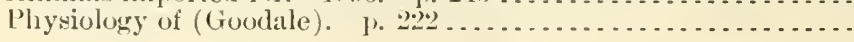

A29.3:24

A:9.6:27

129.6:29

A 29.3:31

A $1.8: 20$

A. $1: 4$

1 $1.7: 8$

19.3:4

A22.3:4

16.3:29

A27.9:29

A27.9:14

A $8.1: 4$

A1.7:8

A9.3:4

A27.9:14

A29.2:B73

A27.4:10

A29.6:27

A29.6:28

110.3:34

1 10.3:85

A 10.3:31

110.3:67

1 10.3:101

A27.9:21

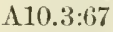

A1.9:112

A 1.9:114

A10.3:67

A27.9:1

A27.9:13

127.9:9

127.9:5

127.9:3

1 10.83:70

11.1:876

A 10.3:1:0

1 1.10:899

A1. $10: 900$

A1. 10:901

\1.10:900

1 $4.1: 897$

11.1:56: 
Breeding-Continued

Sugrested experiments in (Brewer). 1893. p. 162

sante (Brewer). 1893. p. 458 . 1

See clso Aninal - Plant-Stock.

Brefeld, Oskar. Sumt fungi and smut diseases, recent investigations of. 1891. PP. 1, 59, 153

Brendle, A. S. Weather as a topic of conversition. 1899. p. 160.. Brewer, I. N. Climate in Philippines, notes on. 1900. p. 102 ....

Brewer, IT. H. Rainfall and cliarts of rainfall. 1902. p. 229 .... Brewer, William H. Breeding, suggested experiments in. 1893.

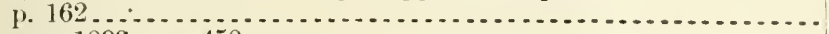

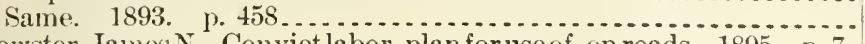
Brewster, Jannes N. Conviet labor, plan for use of, on roads. 1895 . p. 7 . Brick paving for eountry roads. 1896.

Brick wheel-track roads. See Roads.

Bridge and trestle timbers, strength of, report of committee of American International Association of Railway Superintendents of Bridges and Buildings on. 1895. p. 41 .............

Bridges, country road (Wentworth). 1895. p. $48 \ldots \ldots \ldots \ldots \ldots \ldots .$. See also Timber trestle bridges.

Bridges and buildings. See Railway Superintendents of Bridges and Buildings, American International Association of.

Briggs, Lyman James:

Alkali soils, mechanical analysis as applied to, some necessary modifications in methods of. 1900. p. 173.....................

Clay, suspended, filtration of, from soil solutions. 1902 . p. 31.

Eleetrieal instruments for determining moisture, temperature, and soluble salt content of soils. 1899 .

Ground temperature observations at St. Ignatius College, Cleveland, Ohio. 1902.

p. 301.

Salts as influeneing rate of evaporation of water from soils. 1900. 1. 184

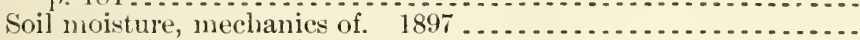

Soils, physical properties of-

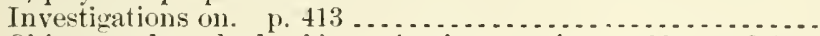

Objects and methods of investigating certain. 1900 . 1. 397.

Water, movement and retention of, in soils. P. $399 . . . . . . .$. See also, as joint author, Cameron, Frank Kenneth - Whit-
ney, Milton.

Briggs, Lyman James, and Lapham, Macy H.:

Salts, dissolved, influence of, on capillary rise of soil waters.

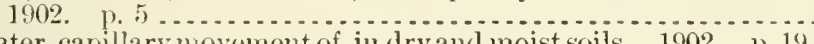

Water, capillarymovement of, in dry and moist soils. 1902 . p. 19

Brigham, Juseph Henry. Govermment aiı in highway improvement.

1902.
See also, for reports as $A$ ssistant Secretary of Agriculture Department, in charge of seed distribution. 1898-1900.

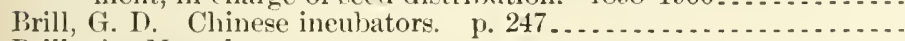
Brillonin, Marcel:

Atunosplere, general circulation of, origrinal memoir on. 1901. ए. 300

Atmospheric electricity: its origin, variations, and perturbations.

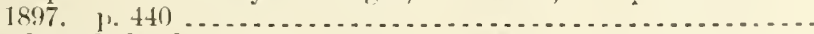

Winds and rlouds, report on, 1897, p. $437 \ldots \ldots \ldots \ldots \ldots \ldots \ldots \ldots$ Jristol, Fingland:

Butter markets (Ashby). p. 210 ........................

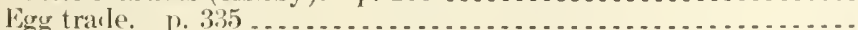

British. See Gruat Britain.

British Americal. Se Canarla.

British Association, Be]fast, 1902, adclresson ineteorology at (Schuster).

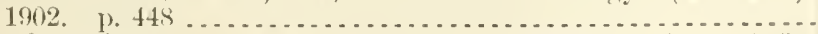

British-Canadian (attle trate, decrease in (Beutelspacher). p. 515.

British Columbia:

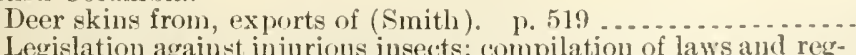

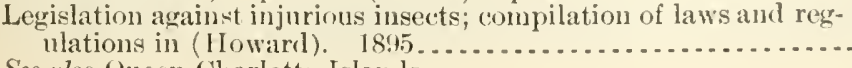

See cilso Queen Charlotte Islands.

A $10.3: 16$

A10.6:4

A $28.5: 6^{2}$

A $29.3: 24$

A $29.6: 28$

A29.6:30

A 10.3:16

A 10.6:-4

122.3:16

A2:2.4:25

113.3:12

122.3:11

A 1.8:64

A26.3:19

A $26.3: 15$

A 29.6:30

A 1.8:64

A26.3:11)

A $26.5: 900$

A 1.10:400

11.10:898

126.8:19

+26.8:19

A $2: 2.3: 25$

124.5:

A $4.1: 9(1)$

A29.6i:2?

A29.6:25

1:9.6:25

A $4.1: 8: 9$

14.1:899

12:4.6:30

14.1:899

14.1:900

19.3:3:3 
British India. Sie India.

British Wes: Indies. See Trindaul - Wrest Indies.

Britton, II. I: :

Nursery inspection in Connecticut. 1899. p. 131

110.3:65

San Jose soale in Comnecticut. 1s.98. p. 81 .............

Trees, bam ling of, to prevent injury by fall caukerwom, obser-

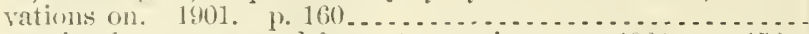

Vegetation honse arranged for jot experiments. 1901. p. 152. Brokels. Ser l'roduce brokers.

Brome errass:

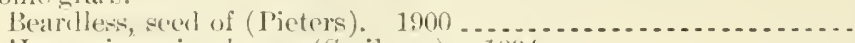

IIngarian, cirrular on (Scribner). Is94 . . . . . . . . . . . . .

Sinwoth, cirrular on (Kennerly). 1sist................. Sie also Chess.

Bromin. Sie l'roteil matters.

Bromms, North American species of, occurring north of Mexico,

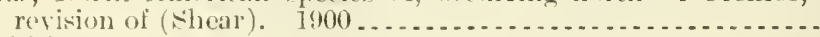

Bronchitis:

Cattle (Willians). p. 603 ...

Parasitic, anong calves (Trumbower). 1. 465 . . . . . . . . .

Verminous, in calves and lambs, ame its treatment by tracheal

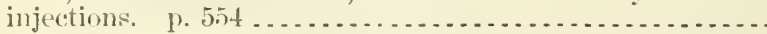
same, p. 27s . .

Bronson, P. H. Weather olservers, voluntary, should not a book be provided for keeping record of issme of instruments and flags to? 1899. p. 126 .

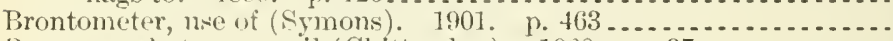

Bromze aplle-tree weevil (Chittenden). 1900. p. 37 ........... Brooklyn, N. I.:

Animals in, contagions diseases of, preliminary report of veterinary inspectors in investigation of (Mclean and others).

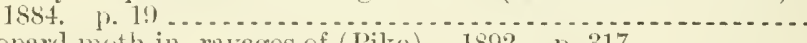
Leopard moth in, ravages of (Pike). 1892. p. $317 \ldots \ldots . . . . .$.

Musem of minteorology at, notes on (Abbe). 1900. p. 163..... Irooks, Wn. I'. Japan, migratory locust in, 188\%. Apl., p. 59... I'rooni-corl]:

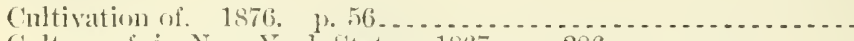

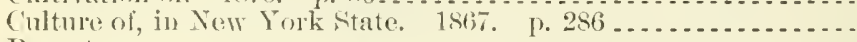

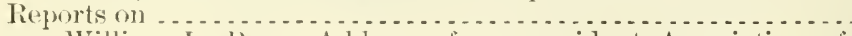

Broun, William L. hoy. Anliress of, as president Association of American Agrienltural Colleges and Experiment Stations, before sixth annual convention. 189:\% b. 58 ..........

Brome (extract)

Brown, Elgar. Ser, as joint anthor, Picters, Adrian John.

Prown, J. P'. Forests of Washington Teritory 188t. p. 388 .... Brown, James H. Adulteration of dairy prolucts. 1898. 1. 54 ... Brown, Ryland T.:

Agriculture, organization of. 18s2. 1) 108..............

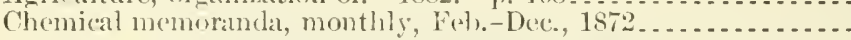
[The more important articies are indexerl under their vurious subjects.]

Sie also, for reports as Chemist, Chemistry Bureau, Agrieulture

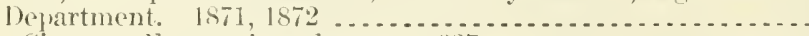

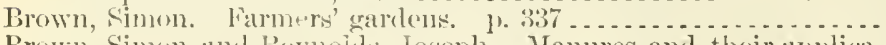

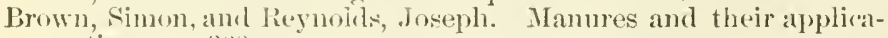

tion. Prown, W. W. Wrather mals, proprosed dassification and index of,

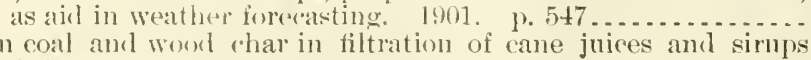

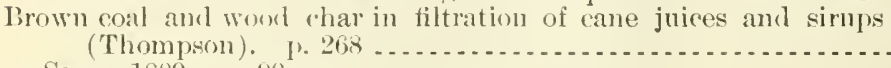

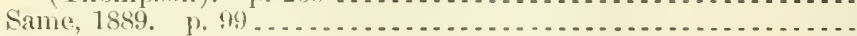

Imown rot. See (iraper.

binwll-tail moth:

Massaclunsetts, report on (Kirkland). 1900. p. 75 . . . . . . . .

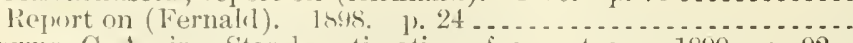
A9.6:17

А 10.3:99

A $10.3: 99$

16.4:25

16. 4:1

1:3.4:18

13.3:23

A1.1:850

A $4.1: 884$

1 1.1:885

14.1:885

1 29.3:24

129.6:29

19.6:22

A1.7:6

A9.7:4

12!.6:28

A8.1:3

1:27.9:14

A $27.9: 5$

110.1:28

A 10.3:16

A $10.2: \mathrm{C} 43^{4}$

A 29.6:26

A $13.5: 4$

A 7.3:41

A 1.8:22

127.9:10

A7.1:

A1.1:863

A1.1:\$65

129.6:29

11.1:887

A $7.3: 17$

A $9.6: 26$

A9.6:17

Browne, C. A., jr. Starel, c,ytination of, report on. 1899. 1.92.. A7.3:57 
Browne, Orris A. Allress of, hefore convention of National League for Goorl Roads, Washingtom. 1893. 1. 24 ............

Bruce, Eugene S. See, as joint author, Hosiner, Ralph Slieldon...

Bruchus, food-plants wi North American suecies of. 1893. \%. ] 15.5 .

Bruette, William A. Horses, export of, irom Chicago market.

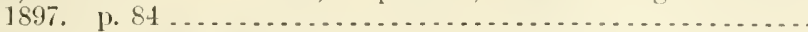

Bruhl, Lowis II. Catania, Jtaly, cost of lauling farm products ofer

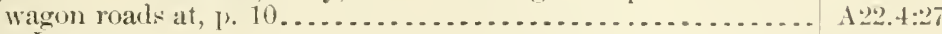

Bruner, Lawrence:

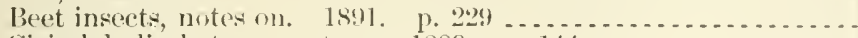

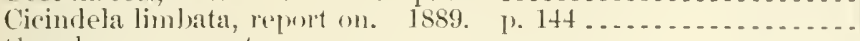

Girasshopper report-

1895. 1. 31 .

1896. 1) $36, \ldots \ldots \ldots$

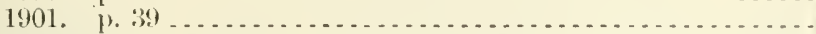

Grasshoppers, outlmak of, in ldaho, report on. 1860. 1) 1:35 ..

Insert injuries in Neloraska in-

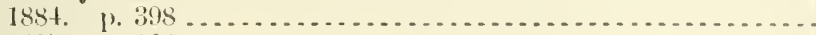

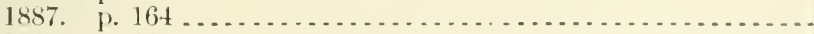

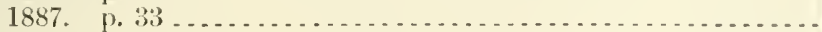

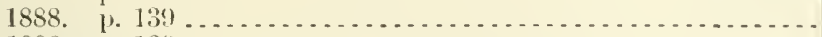

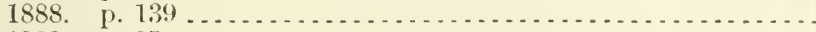

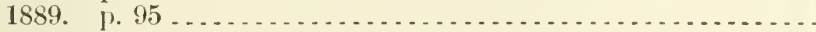

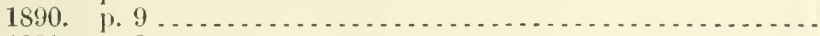

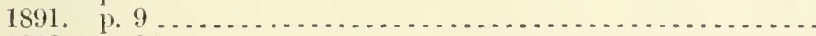

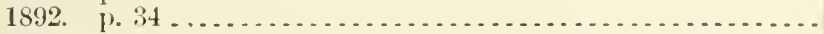

1893. p. 9 . . . . . . . . . . . . . . . . . . . . . .

Locusts, destructive-

found in Anerica, north of Mexico, in 1891, reports on. p. 9.

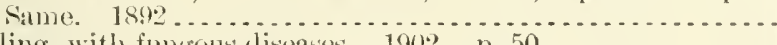

killing, with fumgons discases. 1902 p. p. 50 ... . . . . . . .

North America, with noteson occurrences in 1891. 1891. [. 1.

Orthoptera from ] hath Villey experlition. 1893. 1.266......

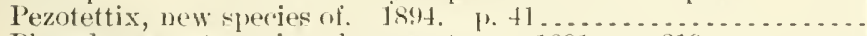

Phosphorescent myrinmls, repmet nn. 1s91. p. 319..........

Rocky Mountain lorenst, observations on-

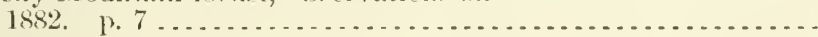

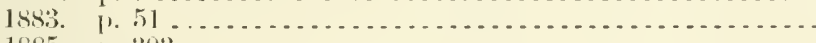

1885. 1. $30 \% 3$

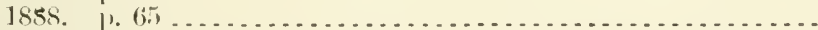

Texas, locusts in, during spring of 1886 . 1857. 1.9.......

Brmnswick, (iermatuy, cost of hauling farm products over wasom

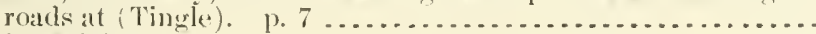

Brussels, Belgium:

Deal animals in, disposition of (lionsovelt). p. 35t ..........

Importation of American horses into (Langhorme). 1897. p. 26.

Brussels, International Veterinary Congress, report of (law). p.321.

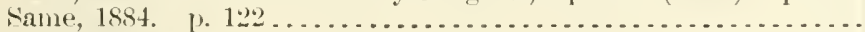

Bryan, Enoch $A$.:

Agriculture Department and experiment stations, conperative

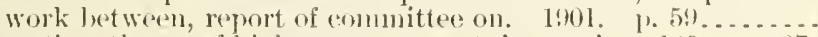

Education, theny of higher, somererent riangesin. ls99. p.87.

Bryan larm. S'se Marvland farm.

Bryant, Arthur l'setum. Dictary studies in IT. S., some results of. 1898. P. 4:39

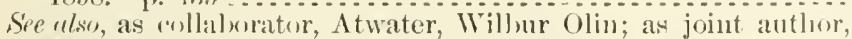
Atwater, Wilhur Olin - Frishy, Almah J.

Bryobia, species of, infesting dwellings, notes on (Webster). 1859.

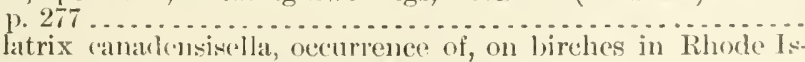

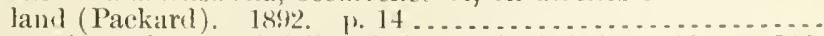

Buchan, Alexander, Rainfall and charts of raiufall. 1902. 1.242. Buchanan, William Inver). (ireat Britain's purchases of calvaliy

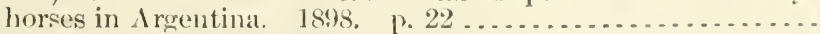

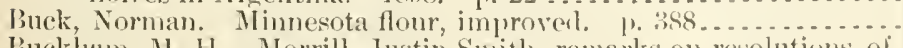
Bucklam, M. H. Morrill, Justin Suitl, remarks on resolutions of respect for. 1900 . 1. 30 .

19.7:3

19.3:2

19.3:4

A1. 1:885

A?.7:1

A9.3:1:3

A2:.4:27

A4.1:899

11.2:1178

14.1:384

A4.2: 1115

110.83:89

A 10.3:(6)

1 $1.1(1: 895$

19. $7: 1$

$19.7: 5$

1:29.(1:30)

11.2:117.

A1,1:\$75

A10.:2:7t 
Buckley, S. B. Sion Merrill, Elmer D.

Buckwheat. See Crops, principal.

Budd, James II. California, road improvement in, extract from governor's message. p. 1 . . . . . . . . . . . . . . . . . .

Buenos Ayres, Argentina, gale at (Abbe). 1895. p. 381 . . . . . . . .

Buffalo, N. Y., and vicinity, export of horses from (Hinkley). 1898.

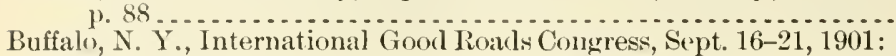

Letter of iuvitation to, inclosing official call. 1901 ..............

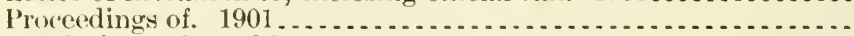

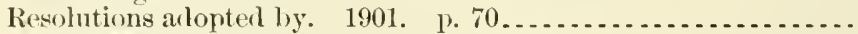

See also Moore, IT. H.

Buffalo, N. Y., Pan-American Exposition, 19()1:

Canadian cattle for exhibition at, orler providing for importa-

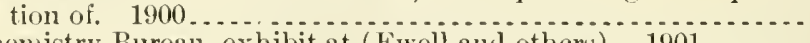

Chemistry Bureau, exhibit at (Ewell and others). 1901 . . . . .

Weather Bureau exhibit at (Maring). 1901. p. $259 \ldots \ldots . . . .$.

Weather map of . . . . . . .

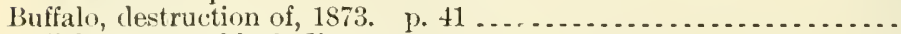

Buffalo-gnats or black-flies:

Notes on Simulium or common, at Ithaca, N. Y. (Howard). 1888.

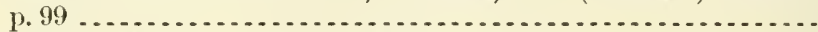

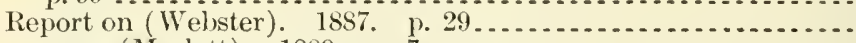

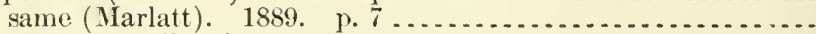

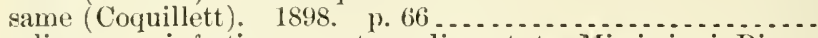

Simulium or, infesting country adjacent to Mississippi River

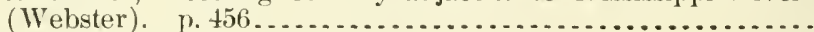

Buffalo moth. See Carpet beetle.

Buffalo tree-hopper:

Circular relative to (Marlatt). $1897 \ldots \ldots \ldots \ldots$

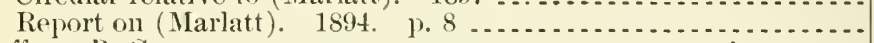

Buffum, B. C.:

Alkali and irrigation, recent investigations by Wyoming experi-

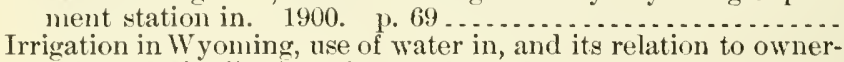
ship and distribution of natural supply. $1900 \ldots . . . . . .$.

Bugbee, E. L. Seacoast telegraph lines, instructions to operators on.

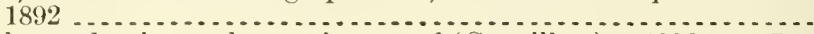

Buhach, production and manufacture of (Coquillett). 1886 . p. 7 .. Buildings:

Harthinake proof (Abhe). 1897. p. 309

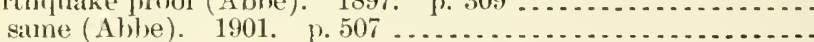

Humidity, relative, inside and outside of (I Henry). 1896 . p. 456 . See also Churches.

Bulls, etc., distributed from U. S. propagating garden, catalogue of

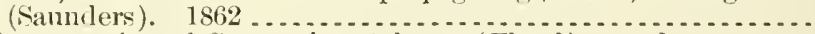

Bulk fermentation of Comnecticut tobaceo (Floyd). n. d ........

Bullets, penetration of snow by (Abbe). 1895. p. 424...........

Bünzli, J. I1. Potato blight, combating, report on. 1891. p. $78 .$.

Bur, or globe, artichokes, circular on (Swingle and Fairchild). 1899 .

Burchard, Oscar. Seed investigation, object and methods of, and estahlishment of seed-control stations. 1893 . pp. 793, 882 ..

Burgess, Albert F.:

Coccinellid, abnormal, report on. 1898, p. $59 \ldots \ldots \ldots . . . . . .$.

Sàn José scale, lime, sulphur, and salt and resin washes for, in Ohio, notes on use of. 1902. p. $33 . . . . . . . . . . . . . .$.

Tan-bark beetle, rlestructive, report on. 1899. p. 107 ........ See also, as joint author, Webster, Francis M.

Burgess, Flwarl. Sce, as joint author, Minot, Charles Sedgwick.

Burke, Frank. Short biography of (Abbe). 1898 , p. 68........

Burke, R. T. Avon. See, as joint author, Bonsteel, Jay Allan.

Burke, R. T. Avon, and Marean, Herbert WV:

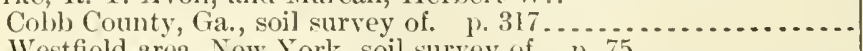

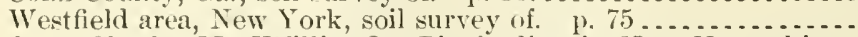

Burkett, Charles M. [William]. Pig feeding in New Hampshire,

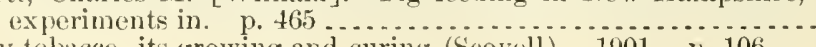

12:2. $4: 33$

A29.6:23

A1.2:H78

A22.2:B86

A $22.3: 21$

A22.3:21

A4.5:65

A7.3:63

A29.6:29

A29.2:P19

A27.9:11

A9.7:1

A9.3:14

A9.7:2

A9.6:10

A4.1:887-8

A9.5:23

A9.7:7

A10.3:76

A 10.3:81

A29.12:Se1

A9.3:12

A29.6:25

A 29.6:29

A 29.6:24

A1.8:2

A $26.4: 5$

A29.6:23

A28.5:6

A6. 4:22

A10.6:4

A9.6:17

19.6:37

A9.6:20

A29.6:26

A26.5:901 1

A26.5:901 ${ }^{1}$

A4.1:899

Burley tobacco, its growing and curing (Scovell). 1901. p. 106... A $10.3: 99$ 
Burma, India, dust storms in, and elsewhere, notes nu $\left(.11 \mathrm{l} \times \mathrm{x}^{\circ}\right.$.

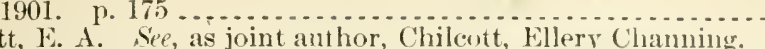

Burnett, F. A. See, as joint anthor, Chilcott, Ellery Chaning.
Burrill, T. J. See, as joint anthor, Shakespeare, Edward Orum.

Burrill, T. J. See, as joint anthor, Shakespeare, lidward Orum.
Burrough, Edwari:

Arldress of, before national roal conference, July, 1894. Pp. 6, 10..

Road building, State aid to, in New Jersey. 1894...........

Burrows, Alvin T.:

Chinook winds. 1901. p, 555.

Hot waves: conditions which produce them, and their effect on arriculture $1900 . \quad$ p. 325 .

Bursattee, disease of horse in India. See Ieeches.

Burtis, F. C. See, as joint anthor, Cottrell, H. II.

Burton, IV. M. See, as joint author, Morse, II. N.

Busck, August:

Cocoanut palms, diseased, in Cuba, report of investigation of.

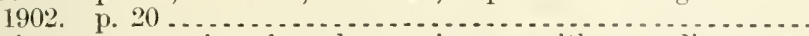

Mushrooms, enemies of, and experiments with remelies, note

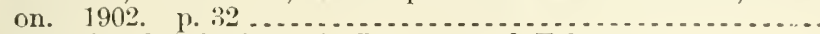

Puerto Rico, brief trip to, in January and February, 1899, notes

See also, as collector, Pergande, Theodore, and Cockrell, Thomas Dru Alison.

Bushel, weights of. 1901. p. 786

Bushnell, Asa S. Ohio, road improvement in, extract from gover-

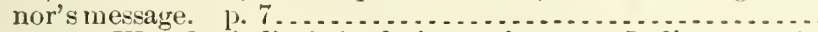

Butler, Amos W. Periodical cicala in southeastern Indiana. 1886.

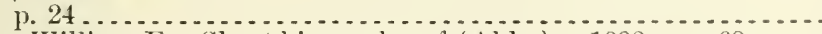

Butler, William E. Short biography of (Abbe). 1898. p. 68....

Butler County, Kansas, southern cattle fever in, ontbreak of 1883 (Trumbower). p. 420

\section{Butter:}

American-

analyses of, averages of (Richards). $1886 . \quad$ p. 23. in Jayan (Ruffin)

Analysis of, method for (Morse and Burton). 1890. 1.99....

Artificial, methods of distinguishing (Besana). 185\%. p. 107...

Borax as a preservative of, letter relating to (Crosisy). 1. 576...

Commercial butter cultures used in comection with pasteurized

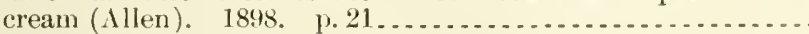

Composition amel analysis of, abstraets of rlata relating to. 1889.

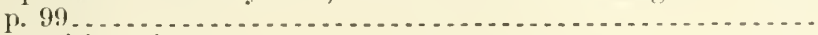

Composition of-

from Chicagu dairy show, December, 1889 (Morrow). p. 18s. influence of foorl on (Von Lookren). 1890. ए. 141 ....... variations in (Bal)cock). 1886. p. 23 ..............

Dubernard method for examination of (Sartori). 1890. \%. 103..

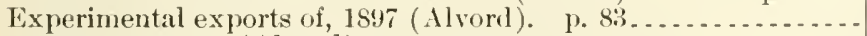

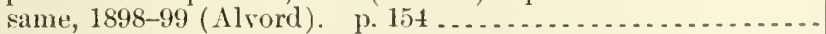

Exported, chemical analyses of. 1. 240.

Fatty volatile acids of, contribution to study of (Spallanzani). 1890. 1. 104.

Foreign and homemade, scores of, in competition. 1899. 1). 226.

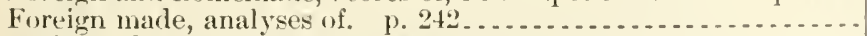

Irimh, trarle in. 1865-67, p. $879 \ldots \ldots \ldots \ldots$

Market quotations on, 1897 and 1899. p. $216 \ldots \ldots \ldots \ldots \ldots$

Markets for. See Ashby, Newton 13.

Melting point and chenical composition of, influence of different

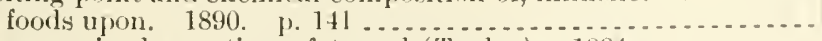

Microscopic olsservations, fats ami (Taylor) 1884 . . . . . . .

Mixed, application of methords Reichert, Meissl, and Wolluy to (Besana). 1890. p. 105.

Nostrums for increasing yield of (Wiley). 1893 . . . . . . . . .

Paraguay (Rutfin). p. $521 \ldots \ldots \ldots \ldots$

Pastemrized and raw cream, comparison of. 189\%. 1.233......

Philadelphia, how made. p. 291.
129. $1: 29$

1 $22.3: 10$

122.3:9

11.10:901

1 $1.10: 1900$

A9.6::38

14.6:38

19.6:22

11.10:901

122.4:3:3

19.3:1:2

129.6:26

At.1:88t

14.2:An5

17.3:16

14.1.898

1 $7.3: 24$

17.3:24

11.1:5Tล

A1.9:10:3

17.3:24

A7.1:889

A7.3:24

17.8:16

17.3:24

14.1:888

14.1:899

14.1:5(s)

A7.3:24

A $4.1: 5 \% 9$

1. $1: 5(9)$

127.9:5

14. 1:5!19)

17.3:24

11.8:34

17. $3: 24$

11.9:12

$1+.1: 5 \div 8$

14.1:र!!9

11.1:56\% 
Buttre-Continued

l'roduction of, type of dairy ew in relation to (Lawson). 1901.

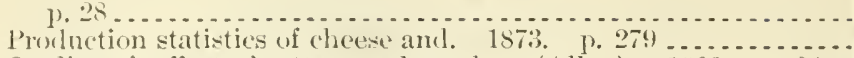

Quality of, effort of cotton-seed meal on (Allen). 1900. p. 24 ..

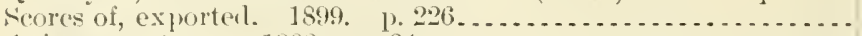

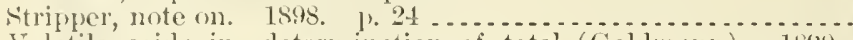

Volatile acids in, determination of total (Coldmamn). 18.30.

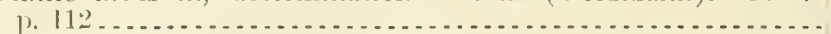

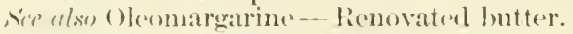

Butter fartories. Sire ('reameries.

Butter fait:

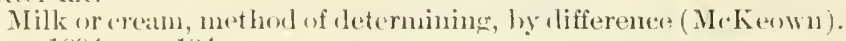

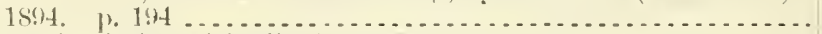

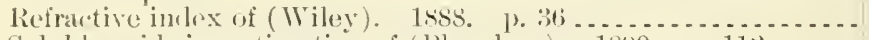

Soluhle acils in, estimation of (1'lanchon). 18:0. p. 112.....

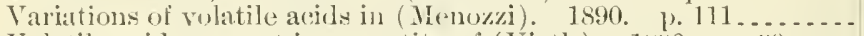

Tolatile aciols present in, quantity of (Tieth). 18:\%. 1. 19..... Butter making:

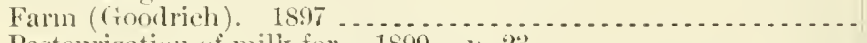

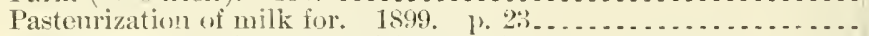

Recently patented proresy of (Salmon). Nov. 20, 1s!7 ........

Swartz system of, in sweden (Andrews). 1876 . 19. $198 . . . . .$.
Testing cows as to, some notes in connection with (soovell). 1899. p. 120

Bitter standari, papes relative to (Curtis). p. 142

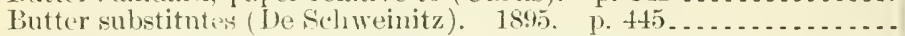

Butterfy, gray lian-streaked, its damage to beans. 1895. 1'.35f_...

Bintterveck, Otto Carl. Culture of tol acco. 189s ..............

Cabloares:

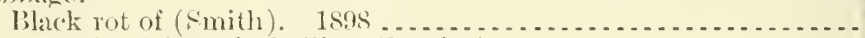

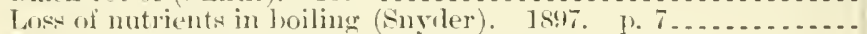

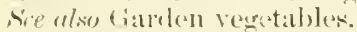

Cablage and allime plants, jacterial disease of (Rusioull). 1s9s.

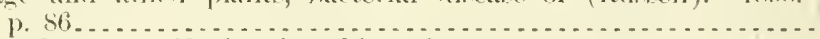

Cabbage bug. Fé llarlecpuin cablvage hug.

Cabbare-moth, note on (clover). 1872. 1. 137.

Cablatgre worms:

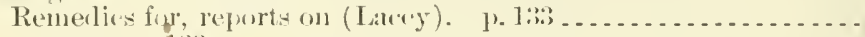

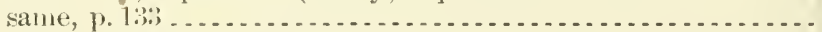

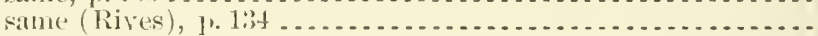

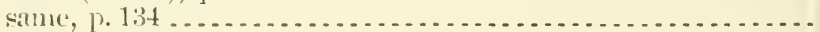

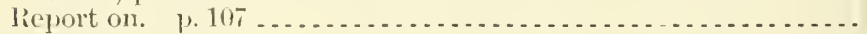

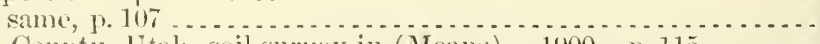

Cache Comity, litali, soil survey in (Means). 1900. P. 115 . . . .

Carche Creek, ('il., irrigation investigations on (Wilion). 1901.

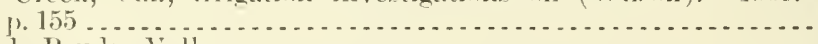

Caclie la Pondre Valley:

Colorato, soil sirvey in (Mcans). 1900. p. 121 .............

Reservoir sytem of, rejort on (Nettleton). 1901.............

Cacecial cerasivorama, oviposition of (IV eed). 1900. 13.33........

Cactus, North Americanspecies of, preliminary revision of (Comlter). $1892.11,9]$

Cactus. The rlso ('oreus-Opmintia.

Cactuses, georraphic and vertical rlistribution of, in cleserts and desert ranges of southern (alifornia, southern Nevala, northwestern 1 rizona, and sonthwestern Utah, notes on (Merriam).

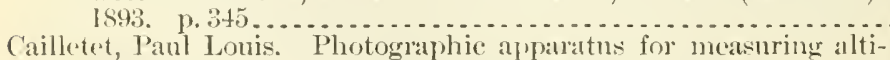
tudeg attained by balloons. 1897. 1\% 443

Caine, Thomas A. See, as joint anthor, Money, Charles $\mathrm{N}$.

Cairo, 111., water travel at, lines of equal time of. $1892 \ldots . . . . . .$.

('ajuri, F. Doudna, Pearl Fusene, short biograpliy of. 1900. p. 202.

('alamarrostis, North American spereses of, revivion of (Kearney). เหตs.

(alamovilfa, notes on (Scribuer and Mlerrill) 1901. 1.2 $2 . . .$.

17..3:43

A $7.3: 19$

A7.3:24

A7.8:24

17.3:2]

A1.9:57

A1.9:92

A21.2:B97

A27.9:14

110.3:65

A1.7:2

A $1.10: 895$

A $9.7: 7$

$11.9: 82$

$11.9: 68$

110.9:-4:3

110.3:49

A27.9:10

11.1:85:;

19.1:853

11.1:883

19.1:853

11.1:858

19.1:88.3

11.8:64

A 10.2: 100

11.8:64

A $10.3: 92$

A $9.6: 26$

16.5:3

15.5:7

A $29.6: 25$

A29.2:R1: ${ }^{1}$

A 29.6:28

A3. 3:11

A3.4:35 
Index

Caleimm carbonate, solubility of, in aqueous solutions of critain clectrolytes in equilibrim with atmospheric air (Cameron

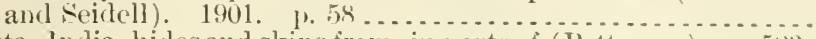

Calcutta, India, hides and skins from, imports of (Tattersin). 1. 5is). Caldwell, George Chapman:

Adetress of, as president of $A$ ssociation of Official Agricultural Chemists, at eirhth amnual meeting. 1891. p. $7 \ldots \ldots . . .$.

Agricultural experiment station as ectucator of farmer. 18,2. 3).20.

Hore, analysis of urine of, in last stages of inflnenza. 1\%247.. Calf. tée Calves.

Calico back eabbage hug. See Harlequin cabluge bug.

California:

Agricultural resources of (Dumn). 1.581 .................

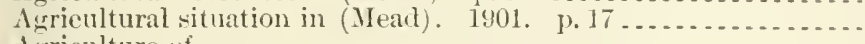

Acriculture of -

1862. 1. 588

1867. 1. 373

$1872 . \quad$ 1. $1992 \ldots$

1878. (1)ilgard). 1. $476 \ldots \ldots \ldots$

Alfalfa in. 1872. p. 2ut6.

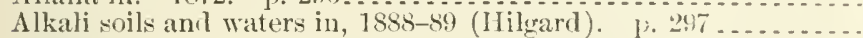

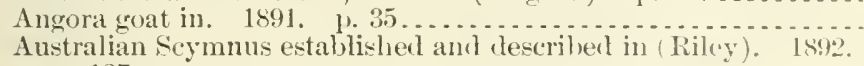
1. 127 .

Beet-sugar factories in, information relative to. 1570. 1\%.

Beet sugal in. 1887. 1. $452 \ldots \ldots \ldots \ldots \ldots \ldots$

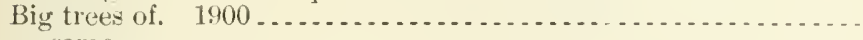
same

Blark scale $\mathrm{in}$, note on. 1886 . 1). 34 .

Black scale of, found in Sonth Carolina, note on. 1886 . 1.36

Blastophaga psenes, first introduction of (Jisen). 1891. 1. 128.

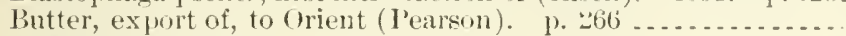

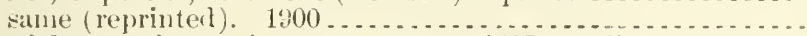

Capri fig experiments in, present status of (Howam). 1899. j. 24

('attleanthrax and soutliern cattle fever among (Bowhill). 1\% 4ti3. same, further investigation (Chamdler). p. $450 \ldots . . . . .$. destruction of, by varions diseases (Mercer). p. 452 . . . . . same, rejort of antopsies (Bowhill). p. 453

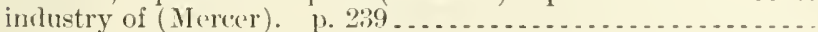
quarantiue line for, orler morlifying-

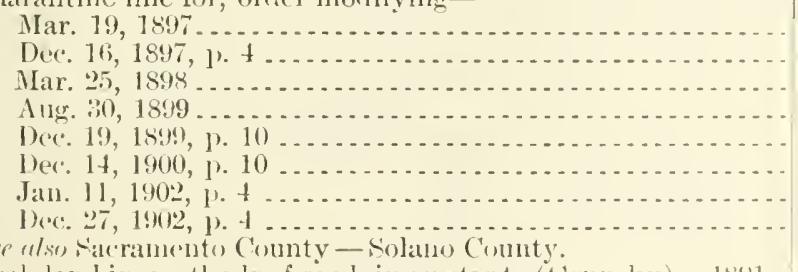
Ser alse Färamento County - Solano County.

Central, land in, methods of applying water to (tirmuky). Isin.

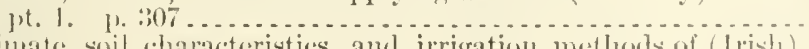

('limate, soil roaracteristies, and irrigation mothosts of (lrish). 18\%5. 1\%. 475

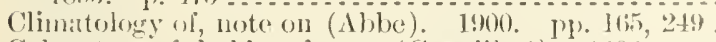

Coleoptera of, hal its of some (Comuilleit). 1892. 1. 2(ic)

Cors worm or loll worm in (Copuillett). 1889) 1).3:1 . . . . .

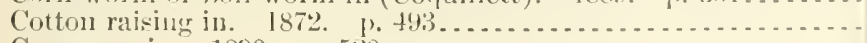

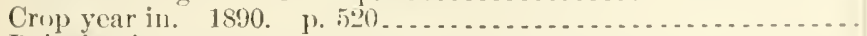

Dairying in--

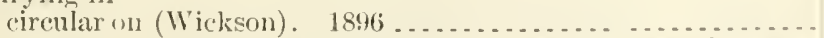
notes upon export of California butter to the (jient and (l'all-

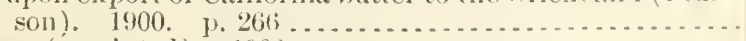

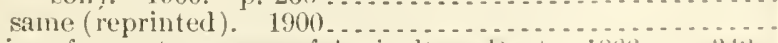

Donations from, at musem of Agriculture lept. I86it. 11. 312.

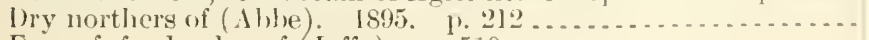

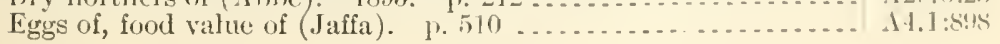

A1.1:S66

1 10.3:100

11.1:81;2

$127.4: 5$

127. $1: 10$

11.1:578

А27.9:10

(15.:2:194

127.9:29)

19.7:5

$127.9: 8$

$127.9: 25$

113.2:1348

$113.3: 28$

19.3:12

19.3:12

19.7:4

14.1:8!9

1 t.:3:2-1

19.6:20

14.1:887-8

A $4.1: 887-8$

1 $1.1: 587-8$

14.1:\$87-8

$14.1: 85 t^{\circ}$

$1+.5: 2$

$1+.5: 5-14$

$14.5: 18$

$14.5: 45$

$1+.5: 4(1-5.5$

14.5:80-87

$1+.5: 913$

$1+.5: 101$

115.2: Ir

11. 10:895

1:31.1:28

1!1. $7:-1$

1!1.7:1

127.41:10

127. ():24

$14.3: 14$

14.1:5:19

it : : : :2-1

1:7.9):-4

12!) (1:2:3 


\section{Index}

California-Continued

Electrie storms of (Barwick). 1897. p. 539 . . . . . . . . . .

Entonolorical work in, in 1893 (Koebele). p. 33 ............

Exotic iruits and useful plants of (llilgarl). 1892. p. 187 ....

Farm resonrces am products of. 1868 . 1. 27.2 . . . . . . . . .

Farmers' institute

Frosts in. (IIilgard). 1896. p. $166 \ldots \ldots \ldots \ldots \ldots$

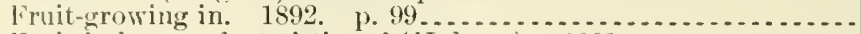

Fruit industry of, statistics of (1Holnes). 1901 ............. .

Fruits from, transportation rates on. 1883. No. 59. 1) 45 ...

Fruits of, tropical and semitropical (Klee). 1891. p. 111 .....

Grape culture in, present condition of (Husmann). 1898. J.551.

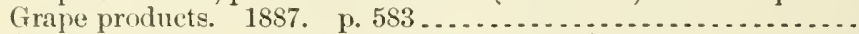

Grasses of, plates and descriptions of (Vasey). 1892..........

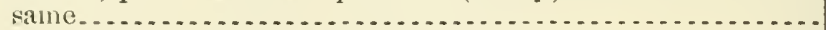

Grasshoppers in, destructive 1872 p. $22 \ldots \ldots$

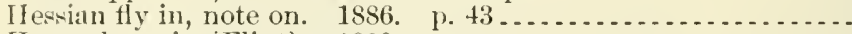

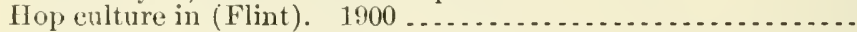

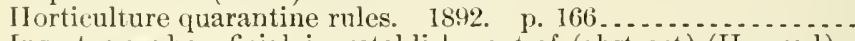

Insect, new beneficial, in, establishment of (abstract) (Howard).

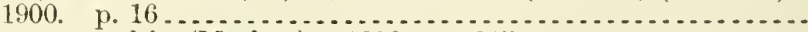

Insect control in (Marlatt). 1896 . p. $217 \ldots \ldots \ldots$

Insect pests in, action taken regarding. 1892 . p. $158 \ldots \ldots \ldots$.

Insects of -

beneficial and injurious, in 1892 (Coquillett). 1893. p. 9. general notes on in 1890 (Koebele). p. 37 ............

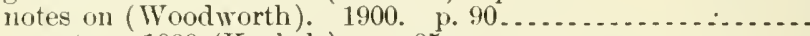

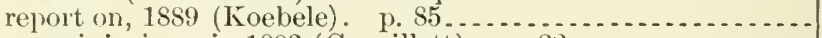
some injurious, in 1893 (Coquillett). p. $22 \ldots . . .2 . . . . .$.

Inspection of trees, plants, fruit, etc., as conducted under laws in (Lelong). p. 12

Irrigation

investigations in, report of. 1901

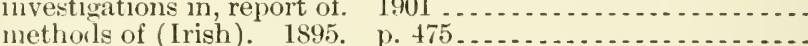

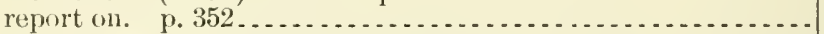

Land drainate in. 1869 . p. 231 . . . list of (Eckfeldt). 1893. p. 291.

Locust invasion of, in 1891 , leport on (Coquillett). p. $34 \ldots . . .$.

lower, plants collected in, by Edward Palmer in 1889, list of

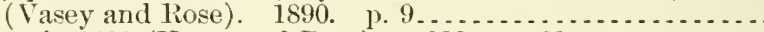

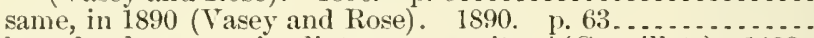

Melanoplus devastator in, dipterous parasite of (Coyuillett). 1892.

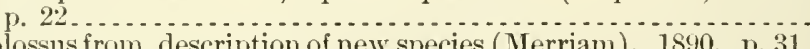

Molossus from, description of new species (Merriam). 1890 . p. 31
Nortl western, stock ranges of, notes on grasses and forage plants and range conditions (Davy). 1902 .

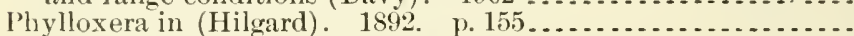

Plants worth trying in (Behr and Klee). 1892. p. $141 \ldots \ldots \ldots$.

Products of-

1866. ए. $2 \cdot 24$

1867. P. 56

1868. 1) 26 .

1869. p. 58

Rainfall, charts of (McAdie). 1902 p. 362.

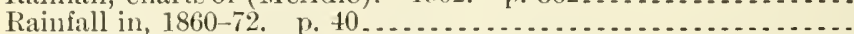

Rainy season in, $1860-69$. p. $481 \ldots \ldots \ldots \ldots$

Red scale of-

hymenopterous parasites of (Howard). 1894. p. 227

various methods for destroying (Coquillett). $1890 . \quad$ p. $9 . .$.

Road improvement in, extract from governor's message (Budd).

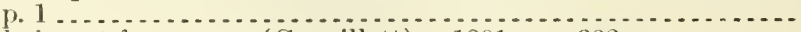

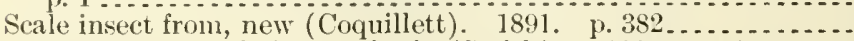

Scale insects and their enemies in (Smith). 1896. p. $46 \ldots \ldots \ldots . . . .49: 6$

A $29.6: 25$

A9.3:32

A1.8:20

A27.9:6

A $10.3: 120$

A $27.9: 28$

A29.6:24

A1.8:20

А $27.8: 23$

A $27.9: 21$

A20.3:1

A 1.10:898

A27.9:25

A6.2: $182^{2}$

A6.3:13

A27.9:10

A9.3:12

A1.9:115

A1.8:20

A9.6:26

A 1.10:896

A 1.8:20

A9.3:30

A9.3:23

A9.6:26

A9.3:22

A9.3:32

A1.8:57

A10.3:100

A1. 10:895

A 1.1:874

A27.9:7

A6.5:1

A9.3:27

A6.5:1

A6.5:1

A9.7:5

A5.5:4

A19.3:12

A1.8:20

A1.8:20

A1.1:866

A27.9:5

A27.9:6

A27.9:7

A $29.6: 30$

A27.9:11

A27.9:8

A9.7:6

A9.3:22

A 22.4:33

A9.7:3 
Seale insects of orange in, and partienlarly icerya ur fluterl saale, alials white scale, alias cottony-colshion scale, cte. (Riley).

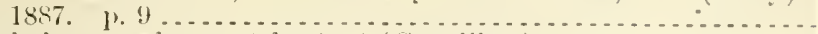

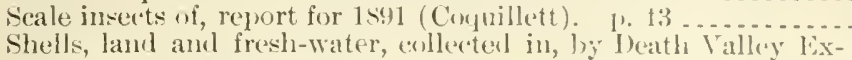

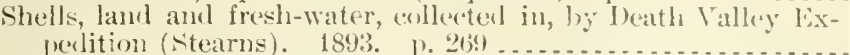

silk culture in, letter on (I'revost). 1867. 1. 285 .........

Soil characteristics of (Irish). 1895. 1). 475 ...........

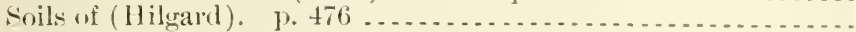

Southern-

agricultural experiment farm, sunshine at (Hemm). 1896. bat, free-tailed, from desert region of, deseription of new spe-

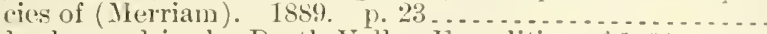

birls observed in, by Death Valley Expedition of 1s91, nutus

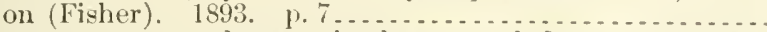

(actuses, yuccas, and agave in deserts and desurt ranges of, geographic and vertical distribution of (Merriam). 1893. 1. 345 .

fishes of Death Valley Expedition, 1891 , collected in, report on, with descriptions of new speeies (tilbert). 1893. p. 229

frosts in, their prediction and prevention ( $\mathrm{ibbe}) .1895$. I).

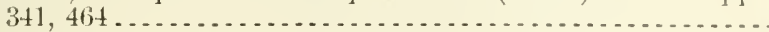

grasses of desert rogion of, plates and descriptions of (Vasey). 1890 same.

plants collected in, by Edward Palmer in 18s8, list of Tass

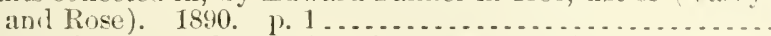
spermophile from, deseription of new (Merriami). 188\%. p. 15. trees and shrubs in deserts and desert ranges of, clistribution of (Merriam). 1883. 1. 285 . . . . . . . . . . . . . . weather crop bulletin, history of (Franklin). 1896. I) $46 \ldots$

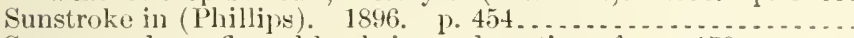
Swamp and overflowed lands in, reelamation of. p. 179 ......

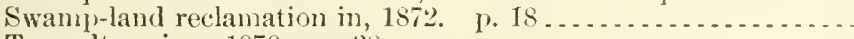

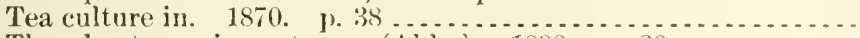
Thunderstorms in, notes on (Ablue). 1898. p. 20........... Tortrieic from, deseription of new (Walsingham). 1891. 1). 465 Vegetables from, transportation rates on. 1883 . No. 59. p. 45. Vine disease, preliminary report of investigations (P'ierce). 1892.

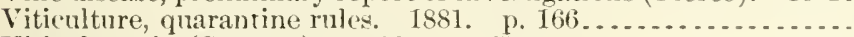

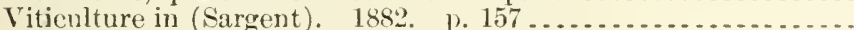

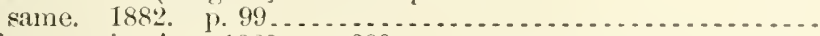
Wine growing in 1868 p. $280 \ldots \ldots \ldots$ Wines and brandies of (IIilgard). 1882, p. 109..........

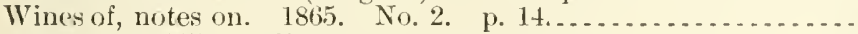

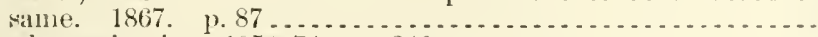

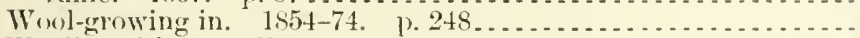
Woolly aphis remedies, note on. 1886 , 1. $43 \ldots \ldots \ldots$

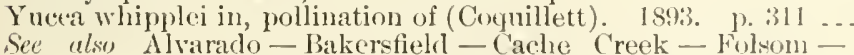
See ulso Alvarado- Bakersfield - Cache Creek - Folsom -
Fresno - Gage Canal - I Ianfort - Honey Lake Bawin Inperial - Fings River - Los Angeles County llorticnlturat Commission - Los Angeles River - Mendoeino county Napa County - Cakland - Riverside - Silcramento - Sileratmento Comnty - Salinas Valley, Monterey County-Siul Bernardino - San Diecro - San Frantisco - Sall Gabriel San Jacinto River-San Joaquin - San Joapnin RiverSanta Ana - Santa Barlara - Sausalito - Shasta, HonntSierra Nevada Mountains - Solano County - Sweetwater River - Tamalpais, Mount-Tule River Basin - Veutura West Berkeley - Yuba County - Vuba River.

California Agricultural Experiment Station, nutrition investigations at, 1896-1898. (Jaffa)

Same, among fruitarians and Chinese, 1899-1901. (Jaffa) .....

A(i.2: $: 18 \cdot 21$

16.3:1:

$16.5: 1$

$1.5 .5: 2$

15.5:7

129.8:18

129.6:2:4

11.1:872

A $27.9: 10$

1:27.9:8

$129.6: 26$

19.7:3

127.9:21

125.3:2

11. $8: 20$

11.5:2:2

A $1.8: 20$

127.9:6

A 1.8:20

A27.9:3

127.9:5

A27.9:13

19.3:1:2

19.7:5

110.3:8t 1 10.3:10 
California, Gulf of:

Ileal of, list of plants collected by Edwarl Palner at, in 1889

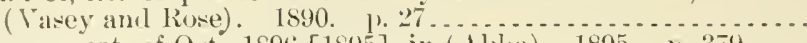
Storm, great, of O(t., $1896[1895]$, in (Alibe). 1895. 1. $379 . .$.

Callencler, (\% IT. Potato raising in Temnessee. p. 657..........

Caloptenus spretus. See Grasshorper.

Calorimeter. Se Respiration calorimeter.

Calorimetric setemination of lieating value of com (Richards).

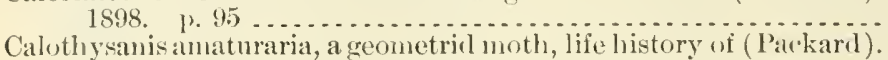

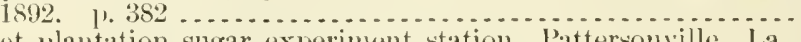

Calumet plantation sugar experiment station, Pattersomille, la., record of experiments at (Edson). Is89 ................

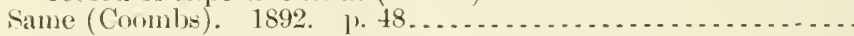

Calvert, Erlgar B.:

Searchlight for weather signals. 1898. 1. 58............

IV eather Bureau-

how it risseminates forecasts and wamings. 1s\%;. J. xii . relation of, to Department of Agrieulture. 1899. P. $54 \ldots .$.

Wreather maj,-

daily, development of. 1899. 1. 14t.

is it appreciated and understuol by the masses? would not postal card weather forecast prove satisfactory substitute

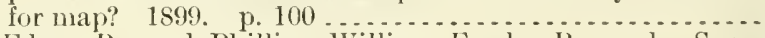

Calvert, Elgar B., and Phillips, William Fowke Ravenel. Snow temperatures, report on, 1899. 1. 55.............................

Calvort, J. C. See, as joint antlor, Kastle, Joseph Hoeing Marvin, I'aul.

Calvert, s. S'e, as joint antlior, Ciibson, H. P.

Calvert County, Mil., soil survey of (Bonsteel and Burke). M.147 ... Calves:

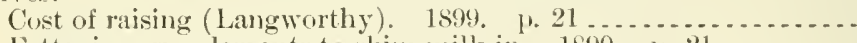

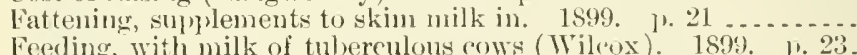

Parasitic bronchitis among ('Trumbower), p. $465 . . . . . . . . .$.

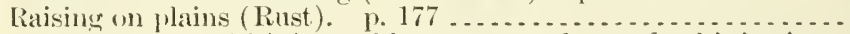

Verminous bronchitis in, and its treatment ly tracheal injections.

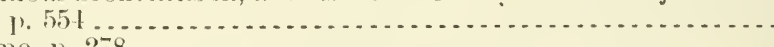

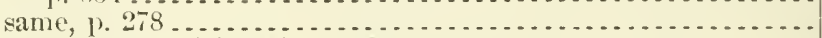

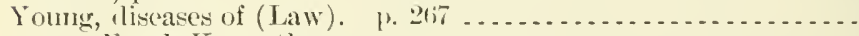

Cameron, Frank Kennetl:

Carbonates and bicarbonates in afuenes solution, estimation of.

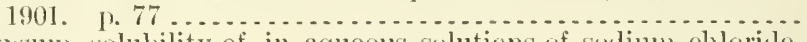

Gypsum, solubility of, in aqueous solutions of sollium eloloride.

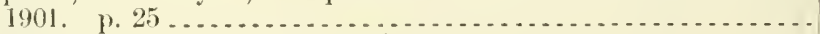

Soliun earlomate, or black alkaliformation of, by plants. 1902. 1.61 ............... resistance to, by certain plants. 1902. p. 71 ............

Soil solutions: their nature and functions, and classification of

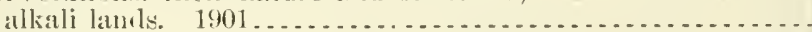

Soils, study af, application of tleory of solution to. 1900. p. 420 .

see ulse, as joint author, De Seloweinitz, Emil MlexarderKearney, 'Thomas IIenry.

Cameron, Frank Kenneth, and Briggs, Lyman James. Carbonates and biearbonateg in aquenus solution, equilibrium between.

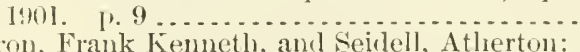

Camernn, Frank Kenneth, and Seislell, Atlierton:

Calcium carbonate, solubility of, in ayucous solutions of eertain electrolytes in equilibrim witl atmospluerie air. 1901. p.58.

(rypsum, solubility of, in aqueous solutions of certain electrolytes.

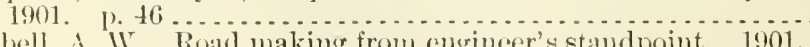

Camploell, A. II. Roal making from engineer's standpoint. 1901.

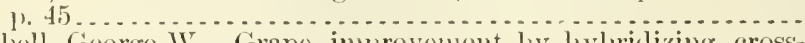

Campledl, George IV. Grape, improvement by hyluriclizing, crossl,reerling, and seedlings. p. 209.

16.5:1

129.6:23

1 $1.1: 880$

1 10.3:49

19.7:-

17.3:28

A7.3::7

129.6:26

129.1:896

A29.3:24

A29.3:24

A29.3:24

A $29.6: 27$

126.5:900 1

A1.9:107

11.9:92

A 1.9:107

A4. 1:884

14.1:886

11.1:885

14.1:855

$\mathrm{A}+.2: \mathrm{C}^{2} 9^{2}$

A26.3:18

A $26.3: 18$

A 1.S:71

11.8:71

$126.8: 17$

1:6.5:(2)00

11.S:64

12ti.3:18

$126.3: 18$

126.3:18

A 22.3:21

11. $1: 862$ 
Campluell, Samuel W. Live-stock industry, comdition of, w Wisen-

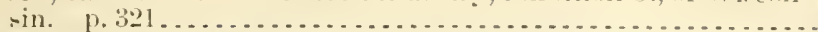

Campluell-Ifepworth, M. II. , se Hepworth.

Camphor harometer, notes on (Abbe). 1s.4!. 1). 255............

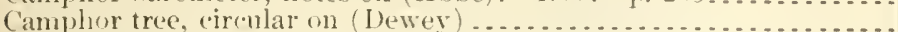

Canada:

Acrionaltural products of, 1805. No. 9. p. 18.

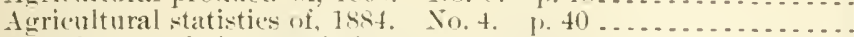

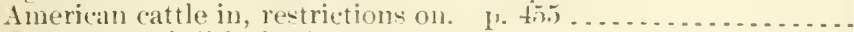

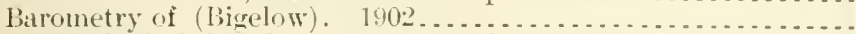

Climatolycical data for, notes on (Abhe). 1899. 1. 25:) . . . . .

Famers institutes in, history and status (Bailey). $1300 . . . . .$.

Grasses of $L^{\top}$. S. and British America (Vasey). 18.2. 1\% 1.....

Inserts, injurious, wif year in, notes mpon (Fletcher)-

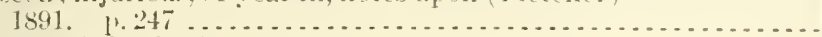

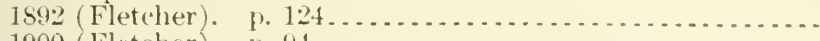

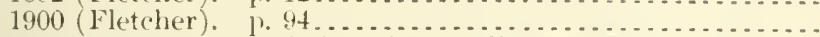

Laws of, relative to restriction of plant diseases (smith). lisgi ..

Live-stock shipments irom, to England. 1. 7 .............. . .

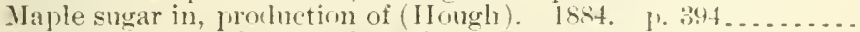

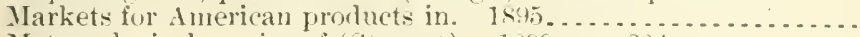

Meteorological service of (Stupart), 1s99. p. $204 \ldots . . .2 . . . .$. same, Pacific cuast division (Abbe), 1899, pl, 102, 212 ....

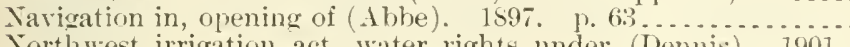

Northwest irrigation act, water rights under (Demnis). 1901. 1. 11 .

Reciprocity treaty with, note on. 1866 . pp. $16,144 \ldots \ldots . .$.

Silos and ensilage, record of practical tests in. 1882............

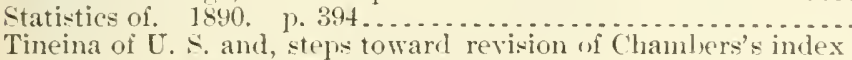

Tineina of $\mathrm{U}$. S. and, steps towar.
of. See Walsingham, Lorl.

Weather forecasting in, long range (Gmi). 1899. 1. 149 . . . .

sie also Dairving - Manitolia - Toronto.

Canada thistle:

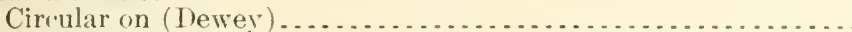

Law conererning. 1869. 1). 300 *

Canadian-British eattle trade:

Decrease in (Beutelspacher). [1. 515.

Canarlian cattle:

From port of Boston, Mass., correspondence with s. W. Aller-

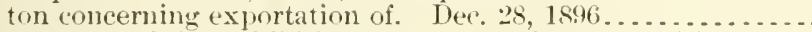

Importation of, tor exhibition at Pan-American Exposition, Buffalo, N. Y., order providing for. 1900

Providing additional ports of export for, in lond. 1899.

Canadian cattle, sheen, and swine, special orler relative to importation of, for exhibition at International Live-Stock lixhibition, Chicagn-

July 13,1900

Sept. 12, 1901

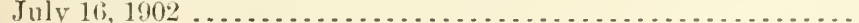

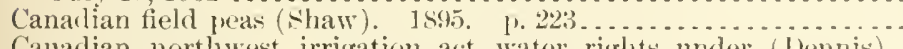

Canadian northwest irrigation act, water rights under (bennis).

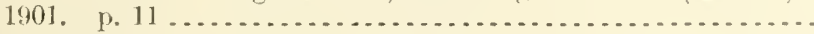

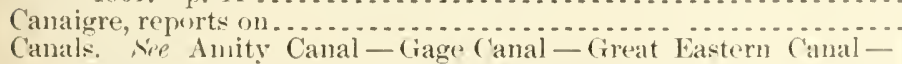
Logan and Kichmonel Canal - Mississippi River.

Cane juices and sirups, brown coal and wood char in filtiation of

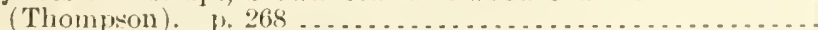

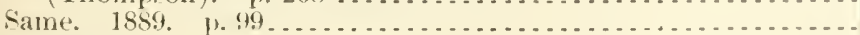

Cane sugar:

Determination of, in presence of commerrial glucose (W" (alder and

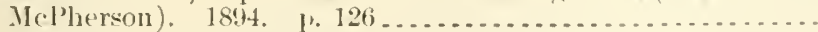

Industry in $U$. S., condition and prospects of $1877 \ldots \ldots \ldots \ldots$

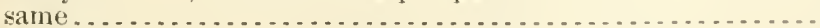
saine. p. 23
C'lamifleatlon no.

\section{$14.1: 889-90$}

A:29.61:27

A6.4:1:2

A27.9:3

A $27.9: 2: 2$

A $4.1: 554$

A29.1:901:

A $29.6: 27$

A 10.3:7?

A6.5:3

$.19 .7: 9$

A $9.7: 5$

A $9.6: 26$

A $28.3: 11$

A4. $1: 895-6$

A $13.5: 4$

A12.3:4

A $29.6: 27$

A $29.6: 27$

A29.6:25

110.3:96

A $27.9: 4$

A 1.6:48

A27.9:28

A.94.6:27

A6. $4: 27$

A27.9:7

A $4.1: 899$

A 1. 2: $\left(2 y^{3}\right.$

14.5:65

1 $4.5: 44$

At.5:(67

14.5:90

A $4.5: 96$

A 1.10:8\%

110.3:(6)

A $1(1.4: 25)$

A 1.1:887

17.3:17

$17.3: 43$

A1.6:1

A].2: ${ }^{1} 7^{2}$

A 1.1:87\%

* By a misprint, this page numbr upiears twice.

$114-04-14$ 
Cane sngar-Continued

l'rulucts of mamufactories, incinerated with sulphuric acid, repert om true ash in (Biard). 18!1. p. $77 \ldots . . . . . . .$. tipe also sugar.

Cance. Tee "Gran cultura"-Orange sorghum cane.

Canker worns:

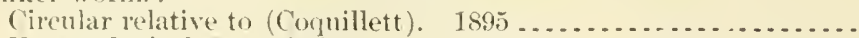

Entomological (ommission, report on, 18s3. p. $157 \ldots \ldots . . .$. Fall, observations on banding of trees to prevent injury by

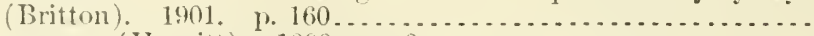

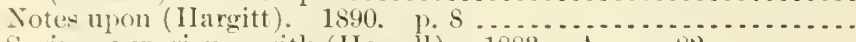
spring, experience witl (Howell). 18s3. Аpp. p.82 ........

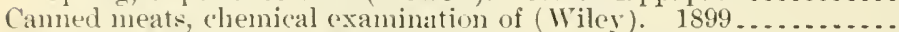
Cammed regetables. Fee Vegetables.

Camine industry, note on-

1859. p. 29

1590.

1891.

(1)

1894 p. 39 -

Cannon, Minna A. Sie, as joint author, Handy, Robert Breckenriclge.

Cannonading, prevention of liail hy (Abbe). 1900, p. $251 \ldots \ldots$.

Canstadt, Germany, milk from, report on (Zeitler). 1890. p. 153. Canterbury, New 'Zealand, nor'westers of (Abbe). 1895. p. $383 \ldots$ Cape Colonv:

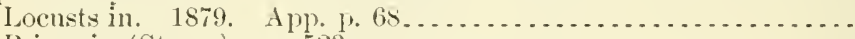

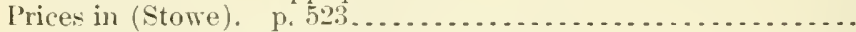

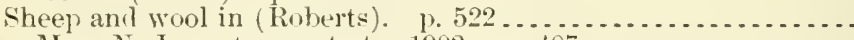

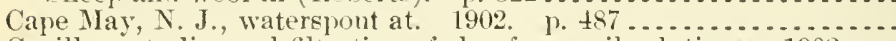
Capillary stuclies anıl filtration of clay from soil solutions, $1902 \ldots$ Caprifig experiments in California, present status of (Howard). 1899.

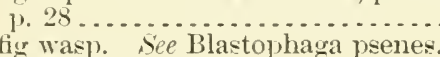

Caprifig wasp.
Capron, Horace:

Adriress of-

at Illinois State Agricultural Society Fair, Decatur, Sept., 1870.

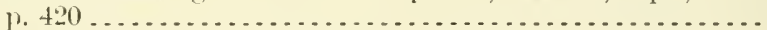
before "Congress of Cotton States," Augnsta, Ga.. Oct., 1870.

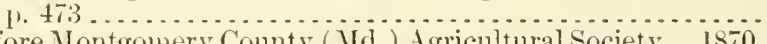
before Montgomery County (Md.) Agricultural Society. 1870.

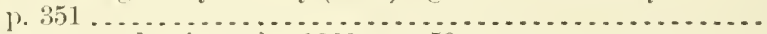

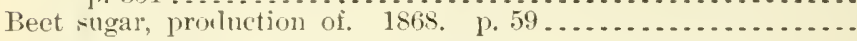
[Also issued as 40 th Cong., 2d sess., H. mis. doe. no. 84; serial no. 1349.]

Farmers of France, circular offering aid to. 1871. p. 65.

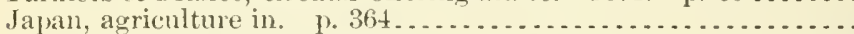
Resignation of, as Commissioner of Agriculture and appointment of his snccessor, Frederick Watts. 1871. p. $255 . . . . . . . .$. See clso, for reports as Commissioner of Agriculture, $1867-1870 \ldots$ Carabid malodorous, Nomins wgmens, dej, notes on (Barrows). 1897. p. 49.

Carbohydrates:

Character of, absiract of payer on (Wohl). 1890. p. $134 \ldots \ldots$.

Fiber in substances rich in, report of committer on estimation of.

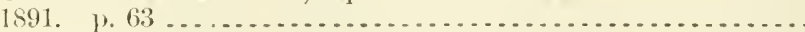

Wheat, maize, flour, and bread (Stone). 1896.............. tipe also Cattle fords.

Carhon, metabolism of, in human organism, with respiration calorimeter of special construction, report of joreliminary investigations

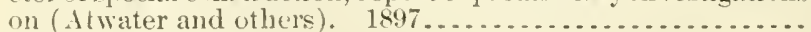
Carbon bisulphid:

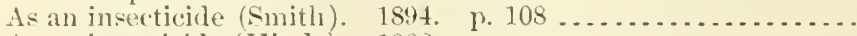

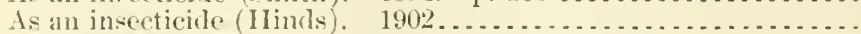

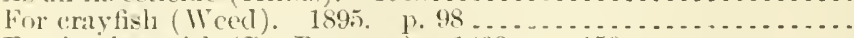

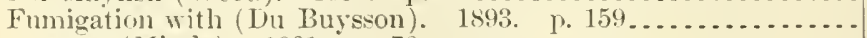

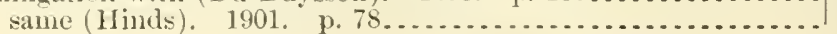

A 10.3:99

A $9.7: 3$

A $8.1: 3$

17.4:5

А27.9:27

A27.9:29

$127.9: 29$

127.9:31

A27.9:32

A 29.6:2S

A 7. 3:24

A $29.6: 23$

AS. 1:3

A $4.1: 898$

A4.1:898

A 29.6:30

A26.3:19

A9.6:20

A27.9:8

A27.9:8

A27.9:S

A27.9:6

A27.9:9

A 1.1:873

A27.9:9

AI.]:

A9.6:9

A7.3:28

A7.3:31

A 10.3:34

A 10.3:4t

A9.7:7

A $1.9: 145$

A9.6:2

A9.7:6

A9.6:30 
Carbon bisulphid-Continned

Sceel treated with, vitality of (Hicks and Dabney) ............ A6.4:11

Carbonate of forla. S're sixla.

Carbonates and hicarbonates in aymeous solution:

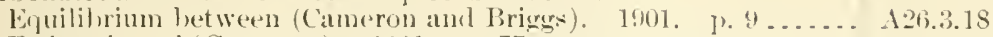

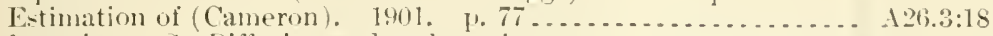

Carbonation. See Diffusion and carbonation.

Carlonic aciel:

liberation of, by respiration and perspiration of various animals

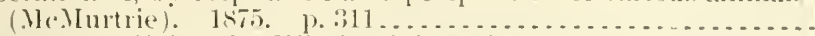

Ise of, in purifying the diffusion juices of sugar cane and sorglum

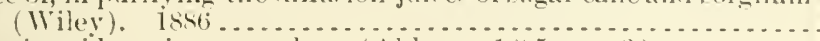

Carbonic-acjel gas in atmesphere (Ahbe) 1595. p. 300 ........

Carcases of pigs, cheminal composition tif (Wiley and others). 1598.
Card, F. W. Elucational status of horticulture, report on. 1901.

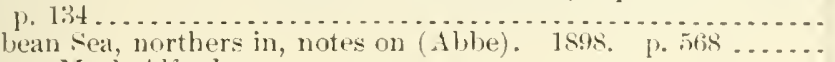

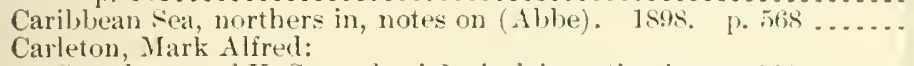

Cereal rusts of $\mathrm{C}$. S., a physiological investigation. $1899 \ldots . . .2-$ Cereals and forage plants cullected in Rassia by, for section of seed and plant introluction, Agriculture Deprartment. 1899.

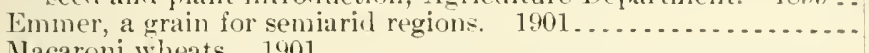

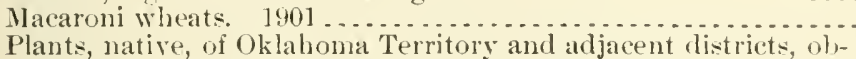

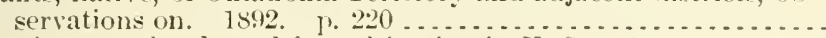

Rusian cereals adapted for cultivation in U. S. $1900 \ldots . . . . .$.

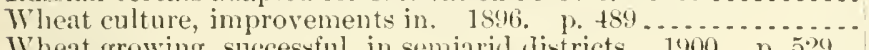

Wheat growing, successful, in semiarid irstricts. 1900. p. 529..

Wheat industry, new, for semiarid West. 1901 .............. .

Wheats, American, basis for improvement of $1900 \ldots . . . . . .$. See also, as collector, Holzinger, J. M.

Carlisle, William IV.:

Marvin's weighing rain and now gauge. $1899 . \quad$ [r. 131 . . . . . . A29.3:24

River gages in upper Mississippi Falley. 1902. p. 22.2 ....... A29.3:31

Carman, Ezra A.:

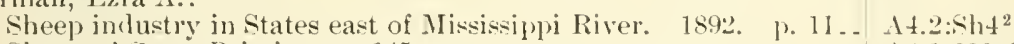

Sheep of Great Britain. p. 145 ......................... 14.1:889-90

Camen Island, plants collected on, lig Eilward Palmer in is 90 , list of (liowe). 1892. p. 129............................... $16.5: 1$

Carnations and other pinks, stigmonose a disease of (Woods). $1900 . \quad$ A25.3:19

Carolina, port. See Port Carolina

Carp (Cyprinus carpio) as an eradicator of fluke disease (Stiles).

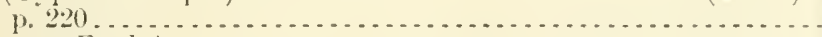

Carpenter, Foril A.:

Fog, utilization of, report on. 1899. p. 195............... A29.6:27

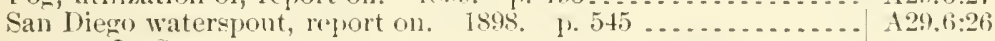

Carpenter, I. G.:

Artesian-well investigation, fieln! work in Colorarlo. 1890. p. 173. same, in Јew Mexico. 1. 233 ..................... Irrigation-

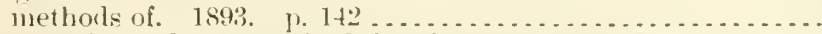

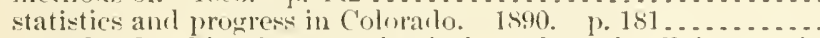

Carpenter, R. C. Bicyclers, mechanical work and efficiency of.

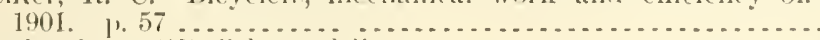

Carpet beetle, or "Jinfialo moth":

Circular relative to (Howarl). 1894.

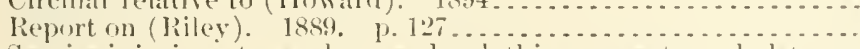

Species injurious to woolen goods, chothing, carpets, upliolstery,

Carr, ()ma:

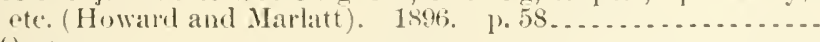

Seed-relection work at Medicine Lodere, Kansas, résmue of. 1893.

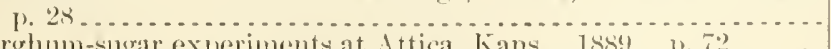

Sorghum-sugar experiments at ittica, Kans. 1s84. 1.72.....

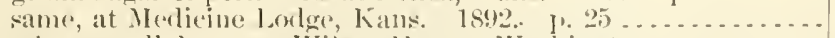
see also, as collaborator, Wiley, Harvey Washington.

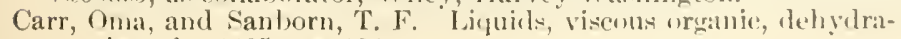

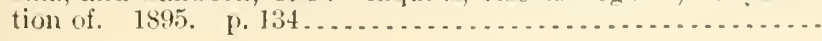

A15.2:Ar 7

115.2:Ar

A 10.3:16

A15.2: P? $94^{2}$

110.3:18

19.5:5

1!1.7:2

A19.15:4 
Carrion crows, communication of hog cholera by (Ford). p. $325 \ldots$

Carroll, Danicl J. Weather Bureau station force, personnel of.

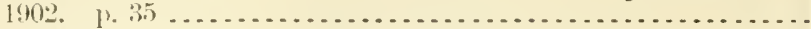

Carrots, loss of nutrients in boiling (snyder). 1897. p. $7 \ldots \ldots . .$.

Carrow, (r. I): :

Cattle farming in the Pampas. p. 486

sluee faming in the Pampas. p. 2:3

Carse, cieorese B. Florisla, climate, soil, productions, and agricultural

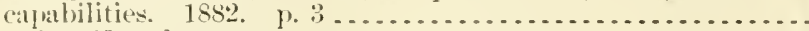

Carsm ('ity, Yevada:

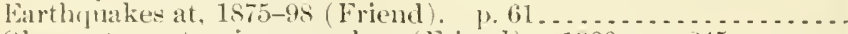

()bervatory at, seismograph at (Friemi). 1900. p. 245......

Cary, C. 1.:

Alabina, farmers institute work aceomplished in. 1902. p. 15. Bacilli, tulerele, growing, for tubereulin. 1898, p. $8 \ldots . . . .$.

Cary area, Nortl (amlina, soil survey of (Coffey and Hearn). 1,311.

Carya alba, stomata on, strange developments of, cansed by phyllox-

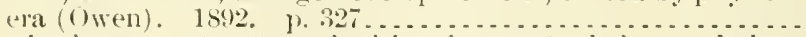

Caryopisis of grasses, structure of, with reference to their morphology

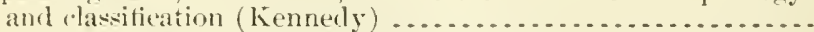

Cascale Mountains of Oregon, forest growth and sleep grazing in Castin: (Coville). 1898

Determination of, in cow's milk (Tan Slyke). 1893. p. 109... Estimation of, by method of Kjeldahl (l'Hote). 1889. p. 170.. Caseous Iymph-adenitis, Orine, nature, canse, and economic importance of (Norgaard and IIohler). p. 635................

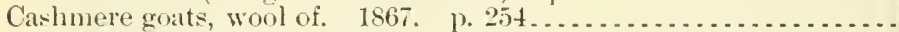

Cass County, Nebraska, swine-plague in (Hines). 1879, p. 177... Cassara:

Starch irom, manufacture of (Wiley). 1900................. Sweet, its culture, properties, and uses (IViley). 1894........

Castor-oil bean, cultivation of-

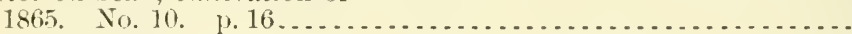
1866.

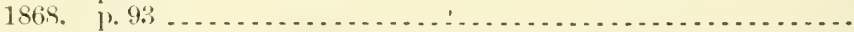

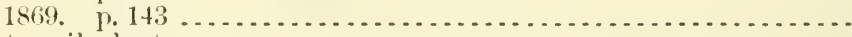

Castor oil plant....

Casualties due to lightning (McAdie). p. $510 \ldots . . . . . . . . . . . .$.

Catalase, a new enzym of general recurrence, with special reference

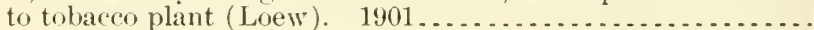

Catalpa, hardy:

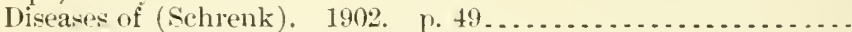

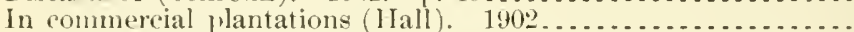

Catania, Italy, cost of hauling farm products over wagon roads at (Bruhi). P. 10 .

Catarrl. See Epizootic catarrh - Sheep.

Caterpillar:

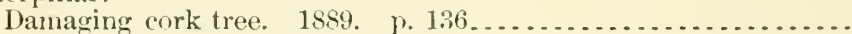

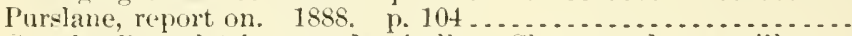

See also Bucenlatrix canadensisella - Clover-seed caterpillar Cotton caterpillars - Hairy catervillars - Tent caterpillar.

Catron, A. Spanish fever, investigation of. 1S6S. p. 357 Cattle:

American-

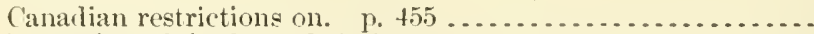

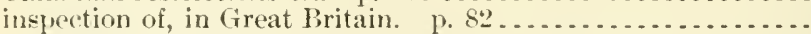
same, p. 70

Anthrax among. See Anthrax.

Argentina, statistics of, 1899 (Jones). p. 515

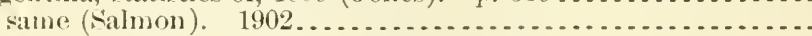
A yrshire, characteristics of (Howard). p. 193........... Beef-

American breeds of, with remarkson pedigrees (Rommel). 1902. "onformation of dairy cattle and' (Soule). 1902. feerling, in Middle States (Lodge).
Classification no.

14.1:\$95-6

A20.3:31

A $10.3: 43$

11.1:865

A $1.1: 864$

1 1.8:21

A29.6:28

1:29.6:28

1 10.3:1:0

14.3:22

A26.5:901

19. $7: 4$

A3.3:19

A13.3:15

17.3:35

A 7.3:24

A $4.1: 899$

A27.9:5

A 1.6:12

A 7.3:58

A7.3:44

А $27.9: 3$

A $27.9: 4$

A27.9:6

A27.9:7

A 1.5:1

A29.1:S91 ${ }^{3}$

11.8:68

A 13.8:37

A13.3:37

$122.4: 27$

19.7:2

A9. $7: 1$

A27.9:6

A $4.1: 884$

A 1.1:890

A 4. 1:889-90

A 4. 1:899

A4.4:37

A 1.1:863

A4.3:34

A $1.9: 143$

A1.1:867 
Blackleg among. Sce Blackleg.

Blood of, persistence of Texas fever organ ism in (Golıroeler). 1). 4:2. 14.1:4en

Bones of, diseases and acridents to (Atkinson). 11.2\$1 ....... 14.2:C292

Breeds of, best, adapted for general farmer of ITestern fiates (Baker). p. $4+5$.

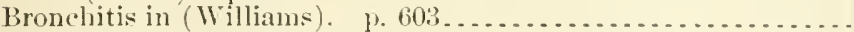

Canadian-British trade in, decrease in (leutelspalcher). p. 515.

Cestodes of, adult, revision of (Stiles and Hassall). 1s:13.......

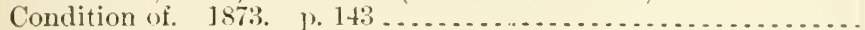

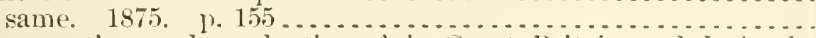

Consmmption and production of, in Great Britain and Irelani.

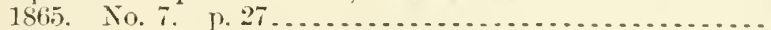

Corm, smutty, ill effects on (Gamgee). 1869. p. $76 \ldots . . . . .$.

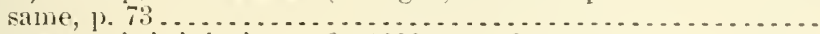

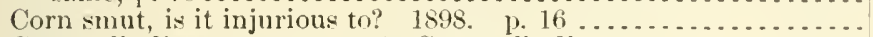

Cornstalk disease among. See Cornstalk diseatse.

Cutaneous disease among, ontbreak of. ए. 361

Dairy. See Dairy cattle.

Decrease of. 1865. No. 4 . p. 13

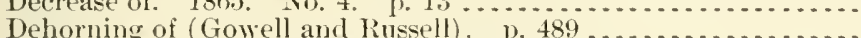

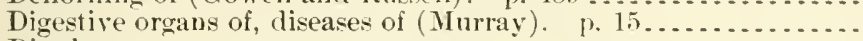

Dipping-

experimental and practical (Nörgaard). 1898. p. 45\%.

for destruction of ticks (Nörgaard). p. $109 \ldots . . . . . . . .$.

Disease among-

in Marshall County, Kans. (Stedilom). p. 382

in Uruguay (Nwalm). p. 385.... p. 382 ........... not distinguishable from rabies. $1896 . \ldots \ldots$ ontbreak of, in Missouri (Nichener). 1891. p. $387 \ldots \ldots . .$. periods of incubation or lateney of. 1900 . p. $740 \ldots \ldots . .$.

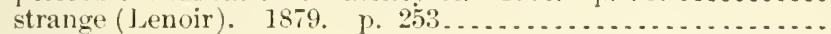

$11.7: 2$

11.1:\$80

1 $4.1: 8.99$

14.3:4

127.4:11

$127.11: 18$

127.9 :3

A $1.2:\left(29^{1}\right.$

1 1.2:(292

A $1.9: 69$

14. $1: 889-90$

$127.9: 3$

At.1:598

14.2:C29 ${ }^{2}$

11.10:898

1+. $1: 895-6$

At. 1:898

A $4.1: 898$

A $4.3: 10$

14.1:889-90

A $1.10: 900$

Diseased-

fluids of, with reference to presence of cryptogamic growths

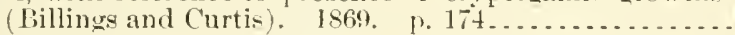

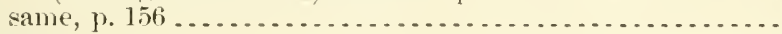

sime....................................

transportation of, letter to railroal and transportation conplanies relative to. $18 \% 0$.

Diseases of-

and cattle feeding. 1892 .

contagions, how they are imported and what they onst

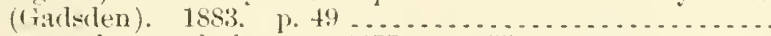

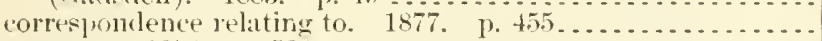

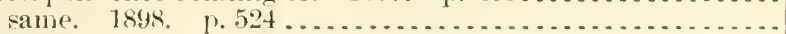
general remarks on (iamgee), 1869. 1. 162 ...........

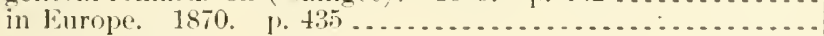

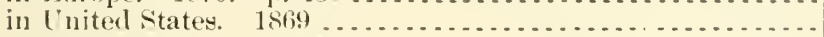

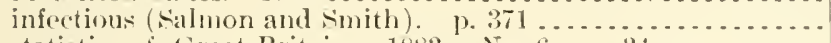
statistics of, (ireat Britain. 18\$3. No. 6. 1. 34 ..........

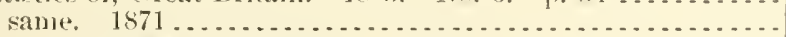
See rlso Diseases of animals.

Ear of, discases of (Trumbower).

Erotisin among. See Ergutism.

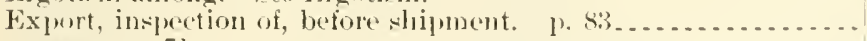

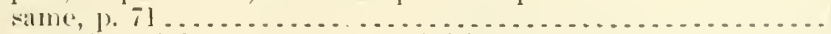

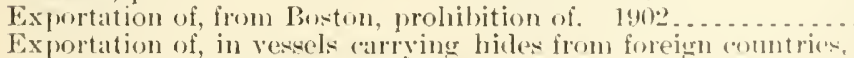
orrlers concerning. 1900 . . . . . . . . . . . . . . . . . .

Fye of, and its appendages, disealses of (Trmmbower) p. pis...

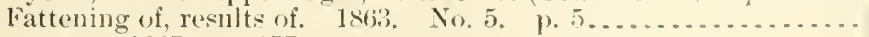

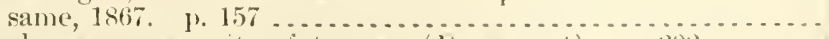

Feed, coarse, necessity of, to grow (1)atremport). 1), $20^{2} \ldots . . . .$.

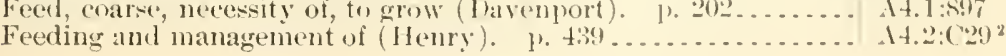


Cattle-Continued

leeding and rearing in Inited States (Morrow). p. 405

Feerling ofaicts to (Abbott). p. 211 .

in Now York (Stewart). 1. 299

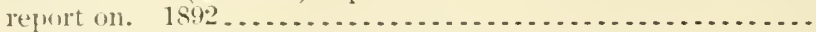

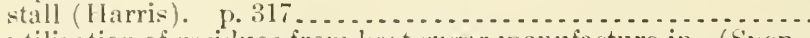

utilization of residnes from beet-sugatr nanufacture in. (Spen-

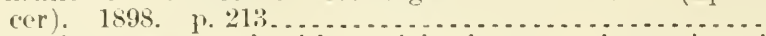

Flukes and tapeworms of, with special reference to inspection of

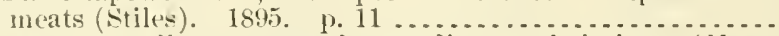
same, compendium, arranged according to their hosts (I las-

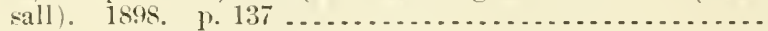
same, bibliography (Hassall). 1898. p. $145 \ldots \ldots \ldots \ldots \ldots$.

Foods of. Siee Cat tle foods.

Foot-and-mouth disease of. See Fout-and-month disease.

Foot of, diseases of (Trumbower). p. 349 .

Foreign, contagion from, protection against-

1898. p. 613

1899. P. 691

1900. ए. 645

1901. p. 624

Generative organs of, diseases of (Law). p. 169

Graded, for Cula, inspection and certification of, regulations for, July 21, 1899

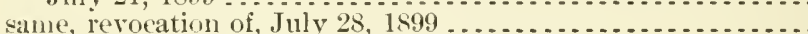

Guernsey, lireed of (Harrison). 1869. p. $302^{*} \ldots . . . . . . . . .$.

Heart and blood-ressels of, diseases of (Harbaugh). p. $75 \ldots .$.

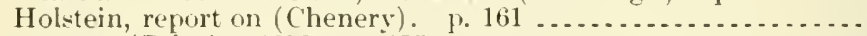

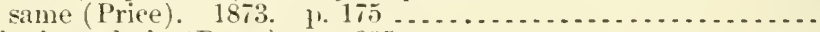

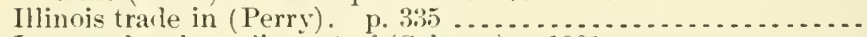

Imported, tubercutin test of (Salmon). 1901 . . . . . . . . . . . .

Imports of, by Great Britain. 189s-1900. p. 606.............

Indian Territory, report on (Shaw). 1885. No. 20 . p. $27 \ldots .$.

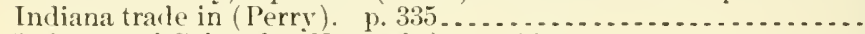

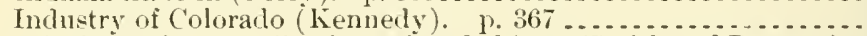

Injuries to, from swallowing pointed objects (Smith and Dawson).

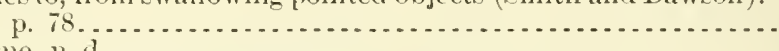

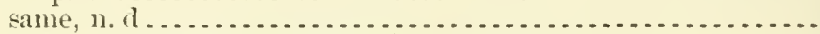

Ixodes bovis, remarks on (Riley). 1869. p. 168.

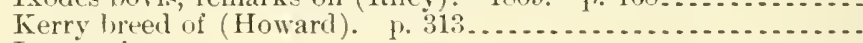

Losses of-

1873. p. 150

18\%万. P. 159

Lumpy-jaw in. See Lumpy-jaw.

Lung plagne of. Sce Pleuro-pnemmonia.

Market, New York, 1858-63. No. 1. p. 33 ................

Markets and aluattoirs in Enrope (Alvord). p. $279 \ldots . . . . . . .$.

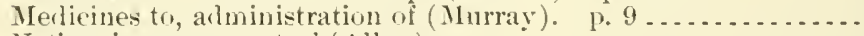

Native, improvement of (Allen)-

1866. p. 294

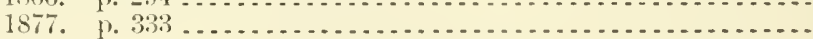

Neat-

distribution and movement of, in U. S. (Loomis). p. 24S... imported, inspection and quarantine of, order concerning, Dec.

2S, 1899 .

same, morlification, Jan. 27,1900

same, amendment, Jan. 1, 1900

same, amendment, Oct. $20,1900$.

samb, amendment, Nov. 10, 1900.

quarantine regulations. p. 451

quarantine stations, report of -

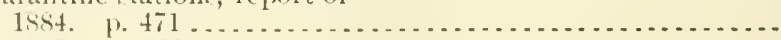

1855. p. $5666_{1} \ldots \ldots \ldots \ldots$

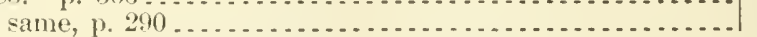

A4.1:857-8

A 1.1:866

A $1.1: 876$

A+.:2:C:292

A $1.1: \leqslant 62$

A1.10:898

A 4.3:19

A4.3:19

A $4.3: 19$

A4.2:C29 2

A1.10:898

A1.10:899

A 1.10:900

A 1.10:901

$\mathrm{A} 4.2: \mathrm{C} 29^{2}$

A $4.1: 885$

A 4.5:39

A $4.5: 40$

A $27.9: 7$

A 4.2:C $29^{2}$

A 1.1:86t

A27.9:11

A $4.1: 885$

A $4.3: 32$

A $4.1: 901$

A $27.9: 23$

A4.1:885

A $4.1: 891-2$

At.1:893-4

A $4.4: 8$

A1.2:C $29^{1}$

A1.1:862

A27.9:11

A27.9:13

A $27.9: 2$

A $4.1: 901$

A $4.2: C 29^{2}$

A $1.1: 866$

A 1.1:877

11.1:\$63

A $4.5: 56$

A $4.5: 58$

A $4.5: 64$

A4.5:77

A4.5:79

A $4.1: 885$

At.1:884

A1.1:885

A 4.1:885

* $B y^{*}$ a misprint, this page number appears twice. 
quarantine stations, reprort of-C'ontinnel

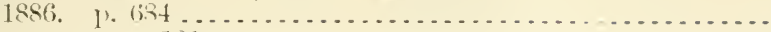

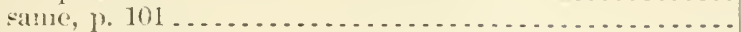

$18.7 .5 \% 521$ Salnie, 1) tis.

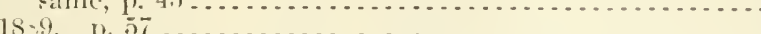
same, 1.15

1890. 1. 104 sime, 1. 9.2

$1891-44.91 \% 34$

1895-96. 1. 38

Nervous systent of, discases of (Harbangh). p. ij $\ldots \ldots \ldots$

Northern-

inoculation to produce immunity from Texas ferer in (wohros-

der). 1. 273

protecting against Texas fever (Wileox). $1900, \quad, 0 . \ldots \ldots$

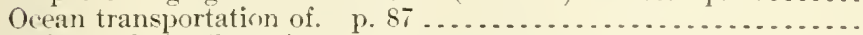

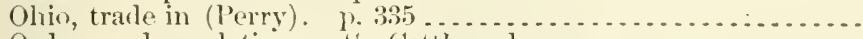

Orders and regulations. Se Cattle orders.

Organs of respiration of, noncontagions diseases of (Lowe). \%. 101.

Parturition of, liseases following (Law). p. 235............

Plague among. See Cattle plague or rinderpest.

Pleuro-pnemmonia among. See Pleuro-pnemmonia.

Poisoning of (Atkinson). p. 63

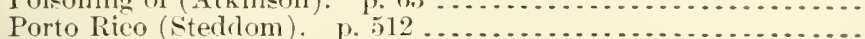

Price of, conditions governing, in United States. p.39......

Pure-lred-

Number and value of, in United states (T'erry). p. 339..... United States, Argentina as a market for (Galmon), $1902 \ldots$

Quarantine of orders for varions States, etr................ See clso Cattle, neat.

Raising and feeding nore, importance of (Taylor). 1) 249

Rearing and feeding in Enited States (Horrow). y. $405 \ldots . . .$.

Rinderpest among. Fee Cattle plague.

Roundworms in, treatment of (Stiles). same. 1902. p. 7 .

Sales of in Madisom County, obio .

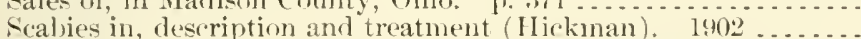
same. 1902

Short-hormedconsirlered with roference to heef and rlairy interests (Allen).

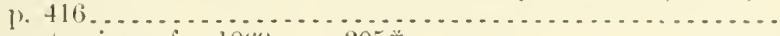
current priens off. 18ti!. p. 305* $\ldots \ldots \ldots \ldots$

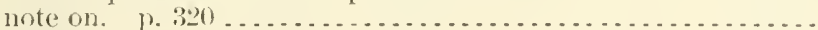

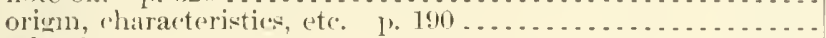
sile of-

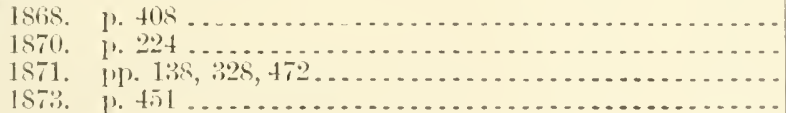

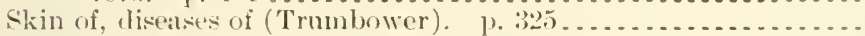

Southern, regulating tiansportation of (Dean). 1\%399 ........

Splenetic fover of, map of rlistrict infecterl with ............

Splenie or poriodic fever of (Cramgee). 1869. 1\% 89. sanje, 1. 8: .

Spomzoun in intestinal vili of, prolinimary motes on (smith).

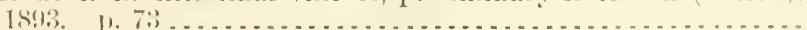

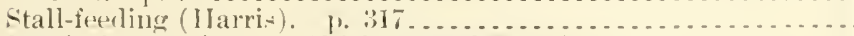

Surgical operations om (Dicksom and lawe). p.

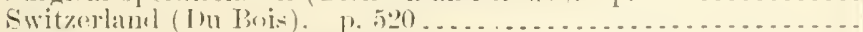

Tapeworms of. are Cattle, fluless ambl tilpeworms.

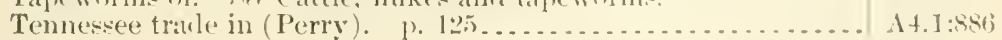

A1.1:886

14.1:\$86

1.1.1:Si

14.1:N87-8

11.1:SSS

1.1.1:587-8

A1.1:\$89

At. $]: 889-90$

A1. 1:890

14.1:889-90

A 4.1 :89: -1

A 4. 1:595-6

At.2:C $29^{2}$

14.1:598

A 1.9:119

At.1:900

14.1:885

A $4.2:(20)^{2}$

A $4.2:(2)^{2}$

A $4.2: C^{2} 9^{2}$

At.1:899)

At. 1:8.87-8

At. $1: 587-8$

A $4.4: 37$

A 4.5 :

11.1:864

A $4.1: \$ 87-8$

At. $4: 3.5$

A $4.3: 35$

A 1. 1:\$69

A $1.9: 152$

A $4.3: 40$

11.1:875

1:7.9:7

A1. I: 666

11.1:86:3

127.9:6

127.9:S

127.9:9

127.9:11

14.2:(2) $)^{2}$

A $+.1: 889-90$

At.6:

11.2:(C)

11.2:(C) $(2)^{2}$

14.8::3

11.1:S6:-2

14. $:()^{2}\left(y^{2}\right.$

14.1:5:18

* By a misprint this page mumber uppears twice. 


\section{Index}

Cattle-Continued

Texas fever uf. Siee Texas fever.

Texas iteh among, in Kansas (Mayo). p. 4 SS ..............

Thelemark, of Norway. 1876. p. 432 .................

Transpurtation of, regulations eoncerning . . . . . . . . . . . . .

Tuber'nlosis among. See Bovine tuberculosis-Tulerrulusis.

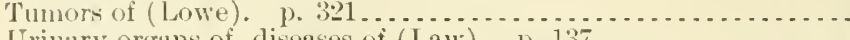

Urinary orcans of, diseases of (Law). p. 137 .............

Venezuclan, shipments of, to Cuba (Ellsworth). p. $516 \ldots . .$.

Verminous diseases of, in Texas (Stiles). p. 356 ............ same, further investigations (Stiles). $\% 223 . . . \ldots \ldots \ldots \ldots$.

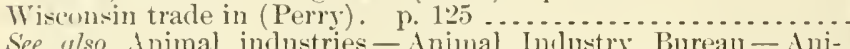
See ulso Animal industries - Animal Industry Bureau-Anileg - Bovines - California - Calres-Canadian cattle-Channel Islands - Colorado-Cornstalk disease-Cows- "Cream pot" stock - Dairy tattle - Dairy herd - Diseases of animals - Jrgotism - Farm animals - Foot-and-month diseaseGuernsey cattle - Holstein cattle - Jayues "cream pot" stock-Kerry breed of cattle - Livestock - Lumpy-jaw Plenropnemuonia - Southern cattle fever-Spanish feverSteers - Texas - Texas fever - Thelemark cattle - Tuberculosis - and headings beginning Cattle.

Cattle and cattle products of Argentine Republic, some statistics of 1899 (Jones). p. 515

Cattle breeders. Nee Chicago, ill, National Convention of Cattlebreeders.

Cattle breeders' associations, list of, with officers-

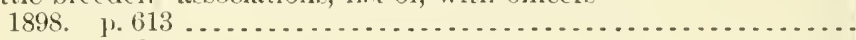

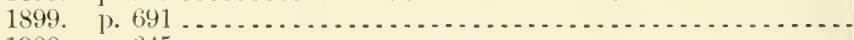

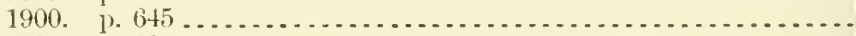

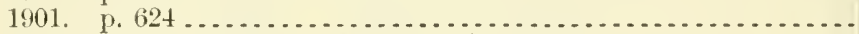

Cattle farming in the Pampas (Carrow). P. 486.............

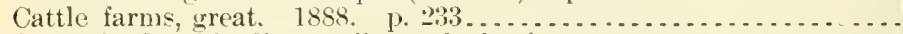

Cattle foods or feeding stuffs, analysis of:

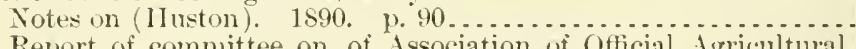

Report of committee on, of Association of Official Agricultural Chemists-

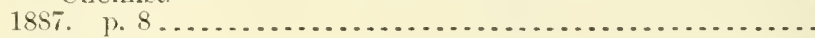

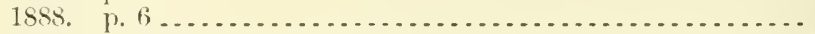

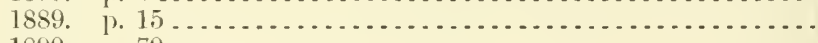

1890. p. $79 \ldots \ldots \ldots \ldots \ldots \ldots$

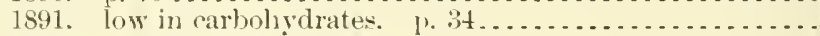

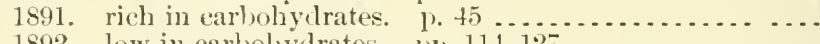

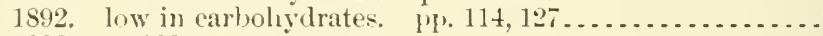

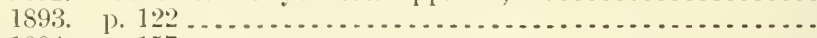

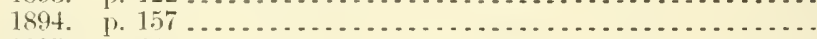

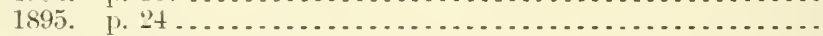

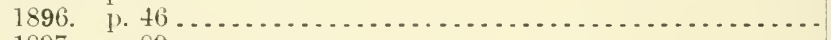

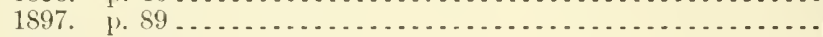

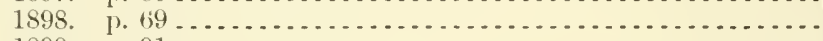

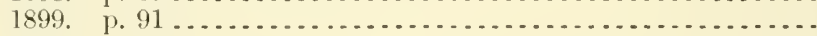

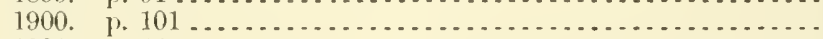

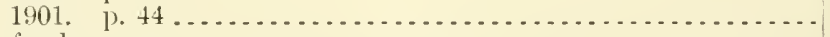

Cattle foorls:

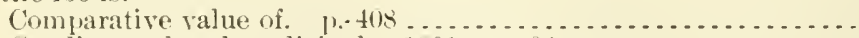

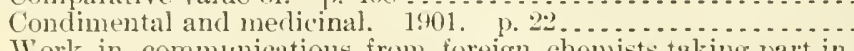

Work in, communications from foreign chemists taking part in

(Fassbender). 1894, p. 170...

See also Cattle, feoding oi - Foclerer.

Cattle Growers' Association, Jational. Ne Kansas City, Mu.

Cattle industry:

Address on, at National Convention of Cattle Breelers, Chicago,

Ill., Nov. 13, 1sst (Loring) . . . . . . . . . . . . . . . . . . .

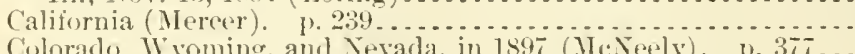

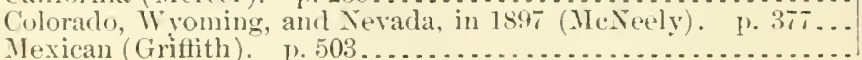

A4. 1:899

$14.1: 598$

127.9:14

14.5:

1+.2: $\left(29^{2}\right.$

14. 1:C $29^{2}$

14.1:899

A $4.1: 900$

Af.1:901

14.1:886

11.10:898

\1.10:899

11.10:900

A1.10:901

11.1:865

A.7.9:26

A 7.3:28

A7.3:16

A 7.3:19

A $7.3: 24$

A7.3:28

A7.3:31

17.3:31

A $7.3: 35$

A7.3:38

17.3:43

A7.3:47

A7.3:4?

A7.3:51

A $7.3: 56$

17.3:57

17.3:62

17.3:67

A $1.1: 5635$

A 1.9:1 14

A $7.3: 43$

A $1.7: 6$

A $4.1: 880^{\circ}$

14.1:898

A $4.1: 900$ 
Cattle industry-Continued

Report on (Cirimell). 1s:3. p. 2:3:

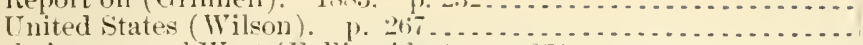

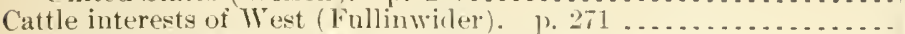

Cattle interests west of Mississiplui liver, amolition of:

1884 (Grinnell). p. 23:3

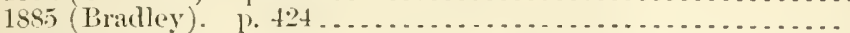

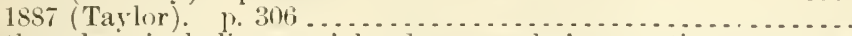

Cattle orders, including special orrers; regulations, notices, ete. mo

lating to cattle transportation, fuarantine, otc.. 1895 to clate..

Cattle plague or rinderpest:

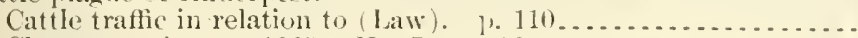

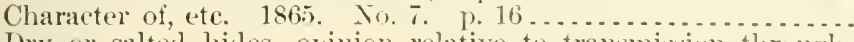

Dry or salted hides, opinion relative to transmission through

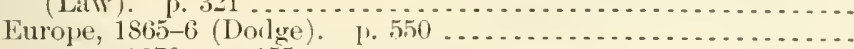

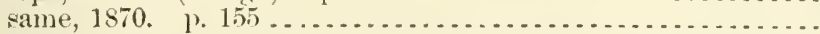

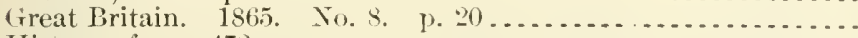

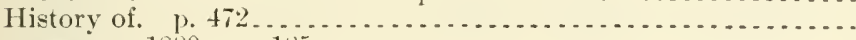

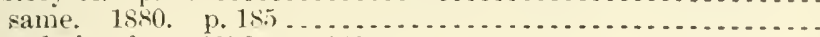

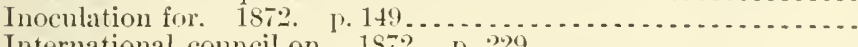

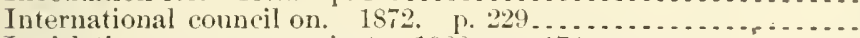

Legislation necessary against. 1866. p. $174 \ldots \ldots \ldots \ldots \ldots \ldots \ldots$

Notes on-

1865. Yo. 9, 1. 20; No. 10, p. 27

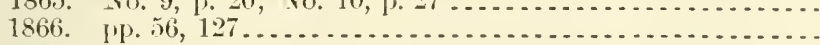

1868. p. 186

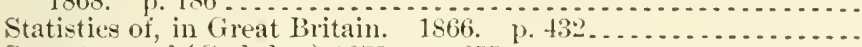

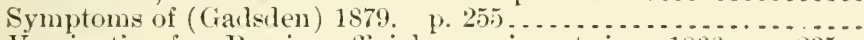

Vaccination for, Russian ofticial experiments in. 1866. p. 205

Cattle-range industry, condition of (Taylor). 1) 105...........

Cattle ranges of Southwest; history of exhaustion of pasturage and suggestions for its restoration (Bentley). 1898.............. . .

Cattle show of Smithfield club, notes on (Rogers). 1. $326 \ldots . . . .$.

Cattle tick. See Ixodes bovis-Southern eattle tick.

Cattlemen, interstate convention of. See lort Worth, Tex.

Caucasus, Russia, agriculture in the. 1893. p. $202 \ldots . . . \ldots \ldots .$.

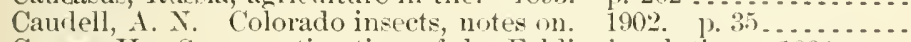

Cause, H. Sugar, estimation of, by Fehling's solution. 1890. p.

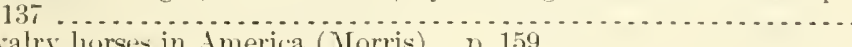

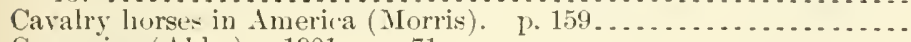

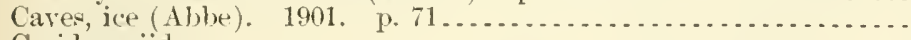

Cecidom yiid:

Injurious to seerls of sorghum (Coquillett). 1898. p. 81 ...... That lives on poison oak (Coquillett). 1895. 1).345.......... Two new, clestructive to buds of roses (Coquillett). 1900. 1). 44 .

Cecil County, Ml., snil survey of (Dorsey and Bonsteel). 1). 103....

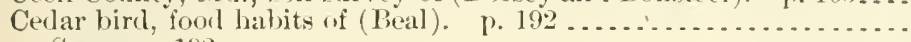

Cedar Falls, Iowa, sorghmm-sugar experiments at (Wiley). 18 .

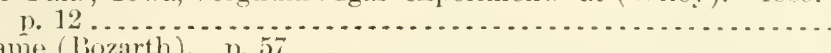

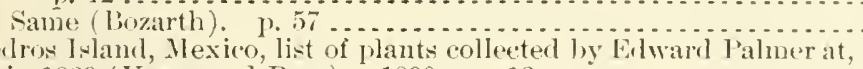

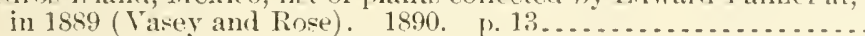

Celery eulture:

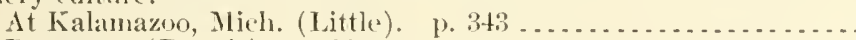

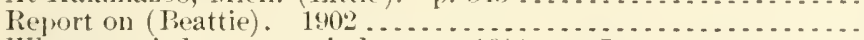

Where carried on, as an industry. 1901 p. p........

Celluluse in plants anil animals (Taylor), $1875, \quad$ p.316.........

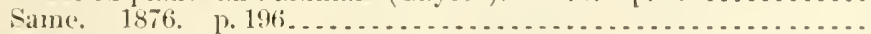

Census:

Austria, agricultural. 1865. No.6. [). 18

Belgium, arrieultural. 1885. No. 24. 1).37............. Eleventl, of U.S., agrienltural statistice of, riscussion of (ilyole).

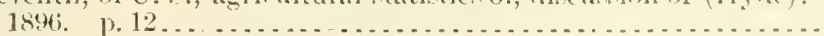

Centiperles:

Honse, fircular on (Marlatt). 1902.

11.7:2

A+.1:901

14.1:88.1

$14.1: \$ 84$

At. $1:$ :

14. $1: \$ 87-8$

14.5:

$11.7: 2$

127.9:3

11.1:\$76

11.1:865

$127.9: 8$

$127.9: 3$

1 1.1:879

A 1.6:22

127.9:10

\27.9:10

127.9:4

$+27.9: 3$

A27.9:4

A27.9:6

127.9:4

A1.6:1:

A27.9:4

A4.1:886

A1.9:72

A+. $1: 895-6$

127.9:31

19.6:38

A 7.3:28

1 1.1:8133

1:29.6:29

19.6:18

19.7:7

19.6:22

$120.5: 900^{1}$

A 1.1:892

A.5.1:89?

A7. $3: 26$

17.3:26

$16.5: 1$

$11.1: 886$

11.9:148

11.9:1333

1:-7.!):13

1.27.9):1-4

127.9:3

$127.9: 23$

14.:3:11

1.9.5:48 
Centipedes-Continued

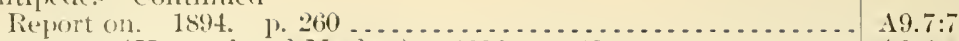

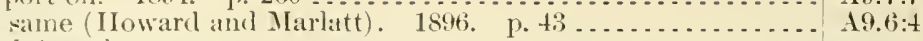

Central Anerica:

Cofiee, discase of, danger of introdncing into IIawaii (Swingle).

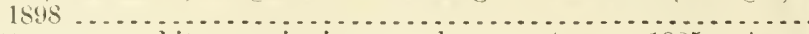
Cotton cropand its enenies in, consular reports on. 1885. Ap.

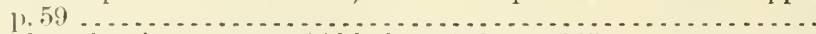

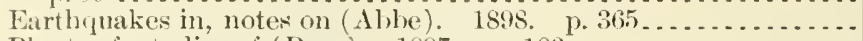
Plants of, stullies of (Rose). 1897. p. 103 .....................

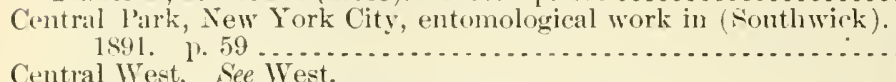

Central West. See West.
Centrifugal dairy. See Deerfoot farm.

Centrifugal force. See Mechanical analysis.

Century, meteorological, note on (Abbe). 1900 . p. 591 .........

Cercospora circumscissa:

Almond disease caused by, remedies for (Pierce). 1891. p. 232.

Treatment of, suggestions in regard to (Galloway). 1891. p. 77 .

Cereal breakiast foods, study of (Langworthy). 1899, p. 19 ......

Cereal crops:

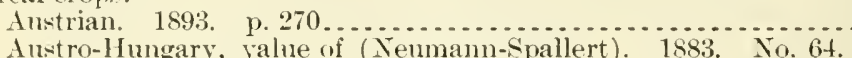

Auntro-Hungary, value of (Neumam-Spailert). 1883 . No. 64.

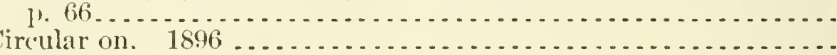

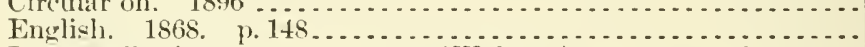

Insects affecting, report on some (Webster). 18:10. p. $63 . . . .$. See also Cereals.

Japanese. 1893. p. 270

See also Farm products - Girain.

Cereals:

Aduteration of cereal products and (Wiley and uthers). 1898.

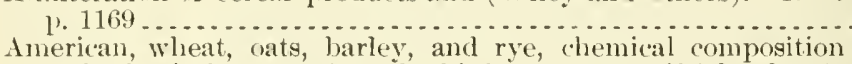
and physical properties of, third report on (Richardson). 18866

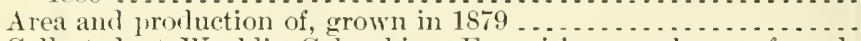

Collecter at World's Columbian Exposition, analyses of, and comparisons with other data (Wiley). $1895 \ldots . . . . . . . .$.

Coliected in Russia by M. A. Carleton, for section of seed and plant introduction, Agrieulture Department. 1899 .......... .

Condition of, monthly notes on ...........................

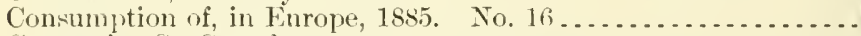
Crops of. See Cereal crops.

Estimaterl production of, of $T$. S., 1881. No. $41 \ldots \ldots \ldots \ldots \ldots$.

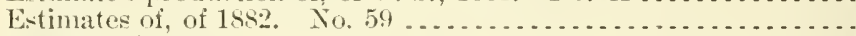

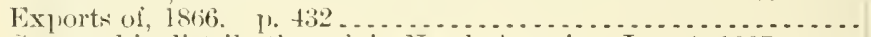

Geographic distribution of, in Xorth America, Jan. 4,1897 ....

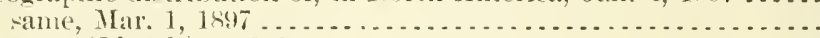

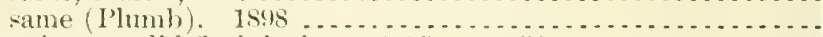

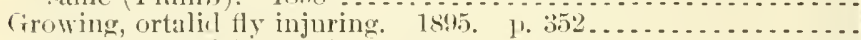

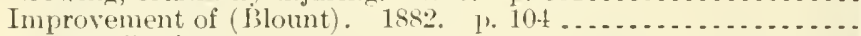

Invects affecting-

destruction of $186 \pi$. p. 158 . . . . . . . . . . . . . . . . . other dry vegetable foods and, report on (Chittenden). 1896.

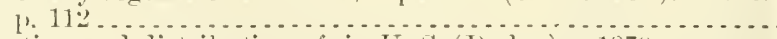

Proluction and distribution of, in $\mathrm{U}$. $S$. (Dorlge). 1879 .......

Production of, in fremany. 1876, p. $367 \ldots \ldots . . . . . . .$.

Russian-

adapited for cultivation in U. S. (Carletom). 1900..........

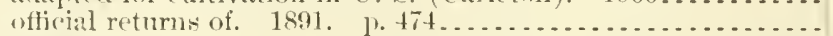

Rusts afferting-

experiments in treatment of (Galloway). 1891. p. 195.....

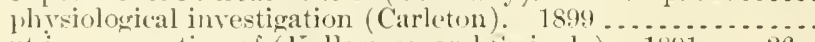

Snut in, prevention of (Kellerman and swingle). 1891. p. 26..

Stored, and other products in Mexieo, insects affecting (Chitten-

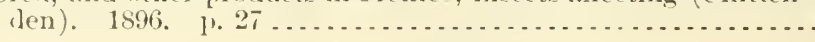

A9.3:23

A27.9:32

A7.3:13 ${ }^{9}$

A $7.3: 9$

A $1.8: 23$

A $7.3: 45$

A6.6:4

A27.9:

1 $27.9: 23$

127.9:20

127.9:21

A27.9:4

15. $4: 21$

A. $4: 22$

A5.3:11

A 9.77

A1.8:22

127.9:5

A9.6:4

A $27.2: C 33$

127.9:14

$16.3: 23$

127.9:29

A28.5:-

A28.3:16

A $28.5: 6$

A9.8:4 


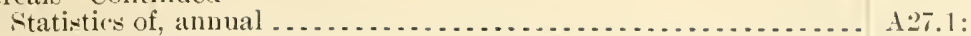

Tariff rates on, in European comntries, 18\%. p.323........... A27.9:32

Variety testing in; how can it he rendered more decirive? (Ilick-

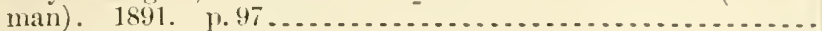

See also Grain, and references therennder.

Cereals and cereal products, adulteration of (Wiley and wthers).

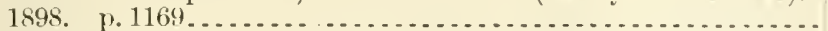

Cerebro-spinal meningitis. See Horses.

Cereus, North American species of, preliminary revision of (Coulter).

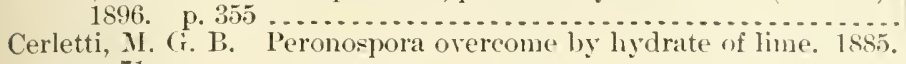
Cestodes:

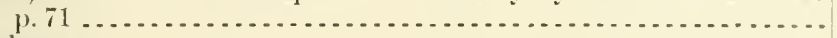

Adult-

of cattle, sheep, and allied animals, revision of (Stiles and

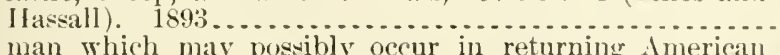
of man which may posvibly occur in returning American
troops (Stiles and Tayler). 1902. p. $43 \ldots . . . . . . . . .$.

Larval, of man which may possibly occur in returning American

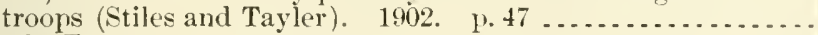

See also Tapewornis.

Chietochloa, North American species of (Scribner and Merrill). 1900. Chaffee, Frank P.:

Meteorology in public schools; how much should be attempterl;

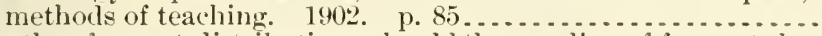

Weather-forecast distribution: shonld the wording of forecasts be confined to vocabulary of present logotype outfit? is it advisable to extend vocabulary of logotype outfit? 1889 . p. 48.

Weather forecasts, stamping, on mail matter, report of committee appointed to investigate subject of. 1896 . p. 51 .

Weather map, low to make synopsis instructive to publie. 1902 .

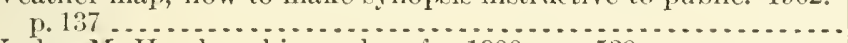

Yerby, M. H., short biography of. 1900 , p. $539 . \ldots \ldots \ldots . .$. Chagres River:

Ratio of lischarges of, to rainfall (Abbot). 1899. p. $541 \ldots \ldots$.

Upver, rainfall and drainage in (Abbot). 1900. p. $243 . . . . . .$. Chalcidida:

North American, from collections of Department of Agriculture and of $\mathrm{C}$. $\mathrm{V}$. Riley, descriptions of, with biological notes, and list of described Forth American speries of family (Howarl).

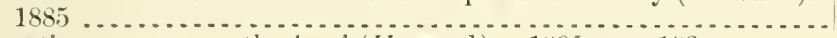

Pupation among, methods of (Howard). 1s91. p. $193 . . .2$. see also Aphelinina.

Chamberlain, W. J. Crop reports, national and international, pajer

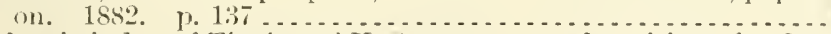

Chambers's index of Tineina of $\mathcal{L}$. IValsingham, Lorl.

Champaign, ]11.:

Swine plagne at (Detmers). 1879 p. 19................

Texas cattle fever investigations in (Jetmers). 1880, p. 291 .

Chancellor, Charles ITilliams. Harre, France, cost of hauling farm profucts over waton roads at. p. 3 .

Chandler, A. E. Duty of water in 'lule River liasin, California.

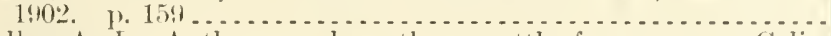

Chandler, 1. J. Anthrax and sonthern cattle fever amomer cali-

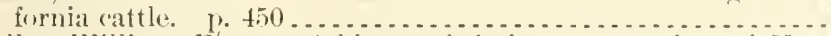

Chandler, William Faton. Adliless of, hefore convention of $\mathrm{Na}$ tional leagne for Good Roads, Washington. 1893. 1) 15...

Changat or mole cricket in Porto Rico (Barrett). 1902............

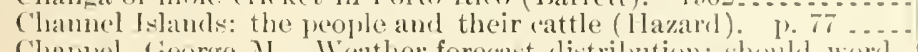

Chapjel, (ienrge 21. Weather-forecast distribution: shonld wording of forecasts be wntined to vocaloulary of present logotype

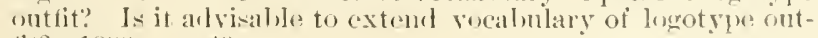

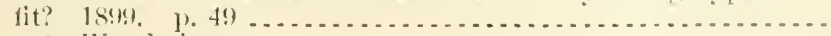

14.3:4

$14.3: 35$

1.3.8:21

A29.3:31

A29.3:24

A 29.3:18

A29.3:31

A $29.6: 28$

A 29.6:27

A29.6:28

19.3:5

19.7:4

$11.8: 22$

11.6:12

$11.6: 34$

1:2:4:27

110.3:119

At.1:45-8

110.3:14

A10.12:2

$11.8: 2: 2$

$1: 93: 3: 24$

Char. sie IVord char. 
Charbon. Nee Anthrax.

Charles, Vera k. See, as joint author, Pieters, Adrian John.

Charleston, s. C., hurricanes at, notes on, 1752-1893 (Abloe). 1901.

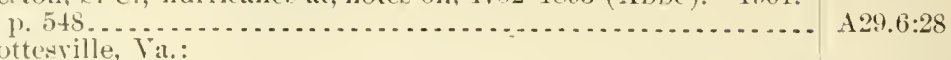

Charlottenville, Va.:

Grapevine, downy millew and black rot wf, treatment of, with

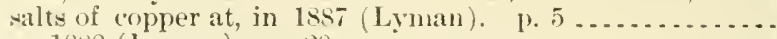

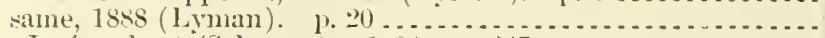

San José scale at (Schwarz). 1894. p. $247 \ldots . . . . . . . . . . .$. Jefferson Memorial and Interstate good-roads convention. letter

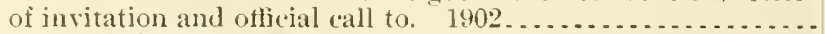
Charpentier de Cossigny, M. J.:

Igricultural hydranlics; translaterl by Mrs. A. F. Wood. 1891.

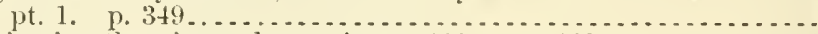
Irrigation theories and practices. 1891. p. $268 \ldots \ldots \ldots \ldots$ Charts of atmosphere humidity, notes on (Able), 1901. p. 1is... Chamveau, A. B. Electricity, atmospheric, methods and instruments

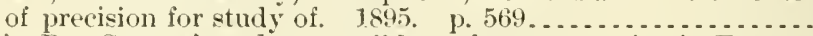
Clauzit, B. Grapevine, downy millew of, treatment for, in France

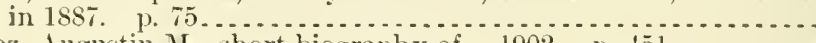
Chavez, Augustin M., short biography of. 1902. p. $451 \ldots \ldots . .$.

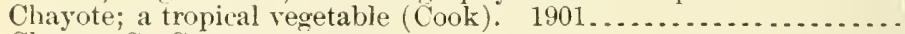
Cheat. See Chess.

Cheese:

Ameriean, deterioration of. p. 384.

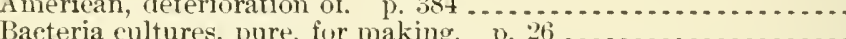

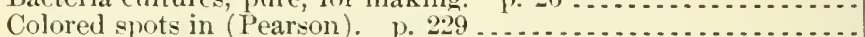
same - . . . . . . . . . .

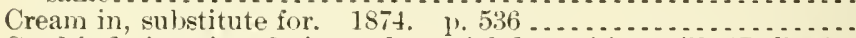
Curd inflation; its relation to bacterial flora of foremilk (Bolley).

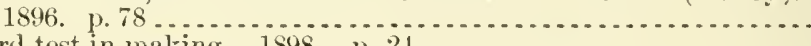

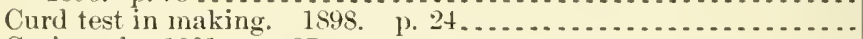
Curing of. 1901. p. $27 \ldots \ldots \ldots \ldots$ Curing rooms, construction and cooling of 1899 p. p. $14 . . .$. Factory for, and how it is made (Merry). 1896. 1. 45 .......

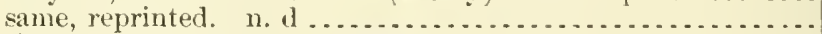
Fat in, determination of (Tan Slyke). 1893. ए. 116 . . . . . .

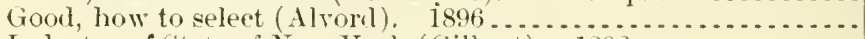

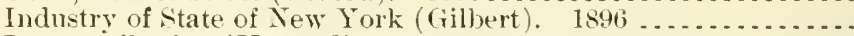

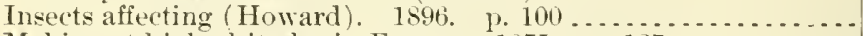
Making at high altitules in France, 1875. p. 127 . . . . . . . . Manufacture and consumption of (Alvord). 1895. p. 453 ..... Manufacture of, as a staple article of export (Goodale). p. 381 .. Market for, in England (Ashy); p. $214 \ldots . . .2 . . .2 . . .2$.

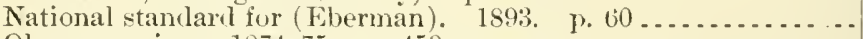

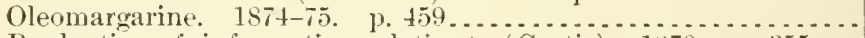
Production of, information relative to (Curtis). 1870. p. 355 ... Proluction statistics of lutter and. $1873 . \quad$ p. $279 \ldots . . . . . .$.

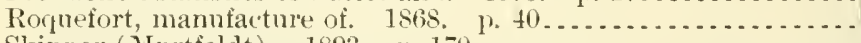

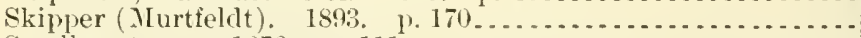

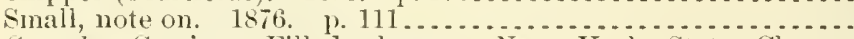
See also Casein - Filled cheese - Jew York State Cheese IIanufacturers' Assuciation.

Chemical analysis:

Agricultural, explanation of some new furms of aplaratus used in (Wiley). 1840. p. 96 . . . . . . . . . . . . . . . . . . . .

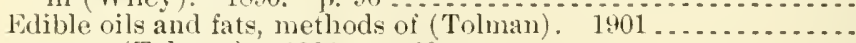
same (Tolman), 1902. p. 20 .......................

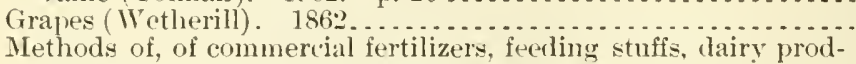
ucts, and fermented liquors, alopterl by Association of Offieial Agricultural Chemists-

$2 \mathrm{~d}$ anmual convention, 1885

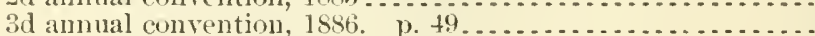
fth :

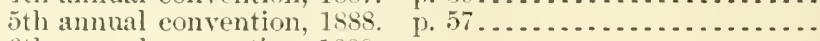

16.3:5

A6.3:10

A9.7:6

A22.2:C38

115.2: $\operatorname{Ir} 7^{2}$

A 15.2:P4t ${ }^{2}$ 129.6:29

129.3:1 $11^{2}$

A6.3:5

A $29.6: 30$

A6.3:28

A $4.1: 889-90$

A 1.9:92

A 4.1:898

14.4:24

A27.9:12

A 10.3:30

A $1.9: 8 t$

A 1.9:144

A $1.9: 97$

A $4.3: 15$

14. $4: 19$

A7.3:38

A $4.4: 11$

14.3:15

A9.6:4

A.7.9:13

A $1.10: 895$

A 1.1:86:3

1 $4.1: 899$

A $7.3: 41$

1:- $9: 13$

A:7.9:5

A27.9:11

127.9:6

19.7:6

A:- $.9: 14$

A 7. $3: 28$

A7.2:Oi5

A7.3:65

A1.8:3

A $7.3: 7$

A $7.3: 12$

A7. $3: 16$

A $7.3: 19$

A 7.3:24 
Methods of, etc.-Continued

ith annual convention, 1890.

Sth annual convention, 1891.

Gth anmual convention, 1842 .

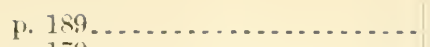

p. 179.

10th annual convention, 1893.

p. $195 \ldots \ldots \ldots \ldots$

1. 169.

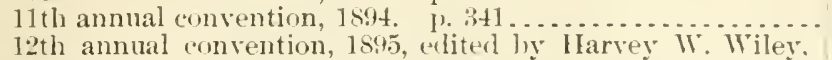

with collaboration of L. L. Van slyke and $\mathrm{W}^{*}$. I). Rigelow 15 th annual convention, 1898, erlited by Harrey W. Wiley ... changes and adklitions, Dee. $12,1896 \ldots \ldots \ldots \ldots \ldots \ldots \ldots$ changes and additions, Dec 11, 1897 ................. outline of. 1901 .

provisional methods, at 1 sth ammual conrention, 1901, editer

by Harvey W. Wiley, with collaboration of $\mathrm{W}$. D. Bigelow. Ser ulso Timning naterials.

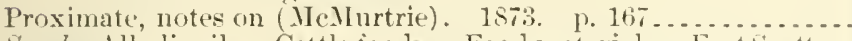
Seeriso Alkali soils - Cattle ioods-Foor materials-Fort foottFruits - Fungicides - Insecticides - Plants _ Soils.

Chemical exhibit. Tee Chieago, Ill., World's Columbian Exposition. Chemical fertilizers. Nee Fertilizers.

Chemieal measuring flasks, testing of, notiee in regard to. 1897. p. 159. Chemical memoranda on agricultural subjects, monthly, Nov,-Dec., 1871 . p. 480 . . . . . . . . . . . . . . . . . . . . . . . Same (Smith), Jan., 1s,:; (Brww), Feb.-Dee., 1872.........

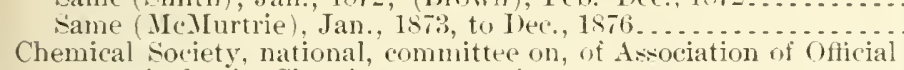
Agriculturist Chemists, report of-

1890. p. 182.

1891. p. 165 ............

Chemicals, weed destruction by means of (Evans). 1901. 1. 19 ... Siee also Enzymes.

Chemistry:

Abstracts of reports of agricultural experiment stations on.

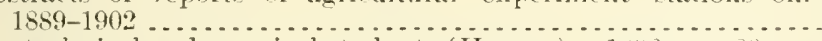

For technical and practical sturlents (Huston). 1896 p. $88 \ldots$ Relation of, to progress of agrieulture (Wiley). p. 201 ....... See floo A sricultural chemistry - Alkali - Cotton.

Chemistry and economy of food, methods ancl results of investiga-

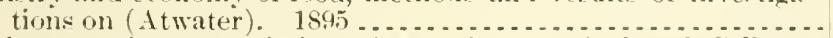

Chemistry section, Association of Ameritan Agricultural Colleges and Experiment Stations, report of:

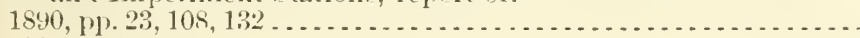

1891. p. 20 . . . . . . . . . .

$1892, \mathrm{p}, 36$

See also Agriculture and chemistry section.

Chemistry liureau, Agriculture Department:

Exhibit of, at Pan-American Exposition, Buffaln, N. Y., 1901 (Ewell and others). 1901_........................

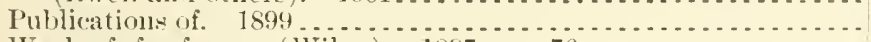

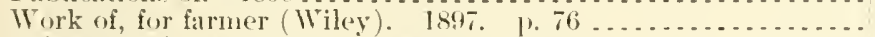

Chemists, Official Agricnltural, Association of:

Historical sketch of (Wiley). 1899 . 1. 16 ............... 17.3:5

2d amnal convention, 1885, profeetlings of, editerl by charles

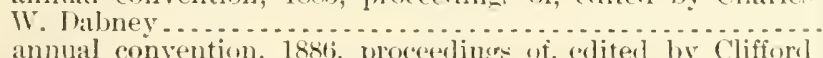

id anmual convention, 18st, proceedinge ot, edited by Clifforl

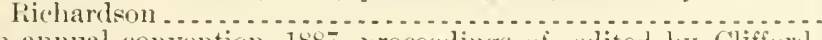

th anmual convention, $188 \bar{s}$, procesdings of edited by cliffori

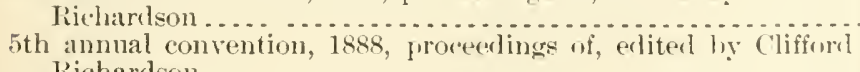

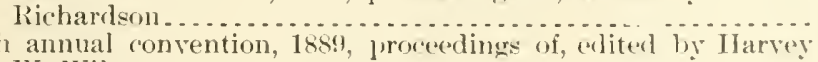

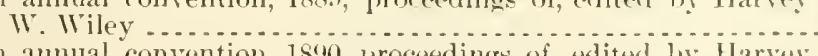
7 th ammal convention, 1890 , proceedings of, eflited ly Harvey

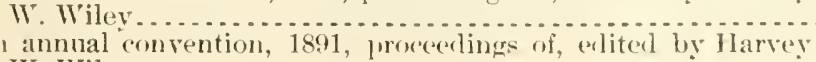

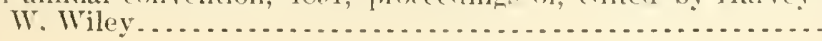

110.6:

A $10.3: 41$

1 $1.10: 899$

$110.3: 21$

A10.5:3

A 10.3:

A10.8:16

$d i$.

17.8:63:3

1 $7.2: 196$

11.10:857

$17.3: 7$

17.3:12

1 T.3:16

A7.3:19

17.3:24

A7.3:28

A7.3:31 
Chemists, Otlicial Aericultural, Association of-Continued

bth ammal comvention, last, proeedings of, edited by Harvey

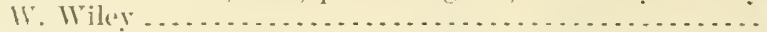

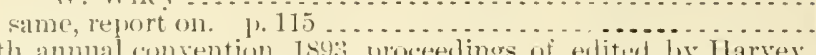

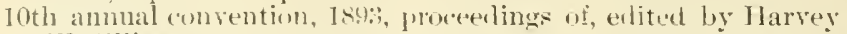

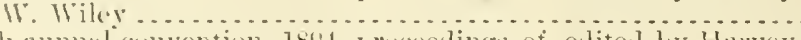

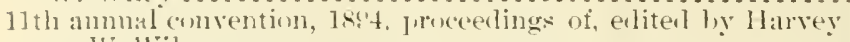

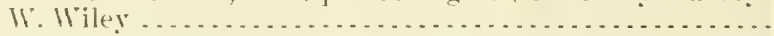

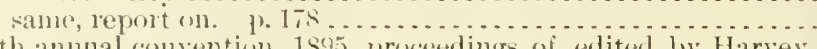

12 th anmual comvention, 1895 , procedings of, exlited by Harvey

II. Wiley . . . . . . . . . . . . . . . . . . . . .

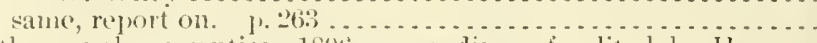

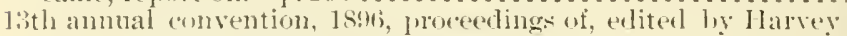

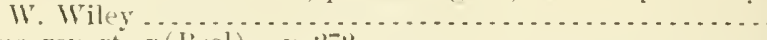
same, report on(Iical). J. 27:

1tth anmal convention, $189 \%$, procediness of, edited by Harvey

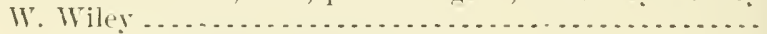

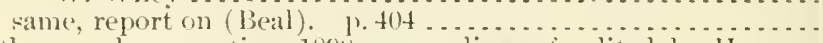

15 th anmual convention, 1898 , proceedings of edited ly Harrey

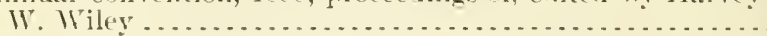

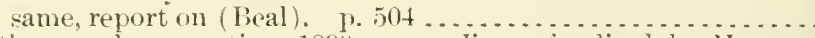
16 th ammal convention, 1899 , proceedings of, colited by Harvey

IV. Wiley . . . . . . . . . . . . . . . . . . . . . . . .

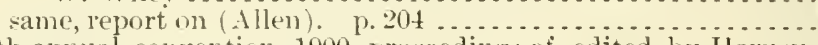
17 th ammal convention, 1900, proceedings of, edited by Harves

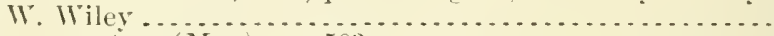

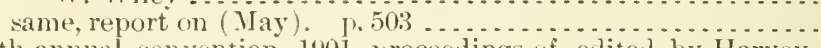
1sth anmal convention, 1901, proceedings of, edited by Harvey

IV. Wiley . . . . . . . . . . . . . . . . . . . . .

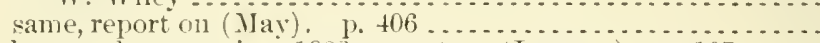
19 th annual convention, 1902, report on (Lawson). 1) 107 .... Chenery, Winthrop 11 :

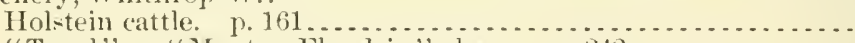

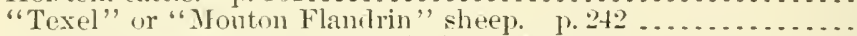
Cherries, fuorl value of (Langworthy) 18.49 p. p. $\ldots \ldots \ldots \ldots \ldots \ldots$ Cherry Hill, N. J. Tormalo at, leport of (Emery). 18.5. 1.252.. Cherry leaves, wild, joisoning by (Evans). p. $1 \dot{6} \ldots \ldots \ldots \ldots \ldots$. Cherry tree, black knot of (Peck). p. 175...................

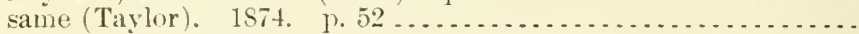

Chesnut, Victor King:

Plants poisonons to stock, preliminary catalogue of. p. 387 .....

Plants nserl by Indians of Jendocino County, California. 1902.

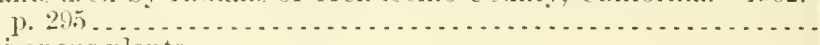

Poisomons plants-

principal, wi C. S. 1898

some, of morthern stock ranges. 1900. 1) 305.

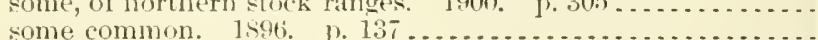

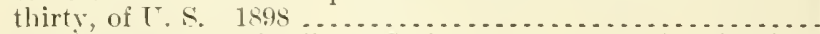

Chesnut, Victor King, and Wilcox, Earley Vernon. Stork-poisoning plants of Montana, preliminary report. $1901 \ldots . . . . . . . .$.

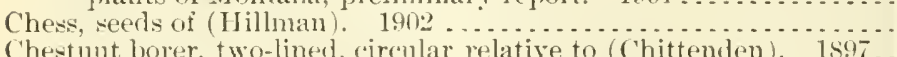

Chestnut borer, two-lined, (iremlar relative to (Chittenden). 1897.
Chestnut oak for railroad ties, circular on (Colman). 1857....... Chestnut trees:

Ilecay ot, in North Carolina. 1867. p. 58 ................

Insect injury to, in Virginia and neighboring states (chitenden).

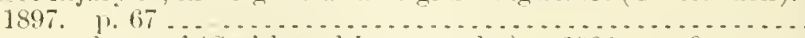

Chestnuts, ('ulture of (smith and l.angworthy) 1900. p. $9 \ldots \ldots$. Chester, Frank Iyer. Copper salts as fungiciles. 1891. p. $21 \ldots$ Chicaero, Ill. :

Ancicnt climates near $(A b b)$. 1895. p. 42t ..............

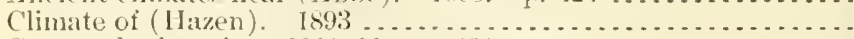

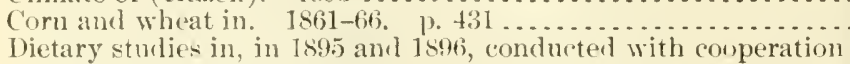
of Jane Addans and Caroline I. Hunt of Hull IJouse (Atwater and Bryant). 1898.

$17.3: 35$

1 10.6:4

$17.3: 35$

$\therefore 7.3: 4: 3$

A $1(1, t ;: t)$

$17.3: 47$

$110.6: 5$

1..3:4!)

1 $10.6: 5$

A7...:5i 1

A I0.(i:9)

$17.8: 56$

A 10.6:19

17.2:57

A10.6:11

A. $3: 3: 10^{2}$

110.6:1:

17.3:6\%

A I0.ti:1:3

A10.6:14

A1.1:86t

11.1:864

1 1.9:105

A29.6:23

A 1.9:103

11.1:4:2

1.7.9:12

14. $1: 848$

A6.5:-

A6.3:20

11.10:900

A ].10:8:96

A I. (1):8it

A6.3:26

A I9.: $)^{\mathrm{n}}:$ IR:31

19.5:24

A 13.4:4

127.9:5

A9.6:-

A 1.91:114

$128.5: 63$

129.6:23

A:9.3:10

127.9:4

A 10.3:55 
Chicago, IH.-Continued

Farm animals at, range or average price of -

1897 and 1898 . p. 579.

1899. 1. 673

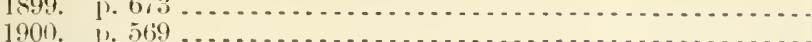

Growth of the Northwest and. 1864. Yo, 2. p.32.........

Horse show of 1890 (Martin). 1891, p. 349 ...............

Horses from, export of (Bruette). 1897. p. $84 \ldots . . . . . . . .$.

Live stock and meat traffic of (Perry). p. 245............

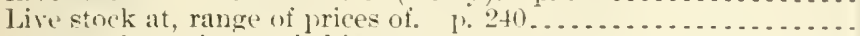

Livestork roceipts and shimments-

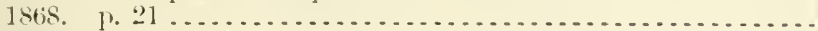

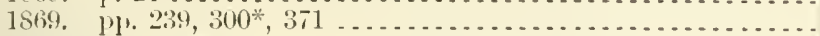

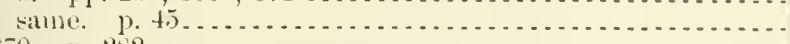

1570. p. 282

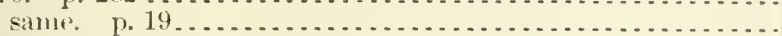

18. 1.8 .89

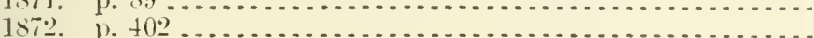

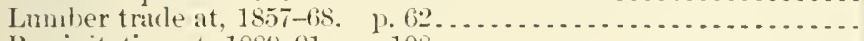

Preciputation at, $1889-91$. p. 108. . . . . . . . . . . . . . . .

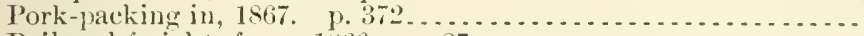

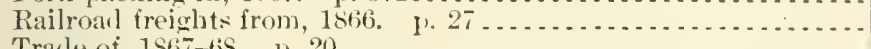

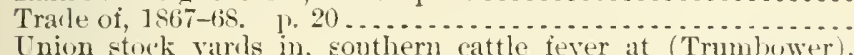

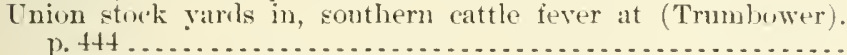

Weather forecat district, monthiy report of-

Sept., 1898-May, 1899 (Cox) . . . . . . . . . . . . . . . . .

June, July, 1899 (Beals) . . . . . . . . . . . . . . . . . . . . . . .

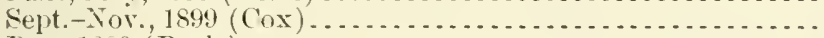

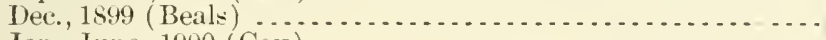

Jan.-June, 1900 (Cox) ............................

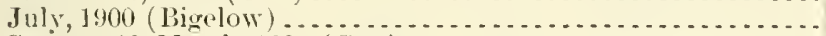

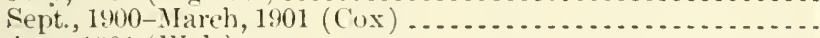

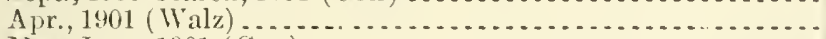

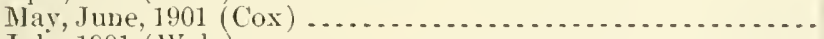

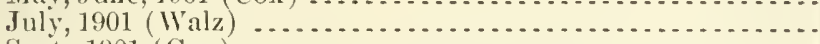

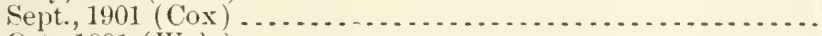

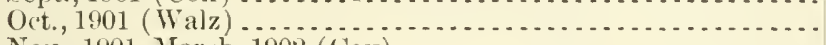

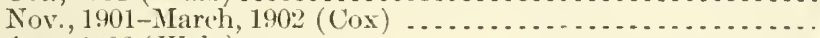

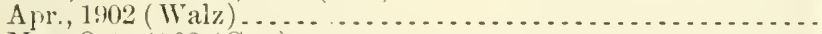

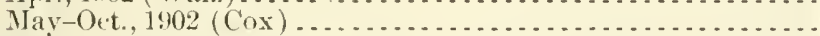

Chicago, ill., Interuational live Stock Fxposition, 1900:

Canalian cattle, sheep, and swine for exhibition at, special order, proviling for importation of-

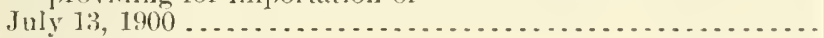

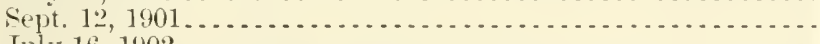

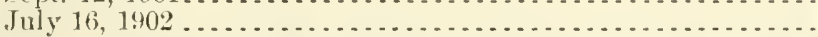

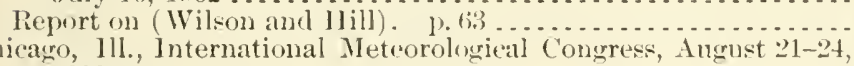
1893:

Proceedings of (Fassig). 1894. p. 20\%

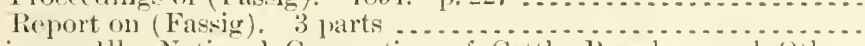

Chicago, Ill., National Convention of Cattle Breolers ami i) Ftockmen, called to consider subject of entagious discases of domestic animals-

[1:t], Nov., 188:, proceeding oì

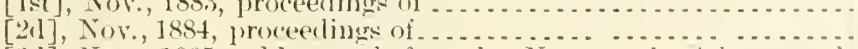

[31], Nov, 1885, adlresses before, ]y Norman J. Cotman ami
1). E. Salnom

Chieago, 111., National Good Roads and Invigation Congress, letter

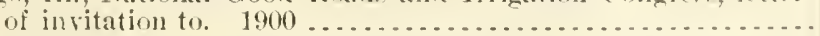

Chicago, 11l., World's Agricultural congresis, rejurt of committere on (Iormw). 1893. p. 104.

Chicater, Ill., World's Colmmlian Exposition, isis:

Agrienltural colleges and "xperiment stations, "ollective "xhibit of circulars relative to

$14.1: 898$

14.1:\$99

1. 1:900

$127.9: 2$

14.1:85!)-90

11.2:117

14.1:584

14. 1:897

127.9:7

1.27.9):7

A27.!: :

127.9:8

A $27.9: 9$

A $27.9: 10$

127.9:10

127.9:7

A29.6:20

127.9:5

A27.9:4

127.9:7

A4.1:\$84

A29.6:

A29.6:27

A29.6:27

A29.6:27

$129.6: 28$

A29.6:28

A 29.6:28, 29

A29.6:29

A29.6:29

A29.6:29

A29.6:29

A29.6:29

129.6:29, 30

129.6:30

129.6:30

$14.5: 67$

$14.5: 90$

14.5:96

A $4.1: 900$

$129.6: 21$

A:9.:3:11

11.8:29?

11.8:3:3

A I.S:3s

$+12: 2 \cdot 2:(143$

111).3:16;

I 1 $11.2: C 43$

* By a misprint, this puge number appears lwice. 
Chinaso, 11l., World's Colmmbian Exposition, 1893-Continued

Agricultural experiment stations, cooperative exhibit at, report of committee on-

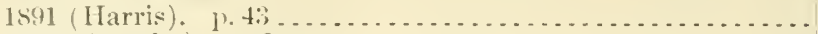

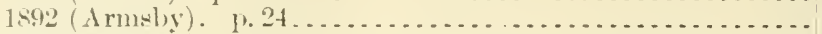

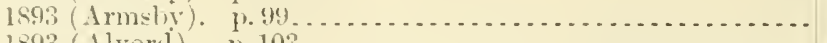

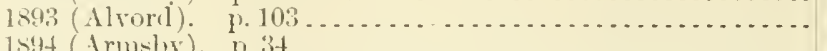

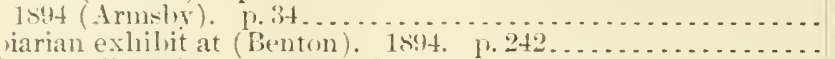

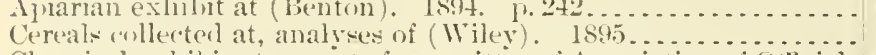

Chemical exhilit at, report of committee of Asoreiation of Official

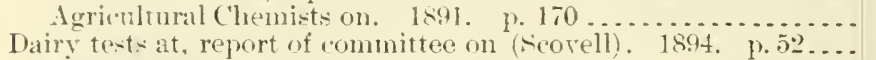

Entomology, ceonomic ratalogne of exhibit at . . . . . . . . . . .

Insects oceurring in foreign exhibits of (Riley). 1894. p. $213 . .$. same, destruction of (Chittenden). 1594. p. 225.........

special report of assistant serretary on, p. 58 .............

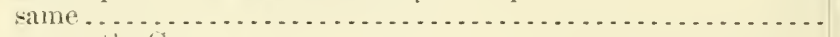

Chick-prea. sie Gram.

Chickamauga Vational Park, torestry report on, p. $321 \ldots \ldots . .$.

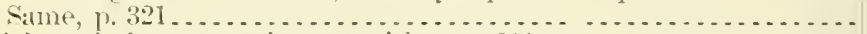

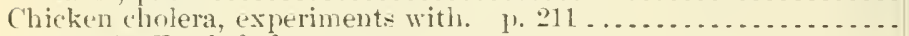

see rela Fonl rholera.

Chicken tirk, note on (Hawall). p. 496 ...................

Chickens:

Animal parasites of, check list of (Hassall), $1896 \ldots \ldots \ldots \ldots \ldots$. . . . .

Apoplectiform septicemia in (Nörgaard and Mohler). $1902 \ldots . .$.

Ibifferent breeds of, weights of eggs of (Emery). p. $474 \ldots . . .$.

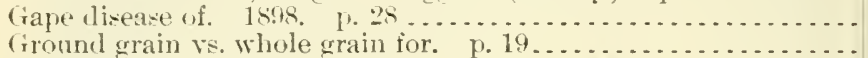

Stanilard varieties of (Howard). 1896. p. $445 \ldots \ldots . . . . . .$.

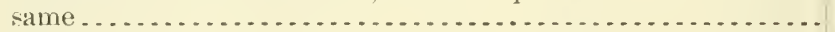

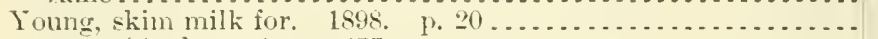

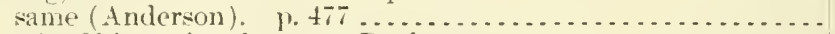

see ulso Chinese incubators - Poultry.

Chickens and their diceases in Hawaii (Selgwick). 1901.

Chicory growing as an aldition to resources of the American farmer

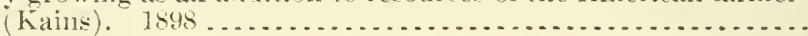

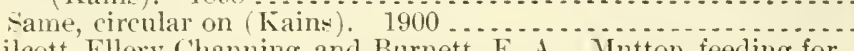

Chilcott, Ellery Chamning, and Burnett, E. A. Mutton, feeding for,

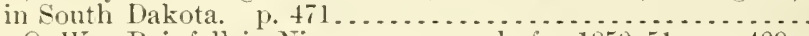

Chilks, O. IV. Rainfall in Nicaragua, record of. 1850-51. p. 409.

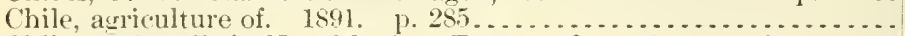
Chilo saccharalis in New Mexico (Townsend). 1s91. p. 24..... China:

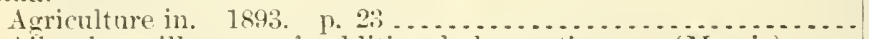

Ailanthus silkworm of, additional observations on (Morris). p. 390

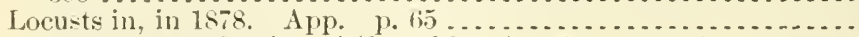
same, extermination of (Scatchkow). App. p. $65 \ldots . . .2$.

Our trade with. 1889-99. (Hitcheock) .....................

San José scale in, résumé of search for native home of. 1902.

Treaty of Shimonoseki, between Japan and, A pr. 17,1895 , and

Sep also Anoy - Indo-China - and headings beginning Chinese.

China grass. See Ramie.

Chincli bug:

Destruction of, in field by artificial introduction of contagious

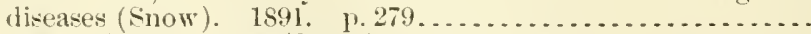

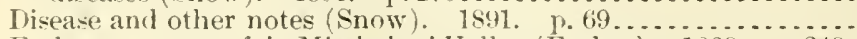

Earlyoccurrence of, in Mississippi Valley (Forlues). 1889. p. 249.

Experiments for destruction of, in field by artificial introduction of contagious diseases (Snow). 1891. 1. 145.

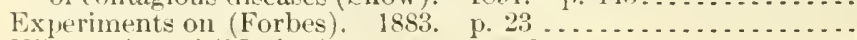

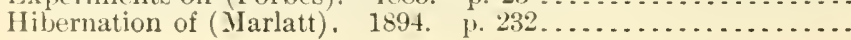

A $10.5: 3$

110.3:7

110.3:16

1 10.3:16

A 10.3:20

A9.7:6

A. $.3: 45$

A. $7.3: 31$

d 10.3:-20

A $9.3: 31$

A9.7:6

A9. $7: 6$

19.7:6

11.1:89:

A5. 1:498

11.1:89.2

A13.1:892 A $1.6: 22$

14. 1:899

A $4.4: 9$

A $4.3: 36$

A 4. 1:899

A1.4:54

11.9:84

A1.10:\$96

$+1.9: 51$

1 $1.9: 84$

14.1:899

A10.9:1

16.3:19

A6.4:29

A 4. 1:898

A $29.6: 26$

A27.9:29

A9.7:4

A $27.9: 30$

11.1:56:

A8.1:3

AS.1:3

A12.3:18

A9.6:37

A12.4:5

A9.7:3

A9.7:4

A9.7:1

A10.5:3

A9.3:2

A9.7:7 
History of (Howard). sanje. 1888

A1.1:887

A9.3:17

Interesting outbreak of, in northern Ohio. 1899 . p. 55 .......

Its probable origin and diffusion, its habits and levelopment, natural checks and remedial and preventive measures, with mention of habits of allied Enropean species. 1898

Ohservations in Iowa in 1894 (Osboru). 1894. p. $230 \ldots \ldots . .$.

Ohio ontlireak of, three years' study of (Welster). 1896. p. 18..

lemedies for (Glover) -

1875. p. 442

1881. 1. 87

1.882. 1. $87 \ldots$

(hincha, see Skunks.

('hinewe and fruitarians, nutrition investigations among, at ('alifornia Agricultural Experiment Station, 18s9-1901 (Jaffa). 1901.

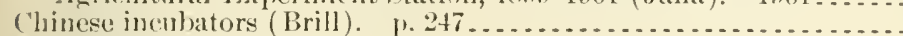

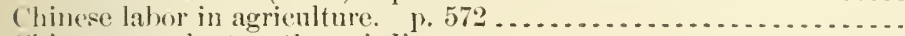

('hinese teatplaut or thea virdis:

Cultiration and manufacture of tea from, in U. S., practicalility

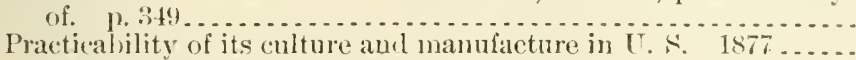
samle. $(2 \mathrm{~d} l, 26)$.

Chinese regetable fool materials, their mutritive and economic value,

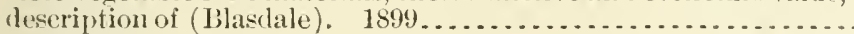

Chinook winds:

Description of (Garriott). 1892. p. $23 \ldots \ldots \ldots \ldots \ldots \ldots \ldots$

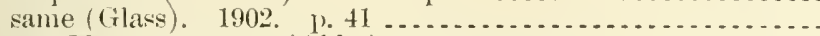

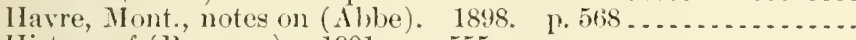

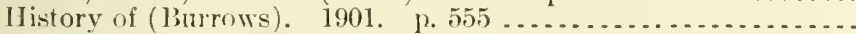

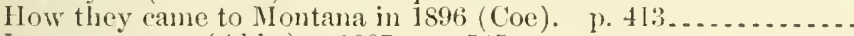
Iowa, notes on (Abbe). 1897. p. $545 \ldots \ldots \ldots \ldots \ldots \ldots \ldots \ldots \ldots$

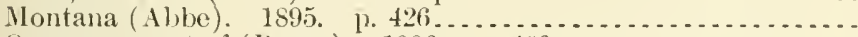

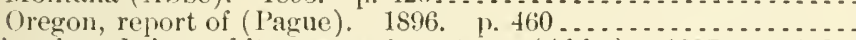
Chinook and signs of its approach, note on (Able). 1897. p. 213. Chinonks and hot winds (Abbe). 1894. p. $77 \ldots \ldots . . . . . . . .$. Chinnoks versus kuro siro, notes on (Able). 18\$8. p. $114 \ldots \ldots .$. Chionolas (oeneis) macounii, preliminary notes upon (Fletcher).

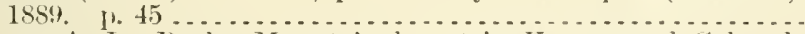

Chipman, A. J. Rocky Mountain loeust in Kansas and Colorado in 1880 . Apl. 1,55 .

Chittenden, Frank Iurlbut:
Agrilus, North American species of, food plants and injury of 1900. 1. $64 \ldots \ldots \ldots$

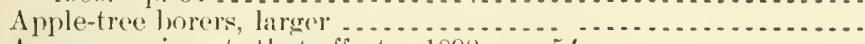

Asparagus, inseets that affert. 1898. p. 54

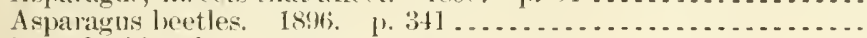

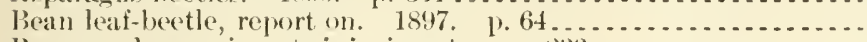

lieans and peas, inseets injurious to. f. 2.:3.

Beetles, certain imported, listrilution of. 1895 . p. $326 \ldots . .$.

Birch trees, destructive borer, enemy of. 1sos. 1. 4t........

Bronze apple-tree weevil. 1900 . 1 37
Cereals, stored, and other produrty in Mexico, insects affectime.

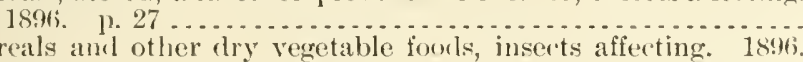

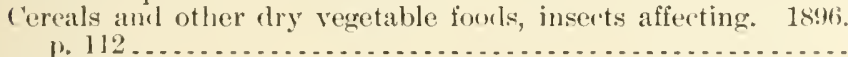
Chestnt and pine trees in Virginia and neighboring States, jusect

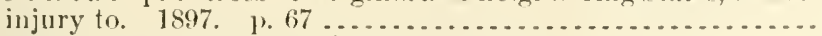

('hestnut lorer, two-lined, eirenlar on. 1897 ................

Chicago, Ill., World's Colmmlian Exposition, 1893destruction of inscets oecurring in foreign exhilitions. 1894.

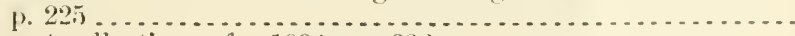

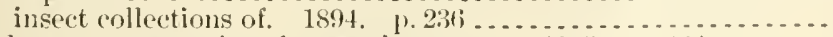

Coleopterons enemies of grapevine, some 18is. p.384......

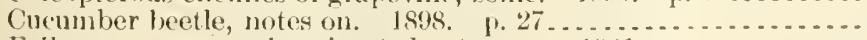

Fall army worm and variegated cutworm. $1901 \ldots . . . . . . .$.

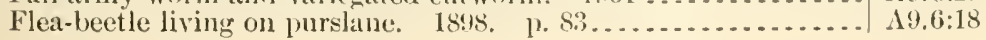

A1.1:877

A1.6:3

A1.2:An $7^{2}$

A10.3:68

A 29.6:20

A29.3:31

A29.6:26

A $1.10: 901$

A29.6:24

A29.6:25

A29.6:23

A29.6:24

A29.6:25

A 29.6:22

\29.6:26

19.7:2

18.1:3

19.6:22

19.5:32

A9.6:10

A1.10:896

A9.6:)

A1.10:898

19.7:7

A 9.6:18

A9.6:22

19.8:4

19.6:4

A $9.6: 7$

19.5:24

19.7:6

A9.7:6

A9.7:7

19.6:10

19.6:2!) 
Chittemlen, Frank Ilmrlbut-Contimmed

Fruit-tre bark-beetle, ("irrulatr (1). 1\$:18 .................. $19.5: 29$

Garlen anel orchard crops, some insects injurioms to. $1899 \ldots . . . \quad$. . . . $0: 19$

Garden (rops, insects injurious to. 1900 . . . . . . . . . . . . . 19.6:23

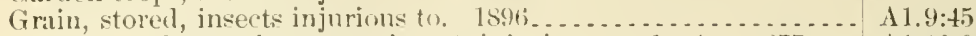

Grain, storel, more important insects injurionsto. 18:4. 1.27. ... $11.10: 894$

Green clover worn. 1901. 1. 45..................... $19.6: 30$

Green pea lonse, destructive, circular on. 1901 ............ $19.5: 43$

Herlyivorous habits of certain dermestilie. 1895. 1. :36....... A9.6:2

Horse-radisl flea-beetle, rejort of. 1895. 1. 404 .......... $19.7: 7$

Hymenopterous parasites of Coleoptera, olservations on some.

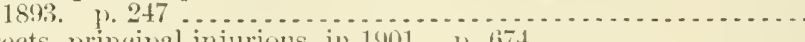

Insects, principal injurious, in 1901 . 1. (iit ...............

Insects and weather; olservations during season of 1899 . p.51..

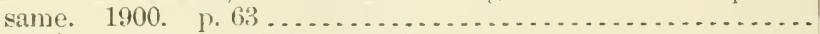

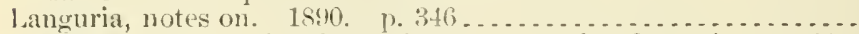

leaf-mining locust heetle, with notes on related species. 1902.

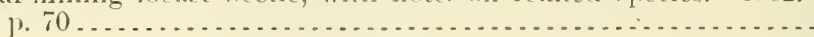

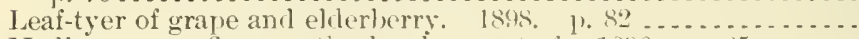

Hediterranean flour moth, fevelopment of. 1896.1 . $85 . . . .$.

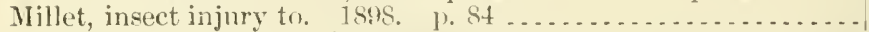

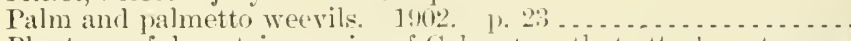

Plants, neful, certain species of Coleoptera that attack, notes on.

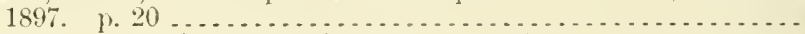

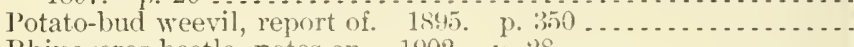

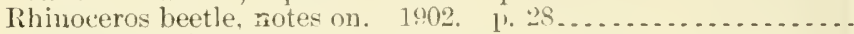

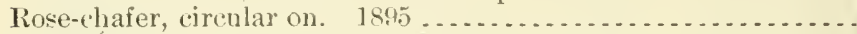

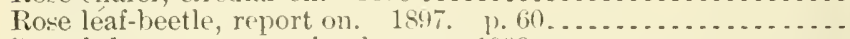

Squash bug, common, eircular on. 1899..................

Squash-vine borer, circular

Strawberry weevil-.

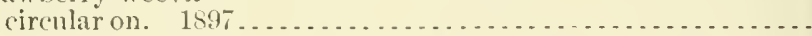
habits and remedies, sipplementary uotes on 1894 p. 14 .. injuries and bibliograpliy, notes on. 1898. p. \$2 ........

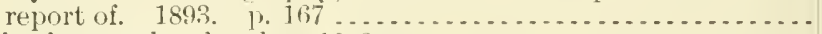

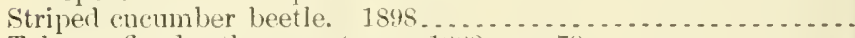

Tobacco flea-beetle, report on. 1sts. p. 79............

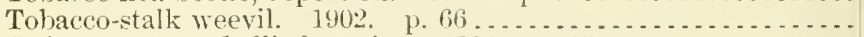

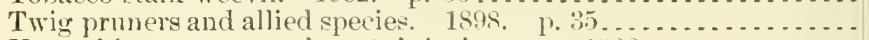

Vegetable crops, some insects injurions to. 1902 . . . . . . . . . . . .

Vegetable products, stored, insects affecting, collection of articles on some little-knowin. 1897.

Violet, rose, and other ornamental plauts, some insects injurious

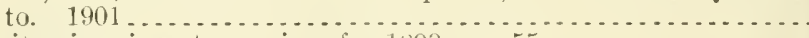

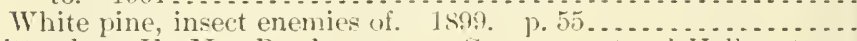

Chittenden, H. M. Road system, Government, of Yellowstome

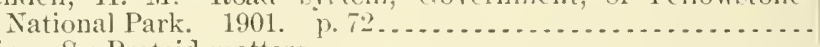

19.7:5

11.10:901

A9.6:2:2

A $9.6: 30$

A9.7:2

19.6:38

19.6:18

19.6:6

A9.6:17

A9.6:38

A9.6:9

A9.7:7

A9.6.38

A9.5:11

\9.6:7

A9.5:39

A9.5:38

A9.5:21

A9.7:7

A9.6:10

A.7.7:5

A9.5:31

A9.6:10

A9.6:38

A9.6:18

19.6:33

A9.6:8

19.6:27

1 13.3:22

1:2.).3:21

Chlorin. See Proteid matters.

Choate, A. 13.:

Address of, before Mimmesota good rouls convention, Jan., 1894.

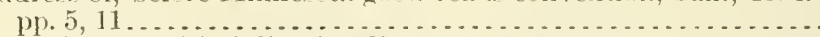

State aid to road building in Mimnesota. $18,9 . \ldots . . . . . . .$.

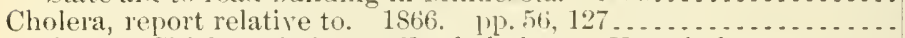

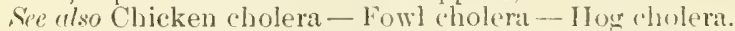

Chowen, IV.S. Address of, before Minnesota good roads comven-

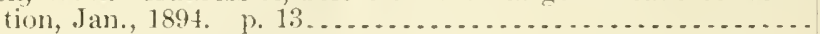

Chwolson, Orest. See Schwolson.

Cliree, Charles. Aneroid barometer, repost on. 189s. p. 547 ...

Christian, George 1. Adrress of, before lirginia good roarls con-

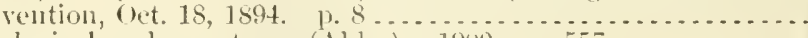

Chronological cyeles, note on (1])he). 1900). p. $557 \ldots \ldots \ldots \ldots . .$.

Chrysalis, curious, report of. 1892 . 1. $131, \ldots \ldots \ldots \ldots \ldots \ldots \ldots$.

Chubluck, Levi. Dairy industry in M Isomri and Kansas. 1897...

Chufa, or earth almond, cultivation of. 1876. p. $37 \ldots \ldots . \ldots . . .$.

Churches, relation of, to State colleges and nniversities (Harris). 1899. p. 100

A 22.3:2

$12.2 .4: 32$ 127.9:4

12:2.3:2

$129.6: 26$

A 22.3:11

129.6:28

A9.7:5

A 4.3:18

А27.9:14

110.3:65 
Cicada, periodical, or seventeen-year locust:

Account of Cicada septendecim, its natmul enemies, and means of preventing its injury, with summary of distribution of different broorls (Marlatt). 1898

Broods of, new momenclature for (Marlatt). $1902 \ldots . . . . . .$.

Circular on-

1897 (Sehwarz)

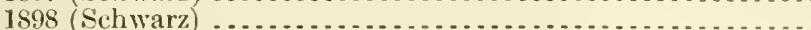

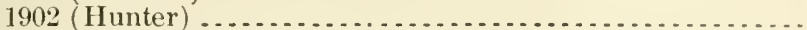

Consideration of validity of old records bearing on distrilution of hroouls of, with particular reference to occurrence of hrools VI and XXHI in 1898 (Narlatt). 1898. p. 59 .............

Feerling habits of adults of (Quaintance), 1902, $1,90 \ldots \ldots \ldots$

Forecast for 1894 (Riley) . . . . . . . . . . . . . . . . . . . . . .

New nomenelature for broods of (Marlatt). 1898. p. 52. . . . . .

Present year's appearances of. 1893. p. 298 _.............

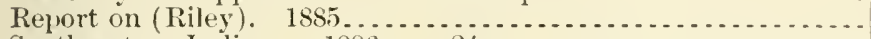

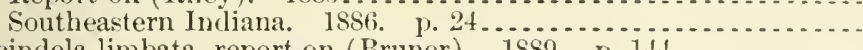

Cicindela limbata, report on (Bruner). 1889. p. $144 \ldots \ldots \ldots \ldots .$. Cider:

Address on, before Assoeiation of Official Agricultural chemists,

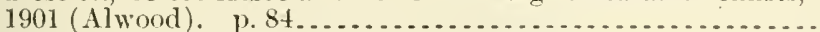

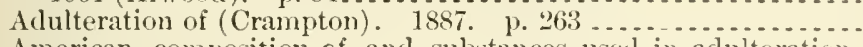

American, composition of, and substances userl in adulteration

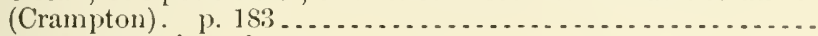

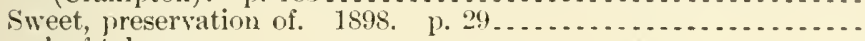
Cigar-leaf tobaceo:

Cultivation of, in Floricla (Floyd). $1899 \ldots$

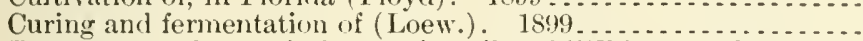

Temperature changes in fermenting piles of (Whitney and Means). 1899.

See also Tobaceo.

Cigar-wrapper leat, methods of experinenting with (Jenkins). 1901.

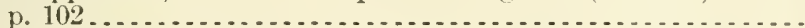

Cimbex, American, adults of, injuring willow and cottonwoor in Cinchona:

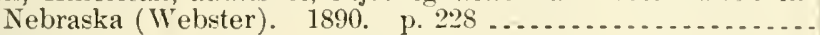

Cultivation of -

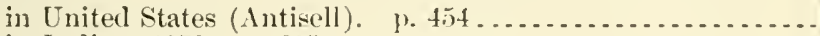

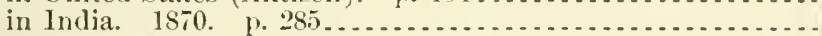

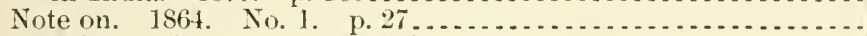

Planting of, in Jamaica (Parry). 1871. 1. 120............ Cincinnati, Ohio:

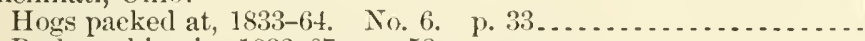

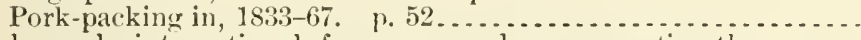

Cipher code, international, for correspondence resperting the aurora and related conditions (Veeder). 1894. p. $26 \ldots \ldots . . . . .$.

Cipher code of wind-signal orders, amending instructions to specialdisplay men. 1892

Circle City, Alaska, meteorological observations near, 1sif-9s

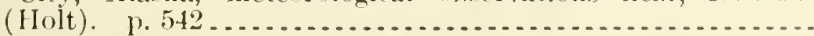

Circumscissa. Dee Cercospora ciremuscissa.

Cirencester, lingland, lioyal Agricultural College at, report on. Iss.).

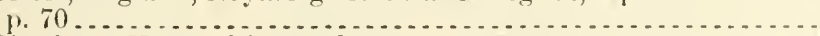

Cist, Charles. IIog and its produets, p. 38: Cities:

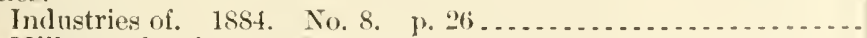

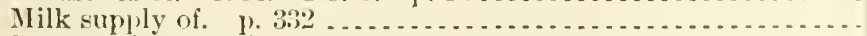

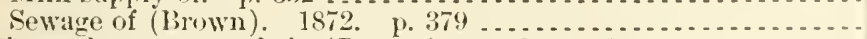

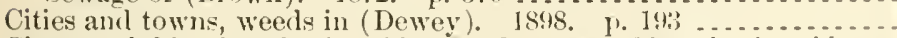
Citrate-soluble phosploric acil. Sice Guanos- Plosphoric acid. Citric acid, aetion of, on basic slag (IInston and Jones). 1896. p. bi... Citrie acid in milk, report on (Soulhet). 1889. 1. 155 .........

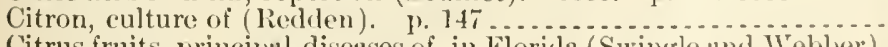
Citrus fruits, principal diseases of, in Florida (Swingle and Viebler). 1896.

See also Orange. 
Citrus trees, seale insert and mite enemies of (Marlatt). 1900. p. 247. Civil service:

Examinations-

assistants in Department of Agriculture (Alube). 1898. p.

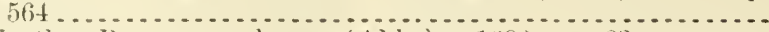

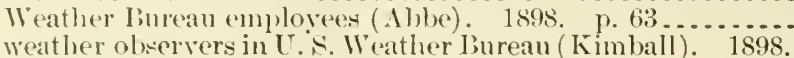

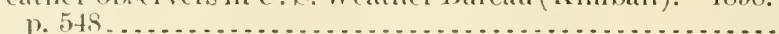
Letters relative to classitied service, ets., in Arriculture Dejart-

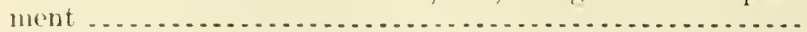

Report on, in Igrieulture Department. 1896............. same $\left(\mathrm{D}_{\mathrm{il}} \mathrm{l}\right.$ mey $) .1897$.

Clam, loner, rapid disappearance of (Beal). 1898. p. 19. . . . . . . .

Clark, 11. C. Meat inclustries of lTnited States, report aecompanying exhilit of Animal Industry Burean, at I'aris Exposition. 1889. p. 359 . . . . . . . . . . . . . . . . . . . . . . . . .

Clark, Josphine Arlelaile:

Agricultural College libraries. 1902. P. 25

Mushroums, edible and poisonous, reference list of publications relating to. 1898 .

Phancogams and Pteridnpluytes, North American, new species of, publisher in 1891 , systematic and alphabetic index.

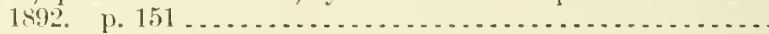

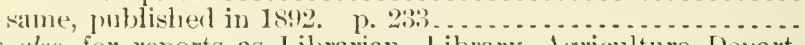

Se also, for reports as Librarian, library, Lgrimiture Depart-

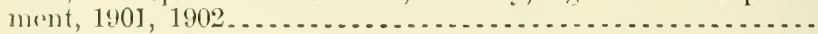

Clark, I. A.:

Apples, keeping qualities of. $1900 . \quad 1 \% 16$
A poles, storine without ioe. 1900.

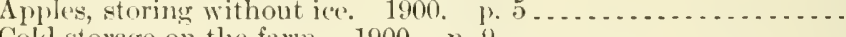

Corn, sweet, aut pole beans, forcinor of under olass 1898.

Fruit, mechanical cold storage for. 1900 . p. $12 \ldots . . . . . . .$.

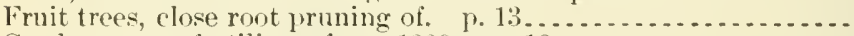

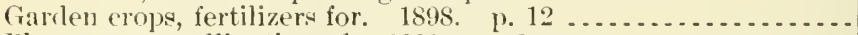

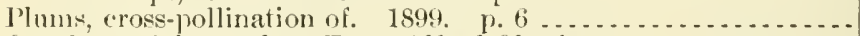

Sie also, as joint author, True, Alfrel Charles.

Clarke, J. WT. Fruit gathering, ripening and keeping. 1. 15:2 ....

Clarke, Jowell. Lamb feeding in Colorado. p. $275 . . . . . . . .$.

Claxton, T. F.:

Mauritins cyclone of Dec. 5, 1897. 1.62.

Tlunnerstorms, two, at Royal ilfred (j)servatory, Manritius.

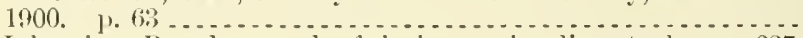

Clay, John, jr. Breeder, work of, in improving live stock. 1.627. Clay":

Filtration of, from soil solutions, capillary sturlies amrl. $1902 \ldots$ Fuspended, filtration of, from soil solutions (Brigrs). 190:2. 1. 31 . Clayton, H. II.:

Cloul ubservations at Blue Hill, 1897. 1. 135 . . . . . . . . . . . Clourls, elifferent, forms of, mean beights and velocities of. 1892.

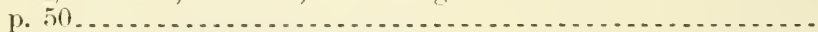

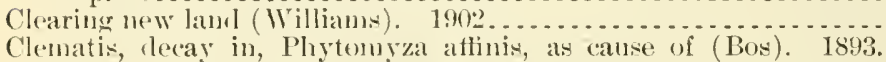
1). 9$)^{2}-$

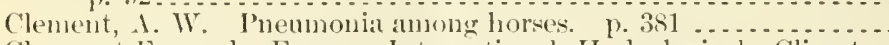

Clemmont-Ferrand, France, International Hyclrological, Climatolosrical, and Geological Congress, Sept. 28 to Oct. 2, 1896 (liotch). p. 367 .

Cleveland, Ohio. see St. Ignatius College.

Clift, J. WV. Roal improvement, requisites to. 1902. P. 26...... Clinate:

Alaska (Henry). 1897. 1. 248.

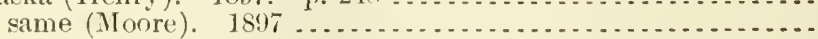

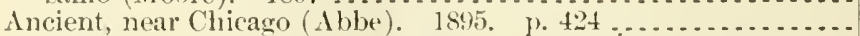

Intigua, Wr. I., seasonal variations in $1890-1900$ (Kimbali). p. 168

Appalachians, southern (1lenry). p. 143 $\ldots \ldots \ldots$

Arkansas, southwestern, 1840-67.
Classiffeation no.

\1.10:900

A 29.6:26

A29.6:26

A29.6:26

$\mathrm{A} 1.2: \mathrm{C}_{49^{1}}$

A1.4:5

A 10.4:33

A1.9:103

A4.1:887-8

\10.3:115

A17.3:20

A6.5:1

A $6.5: 1$

117.1:

A 1.9:119

A 1.9:119

A1.9:119

A I.9:105

A1.9:119

A 1.9:103

A 1.9:105

A1.9:103

11.1:864

A4.1:901

129.6:26

A 29.6:28

A 1.10:899

A $26.3: 19$

A $26.3: 19$

A29.6:25

A 29.6:20

A 1.9:150

A9.7:6

A 4.1:889-90

A 29.6:24

A22.3:23

A29.6:25

A29.2:A11

129.6:23

A29.6:29

A $1.2: \mathrm{Ap}^{2}$

A $27.9: 8$ 
Athens, notes on (Abbe). 1898. p. 55t ................ A29.6:26

Baguio, Philippine Islanils (Stetson). 1902. p. 478 ........ \$29.6:30

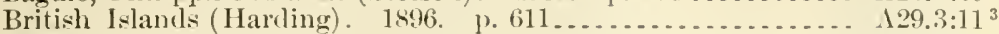

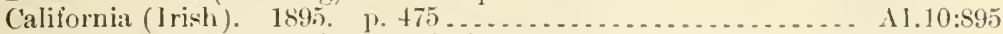

Canada. tie Canada, climatological data.

Changes in lowal (Abbe). 1897. p. 491 ................. 129.6:25

Colorado, and its effert on trees (1'atrons). 1588. 1. 221 ..... 11:3.3:2

Conflict of man with, notes on (.1b)e) 1899 p. $257 \ldots \ldots . . . .429 .6: 27$

Controlling factor in long-distance transmission of electrical

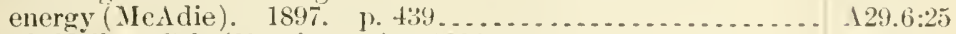

Death Valley, C'al. (1larrington). $1892 \ldots \ldots \ldots \ldots \ldots \ldots \ldots \ldots \ldots . .129 .3: 1$

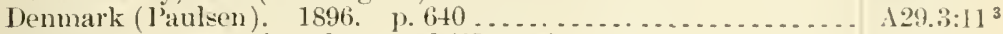

Floricla, statement of products and (Knapj). 1855. No. 19, 11.2:3. 127.9:23

Geological ages (Abbe). 1898. 1.313................ 129.6:26

Georgia (Hemphill). 1882 .......................... 11.6:47

Glacier as an index of, notes on (Abhe). 1901. p. 177 . . . . 129.6:29)

Harjoot, Turkey in Asia, 1898-1900 (Huntington). 1901. ए. 250. $129.6: 29$

IIawaii. Sfe Hawaii, climatological tata.

Idaho, some features of (Blandford). 1901. p) 19

Influence of, on animal life (Dean). 1902. 1. 107...........

Jamaica. See Jamaica, climatological data.

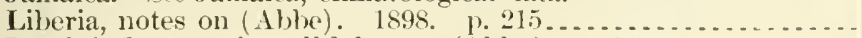

Local, influence of small lakes on (Abhe). 1901. 1,.56;.......

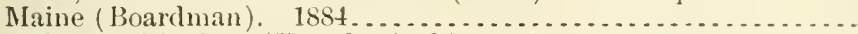

Malay Archipelago (Tan der Stok). 1896. p.66\% ........

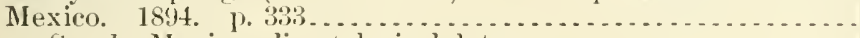
See also Mexico, clinatological rata.

Mexico, City of (Bairiena). 1896. 1.601.................

Mississippi (Hurt). 18st . . . . . . . . . . . . . . . . . . . .

Missouri, notes on (Hackett). 1899. 1) $582 \ldots \ldots \ldots \ldots$

Netherlands (Snellen). 1896. p.627 . . . . . . . . . . . . . .

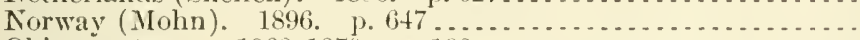

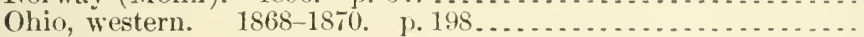

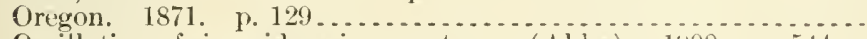

Oscillation of, in arid regions, notes on $(\mathrm{Abbr})$. 1y00. P. $5+4 \ldots$

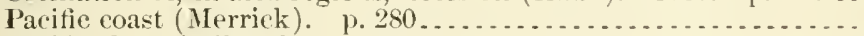

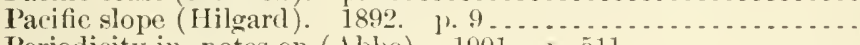

Periodicity in, notes on (Abbe). 1901. 1. 511 ............

Permanence of (Sims). 1901. 1) 121 . . . . . . . . . . . . . .

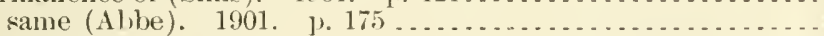

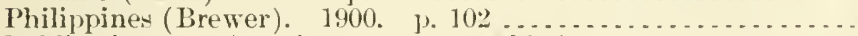

I'ublications on, American, note on (Able). 18!s. 1. 461 .....

P'uerto Ric'o (Harrington). 1898, p. 4:37 ...............

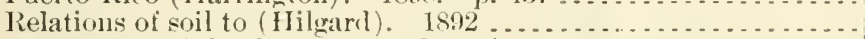

St. Lawrence Island, 1894-99 (Henry), p. 457 . . . . . . . . . .

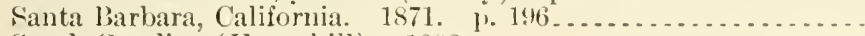

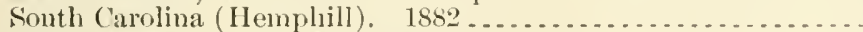

Spokane, Wash., 1882-94 (Stewart). 1. 490.

Statistics of, 1896 , report of (Henry). 1. 277

studies of -

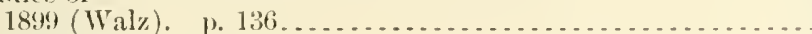

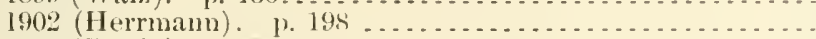

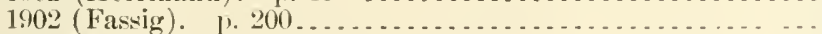

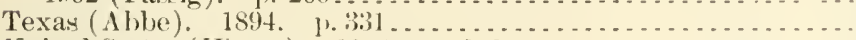

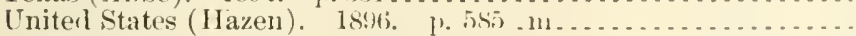

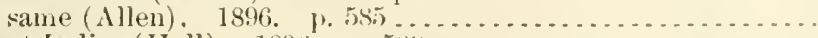

West Indies (IIall). 1896. 1. 5s:!

See also Arid regions-Climatology-Cold Friday-Colil malsesMeteorology-and headings lregiming C'lincitr, Clinatology,

Climate and corn, relation of (II ren). 1901. p. 8 ...........

Climate and crime, relation between (Abbe). 1897, p. $259 \ldots . .$.

Climate and erop and storm-warning services of Weather I3urcan, value of, to industries of Cuba and other islands of West Indies (Hayes.) 190:2. p. $56 . . . . . . . . .$.

129.6:29

A2: $9.3: 31$

129.6:26

129.6:29

11.7:-4

129.3:113

A27.9:32

$129.3: 11^{3}$

11. $7: 3$

$129.6: 27$

$129.3: 11^{3}$

$129.3: 11^{3}$

127.4:9

127.9:(9)

129.6:28

11. 1:867

11.8:20

129.6:29

129.6:29

129.6:29

129.6::28

129.6:26

129.6:26

129.8:3)

129.6::27

1.27.9:9

$11.6 \cdot+7$

129.6:20

19) $1: 597$

129.2:24

129).3:31

120.3:31

$129.6: 21$

129):3:113

$124+3: 11^{3}$

$129.3: 11^{3}$

129.61:299

1:99.6:25

1 $29.3: 31$ 1:9.3:31 
Clinuate and crop bulletins

Climato and crop conditions, are changes in present forms for reporting weekly, advisable? (Mitchell). 1899. p. 126

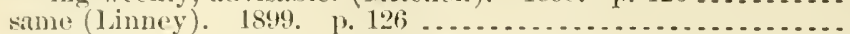

Climate and (rop correspondents, Weather Bureat, how many are required to meet fully the neerls of Bureau in its climate and

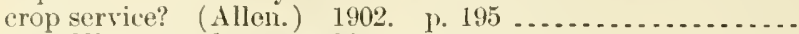
See also Climate and erop service.

Climate and erop sections, Weather Bureau:

Monthly reports of, extracts from $\mathrm{A}$ pr.-Dec. ( $\Lambda$ bbe). 1898

Publications of, necessity for binding and otherwise preserving

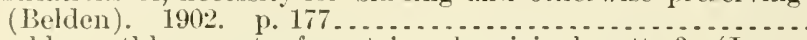
shonld monthly rejorts of, contain onlyoriginal matter? (Iove-

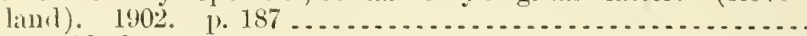
See ulso Alaska.

Climate and crop service:

Anmual summaries of, notes on (Abbe). 1899. p. 254........ Porto Rico, notes (A bbe). 1899. p. 258

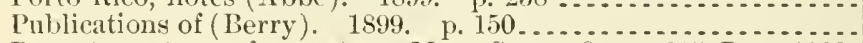
Reports, extracts from, Apr., May, Sept., Oct., 1895-Dec., 1902

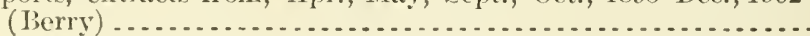

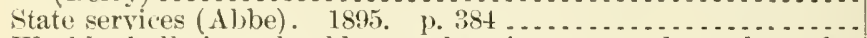
Weekly bulletins, should remarks of enrespondents be pubished?-

1899 (Hackett). p. 107

1899 (Marbury). 1. 108

1902 (Glenn). p. 188.

See also Weather and crop conditions.

Climate and crops:

Notes on (Kimball). 1901. p. 564 ... _... . . . . . . . . . .

Problem with two solutions (Abbe). 1901. p. $419 \ldots \ldots \ldots . . .$.

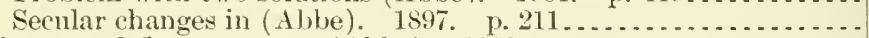

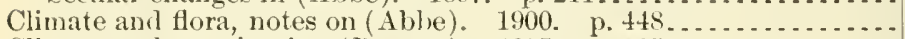

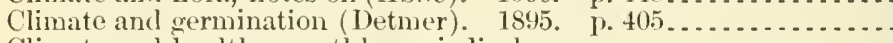

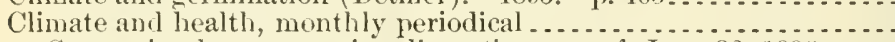

Same, circular announcing discontinuance of, June $22,1896$.

Climate and man, with special regard to climate and climatic elements as curative or causative agencies of disease (Wilson). 1902. э. 104.

Climate and rainfall, relations of, to prevalence of fingus diseases

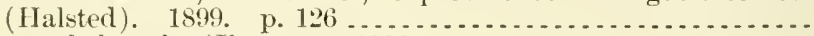

Climate and thought (Easton). 1902. p. 111 ................

Climate and vegetation:

Relation between (Linney). 1902. p. 9S.

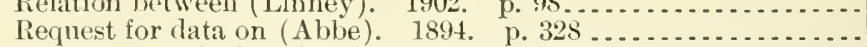

Climatic and agricultural features of aricl regions of Pacific slope

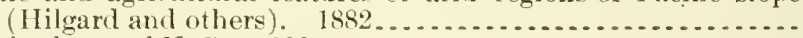

Climatic charts of I. S. 1900

Climatie conditions, g('neral:



Climatological (ongress. See Clermont-Ferrand, France.

Climatolngieal data, interchange of stanclarrl (Mc Adie). p. 1:35 .... See also Canada - Ecuador - Hawaii - Jamaica - Mexico.

Climatology:

American graperines (Lippincott). p. 194.

Antigua, IT. I. (Alexander). 1901.
Classifleation no.

A29.7:

129.3:24

1.9.3:24

A29.3:31

A29.6:26

A29.3:31

A29.3:31

A29.6:27

A29.6:27

A $29.6: 27$

A29.6:

A 29.6:23

A29.3:24

A 29.3:24

A 29.3:31

A29.6:29

A29.6:29

A29.6:25

A29.6:28

A29.3:11 2

A 29.8:

A29.2:C61

A $29.3: 31$

A 10.3:65

A29.3:31

A29.3:31

A29.6:22

A 1.8:20

A29.2:C61

A29.6:21

A $29.6: 22$

A $29.6: 23$

A29.6:24

A $29.6: 25$

A29.6:26

A $29.6: 27$

A29.6:28

A29.6:29

A $29.6: 28$

A29.6:28

A $29.3: 24$

A1.1:862

A29.6:29 


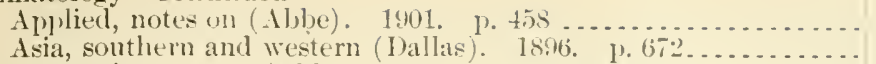

California, note on (Abbe). 1900. 11p. 165, 249 ............

Costa Rica, monthly notes on, Jan., 1901-rict., 1902 (Pittier) ....

Florida, with regaril to erop s (Mitehell). 1902. 11.208.......

German Empire, development of (lieyer). 18:6. p. $652 \ldots . .$.

Hann's handbook of, note on (Harrington). 1898. 1. $358 . . .$.

Ilavana, Cuba-

monthly notes on, Apr.-July, Sept.-Oct., 1901 (Stockman)...

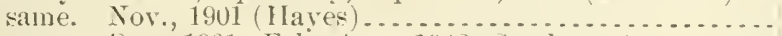

same. Ilec, 1901; Feli.-1pr., 1902 (stuckman) ........

report on (Del i[onte). 1898. 1. 15.2......................

Medieal, synopsis of course of lectures in, to suiner class medical
department University of Texas (Cline). 1902. p. $170 \ldots$

Monthly notes on, June, 1895-Sept., 1 \$ 97 . . . . . . . . . . . . .

Same. Oct.-Dec, 1897 (Ilenry) . . . . . . . . . . . . . . . .

lanama, Isthmus of, inclucling temperature, winds, barometri. pressure, and precipitation (Abbot). 1899. I\%. 198, 302.

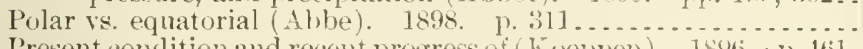

Present condition and recent progress of (Koelpen ). 1896. p. 461.

Relation to cotton cultivation (Whitney). 1896. I. $143 \ldots . .$.

St. Kitts--

notes on (Alexander). 154\%. 1). 583

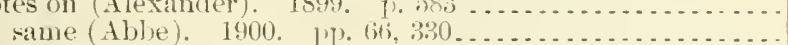
('omparison of lamometer, used in determining (Alexander).

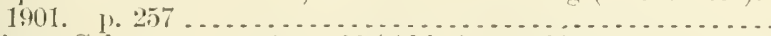

San Diego, Cal., notes on, $1849-99$ (Abbe). p. $20 \ldots \ldots \ldots \ldots$.

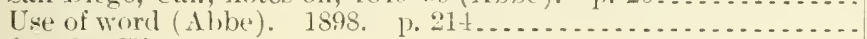
Sire also Climate.

$1: 29.6: 2: 29$

A:29.3:11 3

1.29.6:28

129.6:

A $29.3: 3: 31$

129.3:11 3

$\$ 29.6: 26$

A $29.6: 29$

$129.6: 29$

A $29.6: 29,30$

1.29.6:28

129.3:31

A29.6:

A $29.6: 25$

A29.6:27

A29.6:26

$129.6: 23$

110.3:33

A29.6:27

A $29.6: 28$

1.29.6:29

$129.6: 28$

A29.6:26

Clinatology and horticulture:

Relation of (Wickson). 1900, p. 45 . . . . . . . . . . . . . . A $10.3: 76$

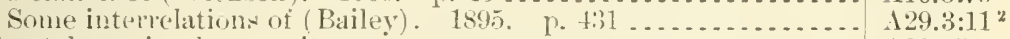

Climatology cireulars, sanitary ............................ 129.15 :

('limatology livision. See Weather Burean, Agricultme I) epartment.

Climatology r. meteorology (Whitney). 1s98. 1).301.........

Cline, Istacic II:

Brazos River Valley, Texas, floods in 1899, with notes on previous overflows. p. 295.

same, 1900 , with report of freshet in other streans. p. $198 . .$.

Floods, (c)lorado Valley, Texas, $A_{\text {p }}$ ril 7 to 17, 1900, special report

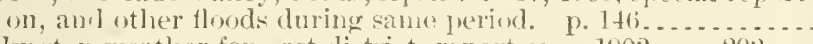

ialvesten weather forecast district, report on, 1902, p. 202. .

Iedieal climatology, synopsis of course of lectures in, to senior class medical clipartment Lniversity of Trxas. 1902. p. 110.

Sew Orleans weather forecast district, wert of, monthly, sept., $1901-$ Oct, 1902

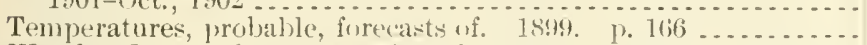

Weather Bureau forceate, value of. 1895 . p. $293 . . . . . . . .$.

Cline, Joweph L. Porto Rico, island of, report on. 1901. 1, 35.3. Clisiocanpa Americana, relations of l'imjla compuisitor to (Weed

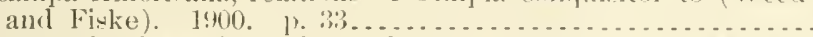

Clock, postal telegraph, and weather hulletin, note on (Alibe). 1897. ]. 35].

$129.6: 26$

A29.6:27

$129.6: 28$

A $29.6: 28$

129.6:29

$129.3: 31$

A $29.6: 29,30$

A $29.3: 24$

1:9.6:2:3

129.6:29

A $1.6: 26$

$129.6: 25$

Cloth. Sie clso Maize-paper and maize-eloth.

Clothes mothis, true:

('ircular relative to (Marlatt).

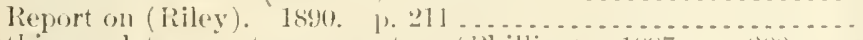

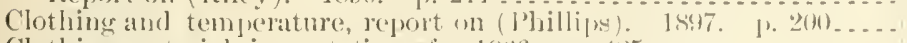

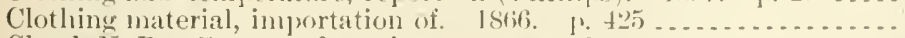

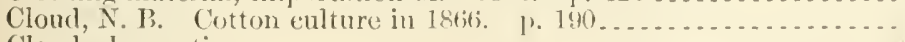
Clond olservations:

Blue Ilill meteorological olscervatory, Milton, Mass. (Rotell).

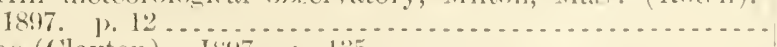

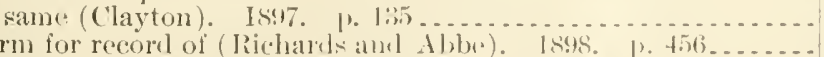

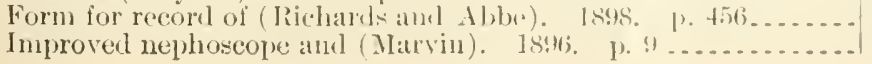


Clond olservations-Continued

International, notes on (Alibe). 1896. p. $461 \ldots . . . . . . . .$.

Ilade in eoperation with seliene of International ('loud cunmission, results of (Bigelow) -

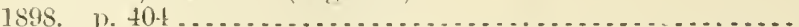

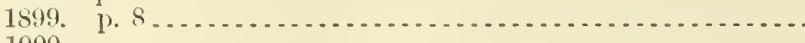

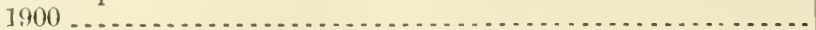

Stmily of upper atmospliere ly means of (Vettin). 189ti. p. 758.

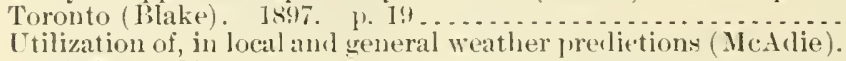

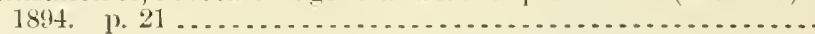

Cloud phenomena:

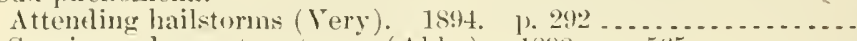

Sumrise and sunset, notes on (Abbe). 1898. 1. 565 ........... Cloud photography:

Apparatus for (Henry). 1895. p. 169.

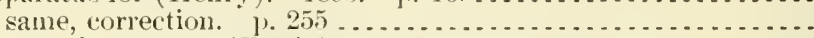

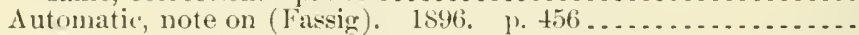

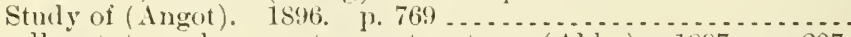
Cloudburst, tornado, or waterspout, note on (Albe). 1897. p. 207 . Cloudburst at Erwin, Tenn. (Worth). 1898. p. 244 ...........

Cloutlbursts in New England, note on (Elmer). 1902. P. 478..... Cloudiness:

Monthly notes on, Jan., 189t-Oet., 1902.

Probable, during total solar eclipe of May 28,1900 (A bbe). p. 422 . Clouds:

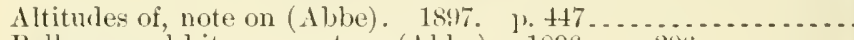

Ballowns and kites, report on (Able) 1896 , j. $206 . . . . . . .$.

Cirru on northwest side of a stem (Richards). 1897. 1.212...

Commlus-

above columns of smoke, notes on (Abbe). 1901, p. 26 ....

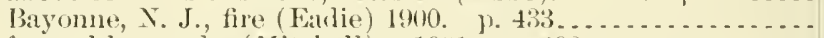
formed by smoke (Nitchell). 1901. p.498 ............ wer a fire, observation of (Warl). 189s. p. 104..........

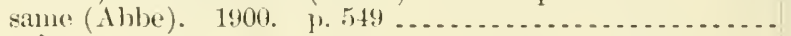

Forms of -

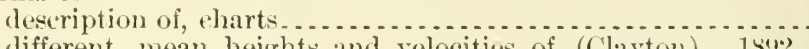
different, mean heights and relocities of (Clayton). 1siv.

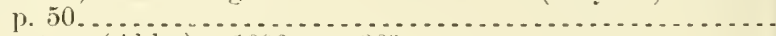
report on (Able). 1896 p. $369-\ldots \ldots \ldots$.

Hail, notes on hombarding (Abbe). $1900, p+2 \ldots \ldots \ldots . .$.

Height of, a problem for students (Abbe). 1897. p. 161 ......

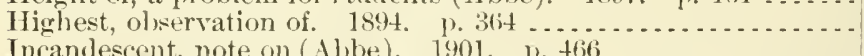

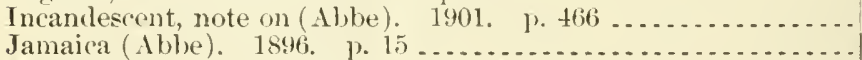

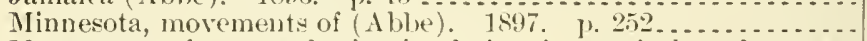

lovements of, atmospherie circulation in tropical eyclones ats shown by (Boyer). 18:96 ... . . . . . . . . . . . . . . . . . .

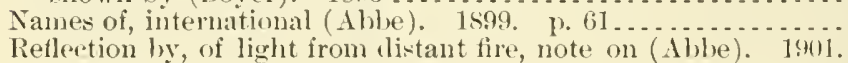

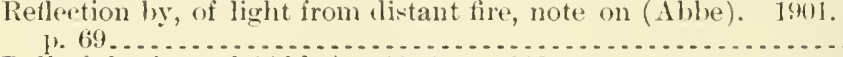

Roll of, horizontal (Abibe). 1895, p. $212 \ldots \ldots \ldots \ldots . . .6$.

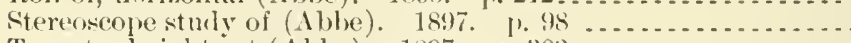

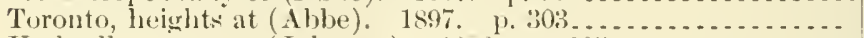

Cinbrella, notes on (Johnson). 18:8, p. 207 ...............

Upper, and weather changes, report on (Richards). ] $898.1 \% 106$.

Wave or billow, report on (Ilenry). 1899. 1.57 ...........

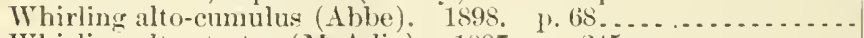

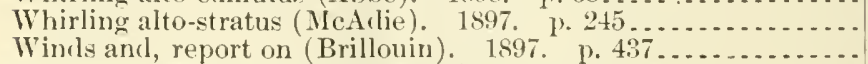

Cloudy condensation, notes on (Abbe). 1897. p. $543 \ldots \ldots \ldots \ldots$

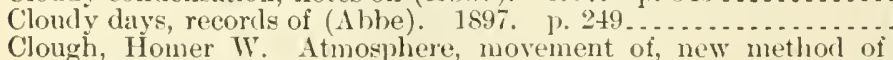

Clough, Homer IV. Atmosphere, movement of, new method of
observing direction of. 1898. p. $250 \ldots \ldots . . . . . . . . . . .$. Clough, William:

Sorghum, or Xorthern sugar cane. p. 5t_... . . . . . . . . . . $11.1: 864$

A $29.6: 27$

A $29.6: 28$

A $29.1: 899^{2}$

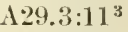

A $29.6: 25$

A $29.3: 11^{1}$

A $29.6: 22$

A29.6:26

A $29.6: 23$

A29.6:23

A29.6:24

A29.3:11 ${ }^{3}$

A 29.6:25

A29.6:28

A $29.6: 30$

A.29.6:

A29.6:27

A29.6:25

129.6:24

A $29.6: 25$

A29.6:25

A 29.6:29

129.6:28

A $29.6: 29$

129.6:20

A $29.6: 28$

129.2:C62

A29.6:20

A29.6:24

A29.6:28

A 29.6:25

129.6:21

129.6:29

129.6:24

A $29.6: 25$

A $29.2: A t 6^{1}$

1:29.6:27

129.6:29

1.29.6:23

$129.6: 25$

A $29.6: 25$

$129.6: 26$

129.6:26

A29.6:27

$\backslash 29.6: 26$

A 29.6:25

129.6:25

A $29.6: 25$

129.6:25

129.6:26 
Clough, William-Continued

Sugar, production of, from sorghmm or Northern sugar ane. p. 307

Clover:

Crops, condition of, June, 1864. No. :3. ए. 10 ............ 127.9:2

Dodders infesting (1)ewey). 1898 ................... 4 (i.4:14

Seed of -

American, chemical composition complarel to that grown in

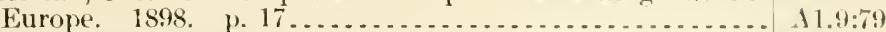

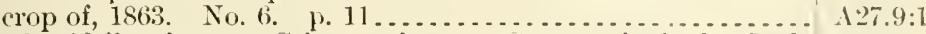

see also Alsike elover - Crimson elover-Crops, principal - Thed clover seed.

Clover hay worm, Asopia costalis, some studies of (Wwhter). 1891.

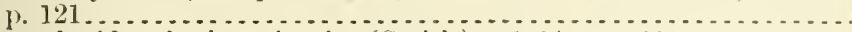

Clover-leaf beetle, invasion by (Smith). 1891. 1. 231 ..........

Clover mite:

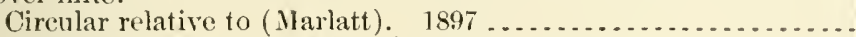

Report on (Riley and Marlatt). 1890 . p. 45 ...............

Clover-seed caterpillar, report on (Osborn and Gossard). 1891. .56.

Clover-seed midge in Wisconsin, note on. 1886 . p. 39. . . . . . . . .

Clover worm. See Green clover worm.

Club-root in U. S., report on (Eycleshymer). 1891. p. 79........

Clubl, Henry $S$. Michigan fruit region, facts relating to. $1870 . \quad$ p. 37 .

Clubs. See Agrieultural and horticultural societies and cluls.

Cluss, Adolph. Se, for report as architect, 1868, $\mathrm{Agriculture}$ department, architect of.

Cluss and Kammerbueber, Agriculture Department, bullding for, specifications of workmanship and materials required in. 1867 .

Clute, Jacob. Noldress of, before National Road Conference, July,

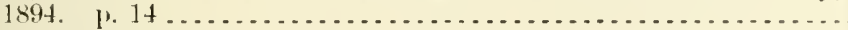

Coal anthracite, production of in Punuylvauia $1820-7.0$. sice also Brown coal.

Coal ashes. Sice Ashes.

Coall oil:

Composition and qualities, manufacture, use in arts, history of discovery, and theory of origin (lesley). p. $429 \ldots . . . . .$. West Virginia (Shattuck). 1).525.

See also Petrolemm.

Coates, C. F., jr. Agrienltural course in the Sonth, prineiples under-

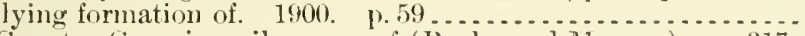

Cohb County, Georgia, soil survey of (Burke and Marean). p. $317 .$. Coccida:

Collected in Puerto Rico by A. Busck in 1899, list of (Jergande

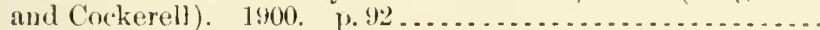

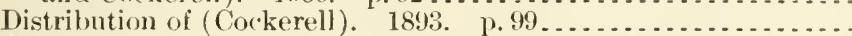

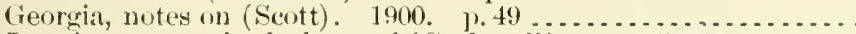
Jamaican, some fool plants of (Cockerell). pp. 158, 245 ...... Japanese, some new species of, with notes (Cockerell). $18,4 \%$.

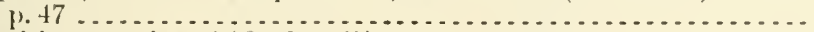

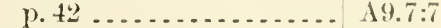

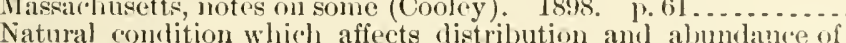
(Cockerell). 1895. p.91 .

New, collected in Mexice iny I'rof.C. H. T. Townsend, notes and descriptions of (Cockereli). 1896. 1).31 ..............

()hio, partial list of (Webster and burgess). 1902. 1. 109......

Parasites of, in collection of Agriculture I)epartment (Iloward).

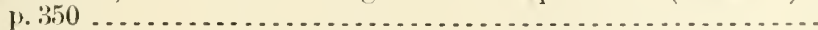

San Franciseo, some found hy Alex. Craw in course of his quallantine work at (Cockerell), 1896, $1,42 \ldots . . \ldots \ldots \ldots . .$. See culso Parasites.

Coceidia:

Hepatic, of rabbits, Eimeria stiedie, correct name for. 1902. 1.18. 14.8:35

New genus of, Eimeriella (Stiles). 1902. p. 18........... $14.3: 3$.

\section{Coceids:}

Fatal temperature for some, in Georgia (Scott), 1899. 1.82 ...

New, on birch (Hubbard and Pergande), 1898. 1\% 13......... 
Coccinellid, abnormal, report on (Burgess). 1898. . 59

Classifieatlon no. see ulso Australian scrmnus.

Coceinellisla:

Conservatory, experiment with (Webster). 1890. 1.363 . . . . 19.7:2

Scale-feeding predatory insects which affect nsefulness of (Mar-

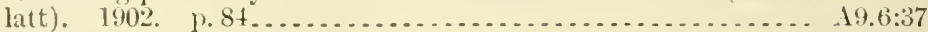
see also Tasmanian coceinellita.

Corkerell, Theodore Dru Alison:

Cocojolse-

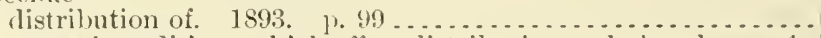

natural conditions which affect rlistribution and abundance of. 1895. 1. 91 ... . . . . . . . . . . . . . . . . . . . . .

new, collected in Mexico, by l'rof. ('. 11. 'Ty ler'Townsench, notes

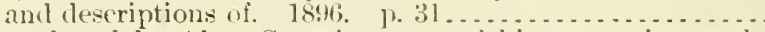
some, found by Alex. Craw in rourse of his quarantine work

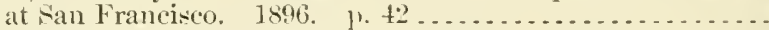
Entomological ethies, report on. 1s!8. p. st $\ldots \ldots \ldots \ldots \ldots \ldots$ Fungi of Custer County, Colo. 1889. p. $\$ 4 \ldots \ldots . . . . . . . .$. Jandican coccicle, some, food plants of. 1893. p. 158, 245 . . . . Japanese coecidip, some new species of, with notes. 1896 . p. 47. Lecanim infesting blackberry, considered identical with $\mathrm{I}$.

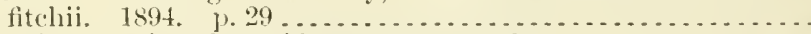

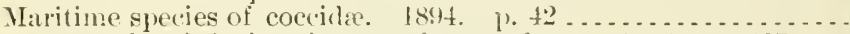

New Mexico, injurious insects of, notes from. 1594. 1\%. $207 \ldots$ New Mexico and Arizona, entomological notes from. 1902. p. 107

Orthezia insignis as garden jest. 1892. p. $89 \ldots \ldots \ldots \ldots \ldots \ldots \ldots$

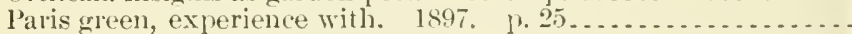

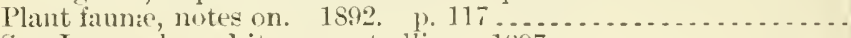

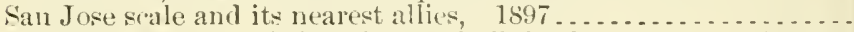
Sawfly, new, which is jujurions to hollyluoks. 1894. 1. 251 ... Slip-records for entomologists, note on. 1893. p. 195 . . . . . . Whet Indian rufous scale, report of. 1592. p. 380............ See also, as joint author, Pergancle, Theodore.

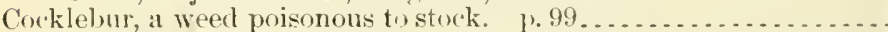

C'nckrill, 13. F. Live-stork interests in Tennesse. 18\%. 1). 22,5... Cockroaches:

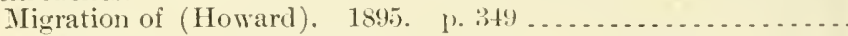

Rejort on-

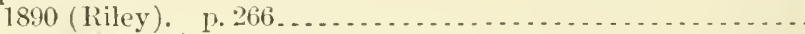

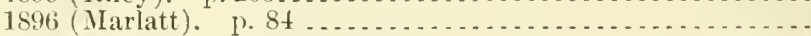

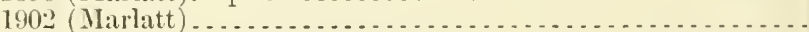

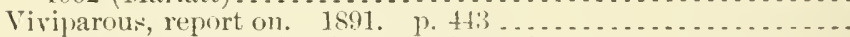

Cocoa paln, origin and distribution of ('ook). 1901. 1. 257 ....

Cocoa preparations, adulteration of (Fpencer). 1892. p. 875.....

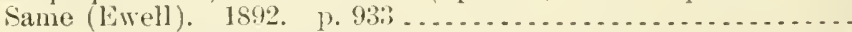

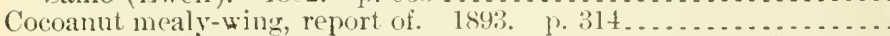

Cocoanut palms, liseased, in Cuba, report of investigation of (Busck).

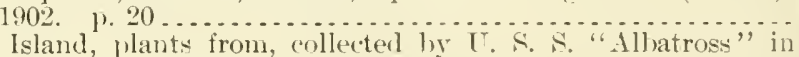

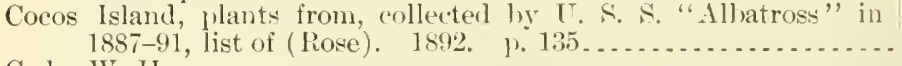

Code, IV. II.:

Arizona, irrigation $\mathrm{in}$, use of water in. 18:19. p. $111 \ldots . . . . .$.

Irrigation in Salt River Valley, Arizona. 1900, p. 83 . . . . . . .

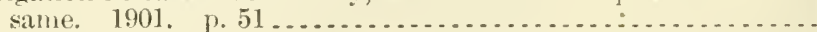

Codling woth:

I)oul,le-lorooded, report of (Marlatt). 1894. p. 245 .........

Investigation of, ju ldaho, 1900 (Nimpon). p. 5l ...........

Investigations in Northwest cluring 1901 (Simpson). 1902 .....

Life listory, studies on (Gillette). 1902. p. $5 \ldots \ldots \ldots \ldots \ldots \ldots . . .5$

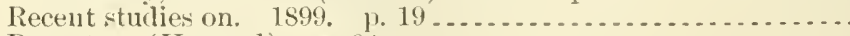

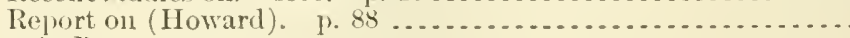

Coe, 1. 13.:

Chinook winds, how they ('ame in 1896. 1). $413 \ldots . . . . . . . .$.

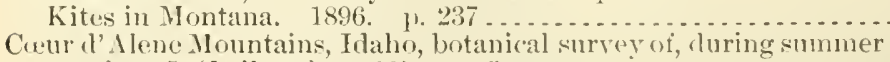

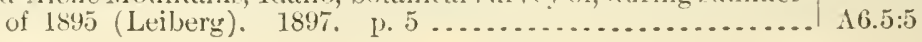

19.7:6

19.6:2

19.8:4

$19.8: 4$

A $9.6: 17$

A28.5:5

A $9.7: 5$

A9.8:4

19.7:7

A9.7:7

A9.7:7

19.6:37

19.7:5

19.6:9

19.7:5

19.8:6

A9.7:7

A $9.7: 6$

19.7:t

14.1:893-4

11. $7: 2$

A9. $7: 7$

19.7:2

A9.6:4

19.5:51

19.7:3

16.5:7

17.3:1: $3^{7}$

A7.8:137

A9.7:5

A.9.6:38

A6.5:1

A 10.3:86

A 10.3:104

110.3:119

19.7:7

19.6:30

A9.6:35

A9.6:31

A1.9:9:2

A1. 1:887

A29.6:24

A29.6:24 
Coffee:

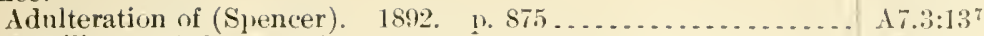

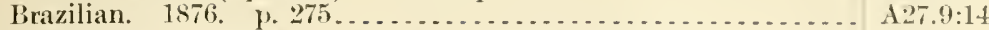

Consumption of, in L. S., per capita of population-

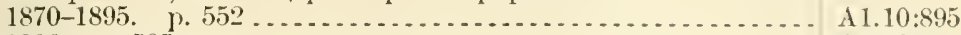

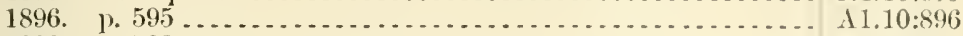

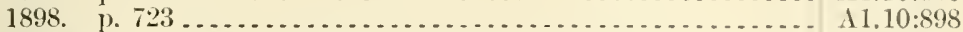

Cultivation of, in Mexico (Foster). 1876. P. 265 ........... A27.9:14

Culture and habits of (Weaver). p. 31 .................. A1.1:879

Culture in Guatemala. 1889 . p. $175 \ldots \ldots \ldots \ldots \ldots \ldots \ldots \ldots$ A27.9:27

Imports and consumption of, in L. S. 1872. p. 35.......... A27.9:11

Plant, cultivation of. p. 25 .................................. $1.6: 3$

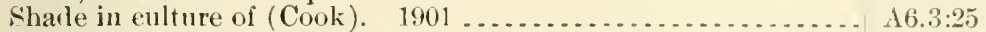

Substitutes (Langworthy). 1900. p. 2.2................ \$1.9:122

Coffey, George N. S'ee, as joint author, Dorsey, Clarence Wilbur.

Coffey, George N., and Hearn, W. Edward:

Soil survey of-

Alamance County, North Carolina. p. 297.

Cary area, North Carolina.

Coftin, Fred. F. B.:

Artesian and underflow conditions in Soutl 1akota. 1s:3. pt.

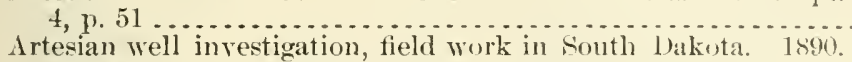
P. $125 \ldots \ldots \ldots$. . . . . . . . . . . . . . . . . . . . . . . . . . . . . . . .

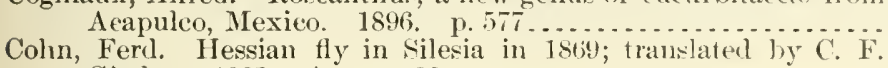

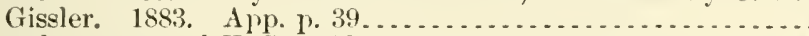

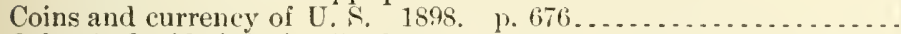

Colaspis flavida injuring Le Conte pear, note on. 1886. p. 40.....

Colkl, wiciespread area of, notes on (Able). 1899. b. 257.......

Cold frames. See Greenhouses and cold frames.

"Cold Friday," Feb. 7, 1807, note on (Ilenry). p. 545 . . . . . . . .

Cold spell of Nor., 1896, in Montana and adjoining states (J Jazen).

Cold storage:

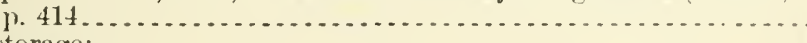

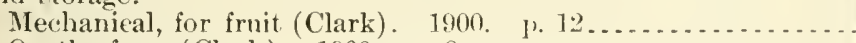

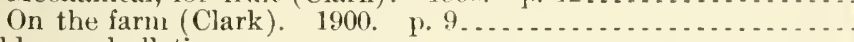

A2!).9:

Colıl waves:

Atmospheric, depth of (Ab]e). 1899. p.6:2 . . . . . . . . . . A:9.6:27

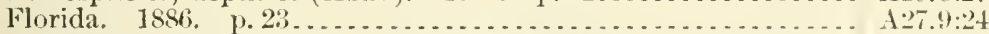

January and Febrnary, 1864, notes on $\left.(1 \mathrm{~W}) \mathrm{e}^{2}\right)$. 1. $114 \ldots \ldots \ldots . .129 .6: 28$

Middle Gulf coast (Garriott). 18:5. 1. $3.34 \ldots . . . . . . . . . .429 .6: 23$

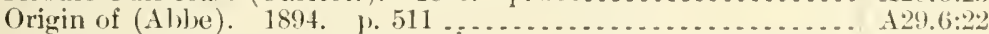

Possilbility of giving warnings of, to stock-raisiner interests ts

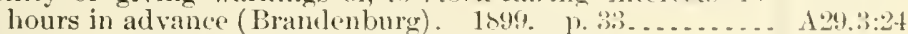
same (Glass). 1899. p. 35 ....................... 129.8:24

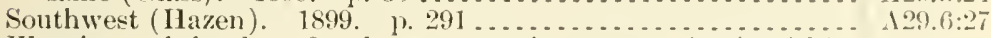

Warnings of, for henefit of tramsportation (ompanies (sunith). 1899. 1. 37

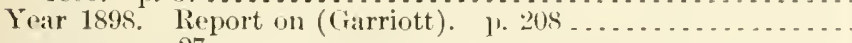
same. P. 27.

Cole, Frank $N$. Barometric pressime, diurnal variations of. 1sit) .

Coleman, Clarence. What nur bad ruals cost $11 \mathrm{~s}, 1895,1.17 \ldots .$.

\section{Coleoptera:}

California, notes on habits of some (Comillett). 1892. 1). 260 .

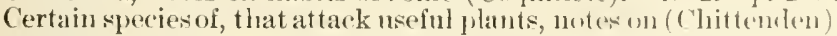
1897. \%. 20

Habits of some species of, observerl in sim I)icgo (comint ('alif.

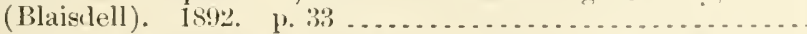

Hymenopterons parasites of, olservations on some (Cinitriulin). 189:3. p. 247

1.29.:3:24

A 1.1:898

1:29. $1: 6 ! 95$

129.:3:(

1:20.:3:1 1

$19.7: 4$

1!) $6: ! 9$

$19.7: 5$

See also licetles.

Coleojterons enenies of grapevine, some (Chittenclen). 1865). 1). 3ist.

Colima, Mexico, plants, collection of, mate in, loy lislwarl l'almere, in the years 1890 and 1891 (Rose). 1895. 1). $293 .$. 
College faculty meetings (Scott). 1S95. p. 80

College Station, Md., sorghm-silgar experiments at (Wiley). j889. $17.3: 26$

College work section, Association of Imerican Agricultural Colleges and Experinent itations, repurt uf:

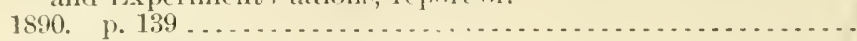

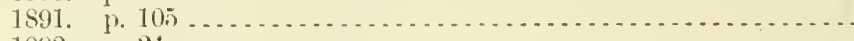

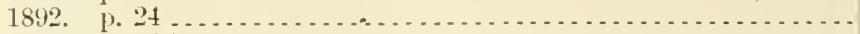

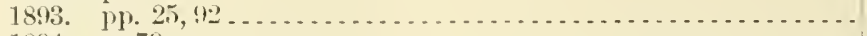

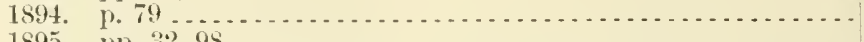

1895. pp. $32,98 . \ldots \ldots \ldots \ldots \ldots \ldots \ldots$

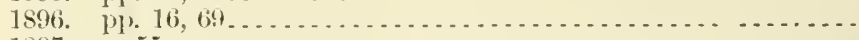

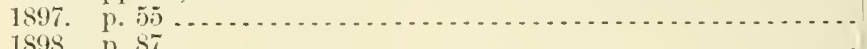

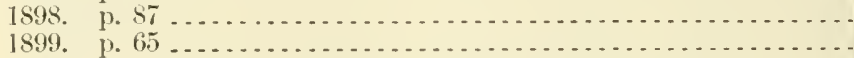

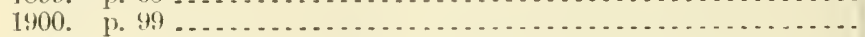

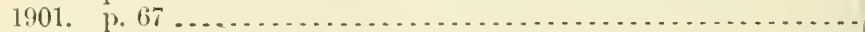

Colleges:

Meteorology in, to what extent is it taught at present; should it be offered as an undergraluate or as a postgraduate comrse?

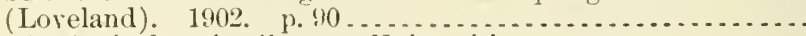
See also Agrienltural colleges - Iniversities.

Colleges and universities:

State, relation of churches to (Harris). 1899. p. $100 \ldots . . . . .$.

Weather Bureau and, notes on (Abbe). 1898, p. 568 ........

Sie ulso Agricultural colleges - Cornell Iniversity - IFarvard University - Johns IIopkins University - Kansas LniversityLake Erie College - Maine State College - Minnesota - Úniversities.

Collier, Peter:

Analytical work done on sorghmm and cornstalks by chemical

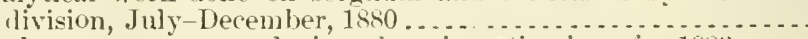

Sorghmm as a sugar-producing plant, investigation of. 185:3..... the also, as joint author, Vasey, George.

se also for reports as chemist, (hemistry Burean, Agriculture Department, $1878-1882$.

Collingwood, H. W. Farmers institute work, hest nethorl of pub-

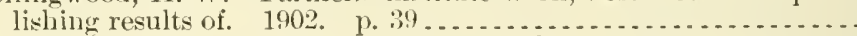

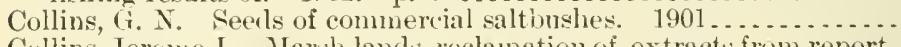

Collins, Jerome.J. Marsh lands, reclanation of, extracts from report

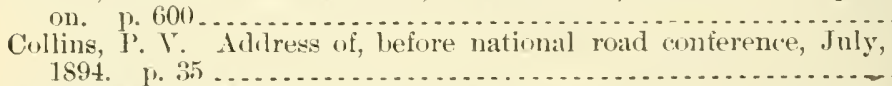

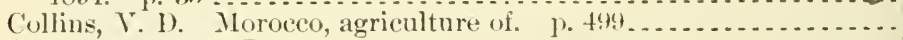
Colman, Norman J.:

Ailiress of-

before Association of Official Agrienltural Chemists. 18s5.

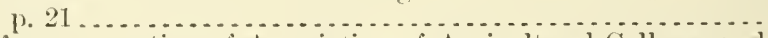
before convention of Association of Agricultural Colleges and Experiment Stations, Washington, D. C., July 8, 1885..... before convention of agriculturists. 1885. 1.5........... before National Cattle Growers' Comvention, Kansas City,

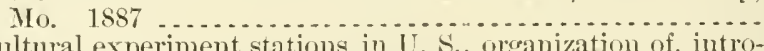

Agricultural experiment stations in U. S., organization of, intro-

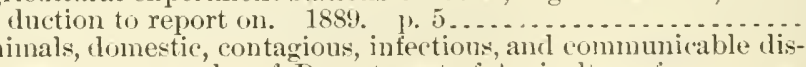
eases amoug, rules of Department of Agriculture for supples-

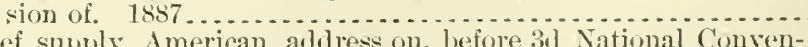

Beef supply, American, aldress on, before 31 National Conven-
tion of Stockmen, Chicago, Nov., $1855 \ldots . . . . . . . . . . . .$. Business methods in Agriculture Department. $18 \mathrm{ss}$........... . .

Chestnut oak for railroad ties, circulat on. $1887 \ldots \ldots \ldots \ldots \ldots . .$.

Downy mildew and black rot of grape, cireular on treatment of. 1887

Dresserl-meat traffic of $\mathrm{U}$. S., answers to questions regarding.

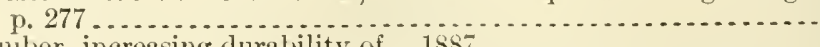

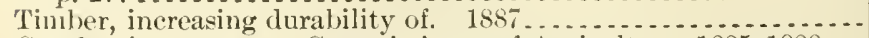

See also, for reports as Commissioner of Agriculture, 1885-1888 ...

A 10.5:3

A 10.3:7

A 10.3:16

A 10.3:20

A 10.3:24

A 10.3:30

A 10.3:41

A 10.3:49

A 10.3:65

A 10.3:76

A 10.3:99

110.3:115

A29.3:31

A 10.3:65

A $29.6: 26$

A1.6:33

A 1.8:27

A10.3:110

16.3:27

A1.1:870

122.3:10

11.1:862

11.8:37

11.7:9

A1.8: 43

110.3:1

A1.8:44

A1.8:38

A1.2:C71

A13.4:4

A 28.4:3

A4.1:886

A13.4:3

A1.1: 
Cologne, Germany, American dried apples in (Wamer). 1895. p. 14. A7.3:48

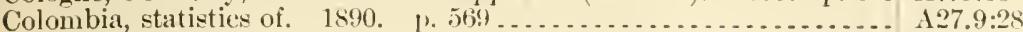
See also Colon.

Colon, Colombia, rainfall at, note on (Able.) 1893-45. p. 36:.... A29.6:26

Colonization:

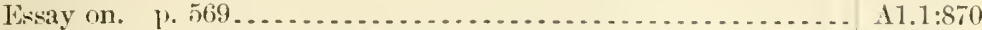

Vineland as a lesson in. p. 410...................... 11.1:869

Color, relation of temperature to, note on (Abbe). 1900. p. 18... A29.6:28

Colorado:

Agricultural progress of. $1869 . \quad$ 1. $226 \ldots \ldots \ldots \ldots \ldots \ldots \ldots \ldots . . . \ldots 27.9: 7$

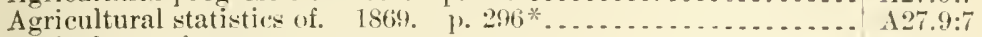

Agrieulture of, notes on-

1866. p. 442

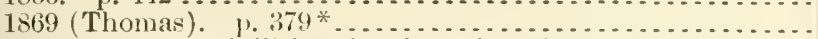

Arid regions of, possibilities of reclamation of by utilizing underlying waters (Miller). 1891. pt. 1, p. 301 ....................

Artesian well investigation, field work (Carpenter). $1890 . \quad$ p. 173.

Cattle and sheep industry of (Kemnedy), p. 367 . . . . . . . . . . .

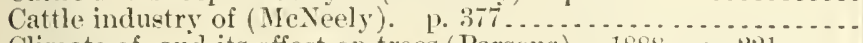

Climate of, and its effect on trees (Parsons). 1888. fr. "2.21 .....

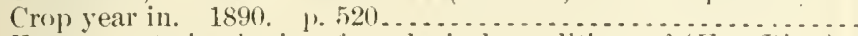

Eastern, artesian lasins of, geolugieal ronditions of (Van I)iest).

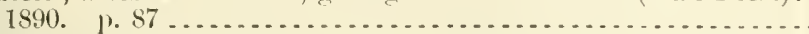

Entomological notes from, rejort on (Gillette). 1900 . 1.76...

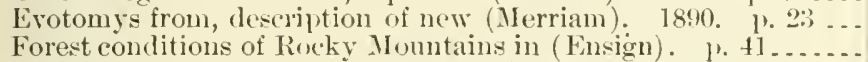

Grasses and forage plants of, notes on (Pammel). $1897 \ldots . . .$.

Grasses of aricl districts of, investigation of (Vasey). 1886.......

Grasshopper disease in (Gillette), 1896. j. $89 . \ldots . . . . . .$.

Insect notes-

1901 (Gillette). p. 51

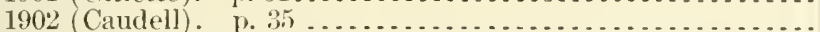

Insects, few, that have been unusually aloundant in, this year

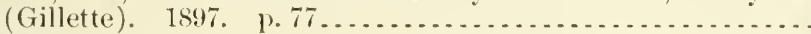

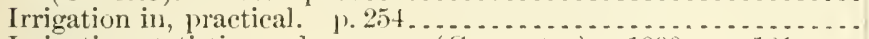

Irrigation statistics and progress (Carpenter). 1890. p. 181....

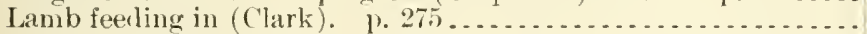

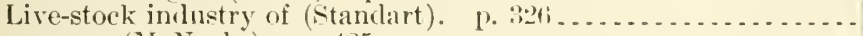

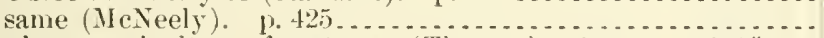

Northern, agriculture of, notes on (Thomas). 1869, [1.284*...

Plants from, deseriptions of new (Holzinger). 1893. p. $286 \ldots$

Rain in, seasonal, note on (Abbe). 1900, p. 155............

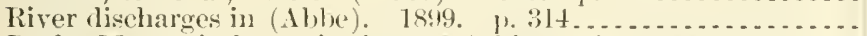

Rocky Mountain locust in, in 1880 (Chipman). 1 P. p. 55....

Seasonal forecast in, 1872-1899, notes on (Ahie). 1. 206......

Sheep industry of, in 1897 (MeNeely). p. 37t . . . . . . . . . .

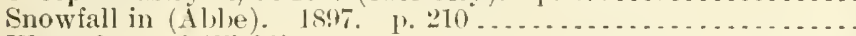

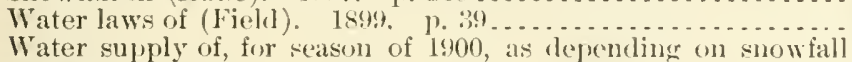

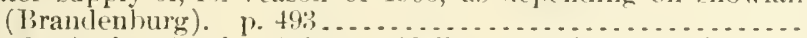

See also Amity (anal - Arkansas Valley - cache la l'uulre Valley - Colorados springs - Custer County - I)enver - Fort Collins - Fort Lyon - Grand Valley - Jefferson County.

Colorado grasslopper. See Cirasshopper, hateful.

Colorado potato beetle:

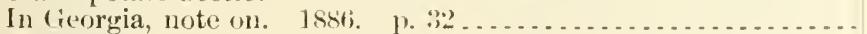

Notes on-

1871. p. 332

1874 (Glover)

Two methods of destroying (Gikerer). 18in. p. 44..........

See also (irosbeak, ruse-breasted.

Colorado Surings, Colo., meteorological reeords at, brief discussion of hourly, from November, 1592, to september, 1814 (Norrill). $1896 . \quad$ 1. 215

A.27.9:4

1.27.9:7

A 15.2:Ir 7

A 15.2:Ar7

A4.1:891-2

A4.1:898

A 13.3:2

A27.9:28

A15.2:Ar 7

19.6:26

A5.5:4

1 13.3 .2

A3.3:9

A6.3:1

A $9.6: 6$

A9.6:31

A9.6:38

A9.6:9

A1.1:871

A 15.2:P94 ${ }^{1}$

14.1:901

14.1:885

14.1:889-9)

127.9:7

A6.5:1

129.6:28

\29.6:27

18.1:3

A $29.6: 28$

14.1:898

129.6:25

$170.3: 58$

A29.6:28

A9.3:12

127.9:9

$127.9: 12$

127.9:13

A $29.1: 896$

Colorado Valley, Texas, flooks in, special report on, $A_{j}$ ill 7 to 17 , 1900, and other floods during s:me period (Cline), 1) $146 \ldots$... A29.6:28

* By a misprint, this page number appears twice. 
Coloring matter for foods, analysis of, provisional method for (Tol-

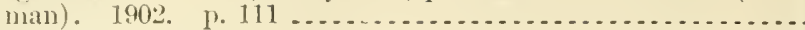

Colmustia River:

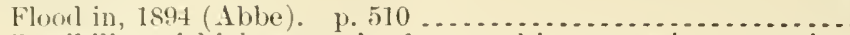

Pensibility of ligh water in, from melting snow in momtains

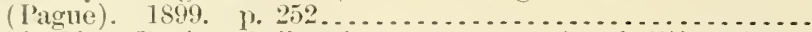

Columbia River Region, Leibergia, a new genus of umbellifera from

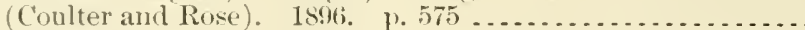

Columbus, Christopler. Diseorery of manetic leclination made

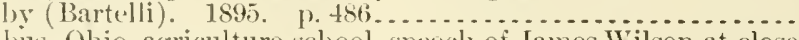

Columbis, Ohio, agrieulture school, speech of James Wilson at close of, July 7,1902

Colvin, Rieluarl. Italian honevhee; or, Culture and Italianization

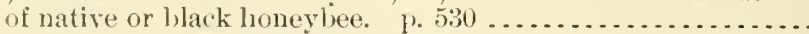

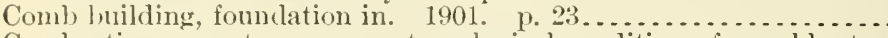

Combustion, spontaneous, meteorologi('al conditions favorable to,

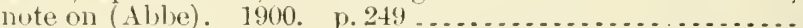

Comes, O., and Deperais, _- Crape-vine, Peronospora of, first results obtained from use of chloride of aluminum and proposal

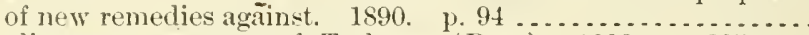

Commelinacex, new genus of, Treleasea (Rose). 1899. 1. 207.... Commerce:

Between I'nited States and Mexico, for 1873, 1875, 1853, 1888, and

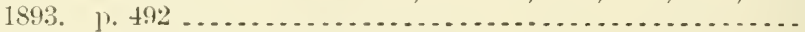

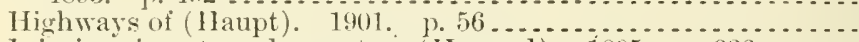

Injurious insects and report on (Howard). 1895. p. $332 \ldots . .$.

International, agricultural contributions to. 1891. 1. 77 ......

Work of meteorologist for benefit of (Bigelow). 1899, p. 71... Commercial borlies, relations of weather ofticials with, how pro-

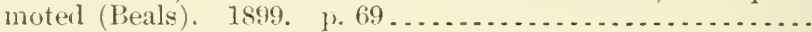

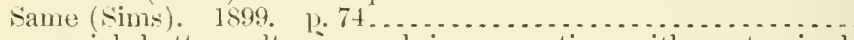

Commercial butter cultures used in connection with pasteurized

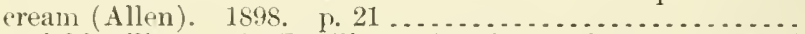

Commercial fertilizers. See Fertilizers, chemical analysis, methods of.

Commercial plantations, hardy (atalpa in (Hall). $1902 . . . . . . . .$.

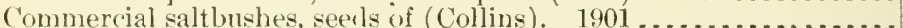

Common sehools. See Schools.

Como, Italy, International Electrical Congress at, 1899, notes on

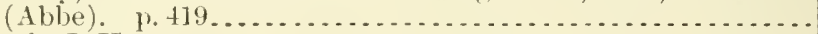

Comstork, J. Henry:

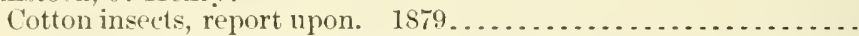

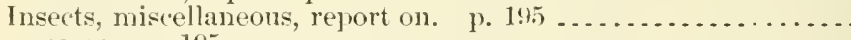

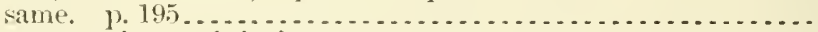

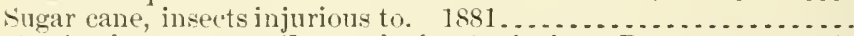

Sipe also, for reports as Entomologist, Agrieulture Department, 1880

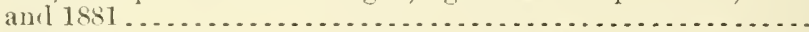

Comstork's rotary spader, description of, 1865 . No. 5 . p. $34 \ldots \ldots$.

Concentrated fertilizers. See Fertilizers.

Conchyliastes musicus. See Mosquito.

Condensation, cloudy, notes on (Abbe). 1897. p. 543 .......... Condensation of atmospheric moisture, report on (Barus). I. $526^{\circ}$. ('onclensert milk. Sipe Milk.

Condimental and medicinal eattle and poultry fools. 1901. J' 22 . Condimental feediug stuffs, use of, in feeling animals. 1898. p. 25. Comdinents. See Spices and condiments.

('onduct and the weather, report on (Dexter). 1899. p. 353......

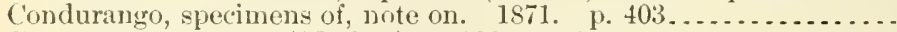

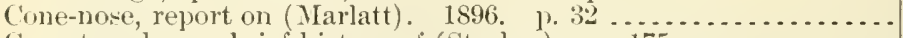
Conestoga horse, brief history of (Strohm). 1. 175 ............. Confections, adulteration of (Wiley and others). 1892 . p. $633 . . .$. Conformation of beef and rlairy cattle (Soule), $1902 . . . . . . . . .$. Conger, Norman B.

Great lakes, wrecks and casualties on, during 1895, 1896, and 1897. Thunderstorms, forecasting of, during summer of $1893 \ldots \ldots . . . .$. Tornaloes of May 25, 1896, in Michigan, report on. p. 156 .... Water temperatures of Great Lakes. 1894. p. $352 \ldots . . . . . . .$.

A $7.3: 65$

A29.6:22

A29.6:27

16.5:3

A29.3:11 ${ }^{2}$

A1.2:W69

A1. $1: 863$

A1.9:133

A29.6:28

A6.3:11

16.5:5

A27.9:32

A $22.3: 21$

A9.7:7

A $27.9: 29$

A1.10:899

A 29.3:24

A 29.3:24

A 1.9:10:3

A13.3:37

A $6.3: 27$

A $29.6: 27$

A9.2:C82

A 1.1:881-2

A9.1:882

A1.6:35

A9.1

A $27.9: 3$

A29.6:25

A29. 1:891 3

A1.9:144

A 1.9:73

A $29.6: 27$

A27.9:9

19.6:4

A 1. 1:863

A $7.3: 13^{6}$

A 1.9:143

A29.2:G81 ${ }^{6}$

A29.3:9

A29.6:24

A29.6:27 
Conger, Norman R.-Continuer

WiTeather forecasts best calculated to aid maritime interests of Great Lakes; methoul of reanhing those interesteml. 1894. 1.20.

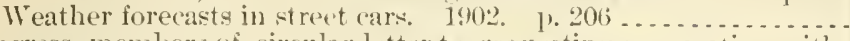

Congress, members of, circular lettor to, requesting (ooperation with

Oflice of Roal Inguiry, Agrieultme Drpartment ... . . . . . . . .

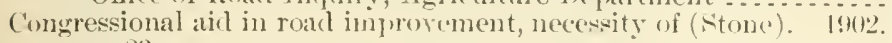

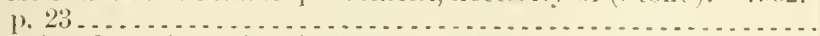

Congressional reprints of agricultural publications for salo ly super-

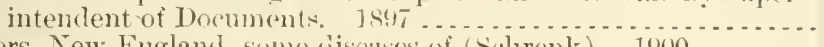

Conilers, New Fugland, some riiscases of (schrenk). $1300 \ldots . . .$.

Conionyeetes tungi. Sir lingri.

Conn, Herbert William:

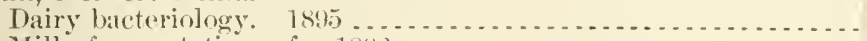

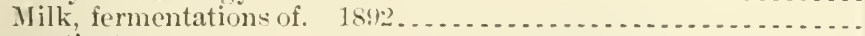

Comnecticut:

Commercial fertilizers in, law on. 1570. 1. 151 . . . . . . . . .

Farm resources and products of, 1868 . 1.9..............

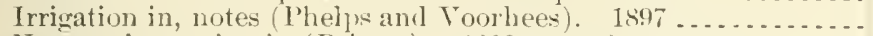

Nursery inspection in (Britton). 1899. p. 131.............

Road improvement in, extrat from governor's message (lomms-

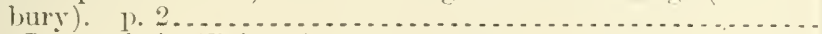

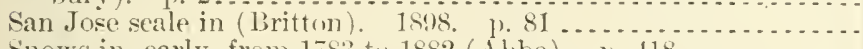

snows in, early, from $178, ;$ to 1882 (Alibe) p. 118 ......... See also. Hartford - New Haven - Thompson.

Connecticut Experiment station:

Arldress on (Atwater). 1901. 1. 51 ... . . . . . . . . . . . . .

Fungi descrilsed in recent reports of (Thaxter). 1891. 1.278...

Connerticut River, tobaeco production on. 1St5. No. 2. 1'. 1S...

Connecticut tol aceo:

Bulk fermentation of (Floyl). 1. 1 . . . . . . . . . . . . . . . .

Physiological stucties of (Lew) $1900 \ldots \ldots \ldots \ldots$

Production of, on Connecticnt livere isti. No. 2. p. is.....

Sharle-grown, to be sold at aitetion May 1, 1902, at IIartforl,

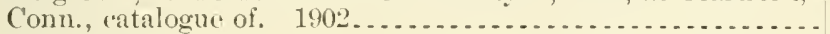

See also Tobaceo.

Connectient Valley:

Soil map of, description of. 1900

Soil survey in (Torsey and Bonsteel) jo0 p. 125 .......

Sumatra tobace, growing under sharle in (Whitney). $1902 \ldots .$.

Connick, I1. D. H. Tuba Piver, nse of water of. 1901. 1. 130...

Commor, Patrick:

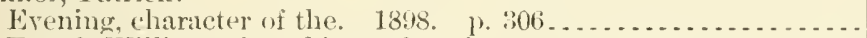

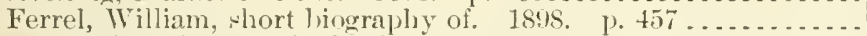

Meteorology for use of schools, primary work on. 1899. p. 102.

Weather forceasts, long-range; can they be made with sufficient precision to be of general utility? 1s99. 1. 44..........

Conservatory, eoccinellide in, experiment with (Webster). 1890.

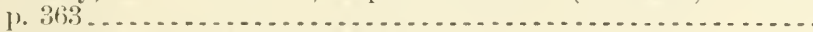

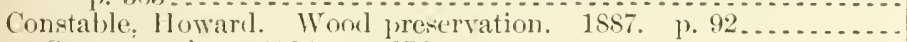

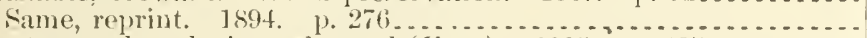

Constants, phenologic or themal (Ihine). 1895. 1\% t27 ........

Consular correspondence of Agriculture Departmont. (Dorlge). p.

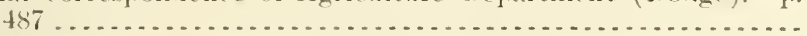

Consuls and comsular agents, reports of, on cotton rop and its enemies in Mexico, C'entral and Sonth America, and West Indies.

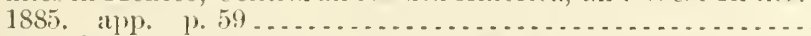

Contagious diseases. See Diseases of animals and reforences thereunder.

Contributions from U. S. National II r r arium ..................

Converse, F. A. Arluress of wrolome, American Issociation of Farmers' Institute Workers, held at Buffalo, N. Y., Sent. 18 and

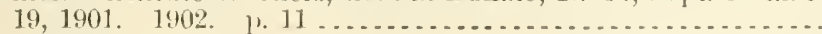

Conviet labor:

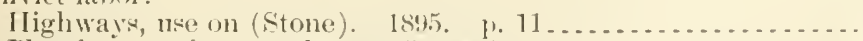

Plan for use: of, on roats. 1895 , p. 7 . . . . . . . . . . . . .

Public roads, use on (Grahans).

$189 \%$.

$1: 9,3: 24$

1 $29.8: 31$

1:2.) $4: 3$

12:2.3:25

121.2:R:29

$128.3: 25$

110.3:25

A10.3:9

127.4:

127.4:6

1 $10.3: 36$

110.3:65

122.4:0:3

19.6:17

129.6:2:2

110.3:99

126.5:7

A $27.9: 3$

1 $20.4: 5$

A1.8:65

127.9:3

A:6.2:T55

$126.4: 7$

11.8:64

126.3:20

110.:2:100

129.6:26

$129.6: 26$

$129.3: 24$

$129.3: 24$

19.7:?

11:3.:3:1

11:3.:: :

129. $3: 11^{2}$

11.1:464

18. 1:t

$16.5:$

$.110 .3: 110$

122.3 .16

12:2.3:16

1:2.3:11 
Convict labor-Continued

Road building, use in (Lyon). 1901. p. 90................

Roar improvement in Nortl Carolina, use in (Holmes). 1895.

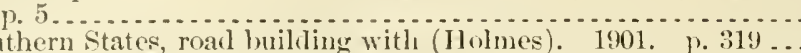

12:2.3:21

Southern States, road buililing with (Holmes). 1901
Comway Springs, Kans., sorghmm sugar experiments at:

1888 (Deming). . 280 .

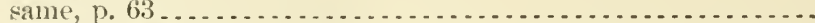

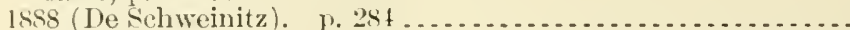

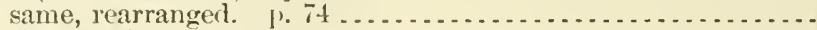

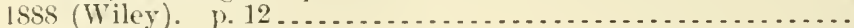

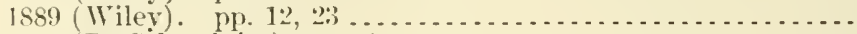

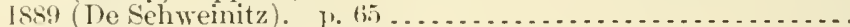

Crok, A. J.:

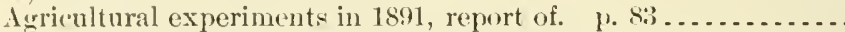
intomologists, work of, in experiment stations. 1891. P. 212 .-

Entonmlogy, teaching, report on. 1890. p. 107.............

Ferosene emulsion and arsenitrs, some listoric notes on. 1891.

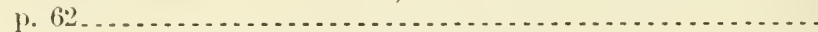

Poplar zonioctena, report on. 1891. p. 67 ..............

Comk, fienrege 11. Agricultural education in New Jersey. 1852. 1\%.7. Sie also, as joint author, Atwater, Wilbur Olin.

c'ook, ()rator Fuller:

Agriculture in tropical islamls of Lnited States. 1901. \%. 349...

Animal inclustry of Porto Rico, notes on. p. 66:3 ............

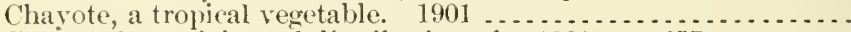

Cocoa yalm, origin and distribution of. 1901. 1. 257 ........

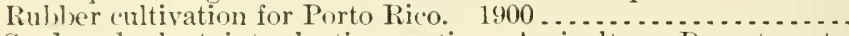

Seed and plant introduction section, Agrieulture Department,

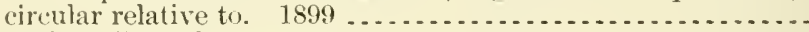

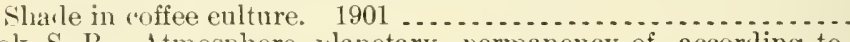

Crok, S. R. Atmosphere, planetary, permanency of, according to kinetic theory of gases. 1902 . p. 401 . . . . . . . . . . . . . . . .

Cook County, Ill., tornado of May 25, 1896, in (Abbe). p. 168....

Cook inlet region, Alaska, natural history of (Osgood). 1901. p.51. Cooke, Wells $\mathrm{W}^{\mathrm{T}}$.

Agriculture, methods of instruction in teaching. 1896. p. 39 ...

Birr migration in Mississippi Talley; erlited and revised by Clinton Hart Merriam. 1888.

llilk, sour, analysis of. 1890.

A22.3:16

A1.10:901

A 1.1:888

17.3:20

A1.1:888

A7.3:20

A7. $3: 20$

A 7.3:26

A 7.3:26

A9.3:26

A9.7:3

A9.7:3

19.7:4

19.7:4

A1.8:2*2

1 $1.10: 901$

14.1:899

16.3:28

А $6.5: 7$

16.4:28

A6. $4: 16$

$16.3: 25$

A 29.6:30

A29.6:24

A5.5:21

A 10.3:30

A5.3:2

A 7.3:31

cooking:

Dininished pressure on, effects of (Ablue). 1900. 1. 160 ...... A29.6:28

Instruction in, in public schools of New York City, history and present status of (Hogan). 1899

Cooley, feorre IV.:

Givel roads in Hennepin County, Minn., methorl of construction

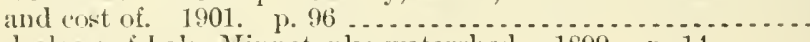

IIylrology of Lake Minnetonka watersher. 1899. p. 14 . . . . . Conley, Robert Allen. Massachusetts coccide, notes on some. 1898. 1. (i1 . Fumers institute work acemplished in Illinois

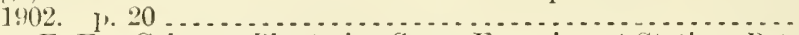

Conmbs, F. E. Calumet Plantation Sugar Experiment Station, Pat-

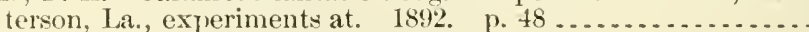

Cooper, Ellwood. Olive industry. 1892. p. 130.............. Sice culso as eollector, Coquillett, Daniel William.

Coortinate axes, standard system of, for magnetie and meteorological olservations and eomputations (Bigelow). 1897. p. 201

Copper-gypsum as remedy for grape mildew (Nessler). 1891. 1\%.73.

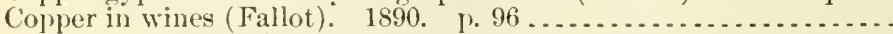

Copper, metallic. See Sugar.

Copper River country, Alaska, notes on (Abererombie). p. 307...

Copper salts as fungicides (Chester). 1891. p. $21 . \ldots . . . . . . . .$.

(Copper-soda as remerly for grape mildew (Nessler). 1891. p. 73...

Copper sulphate and germination; treatment of seed with copper sulphate to prevent attacks of fungi (Evans). $1896 . . . . . . .$.

110.3:56

A $2: 2.3: 21$

A $29.6: 27$

A!).6:17

110.:3:120

17.3:37

11.8:20

129.6:25

A28.5:6

A6.3:11

A10.12:901

A28.5:6 A2S.5:6

\28.3:10 
Coquillett, Daniel Wrilliam:

Australian inserets sent by Albert Koclecle to Ellwool Cooper and B. 11. Lelong, report on. 1893. p. $251 \ldots . . . . . .$.

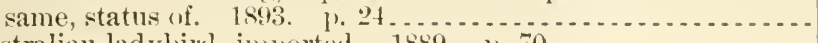

Anstralian ladybire, imported. 1889 . p. $70 \ldots \ldots \ldots \ldots \ldots$.

Buffalo gnats, or black flies, of Cnited states. 1898. p. 66 ....

Buhach, production and manufacture of. 1886. p. 7 . . . . . . .

Cankerworms, cirenlal on. 1895 .......................

Cecirlomyians, two new, destructive to hub of roses. 1900. P.

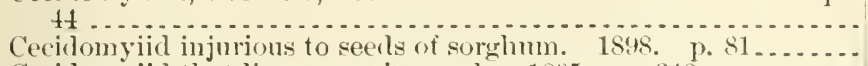

Cecidomyiid that lives on poison oak. 1595. p. $348 \ldots \ldots . . .$.

Coleoptera of California, notes on habits of some. 1892. 1). 260.

Corn worm or boll worm in (alifornial. 1889. 1) 331 ........

Cottony cushion-sale, remedies for. p. 552 - . . . . . . . . . .

Cypress twig borer, report on. 1890, p. 116...............

Cyrtoneura cesia, is [it] an injurious inseet? 1895. I). $338 . .$.

Dipterous insects, two, injurious to enltivated flowers. 1895.

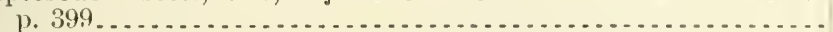

Dipterous leaf-miners, two, on garden regetables. 1895. 1.381.

Dipterous parasite of Diabrotica soror. 1890 . l'as: ........

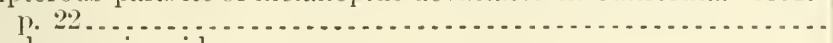

Hydrocyanic acid gas-

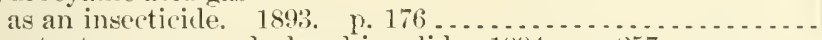
patent on process declarel invaliel. 1894. p. 257 ........ treatment with, for seale inserts, history of. 1s:1. p. $457 \ldots$

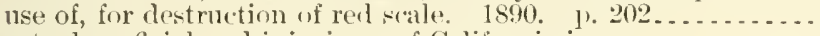

Insects, beneficial and injurious, of California in-

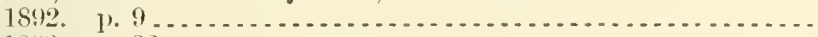

1893. p. $22 \ldots \ldots \ldots \ldots \ldots \ldots$

Locust invasion of California in 1891 , report on. p. $34 . \ldots . . . .$.

Locusts of San Joaquin Valley, California. 1. 289 ............

Lysiphlebus, Praconid genus, variations in. 1891. p. $313 . . .$.

Mosquitoes, North American, synoptie tables of. 1900. 1. 4...

Oseinide and Agromyzide, reared at United States Department

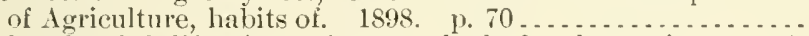

Red scale of California, various methods for destroying. 1890.

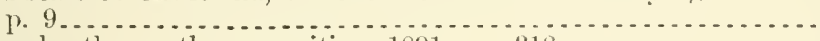

Rove beetle, another parasitic. 1891. p. 318 . $\ldots \ldots \ldots \ldots \ldots$

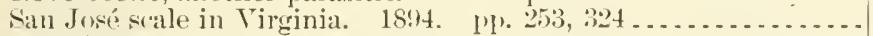

Scale insects-

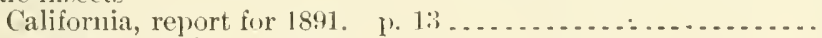

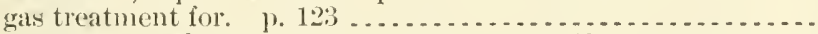
same, supplementary report. 1sss. J. 41............. new, from California. 1891. 1, 382 ................... varions metheds for destroying, annual report on. 18:0. p. 19. various methods for destroying, report on. 1. 12:3 .........

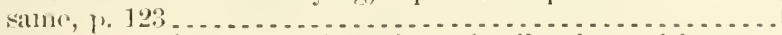

Tachiniclat of America, north of Mexico, a fanily of parasitic two-

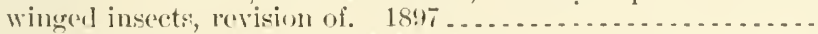

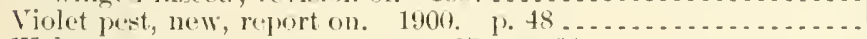

Walnut spanworm, report on. 1897. F. $64 \ldots \ldots \ldots \ldots \ldots$

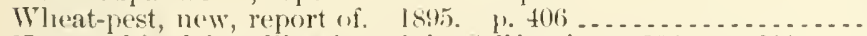

Tneca whipplei, pollination of, in California. 1893. 1.311.... Corbett, Lee Cleveland:

Home fruit garlen, preparation and care. 1901. 1. 431 ......

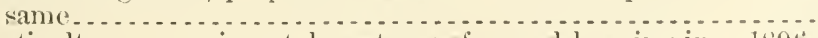

Horticulture, experimental, systems of record kecping in. Is96.

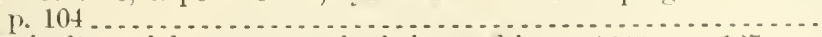

Horticulture, laboratory methous in teaching. 1899. p. 127 ...

Plants, propacistion of. 1902.

Sce also, for report as Ilorticulturist in charge of experinental

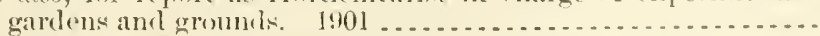

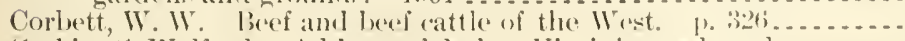
Corbin, $s$ Welford. Neldrese of, leciore Virginia good roarls conven-

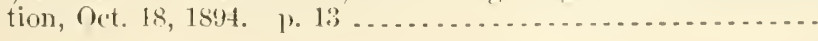

19.7:6

19.7:?

A9.6:10

19.3:1:

19.5:?

19.6:2:2

19.6:18

A $9.7: 7$

19.7:4

19.7:1

A 1.1:886

A $9.7: 3$

19.7:7

$19.7: 7$

A9.7:7

19.7:2

19.7:5

19.7:6

A9.7:7

A9.7:3

A9.7:2

19.3:30

A9.3:32

19.3:27

11.1:885

$19.7: 3$

19.5:40

19.6:10

19.3:2:2

$19.7: 3$

A $9.7: 6$

A9. 3:26

A1.1:887

19.7:1

$19.7: 3$

19.3:23

11.1:888

19.1:888

19.8:7

19.6:2:2

19.6:7

$19.7: 7$

19.7:5

11.10:901

11.9:154

$.110 .3: 41$

110.8:65

11.9:157

114.1:

1].1:Sti2

12.2. 3:11

$114-04-16$ 
Cordley, A. P. Inarsia lineatella zell, notes on. 1897. 1. $71 \ldots \ldots$... A9.6:9

Cordova, Argentina, natiomal exhibition at. 1St39. p. $871 \ldots \ldots \ldots .$. A27.9:7

Cork oak, growth of, in l'nited States, etc. (Jones), 1895. 1\% 9... A13.3:11

Cork-tree:

Caterpillar damaging. 1889. p. 1315...................

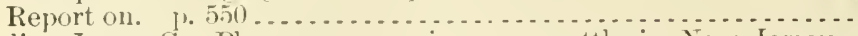

Corlies, James C. Plenro-pmeumonia amone cattle in Tew Jersey,

Corn:

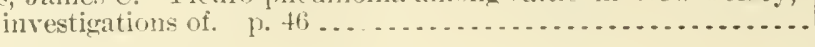

19.7:2

11. $1: 878$

A1.1:\$81-2

American-

composition of, investimation of (Richarkon) -

1883 . . . . . . . . . . . . . . . . . . . . .

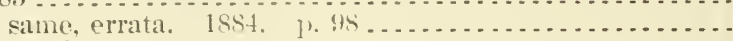

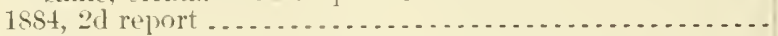

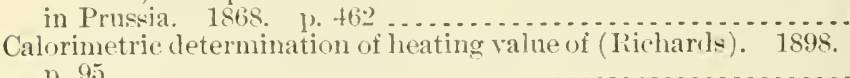

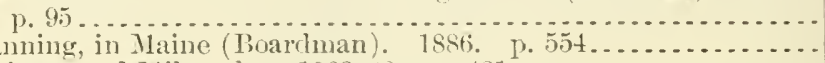

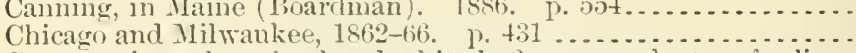

Comparative value of red and white katir corn and, steer-feeding experiments to ascertain (Georgesson). 1. $483 \ldots . . . . .$.

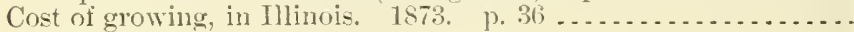

Crop-

condition of, monthly untes on . . . . . . . . . . . . . . . . .

statistics of, annual . . . . . . . . . .

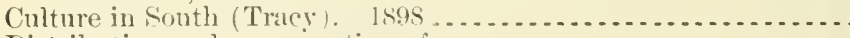

Distribution and consumption of-

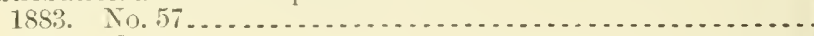

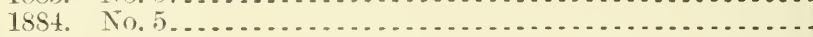

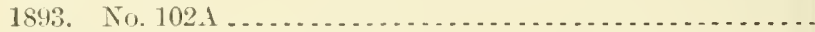

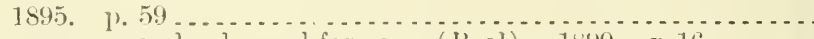

Far vs. corn-and-cob meal for cows (beal). 18!9. p.16 . . . . .

Experiments with. 187. j. 292 . . . . . . . . . . . . . . . . .

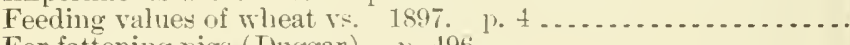

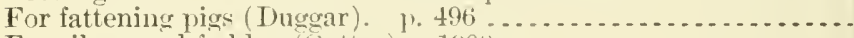

For silage and forder (Gettys). $1900 \ldots \ldots \ldots \ldots$

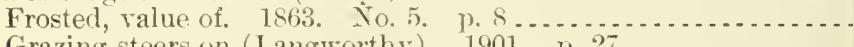

Grazing steers on (Langworthy). 1901. p. 27..............

Insects affecting, observations on, in 1887 (Webster). p. 147...

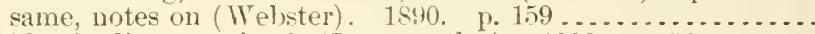

Moldy, feeding to animals (Langworthy). 1900. 1), 26. . . . . . .

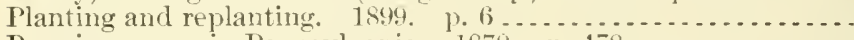

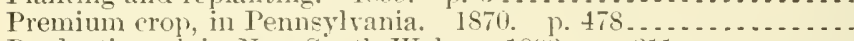

Production of, in New Sinth Wales. 1893. p. $311 \ldots . . . . . .$.

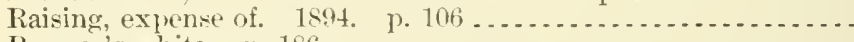

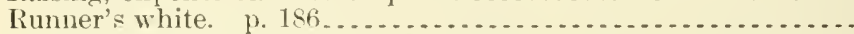

Smut of, is it injurious to eattle? 189s. $p .16 \ldots \ldots \ldots \ldots$

Smutty-

ill effects of, on cattle (Gamgee). 186\%. p. Ts

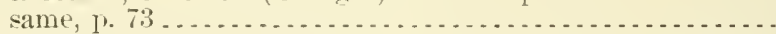

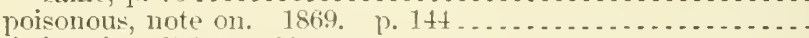

Statistics of. 1875. 1) $234 \ldots \ldots \ldots \ldots \ldots$

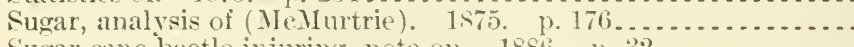

Sugar-cane beetle injuring, note on. 18s6. p. $32 \ldots \ldots . . . . . .$.

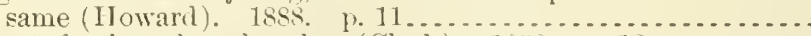

Sweet, forcing of, under glass (Clark). 1898. p. 13 . . . .

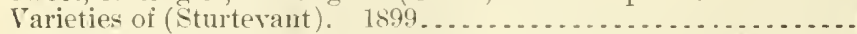

See also Broom corn - Crops, primeipal - Kafir com - Maize, or Indian corn.

Corm and climate, report on, relation of (ITren). 1901. p. 8...... Corn-and-cob meal for cows, ear corn vêrsus (Beal). 1899. p. 16. Corn bill-bugs, life history of one of (Webster). 1859. p. 192 .... Corn crambid, abstract of notes on (Beckwith). 1891. p. 42.....

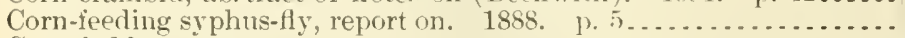
Corn fodder:

Green, for mileh cows. 1. 291

Value of. 1871. p. 470 .

$$
\text { 1. } 291
$$


Corn fodder-Continuer

See ulso Corn stover.

Corn meal as food for pigs (Plumb and Anderson). p. $463 \ldots \ldots \ldots$

Corn plant, feeding value of, at different stages of growth. 1899.

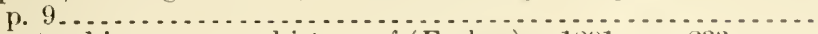

Corn-root aphis, summary history of (Forbes). 1891. p. $233 \ldots$

Corn-root webworm, an old pest in Indiana, note on. 1886. p.33..

Corn stover:

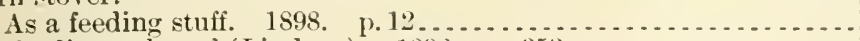

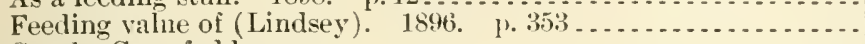

See also Corn fodder.

Corn worm. See Boll worm.

Cornell University, university extension in agriculture at (Craig).

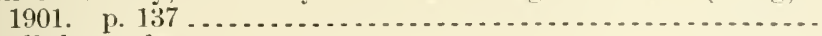

Cornstalk borer, larger:

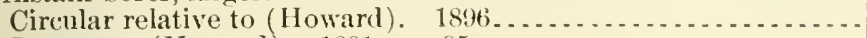

Report on (Howard). 1891. p. 95 . . . . . . .

Cornstalk disease in cattle:

Cornstalks presumably cause of, chemical examination of (De

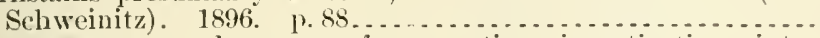

Nature, canse, and means of preventing, investigation. into

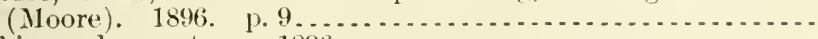

Rabies and, report on. $1896 \ldots \ldots$

Cornstalks:

Analytical work done on, by chemical division, July-Dec., 1880

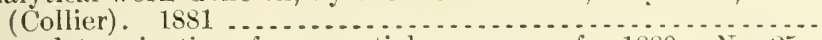

Sugar determinations from, partial summary of. 1880. No. 25.

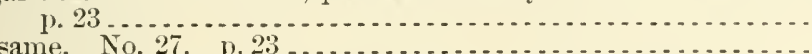

same. No. 27 p. p. 23
Waste in feeding (Beal). 1899 p. p. $16 \ldots \ldots \ldots$

Cornwall, H. B. Baking powder, adulteration of. 1889 . p. $583 .$.

Correspondence courses in agriculture (Craig), 1902, p. $50 \ldots \ldots$.

Corsa, William P. Nut culture in U. S., embracing native and introduced species. $1896 \ldots \ldots \ldots \ldots \ldots \ldots$

Cory, C. L. Electrical engineering laboratory in its relations to

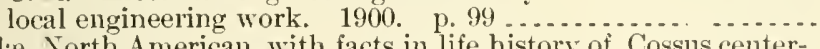

Cossidie, North American, with facts in life history of Cossus center-

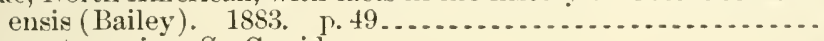

Cossus centerensis. See Cossidæ.

Costa Rica:

Barometric standard of, comparison with (Abbe), 1902. p. 445.

Climatology of, monthly notes on, Jan., 1901-Oct., 1902 (Pittier).

Meteorology in, notes on (Abbe). 1900. P. 541..............

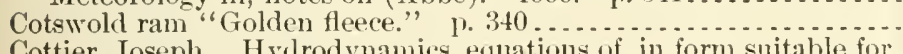

Cottier, Joseph. Hydrodynamies, equations of, in form suitable for application to problems connected with movements of earth's

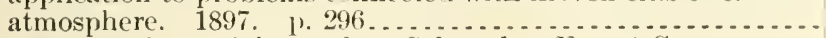

Cotton, W. E. See, as joint author, Schroecter, Ernest C.

Cotton:

Acreage of -

1892. p. 1340

1895. p. $245 \ldots \ldots$

American-

deterioration of (Watts). 187:3. p. 253.

future demand for (Watkins). 1901, $1,193 \ldots \ldots \ldots$

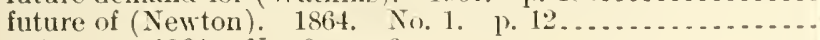

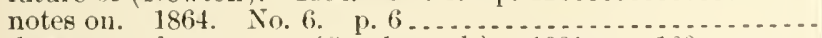

Anthracnose of, report on (Southworth). 1891. p. 100......

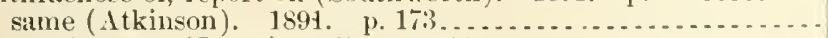

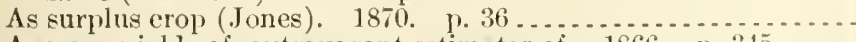

A verage yields of, extravagant estimates of. 1866 . p. $345 \ldots$.

Bibliography of, supplemental. 1896. p. $423 \ldots \ldots \ldots \ldots \ldots$

Bollworm of. See Bollworm of cotton.

Botany of (Evans), 1896, p. $67 \ldots \ldots . . . . . . . . . . . . . .$.

Brazil, antiquity, methods anil extent of cultivation, etc. (Bran-

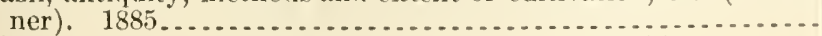

Brief history of what it is and where it grows. p. 104........ 11.1:862

14.1:599

A $1.9: 97$

$19.7: 3$

19.3:12

11.9:84.

A1.10:896

1 10.3:99

19.5:16

19.7:4

A4.3:10

A...3:10

A $4.3: 10$

11.6:33

A27.9:18

A27.9:18

A 1.9:107

A7.8:13 ${ }^{5}$

110.3:110

120.2:N95

A10.3:76

19.3:3

A:99.6:30

A29.6:

$129.6: 28$

A1.1:866

$129.6: 25$

A.27.9:30

A27.9:33

127.9:11

A. 10:901

127.9:2

A27.9:2

125.5:14

A28.5:6

$127.9: 8$

127.9:4

A10.3:33

\10.3:3:3

11.7:8 
Cotton-Continuer

British tracle in. 1866-67. p. 378 .

Chemistry of (McBryde am Beal). 1896. 1) 81

Climatology and soils in their relation to coltivation of (Whit-

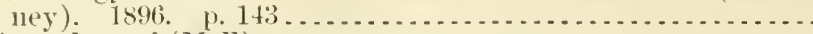

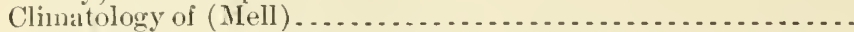

Condition of crop, monthly notes (11 . . . . . . . . . . . . . . . .

Crop statistics-

1868. p. li3s

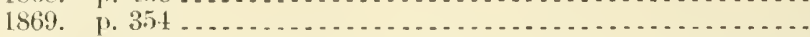

187t. 1. 173

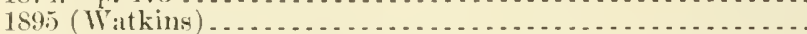

$1896-97$ ( Watkins)

1897-98 (Watkins) ...

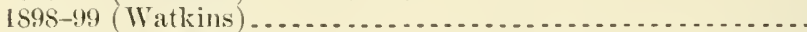

1899-1900 (Watkius)

Cultivatel varieties of (Tracy). $1896 . \quad$ 1. 197.

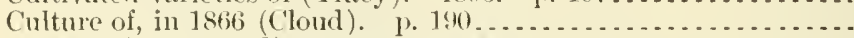
same (Hammond). $1896 . \quad$ p. 225

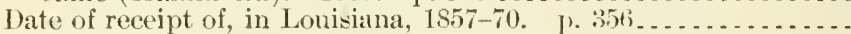

Deterioration of (Watts). 1872. p. $211 \ldots \ldots \ldots \ldots$

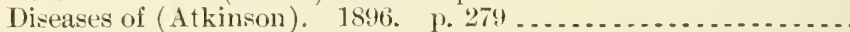

Distribution of. 1893. No. 1011.

Enemies of crop in Mexico, Central and South $\mathrm{Ameri}$ and and Incties, reprorts of consuls and consular agents on. 1885.

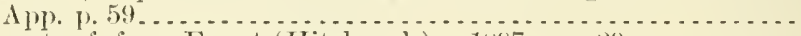

Exports of, from Egypt (Hitchcoek). 1897. 1. 29 ........

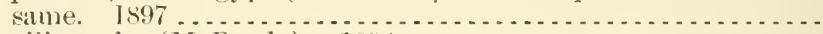

Fertilizers for (McBryde). 1894

Handling and uses of (1 Hammond). 1896. p. 351 . . . . . . . . .

History, botany, chemistry, enlture, enemies, and uses. $1896 \ldots$

History and general statistics of (1landy). 1896. 1. 17......

Imports into Great Britain$1866-67$. p. 249

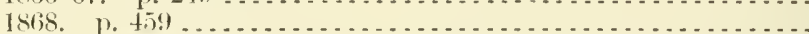

1869. 19. $147 \ldots \ldots \ldots \ldots$

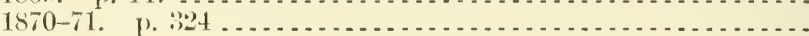

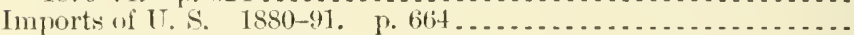

India crop-

1889. p. $16: 3$

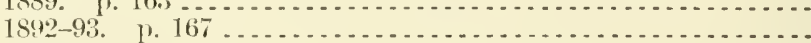

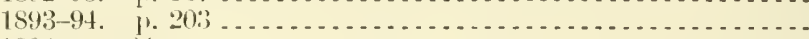
1894. 1. 24 . . . . . . . . . . . . . . . . .

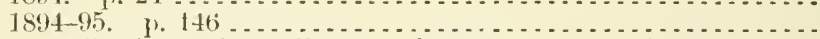

Insects affecting. See Bollworm of cottm - Cotton insects.

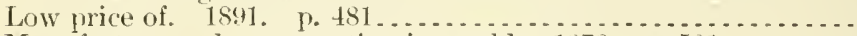

Manufacture and consumption in world. 1876. 1.501 . . . . .

Manufacture of, statistics of. 1869 , p. $371^{*} \ldots . . . \ldots \ldots \ldots$

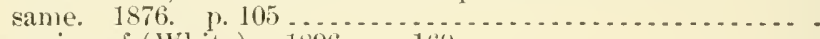

Manuring of (White). 1896. J. 169 .................

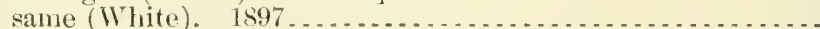

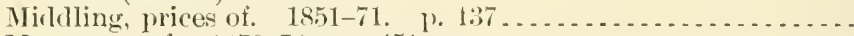

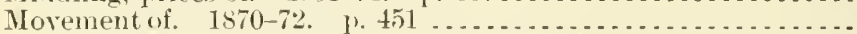

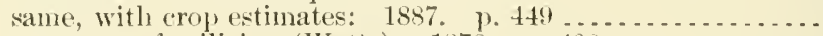

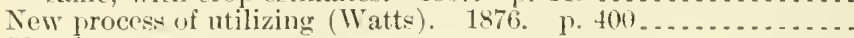

Planting-

directions for (1,yman). p. 193

progress of. 1883. No. 59.

Production and price of, for one hundred years (Watkins). 1895 same, abstract

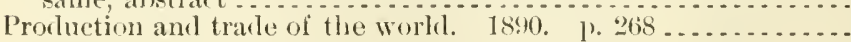

Quality of crop, 1873 , answers to circular regarcling. $1.123 . . .$.

Raising by free labor (Landon). p. $88 \ldots . . . . . . . . . . . . .$.

A:7.4:5

1 $10.3: 33$

1]0.3:33

A 29.3:8

A 27.9 :

A $27.9: 6$

A $27.9: 8$

A27.9:13

A:27.4:4

A27.9:35

A27.4:9

A27.8:17

A27.8:19

A $10.3: 33$

A 1.1:866

A 10.3:33

A $27.9: 8$

A27.9:10

A 10.3:33

A $27.9: 31$

A8.1:4

A 10.3:42

A 12.4:15

A 1.9:14

A27.9:10

A 10.3:33

A 10.3:33

A10.3:33

A 27.9:5

A $27.9: 6$

A $27.9: 7$

A $27.9: 9$

A27.9:29

A 27.9:28

A $27.9: 31$

A $27.9: 32$

A $27.9: 33$

A $27.9: 33$

A27.9:29

A27.9:14

A27.9:7

A27.9:14

A 10.3:33

A 1.9:48

Аะ7.9:9

А $27.9: 10$

127.9:25

A27.9:14

A 1.1:866

127.9:21

127.8:16

A27.8:9

A27. $8^{\mathrm{n}}: \mathrm{C} 82$

A27.9:28

A 27.9:12

A1.1:864

* By a misprint, this page number appears twice. 
Raising in California, 1872, p. 493

Report on best sections. 1866 . pp. $233,280,329$

Root-rot disease of, new (Atkinson). 1891, P. 262 .

season of $1869-70$ in India.

Spinning, atmospherie conditions favorable to, notes on ( 1 l) be).

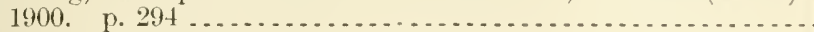

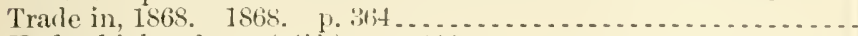

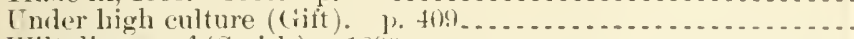

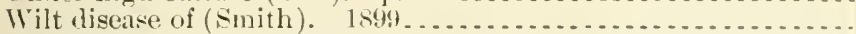

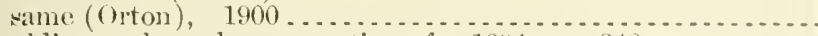

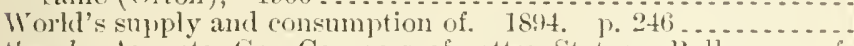

Sie also Augusta, Ga., Congress of cotton States-Boll worm of cotton-Crops, principal-Egyptian cotton-Flax-eottonRaw cotton.

Cotton and currency, 1895

Cotton army wom, origin of, and hest means of destroying (Jones). 1878, p. 356

\section{Cotton-belt:}

Forecast stations of Weather Burean, establishment and inspection of (Narbury), 1899. p. $150 \ldots \ldots \ldots \ldots \ldots \ldots$

Forecast stations of Weather Bureau in, instructions governing. 1892

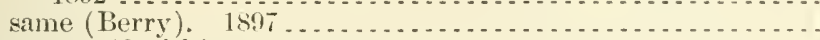

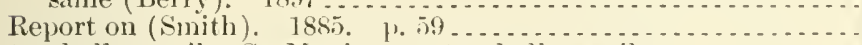

Cotton-boll weevil. See Mexican cotton-boll weevil.

Cotton eaterpillar:

Brazil (Branner). 1885. App. 1, 49 . . . . . . . . . . . . . . . .

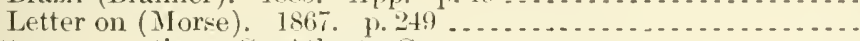

Cotton convention. See Atlanta, Ga.

Cotton cutworm, note on ( $\Lambda$ tkinson). 1891. 1.31 ............. see rilso Cutworms.

Cotton Exehange and Agriculture Department reports. 18st. ]. 4!16.

Cotton exehanges, list of. 1899. p. $759 \ldots \ldots \ldots . . .6$. Same, 1901. p. 696 .

Cotton insects:

Bahama Islands (Sehwar\%). 187s. 11.347

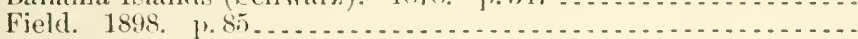

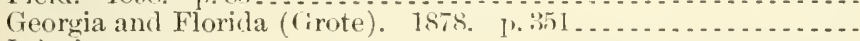

Injurious--

in Brazil, preliminary report of olservations nom (Branner). 18s4. p. 63 . . . .

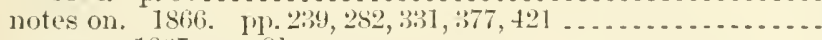

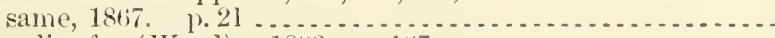

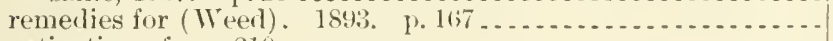

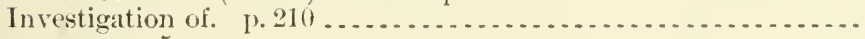

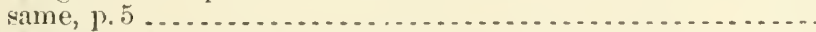

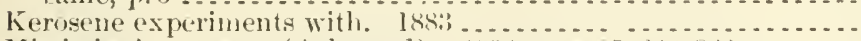

Mississippi, notes on (Aslmear ). 1844. 111. 25, 240, 820.......

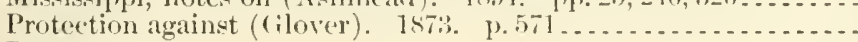

Report on-

1879 (Comstork)

1885 (Stelle). Alp.p. 6 .

Résumé of more important (hapters if rejkort njoll. p. 20is. . . . .

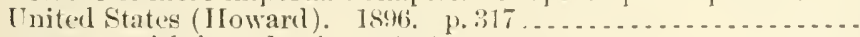
same, with introduction. 1897 .

See alson Bollworm of entton-Cotton raterpillar - cotton rutworm - Cotton plant-lonse - Cotton worm - Mexican cottonboll weevil.

Cotton machinery, adaptation of flax-eotton to (Jarkson). 1. 4th. . - 11.1:sti2 Cotton or melon plant-lonse, report on (Pergande). 18\%5, 1,3019... Cotton seed:

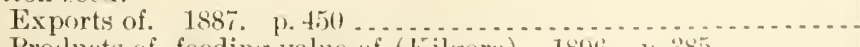

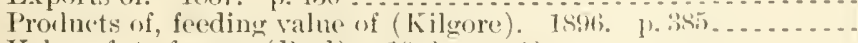
Value of, to farmer (1,al). 1!k)1. 1. Cotton seed and its products. Isini.

A27.9:10

$.127 .9: 4$

19.7:3

128.4:9

1.27.9:S

129.6:28

1.27.9:6

11.1:867

1:28.3:17

$.128 .3: 27$

$127.9: 3:$

$127.8^{4}: C 82$

19.2:C 82

$12 ! 1: 3: 24$

129.12:C8:2 A29.12:C81

18.1:4

18.1:4

$127.9: 5$

19.7:4

$127.9: 24$

11.10:899

11.10:!01

19.2:C82

19.6:18

A9.2:C82

19.3:4

127.9:4

127.9:5

$19.7: 6$

11.1:878

19.1:879

19.3:1

19.7:7

1.27.9:11

10.2:C82

$18.1: 4$

11.1:879

110.3:3:3

11.:1:47

$19.7: 7$

$127.9: 25$

$110.3: 33$

11.9:124

11.9: 34 
Cotton-seed industry (Daugherty). 1901. p. 285

Cotton-seed meal:

Effeet of, on quality of butter (Allen). 1900. p. 24 A1.10:901

Fertilizers containing, determination of available phosporic adid

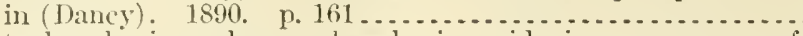

Metaphosphoric and pyrophosphoric acids in, ocenrence of (Ilardin). 1892. 1.50 . . . . . . . . . . . . . . . . . . . .

Vitrifieation of, in different soils (Withers and Fraps). 190\%.

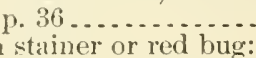

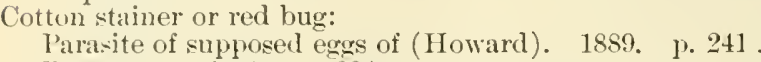

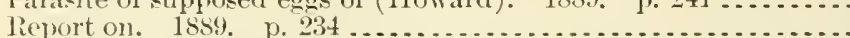

Cotton states, agrienlture in, condition of (1Ioward). p. 215....

See also Sonthern States.

Cotton States and Intemational Exposition, Itanta, Cia., 1895 Sire Itlanta, Ga.

Cotton worm or aletia:

Adrlress on, before cotton convention at Atlanta. 1881 (Riley).

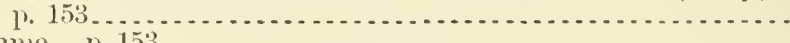

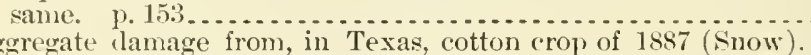

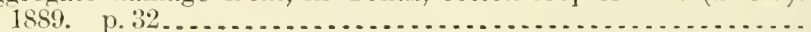

Anatomy of (Minot and Burgess). 1855. p. $45 \ldots \ldots \ldots$

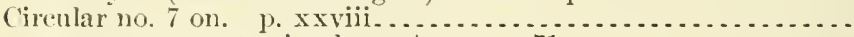

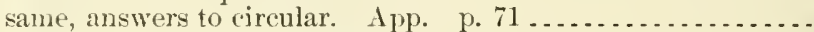

Destrution of, by birds (Redfield). 1883. No. 65. 1. 25......

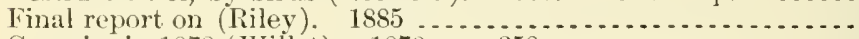

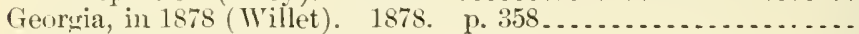
Habits and natural history of (Trelease). is 8 . p. $361 \ldots \ldots \ldots$.

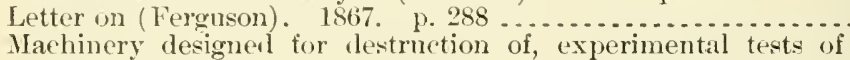
(Bainard) 1883. p. 39

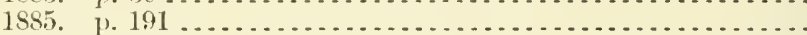

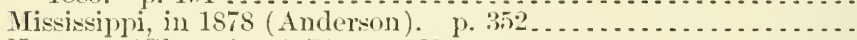

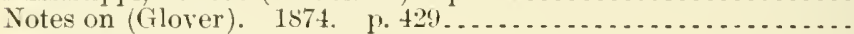

Olservations and experiments upon188:3 (Neal). p. $3 \mathrm{~S}$

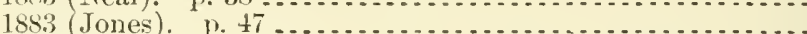

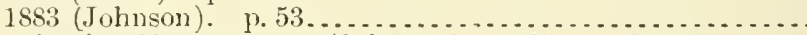

Question in 1894, report on (Schwarz). 1895. p. $315 \ldots \ldots \ldots$

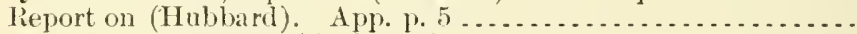

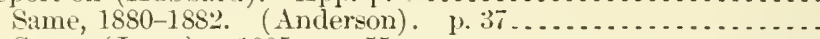

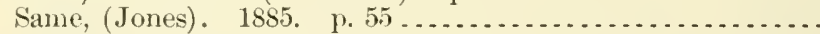

Texas, south, in spring and early smmmer of 1883 , report upon

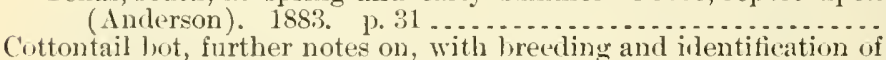
fly (Townsend). 1893. p. 317.

Cottonwood, cimbex injuring, in Nebraska (Welster). 1890. p. 22s.

Cottonwoorl beetle, striped, report on (lintner). 1895. 1. $69 . . .$.

Cottonwood borer, great damage by, note on. 18s6. p. 41 ......

Cottony cushion-seale:

Experiments on (Koebele). 1. jist.

Remedies for (Coquillett). 1, 552 .

See also Scale insects.

Cottrell, H. M., Burtis, F. C., and Otis, D. II. Dairy eow, feed and

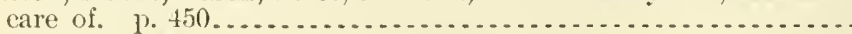
Conlter, John M.:

Apetalre of western Texas, description of. 1894. p. 347 . . . .

Cactus, anhalonium, and lophophora, North Anerican species of,

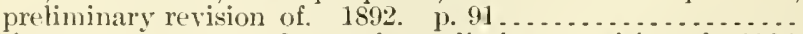

Echinocactus, cereus, and opuntia, prelininary revision of. 1896 .

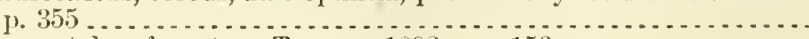

Gamopetalce of western Texas. 1892. 1. 158.

Monocotyledons of western Texas, rlescription of. 1894. p. 421

Phanerogams and pteridophytes of western Texas, manual of. $1891-94$ 
Coulter, John M.-Continued

Polypetalre of western Texas, descriytion of. 1891. p, $6 \ldots \ldots$.

Rio Grande, region of, in Texils, from lirazos santiago to $\mathrm{El}$ Paso County, collertion of plants male hy (i. ( $)$. Nealley, re-

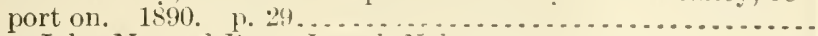
Coulter, John II., and Rose, Jowh Yelson:

Hesperogenia, a new genus of umbelliferæ from MLnnt Rainier.

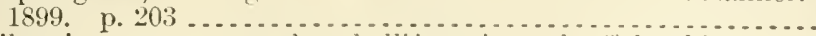

Leibergia, a new gents of umbellifere from the Columbia River region. 1896. p. 575 .

Nexican nmbellifere, mostly from the state of (iaxaca, recently collected by C. G. l'ringle and Ldward William Nelson, re-

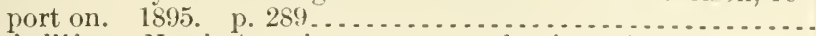

Umbelliferæ, North American, monograph of. 1900 . 1.9.... Country roads. See Roads.

Country slaughterhouse as a factor in sprear of disease (Stiles). 1896. p. 155

Court, meteorologieal records in (Linney). 1902. 1\% $180 \ldots \ldots .$.

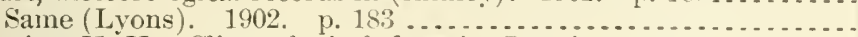

Cousins, H. H. Climatological data for Jamaica. Sent., 1902. p.

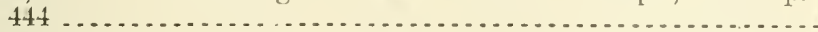

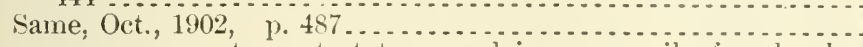

Cover crops grown to proteet trees anrl improve soil of orchards.

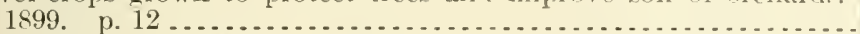

Coville, Frederick Vernon:

Botany, text-books on. 1899. p. $154 \ldots \ldots$. . . . . . . . . . . .

Botany division, Agriculture Department-

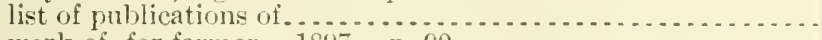

work of, for farmer. 1897 . p. 90 ......................

Crepis occidentalis and its allies. 1896. p. 559 . . . . . . . . .

Crimson elover laair balls, circular on, 1896 . . . . . . . . . . . .

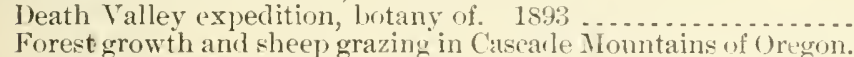
1898

Klamath Indians of Oregon, notes on plants userl hy. 1897.

IIushroom poisoning in D. C., recent cases of, olservations on ...

Plant breeding and seed selection ........................

Vegetable dietary, our, some adllitions to. 1) $205 \ldots . . . . . . . .$.

Weeds, noxious, report on-

1889. p. 382

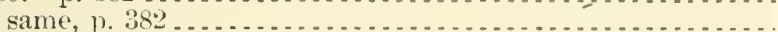

1890. p. 388

same, 1) 388 .

Yakutat Bay, Alaska, hotany of, with field report by lirelerick

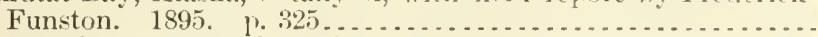

See also, for reports as Botanist, Botany division, Agrieulture I De-

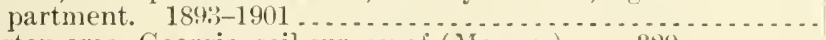

Cóvington area, Georgia, soil survey of (Marean ). p. $329 . . . \ldots .$.

Cowgill, E. B.:

Sorghum-sugar industry in Kansas. 1888, p. 18 ............

Cowpeas: same, abstract, p. 223 . . . . . . . . . .

Fattening pigs (Duggar). 1) $496 \ldots \ldots \ldots \ldots$

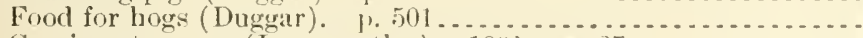

Grazing steers on (Langworthy). 1901. 1, $27 \ldots \ldots \ldots \ldots \ldots$

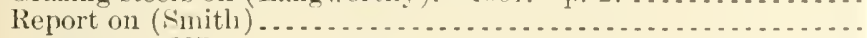

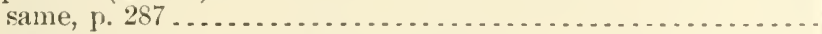

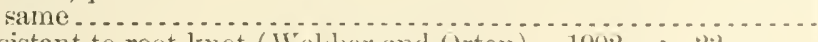

Resistant to root knot (Wel,ber and (j)rton). 1902. 1, 2.2.....

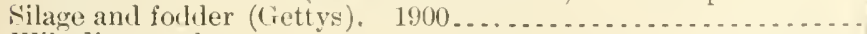

Wilt disease of-

1899 (Smith)

1902 (Orton). 1.9.

Cows:

Abortion in. 1869. P. 29.9*

Clasulfation no.

16.5:2

16.5:1

16.5:5

A6.5:3

$16.5: 3$

$16.5: 7$

A1.10:896

1 $29.3: 31$

129.3:31

A29.6:30

A29.6:30

11.9:87

A29.6:27

16.4:30

A1.10:897

16.5:3

16.4:8

A6.5:4

\13.3:15

A6.5:5

A6.4:13

A6.2:P69

A 1.10:895

A1.1:889

16.1:889

11.1:890

16.1:890

$16.5: 3$

A6.1:

A26.5:801

A7.3:17

11.1:887

14.1:898

A $4.1: 898$

$11.9: 124$

11.9:89

11. $10: 896$

$13.4: 5$

119.3:17

13.4:24

128.3:17

A 19.3:17

127.9:7

* Bу a minprint, this puge number appears twice. 
Cows-Continued

Dairy-

feerl and rare of (Cottrell, Burtis, ant Otis). p. $450 \ldots \ldots .$. scale of points for judgine, regardless uf breeds. 1900. 1\%.737. type of, in relation to milk and butter production (Lawson).

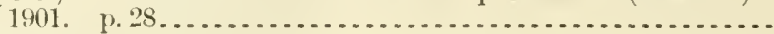

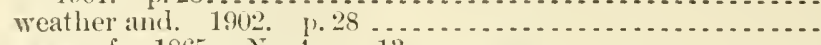
1) crease of. 1865 . No. 4. p. $13, \ldots \ldots \ldots$ Eal corn versus corn-and-(col) noal for (Beal). 189?. 1) 16 . . .

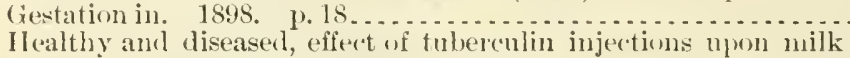

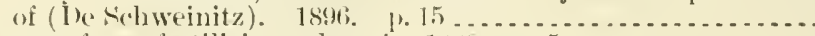

Manure from, fertilizing value of. 1sig. p. p.......... Milchfood of, do volatile arids in, oecur in milk? (Weiske). 1890. p. 141 . . . . . . . . . . . . . . . . . . . . . . . . . .

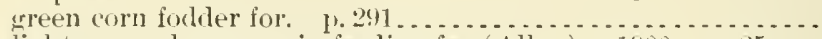
light versus heary grain feeding for (Allen). 1900 . p. $25 . .$. metaholism of, investigations on (Hagemamn). 1894. 1). 103 ,

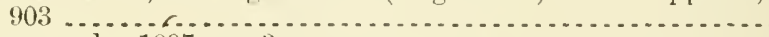

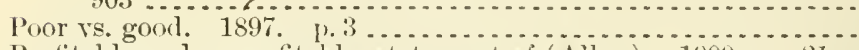

Profitable and umprofitable, statement of (11leil). 1900. 1.21 . -

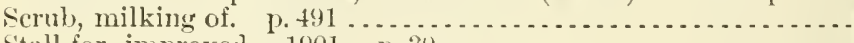

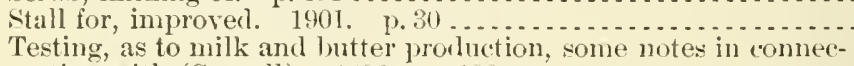

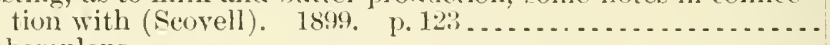

Tuberculous-

feeding calves with milk of (Wilcox). 1899. p. 23.

milk of, observation of presence of tubercle hacilli in, when udder is not visibly diseased (Simith and Schroesler). 1893. 1). 60

See also Animals - Cattle - Dairy - Milk.

Cows and cattle of foreign comitries (Pearion), 1896, 1..3....... Cow' milk. Sep Milk.

Cox, Henry J.:

Chicago weather forecast listrict, monthly report of-

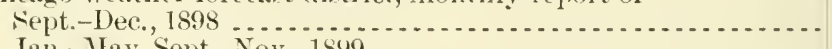

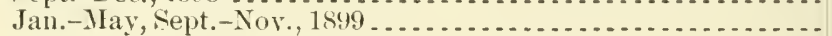

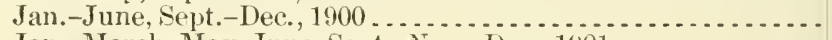
Jan.-March, May, June, Sept., Nov., Dec., 1901 . . . . . . . . . . . .

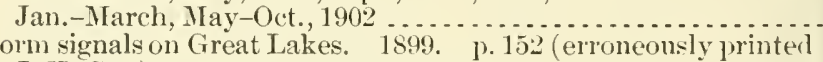
J. H. Cox)

Temperature, should verifying chance of, be smaller, and should not terms "slightly warmer" or "slightly cooler" be credited? 1902. p. 127

Wreather forecasts best calculated to aid maritime interests of (ireat Lakes; method of reaching those interested. 1899 . 1). 19. Cragin, Harry IT. and H. S.:

Thunderstorms, local, observations for, at Skyland, Page County,

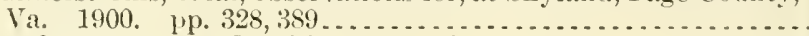

Thunderstorms near Washington, D. C., report on. 1900. p. 287. Craig, John:

Agriculture correspondener, eourses in. 1902. p. $50 \ldots \ldots . . .$.

Comell University, miversity extension in acriculture at. 1901.

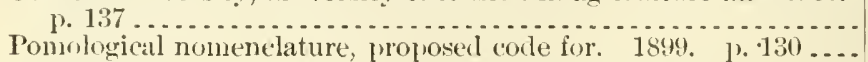
Craig, John A.:

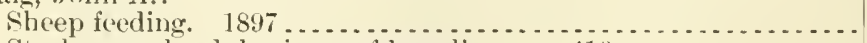

Stock, pure-lired, business of breeding. 1, 416............. Crambid. See Corn crambid.

Crampton, C. A.:

Baking powders-

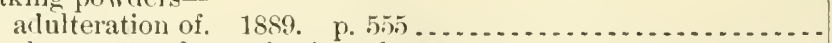

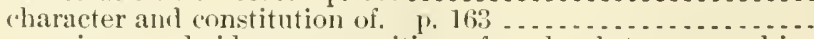

beers, wines, and ciders, composition of, and sulustances used in their alulteration. 1. 183.

A $4.1: 899$

A 1.10:900

A 1.9:124

\1.9:149

Aะ7.9:3

A 1.9:107

11.9:103

A 4.3:13

1 $1.91: 97$

A 7.8:24

A $1.1: 870$

A 1.:1:119

A 10.6:10

A 1.9:56

A1.9:11t

A 4. 1:898

A1.9:1 44

1 10.3:6.5

1 1.4:107

A $4.3: 3$

14.3:11

A.29.6:26

\29.6:27

129.6:28

A $29.6: 29$

129.6:30

A $29.3: 24$

129.8:31

A $29.3: 24$

A 29.6:28

A 29.6:28

A10.3:110

110.3:99

A 10.3:65

A1.9:49

A 4.1:901

A $7.3: 13^{5}$

A7.1:889

A1.1:887 
Des Linges sugar experiment station, Baldwin, La., record of $\mathrm{ex}$ -

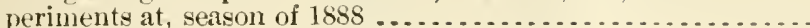

Fats, crystallization of. 1859 . p. 449.

A $7.3: 22$

A $7.3: 13^{4}$

Fermented alcoholic beverages, malt liquors, wine, and cicler,

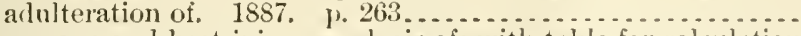

Sugrar-cane and beet juices, analysis of; with table for calculation

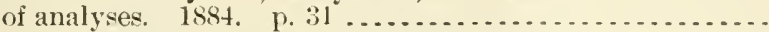
same, at Fort Seott, Kans. 1887. p. 15................ See also, as joint author, Denton, Albert $A$.

Crampton, (. A., and Fake, N. J.:

Chenical work done at Fort Scott in sorghnm-sngar experiment:-

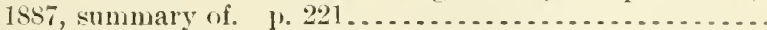
same, p. 15. [Fake is not mentioned in this print.] ....... Sorglum analysis at Fort Scott, Kans., in 1887. p. $5 . . . . . . .$. Cranberries:

Inserts affecting, report on (Smith). p. 393. same, p. 9 Interest in U.S. in, in 1869. p. 204....................

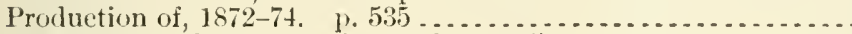
Rotting of, and a proposed remedy (Bkal). 1900. 1). $9 \ldots . . . .$. Cranberry culture:

New Jersey ('Taylor). p. 569

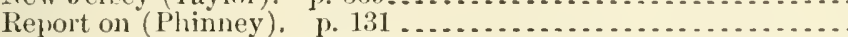
same (Saunders). 1894 .

$17.3: 13^{3}$

17.3:15

17.3:17

11.1:887

17.:3:17

A7.:3:18

A 1.1:884

A $1.3: 4$

A1.1:869

A27.9:12

11.9:114

A1.1:87

A1.1:863

A1.9:1:3

Cranberry fireworm, probable remedy for (Kirkland). 1899. p. 53. $\quad 19.6: 20$

Cranberry gall fungus, treatment of (Halsted). 1891. p. 18 ..... A28.5:6

Cranberry girdler, report of (Scudiler). 1894. p. $1 \ldots \ldots \ldots \ldots \ldots \ldots . .49 .7$

('ranberry leaf-galls, report on (Thomas). 1889. ․ $279 \ldots \ldots \ldots \ldots . . .49 .1$

Cramberry rot, microscopic olservations on (Taylor). 1875. p. 445. A27.9:13

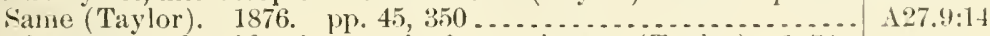

Cranberly rot and scald, microseopic olservations on (Taylor). 1574. 1. 439.

Same (Taylor). 1875. 1) 42

Cranlerry seall treatment of (I

Crane, Arthur S. Long-range weather forecasts, ean they be mate with any degree of aceuracy or profit? 1899. p. 157 . . . . .

Crane, Edward I'. Hanover, (iermany, cost of hauling farm prod-

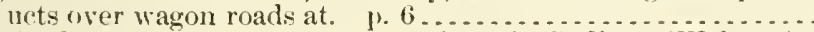

Crane-fly, larve of, lestroying young wheat in Indiana (Viebster). 1890. p. 12

Craw, Alexander:

Nursery stock and orchards, inspection of. 1900 . p. 87 ......

Scale insects found upon plants entering port of San Francisco, list of. $1896 . \quad$ p. 40

See ulso, as collector, Cockerell, Theodure Dru Alison.

Crayfish, carbon bisulphide for (Wreed). 1895, 1.98 . . . . . . . . Cream:

Comparative amount of, from deep or shallow setting of milk.

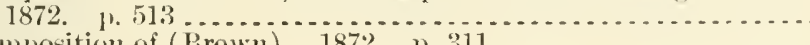

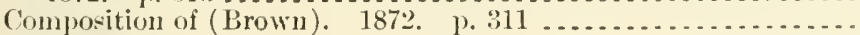

latstenrized-

commercial butter cultures nsed in connection with ( $\Lambda$ llen).

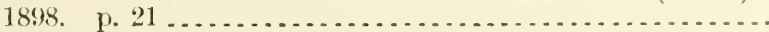

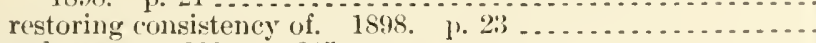

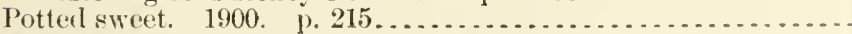

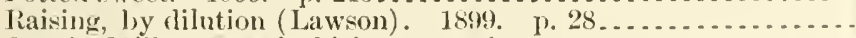
See also Milk - Potash, bichromate of.

"Crean pot" stock, history of (Slingerland). ए. 2!) _.......... Sce also Jacpues "Crean pot" stock.

Creameries or butter factories, advantages, location, oryanization,

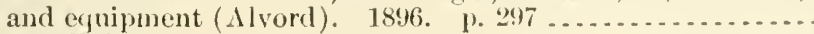
See also Dairy.

Creasy, William 'T. Farmers' views of gooul roats, and how to get

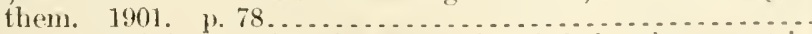

Creatin and creatinin, physiologioal effect of, and thoir value as nutrients (Mallet). 1899 .

127.9:12

1 $27.9: 1 \%$

A25.5:6

1.9.:2:24

$122.4: 27$

A.9.7:3

110.3:76

19.8:4

A9.6:2:2

127.9:10 127.9:10

A $1.9: 10 \%$

A1.9:69

14.1:899

1 $1.4: 10 \%$

11.1:8titi

14.1:3(1)-6

1:2.2.3:21

A10.3:titj 
Credit, popular, French congress on. 1895

Credit associations, cooperative, in Enropean countries and their relation to arricultural interests (Peters). 1S92...............

Credit unions, cooperative, of Germany. 1891. p. 339 A27.9:33

Creelman, Cr. C.:

Farners' institutes in Ontario. 1902. p. $32 \ldots . . . . . . . . . . . .$.

Ontario, farmers' institute work accomplished in. 190*. p. 26.

Live stock, judging of, as farmers' institute work. 1902. p. 113.

See also, as elitor, Fammers' Institute Wurkers, American Association of.

Crepis occidentalis and its allies (Coville). 1596. 1. 559 ........

Cricket:

Tree, carnivorous habits of (Murtfeldt) $1889 . \quad$ 1. 1:30 . . . . . . .

Western, outbreaks of, in Idaho, rejort on (Milliken). 1 s93.
P. 17 ...

Crime. See Climate and Crime.

Crimson clover:

Circular on (Williams). 1899

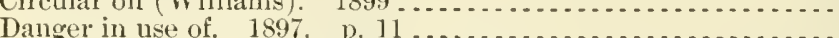

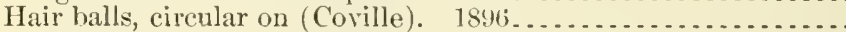

Importance of, as a forage plant. 189s. $\quad$ 1. $8 \ldots \ldots \ldots \ldots \ldots \ldots \ldots$.

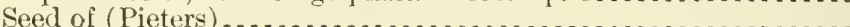

See also Clover.

Critchett, O. A. Irrigation and water rights, abstract of laws of the

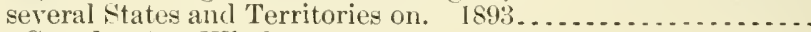

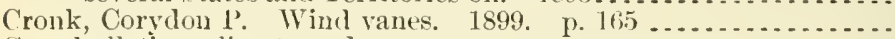

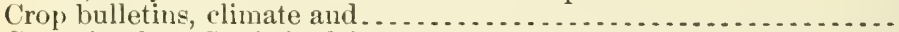

Crop circulars, Statistics Division, Agriculture Department ........

Crop correspondents, manual of instructions to (Robinson)........ See also Climate and crop correspondents.

Crop reporter, Statistics Division, Agriculture Department ......... .

Crop reports:

Indications of, vs. estimates. 1892. ए. $70 \ldots \ldots \ldots \ldots \ldots \ldots \ldots$

National and international, paper on (('hamberlain). p. 1:36 ...

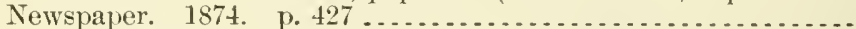

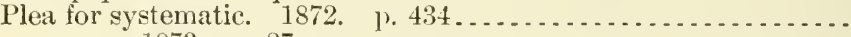

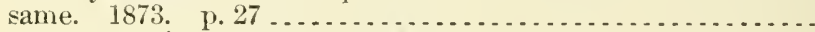

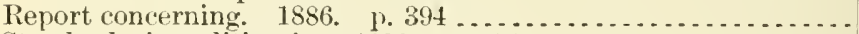

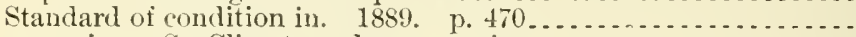

Crop service. See Climate and rop service.

Crop synopsis, monthly, Statistics Division, Agriculture Department.

Crop zones. See Zones, life and crop.

Crops:

Amounts and injuries of, in 1864, table showing. No.6. p. 28 ..

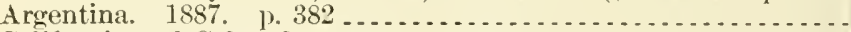

California and Colorado. 1890 p. p20 $5 . \ldots \ldots \ldots$

Climate and-

notes on (Kimball). 1901. p. 564_.....................

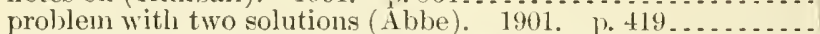

Climatology of Florida with regard to (Miteliell). 1902. 1. $20 \mathrm{~s}$.

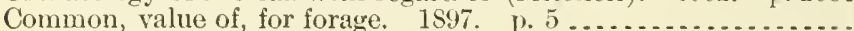
See also Forage crops.

Condition of, monthly report on, June, 1863, to Nor., $18 \% 7$ See also Climate and crop conditions - Weather and ('rop conditions.

Continuation and rotation of, experiments in, at Rothamsted Experiment Station, Ingland, lectures on (Gilbert). 18:3 .....

Depending on meteorological conditions, notes on (Abbe). 1900.

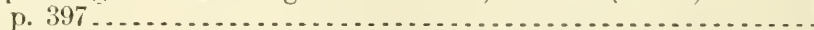

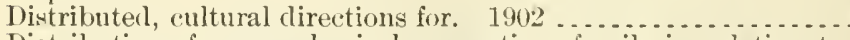

Distribution of, some physical properties of soils in relation to

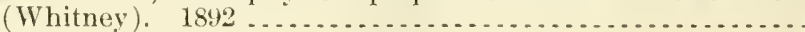

English, and prices, $1861-65$. p. $210 \ldots \ldots \ldots \ldots \ldots$

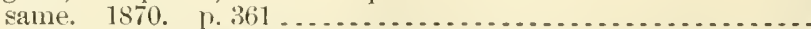

European prospects (Moffat). 1883. No. 61, p. 3t. No. (it, p.28.

No. $65,1.29 . \quad$ No. 1,1 . 18...................... A27.9:21

A3.4:17

A1.9:65

A 6.4:8

11.9:69

16.4:18

115.3:1

129.3:24

A29.7:

A27.5:

A27.2:C88

A27.6:

A27.9:30

A $1.8: 22$

A27.9:12

127.9:10

A27.9:11

A:7.9:24

127.9:27

A27.7

127.9:2

127.9:25

A:7.9:28

129.6:29

A29.6:29

A29.3:31

A1.9:65

127.9

A10.3:22

129.6:28

A19.2:FT4

129.3:4

A27.9:4

A27.9:S 
Fall sown, condition and amount of, for lstit, talble showing. No. 6 , p. 29

Fertilizer, requirements of $(\mathrm{Beal}), 1 \mathrm{~s} 99 . \mathrm{p}, \mathrm{i} \ldots \ldots \ldots \ldots .$.

Foreign-

official statistics of -

1890. p. 155

1891. p. 276

1893. P. 119

$1894 . \quad$ p. 752
state of. 1864.

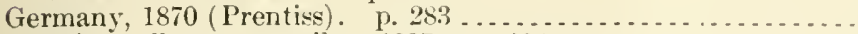

Growing, effect upon soils. 1897. P. 684

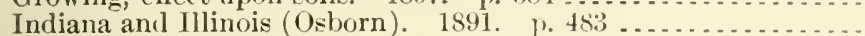

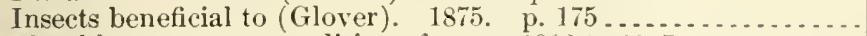

Monthly reports on condition of, ete. 1863 to 18.7

Nitrogen of our, determinations by experiments at liothansted

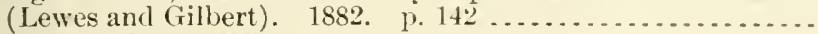

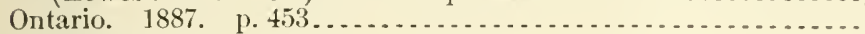

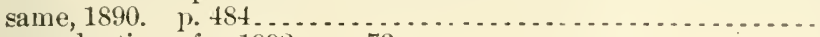

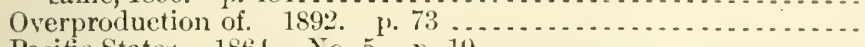

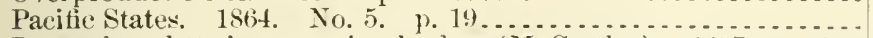

Pests of, and their repression by law (McCarthy). 1897. p. 19.

Prices of. 186t. No. 1. 1,28. No. 2. p. $20 \ldots . . . . . . . .$.

Principal-

acreage, production, and value of. 1897. No. 155 ......... statistices of -

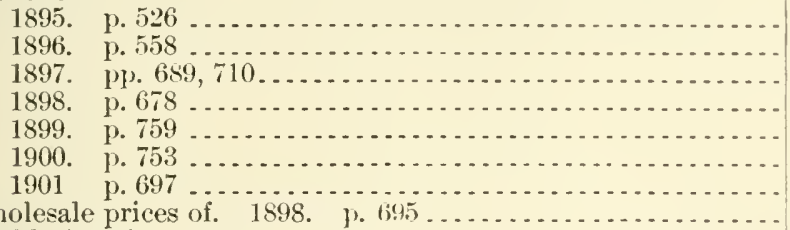

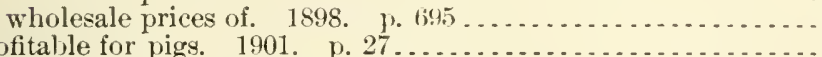

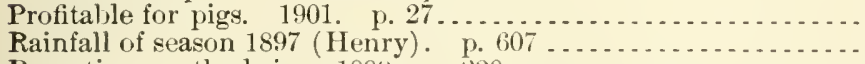

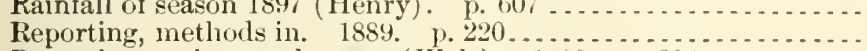

Reporting stations, voluntary (Walz). 1898. p. $208 \ldots . . . . .$.

Results of, publicity of. 1889. p. 468 . . . . . . . . .

Rotation of -

experiments in, at Rothamsted Experiment Station, Lnglaml, lectures on (Gilbert). 1893 . . . . . . . . . . . . . . . . . . .

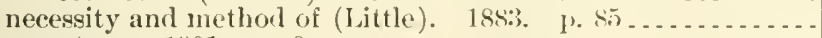

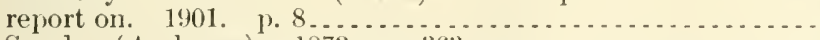

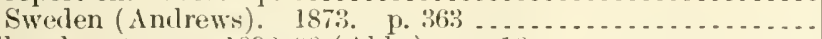

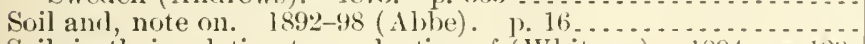

Soils in their relation to production of (Whitney). 1894. p.12\%.

Statisties of-

1865. pp. 19,73 .

Ang., 1866. P. 350

Nov, 1866 , p. 442

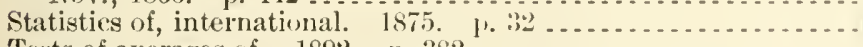

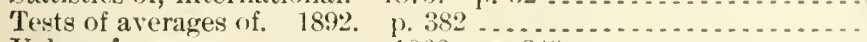

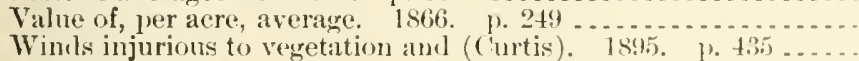

Yield of, per acre-
1864. No. 1.
1884.
No. 1. p. $28 ; N_{1}, .2$
1. 28; No. 2. 1, $20 \ldots . .$.
1885 .
No. 24.

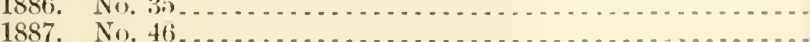

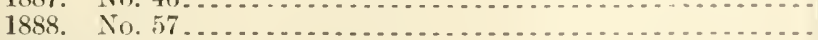

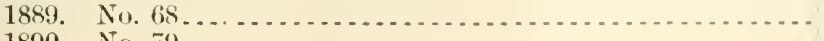
1890. No. 79 .
A27.9:3
A.7.9:2:2
A.7.5:23
127.9:2:
127.9:25
A $27.9: 26$
127.9::27
127.9:28

127.9:28

127.9:29

1 $27.9: 32$

127.9:32

127.9:2

127.9:8

1 1.10:897

A27.9:29

A $27.9: 13$

129.7:

11.8:31

1 $27.9: 25$

A $27.9: 28$

127.9:30

127.9:2

A1.8:57

1.27.9:3

A27.9:35

A1.10:895

A 1.10:896

A1.10:897

A 1.10:898

A 1.10:899

11.10:900

A1.10:901

11.10:898

A1.9:133

A 1.10:897

1 $27.9: 27$

$129.6: 26$

$127.9: 27$

110.3:222

11.8:36

1 1.9:144

A $27.9: 11$

A29.6:28

11.10:894

127.9:4

A27.9:4

127.9:4

127.9:1:3

127.9:30

127.9:4

129.3:11² 


\section{Index}

Crops-Continned

Yield of, per acre-Continned

1891. No. 90

1892. No. 99 А ...

1894. pp. 629,682

A27.9:29

A27.9:30

A27.9:32

See also Acriculture - Agrieultural problucts - Cereal arops Cereals - Climate and crop - Cover crops - Farm protucts Field crops-Forage crops- Fruit crop- Garden crops(irains - Iay - Mop crops - Market-garden crops-orchard rops-Root crops-Tobacco-and lueadings beginning ('rop.

Croshy, D.J. Agricultural colleges and experiment stations, Ameriean, sixteenth annull convention of association of 1902 , report

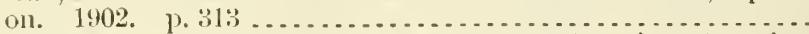

See ulso, as editor, Farmers' Inst itnte Workers, American Association of; as joint author, True, Alfred (harles.

Crosloy, J. Schuyler. Borax as a proservative of butter, letter relat-

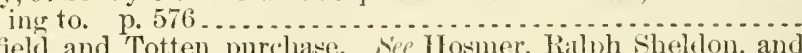

Crossfield and Totten purcluave. Nee llosmer, Kalph Shelton, and Bruce, Eugene S.

Crow blackbirds and their food (Beal). 1894. p. 233 . . . . . . . . .

Crows:

Carrion, communication of hog cholera by (Forl). p. 325.

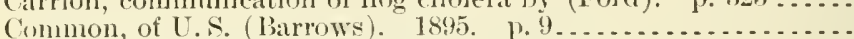

food of, special report on (Barrows). p. $498 \ldots \ldots . . . . . . . . .$.

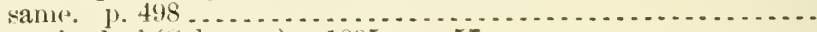

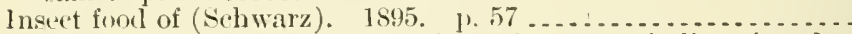

Crozier, A. A. Fungicides, effects of certain, upon vitality of seeds. 1891. 1. 8 .

C'rule fiber. tee Fiber.

Cruelty to animals, prevention of, in District of Columbia, bill rela-

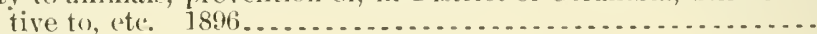

('rump, M. H1.:

Ailitress of -

hefore convention of National League for Good Roads, Wash-

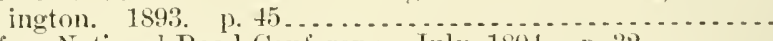
before National Road Conference, July, 1894. p. 32 . . . . . . .

Kentucky higluways, history of old and new systems. $\quad 1895$.... Crustacea of Tres Marias Islands, Mexico, notes on (Rathloun).

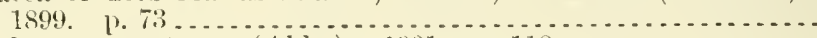

Crystals, snow, notes on (Able). 1901. 1) $118 \ldots \ldots . . . . . . . .$.

Cryptoganicglowtlss, presence of, in fluids of diseased cattle (Billings and Curtis)-

1869. p. 174 .. same. p. 156

1871

Cryptoplas unipunctata, hal)its an curlier stages of, in Australia, Cuba:

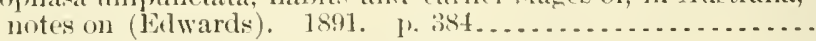

Cattle for, inspection and rertitication of. 1899.

Climate of-

also note on weather of Manila (Phillips). 1898. report on (Phillips). 18:99. p.:007.

Cocoanut palms in, diseased, report of investigation of (Busek).

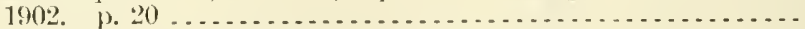

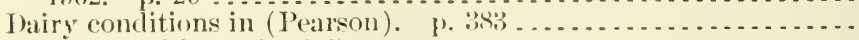

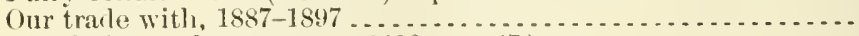

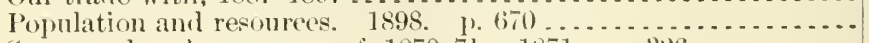

Sugar and molasses crops of, $1870-71 . \quad 1871$. p. $326 \ldots \ldots . . . .$.

Venezuelan cattle to, shipments of (illsworth). p.516.......

Sef also Firmeza - Havana.

Cuba and other islands of IV est Indies, inclustries of, value of climate and crop and storm-warning services of Weather Burean to

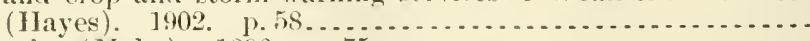

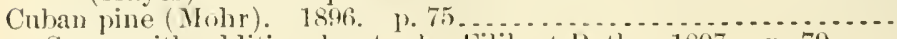
Same, with additional notes by rilibert liotl. $1897 . \quad$ p. $79 \ldots \ldots$ A $13.313^{2}$

A $10.3: 14$

12:.3:10

A22.3:13

A5.5:14

A29.6:29

A1.2:(299

11.2: $\mathrm{C}^{2} 9^{2}$

A 1.2:C $29^{5}$

A9. $7: 3$

A $4.5: 39$

A29.3:24

A29.1:898

A9.6:38

A4.1:901

A12.4:16

A 1.10:898

A $27.9: 9$

A+.1:S99 
Cuckoos, food of (Beal)

Cuckoos and shrikes in their relation to agriculture. 1598

Cucumber beetles:

Notes on (Chittenden). 1898. 1. 2.

Striped, circular relating to (Chittenden). $189 \%$

Cucurbitacese. See Roseanthus.

Cucurbits, crossing of (Pammel). 189\%. p. 94.................

Cull, Edward L.:

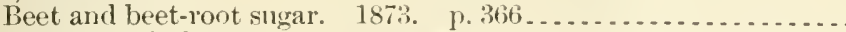

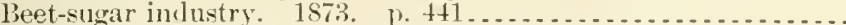

Cultivation by stean:

American inventions for (Brainerd). p. 25:3

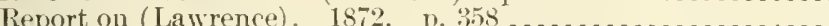

S'e also Steam cultivation.

Cultures, tubercle bacilli found in, franchert forms of (Dorset)

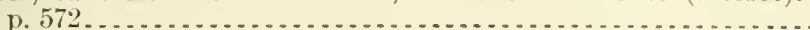

Culver, Garry E.:

Artesian-wells investigation, field geologists' rejort for North and

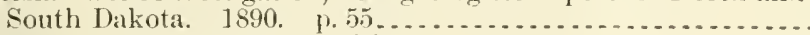

Dakota basin, genlogical conclitions of. pt. $3,1.195 \ldots . . . . .$.

Cuprous oxid. See Sugars.

Curenlio:

How to kill. 1870 .

Jarring for, on extensive scale in ficorria, with list of insect caught (Scott and Fiske). 1902. p. 24

Sé also Plum cureulio.

Curculionidie, breeding and other halitis of some species of, especially of genus Tyloderma, notes on (Webster). 1889. p. 109

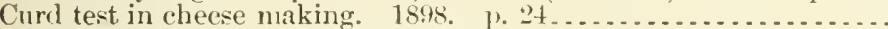

Curds, gassy and tainterl, investigations as to cance of. 1899 . I. 25.

Cureton, Stephen. Tillage and products of soil on irrigated linds. 1887. p. 282 . . . . . . . . . . . . . . . . . . . . . . . . . .

Currant stem-girdler. Report of (Marlatt). 1894. 1. $296 \ldots \ldots \ldots$

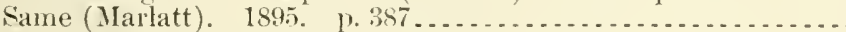

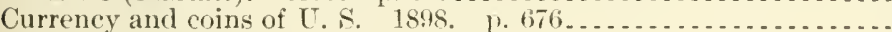

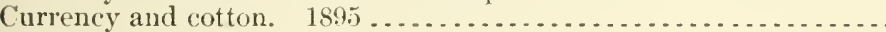

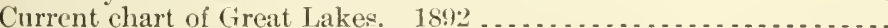

Currents:

Lake Ontario, notes on (Abbe). 1894. 1.259 ..............

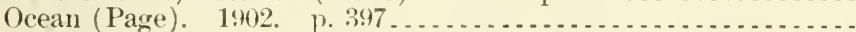

See also Japan current - Winds and currents.

Curryer, J. C. Farmers' institutes, illustration and demonstration work at 1902 o $5 \%$

Curtice, Cooper:

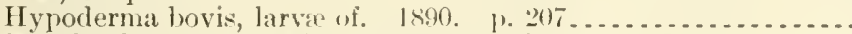

Maryland, outbreaks of sunthern cattle fever in. p. $429 . . . . .$.

Sheep, animal parasites of. 1890 . . . . . . . . . . . . . . . .

Tapeworm diveate of sheep of westerin plains. p. 167 .........

Tuberculosis among cattle, detection of. 1. 2s:3 . . . . . . . . . .

Curtis, Edward. See, as joint anthor, Billings, John shaw.

Curtis, F. D. Swine, address on. 188:3. J. 148.

Curtis, George E.:

Rainfall, canses of, with relation to surface conditions. J. INT.

Rainfall and charts of rainfall. 1902. p. $234 \ldots . . . . . . . . .$.

Winds injurions to vegetation and crops. 1895. p. 435. . . .....

Curtis, H. F. See, as joint anthor, Scovell, Melville Amasa.

Curtis, Thomas I).:

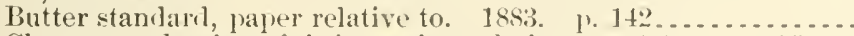
Cheese, production of, information relative to. Ist). p. 35i)...

Curtiss, Charles Franklin:

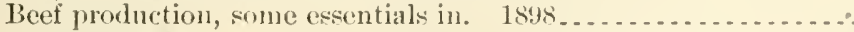

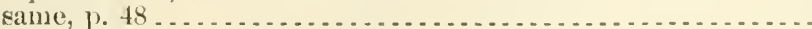

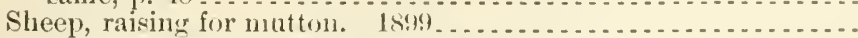

Stock-feeding experiments, significance of. 1899. ए. 116 ..... See also, as joint author, Wilson, Jannes.
15.3:9

A.5.3:9

19.6:10

A9.5:31

A.3.4:2

110.3:16

A27.9:11

A27.9:11

11.1:867

A 27.9:10

A4.1:901

A15.2: $\mathrm{Ar} 7$

115.2: $\operatorname{Ir} 7^{2}$

127.9:8

A9.6:31

A $9.7: 2$

A $1.9: 84$

11.9:92

A15.2:P94 ${ }^{1}$

A $9.7: 6$

19.7:7

11.10:898

A27. $8^{\mathrm{a}}=\mathrm{C} 82$

A29.2:C93

A:9.6:21

A29.6:30

$110.3: 110$

A $9.7: 2$

At. 1:887-8

At.2:Sht ${ }^{1}$

At. $1: 887-8$

14.1:895- 6

11.7:2

113.3:7

A:9.6:30

129.3:11

$11.7: 2$

1.27.9:8

A1.9:71

14.1:5:\%

1 1.9:96

1 10.3:65 
Curtiss, Charles Franklin, and Wilson, James W.:

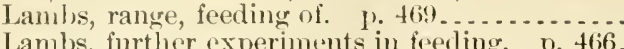

A4.1:898

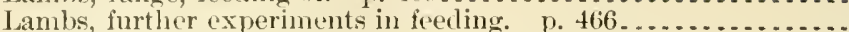

Curtiss, D. S.:

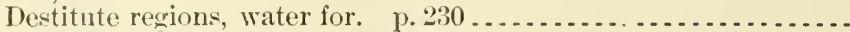

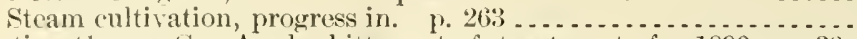

Curtiss, (ieorge C. Apple, bitter rot of, treatment of. 1890. p. 38.

Curve of confort. See Temperatures, sensible.

(ushing, (aleb). Agrieulture in Spain. p. 287

Custer County, Colorado, fungi of (Cockerell). 1889. p. $84 \ldots . .$.

Customs duties:

European, on agrieultural products. 1885. No. 18. p. 39 .....

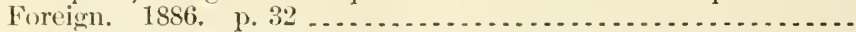

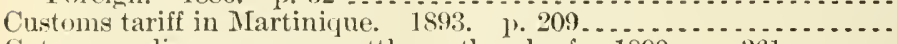

Cutaneous disease among eattle, outbreak of. $1890 . \quad \mathrm{p} .361 \ldots \ldots \ldots$

Cutlubertson, David:

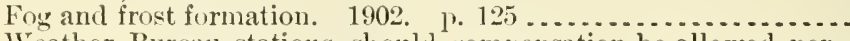

Weather Buresu stations, should compensation be allowed persons not emploved in Bureau while learning station duties to enalole them to perform such dnties in case of emergeney?

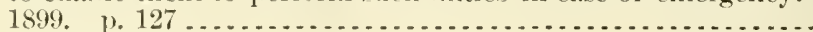

Cutter, IVilliam Parker:

Agrieultmal literature, suggested classification for. 1899 . p. 50 .

Lil)rary of Agriculture Department, work of. 1897. P. $220 \ldots \ldots$

Ruffin, Edmund; pioneer in agricultural science. 1895. p. 493. See also, for reports as Librarian, Library Agrieulture Department, $1894-1900$

\section{Cutworms:}

Anthrax frarasitic on. 1890. p. 353....................

Note on (Glover). 1875. p. 221 . .

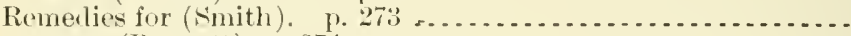
same (Benmett), P. 274.

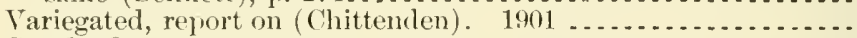
See also Cotton cutwoln.

Cycles, chronologicarl, note on (Abbe). 1900. P. 55T.

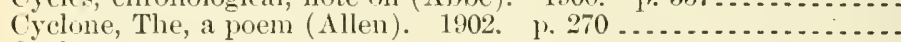
Cyelones:

Development and movement of, as shown in morning and evening weather matps, $\Lambda$ pr. 2-6, 1892 (Marvin). 1893.

llurrieanes, tornadoes, and (Bigelow). 1898. p. 525..........

Martinique, of Aug. 18, 1891. p. 185....................

Mauritius, of Dec. 5, 1897 (Claxton). p. $62 \ldots \ldots \ldots \ldots$

Nicaragua, report on (Claney). 1897. 1. 356 ..............

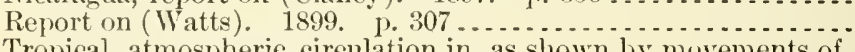

Tropical, atmospheric cireulation in, as shown by movements of clouds (Boyer). 1896

Warm regions in (Abbe). 1894. P. 77

West India, wind direetion at different altitudes around (Boyer).

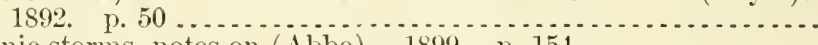

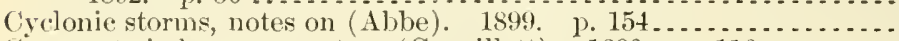

Cypress twig borer, report on (Coquillett). 1890 . p. $116 \ldots \ldots \ldots$.

Cyprinus carpio. Sée Carp.

Cyrtoneura cesia, is [it] an injurious insect? (Coquillett). 1895.

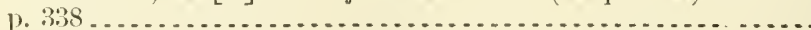

Dalney, Charles William, jr.:

Agrieultural and other eolleges and national defense. 1899.

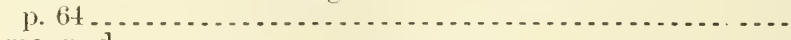
same, n. d.............. Civil service in Department of Agriculture. 1897 .
Cotton plant, its listory, botany, etc. introduction to report on. 1896. p. 13 ... . . . . . .

Grain rusts, letter of inquiry relative to, ete. $1894 \ldots . . . . . . . .$. Seientific work of Agriculture Department. 1895. p. 63 ....... Southern agriculture, progress of, address on. $1896 \ldots . . . . . . .$. See also, as editor of proceedings, 1885, Chemists, Official Agrieultural, Association of. 
Dabney, John Charles. See, as joint authior, Hicks, Gilbort IIenry. Daily river stages . . . . . . . . . . . . . . . . . . . . . . . . . . . . . Dairy:

Awarls for $U^{T}$. $A$ at l'aris Exposition. 1900. 1. 7:34

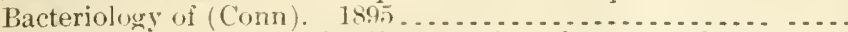
By-products of, profitable disfesal of, at factory and on farm. 1898. [. 20 .

By-products of, utilization of (Alrord). 189\%. 1. 509.

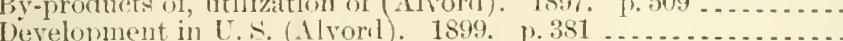
same, 1. 244 .

Interests of Alabama, (reorgia, Illinois, Indiana, and Ohio in ('erry). p. 33.95

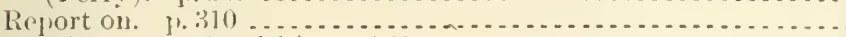

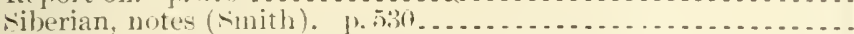

Statistics of, Aericulture l)epartment, report af-

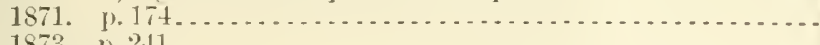

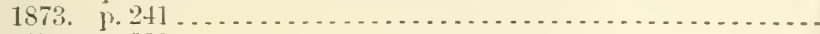

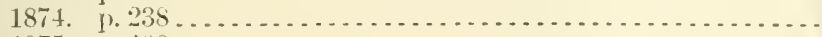

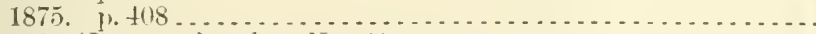

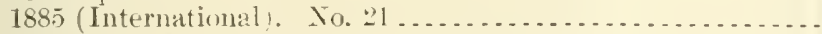

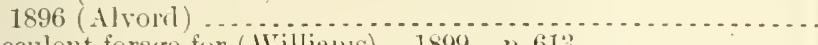

Succulent forage for (IVilliams). 1899. p.613........

Utensils of, care of (Puarson). 1\$96. p. 431 ..............

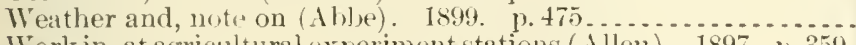

Work in, at agricultural experiment stations (Allen). 1897. 1).359.

See also Creaneries- l)ecrioot farm centrifugal dairy.

Dairy breeds of cattle:

Conformation of beei caltle and (Soul..), 1902...............

lieport on (Aliord). p. 137 . . . . . . . . . . . . . . . . . .

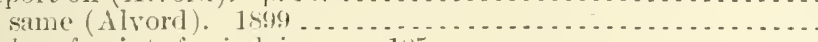

Sirales of points for judering. 1. 1

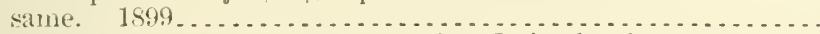

See rlso Beef and dairy cattle-Cattl-Dairy heri.

Dairy building. , see Biological and rlairy builuling.

Dairy Division, Iericulture Department. For publications of this Division se Inimal Industry Bureau ..................

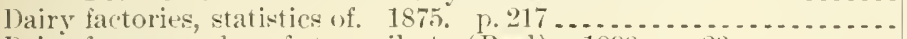

Dairy farmer, value of stave silo to (Beal). 1898, p. 2: ..........

Dairy farming:

Adrlress on (Loring). 1882. 1). 91.

Report on, witl sone acconnt of fam of the writer (I'ratt).

Dairy lierl:

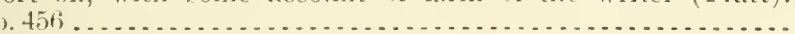

Cooperative tests (Jhelus). 1901. 1. 120.

Formation and management (Alvori), 1894 , p. $295 \ldots \ldots \ldots \ldots$

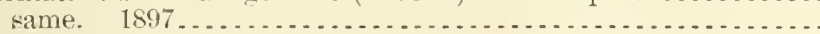
bie also Cattle - Dairy breeris of cattle.

Dairy hushandry in northern Illinois. 187t. 1. 159.

Dairy industry:

Dennark, irogress, report on (Georgeson). 1893.

Missouri and Kansas (Chubbuck). 1897

Nebraska, South Dakota, and North Dakota (Monrai). $1896 \ldots$ Porto Ri(n, with notes upon St. Thomas and Cuba (Pearson). p. 306.

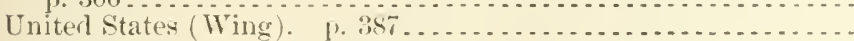

Dairy laws, national and State, in full, 1897 (I'earson). 1.,531 ....

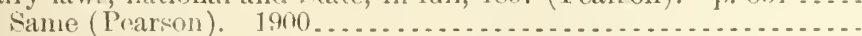

Dairy oflicials, list of-

1898. 1. 610

1899. \%. $68 \mathrm{~S}$

1900. p. $6+4$

1901. p. 1923

Dairy products:

Adulteration of-

1887

1893 (Brown)
129.10 :

11.10:900

\10.3:25

A 1.9:8t

1 $1.10: 897$

11.10:899

14.1:899

14.1:885

11.1:870

At. 1:899

A1.1:871

11.1:873

A1.1:87t

11.1:875

1.27.9:23

A $4.3: 11$

11.10:899

1 1.10:896

129.6:27

110.6:8

11.9:143

14.1:698

A1.9:106

14.1:898

14. $4: 27$

$14:$

127.9:18

11.9:10\%

11.8:2:2

11.1:865

A10.3:99

1 $1.10: 594$

$11.9: 55$

127.9:12

11.8:50

$14.3: 5$

14.3:18

14.3:16

14. 1:901

14.1:887-8

14. $1: 597$

14.3:26

1 1.10:898

A 1. 10:899

1 1.10:900

A1.10:901

17.3:13

A7.3:41 
Dairy products-Continued

Inalysis of, provisional methorls for (Le Cler"). 1902. 1\% 35 .. vee also Chemical analysis, methods of.

Foreign markets for (1)olge). 1890 . p. 626

17.8:65

Foreign trade in, threatenerl. 1890. p. 34 .

A27.9:28

$127.9: 28$

Inspection and marking for export, rules and regulations. (bet. 30,1901

Legall and state standards for-

1898. H. 666 .

1894.9752

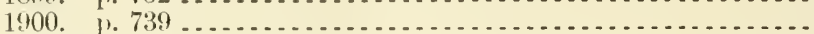

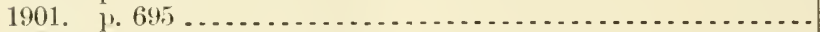

Paris Exposition of 1900 (Alvoril). p. 599 ..................

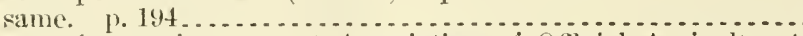

leport of committee on, at Association of Official Agriculturai Chemists-

\begin{tabular}{l}
1887. \\
1888 . p. $12 \ldots \ldots \ldots \ldots \ldots \ldots \ldots \ldots$ \\
\hline
\end{tabular}

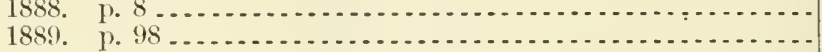

1890. p. 29

1891. p. 16

1892. p. 7

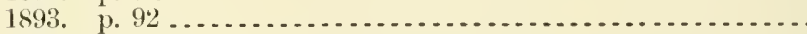

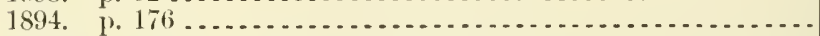

1895. p. 122 .........

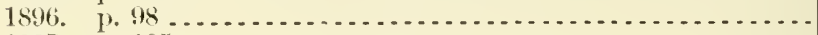

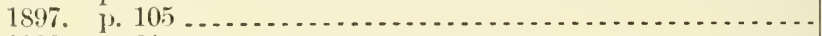

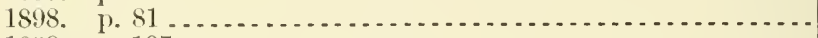

1899. p. 107 ......

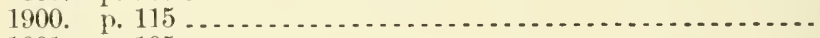

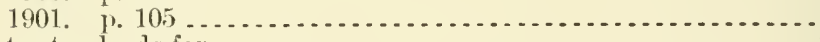

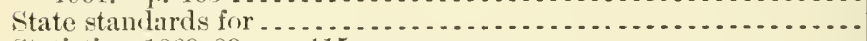

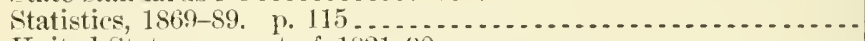

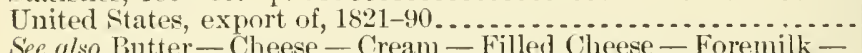

See also Butter-Cheese - Cream - Filled Cheese - Foremilk-
Market milk - Milk - Pasteurized cream - Renovated butter.

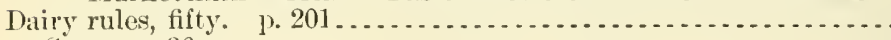

Same, p. 36.

Same (placard)

Dairy salt, study of rarious brands (I

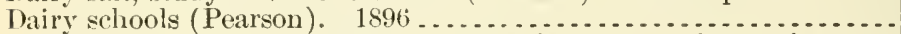

Dairy tests at World's Columbian Exposition, report of committee on

Dairying:

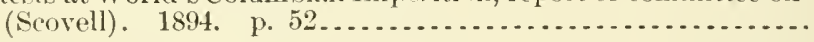

Abstracts of reports of agricultural experiment stations on. $\quad 1889$ 1902 .

\section{American-}

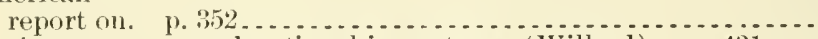

rise, progress, and national importance (Willard). p. $431 \ldots$

Associater, in New England (Myrick). 1.375..............

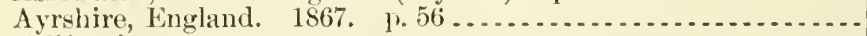

California-

notes upon (Pearson). p. 266.

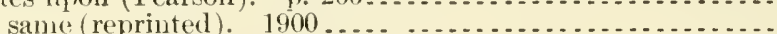

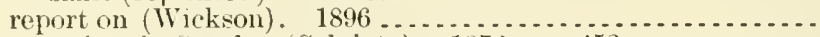

Cooperative, in Sweden (Salviate). 1872. p. $452 \ldots \ldots . . . . .$.

Condition of, in principal dairy States for season of $1885 . . . . .$. .

Directory of departments, boards, societies, colleges, and other organizations in interest of. 1885.

English and American, their points of difference and comparative

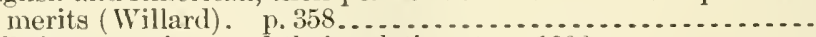

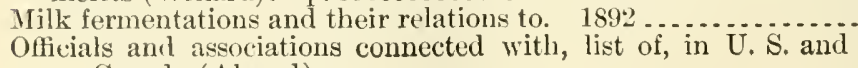
1896 Canada (Alvord) -

1897

1898

A 4.5:91

A1.10:898

A $1.10: 899$

A1.10:900

A1.10:901

A $1.10: 900$

14.1:900

A7.3:16

A 7.3:19

A 7.3:24

A 7.3:28

A7.3:31

A 7.3:35

A7.3:38

A7.3:48

A 7.3:47

A7.3:49

A 7.3:51

A7.3:56

A7.3:57

A 7.3:62

A 7.3:67

A4.4:25

A $27.9: 32$

A1.2:D14

A4.1:898

A1.9:63

A4.2:D14

A 1.9:107

A4.3:17

A10.3:20

A10.6:

A1.1:869

A1.1:865

A4.1:887-8

A 27.9:5

A4.1:899

A4.3:24

A 4.3:14

A27.9:10

A1.8:41

A1.8:39

A1.1:866

A1.9:9

A $4.4: 10$

A 4.4:18

$\mathrm{A} 4.4: 22$ 
Dairring-Continned

Officials and associations connecterl with, ell.-Continued

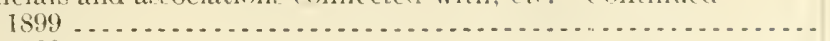

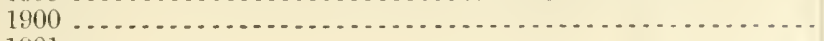

1901

1902 .

Review of recent work on (Allen). 1895. pp. (it3, 104:3 . . . . .

scotland (Higgins). p. 213 ....... . . . . . . . . . . . . . .

South (Tracy). 1902 ..

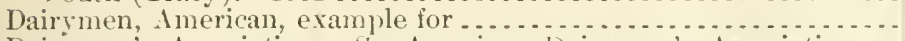

Dairymen's Association. See American Dairymen's Asociation New York Dairymen's Association.

Daisy. See Oxeye daisy.

Dakota:

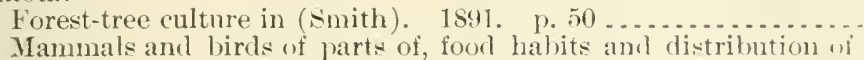
(Bailey). p. 426 . same. p. $426 \ldots \ldots \ldots \ldots$

Tree planting on plains of, experience in. 1891. p. th .......

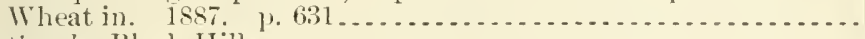

see ulso Black Ilills.

Dakota basin, geological conditions of (Culver). pt. 3. P. 195.....

Dakotak, two:

(ertain elimatic features of (Finley). 1893.

(irasses and forage julants of (Williams). $1897 . \ldots . \ldots . . . . . .$.

Dall, William Healey. Agricultural resources of Alaska. 1, 172...

Dallas, W. ... :

Climatology of southern and western Asia. 1896. p. $672 \ldots . .$.

Cyclical changes in India, preliminary discussion of. 1897. p. 5.:2.

Droughts in India, prediction of. 1894. p. 13...............

IIonsoon region, Indian, upper currents of air above. $1896 . \mathrm{p} .417$.

Daly, Reginald A. Ice drift and theory of ocean currents. 1900. p. 433

Daneing dervishes or lust whirls (Kimball). 1902. p. $316 . \ldots \ldots$

Dancy, F. B. Fertilizers containing cottonseed meal, report un determination of available phosphoric acid in. 1890. p. $161 \ldots$

Daniel, John liarwick. Roads, gool, the question of the hour. 190:.

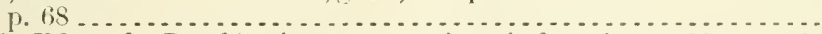

Daniels, Edward. Road lmsiness, a question of ellucation. 1901. 1.66. Dansey's (Captain) kite for stranderl vessels (1 bbe). 1897. p. 2066. Darlington, $15 \mathrm{~m}$. Weeds of American agriculture. p. 509........ Darlington, Md., roarl league, origin and work of. $18: 15 \ldots . . . . .$. Darmstadt, (rermany, experimentstation, report on (Lindsey). 1s:4.

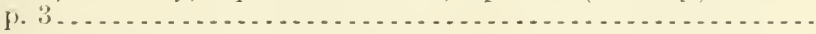

Cultivation of (Porstel). 1883. p. 25 ..................

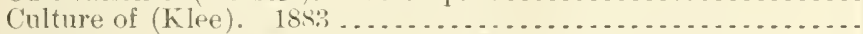

Date line in Pacific Ocean (Page). 190:2. p. $363 . . . . . . . . . . .$.

Date palm:

Climatic data bearing upon ('ulture of (Henry). 189. J. 160...

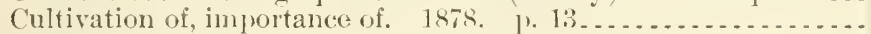

Date palm and its culture (Swingle). $19100.11 .453 . . .6 . . .$.

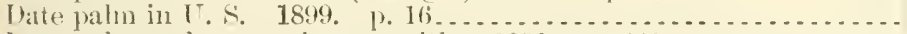

Date-palm scale, experiments with. $1891,1 \%+41 \ldots \ldots \ldots \ldots$

Daugherty, Charles 11 . Cotton-seed industry. 1901. 1. 285......

Daugherty, J. s. Adilress of, before gool roads convention of

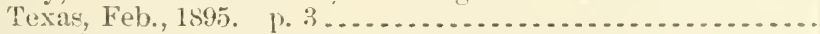

Davenport, Eugene:

Feerl, coarse, necessity of, to grow cattle. p. $202 \ldots \ldots . . . . . . . .$.
Rural life, what "an agricultural colleges do to nomrish al hearty

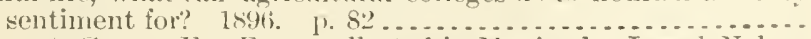

Davenport, (Feorge E. Ferms collecterl in Mlexieo by Joseph Nelson Rose dluring months of $A$ ugust and Septenber, 1847. 1899.

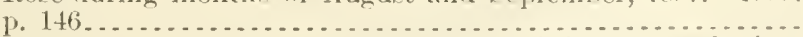

Davidson, Rachel J. Rural road naming and house numbering.

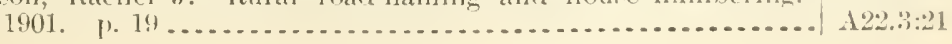

1.4:26i

14.4:2!

At.4:3:3

A $4.4: 31 ;$

110.6:5

14.1:898

A 1.9:151

112.4:4

$113.3 \% 5$

11.1:

1.5.1:887

A 13.3:5

A $27.9: 25$

A15.2:Ir ${ }^{2}$

A29.2:D14

A 3.3:6

A 1.1:868

A29.3:113

129.6:25

A 29.3:11 1

A 29.6:24

A29.6:28

A $29.6: 30$

$17.3: 28$

$122.3: 23$

A.2.:3:21

129.6:2.5

A1.1:865

A22.4:17

A10.6:-

A1.8:24

A 1.8:24

A29.6:30

A2!?.6:26

A1.6i:t

A1.10:900

A $1.9:(1) 2$

A $1.7: ?$

A1. I0::901

A2.23:15

14.1:ล:

110.3:41

16.5:5 
Daridson, S. P., long record of, note on (Abbe). 1900 . I. $450 \ldots \ldots$ Davis, Arthur Powell. Rainfalland temperature in Nicaragua. 1898.

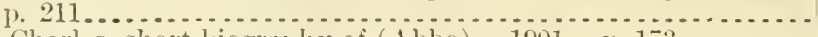
Davis, Charles, sholt Jiograplyy of (Abbe), 1901. p. 173....... Davis, (i. C.:

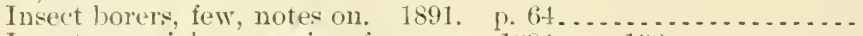
Insects, special economic, of season. 1sit. $13.198 . \ldots . \ldots . .$. Mealy buss and their allies. 1894. p. 168................ Davis, (Iliss) J. A.:

Agricultural experiment stations, general statistics of. 1809.

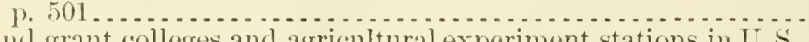
Land grant colleges and agricultural experiment stations in T.S., statisties of, for year ended June 30,1899

Davis, (Mrs.) Lavinia 15 . Female life in open air. p. $430 \ldots . . . .$.

1havis, Robert IV. Address of, before Jefferson memorial and inter-

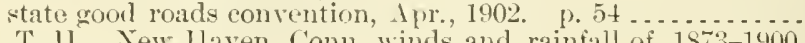

Davis, T. 11. New Ilaven, Conn, winds and rainfall of, 1873-1900.

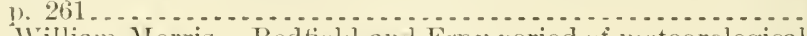

Davis, William Morris. Redfeld and Espy period of meteorological

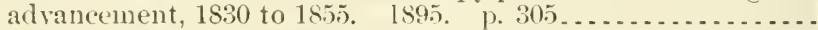

Davison, George Millard. Meteorologs, elementary, talk on. 1599.

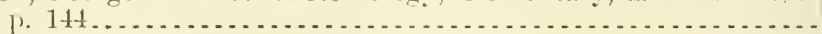

Dary, Joseph Burtt:

IIorticultural herbarium, making of. 1900. 1. 93 ........... Stock ranges of northwestern California, notes on grasses, for-

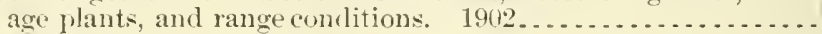

Dary, Iarié:

Ëurope, meteorological phenomena in, Jan, and Feb., 1864.

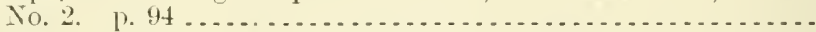
Meteorology and growth of beet. 1879. p. 284 ..............

Dawley, F. F. Farners institute worker, requisites of a good.

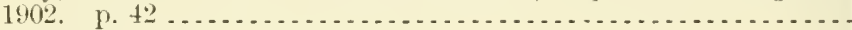
Dawson, Charles Francis:

Asthenia in fowls. p. 329 .

Microorganismal diseases, laboratory methods for diagnosing of

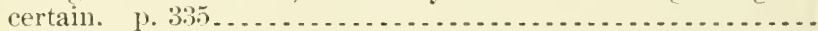

Milk and its products, pathogenic bacteria in, vitality and retention of virulence by certain. p. 2.24 ...................

See rlso, as joint author, Moore, Veranus A. - Smith, Theobald.

Day, Charles M. See, as joint author, Faville, George C.

Day, J'. C. Weather of the month, July, 1900 Same, July, 1901 .

Day wages. Siee Wrages.

Deakin, Alired. Anstralian report on American irrigation, 188t-85.

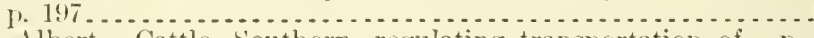

Dean, Albert. Cattle, Southern, regulating transportation of. $p$. 399 ... . . . . . . . . . . . . . . . . . . . . . . . . .

Dean, R. H. Climate, influence of, on animal life. 1902. p. 107 ..

Dean, Seneca. See, for reports as Superintendent, Seed Division, Agriculture Department, 1868-1879 . . . . . . . . . . . . . . . .

Death by lightning, apparent, directions for procedure in case of. 1894.

Death Valley, Cal:

Climate and meteorology of (Harrington) 1892 ............

Noetuidat from, descriptions of (Smitl), 1893. p. $328 \ldots . . .$.

Pyralide from, descriptions of (Fernald). 1894. [. $255 \ldots \ldots \ldots$

Death Valley experlition, 1891:

Biological survey of parts of California, Nevada, Arizona, and Utah, 1891. Part 2. 1893. [Pt. 1 not pul)lished.] ........

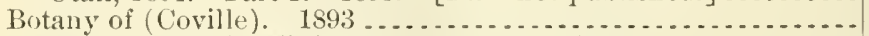

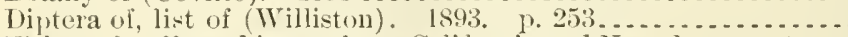

Fishes of, collected in southern California and Nevada, report on, with descriptions oi new species (Gilbert). 1893. 1. 229 ...

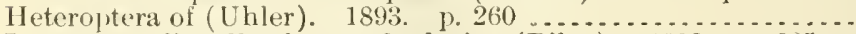

Insects, small, collection made during (Riley). 1893. 1). 235...

Land and fresh-water shells collecterl in Cálifornia and Nevada

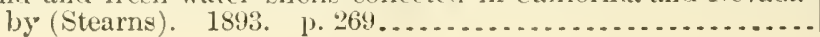

C'lassifleation no. A $29.6: 28$

A29.6:27 129.6:29

19.7:4

A.9.7:7

A $9.7: 7$

A $10.3: 80$

1 10.3:78

A 1.1:866

A22.3:25

129.6:30

A29.3:1] ${ }^{2}$

129.6:27

A 10.3:76

$\$ 19.3: 12$

+27.9:2

A1.6:28

A10.3:110

A 4.1:898

A $4.1: 598$

A $1.1: 898$

A29.6:28

A29.6:29

A 15.2: $\operatorname{Ir}^{-1}$

A 4.1:889-90

129.3:31

A24.1:

A1.10:\$94

A29.3:1

A9.7:5

A9.7:6

A5.5:7

A $6.5: 4$

15.5:7

A 5.5:7

A5.5:7

A5.5:7

A5.5:7 
Death Valley expedition, 1s91-Continued

Lealities visited hy, list of (Palmer), 1s93, p.361 ..........

Ornithology of, conimprising notes on birsis obsersed in southern California, suthtern Nevada, and parts of Arizona and Ctal,

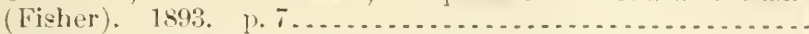

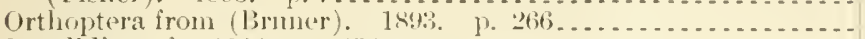

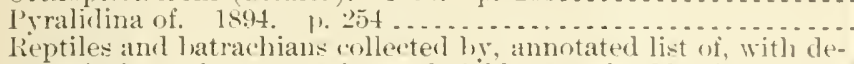
sriptions of new species and firid notes by Merriam (-iejneger). 1893. 1. 159

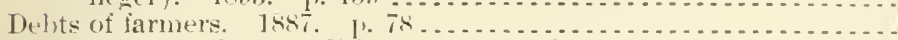

Decomber, weather conditions for. monthly statement of arerace

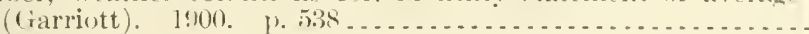

Deriduous fruits. Sip Fruits.

Decimalsytem of weightsand measures (Johnson). 186t. No. t;. y. 20.

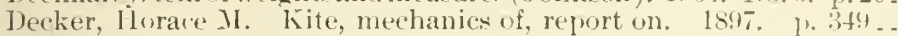

Deeroix, E. Ejizonticcatarrh, information relativeto. 187:3. [?. 180. Dertiell stock fitrm, Frencer Islank, Butler County. Kans., fatal outloreak of southern cattle fever at (Fullinwider). I. $40.3 .$.

Deerfoot farm centrifugal dairy (Sturtevant). p.629 .......... . Deerskins, exports of, from British Colmmlia (Smith). p). 519 .... De Chequier, 1. Commercial fertilizers, sale of, miformity in lexislation with regard to, views on. 18s.5. p. $46 \ldots . . . \ldots . . .$.

De Hart, D. E. Arliless of, before national road conference, July,

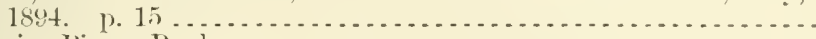

Dehérain, Pielre Paul:

Nitrification in arable soil. 1896. plo. 35.3, $491 \ldots \ldots \ldots \ldots \ldots \ldots$.

Peronospora, milk of line as remesly for, account of visit of, to Italian vineyards treated with. is\$6. P. $75 \ldots . . . . . . .$.

Plants, wrganic matter in, origin and formation of. 1s9s. p. 403.

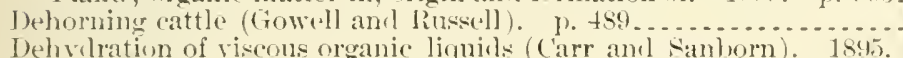

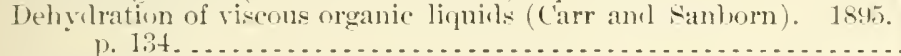

De Kay, Charles. Berlin, fiemany, cost of hanling fam iroturets

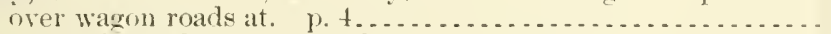

De Lafitte. Sr Lafite, I'rosper le.

De Lagerleim, G.:

Fungi, new species of, from Sorth and Fouth Americat, observa-

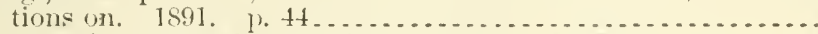

Fungus of potato scab), remarks on. 1sil. 1. $1013 \ldots \ldots \ldots \ldots \ldots$

Puccinia and Phragniclimm, relationship of. 1891. p. $111 \ldots . .$.

De lamanon, (i. Atmosphere, flux and reflux of. 1s9s. I1. $463 .$.

Delaware:

Anthax combating in (Neale). 1) 190 . . . . . . . . . . . . . Entomolowical notes from (Sanderson). 1902. 1. $97 \ldots . . . .$. Farm resinress and prodnets of. 1868. I\% $21 \ldots \ldots . . . . . .$. Famer' institute work accomplished in (Webl). 19(02. 1. 17. Inverts in, notes on (Sanderson). 1900. p.66............. l'leuro-puemmonia, ('ontagious, outbreak of. p. $4+\$ \ldots . . . . . . .$. Roarl improvement in, extract from governor's messige (Tumnell). p. 3. . . . . . . . . . . . . . . . . . . . . . . .

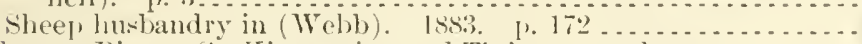
Delaware River Sie Kingsessing and Tinicum mealow.

Del Monte, Enrique. Climatology of Ilavina, Cuba. 184s. 1). 15:Deming, E. W. Sorghmm sugar "xperiments at Comway springs:

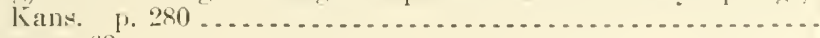

Demography. Se laris, temtl international romeress of hygiene and demograpliy.

Demonswy, Emile. Gilignom Aericultural Fixperiment Station, in-

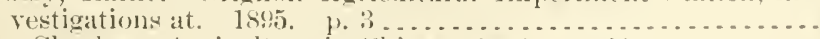

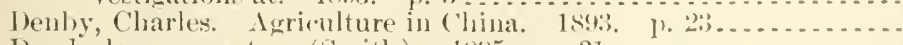

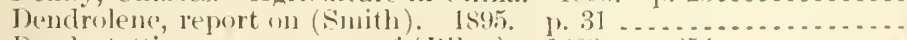
Denclrotettix, gemus, report wi (Riley). 1893. p. 254...........

Denison, Texas. Grapevius treatment for downy milelew at, with

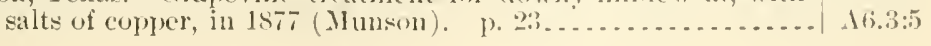

1:4.7:6 


\section{Index}

Denuark:

American boots and shoes in (Blom). 1900. p. $521 \ldots \ldots . . .$.

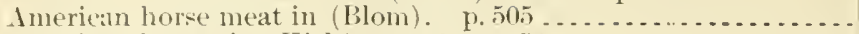

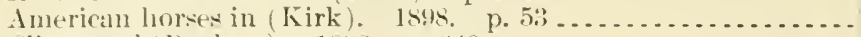

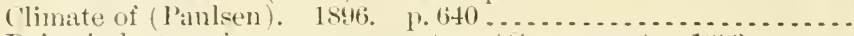

Dairy industry of, progress report on (cteorgeson). $1843 . . . .$.

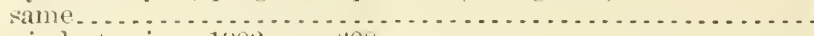

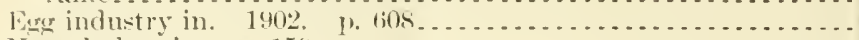

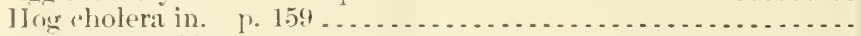

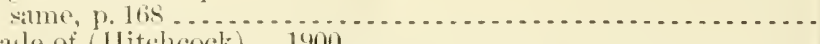

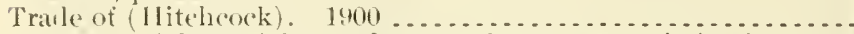

Temmis, J.... Water rights under Canala northwest irrigation act.

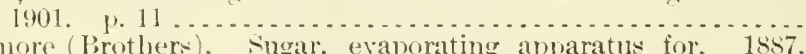

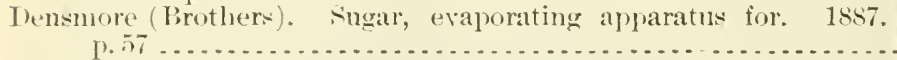

Denson, lee $A$. Weather forecasts, ronble olservation as a means

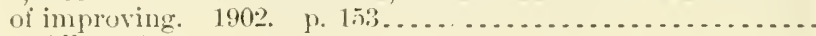

Denton, Albert A.:

Sorglum culture at Sterling, Kans. 1891. p. Ts............

Sorghum sirup, manufactmre of. $1894 . \ldots . \ldots . . . . . . . . .$. same. 1901

Sterling, Kans, sorghum sugar experiments at-

1s: $\quad$ p.

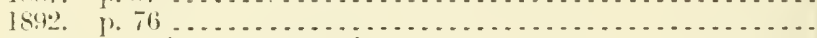

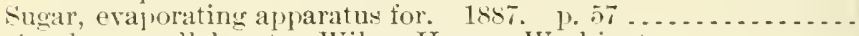
see ulso, as collahorator, Wiley, Harvey Washington.

Denton, Allert A., and Crampton, C. A.:

Sorghum, experiments with, at Sterling Experiment Station-

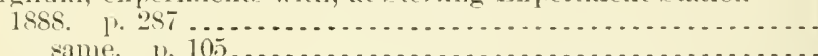

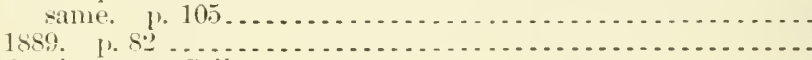

Dentrification. See Soils.

Ienver, ('olorarlo:

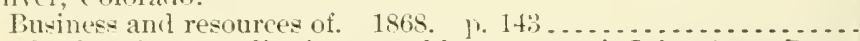

Weather forecast district, monthly reports of, July, seprt.-Dec..

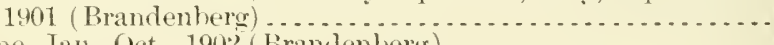
same, Jan, -ret., 1902 (Brandenlerg) .....................

Denza, P. Franceso. Meteorology of Italian momtains. 1896. 1).

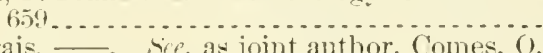

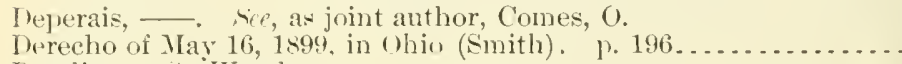

Derelicts. See IV reels.

De Riemer, Alicia, and Abbe, Cleveland. Hail, arerage frequenty of

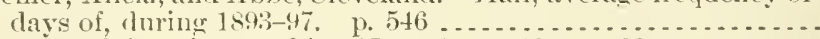

Dermestes vulpinus in goatskins (Jones). 1859. p. $69 . . . . . . . .$.

Dermestidie, herhivorons habits of certain (chittenten). 1845. P.

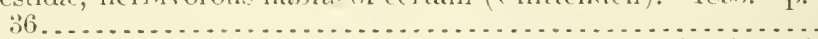

De Roode, Rudolf J. J. Commereial fertilizers, determination of phosphoric aril and nitrogen in, in same reighed guantity of

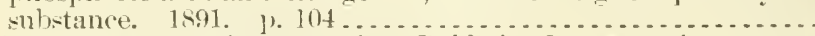

Des Lignes sugar experiment station, Baldwin, La., experiments at,

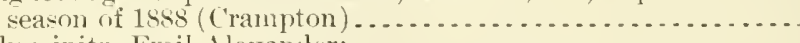

De schweinitz, Emil A lexancler:

Animals, riseases of, results of chemical investigations for preven-

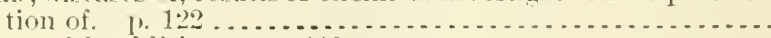

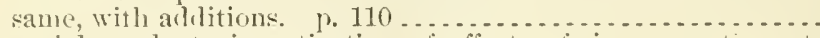

Bacterial products, investigation of effects of, in prevention of

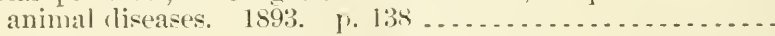

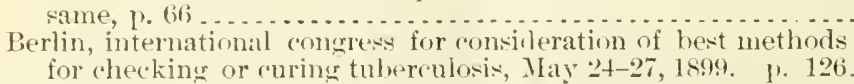

Biochemic laboratory, investigations concheted by1892. P. 119

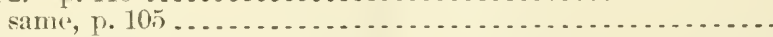

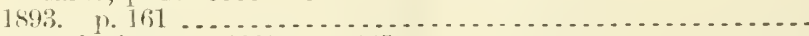

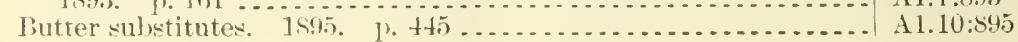


De. Schweinitz, Emil Alexander-Continued

Cormsta!k disease in cattle, comstalks presumahly ('anse of, chem-

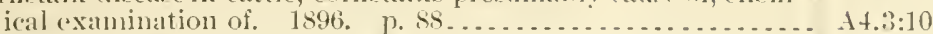

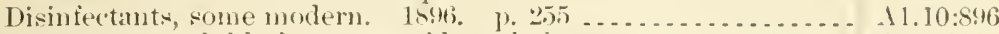

Enzymes, or soluble ferments, of hog-cholera germ. 11.266 .... 14.1:\$9s

Guinea yigs, production of immunity in, from hog cholera by use of blood serum from immunified animals. 11. $269 . . . . . . . .$.

Iowa, hog cholera and swine-plague investigations in. J'relimi-

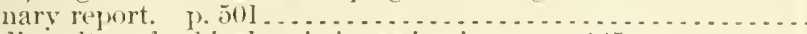

Media culture for biochemic investigations. $[1,145 \ldots \ldots \ldots$.

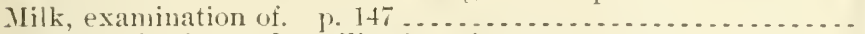
pasteurization and sterilization of. 1894. 1. 331 ..........

Paris-

tenth international congress of hygiene and clemography, hold

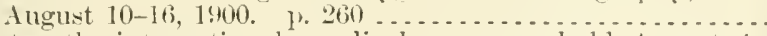
thirteenth international medical congress, held Angust $t$,

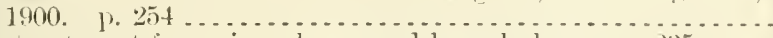

Serum treatment for swine plague and hog cholera. T. 235..... same, with collaboration of Jlarion Dorset and F. C. Schore-

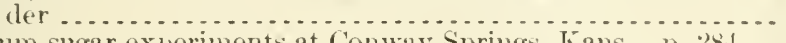

Sorghum-sugar experiments at Conway springs. Kans. p. 2N4...

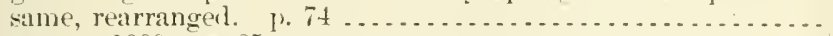

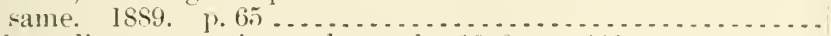

Tuberculin, preparation and use of. 184s, p. $111 \ldots \ldots \ldots \ldots$

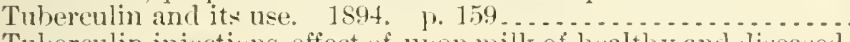

Tuberculin injections, effect of, upon milk of healthy and iliseased

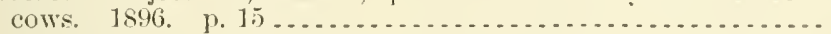

Tuberculosis bacillus-

attenuated, its use in prorlueing immunity from tubereulosic

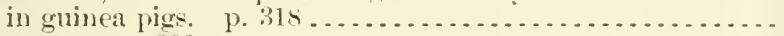

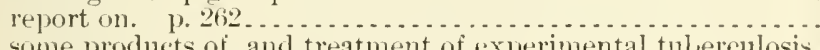
some products of, and treatment of experimental tubereulosis

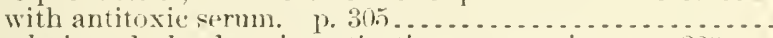

Tuberculosis and glanders, investigations concerning. jo. $289 . .$. De Schweinitz, Emil Alexander, and Dorset, Marion:

Tuberculosis bacilli-

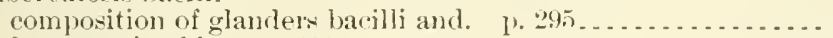

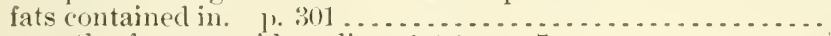
growth of, upon aeid media. 1896. p. 7............... mineral eonstituents of. p. 302 . . . . . . . . . . . . . . . . . . . .

De Schweinitz, Emil Alexander, Emery, J. A., and Cameron, F. K. Tobaceo powders and extracts, nicotin in, report of investigation of nethork for determination of. 1s:s. p. $113 \ldots . . .$.

14.1:898

$14.1: 899$

$14.1: 849$

$14.1: 899$

$11.10: 8: 4$

$14.1: 900$

A $4.1: 900$

$14.1: 898$

$1+.3: 23$

11.1:888

17..2:20

17.:3:26;

$11.10: 598$

$14.3: 7$

$14.3: 13$

14.1:598

$1+.1: 900$

$1+1: 898$

A 4.1:898

14.1:898

At.1:598

14.3:13

14.1:898

$17.3: 56$

De Schweinitz, Emil Alexander, and Schroeder, Frnest C.:

Bovine tulerculosis bacillus, virulence of, for monkeys, and effect of tuberulins made from tubereulosis baeilli derived from

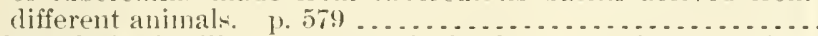

Tuberculosis hacillus, attenuated, further experiments with.

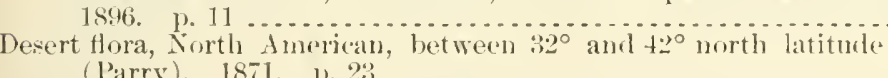

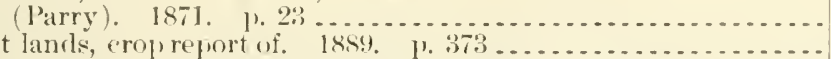

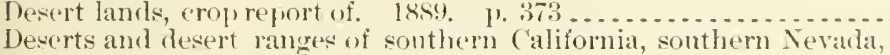
northwestem Arizona, and sontliwestern Ctalı; actuses. yadcas, and agase, geographic and vertical distribution of (Merrian). 1s:3\% p. 345 ... . . . . . . . . . . . . . . .

Same, trees and shruhs in, distribution of (Merriam). 1893. I.

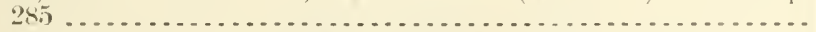

Desiccation of fruits and regetaliles (Watts). 1875. 1, 507 ......

De Soto hoge of Louiviana. 1883. No. 64. ]16............

Destitute regions, water for (Curtiss). p. $230 . . . . . . . . . . . . .$.

Sie also Arid regions.

Detmer, W. Moisture, temperature, and light conditions, influence of, on process of germination. 1845. $11.405 \ldots \ldots \ldots \ldots$

Detmers, II. J.:

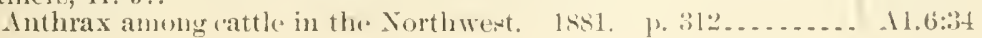


Detmers, II. J.-Continued

Enzoütic cerehro-meningitis among luores in: Texas. 1852. [. 363.

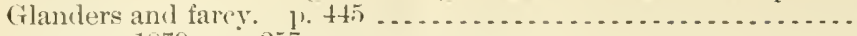

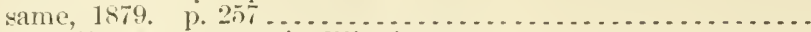

Ilorses, cliseases anong, in Illinois. 1851. p. 35\%.

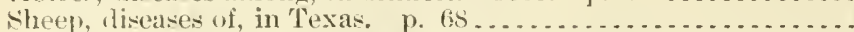

Southern cattle fever, investigation of. p. 42 ti ............

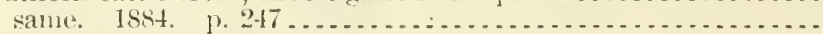
swine-plague, investigations of-

(1st report), 1878. p. 321

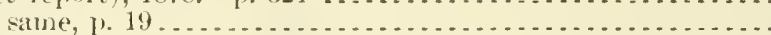

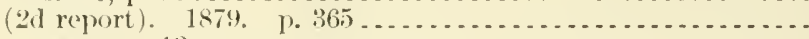

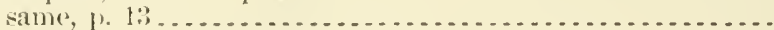

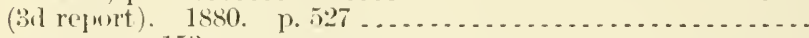
salne, p. $153 . \ldots . . . . .$.

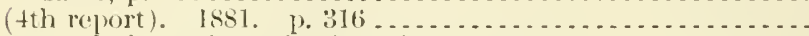

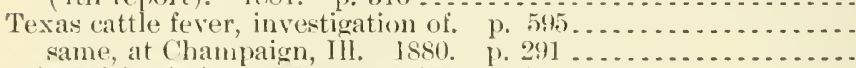

Detroit, Mich., halo at, May, 1900 (Hooper). p. 202 . . . . . . . . . .

Deutsche Scewarte, Handlooks of, notes on (Ables). 18st. P. 401.
De Vilmorin, Henry L. Plants, cultivated, seleetion and its effeets

Devoe, W. S. Pleuro-pneumonia among cattle in Kansas, outbreak

of. p. 322 . Suyst, Paul. See Vust.

Dewey, C. Frank. Hungarian milling, rejort on. 189:3. J. $38 \ldots .$.

Dewey, hyster Hoxie:

Caimplior tree, cireular on.

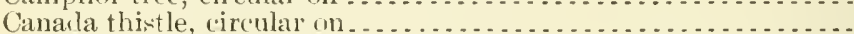

Dodders infesting clover and alfalta, circular on. 1898 ........

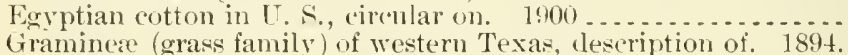

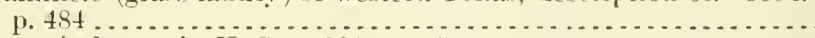

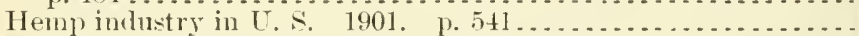

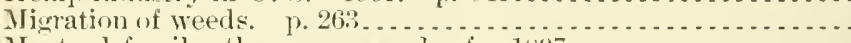

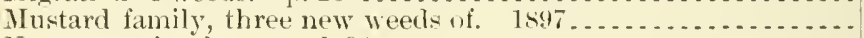

Nut grass, eireular on. I894............................

Russian thistle-

circular on.

history as a weed in $\mathrm{U}$. S., with an aecount of meansavailable

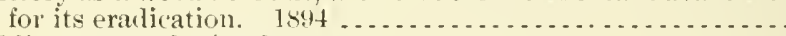

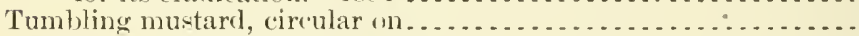

Tegetation, characteristic, of desert region from western Texas

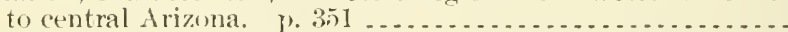

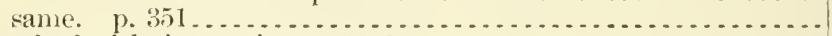

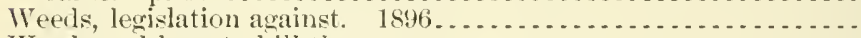

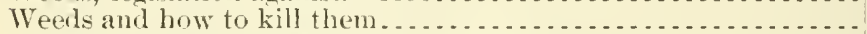

Weeds in cities and towns. 1898. p. 19:3 ..............

Wild garlic, circular on . . . . . .

Dew-point:

Relative humility, ete, tables for obtaining temperatureof. 1897.

Tables of, observed at Honolulu (Lyons). 1899. p. 587 ......

Temperature of, pschrometric tables for obtaining (Marvin). 1900

Value of, in foreeating weatler under certain conditions (Wool). 1902. P. 152.

Sep also Vajor pressure.

Dexter, Edwin tirant. Conduct and the weather, report on. 1899.

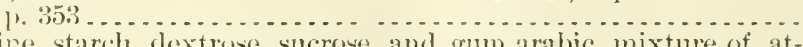

Dextrine, starch, flextrose, sucrose, and gim arabic, mixture of, attempt to analyze (Krug). 1894. [. $167 \ldots \ldots . . . . . . .$.

Dextrose. Soe Dextrine.

Dialıotica soror, rlipterous parasite of (coquillett) 1890 . T. 233 ....

Diabrotica 12-punctata:

Habits and life history of (Riley). 1891. p. 104 . . . . . . . . .

Observations on (Quitintance). 1000. 1. 85...............

. $85 . . . . . . . . . . . . .49 .6: 26$

A $1.1: \$ 81,582$

A $1.1: 878$

A 1.6:12

A1.1:881,882

A1. 1:858

A $4.1: 884$

A $4.2:$ : 5

A 1.1:878

A 1.6:12

A 1.1:879

A $1.6: 22$

A 1.1:880

A 1.6:34

A 1.1:881-2

A 1. 1:880

A 1.6:3t

A 29.6:28

A $29.6: 25$

A10.6:11

A4. $1: 895-6$

Aะ7.9:31

A6.4:12

A6.4:27

A6.4:14

A6. $4: 26$

A6.5:2

A 1.10:901

A $1.10: 896$

16. $4: 10$

A6.4:2

A6.4:3

16.3:15

A6. $4: 7$

11.1:891

A6.1:891

A6.3:17

A 1.9:28

A 1. 10:898

\6. $1: 9$

129.2:D51

A29.6:27

1:21.2:P4.

A 29.3::1

A29.6:27

17.3:4:

A9.7:2

A.7. $7: 4$

A:2.3:3:21 

Dickinson, W. L. Highways, improvement of. 1902. I, t. ......
Dickoré, Villiam. Food examinations, snggestions for better arrangement of. $1893 . \quad$ p. 162 .

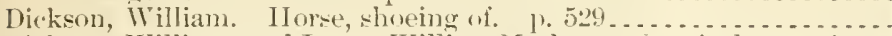

Diekson, William, and Lowe, William Merbert. Surcieal oprerations

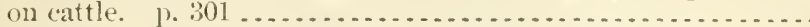

Diehl, Istael S. Croat, hreeding and raising of. p. $216 \ldots . . . . . .$.

Diet. Sce firod and liet.

Dietaries in public institutions (Atwater). 1901. p. 393.........

Dietary studies:

Alabama negro, 1895 and 1896 (Atwater and Words).

Clicagro, 1895, 1896, condueted with eopperation of Jane Jilibums and Caroline L. IImnt, of IIull House (Itwater and Bryant). 1898

Club of women students at Xorth Dakota Agricultural College. (Ladd). 1901. 1. 21 . . . . . . . . . . . . . . . . . . . . . . .

Harvard and Yale boat erews (Atwater and Bryant). 1900 . . . . . Illinois Iniversity (Grindley and Sammis). 1901, 1) 7 . . . . . .

Lake Eric College, Painesville, Ohio (Bevier and Sprague). 1901

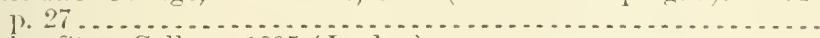

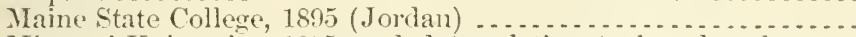

Iissouri Lniversity, 1895, and data relating to bread and ineat consumption in Missouri (Gibson and others). 1896..... same, comments on (Atwater and Woods). p. 21 .........

Tegroes in eastern Virginia, 1897 (Frisell). 1. 7............

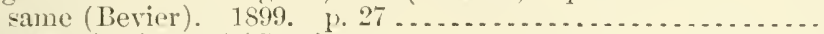

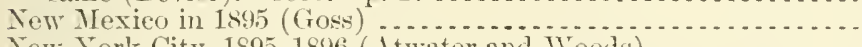

New York City, 1895-1896 (Atwater and Woods) ............. same, 1896 and 1897 (Atwater and Bryant) ................

P'urdue University, Laiayette, Ind. (Stone). 1896 ............. same, comments on (Atwater and Woorls). p. 23 ........

Temessee University, 1895 (Wait) ......................... same, comments on (Atwater and Wools). p.33 .........

United States, some results of (Bryant). 189s. 1. $499 . \ldots . . .$.

Se also Nutrition investigations.

Dietel, P. Uredinex of Ynited States, notes on some. 1891. P. 42. Dietrich, Th. Wilk, fat in, process for estimating by gravinetric

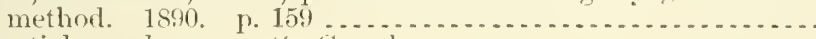

Differential grasshopper. Sie Grasshopler.

Diffusion:

Application to sugar cane, and record of experiments with

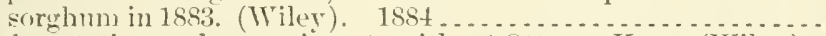

Cubonatation and, experiments with, at ottawa, Kans. (Wiley).

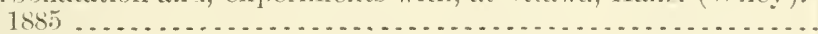

Extracting saccliarine matter from sugar-yielding plants hy.

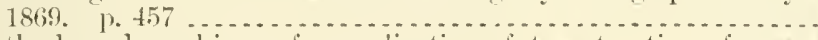

Iethods and machinery for application of to to extraction of sugar from sugar cane and sorglum (Wiley). 18s6.............

Sce also sugar cane.

Digestibility:

Aneriean feeding stuffs (Jordan and Hall). $1900 \ldots . . . . . . . .110 .3: 77$

Feedingstuffs, methods of determining (Kellner). isgs. p.504. A10.6:9

Potatoes and eggs (Anyder). 1897. P. 20.................. A10.3:4:;

Digestion, effect of severeand prolonged muscular work on (Atwater

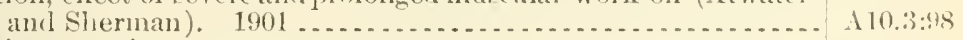

Digestion experiments:

American, report on (Jordan). 1896.1 1. 5 ..............

Is a digestion experinent fallacious? (Amsby). 1891. 1\% 89. .

Recent work abroad (Armsiy). 1891. p. 132...............

Digestive organs, diseases of, of ("attle (Murray). 1) $15 \ldots . . . . .$.

Same, of horses (Michner). J. 15. . . . . . . . . . . . . . . . .

Digcer wasp, larger, report of (Riley). 1s92. 1.245..........

Diked marshes. See Tiulal lands.

Dilution, cream raising hy (Lawson). 1s99. 1. 28 ............ . .

Dines, W. H. Anemoneters in gencral use, relative merits of. 1896. P. 6999 .

Diporlom ys ordii. Sep Kangaroo rats.

A10.6:6

110.5:?

A $10.5: 3$

$1+2: \mathrm{C}^{2}: 9^{2}$

$14.2: 1178$

A $9.7: 4$

$11.9: 105$

$129.3: 11^{3}$ 
Dipter. See Typhlocylua.

Jiptera of Deatl Valley Fxpedition, list of (Williston). 1893. p. 253.

Diptera. see Agromyzide-Iielvosia-Flies-Gnats - MosquitosNecropliagous diptera.

Jipterous insects, two, injurious th enltivated flowers (Coquillett).

Diptrons leafminers, two, on garlen vegetajles (Coquillett). 1895 .

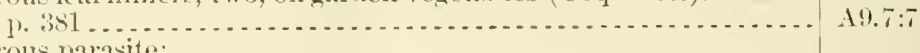

Dipterous parasite:

Dial) rotica soror (Coquillett). 1890. 1. 238... . . . . . . . . .

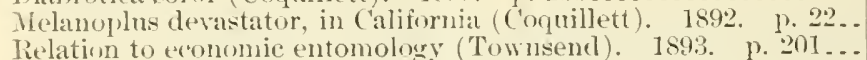
Diphtheria, preliminary investigation of, in fowls (Moore). 1895.

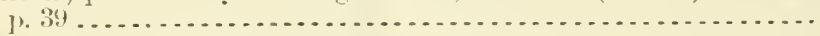

I) iximas:

(arriage of, by flies (IIoward). p. 3!).

('limate and dimatic elements as enrative ur cansative agencies of.

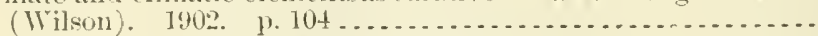
Contagious. sie Chinch bug-Inserts.

Insects as carriers and spreaclers of (Howard). 1901. p. 17t ...

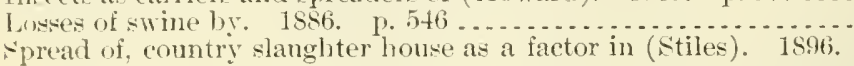
].
ses of animals:

Diseases of animals:
Aurtralian farm pests and. 1887. 1.535.

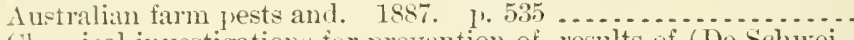
Chemical investigations for prevention of, results of (De Schwei-

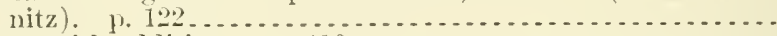

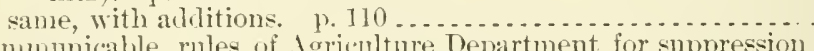

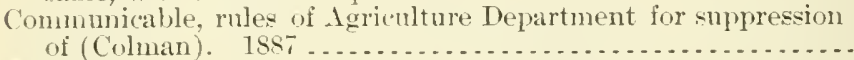

Contagions-

convention to consider suljert of, held at Chicago, Nos., 1858. Eurogean comtries. 1897. 1.69 .................. same. 1898. p. 428 . . . . . . . . . . . . . . . . . . extension of, anil means for their limitation (Hunt)-

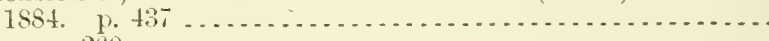
1. 260.

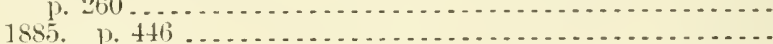

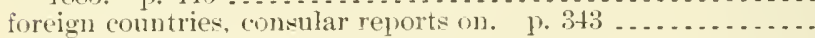
foreign conntries, reports on-

1889. 1. 479 . . . . . . . . . .

1900 (Tlimpson). p. $192 \ldots \ldots \ldots \ldots . .2 \ldots$

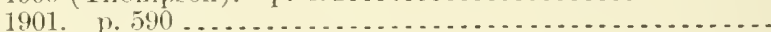

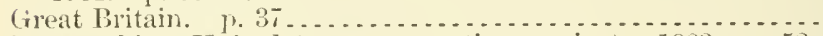
imported into Tnited states, preantions against. $1883 . \quad$ p. 52. investigations-

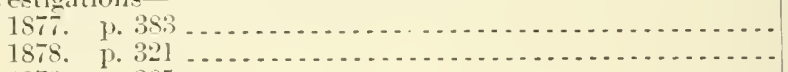

1879. ए. 365

1879

1880 ,

1881-18s3. Soe Veterinary Division.

1883 (Iopkins) p. 44 .

1854-1902. See Animal Industry Bureau.

laws of States and Territories for control of-

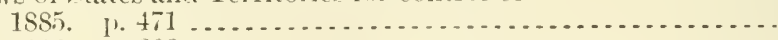

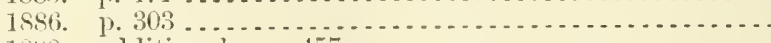

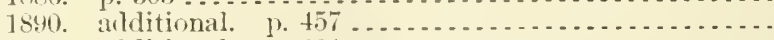

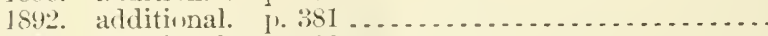

1s.4. additional. $1,108 \ldots \ldots \ldots \ldots$

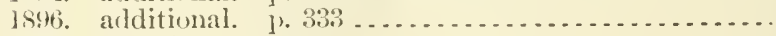

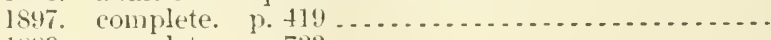

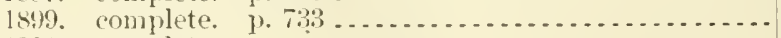

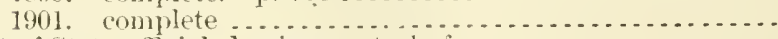

list of State oflicials haviug control of-

$1898.01 \% .603$.

1899. p. $5: 30$.

A5.5:7

A9.7:7

$19.7: 2$

19.7:5

A9. $7: 6$

A $4.3: 8$

A $9.6: 30$

A29.3:31

A1.10:901

A27.9:24

A1.10:896

A27.9:25

A1.1:890

A 4.1:889-90

$11.8: 44$

A1.8:29

A $4.1: 897$

A $4,1: \$ 98$

A $4.1: 88 t$

A $4.2: \operatorname{An} 5$

A4.1:885

At.1:891-2

A4.1:889

A $+.1: 900$

14.1:901

A $4.1: 595-6$

A1.8:29

11.1:877

11:1.578

A1.1:879

A1.6:1:2

A 1.1:880

A1.8:29

A $4.1: 885$

A $4.1: 836$

A $4.1: 589-90$

A $4.1: 891-2$

A 4. 1:893-1

A4. 1:895-6

14.1:897

A4.1:899

14.3:43

A4.1:898

A4. 1:899 
Index

Diseases of animals-Continued

Contagious-Continued

means of suppressing and extinguishing (Law), p. 19....... national legislation for, address on (Salmon). 1855. p. 18...

New York and Brooklyn, preliminary report of inspectors in investigation of (McLean and others). 18.84. J. 19...... prevention of, in Ameriea (Salmon). 18.83. p.3.......... report of-

$18 s 0$
$18 s 1$

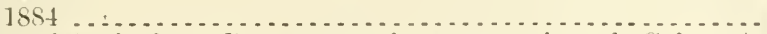

rules of Agriculture Department for smpresion of (Colman).

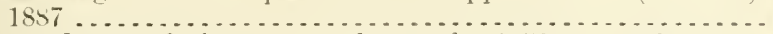

Correspondence relative to prevalences of. 1879. 1. 186 ......

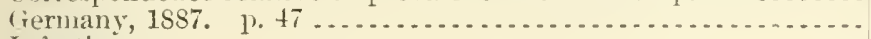

Infections-

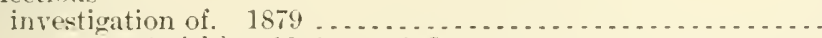
same (Smith). 18:1. p. 10. . . same, p. 93 . . . . . . . . . . . . . . . . . . . . . . . . . . . same, p. 75 .

same, p. $2 s \ldots \ldots \ldots \ldots \ldots$

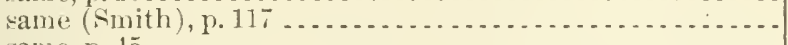

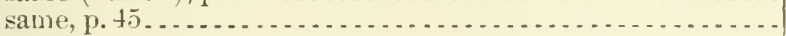

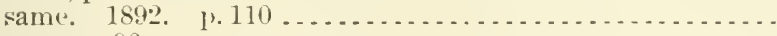

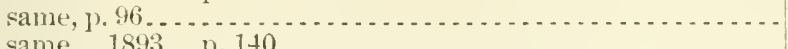

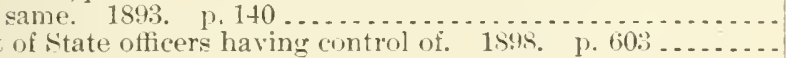

list of State officers having control of. $159 \%$ p. $603 \ldots \ldots \ldots$
same. 1899 p. $5830 \ldots \ldots \ldots$

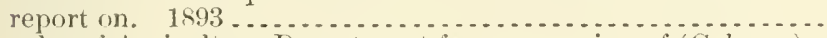
rules of Agriculture Department for suppression of (Colman). 1887

State and Territorial laws relating to. 1901.

variability of, as illustrated hy hog cholera and swime plague

(Sinith and Moore). 1894. p. 81 .........................

Investigations of (Smith). p. 119 ..................................

Letters of correspondents, extracts relating to. 1. 493 . . . . . .

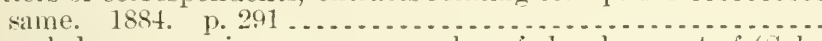

Knowledge concerning, some examples of development of (sil-

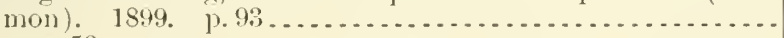

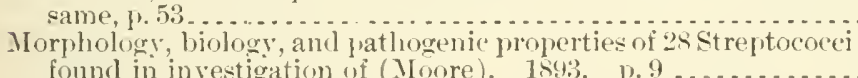

Parasitic, reprort on. 1898.

Prevention of, investigation of efferts of hacterial prouluets in

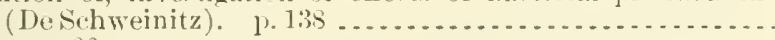

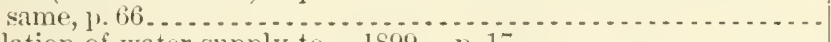

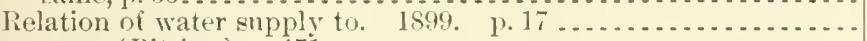

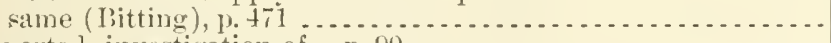

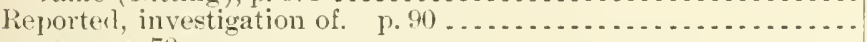
s:une, p. $78 \ldots$ also Animal smallpox - Anthrax - "Big heal"; - Blackleg - "Bottom disease" - Bovine tuberculosis - Bronchitis-Caseons lymph-arlenitis-Cattle-Cholera-Cornstalk disease - Cryptogamic growths - Cutaneous - Diphtheria Distemper - Far diseases - Evizootic aphthe - Epizontic catarrh - Epizontics - Ergotism - Farm aninals - Fetlock diseases - Florida "horse-leech" - Fluke diseases - Foot and mouth disease - Fowl cholera - filanders - Heart Hog cholera - Hog fever - Ibores - Inflnenza in loorses Lameness of horses - Lmm!y jaw - Mal le carleras - Maladie dn coit - Miero-organismal diveares - Millet disease of horses - Ovine caseons lymph-adenitis - Plenro-pneumonia or lung plagme among cattle - Poultry - Rabies - Sherep scab - smallpox - spanish fever of cattle - "Staggers" Streptococei - swine playne - Tapeworm diseates - Triehinosis - Tuberculosis - Tumors.

A1.8:29

$11.8: 35$

A1.7:6

11. $1: 29$

A1.6:2:2

A1.6:24

$1+.2: \operatorname{1n} 5$

11.s: 44

11.6:2:2

A.27.9:28

1 1.6:12

A1.1:890

A 4.1:889-90

A1.1:889

A4.1:889-90

A1.1:891

A 4.1:891-2

A 1.1:592

A $4.1: 892-3$

A1.1:893

At.1:59s

14.1:899

A 4.3:3

A1.8:4t

A..3:43

A+.3:6

At.1:895-6

A t.1:S>t

A 4.2:105

A1.10:899

A t. 1:849

A $4.8: 3$

$14.3: 3$

11.1:891

At.1:591-2

$11.9: 97$

At.1:899

A $1.1: 5: 90$

14.1:859-90 
Disinfectants, some morlern (De Schweinitz). 1896. p. 255 11.10:\$96

Disinfection of kennels, pens, and yards by fire (Stiles). 190:. P. 15. Lismal Swamp region, Va., botanical survey of (Kearuey). 1901. 1. $321 \ldots$

A $4.3: 35$

Displaymen:

- irecial, instructions to, cipher colle of wind-signal orlers, anend-

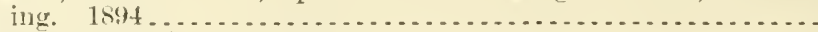

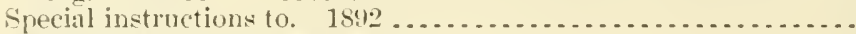

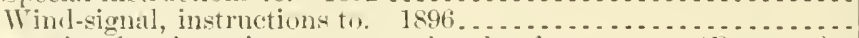

bissosteira lomgipennis, reeent ontlorenk of, notes on (lopenoe).

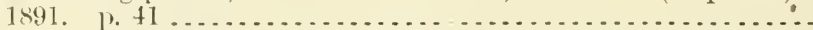

bistemper. See Horses.

Distilled spirits, consumption of, in $V^{*}$. S., per capita of population-

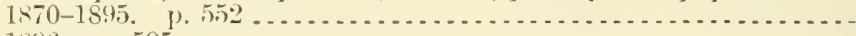
1896. ए. 595 .

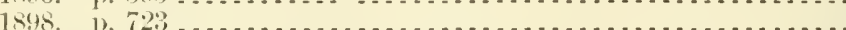
sire also liquol:s.

Distilled water for clrinking purposes (Beal). 1901. p. 5........

Distilling flask, new, for use in Kjellahl proress (Patrick). 1891. 1. 142

District of Colmoia:

Animals in, prevention of cruelty to, bill regarding. $1896 \ldots . .$. Pirls and game in, law for protection of (Palmer). $1901 \ldots . .$. Milk of, Washington, not normal (Richardson). 18ss. p. 24... Mushroon poisoning in, observations on (Coville) ............. Pleuro-pneumonia among ("attle in, investigation of (Rose). p. 51 . Rabies in-

189.5 (Moore and Fish), p. $267 \ldots . . . . . . . . . . . .$.

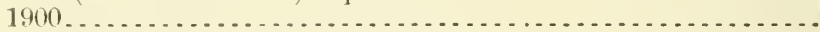
1900 (Salnom) - . . . . . . . . . . . . . . . . . . . . . . . . .

Shacle trees and insect defoliators, lour species which affect trees

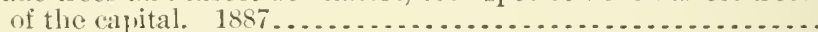

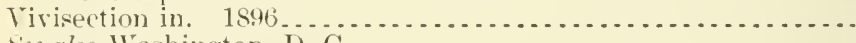
vee also IV ashington, I). C.

District of Columbia Medical Society, committee on public health

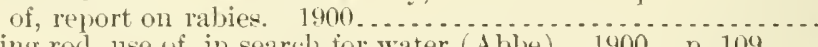

Divining rod, wse of, in searclu for water (Ablue). 1900 . p. $109 \ldots$

Doberck, W. Weather forecasting in Hongkong. 1899. 1. 98 ....

Document and folding room, Agriculture Department, report of superintamient of:

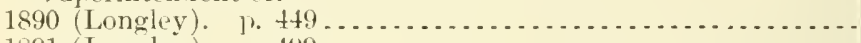

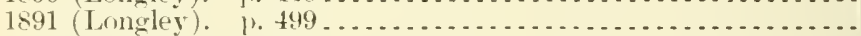

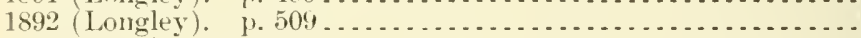

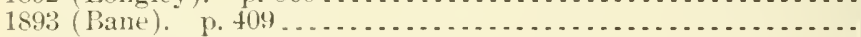

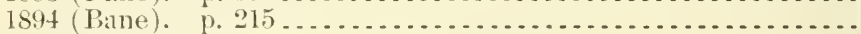

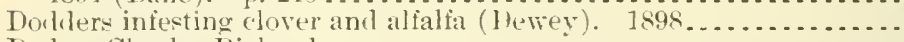

Dorlge, Charles Richards:

Bast filsers, mncultivated, of $\mathrm{C}$. S., including history of previous experiments with plants and fibers, and brief statements relating to allied species produced commercially in the old World. 1894

Fiber Investigations Office, Agriculture Iepartment, work of, for

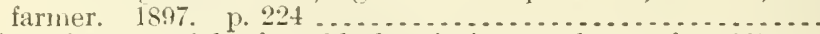

Fiber plants, useful, of worlil, descriptive catalogue of. $1897 \ldots$

Flax, hemp, rauie, and jute, with considerations upon flax and

hemp culture in Euroue, ramie machine trials of 1889 in

Paris, and present status of fiber inclustries in $[$. S. 1842 same, 2il ed

Flax culture-

for tiber, in $\mathrm{I}$. S., etc. 1892.

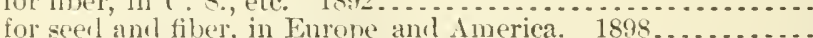

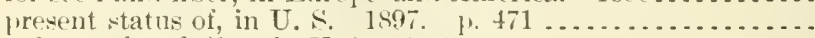

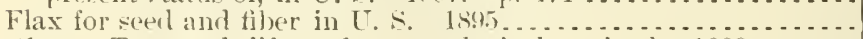

(ilover, Towmend, life and entomological work of. $1888 \ldots . . . .4$ A9.3:18

A 1.10:895

A $1.10: 896$

A $1.10: 898$

11.9:124

1. $.3: 31$

A 1. $4: 4$

A5. 4:34

A7.3:19

A6.4:13 1

A 1.1:881-2

A $4.1: 895-6$

A 4.3:25

A $4.4: 30$

A $9.3: 10$

11. $4: 2$

14.3:25

A $29.6: 28$

A $29.6: 27$

A 1.1:890

11.1:891

A1.1:592

A1.1:893

A 1.1:894

A6. $4: 14$

A 11.5:6

11.10:897

A 11..5:9

A27.8:1

A 11.5:1

A11.5:t

A 11.5:10

A1.10:897

A i. 9:27 
Hemp and jute, culture of, in L'. S., with statements concerning practice in foreign countries, preparation of tiber for market,

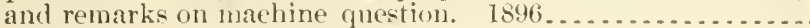

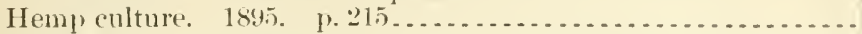
same, in Enroye. 1898

Leaf thers of $U$. S., results of recent investigations rolating to Florida sisal liemp, false sisal hemp of Florida, and other fiber-prolucing agaves, bowstring hemp, pineapple fiber, Ramie-

New Zealand flax, and hear grass. 1893 ................

$111.5: 8$

1 1.10:89.5

111.5:11

$111.5: 5$

cultivation of, in U. S., with statements concerning practice in foreign comntries, cost of cultivation and perventages of yiekl, the machine question, and preparation of fiber for

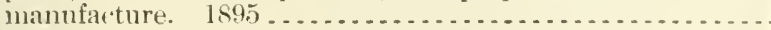

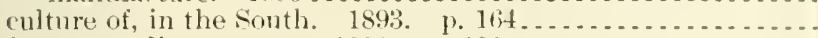

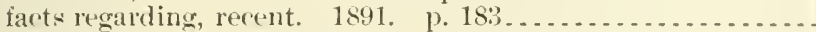

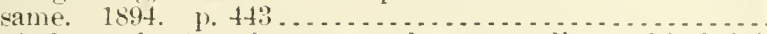

Ramie industry in America, recent facts regarding, with brief statements relating to manufacture in Europe, ets. 1893....

sisal hemp culture in ${ }^{\top}$. S. [Floricla], with statements relating to inclustry in Yucatan and Bahama Islands, and brief considerations upon question of machinery for extracting the fiber. 1891

Vegetable filsers in Agriculture Department eollection at Philadelphia Centennial Exhilnition, 1876. \%. 497.

Woods, native, lescriptive catalogue of manufactures from, as shown in exlithit of Agrieulture Devartment at World's Industrial and Cotton Exposition at New Orleans, La., 1886.

see also, for reports as special acent in charge, Fiber Investigations Office, 1890-1897.

Dorlge, J. A. Ponltry and egg industry, condition of. p. $305 \ldots \ldots$ Dorlige, Jacol, Richards:

Ailinress of-

before 26th annual meeting Patrons of Industry, Concord,

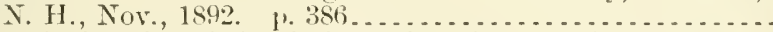
on agricultural statistics, hefore 3 l mational agricultural congress, Atlanta, Ga., 187t. \}. 260 ... . . . . . . . . . . . . .

Agricultural production for American consumption. 1sst. No. 11. 1 1. 41 . . . . . . . . . . . . . . . . . . . . . . . . .

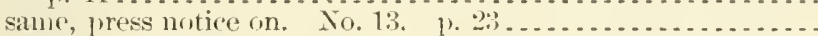

Agricultural statistics-

centennial album of. 18,6 sume. 1889

practical hints from, aldress hefore national agrieultural con-

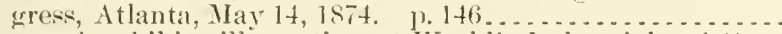
report of exhibits illistrating, at World's Inclustrial and ('otton Exposition, New Orleans, La., 1885.

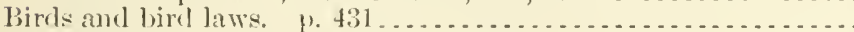

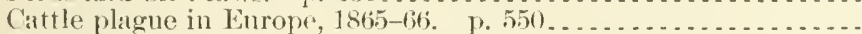
Cereals, production and distribution of, in U. S. 1879 . . . . . . . Consular correspondenee of Agrienlture Department. 1. 487.... Dairy products, foreign markets for. 1890 . p. $626 \ldots . . . . .$. Jacues "Cream pot" stock. p. "292. . . . . . . . . . . . . . . . .

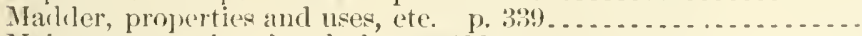

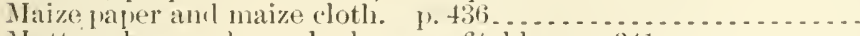
Iutton sheep, why and where profitable. 1. $341 \ldots . . . . . . .$. Ramic or China grass, importance of. 1) 347 .............

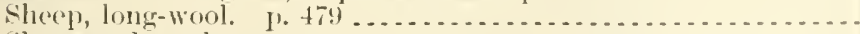
sheeply and worlreview of prouress of American sheep husbandry. 1900)

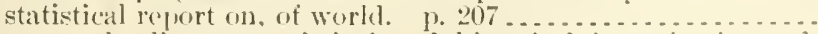

Texas eattle disease, statistioal and historical investigations of progress and results of. 1871. p. 175.

West Virginia, resnurces of, etc, brief history of. 1\% $42 \ldots . . .$. Sere ulso, for reports as editor, Africulture I) pairtment, Istos-1sit. .

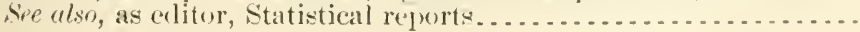

111.5:7

1 $10.3: 16$

$127.9: 29$

11.10:894

111.5:2

$111.5: 3$

11.1:579

111.1:

At. 1:891-2

$127.9: 30$

A27.9:12

127.9:22

127.4:22

A27.2:Ag8 A27.2:St2

\section{1:8:;}

11. $8: 40$

11.1: $\$ 64$

11.1: 565

127.2:(1:3)

1 1.1: 864

127.9:20

A1.1:860

1 1.1:865

11.1:66:3

11.1:86i6

11.1:865

$11.1: 6(6.5)$

11.8:titi

1 1.1:475

A1.2:( $(23)^{2}$

11.1:81i:

1:1.1:

127.9 
Dorlge, Jaeol, Richards-Continued

sipe also, for rejorts as statistician, Igriculture Department.

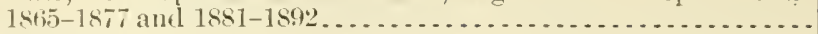

Doclge, (Miso) L. C. Farmers daughters, education of. 1. $4+1 \ldots$ Dodige, Martin:

Iddress of-

before Jefferson memorial and interstate good roads conven-

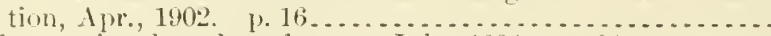
lefore national road conferenee, July, 1894. p. 24 ........ temporary chairman, at international good roads congress,

held at Buffalo, X. Y., Sept. 16-21, 1901. P. 11 ........

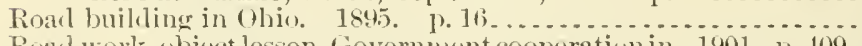

Roal work, object lesson, fovernment cooperation in. 1901. 1. 409 _ Rorales-

good, work of Federal Govermment for, 1902. p. 43 . . . . . relation of, to rural population. 1902. p. 34.............

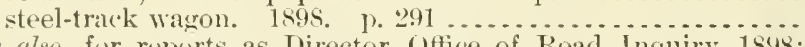

See also, for reports as Director, office of Road Inquiry, 18:8; Director of Office of Publie Road Inquiries, 1900 to $1902 . . .$.

Dodge, Rieluarl $\mathrm{E}$. Ijurnal winds on faint gradient in northwestern New Mexico. 1901. p. 299..................

Doolge (ity, Kansas. Preripitation at, $1889-11$. p. 108 .........

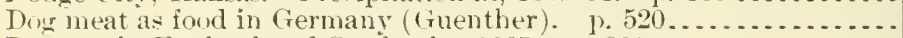

Don tax in England and Scotland. 1867. p. $381 \ldots . . . . . . . . . .$. Dogs:

Breeders of, association of-

18.5. 1. 615

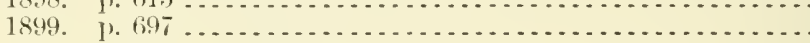

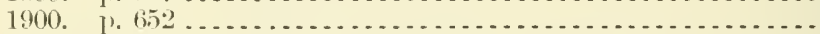

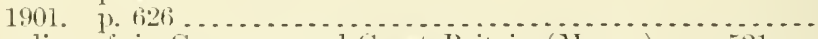

Muzzling of, in Germany ani Gieat Sritain (IIason). j). 521 ...

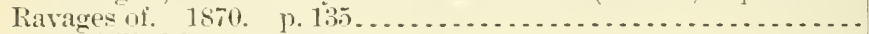

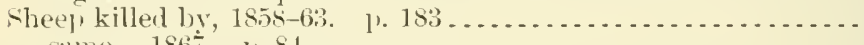

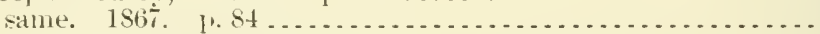

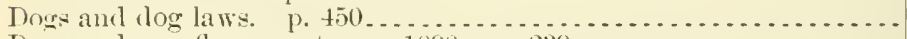

Dowwool saw-fly, report on. 1890. p. 230...................

Dontestie animals. See Animals-Cow-Diseases of animals-DogsHog-IIorse-Pig.

Domestic science, teaehing, in rural distriets (Breed). 1902. p. 91 .

same (Jaeobs). 1902. p. 96 ..........................

Dominica, WI. I. Weather bureau in, note on (Abbe). 1900. p. 252.

Doran, Enlwin ir. Insects, vernacular names of. 1898. p. 90....

Dolner, Otto. Must farmer pay for good roals? 1898 . . . . . . . . . .

Dorr, S. .I. Marbles of Rutland County, Termont. 1. $\$ 4$...... Dorset, Marion:

Eggs, use of, as medium for eultivation of baeillus tuberculosis.

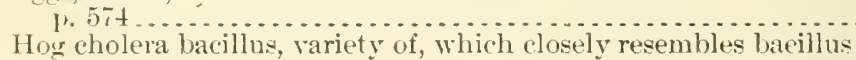

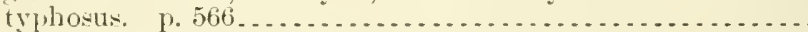

Tulercle haeilli, branched forms of, found in eultures. 1.572...

Tuberculnsis bacillus, new stain for. $1,326 \ldots . . . . . . . .$.

See al*o, as collaborator, De Schweinitz, Emil Alexancler.

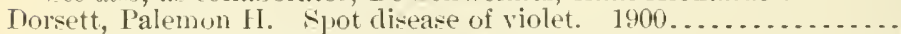
tee chlso, as joint author, Wools, Albert Fred.

Dorsey, Clarence Vilbur. Soil survey around Lancaster, Pa. I'. 61.

Dursey, Clarence Wilbur, and Bonsteel, Jay Allan:

Cecil Co., MA., soil survey of. p. $103 \ldots \ldots \ldots . . . . . . . . .$.

Connectiout Valley, soil sirvey in. 1900. p. 125............

Dorser, Clarence Wilbur, and Coffey, George $X$. Soil survey of

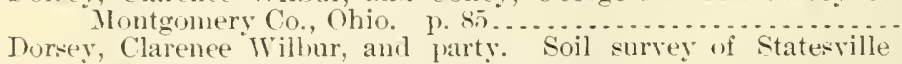

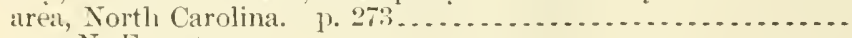
Dorsey, N. Ernest:

Atmospherie ratiation, Profestor Very's memoir on, review of,

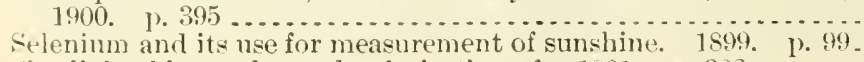
-ky liglit, blue, color and polarization of. 1901. 1.382 .......

127.1:

A1.1:S66

A2.2.3:25

122.3:10

12:2.3:21

A:20.3:17

A 1.10:001

122.3:23

A $22.3: 2: 3$

A $1.10: 895$

12.2.1:

A $29.6: 29$

A:9.6:20

A $4.1: 900$

A $27.9: 5$

A1.10:89S

A $1.10: \$ 99$

A $1.10: 900$

A1.10:901

+4.1:900

A:7.9:8

1 $27.9: 4$

A $27.9: 5$

A 1.1:86:3

A. $9.7: 2$

A 10.3:120

110.3:1:0

A29.6:28

A9.6:17

A2:.4:3\}

1 1.1:86:

A $4.1: 901$

A $4.1: 901$

14.1:401

14.1:898

129.3:23

$126.5: 900^{1}$

126.5:900

A1.8:64

A26.5:900 1

A26.5:901

A 29.6:28

A:9.6:27

A29.6:28 
Double-brooded codling moth, report of (Marlatt). 1894. 1) 248 .. A9.7:7

Dondna, Pearl Eugene, short biography of (Cajori). 1900. [1. 202 - A29.1i:28

Domplass, Kans., sorghmm sugar experiments at (Edson). p. 278... \1.1:858

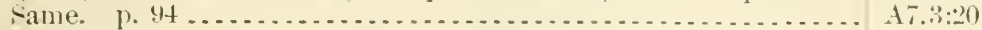

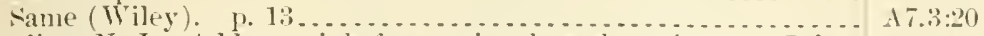

Dowling, N. J. Address of, hefore national roal tonference, July,

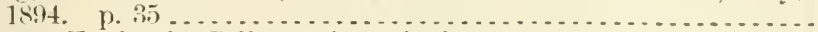

Downton, England, College of Agriculture at, report on. 1885 .

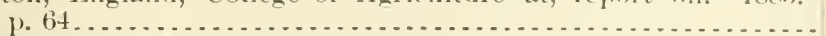

Downy millew. Ne Graje.

Praft upon horses (Fulton). p.511

Drainage:

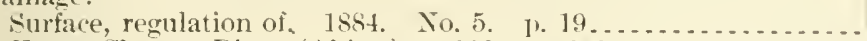
Epper Chasres River (Abbot). 1900. p. 243 ............. Well waters and, lecture on (Warington). 1892. p. 95...... See also Farm drainage - Underlraining.

Trainage water, loss of soil fertility in. 1898. 1. 4...........

Draining, tile, results of. 188?. p. 43 . . . . . . . . . . . . . . . .

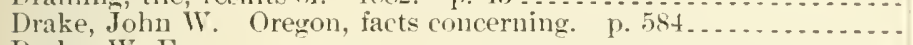

Drake, $\mathrm{II}^{\mathrm{r}}$. E. :

Agrienitural and Mechanical College, relation of, to State. 1901.

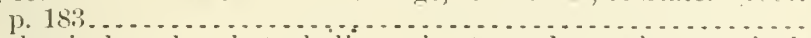

Mechanical work, what, shall we give to student of our agrienl-

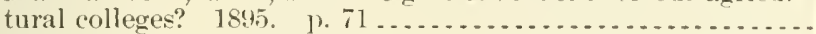

Draper, Daniel:

Precipitation at New York City, 1870-91, 1. 79 ..............

Thermometers, registering maximum and minimum, relative

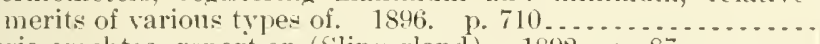

Drasteria erechtea, report on (Slingerland) 1892 p p. $87 \ldots \ldots . .$.
Drennen, IV. M. Address of, hefore good roads convention at Birmingham, Ala. 1902.

Dressel meat. See IIeat.

Dried apples:

American, in Hamburg, 1894 (Robertson). p. 12............ same, in C'ologue, 1895 (Wamer). 1' 14 ..............

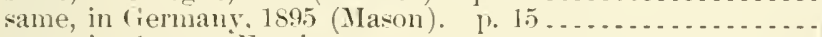

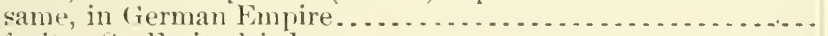

Dried iruit. See Fruit, Aried.

Driscoll, I. (1. Grasshoplers, western, sugrestions regarding.

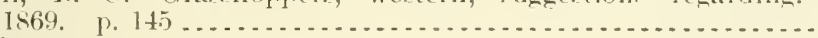

\section{Drought:}

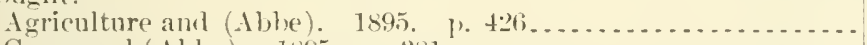

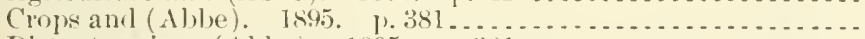

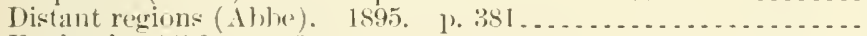

England. 1870. p. 434 _...

Famines and, in India (Eliot). 18.45. 1) $444 \ldots \ldots \ldots \ldots$

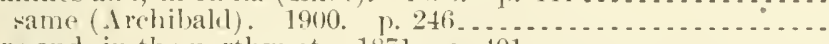

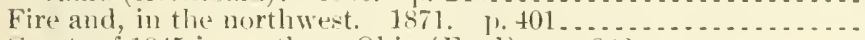

Great, of 1845 in northern Ohio (Forrl). p. 293 .............

Heat, and insect life (Mintfeldt). 190*. p. $97 . \ldots . . . . . . . .$.

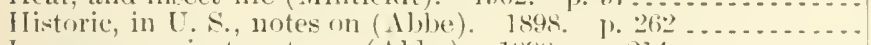

In-urance against, note on (Abhe). 1s9s. p. $14 \ldots \ldots . . . .$.

Misissipri, southwest, in 1899 (Hazen). p. 1.1 ...........

Mlississiploi Valley (Abbe). 1895. 1. 337 ...............

Prediction of, in India (Dallas). 1894. p. 13............

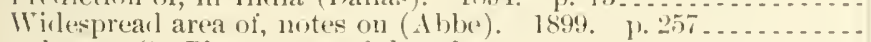

Pruc laws. see Pharinacy and drug laws.

Drugn:

Idiulteration of, extent and character of (Weolderburn). 18:1... 17.8:41

Insects injuring, at Iniversity of Kansas (Kelloger). 18:4. 1 1 31 . . 14.7:7

see also (l) jumn - Potassium.

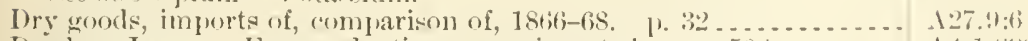

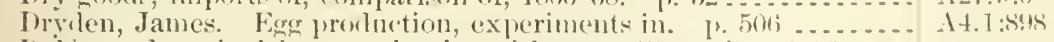

Dubernard methorl for examination of butters (sintori). 1sik). l'.

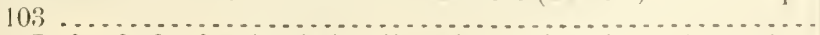

Dublin, Ireland, dead animals in, disposition of (1Vilhure j.34.

Du buis, James T. Iforses, cattle, ete, in fiwitzerland. 1\%,520 ...

12:2.8:10

$14.1: 599$

1:27.9:22

$129.6: 28$

110.3:8

1 1.9:7:3

127.4:20

1 1.1:669

1 10.2:999

110.3:24

129.6:20

129.8:11 3

19.7:5

120.2:298

A $7.3: 48$

17.3:45

1 $7.3: 48$

1 12. $4: 2$

127.9:7

129.6:28

129.6:29

A29.6:28

127.9:8

$29.3: 11$

1.27 9.9

129.6:23

A9.6::3]

129.6:26

$129.6: 26)$

129.6:25

29.6:-2:3

129.8:11

129.1:27

$17.3: 24$

14.1:85:

14. 1:5:95 
I) Buyson, II. Carbon bisulphide, fumigation with, for complete and rapid destruction of insects which attack herbarinm speci-

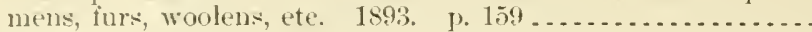
Dilck::

Inimal parasites of, check-list of (Hassall). $1896 \ldots . . . . . .$.

Feeding, lecent experiments in (langworthy). 1899. 1).20....

Dueks and geese, standard breeds and management of (Howard) ....

Dudley, P. II. Timber ties, structure, behavior, and canses of deray of, in roatlbed; with experiments on adhesion of spikes. 1887.

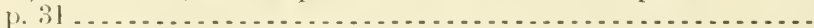

Duenckel, $\mathrm{F}$. We as joint anthor, Hammon, William $\mathrm{H}$.

Dugès, Eugine. Iseonia Rileyi, description of, new meloid genus

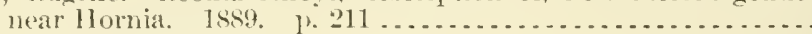

Duggar, John Frederick:

Corn, cowpeas, and wheat hran for fattening ligs. p. 496......

Peanuts, cowpeas, and sweet potatoes as foor for hogs. p. 501 ...

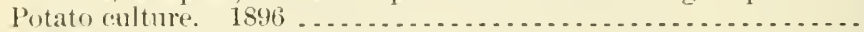

sweet potatoes; culture and nses. 1895 . . . . . . . . . . . . . .

Duluth, Mimn., temperatures at (Richardson). I. $46.3 . . . . . . .$.

Dumble, E. T. Artesian waters, existence of, west of ninety-seventh

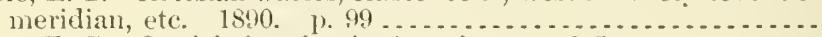

Dunean, T. C. Ostrich farming in Imerica. p. $655 . . .2 . . .2$.

Dumlap, Allert. Swine-plague in fowa. 1879. p. 135 ..........

Dunlap, M. J. Agricnltural machinery and implements. p. $\$ 16 \ldots$

Dumn, H. D. California, agricultural resonrees of, p. $581 \ldots \ldots . .$. Dunwoody, H. H. C.:

Address of-

as president of American Association of state Weather Services at third ammal convention, Brooklyn, X. Y. 1894. p. 8 . as president of American Assotiation of State Weather Services at fourth ammuleonvention, Inrlianapolis, Ind. $1896 . \quad$ p. 10 .

Meteorological ohservations, international, smmary of. $1893 .$.

Nebraska, departures from normal temperature and rainfall, with

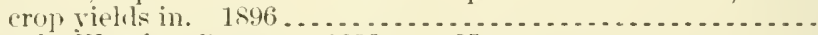

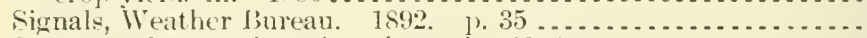

State weather services, functions of. 1894. p. 9 ............

State weather şervice organizations. 1895. 1.285..........

Storm warnings and weather forecasts, monthly notes on. Oet.,

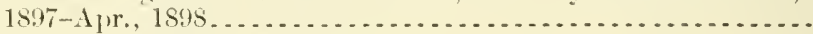

Weather comditions and crops-

1891. ए. 586

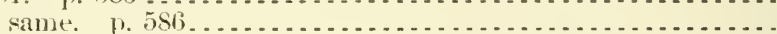

1892. 1\%. 578

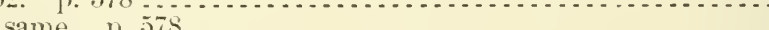

189:3. 1. 113 same. p. 113

189t. p. $509^{\circ}$

Weather forecasts, value of. 1894. 1) 121 . . . . . . . . . . . .

Dupont, C. II. Seed, selection of, importanee of. 1873. p. 553 ...

Durham, II. E. See, as joint author, Kanthack, A. A.

Dust:

Atmospheric-

note on (Abbe). 1899.

sume on C S Rafinesque (jibe) 1900 lo.

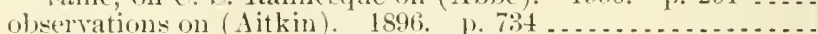

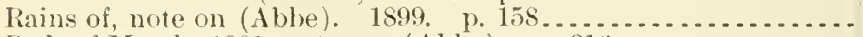

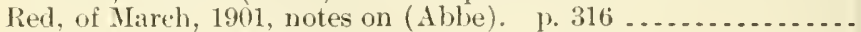

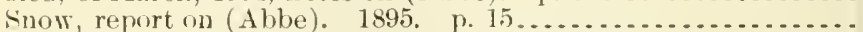

Dust storm and mut shower, note on (Kimbali). 1902. p. 269... Dust stomins:

Burma and elsewhere, notes on (Abhe). 1901. 1. 175 .......

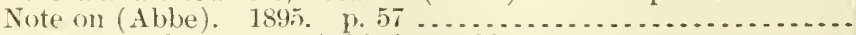

Red rain and, notes on (Abbe). 1901. 1. $120 \ldots \ldots \ldots \ldots \ldots \ldots$

Dust whirl and fairy dances, notes on (Ab)e). 1899. 1. 111 .....

T)tst whirls, or dancing dervishes (Kimball). 1902. 1).316 .....

Dwellings, Bryobia infesting, notes on speeies of (IVebster). 1902. 1. $27 \%$
$19.7: 6$

A $4.4: 13$

11.9:107

11.9:64

113.3:1

19.7:1

A 4.1:898

A $4.1: 598$

A 1.9:35

A $1.9: 26$

A29.6:27

A 15.2:ArT

A 1.1:888

A1.6:12

A1.1:863

A1.1:866

A29.3:14

A29.3:18

A29.5:A

A 29.2: 227

129.3:7

A $29.3: 11^{2}$

129.3:112

129.6:

A1.1:891

A29.1:\$9 ${ }^{2}$

A 1.1:892

A29.1:892

A 1.1:893

A29.1:893

A 1.10:894

A1.10:894

A27.9:11

A $29.6: 27$

A29.6:28

A $29.3: 11^{3}$

A29.6:27

A $29.6: 29$

A24.6:23

A29.6:30

A29.6:29

A $29.6: 23$

A29.6:29

A29.6:27.

A $29.6: 30$

19.7:1 
Eatom, Danicl C.:

Forns irmusouthern Patagonia, collected by [. ..... "Alhatross"

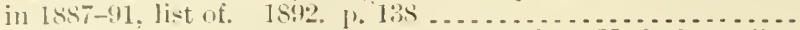

Itosics from Foegia and I'atagonia, collected by U. S. S. "Allha-

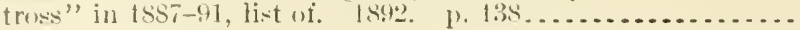

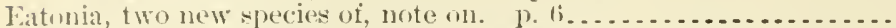

Elreman, W. S. Cheese, national standareł for. 1893. p. 60....

Ehuria quadrimaculata, longevity of early stages of, notes upon

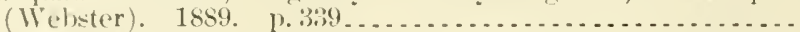

Erhinoeactus, Sorth American succies of, preliminary revision of

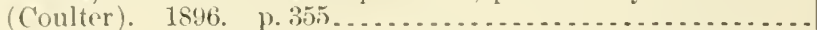

Eckielit, J. II.:

lichens from California and Mexiou, collocted by Elwarl Palmer, from 1888 to 1892 , list of. 1s:3. 1. 2.41 . . . . . . . . . .

lichens from southern Pataunia, collected lo L. . s. "Alba-

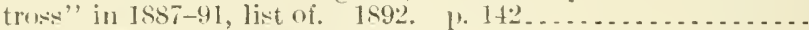

Exkstein, I). Netherlands, auriculture in, in 185.5. 18sti. 1). A.3...

Eiclipe, total, of :-111, May 2s, 1900:

Adrance nutes on (Ables). p. 110.

Felipse meteorolosy and allied poblems (Birelow) 1902 .

belipse shatow bands and correlated atmospheriv phenomena, notes

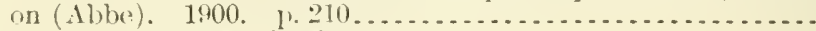

Ecolory, tee Ocracoke Island.

Eomonic entomulogy. See Entomology.

Feonomic ornithology. See ()mithology.

Feonomic plants, catalogue of collection of, in Agriculture DepartEeuador:

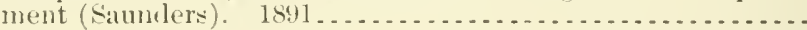

Agriculture in. 1891. p. 484

Meteorology in, note on (Al)he). 1900. 1. 1it ..............

Sie also Galanagos Islanels, S. A. - Playa Riea.

Eilly, William $\mathrm{A}$.:

Fite experiments, recom of some. 189s. p. $450 \ldots \ldots \ldots \ldots \ldots \ldots$

Weather prediction, experiments in. 1s99. p. $96 \ldots . . . . . . . .$.

Edelmann, M. Th. Earth-magnetir justruments, on construction of. 18.15 . 1. 5222

Fdible oils and fats, methods for analysis of not including dairy prod-

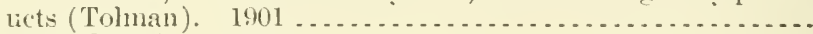

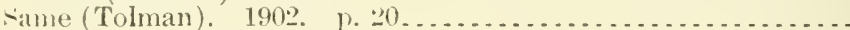

Elinhurgl, Scotland. International forestry exhibition at, 1884,

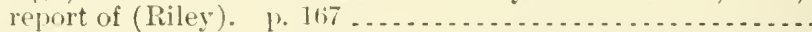

Ethmunds, J. M. Forests, paper on. 1869. p. 22..............

Firon, Hubert:

Calmmet Plantation, sugar experiment station, Pattersonville, La., record of experiments at. 18s9 . . . . . . . . . . . . . .

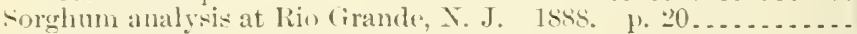

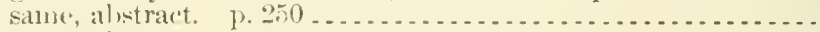

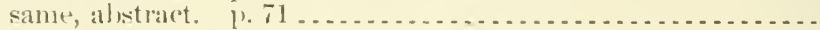

forglum sugur experiments at Doughas, Kans. p. 278........

\section{Elucation:}

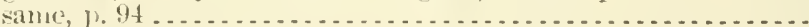

Industrial rlastes (Andrew). 1S64. No. 1. 1. 15............

IIolern, what is of most worth in, adilress on (-tubles). 1901.

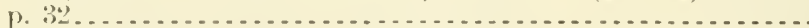

Theory of higher, some recent cllanges in-

18:is. (Bryan). p. st ....

1899 (Silvester)

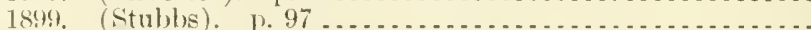

See alse Acrienltural eduration - Technical educatio...

Eduntion, (ommissioner of, correspomlence with, relative to good

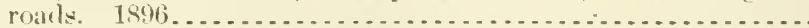

Educational forces in $L$. S. relating to ayriculture, cooperation of Department of Agriculture with (Willits). I'.65

Educational institutions. See A gricultural colleges, ete. 
Erwards, Henry:

Cryptophasa unipunctata, habits and earlierstagesof, in Instralia,

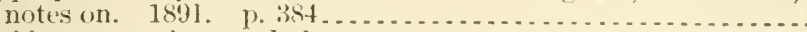

Lepidoptera, noises mate ly, notes on. 18s!?. 1). 11 . . . . . . .

lepidopterous inseet, beantiful exotic, birth of, in New York.

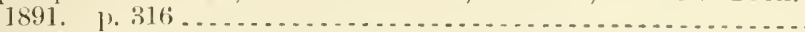

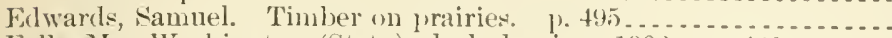
Fells, M. Washington (State), dark daly in. 190:2. 1\%. $440 \ldots \ldots .$. Egeriille. See Noths.

Egg-laying record of plum cureulio (Quaintance and Smith). 1902.

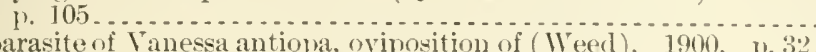
Finglant, locterial divease of (ciuithe Egas:

Bristol trade in. p. 335

California, fool value of (Jaffa). 1). 510

Cost and value of, of different breeds of hens (Emery). p. +76

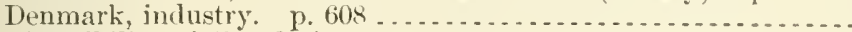

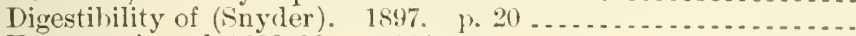

Enumeration of, $1880-90$. p. 113 .

Feedine flavor into (Emery). p. $473 \ldots \ldots \ldots \ldots$

Flavor of, relation of feed to (Langworthy), 1900, ]. 25.....

Foreign markets for. p. $321 \ldots$ birds, importation of, for propagation, regulations for.

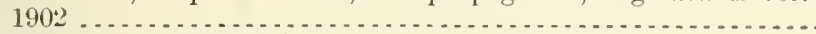

Great Britain (Halstead). p. $508 \ldots \ldots \ldots$

Hamburg, trade in (Ashby). r. 345.

Individual records of, nest box for keeping (Langworthy). 1900. p. 19 . . .

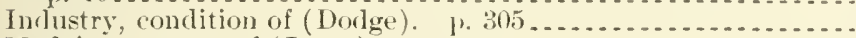

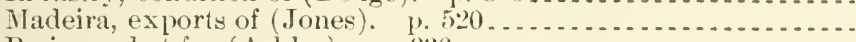

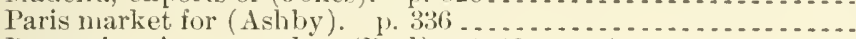

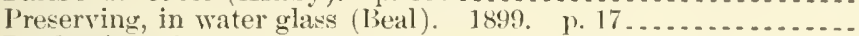

Prorluction ofexperiments in (Dryden). p. 506

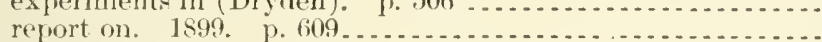

Raising, for market. p. $345 \ldots \ldots \ldots$

Russian exports of (Holloway). 1). 512.

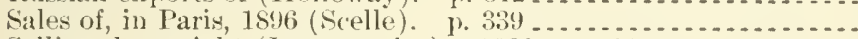

Selling, by weight (I angworthy). 1900. p. $24 \ldots \ldots \ldots$

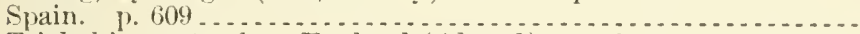

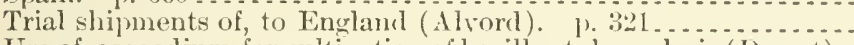
Use of, as medinm for cultivation of lacillus tuberculosis (I)orset).

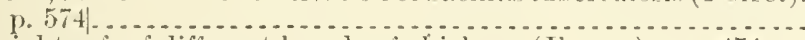

Weights of of rlifferent breeds of chickens (Emery). p. $474 \ldots$

Eggs and their nses as fool (l angworthy) .................... Egleston, Nathanicl H.:

Arloor day; its history and observance. 1896

Forest experiment stations in ennection with agricultural colleges. 1885. p. 153

Forestry, report on, v. 4. 1884 .

Railroals, comnection of, with forest fires. p. $128 \ldots \ldots \ldots \ldots \ldots$

Timber lands, Government, value and management of. 1 sst.

Timber or lorests, preservation of, on pulie domatin, legrislation

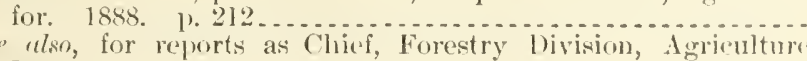
Egyplt: Department, 188:3-85.

Agriculture in, note on. 18S8. 1).359

(rops in, 1848, note on. 185\%. 1\%.267.

A9.7:3

A 1. 1:862

12! $6: 30$

19.6::3:

A $9.6: 2: 3$
1:28.3:12

14.1:899

A $4.1: 898$

A4.1:899

A $4.1: 901$

1 10.3:4:3

A27.9:32

A4.1:899

A 1.9:122

A 4. 1:899

A5.4:37

A $4.1: 900$

A $4.1: 899$

A1.9:114

A4.1:891-2

A $4.1: 900$

A $4.1: 899$

A1.9:108

At.1:898

14.1:901

A $1.1: 862$

A $4.1: 900$

A. 1:89?

A1.9:122

14. $1: 401$

A $4.1: 899$

A4. I:901

A4. $1: 899$ 1 1.9:1:28

A 1.8:56;

A $1.7: 9$

1 19.5:4

A 13.3:1

11.7:5

113.3:2

113.1:

$127.9: 26$

$127.9: 27$

Seeds and plants collected in, by Barbour lathroje amd l)avil (i. Fairchilıl. 1900

Egyptian cotton:

Culture of (Foarlen). 1897.

lixports of. 1897.

1897.

Ali. $\left(i: i^{2}\right.$

110.3:12

112.4:15 same (Hitelreok). 18:7. p. 29. 
ligyptian cotton-Continued

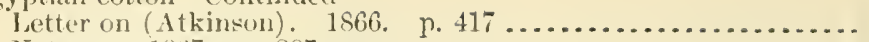

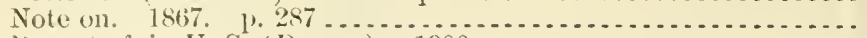

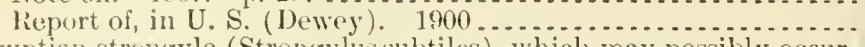

Fgyptian strongyle (Strongylus subtiles), which may possibly occur in returning American troops (Stiles). 1902. p. 41 .........

Limeria stiedie, correct name for liepatic coccidia of rabbits (Stiles).

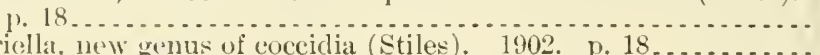

lisen, Gustay:

Blastoplaagal psenes, first introduction of, into California. 1891.

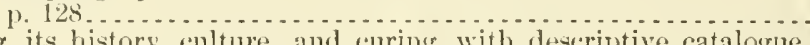

Fig, its history, eulture, and euring, with descriptive catalogue

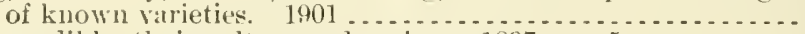

Figs, edible, their conlture and curing. 1897 , p. $5 \ldots \ldots \ldots . . .$.

Raisin grape, cultivation of, by irrigation. 1891. p. $225 . . . . .$.

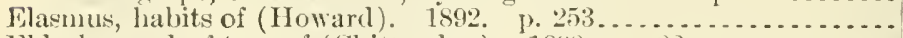

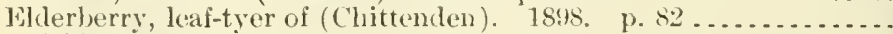

EIdridge, Isurice Owen:

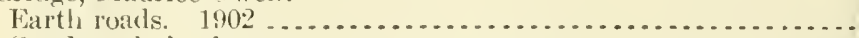

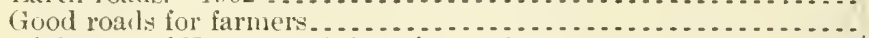

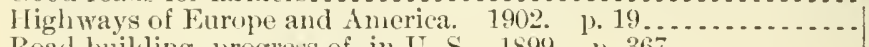

Road builling, progress of, in U.S. 1899. p. $367 \ldots \ldots \ldots \ldots \ldots$

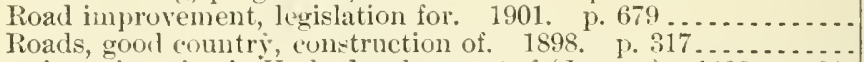

Electric engineering in 't tah, development of (Jensen). 1898. p. 91 .

lilectric phenomena in Euphrates Valley, notes on (Abbe). 1900.

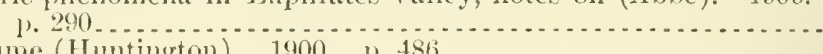

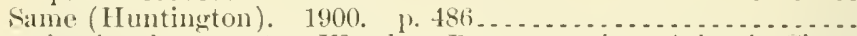

Electric signal apparatus, Weather Bureau station, Atlantic City,

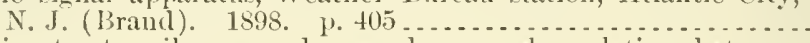

liectric street railways and macadam roals, relation between (North). 1902. 1.59 . . . . . . .

Electric waves in atmosphere, notes on (Abbe). 1847. p. $352 . .$.

Electrical Congress, Intemational, 1899, at Como, Italy, notes on

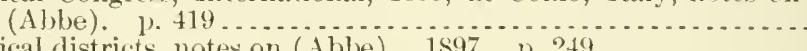

Electrical districts, notes on (Abbe). 1897. p. 249.............

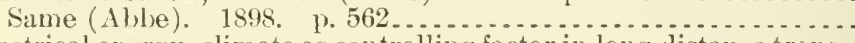

Electrical energy, climate as controlling factor in long-distance trans-

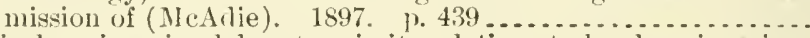

Electrical engineering laburatory in its relations to local engineering

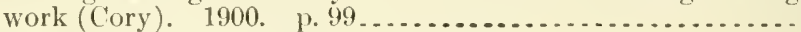

Electrical methods of soil testing. See Soils.

Electrical recording instrumenty, storage battery for, use of (Vose).

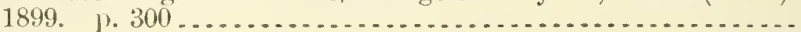

Electricity:

Local, in windstorm in Wyoming (Hunton). 1894. p. 509.....

Static, in Weather Bureau work, importance of (Beals). 1896.

foe also Atmospheric electricity - Roentgen rays - and headings beginning Llectrical.

Electrodynamic radiations from sun, endeavor to discover (Trow-

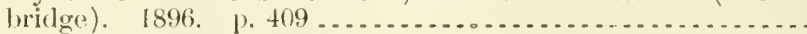

Sée clso A tmospherie rarliation.

lilectroly tes, aqueous solutions of certain, in equilibrium with atmospheric air, solubility of calcium carbonate in (Cameron and

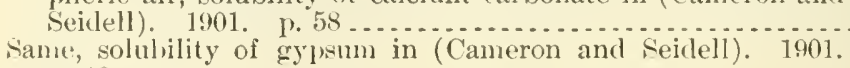
1. 46 .......................

Eleventh Census. See Census.

Eliot, John. Droughts and famines in India. 1895. 1'. $444 \ldots \ldots$.

Ellenberger, Cyrus, short biography of (Abbe). 1900. p. 154 .....

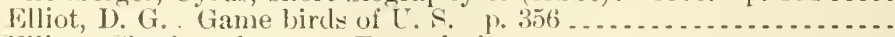

Elliott, (harles Gleason. Farm drainage .........................

Elliott, f. R.:

Apple, pear, and grape, popular varieties of. p. 119......... A1.1:863

A27.9:1

A $27.9: 5$

A6. $4: 26$

14.3:35

14.3:35

1+.3:35

A9.7:4

A20.3:9

A20.3:5

115.2:P94 ${ }^{1}$

A9.7:4

A9.6:18

A 1.9:136

11.9:95

A 22.3:23

A 1.10:899

A1.10:901

A 1.10:898

A 10.3:49

A 29.6:28

A 29.6:28

A29.6:26

A22.3:22

A29.6:25

A29.6:27

A29.6:25

A29.6:26

A29.6:25

A 10.3:76

A29.6:27

A 29.6:2:-

A29.3:18

129.6:24

A 26.3:18

A26.3:18

A29.3:11 2

A29.6:2S

A1.1:864

A1.9:40 
Elliott, F. R.-Continued

Fruits, hardy, popular varieties of-

1864. p. 141

1865. p. 186

1866. P. 131

1867. p. 129

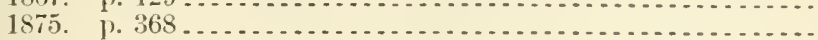

Elliott, Sterling. Address of, before National Roard Conference, July.

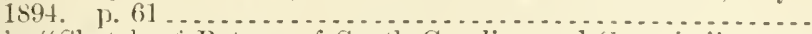

Elliott's "Sketch of Botany of South Carolina and Georgia," notes on grasses in (Scribner). $1901 \ldots . . . \ldots \ldots \ldots . . . . . . . .$.

Ellis, Alston:

Agricultural colleges, work of, some general considerations re-

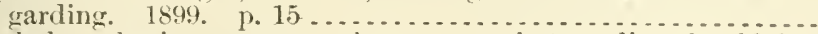

Bachelor of science course, four-year, what studies should be

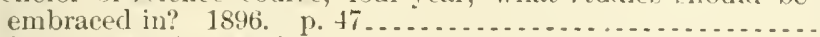

Ellis, G. H. Wond reasoning, experiments in. 1889. p. $57 . . .$.

Ellis, J. B.:

Fungi, some new species of, descriptions of. 1891. 1. $274 \ldots \ldots$

Genus Scleroderma in Saccardo's Sylloge. 1889. p. 23.......

Triblidium rufnlum, report on (Ellis). 18s9. I, $29 \ldots \ldots \ldots$.

Ellis, J. B., and Everhart, Benjamin M.:

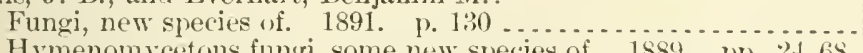

Hymenomycetous fungi, some new speries of. 1889. pp. 24,68 .

Mucronoporus Andersoni, report on. 1891. p. 79..........

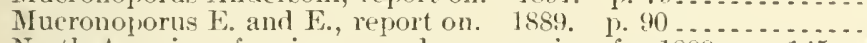

North American fungi, new and rare species of. 1889 . p. $145 .-$
Nummularia and hypoxylon, symopis of North Ameriean spe-

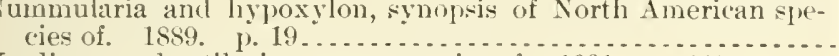

Uredinex and ustilaginese, new species of. 1891. p. $118 \ldots \ldots$.

Ellis, J. B., and Galloway, Beverly Thomas:

Fungi-

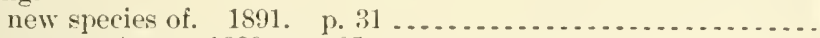

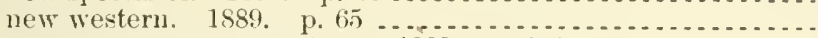

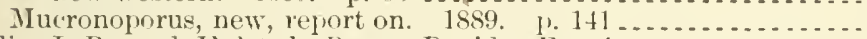

Ellis, J. B., ant Halsted, Byron David. Fungi, new, report on.

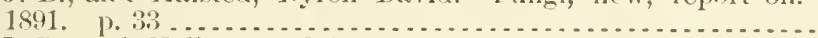

Ellis, J. B., and Kellerman, W. A. Kansas fungi, new specien of.

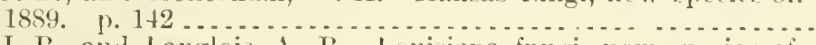

Ellis, J. B., and Langlois, A. B. Lomisiana fungi, new species of.

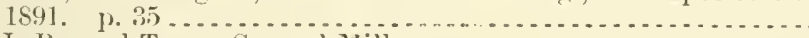

Ellis, J. B., and Tracy, Samuel Mills:

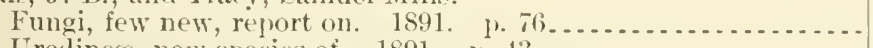

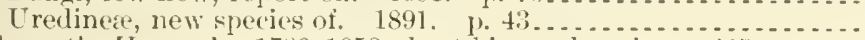

Ellsworth, Henry L., 1790-1858, short biography of. p. $267 . . . . .$.

Ellsworth, Luther T. Venezuelan (attle, shipments of, to Cula. p.516.

Eilzey, M. G. Sheep husbandry sonth, paper on. 18.9:3. p. 173...

Elm insect, newly imported (Howard). 1889, ए. $34 \ldots . . .6 . .$.

Elin leaf-beetle:

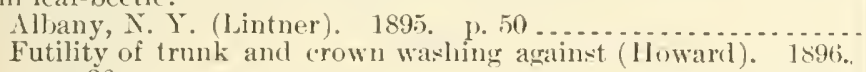
p. 36

Imported-

cireular relative to (Marlatt). 1895.

habits and natural history and means of counteracting its injuries

Washington, 1). C. (Marlatt). 1895. ए. $47 \ldots \ldots \ldots \ldots \ldots \ldots$

Elmer, A. D., jr.:

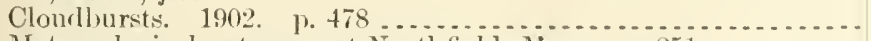

Meteorological extremes at Forthfield, Mass. $1,251 . . . . . . . .$.

El Paso County. Sice Rio Grande region, Tex.

El Paso Del Norte, Mexico. Grape culture and wine making in

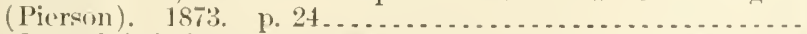

Elster, J., and Ceitel, H. Atmospheric electricity, review of ront

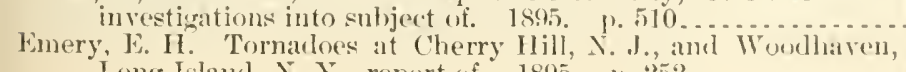

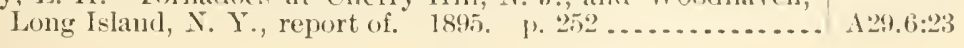

11.1:864

A 1.1:865

A1.1:866

A1.1:867

A1.1:875

A2:.:?:10

A3.4:29

A 10.3:65

A10.3:30

A 13.8:3

A 28.5:7

A28.5:5

A 28.5:5

A28.5:7

A28.5:5

A28.5:6

A28.5:5

A $28.5: 5$

128.5:5

A.28.5:6

A28.5:6

128.5:5

A28.5:5

$128.5: 6$

A $28.5: 5$

128.5:6

A28.5:6

A28.5:7

127:9.9

A4.1:899

A1.7:2

A9.7:?

A $19.6: 2$

19.6:6

19.5:8

A9.3:6

A $9.6: 2$

129.6:30

A $29.6: 26$

1ะร.ง:11

$129.3: 11^{3}$ 
Emery, F, E.:

Agricnitural colleges, manual labor in. 1891. p. 106.

A10.3:7

Eygr:-

cost and value of, of different breerls of hens. 1. 476.

feeding flavor into. p. 473

A $4.1: 899$

14.1:899

wejghts of, of different breeds of chickens. p. $474 \ldots . . . . . .4$. $4.1: 899$

Emery, H. 1). IIogs and pork packing in West. p. 198 ......... A1.1:863

Emery, J. A. See, as joint anthur, De Suhweinitz, Emil Alexanter.

Emery, S. C:

Meteorological records for roference and study, preserving, best

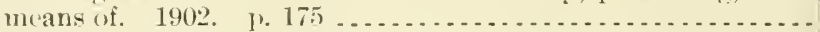

Misvissippi tornalo. 1902 p. 265 . . . . . . . . . . . . .

Tornadoes in Tennesser, Mississippi, and Arkansas. 1900. p. 499.

Emigrants, Florida as home for (Rollins). 1872. p. 495. . . . . . . Emiuration:

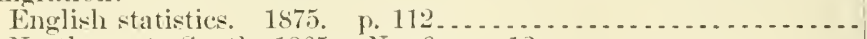

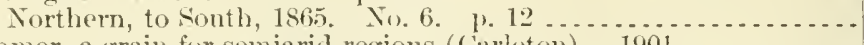

Emmer, a grain for semiarid regions (Carleton). $1901 \ldots . . . . . .$.

Emory fumigator, new method for handling hydrocyanic acid gas in orcharls (Johnson). 1899. p. $43 \ldots \ldots \ldots$

Employment agencies, free, for nse of farmers, list of (West) ......

Emulsion. See Kerosene emulsion.

Encrortid:

New and remarkable, is it parasitic? (Howard). 1890. p. 145 ..

Six-branched antenna, report on (Ashmearl). 1891. p. 455 .... Energy:

Arailable, of ford and borly material (Atwater). 1901. p. 112.

Conservation of, in human body, experiments on (Atwater and

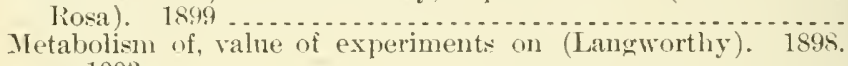
1. 1003 .........

See also Metabolism.
Engineer. See Agricultural Engineer.

Engineering courses. Some oljections to early differentiation of

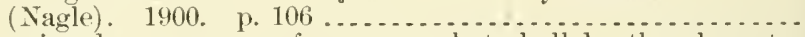

Engineering degree courses, fonr-year, what shall be the character of preparatory work required to enter? (Waller.) $1899 . \quad 1.75$

Engineering experiment stations, report of committee on, before convention of Association of American Agricultural Colleges and Experiment Stations-

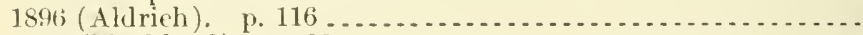

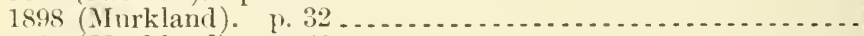

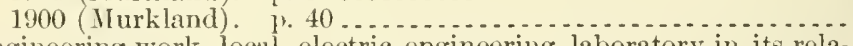

Engineering work, local, electric engineering laboratory in its rela-

England:

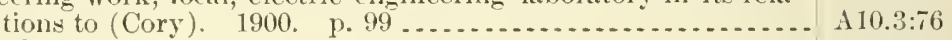

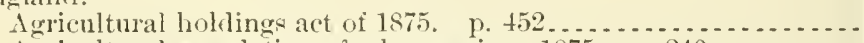

Agricultural population of, changes in. 1875. p. $240 \ldots \ldots . .$.

Agricultural schools in, organization and management of (Welch). 1885 ... . . . . . . . . . . . . . . . . . . . . . . . . . . .

Breadstuff, imports of, Jan. and Feb. 1870 and 1871 p. $143 . .$.

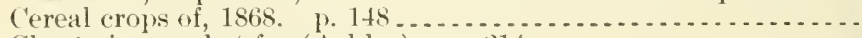

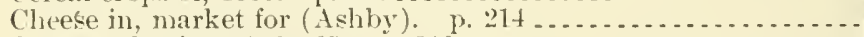

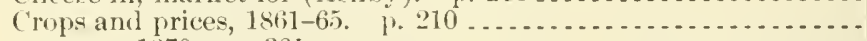

Dairying of $A$ meriea and, their points of lifference and compara-

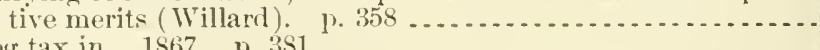

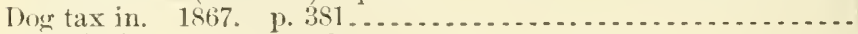

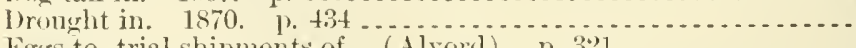

liges to, trial shipments of. (Alvoril) p. 321 .

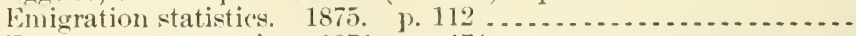

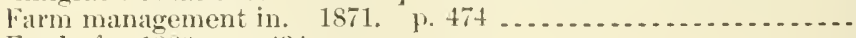

Fond of. 1866 p. 4ist . . . . .

Grain measures of. 1863. No. 5, 1. $1 ;$ No. 6,1 . 2.2........

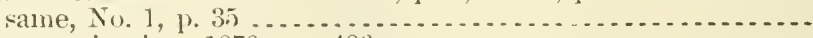

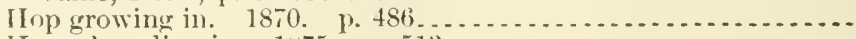

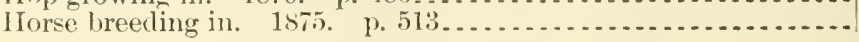

A29.3:31

A:9.6:30

129.6:28

A $27.9: 10$

A27.9:14

A $27.9: 3$

A1.9:139

A9.6:20

127. $4: 13$

A $9.7: 3$

A $9.7: 3$

A10.3:99

A 10.3:63

A 10.6:9

A10.3:76

A 10.3:65

A 10.3:41

A10.3:65

A 10.3:99

A $27.9: 13$

A $27.9: 13$

A 1.8:36

A 27.9:9

A $27.9: 7$

A4.1:899

A 27.9:4

A 27.9:8

A1.1:866

A27.9:5

A 27.9:8

At.1:899

A27.9:14

A27.9:9

A27.9:4

A 27.9:1

A27.9:2

A27.9:8

A27.9:13 
England-Continued

Horses in, American thoromghbred (Wray). 3. 50:3

Lands in, reclamation of, reports of state geologist of Tew Jer-yey, 1869 and $1870 . \quad$ 1. 2.21 . . . . . . . . . .

Live-stock shipments from Canala, Argentina, and Australia to.

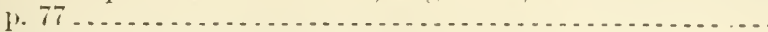

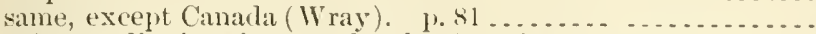

Manchester district of, as market for Anerican proulncts........

Markets of, note on. 1866. 1. $18 \ldots \ldots \ldots \ldots \ldots \ldots \ldots$

Mcteorological literature of, 1337-1699 (symons). 1865. [1.335.

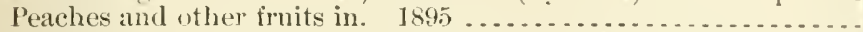

Railway ties in, treatment of (Tratman). 1Ss?. 1.49......

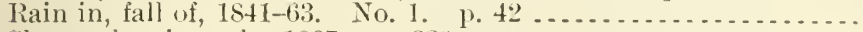

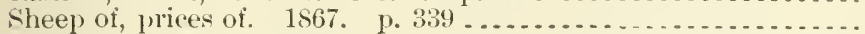

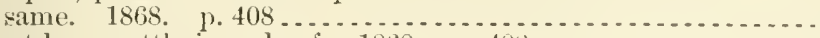

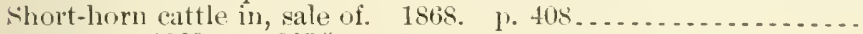

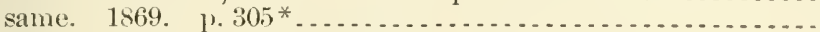

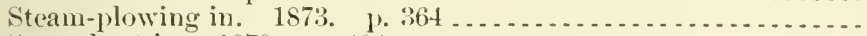

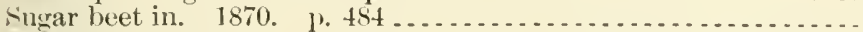

Weatnes telegraphy in $(\mathrm{Al}$ be $)$. 1s:7. p. $205 \ldots \ldots \ldots \ldots \ldots$

Wheat-

culture in, 1870 same, 1855 . No. 23. exportation to, $1867-68$. 1. 325 prices of.

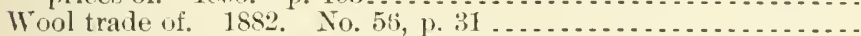

See also Ayrshire - Cirencester - Downton - Great Britain Kew - Leeds - Liverpool - Man.hester - Rothamsted Experimental Station - Sheffield.

Engle, H. \. N. Nut culture, report on. p. 37.

Same, reprinted 1896 .

Fnglish far

English sparrow (Passer domesticns):

Circular on. 1886

Circular to postmasters in relation to. 1886

Insectivorous habits of (Riley). p. 111 .

North America, especially in its relation to agriculture (Barrows). 1889

Note on. 1869 . p. 300

Schedule on, acknowledgment of receipt of See aleo Sparrows.

English walunts, culture of (Heath). 1842. p. 133

Ensign, Edgar T. Forest conditions of Rocky Mountains, esjerially in Colorado, Idaho, Montana, Wyoming, and New Mexico.

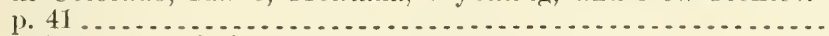

Ensilage in Great Britain. 1885. No. 24. p. $34 \ldots \ldots \ldots \ldots$ See also Silage - Silos and silage.

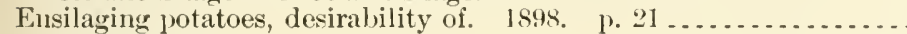
Entilia sinuata:

Habits of (Howard).

Fotes on (Rice). 1893. p. 243

Entero-hepatitis, infectious:

Camsed by protozoa, in turkeys (Smith). 1895. 1. 7 ........

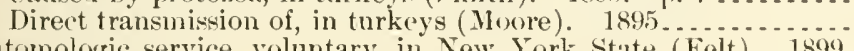

Entomologic service, voluntary, in New York State (Felt). 1899.

Entomological Club, American Association for Advancement of Science, Rochester meeting of, 1892, abstract of proceedings. 1892. p. 132

Entomological Commission, Agriculture Department:

Comments on fifth report of (Hamilton). 1891.

Entomolocrical discoveries and observations in West Virginia in 1894

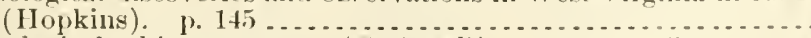

Entomoiucrical ethies report on (Cockerell) 1895 . Entomological exhibition, 1865. Sie Paris.

* By a misprint, this jage number ajupars twice.
Classificatlon no.

$14.1: 599$

11.7:7

A4.1:895-6

14. $1: 89: 50$

112.4:4

A27.9:4

129.:3:1 $\mathrm{I}^{2}$

A12.4:1

A1:3.:3:3

1 $27.9: 2$

A27.9\%

A27.9:6

127.9:6

127.9:7

127.9:11

127.9:8

A $29.6: 25$

A27.9:8

A27.9:2:3

127.9:6

A27.9:2

A 27.9:83

127.9:21

A20.1:894

A:0.4:1

A1. 10:598

A5. 4:2

A5.4:7

A5.3:1

A. $3: 1$

127.9:7

15.4:6

$11.8: 20$

A 13.8:2

A27.9:23

11.9:79

19.6::00

19.7:5

$14.3: 8$

14.4:5

19.6:20

A9.7:5

As.

1.1. $7: 4$

1!). $7: 7$ 19.6:17 
Entomological notes:

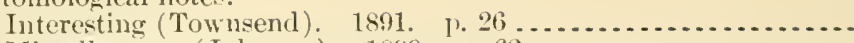

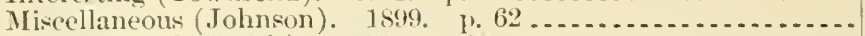

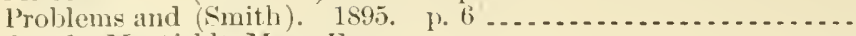
see also Murtfeldt, Mary E.

Entomological record, monthly:

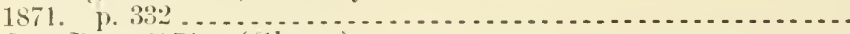

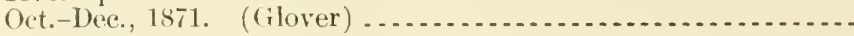

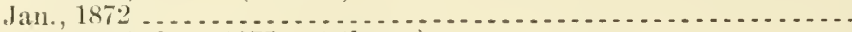

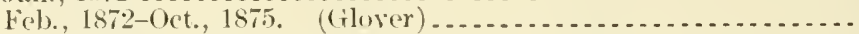

Entomological work:

Agricultural experiment stations (Cook). 1891. p. 212.......

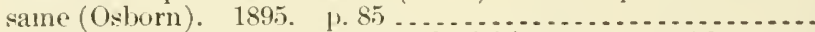
Central l'ark, New York City (Southwick). 1891. p. 59 .... Eenomic, in parks of New York City (Southwick). 1894. p.135. Mississippi (IV eed). 1891. p. 34.......................... Oregonand California; notes on Australian importations (Koebele). 1893. p. 33 . Elso Entomological notes.

See also Entomological notes.

Objects of (Gillette). $1900 . \quad$ p. 5.

Proceedings of-

1st annual meeting of, $1889 . \quad 1 \% 177$

21,1890 . ए. 180 .

$31,1891 . \quad$ 1) 4.

4 th, 1892. p. 67

5th, 1893 . p. 61

6th, 1894. p. 55.

ith, 1895

8th, 1896

9 th, 1897

10th, 1898

11 tl, 1899

12 til, 1900

$13 \mathrm{th}, 1901$

14 th, 1902

Entomologists:

Government and State, and other contributors to literature of American economic entomology, more important writings of; $\mathrm{A}-\mathrm{K}$.

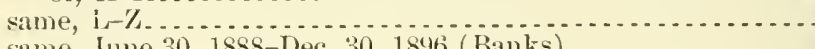

same, June 30, 1888-Dec. 30, 1896 (Banks) . . . . . . . . . . . .

same, Dee. 31, 1896-Jan. 1, 1900 (Banks) . . . . . . . . . . . . .

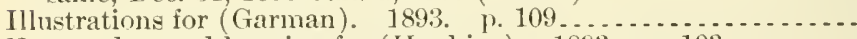

Note and record keeping for (Hopkins). 1893. p. 103........ Official, meeting of, circular calling attention to. 1889 . . . . . .

Slip records for, note on (Cockereli). 1893. p. 198 ............ Station, committee on cooperation among, report of. 1894. 1. 112.

Work of, in experiment stations (Cook). 1891. p. 212 . . . . . .

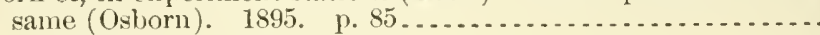
see also Entomological work.

Entomology:

Alstracts of reports of agricultural experiment stations on, 1889-1902 -

American economic, bibliography of more important contributions to.

Applied-

general truths in (Riley). 1,.323.

outlook of, address on (Riley). 189i. p. $181 \ldots \ldots$ parasitic and predaceous insects in (Riley). $1893 ., 130 .$. present and future of, in America (Webster). 1897. p. 5 ....

Economic-

accessions, catalogue of, simple form of (Ball). 1902. p. 37. bibliography of writings of Alpheus Spring Packard on (Henshaw). 1887 . eatalogue of exhibit at World's Columbian Exposition, Chicago, 1893

A $27.9: 9$

A $27.9: 9$

A27.9:10

127.9:

A9.7:3

A10.3:2t

19. $7: 4$

A9. $7: 7$

A9.7:4

A9.3:32

A9.6:26

A $9.7: 2$

A9.7:3

A9.7:4

A9.7:5

A9.7:6

A. $9.7: 7$

19.6:2

A9.6:6

A9:6.9

A9.6:17

A9.6:20

A9.6:26

A9.6:31

A9.6:37

A9.2:B $47^{2}$ A. $9.2: B 47^{3}$

$\mathrm{A} 9.2: \mathrm{B} 47^{6}$

A9.2:B $47^{7}$

A9.7:6

ג9.7:6

A $10.4: 14$

A9.7:6

A9.7:7

A9.7:3

A $10.3: 24$

A10.6:

A9.2:B 47

A1.1:884

A $9.7: 3$

A $9.7: 6$

A9.6:9

A9.6:31

A9.3:16

A9.3:31 
Entomology-Continued

Economic-C'ontinued

catalogue of exhibit of, at World's Industrial and Cotton Centennial Exposition at New Orleans, 1884-85.............. dipterous parasites in their relation to (Townend). 1893. p. 201

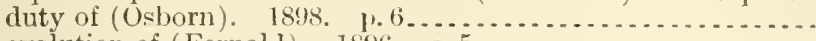
erolution of (Fernalu). 1896. p.5 Florida, report on (Gossard). 1901. p. 178 .............. laboratory method of experimentation in (Woul worth). 1891. p. 266

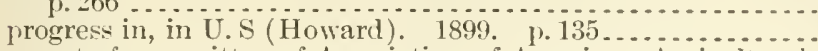
report of committee of Association of American Agricultural Colleges and Experiment Stations on progress in. 1891. p. 29

work in, at University of Kansas for season of 1894 (Snow). p. 140 .

Hatters of international concern in, some recent (Riley). 1888. 1). 126

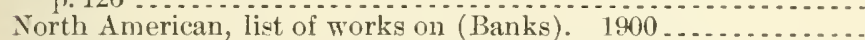

Office and lahoratory organization (Forbes), 1889 . p. $185 \ldots .$.

Official economic, brief account of rise and present condition of (Howard). 1894. p. 55

l'ractical, for farmers' sons. p. 305 .

Relations to regetable production of soil, with reference to both destructive and beneficial insects (Rathvon). p. $372 \ldots \ldots \ldots$.

Suggestions and notes on, presented to entomology section of Association of American Agricultural Colleges and Experiment Stations, at 15th annual convention, 1901 (Slingerland).

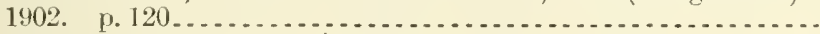

Southern States, report on (Garman). 1901. p. 153......... Teaching, report on (Cook). 1890. p. 107 - See ale Insects - names of States - headings beginning "Lintomological," "Entomologist," and "Entomology."

Entomology Division, Agriculture Department:

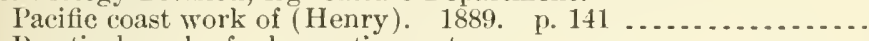

Practical work of, observations, ete $\ldots \ldots \ldots$

Some miscellaneous results of work of-

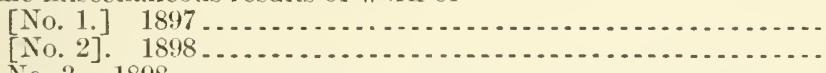

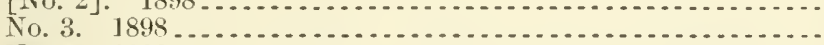

No. 4. 1900 . . . . . . . . . . . . . . .

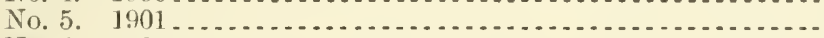

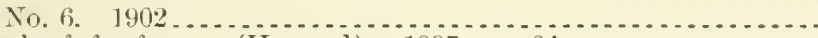

Work of, for farmer (Howard). 1897 p. 84 . Entomology section, Association of American Agricultural Colleges and Experiment Stations, report of:

1890. p. 144

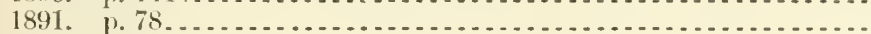

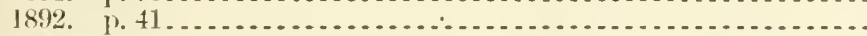

1894. 8.5

1895. pp. $17,95 \ldots \ldots \ldots \ldots$

1896. P. 107.

1897. pp. 16,90

1898. P1 $24,1333^{2} \ldots \ldots \ldots \ldots$

1899. pp. $44,966^{6} \ldots \ldots$

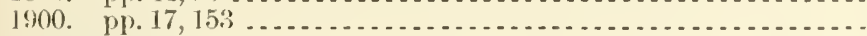

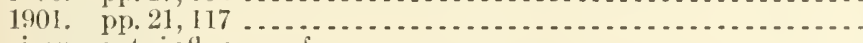

Environment, influence of:

(hemical composition of plants (Wiley). 1901. p. 299.......

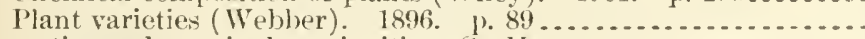

Enzootic cerebro-spinal meningitis. See Horses.

Enzymes, or soluble ferments, of hog cholera germ (Desichweinitz). '?. 266.

See also Catalase.

Enzymic ferments upon starches of different kinds, action of (Stone). 1896

Ephestia interpunctella, Zeller, notes upon (Patton). 1890. p. 158 .

A 9.2: 442

A9.7:6

A9.6:17

19.6:6

A10.3:99

A9.7:

11.10:899

A10.5:3

19.7:7

19.7:1

19.6:24

A9.7:2

19.7:7

A].1: 8658

A 1.1:8632

A10.3:115

A10.3:99

19.7:3

A9.

19.7:2

A9.3:

A9.6:7

A9.6:10

19.6:18

19.6:22

A9.6:30

19.6:38

A $1.10: 897$

A 10.5:3

A $10.3: 7$

A $10.3: 16$

A $10.3: 24$

A 10.3:30

1 10.3:41

1 10.3:49

A 10.3:(5)

A 10.3:76

A10.3::99

A10.3:115

A1.10:901

11.1:896

$14.1: 898$

1 10.3:34

19.7:3 
Fpidemica, how do rains and winds spread? (Abbe). 1895 . p. 295. Epizootic catarrh, information relative to (Decroix). 1873. p. 180 .

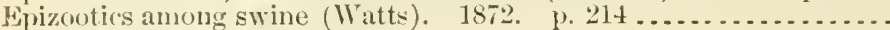
See also Lirgotism.

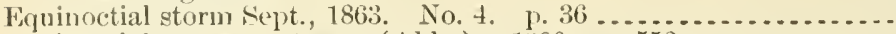
liquinoctial storms, notes on (Abbe). 1900. p. 558.............

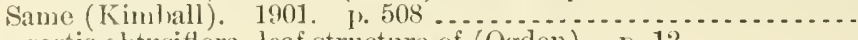

Cragrostis obtusiflora, leaf structure of (Ogden). p. 12 . . . . . . .

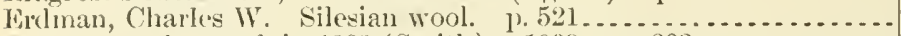
lirgot, prevalence of, in 1889 (Smitlı). 1S89. p. 203 Mrgotism:

Anong cattle in Kansas (Trumbower). p. 310.

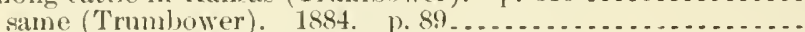
sane (lird). p. 31 . . . . .

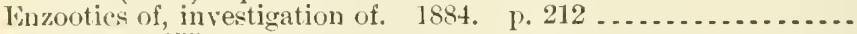
same, p. 175

Irie, Lake:

lufluence of wind and rythmic gusts on level of (Abbe). 1900.

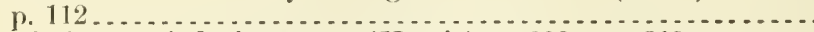

Oscillation, period of, note on (Harris) 1902 p. $312 \ldots \ldots \ldots$

Wind velocity and fluctuations of water level on (II enry) ....... Iirui, Jenri:

Grape disease in Europe, origin, history, phenomena, and cure.

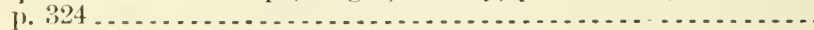

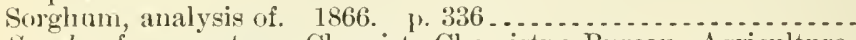
See also, for reports as Chemist, Chemistry Bureau, Agriculture Department, 1863-65 . . . . . . . . . . . . . . . . . . . . . .

Erosion due to heary rains and steep grades, notes on (Abbe). 1900.

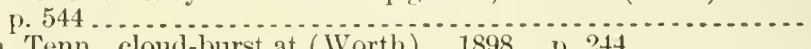

Erwin, Tenn., cloud-burst at (Worth). 1898. p. 244............ Erysiphese:

Of Montana, preliminary list of (Ankterson). 1889. p. $188 \ldots \ldots$ Upon phytoptus distortions (Anderson and Kelsey). 1889. p. 209. Eschenhagen, M. Magnetic instruments, some improvements in.

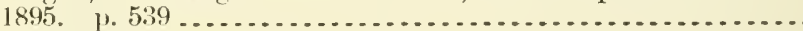

Esparto grass:

Habits, nature, and uses. p. 260

Information on (IcChesney). 1869. p. 233.

Espy, James P., and Franklin Kite Club (Abbe). 1896.

Espy, James I'., and Redfield period, 1830 to 1855 , of meteorological advancement (Davis). $1895 . \quad$ p. 305 . . . . . . . . . . . . . . .

Estabrook, John D. Address of, before Minnesota good roads

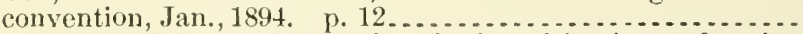

Estes, John M. Tohaceo; instructions for its cultivation and curing. Ither and atmosphere, note on (Abbe). 1899. p. 362 . . . . . . . .

Ether extract, determination of, experiments in (Anderson). 1890.

p. $93 \ldots \ldots$
Etluics, entomological report on (Cockerell). 1898. p. $87 \ldots \ldots .$.

Eucalyptus:

Cultivated in U.S. (MeClatehie). 1902

Growth of, in U.S. (Kinney). 1895. p. $23 \ldots \ldots \ldots \ldots$

Guealyptus globulus:

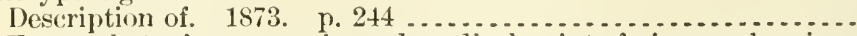

From a botanic, economic, and medical point of view, embracing its introlluction, culture, and uses (Planchon). 1875 ........

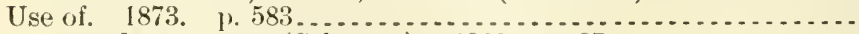

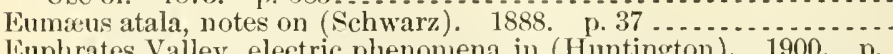
luphrates Valley, eleetric phenomena in (Huntington). 1900 . p. 286 ( Europe:

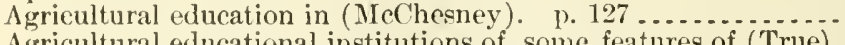

Agricultural erlucational institutions of, some features of (True).

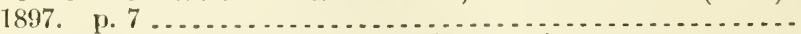

Agricultural experiment stations in (Atwater). p. $517 \ldots . . . .$.

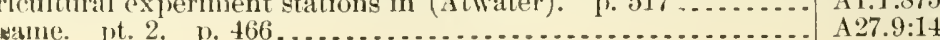


Europe-Continued

Agricultural statistics. p. 577.

Agriculture in. 1873. p. 557.

A $1.1: 57 \%$

A $27.9: 11$

Agriculture of, Anerican competition with. 1883. No.64. 1.31 - 127.9:21

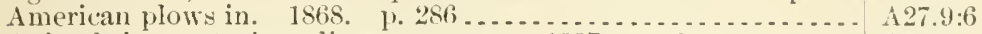

Animals in, contagious diseases among. 1897. p.69 ....... $14.1: 897$

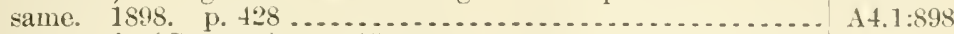

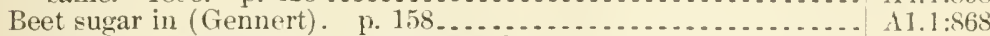

Beet-sugar manufacture in, progress of. p. 334 ............ $11.1: 86$ ?

Cattle in-

diseases of. 1870 . p. 435

foot-and-mouth disease of. 1869 . p. $385 * \ldots \ldots \ldots \ldots$

127.9:8

A $27.9: 7$

Cattle markets and abattoirs in (Alvorl). p. 279 ............. A4.1:301

Cattle plague, in 1865-66 (Dodge). p. 550 . $\ldots \ldots \ldots \ldots \ldots \ldots \ldots \ldots$. $1.1: 865$

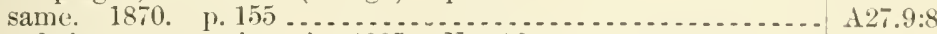

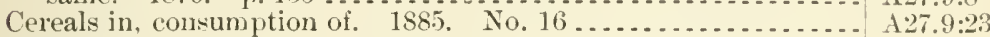

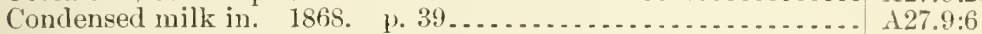

Cooperative credit associations in, and their relation to agricultural interests (Peters). 1892

Crop prospects of (Moffat). 1883. No. 61, 1. 34; No. 64, 1. 28;

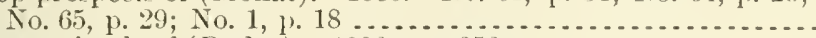

Farm animals of (Ryder). 1886. p. $353 \ldots \ldots \ldots \ldots$

Farm products incost of hauling. 1897

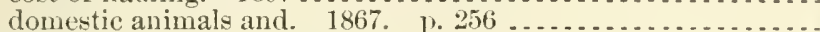

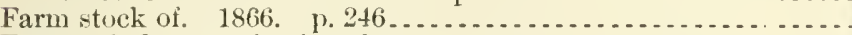

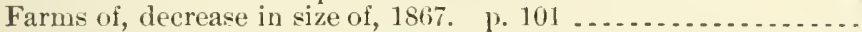

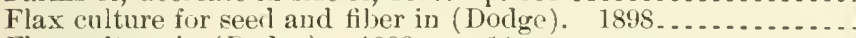

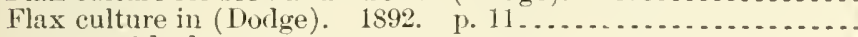

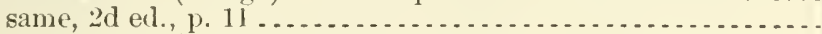

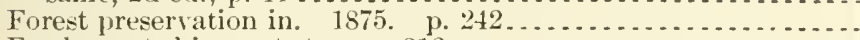

Fresh-meat shipments to. 1. $312 \ldots \ldots \ldots$ same, p. 374 .

Grape disease in; origin, history, phenomema, and cure (Erni).

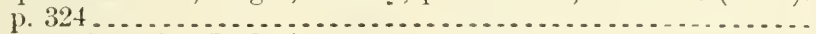

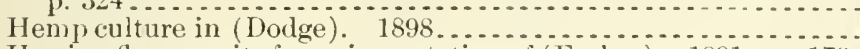

Hessian fly, parasite from, importation of (Forbes). 1891. 1. 179.

Highways of (Eldridge). 1902. p. 19...................

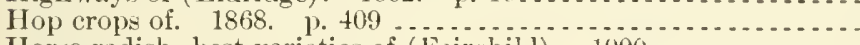

Horse-radish, hest varieties of (Fairchilil). 1900

Insects, two beneficial, introduced into U. S. from (Howard).

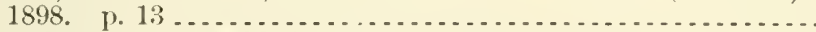

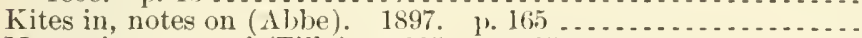

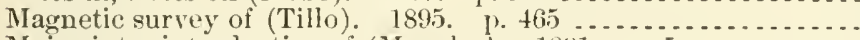

Maize into, introduction of (Murphy). 1891. p. $5 \ldots \ldots \ldots \ldots$

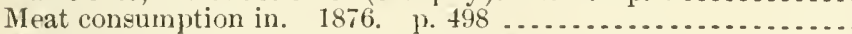

Meteorological phenomena in, Jan. and Feb., 1864 (Davy). No.

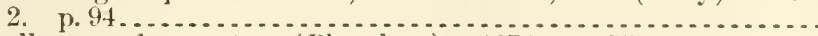

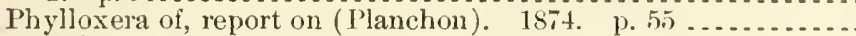

Pure-food laws of, affecting American exports (Bigelow). 1901 .

Ramie in, manufacture of (Dodge). 1893. p. $12 \ldots \ldots \ldots \ldots . . .$.

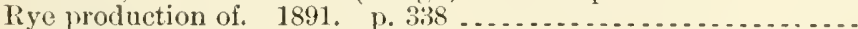

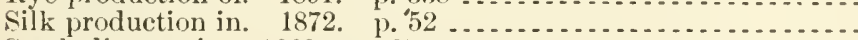

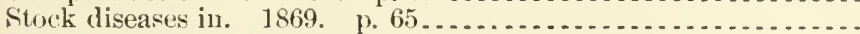

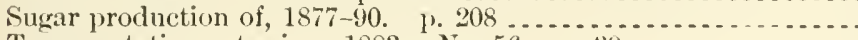

Transportation rates in. 1883. No. 56 . p. $39 \ldots \ldots$

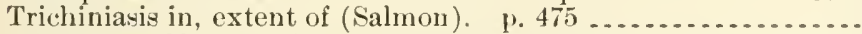
same. 1884. p. 269 . _...

- Trichinosis in, of alleged American origin (Stiles). 1901. p. 156.

Weather correspondence in (Abbe). 1895. p. $56 \ldots . . . . .$.

Western, prunes and prune culture in (Lake). 1901 . . . . . . .

Wheat prospect of (Moffat). Apr., 1883. No. 58. p. 31 ....
European tree sparrow (Passer montanus), at Saint Louls, Mo., history of (Widmann). p. 191

See also Sparrows.

\section{A27.8:3}

A $27.9: 21$ A $27.9: 24$

A $22.4: 27$ A $27.9: 5$

A27.9:4

A27.9:5

A11.5:10

A27.8:1

A11.5:1

A27.9:13

A $1.1: 876$

A $1.1: 877$

A 1.1:865

A 11.5:11

A9.7:4

A $22.3: 23$

ג27.9:6

A23.4:1

A9.6:17

A29.6:25

A $29.3: 11^{2}$

A 1.8:49

A27.9:14

A27.9:2

127.9:12

A 7.3:61

A 11.5:2

A27.9:29

127.9:13

127.9:7

127.9:28

127.9:21

A $4.1: 8.84$

A4.2: A115

14.3:30

12!1.6:23

1:0.3:10

$127.9: 21$

A5.3:1

* By a misprint, this page number appenrs twice. 
Eurytominae. Sep Grass and grain joint-worm flies.

Eustis, lake Comnty, Fla., thunderstorms at (Abbe). 1897. p. 251 . A29.6:25

Enstrotia caduca, prevaratory staces of (Kellicott). 1891. p. 321 .. A9.7:3

Evans, 1. W. Liverworts from southern Patagonia, collected by T.S. S. "Albatross" in 1887-91, list of. 1892. p. $140 \ldots . .$.

Evans, Edward A.:

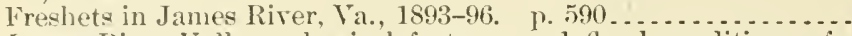

James River Valley, physical features and flood conditions of.

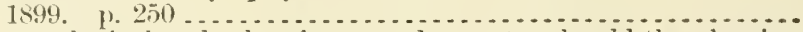

Meteorological and other forms and reports: shonld they be simplified; are modifications desirable? 1902. p. 168 . . . . . . . .

Evans, Frank L. See, for reports as Chief, Accounts and Disbursements Division, Agriculture Department, 1893-1902.

Evans, Walter Halrison:

Agricultural experiment stations, collective exhibit of, at Paris Exposition, 1900. catalogne of. I. 683 . . . . . . . . . . . . . .

Agricultural investigations in Ilawaii, Porto Rico, and Philip-

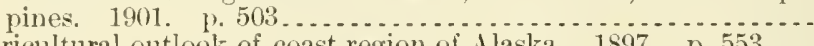
Igricultural ontlook of coast region of Alaska. 1897. p. 553....

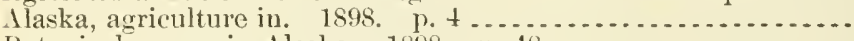
Botanical survey in Alaska. 1898. p. 48 ..................

Copper sulphate and germination; treatment of seed with copjer

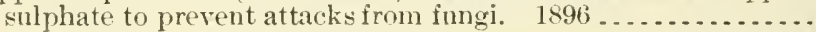

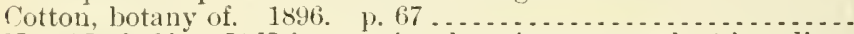

New York City, [2d] international conference on plant breeding and hybridization, 1902 , report on. 1902. p. $208 \ldots \ldots \ldots \ldots$

Paris, international congresses of horticnlture, viticulture, and agriculture. 1901. p. $205 \ldots \ldots \ldots \ldots \ldots$

Wreed restruction by means of chemicals. 1901. p. 19 .......

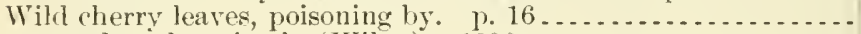

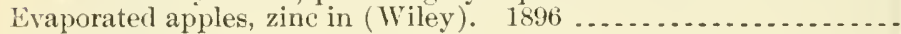

Evaporation:

Experiments on Kings River, Calif. 1901. p. 323.

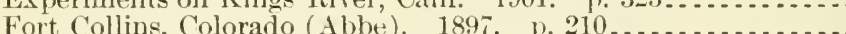

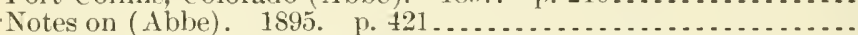

Temperature and, notes on (Abbe). 1898. p. 213........... Unclerground, report on (Balch). 1901. p. $545 \ldots \ldots . . . . . .$. See also Atmidometry.

Evergreen and other forest trees, causes of destruction of in northern New England and New York-

[1st] report (Packard). p. 138. same, p. 138 . .

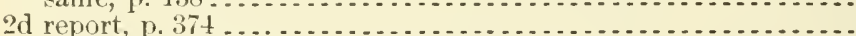

3 d report, in northern New England, p. 319 .................

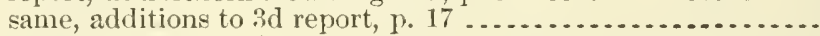

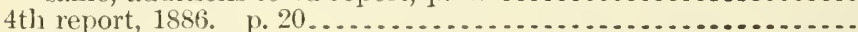

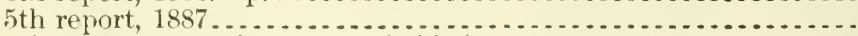

Evening, character of, notes on (Äbib). 1898. p. $215 \ldots \ldots \ldots . .$.

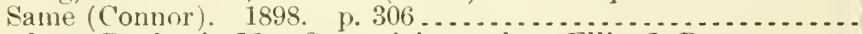

Everhart, Benjanin M. See, as joint author, Ëlis, J. B.

Evotomys:

Black Hills of South Dakota, description of new (Merriam).

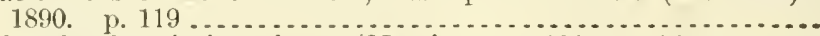

Coloralo, (lescription of new (Merriam). 1890. p. 23........

Two new species of, from Pacific coast region, description of

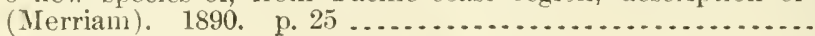

Fwell, Ervin Edgar:

Cocoa preparations, aduiteration of. p. 933 . . . . . . . . . . . .

Farm, every, an experiment station. 1897. p. 291 .............

Fats and oils, specific gravity of, at temperature of boiling water,

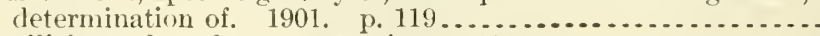

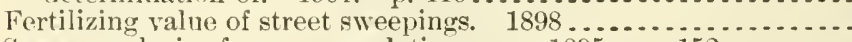

Sugar, analysis of, recommendations on. 1895 . p. $152 \ldots \ldots$

See also, as collaborator, Wiley, Harrey Washington.

Ewell, Ervin Elgar, Bigelow, Willard Dell, and Page, Logan Waller. Chemistry Bureau, Agriculture Department, exhiljit of, at Pan-American Exposition, Buffalo, X. Y., 1901 .................

A6.5:1

A29.6:25

A29.6:27

A $29.3: 31$

12.

A 10.3:80

A1.10:901

A $1.10: 897$

A 10.3:48

A10.3:6:

A28.3:10

A 10.3:33

A10.6:14

A 10.6:12

A 1.9:124

A 1.9:10:3

A 7.3:48

A10.3:100

A 29.6:25

A29.6:23

A29.6:26

A29.6:29

A1.1:883

A9.1:883

A1.1:884

A 1.1:855

A9.3:12

A9.3:13

A8.1:t

A $29.6: 26$

A29.6:26

A5.5:5

A5.5:4

A5. 5:4

A7.3:13

A1.10:897

A7.3:62

A7.3:55

A7.3:47

A7.3:63 
Fxchange Burean. See Information and exchange bureau.

Exchanges, foreign, system of, report on. p. 530.

Exotic collection. Sée Agriculture Department.

Experiment, its conception and methods of procenture (Bolley).

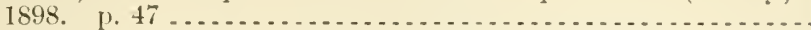

Experiment station, every farm an (Ewell). 1897. p. 291........

Fxperiment station record, vols. 1-11

Experiment station work, nos. 1-20; a series of "brief popular bulletins, compiled from published reports of agricultural experiment stations and kindred institutions in this and other countries," and assigned various numbers in the Farmers' Bulletin series. References to each article will be found

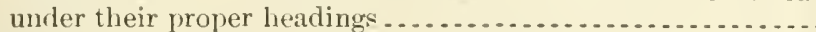

See also Note minder A10.11:

Experiment stations. See Agricultural colleges and experiment stations - Agricultural experiment stations - Engineejing experiment stations.

Experiment Stations Office, Agriculture Department:

Irrigation investigations of, scope and purpose of (Mead). 1902.

p. $417 \ldots \ldots$
Library and publications of circular regarding. $1889 \ldots \ldots$

Nutrition investigations of, scope and results of. 1902. p. $437 \ldots$.

Organization and first work of. 1889. p. 13 ................

Publications of-

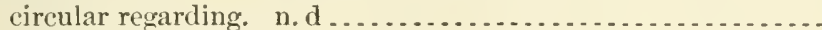

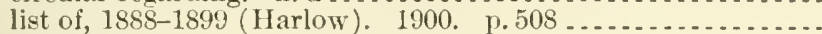

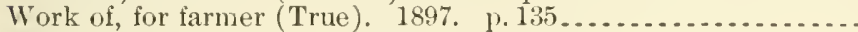

Work of ('True). 1895. p. 39.

Experimental farm, Agriculture Department, report of superintendent, 1865.

$$
\text { p. } 25 \text {. }
$$

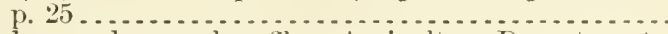

Experimental gardens and grounds, office, Agriculture Department, work of, for farmers (Saunders). 1897. p. 180.

Experiments of Agriculture Department, protest against proposed legislation restricting. [With copy of Senate bill 1063.] May 25,1897

Explosive noises at Franklinville, N. Y. (Kales). 1897. p. $393 \ldots$

Export trade in livestock and meat products, correspondence relating

Exports: to $($ Rusk). 1893

American, pure-food laws of European countries affecting (Bige-

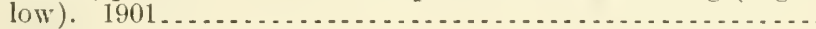

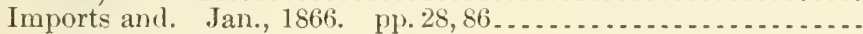
same, reports on, $1893-99 .$.

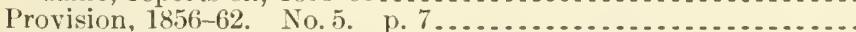

See also Agricultural exports - Agricultural products.

Exsiceati, new, report on (Fairchild). 1889 . p. $160 \ldots . . . . . . . . .$.

Extracts, flavoriug, analysis of, provisional methods for (Mitchell).

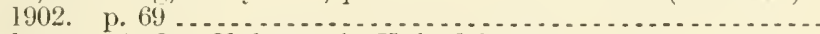

Eycleshymer, A. C. Club root in United States. 1891. p. 79 .... Eye:

Discases of, of horses (Law). p. 247.

Human, trematodes parasitic in (Monostomulum lentis and aganodistonum ophthalmobium) (Stiles). J902. p. $24 \ldots$.

Eye and its appenclages, cliseases of, of cattle (Trumbower). p. 353. Factories, refuse matter of, as fertilizers. 1867. p. $158 \ldots \ldots \ldots \ldots$.

Fartory cheese and how it is made (Merry). 1896. p. 45........

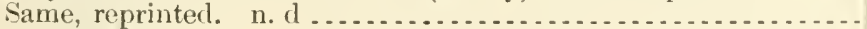
sipe also Cheese.

Fairluanks, George R. Florida freezes for century and half. 1895. p. 336 .

Fairchild, David Grandison:

Berseem, the great forage and soiling crop of Nile Valler. 1902. -

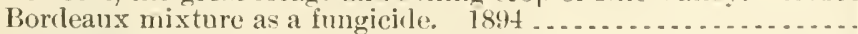

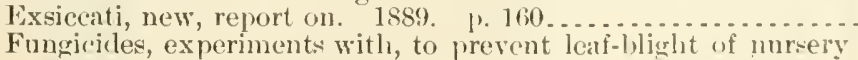

Fungacides, experments with, to prevent leafloliglit of mursely

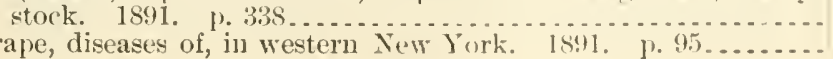

Classiffeation no.

$110.3: \pm 9$

$-11.10: 597$

1 10.6:

11.9:

A10.

A10.12:901

A 10.4:12

A10. $1^{2}: 901$

A 10.3:I

\10.4:16

A10.3:80

A 1.10:897

A $10.3: 24$

A 1.1:865

$+1.10: 897$

11.2:Exf ${ }^{2}$

A $29.6: 25$

A1.8:58

17.3:61

A27.9:4

A 12.4:

127.9:1

A28.5:5

17.3:6.5

128.5:

A $2: 2$ H 15

14.3:35

14.2:C:92

1.27.9:5

14.3:15

At.4:19

129.6:2:3

119.8:23

1:28.3:13

1:28.5:5

128.5:7

$128.5: 6$ 
Fairrhild, David Grandison-Continued

Hop culture in Bohemia. 1899.

Horse-rulish-

best varieties of Europe, and methods of cultivation. 1900.

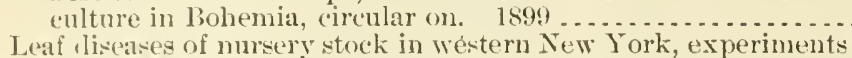

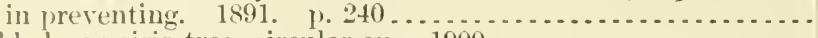

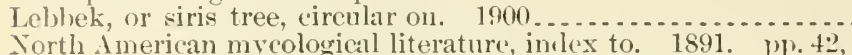

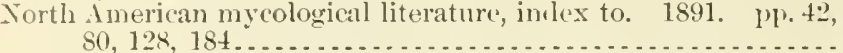

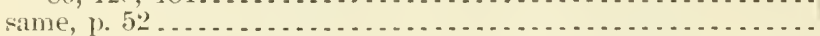

Plant introduction, systematic, its purposes and methorls. 1898. Spanish alnonds, and their introluction into America. 1902... Svalöf, Sweden, station for plant breeling at. 1901. p. 814.... Yams in West Indies, circular on. 1899..................

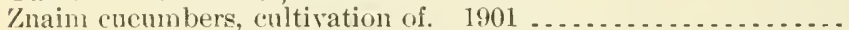
See ulso, als joint author, Galloway, Bererly Thomas- Halsted, Byron David - Lathrop, Barbour - sivingle, Walter Tennyson.

Fairchilil, (reorge Thompson:

Agrieultural education, evolution of, president's aduress to Association of American A gricultural Colleges and Experiment Stations at 11th annual convention, 1897. 1898. p. $32 \ldots . . . . . .$.

Colleges of agriculture, what should be taught in? 1896. p. 69. Study, relation of technical to general course of. 1893. p. $67 \ldots$

Fairfield, W. I1. Water on Laramie Plains, Wyoming, luty of, 1899. $1902.215 \ldots$

Faimun, Charles $\mathrm{E}$ :

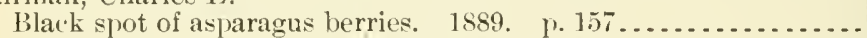

Fenestrate sporidia, development of some, observations on. 1891.

Fungi, new or rare, from western New Jork, notes on. 18s9.

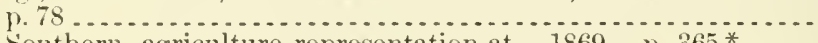

Fairs, Southern, agriculture representation at. 1869 . p. $365^{*} \ldots$.

Fake, N. J. See, as joint author, Crampton, C. A.

Falcones, William:

Mushrom beds, directions for preparation and spawning of. p. 17 .

Hushroom industry, review of. 1894. p. 20.

Mun p. 20................

Falkner, J. .I. Roads, good, duty of general government toward.

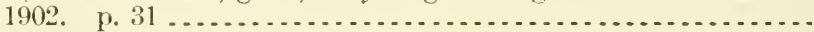

Fall army worm. See Army worm.

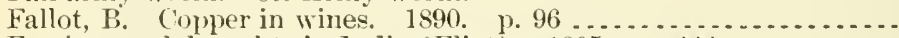

Famines and droughts in India (Eliot). 1895. p. $444 \ldots \ldots \ldots \ldots$.

Famines in India (Archibald). 1900. p. 246 ................

Fariy. See clanders and farey.

Farina or potato-flour, report on (Macrae), p. 390

Farlow, William Gilson. Fungi, some edible and poisonous. 1897.

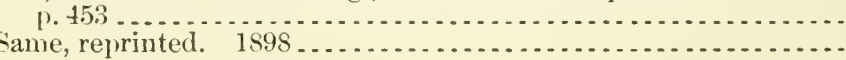

\section{Farm:}

Birds, four common, of garden and (Juld). 1895. p. 405

Birds on, value of (Samnels). p. $201 \ldots . . . . . . . .$.

British, increased production of. 1873 . p. $488 \ldots \ldots \ldots \ldots \ldots \ldots$

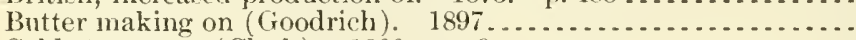

Cold storage on (Clark). 1900 , p. 9 . . . . . . . . . . . . . . .

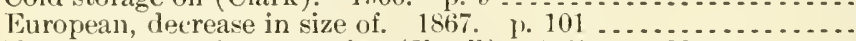

Every, an experiment station (Ewell). 1897. p. 291 ...........

Exodus from the, what are causes of (Koberts). 1896. p. 80 ... See also Dalvenport, li.

Experiment reports for popular use, preparation of. 1885.

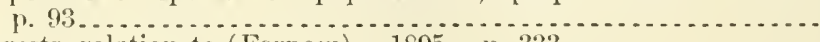

Forests, relation to (Fernow). 1895. p. $333 \ldots \ldots \ldots$

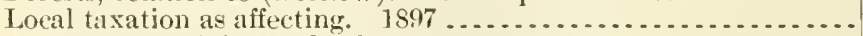

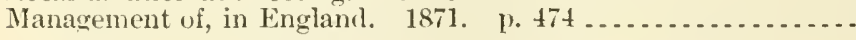
16.4:19

A23.4:1

16. $4: 20$

125.5:7

16. 4:23

A $28.5: 6$

A $28.5: 7$

A 13.3:21

A 19.3:26

A $10.6: 13$

A6.4:21

A 23.4:2

A 10.3:49

A 10.3:41

A $10.3: 16$

A 10.3:104

A $28.5: 5$

A 28.5:6

A $28.5: 5$

A27.9:7

A 18.5:1

A 18.5:1 ${ }^{2}$

A 1.9:53

A $22.3: 23$

A6.3:11

A29.3:11 ${ }^{2}$

A 29.6:28

A1.1:875

A 1.10:897

A28.3:15

A1.10:895

A1.1:867

A 27.9:11

A1.9:57

A1.9:119

A27.9:5

A1.10:897

A 10.3:41

A 1.7:9

A1.10:895

A $27.9: 35$

A27.9:9

* By a misprint, this page number appears twice. 
Milk on, care of (Pearson). 1597

Hodel, and agricultural colleges, letter on (MIChesnev). 1868. p. 460 .

Number and value of, increase and decrease in, $1850-90$. p. 1 it

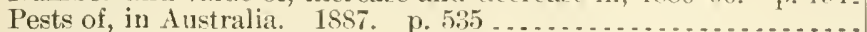

Poultry raising on (Salmon). $1901 \ldots \ldots \ldots \ldots \ldots$ same. p. $235 . . . . . . . . . . . .$.

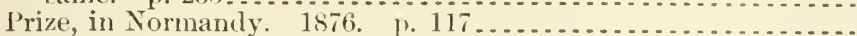

Pure water on, importance of. 1898 p. p...
Resources and products of, special statistics. $1868 . \quad$ pp. 3, 63,

Roads, best for farming districts and (Stone) 1894. p. $501 \ldots .$.

Small, large profits from. 1873. p. 193...................

Succulent forage for (Williams). 1899. p. 613.

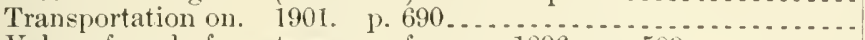

Value of, and of mortgages on farms. 1896. p. $599 \ldots \ldots . . . . .$.

Waste places on, tree planting in (Keffer). 18:4. p. $323 \ldots . .$.
See also Agriculture - Agricultural proclucts - Crops- Experi-

See also Agriculture-Agricultural products - Crops - Experi-
mental farm - Seed testing - headings beginning "Farm," "Farmers," "Farming."

Farm accounts, system of (Bourne).

Farm animals:

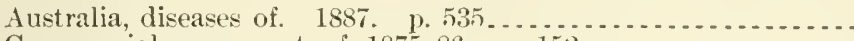

Commercial movements of, $1875-86$. p. $152 \ldots \ldots \ldots \ldots \ldots \ldots \ldots \ldots$

Condition of-

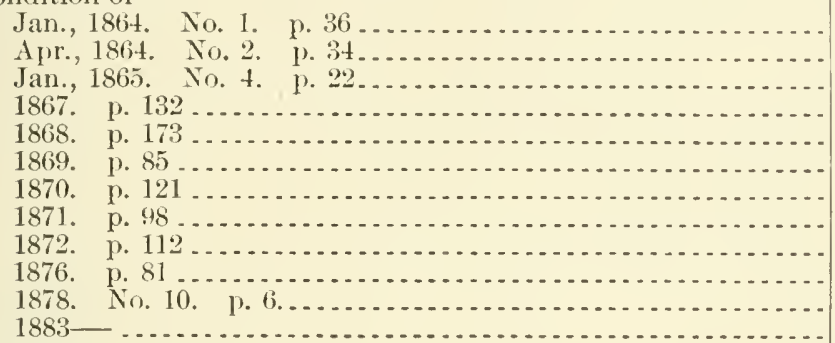

Diseases of -

1870. p. 125

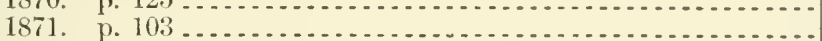

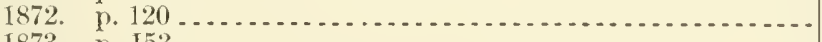

1873. p. 153

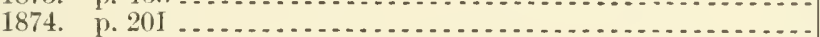

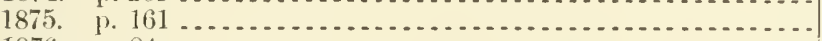

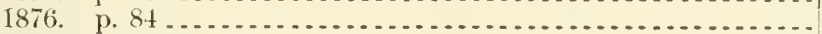

See also Diseases of animals.

Europe (Ryder). 1886. p. 353

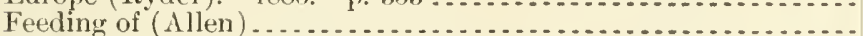

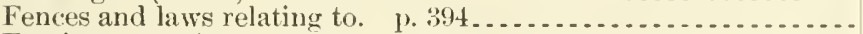

Foreign countries. 1887. p. 135.

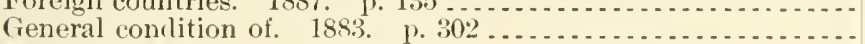

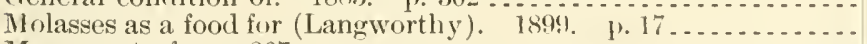

Novement of. p. 207.

Numbers and values of-

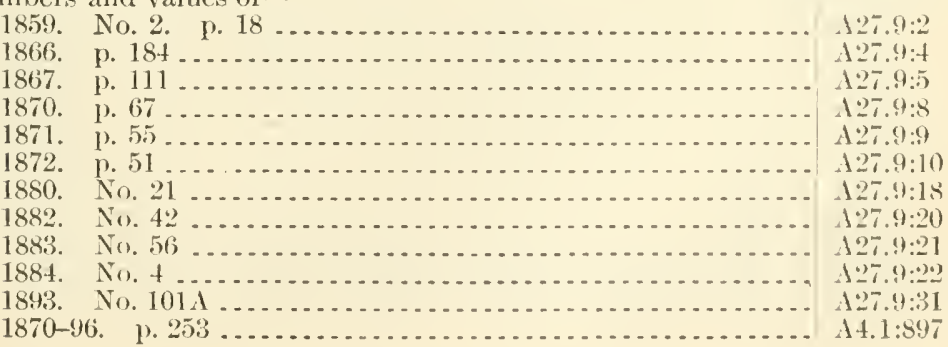


Farm animals-Continued

Tumbers and values of-Continued

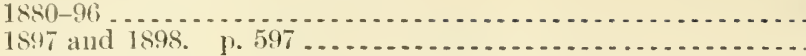

1899. ए. 668

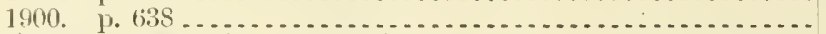

A27.8:11

A 4. 1:898

A 4.1:899

At. 1:901

Range or average price of, at Chicago-

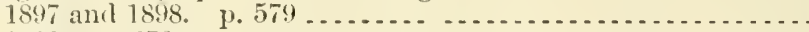

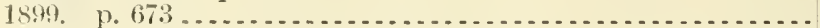

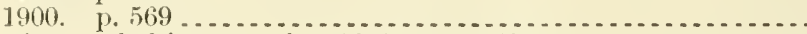

Receipts and shipment of, 1896-98. p. 550

Statistics of-

1895. p. 5333

1896. \%. 559

1.

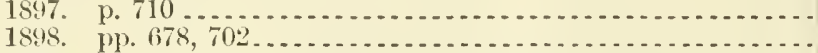

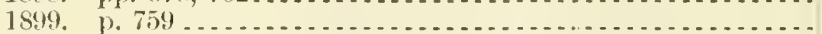

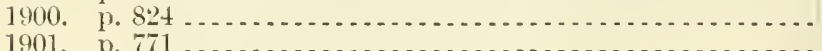

See also, for anmual reports on, $\mathrm{A} 27.1$ :

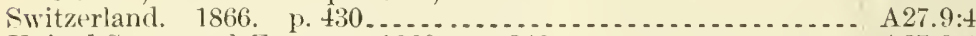

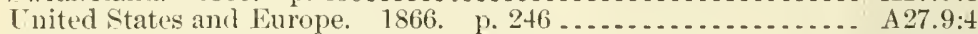

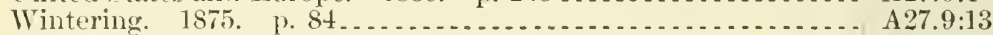

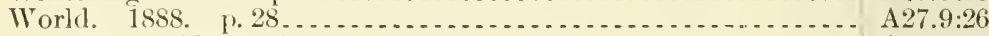

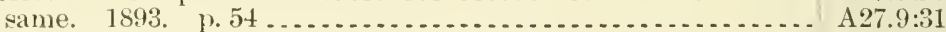

See ulso Animals, clomestie.

Farm animals and their products. 1901. p. $771 \ldots \ldots \ldots \ldots \ldots \ldots \ldots \ldots$. . . A 1.10:901

Farm hnililings:

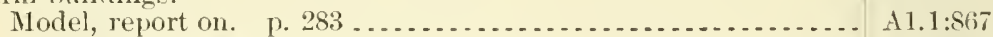

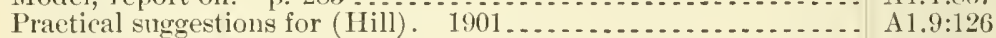

See also Stave silo.

Farm capital. 1870. p. 42 .

Farm crops. See Farm products.

Farm drainage (Elliott). 1896

A $4.1: 898$

4.1:899

A $4.1: 898$

A1.10:895

$10: 896$

A 1.10 .898

A 1.10:899

A 1. 10:900

A1.10:901

A27.9:8

A $1.9: 40$

Fal'm experiments, Agrieulture Department:

1867 (Farquhar). p. 187.

1868. p. 412

1869. p. 267

1870. p. 452

1871. 1. 238

1872. ए. 454

1873. p. 289

1874. 1.255

1875. p. 502

Farm implements:

American and European. 1883. No. 56

Improvel (Todil). p. 225

Farm implements and machinery:

Course of prices of, for series of years (Holmes). 1901.

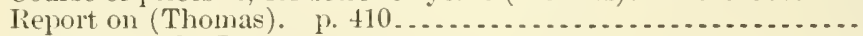

Farm insects. See Insects.

Farm labor:

Irish, wages of. 1870 . 1. $290 \ldots \ldots \ldots \ldots \ldots \ldots$

Whages of, rate of, in U. S.-

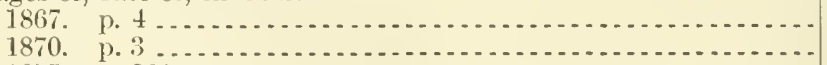

1875. p. 261

1882. No. 4:3

1884. No, 4

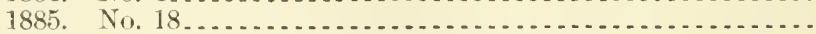

1888. p. 169

1890.200

1840-.92 (Dorlge).

$1866-99$ result of eleven

Farm manure, report on (Hébert). 1895. p. 141 ... . . . . . . . . .

A1.1:867

A1.1:868

A1.1:869

A1.1: 870

A 1.1:871

A1.1:872

A 1.1:873

A1. $1: 874$

A 1. 1:875

A27.9:21

A 1.1:866

A27.8:18

A1. 1:862

A $27.9: 8$

A $27.9: 5$

A27.9:8

A 27.9:13

A27.9:20

A 27.9:22

А $27.9: 23$

A27.9:26

A $27.9: 28$

A27.8:4

A27.8:22

A 10.6:5

Farm practice ancl fertilizers as insecticides (Smitlı), 1893. p. 93... A9.7:6 
Farm prices:

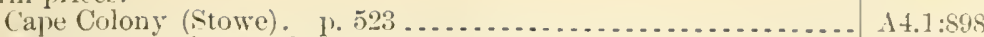

Market quotations and. 1893. ए. 485.

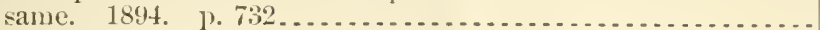

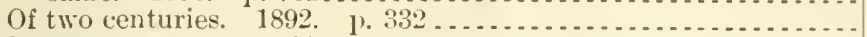

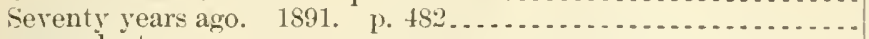
Farm products:

Aereage, production, and value of, 1866 to 1895

Cost of hauling to market or to shipping points in European

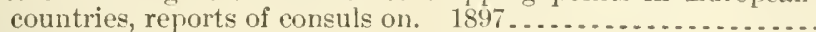

Fertilizing constituents of1894. p. 565

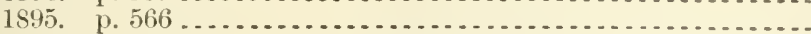

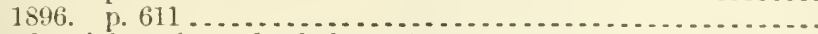

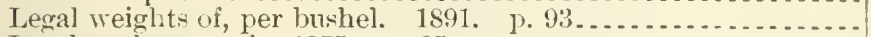

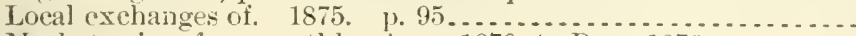

Market prices for, monthly, Aug., 1870, to Dee., 1876 .........

Marketing (Hill). 1897 ................................

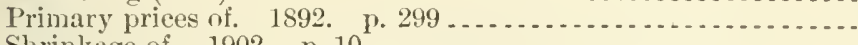

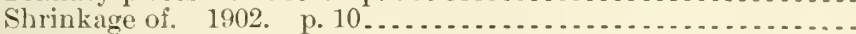

Yield and home prices of -

1869. \%. 14

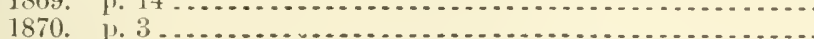

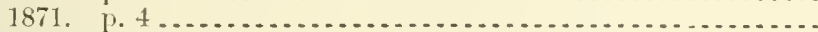

See also Agricultural products - Crops - Produce.

Farm records, $18.50-71$. p. 68.

Farm stock. See farm animals.

Farmers:

Agricultural experiment station as educator of (Caldwell). 1882.

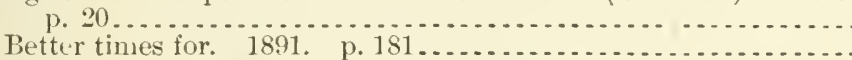

Chicory growing as addition to resources of, in America (Kains). 1898

Closer intimaey between experiment stations and farmers' insti-

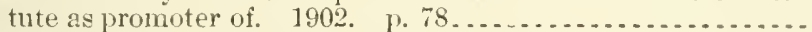

Cotton seed to, value of (Beal). 1901. p. 24..............

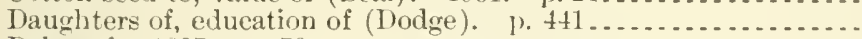

Debts of. 1887. p. 78.............

Employment ageneies for use of, list of (West) $\ldots \ldots \ldots \ldots . . .6$.

Example for American ......

Families of, health of (Hall). p. 459

Forestry for (Fermow). 1894. p. $461 \ldots \ldots$

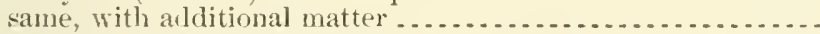

Frauils upon. 1886. 1\%. 71

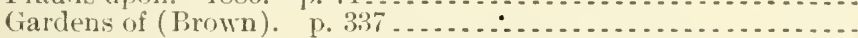

Good roads and how to get them, views on (Creasy). 1901. p. 78 .

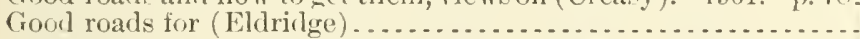

Hawks and owls as related to (Fisluer). 1894. p. 215 .......

Houses of, places and plans for (Hall) p. 313 station reach and interest?
How can agricultural experiment station (Roberts). 1889. 1.30.

Interest of-

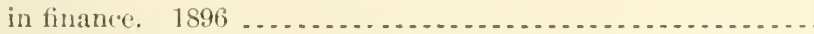

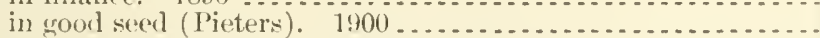

Milling companies for. 1890. p. 294

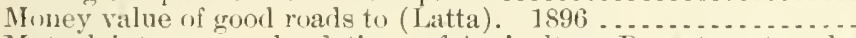

Mutual interests and relations of Agriculture Department and, farmers' institute as medium for developing (True). 1902. 1. 102 .

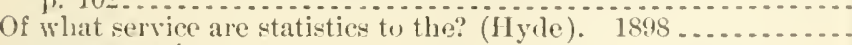

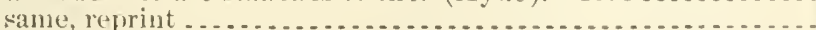

Organizations of-

cooperation of agricultural experiment stations with, in experi-

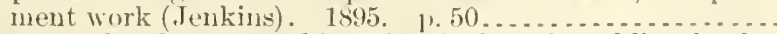
how may they hasten teaching of arriculture in public scolools. 1902. p. 89

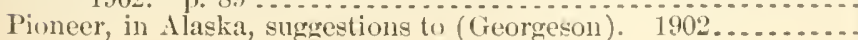

A $27.9: 31$

A $279: 32$

A27. $7: 30$

A $27.5 \cdot 29$

127.4:1

122.4:27

A1.10:894

A 1.10:89.

A 1.10:596

127.9:29

А $27.9: 13$

127.9:

1 1.9:62

$\$ 27.9: 30$

A $1.9: 149$

A27.9:8

A27.9:9

A27.9:10

A27.9:10

A1.8:22

A $27.9: 29$

A6.3:19

A 10.3:120

A 1.9:124

A1.1:866

A27.9:25

127.4:13

A12.4:4

11.1:862

A1.10:8:4

A1.9:67

127.9:24

11.1:S6:3

A22.3:21

A 1.9:05

11.10:894

1 1. 1:86\%,

$110.5: 1$

A:7.4:3

A 1.9:111

127.9:28

12:. $4: 23$

1 10.3:120 11.10:\$97 1:7. $8: 14$

A 10.3:24

110.3:1:0

110.10:1 
Farmers-Continued

P'opular erlucation for, in U. S. (True). 1897. p. 279 ......... l'ractical assistance to, in handling forest lands (l'inchot). 1898.

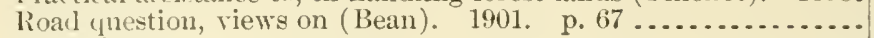
Sions of-

entomology for, practical. p. $305 \ldots . . . . . . . . . . . . . . .$. home life, training, and ambition of (Adams). p. 307 .......

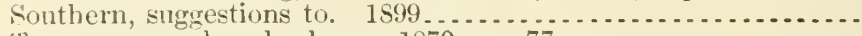

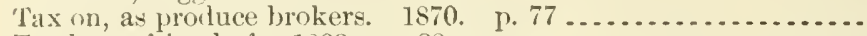

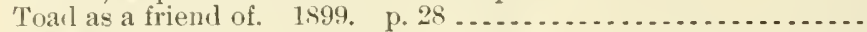

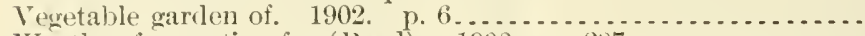
Weather forecasting for (leed). 1900. p. $287 \ldots \ldots . . . . . . .$. What meteorology is doing for (Harrington). 1894. p. 117..... Work of Agriculture Department for. See Names of divisions, bureaus, and offices in Agriculture Department.

See clso Agriculturist - English farms anil farmers.

Farmers' Alliance, National, othicers of. 1898. p. 627 .......... Farmers' bulletins:

Available for distribution, list of ......................... Distribntion of, general orders relative to, $1895-97 \ldots \ldots . . . . .$.

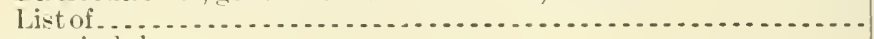
Farmers' clubs:

List of -

1870 .

1872

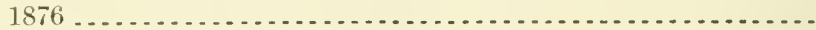

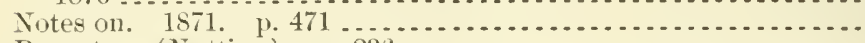

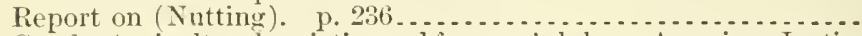

See also Agricultural societies and farmers' clubs - American Institute Farmers' Club - West Newbury (Mass.) Farmers' Club.

Farmers' Institute Workers, American Association of, proceedings of sixth annual meeting, held at Buffalo, N. Y., Sept. 18 and 19 , 1901; ellited by A. C. True, D. J. Crosby, and G. C. Creelman. 1902

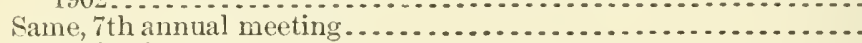

Farmers' institutes:

Factor in creating desire for agricultural education. 1902. p. 68. History and status in U.S. and Canadla (Bailey). $1900 \ldots . . . . .$. Illustration and demonstration work at (Curryer). 1902. p. 52.

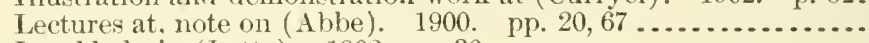

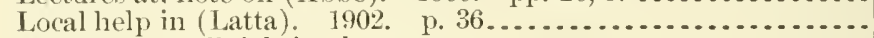

Managers or officials in charge1898

1899. p. 687

1900. p. 643 1901. p. 621

Medium for developing mutual interests and relations of farmers and Agriculture Department (True), 1902. p. 102........

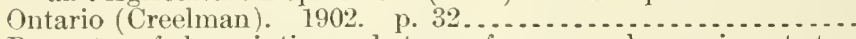

Promoter of closer intimacy between farmers and experiment sta-

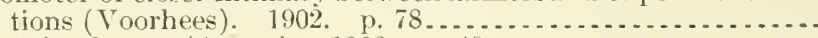

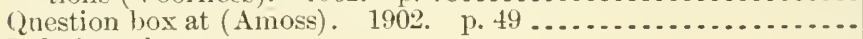

Relation ofagricultural colleges and experiment stations to (Hutchin-

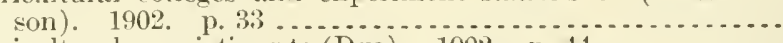
agricultural associations to (Dye), 1902 p. p. $44 \ldots \ldots . .$. Agriculture Department to (True). 1902. p. 22 ........... to our industrial population (Hoard). 1902. p. $20 \ldots \ldots \ldots$

Report of committee of Association of American Agricultural Colleges and Experiment Stations on. 1898. p. 46.

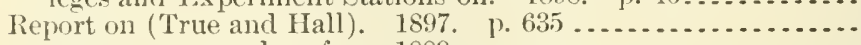

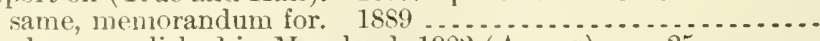

Work acconplished in Maryland, 1902 (Amoss) p. 25 .........

Work of, hest method of publishing results of (Collingwooul). $1902 . \quad$ p. 39

A $1.10: 897$

A 13.4:21

A $2: 2.3: 21$

A $1.1: 868$

A $1.1: 863$

A1.9:98

A27.9:8

A 1.9:87

A 1.9:149

A29.6:28

A1.10:894

A1.10:898

A21.2:F 222

A1.2:P96

A1.9:

A1.8:4

A1.8:5

A1.8:12

A $27.9: 9$

A1.1:867

A10.3:110

A $10.3: 120$

A 10.3:120

A10.3:79

A 10.3:110

A29.6:28

A $10.3: 110$

A1.10:898

A 1.10:899

A1.10:900

A1. 10:901

A10.3:120

A $10.3: 110$

A 10.3:120

A10.3:110

A10.3:110

A10.3:110

A10.3:110

A 10.3:110

A10.3:49

\$10.6:7

A10.4:9

A 10.3:120

A 10.3:110 
Farmers' institutes-Continuer

Worker at-

adelress on, before American Association of Farmers Institute

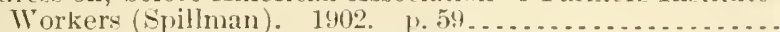

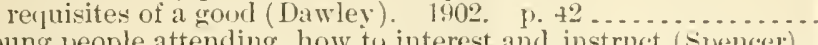

Tounc people attending, how to interest and instruct (Finencer).

See also Women's farm institutes.

Farmers' National Congress, ofticers of:

1898. p. 627

1899. p. 717

1900. p. 671

1901. P. 6.37 .

Farmers' reading courses:

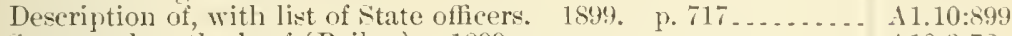

Scope and methods of (Bailey). 1899....................

Farming: same, abridgment............................................ 109

Aroostook County, Maine. 1869. p. 149 ............... 127.9:8

Association in, practical results of. 1) 113................ $427.9: 12$

High, as illustraterl in history of Netherlands (Tilden). p. 527... A1.1:866

Influence of different systems of, on fertility of soil. 1899. 1. 9. A1.9:87

Modern, in America (Taveau). p. 280............................

New Englanddoes it pay? p. 187 report on. p. 255.

Torthern and southern planting (Watts). 18, p. $207 \ldots$

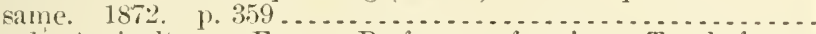

See also Agriculture - Farm - Perfumery farming-Truck farming.

Farquhar, W. II. Farm experiments. p. 187.

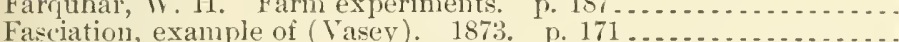
Fassluender, Dr.:

Cattle foods, work in, communications from foreign chemists

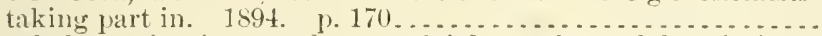

I'otasl determination, results on otheial samples and hescriptions

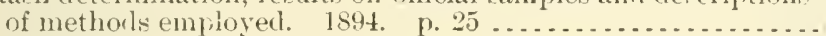
Fassig, Oliver Ianard:

Baltimore temperature curve for May, normal, marked ri ce in.

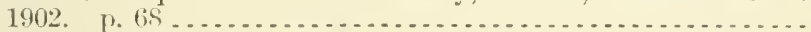

Barometric wave, laily, westward movenent of. 1901. P. 4.5. .

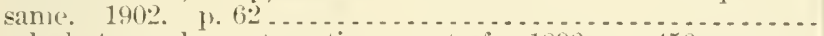

Cloud photography, automatic, report of. 1896. p. 456 .......

Gemman Agricultural Expreriment itations, Asoneiation of, ninth annual convention of, 1896 , rejort on. 1897 . 1. $447 \ldots \ldots .$.

Johns Iopkins Lniversity, meteorolugy at. 1siss. 1. 306j . . . .

Light precipitation, clevice for automatically rocorling becrinning

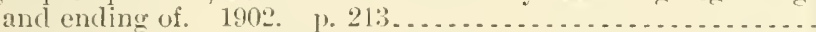

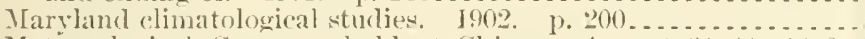

Meteorological Congress, helil at Chicago, Angust 21-2t, 1598 ,

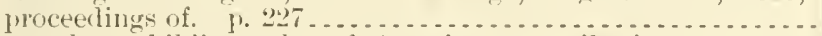

Meteorology, bibliography of American contributions to, note

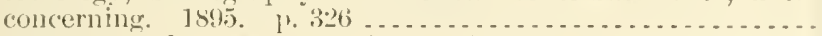

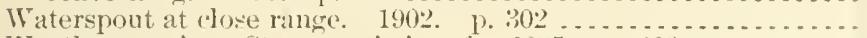

Weather services, State, statistics of. 1845. p. $209 \ldots \ldots . . . . .$.

cee also, as enlitor, report of International Meteorological ('ongress, Chicago, $1899^{3}$

Fat aciols, soluhle and insoluble, notes on methorls for (Jatrick).

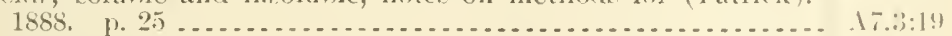

Fats:

Container in tubereulosis bacilli (De Schweinit\% and horset).

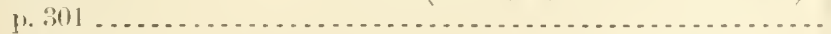

Crystallization of (Crampton) is89 p. $449 \ldots \ldots \ldots \ldots$

formation of, in animal losly (Soskin). 1897. 1\% $179 \ldots \ldots \ldots$.

See ulso butter - Butter fat-cils and fats.

Fatty bodies in vegetable organisms, rejurt on methods of estimution

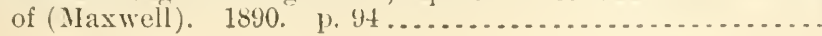

A1.1:87t

A $1.1: 870$

A27.9:10

A27.9:10

A 1.1:865

A $27.9: 11$

17.3:43

A7.3:43

$129.3: 31$

A29.6::29

129.6:31

129.6:24

A 10.6:8

A:4.6:2t)

1:?9.83:31

1:9.3:: 1

$1: 91,6: 21$

129.8:11"

1:9.6:301

1.99.6::2:3

1:9.:3:11

14. $1: 898$

17.3:13

110.6:

17.3:28

$114-04-13$ 
Faunil. See North American fauna.

Faune, plant, notes on (cockerell). 1892. p. 117

Fivean, durustin l. Rice culture, report on. p. 174 A9.7:5

Faville, (reos. C.:

Malalie du coit, extirjation of, in Neluaska and South Dakota.

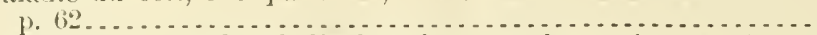

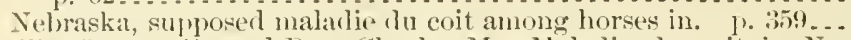

Faville, (ieorge C., and Day, Cluarles M. Maladje du coit in Neliraska, second outlireak of. p. $134 \ldots$

Fayetterille, Ark, experiment station at, laboratory notes from. 1890, p. 13t . . . . . . . . . . . . . . . . . . . . . . .

Featherstone, $1 T$. B. Meterological observations of San Francisco.

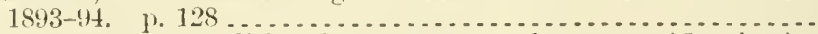

Feloruary, weather condition for, statement of average (Garriott).

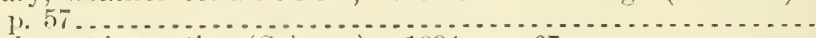

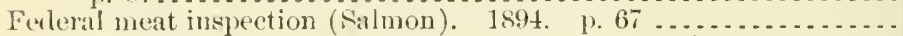

Fred, coarse, neressity of, to grow cattle (Davenport). p. 202....

Feed mills and windmills, 1902 . 1, $31 \ldots \ldots \ldots \ldots \ldots \ldots \ldots . . . . . .$.

Feeding:

Experiments in special points bearing on (Wing). 1891. p.98..

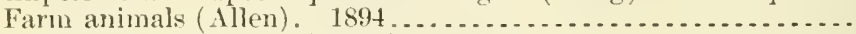

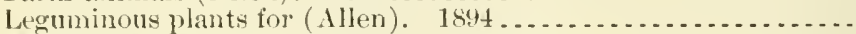

Managenent of cattle and (Henry). p. 439 .................

Value of cotton-seed products for (lilgore). 1896. p. $385 \ldots . .$. See also Foorls.

Feerling stuffs:

Analyses of American, compilation of (Jenkins and Winton).

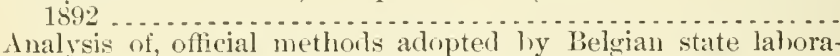
tories and agricultural experiment stations of 11 olland. 1899.

Chemical analysis, methoris of, abstract of literature on. $1890-91$. p. 61 Chemical analysis, methods of.

See also Chemical analysis,
Composition of, for animals-

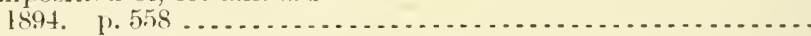

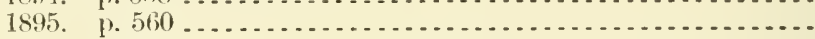

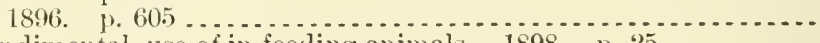

Condimental, use of in feeding animals. 1898. p. 25 ........

Control of, needs and requirements of. 1897. p. $421 \ldots \ldots . . .$.

Digestibility of-

methorls of determining (Kellner). 1898. p. $504 \ldots \ldots . . . .$. report on (Jordan and Hall), 1900....................

Fertilizing constituents of-

1894. p. 565

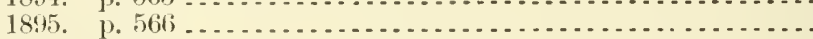

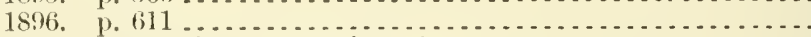

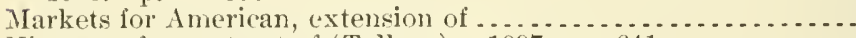

Nitrogen, free extract of (Tollens). 1897. p. 641 .............

Pentaglucoses in, notes on occurrence and quantitative estimation

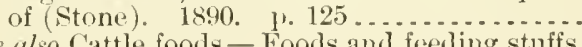

See also Cattle foods - Foods and feeding stuffs.

Fegan, M. E. See, for reports as Chief, Seed Division, Agriculture

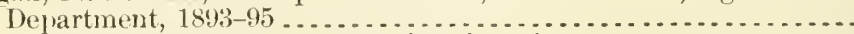

Fehling's solution. See Sugar, estimation of.

Felt, Ephrains Porter:

Entomologic service, New Jork State, voluntary, in. 1899. p.

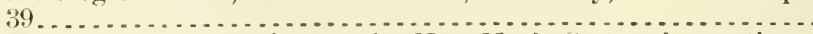

Forest and shade tree insects in New York State, observations

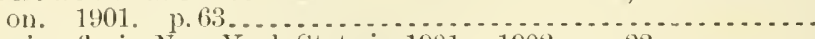

Hessian fly in New York State in 1901 . 1902 . p. $22 \ldots \ldots . . .$.
Insecticides, early spring applications of, on fruit trees, some ef-

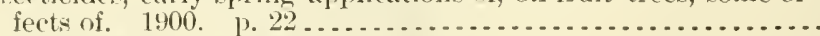

Insects of New York State, notes on-

1898. 1. 16

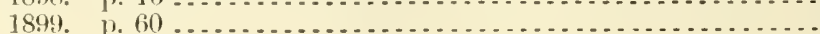

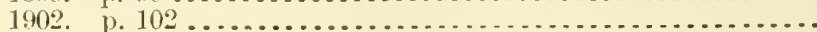

A $1.1: 867$

A $4.1: 89.9-4$

$14.1: 8: 1-2$

A $4.1: 8: 19$

A $7.3: 24$

129.6:2:2

A29.6:29

A 1. 10:894

A 4. 1:897

A1.9:149

A 10.5:3

A 1.9:2:2

A $1.9: 16$

14.2:C29

A10.3:3:3

A10.3:11

A10.6:10

A7.3:31

A1.10:894

A $1.10: 895$

A $1.10: 8.96$

A1.9:73

A1.10:897

A10.6:9

A10.3:77

A 1.10:894

A1. 10:895

A1.10:896

112.4:7

A $10.6: 8$

A 7.3:28

A24.1:

A9.6:20

A 9.6:31

A9.6:31

A9.6:26

A9.6:17

A9.6:20

A $9.6: 37$ 
Felt, Ephraim Porter-Continued

Nursery-inspection laws and rulings, suggestions toward greater

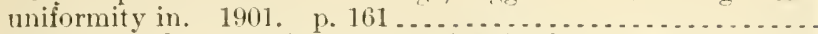

Petroleum, crude, and other inserticides, further notes on. 1902.

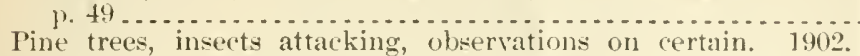
p. 103 . . . . . . . . . . . . . . . . . . . . . . . . .

San Jose scale, experimental work in New York State ayainst.

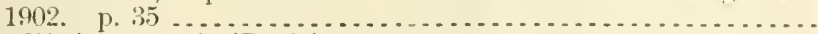

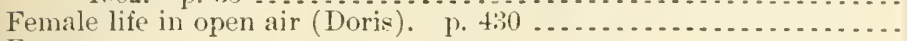

Fences:

laws relating to farm animals and. p. 394

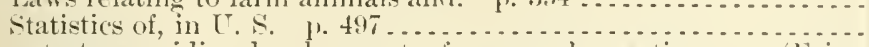

Fenestrate sporidia, development of some, observations on (Fair-

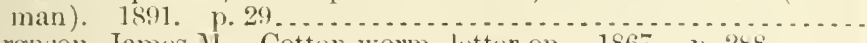

Ferguson, James M. Cotton worm, letter on. 1867. 1. 258 . . . .

Ferguson, Margaret C. Germination of spores of Agaricus campestris and wher basidiomy cetous fungi, preliminary stud! of. 1902.

Fergusson, \&. P.:

Kite experiments at Blue Hill meterological observatory. .1896.

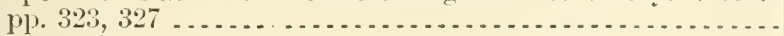

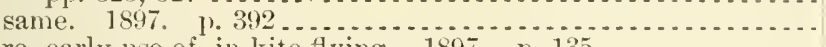

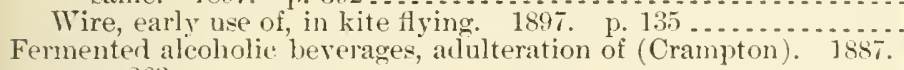

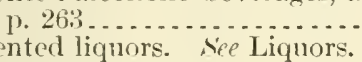

Fermented liquors. Sice Liquors.
Fernald, Charles Henri:

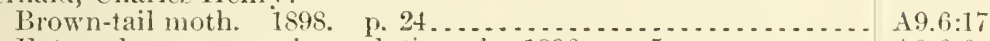

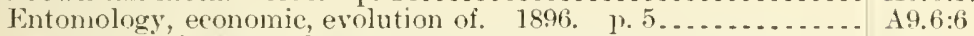

Gypy moth in Massachusetts, notes on. 1895. p. $59 \ldots \ldots \ldots \ldots . .49 .6: 2$

P'yraliclie from Death Valley, deseription of. 1894. 1. 255..... $19.7: 6$

Fernald, II. T. Insects in Massachnsetts in 1901. 1902. p. 119... A A0.3:115

Fernow, Bernhard Ednard:

"Boxed" or "turpentine" timber, strength of ................

Forest conditions of Rocky Mountains, introduction to rejorts

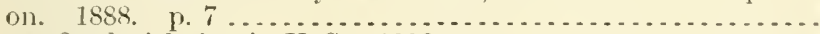

Forest-fire legislation in $\mathrm{U}$. S. $1896 \ldots \ldots \ldots \ldots$

Forest fires, is protection against practicable? ................

Forest influences, introduction and smmmary of conclusions to reporty oll. 1893. 1.9 . 19.2.

Forest resources, our, facts and figures regarding briefly stated.

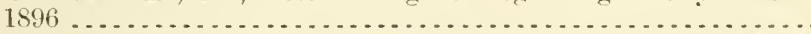

Forest supplies, consumption of, by railroads, and practicathle economy in their nse. 1890. p. 13.

Forestry conditions and interests of Wisconsin, discussion of.

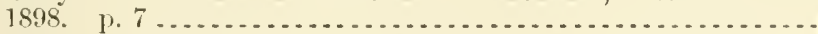

Forestry Division, Agriculture Department, work of, for farmer.

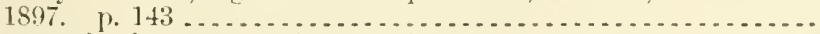

Forestry for famers. 1894. p. $461 \ldots \ldots \ldots \ldots \ldots$ same. . . . . . . . . . . . . . . . . . . . . . . . . . . .

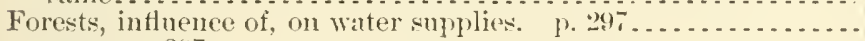

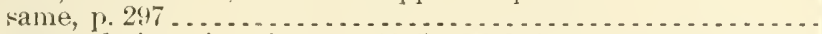

Forests, relation of, to farms. 1895. 1. $333 . . . \ldots \ldots \ldots \ldots . . .6$.

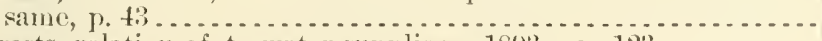

Forests, relation of, to water supplies. 1893. p. 123.......

(iovernment timber tests. . . . . . . . . . . . . . . . . . . . . .

Lumbermen of $\mathcal{U}$. S., sugrestions to, in behalf of more rational

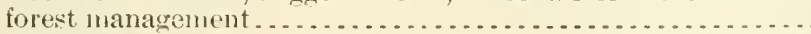

Mechanieal tests on 32 speeies of $\mathrm{American}$ woods, summary of .

Railroarl ties-

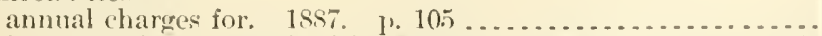
impregnation as practiced for Prussian ralways. 1s9t. 1'. 286.

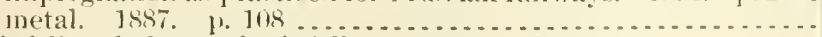

Rainfall and chats of rainfall. 1902 pp. $24,24 \ldots \ldots$

Sanitary significance of forests. 1893. 1) 17] ............

A $13.3: 2$

A $13.4: 1: 3$

1 $13.4: 14$

113.8: 7

113.4:11

1 1:3.3:4

113.3:16

11.10:897

A1. 10:894

A1.9:67

A1. 1:889

1 13.1:\$89

A1.10:59\%

A 1.9:6:7

113.8:-

113.4:7

113.4:10

11:3.4:15

1 13.3:1

1 13.3:9

A 1:3.3:1

1:29.6:30

A 13.3:7 
Fermow, Beruhard Eluard-Continued

snow-slider and avalanches, their formation and prevention.

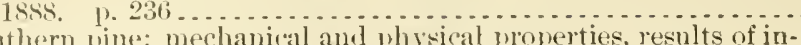

Sonthern fine; mechanical and physeal properties, results of in-
restigations of J. B. Jolnson anel Filibert Roth. $1896 \ldots . .$.

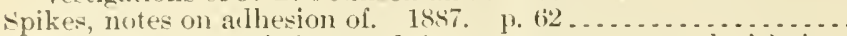

state forestry commissions and forest reserves, recent legislation (111. 1897

Statement before Committer on idgrienlture, Feb. 16, 1845 .....

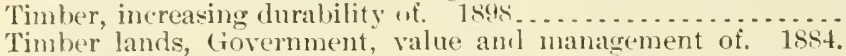
D. 2:)

Timber plyyics, pt. 1 ; preliminary report. 1892.......... same, jt. 2, progress report, introluction. 1893. p.1....

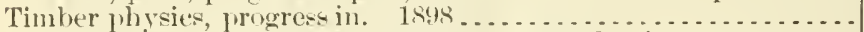

Timber pines of southern [nited States, introduction to report on.

Trees, age of and time of blazing determined by annual rings.

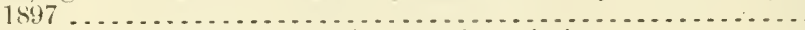

Turpentine gathering, effect of, on timber of pine ...........

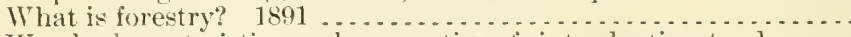

Wool, characteristies and properties of, introuluction to elemen-

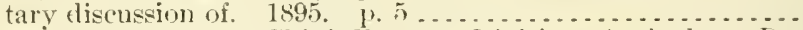

Sie ulso, for reports as Chief, Forestry Ibivision, digriculture Devartment, 1886-1897

Sie also, as reviser, Spalling, $V$. II.

Fermow. Bernliard Eduard, and Ruth, Filibert. Wood, different

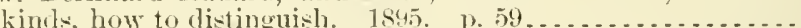

Ferns:

Collecterl in Mexico by J. X. Rose luring months of August and Sentember, 1897 (i)avenport). 1894. 1) $146 \ldots . . . . . .$.

Southern Patagonia, collected Jy U. S. S. "Allatross" in 1857-91,

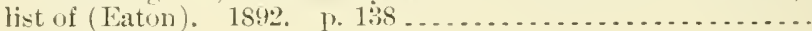

Sep aiso Asplenimm.

Ferrel, William, short biography of (C'omor). 1898. 1. 457 ..... Ferronillat, Panl. Plants, millew and other fungus (iiseases of, ap)-

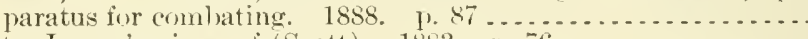

Fertility, Lawes's views of (Scott). 18x3. p. 76..............

Fertilization of soil as affecting orange in health and disease (IVebber). 1894. p. 193.

Fertilizer industry, review of statisties of profluetion and consumption, with abstract of state laws for analysis and sale (Hyde). 1898

Fertilizers:

Alstracts of reports of agricultural experiment stations on. 18591902

Analysis, official methors of, adopted lov Belorian State laboratories and agricultural experiment stations of Holland. 1899.

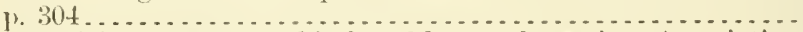

1s insecticiles; paper real before 2fl annul meeting, Associationi of Feonomic Entomologists, $189($ ) (Amith). p. 217 ...... same, 5th annual meeting, 1898 (Mnith). p. $03 . . . . . . .$.

Ishes as-

are they economical at present prices? 1897. p. 24 ....... supply of (Fleischmamn). 1884. No.\% 1. 28.........

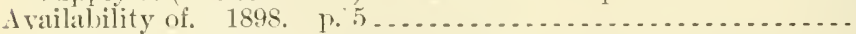

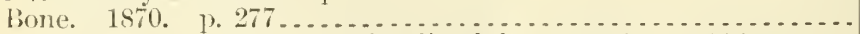

bones used as, new process for clissolving. 1sfit. 1. 337 . . . . . Chemical, germination of seeds as affected ly (tlicks). 1900....

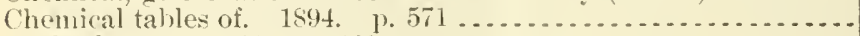

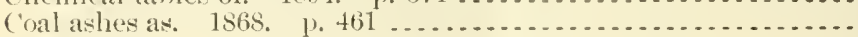

Commercial-

composition and use (Joorhecs). 1896.

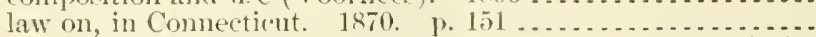
sale of, miformity in legislation with regard to (De Ghequier).

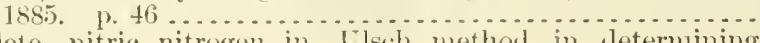

complete, nitric nitrogen in, [lsch mothod in tetermining

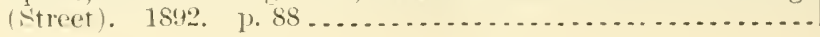

\13.3:2

A13. $4: 12$

A13.3:1

113.4:17

113." :St:"

113. $4: 20$

A1.7:5

A13.3:6

A13.3:6

A13. 4:18

A 13.3:13

A $13.4: 16$

A 13. 4:9

A $13.3: 5$

\13.3:10

A13.1:

113.3:10

16.5:5

A6.5:1

$129.6: 26$

A6.3:5

A1.7:2

A1.10:894

A10.6:

A $10.6: 10$

A9.7:3

A $9.7: 6$

A1.9:65

A27.9:22

11.9:73

A 27.9:8

A27.9:4

16.3:24

11.10:894

A27.9:6

A 1.9:44

127.9:8

17.3:7

A7.3:35 
Fertilizers-Continued

Classileation no.

Concentrated, in Sonthern States. p. 39\%

Containing cotton-seed meal, report on determination of available phosphoric arid in (I)ancy). 1890, $1 \%, 161 \ldots . . . . . . .$.

Containing organio materials, total phosploric ar.ic in, determina-

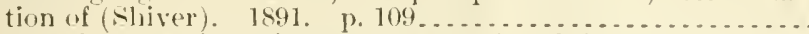

Cooperative experimenting as a means of studying effects of for-

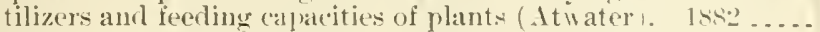

Conperative field experiments with (Thorne) $1889 . . . . . . .$.

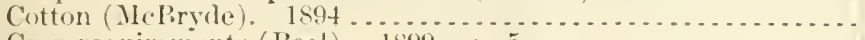

Crop requirements (Beal). 1899. 1, 5 ..................

Determination of phosphoric acid and nitrogen in, in same weighed quantity of substance (De Roode). 1891. p. 104....

Effect of, on proportion of grain to straw or stover. 1897. p. 11.

Effects of, and feeding capacities of plants, cooperative experimenting as a means of studying (Atwater). 185:2. 1. 27....

Experiments withfor prevention and cure of peach yellows, 1Ss9-92 (Smith) ... on fruits and regetables, to study variations of feeding cal at:-

Frand in-

ities of plants due to action of fertilizers. $1891 \ldots . .$.

11.1:S68

A. $.8: 28$

$17.3: 31$

A $1.8: 18$

1 10.4:7

A1.9:14

1 $1.9: 107$

$17.3: 31$

1 1.9:5)

A 1.8:2:2

A $28.3: 4$

A 110.4:19

1870. p. 3 กั

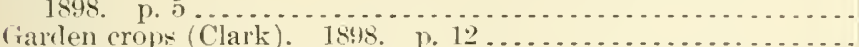

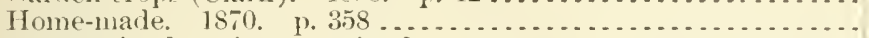

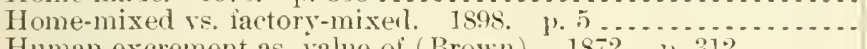

Human excrement as, value of (Brown). 1872. 1.312.......

Inspection lawsproposed reforms in (Wheeler and others) ...................
nniform, report of standing committee of Anerican Agricnltural Colleges and Experiment Stations on. 1900. 1. $5 t$

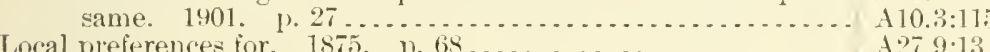

Mineral-

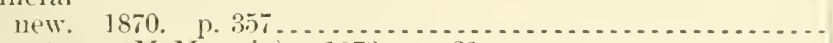

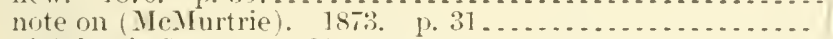

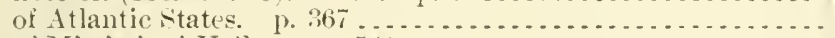

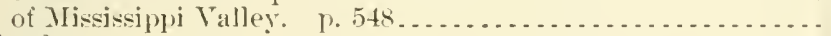

Mixed-

nitrogen in, availability of (Terne). 1893. p. 40.........

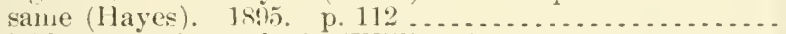
variable anmonia results in (Williams). 1901. p. 28 ....

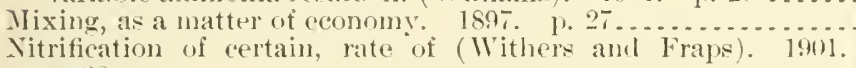

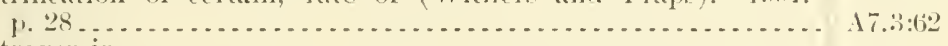

Nitrogen in-

report of committee on (French Association of sugar Chemists).

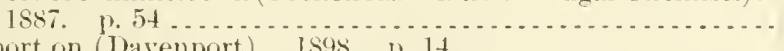

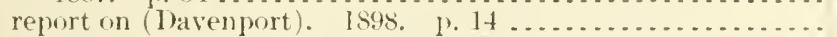

Nitrogenous, for market-gamlen (rop (Nmith). 19(1)1. 1. 12...

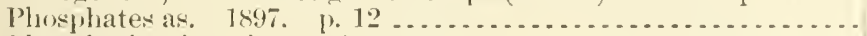

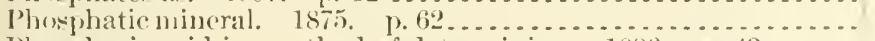

Phosphoric acid in, method of determining. 1ssti. J. $43 \ldots \ldots .$.
Potash in, report on some somrees of error in determination of

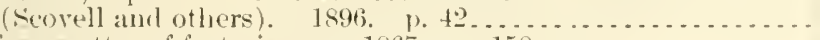

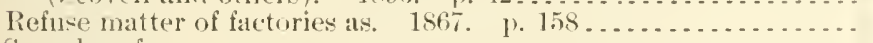

Simplew of-

bottled, loss of nowisture in, when closed with rork (Battle). 1891. 1. 159.

preparation of-

efiect of fince grinding in (Battle). 1891. 11, 160....... $17.3: 31$

for analysis, notes on (Stillwell and (iladding). Isis.

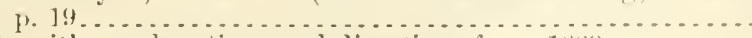

Soil test with, explanations and directions for. $1889 . . .2 . .$.

127.9:8

11.9:79

A $1.9: 10: 5$

A.27.9:8

A1.9:84

A27.9:10

17. 4:3

A 10.3:99

A10.3:115
$+2-9: 13$

A27.9:8

A27.9:11

A1.1: $: 68$

A 1.1:\$69

1. $.3: 38$

A7.3.47

17.:3:6:

1 1.91605

17.8:16

A $7.3: 56$

11.9:124

1 $1.95: 56$

A27.9:14

17.3:12

17.3:49

1:-7.9:5

A7..3:::

A7.3:38

110.4:8

11.9:149 
Fertilizers-Continued

I'se of-

meeting of those interested in, cireular relative to. $1859 \ldots .$.

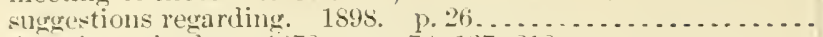

Various formulex for. 1872 . pp. $76,137,218 \ldots \ldots \ldots \ldots \ldots$

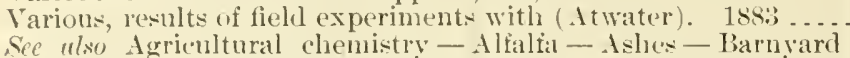
manure - Chemical analysis, methods of - Farm manureGreen manuring and manures - binano - Humm - LimeLimestone-liquid manuring - Manures - Mlarls - Muck Nitric nitrogen - Nitrogen - Potash.

Fertilizing constituents of feeding stuffs and farm products:

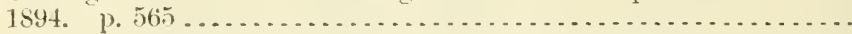

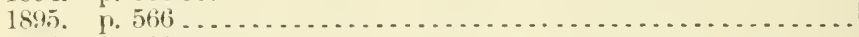

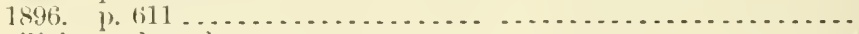

Fertilizing value of:

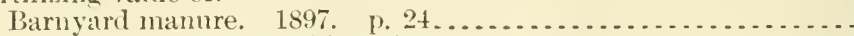

Lime, different forms of (Beal). 1901. 1.12.............

Manure from cows. 1899. p. 5. . . . . . . . . . . . . . . . .

Street sweepings (Ewell). 1898 . . . . . . . . . . . . . . . . . . .

Fetlock, liseases of, of horses (Holcombe). p. 357 ................

Fesler, John H. Rainfall of Amoy, China. 189i-1902, p. $486 \ldots$.

Filer:

Classification of, structural and economie, with deseriptive catalogue of useful fiber plants of the world (Dorge). $1847 \ldots .$.

Crude, determination of -

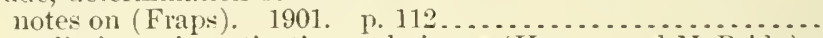

preliminary investigations relating to (Huston and MicBride).

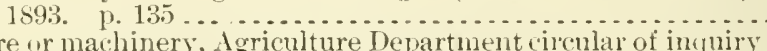

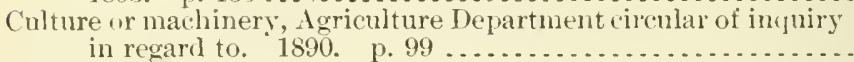

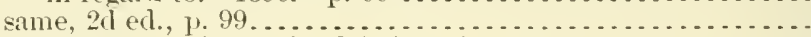

Determination of, in Scotland (Aitken). 18.4. p. 172 .......

E-timation of, in substances rich in carbohylrates, rejort of

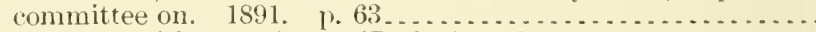

Experiments, history of, ete. (Dolge). 1894 ................

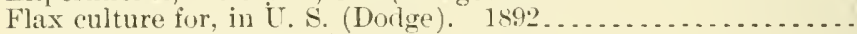

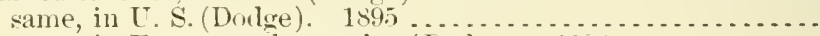
same, in Europe and America (Dorlge). 1898 .............

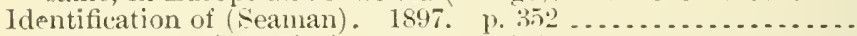

Ixtle, letter on (Murphy). 1869. p. $232 \ldots \ldots \ldots \ldots \ldots \ldots \ldots$.

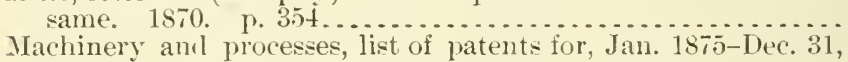

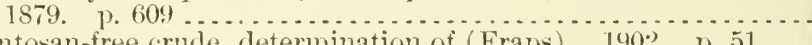

Pentosan-free crude, determination of (Fraps). 1902. p. $51 \ldots$

Production in C. S., present status of (Dodge). 1592. p. $43 . .$.

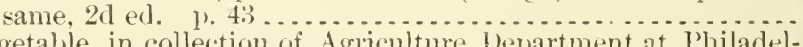

Vegetable, in collection of Agrienlture bepartment at l'hiladelphia Centemnial Exhibition of 1876 (Dodge). p. $497 \ldots . . . . .$.

See also Agaves - Flax - I Iemp-Ixtle fiber - Leaf fibers of
U. S. - New Zealand flax - I'entusan-iree erule fiber-I'ineapple fiber - Textile fibers.

Fiber Investigation Office, Agriculture Department:

W'ork of, for farmer (Dudge). $189 \bar{i}$. p. 224 ..

Fiber plants:

Raising and testing of (Willits). 1890 . P. $124 \ldots \ldots \ldots \ldots .$.

Eseful, of the world, deccriptive (atalogne of (Dodge). $1897 \ldots$

Fibers, textile, of Pacific States (Flint). 1. $471 \ldots \ldots \ldots \ldots \ldots$.

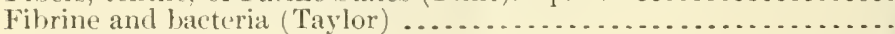

Fieln, John E.:

Irrigation from Big Thompson river.....................

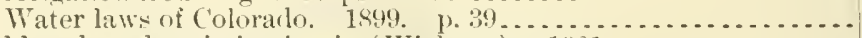

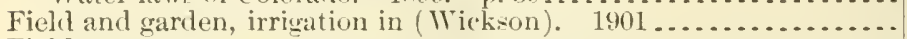

Field crops:

Abstracts of reports of agrieultural experiment stations on, 18891902

A10.4:2

A1.9:69

A27.9:10

A1.8:31

A1.10:894

A1.10:895

A1.10:896

A1.9:56

A1.9:124

A1.9:97

A7.3:55

At.2:H78

A29.6:30

A11.5:9

A $7.3: 62$

A7.3:38

A27.8:1

A11.5:1

A 7.3:43

A7.3:31

A11.5:6

A11.5:-

A 1.9:27

A11.5:10

A11.5:9

A $27.9: 7$

A27.9:8

A1.1:879

A 7.3:67

A27.8:1

A11.5:1

A1.1:879

A11.

A1.10:897

A10.5:2

A11.5:!

A1.1:864

A18.2:F+4

A 10.3:11s

A10.3:58

A1.9:138

A10.6. 
Field crops-Continued

Important data as to.

Parific coast (Jomes).

, 18st. No. \%. 1.37...........

See also A gricultural prodncts - Crops - Farm products.

Fielal cultures of Parcific slope, mircellaneons: (Hilgard). p. $79 \ldots .$.

Field experimentation, plats in, form, size, arrangement, and treal-

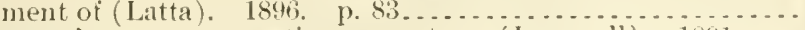

Field experiments, cooperative, report on (Ingersoll). 1891. ए. 109

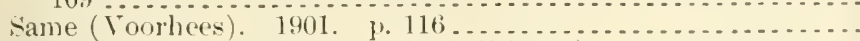

Field operations of Division of Soils (Whitney):

1899

1900

1901

Field parties of Burean of sols, Agriculture Deprartment, instructions to, and deccriptions of soil types. 1902

Field seeds. See seeds.

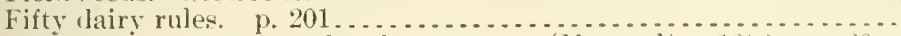

Fig eater, or green Jume beetle, report on (110mari). 18ss. 1\% 20.

Figs:

Cultiration of, ant method of preparing for commerese. 1sis....

Culture of. 1897 ......................................

Edible, their eulture and curing (Eisen), 1897, p. 5 ........

Gulf States, culture of (Earle). 1897. p. $23 . . . \ldots \ldots \ldots \ldots$.

History, culture, and curing, with descriptive catalogue of known

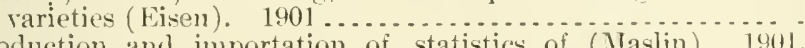

Production and importation of, statistics of (Maslin). 1901.

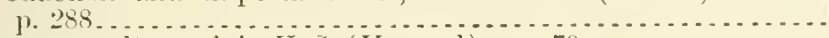

Smyrna, culture of, in U.S. (Jowarrl). P. 79.............

See also Caprifig experiments in California.

Fiji Islands, cotton of, microscopic investigation of (Taylor). 18i2. lands, cotton or, microseopic investigation of (Taylor). 187.

Sice clso Anstralasia.

Files. See Treasury Department.

Filled cheese:

Correspondence defining. 1896

Regulations for, notice of passage of hill for. $1896 \ldots \ldots \ldots . . .$.

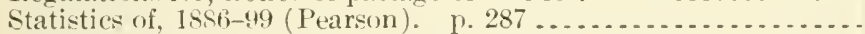

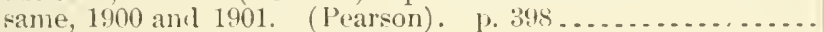

Filter-tube method. See Hirle-powder.

Filtration of cane juices and sirups, brown coal and wood char in

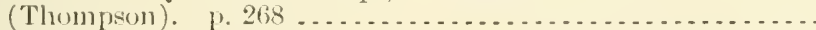
Same. 1889. p. 99

Finance, farmers' interest in. 1896.

Financial transations with $[$. S. Department of Agrieulture, regula-

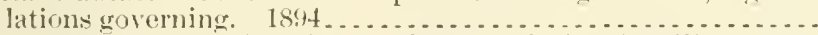

Finland, acricultural edueation and research in (Woll). 1sis.

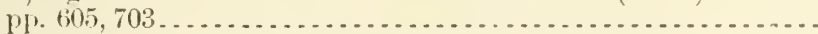

Finley, John ' $\mathrm{l}$. Certain climatic features of two Dakotas. $1893 . .$.

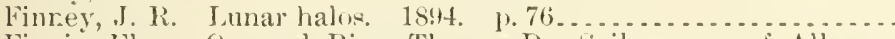
Fippin, Elmer O, ant Rice, Thomas D. Foil survey of Allegan

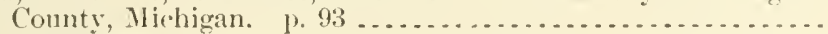

Fir. Siee White fir.

Fireman, Peter. See, as alstractor, Moracherski, V.; ar translator, Mokrzhetski, S. - Porehinski, I. - Sibirtzer, N.

Fires:

Disinfection of kennels, pens, and yards by (Stiles). 1902, p. 15.

Dromght and, in Northwest. 1871. p. 401 ..................

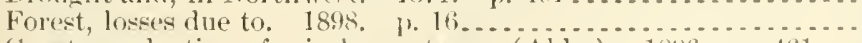

(ireat, production of rain by, notes on (Abhe). 1896. p. $461 \ldots$

tiee also Forest fires - St. Eimo's fire.

Fireworn. Sie Cranberry fireworm.

Fimeza, Cuba. Rainfall at (1lonroe). 1848. 1. 25:2.......... 1246.26

Fiscal regulations of Agriculture Department . . . . . . . . . . . . A A2:152
A1.10:901

$11.8: 20$

1:27.9:22

$11.8: 20$

A $10.3: 30$

A 10.5:3

\$10.3:99

A 1.8:64

A26.5:900

126.5:901

A26.2:F45

14.1:895

A9.6:10

11.6:4

A:0.3:5

A20.3:5

A20.3:5

A20.3:9

A20.3:9

A1.10:900

A27.9:10

A.4:16

A $4.2: F+8$

At.1:899

14.1:901

A1.1:887

A7.3:17

A $27.4: 3$

A2.2:14:3

A 10.6:9

A.29:2:D14

A $29.6: 2.2$

A $26.5:(9) 1^{1}$

A.1.3:35

A.27.9:9

A1.9:7)

A.9.6:2:24 
Fish, l'ierre Augustine:

"Heenes," a diwease of the horse in Florida, histological investigation of two eases of an equine myensis, with hist orical account of supposed similar disease, called bursattee, occurring in

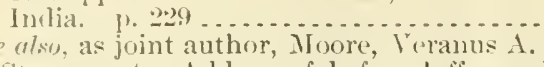

Fish. Stuyvesant. Address of, before Jefferson Iemorial and Interstate Good Roads Convention, Apr., 1902. p. 15 . . . . . . . .

Fish and Fisheries Commission report, 1871-72, review of. 1873. 1". $18 \mathrm{~s}$

Fish as food (Langworthy)

lish-culture:

Directory of departments, boards, societics, colleges, and other

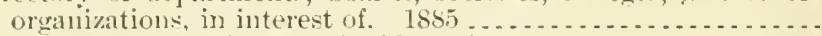

1 mprowents and increase in (fireen). p. 248 ........... Letter on (Woodford). 1869. p. $376 * \ldots \ldots \ldots \ldots$

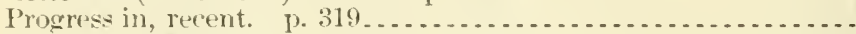
Report on (lioosevelt). 1873. ए. $183 \ldots \ldots \ldots \ldots \ldots$ see also l'iscieulture.

Fisles:

Collected by Death Valley Expedition in southern California and Vevala, in 1891 , report on, with descriptions of new species (cillert). 1893. p. 229.

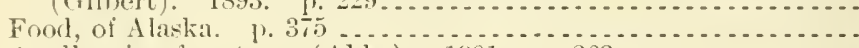

small, rain of, note on (Abbe), 1901, p. 263.............. Fisher, 1 . K.:

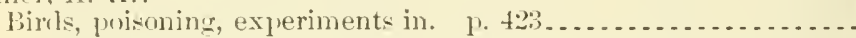

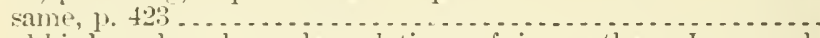
Blacklinls and gophers, depredations of, in northern Iowa and sonthem Ilinmesota in fall of 1857 . p. $454 \ldots . . . . . . .$.

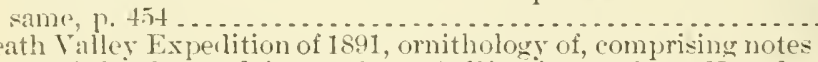

I)
on birth boserved jn southern California, southern Serada, and parts of Arizona and Ctal. 1893. p. $7 \ldots \ldots . . . . . .$.

Ilawks and (1) ls-

as related to the famer. p. 215.

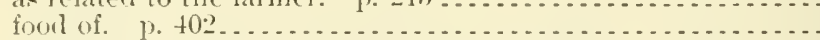

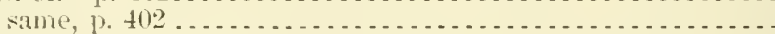

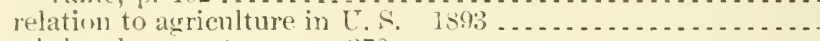

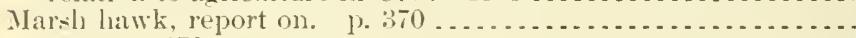
Owl-

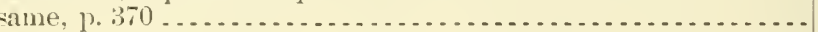

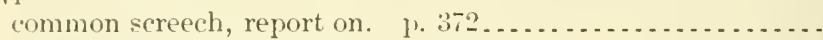

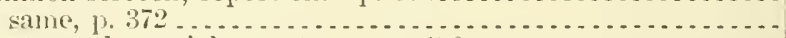
short-eared, special report on. p. $446 \ldots \ldots \ldots$

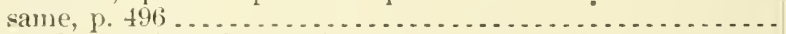

Sparrow, destruction of, by poisons. 18s9. p. 174............ Siarrow hawk, special report on. p. $491 \ldots . . . . . . . . . . . .$.

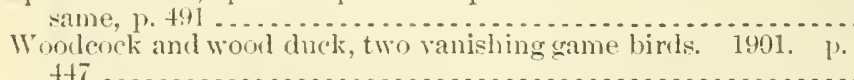

Fisher. D. Tomarlo, March 20,1845 , at Augusta, Gia. p. 92 .... Fisher. E. M. IIofimanseggia, Torth American species of, revision

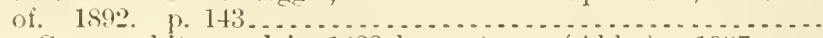
Fisher, George, kite used in 1822 hy, note on (Abbe). isit. p.

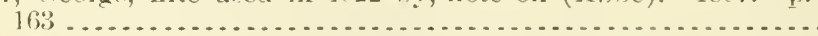

Fiske, William $\mathrm{F}$. See, as joint anthor, Weenl, Clarenes IImosesíentt, II. M.

Fitch, William R. Hides, injury to, by hranding. p. $509 \ldots \ldots . .$.

Flar, Henry, Wood preservation. 1s87. 1.66................ same, reprint. p. 257.

Flage, William J. See, as joint author, Vilier, Marshall P.

Flagstaff, Ariz., ice cave at (Renoe), 1901. p. $54 . . . . . . . . . .$.

Flanmarion, Camille. Juvisy, olservatory of, physical and meteorological researches, principally ou solar rays male at station of agricultural climatology at. 1S!19. PJ. 103, 203........

A $4.1: 595-6$

A20.3:25

127.9:11

11.9:55

A 1.8:39

A $1.1: 5.2$

A $27.9: 7$

A 1.1:868

A:7.9:11

A5.5:7

A $1.1: 870$

A29.6:29

A1.1:SS7

A5. $1: \$ 87$

A1.1:887

A5.1:857

A5.5:7

A1.10:\$94

A1.1:857

A5. 1:S87

A5.3:3

A 1.1:859

A5. 1:884

A1.1:889

A5.1:889

A 1.1:858

A5.1:888

A5.3:1

A 1.1:888

A5.1:888

A 1.10:901

A29.6:23

A6.5:1

A29.6:25

A4.1:899

A13.3:1

A $13.3: 9$

A29.6:29

A $10.6: 10$

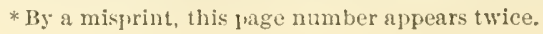


Flat pea, circular relative to (Scribner).

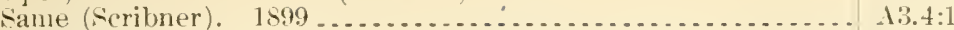

Flather, J. J. Mechanical Irawing in technical schouls. 1sit. p. 81 ... . . . . . . . . . . . . . . . . . . . . . . . . . . . . . . .

Flavoring extracts, analysis of, provisional methols for (Mitchell). Flax:

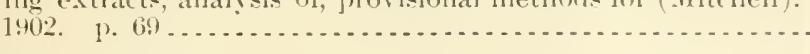

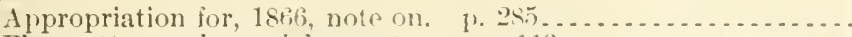

Flax-cotton and, special report on. 1) $113 \ldots . . . . . . . . . .$.

Hemp and, Russia. 1869. 1. 237 ......................

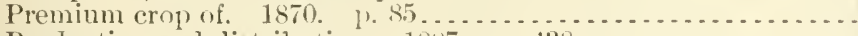

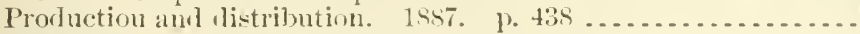

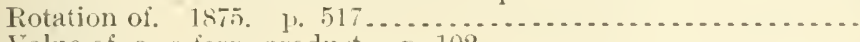

Talue of, as a harm product. p. 102.

See culso Flax rulture.

Flax and Hemp Commission, report of (Moorhearl and others). 186.5. 11.2:F 6

Flax-cotton:

Arlaptation to cotton machinery (Jackson). 1). $40.5 \ldots \ldots \ldots \ldots . .11 .1: 862$

Flax and, special report on. ji. 113.................... A1.1:\$62

Flax culture:

Austro-Hungary (IIawes). 18!2. p. 5. .................

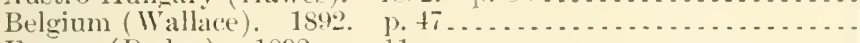

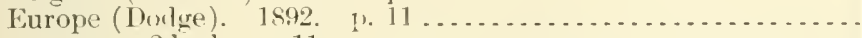

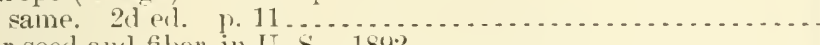

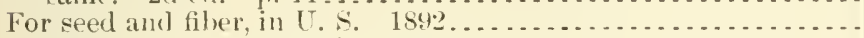

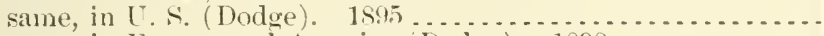
same, in Europe and America (Dodge). 1898

A11.5:4

111.5:4

127.8:1

A $11.5: 1$

A $11.5: 1$

A1.9:2\%

A $11.5: 10$

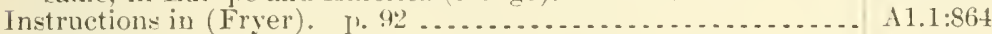

Ireland-

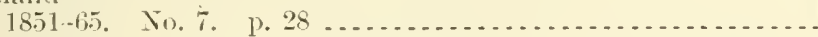

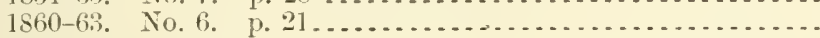

$1851-71 . \quad$ P. 332

1.27.9:3

A $27.9: 1$

A:7.9:9

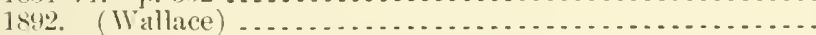

Northwest, investigation of, in 1891 (Bosse). 1892. 1. $40 \ldots \ldots$...

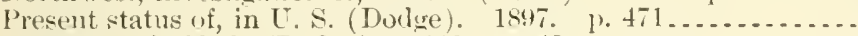

Report on, in U. S. (Dodge). 1892. p. $43 \ldots \ldots \ldots \ldots \ldots \ldots \ldots \ldots$.

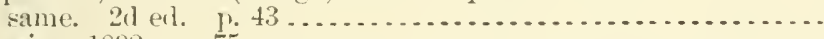
Rusia. 1892. p. 75

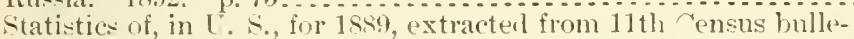
tin no. 177, "Flax and hemj)," by John IIyle. 1892. p. S.3.

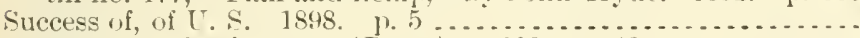
Wisconsin and ilinnesota (Busse). 1892. p. $43 \ldots \ldots \ldots \ldots \ldots \ldots$. Flaxseed. See Crops, principal.

Flea-beetle living on purslane (Chittenrlen). 1898. p. 8.3.

tiee also Horse-radish flea-beetle-Rerl-legged flea-beetle - Tobarco flea-beetle.

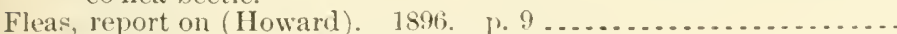

See ulso Hen fleas - Mosyuitoes and fleas.

Fleece. See Ginat.

Fleischmann, Charles L.:

Ishes, supply of, for agricultural purposes. 1884. No. 9. 1. 28. [Erroncously printed "F]eischman."]

l'low's and plowing. 1883. No.64. 1. 64 .

11.5.4

A11.5:4

A $1.10: 897$

A:7.8:1

A11.5:1

111.5:4

$111.5: 4$

11.9:69

A $11.5: 4$

19.6:19

$19.6: 4$

Fleischmann methorl. Sie Van Slyke, L. L.

Floming, foorge. Bovines, contagions pleuro-pnemmonia and infor-

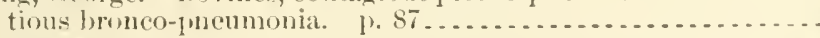

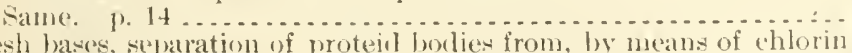

Flesh bases, separation of protein bodies from, by means of chlorin

Fletcher, James:

Address of, as president of Assoeiation of Economic Entomuli-

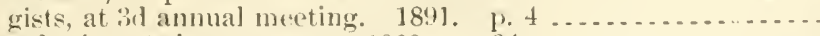

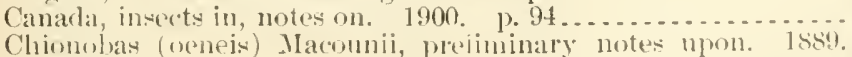

Chimoluas (oneis) Macomnii, preinninary notes npon. 1889.

Insecte, unjurious, of year in Camarla, notes npon. 1s91. 1.247. same. 1892 . p. 124. 
Flies:

Ciuriage of disease by (Howard). p. 39

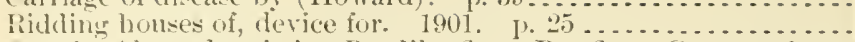
See also Aleyrotes citri - Bee-like fly - Bot-fly - Corn sybusfly-Cyrtoneura cals - Dipteri-Dogwood saw-Hy-Gad flies - Ciall-fly - Grass and gratin joint-worm flies- firass saw-flies - Hessian fly - Hippelates - Hom fly - Honse flics- Lestophonus- Man-infecting bot - Ortalid fiy - Oscinidie - Ox hot - ()x warble - Pearh pest in Bermuda - J'hytomyza athinis - Rose saw - flies-saw-fly - strawbery sawfly - Syphus-Hy - Tabanibe - Tachinila - Tulip tree leaf gall-fly - Violet jest - White-fly- Willow-shoot saw-fly.

Flint, Charles l. Humbresl rears progress in agrienlture. p. 2⿺辶.

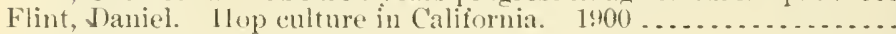
Flint, Larl:

Meteorological observations at Tivas, Nicaragua. 1S99. Pp. 11, $97,153,193,249,299,360,462,509,540 \ldots \ldots \ldots \ldots \ldots$ Nicaragua, central and westem, rainfall in. 1699. 1. 585 .....

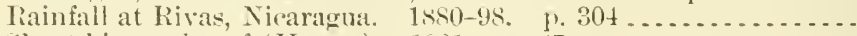
Short biography of (Henry). 1901. y. 67 ..............

Flint, Milson:

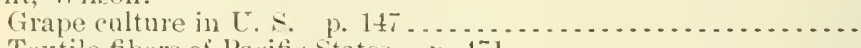

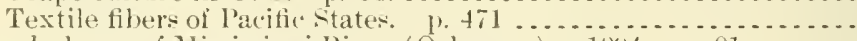

Flood planes of Mississippi River (Ockerson). 1894. 1.81 ...... Flood service:

Note on (Hyatt). 1899. [1.50. same (1'indeil) 1899 19. 51 .

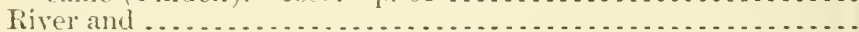

Floods:

Basseterre, st. Kitts, W. I., Jan., 1880 (Alexanıler). P. 196.....

Brazos River Valley, Tex., 1su9, with notes on previousoverflows

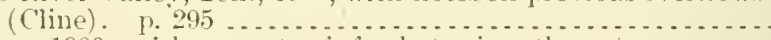
sane, 1900 , with repurt of freshets in other streams. p.

198 . Colorado Valley, Texas, April $T$ to 17,1900 , and uther floods
during same period, special report on (Cline). p. $146 . . . .$.

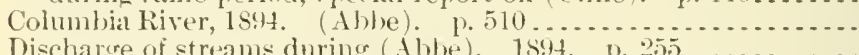

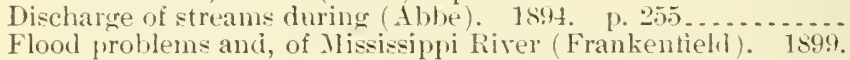

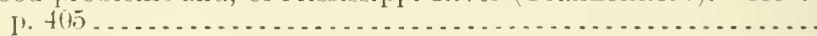

Flool warnings and (Frankentield). 1901. p. $475 \ldots . . . . .$.

Forecasting, method: in use in France (Babinet). is94. p. 94 .

Mississippi Ruver-

report on (Morrill). $189 \%$

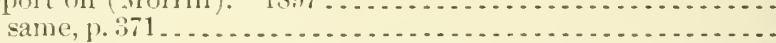

with reference to inundation of allurial valley (Starling).

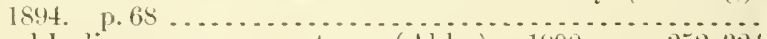

Nile, anul Indian monsonom, notes on (Abhe). 1900. 1'p. 25:2, 324 .

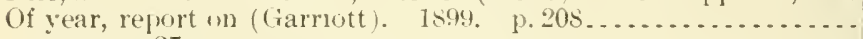

Predicting, in water comses, best means of finding rules for (Ba)-

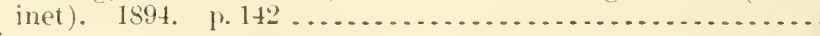

River-

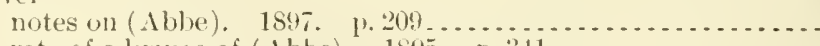

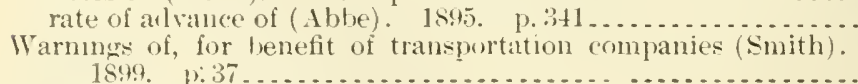

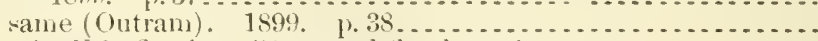
Florit:

Sce ulso vile flools - River and fluod service.

Arborescent, of $\mathrm{U}$. S., nomenclature of (Sudworth). $1597 \ldots . .$.

Bateral, of foremilk, relation of elieese-curil intlation to (Bolley).

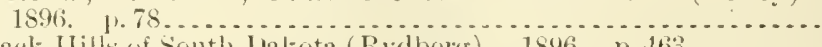

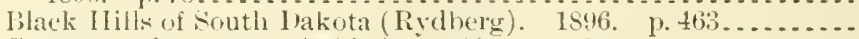

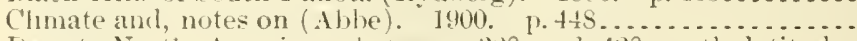

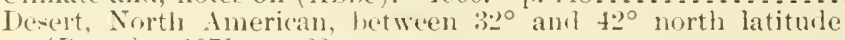

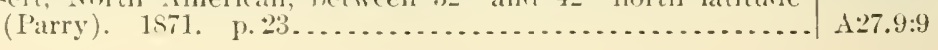

19.6:30

11.9:133

A 1.1:872

A 1.9:115

\29.6:27

A $29.6: 27$

A $29.6: 26$

A29.6:29

11.1:863

11.1:864

129.3:11

129.3:24

A29.3:24

A29.14:

A29.6:27

$129.6: 27$

A29.6:28

A29.6:28

129.6:22

129.6:22

A29.6:27

1 1.10:901

A29.3:11

129.5:E

1.9. $1: 897$

A 29.3:111

A $29.6: 28$

A 1.1:898

A:9.1:898

A 29.:: $: 11^{1}$

A29.6:25

A29.6:23

129.3:24

129.3:24

A13.3.14

$\$ 10.3: 30$

A6.5:3

A29.6:28 
Flora-Continued.

Forest-

of Rocky Momntain region (Sulworth), 1sss. p. 153....... adtitions to, of Torth America, and necessary changes $\mathrm{j}$ nomenclature of important timber species (Fudworth).

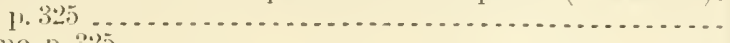

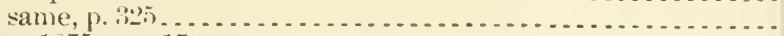

Japan. 1875. 1. 176 . . . . . .

Kansas, southwestem, collection of plants narle ly C. II. Thompson in 1893, report on (Hitcheock). 18!66. 1,5:5 . . . . . . .

Nebraska sand hills (Rydberg), lsis. p. 133. Florence, Italy, Congress on parasitic diseases of the vine, Oct., $1886^{\circ}$, Florida:

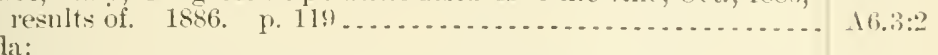

As home for emigrants (Rollins). 1872. [1. 4\%5........... $127.9: 10$

Aurora in, note on (Abhe). 1900. 1.294 .............. A29.6:28

Cigrar-leaf tolacco in, cultivation of (Floyd) $1899 \ldots \ldots \ldots \ldots . . . . . . .11 .8: 62$

Citroms fruts in, principal diseases of (Swingle and 17 elober). 1896. $128.3: 8$

Clinate and prodnets of (Knapp). 1885. No. 19, p.23....... A27.9:2:3

Climate, soil, productions, and agricultural rapalilities-

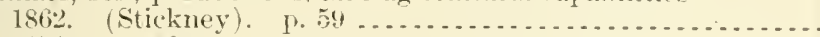

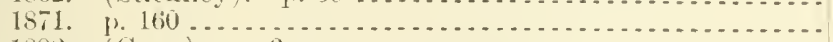

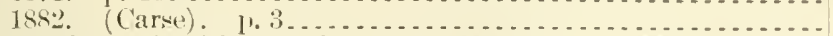

Climatology of, with regard to crops (Mitchell). 1902. 1).208.

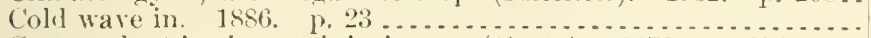

Cotton-flant in, insects injurions to (Grote). 1878. p. 351 ....

Economic entomblogy in (iossard). 1901, p. 178 ..........

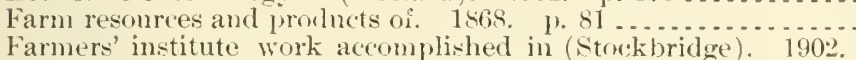

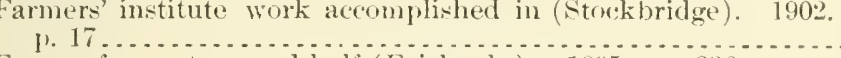

Freezes for century and half (Fairbanks). 1895. I, $336 \ldots \ldots$

Frevzes, two, of $1594-95 \mathrm{in}$, and what they teach (Tebber). 1895. P. 159

Fruit protection in, notes on (Abbe) 1900 , p. 16 .

Frnits, tropical and semitropical of (Reasoner). p. $7 \ldots \ldots . . . .$.

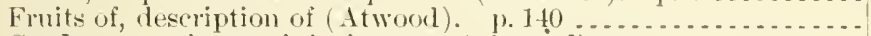

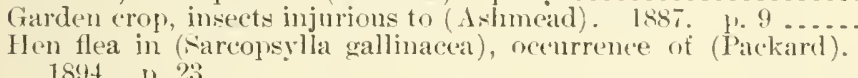

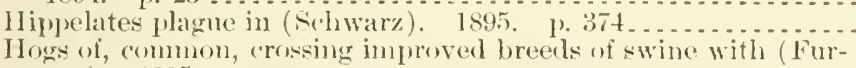

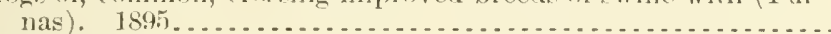

Horses in, lecehes anome ( Fish) p. 22u

Insects in, wbervations anel experimental work (fossaril). 1s(1)2.

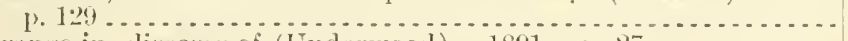

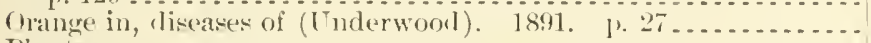

Plants-

list of new (IIolzinger). 1893. p. 285................. report on (simpison). 1). :3s! .

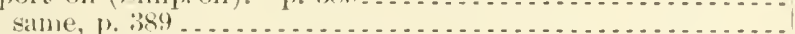

Roas improvement in, plogress of (Jemnings). $1901 . \mathrm{j}$. $60 \ldots .$.

Ront-knot discase of peach, orange, and wther plants in, doe to

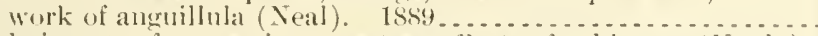

Scale insects of orange in, repurt on cofects of colit upon ( Vuyle).

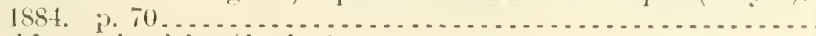

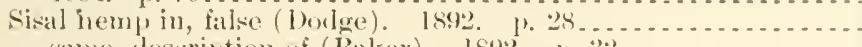
same, description of (Baker). is py. p.

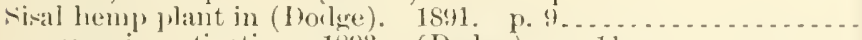

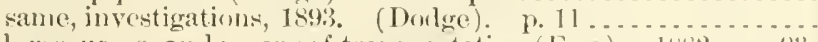

Soil, resumrees, and means of transportation (Foss). 18is. 1. 13.

soils and prolucts of (Sannders). 188:3 . . . . . . . . . . . . . .

Soils of, preliminary report (n) (Whitney) isis............

Sonthern-

hesperomys from, new species of, description of (Merriams).

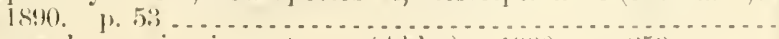

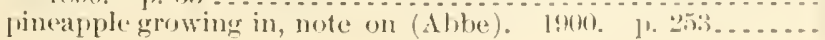

$11.1: 86: 2$

A1.1:5i1

11.8:21

A $29.3: 31$

A27.9:24

A?).2:( 82

A10.8:99

A27.9:6

$110.3: 120$

A24. (5::3)

11.10:595

A $29,6: 28$

1:0.3:1

A1. 1:867

A.9.3:14

19.7:7

19.7:7

14.4:4

A $4.1: 5(9)-6$

110.:3:115

1.25,5:7

A6.5: 1

1 1.1:489

16. $1: 489$

1.2.2.3:2:21

19.8:20

19.:3:4

$111.5: 5$

$111.5,5$

$111.5: 3$

$111.5 \%$

11.6:2]

11. $1:$ ti: $^{2}$

126:3:1:3

127.4::27

15.5:-1

12ulti:s 
Florida-Continueel

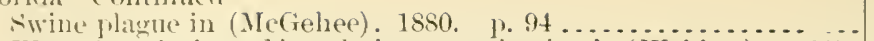

Water lyateintl, and its relation to navigation in (Webber). $189 \%$. se also Eustis-Jupiter-Key West-Pensacola.

Florida begarar weel (Smith). iss9.

Florida elover. See Floricla beguar weet.

Florina "horse-leech." p.97 ...........................

Floridal lanul tortoise, insect guests of (Hubluard) , 18.4. 1) 302... Flour:

Britisli import-, 1875-76. p. tsti

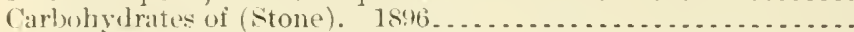

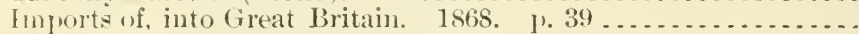

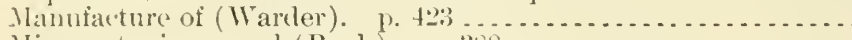

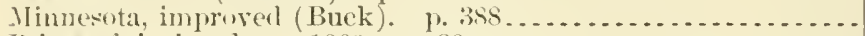

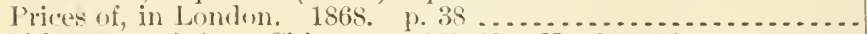

Shipments of, from Chicago. $1838-63$. No. 2 , 1. $33 \ldots \ldots \ldots \ldots \ldots$.

Tariff rates $1 \mathrm{n}$, in Eurojean countries. 1894. p. 323 . . . . . . . .

Typical American composition of. $1897.11682 \ldots \ldots \ldots \ldots \ldots$.

sée ulso Banana flumr - Milk $\mathrm{H}_{0}$ (ur.

Flour moth. See Mediterramean fiour moth.

Flowers:

Cultivated, two dipterous inseets injurious to (Conuillett). 1895.

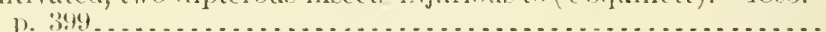

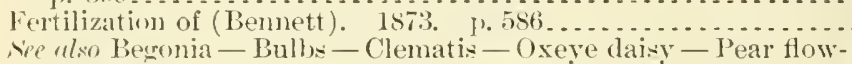
ers-I'inks - Rose-Sunflowers - Violet - Wild Howers.

Floyd, Marcus L.:

Bulk femmentation of Comnecticnt toluaceo ..................

Cigar-leat tobarco, eultivation of, in Florida. $1894 \ldots \ldots \ldots \ldots . .$.

Leaf tolaceo, world's exhibit of, at Paris Exposition of 1900 . p. 157

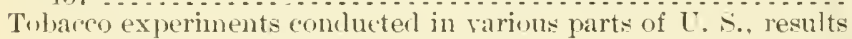

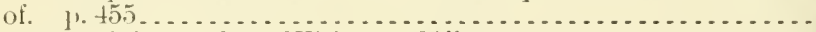

tive rlso, as joint anthor, Whitney, Miltun.

Fluke llisease, frogs, toads, and carp as eradicators of (Stiles). $P$.

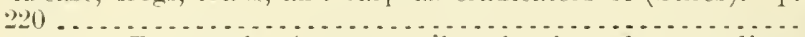

Fluke-worms. Trematodes (monntomnilum lentis and agamodistomum ophthalmobium) parasitic in the human eve (Stiles).

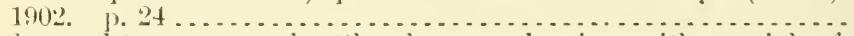

Flukes and tapeworms of cattle, sheep, and swine, with special peference to inspection of meats (stiles). 1898. p. 11 .........

Same, compentium of parasites, arranged accorling to their hosts (Hassall). 1s9s. p. 137 ....................

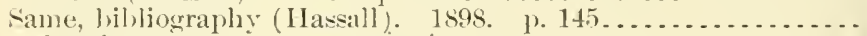

Fluted siale:

Australia, trip to, to investigate natural enemies of fluted seale,

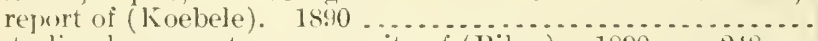

Australian bymenouterous parasite of (Riley). 1890. I. 248...

Tatural enemies of, report of a trip to Australia to investigate

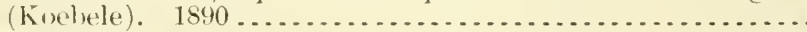

Ser rlsu. Seale insects.

Fly. wie Flies.

Fly weevil. sep Angumois grain moth.

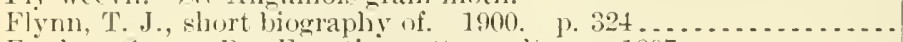

Foadron, fiecroce ?. Egyptian cotton eulture. 1897

Foller:

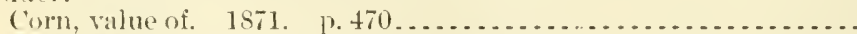

Fow peas anl corn for (fettys) $1900 \ldots$

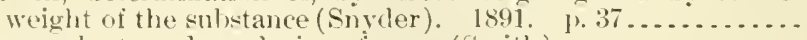

Forace plants and, exclusive of grass (Suith) . . . . . . . . . .

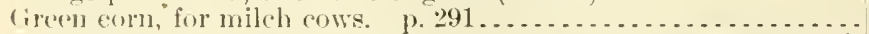

(ireen materials and, fat in, preliminary report on estimation of

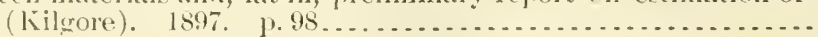

Sir also Dlialfa - Cattle fools and feeding stuffs - Corn fodder Corm stover - Cornstalks - Hay - Straw - Stubl)le.

Forlder plants and grasses on Potomac flats (Ball). 1900. 
Fö̈x, G. Grape-milflew, practical treatments for prevention of.

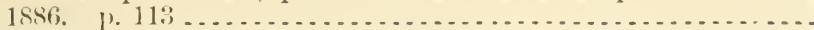

Fog:

Formation of (Cuthbertsun). 1902. 1\% 125.

New York harbor Dec., 1895 ( Mhbe). 1. $40,3 \ldots . . . . . . . . .$.

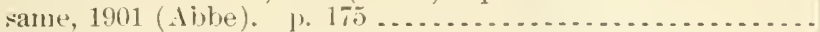

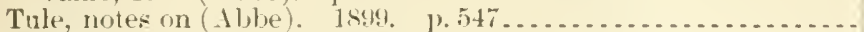

Ctilization of, note on (Ab) 1898 . 1. 466.

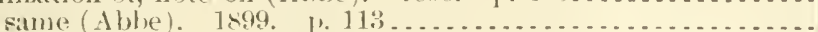

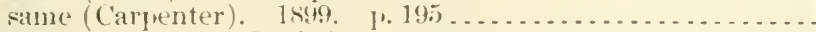

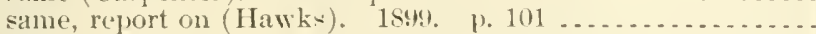
Fog studies:

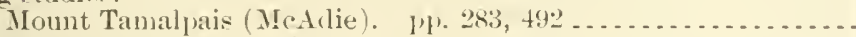

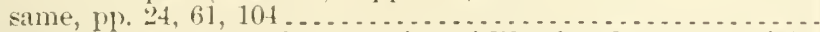

Paper on, read before 2 l convention of Weather limeau otlicials (McAlie). 1902. 1. 31 . . . . . . . . . . . . . . . . . .

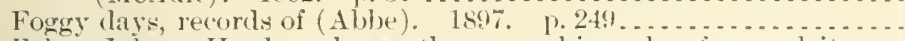

Foley, Juhn. Hardwoods, southern, working plan for, and its results. 1901. p. 471

Foliage, comparative tests with new and old arsenicalson (Marlatt).

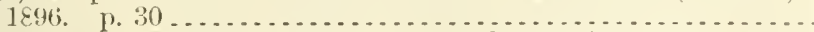

Folsetter, Wun. Glanders among horses and mules in Texas. 11.393. Folsom, California. Loensts near, notes on (Koelsele). 1855. 1.308. Fonde, Henry. Road improvement. 1902. p. $41 \ldots . . . . . . .$. Food:

Abstracts of reports of agricultural experiment stations on, $1889-$ 1902

idulteration of-

extent and character of (Wedderlurn) -

1890

1892

1894

methods for determination of (Bigelow and sweetser). 1897,

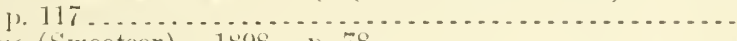

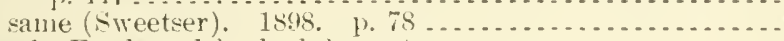

See also Foods and food adulterants.

Animals slaughtered for, necessity for inspecting (salmon). 1889.

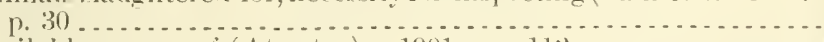

Avalable energy of (Atwater). 1901. p. 112............

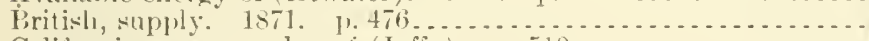

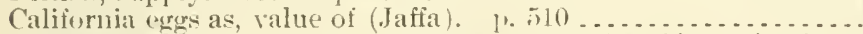

Chemistry and economy of, methods and results of investigations on (Atwater). 1895.

Coluriner matter for, provisional uncthods tor analysis of (Tolman). 1902 . p. 111 .

Consumption of, effect of severe and probonged musisular work on (Atwater and sherman). 1901.

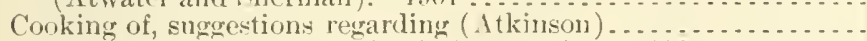

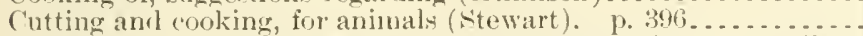

Digestibility of, and metalolism of nitrogen, experiments on effect of muscukar work upon, comducted at I hiver ity of Tennessees $1897-1899$ (Wait). 1901. sane, $1899-1900$ (Writ). 1902

Dry veretable, insects affecting ('hittenden) 1896 . 11.)

Examinations of, suggestions for hetter arrang(ment of (Dickoré). 1893. ए. $16 ; 2$.

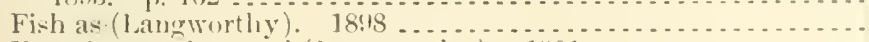

Functions and uses of (Langworthy). 1901 .

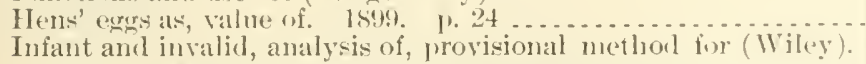

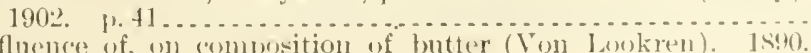

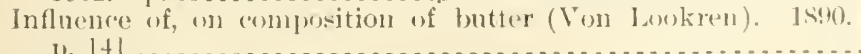

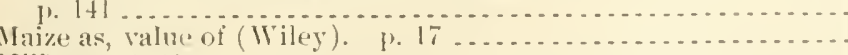

Milk as. 1 sis . . . . .

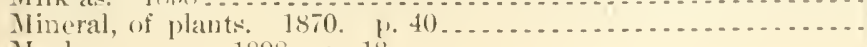

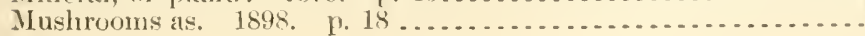

16.3:2

$1: 996: 30$

1:24, (1::2:3)

$\lambda 29 .(i:: 29$

1:99. $6: 27$

129.6:26

A:9.6::27

A29.6::27

1:9.6::27

1:26. $6: 28$

12!.6:29

129.3:31

1:29.6:2:5

$\$ 1.10: 901$

19.6:6

A 4. ]:\$\$9-90

1 1.1:85:5

12:2.3:23

110.ti:

$17.3: 25$

1 $7.3: 32$

17.3:41

17.8:51

17..3:56

17.3:25

A 10.3:99

127.9:1

14.1:898

A 10.3:21

17.8:(6)

A 10.3:98

1 1.8:54

A 1.1:S6.5

110.:3:ล9

1 16.3:117

I. $6: 4$

$17.3: 38$

11.31:25

1 10. $4: 46$

11.11:47

$17.8:(55)$

17.:3:24

1 1.8:4!)

1 1.:1:74

1.2.9:4

A1.21:7! 
Foorl-Continued

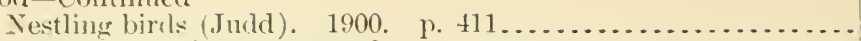

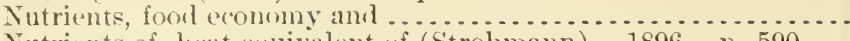

Nutrients of, heat exuivalent of (Strohmann). 1896. p. 590....

Nutritive value and cost of (Atwater). 1894 .................

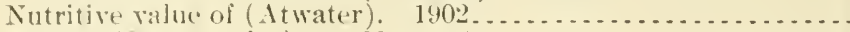

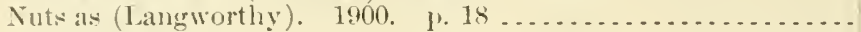

Potatues as-

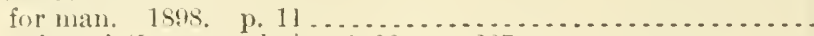

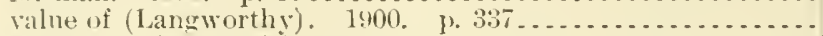

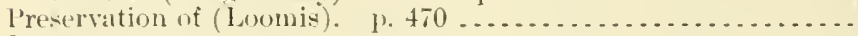
I'ure-

laws of European countries affecting American exports.

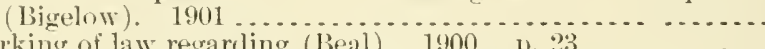

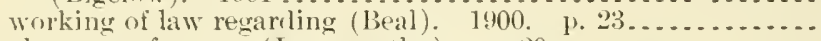

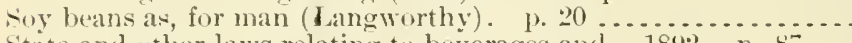

State and other laws relating to beverages and. 1892. p. $87 .$.

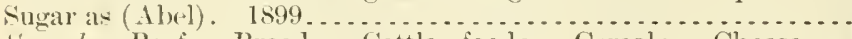

See also Beet - Bread - Cattle fools - Cereals - Cheese -

Chemical analysis, methorls of - Cooking - Exgrs - Fillerl cheese - Fish - Fishes-Hams - Honey - Human foods Infant and invalid foods - Insect food of erow - Jerked beeiLiquor and food ardulteration - Macaroni - Meat - Metabolism - Mushroons - Mutton - Nutrients - Nutrition investigations-Nuts-Olemnargarine-Oleonargarine cheesePlant fool - I'reserved meats - Semolina - Sugar.

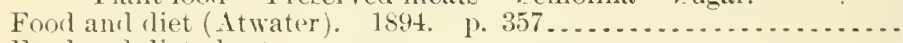

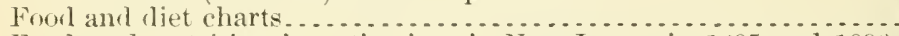

Food and nutrition investigations in New Jersey in 1895 and 1896

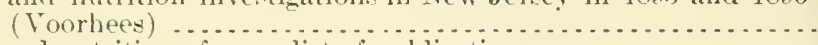

Food and nutrition of man, list of pullications on ...........................
Food legislation, report on, to Association of Official Agricultural

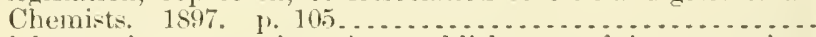

Food laboratories, suggestions tor establishment of, in connection with agricultural experiment stations of $\mathcal{L}$. S. (Atkinson).

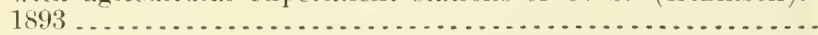

Food materials:

Ameriean, chemical enmposition of (Atwater and Woods). 1896. same, revised erlition (Atwater and Bryant). $1899 \ldots . . . . .$.

Chinese regetable, their nutritive and economic value, description

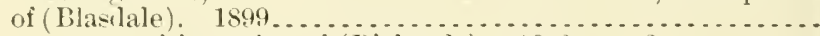

Common, nutritive value of (Richarrls), 1893. p. $3 \ldots \ldots . . .$.

Fool preservatives:

Analysis of, provisional method for (Allen). 1902. p. $107 \ldots .$.

Commercial, composition of. 1900. p. 748...............

tse and abuse of (Bigelow). 1900, p. $551 \ldots \ldots \ldots \ldots \ldots \ldots .$.

Food products:

From diseased animals (Salmon). p. $250 \ldots \ldots . . . . . . . .$.

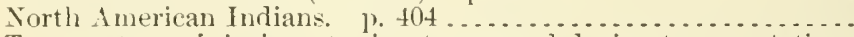

Temperatures injurious to, in storage and during transportation

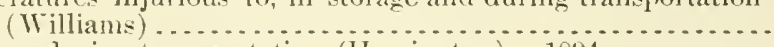

same, during transportation (Harrington). 1894 ..............

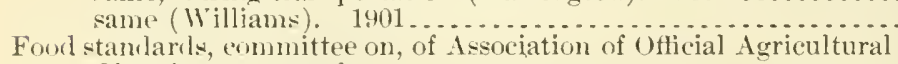
Chemists, report of:

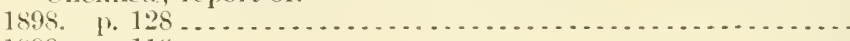

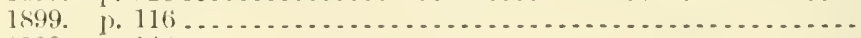

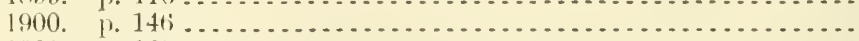

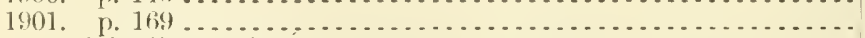

A1.10:894

A10.7:

A 10.3:35

A $10.2: \mathrm{F}: 3$

A 7.3:51

A 10.3:17

A $10.3: 28^{1}$

A $10.3: 28^{2}$

A 10.3:68

A 1.8:54

A 7.3:65

A1.10:900

A 1.10:900

A $4.1: 901$

A1.1:570

A 29.3:13

A29.2:F94

A 1.9:125

$\Lambda 7.3: 56$

A $7.3: 57$

A $7.3: 62$

A7.3:67

Foorls and feeding stuffs:

('hemical sturly of, more thorough, report of committee of Association of Official Agricultural Chemists on ways and means for securing. 1890 . p. 117

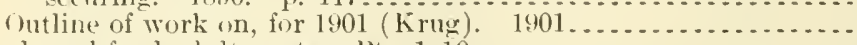

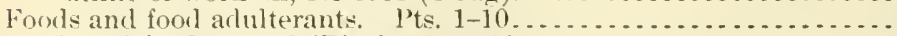

Fools amel food control (Bigelow). $190^{\circ}$ 


\section{Index}

('lassiffention no.

Foot, diseases of, among cattle (Trumbower).

A $4.2:(10) 4^{*}$

Same, among horses (Holeombe), P. 357.

14.2:I I8

Foot-and-mouth disease, or aphthoms lever:

Causes and symptoms of, and measures acrainst. 1) is.5 same, p. 28: ….....

Enrope 18ti9. p. $385 \%$

Instructions concerning inspection of live stock for $1902 \ldots . .$.

Nonexistence of, in the west (Melein). 1881. 11.819........

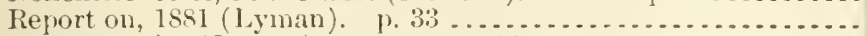

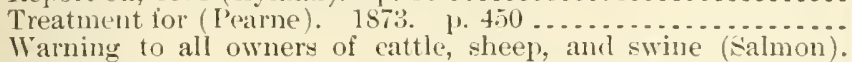
1902.

See ulso Aphtha.

Forage:

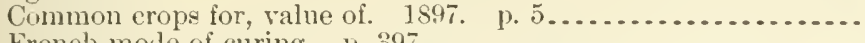

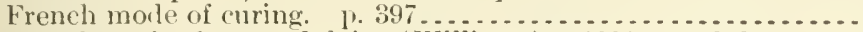

Succulent, for farm and dairy (Williams). 1899. p. $613 \ldots \ldots . .$. Forage conditions:

Eastern Rocky Mountain region (Williams). 1898............

Northern border of Great Basin (Griffiths). 1902..............

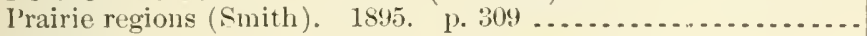

Forage crops:

Cultivated, of Northwestern States (Hitcheock). 1902

A $1.1: \$ 80$

A $1.6: 34$

127.9:7

A $4.2: \mathrm{F}: 3$

11.6:34

1 $1.1: 5.1-2$

A27.9:11

14.4:38

A1.9:65

A $1.1: 875$

1 1.10:899

1.3. $3: 12$

A $19.3: 15$

A $1.10: 895$

Leguminous (Smith), 1897. p. 487 ...............

Range improvement and, progress of experiments in, at Abilene,

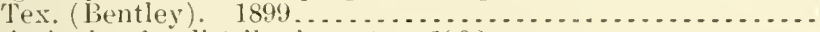

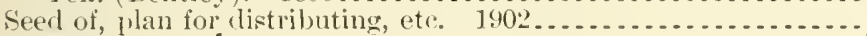

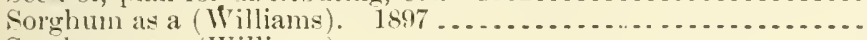

Soy bean as a (Williams) . . . . . . . . . . . . . . . . . . . . . .

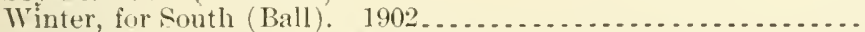

Sep also Pigs-Soy bean-Velvet bean.

Forage plants:

Agrienltural grasses and, of U.s., and sueh foreign kinds as luave been introduced (Vasey) ............................

Arizona and New Mexicn, notes on (Pool). 18ss. p. 46.......

Collected in Russia hy M. A. Carleton, for section of seed and plant introduction, Agrieulture Department. $1899 \ldots . . . . . .5$

Cultivation on alkali soils (Smith). 1898. 1.535............

Experiments with range grass and, at II

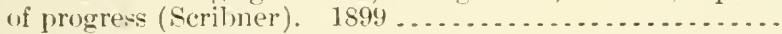

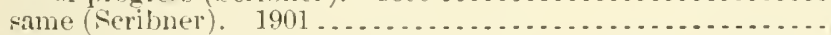

Forige resources and, of Gulf States (Tracy). 1898 ............

Of secondary or undeterninel importance for Sonthern States, and composition of forage plants grown in South (Tracy).

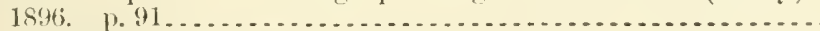

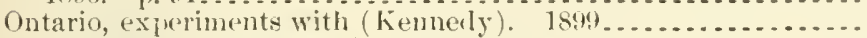

Semiarid West (Georgeson). 1893. 1. 145................

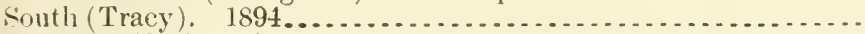

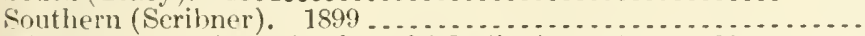

Western Texas, investigation of (Nealley). 1888. 1) $30 \ldots . . . .$. See also Alfalfa-berseem-Commercial salthushes-Corn-Corn plant-Cowpeas-Crimson clover-Fodder-Grass-Grasses and forage plants - Kafir corn - Jaize-Nillets-Ritpe-Salthushes - Sorohum - Soy hean - Velvet Jean - V'etches.

Forage resources, Red Desert of $1 \mathrm{~T}$ yoming ( $\mathrm{T}$ (2lson). 1898

Forlees, Robert II.:

Range improvement and administration. 1902. 1. 85. . . . . . .

Tanning extracts, preparation of, for analysis. 1897 . p. $149 . \ldots$ Forloes, S. $\Lambda$.:

Aildress as first vice-president $A$ ssociation of Eomomic Entomologists, at 4 th anmual meeting, 1892 . p. 68 ..........

Address as president of Association of Economic intomologists,

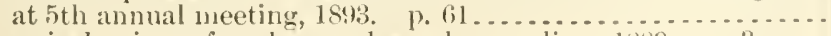

Arsenical poisons for plum and pench cureulio. $1889 . \quad$, $3 \ldots \ldots . \$ 9.7: 2$

* By a misprint, this page number appears twice.

11.8:32

16.3:6

16.6:4

A $1.10: 898$

13.4:2I

13.4:39

A3.3:15

A10.6:6

A3. $4: 20$

1 10.3:16

1 $1.9: 18$

11.9:102

A $6.3: 6$

13.3:13

1 10.3:115

17.3:51

$19.7: 5$

$19.7: 6$

. 


\section{Index}

Forbes, S. A.-Continued

Chinch bugs-

early ocenrence of, in Mississippi Valley, 1859. p. 249.....

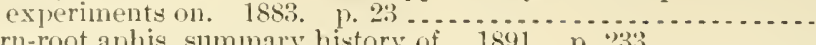

Corn-ront aphis, summary history of. 1891. p. 233 ...........

Entomology, oflice and laboratory organization. 1889 , p. 185..

Hessian fly parasite, importation of, from Europe. 1891. p. 179.

Nursery inspection and orchard insecticide work in Illinois. 1901.

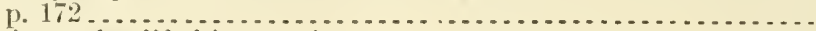

White grubs, life history of 1891 , p. $239 \ldots \ldots \ldots \ldots \ldots \ldots$

Forbush, Elward H.:

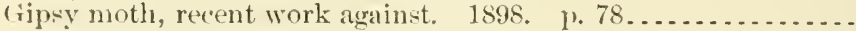

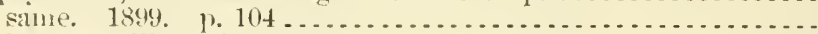

Hairy caterpillars, lestruction of, by bircls. 1899. p. $85 . . . . .$. Forecasting floorls, methods in use in France (Babinet). 1894. p. 94. Forecasting for rivers of small drainage area, especially those of North Carolina (Ilerrmani1). 1902. p. 158 ..................

Forecasts. Se Weather forecasts.

Ford, Nlilton. Fruit milture, paper on, 1883. p. $221 \ldots \ldots \ldots$

Ford, Seabury. Drought, great, of 1845 , in northern (thio. p. $29: 3$

Forl, T. S. Hog cholera, communication of, by carrion crows.

Foreign agricultural experiment stations. See Agricultural experiment stations.

Foreign agriculture, notes on, monthly

Foreign cities:

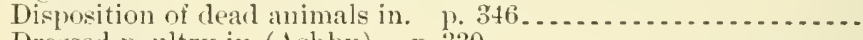

Dressed poultry in (Ashby). p. 330

Foreign comtries:

Agricultural experiment stations in (True and Crosby). 1902 .

Agrienltural statistice of, oflicial. 189\%. p. 79...............

Contagious diseases among domesticated animals in, consular reports on. p. 343

Contalgions diseases of animals in, report on, 1894, p. $479 \ldots$. same. 1900 (Thompson). p. 41:2 ......................

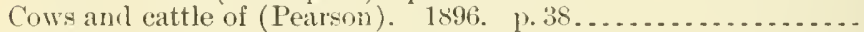

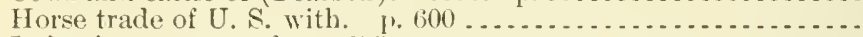

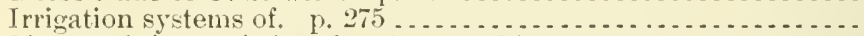

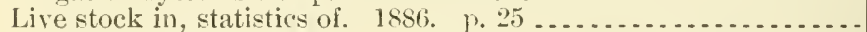

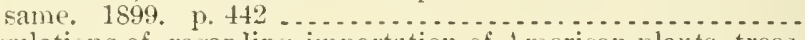

Regulations of, regarding importation of American plants, trees, and fruits (Howard). 1900 ................................

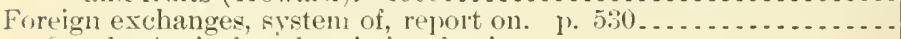

See also Agricultural societies, foreign.

Foreign markets:

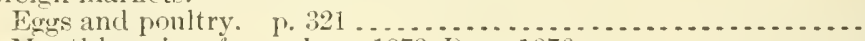

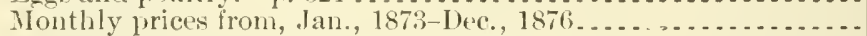

Testimony before Industrial Commission relative tr, for Ameri ('an agricultural products (IItehenek). 1901 ..............

Foreign Markets Division, Agriculture Department [formerly Foreign Markets Section ]:

Work of for farmer (IIiteheork). 1897. 1. 270 . . . . . . . . . .

Foreien trate. Sie Trasle.

Forenilk, bacterial flora of, relation of cheese-curd inflation to

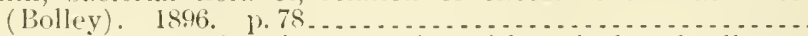

Forest experiment stations in connection with agricultural colleges,

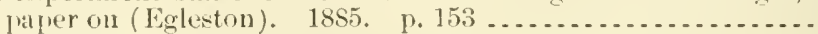

Forest fires:

Comnertion of railroads with (Egleston). 1887. p. 128........

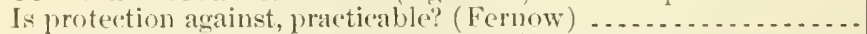

Legislation regarding, in U.S. (Fernow) ....................

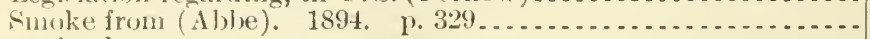

Forest lands:

Pratetical assistance to farmers, ] nmbermen, and others in handling

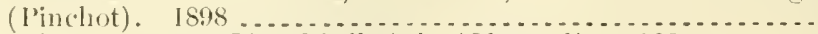

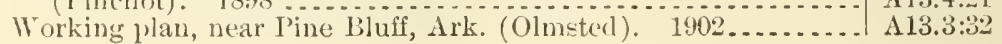

A9.7:1

A 9.3:2

A9.7:3

A9.7:2

19.7:4

A 10.3:99

A9.7:3

19.6:17

A9.6:20

19.6:20

A $29.3: 11^{1}$

A 29.3:31

A 1.7:2

A29.6:23

A $4.1: 595-6$

A27.9:

A4.1:899

A4.1:899

A 10.3:112

A27.9:30

A $4.1: 891-2$

A 4.1:899

A +.1:900

14.3:11

14.1:901

A 1.1:871

A 27.9:24

A4.1:899

A9.5:41

A1.1:868

A 4.1:899

A27.9:

11.8:67

A 12 .

A 1.10:897

A10.3:30

A1.7:?

A13.3:1

A13.4:14

A13.4:13

A $29.6: 22$

A13.4:21. 
Forest nursery, collection of tree seerls and propagation of seedlings

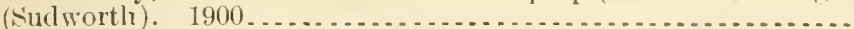
Forest Park meteorological observatury. See St. Louis, Mo.

Forest reserves:

Grazing in (Roth). 1901. p. 333

Proposed, in southern Appalachian, present conditioss of movement for, memorial, reports, and extracts from press. p. 155 .

Legislation, recent, on State forestry eommissions and ..........

Names, locations, areas, etc. 1899. 1\%. 755.

Forest school. See Aschaffenburg, Bavaria.

Forest trees:

Brief instructions on seed sowing and. 1873

Catalogue of, of $\mathrm{U}$. S., which usually attain height of 16 feet or more, with notes and brief descriptions of more important species (Visey). 1876 ...

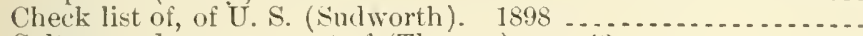

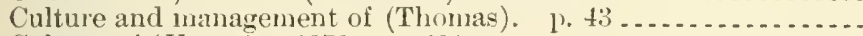

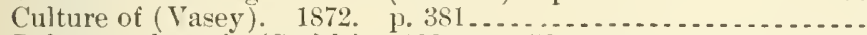

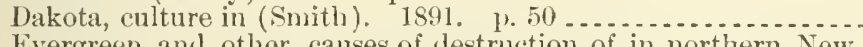

Evergreen and other, causes of restruction of in northern New England, additions to third report on. 1886. p. 17

Fungous diseases of (Schrenk). 1900. p. 199................

Insects of-

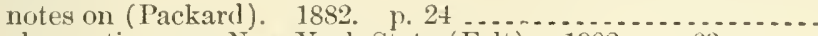
observations on, New York State (Felt). 1902. p. 63 ...... study of (110pkins). 1895 . p. $75 \ldots \ldots \ldots \ldots \ldots$

Insects injurious to, report on (Packard) -

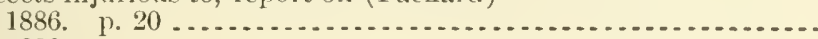

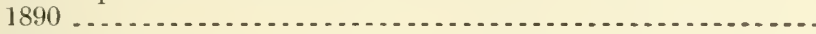

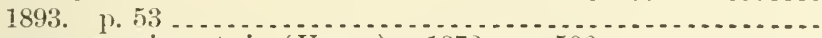

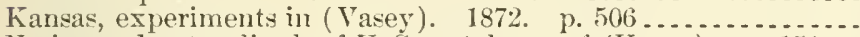

Native and naturalized, of U.S., catalogue of (Vasey). p. 151..

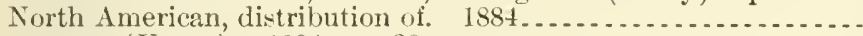
same (Vasey). 1884. p. 38... . . .

Planting of, in Spain. 1876. p. 263 . Arizona (Merriam). 1890.
San Francisco mountain region,

Young, oviposition in, by Tetraopes femoratus, fab. (Gillette). work, States having offices for, list of -

Forest work, States having offices for, list of -
1898 p. p. $620 \ldots \ldots \ldots \ldots$

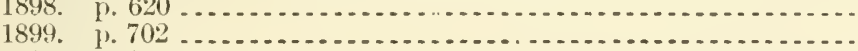

1900. ए. 655

1901. p. 630

Forest working plan for Township 40, Totten and Crossfield purchase, Hamilton Co., N. Y., State forest preserve (Hosmer and

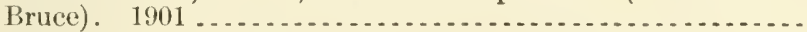
Forestation, re-, and rainfall in Leeward Islands (Alexander). 1901. Forestry:

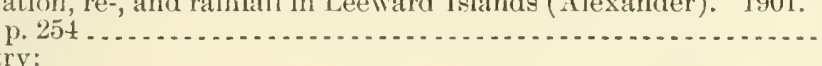

Abstracts of reports of agrienltural experiment stations on. 1889-1902

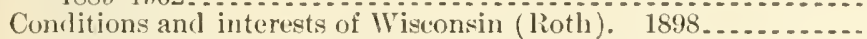

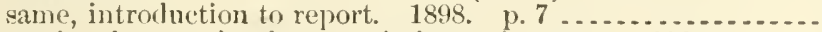

Educational men, circular to, relative to forestry. $1886 \ldots . . . .$. sane, 1887

For farmers (Fernow). 1898. same, 1,ts. $1-1$. 1. 461

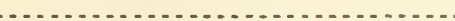
same, pt. 5. p. 3933

Influence of, on rainfall. 1876. p. 103

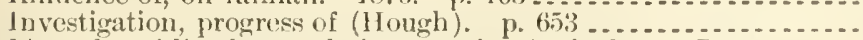
List of publications relating to, in Agriculture Department

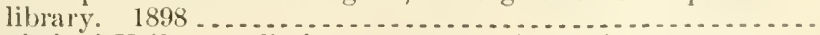

Mississippi Valley, preliminary report on (Baker), 1883....... Ohio and Indiana, certain portions of (Furnas). 1854. p. 346...

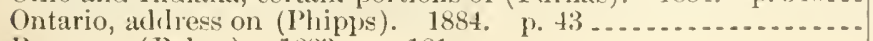

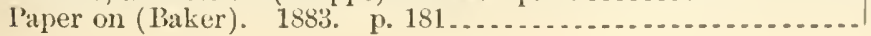

11.2: $\mathrm{Apt}^{2}$

11:3.4:17

A1.10:899

A1.2:Se: $3^{8}$

A1.8:11

A 13.3:17

A 1.1:864

A $27.9: 10$

A 13.3:5

19.3:12

A 1.10:900

A9.3:3

A9.6:31

A9.6:2

A9.3:13

A $8.1: 4$

A9.3:32

A27.9:10

A1.1:875

A $1.7: 5$

A1.7:5

A27.9:14

A5.5:8

A9.6:9

A1.10:898

A 1.10:899

A1.10:900

A 1.10:901

A 13.3:30

A29.6:29

A10.6:

A $13.3: 16$

A $13.3: 16$

A 13.4:1

113.4:2

A1.9:67

A1.10:894

A $1.10: 895$

127.9:14

A1. $1: 880$

A $17.3: 24$

11.8:28

1 13.5:-4

A $1.7: 5$

A1.7:2 
Forestry-Continued

Practical-

in the Arlirontacks (Graves). 1899 ....................

in sonthern Appalachians (P'rice). 1900. p. $357 \ldots \ldots . . .$.

Practice of, by private owners (Graves). 1899. p.415.

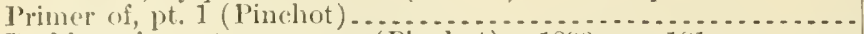

I'roblems in, notes on some (Pinchot). 1898. p. 181.........

Progress in -

$\begin{array}{ll}1899 . & 1.752 \\ 1900 . & \text { 1. } 733\end{array}$

1901. 1. 666

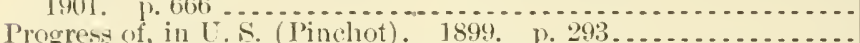

lielation of railroads to forest supplies and (Kern). 1857. p.11.

Reports on, vols. 1-3 (Hough); vol. 4 (Egleston) .............

Seliools of, list of-

1899. 1. 703

1900 . ᄂ. 656

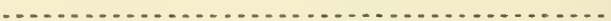

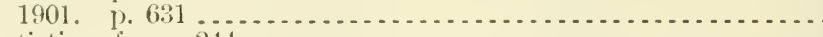

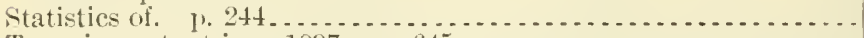

Trees important in. 1897 p. $645 \ldots \ldots \ldots$

United States, address on, before American Forestry Congress, St. Paul, Aug. 8, 1883 (Loring) .........................

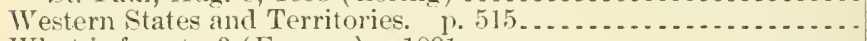

What is forestry? (Fernow). 1891 . . . . . . . . . . . . . . . . . . . . .
Forestry, American Association of. tion.

Forestry, Belgian Exposition of Agriculture and. See Belgian.

Forestry, first international congress of agriculture and, 1893. See Vieuna.

Forestry associations, list of, with officers-

1898. 1. 620 .

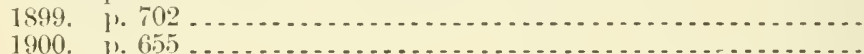

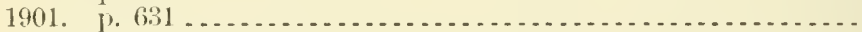

Forestry Bureau, Agriculture Department [formerly Division of

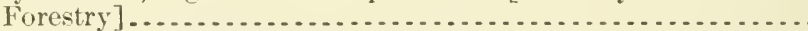

Forestry commissions, state and forest reserves, recent legislation on.

Forestry Division, Agriculture Department, work of, for the farmer (Fernow). 1897. p. $143 .$.

Same (Pinchot). 1898. p. 297

Forestry Exhibition, International, 1584. See Edinburgh, Scotlanil. Forests:

American, their destruction and preservation (Starr), p. 210...

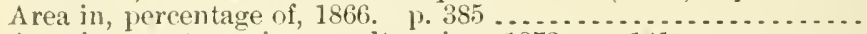

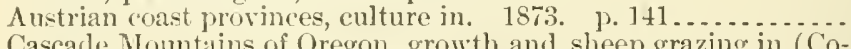

Cascarle Mountains of Oregon, growth and sheep grazing in (Coville)

Clearing and cultivation, effect of, upon water supply and soil, rainfall, temperature (Fulton). $1899 . \quad$ 1) $89 \ldots \ldots . . .$.

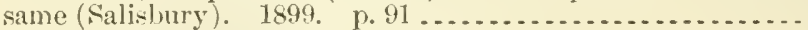

Crop, measuring (Mlodziansky). 1898.................

Culture-

extent and value of, etc. p. 226

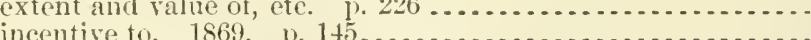

Damage to, by destructive pine bark-beetle (Hopkins). 1893.

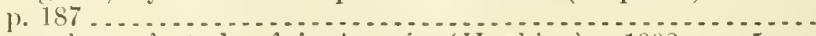

Entomology of, study of, in America (Hopkins). 1902. p. 5...

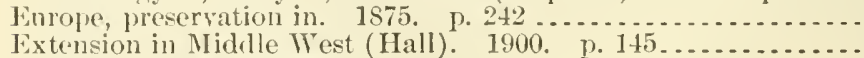

Fires in. Sce Forest fires.

Flora of-

additions to, of North America and necessary changes in nomenclature of important timber species, with notes (Sudworth). p. 325 .

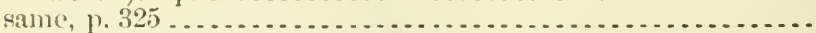

Rocky Mountain region (Sudworth). 1888. p. 153

A 13.3:26

1.10:900

A 1.10:849

1 13.3:24

11.10:598

11.10:899

A 1.10:900

A1.10:901

11.10:899

A13.3:1

A13.5:

A 1.10:899

A 1. 10:900

A 1. 10:901

A $1.1: 875$

11.10:897

A 1.7:1

11.1:87s

A $] 3.3: 5$

A $1.10: 898$

A 1.10:899

A $1.10: 900$

A 1.10:901

A13:

A13.4:17

A 1.10:897

A 1. 10:898

A1.1:865

A27.9:4

A27.9:12

A13.3:15

A29.3:24

A.9.3:24

A 13.3:20

11.1:870

127.9:7

A9.7:5

A9.6:37

A27.9:13

A1.10:900

A1.1:892

A 13.1:892

A 13.3:2 
Forests-Continued

Forest conditions and, of southeru Appalachian Momtain region

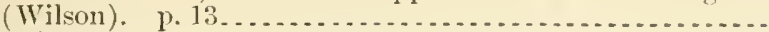

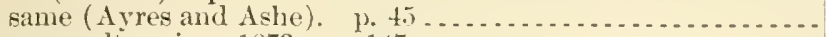

France, culture in. 1873. 1. $147 \ldots \ldots \ldots \ldots$

Germany, area of. $1876.10 .282 \ldots \ldots \ldots$

Government in its relation to (James). 1888 p. 2:".

Growtl and timber consumption, letter to Secretary of $\mathrm{Agricus}$ -

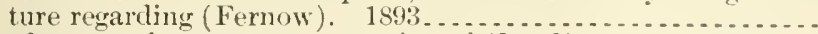

Ilearwaters of streams, preservation of (liead). 1884. p. 27 ...

Influence ofintroduction and summary of conclusions to reports on (Fer-

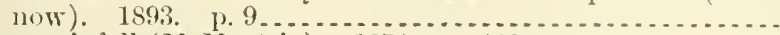

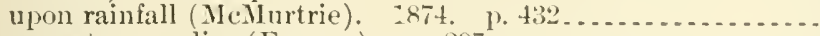
on water suplies (Fernow) 1. $297 \ldots$

Insects injurious to, descriptions of larve of. $1883 . \quad$ p. $251 \ldots \ldots$

Insect enemies of, in Northwest, preliminary report on (110)-

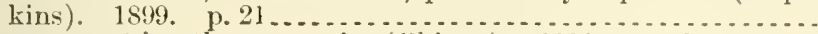

Management in other countries (1'hipps). 185\%, p. 19 .......

Management of, more rational, suggestions in behalf of (Fernow).

Meteorological observations, review of, a study preliminary to (liscussion of relation of forests to climate (Harrington). 1893.

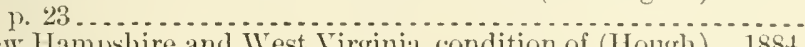

New Hampshire and West Virginia, condition of (Hough). 1884.

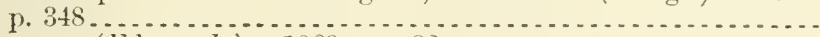

Paper on (Edmunds). 1869 p. p.2

Plains, cultivation on, general discussion of (Plorlget). 1. 316...

Porto Rico, conditions of (Hill). 1899 ... . . . . . . . . . . . .

Precipitation and its bearing on theories of forest influences

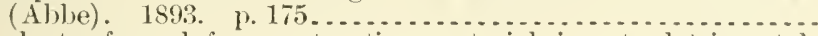

Products of, used for constructing material, insects detrimental and restructive to (Hopkins). 1902. 1).60...........

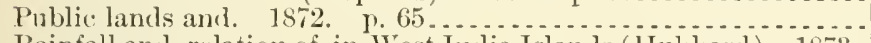

Rainfall and, relation of, in West India Islands (IIuhbard). 1873.

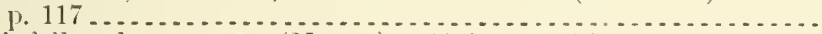

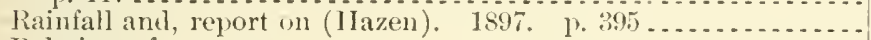

Relation of-

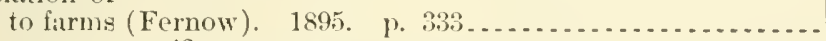
same, 1.43 . . . . . . . . . . . . . . . . . . . . . . . . . . . to water supplies (Fernow). is93. 1. 123.

Resources of U. S., far'ts and figures regarding, briefly stated (Fer-

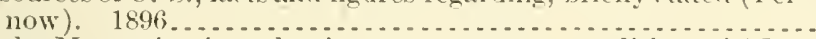

Rocky Monntain, introduction to reports on condition of (Fer-

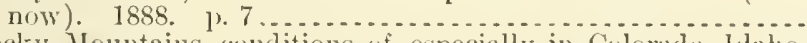

Rocky Mountains, (onditions of, esperially in Colorado, liaho, Nontana, Wyoming, and New Mexiro (Ensign). 1888. ए.41.

Sanitary significance of (Femow). 1893. 1. 171 . . . . . . . .

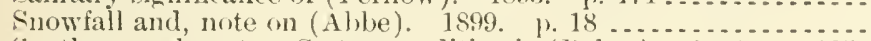

Southern and westem States, condition in (baker). 1s8t. p. 105.

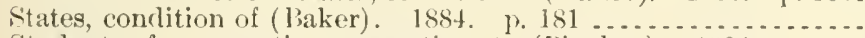

Stulents of, prospective, suggestions to (Pinchot). $1900^{\circ} \ldots . . .$.

Supplies ofconsumption of, by railroads and practicalle economy in their

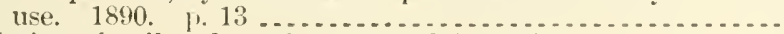
relation of railroads to forestry and (kern). 188\%. p.11 ..

Wrashington Territory (Irown). 1881. p. $388 \ldots . . . . . . . .$.

Western States and Torritories, condition of (limas). 1884. 19. 246,255

Yellowstone National Park, letter relative to, neely of (Ilague). р. 206.

Seecalso Appalachian forests - Fvergreen forests - Forest trees.

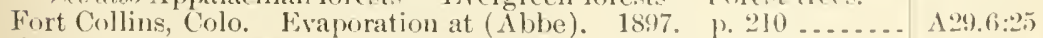

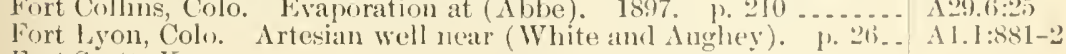

Fort Scott, Kansas:

Sorghum sugar experimonts at, in 1887 -

(Swensoil). 1. 21:3

same, $1,50 . . .+\ldots$

11.2: $\mathrm{Ap}^{2}$

11.2:1 pt

127.9:12

$9: 1$

A 13.2:F 6

11.7:5

113.3:7

A27.9:12

113.1:889

18. $1: 3$

19.6:21

A 1.7:1

113.4:10

A13.8:\%

A 13.5:4

1.7.9:7

A1.1:872

A 13.:3:25

A13.8:7

A9.6::1

A $27.9: 10$

A27.9:11

A $29.6: 25$

A1.10:895

A 1.9:67

A 13.3:7

A13. $4: 11$

A13.3:2

A 13.3:2

A13.2: 7

A29.6:27

A 13.5:4

A13.5:4

113.4:23

A 1.3.3:4

A 13.3:1

A 1:3.5:4

1 13.5:t

11:3.3:2

A 7.3:17 
Fort Scott, Kansas-Continued

Sorghum sugar experiments at, in 1887-Continued

(Crampton and Fake). P. 2:21

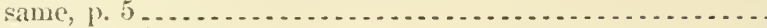

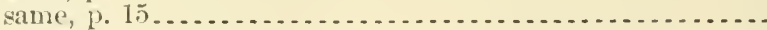

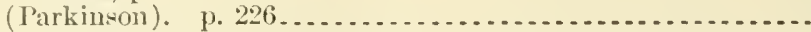
wame, 1,20 .

Sugar, manufacture of, from sorghum and sugar canes, in 1886, ex-

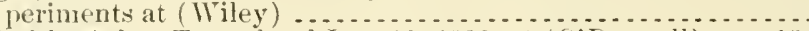
Fort Smith, Irk. Tomado of Jan. 12, 1898, at (O'Donnell). p. 18 . Fort Worth, Texas:

Feeding station at, regulations conceming cattle transportationJan. 3,1898

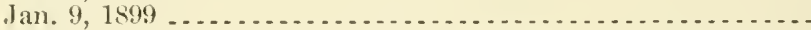

Jan. 20, 1900

Interstate convention of cattlemen liekl, Mar. 11-13, 1890, proceelings of

Fortier, samuel:

Gallatin Valley, Mont., duty of water in. 1900. p. 175 ........

Irrigation investigations in Montana. 1900. p. 267 ........... same. 1901. p. 225.

Foss, James H. Florida, soil, resources, and neans of transporta-

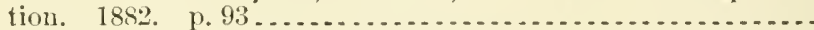

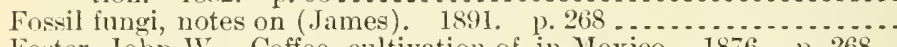

Foster, John IV. Coffee, eultivation of, in Mexico. 1876 . p. $268 \ldots$

Fonl broor, laws relative to, with recent laws against injurious inseets in North Ameriea (Iloward). 1898

Fowl elrolera:

Bacillus obtained from three outbreaks of, study of (Moore).

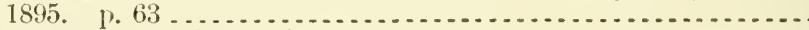

Investigation of (Salmon)-

1880. ए. 13 ...

same, p. 387

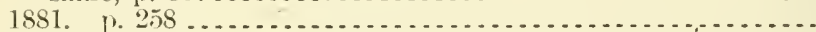

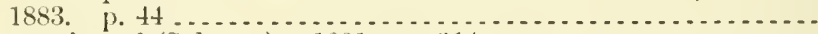

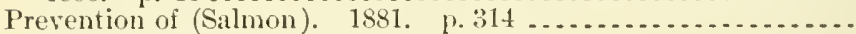
same. (Circular.) Fel. 23, 1881.

See also Chicken eholera - Leukrmia.

Fowl diseases. See Asthenia - Chieken cholera - Diphtheria Entero-hepatitis - Fowl cholera - Gape disease of chickensLeukæmia.

Fowls:

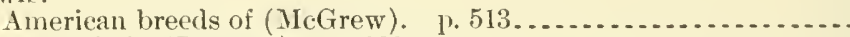

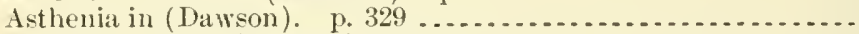

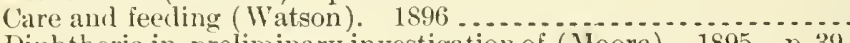

Diphtheria in, preliminary investigation of (Noore). 1895. p.39.

Diseases of, correspondence relating to. 1877. p. $492 \ldots \ldots . .$. same. 1898 . p. $547 \ldots \ldots . .5$.

Domestic, internal parasites in, microseopic observations (Taylor).

$1884 \ldots$
Gape disease of. p. $550 \ldots \ldots \ldots \ldots$

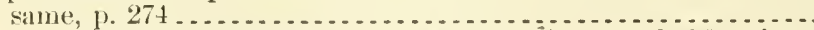

Gape disease of, and parasite by which it is cansed (Meguin).

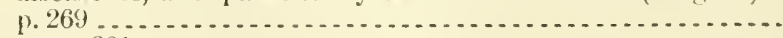

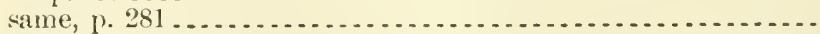
same. 1884. p. 103 . . . . . . .

Infectious leukemia in, bacterial disense frequently mistaken for fowl cholera (Moore). p. 185.

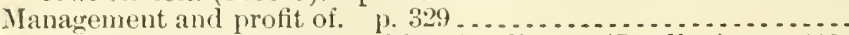

Missouri industry, and annual loss by disease (Bradley). p. 418

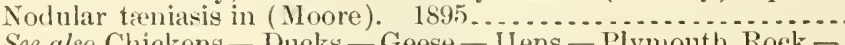

See also Chickens - Ducks - Geese - Ilens - Plymouth Rock l'oultry - Shrikes - Turkeys.

Fox, Charles I'. See, as joint anthor, Schweitzer, Paul.

Fox, William F. Lumber industry of State of New York, history

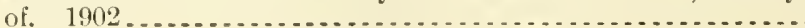

Fox Indian Agency. See Sac and Fox Indian Ageney.

A4.1:901

A4.1:898

A 1.9:41

A4.3:8

A $1.1: 877$

A4.1:898

A $1.8: 34$

A $1.1: 885$

A $4.1: 885$

A 1.1:884

A $t .1: 884$

A 4.2:A 105

A $4.1: 895-6$

A1.1:870

A 4.1:885

A 4.4:3

A 13.3:34 
Agricultural botany, review of publications on, issued in, during

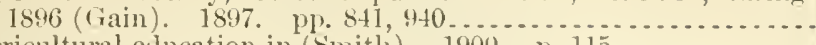
Agricultural eincation in (Smith). 1900. p. $115 \ldots . . . . . . .$.

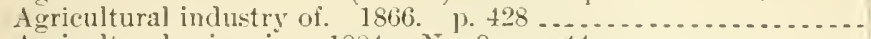

Agricultural prizes in. 1884. No.9. p. $44 \ldots \ldots . . . . . . . . .$.

A gricultural publications of, notes from recent. p. $626 \ldots \ldots .$.

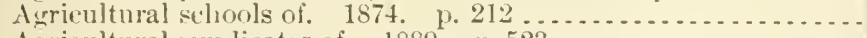

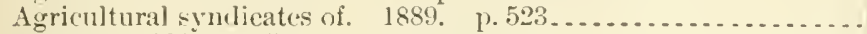

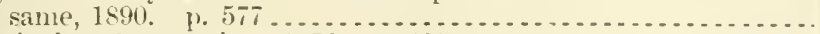

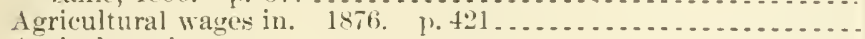

Agriculture in-

187t. p. 131

1875. PP. 243,516 .

1875. p. $115^{\circ}, \ldots \ldots \ldots \ldots \ldots$

1867-1876. p. 419 .

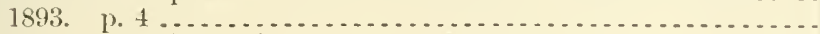

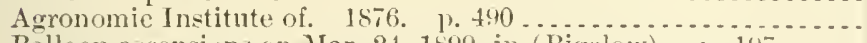

Balloon ascensions on Mar. 24, 1899, in (Bigelow). p. 197 .....

Beet sugar in, progress of manufarture of. $1866.1 \% 179 \ldots \ldots$.

Cheese making in, at high altitudes. 1875. p. 127 . . . . . . . . .

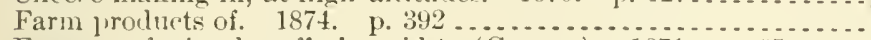

Famers of, eircular offering aid to (Capron). 1871. P. $65 . . .$.

Flood forecasting in, methods in use (Babinet). 1894. p. 94 ...

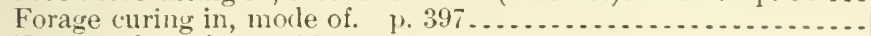

Forest culture in. 1873. p. 147 . . . . .

Grape vine, cultivation in (Bossert). p. 156 ...............

Grape vine in, black rot of (Frechou). $1890.11 .88 \ldots \ldots . . . .$.

Grape vine in, downy mildew of, treatment of, in 1887 (Chauzit). 1888. P. 75 same, 1888 (Prillieux). 1859. p. $49 \ldots \ldots \ldots$

Ilemp industry in (Dodge). 1892. p. $27 \ldots \ldots \ldots \ldots$

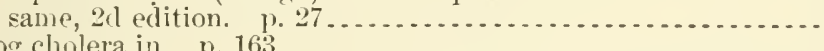

Hog cholera in. p. $163 \ldots \ldots \ldots \ldots$
same. $1.172 \ldots \ldots \ldots$

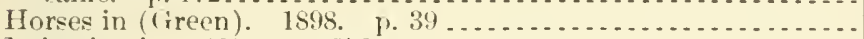

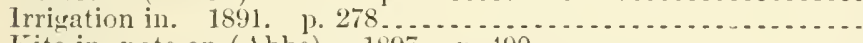

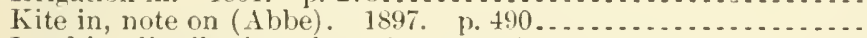

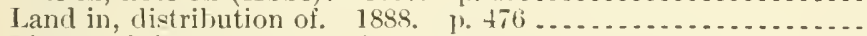

Live stock in, movement of. $1865-67$. $1.380 \ldots \ldots \ldots \ldots \ldots .$.

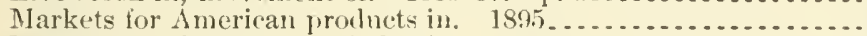

Meteorology in, notes on (Able). 1898, p. $553 \ldots \ldots \ldots \ldots . . .$.

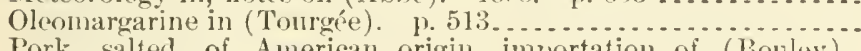

Pork, salted, of American origin, importation of (Bonley).

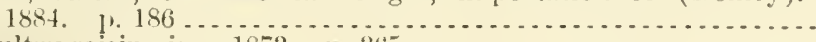

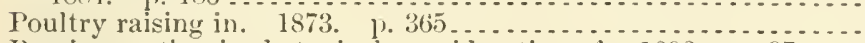

Ramie question in, botanical consideration of. 1892. p. $97 \ldots \ldots$

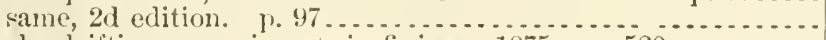

Sands, drifting, experiments in fixing. 1875 . p. $520 \ldots \ldots . .$.

Sugar beet, culture of, and manufacture of sugar therefrom

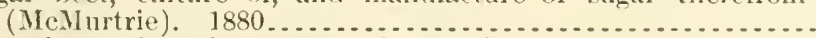

Sngar-leet culture in, notes on (Maxweli). 1890. p. $81 \ldots \ldots$.

Tannery refuse in, utilization of. 1876 . p. $280 \ldots \ldots \ldots \ldots \ldots$.

Tariff and recilmocity treaties. 1892 , p. $181 \ldots \ldots \ldots \ldots \ldots \ldots .$.

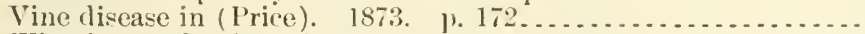

Wine in, production of, 1883 . No. 9. 1. $45 \ldots \ldots \ldots \ldots \ldots \ldots$.

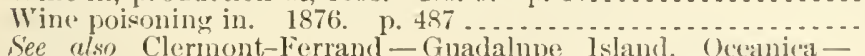

See also Clermont-Ferrand-Guadalnpe lsland, (Geaniea-
Harre - Indo-China - Juvisy - Martinique - Mamritiu Nînes - Roubaix - Trappes.

Franeis, Frederick L. See, as joint anthor, Randolph, lirederick J. Fraukenfield, Harry Crawford:

Atmospheric pressure, high and low, monthly report on, Dee, 1899-Apr., 1900, June-Dec., 1900, Oct. and Nov., 1901 . . . . . .

Daily river stages on principal rivers of U. S., $1896-99$. . . . . . .

Flonds and flood warnings. $1901.1 \% 477 \ldots \ldots . . . . . . . .$.

Mississippi river, floods and floor problems of. 1899. p. $405 \ldots$

A 10.6:8

A $1.10: 900$

A27.9:4

A $27.9: 22$

A 1.1:869

A27.9:12

$127.9: 27$

A27.9:25

A27.9:14

A27.9:13

127.9:13

127.9:14

127.9:14

A27.9:31

A. $7.9: 14$

A29.6:27

127.9:4

A27.9:13

А27.9:13

127.9:9

A29.3:11 1

A1.1:875

127.9:12

A 1.1:863

A 6.3:11

A6.3:5

A $6.3: 10$

A27.8:1

A11.5:1

A $4.1: 85 \bar{\imath}-8$

11.1:888

A 1.2:1178

A 15.2:19.

A 29.6:25

A $27.9: 26$

A27.9:5

A12.3:?

A $29.6: 26$

A4.1:900

A 4.3:30

A27.9:11

A27.8:1

A 11.5:1

A27.9:13

A1.6:28

A $7.3: 30$

A27.9:14

A $27.9: 30$

A 25.9:11

A27.9:2:

A27.9:14

129.6:

A.9.10:6

A1.10:901

A $29.6: 27$ 
Frankenficld, IIarry Crawiord-Continued

River and flood service, monthly notes on, Sept., 1898-Oct., 1902.

Temperature, humidity, and wind direction, vertical gradients, preliminary report on kite observations. $1898 \ldots \ldots \ldots \ldots . . . . .6$

Tornatdo of May 27, 1896, at St. Lonis, Mn. 1). T7 ............

Weather forecasts in State of Missouri. 1895. p. $292 \ldots . . . . .$.

Frankfort-on-the-Main, Ciermany. Cost of hauling farm products

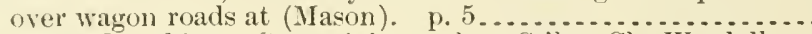

Frankland, IT. Ashby. See, as joint anthor, Stiles, Ch. Wardell.

Franklin, George E.:

California, southern, weather crop bulletin, history of. 1896. p. 46.

Weather Burau stations, should compensation be allowed persons not in employ of Bureau, while learning station duties, to enable them to properly perform such luties in cases of

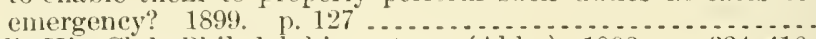

Franklin Kite Club, Philatelphia, notes on (Abbe). 1896. pp. $334,416$.

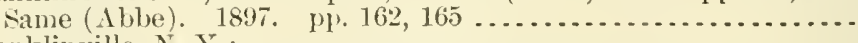

Franklinille, N. Y.:

Fxplosive noises at (Kales). 1897. p. 393.

Thunder storms in (Kales). 1897. P. 309

Franz Josef Land:

Auroral ohservations on 21 Wellmann expedition marle in neighborhood of, 1898-99 (Baldwin). p. $107 \ldots . . . . . . . . . . . .$.

Meteorologieal work in, 1898-99, outline of scope and character

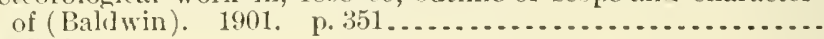

Fraps, G. S.:

Pentosan-free crude fiber, retermination of. 1902. p. $51 \ldots \ldots$

Pentosans and crude fiber, determination of, notes on. 1901.

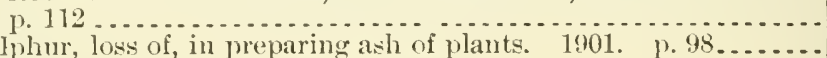
Sulphur, loss of, in preparing ash of plants.
See also, as joint author, Withers, W. A.

Erear, William:

Abstract committee of Association of Official Agrienltural Chem-

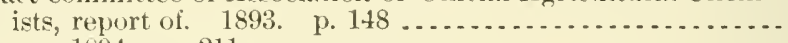

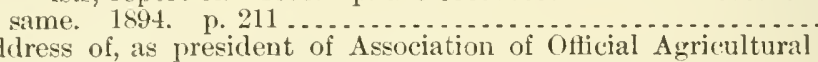
Chemists, at 14 th annual convention. 1897 . p. $7 \ldots \ldots \ldots . .$.

Vinegar, analysis of, provisional method for. 1902 . P. 62 .....

Wheat varieties, extension of tests applied to. 1890. p. 131 ...

Frear, William, and McDonnell, Henry Barnett. Phosphoric acid, available, determination of, comparison of IVagner's and present association method for. 1886. p. 26 .......................

Frechou, - Grapevines, black rot of, in France. 1890 p. 88. Fredericksen, J. I). Sizga beet, introduction of, and manufacture of heet sugar in the Northwest as compared with countries of

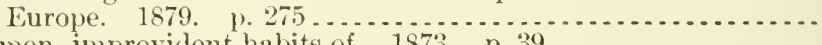

Freedmen, improvident habits of. 1873 . p. $39 \ldots \ldots \ldots \ldots \ldots \ldots \ldots$

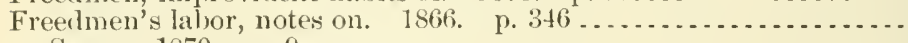

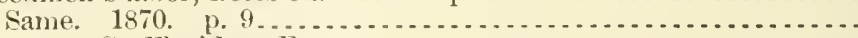

Freezes. See Floricla - Frosts.

Freight rates:

Domestic and trans-Atlantic, monthly, Ang., 1893-Dec., 1895..... Ocean transportation of products of agriculture, Oct. 1, 1895-Oet.

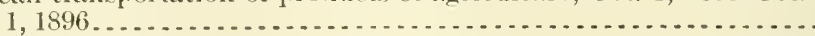

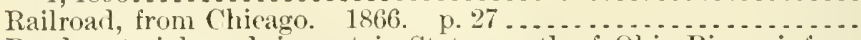
Road materials and, in certain States north of Ohio River, intor-

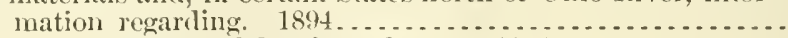

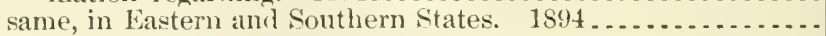

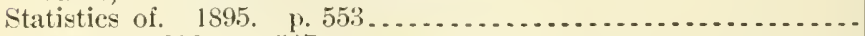
same. 1896. p. 597 .

Transportation companies, monthly notes on, Aug., $1882-J u l y$, $18: 3$.

See also Transportation rates.

Freneh, IIenry F.:

Agrienltural colleges, historical sketch of. p. $137 \ldots \ldots . . . . . .$.

Country roads, deseription of formation of. p. 538.

A29.6:

A $29.5: \mathrm{F}$

A $29.6: 24$

A:9.6:23

A22.4:27

A29.3:18

A29.3:24

A $29.6: 24$

A29.6:25

A 29.6:25

A29.6:25

A29.6:29

A $29.1: 900$

A $7.3: 67$

A $7.3: 62$

A 7.3:62

A . . $3: 38$

A $7.3: 43$

A 7.3:51

A 7.3:65

A 10.5:2

A 7. 3:12

A6.3:11

A1.6:28

A27.9:11

A $27.9: 4$

A $27.9: 8$

A27.9:

A27.8:12

A $27.9: 4$

A 22.3:6

122.3:7

A 1.10:895

A $1.10: 896$

A27.9:

A1.1:865

A 1.1:866 
French, lliram T.:

Feerling sheaf wheat to hogs. 1. 494.

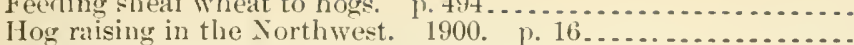
Sheat wheat, feeding to steers. p. 486

A $4.1: 898$

A $1.9: 117$

Wheat in sheaf and chopred wheat for pigs. 1). 494

"French Napoleon," stallion, account of. 1. $320 \ldots . . . . .$.

Frosno, Cal., soil survey around (Means and Holmes)

Friend, Charles $\mathbb{W}^{\top}$.:

Earthquakes at Carson City, Nevarla, 1875-98. p. 64 .........

Seismograph at observatory at Carson City, Nev. 1900.0 .245

Frisby, Almah J., ancl Bryant, Irthur Peyton. Potato, composition of different parts of, and loss of nutrients during process of boiling. 1897. p. 25.

Frissell, I. B. Negroes, dietary studies among, in eastern Virginia,

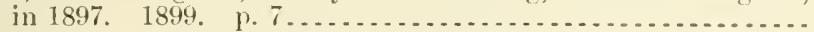

Froelich, Louis. Grape, scuppernong, letter on. 1868. 1. 449...

Frogs as an eladicator of thlke disease (Stiles). p. 220 . . . . . . . Frost:

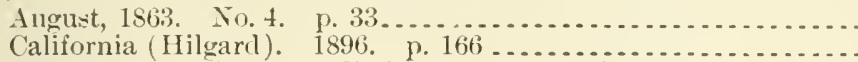

California, sonthern, prediction and prevention ( $\mathrm{Ab}$ be). 1895.

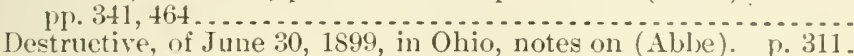

Fighting of (MeAdie)-

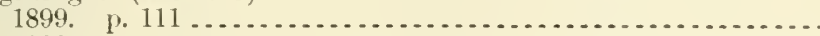

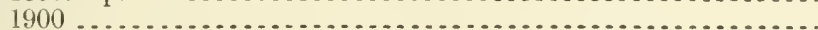

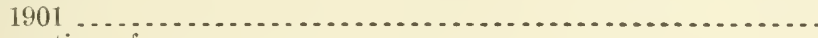

Formation of-

note on (Abbe). 1897. pp. 213, 308

same (Cuthbertson). 1902. 1. 125...................

peenliarities in, over coast region of South Carolina (Jesu-

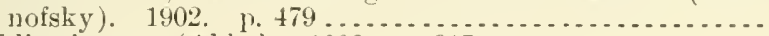
publications on (Able). 1S9S. p. $217 \ldots \ldots \ldots \ldots$ St. Paul, note on (Abbe). 1S97. p. $101 \ldots . . . . . . . . .$.

Hoar, especially rich in nitrogen (Able). 1896. p. $371 \ldots \ldots .$.

First killing, dates of, in Indian Territory and Oklahoma ( 1 bhe).

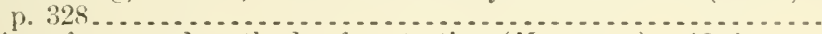

Injury from, and methods of protection (IIammon). $1896 \ldots .$.

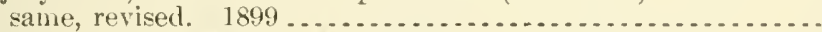

Marlela Springs, MI., in May (Abbe). p. 172.............

Moonshine and, notes on (Abbe). 1898. lip. 115, 261 ........

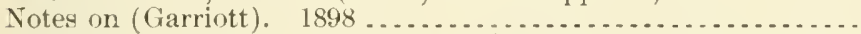

Popular queries about, with answers (Kimball) 1901. 1. 42.2..

Preclictions, valne of, and best methorl of making them locally

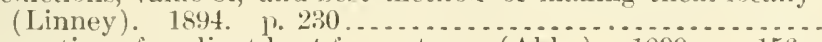

Prevention of, raliant heat for, notes on (Abbe). 1899, ए. 156.

Protection from-

experiments in, notes on (Abbe). 1899. p.62...........

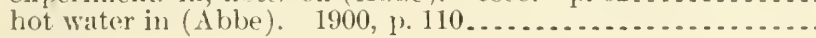
note on-

1894 (Abbe). p. 463 .

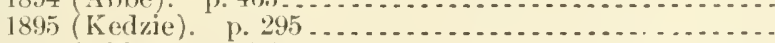

1899 (Albe). p. $475 \ldots \ldots$

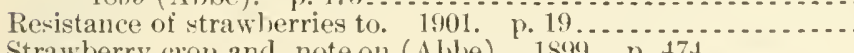

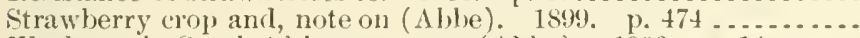

Work on, in Sonth Africa, notes on (Nlbe). 1900. 1. 14......

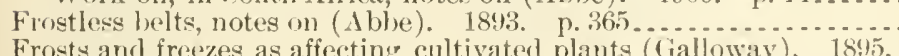

Frosts and freezes as affecting cultivated plants ( ialloway). 1895.

\section{Fruit erop:}

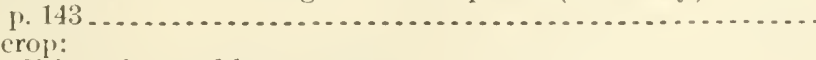

Coulition of, monthly notes on.

Prospects in United States. May 1, 1894 . p. $251 \ldots \ldots \ldots \ldots \ldots$

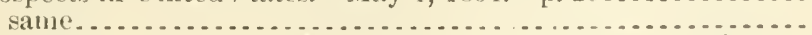

Fruit-culture institute. See ( veisenheim-on-the-Rhine, Prussia.

Fruit garden, howe, preparatiun and care (Corbett). 1902 ....... Fruit growers:

Bees of great value to (Penton). 189\%. p. 254 ............ A! . .

110.3:70

127.9:6;

$14.1: 901$

127.9:1

129.6:24

129.6:2:3

129.6:27

129.3:24

129.3:29

129.6:29

129.6:25

A29.6:30

A29.6:30

129.6:26

A29.6:25

129.6:24

A 29.6:2:

129.2: 592

A29.3:2:3

+29.6:2:3

129.6:26

A 1.9:104

A29.6:29

129.6:21

129.6:27

129.6:27

A29.6:28

129.6:22

A $29.6: 23$

129.6:27

A 1.9:13:3

129.6:27

129.6:28

129.6:21

A1.10:895

A 27.9:

A27.9:3:2

1.27.9n:1.94

A 1.9:15.t 
Fruit growers-Continued

Irrigation practice among, on Pacific coast (Wickson). 1902.

Fruit growing:

Califomia. 1892. 1. 99

Indiana. $1873 . \quad$ p. 356

Irrigation in (Wickson).

1900

Progress in-

1899. p. 748

1900. p. 731

1901 (Ragan). p. 673 Fruit industry:

California, statistics of (Holmes). 1901

Influence of refrigeration on (Taylor). 1900 . p. $561 \ldots . . . . .$. Sulustitution of domestic for foreign-grown fruits and (Taylor).

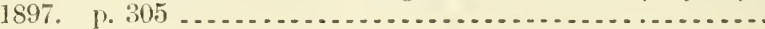
same, reprinted, with historical and descriptive notes on varieties of apples suitable for export trade. $1898 \ldots . . . . . .$.

Fruit-tree bark-beetle, circular relative to (Chittenden). 1898..... Fruit trees:

Arsenical spraying of, while in blossom (Lintner). 1893. p. 181. Close root pruning of (Clark). 1899. p. $13 \ldots \ldots \ldots \ldots \ldots \ldots \ldots \ldots$ Fruits and, of Middle States, propagation, influence of stocks,

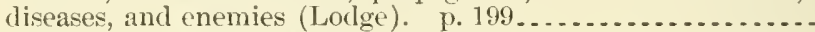

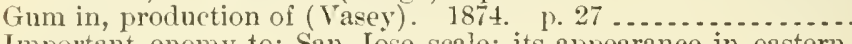

Important enemy to; San Jose scale; its appearance in eastem U. S.; measures to be taken to prevent its spread and destroy it (Howard). 1893

Insecticides on, some effects of early spring applications of (Felt). 1900. p. 22

Winter killing of, note on (Abbe). 1900 . p. $15 \ldots \ldots \ldots$

Fruit worm:

Japanese peach, report on. 1889. p. $64 \ldots \ldots \ldots \ldots \ldots \ldots \ldots \ldots \ldots \ldots$

Morelos orange, report on (Riley). 1888. p. $45 \ldots \ldots \ldots \ldots \ldots . . .$.

Fruitarians and Chinese, nutrition investigations among, at California Fruits: Agricultural Experiment Station, 1899-1901 (Jaffa). 1901...

American-

regulations of foreign governments regarding importation of

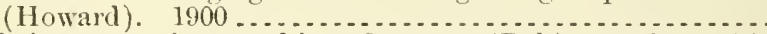
scale insects on, imported into Germany (Reh). $1900 . \quad$ p. 79. American and East Asian, sketch of relationship between (Bailey). 1894. p. 437

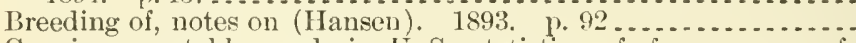

Canning vegetables and, in U.S., statistics of, from census of

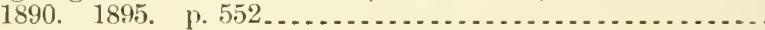
same. $1896 . \quad$ p. 595 .

Catalogue of, recommended for cultivation in various sections of

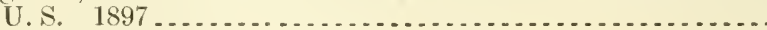
same, including British jrovinces. 1899 ...................

Culture of, paper on (Ford), 188.3. p. 221 . . . . . . . . . . . . . .

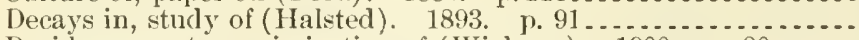
Deciduous, notes on irrigation of (WVickson). 1900 . p. $80 \ldots . .$.

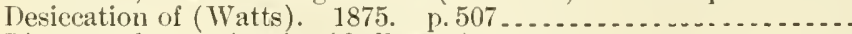
Diseases of, spraying for (Galloway). 1896............... Dried-

San Jose scale on (Howard). 1898. p. 7 ...............

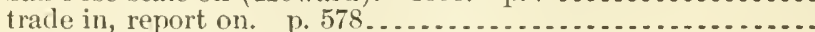

Exotic, of California, notes of (Hilgard). 1892, p. $137 \ldots \ldots .$. Experiments with fertilizers on, to study feeding capacities of plants and variations due to action of fertilizers. 1891 .....

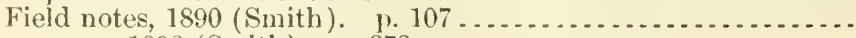

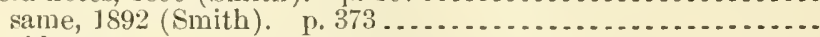

Florida-

description of (Atwood). p. 140

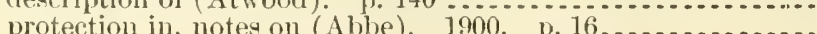

A 10.3:108

A1.9:161

A 1.8:20

A27.9:11

A 1.9:116

A $1.10: 899$

A1.10:900

A 1.10:901

A 1.1:871

A $27.8: 23$

A 1.10:900

A1.10:897

A21.3:7

A9.5:29

A $9.7: 6$

A1.9:103

A1.1:865

A27.9:12

A9.5:

A 9.6:26

A $29.6: 28$

A9.7:2

A9.7:1

A10.3:107

A9.5: 41

A9.6:22

A1. 10:894

A 10.3:16

A 1.10:895

A1.10:896

A20.3:6

A20.3:8

A1. 7:2

A 10.3:16

A 10.3:76

A27.9:875

A1.9:38

A9.6:18

A $1.1: 878$

A 1.8:20

A 10.4:19

A 28.5:6

A28.5:7

A1.1:867

A29.6:28 
Index

Fruits-Continner

Clissifleatlou no.

Fruit trees and, of Middle States, propagation, influence of stocks, diseases, and enemies (Lodge). p. 199 ...................

Gathering, ripening, and keeping (Clarke). p. 15: ...........

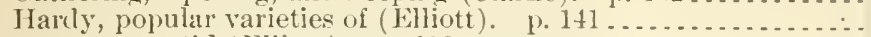

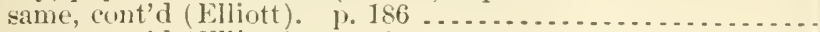

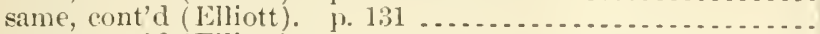

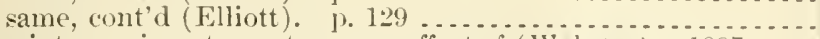

Hemipterous insect punctures on, effect of (Weloster). 18si.

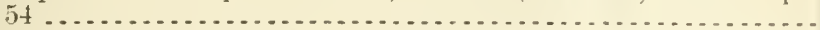

Insects affecting (Howard). $1896, \mathrm{p} .100 \ldots \ldots \ldots \ldots \ldots \ldots \ldots$

Iowa, northern, cultivation of. 1868. 1) 321 ..............

Japanese insects, two, injurious to (Nat:umura). 1598. p. :, 4

Mechanical cold storage for (Clark). 1900 p. $12 \ldots \ldots \ldots$

Michigan, Lake, eastern shore of, statistics of (Ganzhorn). $186 \%$.

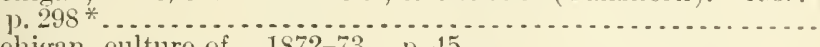

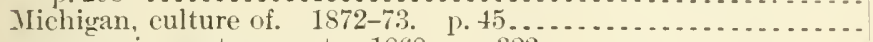

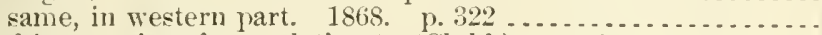

Michigan region, facts relating to (Clubb). $1870,1,37 \ldots \ldots$.

Mississipui rapids, culture on (Gregg). 1869. p. 245..........

Naming and exhibiting, rules for. 1900 . p. $i+2$.................

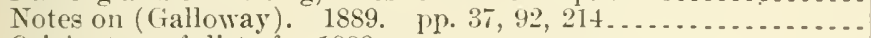

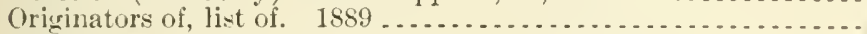
same, with addresses and names of specialties ...............

Our native, improvement of (Bailey). 1896. 1. $297 \ldots \ldots \ldots \ldots$

Peaches and other, in England. 1895 ......................

Planting, distances apart, in commercial plantations. 1897 . p. 689 .

Popular varieties of (Elliott). p. 368

Production of, in U. S. in 1889, and quantities and valnes im-

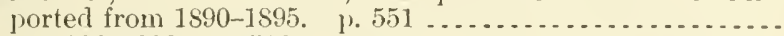

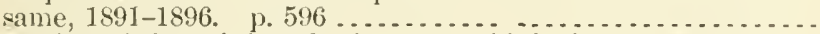

Protection of, from injury by heat or cold during transportation

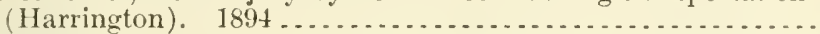

Regions of northern U.S., and their local climates (Lippineott).

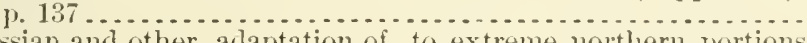

Russian and other, adaptation of, to extreme northern portions

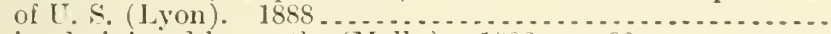

Seriousty injured by moths (Mally). 190:. p. $90 \ldots \ldots \ldots \ldots$.

Setting without pollination, etc. (Hartley). 1902..............

Sinall-

('ulture for market ('Taylor). 1895. p. 2\$3 ...............

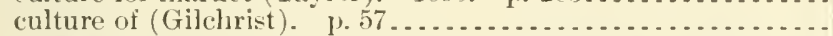

Spraying for insert pests and fungous diseases, with special consicleration of subject in its relation to public health. $1892 \ldots . .$.

Stone, food value of (Langworthy). 1899. p. 20............. See also Peach twig-borer.

Thinning, experiments found profitable. 1898. p. 15 .......

Tropical and semitropical, condition of, in U. S. in 1887; Florida and Gulf States (Reasoner). p. $7 \ldots \ldots \ldots \ldots . . . . . .$. same, California, Arizona, and New Mexico (Klee). p. 111 ..

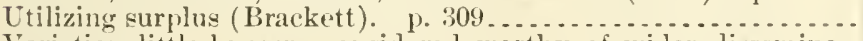

Varieties, little-known, considered worthy of wider dissemina-

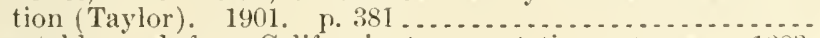

Vegetables and, from California, transportation rates on. 1883.

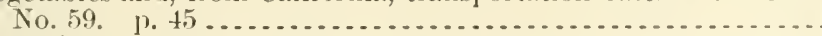

West, far, native, (Thompson). 1. 207 .

West Virginia, inseets, observations on (Hopkins). 1896. p. 71.

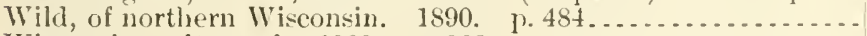

Wisconsin, culture of. 1868. 1. $322 \ldots \ldots \ldots \ldots \ldots \ldots$

See also Apples - A prieots - Iananas - Berries - California Caprifig - Cherries - Citron - Date - last Asian fruits Figs - Grape - Isabella grape - Le Conte pear - Museated raisins - IIuskmelons - Nursery stock - Olive - Orange Peaches - Pear - Pineapule - Plums - Pollination - Ponaceous fruits - l'omology Division - P'runes - (2unne - Rárisin grape - Raisins.

* By a misprint, this jage number appenrs twice.

$11.1: 865$

11.1:864

11.1:864

11.1:865

A1.1:866

11.1:867

A.9.3:13

A9.6:4

A.7.9:6

A9.6:10

A1.9.119

A27.9:7

$\$ 27.9: 13$

\27.9:6

127.9:8

$127.9: 7$

A1.10:900

$125.5: 5$

$110+: 6$

A10.4:18

A1.10:896

112.4:1

11.10:897

AI.1:875

11.10:895

A1.10:896

129.2:F94

A1.1:866

A20.3:2

19.6:31

A19.3:22

A1.10:895

A:0.1:89:5

A 1.9:7

A 1.9:105

A 20.3:1

A0.3:1

A 1.10:\$98

A 1. 10:901

A27.9:21

A1.1:865

A $9.6: 6$

127.9:28

127.9:6 
Fruits and fruit products:

Analysis of, provisional methor for (Munson and Tolman).

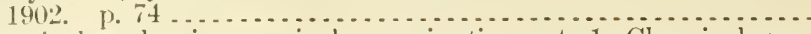
Chemical and microscopical examination, pt. 1, Chemieal exanination ( 11 unson and Tolman). 1902. p. 9. ........ Same; I't. 2, Microscopical examinations (Howard). 1902.

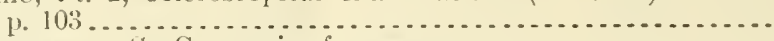
Fruits of grasses. She Caryopsis of grasses.

Fryer, Michael. Flax culture, instructions in. 1. $92 \ldots \ldots \ldots \ldots . . . ;$

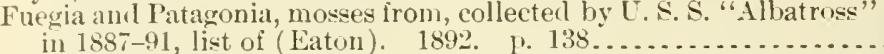
Fuelling, John L.:

Sorghum-sugar experiments at Meade, Kans. 18s9. p. 79.....


Wee ctso, as collaborator, Wiley, Ilarvey Washington.

Fuller (Governor of Vermont). Address of, hefore National Roal

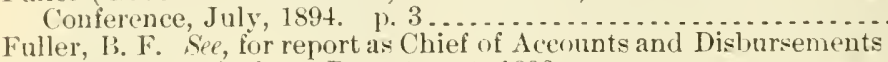

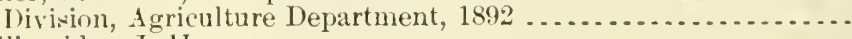
Fullinwider, J. H.:

Cattle interests of West. 1. 271

Sonthern cattle fever, fatal ontbreak of, at Deerfield stock farm,

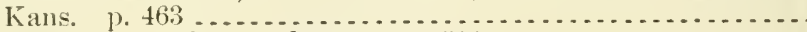

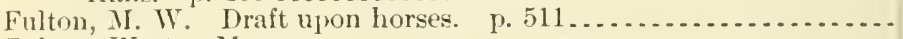
Fulton, Weston M.:

Forest clearing and cultivation, effect of, upon water supply and

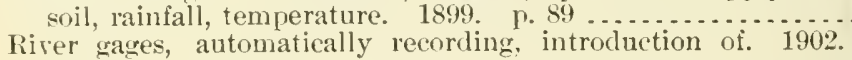
ientific investigation under certain conditions, original, advisability of supplying employees of Weather Bureau with ap-

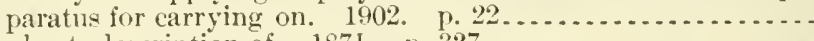

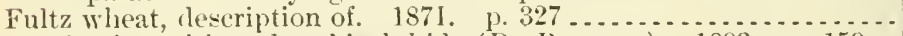

Fumigation with carbon bisulphide (Du Buysson). 1893. p. 159 ..

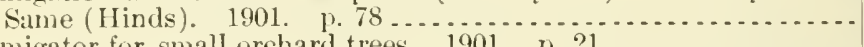

Fumigator for small orchard trees. 1901. p. 21 ...............

Funigator, Emory; new metlod for handling hydrocyanic-acid gas

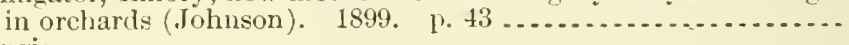
Fungi :

Abnormal structures in, induced by Ustilago zece mays, study of.

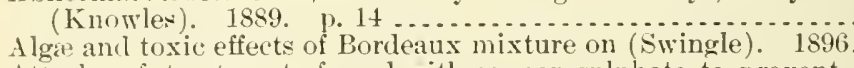

Attacks of, treatment of seed with copper sulphate to prevent.

(Elackberry rust, Perennial mycelium of (Newcombe). 1891.

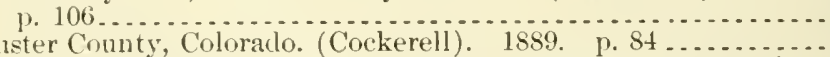

Described in recent reports of Connecticut Experiment Station

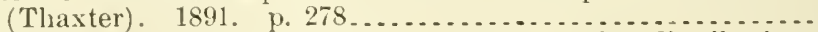

Economic and other, collection of, prepared for distribution

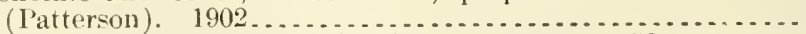

Elible and poisonous, some (Farlow). 1897. p. 453 .........

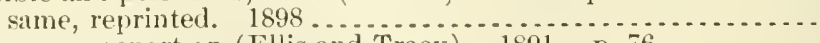

liew new, report on (Ellis and Traey) 1891 p. $76 \ldots \ldots . . . .$. Field olservations with (Halsted). 1894. p. 93 .............

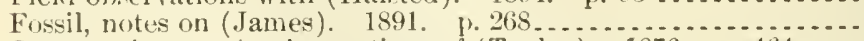
Grape, microscopic observations of ('Taylor). 1876. p. 464.... Hawthorn, microscopic investigations of (Taylor). 18\%3. p. 431 .

Helena, Mont., notes on (Kelsey). 1889. p. $80 \ldots . . . . . . . .$. same, supplement (Andcrson). 1889. p. $82 \ldots \ldots \ldots \ldots \ldots$.

Hymenomycetous, some new species of (Ellis and Everhart).

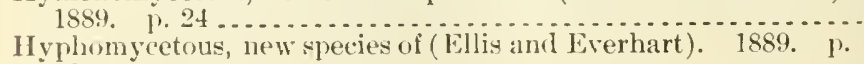

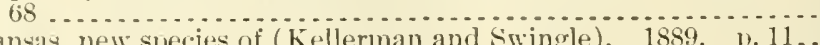

Kansas, new species of (Kellerman and swingle). 1889. p.11..
sane (Ellis and Kellerman). 1889. p. 142 ..............

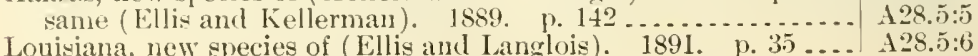

A1.1:\$64

A6.5:1

A $7.3: 36$

A $7.3: 37$

A22.3:10

14.1:S84

A4.1:884

A4.1:898

129.3:24

A29.3:31

A29.3:31

A $27.9: 9$

A9.7:6

A9.6:30

A $1.9: 133$

A9.6:20

A28.5:5

A28.3:9

128.3:10

A $28.5: 6$ A28.5:5

A28.5:7

A 19.3:8

A I. 10:597

A28.3:15

A28.5:6

1 10.3:20

128.5:7

$127.9: 1 \frac{1}{2}$

A27.9:11

A 28.5:5

A28.5:5

A28.5:5

A28.5:5

$128.5: 5$

Louisiana, new species of (Ellis aud Langlois). 1891. p. 3. ... A28.5:6 
Fungi-Continuer

Montana, brief notes on few common (Anclerson). 18s9. ए. 30. 128,5:5

New species of, notes on-

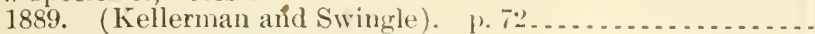

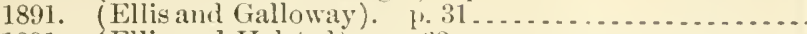

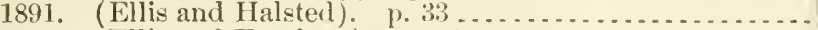

1891. (Ellis and Everhart). p. 130 . . . . . . . . . . . . . . .

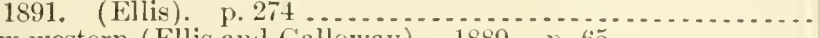

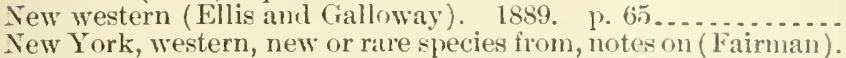

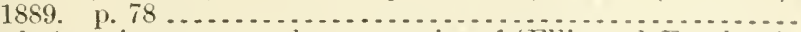

North American, new and rare species of (Ellis and Everhart).

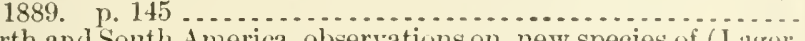

North and Sonth America, observations on, new speeies of (Liger-

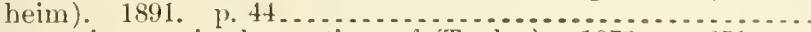

Potato, microseopic observations of (Taylor). 1873. p. 251 ....

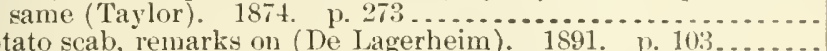

Potato scab, remarks on (De Lagerheim). 1891 . p. $103 . \ldots . . .$.
Smut, recent investigations on. 1889 . p. $87 \ldots . . . . . . . .$. sime (Brefeld). 1891. pp. 1,59, 153 . . . . . . . . . . . . . .

Study of, especially in their relation to plant diseases (Journal

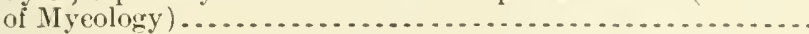

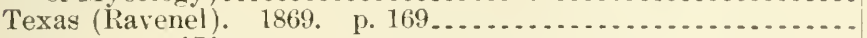

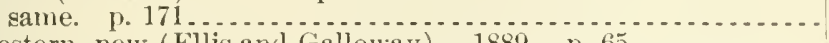

Western, new (Ellis and Galloway). 1889 . p. $65 . . . . . . . .$.

See also Agaries - Agarieus campestris - Black spot - Erysipheæe - Exsiccati - Fossil fungi-Grape fungi-Hymenomyeetes - Hymenomycetous fungi - Hypoxylon - Isaria - Kansas fungi - Leaf-galts - Mucronoporus - Mucronoporus Andersoni - Mushrooms - North Ameriean agaries - Nummularia - Puccinia - Pyrenomyeetes - Saceardo's sylloge - Smut fungi - Uromyces - Ustilago zex mays.

Fungicidles:

Borleaux mixture as (Fairchild). 1894.

Combination with new and old insecticides, some olsservations on (Galloway). 1894. p. 126...........................

Comparative test of, in clieeking potato blight and rot (Jones).

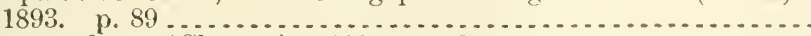

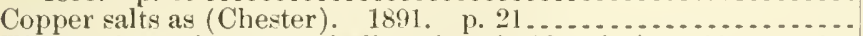

Effects of certain, mpon vitality of seeds (Crozier). 1891. 1. 8..

Experiments withgeneral, in 1889 (Earle). 1890. p. 83 ................... . . in removal of lichens from pear trees (Waite) $1891.264 \ldots$ to prevent leaf blight of nurvery stock (Fairchild). 1891. p. 338.

Formulas for -

$1895 . \quad$ p. 589

1896. p. 627 . $627 . \ldots$.

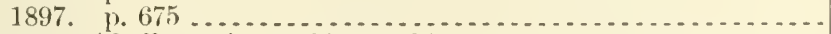

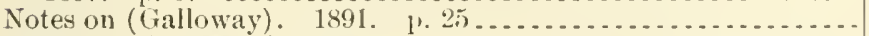

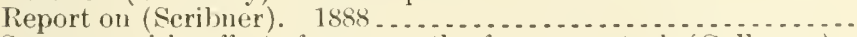

Sprayng with, effeet of, on growtl of nursery stock (Galloway). $1894^{\circ}$.

Fungicides and insecticides:

Chemical analysis, methorls of (Iaywood). 1902.

A28.5:5

A28.5:6

$128.5: 6^{\circ}$

A $25.5: 7$

A $28.5: 7$

128.5:5

128.5:5

128.5:5

128.5:7

A27.9:11

A27.9:12

A28.5:7

128.5:5

A $28.5: 6$

125.5:

11.2:C2 $29^{1}$

11.2:( $29^{2}$

128.5:5

128.3:6

A $9.7: 7$

110.:3:16

128.5:6

128.5:6

16.3:11

A $28.5: 7$

A:28.5:7

A1.10:895

Al.10:896

A 1. 10:897

A28.5:6

A28.4:5

125.3:7

17.4:10

Chemieal composition and effectiveness of certain preparations

(Haywood). 1901.

same (llaywood). 1902.

Report on, hefore $A$ ssoeiation of Aneriean Agricultural Chemists-

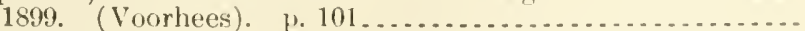

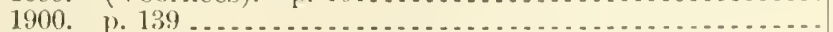

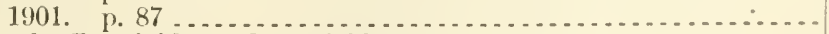

See also Fungicides - Insecticiles.

Fungous diseases:

Forest trees (Schrenk). 1900. p. 199 ................... A1.10:000 (irasshoppers, experimental work with (Howard). 1901. j. 4.5. A 1.10:301

Iowa, new (Pammel). 1891. p. 95 ..................... A:45:7

Killing destructive locusts with (Bruncr). 1902. p. 50 . . . . 19.6:34 
Fungous discases-Continued

Relation of climate and rainfall to prevalence of. 1899. 1\% 126..

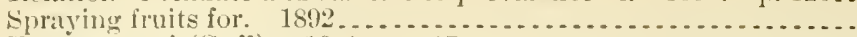

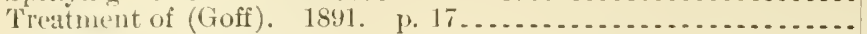
Spe clso Crape- Plants.

Fungont parasite on Aleyrodes citri R. and II., pleliminary notice of (IV cober). 1891. p. 363.3. Sovile, Frederick Vernon.

Funston, Frederick. See Co
Fur animals. Sie Marten.

Furnas, liobert $W^{r}$ :

Arizona and New Mexico, agricultural features of. 1892. p. 173..

Forest conditions and lumber and worl trade of western itates

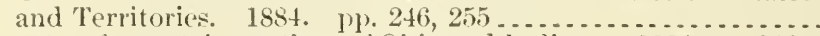

Forestry, for certain portions of Ohio and indiana. 1854. 1,346.

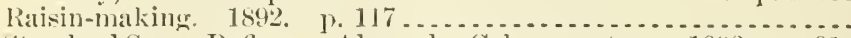
Standarl Sugar Refinery, Alvarado, Cal., report on. 1892. p. 91. Swine, (rossing improved Jureeds of, with common hogs of Florida. 1895

Tree growth, maxim size and age, period of deche, comple-

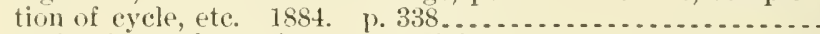

Tree planting and growing on the plains. 1883. p. 20:2......

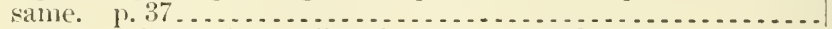

Sice also, as joint author, Hilgard, Eugene Woldemar.

Furs, insects which attack, fumigation with bisulphide of (arbon for (omplete and rapid destruction of (Du Buysson). 1893. p.

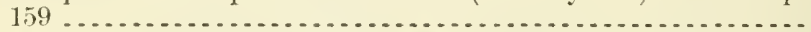

Galflies, remedy for, Porchinski's recent discovery in Russia, with some American obser vations (Howard), 1899. p. 24....... See also Tahanidie.

Gadsilen, Jolin $\mathrm{W}^{\mathrm{r}}$.:

Cattle, diseases of, contagious, how they are imported and what

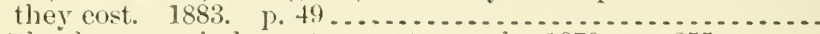
Cattle plague or rinderpest, symptoms of. 1879 . p. $255 \ldots \ldots \ldots$

Pleuro-pnemonia among cattle in Pennsylvania. p. $47 \ldots . . . .$. Gage canal, Riverside, California, duty of water under (Irving):

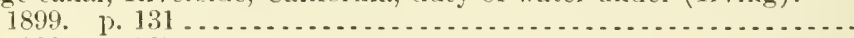

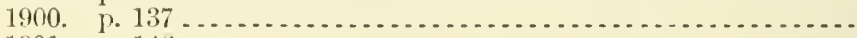

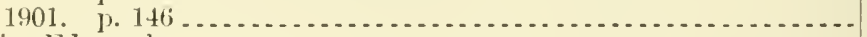

Gain, Edmond:

Agricultural botany, review of publications on, issued in France

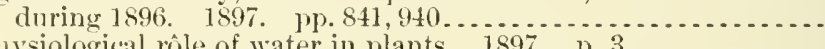

Physiological rôle of water in plants. 1897 . p. $3 \ldots \ldots \ldots \ldots . .$.

Gaines, Richard $\mathrm{V}$. Animal industry of U.S. with especial reference to breeding of eattle, liorses, etc. 1883 . p. $122 \ldots \ldots \ldots \ldots \ldots$.

Galapagos Islands, S. A. Plants from, collected by U. S. S. "Alha-
tross" in 1887-91, list of (Rose). 1892 . p. 136 ............ Galbraith, S. J. Vanilla culture as practiced in Seychelles Islands.

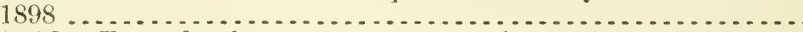

Gale, A. H. Tornado observations, report of. 1899. p. $303 \ldots \ldots$. Gale at Buenos Ayres, Argentina (Abbe). 1895. p. 381 ......... Gales:

Effect of, in causing high water (Abbe). 1894. p. $297 \ldots . . . .$.

January, from Great Lakes to maritime provinces (Welber). 1902 . p. $11 \ldots \ldots \ldots \ldots$

Northwest, of southern Blue Ridge and Piedmont region (Haw-

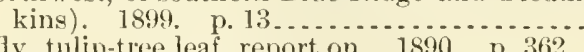

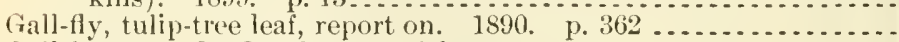
Gall fungus. See Cranberry gall fungus.

Gall gnat. See Rye gall gnat.

Gall makers, notes on (Smith). 1891. p. 27 ................ Gallatin Valley, Mont. Dnty of water in (Fortier). 1900 . p. 175.. Galloway, Beverly Thomas:

Black lot, low row rot, downy mildew, powdery mildew, and anthracnose of grape; pear scab and leaf blight and apple powdery mildew, treatment of. 1891. p. $11 \ldots . . . . . . . . .$.

Black rot of grape, treatment of. n. d . . . . . . . . . . . . . . . . . same. 1889. p. 204

A10.3:65

A $1.9: 7$

A $28.5: 7$

A28.5:7

A1.8:20

A 13.5:4

A 13.5:4

A 1.8:20

A 1.8:20

14.4:4

A 13.5:4

A1.7:2

A1.8:28

A.9.7:6

A 9.6:20

A1.8:29

A 1.6:12

A1.1:881-2

A 10.3:86

A 10.3:104

A10.3:119

A 10.6:8

A10.6:8

A 1.7:2

A6.5:1

16.3:21

A $29.6: 27$

A $29.6: 23$

129.6:21

A29.6:30

A29.6:27

A9.7:2

A 9.7:4

A 10.3:86

A28.5:6

A 28.4:6

A28.5:5 
Galloway, Beverly Thomas-Continued

Cercospora eireumscissa, treatment of, suggestions in regard to.

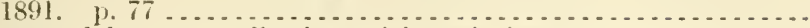

Frosts and freezes as affecting cultivated plants. 1895. p. 143 ..

Fruit discases, spraying for. 1896 . . . . . . . . . . . . . . .

Fruits, notes on. 188\%. pp. $37,92,214$.

Fungicides, effect of spraying with, on growth of nursery stock. 1894

Fungicide and new spraying pump, notes on. 1891. 1), 25....

Fungous diseases of plants, experiments made in 1859 in trentment of. 1890

Grain, new method of treating, by Jensen process for prevention

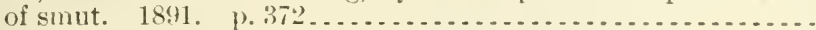

Grape, fungons diseases of, and their treatment. $1891 \ldots \ldots . .$.

Grapevine diseases, circular on. n. d....................

Insect pests and plant diseases, proceerlings of nationa] convention for suppression of, held at $1 \mathrm{~V}$ ashington, D. C., Mar. 5 and 6,1897

Insecticides, new and oll, and their combination with fungicides, some observations on. 1894. p. 126.................

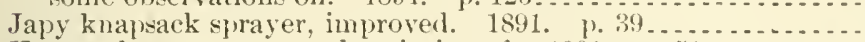

Knapsack sprayer, new, description of. 1891. 1.51 . . . . . . .

Nursery stock, treatment of, for leaf blight and powdery mildew. 1891

Pathology of plants, jines of investiution that might je unclertaken hy experiment stations. 1897. p. 725 .............

Pear leaf blight and apple powdery mildew, experiments in

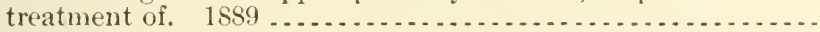

Pine leaf rust, new. 1891. p. $44 \ldots \ldots$

Plant diseases-

progress in treatment of, in U.S. 1899 p. p.191 ............... treatment of, experiments in. 1891. p.12. (Pt. 3. For pts.

1, 2, see (ialloway and Fairchild) ...................

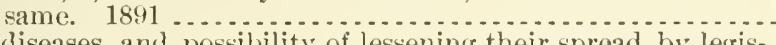

Plant diseases, and possibility of lessening their spread by legislation. 1897. p. $8 \ldots \ldots \ldots \ldots \ldots$

Plants-

eommercial growing of, under glass, progress of. 1S99. 1. 575.

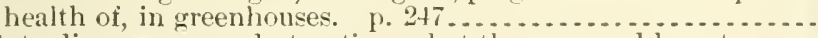

Potato diseases, some destructive, what they are and how to pre-

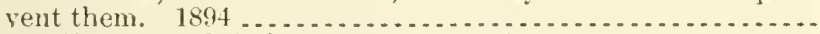

Potato diseases and their treatment. $1899 \ldots$

Rusts affecting wheat and other cereals, treatment of, experiments

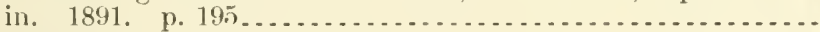

Smut in oats and barley, notes on. 1889. p. $164 \ldots \ldots \ldots \ldots$

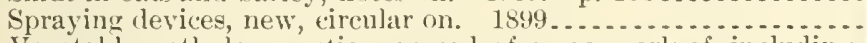

Vegetable pathology section, record of some work of, including correspondence and other commmications. 1889 . p. $41 \ldots$....

Vegetable Physiology and Pathology Division, Agriculture I)e-

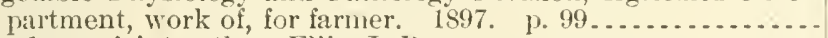

See culso, as joint author, Fllis, J. B.

See also, for reports as Chief, section of vegetable pathology, 188s, 1889; Division of Vegetable Pathology, 1S90-1894; and Division of Vegetable Pliysiology and Pathology, 1896, 1897, 1899, and 1900

See also, for reports as Chief, Plant Industry Bureau, Igriculture

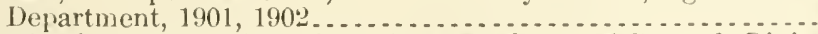

See also, for report as Superintendent, Gardens and Grounds Division, Agriculture Department, 1900

Galloway, Beverly Thomas, and Fairchild, David ( diseases, treatment of, experiments in. 1891. 1). S9, 1:37. (Pts. 1 and 2; for pit. 3, sep (ialloway, Beverly Thomas) ...... Galloway, Beverly 'Thomas, and Southworth, I. A.

Apple scab, treatment of, $1889.1 \% 210 \ldots \ldots \ldots$

Oat disease, new and destructive, preliminary notes on. 18.1. 1. 72

128.5:5

$128.3: 7$

128.5:6

16.3:11

128.5:7

11.9:4

A2S.4:7

11.8:57

19.7:7

d25.5:7

128.5:6

128.4:10

110.6:7

A28.4:8

A28.5:7

A1.10:\$99

$128.5: 7$

A28.3:3

A1.8:57

11.10:\$99

A1.10:895

A1.9:15

A1.9:91

128.5:7

128.5:5

128.4:17

$16.3: 8$

A1.10:897

1:8.1:

119.1:

114.1: 
Galloway, Beverly Thomas, and Woods, Albert Fred:

Trees, sluale and ornamental, diseases of. $1896 . \quad$ p. 237

Vater a factor in arowth of plants. 1894. p. $165 \ldots$

Gall's metlor, manufacture of grape, blackberry, and other iruit wines, on (Bossert)

Galveston, Tex.:

Hurricane of Sept. 8,1900 , special report on. P. 372.

1.10:896

A 1.10:894

A1.1:863

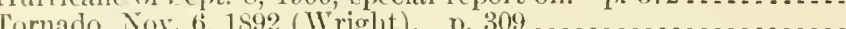

Weather foreeast district, report of (Cline). 1902. p. 292.

A29.6:28

A 29.6:20

A $29.6: 29$

Game:

Information concerning seasons, shipment, and sale (Palmer and

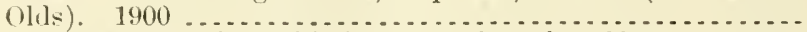

Laws of District of Columbia for protection of. $1901 \ldots . . . . . .$.

Noxious animals and, statisties of, in some foreign countries.

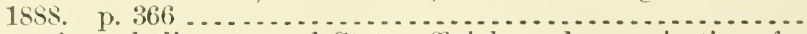

Protection of, directory of State officials and organizations for 1901 (Palmer) same. 1902

Transportation and sale of, laws regulating (I'almer and Olds). 1900

See also Birds and game.

Game birds:

Eggs of, regulations for importation of, for propagation. 1902.

Of Initerl States (Elliot). p. 356.

see also Woodeock - Woodduck.

Game laws, digest of (Palmer and Olds):

1901

1902.

Game laws of Prussia 1871 p 2050.

Gamgee, John:

Cattle diseases, general remarks on. 1869. p. 162.

Corn, swutty, ill effects of, on cattle. 1869. p.78

Pleuro-pnemonia or lung plague of eattle, preliminary revort 1868. p. 432 same, full report. 1869 p. 7 .

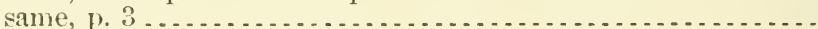

Splenic or periodic fever of cattle. 1869. p. $89 \ldots \ldots \ldots \ldots \ldots \ldots$

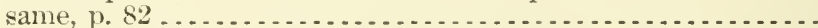

Gamopetalie of western Texas, description of (Coulter). 1892. p.

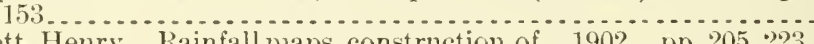

Gannett, Henry. Rainfall maps, construction of. 1902. pp. 205, 223.

Ganzhom, Jacob. Fruits on eastem shore of Lake IFichigan, statis-

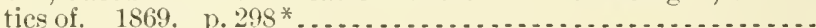

Gape disease:

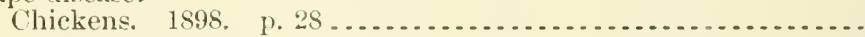

Fomls, p, 550 p. p.

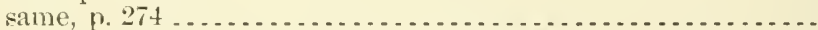

Fowls, and parasite by which it is cansed (Megnin). p. $269 \ldots .$.

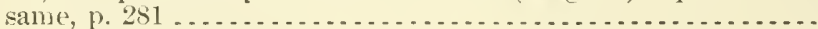

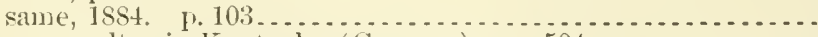

Young joultry in Kentucky (Garman). p. 504.

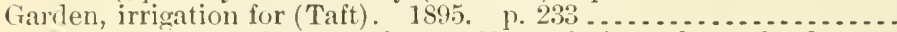

ree also farm - Grass gardens - Home fruit garden - Seed testing - V'egetable garden.

Garden, United States propagating:

Plants, bulbs, tubers, ete., distributed from, and object and aims

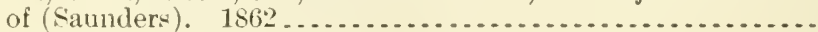

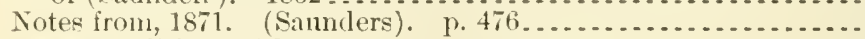
same, 1872 . T. 72 .

Garden, experimental, Agriculture Department. See Experimental fiardens and (irounds Office.

Garlen and field, irrigation in (Wickson). 1901 ...................

Garlen City, Kans., grass and forage experiment station at (Sewall).

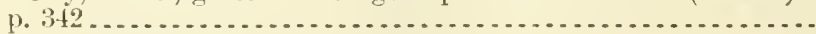

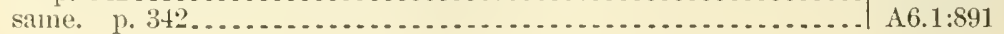

$* \mathrm{By}$ a misprint, this page number appears twice.

15.4:31

A5.4:34

A 27.9:26

A5. $4: 33$

A5.4:35

A5.3:14

A5. $4: 37$

A 1.1:S64

A5.3:16

A1.9:160

A27.9:9

A 1.2:C291

A1.2:C $29^{1}$

A 1.2:C29²

A 27.9:6

A1.2:C291

A1.2:C292

A 1.2:C291

A 1.2:C29 ${ }^{2}$

16.5:2

A29.6:30

A27.9:7

A1.9:84

A1.1:S85

A4.1:885

A 1.1: 884

A4.1:88t

A4.2:An5

A4.1:898

A 1.10:895

A1.8:2

A27.9:9

A27.9:10

A 1.9:138

A 1.1:891 
Garden crops:

Florida, insects injurions to (Ashmead), 18s7. p. 9.........

Insects injurious to (Chittenden). 1899 ....................

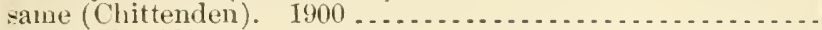

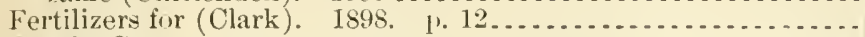
Seer also Crops.

Garlen herharinm, making, and its uses (Selby) ............... (iarilen insects:

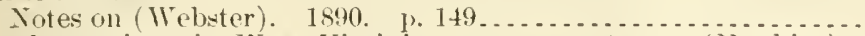

(b)ervations in West Virginia on, sone notes on (llopkins).

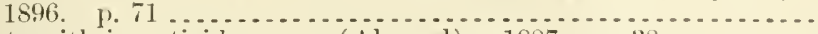

Tests with insecticides upon (Alwood). 1887. p. 38 ..........

See also Garden crops.

Garden pest, Orthezia insignis as (Cockerell). 1892. p. 89 ........

Garden truck, rates of charge for transporting, with notes on growth of industry (Ward and Holmes). 1901.....................

Garden regetables:

Particularly onions, eablage, and squash (Huntington). p. 110 ..

Two rlipterons leaf miners on (Coquillett), 1895. p. $381 \ldots . . .$. See also Potato - Yams.

Gardening:

Hospital. 1865. No. 2. p. 12.........................

Landscape, report on. p. 159..........................

Siee also Agriculture.

Gardening under glass. 1901. p. 11

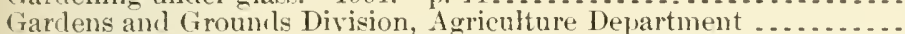

Gardens and grounds. See Experimental Gardens and Gronnds Office.

Garlini, Carlo. IIemp in Italy, special consular report on growth

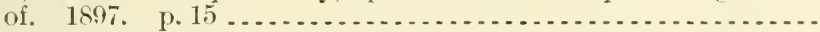

Gardner, Frank Duane:

Electrical method of moisture determination in soils, results and modifications in 1897. 1898 ..........................

Porto Rico Agricultural Experiment Station, amual report for

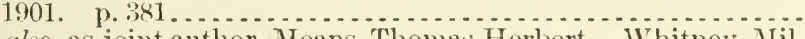

See nlso, as joint anthor, Means, Thomas Herbert - IV hitney, Milton.

Gardner, Frank Duane, and Jensen, Charles A.:

Soil survey in Sevier Valley, Utah. p. $243 \ldots . . . \ldots \ldots \ldots . . . .$.

Soil survey in Weber Co., Utah. p. $207 . . . . . . . . . . . . . . .$.

Garilner, Frank Dnane, and Stewart, John:

Soil survey in Salt Lake Valley, Utah. 1900. p. 77. . . . . . . . . .

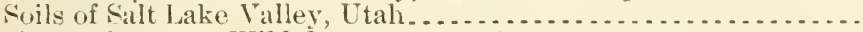

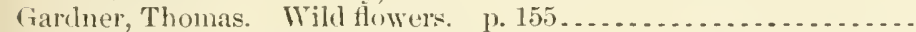

Gardner, W. H. Animals, training, for work. p. $355 . . . \ldots \ldots \ldots$.

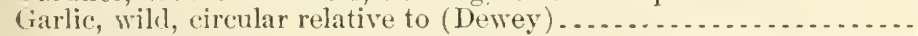

(ialman, H.:

Entomologist, economic, illustrations for. 1893. p. $109 \ldots . . . .$.

Entomology in Southern States, report on. 1901. p. 153.......

Gape disease of young poultry in kentueky, p. $504 \ldots . . . . . .$.

Hessian fly, spring brood of, time of emergence amd oviposition

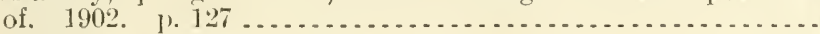

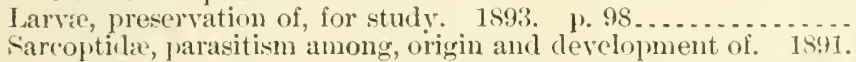

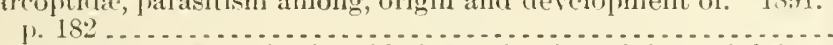

farrigues, W. J. Phosphoric acirl, determination of, by molybolate

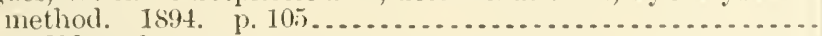

Garrintt, Edward Bennett:

Address, as chairman section of forecasts and forecasting, before second convention of Weather Bureau oflicials held at Milwankee, Wis., Ang. 27-29, 1901. 1902. p. 115 ............

Atmospheric pressure, lighl and low, 1895 to 1898 . p. $593 . \ldots$.

Cllinook winds, report on. 1892. 1.23 ...................

Cold waves on middle (iulf coast, report of. 1895. p. $334 \ldots .$.

Frost, notes onl. 1899 . . . . . . . . . . . . . . . . . . . . . . . . .

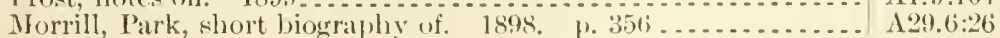

19.3:14

A9.6:19

A9.6:2:3

11.9:10:

$110.3: 76$

19.7::

19.6:6

A.9.3:13

19.7:5

127.8:21

11. $1: 864$

$19.7: 7$

127.9:3

11.1:869

11.9:144

141 .

A26.8:12

$110.1^{2}: 901$

$126.5: 900^{1}$

126.5:900

11.8:64

A26.4:4

A 1.1:862

A 1.1:866

A6. $4: 9^{1}$

19.7:6

1 10.3:99

14.1:895

A 10.3:115

A9.7:6

19.7:4

A 7.3:43

A29.3:31

A $29.6: 26$

A:9.6:30

A29.6:23

11.9:104 
Garriott, Elward Bemnett-Continued

Pacific coast, north, high areas of, in September, October, and November. 1. 249.....................................

River and thood service, monthly notes on tug 1898

St. Lawrence Valley, high areas north of, in October, November,

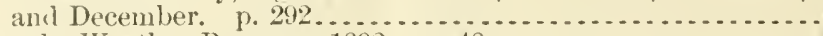

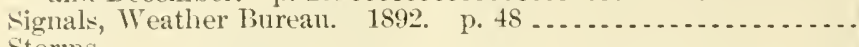
Storms-

floods and cold waves of year, report on. 1. 208. same, p. 27

tropical, of trulf of Mexico ani Atlantic Ocean, in September,

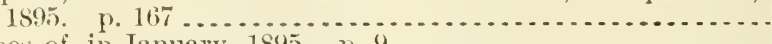

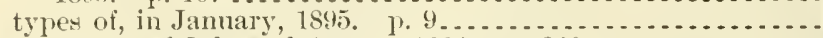

Warm waves of July and August, $1892 . \quad$ p. 223 . . . . . . . . . . .

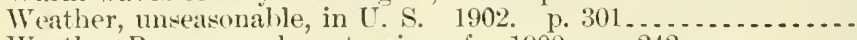

Weather Bureau work, extension of. 1900. p. 242..........

Weather conclitions, monthly statement of average-

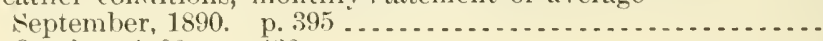

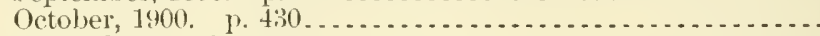

November, 1900 . p. $48: 3$

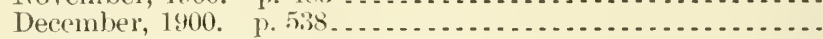

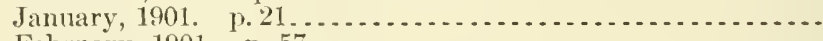

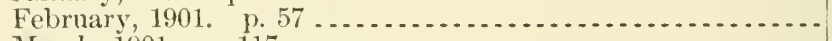

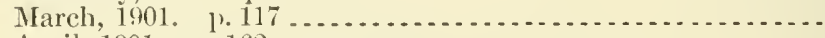

April, 1901. 1. 162 . . . . . . . . . . . . . . . . . . . . .

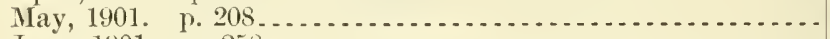

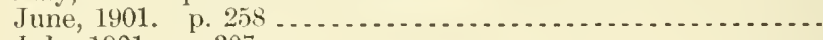

July, 1901. p. 307

Weather forecasts and storm warnings, monthly notes on. Sept., 1898-Oct., 1902 .

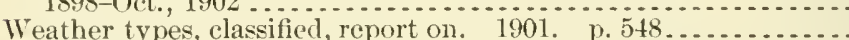

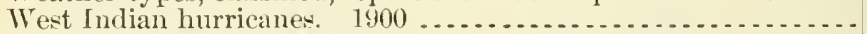

West Indian weather-bureau service. 1898. p. $303 . \ldots . . . . . .$. Gas:

Wind-barometer table, report on. 1897. p. 204.............

129.6:23

129.3:7

1 1.1:\$98

129.1:598

A29.6:23

A $29.6: 23$

A29.6:20

A29.6:30

$+129.6: 28$

A29.6:28

A29.6:28

A29.6:28

A29.6:28

A29.6:29

A 29.6:29

A $29.6: 29$

A 29.6:29

A $29.6: 29$

A29.6:29

A29.6:29

A29.6:

A $29.6: 29$

A $29.5: \mathrm{H}$

A $29.6: 26$

A29.6:25

Illuminating, influence of, upon plants (McMurtrie). 1875.

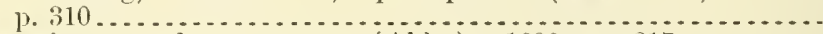

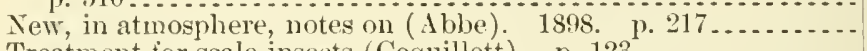

Treatment for seale-insects (Coquillett). p. 123 .............. same (Coquillett) supplementary report. p. $41 \ldots \ldots . . . . .$.

Use of, against scale-insects. 1887.

See also Hydrocyanic-acid gas.

Gayon, M. See, as joint author, Millardet, Pierre Marie Alexis.

Geddings, R. M. Meteorological notes from Porto Rico. 1900.

Geer, T. T. Oregon, road improvement in, extract from governor's inaugural adirese

Geese:

Checklist of animal parasites of (Hassall). 1896.

Ducks and, standard breeds and management of (IIoward)

See also Ducks.

Geisenheim-on-the-Rhine, Prussia. Royal institute for fruit and

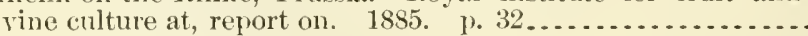

Gieitel, H. See, as joint author, Elster, J.

(iemmell, R. C.:

Big Cottonwood Creek, Utah, duty of water on. 1900. p. 197 ..

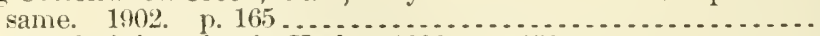

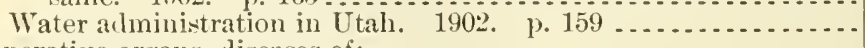
Generative organs, diseases of:

Cattle (Law). p. 169.

Horses (Law). p. 135 .

A27.9:13

A $29.6: 26^{\circ}$

A 1.1:887

A9.7:1

A9.3:15

A $29.6: 28$

A22.4:33

A $4.4: 14$

A 1.9:6t

A 1.9:65

A1.8:36

A10.3:86

A10.3.104

A10.3:104

A4.2:C $29^{2}$

A $4.2: H 75$

Geneva, N. Y. See New York State Fxperiment Station.

Gennert, Theodore. Beet sugar in Furope. p. $158 \ldots . . . . . . . .$.

Geodesy and meteorology, notes on (Abbe). 1900. p. 545 
Ceomaphic distrihution of animals and plants in North Amerioa

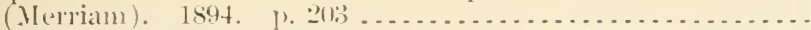

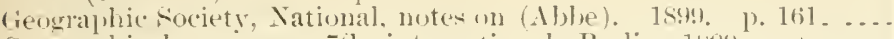
Geographical congress, Th international, Ferlin, 1894, notes on

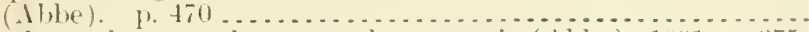
Cieorraphy and meteorolory, popular arrors in (Abbe). 1901. 11.375.

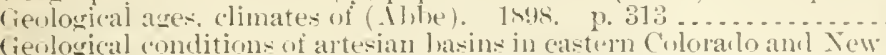

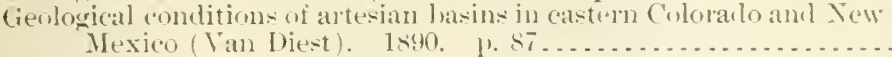
Cieolomical eongress, fer clemont-Ferrand, France.

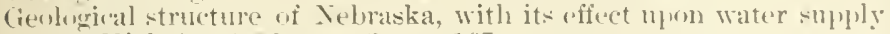

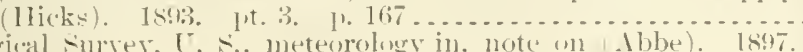

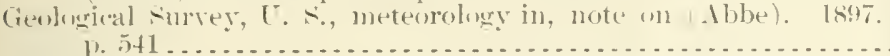
Gienloury:

Finth Hakuta, west of Missonri liver, and Wroming, east of furthills of Rocky Mommatins (Bailey). 1890. P. 65........

sintlem Apualachians (Keith). \%. 111 ................. (ieometrid moth (Calothysanis amaturayia), lite history of (Packard ). 189: p. $382 . .$.

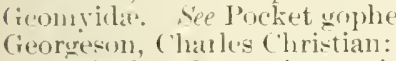

Iericultural experiments in Ilaska. 1s!s. p. 51.7..........

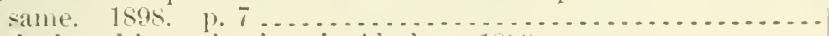

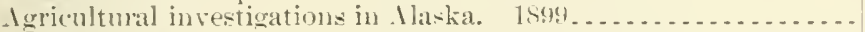
sitme. 1!00

Alaska. jioneer farmers in, surgestions to, 1902..........

1 laska experinent stations, annual report for 1901 . p. $289 . . .$.

Dairy indtustry of Denmark, progress report. 1s93..........

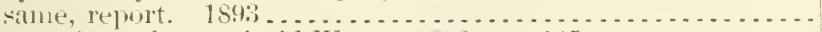

Forage flants for semiarid West. 1693. 1. 145...........

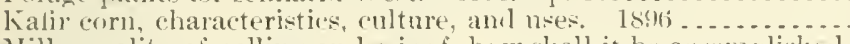

IIIk, yuality of, selling on leasis of, how shall it be acomplished in restail trale. $1896 . \quad 1 \% .93$.

Steer-feerline experiments to ascertain emontarive value of corn and red and white Kafir corn. $1,483 . \ldots . . . . . . . . .$. Lieoruia:

Cattle quarantine of counties in-

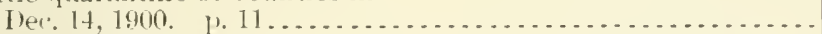
Jan. 11, 1402. P. 11 Hec. $2-7,1902$. P. 11.

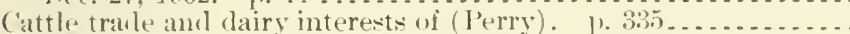
Climate, soil, and agricultural capabilities of (Ilemphill). 188:2.

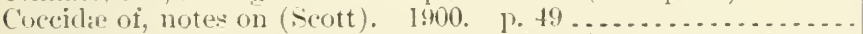
Cocicis in, tatal temperature for some (Scott). 1899. p. 82....

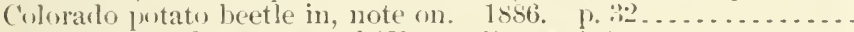
(onditions and resoures of (Ilowarl). 1. 567 ............

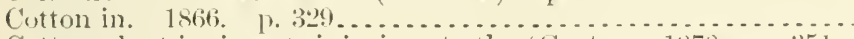
Cotton plant in, insects injurions to the (Grote, . 187s. p. $351 \ldots$

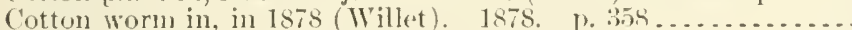

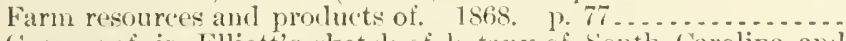
(irasses of, in Elliott's sketcls of botany of fonth carolina and

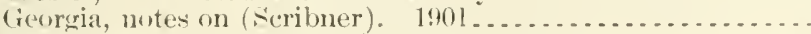

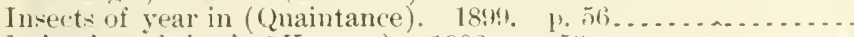
Irrigation of rice in (Keener). 1902. p. 5\%

Jarring for curculio on extensive seale in, with lint of insertcutught (foott and Fisk). 1902. 1). 24...............

l'hms and peaches in, preliminary note on new species of $A$ phis

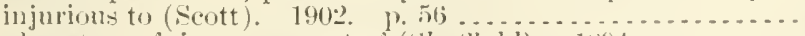

lioarl system of, improvement of (She+lieli) $1894 \ldots \ldots \ldots \ldots$.

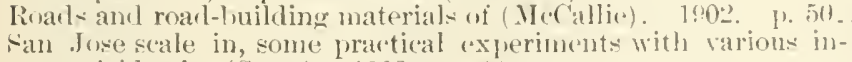

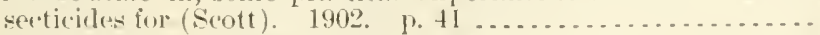

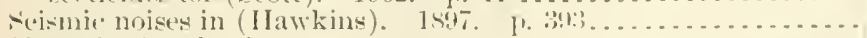

Sheep hasbaulry in-

187.5. 1. $528 . .$.

1877 (IVatts). ए. 11s.
11.11):(4:4

$129.6: 27$

$1: 99.6: 27$

$1: 2 ! 1,(i: 2 !)$

A. $21.6: 26$

115.:2: $1 \mathrm{r}^{2}$

115.2:Ir"

$1: 29.6: 25$

115.2: $21 \mathrm{r}^{7}$

1 1.2:1 $114^{2}$

11.10:548

$110.3: 10^{2} 2$

$110.3: 52$

$110.3: 54$

A 10.10:1

$110.1 \% 901$

A1.8:5)

$1+.: 2: 5$

$110.3: 16$

11.9:37

110.3:+1

$14.1: 565$

$1+.5: 80-87$

14.5:93

14.5::101

A $4.1: 885$

11.6:47

19.1::26

19. $6: 20$

14.:3:1:

11.1:s6t5

A:2.9:4

19.2:(182

19.2:( 82

1.27.9:6i

1.3. $4: 2$ (1)

19.6:20

110.3:11:3

19.6:

1!). $1: 31$

1:20.8:3:3

A2:.:?:2:3

$19,19: 377$

1:2!? (i::5-

1 $27.91: 1: 3$

11.2:5 $11:$ ? 
Creoreria-Continued

-incep huslandry in-Continued

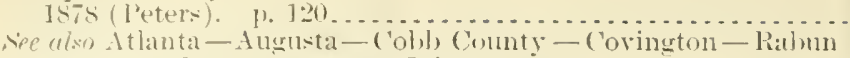

Clakniflation no. ('onnty-Tuwns ( ounty- Lnion county.

Gerland, l. Meteorology, instrumental, historical sketch of. Is ti.

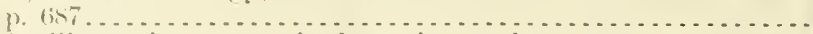

Germ fortilizer, nitrogen as, for legmminons plants. 1s97. 1) $19 .$. German agricultural experiment stations:

lims and temlencies of (Matercker). 1s9s. [1. 103, 20\%.

issociation of ninth anmul conreution of $1840^{\circ}$, report on

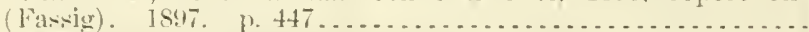

German Intaretic experition, kite work of, jotes on (Able). 1001.

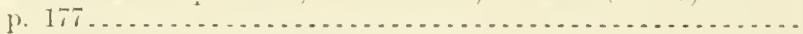

German assuciation of investigators and physicians. annual meeting

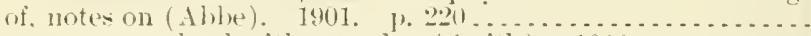
German common school with a garden (smith). 1s99 . . . . . . . . German Meteorological society, eighth general meeting of (Roteh). 1898. P. 160

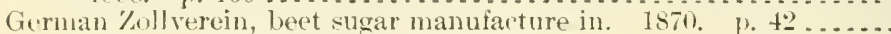
Germany:

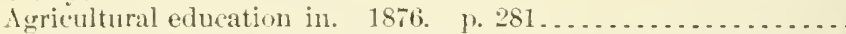

Agricultural schools in, organization and management of (Welch). 1885

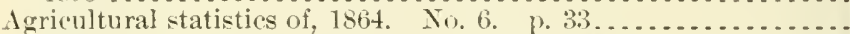

Aericulture of, letter on (Klipuart). 1865. No. $6 . \quad$ p. 6....... American agricultural products, as an importer of. 1894. p. 33.

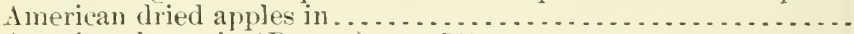

American hams in (Barnes). p. 519.

Imerican hog products, inspection of (Barnes). p. $516 \ldots$

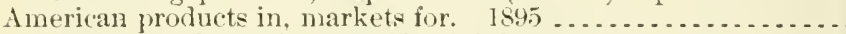
Army lorses of, requirements for (Kuhis). 1898. p. $31 \ldots \ldots .$. . Beet sugar in, progress of inanufacture of. 1866. p. $179 \ldots . .$.

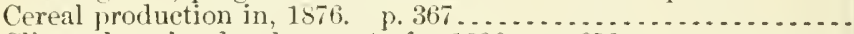
Climatology in, development of. 1896. p. $652 \ldots \ldots \ldots \ldots \ldots \ldots$ Cooperative credit unions or people's banks of. 1891. p. 339.

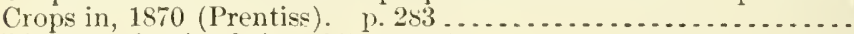

Diseases of animals in, 1887 . p. $47 \ldots \ldots \ldots \ldots \ldots \ldots \ldots \ldots \ldots \ldots$

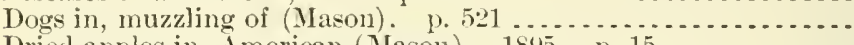

Dried apples in, American (Mason). 1S95. p. 15 ...........

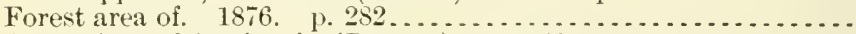

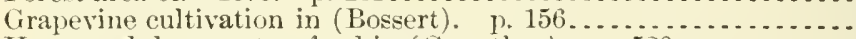

Horse and dog meat as food in (Guenther). p. 520 ............

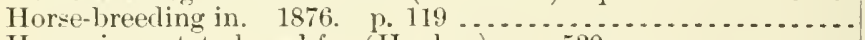

Horses in, potato bread for (Hughes). p. 530

Horses to, experience and observation in shipping (Meyers). 1898. p. 35 .

Leather manufactures in ( $\mathrm{i}$ ason). p. $522 \ldots$

Liparis (psilura) monacha in, ravages of, and means of defense. 1891. p. 379

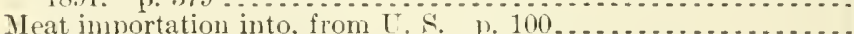

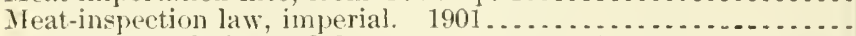
same, translation and German text. p. 523.

Military administration of, in its relations to national horse breer-

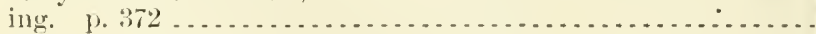

Nettle in, cultivation of (Stanton). p. 560 ..............

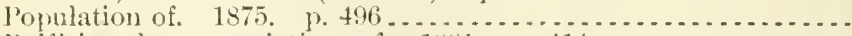

Raiffeisen loan associations of. 1s!1. p. $414 \ldots \ldots . . . . . . . .$.

Scalc inserts on Anerican fruit imported into (Reli). 1900. p. 79 .

Science in, practical. notes on (Abbe). 1597. p. $354 \ldots . . . .$.

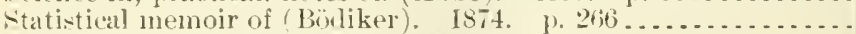

sugar-beet eulture in. notes on (Maxwell). 1s!0. p. 81 . . . . .

Trichinosis in, greneral remaxks on (stiles). 1901. p. 9 ...... same, statistical review during 1851-1s!18 (Stiles). 1901. p. 3i. same, bibliography of (Ilasiall), 19(1) p. $193 \ldots . . . . .$.

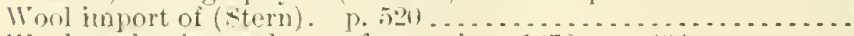

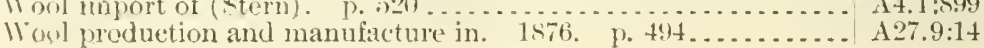

A 12.3:2

A $1.2: \mathrm{H}^{78}$

A 27.9:4

A27.9:14

A29.5:11

A27.9:29

A 27.9:8

A 27.9:28

A $4.1: 900$

A 7.3: 48

A 27.9:14

A1.1:863

A $4.1: 900$

A27.9:14

A4. 1:899

A 1.2:1178

A4.1:899

A9.7:3

A $4.1: 893-4$

A 4.4:32

14. $1: 900$

A 4.1:898

A 1.1:878

A $27.9: 14$

A27.9:29

A $9.6: 22$

A 24.6:25

127.9:12

17.3:30

A $4.3: 30$

A $4.3: 30$

At.3:30

A4.1:8:99
A27.9:14 
Germany-Continued

See also Baden-balen - Berlin - Bernburg L Igrioultural Experiment Station - Brunswick - Canstarlt - Cologne - I birnstatt - Frankfort-on-the-Main - Halle - [ Iam] Iurg - Hanover - Manmheim - Munioh - Planen - Stettin - Ftrasmig.

Germination, influence of moisture, temperature, and light conclitions on pro exs of (Detner). 18\%. 1. 40............. 129.3:112

Fettye, IV. Cowpeas and corn for silage and forkler. 1901)....... . 1:4.24

Ghent, Belginm:

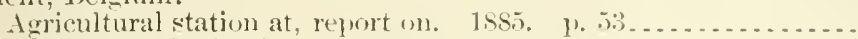

Horticultural school at, refort on. 1895. p. 5t.............

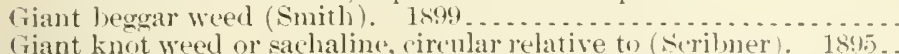

11.8:36

A $1.8: 36$

13. $4: 13$

16.4:5

Giard, II. A. Typhloeyla, parasitie astration of, by larvat of

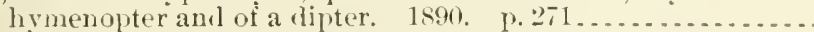

Gibbs, IVilliam H. Rabies, alleged, in Nebraska, investigation of.

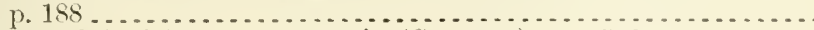

Gilmaltar, Enited States sausages in (Sprague). p. $519 \ldots \ldots \ldots \ldots .$.

Gibson, Charles. Thosphoric acid, reverted, differences in determination of, by ofticial metlorl of analysis. 1890 . p. $1666^{\circ} \ldots$.

Gibson, H. B., Calvert S., and May, David W. Dietary stulles at

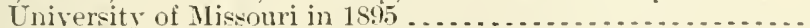

Gifford, George. Horses, Ameriwan, in Switzerland, p. $50.3 . . .$.

Gift, George 11 . Cotton moler high culture. 1. 409 ............

Gilbee, William Armond. Sugar, alcohol in manufacture of, use of.

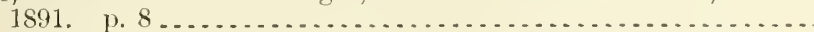

Gilbert, B. D. Cheese industry of State of New York. 1S96.....

Gilbert, Charles Henry. Fishes of Death Talley Expedition, (o)llected in southern California and Nevala in 1891, report on, with descriptions of new species. 1893 . p. 229. . . . . . . . .

Gilbert, Grove Karl. Water level of Great Salt Lake. 1901. 1. 23.

Gilbert, Sir Joseph Henry:

Rothamsted, Fngland-

agricultural investigations at, luring 50 years, six lectures on, delivered under provisions of Lawes agrienltural trust. 1893

$19.7: 2$

A $4.1: 897$

A $4.1: 899$

A7.3:28

A 10.3::1

A $4.1: 900$

A 1.1:867

A7.3:34

14.3:15

A5.5:7

A $29.6: 29$

agricultural investigations at, introduction to six lectures on, delivered under provisions of Lawes agricultural trust.

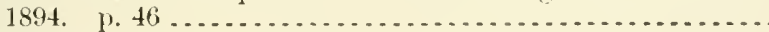

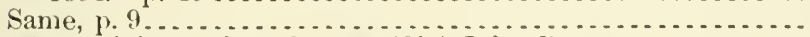
See also, as joint author, Lawes, (Sir) John Bennett.

Gilchrist, Tames B. Fruit, small, culture of. p. $57 . \ldots . \ldots . . .$.

Gilkison, W. F. Industrials [or manual traning], practical importance of. 1900 . p. 96

Gill, Theodore. Pisciculture, with reference to American waters.

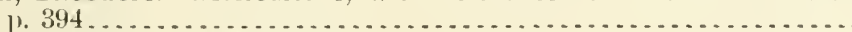

Gillam, Frank. Washington, i). C., hot summers and cold winters at, $1872-98$. 1. 456

Gillette, Clarence P.:

Arsenites and arsenical mixtures as insecticides. 1893. ए. 115. Codling moth, life-history sturlies on. 1902. [1. 5........... Colorado insects, notes oin some. 1902. p. 51 ............... . Intemological notes from Colorado, report on. 1900, 1. 76 ... Entomolocists, Economic, objects of Association of. 1900. 1).5.

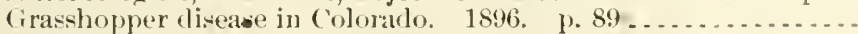
Insect collections, how shall we improve? 1895 . p. 15 ....... Insecto-

few, that have been munnally abundant in Coloralo this vear.

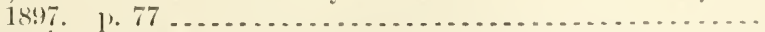

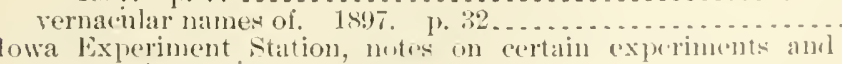

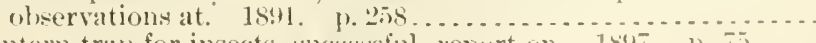

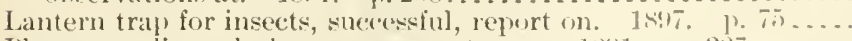

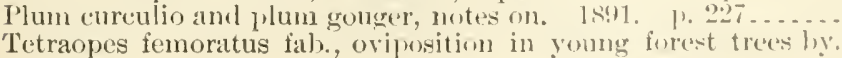
1897. p. 76 
Gilrutl, .J. .1. Flool joisoning (malignant edema) in shesel and

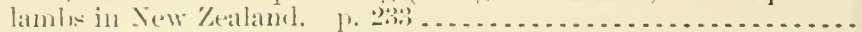
Cinsthen:

American, anmmercial listory, protection, and aultivation (Nash).

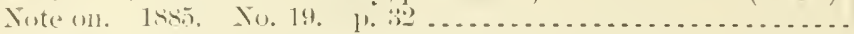
(ripsy encitli:

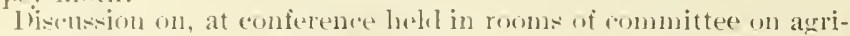
(nlture, lioston, Mass., Mar. 4, 1s91, report wi. 1591. 1). Btis.

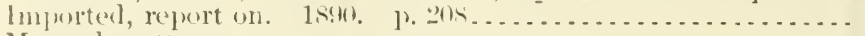

Mas:-ilthusett:-

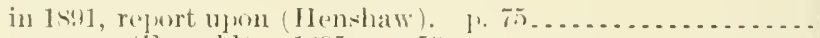

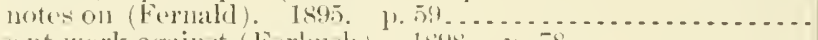

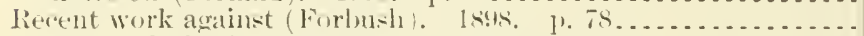

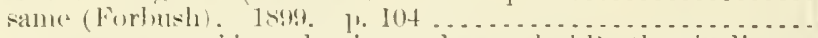

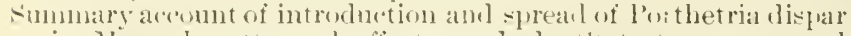

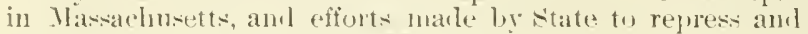

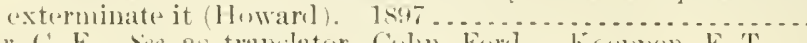

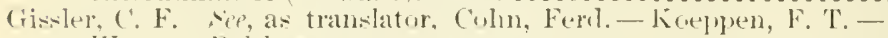
IIatruel, lielthasar.

Githens, John A. Iddrese of, lefore Tatiomal lioar Conference,

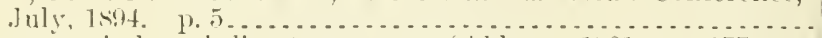

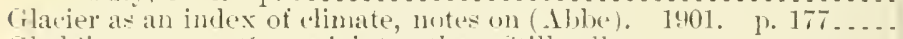

cilarling, $\longrightarrow$. Ne, as joint anthor, stillwell, - .

(ilarbling, Thumas. Guanos, natural, deternination of cit rate-sol-

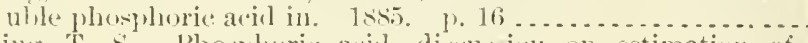

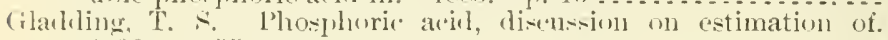

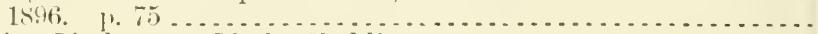

Gladıling-Linko. see Lindo-Glarbling.

Cilanders:

Among horsen (Trumbower). 1. $41 \mathrm{~s}$ same. 1ist.

Anong horses and mules in Texas (Folsetter). p. $393 \ldots \ldots \ldots . . .6$

Bacilli, comprosition of (De Schweinitz and Inset). 10.295 ....

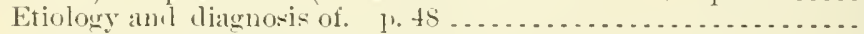

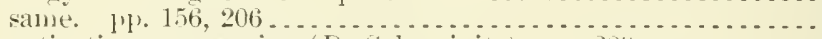

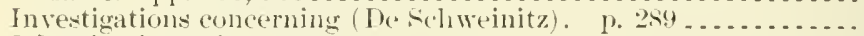

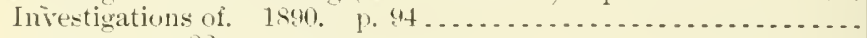

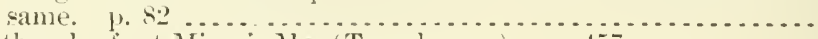

Outbreak of, at Miami, Mn. (Trmmbower). 1). 457..........

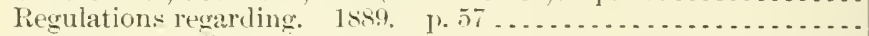

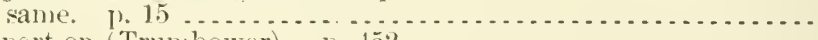

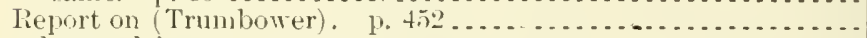

Glanders and farey:

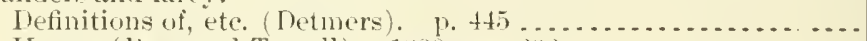

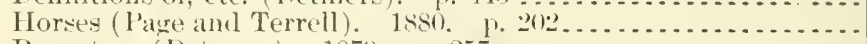

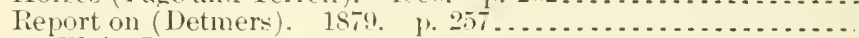
Glass, Elvin J.:

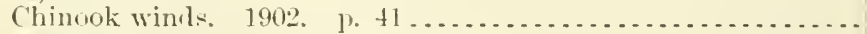

Montana, water supply uf, for seation of 1 !too as depeneling on

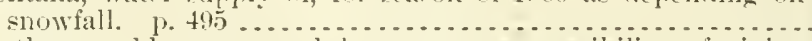

Northers, cold waves, and heavy snows, possibility of giving warnings of, to stock-raising interests, 48 hours in adrance.

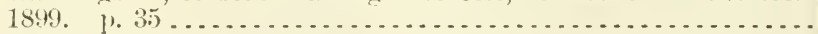

Glass:

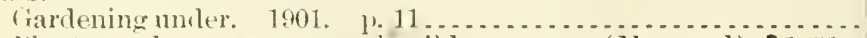

l'lants miler, treatment of miklews mpon (Maynard). $18,91$.

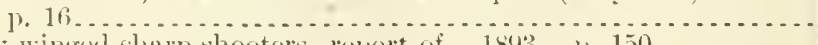
Glasy-winged slarp shooters, rejort of. 18:3. 1) $150 \ldots . . . .$. (ilenil, sinntuel 11 :

Clinate and crop correspondents, Weather Burean; shonlal remarksof, be published in weekly hulletins? 1902.9 p. 188.

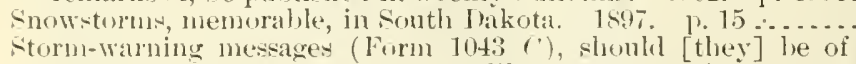
sme distinctive color to more readily attract attention? 1899. 1. $5: 3$.

Globe articluokes. Sce Lur artichokes.
Clanifieatlon no.

$1+.1: 101$

16.3:16

1:7.4:2:3

$19.7: 3$

$19.7: 2$

$19.3: 26$

19.6:2

A9.6:17

$19,6: 20$

19.6i:11

12.2.3:10

A20.6:29

A7.8:7

A7.8:49

A $4.1: 884$

At.2: 1105

At. $1: 889-90$

1+. $1: 848$

14.1:857-8

11.1:588

14. $1: 84.5$

A 1.1:\$90

14.1:859-90

A4.1:\$84

A 1.1:\$89

A $4.1: 889-90$

At.1:88t

11.1:878

A1.6:20

11.6:12

A29.3:31

129.6:28

A $29.3: 24$

11.9:144

128.5:6

19.7:5

1 $29.3: 31$

A $29.6: 25$

A29.3:24 


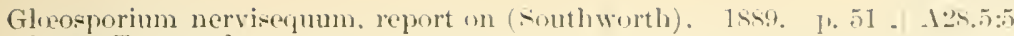

Glover, Townenil:

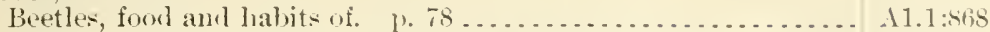

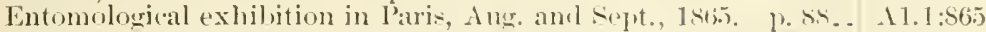

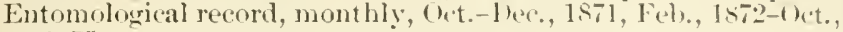
1875

[The more important articles are indexed under their varions suhjects.]

Foreign letters from-

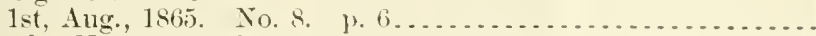

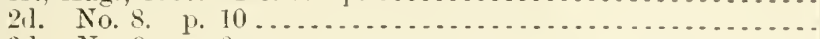

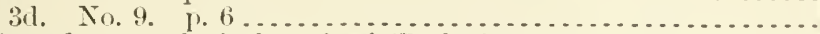

Life and entomological work of (Dorlge). 18s8 .............

See also, for reports as Intumologist, Agrieniture Dopartment, $1863-77$

Glucose, commercial, whe sugar in presence rif, report on determination of (Weluer and M.Pherson). 1894. 1\% 126.

Gnats. see Buffalo gnats - Hippelates - Rye gall-gnat - simulium.

Goats:

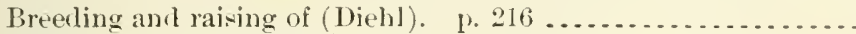

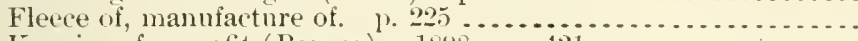

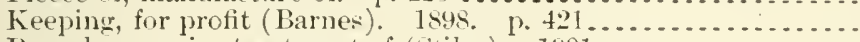

Roundworms in, treatment of (stiles). 1901 ................

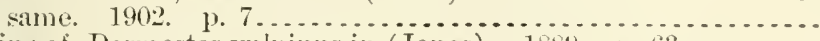

Skins of, Dermestes vulpinus in (Jones). 18s\% p. $68 . . .6$.

Verminous diseases of, in Texas, 1900 (stiles). 1\%.35t) . . . . . .

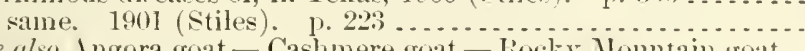
Sie also Ingora goat - Cashmere goat - Jocky Momntain goat.

Goble, W. F. (irasshoppers, sketch of. 1867. p. 290........... Goding, Fredrie W'. Food-plants of some N. A. Membracille. Isi:.

Goff, E. S.:

Apple scal, treatment of-

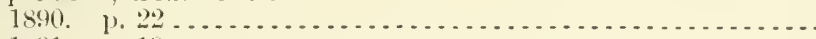

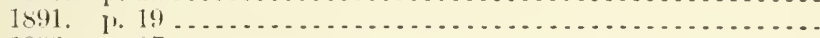

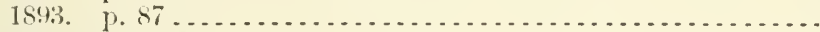

Fungons diseases, treatment of. 1s91. 1). 17..............

Crooseberry mildew and apple seab, experiments in treatment of. 1889.

Horticulture, laboratory work in-

1896. p. 103

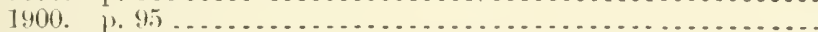

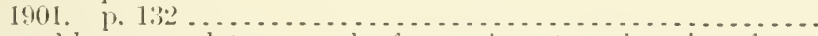

Vegetahle nomenclature, work of experiment stations in reform uf. 1891. 1. 47.

"Going light." se Asthenia.

"Golien Heece," Cotswolil ram. p. 340 .

$127.9:$

$127.9: 3$

1.7.8:3

$.127 .4: 3$

$19.3: 18$

A! ! :

$17.3: 43$

A 1.1:StiB

1 1.1:867

11.10:895

A $4.4: 35$

A4.3:35

19.7:2

At. $1: 900$

14.1:901

127.955

A $9.7: 5$

16.3:11

A28.5:6

110.3:16

1:8.5:7

$125.5: 5$

110.3:41

1 $10.3: 76$

110.3:99

$110.5: 3$

11.1: 1660

Golden (iate fair. see Gaklaml, Cal.

Goldtingel, Max. Mannleim, (iermany, cost of lauling fam prod-

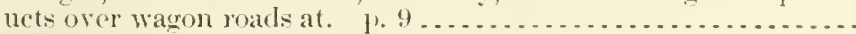

Goldmann, F. Folatileacids in huter, iletermination of total. 1sio). 1. 112. distribution in, chemical stmly of, hefore and after tapping for

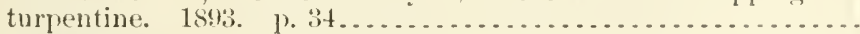

Gonioctena, poplar, report on (couk). 1891. p. $67 \ldots \ldots \ldots \ldots . .$. Good llope, cape of:

Animal prorlucts of, exports and imports. p. 524........... Insects of, notes on (1,omslonry). 1897. 1) 34............. food roats, national leagne for. tiep lioarls.

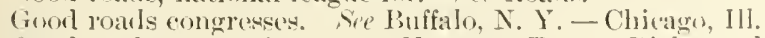

Good roals conventions. Se J Juston, Tex. - Rivinund, Va. - st. Paul, Minn.

Goodale, (ieorge Lincoln:

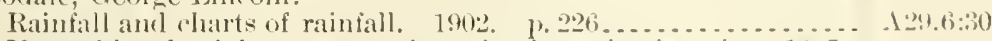

Vegetable physiology, sugrestions for investigations in. 1sis. 1). 438 
Goodale; : 1.:

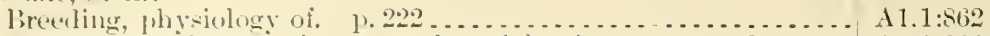

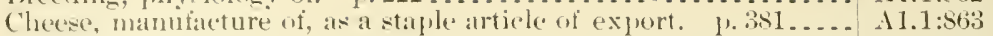

Goodell, lienry Fill:

Arletress of, as president of Assoriation of American Agricultural Collexes and Experiment Stations, at 5th annual meeting.

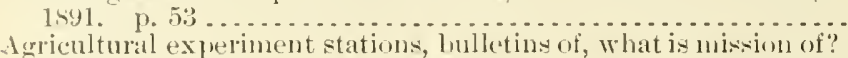

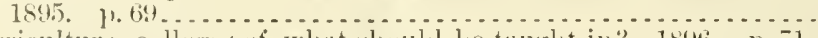
Agrieulture, colleges of, what should lee taught in"? 1896. p. 71.

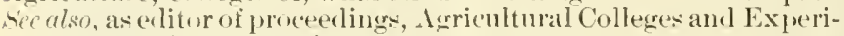
ment Statious, American.

Goodloe, Ininiel R.:

Forth Carolina, agriculture amel clinate of. 1867. 1. $150 \ldots \ldots$. Southern states, resources and industrial condition of. 1865.

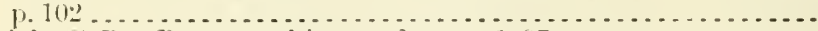

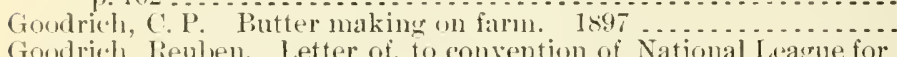
Goodrich, liemben. Letter of, to convention of National League for

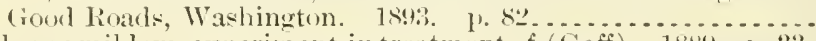

Gooseberry mildew, experiment in treatment of (Goff). 1859. 13.33. Gopliers:

Circular on. 1888 . . . . . . . . . . . . . . . . .

Depredations of, in northern Jowa amd sonthem Minnesota in fall

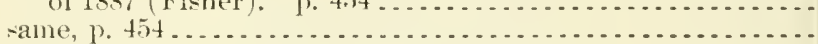

See alson Florida land tortoise - Pocket gophers.

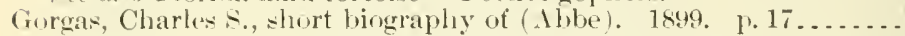
Goss, Arthur:

Beef, report conceming 6.25 protein factor as applied to. 1899.

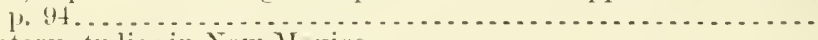

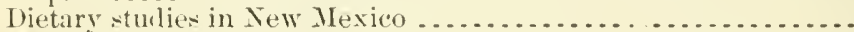

Aineral matter deposited with smow in northern Indiana, Jan.

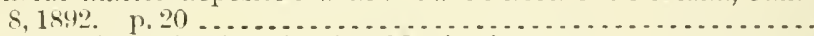

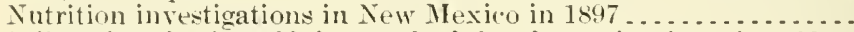
Soils, phospluric acid in, method for letermination of. 1894.

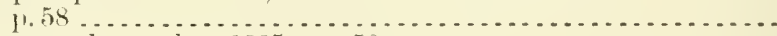

Gossard, II. A.:

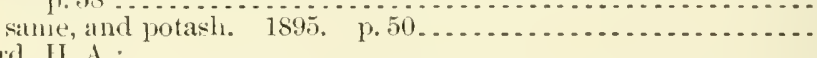

Entomology, cenomic, in Florivla, report on. 1901. p. 178 ... Florida, observations of insects; experimental work. 1902. p. 129. White-fly investigation, review of, with incidental problems.

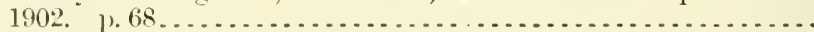
See also, as joint author, Osborn, Herbert.

Gould, H. P. Fruit growers, practical sugrestions for. 1902 . . . . . Government aid in highway inprovement (Brigham). 1902. p. 33. Government entomologists. See Fintomologists.

Government in its relation to forests. 188s, p. $23 . . . . . . . . .$. Gowdy, John K. Animals, dear, disposition of, in Paris. p. 348 .. Gowell, Gillert M., and Ruscell, Fremont L. Dehorning cattle.

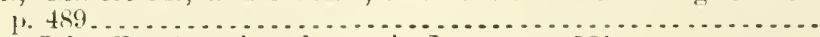

Gowey, John F. American butter in Jajan. p. $521 \ldots . . .2 . .$.

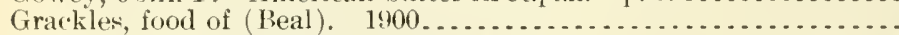
Graduate study at Washington, D. C.:

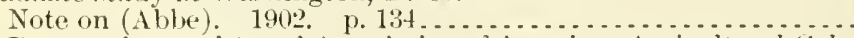
Report of committee of Ascociation of American Agricultural Colleges and Experiment Stations, 1898, on, p. $58 . \ldots . . .$.

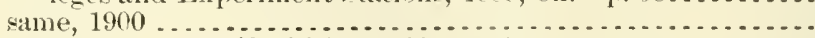

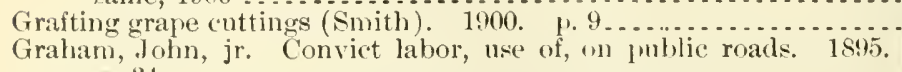
Grain:

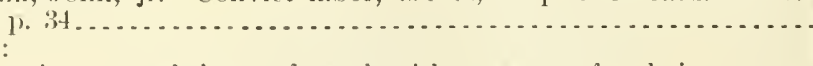

American cereal, insect foes of, with measures for their preven-

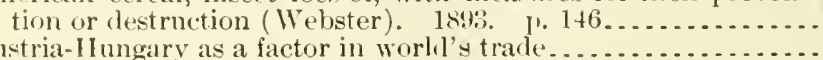

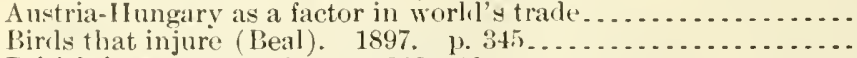

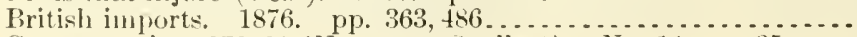
Commerce in, $1879-81$ (Neumann-siallart). No. 14 . 1. $35 \ldots .$. 
Crops, (n)

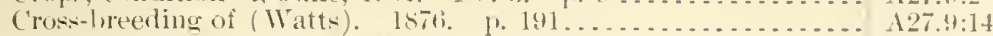

English meastres. 1863. No. 5. 1. 1; No. (i. 1) 2.2....... A27.9:1.

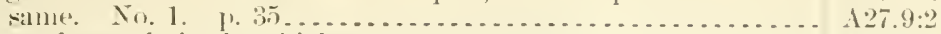

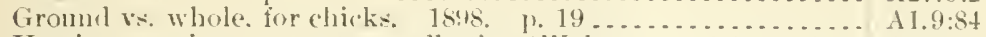

Hemijterous insect punctures afferting (11ebter). 1857. p.54.. A9.3:13

Insects affecting, observations upon (1V ehster). 1890. p. 42.... $49.3: 22$

Light ve. heavy, feetling, for milch cows (Allen). 1900. p. 25... A1.9:11!

Markets and crops, foreign, state of. 1864. No. 5. p. 14..... 1:2.9:2

New methor of treating, by Jensen process for prevention of smut (Galloway). 1891. 1. 372 ..................... A28.5:7

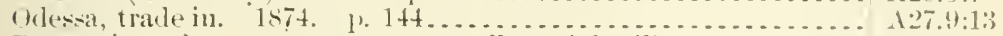

Proportion of, to straw on stover, effect of fertilizers on. $189 \%$.

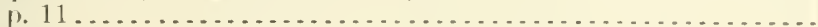

Riusial-

northern. 1870 . P. 89. producing districts of (Moffat). 1882. No. 51 . 14.

Rusts, investigations of, letter relative to (Dabney), 1894......

Sinall, insects affecting (Welster). p. $573 \ldots . . . . . . . . .$.

Smuts in, cause and prevention (swingle). 1894. 1\%. 406......

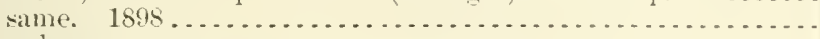

Stored-

inserts injurions to (Chittenden). 1896. more important insects injurions to (Chittenden). 1894 . P.

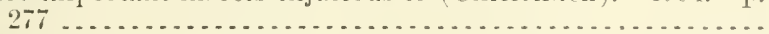

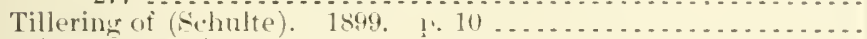

Winter, condition ot-

1869. 1. $119 \ldots \ldots$

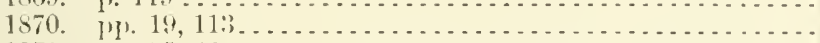

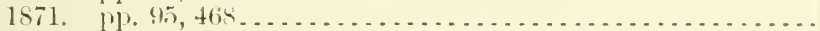

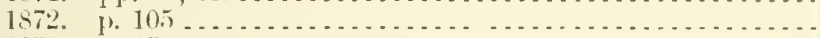

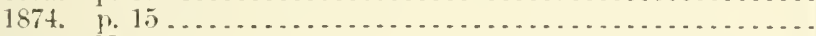

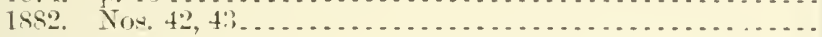

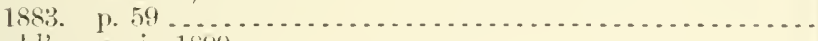

World's crop in 1599.

11.11:56;

A $27.9: 8$

A:7.9:26

A:8. $4: 14$

A1.1:S8ti

A 1. 10:894

A1.9:75

$.11 .9: 45$

A 1.10:6:1

1 $1.9: 105$

A27.9:-

А $27.9: 8$

A $27.9: 9$

A.27.9:10

A27.9:12

A 27.8::00

A 27.91:21

Yield of, rel acre-

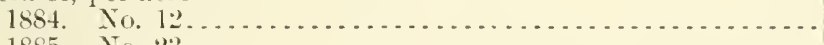

1885. No. 22. . . . . . .

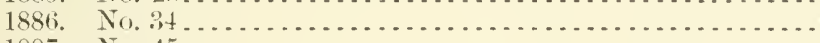

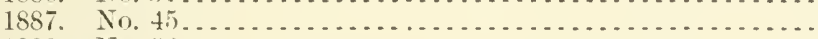

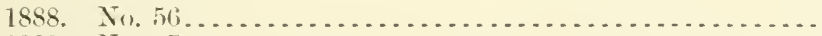

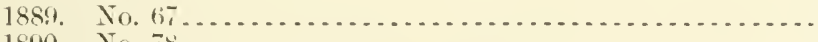

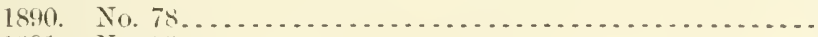

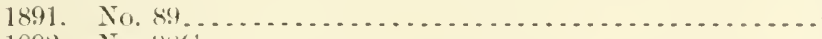

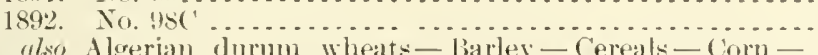

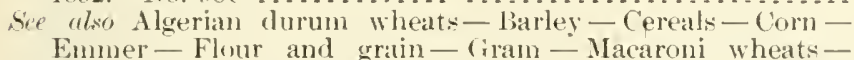
Maize - Oats - Red clover seed - Rice - Runner's white corn-Rye - Wheat.

Grain joint-worm flies. See Grass and grain joint-worm flies.

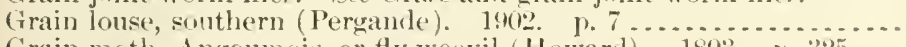
Grain moth, Angoumois, or fly weevil (Howarl). 189\%. 1. 325.... Grain plant-lonse, some new jarasites of (Howard). 18:0. म. 246 Grain Toxopteri, notes on (Welster). 1892. p. 245 . . . . . . . . Gram, chick-pea or liaho pea (Suith). 1898 . . . . . . . . . . . . Graminese (grass family) of wetern Texas, description of (Dewey). 18:14. 1). 484

"Gran cultura", in Iuerto Rico, notes on (Aibe). 1S99. ए. 54s... Granada, Nicaragua, rainfall of (Henry). 1898, pp. 162,305...... Grand Valley, Colorado, irrigation in, 1901 (Stover). 1902. p. 265. Grandean, L. Russia, black soil of. 1872. p. 501 ............. Grandean's method for determination of humms, modification of

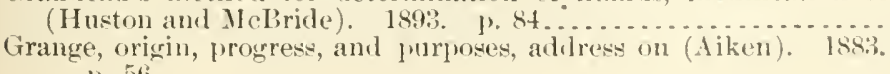
Siane

$19.6: 35$

1!1.7:5

19.7:2

19. $7: 4$

1:3.4:\%

16.5:2:2

1:29.6:27

129.6:26

A 10.3:119]

A:7.9:10

A7.3:3

11.7:.

A 1. $1: 5: 5$ 
Ciranges, state, oflivers ut:

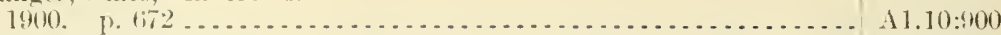

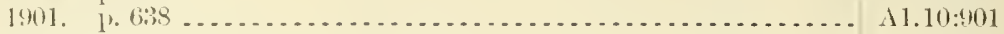

(irape:

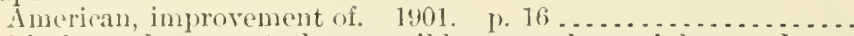

black-rot, lown-rot, downy nillew, pow lery millew, and anthracuose of, treatment of (tialloway). 1891. p.11.......

Black-rot of, experiment in treatment of (Galloway). 18s.9. p. 204 . . . . . . . . . . . . . . . . . . . . . . . . . . . . .

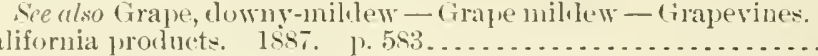

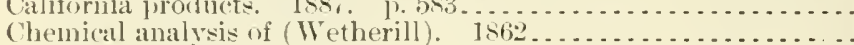

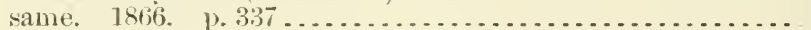

Cuttings, grafting (smith). 1900) p. Diseaves of $\hat{\mathrm{i}}-$

Europe; origin, history, phenomena, anl ture (Emi). p. 324. Pacific coast (l'ierre). 1595 . . . . . . . . . . . . . . . . . . .

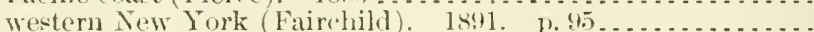
see rolso Grape millew.

Downy mildew and anthraenose, circular asking questions re-

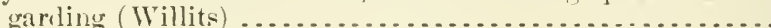

Downy mildew and blatk-rot of. treatment of-

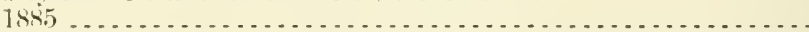

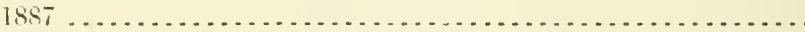

1859

See also Graje, black rot - Cirape mildew - Grapevine.

Fungulus diseases of -

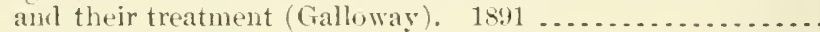

treatment of (Howell). 18s!. p. $49 \ldots . . . . . . . . . . . .$.

Growing at the West (Tlompson). 1. 115.............

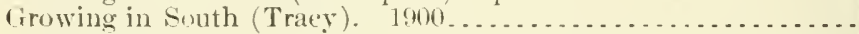

lowrovement hy hybridizing, cross-breeding, and seedlings (Camphell). 1. 209

Insect enemies, principal, of (Marlatt)-

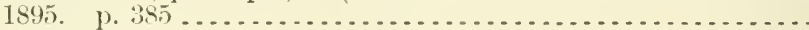

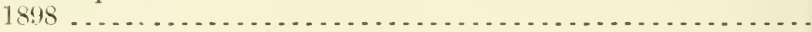

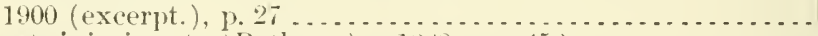

Insects injurious to (Rathvor). 1sis. 1) 45.2. . . . . . . . . .

Isabella, in Sonth America. 1Stit. 1. 4:6 .............

Juice of -

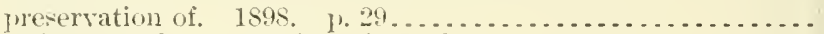

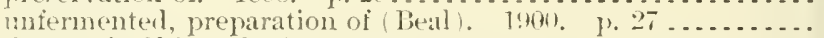

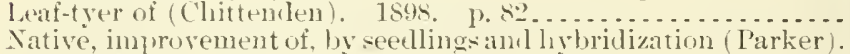
1. 12:2.

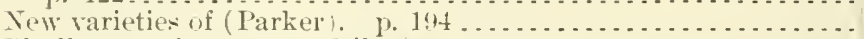

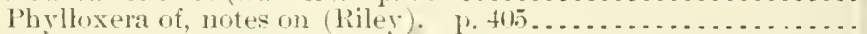

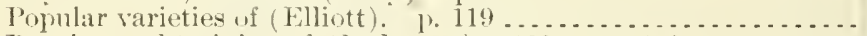

Pruning ancl training of (Lodeman). 1s9ti. 1. $499 \ldots \ldots . . .$.

Raisin, eultivation of, by irrigation (Eisen). 1891. p. 205......

Ripe, rot of (Southworth). 1891. 1) 164.................

foruppernong, letter on (Froelich). 186s. 1. 4t9 ...........

Wild, of Torth America, elaswifieation and generio symesis of

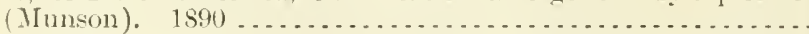

Grape hags, use of, by paper-making wasp (Hurtfelit). 1sit. j). $10 \%$

Grape culture:

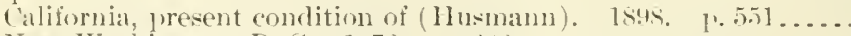

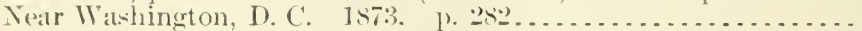

lieport in, in L. S.-

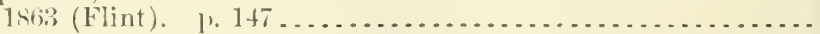

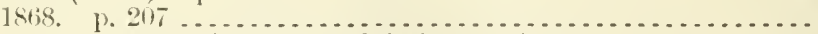

Wine-nakine ami, in lil Jaso del Norte (l'ierson). 1873......

Wine production and, in $\mathrm{U}$. S., for $1 \mathrm{~s}$ so, rejort on statistics of

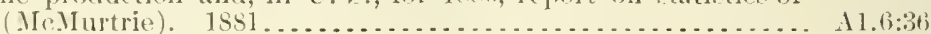

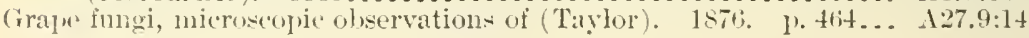




\section{Index}

Grass ant grain joint-rorm flies and their allies, a consideration of some Vorth American phytopharie eurytomina (Howard).

frass "xperiment stations, necessity for (Vasey) 1855. p. 168... Ne'e alse fiarlen City, Kans.

Grass garilens:

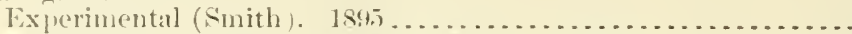

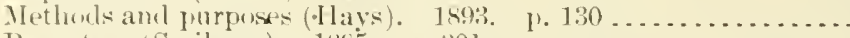

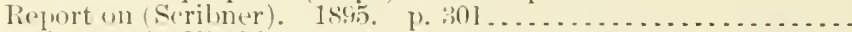

Grass inserets in IVashington, 1). ('., notes on (Oshorn). 1691. p.

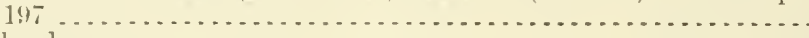
(irass linds:

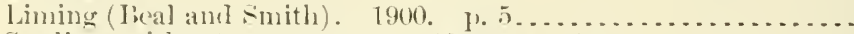

Sceding, withont a nure crop. 1s:s. 1. $11 \ldots \ldots . \ldots \ldots \ldots . .$. Grass saw-tlies, notes on (Riley and Marlatt). 1s91. p. 168 ..... Grass seml and its impurities (llicks). 1895. . 1. 473 ........... Girass sterels:

Collection and distritution of (Shear). 1900.

Number, weiglit, cost of, and amount to sow ler acre-

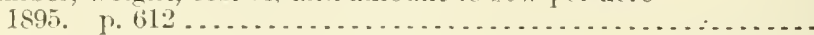

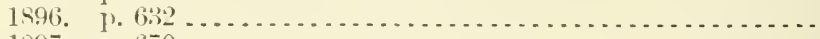
1897. 1. 670

(irass stations, cooperative:

ln South (Tracy). 1\%.:24t same, ]. 844

lu IV

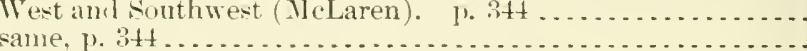

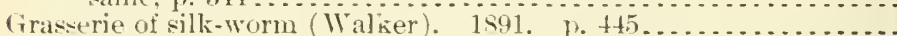
(irasses:

American, chemical composition of, from investigations in laboratory of Department of Agriculture, 18 $8-82$ (Richardson). P. $11 \frac{1}{6}$

American, No. 1, description of, tribes and genera (Scribner) ...

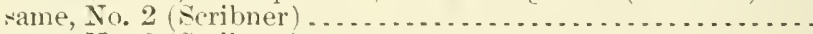
same, Yo. 3 (Scrilner) . . . . . . . . . . . . . . . . . . . .

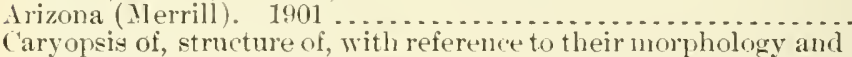
Classification (Kemedy) . . . . . . . . . . . . . . . . . . .

Collected by Dr. E. Palmer in vicinity of Acapulen, Mexico (scrib-

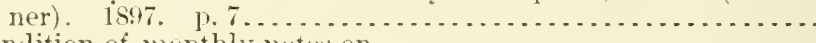

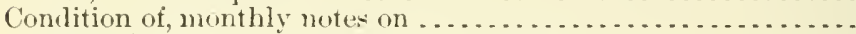

Contributions from U. S. National Herbarium ..............

Cutting, curing, and hauling of. 186t. No. 4. p. $6 . \ldots \ldots \ldots .$.

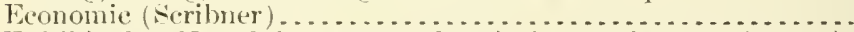

Exhibited at New Orleans, 1885 , descriptive catalogue of (Vasey).

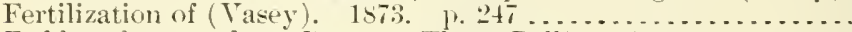

Fodder plants and, on Potomac Flats (Ball). $1900 \ldots . . . . . . . .$.

Herbarium of Dr. H. Muhlenberg (Seribner and Merrill). 1900. .

Insects affecting (Welster). p. $573 \ldots . . . . . . . . . . . . .$.

Kansas, Nebraska, and Colorado, arid districts of (Vasey). 1886.

Mexico, new, from, clescription of ( Vasey). 1893. 1. 2\$1 .......

Needed for agriculture in U. S. (Vasey). 185. 1. 168........

New Mexico, Arizona, Nevada, and [tal, arid districts of, in-

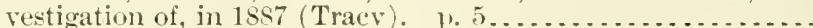

New or little known-

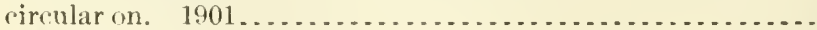
description of (Seribner)-

1897. p. 5

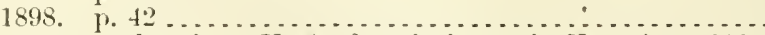

New or noteworthy, from U. S., decriptions of (Vasey). 1893.

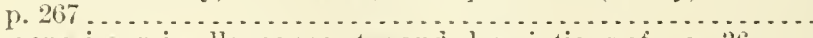

New species, niscellaneous notes and lescriptions of. $1,36 \ldots .$. same (S.rilmer and liall). 1900. 1. $39 . \ldots . . . . . . . . .$.

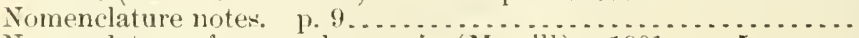

Tomenclature of, some clianges in (Merrill). 1901. 1.5 . . . .

North American -

illustrations of (Vasey). 2 vols

13. $4: 1$

A $10.3: 16$

11.10:895

$19.7: 4$

A 1.9:12:

A 1.9:79

A9.7:4

A $1.10: 898$

A $1.4: 9$

A 1.10:895

A1.10:896

A 1.10:897

A1.1:891

16. 1:891

A1.1:891

16.1:891

+9.7:3

A 1.8:32

13.3:7

A3.3:17

A $3.3: 20$

A3. $4: 32$

A3.3:19

A3.3:t

A 27.9 :

A6.5:

A27.9:3

A3.3:14

A6.2:G76

A27.9:11

A3. 4:28

A3. $4: 27$

A1.1:886

A6.3:1

A6.5:1

A 1. $7: 9$

16.3:6

13.4:30

A3.3:8

A3.3:11

A6.5:1

A3.3:4

A3.3:2t

A3. $4: 27$

A3. 4:35

A6.2: 182 
Vurth American-Continued new sperics of (Foribner). same (-cribner). 1899

$18,19$.

l'aritic shpe, inclurling Alaska ami adjacent jonds. 2 pts.

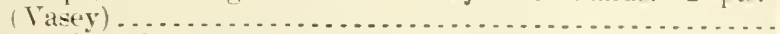

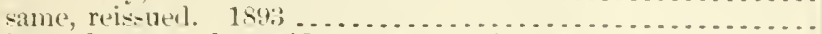

Plains and eastern slope of lioeky Mountains, catalourue of. p. 217.

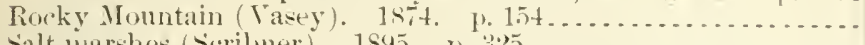

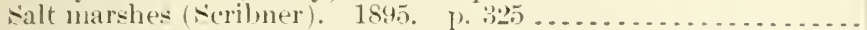
Saml and soil binlers (foribner). 1894. pr. $421,580 \ldots \ldots .$.

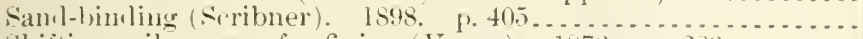
Shifting soil, grasses for fixing (Vasey). 1si: l', 2.3........ Some species of, pulshised ly s. P. Buckley (Merrill) 1901.... South; report on certain grasses ansl forage plants for cultivation in Fouth and sonthwest ( Yarey). 1857................. South ('arolina and Georgia, in Eiliott's sketch (Goribner). 1901.

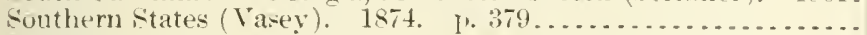

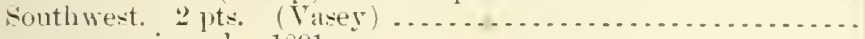

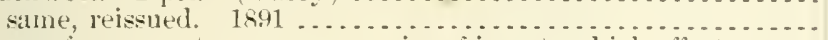

Stems of some, notes on some species of insects which affect upper

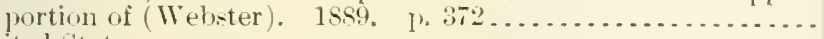

Tnited states-

being synopsis of trihes and genera, with descriptions of genera,

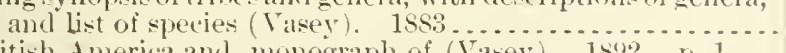

British America and, monograph of (Vasey). isig. $\quad$ \%. 1... lescriptive ratalogue of, including especially grase collextions at Jew Orlean Exposition, $18 s 5$ (Tasey) . . . . . . . . .

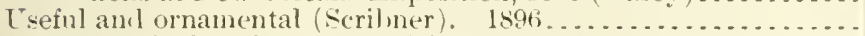

See also Agricultural grasies and forage plant- - Agropyron - Agrostology - Agrostology Division - Aristidal purpurea nut Bear grass - Bearlless hrome-grass - Bermula grass - Blue grass - Brome grass - Bromus - Broom com - Calamagrostis-Chetweliloa-Chess-Clover-Crimson clover - Earth almond - Eragrostis olsusiflora - Ergot - Esparto grass Forage plants - Giant knotweed - iraminex - Horleum Hungarian brome grass - Humgarian grass - Ixophorus Johnson grass - liafir corn - Melica - Mexican grasses Millets - North American grasses - Nut grass - Oreharel grass - Parific sope grasses - Panicum nashianum - Panicum nitidum - Panicuns - Poa - Poa fendleriana - Ramie or Chinagrass - Range grass - Rescue grass - Rocky Momntain grasses - Sitanion - Snooth broom-grass - Spartina Tinotliy.

Grasses anul forage plants:

Coolverative experiments with (Kennedy). $19100 . . . . . . . . .$.

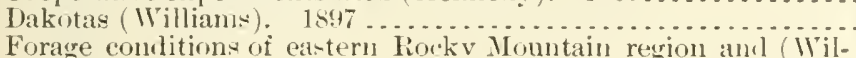

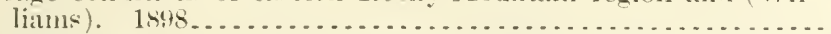

Insects affecting, methorls of treating (i)shorn). 189\%. 1. 7i ...

Investigations with, conperative work of Department of $\mathrm{I}$ ericoulture with State experiment stations-

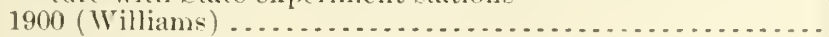

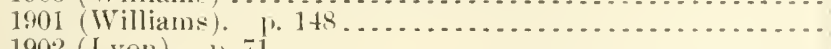

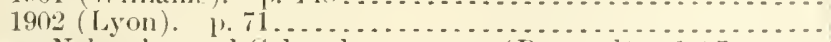

Iowa, Neloraska, and Colorarlo, notes on (Pannel) 1sit.....

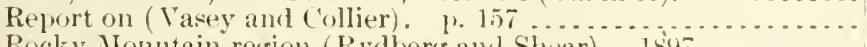

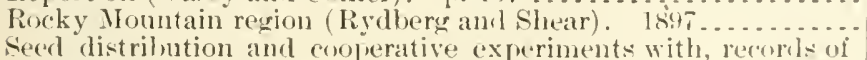

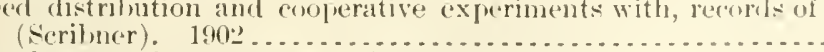

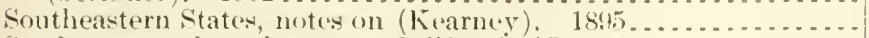

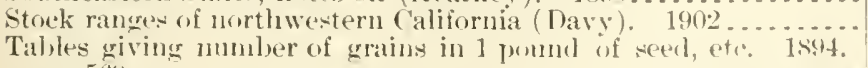
1. 564 .

16.3:13

16.2:15:2

1 1.1:5,0

127.9:12

11.10:\$(1)

11.10:89t

1 1.10:598

127.9:10

13.4:35)

16.3:3

13.4:29

1.7.9:12

16.3:12

16.2:152 ${ }^{1}$

19.7:1

A1.6:(ii)

16.5:3

A6.2:1:76

13.3:3

$10.3: 22$

1:3.3:13

A3.3:12

1!1. $7:$ i $^{2}$

11. 4:8

110.8:89

110.3:115

13.3:1)

11.1:STE

1:3.:3:5

$119.3: 10$

1:3.:3:1

1 111.3:1"

$11.10: 5: 14$

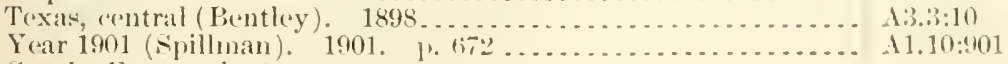
see also Forage plants. 
Grasses and Forage Plants Investigations, Otlice of, list of publiea-

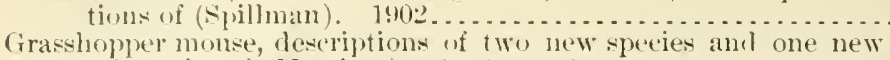
subspecies of (Merriam). 18s9. p. 1...................

Grassluppers:

Damages from, reported, trip to kansas to investigate, faper real before Ascoriation of Economic Entomologists, 1891

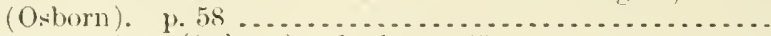

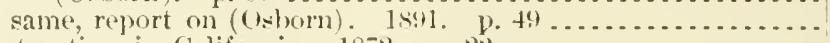

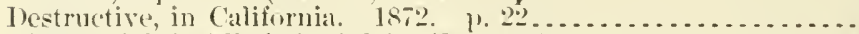

Differential, in Mîssissippi delta (Morgan). p. T............

Direase of, in Colorado (Gillette). 1896. 1. $89 . \ldots . . . . . . .$.
Fungous diseases of, experimental work with (Howari). 1901. 1. 459 .

Ilateful, or Colorado (Caloptenus spretus), information relating

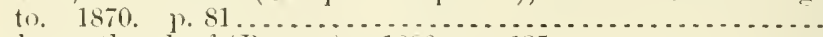

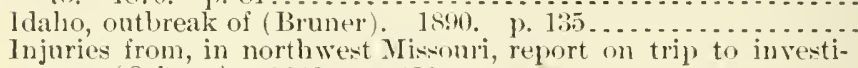

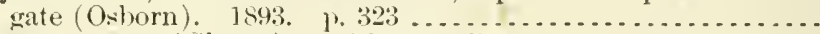

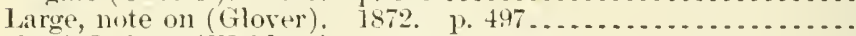

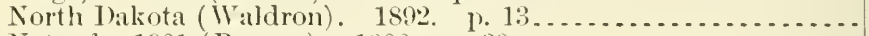

Notes for 1901 (Bruner). 1902. 1.39 ....................

Outlook for, 1892. p. 321 ...................................

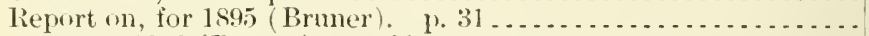

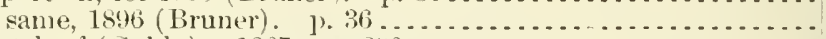

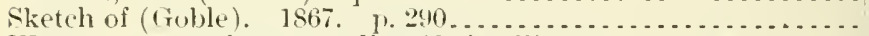

IV estern, suggestions regarding (I riscoll). 1869. p. 145.......

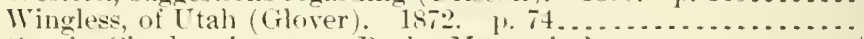

Siep also Cicarla - Locusts - Rocky Jountain locust.

Gravel roats. Sice lioarls.

Gravelius, 11. Rainfall and charts of rainfall. 1902. 1) 228......

Graves, Henry Solon:

Forestry, practice of, by private owners. p. $415 \ldots \ldots \ldots \ldots \ldots$

l'ractical forestry in Ailirondacks. $1899 . \ldots \ldots \ldots . . . . . . . .$.

Woor lot belonging to E. T. Page, at Oaklanel, Bergen Comity,

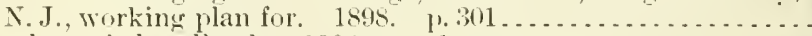

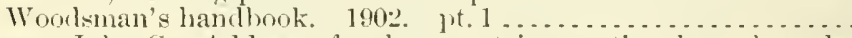

Graves, John C. Address of welcone, at international good roadseongress held at Buffato, N. Y., Sept. 16-21, 1901. p.9. . . .

Gravinetrie method, process for estimating fat in milk by (Dietrich).

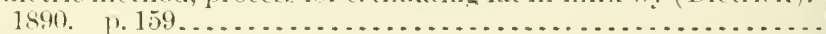
Gravity:

Standard, reduction to, notes on (Ablee), 1598 . p. $500 \ldots . .$.

Terrestrial, variation of, orer the ocean (Al,be). 1902 . 1.370.

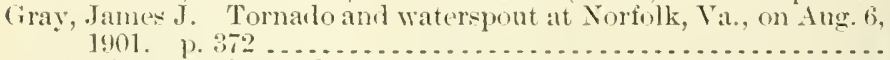

Gray hair-streak buttertly and its damage to heans. 1845. p. 354 .. (ir:izing:

Forest reserves (Roth). 1901. 1.333.......................

Problems in, in Southwest, and how to meet them (Nmith). 1s99.
Rainfall and, notes on (Albe). 1901. p.176 .............

Great basin, northern borler of, forage conditions on (criffiths). 1902

Great Britain:

Agrieultural education in, 1865. . To. 2. p. s ............

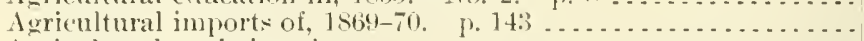

Agrieultural statistics oi-

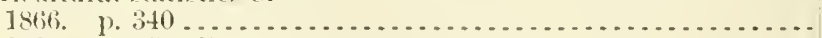

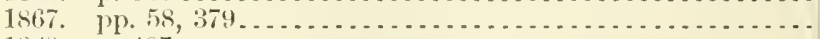

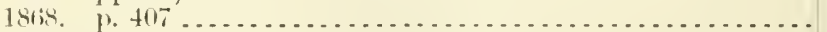

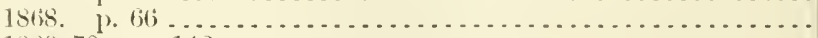

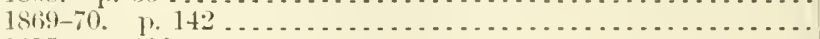

1875. p. 119 . . .

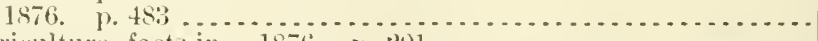

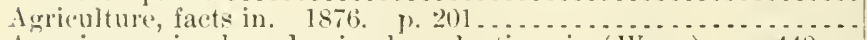

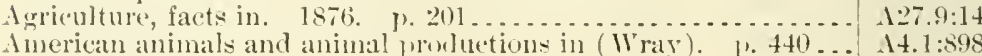

$11 \div .2: P ! 96$

A.5.5:2

19.3:27

A9.7:4

127.9:10

A9.6:30

A9.6:6

A1.10:901

127.9:8

19.7:3

A9.7:5

A $27.9: 10$

19.3:27

A $9.6: 38$

A9.7:4

A9.6:7

A9.6:7

A $27.9: 5$

127.8:7

A 27.9:10

1:9.1::00

A $1.10: \$ 199$

113.3:- 6

11.10:598

A13.3:36

A2.:3:21

A. B::24

1 $29.6: 26$

1.9.6:30

1:29.(i:?

$19.7: 7$

A1.10:901

A3.3:16

129.6:29

119.8:15

127.9:3

1.27.9:6

1.2.9:4

A27.95

A. $7.9: 6$

1:27.9:7

127.9:?

1:27.9:14

127.9:14

14.1:898 
Index

Great Pritain-Comtinned

Amerieall cattle in, in-leetion of. p. s:.................. 11.1:s\%)

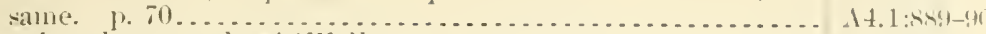

American hore trate of (Wellman). 1897. 1. 4.5........... 11.2:117s

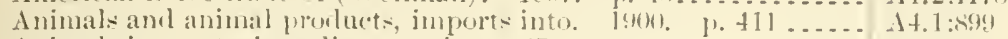

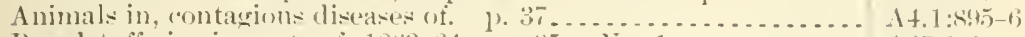

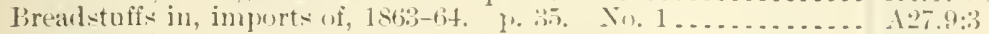

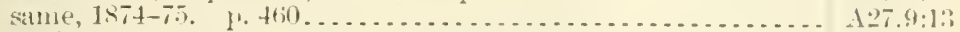

Cattle in-

comsumption and production of. 1ivis. No, T. p. 27.......

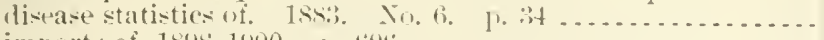

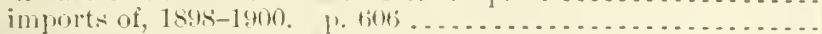

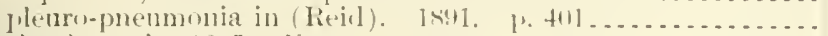

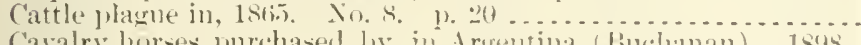

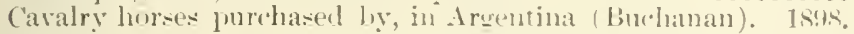

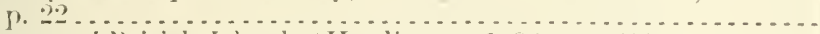

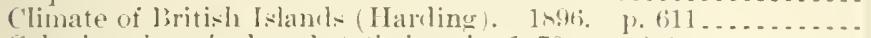

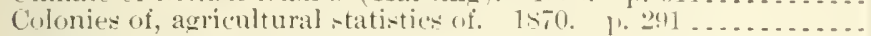
same. 18\%5. P. $45 \overline{5}$.

Cottrin importations of-

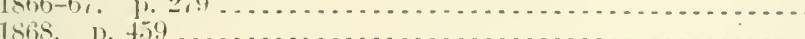

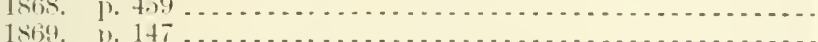

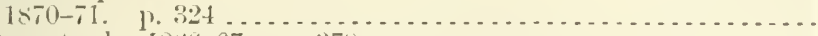

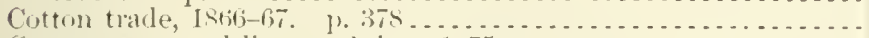

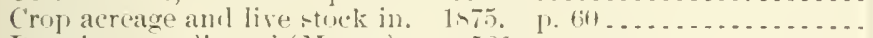

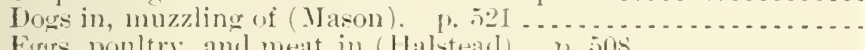

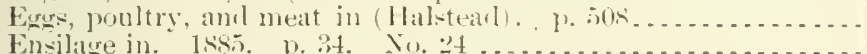

Farms, increaserl production of, $187,1,4$.

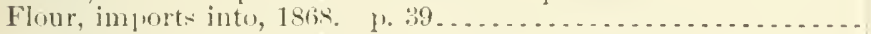

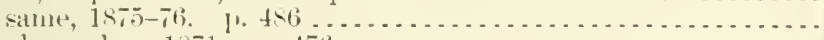

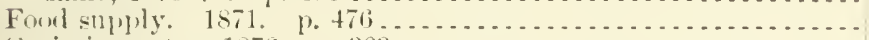

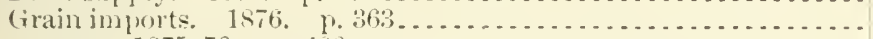

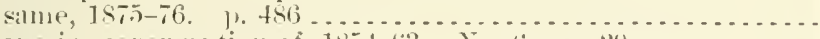

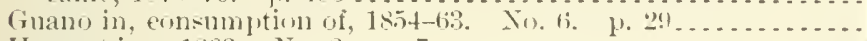

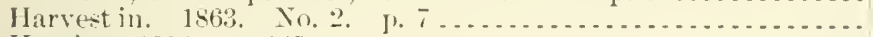

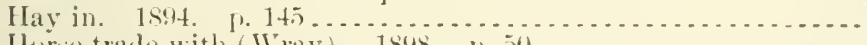

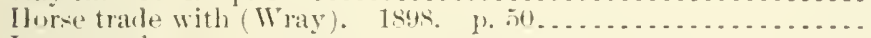

Injorts of-

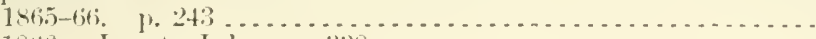

1stib. Jan. to July. P. 338 . .

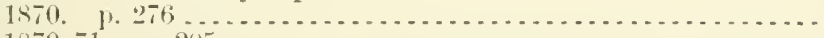
$1870-71 . \quad 1 \% 20.5$

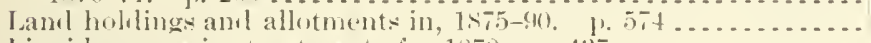

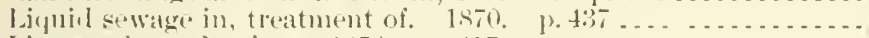

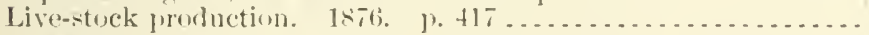

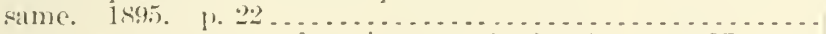

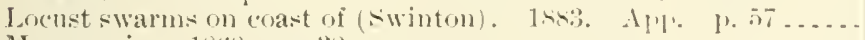

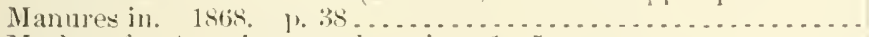

Markets for American products in. 1s.t5. . . . . . . . . . . .

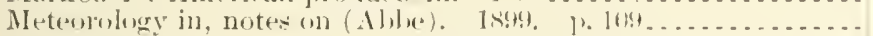

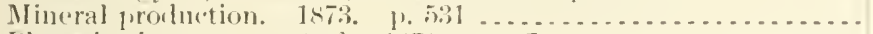

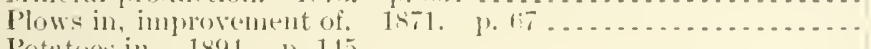

I'otatues in. $1894.1 \%$ 145 . . . . . . . . . . . . . . . . . .

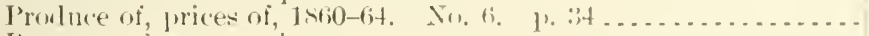

lieventue of, somme oi-

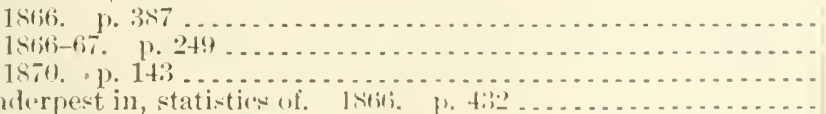

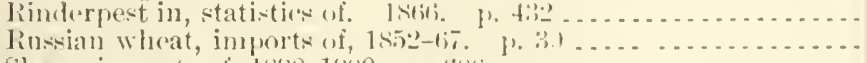

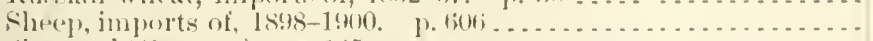

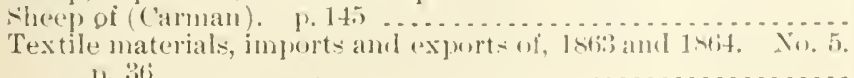

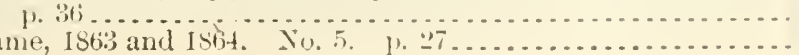

$127,9: 3$

$127.9: 0.2)$

$1+1:($ :(i) 1

14.1:85! -930

1.7.9:3

11.2:117

$129 .: 2: 11^{3}$

$127.9: 4$

1.7.4:1:3

$127.9: 5$

$127.9: t^{2}$

$127.9: 7$

A $27.9: 9$

127.95

127.9:14

14.1:300

14.1:900

127.9:2:3

127.9:11

$127.9: 6$

A $27.9: 14$

$127.9: 9$

127.9:14

127.9:14

A27.9:3

A27.9:2

1'7.9):3;

11.2:1178

127.4:4

127.9:4

127.9:3

1:-7.9:10

127.9:28

127.9:"

127.9:14

1:- $19: 3: 33$

18. $1: 3$

$127.9: 6$

1 12.3:1

12!. $10: 27$

1.27.9:12

$127.4: 4$

$127.49: 3 \%$

127.91:2

$127.9:-1$

$127.9: 5$

$127.9: 4$

A 27.914

1:-7.9:15

14. 1:!10!

1..1:‘:5!1-!10

1.27.4: :2

127.?1:3 
Great Britain-Continuer

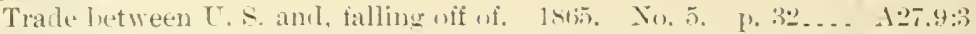

Wheat-

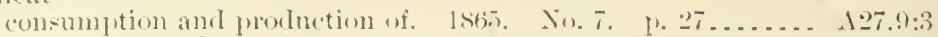

importations of-

$1868 . \quad 1.454 \ldots$
$1869 . \quad 1 \% .147 \ldots$
$1870-71 . \quad 1 \% 324$
$1873-74 . \quad 1 \% 45$

sipply, 1si2-sti. p.64l ...

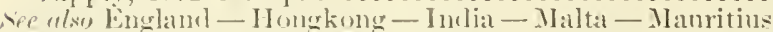

Great Lastern Canal, Platte County, Nofir. Irrigation uncler, 1900

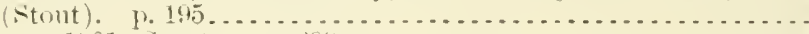

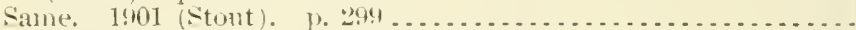

Great lakes:

Aneroil barograph on, instructions for use of. 1897

Commerce on, and its relation to Weather bureau (Ab)e). Iyou.

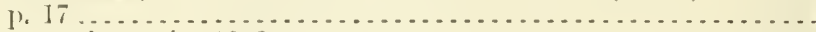

Current chart of. 1892

Currents of, as deluced from movenent of bottle papers, 1 s92 ambl 1893 (Ilarrington) . . . . . . . . . . . . . . . . . . . . . . . .

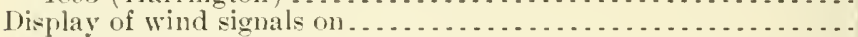

Meteorological charts of . . . . . . . . . . . . . . . . . . . .

Meteomlogical observations on, monthly, sept., I89:3-Dec., 1894 . .

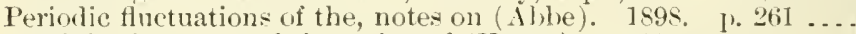

Precipitation, normal, in region of (Henry). 1899. n. $151 \ldots .$.

Rainfall and outflow of the (Abbe). 1898. pp. 164, 215 ......

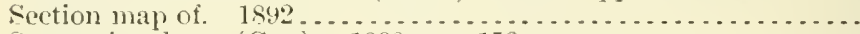

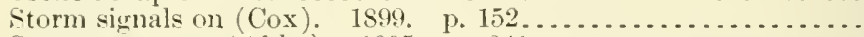

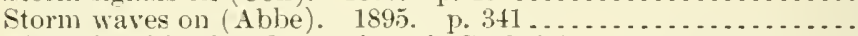

WVater level in the, fluctuation of (Guthrie). $1846 . \quad$ p. 420 . . . . .

Water temperatures of (Conger). 1899. p. 352 ...............

Waterspouts on, notes on (Ábbe). 1898. p. $364 \ldots . . . . . . . . .$.

Weather forecasts best calculated to aid maritime interests of; method of reaching those interested (Cox). 1S99. p. $19 \ldots$

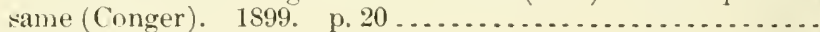

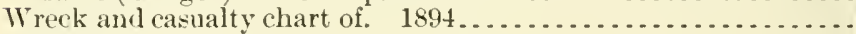

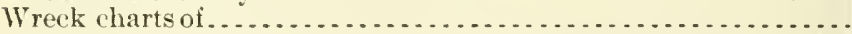

Wrecks and casualties on, during 1895, 1896, 1897 (Conger). 1898.

Wrecks which occurred on, Dec. 17,1885 , to Nov. 15,1893

Great Plains:

Artesian and underflow investigation of, progress report on central

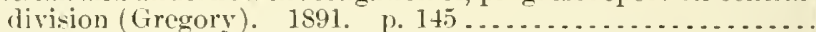

Artesian wells upon, report of geological commission (White and Aughey:). 1882

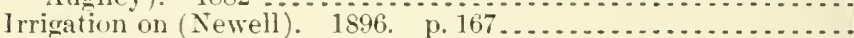

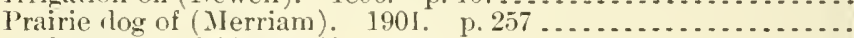

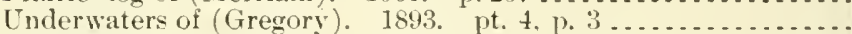

Great salt lake:

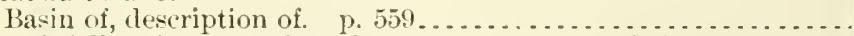

Rainfall and evaporation of, notes on $1874-1900$ (Abbe), p. 68 . . .

Water level of, relation of, to precipitation-

1901 (Murdock). p. 22.

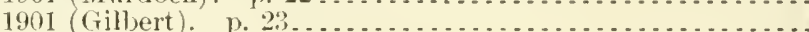

1901 (Mackie). p. 57

Greathonse, Charles Howarl:

Agricultural libraries, development of. 1899. p. $491 \ldots . . . . . . .$.

Agrienlture Tepartment, historical sketch of, its objerts and

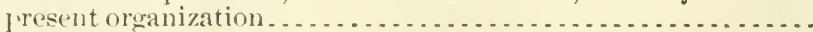

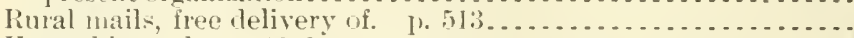

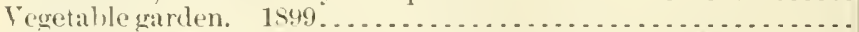

Vearlooks of Agriculture Department, index to 1902 ....... .

Green, Elward M. Horses in France. 1898. 1. 39............ Green, J. L. Tanana Valley, Aluska, notes 1 . 1) 1.30! . . . . . . . . .

Green, seth. Fish enlture, improvenents and increase in. p. 24 s.. Green, samuel B. IIorticultural education in Minnesota. 1898.

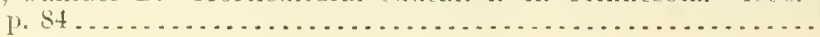

$127.0: 6$

A.27.9:7

1:27. $1: 9$

$127.9: 13$

127.9:25

116.2:104 110.: : 119

.1:4. 12:A113

A29.6:28

129.2:093

A $29.5: 13$

129.2:(781

A29.13:

A:9.6:

A29.6:26

129.6:27

129.6:26

A:9.2:(i8 8

A $29.3: 24$

A29.6:23

A29.6:23

A $29.6: 27$

A29.6:26

A 29.3:24

A $29.3: 24$

$\mathrm{A}^{29.2: \mathrm{G}^{\circ} 1^{3}}$

A 29.2:G81 7

A29.2:G81

A 29.2:G81 5

A15.2:P94 ${ }^{1}$

A I. S:19

A I. 10:896

A 1.10:901

A 15.2: $\operatorname{lr} 7^{2}$

A 1.1:870

A $29.6: 29$

A 29.6:29

A29.6:29

A:9.6:29

A1.10:899

121.3:3

A $1.10: 900$

A 1.9:94

A:1.3:7

1 1.2:1178

A 10. $1^{2}: 901$

1 1.1:872

1 10.3:49 
Ciromel-water on Wisconsin Agricultural Experiment station farm, ulservations and experimentson fluctuations in level and rate

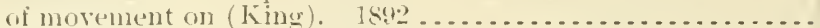

$129.3: 5$

Girout, Jolun H., jr.

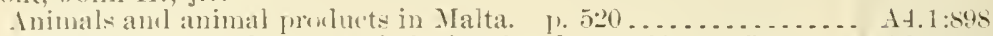

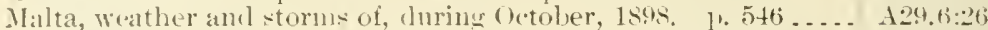

Gmot, Josiah. Vermont, loal improvenent in, extract from qrov-

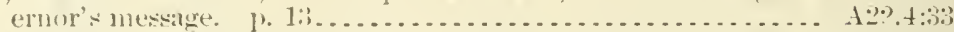

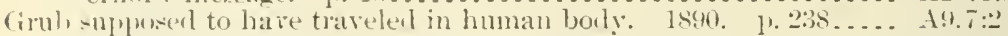
ver "lsw White grubs.

Giunsky, Carl Ewald:

Water, methods of applyine, to land in eentral California. 1891.

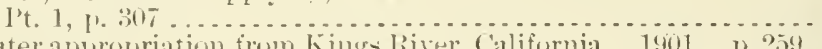

Water appropriation from Kings River, (aliformia. 1901. p. 259. Guarlalupe Island, ()eanica. I.ist rif lantscollected hy Ealward PalGranos:

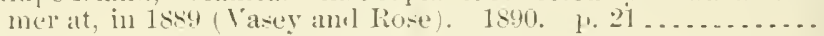

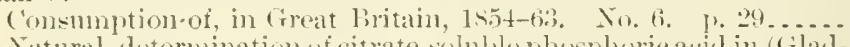

Natural, determination of citrate-soluble phosplumie ar.jil in (i ilad-

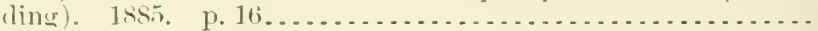

Sie ulso bats, excrement of.

Guatemala. Coiffee culture in. 1ssy. p. 175 .............

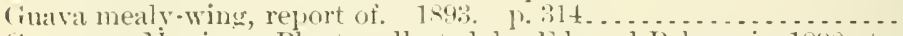

Guamas, diexico. Plante enllerted by Fitward Palnes in 1890 at,

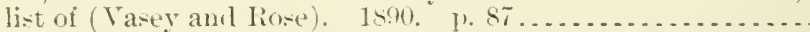

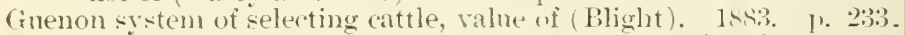
(incuther, Richard. Germany, horse and logmeat as foor in. 1.520. (inem-ey cattle, breed of (llarrison). 1stis. p. 302*..........

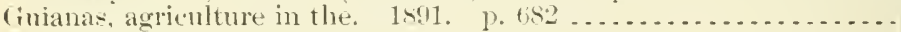
Guinea jigs:

lnmmity from tuberculosis in, use of attemnated bacillus tuberculosis in producing (Ite shweinitz). 1.318...........

Inmunity in, experiments on pouluction of, with reference to hogetiolera and swine plagne bateria (smith and Moore).

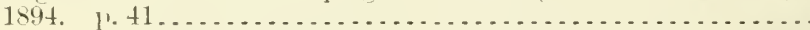

Proluction of immunity in, from hos cholera by use of blood sermm from immmified animals. p. 269 .................

Gulf coasts, are present [stom warnines and isplays loy Hag ancl lantern hest that can be deviserl for". (Smith). "1s49. 12. 27 ..

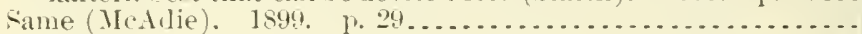

Gulf States:

Fig culture in (Earle). 1s97. p. 23...................

Forage plants and forage resources of (Tracy). 1sets . . . . . . . .

Fruits, tropical and semitropical of (Reasoner). 1\% 7 .........

Gulf strean. Drift of, near Key West, Fla, note on (Abbe). 1900.

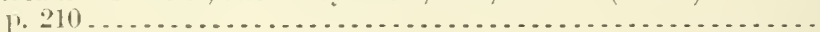

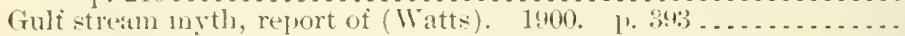
Gullie, F. A.:

- igricultural experimentation, estahlishment of official methous

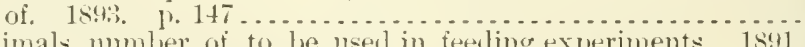

Animals, mumliey of, to he userl in feeding experiments. 1s\$1.

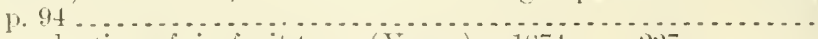

Gum, prometion of, in fruit trees (Vasy). 18it. 1).2...... Gum aralic. Sie Dextrine.

(imm, Janes. Weather forecasting, longr range, in Canala. 1syg.

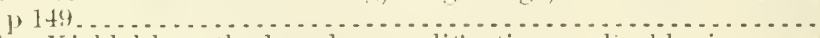

Gumnins-Kjeldahl method and a moditication applicable in presence of nitrates (Voorhees). 1852. p. si ..............

Gurler, 11. B. Swine breeding, experiments in. 18s3. I. 155....

(inthrie, (), ian. Water level, fluctuation of, in the tireat lakes.

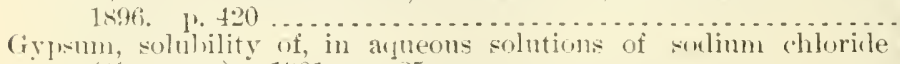
(cancron). 1901. 1). sime, of certain electrolytes (Canteron and ceilell). 19k1. p. 46. 12ti.3:1s ivpsy-motl. Sre (iipsy-noth.

Ilahana, Cuba. See Havina.

* By a misprint, this jagc number aplears twice. 
Hacienda Perla, I'uerto Rico, meteorological observations at (Hansarrl). 1898 .

Hackett, Artluur E:

Climate and (rop service weekly bulletins, should remarks of cor-

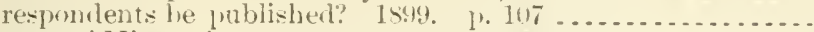

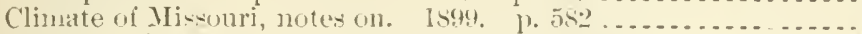

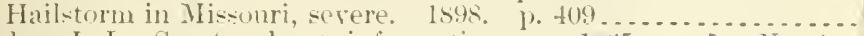

Harlen, J. J. Snut or lumt, information on. 1s6.5. p. 5. Xig. 2 ..

Hageman, t)scar. Mileh cows, metabolism ot, investigations on.

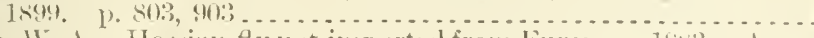

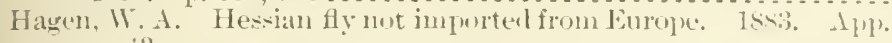

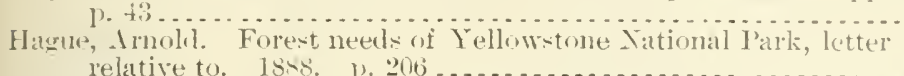

Hail:

A verage frequency of days of, during 1893-1s.7 (De Rienser ant

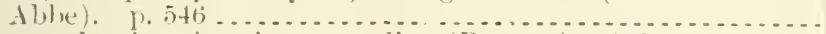

Damare by, in spite of (ammonaling (Pernter). 1901. p. $117 \ldots$

Destruative, frequency and extent of, note on (Abb:). 1900. I)

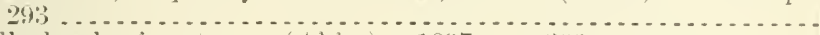

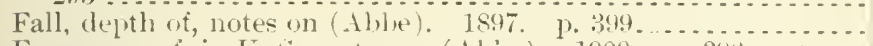

Frequency of, in L. .., motes on (Abie). 1900. p. $39 \% \ldots . .$.

Popular queries about, witl answers (Kimball), 1901. 1. 422..

Prevention of, by cannonading (Abbe). 1900. p. 251 ........

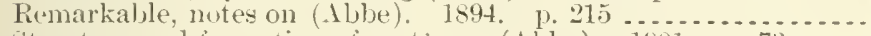

structure and fommation of, notes on (Abbe). 1901. p. $73 . . .$.

Hail and a rain gange fur it measurement (Abbe). 1898. I. 210 ..

Hail and its methode of formation (Abbe). 1900. p. 156 ........

Hail anil thunclerstomis in Oregon, notes on (Abbe). 1901. 1.26:-

Hail cloukls, bombarding, notes on (Abbe). 1900. p. $542 \ldots . . .$.

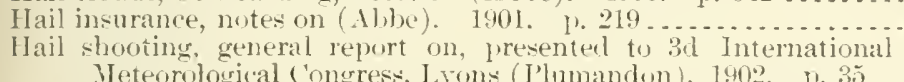

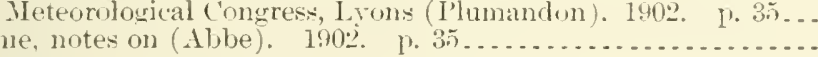
Hailstone:-:

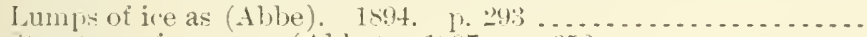
stracture of, note on (1hbe). 1897. I. 352

Hailstorm:

Bombardment of, notes on (Abhe). 1901. 1.176...

Clom thenomena attending (Very). 18.4. 1. 292.

st. Lawrence River, notes on (Alibe). 1901. p. 506 ........

severe-

at st. Louis, Mo. 1902. 1\% $48 \overline{1} \ldots \ldots \ldots \ldots$

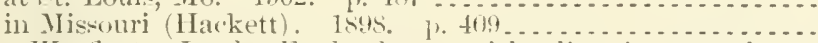

Haines, Warfleet. Leeds, England, c'nt of hauling farm proiluets

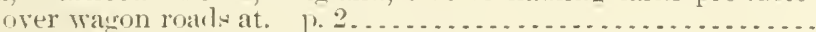

Hair balls. Sie Crimson clover hair balls.

Hairy caterpillars, destruction of, ly birds (Forbush). 1899. 1. (4).

Hairy reteh. See Vetch.

Haiti, weither burean service in, note on (Able ). 1900. 1). 24t....

Hale, Edwin II. Ilex easine, aboriginal Nortl American tea, it: bistory, distribution, and use aneng native Torth Anerican

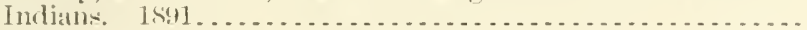

Hale, J. H. Peach culture, notes on. J.50 ..........

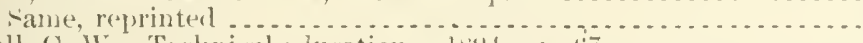

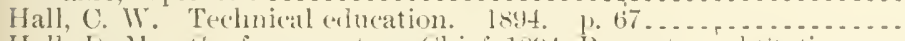

Hall, I. 11. Tee, for reports as (hief, 1s9t, P'roperty and -tationery Division, Agriculture lepartment.

Hall, Frank H.:

Agriculture and agricultural seience, some looks on, published

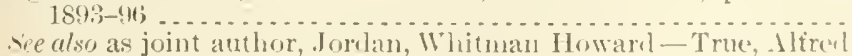
Charkes.

Hall, Maxwell:

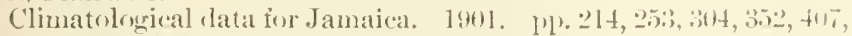

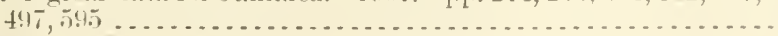

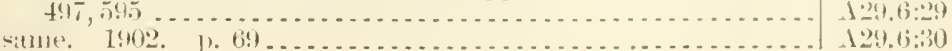


Hall, Maxmell-Continued

Jinlaica weather burean service. 1895 . p. 303.

snn-spot ferisd and temperature and rainfall of Janaica. 1901.

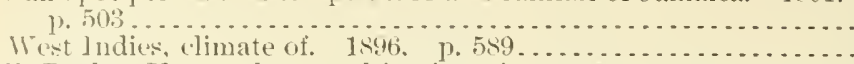

Hall, Ruth. Jlouse plants, enltivation of. 1) $366 \ldots \ldots \ldots \ldots \ldots \ldots$ A1.1:663

Hall, William H. Catalpa, hardy, in commercial plantations. 1902. A13.3:37

Hall, litlliam L. :

Fonest extension in Mirdle West. 1900. 1. 145.

Timber resonres of Tebraska. 1901. 1. $207 \ldots \ldots \ldots \ldots \ldots . .$.

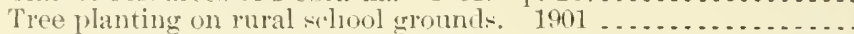

Hall, II. IT:

Farmers families, health of. p. 453

Farmere' houses, plates and plans for. p. 313

A1.10:900

A $1.10: 901$

A1.9:134

A1.1:66:2

Halle, Germany, agricultural experiment station at:

Aparatus and methods of analyss employed at. 1s95. p. tin..

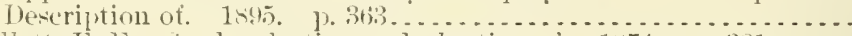

Hallett, F. F. seed, selection and planting of. 187. p. $381 \ldots .$. Halos:

Metroit, Mieh., May, 1900 (Hooper). p. 202.

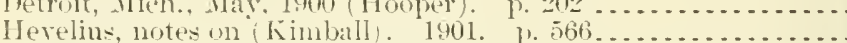

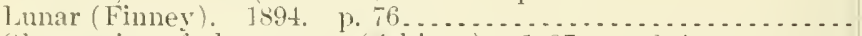

Observation of phenomena (ichipps). 1897. p.24t.........

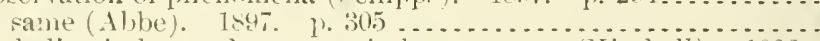

l'arhelic cireles, and contact circles, notes on (Kimball). 1902.

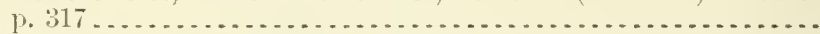

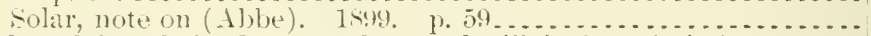

Halsteail, Marshal, Eggs poultry, and milk in Great Britain. p. 508.

Halsterl, Byron Diricl:

Cranberry scald and cranberry gall fungus, treatment of. 1891.

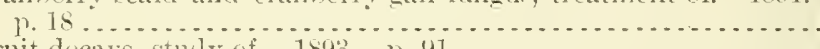

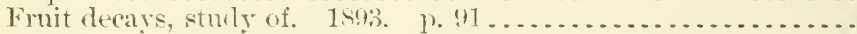

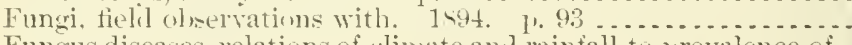

Fungus diseases, relations of elinate and rainfall to prevalence of.

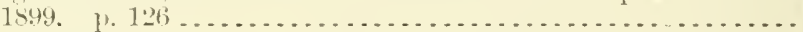

Peronusporese economic, for 1889 in Xew Jersey, some notes upon.

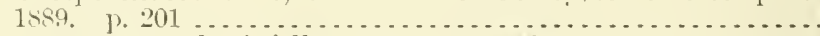

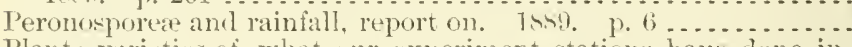

Plants, rarieties of, what cur experiment stations have done in originating, hy erossing, selecting, ete. 1901. p. $143 \ldots . . .$.

Solanli [sum] printing. 1s94. p.93 ..................... Sphærotheca, another, nyon phytoptus distortions. 185\% p. 134. Spherotheca lihytoptophila, notes upon. 1889. p. s. ........

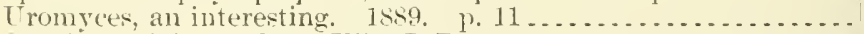
see ulso, as joint author, Ellis, J. B.

Halsted, Byron David, and Fairchild, David Grandison. Sweet-

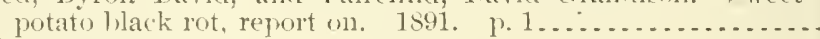

Ifamburg, (iermany:

Agricultural exhibition at, 1863 (Neerham). p. 19 ...........

American dried apples in, 1sy4 (Robertson). p. 12.............

Butter and cheese markets in (Ashby). 1.22:3............

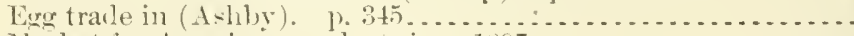

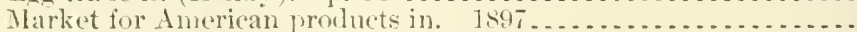

Ilamburg International Exhilition (live stock), 1s.3:

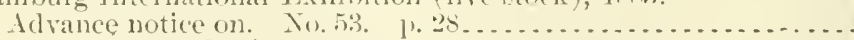

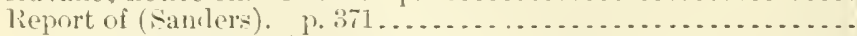

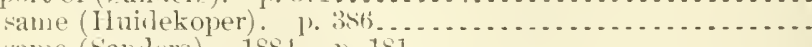

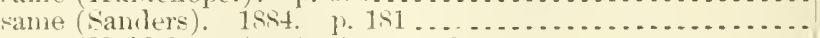

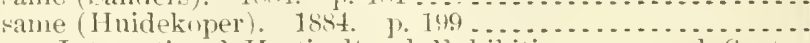

Jambury International Horticultural Exlibition, jroposed, Sept.,

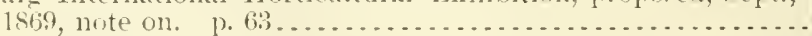

Hamilton, John:

Agricultural education, address on. 1896, r. to

Entomologinal Commision, L. S., fifth report of, comments on.

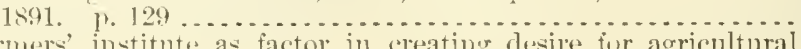

farmers institute as factor in creating desire fir agricultural (ducation. 190:2. p. 68.

A1.1:563

110.6:5

A10.6:5

12:-9:12

A $29.6: 28$

A $29.6: 29$

A.29.6:2:2

$129,6: 25$

A29.6:25

A29.6:30

$+29.6: 27$

14.1:900

A2S.5:6

A $10.3: 16$

A10.3:20

$110.3: 165$

125.5:5

A2S.5:

A10.3:99

A10.3:20

A28.5:5

A28.5:5

A $26.5: 5$

A28.5:7

A1.1:86:

A T.3:45

At.1:\$99

14.1:899

112.4:14

A $27.9: 20$

A 4.1:854

At.1:Nst

1+.2:An5

A $4.2:$ : 115

127.9:7

А10.3:41

A9.7:t

A 10.3:120 
Hamilton, John-Continued

Pennsylyania's road sytem. 1901, 3. 25.................

Hamilton County, X. Y. Sep Hosner, Ralph -., and Bruce, Eugenes.

Hamlin, George H. Address of. before eonvention of National League for Good Roads, Washineton, 1893. p. $17 \ldots . . . . . .$. Hammon, William H.:

Frost, injury from, and methorls of protection. $1896 \ldots . . . . .$.

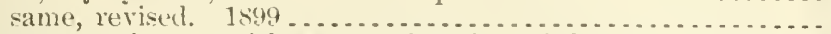

Kites, experiments with, at San Franciso, Cal. 1sit. p.248...

Tamalpais, Mlount, meteorological station, report on operation of,

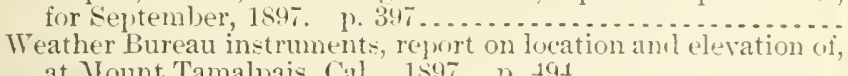

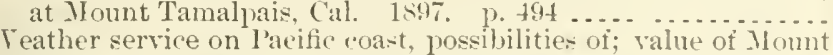

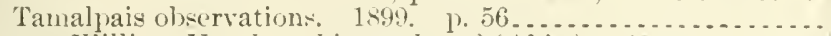
Hammon, William 11., short biography of (Able). 1s99, p. $102 .$. Hammon, William H., and Iuenckel, F. W. Temperatures, ninimum, abstract of comprarison of. recorded at [. S. Weather Bureau and Forest I'ark meteorological observatories, $t . t$.

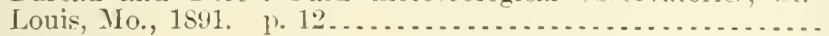
Hammond, Harry:

('otton-

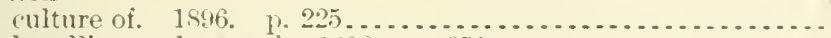

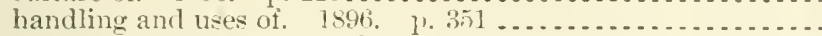

Hampton beach, X. H., tornado at. July $t$, 1898 (Sweetland).

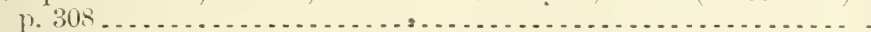
Hams:

American, in Germany (Barnes). 1). 519

('an+1) atlou no.

A:2:2:3:21

A10.:3:14

A 29.2:F92

$129.3: 2: 3$

$129.6: 24$

$129.6: 25$

A29.6:5

$129.8: 24$

129.6:27

A29.6:30

$110.3: 33$

$110.3: 38$

$129.6: 26$

A4.1:598

Insects affecting (Howard), 1896, b. 100 .

Handy, Rołert Breckenridge:

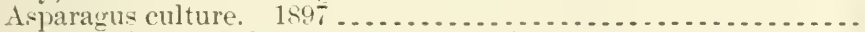

Cotton, history and general statistics of. 1s96. 1. 17.......

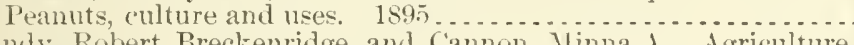

Handy, Rohert Breckenridge, and Cannon, Jimna A. Agrieulture Jejartment publications, from 1840 to June, 1901, list by titles. 190.2

Hanford area, California, soil survey of (Lapliam and Heileman). 1. $44 \pi$

Hann, Julius:

Atmosphere, upper, sturly of, from olservations on mountain sta-

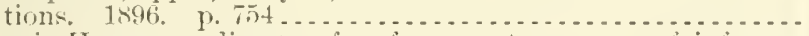

Anstria-Hungary, climate of, references to sources of inforna-

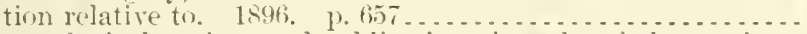

Weteorological stations and publication of results of observations.

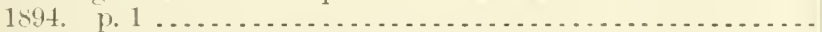

Ieteorology, text-bork of, note on (Ahibe). 1901. 1. $74 . . .2$.

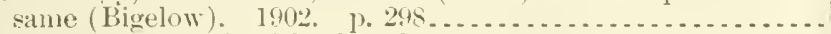

Rainfall, increase of, with altitude above sea level. 1902. II]. 218,227

Hann's handbok of elimatology, note on (Harrington). 1 sis.

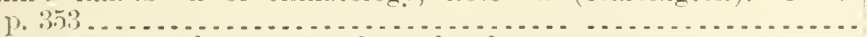

Hanna, Jiareus Alonzo. Southem develolment. 1902. p. 5.; .... Hanover, Germany. Cost of hanling farm products over wagon

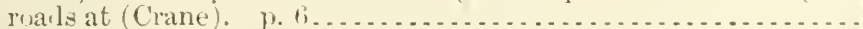

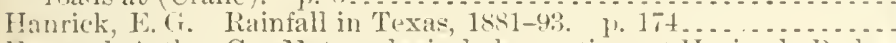

Hansarl, $\Delta$ rthur C. Ileteorological observations at Hacienda Perla,

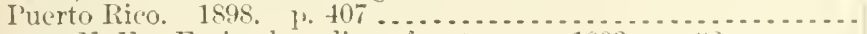

Hansen, N. E. Fruits, breeding of, notes on. 1893. 1. 1.2.......

Harhaugh, W. II.:

Cattle-

heart and llood vessels nif, diseases rif. p. T. . . . . . . . . . .

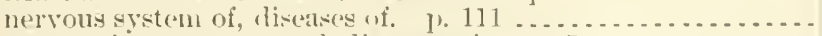
Horse, respiratory organ of, diseases of. 1. si .............. North Carolina. 1. 209 . . . . . . . . . . . . . . . . . . . . .

IIardin, XI. B. Cotton-seerl neal, metaphosphoric and pyrophos-

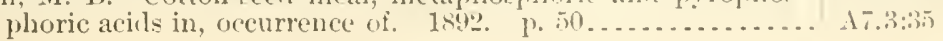


Ilamline, Charles. Great Britain, clinute of Britisls Islanels. $1 \mathrm{~s} 9 \mathrm{o}$.

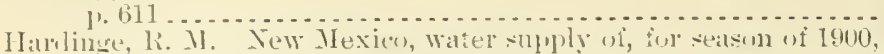

Harlwools, sonthern, working plan for and its result- (Foley). 1901. 1. t71 . Te.....

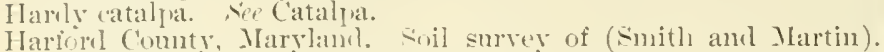

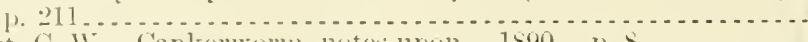

Harutt, C. IV. Cankerwom, notes upon, 1890. p. S ..........

llarkness, William. Stars, shonting, hints to olselvers of. 1899.

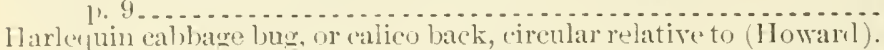

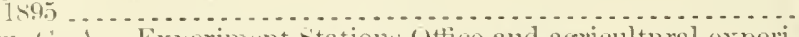

Ilarlow, (т. A. Experiment stations (otfice and agrienltural experinent stations, list of unblications of, 1885-99. 1900. p. 508.

Ifarmon, Jolın H., short bineraphy of (Williams). 1899. 1\% 107... Ilammlen, Enos $s$. See for report as sperial agent on purchase and

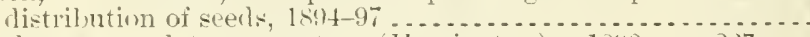

Harpiphorus maculatus, report on (Harrington). 1890. p.227 ... Harpont, Turkey in Asia, climate of, 1s95-1900 (Huntington). p. 250

Harington, Mark Walrod:

Climate and meteorology of Death Valler, Cal., notes on. 189:2.

('limate of P'nerto Rico. 1898. 1) 4:37 . . . . . . . . . . . . . . . . .

Forest meteorological olservations, review of, a study prelininary to discussion of relation sf forests to climate. 1593. 1. 23...

Fruits, regetables, and other food prorlucts, protection of, from injury by heat or cold during transportation. Is?t . . . . . . . .

Great Lakes, currents of, as defuced from movements of bottle

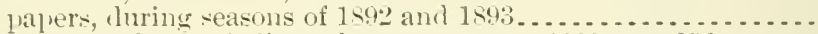

Hann's handhook of climatology, note on. 1898. p. 353 .....

Ieteorological work of agricultural experiment stations and arrioultural colleges, and their relations to Weather Bureau.

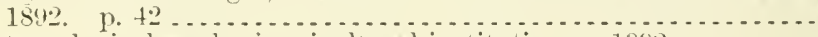

Veteorological work of arricultural institutions. 1892.........

Heteorology, what it is doing for the farmer. p. 117 ........

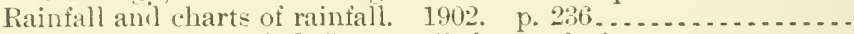

Rainfall and snow of $\mathrm{U}$. S., compiled to end of 1891 , etc.........

Weather map, history of. 1895. ]' 3.7 ................

te also, for reports as Chief, Weather Bureau, Agriculture Department, 1891-1894

Harrington, IV. Hague. II arpiphorus maculatus, report on. 1890.

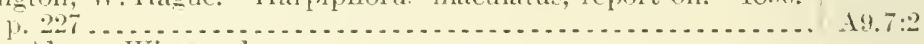

Harris, Abram Winegardner:

Arliress of, as president of Association of American Agricultural Colleges and Experiment Stations, at 15th annual convention. 1901. 1\%. 41

Agricultural experiment stations-

at World's Columbian Exposition, report on. 1s91. p. $43 .$. collective exhilit of, at Paris Exposition, 1900, committee report on preparation and care of. 189s. 1. 43. cooperation with IT. S. Weather Bureau, report of committee

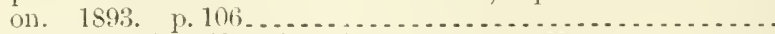
jublications of, muiformity of, rejort on 1894 p. $30 \ldots \ldots .$.

Churches, relation of, to state collewes and universities. 1s?9.

14roticulturist of arricultural experiuent stations, report of meeting at Columbus, Ohio, June $13,14,1889$

se also, for leports as lirector, lixperiment Stations Office, $\mathrm{I} g-$

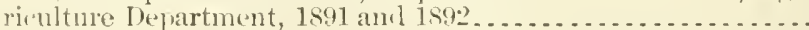

Sor rekn, as edlitor of proceedings, Igrioultural Colleges and Exjerinent Stations, American, Association of.

Harris, Joseph. Stall-feeding (attle and sheep. p.317.

Iarris, liollin Arthur:

Ocean ti.les, principal, partial explanation of someof. 1900. 1.103. Oscillation perior of lake Erie, note on. 190:. 1\%:312. . . . . .

ג:9.3:11 3

A29.6:28

$.11 .10: 901$

A26.5:9012

19.7:3

129.6:27

$-1.5 .5: 10$

110.3:50

A $29.6: 27$

124.5:

19. $7: 2$

129.6:20

\$29.3:1

129.6:26

113.3:

129.2:F94

A $29.5: \mathrm{B}$

A $29.6: 26$

110.:3:7

1 10.:3:10

11.10:S84

A29.6:30

A29.5:C

A29.3:112

A29.1:

110.3:115

A10.5::

110.3:4:9

A10.3:16

A 10.3:20

A10.3:65

A10.3:3

A10.1:

1 1.1:86:2

A 29.6:28

129.6:30 
Harris, William Torrey. Amrinulture, teaching of. 1595. 1. 43... Harrison, Elmund ti:

Macallan roals, revairs of. 1595.

Stone roats in Now Jerser. 1895. J.

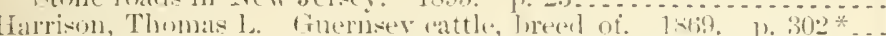

Hart. C. 1 . Wireworms, life listory of. 159]. 1. 246.........

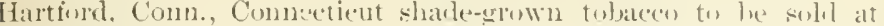

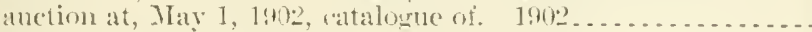

Hartig, Dr. White fir, disease of. liss. p. ltit ................

Hartley, Charles i'. Jollination, premature, injurions afferts of, with general notes on artifieial pollination and setting of fruit without pollination. 190?.

Hartwell, Burt L. J'otexperinent Lo test held observations ancerning soil deficiencies. $1901 . \quad$ I. 7: . . . . . . . . . . . . . . . .

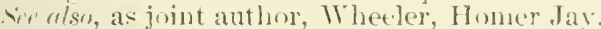

Harvarl and Yale boat crews, dietary sunies of ( Itwater ant

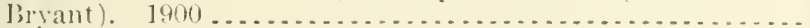

Harvari '[niversity, meteorological station of, note on (iblue): 15\%?. ए. 540. 1901. 1) 69

Harwi, H. J. Live-dock industy, condition of, of Tebraska. I.

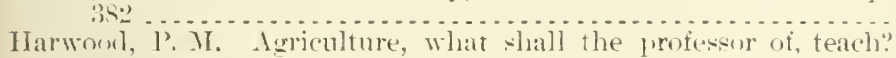

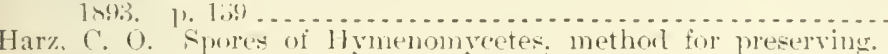
18.9. ए. 16:3.

Hassall, Alluert:

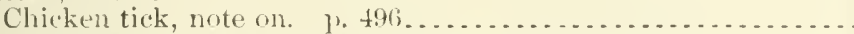

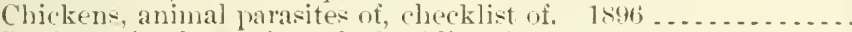

Ducks, animal parasites of, rhecklist of. $1890^{\circ}$.

Flukes and tapeworms of cattle, sheep, and swine, bibliography

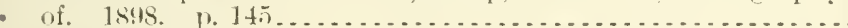

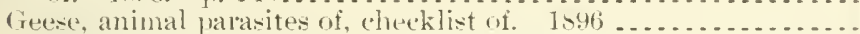

Parasites of cattle, sheep, aml swine, compendium of, arranged

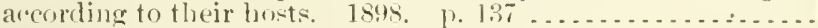

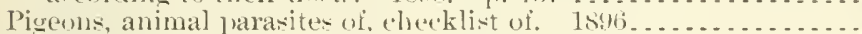

Surra and allied trypano-omatic diseater, biblingraply of. p. 1 tid same, p. 1.81

Tapeworns of poultry, hibliography of, isib, p. si..........

Triehinosis in Germany, hihliegraphy of. 1901. 1. 198. ......

Turkers, animal parates of, checklist of. $1846 . . .6 . . .6$.

sie ulso, as joint anthor, Stiles, Charles Wartell.

Hasse, Adelaide Rosalia. List of publieations of Agrienlture he-

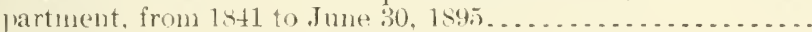

Hateful grassopper. sin Grashoper.

Hank, Jannes Wr. Sorr, at joint anthon, Mrelean, I.

Hanling. Ser Farm problucts.

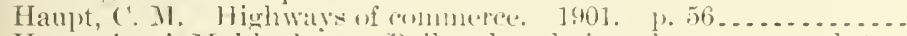

Haupt, Lewis Mulnlenhererg. Ratilroarls, relation of eommon roals to. $1 ! 102 . \quad 1 \% 61$

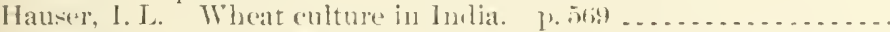

Hantrenx, A. North Atlantic anrents and surfice temperatures. $1894 . \quad 1.392$

Havalia, (ulba:

Climatolong oi, monthly untes on-

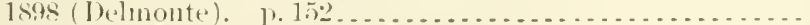

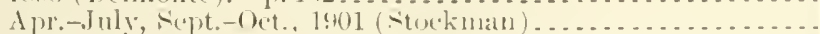

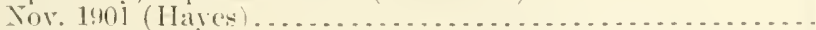

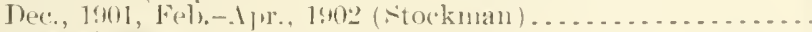

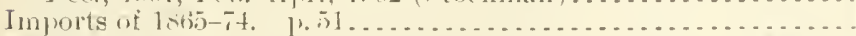

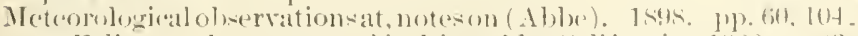

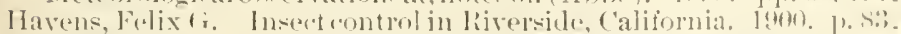

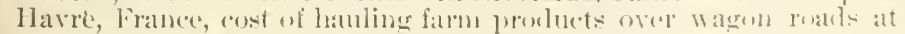

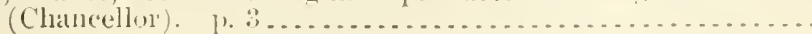

* By a misprint this piece number appesa twice.
$1111.3: 24$

1.2.2. $4: 30$

1.2.:.3:17

$127,9: 7$

$19.7: 5$

$12+1,2: 1,5$

$12(5,5)$

$119.8: 2 \cdot 2$

$17.3: 1: 2$

$110.9: 75$

129.6:25

1.29.15:2?

$12-4.8$

14.1:45:14-90

110.:3:16

1ㄴ.5.5

At.1:549

At.t:9

14.4:13

1t.3:19

14.t:14

At.3:19

At.4:15

14.1:901

At.3:42

1 $4.8: 12$

1 $4.8: 30$

1. $4: 12$

$117.3: 9$

120:8:21

A2:2:8:2:2

11.1:545

1:29:3:11

$12960: 25$

1:2019:40:241

1:29.4:2!

1:3iti:

1:-7.4:1\%

$1: 09.6: 26$

19.6:2:?

$12: 2.4: 27$ 
Have, Montana:

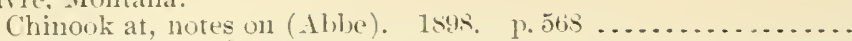

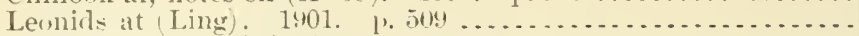

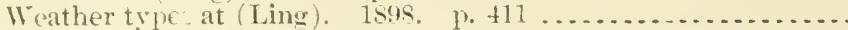

Hawaii:

Agricultural investigations in (Evans). 1901. 1\%.50:.

Agricultural resources and (apabilities of (stubbs). 1901

$129.6: 26$

A29.6:-29

$129.6: 26$

Agriculture in, ete. (Iaxwell). 1894. 1.563............... . . Central tmerican coffee li-ease, langer of jntrolucing into

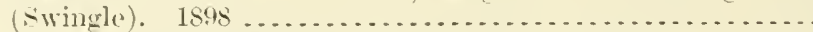

Chickens and their diseares in (sedgwick). litol ............ Climatological data, monthly, May, le0l-1)et, 1902 (Lyons) ....

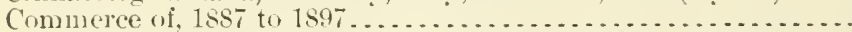
Farmers' institute work acomplished in (True), 1902. 1, 3.3... Irrigation in, report on (Maxwell). 1900.................. . . Teteorology in (Kimball). 1902. p. $364 \ldots . . . . . . . . . .$.

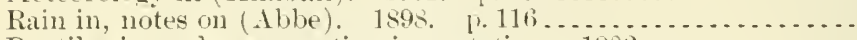
Reptiles in, wrer preventing inportation. 1902............ Sribs of, estimation of lime, potash, and phosphoric acirl in (Maxwell). 189s. Standarel of time, notes on (Ablue). 1900. 1.207........... Sugar of, improtation of, possible influence on beet-sugar pro-

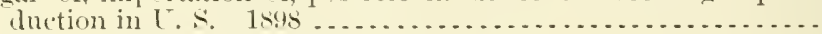

Tolcanic ermptions in, report on (Lyons) $189 \%$ 1899 P.

Weather of, for Feb., 1901, notes on (Ab) $)$. 1. 17t ......... See also Honolulu.

Hawaii Agricultural Experinent Station:

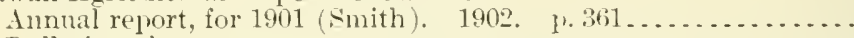

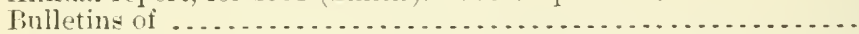
Hawes, Juhn B. Flax culture in Austro-Hungary. 1892. 1. 55 ... Hawkins, Barry C.:

Appalachians, southern, area of, heary raintall in. 1897 . 1). 442.

Blue Ridge, sonthern, and Piedmont region, northwest gales of.

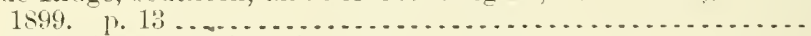

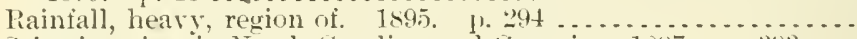
Seismic noises in North (arolina and Georgia. 184\%. p. $393 \ldots .$. Hawks, A. Mc.L. Fog, utilization of, report on. 1899. p. 101 ... Hawks, Emma Beatrice. Poultry, billiography of. $1897 \ldots . . .$. Hawks ancl owls:

Erroneous illeas concerning1895. P. 590. 1896. 1,. 628 .

Food of. 1\%. 40:' same, 1 . 402

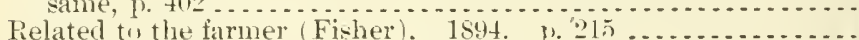

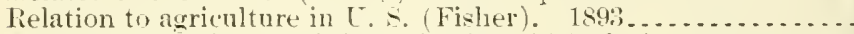

Hawthorn fungi, microscol,icinvestigation of (Taylor). 1873. 1. 431 . Hay, Robert:

Artesian and mnderflow investigation between 97 th meridian of longiturle and foothills of Rocky Mountains, final geological reports on. 1893 . Pt. 3 .

Artesian and underflow investigation, progress report. 1s91. $\}$.

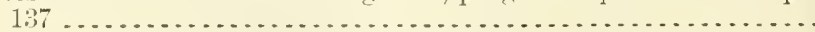
Hay:

Artesian wells, investigation, geologist's report. 1590. p. $37 . .$.

Imoment and value of, reckoning of. 1s9s. p. 669 ..........

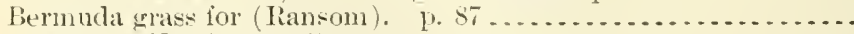

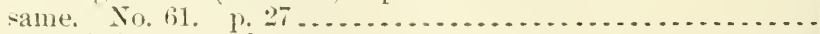

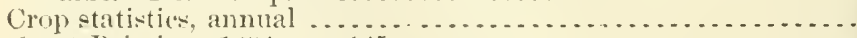

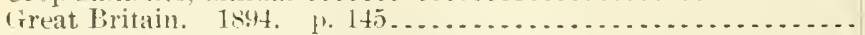

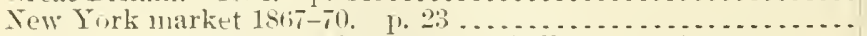

Salt and fresh water marsh, report on (Allen). p. $296 \ldots . . . . .$.

Salt-marsh, abundant growth and feeling value of. $1898 . \quad 1 \% 16$.
syontaneons combustion of (Langwortly). 18\%9. See also Alialfa hay - Crops, principal - Ilash hay.

11.10:901

$110.3: 95$

A 1.10:\$98

A2S. $4: 16$

A 10.9:1

A29.6:

$+12.4: 18$

A 10.3:120

$+10.3: 90$

+29.6:30

A29.6:26

+5. $4: 36$

17.3:56

+29.6:28

A1.4:

A29.6:27

A $29.6: 27$

A.29.6:29

$110.1^{2}: 901$

110.9:

A11.5:4

ג29.6:25

A29.6:27

A29.6:23

129.6:25

A29.6:-

$117.3: 1 \mathrm{~S}$

A $1.10: 895$

+1.10:896

A1.1:S57

d.5. $1: 887$

A1.10:8:14

A5.3:3

127.9:11

115.2:Ir-"

A15.2:P94 ${ }^{1}$

A $15.2: \mathrm{Ar} 7$

11.10:59s

A1.1:853

127.9:21

A27. 1:

A27.9:33

A27.9:9

11.1:\$76

A $1.9: 8 t$

11.9:105 
Hay-making. 1s6t. No. 4. r. 6

127.9:3

Hay-worm. See Clover hay-worm.

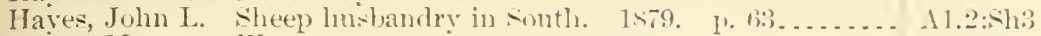

Hayes, IIontrose $1 \mathrm{~K}$ :

C'limatology of Havana, Cuba, note on, Tov. 1901. 1. 491 .... . 1:9.6:29

Industries of C'nba and other' islands of West Indius, value of climate and crop and storm walluing serviees of Weatler Bureau to. 1902. 1,.58.

Hayes,. II. T. Fertilizers, mixed, organic nitrogen in, avilability

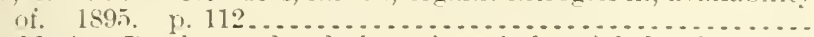

Hays, M. A. Roakl, goorl, relation of, to industrial development. $1902 . \quad 1 \%$. 78

Hars, Willet if:

Agricultural colleges, prepanatory work in. 1s98. p. 6.5......

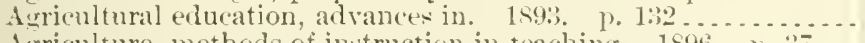

Agriculture, methods of instruction in teaching. 1896,

Cirass gardens, methuds and purposes. 1893. p. $130 \ldots \ldots . . .$.

I'lant and animal breeding, progress in. . 1901. $\quad 1.217 \ldots \ldots \ldots$.

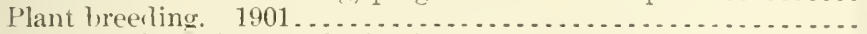

Plat experimenting, methods of. 1596. [1. $84 \ldots \ldots \ldots \ldots \ldots . .$. Hayti. Sie Port au P'rince.

Haiwood, J. K.:

Irsenical insecticinles, report on. 1902. 1.96........... $17.3: 67$

Insecticintes and fimgicirles-

chemical composition and effecticeness of rertairi prepart-

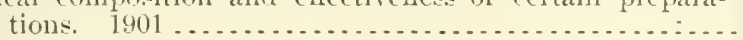

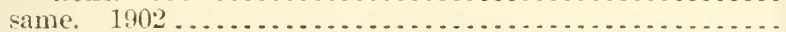

methods for chemical analysis of $1902 \ldots \ldots \ldots \ldots . . .6 . . .6$.

soluble arsenic in arsenical insecticices. $1902.11,51 \ldots . . . . .$.

Hazard, Willis P. Channel Islanels, the people and their rattle.

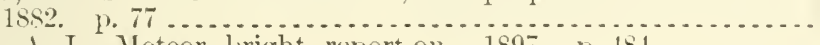

Hazen, A. J. Meteor, Jight, report on $189 \%$ p. $484 \ldots \ldots . . .$. Hazen, Flenry Allen:

Itmospheric pressure-

high and low, monthly report on, June, Nov., Is95-Nov., 1899. low, effect of, in determining weather conditions in upper

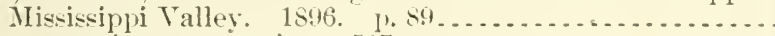

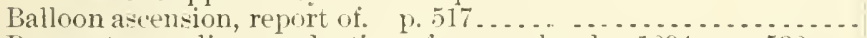

Barometer realings, recluction of, to sea level. 1894 p. $538 . .$.

Barometric troughs of platean region, report on. 1895. 1\%.207..

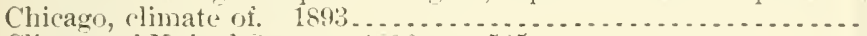

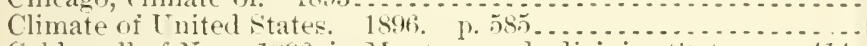

Cold spell of Nov., 1s96, in Montana and arjoining states. p. 414.

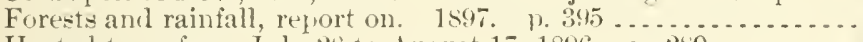

Heaterl term from July 24 to August 17,1896 . 1) $289 \ldots \ldots \ldots$.

Hÿrometric observations, utility of. 1s:19. p. $164 \ldots \ldots \ldots \ldots$.

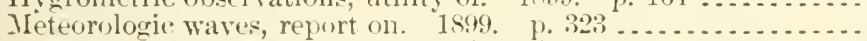

IIoisture in Cnited States, distribution of. 1899. p. $327 \ldots \ldots .$.

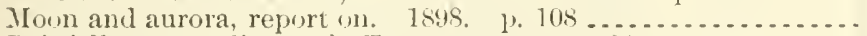

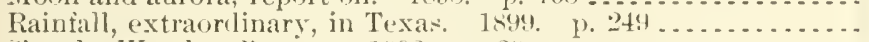

signals, Weather Burean. 1892. 1). 39 ... . . . . . . . . . .

Storms-

local, in United States during 1890,1891 and 1892. p. 505...

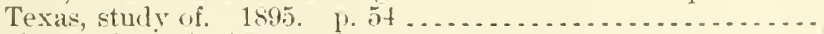

violent, in United itates for 1894 . p. $28.3 \ldots . . . . . . . . .$.

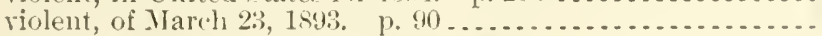

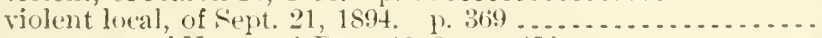

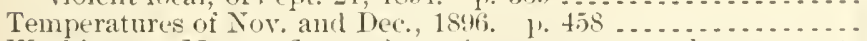

Washington, Mount, fluctuations of temperature and pressure at hase and summit of, $1871-86$. 1\%. 171, 199, 224, 250.

WV

Weather forceasts, long-ranes can they be marle with sulfieitont precision to be of grenemal utility? is99. p. $43 \ldots \ldots . . . . .$.

West Indian storms, relative intensity of. 1894. 1\% $333 . . . .$.

Wind-rush at Washington, 1). C., rejit, 29, $1896.1 \% 32 * 2 . . .$. Hazen, Henry Allen, short biography of (1Jile). 1900, p. 14.... 
IIazen, . I. : :

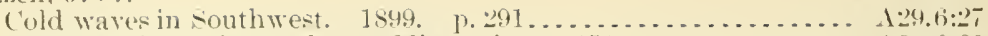

l ronerht of 1899 in southwest Misomi. p. $151 \ldots \ldots \ldots \ldots \ldots \ldots . .104 .6: 28$

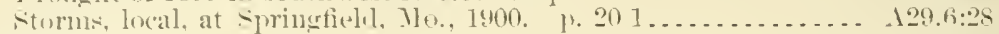

Health:

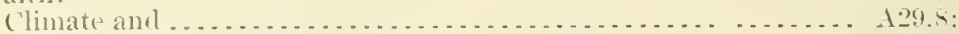

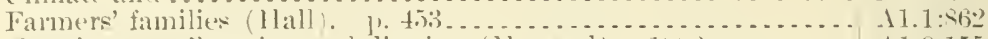

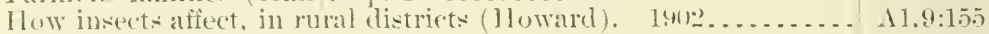

l'eoples:-

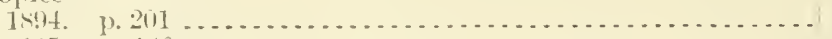

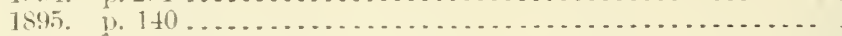

1:7.9:32

$127.4: 33$

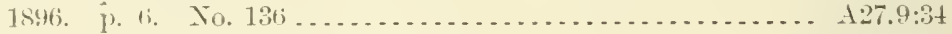

Public-

ambl meteorology, relation between (l'hillips). 18:5, 1\% 1,1.. $129.6: 23$

relations of hovine tulereulosis to (calmon). 1901 . . . . . . . 14.3:33

State board of, experimmt station veterinarian as nember of

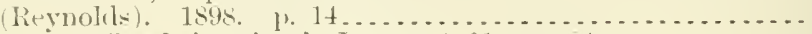

Heaps, 1. $i_{i}$ Road situation in lowa. 1!n1. p. $61 . . . . . . . .$.

Heam, If. Edward. Se, as joint author. Coliey, George $Y$.

Ileart, disedses of:

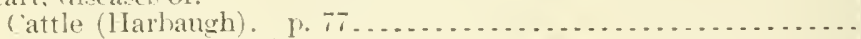

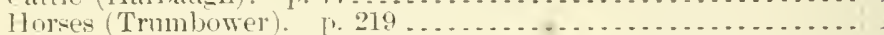

A $1.3: 22$

12:.8:21

Heat:

I) ronght, and insect life (Mnrtieldt). 1902. 1. 97..........

Our killing, report on (Abluot). 1901. 1. $371 \ldots . . . . . . . .$.

Ratliant-

for prevention of frost, notes on (Ahbe). 1549. 1. 156.....

measurement of, noten (Abive). 1900. p. $108 \ldots . . . . .$. see also llarm waves.

Heat equiralent of mutrients of ford (-tolmann). 1896. 1,.590....

Heat rarliation of stars. note on (Abbe). 1s99. 1. 472. . . . . . .

Heaterl term from July 28 to Aug. 17, 1896 (Hazen), 1. 289......

Heath, Il. 1.:

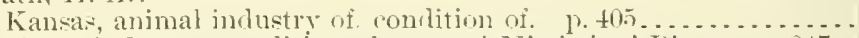

Sheep industry, condition of, west of Mississippi River. p. 2t7.

Heath, H. A., and Yinto, Tohn. Sheep industry west of Mississippi River. 1892. (Chapters 1-4, by Heath; whapter 5, by llinto.)

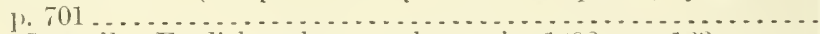

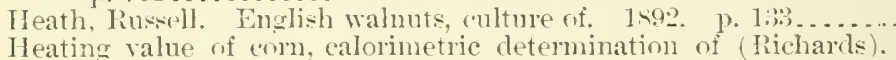
18. 1.95.

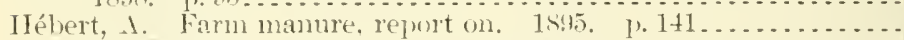

Hedges. tre ( sage helges - 1 ) sage orange.

II

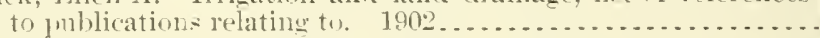

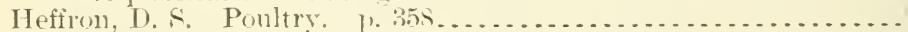

Hehmer nethoul. Sie Van Silyke, Lucius Lincoln.

Heifer heref. Sire Beef.

Heiges, Samuel B. See, for reports as Pomologist, Pomolngy Trivision, Agriculture Dejartment, 1594-1,96 ...............

Heileman, Tr. H. tre, as joint aththor, Lalliam, Mary H.

Heileman. W. Il., and Jlesmer, Lnni-. suil survey of Lake Charles

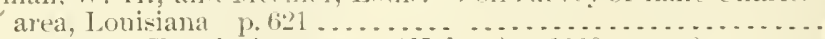

IJejena, Mont. Fungi tif, motes (Kelsey). 1ss9. 1. st.......

Heliothis amigera. See Bollworm.

llellmann, G.:

Ieteorology and terrestrial magnetism in 15th, 16th, and 17th centuries, contribution to bibliography of. 18.45. 1, 3.52...

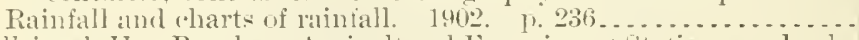

IIellriogel, I1. Bembere Agricultural Jixperiment Station, sand cont-

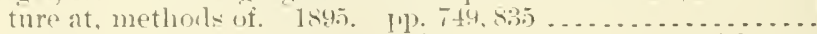

Hemenway, 11. 1). Hydrocyanc-arid gat, experiments with, as means of externimating nealy bugs and other insert pests in greenhonses. 1900 . p. 69. . . . . . . . . . . . . . . . . .

$1+2:\left(209^{2}\right.$

14.2:117s

A.6.6:31

+29.6:29

$129.6: 27$

A.4.6:28

110.6:6

A $24.6: 2-$

A.4.6:24

A $4.1: 589-40$

14.1:589-90

1t.2::h $t^{2}$

A1. $5: 20$

A10.3:49

$170.6: 5$

117.3:41

11.1:862

$.20 .1:$

A26.5:901 ${ }^{1}$

129.5:5

1.24.8:112

1:9.6:30

A10.6:5

$19.6: 22$

Hemiptera. Sie Heteroptera.

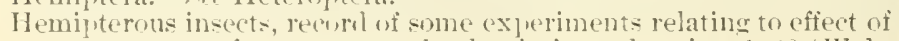
jumeture of some, mpon shrubs. frut, and grams, listo (Weh-

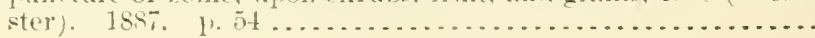


"Hemlock reds," report on experiments with (Inurty). 1s9t.

Hemp: 1. 2010 . .

Crop of. 1isis. 1). 75.

Culture oi-

186:) ( Tradiord).

18.46 ( lodge

Europe, culture of (Dorlge). 1898

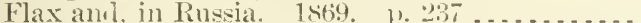

Growth of in Italy, spedal consmlar rejort on (iamiini). 1sit. p. 15 - $:$

Sep also Fibers - Flax - Manila hemp plantain - Sisal liemp.

Hemp industry in France (Dodge ). 1892. p. 27............

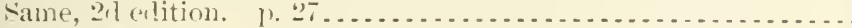

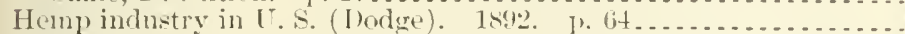

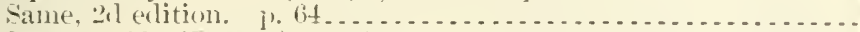

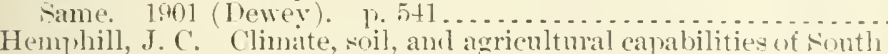

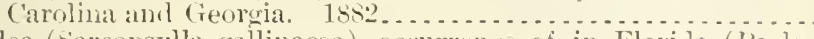

Hen flea (Saropsylla gallinacea), occurrence of, in Florida (l'ack-

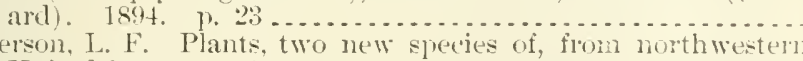

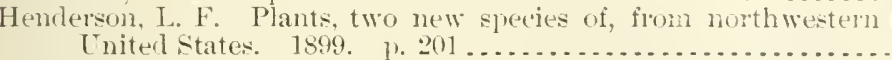

Henderson, Peter:

Mlialfa, cultivation of. p. $566^{\circ}$

Market garlenine in vieinity of New York p.

Secol, maturing, localities hest suited for. p. 572.

Hemepin Comnty, Mimn., gravel roals in, methoul of construetion

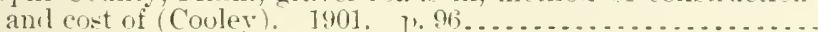

Henry, Alfred Judson:

didress as chairman, section of recorls and reports, before second comvention of Weather Burean officials held at Milwanke,

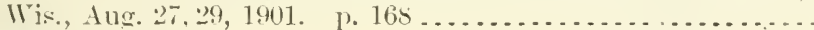

Alaska, climate of-

189\%. 1. 248

1899. 1). 50

American Forestry Assuciation, smmmer meetime of 1902 1. 401

Appalachians, sonthem, (ljuste of. jo 143.

Atmostheric disturlances, loral. 1898. J.589.............

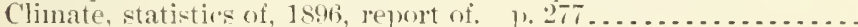

Clinatic conditions, general-

1898. 1). 595

$1899.21), 579$

$1900 . \quad 1 \% .587$

1901. 1. 592

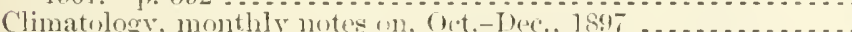

Clomel photograpley, report of. 189. 1) $169 \ldots \ldots \ldots \ldots \ldots \ldots \ldots$.

Clonds, wave op billow, report on. 1s99. 1). $57 \ldots \ldots \ldots \ldots \ldots \ldots$.

Cold Friday, date of. p. 545 . . . . . . . . . . . . . . . . . .

Date palm, climatic rlata bearing upom eulture of. 1sis. J. 160.

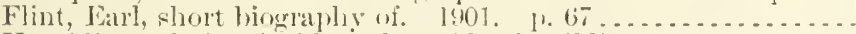

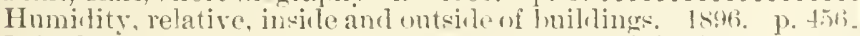
Lake levels, variations of, and atmospleric precipitation, 1sis.. Lake levels and wind phenoment, 1900, p. 20:3 ............. Lightning-

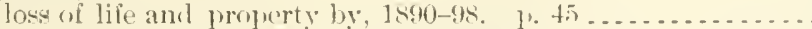
loss wif life loy, in L. . 1899. p. 100

-arra. 1900

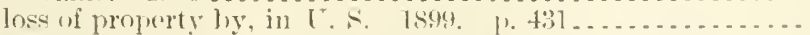

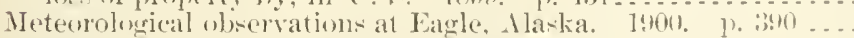

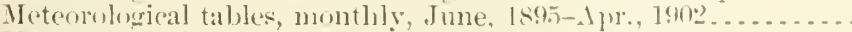

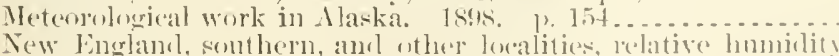

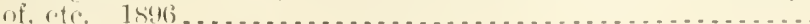

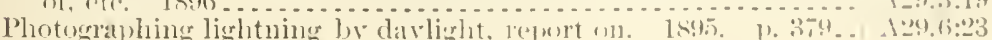

17.3:43

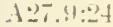

$11.1: 910.3$

11.10:\$4.

A11.5:

111.5:11

1:-7.6:7

111.5:11

12-7.4:1

1 1 1.5:1

127.8:1

A 11.5:1

A $1.10: 901$

A1.1i:4

A!..:

$16.5: 5$

A1.1:Dt

11.1:0ti5

A 1.1:878

$1.32 .3: 21$

$129.3: 31$

$129.6: 25$

A 10.3:6:2

129.6:30

A1. : : A 1 $4^{2}$

129.6:2015

A:29.1:597

$129.6: 26$

$12: 6: 27$

$129.6: 28$

$\therefore 29.6:-9)$

129.6:25

129.6:2:3

1:94. $1:: 27$

1.2(9.6:-27

1:29.6:215

$1: 29,(i: 29)$

1:29, $1:: 44$

12!1.2:115

129.6:20

-1:91.3:206

1:31) (i:2)

i:3(1.:3:30)

$1: 391,1 ;: 24$

$103,1: 28$

1:91.1:

$104010: 26$ 
Henry, Alived Judson-Continned

Precipitation-

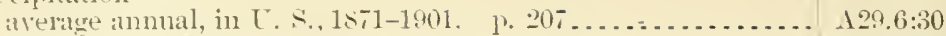

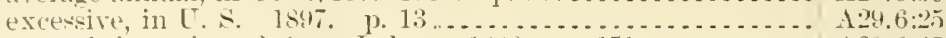
normal, in region of (ireat Lakes, 1899 . p. $151 \ldots . . . . . .$. A29.6:27

Rain gage readings, comparative, at Itlanta, ( ia. 1s99. p. 54\%. $129.6: 27$

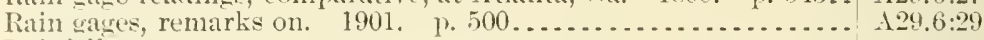

Ritinfall-

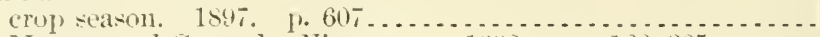

Iasiy and Granada, Nicaragua, 1598. 11) $162,305 \ldots \ldots$.

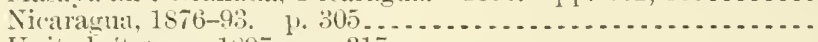

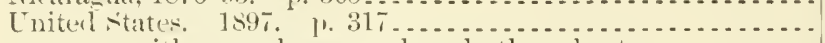

same, with ammal, reasonal, and other eharts.........

Rainfall and charts of rainfall. 1902. p. $2+1, \ldots . .2 .2 . . .2$.

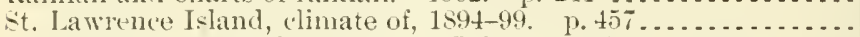

Storms, local, monthly report on, July, 1895 -sept., 1897 ......

sunshine and snowfali, normal annual. 1898. 1. 108 ........

sumshine at sonthem California agricultural experiment farm,

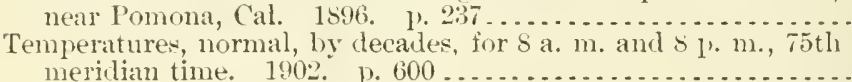

Thermometer readings, comparative, at Jew York, X. Y. 1900.

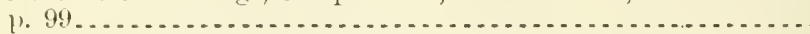

Thermoneters, maximum and minimum, should not temperature forecasts be verified by readings of? 1902. p. $134 \ldots \ldots . . .$.

Thunderstom of Sept. 17-18, 1595, report on. p. $535 \ldots . . . .$.

Thunderstorms, progressive movement of. 1s.6. p. 331 . . . .

Thunderitorms on Ang. 2, 1899, report on. p. $359 . \ldots \ldots \ldots . . .$.

Tormado photographs, spurious, report on. 1894. 1). $203 \ldots \ldots .$.

Tomarloes, 18s9-1896, report of. 1896. p. xxiii - ............

Tornadoes of A pril and May, 1896. P. $82 \ldots . . . . . . . . . . . .$.

WVares, lake-level pressure, surden oscillations in, 1s:49. p. 305 .

Weather Burean oflice, removal of, in New York City. 1895.

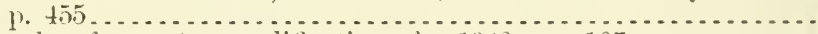

Weather forecasts, amplification of. 1900 , p. $107 \ldots \ldots \ldots \ldots$.

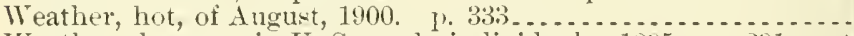

Weather observers in $\mathrm{U}$. S., early inclividual. 1895. p. 291 . . .

Weather of the month, Jan. 1S95-A pr., 1902 . . . . . . . . . . . .

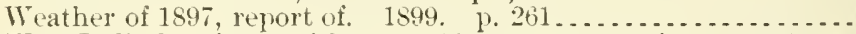

West India hurricane of Sept., 1896, notes concerning. p. 368 ...

Wind velucity and fluctuations of water level on Lake Erie. 1902.

Winters. Are oul winters ehanging? 1898. p. $540 \ldots . . . . .$.

Henry, W. A. :

Ailiress of, as president of Association of American Agricultural Collegres and Experiment stations, at th annual convention. 189. p. 38 . . . . . . . . . . . . . . . . . . . . . . . . .

Animals, physical conditions surrounding, in experimental feeding, especially as relative to stalls and mangers. 1891. p. 92.

Cattle, feeding and management of. p. 439

Entomology division, Agriculture Department, Pacific coast work

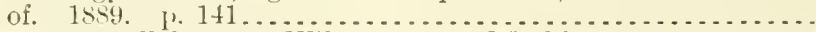
see rlso, as collaborator, Wiley, Harvey Washington.

Hens, laying, number of, that may be profitably kept in one pen

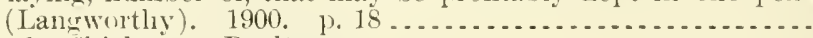
sire also Chickens- Poultry.

Hens' egres, food value of. 1899. 1. "2t ...................

11.10:597

A29.6:26

+29.6:26

129.1:\$97

129.5:D

A29.6:30

129.6:27

129.6:

A29.6:26

A29.6:24

A29.6:04)

A24.6:28

A 29.:3:31

+29.6:26

129.6:24

129.6:27

A29.6:27

A29.1:\$:16

+29.6:24

$129.6: 27$

A29.6:26

11.10:400

$+129.6: 28$

129.3:112

A29.6:

129.1:898

129.6:24

A $29.5: J$

A39.6:26

A10.3:20

110.3:-

$14.2: \mathrm{C}^{2} 9^{2}$

19.7:2

$11.9: 11 t$

A1.9:Svice alar Egus.

Hensluaw, Samuel:

Economic entomology, American, bibliography of more important contributions to-

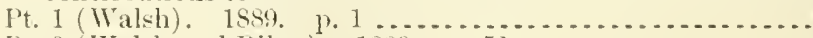

Pt. 2 (Walsh and Riley). 18s9. p. 51 . . . . . . . . . . . . .

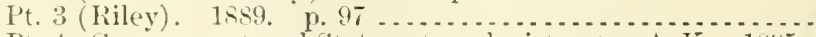

Pt. 4. Govemment and State entomologists, et:, $\mathrm{A}-\mathrm{K}$. 15,15

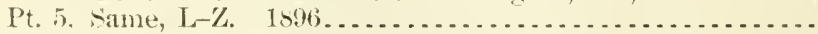

Entomolosical writings of Alpheus spring Packari. 18s7 ......

Gyosy moth in Massachusetts in 1891, report on. 1. 75 ........

19.2:P $47^{1-3}$ A9.2:B+7 ${ }^{1-3}$

A9. $2: \mathrm{B}+7^{-3}$

A9.2:B4t

$+9.2: B+7^{5}$

A9.3:16

19.3:26 
Hepatic mecidia oi rahbits. ce Fimeria stierle.

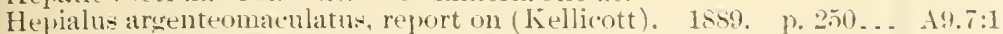

Hejworth, M. W. Campbell. Aurolal anst ralis of Airil 20, 1597, re-

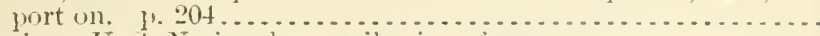

Herbarium, ¿. . S. Sational, contributions.from ................ . .

Herbarium for Forth Ameriea, north of Mexi(n), desiderata of,

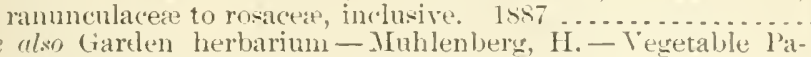
tholesy Division.

Herbarium jest, new, notes on (Riley). 1891. p. 108......... A9.7:4

came, further notes on (Riley). 1692. p. $40 \ldots \ldots . . . . . . .4 .7: 5$

Herbarim specimens, insects which attack, fumigation with lisulphirl of carbon for complete am rapil restruction of (Du

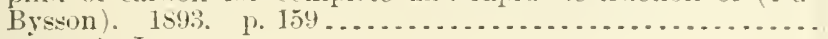

Herbertson, A. J.:

Rainfall, distribution of, over lamel. 1901. p. 67............ 129.6:59

Rainfall and charts of rainfall. $1902 . \quad 1,243 . \ldots \ldots \ldots \ldots \ldots \ldots .124 .6: 30$

Heredia, —, and Hermanos, —_. Sormlım growing in šain.

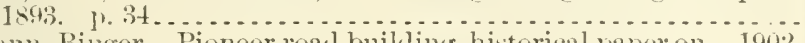

Hermann, Binger. Pioneer roal building, historical paper on. 1902. p. 48.

Hemanos, - tee, as joint author, Heredia,

Herrmanu, Charles F. vou:

Climate, studies of, with reference to crops of the several sections. 1902 . 1. 198

Forecasting for rivers of small drainage area, especially those of Sorth Carolina. 1902. j. 158 .......................

North Carolina, climate and crops in, 1889-1595. p. 58 ........

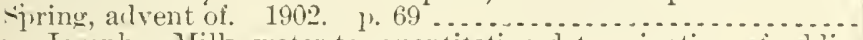

Herz, Joseph. Milk, water to, quantitative determination of acldition of, and removal of cream therefrom. 18s8. 1) $168 . . .$.

Herzerovina. see Tosnia and Herzegovina.

Hesperogenia, anew genms of umbelliferat, from Mount Rainier (Conl-

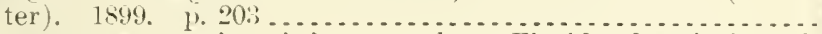

He-peromys, new species of, from southern Florida, description of

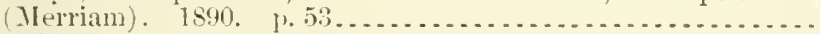

He-sian tly:

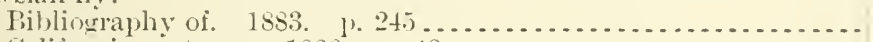

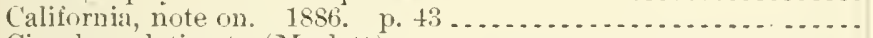

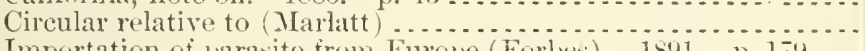

Importation of paracite from Europe (Forbes). 1891. p. 179...

Life history of, new notes on (Marten). 1891. 1\%. 265........

New York state in 1901 (Felt). 1902. 1.22 ... . . . . . . . .

North America, early references to vecurrence of. 1883. Apl., 1).3.

Not inporterl from Europe (Hagen). 1883. App., p. 4:........

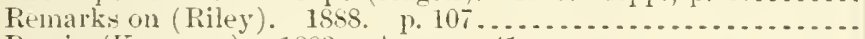

Russia (Krejluen), 1883. 1 pp., P. 41 ..................

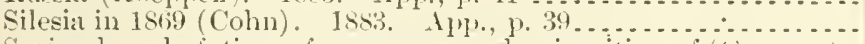

Spring brood of, time of emergence and oviposition of (ciarman).

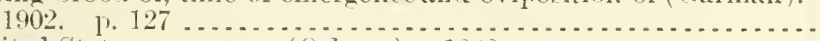

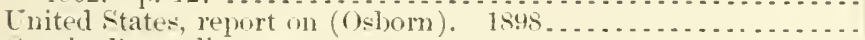

see ulso Rye gall-guat.

Heterntera of Death Valley experlition (I'bler). 1893. 1. 260.... Hevelius, halo of, notes on (Kimball). 1901. 1, 566........... Hewitt, Sarali Conper. Comntry loals, repairs oi. 18!4. j) 17... Heywarl, D. C. Thads, good, suggestions to friemis of. 190:2. 1. $4^{7}$. Hilernation. we Insects.

Hicklin, J. Brown, short biography of. 1901. p. 119 .......... Hickman, J. F.:

Cereals, variety testing in; how ran it be rendered more deeisive"

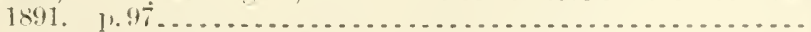

Plants, testing valietics, repurt on. 1s91. p. $103 \ldots . . . . . .$.

Hickman, Richarel W. Fealies in rattle, rlescription and treatment.

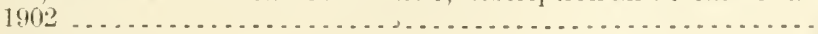
same. $190^{\circ}$.

A6.j:

11..3:4

A $7.3: 40$

A29.3:31

A29.3:31

A27.9:5

129.3:31

17.3:24

A6.5:5

18.1:3

A9.3:12

A9.5:12

19.7:4

A9.7:3

A9.6:31

As.1:3

1.5. 1:3

19.7:1

18. 1:3

18.1:3

1 10.3:115

19. $1: 16$

15.5:7

1.2!.6:29)

$122.3: 8$

1.2.:3:2:3

129).6:29)

$-110.8: 7$

1 10.5:3

11.9:15:2

A $4.3: 40$

Hicks, cilbert Henry:

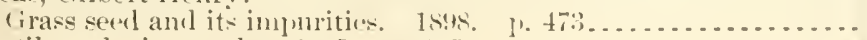

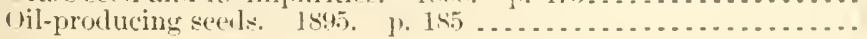


Micks, (rillext Henry-Continued

sereds-

agricultural, standards of purity and vitality uf. 1596 . . . . . .

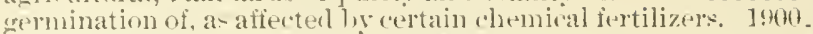

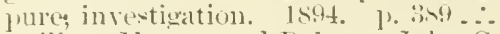

livels, (iilbert Ilemr, and Dalmer, Juhn C.:

Feerl, large, heary, superior value of. 1sith. p. 3in

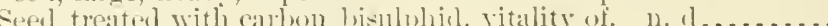

llicks, Gilburt Henry, and Fer. Sothoroll. Fiesl testing. allitional

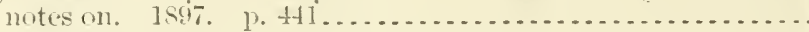

llicks, lewis E.:

-tratigraphy and hytrology of Nebmaka. 1sin. 1. 71....... Emlerflow and sheet water. irrioble lands and geolowical struceture of Neloraskil, with its eifect upon watel suplly. 184:3. pt. 2, 1. $] 67$.

Hille-powder:

Comparative tests, report on (limg). 1901. 1. 13:3........... C'omparison with filter-tnix method (Wiley and Krng). 1:01.

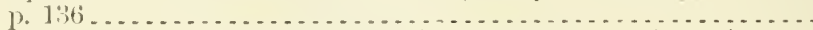
Shake method of determining tamin lor, notes on points of erpor

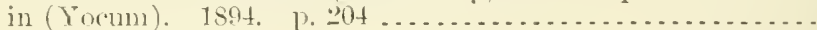

Iilles: vee alsis Filter-tube methoul.

Cattle, shipped to [niter States, lisinfotion of. ?. 50. .......

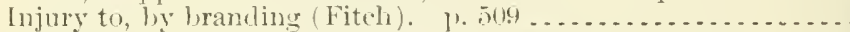
Skins and, imports of, from Calcutta (Patterem). T. 52:3 ......

17 irluee, F. F. Arbor Day for the commonwalth. p. 2S ........

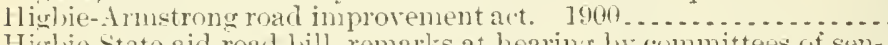

Higlie state aid road bill, remarks at hearing br committees of senate and assembly at Albany, N. Y., Felornary 25, 1897 , on

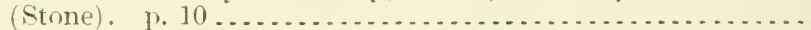

1 liggins, John C. Scotlanu, agrienlture and dairving in. p.213...

IIjghmore, S. Dak., range crast and forage plant experiments.

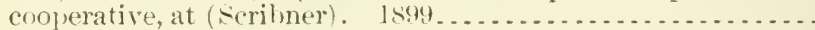

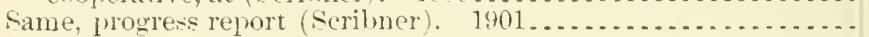

Iighways:

American, functions of Government, State, and comnty in imporse-

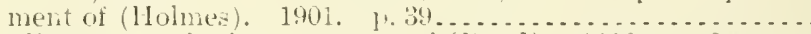

Bonding system for improvement of (bond). 1902. T. 3. . . . .

Construction and naintenance (Ashlurner). 1895. p. 32....

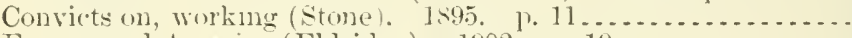

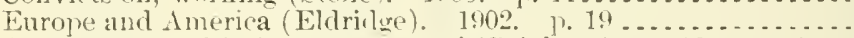

Government ail in improvement of (Brigham). 190\%. 1'.3...

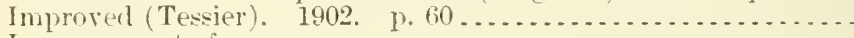

Improrement of-

repint m (Dickinson). 1902. p. 4h.................. shall farmere have airl for, from wealth of nation? (Bailey).

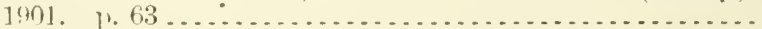

Legislation in Xew York, history of (Wright). 1901. p. 29...

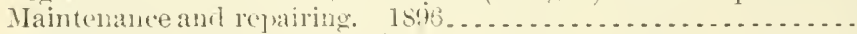

Public, alignment of (Pation). 1902. p. it . . . . . . . . . .

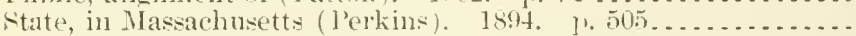

Taxation, comparative results of labor and moneysytens. j id f same, revisert.

see also Roads.

Highwars of commeres (Hanpt). 1901. 1) 5ti...............

Hilgaril, Engene Wuldemar:

Agricultural colleges, preparatory teaching in, 1sis, 11. (i1.....

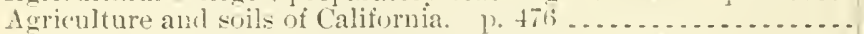

Alkali lanfls, origin, value and reclamation of. 1sis. 1 . $10 . .$.

Alkali soils and waters in Califomia, $1464-89$. p. $297 \ldots . . . .$.

California-

(exotic fruts and useful plants of. 1s92. p. 137 ..........

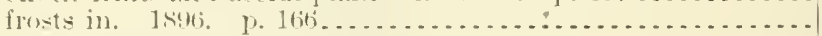

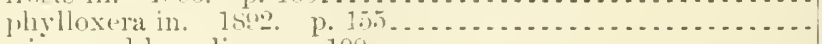

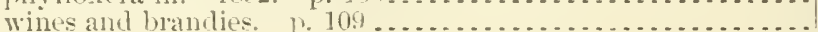

$16,4: 6$

$16.3: 24$

$11.10: 894$

11.10:\$4t A6. $4: 11$

11.10:4.97

A15.2: $: 1 r^{-}$

A $15.2: \mathrm{Ir}^{-2}$

$17.3:(1 ; 2$

$17.3:(6: 2$

$17.3: 4: 3$

$1+.1: 5 ! ?)$

At.1:\$9!

At.1:898

A1.s:5ti

1.2. $4: 35$

A2:.4:28

14.1:5.15

13. $4: 21$

13. $4: 36$

122.3:21

1.20.3:22

1.2.).3:11

122.3:16

12.2.3:2:

120.3:25.5

12:2.3:2:3

$102.3: 25$

122.8:21

A2:2.3:21

120.4:-4

122.3:23

1 1. 10:894

A2.2.t:16

A2.2.4:24

$12.2 .3: 21$

110.3: 49

11.1:8\%

11.10:495

1 15.: $: \mathrm{PQt}^{2}$

1 1.8:20

1 $29.6: 24$

11.5:00

11.6:?0 
Hilerarl, Eugene Woldenall-rontinuerl

Pacitic slope-

dimates of. 1sit. 1. 9... . . . . . . . . . . . . . . . . .

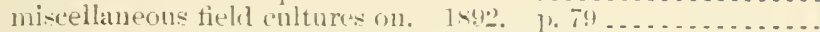

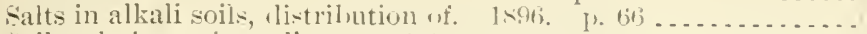

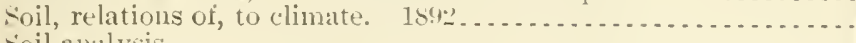

soil analysis-

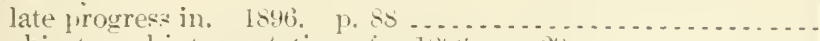

objects and interpretation of. 1sisi;. p.2! ..............

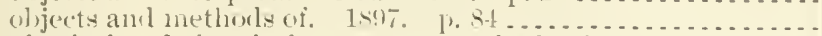

physical and chemical, repurt on methorls wf. 1\$98. 1\% 100... summary ot discussion on, from an article on conten pronluction of I initerl states. p. 170

soils, nitrogen hungrines in, recounition if. 1445.

Water supply, sulyteranean, of San Bermardino Valley and its utilization, stulies of. 190\%. p. 103.

Hilgarl, Eugene Wollemar, Jones, T. C., aurl Furnas, Robert î. Climatic and agricultural features, and auricultural practions. and needs of arid recrions of lacific slope, with notes on

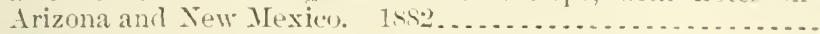

Hill, reorwe $(i$, :

Farm lsaldings, practical sugaestions for. 1901.............

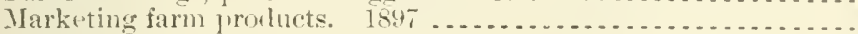

Se ulso, as juint author, IVilson, James $\mathrm{IT}^{\circ}$

Hill, George William:

Englisli farms and farmers, notes on some. 1898. 1). 58: . . . . .

Publications Division, Agrieulture Department, wolk wf, for

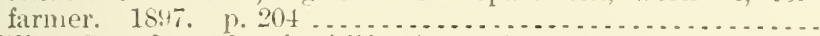

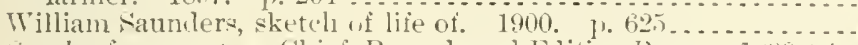

See also, for reports as Chief, Rerords and Eliting Bureau, 1syo-yf; Chief, Division of Publirations, 1s95-9s; and Ellitor and Chief, Division of P'ublications, 189.5-1902

Hill, Robert Thomas:

Irtesian and undergromnd waters in Texas, eastern Vew Vexin, and Indian Territory west of 97 th meridian. 1893. pt. 3 ,

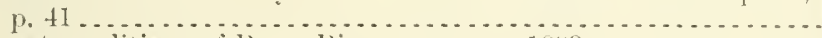

Forest conditims of l'orto Rico, note on. 1899 ... . . . . . . . .

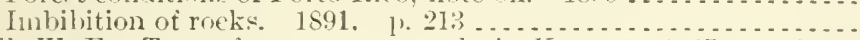
Hill, IV. E. Texas ferer among cattle in Kansas. 1297. 1. B1s. Hill, IT. T. Sparrows, trapping of, for sporting purposes; witl palper descriptive of apparatus and methody employal. 1sis?.

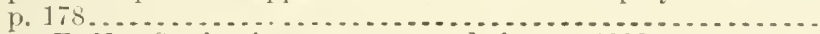

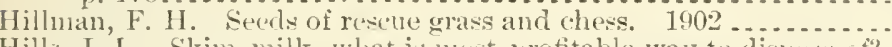
Hills, J. L. Skim milk, what is most protitable way to dispuse ot?

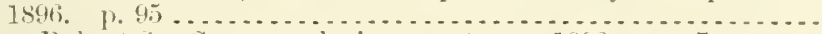

Hilner, Rohert s. Sugal analysis, rejort on. 1898, 1\%. Hinds, IT. H.:

Carbon hisulphid as an insecticile. 1902.

Carbon bisulphirle, fumigation with. 1901. 1. 78...........

Hines, C. M. Swine plague in Cass County, Nebrakka. 1879. p. i7t.

Hinkley, Nelson P. Horses, expmet of, from Lufialo, S. I., and

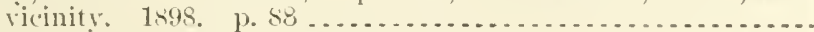

Hinman, C. I. Merlicine Lorlge, Kansas, notes on fiell work at.

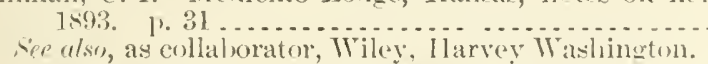

Hinrichs, Crustavus. Rainfall laws, deduced from twenty years' olservations. $189: 3$

Hinton, Richard Josiah:

Arlibess of licofore convention of Sational league for (ioml liuals,

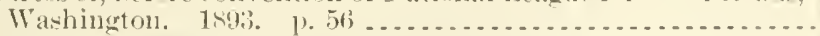

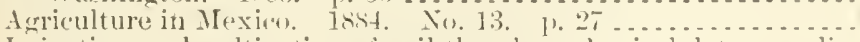

Irrigation and cultivation of soll therehy; physcul clatal comeli-

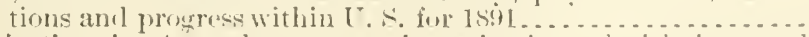

Irrigation in Anstralia; rosent investierations, lowislation, and

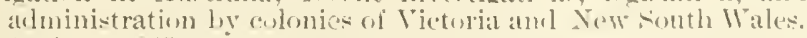

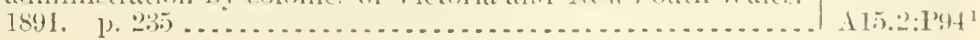

115.2: $\mathrm{Ir}^{\mathrm{T}}$

119.2:25

115.2: $\mathrm{P}^{\mathrm{9}} \mathrm{t}^{1}$

$1+1: 895-1 ;$

A5.3:1

A19.3 ${ }^{\mathrm{a}}: \mathrm{R:}$ 1

110.3:41

17.3:56

1 1.9:1 15

1.6.6:30

A 1.ti:12

11.2:117S

A $1.3: 40$

A29.2:111:3

110.3:11

127.11:202

$.115 .2: 11^{-2}$ 
Ilinton, Richard Josiah-Continnerl

Irrigation in varjoms countries, lacts am eomlitions relating to.

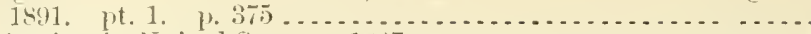
Irrigation in linited States. 1887....................

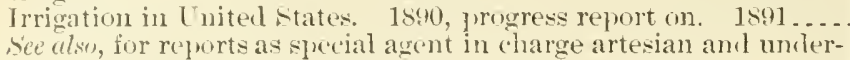
flow investigation and irrigation inquiry, 1890 and 1891

Hinton, Richard Josiah, and others. Artesian wells within area of nimety-serenth merilian and east of foothills of Rocky IIountains, preliminary investigation to determine

Hippelates platgue in Florida (Schwarz). Is95. p. $374 \ldots \ldots \ldots \ldots$. Hitehcock, 1. S.:

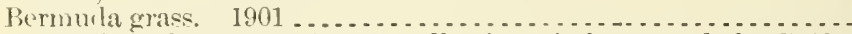
Flora of southwestern Kansas, collection of flants made by $(\mathrm{C} .11$.

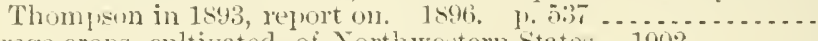
Forage crops, cultivated, of Northwestern states. 1902 ....... Hitehenck, Frank Harris:

Agricultural crports of Cnitel states, distribution oi-

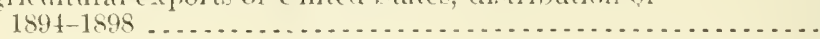

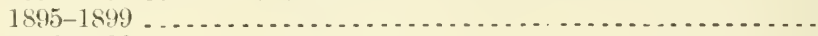

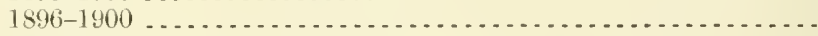

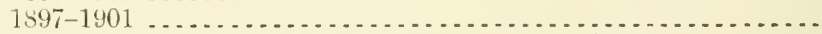

Agricultural imports of Lnitul states, sumees of-

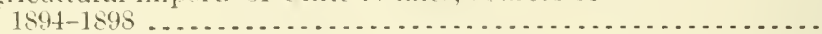

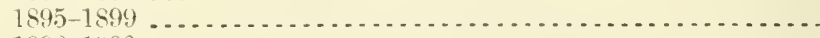

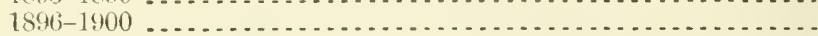

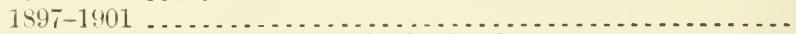

Agricultural imports of the Tnited Kinglom, 1s96-1900. 1902... Agricultural products, our foreign trade in$1893-1897$

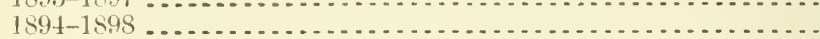

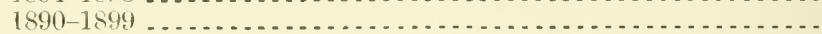

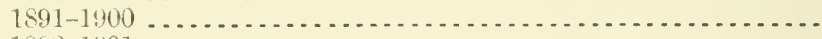
$1899^{\circ}-1901$

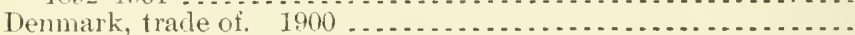

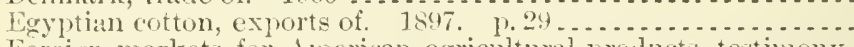

Foreign markets for American agricultural promets, testimong before Industrial Commission relative to. 1901.

Foreimn Markets Sfetion, Agriculture Department, work of, for

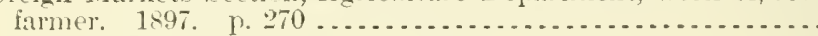

Philippine I-lands-

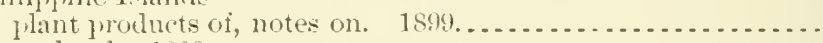

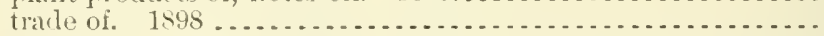

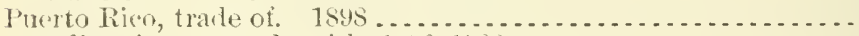

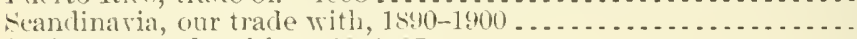

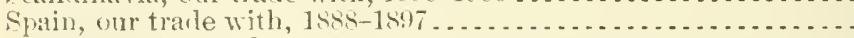

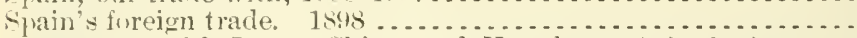
Trade, our, with Japan, China, and IIongkong, 1ssy-1s99 . . . . . se also, for reports as Chief, Section of Foreign Markets, Agricultire Department, $18.7-1902$

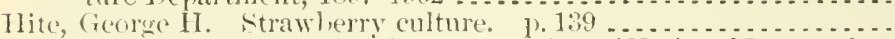
Ihoard, H. F. Adluess of, before comvention of Xational Leagne for

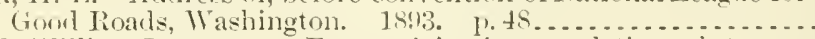

Iloard, William Dempster. Farmers institute, relation of, to om

IIobls, Hermann E. Toleanie and atmospheric phenomena. 1902 .

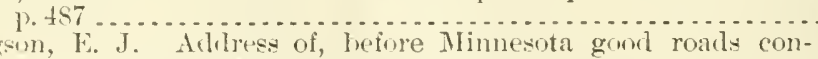
rention, Jan., 1s4t. p. 15..........................

Hofiman, J. 1). Mechanic arts, student applentice of. 1901.1 186. IToffmansegria, Torth American species of, revision of (Fislier): 14.12 . 1. 143.

Hocr and its products (Cist). 1) 382

liogecholera bacillus:

A-soriated with fatal disease in pigenns (Noore). 1895. P.71_..

Cin luacillus of hog cholera be increased in vimlence hy passing it through a series of rabluts? (Hoore) 1s94. p. $97 . . . .$.

A $15.2: \operatorname{Ir}^{2}$ A15.2:Ir-1 115.2: $\mathrm{P}^{2} 4^{1}$

11.5.1:

115.2: $1 \mathrm{rr}^{-}$ 19.7:7

13. 4::1

16.5:3

1 19.3:31

1 12.3:16

+1 $12.3: 20$

A $12.3: 25$

A12.3:29

112.3:17

11:2.3:21

A12.3::4

A12.3:28

112.3:26

112.3:10

A12.3:15

112.3:19

112.3:20

112.3::

A12.3:

110.3:4:

A1.8:15

$.11 .10: 897$

16.4:17

112.3:14

A12.3:13

112.3:202

112.8:12

112.3:11

112.3:18

112.1:

11.1:56:3

A10.8:1t

\10.3:110

120.6i:30

A 2.2.3:2

$+10.3: 19$

16.5:1

11.1:560

A $4.3: 5$

A $4.3: 6$ 
Hocr-eholera bacillus-Continuer

Experiments on attenuation of, l,y heat. 1.117 same, p. 17.5

Experiments on prorluction of immunity in rabits and guineapigs with reference to swine plague and (smitl and Jlowr'. 1834 .

Group of liog-eholera hacteria (smith). 1s.at. p. 9 ..........

Variety of, which closely resembles bacillus typhosins (I)oret :. 1. 566

What beomes of hog-chuler and swine-plagne bacteria when injected in small numbers into subentancous tissues of pigs? (Ioore). 189t, p. 103.

Hog cholera:

Commmication of, ly carrion crows (ford). 11. 325...........

(iem of, enzyones, or soluble ferments of (De ficlueinitz). l. 266 See ulso Hoor-cholera hacillus.

Ilistory, nature, and treatment, as determinerl hy inıuiries aml investigations of Burean of Animal Industry (Salmon). 1sis?.

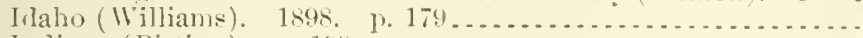

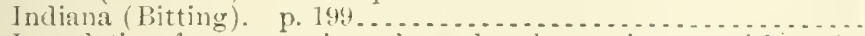

Inoculation for prevention of, results of experiments with (sal-

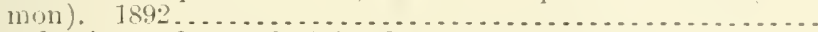

Introduction and spread of, in $\mathrm{L}$. S., correspondene peliting trs.

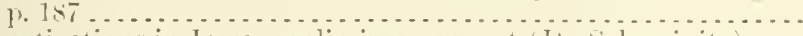

Investigations in Iowa, preliminary report (Le chbweinity). p. 501

Invertigations of1.ist. p. 603

same, P. 20

$1<\$ \overline{1}$. 1. 481

same, p. 633

Iuwa (Niles).

1. 500

Note on-

1866. PP. 56,127

1868. p. 320

18 \& (Trumbower) $1 .+191$.

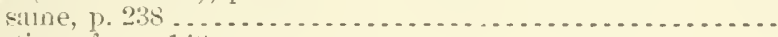

I'revention of. 1'. 148. same, 1. 156 .

Report on (Law). 1875 p. tob .

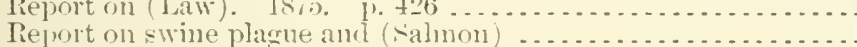

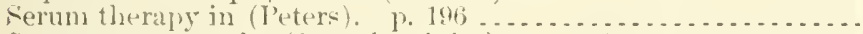

Serum treatment for (1) schweinitz). 1\%.235. same - e.

Stamping ont, in Page Comnty, Iowa, experiments in. p. 24! ...

Sweden, Demmark, and France. 1. $154 \ldots$ same, 1. 168.

Variability of infections di-eases as illustrated by (sinith and

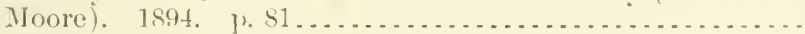

Varicty of, which closely resembles hacillus typhosus (Durret). 1. 566 i.

sie ralso Cattle orlers - swine plague.

Hog ferer, insestigation of, in Forth Carolina (Salmon). P. 432 ..

Hogm, Mrs lontie li. Shimer (reporter). Cooking, instrution in. in jublie schonls of New York, history and present status of, with introdnction by difed Charles True. 1599.

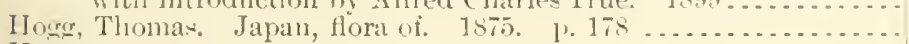
Hoigs:

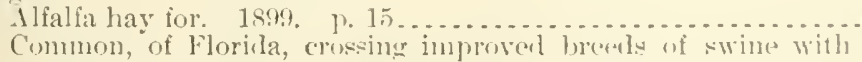
(Furnas). 184is.

Conditions affecting jurice of. 11. Sit same. 1) 84 (1)

Crop, 1 s.50-4i3. Xo. ti. 1\%.211.

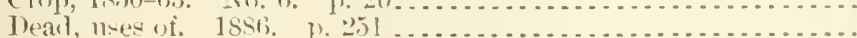

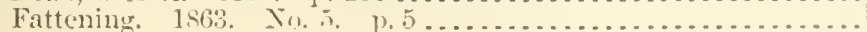

A $1.1: 4:-1-$

$.11 .1: 568$

$.1+.3: 6$

$1+.3: t^{2}$

$14.1: 901$

$14.8: 3$

$14.1: 4(35-1 ;$

$14.1: 3: 9$

A $1.5: 46$

A $4.1: 8 \%$

A $4.1: 597$

$11.9: \mathrm{a}$

$14.1: 4: 5-8$

A. 1:8999

A1.1:586

$14.1: 886^{\circ}$

A1.1: 58

A $4.1: 587-8$

A 4.1:894

A $2-7.9: 4$

A.2. $-9: 6$

At.1:85t

At.2:An

$14.1: 957-8$

11.1:858

A1.1:855

11.9:24

14.1:897

14.1:895

A $4.3: 23$

At. $1: 598$

1t.1:S87-

d].1:885

$1+.8: 6$

$14.1: 101$

11.1:5\%

A 10.3:5ti

1:7.9:13

11.4:1:4

1t.t:4

1.1:s:11)

1t. $1:(25)-(9)$

1.7. $9: 1$

127.9:24

12-19:1 
Hogs-Continued

Fereling sheal wheat to (French). p. 495

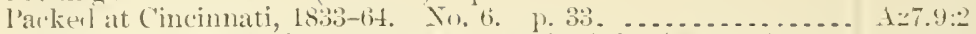

l'eanuts, cowpeas, and sweet potatoes as foul for (luggar). p.

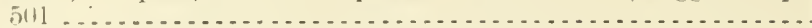

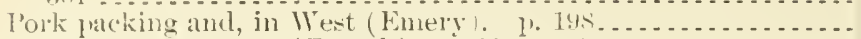

Raising in Northwest (French). 1900. p. 16 .............

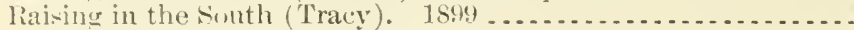

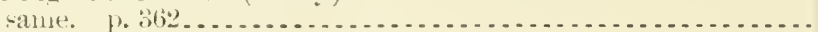

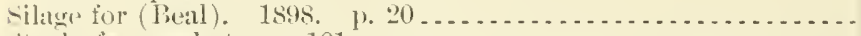

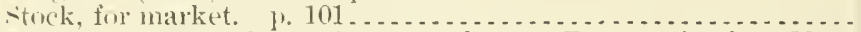

See diso Cattle orters-De soto hogs-Farm animals-IIog eholera - Sivine plange.

Hogne, Alvesto S. Animals, deal, disposition of, in Viema. 1" :30. At.1:499

Holcombe, 1. 1.:

Horse, fetler.k, ankle, and foot of, rliseases of. p. 357 ........

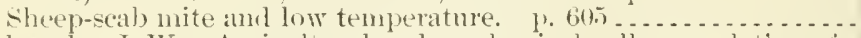

Holcombe, J. IT. Agricultural and nuechanical colleges, relation of, to Department of Interior. 1893. 1). 114 ...............

Holren, E. S. San Joaquin County, California, resources of. $186 \%$.

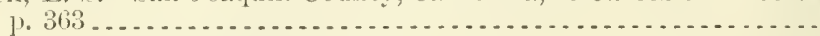

Holidays. See Legal holidays.

Holladay, 1. L. Cirape vine, black-rot aml mildw of, experiments

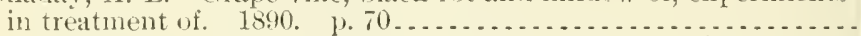

liolland, E. I, See, as joint anthor, Lindsey, Joseph Bridges.

Holland, rectamation of lands in, repurts of State geologist of Tew

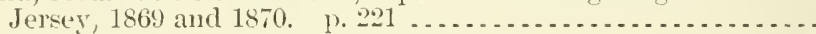
Sie also Java.

Holland agricultural experiment stations:

()thicial methorls of analysis of fertilizers and feerling stuffs artopted

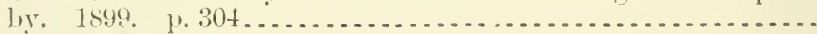

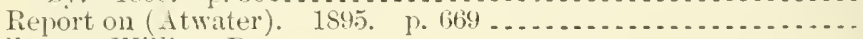

Holluway, IVilliam R.:

Animals, dead, disposition of, in St. Petersbur. p. 360

A $4.1: 598$

A1.1::6ti:3

11.9:117

11.9:100

$1+.1: 5999$

11.9:10:3

1. $1: 1:(9: 3)-4$

14.2:1178

A. $1: 901$

A10.3:16

1:7.4:65

$-16.3: 11$

A1.7:7

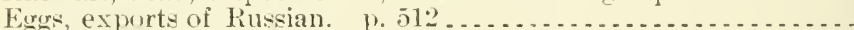

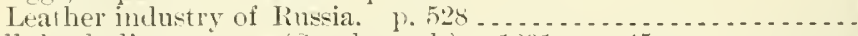

Hollyhock divease, new (Southworth). 1891. 1\% 45.........

Hollyhocks, sawtly, new, which is injurions to (Cockerell). 1894.

Holn, Theo. Panciuns, Ameriean, in herbarim Berolinense and in herbarimm of Willdenow. 1897. p. 17............

Hotmes, Edwin s., jr: :

Prazos River, Texas, flood of June-July, 189y, its effects upon

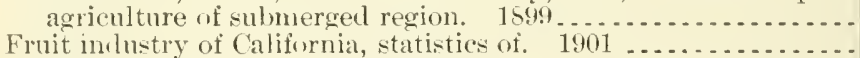

Wheat-growing and general agricultural comblitions in l'acifie

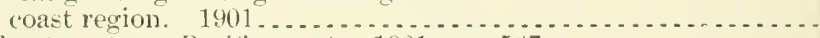
Wheat ports on Pacific eoat. 1901. 1. $567 \ldots \ldots \ldots \ldots \ldots \ldots \ldots \ldots . \$ 1.10: 901$ See ulso, as joint anthor, Ward, Edward C., jr.

Holnes, ficorge Kirby:

Acrieultural production and prices. 1897 . p. 577

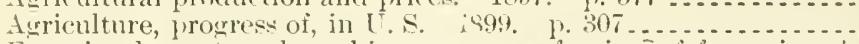

Farm inplements and machinery, conres of prices of for series of years. 1901 .

Holmes. Jiseph Austin:

Adilress of, hefore national roal conference, July, 1894. 1. 17...

Agricultural colucation in North Carolina. 188., p. 84 . . . . . . .

Convict labor, nse of, in roar improvement in North Carolina.

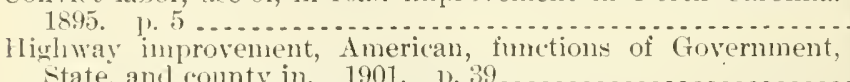

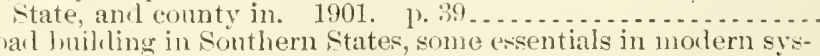

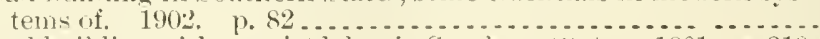
Roal bulding with convict labor in Sonthern Ftates. 1901. 1.319. Roals, public, improvement of, in North Carolina. 1894. p.513.

Hohnes, J. (iarnett. Soil smrey armmil Santa Ana, Cal. 1. $385 . .$. sice clor, as joint author, Means, Thomas Herbert. 
Holmes, J. Garnett, and Mesmer, Louis:

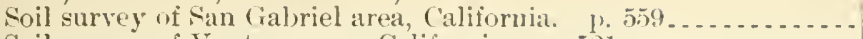

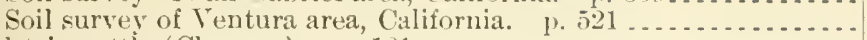

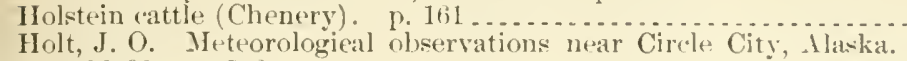
1896-9s.

Holzinger, John II.:

Plants-

collected by C. S. Sheldon and M. A. Carleton in the Indian Territory in 1891, list of. 1892. p. 189.

collection of, made by J. H. Sandberg and assistants in northern Idaho in 1892 , report on. 1895. p. 205............ new, fron Texas and Colorado, rescriptions of. 1893. p. 286.

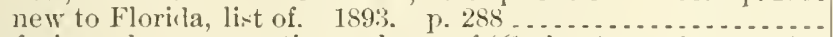
Home fruit garden, preparation and care of (corbett). 1901. 1).431. Same

Home vineyard, with special reference to northern conditions (Ragain). $1902 .$.

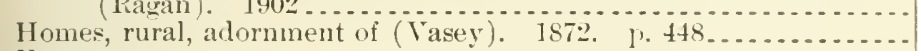

\section{Honey:}

Adulteration of (Wiley and others). 1892. 1. 633........... Production of, 1869-89.

See also Bees.

Honey bee. Manual of instruction in apiculture (Benton) See also Bees-Italian honey bee.

Ifoney Lake Basin, California, irrigation jroblems of (Amythe). 1901. P. T1

\section{Hongkong:}

Our trade with, 1889-1899 (Hitcheock)

Typhoon of Tor. 10, I900, in, note on (Alibe)

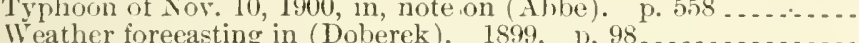
Wonolulu, Hawaii:

Meteorological observations, monthly, at, Mar., 1894-Arril, 1901 (I. yons).

Tables of dew-point observed at (Iyons). $1899.1 \% 587 \ldots \ldots$

Honkworm disease (uncinariasis or anchylostomiasis), significance of recent American cases of, in main (Stiles). 1\% $183 \ldots . . .-$

Honper, John K. Halo at Detroit, Mich., May, 1900. 1. 202....

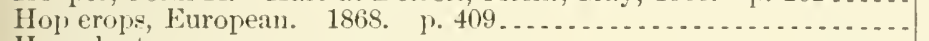

Hop plant:

Cultivation of (Bollman).

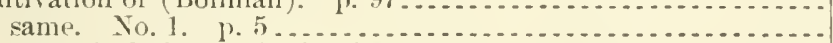

same, in Bohemia (Fairchild). 1899.

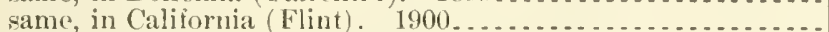

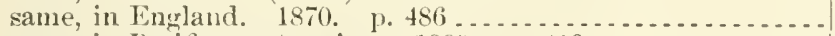

same, in Pacifif: coast region. 1889. 1) $+10 \ldots \ldots \ldots$

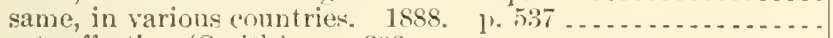

Insects affecting (Smith). p. $393 \ldots \ldots$ same (Smith). 188t. 1.9......

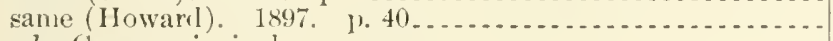
See also C'rops, principal.

Hop plant-louse:

Experiments with, in Oregon and Washington (Koebele). 1898.

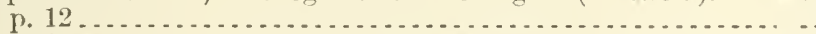

Experiments with remedies against (Alwood). p. 102 ........ same. p. $102 \ldots \ldots \ldots$

Further notes on (Riley). 18ss. p. 70 .

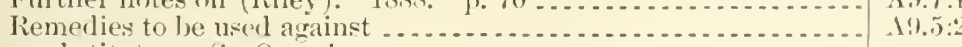

A26.5:90]

A $26.5: 90\}^{\prime}$

A $1.1: 864$

A:9.6:6:26

$16.5: 1$

$16.5: 3$

26.5:1

A $6.5: 1$

A 1.10:901

$11.9: 154$

A $1.9: 156$

A $27.9: 10$

A7.3:13\%

A $27.9: 32$

A $9.6: 1$

A 10.3:100

A 12.3:18

A $29.6: 28$

A29.6:27

A29.6:

A 29.6:27

Af.1:901

A $29.6: 28$

127.9:6

A 1. 1:864

127.9:3

16.4:19

A 1.9:115

A27.9:8

A27.9:27

127.9:26

A 1.1:884

A. . $3: 4$

A9.6:7

II p substitutes. Sire Quassia.

Hopkins, Antrew Delmar:

Entomologist, economic, note and reeorel keeping for. 1893.

p. $103 \ldots \ldots$

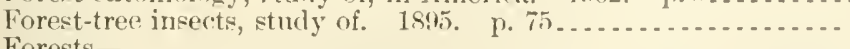

Forests-

damage to, by destructive quine hark-heetle. 1893. 1\% 187 ... A9.7:5) insect cnemies of, in Northwest, preliminary report on. 189!9 $19.6: 21$

$114-04-2-3$ 
Hopkins, Andrew Delmar-Continued

Invects detrimental and destructive to forest products need for

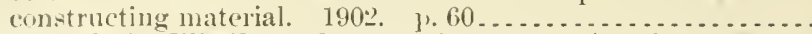

Pine in Black IIills Forest Reserve, insect enemies of. 1902.... Scolytids, destructive, and their imported enemy. 1893. 1. 123. Spruce, insect enemies of, in Northeast. 1901 ............... W'est Virginia('ntomological discoveries and observations of year in. 1894.

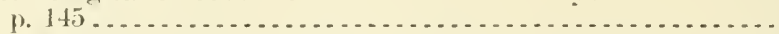

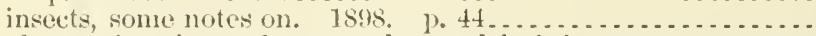
observations in, on farm, yarden, and frnit insects, sume notes

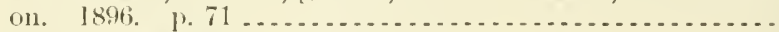

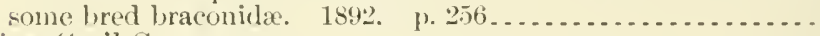
Hopkins, Cyril George:

Alkalies in soil analysis, separation of, by official method. 1902. p. 43 . . . . . . . . . .

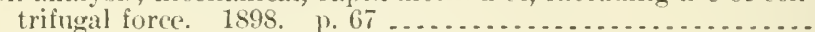
Soil particles, division of, in mechanical analysis, plea for scien-

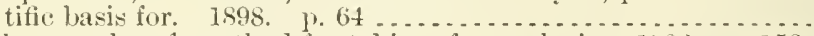

Soils, samples of, method for taking, for analysis. 1902. P. 152 . Hopkins, Cyril George, and Powers, W. A. Milk and cream, acillity

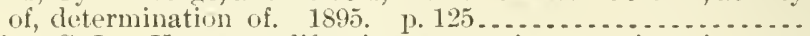

IIopkins, C. L. Yanessa californica, mountain swarming of. 1890.

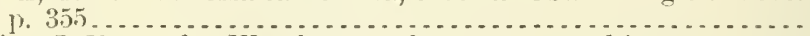

Hopkins, J. Iloward. Weather prophet, everyman hisown. 18.9 .

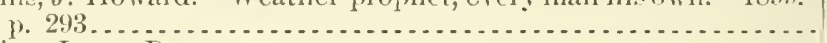

Hopkins, James D.:

Animals, domestic, in C. S., contagious diseaves among, investi-

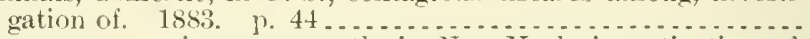

Pleuro-pnemonia among eattle in New York, investigation of.

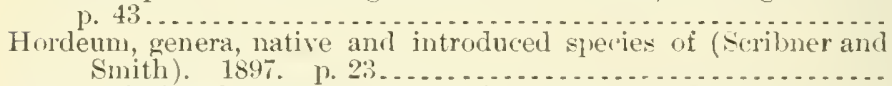
Smith). 1897. p. 23.

Horgen, Switzerland. Cost of hauling farm products over wagon

Horn fly:

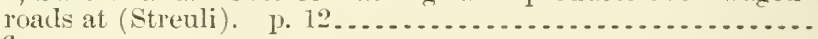

Ohio, note on (Kellicott), 1891. p. 35...................

Remedies for, notes on (Alwood). is91. p. 68 .............

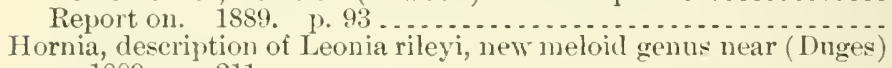
1889. p. 211 ..................................

Hornworm of tobaceo. See Protoparce carolina.
Horr, Thomas J. See, as joint anthor, JeLean, I.

Horse-radish:

Best varieties of Europe, and methods of cultivation (Fairchild). 1900

Circular on (Kains) is98

Culture in Bohemia (Fairchild ). $1899 . \ldots . . .6$.

Horse-radish flea-beetle, report of (Chittenden). 1895. p. $404 . .$.

Horse breeders' associations, list of, with officers:

1898. p. 613 .

1899 p. 693 . .

1900 p. 647 .

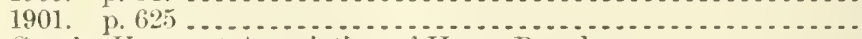

See alsn Vermont Association of Horse Breeters.

Horse show, Chieago, Ill., 1890 (Martin). p. 349.

Horses:

American-

importation of, into Brussels (Langhorne). 1897. p. 26....

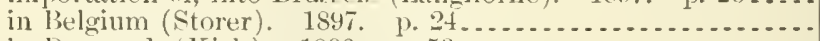

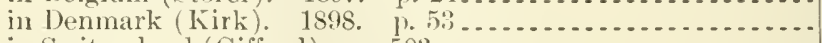

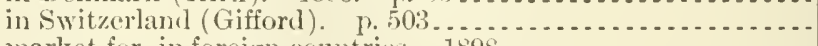
market for, in foreign eountries. 1898.

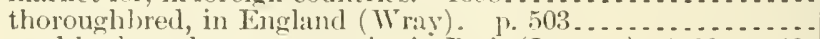
used by large horse companies in Paris (Loncey). 1898. p. 42. Jarley as food for. 1901. p. $29 \ldots \ldots \ldots . . . . . . . . . . . . .$.

A9.6:31

A $9.6: 32$

A9.7:6

19.6:28

A9.7:7

A9.6:17

A9.6:6

A9.7:4

A7.3:67

17.3:56

A7.3:56

A $7.3: 67$

A7.3:4

A9.7:2

1 $29.6: 27$

A1.8:29

11.1:881-2

A3.3:4

A2:. $4: 27$

19.7:4

A $9.7: 4$

A $9.7: 2$

A9.7:1

A23.4:1

A6.4:15

A6. 4:20

A9.7: 7

A1.10:898

A1.10:899

A1.10:900

A 1.10:901

A 4.1:889-90

A1.2:H78

A1.2:1178

A1.2:H78

A $4.1: 900$

A1.2:H78

At.1:899

A 1.2:H78

A 1.9:133 


\section{Horses-Continued}

Bloorl, essay on (Jaekson). 1882. p. 50 .

('lassifleatlon no.

Bottom disease among, in Soutl, Dakota (Sclurosder). 1. 37 .

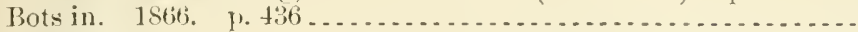

Breerling-

Belgimu (Winslow). p. 503.

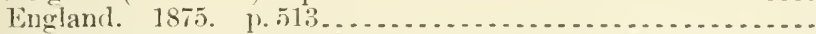

for turf, road, and farm (Nanders). 188\%. p. 29

national, military arministration of Germany in its relations to. 1). 372.

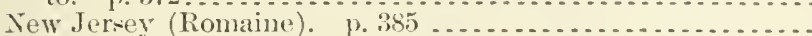

Cavalry-

report on, etc. (Gaines). 1. 122 ......................

America (Morris). p. 159.

Great Britain's purchases of, in $\mathrm{A}$ rentina (Buclunan). 1898.

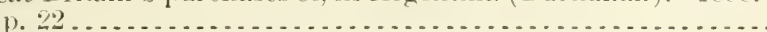

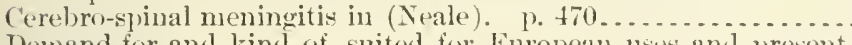
Demand for and kind of, suited for Enropean uses and present status of horse trade in different comntries (Stulbs). 1898.

Digestive organs of, diseases of (Jiehener). p. $15 \ldots$

Diseases among mules and. 1868. p. $360 \ldots \ldots \ldots \ldots \ldots \ldots \ldots$

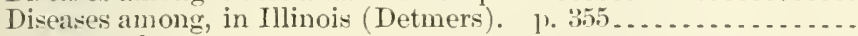

Diseases of-

correspondence relating to. 1877. 1. 471

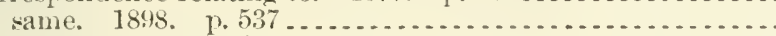

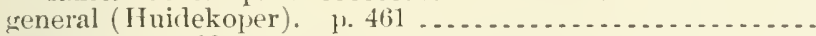
report on. 1890.

Draft upon (Fulton). p. 511 .

Enzoütic cerebro-spinal meningitis in Idabo (Williams). 1898.

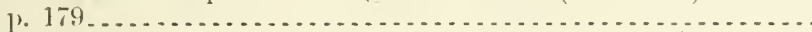
Fnzoötic cerebro-meningitis among, in Texas (Detmers). p. 363. lixport of-

Buffalo, N. Y., and vicinity (Hinkley). 1898. p. $88 . . . .$.

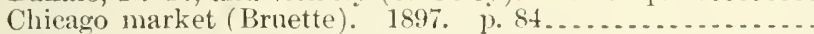

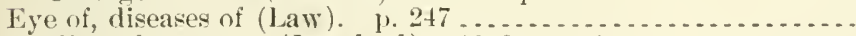

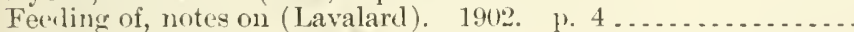
Fetlock, ankle, and foot of, direases of (Holeombe). 1). $357 \ldots .$.

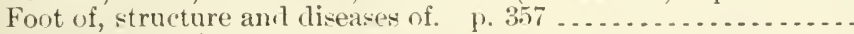
France (Green). 1898. p. 39 ......................... Generative organs of, diseases of (Law). p. 135 . . . German army, requirements for (Kuhn). 1898. p. 31. Glanders anounreport on (Trumbower). p. 418. sanue, 1). 237

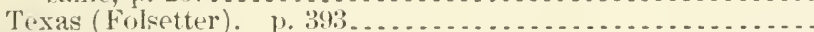

Heart and blool-vessels of, diseases of (Trumbower). p. 219... Imported into ${ }^{\top}$. S., regulations for inspection and quarantine of, Dec. 28, 1899 same, modification, Jan. 27,1900 same, amendment, June 1, 1900. same, amendment, Oct. 20,1900 same, amendment, Nor. 10, 1900

Industry of the Northwest (Nelson). 1900. p.23 . . . . . . . . Influenza in (Law). 1. 203........................... Lameness of, its canses and treatment (I iantari). p. $269 \ldots \ldots$.

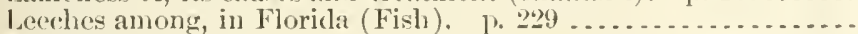
Maladie du coit among-

Tebraska and Sonth Dakota, extirpation of (Norgaard). 1). 62. Nebraska (Faville). I). 359

Market elasses of (Romnel). b. 4i3i). same. 1902

Meat of-

Ameriean, in Denmark (Blom). p. 505.

A1.8:20

1 $4.1: 891-2$

A $27.9: 4$

A $4.1: 900$

A27.9:18

$11.7: 2$

14.1:898

A $4.1: 889-90$

11.7:2

11.1:86:"

A $1.2: 11 \%$

A4. 1: \$19

A1.2:1178

A $4.2: 1178$

127.9:6

11.1:881-2

A1.1:877

A4.1:898

14.2:H78

A4.2:H78

14.1:898

A $4.1: 597$

1 1.1:881-2

A 1.2:H78

A1.2:1178

14.2:1478

A $10.6: 12$

14.2:1178

1 $1.1: 870$

A 1.2:H78

A4.2:H78

11.2:1178

14.1:884

14.2:Anर

14.1: 18 8. 90

14.2:1178

A $4.5: 56$

A 4.5 .58

A $+.5: 6+$

A+.5:7\%

A $4.5: 79$

A 1.9:117

1 1. I:S7:

1+.2:1178

A $4.1: 895-6$

1 $4.1: 89: 3-4$

14. 1:8:1-2

14. 1:101

1+.3:37

14.1:900

$14.1: 900$

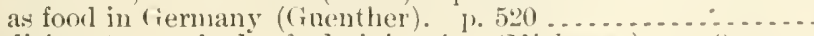

$1+.2: 1178$ 
Horse:-Continued

Yillet disease of. same. p. 539

1898.

p. 20

A $1.9: 69$

A $4.1: 898$

Tational horse of America (Macleorl). p. 691

Nervous system of, diseases of (Trumbower). p. 181

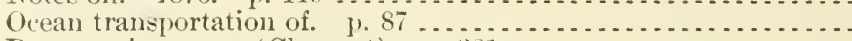

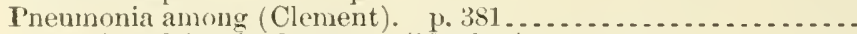

Potato brearl for, in Germany (Hughes). p. p30..

Principles of form required to adapt him to special purposes, notices of breeds, ete. (Howard). p. 335 .

Report on, from practical experience in Amy, origin and usefulness (Ringwalt). P. 321

Respiratory organs of, diseases of (Harbaugh). ․ $87 \ldots . . . . .$.

shipping, to Germany, experience and obervation in (Meyers).

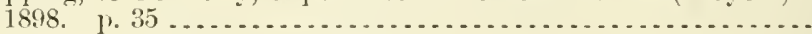

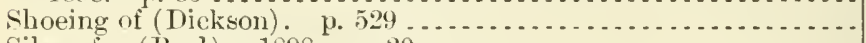

Silage for (Beal). 189s. p. 20

Skin of, diseases of (Law). p. 419.

"Staggers" among, in Virginia and Forth Carolina (Ilarbaugh). p. 209 ... . .

switzerland (Du Bois). p. $520 \ldots \ldots \ldots \ldots$

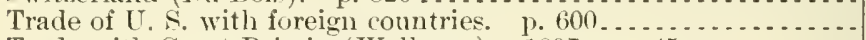

Trade with Great Britain (Wellman). 1897. p. $45 . \ldots \ldots \ldots . .$.

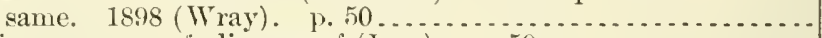

Urinary organs of, diveases of (Law) p. 59 .

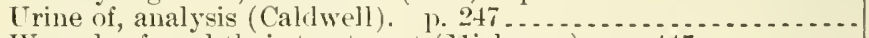

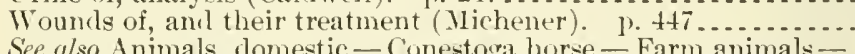

See also Animals, domestic - Conestoga horse - Farm animals-
French Napoleon stallion - Mares - Roadsters and trotters.

Horticultural ancl kindred societies, officers of:

1898. p. 621 . . . . . . . . .

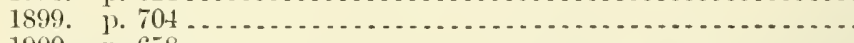

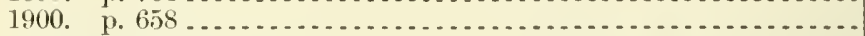

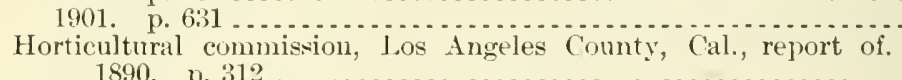

Horticultural exhibition, international, proposed to be held at Ham-

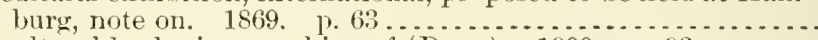

Horticultural herbarium, making of (Davy). 1900. p. 93 .......

Horticultural periodicals. See Agricultural and horticultural periodicals.

Horticultural quarantine rules of California. 1892. p. 168 . .......

Horticultural sehool. See Ghent, Belgium.

Horticultural societies, list of:

1867. p. 364.

1869

A1.1:887

A $1.2: \mathrm{H} 7 \mathrm{~S}$

A27.9:14

A $4.1: 900$

At.1:889-90

A. 1:899

A1.1:86i2

A1.1:866

A 4.2:H7s

A1.2:H78

A 4.2:H78

A1.9:103

A 4.2:117

At.1:886

14.1:898

A t.1:901

A 1.2:H78

A1.2:H78

A4.2:H7s

A1.1:872

A $4.2: 478$

A1.10:898

A1.10:899

A1.10:900

A1.10:901

A9.7:?

A27.9:

A10.3:76

A1.8:20

A1.1:867

A1.2:Sol

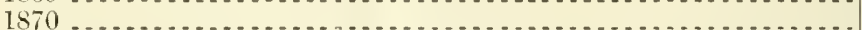

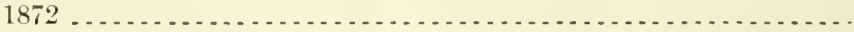

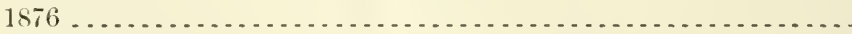

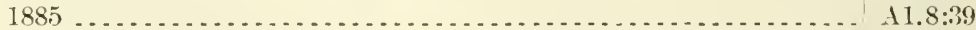

Horticulture:

Abstracts of reports of agricultural experiment stations on.

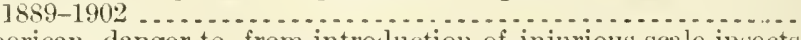

American, danger to, from introduction of injurious scale insects

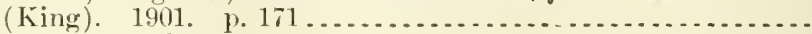

Climatology and-

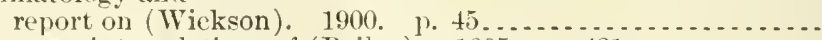

some interrelations of (Bailey). 1895. 1. 431 . . . . . . . . . .

Directory of departments, boarrls, societies, colleges, and other

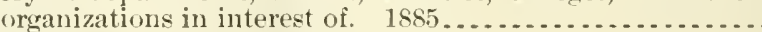

See also Iforticultural societies.

Education in Mlinnesota (Green). 1898. p. $84 \ldots . . . . . . . . . .$.

Educational status of, report on (Card). 1901. p. 134 ........

Experimental, systems of recorl keeping in (Corbett). 1896.

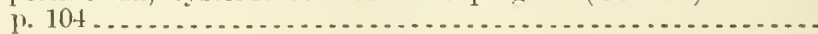

A10.6:

A10.3:99

A10.3:76

A 29.3:11 ${ }^{2}$

A1.8:39

A10.3:49

A 10.3:99

A 10.3: 11

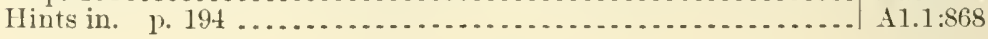


Honse ants:

Circular relative to (Marlatt). 1898.................... A9.5:34

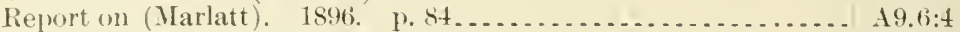

IIonve centipede, circular on (Marlatt). $1902 \ldots \ldots \ldots \ldots \ldots \ldots \ldots \ldots . . .19 .5: 48$

House tlies:

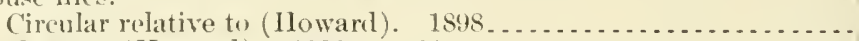

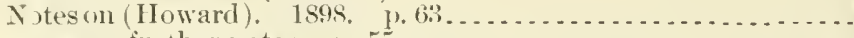

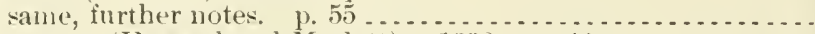

Report on (Howart and Marlatt). 1896, p. ti3 ............. S'e also Flies.

House numbering and mual road naming (Davidson). 1901. p. 19.

Honse plants, cultivation of (Hall). P. 366 . . . . . . . . . . . . .

Honse sparrow (Passer domesticus), at Saint Louis, Mo., history of

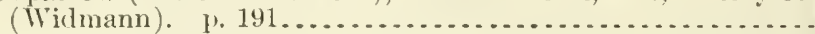
See also Sparrows.

Ionseholi insects:

Hydrocyanic-acid gas for exterminating, use of (Beattie). 1902. p. 80 . . . . . . .

Principal, report on (Iloward and Harlatt) $\ldots . . .2 \ldots$

Temperature effects on (Howard). 1896 , ए. 13............ Use of hydrocyanic-acid gas against. 1902.

see also Insects, and references thereunder.

Household tests for detection of oleomargarine and renovated butter

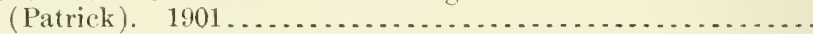

Hovenden, Thomas. Kites within a thunder cloucl. 1898. p. 251.

Iloward, Burton J. Frnits and fruit products, microscopical exam-

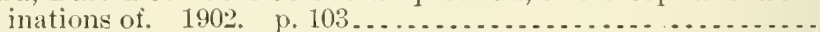

Howard, C. W.:

Cotton States, condition of agriculture in. p. 215.

Georgia, conditions and resources of. p. $567 \ldots \ldots \ldots$

Howarl, (ieorge Ellsworth:

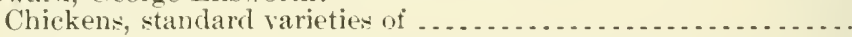
same. P. 44.5 .

Ducks and geese, standard breeds and management. $1897 \ldots .$.

Howard, Leland Ossian:

Angoumois grain moth or "fly weevil." 1893. p. $325 . \ldots \ldots . .$. Aphelinine of North America, a subfamily of Hymenopterous of

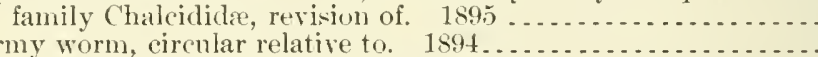
Army worm, circular relative to. $189 t \ldots \ldots \ldots$

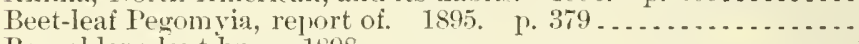

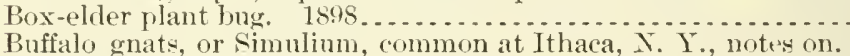

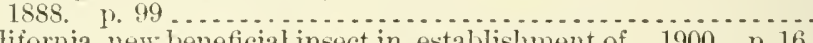
Cafifornia, new beneficial insect in, establishment of. 1900 . p. 16. Capri fig experiments in California, present status of. 1899. p. 28. Carpet beetle, or "Buffalo moth," circular on. 1s94 .......... Chalcidid:e-

Sorth American, from collections of U.S. Department of Agriculture and of C. Y. Riley, with biological notes; 1st paper, with list of described North American species of family, descriptions of, ete. 1885 . . . . . . . . . . . . . . . . . . pupation among, methods of. 1891. p. 193 . . . . . . . . . . . Cheese, hams, fruit, and vinegar, some insects affecting. 1896.

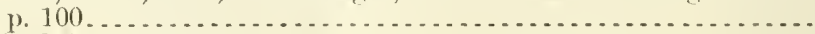

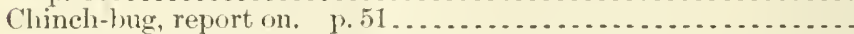

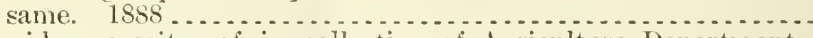

Coccide, parasites of, in collection of Agriculture Department.

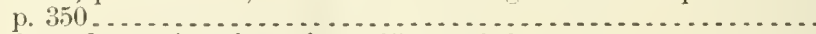

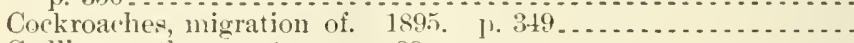

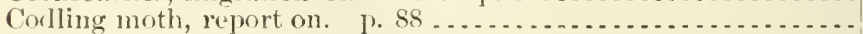

Cornstalk borer, larger-

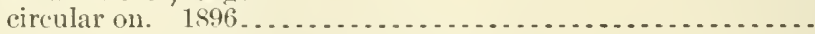

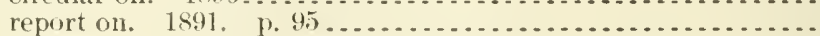

Cotton plant, insects affecting. Jan., 1897 ...............

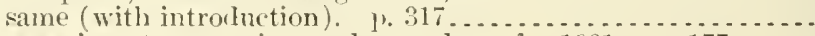

19.5:35

A9.6:10

A $9.6: 17$

A $9.6: t$

A $20.3: 21$

11.1:S63

A5.3:1

19.6:31

19.6:4

A9.6:6

19.5:46

A1.9:131

129.6:26

17.3:66

11.1:874

A1. 1:866

$+1.9: 51$

A1.10:896

1 1.9:64

19.7:5

19.8:1

19.5:4

A9.7:2

A9.7:7

A9.5:28

A9. $7: 1$

A9.6:26

A.9.6:20

A9.5:5ّ

19.3:5

A9.7:4

A9.6:4

A 1.1:887

A9.3:17

A1. 1:880

19.7:7

A1.1:887

19.5:16

A9.7:4

A1.9:47

A 10.3:33

Disease, insects as carriers and spreaders of. 1901. 1) 17\% .... A $1.10: 901$ 
Howarl, Leland Ossian-Continued

Elasmus, habits of. 1592. p. 253 ....................... 19.7:4

Elm insect, newly importel. 1ss9, p.3t .............. $19.7: 2$

Elm leaf beetle, futility of trunk and crown washing against.

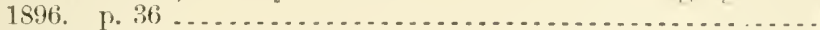

Encyrtid, new and remarkal,le, is it parasitic? $1890 . \quad$ p. $145 \ldots .$.

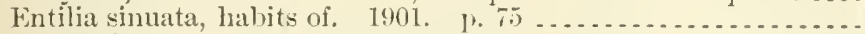

Entomology-

economic, progress in, in Uniterl States. 1899. p. 135...... official economic, brief accomnt of rise and present condition of. 1894. p. 55.

Entomology livision, Agriculture llepartment, work of, for

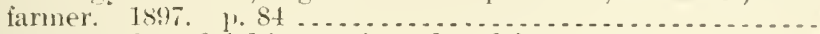

Europe, two heneficial insects introduced from. 1898. 1. 13...

Fig-eater, or green June beetle, report on. 1898. 1\%.20 .......

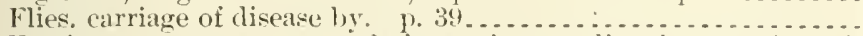

Foreign govermments, regulations of, regarding importation of American plants, trees, and fruits. 1900

Fruit trees, important enemy to; San Jose seale, its apprearance

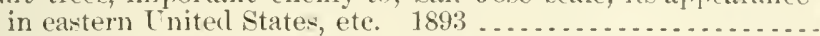

(iadflies, remedy for, Porchinski's recent discovery in Risssia, with some American observations. 1899 . p. $24 \ldots \ldots . . . .$.

Cirain plant louse, some new parasites of 1890 . p. $246 \ldots . . .$.

Grass and grain joint-worm flies and their allies; a consideration of some North American Phytophagic eurytomince. $1896 . . .$.

Grasshoppers, fungons diseases of, experimental work with. 1901. p. 459

Gypsy moth in America; a summary acconnt of introduction and spread of Porthetria dispar in Massachusetts, and efforts made by State to suppress and exterminate it. 1897.

Harleruin cablage bug, or calico back, circular relative to. 1895 .

Itealth, how insects affect, in rural districts. $1902 . . . . . . . . .$.

llibernation of injurious insects, temperature experiments as

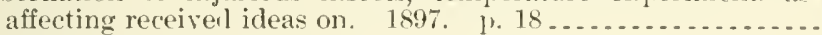

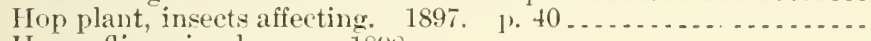

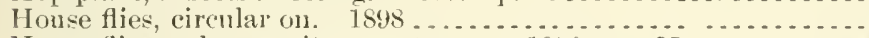

Honse flies and mosquitoes, notes on. 1898, p. $55 . . . . . . .$.

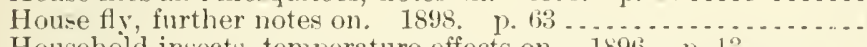

Household insects, temperature effects on. 1s9t, p. $13 \ldots . . .$.

Hydroeyanic acid gas, use of, against household insects. 19(1)2...

Hymenoptera, parasitic, host relations of, $1891, p .277 \ldots \ldots .$.

Jymenopterons parasites of California red scale. 1894. 1).207..

IT Y peraspis signata, beneficial work of. 1900 . 1. 17........

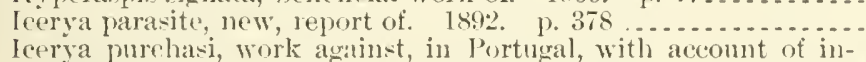
troduction from America of Novius cardinalis. 1898 . 1. 30 ..

Insect parasitism, study in, consideration of parasites of whitemarkerl tuswock moth, with account of their habits and interrelations, with description of a few suecies. $1897 \ldots . . . . . .$.

Insect pests, danger of importing. 1897. p. 529............

Insects, foreign, desirability of an inspertion systen against.

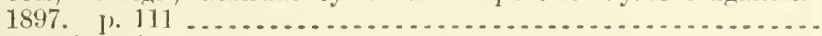

Insects, injurious-

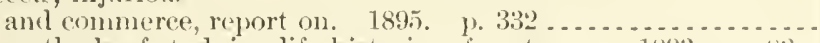
methorls of studying life histories of, notes on. 1893. 1\%. 82.

Irrigation an! injurions inseets. 1890. 1.215 ... . . . . . . . . .

Kissing bug, inceets to which name becanc applied during smm-

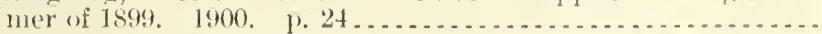

Laws against insects, injurions, in North Aneriea, recent, with

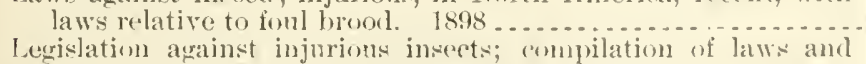
regulations in [. S. and British Columbia. 189.7.........

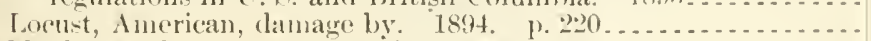

Maple psewhocoecus, report of. 1894. p. 23) .............

Mexican cotton-loll weevil1895

same (in Spanish)

19.6:6

19.7:3

19.6:30

11.11:8999

19.7:7

A1.10:597

A9.6:17

19.6:10

A9.6:30

A $9.5: 41$

$19.5: 3$

19.6:20

19.7:2

A9.8:2

A1.10:001

A9.6:11

A9.5:10

A1.9:155

19.6:9

A9.6:7

19.5:35

19.6:17

A9.6:10

19.6:6

19.5:46

A9.7:3

19.7:6

19.6:26

19.7:4

19.6:18

19.8:5

A $1.10: 897$

A $1.8: 57$

19.7:7

19.7:6

19.7:2

A $9 .(1: 202$

19.6:13

19.3:3:3

1). $7: 7$

19.7:7

$19.5: 0^{1}$

$19.5: 1 i^{2}$ 
Iloward, Leland Ossian-Continned

Mexican cotton-boll weevil-Continued

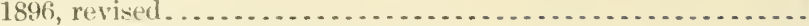

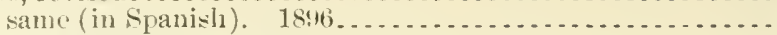

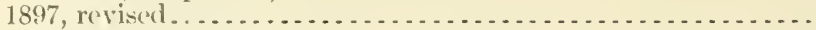

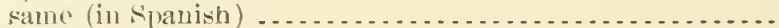
same (in German)

1897, revised.

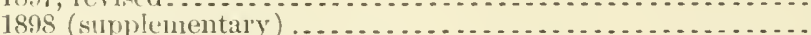

osquitries-

different, of North America, low to distinguish

$19.5: 14^{1}$

$19.5: 14^{2}$

A9.5:18

A $9.5: 18^{2}$

$19.5: 18^{3}$

A $9.5: 27$

A9.5:3:

experiment algainst-

1892. 1) 12

Mosquitoes and Heas-

circular on ....................................... A9.5:13

report on. 1896. 1. 9 ............................ A9.6:4

Mosquitoes of Uniterl States, notes on, giving some account of their strueture and biology, with remarks on remelies. 1900

Mytilaspis pomorum, new parasite of. 1594. 1. 256..........

Orchard, some scale insects of. 1894. p. 249 . . . . . . . . . . .

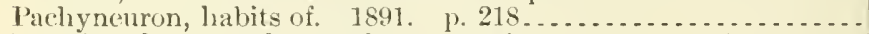

Parasite of supposed eggs of cotton stainer. $1889 . \quad 1 \% 2+1 \ldots \ldots$.

Parasites-

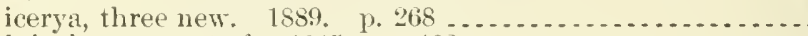

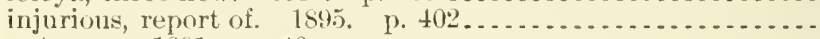

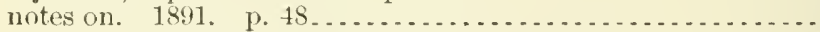
orgyia leucostigma, aditional observations on. 1897. 1. 15.. two, of important scale insects. 1894. 1. 5 . . . . . . . . . . .

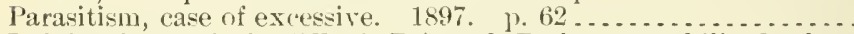

Pulvinaria acericola (W. \& R.) and P. innmmerabilis Ratliv. 1898. p. 57

Pulvinarias, two most abmilant, on maple. 1900. 1. T......

San Jose seale in 1896-1897 . . . . . . . . . . . . . . . . . . . .

San Jose scale on dried fruit. 1898, p. $7 \ldots \ldots \ldots \ldots \ldots$

San Jose scale-

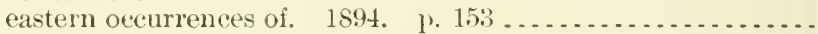

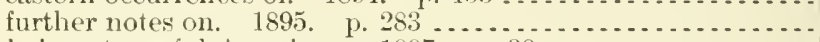

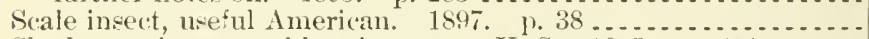

Shade-tree insect problem in eastern $\mathrm{C}$. S. 1845. p. 361 ......

Sluade-tree insects of Springfield and other New England cities. 1895. 1. 40

Shade trees-

inseets which defoliate, in eities and towns, general work

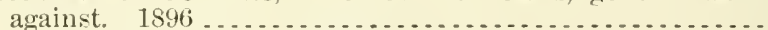

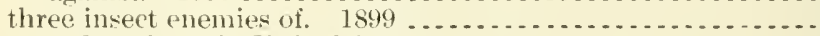

Smyrna fig culture in Uniterl States. 1900 . J. $79 \ldots . . . . . . .$. Spider-egg parasites, two-

1890. 1р. $269,359$.

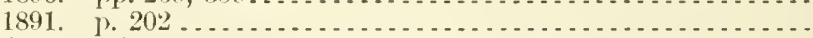

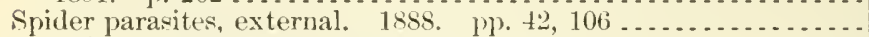

Spraying, use of stean apparatus for. 1896 . p. $69 \ldots \ldots \ldots \ldots$.

Sugar-lseet wehworm, conpleted life history of. 1894. 1. $364 \ldots$

Sugar-cane beetle injuring corn. 1888. p. $11 \ldots . . . . . . . . . . .$.

Tiger swallow-tail, abnormal, report of. 1894. p. $44 \ldots . . . . .$.

Timothy grass, new enemy to. 1892. p. $90 \ldots \ldots \ldots$

Tobaceo plant, principal insects affecting .................. . . same, 1). 121 .

Yellow-spotted willow sling, report on. 1sss. p. 3i..........

See also, as joint erlitor of Insect Life . . . . . . . . . . . . . . . . .

See also, for rejorts as Entomologist, Entomology Division, Agriculture Dejartment. 1894-1901.

See also, as joint author, Riley, Charles Valentine.

Howard, Jeland Ossian, and Mailatt, Charles Lester:

Carpet beetle or buffalo moth, speeies injurious to woolen goods, clothing, carjets, upholstery, ete. 1896. p. 58..........

$19.7: 5$

$19.7: 6$

\9.6:25

19.7:7

A1.10:894

19.7:3

19.7:1

19.7:1

19.7:7

19.7:4

A9.6:9

19.7:7

A $9.6: 7$

A9.6:17

\$9.6:22

19.6:12

A9.6:18

A9.7:7

19.7:7

A9.6:9

11.10:595

A9.6:2

A9.5:15

11.9:99

11.10:900

19.7:2

19.7:4

19.7:1

A1.10:896

19.7:6

19.7:1

19.7:7

19.7:5

A 1.9:120

A1.10:898

A. $7: 1$

A.7. 7 :

A\%.1:

$19.6: 4$ 
Howard, Leland Ossian, and Marlatt, Charles Lester-Cuntinuerl House flies, centipedes, and other insects that are annoying rather than direetly injurious. 1896. ए. 43 ..................

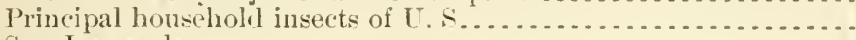

Sam Jose scale-

its occurrences in United sitaites, full account of its life history,

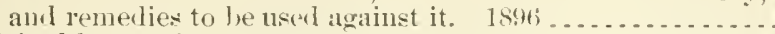
original home of. $1899 . \quad 0.36 \ldots \ldots \ldots \ldots \ldots \ldots$

Howarl, Sanforl:

Ayrshire cattle, characteristies of. p. 19:3

Horse, principles of form required to adapt him to sjecial jur

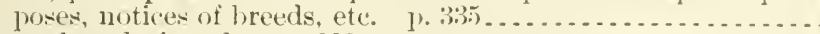

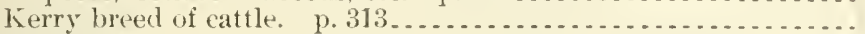

Howell, A. MI. :

Grape and tomato, fungus diseases of. 1859. p. 49 . . . . . . . . . Grape vine, diseases of, in South Carolina. 1S8R. p. 35 ......

Howell, Arthur H. skunks of genus Chincha, revision of. 1901... Howell, Martin A., jr. Canker worm, sying, experience with. 1883.

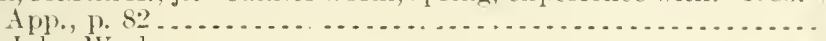

Hoyt, John Wesley:

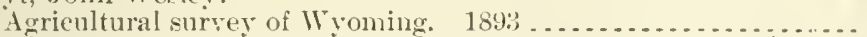

London, International Exhibition of 1862 , account of. I, $27 \ldots \ldots$ Hubluar, Frederick. Forests and rainfall in West India islands,

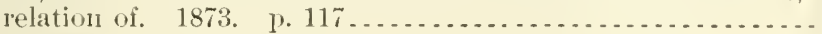

Hubluad, Ifenry Guernsey:

Aletia, rejort on. 1885.

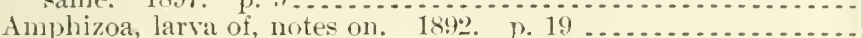

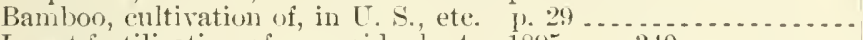

Insect fertilization of an aroid plant. 1895. 1\%. $\$ 40 \ldots \ldots \ldots \ldots$.

Insect guests of Florida land tortoise. 1894 . p. $302 \ldots \ldots \ldots \ldots . .$.
Orange, insects affeeting, with practical surgestions for their control or extermination. 185.5.

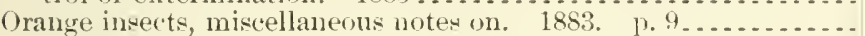

Rust of the orange. p. 361 ..........................

Scale insects, experiments on, progress in, etc. p. 152 ........ same, p. 152

Scale insects of orange; remedies and their application. p. 106.

Hubbard, Henry Guernsey, and Pergande, Theodore. Coccil, new,

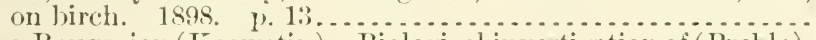

Hurl-on Bay region (Keewatin). Biological investigation of (Prelide). $190) 2^{\circ}$

Iuxlson County, N. J., tornado in, Aug. 24, 1901 (Eadie) 1) 355... Hughes, Ilenry l.: $^{-}$

Sorghum-sigar (xperinents at Rio Grande, X. J.1887. 1). 246 same, 1.67

-

4ame, with al litiounl

Soroliun-sugar manufacture, process for, used at Rio (irante,

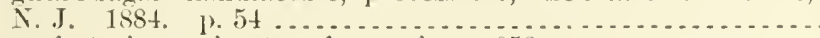
Sugar factories, estimates of fost of. 1) $252 \ldots \ldots \ldots \ldots \ldots \ldots \ldots \ldots$ same, 11. 73:

Hughes, Oliver J. I. Jotato hreal for horses in Germany. p. 530. Huillekoper, Rush Shippen:

Jamburg International Wxhihition (live stock) of 188:, report on. p. 386.

same. 1884. p. 199

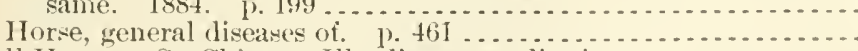

IInll House. See Chicago, Ill, dietary studies in.

Inlse, (i. W. Beet sugar, manufacture of. 1870 . p. It7.

Human body:

Conservation of cnergy in, experiments on (Atwater and Rosa). 1899

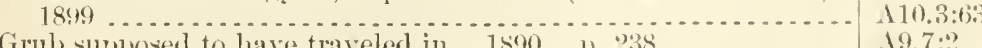

11.1:887

A $7.3: 17$

A1.1: 858

A7.3::0

17.8:3

$11.1: 887$

17.3:17

A4. 1:599

At. I:SSt

14.2:1 115

14.2:H78

1.27.9:8

$.19 .7: 2$ 
Iluman boly-Continnerl

Hetabolism of matter and energy in, experiments m ( Itwater

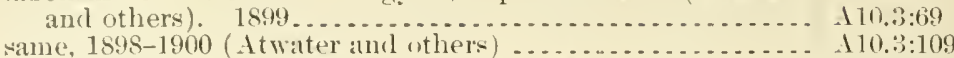
see also Bladkler - Blond - Borly material - Bones- Mneriy.

IIuman fools, composition of, ete.:

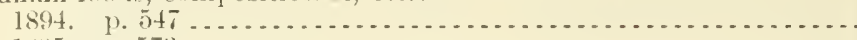

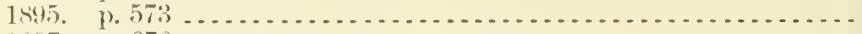

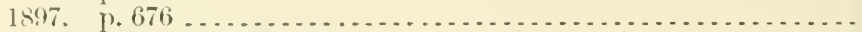

. Vevala tericultural interest in 1868.

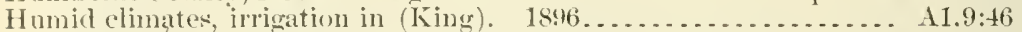

llumidity:

Atmosphere, charts of, note on (Ablue). 1901. J. 11s........

Atmospheric, olservations on (Lippincott). p. $520 \ldots \ldots \ldots \ldots .$.

Monthly notes on, Oet., 189t-Oet., 1902...................

Relative-

inside and outside of buildings (Henry). 1896. p. 456...... psychrometric tables for obtaining (IIarvin). $1900 \ldots . . . . .$.

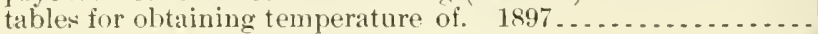

Sau Juan, Porto Rico, report on (Phillins). 1899. p. 319 . . . . .

Vertical gradients of (Frankentield). 1898................. tee also Vapor pressure.

Humphreys, D. C. Roads, stone and shell. 1894. p. 52........ Hnmus:

Granifeau's method for letermination of, modification of (HInston

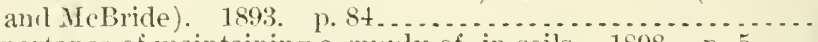

Importance of maintaining a smply of, in soils. 1898. p. 5 ...

In its relation $\mathrm{to}$ soil tertility (Snyler). 1895. p. 131 . . . . . .

Hunctred years' progress in agriculture (Flint). 1. 274 . . . . . . .

Hungariai lorome grass, circular on (Scribner), 1894 ...........

same, notice of circular.

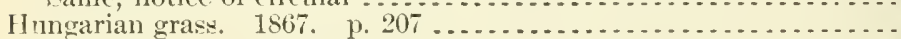

Hungary:

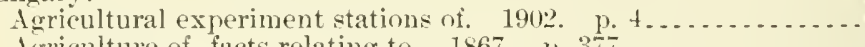

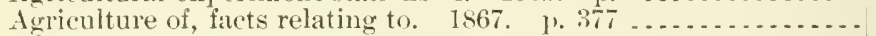

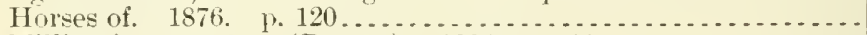

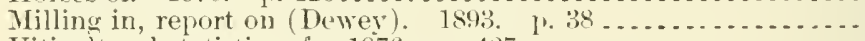

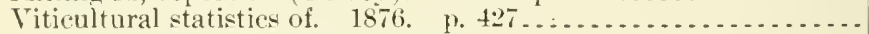

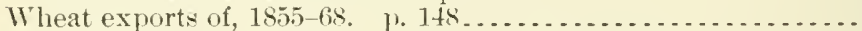

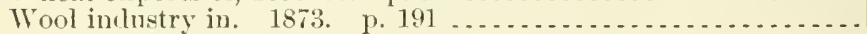

See also Austria-Hungary.

Hunt, Caroline L. See Atwater. Wilbur Olin, and Bryant, Arthur Perton.

Hunt, Ezra M. :

Animal diseases, contagious. p. 437

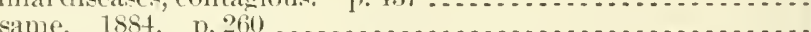

Animal diseases, contagious, extension of, and methods for their

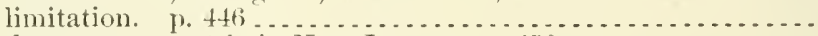

Anthrax among rattle in New Jersey. p. 359 . . . . . . . . . . . .

Plenro-pneumonia, contagious, in New Jersey. p. $297 \ldots . . . .$. Hunt, George E. :

Atmospheric pressure, high and how, monthly notes on, May, 1900, June-Aug., 1901, Jan.-Oct., 1902 . . . . . . . . . . . . . . . . . .

Rirer and flood service, monthly notes on, June, $1902 . . . . . .$.

Rivers and floods-

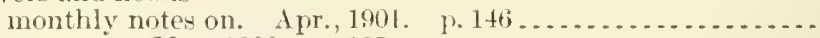

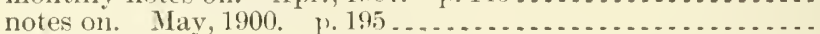

Ilunt, Thomas F.:

Agriculture, methots of instruction in teaching. 1896. p. 35...

Plats, equalizing irregularities of, caused by defective germina-

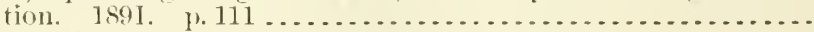

Innter, Walter 1).

Cicarla, prerodical, in 1902, circular on. 1902.

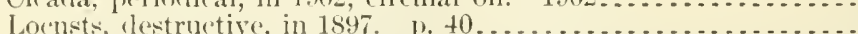

Melanoplus sprotus, investigation to tetermine whether, breeds permanently in Turtle IIountains, in North Dakota. 1900.

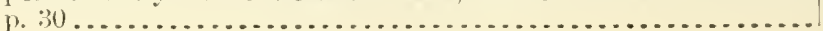

129.6:29

$11.1: 865$

A29.6:

129.6:24

A29.2:P95

+29.2:D51

+29.1:898

A29.5: $\mathrm{F}$

A22.3:11

A7.3:38

A1.9:78

A1.10:895

A 1.1:8\%:

16.4:1

A1.2:H89

A $27.9: 5$

A 10.6:13

A27.9:5

A $27.9: 14$

A27.9:31

A. $2.9: 14$

A $27.9: 7$

A $27.9: 11$

A $4.1: 884$

A4.2:Ano

A $4.1: 885$

A1.1:881-2

A $4.1: 884$

A.9.6:

A $29.6: 30$

A $29.6: 29$

129.6:28

A 10.3:30

A10.5::3

19.5: 44

A9.6:10

A.9. $6: 2: 2$ 
Hunter, Walter D.-Continued

Clamifeation no.

Ilexican cotton-boll weevil in the Inited statu, present statusof. 1901. p. 369 ....

Intington, Ellsworth:

Clinate of IIarpoot, Turkey in Asia, 1s9s-1900. 1\%. $250 \ldots . . .$.

Electric phenomena in Euphrates Valley. 1900. p. 286.......

Huntington, T. G. Garden vegetables, particularly onion, calibige, and squash. p. 110 .

FInnton, John. Electricity, local, in windsturm in $W^{2}$ oning. 1894.

Hurricanes:

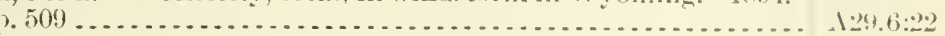

Charleston, .. C., 1752-1893, notes on (Abbe). p. 54. . . . . ... A29.6:2s

Destructive forces of, and conditions of safety anil damerer

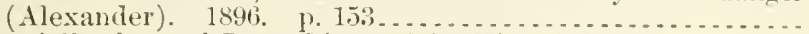

Especially those of Porto Rico and St. Kitts (Alexander). 1!\%2.

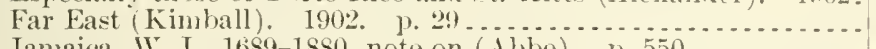

Januaica, IV. I., 1689-1880, note on (ißibe). p. $550 \ldots . . . . . .$.

Louisiana and Miscissippi coasts, Aug. 13-16, 1901, special report on. 1901

Origin of (Abije). $1896 . \quad$ p. 417 .

Philippine Archipelago, 1895 and 1896 (Stetson) ए. 101......

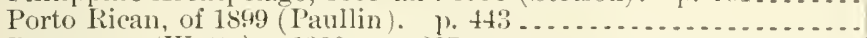

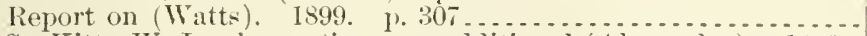

St. Kitts, IV. I., observations on, additional (Alexander). 18 s.9.

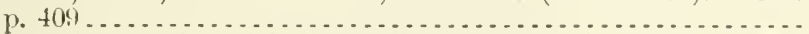

Tracks of, recurving of, in North Atlantic (Abbe). 1899. 1. 468.

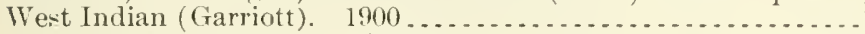
same, Sept. 29, 30, 1896 (Henry). p. 368..............

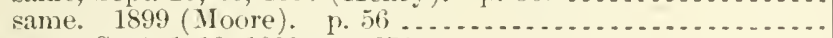

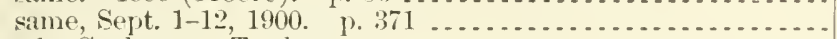
See rlso Cyclones-Typhoons.

Hurt, A. B. Mississippi; climate, soil, productions, and agricultural ('apabilities. IS89

Hurty, J. N. "Hemlock leds," report on experiments witl. 1894.

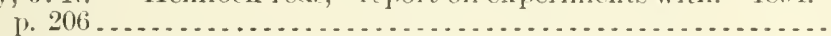

Huslanilry, rejresentation of, in Congress. 1871. 1. 119 ...... See also Patrons of husbanily.

Husmann, treorge:

Grape culture, present condition of, in California. 1898. p. 551.

Wine and wine-making, Inericam, p. $154 \ldots \ldots \ldots \ldots . . . . .$.

Winc industry of Napri County, Cal. 1s91. 1. 5isi ...........

Husmann, George C. Grape must, nnfermented, manufacture and preservation of. 1902 .

Huston, Ilemry Augustus:

Adrlress of, as president of Association of Othicial Agricultural Chemists, at 12th annual convention, 1895. 1.9.........

Immonic citrate, action of, on high-grade aluminie phosphate. 1890. p. 170 .

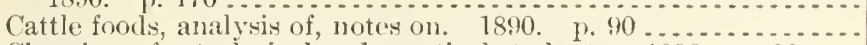

Chemistry for technical and practical students. 1896 . p. 88 ...

Plospluates, determinations of loss on lienting samples of, 1892. 1892. 1. 47

See also, as collaborator, Wiley, Harvey Washington.

Huston, IJenry Augustus, and bartlett, James. Ionroe. Soil solvents for available potasl and phosploric acid.. 1896. p. 91 .....

Huston, Henry Augustus, and Jones, William J. Basic slag, action of ammonimm citrate and citric arid on. 1896. 1).68......

Huston, Henry Augustus, and Mcliride, F. Ir.

Cruble fiber, determination of preliminary investigations relating

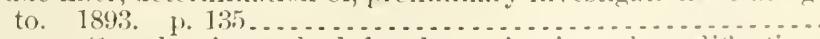

Humus, (irandean's method for determination of, modiliation

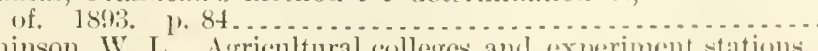

Intchinson, W. L. Agricultural colleges and experiment stations,

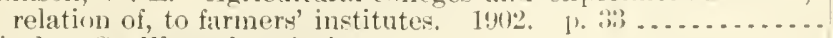

Ilyacinth. Spe IV ator hyacinth.

Hyaeintl germ, Wakker's (Kmith), 1901 .................

Hyatt, Robert J. River and flool service. 1sig. 1.50.......

A1.10:!)(1)

$1: 94.6: 29$

$129.6: 28$

11.1:\$64

1:4.6:202

A29.6:24

129.3:32

A:9.6:30

A29.6:25

A:29.2:1194

129.6:24

A29.6:28

A29.6:28

A29.6:27

A $29.6: 27$

A29.6:27

A 29.5:II

129.6:24

A29.3:24

A29.6:28

A1. $7: 3$

$17.3: 43$

A27.9:9

1 1. 10:\$98

1 1.1:867

1:7.9:20

1 19.3:24

$17.3: 47$

$17.3: 28$

17.3:28

110.:3:41

$17.3: 35$

17.3:4!

1...: :4!)

$17.3: 3 \mathrm{~S}$

$17.3: 38$

111).:2:111)

$120.3: 236$

104. $3: 24$ 
Hybrict offspring, quantitative studies on transmission of parental

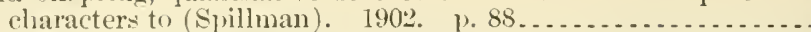

\section{Hrbridizing:}

Cultivation and, of wheat (Watt*). 1872. v. 432.

Improvement of grape by (Camploell). Siee ulso Evans, Walter H.

Hybris and their ntilization in plant breeding (Swingle and

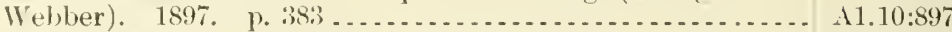
Irde, (Fustarus A., notes on (Abbe). 1901. p. 220........... A29.6:29 Hive, John:

Agricultural statistics of Elerenth U.S. Census, discussion of.

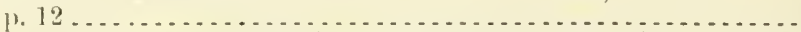

Fertilizer industry, production and consmuntion, review of statistics of, with abstracts of State laws for analysis of sale. 1898.

Flax and lemp, extracts from Elerenth Census bulletin on. 1892. p. $83 .$.

tatistic Division, Agricniture Department, work of, for farmer. 1897. p. 258. same, reprinted with title "of what service are statistios to the farmer?"

See also, for reports as Statistician, Agriculture Department,

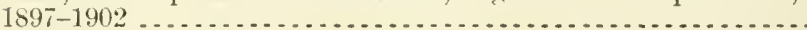

Hydrocyanic-acid gas:

As an insecticide (Coquillett). 1893. p. 176

Experiments witl, as means of exterminating mealy bugs and other insect pests in greenhouses (Iemenway). 1900. p. 69.

Fumigating greenhouses and cold frames, use of (IVoods and Dorsett)

Low-growing plants, as an insecticide on (Sanderson and Pemny).

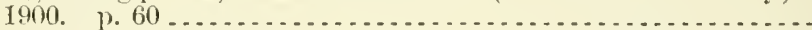

New method for handling, in orcharls; Emory fumigator (John-

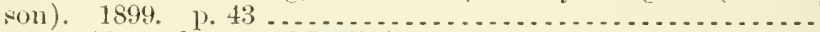

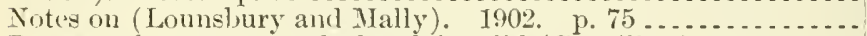

Process of, patent on, declared invalid (Coquillett). 1894. p. 257

Remedy for San Jose scale and other insects (Johnson). 1898. 1. 39 . . . . . . . . . . . . . . . . . . . . .

Results with, for destruction of insects in large buildings (Jolnu-

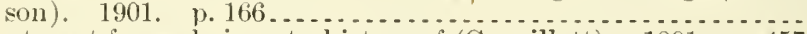

Treatment for scale insects, history of (Coquillett). 1891. p. 457.

Tise of-

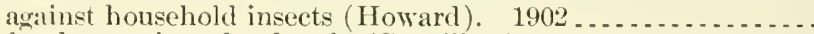
for destruction of red scale (Coquillett). 1890. p. 202...... for exterminating houselsold insects (Beattie). 1902. p. 50 .

Hydrodynamic equations for atmosphere, note on (Abbe). 1897.

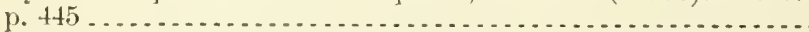

Hylrodynamies, equations of, in form suitable for application to problems connected with movements of earth's atmosphere (Cottier). 1897. p. 296

Hydrographic Office, U. S., voluntary meteorological observers of,

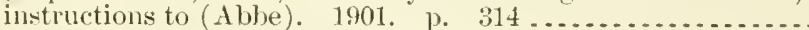

Se also Marine Meteorology Division.

Hydrography of southern Appalachians (Pressey and Myers). p. 123. Hydrologicail congress. See Clermont-Ferrand, France.

Hylrology and stratigraphy of Nevada (Hicks). 1890, p. 71 .... Hydrology of Lake Minnetonka watershed (Cooley). 1899. p. 14.. Hygiene and demography congress, 1900 . See Paris, tenth international congress of hygiene and demography.

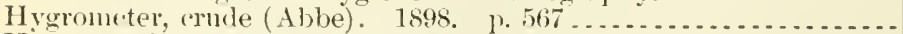

Hygrometric observations, ntility of (I'enmell). 1899. 1. 162....

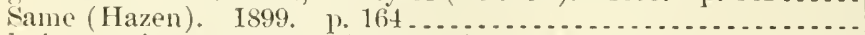
Hylesinus sericens, notes on (Sehwarz). 1894. p. $254 \ldots . . . . . .$. Hymenomycetes, spores of, method for preserving (Harz). 18s9.

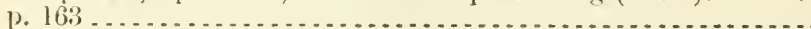

Hymenomycetons fungi, some new species of (Ellis and Everhart). 1889. 1\%. 24

A1.10:897

A27.8:14

A27. 1:

A9.7:6

A9.6:22

A9.5:87

A $9.6: 26$

A $9.6: 20$

A9.6:31

A9.7:7

A9.6:17

A 10.3:99

A9.7:3

A $9.5: 46$

A $9.7: 2$

A9.6:31

A29.6:25

A29.6:25

A $29.6: 29$

A $1.2: \mathrm{Ap}_{\mathrm{p}}{ }^{2}$

A15.2: $\mathrm{Ar}^{-}$

A29.6:27

\29.6:26

A29.3:24

129.3:24

A9.7:7

128.5:5

A28.5:5 
Hymenoptera:

Brerl parasitic, in the national collection, sump of--

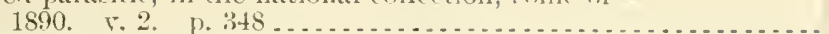

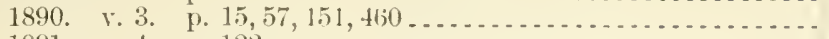

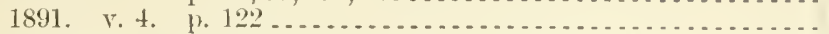

Hymenopterous parasites:

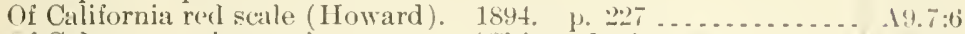

of Coleoptera, observations on some (Chittenclen). 1893. p.247. 1:.7:5

see also Aphelinince.

Hyperaspis signata, beneficial work of (abstract) (lloward). 1900.

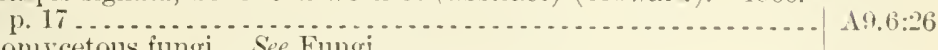

Hyphomycetons fungi. See Fungi.

IIypoderas columber, note on (Kellicott). 1s92. p. 7.

IIvpoderma bovis, larve of (Curtice). 1890 , j. 207

Hypoxylon, North Ameriean species of, sympsis of (Ellis and Ever-

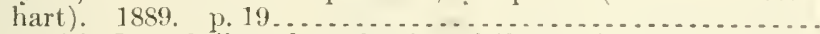

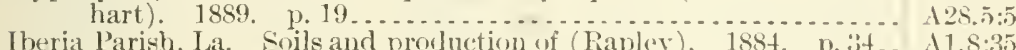
Ice:

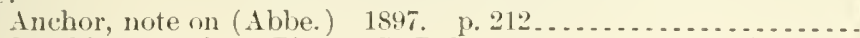

Breaking up of, at Pierre, S. Dak., notes on, $1846-89$ ( $\mathrm{Ab}$ b)

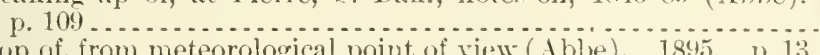

Crup of, from meteorological point of view (Ablue). 1895. 1) 13 .

Drift, and theory of ocean currents (Daly). 1900 . p. 433.......

Jam in Niagara River, note on (Al)be). 1899 p. p1 ..........

Kennebec River, report of (Abbe). 1897. 1. 98 . . . . . . . . . . .

Lake, sndden disappearance of, note on (Abbe). 1900 . p. 114..

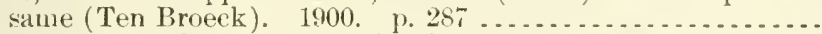

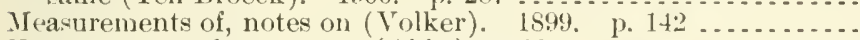

Vapor pressure for, note on (Abbe). 189., p. $476 \ldots \ldots \ldots$

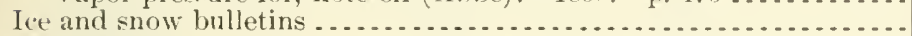

Ice caves:

As meteorological phenomena (Kimball). 1901. !. 366 .......

Flagstaff, Ariz. (Renoe). 1901. b. 54 . . . . . . . . . . . . . .

Freezing wells and, notes on (Kinball). 1901. 1.509......

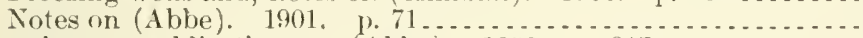

Ice columns, publications on (Abbe). is9s p. 217..........

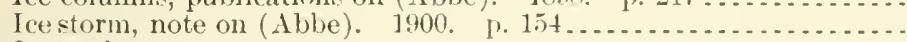

Ice trade:

History of (Wetherell). p. 439 ...................

Weather Burean and, note on (Abbe). 1899. p. 63

$19.7: 5$

A9.7:2

A1.8:35)

1.9.6:2:25

A:29.6::27

$129.6: 2: 3$

129.6:28

A $29.6: 27$

129.6:25

129.6:28

A29.6:28

A29.3:24

A24.6:27

A.9.16:

A $29.6: 29$

1:39.6:29

129.6:29

1.9.6:29

A:4.6:26

129.6:25

11.1:86:3

$129.6: 27$

Iceland, neteorological reports by cable from, noteson (Abbe). 1899.

Ieerya:

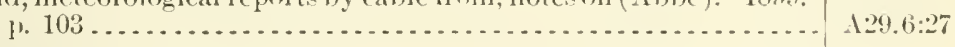

Its probable origin the islands of Bourbon and Mauritius (Riley).

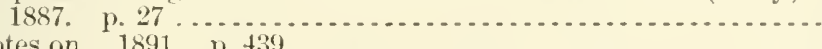

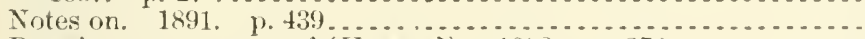

Parasite, new, report of (Howard). 1892. 1. $378 . . . . . . .$.

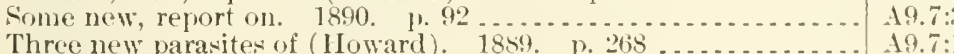

Sire also Scule insects.

Icerya purcliasi:

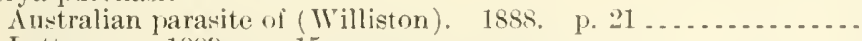

Letter on. $1859 . \quad$ p. $15 \ldots \ldots \ldots \ldots \ldots$

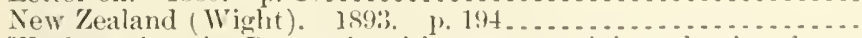

Work against in Portugal, with acount of introduetion from Irlaho:

America of Novius cardinalis (110ward), 18:18. p. $30 \ldots \ldots$.

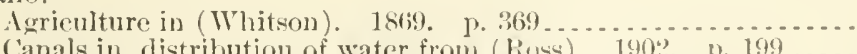

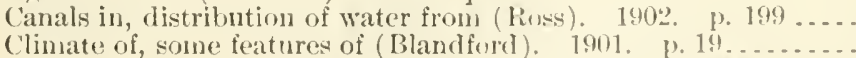

Cricket, western, anul certain locusts in, outloreaks of (Milliken).

Forest condition of Rocky Monntains in (Ensign). p. 41.....

Grasshoppers in, outbreak of (Pruner). 1890. 1. $135 \ldots . . . .$.

Hog cholera and enzootic cerebro-spinal meningitis among horoses in (Willians). 1898, ๒. 179 .

19.7:4

$49.7: 3$

19.7:1

$19,7: 1$

19. $7: 2$

19. $7: b$

19.6:15

$127.9: 7$

110.3:119

1 $24 .(3: 29$

19.7:15

11:3.:2:2

19.7:3

1 +.1:597 
ldaho-Continued

Invertigation of codling moth in, 1900 (Simpson). 1. 51 ....... Irrigation in, in 1890 (Nimmo), p. 149 ...................

North, insects of, notes on (Akrich). 1894. p. $201 \ldots \ldots \ldots \ldots$

Northern, plants in, collection of, made ly. J. H. Sandberg and asvistants in 1892, report on (Holzinger). 1895. p. 205.....

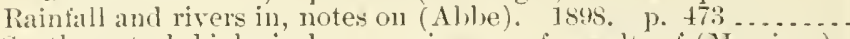
South central, biological reconnaissance of, results of (Merriau). 18.91

Thunclerstorm of May 16, 1900, in, notes on (Alibe). p. 207....

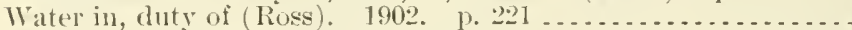
Water supply of, for season of 1900 as lepending on snowfall

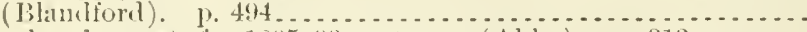
Weather forecasts for 1895-49, notes on (Abbe). p. $313 \ldots . . .$. see also Boise Valley - Cour d' Alene .11ountains - Paeific Northwest.

Jlaho pea. see Gran.

Ignis fatmus or Jack-o-lantern (Abbe). 1897. p. 211 ............ Thne, Egon. Phenologic or thernal constants. 1895. p. $427 \ldots \ldots$. llex cissine, aboriginal North American tea, its history, distribution, and use among native North American Indians (Hale). 1891. Sice also Yaupon.

\section{Illinois:}

Cattle trade and dairy interest of (Perry). 1, 335 ............

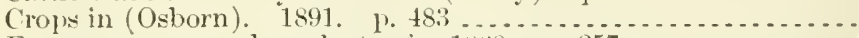

Farm resources and products of. 1868 , 1) $257 \ldots \ldots \ldots \ldots \ldots \ldots$

Farmers institnte work accomplished in (Coolinge). 190:. 1). 20

Horses in, diseases anong (Detmers). p. $355, \ldots \ldots \ldots$

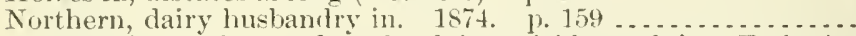

Nursery inspection and orchard insecticide work in (Forler).

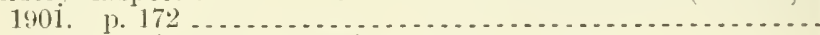

Oats and corn in, cost of growing. 1873 , p. $36 \ldots \ldots \ldots \ldots$

Road improvement in, address on (Stone). $1897 \ldots \ldots \ldots \ldots$.

Swine plague in (Detmers). $1880.19 . \ldots . \ldots . . . . . . .$. see also Cairo - Champaign - Cook county - Ottawa.

1llinois, University of:

College of Agriculture, building for. 1901. p. 604............

Dietary studies at (Grindley and simmis), 1901. 1. 7 ........

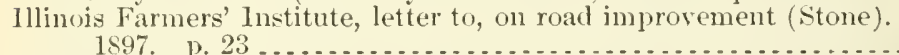

11 inois State Agricultural Society fair, Decatur, Sept., 1870 (Capron)

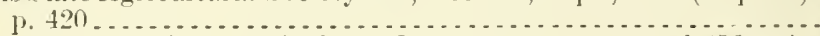

llhstrations Division, Agriculture Department, report of (Marx):

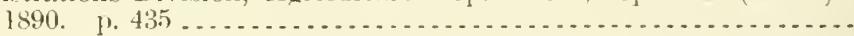

1891. 1. 485 . . . . . .

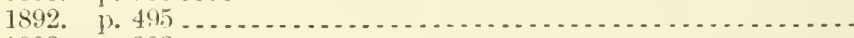

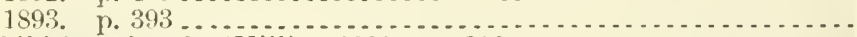

Imbibition of rocks (Hill). 1891. p. 213 ....................

Immigration statisties:

1864, Jan.-June; No. 4, p. 8; July-Sept., No. 5, 1. 37 ...........

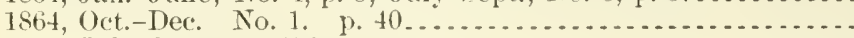

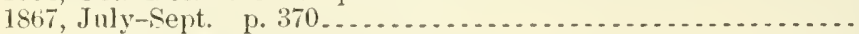

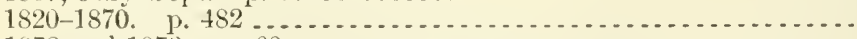

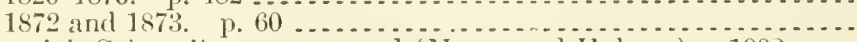

Imperial, Cal., soil survey around (Jieans and Holmes). 1902 ....

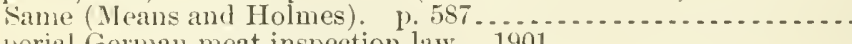

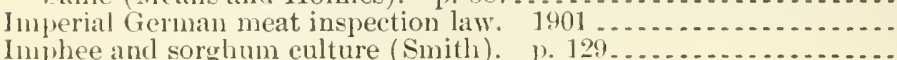

Inphee and sorghum culture (Smith). p. $129 \ldots \ldots \ldots \ldots \ldots \ldots \ldots$
Inplements. See Agriculture implements.

Import cluties, foreign, on wheat. 1893 . p. $248 \ldots . . . . . . . . .$.

Imports and exports, agricultural, reports on, $1893-1899 \ldots \ldots \ldots \ldots$.

See clso Agricultural imports - Names of countries.

Incubators. See Chinese incubators.

Indexes of Agriculture Department. Sie Agriculture Department, indexes and lists.

$19.6: 30$

A 15.2:1) $14^{1}$

19.7:7

$16.5: 3$

+29.6:27

1.5.5:5

1 $29.6: 28$

1 $10.3: 104$

$129.6: 28$

$129.6: 27$

A29.6:25

129.3:112

16.8:14

A4.1:885

A 27.9:29

A27.9:6

A 10.3:120

11.1:851-2

A $27.9: 12$

A 10.3: $: 99$

A 27.9:11

122.4:25

A1.6:2:2

A 10.6:12

A 10.3:91

A22.4:28

A27.9:S

A1.1:890

A 1.1:891

A1.1:89²

A 1.1:893

A 15.2:P94

127.9:2

A $27.9: 3$

A27.9:5

A $27.9: 8$

A27.9:12

A 26.4:9

A26.5:901'

A 4. 4:32

A1.1:862

A27.9:31

A 12.4 
India:

Agricultural statisties of. 1845. p. $448 \ldots . . . \ldots \ldots . . . . . . .427 .4: 13$

Agriculture in, account of (Siva). 187t. p.389............ 127.9:12

Cinchona cultivation in. 1870. 1. 285................... 127.9:8

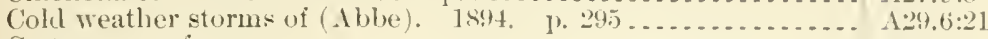

Cotton erop of-

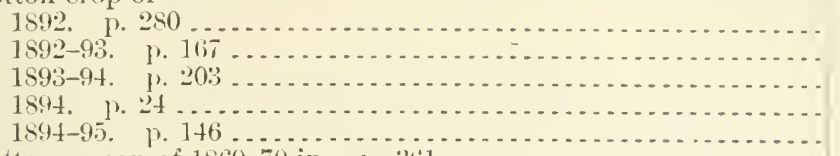

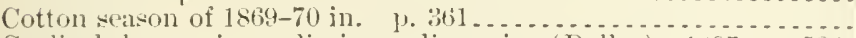

Cyclical changes in, preliminary discussion (Dallas). $1897 . \quad$ p.532.

Droughts, famines, and forecasts in (Archibald). 1900. p. $246 .$.

Droughts and famines in (Eliot). 1895 . p. $444 \ldots . . . . . . . .$.

Dronghts in, prediction of (Dallas). 1894. I. 18.

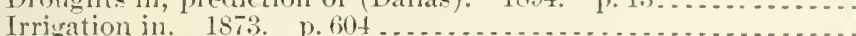

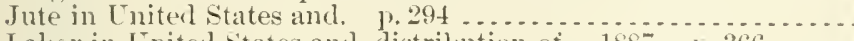

Lalor in Enited states and, distribution of. 1887, 1, 366......

Ieteorological work in, history of (Kimball). 1902, p. 31 ....

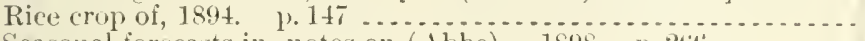

Seasonal forecasts in, notes on (Abbe). 1898. p. $260 \% \ldots . . . . .$.

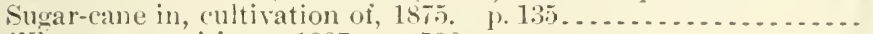

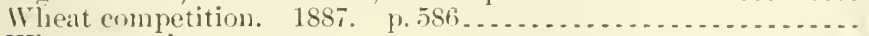

Wheat crop in-

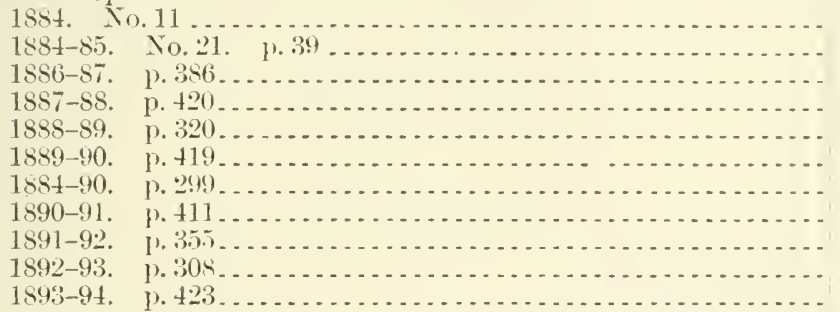

Wheat eulture in (11auser). p.569....................

Wheat production and exportation in, rourse of, 1880 1896 .....

A27.9:30

$127.9: 31$

A.7.9:32

A27.9:3:3

127.9:3:3

A $27.9: 8$

129.6:25

A29.6:28

129.8:112

A $29.8: 11^{1}$

A27.9:11

11.1:5.4

127.9 .25

A:9.6:30

A $27.9: 33$

A29.6:26

A27.9:13

127.9:25

A $27.9: 22$

127.9:2:

127.9:25

A27.9:26

A27.9:27

A27.9:28

A27.9:28

A27.9:29

A 27.9:30

127.9:31

$127.9: 32$

11.1:885

A12.4:10

Se ulso Bengal - Burma - Calentta - Madras - Punjab.

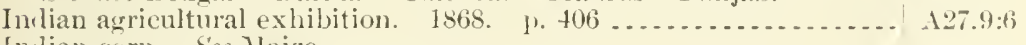

Indian corn. See Naize.

Indian mallow. See Abutilon avicenze.

Inclian monsoons and Nile flonds, notes on (Abbe). 1900. p. 252. A29.6:28

"Indian summer," note on (1atthews). 1902. pl. 19,69. . . . . . A29.6:30

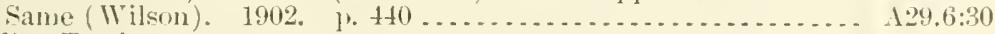

Indian Territory:

Artesian and undergrounl waters in, west of 97 th meridian (11ill).

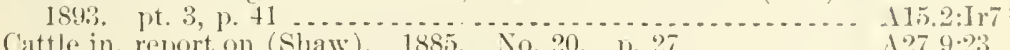

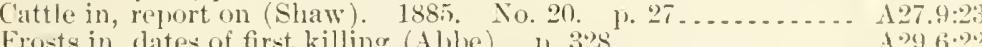

Plants eollected in, by C. S. Sheldon and MI. A. ('arleton in 1891

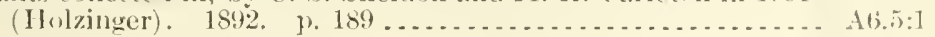

Indiana:

Cattle tralle and dairy interests of (l'erry). 1. 335 .......... $14.1: 855$

Corn-lout wel)-worm an old pest in, note on. 1886. 1.33 ..... 19.8:12

Crops in (0sborn). 1891. p. 483 ....................... 127.9:29

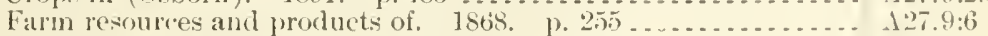

Farmers institute work accomplished in (1atta). 1902. 1).21 . . A10.3:120)

Forestry for certain portions of (Fumas). 18st. 1. 346 _..... $113.5: 4$

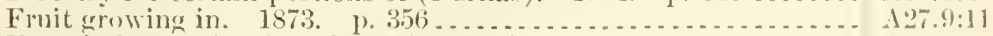

Hog cholera and swine plague in (Bitting). 1) 199 .......... At.1:897

Larve of erane-fly destroying young wheat in (Wohster). 1890.

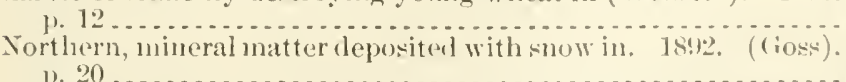

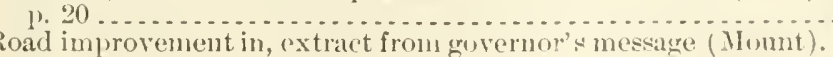

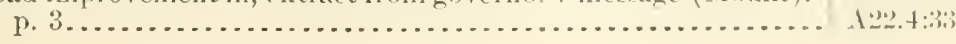


Intiana-Continued

Sontheantern, pericdical cicada in. 1856. p. 24 ............ Strawberry-leaf flea beetle in (Webster). 1891. p. 137 ......

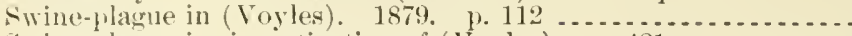
Swine-plagne in, investigation of (loyles). p. $421 \ldots . . . . . .$. See also l’urdue University.

Indians, North American:

Food products of. p. 404 .

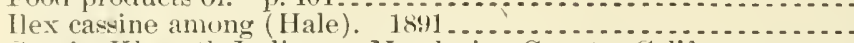
See also Klamatl Indians-Mrndocino County, Calif.

Indigo plant, cultivation of, in I. S. p. 255 . . . . . . . . . . . Inrlo-China, Frencl, meteorology in, notes on (Abbe). 1901 p.

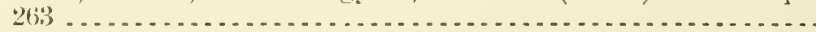

Industrial classes, education of (Andrew). 1864. No. 1. p. 15... Intustrial colleges:

Builelings for, general plan, with necessary aids to instruction in each department of education (Owen). 1864.............

IIistorical sketch. [1. $317 \ldots \ldots \ldots \ldots$

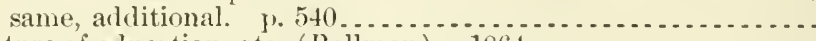

Nature of elucation, etc. (Bollman). $1864 \ldots$

Industrial development, relation of gool roads to (Hays). 1902.

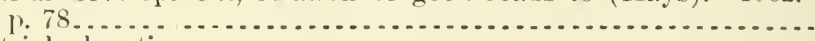

Inrlustrial efheation:

Paper on (Willits), 1885. p. $55 \ldots \ldots \ldots \ldots$ same (McWhirter). 1885. p. $105 \ldots \ldots \ldots$

Progress of-

1869. p. 452

1870. p. 467 .

1871, p. 306 .

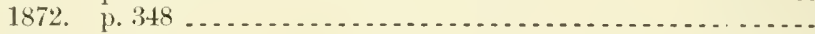

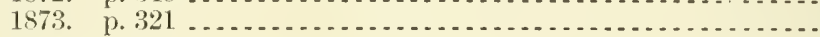

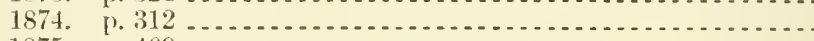

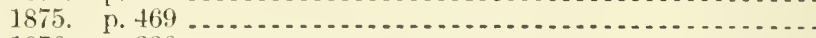

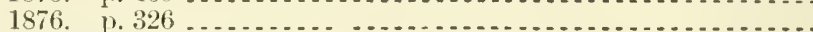

See also Agricultural edncation.

Inclustrial expositions. $1872 . \quad$ p. 288.

Industrial population, relation of farmers institute to (Hoard).

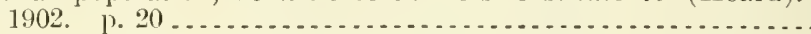

Inclustrials [or manual training], practical importance of (Gilkison).

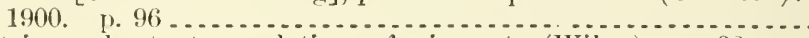

Industries and arts, true relations of science to (Viley). p. $32 \ldots .$. Industry:

Profits of. 1865. No. 2. p. 15.

Southern, notes on. 1866. p. 412. Southern, notes on. $1866 . \quad$ p. $112 \ldots \ldots$
same. 1867. p. $371 \ldots \ldots \ldots$
Ys. speculation. 1892. p. $134 \ldots \ldots \ldots$

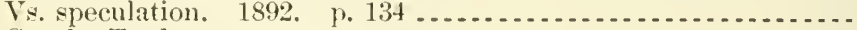
See also Trade.

Infant and invalid foods, analysis of, provisional method for (Wiley).

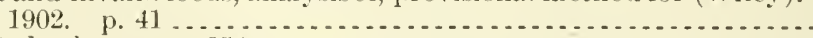

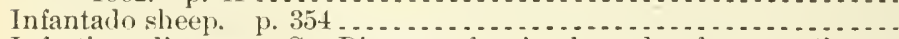

Infectious diseases. See Diseases of animals and references tliereunder.

Influenza in horses (Law). p. 203.

Jnformation and Exchange Burean, Agriculture Department, creation of, aldress favoring (Woodhull). 1885. p. $90 \ldots . . . .$.

Ingersoll, C. L.:

Agricultural experiment stations bulletin, present and prospec-

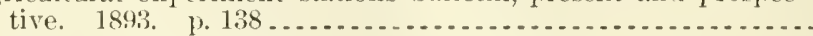

Field experiments, cooperative, report on. 1891. p. 109..... Inoculation:

As a preventive of swine liseases. p. 58.

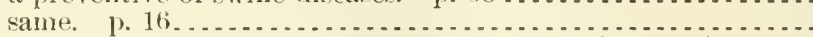

For prevention of hog cholera, experiments with (Salmon). 1892 .

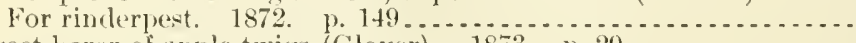
Insect borer of apple twigs (Glover). 1873. p. $29 \ldots \ldots \ldots \ldots \ldots \ldots$ Insect borers, few, notes on (Davis). 1891, p. 64............. Insect food of crow (Schwarz). 1895, p. 57 .

A9.3:12

A9.7:3

A $1.6: 12$

A1.1:878

A $1.1: 870$

A6.3:14

A1.1:873

A:9.6:29

A27.9:\$68

A27. 2: $\ln 2$

A1.1:\$67

A 1.1:868

A27.2:In2

A22.3:23

+1.7:9

A1.7:9

A1.1:869

A1.1:870

A1.1:871

A1.1:872

A $1.1: 873$

A1.1:874

A I.1:875

A $1.1: 876$

A27.9:10

A $10.3: 110$

A $10.3: 76$

A 1. 7:2

A27.9:3

A27.9:4

A27.9:5

A27.9:30

A 7. 3:65

A $1.1: 866$

A 1.1:872

A 1. $7: 9$

A10.3:16

A 10.5:3

A1.1:859

A4.1:889-90

A $1.9: 8$

A27.9:10

A 27.9:11

A9.7:4

A5.3:6 
Insect collection of a large museum, suggestions for (Riley). 1890.

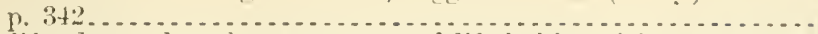

Insect life, devoted to the economy and life habits of inserts, especially in their relation to agriculture; edited by C. V. Riley and 1.0 . Howard. vols. 1-7. Index, $1888-18 \% 5 \ldots . . .$. See also Murtfeldt, Mary E.

Insect pests:

Action taken regarding, in California. 1892. 1\% $158 . \ldots . . . .$.

Danger of importing (Howard). 1897. p. 529 . . . . . . . . .

Fonr imported, notes on (Kirkland). 190\%. p. 9:3 ...........

Household-

bedbugs and red ants (Riley). 1ss?. p. 10t.............. carpet beetle, or so-ealled buffalo nuth (liley). 185?. p. $1: 27$

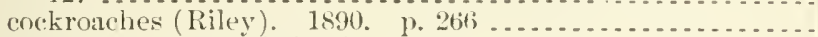

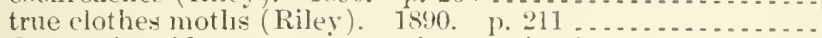

Hydrocyanic-acid gas as a means of exterminating (Hemenway). 1900. ए 1. 69

Plant diseases and, proceedings of national convention for suppression of (Galloway). 1897

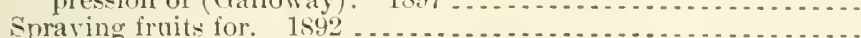

Trinilad, British West Indies, notes on some (Urich). 18 93.

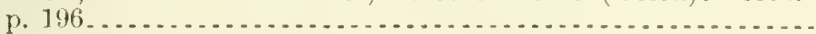

Insect powder. See Buhach.

Insect vivaria, how are [they] to be lighted? (Swinton). 1890. p. 1s.

Insectary and office methods in use in entomological department of ohio Agricultural Experiment Station, report on (Welster).

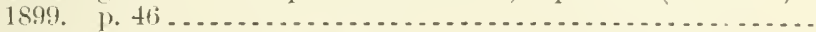

Insecticisle appliances, report on (Riley). 1859. p. 243, 263. . . .

Insecticide soaps, report on (Marlatt). 1896. p. $38 \ldots . . . . . . .$. Insectiriles:

Arsonical, soluble arsenic in (Haywood). 1902. 1).51 ........

Arsenites and arsenical mixtures as (Gillette). 1893. 1\%. 115....

Carbon bisulphide as an (Smith). 1s94. p. 108............

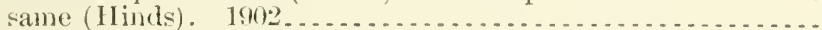

Crude petrolem as (Viloox). 1900. 1) $15 \ldots \ldots \ldots \ldots$

Early spring applications of, on fruit trees, some effocts of (Felt).

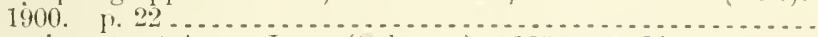

Experiments at Ames, Iowa (Gobome) $188 t$ p. $23 . . . . . .$.

Experiments at Trenton, N. J. (Bemnett). 1sist. 1. $27 \ldots \ldots .$.

Experiments with, some (Marlatt). p. 33 ................

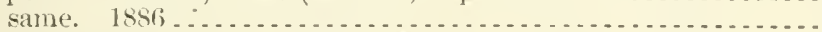

Fam practice and fertilizers as (smith). 1sis. 1.93......

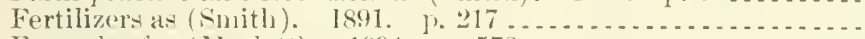

Formulas for (Marlatt). 1894. 11.572................

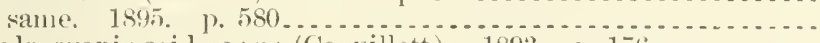

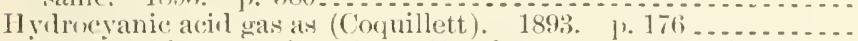
same, on low-growing plants (Sanderson and P'enny). $19(0)$.

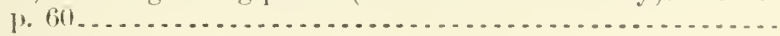

Importantcomlensed information conceming, May, 1891 ............ directions for preparation and use (Marlatt) .............

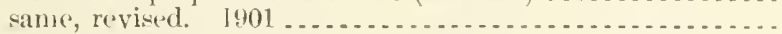

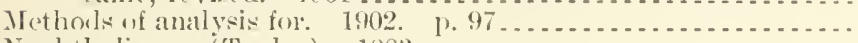

Naplithaline as (Taylor). 1883

New and oli, and thir combination with fungicides, some olservations on (Galloway). 1894. 1. 126

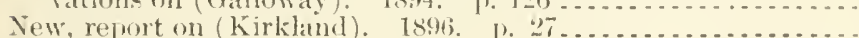

Notes on (Marlatt) -

1894. 1. 115.

1895. ए. $19 \ldots$

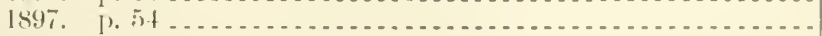

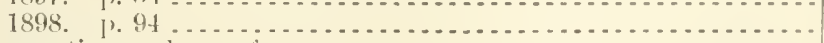

Preparation and usc of-

1896. 1) (i1)

1897. 1. 6337

1898. 1. 6is?

Classiffation no.

119.7:2

\1.8:20

A $1.10: 397$

A9.6:31

19.7:2

19.7:?

A $9.7: 2$

19. $7: 2$

$19.6: 1: 2$

11.8:57

A 1.9:7

A $9.7: 6$

19.7:3

A9.6:20

A9. $7: 1$

19.6:6

A9.6:37

$19.7: 6$

19.7:7

11.9:1 5

11.9:114

A9.6:26

19.3. 11

19.3:11

19.6: $0^{2}$ ( )

19.8:11

19.7:6

19.7:3

1 $1.10: 894$

11.10:895

$19.7: 6$

19.6:26

19.5:1

11.9:19

11.9:12\%

17.3:67

A 18. $2: 116$

1!1. $7: 7$

$19.6: 6$

19.7:7

1!1.6:2

19.6i:?

1:1.6:17

$.11 .10: 5010$

11.10:847

11. $10: 598$

$114-04-24$ 
Insecticides-Continued

Tests with, upon garden insects (.11wood). 1887.

U-e of, practical notes on (Beckwith). 1891. p. 269

19.3:13

$19.7: 3$

Sere ulso I rsenical insecticides-Fungicides and insecticides- $\mathrm{H} \mathrm{y}$ - drocyanie-acid gas-Kerosene-Kerosene emulsion-Naphthaline-Oil emulsions-Orehard insecticide work in Illinois-Paris green-Petroleum-Pyrethrum-Spray machinery.

Inserets:

Icom, primary and secondary (Murtfeldt). 1894. p. 315.....

Animals, domestic, insects affecting (Osborn). $1896 \ldots . . . . .$.

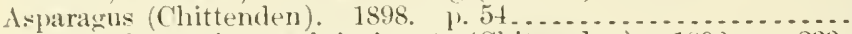

Beans and peas, insects injurious to (Chitenden). 159s. p. 233.

Carriers and spreaders of disease (Howard). 1901. p. 177. ...

Collection of, small, marle during J) wath Valley expedition, re-

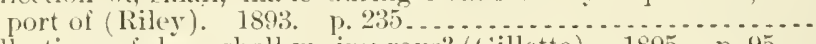

Collections of, how shall we improve? (cillette). 1895. p. 95... Contagions diseases, use of, in contending with (Osborn). 18.10.

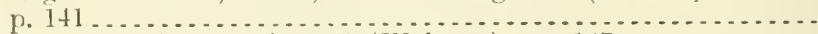

Corn, observations on, in 1887 (Webster). p. $147 \ldots \ldots . . . . .$.

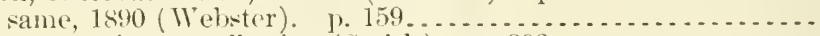

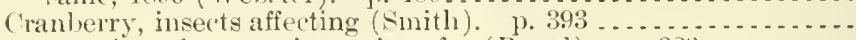

Destruction of, recent inventions for (Breed). p. $323 . . . . . .$. Sie also Insecticilles.

Dipterous, two, injurious to cultivated flowers (Coquillett). 1895.

Druge injured by, at University of Kansas (Kellogg). 1894. p. 31 .

Economic, of season, special (Daris). 1894. 1' 198..........

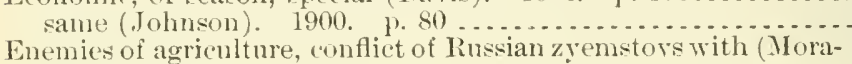

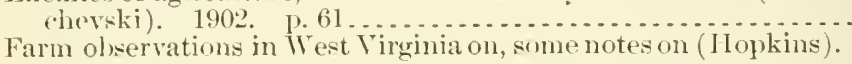

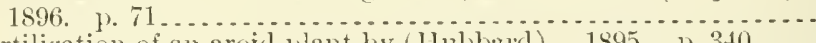

Fertilization of an aroid plant by (IImbard). 1895 . p. $340 \ldots \ldots$

Fertilization of muskmeloms by, notes on (Rane). 1898. I. 75..

Foreign, lesirability of an inspection system against (Iloward).

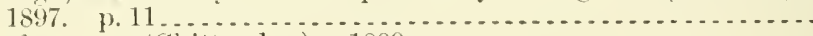

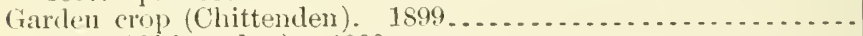

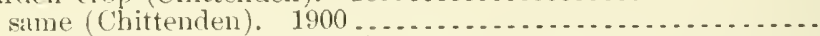

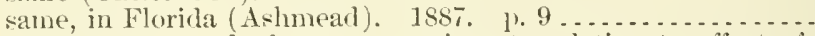

Hemipterous, record of some experiments relating to effect of punctures of some, upon shrubs, fruit, and grains, 1886 (Web-

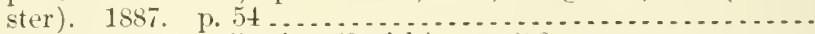

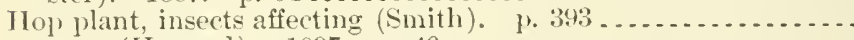

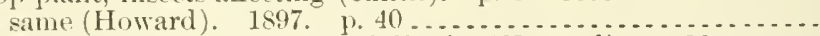

IJow they affect health in rural district (Howarl). $1902 . . . .$. .

ldaho, north, notes on (Aldrich). 1894. p. 201 ............

Importation and repression of, destructive (Webster). 1895. p. 79.

Injuries from. See Crops.

Injurious-

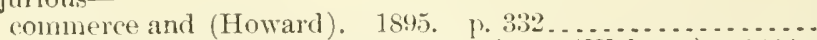
early published references to some of our (Webster). 1892.

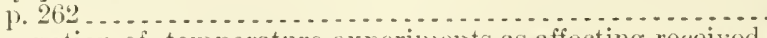
hibernation of, temperature experinemts as affecting received

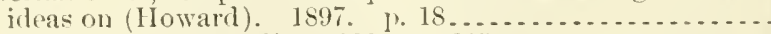

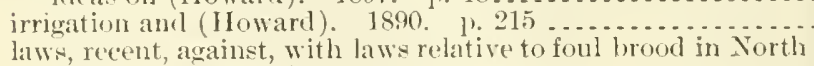

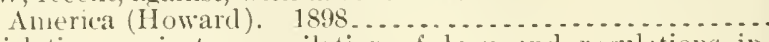
legislation against, compilation of laws and regulations in [?. S. and Pritish Columbia (Howard). 1895...........

list of principal1899. 1). 745

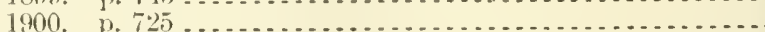

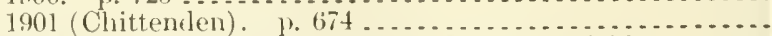
methorls of eontrolling, with formulas for insecticides1894 (Marlatt). p. 572.

A9.7:6

A $9.6: 5$

\$9.6:10

1 1.10:898

A1.10:901

A5.5:7

A9.6:2

19.7:3

11.1:887

19.7:3

11.1:884

11.1:876

A9.7:7

A9.7:7

A9.7:7

A $9.6: 26$

19.6:35

19.6:6

19.7.7

19.6:17

A 1.8:57

A9.6:19

A $9.6: 28$

A9.3:14

19.3:13

A1.1:S84

A9.6:7

A 1.9:155

A9.7:7

A9.6:2

19.7:7

A.9.7:4

19.6:9

19.7:2

A9.6:13

19.3:33

A 1.10:899

A $1.10: 900$ A 1.10:901

A $1.10: 894$ 
Injurions-Continued

methorls of controlling, ete.-Continuer

1895. p. 580

1898. p. 657 ........................

methods of studying life histories of notes on (Howar]).

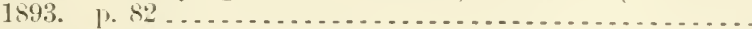

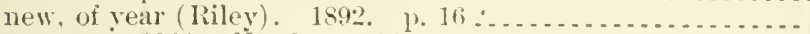

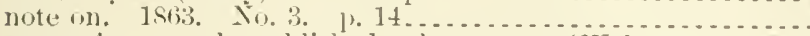
some of our, early publisherl references to (Welster). ] s.9?.

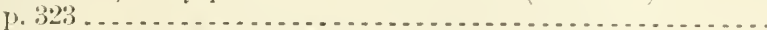

Sie also Packarl, Alpheus fipring.

Laiswer-faire philosophy applied to insect problem (Marlatt).

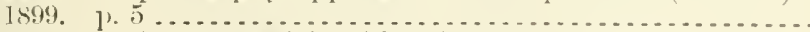

Lantern trap for, suecesful (Gillette). 1s97. 1, 75 . .

Little-known, of economic importance, noter on some (Johnson). 1897. 1. S:3

Millet, insect injury to (Chittenden). 1898. p. $84 . . . . . . .$.

II iscellaneous extracts from correspondence of Entomology I)ivision relative to. 1883. same. 1884

Vive ellaneons report on (Comistork) (Comstock). p. 195 ................. same, p. 195

North American, enumeration of published svmopses, (atalognes, anul lists of, etc

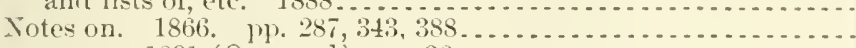

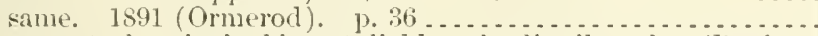

Nursery stock, principal insect siable to he distributed on (lianks). 1902

Orange and other plants of eitrus fanily, with practical sucresestions for their control or extermination (Hubbard). $1855 .$.

Parasitic-

report on predaceous and, in applied entomology (Riley).

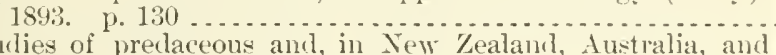
studies of predaceous and, in New Zealank, Australia, and
adjacent islands (Koebele). $1893 . . . \ldots . . . . . . . . .$.

Petroleum, crude, and its effects upon, notes on (Smith). 1901.

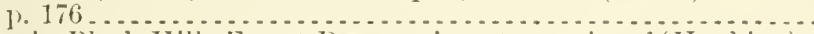

I'ine in Blask Hills Forest Reserve, insect enemies of (Hopkins).

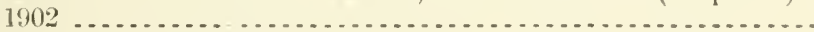

Pine tree, observations on certain (leit). 1902. p. $103 . . . .$.

Plants and, some interrelations of (Riley). 1892. p. 358.......

Prerlaceons-

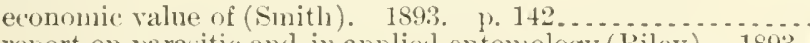
report on parasitic and, in applied entonology (Riley). 1893. 1). 130 stuelies of parawitic and, in New Zealand, $A$ ustralia, and adjacent islanels (Koelele). $1893 \ldots . . . \ldots . . . . . . . . . . . .$.

Preclatory-

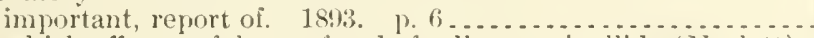
which affect tosefulness of frale-feeding coccinellidis (Marlatt). 19012. 1. 84 .

Rose, violet, and other ormamental plants, some insects injurious

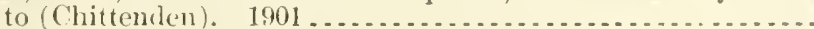

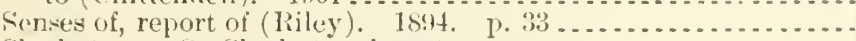

Sharle tree. Sire Sharle-tree insects.

Spruce in Northeast, insect enemies of (IIopkins). 1901 .......

Systematic position of Orthoptera in relation to other orilers of.

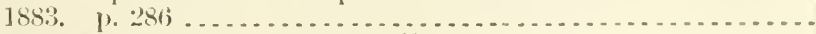

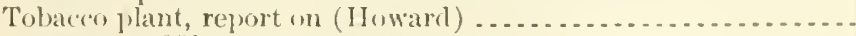

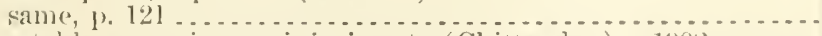

Vegetable crops, inscets injurions to (Chittendern). $190^{2}$.......

Vegetal,le prouluets, storerl, some little-known inserts affeeting (Chittenden). 1897 ............................... 1883. p. 35

11.10:895

11.10:897

11.10:898

A9.7:6

$19.7: 5$

127.9:1

19.7:t

A $9.6: 20$

A $9.6: 9$

A9.6:9

19.ti:17

A.8.8:2

A9.3:4

A1.1:881-2

19.1:S82

19.8:19

A27.9:4

A9.7:4

19.6:34

A9.2:Or1

A9.7:6

A $1.8: 51$

A10.3:09

A9.6:32

19.6:37

A9.7:t

19.7:6

19.7:6

A1.s:51

19.7:13

19.6:37

A9.6:27

19.7:7

19.6:28

A. $8.1: 3$

A1.1:1:0)

A 1.10:8:18

A9.6:33

19.1i:

A.9.3:1 
Insects-Continued

Vernatular names of (tillette). 1897. 1. 32............... same (I)oran). 1s9s . . . . . . . . . . . . . . . . . . . . . . .

Violet, rose, and oflıer ornanental plants, sone insects injurious

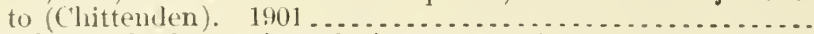

Theather and, olservations during seasom of 1899 (chittenden). 1900. P. $5 \mathrm{I}$ same, 1900 (Chittenlen). p. 63 . . .

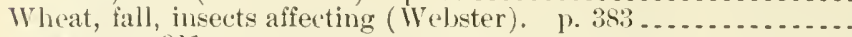

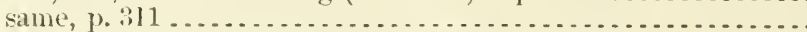

Wheat, rrowing, insect enemin's of (Marlatt). 1901..........

White pine, insect enemies of (Chittenden). 1899. p. 55 ......

See also Agromyzidite - Anarsia lineatella - Anthomyia - Aphelenchus olesistus - A phididse - Aphis - Apple-tree borers Apple-tree weevil - Apple-twig insect borer - Aquatic: bug Argyrestluia - Arkansas - Army worm - Asiatic larlybird Asupia costalis (clover hay worm)-Australia-Australian ladyhirl - Australian lamellicorns - Axima - Bahamas - Bean weevil - Bers - I beet insects - Bect leaf pegomvia - BeetleBelrosia - Bibioalbipennis-Blackberry borery-Blastophaga psenes - Blood louse - Boll worm - But - Box-elder plantbug - Braconicla - Brazil - Bronze apple-tree weevil - Bruchus-Bryobia - Bucenlatrix canarlenvisella-Bufialo-gnatsBuffalo tree-hopper - Butterfly - Cablage worm - Cacuecia cerasivorana - California - Canada-Canker-worms-Caterpillar - Cattle tick - Cecidomyians - Cecidomyiid - Centipede-Cereals-- Changa-Chestnut borer-C'hicago Worlds' Columbian Exposition - Chitken tick - Chilo saccharalis Chinch bug - Chionobas macounii-Chrysalis-Cicada-Cimbex-Clisiocampa Americana-Clover-nite-Clover-seed caterpillar - Clover-seed mirlge - Cockroaches - Cocoanut mealy-wing - Colaspis flavida - Coleoptera - Colorado Cone-nose - Com bill bugs - Corn crambid - Corn-feerling syphus-fly - Corn-root aphis - Corn-root web-worm - Corn stalk-borer - Cossida - Cotton army worm - Cotton caterpillars - Cotton cutworm - Cotton insects - Cotton or melon plant-louse-Cotton worm - Cottontail bot-Cotton stainer-Cotton wool borer-Cranberry fireworm - Cranberry gall fungus - Cranberry girdler - Cranberry leaf-galls - Crane-fly Crickets-Cryptophasa unipunctata-Cureulio-Currant stem girdler - Cut-worm - Cypress twig borer - Cyrtoneura Delaware - Dendrotettix - Dermestes vulpinus - Diggerwasp - Diptera - Dipterous insect - Dipterous leaf-miners Dogwoor saw-fly - Elm insect - Encyrtid - Entilia sinuataErysiphere - Eumænsutala - Europe - Eustrotia caduea Fall army worm - Fleas - Flies - Florida - Fluke-worms Flukes and tapeworms of cattle - Forest trees-Forests Fruit-worm - crall makers - Garden insects - Garden pest Georgia - Good Hope, Cape of - Grain - Grain louse - Grain plant louse - Grain toxoptera - Grape - Grapevine hopper Grass insects - Grasshoppers - Grasses - Green elorer worm-Cireen pea lonse- Cinava mealy wing - Hairy caterpillars - Harlequin cablage bug - Hemipterous insect:Hen flat - Homse ants-House centipede-Household insects - Hydrocyanic: acid gas - Ilymenoptera - Insect borers - Insect life - Insect pests - Insert vivaria - Insecticides - Jowa - Japanese insects - Japanese poach fruitworm - Kidney worm of swine - Kising-bug - Larve Lepidopteroms insect - Lestophonus - Library pest - Lignivorous insert - Locmsts - Lucilia nobilis - Lysiphlebus Maryland - Massachusetts - Mealy bues - Mealy-wing Mediterranean flowr moth - Membraciste (tree hoppers) Mexico - Michigan - Mississippi - Miswour - Mite - Mole cricket - Monephora bicinta - Momomorium pharaonis Morelos ormge frnit-worm - Mosquito - Moths - Myriopods - Nelorask - Nematole leaf disease - New Jersey New Mexico - New York State - New Zcaland - New 
Cealank katipo - Norway and Sweden - Ohio - OrangeOrthezia insignis - Urthoptera - Paper-naking wasp - Parasites - Parsnip wel-worm - Pea lonse- P'eacl curculio I'each twig-borer - Pear insect - Pear-leat hlister mite Pear midge - Pediculi - Perliculirla - Phosphorencent myriopods - Poisonons spider in Marlagascar - P'romnha - J'ulvinaria acericoli - Purslane caterpillar - Rerl ants - Rerl spiclers - Roaches - Rye gall-gnat - Scale insects - reepsis edwardsii — Schizonenra panicola - Scorpions - Shate-tree insects-six-spotted mite-Sonth African ticks - Sonthern grain lonse-Spinlers - Squash Jug - Squash-rine borerStalk worm - Stibadium spmmaem - Stomata-Sugar-beet web worm - Syntomeida-epilais - Tarantulas - Tasmania Texas - Thalessa - Thripide - Tiger swallow-tail — Tineir Tortricid - Toxoptera-Tree crickets - Tremex - Twig jomers - Tylodirma - Trphlocyba - Vanes-a antiapa - Vanesa Californica - Velalia cardinalis - Viviparous corkroale Walunt spanworm - Water bue - West Viruinia - Western cricket - "Wheel bugs" — White ants - White grubsWooly aphis - Xanthium trypeta - Xiphidim ensifermm Yincea inserts.

Inspectors, general order to, relative to humane treatment of animals. TIay 13,1896

Institutions, jublic, lietaries in (Atwater) 1901 p. $393 \ldots$ Instrument room or division circulars . . . . . . . . . . . . . . . . . . . Insurance, hail, notes on (Abbe). 1901. p. 219.............. Interior Department, relation of acricultural and mechanical colleges to, 1593 (Holcomb). [\%. 114.

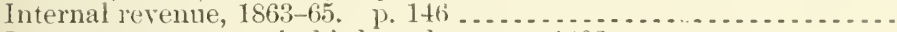

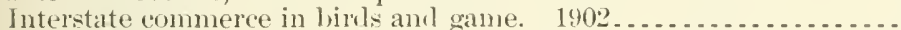

Interstate convention of cattlemen, 1s90. Nee Fort Worth.

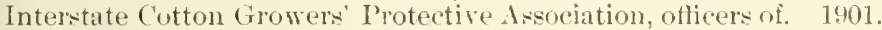
1. 637 .

Intestinal fever in swine. See Hog clusleri.

Invalid and infant foods, analysis of, provisional method for (IViley). 1902.

Inventions:

Americun, for cultivation by steam, history of (Brainerl). p. 253.

Recent, for insect destruction (Breed). 1. 323.............

Iodide of potassimm, treatment of lumpy jaw with (Nolgatarl). p. 135.

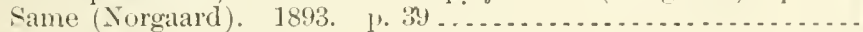
Iowa:

(hinch-bug olservations in, in 1894 (Osborn). p. $230 \ldots \ldots . .$. (hinorks in, notes on (Abbe). 1897. p. 5t5............... Farm resources and proluets of. 1stis. p. 202.............. Fungons diseases of, new (Pammel). 1891. p. 95........... Grasses and forige plants of, motes on (l'ammel). 1897 ....... Hog cholera amb swine plague insestigations in, preliminary re-

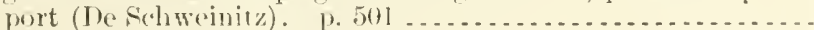

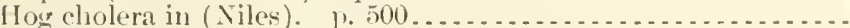
Insects of (Osborm)-

1887 .

1859.

1. 154

1890 .

1. 18

1). 57

1891.

[1. 57

$1892.41)+4$

189:3. p. 4 i;

lnsects of, as reported to Issociation of Economic: Entomologist ((), s)orn ) -

18\%2. 1). 111

1893. p. 1933.

1896. 1\%, 7s

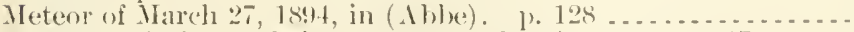
Ileteorological records in, notes on (iblue.) 1899. 1. $17 \ldots . .$.
11. $2: \operatorname{In} 7$

11.10:901

A29.11:

A29.6:29

A10.3:16

A $27.9: 4$

A $5.4: 38$

11.10:901

$17.3: 65$

11.1:567

11.1:876

A+.1:891-2

$1+.3: 2$

19.7:7

129.6:25

127.9:6

128.5:7

A.3.3:9

$1+.1: 899$

14.1:598

11.1:587

19.3::0.2

19.3:23

19.3:21;

19.3:30

19.3:3:

$19.7: 5$

19. $7: 6$

19.6:1;

1:29.6:0:2

1.9.6:27 
Iowa-Continued

Northern-

blackbirds and gophers in, deprrations of, in fall of 1887

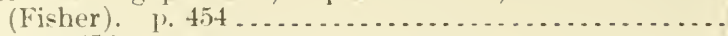

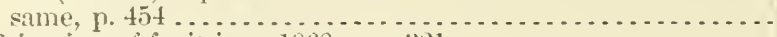
cultivation of fruit in. 1868. p. $\$ 21 \ldots \ldots \ldots \ldots \ldots \ldots .$.

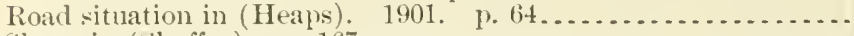

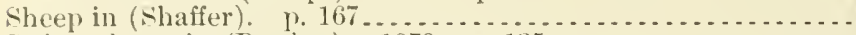

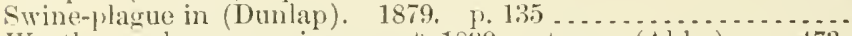
Weather and crop service report, 1899 , notes on (Abbe). p. 473. See also ('elar Falls - Mon roe County - Page County.

Iowa College of Agriculture and Mechanic Arts, Ames, Iowa, shopwork instruction at (Bissell). 1894. 1. 65 ...............

Iowa Experiment Station, notes on certain experiments and observaIreland: tions at (Gillette). 1891. p. $258 \ldots . . . . . . . . . . . .$.

Agricultural statistics of-

1866.
1867.

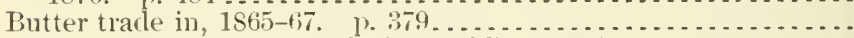

Cattle in, pleuro-pneumonia in (Reid). p. $401 . . . . . . . . . .$.

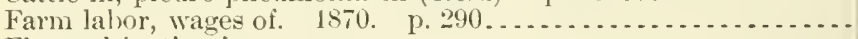

Flax cultivation in--

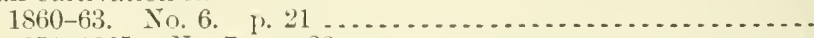

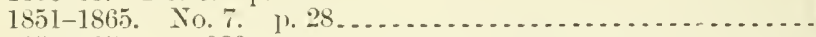

1851-1871. p. 332 ...................................

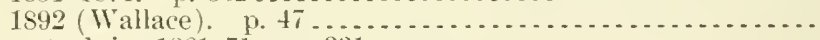

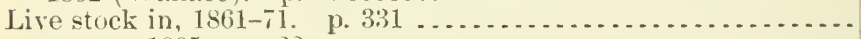

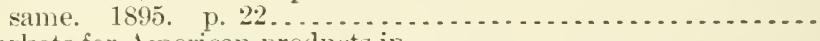

Niarkets for American products in .................................

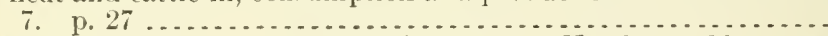

Wheat production in, decrease of, $1547-62$. Yo. 6 . p. $21 \ldots \ldots .$. A27.9:1

See also Belfast-Dublin.

Irish, Charles W.

Artesian water in Nevada. 1891. p. 199.

California, climate, soil, characteristics, anil irrigation methods of. 1895. p. 475 . . . . . . . . . . . . . . . . . . . . . . .

See also, for reports as special Agent in charge of irrigation in- quiry, 1893, and as Chief, Office of Irrigation Inquiry, 1894

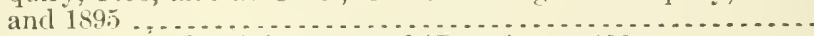

Irish moss, curing of, brief account of (Bates). p. $423 \ldots \ldots \ldots \ldots$

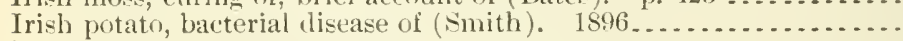
Iron:

Determination of, in phosphates, methods of (McDowell). 1897.

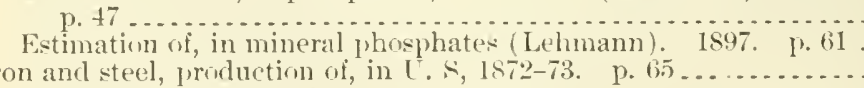

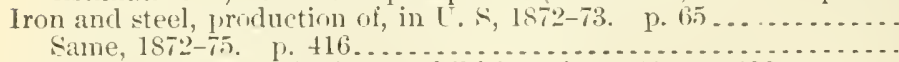

Iroquois Agricultural society, exhibition of. 186s. p. $406 . . .2$. Irrigable lanrls of Neliranka (Ilicks). I 893. , t. 3, p. 167 ........ Irrigater lands, tillage and products of soil on (Cureton). 1887.

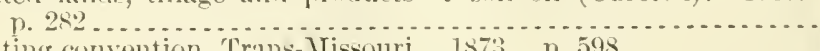
Irrigating convention, Trans-3Yissouri. 1s73. p. $598 \ldots \ldots \ldots \ldots$ Irrigation:

Agriculture Department, what it is doing for (Mead). 1902 ..... Alkali and, recent invertigations by Wroming Experiment Station in (Buffum). 1900. 1) 69 . . . American, Australian report on 1884-85 (Deakin). p. $197 \ldots . .$. Arizma Experiment Station farm (IICClatehie). 1900 . p. 125.

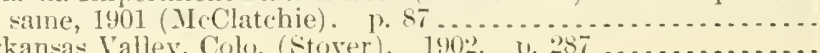
A1.1:887 A5.1:887 A 27.9:6 122.3:21 A1.1:864 A1.6:12

A29.6:27 A 10.3:20 A9.7:3

A $27.9: 4$ A $27.9: 5$ A27.9:6

A 27.9:8

A27.9:10

A 27.9:13

A27.9:14

A 27.95

A 4.1:589-90 A27.9:8

A27.9:1

A27.9:3

A $27.9: 9$

A11.5:4

127.9:9

A $27.9: 33$

A12.3:1

A $27.9: 3$

A15.2:P94 ${ }^{1}$

A1.10:595

A15.1:

A1.1:866 A28.3:12

17.3:51

A7.3:51

A27.9:12

A $27.9: 14$

A27.9:6

A $15.2: \mathrm{Ir}^{2}{ }^{2}$

115.2:P94 ${ }^{1}$ A $27.9: 11$

A10.4:48

A 10.3:76

A15.2:Ir 7

A10.8:104

\$10.3:119

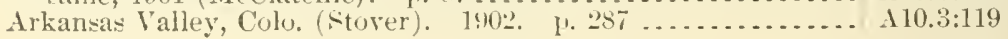


Irrigation-Continued

Artesian wells in Algiers. 1891. pt. 1. p. 369.

Azores, as presented in Census Bulletin To. 35, Feb. 27, 1891.

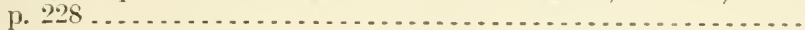

Bear River Valley, Utah, 1901 (Stover). 1902. 1. 243........

Big Thon pson River (Field). 1902... . . . . . . . . . . . . .

Boise Valley, Idaho, duty of water as related to problims of

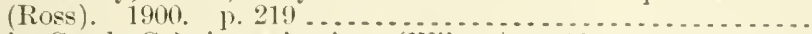

Cache Creek, Cal., investigations (Vi]son). 190i. p. 155......

Colorado-

practical, in. I'. 254

statisties and progress (Carpenter). 1890. p. 181.

Connecticut and New Jersey, notes on (Phelps and Voorhees) 1897

Cultivation of raisin grape by (Gisen) 1891 .

Decidnons fruits, notes on (Tickson). 1900. p. $80 \ldots \ldots . . . .$.

Discharge records and diagrans, computation of (Johnston).

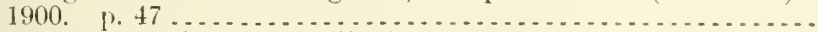

Ditehes for, small, how to build (Johnston and Stannard), 1902.

Evils, remedies, and compensations of (Marsh). p. 362.......

Excessive, danger from, and the remely (Beal). 18:9. p. $5 \ldots$. .

Facts and conclitions relating to, in various countries (Hinton). 1891. pt. 1. 1. 375

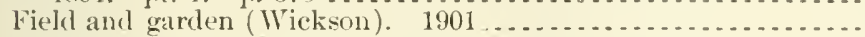

France, Italy, and spain. 1891. p. $278 \ldots \ldots \ldots \ldots$

Fruit growers on Pacific coast, practice among (Wickson). 1902. -

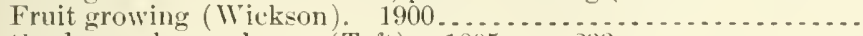

Giarden and greenhouse (Taft). 1895. p. 233.............

Grand Valley, Colo., 1901 (Stover). 1902. p. $265 \ldots . . . . . .$.

Great Eastern Canal, Platte County, Nebraska, 1900 (Stout). p. 195

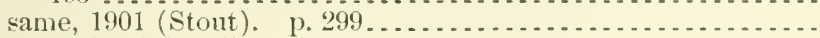

Great Plains (Newell). 1896. p. 167........................

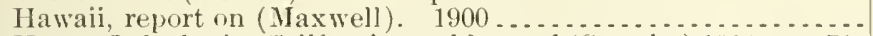

Honey Lake basin, California, problems of (Smythe) 1901. 1. 71.

Humid climates (King). 1896 ..........................

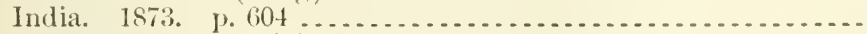

Injurious insects and (110ward). 1890, p. 215.............

Investigations-

(iiscussion of (Mead). $1900 . \quad$ p. 15.

employment of agents in. $1899 . \quad$ 1. $27 \ldots \ldots \ldots \ldots \ldots$

for 1900 , report $n$. . . . . . . . . . . . . . . . . . . . . . . . .

same, discussion of (Johnston). 1.21 .............

same, review of (Mead). p. 13 . . . . . . . . . . . . . . .

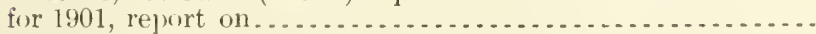

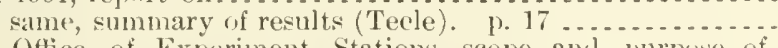
of Oflice of Experiment Stations, scope and jurpose of

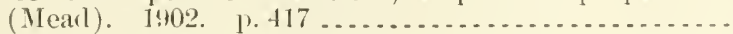
same, lists of publications of oflice on .......

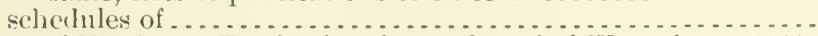

Laws of Nortluwest Territories of Canada and of Wyoming. 1901. Sie ulso Canadian northwest irrigation act.

Laws of States and Territories on water rights and, abstract of (C'ritchett). 1893

Lists of publications of experiment stations office on _... . . . . .

Lugan River canals (fiwendsen). 1902. p. 179..............

Measmrement in, etc. -

18.5. ए. 610 .

18:16. 1). 6330

18:\% . P. 640 .

Tethods of (Carienter) 1893.

IIisouri experiment station, experiments at (IIaters). I?(1)2.

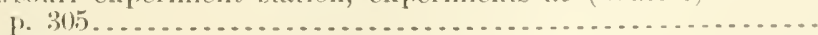

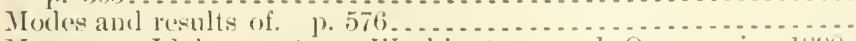

IIontana, Idaho, eastern Washington, and Oregon in 1 sisu (Nimmo). 1. 14! . . . . . . . . . . . . . . . . . . .

Montana, investigations in, 1900 (Forticr). 1.267..........
Classiffeatlou no.

$115.2: \ln 7^{2}$

$115.2: 1^{3} 94^{1}$

1 10.3:11!3

A10.3:118

1 10.8:86

$+10.3: 100$

A1.1:871

A 15.2:P94

$110.3: 36$

1 $15.2: 1^{3} 94^{1}$

A $10.3: 76$

1 10.8:86

11.9:158

A1.1:874

A 1.9:10:3

A $15.2: \operatorname{Ir} 7^{2}$

A 1.9:138

A 15.2: ${\text { P } 94^{\prime}}^{\prime}$

A 10.3:108

A 1.9:116

11.10:84i

A 10.3:119

A 10.3:104

A 10.3:119

A $1.10: 896$

A $10.3: 90$

A 10.3:100

A1.9:4t:

A27.9:11

A9.7:2

$110.3: 86$

11.9:97

A 10.:3:104

1 10.3:104

A 10.3:10t

A 10.3:119

A 10.3:11!

$110.1^{2}: 901$

A 10.2:I $r 7$

110.8:

1 10.3:96

A 15.3:1

1 10.2:1 17

$110.3: 10$.

A1. 10:ה!)

11.10:sem;

11. 10:85:17

$110.3: 16$

$110.3: 11 !$

11.1:870

A $15.2: 1^{3}: 44^{1}$

110.3:10.4 
Irrigation-Continued

II mantal, investigations in, 1901 (Fortier). n. 225 . . . . . . . .

Nevala, investigations in (Wilson), 1902. p. 147.........

New Jersey, report on (Voorhees). 1900 ................

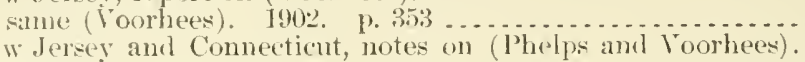

Now Jersey and Connecticut, notes on (Phelps and Voorhees).

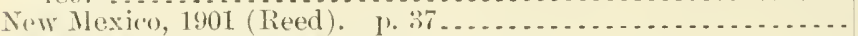

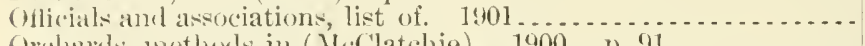

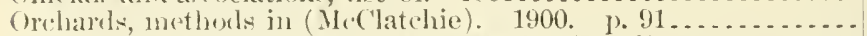

T'en:s River and its tributaries, New Mexico (Reed). 1902. p.61.

Pussille and actual influence of, on insect injury in New Mexico

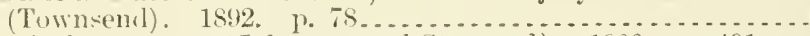

I'ractical, report on (Johnston and Stannard). 1900. p. $491 \ldots .$.

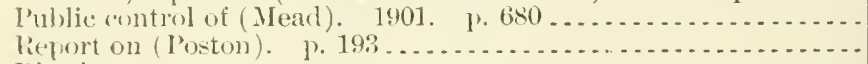

Rice in-

Sinth (arolina, Sonth Carolina, and Georgia (Keeney). 1902. p. 59 . . . . . . . . . . . . . . . . . . . . . . . . . .

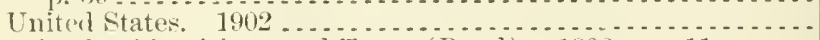
uplands of Louisiana and Texas (Bond). 1902. p. 11 ..... Rise and future of, in L. S. (Mead). 1899. p. 591 . . . . . . . . Rorky Momntain States (Ulrich). 1899 . . . . . . . . . . . . . . Salinas Valley, Cal, problems in (Marx). 1901. p. 193 . . . . . . Salt River Valley, Arizona, investigations in, 1900 (Code). p. 8..

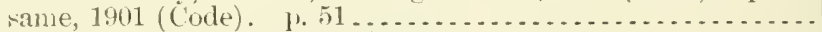

San Joaquin River, Cal. (Somlé). 1901. p. 215............. . . Goutlem states, some of. 1891. I't. 1, p.323 ............

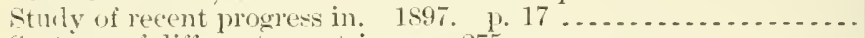

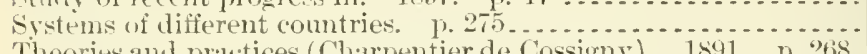
Theories and pratices (Charpentier de Cossigny). 1891. p. 268. United States, testimony of Flwool Mead before $T$. S. Industrial

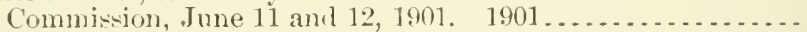

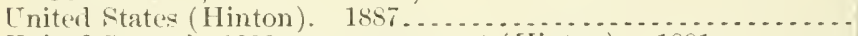

United states in 1890, progress report (Finton). 1891 . . . . . . .

Ure of water in, report of investigations made in 1899 , including

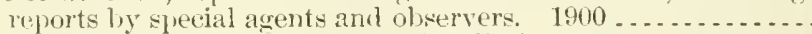

Washington, nse of water in, 1901 (Waller). 1902. 1\% 191 . . .

Water measurements for (Abbe). 1897. pp. 208, 545 .......

Water supply and, in Mexico. 1885. p. 223 ... . . . . . . . . .

Wheatland, Wyo., nse of water for (Johnston). 1902. P. 207...

Tinter-

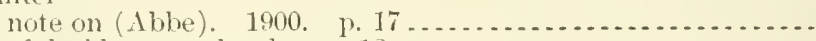

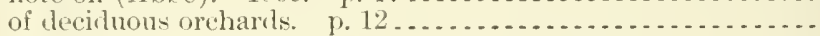

Wire in, use of, report on (Betts). 1899. J.301 ...........

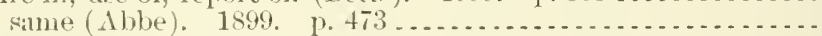

Wisconsin, experiments in (King). 1902. 1. $313 \ldots . . . . . . .$.

Yakina V'alley, Wash., use of water in (Waller). 1902. p. $2+1 \ldots$

See rlso Artesian and underflow investigation-California Draining - TV yoming.

Irrigation and eultivation of soil therelyy, physical data; conditions and progress within I. S. for 1891 (Ilinton) ..............

Irrigation and its relation to state weather-service work (Salisbury).

Irrigation and land drainage, list of references to publications relating to (IJedrick). 1902

Irrigation conference, 1890. 'see Jelbowrne, Australia.

Irrigation concress, 1900. See Chicago, 111., national good roads and imigation congreses.

Irrigation Inquiry Office, Agriculture bejartment............. Irrigation investigations. See Irrigation.

Irving, $1 \mathrm{I}^{*}$ :

Fage canal, Riverside, California, duty of water under-

1899. p. 131

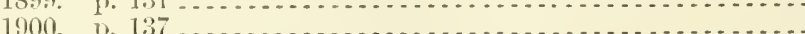

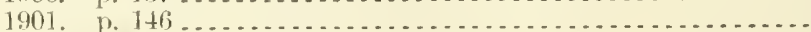

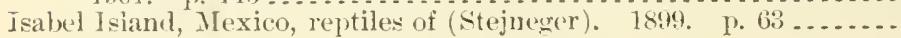

10.3:119

A10.:3:104

110.3:87

1 10.3:119

A 10.3:36

110.3:119

11.10:901

A10.3:76

110.3:104

19.7:5

A1. $10: 900$

11.10:901

A1.1:867

+10.3:113

1 10.3:113

1 10.3:113

A1.10:899

110.3:73

A 10.3:100

A 10.3:10t

110.3:119

110.3:100

1 15.2: $\operatorname{Ir} 7^{2}$

11.9:56

A 1.1:Si 1

115.2:P9 $4^{1}$

110.3:105

1 15.2:Ir ${ }^{-1}$

115.2:194

$110.3: 86$

A10.3:119

129.6:25

A 15.2:1r ${ }^{-1}$

A 10.3:104

$+29.6: 28$

$11.9: 1+4$

129.6:27

A29.6:27

1 ]0.3:119

110.3:104

A15.2:Ir $7^{2}$

A 29.3:14

117.3: 41

$\$ 15$.

110.3:86

110.3:104

1 10.3:119

A5.5:14 
Jafia, MIver F.-Continued

California eggs, food value of. p. 510 .

Fruitarians and Chinese, nutrition investigations among, at ('alifornia Igricultural Experiment Station, 1899-1901

Nutrition investigations at California Agritultural Experiment Station, 1896-98

Jamaiea, West Indies:

Cinchona planting in (Parry). 1871. P. 120.

Climatologinal data for-

1897 (Able). pp. 259, 308, 356, 4t4

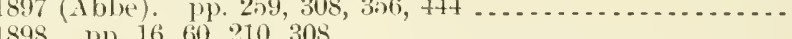
1901 (Hall). pp. $214,253,304,352,407,497,595 \ldots \ldots \ldots \ldots$

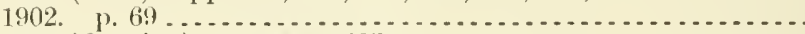

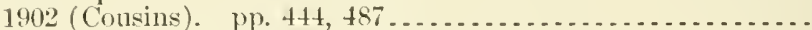

Hurricanes in, 1689-1880, note on (Ahbe). p. $550 \ldots . . . . . . . .$.

Meteorological service, note ou (Abbe). 190\%. p. 183.

Rainfall of May, 1870-98, in, notes on (Abbe). p. 415

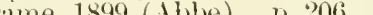
un-spot perior and temperature and rainfall of (Hail). 1901 ए. 503

Thunderstorns and clouds in (Abihe) 1896.

Weather bureau high level stations, note ou (Ablue). $189 \%$.

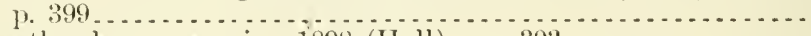

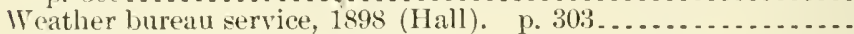
same, 1899 (Abbe.). p. 161 . . . . . . . . . . . . . . . . . . . . . Jamaican coccidie, foor plants of some (Cockerell) 1593. pp. 158,

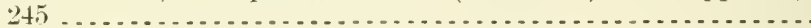

James, C. C. Agriculture, teaching, in public schools. 1902. p. 84. James, E. J. Government in its relation to forests. 18s5. p. $23 .$. James, Joseph F. Fossil fungi, notes on, 1891. p. $268 \ldots \ldots . . . .$. James River, Ya. Freshets in, 1870-99 (Ablee), p. 156 ......... Same, 1893-96 (Evans). 1. 590

A $1.1:$ S98

A10.3:107

1 $10.3: 84$

A27.9:9

A29.6:25

A29.6:26

A 29.6:29

A29.6:30

A 29.6:30

A $29.6: 28$

A:9.6:30

A $29.6: 26$

A29.6:28

A29.6:29

A $29.6: 24$

A $29.6: 25$

A $29.6: 26$

A $29.6: 27$

A9.7:5

A 10.3:1:0

A 13.3:2

A28.5:7

A29.6:28

A $29.6: 28$

James River Valley, physical featuresand flood conditionsof (Evans). 1899. 1). 250 .

Janney, Sammel M. Jirginia; her past, present, and future. 17 January, weather conditions for, statement of average(Garriott). 1. 21 . Japan:

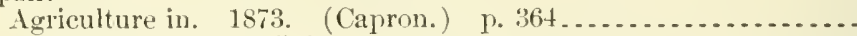

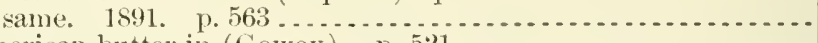

American butter in (Gowey). p. 521 .....................

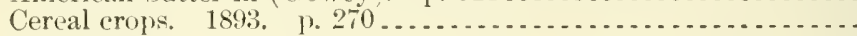

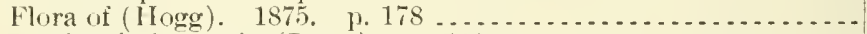

Lether industry in (Lyon). p. 5:6 ....................

locust in, migratory, occurrence of, in 1883 (Brooks). App. P. 59 .

()ur trarle with, $1889-1899$ (Hitclucock) . . . .

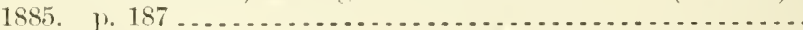

San Jose suale in, preliminary report on (Marlatt). 1902. 1.41.

Tea culture in. 1872. 1. 286 . . . . . . . . . . . . . . . . . . .

Treaty of Shimonoseki between China and, Apr. 17, 1895, and

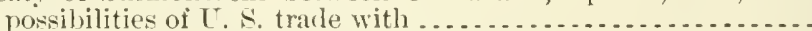

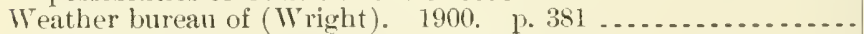

Winds of Arizona and (fl)

See calso Marlatt, Charles Lester.

Japan current, studies of (Abbe). 1898, r. 3ti6 ................. Japanese Corcitie, some new species of, with notes (Cockerell).

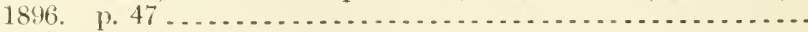
Japanese insects:

Injurious, liable to be introduced into United States. 1896.

A29.6:27

A $1.1: 864$

A29.6:29

A1.1:873

A $27.9: 29$

A4.1:898

A27.9:32

A27.9:13

A4. 1:899

A8. 1:3

A $12.3: 18$

A $1.7: 9$

A9.6:31

A27.9:10

A12. $4: 6$

A 29.6:28

A29.6:23

A29.6:26

A9.8:4

A.9.8:4

Injurious to fruit, two (Mat-umura). 1898. 1. $36 \ldots . . . . . . . .$. Japanese oak-feerling silkworm, notes on cultivation of (Webster).

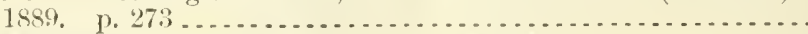

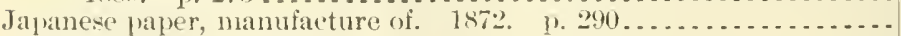
Japanese puali fruit-worm, report on. 18s9. p. 6t . . . . . . . . . . Japanese silkworm, parasite of, Trimyia sericarla rond. (Mik). 1891. 1). 113

A9.6:10

19.7:1

A27.9:10

19.7:2

19.7:-1 
Japanese strongyle (Atrongylus subtiles) which may possibly necur in returning American troops (Stiles). 1902. p. $41 \ldots \ldots .$. A . . . . $3: 35$

Japy knapsack sprayer, improved (Galloway). 1891. p. $39 \ldots \ldots .$. A28.5:7

Jaques "cream pot" stock (Dodge). p. 292. .................. A1.1:866

See also "Cream Pot" stock.

Jarring for curculio on an extensive sale in Georgia, with list of insects caught (Seott and Fiske), 1902. p. 24 ............. Java:

Dutch East Indies, sugar-('ane borers of (Zehntner). 1898. p:

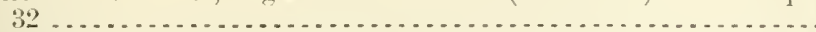

Sugar in, diffusion and carbonatation of, extracts from report on

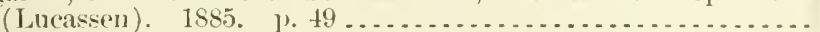
Jefferson, Mark $S$. W :

Rain gages, reduetion of records of. 1901. p. 499 .............

Rainfall of Leeward and W'indward islands. 1901. p. $56, \ldots . .$. Jefferson, Thomas, as meteorologist (Randolph and Francis). 1896.

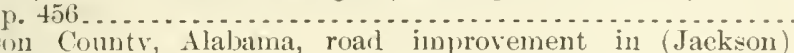

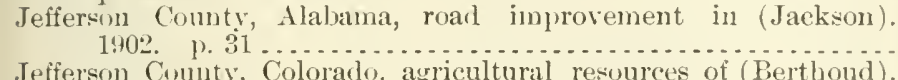

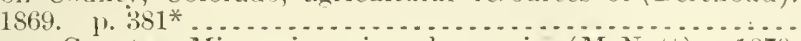
Jefferson County, ITissouri, swine-plagne in (McNutt). 1879.

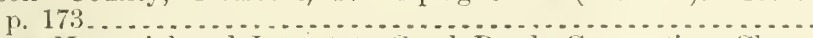

Jefferson Memorial and Interstate Good Roads Convention, Charlottesville, Va., Apr. 2-4, 1902, proceedings of. 1902......

Jefferson wemorial roakl, Va. (Shaw). 1902. p. $27 \ldots \ldots \ldots \ldots$. Jenequen. ,ee Sisal hemp.

Jenkins, Eelward Hopkins:

Aildress of, as president of Association of Oflicial Agrieultural Chemists at fourth anmual convention. 1887. p. $6 \ldots . . . .$.

Agricultural experiment work, cooperation of agricultural experiment stations with farmers' organization in. 1895. p. $50 \ldots$

Cigar-wrapper leaf, methods of experimenting with. 1901. 1).

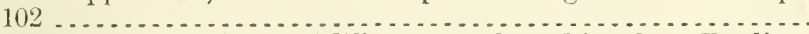

Jenkins, Eilward Hopkins, and Winton, Andrew Lincoln. Feelling stuffs, American, compilation of analyses of. $1892 \ldots . . . .$.

Jenks, Charles $\mathrm{N}$. Sheev husbandry in Texas. 1877 . p. $122 \ldots .$. Jennings, Thorp Buttolph. Storm-warning messages (Form $1043 \mathrm{C}$ ), should [they] be of some distinctive color to more readily

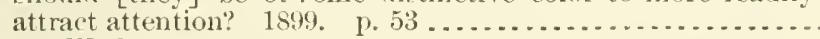

Jennings, Wr. S.:

Road improvement in Florida, progress of. 1901. p. $60 . . . . .$. speech of, as permanent chairman, International Good Roarls Comgress, held at Buffalo, N. Y., Sept. 16-21, 1901. p. $17 . .$. Jensen, Charles $\Lambda$. See, als joint author, ciarduer, Frank Duane.

Jensen, Charles $\Lambda$., and (Mshausen, B. A.:

Soil survey of Boine area, Irlaho. p. 421

Soil survey of Yakima area, Waslington. p. $389 . . . . . . . . . .$. Jensen, Joseph. Electric engineering in Utah, development of.

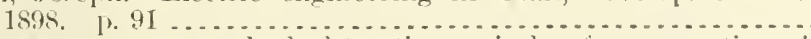

Jensen process, new nethod of treating grain by, for prevention of

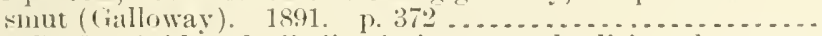

Jenter, C. (i. Acid and alkali solutions, standardizing the more

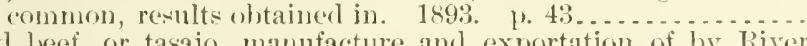

Jorkend heef, or tasajo, manufacture and exportation of hy hiver

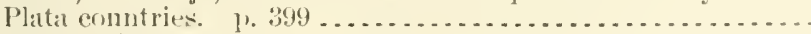

Jerusalen artichokes:

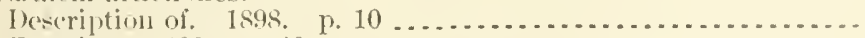

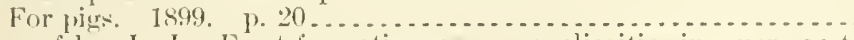

Jesunof ky, L. J. Frost iormation, some peculiarities in, over coast region of South Carolina. 1902. p. 479 .................

Jewell, i. E. Ayueous vapor, relative qualities of in atmospliere, letermination of, by means of absorption lines of the spect sum.

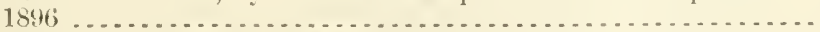

A9.ti:31

A9.6:10

A7.3:8

A 29.6:29

A $29.6: 29$

A29.6:23

A $202.3: 23$

$127.9: 7$

$\$ 1.6: 12$

122.3:25

1 $202.3: 25$

A7.3:16

A10.3:24

A10.3:99

A10.3:11

A 1.2:Sh3

A 29.3:24

A $2 \cdot 2.3: 21$

A $22.3: 21$

A 26.5:801

A $26.5: 901$ '

110.3:49

A.8.5:-

A7.8:38

1. $4.1: 849$

A 1.9:0:

11.9:(4)?

1.?.6:30

129.8:16

129,6:26

* By a misprint, this page number appears twice. 
Jolnnson, 1. L. Timber trestle bridges, exonomical designing of....

Jolnson, lienjamin P., short biography of. 1869. p. $136 . . . . .$.

Johnson, Erhmml. Agriculture of Tuspan, Mexien. 1sĭt. p. 498. A 13.3:12 A27.9:7 Jelunson, J. B.:

11vorkmechanieal tests mate at Washington Tniversity testing lab-

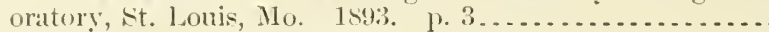

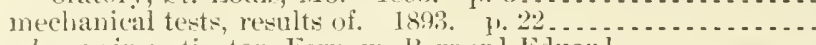
See also, as investigator, Fernow, Bernarul Eduard.

Joln:on, Isawrence:

Boll-worn (IIeliothis armigera), report on. 1880. P. 150

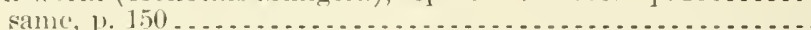

Cotton worm, boll worm, and other insects, report on. 1883. p. 53 . Johnson, R. E. Decimal system of weights and measures. 1864.

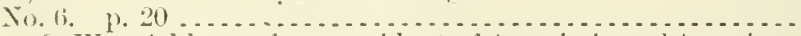

Jolmson, S. W. Address of, as president of Assuediation of American Agricultural Colleges and $\mathrm{F}_{\mathrm{x}}$ jeriment stations at 10 th annual convention, 1896 . p. 43 .

Sie clso, as joint author, Itwater, Willum olin.

Johnson, Willand Drake. Clonds, mulorella, notes on. 1898. J. 207. Jolnson, Willis Grant:

A phelinus fuscipennis, an important parasite upon San Jose scale

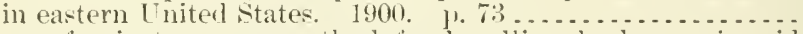

Emory fumigator; new method for hanclling hyclrocyanic-acid

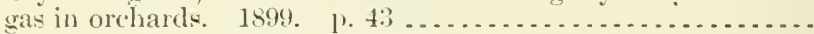

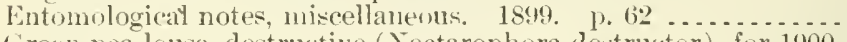

Grecn pea louse, destructive (Nectarophora destructor), for 1900 ,

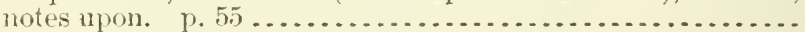

Hz̧llocyanic-acid gasas remedy for San Jose scale and other insects. 1898. p. 39. results with, for destruction of insects in large buildings. 1901. 1). 166

127.9:12

A13.3:8

A13.3:8

A $1.1: 881-2$

A9.1:88:

A9.3:1

127.9:2

A 10.3:41

$129.6: 26$

A9.6:20

A9.6:20

A9.6:20

A9.6:26

A9.6:17

A 10.3:99

Insects-

little-known, of economic importance, note on some. 1897.

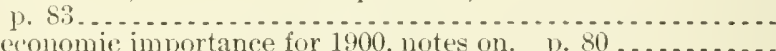

Maryland-

entomologieal notes from. 1896, p. $63 \ldots \ldots . . . \ldots \ldots . . .$. insects, juincipal injmious, of year, notes on. $1897 . \quad$ p. $80 \ldots$

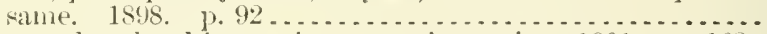

Norsery and orchard inspection, experiences in. 1901. p. 163.

Pea louse, destructive, new and important economic species of

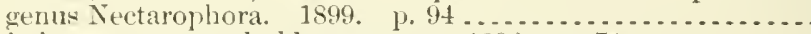

Scale insects, new and old, notes on. 1896. p. 74 ...........

Stalk worm, new enemy to young tobacco. 1899. p. 99 ...... Johnson grass, investigations inade cluring season of 1901 (Ball). 190.2

Jolnston, (

Inrigation discharge records and diagrams, computation and

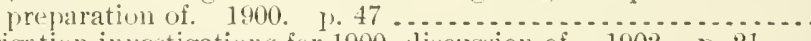

lyrigation investigations for 1900 , (liscussion of. 1902. 1. 21 ...

Water for irrigation at Wheatland, Wyo., use of. 1902. p. 207.

Whater supply of Bear River amel its diversion. 1899. p. 9 .....

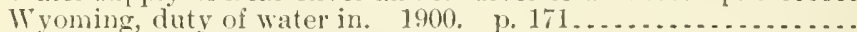

Johnston, C. T., and Stannard, J. D.:

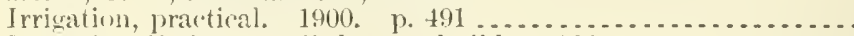

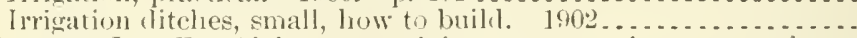

Johnstom, Jos. F. Alabama, roal implovement in, extract from

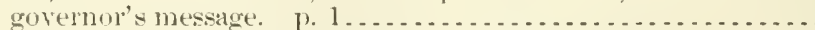

Joint-woln attak, ap\}arent, some features of (Webster). 1s!2.

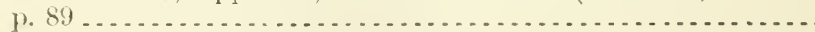

Joint-worm flies. See Grass and grain joint-worm flies.

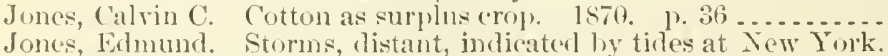

Jones, Franeois S. Argentine Repulblic, cattle and cattle products of, some statistics of. 1899. p. 515..................... 14.1:899 
Jones, Frank M. Dermestes rulpinns in goat skins, 1889. p. $63 .$.
Jones, Istac. Alaska, interior of, recomnoistance along trail from

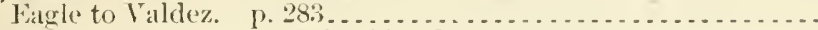
Jone, J. I). Cork oak, growth of in [T. S. 18\%5. 1). $9 . \ldots \ldots \ldots$ Jones, J. L. Mule, its nses, how to breerl, yrow, prepare for the market, and sell. p. 335 .

Jones, L. R. Potato blight and rot, comparative test of fungicides

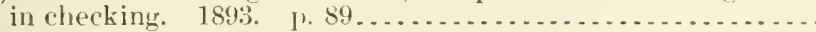
Jones, R. WI.:

Boll worm of entton, report on. 1885. App. p. 17.

Cotton worm (Aletia xylina), observations and experiments on,

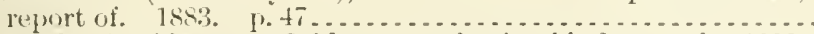
Jones, T. C. Pacific coast, field crops and animal industry of. 1892.

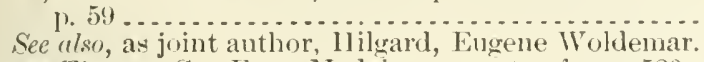

Jones, Thmmas C. Eggs, Madeira, exports of. 1. 520 ........... Jones, William J.:

Aletia, report on. 1885. App. p. $55 \ldots \ldots \ldots \ldots$

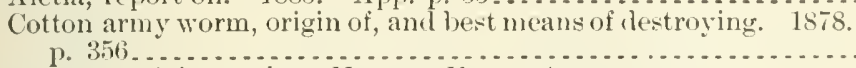

See also, as joint anthor, Huston, Henry Augustus.

Jordan, Whitman Howard:

Agricultural experiment stations, American, growth and purpose

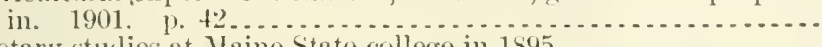

Dietary studies at Maine state college in 1895 ...............

Digestion experiments, American, report on. 1896. p. 5 ...... Jordan, Whitman Howard, and Hall, Frank H. Digestibility of

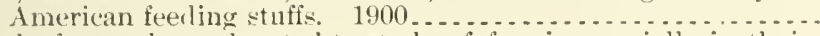
Journal of mycology, devoted to stuly of fungi, especially in their

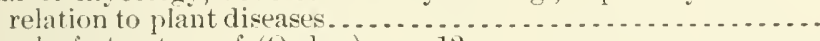

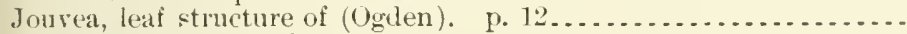
Jurd, Nylvester Dwight:

Birds-

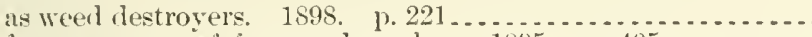
fortr common, of farm and garden. 1895. $10.405 \ldots \ldots \ldots$. of a Maryland farm. 1902 ............................

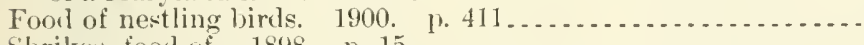

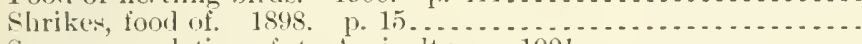

Sparrows, relation of, to Agriculture, 1901 . . . .
dd, Thmmas. Almonl in southwest Utah and southeast Nevada.

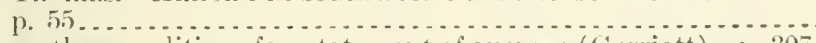

July, weather conditions for, statement of average (Garriott). p. 307. Jumping nice of the genus zapns, revision of (Preble). $1899 \ldots \ldots$. . June, weather condition for, statement of a verage (Garriott). p. 258. Jungfleisch, $\longrightarrow$, and Grimbert, - Sugars, analysis of, some

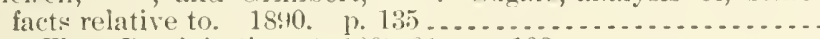
Jupiter, Fla. Precipitation at, $1889-91$. p. $108 \ldots \ldots \ldots \ldots \ldots \ldots$ Jutr:

Bengal ('rop. 1888, p. 539

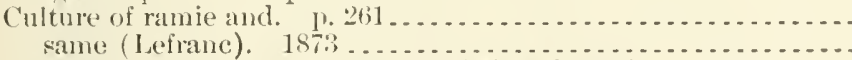

Culture, national importance, etc. (Waterhomse). p. $289 . . . .$. same (Waterhouse). 188.3

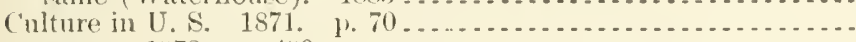

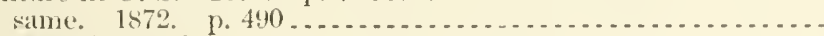

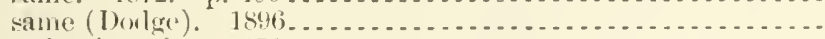

Introduetion of p. $171 \ldots \ldots \ldots \ldots$

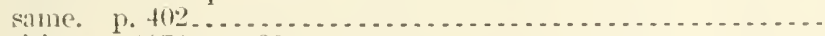

Louiniana. 1874 p. $389 \ldots \ldots \ldots$

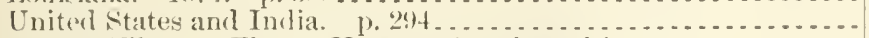

See also Fibers - Flax - Hemp - Ranie and jute.

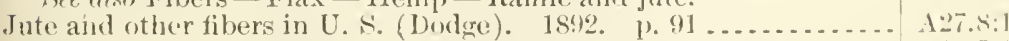

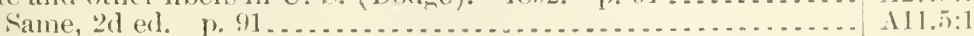

Juvisy, France, observatory of, physieal and netcomologinal reseatrches, principally on solar rays, manle at station of agricultural climatology at (Flammarion). 1899, p1. 103, 203.... 
Kafir corn:

Claracteristics, culture, and uses (Georgeson). $1896 \ldots \ldots \ldots \ldots$

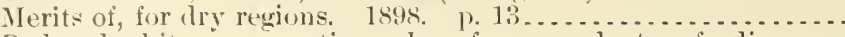

Red and white, comparative value of corn and, steer-feeding ex-

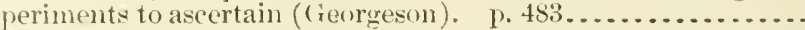

Kain, samuel $1 \mathrm{~V}$ :

Thunderwtoms in New Brunswick, 1897. p. 105 ............

Whirlwinds, local, in New Brmswick, notes on. 1900. p. 48s.. Kain, Samuel WV., and others. Seismit and oceanic noises, report

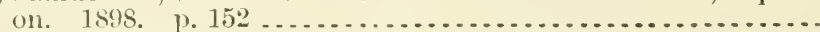

Kains, Manrice Grenville:

Chienry growing. 1900

Chicory rowing as addition to resources of American famer. 1898.

Horseralish, cireular on, 1898.

ice also, as revisor, Nash, Georare $V$.

Kalamazoo, Mich., celery culture at (Little). p. $343 \ldots . . . . . . .$. Kales, John $\mathrm{IT}^{\mathrm{T}}$ :

Explosive noises at Franklinville, N. Y. 1897. p. 393.

Lightning, serpentine. 1899. p. 461 .

Thunclerstorms in Franklinville, N. Y. 1897. p. $309 \ldots . . . .$.

Kammerhueber, —. See Cluss and Kammerhueber.

Kangaroo rats, three new, descriptions of, with remarks on identity Kansas: of Dipodomys ordii of Woodhouse (Merriam). 1890. p. 41..

Animal industry of, condition of (Teath). P. 405

Aril regions of, possibilities of reclamation by utilizing under-

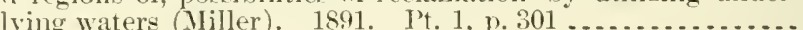

Cattle in-

ergotism among ('Trumbower). 1) 310

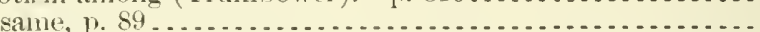

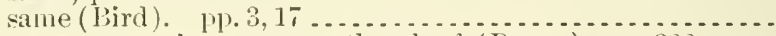

pleuro-pneumonia among, outloreak of (Devoe). p. 322..... southern cattle fever among, outbrenk of (Trumbower). p. 393.

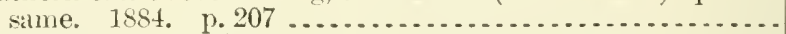

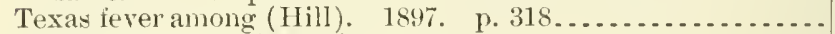

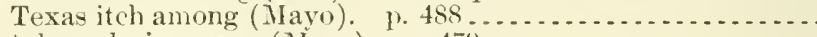

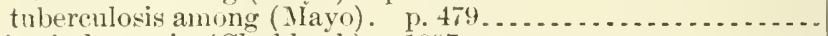

Dairy industry in (Chubbuck). 1897 ......................

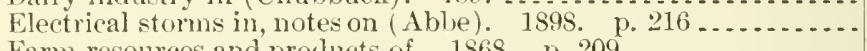

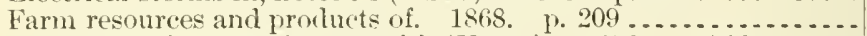

Forest trees in, experiments with (Vasey). 1872. p. $506 \ldots . . . .$. Grasses of arid districts of, investigation of (Vasey). $1856 \ldots . .$.
Insect enemies of farmer in, motes on (Kellogg). 1892. p. 114..

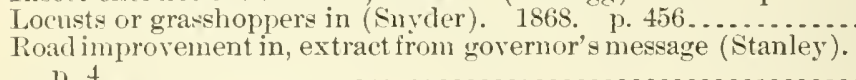
1. ${ }^{4}$ IIountain locust in, in 1880 (Chipman). App., p. $55 \ldots .$. Soruhum culture in, history of (Atams). 18st. p. $71 \ldots . . . . .$.

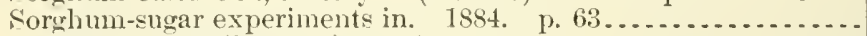

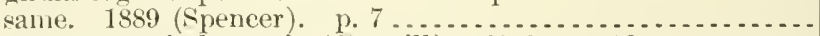

Sorghum-sugar judustry in (Cowgill). 1888. p. $18 \ldots \ldots \ldots . .$.

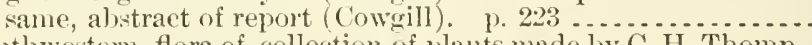

Southwestem, flora of, collection of plants made by C. H. Thompson in 1893, report on (Hitchcock). 1896. p. $537 \ldots . . . . .$.

Storm, local, of Sept. $8,18.5$, in ( 1 blue $)$. p. $338 . . . . . . . . . . .$.

Trip to, to investigate reported clamages from grasshopperspaper rear before Association of Economic Entomologists,

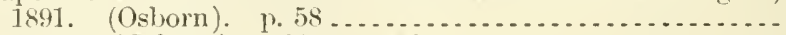

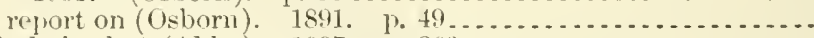

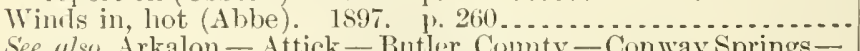
See also Arkalon - Attick - Butler Comty - Conway Springs Dorlge City - Douglass - Fort Scott - Garten City - Liberal Marshall County - Meade - Medicine Lodge - Minneola Ness City - Ottawa - Sterling.

A1.9:37

A 1.9:73

A4.1:898

A29.6:26

A29.6:28

$+29.6: 26$

A6.4:29

A6.3:19

16.4:15

A1.1:886

A29.6:25

A29.6:27

A29.6:25

A5.5:4

A4.1:889-90

A15.2:Ir $7^{2}$

A4.1:854

A4.2:An5

A4. $1: 895-6$

A4.1:895-6

A4.1:884

A4.2:Ano

A 4.1:895-6

At.1:898

14.1:898

A 4.3:18

A29.6:26

A 27.9:6

A27.9:10

A6.3:1

A9.7:5

A27.9:6

A 22.4:33

A8.1:3

A $7.3: 3$

A7.3:3

A7.3:26

A 7. 3:17

A].1:887

A6.5:3

A29.6:23

A $9.3: 27$

19.7:4

A $29.6: 25$ 
Insects injuring (lrugs at (Kellogg). 1894. p. $31 \ldots . . . . . . .$. Work in economic entomology at, for season of 1894 (Snow).

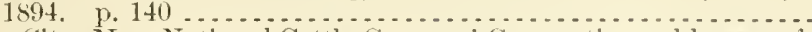
Kansas City, MIo., National Cattle Growers' Convention, arldresses of Norman J. Colman and D. E. Salmon before. 1887 ......... Kansas fungi, new species of (Kellerman and Swingle). 1889. p. 11. Same (Ellis and Kellerman). 1889. p. $142 \ldots . . . . . . . . . .$. Kansas State Agricultural College, agrieultmral building (new) at. 1901. 1. 103 .

Kanthack, A. A., Durham, H. E., and Blandfori, W. F. H. Nagana,

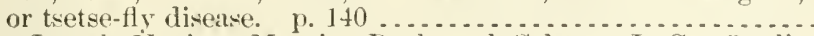

Kastle, Joseph IIoeing, Iarvin, Paul, and Calvert, J. C. Oxalic acis, action of, upon phosphates, silicates, and soil. 1894. 1).53.

Katipo, New Zealand, report on (IV'ight). 1889. p. 134_........ Kearney, Thomas Henry, jr.:

Botinical survey of Dismal Swamp region. 1901. p. 321 . . . . . Calamagrostis, North American speries of, revision of. 1898. p. 7 . Grasses and forage plants of southeasteru States. 1895 . ......... Plant covering of Ocracoke Island; a study in ecology of North Carolina strand regetation. $1900, p .261 \ldots \ldots . . . . . . . .$. Kearney, Thomas Henry, and Cameron, Frank Kenneth:

Alkali soils, certain components of, effect upon seerlling plants. 1902 p. 7 . . . . . . . . . . . . .

Alkali soils and regetation, some mutual relations between. 1902. A9.7:7

A9.7:i

A1.8: 43

A28.5:5

128.5:5

A $10.6: 12$

A 4.1:901

A7.3:43

A9.7:2

A 6.5:5

\3.3:11

A3.3:1

A6.5:5

A1.8:71

A1.8:71

Kerlzie, R. C.:

Address of, as president of Association of Official Agricultural Chemists, at 16 th annual convention. 1899 . p. 9..........

Frost, protection from. 1895 . p. 295 .......................

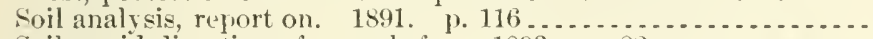

Soils, acid-digestion of, ressels for 1893 . 1. $82 \ldots \ldots \ldots \ldots \ldots$ Keeney, George H. Irrigation of rice in North Carolina, Sonth Carolina, and Georgia. 1902. 1. $59 \ldots \ldots \ldots . . . . . . . .$.

Keewatin. See Hudson Bay region.

Keffer, Charles Albert:

Tree planting--

experimental, in the Plains. 1898

waste places on farm. 1896 . p. 323 .

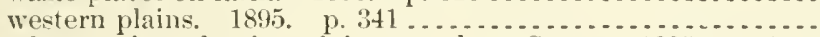

Wattle tree, introduction of, into southern States. 1895. p. $19 .$.

Keith, Arthur. Topography and geology of southern Appalachians.

Kellerman, W. A. See, as joint anthor, Ellis, J. B.
Kellemman, W. A:, and Swingle, Walter Tennyson:

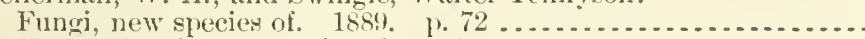

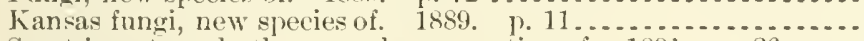

Smut in oats and other cereals, prevention of. 1891. 1.26.....

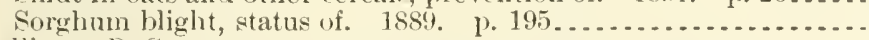

Kellicott, D. S.:

Enstrotia caduca, preparatory stages of. 1891. P. 321 ........ Ilepialus argenteomaculatus, report on. 1889. 3. $250 \ldots \ldots \ldots$.

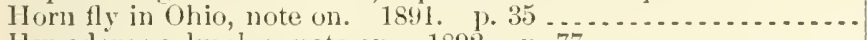

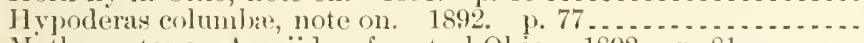
Moths, notes on Aegriidie of central Ohio. 1892. p. $81 \ldots \ldots . .$.

Kellner, $O$. Feeding stuffs, methods of determining digestibility of. 1898. p. 504

Kelloge, Vernon L.:

Insects injuring drugs at University of Kansas. 1894. p. 31 ...

Kansis farmer, insect enemies of, notes on. 1892. p. 114.....

Kelly, O. II. Minnesota, revturees of, ete., lorief listory of. p.31..

Keliey, F. D. Fungi of Ilelena, Jont., notes on. 18s9. p. $80 \ldots$ See also, as joint atuthor, Anderwon, F. W.

Kelsey, S. F. Road buikling in mountainous country. 1902. p. 63.

Kenai Hxperiment Station, Alaska, report of, 1901 (Niclsen). 1902.

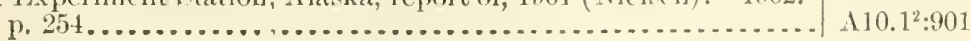

A 7.3:38

A 10.3:113

A13.3:18

A1.10:896

A1.10:895

A13.3:11

A1.2: $\mathrm{Ap}^{2}$ 
Kenealy, James:

Liqhining recorders and their utility in forecasting thunderstorms.

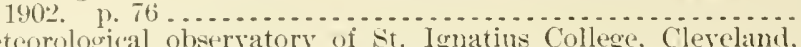

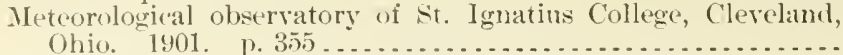
Kennebee liver, ice in, report of $(16)$ e) . 1897. [1. 98.........

Kennedy, A. R. Cattle and sheep industry of Coloralo. P. 367...

Kennedy, I'atrick Beveridge:

('aryopsis of grasses, structure of, with reference to morphology

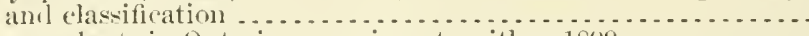

Forage plants in Ontario, experiments with. 1899 ...........

Cirasses and forage plants, cooperative experiments with. 1900..

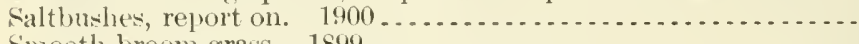

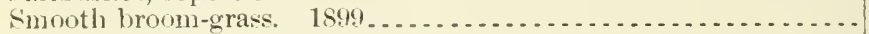

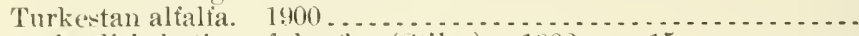

Kemmels, disinfection of, by fire (Stiles). 1902. P. 15 ..........

Kemmer, Lil., sorghum sugar, experinents at:

1888 (stubbs). p. 273 .

same, with additional matter, p. 46 .

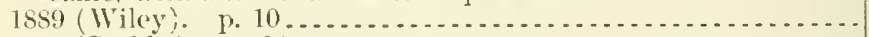

$18 s 9$ (Stubbs). p. 64 . . . . .

1889 (Wiley). P. 21 . . . . . . . . . . . . . . . . . . . . . . .

Kent County, Hd., soil survey of (Bonsteel). 1.173............

Kentucky:

Agricultural and mechanical college of. 1865. Yo. 6. p. 32....

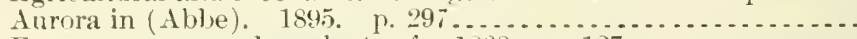

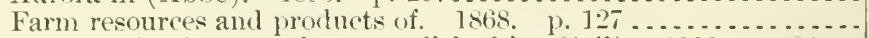

Farmers' institute work accomplished in (Nall). 1902. p. 2.3...

Gape disease of young poultry in (Garman). p. 504 ..........

Guod roars in, organizations for (Van Pelt). 1901. p. 81 .....

Himbway, history of old aul new systems (Crump). 1895......

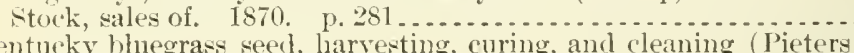

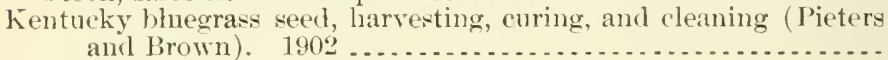

Kentucky sheep, improved (scctt). 1.334 ...................

Kenwortly, Charles J. Wool-growing in Australia. p. 204.......

Kerkam's kites with rocket signals (Abhe). 1897. p. 206 ........

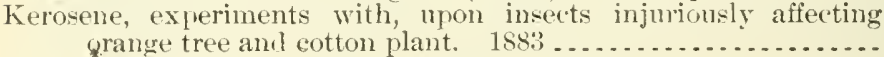

Kerosene emulsion:

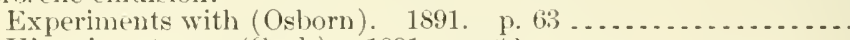

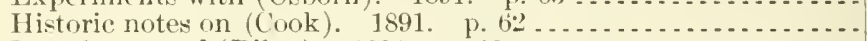

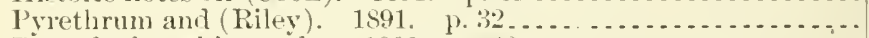

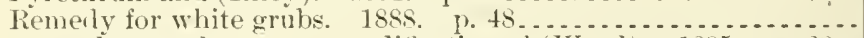

Kerosene knapsack sprayer, modification of (Weerl), 1895. p. 22.. See clso Knapsack.

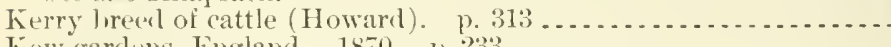

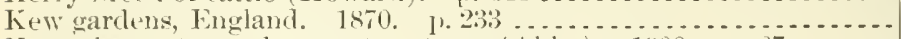

kew Observatory, change at, note on (Ahbe). 1900 , p. $67 . \ldots .$.

Key, Sothoron. See, as joint author, Hirks, (rilbert llenry.

Key West, Fla.:

Gult stream near, drift of, note on. 1900. p. 210

Watersponts at (Boynton) 1899 . 351 P. -10 ..............

Kickbusch, F. W. Stettin, Germany, cost of hanling farm products

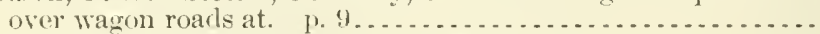

Kirlney worm of swine, our present knowledge of (Tayler). p. 612.

Kieman, John A. Cattle notes of sonthwestern Texas. 1. 511....

Killorme, F. L. Abortion in mares, outbreak of. 1893. p. 49.... See also, as joint author, Smith, Theolsald.

Kilborne, 1: L., and Schroeder, Ernest C. Bovine tuberculosis in soldiers' Home herd of 60 cattle, clinical notes on. 1894.

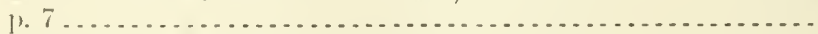

Kilgore, benjamin Wesley:

Address of, as president of Association of official Agricultural Chemists, at 17 th annual convention. 1900. 1. 7 ..........

Ammonia, phosplomolyblate of, report on estination of phosphoric acid by titration of yellow precipitate of. 1894. \%. 100 .

129.3:31

A $29.6: 29$

A29.6:25

A4.1:891-2

A3.3:19

A3.4:20

A3.3:22

A1.9:108

A3.4:18

A3.4:25

A 4.3:35

A1.1:888

A 7.3:20

A7.3:20

A7.3:26

A 7.3:26

A 26.5:900 1

A $27.9: 3$

A $29.6: 23$

A 27.9 .6

A 10.3:120

1.1:898

A 22.3:21

A 22.3:13

A27.9:8

A 19.3:19

A1.1:866

A1.1:864

A29.6:25

A9.3:1

A9.7:4

A9. $7: 4$

A 9.7:4

19.7:1

A9.6:2

A1.1:862

A.27.9:8

A $29.6: 28$

A 29.6:28

A:9.6:27

A 22.7:27

A 4.1:899

A 4. 1:899

A $4.3: 3$ 
Kilgore, Benjamin Wesley-Continued

Cotton-seed products, feeding value of. 1896. p. $385 . . . . . . .$.

Fodders and green materials, fat in, preliminary report on estimation of. 1897. p. 98

Phosphoric acil, P'emberton's methor of determination, comfarison of, with official methorl l,y Francis Bergami. 1894. p. 97

110.3::33

A7.3:5

A7.3:43

Ilant foml, artificial requirements of soils. $1902.1 \% 73 \ldots \ldots$.

Filerore, Penjamin Weslẹ, and Williams, C. B. Phosploric acid, citrate-insoluble, comparison of results ly uld and new meth-

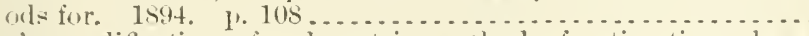

Filgore's modification of volumetric methol of estimating phosphoric acid (Williams). 1901. 1. 5.5...................

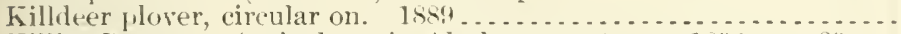

Killin. Benton. Agriculture in Alaska, report on. 1898. p. 29... Kimball, Herbert H.:

Atmosphere, creneral circulation of, especially in Aretic regions.

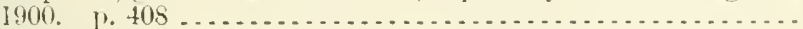

Civil service examinations for weather olservers in U.S. Weatler

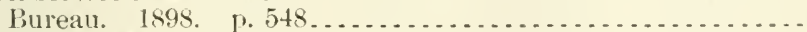

('limate of Antigua, IV. I., seasonal variations in. 1890-1900. P. 168 . . . . . . . . . . . . . . . . . . . . . . . . . .

Earth-line, varialility of, some causes of. 1901. p. $209 \ldots \ldots$.

Ice caves and frozen wells as meteorological phenomena. 1901.

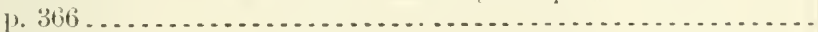

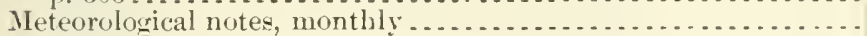

[Individual articles are entered in index under their specific subjects.]

Rainfall from convectional currents. 1900. p. $483 \ldots . . . . . . .$.

Sun sprits and weather, report on. 1901. p. $248 \ldots . . . . . . . .$.

Thunderstorm, automatic records of. $1899 . \quad$ ). $355 \ldots \ldots \ldots . .$. King, Franklin Hiram:

fround water, fluctuations in level and rate of movement of. on Wisconsin Agricultural Experiment Station farm and at Whitewater, Wis., observations and experiments on. $1892 .$.

Irrigation experiments in Wisconsin. 1902. p. $313 . . . . . . .$.

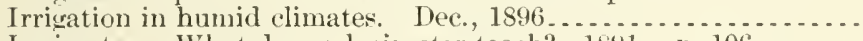

Lysimeter. What does a lysimeter teach? 1891. P. $106 . . . . .$.

King, If. B. Horticulture, Anerican, danger to, from introduction of injurious scale insects. 1901. p. $171 \ldots \ldots \ldots$

Kins, William M. See, for reports as Chief, Seerl Division, Agriculture Department, 1885 - 88 . . . . . . . . . . . . . . . . . . .

King, William Rice. Orange, relative merits of various stocks of, witl notes on nal di goma and mutual influence of stock and

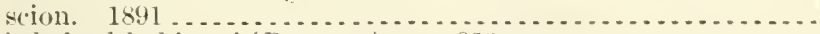

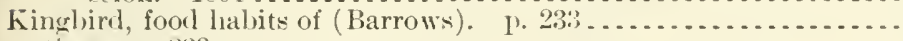

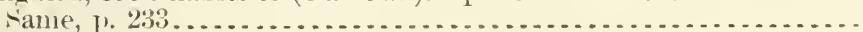

Kings River, Cal.:

Evaporation experiments on. 1901, [1.833...............

Water appropriation from (irmusky). 1901. [1. $259 \ldots \ldots \ldots . .$.

Kingsessing and Tinicum meadow district, "n Itelaware River, drain-

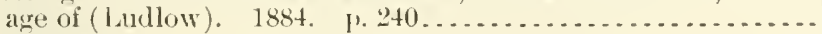

Kinney, Ablot:

Eucalyptus, growth of, in $\mathrm{C}$. S. 1895. 1. 23...............

Forests of Los Angreles, San Diego, and Sin Permardino counties,

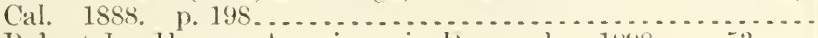

Kirk, Rohert J. Horses, American, in Jenmank. 1598. 1. 53 ...

Kirkland, Arehie Howari:

Arsenate of learl-

improvenent in manufacture of. 1899 . [1. 102 ..........

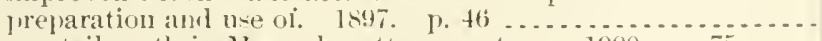

Brown-tail moth in Massachusetts, report or. 1900. [1. 75..... Cranberry fireworm, probalule remedl for. 1899. p. $53 . . . .$.

Insect perts, fonr imported, notes on, 1902. p. $93 . . . \ldots \ldots . .$.

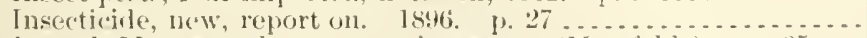

Kirkwood, Wo., fyretlirum experinents at (Murtfeldt). I. $85 . .$. Same, 1. 85.

129.3:5

A 10.3:119

A $1.9: 46$

A 10.5:3

A $10.3: 99$

A:0.3:4

A 1.1:893

A5. 1:893

110.3:100

A10.3: 100

A13.3:11

A 13.3:2

11.2:1178

1!1. $6: 20$

19.6:4

1!1.6:2: 6

19.6:20

19.6::1

19.6:0

11.1:881-

A!. 1:88:2 
Kissing bug, inserts to whirh name becane applied huring summer

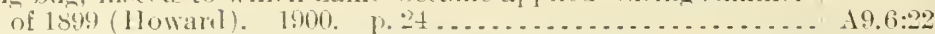

Kitehen and table wastes, importance of loss of. p. 25 . . . . . . . A1.9:69 Kite and balloon station near Berlin, (ielmany, note on ( $1 \mathrm{bj}$ ).

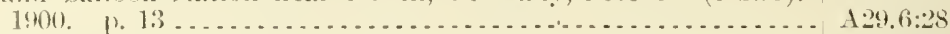
Kite wire, liglitning on, notes on ( 1 blue) $1898 . \quad$ [p. $170,257 \ldots \ldots . .429 .6: 26$ Kites:

Aerial reyateres by, motes on (Roteh). 1900. 1. $553 \ldots \ldots . . .$.

America and Enope, notes on (Abbe). 1897. p. 165 .......

Another use for, note on (Abbe). 1900. p. 252. . . . . . . . . .

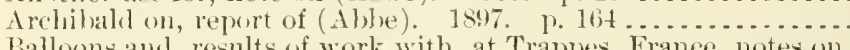

Balloons and, results of work with, at Trappes, Franee, notes on

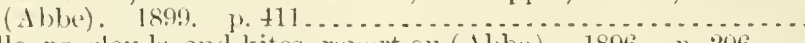

Balloons, chouls, and kites, rejurt on ( $\mathrm{Al}$ ibe). 1896. p. $206 \ldots$

Chicago eonference, Anerust, 1s\%3, notes on (Al)be). p. $310 \ldots .$.

Development of, by European scientists (Abbe). 1897. p. 58...

Experiments with, record of some (Eldy). 1898. p. $450 \ldots . .$.

Exploration of air with, progress in, at Blue Hill Ulservatory,

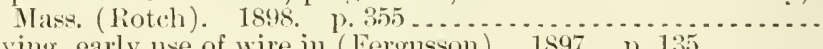

Flying, early use of wire in (Fergusion). 1897. p. 135......

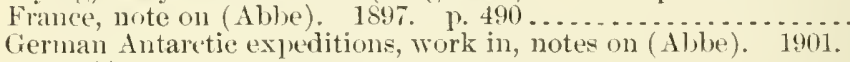

P. 177 . 1901.

Kerkam's, with rocket signals (Abbe) 1897. 1). 206 . $\ldots . .$.

Madeira, work in, notes on (Ablue). 1898, p. 5.5 .........

Mechanies and equilibrim of (Marvin), 1897, p. $136 \ldots . . .$.

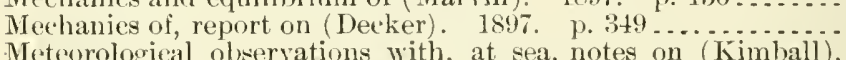

Meteorological observations with, at sea, notes on (Kimball).

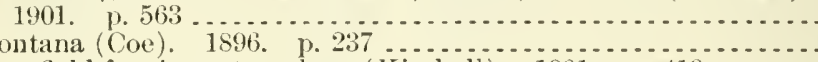

New field for, in meteorology (Kimball). 1901. p. 419 . . .

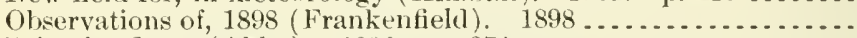

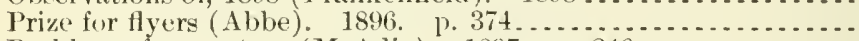

Problem of, report on (McAdie). 1897. p. $246 \ldots \ldots . . . . . .$.

San Franciseo, Cal., experiments at (Hammon). 1896. p. 288 .-

Spool, and kites with radial wings, notes on (Abbe). 1899. p. 154.

Systematic exploration of atmosphere by means of, method for

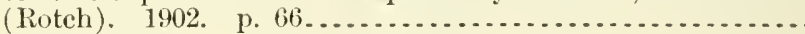

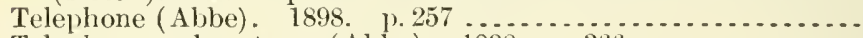

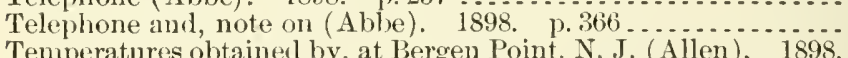

Temperatures obtained by, at Bergen Point, N. J. (Allen). 1898.

Use of-

in exploration of upper air (Marvin). 1898. p. 201

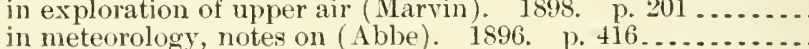

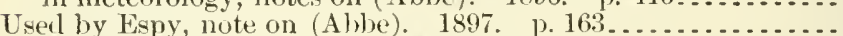

Weather Bureau experiments (Marvin). 1896. pl. 113, 156, 199,

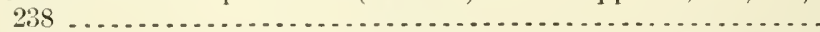

Weather Bureau kite, report on (Marvin). 1896. 1. $418 \ldots . . .$.

Weather Bureau observations in 1898, preliminary results of

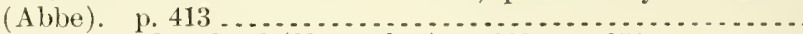

Within a thunder eloud (Hovenden). 1898. p. $251 \ldots . . . . .$.

Work in, progress in, notes on (Albbe). 1898. p. 552 .........

See also Bayonne, N. J. - Blue Hill Meteorological Observatory Dansey's - Fisher, George - Franklin Kite Club-Newton, Isaae.

K jeliahl-Gunning method and a moditieation applieable in presence

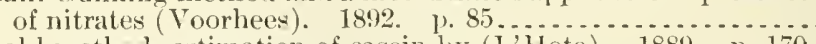

Kjelilalıl metlod, estimation of easein ly (J'Hote). 1889. p. 170

Sée adso Distilling flask - Nitrogen.

Klamath Indians of Oregon, plants used by, notes on (Coville).

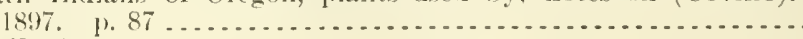

Klee, IV. Ci.:

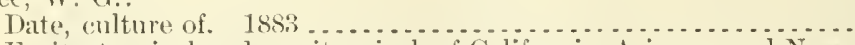

Fruits, tropical and semitropical, of California, Arizona, and New

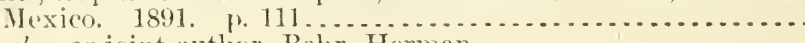

we ulso, as joint author, Behr, Herman.

A $29.6: 28$ A $29.6: 25$ A $29.6: 28$ 1.9.6:25

A $29.6: 27$ A29.6::24 A29.6:25

A 29.6:25

A29.6:26

A $29.6: 26$

A29.6:25

A29.6:25

129.6:29

A29.6:25

129.6:26

A $29.6: 25$

A29.6:25

A29.6:29

A $29.6: 24$

A29.6:29

A 29.5:F

A29.6:24

A29.6:25

A $29.6: 24$

A29.6:27

A 29.3:31

A $29.6: 26$

A $29.6: 26$

A29.6:26

A 1.10:898

A29.6:24

A $29.6: 25$

A29.6:24

A $29.6: 23$

A29.6:27

A29.6:26

A $29.6: 26$

A 7.3:35

A $7.3: 24$

A 6.5:5

A 1.8:24

A20.3:1 
Klein. J. Milk, extimation of fat in, by soxhlot's areometric

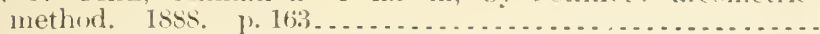

Klippart, John 11.:

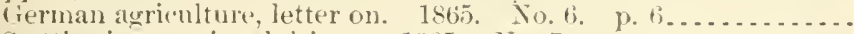

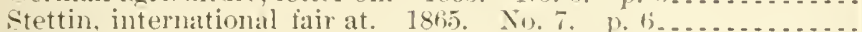
Klonilike:

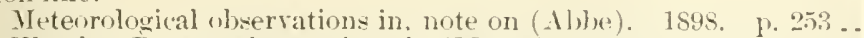

Weather Bureau observations in (1Iyers). 16:15. 1. 209. . . . . . Klotz, O.J. Langslorf, royage of, $1803-7$, notes from. 189s. 1). 463. Knapp, J.G. Climate and products of Floricla, statement of. Issi). No. 19 . p. $2:$

Knapp, Seaman A.:

Agricultural resources and capalilities of Porto Iiton, with special reference to extablishment of an agricultural experiment sta-

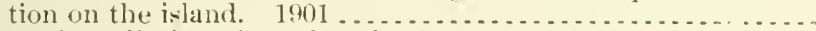

Education, limits of, moler the law, at aoricultural collegres. 188.5. p. 16.3

Rice culture in $\mathrm{C}$.

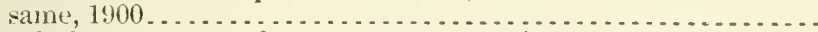
Knapsark kerosene attachment, some experiments with (Weed).

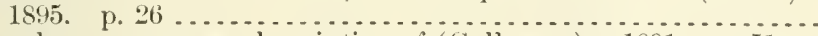
Knapsack sprayer, new, deseription of (Galloway). 1891. p. $51 \ldots$ See also Japy knapsack sprayer.

Knight, O. W. Sugars, estimation of, by weighing precipitaterl euprous oxin as such and as metallic copjer, notes on. 1901.

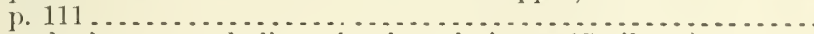

Knotweer, giant, or sachaline, circular relative to (scribner). 1895 .

Knowles, Etta L. Fungi, abnormal structures in, induced by Ustilago zere mays, sturly of. 1889. p. 14 .................. Knoxville convention, extract from proceedings of. $1889 \ldots \ldots . . .$. Koebele, Albert:

Anstralia, report of trip to, to investigate natural enemies of fluted

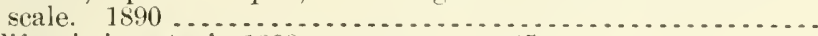

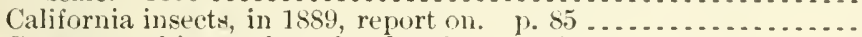

Cottony cushion-seale and red seale, experiments on. p. $558 \ldots \ldots$

Entomological work in Oregon and California, notes on Australian

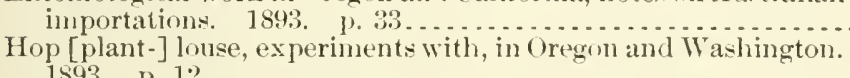

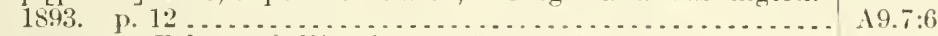

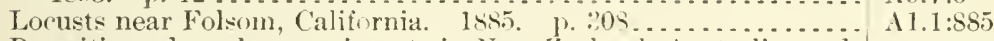

Parasitic and predaceons insects in New Zealand, Australia, and adjacent islaurls, studies of. $1893 \ldots . . . . . . . . . . . . . .$.

Resin componnds, experiments with, on phylloxera, and general

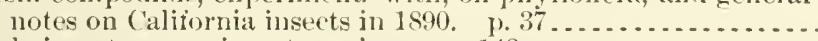

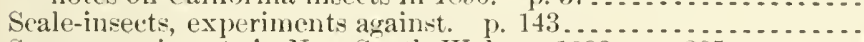

Sugar-cane insects in New South Wrales. 1892 . p. $385 \ldots . . . .$. Sice also Coquillett, Daniel Willian.

Koeppen, F. T. Hessian fly, in Russia, translaten by C. F. Gissler.

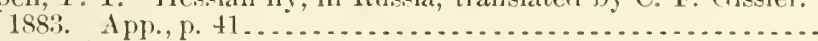

Koeppen, ir.:

Climatology, present condition and recent progress of. 1896. p.

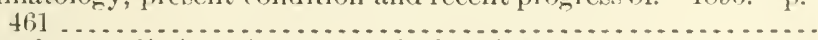

Weather predictions, best method of testing. 1894 p. $29 \ldots \ldots$ Kremser, Victor:

Atmosphere, upper, study of, by means of ballonns. 1s96. p.

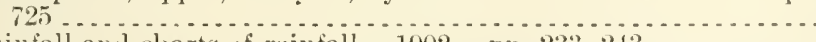

Rainfall and charts of rainfall. 1902 pp. $233,243 \ldots \ldots \ldots$

Krichelt, F. WT. River and floor service, montlily notes on, JuneJuly, 1898.

Simir Jume-July, 1896

Krug, William H('nry:

Dextrine, stareh, dextrose, sucrose, and gum arabie, mixture of,

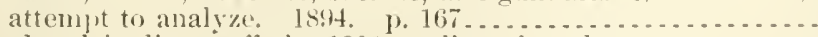

Fond and fecding stuff for 1901 , outline of work on . . . . . . . . . Hide-powder tests, comparative, report on 1901 j. $133 \ldots . .$.

Chemists, 1901, report on meeting of. 190\%. p. 147..... 17.3:67

A1.8:51

$\Lambda 9.3: 23$

A1.1:887

A9.7:4

A $8.1: 3$

129.6:23

A $29.3: 11^{1}$

$129.3: 11^{3}$

129.6:30

1:30.6:20 100.11:27

17.8:43

$17.4: 7$

17.3:t2 
Krucr, William Henry-Continued

see also, as collaborator and as joint author, Wiley, Ilarvey Washington.

Kü̈hn, Julius. Animals, domestic, feeding standards for. 1893.

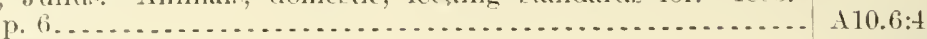

Kïhn, M. :

Nilk-

culder, fat in, estimation of content of $1890, p, 162 \ldots \ldots$. fat in, estimation of content of, ly methor of Soxhlet-Engström and schmoeger-Neubert. 1890 . p. $158 . . . . . . .$.

Kubn, von. German army horses, requirements for. 1898. p. 31. Kuro siro, chinooks versus, notes on (Abbe). 1898. p. 114......

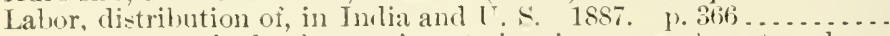
Laboratory method of experimentation in economic entomology

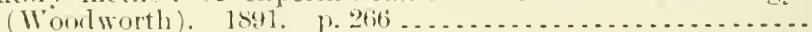
Laboratory work. See llorticulture.

Lace, description and history of (Wilson). 1897. 1. 359 . . . . . .

Lacey, K. .. ('abhage worms, remedies for. 1) 1:3:3 ............

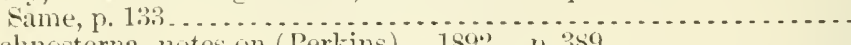
Lachnosterna, motes on (Perkins). 189.2. p. 3s9 . . . . . . . . . . Lachnosterna damage, case of. 188\%. 1. 3ti. . . . . . . . . . . . . La.hmosterna fusca, notes on (Smith). 1888. p. $180 \ldots . . . . . .$. La Crosse, Wis., rainfall at, heaviest, notes on (Ablie). 1900 . P. 448. Ladd, Eugene F. Dietary study of clul, of wonen students at North.

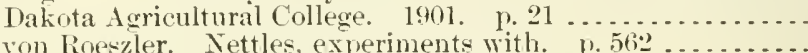
Larlé, yon Roeszler. Nettles, experiments with. p. 56.2 .........
Ladoua, Lake, from thermic point of view (Schokalsky). 1901. p. 63. Ladylird:

Asiatic, importation and present status of, preliminary report on

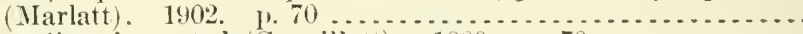

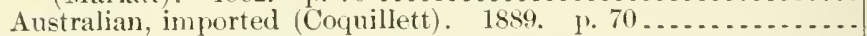

Parasite, report on (Riley). 188s. p. 101 ................... Lafayette, Ind. See Purdue Tniversity.

Lafayette Parish, La., soils and products of (Rapley). 1884. p. 14..

Lafitte, Prosper de. Grape miliew, artion of sulphate of copper on.

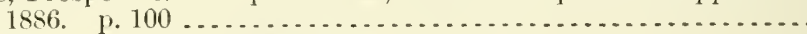

Lagerheim, C. See De Lagerhein.

Lagoon Head, list of plants collected by Edward Palmer at, in 1889

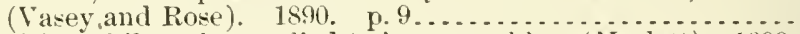

Laisser-faire philosophy applied to insect problem (IIarlatt). 1899.

Lake, E. Edward R.:

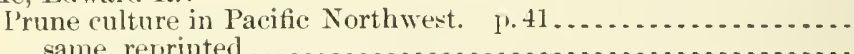

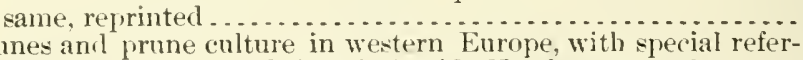
ence to existing conditions in I'acific Torthwest. 1901 ..... .

Lake Charles area, La., soil survey of (Heileman and Mesmer. ) p. 6:1 Lake commerce and insurance, notes on (Abbe). 1900. p.556...

Lake County, Ohio, potato culture in (Ahbott). P. 295 ..........

Lake Erie College, Painesville, Ohio, dietary studs at (Bevier and

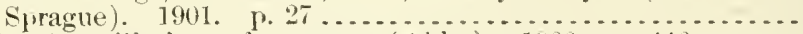

Lake level, oscillations of, notes on (Al)be). 1900, p. 446......

Lake levels, variations in, and atmospheric precipitation (Henry). 1899.

Lake levels and wind phenomena (Henry). 1900. p. $203 \ldots . . .$.

Lake water, temperature of, notes on (Ibbe), 189s, p. 167..... Lakes:

Deep, temperature of, notes on (Abbe). 1901. p. $71 \ldots \ldots \ldots$.

Fresh water, increase and decrease of (Abbe). 1898. P. 363...

Ice in, sudien disappearance of, note on (Abbe). 1900. I. 114..

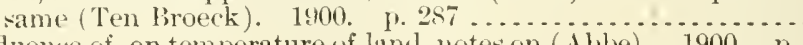
Influence of, on temperature of linil, notes on (Abbe). 1900 . p. 343

Oscillation of, in arid regions, notes on (Abbe) 1900.11 .544$. small, intuence of, on local climate (Able). 1901. P. $563 .$.

A 1.2:H78 A $29.6: 26$ A. $7.9: 25$

A9. $7: 3$

A11.5:9

A1.1:88:

19.1:883

A9.7:4

19.7:1

19.7:1

A29.6:28

$\$ 10.3: 91$

A1.1:578

A $29.6: 29$

A9.6:37

A9.7:2

A9. $7: 1$

A 1.8:35

16.3:2

A6.5:1

A9. $6: 20$

120.1:894

A $20.4: 2$

A 20.3:10

A 26.5:901 1

A29.6:28

A1.1:865

A10.3:91

A $29.6: 28$

A29.2:L15

129.6:28

A29.6:26

429.6:29

A29.6:26

A29.6:28

A $29.6: 28$

A 29.6:28

A $29.6: 28$

A29.6:29

Lambs:

Feeding, in Culorarlo (Clarke). 1). 275....................... A4.1:901 
Feeding of, experiments in (Curtiss and Wilson). pr. 463,466 ,

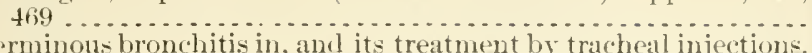

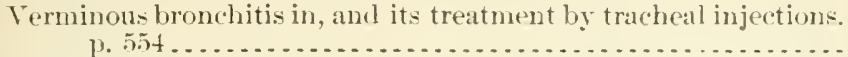

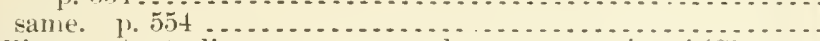

Lamellicorns, Australian, new genus and two new species of (Sharp).

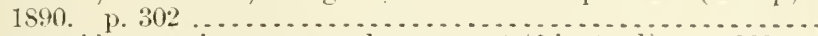
Lamenes of horses; its causes and treatment (Liautard). p. 269 ... A t Lamson-Scribner. Sie Scribner, Frank Lamson.

Lancaster, 1'a. Soil survey around (Dorsey). p. $61 \ldots \ldots \ldots \ldots \ldots$. Lan']:

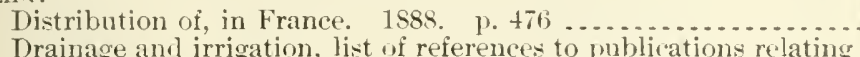
Drainage and irrigation, list of references to publications relating
to (Herlrick). $1902 \ldots \ldots \ldots \ldots \ldots \ldots \ldots \ldots \ldots \ldots \ldots \ldots$

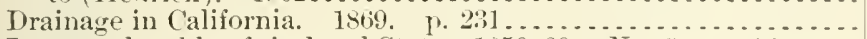
Improved, talle of, in loyal States, $1850-60$. No. (5. J) 12....

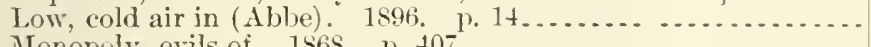

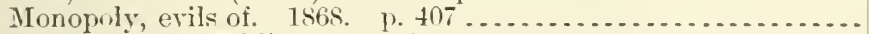
New, clearing (Williams). 1902.

Public-

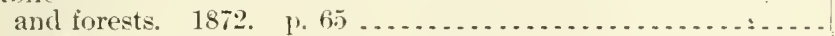

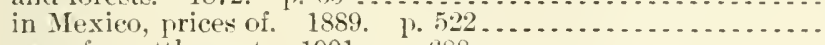
open for settlement. 1901. P. 688

A $1.9: 150$

Reclamation of, in New Jersey, England, and Hollam, reports of State geolngist of New Jersey, 1869 and 1870 . 1. 221 ...... Swamp and overflow, reclamation of, in California. p. 179.1600
Temmerature of, influence of lakes on, notes on (Al,be). 1900 .

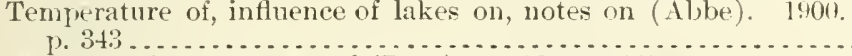
Worn-out, improvement of (Page). 1883. p. $207 \ldots \ldots \ldots \ldots$. See also Alkali lands - Forest lands - Grass lands-Marsh landsPrairie lands - Salt-marsh lands - Tidal lands-Timber lands.

Land birds of New England, oology of some, as a means of identifying injurious or beneficial speries (Sammels). p. $386 . . .$.

Land-grant and bond-aided railroads, alphabetical iist of, in U.S. 1902

Lanilgrant colleces. See Igricultural colleges - Agricultural colleges and experiment stations.

Land tortoive. See Florida land tortoise.

Landis, D. S. Leonids at Phoenix, Ariz. 1901. p. 509. . . . . . . .

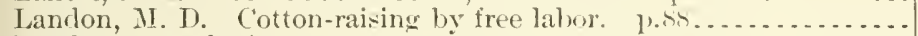

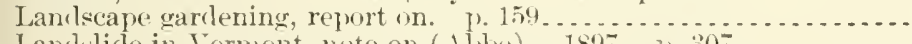
Landslide in Vermont, note on (Ahbe) 1897 . 13 $307 . \ldots \ldots \ldots$.

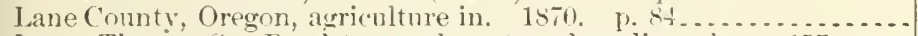
Lang, Themas. Roaristers and trotters, breeding of. p. $157 . \ldots$. Langdon nonswarming device, rejort of (Benton). 1593 . 1. $2: 30 .$.
Langhorne, G. T. Lrussels, importation of American hores into.

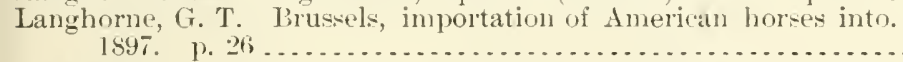
Langley, Samuel Pierpont:

Jeteorological work of Smithsonian Institution. 1895. P. 216 .. smithonian Institution, Astrophysical (Hbeervatory of, annals of. 1902 . 1. 258 . See as joint author, Ellis, J. B.

Langlois, A. L. See, as joint author, Ellis, J. B.

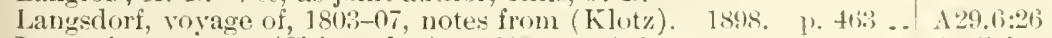
Languria, notes on (Chittenden). 1890. 1. $346 \ldots \ldots \ldots \ldots \ldots \ldots \ldots$. Langwortlyy, Charles Ford:

Alfalfa, when to cut. 1849. p. $24 \ldots$

Apricots, cherries, peaches, plums, and pumes, fored value of.

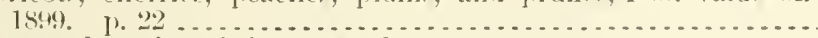

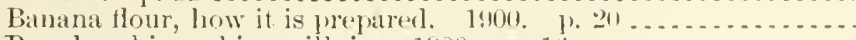

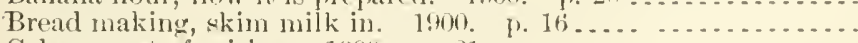
Calves, cost of raising. 1899. p. 21 . . . . . . . . . . . . . . . .

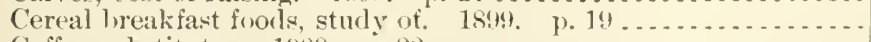

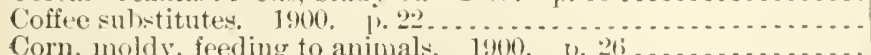
Corn, moldy, feeding to animals. 1900 . p. $26 \ldots \ldots \ldots \ldots \ldots$
Ducks, fueding, recent experiments in. $1899 . \quad$ p. $20 \ldots \ldots \ldots$ Egg records, indlividual, nest box for keening. 1900) p. 19.... 
Langworthy, Charles Forr-Continuerl

Firgs-

flavor of, relation of feed to. $1900 . \quad$ 1) 25.

A $1.9: 12: 2$

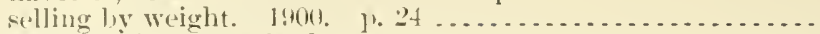

Egers and tlieir nees as ford . . . . . . . . . . . . . . . . . . . . .

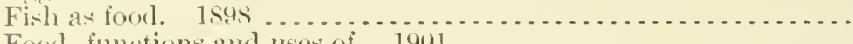

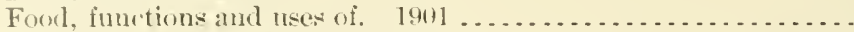

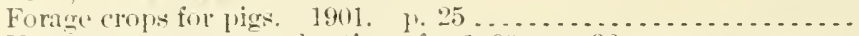

Hay, spontanenus combustion of. lsog. p. $26 \ldots . . . . . . . . .2$.

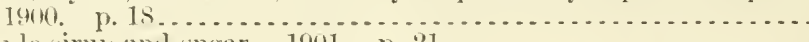

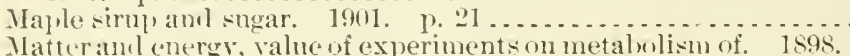

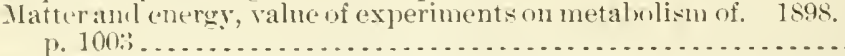

Molases as a food for farm animals isy9. p. $17 \ldots \ldots \ldots \ldots$

Nitrogen, metabolized, exretion of, by animals. 1897. p. 817.

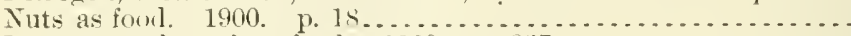

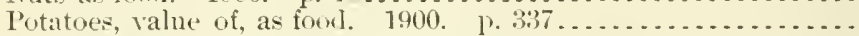

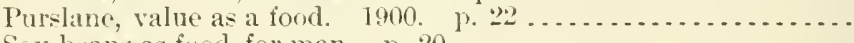

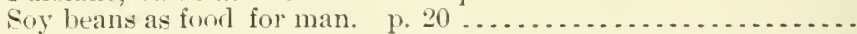

Steers, grazing on corn and cowpeas. 1901. 1. 27...........

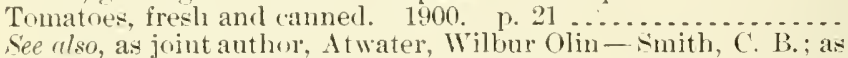
translator, Stuhmann, F.

Lantern trap, for insects, sncessul, report on (Gillette). 1897. ).

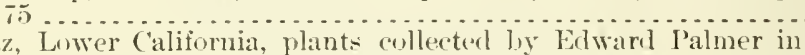

La Paz, Lower Califomia, plants collectod loy Edward I'almer in

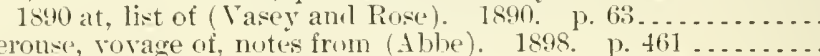

La Perons', rovage of, notes from (Abhe). 1898. p. $461 \ldots . . . .$.
Laphan, Increase Allen, liographical sketch of (Laphan). 1896.

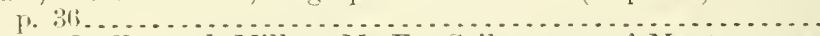

Lapham, J. F., and Xiller, XI. F. Soil survey of Montgomery

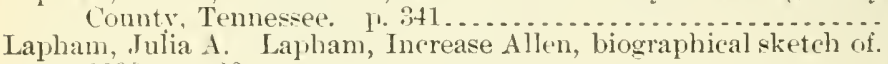

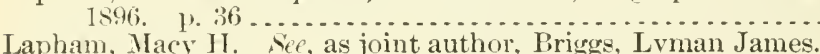

Lapham, Macy H., and Heileman, IT. H.:

Soil survey of Hanford area, Califormia. p. 447 ............

Soil survey of lower Salinas Valley, California. p. 481 .........

Laramie Plains, Wyoming, duty of water on. 1899 (Fairfield).

Lard:

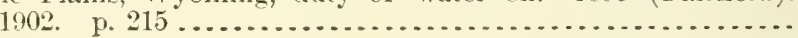

Composition of, from dairy commissioner of Minnesota (Ires).

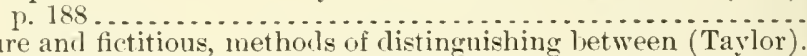
1893

Lard and lard adulterants (Wiley). isso. p. 405

1 $1.9: 122$

11.4):128

11.4:85

1 1). $4: 46$

1 $1.9: 124$

A 1.:1:105

11.9:114

1 1.9:124

A10.6:9

A 1.9:107

A 10.6:7

A $1.9: 122$

A I. 10:900

A1.9:119

11.9:58

A 1.9:124

A 1.9:119

A $9.6: 9$

16.5:1

A $29.6: 26$

A29.3:15

A $26.5: 901^{1}$

+29.3:18

A26.5:901 1

+26.5:901

110.3:104

A7.1:889

1 18.5:3

A $7.3: 13^{4}$

Larger cornstalk horer. Sie Cornstalk borer, larger.

Larkspur poisoning of sheet, (Wilcox). p. 473.

A4.1:898

Larned, Ellen D:

Snow in New England, report of, $1817-40$. p. 75

Temperature observations at Thompson, Windham County,

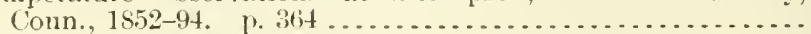

Larrabee, J. II. Apiculture, experiments in. 189.2. p. $57 \ldots \ldots .$. Larvis:

Comparative tests with new and old arsenicals on (Marlatt).

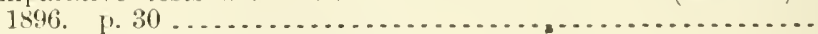

Preservation of, for stuly (Garman). 1893. p. $98 \ldots \ldots \ldots \ldots$

Larval cestorle (Sparganum mansoni) of man, which may possibly oc'mr in returning American troops (Stiles and Tayler). 1902.

Lathrop, Barbour, and Fairohild, David (irandison. Foreign seeds and plants collected by, in Austria, Italy, and Egypt. 1900 .

A $29.6: 22$

A29.6:21

A9.3:30

19.6:6

19.7:6

A $4.3: 35$

$+6.6: 6$

Latta, William Carroll:

Address of, before American Association of Farmers' Institute Workers, at seventh annual meeting. 1902 . p. $1: 3 . . . . .$. A $10.3: 120$

Indiand, farmers' institute work accomplished in. 1902 . p. $21 \ldots$ A10.3:120 
Local lielp in farmers' institutes. 1902. n. 36............. A10.3:110

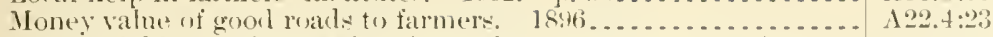

Plats in tielit experimentation, form, size, arrangement, anel treat-

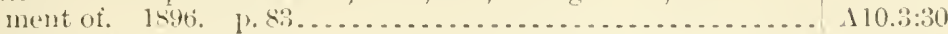

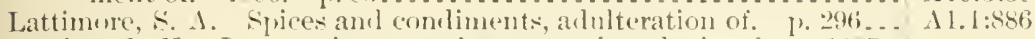

Lauder, J. N. Loconnotives, smoke-consmining deviere for. 1 ss7.

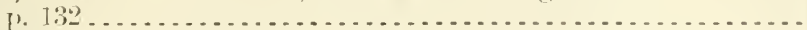

Lavalard, E. Horse feeding, notes on. 1902. p. 4 . . . . . . . . . .

Law, James:

Inimals, contagions diseases of, and means of supwessiner and

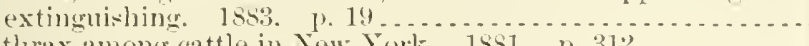

Anthrax among cattle in New York. 1981. p. 312 ...........

Brnsels, International Veterinary Cougress, report of. I). $321 \ldots$

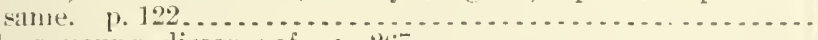

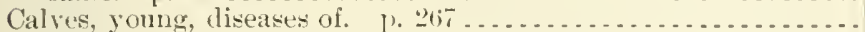

Cattlegenerative organs of, diseases of. I. 169 .............. parturition of, diseases following. p.255................

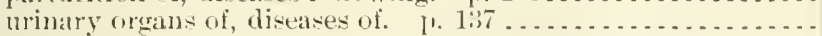

Cattle plague or rinderpest, tramsmission of througl medinm of dry or salted hirles, opinion relative to. [).321

Cattle traftic in relation to cattle plague. 1883. p. $110 . . . . . . .$.

llog-cholera; intestinal fever in swine. p. $426 \ldots . . . . . . . .$.

Ilor'se-

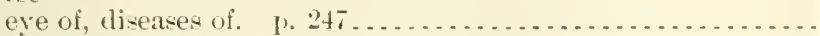

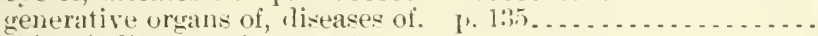

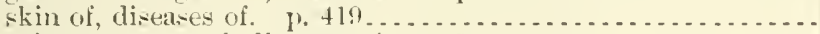

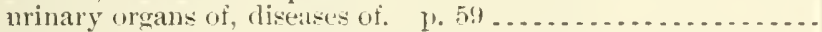

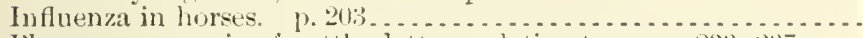

I'leuro-pnemmonia of cattle, letters relative to Ho. 233,237 ....

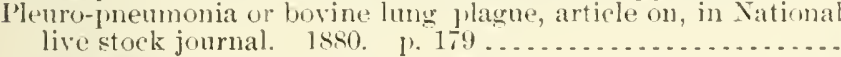

swine plagne, report on, 1579 . p. $420 \ldots \ldots \ldots \ldots \ldots \ldots \ldots \ldots$ same, 1880. p. 455 .

Swine plague near Ithaca, N. Y.-

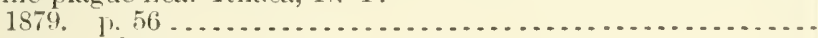

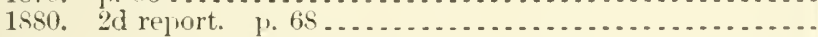

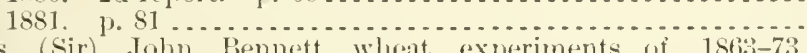

Lawes, (Sir) John Bennett, wheat experiments of, $1863-73$,

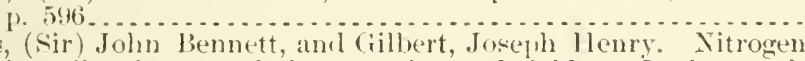
in soils of some of the experinental tiedss at Rothansted, determinations of, and bearing of results on question of

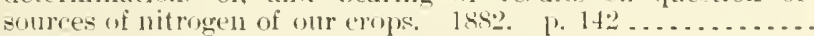

Lawes, John Bemett, and Gilbert, Jowen Itenry:

Soil, composition of, some points on, summary and conclusion.

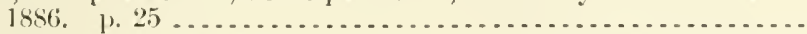

Wheat grain and wheat straw, grown at lothamsted, in different seasons and hy different manures, composition of ash of.

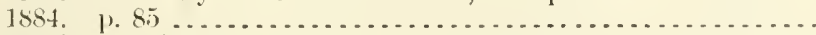

Lawes Agricultural Trust:

Six lectures delivered under, on investigations at loothamsted experimental station, Englamd, 18!2 (Warington)........

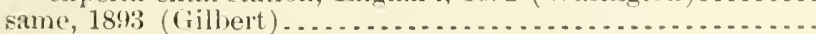

\section{See also Dver, Bernard.}

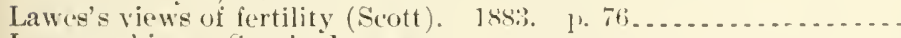

Lawn-making. Sce also lawns.

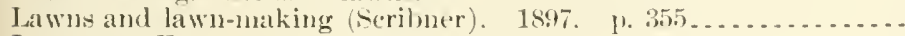

Lawrence, E.:

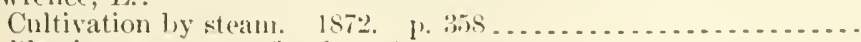

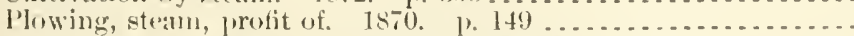

Lawrence, 11. E. Stean plowing in Louisiana. 1, $278 . \ldots \ldots \ldots .$. Lawrence, La.:

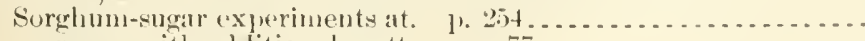

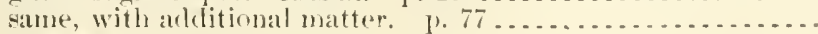

A1:3.3:1

A10.6:12

A1.8:2:9

A1.6:34

A t.1:8st

A4.2: Ani

A $+2: \mathrm{C}^{2} \cdot \mathrm{y}^{2}$

A $4.2:\left(: 2 y^{2}\right.$

$1+2:(29)^{2}$

$1+2: C 29^{2}$

$11.1: 576$

$11.7: 2$

$11.1:-5$

A4.2:1178

14.2:1178

At.2:1178

A $4.2: 1478$

1 1.1:872

A1.6:1:

A1.6:2:2

A1.1:579

A 1.1:880

11.6:12

A1.6:2:2

A $1.6: 34$

A27:9:11

A1.8::1

A $7.8: 10$

$17.3: 4$

$110.8: 8$

$110.3: 2: 2$

$11.7: 2$

11.10:8:17

1.27.9:10

A27.9:5

A1.1:Stiq

A1.1:ละ

A7.3:17

See ulso Margnolis station. 
I ilwon, 11. I1. C'hemists, Oflivial Agricultural, Association of, 19th ammual convention, $190^{\circ}$, report on, 1902. 1. $10 \% \ldots . . . . \$ 10.6: 14$

La

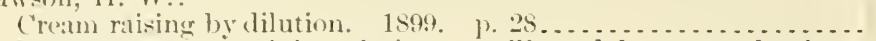

1)airy cow, type of, in relation to milk and butter pron?ution.

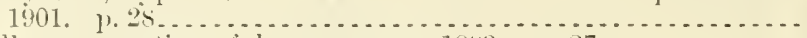

Milk, prescrvation of, by pressure. 1S:99. p. 27...........

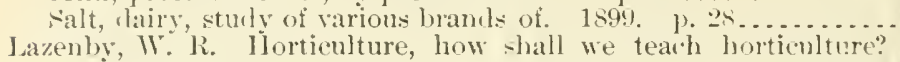

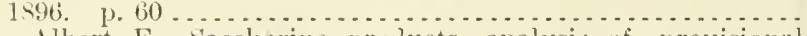

Leach, Albert E. saccharime produets, analysis of, provisional

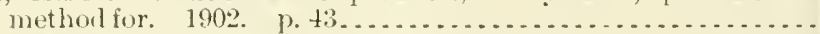

Lead, arsenate of:

Improvement in manufacture of (Kirkland). 1899. p. 102. ... l'reparation and use of (Kirkland). 1897. [1. $16 \ldots . . . . . . .$.

Leaf-blight, treatment of (Galloway). 1S91. p. 11............ See also Nurwery stock.

Leaf curl of peath trees, letter of inquiry relative to (Willits). 1898.

leaf-cutter. See Noming-glory leaf-cutter.

Teaf disease. See Nematorte leaf disease.

leaf fibers of $T$. S., report on (Dorlge). $1893 \ldots \ldots \ldots \ldots \ldots \ldots \ldots \ldots .111 .5: 5$

Leaf-galls, cranberry, report on (Thomas). 1859. 1). 279........ $19.7: 1$

Leaf-mining locust beetle, with notes on related species (Chittemlen).

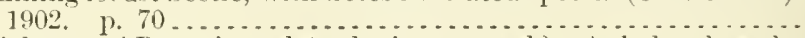

Leaf sickness of Begonia and Asplenimm caused by Aphelenchusole-

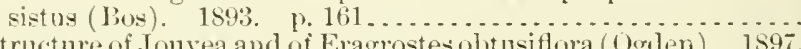

Leaf structure of Jourea and of Eragrostesobtusiflora (Ogilen). 1597. p. 12 . . . . . . . . . . . . . . . . . . . . . . . . . . . .

Leaf tobacco, world's exhibit of, at I'aris Exposition of 1900 (Flovil).

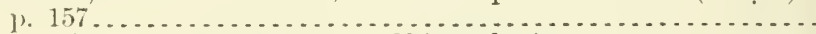

Leat-tyer of grape and elderluery (Chittenden). 189s. 1). s..... Leather:

American proluction of (Bailey).

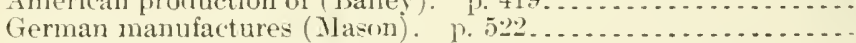

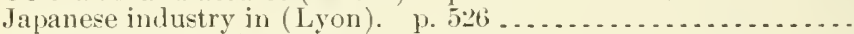

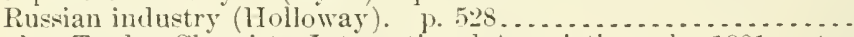

Leather Trades Chemists, International Association of. 1901. veo Liège, Belgimm.

Lebanon area, Pennsylvania, soil survey of (smith and Bennett).

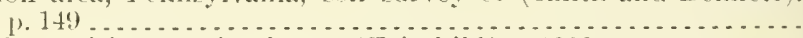

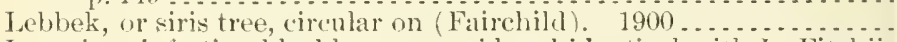

Lecanium infesting blackberry, considered identioal with L. Fitchii

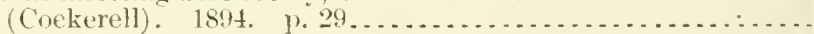

Le Clerc, J. A. Dairy produets, analysis of, provisional methouls

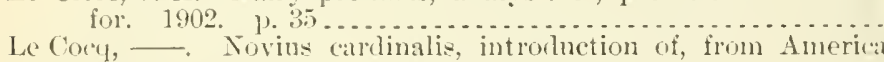
into Portugal, acrount of; translated by Frank Fenton. 1895.

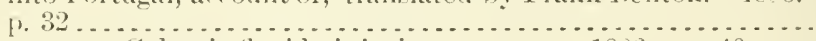

Le Conte pear, Colaspis flavida injurine, note on. 18\$6, 1, 40... 19.3:12

Le Duc, William (iates:

Agriculture Department, work and needs of ...............

Naize and sorghum sugars, circular letter relative lo. $1879 \ldots . .$. Sorghum sugar, letter to chairman of Senate C'ommittee on Agri-

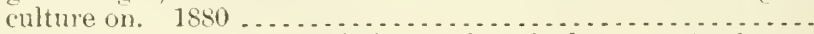

See also, for reports as Commissioner of Agriculture, $1877-80 \ldots .$.

Ledyard, F. IV. Aldress of, before convention of National Lealuni. for Good Roads, Washington. 1s93. 1. 27 .............

Lee, Fitzhugh. Address oi, before Jefferson memorial and interstate good roads convention. Apr.. 1902. p. $11 \ldots . . . . . .$.

Lee, J. G. Louisiana, farmers' institute workaceomplisherl in. 1:012.

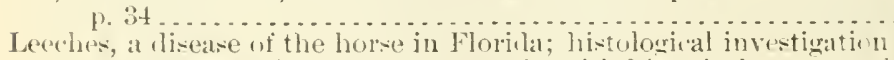
of two eases of an equine myons, with historical accomnt of supposer , inilar disease, callinl bursattec, occurring in Indial

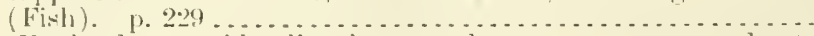

Leeds, kneland, cost of hamling fam jooluets over wagum roads at

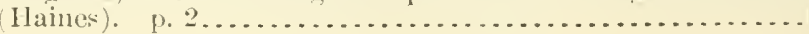


Leeward Islands:

Rainfall of (Jefferson). 1901. p). $56 \ldots \ldots \ldots \ldots \ldots \ldots \ldots \ldots \ldots \ldots . . . \pm 29.6: 29$

Reforestation and rainfall in ( 1 lexander). 1901. 1. 254...... $129.15: 20$

Lefranc, Emile. Ramie and jute. culture and manufariure of is C.S. 1873.

$11.8: 8$

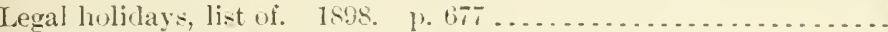

Legumes, fie Beans-Forage crops-P'eas- plasits.

Lelmann, G. IV. Mineral phosphates, iron and alumina in, etimation of. 1897. 1.61 ... . . . . . . . . . . . . . . . . . . .

L'llote, I. C'asein, estimation of, hy nethor of lijelalahl. Isis.

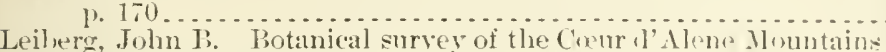
in Jiaho during summer of 1895. p. $5 \ldots . . . . . . . . . .$.

Leibergia, a new gems of mbellifere from Colmubia River region

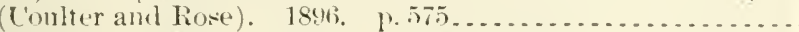

Leisenring, O. 1). River gage, lorass, description of, at liohmond, Ya., and its method of support. 1899. p. $456 \ldots . . . . . . .$.
b. F. Trees, plants, fruit, ete, inspection of. as condu.tei

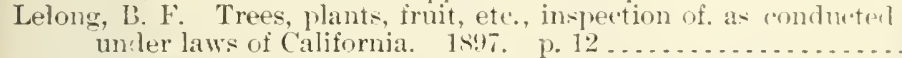
Lelong, B. II. Sre, as collector, Coruillet, Daniel William.

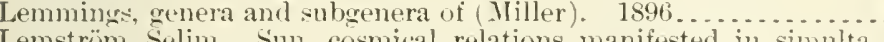
Lemström, Selim. Sun, cosmieal relations manifested in simulta-
neous disturbances of. aurora, and terrestrial magnetic field.

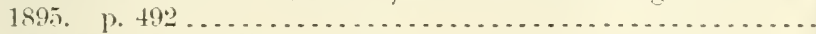

Lenoir, IV. IV. Cattle lisease, strange. 1879. p. 253.......... Leonia rileyi, description of, new melojd genus near Homia (Dnges).

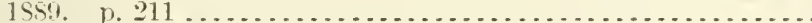

Leonirls at Iavre, ILont. (Ling). 1901. p. $509 \ldots . . . . . . . . .$.

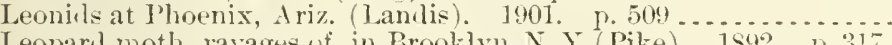

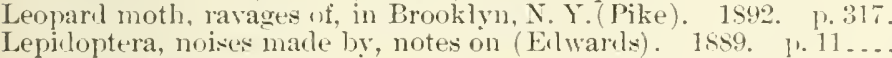
sice also Moths.

Lepidopteroms insert, beautiful exotic, lirth of, in New Jork

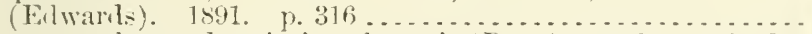

Lepidopternus larva, description of certain (Dyar). 1890. 1) 1.61, 349. Leplay, II Iippolyte. Sorghm cane, culture amb listillation of. 1897.

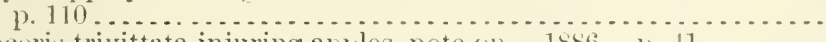

Leptoreris trivittata injuring aples, note 11. 18:6. 1. +1 . . . . .

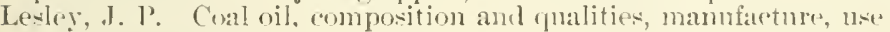
in arts, history of discovery, and theory of origin. 1. 4:y ....

Lestophoms genus, note on (Wiliston). 18s9. p. 3.2. . . . . . .

Lettue':

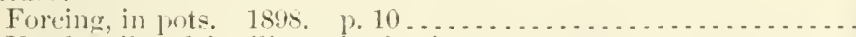

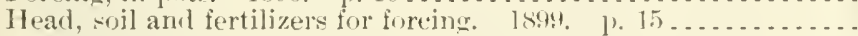

Lenkiemia, infections, in fowls, a bacterial disease frequently mistaken for fowl cholera (Moore). p. 1s5 ...............

Leverett, T. II. Root ('rops; ("nltivation of, in U. . . p. 9. ........

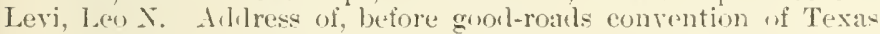
F(2). 1895).

Lewis, Lowery laymon. Teterinarians, value to, of cooperative ex-

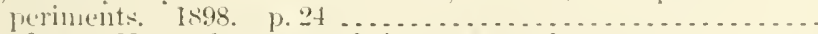

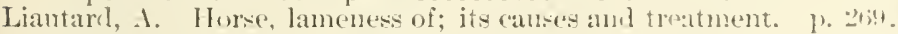

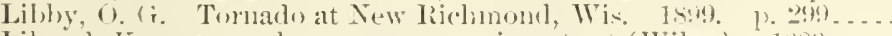
Lilueral, Kansals, sorghmm-smar experiments at (Wiley). 188:) .... Liheria, climate of, notes on (Ablue). 1898. p. 215............

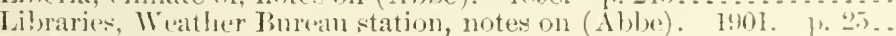
sive retso derionltural libraries.

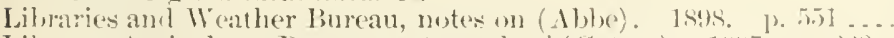

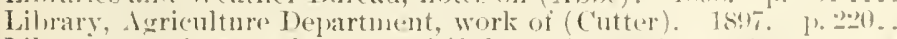

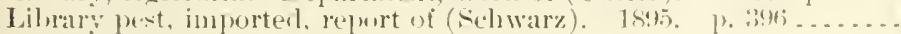
Liclene:

California and Mexico, collected lo Goward l'aluner from lsis

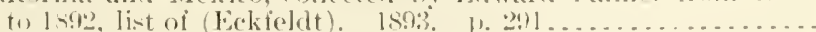

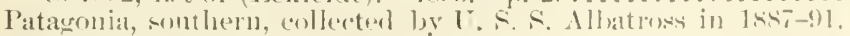

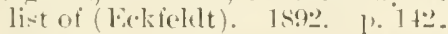

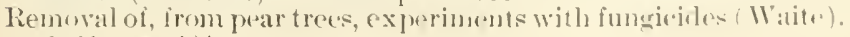
1591. 1. 264

11.10:898

\section{$17.3: 51$}

$17.3: 24$

$1(5.5: 5)$

A6.5:3

$1: 9.6: 27$

A1.8:57

A5.5:12

A29.3:112

11.6:12

A9.7:1

A $29.6: 29$

A $29.6: 29$

A.9.7:4

A. $7: 2$

4!1. $7: 3$

A9.7:3

A 7.:3:18 A!9.3:12

A1.1:562 1!. $7: 1$

11.9:6: $11.9: 9^{\circ}$

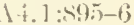
A $1.1: 4(0 ; 3)$

1 …2:3:15

$14.3::^{30}$

$14.2: 1175$

$129.6: 27$

17.8::-3

$129.6: 26$

1:99.6:2!3

$129.6: 26$

$11.10: 597$ 1!). $7: 7$

1(i.j:1

$1(i, 5): 1$ 
Livoricemont ("mltivation, 1867-71. ए. T:2

liebsher, (i. Plants, cultivated, principles and methods of breeding. 18:7. p. 347.

Livere, Peterium, international Association of Jeather Trades Chemists, 1901 , report on luceting of (Krug). 1902. p. 147 .....

Life, les of, by lightning (Henry):

$1690-1$ sis, $11 .+5)$

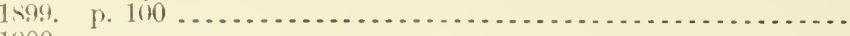

Life zones. Ver Zones, life and erojl.

Licrlit:

Conditions, influence of, on process of gernination (Detmer).

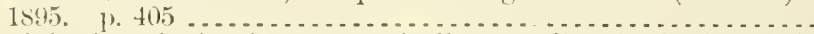

l'recipitation, device for antomatiobly recording beginnine and

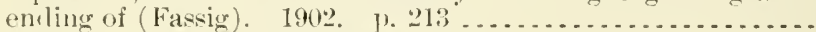

lightning:

Ball-

instance of, at sea (Seyboth). 1901. 1) 24!).

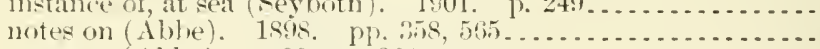

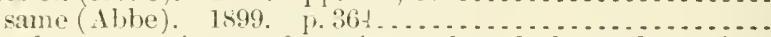

Can we, hy automatic records at three selected places, determine the energy of a flash of? (McAllie). 1894. p. 1it.........

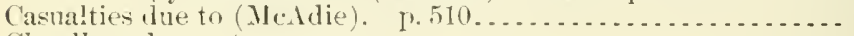

Clomlless sky, notes on-

1900 (Ablie). pl. $292,56$.

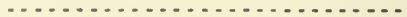

1900 (1'agne). p. 429.

Death by, apparent, directions for procelure in case of. 1) 533.

Destruction by, in State of New York, Aug., 1898 (Allen). p. 857.

Distant, currents induced by, note on (Abbe). 1898. p. 257 ... silune (Abbe). 1899. P. $865 \ldots \ldots \ldots$

Does it ever strike ocean? (Trowbridge). 1902. p. 4 ti .......

Electricity of air and (Mctdie). 1899. 1.9 .............

Fillet or ribbon, notes on (Abbe). 1899. 1, 365 ..........

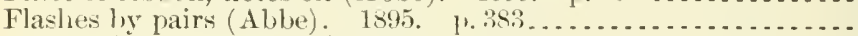

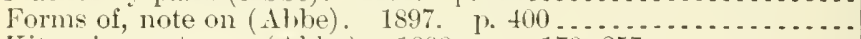

Kite wire, notes on (Able). 1S98. pp. 170, 257 ...........

Loss of life and property by (I Ienry) -

1890-98. P. 45 ....

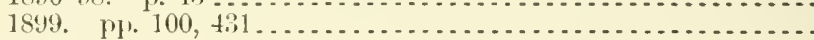

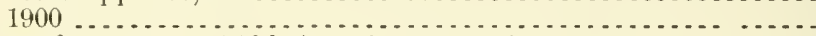

Losses by, note on (Ajibe). 1899. p. $475 \ldots \ldots$

Iranetic rocks and, note on (Al)be). 1897. p. $352 \ldots \ldots \ldots \ldots \ldots$

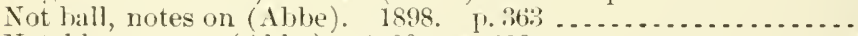

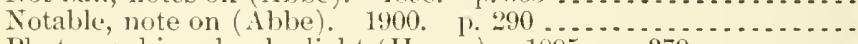

Plotographing, by daylight (Henry). 1895. 1. $379 \ldots \ldots . . . .$.

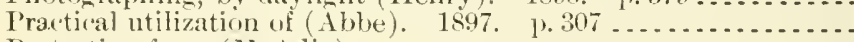

Protection from (Medrie) . . . . . . . . . . . . . .

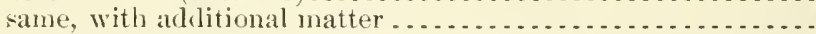

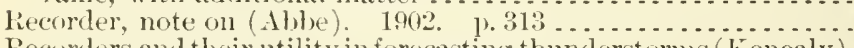

Recorders and their utility in forecasting thunderstoms (Kenealy).

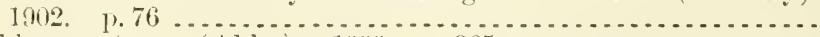

Rilbbur, notes on $(A$ libe $)$. 1898, p. $865 \ldots \ldots \ldots$ same (Abbe). 1899. p. 255 . . . . . . . . . . . . . . . . .

Safety fuse for, on anemoneter, notes on (Abbe). 1898. 1.25\%.

Serpentine (Kales). 1899. p. 4ti ......................

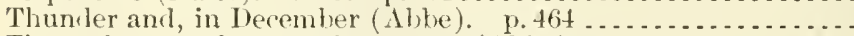

Tin roofs as conductors of, notes on (Able). 1898.5160 .258$.

Which trees attract lichtning? (Ablue). 1898, 1.25\% . . . . . .

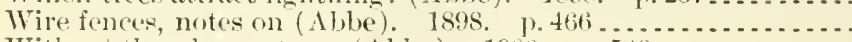

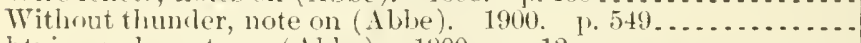

Lightning rols, note on (Ahbe). 1900. J. 12................

Liggett, IT. M. Agricultural education, pratical and soientific. 1900 . 1. 48.

Lignivorous insect, Anthomyia angustifrous, note on. 1886. p. 38 . A9.3:12

A 29.6:29

A:9.1::26

A29.6:27

A $29.3: 11^{1}$

129.1:891 ${ }^{3}$

A 29.6:28

129.6:28

A $29.6: 28$

A 1.10:894

A29.6:26

A29.6:26

A29.6:27

A29.6:30

129.3:26

129.6:27

+29.6:23

129.6:25

1.9.6:26

A29.3:26

129.6:28

A29.3:30

A29.6:27

A29.6:25

129.6:26

A $29.6: 28$

A $29.6: 23$

A $29.6: 25$

129.2:1.62

A $29.3: 15$

A29.6:30

A 29.3:31

A $29.6: 26$

A29.6:27

A29.6:26

129.6:27

A $29.6: 23$

A $29.6: 26$

129.6:26

A $29.6: 26$

A29.6:28

A $29.6: 28$

A 10.3:76 
Limax campestris, fool of, further notes on (Webster). 1892. p. 128. A9.7:5

Lime:

Determination of, in soils (Snyder). 1805, 1. 45............ Effect of, on different erops on acis soils. $1901,1,6 . . . . . .$.

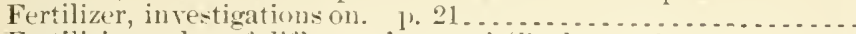
Fertilizing value of different forms of (Beal). 1901. p. 12.... Hydrate of, Perono-pora overcome by (Cerletti). 1855. 1. 71 .

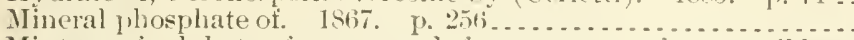
Mixture of sulphate of copper and, for treatment of grape millew (1lillarlet and (iayon). 1885. J. 708 .

A $7.3: 47$

A $1.9: 13: 3$

A $1.9: 65$

A 1.9:124

A6.3:2

127.9:5

Relation toplant gwwth, experimental study (Jay). 1901. p.37. Use of, in purifying the diffusion juices of sngar cane and forghum

(Wiley).

Sie rlso Hawailan soils.

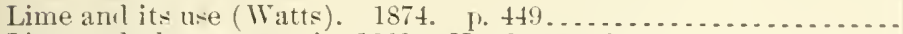

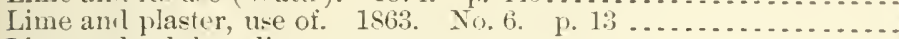

Lime-anc-sulphur dip:

Experiments with, p. 506

Reply to criticism, 1 . 5ts

Lime wash. See San Jose scale.

Limekiln, economicul. 1873. p. 360 .......................

Limestone, use of, for agricultural purposes. 1875 . p. $123 . \ldots \ldots \ldots$

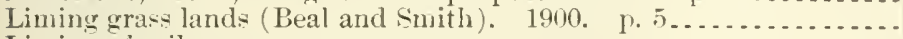

Liming of soils:

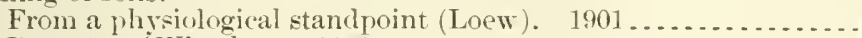

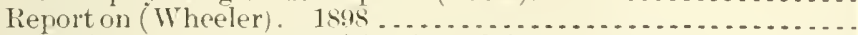

Lincoln, Cieo. F. Ponltry raising in Belgium. p. 506

$16.3: 2$

$\Lambda 19.3: 1$

$17.3: 8$

A $27.9: 12$

A27.9:1

A $4.1: 549$

A $4.1: 598$

A27.9:11

$127.9: 13$

11.9:1:2

A19.3:1

$11.9: 7 \%$

A $4.1: 900$

Lindenthal, $r$. Timber-trestle brilges, economical designing of, review of report of $A$. L. Jolmen, p. $31 \ldots \ldots . . . . . . . .$.

Lindo-Gladding method of determining potash, use of sodium chlo-

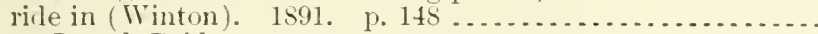

$113.3: 12$

A $7.3: 31$

Lindsey, Joseph Bridges:

Darmstadt experiment station, report on. 1897. p. 3.........

Feeding value of corn stover. $1896 . \quad$ 1) 353

Wagner method of pot culture 1897 . $77^{-}$.

Lindkey, Joseph Bridges, and Holland, E. B. Phloroghicin methorl fur estimation of pentosans. 1896. p.53 ................

Linell, Martin L. See, as translator, Meinert, Fr.

Linen industry in Silesia. 1873. p. 433 . . . . . . . . . . . . . . . . .

Ling, Charles W.:

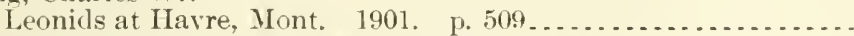

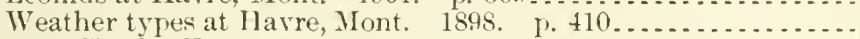

Linney, Charles E.:

Climate and crop conditions, are changes in present forms for reporting weekly, advisable? 1899 . p. 126.............

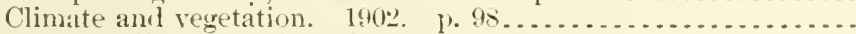

Frost predictions, value of, and best method of making them

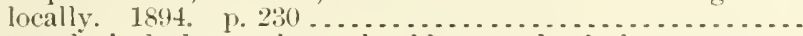

Meteorological observations, should not a book for permanent record of, be furnished to section centers and voluntary sta-

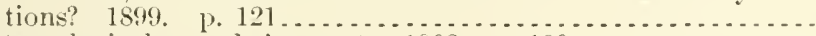

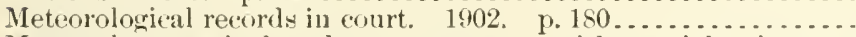

Meteorology, ayricultural, some notes on, with special referente

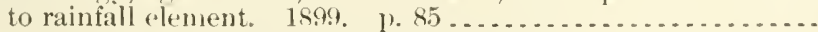

Storms, approaching, effect of, upon song biris. 1sis. 1). $854 \ldots$

Linseed, linseed cake, ete. 1868, p. $3 \overline{7} \ldots . . . . . . . . . . . . .$.

Lintner, J. A.:

Adrlress of, as president, $A$ scociation of Eeonomic Entomologists, at 4 th anmol meeting. $1892 . \quad 1.67 \ldots \ldots . . . . . . . .$.

Arsenical spraying of fruit trees while in l, lossom. 1893. p. 181.

Cottonwood heetle, striped. 1895. [.69 . . . . . . . . . . . . . . .

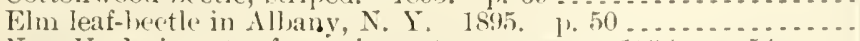

New York, insects of year in, notes on sone. 1s96. p. 54.....

Liparis (Psilura) monacha, ravages of, in Germany, and nueans of

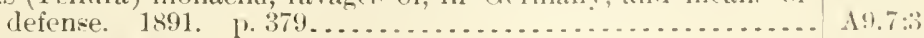

Lippincott, James S.:

Atmosphere, humidity of, observations (11, f, 520

A10.6:7

A $1.10: 896$

A $10.6: 7$

A $7.3: 49$

A27.9:11

A29.6:29

A29.6:26

A29.3:24

A29.3:31

A 29.6:21

A29.8:24

A 29.3:31

129.3:24

129,6:26)

127.9:6

A.7.5

1!.7.6

19.6:?

19.6:2

A!1.6:(1)

A1.1:stis 
Lippincott, James S.-Continued

Fruit regions of northern $[Y$. S., and their local climates. p. 137. Grape vines, imerican, climatology of. p. 1!t . . . . . . . . . .

Market products of west New Jersey. p. 249..............

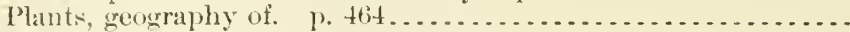

Liquid air:

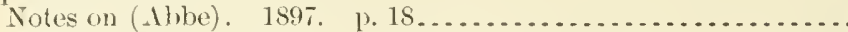

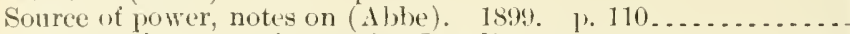

Liquid manuring, experiments in (Rand). p. 184..............

Liquids, viseous organic, dehyelration of (Carr and Sanborm). 1895.

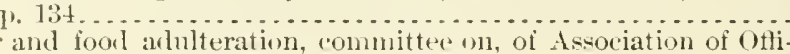

Liquor and food arlulteration, committee on,
cial Agrieultural Chemists, report of:

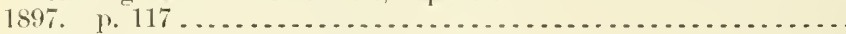

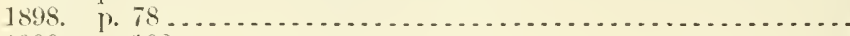

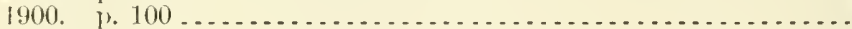

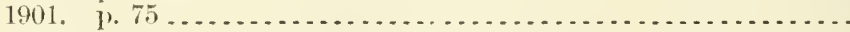

Liquors:

Distilled, examination of, provisional nethods for. 1896 . p. 113.

Fermented, committee on, of Association of Official Agricultural Chemists, report on-

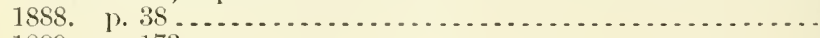

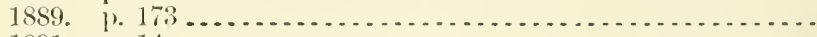

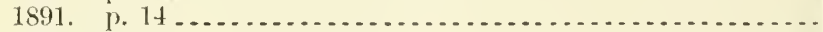

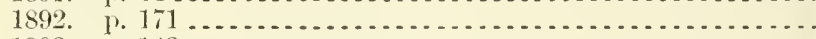

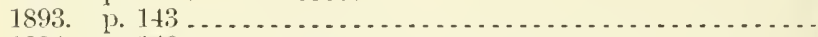

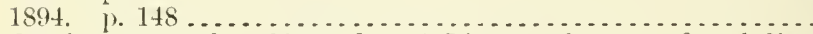

See, for reports for 1595 and 1896 , Liquors, fermented and distillerl, tommittee on.

Fermented and distilled-

analywis of, provisional methor for (Figelow). 1902. 1). 81 . cominittee on, of Association of otficial Agricultural Chemists, report of. 1895 . p. 95 .

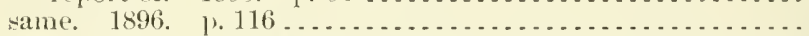

See also Alcoholic beverages - Beel - Brandies - Chemion analysis, methods of-Distilled spirits-Fermented alcoholic: beverages - Malt liquors - Wines and references theremnder.

Lists of publications of Agriculture Department. See Agriculture Department, indexes anr! lists.

little, Frank. Celery culture at Kalamazoo, Mich. 1. 843 ...... Little, 11. I. C'rops, rotation of, necessity and method of. 18s:?.

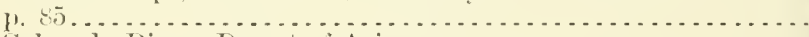

Little Colorado River, Desert of Arizona-

Reptiles and batrathians of (-tejneger). 1890. p. 103 . . . . . . .

Biological survey of, results of (1] rriam). $1890 \ldots . . . . . . .$.

Littlefield, Charles E. Adtress of, before Jefferson memorial and

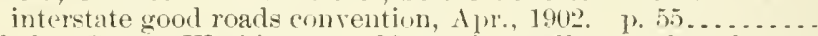

Littlehales, George Washington. Magnetic needle, recular change in direction of: its cause and period. 189t. p. 17t .......

Live stock:

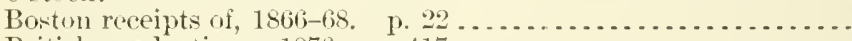

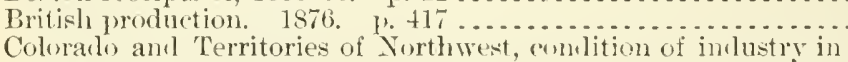
(Standart). p. 326 . . . . . . . . . . . . . . . . . . . . .

Colorato and Wyoming industry, (onnlition of (MeNeely). I).

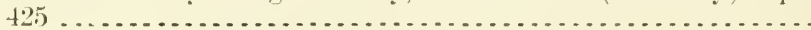

Conrlition of-

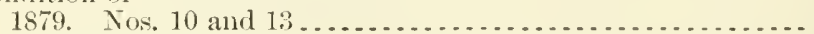

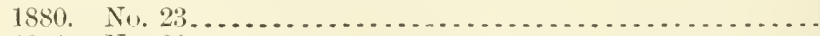

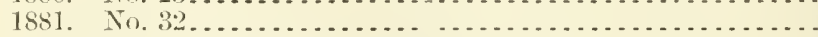

Foot-and-mouth disease of-

instructions conceming inspection for. $1902 \ldots . . . . . . . .$. waming to all owners of cattle, slseep, and swine (Salmon)

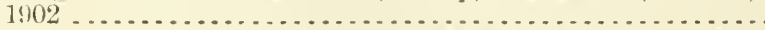

Foreign and interstate shipments of, federal inspection of (sal-

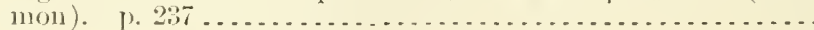

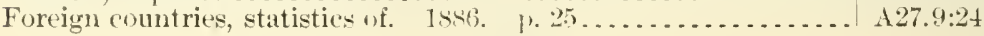

A1.1:566

1 1.1:862

A $1.1: 865$

A 1.1:86:

$129.6: 25$

12!).6:27

A $1.1: 867$

17.:3:47

17.8:51

17.3:56

17.3:6:

A7.3:67

A7.3:49

17.8:19

17.:2:2t

17.3:31

17.8:35

17.3:38

17.3:43

A $7 .: 3: 65$

17.8:47 17.8:49

11.1:886

1 1.8::31

$15.5::^{3}$

A5.5:

$10: 2,3: 2: 25$

12?9.3:111

A27.9:7

127.9:14

At.1:885

A $+.1: \$ 59-90$

127.9:17

A.7.4:18

$127.9: 19$

1 +.:2:F73

A 4.4:38

$4+1: 901$ A27.9:24 
Live stock-Continued

Freight rates an, irom Chicago to New York. 189.5. 1. 5ถ้3...

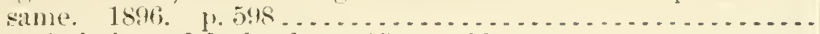

Great britain and Ireland. 1595. p. 22 . . . . . . . . . . . . . .

Industry in, and weather (Brandenburg), 1900. p. $585 . . . .$.

Inspectorsmiscellaneous repurts wi. 1897. J. 317 reports from. 1\$4: p. $875 \ldots \ldots \ldots \ldots$

International exhibitions of. Ne Hamburg, 1853; Chicago, Ill., 1900.

Ireland, $1861-71$. P. 331

Items of interest from corresmulents lelative to1585. p. 461

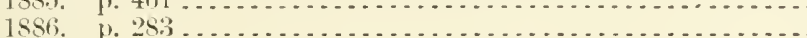

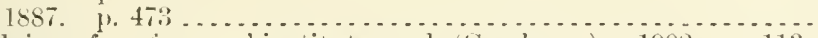

Judging of, as larmers' institute work (Crelman). 1902. p. 113.

Maryland, interests of (Patterson). p. $254 \ldots . . . . . . . . . .$.

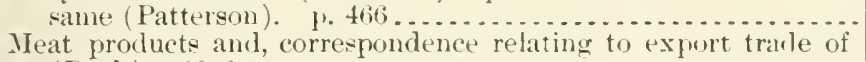
(Rusk). 1893.

Mississip pi River, industry west of, conditim ( Vilson). p. 429.

Hovement of, in France, 186. -ti. p. $380 \ldots \ldots \ldots \ldots$

Nebrakka inclustry, condition of (Harwi). 1. $382 . . . . . . . .$.

New York receiptu of, $1867-68$. p. 21 . . . . . . . . . . . . . . . .

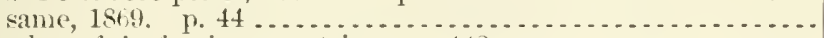

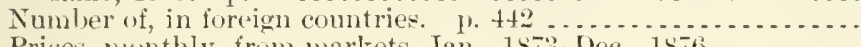

Prices, nunthly, from markets, Jan., 1873 Dec., $1866 \ldots . . . .$.

Russian Empire, for 1898 . 1) 606

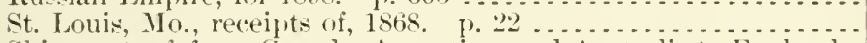

Shipments of, from Canada, Argentina, and Australia to England. р. 77. same, except Canada ( Wray). 1'. 81

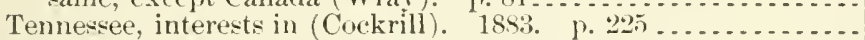

Wisconsin, industry, condition of (Campbell). p. $321 \ldots \ldots . . .$.

Live stock and the markets-

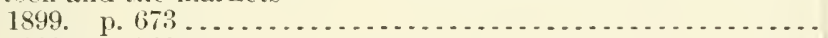

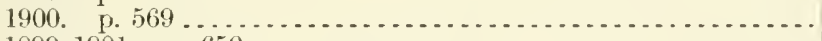
$1899-1901$. p. 650 .

Live stock and their products, inspection of, rules and regulations

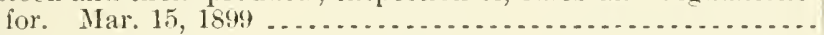

Same, amendiment. Oct. 22,1900

Live Stock Association, National, officers of-

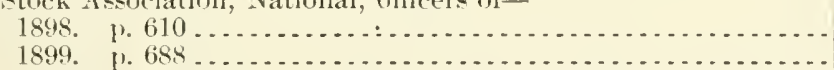

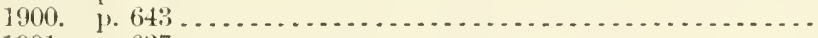

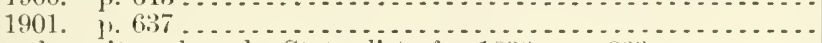

Live stock sanitary boards, State, list of. 1898. 1. 60:3 ..........

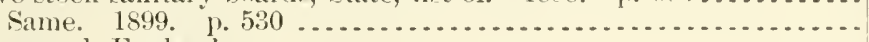
Liverpool, Englani:

Trade of, with U.S. (Boyle). p. 517.

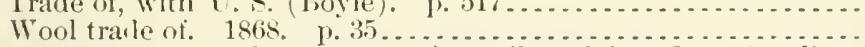

liverworts from sonthem Patagonia, collected by $I^{\top}$. S. Allat tross in 1867-91, list of (Evans). 1892. p. $140 \ldots . . . . . .$. Loan association, Raiffeisen, of (iermany, 1891, 1. 414 .......

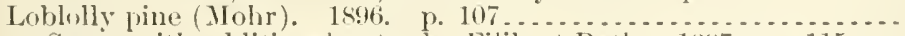

Same, with adlitional notes liy Filibert Roth. isit. i . $115 \ldots$

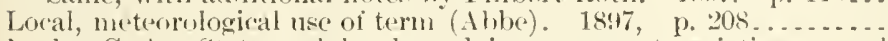
Locke, C. A. State and loeal road improvement societies, appeal

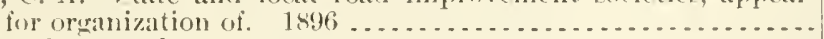
Lockwool, Simmel:

Army worm, invasion of 1880 , in New Jersey, acount of. 188.3.

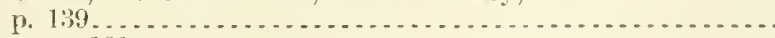

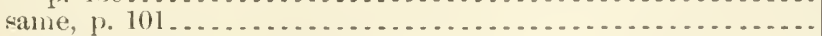

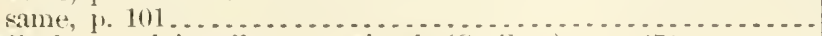
A1.10:895 A $1.10: 896$ A27.9:3:3

A29.6:27

14.1:895-6 14.1:891-2

$127.9: 9$

A4.1:885

A4.1:581;

A 4.1:887-8

A 10.3:1:0

A4.1:886

14.1:887-S

A1.8:5:

A $4.1: 885$

A:7.9:5

A4.1:\$89-90

A $27.9: 7$

A27.9:S

14.1:899

127.9:

A4.1:901

A27.9:7

A $4.1: 8.5-6$

A 1. 1:895-6

A $1.7: 2$

A 4.1:\$89-90

A 1.10:899

14.1:899

14.1:900

A 4.1:901

1+.5:33

A $4.5: 78$

A 1.10:898

A 1.10:\$99

A1. 10:500

A 1.10:901

At.1:898

14.1:8!9

14.1:8:14)

1:27.9:0

$16.5): 1$

$127.9: 29$

1 13.3:1: ${ }^{1}$

1 18.3:132

1 $24.6: 25$

12:2. 4:2:2

15.1:3

11.1:881-882

19.1:\$8: 14.1:886 
Locomotives, smoke-consmming levios for (Lamler). 18s, p. 132. A13.3:1

Lorlust betle, leai-mining, with nots on related specit's (ChittenLoenst: :

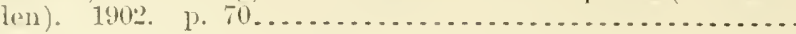

American, damage by (Howard). 1894. p. 2:0

A $9.7: 7$

California invasion, in 18 s. report on (Comuillett). j. 3t.....

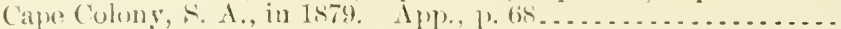
('ertain outhreaks of, in Idaho (Milliken). 1\$93. p. 17 ......

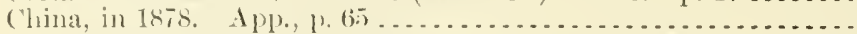
same, extermination of (Seatehkow). Alp. p. 65..........

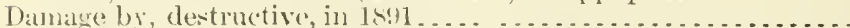

lestructive, found in Amerian, north of Mlexico (Bruner) -

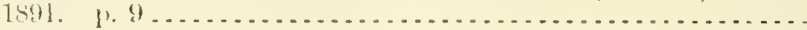

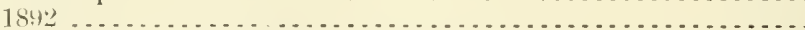

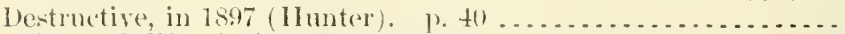

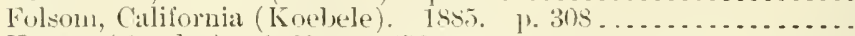

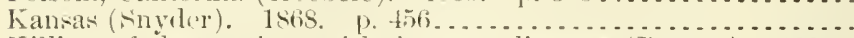

Killing of destructive, with fungous diseases (Bruner). 1902.

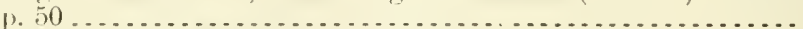

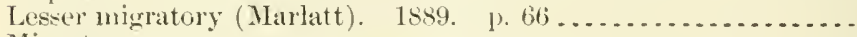
Miguatory-

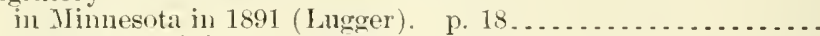

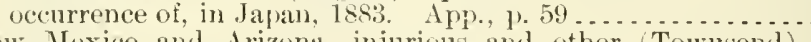

New Mexico and Arizona, injurions and other (Townsend). 1893. p. 29 .

North Americandestructive, with notes on occurrences in 1891 (Bruner). 1891.

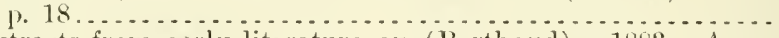
extracts from early literature on (Berthoud). 18s3. App.,

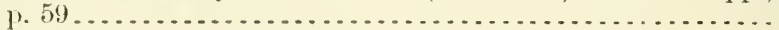

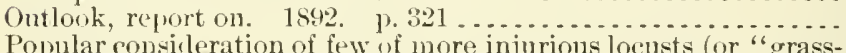

Popular consicleration of few of more injurious loeusts (or "grass-
hopyers") of U. S., with best means of destroying them

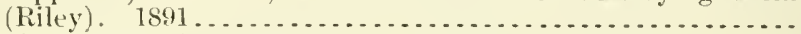

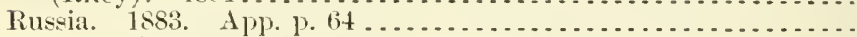

San Joaquin Valley, California (Coquillett). p. $289 \ldots \ldots \ldots \ldots$.

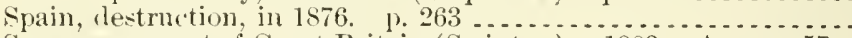
Swarms on eoast of Great Britain (Swinton). 1883. Apl. p. 57. Texas, during spring of 1886 , report upon (Bruner). 1887. p. 9. See also Dissosteira longipennis - Grasshopper-Melanoplus spretus - Pezotettix - Rocky Mountain locusts.

Lodeman, E. G. Grapes, pruning and training of. 1896. p. 499... Lodge, William C.:

Beef cattle, feerling, in Mirldle States. p. 212.

Fruits and fruit trees of Middle States; propagation, influence of stoeks, diveaces and enemies. p. 199 .

Wine making and vine culture in Middle States. p. $118 . . . . . .$. Loew, Hermann. Rye gall gnat, description of. 1883. App. p. 6 . Loew, Osear:

Catalase, new enzyme of general wecnrrence, with special reference to tobaceo plant. 1901 .

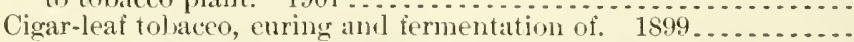

Connectieut tobacen, physiolonical studies of. $1900 \ldots . . . . . . . .$.

Nlineral nutrients, physislogical rôle of. 1899 ...............

Soils, liming of, from a plyysiologieal standpoint. $1901 \ldots . . . . .$.
Logan and Richmond Canal, Ttah, duts of water under (Swend-

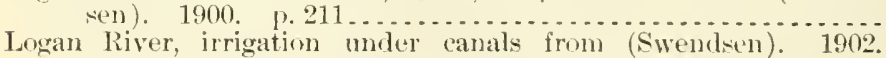

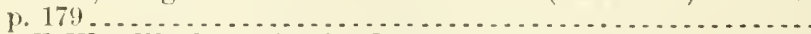

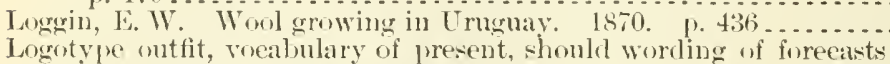
be confined to? is it arlvisable to extend rocabulary of logo-

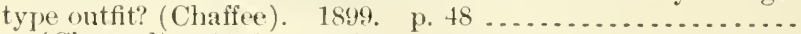

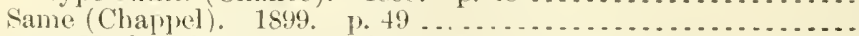

Lonecy, H. lle. Horses, American, used hy large horse companies

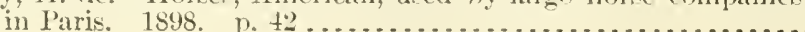


Lomilon, H. A. Aduress of, hefore national road comference, July, 1894. D. 2] - 1 -

Lonrlon:

Butter trarle (A-hby). 1). 211 .......................

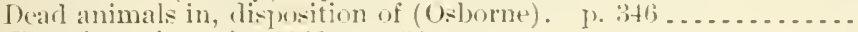

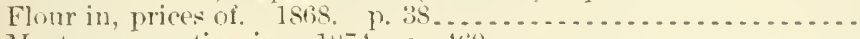

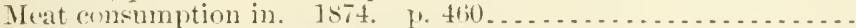

Meteorological oflice, notes on (Abbe). 1901\% 1).68........

Punltry fur Lamlon market, preparing (Lowe). p. .13:3........

Wastes of, method of disposing of (Manning). 15:2. p. 37, ...

Londom International Fxhibition of 1862, aceome of (Hoyt), p. 27..

Lons, I). N. Brick wheel-track roak. 1901. p.68..............

Long Branch, I. J., local contrast of weather at, Jan. 1895 (Abhe). p. $13 .$.

Loner Island:

IIenhaten fisheries of. 1870. P. 39.

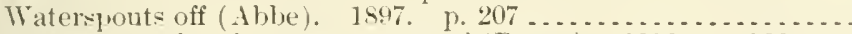

Lome-range weather forecasts, report of (Pague), 1896. 1). 166....

Lonetailextshrews. top Shrews.

Longino, A. H. Road yuestion, importance of. 1. 18..........

Longleat pine:

Report on (Mohr). 1896. p. 29 same, with alditional notes by Filibert Roth. 1597.

Timber of, effect of turpentine gathering on (Femow) . . . . . . . . .

Trees of, themical study of resinons contents and their distribution in, before and after tapping for turpentine (Gomberg). 1893. p. 34

Longley, 1. T.

Sce, for reports as Chief, 1890-92, Docmment and Foliling Room, Agrieulture Dejartment.

See, for reports as Chief, Seed Division, Aqriculture Department.

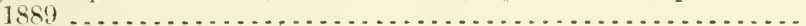

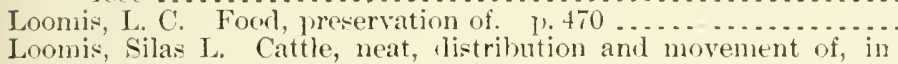

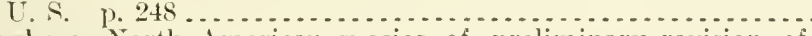

Lophophora, Jorth American species of, preliminary revision of

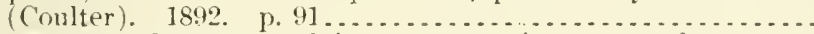

Lord, Wn. P. Oregon, road improvement in, extract from gov-

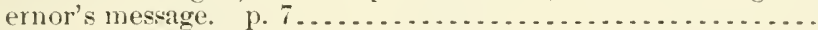

Loring, ficorge Bailey:

Adilress of, with other proceedings of eotton convention, Atlanta, Ga., Nov. 2, 1881 . . . . . . . . . . . . . . . . . . . . . . . . . . .

Cattle industry, address on, at National Comvention of Cattle Breeders, Chicago, Ill., Nov. 13, 1884.

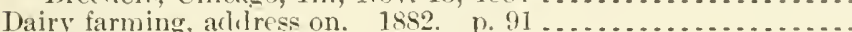

Forestry in T. S., arliness on, before American Forestry Congress,

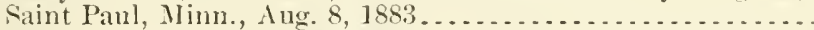

Sorghmm-sugar industry, atliress on. $1853 \ldots . . . . . . . . .$.

Sep rlso, for reports as Commissioner of Agriculture, 1881-81 ....

Los Angeles County, Cal.:

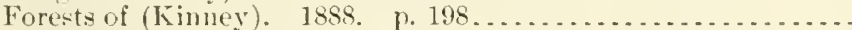

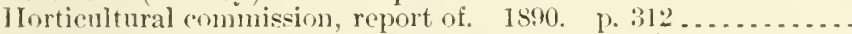

Los Anceles River, Cal., sturly of water rightson (Boggs). 1901. 1).327.

Lotsy, J. 1'. Nitrogen, free atmospheric, assimilation of, by white and l)lack mustard, contribution to investigation of. 1894...

Loughridge, R. H. Soils, physical tests of. 1893. p. $156 \ldots \ldots .$. Jouiviana:

Anthrax in, in $1896(M+$ Qneen).

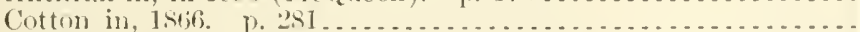

Cottom in, date of receipt of, $1857-70$. p. 3iti. . . .

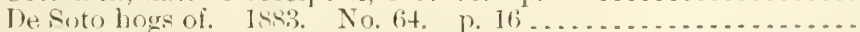

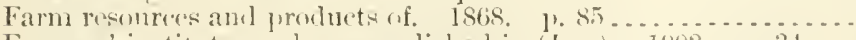

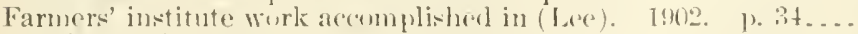
Hurricane of Angu-t $1 ;-16,1901$, on colat rit..............

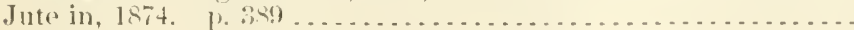
Rice rop, statenuent on. 1s60-6is. p. tion . . . . . . . . . . . . . Southwestern, soils and produets of (Rauley). Ixit . . . . . . . . .
1.2.:3:10

A. $1: 1: 9.93$

14. 1:899

127.9:6

127.9:13

A:9.6:28

At.1::999

Aะ7.9:10

A 1.1:86:

A22.3:21

A $29.6: 2:: 3$

A $27.9: \mathrm{x}$

A29.6:25

A29.6:24

A 22.2.3:21

A 13.: : :13 1

A $13.3: 13^{2}$

A 13.4:9

A $13.3: 8$

A24.1:

A 1.1:862

A1.1:863

A 6.5:3

A 22.4:33

A 1.8:17

d].7:6

A $1.8: 22$

A1.7:1

11.6:54

A1.1:

113.3:2

19.7:2

110.3:100

110.3:18

110.3.16

A $4.1: 597$

127.9:4

1.2.9: :

127.9:2]

A27.9:6

1 10.3:1:20

129.2:1194

1:7.9:12

127.9:

11.8:35 


\section{Index}

Louisiana-Continued

Stean ploughing in (Lawrence). p. 278

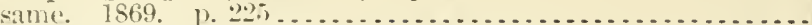

A1.1:867

127.9:7

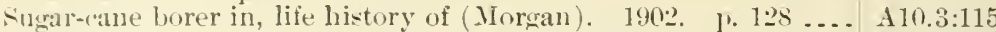

Fugar ("ane in, diffusion process as applied to (Seig). p. 40..... A1.1:884

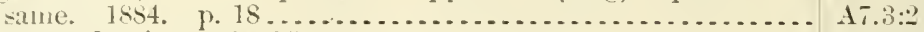

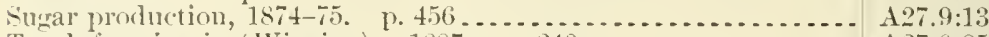

Truck firming in (Wiggins). 1887. p. 240 ............. 127.9:25

Uplands of, irrigation of rice on (Bond). 1902. p. 11 ......... $\$ 10.3: 113$

See also Cilumet plantation sngar experiment station-Des Linges sngar experinent station - Iberia parish - La Fayette prarish - Lake Charles - Kenner-Marnolia StationNew Orleans - St. Landry parish — St. Martin parish — St. Nary parish - Vermilion parish.

Lonisiana fungi, new species of (Ellis and Langlois). 1891. p. 35.

Louisville, Ky., convention of tolyaco growers at, 186.5, comments

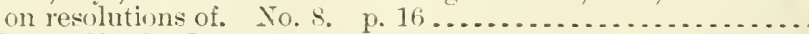

Lounsbury, Charles I':

Goor II Iope, Cape of, insects of, notes on. 1897. p. $34 . \ldots . . .$.

Sonth African ticks, motes on some. $19(100.61 \% 41 \ldots \ldots \ldots \ldots$.

Lomsbury, Charles P., and Mally, C. IV. Hydroeyanic-acid gas,

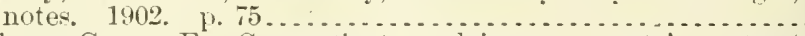

Lounsbury, George E. Connectient, road improvement in, extract

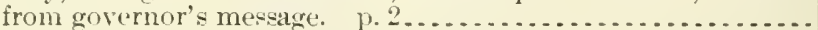

Loveland, George A. :

Climate and crop sections, Weather Burean, should monthly reports of, contain only original matter? 1902. p. 187 ........

Meteorological observations, should not a hook for permanent record of , he furnisher to section centers and voluntary stations? 1899 . p. 120 .

Meteorology in colleges; to what extent is it taught at present; shonld it be offered as an undergrarluate or as a postgraduate course? 190:. p. 90.

A $28.5: 6$

A $27.9: 3$

A9.6:9

A9.6:26

$19.6: 31$

A22.4:33

A:29.3:31

A29.3:2t

A29.3:31

A $4.1: 899$

Lowe, William Ilerbert:

Cattle, organs of respiration of, noncontagious diseases of. P. 101.

Tumors of cattle. p. 321 .....................................

See also, as joint author, Dickson, William.

Lower California. See La Paz - Santa Agneda - Santa Rosalia.

Lower Colorado River, Arizona, free-tailed hat from, description of new species (Merriam). 1859. p. 25.................

Lowndes, Lloyd. Maryland, road improvement in, extract fom

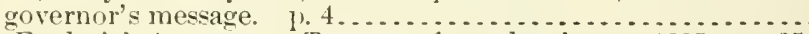

Lucas, Frederick A ugustus. Tongues of woodpeckers. 1895. I, 35 .

Lucasen. M. D. Sugar, (liffusion and earbonatation of, in Java,

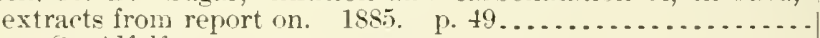

Lneern. Sie Alfalia.

Lucilia nobilis parasitic on man (Meinert). 1892. p. $36 \ldots \ldots . . .$.

Ludlow, William. Kingsessing and Tinieum meadow district, on Delaware River, drainage of. 1884 . p. $240 \ldots . . . . . . . . .$.

\section{Lingger, Otto:}

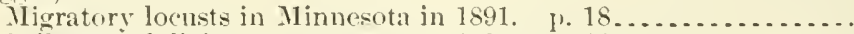

Siflosoma fuliginosa, report on. 1890, p. $236 \ldots \ldots . . . . . . . .$.

Lumber:

Consumption of ties and other, by railroads in U.S. P. $41 \ldots \ldots$

New York State, industry, history of (Fox). 1902............

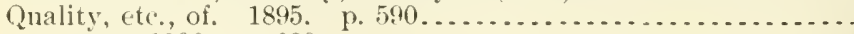

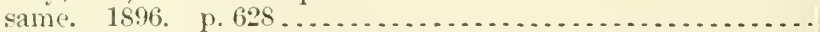

Lumber trade:

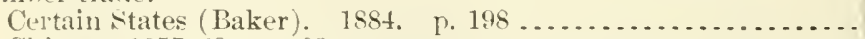

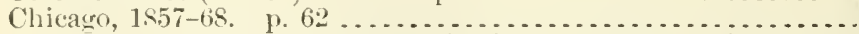

Letter from agent of Forestry Division requesting information

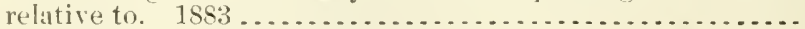

New Hampshire and West Virginia (llough). 188t. 1.348...

Western states and Territories (Furnas). 1884. pp. 246, 255...

A $4.2: \mathrm{C} 29^{2}$ A $4.2: \mathrm{C}^{2} 9^{2}$

A5.5:2

A22.4:33

A5.3:T

A 7.3:8

A $9.7: 5$

\section{A1.7:7}

A9.3:27

19.7:2

A13.3:4

A13.3:34

A1.10:895

11.10:896

A13.5:4

A27.9:7

A13.2:L97

A13.5:4

A13.5:4

Lumbering:

Conservative, and water supply, discussion of (Newell). 1901. p.3. A13.3:30 
milex

Classifleation no.

Lumbering-Continued

Southern Appalaehians now and under (iovernment ownerwhip

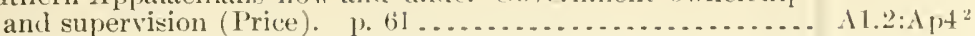

\section{Lumbermen:}

Practical assistance to, in handling forest lamds (Pinchot). 1898 . A18.4:21

Suggestions to, relative to more rational forest management (Fer-

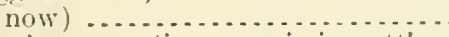

Lumpy jaw, or artinomycosis in cattle:

Investigations relating to treatment of (Nalmon)$18: 11$ and 189:. ए. 109

1893

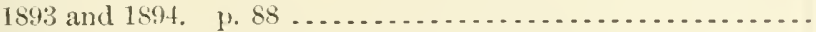

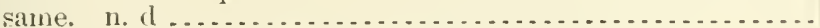

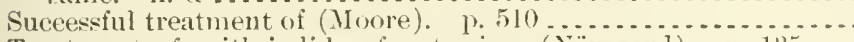

Treatment of, with iodicle of potassinm (Nörgaard). p. $135 . .$.

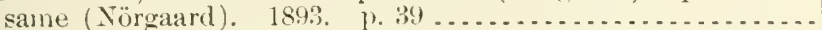

Lunar halo and luna corona, notes on (13)e). 1901. p. $566 \ldots . .$.

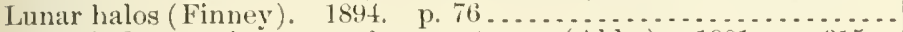
Lunar influences in meteorology, notes on (Abbe). 1901. p. 315 .. Lunar rainbow, notes on (Able) .1898 . pp. 67, $364 \ldots . . . . . . .$. Lung plague of cattle. See Pleuro-pneumonia.

Lupton, X. T. Adrlress of, as president of Association of Official

Agricultural Chemists, at 9th annual meeting, 1892 . 1).2...
Lurman, Gustav W. Address of, before consention of National League for Good Roads, Washington. 1893. p. 18 .........

Lyman, Charles P.:

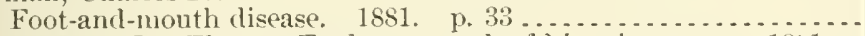

Letter to Dr. Thomas Taylor on work of his microtome. $1881 \ldots$

Pleuro-pnemmonia, contagious, in cattle1st report, $1879 . \quad$ p. 456.

[Also issued as 46 th Cong., $2 d$ sess., S. mis. doe. 7t; serial no. 1891.]

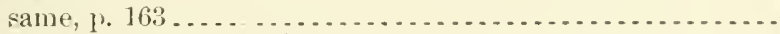

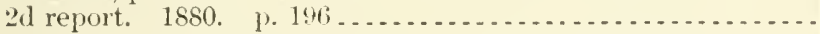

[Also issued as 46 th Cong., 3 r sess, S. ex. doc. 5; serial no. 1941.]

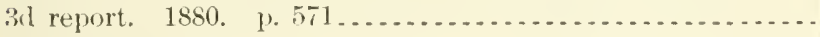

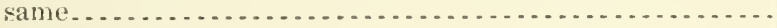

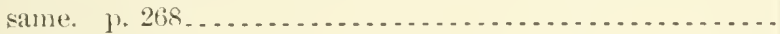

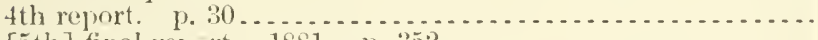

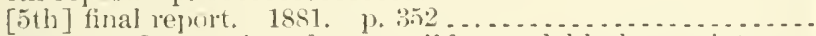

Lyman, H. L. Grape vine, downy mildew and black rot of, treatment of, with salts of (opper at Charlotesville, Va., in 1 sis.

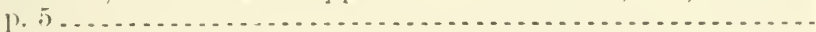

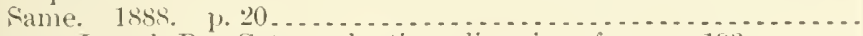

I.vman, Josephl R. Cotton planting, dirertions for. ]. 193 .......

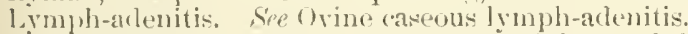

lyon, Frank II. Conviat labor, nse of, in road building. 1901.

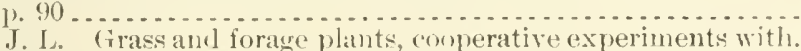

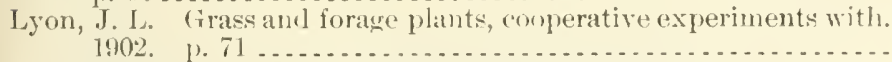

Lyon, Samnel S. Ledther industry in Japan. p. $526 \ldots . . . . . .$.

Lyon, T. T. Russian and other fruits, arlaptation of, to extreme

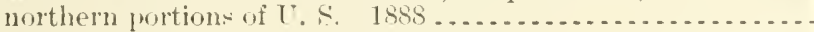

Lvons, Curtis J.:

Dew-point, talsles of, observed at Honoluln. 18:9. p. $587 \ldots \ldots$.

Hawaian climatologrical data, monthly, May, 1901-Oet., 1902....

Meterological observations, monthly, at IIonolulu, Hawaibun Islands, Mareh, 1894-1pril, 1901 . . . . . . . . . . . . . . . .

Sun spots and IIawaidan crubtions, report on. 1897, p. 144....

Volcanic eruptions in Iawait. 1899. p. 29s . . . . . . . . . . .

Lyons, l'atrick F:

Metenrological records in comrt. 190:2. 1) 18: .............

Weather foresast, distrihution of, by mail. 1899. [. 161 _.....

Weather forecasts, should temperature le veritied by maximum

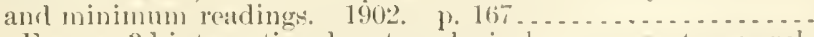

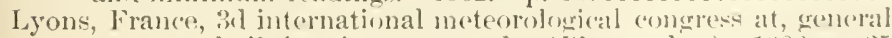
report on hail shooting presented at (I'lumandon). 1902. 1). 35.

$13,4: 10$

A $4.1: 891-2$

A $4.3: 2$

A $4.1: 893-4$

$14.4: 7$

14.1:8:99

$14.1: 891-2$

14.8:2

A:2).6:29

129.6:22

А $29.6: 29$

A 29.6:26

A7.3:35

A 10.8:14

11.1:881-2

A 18.2:1158

11.1:879

A1.6:2:2

A1.6:34

A 1.1:880

A1.6:31

A1.6:34

A1.1:881-2

A1.1:\$81-2

A6.3:5

A6.3:10

A 1.1:866

122.3:21

$110.9: 115$

14.1:8!:99

$120.3: 2$

A:4.6:2:27

129.6:

\29.6:

1:96.6:27

1:29.6:27

129.9:31

124.8:24

1:9.3:31

129.6:30 
Lysimeter. What does a lysimeter teach? (King). 1891. p. 106_.. A 10.5:3

Lysiphlebus, braconid genus, variations in (Coquillett). 1891. 1.313. $19.7: 3$

Maradam, Robert $\mathrm{L}^{-}$. North Ameriean agaries, report on. 1889.

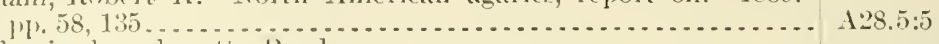

Macarlanized roads. Sie lioads.

Mcddie, Alexanter (ix.:

Ire-plysical observatory, equipment of. 1896. p. 453 .......

Alto-stratus, whirling, rejort on. 1897. p. $245 \ldots . . . . . . .$.

Atmospleri, eleetricity, some experiments in. 1891 1. 17i .

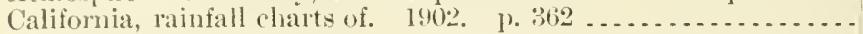

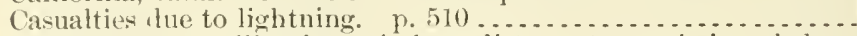

Climate as controlling factor in long-distance tansmission of elee-

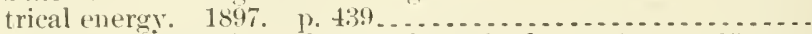

Climatological data, interchange of stam lard. $1899.13 .135 \ldots .$.

Cloud observations, utilization of, in local and general weather

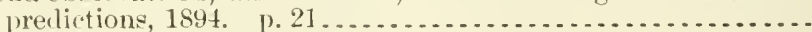

Fog studies on Mount Tamalpais, etc.-

1900. р). $283,492$.

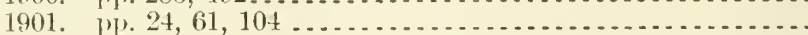

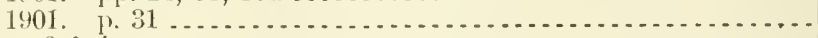

Frost fighting-

1899. p. 111

1900

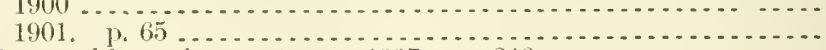

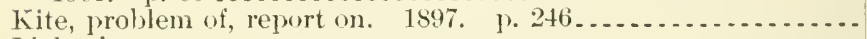

Lightning-

(an we, by automatic records at three selected places, determine the energy of a flash of? 1894. p. 18............

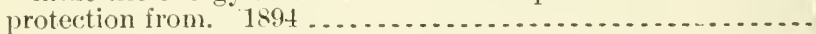

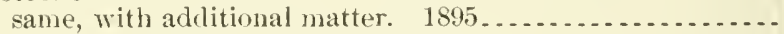

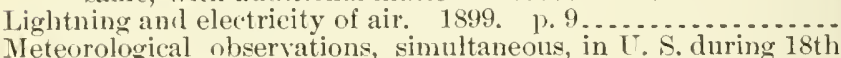

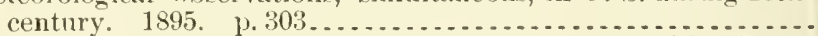

San Francisco weather forecast district, report of, monthly, Apr.July; Sept., 1899-July, 1900; Nor., 1900-July; 1901; Sept.-

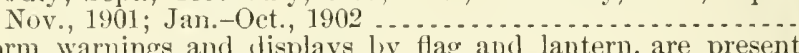

Storm warnings and displays ly flag and lantern, are present
best that can be devised for Atlantic and Gulf coasts? 1899.

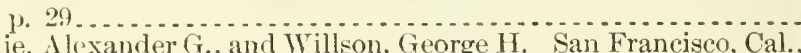

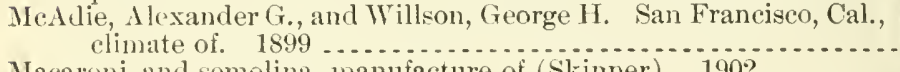
Macaroni and semolina, manufacture of (Skinner). $1902 \ldots \ldots \ldots .$.

Macaroni wheats (Carleton). 1901 .........................

McBride, F. IV. Se, as joint anthor, Huston, Henry Augustus.

Mebryde, J. Bolton, and Beal, Walter Henry. Cotton, chemistryof.

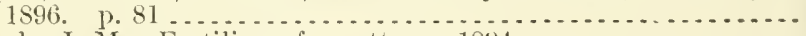

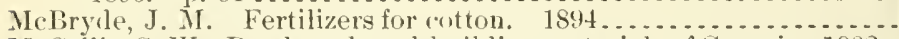

McCallie, S. WT. Roarls and road-lunilding materials of Georgia. 1902.

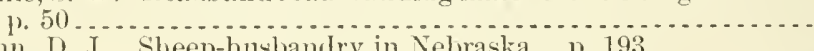

M'Cann, D. J. Sheep-husbantry in Nebraska. p. 193 ..........

McCarthy, Gerald. Crop-pests and their repression by law. 1897.

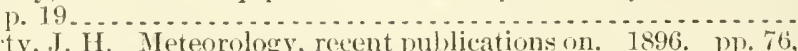

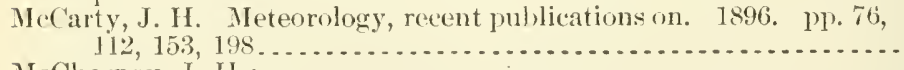

MeChesney, J. II.:

Agricultural colleges and model firms, letter on. 1868. 1. $460 \ldots$

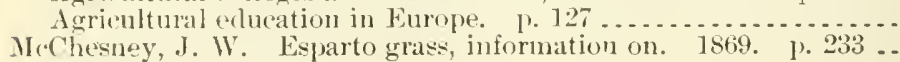

Mc Clatehic, Alfred James:

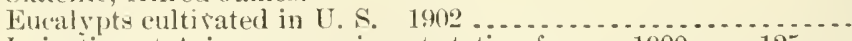
Irrigation at Arizona experiment station farm. 1900 . p. $125 \ldots$

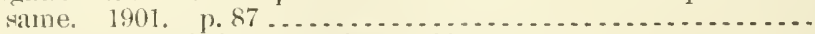

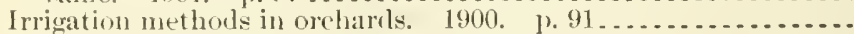

McCormack, H. sie, as joint anthor, Girindley, H. S.

M(Donnell, llenry Barnett. See, as joint author, Frear, Willian.

IleFlroy, Karl P.:

Sorghum-sugar experiments at Ness City, Kans. 1889. p. $81 \ldots$.. \7.3:26

129.6:24

A:9.6:25

129.6:19

A29.6:30

+29.1:891 3

$129.6: 25$

129.3:24

A29.3:111

1 29.6:28

A $29.6: 29$

A29.3:31

A 29.3:24

A29.3:29

+29.6:29

+29.6:25

A29.3:11 1

A29.2:L62

A 29.3:15

A29.3:26

A29.3:11²

A29.6:

A29.3:24

A 29.3:28

A19.3:20

A19.3:3

\$10.3:33

A 1.9:14

A.22.3:23 11. 1:S64

A1.8:57

A:99.6:24

127.9:6

A 1.1:868

A27.9:7

A 13.3:35

A 10.3:104

\10.3:119

A $10.3: 76$ 
IfElroy, Karl P.-Continued

Tegetables, canned, report on, with collaboration of $\mathrm{W}$. I). Bige-

See culso, as collaborator, Wiley, Ilarvey Washington.

IeFarlani, Byron. Thunderstorm; new explanation of one of it: phenomena. 1901. 1. 297.

IfGann, Edward W. IIeteorological statistics, how to imurove them to meet the neerls of niedical protesion, ete. 1899. p.

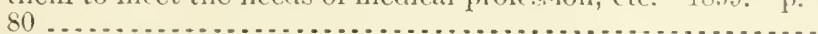

MIcGehee, John MI.:

Swine diseases, special report no. 12 , review of. 1879 , p. $89 . \ldots$.

Swine plague in Florida. 1880 . p. $94 \ldots \ldots . . . . . . . . . . .$.

Magrew, T. F.:

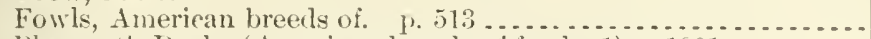
Plymouth Rocks (American breeds of fowls, 1). 1901 ...........

Wyandotte (Ameriean breerls of fowls, 2). 1901 ............... Machen, August W.:

Remarks of, at $2 \mathrm{l}$ convention of Weather Bureau officials, Mlil-

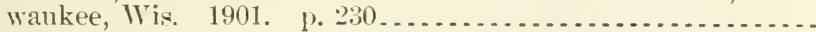

Rural free mail delivery in relation to road improvement. 1901.

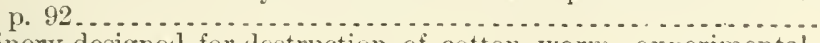

Machinery designed for destruction of cotton worm, experimental

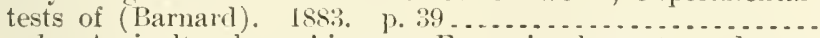

See also Agricultural machinery - Farm implements and machinery.

MeKeown, S. W. Milk or cream, lutter fat in, methorl of determining by difference. 1s94. p. $194 \ldots . . . . . . . . . . . . . .$.

McKerrow, George. W'isconsin, farmers' institute work accom-

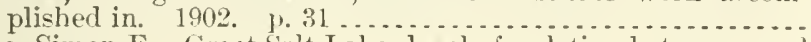

Mackie, Simon F. Greats Salt Iake, level of, relation between, and

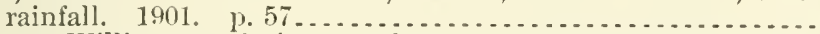

McKinley, William, resolutions on death of, at International Good Roads Congress held at Buffalo, N. Y., Sept. 16-21, 1901.

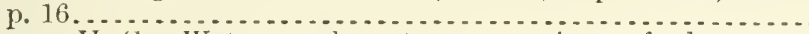

McKinner, H. G. Water supply, notes on experience of other countries in administration of their. 1891 . p. $261 \ldots \ldots \ldots \ldots$.

MeLain, Nelson W.:

Apiculture, experiments in-

1885. p. 333

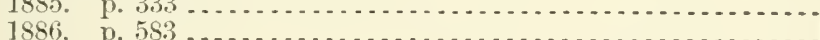

1887 p. $1700^{2}$

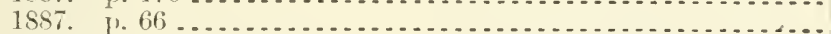

McIain, Thomas. Sisal hemp industry in Bahama Islands. 1891.

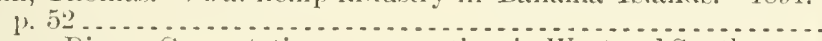

Mclaren, Dice. Grass stations, cooperative, in West and Southwest.

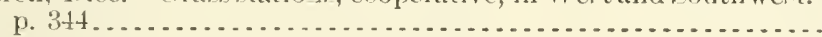

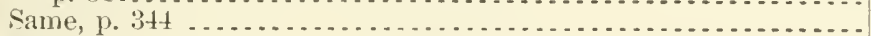

MeLea1, L.:

Anthrax among cattle in the Northwest. 1881. [. $311 \ldots \ldots . . .$.

Anthrax in New Mexico, nutbreak of. 1881. p. 317 ..........

Foot-and-mouthdisease, nonexistence of, in the West. 1881 . 1.319

McLean, L.; Miller, Wm. B. E.; Miehener, Ch. B.; I Iorr, Thomas J.; Hauk, James W.; Roland, H. Whitfield. Animals in New Tork and Brookiyn, contagious cliscases of, preliminary report of inspectors in investigation of. 1884. p. 19..........

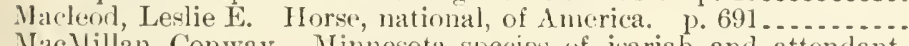
Macllillan, Conway. Minnesota species of isariah and attendant

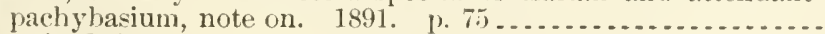

Me.lurtrie, William:

Chemical memoranda, monthly, Jan., 1878, t» Dec., 1876.

tlassiflation no.

$17.8: 13^{8}$

1:99.6:29

1:99.3:24

A1.6:2:

11.6i:22

At. 1:901

A $4.3: 29$

14.3:31

A:29.3:31

A22.3:21

A9.3:3

A7.3:43

A 10.3:120

A 29.6:29

A22.8:21

A 15.2: ${\text { P } 94^{1}}^{1}$

A1.1:885

A $1.1: 886^{\circ}$

A1.1:887

A 9.3:13

A11.5:3

A1.1:891

A6.1:891

A1.6::4

A1.6:3t

A1.6:34

A1.7:6

A1.1:887

A28.5:6

A27.9:

(The more important articles are indexer under their various subjects.]

Grape culture and wine prouluction in L. S. for 1880 , report on

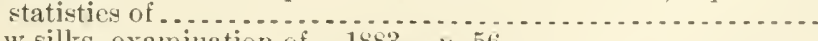

Raw silks, examination of. 1883 . 1. $56 \ldots \ldots$ of
Sugar beet, culture of, preliminary report mear I'ortland,

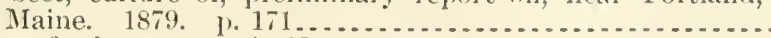
same, final report on, in New England. 1879. p. 181 ....... 
McJurtrie, William-Continued

Sugar beet, eulture of, and manufacture of sugar therefrom in France and United States. 1880.

A $1.6: 28$

A $1.6: 26$

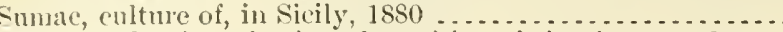

Wine, production of, mineral nutrition of vine for. 1852 . p. 180 . Wools and other animal filsers, examination of. $1886 \ldots . . . . . .$.
See also, for reports as Chemist, Chemistry Burean, Agrieulture

Department, 1S73-1877

Mc Vamee, James. Address of, liefore convention of National Leagne for Crood Roads, Washington. I893. p. $76 \ldots . . . . . . . .$.

Me Teely, J. F. M. Live-stork industry, condition of, of Colorado aind Wyoming. P. 425 .

McNeely, John T. Cattle industry of Colorado, Wyoming, and Nevarla, and sheep industry of Colorado in 1897. 1. 377 ....

MeNutt, J. N. Swine-plagne in Jefferson Co., Mo. 1879. 1. 173 ..

MePherson, William. See, as joint author, Weber, Henry Alam.

IcQueen, Asa $\mathrm{N}$. Anthrax in Louisiana in 1896. p. 176 ........

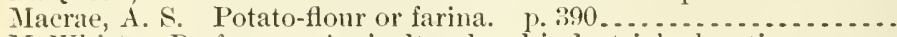

McWhirter, Professor. Agricultural and industrial education, paper

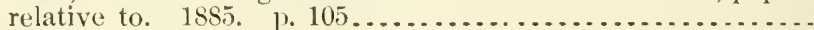

Marlagascar:

Meteorology in, note on (Albe). 1901. P. 375.............

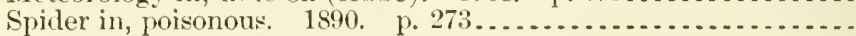

Madder:

Dyer's eulture of (Newton). 1866. p. 94................

Properties and uses, etc. (1)odge). p. $339 \ldots \ldots \ldots$

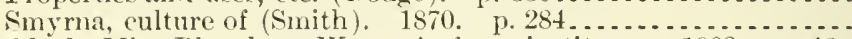

Maldock, Miss Blanche. Women's farm institutes. 1902. p. 46.

Marleira:

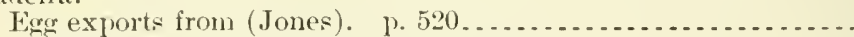

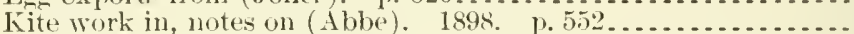

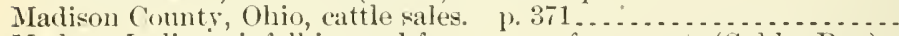

Madras, India, rainfall in, and frequency of sun spots (Subla Rao). $1902 . \quad$ 1. 438 . . . . . . . . . . . . . . . . . . . . . . . . . .

Maercker, MI. Gierman agricultural experiment stations, aims and

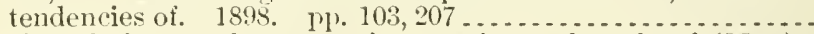

Magnesia, relation to plant growth, experimental study of (May).

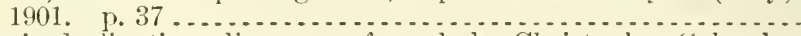

Magnetic declination, discovery of, made ly Christopher Columbus

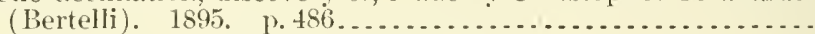

Nagnetic field. See Terrestrial nuanetic field.

Iagnetic instruménts, some improvements in. 1895. p. 539...... tee also Earth-magnetic instruments.

Magnetic needle, secular change in direction of, its cause and periert

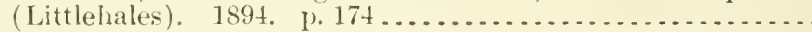

Magnetic observations:

Coorlinate axes for magnetic and meteorologiral observations, stanclard sytem of (Bigelow). 1897. p. 201 ............

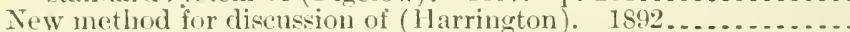
Se also Mleteorological observations.

Magnetic rocks and lightning, note on (Abbe), 1897. 1. 352.....

Magnetic surver:

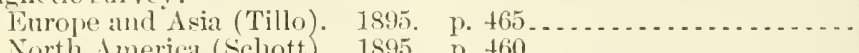

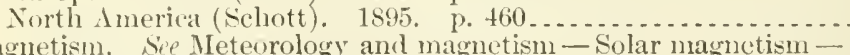

Iagnetism. See Neteorology and magnetism - Solar nagnetism -

Magnolia Station, Lawrence, Ia:

Ianufacture of sugal at, experiments in (Spencer)-

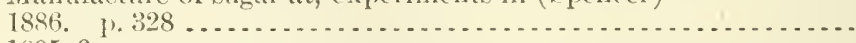

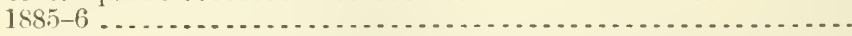

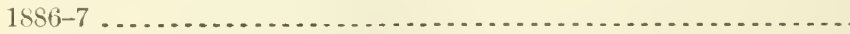

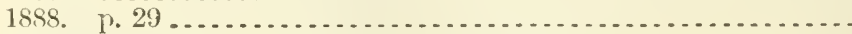

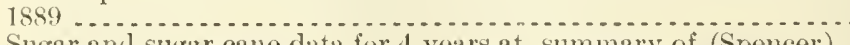

Sugar and sugar cane data for 4 years at, summary of (Spencer).

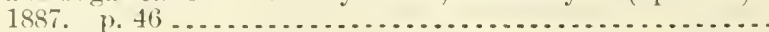

See also Lawrence, La.

Magruder, Ww. T. Agricultural engineser. 1900. p. 103........ A10.3:76

A 1.1:886

A 7.3:11

A 7.3:15

4 7.3:18

A $7.3: 21$

A7.3:18 
Mahany, Michael, short biography of (Abbe). 1898. 1. 550 Mails. See Rural iree delivery.

IIaine:

Agriculture of, some ontlines of (Boardman). p. 39

Beet-sugar in (Blackwell). 1888. No.61. 1.

Climate, soil, physical resonres, and agricultural "apabilities of, with special reference to occupation of its new lands (Boarcl-

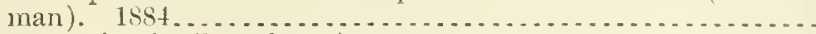

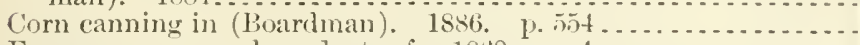

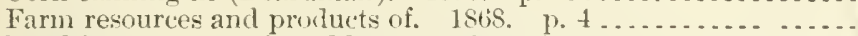
Road improvement in, address on (Stone). 1sit . . . . . . . . . . Starch factories in, report on (Boarhman). Isis. Ni) 19. 1).2\%. Starch manufacture in. 188f. 1. 22..................... See also Aroostook County - Portland - Sebago lakr.

Iaine State College. Dietary studies at, in IS:5 (Jorlan)

Maize or Indian corn:

Carbohylrates of (Stone). 1896 . . . . . . . . . . . . . . . . . Composition of, including urain, meal, stalks, jith, forkler, and cobs (Wiley). 1598.

same (French abstract). 1900.

Food value of (Tiley). p. $17 \ldots$

In manufacture of beer (IVahl)

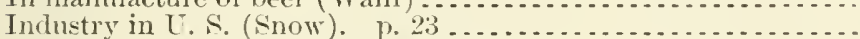

Introduction of, into Europe (Nurphy). 1891. 1.5.......

Sorghum and, as sugrar plants, report on. 1). $228 \ldots \ldots . . . . . .$.

Use of, in Europe, and possibilities of its extension. 1892...... Use of, in Mexico. 1893. p. $256 \ldots \ldots \ldots \ldots \ldots \ldots$ Xenia, or immediate effect of pollen, in (Webber). $1900 \ldots \ldots$. See also Corn.

Maize and sorghum sugars, manufacture of, circular relative to (Le Duc). $1879 .$.

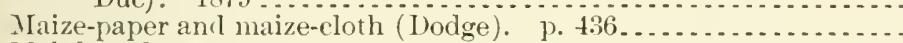

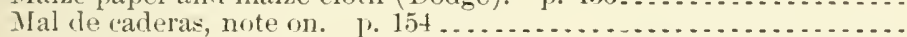

Mal di gona. ,iee King, Villiam Rice.

Malarlie du coit:

Extirpation of, in Nebraska anı Sonth Dakota (Faville). p. 62.. Second outhreak of, in Tebraska (Faville and Day). p. 134.... Supposerl, among horses in Nebraska (Faville). 1\%.359 ........ Malaga, Spain, muscatel raisins in, production of (Mark). 1875. 1. 319

Malanesia, se dustralasia.

Malay Archipelago, clinrate of (Van der Stok). 1896. p. 6ti9 ..... tice also dustralasia.

Malignant edema. se Blood poironing.

Mallein, distribution of. 18:99. 1). 582 .

Mallet, John William:

C'reatin aul creatinin, physiological effert of, and their value as

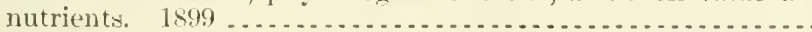
Nitrogen of proteids, and that of simpler amids or amido-acids, in restication of analytical methorls for distingmishing between. 1898

Mallophaga or bird-lice, affecting man and lower animals ((), borm). 18,1

Mallopliaga:

Thevelopment in, note on period of (Oshorn). 1s90. 1. 115....

Parasitic, habit in, origin and development of (Osborn). 1891. P. $18 \%$

Ially, C. W., fruit seriously injured by moths $1902 . \quad$ p. $90 \ldots \ldots . .$. See also, as joint anthor, Lomsbury, Charles L'. - Vebster, Eran(.is M.

Mally, Frederick W.:

Boll worm of cotton, report of progress in supplementary investigation of this insect-

1891

$1899^{\circ}$.

18993 
Maily, Frederick $\mathrm{W}$.-Continuer

IIexican cutton-boll weevil.

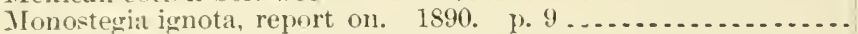

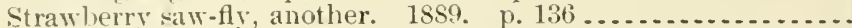

A 1.9:130

A.7.7::

A9.7:2

Malt linuor:

Adulteration of (Crampton). 1887. 1. $263 \ldots . . . . . . . . . .$.

A $7.3: 13^{3}$

American, composition of, and thesubstances used in their adulter-

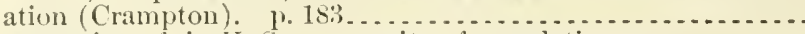

Consumption of, in I. S., per eapita uf population-

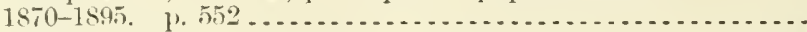
1896. 1. 595

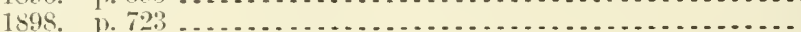
sice also liquors.

Malta:

Animals aud animal products in (Grout). p. 520 .

A1.1:887

A1.10:895

11.10:\$96 A $1.10: 598$

Weather and storms of, during October, 1898 (Grout). p. $546 \ldots$ Iammalogy and ornithology of New England, with reference to agricultural economy (Samuels). 1. $265 \ldots . . . . . . . . . .$.

Mammalogy Division. Siee Ornithology and Mammalogy Division,

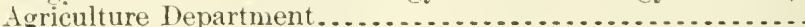

\section{Mammals:}

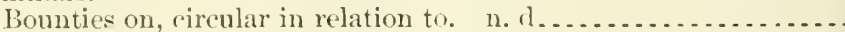

Econonic relations of, circular on. 1886 .

Food habits and distribution of, in parts of Nimnesota and I)akota

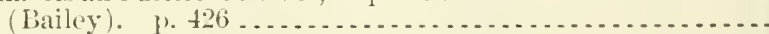

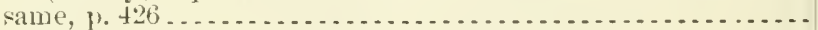

North American-

descriptions of fourteen new species and one new genus of

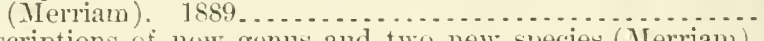
descriptions of new genus and two new species (Merriam).

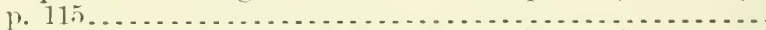
descriptions of twenty-six new species of (Merriam). 1890...

Small, directions for measurement of (Merriam). 1859 ........ See also Tres Marias Islands, Mexico- Yukon region.

A $4.1: 898$

1:9.6:2: $6^{2}$

A1.1:S6:

A5.1:

A.̄. $4: 19$

A5. $4: 3$

A 1.1:S87

A.5.1:887

$15.5: 2$

A.5.5:5

1.5.5:4 15. $4: 11$

Mammitis. See Cows.

Man:

Conflict of, with clinnate, notes on (Abbe). 1899. p. 257. 129.6:27

Food and nutrition of, list of publications on $\ldots$ See also Plants.

Lucilia nobilis parasitic on (Meinert). 1892. p. $36 \ldots \ldots . . . . .$.

Pediculi and mallophaga affecting lower animals and (Osborn). 1891

See also Climate and man.

Man-infesting bot, abstract of paper on (Matas). 158\%. p. 76.....

Manchester, England:

Butter market (Ashby). p. 201

110.2:F73

$19.7: 5$

$+9.3: 5$

19. $7: 1$

Market for American products

Manderson, Charles F. Address of, before convention of Jational League for Good Roads, Washington. 1893. v. $11 \ldots \ldots . .$.

A10.3:14

Manila, Philippine Islands:

Note on weather of (l'hillips). 1898...................

Weather normals for $1865-98$ (Abbe). p. $119 \ldots \ldots \ldots \ldots \ldots \ldots$

Weather of, report on (Phillips). 1899. p. $321 \ldots \ldots \ldots \ldots \ldots$.

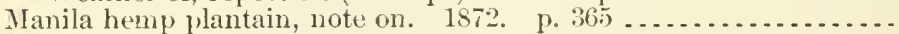

Manitoba:

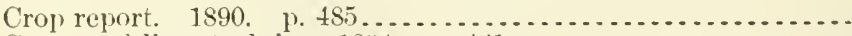

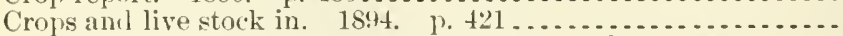

Mannheim, Giermany, cost of hauliug farm products over wagon

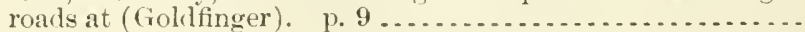

Ianning, James Alexander. London, wastes of, method of dispos-

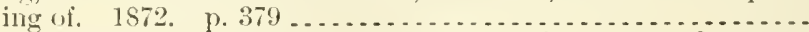

Manson, Marsden. Yuba River, California, features and water

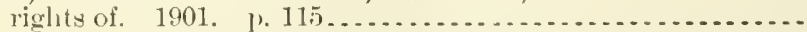

Iantis egre parasites, genus of. 1892. p. $242 \ldots \ldots \ldots \ldots \ldots \ldots \ldots \ldots$.

Mannal training, practioal importance of (Gilkison). 1900. p. 96..

Wanual training and apprentice system (Richards). 1894. p. 73...

Manufacturing conditions and resourees of U.S. (Newton). 1862...

A $29.3: 20$

A $29.6: 29$

129.1:898

A27.9:10

A27.9:28

A27.9:32

A22.4:27

127.9:10

A 10.3:100

A9.7:4

110.3:76

110.3:20

A1.8:1 


\section{Manures:}

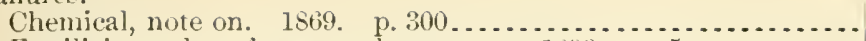

Fertilizing value of manure from cows. 1899. p. $5 \ldots \ldots . . . . .$.

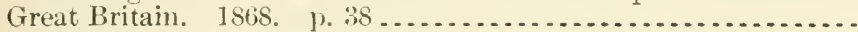

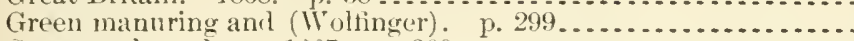
Greensand marl as. $186 \overline{6}$. p. 368.

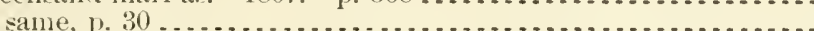

IIneral, Iresent theory and practice of. 1, 428 .............. Potaşh as. 1870 . p. 287

see clso Jarnyard manure-Chemieal manures-Farm manureFertilizers - Woule's earth-closet system - Stable manure.

Manures, and how to apply them. 1868. p. 93 ................ A27.9:6

llanures and their application (Brown and Reynolds). p. 368...... A 1.1:865

Manuring:

Cotton (White). 1896.

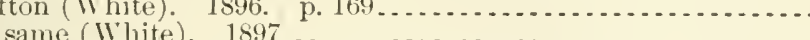

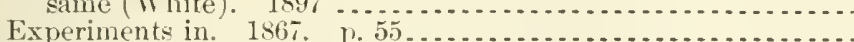

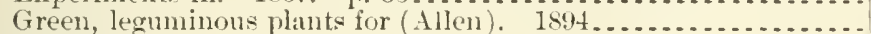
See also Liquid manuring - Soils.

Maple sugar:

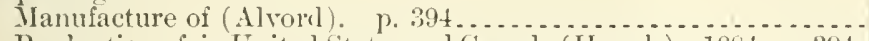
Production of, in United Statesand Canada (Hough). 188t. p. 394. Table showing amount of, June, 186t. No.3. p. 8.......... See ulso Sugar industry of United States.

Maple:

Forth American (Vasey). 1875. p. $313 \ldots . . . . . . . . . . . .$. Pulvinarias on, two most abundant (Howard). 1900 . p. 7 ..... Maple pseudococeus, report on (Howard). 1894. p. 235 .........

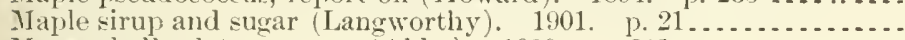

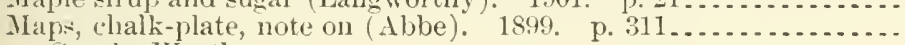
See also Weather maps.

Marbles of Rutland County, Vermont (Dorr). p. $448 \ldots . . . . . . .$. Marbury, John B.:

Climate and crop service weekly bulletins, should remarks of correspondents be published? should weekly reports of temperature and rainfall be telegraphed from voluntary stations? 1899. p. 108 .

Weather-forecast stations, voluntary, river and cotton-belt, estahlishment and inspection of. 1899 . p. $150 \ldots \ldots \ldots \ldots . . . . .$.

Theather forecasts, verification of. $1902.1 \% 156 \ldots \ldots . . . . . . .$. March, weather conditions for, statement of average (Garriott) $\quad 1.117$. Mardela Springs, 1$]$ l., frosts in May at (Abbe). p. 172 ...........

Ilarean, Herbert W., soil survey of Covington area, Georgia. p. 329 . See also, as joint autlior, Burke, R. T. A ron.

Marean, Ralph B. Mist, small whirling columns of. 1899. P. 409. Mares:

Abortion in, outhreak of (Kilborne). 1893. p. 49 ........... Infectious abortion of (Williams). 1. $449 \ldots \ldots \ldots \ldots \ldots \ldots \ldots \ldots$ Tagina of, pathogenic bacillus from, after abortion (Snith). 1893 . 1. 53.

Marine Ifeteorology, Division of, in IIydrographic (iffice, Navy Department, origin and work of (Beehler). 1895. p. 221.....

Marine neploscope and its usefulness to navigator (Abbe). 1894.

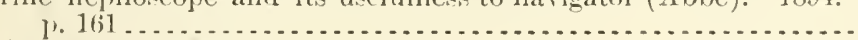
See "rlso Nephoscope.

Marine plants, uses of, with a brief account of curing of Irish moss

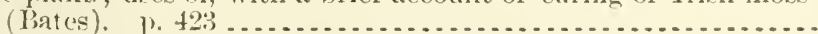

Maring, Delos T.:

Sunshine recorler, improved, report on. 1897, p. 485......... Weather Burean exhibit at I'an-American Exposition, Buffalo, X. Y. 1901. I. 25!)

Jaritime species of Coccide (Cockereli) 1 Mark, John A. Inscatel raisins, production of, in Mialaga. 1875.

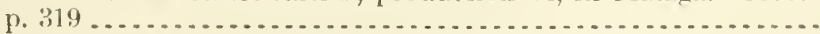

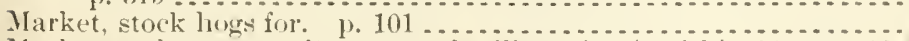

Mlarket-garden crops, nitrogenous fertilizers for (smith). 1901. p. 12. Market gardening in vicinity of New York (Ifenderwon), p. 243 ...

A $27.9: 7$

A $1.9: 97$

A $27.9: 6$

A 1.1:864

A $27.9: 5$

A27.9:6

A 1.1:870

A27.9:8

A10.3:33

A 1.9:48

A27.9:5

A $1.9: 16$

A1.1:862

A 13.5:4

A $27.9: 2$

A27.9:13

A9.6:22

A9.7:7

A1.9:124

A $29.6: 27$

A1.1:862

129.3:24

A29.3:24

A29.3:31

A 29.6:29

A 29.6:2:

A26.5:901

A29.6:27

A $4.3: 3$

At.1:889-90

A $4.3: 3$

A $29.3: 11^{2}$

A 29.3:1 I

A1.1:8tit

A.9.6:25

A2! 6: $: 29$

A9.7:7

127.9:13

1 $1.1: 89: 3-1$

A 1.9:1:24

A1.1:865 
Narket milk, plan for its improvement (Pearson). P. 158.

Market products of west New Jersey (Lippincott). 1. 249........

Market quotations and farm prices. 1893. 1. 485 .............

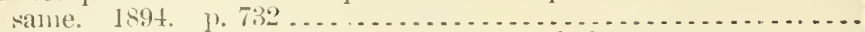

Market systems of the country, their uses and at)mes. p. 241 .....

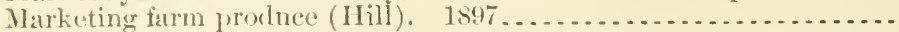

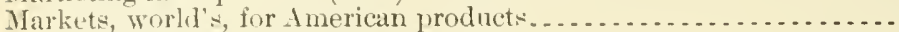
Se also Foreign markets.

Marl region of Tirginia. p. 389.

Marlatt, C'harles Lester: Arsenicals, new and old, comparative tests with, on foliage and

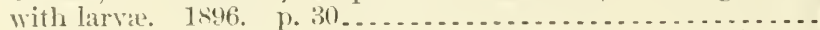
Asiatic ladylird, importation aml present status of, preliminary

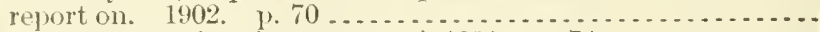
Aspidiotus ostreceformis, accomnt of, 1899 . 1.76 . . . . . . . . . Bedbug and cone-nose, report on. 1896. 1. 32............

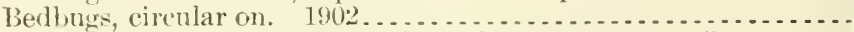
Buffalo gnats, report of trip to investigate. 1884, p. $7 \ldots \ldots \ldots$. Buffalo tree-liopjer-

circular on. 1897 report of. 1894.

Cicada, periodical-

accomt of Cicada septendecim, its natural enemies and means of preventing its injury, with simmary of distribution of different loogds. 1898

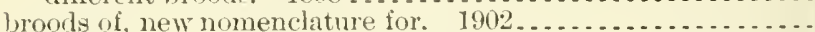
consideration of valiclity of old recorls bearing on distribution of broods of, with partienlar reference to occurrence of broods VI and XXIII in 1898. 1898. p. 59... new nomenclature for broods of. 1898. p. 52 Coccinellidie, scale-feeding, pretafory insects which affect useful-

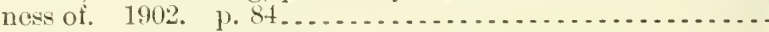

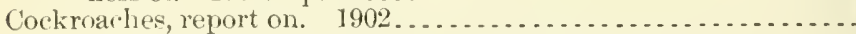

Cockroaches and house ants, report on. 1896. p. $84 \ldots \ldots . . .$. Codling moth, donble-brooded, report on. 1s94. p. 248........ Currant stem-girdler, report on. 189t. p. $296 \ldots \ldots \ldots \ldots \ldots \ldots \ldots$ same. 1895.

Elu leaf-beetle-

importer, circular on. 189.5

in Washington, D. C. 1895.

Grape, principal insect enemies of-

1895. 1). 385.

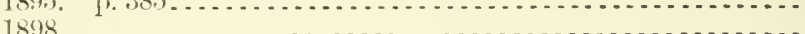

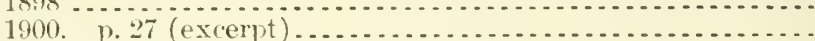

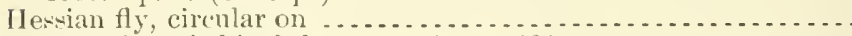

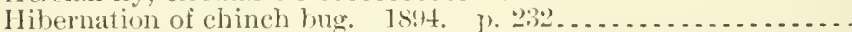

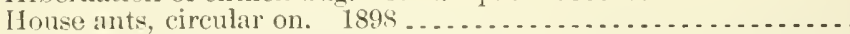

Honse (entipede, cireular on. 1902 ...

Insect control in C'alifornia. 1s!ti. p.217 . . . . . . . . . . . .

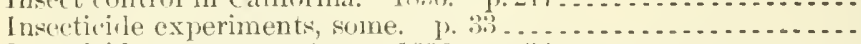

Insecticide soaps, report on. 1896. 1. 3. . . . . . . . . . . . . .

Insecticides, important directions for their preparation and use .. sume, revised. 1901

Insectiviles, motes on-

189t. \%. 115

189.5. 1. 19

1897 . 1. 54.

1895.94.

Inserts, injurions, methodsof controlling, with formulas for insec-

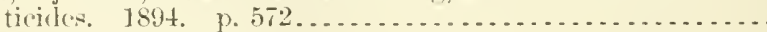
sanı. 1895. p. 580

Laisser-faire philosophy applied to inseret problem. 1899 . 1. 5.

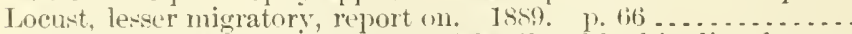
Nematina of North America, a subfamily of leaf-feerling hyme-

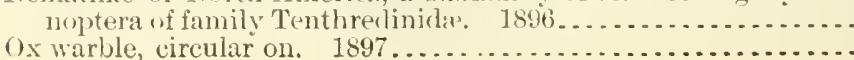

14.1:900

A 1.1:865

A27.9:31

127.9:32

A 1.1:870

A1.9:62

112.3:

A1.1:868

A9.6:6

19.6:37

19.6:20

19.6:4

A9.5: 47

19.7:2

A9.5:23

19.7:7

19.6:14

19.5:45

A9.6:18

19.6:18

A9.5:19

19.6:37

A9.5:51

A9.6:t

19.7:7

A9.7:6

19.7:7

A9.5:8

19.6:2

A1.10:895

A $1.9: 70$

A1. 9:118

19.5:12

A9.7:7

A9.5:34

A9.5: $4 \mathrm{~s}$

11.10:896

A9.6:30

19.6:6

A1.9:19

A1.9:127

19.7:7

19.6:2

A9.6:9

A9.6:17

11.10:89t

11.10:895

19.6:20

A9.7:2

19.8:3

$+9.5: 25$ 
Marlatt, Charles lester-Continued

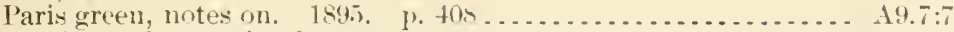

Peach-tree borer, circular on. 18\$6 ..................... A9.5:17

Peach twig-borer-

an important enemy of stone iruits. 1s!s . . . . . . . . . . . \$1.9:80

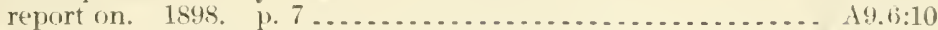

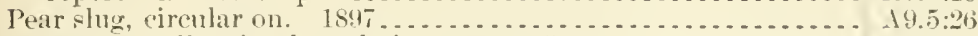

Pear-tree peyla, circular relative to. 1895................. 19.5:7

Pear-tree peitla in Maryland. 18.t. p. 175................ 1:1,7:7

San Jose scale-

experiments with winter washes against, season of $1894-95$.

1895. p. 3655 . . . . . . . . . . . . . . . . . . . . . . . . . . .

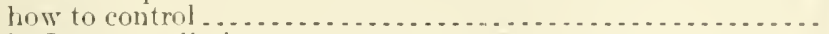

in Japan, preliminary report on. 196. p. $41 \ldots . . . . . . .$.

native home of, résimé of search for, in Jajan and China.

Scale insert and mite enemies of itrus trees. 1900 . p. $247 \ldots$

Scale insects, temperature control of. 1899. p. $73 \ldots \ldots . . . .$.

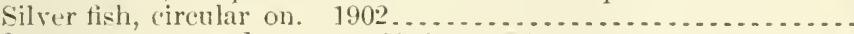

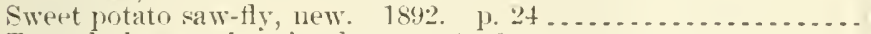

True clothes moths, circulat un. 1s:ts ....................

Wheat, growing, principal inrect enemies of. $1901 \ldots . . .6 .$.

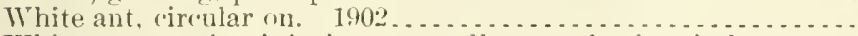

Thite ant, species injurious to wall paper, looks, timbers, ete. 1896. p. 70 . . . . . . . . . . . . . . . . . . . . . . . . .

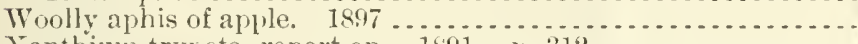

Xanthium trypeta, report on. 1891. 1. $312 \ldots \ldots \ldots \ldots \ldots \ldots$

See, for report as acting Chiet, Entomology Division. 1902 ......

See ralso, as joint author, Howard, Leland Ossian - Riley, Charles

Marls: Valentine.

Chemical examination of (Brown). 1872. P. 307 .......... A27.9:10

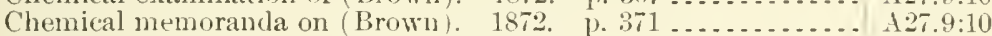

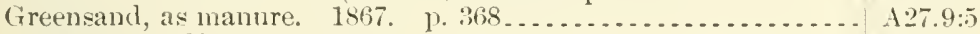

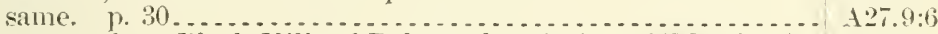

Marmot, new, from Black Ilills of Dakota, deseription of (Jerriam).

IIars:

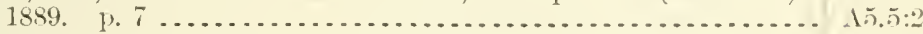

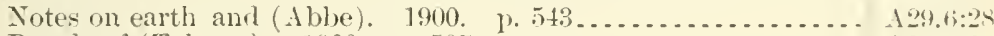

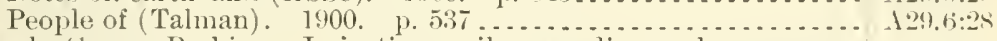

Marsh, George Perkins. Irrigation, evils, remedies, am compremiat-

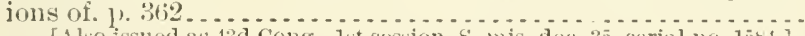

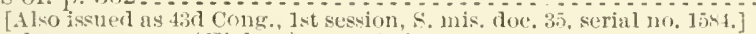

Marsh hawk, report on (Fisher). P. 370.

Same, 1). 370 .

Marsh hay, salt and fresh water (ilien). $1.296 . . . . . . . . . . .$.

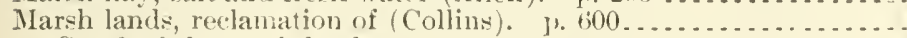
See also Salt marsh lanks.

Marsh or pond pine, observations on (Roth). 1897. 11. 169.......

Marsh soils. sir Soíls.

Marshall County, Kansas, artle disease in (Stedclom). 1. 35.2.....

Marten, John:

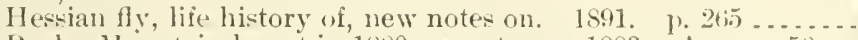
Pocky Mrintain locust in 1880 , report on. 1883. App. 1. 56 ...

11.1:Sit

A1.1: $\mathrm{k} \cdot \mathrm{s}$

A.5.1: $: 409$

A1.1:R7t

11.1:8:0

11:3.:3:1:3:

$14.1: 598$

$19.7: 3$

$18.1: 3$

Marten, new (Mnstela canrina), from northwest coast region of $L^{\prime} .3$. description of (Merrian). $1890 . \quad$ 1. 20

Martin, F, 0. Sre, as joint author, Mooney, (harles I.

Martin, George A. Chicago horwe show of 1890 . 1891. ]. 34. . . .

Martin, J. 1., soil survey of Willis area, Texas. 1) 607 .......... Sice also, an joint author, smith, Willian G.

Martinique, Wrest Indies:

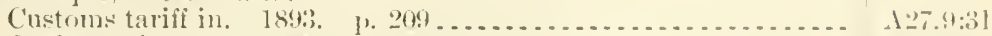

Cyclone of tug. 1s, 1891 . 1. 185 ........................ 129.1:19

Eruption at, neteorologiral eonlitions following (Kimball). 1902. 1.267.

Weather service, cetablishment of (himbali), 1901. p. $512 .$. See also P'eleer, Momnt. 
Marvin, Charles Frederick:

Idiress as (hairman, section of instruments and exposure, before seconl convention of Weather Burean oflicials, held at Mil. wankee, Wis., Aug. 27, 28, 29, 1901. 1902. p. 212

Aerial observers, instructions for. 1848 .

Anemomeiry, general information respecting theory and operation of typical instruments for indicating and measuring and antomatically recording wiud movement and direction, etc ...

Aneroid barometer, report on. 1898. 1) 410................

Barometer readings, metric and English, crroncous conversion of. 1898. p. 302

Barometers and measurement of atmospheric pressure

Clond observations and an improved nephoseove. 1896 . p. 9...

Cyclones, development and movement of. $1892 \ldots \ldots \ldots \ldots \ldots$. . . . . .

Farthquake of Oet. 31,1895 , report upon. p. $374 \ldots \ldots \ldots \ldots \ldots \ldots$.

Kite experiments at Weather Burean. 1896. pp. 113, 156, 199, 238.

Kites, mechanies and equilibrium of 1897 , b. $106 \ldots \ldots \ldots \ldots$

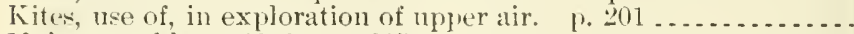

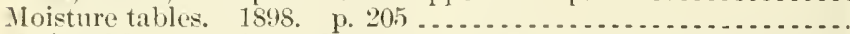

National Burean of standards, cireular of information relating to. 1902. 1) 135

Precipitation, measurement of $\ldots \ldots \ldots \ldots$

Psychrometric tables for rapor pressure, relative humidity, and

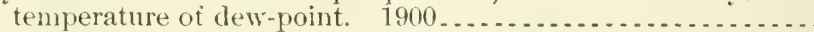

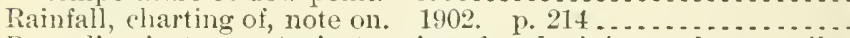

Recorting instruments, instructions for obtaining ancl transcrib-

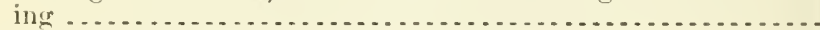

Seismic changes caused $b_{y}$ builling operations. 1899. 1. $582 \ldots$ Seismograph, Marvin, report on. 1895. p. $250 \ldots \ldots \ldots \ldots \ldots .$. Signals, Weather Bureau. 1892. p. 41 .................... Sunshine, measurement of, and preliminary examination of $\mathrm{Ang}$ -

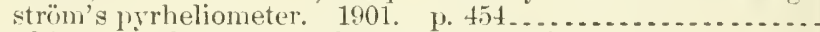

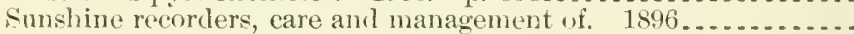

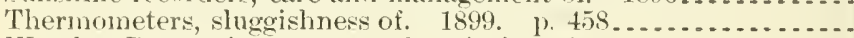

Weather Burean instruments, description of-

1893.

1894

1895 .

1896.

1.. 19

p. 17

1. 14

1.. 8.

Weather Bureau kite, report on $1896 \ldots$

Marvin, Charles Frederick, and Whitney, Milton:

Soil thermometers, maximum and minimm, combined, instruc-

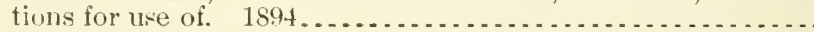

Thermometers, maximum and minimum radiation, instructions

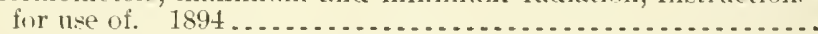

Iarvin, Paul. See, as joint author, Kastle, Joseph Hoeing.

Marvin's weighing rain and snow gange (Carlisle). 1899. p. 131.. Same, instructions for using. ..........................

Marx, Charles D. Irrigation prololems in Salinas Valley, Cal., rejort on. 1901. p. 193.

Marx, George. See, for reports as Chief, 1890-93, Illustrations i)jvision, Agriculture Department.

Maryland:

Irmy worm and some other insects affecting grain in, ontbreak

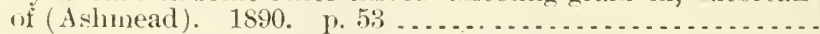

Climatological studies (Fassig). 1902. 1.200............ Coll weather in March in, records of $182:,-44$ (Acworth) . 1\%, 126.. Entomologieal notes from (Johnson). 1896. p. 63..........

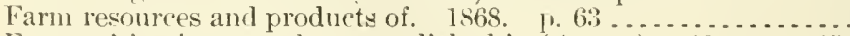
Farmers institute work accomplished in (Amoss). 190\%. p. 25. lusects, principal injurious, of year (Jolnson). 1897. p. $80 \ldots .$.

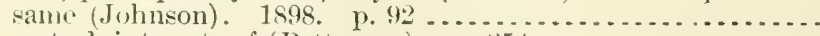

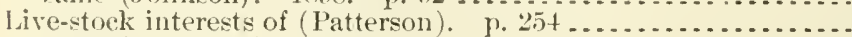
same (Pattersou). p. 466
129.3:31

A $29.11: K$

A29.6:28

A $29.11: \mathrm{D}$

A:9.6:26

A29.6:26

129.11:F

129.6:24

A29.2:C99

A29.6:23

A29.6:24

129.6:25

A1. 10:898

A $29.6: 26$

A29.6:30

$+29.11 \mathrm{~F}$

А29.2:P95

129.6:30

A29.11:A

$+29.6: 27$

129.6:23

A29.3:7

A29.6:29

A29.11: $\mathrm{G}^{2}$

A29.6:27

A29.1:891 3

A29.1:893 ${ }^{2}$

A29.1:894

A2\%.1:896

A29.6:23

A29.11:G

129.11:H

129.3:24

A $29.11: \mathrm{E}$

A10.3:100

49.7:3

A29.3:31

129.6:20

A9.6:6

A27.9:6

A 10.3:120

A. $6: 9$

A9. $6: 17$

A4.1:886

A $4.1: 887-8$ 
Naryland-Continued

Orchard injuries by red-leggerl flea-beetle (Schwarz). 1893.

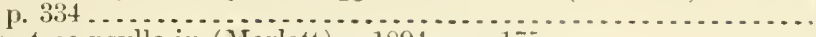

Pear-tree psylla in (Marlatt). 1894. 1' 175...................

Pleuro-pueumonia among cattle in, investigation of (Rose). p. 51 .

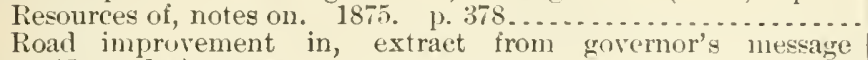

(Lowndes). p. 4 ......................................
san Jose scale in, experiments with lime, salt, am sulphur wash

Southern eattle fever in, outbreak of (Curtice). 1. 429........

Swine plague in, outbreak of (Rose). p. $\$ 46 \ldots \ldots \ldots \ldots . .$.

Weather service, 1st report, notes on (Abbe). 1849. p. 472 ...

See ulso Calvert County - Cecil County -College station - Harford County - Kent County - Mardela Springs - Montgonery County - I'rince (ieorge Count y-St. Mary County.

Maryland farm (Bryan farm), birds of (Judd). 190: . . . . . . . . . . Masaya, Nicaragua, lainfall of (Henry). 1898. pl) $162,305, \ldots . .$.

Iaslin, E. W. Figs, produetion and importation of, statisties of.

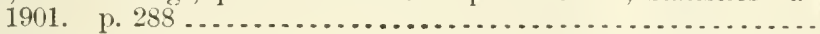

Mason, Frank $\mathrm{H}$ :

Animals, dearl, disposition of, in Berlin. p. 349 (erroneonsly

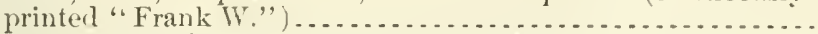

Dogs, muzzling of, in Ciermany amm (ireat Britain. 1\% $521 \ldots \ldots$. . .

Dried apples, American, in Gemany. 1845. p. 15 .........

Frankfort-on-the-Main, Germany, cost of hauling farm products

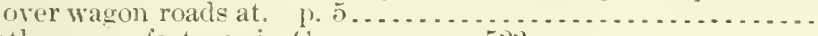

Leather manufactures in Germany. p. $522 \ldots \ldots \ldots . . .6$.

\section{Massachusetts:}

Brown-tail moth in, report on (Kirkland). 1900. 11. $75 . . . .$.

Coccidre, notes on some (Cooley'). 1848. p. 61...................

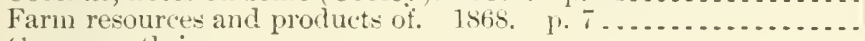

Gypsy moth in-

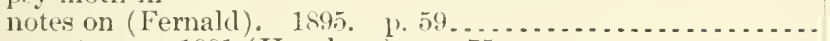

report upon, 1891 (Henshaw). p. 75 .

Insects in, 1901 (Fernald). 1902. 1. 119 . . . . . . . . . . . . .

Porthetria dispar in, introdnction and spread of, and efforts nuale by State to repress and exterminate it (Howard). $1897 \ldots .$.

Roari laws and road buikling in (Ross). 1901. p. 34 .........

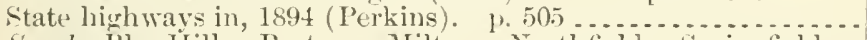
See also Blue Hill - Boston - Milton - Northfield - Springfield-
West Newbury.

Nassee, George:

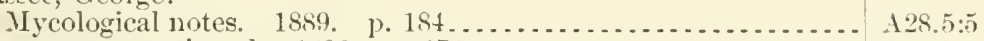

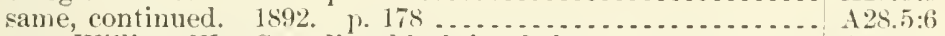

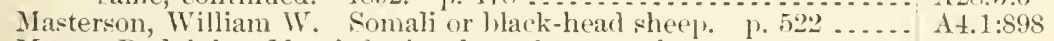

Matas, Rudolph. Man-infesting bot, abstract of paper on. $18 s 8$.

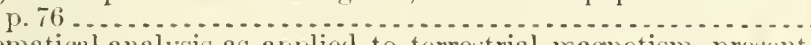

Mathematical analysis as applied to terrestrial magnetism, present

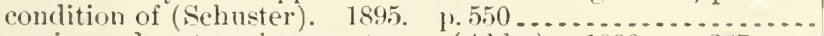

Mathematics and neteorology, notes on (Abbe). 1898. p. $267 . .$.

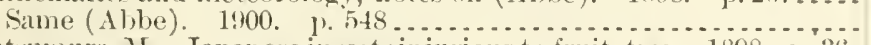

Matter and energy. See Metabolism.

Matthews, Albert. "Indian summer." 1902. p). 19,69........

\section{Mamitius:}

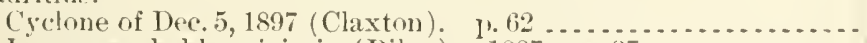

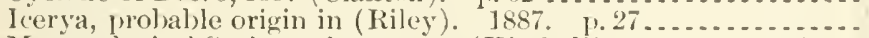

Meteorological Society of, notes on (Kimball). 1901. 1.565...

Meteorology and crops, note on (Alibe). 1897 , p. $354 \ldots \ldots$
Royal Alfrem Observatory, thunderstorms at (Claxton). 190.

Royal Alfred Observatory, thunderstorms at (Claxton). $19(00$.

Weather and sugar crop in, $1880-96$ (Ahbe). p. 412 ..........

Maurice, Professor. What an agricultural college ought to be.

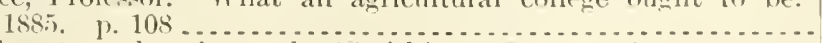

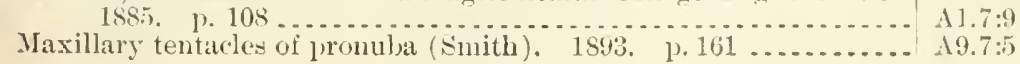

A $29.3: 11^{2}$

$\Lambda 29.6: 26$

A $9.6: 10$

1:9.6:30

129.6:26

A9.3:15

A $2(1,6: 29$

A $29.6: 25$

A $29.6: 28$

A $29.6: 26$ 


\section{nudex}

Maxwell, Walter:

Hawaiian Islands, agriculture in, ete. 1898, n. 563

Hawailan soils, estimation of lime, potash, and phosphoric acid

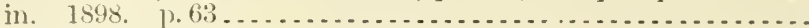

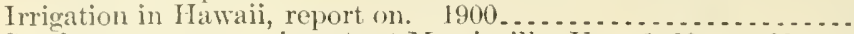
Sorghum-:ugar experiments at Morrisville, Va. $1889 . \quad$ p. $63 . .$. Sugar-bect culture in France and Germany, noteson. 1890, p. 81 . Sugar-bect experiment station at Schuyler, Nebr., annual report of. 1891. p. 118

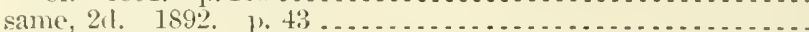

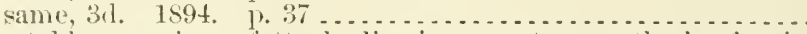

Vexctal)le organisms, fitty hodies in, rejort on method of esti-

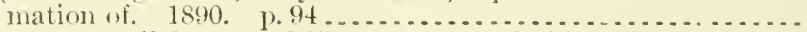
See also, as eollaborator, Wiley, Harvey Washington.

May, Davisl WT:

Chemists, Otheial Agrieultural Association of, 1900, convention of, report on. p. $503 \ldots \ldots \ldots \ldots$

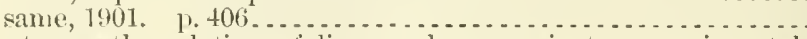

Plant growth, relation of line and magnesia to, experimental

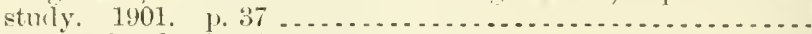

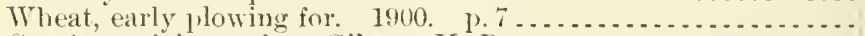
See also, as joint anthor, Gilson, H. B.

May, Davill WV., and Beal, Walter IJenry. Plants, leguminous, soil

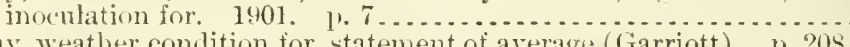

May, weather condition for, statement of average (Garriott). p. 208 .

Maynard, S. T. Mildews upon plants mnder glass, treatment of.

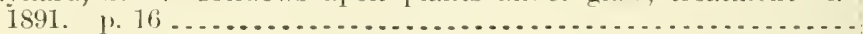
Nayo, X. S.:

Texas fever of cattle, transmission of, by cattle tirk. p. $481 \ldots .$.

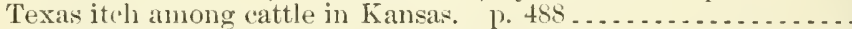
Tuberculosis anong eattle in Kansas. p. 479 ................ Mearl, Flwnod:

Agricultural situation in California. 1901. p. 17 . . . . . . . . . . Duty of water, general instructions to observers. 1899 ........ Irrigation-

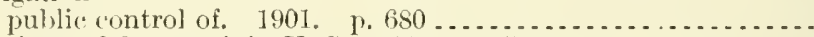
rise and future of, in U. S. 1899 . p. $591 \ldots \ldots \ldots \ldots \ldots \ldots$ what the Department of Agriculture is doing for. $1902 \ldots . .$. .

Irrigation in IT. S., testimony oi, before Uniterl States Industrial

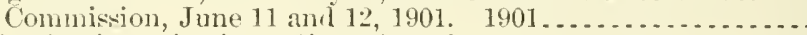
Irrigation investigations, fliscussion of. $1900 . p, 15 \ldots . . . . . .$. Irrigation investigations, for 1900 , review of. 1902 . P. $13 \ldots \ldots$. Mississippi River, and tributaries, water from, abstract of laws for acquiring title to, with legal forms in use. 1899 ......... Reservoirs, some typical, in Rocky Momntain States. 1901. p. 415. Scope and purpose of irrigation investigations of Office of Experiment Stations. 1902. p. 417.

Water rights on Missouri River and tributaries. 1899 ...........

Mearle, Kansas, sorghum sugar experiments at (Wiley). 18s9.....

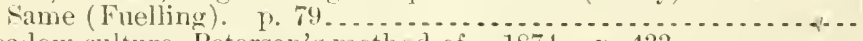

Mearlow rulture, Peterson's method of, 187t. p. 433 ...........

Meadow lark and Baltimore oriole (Peale), 1895. p. 419 ........

Mearlow's and pastures, formation and eultivation in Middle Eastern States (Smith) . . . . . . . . . . . . . . . . . . . . . . . . . . . . . .

Mealy lugs and their allies (Davis). 1894. P. 168.............

Mealy bugw in greenhomses, experiments with hydrocyanic-acid gas as means of exterminating (Hemenway). 1900. p. $69 . \ldots . . .$.

Mealy-wing, cocnanut and guava, report of. 1893. p. $314 \ldots \ldots \ldots$. Sie also Orange mealy-wing.

Means, Thomas I Ierbert:

Salt marsh lands, reclamation of. $1901 \ldots \ldots \ldots \ldots \ldots \ldots \ldots . . . . . . . . .426 .4: 8$

Soil survey in-

Cache la Poudre Valley, Colorado. 1900, 1. 121 ..........

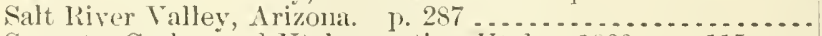
Sampete, Cache, and Utah counties, Utalı. 1900. p. 115.... Soils, soluble mineral matter of. 1898 . p. 495 ............... See also, as joint author, Whitney, Milton. 
Means, Thomas Herbert, and Gardner, Frank Duane:

soil survey in I'eros Valler, New Mexico, 1900, p. 86........ A A.8:64

Soils of Pecos Valley, New Mexico. n. d.................. A26.4:3

Means, Thomas Ilerbert, and llolmes, J. Garnett:

Soil survey around Fresno, Cal. p. 333 .

Soil survey of Imperial, Cal. p. 587

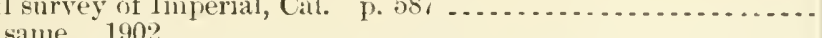

Measurements, english vs. metric system of (Abbe). 1901. 1. 73...

leasures. Siee Weiglits and measures.

Meat:

Analysis of, testing of apparatus and methor (Schweitzer and

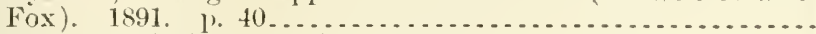

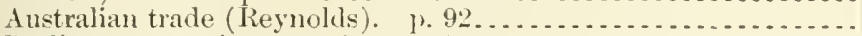

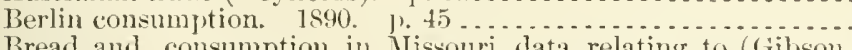
Brear and, consumption in Miswonri, data relating to (Gibson and others). 1896 .

Canned, chemical examination of (Wiley). 1899............

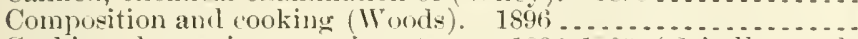

Cooking, losses in, experiments on, 1898-1:100 (crinuley ami

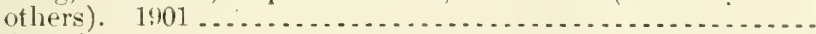

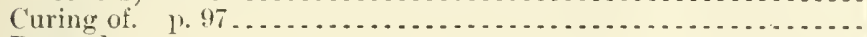

Dresserl-

freight rates on, from Chicago to New Jork. 1595. p. 553. same. 1896. 1. 598 .............................. traffic in United States, answers to questions regarding (Col-

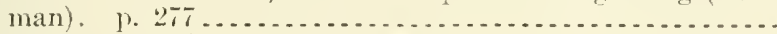

European consumption. $1876 . \mathrm{p}, 498 \ldots \ldots \ldots \ldots \ldots$ Federal inspection (salmon). 1894. p. $67 . \ldots \ldots \ldots \ldots . . .6$.

Fresh, shipments of, to Europe. 11. 312.

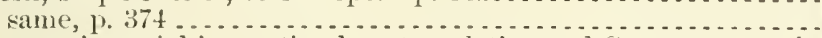

German imperial inspection law, translation and German text of. 1. 523. same. 1901

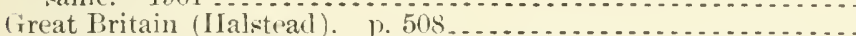

Importation into Germany from $\mathrm{C}$. $\mathrm{s}$. 1896. p. 100 .........

Industries of United States (Clark). P. 359 ................

Inspection of, for animal parasites. 1898.................

London consumption. 1874. p. $460 \ldots \ldots \ldots \ldots \ldots$

Meat products and-

Analysis of provisional methods for (Bigelow) 1902. 1'. $7 . .$. At Paris Exposition, 1900 (Alyord). p. 220...............

Packing, salt used in. p. 491 .

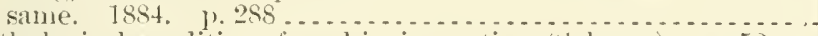

Patlological conditions found in insiection (Salmon). p. $52 \ldots$

Presersed, adulterations of (IBigelow and others). 1902. 1. 375.

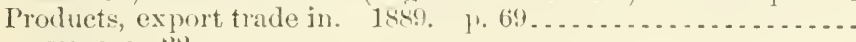

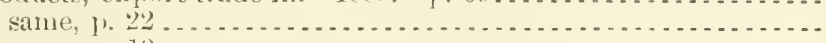

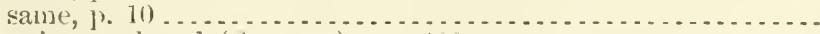

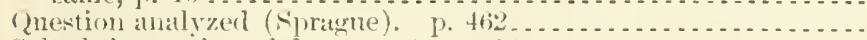

Salted, inspection of, for export. p. ss...................

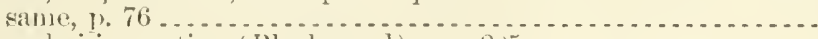

Shanghai inspection (Blackword). 1, 2115 ................

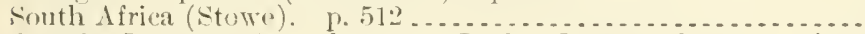

See wlso Bacon-Canned meats-Pork-Preserver meat-Live itrck-Saturages.

Meat or cheese skipher (Murtielelt). 1893. p. 170 .............

Mechanic arts:

Colleges of. See Agricultural molleges.

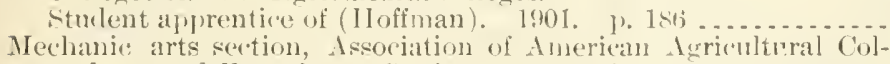
leges and Experiment fitations, report of:

$189: 3.0 .95$

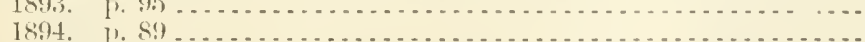

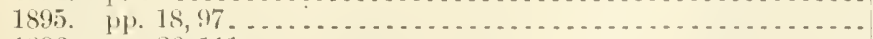

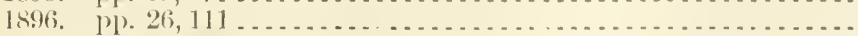

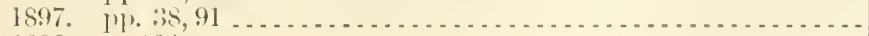

1898. p. $134 \ldots \ldots \ldots \ldots$

$126.5: \div 00^{1}$

$126.5: 901^{1}$

126. $4: 9$

A $29.6: 29$

A7.3:31

A $4.1: 893-4$

A27.9:28

110.3:31

A $7.4: 5$

A1.9:34

A $10.8: 10: 2$

At.1:895-6

A1.10:8\%

A1.10:8! 16

At.1:886

A27.9:14

A1.10:894

A1.1:870

A1.1:877

At.1:900

A.4:32

A $4.1: 900$

At.1:893-4

A.t.1:887-8

A $4.3: 19$

A27.9:13

A7.8:65

14.1:900

A 4.1:884.

14.2:An5

At.1:900

A7.3:13

A1.1:889

A t.1:889-90

A4.2:B39

11.1:883

A 1.1:890

A 4.1:889-90

14.1:898.

14.1:900

$-19.7: 6$

1 10.3:999

1 10.:3:20

110.3:24

A 10.3:30

A 10.3:41

A10.3:4.9

A10.3:65 
Iechanic arts section, Association of Ameriean Agricnltural Colleces and Experiment stations, report of-Continmed

1899. , 1. (14).

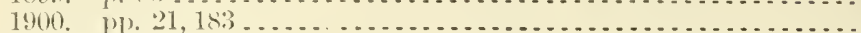

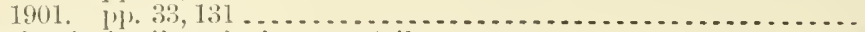

Merhanical suil analysis. tre soils.

Mechanical rlawing:

Conrse of instruction in (Randolph). 1901. p. 1St .......... $\$ 10.3: 99$

Teronical schools (Flather). 18!4. p. S1 ................ $110.3: 20$

Mechanical cuginecring and mochanic arts, eilueation in (Thurston).

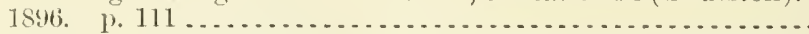

Mechanical work, what shall we give to students of cur agricultural Media: colleges? (D)

Acirl, growth of tuberculosis baeillus upon (De Schweinitz and Dorret). 1896. p. 7

igrestigations (T)e

Medical climatology, synopsis of enuse of lectures in, to seniog class medical depatiment University of Texas (Cline). 1902. 1'.

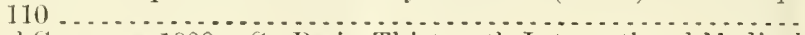

Medieal Congress, 1900 . See Paris, Thirteenth International Mledical Congress, 1900.

Medical zöology. See Zïology.

Medicinal and condimental cattle and poultry foods. 1901. 1. 22. Medicine Lodge, Kansas:

Field work at, notes on (Hinman). 1898. p. $31 \ldots \ldots . . . . .$.

Seed-selection work at, résumé of (Carr). 1893. p. 28 .......

Sorghum sugar experinents at1889 (Sanborn). p. 77.

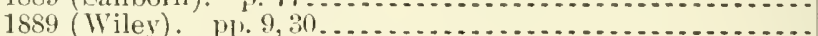

Merlicines:

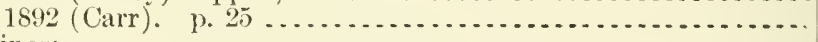

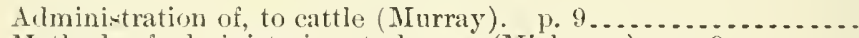

Methorls of administering, to horses (Nichener). p. $9 \ldots \ldots \ldots . .$.

Mediterranean flour moth:

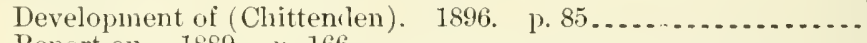

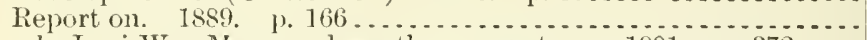

Meech, Levi WT. Moon and weather, report on. 1901. p. 372....

Megilla lvarasite, additional note on (Riley). 1889. 1.338 .......

Megnin, II. I'.:

Gape disease of fowls, and parasite by which it is caused; trans-

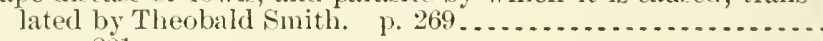

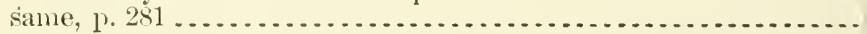

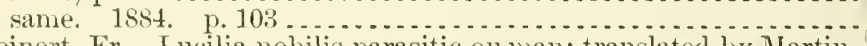

Meinert, Fr. Lucilia nobilis parasitic on man; translated by Martin

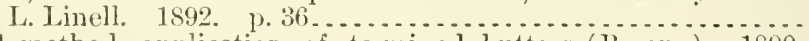

Meiss] methol, application of, to mixed butters (Besana). 1890.

Melanoplus devastator, dipterous parasite of, in California (Coquil-

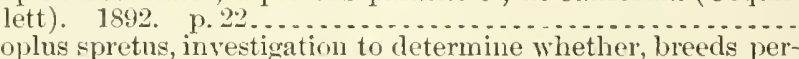

Melanoplus spretus, investigation to determine whether, breeds per-
manently in Turtle Mountains in North Dakota (Hnuter).

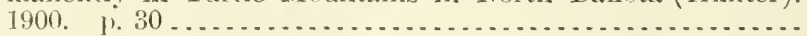

Melber, F., adilress of, before national road conference, July, 1894.

Melbourne, Anstralia, irrigation conference, Mar. 25-28, 1890, nofes of. 1891. p. 250 .

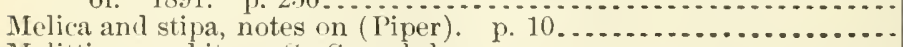

Nelittia cneurbitie. See Synash borer.

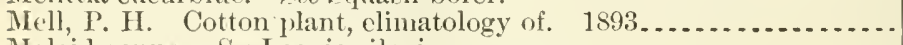

Meloir genus. See Leonia rileyi.

Melon-plant lonse. See Cotton-plant lonse.

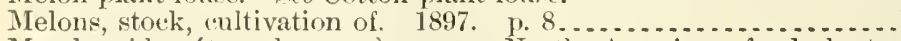

Membracicle (tree hoppers), some North American food-plants

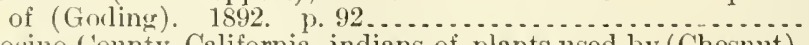

Mendocino County, California, indians of, plants used by (Chesnut). 1902. p. 295

110.3:41

$.110 .3: 24$

$10.3: 76$

110.3:99

\10.3:115

A $4.1: 899$

A:9.3:31

A1.9:144

A $7.3: 40$

A $7.3: 40$

A $7.3: 26$

A 7.3:26

A $7.3: 37$

$\mathrm{A} 4.2: \mathrm{C}_{29^{2}}$

At.2:H78

А9.6:6

A9.7:2

429.6:29

A9.7:1

11.1:88t

A4.1:88t

A4.2: $\operatorname{An} 5$

A9.7:5

$17.3: 24$

19.7:5

A. $6: 22$

A 22.3:10

A15.2:P9. ${ }^{1}$

A3. $4: 27$

A 29.3:8

A 1.9:65

A9.7:5

A $6.5: 7$ 
Meng, J. S. Phosphoric acil, additional notes on. 1892. p. 27.... A7.3:35

Menhaden fisherie of Long Island. 1870 . p. 39. . . . . . . . . . . .

Menozzi, - Volatile acids, variations of, in lutter fat. $18 \% 0$.

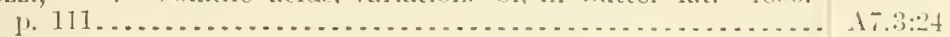

Nercer, A. S.:

California cattle, destruction of, by various dixeases; with report

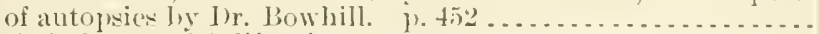

Cattle industry of California, p, 2:39...................

Merchandise, domestic, total value of exports of, 1890-95. J, is 1 . . . .

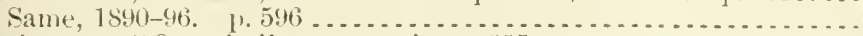

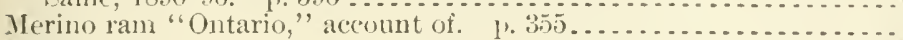

Merinos:

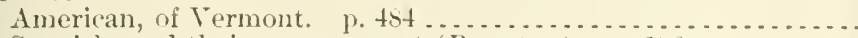

Spanish, and their management (Boynton). 1. 196..........

Merriam, Clinton Hart:

Arvicolina, description of new genus (Phenacomys) and four

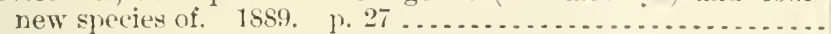

Bats, free-tailed-

from desert region of southern California, description of new

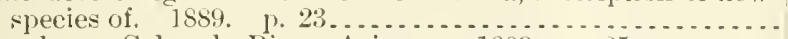
from lower Colorado River, Arizona. iss9. p. $25 \ldots \ldots \ldots$.

Biological reconnaissance of south-central Idaho, 1891 .........
Biological Survey, Agriculture Department, work of for farmer.

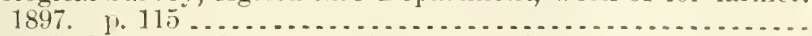

Biological survey of San Franciseo mountain region and desert of Little Colorailo, Arizona. 1890

Birds which feed on mulberries. p. 285 .

Cactuses, yuccas, and agave, geographic and vertical distribution of, in deserts and desert ranges of southern California, southern Nevada, northwestern Arizona, and southwestern Utah. 1893. p. 345

Evotomys, new, from-

Black Hills of South Dakota, description of. 1890. p. 119 ...

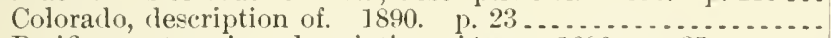
Pacific coast region, description of two. 1890 , 1. 25 ......

Forest trees of San Francisco mountain region, Arizona. 1890.

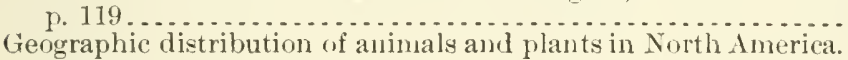

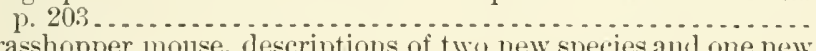

Grasshopper mouse, descriptions of two new species and one new
subspecies of. 1889. p. $1 \ldots \ldots \ldots \ldots \ldots \ldots \ldots \ldots \ldots \ldots \ldots \ldots \ldots$ subspecies of.

five new, of genus Tamias, descriptions of. 1890, p. $17 \ldots \ldots$ new species of, from arid lands of the Southwest, description of. 1889 . p. 19

three new, of spermophilus spilosoma group, descriptions of.

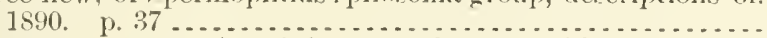

Hesperomys, new species of, from sonthern Florida, description

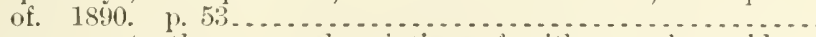

Kangaron rats, three new, descriptions of, with remarks on identity of Dipodomys orlii of Woodhouse. 1890 . p. $41 \ldots \ldots$.

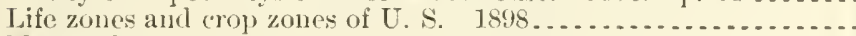

Mammals-

new genus and two new speries of, description of. 1891. p. 115 . North American-

descriptions of fourteen new species and one new genus. 1889

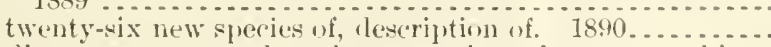
small, measturement of, and preparation of musem skins,

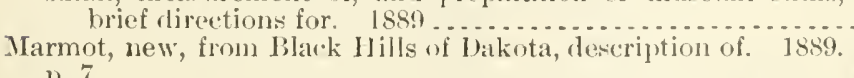

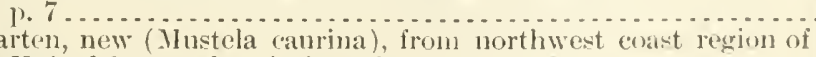

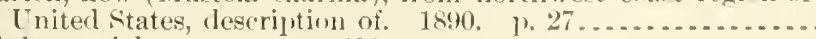

Iink, special report on. p. 48 . . . . . . . . . . . . same, p. 488 
Merriam, Clinton Hart-Continued

Iolnssns, new species of, from California, description of. 1890.

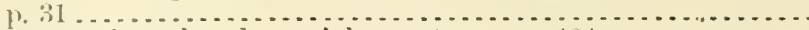

The:isints, introduced, special report on. p. $484 \ldots \ldots \ldots \ldots \ldots . .$.

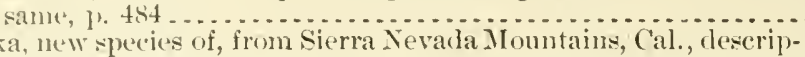

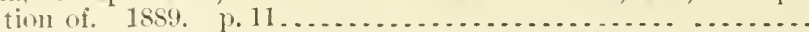

Pocket gopher, of genus Geomys, from western Nebraska, descrip)-

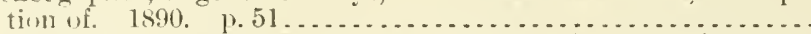

Pocket gophers, family (ieomyidia, exchsive of species of Thom-

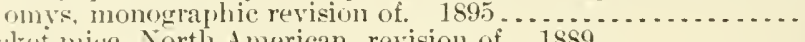

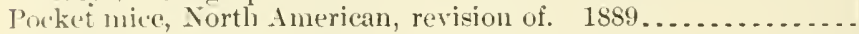

I'ratirie $\log$ lestruction of, directions for new, from Wyoming, description of. 1890 p. $33 . . . . . .$.

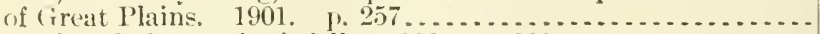

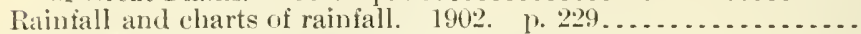

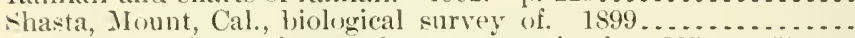

Shrews, American, of genus Sorex, syupsis of. 1895. p.57 ...

Shrews of American genera Blarina and Notiosorex, revision of.

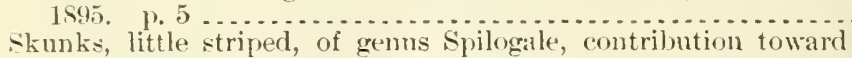
revision of, 1S90. p. 1

Spermophile, new, from-

Arizona, northwestern, description of. 1889. p. 17

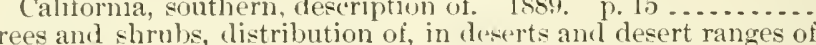
southern California, southern Nevada, northwestern Arizona,

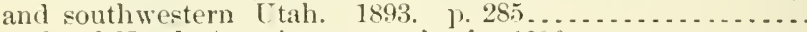

Weascls of North America, symopsis of. 1896................

See also, for reports as Chief, Biological Survey Division, Agri-

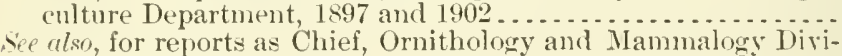

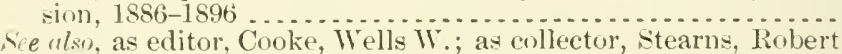
Elwards Carter -. Stejneger, Leonhard.

Merrick, E. C. Pacific coast, climate of. P. 280.

Jerrill, Elmer D.:

Aristila purpurea nutt., and its allies. 1901.

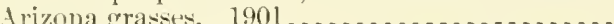

Grasues-

nomenclature of, some changes in. 1901. p. 5........... some species of, pulslished hy S. B. Buckley. $1901 . . . . . . . .$.

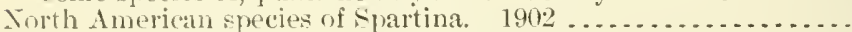

Sie clso. as joint author, Seribner, Frank Lamson.

Merrill, L. H. See, as joint author, IVoods, Charles Dayton.

IIerrill, dewis A. Vaccination against blackleg in Ctah. p. 469 ..

Verry, $(i$. Factory cheese and how it is made. 1896. 1) 45 .....

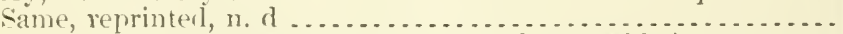

Mersivan, Turkey, temperature and rainfall at (Able). 1897. p.

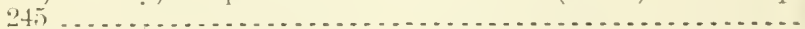

Mesmer, Louis. See, as joint author, Ileileman, W. U. - Holmes. J. Garnett

Mesquite tree as tanning material (Me Murtrie). 18,3. p. $31 \ldots \ldots$

Metabolism:

Effects of severe and prolonged muscular work on (Atwater and -lierman). 1901.

Experiments in which balance of income and ontgo was determined, digest of (Atwater and Langworthy ) . . . . . . . . . . .

Experiments on effect of musenlar work upon digestibility of food and metabolism of nitrogen, combucted at Lniversity of

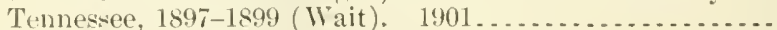

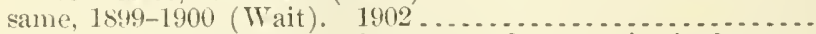

Experiments on metabolism of matter and energy in the human

hody (Atwater and others) - . . . . . . . . . . . . . . . . same, value of (1angworthy). 189s. p. 100:3 ........... same, 1900 (Atwater and others) . . . . . . . . . . . . . . .

A.5.5:4

A1.1:888

A5.1:888

$15.5: 2$

A5.5:4

A5.5:8

A5.5:1

A5.4:32

A 5.5:4

A $1.10: 901$

129.6:30

A5. $5: 16$

A5.5:10

A5.5:10

A5. $5: 4$

15.5:2

A5.5:2

+5.5:7

A5.5:11

A.5.1:

15. 1:

A1.1.867

-13.4:34

A3. 4:32

A.3. 4:35

A3. 4:35

A 19.3:9

A4.1:899

A4.3:15

At.4:19

1.29.6:25

A:7.9:11

A 10:3:98

A10.3:45

110.3:89

A10.3:117

A $10.3: 69$

A $10.6: 9$

A10.3:109 
Metabolism-Continued

Experiments on netabolism of nitrogen, sulphur, and phosphorus in human organism (Shermat1). $1902 \ldots . . . . . . . . . .$.

Milch cows, investigations on (Hagemanm). 1899. p1. $803,90: 3$. A10.3:121

A 10.6:10

Nitrugen and carbon in hmman organism, metakolism of, witl respiration calorimeter of special construction (Atwater and others). 1897.

Nutrients in animal borly, metabolism of, and sonree of mustular

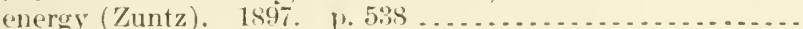

Metabolizel nitrogen, excretion of, by animals (Langworthy). 1897.

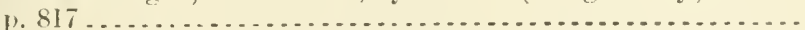

Netal railway tracks. See Railway tracks.

Metals. Se Aluminum - Copper - Iron - Learl.

Metaphosphoric acid. See Cotton seed meal.

Meteor:

Bright-

note on (Abbe). 1597. p. 261.

same (Ablue). 1898. p1). 20, 318, 569

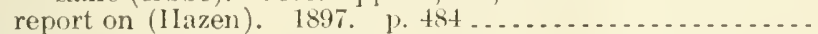

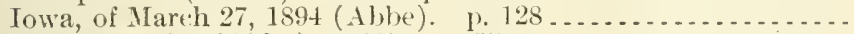

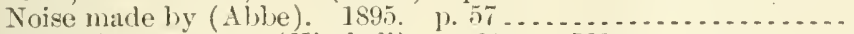

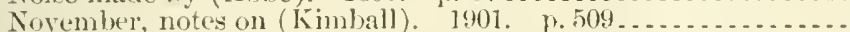

Metcoric story, sensational, note on (Abbe), 1898. p. 363 .......

Meteorologic waves, report on (Hazen). 1899. p. 32:3

Meteorological aurl other forms and reports: should they be simplified? are modifications desirable? (Evans). 190:2. 1\% 168...

Teteorological balloon ascension at Strassburg, Germany (Roteli).

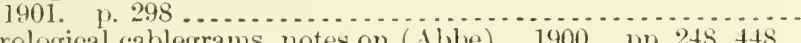

Meteorological cablegrams, notes on (Ahbe). 1900. pp. $248,448$.

Meteorulowical century, note on (Abbe). 1900. p. 591 ..........

Meteorological charts of Great Lakes . . . . . . . . . . . . . . . . . . .

Meteorological commission, proposed, note on (Ahbe). 1901. 1).312.

Jeteorological committee, international:

Note on (Abbe). 1899. 1. 103.

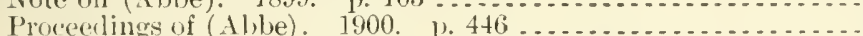

Report on (Kimball). 1902. 1'. 134.

Teteolological conferences. Sie Mnnich - I'aris.

Meteorological congresses. See Chicago-Mexican national neteornlogical congress - Paris.

Meteorolmical institute of Prussia, work of, notes on (Able). 1901. 1. 70 ... . . . . . . . . . . . . . . . . . . . . . . . . . .

Teteorological institution, Royal Prusuian, celelration of semi-

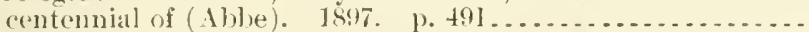

Meteorological jommal, new, notes on (Albe). $1900.40 .160,252$.

Meteorological library, note on (Ablee). 1900. 1. 208..........

Meteorologieal notes:

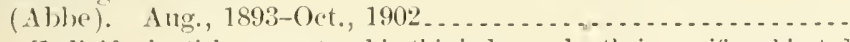

[Individun articles are entered in this index nuder their specific subjects.]

Monthly (Kinball) ..................................

[Individual articles are entered in this index under their speeific subjects.]

Meteorological notes by $\mathrm{Wm}$. Scoreshy, jr., leport on (Ab)e). 1897.

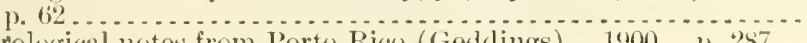

Neteorological notes from l'orto Rion (Geddings). 1900. p. 287 ..

Metcoro.ogical observations:

Alaska, 18:4 (Tibbey). 1). 17t

Bayonne, N. J., during burning of plant of Standarl (Oil Company

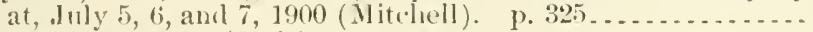

('ircle City, Naska (Holt). 1896-98. p. $5+2 \ldots \ldots \ldots \ldots \ldots \ldots \ldots$

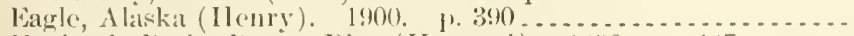

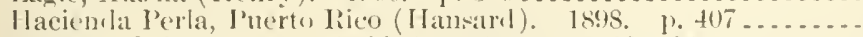

IJavana, Culsa, notes on (Al)be). 18:19. pl). 60, 104.........

Jonolulu, IIawaiian Islands, monthly, March, 1894-1 pril, 1!(0) ( I yons)

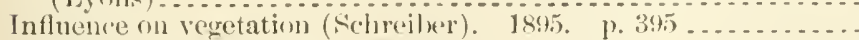

International, simmary of (J)nnwooly), 189; ............

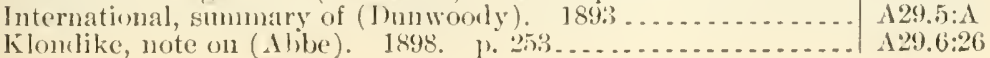

1 $29.6: 2 !$

A $29.6: 25$

A29.6:28

1 $29.6: 28$

129.6:

A29.ti:

1:39.6:25

129.6:28

12019.6:2:2

129.6:28

129.6:26;

129.6:28

A:39.6:26

A:9.6:26

129.6:

$129.3: 11^{2}$ 
Meteorological oloservations-Continued

Made to dotermine prohable state of sky at several stations along path of lotal eclipse of sim, May 2S, 1900 (Bigelow). 1897.

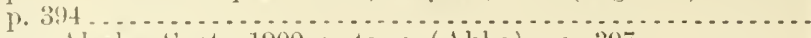

Nome, Alaska, Sept., 1900, note on (Abbe). p. 397........... Permanent recorrl, should not a buok for, be furnisherl to section centers and roluntary stations?-

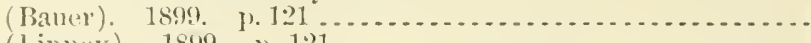

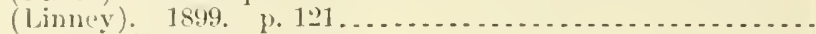

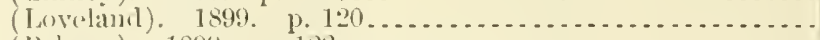

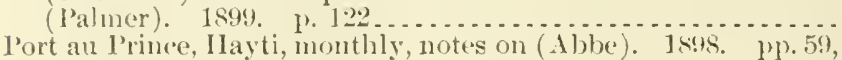

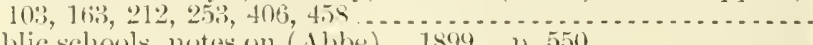

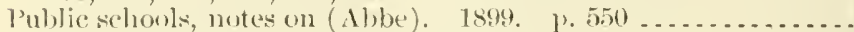
sane (Wilkinson). 1899. ए. 550 . . . . . . . . . . . . . . lieports hy cable from Iceland, notes on ( 1 ble $)$ isis. p. 103. heports of voluntary olservers, monthly, examination of; is it lesirable to report back to voluntary obscrves errors and irregularities discoverel in his report? (Bance). 1902. 1. 172... Rivas, Nicaragua, montlaly, nutes on, 1898 (Abbe). JU. 61, 16:,

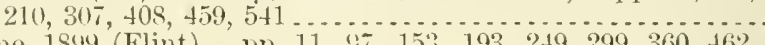
same, 18.49 (Flint). pp. 11, $37,15 \%, 193,249,299,360,462$,

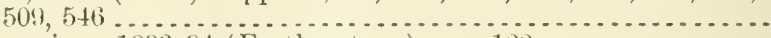
San Francisco, 1893-9t (Featherstone) p. $128 \ldots \ldots \ldots \ldots$ Simultaneous, in U. S., in 18th century (McAdie). 1895. 1.303..

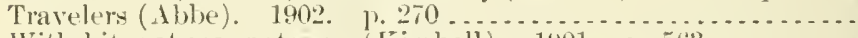
With kites at sea, notes on (Kimball). 1901. 1. $563 \ldots . . . .$. See also Hagnetic observations - Meteorolowical work.

Meteorological olsservatories:

Creation of, on islands comnected by cable with a continent (Albert, Prince of Monaco). 1894. p. $158 \ldots \ldots . . . . . . . .$.

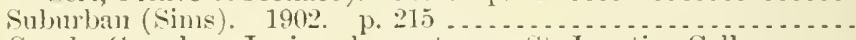
See also Canarla - Juvisy observatory - St. J gnatius Collere.

Meteorological observers:

Arctic aml Antarctic, notes on (Ab)e). 1901. 1.558........ A29.6:28

Volumtary-

for Monthly Weather Reriew, lists of. 1891. following pr.

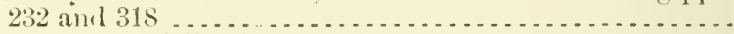
same. 1892 . following p. $346 \ldots \ldots \ldots$ of U.S. Hydrograplice Othee, instructions to (Abbe). 1901.

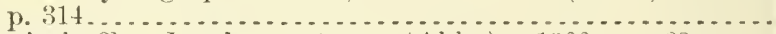
Meteorological office, London, notes on (Abbe). 1900. P. $68 . . .$.
Meteorological optics, J. M. Pernter's, note on (Abbe). $1902 . \quad$ p. 132.

Meteorological phenomena:

Ice caves am frozen wells as (Kimball). 1901. p. 366 ........

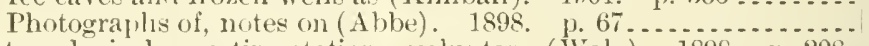

Meteorological reporting stations, voluntary (Walz). 1S9s. p. 208.

Meteorological records:

Varly, notes on (Abbe). 1901. p. $565 \ldots \ldots \ldots \ldots$

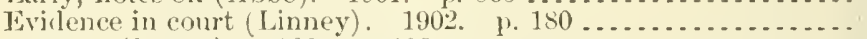

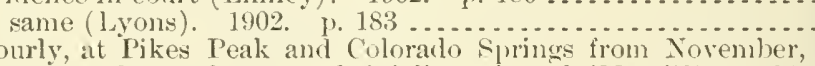

Hourly, at Pikes Peak and Colorado Springs from November,
$189^{\circ}$, to September, 1894, brief discussion of. (Morrill). 1896.

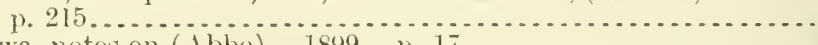
Iowa, notes on (Abbe). 1899. p. $17 \ldots \ldots \ldots \ldots$

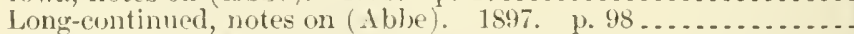

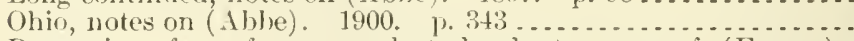

Preserving, for reference and stucly, best means of (Enery).

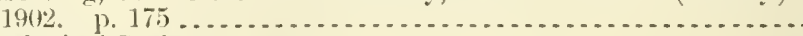

Ieteorological Societr:

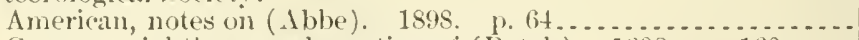
German, eighth gremeral meeting of (Roteh). 189s. 1. $160 \ldots .$. Manritius, notes in (Kimball). 1901. p. $565 \ldots . . \ldots \ldots \ldots . . . .$.

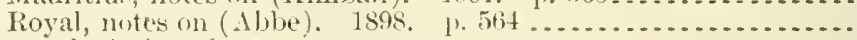
Meteorological stations:

Experimental agriculture at $(1 \mathrm{~b}) \mathrm{b}), 1902, \mathrm{p}, 410$. 
IIarvard Cniversity, note on (Abhe)-

1897.

1). 540 .

1901. p. 69

Highest station in world, visit to (IVarr). 1898 . 1500

Mountain, in Anstralia (Abbe). 1s!18. 1. 166t..............

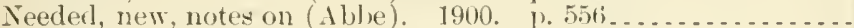

Publication of results of observations (Hamn), 18:4. P. $1 \ldots \ldots$

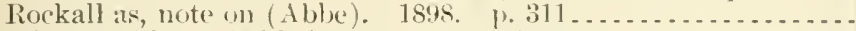

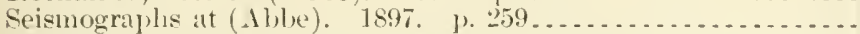

Tierra del Fuego, notes on (Al,be). 1897, p. $193 \ldots \ldots \ldots \ldots$. Meteorological superstitions, notes on (Ablse). 18ss. p. 216 ......

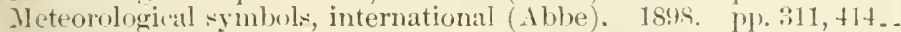

Meteorological tables:

Monthly temperature, rain, etc., from Smithsonian Institution,

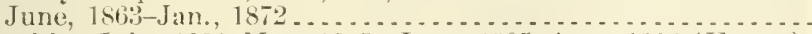

Monthly, July, 1891-1Iay, is 15 ; June, 1895-Apr., 1902 (Henry)Meteorological tables and charts, monthly, description of, Maty-Oet., 1902 (Stockman)

\section{Meteorologieal terms:}

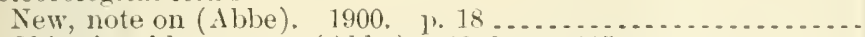

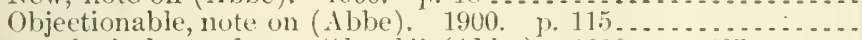

Meteorologieal use of term "local" (Abbe). 1898. p. $207 \ldots . .$.

Meteorological work:

Agrieultural experiment stations and agricultural colleges and their relations to Weather I3urean (Ilarrington). 1892. p. 42.

Agricultural institution (Harrington), 1892............... Alaska (Henry). 1898, p. 154 ..........................

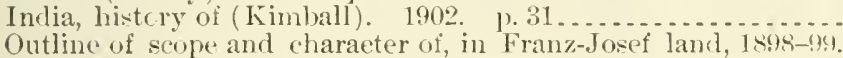

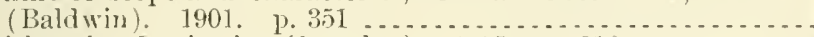
Smithsonian Institution (Langley). 1895, 3. 216 . . . . . . . . . Enited States Signal Service, 1870 to 1891 (Abhe). is95. ]. 232. See also Meteorological observations.

Tieteorologist:

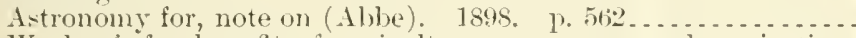

Work of, for benefit of agrieulture, commeree, and navigation

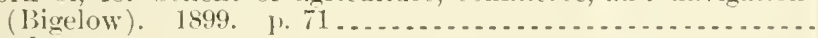
Neteorology:

Abstracts of reports of agrieultural experiment stations on, 18s?-

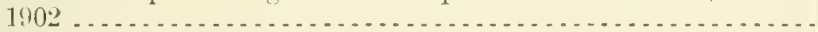

Addresson, at British association, Belfast (Schuster). 1902. 1. 4t8. Agriculturalnotes on, with special reference to rainfall element (Limney).

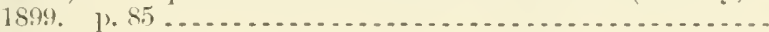

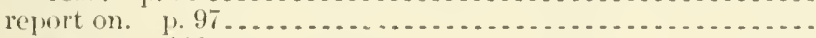

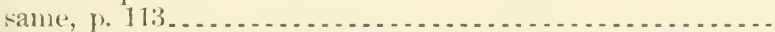

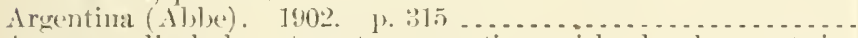
Army medical department, comnection with development in

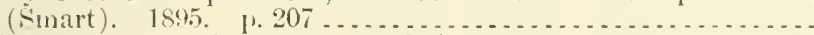

Belgium, history of, motes on (Ab)e). 1901. p. 69 .......... Bibliography of American contributions to, note conceming

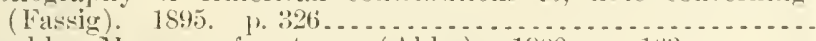

Brooklyn liusemin of, notes on (Abbe), 1900, J) 103......... Climate and, of Death Valley, (all. (Harrington). 1892........ Climatology ve. (Whitney). 1898. 1.301 .................

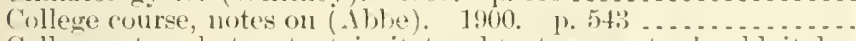
Colleges; to what extent is it taught at present; should it he? uffererl as an indergraduate or as a posteraluate condrec? (Lovelandi). 1902. 1.90..

(onditions tavorable to spontaneous combustion, note onl ( $\mathrm{dl}$ hibe). 1900. P. 249 .

Comblions following st. Vincent and Jartinique eruptions, 1942

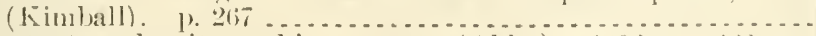
Constants and units used in, nutes on (Abbe). 1s96, 1. thiz...

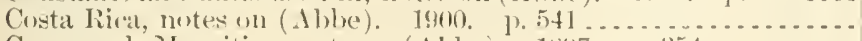
Crops and, Mauritius, note on (Ah,e), 1s:97, p.354 ........

\29.6:25

$129.6: 29$

A $29.6: 266^{3}$

A2!).6:26

129.6:28

129.3:11"

129.6:20

129.6:25

A29.6:2:5

1:9.6:26

$129.6: 26$

127.9:

1.29.6:

A29.6:30

129.6:28

129.6:28

129.6:25

110.3:7

110.3:10

129.65:26

1:20:600

129.1:900

129.3:11

A29.3:11"

$.129 .6: 26$

11.10:599

110.6:

A:9.6:30

129.3:24

A 1.1:869)

$11.1: 870$

A $29.6: 30$

129.3:11

A $29.6: 29$

A29.3:11

A $29.6: 28$

A29.3:1

A $29.6: 26$

129.1:28

\section{3:31}

$129.6: 28$

1:9.6:30

1.29.6:24

A29.6:28

$129.6: 25$ 
Meteorology-Continued

Cyeles in-

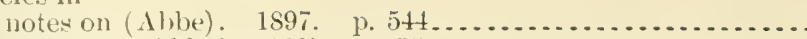

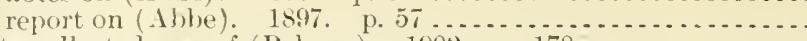

Data collected, use of (Palmer). 1902. p. 178.

Eelipse and allied problems (Bigelow). 1902 ...............

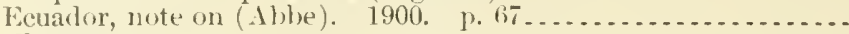

Elementary-

talk on" (Davison). 1899. p. 144.

text-books and works of reference for students of (Phillips).

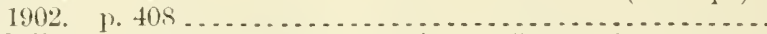

English literature, $1337-1699$ (Symons). 1895 p. $333 . \ldots . . .$.

Extremes at Northtiek, Mass. (Elmer). p. $251 \ldots . . . . . . . .$.

France, notes on (Abbe). 1sis. p. 55: ...................

French Indo-China, notes on (Ahbe). 1901. p. 263......... (ieoklesy and, notes on (Abbe). 1900. 1) 545...............

Geosraply and, popular errors in (Abbe). 1901. p. 375 ....... Geological Survey, note on (Able). 1897. p. 541........... Great Britain, notes on $(A b b c)$. 1899. p. 109 ..............

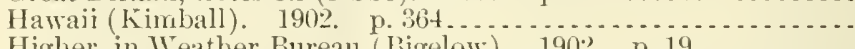
Higher, in Weather Bureau (Bigelow). 1902. p. 19........

Historical events in, note on (Abbe). 1900. p. 17........... Instrumental, historical sketch of (Gerland), 1896. p. 687..... Instruments, elastic suspension for (Abbe). 1894. p. $25 \ldots . .$. Is every seventh year a wet one? 1865. No. 6. p. 15........ Italian momntains (Denza). 1896. p. (559 . . . . . . . . . . . . . Johns Hopkins Lniversity (Fassig). 1898. p. $306 \ldots \ldots . . . . .$.

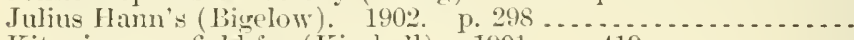

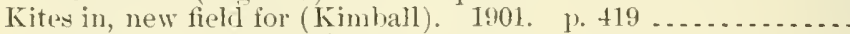

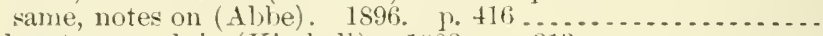

Laboratory work in (Kimball). 1902. p. $313 \ldots . . . . . . . . . .$. Lectures on-

in schools, note on (Abbe). 1900. p. 19 notes on (Abbe). $1900 . \quad$ I). 164, 208

popular, including lectures to farmers institutes, social gatherings, societies, etr.; are such lectures valuable in proportion to time given? what should be the general character of

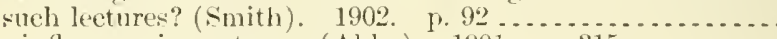

Lunar influences in, notes on (Abbe). 1901. p. $315 \ldots \ldots \ldots$

Madagasear, note on (Abbe). 1901. p. 375.............

Magnetism and-

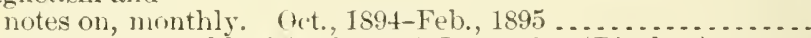
report on, nonthly, March, 1895-June, 1896 (Bigelow) ......

Mathematics and, notes on (Able) . 1898. p. $267 \ldots \ldots . . . . . .$.

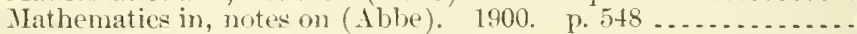
Mexien, brief sketeh of develoment of (Aquilar y Santillan). 1895. 1). 335

See also Mexican National meteorological eongress.

Ionthly list of papers bearing on, Jan., 1899-Dee., 1902 (Phillips). A29.6:

Mountainstations for (Al)be). 1902. p. 410 .............. A29.6:30

New elementary treatise on (Abbe). 1898. p. $563 \ldots \ldots . . . . .$. . $29.6: 26$

North Atlantic, monthly notes on, J:1n., 1894-June, 1895 . . . . . . A29.6:

Obscure prints in, notes on (Abbe). 1899. p. 108.......... A29.6:27

Optical, rireumhorizontal are in (Bexon). 1902. p. $486 \ldots \ldots . . \$ 29.6: 30$

Panaina-

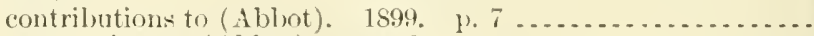

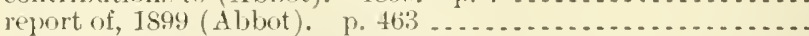

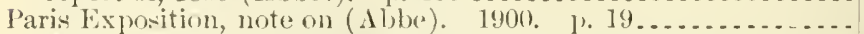
See also Paris intermational notenrolonical congress.

Perioxlic terms in, llue to rotation of sun on its axis (Bigelow)

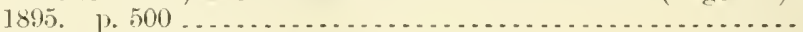

Periodicity in, notes on (Able) 1900 p. $547 \ldots \ldots \ldots$

Photography in, notes on (Abbe). 1900, p. 15i..........

Physics and-

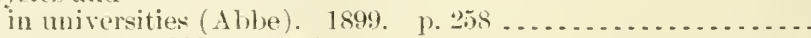
notes on. 1902. 1. 445 ... . . . . . . . .

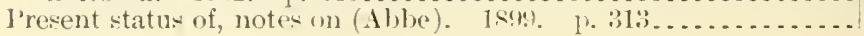

A29.6:2S A $29.6: 27$ A29.6:28 
Index

Meteorology-Continued

Primary work for use of schools (Connor), 1899, 1. 102...... \$29.3:24

Public health and, relation between (Philips). 1895. 1) $171 \ldots$.. $129.6: 23$

Public schools-

how much should be attempted; methods of teathing (Chat-

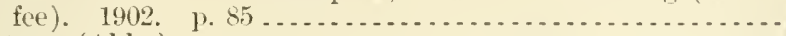
note on (Ablue)-

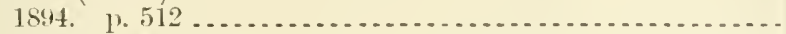

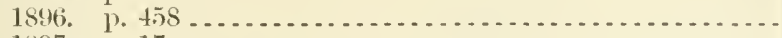

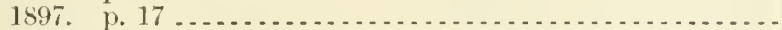

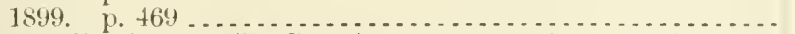

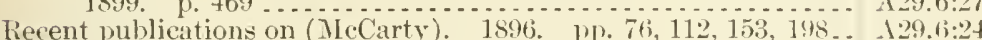

Redfeld and Espy period of, 1830 to 1855 (Davis). 1895. P. 305 . A29.3:112

Report on-

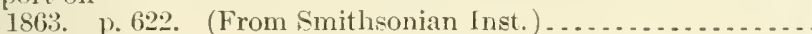

1864. 1). 609 .

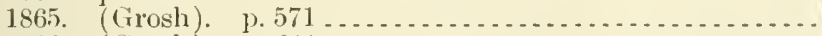

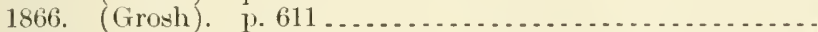

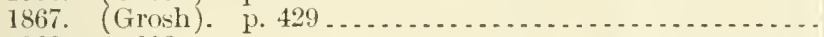

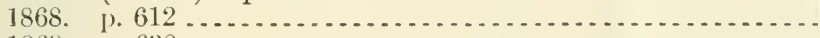

1869. p. 638 ...

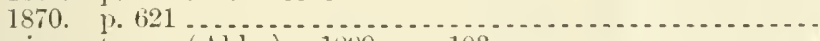

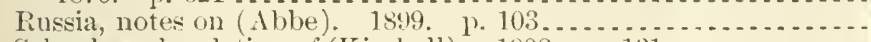

Schools and, relation of (Kimball). 1902 . p. $131 \ldots \ldots \ldots \ldots$

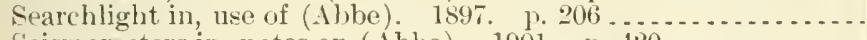

Seismoneters in, notes on (Abbe). 1901. p. $420 \ldots \ldots . . . . . .$.

Solar and terrestrial magnetism in relation to (Bigelow). 1898...

Solar magnetism in relation to (Bigelow). p. $519 \ldots \ldots . . .2 . .$.

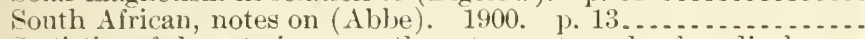

Statistics of, how to improve them to meet needs of medical pro-

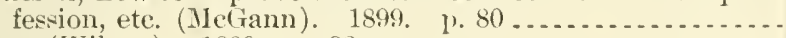

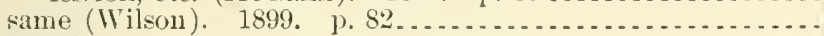
sturly of-

by correspondence (Abbe). 1898. 1) 267 ............... under existing conditions of Weather Bureaul station work,

is it practicable to require assistants to pursue a systematic

course of"? (Salisbury), 1902. 1. 82 ...............

Subjects in, explanation of (Newcomb). 1902. p. $127 \ldots \ldots \ldots$.

Sun spots and, notes on (Abbe). 1901. 1. 263...............

Teaching of, by laboratory method. 189y. ए. 4t8 ............

Terrestrial magnetism and, in 15 th, 16 th, and 17 th centuries, contribution to bibliography of (Hellnam). 1895. p. 352......

Text-book of, Julius Hann's, note on (Abbe). 1901. p. 74 . . . . .

Theoretical, in U.S., 1855 to 1870 , some remarks on (Waldo).

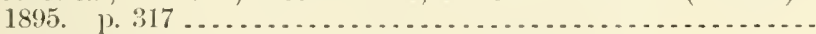

Thermometric scale used in (Abbe). 1895. p. $255 . . . . . . . .$.

Universities and, notes on (Abbe)-

1899. pl. $155,420,549$

1900. 1). 165

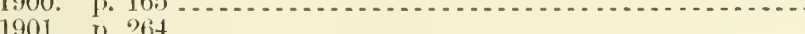

Weather Bureau men as instructurs in, notes on (Abbe). 1900.

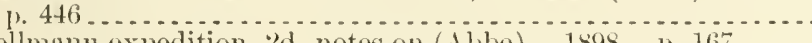

Wellmann expedition, 2d, notes on ( 1 hbe) 1898. p. 167.... What meteorology is doing for farmer (Harrington). 1894. 1.117. Yukon, report an (Myers). 1899. 1. 100

See relso Barometer-Blizzard-Climate-Climatolony-EclijoseMarine Meteorology Division - New lingland Neteorological Society - Pogonip - Sulphur rains - Sun spots - Weather.

Meteorology and the growth of the beet (Davy). 1879. 1). 284....

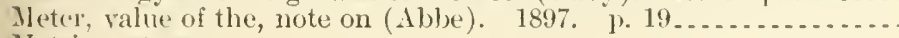
Metric: system:

Austria. 1878. p. 13\%.

English vs, notes on (ibie) 1901. J.

Explanation of-

1895. p. 614

1896. p. 6i34

1897. p. 672 .

A 1. 1:86:3

11.1:864

11.1:865

A 1.1:866

A1.1:867

A1.1:868

A 1.1:869

A $1.1: 870$

129.6:27

A29.6:30

129.6:25

A29.6:29

A29.3:21

A29.1:891 ${ }^{3}$

129.6:28

A 29.3:24

A $29.3: 24$

129.6:26

A29.8:91

129.6:30

129.6:29

129.6:27

129.3:11

A 29.6:29

A 29.3:112

129.6:2:

129.6:27

129.6:28

129.6:29

1 $29.6: 2 \mathrm{~S}$

129.6::2ti

1 1.10:894

129.6:27

$11.6: 28$

1:9.6:2:5

A.27.4:11

129)(i:2)

11. 10:84. 5

11. $10: 8.76$

11.10:897 


\section{Index}

Mexican cotton-boll weevil:

Present status of, in [". S. (Ihmter). 1901, p. $369 \ldots \ldots . . . . .$.

Report on-

1895. (Howard) same (in Spanish)

1siti. Revised

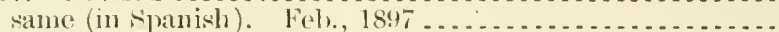

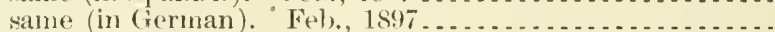

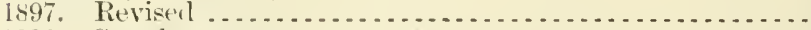

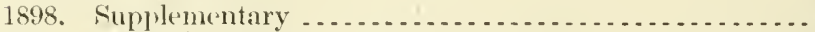

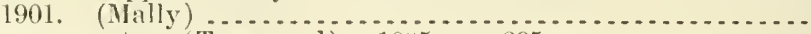

Texas, report on (Townsend). 1895. p. $295 \ldots \ldots \ldots \ldots \ldots \ldots \ldots$. See also Cotton insects.

Mexican grasses:

Collected by E. W. Nelson in Mexien, 1894-95 (Scribner and

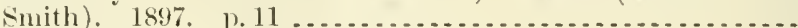

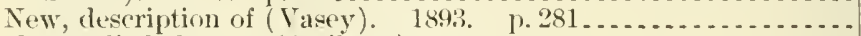

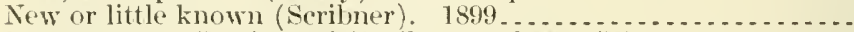

Some recent collections of (Seribner and Merrill). 1900. p.5...

Mexican national meteorological conguess-

1st, notes on (Abbe). 1900. 11.557.

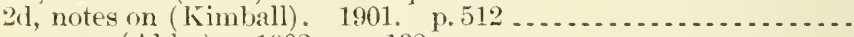
sante (Abbe), 1902. p. $132 \ldots . . . . . . . . . . . . . . . .2 .0$.

Mexican telegraph company, stations of, note on (Ab)e). 1900. p. 112

Mexican umbellifere, mostly from state of Oaxaca, recently collected by C. G. Pringle and E. IV. Nelson (Conlter and Rose). 1895. p.

Mexico:

Agricultural production of, for 1889 and 1892 . . . . . . . . . . . .

Agrienlture in, note on (1linton). 1884. No. 13. p. 27.......

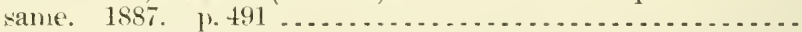

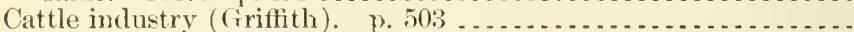

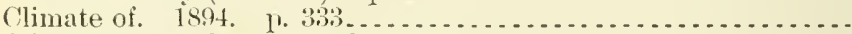

Climatologieal data, monthly, notes on, Jan., 1896-July, 1899

(Abbe); Sept., 1899-Oet., 1902 (Pastrana) ..............

Coast of, Septembe: "norther" on (Baturoni). 1892. 1. 252 ..

Coccida, new, eollecterl in, by C. H. T. Townsend, notes and

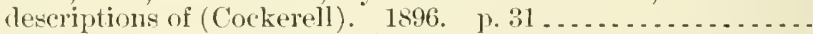

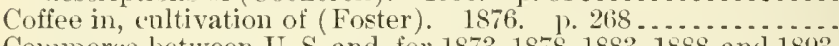

Commerce hetween U.S. and, for $1873,1875,1883,1888$, and 1893.

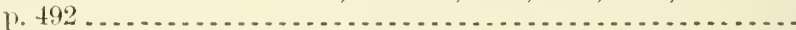

Cotton cropand its enemies in, consular reports on. 1855. Apl.

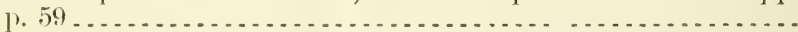

Ferns collecter in, by J. X. Rose during months of August and September, 1897 (Davenport). 1897. p. 146............ Insects affecting stored cereal and otler prodnets in (Chittenden).

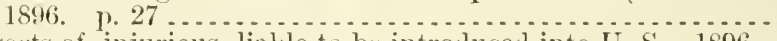

Inserts of, injurious, liable to be introduced into U. S. $1896 \ldots$

Insects of economic importance in, report of trip to investigate

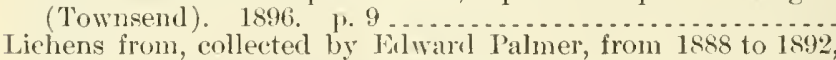
list of (Eckfeldt). 1893. 10. 291 ......................

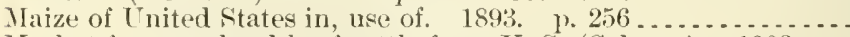

Market for pure-bred becif eattle from U. S. (Salmon). 1902 ....

Meteorology in, brief sketch of development of (Aquilar y San-

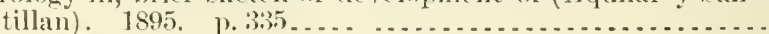
Sie also Mexican national meteorological congress.

Plants-

mostly new, from $T$. S. and, descriptions of (Rose), 1895.

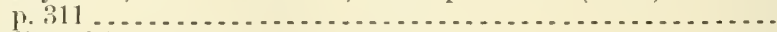
studies of (Rime). 1897. ग. 109.

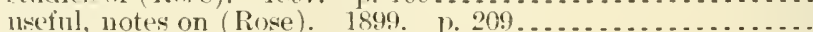

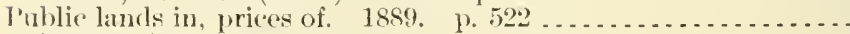

liailways of, statement of. 1s94. $\quad$ 1. $355 \ldots \ldots \ldots \ldots \ldots \ldots \ldots \ldots$

$11.10: 901$

$19.5: 6$

A $9.5: 6^{2}$

A9.5:14

$19.5: 14^{2}$

19.5:18

$19.5: 18^{2}$

A9.5:18 3

A9.5:27

19.5:3:3

A1.9:130

$19.7: 7$

A3.3:4

A6.5:1

A3. 4:19

A3.3:24

A29. $6: 28$

A 29.6:29

A29.6:30

A29.6:28

A6.5:3

427.9:32

A $27.9: 22$

A27.9:25

A $+1: 900$

A $27.9: 32$

A29.6:

A29.6:20

19.8:t

A27.9:14

A27.9:32

As. $1: 4$

16.5:5

19.8:4

19.8:4

19.8:4

A6.5:1

A 27.9:31

A $4.3: 41$

129.3:112

A6.5:3

A $6.5: 5$

16.5:5

127.9:27

$127.9: 32$ 
Storms, local, on trest coast of (Rogers). 1894. 1 $510 \ldots \ldots$

Water supply and irrigation in. 185i, p. 223............... Weather forecasts in, notes on $\left(\Lambda b b e^{2}\right)$. 1900. p. $540 \ldots \ldots . .$. Weather map for, daily (Abbe). 1899, p. 107.............. Weather stations, barometric pressure at (Abue). 1901. p.218. Western, list of plants colleeted in, by Edward Palmer in 1890

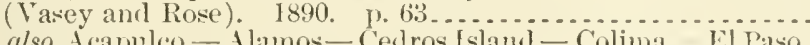
See also Acapuleo - Alamos-Cedros Island - Colima El Paso del Norte - inaymas - Lower Calitornia references Oaxaea - San Benito Island - Sonora - Tampico - Tres Marias Islands - Tuspan - Vera Cruz.

Mexico, City of, elimate of (Bárcena). 1896. p. 601 ..............

Mexico, Gulf of:

Cold waves on midtle enast (Garriott). 1895. p. 334 .........

Northers in, notes on (Abbe). 1898. p. $568 \ldots . . . . . . . . . . .$.

Storms of, tropical, in September, 1895 (Garriott). p. 167 .....

Neyer, Ifugo. Climatology in German Empire, development of. 1896. p. 652

Meyers, John A. Germany, shipping horses to, experience and observation in. 1898 . p. 35

Miami, No. (ilanders at, outbreak of (Trumbower). p. $457 \ldots \ldots$.

Hiee. See Erotomys - Grasshopper mouse - Jumping mice Pocket mice.

Michener, Ch. B.:

Horse-

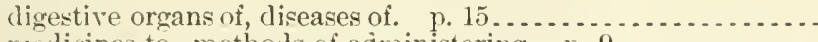

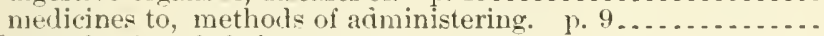
wounds of, and their treatment. p. $447 \ldots \ldots \ldots \ldots \ldots . . . . . . .$. Missouri, cattle in, outbreak of disease among. p. $387 \ldots . . .$. See also, as joint author, McLean, L.

Michener, E. Agricultural ornithology. p. $287 \ldots \ldots \ldots \ldots \ldots$. Michigan:

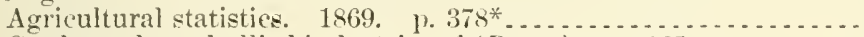
Cattle trade and allied industries of (Perry). p. 125 ......... Farm resources and products of. 1868. p. $189 \ldots \ldots \ldots \ldots \ldots$. Farmers' institute work aceomplished in (Taft). 1902. p. 35 . .

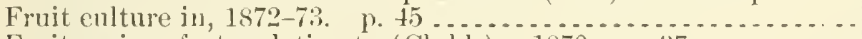
Fruit region, facts relating $t_{1}$ (Clubb). 1870. p. $37 \ldots \ldots \ldots$. Insects, injurious in, some notes recorded on (Townsend). 1889. P. 42

San Jose scale in, jresent status of (Barrows). 1897, p. $27 .$. Snow, yellow, in (Kimlall). 1902. p. 29 .................. Tornarloes of May 25, 1896, in, report on (Conger). p. 156.....

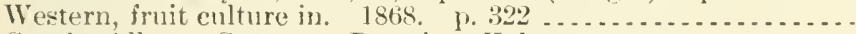
See also Allegan County - Detroit - Kalamazoo.

Michigan, Lake:

Eastern shore of, agricultural notes on. 1866. p. $415 \ldots . . . . .$. Fruits on eastem shore of, statisties of (Ganzhorn). 1869. ए. 298*.

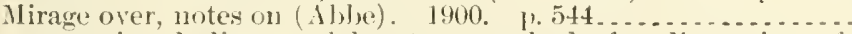

Vicro-organismal diseases, laboratory methods for diagnosing of

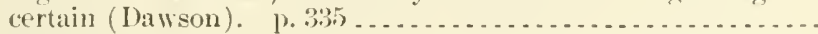

Vicro-photographs of snow crystals, notes on (Abbe). 1900. p. 5t1 . IFicroscopic investigations along agricultural lines, monthly (Taylor).

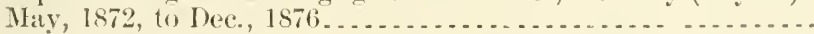

Mieroscopic inventigations as to internal parasites in domestic fowls, and butter and fats (Taylor). 1884

Mieroscopieal examinations of fruits and fruit prohucts (Ifoward). 19(1). - 1. 10:3

Microscopists, instructions for, in examination of pork for trichina. $1896^{\circ}$

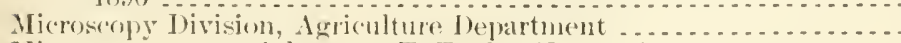

Mierotome, work of, letfer to T. Taylur (Lymain). 1881 ..........

Mierotus. See Voles, Anerican.

A $27.9: 28$

A29.6:2:

A $15.2: \operatorname{lr}^{1}$

129.6:28

129.6:27

A29.6:29

A6.5:1

A $29.3: 11^{3}$

A $29.6: 23$

A $29.6: 26$

A $29.6: 23$

A29.3:1 $11^{3}$

A1.2:1178

A $4.1: 884$

A $1.2: 1178$

14.2:1178

At.2:1178

A 4.1:889-90

A1.1:863

A27.9:7

A $4.1: 886$

A27.9:6

A 10.3:120

A27.9:13

127.9:8

19.7:2

19.6:9

A29.6:30

A29.6:24

A27.9:6

A27.9:4

127.9:7

A29.6:28

A4.1:8918

A29.6:28

127.9:

A1.8:34

17.3:66

1 $+.2: 1 ' 42$

A18.

$118.2: 1158$ 
Midille States:

Beef ('ittlo in, feeding (Lodge). p. 212 ... . . . . . . . . . . . . .

Fruits and fruit trees of, propagation, influence of stocks, diseases,

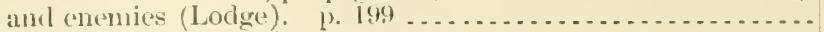

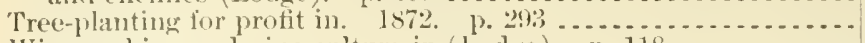

Wine-nuking and vine culture in (lodge). p. $118 \ldots . . . . . . .$. tre also Names of States.

Middling cotton. Sépe Cotton.

Migration of weeds (1)ewey). 1896. p. 263.................

Mik, Joseph. Terimyia sericarlie ronel, parasite of Japanese silk-

Milan, Italy, cost of hanling farm profucts over wagon roads at

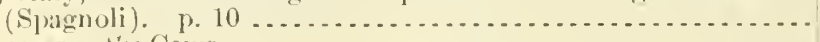

Vileh cows. ree Cows.

Milklew:

Notes on. 1863. No. 3, p. 13 . . . .

Upon plants moler glass, treatment of (Maynard). 1891 . p. 16
See also (irate miliew and references.

Miles, Nelom Appleton. Goorl roads, importance of, in war and

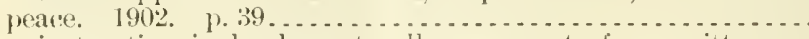

Military instruetion in land-grant colleges, report of committes on Milk:

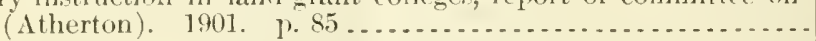

A cirlity in, determination of ( 'an Slyke). 1893. p. 117 ......

A(rility of cream and, letermination of (Hopkins and I'owers).

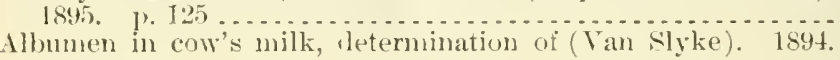

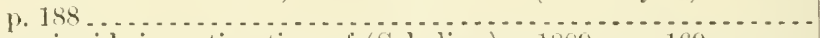

Albuminoids in, estimation of (S(d)elien). 1859. 1). $169 \ldots \ldots . .$.
Analysis of, with view to (letermining its adulterations (Boureart), $1889 . \quad 1 \% 167$

As food. 1898 .

Bacteria in freshly drawn milk, preliminary investigations fon-

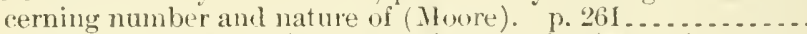

Bacteria in, inefleiency of separatos in removing (Moore). 1895. 1. 431 .

Bicarbonate of soda in, detection of (Pade). 1889. p. $170 \ldots .$.

Buston and other New England cities, supply of (Whitaker). 1898

Butter fat in cream or, method of determining, by difference (Mc-

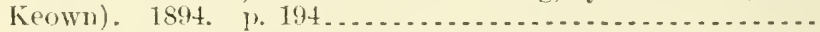

Canstart, report on ('witler). is90. p. $153 \ldots \ldots \ldots$

Care of, on the fam (Pearson). 1897 . . . . . . . . . . . . . .

Casein in cow's milk, (letermination of (Vanslyke). 1893. p. 109.

Citric acid in, report on (Soulhet). 1889. p. 155 ...........

City snpply of. p. 33.2 - . . . . . . . . . . . . . . . . . . . .

Composite samples in laboratory (Patrick). 1891, 1. 26 .....

Condensed-

composition of (Shenstone). 1890. p. 149.

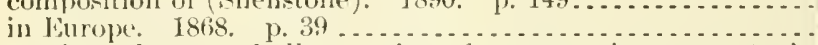

Crean fron deep or shallow setting of, conmuarative amonnt of.

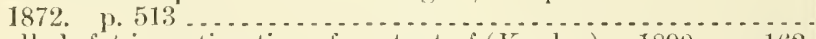

Curdled, fat in, estimation of content of (Kuehn). 1890. p. 162.

Diphenylamine reaction in examination of, significance of ( 1 iis-

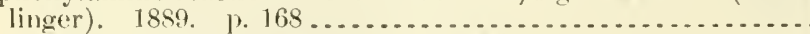

Examination of (De Schweinitz). p. 147 ...

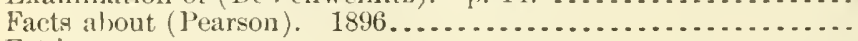

Fat in-

determination by-

gravinetric niethorl (Dietrich). 1890. p. 159.

Patrick mothod $1890,0 . . . . .$.

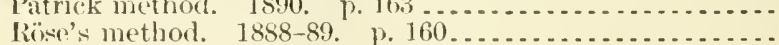

Soxhlet's areometric method (Klein). 1888. p. 163.....

Soxhlet-Lngström anl schmoeger-Neubert methoil

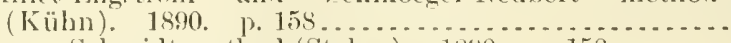

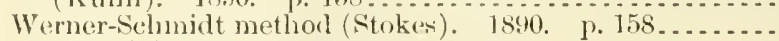
estimation of (Richmond). 1890 . 1) $162 \ldots \ldots \ldots \ldots \ldots \ldots \ldots$

A1.10:896

$120.4: 27$

А $27.9: 1$

128.5:6

122.3:25

A 10.3:99

17.3:38

A $7.3: 47$

A 7. $3: 43$

17.3:24

1 7. $3: 24$

A 1.9:74

14. $1: 895-6$

A 1.10:895

A $7.3: 24$

A $4.3: 20$

A 7.3:43

A $7.3: 24$

A 1.9:63

A 7.3:38

A $7.3: 24$

A 1.1:872

1 $7.3: 31$

A 7. 3:24

A $27.9: 6$

127.9:10

A 7.3:24

17. $3: 24$

A $4.1: 89$ ท

A1.9:42

A 7.3:2t

A 7.3:24

A 7.3:24

A7.3:24

A7.3:24

A 7. $3: 24$

17.3:24 
Fermentations and their relations to dairying. $1892 \ldots \ldots \ldots \ldots \ldots$
Fermentations of (Conn). $1892 \ldots \ldots \ldots \ldots \ldots \ldots \ldots \ldots \ldots$

Healthy and discased cows, effects of tuberculin injections upon.

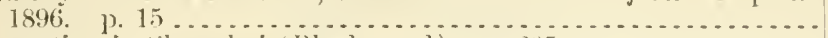

Inspretion in thanerhai (Blackwood). 1, 2015.............

Market, plan for its improvement (Pearson). 1. 15i.........

Nature of (Bechamp). 18!0. p. 154 ... . . . . . . . . . . . .

Pasteurization and sterilization of (De sohweinitz). 1894. 1.331.

Pastenrization of -

directions for. .

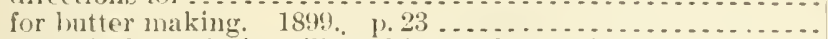

Pathogenic bacteria in milk and its products, vitality and retention of virulence ly certain (Dawson). p. 224 ...........

Preservation of, by pressure (lawson). 1899. p. 27..........

Productiontesting cows as to, some notes in connection with (scovell).

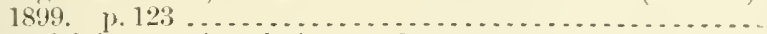
type of dairy cow in relation to (Lawson). 1901. p. 28. . . .

Qualities in, science of developing and perpetuating (Roberts). 1882 . 1). $86 j$

(quality of-

selling on basis of, how shall it be accomplisled in retail trade

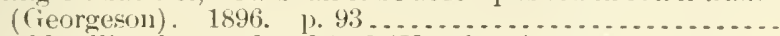
should sel]ing be reguiated by? (Voorhees). 18!6. 1.91 ...

Raw, pasteurized, and cooked, digestibility of. 1902. 1.27...

Ropy (ream and, examination as to cause of (Allen). 1899. 1. 26.

colicis and fat in, Balscock gravimetric method for determination of (drying with asbestos in perforated metal cylinder)

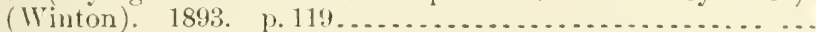

Solis in, calculation of total from per cent of fat and specific. gravitw, according to formulas of liabcock, Fleisehmann, and Hchner and Richmond, compared with gravimetric methol

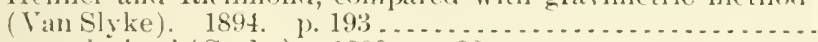

Somr, analysis of (Cooke). 1890. p. 22..................

Souring of, and other changes in milk products. $1895 \ldots \ldots \ldots$.

specific gravity ofdetermination of rise in, on allowing milk to stand after milking (Richmond). 1894. p. 191 .

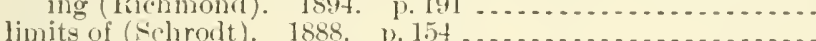

Sterilization or yastemization of, directions for $\ldots \ldots \ldots$

Test, standard, report on (Patrick). 1891. p. 123 ..........

Testingeream and, modification of Babcock method and apparatus

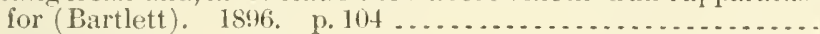

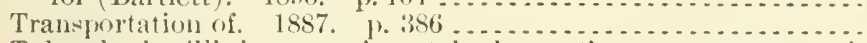

Tuberele bacilli in, experimental observations on presence of

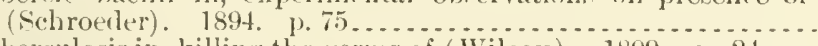

Tuberculosis in, killing thr germs of ( $\mathrm{Wilcox}$ ). 1899. p. $24 \ldots$

Tulerculous cows, tubercle baeilli in, some experimental obsep-

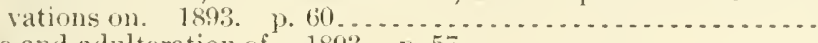

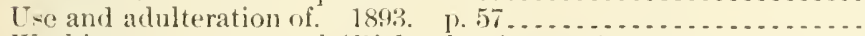

IF ashington, not nomal (Richamlson). 18s8. p. 24 ..........

Water to, quantitative letermination of addition of, and remosil of cream therefrom (Her\%). 1888. 1). $168 \ldots . . . . . . .$.

Sce also Foremilk - Skim milk.

Milk thom in Swerlen. jo. (i10.

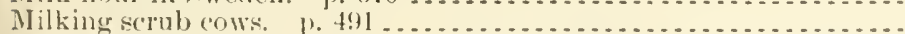

Millardet, Pierre Mare Alexis. Grapes, mililew ani rot of grapes,

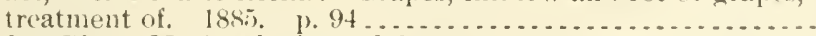

Millardet, P'ierre Marie Alexis, and Gayon - :

Copper, search for, on vines treated with lime and sulphate of copper mixture, and in laarvest. 1885. 1).116..............

Grape mildew, treatmont of, by mixture of sulphate of coplepe and

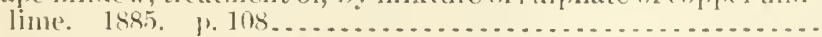

Grape vinc, mildew on, effects of, and influence of eflicint treat-

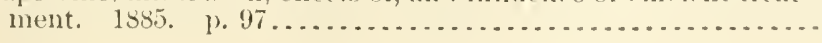

A1.9:4

A $10.3: 9$

$1+.3: 13$

14. 1:898

A $4.1: 900$

17.8:24

A 1.10:894

14.4:1

A1.9:4:

A $4.1: 898$

A 1.9:105

A 10.3:6.5

A 1.9:124

A $1.8: 2: 3$

A10.3:41

A 10.3: 41

A 1.9:1 49

A 1.9:10\%

A7.3:38

A $7.23: 4: 3$

A 7.:3:31

A 1.9:29

A. $3: 43$

A 7.3:24

A 4.4:1

A10.5:3

A7.3:49

127.9:25

14.3:7

11.9:107

A $4.3:: 3$

A 7.3:41

A7.3:19

17.:3:24

$14.1: 901$

14.1:898

$16.3: 2$

Ali.:B:?

A( $3.3: 2$

A6, 3:2 
Miller, Gerrit Smith, jr.:

Bats, North American, of iamily Tespertilionide, revision of.

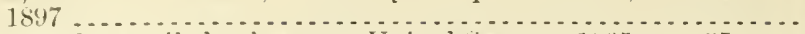

Shrews, long-tailed, of eatem Luited states. 1895. p. $35 \ldots . .$.

Voleg and lemmings, genera and sulgenera of. $1596 \ldots \ldots . . . .$.
Miller, If. K. Acil, normal, and alkali solntions, standardization

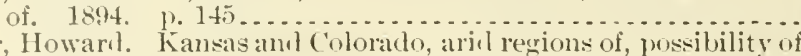

Miller, Howart. Kansas and Colorado, aril regions of, possibility of
reclamation of, by utilizing underlying waters. 1891. pt. 1.

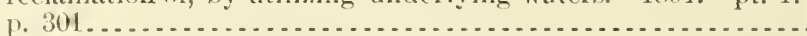

Miller, MI. F. Nee, as joint author, Lapham, J. E.

Miller, Nerritt Finley. Reaping machines, evolution of. 1902.... Miller, Wm. B. F. Pleuro-pneumonia in New Jersey, investigation

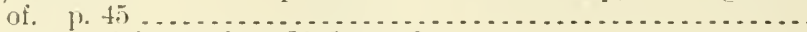
See also, as joint author, Miclean, I.

Miller, W. W. Ohin, tarmers' institute work accomplished in.

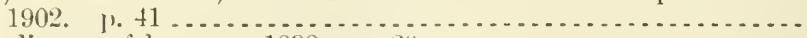

Millet disease of horses. 1898. 1. $20 \ldots \ldots \ldots \ldots \ldots$

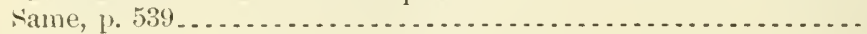

Nillets:

Composition of other forage plants and. 1898. p. 655.

Insect injury to (Chittenden). 1988. 1. $84 \ldots . . . . . . . . . .$.

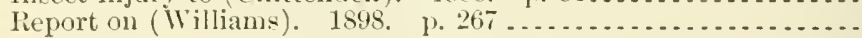
same Robert. Cricket, western, outbreaks of, and of certain

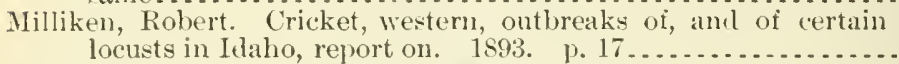

Milling, Hungarian, report on (Dewey). $1893, \quad$ p. $38 \ldots \ldots \ldots . . .$.

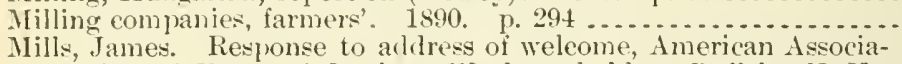
tion of Farmers' Institute Workers, hell at Buffalo, N. Y.,

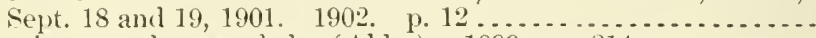

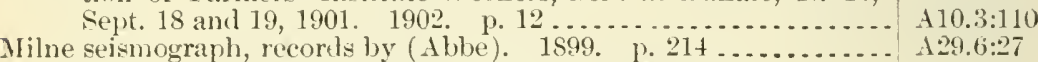

Milner, R. D. See, as joint author, True, Alfrerl ('harles.

Milton, Mass. Sie Blue Hill Meteorologieal Olservatory.

Milwankee, Wis.:

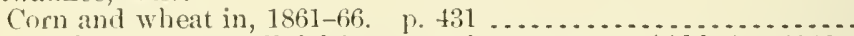
Weather Bureau officials' convention, notes on (Abbe). 1901.

Pl). $25,317 \ldots \ldots \ldots \ldots \ldots$
Mimosa bark or wattle bark, report on. p. $507 \ldots \ldots \ldots \ldots \ldots \ldots \ldots$ See also Wattle tree.

Mineral conditions and resources of U. S. (Newton), 186, ........

Mineral constituents of tubercle hacilli (De Schweinitz and Dorset). 1). 302

Mineral fertilizers. Sipe Fertilizers.

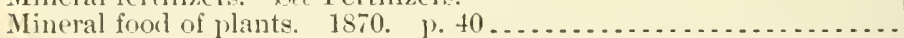

Wineral matter cleposited with snow in northern Indiana, Jan. 8,

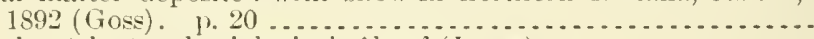

Mineral nutrients, physiological rôle of (Loew) ................

Mineral phosphates:

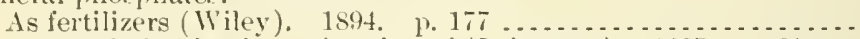
Iron and almmina in, estimation of (Lehmann). 1897, 1).61 ...

Mineral production, Britislı. 1873. p. 53: ..................

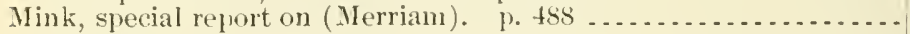

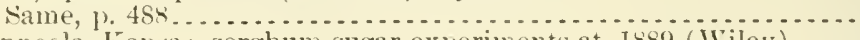

Minneola, Kansas, sorghum-sugar experiments at, 1889 (Wiley)....

Minnesota:

Farm resonrees and proulucts of. 1868. p. 198.............

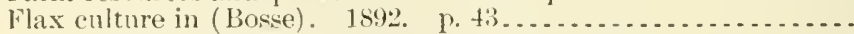

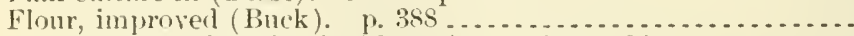
Horticultural education in (Green). 1898. p. $84 \ldots . . . . . . . .$. Isura and attendant pachybasium, note on speeies in (Macilil-

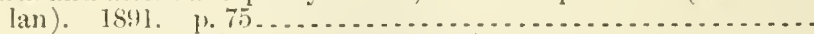

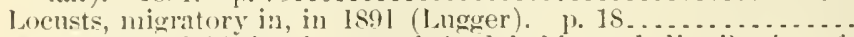
Mammals and lirils of parts of, tood habits and distrihution of

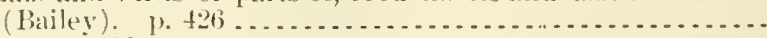

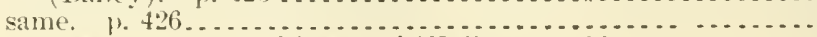
Resonres of, cte, brief history of (Kelly). p. $31 \ldots \ldots \ldots \ldots \ldots \ldots$

A5. $5: 13$

A. $5: 10$

A5.5:12

17.3:43

A 15.: $: \operatorname{Ir}^{2}$

A 10.:3:10:3

11.1:\$\$1-2

A 10.3:1: 20

A I.9:69

A $4.1: 598$

11.10:898

A9.6:17

1 $1.10: 898$

A1.9:101

A9.7:6

A27.9:31

A 27.9:28

A27.9:4

A $29.6: 29$

A1. 1:S78

11.8:1

A 4. $1: 598$

A27.9:S

$+29.6: 20$

A28.3:18

A 1. 10:59t

A7.3:51

A27.9:12

A 1.1:888

A5. 1:888

A $7.3: 26$

A27.9:6

A11.5:t

A 1.1:855

A 10.3:49

A $28.5: 6$

A $9.3: 27$

A1.1:S87

A5.1:887

A1.1:863 


\section{Minnesota-Continued}

Road building in, State aid to (Choate). 1898 .

Russian thistle and other tronblesome werts in wheat region of, 1893

Southern, blackl,irds and gophers in, lepreclations of, in fall of

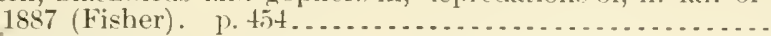

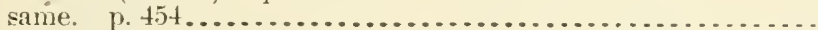

Wheat crop of-

1865. p. 12

1869. p. $144 \ldots \ldots \ldots$

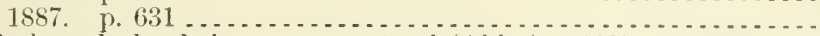

Winds and clonds in, movements of (ibhe). 1897. p. 252....

See also Juluth - Hennepin County.

Minnesota, University of, bread and bread making at, stuclies on, in

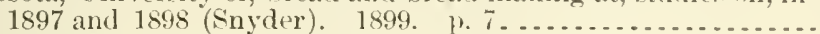

Same. 1899 and 1900 (Snyder), $1901 \ldots \ldots \ldots \ldots \ldots \ldots$

Minnesota good roads convention, St. Paul, proceedings of, Jan. 25, 26,1894

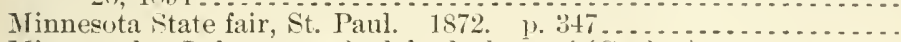

Minnetonka, Iake, watersherl, hydrology of (Cooley). 1899. p. 14.

Iinot, Charles Sedgwick, and Burgess, Edward. Aletia, anatomy of. 1885 . p. 45.

Minto, John. See, as joint author, Heath, H. A.

Mirage:

Note on (Abhe). 1900. p. 17

Over Lake Vichigan, notes on (Albe) 1900 p. 544

Mirobia and seiches, notes on (Ablue). 1s98. p. 562

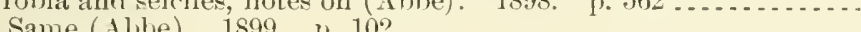

Mississippi:

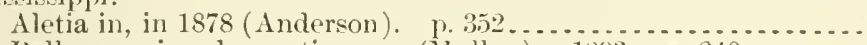

Boll worm in, observations on (Mullen). 1893 p. $240 \ldots \ldots .$.

Climate, soil, productions, and agrieultural capabilities of (Hurt).

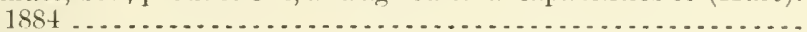

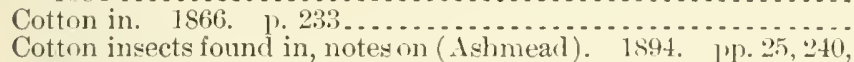

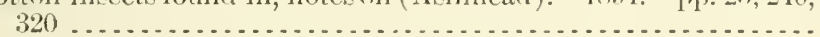

Delta of, differential grasshopper in (Morgan). p. 7 ...........

Entomological work of season in (Weed). 1891. p. $34 . \ldots . .$.

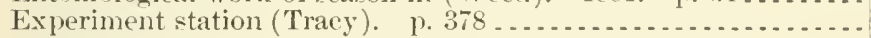

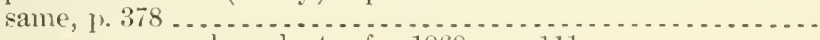

Farm resources and prorlucts of 1868 , p. $111 \ldots \ldots \ldots$

Hurricane on coast of, Ang. 13-16, 1901 . . . . . . . . . . . . . . . . .

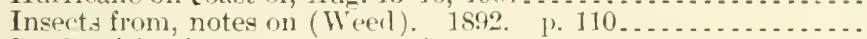

Stock raising in. 1869 , p. $299^{*} \ldots \ldots \ldots \ldots . . .6$.

Tea plant in. 1869. p. $301^{*} \ldots \ldots \ldots$

Tornarloes in (Enery), 1900, p, 499 . same (Emery). 1902. p. 265 .............................

Winter thunderstorms in, note on (Abbe). 1900. 1\% is .......

Seerlso Yazoo.

Missisippi rapids, fruit culture on the (Gregg), 1869, 1\% 225 .... Missis-ippi River:

Canal from, to Lake Borgne. 1870. 1. 357 ..............

Cattle interests west of (firinnell). 1.233.................

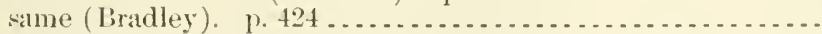

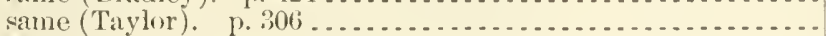

Flood, $A$ pr. 12, 1897 .

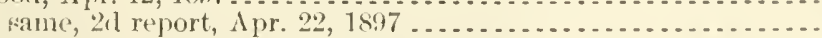

Flond and flood problems of (Frankenfiedd). 1899, p. 405 ...

Flood planes of (Orkerson). 1894. p. $81 \ldots . . . . . . . . .$.

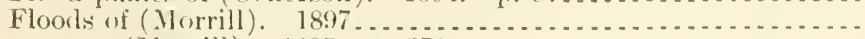

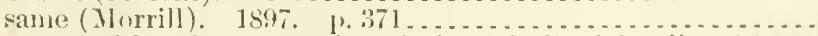
same, with reference to inumdation of alluvial valloy (rtall-

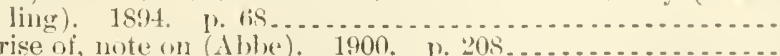

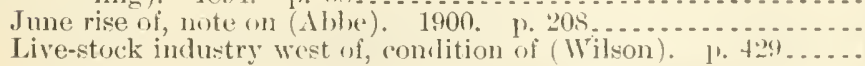

('lassiffation no.

A22.4:3:2

$11.9: 10$

A1.1:88

A5. $1: 887$

A27.9:4

A $27.9: 7$

A $27.9: 25$

A29.6:25

110.3:67

A 10.3:101

122.3:2

A27.9:10

A $29.6: 27$

18.1:4

A 29.6:28

A29.6:28

A $29.6: 26$

A29.6:27

A9.2:C82

A9.7:5

$11.7: 3$

A27.9:4

A9.7:7

A9.6:30

A $9.7: 4$

A 1.1:890

A6.1:890

127.9:6

A29.2:H94

19.7:5

A27.9:-

127.9:7

A29.t:28

\29.6:30

129.65:28

127.9:7

127.9:8

14.1:854

14.1:885

14.1:887-S

11.5:2

A1.5:3

A:9.6:2:-7

129.3:11

$129.5: \mathrm{L}^{2}$

Aะ9.1:597

A29.3:111

1.9.6:20

1.1.1:855

* By a misprint, this prize number apunars tuice. 
Mississippi River-Continned

hiver and thoud service, charts of area covered by, in April, 1897. Sherep industry west of, condition of (I heatl ). p. 247 .........

Missiswipli River and tributaries in periods of low water, importance of river-stage forecasts of (smyth). 1902. p. $146 \ldots . . . .$.

Misisipipi Valley:

Bircl nigration in, in 1884 and 1885 (Cooke). 1888.... . . . . . . Chinch bug in, early ocenrrence of (Forbes). 1859. p. 249....

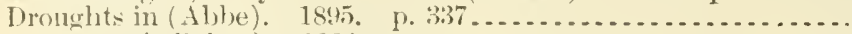

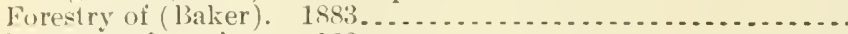

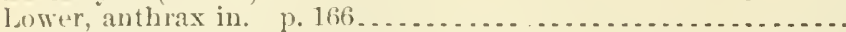

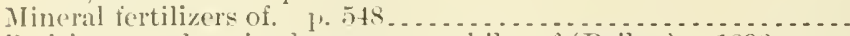
l'airie ground squirrels or spermophiles of (Bailey). 1893...... Frermophiles and pocket gophers of (Bailey). p. 185 .........

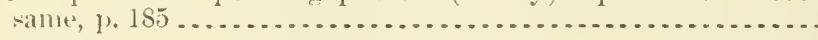
Ijunteriver gages in (Carlisle). 1902. P. 22:2. weather conditions in, effect of low atmospheric pressure in Mis-ouri:

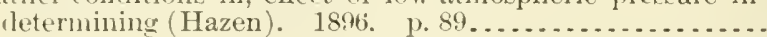

A 1.8:28

A $4.1: 897$

A 1. 1:869

A5.3:4

A 1.1:892

15.1:892

A 29.3:31

A29.6:23

Brearl and meat consumption in, data relating to (Gilson and

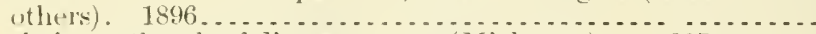
Cattle in, outhreak of disease among (Nichener). 1. 1.387 ....... Climate of, notes on (Hackett). 1899. p. $582 \ldots \ldots \ldots \ldots . . . . .$. (limatic divisions of, note on (Ahbe). 1900. J. $160 \ldots \ldots \ldots .$.

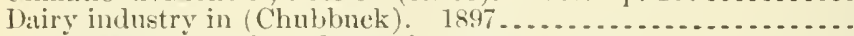
Farm resources and products of. 1868. p. 263................

Hailstorm in, severe (Hackett). 1898. p. 409 ............. Insects of. See Minrtfeldt, Mary E.

Movinur cattle from two northern tiers of counties in Arkansas into. Mar. $8,1899$.

Northwest, grasshopper injuries in, report on trip to investigate (Oshorn). 1893. p. 323 .

Roal improvement in, extract from governor's message (Ste-

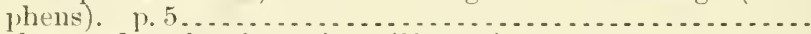

Southwest, drought of 1899 in. (Inzen.) p. 151 ............. Swine and fowl industry of, and ammual loss by disease (Bradley).

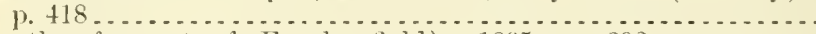

Weather forecasts of (Frankenfield) 1895. p. $292 \ldots \ldots \ldots$

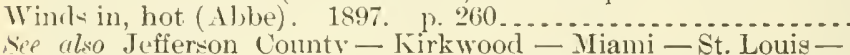
springfield.

Mi-souri, University of, dietarystudies at, in 1895 (Gibson and others).

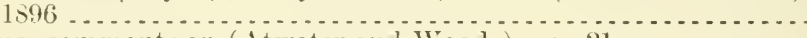

Same, comments on (Atwater and Woods). p. $21 . . . . . . . .$.

Missonli Experiment Station, irrigation experiments at, 1901

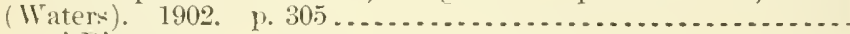

Misiouri River:

June rice of, note on (Abbe). 1900, p. 208...................

Wrater from, abstract of laws for acquiring titles to (Mead). 1899.

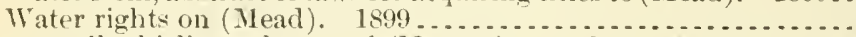

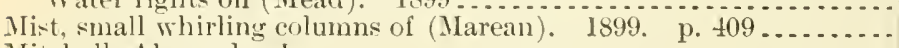

Mitchell, Alexander J.:

Climate and crop conditions, are changes in present forms for re-

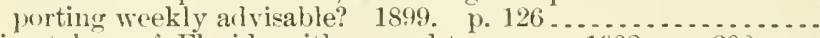

Climatology of Florida with regard to crops. 1902. p. $208 \ldots .$. State weather services, their importance and equipment. 1896. 1. 44 .

Weather forecast stations, voluntary, their object and collateral

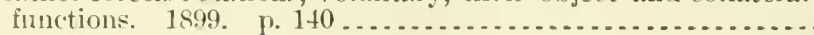

Mitchell, A.S. Extracts, flavoring, analysis of, provisional methods for. 1902. p. 69

Mitcluell, W. H.:

Clouds, cumnlns, formed by smoke. 1901. p. 498

Kite corps at Bayonne, N. J., recoris hy. 1900 . p. 539 . . . . .

Meteological ohservations du ring burning of plant of Standard Oil Company at Bayomne, X. J., July 5, 6, and 7,1900 . p. 325 ..

A10.3:31

A $4.1: 889-90$

A $29.6: 27$

A29.6:28

A $4.3: 18$

A $27.9: 6$

A29.6:26

A $4.5: 32$

$19.7: 5$

A22.4:33

A29.6:28

A4.1:885

A $29.6: 23$

A 29.6:25

A 10.3:31

110.3:31

A10.3:119

A 29.6:28

A 10.30:6

A $10.3: 58$

A $29.6: 27$

A 29.3:24

A29.3:31

129.3:18

129.3:24

A $7.3: 65$

A29.6:29

A29.6:28

A 29.6:28 
Mite:

Enemy of citrus trees (Marlatt). 1900. p. $247 \ldots \ldots \ldots \ldots \ldots \ldots . .11 .10:(100)$

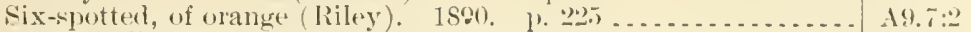

See rlso Blister mite - Clover mitr.

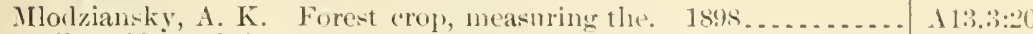

IIoffat, Edrinmel J.:

Crop prospects of Europe. 1883. No. 61, 1. 34: No. 64, 1. 28;

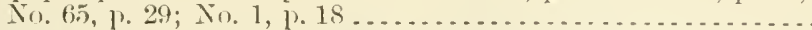

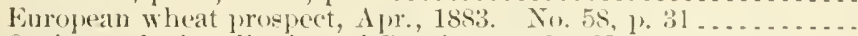

Grain producing districts of Russia. 1882. No. 51, 1, 14.....

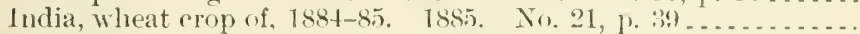

Mohair and mohail manufactures (Thompson), 1901, 1).271 ....

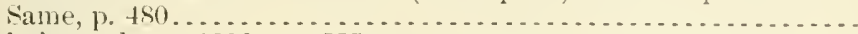

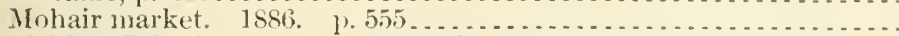

Mohler, John R. See, as joint anthor, Nörgaard, Victor Andreas.

Mohn, llenrik. Norway, climate of. 1896. p.647

Mohr, Charles:

Plant life in Alabama; prepared in cooperation with geological

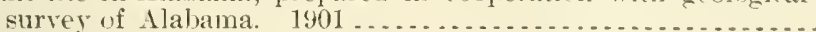

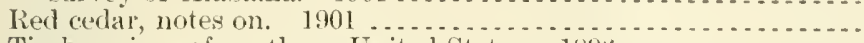

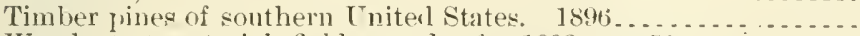

Woorls, test material, ficld records of. 1893. 1. $50 \ldots . . . . . . .$.

Hoisture:

Conditions, influence of, on process of germination (Detmer). 1895. 1'. 405

Determination of, experiments in (Ander:on). 1890. 1).93....

Distribution of, in Trited States (Hazen). 1899. p. 327......

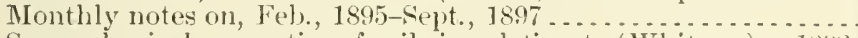

Some physical properties of soils in relation to (Whitney). 1842.

Tables of, report on (Marviu). 1898. 1.205...............

See also Atmospherie moisture - Soils.

Mokrzhetski, S. Bhool louse, olservations on cycle of suxual (levelop-

\section{Molasses:}

ment of, translated by P. Fireman. 1898. p. $78 \ldots . . . . .$.

Adulteration of sirup and (Wiley and others). 1892. 1. 63:3...

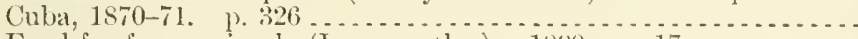

Food for farm animals (Langworthy). 1899) 1\% 17 . . . . . . .

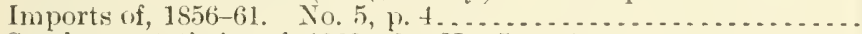

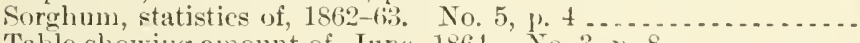

Table showiug amount of, June, 1864 . No. 3 , p. 8 ..........

Trate of Inited States, 1867-68. p. $16 \ldots \ldots \ldots \ldots \ldots$ Sipe also Sirup.

Mole ericket or rhanga in Porto Rieo (Barrett).

Mollusks. See Clam - Limax eampestris.

Molossus, new species of, from ('alifornia, description of (Merriam).

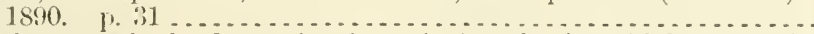

Molybrate mothod, determination of phosploric acid ly (Garri-

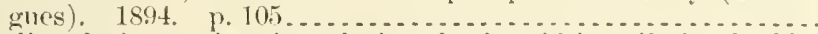

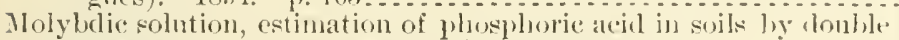
precipitation with (Willians). 1895. p. $82 \ldots . . . . . . . .$.

Nonace, Prince of. She Albert, l'rince of Nonaco.

Monchamp, $i$. Barometer, history of, letter relative to, comments

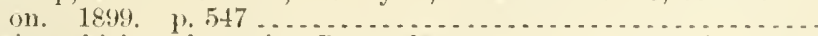

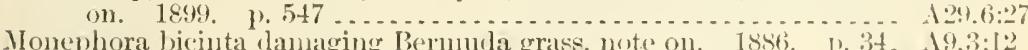

Monocotyledons of western Texas, description of (Coulter). 1 sil. p. 421

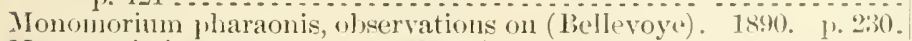

Monostegia jenota, report on (Mally). 1890. p.

Innostomulum lentis. Se Trematodes.

Monrar, Joln Il. 1)aily industry in Nebraska, Sionth Dakotal, and

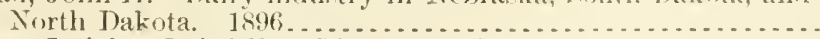

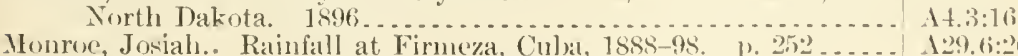

IIonroe Comnty, Iowa, agricultural statisticy of. 1869. 1).301* . . $127.9: 7$

Ionsoon lains:

Forecasting $(A b)(x)$. 184:. P. 21:3

113.:3:3

1 13.3:1?

$112.3: 8$

$.120 .9: 11^{2}$

$17.3: 28$

129. 1:498

129.6:

129.2:4

129.6:26

19.6:18

A7.3:18'

127.9:9

A1.9:107

A:-7.9:1

127.9:1

127.9:2

$127.9: 7$

A10.12:2

1.5.5:4

A7.:D:4:3

1. $.: 3: 47$

16.5:2)

19.7:2

19.7:3

A $29.60: 23$

* Вуя unisprint, this puge number apperars twire. 
Jonsoun rains-Continuel

Nile tloots and. 1900. 1). 824.

See rlso Indian monsonons.

Jonsoon region, Inilian, uyper currents of air above (Dallas). 1896.

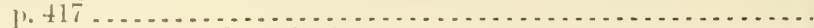

Montague, A. J. (iood roarls, how to secure. 1902. p. 36 ......

Montana:

Ierienltural notes on. 1566. I). 380

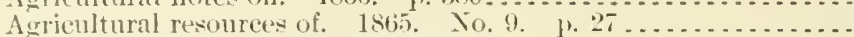

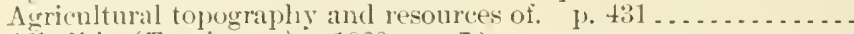

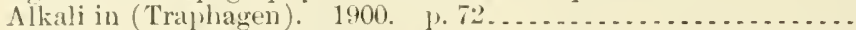

Chinook in (Ablue). 1895. 1. 426 . . . . . . . . . . . . . . .

Colle spell of Yov, 1896, in (Hazen), $1.414 \ldots . . . . . . . . .$.

Earthqnakes in, uotes on (Abbe). 1901. p. 175 ............

Erysiphese of, preliminary list of (Anderson). 1889. p. 156....

Forest conclitions of Rocky Mountains in (Ensign), 1) $41 \ldots . .$.

Fungi of, common, brief notes on few (Anderson). 1859. p. 30.

Irriuation in, in 1590 (Nimmo). p. 149

Irrigation investigations in (Fortier) -

1900. p. 267.

1001. p. 225 .

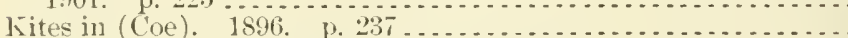

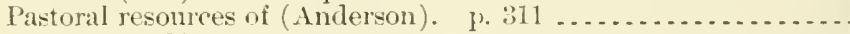

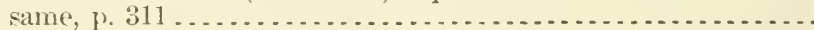

Plant poisoning of stock in (Wilcox). p. (41..

Stock-poisoning plants of, preliminary report (Chesnut and iril-

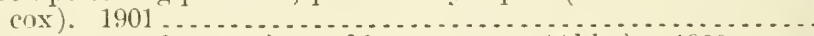

Temperature changes in, suddem, note on (Abbe). 1900. Pp.

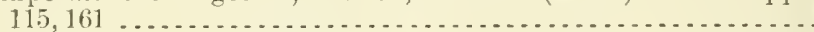

Water supply of, for scason of 1900 , as depending on snowtall

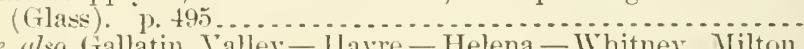

See also Gallatin Valley-IIavre - Helena - Whitney, Milton, and Means, Thos. H.

Ionterey County, Cal. See Salinas Valley.

IIonterileo, wool exports trom, in 1901. p. 607.

Iontgomery County, Maryland, Agricultural fociety, address betore

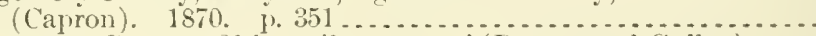

Jontgomery County, ohio, soil survey of (Dorsey and Coffey). P.

Iontgomery County, Tennessee, soil survey of (Lipham and Miller). p. 341 ..

Jonthly cropsynopis, Statistics Division, igriculture Department

Ionthly list of publications of $A$ grieulture Department. . . . . . . . . . .

IIonthly IV eather Reriew, French edition of, note on (Ahje). 1900.

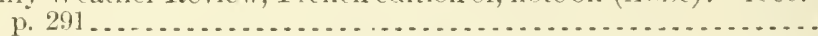

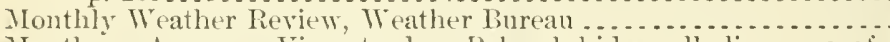

IIntlaur, Amaury, Ticomte de. Polysulphides, alkaline, use of,

Iron:

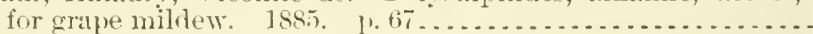

Aurora and, report on (Hazen). 189s. p. 108 ...................

Effect of, on vegetation, notes on (Kimball). 1901. p. 215....

Waltemath's (feorge), notes on (1 bbe). 189s. p. 19.......

Weather and, note on relation of-

1898 (Abbe). p. 569.

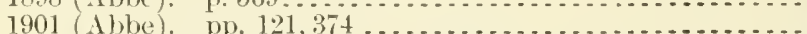

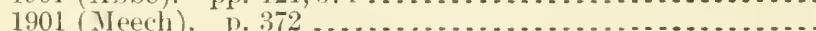

Iooney, Cliarles N., and Caine, Thonias $\mathrm{N}$. Soil survey of Prince Elward area, Tirginia. p. 259

Iooney, Charles N., Martin, F. O., and Caine, Thomas A. Soil sur-

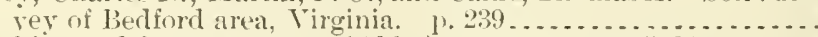

Momshine and frosts, notes on (Abbe). 1898 pp. $115,261 \ldots \ldots$.

Joore, C. C. Plant fond, available, plan for cooperating in study of. 1902

Inore, J. A. Jmmpy jaw, successul treatment of. p. $510 \ldots \ldots \ldots$

Moore, Veramus Alva:

Animal diseases; norploblogy, biolory, and pathogenic properties of 28 streptococei found in invertigation of. 1893 . p. 9.....

A:99.6:28

129.6:24

$\wedge 22.3: 25$

$127.9: 4$

A $27.9: 3$

A1.1:871

A 10.3:76

A 29.6:23

A29.6:24

A29.6:29

A28.5:5

113.3:2

A 28.5:5

A 15.2:P94 1

A 10.3:104

A 10.3:119

A29.6:2t

A 1.1:888

A6.1:888

A $4.1: 900$

A6.3:26

A29.6:28

129.6:28

At. 1:901

A27.9:870

126.5:900

A 26.5:901

127.7:

121.6:

A29.6:2S

A29.6:

A $6.3: 2$

A $29.6: 26$

A $29.6: 2$ ?

129.6:26

A $29.6: 26$

A $29.6: 29$

$+29.6: 29$

A26.5:9011

A 26.5:901 ${ }^{1}$

129.6:26

A7. $4: 9$

14.1:899

14.3:3 
Moore, Veranus Alva-Continued

Animals, domesticated, mpjer air passages of, pathogenie amb

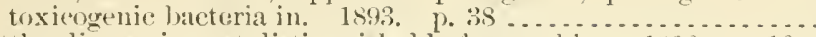

Cattle, disease in, mot distinguishable from rabies. 1896. 1. 10.

Cornstalk disease of cattle, nature, cause, and means of prevent-

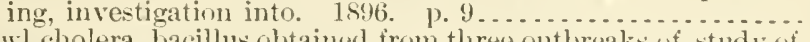

Fowl cholera, bacillus obtained from three outbreaks of, study of. 1895. p. 63.

Fowls, diphtheria in, preliminary incestigation of. 1895.7 .39$.

Hog cholera, can bacillus of, be increased in virnlence by passing

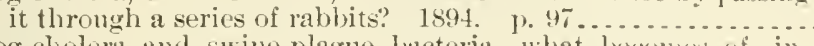

Hog-cholera and swine-plague bacteria, what berones of, injected in snall numbers into sulutaneons tis-ne of pigs. 1894. 1). 103

Leukremia, infectious, in towls, a bacterial disease frequently mistaken for fow] cholera. p. 185 .

Milk, freshly drawn, number and nature of bacteria in, prelini-

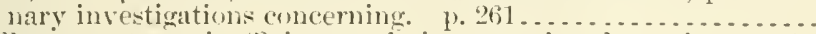

Milk separators, inetficiency of, in removing barteria. 1895.

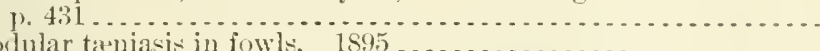

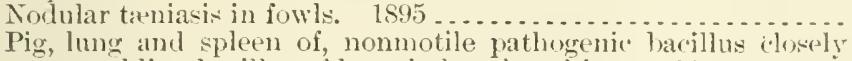
resembling bacillus of hog cholera fomm in. 1893. 1).81 ...

Pigeons, fatal disease of, pathogenie bacillus of hog-cholera group

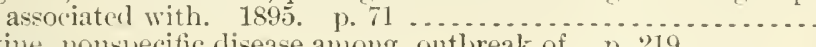

Swine, nonsulecitic disease anong, outhreak of. p. 219 ..........

Turkers, infectious entrohepatitis in, direct transmission uf. 1896

See also, as joint author, Smith, Theobald.

Moore, Veranus Alra, and Dawson, Charles Francis. Tuberculosis in swine; nature of disease, with report of three cases. p. 207.

Moore, Veranus Alva, and Fish, Pierre Augustine. Rabies in Washington, D. C. p. 267 .

Moore, W. H.:

iddress ofat international good roads congress, held at Buffalo, X. I.

Sept. 16-21, 1901. p. 5 ........................ hefore Jefferson memorial and interstate good roads convention, Apr., 1902. p. 21 ............................

Good roads and material progress, 1902 . p. $26 \ldots \ldots . . . . .$. Roarl subject, social, commereial, and economic phases of. 1900 . What is our duty? Address before international foor roals

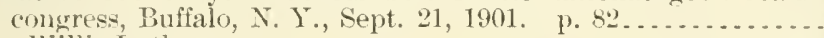
Moore, Willis Luther:

Adtress before convention of Weather Bureau oflicials, Omaha, Nelsr., Oct. 13, 1898.

Alaska, climate of. 1897 .

Aricl regions, some elimatic features of, communicated to lational

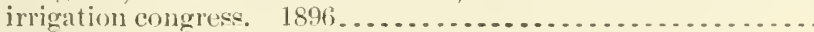

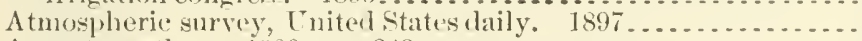

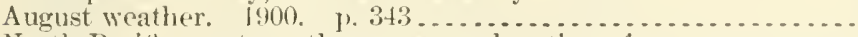

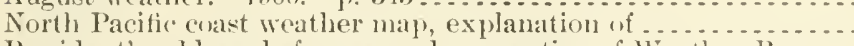

President's arddress before second convention of Weather Burean ollicials, Milwatuee, Wis., Ang. 27-29, 1901. p. 16.........

Weather Bureau, Agriculture Dejartment-

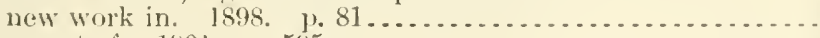
report of. 1901. p. 595

work of, for farmer. 1897 . 59 .

IVeather forecanting; some facts, historical, practical, and theorretical. 1899 .

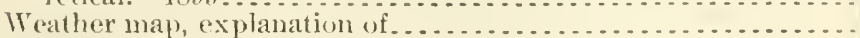

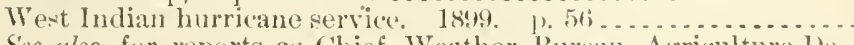

See wlso, for reports as Chief, Weather Burealu, Agriculture lopartment, $1895-1902$

Mowrhearl, J. K., Warder, Jno. A., and Jackson, Chas. Ropurt if

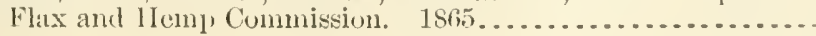


Moracherski, V. Russian zyemstros, conflict of, with enemies of acriculture; abstract fy P'. Firenan. 1902. p. 61 . . . . . . .

Morelos orange 1ruit-worm, report on (liley). 1sss. 1. t5...... Morgan, 11. i.:

Irtace punctistriga, some observations upon. 1901. 1\%. 15.2... (ilashopper, differential, in Mississippi lelta; other eommon

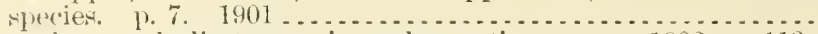
Mosifuito, conchyliastes musicns, observations upon. 1902. p. 113. ()il enulsions, simple device for preparation of. 1896. 1.93... sugar-cane borer, life history of, in Lomisiana. 1902. p. I2s... Moroceo, agrienlture of (Collins). p. 499 . . . . . . . . . . . . . . .

Inrrell, Robert. sheep, Hamphire Down, note on. 1868. p. 46:.

Morrill, Justin Sinith:

Legislative career of (Atherton). 1901. p. $60 \ldots \ldots \ldots \ldots . . . .$.

Resolutions of respect for, joposed for alloption of $A$ ssociation of American Agricnltural Colleges and Experiment Ftations, at 13 th annul conrention (Buckham). 1900 . p. 30 ......

Morrill, l'ark:

Areas, high and low. 1895. p. 157

Barometric pressure, reduction of, to sea level. 1896 . p. $492 \ldots$ Daily stages of principal rivers of United States. Pt. 5, 1893-95. Floods of Mississippi River, report on. 1897 . . . . . . . . . . . . wa11se. p. 371 .

Meteorological records, hourly, at Jikes Peak and Colorado Springs from November, 1892, to September, 1894, brief discussion of. 1896. T. 215

River and flood service, monthly notes on, Nov., 1896-May, 1s98. Temperature and pressure, rednetion of. 1897 . 1. $572 \ldots . . .$. Weather forecasts and storn warnings, notes on, May, 189s. p. 195

Morrill, l'ark:

Published works of (Abbe). 1898. p. 356 -

Short biography of (Garriott). 1898. p. $356 \ldots \ldots \ldots \ldots \ldots \ldots$

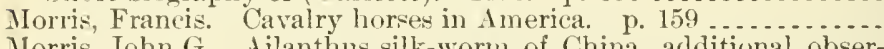

Morris, John G. Ailanthus silk-worm of China, additional obserrations on. p. 390 .

Iorris, Paschall:

Piggery, nodel, plan of. 1) 476

IVhite Chester breed of swime.

Morrisville, V'a., sorghum-sugar experiments at, 1889 (Wiley). p.

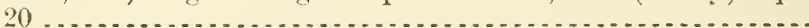

Same (Maxwell).

Morrow, George E.:

Adlress as acting president of Association of American Agricultural Colleges and Experiment Stations, at 8th ammul con-

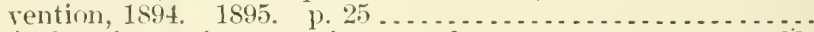

Agrienltural experiment station records, report on. 1891. p.102. Agricultural experimental work, relation of teaching to. 1891. p. 67 . . . . . . .

Animal husbandry in central West 1882 p. p. $62 \ldots \ldots \ldots \ldots \ldots$

Beef, loreeding and feeding for. 1883. p. 127 ...............

Butter, composition of, from Chicacro dairy show, Decenber,

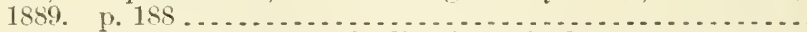

Cattle and swine rearing and feeding in United States, report accompanying exhibit of Animal Inclustry Burean, at Paris Exposition of 1889 . p. 405

Chicago, 11l., World's Agricultural Congress, report of committee

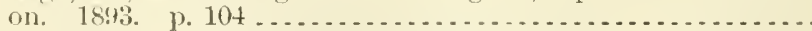

Norse, Eldridge. Tide lands of Washington Territory. Is85. p. 62 .

Morse, Fred WT. Phosphoric acid, insoluble, paper on. 1891. p. 106

Morse, Ger. W. Cotton caterpillar, letter on. 1867. p. 249.....

Morse, H. X., and Burton, W. M. Butter, oleomargarine, ete., anal-

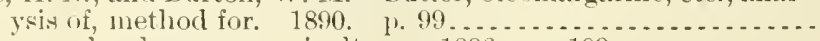

Mortgage, a burden upon agriculture. 1886. p. $189 \ldots \ldots \ldots \ldots \ldots \ldots$

Morton, Julius Sterling:

Addres, before Association of American Agricultural Colleges

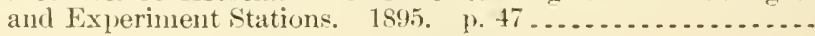

19.6:35

19.7:1

A 10.3:99

19.6:30

$19.6: 37$

19.6:6

\10.3:115

11.1:862

$127.9: 868$

$+10.3: 99$

A10.3:76

A29.6:23

A29.6:23

A29.10:5

A $29.5: \mathrm{E}$

A29.1:897

A29.1:896

A $29.6: 24$

A29.6:25

A29.6:26

A29.6:26

A29.6:26

A1.1:863

$.11 .1: 862$

A1.1:\$65

11.1:865

A $7.3: 26$

A $7.3: 26$

110.3:-94

1 10.5:3

A 10.3:-

$11.8: 2: 2$

$11.7: 2$

A. 1:859

At. 1:887-8

110.8:16

1 $1.7: 7$

17.3:31

127.9:5

A $7.3: 24$

127.9:24

A 10.3:24 
Morton, Julius Sterling-Continued

Arbor Day; its origin and growth. 1887. p. 22............ \$1.8:56

See also for reports as Secretary of Agriculture, $1893-1896$. . . . . . A 1.1

Mosaie disease of tobacco (Woods). 1902 _................ A19.3:18

Moses, Alfred G. Public improvement, citizens' duty to. 1902. I).

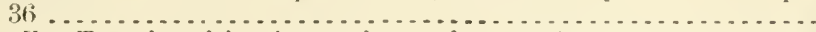

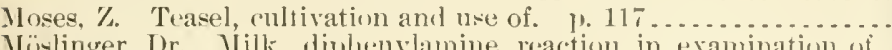

Möslinger, I)r. Milk, diphenylamine reaction in examination of,

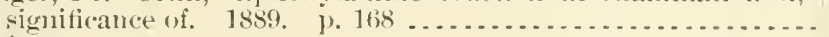

Mosquito:

Conchyliastes musicus, olservations on (Morgau). 1902. 1. 113. 19.6:37

Experiment against (Howard) -

1892. 1. 12

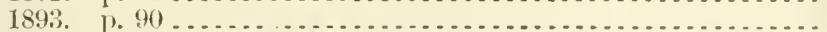

How to distinguish different, of North America (Howari) . ..... North American, synoptic tables of (Coquillett). 1900. H. 4...

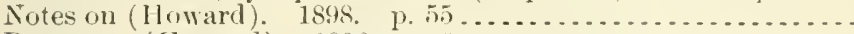

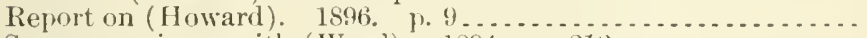
Some experience with (Weed). 1894. I. 212............... Structure and biology, notes on, with remarks on renedies

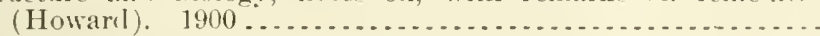

Mosquitoes and Heas, circular relative to (Howard) ...............

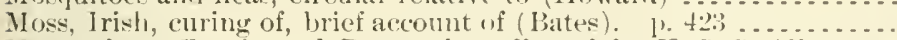
Mlosses from Fuegia and Patagonia, collected hy $\mathrm{C}$. S. S. Albatross Moths: in 1887-91, list of (Eaton). 1892. p. 138 ...............

Eqeriidie of central Ohio, notes on (Kellicott). 1892. 1. 81 ... A9.7:5 Fruit serionsly injured by (Mally). 1902. p. $90 \ldots \ldots \ldots \ldots \ldots$ A9.6:31 See also Angommois grain moth - Bombycide - Brown-tail moth - Cabbage moth - Calothysanis amaturaria-Clothess moths - Commelina owlet moth - Drasteria erechtea - Endiupta owlet moth - Epliestia interpunctella - Geometrid moth-Gipsy moth-Grain moth-Hepialus argenteomaculatus-Herbarium pest-Leopard moth-LepidopteraLepidopterous larvie - Mediterranean flour moth - Noctuidae-Oncoenemis - Orgyia lencostigma-Osage orange pyralid-Peach-tree borer-Porthetria dispar-Potato-tuber moth - Privet web-worm - Protoparce carolina - Pyralid Pyralide - Pyralidina-Spilosoma fuliginosa-SphingidaSquash borer-Sugar cane borer-Theophila mandarinaTussock inoth-Wood-leopard motl.

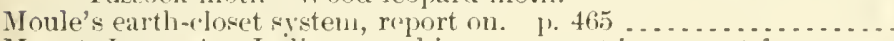
Mount, James A. Indiana, road improvement in, extract from gow-

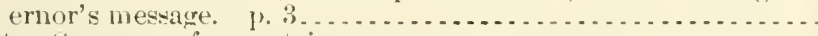

Nount. hee name of mountain.

Ilountain peaks, minimum temperatures on (Al,be). 1899. 1. 4:1. A 29.60:27

Mountain roads. See livads.

Iountain shadow, photograph of note on (Abbe). 1894. p. 510.. Mountain slopes, precipitation on, theory of formation of (Pockels).

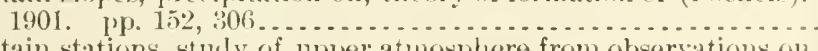

Mountain stations, sturly of upper atmosphere from observations on

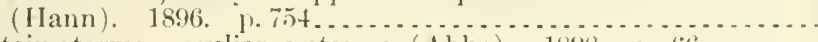
Mountain storms, peculiar, notes on (Abbe). 1898. p. $66 . . . .$. Mountains:

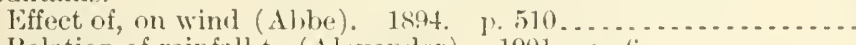
Relation of rainfall to (Alexander). $1901, \mathrm{I}, 6 \ldots \ldots \ldots \ldots \ldots$ See ulso Appalachian - Cascade-Coeur d'Alene.

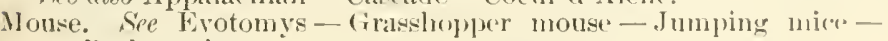
Pocket mice.

Mouth disease of cattle. Sire Foot-and-mouth disease of rattle.

Ionton flanlrin sheep, Texel sheep or, report on (Chenery). p. 242. \$1.3:864

Muck or peat, value of. 1901. …..................... 11.9:149 sice also Soils.

Mucronoporus, report on (Ellis and Everhart). 1889. 1.90_..... Same, new (Ellis and Galloway). 1889. 1. 141 ...........

Mucronoporus Andersoni, report on (Ellis and Everhart). 1891.

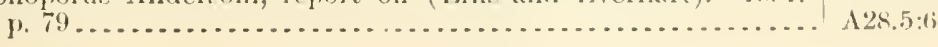

$114-04-28$ 
Minu, mains oi, notes on (Athe). 1899. p. 158............... A29.6:27

Mueller, Charkes. Cattle, I)utch or Holstein. 1873. 1. 175...... A27.9:11

Mulnlenberir, II. Grasces of herbarim of (Feribner and IIerrill).

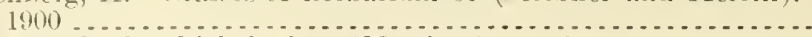

Mulberries, birds which feed on (Merrian). p. $255 . . . . . . . .$.

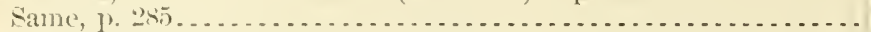

Milberry silkwom, report on (Riley) ser alion silkworm.

Mulere, Enile. Tobaces, cultivation of, in Sumatra. 1898

Mules:

Diseases of, correspondence relating to. 18\$8. p. $537 \ldots . . .$. Gilanters among, in Texas (Folsetter). 1. 393..............

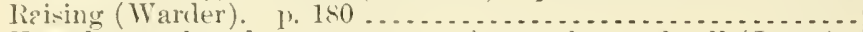
[ses, how to breed, grow, prepare for market, and sell (Jones). 1. 335. see relso Farm animals.

Mull, Cieorge. Arbor Day, ralue and uses of. I'. 29

II ullen, S. li. Boll worm, olsservations on, in Missisipini. 1893.

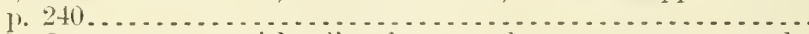

In miel, Germany, cost of hauling farm products oier wagon roads

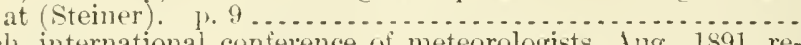

Munich, international conference of meteorologists, Iug., 1891, report of (Abbe). p. 6206

Same, 1. 626.

13.4:27

A1.1:890

15. $1: 890$

19.3:9

11.8:58

A 4. 1:1898

A $4.1: 889-90$

A1.1:\$63

14.1:891-2

A $1.8: 56$

A 22. $4: 27$

A 1.1:891

129.1:8912

Ifunich, meteorological congress, 1892 ; international weather symbuls recommended for use (Harrington) ................... . .

Munroe, Ralph M. Pineapple fiber, results of recent investigations

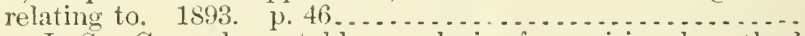

Munson, I. S. Cannerl vegetables, analysis of, provisional methor

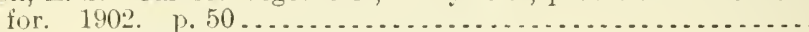

See also, as collaborator, Bigelow, Willard Dell.

Munson, L. S., and Tolman, L. M.:

Fruits and fruit products-

analyis of, provisional method for. 1902 . p. $74 \ldots . . . . .$. (hemical examination of. 1902. p. 9 ..................

IIunson, T. V.:

Grape-vine, downy milkew and black-rot of, treatment of, with salts of copper at Denison, Texas, in 1887 . p. 23 ........

Grapes, wild, of North America, classification and generic synopsis of. 1890 .

Muntz, A. Grape mildew, treatment of, by sulphate of copper.

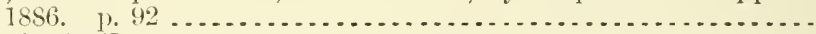

llurilocl, L. H.:

Precipitation, eveles of. 1902. p. 482

[Tah, water supply of, for season of 1900 , as depending on snow-

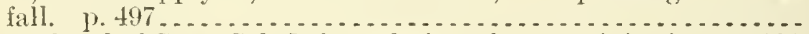

Water level of Great Salt Lake, relation of, to precipitation. 1901.

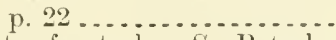

Muriate of potash. See Potash.

Murkland, Charles S. Engineering experiment stations, report of committee on, before convention of American agricultural colleges and experiment stations. 1898. p. 32.

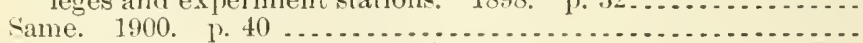

Murphy, Charles J. Maize, introduction of, into Europe. 1891.

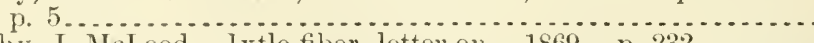

Murply, J. MeLeod. Ixtle fiber, letter on. 1869 p. $232 \ldots . .$.

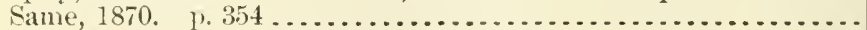
Iurray, A. J.:

Cattle-

ligestive organg of, diseases of. p. 15

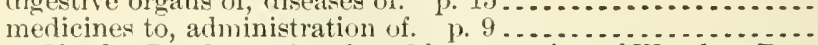

Murray, Charles B. Remarks of, at $2 \mathrm{~d}$ convention of Weather $\mathrm{Bu}$ reau officials, Milwaukee, Wis. 1901. p. 224 ............ Murtfeldt, Mary l: :

Acorn insects, primary and secondary. 1894. p. 318 Cheese or meat skipper. $1843 . \quad$ p. $170 \ldots \ldots . . . . . . . . . . . .$. Drought, heat, and insect life. 1902. p. $97 \ldots \ldots \ldots \ldots \ldots \ldots \ldots \ldots$ A29.2:InS

A11.5:5

A7.3:65

A $7.3: 65$

A 7.3:66

A6.3:5

A20.3:3

A6.3:2

$129.6: 30$

A $29.6: 28$

A29.6:29

A10.3:65

A10.3:99

A1. $8: 49$

A27.9:7

A27.9:8

A $1.2: \mathrm{C}_{29^{2}}$ A $4.2: \mathrm{C}^{2} 9^{2}$

A29.3:31

A9.7:6 A9.7:6 A9.6:31 
Entomological memoranda for 1893. 1894. p. $257 \ldots \ldots \ldots \ldots . .49 .7: 6$

Grape bags, use of, by paper-making wasp. 1891. p. 192...... A4.7:t

Graftodera foliacea, life-history of. 18s8. p. $74 \ldots \ldots . . . . .$. A . . . $7: 1$

Missouri, injurious insects for season-

1886. p. 59 . . . . . . . . . . . . . . . . . . . . . . . .

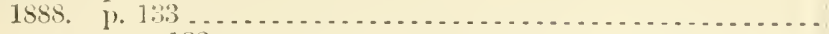

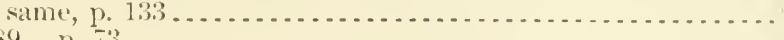

1889 p. 73 .

1890. p. 45 . . . . . . . . . . . . . .

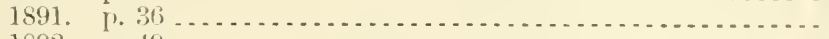

1892. [. 49 .

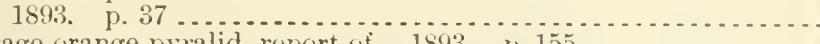

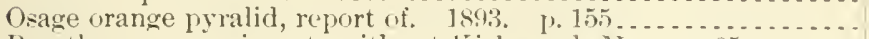

Pyrethrum, experiments with, at Kirkwod, Mo. p. 85 .......

Same, p. 85 ...........

Serew worm, hominivorons habits of, in st. Loinis. 1891. p. 200.
Stibadium spumosum, habit of 1894 . p. $301 \ldots \ldots \ldots \ldots \ldots \ldots$

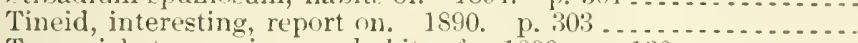

Tree crickets, carnivorous habits of. $1889 . \quad$ \% $130 \ldots \ldots . . . . .$.

Nuscatel raisins, production of, in Malaga (Mark). 1875. p. 319 .

Muscular energy, source of, metabolism of nutrient. in animal borly and (Zuntz). 1897. I. 538 .

Muscular work:

A! $1.3: 13$

A1.1:858

19.1:688

$19.3: 2: 2$

19.3:2:3

$19.3: 26$

$19.3: 30$

19.3:32

19.7:5

A1.1:S81-2

A9.1:852

A9.7:4

A9.7:6

A9.7:2

A9.7:2

A $27.9: 13$

A $10.6: 7$

Experiments on effect of, upon digestibility of foor and metabolism of nitrogen, conducted at University of Temessee, 189799 (Wait). 1901

Experiments on effect of, upon digestibility of food and nuetabolism of nitrogen (Wait). 1902 .

Severe and prolonged, effect of, on foorl consumption, digestion, and metabolism (Atwater and Sherman). 1901.

Mushroms:

A. food. 1898. p. 18 .

Becls for, directions for preparing and spawning of (Falconer). p. 17

Edible and poisonous, reference list of publications relating to

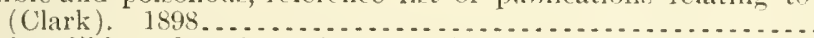

Eight edible and twelve poisonous, of United States, with directions for culture and culinaty preparation of edible species (Taylor). P. 366

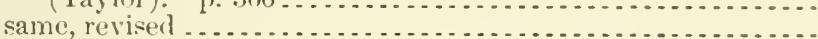

Enemies of, and experiments with remedies, notes on (Busck). 1902 . p. 32

Four edible, of United States (Taylor). 1893. p. $7 \ldots \ldots \ldots \ldots$

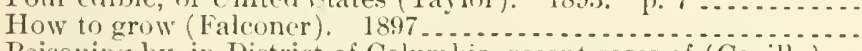

Poisoning by, in District of Columbia, recent cases of (Coville)...

Ieview of industry (Falconer). 1894. p. 20................ Twelve edible, of United States, with directions for identification and preparation as food (Taylor). 1, $100 \ldots \ldots . . . . .$.

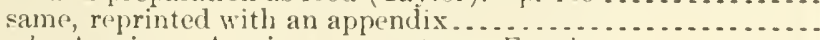
See also Igarics - Agaricus campestris - Fungi.

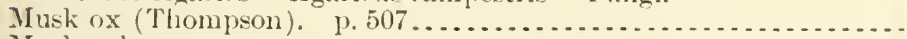

Muskntelons:

Fertilization of, by insects, notes on (Rane). 1898. p. $75 . . .$.

Transplanting, experiments in (Smith). 1900. p. $20 \ldots \ldots .$.

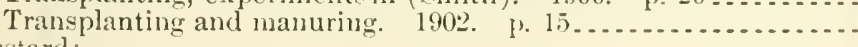

Mnstard:

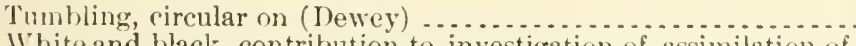
White and black, contribution to investigation of assimilation of
free atmospheric nitrogen by (Lotsy). 1894

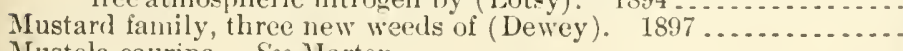

Mustela caurina. See Marten.

Mutton:

Feeding for, in South Dakota (Chileott and Burnett), p. 471... At.1:S:18 Raising sheep for (Curtiss). 1899....................... $11.9: 96$ See also sheep. 
Mycological literature, North American, inctex to (Fairehild). 1891.

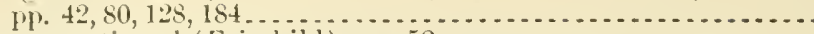

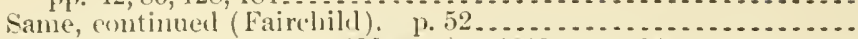

Mycological notes, report on (Massee). 1889. p. 184............

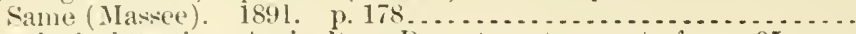

Mreological section, dericulture Department, report of. p. $95 \ldots .$.

Mycologr, jomrnal of, devoted to sturly of fungi, especially in their relation to plant diseares . . . . . . . . . . . . . . . . . . . . . . . .

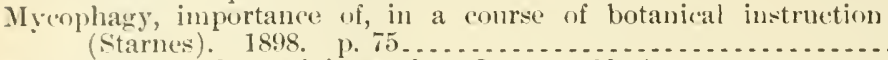

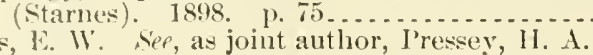

Myers, E. II.

Actiress of, as president of Association of Official Agrieultural Chemists, at sixth annual convention. 1889 . p. 8 .........

Agricultural experiments stations, organization ant methods. 1889. ए. 99 . . . . . . . . . . . . . . . . . . . . . . . .

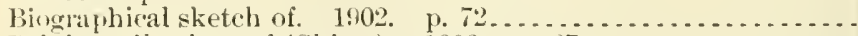

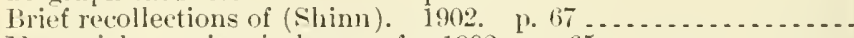

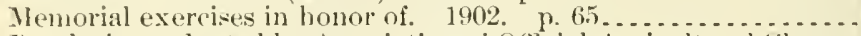

Resolutions adopted by Association of Official Agricultural Chem-

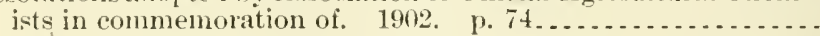
Mrers, Li.:

Klondike, Weather Burean observations in. 1898. p. 209.....

Meteorology of Yukon, report on. 1899. p. $100 \ldots \ldots \ldots \ldots \ldots$.

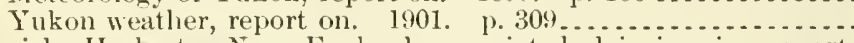

Iyrick, Herbert. New England, assoeiated dairying in, report accompranying exhibit of Animal Industry Burean at l'aris

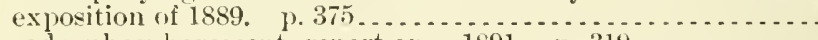

Myriopods, phosphorescent, report on. 1891 p. p. $319 \ldots \ldots . . . . . .$.

Mytilaspis pomorum, new parasite of (Howard). 1894. p. 25ti....

Tagana, or tsetse-fly disease (Kanthack and others). ․ 140...... Nagle, J. C.:

Engineering courses, some objections to early differentiation of.

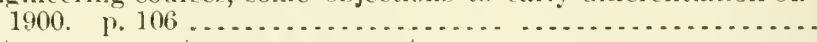
Silt measurements, progress report on1891. 1. 293

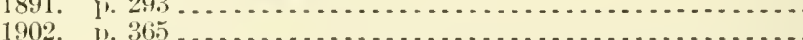

Nall, I. B. Kentucky Farmers' institute, work acomplished in.

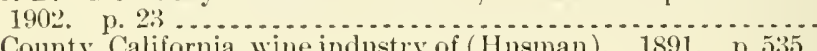

Napa County, California, wine industry of (Husman). 1891. p. 5.35
Napthaline, as an insecticide, etc., its effect on seeds, plants, and animals ('Taylor). 1883.

Nash, George V. American ginseng, its ('ommereial, history, protec-

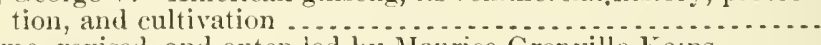

Same, revised, and extenied by Manrice Grenville Kains........

National Bureau of Standards, circular of information relating to

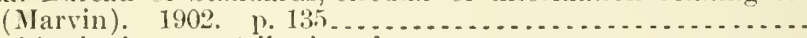

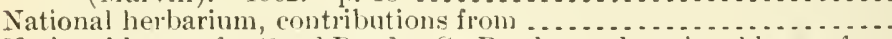

National League for Good Roads. See Roads, good, national league for.

National road conference. See Asbury l'ark, N. J.

National road parliament. See Road parlament.

Natural history:

Queen Charlotte Islands, British Columbia, and Cook inlet region, Alaska (Osgood). 1901 . . . . . . . . . . . . . . . . . . . . .

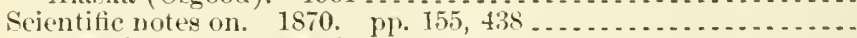

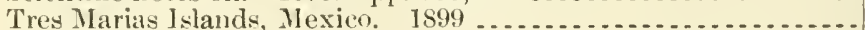

See also Names of animals.

Naval engineermg, hill to establish and maintain courses in, report "f committee of Association of American Agricultural Colleges

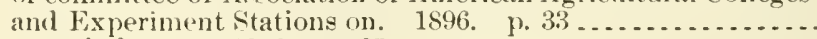

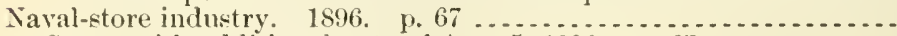

Same, with additional note of Ang. $5,1896 . \quad$ p. $67 \ldots \ldots \ldots \ldots$ Navigation:

Inland, monthly notes on, July, 1891-Oct., 1896.

Work of meteorologist for benefit of (Bigelow). 1899. P. 71...

Navigator, marine nephoscope and its nsefulness to (Abbe). 1894. 1. 161

A.5.5:21

A27.9:S

A $5.5: 14$

A 10.3:41

A $13.3: 13^{1}$

A 13.3:13 2

A 29.6:

A $1.10: 899$

A29.3:11 1 
Neal, J. C.:

Cotton and orange insects, report of olservations and experi-

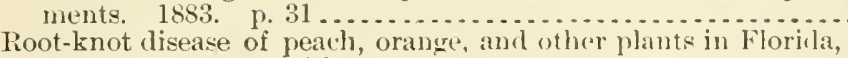

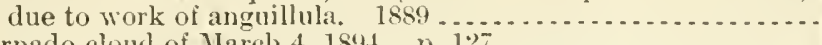

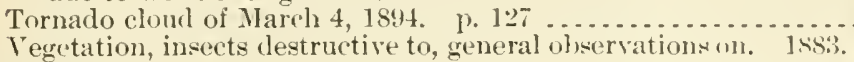

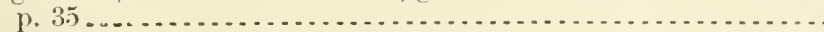

Neale, Arthur T.:

Anthrax in Delaware, combating. 1. 190

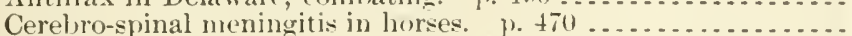

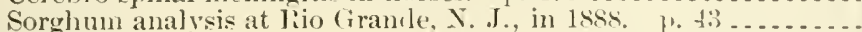

Nealley, G. C.:

Collertion of plants marle by, in the recion of Rio (irancle, Texas, from Brazos Santiago to El Paso County (Coulter). 1890.

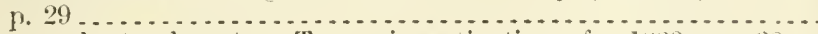

Forace plants of western Texas, investigation of. Is\$8. \%. $30 .$. Neat cattle. See Cattle.

Nebraska:

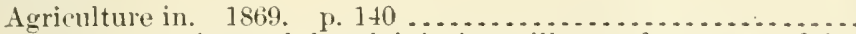

Cimbex, American alults of, injuring willow and cottonwod in

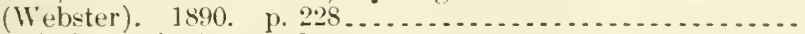

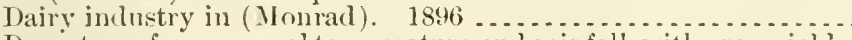

Departures from normal temperature and rainfall, with crop yields

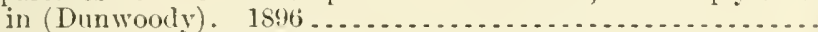

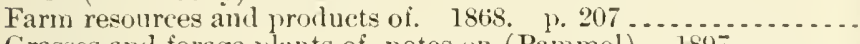

Grasses and forage plants of, notes on (Pammel). $1897 \ldots . . .$.

Grasses of arid districts of, investigation of (Vasey). 1856 . . . . .

Insect injuries in-

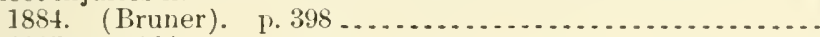

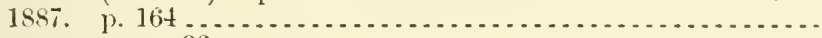

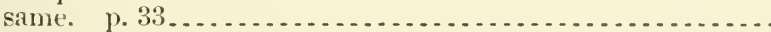

1888. p. $139 \ldots \ldots \ldots$

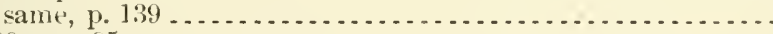

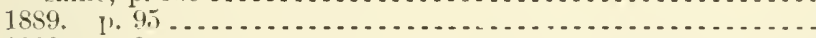

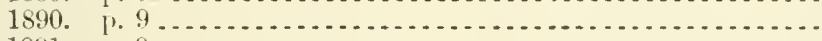

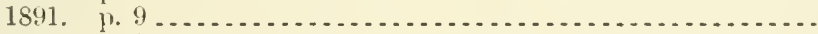

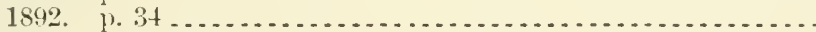

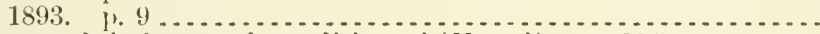

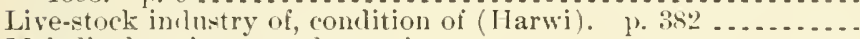

Maladie du coit among horses in-

extirpation of ( Forgaard). ए. 62.

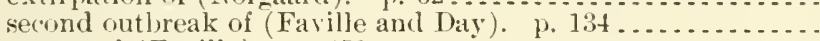

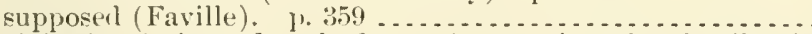

Preeipitation (rain and melted snow) at stations in, details of. 1894

Rabies in, alleged, investigation of (Gibbs). p. 188...........

Sand hills of, flora of (Ryilberg). 1895. p. $133 . . . . . . . . . .$.

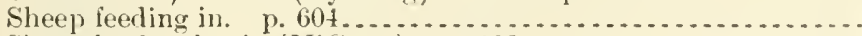

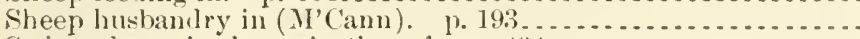

Swine plague in, investigation of. p. $434 \ldots \ldots \ldots \ldots$

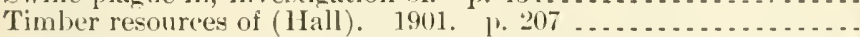

Underflow and shcet waters, irrigable lands, and geolocical structure of, with its effect upon water supply (Hicks). 1893.

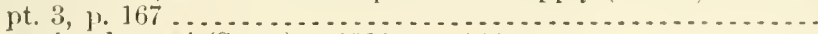

Water in, duty of (Stout). 1900. p. 149..................

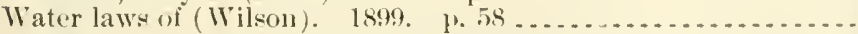

Western-

benefits of Weather Bureau to (1'iercy). 1899. p. 144...... pocket gopher of genus Geomys from, deseription of ( 1 (e)riam). 1890 . 11. 51

Wheat in. 1867. p. 366.

See also Cass Comnty - Cireat Fastern Canal-shuler.

Necropluagous rliptera, notes on species of (Webster"). "1590. p. 3ist.

Nectar, what it is, and some of its uses (Trelease). p. 319.........

Nectarophora destructor. Sere Green-pea louse.

Needlam, Daniel. Agriculturat exhilution at Hamburer. 1. 19...

19.3:20

A $29.6: 22$

19.3:1

A $4.1: 897$

A $4.1: 899$

1. $3: 20$

16.5:1

A6.:\%:6

$+27.9: 7$

A.9. $7: 2$

A $4.3: 16$

129.2:1727

A27.9:6

13.3:9

A6.3:1

A1.1:884

A1.1:887

19.3:13

A1. 1:888

19.1:888

A9.3:22

19.3:23

19.3:26

19.3:30

$19.3: 32$

14.1:\$8́9-90

14.1:893-4

A+.1:899

14.1:891-2

A29.2:P(1) ${ }^{1}$

14.1:897

A6.5:?

At. 1:901

11.1:86t

A $1.1: 855$

11.10:901

115.2:11\%

$110.2: 86$

110.3:58

1:9.3:24

1.5. $5: 4$

127.9:5

19. $7: 2$

19.2:( 82

11.1:8ti3 
Neely, Samuel T. Traction tests on publie roads. 1896. A22.3:20

Negrues:

Dietary studies among, in eastern Virginia, 1897 (FrisselJ). 1. 7. A10.3:70 same. 1898 (Bevier). 1. 27 ...................... $110.3: 70$

Fond of, in Alabama in 1895 and 1896 , dietiry studies with refer-

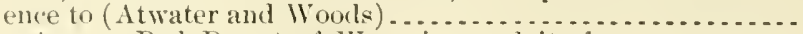

Selson, Aren. Red Desert of 11 yoming and its forage resonrces.

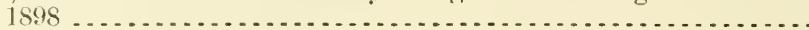

Nelson, Elward William:

Mexican grasses collected by, in Mexico, 1S94-95 (Scribner and

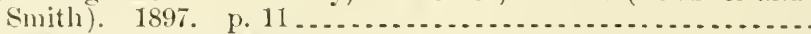

Tres Marias Islands, Mexico-

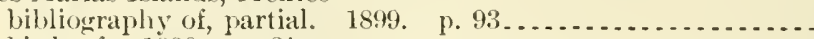

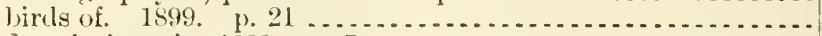
description of. 1899. p. 7

mammals of. 1899. p. 15.

See also, as collector, Coulter, John M., and Rose, Juseph Nelson. Nelson, S. 13.:

Horse industry of the Northwest. 1900. p. 23.

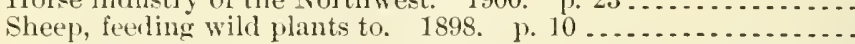

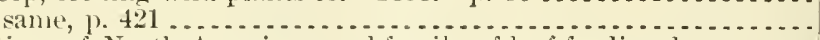

Nematince of North America, a subfamily of leaf-feeding hymenoptera of fanily Tenthredinidre, revision of (Marlatt). I896...

Tematode leaf disease, note on (Atkinson). 1891. p. 31 ........

Nematoid worm. See Anguillula aceti - A phelenchus olesistus.

Neosho, Mo. See Jaeger, Hermann.

Nephoscope, improved, report on (Marvin). 1896. p. 9

See also Marine nephoscope.

Nervisequum. See Glwosporium nervisequum.

Tervous system:

Diseases ofof cattle (Harbaugh). p. 111.

of horses (Trumbower). p. 181

Nesbit, D. M. :

Sweet potatoes.

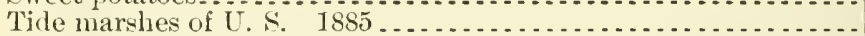

Ness City, Kansas, sorghum-sugar experiments at, 1889 (Viley) ...

Same (Mcliny). p. SI . . . . . . . . . . . . . . . . . . . . . .

Nessler, J. Grape mildew, copper soda and copper gypsum as reme-

Nest box for keeping individual egr record (Langworthy). 1900. p. 19.

Netherlands:
Agricultural statistics of. 1886. p. 406

1 $10.3: 38$

$\$ 3.3: 13$

A3.3:4

A.5.5:14

A5.5:14

A5.5:14

A5.5:14

A1.9:117

A $4.3: 22$

A4.1:89S

A9.8:3

A9.7:4

A $29.6: 24$

Agriculture in. $1869, \quad$ p. $387 \ldots$

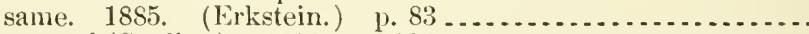

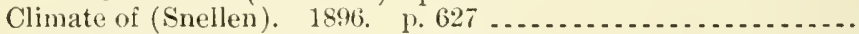

History of high farming as illustrated in (Tilden). p. $527 \ldots . .$.

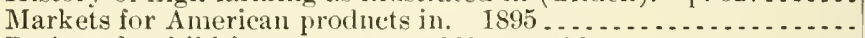

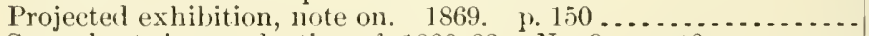

Sugar beets in, production of, $1866-82$. No. 9 . p. $46 \ldots \ldots \ldots \ldots$ See also Amsterdam - Amheim.

Nettle:

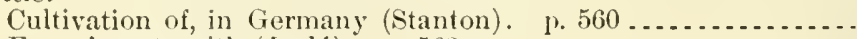

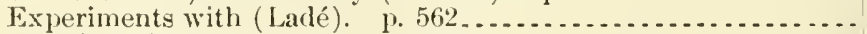

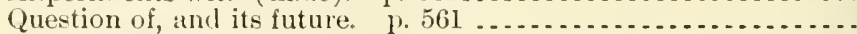

Nettleton, Edwin S.:

Artesian and underflow investigation hetween ninety-seventh degree of west longitude and foothills of Rocky Mountains. 1891

Artesian and molerfow investugation, final report of. 1893. Pt.2. Artesian wells investigation, field work in. 1890 . p. 31 ....... Reservoir system of Cache la Poudre Valley, report on. 1901....

Neumann-Spallert, F. X. von:

Cereal erops of Austro-Hungary, value of. 1883. No. 64. p. 66. A27.9:21

Grain, commerce in, 1879-81. No. 14. 1. 35................. 127.9:22 
Nevada:

Classlficutlon no.

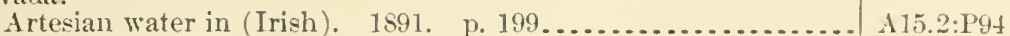

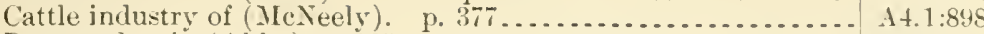

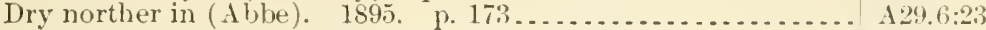

Farm resources and products of. 1868 , p. $271 \ldots \ldots \ldots \ldots \ldots . . .27 .9: 6$

Fisles of Death Valley expedition, 1891, collected in, report on, with descriptions of new suecies (filbert). 1893. y. 2:29.

Land and fresh-water shells colleeted in, by Death Valley expedition (Stearns). 1893. p. 269

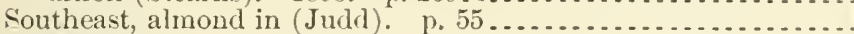

Southern-

birds observed in, by Death Valley expedition of 1891, notes

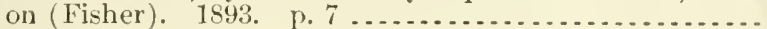
cactuses, yuceas, and agave in deserts and desert ranges of, geographic and vertical distribution of (Merriam). 1893.

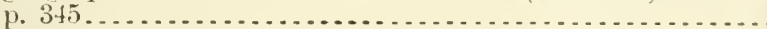
trees and shrubs in deserts and desert ranges of, distribution

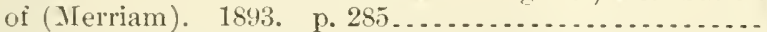

Stratigraphy and hydrology of (Hicks). 1890 p. $71 \ldots \ldots \ldots . .$.

See also Carson City - Humboldt County - Nye County - Winnemucea.

New Brunswick:

Earthquakes in, notes on (Abbe). 1898. p. 266.

Thunderstorms in, 1897 (Kain). p. 105 P.

Tidal lands and diked marslies of (Boardman). 1855. p. 33...

Whirlwinds in, notes on local (Kain). 1900. p. $458 \ldots . . . . .$.

Lew England:

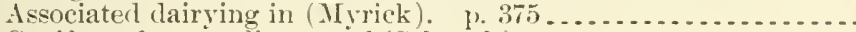

Conifers of, some diseases of (Schrenk). 1900

Farming in-

does it pay? p. 187

report on. p. 255

Land birds of, oology of some, as a means of identifying injurious

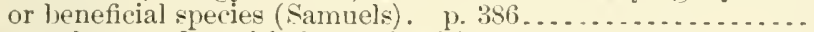

Mammalogy and ornithology of, with reference to agricultural

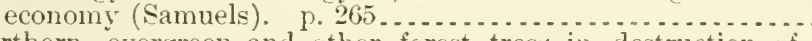

Northern, evergreen and other forest trees in, destruction of, causes of (Packard) -

[1st] report. 1883. 1. 138 . same, 1). 138.

$2 \mathrm{~d}$ report, p. 374

3 il report, p. 319

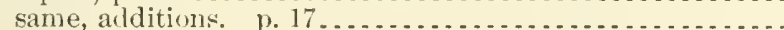

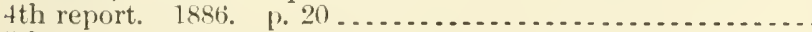
5 th report. $188-$

Quarantine of eattle, sheer, and other ruminants, and swine. 1902

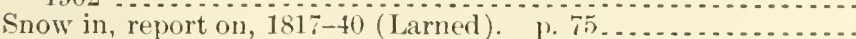

Southern, and other localities, relative humidity of (Henry). 1896

Sugar beet, eulture of (ICiiurtrie). 1879. p. $181 \ldots \ldots$

Thunderstorms in, investigation of (Ward). 1893. p. 30 - . . . New Ingland Meteorological Society, $36 \mathrm{th}$ regular meeting of, notes on (Abbe). 1896. p. 13.

New Hampshire:

Farm of J. B. Walker, at Concord. 1870. ए. $76 \ldots \ldots \ldots \ldots \ldots \ldots$

Farm resources and products of. 1868. p. 5.

Forest condition and lumber and wood trale of (Hongh). 1884. p. 348 .

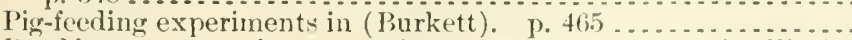

Road improvement in, cxtract from governor's megsage (Rollins). P. 5 .

Wheat growing in (Bartlett). p. 96

See also Hampton Peach - Vashington. Mount.

New Haven, Conn., windsand rainfall of, 1873-1900 (Davis). ). 261.

A29.6:26

A29.6:26

A1.7:7

A28.6:28

A4.1:857-8

128.3:25

A1.1:8it

A $1.1: 870$

$11.1: 864$

A1.1:863

A1.1:853

Ay.1:853

A1.1:884

A1.1:855

A9.3:12

A9.3:13

A8.1:4

A $4.5: 99$

A29.6:22

A 29.3:19

A1.6:28

129.3:9

A 29.6:24

A $27.9: 8$

$127.9: t$

1 13.5:4

A 4.1:899

A $22.4: 3: 3$

1 $1.1: 86 \%$

A2!.ti:30 
New Jersey:

Abutilon avicenna in, ("ultivation of (Waterhouse). p. 606

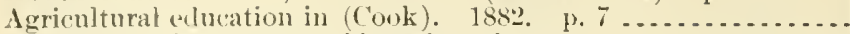
Army worm in, aceount of invasion of1880 (Lockwood). J. 139 1881 and 1882. p. 101.

Cattle in, anthrax among (Hunt). y. 359 -

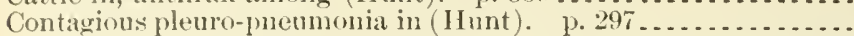

Cranberry culture in (Taylor). y. 5tis . . . . . . . . . . . . . . . . .

Feonomic peronosporeie for $1889 \mathrm{in}$, some notes upon (IIalsted).

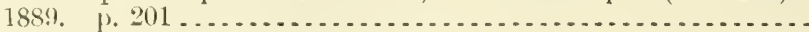

Farm resources and produets of 1868 . p. $15 \ldots \ldots \ldots \ldots$

Farmers' institnte work accomplished in (Voorhees). 1902. 1.37
Food and nutrition investigations in, 1895 and 1896 (Voorhees).

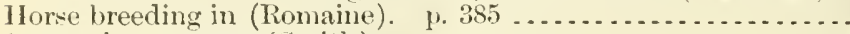

Insects in, notes on (smith) -

1891. p. 43

1892. 1. 93

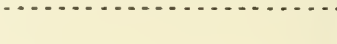

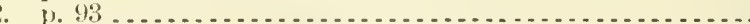

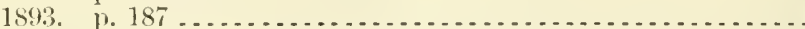

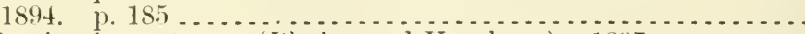

Irrigation in, notes on (Phelps and Voorhees). $1897 \ldots . . . . .$.

Irrigation in, report on (Voorhees) -

1900

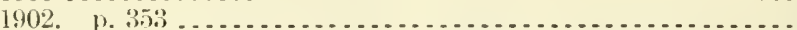

Pleuro-pnemonia among cattle in, investigation (Miller). p. 45.

Rame (Corlies). p. $46 \ldots \ldots$. . . . . . . . . . . . . . . . . . . . . . .

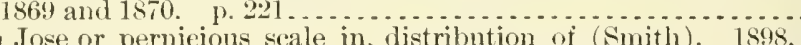

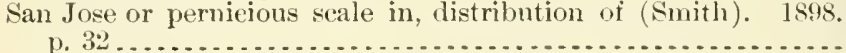

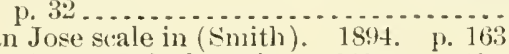

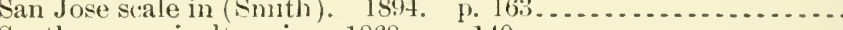

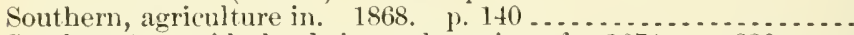

Sonthwestern, tiıle lands in, reelamation of. $1870 . \quad$ p. $230 \ldots . .$.

State aid to road builling in (Burrough). 1894 ..............

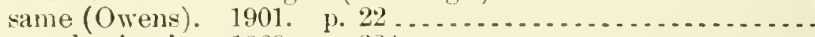

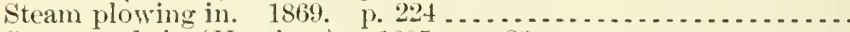

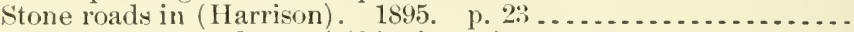

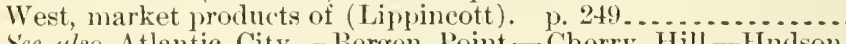
Sie also Atlantic City - Bergen Point - Cherry Hill-Hudson
County - Long Branch-Oakland - Rio Grande-Salem Trenton - Vineland.

New Mexieo:

Agricultural features of (Furnas). 1892. 1. 173.............

Agrieulture of, notes on (Thomas). 1869. \%. $379 *$

A1.8:20

A $27.9: 7$

Anthrax in, outloreak of (Melean). 1851, p. $317 \ldots \ldots . . . . .$.

Artesian basins in, geological eonditions of (Van Diest). 1890. p. 87 .

Artesian well investigations, field work (Carpenter). 189t. p. 233.

Chilo sacharalis in (Townsend). 1891. p. $24 \ldots \ldots$

Climaticand agrienltural features of, note on (1 lilgard and others): 1882

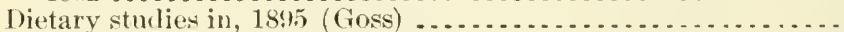

Fastern, artesian and underground waters in, west of 97 th mericl-

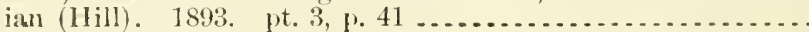

Entomologieal notes from (Corkerell). 1902. p. 107 . . . . . .

Farm resources and products of. 1868. p. $279 \ldots \ldots \ldots \ldots \ldots \ldots . . .6$.

Forage plants of, notes on (Pool), 1888, p. 48 ............

Forest conclitions of Roeky Mountains in (Ensign). 1. 11 . . . . .

Fruit of tropical and semitropical (Klee). 1891. p. 111 . . . . .

Grasses of arid districts of, investigation of (Tracy). 1888. 1.5.

Grasses of desert region of, plates and descriptions of (Vasey). 1890

A1.1:87!)

11.8:22

18.1:3

A1.1:881-2

A9.1:852

11.1:881-2

1 4.1:884

A1.1:877

$128.5: 5$

А27.9:6

A $10.3: 120$

A 10.3:35

A4.1:889-90

$19.7: 4$

A9.7:5

A9.7:6

A9.7:7

A $10.3: 36$

A 10.3:87

A10.3:119

A 1.1:881-2

11.1:881-2

A1.7:7

A9.6:17

A9.7:7

A 27.9:6

A27.9:8

A2:.3:9

A $22.3: 21$

A27.9:7

A $22.3: 17$

A1.1:865

A1.6:3

115.2:Ar 7

A15.2:Arí

A9.7:4

11.8:20

A 10.3:40

A $15.2: \operatorname{Ir}^{2}$

A9.6:3?

A27.9:6

A6.3:6

A13.3:2

A20.3:1

A6.3:6

16.2: $\mathrm{N82}$

A6.3:12

* By a misprint, this page number appears twice. 
New Mexico-Continued

Insect injury in, jossible and actual influence of irrigation on

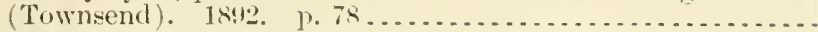

\section{Insects-}

biologic notes on (Townsenrl). 1892. I. 37

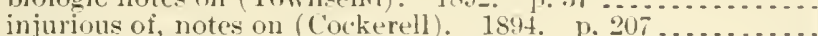

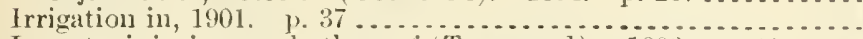

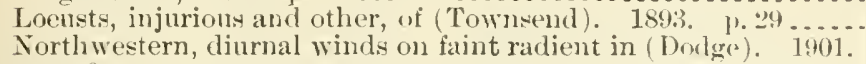

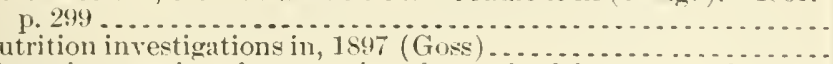

Plants in, certain, of economic value as foor for man and stock

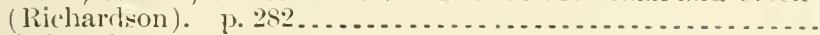

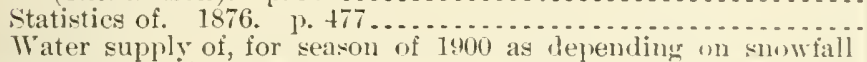
(IIardinge). p. $4166^{\circ}$.

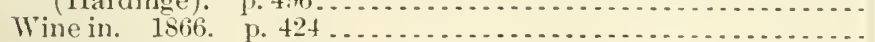

See also Pecos River-Hecos Valley.

New Orleans, La. :

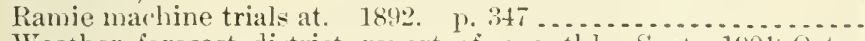

Weather forecast district, report of, monthly, Sept., 1901-0, (1., 1902 (Cline) . . . . . . . . . . . . . . . . . . . . . . . . . . .

New Orleans, La., World's Industrial ami Cotton Centemnial Exposition, 1884-5:

Agrieulture Department, exhibit of manufactures from native

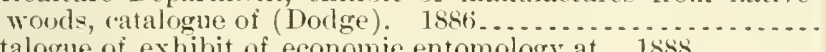

Catalogue of exhibit of economie entomology at. 1888 .......

Exhibits illustrating agrienltural statisties (Dodge). $188 . \ldots . . .$.

Grass collections at, deseriptive catalogue of ( Tasey) . . . . . . . .

New Richmond, Wis., tornado at (Libby). 1899. p. 299.........

New South Wales:

Cattle tir.k and tubereulosis in (Baker). 1) 386.............

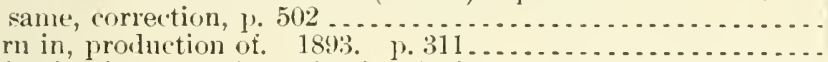

Irrigation in, recent investigation, legislation, and administration

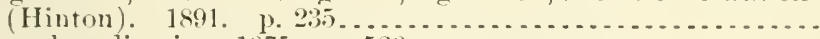

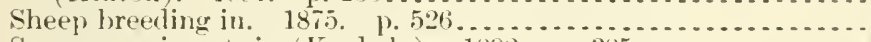

Sugar-cane insects in (Koebele). 1892. J. $385 . . . . . . . . . . .$.

New York Agricultural Society, Alhany, Feb.. 1s71, amnal menting of. P. 66.

New York City:

Animals in, contagions diseases of, preliminary report of veterinary inspectory in insestigation of (McLean and others).

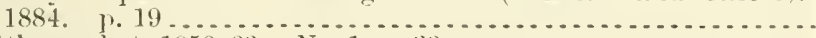

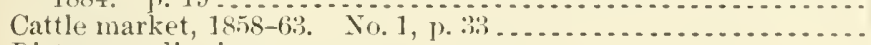

Dietary studies in-

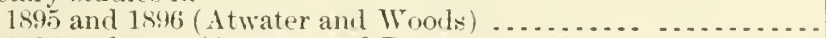
1896 and 1897 (Atwater and Bryant). 1902

Entomological work in Central Park, 1891 (Conthwick). p. 59. .

Exports and imports of, 1863. No. 5, p. 10; No. 6, p. 19. . . . . same, 1864 . No. 1, \}. 30; No. 2, p. 27; Yo. 3, p. 6; No. 4, ].

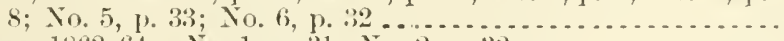

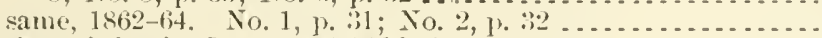

Harlyor of, fog in, Dec., 1895 (Abbe). 1. 463.................

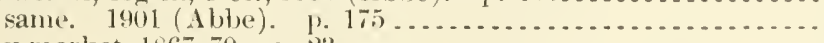

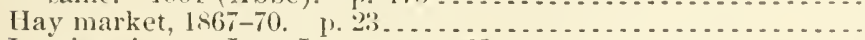

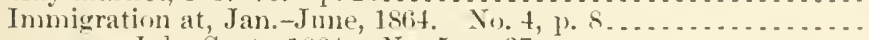

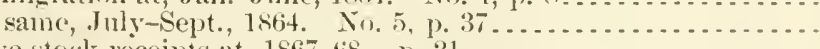

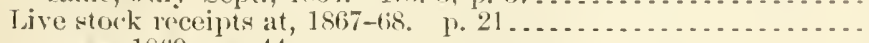

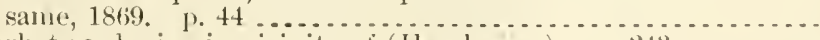

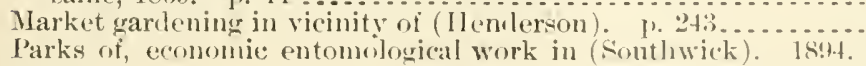
3. 135 ) . .

Poultry in, sale of. 1869. 1\% $300^{*}$

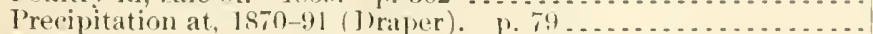

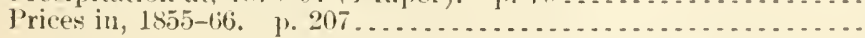

Classifacatlon no.

$19.7: 5$

$19.7: 5$

19.7:7

_. $\$$ 10.3:119

$19.7:(3)$

$.129 .6: 29$

170.354

11.1:S5T

А:-. $4: 14$

1297.6:25

+27.4:4

A27.9:30

129.6

11. $7: 10$

19.2: 142

A 1.s:40

A6.2:( 776

A.9.6:27

A4.1:898

A4.1:849

A.7.9:31

115.2:P94 ${ }^{1}$

A27.9:13

A9.7:4

$127.9: 9$

A1. $7: 6$

A27.9:2

A10.3:4ti

$110.3: 116$

19.7:4

A27.9:1

127.9:2

127.9:3

A39.6:2::

129.6:29

A $27.9: 9$

127.9:2

1:7.9:2

127.9:7

127.9:8

11.1:865.

19.7:7

1:2.4:

1:9. $(1:-3)$

1:2. $1.4: 4$

* By a misprint, this page number nppears twive. 
New York City-Continued

Pullic schools of, cooking instructions in, history and present

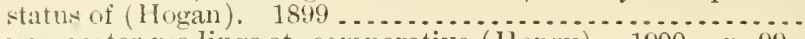

Thermometer rearlings at, comparative (Henry). 1900. p. 99 ..

Tides at, distant storms indicated by (Jones). 1894. p. 372 ....

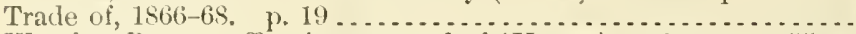

Weather Bureau office in, removal of (IIenry). 1898, p. 455...

Woorl-leopard moth in parks of (Southwick). 1894. p. $138 \ldots . .$.

New Tork City, [2d] international conference on plant breeding and hybridization, 1902, report on. 1902. J. $208 \ldots \ldots \ldots$. .....

New Tork Dairymen's Ascociation, 14 th meeting, Dec. 9-11, 1890

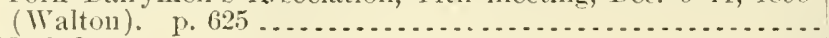

New York State:

Anthrax among cattle in (Law). 18s1. p. 312...............

Boarls of supervisors of, thirr annual good-road convention, Alluany, 1902

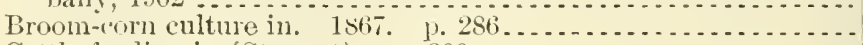

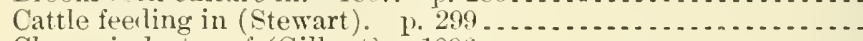

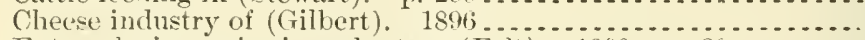

Entomologic service in, voluntary (Felt). 1899. 1. 39 ........

Farm resources and products of. 1868 . p. $10 \ldots \ldots \ldots \ldots \ldots$

Forest and shade tree insects in, observations on (Felt). 1901.

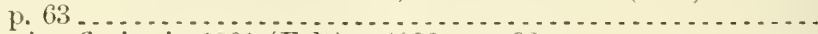

Hessian fly in, in 1901 (Felt). 1902 p. 22 .......

Highway legislation in, history of (Wright). 1901, p. $29 \ldots .$.

Insects of, notes on-

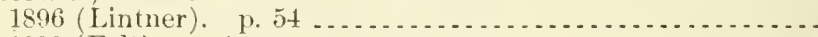

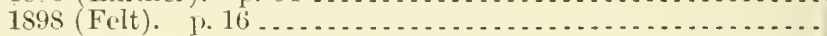

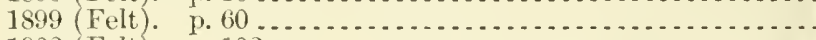

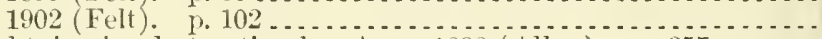

Lightning in, destruction by, Aug, 1898 (Allen). p. $357 . . . .$.

Lumber industry, history of (Fox). $1902 \ldots \ldots \ldots \ldots \ldots$

Northern, evergreen forests in, causes of destruction of (Parkard) $[1 \mathrm{st}]$ report, p. 138 same, p. 138 .

2d report, p. $27+$ t

Pleuro-pneumonia among cattle in, investigation of (Hopkins).

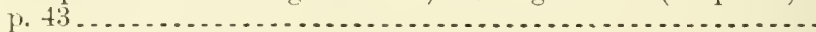

Road improvement inaddress on (Stone). 1897 extract from governor's message (Rooseveit)

Roalsconstruction of, by local assessment, act for, $1894 \ldots . . . . .$.

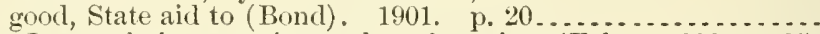

San Jose scale in, experimental work against (Felt). 1902. p. 35. Snow country of central, note on (Kimball). 1902. p. 135 ...... Thunderstorms of May 3, 1892, in (Turner). 1892. p. $139 \ldots .$. Tuberculosis among cattle in, prevalence of (Schroeder). 1896.

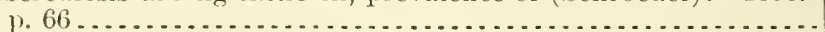

Western-

grape in, diseases of (Fairchild). 1891. p. 95. leaf diseases of nursery stock in, experiments in preventing

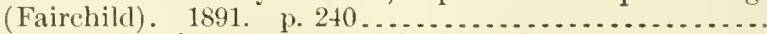
new or rare fungi from, notes on (Fairman). 1889 . p. $78 \ldots$

See also Albany - Buffalo - Franklinville - Ithaca - Poughkeepsie - Riclimond County - Syracuse - Utica - Westfield Willets Point - Woodhaven.

New York State Agricultural Experiment Station, Geneva, N. Y.:

Biological and dairy building of, report on. 1899. p. 401 .....

Methods of keeping records of horticultural work at (Beach).

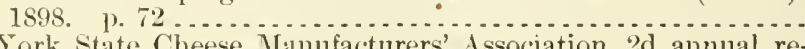

New York state Cheese Manufacturers' Association, $2 d$ annual re-

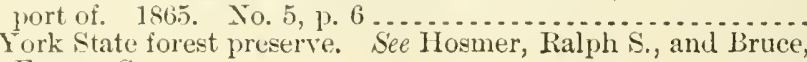
Eugene S.

New Zealand:

Icerya purchasi and Vedalia cardinaliw in (Wright). 1893. p. 194. A9.7:6

A 10.3:56

129.6:28

A29.6:22

A $27.9: 7$

A $29.6: 26$

A9.7:7

A $10.6: 14$

A27.9:28

A1.6:34

A22.3:22

A27.9:5

A1.1:876

A $4.3: 15$

A $9.6: 20$

A27.9:6

A9.6:81

A9.6:31

A2:2.3:21

A9.6:6

A9.6:17

A9.6:20

A9.6:37

A 29.6:26

A13.3:34

A1.1:883

A9.1:883

A1.1:88t

A1.1:881-2

A22.4:28

A22.4:33

A 22.4:15

A22.3:21

A9.6:37

A $29.6: 30$

A29.6:20

A4.1:893-4

A28.5:6

A28.5:7

A28.5:5

A 10.6:10

A 10.3:49

A27.9:3 
Index

New Zealand-Continued

Insects in. parasitic and predareous, studies of (Koebele). 1893.. A1.8:51

Root fungus of (W'ight). 1889. 1. 199 ................... A28.5:5

Sheep in, blood poisoning in (Gilruth). p. 233.............. A4.1:901

Sheep.scab, how stamped out in. p. 505 ........................ $14: 900$

See also Australasia - Canterbury.

New Zealand flax, results of recent investigations relating to (Dorlge)

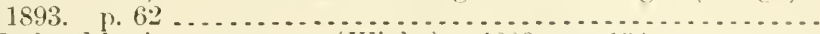

New Zealand katipo, report on (Wight). 1889. p. 134 .........

Newberne, N. C., soil survey from Raleigh to (Snith). p. $187 \ldots .$.

Newcoml, llarry T. Railway aml other tramsportation services,

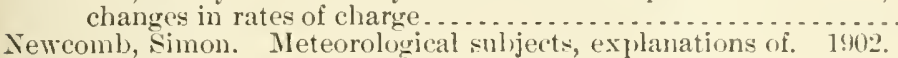

p. 127
Newcombe, F. C. Perennial mycelium of fungus of blackberry rust. 1891. p. 106 .........

Newell, Frerlerick Haynes:

Irrigation on Great Plains. 1896. p. 167 . . . . . . . . . . . . . .

Lumbering, conservation, and water-supply. 1901 . p.3.......

Rainfall and charts of rainfall. 1902 . PI. $225,226 \ldots \ldots \ldots \ldots$

Newell, Wilmon. Siee, as joint author, Welster, Francis II.

Newspaper and the weather forecaster (Watts). 1901 ............

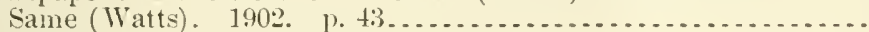

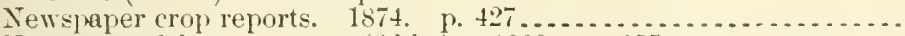

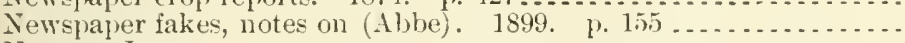

Newton, Isaac:

Cotton and wool, American, future of. 1sitit. No. 1. p. 12....

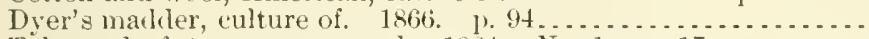

Tobacco leaf, tax on, proposed. 186t. No. 1. p. 17 .........

See also, for report as Commissioner of Agriculture, $1862-18665 . .$.

Kewton, Isaac, short biography of. 1867. p. $189 \ldots \ldots \ldots \ldots \ldots$.

Newton, Isaac, and his kites (Ábbe). 1896. p. 458.............

Niagara River, ice jan in, note on (Ablue). 1899. I. 61 ..........

Nicaragna:

Central and western, rainfall in (Flint). 18!9. [1. $587 . . . . .$.

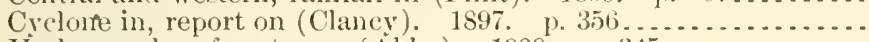

Hydrography of, notes on (Abbe). 1900 , p. $345 \ldots . . . . . .$.

Rainfall and temperature in (Davis). 1898, p. 211 ..........

Rainfall in, record of $1850-51$ (Childs). p. $40 \% \ldots . . . . . . . . .$.

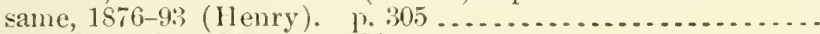

See also Granada - Masaya - Rivas.

Nichols, George. Phreatic waters in Nye Comnty, Nev. 1891. p.207.

Nicholson, H. H. See, as collaborator, Wiley, Harvey Washington.

Nicol, T. W. Orange sorghum cane, enltivation and manipulation of, communication relative to. $188^{2}$. p. 122.............

Nicolaj, II. E. Agricultural work at Dyea, Alaska, during season of

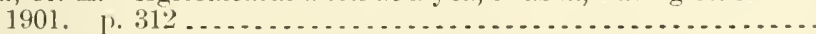

Nicotin. See Tobaceo powders and extracts.

Nielsen, H. l'. Kenai experiment station, Alaska, report of super-

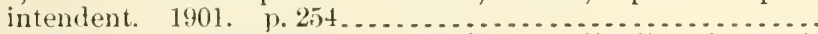

Night forecasts, Weather Bureau, is it advicable to distribute ly rural

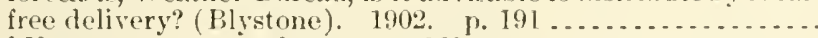

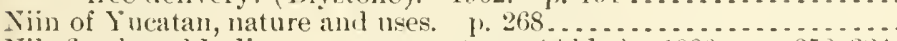

Nile floodsand Indian monsons, noteson ( 1 ibie). 1900. pp. 252, 324.

Nile River (Willcocks). $1894 . \quad$ P. 121 . . . . . . . . . . . . . . . .

Vile Valley, berseem, forage and soiling (rop of (Fairchild), 1902..

Niles, W. 13. Hog choleril in lowa. p. $500 \ldots . . . . . . . . . . .$.

Nimes, France, pipular credit congress, 1895 , notice on. P. $26 . .$.

Nimmo, Joseph W., jr. Irrigation in Montana, Idaho, eastern Wash-

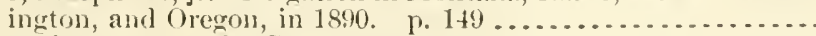

Nineteenth century See Century, new.

Nitragin, a germ fertilizer for legmininous plants. 1897. p. $19 \ldots \ldots$

Nitrates:

Gunning-Kjeldahl methorl and a modifieation apllicable in pres-

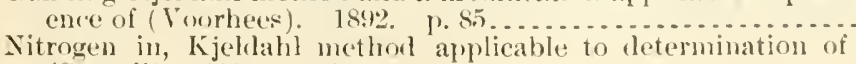
(Scovell). 1887. 1.51

$111.5: 5$

$19.7: 2$

A $26.5: 900^{1}$

127.8:15

A29.6:30

A28.5:6

A1.10:896

A13.3:30

A29.6:30

A29, 2:F76

A $9.9 .3: 31$

A27.9:12

A $29.6: 27$

A27.9:2

A27.9:4

A 27.9:2

A1.1:

A $27.9: 5$

A.9.6:24

A29.6:27

A29.6:27

A29.6:25

A $29.6: 28$

129.6:27

A 29.6:26

A 29.6:26

A15.2:P94?

A 1.8:-2:-2

A $10.1^{2}: 901$

A10. $1^{2}: 901$

A 29.3:31

A1.1:868

A 29.6:28

129.3:1

A 19.3:2:3

A 4.1 :898

A $27.9: 33$

115.2:199.1

A1.9:65

A $7.3: 3 \% 5$

A7.3:16 
Nitric acicl:

Determination in soils, by Sehloesing's method, at Rothansted

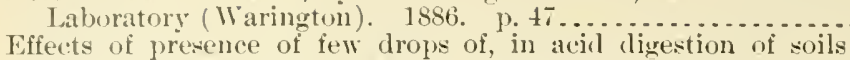

Method for whosphoric acil determination (Richards). 1886. p. 24

Nitrie nitrogen:

Complete fertilizers, Ulseh methol in determining (Street). 189.2. p. $8 \mathrm{~S}$

Determination of-

by zime-iron nuethorl (Shiver). 189t. p. 142 ..............

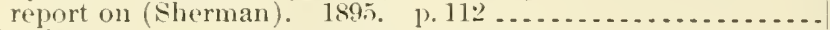

Nitrification:

Arable soil (Deherain). 1896. pp. 353, 491 ..............

Element of soil productiveness (IVithers). 1902. 1). $87 \ldots \ldots . .$.

Rate of, of certain fertilizers (Withers and Fraps). 1901. 1.,25.

See ulso soils.

Nitrogen:

Availability of, in mixed fertilizers (Terne). 1893. p. 40......

Determination ly hjeldahl method of-

distilling with and without potassium sulphid (Sweetser).

effect of presence of metals precipitable ly potassium sulphide

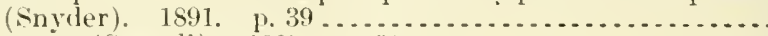

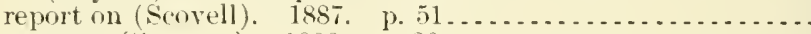

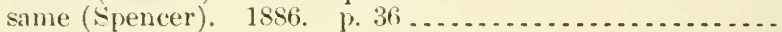

Determination of-

in fertilizers, report of committee on (French Association of

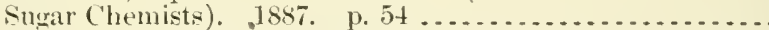

in soils of some of the experimental fields at Rothamsted, and bearing of results on question of source of nitrogen of our crups (Lawes and (iilbert). 1882. p. 142.........

report of committee for, at Association of Othicial Arricultural Chemists-

1885. p. 43

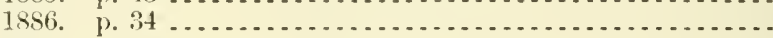

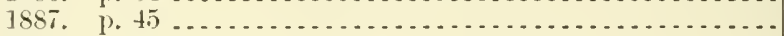

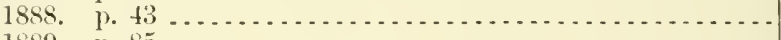

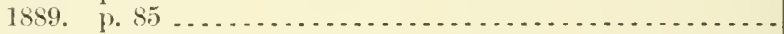

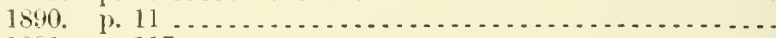

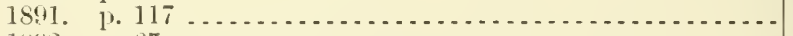

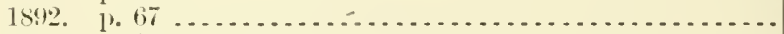

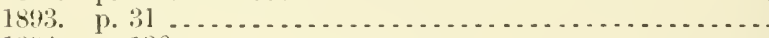

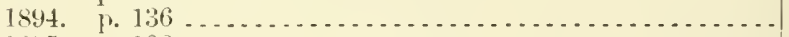

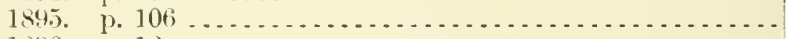

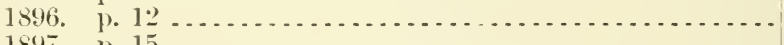

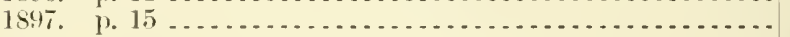

1898. p. $14 \ldots \ldots \ldots \ldots \ldots \ldots \ldots$

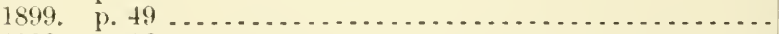

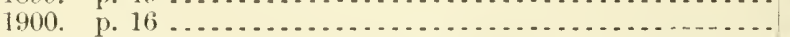

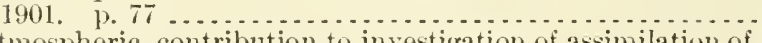

Free atmospheric, contribution to investigation of assimilation of, by white and black mustard (Lotsy). $1894 \ldots . . . . . . . . .$.

Hoar frost especially rich in (Abbe). 1896. 1\%371.

Metabolism of-

and digestibility of food, experiments on effect of muscular work upon, condncted at University of Tennessee, 18971899 (IVait). 1901

effect of museular work upon, experiments on, conducted at University of Temnessee, 1899-1900 (Wait). 1902.......

in human organism, experiments on (Sherman). 1902 .....

in human organism, with respiration ealorimeter of special construction, report of preliminary investigations on

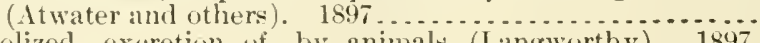

Metabolizerl, excretion of, by animals (Iangworthy). 1897. 1). $\$ 17$

A10.6:6

A 10.3:115

A7.3:62

A $7.3: 38$

A7.3:49

17.3:31

A7. $3: 16$

17.3:12

A7.3:16

A 1.8:31

A7.3:

A $7.3: 12$

A7. $3: 16$

A7.3:19

A 7.3:24

A7.3:28

A7.3:31

A7.3:35

A7.3:38

A7. $3: 43$

A7.3:47

A7.3:49

A7.3:51

A $7.3: 56$

A $7.3: 57$

A $7.3: 62$

A $7.3: 67$

A 10.3:18

A:9.6:24

A 10.3:89

A 10.3:117

A 10.3:121

A10.3:44

A10.6:7 
Nitrogen-Continued

Organic, in mixerl fertilizers, availahility of (Hayes). 1895.

p. 112 Abuninoid nitrogen-Xitric nitrogen-Phoshoric acid. Nitrogen assimilation in its application to practical agrifulture. 1897 . 1. 906

Nitrogen-free extract of plants and feeding stuffs (Tollens). 1897.

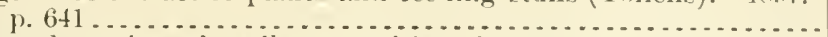

Nitrogen hungriness in soils, recognition of (Hilgard). 1s 15.

Nitrogen of proteids and that of simpler amids or amido-acids, investigation of analytieal methorls for distinguishing between

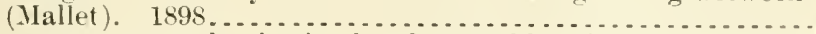

Nitrogenous eompounds of aninal and vegetable substances, suggestions regarding nomenelature of (Atwater). 1899. 1. 118...

Noctuisle, from Death Valley, deseriptions of (Smitll). 1843.

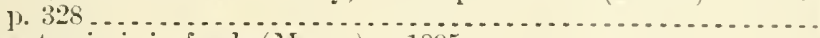

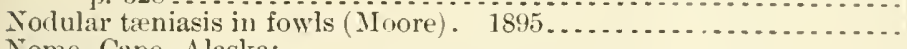

Nome, Cape, Alaska:

Meteorological report from, Sept., 1900, note on (Abbe). ए. $39 \%$.

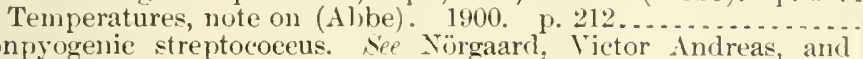
Mohler, John R.

Norfolk, Va., tornado and waterspout at, on Aug. 6, 1901 (Gray).

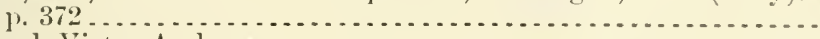

Nürgaard, Victor Andreas:

Anthrax, prevalence of, among domestieated animals. p. $40 \ldots$

Baden-Baden, Germany, Seventl, International Veterinary Con-

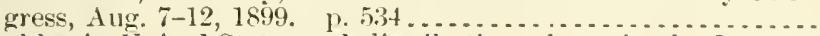

Blackleg in United States and distribution of vaccine by Bureau

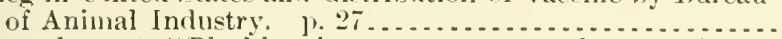
same, abstract; "Blackleg, its nature, eause, and prevention." 1900

Blackleg; its nature, cause, and prevention . . . . . . . . . . . . . .

Blackleg vaceine-

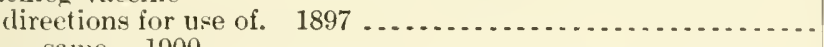

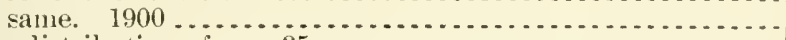
free distribution of. p. $35 \ldots \ldots$

Cattle, lumpy jaw or actinomyeosis in, treatment with iodide of

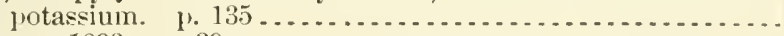
sane. 1893. p. 39 . . . . . . . . . . . .

Cattle dipping, experimental and practical. 1898. p. 45\%......

Dipping eattle for destruetion of ticks. p. 109 ................

Vaceination, preventive against l, laekleg. $1897 \ldots \ldots \ldots \ldots \ldots . . .6$.

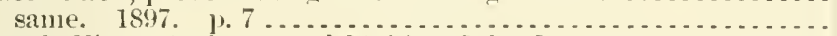

Nörgaard, Victor Andreas, and Mohler, John R.:

Apoplectiform septicemia in chickens, preliminary report on highly fatal disease caused ly a nonpyogenic streptococens. 1902

Ovine caseous lympl-adenitis, nature, cause, and economic im-

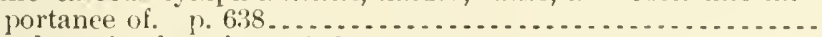

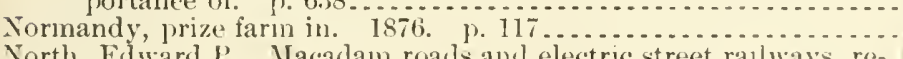
North, Edward P. Nacadam roads and electric street rallways, re-

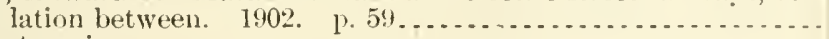

North America:

Animals and plants in, geographic distribution of (Merriams). p. 203.

Cereals in, geographic distribution of (Plumb). 1898........

Desert flora between $32^{\circ}$ and $42^{\circ}$ north latitude (Parry). 1871.

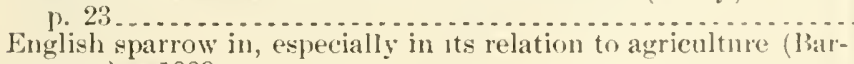
rows).- 1889

Fungi from-

new and rare speeies of (Ellis and Everhart). 18s.\%. P. 145. observations on new speries of (Lagerheim), 1891. 1) 44...

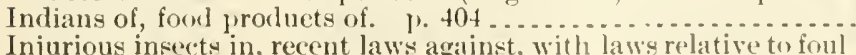

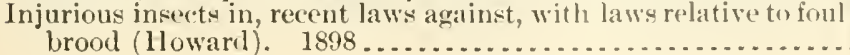


North America-Continued

Locusts in-

(lentructive, with notes on occurrences in 1891. p. 18 ....... extracts from early literature on (Berthoud). 185.3. Apl.,

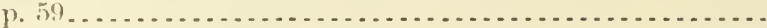

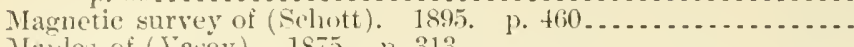

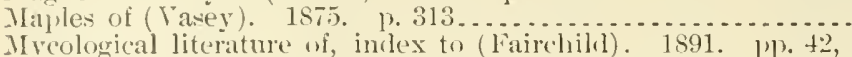

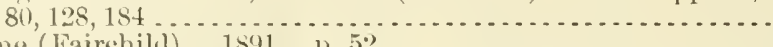
same (Fairehild). 1891. p. 52 . . . .

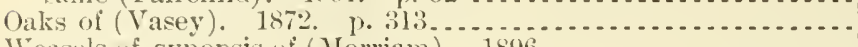

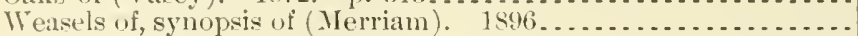

North American.

[Titles beginning with the words "North American" are entered under the distinctive words of such titles.]

Nort! American fauna, nos.' $1-19$

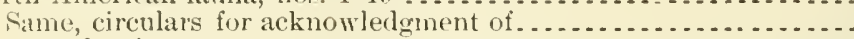

Nortin Atlantic:

Currents and surface temperatures (Hautreux). 1894. p. 192.. IIuricane tracks in, recurving of (Abbe). 1899. p.468......

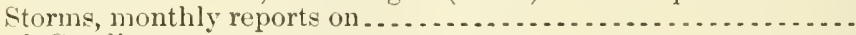

North Carolina:

Agricultural education in (Holmes). 1883. p. $84 \ldots \ldots . . . . . . .$. Agriculture and climate of (Goodloe). $1867 . \quad 1.150 \ldots \ldots \ldots \ldots$ Cattle quarantine of counties in-

Dec. 16,1897 . p. 9

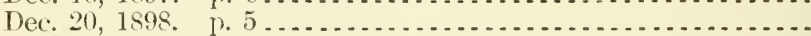

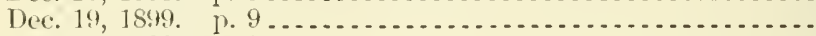

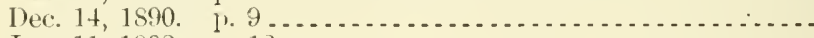

Jan. 11, 1902. p. 12 . . . . . . . . . . . . . . . . . . . .

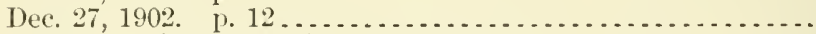

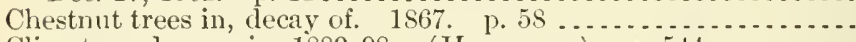
Climate and crops in, 18s9-98. (Hermann). p. $544 \ldots . . . .$.

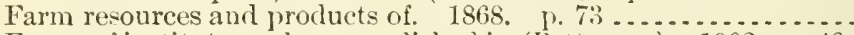
Farmers' institute work accompliahed in (P'atterson). 1902. P. 40. Forecasting for rivers of small drainage area, especially those of (Hermann). 1902. p. $158 .$.

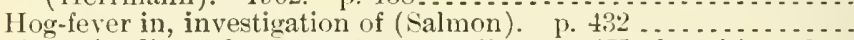
Horsesin, diseaseknown as "staggers" among (Harbaugh). p. 209. Irrigation of rice in (Keeney). 1902. p. 59 Mountain meteorological stations in, note on (A blbe). 189\% P. 445.

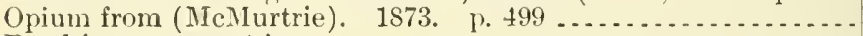
Road improvement in-

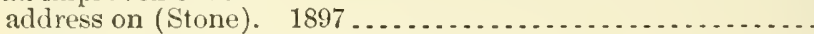

extract from governor's message (Russell). p. 6........... use of convicts in (Holmes). 1895 , p. 5 ................ Roads in, public, improvement of (Iolmes). 1894. p. $513 \ldots \ldots$

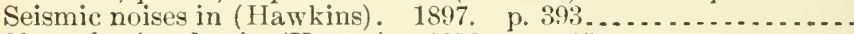
Sheep husbandry in (Young). 1878, p. 115 ............ Swine-plague in (Salmon), 1879. p. 123 . . . $\ldots \ldots \ldots \ldots \ldots \ldots$

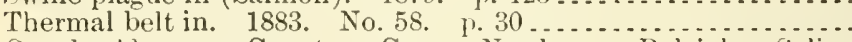
See also Alamance County - Cary - Newbern - Raleigh - Salisbury - Statesville - IVinston-Salem.

North Carolina strand vegetation. See Ocracoke Island.

North Dakota:

Artesian well investigation, field work (Culver). 1890. p. 5.5 ..

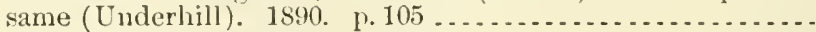

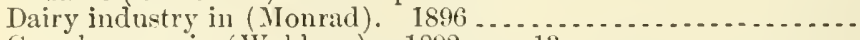

Grasshoppers in (Waldron). 1892. p. 13 ..................

Russian thistle and other troublesome ireerls in wheat region of .. Snowfall in, 1895 (Abbe). p. 463

See also Turtle Mountains.

Torth Dakota Agricultural College, club of women students at, diet-

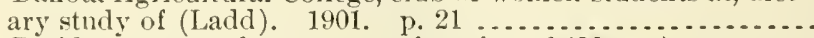

North Pacific coast weather map, explanation of (Moore) ..........

Northeast, insect enemies of spruce in (Hopkins). 1901

A9.7:4

A $5.1: 3$

129.3:11 2

А $27.9: 13$

A $28.5: 6$

128.5:7

A27.9:10

45.5:11

A.5.5:

45. 4 :

429.3:11 I

129.6:27

A29.6:

A1. $7: 2$

A27.9:5

A $4.5: 8-14$

A4.5:25-29

A $4.5: 49-55$

A $4.5: 80-87$

A $4.5: 93$

A 4.5:101

A27.9:5

A29.6:26

A27.9:6

110.3:120

A29.3:31

11.1:878

A4.1:856

A 10.3:113

A 29.6:25

127.9:11

A22.4:28

A22. 4:33

A22.3:16

A1.10:891

A29.6:25

A1.2:Sh3

A $1.6: 12$

127.9:21

A 15.2: $\mathrm{Ar}^{7}$

A 15.2: Ar 7

A $4.3: 16$

A9.3:27

A 1.9:10

A29.6:23

A10.3:91

A29.2:N81

A9.6:28

Northern farming. See Farming. 
Northern stock ranges, some poisonous plants of (Chesnut). 1900.

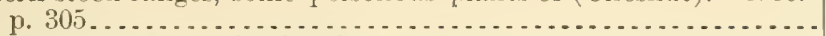
Classideation no.

Northern sugar-cane. See Sorghum.

Northern sugar industry, record of its progress during season of 1883

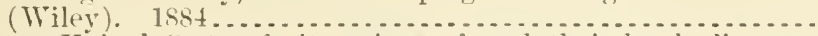

Northern United States, fruit regions of, and their local elimates Northers:

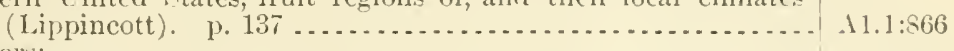

Cariblean Sea and Gulf of Mexico, notes on (Abbe). 1898. p.

Cold waves and heary snows, posibility of gring warnings of, to stock-raising interests ts hours in allvance (Branden-

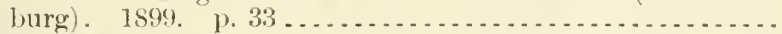
Dry-

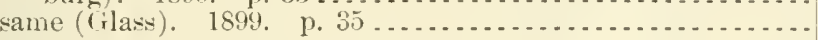

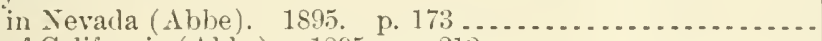

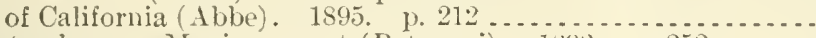
September, on Mexican coast (Baturoni). 1892. p. $252 \ldots \ldots \ldots$ Tampico and Tera Cruz, notes on (Abbe). 1893. p. 363 ......

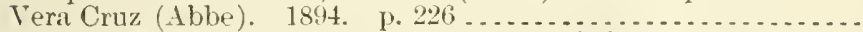
Northfield, Mass., meteorological extremes at (Ehmer). p. 251 .... Northrop, B. G. Arbor Day, observanee of, by schools. p. $27 \ldots .$. Northwest:

Anthrax among cattle in the (Detmers). 1881. p. $312 . . . . .$.

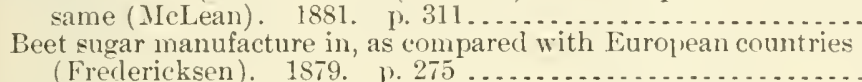

Codling moth, investigations in, in 1901 (Simlson). $1902 \ldots \ldots$.

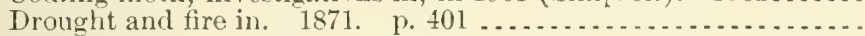

Flax culture in the, in 1891 (Bosse). 1892. p. $40 \ldots \ldots . . . . .$.

Forage crops of, eultivated (Ilitehcock). 1902................

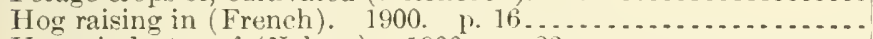

Horse industry of (Nelson), 1900, p. $23 \ldots \ldots \ldots \ldots$

Insect enenies of forests in, preliminary report on (Hopkins).

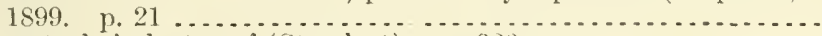

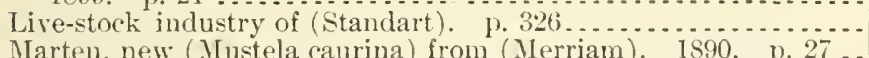

Marten, new (Mustela caurina) from (Merriam). 1890. p. $27 .$.
Plants from, two new species of (Henderson). 1899. p. 201...

Rocky Mnuntain locusts in 1882, observations on (Bruner).

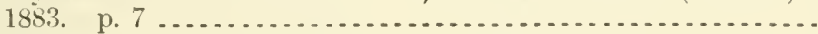

Seed wheat for, correspondence on. 1868. p. $285 . . . . . . .$.

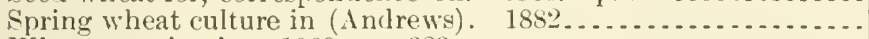

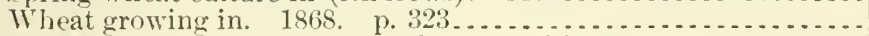

See also Pacific Northwest - and names of States.

Northwesters of Canterbury, New Zealand (Able). 1895. p. $383 .$. Norway:

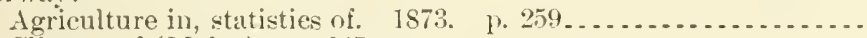

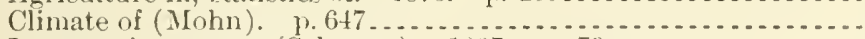

Insects of, notes on (Schoyen). 1897. p. 79 ...............

Markets for Anerican products in . . . . . . . . . . . . . . . . .

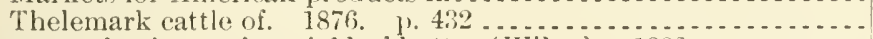

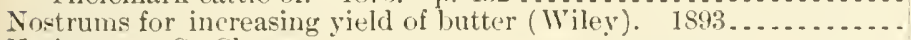

Notiosrex. See Shrews.

Nova Scotia, tidal lands and diked marshes of (Boardman). 1885.

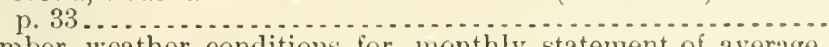

November, weather eonditions for, monthly statement of average (Garriott). 1900. p. 483.

Novius cardinalis, introduction of, from America into Portugal, ac-

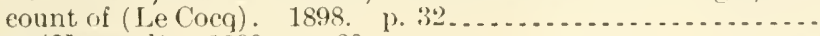

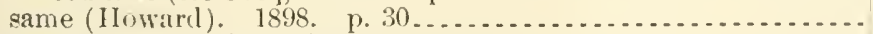

Noxious animals. See Animals, noxious.

Noxious weeds (Coville):

1889. p. 382 ... same, p. 382 .

1830. 1. 388 ...

same, p. $38 \mathrm{~s}$.

A 1.8:56

A $1.6: 34$

A 1.6:34

A $1.6: 28$

A $9.6: 35$

127.9:9

A11.5:4

A 19.3:31

A1.9:117

A 1.9:117

A9.6:21

A4.1:855

A 5.5:4

A6.5:5

A9.3:2

A27.9:6

A $1.6: 40$

A $27.9: 6$

A29.6:23

A27.9:11

A29.3:11 3

A $9.6: 9$

A12.3:7

A27.9:14

A 1.9:12

A1.7:7

A29.6:2S

19.6:18

A9.6:18

A 1.1:589

A6.1:889

A 1.1:890

A6. $1: 890$ 


\section{Index}

Noves, G. Harold:

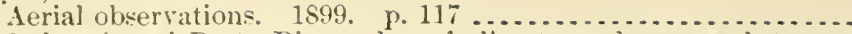

Inclustries of Porto Rico, value of climate and crop and stormwarning services of Weather Bureau to. 1902. p. $60 \ldots \ldots . .$.

Noyes, La Verme W. Remarks of, at 2 d convention of Weather Bureau officials, Milwankee', Wis. 1901. p. 226...............

Numunlaria, North American species of, synopsis of (Ellis and Ever-

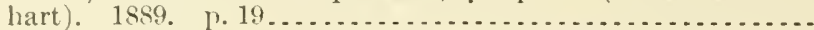

Numn, Roscoe. C'areer Weather Bureau service offers to young men.

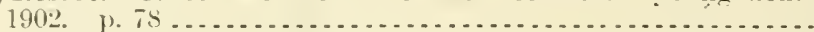

Nursery inspection:

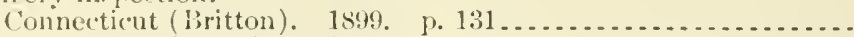

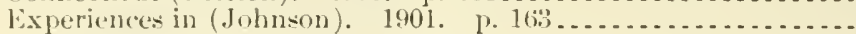

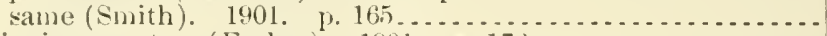

Illinois, report on (Forbes). 1901. p. 17.2 . . . . . . . . . . . . .

Laws and rulings, suggestions toward greater uniformity in (Felt).

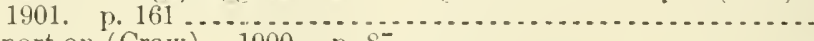

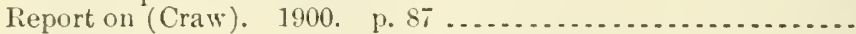

Nursery stock:

Growth of, effect of spraying with fungiciles on (Galloway). 1894. Leaf-blight and powdery milclew in, treatment of (Galloway). 1891

Leaf-blight of, experiments with funcieides toprevent (Fairchild).

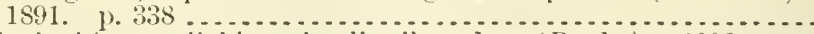

Principal insects liable to be distributed on (Banks). $1902 \ldots . .$. Western New York, leal diseases of, experiments in preventing

Nut grass:

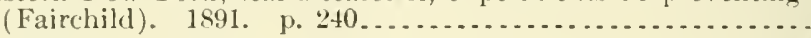

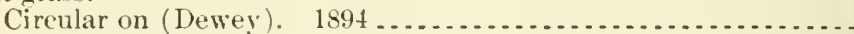

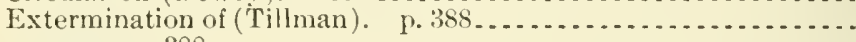
same, p. 388 .

Nutrients:

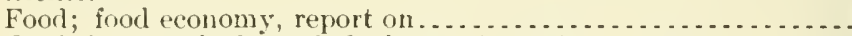

Food, heat equivalent of (Stohmann). 1896. p. $590 . \ldots . . . .$.

Loss of, in boiling potatoes, carrots, and cabbage (snyder). 1897.

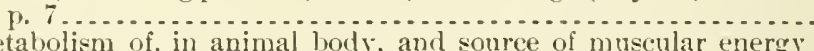

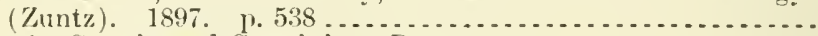
See also Creatin and Creatinin - Potato.

Nutrition:

Principles of, and nutritive value of food (Atwater). 1902.

Relation of, to health of plants (Woods). 1901. p. 155 ...... see celso Food and nutrition.

Nutrition investigations:

Agrieulture Department, development of, 1899. (True and

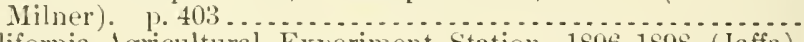
California Agricultural Experiment Station, 1896-189s (Jaffa). 1900

Illinois University, North Dakota Agricultural College, and Lake

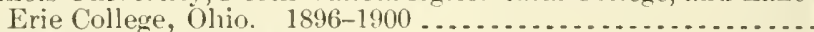

New Mexico, 1897 (Goss) . . . . . . . . . . . . . . . . . . . . . . .

Of Office of Experiment Stationslists of publications of office on .

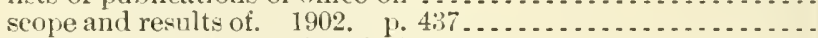

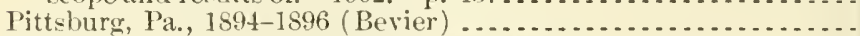

Tennessee University, 1896 and 1897 (Waite) . . . . . . . . . . .

See ulso Dietary studies - Food - Food and nutrition - MetaljoNuts: lism investigations.

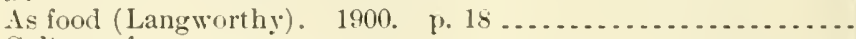

Culture of-

in U. S., embracing native and introduced species(Corsa). 1896.

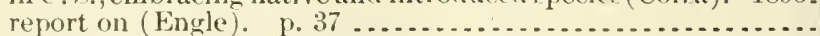

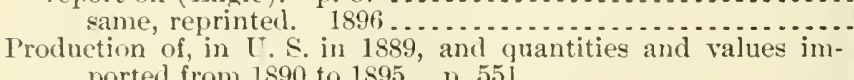
ported from 1890 to 1895 . p. 551 .................... Same, 1S91-1s96. p. 596 
sep alsn Almomls - Chestnuts - English walnuts - Peanuts pecan - spanish almonds.

Nutter, Eslwarl H. Water-bearing gravels and formations tributary to underground water supply of Salinas Valley, IIonterey

Cointr, Cal. 1901. p. 208 ..........................

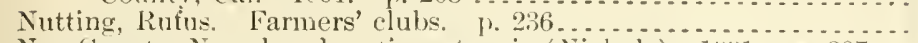

Nye County, Nevarla, phreatic waters in (Nichols). 1s 91 . p. $207 \ldots$

Oak-feerling silk-worm. tie Japanese oak-feeding silk-worm.

Oaklanıl, Cal., Golılen Gate fair, cattle exhibited at, order provid-

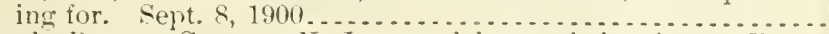

Oaklanl, Bergen County, $\mathbf{X}$.J., wood lot at, belomging to E. J). Page, working plail for (Graves). 1898. p.301 ..............

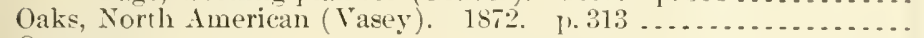
Oats:

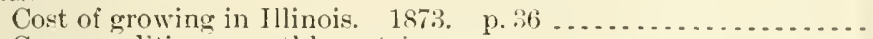

Crop condition, monthly notes on . . . . . . . . . . . . . . . . .

Crop statisties, anmual.

Disease of, new and destructive, preliminary notes on (callowaty

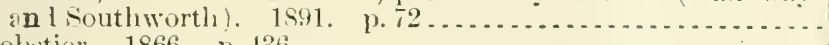

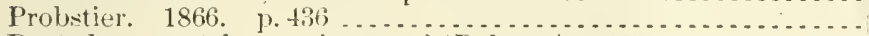

Rusted, request for specimens of (Dabney). 1894 ............

Smut in-

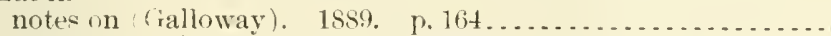
jrevention of (Kellerman and Swingle). 1891. p. $26 \ldots \ldots$.

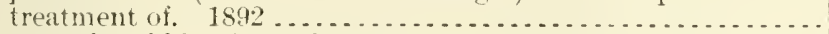

Straw and stublule of, sjeerimens requesterl (Rusk). 11. 11......

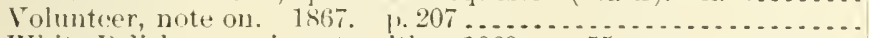

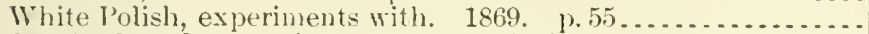

See also Cereals, American - C'rops, principal.

Oaxaca, State of, Mexico, Mexicm umbellifere, mostly from, collected by C. G. Pringle and E. W. Nelson, report on (Coulter and Rose). 1895. p. 2849.

Oberholzer, f. R. Thermoneters, naximum and minimum are too fragile; can not effective protertion le devised withont impairing sensitiveness? should not aluminum suales be dis-

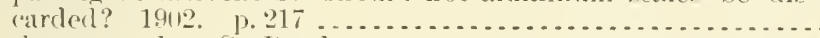
Object-lesson roali: Sep Roads.

O'Brien, Glenn, Sorghum-sngar, cold clarification, 1892 . p. $88 \ldots$ Sice alson, as collaborator, Wiley, Harvey Washington.

Observatory, aero-physical, equipment of (McAlie). 1896. p. t53. Ocean:

Currentes of-

drift ive and theory of (Daly). 1900. p.483 .............

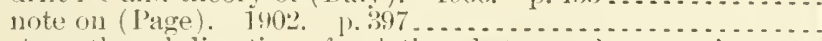
strength and direction of, relations between baronetric pres-

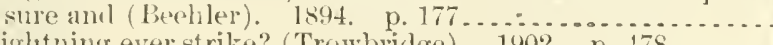
Does lightning ever st rike? (Trowbridge). 1902. p. $478 \ldots \ldots$.

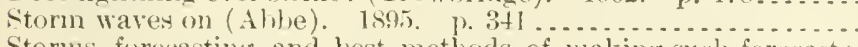
Stoms, forecasting, and hest methods of making such forecasts available to commerce (Allingham), 1894. p. $150 \ldots . . .$.

Tempreratures and meteorology, notes on (Abbe). 1898. p. 310 .

Tides innotes on (Able). 1900. p. 109 .... . . . . . . . . . . . . . partial explanation of some (Harris). 1900 j. $103 \ldots \ldots \ldots$ jrincipal, partial explanation of some of (Harris). 1900. \% $10: 3$.

Ocean transportation:

Cattle and horses. p. 87.

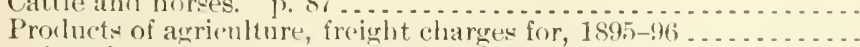

Oceanic noises, report on (Kain and others), 1898. 1\% 152 ......

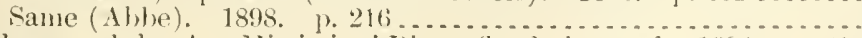

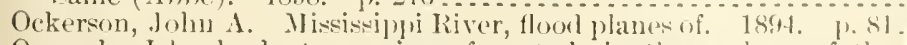
Ocracoke Island, plant covering of, a sturly in the ecology of the North Carolina strand vegetation (Kearney). 1900. p. 261 . Oetoler, weather conditions for, monthly statement of average (Garristt). 1900. 1. 430 .

A 10.3:100

A1.1:\$67

A $15.2: P^{2} 94^{1}$

A $4.5: 73$

$\$ 1.10: 898$

1. $7.9: 10$

127.9:11

A27.9:

A27.1:

A28.5:6

A:7.9:4

A:28. $4: 14$

A28.5:5

A28.5:6

A $1.9: 5$

1.28.4:12

A.27.9:5

A27.9:7

A6.5:3

A29.3:31

A7.3:37

1 29.6:24

A $29.6: 28$

A $29.6: 30$

A:9.3:11

A $29.6: 30$

A 29.6:3:3

1:99:3:11

$129.6: 26$

$129.6: 28$

$129.1 ;: 28$

$129.19: 28$

14. $1: 1900$

A27.5:12

$129.6: 26$

A2! $6: 26$

1 $29.3: 1^{1}$

A6.5:5

A:9.6:28 
Odenbach, F. I. Remarks of, at 2 d convention of Weather Bureau

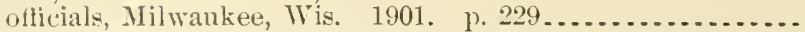

Odeswa, Russia:

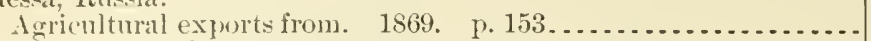

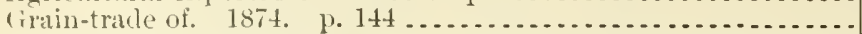

Trade of 1874. p. 170 .

O'Donnell, John J. Tornado of Jan. 12, 1898, at Fort Smith, Ark.

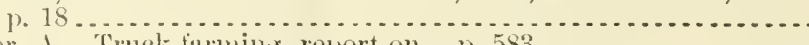

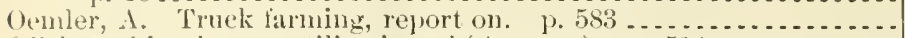

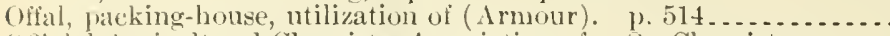

Oflicial Agrienltural Chemists, Astociation of. Sie Chemists.

Ogden, Miss E. L. Leaf structure of Jouvea and of Eragrostis obtusiOhis: flora. 1897. p. 12

('attle trade and dairy interests of (Perry). p. 335

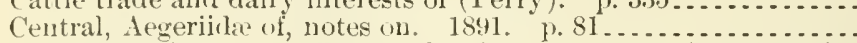

Chinch loug in, three years' study of an outbreak of (Webster).

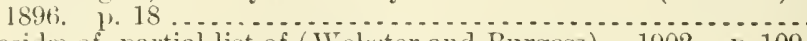

Coccidae of, partial list of (Welsster and Burgess). 1902. p. 109.

Derecho of May 16,1899, in (Smith). 1900. p. 196...........

Farm resources and products of. 1868. p. 249 . . . . . . . . . . . .

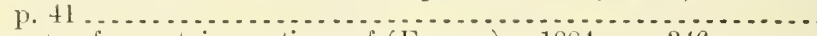

Forestry for certain portions of (Furnas). 1884 p. 346

Frost of June 30,1899 , in, lestructive, notes on (Abbe). p. 311.
Horn $\mathrm{Hy}$ in, note on (Kellicott). 1891. p. 35...............

Insects in-

as reported to Association of Economic Entomologists-

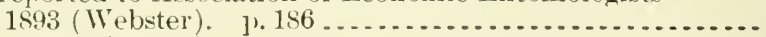

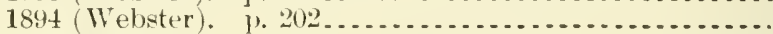

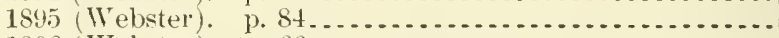

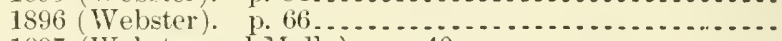

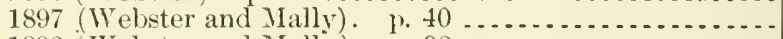

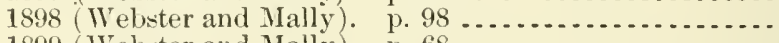

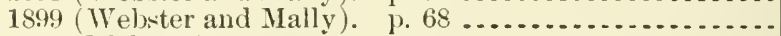

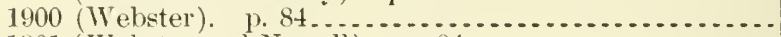

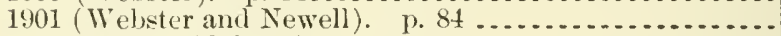

1902,1 st half (Osborn). p. 115

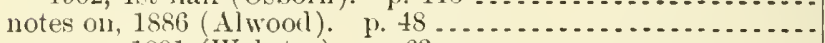

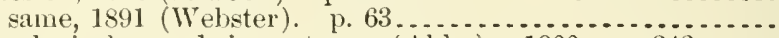

Meteorological records in, notes on (Abbe). 1900. p. $343 \ldots . .$.

Northern-

chinch bug in, interesting outbreak of (Webster). 1899 ,

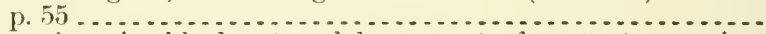
grapevines in, black-rot and brown-rot of, extent, severity, and treatinent of (Seribuer). 1889. p. $76 \ldots \ldots \ldots \ldots . . . . . .$. great drought of $1845 \mathrm{in}$ (Ford). p. $293 . . . . . . . . . . . . .$.

Phenology in, note on, 1856-99 (Abbe). p. $156 \ldots \ldots . . . . . . . .$.

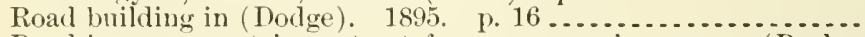

Road improvement in, extract from governor's message (Bush-

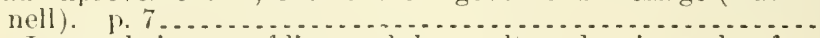

San Jose scale in, nse of lime, sulphur, salt, and resin washes for

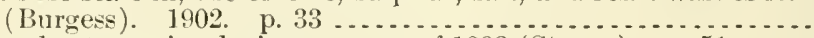

Thunderstorms in, daring summer of 1892 (Strong). p. $51 \ldots \ldots$.

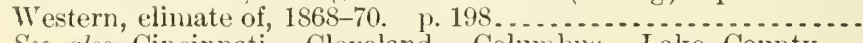

See also Cincinnati - Cleveland - Columbus - Lake County Lake Erie College, Painesville - Madison County-Montgomery County.

Ohio Agricultural Experiment Station, insectary and office methods used at (IVebster): 1899. p. $46 \ldots . . . . . . . . . . . . . .$.

Ohio River and tributaries in periods of low water, importance of water-stage forecasts of (Smyth). 1902. p. $146 \ldots \ldots . . . .$.

Oil. see Oleo oil.

Oil emulsions, simple device for preparation of (Morgan). 1896.

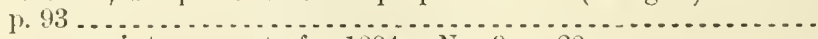

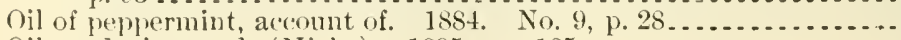

Oil-producing seeds (Hicks). 1895. p. $185 \ldots \ldots \ldots$

A29.3:31

A $27.9: 8$

A27.9:13

A27.9:12

A29.6:26

A 1. 1:885

A 4. 1:900

A3.3:8

A4.1:885

A9.7:5

A9.6:6

A $9.6: 37$

A $29.6: 27$

A27.9:6

A10.3:120

A 13.5: 4

A:29.6:27

19.7:4

A9.7:6

A9.7:7

A $9.6: 2$

A $9.6: 6$

A9.6:9

A 9.6:17

A9.6:20

A $9.6: 26$

A9.6:31

A 9.6:37

A9.3:13

A 9.3:26

A29.6:28

A9.6:20

A 6.3:11

A 29.6:23

A29.6:28

A22.3:17

A22.4:33

A9.6:37

A29.3:9

A27.9:9

A9.6:20

A29.3:31 
Oils and fats:

Edible, not including dairy products, methods for analysis of

(Tolman). 1901 ................................... 17.2:0i

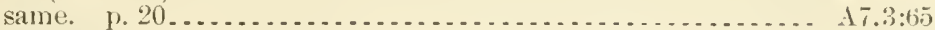

Specific gravity of, at temperature of boiling water, cletermination

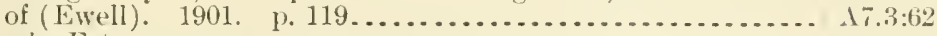

Siee also Fats.

Oklahoma:

Cattle, quarantine line for, orcler morlifying-

Apr. 26, 1897

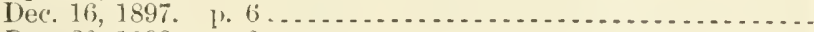

Dec. 20,1898 . p. 2 $2 \ldots \ldots \ldots \ldots \ldots \ldots \ldots \ldots$

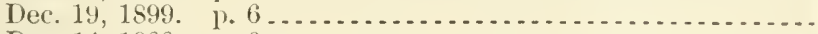

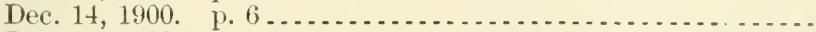

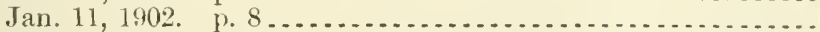

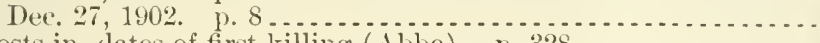

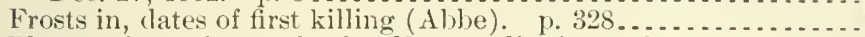

Plants of, native and of adjacent districts, observations on,

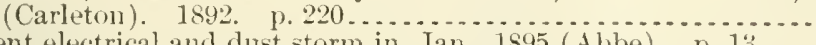

Silent electrical and dust storm in, Jan., is95 (Ajbe). p. 13...

Wint-roses for; notes on (Ablue). 1891-99. p. 21........... See also Washita County.

Olds, Henry Wurthingtom. See, as joint author, Palmer, Theodore Sherman.

O'Leary, T. S. Barometer at sea. 1594. p. $167^{\prime}$.

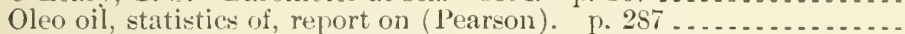

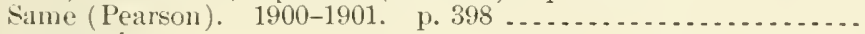

Oleomargarine:

Analysis of, method for (Morse and Burton). 1890. p. 99. - . -

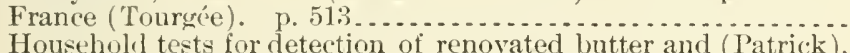
1901

Ingredients of (Wilson). p. 513

Legislation relating to. 1886 , p. $195 \ldots \ldots \ldots \ldots$

Statistics of (Pearson). p. $287 \ldots \ldots \ldots \ldots$

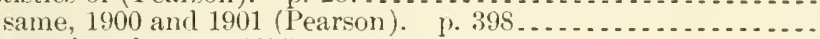

Oleomargarine cheese. 1875 . p. 459 .

Olive:

Cultivation of in United States.

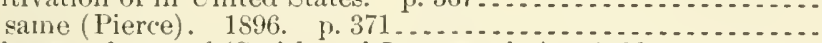

Culture and uses of (Smith and Langworthy). 1900. p. $11 \ldots \ldots$

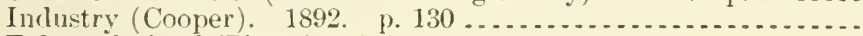

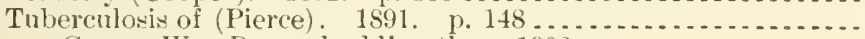

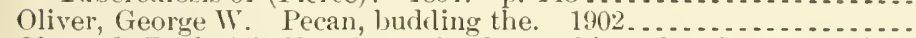

Olmsted, Frederick E. Forest lands, working plan for, near Pine

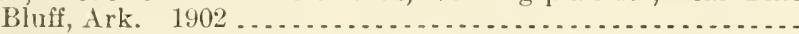

Olshausen, B. A. See, as joint author, Jensen, Cliarles A.

Omaha, Nebr.:

Convention of Weather Bureau officials, notes on (Ab)e). 1898. P). 213,412

Experiment station veterinarians, second annual meeting, 1898, proceedings of. 1898.

Trans-Mississippi and International Exposition, work of Animal

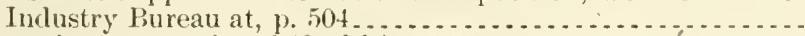

Oncocnemis, new species of (Smith). 1888. p. 1s............ Onion:

Blight and smut, microscopic investigations of (Taylor). 1872. p. 449 . . . . . . . . . . . . . . .

Culture of (Watts). 1896

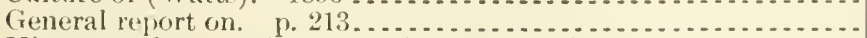

History, culture, and preservation of (Slade). p. $235 \ldots . . . . . .$.

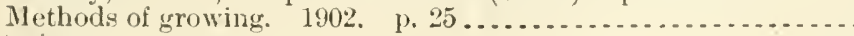

Ontario:

Agricultural statistics of. 1874. p. 462

Crop report, 188:-84. No. 11, p. 39.

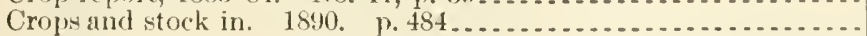

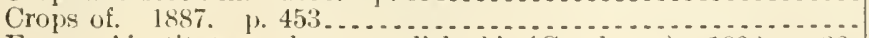

A $4.5: 3$

$1+.5: 8-14$

$1+.5: 25-29$

$14.5: 49-55$

14.5:80-87

14.5:9:3

14.5:101

124.6:22

16.5:1

129.6:23

129.6:28

129.3:11

A4. 1:\$99

Af.1:901

A 7.3:24

At.1:900

A 1.9:131

A 4. 1:900

A $27.9: 24$

A4. 1:899

A $4.1: 901$

A27.9:13

A 1.1:577

A $1.10: 896$

1 1.9:122

11.8:20

A 28.5:6

A19.3:30

A 13.3:32

129.6:26

14.3:22

A4.1:899

A9.7:1

127.9:10

11.9:39

A 1.1:869

1 1.1:\$65

A $1.9: 149$

127.9:13

1:7.9:2:2

A27.4:2:8

A $27.9: 25$

Farmers' institute work aecomplishel in (Creelman). 1902. p.26. $\Lambda 10.3: 120$ 
Ontario-Continued

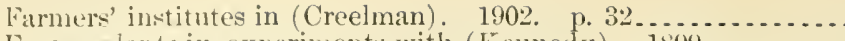

Forace plants in, experiments with (Kennedy). 1899.

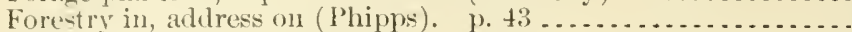

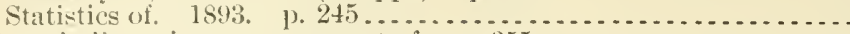

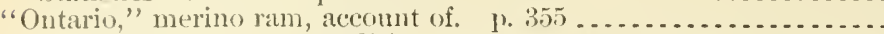

Ontario, Oreg. Forage conditions between Winnemucea, Nev., and (Ciriffiths). 1902 . . . . . . . . . . . . . . . . . . . . . . .

Ontario, Lake, eurrents of, notes on (Abbe). 1894. p. $259 \ldots . . .$.

Öology of some land birds of New England, as a means of identifying injurions or beneficial species (Sannels). p. $386 \ldots . . . . . . . .$.

()pium from North Carolina (IIcJurtrie), $1873, p, 499 \ldots \ldots . .$.

Opium poppy:

Cultivation of, experiments in. p. 206

Culture of, in smyrna.

Ophthalnia. Seee Cattle.

Optical phenomena:

Notes on (Alibe) -

1895. 1). 14, 298

1898. p. 569

Washington, 1). (., Feb. 13,1895 (Abbe), p. $56 \ldots$

Opuntia, North American species of, preliminary revision of (Coulter). 1896. p. 355

Orange:

Cultivation and consumption of, facts regarding. p. 561

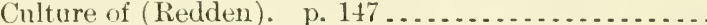

Fertilization of soil as affecting, in health and disease (Teliber). 1894. p. 193

Florida, diseases of (Underwood) 1891 .

Fluted scale of, and its natural enemies in Australia (Koebele).

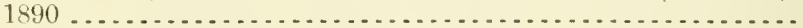

Insetts affecting, with practical suggestions for their control or extermination (IIublbard). 1885

Insects injurious to, in Brazil, preliminary report of observations

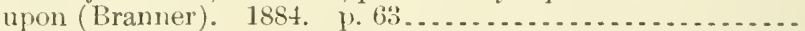

Insects injuriously affecting orange tree, experiments with kerosene upon . . . . . . . . . . . . . . . . . . . . . . . . . . . . .

Insects of, miscellaneous notes on (Hubbard). 1883. 1).9....

Mite of, six-spotted (Riley). $1890 . \quad$ p. 225
Propagating other citrus fruits and, methods of (Vebber). 1896. p. 471 .

Root-knot disease of, in Florida, due to work of Anguillula

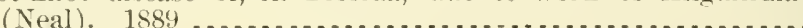

Rust of-

mieroscopic observations of (Taylor). 1873. p. 588

Scale-insects of -

experiments upon (Voyle). 1883, p. 19

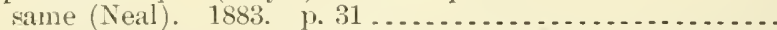
in California, and particularly icerya or fluted scale, alias white scale, alias cottony cushion-scale, etc., (Riley). 1887. 1. 9. in Florida, effects of cold upon (Toyle). 188t. p. 70 ....... remedies and their application (Hubbard). p. $106 \ldots . . . .$.

Sooty mold of, treatment for (Webber). 1895 ................

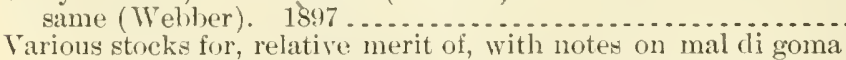

and mutual influence of stock and scion (King). $1891 \ldots \ldots$
See also Aleyrodes citri - Morelos orange fruit-worm - Osage orange.

Orange sorghum cane, cultivation and manipulation of, communica-

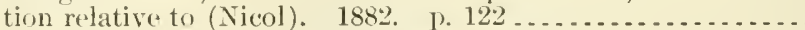

Orcharrl grass, spot distase of (Trelease). 1, 129 . . . . . . . . . .

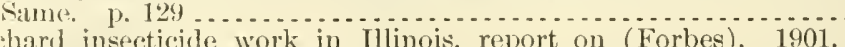

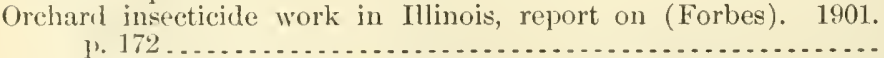
Orchard-spraying outfit, cheap, note on. 1895. p. $586 \ldots \ldots \ldots \ldots .$.

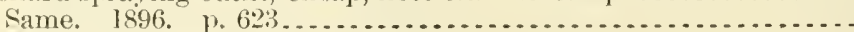
Orchard trees, small, fumigator for 1901.

A29.6:23

A $29.6: 26$ A29.6:23

A $6.5: 3$

A1.1:877

A1.1:867

A $1.10: 894$ A28.5:7

A9.3:21

A9.2:Or1

A9.3:4

A9.3:1

A9.3:1

A9.7:2

A1.10:896

A9.3:20

A 27.9:11

A1.1:88t

A 9.3:1

A9.3:1

A9.3:15

A9.3:4

A9.1:882

A $28.4: 15$

A28.3:13

A20.3:4

A1.8:22

A1.1:886 A28.1:886

A10.3:99

1 $1.10: 895$

A1.10:896 A1.9:133 
Orchards:

Cover crops grown to protect trees and improve soil of. 1899.

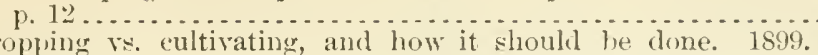

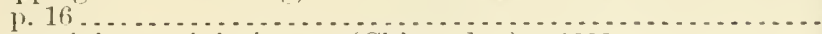
Crops of, insects injurious t) (Chittenden). $1899 \ldots \ldots \ldots . . . . .$.

Deciduous, winter irrigation of. 1901. p. 12.............. Fnemies to, in Pacific Northwest (Piper). 1902 . . . . . . . . . . .

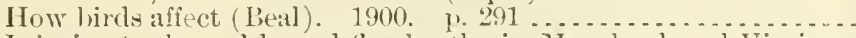
Injuries to, by red-legged flea-beetle, in Jiaryland and Virmina

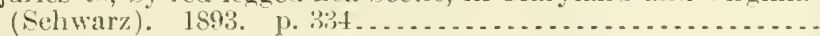

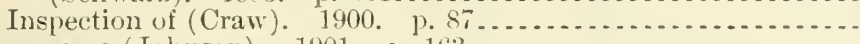

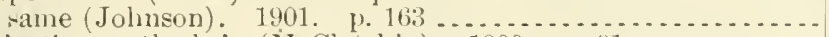

Irrigation methords in (IIcClatehie). 1900 . p. 91 ............

Pear leaf-blight in, treatment of (Waite). 1891. 1. 333 .......

Scale insects of (Howard). 189t. p. 249 ...............

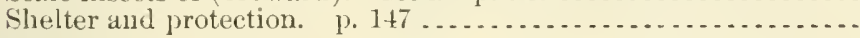

Oregon:

Agricultural possibilities of. 1870. p. 229 .

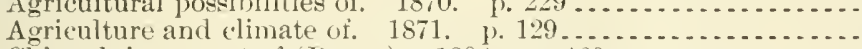

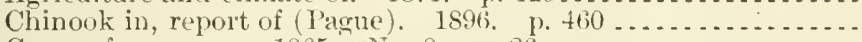
Crops of, per acre. 1865. No. 8. 1) 26 .................. Eastern, agricultural resources of (Ritz). 1869. p. $384^{*} \ldots \ldots \ldots$ Entomological work in, in 1893 (Koebele). p. $33 \ldots \ldots \ldots . . . . .$.

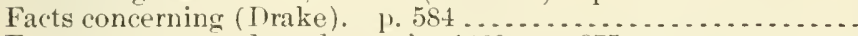
Farm resources and products of. 1868 , p. $275 \ldots \ldots \ldots$ Grases of, plates anil (lescriptions of (Vasey). 1892..........

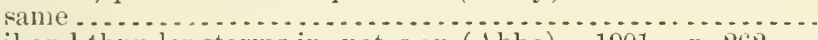
Hail and thunder storms in, notes on (Abbe). 1.901. p. $262 \ldots$ Hop lonse in, experiments with (Koebele). 1893. p. 12 ..... Irrigation in, in 1890 (Nimmo). p. 149 . . . . . . . . . . . . . . . Klamath Indians of, plants used by, (Coville). 1897. p.87 ... Long-range weatter forecasts in (Abbe). 1895. p. 423....... Roarl implovement inextract from governor's inaugural adlress (Geer). p. 8..... extract from governor's message (Lord). 1. 7 . . . . . . . . . .

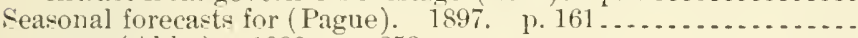

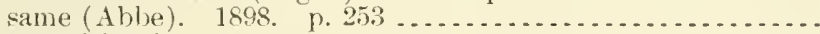

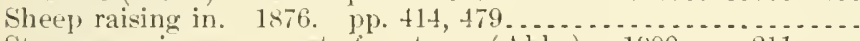
Storn wamings on coast of, note on (Al,be). 1900. p. 211.... Weather of, and Bering Sea ice, notes on, 1890-99 (Ablue). If. 163,

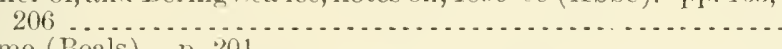

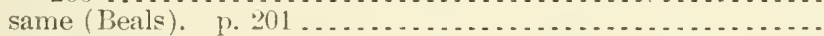

Weather forceasts for, notes on, 1895-99 (Abbe). 1. 313........ See clso Cascarle Mountains - Lane County - Ontario - Pacific: Northwest - Portland.

Organic nutter in plants, origin and formation of (Dehérain).

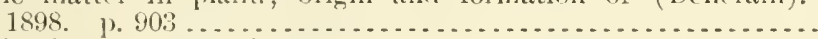

Organic nitrogen. Se Nitrogen.

Orgyia leucostigma, parasites of, additional observations on (HowOrient:

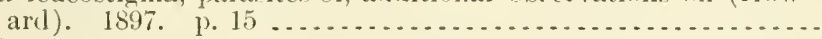

Export of Califomia butter to (Pearson). p. 266

A. $9.6: 9$ same (reprinted). 1900.

See rlso Typliouns.

Oriole, Baltimore, and mearlow lark (Beal). 1895. p. 419.

Ormerod, Elemor A. Insects, notes of season on. 1891. 1). $36 \ldots$

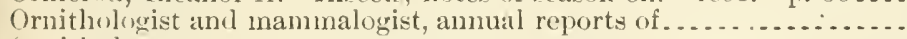
Ornithology:

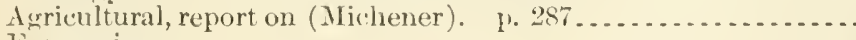

Economic-

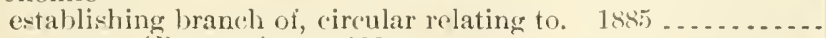

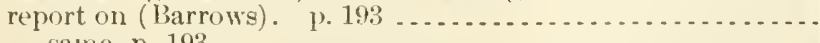

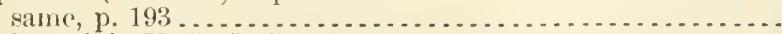
review of, in U. S. (Palmer). 1899. p. $259 \ldots \ldots \ldots \ldots$ A10.6:9

1. $1.1: 899$ A $4.8: 24$ 
Ornithology and IIammalogy Dirision. See Biological Survey, Agri-

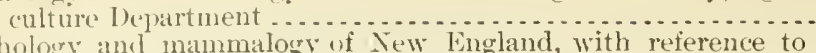

Ornithology and mammalogy of New England, with reference to

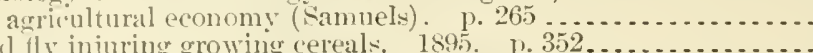

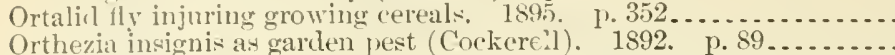

Orthojtera:

New species of, from Death Valley expedition (Bruner). 1893.

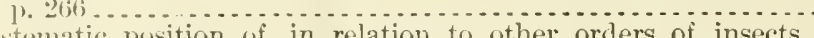
Systematic position of, in relation to other orders of insects. 1893. P. 286 .

Orton, II. A.:

P'lant disedses in United States. 1901. p. 668.

IVilt disuase of cotton and its control.

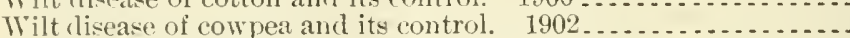
See clso, as joint anthor, Webher, Herbert John.

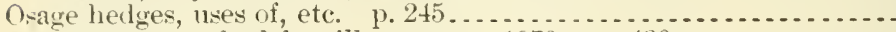
Osage orange as feed for silk-worms. 1870 . p. $430 \ldots \ldots \ldots \ldots \ldots$

Osace orange pyralid (Murtfeldt). 1893. p. $155 \ldots \ldots \ldots \ldots \ldots \ldots$

Osborm, Herhert:

Chinch bug observations in Iowa in 1894. 1894. p. 230........

Entomological work in agricultural experiment stations. 1895. p. 8.5

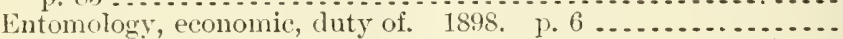
Grass insects in Washington, D. C., notes on. 1891. 1. 197....

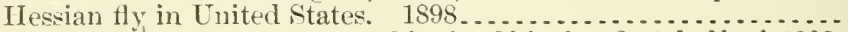

Insect occurrences, some notable, in Ohio for first half of 1902. 1902

Insecticile experiments at Ames, Iowa. 1886 . p. $23 \ldots \ldots . . .$.

Insects, injurions, use of contagions diseases in contending with. 1890. p. 141

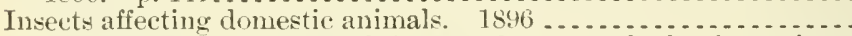
Insects affecting grasses and forage plants, methods of treating.

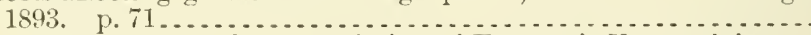

Iowa insects reported to Association of Economic Entomolgists-

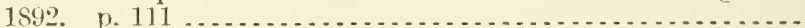

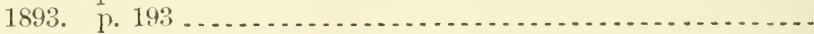

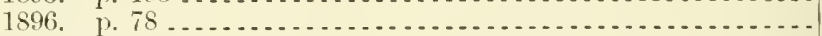

Iowa, insects of1887. ए. 154 1889. T. 18 $1890 . \quad$ 1. 57

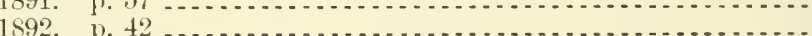
1893.

Kansas, trip to, to investigate reported damages from grasshoppers-

paper read before Association of Economic Entomologists.

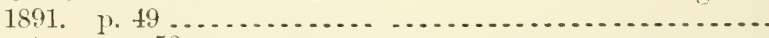

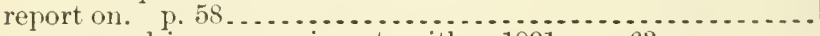

Kerosene emulsions, experiments with. 1891 . p. $63 \ldots \ldots . . . . .$.

Mallophaga, development in, notes on period of. 1890 . p. 115 .
Mallophaga and pediculicle, parasitic habit in, origin and development of. 1891 . P. 187

Missouri, northwest, grasshopper injuries in, report on trip to

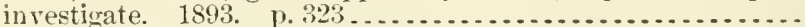

Parasites of domestic animals, methods of attacking. 1893, p. 163.

Pediculi and nallophaga affecting man and lower animals. 1891 .

Schizoneura panicola thos. and S. corni fab., identity of. 1889.

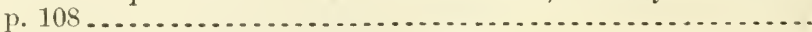

Thripicla, food habits of. 1888. P. $137 \ldots$

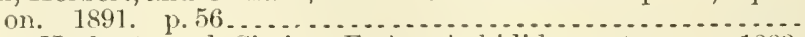

Oshorn, Herbert, and Sirrine, F. A. Aphidida, notes on. 1893.

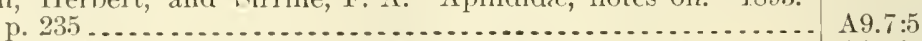

Osborn, J. M. Crops in Indiana and Illinois. 1891. p. $483 \ldots . .$. A27.9:29 
Index

Osborne, William MeKinley. Animals, learl, disposition of, in

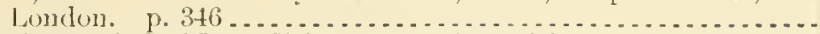

Oscillation neriod of Lake Erie, note ou (Harris). 1902. p. $312 \ldots$

Orcillations of lake level, notes on (Albe). 1900. p. $446 . . . . .$.

Oscinidx, reared at United States Jepartment of Agriculture, habits

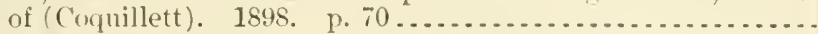

Osgoorl, Wilfred H.:

Natural history of Queen Charlotte Islands, British Columbia,

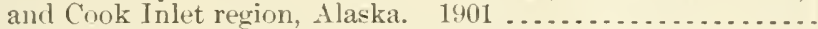

Pocket mice of genus Perognathus, revision of. $1900 \ldots . . . . . .$.

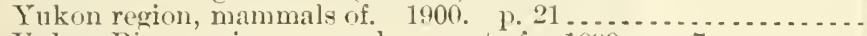

Yukon River region, general account of. 1849. p. 7 ........

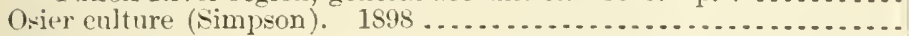

Osier willow:

Culture and economic importance of. 1. 254 ... . . . . . . . .

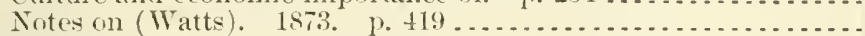

Osteomalacia or creeps. See Cattle.

Osteoporosis. See Horses.

Ostrich farming in America (Duncan). 1) 685.

Otis, I. H. See, as joint author, Cottrell, H. M.

Ottawa, Jllinois, swine plagne at (Dyer). 1879. p. 156...........

Ottawa, Kans., diffusion and cartomatation at, experiments with

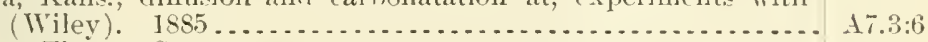

Outram, Thomas S.:

Washouts, floods, cold waves, ancl heary snowfalls, wamings of, for henefit of transportation companies. 1899. p. $38 \ldots \ldots .$.

Weather Bureau stations, is exposure at, satisfactory for all

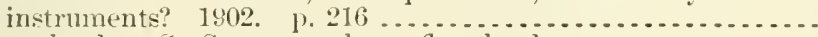

Overflow lands. See Swamp and overflow land.

Orine caseous lymph adenitis, nature, canse, and economic importance of (Xörgaard anrl Mohler). p. 638 ..................

Owen, D. A. Stomata, strange levelopments of, on Carya alla

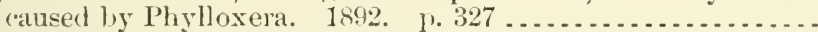

Owen, Richard. Inilustrial colleges; general plan of juildings, with necessary aids to instruction in each department of education. 1864.

Owens, James F. State aid to rod construction in New Jersey.

Owl: 1901.

p. 2:

Ftate aid to road construction in New Jersey.

Common screech, report on (Fisher). 1) 372.

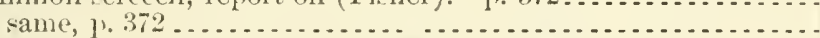

Short-eared, special report on (Fisher). p. 496 same, 1. 446.

See colso Hawks and Ow ls.

Ox bot in United States (Riley). 1892. p. 302.

Ox warble:

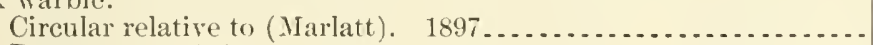

Report on. 1889. p. 172 . . . . .

Oxalic acir, action of, upon phosphates, silicates, and soil (Kastle

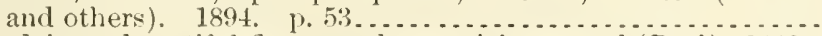

Oxeye daisy, a beautiful flower and pernicious weed (Beal). 1899.

Pachybasium, attendant, Jinnesota species of, note on (Mac.Millan). 1891. p. 75 .

Pachrneuron, habits of (Howari). 1891.

Pacific roast:

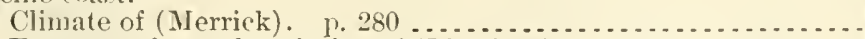

Evotomys from, description of (Merrian). 1890. p. 25 ......

Field crops and animal industries of (Jones). 1892. p. $59 \ldots \ldots$

Fruit growers on, irrigation practice among (Wickson), $190 \% \ldots$

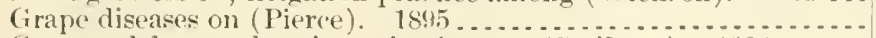

Grass and forage plant investigations on (Scribner). $1899 . . . .$.

(irasses, notes on some (Vasey). 1893. 1. 265 ...............

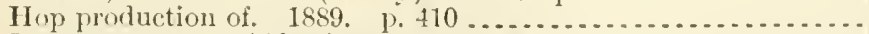

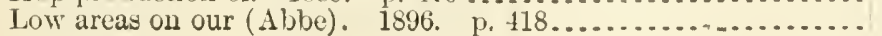

14.1:899

1.9.6:30

129.6:28

19.6:10

15.5:21

A5.5:18

15. $5: 19$

A.5.5:19

A13.3:19

11.1:573

127.9:11

A1.1:888

A 1.6:12

$129.3: 24$

$+29.3: 31$

At.1:899

19.7:4

127.2:In2

122.3:21

A1.1:889

A5.1:889

A 1.1:858

15.1:858

19.7:4

A9.5:25

A $9.7: 2$

A7.3:43

A1.9:10:3

128.5:(6)

19.7:3

1 1.1:5617

15.5:4

1 1.8:20

1 10.3:108

A $1.9: 30$

13. $4: 2: 2$

16.5:1

127.9:27

129.6:24 
Pacific coast-Continmed

Forth-

high areas of, in September, October, and November (Garriott).

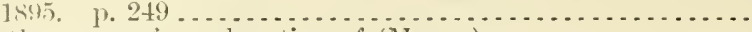

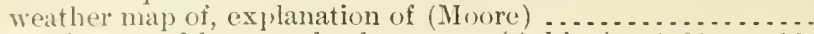
States of, seasonal forecasts for, long range (Ashley). 1901. j.16. Weather on, of Angust, notes on (Al)be). 1899. 1. $421 \ldots \ldots . .$. Theather service on, possibilities of (Hammon). 1899. p. 56 ...

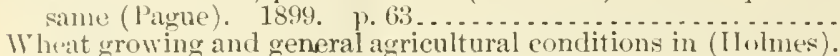
1901 . . . . . . . . . . . . . . . . . . . . . . . . . . . .

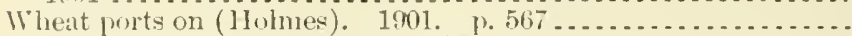

Work of Division of Entomoling (Hemry). 1889. p. 1+1...... Se $u(s)$ - Pacific Northwest - Pacific slope-Pacific States-and names of Sitates.

larific coat division of Canadian meteorological service, motes on

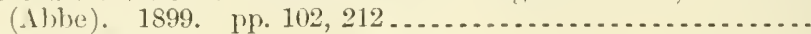

Pacifie Nolthwest:

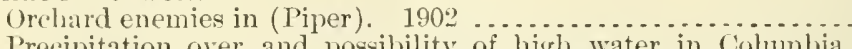

Precipitation over, and possibility of high water in Columbia ['iver] from meltingsnow in mountains (Pague). 1899. 1. 252.

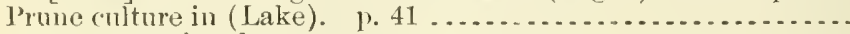

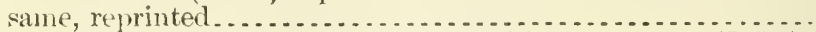
Prunes and prune culture in, existing ennditions, ete., 1901 (Lake) Sheep husbandry in (Witheonibe). 1900 . p. 5 .............. tre also - Northwest - and names of States.

Pacific Ocean:

Ilate line in (Page). 1902. p. $36 ; \%$... . . . . . . . . . . . . . . Stom centers in, notes on (Abbe). 1899. p. 114 ............. Pacific slope:

Arid regions of, elimatic and agricultural features of, etc. (Hilgard

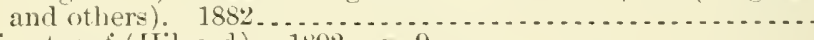

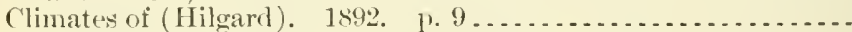

Field cultures on, miscellaneous (llilgard). 1892. 1). $79 \ldots \ldots .$. (irasses of, including Alaska and adjacent islands. 2 pts. (Vasey.).

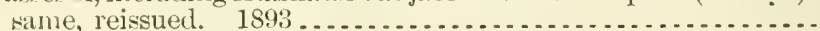
North-

weather forecasting and weather types on (Pagne and Bland-

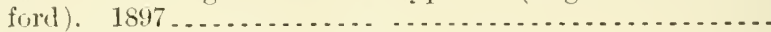
weather types of (Pague). 1s95. p. $417 \ldots . . . .$.
See colso-Iacific Northwest - Pacific States - and names of States.

Pacific States:

Agriculture of Territories and. 1865. No.5. p.18; No.10. p. 24.

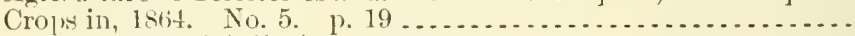

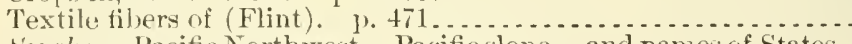
Se also - Pacifie Northwest - Pacific slope - and names of States. Parkari, Alphens spring:

Bucculatrix canadensisella, occurrence of, on birch in Rhode Isiant. 1892. p. 14 ................................

Calothysanis amaturaria, a geometrid moth, life history of.

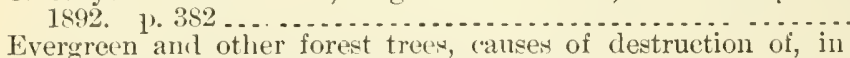
northern New England and New York-

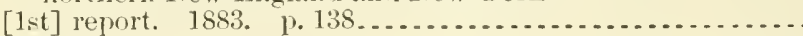

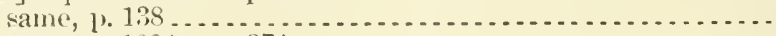

2 report. 1884 p. pit. $374 \ldots \ldots \ldots \ldots$

3 report, in northern New England. 1) $319 \ldots \ldots . . . . . . .$.

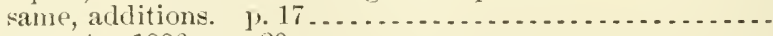

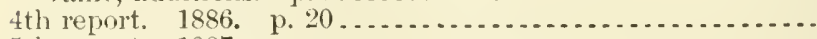

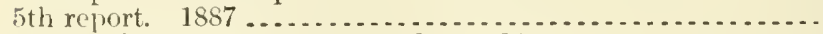

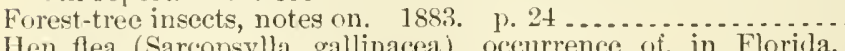

Hen flea (Sarcopsylla gallinacea), oceurrence of, in Florila.

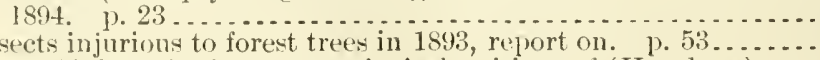

Insects injurious to forest trees in 1893 , report on. p. $53 \ldots \ldots \ldots$.
ackarl, Alpheus Spring, entomological writings of (Henshaw) .... Padr, L. Milk, bicarbonate of soda ill, detection of. 1889.1 . 170.

A $29.6: 23$

A:9.2: 181

129.6:29

A29.6:27

A29.3:24

A:9.3:24

A27.8:20

11.10:901

19.7:2

129.6:27

A 1.9:158

A29.6:27

A20.1:894

A20.4:2

A20.3:10

A1.9:117

A29.6:30

A29.6:27

A1.8:20

A 1.8:20

A 1.8:20

A 6.3:13

A6.2:

129.2:P11

A 29.6 .23

A27.9:3

A27.9:2

11.1:864

A9.7:5

19.7:4

A1.1:883

A.9.1:883

A1.1:884

A1.1:885

A9.3:12

A.9.3:13

A $8.1: 4$

A9.3:3

A9.7:7

19.3:32

A $9.3: 16$

A7.3:24

Page, E. D. See Graves, Henry S. 
Page, J. W. Scuppernong wine, analysis of. 1S6ৎ. p. 362........

Page, James:

Barograph on shiphoarl, report of. 1900. 1) $5: 10 \ldots . . . . . .$.

Date line in Pacific Ocean. 1902. p. 3633 ..................

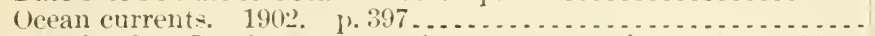

Page, John R. Lands, worn-ont, improvement of. 1ss3. p. 207.

Page, John R., and Terrell, J. J. cilanters and farcy in horves.

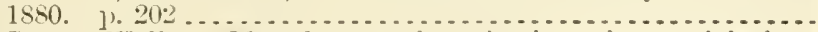

Page, Logan Walls. Macalan roarls, selection of materials for. 1900. P. 349 ...............................

See also, as joint author, Ewell, Ervine Elgar.
age Connty, lowa, hog cholera in, experiments in stamping out.

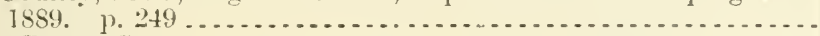

Pague, Bemer.:

Chinook winds in Oregon, report of. 1896. p. 460............

Lightning from cloudless sky. 1900. p. 429................

Long-range weather forecasts, report of. 1596,1 , $166 \ldots \ldots \ldots$

Oregon, seasonal forecasts for. 1897. 1. $161 \ldots$................ ter in Columbia river from melting snow in mountains. 1899.

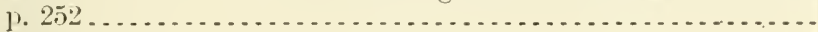

Weather Burean, official of, his iluties and qualifications. 1899.

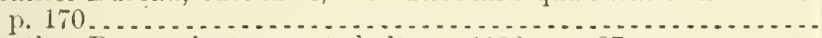

Weather Bureau instrument shelter. 1893. p. 27 .............

Weather forecasts, long-range. Can they be made with sufficient precision to be of general utility? 1899 . p. 46 .........

Weather service on Pacific coast, possibilities of, 1899 p. p3...

Weather types of North Pacific slope. 1895 , p. $417 \ldots \ldots . . . .$. Pague, Bemer., and Blandford, Samuel M. Weather forecasting and weather types on North Pacific slope. 1897............

Painesville, Ohio. See Lake Erie College.

Palm. Seee Date palm.

Palm and palmetto weevils (Chittenden). 1902. p. 23..........

Palmer, Edward. See, as collector, Eckfeldt, J. W. - Scribner, Frank Lamson - Vasey, George, and Rose, Joseph Nelson.

Palmer, Theorlore Sherman:

Animals and birds, noxious, danger of introducing. 189s. p. S7.

Birds and game, protection of, directory of State officials and or-

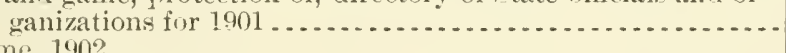

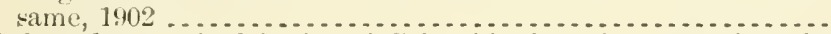

Birds and game in District of Columbia, laws for protection of. 1901

Birds other than game birls, legislation for protection of. 1900.

Death Valley expedition, 1891, localities visited by, lint of. 1893.

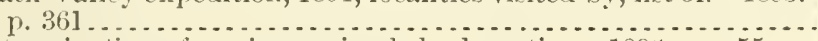

Extermination of noxious animals by bounties. $1896 . \mathrm{p} .5 \mathrm{n} . .$.

Jack rablit of Uniterl States _ . . . . . . . . . . . . . . . . .

Ornithology, economie, in U. S., review of 1899 . p. $259 \ldots \ldots$.

See also, for report as aeting Chief, Biological Survey, 1898-1901 ..

Palmer, Theodore Sherman, and Olds, Henry Worthington:

Game-

information concerning seasons, shipment, and sale of. 1900.. transportation and sale of, laws regulating. $1900 \ldots . . . . .$.

Game laws for 1901, ligest of . . . . . . same, 1902

Palmer, IV. S.:

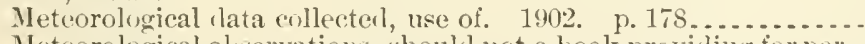

Meteorological olservations, should not a book providing for permanent record of, be furnisherl to section centers and voluntary stations"? 1899. p. 122. . . . . . . . . . . . . . . . . . . .

Wyoming, water supply of, for season of 1900 , as depending on

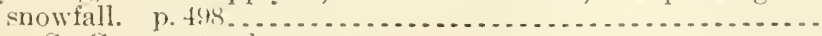

Palms. Sre Cocoanut palms.

Pammel, L. H.:

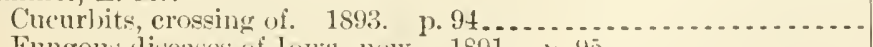

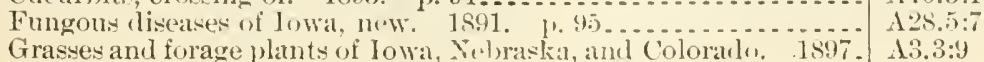

$110.3: 16$

13.3:1 
Paimpas, The:

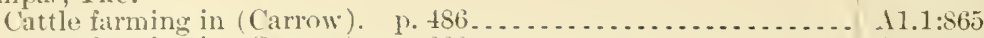

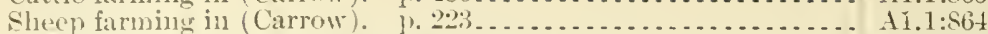

Pamperos and cyclonic stoms, notes on (Able ). 1s:94. p. 15t . . A29.6:27

Pan-American Exposition. Se Buffalo, T. Y.

Pan-American trale, 1890 . P. 454 .

Panama, Isthmus of, climatology of inclucling tomperature, winds, barometric pressure, and precipitation ( 1 bhot). 1899. pp.

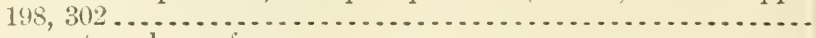

Panama, meteorology of:

Contributions to (Ablot). 1899. p. 7 .

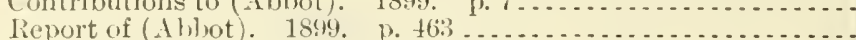

Panchlora, further notes on (Riley). 1891. j. 119............

Panicum nashianum, new varicty of. p. 9 . . . . . . . . . . . . . .

Panicum nitidum, Panicum scoparinm, and Panicum pubescens, notes on (Scribner and Merrill). 1900. 1. $31 \ldots . . . . . . .$.

Panicums:

American, in herharium Berolinense and in herbarium of Willde-

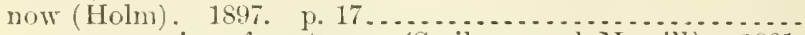

Three new speries of, notes on (Seribner and Merrill). 1901.

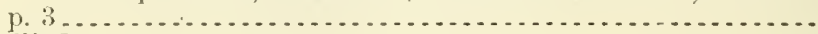

Paparelli, L.:

Agricultural education in Italy. 1893. p. $326 \ldots \ldots \ldots \ldots . . . . .$.

Italy, institutions for agricultural investigation in. $1893 . p$.

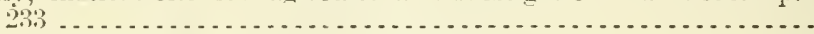

Paper. See Japanest paper - Maize-paper.

Paper-making wasp, use of grape bags by (Murtfeldt). 1891. p. 192

Paraguay:

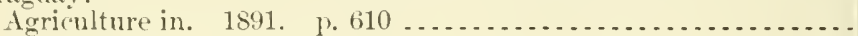

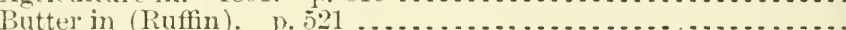

Parasites:

Cattle, sheep, and swine, compendium of, arranged according to

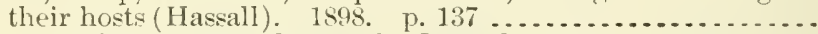

Cotton stainer, supposed eggs of (Howard). 1889 . p. 241 .....

Domestic animals, methods of attacking (Osborn). 1893. p.163.

Economic value of (Snith). 1893. p. 142 ...............

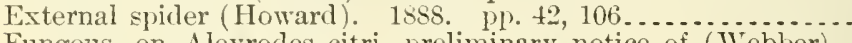

Fungous, on Aleyrodes citri, preliminary notice of (Webber).

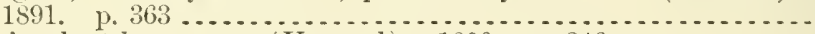

Grain plant-louse, new (Howard). 1890. 1. $246 \ldots \ldots \ldots \ldots \ldots$

Hymenopterous-

host relations of (Howard). 1891. p. $277 \ldots \ldots \ldots \ldots . . . . . . .$. of California red scale (Howard). 1894. p. $227 \ldots . . . . . .$. of Coleoptera, observations on some (Chittenden). 1893.

\section{Icerya-} p. 247.

new, report of (Howard). 1892. p. $37 \mathrm{~s}$.

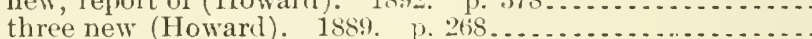

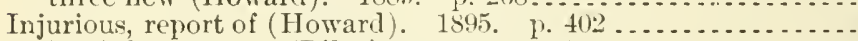

Lady-bird, report on (Riley). 18s8. 1. $101 \ldots . . . . . . . . . . .$.

Mytilaspis pomorum, new (Howard). 1894. p. $251 . \ldots \ldots \ldots \ldots$.

Note on (Howard). 1891. P. 48.......................

Orgyia leucostigma, additional observations on (Howard). 1897.

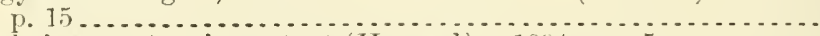

Scale-insects, two important (Howard). 18st. p. $5 \ldots . . . . . .$.

spider, new, report of (Ashmead). 1894. 1). 259 ............

Spider-ege, two (Howard). 1890 . py. $269,359 \ldots \ldots \ldots \ldots \ldots .$.

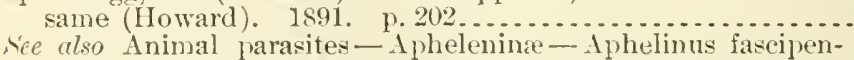
nis - Australian parasite - Cercospora circumscissa - Cestodes - Chalcidirlat - Chicken-tick - Coecilia - Dipterous parasite - Egyptian strongyle - Flasmus - Insects - Jointworm - Malloplaga and pediculicle — Mantis egg-parasites Megilla parasite - Pachyneuron - Phytoptus distortionsPimpla comquisitor - Pine leaf rnst - Jlatypsyllus - Pseudomanas hyacinthi - Roundworms - Sarcaptide - Sarcospo- 
ridia - Sheep scab mite - Sonthern cattle ticks - Spider-egg parasites - spieler parasites - Sprorozon - Taclinide Ticks - Trichina spiralis - Trypanosomiasis - Ugimyia sericarla - Vinegar eel.

Parasitie bronehitis. Se Bronchitis.

Parasitic diseases. See Diseases of animals-Grape vine.

Parasitic two-winged insects, see Tachinide.

Parasitism:

Among Sarcoptide, origin and derelopment of (farman). 1591.

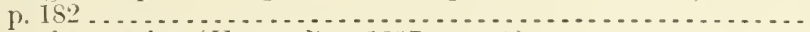

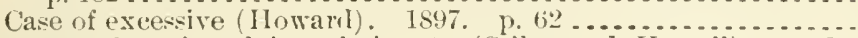

Host, eolor of, and its relation to (Stiles and Hassall). 1892.

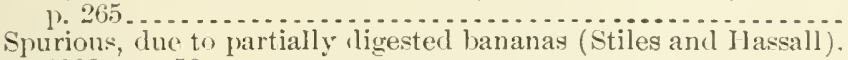

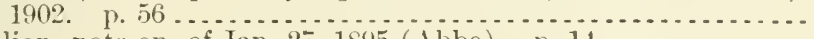

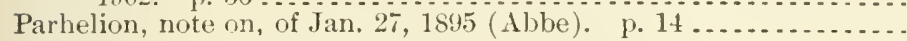

Paris:

American horses used by large horse companies in (Loncey).

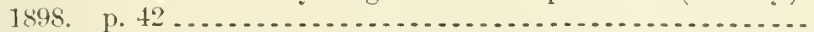

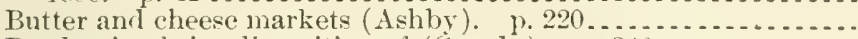

Dead animals in, disposition of (Gowdy ). p. $348 \ldots \ldots \ldots \ldots .$.

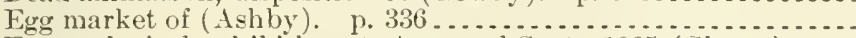

Entomological exhibition at, Aug. and Sept., 1865 (Glover). p.

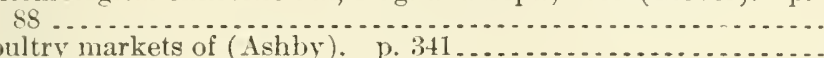

Poultry markets of (Ashby) p. $341 \ldots \ldots \ldots \ldots$
Ramie machine trials in, in 1889 (Dodge). $1892 . \quad$ p. $32 \ldots \ldots \ldots$ same, 2 d ed. p. $32 \ldots \ldots \ldots \ldots$. . . . . . . .

Paris Exposition of $186 \bar{t}$, report of committee on culture and prod-
uets of vine, made to U. S. Commissioners (Willer and

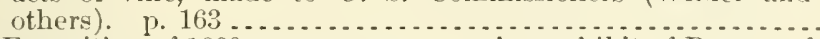

19.7:4

A9.6:7

19.7:4

A 4.3:35

ג29.6:23

A 1.2:H78

A $4.1: 899$

14.1:899

At.1:899

A1.1:865

A4.1:899

A 27.8:1

A11.5:1

A1.1:867

Paris Exposition of 1889, papers accompanying exhibit of Bureau of Animal Industry at. p. 359.

Paris Exposition, 1900:

Agricultural experiment station veterinarians, exhibit at (Peters). 1898. p. 22 .

Agricultural experiment stations, collective exhibit at-

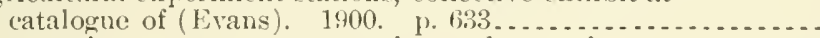
committee report on preparation and care of-

1898 (llarris). p. 43

1899 (Armsby). p. 30

1900 (Amoby) p.

1900 (Armsby). p. 20 . . .

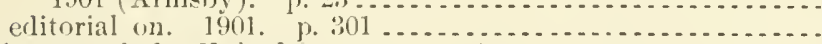

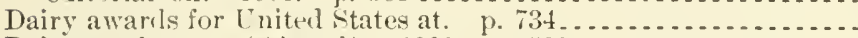

Dairy prorluets at (Alrord). 1900. p. 599

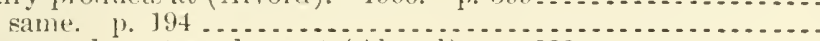

Meats and meat products at (Alyorl). p. 223................

W'eather liureau at, notes on (Al,he). 1900. p. $445 \ldots \ldots \ldots .$.

World's exhibit of leaf tobacco at. p. 157....................

Paris, International Congresses of Horticulture, Viticulture, and Agriculture, 1901 (Evans). p. 205.

Paris, International Industrial Fair, 1867, note on. No.10. p. 20...

Paris, International Meteorolngical Conference, Sept., 1896, report

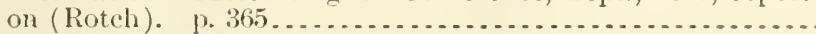

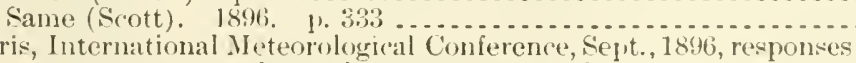
to programme of questions proposed for discussion at . . . . . . . .

Paris, International Meteorological Congress, Sept., 1900, notes on

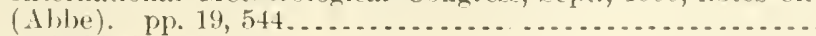

Same (Abbe), 1, $265 \ldots \ldots \ldots \ldots$

Paris, Tenth International Congress of Hygiene and Demograply, held August 10-16, 1900 (De Schweinitr). p. 260...........

Paris, 'Thirteenth International Medical Congress, heli August 4, 1900 (De Sehweinitz). p. 254 .

Paris green:

As protection against cotton insects (ilover). 1873, 1. 572 ... A27.9:11

A $4.1: 887-8$

A 4.3:22

110.3:80

A10.3:49

A $10.3: 65$

A 10.3:76

A $10.3: 99$

A $10.6: 12$

A1.10:900

A $1.10: 900$

A $4.1: 900$

A 4.1:900

A29.6:28

A $1.10: 900$

A $10.6: 12$

A $27.9: 3$

129.6:24

$A: 9.6: 24$

A29.2:P'21

129.6:28

A29.6:29

A4.1:900

A4.1:90() 
Paris yreen-Continued

Experience with (Cockerell). 1897. p. 25 ................

Its use in agri(ulture (11c.llurtrie). 1874. p. $507 \ldots \ldots \ldots \ldots \ldots$.

Low-grale, use of, to iruit-growers (Wilcox). 1900. p. 14 ....

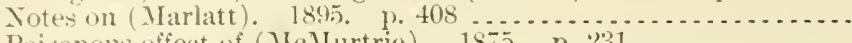

Poisonoms effect of (Mellurtrie). 1875. p. 2:31 ...........

Parker, S. J :

Grapes, native, improvement of, by seedlings and hybridization.

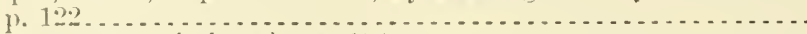

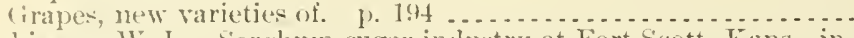

Parkinson, IV. L. Forghum-sugar industry at Fort Scott, Kans., in

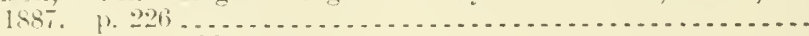

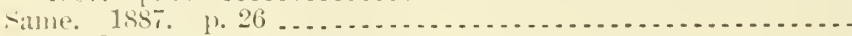

Parry, ( . C.:

Litanical explorations in last Tennessee. 1870. 1. 221.

Cinchona plantine in Jamaica. 1871. 1. 120 ...............

Yorth American fesert flora between $32^{\circ}$ and $42^{\circ}$ north latitude. 1871. 1). 23.

See rlso, for reports as Botanist, Botany Division, Agriculture

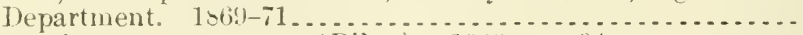

Par-nip wel-worm, report on (Riley) 18s8. p. 94...........

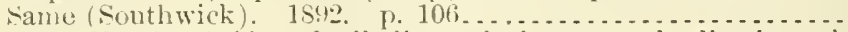

Parsons, E. M. Acid and alkaline solutions, standardization of,

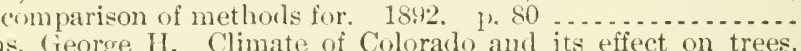

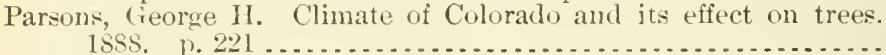

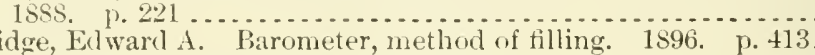

Parser domesticus. See House sparrow.

Passer montanus. See European tree sparrow.

Pasteurization. See Milk.

Pasteurized cream, restoring consistency of. 1898. p. 23 .........

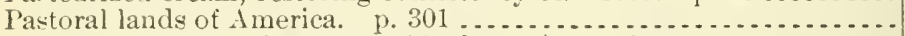

Pastoral resources of Montana (Anderson). p. 311 .............

Pantrana, Manuel E. Mexican climatologital data, monthly notes

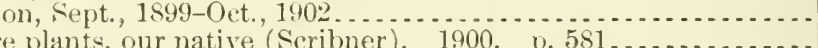

Pasture plants, our native (Seribner). 1900 , p. $581 \ldots . . . . . . . .$.
Pastures. The Cattle ranges of Southwest - Mearlows and pastures.

Pastures: We Cattle

Ferns from, collected by U. S. S. Albatross in $1887-91$, list of

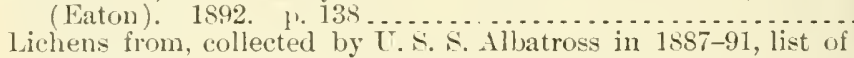

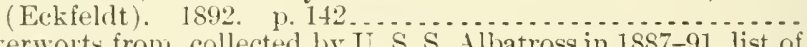

Liverwort, from, collected by U.S. S. Albatross in 1857-91, list of (Evans). 1892. p. 140 ...

Patents:

See also Fuegia and Patagonia.

A gricultural, of year 1869. p. 315.

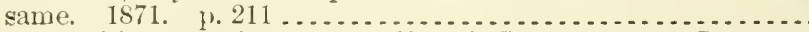

Fiber machinery and processes, list of, Jan., 1875, to Dec. 31,

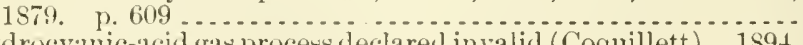

Hydrocyanic-acid gas process declarerl invalid (Coquillett). 1894.

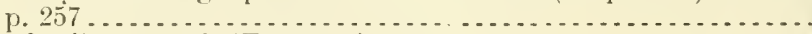

Metal railway track (Tratman). 18s9. p. 36 ..............

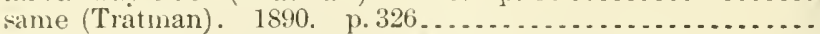

Pathogenie bacteria. See Bacteria - Milk and its products.

Pathological conditions found in meat inspertion (Salmon). p. 52 .

Pathology of plants, lines of investigation that might be undertaken by experiment stations (Galloway). 1897. p. 725......... Patrick, George Edward:

Butter, renovated, report on identification of. 1902 . p. 115 ....

Distilling flask, new, for use in Kjellahl process. 1891. p. 142.

Fat acids, soluble and insoluble, notes on methods for. 1888. p. 25

A9.6:9

A $27.4: 12$

+1.9:114

19.7:7

Аะ $7.9: 13$

11.1:864

A 1.1:865

1 1.1:S8T

A7.3:17

A:7.9:8

A27.9:9

A $27.9: 9$

A6. 1:

A9.7:1

A9. $7: 5$

A $7.3: 35$

A 13.3:2

129.6:24

$\mathrm{A} 4.2: \mathrm{C}_{29^{2}}$

A1.9:69

A 1. 1:870

A1.1:888

A6.1:S88

A29.6:

A $1.10: 900$

+6.5:1

A6.5:1

\6.5:1

A 1.1:869

A 1.1:871

A $1.1: 879$

A $9.7: 7$

A 13.3:3

A 13.3:4

A4.1:900

A 10.6:7

A 7. $3: 67$

A $7.3: 31$

A $7.3: 19$ 
Patrick, George Edward-Continued

Household tests for detection of oleomargarine and renovated but-

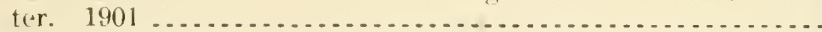

Milk, comprosite, samples in laboratory 1891. p. $26 \ldots \ldots \ldots$.

Milk test, standard, report on. 1891. 1) 123...............

Patrick method of determination of fat in milk. 1889. p. $163 \ldots . .$.

Patrons of Husbandry:

List of officers-

1898. p. 624

1899. p. 717

1900. p. 671 .

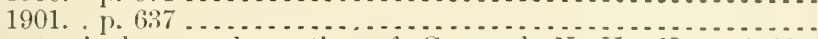

Twenty-sixth annual meeting of, Concord, N. H., Nor., 1892.

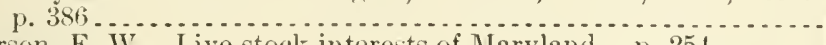

Patterson, F. W. Live-stock interests of Maryland. p. 254 . . . .

Same, P. $466 \ldots$ W. Fungi, economic and other, collection of, pre-

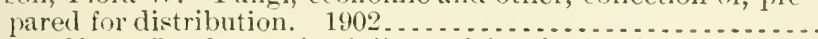

Patterson, Harry Jacob. Animal, live weight of, what is the? 1893. 1. $150 \ldots \ldots$.

Patterson, J. K. Elucation at agricultural colleges, general drift of. 1901. p. 99

Patterson, Robert F. Calcutta, hides and skins from, imports of. p. 523

Patterson, S. L.:

Address of, before gond roads convention, at Winston-Salem, X. C.

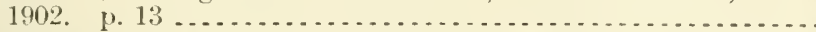

Sorth Carolina, farmers' institute work aremmplished in. 1902.

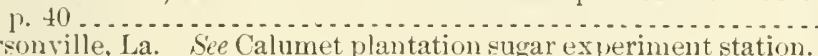

Pattersonville, La. See Calumet plantation sugar experiment station.
Patton, W. M.:

Highways, public, alignment of. 1902. p. 7t . . . . . . . . . .

Roarls, location and construction of. 1902 . $1 \% 30$. $30 . . . . . . . .$.
Patton, Wh. Hampton. Ephestia interpunctella zeller, notes upon.

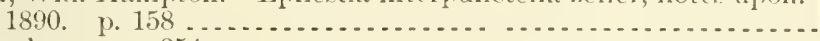

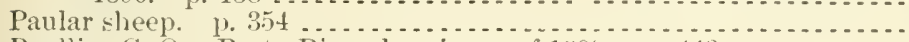

Paullin, C. O. Porto Rican hurricane of 1899 . 1. 443 . . . .

Pauken, Adam. Denmark, climate of. 1s96. p. $640 \ldots \ldots \ldots \ldots$

Payne, Allans S. Swine-plaque in Tirginia. 1879. p. 165.......

Pea. Sice l'eas.

Pea louse, lestructive, new and important ecommic species of genus Teetarophora (Johnson). 1899. p. 94 ...............

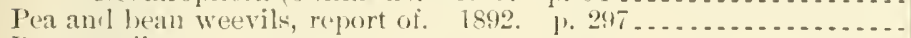

Pea weevil:

Larval stage oi, first. 189?. 1. 392. . . . . . . . . . . . . . . .

Report of. 1592. 1. $297 \ldots \ldots \ldots$

Peaborly, Selim H. Agriculumal institutions founderl on Congressional grant of 1862 , what work is legitimate to? 1892. p. 42.

Peach blight:

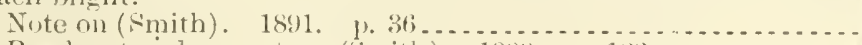

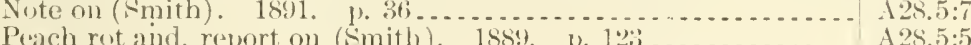

Sep also l'atches.

Peach (urculio, arsenical poisons for (Furbes). 1889, p.3. . . . . 19.7:2

Peach leaf curl, its nature and treatment (l'ieme). 1900 ......... A25.3:20

Peach lecanim, report on (Pergande). 1898. p. 26 ........... 19.6:18

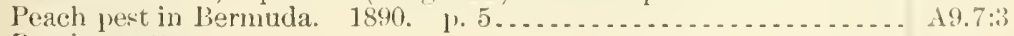

Pearch rosette:

Communical,ility of (Smith), 1891 ....................

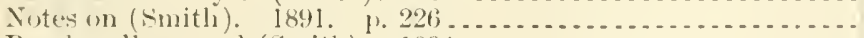

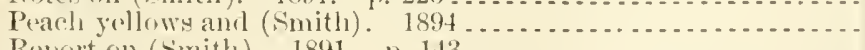

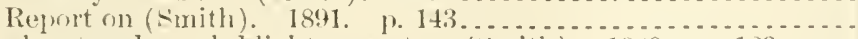

Pearh rot and peach blight, report on (Sinith). 18s9. 1.123.....

Peach-tree lorer, circular relative to (Marlatt). 1896 ............

Peach-tree scale, new and destructive. 1894, 1.287 ..............

Peach trees:

Leaf curl of, letter of incuiry relative to (Willit:). $1893 \ldots \ldots$.

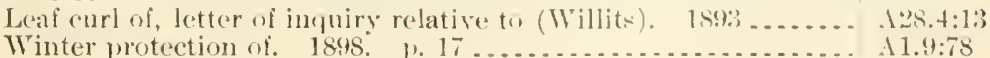

A28.:3:1

A.28:5:7

A1.9:17

1:25.5:6

A:S:5:5

A $9.5: 17$

A $9.7: 6$

11.9:75 
Peach twig-borer:

Impurtant (memy of stone fruits (Narlatt). 1898.

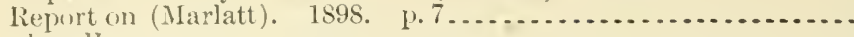

Peach yellows:

('ommunicability of (Smitl ). 1891.

Note on (Taylor). 1872. p. 357

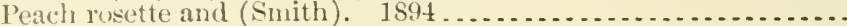

I'reliminary report on (Smith). $1888 \ldots \ldots \ldots$

I'revention and cure of, experiments with fertilizers for, 1859-92.

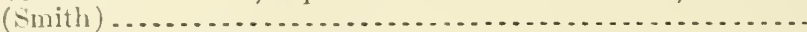

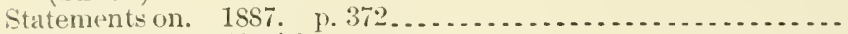

What to do for? (Snith). 1891. p. $15 \ldots \ldots \ldots \ldots \ldots \ldots \ldots \ldots \ldots \ldots$

Pealclies:

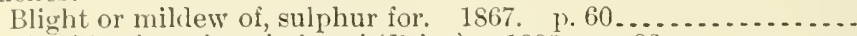

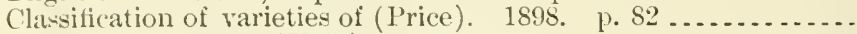

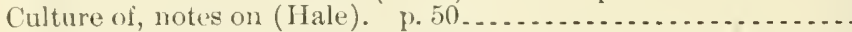

Different races of, report of progress by committee on cooperative

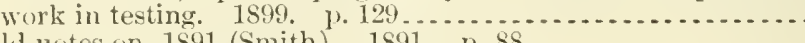

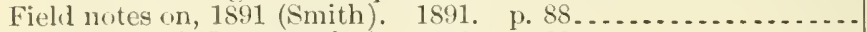

Fond value of (Langworthy). 1899. p. 22.................

Growing for market (Smith). 1895 ...

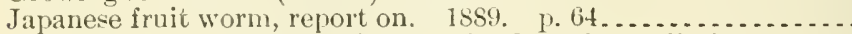

New species of aphis injurious to, in Georgia, preliminary note on (Scott). 1902. 1. 56

Propagation, cultivation, varieties, ete.(Pullen). p. $191 \ldots \ldots$.

Root-knot disease of, in Florida, due to work of Anguillula (Neal). 1889

Spotting of, report on (Smith) 1859 p. p. $32 \ldots \ldots \ldots \ldots \ldots \ldots$

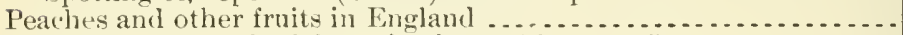

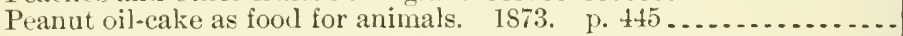

Peanuts:

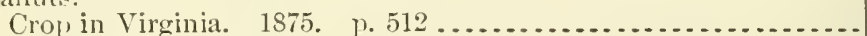

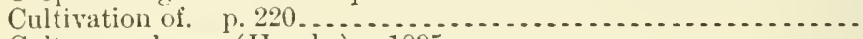

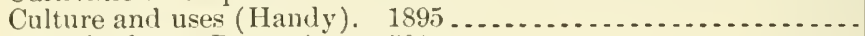

Fooul for hogs (Duggar). I). 501

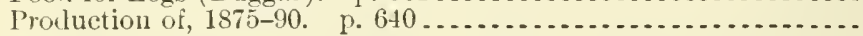
Pear:

Aphids of (Sanderson). 1902. p. 123

Commercial culture of (Waite). 1900 , p. $369 \ldots \ldots \ldots$

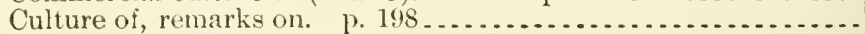

Description of leading popular varieties. p. 163

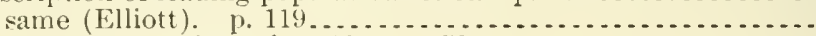

Summer, new variety of. 1867. p. 59.

See also Le Conte pear.

Pear blight:

Cause and prevention of (Waite). 1895. p. 295

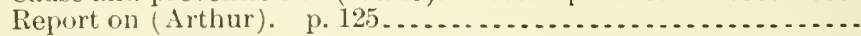
same, r. 125 -

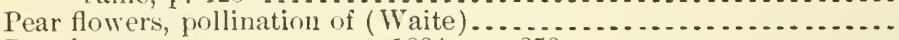

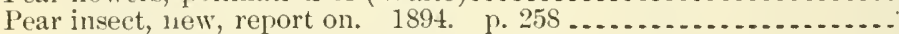

Pear leat blight:

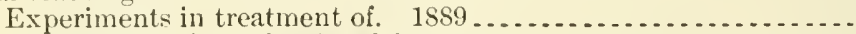

Treatment of, in orchard (Waite). 1891. p. $333 \ldots \ldots \ldots \ldots \ldots .$.

Pear-leaf blister mite, report on (Slingerland). 1892 , p. $104 \ldots .$.

Pear midge, habits of (Schmidberger). p. 286 ..................

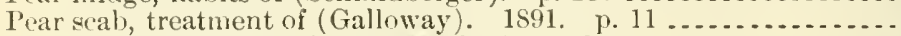

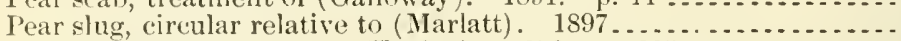

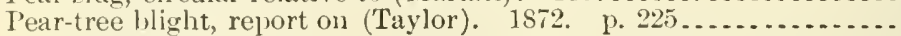

Pear-tree psylla:

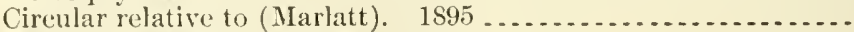

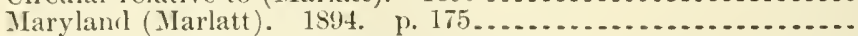

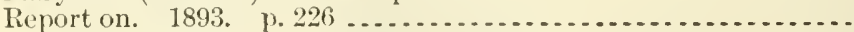

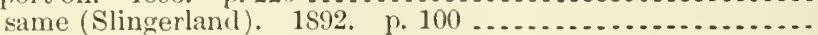

Three, report on. 1891. p. $127 \ldots \ldots \ldots \ldots$

Pear trees, experiments with fungicides in removal of lichens from

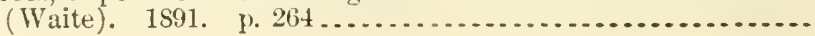

A1.9:80

A9.6:10

A28.3:1

A $27.9: 10$

A1.9:17

A6.3:9

A28.3:4

127.9:25

125.5:6

$127.9: 5$

1 10.3:49

A20.1:894

A20.4:3

1 10.3:65

1.28.5:7

A1.9:105

1 1.9 .33

A9.7:2

A9.6:31

A 1.1:865

A9.3:20

A28.5:5

112.4:1

A27.9:11

A27.9:13

A 1. 1:568

A1.9:25

A $4.1: 598$

A $27.9: 28$

A 10.3:115

A1.10:900

A 1. 1:869

A 1. 1:862

A 1.1:863

A27.9:5

A1.10:895

A 1.1:856

A2S.1:S86

A $28.3: 5$

A9.7:7

A28.4:8

A28.5:7

A9.7:5

A 1.1:585

A28.5:6

A $9.5: 26$

127.9:10

A9.5:7

A.9.7.7

A9.7:5

A9.7:5

A 9.7 .4

A28.5:7 
Pearne, Thomas H. Foot-and-mouth disease, treatment for. 1873. 1. 450 ...... F.

Pearson, Alexander $\mathbf{W}$ :

Grape rot and grape mildew, remarks on, 18st). p. 54........ Grape-vine, downy milkew and black-rot of, treatment of with salts of copper, at Vineland, X. J., in 1SS7. p. 17........

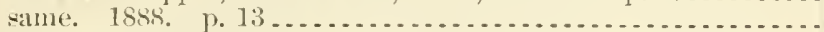

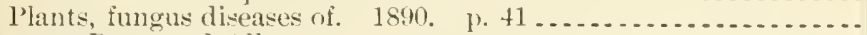
Pearson, Raymond Allen:

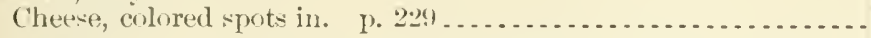

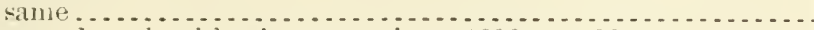

Cows and cattle of foreign countries. 1896 . p. $38 \ldots \ldots . . . . .$.

Dairy industry and dairy markets of Porto Rico; with notes upon St. Thomats and Cuba. p. 306 . . . . . . . . . . . . . . . . . .

Dairy laws, national and State, abstract of. p. $531 \ldots \ldots \ldots \ldots . . .6$.

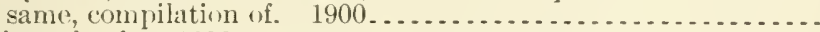

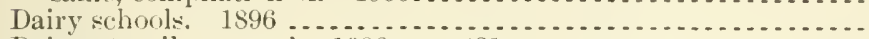

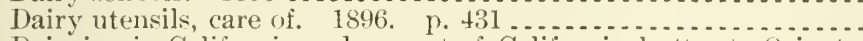

Dairying in California and export of California butter to Orient.

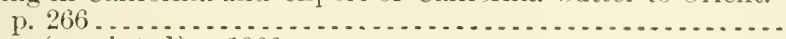

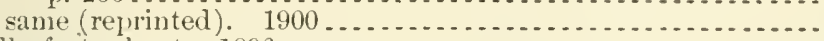

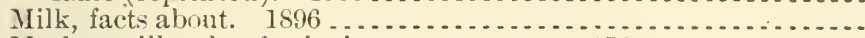

Marker milk, plan for its improvement. p. 158. . . . . . . . . . .

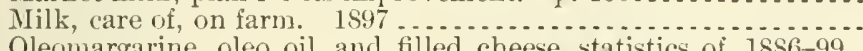

Oleomargarine, oleo oil, and filled cheese, statistics of, 18S6-99.

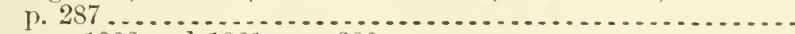

Peas: same. 1900 and 1901 . p. 398 .

Canadian field (Shaw). 1895. p. 223.

Insects injurious to (Chittenden). 1898. p. 233

See also Flat pea.

Peas, beans, and other legumes as food (Abel). 1900

Peat. See Muck.

Pecan:

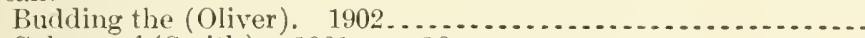

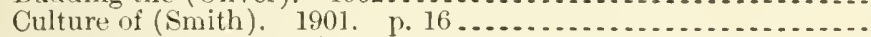

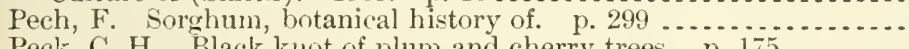

Peck, C. H. Black kuot of plum and cherry trees. p. $175 \ldots . . . .$.

Peck, J. B. See, for report as Chief, Seed Division, Agrieulture Department, $1890-92$

Pecos River and its tributaries, New ilexico, irrigation along (Reed). 1902. $1 \% 61$

Pecos Valley, New Mexico-

Irrigation in, use of water in (Reed). 1900. p. $85 . \ldots . . . . .$.

Soil survey in (Means and Gardner). 1900. 1. 36.............

Soils of (Means and Garlner). n. d . . . . . . . . . . . . . . . . .

Pediculi affecting man and lower animals (Osborn). $1891 \ldots . . . .$.

Pediculidre, parasitic habit in, origin and development of (Osborn).

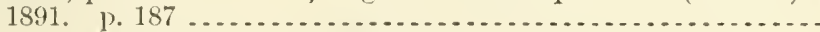

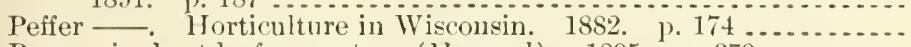

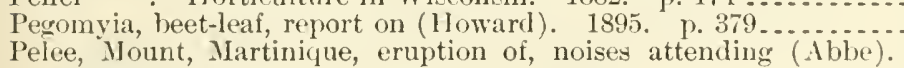

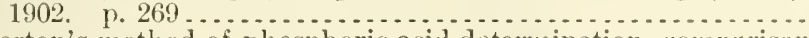

Pemberton's method of phosphoric acid determination, comparison of, with oflicial method by Francis Bergami (Kilgore). 1894.

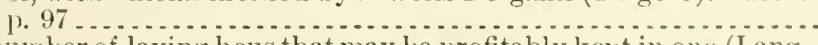

Pen, number of laying hens that may be profitably kept in onc (Lang-

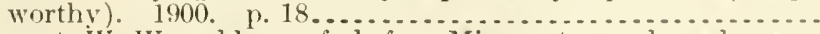

Pendergast, $W$. W., address of, before Minnesota good roals con-

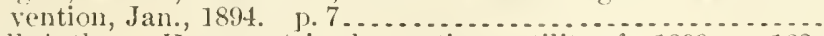

Pennell, Arthur. Hygrometric olsservations, utility of. 1899 . p. 162 . Pennsylvania:

Anthracite coal in, production of. 1820-72. p. $36 \ldots \ldots . . . .$.

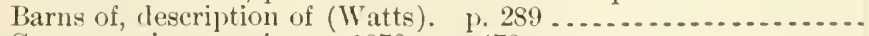

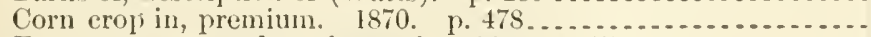

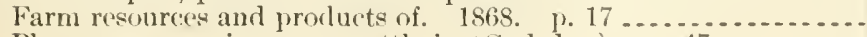

Pleuro-pneumonia among eattle in (Gadsden). p. 47.
A27.9:11

16.3:2

A $6.3: 5$

16.\$3:10

A6.3:11

14.1:898

14.4:24

A4.3:11

A $4.1: 901$

A $4.1: 897$

A $4.3: 26$

A4.3:17

11.10:896

A $4.1: 599$

A $4.3: 24$

A 1.9:42

A $4.1: 900$

A 1.9:63

A4.1:899

A 4. 1:901

A1.10:895

A1.10:898

A1.9:121

A 19.3:30

A 1.9:124

A1.1:865

A $1.1: 872$

124.1

A10.3:104

A10.3:86

A1.8:64

A $26.4: 3$

19.3:7

19. $7: 4$

11.8:22

19.7:7

A29.6:30

17.3:43

A 1.9:114

122.3:2

A $29.3: 24$

127.9:11

11.1:864

127.9:8

127.9:6

A 1.1:851-2 
Pennsylyania-Continner

Roarlsstem in (1Tamilton). 1901, p. 25.

the also Lancaster - Iubanon - Plibadel phia - Pittslur.

Pennsyliania Agricultural College, ex periments with wheat at. 187:?.

1) Charles ]. See, a joint author, Sanderson, E. Dwight.

Penny, Charles J. See, a joint anthor, Samlerson, li. Dwight.
l'ennywit, Henry. Seasons, warm and cold, relative length ,

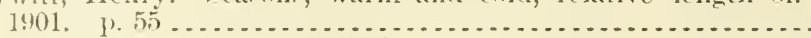

Pens, disinfeetion of, by tire (Stiles). 1902. p. 15 .............

Pensaeola, Fla., old thermoncter record at (Able) . 1901. p. 17T.

Pentaglncoses in feeding stuffs, notes on oreurrence and quantitative estimation of (Stone). 18.0. p. 125 . . . . . . . . . . . . . .

Pentosin, free crulle filer, letermination of (Fraps). 1902. 1.51.. Pentosans:

Determination of, notes on (Fraps), 1901. p. 112............ Estimation of, phlorogluein method for (Lindsey and Holland).

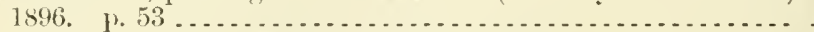

Pentstemon, notes on (Vasey). 187t. J. 4is

People, health of:

1894. 1. 201 .

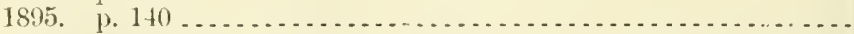

1896. †o. 136 ,

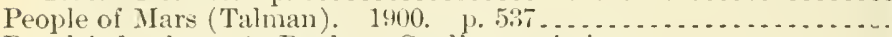

People's hanks. we Banks-Credit associations.

Peppermint, oil of, accomt of. 1884. No. 9. p. 28........... See also Oil of perpuermint.

Peppers, American varieties of, list of (Traey), $1902 \ldots . . . . . . .$.

Peremial myeelium of fungus of liackberry rust (Newcombe).

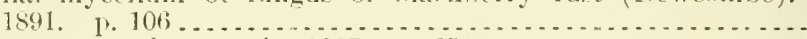

Perfunery farming, wan it succeed in L. S.? (steele). 1s9s. 1. 37. $11.10: 898$

Pergancle, Thendore:

Cotton or melon plant-louse, report on. 1895. 1. 3in . . . . . . .

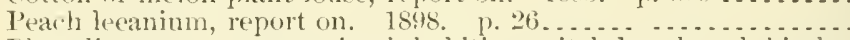

Plant-lice, two new species inhabiting witch-hame] and birch,

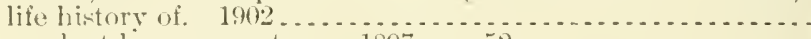

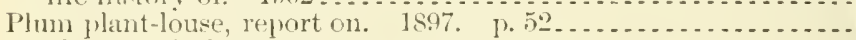

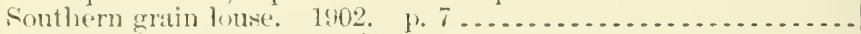

Thripidie, eertain, observations on. 1895 . 1. $390 \ldots \ldots \ldots \ldots \ldots$ sice also, as joint author, Ilnblord, Henry Givernsey.

Pergande, Theorlore, and Cockerell, Theorlore Dru Alison. Coceidie collected in l'uerto Rico by A. Busch in 1899, list of. 1900. p.92

Periorlic fever. sep splenic fever.

Periodical cicarla. ,ie Cicalat.

Perishable goods, extremes of temperature safe for. 1900. 1) 741 . $11.10: 900$

Perkins, (i. Il. Iachnonterna, notes on. 1892. 1. 38: . . . . . . . 19.7:4

Perkins, fieorge A.:

Aildress of, wefore national roar conference, July, 16:4. 1. 53...

Hirlivays, State, in Massichusetts. 1894. p. 505............

Pernicions scale. tiee sin Jusciscale.

Pernter, J. M. Hail, clamage by, in spite of ramnomaling. 1901.

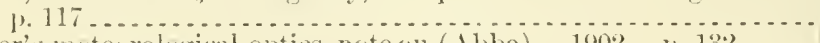

Pernter's meteolological optios, note on (A1)be). 1902. I'. 132....

Peromathms. See Poeket mice.

Peronosinorea:

Economic, for $1889 \mathrm{in}$ New Jersey, some notes upon (IIalsted).

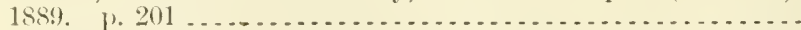

Grape yne, first results obtained from use of chloride of aluminum and proposal of new remedies against (cmes and Deperais).

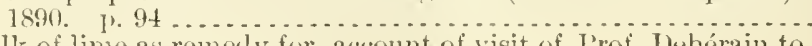
Iilk of lime as remedy for, account of visit of J'rot. Ithérain to

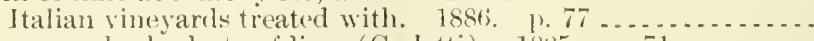
Overeome liy hydrate of lime (Cerletti). 1855. p. $71 \ldots . . .$. Rain-fall and, report on (Halsted). 18s9. 1) 6 . . . . . . . . . . fome, in herburinm of Vegetal,le Jathology j)ivision (Awingle).

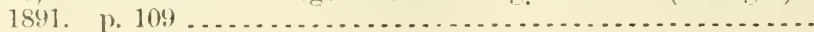

Two new species of description of (Wate). 1841. p. 105 .... A28.5:7

A $1.7: 7$

$19.6: 18$

19.8:1

A $4.6: 7$

A $9.6: 38$

19.7:7

19.6:22

12. $3: 10$

11.10:894

A29.6:29

А $29.6: 30$

A:8.5:5

16.3:11

A6.3:2

A6.3:2

128.5:5

128.5:7 
Perrey, Mr. A. Grape millew, destruction of, ly sulphate of (npler. 1886. T. 89 .

Jerry, Edwart II.:

Cattle, pure-bred, number and value of, in Unitedstates. p. 33s.

Cattle trade and allied industries of Michigan, Wisconsin, and

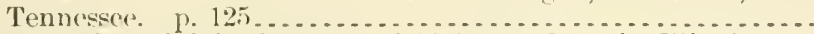

Cattle trade and ilairy interests of Alabama, Georgia, IHinois, In-

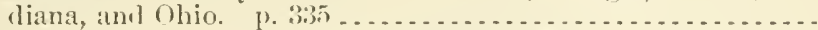

Live stock and meat traflic of Chicato. p. $245 \ldots . . . . . . . .$.

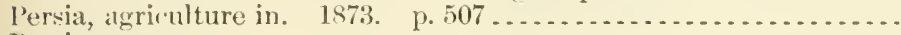

Persimmons:

besirable qualities as a fruit (Smith and Beal). 1899. p.9.....

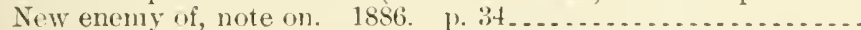

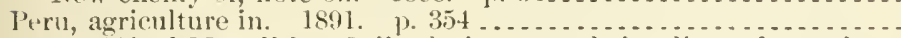

l'eter, Alfred Meredith. Soil solution, potash in, dirot determina-

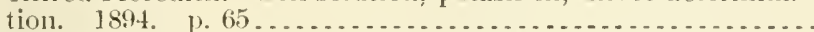

See ulso, as joint anthor, Seovell, Melville Amasa.

Petermann, A. Agricultural experiment utations in Belgium. 1895.

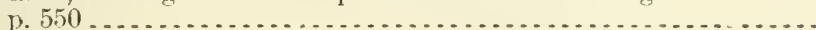

Peters, A. T.:

Paris Exposition, 1900, exhibit of U.S. experiment station veter-

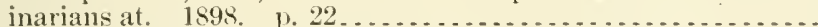

Serum therayy in hog cholera. p. 196.

Peters, Fdward T: :

Credit associations, cooperative, in rertain European conntries and their relation to agricultural interests. $1892 \ldots \ldots \ldots \ldots$.

Foreign trale, recent features of our. $1894 \ldots . . . . . . . . . . .$.

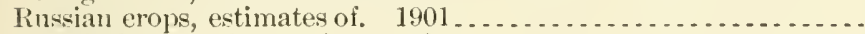

Rye, influence of, on price of wheat. 1900 . p. $167 \ldots \ldots \ldots \ldots$.

Peters, Richard. Sheep husbandry in Georgia. 1878. p. 120.....

Peters, Theodore C. Agrieultural survey of the South, report on.

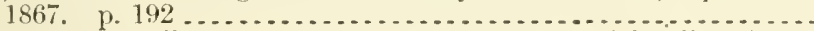

Peters, Thomas Willing. Platen, Germany, cost of hauling farm

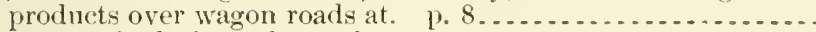

Peterson's method of meadow-eulture. 1874. p. $438 \ldots \ldots \ldots \ldots \ldots .$.

Petroleum:

Crude-

and other insecticides, further notes on (Felt). 1902. 1). 49.. as an insecticile (Wilcox). 1900. p. $15 \ldots \ldots \ldots$ notes on, and its effects upon plants and insects (Smith).

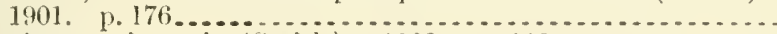
year's experience in (Smith). 1902. p. $118 \ldots \ldots \ldots$

Exports of-

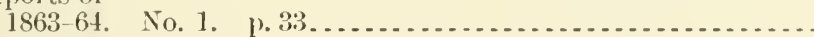
1863-69. p. 47 ........

Sce also Coal oil - Dendrolene - Raupenleim.

Pezotettix, new species of (Bruner). 18:4. 1). 11

Plianerogans:

North Ameriean, new species of, published in 1891, systematic and alphabetie index of (Clark). p. 151 .............

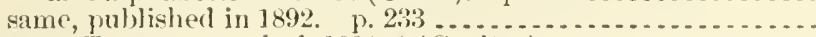

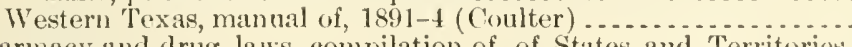
Pharmacy and drug laws, compilation of, of States and Territorics

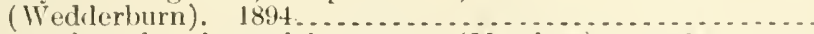

Pheasants, introduced, sperial report on (Merriam). p. 484......

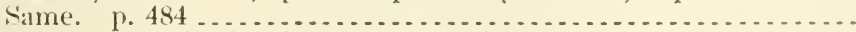

Plıcl]s, C. S. Dairy-herd tests, cooperative, report on. 1901. 1. 1:20. Phelps, C. S., and Voorhees, lidwart Purnett. Irrigation in Connereticnt and New Jersey, notes on. $1897 \ldots . . . . . . . . . . .$.

Phenaconys. See Arvicolinir.

Phenologic or thermal eonstants (Ihne). 1895. p. 427 . . . . . . Phenological data (Smith). 1902, p. 196. . . . . . . . . . . . . . Phenological olservations, instructions for taking (Bailey). Isiti.

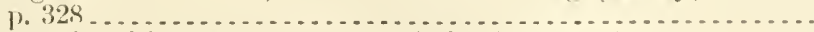

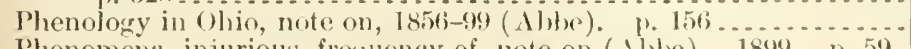
Phenomena, injurious, frepuency of, note on (Abbe). 189\%. p. 59. See also Optic'al phenomena.

\section{A $6.3: 2$}

A. $1: 887-8$

14.1:886

14. 1:885

14. 1:884

A27.9:11

A $1.9: 107$

A $9.3: 12$

A $27.9: 29$

A7.3:43

A 10.6:5

A4.3:22

A 4.1:897

A $27.8: 3$

A $27.8: 8$

A27.4:14

A 1.10:900

A 1.2:Sh3

A27.9:5

A $2: 2.4: 27$

A $27.9: 12$

A9.6:31

A 1.9:114

1 10.3:99

A $10.3: 115$

A $27.9: 3$

127.9:8

A.9.7:7

A6.5:1

Ati.5:1

A6.5:2

A7.3:42

A 1.1:888

A5. 1:888

110.3:99

110.3:36;

129.3:112

129.3:31

A:9.6:24

1:29.6:28

1:29.10:27 
Plikadelphia, Pa. Sep Franklin Kite Club.

l'hiladelphia, Pa., ('entemuial Exposition, 1876:

Address of Frederick lWatts at, July 4, 1875. p. 440 ......... A27.9:13

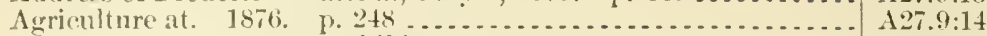

Agriculture Department exhilit at-

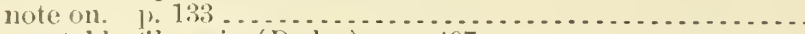

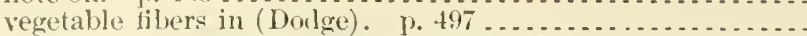

Participation of Agriculture I) Dartment in (Saunclers). 1884.

Relation of agriculture to. $1871, \quad$ p. $288 \ldots . . . . . . . . . . .$. See also Agriculture, humdrerl years progress in.

Philarlelphia, l'a., national agricultural congress, 5th, fept. 12-14,

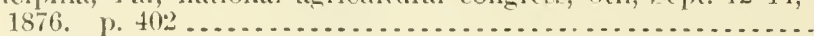

l'hilipuine Islands:

Agricultural investigations in (livans). 1901. p. 50\%.

Animals from, order prohibiting landing of, at any port of $\mathrm{l}$. S., or dependencies thereof, Dec. 13, $1901 \ldots . . . . . . . . . . .$.

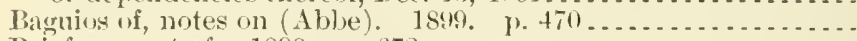

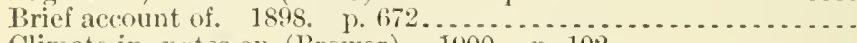

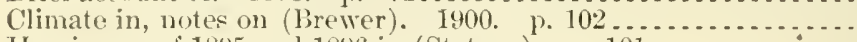

Hurricanes of 1895 and $1896 \mathrm{in}$ (Stetson). p. 101 ............

Plant, products of, notes on (Hitcheock). 1899 ..............

Trarle of (Hitchcock). 1895 . . . . . . . . .

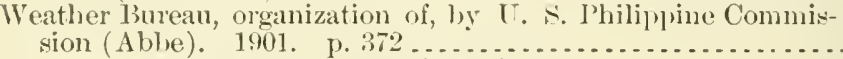

Weather service, new, notes on (Aibe). 1901. 1. 120 .......

See also Jaguio - Manila.

Phillips, James J". Texas fever of cattle, or southern cattle "dis-

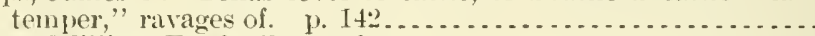

Phillips, William Fowke Ravenel:

Address, as chaiman of edneational section, before second convention of Weather Bureau ufficials, lueld at Milwaukee, Wis., Aug. 27-29, 1901. p. 81 _ . . . . . . . . . . . . . . . . . . . .

Atmos] heric temperatures during month of July, 1895. p. 253 ..

Climate of Cubareport on, with note on weather of Manila. 1598 ........

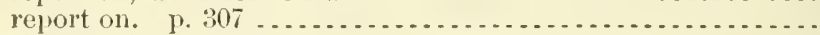

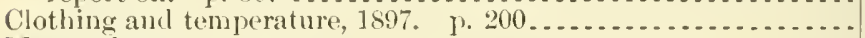

Meteorologyelementary, text-books and works of reference for students

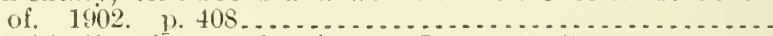
monthly list of papers bearing on, Jan., 1899-Dec., 1902 . . . . relation between public health and. 1895. p. $171 . . . . . .$.

Sunstroke in California and Arizona. 1896. p. 454 ...........

Sunstroke weat her of August, 1896. ए. 409.................

Temperature, rainfall, and hmmidity at San Juan, lorto Rico. 1899. p. 319

Weather Bureau library, monthly alditions to, Dec., $189 \overline{7}-\mathrm{j} a \mathrm{r}$,

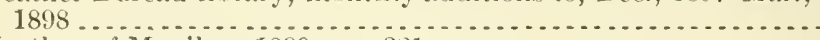

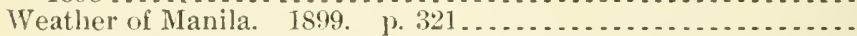

See also, as editor, Weather Bureau officials, proceedings $2 \mathrm{~d}$ convention of; as joint author, Calvert, Edgar B.

Phinney, S. B. Cranberry culture. I. I31

Thipls, R. IT.:

Forestry in Ontario, address on. 1ss4. p. $43 \ldots \ldots \ldots \ldots \ldots \ldots . .$.

Forests and their management in other countries. IS83. p. 19. lhloroglucin method for estimation of pentosans (Lindsey and Hol-

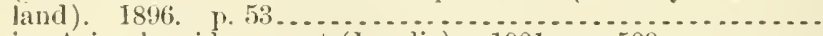

lhoenix, Ariz., leonids seen at (landis). 1901. p. $509 \ldots \ldots . . .$. Thosphate acid, insoluble, paper on. 1891. p. $106 \ldots . . .2 . .$.

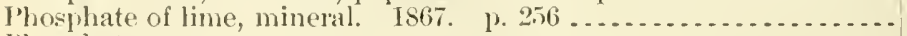
I'losphates:

Action of oxalic aciol upon (Kastle and otlers). 1894. p. 53 ...

Asfertilizers. 1897 . 1. $12 \ldots \ldots \ldots$. . . .

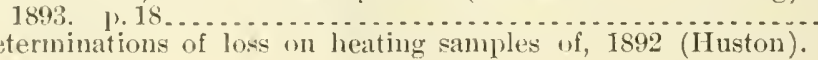

A $27.9: 14$

A1.1:879

11.2:P5:

A1.1:871

1:7.9:14

A1. $10: 901$

A $4.5: 92$

129.6:27

A I. 10:898

A29.6:28

129.6:2S

16.4:17

1I2.3:14

A29.6:29)

A29.6:29

11.6:22

A29.3:31

A29.6:2:)

A29.3:2:2

A29.1:598

129.6:25

129.6:30

A29.6:

A29.6:23

129.6:24

129.6:24

A29.1:898

129.6:

A29.1:898

\1.1:863

A1.7:5

A I. 7:I

A7.3:49

A29.6:29

A 7.3:31

A27.9:5

A7.3:43

A1.9:56

A7.3:38

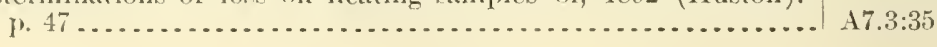


Index

Phospluates-Continued

Irom and alumina in, retermination of, method of. 1897. $), 47 . \quad 17.3: 5]$

Mineral, as fertilizers (Wiley). 189+. p. 177..............

Native, containing iron and alominum, analysis of, proposed method for (ITilkinson). 1891. p. 107..............

Russian mineral (Yermoloff). 187.3. p. 2.................. see also Mineral phosphates.

Phosphatic slag, hasic, mechanical analysis of (Wiley). 1846. p. 7s . . A7.3:49

l'hosphomolybutate. See Ammonium phosphomolylydate.

Phosplioric acid:

Adrlitional notes on (Menur). 1892. p. 27.

A vailable-

determination of, comparison of Wagner's and present Association method for (Frear and M.1)omnell). 1856. p. 26...

in fertilizers containing (ontton-sed nedeal, deternination of (Dancy). 1890. y. 161

Citrate-insoluble, comparison of results by old and new mothous for (Kilgore and Williams). 1894. r. 108 ...............

Citrate-soluble, determination of (Ross). 1893. 1 p. 16 ........

Citrate soluble and insoluble, as determined by different methouls

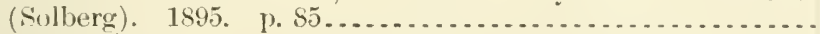

Determination of-

by molybulate method (Garrigues). 1894. p. 105 ......... comparison of official and nitric-acid methods for (Richards). 1886. p. 24 ... . . . . . . . . . . . . . . . . . . . . .

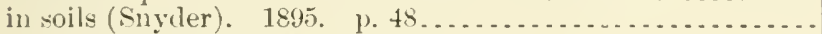
same (Goss). 1894. 1. 5. . . . . . . . . . . . . . . . . . same (Goss). 1895. 1). $50 \ldots \ldots \ldots \ldots \ldots$ increased accuracy in (Wheeler). 1901. p. $44 \ldots . . . . . . .$. nitrogen and, in commescial fertilizer's in same weighed ynantity of substance (De Roole). 1891. p. 104............ we of ammonium nitrate in (Wheeler and Hartwell). 1892.

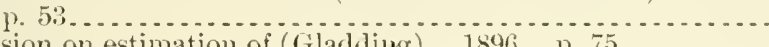
Discussion on estimation of (Gladding). 1896. p. $75 \ldots \ldots \ldots \ldots$

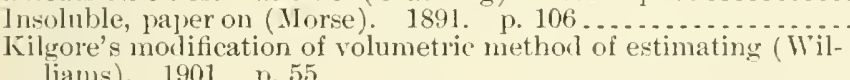

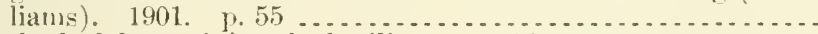

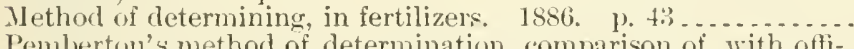
Pemberton's methor of determination, comparison of, with offi-
cial method by Francis Bergami (Kilgore). 1894. p. $97 \ldots . .$. Rendered soluble by digestion with ammonium eitrate at $6.5^{\circ} \mathrm{C}$.. amount of washing required to remove (Veitch). 1896. ए. 73.

lieverted-

differences in determination of, hy ofticial methor of analysis

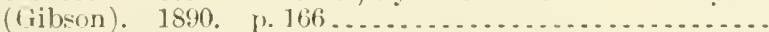

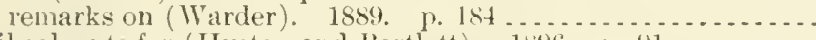

Soil solvents for (Huston and Bartlett). 1596. I. 91 ......... ser also
soils.

Plosphoric acid, committec on, report of, at Convention of Associaltion of Oflicial Agrienltural ('hemists:

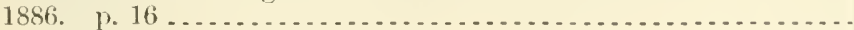

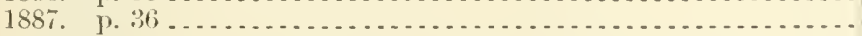

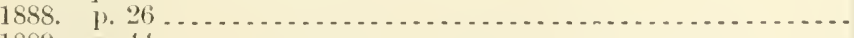

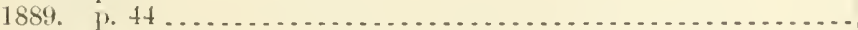

1890. 1. $15 \% 3 \ldots \ldots \ldots$

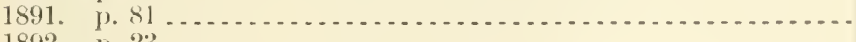

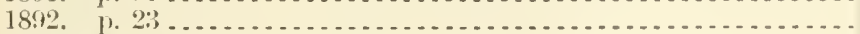

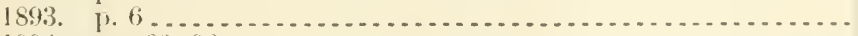

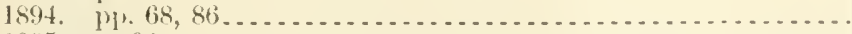

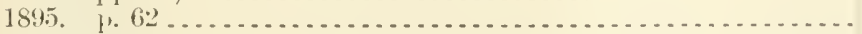

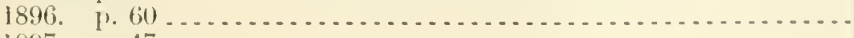

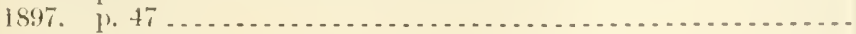

1898. 1. $36 \ldots \ldots \ldots$

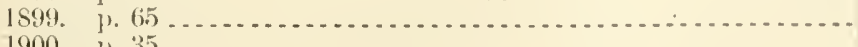

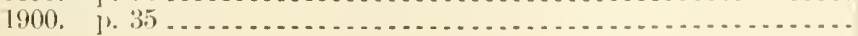

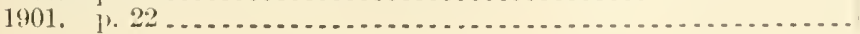

1 1.10:5!) 4

A 7.3:31

A27.9:11

$17.3: 35$

17.3:12

A7.9:28

A 7.:3:48

17.3:38

17.3:47

17.8:43

17.3:12

17. $3: 47$

A 7.3:4:3

17.3:50

17.:3:62

A 7.:3:31

A 7.8:35

1 7.3:49

17.8:31

17.3:6:2

A $7.3: 12$

A7.3:4:3

A $7.3: 49$

17.3:28

A $7.2: 24$

A $7.3: 49$

17.3:12

A $7.3: 16$

17.3:19

17.3:21

17.:3:28

17.3::31

17.3:35

A7.3:38

17.3:43

17.3:47

17.3:49

17.:3:5]

17.3:56

17.3:57

17.3:(t:2

17.3:67 
Phosphorescent myriopods (Brmer). 1891. p. 319

Phospliorus, metaholism of, in human organism, experiments on

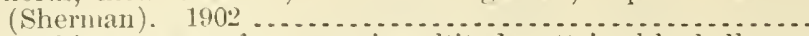

Photographic apparatus for meatsuring altitudes attained by ballooms

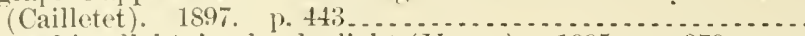
Photographing lightuing by daylight (11 ('n ry). 1895. p. 379 . . . . Pliotographs, micro-, of snow crystals, notes on (Abhe). 1900.

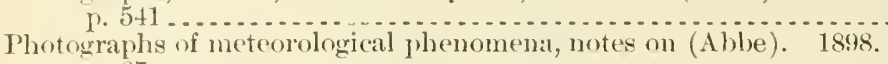
Photography in meteorologr, notes on $(\Lambda \mathrm{h} b \mathrm{~h}) .1900 .1 \mathrm{p} .159 \ldots \ldots$ See ulso Clond photography - Tornado photographs.

Phragmidium. Ste Puccinia and phragmidium.

Phreatic waters in Nye Countr, Nevada (Nichols). 1891. 1. 207 .. A15.2:1394 See also Enterground draining.

Phylloxera:

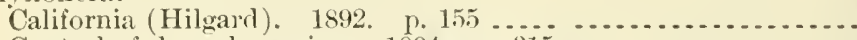

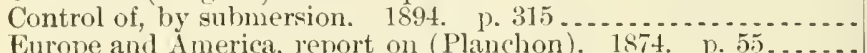

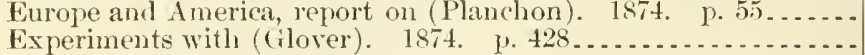

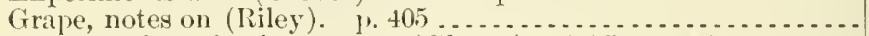

Notes on, from foreign sources (Gilover). 1875. p. 40 .........

Problem abroarl as it appears to-day. $1890 . \quad$ p. $310 \ldots . . . . . . . .$.

Remarks on (Glover). 1874. p, 43........................

Resin compounds on, experiments with, in 1890 (Koebele).

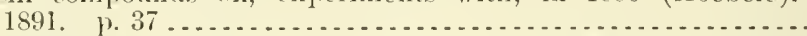

Stomata on Carya alba caused by, strange develojments of (Owen).

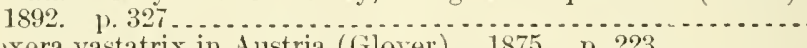
Phylloxera vastatrix in Austria (Glover). 1875. p. 223 ......... Physical geograpliy, laboratory work in (Kimball), 1902 . p. 313.. Physical researches at Juvisy observatory, principally on solar rays

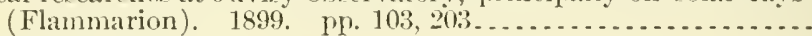

Physics and meteorology:

In universities, notes on (Albbe). 1899. ']. 258 ............

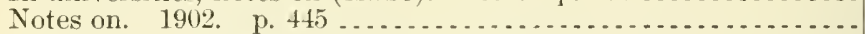

Physiological rôle of water in plants (Gain). 1897. p. 3........ Physiolngy. See Vegetable physiology.

Phytomyza affinis as cause of decay in clematis (Bos). $1893 . \quad$ p. 92. Phytophagic eurytomine. See Grass and grain joint-worm flies.

Phytoptus distortions, erysiphese upon (Anderson and Kelsey).

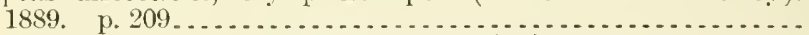

Piedmont region, northwest gales of (Hawkins). 1899. p. 13.... Pierce, Newton Barris:

Almond disease caused by Cereospora circumscissa, remedies for.

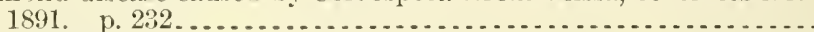

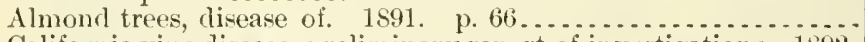

California vine disease, preliminary report of investigations. 1892.

Grape diseases on Pacific coast. 1895 ... . . . . . . . . . . . . .

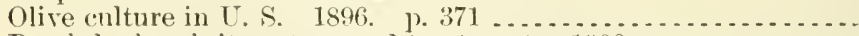

Peach leaf curl, its nature and treatment. $1900 \ldots . . .2 . . .2 .$.

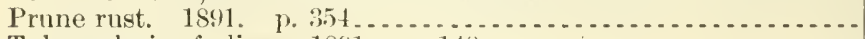

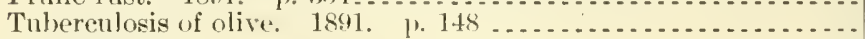
Piercy, Josepli C.:

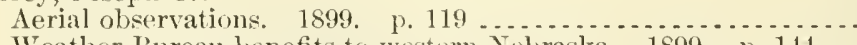

Weather Bureau benefits to western Neloraska. 1899 . p. $144 \ldots$
Pierre, S. Dak., ice at, breaking up of, notes on, $1846-89$ ( $\mathrm{Abl}$ ). P. 109 William i. Grape-culture and wine-making in El Paso

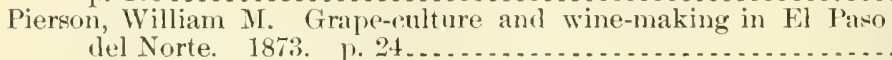

Pieters, Adrian Jolın:

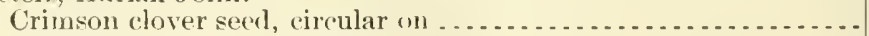

Farmers' interest in goorl seed. 1900 . $\ldots . . .2 \ldots \ldots \ldots$

Red clover seedcircular on. 1900 . information to purehasers. $1901 \ldots \ldots \ldots \ldots \ldots$ Seedof bearlless brome grass.

1900.
A9.7:3

110.3:121

129.6:25

A29.6:23

A29.6:28

A $29.6: 26$

A $29.6: 28$

A 1.8:20

A9.7:6

A27.9:12

A $27.9: 12$

A 1.1:88t

A27.9:13

19.7:2

A27.9:12

A9.3:23

A.9.7:4

+ $27.9: 13$

A29.6:30

$\$ 10.6: 10$

1 29.6:27

129.6:30

19.7:6

A28.5:5

129.6:27

A28.5:7

128.5:7

128.3:2

A 1.9:30

A 1.10:896

A28.3:20

A28.5:7

A28.5:6

A29.3:24

A $29.3: 24$

A $29.6: 27$

A27.9:11

A6. 4:18

A1.9:111

A6. 4:24

A $1.9: 123$

A6.4:25
1 $10.6: 8$ 
]'ieters, Adrian John-Continued

reed-Continned

production and seed saving. 1896. p. $207 \ldots \ldots \ldots \ldots \ldots \ldots$

selling, growing, and testing. 1899. p. 54 . . . . . . . . . . . . testing, methods of, and their relation to farm and garden.

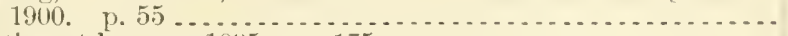

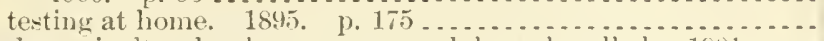
Seeds, agricultural, where grown and how handleil. 1901. p. 233

Sugar-beet seed, production and testing. 1902. p. $101 \ldots \ldots$.

Pieters, Adrian John, and Jrown, Edgar. Kenturky blue-grass soed,

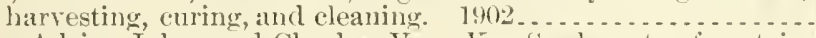

I'ieters, Adrian John, and Charles, Vera K. Secol coats of certain I'igeons:

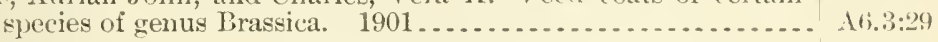

Animal parasites of, checklist of (llassall). 1896 ............

Fatal ilisease of, pathogenic bacillus of hog-(cholera group asso-

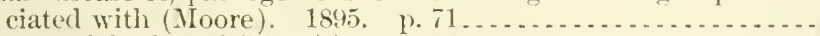

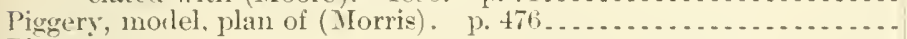
Pigs:

Carcasses of, chemical compowition of (Wiley and others). 189.

Corn, compeas, and wheat fran for fattening (Juggar). p. 496..

Corn meal and wheat shortis, as food for (Plumb and Anderson). p. $46: 3$

Feeding in Few Hampshire, experiments in (Burkett). 1. 465..

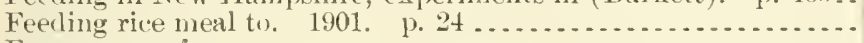

Forage crops for-

1897. 1). 6 .

1898. p. 18 ..................

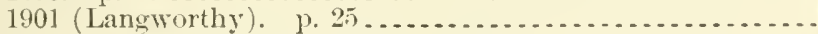

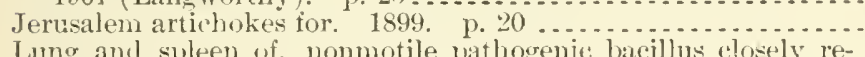

Jung and spleen of, nommotile pathogenic bacillus closely resembling bacillus of hog cholera found in (Moore). 1898.

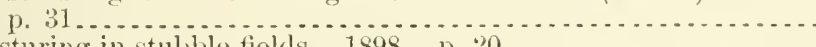

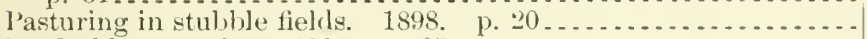

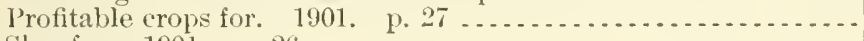

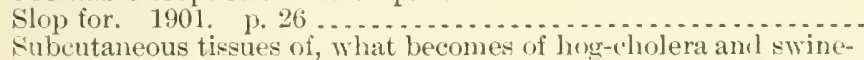
plague bacteria injected into (Moore), 1894. p. 103 .......

Wheat in sheaf, and chopped wheat for (French). p. 494...... see also suws.

Pika, new species of, from Sierra Nevala Mountains, Cal., descrip-

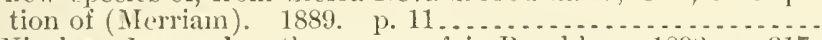

Pike, Nicolas. Leopard moth, ravages of, in Brooklyn. 1892. 1.317. P'ikes Peak, hourly meteorological records at, November, 1892 , to September, 1894, brief discussion of (Morrill). 1896. p. 215..

l'impla conquisitor, relations of, to Clisionampar americana (Weed

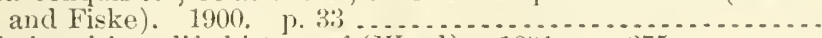

P'impla inquisitor, life history of (Weed). 1891. p. 275 ......... P'incliot, Gifford:

Forest lands, practical assistance to farmers, lumbermen, and

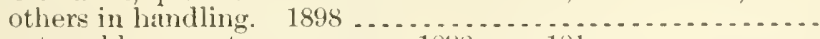

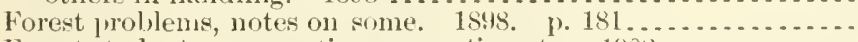

Forest students, prospeetive, suggestions to. $1902 \ldots . . . . . .$.

Forestry, progress of, in United States. 1899. p. 293 . . . . . . . .

Forestry Division, Agriculture Department, work of, for firmer.

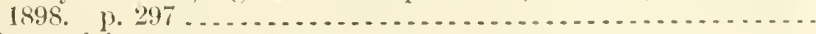

I'rimer of forestry, jt. $1 . \ldots \ldots \ldots \ldots$

Trec planters, practical assistance to . . . . . . . . . . . . . . .

See clso, for reports as ('hief, Forestry Division, 1sis; as Forester, Forestry Division, 1899-1901; and as Forester, Forestry Bu-

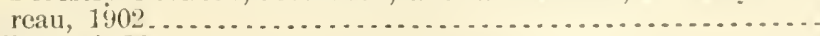

Pinclell, Lew is M.:

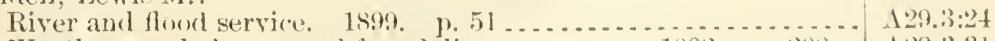

Weather symbolw on rumal freedelivery wagons. 1902. 1).205.. $129.3: 31$

11.10:896

A $1.10: 899$

110.3:76

1 $1.10: 895$

11.10:901

11.8:-2:

A 19.3:19

14. $4: 15$

$14.3: 8$

11.1:\$65

17.3:5:

14.1:898

14.1:899

A $4.1: 899$

A 1.9:144

11.9:56

A $1.9: 84$

A 1.9:124

$+1.9: 92$

A+.3:3

A1.9:79

A1.9:13:3

11.9:13:3

A $4.3: 6$

A4.1:898

A5.5:2

19.7:4

129.1:896

19.6:26

19.7:3

113.4:21

11.10:898

113.4:23

A1. 10:899

11.10:898

1 13.3:24

129.6:30

113.4:2:2

113.1: 
Pine:

Insect enemies of, in Black llills forest reserve (Hopkins). 1902

lnsect jujury to trees in Virginia and neighboring States (Chit-

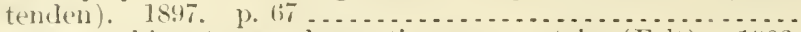

Insects attacking tries, olservations on certain (Felt). 1902.

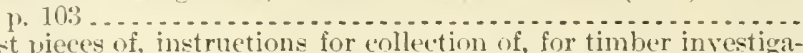
tions . . . . . . . . . . . . . . . . . . . . . . . . . . . . . .

See also (uban pine - Loblolly pine - Long-leat pine - Marsh or pond pine - Naval store industry - Short-leaf pine - Timber pine - IVhite pine.

l'ine lark-beetle, destructive, damage to forests ly (Hopkins). 1893.

Pine Bluff, Ark. working plan for forest lands near (i) lusterl). 1902.

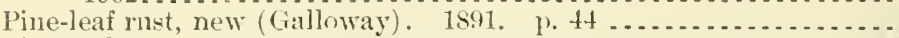

Pineapple:

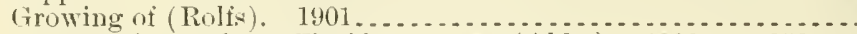
same, in sonthern Florida, note un (Abbe). 1900. ए. $253 \ldots$.

Industry of the I.S. (IVebber). 1895. p. 269............... Pineapple fiber, results of recent investigations relating to (Dodge).

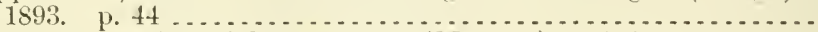

Same, report of speeial agent, 1892 (Munroe). 1893. p. $46 \ldots .$.

Pinehurst, S. C., tea gardens of Dr. Charles T. Shepard, report on

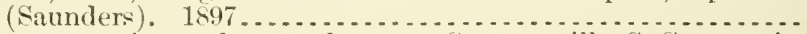

Pinehurst experimental tea garien, near Summerville, S. C., tea rais-

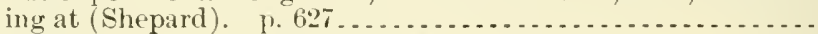

Pinheiro, A. P. Storms in Soutl Atlantic. p. $204 \ldots . . . . . . . . . .$.

Pinks, earnations and other, stigmonose, a disease of (Woods). 1900.

Pioneer in agricultural science, Elmund Ruffin (Cutter). 1895. 1. 493

Piper, C. I. :

Melica and Stipa, notes on. 1900. p. 10.

Orehard enemies in Pacific Nortbwest. 1902 . . . . . . . . . . . . . .

Piper, Horaee. Plants, hyloridizing, cross-loreeding, and degenera-

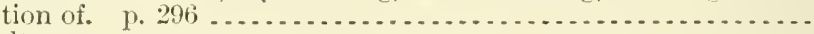

Piscieulture:

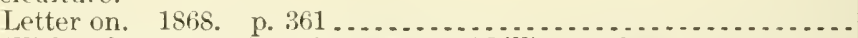

With reference to Ameriean waters (Gill). p. $394 \ldots . . \ldots \ldots . .$.

Pittier, H. Climatology of Costa Rica, monthly notes on, Jan., 1901Oet., 1902 . . . . . . . . . . . . . . . . . . . . . . . . . . . .

Pittsbury, Pa., nutrition investigations in, 1894-1896 (Bevier) . . . . . .

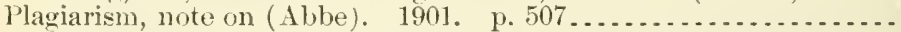
Plague. See Cattle plague - Hippelates - Pleuro-pneumonia.

Plains:

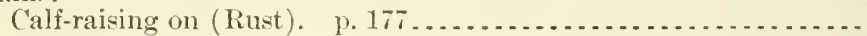

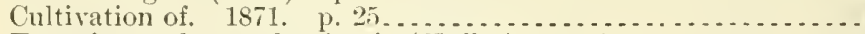
Experimental tree-planting in (Keffer). 1898 . . . . . . . . . . . . Forest cultivation on, general discusion of (Bloclget). p. 316 .. Grasses of eastern slope of Rocky Mountains and, "atalogue of.

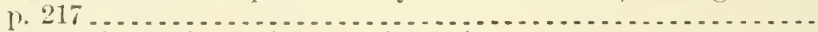

Tree planting and growing on (Furnas). 1858. \%. 202 .......

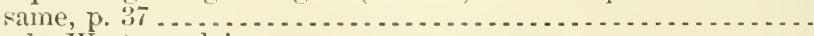

see also Western plains.

Planehon —. Phylloxera of Europe and Ameriea. 1874. p. 55.. Planchon, J. E. Eucalyptus glolulus from botanic, economic, ani] medical point of riew, embracing its introduction, culture,

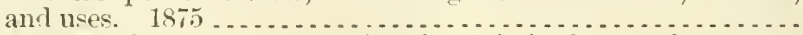

Planehon, $Y$. Solnble acids, estimation of, in butter fat. 1890.

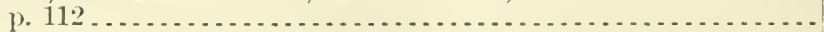

Plant breeding:

Hybrids and their utilization in (Swingle and Webber). $189 \pi$.

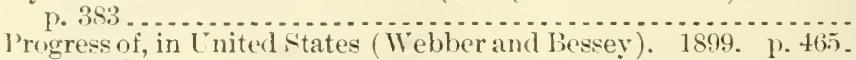

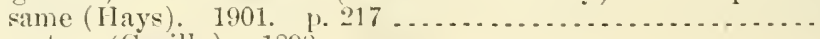

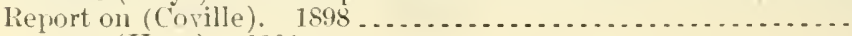
same (Hays).

901.

(1:16:3:

19.1i:7

19.1i::37

113. $2: 1^{\prime} 6$.

19.7:5

113.3:32

A28.5:7

11.9:140

129.6:28

A 1.10:89.5

A11.5:5

111.5:5

A14.4:1

11.1:8:?

129.3:11

A28.3:19

$11.10: 895$

13.4:27

A1.9:153

A1.1:86i7

A27.9:6

A1. 1:866

129.6:

A 10.3:52

129.6:29

14.1:886

127.9:9

113.3:18

11. 1:872

11.1:570

$11.7: 2$

$11.8: 28$

1.7.9:12

1].8:9

A7.3:24

11.10:897

11.10:898

A1. 10:901

16.2: $\mathrm{P} 69$

128.3:29 
Plant breeding-Continued

tre also Erans, Walter Harrison- Kenia.

Ilant-breeding station, Sraliif, sweden (Fairchild), 1901. p. 814..1 A10.6:1:3

Plant diseases:

Abstracts of reports of agricultural experiment stations on,

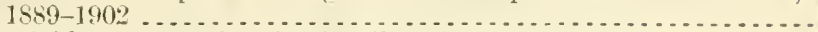

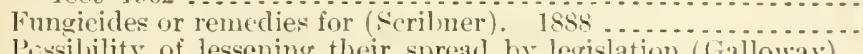

Pessilulity of lesening their spreal by legislation (fralloway).

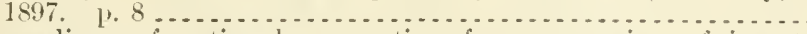

Proceedings of national convention for suppression of insect

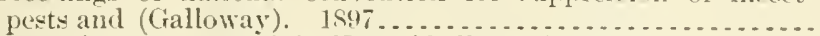

Progress in treatment of, in U. S. (Galloway). 18i9. p. 191 ...

Restriction of, legal enactments for; compilation of laws of $U$. S.

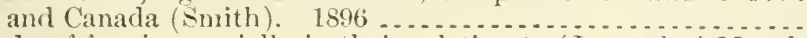

Study of fungi, especially in their relation to (Journal of IIyor)-

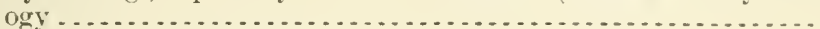

Treatinent of, expriments in, 1891-

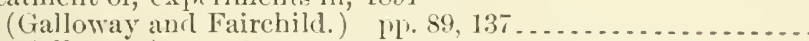

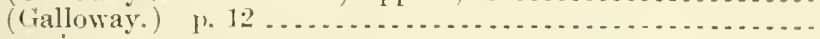

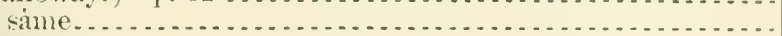

United States-

1898. 1. 652.

1999. p. 750 .

1900. 1. 799 ...

1901 (Orton). 1. 668 . . . . . . . . . . . . . . . . . . .

Se also Almond disease - Apple scal-Bermuda lily disease Black knot - Black spot - Blackberry rust - Blight - Blister mite-Cereal rusts-Club root-Cranberry gall fungusCrauberry rot and scald-Glceosporium-Gooseberry mildew - Grape mildew - Iollyhock disease - Hyacinth germ, Wakker's - Leaf blight-Leaf curl of peach trees-Leaf sickness of begonia and asplenium - Mosaic disease of tobaceo Peach blight - Peach-leaf curl -- Peach rosette - Peach rot Peach yellows - Pear blight - Pear-leaf blight - Pear scal- Pear-tree blight - Peronosporese-Potato blight - J'otato fungus - Potato rot - Potato scab - Powdery millew - Prune rust - Ripe rot-Root fungus - Root knot - Root-rot diseast - Rust mite - Smut-Sooty mold of orange-Sorghum blight - Sphrerotheca rhytophila - Spot disease - Spotting of peaches - Stigmonose - Sweet-potato black rot - Triblidium - - Tredinee - Ustilaginere - White fir - Wilt disease. Jlant faunc, notes on (Cockerell). 1892. p. 117 ............. Plant food:

Artificial, requirements of soils (Kilgore). 1902. p. 73........

Available, plan for cooperating in study of (Moore). $1902 \ldots .$. l'lant growth, relation of lime and magnesia to, experimental study

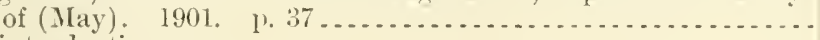
l'lant introduction:

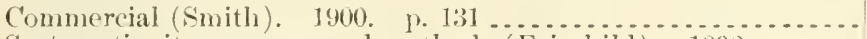

Systematic, its purposes and methorls (Fairchilil), 189s ...... tiee also sied and plant introduction.

I'lant lice, two new species, inhabiting witch-hazel and bircli, lifo history of (I'ergande). 1901 ... . . . . . . . . . . . . . . .

See relso A juidida - Aphis-Green-pea lonse- Iop-plant lousePear-tree psyla - Phylloxera - Plyylloxeral vastatrix - Plunplant louse.

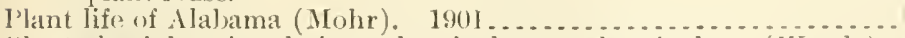
l'lant pliysiology in relation to horticulture and agriculture (Wools).

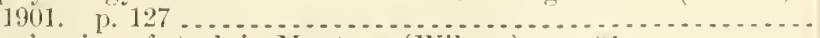

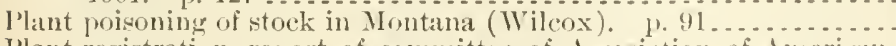
Plant registration, rejort of committee of Asociation of imerinan Agricultural Colleges and Experiment Stations on. Is98. 1. iti. Jlant soil tests:

Danger of drawing erroneons conelusions from (Wheelor). 1sos. T). 60 ( ).

Possibility of drawing erronents anderions from (VIjecler).

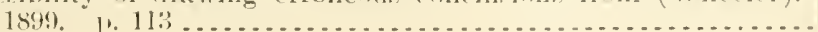

Clawification no.

111.6:

$1: 3.4: 5$

$11.4: 57$

11.5.57

11.10:8:19

128.3:11

$-128.5:$

$128.5:(6$

128.5:7

$1: 28.3: 3$

$11.10: 898$

1 1. 10:899

$11.10: 900$

A1.10:901

19.7:5

$110.3: 115$

17.4:9

119.3:1

$+1.10: 900$

A13.3:2]

$19.8: 9$

A(i.j): (i)

110.3:99

14.1:900

110.3:4:4

$17.3: 56$

A $10.33:(65)$ 
Plant varieties, influenee of enviromment in origination of (Tebber).

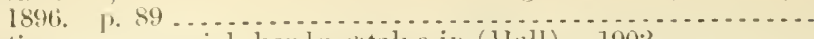

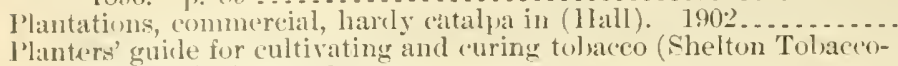

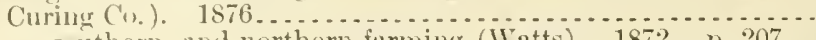
l'lanting, sonthern, and northern farming (Watts). 1872. p. 207 .. l'lants:

American, regulations of foreign govermments regarding importal-

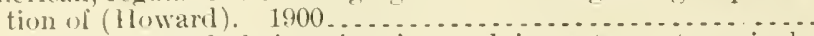

Aslo (onstituents of, their estimation and importance to agricmltural chemistry and agricultur' (Tollens). 1902. pp. 207, 305. Ash of, loss of sulphur in preparing (Fraps). 1901. p. 98 ..... Bacteria parasitic on, four one-flagellate yellow, cultural charac-

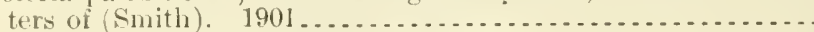

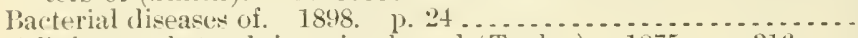

('ellulose and starch in animals and (Taylor). 1875. 1).316 ...

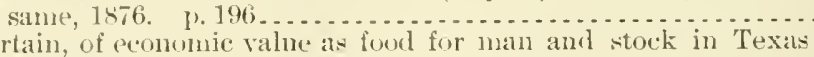
and Yew Mexico (Richarlson). p. 28:2 .................. ('hemical eomposition of, influence of environuent on (TViley).

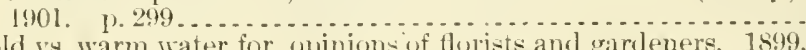

cold ve. warm water for, opinions of florists and garleners. 1899. p. 13 ... . . . . . . . . . . . . . . . . . . . . . . .

('ommereial growing of, muler glass, progress of (Galloway). 1899. 1).575 ...

Contributions from $\mathrm{C}^{\mathrm{S}}$. S. Sational Herbarium . . . . . . . . . Crule petrolemm and its effects upon, note wl (Smith). 1901.

Gultivateri-

frosts and freezes as affecting. 1895. p. 143.............. principles and methods of breeding (liebscher). 1897. 1. 347 . selection and its efferts on (De Vilmorin). 1900. p. 3.....

Cultivation of, relation of pliysical properties of soil to (Wollny).

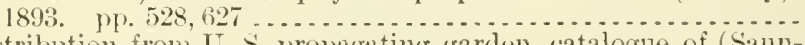

I)istribution from $U$. $s$. propagating garden, ('atalogue of (Samn-

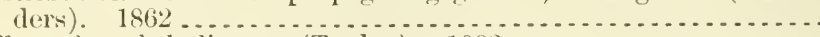

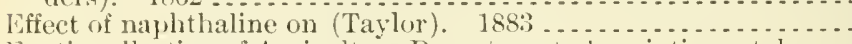

Fxotic eollection of Agriculture Department, lescriptive catalogue of (Samilers). 1872 .

Fecding caparities of-

cooperative experimenting as means of studying, ete., fertilizers and (Atwater). 1882. p. 27 ............................. experinents with fertilizers on fruits and vegetables to study variations due to action of fertilizers. 1891 . . . . . . . . . .

Fiber experiments with, history of, cte. (Dodge). 1594.......

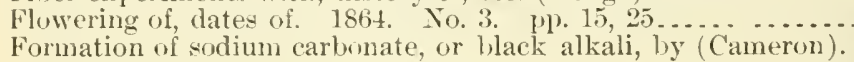

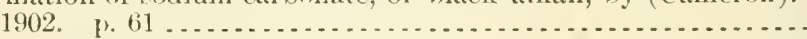

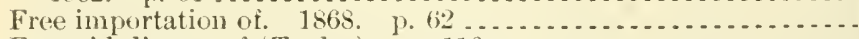

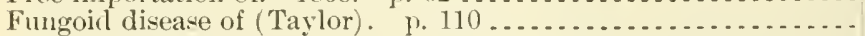

Fungous diseases of -

experiments matle in 1889 in treatment of (Galloway) ....... outlines of certain, with remarks upon apllication of remedies

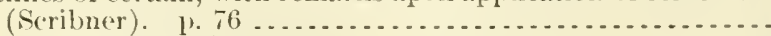

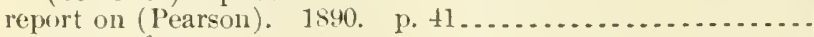
treatment for -

1895. p. 587

1896. p. $625 \ldots \ldots \ldots \ldots \ldots$

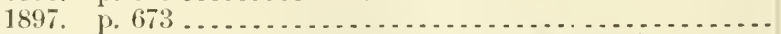

(iengraphic distribution of, in North America (Merriam). p. 203.

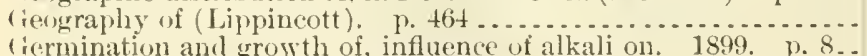
Germination and growth of, influence of alkali on. $1899 . \quad$ p. $8 \ldots$
(rrowtl of, increasing vigor of. 1872 . p. $143 \ldots \ldots \ldots \ldots$ Ilealth of-

in greenhouses (Galloway). 1895. p. 247. relation of 111 trition to (Voods). 1001. p. $155 \ldots \ldots \ldots . . . .$.

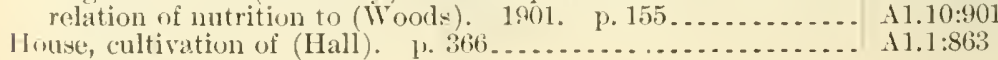

A $1.10: \$ 96$

A $13.3: 37$

A1.8:10

A $27.9: 10$

19.5: 41

A $10.6: 13$

A 7.3:62

A28.3:28

A 1.9:78

A27.9:13

A27.9:1t

11.1:887

\$1.10:901

A 1.9:92

A 1.10:899

16.5:

\10.3:99

A1. 10:895

A 10.6:5

A10.6:11

A10.6:4

A1.8:2

A 18.2:\$16

11.8:6

A 1.8::"2)

A10.4:19

A11.5:6

A27.9:2

11.8:71

127.9:6

A1.1:87 1

A6.3:11

A1.1:S85

16.3:11

A $1.10: 595$

11.10:896 A $1.10: 897$

11.10:894

11.1:863

\1.9:97

A $27.9: 10$

A $1.10: 895$ 
Hybridizing, cross-breeding, and legeneration of (Piper). p. 296. Improvement of, by selection (Weliber). 1895. 1.355........ Influence of illuminating gas mon (M/2lurtrie). 1875. 1.310.. Insects and, some interrelations of (Riley). 1892. p. $358 . . .$. Legmminoms-

for green manuring and feeding (Allen). 1894 ............ nitrogen, a germ fertilizer for. 1897. 1. 19 . . . . . . . . . . soil inoculation for (May and Beal), 1901. p. $7 \ldots \ldots . . .$. Low-growing, hydrocyanie-acid gas as insecticive on (Kanlerson

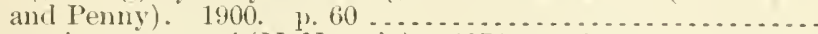

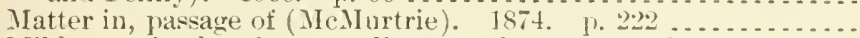
Mildew and other fungous diseases of, apparatus for combating (Ferrouillat). 1888. p. 87

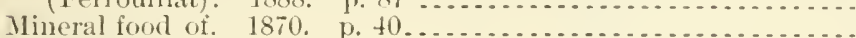

Nitrogen-iree extract of (Tollens). 1897. 1. $6+1 \ldots \ldots \ldots \ldots \ldots$. Organie matter in, origin and formation of (Deherain). 1898.

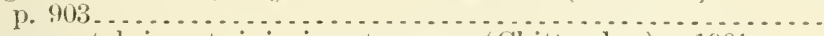
() rnamental, insects injurious to, some (Chittenden). $1901 \ldots \ldots$ Pathology of, lines of investigation that might be unchertaken by experiment stations (Galloway). 1897. p. 725 ..........

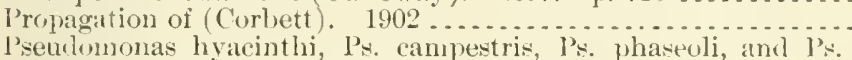
stewarti-four one-flagellate yellow bacteria parasitic on, cultural characters of (Snith). 1901

Resistance of certain, to black alkali (Camerom). 1902. 1. 7i.

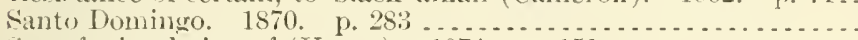

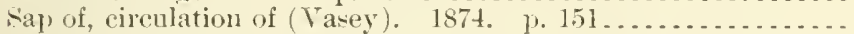

Scale insects found upon plants entering port of San Franciseo,

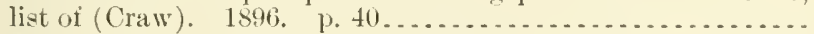
Seedling, effect of certain components of alkali soils upon

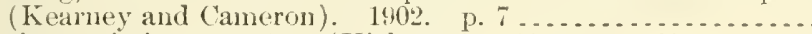
Testiner varieties, report on (Hickman). 1891. p. 103....... Three new, lestriptions of (liose). 1893. p. $289 . . . . . . . .$. Under glass, treatment of mildews upon (Maynard). 1891. p. 16. Enited States, in Agriculture Department, catalogue of. 186-... Used hyIndians of Thendocino County, California (Chesnut). 1902.

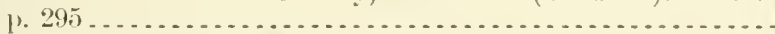
Klamath Indians of Oregon, notes on (Coville). 1897. 1, 87. ['setul-

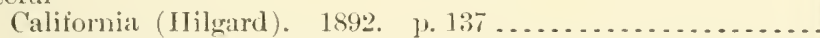
certain species of Coleoptera that attack, notes om (Chit-

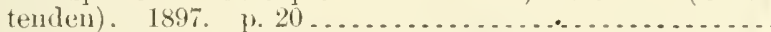

Varieties of, what our experiment stations hase lone in orisinating, by erossing, selecting, etr. (II alsted). 1901. 1) 143.. Varicty testing, methods of work in (Green). 1891, P. 49...

Water as a factor in the growth of (Calloway and Wows). 1894.

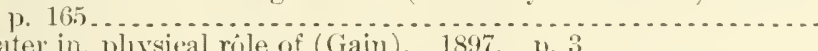

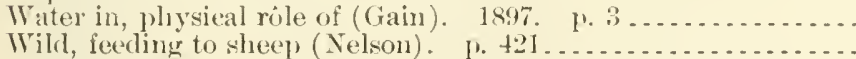
salle, 1. 10 .

See also Agave - Agriculture - Alsike clover - Anlialonium Apetalie - Arborescent flora - Arod plant - Asplenimu Berscem - Brassica - Burley tobacco- Cactus (flower) Calamovilfa - California - Canada thistle - Camairro- Cassava - Castor-oil lean - Castor-oil lilunt - Collulose Chicory - Chinese tea-plant-Chufa - Cigar-leaf toluaceoCocklebur - Coena palm-Coffer-Conamelinatea-Condurango - Crepis oceidentalis - Cucurbits - Dorkers-Dyer's madder - Echinocatus - Economie plants - Fammit Ferms - Fertilizers - Fiber plants - Fat-peal - Flax - Flax-

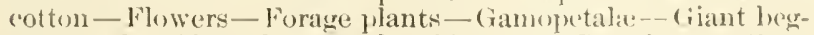
gar weed-Giant knotweed-Ginseng-Graminese-Giran ('ultura - firasses and forage plants - Hemp - Herperogenia - Hofinansegria - Hollyloeks - Hop flant - Hows" plants-Indigo plant - Irish inoss - Jnuver - Jute - Knot-

11.1:867

A1.10:898

A27.9:1:3

19.7:4

A1.9:16

11.9:65

A $1.9: 124$

A.1. $15: 26$

A27.8:12

A $6.3: 5$

A:7.9:8

110.6:8

\$10.6:9

19.6:27

110.6:7

1 1.9:157

128.3:28

A 1.8:7]

127.9:8

A27.9:12

19.8:

11.8:71

A 10.5:5

A6.5:1

ג28.5:6

11.2:16!

A6.5:7

16.5:5

11.8:21)

19.6:9

1 10.3:49?

А10.5:3

11.10:894

A $10.6: 8$

A $4.1: 898$ $14.3: 22$ 
Plants-C'ontinued

weed - Larkpur - Leibergia - Lichens - Licorice - Liverworts - Loeo plant - Lophophora - Madder - Manila hemp - Marine plants - Monocotyledons - Moss - Mustame - Nut grass - - )pinm poppy - (jpuntia - Osier culture()ser-willow - Pachybasim - Ialmer, Edward - Pasture plants - Pentstemon - Peppermint - Phanerogams - Poison oak - Poisonons plants - Polypetalie - Pteridophytes Pyrethrum - Quassia - Ramie - Rhubarb - Roseanthus Sap — Sceds and plants - Shrubs - Soils - Sorghum Starch - Sugar cane - Sugar-yielding plants - Tea - Teasel Tobacen - Tradescantia - Trees - Trelease - Tres Marias Islands, Mexico - Umbelliferse - Water hyacinth - Woody plants - Yucea - Yucea whipplei.

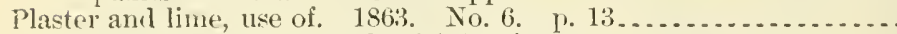

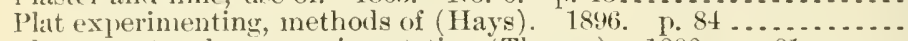
Plat s. pot or box experimentation (Thorne). 1890 , p. 81 . . ...

l'lateau region, harometric troughs of, report on (Iazen). 1895. p. 207 equalizing irregularities of, canserl by defective germination

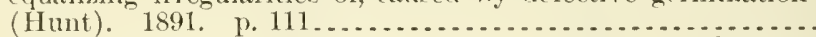

l'ats in field experimentation, form, size, arrangement, and treat-

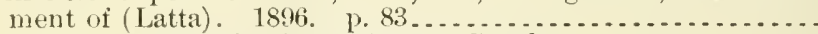
I'latte County, Nebr. Sce Great Eastern Caual.

Platypsyllus:

Fgg and ultimate larva (Riley). 1890 , p. $244 \ldots \ldots \ldots \ldots . . . . .$. Systematic relations of, as determined by larva (Riley). 1889. Plauen, Germany, cost of hauling farm products over wagon roads

Playa Rica, Ecuador, climatological data from (Stapletou). 1898. 1. 460

Pleasants, Thomas S.:

Agricultural production, liversity in. p. 247.

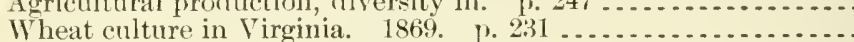

Pleuro-pnemmonia, or lung plague of eattle:

Article on-

in Nitional Live Stock Journal, 1880 (Law). 1. I79........

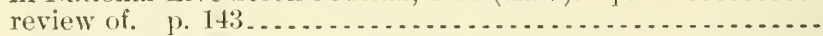
contagionssame, p. $436 \ldots \ldots \ldots \ldots \ldots \ldots$

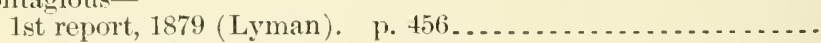

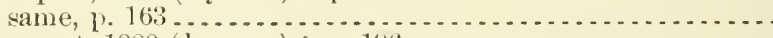

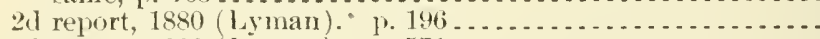

3 (l rejort, 1880 (Lyman). p. $571 \ldots \ldots \ldots \ldots$

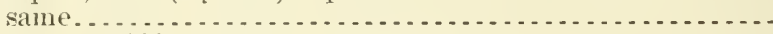
same, p. 268 _.

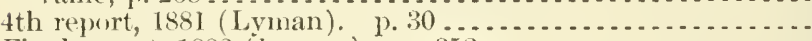
Final report, 1882 (Lyman). 1. $352 \ldots \ldots \ldots \ldots$

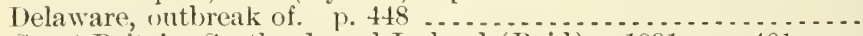
Great Britain, Scotland, and Ireland (Reid). 1891, 1. 401 .... History of, in Richmond County, New York (Rose). p. 468 .... Investigation of; inspection of stables. 1885 . 1. 558 .........

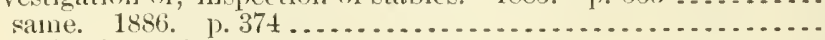
Investigations of-

in Kansas (Devoe). p. 322 .

in Maryland, District of Columbia, and Virginia (Rose). p. 51 . in New Jersey (Corlies). p. 46...................... same (Ililler). 1. 45 . . . . . . . . . . . . . . . . . . .

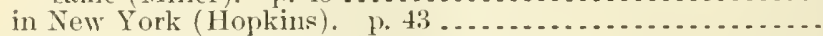

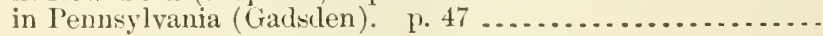
report on-

1884. p. 181

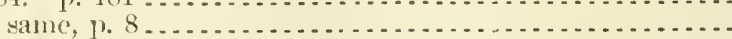

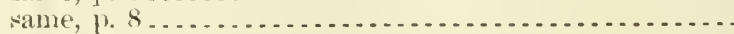

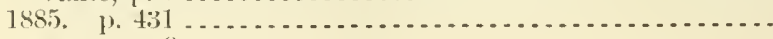
same, p. 9 
Pleuro-pnemmonia, or lung plague of cattle-Continued Investigations of-Continued report on-Continued

1886. ए. 593 same, 1. 9

1887. 1. 458 same, ]. 9

1859. p. 49

1890. same, 0.62

1891. 1. 94 same, p. 22

189:2. p. 85 same, p. 71

Legislation relative to, leport on.

Letters relative to (Law). pl'. 233, 237.

New Jersey (Hunt)

29

1. $233,237$.

Pathological anatomy and histology of respiratory organs in

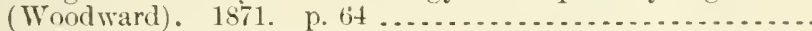

Preliminary report on (Gamgee). 1868. ๆ. 432.

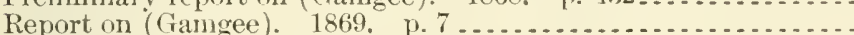

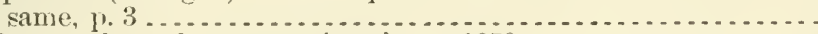

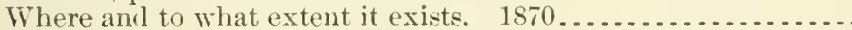

See also Tuberculosis.

Plover, killdeer, circular on. 1859

Plow:

American, in Europe. 1868. 1. 286.

British improvement in. 1871. p. 67

Steam, in Louisiana. $1869 . \quad$ p. 225

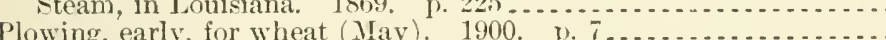
See relso Steam plowing.

Plows and plowing (Fleischmann). 1883. No.64. 1.64....... Plum curculio:

Arsenical poisons for (Forbes). 1889. p. 3.

Egg-laying record of (Qmaintance and Smith). 1902. p. 105...

Experinnents in rearing, from plums and other fruits (Webster).

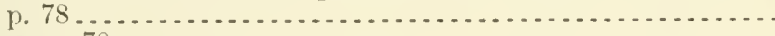

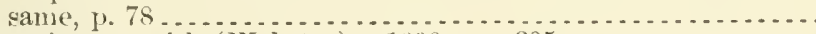

Experiments with (Webster), 1890. p. 305 ..............

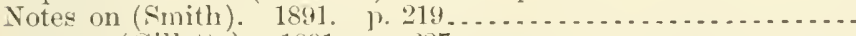

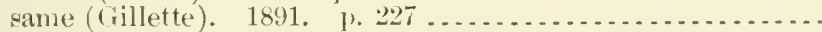

Report on (Riley and Howard). p. 57

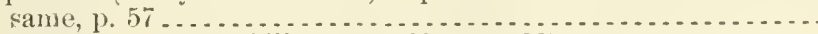

Plum gouger, notes on (Gillette). 1891, p. 227...............

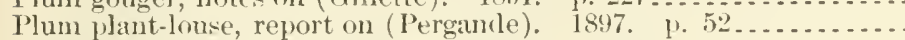
P'lum trees, black knot of (I'eck). p. 175.

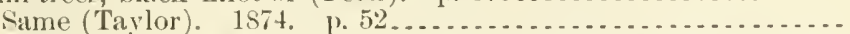

Plumandon, J. R. IIail slooting, geseral rejort on, presented to congress at Lyons; translated by Mrs. R. S. Hotze. 1902. P. 35.

Plumb, Charles Simmer:

Cereals, geographic distribution of, in North America. 1898 . . . 15.33:11

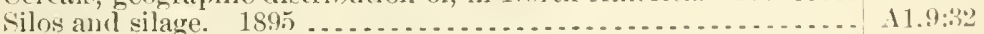

Plumb, Charles Sumner, and Anderson, IV. B. Corn meal and

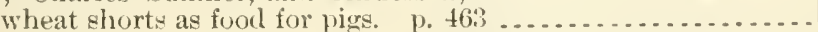
Plums:

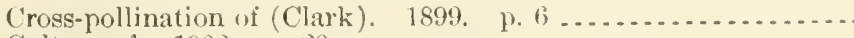

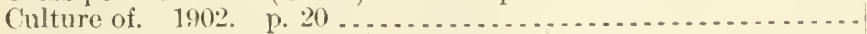

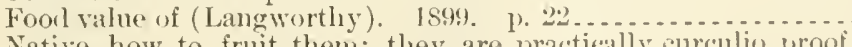

Native, how to fruit them; they are practically eurculio pront (1Vier). 1887 , wheries of aphis injurious to, in Georgia, prelinimary nots

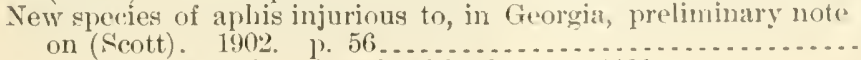

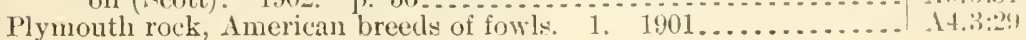

A 1.1:886

A $4.1: 886$

A 1.1:887

14.1:887

11.1:888

1..1:887-9

A 1.1:889

A $4.1: 889-90$

A1.1:890

A $4.1: 889-90$

A 1.1:891

A4.1:891-2

1 1.1:892

A4.1:891-2

A 1.8:22

A1.6:12

At.1:88t

A 1.2: $229^{2}$

A27.9:6

A 1.2:( $29^{1}$

A1.2:( $2 y^{2}$

A1. $2:$ (1.29 $^{6}$

15. $4: 10$

127.9:6

A $27.9: 9$

A $1.10: 898$

A27.9:7

A 1.9:1:2

A27.9:21

19.7:2

A9.6:3

11.1:848

A9.1:8s

A9.7:2

19.7::3

A9.7::

11.1:898

19.1:885

A9.7:3

A9.6:7

11.1:872

1 $27.9: 12$

$129.6: 30$

14. 1:899

$11.9: 10: 3$

A $1.9: 14 !$

11.9):10:

$19.3: 1$

19.6:31 
Pnemunia. Sce Horses-Pleuro-pneumonia - Swine-plagne.

Poa, now species of, note on. 1901. p. 4 ............... A3.4:35

Poa fendleriama and its allies (IVillians). $1599 \ldots \ldots \ldots \ldots \ldots \ldots \ldots . . .13 .4: 10$

Pockels, F. Precipitation, theory of formation of, on mountain

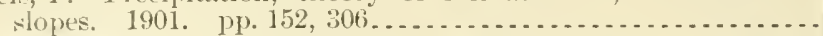

Pocket gopher:

Geomyicla family, exclusive of specics Thomomy, monographic:

levision of (Merriam). $1895 \ldots \ldots \ldots$
Geomys, genus, from westem Nebraska, (lestription of (Merriam).

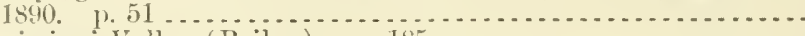

Missiswippi Valley (Bailey). p. Is. . . . . . . .

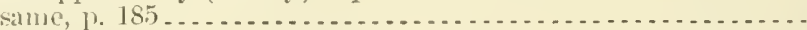

United States (Bailey). 1895 ... See also Gophers.

Pocket mice:

North imerican, revision of (Merriam). 1Ss9 . . . . . . . . . .

Of the genus Perognathus, revision of (Osgood). $1900 \ldots . . . .$.

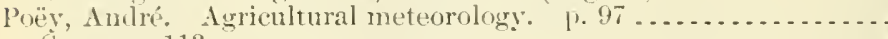

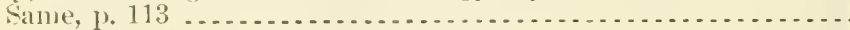

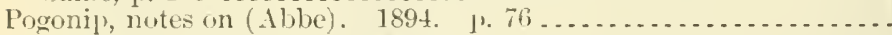

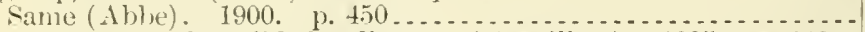
Poison oak, Cecidomyid that lives on (coquillett). 1895. p. 348.. Poisoning ly:

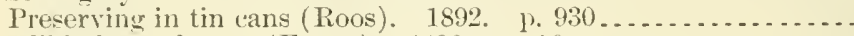

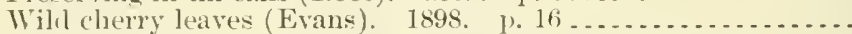

Poisonons insects. See Centiperles - Scorpions - Tarantulas.

Poisonons plants:

Northern stock ranges (Chesnut). 1900. p. 305

Principal, of United States (Chesnut). 1898

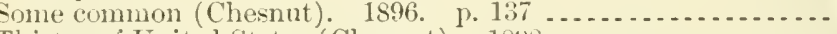

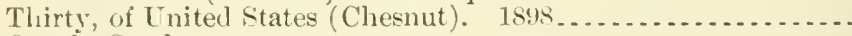

See also Stock.

Poisonous spider in Madagascar. 1890 . p. 273 ................

Poisons, rlestruction of sparrow by (Fisher). 18s9. p. 174 ......

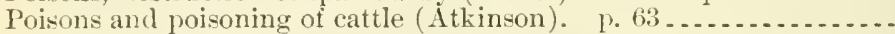

Polar expeditions:

International, 1882-83 (Börgen). 1895. p. 469 .............

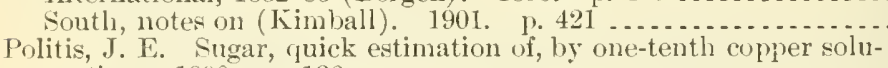

tion. 1890 . p. $136 \ldots$. . . . . . . . .

Pollination:

Cross, relation to fruitfulness. 1897. 1. 14 ...............

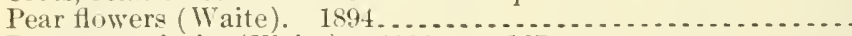

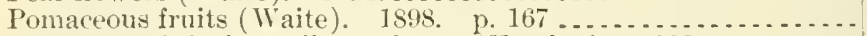

Premature, injurious effects of, etc. (Hartley). 1902..........

Yucea whipplei, in California (Coquillet). 1893. p. 311 .....

Polsley, F. A. Road system, better, simple plan for. 1901. P. 98.

Polypetalie of western Texas, description of (Coulter). 1891. 1.6..

Polysulphicles, alkaline, use of, for grape millew. 1S85. P.67....

Pomaceous fruits, pollination of (Waite). 1898. 1. 167 . . . . . . . . .

Pomological nomenclature, proposed code for (Craig). 1S99. p. 130.

See cilso Agricultural nomenclature.

Pomological societies, list of:

1870
1872
1876
See also American Pomological Society.

Pomology Divicion, Agriculture Departinent:

Work of, for farmer (Brackett). 1897. p. 111 ..............

Pomology in Wurtemberg (Schickler). 1870. p. 158.............

Pond pine, See Marsh or pond pine.

Ponta Delgata, Azores, storm at, Dec. 8, 1894 (Ab)e). p. 508..... A29.6:22

Pool, J. Forage plants of Arizona and New Mexico. 1888. p. 48.. A6.3:6

Poore, Ben: Perley. Agriculture of U. S., history of. p. 498 ...... A1.1:866

Popence, E. 1. Dissosteira longipennis, recent (outbreak of, notes on. 1891 P. 41

A 1. 1:869

1 1.1:870

A29.6:22

A $29.6: 28$

19.7:7

17. $3: 13^{i}$

A 1.9:103

1 1.10:900

A6.3:20

1 1.10:896

A 1.9:46

A9.7:2

A 5.3:1

14.2:C $29^{2}$

A $29.3: 11^{2}$

129.6:29

17.3:28

A28.3:22

11.9:65

A $28.3: 5$

11.10:898

A 19.3:2.2

A.9.7:5

120.3:21

16.5:2

$16.3: 2$

11.10:898

A10.3:65

A 1.8:4

11.6:5

1 1. $9: 12$

A20.

1J. $10: 897$

127.9:8

A9.7:4 
Poplar gonioctena, report on (Cook). 1S91. p. $67 \ldots \ldots \ldots \ldots \ldots$. Classiffation no.

Poppelsdorf, Prusia, royal anricultural academy at, report on. 1885.

Poppy. see Opimm mups.

Popular credit congress, Nimes, France, 1595, notice on. p.2013.....

Population. See Influstrial population - Rural population.

Porchinski, I. Tabanirla (gadflies) and a very simple means of dePork: stroying them, translated by I'eter Fireman. 1899. 11.25...

$19.7: 4$

1].8::30

$127.91: 3: 3$

A $19.6: 20$

American, Italian interliction of. 1889. p. 129........... 127.9:27

Consumption of, in Saxony, 1887. p.591............... 127.4:2

Examination of, for trichina, instructions for microscopists in. 1896

Salted, of American origin, importation of, into France (Bonley).

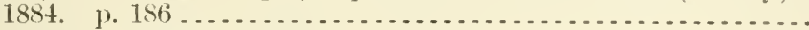

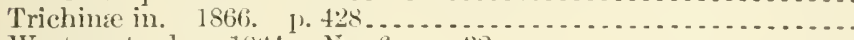

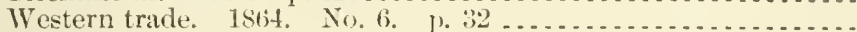

Pork-packing:

Chicago, 1867. p. 372 ...

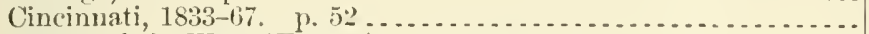

Hogs and, in West (Emery). p. 198 . . . . . . . . . . . . . . .

Middle Wrest, 1867-1868. p. 141. same, 1868 . p. $15 \ldots \ldots \ldots \ldots \ldots \ldots$

United States, $1878-87$. p. $154 \ldots \ldots \ldots \ldots$

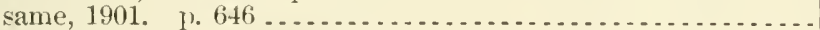

West, $1864 . \quad$ No. 1, p. 34; No. 2, 1. 22

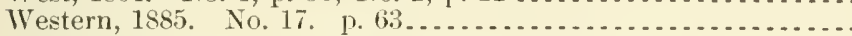
Port au Prince, Hayti, meteorological observations at, monthly, notes on (Abbe). 1898. pp. 59, 103, 163, 212, 253, 406, 458...

Port Carolina, South Australia, earthquakes, clouds, and gales at

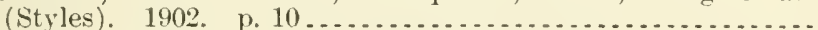

Porter, H. C. See, as joint author, Grindley, H. S.

Porthetria dispar, introluction and spread of, in Massachusetts (Howarl). 1897.

Portland, Maine, sugar-beet eulture near (MeMfurtrie). I879.

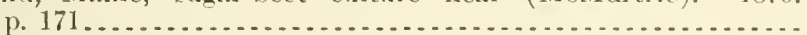

Portland, Oreg., weather forecast district, monthly report of-

A pr.-July, 1900 (Beals) . . . . . . . . . . . . . . . . . . . . . .

Sept., 1900 (Wollaber) _. $\ldots \ldots \ldots \ldots \ldots \ldots$

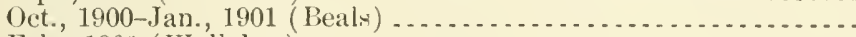

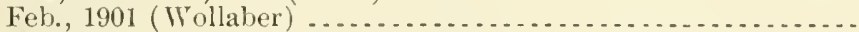

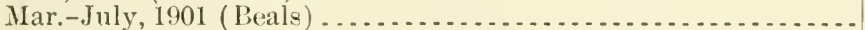

Sept., 1901-Oct., 1902 (Beals).

Porto Rico:

Agricultural investigation in (Evans). 1901. p. 503

Agri ultural resources and capalbilities of, report on, with special reference to establishment of an agricultural experiment station on the island (Knapp). 1901

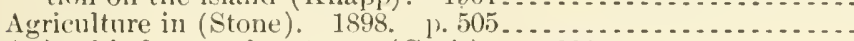

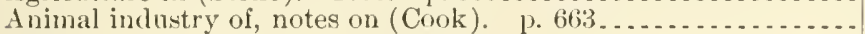

Animals and animal products, trade in. 1. $405 \ldots . .$.
Brief trip to, in January and Feloruary, 1899, notes on (13us.k). 1900. 1). 88

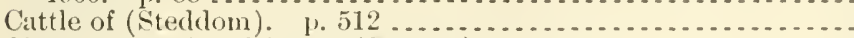

Clianga or mole cricket in (Barrett), $1902 \ldots \ldots \ldots . . .6$.

Climate and crop service in, notes on (Ablue). 1899. 1).258 ...

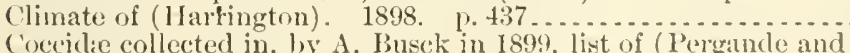

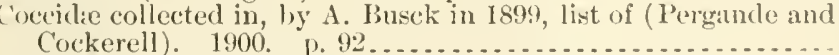

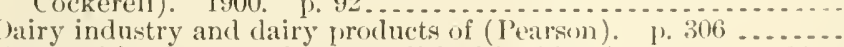

Farmers' institute work accomplished in (True). 1902. 1. 33..

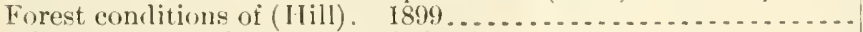

"Gran cultura" in, notes on (Al)e) 1899. p. 548.......

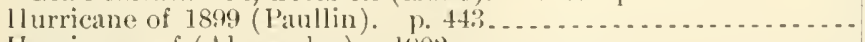

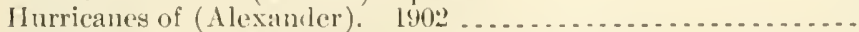

Industries of, value of climate and rep anel storm-waring services of Weather Burcau to (Noyes). 1902. 1\% $60 \ldots . . . . .$.

14.2: $\mathrm{I}^{2}+2$

A $4.3: 30$

127.9:4

A27.9:2

A $27.9: 5$

A27.9:5

A1.1:863

127.9:6

A $27.9: 7$

A $27.9: 25$

A 4.1:901

A $27.9: 2$

127.9:2\%

A29.6:26

A 29.6:30

A9.6:11

A $1.6: 28$

129.6:28

A $29.6: 28$

A29.6:

A 29.6:29

A 29.6:29

A 29.6:

A1.10:401

A 10.2: 1283

A1.10:898

A 4.1:\$99

14.1:899

A9.6:2:2

At.1:899

110.12:2

A29.6::27

1.29.6:26

A9.6:2:2

A $4.1: 9+1$

A 10.3:1:0

A 13.3:25

$129,6: 27$

129.6:28

$129.3: 32$

129.3:31 
Purto Rico-Continmed

Meteorological notes from (Gedlings). 1900. p. 25T.

Report un (Cline). 1901, p. 353 ........... Rubluer cultivation in (Cook). $19(00 \ldots . . . . . . . . . . . . . . .$.

Tracle of (Hitcheock). 1898 ...........................

Weights and measmes in, notes on $(\Lambda \mathrm{b} b \mathrm{~s})$. 1898, $1.567 . . .$. Sep ulso Hacienda P'erla - San Juan.

Porto Rico Agricultural Fxperiment Station:

Anunal report for 1901 (Garlner). 1902. 1. 381.

Publications of

Portugal:

Agriculture in. 1871. p. 141

Icerya purchasi in, work against, with accomt of introduction from America of Novius eardinalis (Howard). 1898. p. 30.

Novius cardinalis in, intruduction from America, accont of (Le ('ocq). 1898. p. 32.

Pust, J. IV. Railroads, track on worden and metal ties, expenses

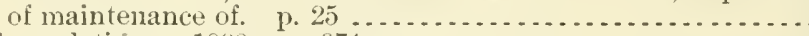

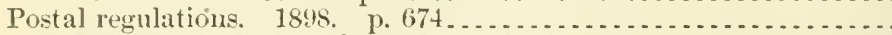

Postal telegraph clock and weather bulletin, note on (Abbe). 1897.

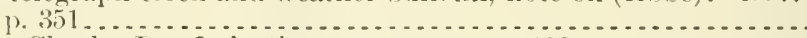

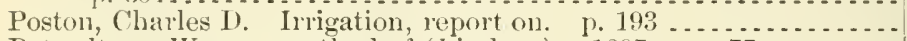

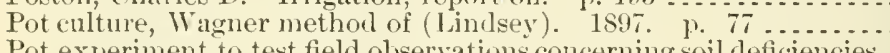

Pot experiment to test field observations concerning soil deficiencies.

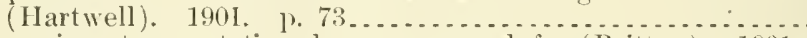

Pot experiments, vegetation house arranged for (Britton). 1901.

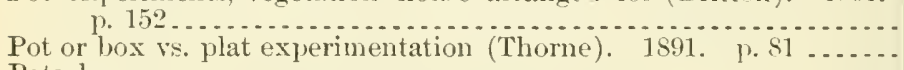
Potash:

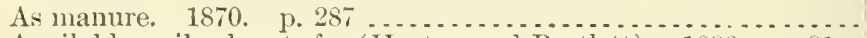
Arailable, soil solvents for (Hnston and Bartlett). 1896. p. 91. -
Bichromate of, does crean lose fat on keeping for long time with and withont? (Winton). 1894. 1\%. 192.

Determination of-

in fertilizers, some sources of error in (Scovell and other:-).

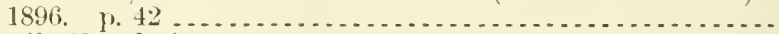

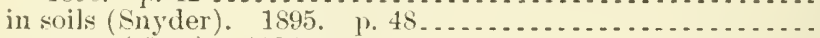

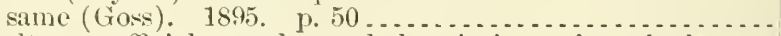
results on official samples and clescriptions of methorls em-

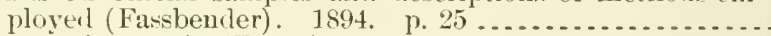

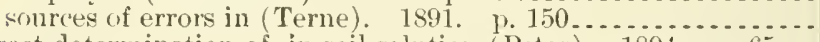

Direct determination of, in soil solution (Peter). 1894. p. 65...

Estimation of, abstract of report on (committee of French Association of Sugar Chemists). p. 43 .

Lindo-Gladiling method of determining, report of nse of sodim

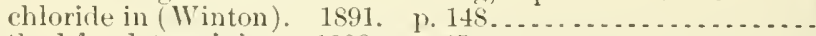

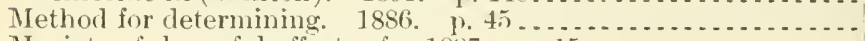

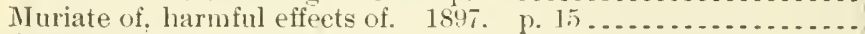

See ulso Hawaiian soils - Suint.

Potash eommittee, Association of Otticial Agricultural Chemists, report of:

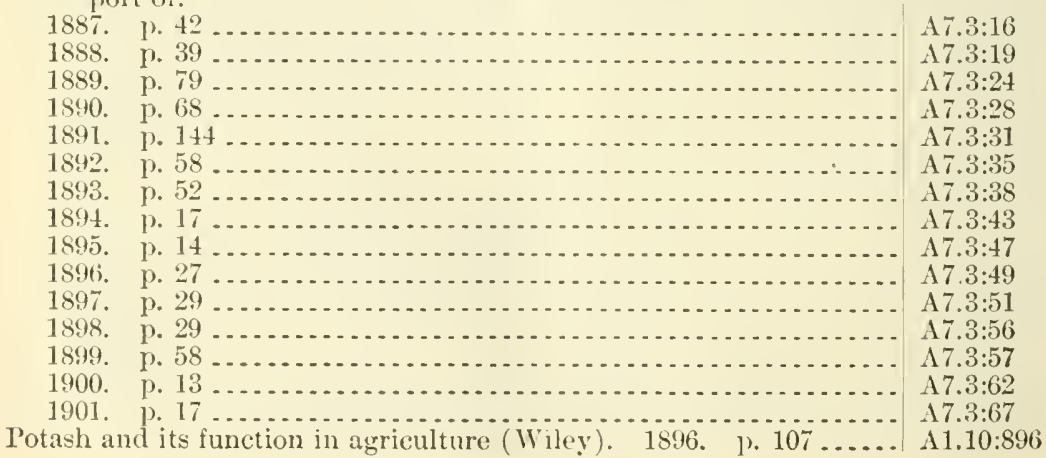


Potassium, iodide of, treatment of lumpy jaw with (Nörgaard). 1, 135. A4.1:891-2 Same (Nörgaars). 1893. p. 39 ............................. At.3:2

Potasium sulphide. So Nitrogen determination.

Potato:

Composition of different parts of, and loss of nutrients during process of hoiling (Frisby and Bryant). 1897. 1. 25. .......

Crop-

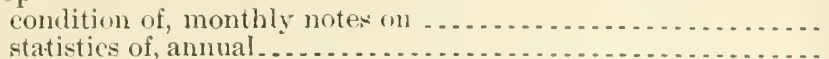

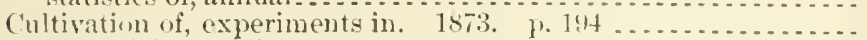

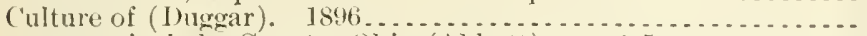
same, in Lake County, Ohio (Abbott). p. 245 ..........

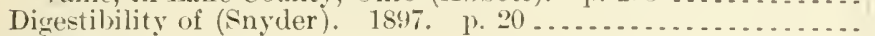

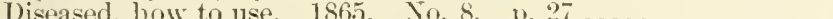

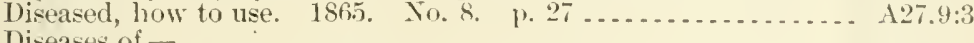

and their treatment (Galloway). $1899 \ldots \ldots \ldots \ldots \ldots \ldots \ldots . . . . . . .9191$

canse and cure of (Taylor). 1869. p. 64................. 127.9:7

some destructive, what they are and how to prevent then

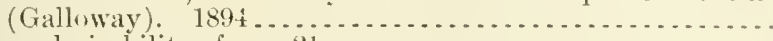

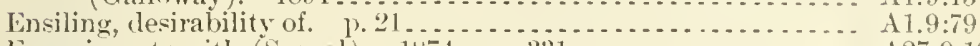

Experiments with (Sovel). 1sit. 1.331................ 127.9:12

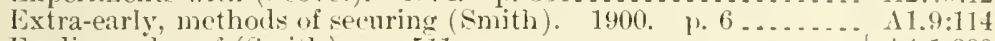

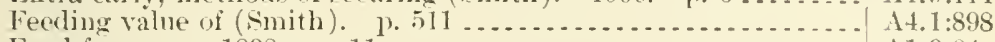

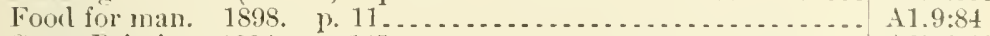

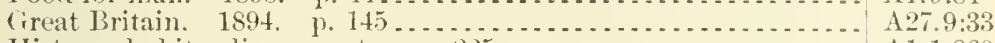

History, habits, diseases, ete 1. 225 ................... A1.1:868

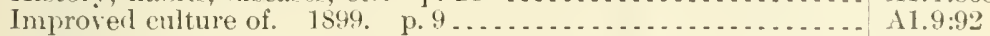

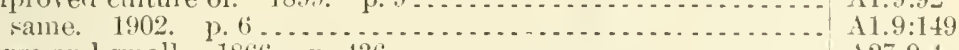

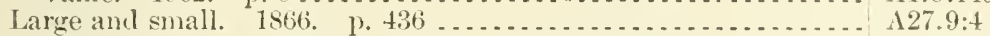

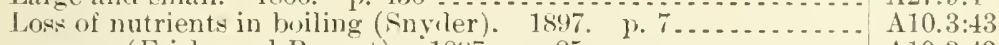
same (Frisby and Bryant). 189\%, p. 25.............. $110.3: 43$

Profuction, imports, and exports of, 1885-94. p. 142 ........ A27.9:33

Raiving in Tennessee (Callender). p. 657 .................. A1.1:880

Second-crop, for seed. 1899 . P. 11 .................. $11.9: 92$

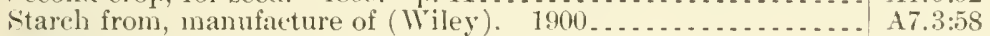

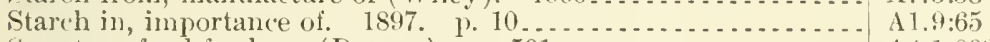

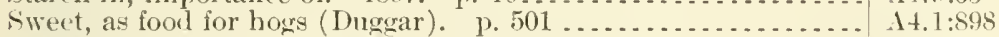

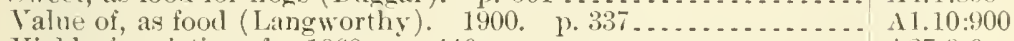

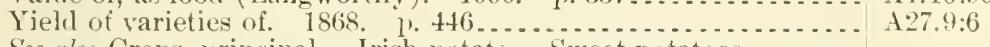

See also Crops, principal - Irish potato - Sweet potatoes.

Pentato beetle. Sice Colorarlo potato beetle.

Potato blight and rot:

Combating, report on (Bünzli). 1891. p. 78 .............. A28.5:6

Comparative test of fumgicides in checking (Jones). 1893. p.89. $110.3: 16$

Mierowcopic investigations of (Taylor). 1872. p. 507......... A27.9:10

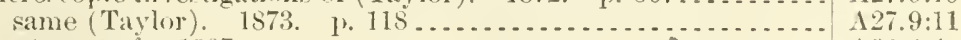

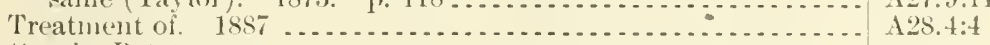

Siee calso I'otato rot.

Potato bread for horses in Germany (IIughes). p. 530 . . . . . . . . 14.1:899

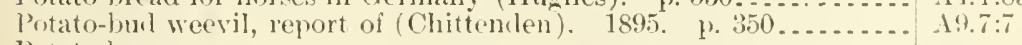

Potato bug:

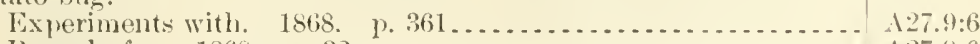

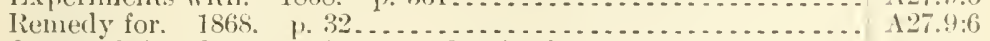

See rlso Colorado potato beetle - Growbeak, jose-breasted.

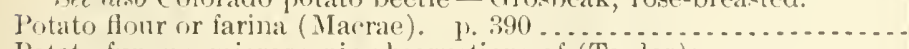

Potato fungus, microscopic obervations of (Taylor):

1873. 1. 251 .

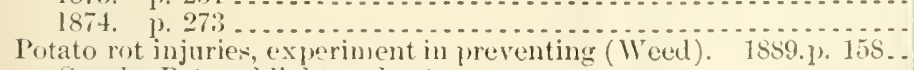
See ulso Potato blight and rot.

Potato scab:

Cause and means of prevention of. 1897. p. $20 \ldots \ldots \ldots . . . .$.

Fungus of, renarks on (De Lagerheim). 1891. p. $103 \ldots \ldots$.

Report on (Soraver). 1Ss9. p. $47 \ldots \ldots . . . . . . . . . . . .$.
Potato-tuber moth, report of:

1892. p. 239 ... . . . . . . . . . . . . . . . . . . . . . . . . . . . $19.7: 4$

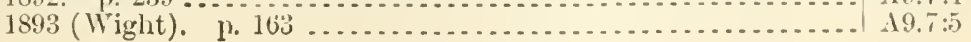


Potomae Flats, grasses and fodrler plants on (Ball). $1900 \ldots . . . .$. Potomac lands of Virginia for agricultural purposes. 1872. p. 16... Potomac liver, phenological observations on (Very). 1900. p. 154. Potter, C. . W. Wool-growing, profits of. 1s6it. No. 1. p. 22 ....

I'otter, Isnac B. Address of, before national road conference July, 1894. 1. 50

Poughkeepsie, N. Y., sphingida and Bombycide taken by electric

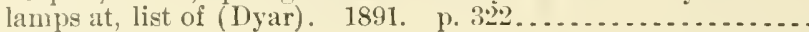
Poultry:

Anímal matter a necessity for.

p. 16.

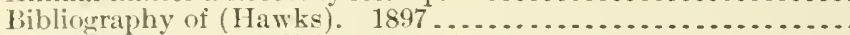

Condimental and medicinal foods for. 1901 . p. $22 \ldots \ldots \ldots \ldots$.

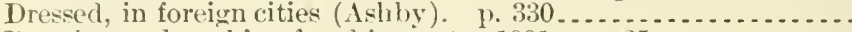

Dressing and patcking for shipment. 1901. p. 25 ............

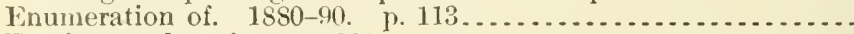

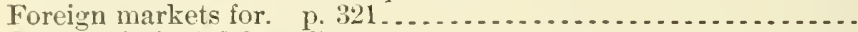

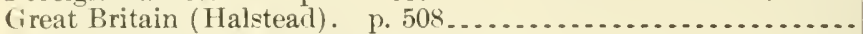

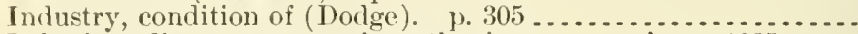

Infectious diseases among, investigations concerning. 1895.....

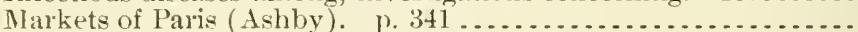

Preparing for London markets (Lowe). p. $333 \ldots \ldots \ldots \ldots . . . .$.

Raising-

for market. p. 345

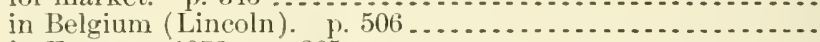

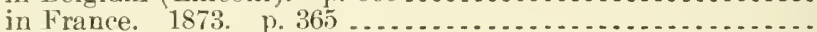

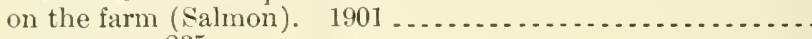

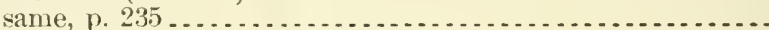

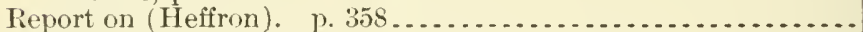

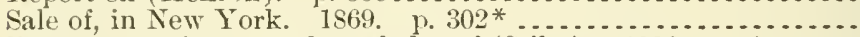

Tapeworms of, present knowledge of (Stiles). 1896. p. $9 \ldots \ldots$.

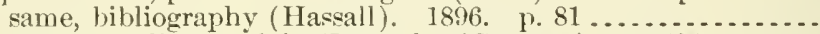
Young, gape disease of, in Kentucky (Garman). p. 504 ....... See also Chickens-Farm animals.

Poultry associations, list of:

1898. p. 615

1899. p. 697

1900. p. 652

1901. p. 627

Powdery mildew, treatment of nursery stock for (Galloway). 1891. Sce cilso Grapes.

Powell, E. P. Agriculture in rural schools. 1902. p. 109.

Powell, John IVesley, address of, before convention of National

League for Good Roarls, Washington. 1893 . p. 17 .........

Powers, W. A. See, as joint author, Hopkins, Cyril George.

Prairie dog:

Destruction of, directions for (Merriam)

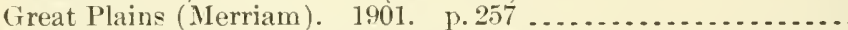

New, from Wroming, description of (Merriam). 1890, p. $33 \ldots$

Prairie ground squirrels. See Squirrels.

Prairie land, tile-horned prionus in, note on. 1886. p. 39 ........

Prairie pastures, worn-out native, renewing of (Williams) .........

Prairie region:

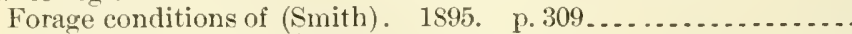

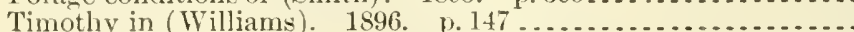

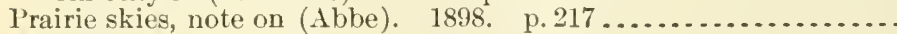

Prairies:

Sheep on (Grinnell). p. 300

Timber on (Edwards). p. 495.

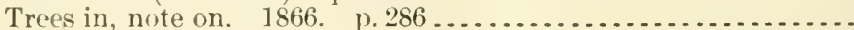

See also Destitute regions.

Pratt, /adock. Dairy farming, with some account of farm of the

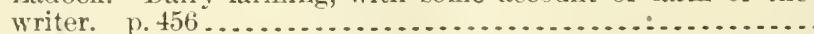

Preble, Edward A.:

Piological investigation of (Keewatin) Hudson Bay region. 1902. Jumping mice of genus /apus, revision of. 1899.

* By a misprint, this puge number appears twice.
Classlfication no. A3. $4: 28$

$127.9: 10$

A $29.6: 28$

A27.9:3

A $22.3: 10$

19.7:3

A1.9:97

A17.3:18

A1.9:144

A 4.1:899

A1.9:144

A27.9:32

A4.1:899

A $4.1: 90 \mathrm{C}$

A4.1:891-:2

A4.3:8

A4. $1: 899$

A4.1:899

A1.1:862

A 4. 1:900

A27.9:11

A1.9:141

A 4. 1:900

A1.1:862

A2 $6.9: 7$

A4.3:12

A $4.3: 12$

A4.1:898

A1.10:898

A1.10:899

A1.10:900

A1.10:901

A28. 4:10

110.3:120

A 10.3:14

A.5. $4: 32$

A1.10:901

A5.5:4

A9.3:12

A3.4:4

A1. 10:895

A1. 10:896

A29.6:26

A1.1:862

A 1.1:862

A27.9:4

A1.1:865

A5.5:22

A5.5:15 
Index

Classlfeation no.

Precipitation:

Average anuual, in Enited States, 1871-1901 (Henry) p. 207.....

Boston, Mass., Chicago, Ill., Dodge City, Kuns., Jupiter, Fla., St. Louis, Mo., and San Francisco, Calit., 1889-91. 1. 108... .

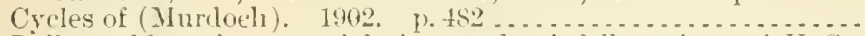
Daily, talles of, at special river and rainfill stations of L. S. it eather Bureau, for 189:3, 1894, 1895. 1900.............. Depth of, corresponling to given weights, table showing. 18:2. Details of, at stations in Nebraska and south Dakota. 1s94 ..... Excessive, in United States (Ilenry). 1897. p. 13 ............... Homogeneity and miformity of, at Weather Burean stations, notes on (Albe). 1897. p. 249.

Veasurement of (Marvin)

Wunthly notes on, July, 1891-()ct., 1902 . . . . . . . . . . . . . .

New York City, 1870-91 (Draper). p. $79 \ldots \ldots \ldots \ldots \ldots \ldots$

Tormal, in-region of Great Lakes (Henry), 1819. p. 151 . ....

Pacific Yorthwest, and possilility of high water in Columbia [river] from melting snow in mountains (Pague). 1849, p. 252.

Relation of water level of (Great Salt Lake to (Murloch). 1901.

p. 22
Theory of formation of, on monntain slopes (Pockels). 1901. Pp. 152,306

True amount of, detemination of, and $\mathrm{its}$ bearing on theories of

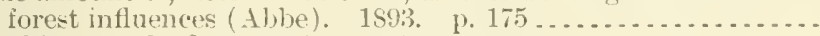

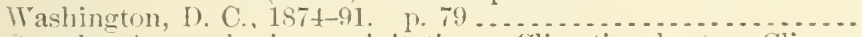
See al:o Atmospheric precipitation - Climatic charts - Climatology.

Predaceous insects. rioe Insects.

Preserved meats, atulterations of (Bigelow and others). 1902. p. 375 . F'ress:

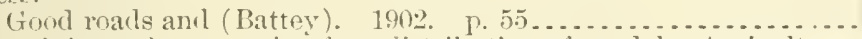

Gpinions of, concerning free distribution of seed by Agriculture

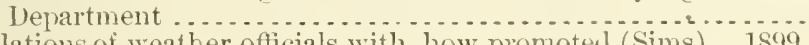

Relations of weather officials with, how promoted (Sims). 1899. p. 74.

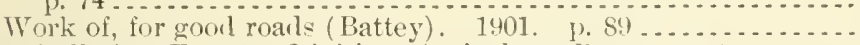

Press bnlletins, Forestry Division, Agriculture Iepartment ........

Pressey, H. A., and IIyers, E. W. Hydrography of southern APIa-

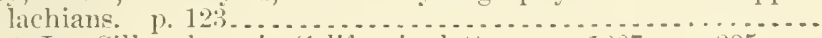

Prevost, L. Silk eulture in California, letter on. 1867. p. 285 ...

Price, M. II. Vine dicease in France. 1873. ए. 172...........

Price, Overton $\mathrm{IV}$ : :

Forestry, practical, in southern Appalachians. p. $357 \ldots \ldots$....

Lumbering in wothern Aplalachians now and under Govern-

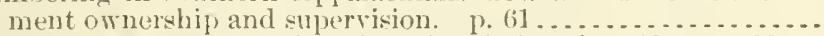

Price, R. H. Peaches, classification of varieties of. 1895. 1. 82 ..

Price lists of publications of Agriculture Department . . . . . . . . . . . .

Prillieux, Eilonard Ernest:

Aiguillon, France, black-rot of grape vine, treatment of, experi-

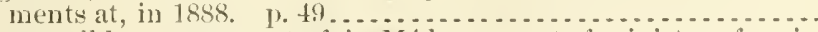

Grape millew, treatment of, in Médoc, report of minister of agri-

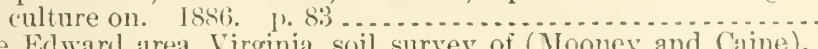

Prince Elward area, Virginia, soil survey of (Mooney and Caine).

Prince George County, Mil., soil survey of (Bonsteel and party). P. 173. Gee, as collector, Coulter, John if, and Rose, Joseph Nelwon.

Printing, Solandi [sun]. [Halsterl.] 1894. p. 93................

Printing office, Agriculture Department, report of foreman (Skin-

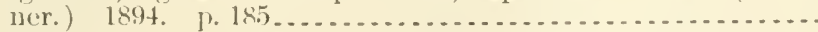

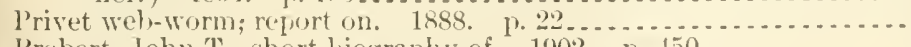

Probert, John T., short biography of. 1902 . p. t50 ...........

Proconia undata in injurious numbers, note on. 1886.1 . $42 \ldots \ldots$.

P'roctor, Frank WV.:

Atmospheric rolis, horizontal, report on. 1896 . p. $367 \ldots . . .$.

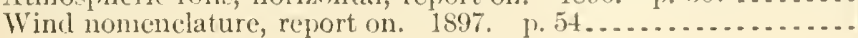

12:3.6:30

129.6:20

129.6:30

+29.2:P91

A 29.2:19913

129.2: $\mathrm{P}^{2} 1^{1}$

$129.6: 25$

A29.6:25

1 $29.11: \mathrm{F}$

129.6

129.6:20

A2! $6: 27$

129.6:27

1:29.6:29

$129.6: 29$

A $13.3: 7$

A 29.6:20

$\Lambda 7.3: 13^{10}$

A22.3:22

A1.2:S2.

A29.3:24

A $202.3: 21$

A13.6:

$11.2: \mathrm{Ap}^{2}$

A $27.9: 5$

A27.9:11

A1.10:900

11.2: $\mathrm{Ap}^{2}$

A10.3:49

121.8:

A6.3:10

A6.3:2

A26.5:901

A26.5:901 ${ }^{1}$

110.3:20

A1.1:S94

1. $7: 1$

A29.6:30

19.3:12

1:9.6:24

A:9.6:25

$11+-0 t-31$ 
Prorluce:

Exports and prices of, 1864 . No. 3, ?. 6; No. 4, p. 8; No. 5, p. 33;

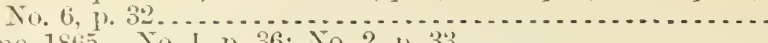

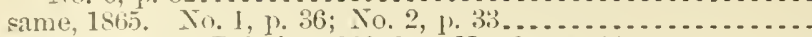

Prices of, in Great Britain, 1860-64. No.6. p. $34 \ldots . . . . . . . .$. Statistics of Uniterl Kinglom. 1893. p. 210................. . . See also Farm prorhets.

Proluce brokers, farmers as, tax on. 1870. p. $77 \ldots \ldots \ldots \ldots \ldots \ldots$. Tronuba, maxillary tentacles of (Smith). 1593. p. 161.......... Ironuba pollination, notes on (Riley). 18s9. p. $367 \ldots . . . . . .$. Propagating garclen. Sie Garlen, United States propagating.

Property, loss of, by lightning (Henry). 1899. ?. $45 .$.

Iroperty and Stationery I ivision, Agriculture Department, report of Chief of (Hall). 1894. 1. 209

Proteid matters, separation of flesh bases from, by means of chlorin

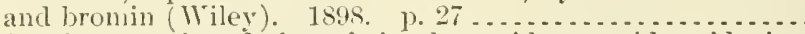

Proteids, nitrogen of, and that of simpler amids or amilo-acids, investigation of analytical methods for distinguishing between

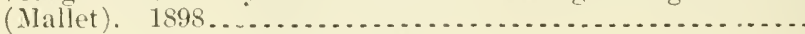

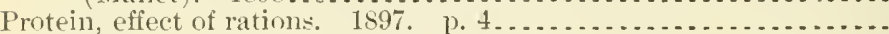
Protoparee carolina, life history of (Alwood). 1898. p. $72 \ldots . . .$. Protozoa, infectious disuse, entero-hepatitis, among turkeys, caused

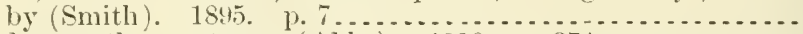

Proverlis, weather, notes on (Abbe). 1896 . p. $374 \ldots \ldots . . . . . .$.
Providence, R. 1., resestreh at, on atmospheric radiation (Very). 1900

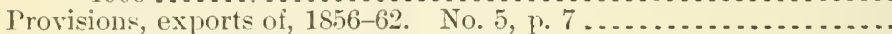

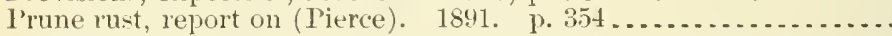
Prunes:

Culture of, in Pacific northwest (Lake). p. 41 same, reprinted.

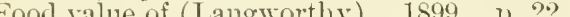

Prunes and prume eulture in western Europe, with special reference to existing conditions in Pacific northwest (Lake). 1901.

Pruming. see Trees - Woody plants.

Prussia:

Agrieultural expositions in, results of. 1871. p. 456

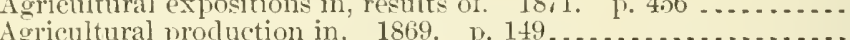

Agriculture in, 1867. p. 41 .............................

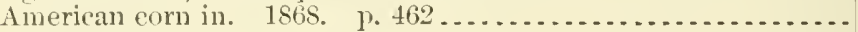

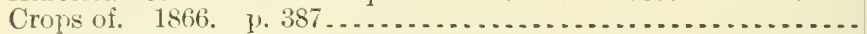

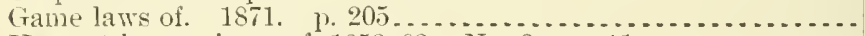

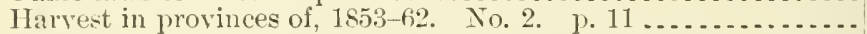

Meteorological Institute of, work of, notes on (Abbe). 1901.

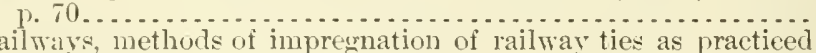
for (Fernow). 1894. p. 286

See also Geisenheim-on-the-Rline-Ioppelsdorf.

Pseudlocoecus. Tee Maple pseudocorcus.

Pseudomanas hyacinthi, Ps. eampestris, Ps. phaseoli, and Ps. stewarti-four one-flagellate yellow baeteria parasiticon plants, cultural charaeters of (Smith). 1901.

See also Wakker's hyacinth germ.

Psychrometric talles, note on (Abbe). 1900. 1) 449.

A27.9:2

A $27.9: 3$

A $27.9: 2$

A27.9:31

A $27.9: 8$

A9.7:5

A9. $7: 1$

A29.3:27

A 1.1:894

A7.3:54

A. $.3: 54$

A 1.9:56

A9.6:17

A4.3:8

A:9.6:24

A29.5:G

A27.9:1

A28.5:7

A20.1:894

A20.4:2

1 1.9:105

A20.3:10

A27.9:10

A $27.9: 7$

A $27.9: 6$

A $27.9: 6$

A $27.9: 4$

A27.9:9

A $27.9: 2$

A:29.6:29

A13.3:9

I'sylla. Sie l'ear-tree psylla.

Iteridoplista of western Texas, descriptions of (Underwood). 1894.

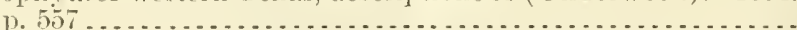

Pteridoplytes, North American, new species of, pullished in 1891 , systenatic and alpliabetic index of (Clark). p. 151 .........

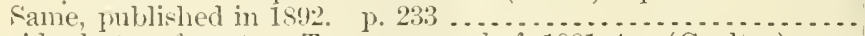

Pteridophytes of mestern Texas, manual of, 1S91-4. (Coulter) .....

Public and weather forecaster (Watts). 1902. 1). 142 . . . . . . . . .

Public and weather foreeasts (Boyer). 1902. p. 151 ............

Public domain:

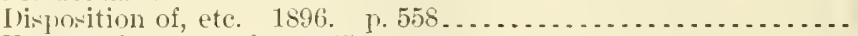

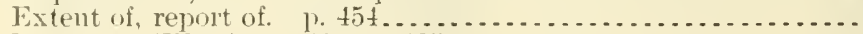

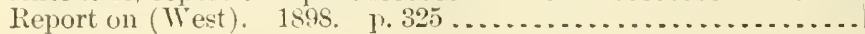

128.3:28

A29.6:25

A6.5:2

16.5:1

A6.5:1

A6.5:2

A29.3:31

A29.3:31

A1.10:896

A1.1:868 A 1.10:898 
Public domain-Continued

Timber or forests on, legislation for preservation of (Egleston).

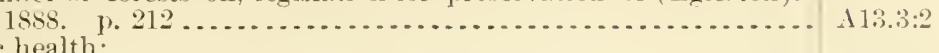

Public health:

Relation of bovine tuberculosis to (Salmon). $1901 \ldots . . . . . . .44 .3: 33$

Spraving fruits in its relation to, special consideration of. $1890^{2}$. . A $1.4: 7$

Public improvement, citizen's duty to (Joses). 1902. 1, 36 ...... A22.3:23

Public: institutions, dietaries in (Atwater). 1901. 1.393 ........ A1.10:901

Public lands. tiee Lands-Public lomain.

Public Road Inquiries Office, Agriculture Iepartment (formerly Office of Road Inquiry) ............................ .12.2.

Public roads. sie Ruads.

Public schools, meteorology in, how much should be attempterl, methods of teaching (Chaffee). 1902 . p. $85 . . . . . . . . .$.

Publications Division, Agriculture Department (formerly Division of Reconds and Eiliting):

Work of, for farmer ( Hill). 189\%, 1). 204 ..................

Puccinia, new species of, teseriptions of (Tracy). 1s91. 1). 281 ...

Puccinia and phragmidimm, relationship of (De Lagerbeim). 1891.

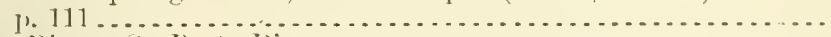

Puerto lico. Siee P’orto Rico.

Pullen, Isaac. Peach, propagation, cultivation, varieties, etc. p. 191.

Pulvinaria acericola ( $\mathrm{W}$. \& R.) and $\mathrm{P}$. inmmerabilis rathr. (How-

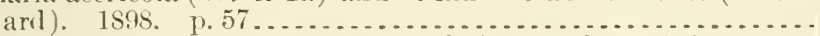

Pulvinarias, two most alsundant on majele (Howard). 1900. 1\%. 7 ..

Pump, suraying without (Alirich):

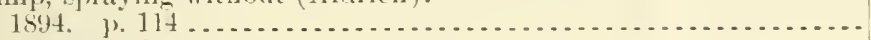

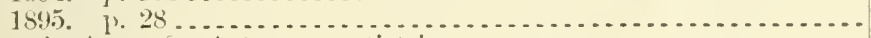

Punctistriga. Sce Artace punctistriga.

Punjab, India. Cotton erop of. 1589. 1. 163 . . . . . . . . . . . .

Pupation, methods of, among Chalcidide (Howard). 1891. ग. 198.

Purlue Lniversity, Lafayette, Inul.:

Agricultural building (new) at. 1901, p.612.............

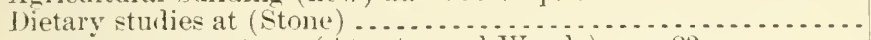
same, conments on (Atwater and Woods). p. 23.........

Pure-food law, working of a (Beal). 1900, p. 23.............. Pure-food laws of European eountries affecting American exports

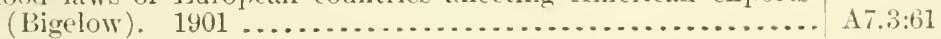

Purslane:

Flea-beetle living on (Chittenden). 189s. p. $83 . . . . . . . . .$.

Value as a fuod (Langworthy). 1900. p. 2.................

Purslaue caterpillar, report on. 18s6. p. 104 . . . . . . . . . . . . .

Purssell, B. .I. Signals, Weather Jureau. 1892. p. $47 \ldots . . . . .$.

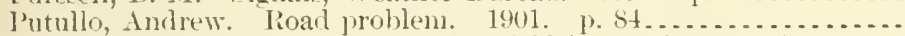

l'yralirl, osage orange, report of (Murtfeldt). $1893.1 \% 15 . \ldots \ldots .$.

P'yraliıl $a^{2}$, rescriptions of, from Deatl Valley (Fernald). 18!4. I'.

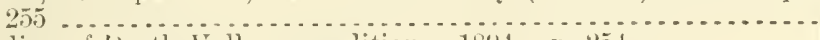

Pyralinlina of Weath Valley expedition. 18it. p. $254 \ldots . . . . . .$.

prenomveres, history of develejment of, contributions to (Von P'vethrum:

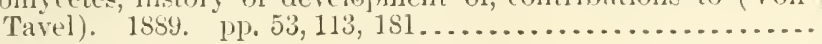

Experinents with-

Kirkwood, Mi. (Murtieldt). p. 85 ..................

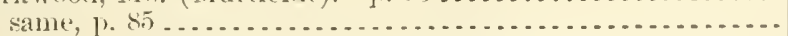

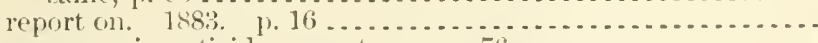

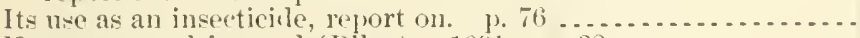

Kerosene enulsion and (Riley). 1891. 1) $32 \ldots . . . . . . . . .$.

Pyrheliometer, Angström's, examination of (Marvin). 1901. 1). 454. Pirophosphoric acid. see Cotton-secel meal.

(juinitance, A. l.:

Aleurndice, American, comtributions toware a monograph of.

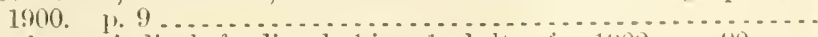

Cicarla, periodical, feeding halits of adults of. 1902. j. 10 ...

Jiabrotica 12-punctata oliv, obecrvations on, 1900. 11. 35.....

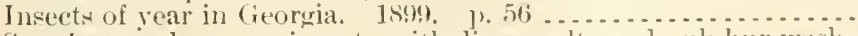

San Jose scale, experiments with line, salt, and sulphur wash

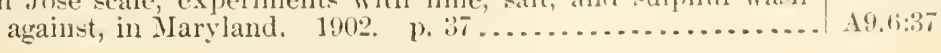


(Unaintance, 1. L., and smith, Ralph 1. Fgg-laying record of plum:

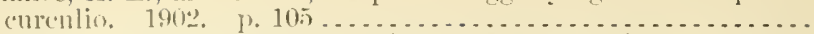
Quarantine. See also Cattle quarantine - Sonth Ameriea.

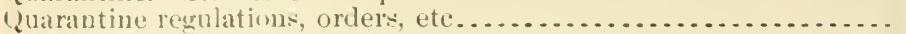
Sie also Cattle urders.

Quarantinestations, imports of animals at. 1847. p. 250 (Zuassia and other hof) substitutes in beer, improved methor of

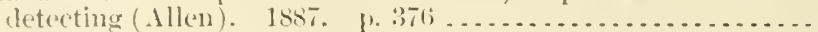

Qneen Charlotte Islands, British Columbia, natmal history of

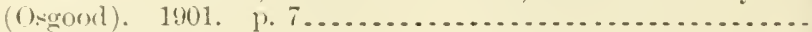
See alieo Alstralasia.

1) nestion box at farmers' institutes (Amoss). 190:2. ए. 49 . . . . . .

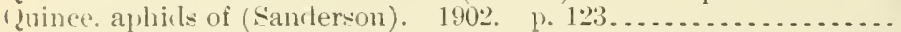
Rablits:

He]atic coecidia of, Fimeriastieda correct name for (Stiles). p. 1s.

Innmity in, experiments on probluction of, with reference to hog eholera and swine-plagne bacteria (smith and Hoore).

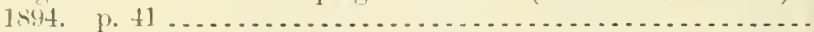

\section{Rabies:}

Allegerl, in Nebraska, investigation of (Gibbs). p. 1 ss

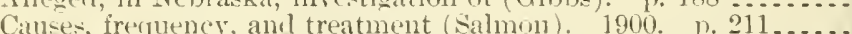

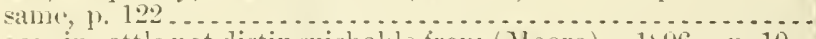

Disease in wattle not distingnishable from (Moore). 1396. p. 10..

bistricts afferted with, movement of animals from, order con-

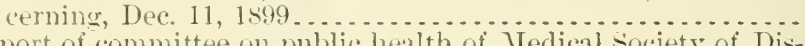

Report of committee on public health of Medical society of District of Columbia. 1900.

Waklington, I. C. (Moore and Fish). p. 267 ............

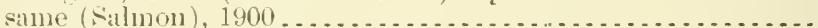
see ulso Animals.

Rabun Comnty, (ia., cattle in part of, releasing from ynarantine, 1598.

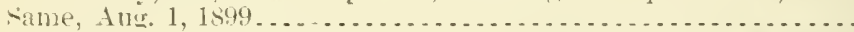

Ratlkufer, L. Saphindaces, three new species of, from western Mexicn and Lower California. 1893. p. $367 . . . . . . . . . .$.

Ratinesque (C. S.) on atmospheric clust, notes on (Abbe). 1900.

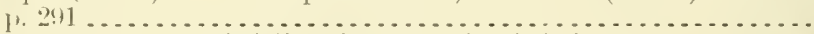

liafter, feorce $T$. Rainfall and charts of rainfall. 190: p. 230..

Sagan, IV. II. :

Fruit growing, progress in. 1901. p. $673 \ldots \ldots . . . \ldots . . . . .$.

Home vineyard, with special reference to northern conditions. 1902.

Faiffeisen loan associations of Germany. 1891. p. 414 .......... Pailroarl companies, letter to, relative to exportation of diseased

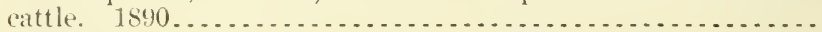

Railroad ties:

Annual charges for (Fernow). 1S87. p. 105.

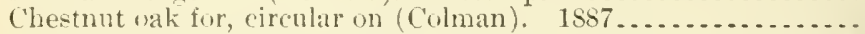

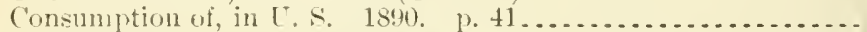

Inpregnation of, methoils as pratticed for Prussian railways

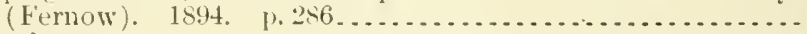

Metal-

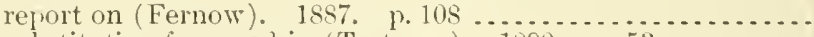
substitution for woor in (Tratman). 1890, p. 5i3 .........

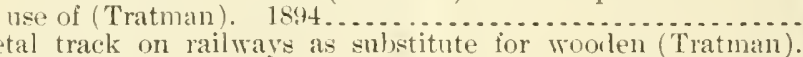

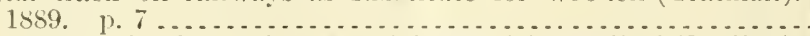

structure, behavior, and eauses of decay of, in roalberl (Dudley).

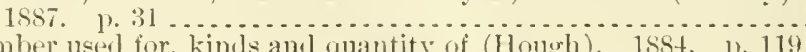

Timber used for, kinds and quantity of (Hough). 1884, 1). 119. Treatment of, in England (Tratmaii). 188s. p. 49.......... Railroads:

Connection of, with forest fires (Egleston). 18si. p. 12S......

Construction of-

1S8\%. p. $4 \mathrm{~S}$

$1690 . \quad$ 1. 37

18.91. 1). 27

Consumption of forest supplies by, and practicable economy in their use. 1890. 1. 1:3.

\section{Classifleation no}

$19.6: 37$

A4.5:

At.1:\$97

A $7.3: 13^{3}$

A5.5:21

A 10.:3:110

110.3:115

A4.3:35

A4.3:6

14.1:897

A1. 10:900

A4.1:900

1 $4.3: 10$

A4.5:4s

A4.8:25

14.1:895-6

A $4.4: 30$

A $4.5: 21$

$1+5: 41$

A $6.5: 1$

+29.6:28

1.29.6:30

A $1.10: 901$

-11.9:156

$127.9: 29$

11.2:P13

A 13.3:1

A 13. $4: 4$

A 13.3:4

113.3:9

A 13.8:1

A 13.3:4

A 13.3:9

A 13.3:3

A 13.3:1

1 13.5:4

A 13.3:3

A 13.3:1

A27.9:28

A27.9:29

127.9:30

A13.3:4 
Information furnisled hy, regarding roakls, roat materials, and freight rates in certin states west of Mi-sisilpi River. $18: 14$. same, in (ertain states north of Ohio River. 1s.) ..........

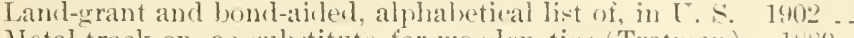
Metal track on, as substitute for wooklen ties (Tratman). 14t?.

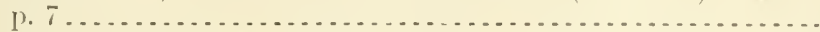

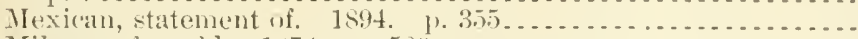
Milealge of workl. ]sit6. ]).

Presilents of, circular letter to, reguesting cooperation witlo iflice of Road Inquiry, Agriculture lepartment ...............

Relation of-

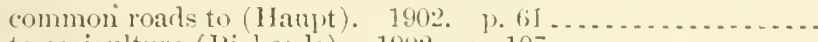

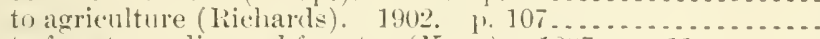
to forest supplies and forestry (Kerm). 1sst. 1. 11 .......

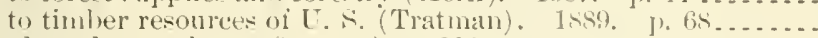
Roads and, speech on (Fuencer), 1902. p. 1] . . . . . . . . . . .

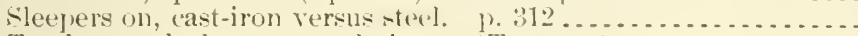
Track, metal of, patents relatiner to (Tratman)-

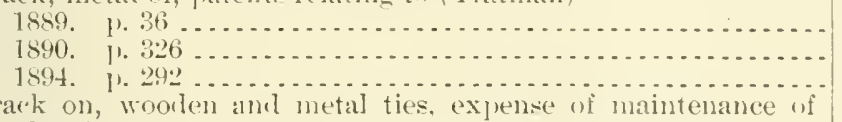

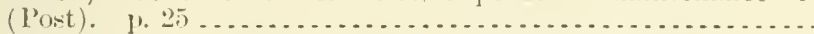

Transportation services, (changes in rates of charge for (Newcomb).

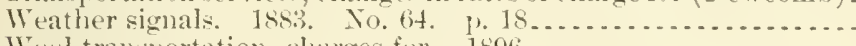
Wool transportation, clatrges for. 1896

Railway Superintendents of Bringes and Buildings. Aimerican International Association of, report of committee of, on strength of Rain:

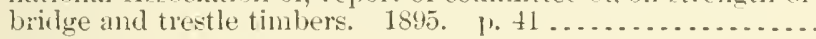

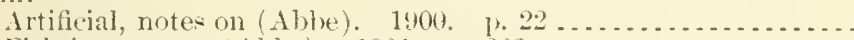

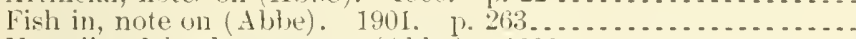

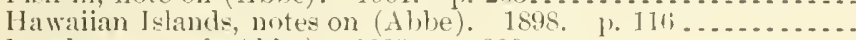

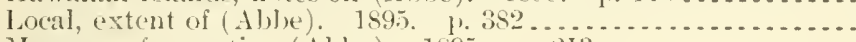
Monsoon, forecasting (Ab)e). 1895. p. 2I3 . . . . . . . . . . . . Popmlar yueries alout, with answers (kinbali). 1901. p. 42... Prorluction of, by great fires, notes on (Able). 1s96. P. 461 ...

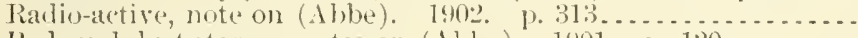
Red, and dust storms, notes on (Al) be). 1901. p. 120....... Sand, dust, and mud, notes on (Ab)e). 18s4. p. $158 \ldots . . . .$.

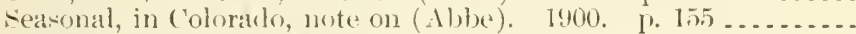

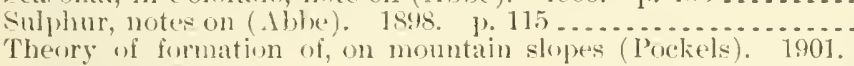

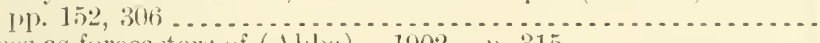

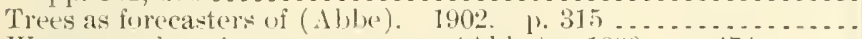
Worms, and angleworms, note on ( 1 bbe). 1s99. p. $474 \ldots . .$. See also snow ast rain - Sulphur rains.

Rain and snow gage, Marvin's wejghing (Carlisle). 1899. p. 131 .. Sane, instrution for using . . . . . . . . . . . . . . . . . . . . Rain gages:

For measurement of hail (Albe). 1898. p. 210............. lustructions for t1su of . . . . . . . . . . . . . . . . . . . . . . . . Realings, (omparative, at Atlanta, (ia. (Ilenry). 1sig. 1. 5t: .

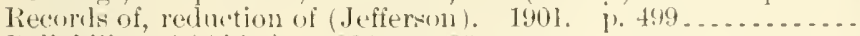

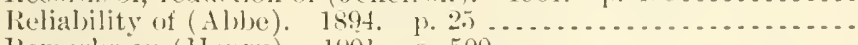

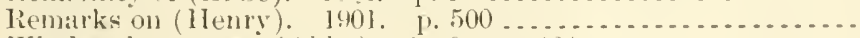

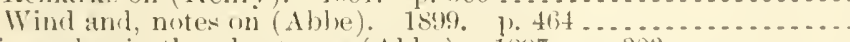

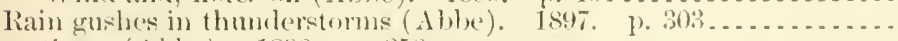

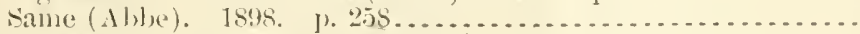

Rain-producing processes, some (Garriott). 18.49. 1\% $67 . \ldots . .$.

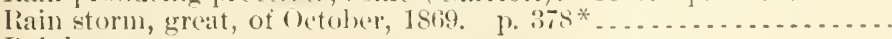
Rainl)ow:

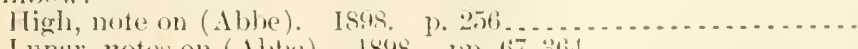
12:. $3: 5$ 1.2.2.:3:(6)

113.2:1213"

113.:3:03

A $27.4: 32$ 1:-7.:1:14

$122.4: 5$

1 $22.8: 2.2$

1 $10 .: \therefore: 120$

113.3:1

A13.8::

12.2.3:2:25

A13.3:1)

A13.:3:3

A 13.8:4

A 13.3:4

A 13.3:3

A:7.

A27.9:21

A $27.8: 10$

A 13.3:12

A29.6:28

A29.6:29

A29.6:26

A29.6:23

129.6:23

129.6:29

A.9. $6: 24$

A $29.6: 30$

A $29.6: 29$

129.6:27

124.6:2s

A29.6:26

A2!.6:29 129.6:50 A2?.6:2-

1.29.3:24

Aํ. $11: \mathrm{J}$

A29.6:25

1:2).11:C A:24.6:21:39.13:29? 1.29.6:2:2 1:29.(i::) 1:29.6:27 1:9.6:25 A.9. $6: 26$ $129.3: 24$ 127.4:7

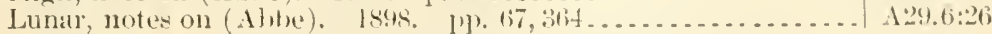
* By a misprint, this puge number appears twice. 
Raindrops:

Large, formation of, notes on (Abbe). 1900. p. 159 ......... A29.6:28

Size and rate of fall, note on (Ahbe). 1897. p. 445 ............ 129.6:25

Sturlies in, notes on (Abbe). 1900. p. $158 \ldots . . . . . . . . . .429 .6: 28$

Rainfall:

Amoy, China, 1897-1902 (Fesler). ․ 4\$6 ............... A29.6:30

Baminetric pressure and (Alihe). 1s\$5. p. 172............ $129.6: 23$

Catch of, effect of wint on (Abbe). 1899. p. $30 \mathrm{~s} \ldots \ldots \ldots \ldots . . .429 .6: 27$

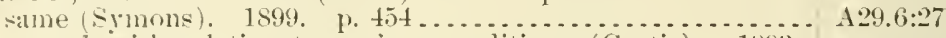

Causes of, with relation to surface conditions (Curtis). 1893.

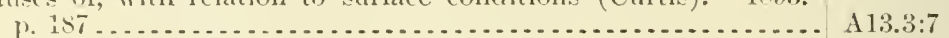

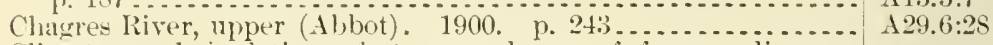

Chimate and, relation of, to prevalence of fungus diseases

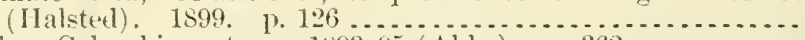

Colon, Colombia, note on, $1893-95$ (

Convectional currents causing (Kimball), 1900, p. $483 \ldots \ldots$.

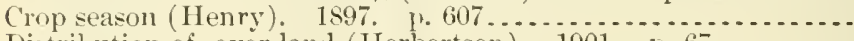

Distritution of, over land (Jerbertson). 1901. p. 67 .........

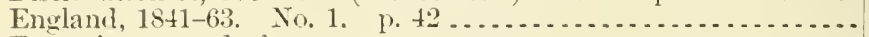

Excessive, record of-

1898-99. ค. 300

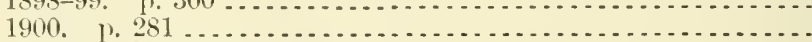

1901. p. 268 ...........

Experimental, report of (Abbe). 1896. p. $373 \ldots \ldots \ldots \ldots \ldots$

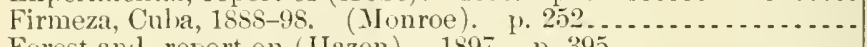

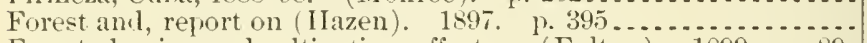

Forest clearing and cultivation, effects on (Fulton). 1899. P. 89.

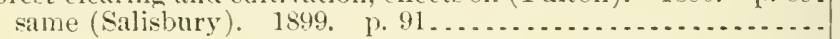

Forests-

influences upon (McMurtrie), 187t. p. $432 \ldots . . . . . . . .$.

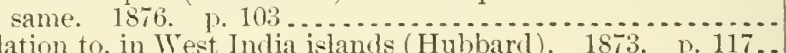
relation to, in West India islands (Hubbard). $1873 . \quad$ p. 117..
razing and, notes on (Abbe). 1901. p. $176 \ldots . . . . . . . .$.

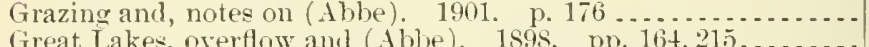

Great Salt Lake level and, relation between (Mackie). 1901.

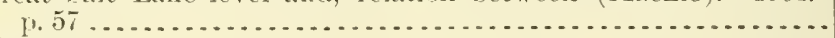

Heary-

area of, in southern Appalachians (Hawkins). 1897. p. 442. in local storms, notes on (Able). 1900. p. 207 ............

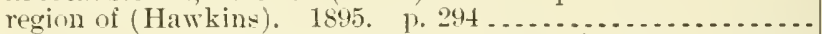

High, Weather Burean stations, notes on (Abbe). $1899 \mathrm{O}, 257$.

Hourly results from self-registers for recording (Abbe). 1897.

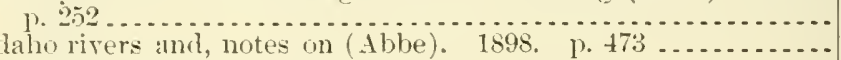

Jamaica, notes on-

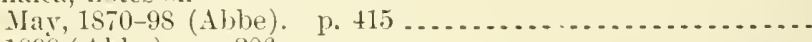

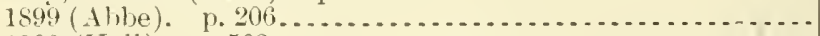

1900 (Ha11). p. 503 . . . . . . . . . . . . . . . . . . . . . .

Leeward and Windward Islanis (Jeffersom). 1901. 1.56 .....

Leeward Islanis (1lexander). 1901. p. $254 \ldots . . . . . . . . .$.

Matras, India, and frequency of sun spots (subha Rao). 1902.

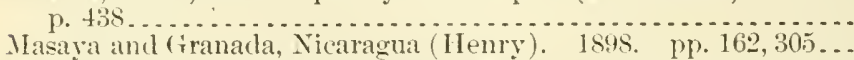

Measurements on ships, notes on (Abbe). 1898. p.313.......

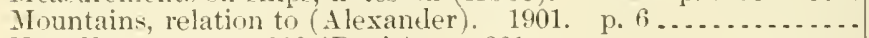

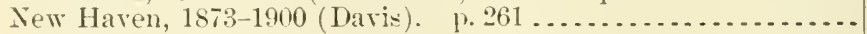

Nicaragua, record of-

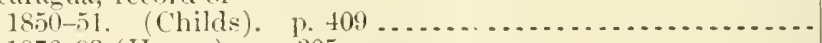
$1876-93$ (Henry). p. 305 . . . . . . . .

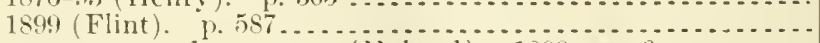

Peronosprovete and, report on (lialsted). 18s9. -1). 6 ........ Quantity of, corresponding to given depths (Henry). 1898 . p.

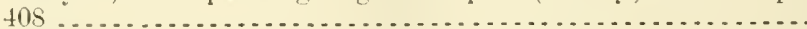

Ratio of, to discharge of Chagres River, 1899 (Abbot). p. 541...

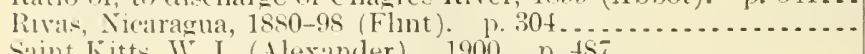

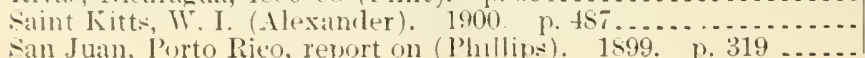

A10.3:65 A29.6:26 A29.6:28

A 1.10:897

A 29.6:29

A $27.9: 2$

A 29.1:900

A29.1:901

A29.1:902

A29.6:24

A29.6:26

A 29.6:25

A 29.3:24

A29.3:24

A27.9:12

A $27.9: 14$

A 27.9:11

A $29.6: 29$

A 29.6:26

A29.6:29

A 29.6:25

A 29.6:28

A 29.6:23

A29.6:27

A29.6:25

A $29.6: 27$

A29.6:26

A29.6:28

A29.6:29

A $29.6: 29$

A 29.6:29

A29.6:30

A $29.6: 26$

129.6:26

A29.6:29

A29.6:30

A 29.6:26

A $29.6: 26$

A $29.6: 27$

A28.5:5

A 29.6:26

A $29.6: 27$

A $29.6: 26^{2}$

A29.6:28

A 29.1:598 
Rainfall-Continued

Shonld weekly reports of, be telegraphed from voluntary stations:? (Marbury). 1899. p. 108.......................... Snow and, of Cnited states, to end of 1891 (Harrington) .......... Temperature and, at Mersivan, Turkey (1bbe). 1897. p. 245..

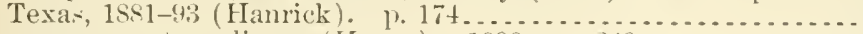

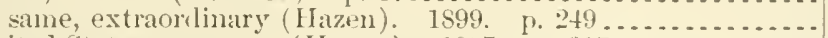

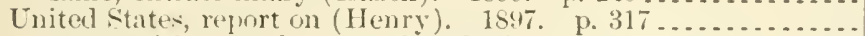
same, with amnual, seasonal, and other charts (Henry). 1897. See ulow California - Sulphur rains.

Rainfall and charts of rainfall. 1902, p. $205 \ldots . . . \ldots . . . . . . .$. Rainfall chart, lines of equal time of water travel at Cairo, ill. 1892. Rainfall laws, leduced from twenty years' observations (Hinrichs). 1893

Rainfall observers, special, instructions to. 1893.

Same 190"

Rainier, Mount, Washington. Hesperogenia, new genus of umbel-

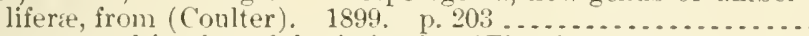

Raisin grape, cultivation of, by irrigation (Eisen), 1891, p. 225...

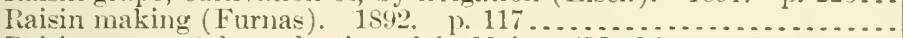
Raisins, muscatel, production of, in Malaga (Mark). 1875. 1. 319. Raleigh, X. C.:

AdAress at, on roal improvement, Feb. 5, 1897 (Stone). p. 19 .

Soil survey from, to Newbern, N. C. (Simith). p. $187 \ldots . . . . .$.

state fair, cattle exhibited at, order providing for return of non-

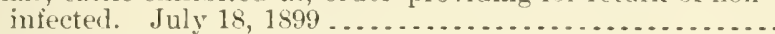

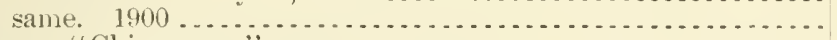

Ramie, or "China grass":

American inlustry in, recent facts regarding (Dorlge). $1893 \ldots . .$.

Botanical eonsiderations of, in France. 1892. p. $97 \ldots \ldots . . .$.

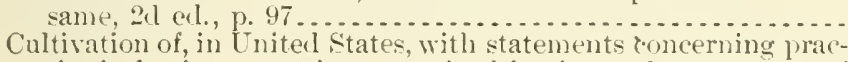
tice in foreign comtries, eost of cultivation and percentages of yield; the machine question, and preparation of fiber for manufacture (Dodge) - . . . . . . . . . . . . . . . . . . . . . . . . . .

Culture and manuacture of jute and, in United States (Leiranc).

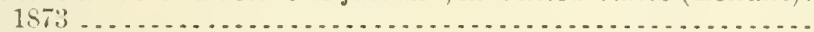

Culture of jute and. p. 261 ....

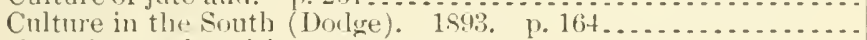

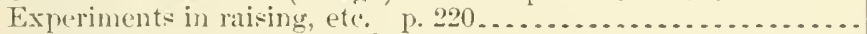

Facts regarding, recent (Dodge)1891. ए. 183

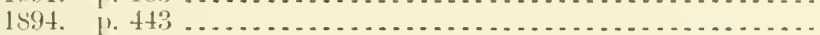

Importance of (Dorlge). p. $347 \ldots \ldots \ldots \ldots \ldots \ldots . . .6$.

Letters concerning-

1569. ए. 137

1879. P. 78

Machine trials-

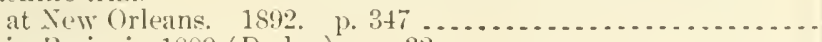
in Paris, in 1859 (Dodge). 1\%32.

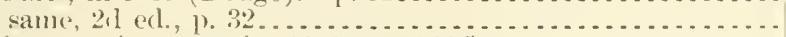

Mannfarture of, status of. 1869 p. $369 \%$

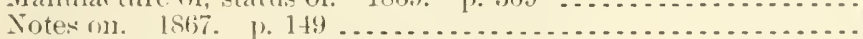

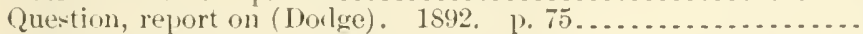

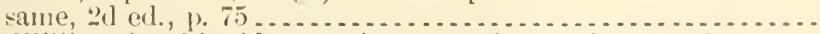

Rand, Williams. tiquid manuring, experiments in, p. 194 .... Randall, Henry s. Slieep, selection, treatment, and diseases of, in

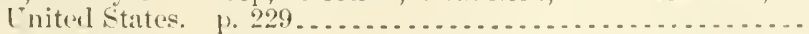

Randolph, Fred. J., and Francis, Frerl. I. Thomas Jefferson ate

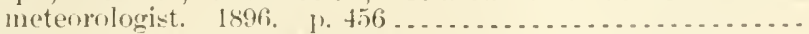

Randolph, L. S. Jechanical drawing, course of instruction in.

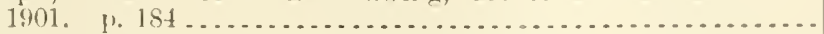

Rane, F. William:

Agricultural experiment station work, progress of variely testing

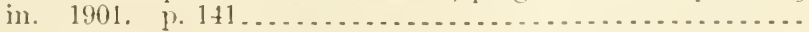

* By a minprint, this [mge number nupears twice.
Classifleation no.

$129.3: 24$

A29.5:C

129.6 .25

$129.6: 2 \cdot 2$

$129.6: 27$

129.1:8:17

A29.5:D

A29.6:30

A29.2:R13:

129.2:1213

A29.12:R13

A29.12:1 $52^{3}$

A 6.5:5

1 15.2:P94'

A 1.8:20

A $27.9: 13$

122.4:28

A26.5:900

A $4.5: 37$

A.5:50

111.5:2

127.8:1

A11.5:1

A11.5:

A1.8:S

A1.1:87?

$110.3: 16$

A1.1:\$67

127.9:2!?

11.10:894

A1.1:865

A:7.9:7

$127.9 \mathrm{~s}$

A $27.9: 30$

A27.8:1

A11.5:1

$127.9: 7$

A.7.9:5

A:7.s:1

A11.5:1

A1.1:N67

$11.1: \mathrm{s}(i)$

1.9.6:2:3

A10.8:4!9

$.110 .3: 199$ 
Rane. F. Willian-Continued

Horticulturists at agricultural experiment stations, some undefined duties and methods of. 18:6. p. $76 \ldots . . . . . . . .$. Muskmelons, fertilization of, ly inserets, notes un. 1898. p. 75 Ramge crats and forage plant experiments at IIghmore, S. Dak.

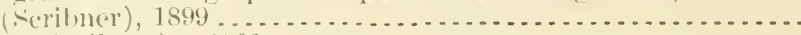
Gank (Acribner). 1901

Rallere improvement:

Administration and (Foubers). 1902. p. S5

Arizoma (Griftitlss). 1901 .

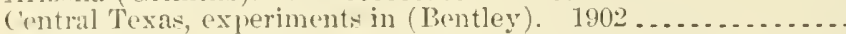

Exprements in (Smith). 1898 . . . . . . . . . . . . . . . . . .

Forage (rops, and progress of experiusents in, at Abilene, Tex.

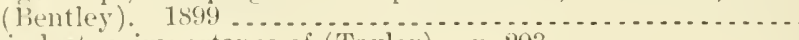

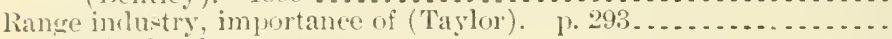
see also Strock ranges.

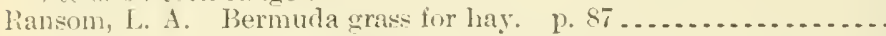

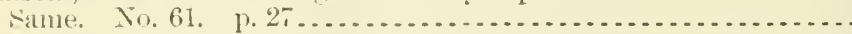

Rape plant:

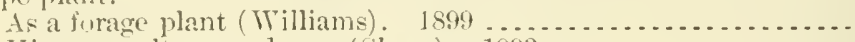

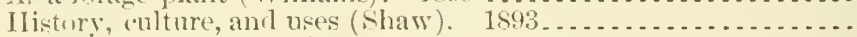

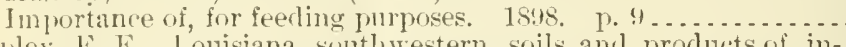
Rapley, E. E. Louisiana, sontliwestern, soils and products of, incluling parishes of Saint Landry, Lafayette, Trmilion, Saint

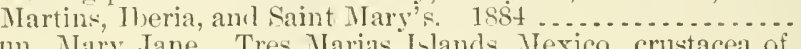
Rathbun, Mary Jane. Tres Marias Iblands, Mexico, crustacea of,

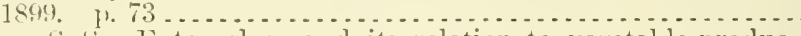

Rathvon, $\leftrightarrow$. S. Fntomolugy and its relation to vegetable prorluetions of soil, with reference to destructive and beneficial in-

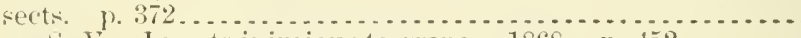

Rathvon, s. V. Insects injurions io grape. 1868 . p. $452 \ldots . . .2$

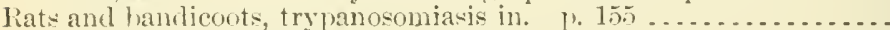
Siee also Kangaroo rats.

Raupenleim, report on (Smith). 1895. 1. 31............

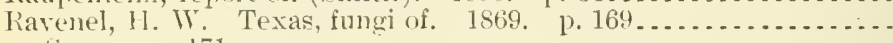

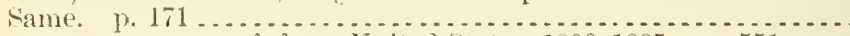

Raw cotton, exports of, from Inited States, 1890-1895. 1. 551 ....

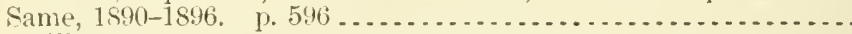
Raw silk:

Fxamination of (McMurtrie). 1883. ․ 56.

Tenacity, elasticity, and ductility of, notes on (Walker). $18 s 9$.

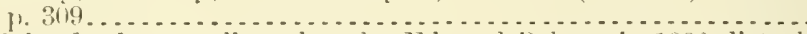

Laza lslaud, plants collected at, by liward Palmer in 1890 , list of

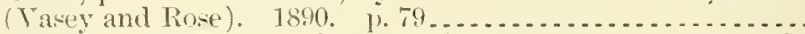

liead, M. C. Forests on headwaters of streams, preservation of.

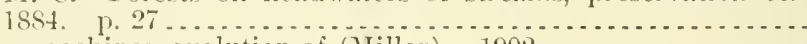

Reaping machines, evolution of (Miller). 1902............. Reasoner, 1'. WT. Fruits, tropical and semitropical, of Florida and

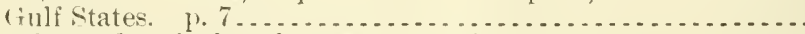

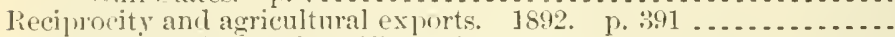

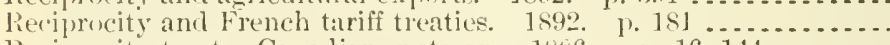
Reciprocity treaty, Canadian, note on. 1st6. pp. $16,144 \ldots . . . .$. Recorling instruments. Tee Weather recording instruments.

Records and Eliting Division, now Publinations Division, Agriculture Department..................................

Recorls lisisinn, Weather Bureau, tables for dividing by 672,720 , $744,56,60,62$

Red and black seales, 1 stralian enemies of 1892 , p. $41 \ldots \ldots \ldots$

Red ants, report on (Riley). 1889. p. 104 ...................

Rerl bug. See Cottonstainer.

Rieil cerlar:

Notes on (Molyr) 1901

Two diseases of, (aused by Polyporus juniperimus n. sp. and Polyporus carnens nees (Schremk). 1900 ..............

Red elover seed:

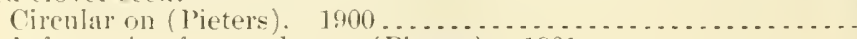

Infolmation for purchasers (Pieters). 1901

110.3:30

14.6:17

1.3.4:21

13.4:38

110.3:115

119.3:4

119.3:13

13. $4: 8$

A. $4: 28$

1. 1 1:855

11.1:883

A27.9:21

1. $4: 12$

A 1.9:11

A1.9:78

A1.8:35

A5.5:14

A1.1:862

A27.9:6

A4.1:901

A9.6:2

A1.2:C29

A1.2:C $29^{2}$

A1. 10:895

A1. 10:896

A9.3:3

A9.7:1

A6.5:]

A $1.7: 5$

A 10.3:103

A20.3:1

127.9:30

A27.9:30

+27.9:-1

A21.

A 29.2:T11

A9.7:5

A9.7:2

A 13.3:31

A28.3:21

A6.t:24

A 1.9:12: 
Fed desert of Tryoming and its forace resonress (Nelson). 1898... 13.3:13

lied katir forn. "See hafir corn.

Rerl-legged thea-hectle, its injuries to orrhard trees in Waryland and

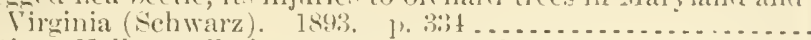

Red liver Valley, soils in, temperature and moisture of, notes on,

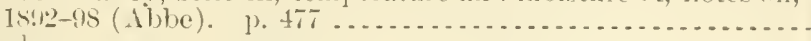
Rerl sorale:

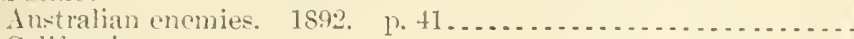
Califormia-

hymenopterons parasites of (Howarl) 1894, 1 $.227 \ldots . .$. various methork for destroying (Coquillett). 18:0. 1.. $9 . . .$. Destruction of, use of hylrogranic-acil gas for (Corpullett).

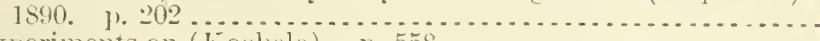

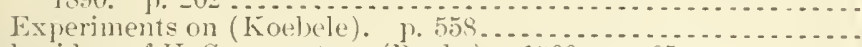

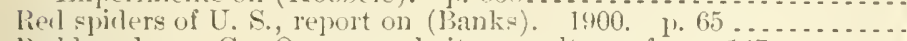
Rerklen, laura C. Orange and (itron, culture of. p. $147 \ldots \ldots . .$. Redfield, John A. ('otton worms, destruction of, by biris. 1ssis.

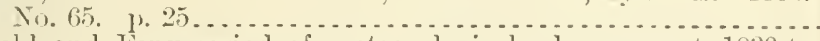

Rerlfielil and Expy period of meteorological arlvancement, 1830 to 185.5 (Davis). 18.95. p. 305.

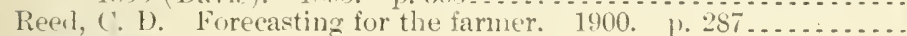
Reed, IV. II.:

Irrigation in New Mexicn, 1901. 19102. p. $37 \ldots \ldots . . . . . . .$. Pecos River and its tributaries, New Mexico, irrigation along.

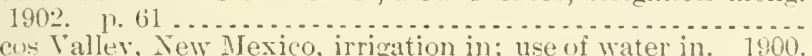

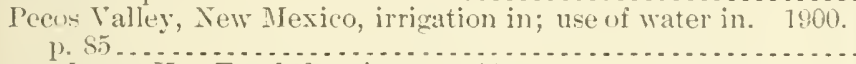

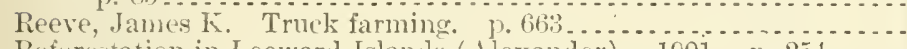
Refurestation in Leeward Islancls (. llexander). 1901. p. 254 . . ... Refrartions, atmospheric, at surface of water (Abbe). 1896. p. 371 . Refrigeration, influence of, on fmit inclustry (Taylor). 1900. 1.561. Reh, 1. Scale insects on American fruit imported into Germany, ah-tracted and translated by $\mathrm{l}$. A. Schwarz. 1900. p. $79 . .$. Rehart, S. I'. Snow and rain, seasomal, prediction of. 1894. p. 26. Reichert methods, application of, to mixed butter's (Besana). 1890.

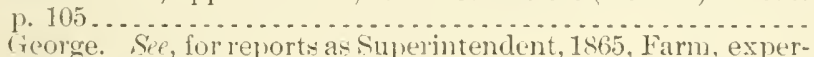
imental, Agriculture Department.

Reid, james 1). Pleuro-pmemmia among cattle in Great Britain,

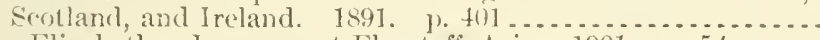
Renoe, Elizabeth. Ice cares at Flagstaff, 1 riz. 1901. 1.54..... Renoe, Milton G., short biograpliy of. 1897. 1). 484 ............ Renosaterl loutter:

llouschold testy for detection of olenmargarine and (Patrick).

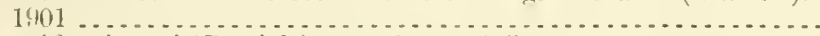

Identification of (Patrick). 1902. p. $115 \ldots \ldots$ Renovaterl lutter and other dairy proilucts, mules and regulations preseriber for inspertion of, wnder act of $\mathrm{May} 9,1902$, and information concerning "arlnlterated butter," June 21, $1902 \ldots$

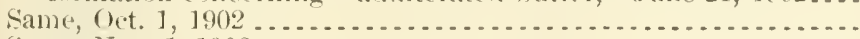

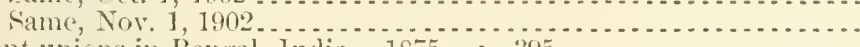

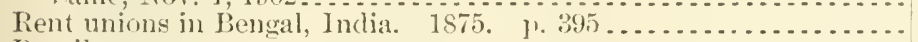
Reptiles:

Annotated list of, collected in Iraho by C. Ilart Merriam and

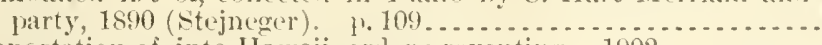

Importation of, into Hawai, order preventing. $1902 \ldots \ldots \ldots . .$. see also Tres Marias Islands, Mexico.

Reptile's and latrachians:

Collecterl by ('. Hart Merriam and Vernon Bailey in San Fran(isen 1!nuntain platean and desert of liftle Coloralo, Ari\%ona. amnotated list of, with clescriptions of new species (Stejnexper). 1890.0 .103

Collected by C. Hart Merriam and party in Ilaho, 1300 , anno-

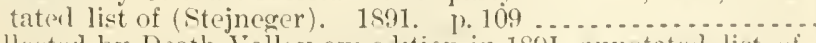

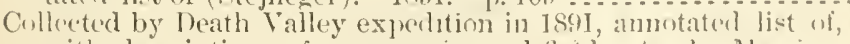
with elescriptions of new species amel field notes by Mleriand (Stejnerorer). ]). 159 .

\section{7:5}

$129,6: 27$

$19.7: 5$

$19.7:(i)$

19.8:2:2

$19.7: 2$

11.1:\$86

A.).5:5

11.1:2667

127.9:2]

129.8:112

$129.6: 25$

A10.8:119

1 10.8:104

110.3:56

A 1.1:858

A29.6:29

A29.6:24

A].10:900

A $9.6: 22$

A29.6:24

A 7.3:24

14. $1: \$ 59-90$

129.6:2:1

A.9.6:25

A 1.9:131

A7.3:67

$14.5: 94$

$14.5: 97$

A $4.5: 48$

A:7.9:13

1.5.5:5

15. $4: 36$

\section{5:3}

15.5:5

15.5:7 
Resine grass:

("ircular on (Shear). 1900

Feenls of (Hillman). 1902

Reservir system of Cache la Pondre Valley, report on (Nettleton).

Rescrvirs, sometypital, in Rocky Jomitain States (Mearl). 1901.

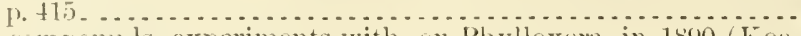

liesin compoumls, experiments with, on Phylloxera, in 1890 (Koxbele). 1. 37 . . . . n

Resinons contents and their distribution in trees of long-leaf pine,
chemical sturly of, before and after tapping for turpentine

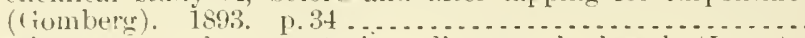

Respiration, organs of, noncontagious diseases of, of cattle (Lowe). 1. 101 .

Respiration calorinteter, new, description of, and experiments on conservation of eneroy in human body ( 1 twater and Rosa). 1899

Respiration ealorimeter of special construction, preliminary investigations of metaloolism of nitruen and carbon in human organism with (Atwater and others). 1897.

Respiratory organs, diseases of, of horses (Harbaugh). p. $87 \ldots \ldots$.

Revenue, mountain roals as a source of (Abbott). 1901. p.527 ...

See ulso Internal revenue.

Reymolds, A. and M. Australasia, meat trate of. P. 92

Revmolks, Joseph. See, as joint author, Brown, Simon.

Reymolds, M. H. Veterinarian, experiment station, as member of State board of health. 189s. p. 14 ....................

Hhawn. William H. Adlressof, before national road conference. July, 1894. p. 39.

Theea fiber, information concening (Bleclynder). 1870 . 1. 227.

Rhine region, regimen of, high-water phenomena and their predic-

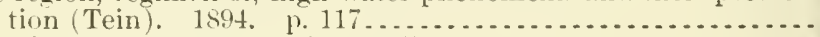

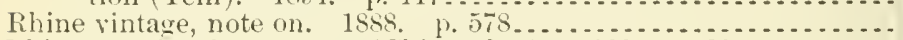

Rhinocros beetle, notes on (Chittenden). 1902. p. 28......... Rhorle Jsland:

Birches in, occurrence of Bucculatrix canadensisella on (Pack-

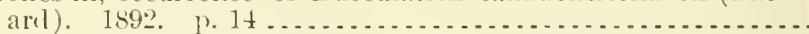

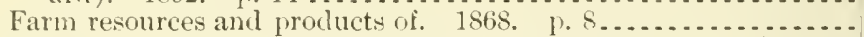

Road improvement, extract from governor's message (Dyer). p.9.

Weather of, notes on (Abbe). 1898. p. 565................

Sie also Providence.

Rhubarh, forcing, results of (Sinith). 1899. 1. 13............

Rice, (Mrs.) M. F. Entilia sinnata, notes on. 1893. p. $243 \ldots . .$.

Rice, Thomas D. See, as joint author, Fippin, Elmer O.

Rice:

Cnltivation, production, and distribution of, in United States and foreign countries. . . . .

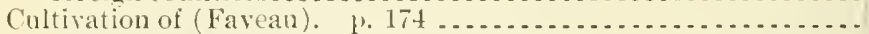

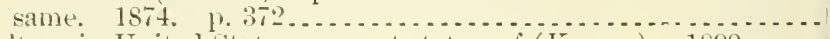

Culture in United States, present status of (Knapp). 1899.....

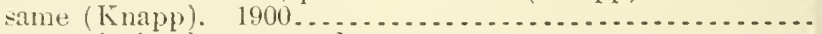

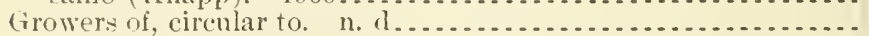

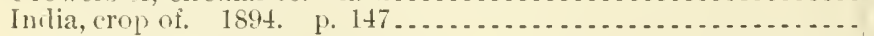

Irrigation of- in North Carolina, Sonth Carolina, and Cieorgia (Keeney).

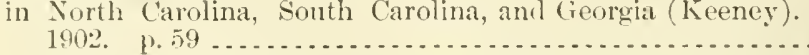

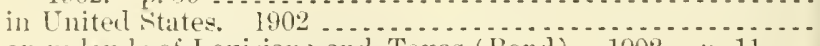
on uplands of Lonisiana and Texas (Bond). 1902. p. 11...

Japan culture (Tamari). 18s.5. p. 18i .................

Louisiana ('rop), statement on, $1860-1869$. p. 430 .............

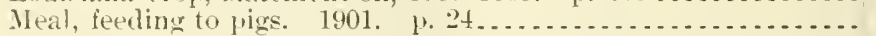

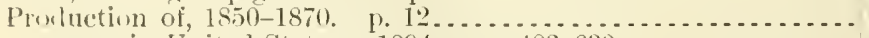
same, in [nited States. 1894. II) $483,630 \ldots \ldots . . . . . . .$.

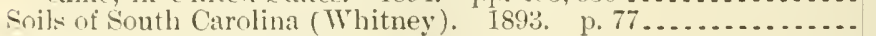
See also Crops, principal.

Rice Asociation, American, officers of. 1900. p. $643 \ldots . . . . . . . .$. A1.10:900.

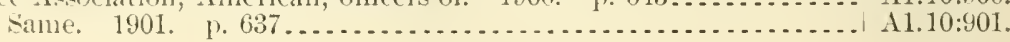

A3. $4: 20^{2}$

A $19.3^{\mathrm{a}}: \mathrm{R} 31$

A 10.3:9:2

11.10:901

$19.3: 23$

ג13.3:8

$\mathrm{A} 4.2: \mathrm{C}^{2} 9^{2}$

A 10.3:63

A 10.3:4t

A4. 2:1178

A 1.10:901

A t. 1:893-1

A4.3:22

A2:2.3:10

A $27.9: 8$

A29.3:11

A27.9:26

A9.6:3S

19.7:5

A27.9:6

122.4:33

A $29.6: 26$

11.9:107

A9.7:5

A27.8:6

11.1:667

A27.9:12 A $6.3: 22$

A1.9:110

1.5. 4:5

127.9:33

110.3:113

A10.3:113

A10.3:113

A $1.7: 9$

127.9:8

1.9:14t

127.9:14

A $27.3: 32$

A $2 \% .3: 6$ 
Fice region, Weather l'ureau Service, instructions governing (Berry). Rice stations of Weather Burean, instructions and corle for encipher-

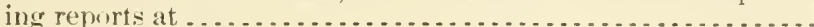

Richarls, Charley Riss:

Heating value of corn, "alorimetric: letermination of. 15:s. p.95.

Iannal training and apprentice system. 18:4. I. 73 .........

Richarrls, Eigar:

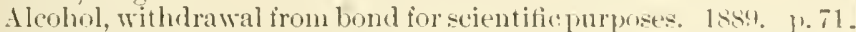

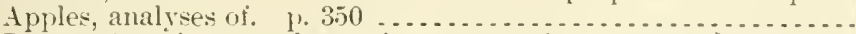

Butter, American, analyes of, averages of. 1886. p. 23 . . . . .

Phosphoric acid determination, comparison of official and uitric

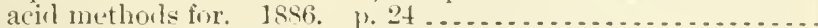

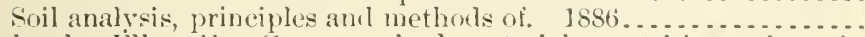

Richarls, Ellen 11. Common food materials, nutritive value of.

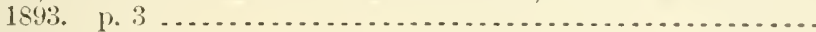

Richaris, George ir.:

Clouls-

cirrus, on northwest sile of a storm. 1897. p. 212 ........ upper, and weather changes. 189s, p. $106 \ldots . . . . . . . . .$.

Richards, George $\mathrm{W}$. and Albe, Cleveland. Clond observations,

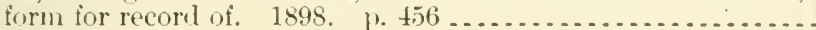

Richards, M. V.:

Railroals, relation of, to agriculture. 1902. p. $107 \ldots \ldots \ldots \ldots \ldots$

lioal improment, prospects for, in the South. 1902. 1.17..

Richarison, Clifford:

Ammonimm citrate solution, nentrality in, indicator for detection

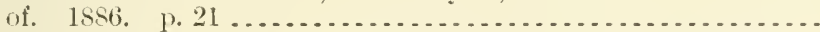

Cereals, American, wheat, oats, harles, and rye, chemical composition and physical propertices of, $3 \mathrm{~d}$ report, 1886 ...........

Grasses, Anerican, chemical composition of, from investigations in laboratory of Department of Agriculture, 1878-1882. p. 117.

IIilk of Washington not normal. 18s8. p. $24 \ldots \ldots \ldots \ldots \ldots \ldots$.

Plants, certain, of economic value as fool for man and stock, in Texas and New Mexico. p. 282 .....................

sorghum and sugar production, character and composition of

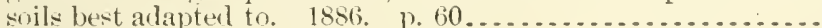

Slices and condiments adulteration of1886. 1). 291

Wheat, what science can teach abont 1853 p. 67

Wheat and corm, American, investigation of composition of-

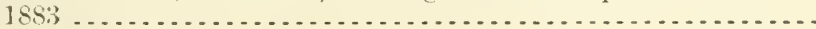

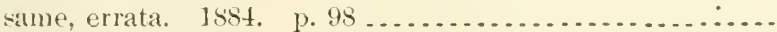

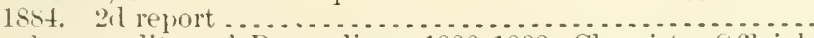

See also, as editor of Proccedings, 1886-1858, Chemists, Official Agricultural, Asweriation of.

See also, for report as assistant chemist, Chemistry Burean, Igrirulture: Department. 1883.

Richardson, H. II.:

Acetylene gas, substitution of, for oil in storm-warning lanterns.

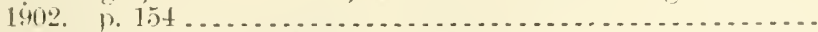

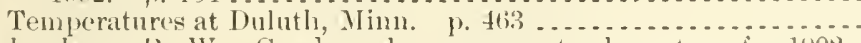
Richarlson, li. W. Goorl roals movement, character of. 1902.

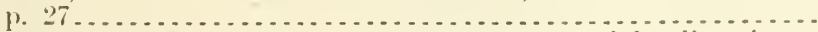

Richman, Irving B. St. Gall, Switzerland, cost of hauling farm

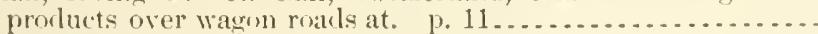

Richmond, II. Droop:

Milk, fat in, estimation of. 1890 . p. $162 \ldots \ldots \ldots \ldots \ldots \ldots \ldots .$.

Specific gravity, letermination of rise in, on allowing milk to

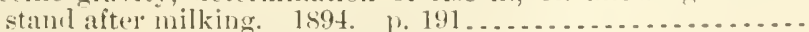

Rielnmond, - Sie Van Slyke, Iucius Lincoln.

Richmond, Va., brass river gage at, description of, and its methoul of support (Leisenring), 18i9. p. $456 \ldots . . . . . . . . . .$.

Sep relso Virginia gond roakls convention.

Richmond Canal. See Logan and Richmomel canal, Utah.

Richmond County, X. X. lung plague in, history of (Rose). 1). $468 .$.
129).12:( 81

129.12:C82

110.3:49

A $10.3: 20$

17.3:24.

11.1:886

A $7.3: 16$

1 $7.3: 12$

17.3:10

11.8:54

129.6:25

A:9.6:26

A:9.6:26

A 10.3:120

A2:. $3: 23$

A $7.3: 12$

17.3:9

A $1.5: 32$

A 7.3:19

A 1.1:887

A $7.3: 10$

11.1:\$56

A7.3:13"

1 $1.7: 2$

17.3:1

17.3:4

17.3:4

A7. 1

129.3:31

129.6:27

1 $202.3: 283$

122.4:27

$17.3: 24$

17.3:43

129.6:27

14.1:584 
Riley, Charles Valentine:

Adalres of as presiclent of Association of Economic Entomolo-

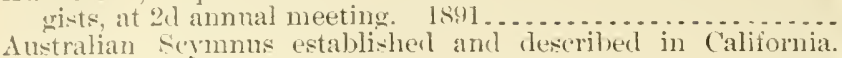

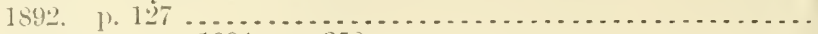

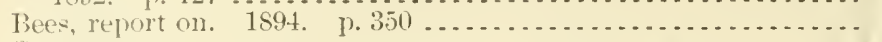

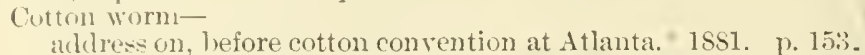

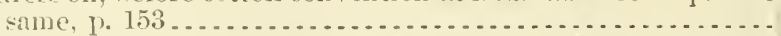
final refort on, and chapter on boll worm. $185 . . . . . . . .$.

Dembrotettix genus, report of. 1893 . 1. $254 \ldots . . . . . . . . . .$. Diabrutica 12-pmnetata, habits and life history of. 1591. p. 104. Digger-was], larger, report on. 1892. p. $245 . \ldots . \ldots . . . . . . .$. English sparrow, insectivorous hahits of. 1889. p.111 ......... Entumology, applied-

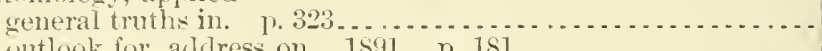

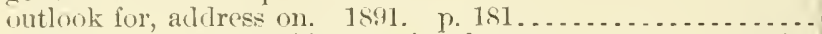
some recent matters of international concern. 18ss. P. 126..

Fluted seale, Australian hymenopterous parasite of. 1890. 1. 248.

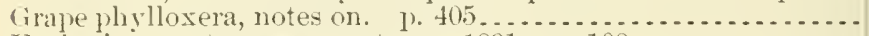

Herbarium pest, new, report on, 1891. p. 108.............. same, further notes on. 1892. p. 40 . . . . . . . . . . . .

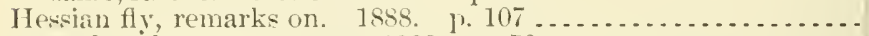

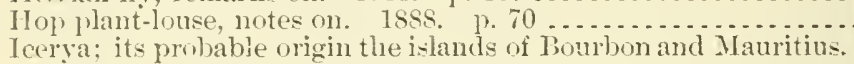

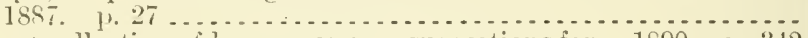

Insect collection of large museum, suggestions for. 1890 . J. 342 . Insect pests of household-

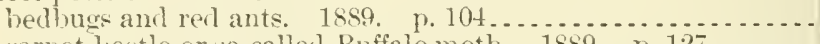
carpet beetle or so-called Buffaio moth. 18s9. p. $127 \ldots . .$.

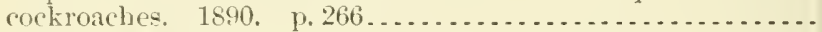

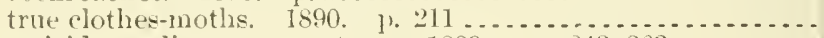

Insecticide appliances, report on, 1859. P. $243,263 \ldots \ldots \ldots$. Insects-

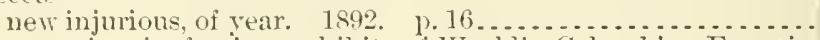
occurring in foreign exhibits of World's Columbian Exposi-

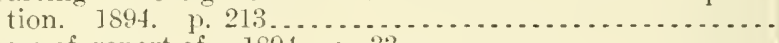

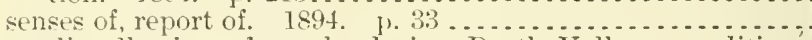
small collection of, marle during Death Valley expedition.

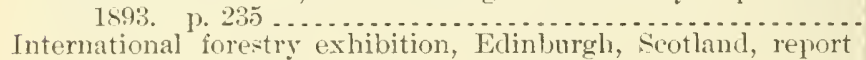

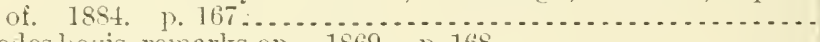

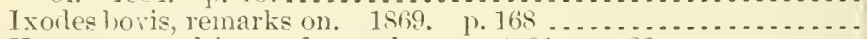

Kerosene emulsion and prrethrum. 1891. p. $32 \ldots \ldots \ldots \ldots$.

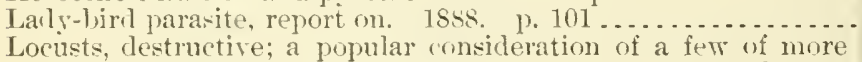
injurious loctsts (or "grasshoupers") of U. S., with best

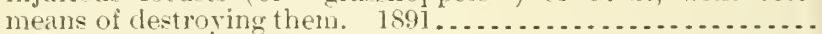

Megilla frarasite, arditional note on. 1889. p. $338 . \ldots \ldots \ldots \ldots$

Mite, six-spotted, of orange. 1890 , 1. 225 . . . . . . . . . . . . .

Morelos orange fruit-worm, rejort on. 188s. j. $45 \ldots \ldots \ldots . .$.

Mulherry silkworm . . . . . . . . . . . . . . . . . . . . . . .

$\mathrm{Ox}_{\mathrm{x}}$ bot in United States. 1892. p. $302 \ldots \ldots \ldots \ldots \ldots \ldots$

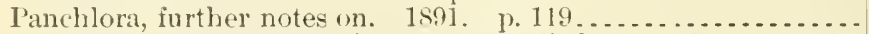

Parasitic and predaceous insects in applied entomology. 1893.

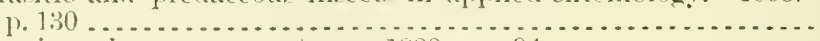

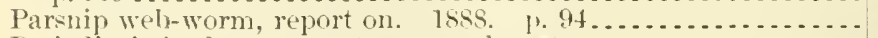

Periorlical cicarla, or seventeen-year locust-

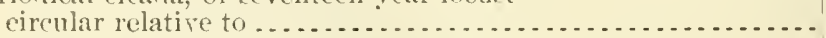

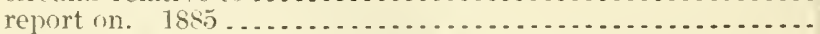

Plant and insects, some interrelations of. 1892 . p. $358 . \ldots$. Platypsylus-

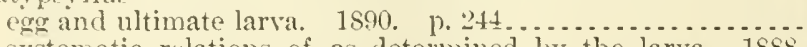
systematic relations of, as determined by the larva. 1888.

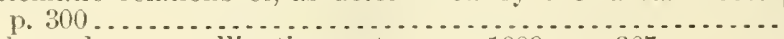

Y'ronuba and yueca pollination, lotes on. 1889. p. $367 \ldots \ldots .$. $19.7: 3$ 19.7:6

A1.1:S81-2 19.1:\$\$2

A 8.1:4

$19.7: 5$

A9.7:4

19.7:4 A 5.3:1

A1.1:884

19.7:3

A $9.7: 1$

A9. $7: 2$

A1.1:884

A $9.7: 4$

A9.7:5

A9.7:1

A9.7:1

19.3:15

$19.7: 2$

A9.7:2

A $9.7: 2$

A9.7:2

A9.7:2

A 9.7:1

A9. $7: 5$

A9.7:6

A9.7:7

A5.5:7

A1.1:SS4

A $1.2: \mathrm{C}^{2} 9^{1}$

A $9.7: 4$

A9.7:1

19.3:25

A $9.7: 1$

A9.7:2

A $9.7: 1$

A.9.3:9

A9.7:4

A9.7:4

A9.7:6

A9.7:1

A9.2:P 11

A $9.3: 8$

A9.7:4

A9.7:2

A9.7:1

A 9.7:1

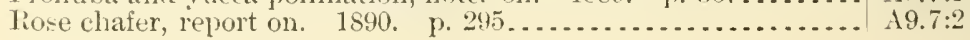


Riley, Charles Valentine-Continued

Rosesaw-flies in Lnited states. 1892.

scale insects of orange in California, partienlarly the icerva or flutel swale, alias white scale, alias cottony cushion-seale, etc',

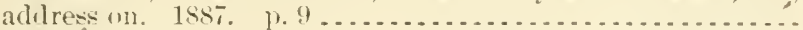

Silkworm, heing lorief manual of instructions for production of

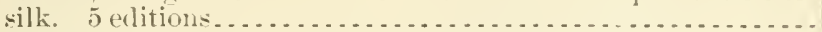

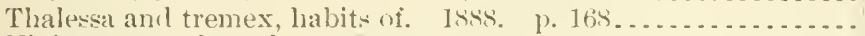

Viviparous cockroach. 1891. p. H3......................

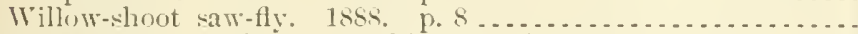

Fucea insects and yucea follination, further notes on. 1s.3.

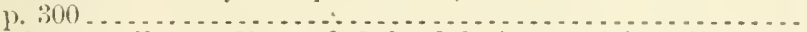

See clso, as collector, Howard, Leland Osian; as joint ellitor, Insect life

see also, for reports as Entomolngist, Agriculture Jejartment, $1879,1852-43$

See ulso, as joint author, Walsh, Benjamin Dann.

Riley, Charles Valentine, and lloward, Leland Oscian. Plum eurculio, report on. 1. 万ิ

same, 1.57 .

Rilev, Charles Valentine, anil Jarlatt, Charles Iester:

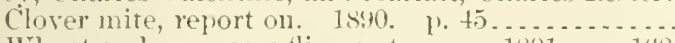

Wheat

Riley, Charles Talentine, entomological writings of, bibliograplyy of more important (Henshaw). 185\%. p. $99 \ldots . . . . . . . . .$.

Rinlerpest. sire Cattle plagne.

Ringwalt, Samuel. Horse, report on, from practical experience in Army. p. 321 .

Ringworm. Siee ('attle.

Rivile Janeim, exhibit at, note on. 1866. 'p. 235.

"Rio de Janeiro," l'acific mail steamship, wreck of (McAclie). 1901.

Rio cirande, N. J.:

Sorohum stuar experiments at -

1887 (Hughes). p. 246

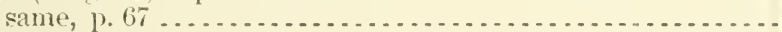

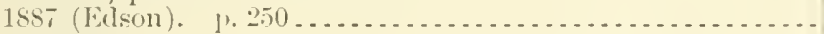

sane, p. 11 .

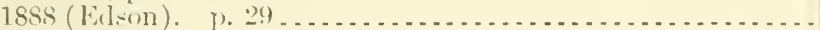

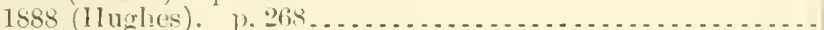

same, with additional matter. p. 29 ................

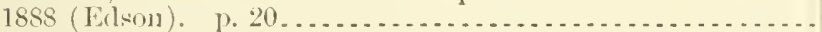

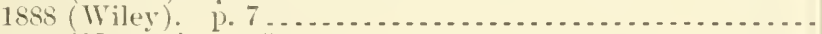

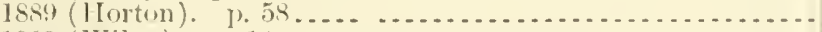

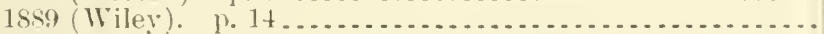

Sorghum-sugar tactory at, methods employed by (Hughes).

Rio cirande rewion, Texas, from Brazos Santiago to Ei Paso Comnty, collection of plants marle by $(i, C$. Nealley in region of

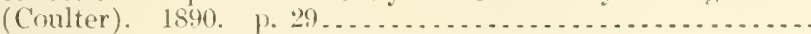

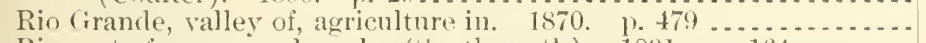

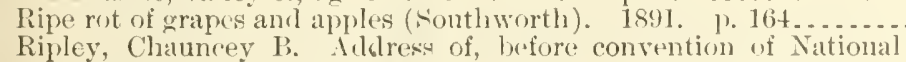
Leagne for Good Roals, Washington. 1893 . W. $70 \ldots \ldots . .$.
, W. B. Sie, as collalorator, Wiley, Harvey Washington.

Rising, W. B. Se, as collalorator, Wiley, Harvey Washington.
Rity, Philip. Agricultural resources of eastern Oregon and Wats-

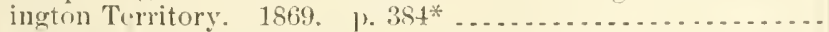

Rivas, Nicaragua:

Jetenrological noservations at, monthly notes on 1899 ( 1 blue).

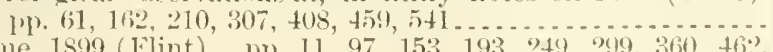
same, 1899 (Flint). PI. 11, 97, 153, 193, 249, 2919, 360, 4ti2,

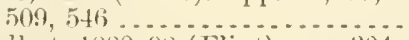

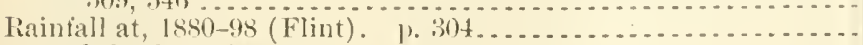

River and flowl service:

liulletins of.

A9.3:15

11.6:11

A $\div .7: 1$

$19.7: 3$

A $9.7: 1$

$19.7: 5$

A9.7:

A9.1:

11.1:6.8

19.1:888

A $9.7: 3$

19.7:t

A9.2:B+ $\mathrm{I}^{-1}$

A 1.1:866

A27.9:4

129.6:29

A1.1:587

A7.3:17

11.1:58

17.3:17

A 7.3:18

A 1.1:588

A 7.3:20

17.3:18

A $7.3: 20$

A7.3:26

17.3:26

17.3:3

A6.5:1

A.27.9:8

A.8.5:6

110.3:14

$127.9: 7$

$1: 39.6: 26$

A 29.6:27

A. $29.6: 26$

A29. $14:$

129.2:1552

* By a misprint, this page number appenrs twice. 
River and flood service-Continuerl

dlonthly notes on-

Nov, 1896-1Iay, 1898 (Norrill)

June-July, 1898 (Kriechelt)

Aug., 1 sis (Garriot)

Sept., 1895-1lay, 1899 (Frankenfield)

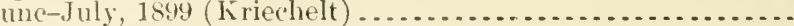

Aug., 1899-1lay, 1902 (Frankenficld)...................

June, 1902 (Hint)

July-(1et., 1902 (Frankenfield) ............................

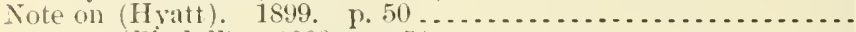

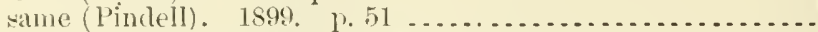

River and flood service charts, showing area covered by water of Mlississippi River in April, 1897

River and rainfall observers, special, of Weather Bureau, instructions to. 1902 .

See also Ratinfall olservers.

River and rainfall stations, special, daily precipitation at, 1893-95. 1900 .

liver floods:

Note on (Abbe). 189i. p. 209

Rate of arlvance of (Abbe). 1895 , p. 341

River forecast stations, establishment and inspection of (Marbury). 1899. p. 150

River gages:

Automatically recording, introduction of (Fulton). $1902 . \quad$ p. 220

Brass, description of, at Richmonl, Va., and its method of sup-

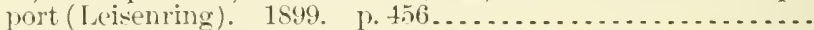

Mississippi Valley, upper (Carlisle). 1902. 11.222 ...........

River observers, special, instructions for (Russell). $1892 \ldots \ldots \ldots .$.

River Plata countries, manufacture and exportation of tasajo or

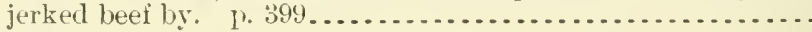

River stages:

Daily

Daily, charts showing, in feet. 1892 ......................

Forecasts of Mississippi and Ohio rivers and tributaries in periods of low water, importance of (Snyth). 1902. 1. 146........ Predictions in Inited States (Russell). 1894. p. $89 . . . . . . . .$.

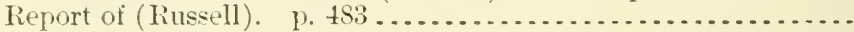

Rivers:

Four great, of siberia (Sperk). 1s94. p. 101 ..................

Freezing and opening of, dates of. 1864. No. 2. p. 64; No. 3.

of small drainage area, forecasting for, especially those of North

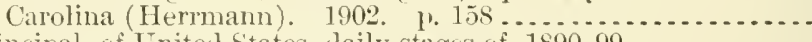
Principal, of United States, claily stages of, $1890-99 \ldots \ldots \ldots . . .$. Teather Bureau work in connection with. $1896 \ldots . . . . . . . .$.

Riverside, California, insect control in (Havens), 1900. p. $83 . . .$. Siee rilso (iage canal.

Rives, Wright. ('al)bage morms, remedies for. p. $134 \ldots . . . . . . .$.

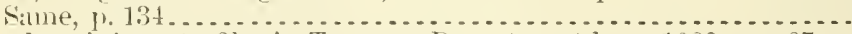

Roaches, injury to files in Treasury Department by. 188s, ].67... Roarl associations, national, State, and local, and kindred, organizations in United states, list of ........................

Road builuling:

Convict labor in. See Convict labor.

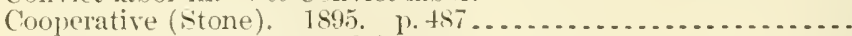

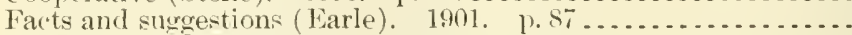

Few practical suggestions on (Ross). 1902. p. 18 ............

From engineer's stanclpoint (Campluell). 1901. p. 45 .........

Massachunetts roarl laws and (Ross). 1901. p.34 ............

Minnesota State aid to (Choate). 1898.....................

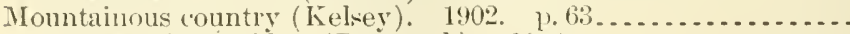

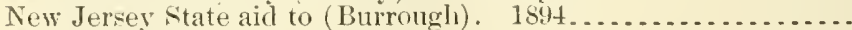

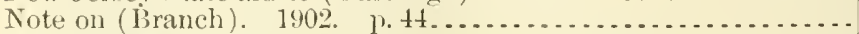

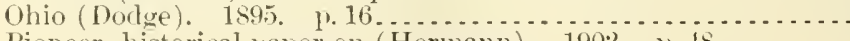

Pioneer, historical paper on (Hermann). 1902. jo ts......... A22.3:25

A29.6:24

A 29.6:26

A29.6:26

A29.6:26-27

A $29,6: 27$

A29.6:27-30

A29.6:30

A29.6:30

A 29.3:24

129.3:24

A29.2:R52"

A29.12:R52 $2^{3}$

A29.2:P91

A29.6:25

A29.6:23

A29.3:24

A29.3:31

A29.6:27

A 29.3:31

A29.12:R52

A4.1:849

A29.10:

A29.2:C38

A 29.3:31

A29.3:1 $1^{1}$

A29.1:891

A29.3:11

A27.9:2

A29.3:31

A29. 10:

A $29.3: 17$

A9.6:22

A 1.1:\$83

A9.1:853

A9.7:1

A22. $4: 36$

A 1.10:89:

1.22.3:21

A22.3:22

A 22.3:21

A 22.3:21

12. $4: 32$

A22.3:23

A2. $2.3: 9$

A $22.3: 23$ 
Road building-Continued

Practical problems in (Twiggs). 1902. ․ 53 .............. A22.3:23

Progress of, in United States (Eldridge). 1899. p. 367 ........ A1.10:899

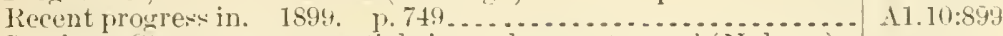

Southern States, some escentials in morlern systems of (Holmes). 1902

Uniterl states-

historical and technical papers on (Stone). 1895 progress of, reports ly delegates to national road parliament,

Atlanta, Ga., Oct. $1 \div-19,1895 \ldots . . . . . . . . . . . . . . . .$.

Roar business a question of education (I)aniels). 1901. p.66..... Road conference, national. See Asbury Park, I. J.

Roads congress. See Buffalo, N. Y., International good roads congress.

Road conventions in Southern States and object-lesson roads constructerl under supervision of Office of P'ublic Road Inquiries with cooperation of Southern Railway, 1902.

See relso Jefferson memorial and interstate good roads conventionMinnesota good roads convention-New York State, boark of supervisors of-Texas good roads convention-Virginia good roails consention.

Roarl Inquiries Office, Public, Agricu]ture Department [formerly Oftice of Road Inquiry]:

Circular letters relative to eooperation in work of ..............

Work of, for farmer (Stone). 1897. p, $175 \ldots . . . . . . . . .$.

Road materials:

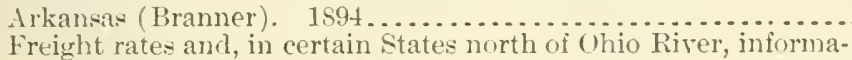

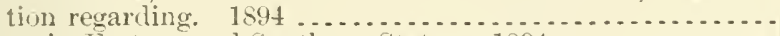
same, in Eastern and Southern States. 1894 .............

Lahoratory for physical and chemical examination of ..........

Transportation rates and, information regarding, in certain States

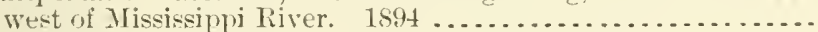
Roarl parliament, national:

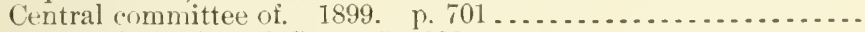

Notice of meeting of, Sept. 15, 1898........................

See also Atlanta, Ga., national road parliament.

Road problem (Patullo). 1901. p.84.................... A22.2.:21

Road question:

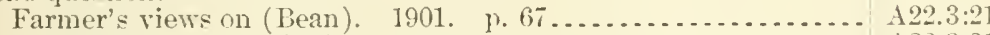

Importance of (longino). p. 18...................... A22.3:21

Social, commercial, and economic phases of (Iroore). $1900 \ldots .$. A22.4:34

Road situation in Iowa (Ileaps). 1901. p. 64 ................ A22.3:21

Road strones and problems therewith comnected (Whittle). 1897 ... 122.4:29

Road system:

Better, simple plan for (Polsley). 1901. p.98............. 122.3:21

(icoryia, inprovement of (Sheffield). j894 ................. A22.3:3

Govermment, of Yellowstone National Park (C'hittenden). 1901.

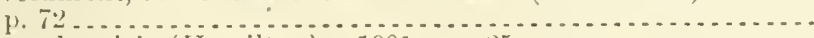

Pennuylvania' (Hamilton) 1901 b

Roarls:

Act to provicle for construction of, by local ascessment, county, and tite aid yassed by New York assembly, Oct. 13, 1894...

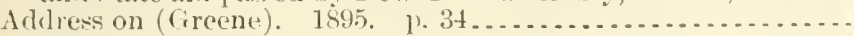

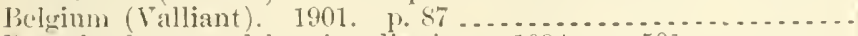

Best, for farms and farming districts. 1894. p. $501 \ldots . . . . .$.

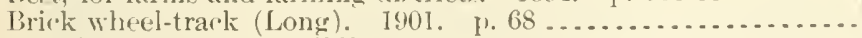

linilding. , tise Road building.

Common, and railroads, relation of (Haupt). 1902, 11.61 ..... A22.3:2:2

Common schools as affected by (Abereromlie). 1902. p. $39 \ldots . .422 .3: 23$

Conviet lahor on. See Convict labor.

Country-

hrick paring for. 1896 .

$122.4: 25$

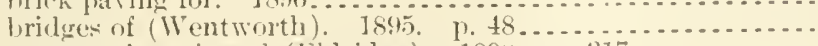

construction of good (Eldridge). 1898. 1) $317 \ldots \ldots \ldots \ldots$.

description of formation of (Frencls). p. $535 \ldots . . . . . . .$.

A2:2.3:11

11.10:\$98

A1.1:S66 
Roats-Continued

Country-Continued

maintaining, comments on systems of. 1896

A $22.4:: 0$

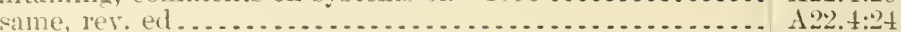

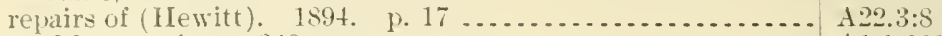

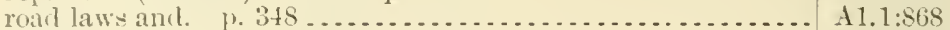

Earth-

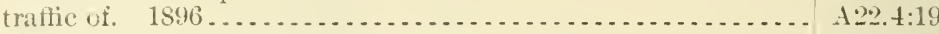

hints on their construction and repair (Stone). 1894 ....... A2*.3:8

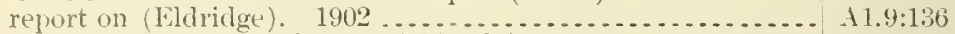

Forces which operate to destroy (Whittle). $1597 \ldots \ldots . . . . . . .422 .4: 29$

froud -

duty of General Government toward (Falkner). 1902. P. 31. A22.3:23 extracts from messages of governors (Stone). $1895 \ldots . . . .$. A22.3:14 farmers' views of, and how to get them (Creasy). 1901. p. 78. A22.3:21 for famers (Ellriclge) ........................... $11.9: 95$ going in rebt for (Thayer). $1897 \ldots \ldots \ldots \ldots \ldots \ldots \ldots \ldots \ldots \ldots \ldots . . .2 .4 .26$ hearings on, before Agriculture Committee, IJumse of Repre-

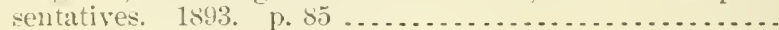
how to procme means to build (Jackson). 1895. 1. 29 .... how to secure (Montague). 1902. p. $36 \ldots . . . . . . . . . . .$. importance of, in war and peace (Miles). 1902. p. $39 . . .$. . Kentucky organizations fi:p (T'an Pelt). 1901. p. $81 \ldots . . .$. material proveses and (Hoore). 1902. p. 26.............

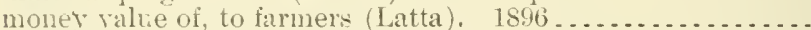
movement, character of (Richardson). 1902. p.27 ......

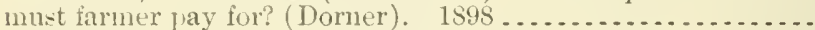
press and (Battey). 1902. p. 5̆ ......................

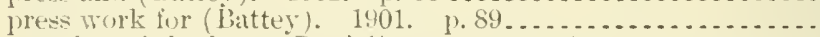
question of the luen (Daniel). 1902. 1. $158 \ldots . . . . . . . . .$. relation of, to industrial development (Hays). 190.2. p. $78 .$. stereoptic(n views of. 1901. 1).71 ................... suggestions to friends of (Heyward). 1902. p. $47 \ldots \ldots \ldots .$. work for new century (Stone). 1901. p. 52.............. work of Federal Government for (Dolge). 1902. p. 43 .... See cilso Asbury Park, N. J., national conference, $1894-\mathrm{New}$ Jersey-New York.

Gravel, in Hennepin County, Minn., method of construction and

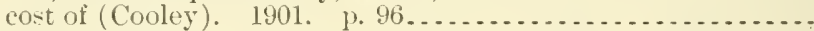

Improvement of-

adrlress at Raleigh, ‥ C., on, February 5, 1897 (Stone). p. 19.

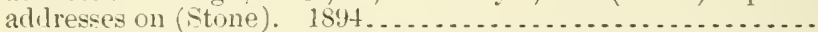
Congressional action in, necessity of (Stone). 1902. p. $23 \ldots$ convict labor in, plan for use of (Brewster). 1895. p. 7 . . . . Florida, progress of (Jennings). 1:01. p.60...........

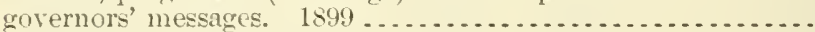

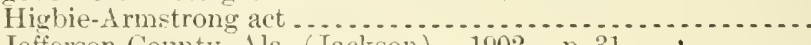
Jefferson County, Ala. (Jackson). 1902. p.31 ........... legislation for (Elflridge); 1901. p. 679 ................ letter to Illinois Farmers' Institute on (Stone). 1897. 1. 23. North ('arolina, use of convicts in (Holmes). 1S95 ......... prospects for, in the South (Richards). 1902. p. $17 \ldots \ldots .$.

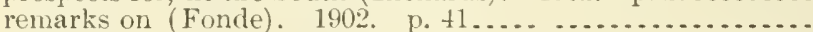

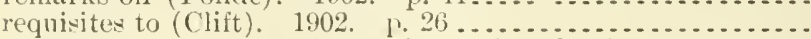
rural free mail delivery in relation to (Iachen). 1901. p. 92. societies for, State and local, appeal for organization of. 1896.

Location and construction of (Patton). 1902. p. $30 \ldots \ldots . . .$.

Nacarlanized-

electric street railways and, relation between (North). 1902.

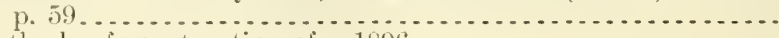

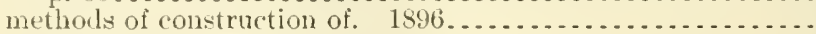

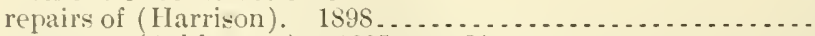

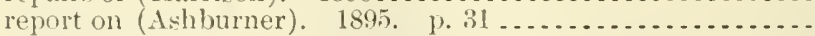

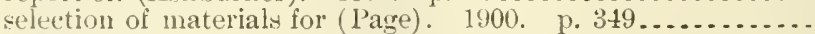

Ianagement of-

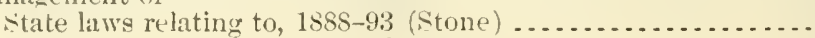
state laws relating to, enacted $1894-95$

A 10.3:14 A2:2.:2:11 A22.3:25 A22.3:2:5 A $20.2 .3: 21$ A 22.3:23 A2.2. $4: 2: 3$ 122.3:23 A2:. 4:31 A2:. $3: 2: 2$ 1 $22.3: 21$ A $2: 2.9: 2: 3$ 122.8:2:3) $12: 3: 21$ 12:2.3:2:3 A $20.3: 21$ 12.2.3:23

A2:2:3:21

122.t:28

12.2. 4:14

12:.3:25

12:.3:16

A 22.5:21

A2. $4: 33$

12.2.4:3.5

A2.2.3:23

11.10:901

12:4:28

A $2.2 .3: 16$

A22.3:28

A2:. 5:23

A $22.3: 23$

A20.3:21

122.4:20

A22.3:25

A 22.3:2:2

A22.4:21

122. $4: 30$

A 22.3:17

A $1.10: 900$

A 22.3:1

A22.3:18 
Materials for. See Road materials.

Iountain-

as a source of revenue (Abbott). 1901. 1). 527 ........... \$1.10:901

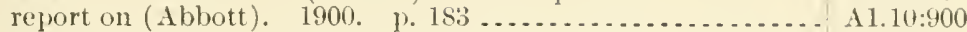

Object lesson-

Government cooperation in work (Dodge). 1901. 1).409....

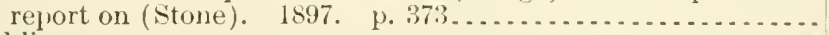

Public-

convict labor on, use of (Graham). 1895. 1. 34 ......... 122.3:11

improvement of, in Nurth Carolina (Holmes). 1894. 1).513. A1.10:894 traction tests on (Neely). 1896 ....................... $122.3: 20$

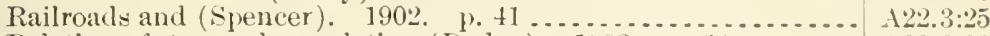

Relation of, to rural population (Doclge). 1902. p. $34 \ldots \ldots \ldots . .122 .3: 23$

Road-building materials and, of Cieorgia (McCallie). 1902. 1).

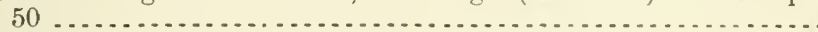

Road materials and freight rates in certain States north of Ohio

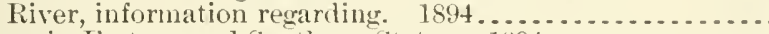

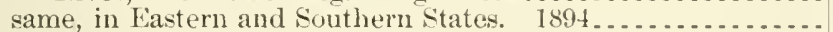

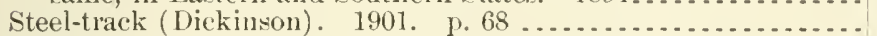

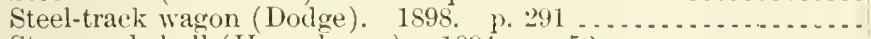

Stone and shell (Humphreys). 1894. p. 52 ...............

Stone, in Yew Jersey (Harricon). 1895. 1). 23.............

What our bad roads cost us (Coleman). 1895. 1). $17 \ldots \ldots \ldots \ldots$.

See also Convict labor - Higliways.

Roads, (rood, National Association of, oflicers of:

1900. p. $66 t$

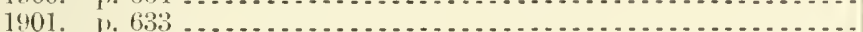

Roarls, Good, National League for:

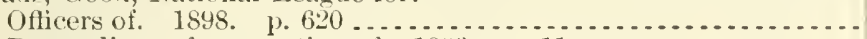

Proceedings of convention of. 1893. p. $11 \ldots \ldots \ldots \ldots . . .6$.

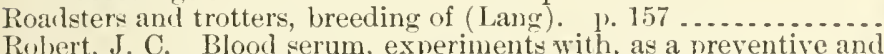

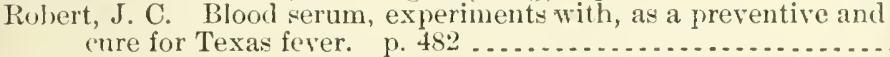

Roberts, lrank W. Sheep and wool in Cape Colony. p. 52: ..... Roherts, Isaac Phillips:

Agricultural courses in the East, principles underlying formation

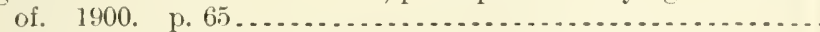

Agricultural experiment stations, how can they reach and in-

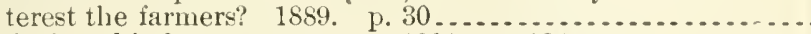

Agricultural industry, our new. 1901. p. 124................

Farm, exodus from the, what are causes of? 1896 . p. $80 \ldots \ldots$...

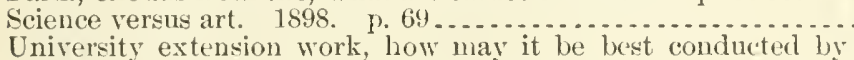

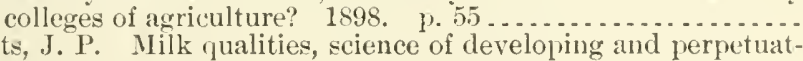

Roberts, J. P. Milk qualities, science of developing and perpetuat-

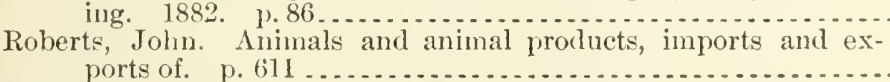

Robertson, W. Henry. Hamburg, dried apples in. 1894. p. 12...

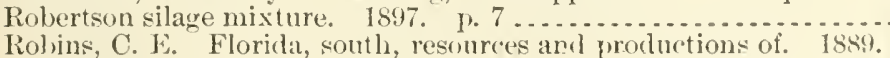

Rolinson, Henry $A$ :

Crop correspondents, manual of instructions to . . . . . . . . . .

Publications of Statistices J)ivision, letter relatine to. $1895 \ldots . .$.

See also, for reporty as Statistician, Agriculture Department, $1893-1896$

Rolinson, Jesse II:

Seacrast telegraph lines, instructions to operators on. 1897 .....

Telewaph and weather service. 1902. 11. 145 . . . . . . . . . .

Telegraph service with West Indies. 1898. p. $410 \ldots . . . . . .$. Rolson, W. S., adılress of, before good roads convention of Texas,

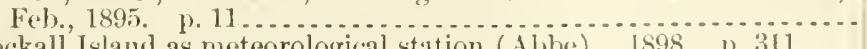
A2:. $.3: 23$

A $22.3: 6$

12:2.3:7

122.3:21

11.10:898

A2.2.3:11

120.3:17

A22.3:11

\1.10:900 A $1.10: 901$

1 1.10:898

A 10.3:14

A1.1:\$6t

A4.1:898

At.1:898

A10.3:7i

A 10.5:1

1 10.3:9:

A 10.3:41

A $10.3: 49$

1] $10.3: 49$

A1.8:22

14.1:901

1 $7.3: 48$

11.9:56

1.7.9:27

127.2:088

127.2:1996

A 27.1 :

$129.12: \mathrm{Sel}^{2}$

1:9.3:31

129.6:26

1:2.:3:15 1:29.1i:26

Rocket signals. See also Kerkam's kites with rocket signals. 
Rocks, imbihition of (Ilill) see also Magnetic rocks.

liocky Mountain areas, agricultural notes on. 1866. p. 379......

Rocky Mlountain basins, botany and agriculture of (Thompson). ?. 125.

Rocky Momtinin goat:

Note on. 1si9. p. 56.

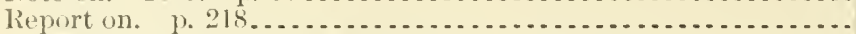

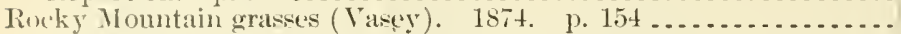

Rocky Momtain locust:

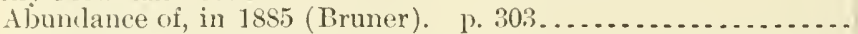

Fntomological Commission reports on ...................

Ilabits, natural history, and means of comnteracting injuries of (chaps. 8 and 13 of 1.t Report of $[$. S. Entomological Com-

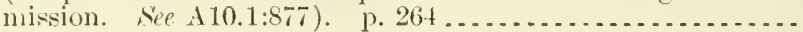
Kansas and Colorado, in 1880 (Chipman). 1883. App. p. 55.

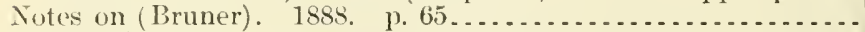
Observations on-

during summer of 1883 (Bruner). 1884. p. $51 \ldots \ldots . . . . .$. in Northwest in 188. (Bruner). $1883.1 \% .7 \ldots \ldots . . . . . . .$.

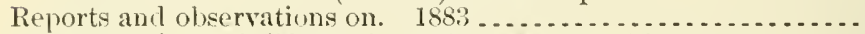
Report on, in 1880 (Marten). 1883. App., p. $50 \ldots \ldots \ldots \ldots \ldots . .$. See also Locust - Melanoylus spretus.

Rocky Mlountain region:

Eastem, grasses and forage plants and forage conditions of

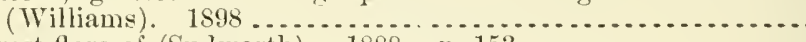
Forest flora of (Sndworth). 188s. p. 153 ................... Grasses and forage plants of (Rydberg and Shear). 1897.......

Rocky Mountain States:

Irrigation in (Tlrich). 1899.

Reservoirs in, some typical (Mead), 1901, p. $415 \ldots \ldots \ldots$

Rocky Mountains:

Eastern slope of, grasses of Plains and, catalogue of. p. 217.

Forest conditions of, especially in Colorado, Idaho, Montana, Wyoming, and New Mexico (Ensign). p. $41 \ldots . . . . .$.

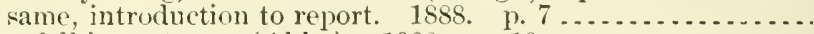

Snowfall in, notes on (Abbe). 1900. p. $18 \ldots \ldots$

Rod, divining, use of, in search for water, note on (Abbe). 1900.

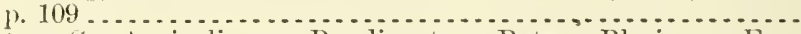

Rodents. Se Arvicoline - Bandicoots - Bats - Blarina - Evotomys - Gophers - Grasshopper mouse - Ground squirrels Guinea pigs - Hesperomys - Jack rabbits - Jumping mice Kangaroo rats - Lemmings - Pika-Pocket gophers - Pocket mice - Rabbits - Rats - Voles.

Roentgen rays, report on (Trowbridge). 1897. p. 348 ..........

Roesler, F. E. Artesian well investigation, field work in Texas. 1890. p. 243.

Rogers, G, O. Stoms, local, on west coast of Mexico. 1894. p. 510

Rogers, George. Cattle show of Smithfield Club, notes on. 1). 326 .

Roland, H. Whitfield. See, as joint author, McLean, L.

Rolfs, Peter H. Pineapple growing. 1901.

Rollins, Frank IV. New Hampshire, road improvement in, extract from governor's message. p. 5 ..............................

Rollins, John F. Florida as home for emigrants. 1872. p. 495...

Romaine, Helmas:

Horse breeding in New Jersey. p. 385 . . . . . . . . . . . . . . . . . Vermont Association of Road and Trotting Horse Breeders, exhj-

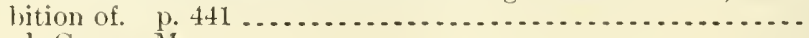

Rommel, George II:

Beef cattle, American breeds of, with remarks on pedigrees. 1902 .

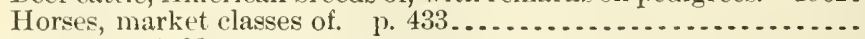
same. 1902 . . . . . . . . . . .

Röntgen rays and cloudy condensation (Abje). 1896. p. $167 \ldots$ Roofs, tin, as lightning conductors, notes on (Abbe). 1898. pp. 166,

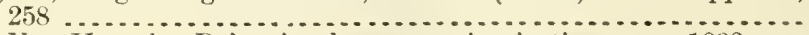

Roos, Van Hamel. Poisoning by preserving in tin cans. 1892 . p.

A27.9:4

$\triangle 1.1: 566$

127.9:7

1].1:867

127.9:12

A1.1:885

AS.1:

11.1:877

18.1:3

A9.7:1

A9.3:4

A9.3:2

A9.3:2

A8. 1:3

\3.3:12

A $13.3: 2$

A3.3:5

A 10.3:73

A1. 10:901

A1.1:870

A 13.3:2

A 13.3:2

A29.6:28

129.6:28

A29.6:25

A15.2:Ar

A29.6:22

A 4. 1:895-6

A1.9:140

A22.4:33

A27.9:10

A4.1:889-90

A4.1:889-90

A4.3:34

A4.1:901

A4.3:37

A29.6:24

A29. $6: 26$

A7.3:13 
Roosevelt, Creorye $11 .:$

Classificatlon no.

Animals, lead, disposition in Belgium, especially Brussels. p. 35t. At.1:899

Belginm, cost of hauling farm products over wagon roals in. p. 1. . A22.4:27

Roosevelt, Robert B. Fish (ulture, report on. 1573. 1). 183...... 127.9:11

Roosevelt, Theorlore:

Message, transmitting report of Secretary of $\mathbf{A g r i c u l t u r e}$ on forests, rivers, and mountains of southeru Aplatatehian region.

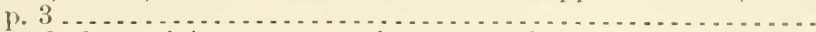

Tew York, road improvement in, extract from governor's mes-

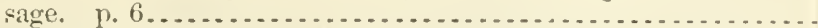

Root crops, cultivation of, in United States (Leverett). 1.95 .... Root fungus of New Kealand (Wight). 1859. p. $199 \ldots \ldots . . . . .$. Root knot, cowpea resistant to (W'ebluer and Orton), 1902 . 1).2.. Root-knot dicease of peach, orange, and other plants in Florida, due

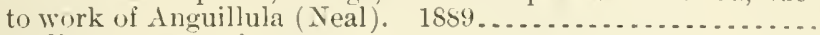

Root-rot disense, new, of cotton:

Circular of inquiry on (kusk) . . . . . . . . . . . . . . . . . . . . .

Report on (Atkinison). 1890. p. 262....................

Root rot of tiro (Sedgwick). $1902 \ldots \ldots \ldots$

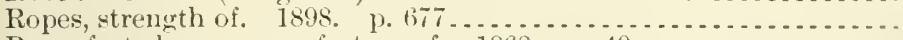

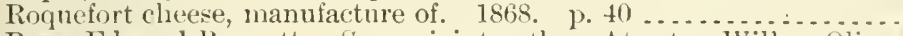
Rosil, Edward Bennett. See, as joint author, Atwater, Wilbur Olin. Rose, Joseph Nelion:

Big Horn Mountains of Wyoming, plants from. 1896. p. $567 .$.

Carmen Island, plants collected by Edward Palmer in 1890, on,

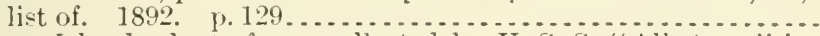

Cocos Island, plants from, collected by U. S. S. "Albatross" in $1887-91$, list of. 1892 . P. 135

Galapagos Is]ands, plants from, collected by U.S. S. "Albatross"

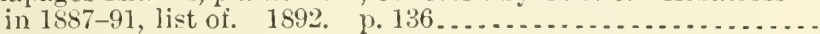

Mexico-

useful plants of, notes on. 1899. p. 209. western, and Arizona, list of plants collected by Edward

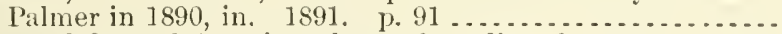

Mexico and Central America, plants of, studies of. 1897. P. 103.

Mexico and United States, plants, mostly new, from, description

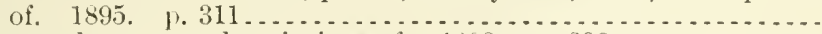

Plants, three new, descriptions of 1893 . p. $289 \ldots \ldots . . . . . . .$.

Sonora and Colima, States of, Mexico, collection of plants made in, by Edward Palmer in years 1890 and 1891, report on.

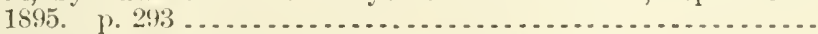

Tradescantia, three new species of, from IT. S. 1899. 1). $204 \ldots$

Treleasea, a new genns of Commelinacere. 1899 . p. $200^{\circ} . . . . .$.

Tres Marias lslands, plants of. 1899 . p. $77 . \ldots \ldots \ldots \ldots \ldots$

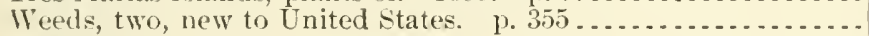

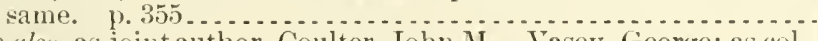

See alss, as joint author, Coulter, John Mi. - Vasey, George; as collector, Davenport, George E,

Rose, W. II.:

Pleuro-pneumonia among cattle in Maryland, District of Colum-

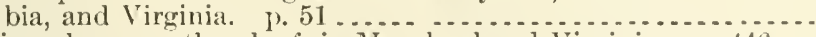

Swine plague, ontbreak of, in Maryland and Virginia. p. $446 \ldots$

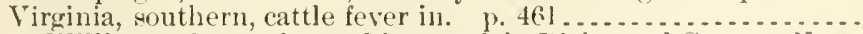

Rose, William. Lung plagne, history of, in Richmond County, New York. p. 468 .

Rose, insects injurious to, some (Chittenden). 1901 . . . . . . . . .

Rose bug:

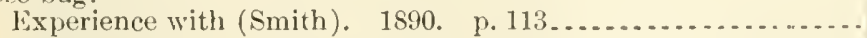

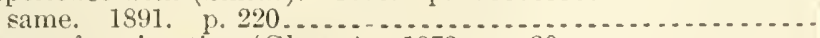

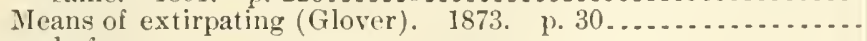
Rose-chafer:

Circular relative to (Chittenden). $1895 \ldots \ldots \ldots \ldots . . .6 . . .6$.

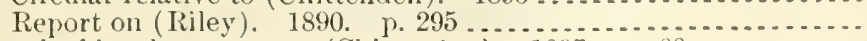

Rose leaf-beetle, report on (Chittenden). 1897. p. $60 \ldots \ldots . . . .$.

See also Fuller's rose beetle.

Rose saw-flies in United States (Riley). 1892. p. $6 \ldots \ldots \ldots \ldots . . . . . . .49 .7$

A 1.1:S81-2

At.1:884

A $4.1: 881$

$14.1: 884$

$19.6: 27$

A $9.7: 3$

$A 9.7: 3$

127.9:11

A $9.5: 11$

A $9.7: 2$

A $9.6: 7$ 
Roseanthus, a new genus of Cucurbitacer, from Acapulco, Mexico

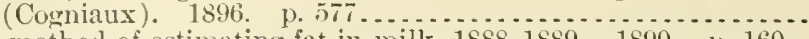

Röse's method of estimating fat in milk, $1858-1859.1890$. 1r. 160_. Roses:

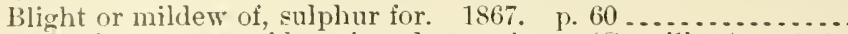

Buds of, two new cecidom yians rlestructive to (Coquillett). 1900. p. 44 See Peach rosette.

Rosette. Se
Ross, B. B.:

Address of, as president of Association of Official Agrieultural

Chemists, at thirteenth annual convention. 1896 . p. $6 . . . .$.

Ammonium phosphomolyblate, new reaction with. 1854. p. 97. Citrate-soluble phosphoric acid, determination of. 1893 , p. 16.. Ross, Charles $\mathrm{IT}$ :

Road building, few practical suggestions on. 1902. p. 18...... Roarl laws and road bnilling in Massachnsetts. 1901. p. 34 ...

Ross, D. B. Sugar analysis, notes on. 1889. p. $179 \ldots \ldots \ldots \ldots \ldots$

Ross, D. W.:

Boise Valley, Idaho, duty of water as related to irrigation prob-

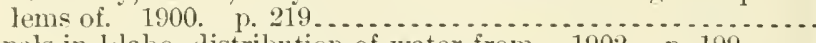
Canals in ldaho, distribution of water from, 1902. p. 199.....

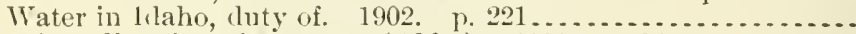

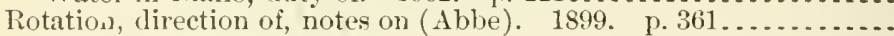
Rotch, Abbott Lawrence:

Aerial royages by balloons and kites. 1900. p. 553

A eronautical conference, international, Strassburg, Germany, re-

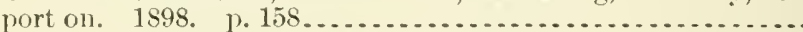

Aeronantical congress, international, at Berlin, report on. 1902. p. 356

Air, exploration of, progress in, with kites at Blne Hill Observa-

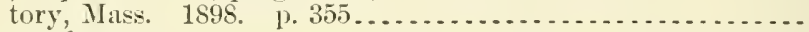

Atmosphere-

circulation of, in tropical and equatorial regions. 1902. p. 181. systematic exploration of, by means of kites, method for. 1902. p. 66

Clermont-Ferrand, France, international hylrological, climatological, and geological congress, Sept. 28 to Oct. 2, 1896 . p.

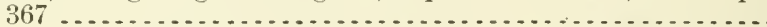

Cloud observations at Blue Hill Meteorological Observatory, Milton, Mass. 1897. p. 12 ...........................

German Meteorological Society, eighth general meeting of.

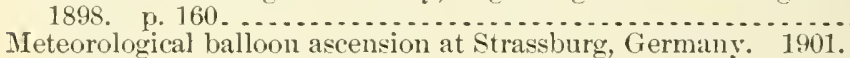
p. $298 \ldots \ldots \ldots$ Paris, international meteorological conference at, Sept. 1896 , re-
port on. 1. $365 \ldots \ldots \ldots \ldots \ldots \ldots \ldots \ldots \ldots \ldots \ldots \ldots \ldots \ldots$

Roth, Filibert:

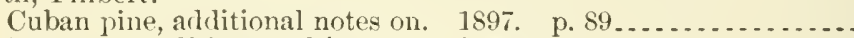

Forestry conditions and interests of Wisconsin. $1898 \ldots . . . . .$.

Grazing in forest reserves. 1901. p. $333 \ldots \ldots \ldots \ldots \ldots \ldots \ldots \ldots \ldots$

Loblolly pine, arlditional notes on. 1897 p. $133 \ldots \ldots \ldots \ldots \ldots \ldots$

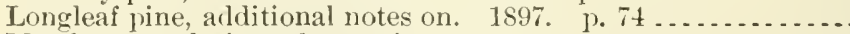

Marsh or pond pine, observations on. 1897. p. $169 \ldots \ldots \ldots \ldots$.

Shortleaf pine, additional notes on. 1897. p. 111_........

Timber, an elementary discussion of characteristics and proper-

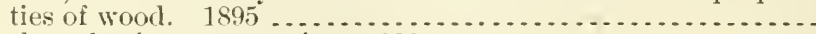

Timber physics, procress in. 1s98........

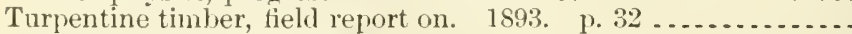

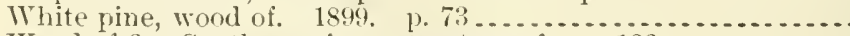

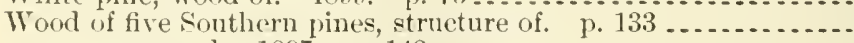

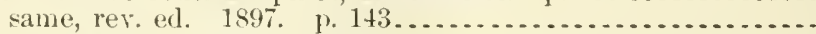

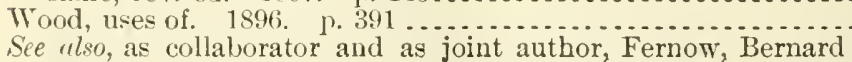
Eduard.

A6.5:3

A $7.3: 24$

A $27.9: 5$

19.6:22

A7. $3: 49$

A. $3: 43$

A $7.3: 38$

A 22.3:22

A 22.3:21

A $7.3: 24$

A 10.3: 86.

A 10.3:119

A 10.3:104

A29.6:27

A29.6:28

A29.6:26

A $29.6: 30$

A29.6:26

A29.6:30

A29.3:31

A $29.6: 24$

A29.6:25

129.6:26

A29.6:29

A29.6:24

A $13.3: 13^{2}$

A13.3:16

A1.10:901

A $13.3: 13^{2}$

A13.3:1:32

A $13.3: 13^{2}$

A13.3:13"

A13.3:10

A 13. 4:19

A 13.3:8

A 13.3:22

A 13.3:13 1

A 13.3:13 2

A1.10:896 
Rothamsted Experimental Station, England:

Agricultural investigations at, six lectures on, under provisions of Lawes Agricultural Trust-

1892. (Warington)

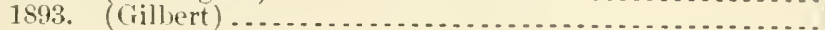

same, introduction (Gilbert). p. 46 ............................

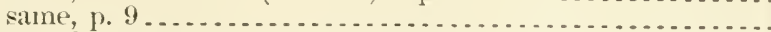

History and work of, lecture on (Warington). 1892, j. $7 \ldots \ldots$

Laboratory of, determination of nitric acid in soils ly Schloesing's

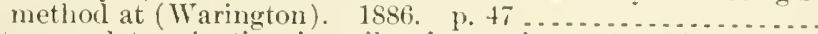

Nitrogen determination in soils of experimental fields at, and bearing on question of source of nitrogen of our crops (Lawes and Gilbert). 1882. b. 142

Soils at, results of investigations on, heing lectures delivered under provisions of Lawes Agricultural Trust (Dyer). 1902 .

Itheat grain and wheat straw grown at, in different seasons and by different manures, composition of ash of ( lawes and Gilbert). p. 85 .

Rothrock, J. T. Trees, planting, a patriotic diuty. 1895. p. $32 \ldots$ Roubaix, France, cost of hauling farm proulucts orer wagon roails at (Angell) , p. 3 . . . . . . . . . . . . . . . . . . . . . . .

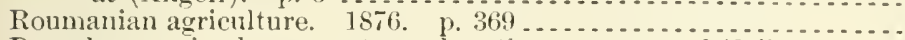

Rounlworms in sheep, goats, and cattle, treatment of (Stiles):

1901

1902.0 .7 .6$.

See also Verminous di.ceases.

Rove beetle, another parasitic (Coquillett). 1891. p. 318 ....... Rowe, H. M. "Big head" (disease) of sheep in Utah. p. $230 \ldots$. Royal Agricultural Academy of l'russia. See Poppelsilorf, Prussia. Royal Agricultural College of England. See Cirencester, England. Royal Forest School of Bavaria. See Aschaffenburg, Bavaria.

Royal Institute for Fruit and Vine Culture of I'russia. See Geisenheim-on-the-Rhine.

Royal Prussian Meteorological Institution, semicentemnial of, cele-

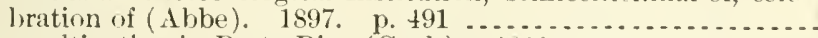

Rubber cultivation in Porto Rico (Cook). 1900 ................... Rubenson, Rolert, short biography of. 1902 . p. $488 \ldots \ldots \ldots$
Ruffin, Edmund, pioneer in agricultural science (Cutter). 1895.

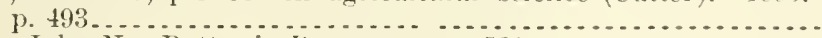

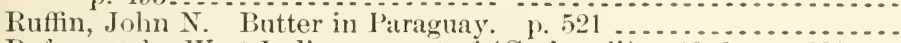

Rufous scale, West Indian, report of (Cockerell). 1892. p. $381 . .$.

Runner's white corn. p. 186 ............................

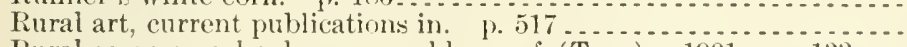

Rural common school, some prolylems of (True). 1901. p. 133...

Rural cooperative banks in Russia. 1891. p. 146 ...............

Rural districts-

How insects affect health in (Howard), 1902 ................

Teaching domestic science in (Breed), 1902, p. 91 ...........

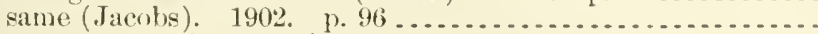

Rural ecomony, works on agriculture and, list of. p. $597 \ldots \ldots \ldots$.

Rural free delivery:

Is it advisal)le to distribute night forecasts of Weather Burean

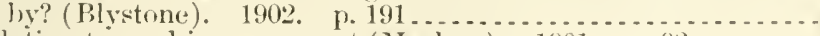

Relation to road improvement (Machen). 1901. 1).92 .......

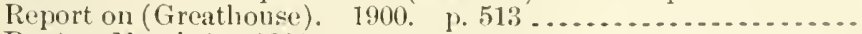

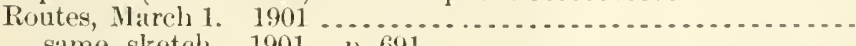

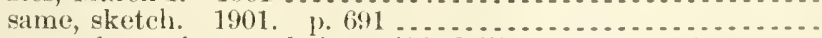

Wagons of, weather symbols on (Pindell). 1902. p. $208 \ldots .$.

Weather forecast cards by, note on (Ablye). 1900, p. 162.....

Rural life, what can colleges of agriculture do to nourish a hearty sentiment for (Davenport). 1896 . p. $82 \ldots \ldots \ldots \ldots \ldots$

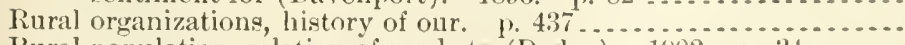

Rural population, relation of roads to (Dorlge). 1902, 1 $34 \ldots . .$.

Rural production, applied science as a factor of. 1885. No.20. p.3 ... 127.9:23

110.3:S

$110.3: 2 \% 2$

$110.3: 20$

$110.3: 2: 3$

A10.3:9

1 $7.3: 11$

A1.8:31

A $10.3: 106$

A7.3:4

A1.8:56

A2:.4:27

A27.9:14

A 4.4:35

A4.3:35

A9.7:3

14.1:901

A 29.6:25

16.4:28

A:9.6:30

A1.10:895

A4.1:898

19.7:4

A1.1:874

A1.1:870

A1.10:901

127.9:29

A1.9:155

110.3:120

110.3:120

11.1:868

129.3:31

A 20.3:2:21

1 $1.10: 900$

A 1.10:900

11.10:801

1:29.3:31

A $29.6: 28$

$110.3: 41$

1 1.1:875

1:20.3:3:3 
Rural publications, Agriculture Department, recent:

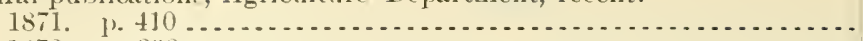

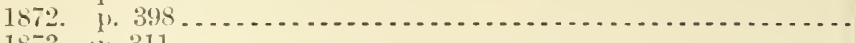

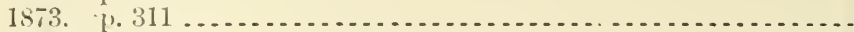

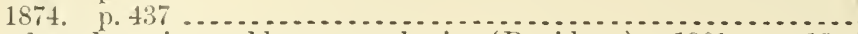

Rural road naming and housenumbering (Davidson). 1901. p. 19.

Rural schools. Tee Schools, rural.

Rusk, Jeremiah McLain:

Adiress of, before convention of National League of Good Roads,

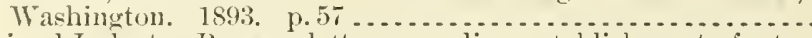

Animal Industry Bureau, letter regarding establishment of, etc. 1890

Annual reports [and] selected correspondence relating to export trade in live stock and meat products, $1889-92$.

11.1:871

A $1.1: 872$

A $1.1: 873$

A $1.1: 874$

A $2.2 .3: 21$

A10.3:14

A1.2: $\ln 5^{2}$

A1.2:R89

Live stock and meat products, selected correspondence relating to export trade in. 1893.

Root-rot of cotton, circular of inquiry on Straw and stublule of wheat, oats, rye, and barley, questions asked and specimens of, soliciter. n. d .................

See also, for reports as Secretary of Agriculture, 1889-1892 . . . . . . .

Russell, Daniel 1. North Carolina, road improvement in, extract

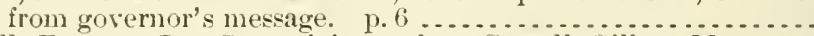

Russell, Fremont L. See, as joint author, Gowell, Gilbert M.

Russell, H. L. Cabbage and allied plants, bacterial disease of.

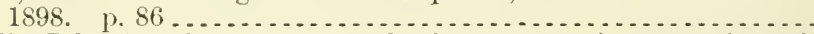

Russell, John L. Seasons, natural phenomena of, connection of

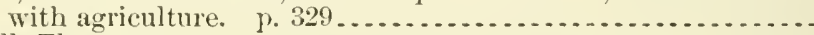

Russell, Thomas:

Daily river stages on principal rivers of $\mathrm{L}$.S., $1890-92 \ldots . . .2$.

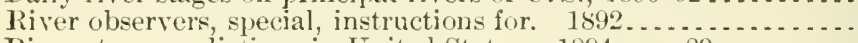
River stage prerlictions in United States. 1894. p. 89 .........

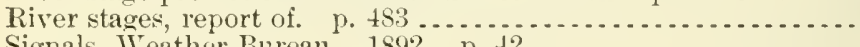
Signals, Weather Burean. 1892. p. $42 \ldots \ldots \ldots \ldots \ldots \ldots \ldots \ldots \ldots \ldots$ Russia:

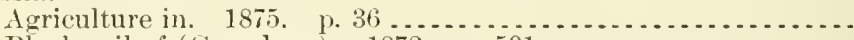

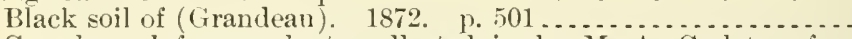

Cereals and forage plants collected in, by M. A. Carleton, for Section of seed and Plant Introduction, Agriculture Department. 1899.

Cereals of-

adapted for cultivation in United States (Carleton). 1900...

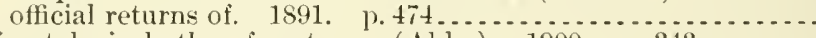
Climatological atlas of, notes on (Abbe). 1900. p. $343 \ldots \ldots . .$.

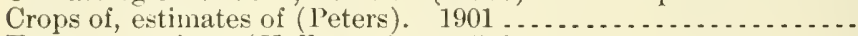

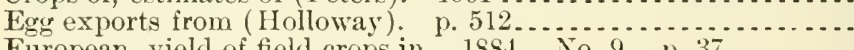
European, yield of field crops in. 1884 . No. 9. p. 37 .......

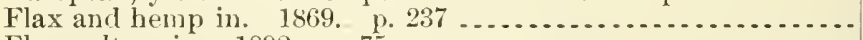

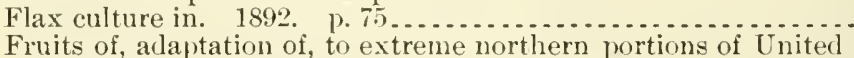

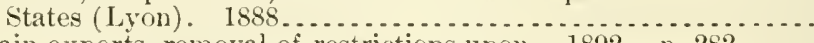
Grain exports, removal of restrictions upon. 1892 p. $282 \ldots$.... Grain-producing distriets of (Moffat). 1882. No. 51. p. 14... Hessian fly in (Koeppen). 1883. A pp., p. $41 \ldots . . . . . . . .$.

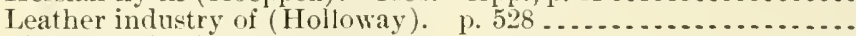
Live stock in, for 1898 . p. $606 \ldots \ldots \ldots \ldots$ Locust in 1883 p. p4 $64 \ldots \ldots \ldots$

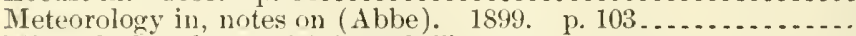

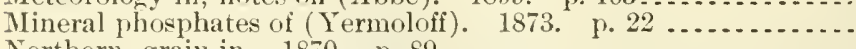

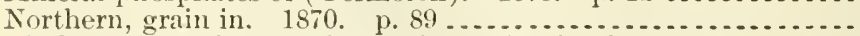
Rinderpest, official experiments in vaccination for. 1866. ,p. 235 . Rural cooperative banks in. 1891. p. $146 \ldots \ldots \ldots \ldots . . .6 . . .6$. Soil investigations (Sibirtzer). pp. 704,807.............. Wheat of, British imports of $1852-67$. P. $39 \ldots \ldots \ldots \ldots \ldots \ldots \ldots$ Wheat production and exportation in, course of, 1880-96. A1.8:53 A28.4:9

A28.4:12

11.1:

A2:. 4:33

A10.3:49

A1.1:S6t

A29.10:4

A29.12:R52 1

A29.3:11 1

A29.1:891 ${ }^{3}$

A29.3:7

A27.9:13

A27.9:10

A6.6:4

A6.3:23

A27.9:29

A $29.6: 28$

A27.4:14

A4.1:900

A27.9:22

A27.9:7

A11.5:4

A20.3:2

A27.9:30

A27.9:20

A8.1:3

A $4.1: 899$

A $4.1: 901$

A8.1:3

A $29.6: 27$

A $27.9: 11$

A27.9:8

A $27.9: 4$

A $27.9: 29$

A 10.6:12

A $27.9: 6$

A12. $4: 10$

See also Caucasus - Odessa - St. Petersburg.

Russian thistle:

Circular relative to (Dewey) ....................................... 
Russian thistle-Continued

Its history as a weed in United States, with an account of the means available for its eralication (1)ewey). $1894 \ldots . . . . .$.

Russian thistle and other troublesome weeds in wheat regrion of Minnesota and North and South Dakota. 1893 ...............

Russian veteh. See Vetch.

Russian zyemstvos, conflict of, with enemies of agriculture (Mora-

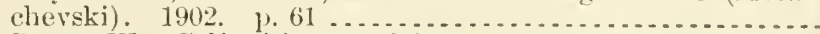

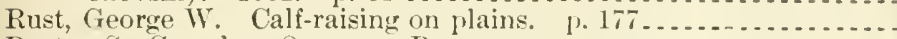
Rust. See Cereals - Orange- I'rune.

Rust mite and other orange pests, notes on. 1883. p.9........

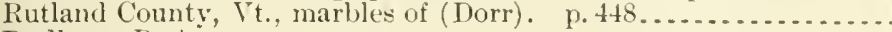
Rydberg, P. A:

Flora of Black Hiłls of South Dakota. 1896. p. 463.

Flora of the sand hills of Nebraska 1895. po. 13\% . . . . .

Rydberg, P. A., and Shear, Cornelius L. Grasses and forage plants

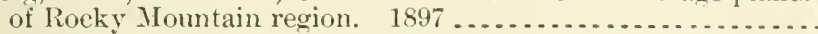

Ryder, Henry B. Farm animals of Europe. 1886 . p. $353 \ldots . . .$. Rye:

Crop condition, monthly notes on . . . . . . . . . . . . . . . .

Crop statistics, annual. . . . . .

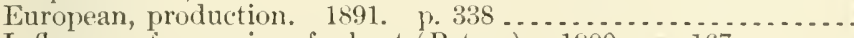

Influence of, on price of wheat (Peters). 1900. 1. 167 . . . . . .

Rusterl, request for specimens of (Dahney). 1894 .............

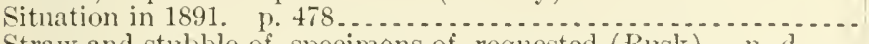
Straw and stubble of, specimens of, requested (Rusk). n. d ... See also Cereals, American - Crops, principal.

Rye gall-guat:

Deseription of (Loew). 1883. App. p. 6.......................... A8.3

New crop of, 1861 , observations on (Wagner). 1883. App., P. 8. As.1:3

See also Hessian fly.

Rykatcheff, M. Balloon ascension, results of, at st. Petershurg,

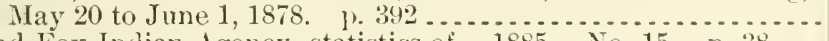

Sac and Fox Indian Agency, statistics of. 1885. No. 15. p. $38 . .$.

Saccarlo's Sylloge, genus Scleroderma in (Ellis). 1889. p. 23 ....

Saccharine prorlucts, analysis of, provisional method for (leach).

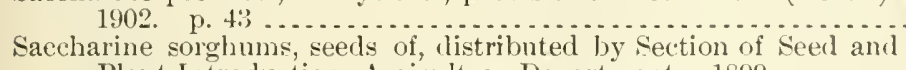
Plant Introduction, Agriculture Department. 1899 .........

Saceharine matter, "diffusion process" for extracting, from sugar-
yielding plants. $1869 . \quad$ p. $457 \ldots \ldots \ldots \ldots \ldots \ldots \ldots \ldots \ldots \ldots \ldots \ldots \ldots \ldots$ yielding plants. 1869.

Sachaline. Sce Gid
Sacramento, Cal.:

Electric stoms at, notes on (Abbe). 1897. p. $542 \ldots \ldots \ldots \ldots$. . .

State fair, eattle exhibited at, order providing for return of noninfected. 1899 . same. Aug. 18, 1900

A $29.6: 28$

A $27.9: 23$

A $28.5: 5$

A $7.3: 65$

A6.6:3

\27.9:6

A29.6:25

A $4.5: 43$

A $4.5: 69$

Saeramento County, Cal., cattle cuarantine order for. Feb. 26, 1900. . $44.5: 59$ Sage, John R.:

Weather forecasts, what elasses are most benefited by? are they just what are needed? are they properly disseminated and

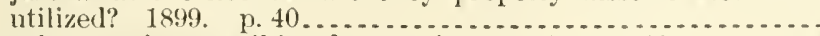

Weather service, possible advances in. 1895 . p. $463 \ldots \ldots \ldots .$.

St. Domingo. Sce Santo Domingo.

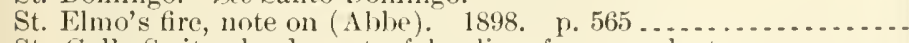

St. Gall, Switzerland, cost of hauling farm products oper wason

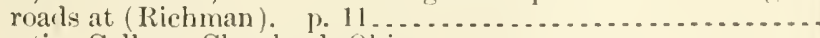

St. Ignatius College, Cleveland, Ohio:

Gromnd temperature observations at. 1902. p.301............ Meteorological olsservatory of (Kenealy). 1901. 1).355......

St. Kitts, W. I. :

Climatology of-

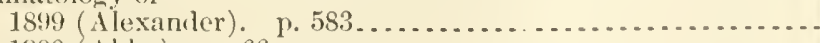

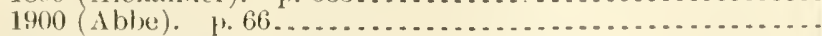

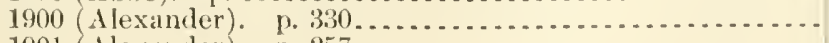

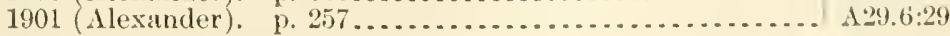


St. Kitts, IV. I.-Continued

Hurricanes of (Alexanter) -

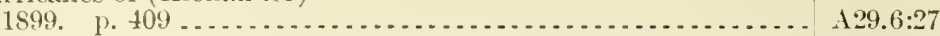

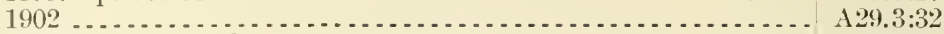

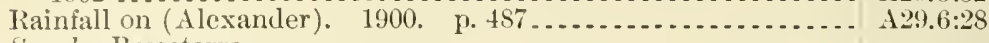

See ulvo Bisseterre.

St. Landry Parish, la., soils and products of (Rapley). 1884. p. 29_ A1.8:35

St. Lawrence Island, climate of, 1894-99 (Ihenry). 1). 457 . . . . . . A29.6:27

St. Lawrence River, hailstorm on, notes on (Abhe). 1901. p. 506 . A29.6:29

St. Lawrence Valley, high areas north of, in October, November,

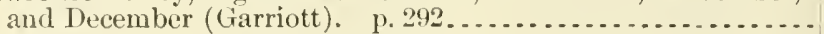

St. Louis, Mo.:

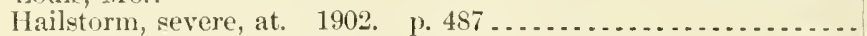

House sparrow and European tree sparrow at, history of (Wid-

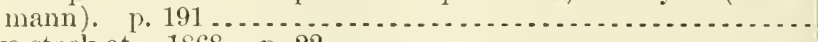

Live stock at. 1868 p. p2 $22 \ldots \ldots \ldots \ldots \ldots \ldots$

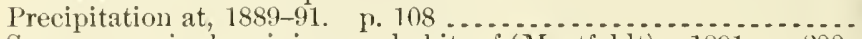

Screw worm in, hominivorous habits of (Murtfeldt). 1891. p. 200.

Tornato of IIay 27,1896 , at-

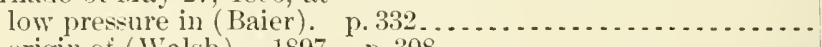

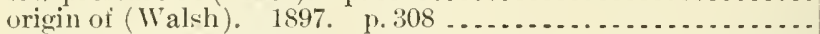
report on (Frankenfield). p. 77 .

sane (Abbe). 1896. p. 225 .

United States Weather Burean and Forest Park meteorological observatories, abstract of comparison of minimum temperatures recorlerl at, 1891 (I Iammon and Duenckel). p. 12..... See also Washington University.

St. Martiu's parish, La., soils and products of (Rapley). 1884. p. 9. St. Mary County, Mfd., soil survey of (Bonsteel). p. 125...........

St. Marys Falls Canal, water level in, relation of certain atmospheric

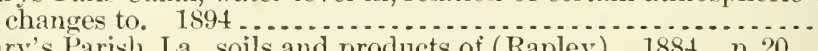

St. Mary's Parisl, La., soils and products of (Rapley). 1884. p. 20.
St. Michael, Alaska, ice and navigation at, notes on, 1878-99 (Abbe), p. 162

St. Panl, Minn., frost formation in, note on (Abbe). 1897. p. $401 .$. See also Minnesota good roads convention.

St. Petersburg, Russia:

Balloon ascensions at, results of, May 20 to June 1, 1878

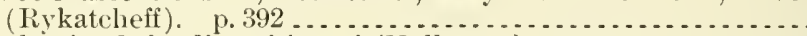

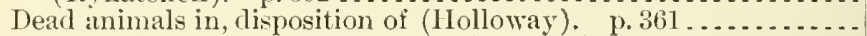

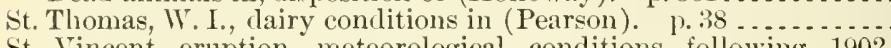
St. Vincent eruption, meteorological conditions following, 1902

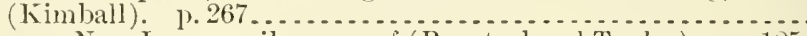

Salem area, New Jersey, soil survey of (Bonsteel and Taylor). p. 125 Salinas Valley, lower, California, soil survey of (Lipham and

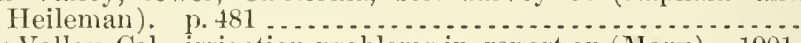

Salinas Valley, Cal., irrigation problems in, report on (IIarx). 1901.

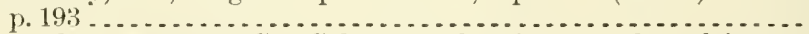

Salinas Valley, IIonterey Co., Cal., water-bearing gravels and formations tributary to undergromel water supply of (Nutter). 1901. p. 208

Salisbury, George N.

Forest clearing and cultivation, effect of, upon water supply and soil, rainfall, temperature. 1899. P.91........................

Irrigation and its relation to State weather-service work. 1894.

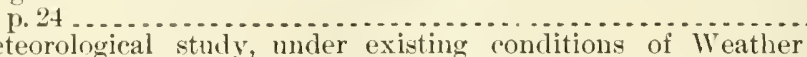
Bureau station work, is it practicable to require assistants to

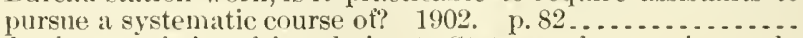

Utah, characteristics of, in relation to State weather-service work.

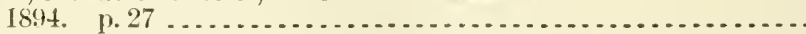

Weather Burean and the public, relations between. 1899 p. 14. Salisbury, N. C., feerling stations at, regulations concerning cattle transportation at-

Jan. 3, 1898 .

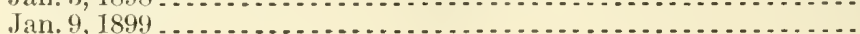

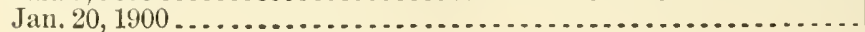

A29.6:23

A29.6:30

A5.3:1

A27.9:7

A $29.6: 20$

A9.7:4

A 29.6:24

A29.6:25

A29.6:24

A29.6:24

A29.6:30

A1.8:35

A26.5:9001

A 29.2: $\mathrm{Sa}^{2}$

A 1.8:35

A $29.6: 28$

A $29.6: 25$

A29.6:28

A 4.1:899

A 4.1:901

A29.6:30

A26.5:901 1

A26.5:901 1

A 10.3:100

A10.3:100

A29.3:24

A29.3:14

A29.3:31

A29.3:14

A 29.3:24 
Address of, before national cattle growers' convention, Kansas

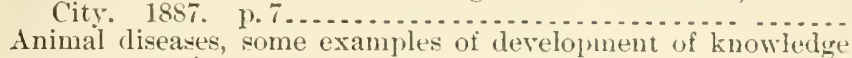

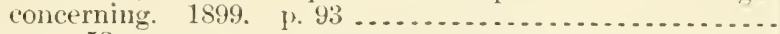

Animal Industry Bureat, Agriculture Department, work of, jor farmer. 1897. 1. $2: 36$ same, reprinted. ए. 25

Animals, contagions discases ofnational legislation for, address on, hefore 31 national (onnvention of stockmen, Chicugo, Nov., 188.5. 1) 1:3.

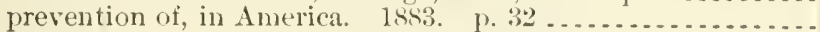

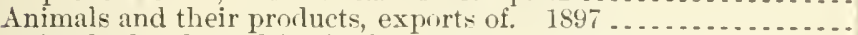

Animals slaughtered for fool, necessity of insperting. 1889 . 30

Argentina as a market for pure-lored cattle from Tniterl States, preliminary report on. 1902

Beef supply of United States and export trade in animals and

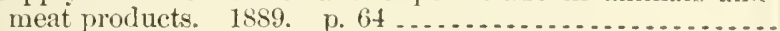
same, 1890

Black quarter or black leg. p. 84

Bovine tuberculosislegislation with reference to. 1901

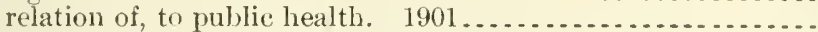

Butter making, recently patented process of.................

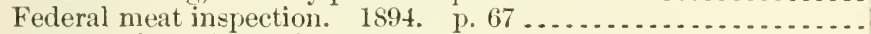

Food products from diseased animals. p. 250 ...............

Foot-and-mouth disease, warning to all owners of eattle, sheej,

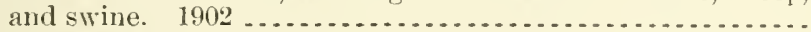

Fowl cholera, prevention of. 1881. p. $314 \ldots \ldots \ldots \ldots$

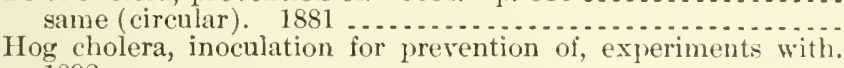
1892

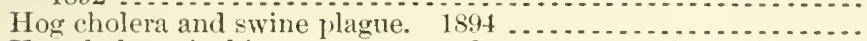

Hog cholera; its history, nature, and treatment, as letermined by inquiries and investigations of Bureau of Animal Industry. 1889

Hog fever, investigation of, in North Carolina. p. $432 \ldots . . . . .$.

Live stock, loreign and interstate shipments of, Federal inspection

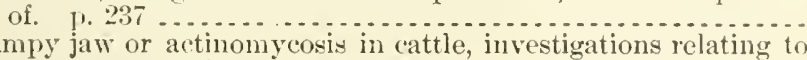

Lumpy jaw or actino 1593. 1. 109

1893

1894

Mexico as market for pure-bred jecf cattle from U, 1902

Pathological conditions found in meat inspection. 1\%.52 ......

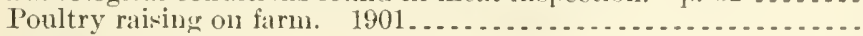

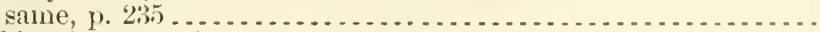

Rabies, its cause, frequency, and treitment. 1900. p. 211 . . . .

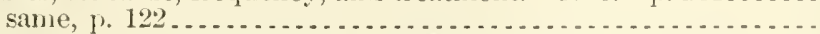

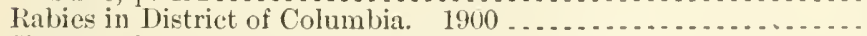

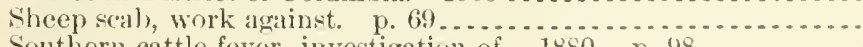

Sonthern cattle fever, investigation of 1880 p. p. $98 . . . . . .$.
Swine plague, fowl cholera, and sonthern cattle fever, investiga-

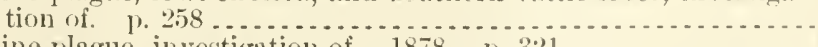

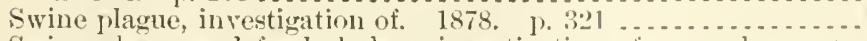

Swine plague and fowl cholera, investigation of, senol report.

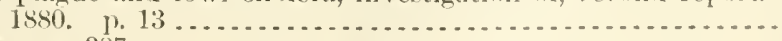

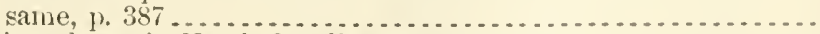

Swine plague in Jorth Carolina. 1879. p. 123............. Texas cattle fever and fowl chulera, investigation of. 185:3. 1). 18.

Trichiniass, extent of, in America and Europe. p. 775 ....... same. 1854. p. 269 
Salmon, Daniel Elmer-Continuer

Tuberculin test for tuberculosis.

Tuberculin test of importer cattle. $1901 \ldots . .$.

1901. p. 581 .................

Tuberculosis of animals in some of its relations to human tuberet-

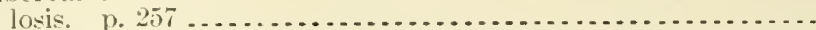

Wheat as food for growing and fattening animals, n. d .........

See also, for report as Chief of V'eterinary Division, Agriculture Department, 1883; for reports as Chief of Animal Jndustry

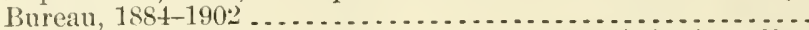

Salmon, Daniel Elmer, and Smith, Theobald. Cattle, infectious dis-

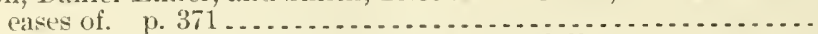

Salmon, Daniel Elmer, and Stiles, Charles Wardell:

Cattle ticks (Ixodoidea) of Uniterl States. p. 380..............

Sheep scab; its nature and treatment. p. $98 . . . . . . . . . . .$.

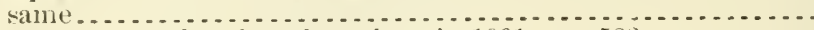

Sheep scab, results of work against, in 1901 . p. $583 . \ldots . . . . .$.

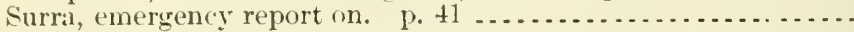

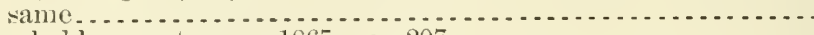

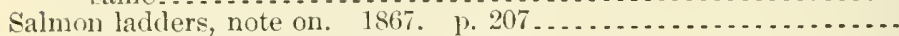

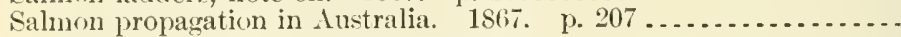
Salt:

Dairy, study of various brands of (Lawson). 1899. p. 28. . . . . . Influence of salt and similar substances, on soil moisture (Beal).

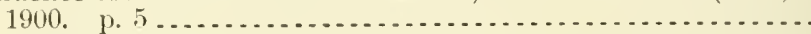

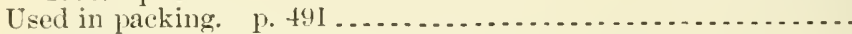

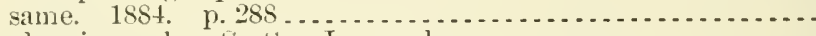

Salt and resin wash. See san Jose scale.

Salt Lake Valley, Utah. Soils of (Gardner and Stewart). n. d ...

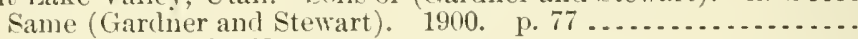
Salt-marsh hay. See Hay.

Salt-marsh lands, reclamation of (Means).

Salt marshes, grasses of (Scribner). 1895, p. $325 \ldots$

Salt River Valley, Arizona:

Irrigation investigations in, 1900 (Code). 1902. p. 83 same, 1901 (Code). p. 51 .... p.

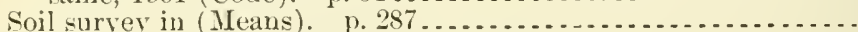

Saltuushes:

Commercial, seeds of (Collins). 1901

Report on (Kennedy). 1900. same (Smith). $1896 . .$.

Salted meats. See Meat-Pork.
Salts:

Dissolyed, influence of, on capillary rise of soil waters (Briggs

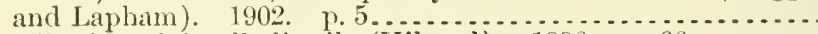

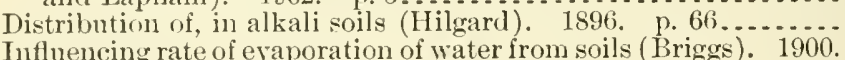

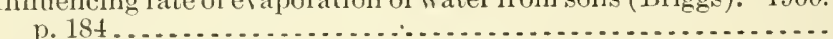

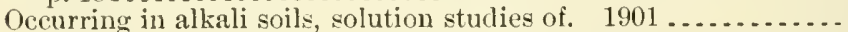

Salviate, F. de. Dairying, cooperative, in Sweden; translated by

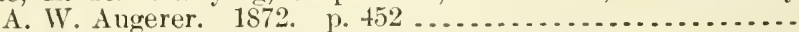

Sammis, J. L. See, as joint author, Grindley, H. S.

Samuels, Edward A.:

Birds on farm, value of. p. 201

IIammalogy and ornithology of New England, with reference to

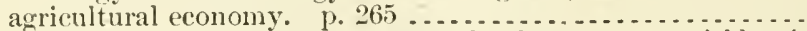

Oology of some land birds of New England as a means of itlentifying injurious or beneficial species. I. $386 \ldots . . . . . . . . .$.

San Benito Island, Mexico, list of plants collected by Edward Palmer at, in 1889 (Tasey and Rose). 1890. p. 20 ..............

San Bernarlino County, Cal., forests of (Kinney). 1888 . p. 198.. San Bernardino Valley, Cal., studies of sulsterranuan water supply of, and its utilization (Hilgard). 1902. p. $103 \ldots \ldots . . . . . .$. Sanborn, J. IV. Soil physics, relation of tillage to. 1891 . p. $97 \ldots$ Samborn, T. F. Sorghum-sugar experiments at Medicine Lodge, Kans. 1889 . p. 77.

See ulso, as joint author, Carr, Oma.

A1.10:901

A $+.3: 32$

A $4.1: 901$

A $4.4: 2$

A4.1:

$\mathrm{A} 4.2: \mathrm{C}_{2} 9^{2}$

A $4.1: 900$

A $4.1: 897$

A $+.3: 21$

\t.1:901

A 4.1:901

A $4.3: 42$

127.9:5

A $27.9: 5$

A1.9:107

A1.9:114

At.1:854

A4.2:An 5

A26.4:4

A1.8:64

A26.4:8

A1.10:895

A 10.3:104

A 10.3:119

A26.5:900 1

A6.3:27

A1.9:105

A3.4:3

A26.3:19

A10.3:30

A1.8:64

A26.3:18

A27.9:10

A1.1:867

A 1.1:863

A 1. 1:S64

A6.5:1

A13.3:2

A 10.3:119

A 10.5:3

A7. $3: 26$ 
Sand:

Drifting, French experiments in fixing. 1875. p. 520 ....... A27.9:13

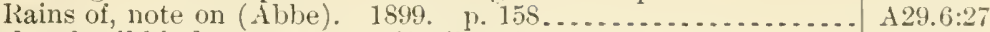

Sand and soil binders, grasses as (Scrilmer). 1894. 1. 421 ...... $11.10: 894$

Sand-binding grasses (Scribner). 1898. p. 405 . . . . . . . . . . . ... A 1.10:898

Sand blizzard, note on (Ablue). 1895. p. 381

Sand cultures, methods of, at Bernburg Experiment Station (Helirie-

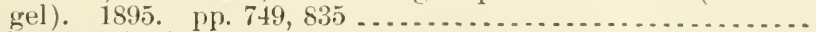

Sand dunes and wind, notes on (Abbe). 1901. 1. 176 .........

Sand hills of Nebraska, flora of (Rydberg). 1895. 1. 133......... Sanrl vetch. See Vetch.

Saniberg, J. H. „ee, as collector, Holzinger, John II.

Sanclers, J. H.:

Hamburg international exhibition, 1883, report of. p. $371 \ldots .$.

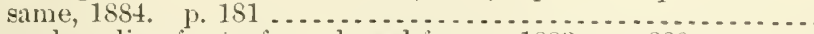

Horse breeding for turf, road; and farm. 1883. ए. $229 \ldots \ldots . .$.

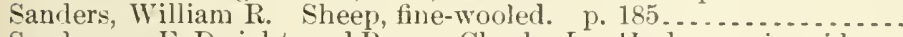

Sanderson, E. Dwight, and Penny, Charles L. 11 ydrocyanicacill gas as insectieide on low-growing plants, 1900 . p. $60 \ldots \ldots . .$.

Sanderson, E. Dwight:

Aphids of apple, pear, and quince. 1902. p. 123...........

Delaware-

entomological notes from. 1902. p. 97 .

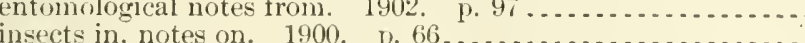

San Diego, Cal.:

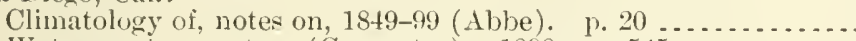

Waterspout, report on (Carpenter). 1S98, p. $545 \ldots \ldots \ldots \ldots . .$.

San Diego County, Cal.:

Coleoptera observed in, notes on habits of some species of (Blais-

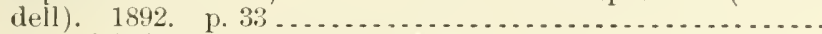

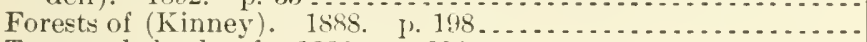

Trees and shrubs of. 1888. p. $202^{\circ} \ldots \ldots \ldots \ldots$

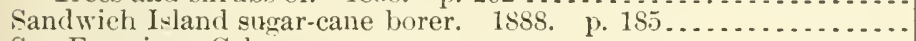

San Francisco, Cal.:

Climate of (McAdie). 1899

Coecidie, some found by Alex. Craw in course of his quarantine

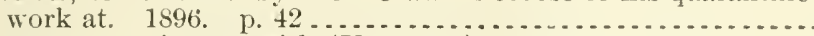

Kites at, experiments with (Hammon). 1896. p. $288 \ldots \ldots . .$.

Meteorological olsservations of , 1893-94 (Featherstone). p. 128..

Port of, scale insects found upon plants entering, list of (Craw)...

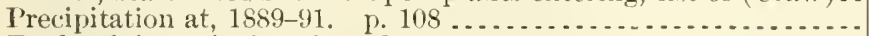

Trade of, in agricultural products, $1864-65$. No. 6 . p. 28......

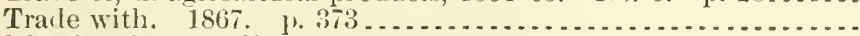

Weather forecast district, report of-

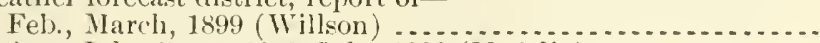

A pr.-July, Sept., 1899-July, 1900 (MeAilie) ................

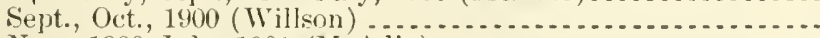

Nov., 1900-July, 1901 (MeAdie) .........................

Sept.-Nov., 1901 (McArie) . . . . . . . . . . . . . . . . . . . .

Jan.-Oct., 1902 (McAdie) .............................

San Franeisco mountain region:

Arizona-

biological survey of, results of (Merriam). 1890

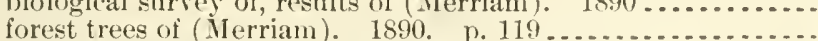

Reptiles and batrachians of (Stejneger). 1890 . p. $103 \ldots . . .$. San Gabriel area, California, soil survey of (Holmes and Mesmer).

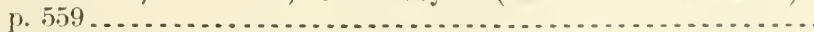

Sanger, J. I', address of, before convention of National I,eague for Grod lioarls, Washington. 1893. p. $69 \ldots . . . . . . . . . .$.

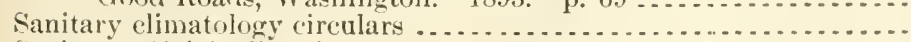
Sanitary officials, list of:

1898. 1. 616

1899. I. 698

1900. \%. 6.5.3

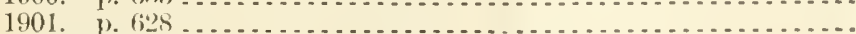

At.1:88t

A4.2: $\mathrm{An} 5$

1 1.7:2

A1.1:S6t

A $9.6: 26$

A 10.3:115

A9.6:37

A9.6:26

A 29.6:28

A29.6:26

19.7:5

A13.3:2

A 13.3:2

19.7:1

ג29.3:2s

A9.8:4

A 29.6:24

A29.6:2:

19.8:

A $29.6: 20$

A27.9:3

A27.9:5

A29.6:27

129.6:

129.6:28

A29.6:

129.6:29

А29.6:30

A.5.5:3

A $5.5: 3$

A5. $5: 3$

A26.5:901 2

110.3:14

129.15:

A1. 10:898

11. 10:899

11. $10:(1)(0)$

A $1.10: 90 \mathrm{I}$

113.3:7 
San Jacinto River, Cal., problems of water storage on torrential streams of southern (alifornia as typified by (Schuyler).

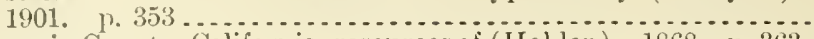
San Joaquin County, California, resources of (Hollen). 186s. p. 363. Sin Joaquin River, Cal., irrieration from (Soulé). 1901. p. 215 ... Sin Joaquin Valley, California, locusts of (Coquillett). p. 289 ..... Say Jose or pernicious scale:

Aphelinus fuscipeunis, an important parasite upon, in Eastern

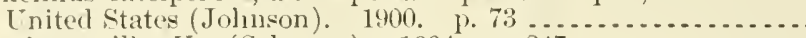

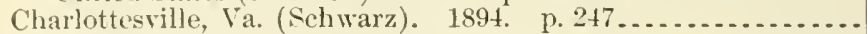

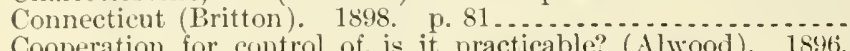
Cooperation for control of, is it practicable? (Alwood). $1896^{\circ}$.

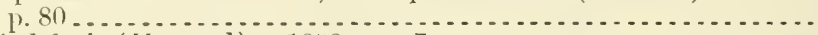

Dried fruit (Howard). 1848. 1. 7 ......................

Fastern United States, aplearance in, and measures taken to prevent its spread anrl to destroy it (Howarl). $1893 . . . . .$.

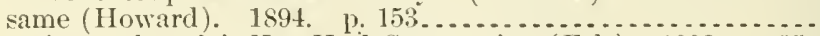

Experimental work in New York State against (Felt). 1902. p. 3.5. Experiments with winter washes against, season of 18.44-9.5

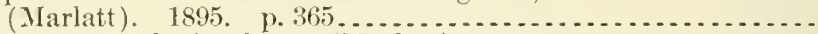

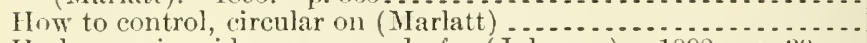

Hydrocyanic-acid gas as remedy for (Johnson). 1898. 1. 39 ... Insecticides for, various, some practical experiments with, in

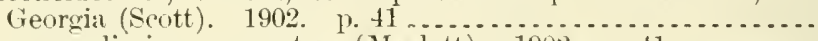

Japan, preliminary report on (Marlatt). 190:. I. $41 \ldots \ldots . . .$.

Lime, sulpluur, and salt and resin washes for, use of, in Ohio

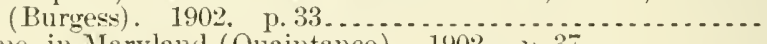
same, in Maryland (Quaintance). 1902. y. $37 \ldots \ldots \ldots \ldots$

Michigan, present status in (Barrows). 1897. p. $27 \ldots \ldots . . . .$.

Native home of, résumé of search for, in Japan and China (Mar-

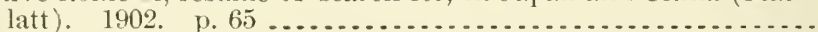

New Jersey (Smith) -

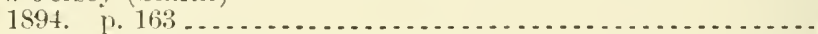
1898. p. $32 \ldots$

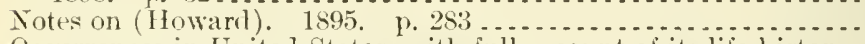

Occurrences in United States, with full account of its life history and remedies to he userl against it (Iloward and Marlatt)....

Original home of (Howarl and Marlatt). 1899. p. $36 \ldots . . . . .$. Rejort on1894 P. 360 .....

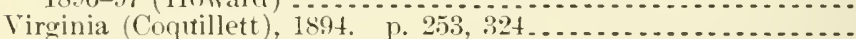
San Jose scale and its nearest allies (Cockereli). $1897 \ldots \ldots . . . . . .$. Sall Juan, Porto Rico, temperature, rainfall, and humidity at

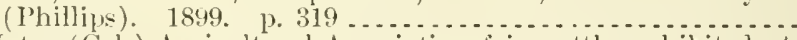

San Mateo (Cal.) Agricultural Association fair, cattle exhibited at,

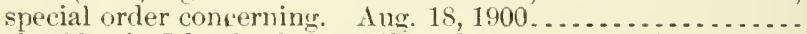

San Pedro Martin Island, plants collected at, by Elward Palmer in 1890, list of (Vasey and Rose). 1890. p. TS...............

Sanpete County, Ltah, soil survey in (Means). 1900 . p. 115 ..... Santa Agueda, Lower California, plants collected by Edward Palmer in 1890 at, list of (Vasey ancl Rose). 1890. p. 80 ........

Santa Ana, Cal., soil survey around (IImes). p. 385 . . . . . . . . .

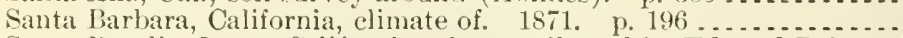

Santa Rosalia, Lower California, plants collected by Edward Palmer in 1890 at, list of (Vasey and Rose). 1890 . p. $80 \ldots \ldots . . .$. Santillan, Rafael Iquilar y. See Aquilar y Santillan, Rafael........ Santo Domingo, plants from. 1870. p. 283 ................

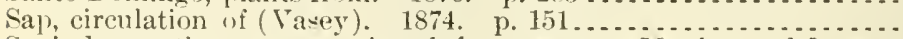
Sapindaces, three new species of, fron western Mexico and Lower

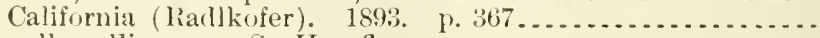
Sarcopsylla gallinacea. See Hen flea.

Sarcoptidie, parasitism among, origin and development of (Gar-

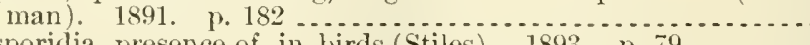
Sarcosporidia, presence of, in birds (Stiles). 1893. p. 79....... Sargent, A. A. Viticulture in California. 1882. p. 157 ......... Sargent, C. S. Raiufall and charts of rainfall. 1902. p. $227 \ldots .$.

A 10.3:100

A $27.9: 6$

A $10.3: 100$

A1.1:885

A $9.6: 26$

A9.7:6

\9.6:17

A9.6:6

A9.6:18

19.5:3

19.7:7

A9.6:37

A9.7:7

A9.5:42

A9.6:17

A9.6:37

A9.6:31

A9.6:37

A $9.6: 37$

A9.6:9

A9.6:37

A9.7:7

A9.6:17

19.7:7

19.6:3

A9.6:20

A9.7:6

A9.6:12

A9.7:6

A9.8:6

А 29.1:898

A 4.5:69

A6.5:1

A. 1.64

A6.5:1

A26.5:900

A 27.9:9

A6.5:1

127.9:8

A27.9:12

A6.5:1

A9. $7: 4$

A $4.3: 3$

A1.8:22

A29.6:30 
Sartori, Giuseppe. Dubernaml method for examination of butter.

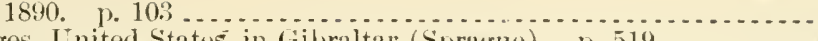

Sausages, United States, in Gibraltar (Spranue), p. $519 \ldots \ldots \ldots \ldots$.

Sausalito, California, storm wave at (Abbe). 1895. p. $424 \ldots . . .$.

Saunders, William:

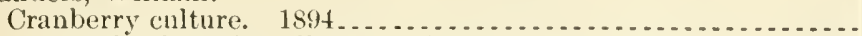

Economic plants in collection of Agriculture Department, cata-

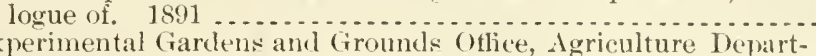

Experimental Gardens and Grounds (othee, Agriculture Depart-
ment, work of, for farmer. 1897. p. $180 \ldots \ldots \ldots \ldots . . . .$.

Garden, notes of the-

1871. p. 476

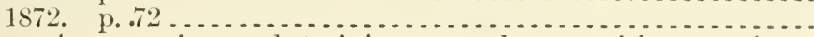

Grapevine, pruning and training, remarks on, with quotations

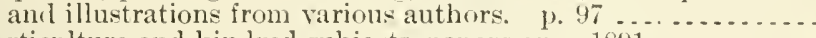

Horticulture and kindred subjects, papers on. $1891 \ldots . . . . . .$.

Participation of Agriculture Department in Philadelphia Inter-

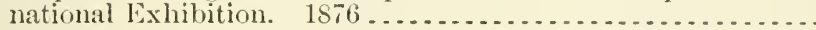

Plants, bulbs, tubers, ete. for clistribution from U. S. propagating garden, catalogue of, with report on olject and aims of gar-

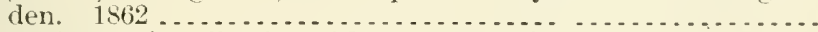

Plants in exotic collection of Department of Agriculture, ilecrip-

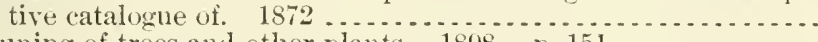

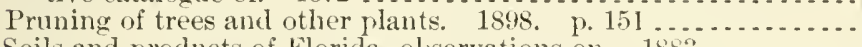

Soils and products of Florida, olservations on. 1853 .........

Tea culture, experiment in, report on tea garlens of Dr. Charles

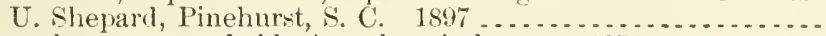

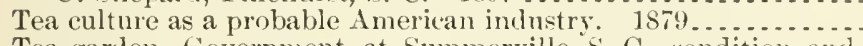

Tea garden, Government, at Summerville, S. C., condition and

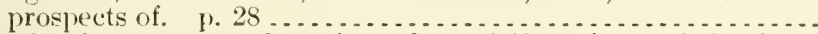

See also, for reports as Superintendent of Experimental Garlen, 1862-1867; and as Superintendent of Gardens and Grounds, 1868-1899 . . . . . . . . . . . . . . . . . . . . . . . . . . . . . . . Saunders, William, sketch of life of (Hili) 1900 . 1. $625 \ldots \ldots .$. Saw-fly:

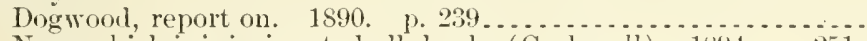

New, which is injurious to hollyhocks (Cockerell). 1894. p. 251.

Rose, in Uniter States (Riley). 1892. 1) 6..............

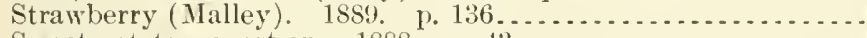

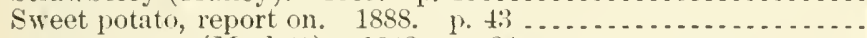

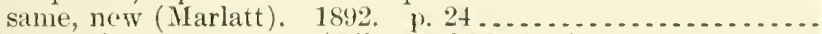

Wheat and grass, notes on (Riley and Marlatt). 1891. p. 168..

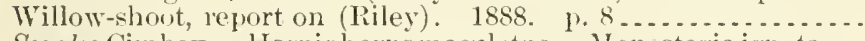

See also Cimbex - Harpiphorus maculatus - Nonostegia ignota Nematinre-Pear she - Sweet potato saw-Hies - Wheat sawflies.

Saxony:

Beef and pork in, consumption of. 1887. p. $591 \ldots \ldots \ldots \ldots \ldots$

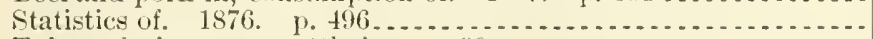

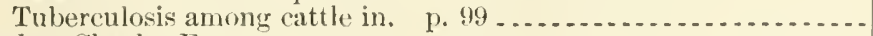
Saylor, Charles F.

Beet-sugar inclustry of United States, report as special agent-

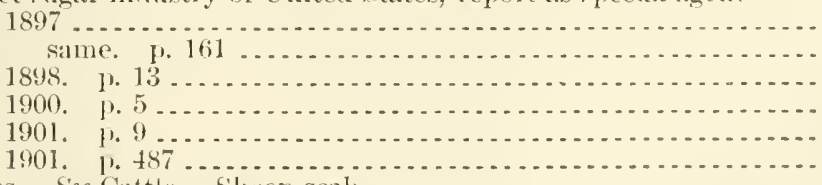

Scabies. See Cattle-Siheep scab).

Scale. See also Red sale.

Scale insects:

American fruit imported into Germany (Rel). 1900). 1\%. 74 . . .

California, report for 1891 (Coquillett). p. 13 . . . . . . . . . . . .

Destroying, various methods for, report on (Coynillett)-

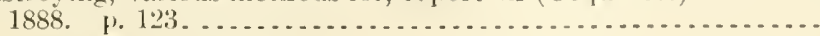

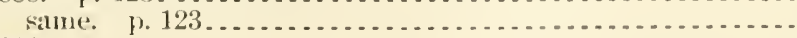
1890. 1) 19

A $27.9: 25$

1 $27.9: 14$

$14.1: 893-4$

11.2:13:392

A $1.2: 13: 39^{1}$

A 1.2:13:394

11.8:(5)

11.8:72

11. 10:901

19.6:2:3

19..3:26

11.1:888

19.1:888

19.3:23 
Scale insects-Continued

Enemies in California (Smith). 1896. p. 46.

Enemy of cituus trees (Marlatt). 1900. 1. 247

A9.6:6

(1....................

\$1.10:900

Experiments on, progress in, ete. (Hubbarl). p. 152........

A1.1:SST

1 $1.1: 883$

Found upon plants entering port of Sin Francisco, list of (Craw), 1896. 1. 40 . . . . . . . . . . . . . . . .

19.1:S83

A9.8:t

Gas treatment for, report on (Coruillett) -

1857. p. 123

sane. 35

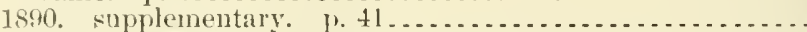

Hydrocyanic acid gas treatment for, history of (Coquillett). 1891. 1. 457 . . . . . . . . . . . . . . . . . . . . . . . . . .

Important, two, parasites of (Howarl). 189t. p. $5 \ldots . . . . . .$. Injurions, danger to American horticulture from introduction of

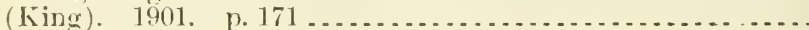

New, from California (Coquillett). 1891. p. 382............

New and old, notes on (Johnson). 1896. p. 74 ............

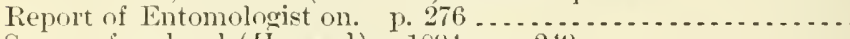

Some, of orchard (Howard). 1894. p. 249 ................

Temperature control of (Marlatt). 1899. p. $73 \ldots \ldots \ldots \ldots \ldots \ldots$

Useful American (1Ioward). 1897. p. 38...................

See also Aleurorlida - Aleyrodes - Aspidiotus ostreseformis -

Blackscale - Coccicle - Coccids - Cottony cushion-scale Date-palm scale - Eimeria stieda - Eimeriella - Fluted scale - Icerya - Jamaicau coccirla - Japanese coccilie Lecanium - Maple pseudococeus - Mytilaspis pomorum Orange - Peach lecanium - Peach-tree scale - Red scales San José scale.

Scandinavia:

Agricultural education in, notes on (Woll), 1897, p. 7 .......

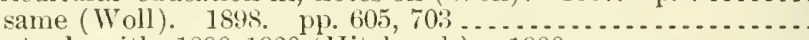

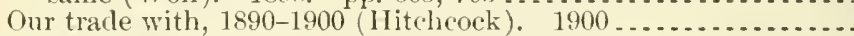
Seed-control stations in, report on (Wull). 1899. p. $4 \ldots \ldots \ldots .$. Seatehkow, K. Jocusts in China, extermination of. 1853. App., ple, Ch. Ega sales of Paris, 1896 ; translated by Newton B. Asliby. 1. 339

Scepsis edwardsii, preparatory stages of (Dyar) 1890.0 .360 Scheffer, Theo H. Twig giriler, notes and observations on. 1895. p. 345

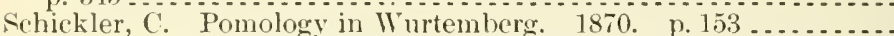
Schipps, K. Halo phenomena, observation of. 1897. p. 294..... Schizoneura panicola thos. and S. corni fab. identity of (Osborn). 1889. p. 108 .

Sehloesing's methor. See Nitric acid in soils.

Schmidberger, - Pear midge, habits of. p. 286.

Schmoger-Nenbert. Estimation of content of fat in milk by

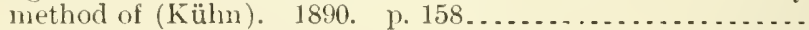

Schokalsky, Jules de. Ladoga Lake, from thermic point of view.

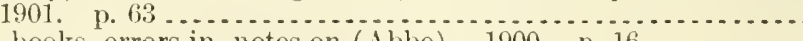

School hooks, errors in, notes on (Abbe). 1900 . p. $16 \ldots \ldots . . .$. Schools:

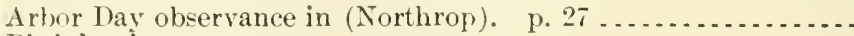

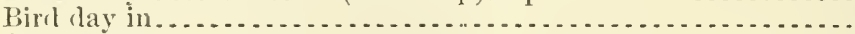

Common-

agrrienlture in. 1868. p. 92 .

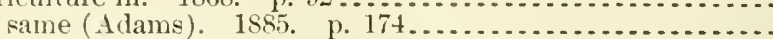

as affected by roads (Abercrombie). 1902 . p. $39 \ldots \ldots \ldots \ldots$

Meteorology and relation of (Kimball). 1902. p. 131 .........

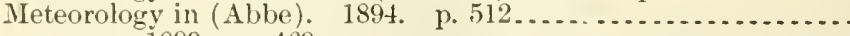

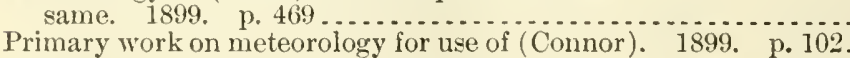
Public-

how may farmers' organizations hasten teaching of agriculture in? (Voorhees). 1902. p. 89.

110.4:32

A 10.6:9

A $12.3: 22$

1 $10.6: 10$

A8.1:3

14.1:899 19.7:2

19.7:7

127.9:8

A $29.6: 25$

A9.7:2

A1.1:885

A7.3:24

A $29.6: 29$ A $29.6: 28$

A1.8:56 A5.4:17

A27.9:6

A 1.7:9

A 22.3:23

A $29.6: 30$

A29.6:22

A 29.6:27

A29.3:24

A $10.3: 120$ 
Public-Continued

meteorological observations at, notes on (Abbe). 1899. ]).

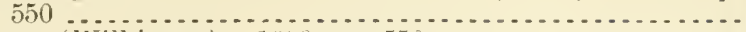

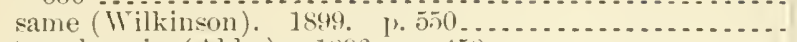

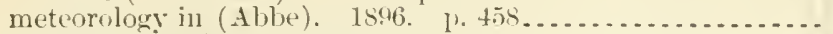

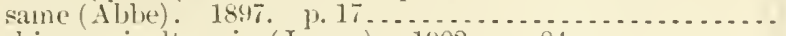
teaching agriculture in (James). 1902. p. $84 \ldots . . . . . . .$. Rural-

agriculture in (Powell). 1902. p. 109 ................... grounds of, tree planting on (Hali). 1901 ................. Technical, mechanical, drawing in (Flather). 1894. p. $81 . . .$. See also Agricultural colleges - Technical schools - Weleh, A.s. Schott, Charles Anthony:

Magnetic survey of North America. 1895. p. $460 \ldots . . . . . . . .$.

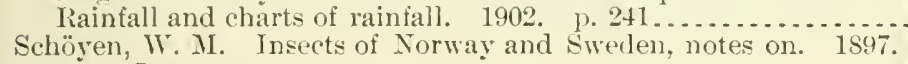

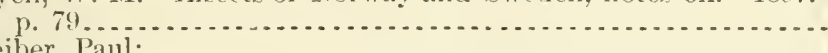
Schreiber, Paul:

Ieteorological observations considered with special reference to

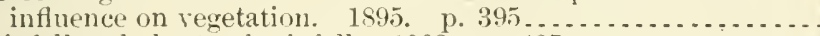

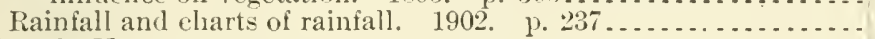
Schrenk, Hermann yon:

Catalpa, hardy, cliseases of. 1902. p. 49 . . . . . . . . . . . . . . . .

Fungous diseases of forest trees. 1900. p. 199

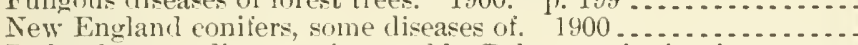

Red cerlar, two diseases of, caused by Polyporus juniperinus n. sp. and Polyporus earneus nees, preliminary report. $1900 . . . .$.

Timber, decay of, and methods of preventing it. 1902 ..........

Schrodt, MI. Specific gravity of cow's milk, limits of. 1888. p. 154 . Schroeder, Ernest C.:

Blood and serum injections in connection with Texas fever inves-

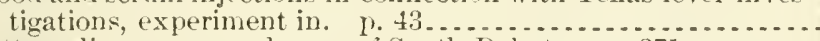

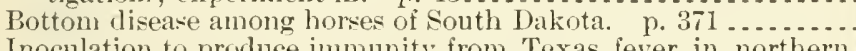

Inoculation to produce immunity from Texas fever in northern cattle. 1. 273

Southern cattle tick, vitality of. p. $^{2}+1$.

Texas fever organism, persistence of, in blood of cattle. p. $42 \ldots$

Tubercle baeilli in milk of cows, experimental observations on

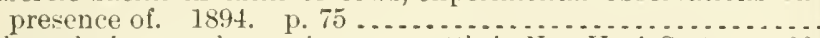

Tuberculosis, prevalence of, anong eattle in New York State. p. 66.

See also, as collaborator, De Schweinitz, Emil Alexander; as joint author, Kilborne, F. L.- Smith, Theohald.

Schroeder, Ernest C., and Cotton, W. E. Sonthern cattle ticks, growing noninfecter and afterwarls infecting them with

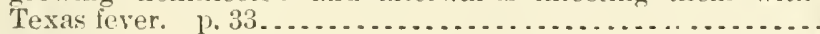

Schulte, J. I.:

Grains, tillering of. 1899 p. $10 \ldots \ldots \ldots \ldots \ldots \ldots \ldots \ldots \ldots \ldots$

Tobacco, work of agricultural experiment stations, with introrluction and comments by Milton Whitney, $1900 \ldots . . . . . . . . .$.

Schultz, L. G. Sky polarization, sturly of, with reference to weather

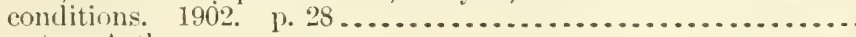
Schuster, Arthur:

IIathematical analysis as applied to terrestrial magnetism, pres-

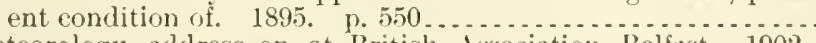

Meteorology, address on, at British Association, Belfast. 1902.

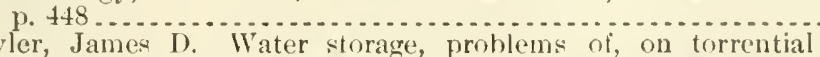
streams of southern California as typified by Sweetwater and

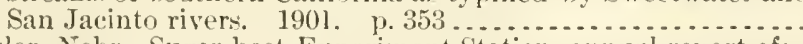
Schuyler, Nebr., Sugar-beet Experiment Station, annual report of:

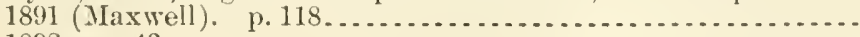

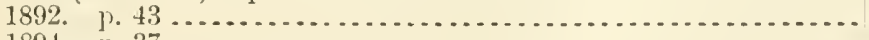

1894. p. 37 .

Schwarz, Eugene Amandus:

Cicada, periodical, in 1897 , circular on ................. $19.5: 22$

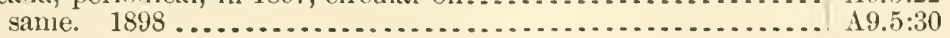

A29.6:27

A $29.6: 27$

129.6:2:3

$129.6: 25$

110.3:120

A10.3:120

A $1.9: 134$

A10.3:20

A $29.3: 11^{2}$

A29.6:30

A9.6:9

A29.3:112

A 29.6:30

A13.3:37

A1.10:900

A28.3:25

A28.3:21

A19.3:14

A 7.3:24

A4.1:899

A4.1:891-2

At.1:898

A4.1:899

At.1:899

A 4.3:7

A 4.1:893-4

At.1:899

A 1.9:105

A1.8:63

A29.3:31

A29.3:112

A29.6:30

A 10.3:100

A7.3:33

A7.3:37

A7.3:39 
Schwarz, Eugene Amandus-Continued

Cotton-worm question in 1894 . 1. 315

Crow, insect foorl of. 1895. p. 57.

Eumieus attala, notes on. 1888. p. 37.

Hippelates plague in Florida. 1895. p. 374

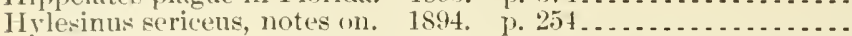
Insects living on or injurious to the cotton plant in Jahama Islands. 1878. p. 347

Library pest, imported, report of. 1895. p. 396 . . . . . . . . . .

Red-legged flea-beetle, its injuries to orehard trees in Maryland

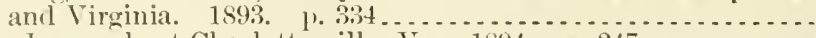

San Jose scale at Charlottesville, Va. 1894. p. $247 \ldots \ldots \ldots \ldots .$.

See also, as translator, Reh, I.

Schweinitz, Emil Alexanter, de. See De Schweinitz.

Schweitzer, Jaul, and Fox, Charles P. Neat analysis-testing of

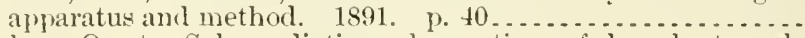

Schwolson, Orest. Solar radiation, observations of; how best made

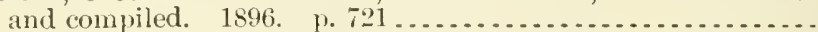

A9.7:7

A5.3:6

19.7:1

A9.7:7

A9.7:7

19.2:C82

A9.7:7

19.7:5

A9.7:6

Science:

Applied, as a factor of rural production. 1855. No. 20. p. 31 ..

Puetry (Able). 1902. p. 269.........................

True relations of, to industries and arts (Wiley). I'. $32 \ldots \ldots . .$.

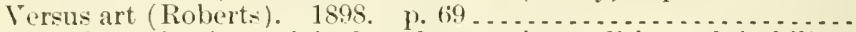

scientific investigation, original, under certain conditions advisal)ility of supplying employees of Weather Bureau with apparatus for

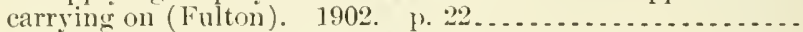

Scientific investigators, training needed to become, notes on (Abbe).

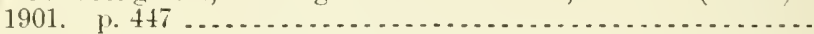

Scientific organizations, relations of weather officials with, how promoted (Beals). 1899. p. 69 ........................

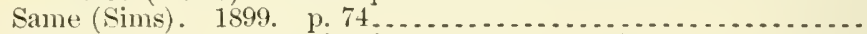

Scientific research, instruction in, notes on (Abhe). 1898. p. 413..

Scientific work of Agriculture Department, recommendation for appointment of director in chief of, etc . . . . . . . . . . . . . . .

Sclerolerma, genus, in Saccardo's Sylloge (Ellis) 18s9. p. 23....

Scofield, Carl S. Algerian durum wheats, classified list, with lescrip-

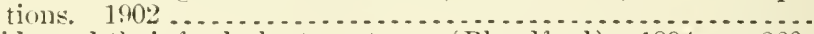

Scolytidie and their food plants, notes on (Blandford). 1894. p. 260.

Scolytids, destructive, and their imported enemy (Hopkins). 1893.

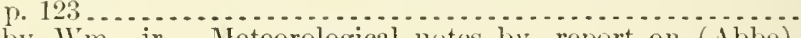

Scoresby, Wm., jr. Meteorological notes by, report on (Abbe).

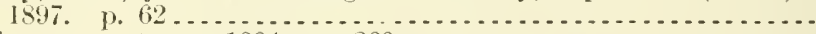

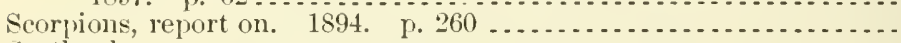
Seotland:

Acriculture and dairying in (Higrins). p. 213

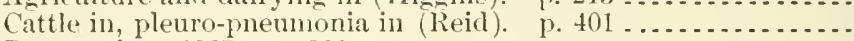

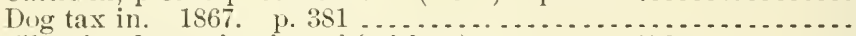

Fiber in, determination of (Aitken). 1894. p. $172 \ldots \ldots . . . . .$.

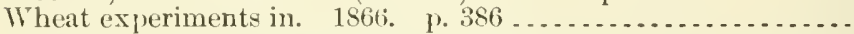

See also Ben Neris observatory - Elinbu rgh.

Scott, John. Beef, breeding and feeding for, and supplying market.

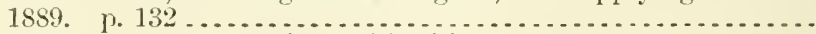

Scott, Martin I'. Jawes's views of fertility. $1883 . \quad$ p. $76 \ldots \ldots \ldots$. Scott, Robert H.:

Paris, international meteorological conference at. Sept., 1896. p. 333 . . . . . . . . . . . . . . . . . . . . . . . . . . .

Weather maps and bulletins, daily, jublication of. 1894 p. 6 .

Scott, Robert W. Kentucky sheep, improved. p. $334 \ldots . . . . . . . .$. Scott, W. H. College faculty meetings, 1895. p. $80 \ldots \ldots \ldots \ldots$. . Scott, IV. MI.:

Aphis, new species of, injurious to plums and peaches in Genrgia,

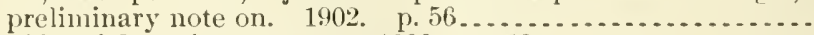

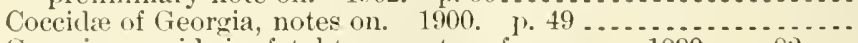
Georgia, coccids in, fatal temperature for some. 1899 . p. $82 \ldots$ San Jose scale, some practical experiments with various insecticides for, in Georgia. 1902. 1). 41

$129.3: 11^{3}$

A $27.9: 23$

A29.6:30

$11.7: 2$

A10.3:49

A29.3:31

A29.6:28

A29.3:24

A29.3:24

+29.6:26

A1.2:Sci1

A28.5:5

A19.3:7

A9.7:6

A9.7:6

A29.6:25

A $9.7: 7$

A4.1:898

A 4.1:889-90

A $27.9: 5$

A7.3:43

A27.9:4

A1.7:2

A1.7:2

A.9.6:24

129.3:11

A1.1:\$66

A 10.3:24

A9.6:31

A9.6:26

19.6.20

A9.6:37 
Scott, W. M., and Fiske, WT. F. Curculio, jarring for, on extencive sale in (ieorgia, with list of insects canglit. 1902. [.24 . . . sonel, J. V. H. Potatoes, experiments with. 1874. p. $331 \ldots 1 . .$. scovell, Melville Amasa:

Address of, as president of Association of Otlieial Agricultural Chemists, at serenth annul conrention. $1890 . \quad$ I. $6 . . . . .$.

Burley tolbaco, its growing and curing. 1901. p. 106.........

Cows, testing as to milk and butter prorluction, some notes in

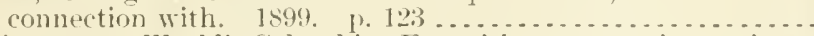

Dairy tests at World's Columbian Exprosition, report of committee

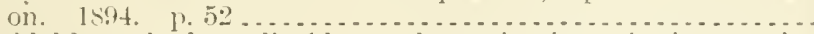

Kjeliahl method applicalile to determination of nitrogen in

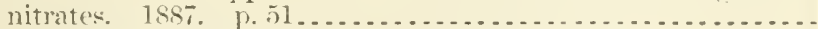

See also, a collalonator, Wilev, Ilarver Washington.

Scovell, Melville Amasa, Peter, Alfred Meredith, and Curtis, H. E. Fertilizers, potash in, report on some sources of error in de-

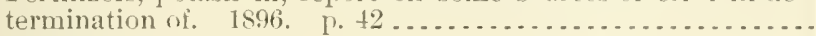
Screech owl. See Owl.

serew wolm, hominivorous haljits of, in st. Lonis, Mo. (Murtieldt).

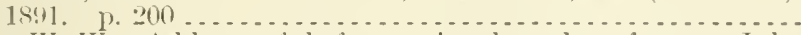
screws, IV. WT. Ailiress of, before national road conference, July,

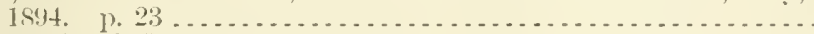

Scribner, Frank Lamson-:

Agrostology, economic and scientific, progress of. 1s99. 1. $347 .$.

Agrostology Division, Agrienlture Department-

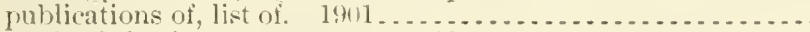

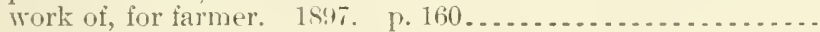

Imerican grasses, report on ...

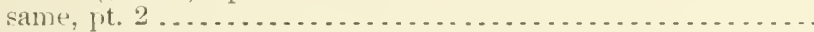

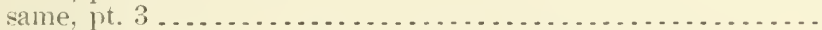

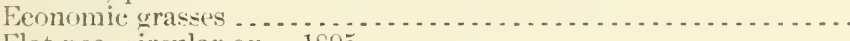

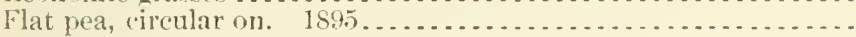

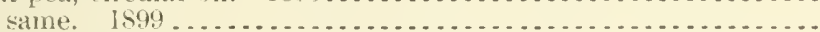

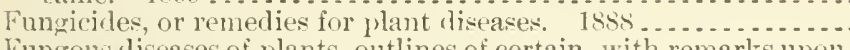
Fungous diseases of plants, outlines of certain, with remarks upon apjlication of remedies. p. 76.

Giant knotweed, or sachaline, circular on. 1895.

irapevine-

black-rot and brown-rot of, extent, sererity, and treatment of,

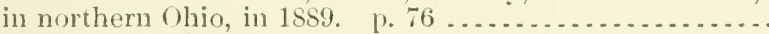

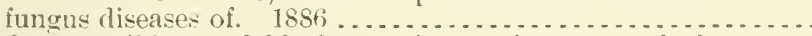
downy mildew and black-rot of, experiments marle in treatment of, 18s7, with chajter on aplaratus for applying remedies for these liseases.

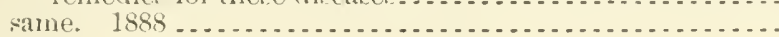

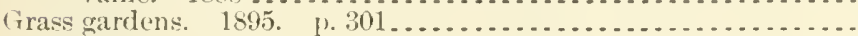

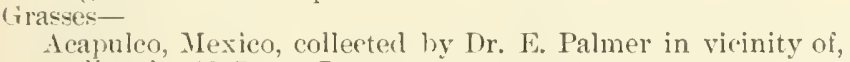

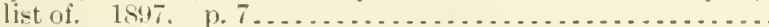

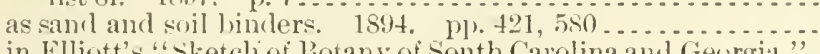
in Elliott's "sketeli of liotany of South Carolina and Georgia,", notes on. 1901.

new or little kunwn, description of1897. I. 5 .

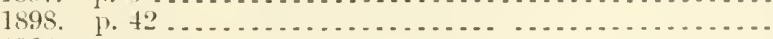

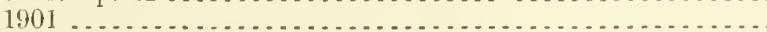

of salt marshes. 1sis. p.

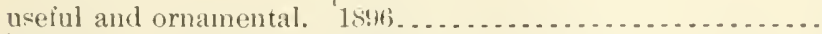

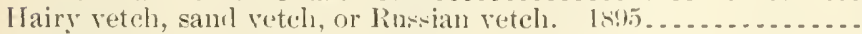
Ilungarian brome grass, circular on. 1894 ................

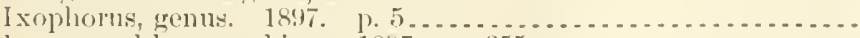

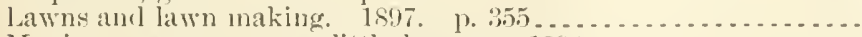
ILexican grasses, new or little known. 1ssy .............. Torth American grasses, new speriess of. Feb., 1 sig . . . . . . . same, June, 1899 . . . . . . . . . . . . . . . . . . . . . . . . . .

Pacific roast, grass anl forage plant investigations on. 1899 . . . .

Pasture plants, our native, 1900 . p. $5 \$ 1 \ldots \ldots . . . . . . . . .$.
1:1.6:31

$127.9: 12$

$17.3: 28$

110.3:99

A 10.3:65

$110.3: 20$

$17.3: 16$

17.3:4!

A9.7:4

12.2.3:10

1 1.10:899

A. $4: 36$

1 $1.10: 897$

\$3.3:7

A $3.3: 17$

A3.3:20

A3.8:14

A6. 4:4

A $3.4: 11$

A28.4:5

11.1:885

A6.4:5

A6.3:11

A 6.3:2

Af $6.3: 5$

A6.3:10

A $1.10: 895$

A.3.3:t

A1.10:594

A:. $4: 29$

ג3.3:8

1.3.3:11

1.3. $4: 30$

A1.10:895

13.3:3

13. $4: 2$

16. $4: 1$

1.3.:3:4

1 1.10:897

1.3. $4: 19$

13. $4: 9$

A.3. $4: 16$

13. $4: 2: 2$

11.10:900

$114-04-3: 3$ 
Sclibner, Frank Lamson-Continued

Potato and tomato, treatment of, for blight and rot. $1897 \ldots \ldots .$.

lanne grass and forage plant experiments, cooperative, at High-

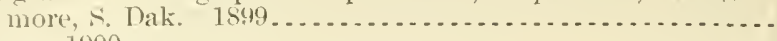

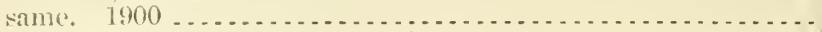

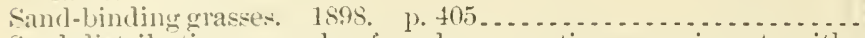
Seerl distribution, records of, and cooperative experiments witl

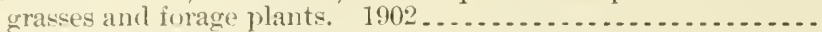

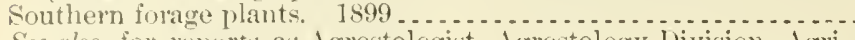
See also, for reports as Agrostologist, Agrostology l livision, Agrirulture Departme11t, 1895-1901 . . . . . . . . . . . . . . . . . .

Sce rlso, for report as Chief, Vegetable Pathology Section, Agri('ulture Department, 1887

See also, for leport as Mycologist, Agriculture Department, 18st....

Scribnel, Frank lanson-, and Ball, Carleton li. Frasses, miscel-

laneous notes and descriptions of new slecies. $1900 . \quad$ p. $39 \ldots . .$.

Seribner, Frank Jamson-, and Merrill, Elmer D.:

Calamovilfa, notes on. 1901. p. 2....................

Cluaturhloa, North American species of. 1900 ................

Grasses of herbarium of Dr. H. Muhlenberg. 1900 ............

Mexican grasses, some recent collections of. 1900. 1.5 . . . . . .

Panicnu, three new species of. 1901. p. 3.................

Panicum nitidum, Panicum seoparium, and Panicum pubescens,

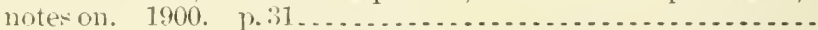

Srribuer, Frank Iamson-, ant Smith, Jared Ginge:

Hordenm and Agropyan, genera, native and introduced species

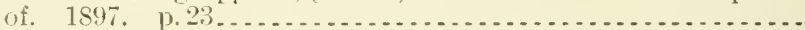

Mexican grasses eollected ly E. IT. Nelson in IIexico, 1s94-95.

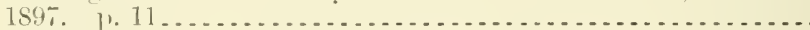

Scribner, Frank Lamson-, and Viala, Pierre. Blark rot of grapevine.

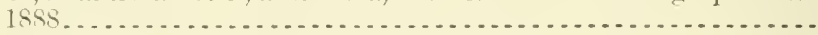

Sicudiler, sammel II. Cranberry girdler, report on. 18:4. p. 1 ....

Scuplemong wine, analysis of (Page). 1864. p.362........... Sernmus:

Australian, established anr rlescriberl in ('alifomia (Riley). 1892.

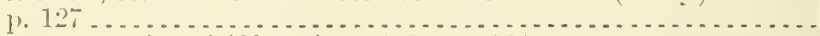

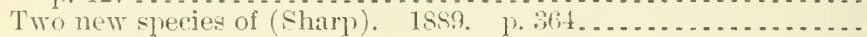
Sea:

Ball lightuing at, instanee of (Beyloth). 1901. 1. 249........

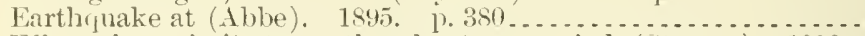

Effect of proximity to, on thunderstorm periods (stearns). 1898.

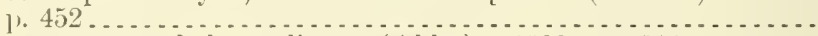

Temperature and shore climate (Albe). 1902. 1) $314 \ldots . . . . .$. Seacoast telegraph lines, instructions to operators on (Buglee). 1892.

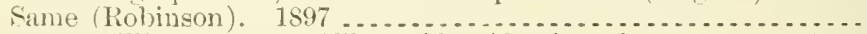

Seaman, William Henry. Fibers, identifieation of. 1897. 1. $352 \ldots$ Searehliglit:

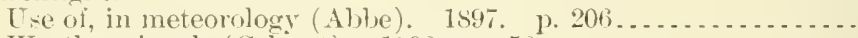

Weather signals (Caliert). 1s9s, 1) $5 s^{2} \ldots \ldots \ldots \ldots$ Seasonal forecasts:

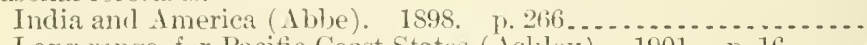

Long range, for Pacific Coast States (Ashley). 1901. p. 16......

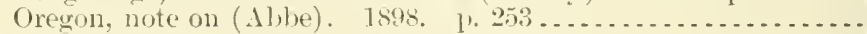
Seasons:

frood and had, periodicity of (Abbe). 1896, p. 290.........

Natural phenomena of, comnection with agrionlture (kinssili).

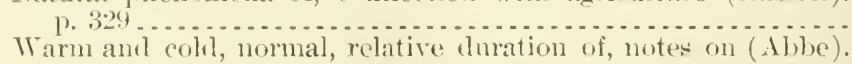

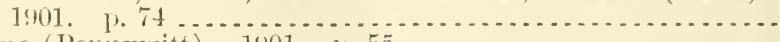

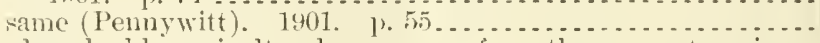
Scaweed, valuable agricultural resource of northern coast regioms (Beal). 1899. 1.5............................... Sebago Lake, Maine, temperature of watex of (Al)be), 1894. 1).507.. Srbelien, J. Albuminoids in milk, estimation of. 1889. 1). 169... Serdgwick, T. F.:

Chickens and their diseases in Hawaii. 1901 ...............

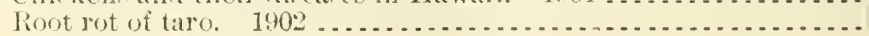

1:2:.4:-4

13.4:21

13. $4: 33$

11.10:S9S

119.3:10

11.9:102

A3.

128.1:

128.1:

A.3.3:24

A3.4:35

A3.3:21

A.3.4:27

A3.3:24

A3.4:35

A.3.3:24

A3.3:4

A3.3:4

A6.3:7

A9.7:7

A $27.9: 6$

19.7:5

19.7:1

129.6:29 A29.6:23

A 29.6:26

$129.6: 30$

A29.12:Se1 1

A29.12:Se1 ${ }^{2}$

A11.5:9

A29.6:25

A29.6:26

A29.6:26

1 $29.6: 29$

129.6:263

129.6:24

A1.1:864

A:9.6:29 A $996: 29$

A1.9:105

129.6:22

A7.3:24

A 10.9:1

A12.9:2 
Seed and Plant Introduction:

Section of, Agriculture Department, circular relative to (Cook). 1899.

Work of Agrienlture Department in, since 1897 (Smith). 1901.

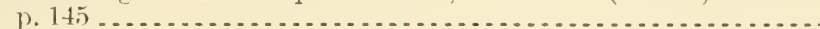

Seed crats of certain species of genus Brassica (Pieters and Charles). 1901

Seed-control stations:

Estalishment of (Burchart). 189:3. Pl\%. 79:3, 88:.

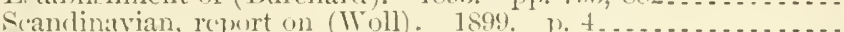

Seed Division, Agriculture Department........................

Seed wheat for Northwest, correspondence on. 1S6s. 1) 285..... seeds:

Abstracts of reports of agricultural experiment stations on, $\left.1889-190^{\circ}\right)$

Aiulteration of. 1869 . 1. 146.

Agricultural-

standards of the purity and vitality of $(11 \mathrm{i} \cdot \mathrm{k} s), 1896 \ldots . . .$.

where grown and how landled (Pieters). 1901. 1. 203.....

Agriculture Department-

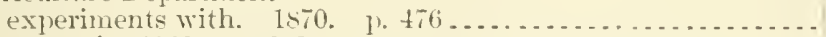

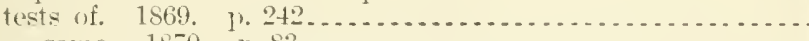
sasne. 1870. p. 8 .

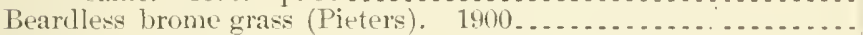

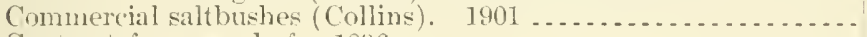

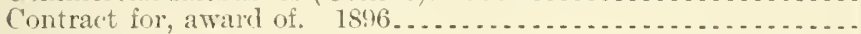

Distribution of-

circulare relative to, July 25, 189.5

reorls of and cooperative experiments with grasses and forace plants (s'rilmer). 1902.

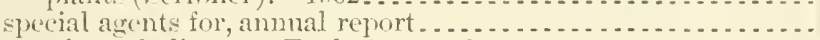

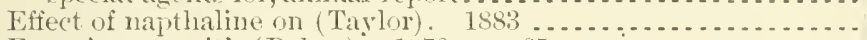

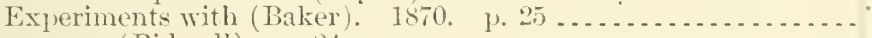
same (Bidwell). 1).24 . . . . . . . . . . . . . . . . . . . . .

Farm and garden, experiments with. 1869. p. $292 \ldots . . . . . .$.

Fiel, l-

experiments with. P. fo5.

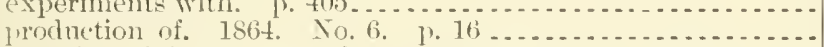

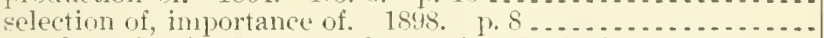

Flax culture for, in Europe and America (1)olge). 1s9s.......

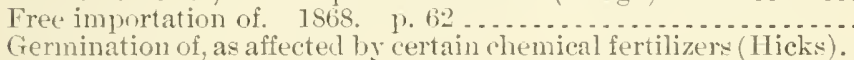
1900

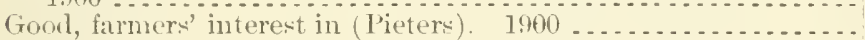

Growers of, bees of great value to (Bentoni). 1892. p. 254 ....

Investigation, olject and methools of (Burduarl), 189:3. p1. 79:3, Si:

large, heary, superior value of (Hicks and Inabner). 1896.

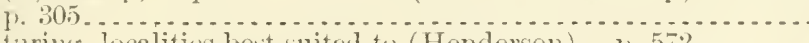

Maturing, localities best stuted to (Henderson). 1.572......

Tovelties and specialties in, distrilmtion of $\ldots . . .6 . . .6$.

Planting by hirds (Barrow ). 1. 280 . . . . . . . . . . . . . .

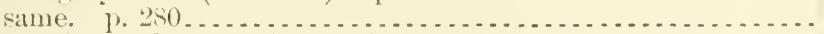

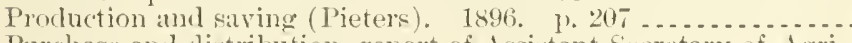

Purcliass and rlistribution, report of Assistant Secretary of Agriculture rin-

18:9. 1. 1

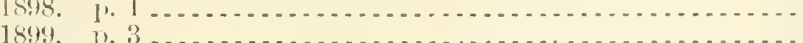

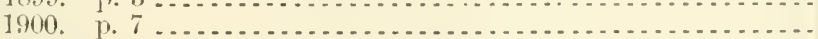

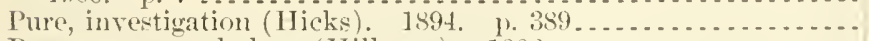

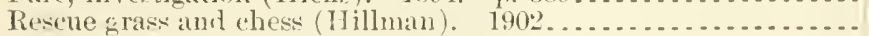

Selertion and planting of (Hallett). 187t. 1.381............

Selection of-

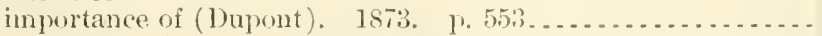

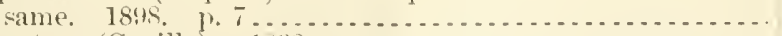

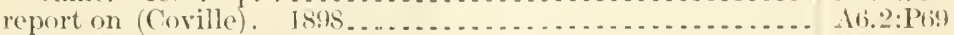
work at Iledicine Lodgre, Kansals, résumé of (Carr). 1503, 1),25. A 7.3:10 
Sereds-Continued

s.lling, rrow ing, and testing of (P'ieters). 1s99. p. 5ั49

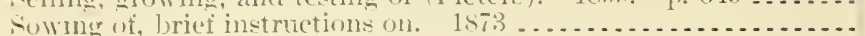

Testing-

additional notes on (Flicks and Key). 1897. p. 141.

11.10:599

11.2:Se3 ${ }^{\circ}$

at home (Pieters). 1845. p. $175 \ldots . . . . . . . . . . . . . .$. methods of, and their relation to farm and garlen (Pieters).

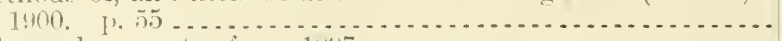

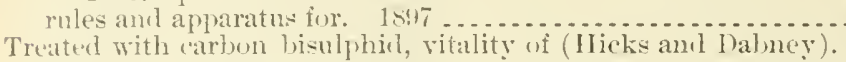

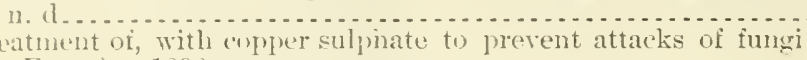

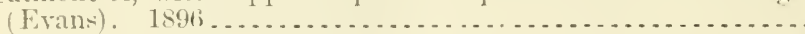

Vitality of, effects of tertain fungicides upon (Crozier). 1891. I. Linseerl - oil-producing seels - Red clover seed - Saccharime sorghums.

Seeds and plants:

Forpign-

(ollected in Anstria, Italy, and Egypt, by Barbour Lathrop' and David G. Fairchild for Section of Seed and Plant Introduetion, Agriculture Derartment. 1900 .

importal by Section of Seed and I'lant Introluction, Agrienlture Department-

Yos. $1-1000$, n. 1......

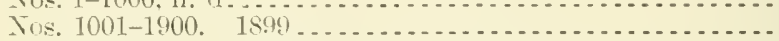

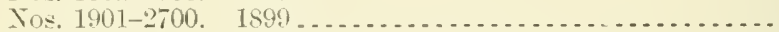

Tos. 2701-3400. $1900 \ldots \ldots \ldots \ldots \ldots \ldots$

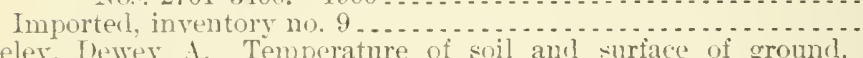

Seeley, Wewey 1. Temperature of soil and surface of gromel.

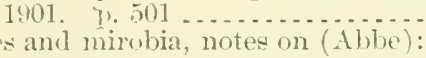

Feiches and mirobia, notes on (Abbe):

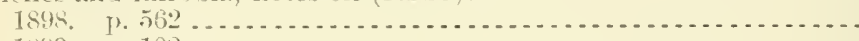

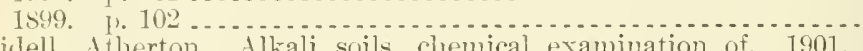

Seidell, Atherton. Alkali soils, chemical examination of. 1901.

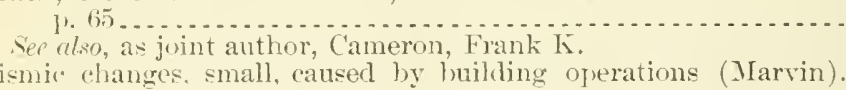

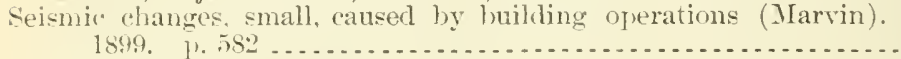
Seismic noises:

Torth Carolina and Georgia (Hawkins). 1897. p. 393........

Totes on (Ahbe). 189s. एp. 216, 5ti2 . . . . . . . . . . . . . .

Report on (Kain and others). 1898. 1) 152 ............... Seismograph:

Marvin, report on (Marvin). 1895. p. $250 \ldots \ldots \ldots \ldots \ldots \ldots . . .6$.

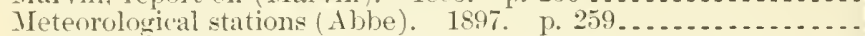

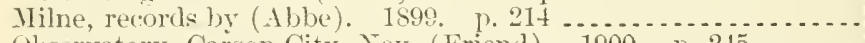

Observatory, Carson City, Nev. (Friend). 1900. p. 245 . . . . . .

Stations in United States, notes on (Abbe). 1899. p. $310 \ldots . . .$.

Seismometers in meteorolngy, notes on (Abhe). 1901. p. $420 \ldots . .$.

celby, A. I). Cramlen her] rarimm, making and it-uses. 1900. p. 92..

Selenium and its use for measurement of sunshine (Dorsey). IS99.

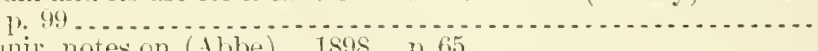

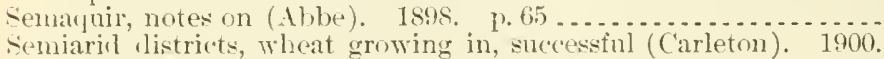

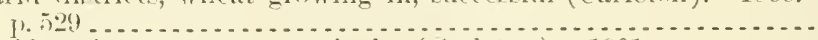

Sentariol regions, emmer, a grain for (Carlotom). 1901 .........

Semiariul West, new wheat industry for (Carleton). 1901 .......

Semolina and macaroni, mamufacture of (skinner). $1902 \ldots . . . . . .$.

September, wather conditions for, statement of average (Garriott).

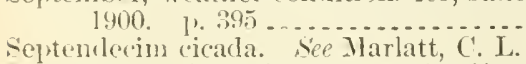

Septicemia. see (hickens, apoplectiform septicemia.

serimeter, report of (Walker). 1SS9. 1),333..................

sorrell antomatic silk reel, report of (Walker). 18s7. 1. 52 ....

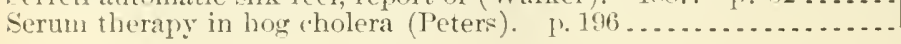

A1.10:S:7

11.10:8: 5

A10.3:76

110.4:34

16. $4: 11$

128.:3:10

A $25.5: 6$

A6.6:6

A6.6:1

+16.6:2

A6.6:5

A6.6:7

$119.3: 5$

A29.6:29

A $2(7) 6: 26$

A:9.6:27

126.3:18

A29.6:27

A:29.6:05

129.6:26

A $29.6: 26$

$129.6: 23$

129.6:25

129.6:27

A29.6:28

129.6:27

129.6:29

110.3:76

A:99.6:27

129.6:26

11.10:900

1 $1.9: 139$

A.3. $4: 18$

A 19.3:20

$129.6: 28$

19.7:1

19.3:14

A4.1:897 
Serum treatment for swine plague and log (Dolera (I) Ficloweinit\%)

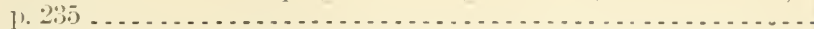

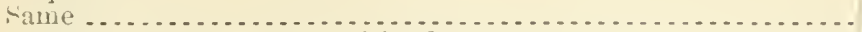
Sep alsn Antitoxic selmm - Blood sermm.

sevier Valley, Ltah, soil survey in (Carlner ami Jensen). 1). 243... sewage:

(itices, note on (Brown). 1872, 1,379................. I)isposal on farm and protection of drinking water (smith). 1sit) Liquid, treatment of, in Gireat Britain. 1870, 1. $437 \ldots \ldots \ldots \ldots$

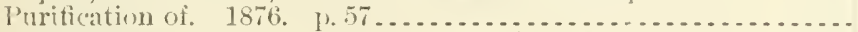
Value of deposit of eity of Washington (Antisell). 1sitg. 1.228. Sep also Wastes.

Fewall, J. 1. Garden City. Kans, grass and forage experiment sta-

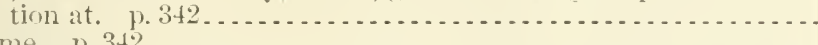

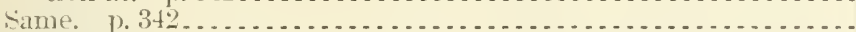
Seyboth, Robert. Lightning ball at sea, instance of. 1901. p. 249. Seychelles Islands, vanilla culture as practiced in (Galbraith). 1sus. shate in coffee culture (Cook). 1901.

sharle-tree insects:

Four species of defoliators which affect trees of the capital. 1887. feneral work acainst, in cities and towns (Ilomanl) .......... Injurious, report on (Packard). 18s,. 1. $20 \ldots \ldots \ldots \ldots . . . . .$. same (Packard). 1s90 . . . . . . . . . . . . . . . . . . . . . . . . Observations on, in New York State (Felt), 1902. p. 63...... I'roblem in eastern Enited States (Howard). 1895. p. $361 \ldots .$. Sipringfield and other New England cities (Howard). 1895.

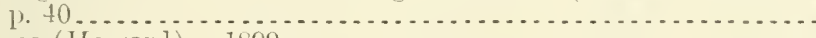

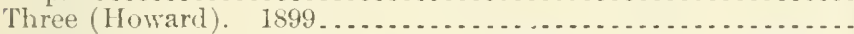

Shatle trees, diseases of (Galloway and Woods). 1896. 1. 237 .... Sie als Trees.

Slicilow, mountain, photograph of, note on (Ablue). 1894. 1).510. Shaffer, J. MI.:

Barley and its uses. $]$. 355 . . . . . . . . . . . . . . . . . .

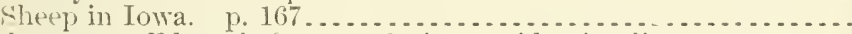

Shakespeare, Edwarl Grum. Swine, epidemic: diseases among,

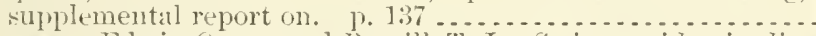

Shakespeare, Elwin Orum, and Burrill, T.J. Swine, epidemic diseases among, report of United States board of inquiry encern-

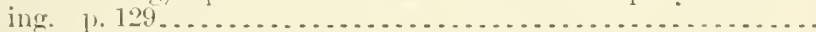
Shanghat, meat and milk inspection in (13lackwood). 1. 205 ..... Sharl, David:

lamellicorns, Australian, new genus and two new species of. 1890. 1). 302

Scymmus, two new species of. 1859. p. 364 .

Sharpe, Benjamin $\mathrm{F}$. Sounds, measuring and photograpling, ad-

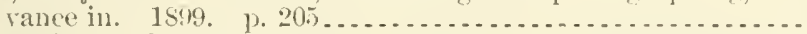
Sharples, S. P. See, as collaborator, Wiley, Harey Washington. Sharpshooter, glassy-wingesl, report of. 1893. P. $150 \ldots \ldots . . . .$. Shasta, Mount, Cal., biologieal survey of, results of (Merriam).

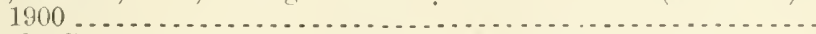

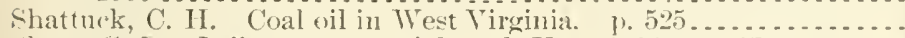
Shaw, ('. I'. Jefferson menorial road, Va. 1902. 1. 27 ....... Fhaw, R. E. Jefferson memorial road, Ta. 1902. 1.9......... Shaw, Thomas:

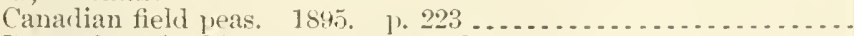

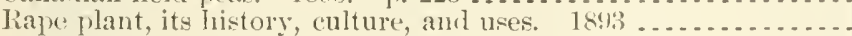
Shaw, W. B., jr. Cattle in Indian Territory, rejort on. 1ssis.

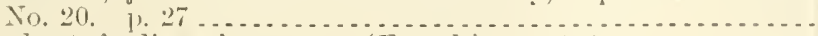

Sheaf wheat, feeding of, to stcers (French). j) titi............. Shear, Cornelius L.:

Agrostology livision, Agrionlture Department, fiekl work of,

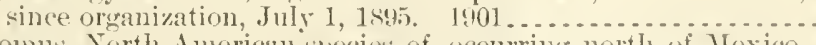

Bromus, North American speeses of, ocenring north of lifexico,

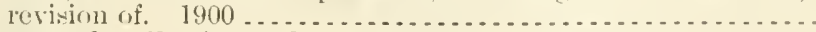

Grass seed, collection and listribution of; field work. 190k ....

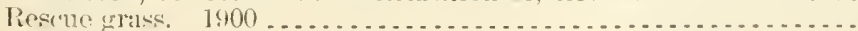
see also, as joint author, Rivllierer, $\mathrm{I}$. $\mathrm{A}$.

Clamifleatlon no.

14.1:8:98

14.3:28

126.5:0001

$127.4: 10$

1 1.9: $1: 43$

$127.9: 5$

A:7.9:14

1.27.9:7

11.1:\$91

16.1:891

A29.6:29

16.3:21

16.3:25

$+9.3: 10$

A9.5:15

A9.3:13

18.1:4

A9.6:31

\1.10:595

A9.6:-2

A 1.9:94

A1.10:\$96

A29.6:22

11.1:865

A 1.1:864

14.1:\$89-90

A4.1:689-90

14.1:595

19.7:2

19.7:1

A29.1:2:2

A. 9.5

15.5:16

11.1:863

122.3:25

120.3:25

A $1.10: 595$

A 1.4:11

127.9:23

14.1:848

A3.3:25

1.2.2:2:3

11.4:9

13. $4: 06$ 
Sheely:

Animal parasites ot (Curtice). 1890

At.2:Sht

"Big heal" (,liscase) of, in Utah (Rowe). p. 230............. At.1:901

Blogl poisuning in, in New Zealand (Gilruth), p. 233......... At.1:901

Breeding, in New south Wales. 1875. p.526 . . . . . . . . . . . A27.9:13

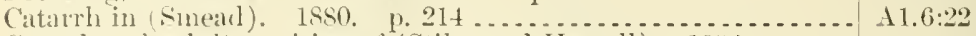

Cestorles of, astult, revision of (Stiles and IIassall). 1S93.

Comblition of-

1866. 1. 288

1873. 1. $14: 3$

1875. P. 155

A $4.3: 4$

A $27.9: 4$

A $27.9: 11$

A27.9:13

Disentes of -

correspondence relating to. p. 486

A1.1:\$77

same, 1). 542 .

in Teras (Detmers). p. 68

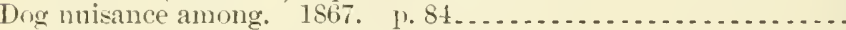

English, prices of. 1867.

1). 339.

Exportation of-

from Roston, prohibition of. 1902

in vessels carrying hicles from foreign countries, order con-

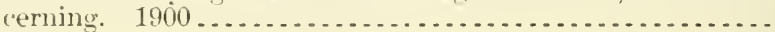

Farming-

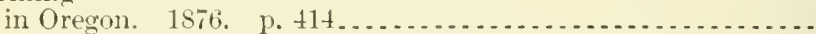

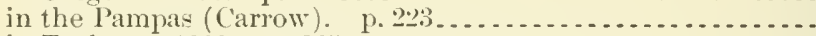
in Turkey. 1868. p. 365

Feeding of (Craig). 1897

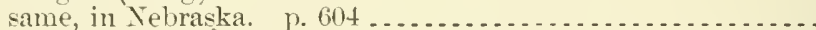

Feeding wild plants to (Nelson). p. 421 same, p. 10 10 (Xelon)

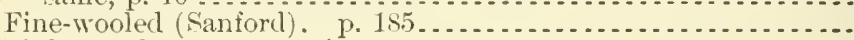

Flukes and tapeworms of-

bibliography (Hassall). 189s. p. 145 ................... compendim, arranged according to their hosts (Hassall).

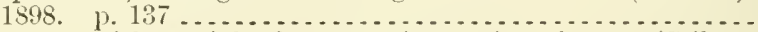
report on, with special reference to inspection of meats (Stiles).

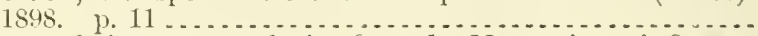
Grazing, and forest growth in Cascade Nountains of Oregon

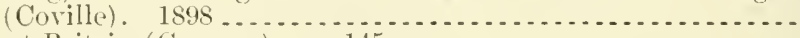
Great Britain (Carman). 1. 145........................ Hampshire Down, note on (Morrell). 1868. p. 462........ Importation of. 1867. 1\%. $20: 3$

Imported into United States without quarantine. 1595. Imported into United States, regulations for inspection and quarantine-

Dec. 28, 18,49

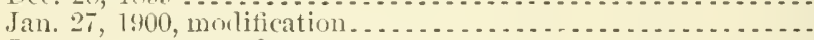

Jnne 1, 1900, amendment . . . . . . . . . . . . . . . . . . . . .

Oct. 20, 1900, amenilment

Nov. 10, 1900, ameniment. . . . . . . . . . . . . . . . . .

Imports of, by Great Britain, $1898-1900$. p. $606 . . . . . . . . .$.

Inclustry in. see Sherep husbandry.

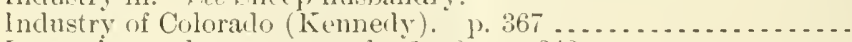

Insprection and morement of. 1 s 96 . p. $242 \ldots \ldots \ldots \ldots$

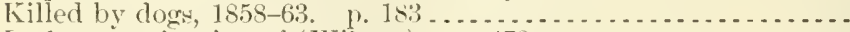

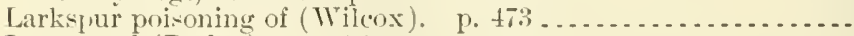

Long-wool (Dorlge). p. t79....

Losses of-

1873. p. 150

1875. p. 159

IIutton-

establishing a flock of (Peal). 1900. p. 2:)

why and where profitable (Dodge). p.341.

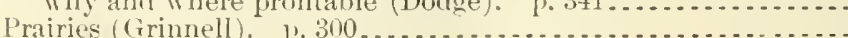

Quarantine of, in New England States. 1902 .............

Raising, for mutton (Curtiss). 1899

vee rilso Sheep hushaudry.

Raicing and feeling, importance of (Taylor). p. 249 ......... A1.1:864

A4.5:56

A $4.5: 58$

At.5:64

A $4.5: 77$

A+.5:79

1.1:901

14.1:891-2

A4.1: $४ 97$

127.9:4

14.1:898

A1.1:865

A27.9:11

A27.9:13

A1.9:119

A1.1:866

A1.1:562

A4.5:99

A1.9:96 
Roundworms in, treatment of (Stiles) -

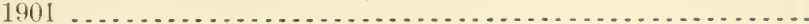

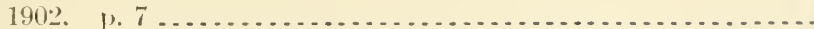

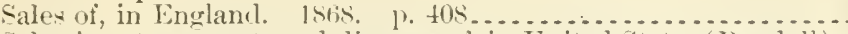
Selection, treatment, am disealses of, in Lniterl States (liandall). 1. 229.

Stall-feerling (llarris).

Taueworm di-ease of, of weteru plain (Curtice) p. 167.....

Verminous diseases of, in Texas (stiles). p. $356 \ldots . . . . . . . . .$. same, further investigations of (stiles). y. 20.3..........

See rlso Animals, domestie-Cattle orlers-Farm animals "liolden Hecee" - Infantarlo sheep - Kentucky sheep - Live stock - Iterinos - Mutton - "Ontario," merino ram - Ovine caseous lymph-adenitis - Paular seep-Quarantine-Somali sheep-Fpanish merinos - Texel or Mouton Flandrin sheep.

Shetp anıl wool:

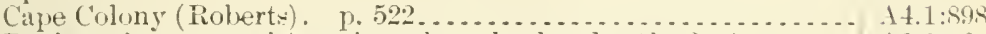

Review of progress of American sheep husbandry (1)ordge). 1900.. A1.8:66

Statistical report on, wf the world (1)odge). p. $207 \ldots \ldots \ldots \ldots . . .11 .1: 875$

Sheep breeters' associations, list of, with ofticer's:

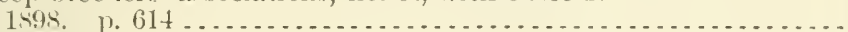

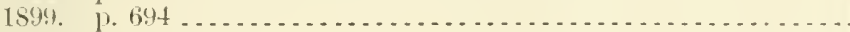

1900. p. $64+$ ?

1901. p. 625

Sheel husloniry:

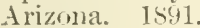

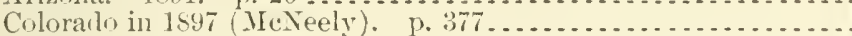

Condition and prospects of, in Uniterl States. p. 2t:...........

Condition of sheep industry west of Mississipli River (Heath).

$$
\text { 1. } 247 .
$$

Connection of tobaces eulture with. 187s, J. 125..........

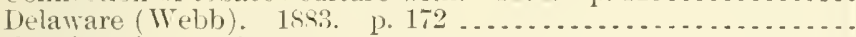

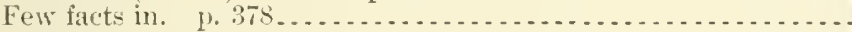

Geolyia-

1.575. 1). 523.

1STS. (Peters). p. 120 .

A. $4.4: 35$

At.3:35

127.9:6

A 1.1:86:

A $1.1: 86:$

A $4.1: 88 \bar{i}-8$

At. 1:900

14.1:901

A1.10:898

A1.10:\$99

A1.10:\$00

A1.10:\$01

A27.9:29

1.1:898

$11.1: 460^{\circ}$

At.1:589-90

A 1.2:-2h:3

A1.7:2

A1.1:869

$127.9: 13$

A1.2:-11:\%

History and present condition of sheep industry in $U_{\text {. }}$. 1s9:2 . At.2:Sht² Contents:

1. In States east of Mississippi River (Carman). @. 11 .

2. West of Mississippi River (Heath and Minto). p. 701.

Iowa (shaffer). 1. 167

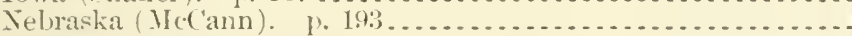

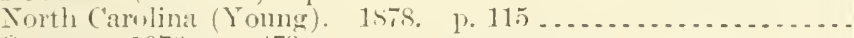

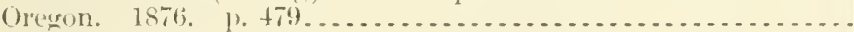

Parifie Northwest (Withenmbe). 1900. p.5..............

sinutli-

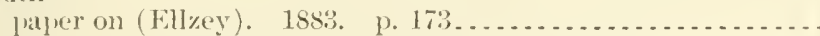

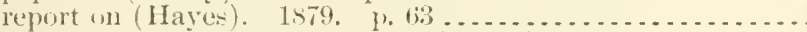

South Carolina, (ierroria, and Texas (Watts). 1877. p. 115....

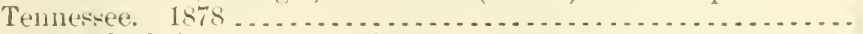

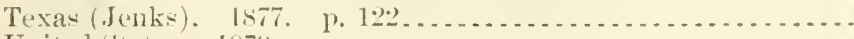

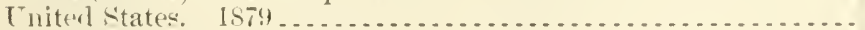

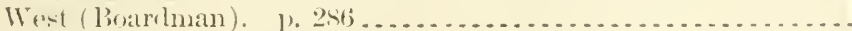
Slie(s) seath):

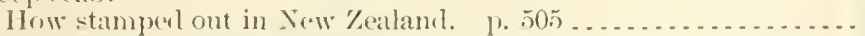

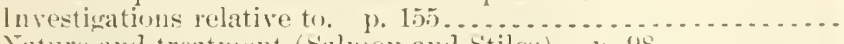

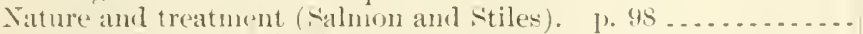

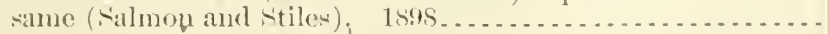

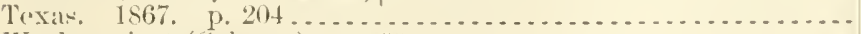

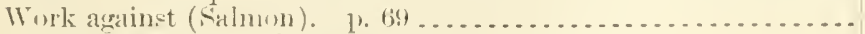

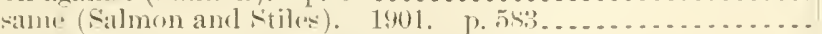

sie ulso Cattle rirclers- hime-and-sulphur dijs.

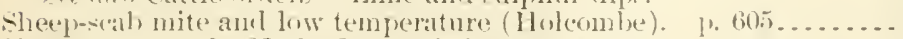

A $1.1: 864$

A $1.1: 864$

A1.2:- Hi:

127.:1:14

A1.9:117

11.7::

11.2:S $]_{103}$

$11.2: 113$

$11.2: 11: 3$

$11.2:-11: 3$

11.2: :h3

11.1: $66^{\circ}$

14.1:900

1 $4.1: 1: 7$

14. 1.897

14.3:21

127.9 .5

1 $4.1: 900$

1. $1: 101$

Slewet waters. See Undrerfluw and sheet waters.

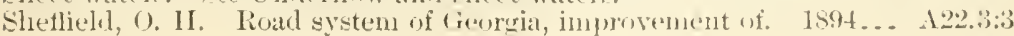


Shefliel, Fngland, cost of hauling farm products over wagon roarls

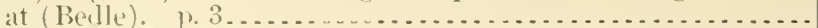
Sielılon, C. . Sor, as collector, Holzinger, J. II.

shell routs. Sier lioals.

Slulls, land and fresh-water, collected in California and Fevada hy 1)ath Valley experlition, with tew alditional species nbtained Jy C. Hart Jerrian and assistants in parts of southwestern [nitel States (Ntearms). 1893. [1. 269................

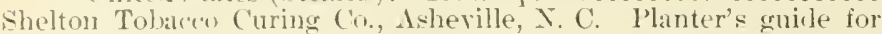
(ultivating and curing tolate(o), with information and instruction concerning the She]ton tobaceo hanger. $1876 \ldots . . . . .$.

Shenstont, J. C. Condensel milk, componitiun of. 1890. p: 149.. shepard, Charles $\mathrm{U}$.:

Te: culture, the experiment in South Carolina. $1899 . . . . . . . . .$.

Teal raising at Pinchurst exjerimental tea garlen, near Summerville, soutl Carolina, speeial report on. 1. $627 \ldots . . . . .$.

tee ulse samnelers, Willian.

Sliemmall, 11, C.:

Metaloulism of nitrogen, suluhur, and phosphorus in human

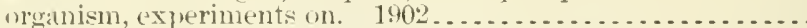

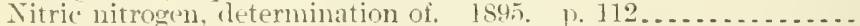

'Se' (Ilon, as joint author, Atwater, Wilbur Olin.

Sherwoul, E. R. Remarks w, at 2nl convention of ITeather Burean

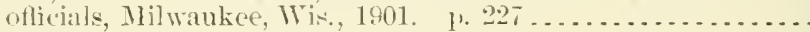

Shimonoseki, treaty of, between China and Japan of April 17, 1595, and our possibilities of trałe with those countries. . . . . . . . . .

shinn, ('harles H. Myers, John 1., lirief recollections of. 1902.

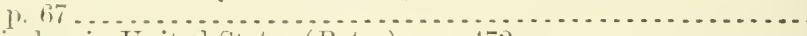

Ship timler in Tniterl States (Bates). 11. t72................ Ships:

Barograph on, note on-

1848 (Albe). p. 567

1.5.9 (Ablue). 1.60

1900 (Page).

Rainfill measurenents on, notes on (Abbe) 1898 p. $313 . .$. Shiver, Frank Seott:

Fertilizers containing organic materials, total phospluoric acir in,

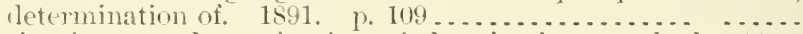

Nitric nitrogen, determination of. ly zinc-iron method. 1 sit.

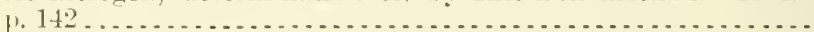

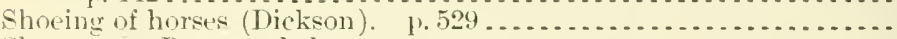
shoes. vie Boots and shoes.

Shore climate and sea temperature (Abbe). 1902. 1. 314. Shorthorned cattle. See ('attle.

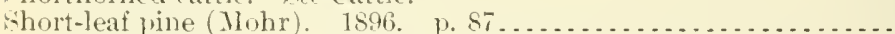

Same, with additional notes by Filibert Roth. 1897. p. $93 \ldots . .$. Shorts. Sie Wheat shorts.

shower, mud, note on (Kimlall). 1902. 1. $269 \ldots . . . . . . . .$. shrews:

Imerican (Blarina and Totiosorex), revision of (Merrian).

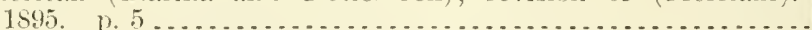

Anerican (sorex), synopsis of (Merriam) 1895. p. $57 \ldots \ldots .$.

Long-tailed, of eastern [niterl States (Miller). 1895. 1. $35 \ldots$. Shrikes, fook of (Judil). 189s. p. $15 \ldots . . . . . . . . . . . . .$. shriver, Howarl, short biography of (Aj) $)$. 1901. p. $67 . \ldots .$. shrulss:

Effect of punctures of hemipterons insects on, 1886 (Wehster).

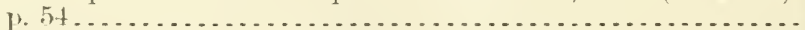

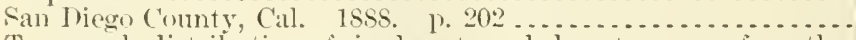

Trees and, distrilution of, in deserts amb desert ranges of soutlern California, sonthern Nevala, northwestem Arizona, and Siberia: sonthwestern Utah, notes on (Merriam). 1893. ]. 285.....

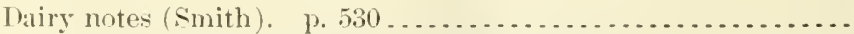

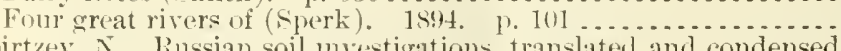

Sibirtzey, $\mathbf{N}$. Russian soil nnvestigations, translatel and condensed by Peter Fireman. ju. 704,807 . 
Sicily, sumac in, culture of (McMurtrie). 1880

Sieg, R. sugar cane, diffusion process as applied in Louisiana.

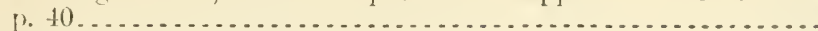

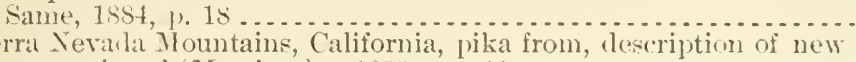

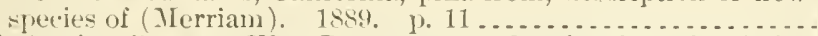

Signal Service Bureau, IVar Department, sketch of work of, for agriculturist (Birkheimer). 1882. p. $110 \ldots \ldots . . . . . . .$.

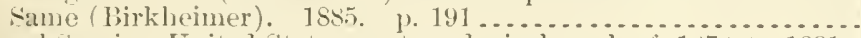

signal service, United States, meteorological work of, 1 is

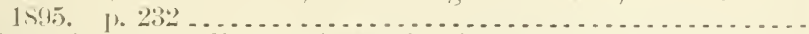

Signal service, expenditures of IVeather Bureau and, statements oi. Signals. wee Weather Bureau signals.

signata. Sie llyperaspis signata.

Signs and weatlier, note on (Kimball). 1901. 1. 508............ Silage:

Ilfalfa, report un (Beal). 1901. 1. 25

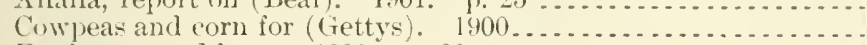

For horses and hogs. 1898, p. $20 \ldots \ldots \ldots$

Loskes in preparation of 1901. p. $31 \ldots \ldots \ldots$ See rilso Ensilage - Silos and silage.

Silage mixture (Robertson). 1897. p. 7

Silesia:

Hesian fly in, in 1869 (Cohn). 1883. Alp., p. $39 . \ldots . . . . .$.

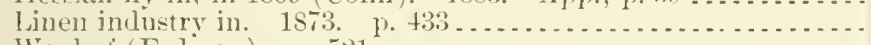

Trool of (Erdman). p. 521 $\ldots \ldots \ldots$

Silicate, action of oxalic acid on (Kastle and others). 1894. 1.53.

Silk ('ulture:

Abetract of note on (Wallace). 1891. p.61_...............

Agriculture Department-

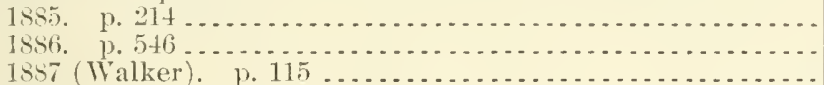

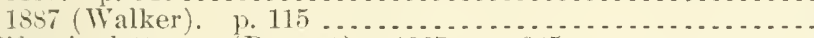

Califoruia, letter on (Prevost). 1867. 1. 255 ..............

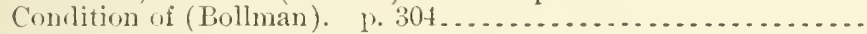

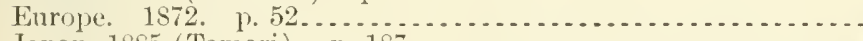

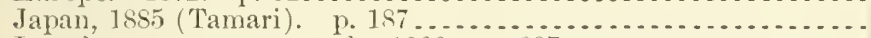

Law for encomagement of. 1866. 1.287 ...............

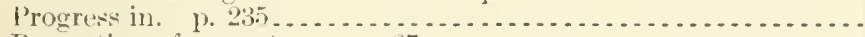

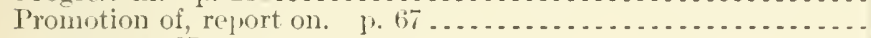

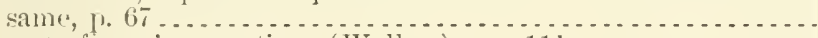

Report of year's operations (Walker). p. 11i ............

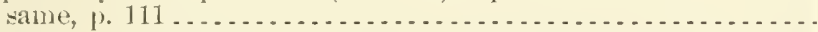

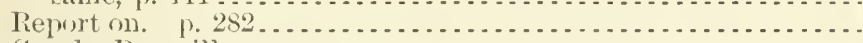

Síe ulso Raw silk.

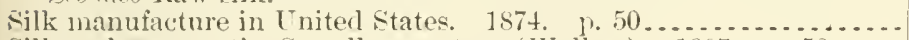

Silk reel, antomatic, Serrell, report on (Walker). 1887. 1).52....

Silk Section, Agriculture Department . . . . . . . . . . . . . . . . . .

\section{Silkworms:}

Ailanthus, of China, arlditional observations (Morris). p. $390 \ldots$

Brief manual of instructions for prorluction of silk. j. 215 .... samic, 1) 10 same (Riley)

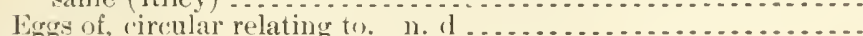

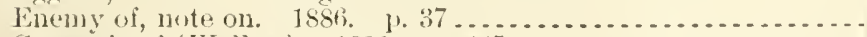

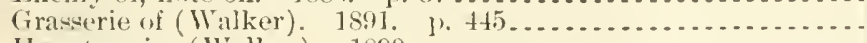

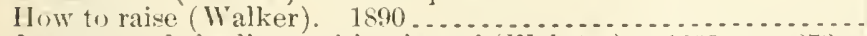

Jajancse oak-feeding, cultivation of (Welster). 1889. p. 27: .

Japanese, parasite of, Egimyia seriearlac rond. IS91. 1) 113...

Notes on. 1. 101 ... . . . . . . . . . . . . . . . . . . . . . sall1e, 1), 101.

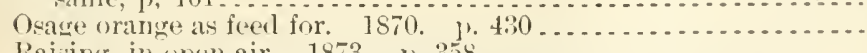

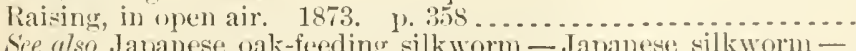
See also Jajanese oak-feeding silkworm - Japanese silkworm -
Mlulberry silkworm.

Silo, stave, value of, to dairy farmers (Beal). 1898. 1. 23....... A1.4:1(1.) 
Silos and encilage, record of practical tests in several states and

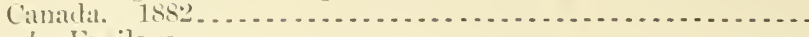
Sce ulso Ensilane.

Silos and silage: (P'lumb). 1895.

silt nucasurenuents, progress report on, 1900 ( Nagle). 1. 293.

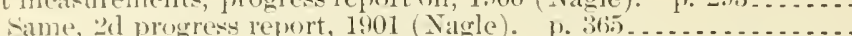

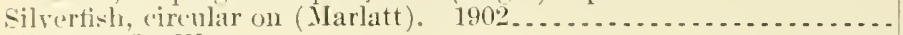
silvester, R. II: :

dildress of, before Ameriean Association of Farmers' Institute Worker's, at seventh annual meeting. 190:2. p. $45 \ldots . . . .$.

Elucation, theory of higher, some recent changes in. 1899. 1 .

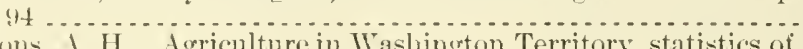

Simmens, 1. H. Agriculture in Waslington Territory, statistics of.

Simmons, F. II. adilress of, before Good Roads Convention at

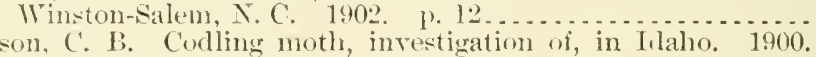

Simpson, ( . B. Codling moth, investigation of, in lilaho. 1900.

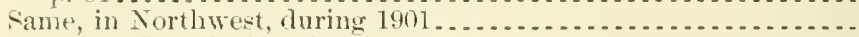

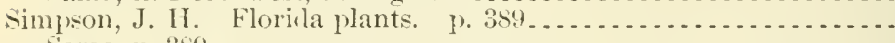

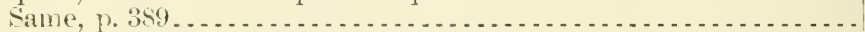

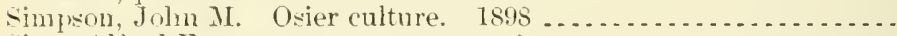

sines, Hifred F.:

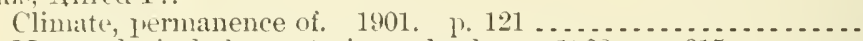

Ifeteorologieal observatories, suburban. 1902. p. $215 \ldots \ldots \ldots . .$.

Press, commercial bodies, and scientific organizations, relations of weather officials with, how jromoted. 1899. p. it .......

Tormarlo, March 26,1895 , at Albany, $\mathrm{X}$. Y., report of. p. $92 \ldots$ Simulinm. Nep Buffalo-gnats.

Sinclair, Angus. Transportation, development of, in Tnited States.

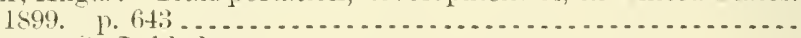

siris tree. we Leblek tree.

sirrine, F. A.:

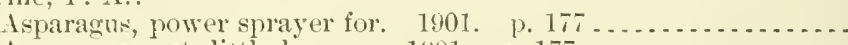

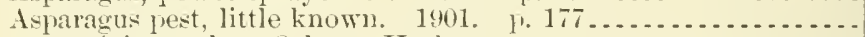

sie, as joint author, Osborm, Herlert.

sirups, makiner, and sugar and imphee and sorghum culture, report

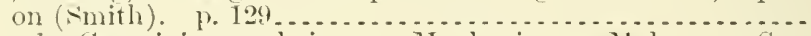

See also Cane juices and sirups - Japle simp- Molasses- Sorghum sirnp - T'able sirups.

sisal hemp, or jenequen:

Culture in Enited States [Florirla], with statements relating to industry in Yucutan and Tahama Islands, and brief considerations upon questions of machinery for extracting fiber

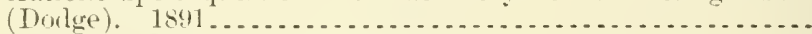

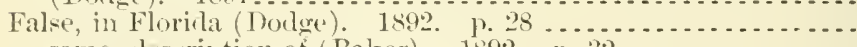
same, teccription of (Baker). 1892. p.32 .............

Industry in Bahama Islands (MeLain). 1891. p. $52 \ldots . . .2 .$.

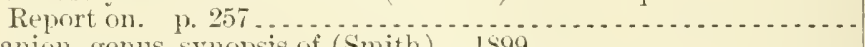
Sitanion, genus, synopsis of (Smith). 1899 . . . . . siva, C. Samba. Agrienlture in Inclia, account of. 1874. p. $389 .$. Six-spotted mite of orange (Riley). 1890, 1. 20.5 ........... skies. See sky.

skim milk:

As food for young ehickens (Anclerson). p. tit .............

Bread making and. 1900 . p. 16 ...................

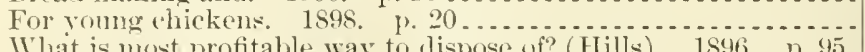

What is most profitable way to dispose of? (Hills). 1896. p. 95. Skin cliscase anong:

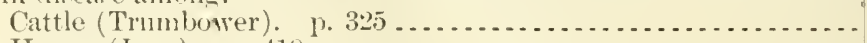

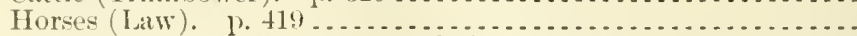

Skinner, Charles R. Arbor Day, relation of, to agriculture and hor-

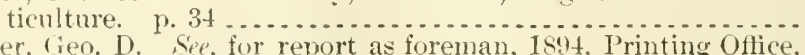

Skimner, Geo. D. See, for report as foreman, 1894 , Printing Office,
Anriculture Department.

skinner, Robert P. Semolina anı mararoni, mannfacture of. 1902. A19.3:20

A1.1:869

13.3:18

A 27.9:12

19.7:2

1t.1:899

A 1.9:114

A 1.9:8t

A 10.3:41

$1+.2:\left(: 29^{2}\right.$ 14.2:H78

A 1.8:56 
Skins, museum, preparation of (Merriam).

Classifleatiou no.

See also Hides and skins.

Skipper. See Cheese or meat skipper.

skunks:

Little striped, of renus spilogale, contribution toward revision of

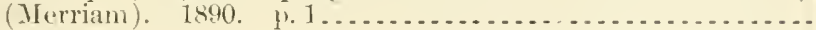
Sky:

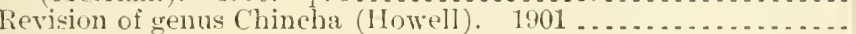

ג.5.5:4

15.5:20

1.29.6:27

A29.6:28

129.6:28

A $29.6: 28$

$129.3: 31$

A29.6:26

A29.6:26

A29.6:28

A $29.6: 25$

A29.6:28

A 1.1:\$65

11.10:896

$1: 99.6: 29$

A $29.6: 28$

A $9.7: 5$

A9.7:5

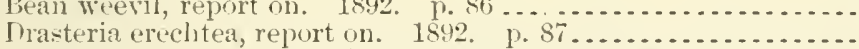

Eutomologr, some surgestions and notes on, presented to Entomology Section of Association of American Agricultural Colleges and Experiment Stations, at fifteenth annnal meeting,

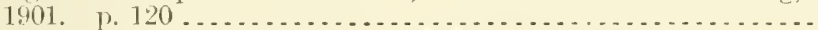

Pear-leaf hlister mite, report on. 1892. p. 104 . . . . . . . . . . .

Pear-tree nsylla, report on. 1892. 1) 100.................

Slingerland, William $H$. "Crean-pot" stock, history of. p. 231 ... slip-records for entomologists, note on (Cockerell). 1893. p. 198...

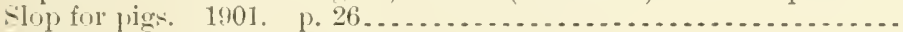

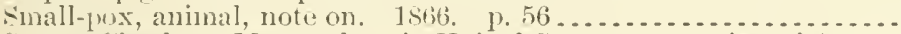
Snart, Charles. Meteornlogy in Inited States, connection of Army Merlical Dept. with elevelopment of. 1895. p. 207

Smart, James II., alllress of, as president of Association of Anerican Agricultural Collegres and Experiment Stations, at fourth

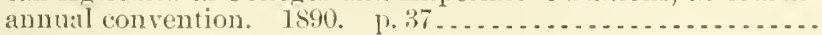

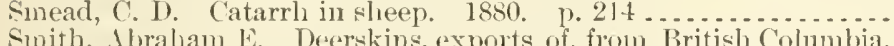

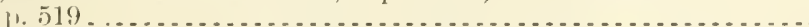

Smith, Augustine J. Agricultural education, necessity of. $18 \times 3$.

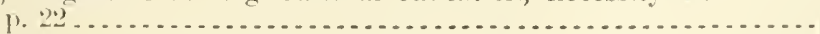

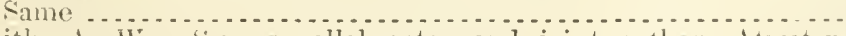

Smith, 1. IT. sie, as collaborator and joint author, itwater, Trillur olin.

Smith, C. li.:

Igricultural conditions, general, in Tniter States, as relaterl to work of agricultural experiment stations. 1900 . 1. 14.....

Agricultural education in France. 1900. p. $115 \ldots . . . . . . . .$.

Blucherries, improvement of. 1900 . 1. 18.................

Fertilizers, nitrogenous, in market-garten cropss. 1901. 1\% 12 ..

German (onmmon schonl with a garden. 189t. . . . . . . . . . . . .

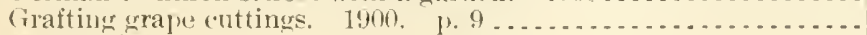

Juskmelons, transplanting, experiments in. 1900. 1\%:0.....
A 10.3:115

A9.7:5

A9.7:5

11.1:866

A9.7:6

A1.9:13:3

127.9:4

$129.3: 11^{2}$

A10.5:;

1 1.(i:2:2

$14.1: 900$

11. $7: 2$

11.5:25

110.3:80

1 1.10:900

A $1.9: 119$

1 $1.9: 124$

$110.4: 4: 2$

11.9:12:2

11.9:119 
Smith, C. B.-Continued

Pecan culture. 1901.

Potatoes, extra-early methocls of securing.

Rluubarl, forcing, results of. $1899.13,13 \ldots$

A1.9:12t

A 1.9:114

sice also, as joint author, Beal, Walter II enry.

Smith, C. B., and Beal, Walter Henry. Persinmons, desirable

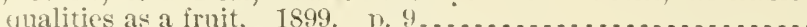

smitl, C. 3., and langworthy, Charles Ford:

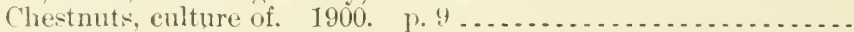

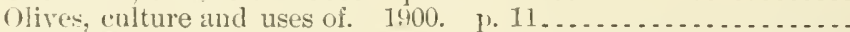
1.9:107

A $1.9: 107$

A1.9:114

A1.9:122

Smith, C. I).:

Anmual address of president at meeting of American . 1ssociation of Farmers' Institute Workers, held at Buffalo, N. Y., Sept. 18

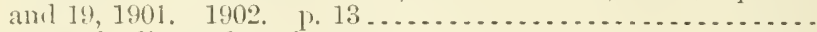

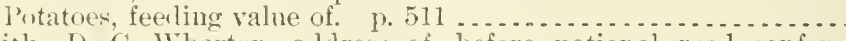

smith, D. C. Wharton, address of, hefore national road confer-

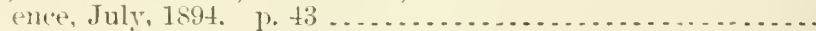

Smith, E. . Madder, culture of, in Smyrna. 1870. p. $284 \ldots . .$.

Smith, Elward C. Vermont, road improvement in, extract from

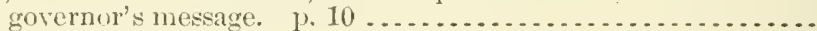

Smith, Erwin F.:

Bacterial disease of tomato, eggplant, and Irisl potato. $1896 \ldots$

Black rot of cabbage. I898 ............................

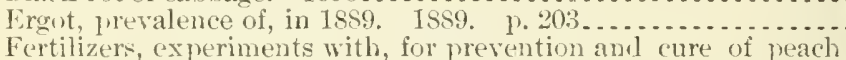
vellows, 1889-92

Field notes, 1892 , rejort on. 1891.

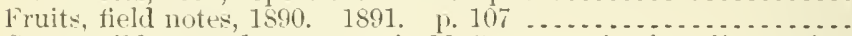

Grape mildews and grape rot in U. S., synopsis of replies to cir-

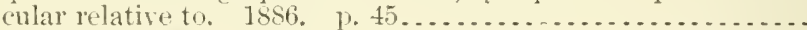

Legal enactments for restriction of plant diseases, compilation of

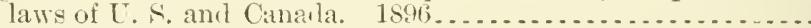

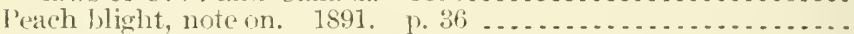

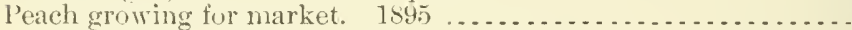

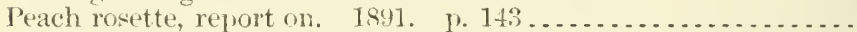

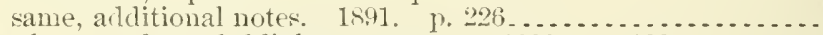

Peach rot and peach blight, report on. 1889. p. 123.........

Peach vellowsprejiminary report. 1888

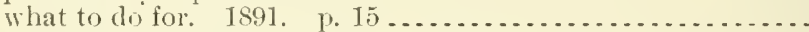

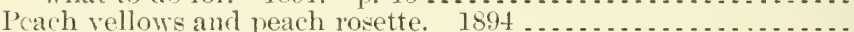
same, alditional evidence on communicability of. 1891 .....

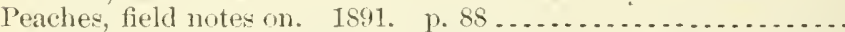

Pseudomonas hyacinthi, Ps. campestris, Ps. phaseola, and Ps. stewarti, four one-flagellate yellow bacteria parasitic on plants,

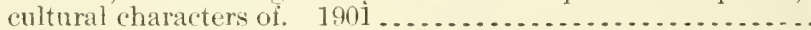

Spotting of peaches, report on. 1889. 1. 32 ..............

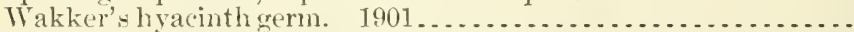

Wrilt diseave of eotton, watermelon, and cowpea. $1899 . . . . . .$.

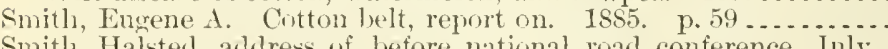

Smitl, Halsterl, arldress of, before national roarl conference, July,

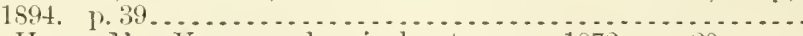

Smith, Hemry 11. Taupon, chemical notes on. 1s72. p. $20 \ldots .$.

Smith, Herman IV. Weather Bureau Library, monthly additions tr, Apr.-Nov. 1897

Smith, J.H. Imphee and sorghum enlture and sugar and simp mak-

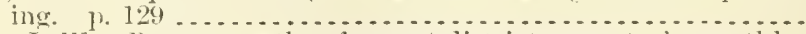

Smith, J. W. Boston weather forecast district, report of, monthly. July, Oct.-Dee., 1901 . . . . . . . . . . . . . . . . . . . . .

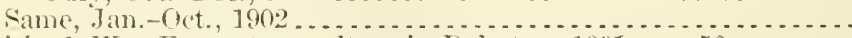

Smith, J. IT. Forest-tree culture in Dakota, 1891, 1.50 ........

Smith, J. Warren:

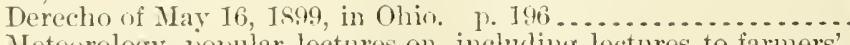

Ieteorology, jopular lectures on, including lectures to farmers' institutes, social gatherings, societies, etc.; are such lectures valuable in proportion to time given? what should be the general character of such lectures? 1902 , 1) $92 \ldots \ldots \ldots$.

110.3:110

At.1:898

A22.3:10

A27.9:8

A $22.4: 33$

A $28.3: 12$

A 1.9:68

A2S.5:5

A28.3:4

A28.5:7

A28.5:6

A 6.3:2

128.3:11

A2 $2.5: 7$

A1.9:33

A28.5:6

A28.5:7

A28.5:5

A6.3:9

128.5:6

A $1.9: 17$

A28.3:1

A 28.5:7

A28.3:28

A28.5:5

A25.3:26

A28.3:17

A8.1:4

A22.3:10

A $27.9: 10$

A29.6:25

A1.1:862

A 29.6:29

A 29.6:30

A 13.3:5

A29.6:27

A29.3:31 
Trashouts, flookls, cold waves, heavy snowtills, wamings of, for benefit of transportation companies. 189!? 1. $37 \ldots \ldots . .$.

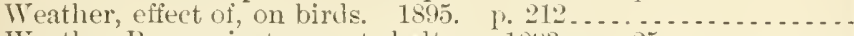

Weather Bureau instrument shelter. 18!18. p. $25 \ldots \ldots \ldots \ldots \ldots$.

Weather Bureau observers, stations of instruction for newly ap)pointer; should not certain important Weather Bureau stations be designated? 1899. p. 105.

Finith, Jared Gage:

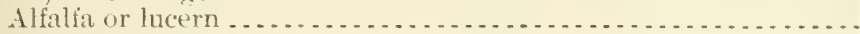

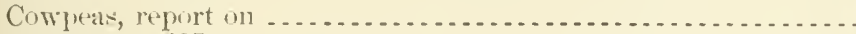
S:alle, l). $28 \mathrm{~T}$

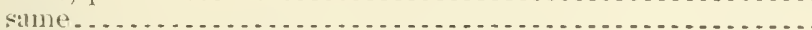

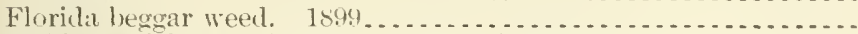

Forlder and forage plants, exclusive of grasses .............

Foragu conditions of prairie regions. 1595. 1\% $309 \ldots \ldots \ldots$

Forage plants for cultivation on alkali soils. 1898. p. $535 . . .$.

Gram, chick-pea, or Illaho pea. 1898 ......................

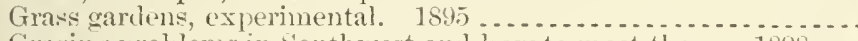

Grazing problens in sonthwest and how to meet them. $1898 . .$.

Hawaii Agricultural Experiment Station, aunual report for 1901 . 1. $: 361$

Leguminous forage elops. 1897 p. 487

Ieaclows and pastures, formation and cultivation in midile East ern States

Plant introduction, commerial. 1900. p. $131 \ldots \ldots$

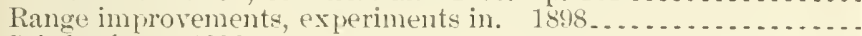

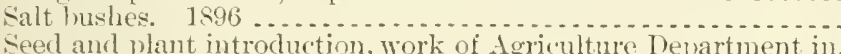

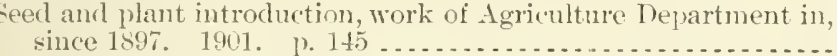

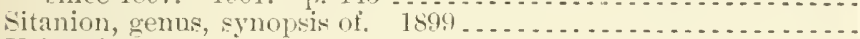

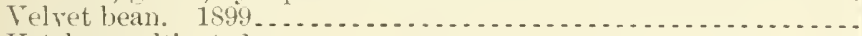

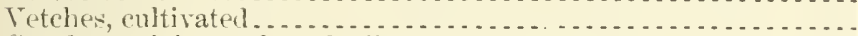

See vlso, as joint anthor, Scrilmer, Frank Lamson-.

Smith, Joln Bernharl:

Aphidirle, some question relating to. 1891. p. 226......... Blackberry lorers and gall makers, notes on. 1891. 1. 27..... Carbon bisulphide as an insecticile. 1894. p. 108 . . . . . . . . . Clover-leaf beetle, invasion by. 1891. p. 231 ............... Cranberry and hop insecti, report upon. 1884.1 1. $9 . \ldots \ldots$

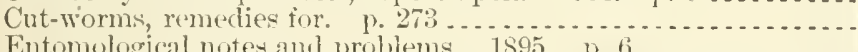
Entomological notes and problems. 1895. p.6 . $6 \ldots \ldots \ldots \ldots$

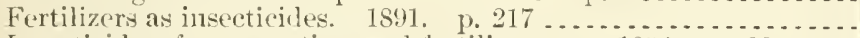
Insecticicles, fam practice, and fertilizers as. $1893.1 \% 93 \ldots \ldots$ Insects affecting the hop and cranberry p. $393 \ldots . . . . . . . .$.

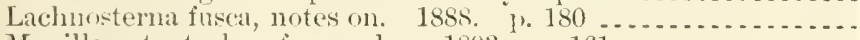

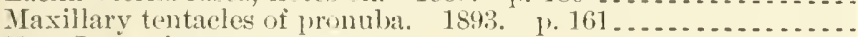

New Jersey insects, notes on-

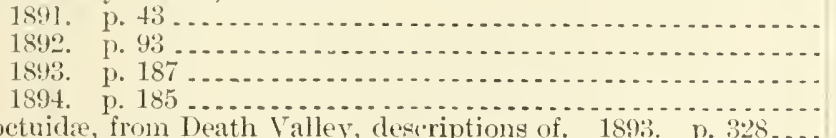

Nursery inspection, 1901. 1. 165........................

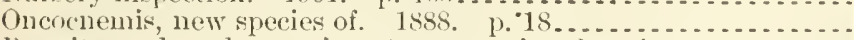

Parasites and predaceous insects, economic value of. 1893. p.142. Petroleum, erudenotes on, and its effects upon plants and insects. 1901. 1.176.

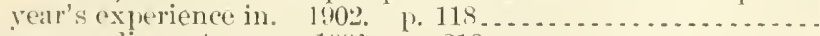

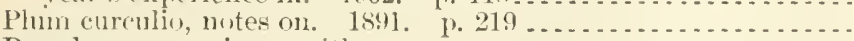

Rose hugs, experience with1890. ए. 113. 18. 1. 2:0

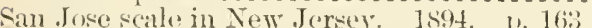
San Jose or pernicions seale, distrilution of, in New Jersey. 1 s!s.

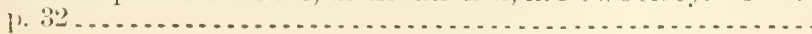

A $24.3: 31$

$129.3: 24$

$12 \div .6: 203$

$123.3: 7$

$124.3: 24$

11.9::31

A1.4):4!

11.10:596

1:3. $4: 5$

A:3. $4: 13$

A:3.: $: 2$

11.10:895

11.10:498

1. $4: 5$

1. $4: 1$

1.3.3:16

110.12:001

A1.10:\$97

A1.9:66

A $1.10: 900$

13.4:8

A3. $4: 3$

\10.3:99

1:3.8:18

13. $4: 14$

13. $4: 6$

19.7:3

19.7:4

19.7:7

$19.7: 3$

19.3:1

11.1:985

19.6:2

A9.7:

19.7:6

A 1.1:884

19.7:1

1.9.7:5

1.7. $7: 4$

A $9.7: 5$

19.7:6

A.9.7:7

19.7:5

1 10.3:\$99

19.7:1

19.7:0

110.8:8:98

1 10.3:115

19.7:3

1!).7::3

19.7:3

A $9.7: 7$

A9.1i:17 
Smith, John Bernhard-Continmed

Scale insects and their enemies in California, 1896. p. $46 \ldots .$.

Squash borer (Melittia cucurbita) and remedies therefor. 1891.

Smith, John II, "Rampenleim, and "Dendrolene," report on.

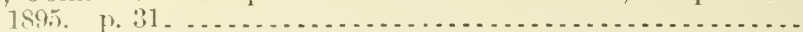

Smith, John WT. Storm warnings and displays by flag and lantern, are present, hest that can he devised for Atlantic and Gulf coasts?" 1899. p. 27

Smith, Oberlin, address of, before convention of National Leagne for Good Roads, Washington. 1893. p. 59 ...............

Snith, Ralph I. See, as joint author, Qmaintance, .. I.

Smith, Theolalel:

Animals, domesticated, infectious cliseases of, inrestigation of-

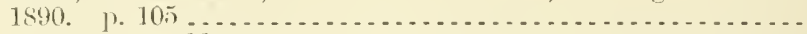

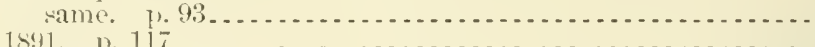

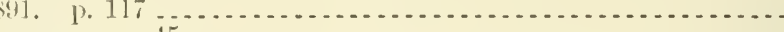
p. 45. 18:2. p. 110

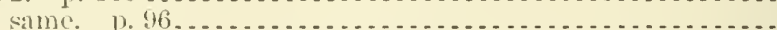
1593. p. 140

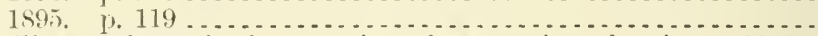

Bacillus, frathogenie, from vagina of mare after abortion. 1813.

1). $5.3 \ldots \ldots \ldots$
Bacteria, practical bearing of investigations in. $1894 . \quad$ p. $109 .$.

Bovine tulerculosisSoldiers Home herd of 60 cattle, pathological notes. 1) 26 . stulies in, with special reference to prevention. 1894. J. 88 ..

Cattle, sporozoön in intestinal rilli of, preliminary notes on. 1893.

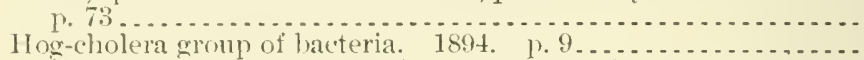

Protozoa, infectious disease (entero-hepatitis) among turkeys

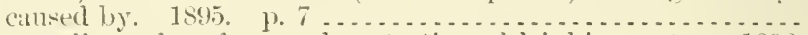

Sewage disposal on farm and protection of drinking water. 1896

Sirine plaque, calue and prevention of. $1891 \ldots . . . . . . . . . .$.

Tuberculosis, lovine-

practical snggestions for suppression and prevention of. 1894.

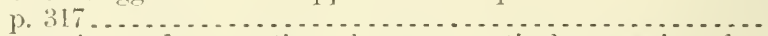
suppression and prevention of, some practical suggestions for. 1894. P. 129

Turkers, nnknown diseases in, preliminary investigations. p. 82 .

Sce ulso, as joint author, Salmon, Daniel Elmer; as translator, Megnin, M. P.

Smith, Theolalu, and Dawson, Charles Francis. Cattle, injuries to, from swallowing pointed objects. p. is ................

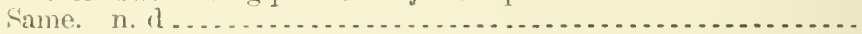

Smith, Theobald, and Kilborne, F. L.:

Southern cattle fever, investigations into nature, cansation, and

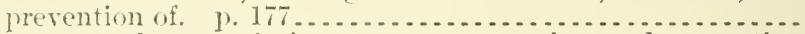

Texas or southern cattle fever, nature, cancation, and prevention

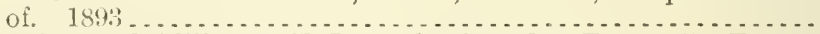

Smith, Theobald, Kilborne, F. L., and Schroeder, Ernest C. Texas cattle fever, additional observations on. 1893. p. $6 \tau$.......

Snith, Theobald, and Moore, Veranus Alya:

Inmmnity, experiments on production of, in rablits and guineat pigs with reference to hog-cholera and swine-plagne bacteria.

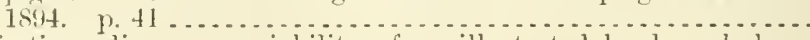

Infections discases, variability of, as illustrated ly hog cholera

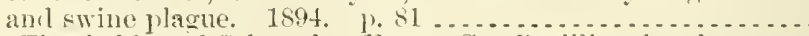

Smith, Theobald, and Schroeder, Ermet C. Bacilli, tubercle, some experimental observations on presence of, in milk of tuberculous cows when udder is not vivibly diseased. 1893. p. 60 ..

Smith, Thomas. Silherian dairy notes. p. $530 \ldots \ldots \ldots \ldots \ldots \ldots$ Sinith, Thorn. Foods and feedling stuffs, report on. 1899. 1). 91 .. Smith, William (i. Soil survey from Raleigh t" Newberne, N. C. 1. 187

A1.1:890

A $4.1: 889-90$

A 1.1:\$91

A 4.1:891-2

A1.1:892

A $4.1: 891-2$

A1.1:\$93

A $4.1: 895-6$

A4.3:3

A $4.3: 6$

A4.3:-

A4.3:7

A $4.3: 3$

14.3:6

At.3:8

A $1.9: 43$

14.2:Sw5

11.10:8\%4

$14.3: 7$

A $4.1: 893-4$

At.1:893-1

14.4:5

$14.1: 891-2$

At.3:1

A $4.3: 3$

A $4.3: 6$

A 4. $3: 6$

A4.3:3

A 4.1:899

A $7.3: 57$

A $26.5: 400^{1}$ 
Smith, William G., and Bennett, Frank, jr. Suil surrey of Jebanon

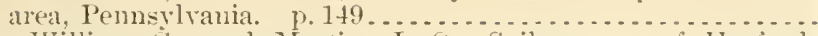
Smitls, William (i., and Martin, J. (). Soil survey of Harforil

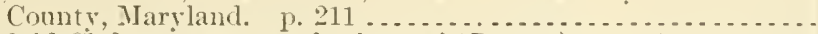

Smithfield Clul, notes on eattle show of (Rogers). p.32f....... Sinithsonian Institution:

Astrophy ro"al Olsservatory, annals of (langley). 1902. 1". 25s.

Meterrojugiral work of (Langley). 1595. ए. $216 \ldots . . . . . . . .$.

Weather predictions, notes on (Abbe). 189s. p. 263........ Smoke-consuming device for locomotives (Lanler). 18\$7. 1. 182. smooth lorome grass (liemnedy). 1899 Sinut:

Few method of treating main Jy Jensen proces for prevention

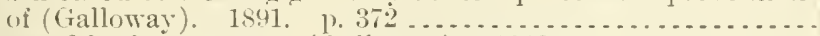

()at and barley, notes on (cialloway). 1ss9. p. 1tit .........

(oats and other cereals, prevention of (Kellerman am swingle).

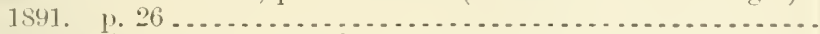

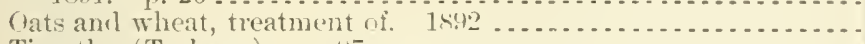

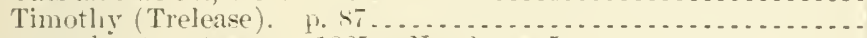

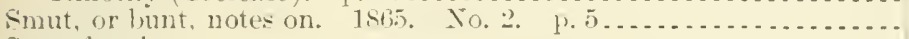

Sniut fingr:

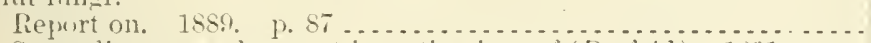

Smut rliseases and, recent investigations of (Prefeld). 1891. lp.

\section{Smxina:}

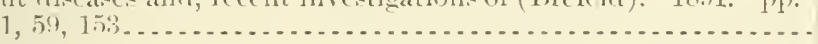

Harkler in, culture of (Smith). 1870. p. 284.

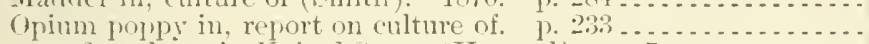
Smyrna-fig culture in [nited states (Howarl). p. 7y........... smyth, 1'. Il. River-stage forerasts of Jissisippi and ohio rivers and tributaries in periods of low water, importance of. 1902.

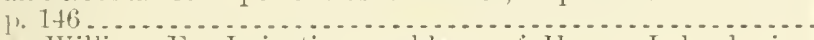

Snyth, William E. Jrrigation problems of Iloney Jake basin,

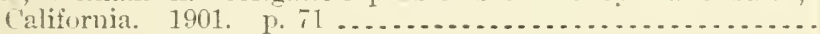

Snake morm. Sep ITorm.

Snell, J. F. See, as joint author, Atwater, Wilbur Olin.

snellen, Maurits. Tetherlands, climate of. 1896. p.627.

snow, B. II:

Cotton worm, acgregate damage from, in Texas rotton crop of

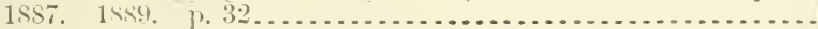

Indian-corn industry in [ nited States. 1891. 1. 23......... Snow, Francis il :

Chinch lone disenve anel otluer notes. 1891. p. 69 ...........

Chineh hu!g-

lestruction of, in fieln by artificial introlnction of contagions

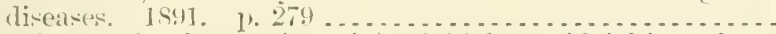
(xperiments for destruction of, in fielal by artificial introdnetion of (4) ntagiou distases. 1s.91. 1) $145 \ldots . . . . . . .$.

Entonoloery, economic, wa)r in, at Lnirersity of Kansas for sest-

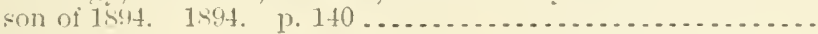
S110س:

Colorerl, notes on (Kimball). 1901. p. 46. . . . . . . . . . . . .

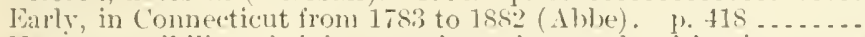

Heavy, [ossil,ility of giving warnings of, to stock-raising interests 48 henrs ju advance (Brandenlurg). 1si9. p. $33 . . . .$.

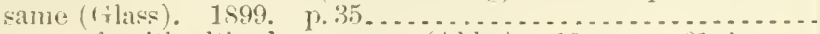

Increase of, with altiturle, note on $\left.(\Lambda b)_{e}\right)$. 1sis!. I1.61_....

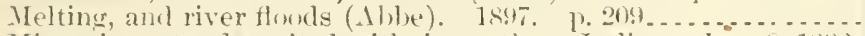

Mimeril matter deposited with, in northern Iniliana, dais. s, 1s.te

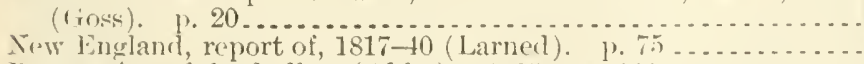

P'enetration of, hy bullets (Ablic). 1895. 1. t't . . . . . . . . .

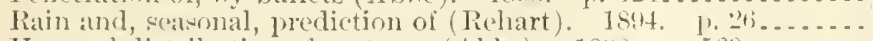

Enequal distribution of, note on (Ahbe). 18:s. 1, 569.......

Enited states, to coul of 1891 (Hamington) . . . . . . . . . . . . . .

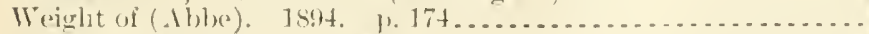

Yellow, in Nichigan (Kimball). 1902. p. 29........... Ser ulo Rainfall.

A26.5:901

126.5:901

$14.1:(995)-15$

$129.6: 30$

129.9:112

1:9.6:26

A 13.8:1

A3.4:18

A25.5:-

$+26.5 .5$

128.5:6

A1.9:5

1 1. 1:885

A.7.4:3

12ง.5:5

A28.5:6

A27.9:8

11. 1:669

A $1.10: 900$

129.8:31

110.3:100

A29.8:11 3

19. $7: 2$

11.8:4.9

A9. $7: 4$

$+9.7: 3$

A10.5:

19.7:7

A:9.6:209

1:29.6:2:2

1.29.8:24

1 $29.3: 24$

$129.6: 27$

1 $20.6: 25$

1:9.6:20

1:2) (0:0):2

$129.6: 23$

129.6:20

A $29.6: 26$

A29.5:C

1:29.6:2:2)

129.6:30 
Sinw ant ice bulletins

Snow anl ice measurements (Volker). 1899. p. $142 \ldots \ldots \ldots \ldots . . . .424 .3: 24$

Snow (rystals:

Mlirro-pliotographs of, notes on (Abbe). 1900. p. $541 \ldots . . .$.

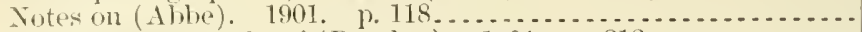

Twenty years study of (Bentley). 1901. 1.212 ...........

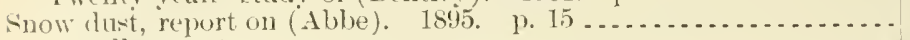

snow rollers, note on-

1845 (Abbe). p. 465.

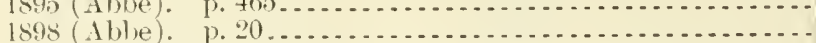

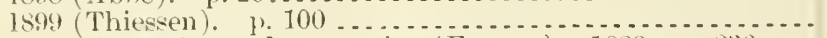

Snow slides, formation and prevention (Fernow). 18s8. p. $236 \ldots$

Snow temperatures, report on (Calvert aml l'hillips). 1S99. 1.55.

Sirowfall:

Anumal, report on (Ablue). 1896. p. 491 ................

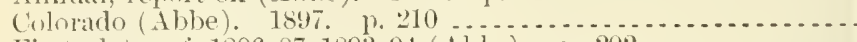

First, lates of 1886-87, 1893-94 (Ablue). 1. 292 ...........

Forests, anr, note on (Abbe). 1899. p. 18 ................

lleary, warnings of, for benefit of transportation companies

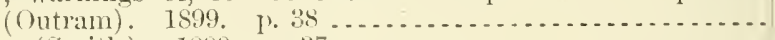

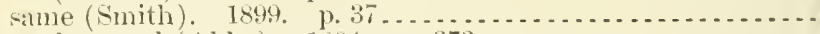

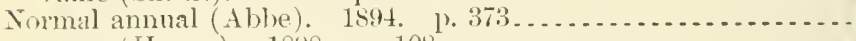

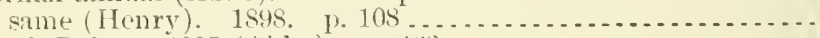

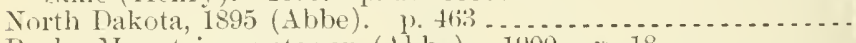

Rocky Mountains, notes on (Abbe). 1900. p. 18..........

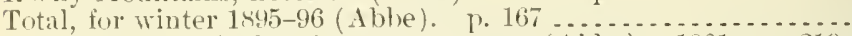
Snowfall and its equivalent in water, notes on (Abbe). 1901. p. 219. fnowtall bulletins, special (Abbe). 1s.9s. p. 21 ............. Snowstorms, memorable, in South Dakota (Glenn). 1897. p. 14... Snycler, Harry:

Albuminoid nitrogen, retermination of, error in present official methor for; and effect of presence of metals precipitable by potassium sulphide in determination of nitrogen by Kjeldahl's

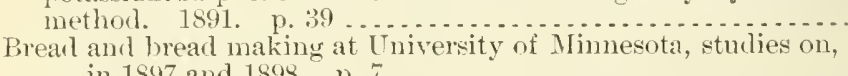

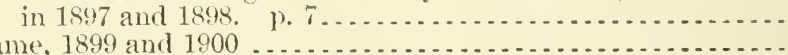

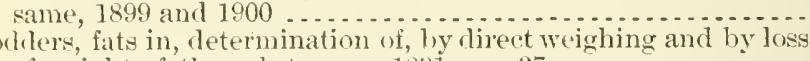
of weight of the substance. 1891. p. $37 \ldots . . . \ldots . . . . .$.

Humus in its relation to soil fertility. 1895. $\mathrm{P}, 131 \ldots \ldots \ldots \ldots$

Nutrients, loss of, in boiling potatoes, carrots, and cabbage. 1897. p. 7 . . . . . . . . . . . . . . . . . . . . . . . . . . . .

Potatoes and eggs, digestibility of. 1897 . p. $20 \ldots \ldots \ldots \ldots \ldots$

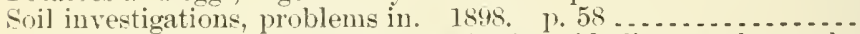

Soils, total insoluble matter, phosphorie acid, lime, and potash

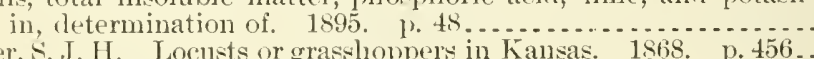
Snyder, s. J. H. Locusts or grasshoppers in Kansas. 1868 . p. 456.. coaps, insecticicle, report on (Mar
societies. See Names of societies.

Soda ash for wirewoms. 1869 . p. 300.

Sodium carbonate, or black alkali:

Formation of by plants (Cameron). 1902. p.61 ...........

liesistance to, by certain plants (Cameron). 1902. p. $71 \ldots . .$. sorlium chloride, aqueous solutions of, solubility of gypsm in

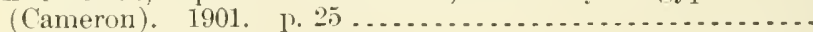
See also l'otash.

Soil analysis:

Discussion of, summary (Hilgard). p. 170

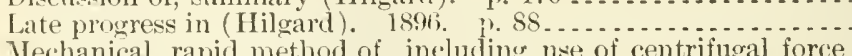

Mechanical, rapid method of, including nse of centrifugal force

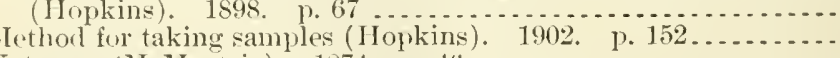

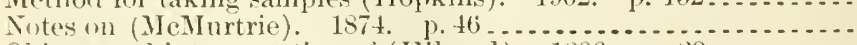

Objects and interpretation of (Ililgari), 1886 , p. 29........ Ohjects and methorls of (Ililgarel), 1597. p. $84 \ldots . . . . . . . .$. A24.6:28 A29.6:29 A:9.6:29 1:29.15:23

129.6:23

129. $6: 26$

A:99.6:27

A13.3:2

129.6:27

129.6:2:3

A $29.6: 2:$

1:99.6:2:2

A29.6:2:-7

A $29.3: 24$

A $29.3: 24$

A $29.6: 22$

A29.6:26

A29.6:23

A29.6:25

A29.6:2t

A $29.6: 29$

A $29.6: 26$

A:9.6:25

$17.3: 31$

A10.3:67

110.3:101

A7.3:31

A $1.10: 895$

A $10.3: 43$

A $10.3: 49$

A $7.3: 56$

A $7.3: 47$

A27.9:6

19.6:6

A $27.9: 7$

A1.8:71

A 1.S: 71

126.3:18

A1.1:855

A 10.3:30

A. $.3: 56$

A 7. $3: 67$

A27.9:12

A7. $3: 10$

A7.3:51

A 7.3:38 
Principles and nethods of (Richards), $\quad 1886$............... A7.3:10

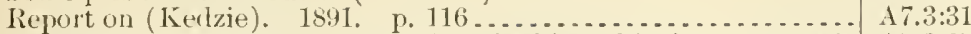

Separation of alkaliesin, by official method (Hopkins). 1928. p. 43. A7.3:67

Soil collection of Division of Soils, Agriculture Department, first

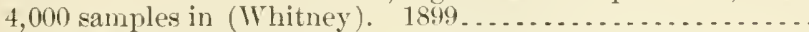

Soil map of Connecticut Valley, description of. $1900 \ldots \ldots . . . . . .$. Soil physic's, relation of tillage to (Sanborn), 1891, p. 17 ....... Soil solutions:

Capillary studies and filtration of clay from. $1902 \ldots . . . . . . .$.

Filtration of suspended elay from (Briggs). 190\%. 1.31 . . . . .

Potash in, note on direct determination of (Peter). 1894. 1. (65).

Their nature and functions, and classification of alkali lands

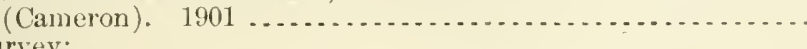
Soil survey:

Abstracts of reports of agrienltural experiment stations on, 18891902

Alamance County, Forth (Carolina (Coffey and Heam). p. 297.

Allegan County, Michigan (Fippin and Rice). p. 93 ..........

Bedford area, Virginia (11ooney and others). p. 239 ..........

Boise area, Idaho (Jensen and Olshausen), p. 421 ...........

Cache la Pourtre Valley, Colorarlo, 1900 (Means). p. 121 ......

Calvert County, Maryland (Bonsteel and Burke), p. 147 ......

Cary area, North Carolina (Coffey and Hearn), 1. $311 \ldots . . .$.

Cecil County, Maryland (Dorsey and Bonsteel). p. 10:3........

Charles Lake area, Louisiana (Heileman and Mesmer). P. 621 ..

Cobh County, (ieorgia (Burke and Marean). p. $317 \ldots \ldots \ldots .$.

Connecticut Valley (Dorsey and Bonsteel). 1900. P. 125......

Covington area, Georgia (IIarean). p. 329 .................

Fresuo, California (Means and Ilolmes), p. 333...............

Hanford area, California (Lapham and Heileman). p. $447 \ldots \ldots$

Harford County, Maryland (Smith and Martin), 1. 211 .......

Imperial, California (Means and Hohmes). p. $587 . \ldots . . . . .$. same (Means and Holmes). $1902 \ldots . . . . . . . . . . . . . . . .$.

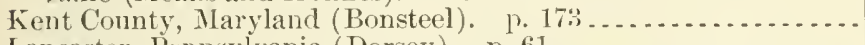

Lancaster, Pennsylvania (Dorsey). p. 61 ........................

Lebanon area, Pennsylvania (Smith and Bennett). p. 149 ......

Montgomery County, Ohio (Dorsey and Coffey). p. 85 .......

Montgomery County, Tennessee (Lapham and Miller). I. 3t1 ..

Peens Valley, New Mexico (Means and (iarlner). 1900. p. 36.

Prince Ed ward area, Virginia (Mooney and ('aine). p. $259 \ldots .$.

Prince George County, Mlaryland (Bonsteel and party). p. 173..

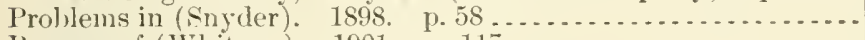

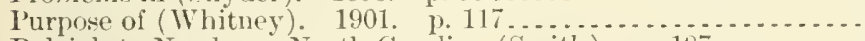

Raleigh to Newbern, North Carolina (Smith). 1.187.........

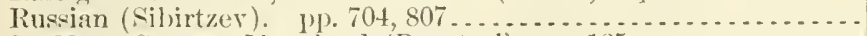

St. Mary Connty, Maryland (Bonsteel). p. 125 ..............

Salem area, New Jersey (Bonstuel and Taylor). p. 125 ........

Salinas Valley, lower, Calitornia (Lapham and Iteileman). P. 481 .

Salt lake Valley, Utah (Gardner and Stewart). 1900. 1. 77 .

Salt River Valley, Arizona (Means). p. $287 \ldots \ldots . . . . . . . . .$.

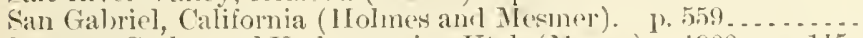

Sanpete, Cache, and Utah counties, Utah (Means). 1900. p.115.

Santa Ana, California (llolmes). p. $385 \ldots . . . . . . . . . . .$.

Sevier Valley, Itah (Garrlner and Jensen), p. 243 . . . . . . . . .

Statesville area, North Carolina (Dorsey and party). 1) 273....

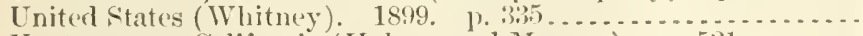

Ventura area, California (IJolmes and Mesmer). p. $521 \ldots . .$.

Weber County, Utah (Cardner and densen). 1). $247 . \ldots . . .$.

Westlield area, New York (Burke and Marean). 1. 75 ........

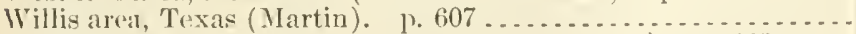

Yakima area, Washington (Jensen anel Olshausen). p. 3s......

Yazno area, Mlississippi (Bonsteel and party). 1, 359) .........

Soil thermoneters, maximmu and minimun, embinesl, instrusSoils:

tions for use of . . . . . . . . . . . . . . . . . . . . . . . .

Aeid, effert of lime on different cropss on. 1901. p.6.......

126.3:16

A $26.4: 7$

$110.5: 3$

A26.3:19

$126.3: 19$

A 7.3:43

A26.3:17

A10.6:

A 26.5:901 ${ }^{1}$

A26.5:901 '

126.5:901

A26.5:901

1.8:64

A $26.5: 900^{1}$

+26.5:901 ${ }^{1}$

A $26.5: 900^{1}$

A26.5:901

A26.5:901'

A 1. $8: 64$

A26.5:901 ${ }^{1}$

A26.5:900 ${ }^{1}$

A26.5:901'

A26.5:901 ${ }^{1}$

126.5:901

A26.4:9

A 26.5:900

A 26.5:900'

A26.5:901'

A26.5:900

A26.5:901'

A1.8:6t

126.5:901

126.5:901

A 7.3:56

A 1.10:901

A26.5:900

A10.6:12

A26.5:900 ${ }^{1}$

$126.5: 901^{1}$

A $26.5: 901^{1}$

A1.8:64

A26.5:900 1

A26.5:901

A I.8:64

A.26.5:900

A26.5:900

A26.5:901

1 1:10.899

A2ti.5:901

A26.5:900

1263.5:901

A26.5:901'

A 26.5:901 ${ }^{1}$

A26.5:901

1:9.11:8;

A1.9:13:3

$114-04-34$ 


\section{Index}

Soils-Continued

Acid digestion of-

effects of presence of few drops of nitric acid in (Thompson).

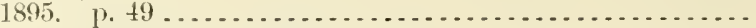
ressels for (Kedzie). 1893. p. $82 \ldots . . . . . . . . . . . . . .$. Acidity on upland or naturally well drainerl, report on necessity of tests for (Wheeler). 1845 . p. $45 . \ldots \ldots \ldots . . . . . .$. Action of oxalic acid upon (Kastle and others). 1894. P. $53 . .$. Arable-

moisture content of, electrical method of letermining (Whit-

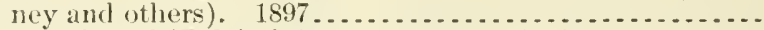
nitrifieation of (Dehérain). 1896. plo. 353,491 ........... Artificial plant food, requirements of (Kilgore). 1902, p. 73... Black, of Russia (Grandeau). 1872. p. 501................ Composition of, some points on, summary and conclusion (Lawes

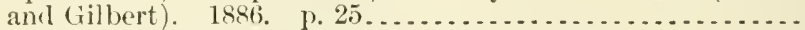

Cotton cultivation and (Whitney). 1896. p. $143 \ldots \ldots \ldots \ldots .$.

Crop production and (Whitney). 1894. p. $129 \ldots \ldots . . . . . .$.

Crops anrl, note on, 1892-98 (Abbe). p. 16 ................

Cultivation of, by irrigation, 1891 (Hinton) $\ldots . . . . . . . . . . . .$.

Deficiencies in, pot experiment to test field observations concern-

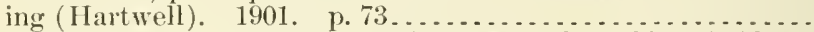

Different, ammonium sulphate and cotton-seed meal in, nitrifica-

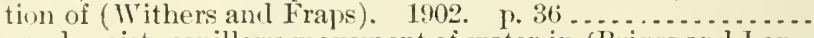
Dry and moist, capillary movement of water in (Briggs and lap-

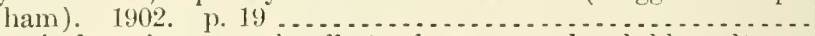

Electrical resistance of, effect of water and soluble salts on

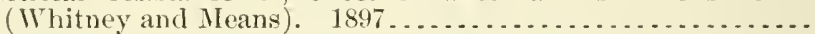

Evaporation of water from, salts as influencing rate of (Brirgss). 1900. p. 184

Exhaustion and abandomment of, testimony of Iilton whitney before Industrial Commission. 1901 .......................

Features of, that shonll be recognized in all plat work (Whitney).

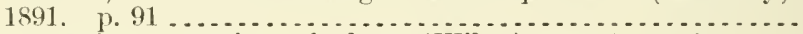

Ferments important in agriculture (Wiley). 1895. p. $69 . \ldots$. Fertility of-

humus in its relation to (Snyder). 1895. p. 131 ........... influence of different systems of farming on. p. $9 \ldots . . . . .$.

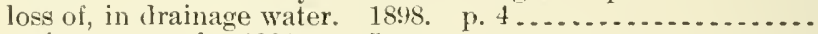

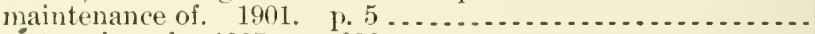
réstoration of. 1897. p. 686

Fertilization of, as affecting orange, in health and disease (Web-

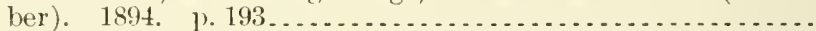

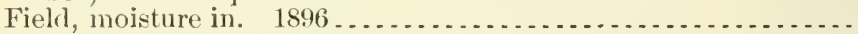

Forest clearing and cultivation, effect on (Fulton). 1899. p. 89. same (Salisbury). 1899. p. 91 … _..................

Growing various crops on, effect of. 1897 . 1.684 ............

Humns in, importance of maintaining a supply of. 1898, I. $5 .$.

Inoculation for leguminous plants (Mlay and Beal). 1901. p. 7 .

Investigation of. See Soil survey.

Liming of -

from a physiological standpoint (Loew). 1901 . . . . . . . . . . .

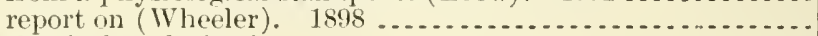

Mechanical analysis of-

methorls of. 1896 .

some necessary modifications in methors of, as applied to alkali soils (Brigos). 1900. p. 173 .

\section{Moisture in-}

conserving and economizing. 1899 . p. 5 ....................... determination by electrical methor (Gardner). 1898 . . . . . . electrical instruments for determining (Briggs). $1899 \ldots \ldots .$. influence of salt and similar substances on (Beal). 1900 . p. 5.

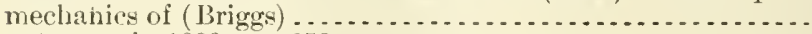

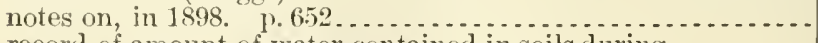
record of amount of water contained in soils during-

May, 189.5

Jume, 1895

A 7.3:47

A7.2:38

A 7.3:47

A $7.3: 43$

А $26.3: 6$

A 10.6:6

A 10.3:115

127.9:10

A7.3:10

A $10.3: 33$

A1.10:894

A 29.6:28

A15.2:1r 7

A 7.3:62

A7.3:67

A26.3:19

A26.3:8

A1.8:64

A1.8:70

A 10.8:7

A1.10:895

A1.10:89.5

A1.9:87

A1.9:73

A 1.9:144

A1.10:897

A1.10:894

A26.3:4

A 29.3:24

A29.3:24

A1. 10:897

A 1.9:78

A1.9:124

A19.3:1

A1.9:77

A26.3:4

A1.8:64

A1.9:87

A26.3:12

A26.3:15

A1.9:114

A26.3:10

A1.10:898

A 26.3:1

A26.3:2 


\section{Mristure in-Continued}

record of amount of water contained in soils durins-Cont'd.

July, 1895 .

1896, crop season (Whitney and Hosmer)

Nitric acid in, determination of, ly Schlorsing's methor, at Roth-

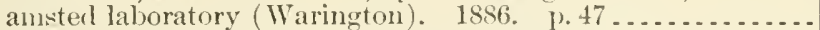

Nitrification and denitrification in, lectures on (Warington). 1842.

Nitrogen hungriness in, recognition of (Hilgarl). 189.5. 1. $58 .$.

Nitrogen in, of some of the experimental fields at Rothamsted, determination of, and bearing of results on question of source of nitrogen of our crops (Lawes and (iilhert). 1882. 1. 142..

Particles, division of, in mechanieal analysis, plea for scientific:

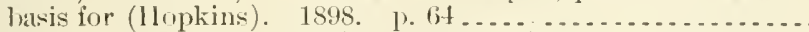

Phosphoric acid and potash in, determination of (loss). 1895. I). 50.

Plosphoric acis in-

estimation of, by double vrecipitation with molyhlic solution and titration of ammonium phosphomolybrlate with stand-

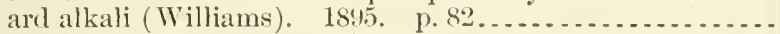
method for determination of (Goss). 1894. p $58 \ldots \ldots \ldots . .$.

Physical analysis of (Whitney). 1895. ए. 60.............

Physical properties of-

adaptation of methods of (cultivation and manuring to ( $\mathrm{W}^{\mathrm{T}} \mathrm{ullny}$ ). 1900 . p. 805 .

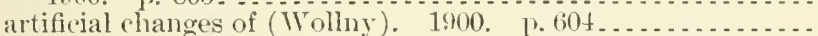

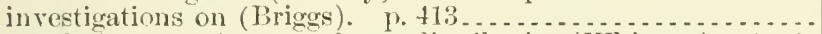
in relation to moisture and crop) distribution (Whitney). 1892. nature of (Wollny). 1896. Pp. 761, 853, 948 ............. objects and methorls of investigating certain (Briggs). 1900. p. 397 relation of, to cultivation of plants (Wollny). 1893. pl. 528 , 627

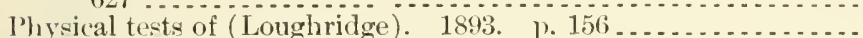

l'roblems, some interesting (Whitney). 1897. p. 42y ........ 1'rorluctiveness of, nitrification aselement in (1Vithers). 1902. 11.87 Products and, of southwestern Lonisiana (Rapley). 1884.......

lieasons for cultivating (Whitney). 1895. p. 123........... Relations of climate to (Hilgard). 1892 . . . . . . . . . . . . . .

Samples ofinstructions for taking, for moisture retermination (Whitney).

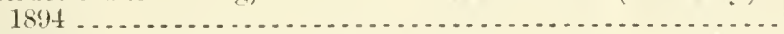
methor for taking, for analysis (IJopkins). 1902. p. 15:...

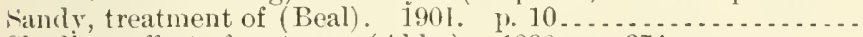
Sharing, effert of, notes on (Abbe). 189t. 1.374........ Shifting, grastes fol fixing (Vasey). 1872. 1. 223 . . . . . . . . . Soluble mineral matter of (Means). 1898. p. 495 . . . . . . . . . . Soluble salt content of, electrical method of determining (Whit-

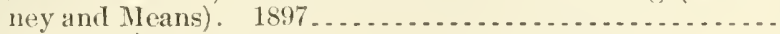

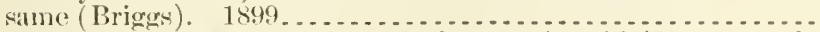

Solvents for available potash, and phosphoric arid (Ilustun and

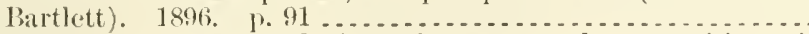

forchum and sugar producing, chatacter and composition of (Ricliardson). 1856. 1. 60 ...

Strawberry. 1902. p. 16.

Study of, application of theory of solution to (Cameron). 1899.

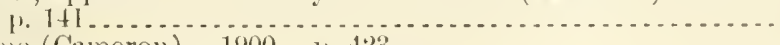

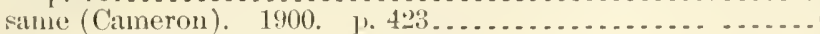

survey of. See Soil survey.

Swamp, marsh or muck, ntilization of. 1898 . p. 7..........
Temperature and moisture of, in Red River villey, notes on,

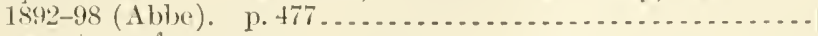

'Temperature ofchectrical instruments for letermining (Briggs). 1899 . . . . . . elertrical method of determining (Whituey amb lingurs). Is97.

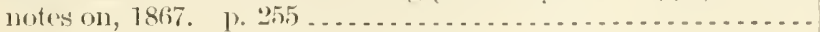

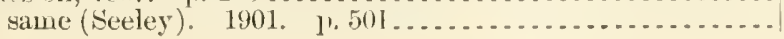

A26.3:3

1:26.3:!)

17.8: :11

110.:3:8

i $7.3:+7$

11.8:31

A7.:3:56

17.:3: 47

17.:3:47

17.8:4:3

17.:2:47

10.6:1

A $10.6: 11$

A $26.5:\left(300^{2}\right.$

129.3:4

110.6:6

A1.10:900

110.6:-1

A10.3:16

A $1.10: 897$

110.3:115

A1.8:35

1 $1.10: 895$

12!).3:3

$126.4: 2$

17.3:67

1 1.9:124

129.6:2:-

127.9:10

11. 10:8:18

$126.3: 8$

1:6.3:15

17.8:40

17.:3:10

1 $1.9: 149$

A1.6:64

$1: 21,5: 1) 0()^{1}$

11.9:75

$1231.6: 27$

A20.:2:15

12ti.3:7

$127.99: 5$

129.6:2y 
Soils-Continued

Tests with fertilizers, explanations and directions for. $1889 \ldots \ldots . .110 .4: 8$

Texture of some typical-

$1895 . \quad$ 1. 556

1896. 1). 602

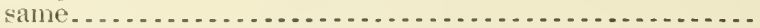

Tillage and products of, on irrigated lands ('ureton). 1887. p. 282.

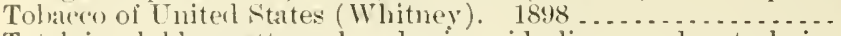

Total jnoluble matter, phosphoric acid, lime, and potash in, determination of (Snyder), 1895. p. $48 \ldots . . . . . . . . .$.

Types of-

descriptions of. 1902 ................................ list of, established by Division of Soils in 1899 and 1900 , with

brief description

Vegetalule productions of, relation of entomology to, with reference to destrutetive and beneficial insects (Rathron). p. 372.

Wrasher, how to prevent and reclaim them. 1894 ..............

Water in-

capillary rise of, influence of diwsolved salts on (Briggs and

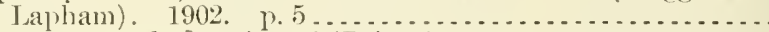
movement and retention of (Briggs). 1898. p. $399 \ldots \ldots \ldots$. . . .

See ulso Alkali soils-California-Clay-Florida-GeorgiaHawaiian soils - Maine - Mississippi - Mnd - Plant-soil tests - Salt Lake Valley, Utah - Sand-South Carolina.

Soils and ash. See also Ash.

Soils and ash, committee on, report of, at Convention of Association of Official Agricultural Chemists:

1891 (Avils only). p. 116 . . . . . . . . . . . . . . . . . . . . .

1892. p. 93 ...................

1894. P. 28 ...................

1895. p. 30 ......

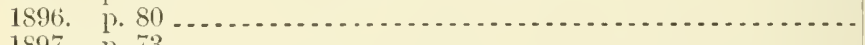

1897. p. 73 ...........

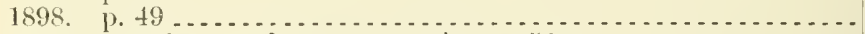

1898. Supplemental report on ash. p. 56..................

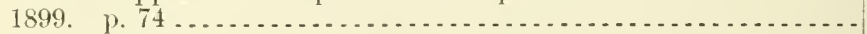

1900. (Soils only.) p. 60 ... . . . . .

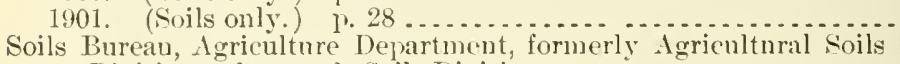
Division; afterwards Soils Division:

Fielıl operations of-

1899. (Whitney)

1900

1901 -

Feld parties of, instrutions to, and ieseriptions of soil types. 1902

Soil collection of, catalogue of first 4,000 samples in (Whitney). 1899

Work of, for farmer (Whitney). 1897. P. 122...............

Solandi [sun] printing (Halsted). 1894. p. 93 ................

Solano County, Cal., cattle quarantine, order for. Feb. 26, $1900 \ldots$

Solar and terrestrial magnetism, and their relations to metenrology

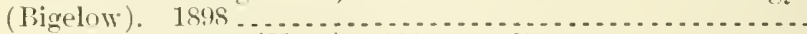

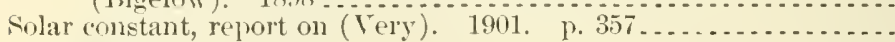

Solar eclipse:

Oleservations during, notes on (Albhe). 1900, p. 449..........

Total, of May 28,1900 , probable elondiness during (Abbe). p. 422.

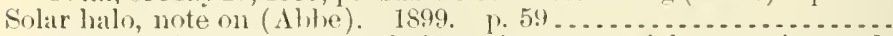

Solar magnetism, report on relations of, to terrestrial magnetism and meteorology (Bigelow). P. 519

Solar raliation, observations of; how hest marle and compiled

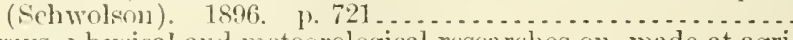

Solin rays, jhysical and meteorological researches on, made at agricaltural climatology station, Juvisy obervatory (Flammarion).

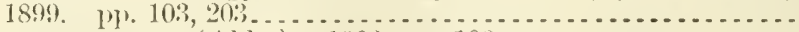

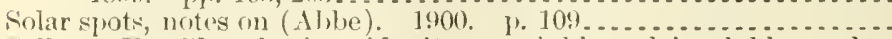

Solberg, E. l'hosphuric acid, eitrate, solnble and insoluble, as ifetermined by different methods. 1895 . P. 85.

A $7.3: 47$

A $7.3: 49$

A $7.3: 51$

A7.3:56

A7.3:56

A7.3:57

A7.3:62

$17.3: 67$

A26.

A1.8:64

A26.5:900

A26.5:901

A26.2:F45

A26.3:16

A 1.10:897

A $10.3: 20$

A $4.5: 59$

A 29.3:21

A 29.6:29

A29.6:28

A29.6:27

A 29.6:27

A 29.1:89 ${ }^{3}$

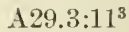

A10.6:10

A29.6:28

A7.3:47 
Soldiers' Home herd of eattle. Sif Povine tuberenlosis.

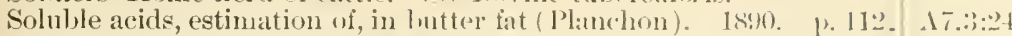

Solulile ferments. See Enzymes.

Soluble salts. Tiee Soils.

Solution, theory of, application of, to sturly of soils (Camerom).

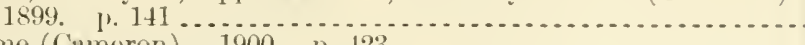

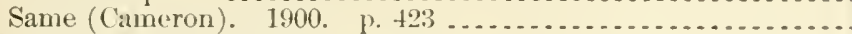

Solvents. See Sioil solvents.

Somali, or black-head, sheep (Masterson). 1. 522.

A1.8:64

+ $26.5: 900^{1}$

Sommers, Miss Sarah I. Lanel-erant eolleges and agricultural exprelimental stations in Cnited States, compilation of statistics of, for 1897

14.1:898.

A10.3:51

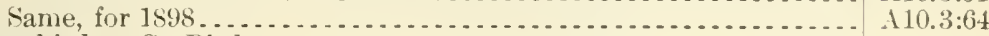

Song birds. See Birds.

Sonora, Mexico, plants of, collected by Edward Palmer in the years 1890 and 1891 (Rose). 1895. p. 293.

Sooty mold of rrange, treatment of (Vebber)

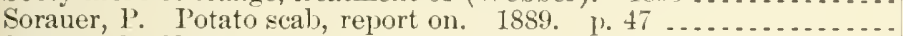

Sorex. See Shrews.

Sorgho-canes, sugar leterminations from, partial summary of. 1880.

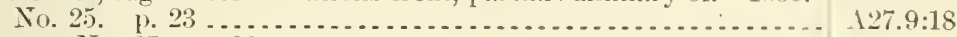

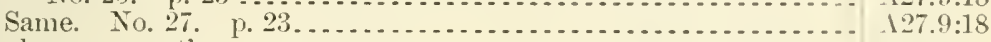

Sorghum, or northern sngar cane:

Analysis of (Erni). 1866. p. 336 . . . . . . . . . . . . . . . . .

Analytical work done on, by Chemical Division, July-Dec., 1880

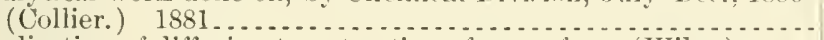

Application of diffusion to extraction of sugar from (Wiley) .....

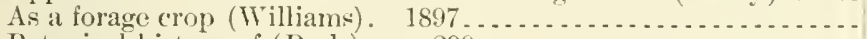

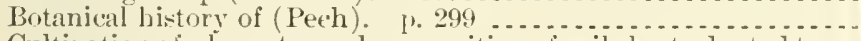

Cultivation of, character and composition of soils best adapterl to-

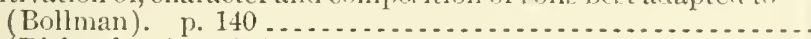
(Richartson), 1886. p. 60 . (Snitl). p. 129.

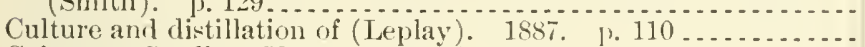

Culture at Sterling, Kans. (Denton). 1891. 1. $78 \ldots \ldots . . . . .$. See clso Sterling, Kans.

Data relating to, as sugar-producing plant. 18s7. p. 59 .......

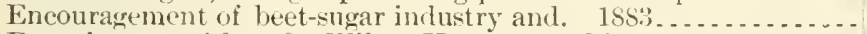

Experiments with. See Wile'y, Havey Washingtom.

Growing in spain (Heredia and llermanos). 1893. [1. 34. . . . .

Improvement of, by selection. 1899 . ए. $7 \ldots \ldots \ldots \ldots \ldots$

Introduction of, into United States. 1883. No. 2. p. $24 \ldots . .$.

Investigation of, as a sugar-producing plant (Collier) $\ldots . . . . . .$.

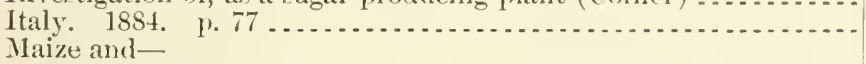

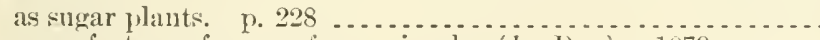
manufacture of sugars from, circular (Le I)uc). 1879 ......

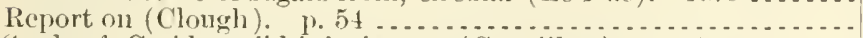

Sceds of, Cccirlomyiirl injurioms to (Copuillett). 1898. 1\%. 81 ...

See also Orange sorghmm canc- Saccharine sorghums.

Sorghum blight, status of (Kellerman and Swingle). 1859. p. 195.

Sorghum molasses, statisties of. 1862-63. No. 5. p. 4......... Sorghum sirup:

Manufacture of-

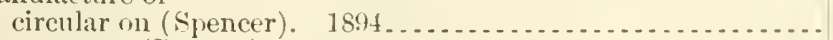
report on (Denton). $1901 \ldots$

127.9:4

11.6:33

17.3:8

11.9:50

11.1:865

A 1.1:862

A 7.:3:10

A 1. 1:862

17.3:18

A7.8:34

17.3:18

11.8:26

17.3:40

1 $1.9: 92$

$127.9: 21$

1 1.8:27

17.3:3

1].1:877

11.8:15

A1.1:864

19.6:1S

128.5:5

127.9:]

17. 4:1

A1.9:135

1 $1.9: 90$

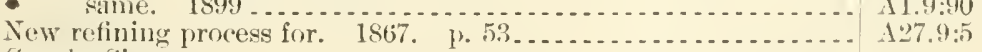

Sée ulso Sirups.

Sorghum sugar:

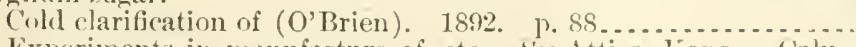

Experiments in mannfacture of, ete. Sire Attica, Kans. - ('alumet plantation sngarexperiment station - Cerlar lialls, lowa Conway Springs, Kans.-Douglas, Kans. - Fort Sontt, Kans. - Kansas - Kenner, La. - Jawrence, La. - Meade, Kans. - Medicine Lodge, Kans. - Morrisville, Vat. - News City, Kans. - Rio Grancle, N. J. - Sterling, Kans. 
Sororlum sugar-Continued

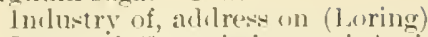

Letter of Commissioner of Agriculture to Fenate Committee on

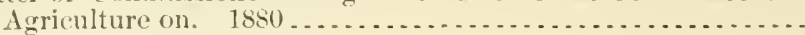

Manufacture of-

cireular relative to (Le Duc). 1879

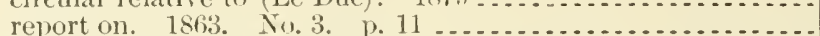

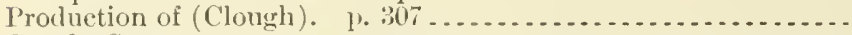

Sie al:o Sugar.

Soskins, Selik. Fat, formation of, in animal borly. 1897. p. 179.

Soule, Andrew M. Beef and dairy cattl12, confolmation of. 1902...

Soulé, Frank. Irrigation from Sin Joaquin River, Cal. 1901. p. 215

Soulhet, F. Citric ateid in milk, rejort on. 1889 p. $155 \ldots \ldots \ldots$.

Sounds, measuring and photographing, advance in (Sharpe). 1899.

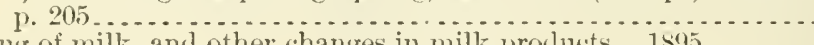

Souring of milk, and other changes in milk products. $1595 \ldots . .$. South:

Agricultural courses in, principles muderlying formation of

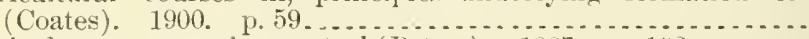

Agriculture survey of, report of (Peters). 1867. p. 192....... See also Southern agriculture.

Cooperative branch grass stations in (Traey). p. 34t .........

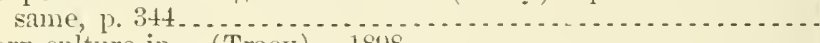

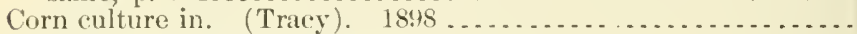

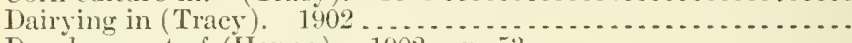

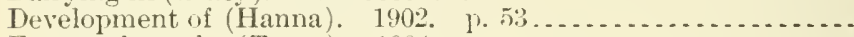

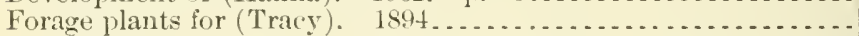

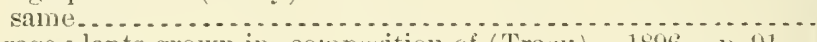

Forage plants grown in, compinstion of (Tracy). 1896. p. pi

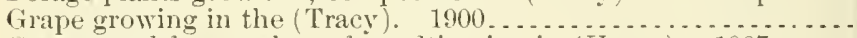

Grasses and forage plants for cultivation in ( $T$ asey $) .1887 \ldots .$.

Hog raising in (Tracy). $1899 \ldots \ldots \ldots \ldots$

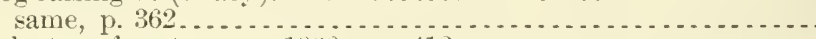

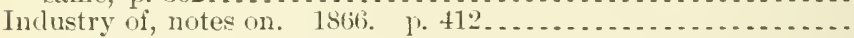

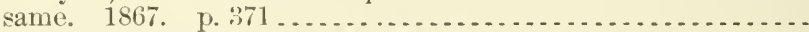

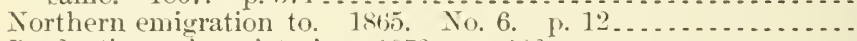

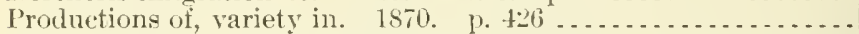

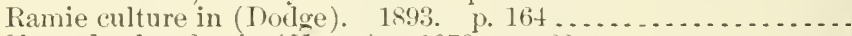

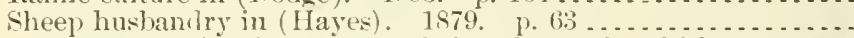

Urban population in; country lueing leserted; whither are we tending? 1894. 1). 572

Winter forage crops tor (Ball). 1902

Sice also Southern States - and names of State:

South Africa. See Africa.

South African ticks, notes on some (Lounshury). 1900. P. 41 .... South America:

Agriculture of, with maps and latest statisties of trade (Barnes).

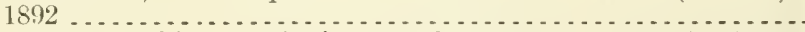

Cotton crop and its enemies in, comsmlar reports on. $1885 . \mathrm{A}$.

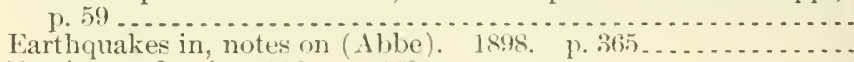

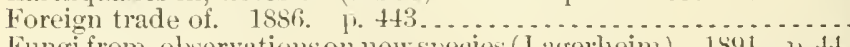

Fungi from, observationson new specjes (Jatgerheim). 1891. 1.44.

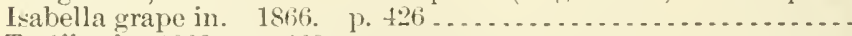

Tariffs of. 1890. p. 460 . $16 . \ldots \ldots \ldots \ldots \ldots$

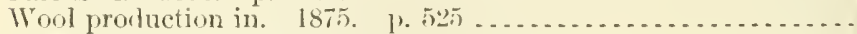

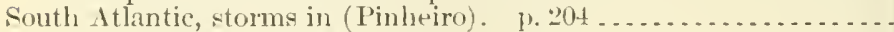

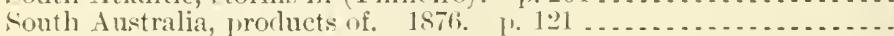

Sie celso Port Carolina.

Soutl Carolina:

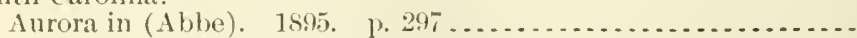

Blark seale of California found in, note on. 18sti. 1, $36 \ldots \ldots .$.

Climate, soil, and agricultural capaliblities of (Hemphill). 1882.

Coast recrion of, frost formation over, some peculiarities in (Jesu-

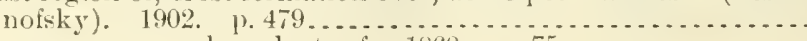

Farm resources and ploduets of. 1868 , ․ $75 \ldots \ldots \ldots \ldots \ldots \ldots . . .627 .9: 6$

A 10.3:76

A27.9:5

A1.1:891

16.1:891

A1.9:81

A1.9:151

A 2.2.3:25

A 1.9:18

A $1.9: 18^{2}$

A 10.6:6

A 1.9:118

16.3:3

A 1.9:100

A $4.1: 899$

A $27.9: 4$

A27.9:5

127.9:3

A $27.9: 8$

110.3:16

1 1.2:Sh 8

+27.9:3:2

$+11.9: 147$

A.9.6:26

A27.8:2

A8.1:4

A 29.6:26

127.9:24

128.5:7

127.9:4

1 $27.9: 28$

А.27.9:13

129.3:11 1

1.7.9:14

129.6:23

A9.3:12

11.6:47 
South Carolina-Continued

Farmers' institute work accomplished in (Tindall). 1902. 1. 2S. Grapevine tliseases in (Howell). 1888. p. 35 ..................... Grasses of, in Elliott's Sketch of botany of Soutl Carolina and Georgia, notes on (Scribner). 1901 ............................ Irrigation of rice in (Keeney ). 1902. I, 59..................

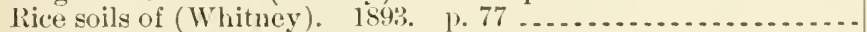
Sheep husbandry in (Watts). 1877. p. 118................ Storm waves of (Alexander). $1900, \quad$ p. $381 \ldots . . . . . . . . . . .$.

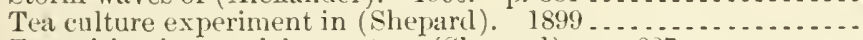
Tea raising in, special report on (Shepard). p. $627 \ldots \ldots . . . .$.

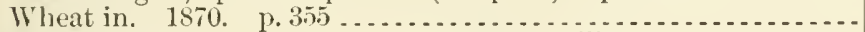
See also Charleston - Pinehurst - Summerville.

South Dakota:

Artesian and underflow conditions in (Coffin). 1893. I,t. 4,

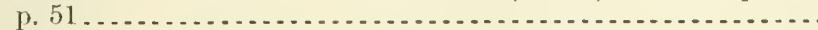

Artesian well investigation, field work(Coffin) 1890. p. 125 .

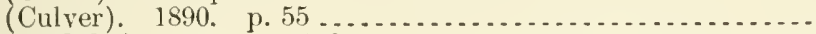

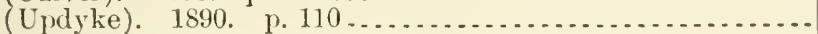

Bottom disease among horses of (Schroeder). p. 371...........

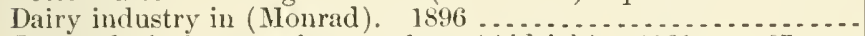
Entomological notes of season from (Aldrich). 1891. p. 67.... Geology of, west of Missonri River (Bailey). 1890. p. 65 ...... Maladie du coit among horses in, extirpation of (Nörgaard). p. 62 . Mutton in, feeding for (Chileott and Burnett). p. 471 ......... Precipitation (rain and melted snow) at stations in, details of. 1894

Russian thistle and other troublesome weeds in wheat region of. 1893

Snowstorms, memorable, in (Gleun). 1897, p. 15 .......... See also Black Hills - Highnore - Pierre.

Sontheastern States, grasses and forage plants of, notes on (Kearney).

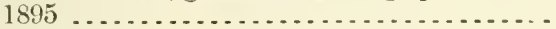

Sonthern agriculture, condition and prospects of:

1867. p. 412

1868. (Trenchard). p. $447 \ldots \ldots \ldots \ldots$

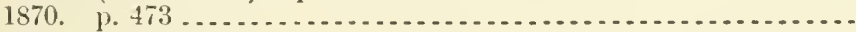

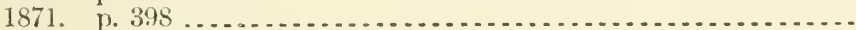

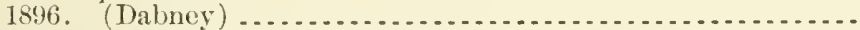

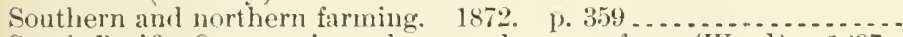

South Pacific Ocean, winter barograph curve from (Ward). 1897.

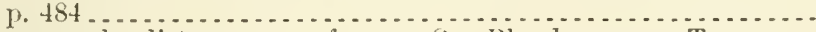

Southern cattle distemper or fever. See Blood serum-Texas or Southern cattle fever.

Southern cattle ticks:

Growing moninfected, and afterwards infeeting them with Texas

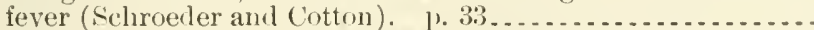

Transmission of Texas fever by (Mayo). P. 481 ...................

Tubereulosis and, in New South Wales (Baker). ए. 386 ........ same, correction, 1. 502

United States (Salmon and Stiles). p. $380 \ldots . . . . . . . . . . .$.

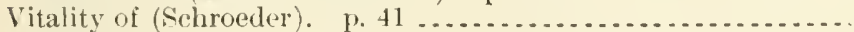

See also Ticks.

Sonthern fairs, agricnltural representation at. 1869 . p. $365^{*} \ldots \ldots$.

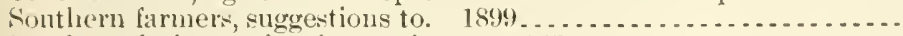

Southern fruit growing for market. p. 143 ...................

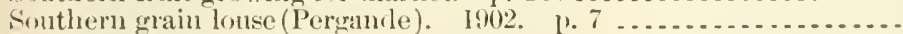

Southern interstate fair. Sce Atlanta, (ia.

Southern pines:

Five, structure of wook of (Roth).

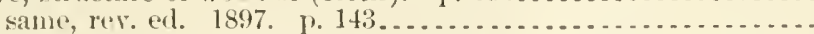

Mechanical and physieal properties (Fernow). $1896 . . . . . . .$.

Southern planting and northem farming (Watts). 1872. p. $207 \ldots$ See also Farming.
A 10.3:120

$16.3: 10$

A3.4:29

110.3:113

A27.8:6

11.2:Sh3

A:29.6:28

A1.8:61

A 1.1:892

A27.9:8

A $15.2: \operatorname{Ir}^{2}{ }^{2}$

115. $2:$ Ar 7

A 15.2:Ar7

A15.2:Ar7

A4.1:891-2

14.3:16

19.7:4

A15.2:Ar7

A 4.1:893-4

A4.1:898

A29.2:P91

A1.9:10

A 29.6:25

A3.3:1

A1.1:867

A27.9:6

A27.9:8

127.9:9

A 1.4:3

A 27.9:10

A29.6:25

A4.1:899

A4.1:898

A 4.1:898

14.1:899

14.1:900

At.1:899

127.9:7

A $1.9: 98$

11.1:871

19.6:38

A13.83:13 ${ }^{\mathrm{I}}$

A 13.3:13 ${ }^{2}$

A 13. 4:12

A27.9:10

* Bу a mispritu, Ihts gage number apreurs twice. 


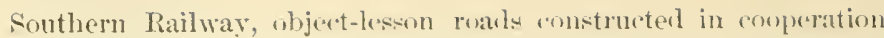

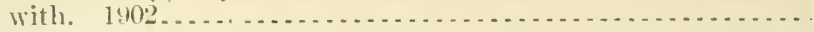

Southerus siates:

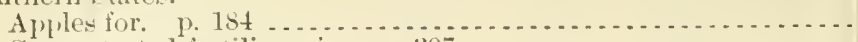

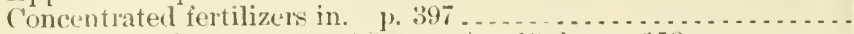

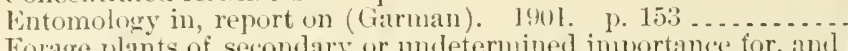

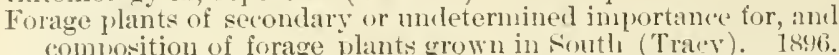

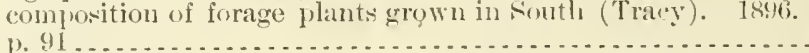
Forests, timber culture, etc., in, conclition of (Baker). 1sst. 1. 105 . . . . . . . . . . . . . . . . . . . . . . . . . . .

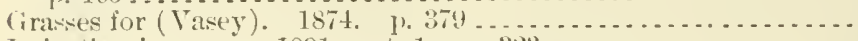

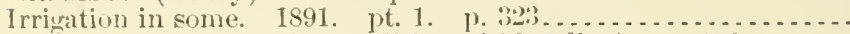

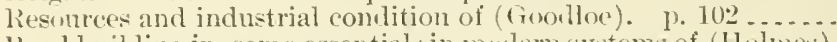
Road luilding in, some essentials in molem systems of (Holmes).

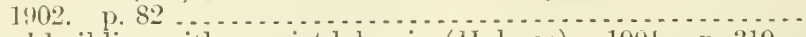

Roarl builling with convict labor in (IIolmes). 1901. p. 319 ...

Road conventions in, and object-lesson roads constructed under supervision of Office of P'ublic Roar Inefuiries, with coopreration of Sonthern Railway. 1902 . . . . . . . . . . . . . . . . .

Roits and roal-making materials in certain. $1894 \ldots . . . . . . .$.

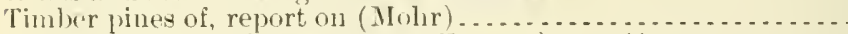
same, introduction to report (Fernow). p. $11 \ldots . . . . . .$.

Trese, come foreign, of economic value adapterl to planting in.

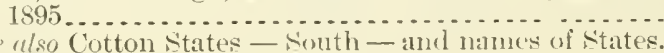

Sonthwest:

Arid lands of; new species of ground squirrel from, description

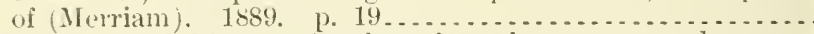

('attle ranges of, history of exhanstion of pastulage and sugges-

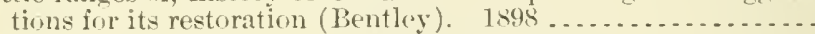

Cooperative grass stations in (Mclaren). 1, $844 . . . . . . . .$.

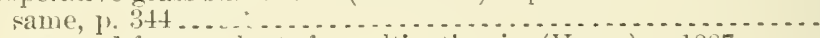

(irasses and forage plants for cultivation in (Vasey). $1887 \ldots .$.

(irasses of. 2 pts. (Vasey) . . . . . . . . . . . . . . . . . . . . . .

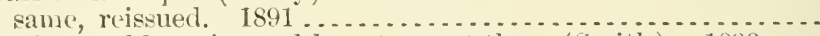

Grazing problems in, and how to meet them (Smith). $1899 \ldots$

Sce clso names of States. . . . . . . . . . . . . . . . . . . . . . . .

Southwick, E. B.:

Entomologiral, economic, work in parks of New York City.

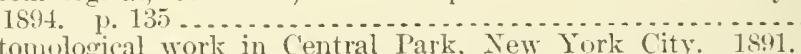

Entomological work in Central Park, Tew Tork City. 1891.

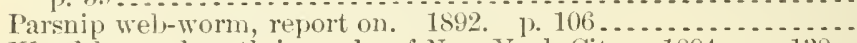

Wood-leopard moth in parks of New Tork City. 1s9t. p. 138..

Southworth, E. A.:

Anthracnose of cotton, report on. 1891. 1) 100_.... . . . . .

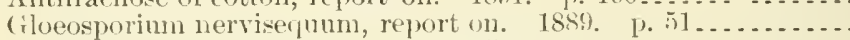

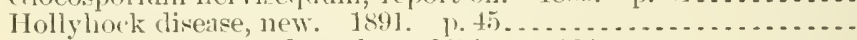

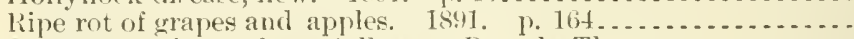

Sie also, as joint author, (ialloway, Beverly Thomas.

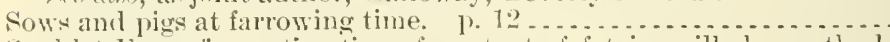

Soxhlet-Hngström, estimation of content of fat in milk by methenl of (kithn). 1890 p. $158 \ldots \ldots \ldots$

Soxhlet's areometric methol, estimation of fat iu milk ly (Klein).

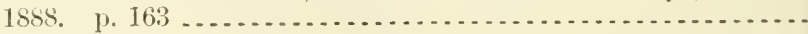

Soy bean:

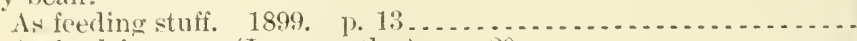

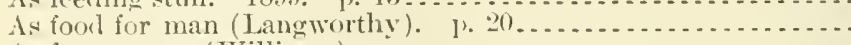

As forage crop' (Williams) .

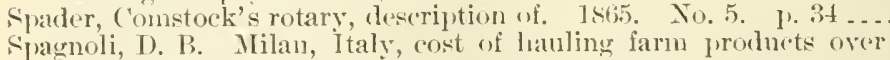

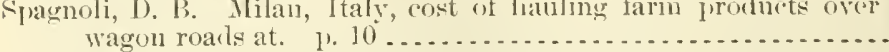
Spain:

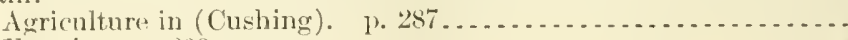

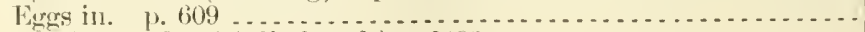

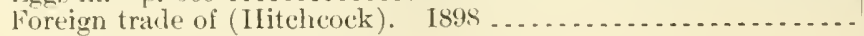

(12:):3:2:3

11.1:869

$11.1: 868$

110.3:99

$110.6: 6$

113.5:4

127.9:12

115.2:Ir $7^{2}$

1 1.1:865

A $22.3: 23$

A 1.10:901

122.3:28

122.3:7

113.3:13

113.3:13

113.3:11

Aร. $5: 2$

1 1.9:72

11.1:891

16.1:891

A6.3:3

A6.3:12

16.2: ${ }^{7} 82^{1}$

\3.3:16

19.7:7

A.9. $7: 4$

19.7:5

A?.7:7

$128.5: 6$

128.5:5

128.5:6

1:8.5:6

$11.9: 97$

$17.3: 24$

$17.9: 24$

A $1.9: 97$

A $1.9: 58$

1 $1.9 \% 58$

127.9:3

122.4:27

A 1.1:876

14.1:901

A12.3:11 
Forest trees in, planting of, and destruction of locusts. 1876. p. 263 . . . . . . . . . . .

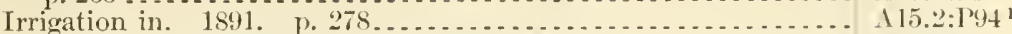

Our trade with, 1885-97 (IIitcheock). 18\$8 .............. $112.3: 12$

Sorghum growing in (Heredia and Hemnanos). 1893. p. 34 ... $47.3: 40$

See also Malaga.

Spalding, V. M. White pine, report on, revised and enlarget hy B. E. Femow. 1899 . . . . . . . . . . . . . . . . . . . . .

Spallanzani, Pellegrino. Volatile acids, fatty, of butter, contribution to study of. 1890 . p. $104 \ldots \ldots \ldots \ldots \ldots \ldots \ldots \ldots \ldots$.

Spanish almonds and their introduction into Ameriea (Fairchild). 1902

Spanish fever of cattle:

Investigation of (Catron). 1868, p. 357 .

Note on-

1867. W1. 54, 135 .

1868. pp. 180, $40 t$

Spanish merinos and their management (Boynton) p. 196

Spanworm, walnut, report on (Coquillett). 1897. y. $64 \ldots \ldots \ldots$.

Sparganum mansoni. See Larval cestode.

Spark-arresters, importance of (Tilton). 1887, p. 136 ..........

Sparrows:

Destruction of, by poisons (Fisher). 1889. p. 17t ..........

Relation of, to agrieulture (Judd). 1901 .....................

Trapping of, for sporting purposes, with paper deseriptive of ap-

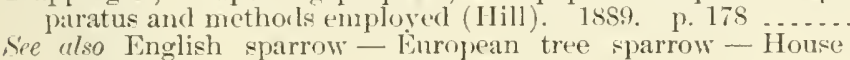
sparrow.

Sparrow lawk, special report on (Fisher). p. 491 ...............

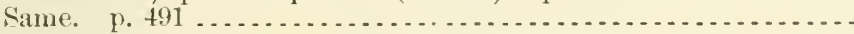

Spartina:

North Anerican species of (Merrill). 1902 ..................

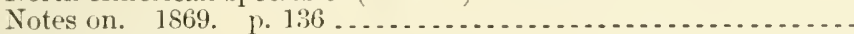

Sperifie gravity:

Determination of, standard temperatmes for, rejort on. 1897 .

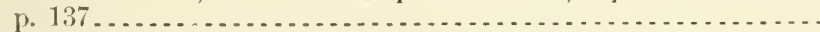

Limits of, of cow's milk (Schrodt). 1888. p. 154 ............

Rise in, determination of, on allowing milk to stand after milk-

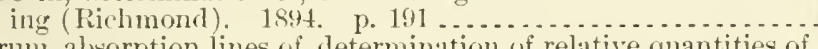

Spectrum, absorption lines of, determination of relative quantities of aqneous vapors in atmosphere by means of (Jewell). 1896..

Speculation $v$ industry. 1892. p. $134 \ldots \ldots \ldots \ldots$

Spencer, Guilford Lawson:

Beet sugar, machinery and processes for manufacture of, recent

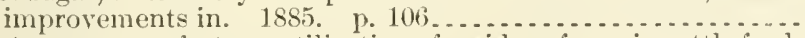

Beet-sugar manufacture, ntilization of resilues from, in cattle feed-

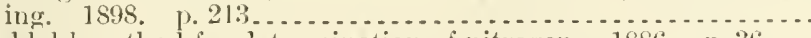

Kjeldahl method for determination of nitrogen. 1886 . p. $36 \ldots$

Magnolia, sngar and sngar-cane data for four years at, summary

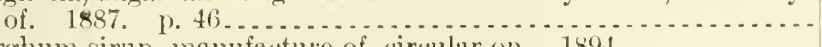

Sorghum sirup, manufacture of, circular on. 1894 . . . . . . . . . .

Sorghmm-sugar experinents by various companies in Kansals.

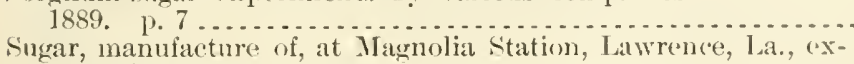
periments in-

$2 d$ report, season of $1885-6$. . . . . . . . . . . . . . . . . . . . .

3 report, $1886-7$. . . . . . . .

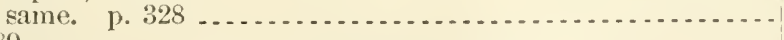
1889

Teat, coffee, and cocua preparations, alululteration of. 1892. p.875.

Siee ulion, as eollaborator, Wiley, Harvey Washington.

See also, as revisor. . . . . . . . . . . . . . . . . . . . . . . . . . . . Spencer, John W. Young people attending farmers institutes, how to interest and instruct. $1902.20 .42 \ldots \ldots \ldots \ldots \ldots . . .10 .3: 110$

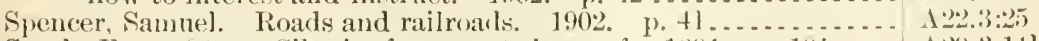
Sperk, Franz Utto. Siberia, four great riverw of. 18\%. p. 101.... $129.3: 11^{1}$ 
Spermophile:

Mississipl, Valley (Bail(y). p. 185).

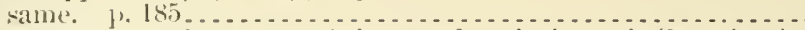

Tew, from nortliwestern Arizona, description of (Merriam).

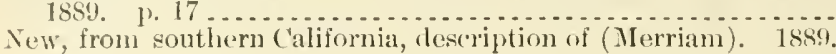
p. 15 .

tie also Sipuirrels.

Spermophilus spilosoma group. See Ground squirrel.

Spethmann, Miss Marie T. Land-grant colleges and agricultural experiment stations in United States, compilation of statistics of, for 1900

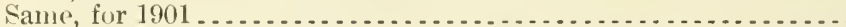

Splirerotheca, another, upon Pliytoptus distortions (Halsted). 1889.

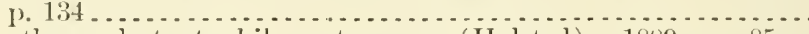
Sphaerotheca phytoptophila, notes upon (Halsted). 1859. 1. $85 .$. Sphingicle, list of, taken by electric lamps at Ponghkepsie, N. I. (Dyar). 1891. p. 322................................... Spices, analysis of, provisional methor for (Winton). 1902. p. 55. . Sipices and condiments, adulteration of:

18s6. (Richardson). p. 291 ... . . . . . . . . . . . . . . . . .

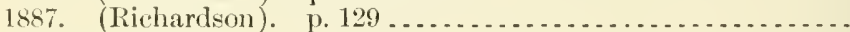

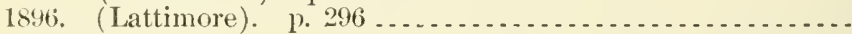
Sier also Peppers.

Spicler bites, fatal, contribution to literature of. 1889, ?. 204_.... Spicler-eger parasites, two (Howard). 1890. pp. 269, 359.........

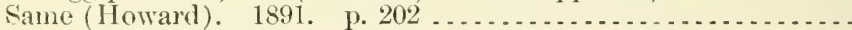

Spicler parasites, external (Howarl). 18s8. pp. 4*, $106 \ldots \ldots \ldots \ldots$.

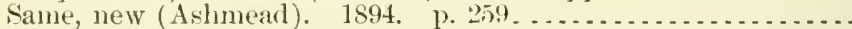

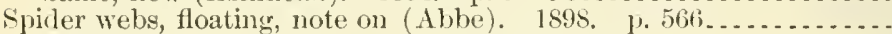
Spiders:

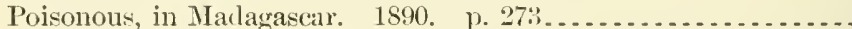

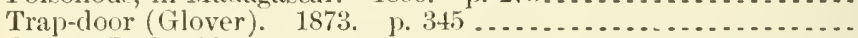

See also Red spiders.

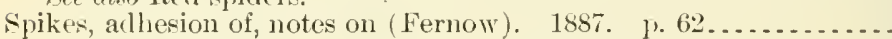
Spillman, IT. J.:

Farmers' institute worker. 1902. p. 59 .................... Grass and Forage Plant Investigations Oflice, and Agrostology Division, lists of publications of. 1902

Grasses and forage plants for year 1901. p. 672.

Hybrid offspring, quantitative stuclies on transmission of parental

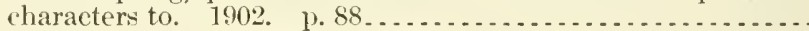

Washington (State) farmers' institute work accomplished in.

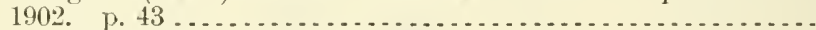

Spilogale. Sce Skunks, little striped.

Spilosoma fuliginosa, report on (Lugger). 1890, p. 236 ...............

Spinning cotton, atmospheric eonditions favorable to (Abbe). 1900.

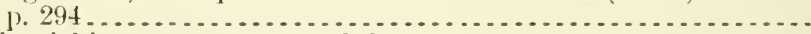

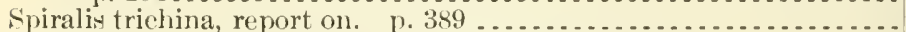
Splenetic fever. Sre Texas or Southern eattle fever.

Spokane, Wash,. elimate of, $1882-99$ (Stewart). p. 490.

Spontaneons combustion, meteorological conditions farorable to, note on (Abhe). 1900. p. 249. . . . . . . . . . . . . . . . . .

Spores of Agarieus campestris and other Basidiomycetous fungi, pre-

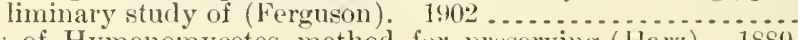
Spores of Hymenomycetes, method for preserving (Ilarz). 1889.

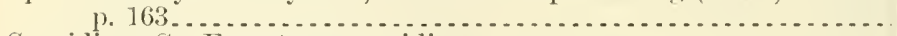
Sporidia. See Fenestrate sporidia.

Sporozoön in intestinal villi of cattle, notes on (Smith). 189:3. 1).73. Spot discase of orchard grass (Trelease). 1. 129 . . . . . . . . . . . Same. p. 129

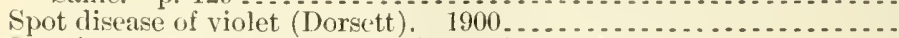

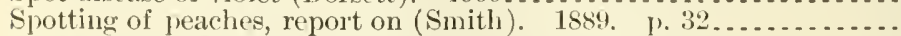
Sprague, Elizabeth C. See, as joint author, Bevier, Isabel.

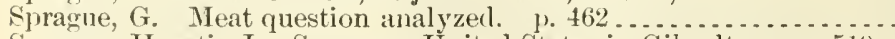
Sprague, Horatio J. Sausages, United States in Gihraltar. p. 519. . Sprayer. See Japy linapsack sprayer-Lerosene knapsack sprayer.

11.1:\$92 15. $1: 892$

A5.5:2

$15.5::^{2}$

A $10.3: 97$

1 10.3:114

A28.5:5

A28.5:5

19.7:3

A7.3:65

A 1.1:886

A7.3:13 ${ }^{2}$

A1.1:896

A9.7:1

A9.7:2

19.7:4

A9.7:1

19.7:6

129.6):26

19.7:2

A 27.9:11

113.3:1

A10.3:120

119.2:P96

A1.10:901

110.3:115

A 10.3:120

A9.7:2

A29.6:28

A1.1:869

ก $29.6: 28$

A29.6:28

A 19.3:16

1:28.5:5

1+.3:3

A 1.1:886

A28. $1: 886$

A28.3:23

A $28.5: 5$

11.1:88:3

1..1:899 
Spraying:

Devices for, new, dircular on ((iallovay). 1899............. 124.t:17

Machinery for-

manufacturers of, letter to.

A 10.4:17

standard fittings for (Alwood). 1891. p. $58 \ldots \ldots \ldots . . . . .$.

Power sprayer for asjaragns, report on (Sirrine). 1901. 1) 177 .

Pump, new, notes on (Gilloway). 1891. 1, 25............

Use of steam apparatus for (II)ward). 1896. p. $69 . \ldots \ldots \ldots$.

Without pump, preliminary notice (Alirich) -

1894. p. 114

$1895, \mathrm{p}, 28$.

See also Fruits - Knapsack sprayer.

Spring, advent of (IJermann). 1902. p. $69 . \ldots \ldots . . . . . . . . . . .$.

Spring wheat. See Trheat.

Springfield, Mass., shade-tree insects of, and other New Fngland

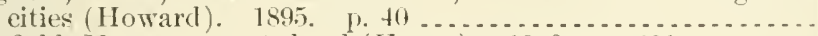
Springfield, Mo., storms at, local (Hazen). 1900, p. 201 ........ Spruce, insect enemies of, in Northeast (llopkins). 1901......... Spruce-bark beetles, notes on (TFeed and Fiske). 1898. 1.67 ....

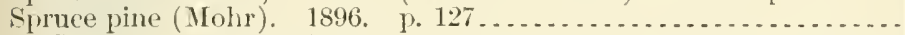

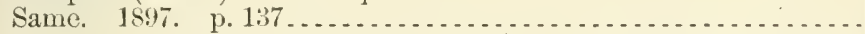

Sprung, A. Thermometers, on construction of registering air, to replace ordinary alcohol and merurial thermometers. 1896.

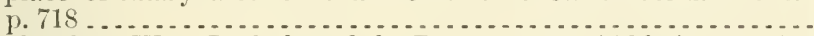
Squall, local, at West Berkeley, Cal., Dee. 11, 1894 (Ahbe). P. 509 , squash. Siee Garden regetables.

Squash borer (Melittia cucurbitæ) remedies for (Smith). 1891. P. 30 . Sruash bug, common, circular relative to (Chittenden). 1899 . . . . . . Squash-vine borer, circular relative to (Chittenclen). 1899 . . . . . . . . Squirrels, prairie ground, or spermophiles of Mississippi Valley

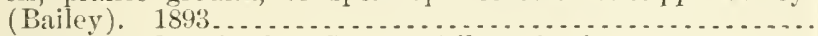

See also Ground stuirrels - Spermophile and references.

Stable manure, value of. 1901. p. 5 . . . . . . . . . . . . . . . . . . .

"Staggers," disease known as, among hor:es in Virginia and North Carolina (Harbaugh). p. 209 ........................

Stalk worm, new enemy to yonng tobacen (Johnson). 1899. p. 99.

Stalker, MI. "Loco" plant and its effect on animals. p. 271 ......

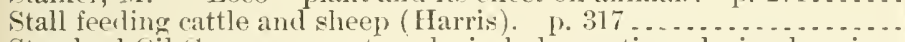

Standarl (fil Company, meteorological observations during burning of plant of, at Bayonne, N.J., July 5, 6, and 7, 1900 (Mitchell).

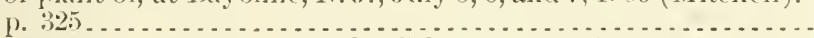

Standard Sugar Refinery, Alvarado, Cal., report on (Furnas). 1892.

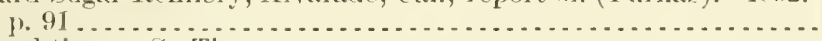

Standarl time. See Time.

Standards, National Burean of, eirenlar of information relating to (Marvin). 1902. p. 135

Standart, S. II. Live-stor $k$ indlustry of Colorado and Territories of Northwest. 1):326

Stanley, W. E. Kallsas, roal improvement in, extract from gov-

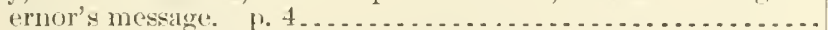

Stannarl, J. D. See, as joint anthor, Johnston, C. T.

Stanton, Eilgatr. Nettle, cultivation of, in Germany. p. 560 .....

Stapleton, D. C. Clinutological data from I'laya Rica, Ecuator.

Stareh:

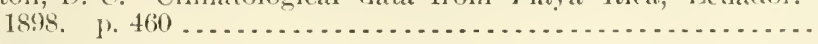

Determination of, comparison of methods (Stone). 1894. p. 162.

Enzymic ferments upon (Stone). 1896 ...................

Estimation of, report on (Browne). 1899. p.92 ...........

Fateries in Mane (Boardman), 1885. No. 19. [1.23.......

Mannfacture of-

from protatoes and cassava (Wiley), 1900 ...............

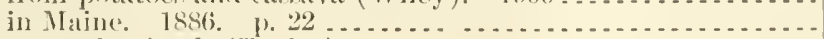

Plants and animals (Taylor)-

1875. p. 316

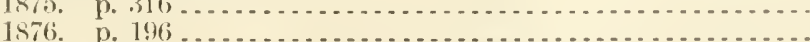

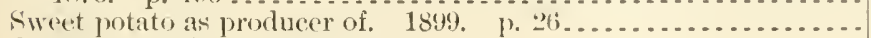

A $9.7: 4$

110.3:99

A28.5:6

A1.10:896

A9.7:7

$19.6: 2$

A29.3:31

19.6:2

A29.6:28

A9.6:28

A9.6:17

A $13.3: 13^{1}$

A 13.3:132

129.3:11:

A29.6:22

19.7:4

19.5:39

19.5:38

A5. :34

11.9:133

A4.1:886

A9.6:20

A 4.1:886

11.1:862

A29.6:28

A1.8:20

A29.6:30

A4.1:885

1.2.2. $4: 33$

11.1:578

1:9.6:26:

17.3:43

110.3:34

17.3:57

A27.9:2:3

A7.3:5

127.9:24

127.9:13

127.9:14

11.9:57 
Starling, William. Mississippi River, flools of, with reference to

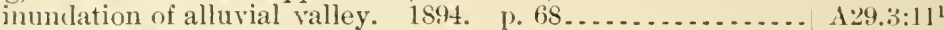

Starnes, II. N. Mycophatgy, importance of, in a eourse of hotanieal instruction. 1898. 1\%. 75 .

Starr, Frederick. Forests, Anerican, their destruction and preser-

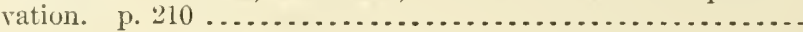

Stars:

Ileat radiation of, note on (Abbe). 1899. ]. 472

Shouting-

hints to observers of (Harkness). 1899. p. 9...........

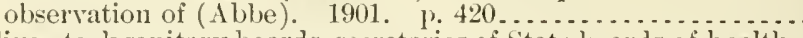

State live-stock sanitary boards, secretaries of State boards of health, and State veterinarians having control of contagions and infections diseases among domestie animals, list of. 1898.

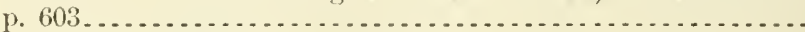

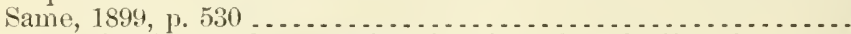

State veterinarians and secretaries of sanitary boards, list of:

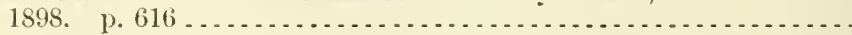

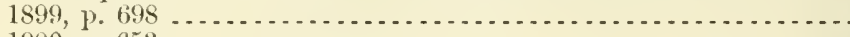

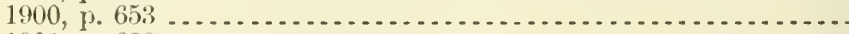

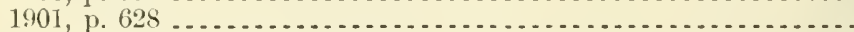

State weather services:

Characteristies of Utah in relation to State weather-service work

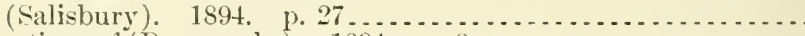

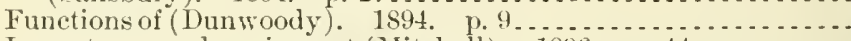

Importance and equipment (Mitchell). 1896. p. $44 \ldots \ldots . . . .$.

Irrigation and its relation to (Salisbury), 1894 . 1. 24........

Monthly notes on, July, 1891-March, 1895; Jume-August, 1895 ...

Organizations of (Dunwoody). 1895. p. 285 . . . . . . . . . . .

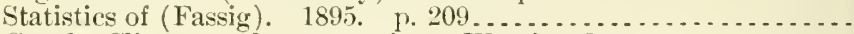

See aiso Climate and crop service- Weather liurean.

State Weather Services, American Association of, proceenliness of:

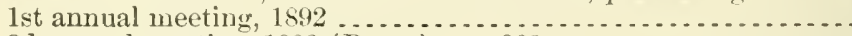

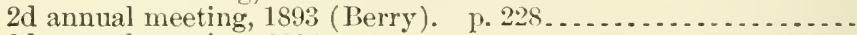

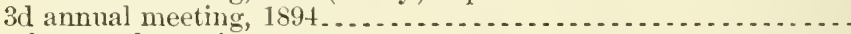

4 th annual meeting, 1895

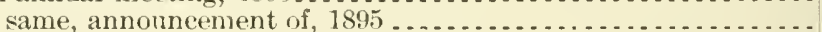

States:

Agrieulture reports of. See Agriculture.

Forest condition of (Baker). 1854. p. 181

Geologists nf, circular letter to, requesting conperation with office of Road Inquiry, Agrienlture Department . . . . . . . . . . . . . .

Governors of, extraets from messages of, relating to gool roads (Stone). 1895

Laws relating to management of roakls, enacterl $1889-9: 3$ (Stone) same, 1894-95 (Stone) ... . . . . . . . . . . . . . . . . . . .

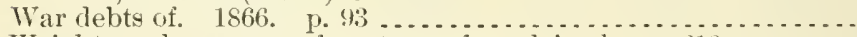

IV eights and measures of, systems of, explainerl. p. 218....... States and Territories:

Governors of, cireular letter to, requesting cooperation with oflice

of Road Inquiry, Agriculture Department. . . . . . . . . . . . same, to secretaries of state . . . . . . . . . . . . . . . . . . . .

1 aws of, for control of contagious animal diseases-

1885. p. 471

1886. 1) $3030 . \ldots \ldots \ldots$

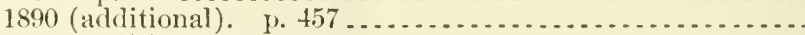

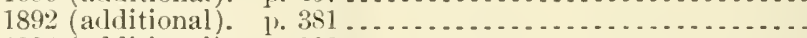

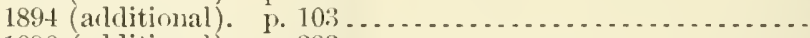

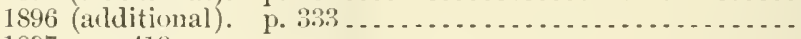

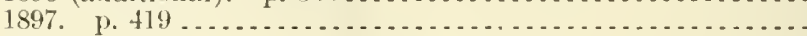

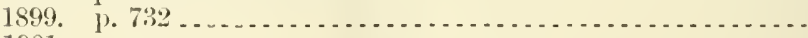

Laws of, on irrigation and water rights, abstract of (Critehett). 1893

See also Atlantic States - Lastern states.

Statesville area, North Carolina, soil survey of (Dorsey and party). 1. 273.

129.3:7

A 29.6:21

A29.3:14

A29.3:18

A29.6:23

113.5:t

122.4:4

A22.3:14

A2). 3:1

A22.3:18

1.27.9:1

11.1:871

122.4:1

122.4:2

At.1:885

At. $1: 886$

A $4.1: 889-90$

At. $1: 891-2$

At.1:893-4

A $4.1: 895-6$

ㄴ.1:897

A+. 1:89!1

A $4.3: 43$

A15.8:1

A26.5:401 ${ }^{1}$ 
Index

Static electricity. See Electricity.

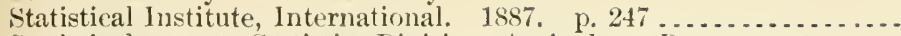

Statistical reports, Statisticy Division, Agrienlture Department ...... .

Statistician, Agriculture Department, symoptical index to reports of,

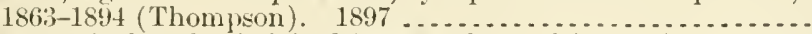

Statistics, agricultural, of Uniterl States, album of (Dodge)......... Statistics Division, Agriculture Department:

Work of, for firmer (Hyde). 1897. P. 258 same, reprinted with title "Of What Service are statistics to

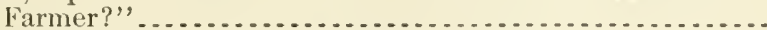

Statisties in agriculture. 1882 . No. 49 , 1. $23 \ldots . . . . . . . . .$.

Stave silo, value of, to dairy farmer (Beal). 1898. 1).23 ........

Steam, cultivation by:

History of American inventions for (Brainerd). 1. 253 . . . . . .

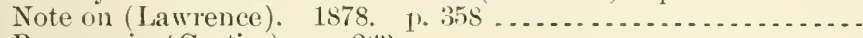

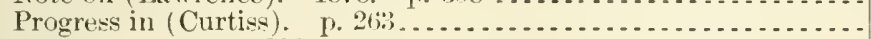
same, $1869 . \quad$ p. $296 \ldots \ldots \ldots \ldots$

Steam plowing:

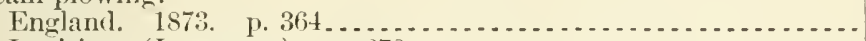

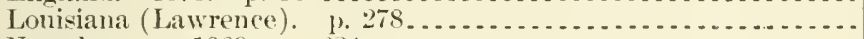

New Jersey. 1869. p. 224...

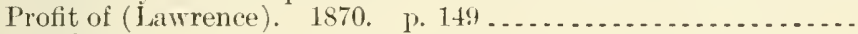
Steam plows:

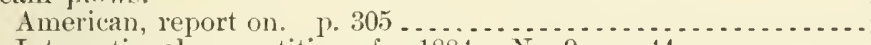

International eompetition of. 1884. No.9. P. $44 \ldots \ldots . . . . .$.

Stearns, Herman De C. Sea, effect of proximity to, on thunderstorm

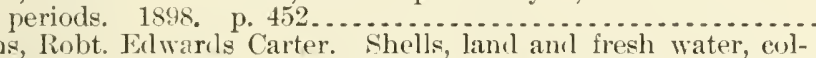

Stearns, Robt. Elwarls Carter. Shells, land and fresh water, col-
lected in California and Nevarla by Death Valley experlition, including few additional species obtained by Clinton Hart Merriam and assistants in parts of southwesterin United States, 1893. 1. 269

Stedilom, Rice P.:

Cattle, disease among, in Marshall Comnty, Kansas. ए. 382 ....

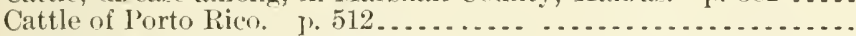

Steel track wagon roads. Sce Roarls.

Steele, Elwarl Strieby. Perfumery farming, ean it suceed in U. S.?.

Steele, J. P. Cotton inseets, report on. 1885. А I I., 1. 25......

Steer beef. S'ee Beef.

Steers:

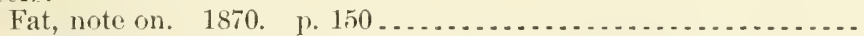

Feeling experiments with, to ascertain comparative value of corn and red and white kafir eorn (Georgeson). p. 483........

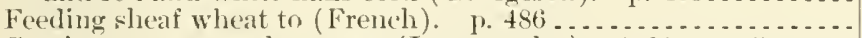

Grazing, on corn and cowpeas (Langwortly). 1901. p. 27..... Steiner, Ralph. Munielu, fermany, cost of hanling firm products

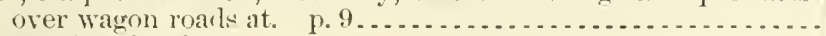

Stejneger, Leomharil:

Reptiles atml hatrachians-

collected by beath Valley expedition in 1891, annotater list of, witli descriptions of new species, and ficlel notes ly Clinton Hart Merriam. 1893. 1. 159 ................ . . . collected by Clinton Hart Merriam and party in Iraho, 1890,

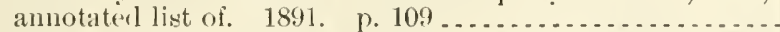
collecterl hy Clinton Hart Merriam and Vernon Bailey on San Francisco MInuntain platean and desert of Jittle Colorulo, Arizona, ammotated list of, with deseription of new species. 1890. I) $10: 3$

Tres Marias and Isabel Islands, leptiles of. 1sit. 1.63 ...... Stem-girller. See Currant stem-girller.

Steplens, Lon V. Missouri, road improvennent in, extract from

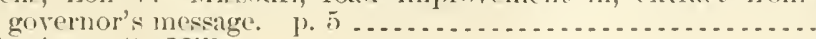

Sterilization. She Milk.

Sterling, Kans.:

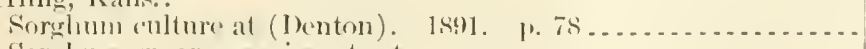

Sorglum sugar (xperiments at1887 (Denton). ए. 57.

Classifieation no.

A27.9:25

+ 27.9 :

1:21.3:2

1 $27.2: 5+2$

A 27 .

A1.10:897

A27.8:14

A $27.9: 20$

A1. $9: 10 \%$

A 1.1:867

1:7.9:10

A1.1:867

A 1.1:869

A27.9:11

A 1.1:867

127.9:7

A 27.9 .8

A1. $1: 869$

A27.9:22

А29.6:26

A5.5:7

A4.1:898

A 4.1:899

11.10:898

18.1:4

127.9:8

A4.1:898

A $4.1: 898$

A1.9:124

122.4:27

15.5:7

15.5 .5

$45.5: 3$

1.5.5:1.1

1:20.4:3:3

17.:3:13.1

A7.3:17 
Sterling, Kans._Continuerl

Sorglium sugar experiments at-Continued

1888 (Denton and ('rampton). p. 287.

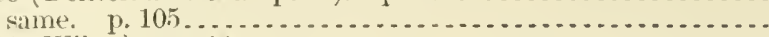

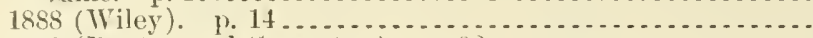

1889 (Denton and Crampton). p. 82.................

1892 (Fuelling). 10.30.............................

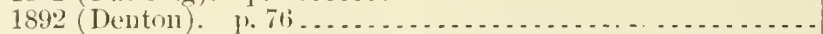

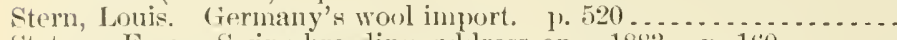

Stetrom, Ezra. Swine breeding, address on. 1883. p. $160 \ldots \ldots$. Stetion, Frank 0. :

Clinate of Baguio, Philippine Islands. 1902, p. 478 .........

Hurricanes of 1895 and 1896 in Philippine Archipelago. 1. 101..

Stettin, Giermany:

Cust of hauling farm products over wagon roads at (Kickbusch).

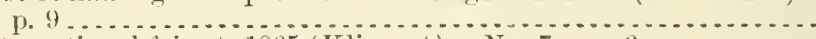

International fair at, 1865 (Klippart). No. 7 . p. 6 ...........
Sterens, James S. Atmidometry, some experiments in. 1902.

Sterenson, J. C., aldress of, before National Road Conference.

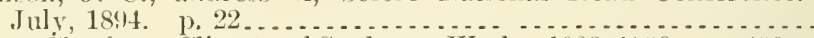

Stewart, Charles. Climate of Spokane, Wash., 1882-1899. p. 490 ..

Stewart, I. W.:

Cattle feeding in New York. p. 299 ......................

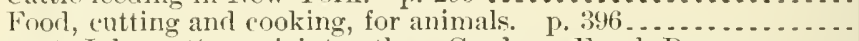

Stewart, John. '̌ee, as joint author, Gardner, Frank Duane.

Stibadium spumosum, luabits of (Murtfeldt). 1894. p. 301 ........

Stickney, L. I). Florida, soil, elimate, and productions. p. 59 ....

Stigmonose, disease of carnation and other pinks (Woods). $1900 \ldots$

stiles, Charles Wardell:

Country slaughter-house as a factor in sprearl of clisease. 1896.

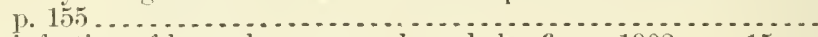

Disinfection of kemels, pens, and yards by fire. 1902 , p. $15 \ldots$

Limeriella, new genus of coccidia. 1902. p. $18 \ldots \ldots . . . . . . .$.
Flukes and tapeworms of cattle, sheep, and swine with special

Flukes and tapeworms of cattle, sheep, and swine with special
reference to inspection of meats. 1898. p. $11 \ldots . . . . . . .$.

Frogs, toark, and carp (Cyprinus carpio) as eradicators of fluke disease. p. 220

Hepatic coccilia of rabits, Fimeria stiedre, correct name for.

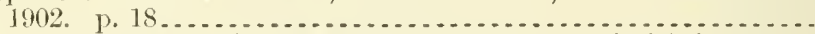

Hookworm disease (uncinariasis or anchylostomiasis) in man, significance of recent American cases of. p. 183 ...........

Rounlworms in sheep, goats, and cattle, treatment of. 1901 ....

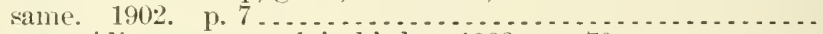

Sarcosporidia, presence of, in birds. 1893. p. $79 . \ldots . . . . .$.

Strongyle, Egyptian and Japanese (Strongylus subtilis), which may prossibly occur in returning Ameriean troops. 1902. p.

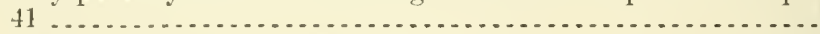

Tapeworms of ponltry, present knowledge of. $1896 \ldots . . . . . . . .$.
Trematodes (AIonowtomulum lentis and Aganodistommon ophthalmobium) parasitic in the human eye. 1902. 1.24 ........

Trichinosis in Europe of alleged American origin. 1901. p. 156.

Trichinosis in Germany, general renarks on. 1901, p.9..... same, statistical review, during 1881-1898. 1901. 3\% $35 \ldots \ldots$.

Vorminons disease of cattle, sheep, and goats in Texas. p. 356 ...

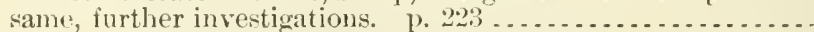

See also, as joint author, Salmon, Daniel Elmer.

Stiles, Charles Warlell, and Frankland, W. Ashloy, Vinegar eel (Anguillula aceti) infection in human bladder, ease of. 1902. p.

Stiles, Charles Wardeli, and ITassall, Albert:

Binanas, partially digested, spurions parasitism rlue to. 1902.

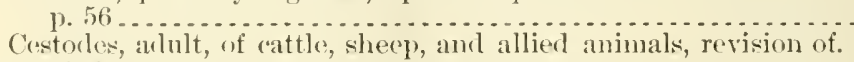

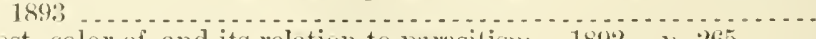

llost, color of, and its relation to parasilism. 18:2. 1.265.....

Parasites $(50-52)$, notes on. P. 558 .

A1.1:888

17.3:20

A $7.3: 20$

17.3:26

A7.3:37

17.3:37

A $4.1: 899$

\1.7:2

A29.6:30

1 $29.6: 28$

122.4:27

A $27.9: 3$

A29.6:30

12:.8:10

A29.6:28

A $1.1: 876$

A 1.1:865

19.7:6

A $1.1: 866^{\circ}$

A:28.3:19

A $1.10: 896$

A $4.3: 35$

A $4.3: 25$

A 4.3:1!

14.1:901

A $4.3: 35$

A 4.1:901

A4. 1:35

14.3:35

A $4.3: 3$

$14.3: 35$

14.3:12

14.3:35

14.3:30

14.3:30

A $4.8: 30$

A. $1: 900$

14.1:901

$14.3: 35$

A4.3:35

A+. $\because 4$

1!. $7: 4$

A. 1:899 
Stiles, Charles Warlell, and Hassall, Albert-Continued

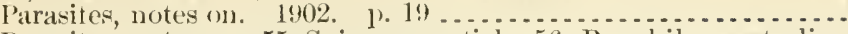

Parasites, notes on: 55, Spinosa ear tick; 56, Boophilus australis; 57, new host for Strongylus contortus and Cysticereus tenui-

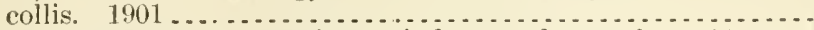
(190) Stiles, Charles Wardell, and Tayler, Louise:

Cestode, adult (Diplogonoporus grandis), of man which may possibly oceur in returning American troops. 1902. p. 43 ..... Larval eestode (Sparganmm mansoni) of man which may possibly occur in returning American troops. 1902. 1) 47 ........

Stillwell and Gladding:

Fertilizer samples for analysis, preparation of, notes on. 1893.

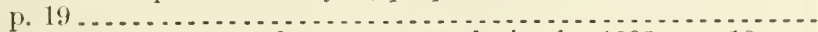

Phosphate, concentrated, notes on analysis of 1893 . p. $18 \ldots$ Stipa. See Melica and Stipa.

Stock:

Crops and, in Ontario. 1890. P. 484

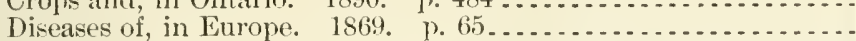

Epizootic aphthe anong; nature, causes, treatment, etc. p. 352.

Feeding experiments, significance of (Curtiss). 1899. 1) 116...

Food for. See Plants.

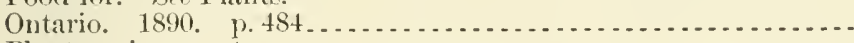

Plants poisonous to-

preliminary catalogue of (Chesunt). p. $387 . \ldots . . . . . . .$.

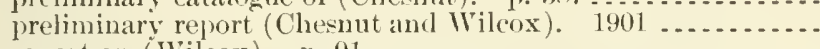

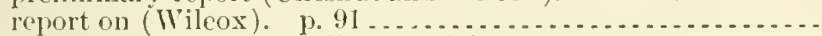

Pure-bred, business of breeding (Craig). 1. $416 \ldots \ldots \ldots . . . . .$.

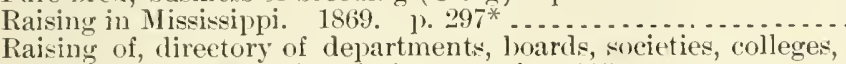
and other organizations in interest of. 1885.

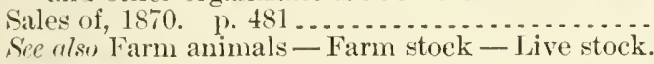

Stock ranges:

Northern, some poisonous plants of (Chesnut). 1900. p. 305 .

Northwestern California, notes on grases and forage plants and

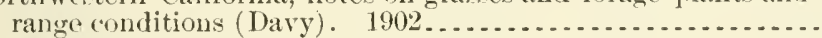
See also Range.

Stock yards, Union, See Chicago.

Stockbriclge, H. E. Florida, farmers' institute work aceomplished

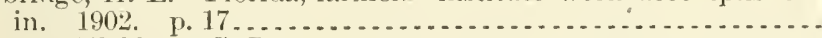

See also Walkiron, C. B.

Stockholn, dear animals in, disposition of (Winslow). 1). 360 ..... Stoekman, William B.:

Climatoling of llavana, Cuba, monthly notes on Apr.-July, Sept.-Oct., Dec., 1901; Fel. $-A_{\text {pr., }} 1902 \ldots . . . . . . . . . . .$.

Meteorological tables and charts, monthly, description of, MayOct., 1902 . . . . . . . . . . . . . . . . .

Weather Bureau service, monthly reports of, in West Indies,

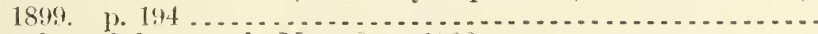

Weather of the month, May- Oet $190^{\circ}$

Stockmen, national convention of. See Clicago, Ill.

Stohmann, F. IJeat equivalent of nutricnts of food; translated ly Charles lord Langworthy. 1896. 1).590 ...............

Stokes, $\Lambda$. W. Milk, fat in, determination of, by TVerner-smith

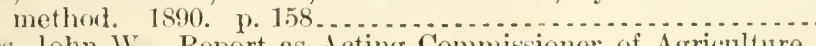

Stokes, John W. Report as Jeting Commissioner of Agriculture, 1867 ........................

Stomach staggers. Sce Cattle.

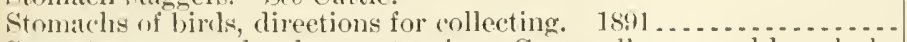

Stomata, strange developments of, on Carya alba, eamed by jhylloxera (Owen). 1892. 1. 327

Stone, (i. I: :

Botanist at agrieultural experiment station, functions of. 1901.

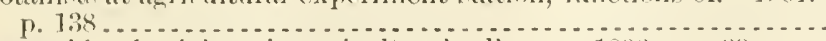

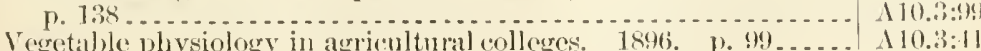

* By a misprint, this page number appears twice.

A7.3:38

17.:3:38

A27.9:28

A $27.9: 7$

11.1:870

1 10.3:65

127.9:28

14.1:898

A $7.3: 26$

A $4.1: 900$

A $4.1: 901$

127.9:7

11.8:39

127.9:8

A $1.10: 900$

A 19.3:12

A $10.8: 120$

14.1:8!?!

A.9.6:

$1: 2)(1:: 30$

$1: 29.6: 27$

12).6:30

110.6:6

17.8::24

11.1:667

15. 4:12

1.). $7: 4$ 
Stone, Richmond. Roarl hnilding, national, in United States, his-

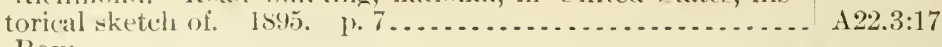

Stone, Roy:

Adilress of-

before national road ennference, Inly, 1s94. 1). T......... hefore Virginia good roals convention, oct. $18,1894.14 .14$

Addresses on road improvement in Maine, New York, North

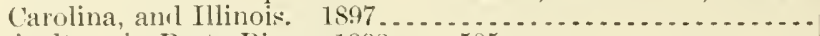

Agrienlture in Porto Rico. 1898. p. 505.

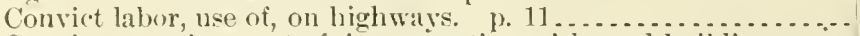

Convicts, employment of, in connection with roanl huilding . . . . .

Earth roads, hints on their construction and repair. $1894 . . . .$.

Higlie State aid road bill, remarks at hearing hy committee of sellate and assembly at Albany, N. Y., Feh. 25, 1s97. $P .10$.

Illinois Farmers' Institute, letter to, on road improvement. 1897.

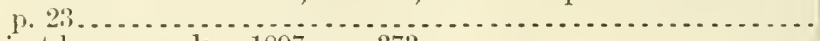

Oliject-lesson roads. 1897 p. $373 \ldots \ldots$.

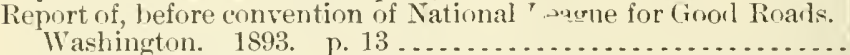

Rioad luilding in U. S. -

historical and technical papers on. 1895

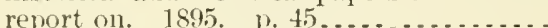

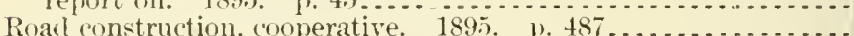

Road improvement-

address on, at Raleigh, N. C., Fel). 5, 1897. 1. 19..........

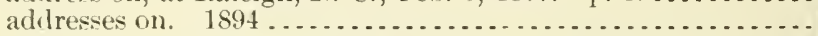
necessity of Congressional action in. 1902 p. p:3 . . . . . . .

Road improvement in Maine, New York, North Carolina, and

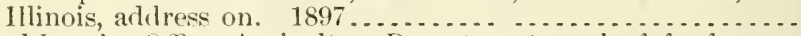

Road Inquiry Office, Agricultme Department, wolk of, for farmer.

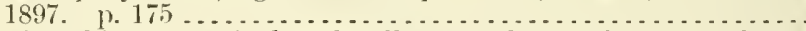

Roal making at agricultural colleges and experiment stations, letter relative to cooperation of Road Incuiry Oflice in aid of..

Roads-

best, for farms and farming districts. 1894. p. 501 ........ good; extracts from messages of governors. 1895 .......... good, work for new century. 1901. p. 52 .............

State laws relating to manageinent of roads$1888-93$

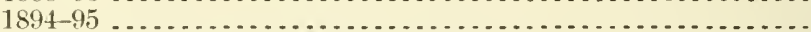

Wheelmen, American League of, remarks at good-roads banquet of, at Albany, Y. Y., Feb. 11, 1897. p. 15 ...............

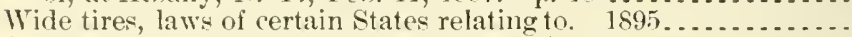

See also for reports as special Igent and Eugineer for lioad Inquiry, 1893 to 1896; Director of Oflice of Road Inquiry, 1897, and Director of Office of Public Roar Inquiries, $1899 \ldots . . . . . .$.

Stone, Winthrop Ellsworth:

Carbohydrates of wheat, maize, flour, and bread, and action of enzymic ferments upon starches of different origin. 1896....

Dietary studies at Purdne University in 1895 . . . . . . . . . . . . .

Feeding stuffs, pentaglucoses in, notes on oceurrence and quanti-

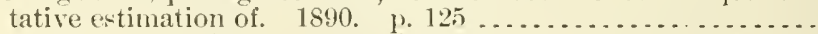

Stareh, determination of, comparison of methods for. 1894. P.

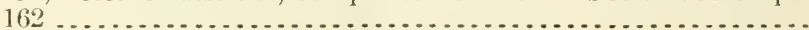

Stone fruits. See Fruits.

Stone roads. See Roads.

Stones. See Marhle-Semaquir.

Storage hatters, use of, for electrical recording instruments (Vose)

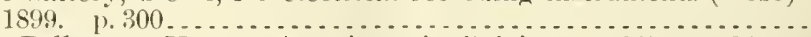
Storer, Bellany. Horses, American, in Belgium. 1897. p. 24...

Storm bulletins . . . . . . . . . . . . . . . . . . . . . . . . . . .

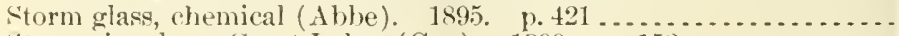

Storm signals on Great Lakes (Cox). 1899. p. 152 ...........

See relso IT eather Bureau signals.

Storm-warning lanterns, sulstitution of acetylene gas for oil in

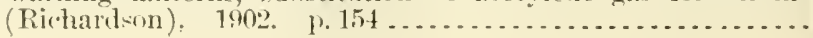

A22.3:11

A2:. $4: 28$

11.10:898

1:2.3:16

A.2. $3: 16$

A $22.3: 8$

A2:. 4:28

A2. $4: 28$

A1.10:897

A 10.3:14

A 22.8:17

122.3:17

A1.10:895

A22. $4: 28$

122.4:14

122.3:25

A22.4:28

A $1.10: 897$

A2:.2: $\lg 8$

11.10:894

A22.3:14

A22.3:21

A22.3:1

A22.3:18

122.4:28

+22.3:12

A22.1:

A10.3:34

A 10.3:32

A7.3:28

A 7.3:43

A29.6:27

A 1.2:H78

A 29.17 :

129.6:23

A $29.3: 24$

A 29.3:31 
Storm-warning messages (Form 1043C), slunuld [they] he of some distinctive color to more readily attrart attention? (Glomn).

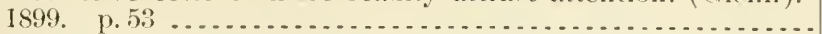

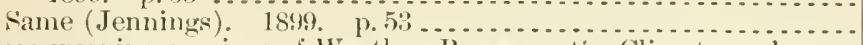
Storm-warning services of Weather Bureau. See Climate and crop' and storm-warning services of Weather Bureau.

Storm warnings:

Forecasts and, how Wrather Burcan disseminates (Calvert). 1896. p. xxii.

Monthly notes on-

Oct., 1897-lipr., 1898 (Dunwoody)

May, 1898 (Morrill). p. 195 June-Aug., 1898 (Bigelow)

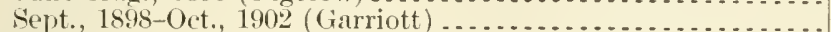

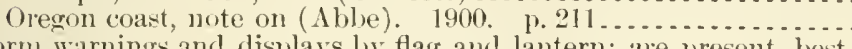
Storm warnings and displays ly flag and lantern; we jresent, best that can be devised for Atlantis and Gulf coasts? (Smith).

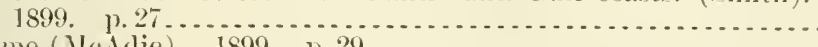

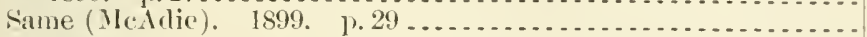
Storm waves:

Great Lakes and ocean ( $\mathrm{Ab}$ be). 1895. p. 34].

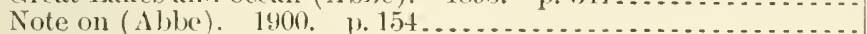

South Carolina and Texas (Alexander). 1900. 1.381 ........

What is a storm wave? (Kimball). 1901. 1. 460........... Sitorms:

Aplroaching, effect of, upon song birds (Limney). 1898. p. 354.

Angust 2, 1899, notes on (Abbe). p. $365 . . . . . . . . . . . . . .$.

Benefits and injuries due to, note on (Ablse). $1900.1114 \ldots .$.

Centers in Pacific, notes on (Abbe). 1899. p. 114...........

Cold weather, of India and America (Abbe). 1894. p. 295 ....

listant, imlicated by tides at New York (Jones). 1894. p. 372.

l)ust-

and red rain, notes on (Abbe). 1901. b. 120 .............

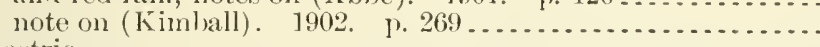

Electric:-

California (Jarwick). 1897. p. 539.

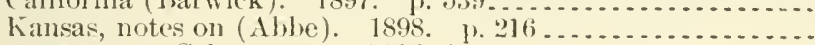
Sacramento, Cal., notes on (Ab) be). 1sit7. p.542........

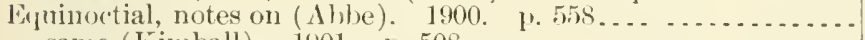
same (Kimball). 1901. 1. 508 ...

Fake, report on (Able). 1897. p. $307 \ldots \ldots \ldots \ldots$

Forecasts of, commercial importance of, notes on (Ablje). 1900.

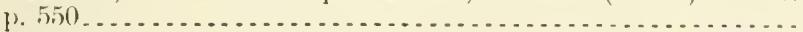

Great storm of Oet. 1896 [1895], in (Fulf of California (Ab)e).

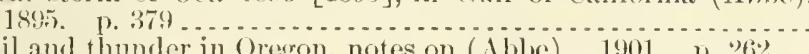

Hail and thunder in ()regon, notes on ( $\mathrm{Abl}$ ) $)$. 1901. 1) 262...

llomolulu to lowa, notes on (Ablue). 1899. 1. $\$ 62 . . . . . . . .$.

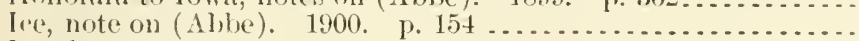

Jocal-

lo they follow river valleys? ( $\mathrm{Ab}$ be). $1899 . \quad$ p. 363.

luavy rainfall in, notes on (Able) 1900. in Inited Sitates during 1890, 1891, and 1892 (Hazen). p. 50 \%. monthly report on, July, $1895-$ Sept., 1897 (Henry) ......... sime, in Kansas, Sejet. 8, 1895 (Abl)e), p. 338 ..........

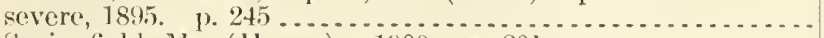

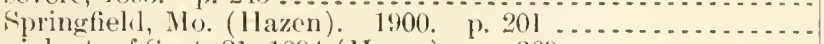

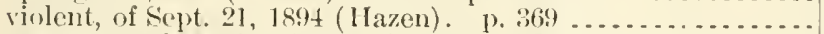
west coast of Mexico (Rogers). 1894. 1. 510............

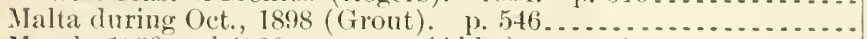

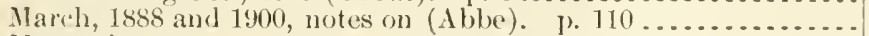

Mrountain-

note on (Athe). 1897. 1. 307

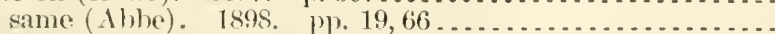

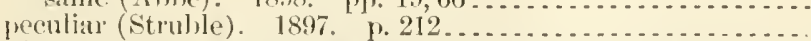

North Itlantic, monthly notes on, July, 189i-j)ec., 1893 . . . . .

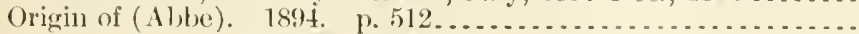

Ponta Delgata, Azores, Dec. 8, 1894 ( $\Lambda$ b be). 1. 508 .
Clasiffation no.

A 29.8:24

129.3:24

129.1:896

A29.6:

1 $29.6: 26$

A $29.6: 26$

A29.6:

129.6:28

129.3:24

A $29.3: 24$

129.6:23

129.6:28

1 $29.6: 28$

A 29.6:29

$129.6: 26$

A 29.6:27

129.6:28

129.6:27

A $29.6: 21$

A $29.6: 22$

A $29.6: 29$

$129.6: 30$

129.6:25

A:9.6:26

A $29.6: 25$

129.6:28

129.6:29

A:9.6:25

129.6:28

129.6:23

1:9.6:29

A:9.6:27

129.6:28

129.6:27

1 $29.6: 28$

$12 \% .1: 891^{3}$

129.6:

\29.6:23

А29.1:896

129.6:28

A $29.6: 2: 2$

129.6:22

1:?.6:26

$129.6: 28$

129.6:25

1:29.6:26

129.6:25

A:29.6:

129.6:2:2)

129.6:2:2 
Storms-Continued

Silent eleetrical and dust, in Oklahoma, Jan., 1895 ( $\mathrm{bbbe}$ ). P.13. A29.6:23

Sleet, note on (Abbe). 1900. p. $113 \ldots . . . . . . . . . . . . . .429 .6: 28$

Slecet and snow, memorable, notes on (Abhe). 1900. p. 548 ... A29.6:28

South Atlantic (Pinleiro), p. 204 ..................... A29.3:1 ${ }^{1}$

Texas, study of (Hazen). 1895. p. 54................. A29.6:23

Tornaklues and, severe local, chronological list of. 1896. p. 308. A29.1:897

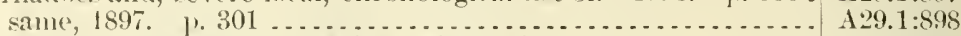

Track of and weather forecasting (Bigelow). 1897 . . . . . . . . 129.3:20

Track of periodic and nomperiodic: Huctuations in latitucle of

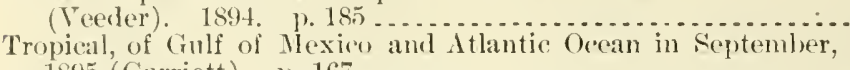

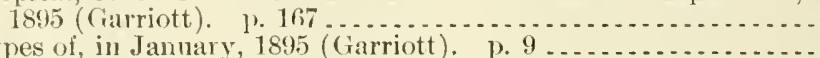

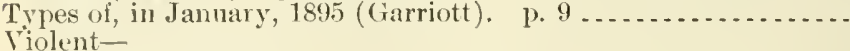
in United States-

1893 р. 317.

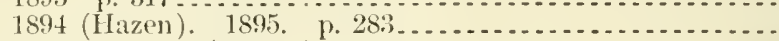

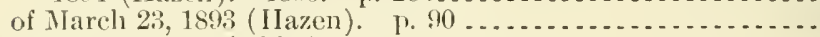

Wrells and, note on (Ab)e). 1900. 1. 293 ................ West Indian, relative intensity of (llazen). 1894. p. $3.33 \ldots \ldots$

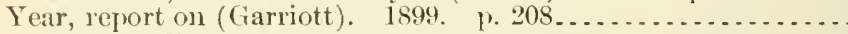

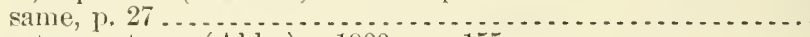

Yueatan, note on (Abbe). 1900 . p. 155................. See also Baguios - Norther - Northwesters - Ocean storms Sand blizzard - Thunderstorms - Tornadoes.

Stout, O. V. P.:

Irrigation under Great Eastern Canal, latte County, Nebr.: 1900. 1). 195 .

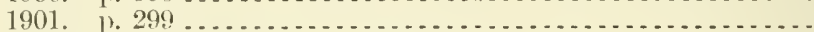

Nebraska, duty of water in. 1900 . p. $149 \ldots \ldots$ Stover, Arthur P.:

Irrigation in-

Arkansis Valley, Coloratlo. 1902. P. 287

Grand Valley, Colorato, 1901. 1902. 1. 265............. valley of Bear River, in Utah, 1901 . 1902, p. $243 \ldots \ldots \ldots$. Stowe, James G.:

Animal [rodnets in South Africa.

lleat in Soutlı Africa. p. 512 .

Prices in Cape Colony p. $523, \ldots$

Strassburg, Germany:

International aeronautical conference at (Roteh). 1898. p. 158..

Meteorological balloon aseension at (Rotch), 1901. p. 298......

Stratigraphy and hydrology of Nebraska (llicks). 1890. 1. 71 ....

Straw or stover:

Composition and feeding value of. 1867. p. 37t_...........

Proportion of grain to, effect of fertilizers on. 1897. [. $11 \ldots \ldots$ Strawberries:

Culture of (Hite). p. 139

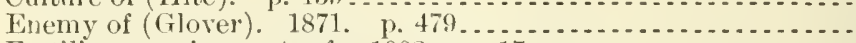

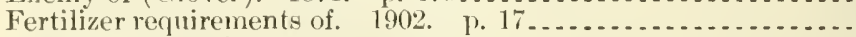

Resistance of, to frost. 1901. P. 19.............

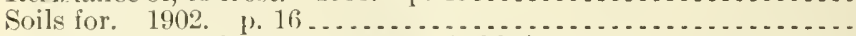

Strawberry crop and frosts, notes on ( 1 blue). 1899. 1. 474 . . . . .

Strawberry-leaf flea beetle in Indiana (Webster). 1891. 1. $317 \ldots$

Strawberry saw-tly, another (Malley). 18s9. p. $137 \ldots \ldots \ldots \ldots \ldots$.

Strawberry weevil:

Circular relative to (Chittenden). 1897

Ilabits and remedirs, supplementary notes (Chittenden). 1894.

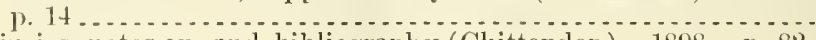

Injuries, notes on, and bibliography (Chittenden). 1898 . p. 82.

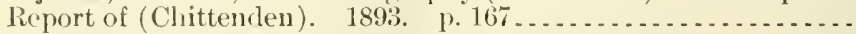

Streams:

Diselaarge of, during floods (Abbe). 1894, p. $255 \ldots \ldots . . . . .$.

Ileadwaters of, forests on, preservation of (Read). 1884. P. 27.

Street, John phillips. Fertilizers, complete, nitric nitrogen in,

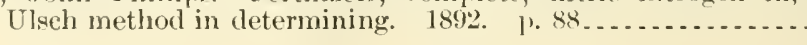

129.3:1 $11^{1}$

A29.6:23

129.6:23

129.1:89.2

A29.1:894

A 29.6:21

A29.6:28

129.6:21

A 1.1:898

129.1:898

A29.6:28

A 10.3:104

A 10.3:119

A 10.3:86

\10.3:119

A 10.3:119

A 10.3:119

14.1:898

A $4.1: 900$

A4.1:898

A29.6:26

A 29.6:29

A15.2:ArT

A $27.9: 5$

A $1.9: 56$

11.1:863

- $27.9: 9$

A 1.9:149

А 1.9:133

A 1.9:149

129.6:27

A9.7:3

A $9.7: 2$

19.5:21

A9.7:7

A9.6:10

A9.7:5

A 29.6:22

A 1.7:5

17.3:35 
Street cars, weather foreeasts on (Conger). 1902. 1). 206 ......... A29.3:31

Street sweepings, fertilizing value of (EweH). $1898 \ldots \ldots \ldots \ldots \ldots . .77 .35 .55$

Streptococer; morphology, liology, and pathogenic: properties of 28 , found in investigation of animal discases (Monre). 1893. p.9. A4.3:2

Strenli, William. Horgen, Switzerland, cost of hanling farm prosluets over wagon roarls at. p. $12 \ldots . . . . . . . . . . . . . . .$.

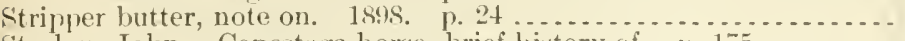

Strohm, John. Conestoga horse, bricf history of. p. 175 ........

Strohmer, - S. Sugar beet, nitrates and phosphates in, physio-

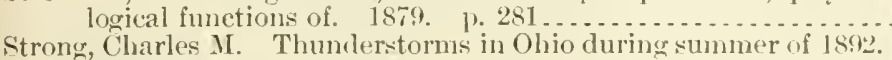

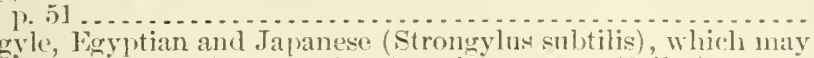
possible occur in returning Imerican truops (Stiles). 1902.

Struble, Jnseph. Storms, momtain, peculiar. 1897 p. $212 \ldots \ldots .$.

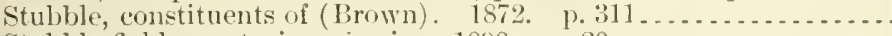

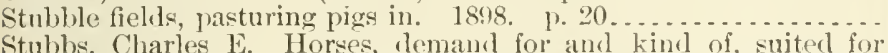

Stubbs, Charles E. Horses, demand for and kind of, suited for
Furopean uses; and present status of luores tracle in different

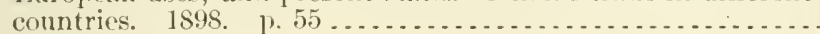

Stublos, Joseph Edward:

Edueation-

modern, what is of most worth in, arldress on. 1901. p. 32.. theory of higher, some recent ehanges in. 1899. p.97.....

1:2:4:4:27

1 $1.9: 84$

$11.1: 86: 3$

11.6:28

$1291 .: 3: 9$

14.3::35

1 $29.6: 2: 5$

A:7.9:10

11.9:79

$11.2: 1178$

Stublos, William Carter:

Agricultural resonces and capabilities of Hawaii. 190] . . . . . . .

Sorghnu sugar experiments at Kenner, La.1888. 1.273

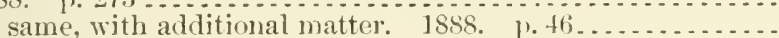

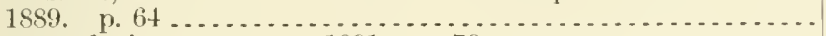

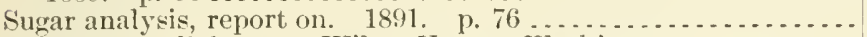

See also, as collaborator, Wiley, Harrey Washington.

Student assistants. "See Agriculture Department.

Study, relation of technical to general conrse of (Fairchild). 1893.

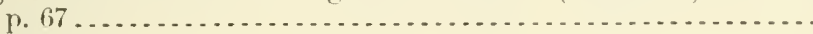

Stupart, R. F.:

Meteorologieal service of Canada. 1809. 1. 204 . . . . . . . . . .

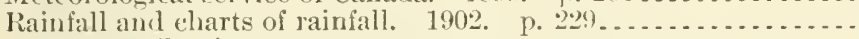

Sturterant, E. Lewis:

Corn, varieties of. 1899

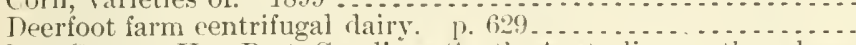

Styles, George H. Port Carolina, Sonth Australia, earthoualis,

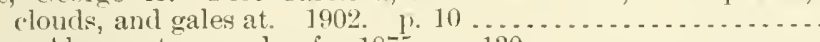

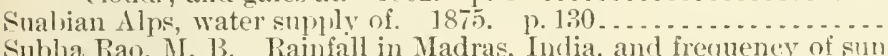

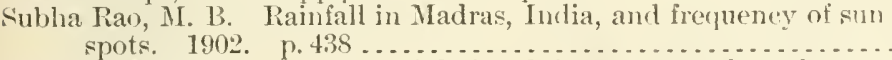

Sublette, (ieorge B. Adrlress of, before Minnesota goorl roarls con-

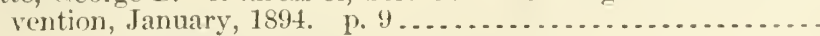

Sucrose. Sice Dextrine.

Surlworth, George Bishop:

Mborescent flora of U.S., nomenclature of. 18.97

Forest flora, additions to, of Nortl Ameriea, and necesary changes in nomenclature of important timber speries, with motes. p. 325 . same, p. 325 .

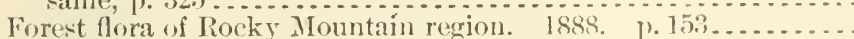

Forest nursery, collection of tree scerls and propagation of serellings. $1900^{\circ}$

$110.3: 99$

110.3:(i5

$110.3: 95$

11.]:888

A7.3:20

$17.3: 26$

1 7.3:31

110.3:16

A 29.6:27

$129.6: 30$

110.3:57

A $1.1: 8.80$

1:9.6:30

$127.9: 1: 3$

1:?1.6:30

1:20.:3:2

1 $1: 3,3: 14$

1 $1.1: 812$

1 1:3. 1:89:2

11:3.8:2

1 1:3.:3:2:19

A1:3,3:17

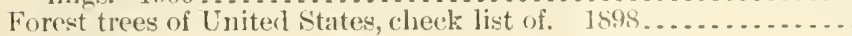
Singar:

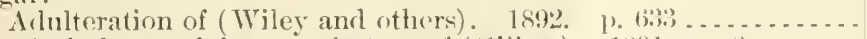

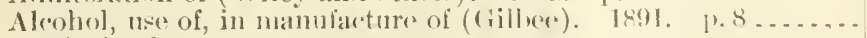

Analysis of-

micthouts of ; notes on (Wiley). 1890, ]. 129............

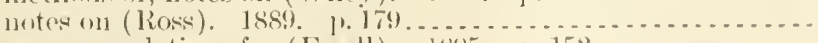
recommenclations for (Ewe+l). isit). 1. 152 ........... 17.3:17 


\section{Index}

Sugar-Continued

Analysis of-Continued

remarks on report of committee on surar, Issoxiation of Offi(jal Agricultural Chemists (Wiley). Is8s, 1.54 ........

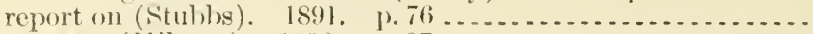

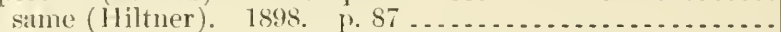
some facts relative to.(Jungfleisch and Grimbert), 1890. 1'. 135

See also Chemital analysis, methods of - Sugar analysis, committee on.

As food (A bel). 1899

A verage price and (onsumption of-

1895. 1. 55:

1896. 1.. 595

-

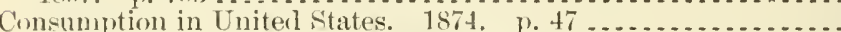

Crop and weather, in island of llauritins, $1880-96(\mathrm{~A}) \mathrm{be})$. p. 412

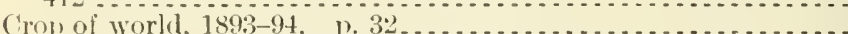

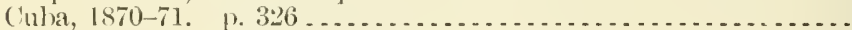

Diffusion and carbonatation of, in Java, extracts from report on

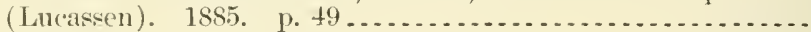
Estimation of-

by Fehling's solution (Causse). 1890. p. 137.

liy weighing precipitated cuprous oxid as such and as metallic

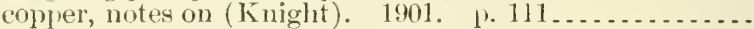

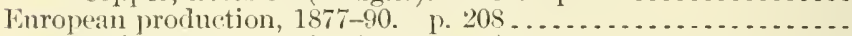

Evaporating apparatus for (Densmore). 1887. p. $57 . \ldots . \ldots .$. same (Denton). 1887. p. 57

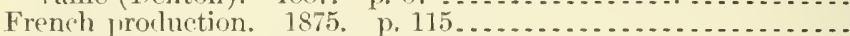

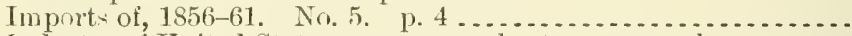
Industry of United States; cane sugar, beet sugar, sorghum sugar,

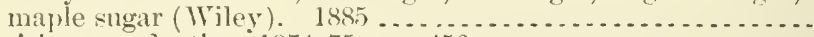

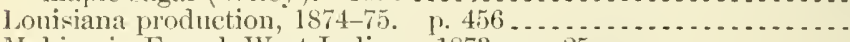

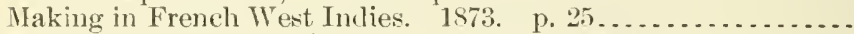

Manufacture of, use of indigo-carmine in (Mcllurtrie). 1873.

Northern, inclustry, record of its progress during season of 1883

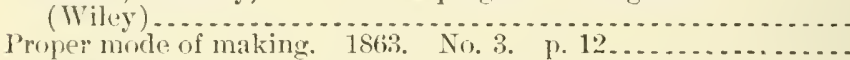
Quick estimation of, by one-tenth eopper solution (Politis). 1890. l. 136

Statistios of-

$1894-1898$.

$1895-1899$.

$1896-1900$. 1. 858

(1)

Worll's prouluction. 1886 . ए. 559

See also Beet sugar - Cane juices and sirups - Cane-sugar inclustry - Crops, principal-Des Linges sugar experiment station-Magnolia Station - Maize and sorghnm sugarsMaple sugar - Pentaglucoses - Sirup - Sorghum sugar Wiley, Havey Washington.

Sugar analyis, (ommittee on, Association of Official Agricultural Chenists, report of:

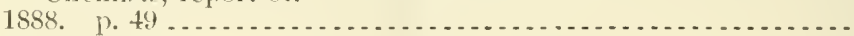

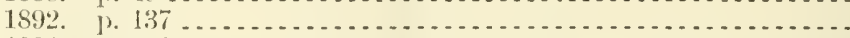

1893. p. $149 \ldots$

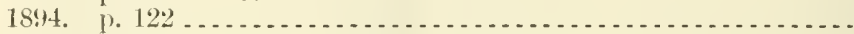

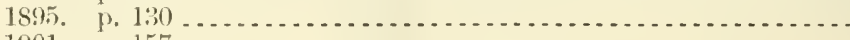

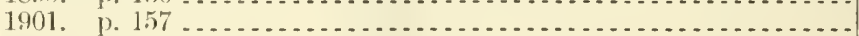

Aingar beets:

Composition of, influence of enviromment upon (Wiley), 1901 .. Culture, seed dovelopment, mannfacture, and statistics of (Wiley) Culture of-

and manufacture of sugar therefrom in France and United

States (McMurtrie). 1880. 
Sugar beets-Continned

Culture of- Continuel

and manufacture of beet sugar (Wiley). 1890.......... A7.3:27

in France and Germany, notes on (Iaxwell). 1890, p. 81.. A7.3:30

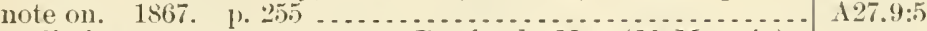

preliminary report on, near I'ortland, Me. (MeMurtrie).

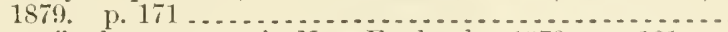

same, final report on, in New England. 1879. p. $181 \ldots$ report on (Wiley). 1891 . . . . . . . . . . . . . . . . . . . . successful, on alkali soils. 1899 . 1) 5 .................

Diseases of, some (Townsend). 1902. p. $90 \ldots \ldots \ldots$

England. 1870. p. $484 \ldots \ldots \ldots \ldots \ldots \ldots \ldots$

Experiments with -

1890 (Wiley).

1891 (Wiley and others) .....

1892 (Wiley and Maxwell) _............................

1893 (Wiley and Maxwell) ........ 1897 (Wiley) ...............

Feeding value of. 1898 . p. $15 \ldots \ldots$

Grown in various States, analyses of (Wiley) same, p. 135 .

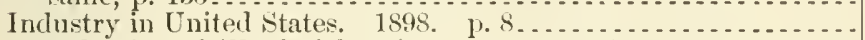

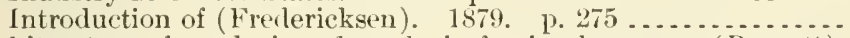

literature of, exclusive of works in foreign langmages (Barnett). 1897

Nitrates and phosphates in, pliysiologieal functions of (Strohmer).

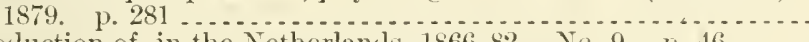

Prorluction of, in the Netherlands, $1866-82$. No.9. p. 46 .....

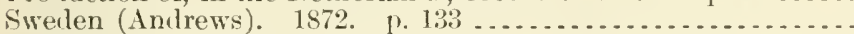

Wrisconsin, experiments in (IVoll). 1891 . 1. 90
See also Beet sugar-Schuyler, Nebr., Sugar-bet Fxperiment Station.

Sugar-beet seed, production and testing (Pieters). 1902. 1. 101_... Sugar-beet webworm:

Completed life history of (Howarl). 1894. 1).369............

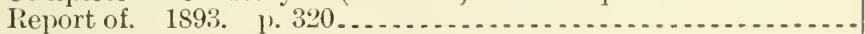
Sugar cane:

Analysis of-

at Magnolia Station, Lawrence, La. 1888. p. 29 . . . . . . . . . with table for calculation of analyses (Cranuton), p. 31.... same, at Fort Scott, Kans. (Crampton). 1887. p. 15.....

Applieation of diffusion to extraction of sngar from (Wiley) ....

Cultivation of character and composition of soils hest arlapted to (Richardson). 1886 . p. 60 .

in India. 1875. p. $135 \ldots \ldots \ldots \ldots$

Deterioration of1866. p. 341 .

1872. (Watts). 1). 211

A $1.6: 28$

A1.6:28

1 $1.9: 3$

A $1.9: 92$

11.8:72

127.9:8

A $7.3: 30$

A 7.3:33

17.3:36

17.3:39

A $7.3: 52$

11.9:84

1. $2: \mathrm{B}^{3} 9^{3}$

A 1.2:B39 ${ }^{1}$

A 1.9:79

A $1.6: 28$

A17.8:16

1 1.6:28

A $27.9: 22$

A $27.9: 10$

17.3:33

A1.8:72

A9.7:6

A9.7:5

17.3:18

A 7.3:15

A7.3:17

A $7.3: 8$

17.3:10

127.9:13

A $27.9: 4$

A $27.9: 10$

17.3:2

11.1:884

17.3:2

Diffusion process as applied to, in Louisiana (Fieg). p. 40 ....

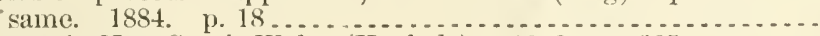

Insects in New South Wales (Koeluele). 1892. p. $385 \ldots \ldots \ldots \ldots \ldots$. . . . . . 144

Insects injurious to-

in Brazil, preliminary report of observations upon (Branner).

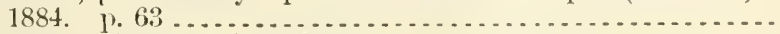

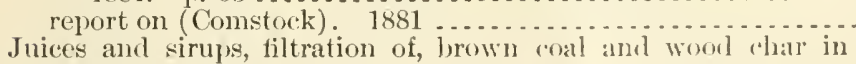
(Thompson). 1). 268

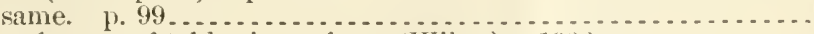

Manufacture of table sirups from (IViley). 190:2.......... $77.3: 70$

See also Sorghum.

Sugar-cane bectle injuring corn, note on:

1886. p. 32 ................

1888. (Howard). 1. $11 \ldots \ldots \ldots \ldots \ldots \ldots$ Sugar-cane borer:

Java (Zehntwer). 1898. 1. 32. 
Sugar-cane horer-Continuel

I nuisiama, lifo history of (Morgan). 1902. p. 128.

Samelwich Islands. 1888. 1\% 185

A10.3:11:

sugar chemists:

Committes of Fronch Assoration of, potash, estimation of, alstratet

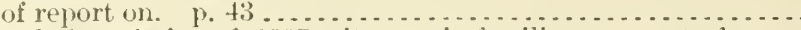

French Association of, 1857 , nitrogen in fertilizers, report of com-

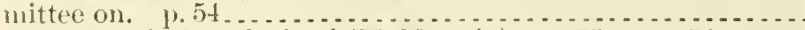

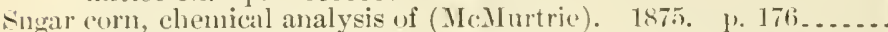

Singar deterninations, partial smmmary of, from sorglo eanes and

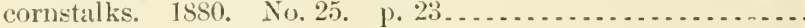

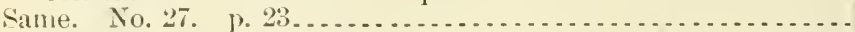

sugar factories, cust of, estimates of (Hughes). 1) "252 ..........

Same, p. $73 \ldots \ldots \ldots \ldots \ldots \ldots \ldots$

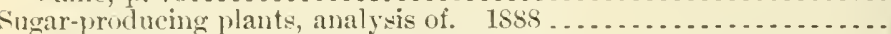

sie also sugar and references thereunder.

Sugar refinery. See Standard Sugar Refinery, Alrarado, Cal.

sugar rugion, Weather Bureau service, instructions governing (Berry).

Sugar stations of Wreather Bureau, instructions and cocle for encipher-

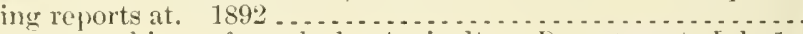

Sugarliouse machinery for sale by Agriculture Department, July 1 , 1895

Sugar-yidding j]ants, "diffusion process" for extracting saccharine

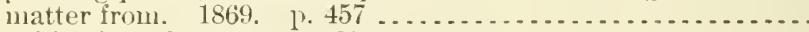

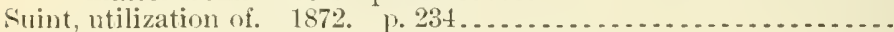

Sulphur:

Loss of, in preparing ash of plants, report on (Fraps). 1901. p.98.

Metaholism of, in human organism, experiments on (Sherman). $190^{\circ} \%$

Use of, for blight or mildew on peaches and roses. 1867 . 1.60.

Sulphur rains, notes on (Abbe). 1898. p. $115 \ldots . . . . . . . . . .$.

Sulpliur wash. See San Jose scale.

Sulphuric acid. See Cane-sugar manufictories.

Sulplunrous acid, use of:

In manufacture of alcohol (McMurtrie). 187:. p. 32.........

In purifying the diffusion juices of sngar ane and sorghtum (Wiley) . . . . . . . . . . . . . . . . . . . . . . . . . . . . .

Sulphurous oxille, effect of, on vegetation (II Murtrie). 1873. p. 32 . Sumac:

American-

importations of. 1869 . p. $377^{*}$

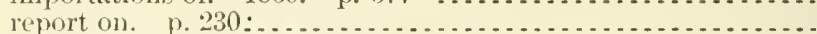

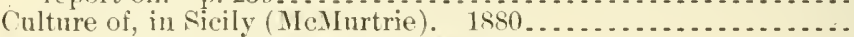
Simatra, tobaceo in, cultivation of (Mulder). 189s.............. Sumatra tobacco, growing, under sharte in Connecticut Valley summer:

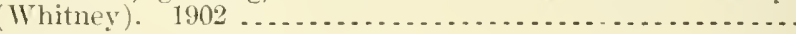

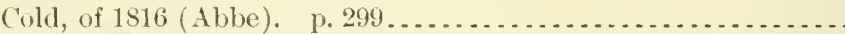

Indian (Matthews). 1902. pp. 19, 69

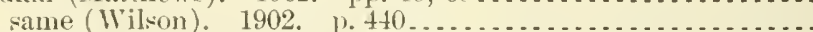

Summerville, S. C., tea garden at, Covernment, condition, and pros-

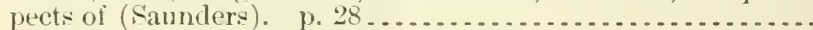

Sill :

Sip Pinehurst Experimental Tea Garden.

Cismical relations manifester in simultaneons disturbances of, anrora, and terrestrial magnetic field (Lemstrïm). 1895. p. 492

Electrodymamic radiation from, andeavor to discover (Trow-

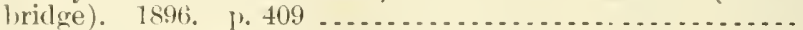

Green-colored, wi sept. 9 and 10,1883 (Able). p. $173 \ldots \ldots . . .$.

Proindic terms in meteorology due to rotation of, on its axis (Bigelow). 1895. p. 500 ...

Tutal eclipse of, May $28,1900-$

meteurological observations made to determine probable state of sky at several stations aloug path of (Bigelow). 1897. 1. 394 1597.

1!1. $7: 1$

17.3:16

A27.9:19

127.9:18

A27.9:18

A1.1:887

A7.3:17

A7.3:18

129.12:C81

+29.12:C82

A1.2:Su $3^{2}$

127.9:6

+27.9:10

A. $3: 62$

A 10.3:121

A27.9:5

A $29.6: 26$

A27.9:11

Aт.3:8

А $27.9: 11$

127.9:7

A1.1:869

A1.6:26

A1.8:58

$\mathrm{A} 26.3: 20$

A:9.6:23

A 29.6:30

A29.6:30

A1.1:8s1-2

A $29.3: 11^{2}$

A29.6:24

A $29.6: 23$

A29.3:11²

A29.6:25

* By a misprint, this page number appears twice. 
Total eclipse of, May 2s, 1900-Continued

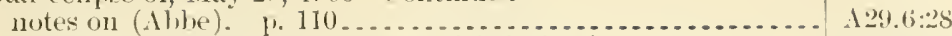
probable state of sky along pith of (15igelow). $1899 \ldots \ldots \ldots . . .429 .3: 27$ kame (Bigelow). p. 404 ............................ A29.6:26 Sun printing, Solandi (Halsted). 1894. p. 93 ............... A $10.8: 20$ Sun-spot cyele, relation of, to neteorology (Abbot). 1902. p. 178. A29.6:30 Sun-spot period and temperature and rainfall of Jamaica (Hall).

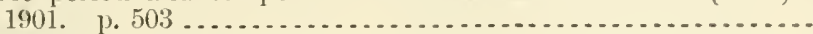
Sun sprots:

Frequeney of, at Madras, India (Sulha Rao). 1902. p. 438 _...

Meteorology and, notes on (Ablue). 1901. p. 263.............

Relative frequeney of, $1749-1900$ ( $A$ bbe) p. p $505 \ldots \ldots \ldots \ldots \ldots$

Relative numbers, Wolf's, revision of (Wolfer). 1902. p. 171 .

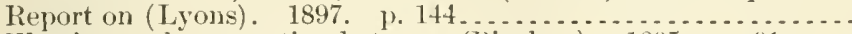

Weather and, comection between (Bigelow). 1895. p. 91 ....

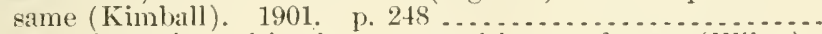
Sunflower plant; its cultivation, composition, and uses (Wiley).

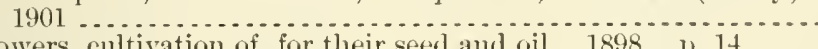

Sunflowers, enltivation of, for their seed and oil. 1898, p. $14 \ldots . .$. Sunshine:

Hourly results from self-registers for recording (Abbe). 1897.

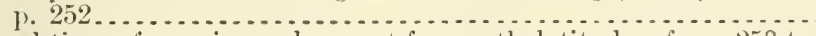

Local time of sunrise and sunset for north lititudes, from $25^{\circ}$ to

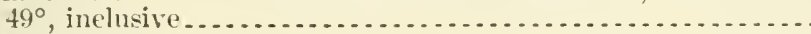

Measurement ofand preliminary examination of Angström's pyrheliometer

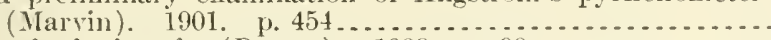

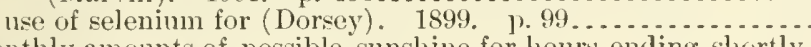

Monthly amounts of possible sunshine for hours ending shortly

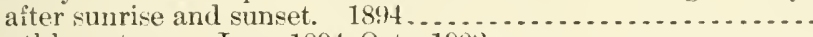

Monthly notes on, Jan., 1894-Oct., 1902 . . . . . . . . . . . . . . . .

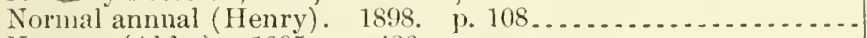

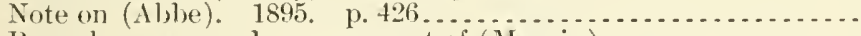

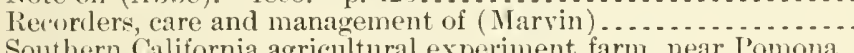
Southern California agricultural experiment farm, near I'omona,
Cal. (1lenry). 1896. p. $237 \ldots \ldots \ldots \ldots \ldots \ldots \ldots \ldots$

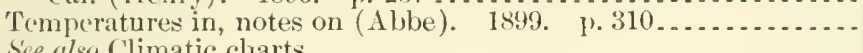

see also Climatic charts.

Sunshine recorder:

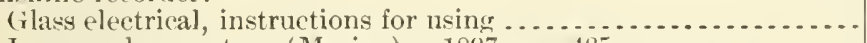

Improved, report on (Maring). 1897. p. $485 \ldots \ldots \ldots \ldots \ldots \ldots$ Sunstroke in California and Arizona (Phillips). 1896. p. $454 \ldots .$. Sumstroke weather of August, 1896 (Plillips). p. 409 .............. Supan, Alexanter. Rainfall, distribution of. [p. 220.............

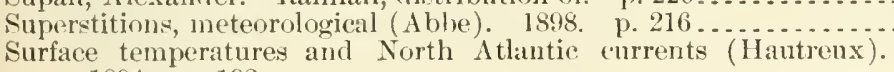
1894. P. 192 .

Surgical operations on cattle (Dickson and Lowe) p. 301 . . . . . . Surplus, Ameriean, and foreign trade. 1889 . p. 159 .......... Surra:

And allied trypanosomatie diseaces, bibliography of (Hassall).

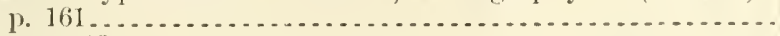

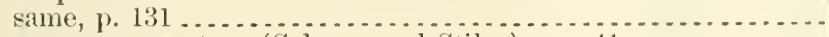

Emergency report on (Salmon and Stiles). p. $41 \ldots \ldots . . . . .$. same.

See also Nagana - Mal de carleras - Trypanosomiasis.

Suspended clay. See Clay.

Svalöf, Swerlen, station for plant breeding at (Fairchild). 1901.

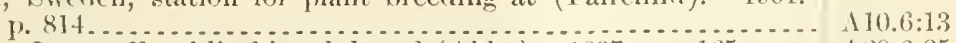
Swain, James, Franklin kite (lub and (Abbe). 1897. p. 165.... A A29.6:25 Swalm, Allert $\mathrm{W}$ :

Bones and bone ash, export of, from Uruguay. p, $519 \ldots \ldots . .$.

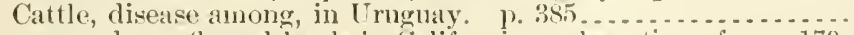
Swamp and overflowed lands in California, reclamation of. p. 179.. Swamp-land reclanation in California. 1872, p. 18............ Swamp soils. See Soils. 
Swank, James Moore. AgrienIture Dejartment, history and oljects.

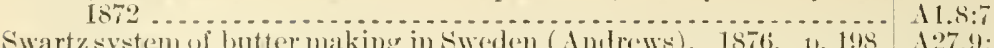
swerlen:

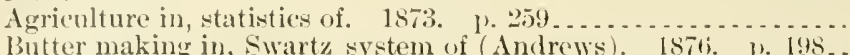
Butter making in, Swartz system of (Andrews). 1876. 1. 198.
Cooperative dairies in (Salviate). 1872. p. 452........... Crops in-

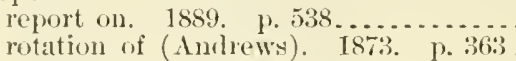

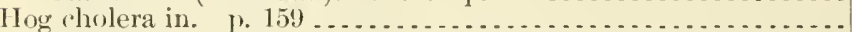

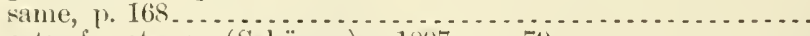
Inserts of, notes on (Schöyen). 1897. P. 79...........

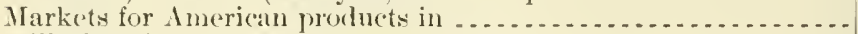

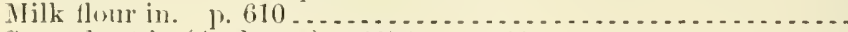

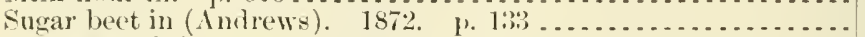
the relso Sralït.

Sweet Cassava. See Cassava, sweet.

Siwert potato:

As starch producer. 1899. 1).27

Ciulture and uses (Dugar).

('ulture of, at Nortl, and modes of preserving throngh winter

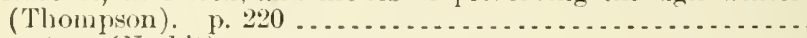

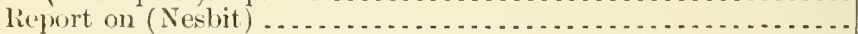
Swect-potato black rot (IIalsteri and Fairelilid). 1891. 1.1 . . . . . Sweet-potato saw-fly:

New (Marlatt). 1892.

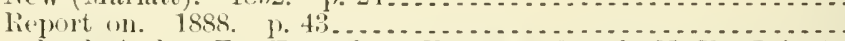
Sweetland, Arthur E. Tomato at Hampton Beach, N. II., July 4, 1898. 1\%. 308.

Swcetser, William S.:

Food adulteration, report on. 1898. p. 78. . . . . . . . . . . . .

Nitrogen determination, by Kjeldahl method, distilling with and without jotassium sulphid. 1896 . p. $25 \ldots$

Sep relso, as joint anthor, Bigelow, WVillard Dell.
ecetwater River, Cal., problems of water storage on torrential streams of southern California, as typified by (Schuyler). 1901. 1. 353.

Swells. See Tegetables.

Swondsen, freorge L.:

Irrigation nnder canals from Logan River. 1902. 1. 179 . . . . . .

I ogan and Richmond canals in Utah, dnty of water nnder. 1900. p. 211 .

Swenson, Magnus:

Letters latent granted to, in process of making sugar. p. $242 \ldots$

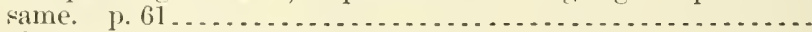

Sorghum sugar, experiments at Fort Goott. 1. $213 \ldots \ldots \ldots \ldots \ldots$. Siwine:

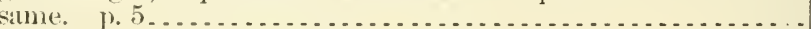

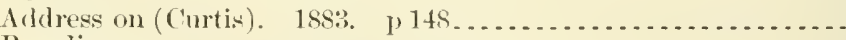

Preeding-

address on (Stetson). 1883. 1\%. 160

America. 1885. No. 25. p. 24...

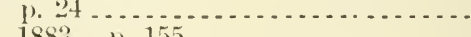

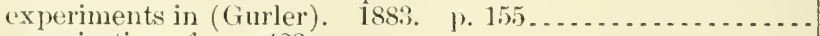

Crossing improverl breets of, with conmon hogs of Floriala (Furnas). 1895

Discalses of eridemic-

report on (Bolton). p. 135.

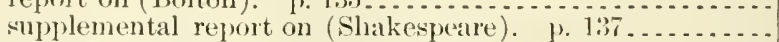

United States hoard of inculiry concerning, report of (Sluakespeare and Burrill). 1891. 1. 129........ infectious, additional investigations concerning. $1894 \ldots \ldots .$. inoculation as a preventive of. p. 58 . saine. I. 16 .

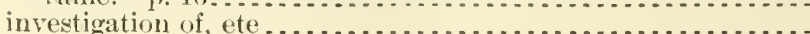

A $27.9: 11$

1:27.9:14

A27.9:10

$127.9: 27$

Aㄴ.9:i1

A $4.1: 587-8$

A1.1:888

A $9.6: 9$

A I2.3:8

14.1:901

127.9:10

A $1.9: 87$

11.9:26

A 1.1:862

1 1.9:129

128.5:7

A $9.7: 5$

19.7:1

129.6:20

A7..3:56

17.3:49

A10.8:100

A 10.3:104

A $10.3: 86$

A1. 1:887

A7.3:17

A 1.1:887

A $7.3: 17$

A $1.7: 2$

A1.7:2

A 27.9:2:3

A $1.7: 2$

A1.1:872

A $4.4: 4$

A $4.1: 889-90$

A 4.1:889-90

A4.1:\$89-90

A4.3:6

A1.1:889

A $4.1: 889-90$

A 1.6:12 
Index

Swine-Continued

Jiatases of-Continuer

report on. 1. 382.

reports from inspectors and comespoulents. p. $375 \ldots . . .$.

scientific investigations. 1890. 1.93.................

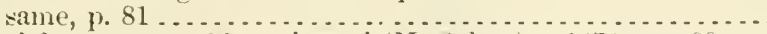
special report, no. 12, review of (Mc(rehee). 1879. 1. $89 . .$.

Epizooties among (Watts). 1572. p. 214 ................

Exportation of, from Boston, prohilution of. 1902...........

Fecundity of. 1899

Flukes and tapeworms of-

bibliograjhy (Hassall). 1898. p. 145...............

compendium, arranged according to their hosts (Hassall). 1S98. 1. 137.

report on, with special reference to inspertion of meats

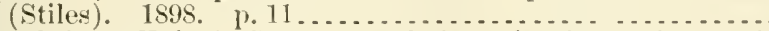

Imported into United States, regulations for insection am quarantine of -

Dec. 2S, 1899

Jan. 27, 1900, modification ............

June 1, 1900, amendment. . . . . . . . . . . . . . . . . . . . . .

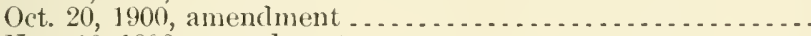

Nov. 10, 1900, amendment. . . . . . . . . . . . . . . . . . .

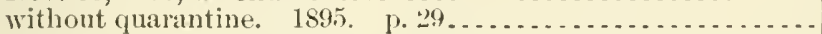

Kidney worn of, our present knowlenge of (Tayler). 1,612...

Losses of, by direase. 1886. p. 546 . . . . . . . . . . . . . . .

Missouri, industry, and annual loss by disease (Bralley). p. 418 .

Nonspecific disease among, outbreak of (Moore). p. 219.......

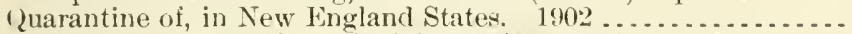

Rearing and feeding in I'nited States (Morrow). 1). 405.......

Tuberculosis in; natmre of disease, with report of three cases

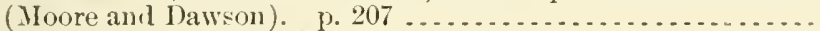

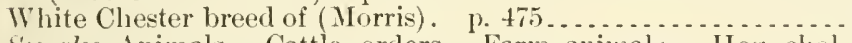

See also Animals - Cattle orlers - Farm animals - Hog cholera - Live stock - Sows - Swine plague.

Swine Breeders' Associations, list of, with officers:

1S98.

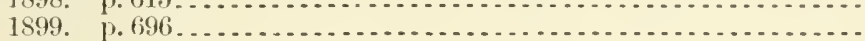

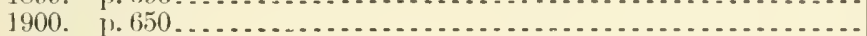

1901.026

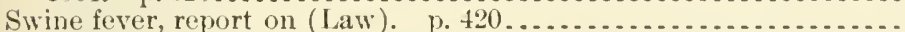

See also Swine plague.

Swine plague:

Cass County, Nebraska (Hines). 1879. p. 177

Cause and prevention of (Smith) $1891 \ldots \ldots \ldots \ldots$

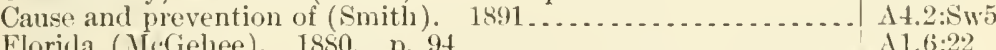

(Hog cholera), investigation of (Salmon)-

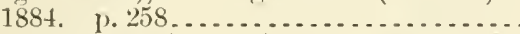

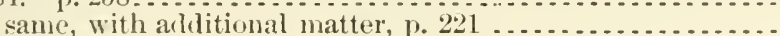

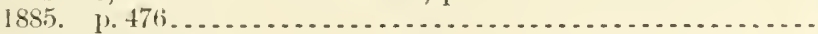

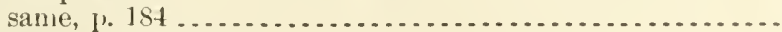

See also llog cholera.

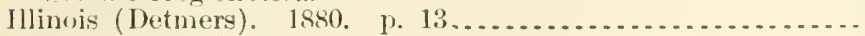

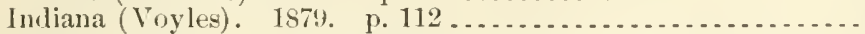

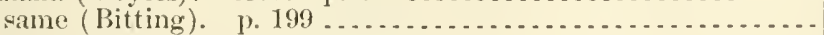

(Infections pneumonia) investigation of-

1886 (preliminary). p. 659 . same, 1). 76

1887. p. 491

same, 1. 86.

See rilso Salmon, Daniel Elmer.

Investigation of, in Indiana (Voyles). n. 421. same (De Schweinitz). p. 501 .

Ithaca, N. Y. (Law)-

1879. p. 56 .

1880. p. 69

11.1: $: 375$

A $4.1: 559-90$

A $1.1: 890$

A4.1:85?-90

11.6:2:3

A:7.9:10

14.5:100

11.9:87

A $4.3: 19$

A 4.3:19

A $4.8: 19$

A4.5:56

A $4.5: 58$

A $4.5: 64$

A $4.5: 77$

A $4.5: 79$

14.1:895-6

14.1:899

1 $27.9: 24$

A $4.1: 585$

At.1:895-6

1 $4.5: 99$

A4. 1:887-8

A $4.1: 895-6$

11.1:865

1 1.10:898

A 1.10:899

A $1.10: 900$

1 1.10:901

A 1.1:879

A 1.6:12

A 1.6:22

A 1.1:854

14.1:884

A 1.1:885

A t.1:885

A1.6::2:2

A1.6:12

A $4.1: 897$

1 1.1:8S6

A $4.1: 886$

11.1:887

14.1:857-5

11.1:878

11.6:12

A 4.1:899

11.6:12

$\Lambda 1.6: 22$ 
Swine platerue-Continued

Ithita, N. Y. ( Law)-Continued

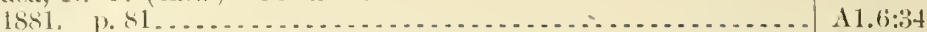

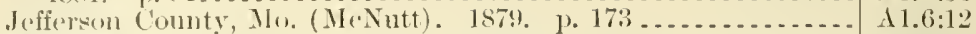

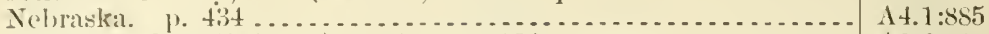

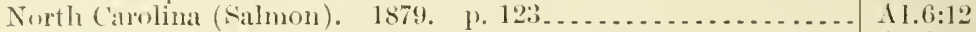

()ttawa, Ill. (1)yas). 1879. 1) 156................... 11.6:12

Outbreak of, in Marylanel and Virginia (Rose). 1. $446 \ldots . . . . .14 .1: 884$

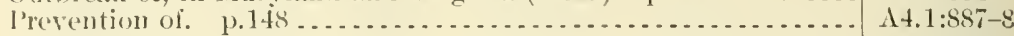

Report on-

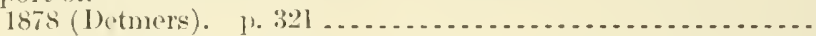

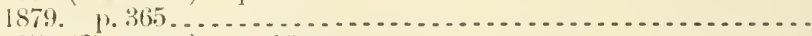

1879 (I)etmers). p. 19 .

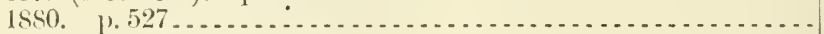

1880 (1)etmers). p. 15:' . . . . . .

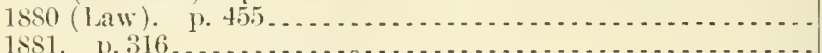

1881. p.316 $\ldots \ldots \ldots \ldots$

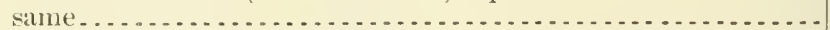

Sonthwest, character of (Thornton). 1879. 1). $84 \ldots \ldots \ldots \ldots . .$.

Variability of infections diseases as illustrated by (Smith and

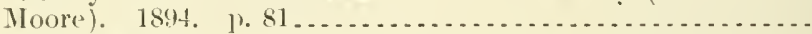

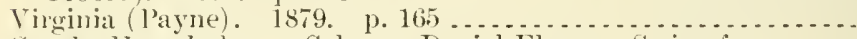

Se also llog cholera - Salmon, Damiel Elmer - Swine fever.

Sivine plague bateteria:

Experiments on production of immmnity in ral)bits and guineapigs with reierence to hog-cholera and (Nmith and Moore). 1594. 1. 41.

What hecomes of hog-cholua and swine-ylague bacteria when injected in small numbers into subentancous tissues of pigs"? (Moore). 1894. p. 103.

Swingle, Walter Tennysin:

Borleanx mixture-

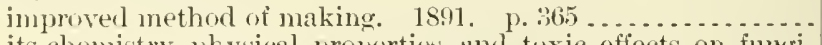
its chemistry, physical properties, and toxic efferts on fungi

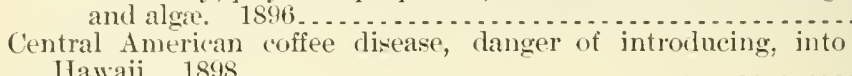

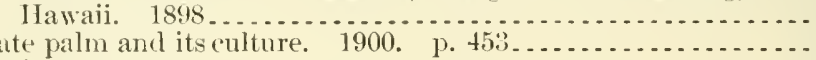

Grain smuts-

how cansed and how to prevent. 1898

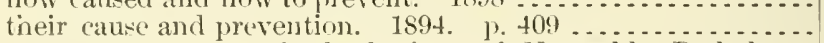

Peronosporacese, some in herbarium of Vegetable Pathology

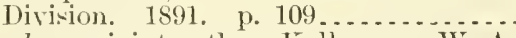

See also, as joint author, Kellerman, IT. A.

Swingle, Walter Temnyon, and Fairchihl, David Grandison. Jiur,

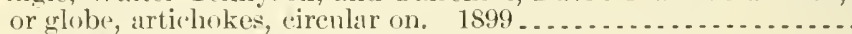

Swingle, Walter Tennyson, and Webber, Herbert John:

Citrons fruts, principal cliseases of, in Floricla. $1896 \ldots . . . .$.

Hylorids and their entilization in plant breeding. 1897. 1.383.. Sirintor, 1. H.:

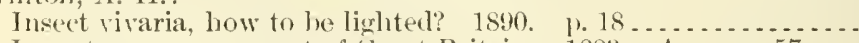

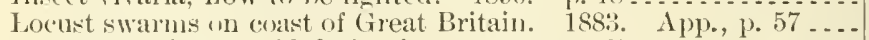
Vanessa antiopa, stridulation in. 1889. 1. $307 \ldots \ldots \ldots \ldots \ldots . .$. Switzerland:

Agricultural investigation in (Grete). 1896. ए. 681

Agriculture of. 1873. p. 568 ...

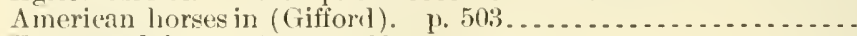

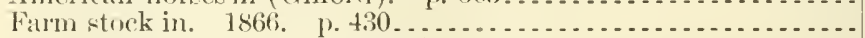

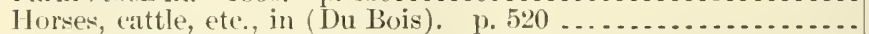

see also IIorgen - St. Gall.

Symons, George James:

England, meterological literature of, 1337-1699. 1895. T. 338.

Thumlerstorms, barometric oscillations luring; and use of brontometer, an instrument designed to facilitate their study. 1901. 1) 463 .

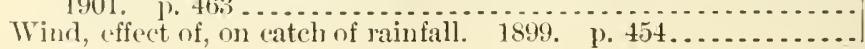

A1.1:878

A1. $1: 879$

A $1.6: 12$

11.1:880

11.6:i)t

A1.1:880

1 1. 1:881-2

A $4.1: 898$

A $4.8: 2: 3$

A1.6:22

A+.8:6

A1.6:12

A $4.9: 6$

14.3:6

A28.5:7

128.3:9

A:S.4:16

A1.10:900

A 1.9:75

A 1.10:894

A28.5:7

A6.4:22

A 28.3:8

A 1.10:897

19.7:3

A8.1:3

A9.7:1

A 10.6:6

A27.9:11

A 4. 1:900

A27.9:4

A4.1:898

A29.3:112 


\section{Index}

Classificution no.

Symons, feorge James, short biograplyy of. $1900 . \quad$ p. $68 \ldots \ldots .$.

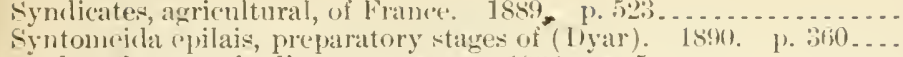

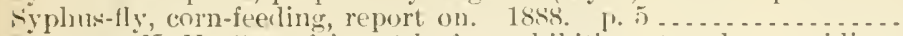
Syracuse, $\mathbf{X}$. Y., state fair, "attle for exhibition at, orrler provilling

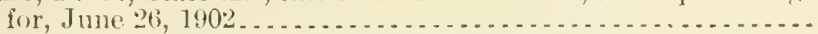
Systematic plant introduction. See Plant introduction.

Tabanilie (gatllies) and a very simple means of destruying them

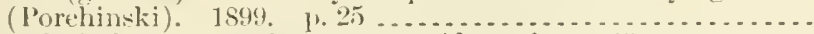

Table and kitehen wasters, importance of loss of. p. 25.......... Table sirups, manufacture of, from sugar cane (Wiley). $1902 . .$. Tarchinide of America north of Jexico, revision of (Coy uillett), 18917.

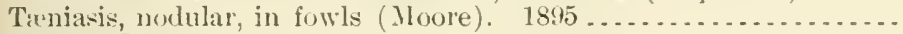
Taft, L. R.:

Apples(ab), remedies for, experiments with. 18!0. P. $30 \ldots .$. Irrigation for garden and greenhouse. 1895. p. $233 . \ldots \ldots \ldots \ldots$ Jichigan Farmers' Institnte, work acomplished in. 1902.

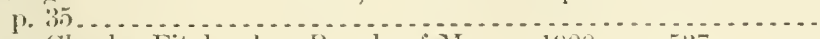

Talman, Charles Fitzhugh. People of Miars. 1900 , p. $58.7 . . .$. Tamalpais, Mount:

Fog studies on (McAdie). pp. 283, 492.

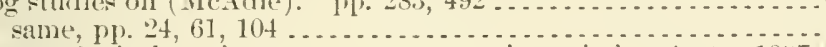

Meteorological station, report on operation of, for sept., 1897

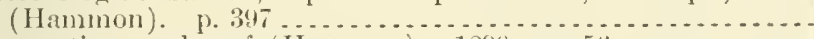

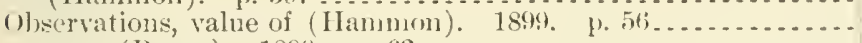

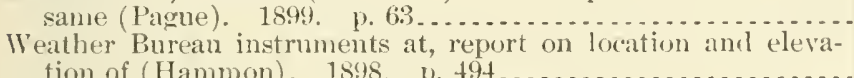

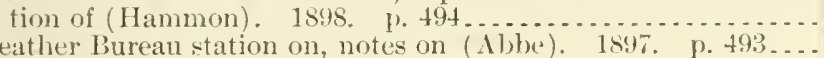

Weather Bureau station on, notes on $(\Lambda \mathrm{b} b e)$. 1897 . p. $493 . .$.
Tanari, Kize. Japan, rice and silk culture, and agriculture educa-

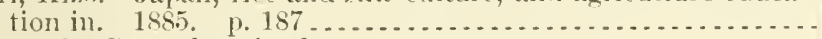

Tamias. S'ee Ground squirrel.

Tampico, Mexico, northers of (Abbe). 1893. 1. 363............

Tanana Valley, Alaska, notes on (Green). p. 309 ................. Tun-bark beetle, destructive, report on (Burgess). 1899. p. $107 \ldots$ Tammery refuse, utilization of, in France. 1876. 1). $280 \ldots \ldots \ldots .$. Tamnin, committee on, of Association of Official Agricultural Chemists, report of:

1894. p. 194.

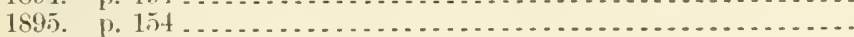

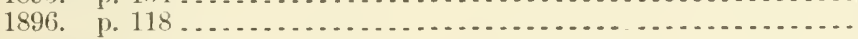

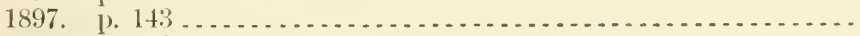

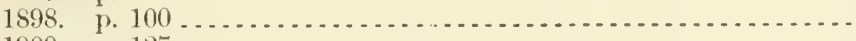

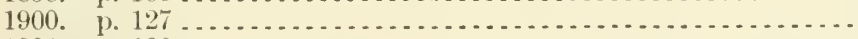

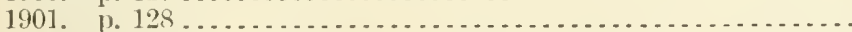

Tannin, cletermining, by hick jower, notes on points of error in shake

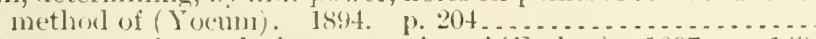

Tanning extracts for analysis, preparation of (Forbes). 1897. p. 149. Tamning materials:

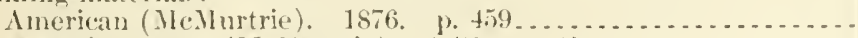

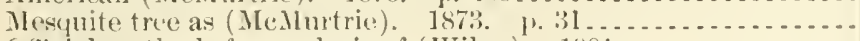
Oflicial methorls for analysis of (Wiley), 1901 .............. Tape-worm disease of sheep of Western plains (Curtice). J. $167 . .$. Tapeworms. Siee Cestodes - Flukes and tapeworms - l'oultry.

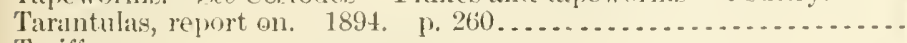
Tariff:

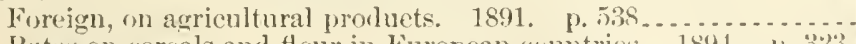
Rates on cereals and flour in European conntries. 1894. p. 323. Reciprocity treaties and, French. 1892. p. $181 \ldots . . . . . . . .$.

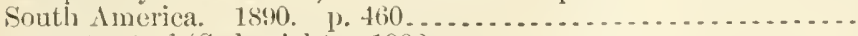
Taro, root rot of (Sedgwiek). 1902 . Tasajo, or jerked beef, manufacture and exportation of, hy liver

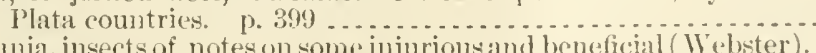
Tasmania, insects of, notes on some injurions and benefrolal (Webster). Sie ulso Austrulasia.

Tasmanian Coccinellicla, notes on (Thumpson). 1893 p. 11 ..... A4.7:ti 
Taveau, Angustine I. Farming, modern, in America. p. 280.

'1'axation:

Higlway, comparative results of labor and noney systems. 1894.

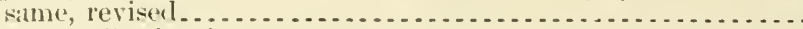

Local, as affecting farms. 1897 .

127.915

A $22.4: 16$

12:2. $4: 24$

Tayler, lonise. Kidney worn of swine, our present knuwledgo of.

See also, as joint author, Stiles, Charles Wariell.

Taylor, Charles WT. Cattle and sheep, raising and feeling more,

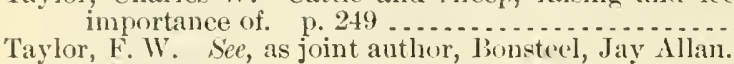

Taylor, H. MI. :

Cattle interests, condition of, west of Mississippi River. p. 306.

Cattle-range industry. p. 105...................

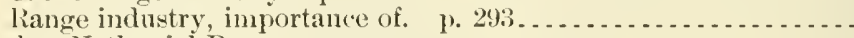

Taylor, Nathaniel R.:

Atmospheric pressure, high and low. 1897. p. 351

Weather observer. What a weatler observer should know.

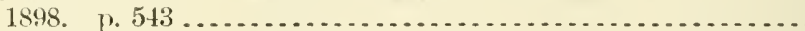

Taylor, Thomas:

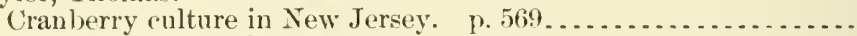

Fibrine and bavteria ........

Fungoid diseases of plants. p. 110.....................

Internal parasites in domestic fowls and lutter and fats, microscopic observations. . . . . . . . . . . . . . . . . . . . . . . .

Lard, pure and fictitions, methods of distinguishing between. 1893 . . . . . . . . . . . . . . . . . . . . . . . . . . . . .

Mieroscopic investigation along agricultural lines, monthly, May, 1872 , to Dec., 1876.

[The more important articles are indexed under their various subjects.]

IIushrooms-

eight edible and twelve poisonous, of U. S., with direetions for culture and culinary preparation of erlible suecies. p. 366

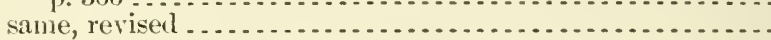

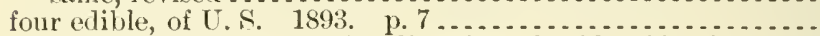
twelve edible, of U. S., with directions for illentification and preparation as food. p. 100 ...

A27.9:35

A4. 1:899

A $1.1: 864$

A $4.1: 887-8$

At.1:886

A $4.1: 88.5$

$129.6: 25$

1:9.6:26

A1.1:877

A 18.2:F4t

A 1. 1:871

11.8:34

A18.5:3

1.27.9:

A 1.1:890

A18.5:2

A $18.5: 3$

A1.1:885

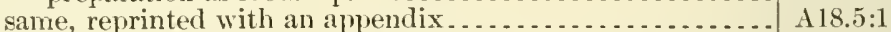

Napthaline as an inseeticide, etc., its effect on seeds, plants, and

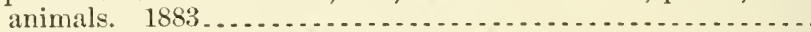

See also, for reports as Mieroscopist, Agriculture Department,

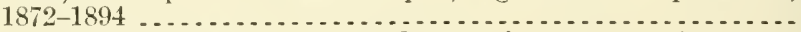

Taylor, W. Potato disease, cause and cure of. 1869. p. $64 \ldots \ldots \ldots$ Taylor, William Alton:

Fruit industry, and substitution of domestic for foreign-grown

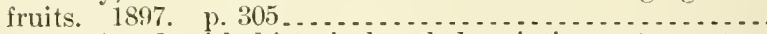
same, reprinted, with historical and descriptive notes on ten varieties of apples suitable for export trade. 1898 .......

Fruit varieties, little-known, considered worthy of wirler distemi-

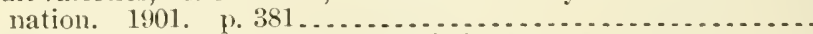

Refrigeration, influence of, on fruit industry. $\quad$. $561 \ldots \ldots . . .$.

Small-fruit culture for market. 1895 . 1. $283 \ldots \ldots \ldots \ldots \ldots$
See also, for reports as Assistant Pomologist, 1893, Acting PomoloTea: gist, 1900, Pomology Division, Agrienlture Department . . . . . .

A 18.2:N16

A 18.1:

A $27.9: 7$

A $1.10: 897$

\$21.3:7

A 1.10:901

A1.10:900

A 1.10:895

A20.1:

Aboriginal North American. See Ilex cassine.

Adulteration of (Spencer). 1892. p. 875

California, culture. 1870. p. 38 .......................

Consumption of, in United States, per eapita of population-

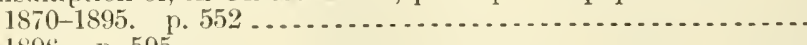

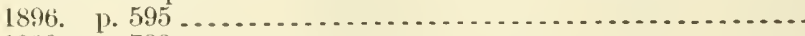

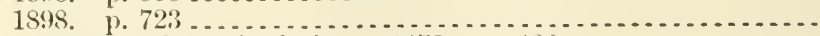

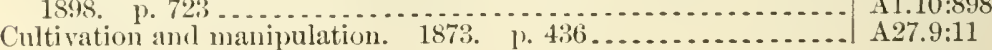

A $7.3: 13^{7}$

A27.9:8

A $1.10: 895$

\1.10:896

A 1.10:898 
experiment in, report on tea gardens of Dr. Charles T. Shepard,

l'inchurst, S. C. (Saunders). 1897.................. \$14.4:1 experiment in Sonth ('arolina (Shepard). 1899 .............. A 1.8:61 in Unitel States. 1). 235 ............................... A 1.1:869 probable Anerican industry (Saunders). 1879 . . . . . . . . . . . A 1.6:18

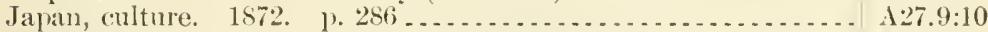

Miswisippi, cultivation of plant. 1869. p. $301^{*} \ldots \ldots \ldots \ldots \ldots \ldots . . . . .27 .9: 7$

Raising, at Pinehurst Experimental Tea Garden, near summer'ville, S. C., special rejort on. I. 627

Ser rlso Chinese tea plant.

Tea garlen, Government, at Summerville, S. C., ('ondition anrl

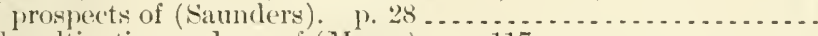

Teasel, cultiration and use of (Moses). p. $117 \ldots \ldots . . . . . . . . .$.

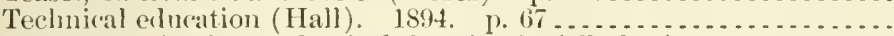
Technical schools, mechanical trawing in (Flather). 1894. p. $81 .$. Teele, R. 1'. Irrigation investigations, 1901, summary of results of. 1902. p. 17

\1.1:892

A $1.1: 881-2$

A $1.1: 863$

A10.3:20

1 10.3:20

Tein, M. von. Rhine region, regimen of; high-water phenomma

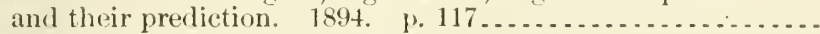

Teisserenc de Bort, Lern. Atmosphere, studies on, at Trappes,

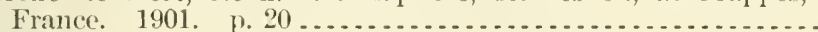

\section{Telegraph:}

Weather service and (Robinson). 1902. p. 145...............

West India service (Robinson). 1898 . p. 410.

\10.3:119

A29.3:11

A $29.6: 29$

A29.3:31

See also seacoast telegraph line - Weather telegraphy - Wireless telegraphy.

Telephone and kite, note on (Abbe). 1898. p. 366

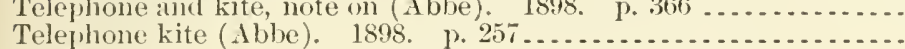

Temperature:

Air, monthly notes on, July, 1891-Oct., 1902

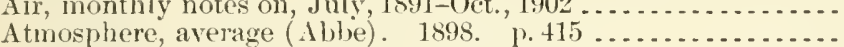

Atmospheric, during month of July, 1895 (Phillins). p. 253

Average, of upper strata, notes on (Ahbe). 1901. p. $177 \ldots . .$.

Baltimore, Md., study of (Walz). 1899. p. 2!98. . . . . . . . . . .

Bergen Point, N. J., kite determinations (Allen). 1898, p. 161 ..

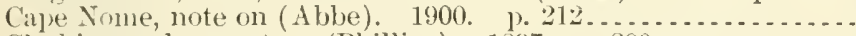

Clothing and, report on (Phillips). 1897. 1.200.............

Comparison of, with magnetic horizontal force (Bigelow) -

1894. J). $415,460,504$

1895. P. 7

Control of scale insects by (Mariatt). 1899 , p. $73 . \ldots \ldots \ldots .$.

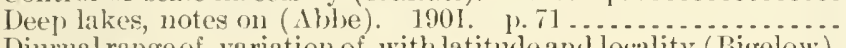

Dimmal rangeof, variation of, with latitude and locality (Bigelow).

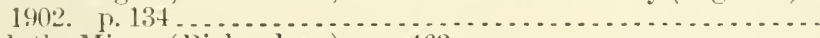

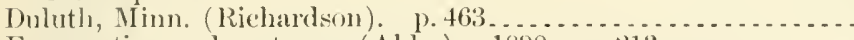

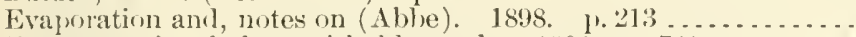

Extrenes of, safe for perishable goods. 1900. 1. $741 \ldots \ldots \ldots$.

Forest clearing and eultivation, effect upon (Fulton). 1899. p. s!.

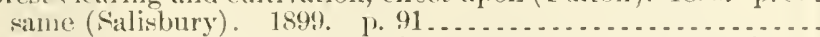

Homogeneity and uniformity of, at Weather Burean stations,

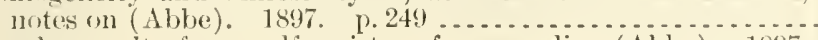

Hourly results from self-registers for reording (Abhe). 1897.

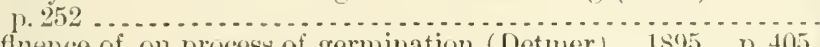

Influence of, on process of germination (Detmer). 1895. p. 405 .

Injurions, protection of food products from (Williams). 190! . .

Injurions to food products in storage and during transportation

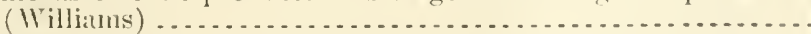

Jamaica (Hall), 1901, p. 503 . .

Low, cause of, for Augnet, 1895 (A3be), p. 296 . . .

May, and of the year, $1790-1888$ (Abbe). p. 216...........

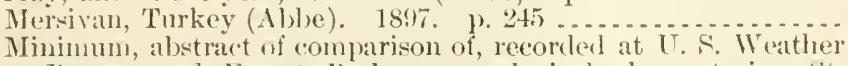
Burean ausd Forest l'ark meteorological observatories, st. Louis, 11\%., 189I (I tammon and Duenckel). 1. 12......... 
Temperature-Continnel

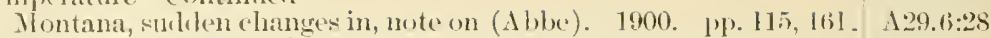

Monthly statement of ............................. 129.6 :

Normal, by decales, for 8 a. m. and 8 l. m., 7ñth mericlian time

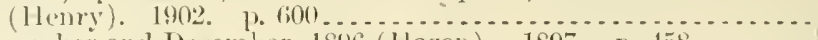

Novenber and December, 1896 (Hazen). 1897. p. 4is........ P'robable, forecats of (Cline). 1999. p. 166 .............

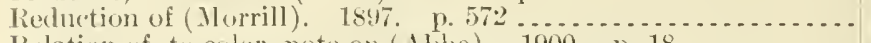
Relation of, to color, note on (. Hbbe). 1900. J) 18 . . . . . . . . Sin Juan, Porto Rico, rejort on (Phillips). 1899. J. $819 . . . .$. Sensible, or curve of comiort (Ahbe)-

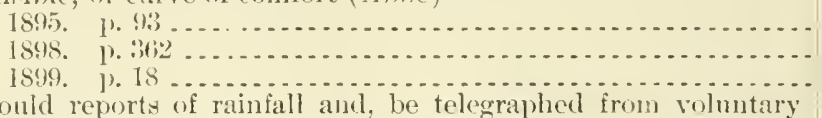

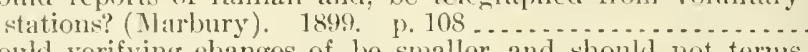

Should verifying changes of, be smaller, and should not terms "slightly warmer" or "slightly cooler" be credited? (Cox).

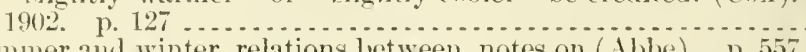

Snmmer and winter, relations letween, notes on (Abbe). p. 557.

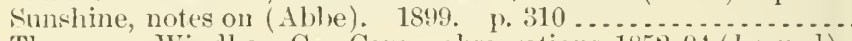
'Thompson, Windham Co., Comn., observations, 1852-94 (I armed).

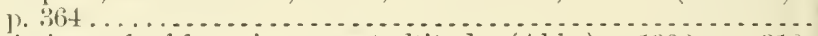

Variations of, of free air at great altitudes (Abbe). 1902. P. 316 .

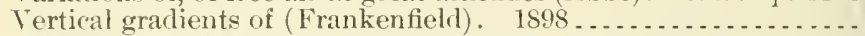

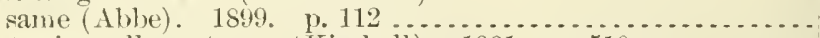

Water in wells, notes on (Kimbali). 1901. p. $510 \ldots \ldots \ldots \ldots . .$.

Wind and, notes on (Albe). 1901. p. $218 \ldots . . . . . . . . . . .$.

Sce also Climatic charts - Climatology - Meteorological obsarvations - Suils - Thermometers - Wam waves.

Temple, O. T', arldress of, hefore Association of American Agricultural Colleges and Experiment Stations, at :d annual conven-

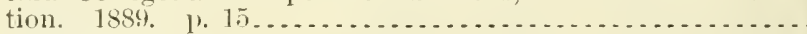

T'n Broeck, H. H. :

Aurora, remarkable, at Praidentown, Fla., Nov. 18, 1899. p. 582.

Auroral-lunar halo display, report of. 1901. p. 551 ...........

Ice on lakes, sudden disappearance of. 1900. p. $286 \ldots . . . . .$.

Tennessee:

Agricultural resources of. 1872. p. $201 \ldots \ldots \ldots \ldots \ldots \ldots$

Cattle quarantine of counties in-

A $119.16,1897$

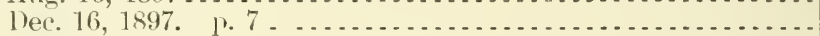

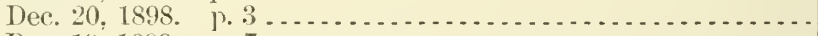

Dec. $19,1899$. P. $7 \ldots \ldots \ldots \ldots$

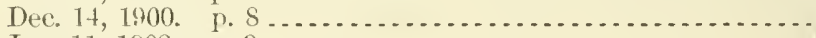

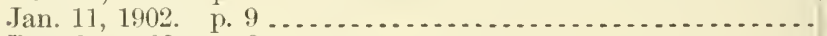

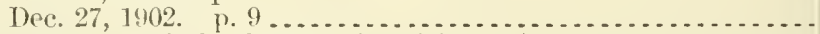

Cattle tracle and allied inclustries of (Perry). P. 125 . . . . . . .

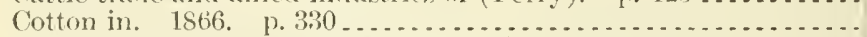

last, botanical explorations in (Parry). 1870. p. 221 ......

Farm resonrees and products of. 1868. p. 122 . . . . . . . . .

Jive-stock interests in (Cockrill). 1883. p. $225 \ldots \ldots \ldots \ldots \ldots$.

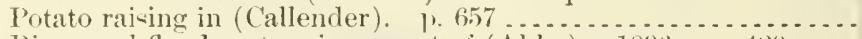
River and flood system in, report of $(\mathrm{Abl} x)$. 1896. p. $+20 . .$.

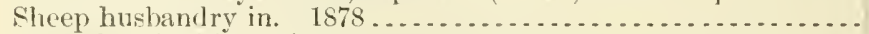

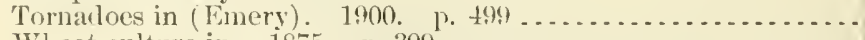

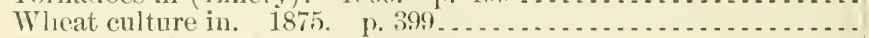

Sce rilso Erwin - Montgomery ('ounty.

Temuessee, University of:

1)ietary studies at, in 1895 (IVait).

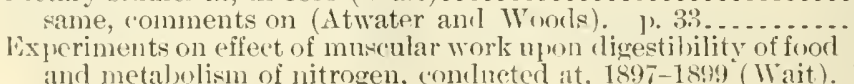
1901

Nutrition investigations at, 1896 and 1897 (Wait).

$129.6: 2: 1$

$129.6: 24$

$129.3: 24$

$129.6: 25$

129.6:28

A2). 1:898

129.6:23

A: $29.6: 26$

129.6:27

129.3:24

A29.3:31

A $29.6: 28$

A29.6:27

129.6:21

A29.6:30

A29.5:F

A $29.6: 27$

A $29.6: 29$

A29.6:29

A $29.6: 27$

A $29.6: 29$

A29.6:28

127.9:10

$1+.5): 7$

At.5:\$-14

A $4.5: 25-29$

A 4.5$): 49-55$

A $4.5: 80-87$

A $4.5: 93$

A $4.5: 101$

14.1:886

A $27.9: 4$

A $27.9: 8$

A $27.9: 6$

A 1. $7: 2$

11.1:880

A:9.6:24

A 1.2:Sl13

$129.6: 28$

A $27.9: 13$

110.3:2:9

1 10.3:29

A 10.3:89

A 10.3:5:3

A $\$ .6: 17$

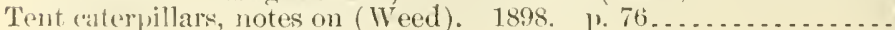
Tenthroliniclie. See Nematinæ. 
Terne, Bruno:

Fertilizers, mixed, nitrogen in, availability of. 1843. p. $40 \ldots . .17 .3: 34$

Potash, determination of, sonres of errors in. 1891. p. 150_... $17.3: 31$

Terra del Fnego, meteorologieal station in, notes on (Ahbe). 1897.

Terrell, J. J. See, as joint autlow, liage, Jolun R.

Terrell, Ninister. Angora, agrisulture in, motice relative to letter

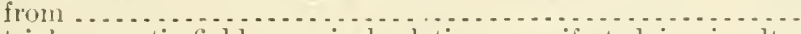

Terrestrial magnetic field, cosmical relations manifested in simultaneous disturlances of, smu, anl anrora (Lemstrüm). 1845. 1). 492.

Terrestrial magnetism:

In 15th, 16th, and 17th centuries, contribution to bibliography of

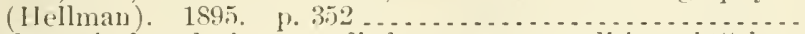

Mathematical analysis, as applied to present condition of (Nehuster). P. 550 ...

Relations of solar masnetism to, report on (Bigelow). p. $519 \ldots$

Terrestrial phenomena, notes on (Ahbe). 1900. p. 109..........

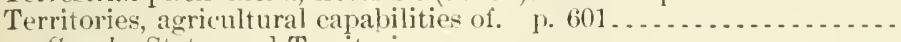
Sire also States and Temitories.

Tessier, E. L., jr. Highways, improved. 1902. ए) 60

Testing varieties. Sce l'lants.

Tetraopes femoratus fab., oviposition in young forest trees by (Gil-

Texas:

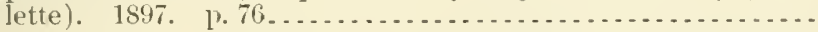

Artesian and undergromnd waters in, west of 97 th meridian

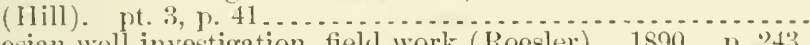

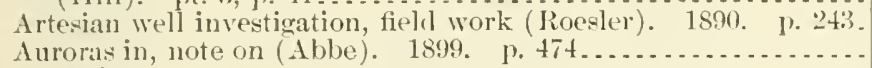

Cattle in-

note on-

1866. p. 343

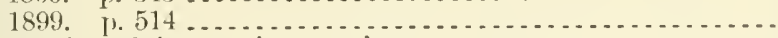

quarantine of, in certain comnties-

July 6,1897 .

Dee. 16,1897 .

Ang. 17, 1898

Sept. 30, 1898

Der. 20, 1898

Jan. 9, 1899 .

June 27,1899

Dee. 1!), 1899 .

Dec. 14, 1900 .

Jan. 11, 1902.

Dee. 27,1902 .

P. 5.

(1.2.

$1: 9.6: 25$

$11.2: \mathrm{An} \cdot 1$

$1: 9.3: 11^{2}$

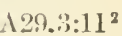

A29.3:112

A $29.1: 891^{3}$

A $29,6: 28$

A1.1:869

A $22.23: 23$

A $9.6: 9$

115.2: $: \operatorname{Ir}^{2}$

115.2:Ar7

$\Lambda 29.6: 27$

A27.9:4

A $4.1: 899$

A $4.5: 6$

A $4.5: 8-14$

14.5:20

14.5:22

A $4.5: 25-29$

A $4.5: 30$

A $4.5: 36$

A $4.5: 49-55$

A $4.5: 80-87$

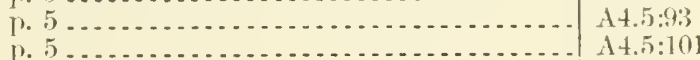

raising -

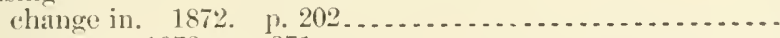

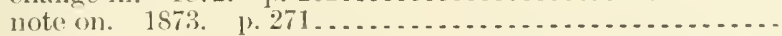

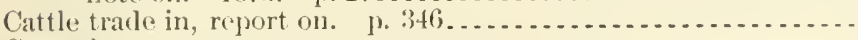

Central-

grasses and forage plants of (Bentley). 1898

range improvement in, experiments in (Bentley). 1902.

127.9:10

A $27.9: 11$

A $1.1: 570$

A.3.:3:10

$119.3: 13$

$1: 29.6: 21$

Cotton erop of 1857 , aggregate lamage from eotton worms in

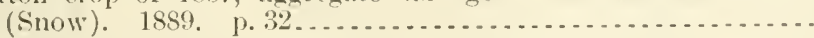

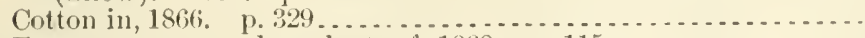

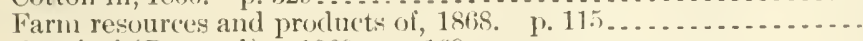

fHungi of (Ravenel). 1869 . p. 169.

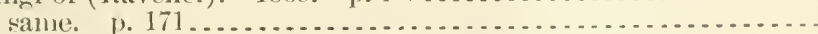

Glanilers anong liorses and mules in (Folsetter). p. $393 . . .$.

Hurses in, enzootic cereloro-meningitis among (Detmers). p. 36i3

Insects, injurions and other, observations on (Welster). 1sin.

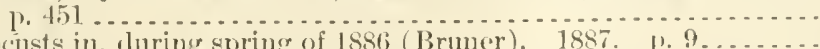

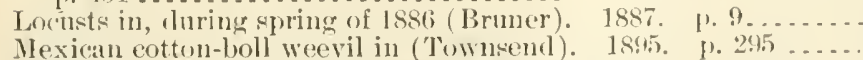

A $19.7: 2$

$12-9: 4: 4$

127.:1:(i)

$11: 2:(29) 1$

11.2:(2:)! $)^{2}$

14.1:5: $: 9-90$

A1.1: $: 51-2$

A $19.7: 3$

A9.:1:1:;

A.7.7:7

Plants from, descriptions of new (Holzinger). 1893, p. $286 . . . .16 .5: 1$ 
Texas-Contimed

Plants in, certain, of economic value as food for nan and stock

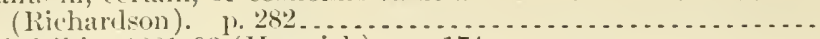

Rainfall in, 18s1-93 (Hamrick). p. 174 . . . . . . . . . . . s:mme, extraordinary (Hazen). 1899. p. 24!.

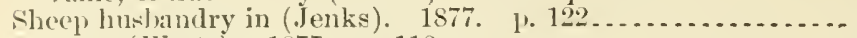

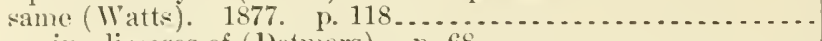

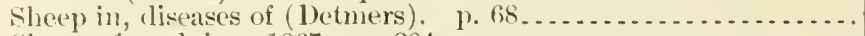

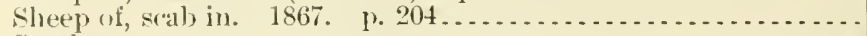

Sonthern-

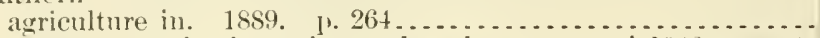
cotton worm in, in spring and early summer of 1883 ; report

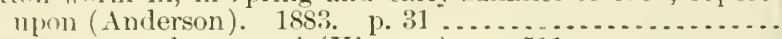

Sonthwestern, cattle notes of (Kiernan). p. $511 \ldots . . . . . . . .$.

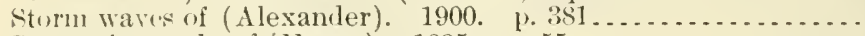

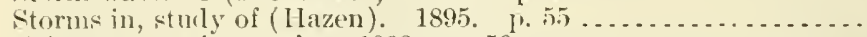
Tolacere (x) periments in. 1893 . p. $50 \ldots \ldots \ldots \ldots$ Iplankls of, irrigation of rice on (Bond), 1902. p. 11 ........ . Verminons discases of cattle, sheep, and goats in, investigations

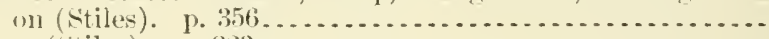
same (ktiles). 1). 223

Western-

apetalie of, lescription of (Coulter). 1894. 1'. $347 \ldots \ldots . .$. desert region from, to Central Arizona, characteristic vege-

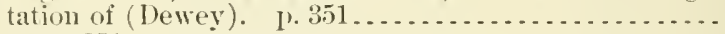

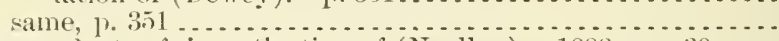
forage plants of, investigation of (Nealley). 18s8. p. $30 \ldots .$. gamopetalie of, description of (Coulter). 1892. 1. $153 \ldots \ldots$ graminere (grass family) of, description of (Dewey). 1894.

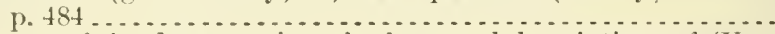
grasses of the desert region of, plates and descriptions of (Va-

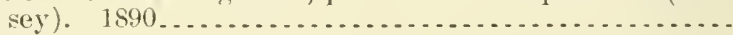

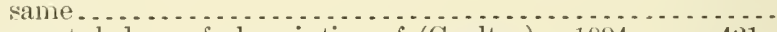
monocotyledons of, lescription of (Coulter). 1894. p, 4:1 phanerogams and pteridophytes of, manual of 1s:1-1894.

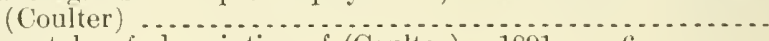
polypetale of, description of (Conlter). 1891. p. 6......... pteridopleyta of, description of (Underwood). 1894. p.557.

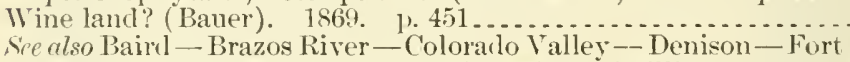
Worth - Galveston - Rio Grande region - Willis.

Texas, University of, medical department, synopsis of conrse of lectures in medical climatology to senior class (Cline). 1902. 1). 110

Texas good-roads convention, Honston, Tex., February 19, 1s.95,

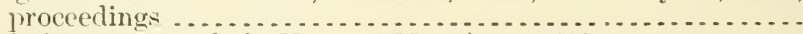

Texas itch among cattle in Kansas (Mayo). p. 488 ............ Texas or sonthern cattle fever:

Adlitional observations on (Smith and others). 1893. 1.67...

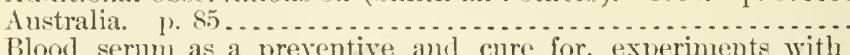
(Robert). p. 482 . same (Scliroeder) p. 43

Butler County, Kans., ontbreak, 1883 . (Trumbower). p. 420.

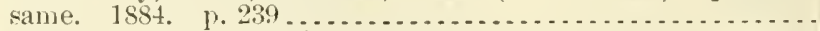

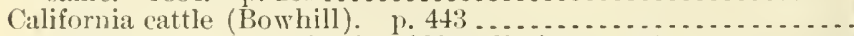
same, further investigation (Chamdler). p. $450 \ldots \ldots . . . . .$. Champaign, 1ll., investigations (Detmers). 1880. p. 291 ....... Chicago Union Stock Yards (Trumbower). p.44 ............

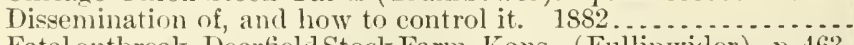
Fatal outbreak, DeertieldStock Farm, Kans. (Fullinwiler). p. 463. Geological distribution of-

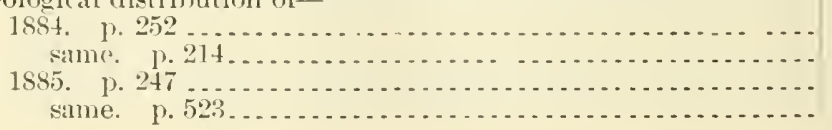

A1.1:887

A $29.6: 22$

129.6:27

1.1:24h?

A. $1: 2 \mathrm{sh}$

11.1:883

A $27.9: 5$

A27.9:27

A9.3:3

A4. $1: 899$

A29.6:28

129.6:23

127.9:31

110.3:11:

14. 1:900

A+. 1:901

A6.5:2

A 1:1:891

A6. 1:891

A6.3:6

16.5:2

$16.5: 2$

16.2:182

16.3:12

A6.5:2

16.5:2

16.5:2

A6.5:2

127.9:6

129.3:31

122.3:15

A $4.1: 898$

At.3:3

A 4. 1:895-6

A4.1:898

14.1:899

A4.1:88t

A4.2:An5

14. $1: 887-8$

14.1:887-8

A 1.6:34

A4.1:884

A $1.6: 50$

A4.1:884

A1.1:884

A4.1:SSt

A1.1:855

A4.1:885 
Texas or southern cattle fever-Continned

Investigations into nature, ransation, and prevention of (Nimith and Kilborne). p. $177 \ldots$

Investigation of-

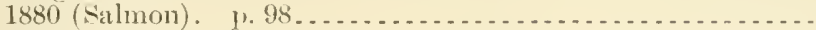

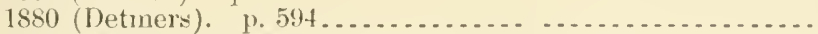

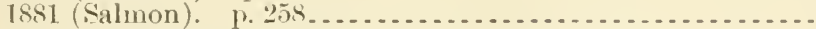

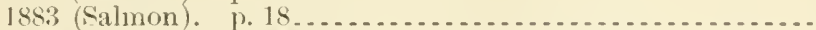

$188+$ (Detiners). p. $4: 26$. same. p. $24 \pi$

hansas outbreak-

1884 (Trumbower). 1..393. same. p. 207.

1895 (Hill) p. 318 .

Maryland outbreaks (Curtice). p. $429 \ldots \ldots \ldots$

Nature, cansation, and prevention of (Fuith and Kilborne). 1893.

Northern cattle-

inoculation to prorluce immunity from (Schroeder). ए. $27 \%$. protecting against (Wilcox). 1900. p.27...............

Organism in blood of cattle, persistence of (Schroetler). p. 42...

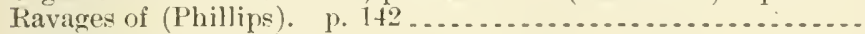

Regulations concerning-

1889. Г. 55 . . . . . . same. pp. $\$ 3,6$ 1890. 1. 79

Report on1869 (Gamgee). same. p. $82 \ldots . . .$. $188+$ (Trumbower).

Reports of inspectors and correspondents. p. 376 same. p. 80

Statistical and historical investigations of progress and results of

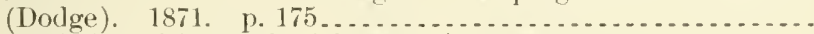

Transmission of, by (attle tick (llayo). 1. 481 .............

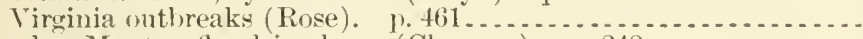
Texel or Mouton flandrin sheep (Chenery). p. 242.

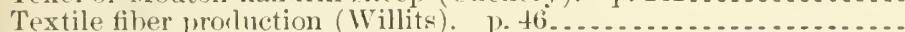
Textile filures of Pacific States (Flint). b. $471 \ldots \ldots \ldots$ Textile material, imports and exports of, hy Great Britain, 1863-64.

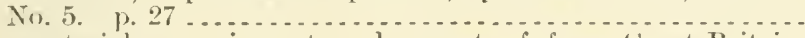

Textile materials, raw, inports and exporta of, from Great Britain,

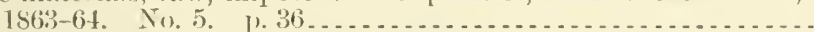

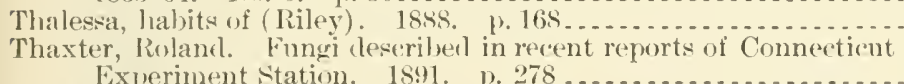
Thayer, F. II.:

Arliless of, bofore convention of National League for food Roark, Washington. 1893. 1). 6.3

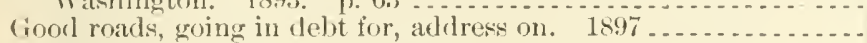

Thea virclis. Gie Chinese tea plant.

Thelemark cattle of Norway. 1876. p. 432 . . . . . . . . . . . . Theophila nandarina, history of, contribution to (Valker). 1SSs.

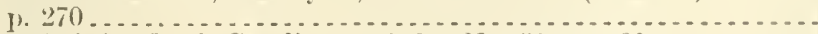

Thernal belt in North Carolina. 1883. No. 58. p. $30 \ldots \ldots \ldots$ Thermal bolts, notes on (Abloc). 1893. 1\% 365........... Thermal or phenologic constant (lhne). 1895. 1\%, $427 \ldots \ldots \ldots \ldots$. Thermographs, furnishing of, to voluntary olscervers, recorts to be kept at section renters (Wollaber). 1902. 1.219.........

Thermoneter seales, (ompratison of. 18:12.................

Thermoneters:

Comstruction of registering air, to replate orelinary aloohol and

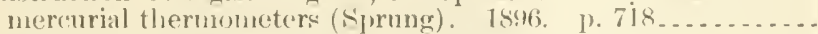

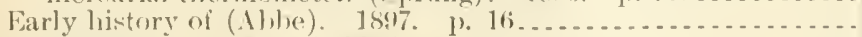

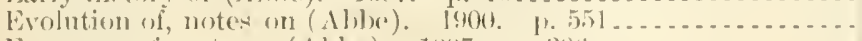

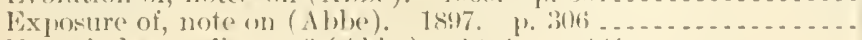

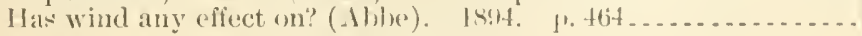

1..1:8!11-2

11.6::2:2

1 $1.1: 850$

1 1.1:851-2

1 1. 1:8.8:3

A $4.1: 884$

A $4.2: A 105$

14. $1: 884$

14.2: 1115

A $4.1: 895-6$

At.1:887-8

14.3:1

A $4.1: 898$

A $1.9: 11$ !)

A +. 1:899

1 1.6:2:2

A 1.1:889

A $4.1: 889-90$

A 1. 1:\$90

A 1.2:C29 ${ }^{1}$

11.2:C29 ${ }^{2}$

14.1:88t

A $4.1: 889-90$

A 1.1:890

A $4.1: 889-90$

A $1.2:(29)^{2}$

A $4.1: 898$

A $4.1: 884$

A 1. 1:864

1 1. 1:889

A1.1:864

127.9:3

127.9:2

19.7:1

A24.5:7

110.3:14

A:2:. $4: 26$

127.9:14

19.7:1

1:7.9:21

1:29.6:2:1

1:29.8:112

1:29.:3:31

1:34.:2:9:34

1:29.:1:1 $11^{3}$

1:2!) $(1: 255$

1:96.6:28

1:9! (6:25)

1:39.6:22 
Thermometers-Continued

Maximum and minimum are too fragile, cannot effective protection be devisal without impairing sensitiveness? should not aluminum seales be discarled? (Oberholzer). 1902. 1.217..

Maximum and minimum-

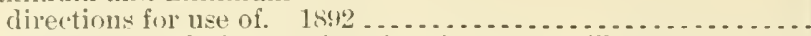
registering, relative nuerits of various types (Draper). 1896.

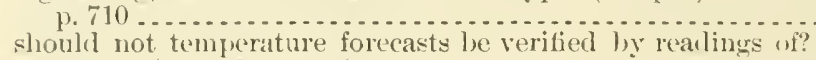

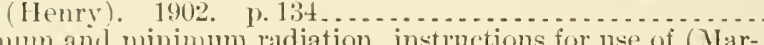

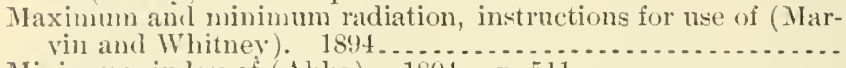

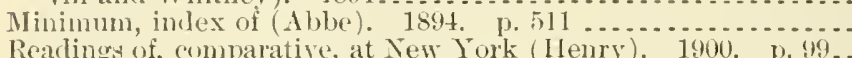

Record of, old, at Pensacola, Fla. (Abbe). 1901. p. 177 ..... Sluggishness of (Marvin). 1899. p. 458 . . . . . . . . . . . . . . soil, combined maximum and minimum, instructions for use of (Marvin)

Thermometric scale used in meteorology (Abbe). 1895. p. $255 . .$. Thermoscope, chemical, notes un (Abbe). 1898. p. 5.)2........ Thiesen, Max. Vapor, saturated aqueous, pressure of, at temperatures below freezing. 1899. ․ 106 ...................

Thiessen, Alfred H. Snow rollers, report on. 1899. 1. 100...... Thistle. See Canadian thistle - Russian thistle.

Thomas, Cyrus:"

Agriculture of Colorado and New Mexico, notes on. 1869. p.

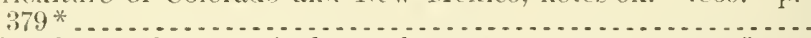

Colorado, northern, agriculture of, notes on. 1869. p. $284^{*} \ldots$

Thomas, Fr. Cranberry leaf-galls, report on. 1859. p. $279 \ldots . .$. Thonas, John J.:

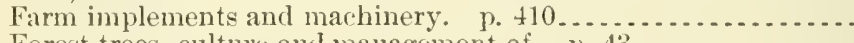

Forest trees, culture and management of. p. $43 \ldots \ldots \ldots \ldots \ldots . .$.

Thonas slag. 1901. 1.6 . . . . . . . . . . . . . . . . . . . . . . .

Thompson, Alexander. See, as joint author, Wilder, Marshall I'.

Thompson, C. H. See, as collector, Hitchcock, A. S.

Thompson, E. H. Tasmanian coccinellidie, notes on. 189.3. p.11.. Thompson, George Fayette:

Agriculture Department, documents of, index to anthors, with

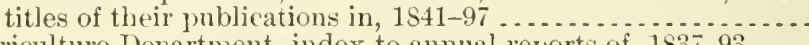

Agriculture Department, index to amnual reports of, $1837-93 . . .$.

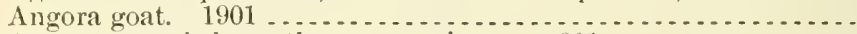

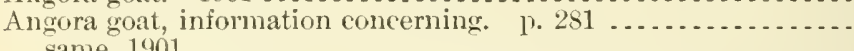

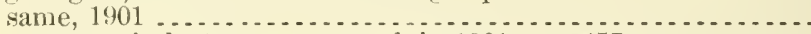

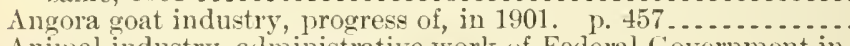

Animal industry, arministrative work of Federal Government in

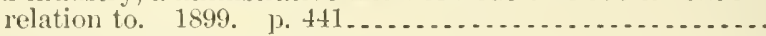

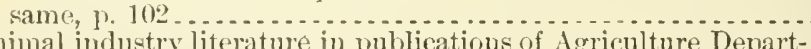

Animal industry literature in priblications of Agriculture Depart-

Animals, contagious diceases of, in foreign countries. p. $492 .$.

Animals and animal products, imports and exports of, 1892-99. p. 421 ... same. 1900

Holair and mohair manufactures. 1901. p. $271 \ldots \ldots \ldots \ldots \ldots \ldots$

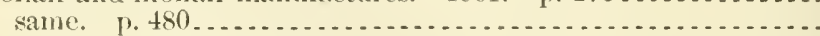

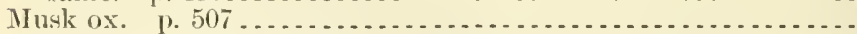

Statistician of Department of Agriculture, synoptical index of

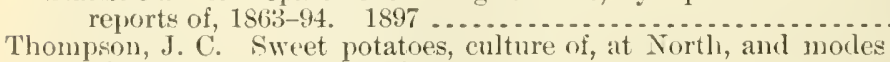

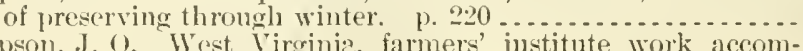

'Thompson, J. (). West Virginia, farmers' institute work accom-

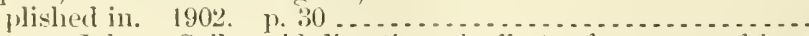

Thompson, John. Soils, acid digestion of, effects of presence of few

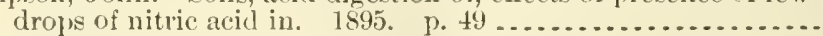

Thompson, R. O.:

liotany and agriculture of Rocky Nountain hasin. p. 125 ......

Classifteation no.

$129.3: 31$

A29.11:33

1 $29.3: 11^{3}$

A29.3:31

A29.11:H

A 29.6:22

A29.6:28

A 29.6:29

129.6:27

A29.11: $\mathrm{i}^{1}$

A29.6:23

A29.6:26

129.6:29

A29.6:27

A27.9:7

A27.9:7

A9. $1: 1$

A1.1:862

A 1.1:864

1 1.9:1+4

19.7:6

A21.3:4

A21.3:1

A1.9:1:3

A4.1:900

A $4.3: 27$

A4.1:901

A 1.10:899

A4.1:899

121.3:5

A4.1:900

\4.1:899

A $4.1: 900$

A 1.10:901

A4.1:901

A $4.1: 901$

A21.3:2

A 1.1:S62

A 10.3:120

A $7.3: 47$

A1.1:866

* By a misprint, this page number appears $t$ wice. 
Thompson, R. O.-Continued Fruits, native, of Far West. (rrape-growing at the West.

Thompson, Wibray J.:

Brown coal and wood cliar in filtration of cane juices and sirups. l. 268 .

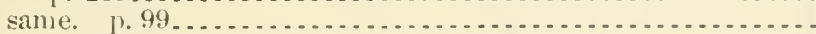
See also, as enllaborator, Wiley, Harvey Washington.

Thomperon, Windham County, Conn., temperature olservations at,

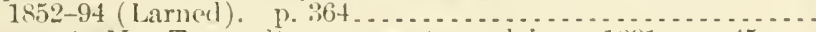

Thomson, 1. II. Tree culture on western plains. 1891. 1\% $45 \ldots$ Thorne, Charles E.:

Agricultural experiment stations, officers of, how can we increase the attendance of, at onr annual conventions? 1894. f'. 61...

Fertilizers, eooperative field experiments with, report of conference of representatives of experiment stations regarding. 1889.

l'ot or box ve. plat experimentation, report on. 1891. p. $81 \ldots$

Thornton, C. C. Swine plague in the Southwest, character of.

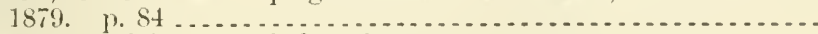

Thought. See Climate and thought.

Thripide:

Certain, observations on (Pergande). 1895. p. 390

Food habits of (Osborn). 1888. 1. 187 ................

Thuncler:

Distant, note on (Abbe). 1898, p. 566.

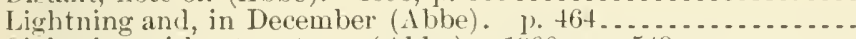

lightuing without, note on (Ahbe). 1900. p. $549 \ldots . . . . . .$.

Thunder eloud, kites within (Hovenden). 189s. p. 250 . . . . . . .

Thunder storms:

Air currents in, note on (Abbe). 1899. p. 366.

Antigua, IV. I. (Alexander). 1900. p. 880

Apparatus for registering (Able) . 1902, p. 313

August 2, 1899, report of (Henry). p. $359, \ldots \ldots \ldots \ldots$

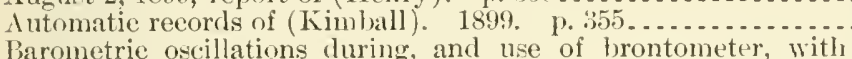

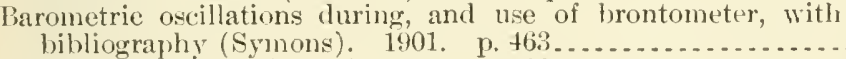
California, notes on (Abbe). 1898. 1. 20......

Do they advance against the wind? (Abbe). $1895 . \quad$ p. $296 \ldots .$.

Eustis, Lake County, Fla. (Abbe). 1897. p. $251 \ldots \ldots$

Forecasting, lightning recorders and their utility in (Kenealy).

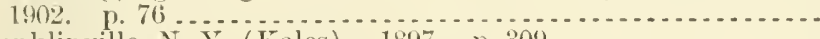

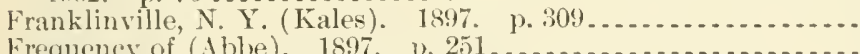

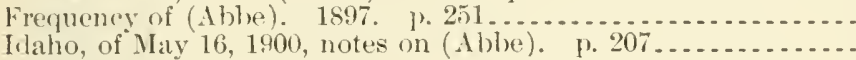

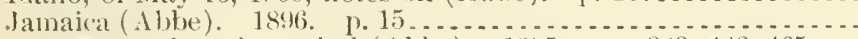

Iovement of, against wind (Abl)e). 1895. एए. $383,423,465 \ldots$

New Brunswiek, 1897 (Kain). p. 105..................

New England, investigation of (Ward). 1893. p.:30 .........

Sew explanition of one of its phenomena (MeFarland). 1901.

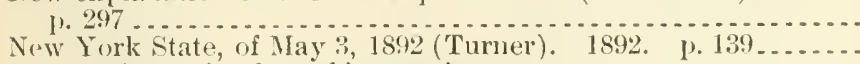

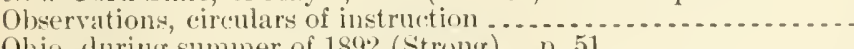

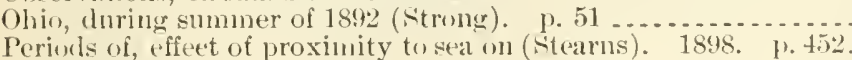

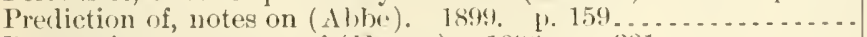

Progressive movement of (Henry). 1896. J.331 . . . . . . . . .

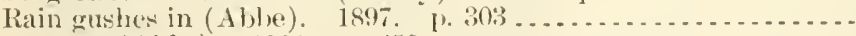

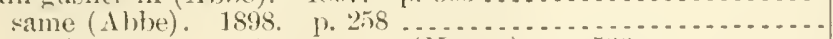

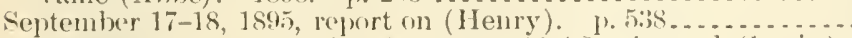

Skyland, Page Comnty, Va., August, 1900 (Cragin and Cragin). 1. $3: 3$.

Simmer of 1892 foredastiue of (Conger). 1893 .............

Two, at Royal Alfred Observatory, Mauritius (Claxtom). 1900.

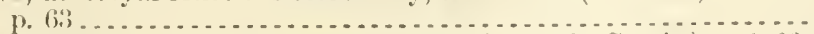

Washington, D. C., report on (Cragin and Cragin). 1900.

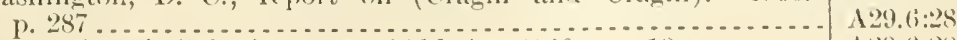

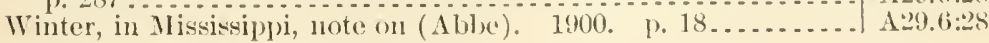


Thurston, Robert Henry. Mechanical enginecring and mechanic arts,

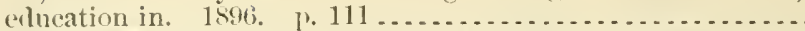

Tibbey, H.S. Meteorological observations in Ilaska. 1894. p.174. Ticks:

Dipping cattle for destruction of (Nörgatri). p. 109.......... Sonth African, notes on some (lomsbury). 1900. 1. $41 \ldots \ldots .$. Sep also Sonthern cattlo ticks.

Tirlal lands:

Dikel marshes and, of Nova Scotia and New Brunswick (Board-

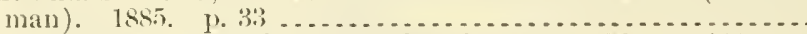

Reclamation of, in southwestern New Jersey. 1870. p. 230....

Washington Territory (IIorse). 1885. p. 62...............

Tille marshes of United States (Neshit). 1885 . . . . . . . . . . . . .

Tirles. See Ocean tides.

Tiger swallow-tail, almormal, report of (Howarl). 1894. 1'. 44...

Tililen, L. L. Farming, high, as illustrated in history of Netherjands. p. 527

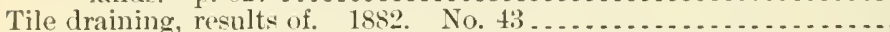

Tile-horned prionus in prairie land, note on. 1886. p. 39........

Tillage, relation of, to soil physics (Sanborn). 1891. p. $97 \ldots . . .$.

Tillage and products of soil on irrigated lands (Cureton). 1887. 1.252.

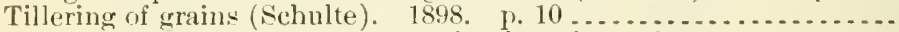

Tillman, G. D. Nut grass, extermination of. T. 388...........

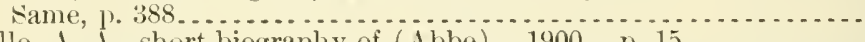

Tillo, A. A., short biography of (Abbe). 1900 . p. 15 . . . . . . . .

Tillo, Alexis de. Magnetic survey of Europe and Asia. 1595. p. 465.

Tilton, G. W. spark arresters, importance of. 1887, . $136 \ldots \ldots$

Timber:

"Boxed" or "turpentine," strength of (Fernow)

Consumption of, letter regarding (Fernow). 1893

Culture of, condition of, in Sonthern and Western States (Baker).

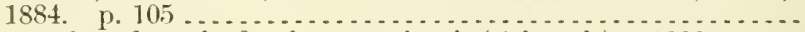

Decay of, and methods of preventing it (schrenk). 1902....... Elementary discussion of characteristics and properties of word

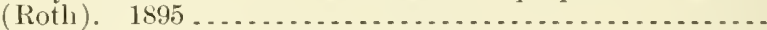
same, introrluction to (Fernow). 1895. p. $5 \ldots . . . . . . .$. Forests and public domain, legislation for jreservation if (Egles-

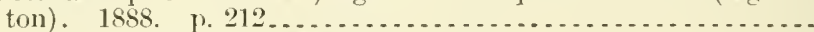

Government tests (Fernow) ....................

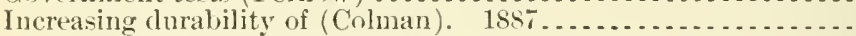
same (Fernow). 1898 ............................

Investigations, collection of test pieces of pines for, instructions

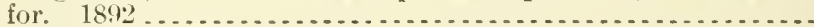

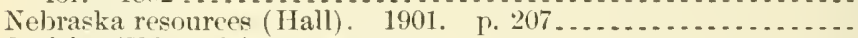

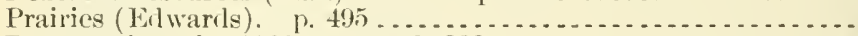
Preservation of. 1866. pp. $142,382 \ldots \ldots \ldots \ldots \ldots \ldots \ldots \ldots \ldots$

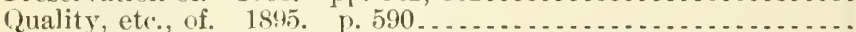

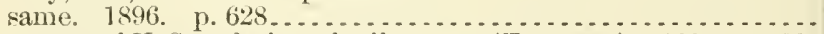
Resources of U.S., relation of railways to (Tratman). 1889. p. 68 . Ship, in United States (Bates). p. $472 \ldots . . . . . . . . . . .$. Turpentine, field report on (Roth). 1893. p. $32 \ldots \ldots \ldots \ldots . .$. Sep also Bridges and trestle timbers-Railroad ties - Wood.

Timber lands, Government, proper value and management of:

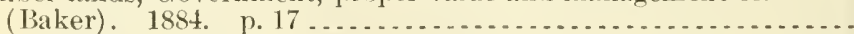

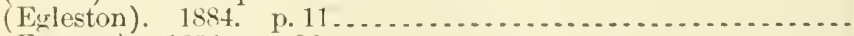

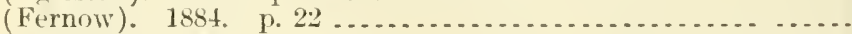

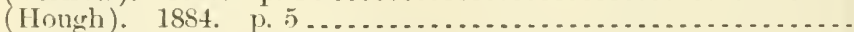

Timber pliysies:

Part 1 ; preliminary report (Fernow). $1892 \ldots \ldots \ldots \ldots \ldots \ldots . .$.

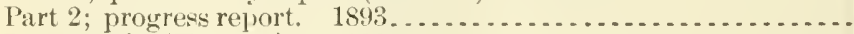

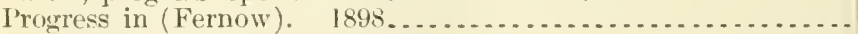

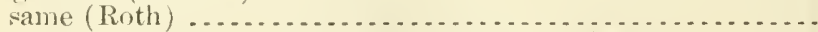

Timber pines of soutlem Inited states, report on (Mohr) ........ Same, introduction to report (Fermow). p. 11...............

Timber trestle bridges, economical lesigning of, report on (Johnson) Same, review of report ( 1 indenthal).

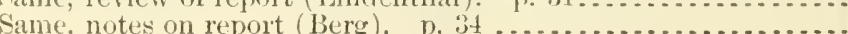

A1.7:7

A27.9:8

A $1.7: 7$

A $1.7: 7$

A9.7:7

A1.1:866

A27.9:20

A $9.3: 12$

A 10.5:3

A 15.2:P94 $4^{1}$

A 1.9:105

A 1.1:889

A6.1:889

A29.6:28

A29.3:11 2

A13.3:1

A13. $4: 8$

A13.2:FT6

A13.5:4

+19.3:14

A 13.3:10

A $13.3: 10$

A 13.3:2

A13.4:7

A13.4:3

113.4:20

A 13.2:P65

A1. 10:901

A1. 1:86:2

A27.9:4

A 1.10:895

A1. 10:596

A 13.3:3

A1.1:866

A13.3:S

A $1.7: 5$

A1.7:5

A $1.7: 5$

A1.7:5

A13.3:6

A 13.3:8

A 13.4:18

A13.4:19

A 13.3:13

A 13.3:13

A 13.3:12

A13.3:12

113.3:12 
Tinse:

Hawadian standard of (Abbe). 1900. p. 207 ............... A29.6:28

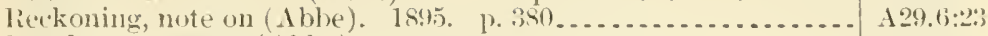

Standard, notes on (Al)be)-

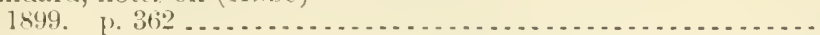

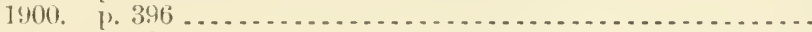

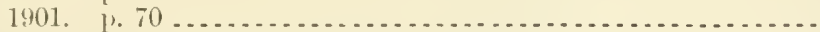

Timothy:

Jew enemy to (Howarl). 1892. 1.90

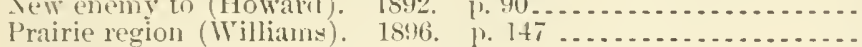

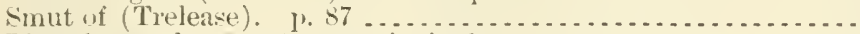

Timothy seed. see Crops, prineipat.

Tin rans, joisoning by preserving in (Rons), 1892. p.930.......

Tin roofs as lightning conluetors, notes on (.1bbe). 1898. pl. 166, 258 . . . South Carolina, farmers' institute work accomplished

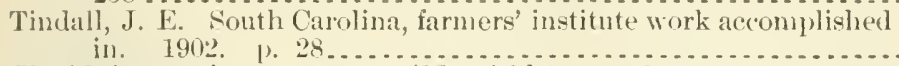

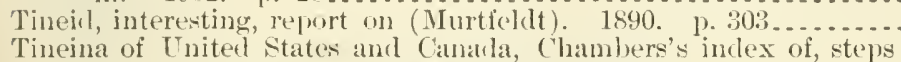
toward revision of. Se Walsingham, Lord.

Tingle, E. IT. S. Brmewick, Germany, cost of hauling farm prod-

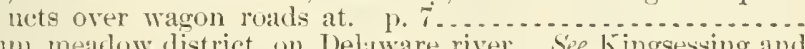

Tinicum mealow district, on Delaware river. See Kingsessing and Tinicum meadow district.

Tipton, J. C., arldress of, before national road conference, July,

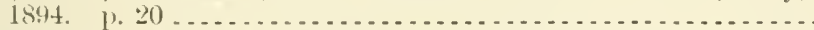

Tisserand, E. Ideal department of agriculture and industries. 1896. 1. $5+3$.

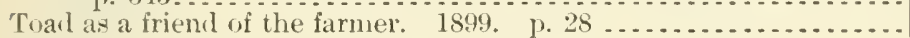

Toads as an eradicator of fluke disease (Stiles). p. 220.........

Tobaceo:

Acreage, report on. 1887. 1). $421 \ldots$

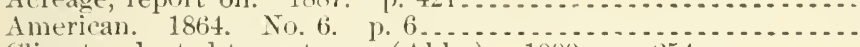

Climate adapted to, notes on (Abbe). 1899. p. $54 . . . . . . .$.

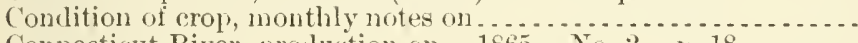

Connecticut River, prouluction on. 1865. No. 2. 1, $18 \ldots \ldots . .$.

Crop, report on-

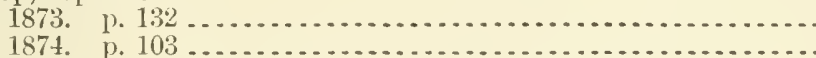

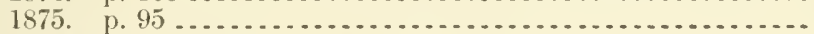

Crop, statisties of, annual.

Cultivation and curing of, instructions for (Estes)

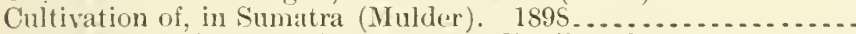

Cultural directions for different types distributed. 1902

Culture and management of-

1863 (Brailford). p. 87.

same, witl additional matter. No 1 p. $26 \ldots$ 1867 (Bowie). p. 179 ...............................

Culture of-

briet history oi. p. 123.

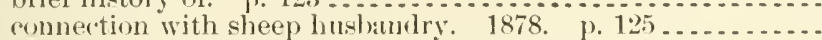
report on (Butterweck.) 1898

A29.6:27

$129.6: 28$

129.6:2?

19.7:5

1 1.10:896

A 1.1:885

A7.3:13

A29.6:26

A 10.3:120

19.7:2

12:. $4: 27$

A22.3:10

A1.10:896

A 1.9:87

A4.1:901

A 27.9:25

A $27.9: 2$

A29.6:27

A 27.9:

127.9:3

A27.9:12

A27.9:13

A27.9:14

A27.1:

A 1.9:6

A 1.8:58

A 19.2:Т5้

A1.1:96\%

127.9:2

11.1:867

A1.1:86.

11.2:5 13

1 1.9:8:

Experinents with, conducted in various parts of United states, results of (Floyd). p. 455

Fertilizers for 1873.1939 .6$.

Industry, growth of (Whitney and Floyd). 1899. p. $429 . \ldots .$.

Insects, principal, affecting plant (Howard) ..............

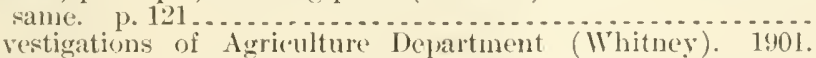

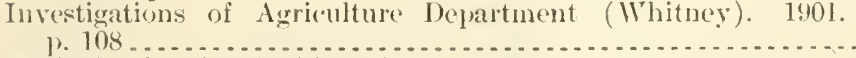

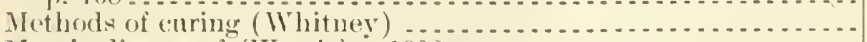

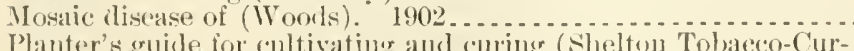

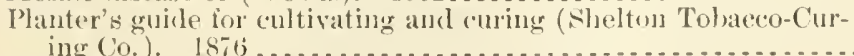

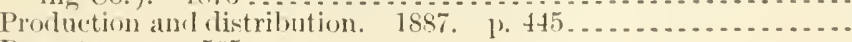

Report (11. 1). $565 \ldots \ldots \ldots \ldots \ldots \ldots$

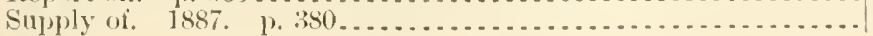

126.5:900 1

127.9:11

11. 10:8:99

11.9:120

11.10:8:98

1 10.3:99

1 1.9:60

119.3:18

11.8:10

A:7.9::25

11.1:878

A:7.91:25 


\section{Tobaceo-Continued}

Texas, experiments in. 1893. p. $50 \ldots$

Work of agricultural experiment stations on (schulte). $1900 \ldots$.

Young, stalk worm, new enemy to (Johnson). 1899. p. 99....

See Burley tohace - Catalase - Cigar-leaf tobaceo-Connecticut leaf tohaceo-Crops, principal - Leaf tolnceo-sumatra Sumatra tobaceo.

Tobacen flea-heetle, report on (Chittenden). 1898. P. $79 \ldots \ldots \ldots$.

Tobacco growers, convention of, at Lonisville, Ky., comments on

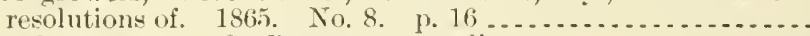

Tobacen horn-worm. See Protoparce carolina.

Tobaceo leaf:

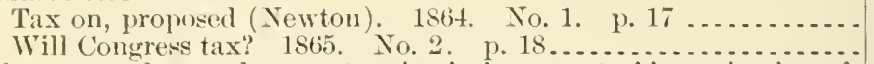

Tobaceo powders and extracts, nicotin in, report of investigation of methods for determination of (De Schweinitz and others).

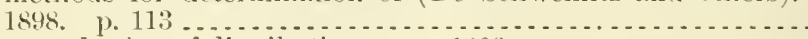

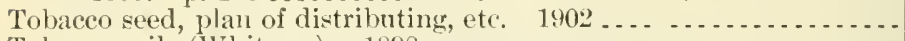

Tobaceo soils (Whitney). 1898 ................................

Tobaceo soils of United States, a lireliminary report upon soils of
principal tobaceo districts (Whitney). $1898 \ldots \ldots \ldots \ldots \ldots \ldots$

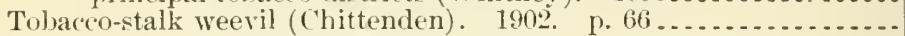

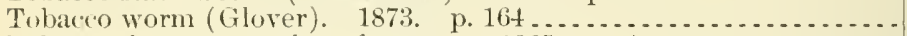

Tolbacconists, convention of, recent. 1865 . p. 4 ........................
Tod, John G., address of, before good roads convention of Texas.

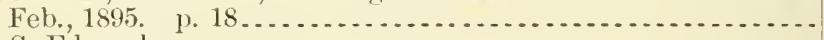

Todl, S. Elwards:

Farm implements, improved. p. 225

Underdraining, practieal notes on. 1. 584.

Tollens, $\mathrm{B}$.

Ash constituents of plants; their estimation and importance to agricutural chemistry and agriculture. 1902, pp. 207,305...

Nitrogen-free extract of plants and feeding stuffs. 1897. p. 641 .

Tolman, L. MI. :

Coloring matter for fuods, analysis of, provisional method for.

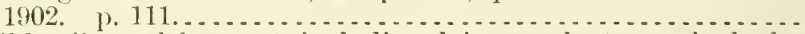

Edible oils and fats, not including dairy produets, methods for chemical analysis of. 1901 ...........................

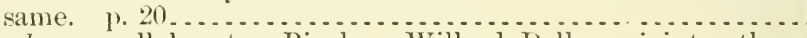

See also, as collaborator, Bigelow, Willard Dell; as joint author, Munson, L. s.

Toniatoes:

Bacterial disease of (Smith). 1896.

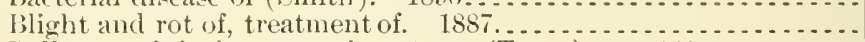

Boll worm injuring, experiments on (Tracy). p. 1t1 ..........

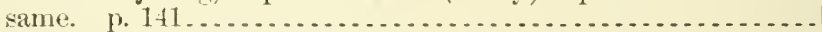

Fresh and eanned (Langworthy), 1900. p. $21 \ldots \ldots . . . . . .$.

Fungus diseases of, treatment of (Howell). 1889. P. $49 \ldots \ldots$.

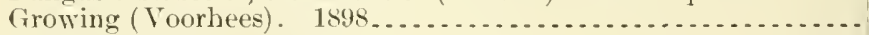

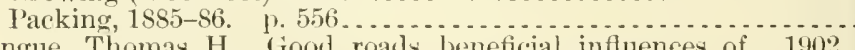

Tongue, Thomas H. Good roads, beneficial influences of. 1902.

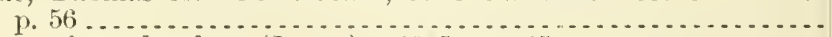

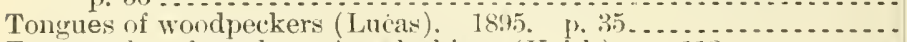

Topography of southern Appalarhians (Keith). p.113...........

Tonography. See Agricultural topography.

Tornado cloud of March 4, 1894 (Neal). p. $127 \ldots . . . . . . . . . .$.

Tornalo fake, newspaper, notes on (Ab)e). 1899. p. $360 \ldots \ldots . .$.

Tornarloes:

Alarms, unnecessary, notes on (Abbe). 1899. [1. 255 ...........

Albany, $\mathrm{N}$. Y., Nareh 26, 1895, report of (Sims). p. $92 \ldots \ldots .$.

April and May, 1896 (Henry). p. 82 ......................

Augusta, Ga., March 20, 1895, report of (Fisher). p. 92 ......

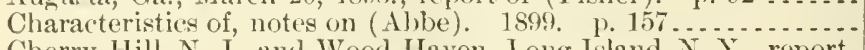

Cherry Hill, N. J., and Wood IIaven, Long lsland, N. Y., report

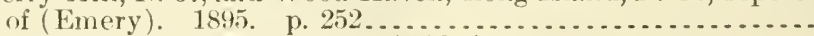

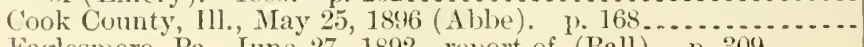

Eaglesmere, Pa., June 27, 1892 , revort of (Ball). p. 309...... A29.6:20 
Tornarloes-Continued

Force of ( iroat). 1899.

(Cassifleatlon no.

Fort Smith, Ark., of Jan. 12, $1898\left(\mathrm{O}^{\prime} \mathrm{j}\right)$ onmell $)$. p. 18.........

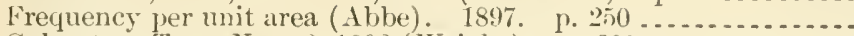

Galveston, Tex., Nov. 6, 1892 (Wright). p. 309..............

Hampton Beach, X. H., July 4, 1898 (Sweetland). p. 308 .....

IIudson Co., N. J., on Aug. 24, 1901 (Eadie). p. 3in. .........

Iowa and neighboring States, May 3, 1895 (Abbe). p. 173......

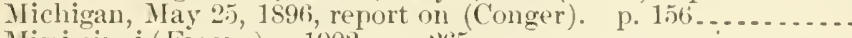

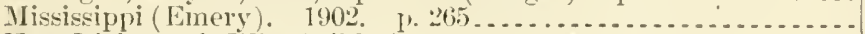

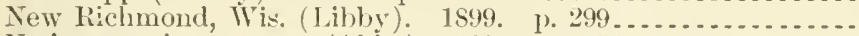

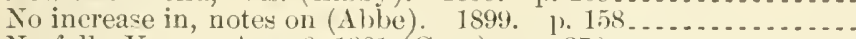

Norfolk, Ya., on Aug. 6, 1901 (Gray). p. 372 ..............

Observations of, report of (Gale). 1599. p. 303..............

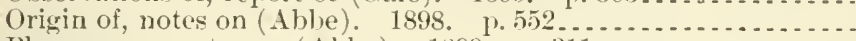

Plienomena, notes on (Abbe). 1899. p. $311 \ldots . . . . . . . . . . .$.

Photograplis of, spurinus, notes on (1bbe). 1899. 1. $313 \ldots .$.

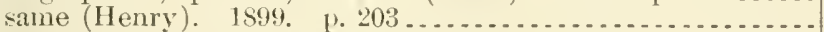

Prediction of, notes on (Abbe). 1899. p. 159 .............

Report of, 1889-1896 (Henry). 1896. p. xxiii ............

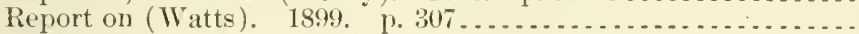

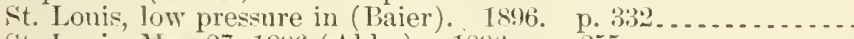

St. Lonis, May 27, 1896 (Abbe). 1896. p. 255.

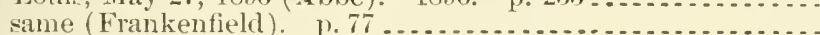

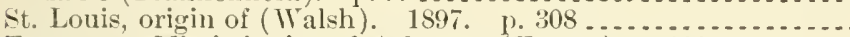
Tennessee, Mississippi, and Arkansas (Emery). 1900. 1. $499 \ldots$ Tracks, ancient, note on (Abbe). 1899. p. 366............... Waterspout, elond-burst or, note on (Abbe). 1897. p. 207....

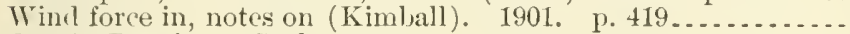
See also Baguios - Cyclones.

Toronto, Canada:

Cloud heights at (Abbe). 1897. p. 303.

Cloud observations at (Blake) 1897.

Tortoise. See Florida land tortoise.

Tortricicl, new, from California, description of (Walsingham). 1891.

Totten and Crossfiel. purchise. Sce Hosmer, Ralph S., and Bruce, Eugene 5 .

Tomney, J. W. Tree planting, practical, in operation, 1900...... Tonrgée, Albion IV. Oleomargarine in France, p. $513 . . . . . . .$.

Towns County, Ga., cattle in, order releasing from quarantine. 1898. Same, Aug. 1, 1899.

Townsend, C. II. Tyler:

Biologic notes on New Mexico insects. 1892. ए. 37.

Chilo sac.haralis in New I Jexico 1891 .

Cottontail bot, further notes on, with breerling and identification

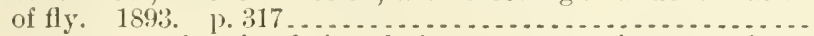

Dipterous parasites in their relation to economic entomolugy. 1893. 1). 201 .

Entomological notes of interest. 1891 .

Insect injury in New Mexico, possible and actual influnce of irri-

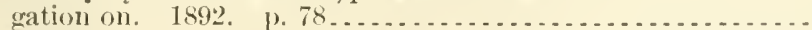

Locusts, injurious and other, of Jew Jexico and Arizona. 1893. p. 29.

Mexican cotton-boll weevil in Texas, renort on. 1ses. 1. 295. ..

Mexico, insect of economic importance in, report of trip to investigate. 1896. p.9.

Micligan, injurious insects in, some notes recorded on. 1 sist.

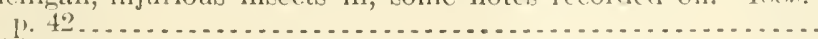

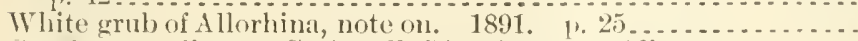

See also, aw eollector, Cockerell, Theodore Dru Alison.

Townsend, ( ${ }^{\text {. }}$ (). Sugar beet, some diseases of. 1902. p. !) ......

Townsend, Theodore $\mathrm{F}$. Weather map, is it appreciated and muderstood by the massese? would not postal earl weather forecast provestislactory substitute for nap? 18!9. p. 102........

Toxnptera, grain, notes on (Welster). 1892. p. $245 \ldots . . . . .$. Tracheal injections. Sce Bronchitis, verminous.

A $29.6: 2: 27$

A $29.6: 26$

1 $29.6: 25$

A29.6:20

1:9.6:26

A29.6:29

A.29.6:2:3

A:9.6:24

A:9.6:6:30

A29.6:27

1:29.6:27

A29.6:29)

129.6:27

A $29.6: 26$

129. $6: 27$

129.6:27

A $29.6: 27$

A:9.6:27

1:9. $1: 8.16^{\circ}$

A29.6:27

A29.6:24

A29.6:24

A:? $9.6: 2+1$

A29.6:25

129.6:28

A29.6:27

A:9.6:25

A29.6:29

129.6:25

129.6:25

A!1. $7: 3$

113.3:27

14.1:900

A $4.5: 21$

14.5:41

19.7:5

19.7:4

A.9.7:5

A!1. $7: 6$

A!1.7:4

19.7:5

Aษ. $7: 6$

1!1.7:7

1!1.8:4

19.7:2

19.7:4

11.4:72

$129.3: 24$ 1!1.7:4 
Tration tests on public roals (Neely). 1896

Trater, samuel Mills:

Civoperative branch grass stations in south. p. $34 t$

A $2 \cdot 2.3: 20$

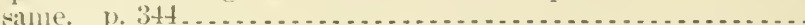

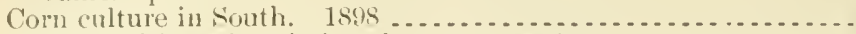

Cotton, cultivated varieties of. 1896. 1. 197 ...............

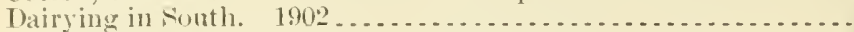

Forage plants and forage resources of Gulf States. 1898 . . . . . . .

Forage plants for the South . . . . . . . . . . . . . . . . . . . . .

Forave plants of secondary or undeterminel importance for southern States, and composition of forage plants grown in sousth.

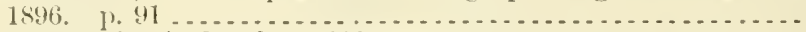

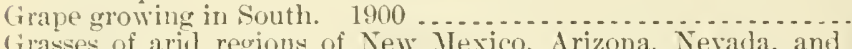

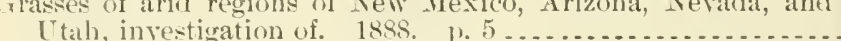

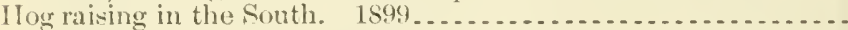

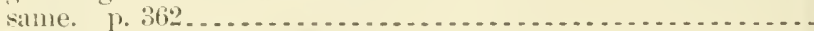

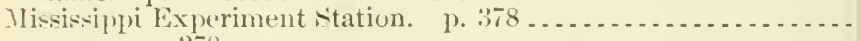

Puccinia and nromyces, new species of, descriptions of. 18.11.

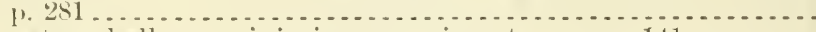

Tomatoes, boll worm injuring, experiments on, p. $1+1 \ldots \ldots . .$.

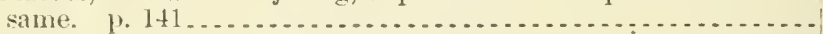
Nip ulso, as joint author, Ellis, J. B.

Tracr, IV. W., jr.:

Peppers, Anerican varieties of. 1902... . . . . . . . . . . . .

Veretables, conmercial varieties, testing of. 1900 . p. $543 \ldots .$. Tracle:

Domestic and foreign industry and, notes of. 1892. p. $360 \ldots . .$.

Export, of U.S., in live stock and meat products, 1889-1892(Rusk).

Falling off of, between Great Britain and U.S. 1865. No. 5. 1. 32 .

Foreign-

agricultural products-

189:. p. $30 \mathrm{~s}$

1893-1897. (Iitehock)

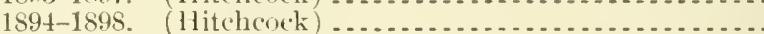

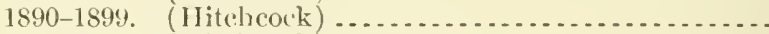

1891-1900. (11itcheock ...

1892-1901. (IIitcheock) . . . . . . . . . . . . . . . . . . .

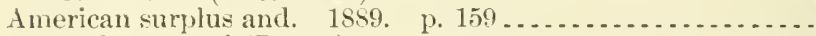

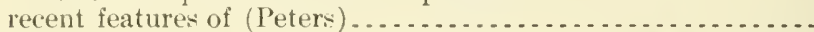

Japan, China, and Hongkung, 1889-1899, our trade with (Hitchcock) 1900

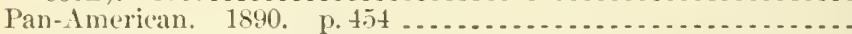

Scandinavia, our trade with, $1890-1900$ (Hitchcock). $1900 \ldots . .$.

Tradescantia, three new species of, from U.S. (Rose). 1899. p. 204.

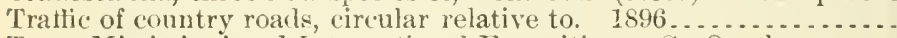

Trans-Mississippi and International Exposition. See Omaha.

Trans-Missouri irrigating convention, 1873 , p. $598 \ldots \ldots . . . . . . .$.

Transportation:

Development of, in Lnited states (Sinclair). 1899. p.643.....

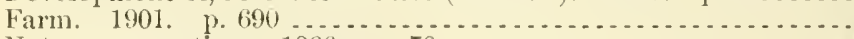

Notes on, question. 1866 . p. $70 \ldots \ldots \ldots \ldots$

Transportation companies:

Freiglit rates of, monthly notes on, $1 \mathrm{ug} ., 1882-\mathrm{D}_{\mathrm{t}}\left(\mathrm{C}_{.}, 1895\right.$

Letter to, relative to exportation of rliseaser catte. $1890 \ldots . . .$.

Warnings of washouts, floods, cold waves, and heavy snow falls for benefit of (Outrans), 1899. p. 38 .............

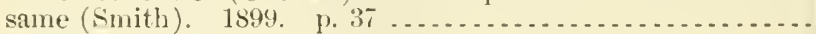

Transportation rates:

Eurnpean. 1853. No.56, p. 39 . . . . . . . . . . . . . . . . . .

Farm products, cost of hauling to market or to shipping points in

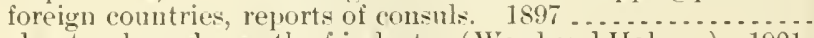
Garden truck, anel growth of inclustry (Warl and Ifolmes). 1901. lieport on-

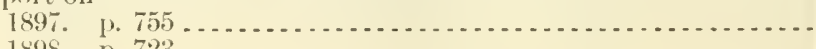

A1.1:891

\6.1:891

A 1.4:81

110.3:33

A1.9:151

A3.3:15

A1.9:18

A10.6:6

A1.9:118

A6.3:6

A 1.9:100

A4.1:899

A1.1:890

A6. $1: 890$

A $28.5: 7$

A 1.1:888

19.1:888

\$19.3:6

A $1.10: 900$

A 27.9:30

A1.2:RS?

A27.9:3

A27.9:30

A 12.3:10

A12.3:15

A 12.3:19

A 12.3:23

A 12.3:27

A $27.9: 27$

A27.8:8

A 12.3:18

A:27.9:28

A 12.3:22

A $6.5: 5$

122.4:19

127.9:11

A1.10:899

A 1. 10:901

A27.9:4

127.9:

11.2:R13

129.3:24

A29.3:24

A27.9:21

122.4:27

+27.8:21

A1.10:89

1 $1.10: 89 \mathrm{~s}^{3}$ 
Roarl materials and, in certain states west of Miscissippi River, information recarding. 1894

See ulso Freight rates.

Trap for insects. Sce Lantern trap for insects.

Traphagen, F. WT. Alkali in Montana. 1900.

Trappes, France:

Atmosphere at, studies on (Teisserenc de Bort). 1901. p. 20...

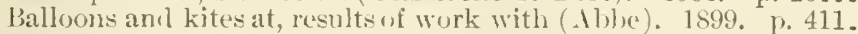

Trapping of sparrows for sporting purposes, with laper tescriptive of apparatus and methods emploved (IIill). 1889. p. 178...

Trutman, Edward Ermest Russell:

Metal track on railways as substitute for wooden ties, preliminary

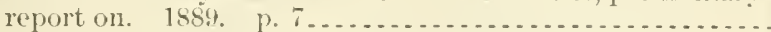

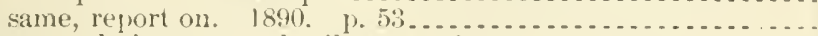
Patents relating to metal railway track-

1889

1890 .

p. 30 ..

1). 326

1894 p. 292

Railwars, relation of, to timber lesources of $\mathrm{C} . \therefore$. $188 \%$ p. 68.

Railway ties in England, treatment of. 1889. p. $49 . \ldots . . .$.

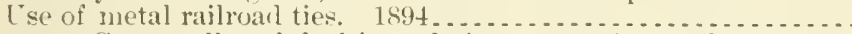

Treasury, Comptroller of, flecision relative to use of annual appropriations, Apr. 18, 1900 .

Treasury Department, files in, injury dome by roaches to. 18s8. p. 67 .

Treaty. Se Reciprocity treaty.

Tree crickets, camivorous habits of (Murtfeldt). 1889. 1. 130....

'Tree hopper. See Buffalo tree hopper-Membracida.

Tree planters, practical assistance to (Pinchot) ................. . . .

Tree seerls, colloction of, and propagation of seellings (Sudworth). 1900 Trees:

Sipe also Forest nursery.

Age of, and time of blazing detemined by anumal rings. 1897 .

American, regulations of foreign governuents regarling importatation of (Iloward). 1900

Banding of, to prevent injury by fall (ankerworm, observations

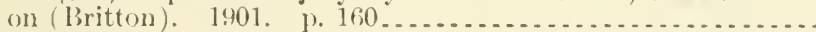

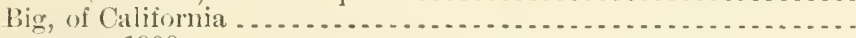
same, 1900.

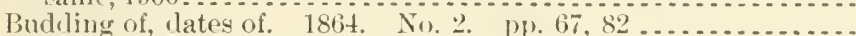

Climate of Coloralo and its effect on (Parsons). 1858. p. 221.

C'ulture on western plains (Thomson). 18.t1. P. 4.5 ........

Distribution of shrulos and, in deserts and desert ranges of southcrn California, southern Tevada, northwestern Arizona, and southwestern l'tah, notes on (Merriam). 1893. p. 285....

Furecasters of rain (Abbe). 1902. p. \$15 .............

Girwill of-

maximmm size and age, period of alecline, completion of ryele,

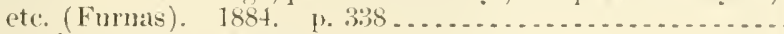

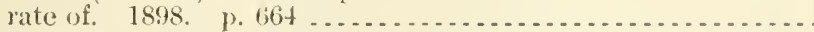

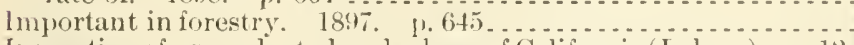

Inspection of, as comlucted unler laws of California (Lelong). 1.12

Nursery inspection in ('mmecticut (Britton). 1894. 1. $131 \ldots .$.

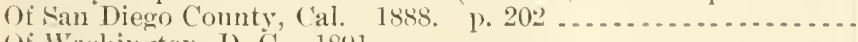

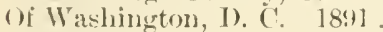

l'lanting-

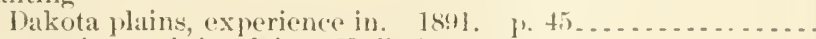

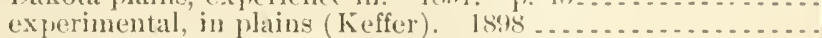
for profit in Mirldle states. 1872. p. 293 ................

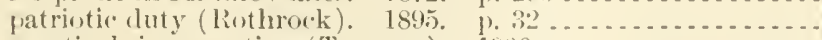

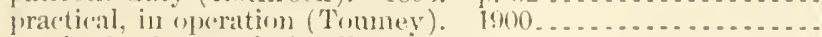

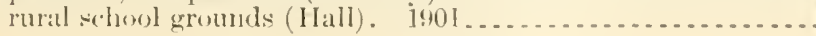


Trees-Continuel

lantins-Continued

waste places on farm (Keffer). 1896. p. 323 ............ A1.10:896

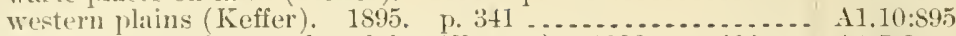

Planting and growing on the plains (Fumas). 1883. p. 202... A A.7:2

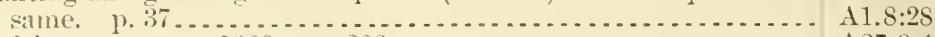

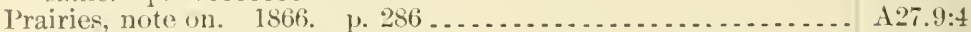

Pruning of other plants and (Samders). 1898. p. 151 ...... $11.10: 898$

Seedlines, instructions for growing ..................... $113.4: 6$

Some foreign, of eeonomic value adapted to planting in Southern

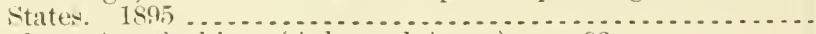

Southern Appalachians (Ashe and Ayres). p. $93 . . . . . . . .$.

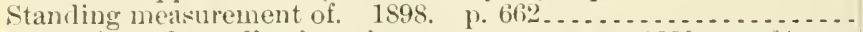

Transplanted, application of water pressure to. 1899. p. $21 \ldots$

Which trees attract liglıtning? (Abbe). 1898. p. 257 ..........

See also Almond-Apple-Arbor day-Arborescent flora Bamboo - Beech - Bireh - Boxed or turpentine timber Camphor - Carya alba - Catalya - Cherry - Chestnut - Cinchona-Citrus trees-Cocoa palm-Cocoanut palms-Conifers-Cork oak - Cork tree - Cottonwood - Cuban pineDate palm - Eucalyptus - Evergreen - Forest trees - Fruit trees-Hard woods-Lebbek - Lol lolly pine-Longleat pine - Maple-Marsh or Pond pine-Mesquite-Oaks-Orchard trees - Osageorange - Peach trees - I'ear trees - Pine-Plum trees - Red ceclar - Sapindace:e - Shade trees - Shortleaf pine - Southern pine-spruce pine - Timber - Timber pineWattle tree - Western hemlock - White pine - Willow Witch-hazel - Woody plants-Zamia.

Trelease, William:

Aletia, habits and natural history of, $1878.17 .361 \ldots \ldots . . . .$.

Tectar, what it is, and some of its uses. 1879 . p. 319 . . . . . . .

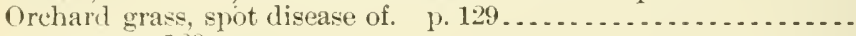

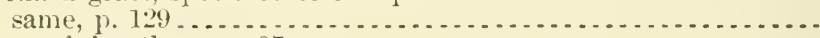

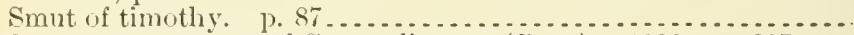

Treleasea, a new genus of Commelinacese (Rose). 1899. p. 207.... Trematode H. similis looss. See IIæmatoloechus.

Trematodes. Sipe Fluke-worms.

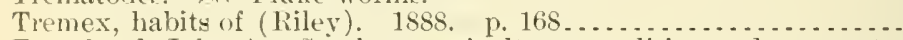

Trenchard, Joln 1 . Southern agriculture, condition and prospeets of. 1868. ஒ. 447 ..

Trenton, N. J., insecticide experiments at (Bennett). 18s6. p. 27.. Tres Marias Islands, Mexico:

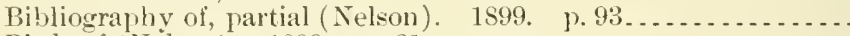

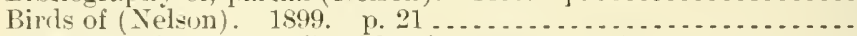

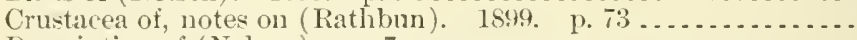

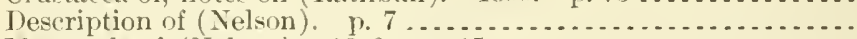

Mammils of (Nelson). 1899, p. 15......................

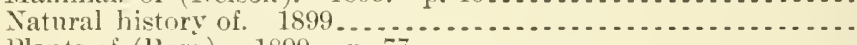

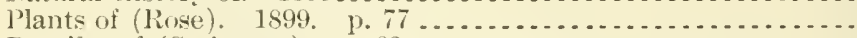

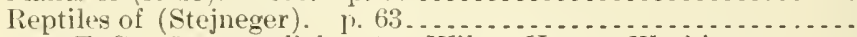

'Trescot, T. C. Sce, as collaborator, Wiley, Harvey Washington.

Trestle bridges, timber, economical designing of:

Report on (Johnson).

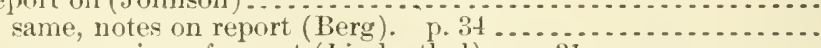

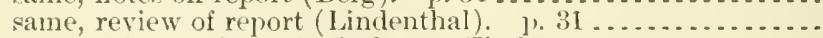
See also Bridges and trestle timbers - Timber.

Triblidium rufulum, report on (Ellis). 1889. p. 29............

Trichina spiralis, report on, p. $389 \ldots \ldots \ldots \ldots$ Trichinge:

Ameriean (Virchow). 18st. p. 181..................... German inspection of American hog products (Bames). p. $516 .$. See also Pork.

Trichinosis:

Europe, of allegert American origin (Stiles). 1901. p. 156 ..... A4.3:30

Extent of, in America and Europe (Salmon), p. $475 \ldots . . . . . . . . A 4.1: 884$ same. 1884. p. 269. 
German $\mathrm{F}-$

bibliography of (Hassall), 1901. p. 193.

A4.3:30

general remarks on (Atiles). 1901. p. 9................ A $4.3: 30$ statistical review, during 1881-1898 (Stiles). 1901. p. 35.... A A .3:30

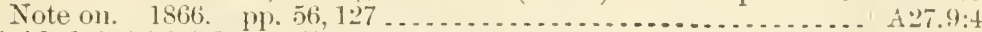

Triniclad, British West Indies, insect jests of, notes on sone (Urich).

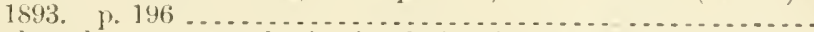

Tropical eyclones, atmospheric circulation in, as shown by move-

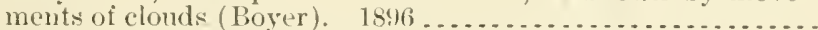

Tropieal islands of U. S., agricnlture in (Cook). 1901. p. $349 \ldots \ldots$

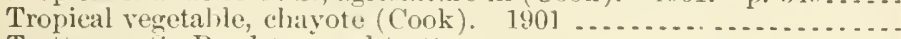

Trotters. Sice Roadsters and trotters.

Troughs, barometric, of Plateau region, report on (Hazen). 1S95. 1. 207

19.7: $:$ i

A 29.2: 1 t $6^{1}$

A].10:901

A6.3:28

129.6:23

Trowbridge, Jolin:

Electrodynamic radiations from sun, endearor to discover. 1896.

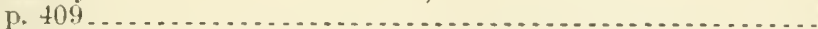

Lightning, does it ever strike ocean? 1902. p. $478 \ldots \ldots . . . . .$.

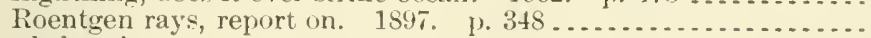

Truck farming:

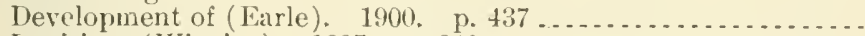

Louisiana (Wiggins). 1887. p. 240......................

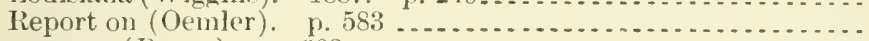
same (Rieeve). p. 663

True, Alfred Charles:

Advertising in our agricultural experiment station publications.

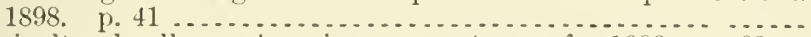

Agricultural colleges, American, some types of. 1898. p.63...

Agricultural colleges and experiment stations, American, report

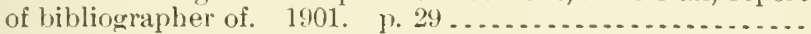

Agriculture Department, relation of, to farmers' institutes. 1902.

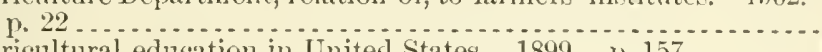

Agrieultural education in United States. 1899. p. 157 ........

Agrienltural education and research in Belgium. 1896. 1). $361 \ldots$

Agricultural experiment station movement in United States-

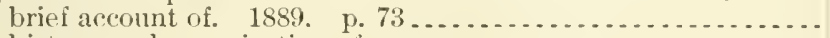
history and organization of . . . . . . . . . . . . . . . . . . .

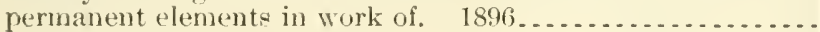

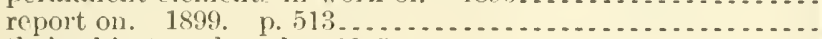

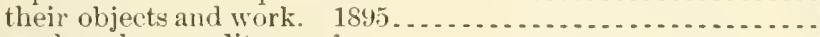

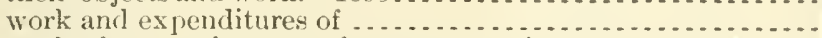
work of, some elements of pemanency in. 1896. p. 42 ....

Bibliographer of Association of Ameriean Agricultural Colloges and Experiment Stations, report of1897.

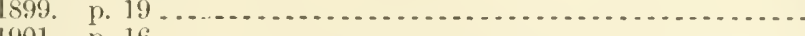

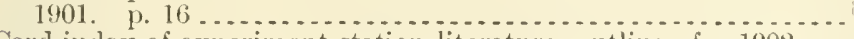

Card index of experiment station literature, outline of. $1902 \ldots$. See also, Agricultural literature, index to.

Education and researth in agriculture in Uniterl States. 1894.

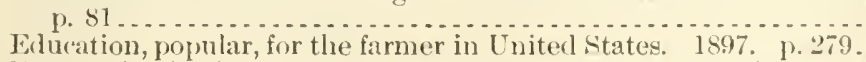

Europe, institutions for agricultural education in, some features

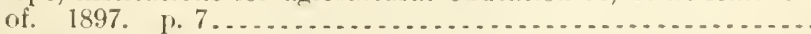

Experiment Stations Office, Agriculture Department-

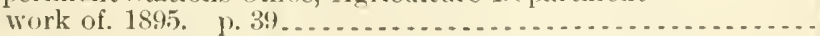
work of, for farmer. 1897 p. $135 \ldots \ldots \ldots \ldots$

Farmers' institute as medimm for developing mutnal interests and relations of farmers and United States Department of Agri-

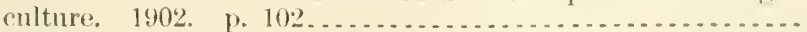

Farmers' institute work in Alaska, Hawaii, and Porto Rico.

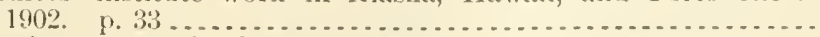

Rural common school, some problems of 1901. p. $1333 . . . .$.

See also, for reports as Director, Hixperiment Nitations (Ollice, Agriculture Dejartment, 1893-1902. . . . . . . . . . . . . . . . . . 
True, Alfred Charles-Continued

see also, as elitor of proceedings, Agricultural Colleges and Experinrent Stations, American, Association of; Farmers' Institute Workers, American Association of-Hogan, Mrs. Lonis li. shimer.

True, Nifred Charles, and Clark, T. 1. Agrieultural experiment

True, Alfred Charles, and Crosby, i). J. Igrioniture experiment

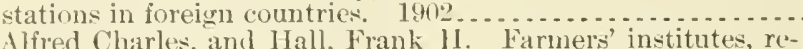

'True, Alfred Charles, and Hall, Frank H. Farmers' institutes, re-

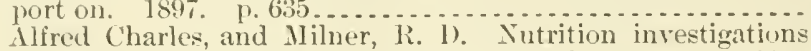

True, Alfred Charles, and Milner, R. 1). Nutrition investigations
of Agriculture Department, development of. 1899. H. $403 \ldots$.

$110.3: 80$

110.3:11:

110.6:7

Trumbuwer, MI. R.:

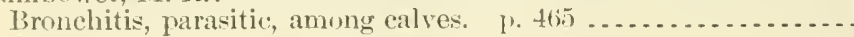

C:ittle-

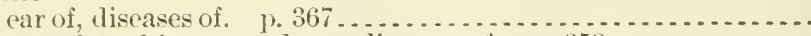

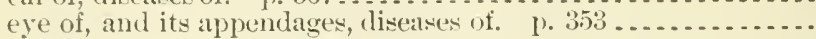

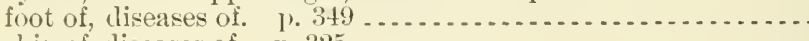

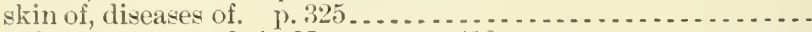

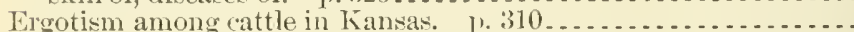

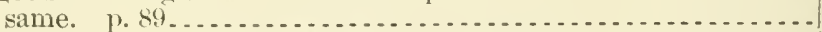

Glanders, outbreak of, at Miami, Mo. p. $457 \ldots \ldots \ldots \ldots$

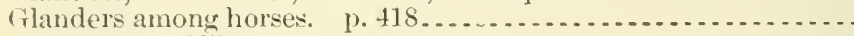

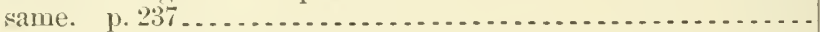

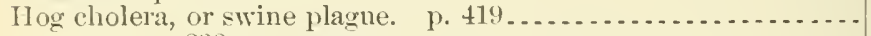

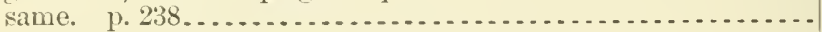

Horse-

heart and blood ressels of, diseases of. p. 219. nervous system of, diseases of. p. 181

Kansas, Southern cattle fever in, outbreak of. p. $393 \ldots . . . . .$.

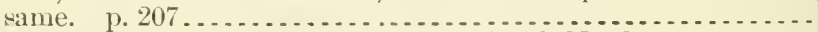

Soutliern cattle fever at Chicago Union Stock Yards. J. 444 ..-
Southern cattle fever, outbreak of, in Butler County, Kans. 1883.

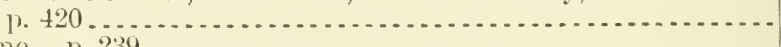

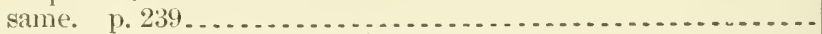

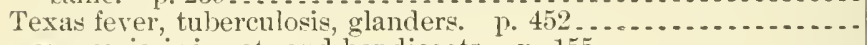

Trypanosomiasis in rats and bandicoots. p. 15.5

see also surra.

Tsetse-fly disease. See Nagana.

Tubereulin:

Distribution of. 1899 p. 532

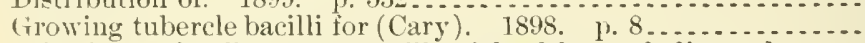

Injections of, effects upon milk of healthy and diseased cows

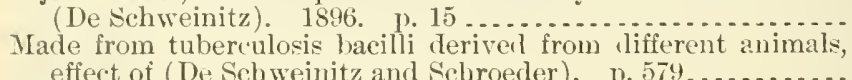
effect of (De Schweinitz and Schroeder). p. $579 \ldots \ldots \ldots \ldots$.
Preparation and use of (De Schweinitz). 1898. p. p. $111 \ldots \ldots \ldots$

Test for tuberculosis (Salmon), 1901. p. $581 \ldots \ldots \ldots \ldots . . . . . .$.

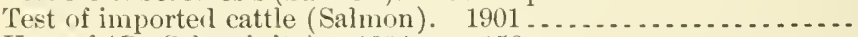

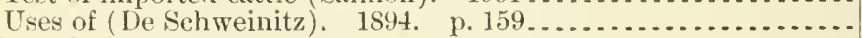
Tuberculosis:

Among domestic animals, preventive measures against (Bang).

Animal, in some of its relations to human tuberculosis (Salunom).

Bovine, practical suggestions for suppression and prevention of (Snith). 1894. p.,317.

Cattle-

detection of (Curtice). p. 283.

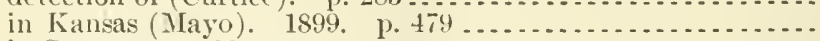

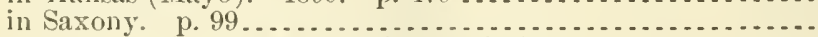
prevalence of, in New York (Schroeder). p. 66 ..........

Cattle and other animals, necessity of reducing. 1898. p. 22... Germs of, in milk, killing (Wileox). 1899. p. 24............

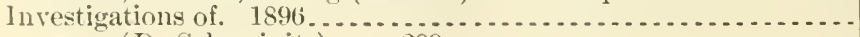
same (De Schweinitz). p. 289.

A1.10:899

14.1:88t

$\mathrm{A}+.2: \mathrm{C}^{2} 9^{2}$

$\mathrm{A}+2: \mathrm{C}^{\circ}: 9^{2}$

A 4.2:( $29^{2}$

14.2:(2): ${ }^{2}$

A4.1:884

A4.2: 1 n5

A4.1:884

A $4.1: 884$

A4.2: An5

At.1:S64

14.2:An5

A4.2:H78

At.2:1178

A 4. 1:884

A4.2: An 5

14.1:884

A 4. 1:88t

At.2:A11 5

At. 1:88t

A $4.1: 901$

At.1:899

A $4.3: 22$

A $4.3: 13$

A4.1:901

A 1.10:598

A 1.10:901

A $4.3: 32$

A4.3:7

A.1:899

A4.1:901

A1.10:894

A4.1:895-6

A $4.1: 898$

A $4.1: 893-4$

A4.1:893-4

A1.9:69

A1.9:107

A $4.3: 13$

A4.1:898 
Tuberculosis-Continuel

New South Wrales (Baker). 1). 396 same, correction, 1. 502

Olive (Pierce). is91. 1.148.

Report on (Trumbower). 1'. 452

Suppression and prevention of, some practical surgestions for

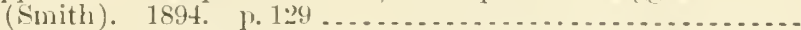

Swine; nature of disease, with report of three cases (Noore and Ja 1 son ). ए. 207 .

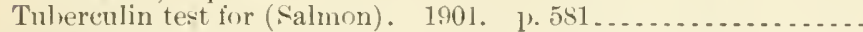

See also Berlin, international congress on tuberculosis - Bovine tuberenlosis - Cattle orler's.

Tubereolosis hacillus:

Attenuated-

further experiments with (De Schweinitz and Schroeder).

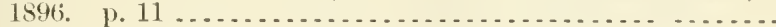
its use in producing immunity trom tuberculosis in guinea

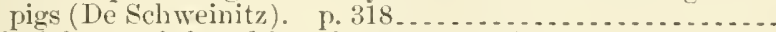

Branched forms of, found in cultures (Dorset). p. $572 \ldots . . . .$.

Composition of (De Schweinitz and Dorset). p. 295 ...........

Cultivation of, use of eggs as medium for (Dorset). p. 57t.....

Derived from different animals, effect of tuberculins marle from

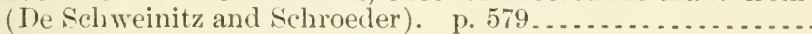

Experimental observations on presence of, in milk of cows

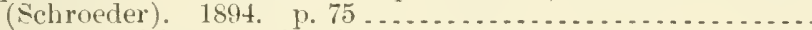

Fats contained in (De Schweinitz and Dorset). p. $301 \ldots . . . .$. Growing, for tuberenlin (Cary). 184s. 1. 8 ................ Growth of, upon acid media (De Schweinitz and Dorset). 1896.

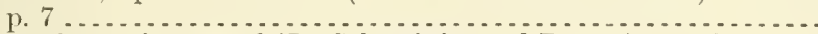

Mineral constituents of (De Schweinitz and Dorset). p. 302....

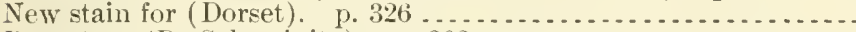

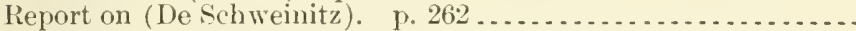

some experimental observations on presence of, in milk of tuberculous cows when udder is not visibly diseased (Smith and

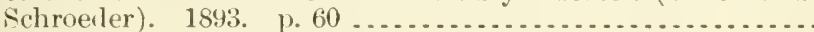

Some products of, and treatment of experimental tuberculosis with antitoxic serum (De Schweinitz). p. $305 \ldots . . . . . . . . .$.

Tubers. See Plants.

Tule River Basin, California, duty of water in (Chandler). 1902.

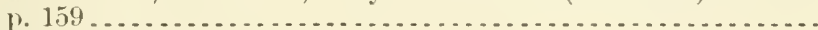

Tulip tree leaf gall-fly, report on. 1890. 1. $362 \ldots \ldots \ldots \ldots \ldots \ldots$ Tumbling mestard. ,eee Mustard.

Tumors of cattle (Lowe). p. 321 .............................

Tunnell, Ebe $W^{*}$. Delaware, roar improvement in, extract from

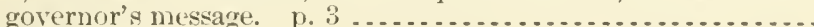
Tupper, Irs. Fllen S.:

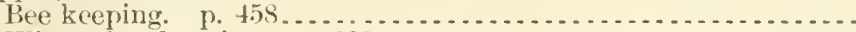

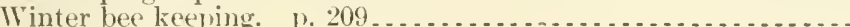

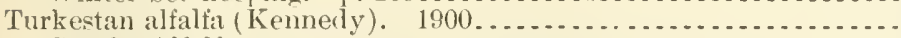
See also Alfalta.

Turkey, sleep farming in. 1868. p. 365.

See also Angora - Nervivan.

Turkey in Asia. See llarjoot.

Turkeys:

Animal parasites of, check list of (Hassall). 1896

Donestic oricrin of (Baird) p 288 .

Entero-hepatitis in, infections, direct transmission of (Moore). 1895

Infectious disease (entero-lepatitis) among, ('ansed by protozoa (smith). 1895.

[nkmown diseases in, prehiminary incestivations of (Smith) 1). 82 .

Turks Island, ITeather Bureau station on, note on ( $\mathrm{Ab}$ be). 1900 .

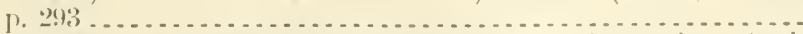

Turner, F. M. Collegre work section, Assonation of Amerion Aericultural Colleges and Fxperinent Nitations, refort of. 1893.

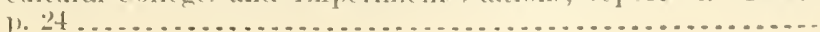

Classifleation no.

A $4.1: 898$

A $4.1: 899$

A28,5:6

A4.1:884

14.3::"

A 4. 1:895-6

A1.10:901

A4.3:13

A4. 1:898

At. 1:901

A 4. 1:898

A4. 1:901

A $4.1: 901$

A $4.3: 7$

A 4. 1:898

A $4.3: 22$

A4.3:13

A4.1:898

A4.1:898

A. $1: 900$

A4.3::

A $4.1: 898$

110.3:119

A9.7:2

$A+.2: \mathrm{C}_{2} 9^{2}$

122.4:33

11.1:865

A1.1:867

A.3.4:25

127.9:6

14. $4: 12$

11.1:sibi

$1+.4: 5$

A4.3:

A $4.1: 89: 3-4$

129.6:2:

$.1 / 10.3: 16$ 
Turner, E. T. Thuuderstorms of May 3, 1892, in New York State.

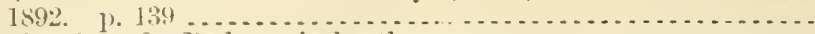

Turnip beetle. See Red turnip, beetle.

Turpentine gathering, effect of, on timber of longleai pine (Fernow) Turpentine timber. See Boxed or turpentine timber.

Turtle Mountains, Jorth Dakota, investigation to determine whether Melanoplus spretus breeds permanently in (Hunter).

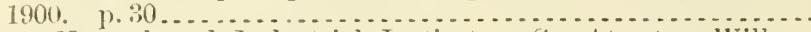

Tuskegee Normal and Industrial Institute. Sce Atwater, Wilbur Olin, and Woods, Clias. D.

Tuspan, Mexico, agriculture of (Johnson). 187t. p. 498 . . . . . .

'russock moth, white narked, consideration of parasites of, etc.

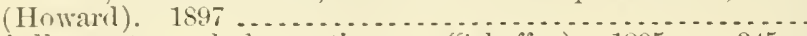

Twig girdler, notes and observations on (Scheffer). 1895. 1\% $345 \ldots$

Twig pruncrs and allied species (Chittemden). 1898. p. 35 ........

'Twiggs, John D., jr. Road building, practical problems in. 1902. p. 53 ..............................................

'Two-lined chestnut borer. See Chestunt borer.

'Tyloderma, breeding and other habits of some species of Curculionidie, especially of, notes on (Webster). 18s9. p. 109...

Typhlocyba, parasitic castration of, by larva of Hymenopter and of

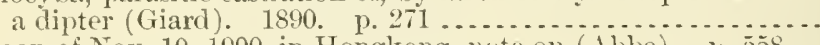

Typhoon of Nov. 10, 1900, in Hongkong, nute on (Abbe). 1. 5.5. .

Typlıons of Orient, origin, paths, and limiting zones of (Bergholz).

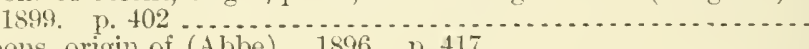

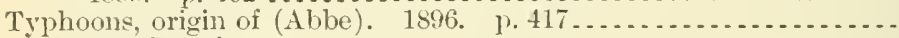
See also Bagnios.

Ugimyia sericarlae rond, parasite of Japanese silkworm (Mik).

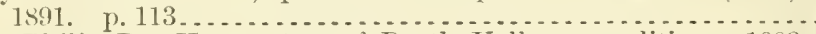

Uhler, Philip R. Heteroptera of Death Valley expedition. 1893.

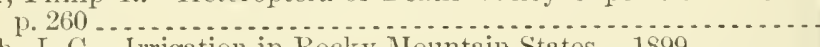

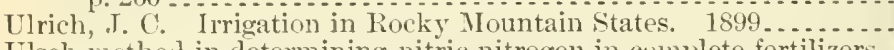

Ulsch methoul in determining nitric nitrogen in complete fertilizers.

1892. P. $88 \ldots \ldots \ldots \ldots \ldots$
Umbelliferce, North American, monograpl of (Coulter and Rose).
1900. See also 11 esperogenia - Jeibergia - Mexican umbelliferæ.

Uncinariasis. See Hookworm diseave.

Underlraining, practical notes on (Todd). p. $584 \ldots . . . . . . . . . .$. See also Plireatic waters.

Underflow and sheet waters of Nebraska (Hicks). 1893. pt. 3.

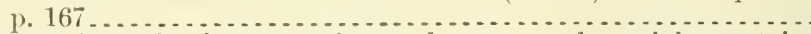

Underflow investigations, artesian and, reports of special agent in

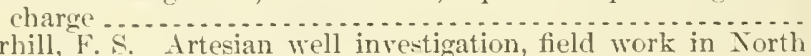

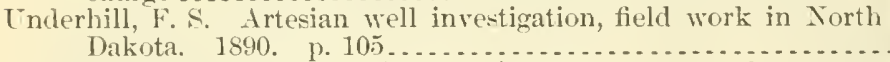

Underwaters of Great Plains (Gregory). 1843. pt. 4, p. $3 \ldots \ldots . .$.

Underwood, Lucien M.:

Orange in Florida, diseases of. 1891. p. $27 \ldots \ldots \ldots \ldots \ldots$

Pteridophyta of western Texas, rescription of. 1594. p.557....

Tnfermented grape juice, preparation of (Beal). 1900. p. 27 .....

Union Comnty, Georgia, cattle in, orler releasing from quarantine. 1898 .

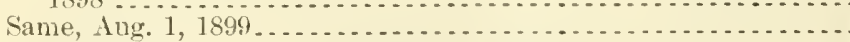

Uniterl Kingdom:

Agricultural imports of, 1846-1900 (1litchcock). 1902 . . . . . . . .

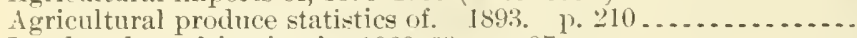

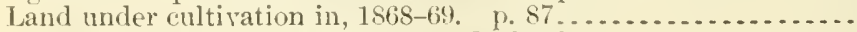

See also England - Great Britain - Ireland.

United states Propagating Crarden. sice Garden.

Universities:

Mreorology in (Abbe)-

1899. pp. $155,420,549$

1900. P. $16 \overline{5}$

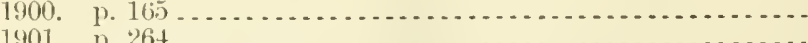

Weather Bureau men in, note on $(\mathrm{Abbe})$. 1900 p. p. $114 \ldots . .$.

A29.6:20

A13. $4: 9$

$19.6: 22$

A27.9:12

19.8:5

A9.7:7

19.6:18

12:.3:23

$19.7: 2$

A9.7:2

A29.6:28

A29.6:27

A29.6:24

A9.7:4

A5.5:7

110.3:7:

17.3::5

A6.5: 7

A1.1:8\%0

115.2: $\mathrm{Ir}^{-2}$

A15.1:

115.2:Ar 115.2:Ir ${ }^{-2}$

128.5:7

16.5:2

A 1.9:12:

A $4.5: 21$

1 $4.5: 41$

112.3:26

127.9:31

A27.9:8

+29.6:27

A $29.6: 28$

A29.6:29

+29.6:28 
See ulso Agricultural and mechanical colleges - Agricultural colleges - Colleges and universities, State-Johns Ilophins University - Purdue University - Washington Eniversity, St. Louis, Mro.

Iniversity boat crews. See Harvard and Yake boat crews.

Cniversity extenion:

Agriculture at Cornell University (Craig). 1901, fr.137....... Attitude of agrieultural colleges toward (Voorhees). 1895. p. 49 . Work, how may it be hest condueted by colleges of atriculture? (Roberts). 1898. p. 5.5

110.3:99

A10.:3:24

Iniversity lecturers, Weather Burean men as, notes on ( $\mathrm{A}], \mathrm{be})$. 1893.

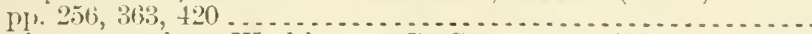

University researeh at Washington, $\mathrm{D}$. C., note on (Ab)e). 1901 .

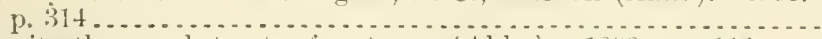

Lnirersity theses, abstracts of, notes on (Albe). 18s9. p. $114 \ldots$.

Lpdyke, Stephen G. Artesian well investigation; field work in south

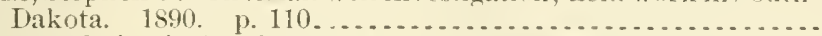

Urban population in Sonth; country being cleserted; whither are we

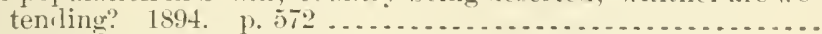

Trerline:e:

Tew species of (Ellis and Everhart). 1891. p. 118..........

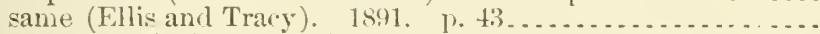

Notes on certain (Anderson). 1891. p. 121...............

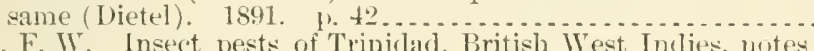

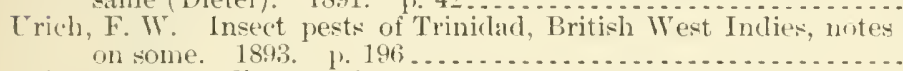
Trinary organs, diseases of:

Cattle (Law). P. $13 \bar{\imath}$.

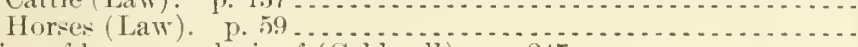

A 10.3:49

A29.6:27

A29.6:29

A29.6:27

A15.2:Ar

A27.9:32

A 28.5:6

A 28.5:7

A 28.5:6

A28.5:7

A9.7:6

$\mathrm{A} 4.2: \mathrm{C} 29^{2}$

A4.2:H78

Trine of horse, analysis of (Caldwell). p. 247............... A1.1:872

[romyes:

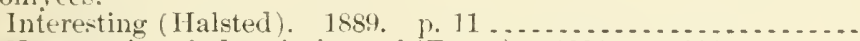

New species of, descriptions of (Tracy). 1891. p. 281........

Eruguay:

Agrienltural statistics of. 1894. p. 268 ...................

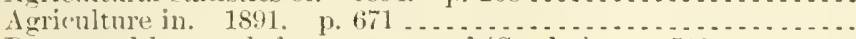

Bones and hone ash from, export of (Swalm). p. 519 ........

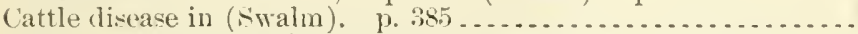

Wheat production and exportation in, course of, 1850-1896 .....

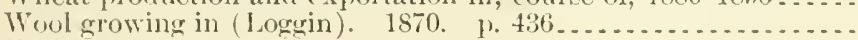

I'stilaginere:

New species of (Ellis and Everhart). 1891. p. $118 \ldots \ldots . .$.

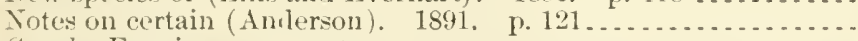

Siee also Fungi, comomycetes.

Lstilago ze:e mays, abnorinal struetures in fungi inducerl by, study

Utah:

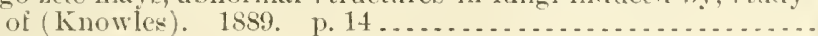

Aericultural statisties of. 1865 . I. 90

Isirds olserved in narts of, by Death Valley expedition of 1891 ,

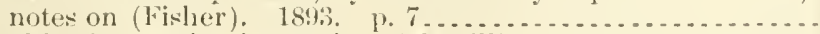

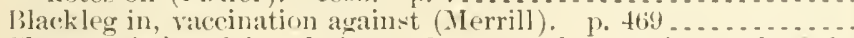

('haracteristies of, in relation to State weather-servioe work (sal-

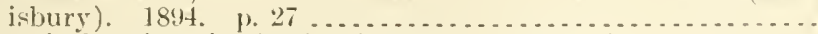

Electrical engincering in, developnent of (Jensen). 1898. 1).91.

Grasses of arid districts of, investigation of (Tracy), 188s. 1, 5.

Sheep in, "big head" (dicease) of (Rowe), 1. 230 ..........

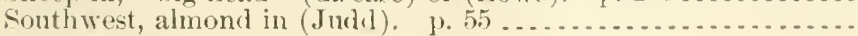

Soutliwestern-

eactuses, ynecas, and ayave in deserts and desert rangess of, geographic: and verticul clistribution of (Mcrrians). 1893.

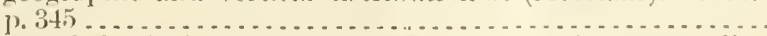
trees and shrubs in deserts and desert ranges of, antes on dis-

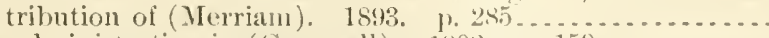

Water administration in (cemmell), 1902 , p. 159 ...........
Water supply of, for seatson of 1900 as depending on smowfalj

A $28.5: 5$

A28.5:7

A27.9:32

A $27.9: 29$

A $4.1: 900$

14.1:898

A12.4:10

127.9:8

A28.5:6

128.5:6

A28.5:

A27.9:4

A.5.5:7

14. $1: 599$

129.3:14

A 10.3:49

A6.3:6

A. $1: 901$

120.1:595

15.5:7

1.5.5:7

110.3:10-1

1.29.6:28 
Utah-Continued

Wingless grasshopper of (Glover). 1872. p. 7t..............

Sce also bear River Yalley-Big Cottonwood Creek - Cache County - Logan and Richmoni canals - Salt Lake Valley Sampete County-Sevier Valley-Utah County-- Veber County.

Itah County, Itah, soil survey in (Means). 1900. p. 115.........

I'tica, N. Y., American Dairymen's Association at, Jan., 1871, no-

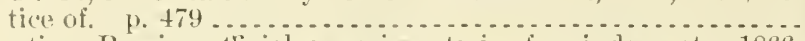

Vaccination, Russian otficial experiments in, for rinderpest. 1866.

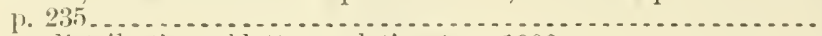

Vaccine, distribution of letters relating to $1900 \ldots \ldots . . . . . . .$. see ulso Blackleg.

Vallez to Eagle, Alaska, trail from, reconmoissance of (Jones). p.

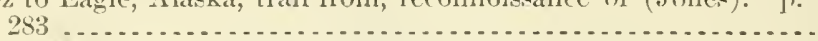

Valliant, M. Victor. Roads of Belgimm. 1901. p. $87 . \ldots . . . .$.

Van Bebber, W. J. See Bebber.

Van Deman, H. E. See, for reports as Chief, Pomology Division, Agriculture Department, 1886-92 . . . . . . . . . . . . . . . . . . . . .

Van der Stok, J. P. Malay Archipelago, climate of. 1896. p. 669 .

Van Diest, P. H. Geological conditions of artesian basins in eastern Colorado and New Mexico. 1890. p. $87 \ldots \ldots . . .6 . . .6$.

Vanessa antiopa:

Egg parasite of, oviposition of (Weed). 1900. p. 32 .........

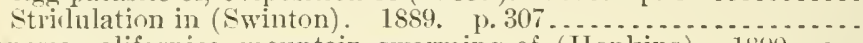

Vanessa californica, mountain swarming of (Hopkins). 1890. p. 355

Vanilla culture as practiced in Seychelles Islands (Galbraith). 1898.

Van Pelt, J. C. Good roads in Kंentucky, organizations for. 1901.

Van Slyke, Lucius Lincoln:

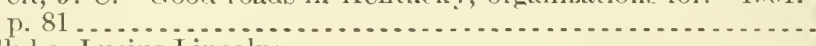

Address of, as president of Association of Official Agricultural Chemists, at 18th annual convention. 1901. 1. 8 . . . . . . . .

Albumen, determination of, in cow's milk. 1894. p. $188 \ldots \ldots .$.

Cheese, fat in, retermination of. 1893. p. 116............... Cows, milk of, casein in, determination of. 1893 . p. $109 \ldots \ldots$. IIilk-

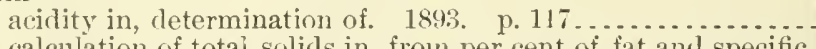
calculation of totai solids in, from per cent of fat and specific gravity, according to formulas of Babcosk, Fleischmann, and of Hehner and Richmond, compared with gravimetric

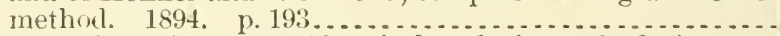

See also, as joint editor, 1895 , Chemical analysis, method of.

Vapor:

Aquenus, total quantity of, in atmosphere (Abbe). 1894. p. 539.

New determination of tension, notes on (Abbe). 1901, p. $74 .$.

Pressure of, for water and ice, notes on (Abbe). 1899. p. 476.-

Psychrometric tables for obtaining pressure (Marvin). $1900 \ldots .$.

Saturated aqueous, pressure of, at temperatures below freezing

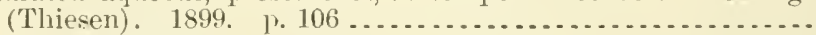

Sie also Atmosphere.

Variegated cutworm. See Cutworm.

Variety testing. See Plants.

Vasey, (ieorge:

Agricultural grasses and forage plants of Uniterl states, and such foreign kinds as have been introduced...................

Botanical collectors, instructions to . . . . . . .

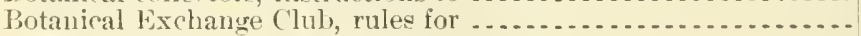

Botanical notes-

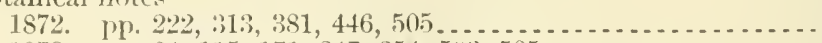

1873. pp. $34,115,171,247,354,503,585 \ldots \ldots \ldots \ldots \ldots \ldots$

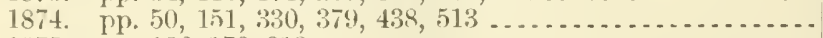

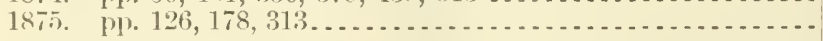

[The more important articles are indexed under their various subjerts.]

Botany Division, record of some work of, including extracts from correspondence and other communications. 1889 . p. $7 \ldots \ldots$ 
Vasey, George-Continued

First words of, as Botanist, Department of Agriculture. 187:2.

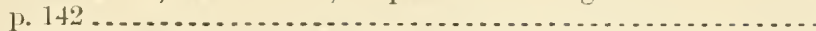

Forest trees, North American, distribution of. Isst. p. $38 . .$. Forest trees of L'nited States-

native and naturalizerl, catalogne of. $p .151 \ldots . . . . . . . .$. which usually attain height of 16 feet or nore, catalogue of.

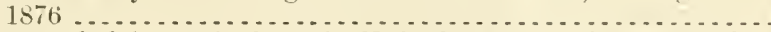

Grasses needed for auriculture in Luited States, and necessity for

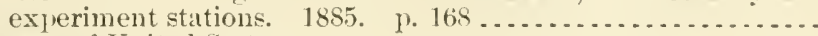
Grasses of I'nited States-

descriptive catalogue of, including especially grass collections at New Urleans Exposition. 1885 ............. . . . synopsis of tribes and genera, with descriptions of genera and

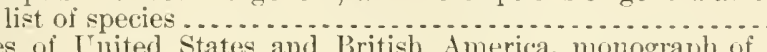
Grasses of L nited States and British America, monograph of. 1892.

Grasses-

arid districts of Kansas, Nebraska, and Coloralo, investi-

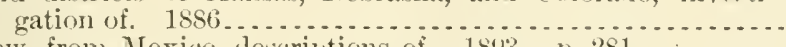
new, from Mexico, descriptions of 1843 . p. $281 \ldots \ldots \ldots$. new or noteworthy, from United States, description of. 1893.

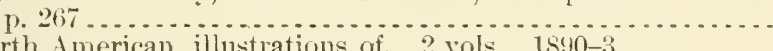
North American, illustrations of. 2 vols. $18130-3$. . . . . . .

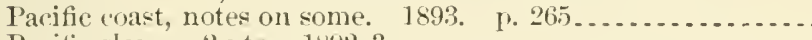

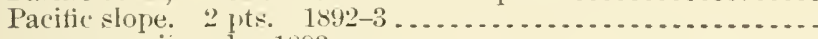

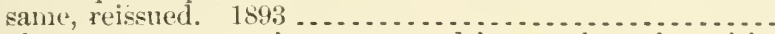

Sonth; a report on certain grasses and forage plants for culti-

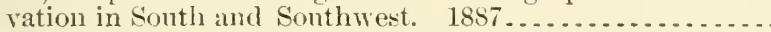

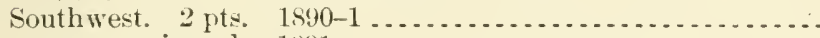

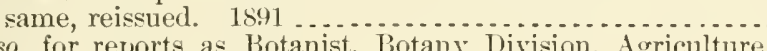

See also, for reports as Botanist, Botany Division, Agriculture Department, $1872-1892$.

Yasey, George, and Collier, Peter:

Grasses and forage plants. p. $15 \%$

Vasey, George, and Rose, Joseph Nelson:

California, southern, plants collected by Edward Palmer in 1s8s,

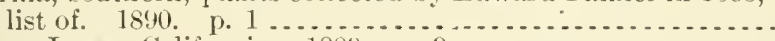

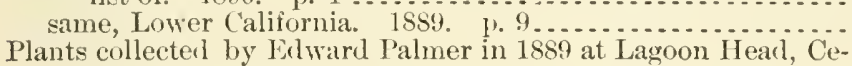
dros Island, San Benito Island, Guadalupe Island, and head of Gulf of California, list of. 1890 . p. $9 \ldots . . . . . . . . . .$. Plants collected by lilwarl Palmer in 1890 in Lower California and western Mexico, at La I'az, San Perlro Martin Island, Raza Island, Santa Rosalia, Santa Agueda, and Guaymas, list

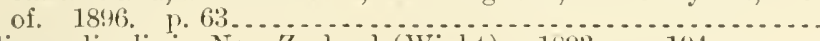
Vedalia carlinalis in New Zealand (Wight). $1893.1 \% 194 \ldots \ldots$.

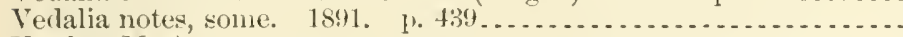
Veeder, II. A.:

Cipher code, international, for correspondence respecting the aurora and related conditions. 1894. 1) $26 \ldots . . . . . . . . .$. Storm tracks, periolic and nonperiodic fluctuations in latiturle of. 1894. [. 185

Vegetable cellulose. See ('milulose.

Yegetable crops, some insects injurious to (Chittenden), 1902....

Vegetable dietary, our, sone additions to (Coville). 1895. p. 205..

\section{Tegetable fibers. See Fibers.}

Tegretable foods, dry, insects affecting (Chittenden). 1) 112...... See also Chinese vegretable food materials.

Vegetable garden (Greathonse). 18!!

See also Farmers' vecretable garclen.

Vegetable nomenclature, work of experiment stations in reform of

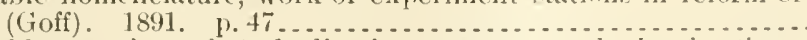

Vegetable organisms, fatty borlies in, report on methorls of retimation of (Maxwell). 1830. p. 94.

Vegetable physiolngy:

Agricultural colleges (Stone). 1896. p. 99

A27.9:10

A $1.7: 5$

A1.1:875

A 1.8:11

A1.7:9

16.2:9776

11.6:6:3

A6.5:3

A6.3. 1

+6.5:1

A6.5:1

A6.2:N82

A6.5:1

A6.3:13

A6.2: ${ }^{5} 82^{2}$

A6.3:3

A6.3:12

A6.2: $\mathrm{NS}^{2}{ }^{1}$

A6.1:

A1.1:878

16.5:1

16.5:1

ג6.5:1

A6.5:1

A9.7:6

A9.7:3

129.8:11 1

A29.3:11 1

A9.6:3:3

A1.10:895

A!.6:4

1 $1.9: 14$

110.5::3

$17.3: 28$

1 10.3:41

$114-04-37$ 
Vexptable physiology-Continued

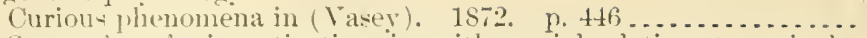

Sugretions for investigations in, with special relations to aurieulture (coodale). 1897. p. 435 .

Vegetal)] P'hysiology and l'athology Division, Agricultare Departnent (formerly l)ivicion of lexutable Pathologr):

Jerbarinm of, sonie l'ernmsporacese in (swingle), 1s91, l'. 104. .

Recoril of some work of, including extracts from corresiondence and other communications (Galloway). 1889. 1. 41 ......

Work in (Wuods). 18!s. p. 261 .......................

Wurk of, for falmer (fralloway). 1897. p. $99 \ldots \ldots \ldots \ldots \ldots \ldots \ldots$.

Sce also Botany Division.

Veretable products:

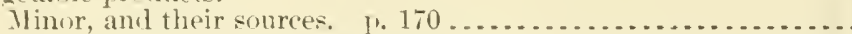

Stored, some little-known insects affecting (Chittenden). 1897 .. Verctable substances, nitrogenems compomnds of, suggestions regard-

\section{Tegetiales:} ing nomenclature of $($ Itwater $)$ 1899. p. $115 \ldots . . . . . .$.

Commercial varieties, testing of (Tracy $) .1900 . \quad$ r. 54.3.

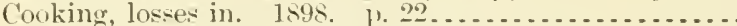

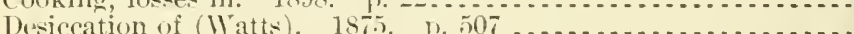

Experiments with fertilizers on, to study feerling capacities of płants and variations clue to action of fertilizers. 1s!1 . . . .

Loses in boiling, and composition and digestibility of potatoes and eggs. 1897 .

Originators of, list of, with adilreses and names of specialties....

Protection of, from injury by heat of ("ull during transportation (Harrington). 1894:

Rules for naming. 1889 .

See also Asparagus - Beans - Beet - Bur or globe artichokesCabhage - Canadian field peas-Carrots-Celery-Chayote - Cucumbers - Cucurbits - Egg plant - Fruits and vegitables - iarden regetables - Horse-radish - Jerusalem artichokes - Lettuce - Melons - Onions - Peas - Potatoes Sugar beets-Sweet potatoes-Tomatoes-Znain cucumbers.

Vegetables, canned:

Adulteration of (McElroy). 1893. p. 1015 ................ . .

Analysis of, provisional method for (Iunson). 1902. p. $50 \ldots .$.

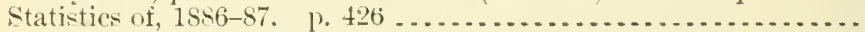

"Swells in," cause and prevention of. 1898. p. $28 \ldots \ldots . . .$. Vegetation:

Alkali soils and, some mutual relations between (Kearner and

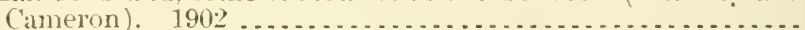

Characteristic, of desert rexion flom westem Texas to central

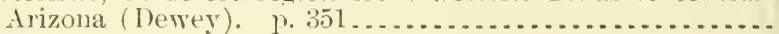

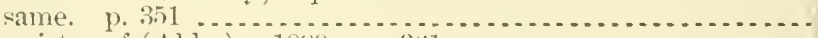

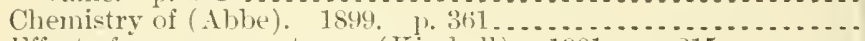

Effect of mon on, notes on (Kimball). 1901. p. $215 \ldots . . . .$.

Insects destructive to, general observations on (Yeal). 1583.

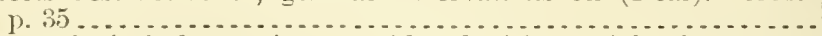

Metenrological observations considered with special reference to influence on (Schreiher). 1895, 1) $395 \ldots . . . . . . . . . . .$.

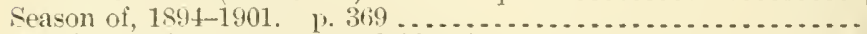

Winds injurious to crops and (Curtis). 1895. p. $435 \ldots . . . .$.

See ulso climate and regretation.

Tegetation house arranged for pot experiments (Fritton). 1901. p.

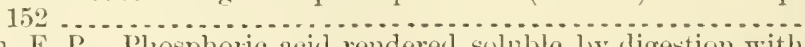

Veitch, F. P. Plosphoric acir rendered soluble loy digestion with ammonim citrate at $65^{\circ} \mathrm{C}$., amount of washing required to

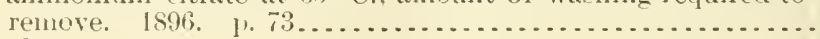

Velvet hean:

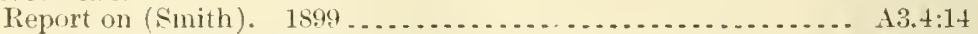

Valuable forage crop and soil renovator. 189s. p. $12 \ldots . . . . .$. A1.9:7s

Venezuela, statistical view of. $1890 . \quad 1.469 . \ldots \ldots \ldots \ldots \ldots \ldots \ldots . . .427 .9: 28$

Venezuelan cattle, shipments of, to Cuba (Ellsworth). 1. 516..... $14.1: 899$

Ventura area, (alifornia, soil survey of (Holmes and Mesmer). p.

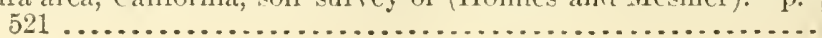


Inciex

Classification no.

Vera Cruz, Mexico, northers of (Abbe). 1894. pp. 226,363......

Vergnette-Lannotte, Girard Elisabeth Alfred, Vicomte de. Cirape mildew, remedy for. 1886 . p. $80 \ldots \ldots \ldots \ldots \ldots \ldots \ldots \ldots \ldots . \ldots \ldots . . .2$

Vermilion P'arish, La., soils and products of (Rapley). 1854, 1) 17.. A1.8:35

Verminous bronchitis. , See Bronchitis.

Verminous diseases of cattle. sleep, and goats in Texas, further in-

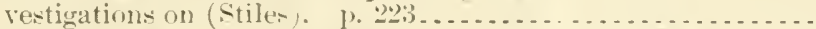

Verminous diweases of (attle, sheep), and goats in Texas (stiles). p).

Vermont:

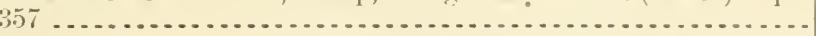

$14.1: 901$

$A+1: 900$

American merinos of. p. 484.

Farm resources and product of

Laudslide in note on (Abbe) 1897. po

hoad improvement in, extract from governor's inessaue (smitli).

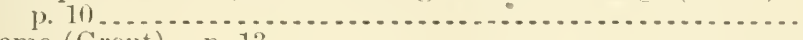

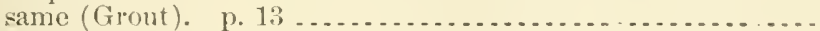

Sie clise Rutland ('ountr.

Vermont Association of Roal and Trotting Horse Breelers, exhili-

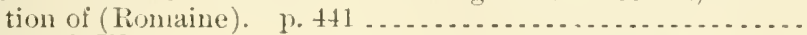

Very, Frank W.:

Atmospheric radiation, research conducted at Alleghany Observa-

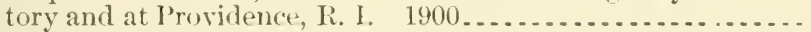

Cloud phenomena attending hailstorms, $1894 . \quad$ b. $292 \ldots \ldots \ldots$.

Potomac River, phenologieal olservations on. 1900. p. 154 ..

Solar constant, report on. 1901. p. 357 ........................

Vespertilionidae, family. See Bats.

Vessels, stranded, Captain Danse'y's kite for (Abbe). 1897. P. 206

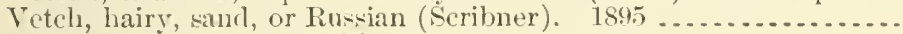

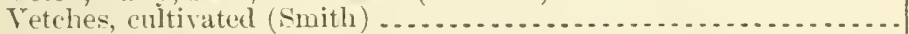

Veterinarians:

Experiment station, and local veterinarians in state, desirability of cooperation between (Bitting). 1898. p. 20.........

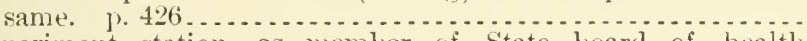

Experiment station, as member of State board of health

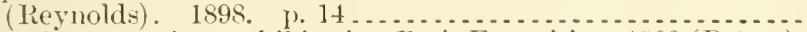

Experiment station, exhibit of, at Paris Exposition, 1900 (Peters).

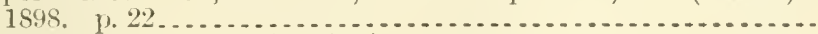

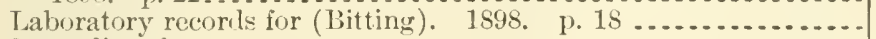
State, list of -

1898. 1). 602 same. p. 616 .

1899. 3. 530 ...

same. 698 . 698

$1900 . \quad$ 1. $65 \%$

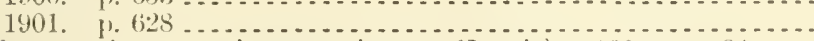

Talue to, of cooperative experiments (Lewis). 1898. 11.24...

See also Onaha, Nebr., Experiment Station veterinarians.

Veterinary concreeses, international. See Barlen-IBaden - Brussels.

Veterinary 1)ivision, Agriculture Department, report of:

1881 and $188^{\circ}$. 1). 257

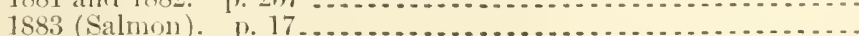

See also note under $\mathrm{A} 1.4$.

Veterinary science and practice, abstracts of reports of agricultural

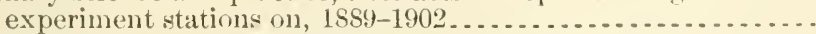

Veterinary \%onlogy. Sie $/$ oology.

Vettin, Ulrich Franz Friedrich. Atmosphere, upper, study af, ly! means of cloud observations, 1896 . p. $758 \ldots \ldots . \ldots . . . .$.

viala, l'ierre. See, as joint author, Seribner, Frank laimson-.

Victoria, Australia:

Irrigation in, recent investigation, legislation, and arlministration

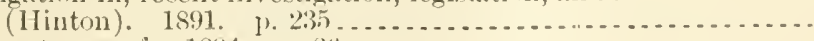

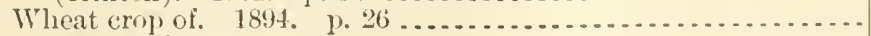

See also Melbourne.

Yienna, Austria, dead animals in, disposition of (Hogue), 1. $350 \ldots$

Vienna, Austria, first international congress of acriculture and forestry, 1873 , decisious of

A1.1:86:5

A27.9:6

$129.6: 25$

122.4:33

122. $4: 33$

A4. 1:\$89-90

A $29.5: G$

A29.6:22

A29.6:28

+29.6:29

A $29.6: 25$

13.4:2

A3. 4:6

A4.3:2:2

A4.1:895

A $4.3: 2: 2$

A $4.3: 2: 2$

A $4.3: 22$

14.1:898

1 1. 10:598

14.1:599

11.10:899

A1.10:900

1 1.10:901

At.3:2:2

11.1:\$81-2

1 1. $1: 583$

.110 .6

1.2) $3: 11^{3}$

A15.2:1'94:

A27. $91: 3.3$

$14.1: 8319$

ะา.9:1: 
Vienna, Anstria, International Exhibition, 1894, notice relating to .. A A.2:V67

Vieth, I'. Tolatile acids present in butter fat, yuantity of. $185 \%$. 1.9.9. A7.3:24

Vine:

Culture and products, report to United States Commission of Paris Exposition of 1867 (Wikler and others). p. 164......

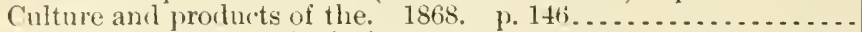

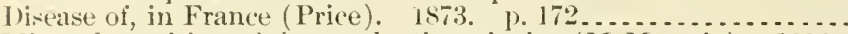

Mineral nutrition of, for production of wine (Mc.Murtrie). 18s:. p. 180

Parasitic discases of, congress on. See Florence, Italy.

See ulso Grape - Girapevine - Wine.

Vine culture institute. See Geisenheim-on-the-Rhine, Prussia.

Vinegar:

Analysis of, provisional method for (Frear). 1902. p. 62.....

Insects affecting (Howard). 1896. p. $100 \ldots . . . . . . . . . . . .$.

Vinegar eel (Anguillula aceti), infection in liuman blarlder, casse of (Stiles and Frankland). 1902. 1. $35 \ldots . . . . . . . . . .$.

Tineland, N. J.:

Graperine, downy mildew and black rot of, treatment with salts

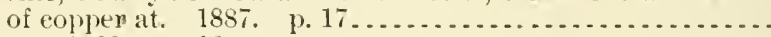
same. 18ss. 1) 13... . . . .

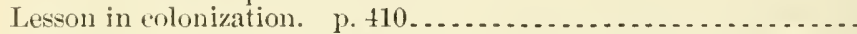

Vinevard, home, with special reference to northem conditions

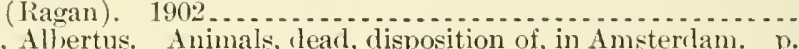

Vinke, Alhertus. Animals, clearl, disposition of, in Ansterlam. $p$.

Vintage, Rhine, note on. 1888 . 578

A $1.1: 867$

A $27.9: 6$

A:7.9:11

A $1.8: 22$

A $7.3: 65$

A9.6:4

A4.3:35

A6.3:5

A6.3:10

A1.1:869

A 1.9:156

A4.1:899

A $27.9: 26$

Violet:

Insects injurious to, some (Chittenden). 1901.

Spot disease of (Dorset). 1900 .

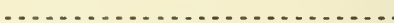

Tiolet pest, new, report on (Coquillett). 1900 . p. $48 \ldots . . . . . . . .$.

Virchow, Rudolf. American trichinse. 1884. p. 181

Virginia:

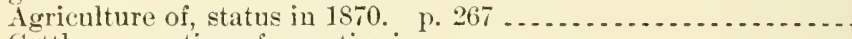

Cittle quarantine of counties in -

Dec. 16,1897 . p. 8

Dec. 20,1898 . p. 4

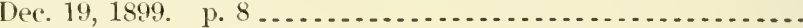

Dec. 14,1900 .

Dee. 27,1902 .

Eastern, negroes in, dietary studies among, in 1897 (Frissell).

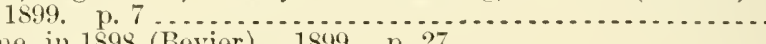

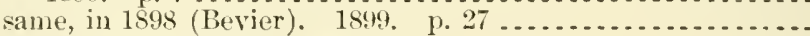

Farm resources and products of. 1868. p. 67 ...............

Her past, present, and future (Jammey). p. 17 . . . . . . . . . . . .

Horsesin, disease known as "staggers" among (Harbangh). p. 209

Insect injury to chestnut and pine trees in neighboring states

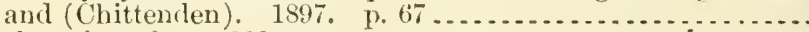

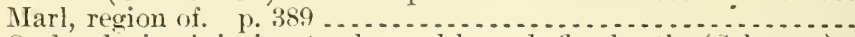

Orchards in, injuries to, by red-legged flea-beetle (Schwarz).

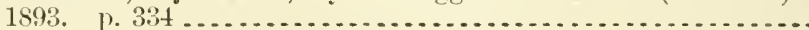

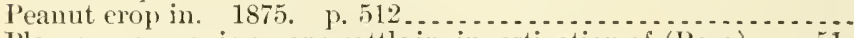

Pleuro-pneumonia among cattle in, investigation of (Rose). p. 51 .

Potomac lands of, for agricultural purposes. 1872 . p. 16 ......

San Jose stale in (Coquillett). 1894. pp. 253, $324 \ldots \ldots \ldots \ldots \ldots$.

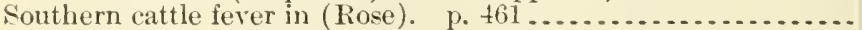

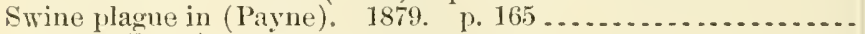

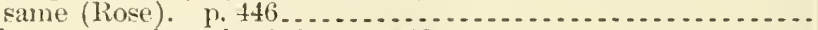

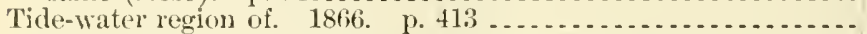

Wheat culture in (Pleasants). 1869, p. 231 ...............

See also Berlford - Charlottesville - Dismal swamp - James River - Morrisville - Norfolk - Prince Edward - Richmond-Skyland.

Virginia good roads convention, Richmond, Va., Oct. 10, 11, 1S95:

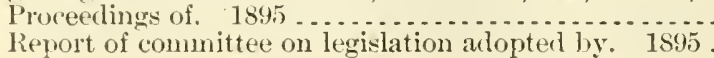

A $9.6: 27$

A $28.3: 23$

A9.6:22

A $4.3: 30$

A1.1:870

A4.5:8-14

A 4.5:25-29

A $4.5: 49-55$

A4.5:80-87

A4.5:101

A10.3:71

A10.3:72

A27.9:6

A1.1:864

A. 1:886

A9.6:7

A $1.1: 86 \mathrm{~S}$

19.7:5

A27.9:13

A1.1:881-2

A27.9:10

19.7:

A $4.1: 884$

A 1.6:12

A 4.1:884

A27.9:4

A27.9:7 
Calif́rnia. 1882. p. 99.

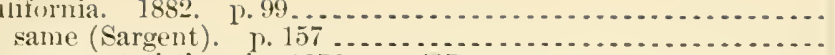

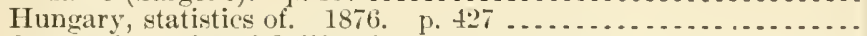

Quarantine rules of California. 1882. p. 16t.

See also Evans, Walter 11.

Viviparous coekroach, report on (Riley). 1891. 1. 443.

A $1.8: 22$

$127.9: \mathrm{i}^{2}$

A $1.8: 20$

Virisection in District of Columbia.

Volatile acids:

Determination of total, in butter (Goldmann). 1890. p. 112....

Fatty, of butter, contribution to sturly of (Spallanzani). 1890.

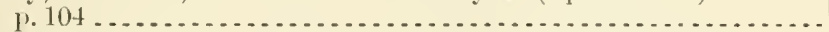

Quantity of, present in butter fat (Vieth). 1890. p. $99 \ldots \ldots . .$.

Variations of, in butter fat (Мenozzi). 1890. p. $111 \ldots . . . . .$.

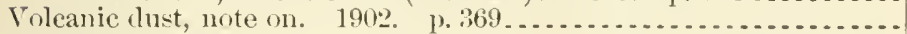

Volcanic eruptions, Hawaiian, report on (Lyons):

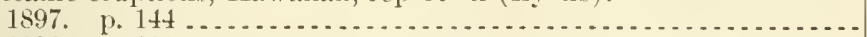

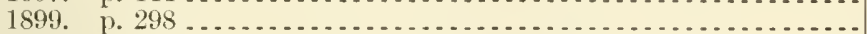

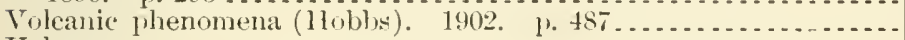

Toles:

American, of the genns Microtus, revision of (Bailey). 1900 ....

Genera and subgenera of (Miller). 1896 ...................

Volker, Hermann. Snow and ice measurements. 1889, p. 142...

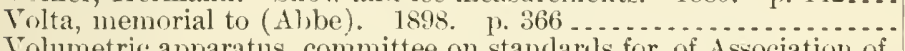

Volumetric apparatus, committee on standares for, of Association of Official Agricultural Chemists, report on. 1897. p. $137 \ldots . .$.

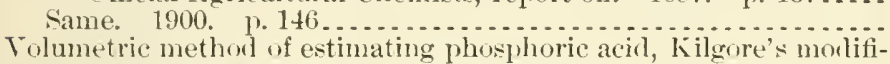

cation of (Williams), 1901 . p. $55 \ldots . . . . . . . . . . .$.
Voluntary observers. See Weather observers, voluntary.

Ton Hermann, C. F. North Carolina, climate and crops in. 1889-98.

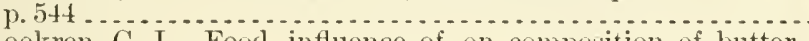

Ton Lonkren, C. J. Food, influence of, on composition of butter.

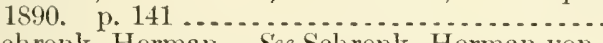

Von Schrenk, Herman. See Schrenk, Herman von.

Yon Sehweinitz. Sep De Sehweinitz.

Fon Tavel, Franz. Pyrenomycetes, history of development of, contributions to. 1889. p.p. 53, 113, 181 .

1 1.4:2

A7.3:24

A 7.3:24

A $7.3: 24$

A 7.3:24

A29.6:30

A 29.6:27

A $29.6: 27$

A 29.6:30

A5.5:17

A5.5:12

A 29.3:24

A 29.6:26

A7.3:51

A 7.3:62

A7.3:62

A29.6:26

A7,3:24

Foorhees, Edward Burnett:

Address of, as president of Association of Official Agricultural Chemists, at 11th annual meeting. 1894. p.7 ...........

Agrieultural Colleges, attitude of, toward university extension.

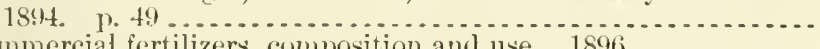

Commercial fertilizers, composition and use. 1896 ............

Farmers' institute as promoter of closer intimacy between furmers

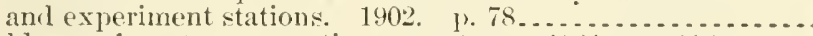

Field experiments, cooperative, report on. 1901. p. 116 ......

Food and nutrition investigations in New Jersey in 1895 and 1896.

Gunning-K jeldahl method and a modifieation applicable in pres-

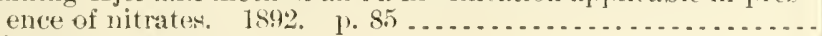

Irrigation in New Jersey, report on1900.

$1902 . \quad$ 1. 353 . . . . . . . . . . . . . . .

Milk, quality of, shonld welling he regulated by? 1896. p. $91 .$.

New Jersey, farmers' institute work accomplished in. 1902. 1.37.

Schools, public, how may farmers' organizations hasten teaching

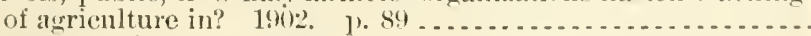

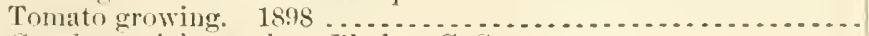

See colso, as joint author, Phelps, C. S.

Voorhees, Lonis 1 .:

Breall, process of making, losses in. 1899. p. 37 . . . . . . . . . .

Fungicicles and insecticides, report on, belore Association of Oflicial Agrientural ('hemists-

1899. P. 101

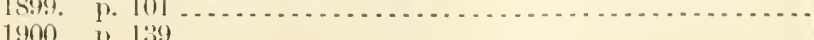

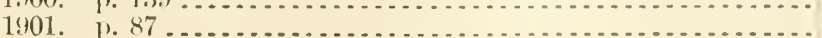

A28.5:5

A $7.3: 43$

A 10.3:24

A1.9:44

110.3:120

1 10.3:99

A 10.3:35

A7.3:35

A10.3:87

A 10.3:119

1 10.3:41

110.3:1:0

A10.3:120

A1.4:76

110.3:6

$17.8: 57$

$17.83: 62$

$17.3: t i 7$ 
Vose, Elisha C. Storage battery, use of, for electrical recording

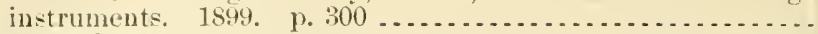

Toyle, Joselili:

Scale insects affecting orange, experiments npon. 1883. p. $19 .$. Scale insects of orange in Florida, report on effects of cold upon. 1884. p. 70 .

Voyles, D. 11 :

Swine plague in Indiana-

1878. p. 421

1879. P. 112

Vuyst, Paul de:

Agricultural associations in Belgium. 189s. p. 3 ...........

Agricultural elucation in Belgium. 1893. p. $703 \ldots . . . . . . .$.

liages:

Agricultural, in France, 1876 .

Farm labor in United States-

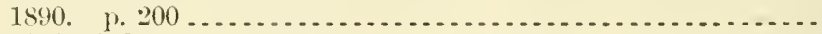

$18+0-1892$.

1866-1899, results of eleren statistical investigations

Farm laborers in United States-

1867. p. $t$

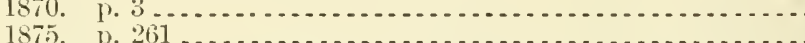

Wagner, Balthasar. Rye gall-gnat, new erop, 1861 , observations on,

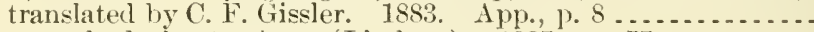

Wagner method of pot eulture (Lindsey). 1897. p. 77.........

Wragon roads. iee Roads.

Wahl, Rolvert. Indian corn (or maize) in manufacture of beer. 1893.

Wait, Charles Edmund:

Dietary studies at University of Tennessee in 1895

Muscular work, experiments on effect of, npon digestibility of foorl and metabolism of nitrogen, conducterl at University of Tennessee, $1897-1899$.......................... same, $1899-1900$. . . . . . . . . . . . . . . . . . . . . . . . . . .

Nutrition investigations at University of Tennessee in 1896 and

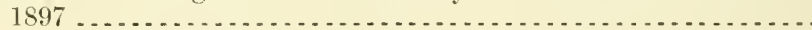

Wait, Robert E. Agrisulture Department, work of, as illustrated at Atlanta Exposition. p. 503 .

Waite, Merton Benway:

Fungicides, experiments with, in removal of lichens from pear

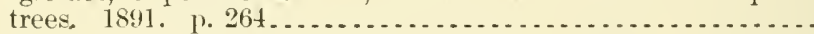
Pear blight, cause and prevention of. 1895. p. $295 \ldots \ldots \ldots \ldots$

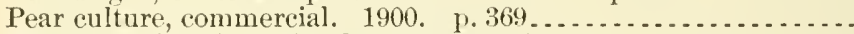
Pear leaf-blight in orchard, treatment of. 1891. p. 333 ......... Peronospora, two new species of, description of. 1891. 1.105... Pollination of pear flowers. . . . . . . . . . . . . . . . . . . . . . .

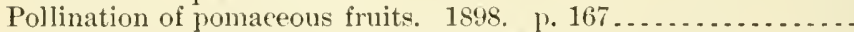

Wakker's hyacinth germ (Pseudomonas hyaeinthi) (Smith). 1901 . .

Waldo, Frank. Meteorology, theoretical, in United States, 1855 to

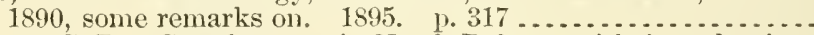

Wallron, C. B. Grasshoppers in North Dakota, with introduction

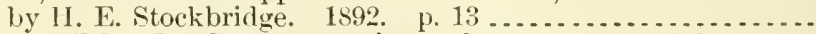

Walfinger, John F. Green manuring and manures. p. 299.......

Walker, J. B., farm of, Concord, N. H. 1870. p. $76 \ldots \ldots \ldots \ldots .$.

Walker, Philip:

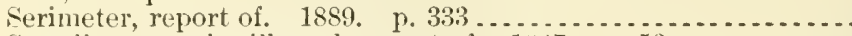
Serrell automatic silk reel, report of. 1887. 1. 52........... Silk eulture, report of year's operations. p.111 .............

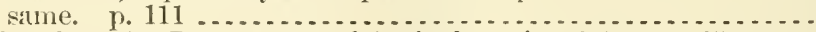
Silk culture by Department of Agriculture in 1887 . p. $115 \ldots \ldots$ Silk, raw, tenacity, elastieity, and ductility of. 1889 , p. $309 .$.

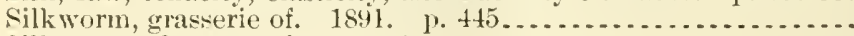

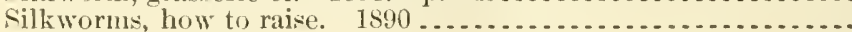
Theophila mandarina, history of, contribution to. 1889. p. 270.. See also, for reports as Chief, silk Section, Agrieulture Denart-

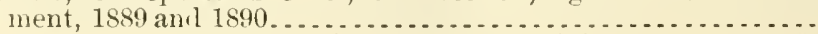

Wallace, Henry. Flax eulture in Ireland and Belgium. 1892. p. 47.
A:4.6:2:27

A $1.3: 1$

A $9.3: 4$

A1.1:878

11.6:12

A 10.6:9

A10.6:4

127.9:14

A 27.9:28

A27.8:4

A27.8:2:

A27.9:5

A 27.9:5

A27.9:13

A8.1:3

A 10.6:7

A1.8:52

A 10.3:29

A 10.3: 89

A10.3:117

A10.3:53

A $1.10: 895$

A $28.5: 7$

A 1.10:895

A 1.10:100

A28.5:7

128.5:7

A28.3:5

A1.10:898

A28.3:26

A29.3:112

A9.3:27

A 1.1:86t

A27.9:8

A9.7:1

A9.3:14

A 1.1:888

A9.1:858

A1.1:857

A9.7:1

A9.7:3

A25.3:1

A9.7:1

A25.1:

A 11.5:- 
Wallace, Paul. Silk culture, alstract of note on. 1891. p. 64.....
Wallace, Shippen. See, ats collaburator, Wiley, Harvey Wakington.

Waller, Osmar L.:

Engineering-degree courses, four-year, what shall be the character of preparatory work required to enter? 1899. 1. $75 \ldots . . . .$. Irrigation in-

Wrashington State, mse of water in 1901. 1902. p. $191 \ldots . .$. Yakima Valley, Wash., use of water in. 1902. p. $241 \ldots . . .$. Wallis, H. Sowerby. Rainfall and cliarts of rainfall. 1902. 1).228.

Walnut spanworm, report on (Coquillett). 1897. 1), 64..........

Walnuts. See English walnuts.

Walsh, Benjamin Dam, more important entomological writings of, bibliography of (Henshaw).

Walsh, Benjanin Dann, and Riley, Charles Valentine, nore important joint entomologieal writings of bibliography of (Hen-

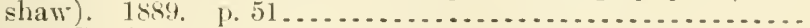

Walsh, II. C. St. Louis tomado, origin of. 18,7, p. $30 . \ldots . . .$. Thalsingham, Lorl:

Argyresthia, notes on, with descriptions of new species. 1890.

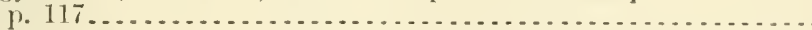

Chamber's index of Tineina of $[$. S. and Canada, steps toward a revision of, with notes and descriptions of new species-

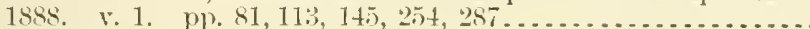
$1889-90$. ․ 2 . ‥ $23,51,7 \%, 116,100,284,322 \ldots \ldots \ldots \ldots$

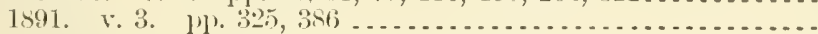

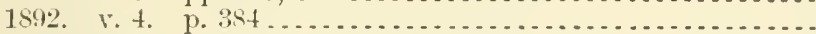
Tortricic, new, from California, description of. 1891. [1. 465... Waltemath's (George), moon, notes on (lbbe), 1898. p. $19 \ldots \ldots$ Walz, Ferdinand J,:

Chicago weather forecast district, monthly report of, Apr., July,

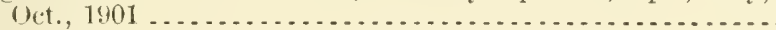

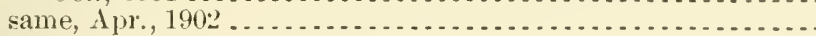

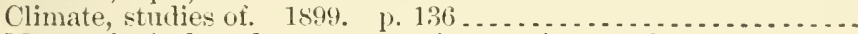
Meteorological and (rop) reporting stations, voluntary. 1898.

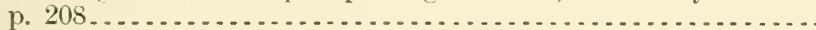

Temperatures, study of, at Baltimore, Mi. 1899. 1. $293 \ldots . .$. Weather Bureau anil the public, relations between. 1899. 1. 12. Weather forecasts, general and local, relation between. 1902.

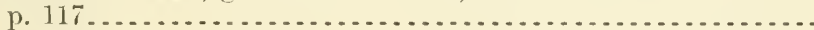

Wamer, William D. American dried apples in Cologne. 1895. p. 14. Wappenhans, C. F. R., slort biography of (Williams). 1902. p. 87.

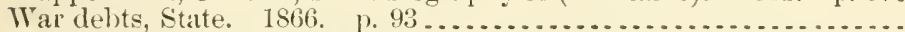
Warbles in cattle. See Cattle.

$W^{r}$ ard, Edward G., jr. Railroad freight elassitications, changes in, 1900

Ward, Edward G., jr., ano Holmes, Eiwin s., jr. Girden truck, rates of charge for transporting, with notes on growth of the industry. 1901

Warl, H. Marshal. Sinut fungi, report on. 1889 , p. $87 \ldots \ldots . .$.

Ward, Robert De Courey:

Barograph curve, winter, from South Pacific ocean. 1897. p. 484.

Clouds, cumulus, over a fire, observation of. $1898, \quad$ p. 104.....

Ieteorological station, highest, in world, visit to. 1898. p. 150 .

Thunderstorms in New Englanr, investigation of. 1893. p. 30.

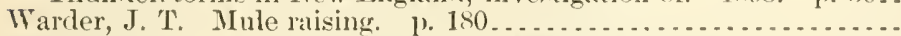

Warter, Jno. A. See, as joint author, Moorheal, J. K.

Warter, Robert B. Plosphoric ateid, revertel, remarks on, ISs9.

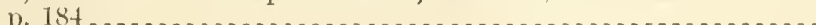

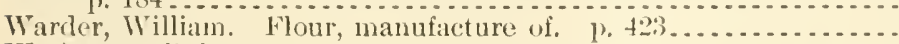
Warington, Robert:

Nitric acicl in soils, determination of, by Schloesing's methorl, at

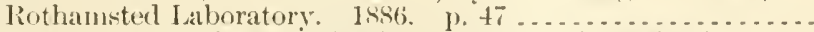

Rothamster Experimental Station, England, investigutions at, six leetures on, lelivered under provisions of Law Agrinultural Trust. $189^{\circ}$.

Warm wave:

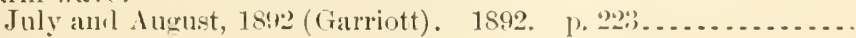

Clasifficatlou no.

A9.7:4

A10.3:65

A 10.3:119

A 10.3:104

A29.6:30

A9.6:7

19.2: $\mathrm{BH}^{-13}$

19.2:B+7 1.3

129.6:25

A $4.7: 3$

A9.7:1

A $9.7: 2$

A $9.7: 3$

A. $7: 4$

A4. 7:3

A:9.6:-2

A $29.6: 24$

A $29.6: 30$

129.3:24

A $29.6: 26$

A $29.6: 27$

A29.3:24

A2().3:31

1 7.3:48

A $29.6: 30$

A27.9:4

127.4:12

127.8:21

A28.5:5

129.6:25

A: $29.6: 26$

A29.6:26

12!).3:?

A 1. 1:86\%

17.3:24

11. $1: 862$

17.3:11

$110.3: 6$

12:9.6:20 
Warm wave-Continued

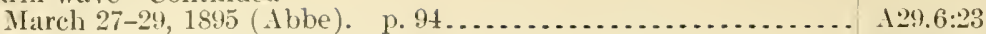

Washed soils; how to prevent and reclaim them. $1894 \ldots . . . \ldots \ldots . . .11 .9: 20$

Washes, tice San Jose seale.

Washington, D. C.:

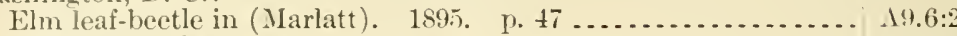

Graduate study at-

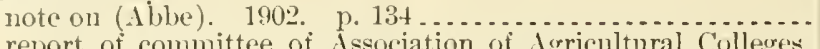
report of committee of Association of Agricultural Colleges
and Experiment Stations un. 1898. p. $58 . . . . . . .$.

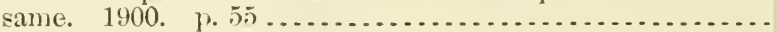

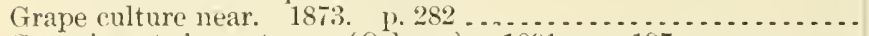

Grass insects in, notes on (Osborn) 1891. P. 197 ..........

Hot summers and cold winters at, $1872-98$ (Gillam). P. $456 \ldots$.
Optical phenomena at, Feb. 13,1895 (Abbe). p. 56 .........

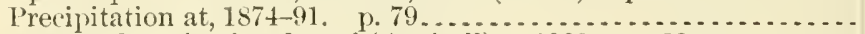

Sewage cleposit of, value of (Antiseli). 1869. P. 228 .........

Thunderstorms near, report on (Cragin and Cragin). 1900. p.

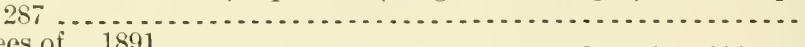

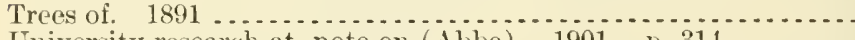

University research at, note on (Abbe). 1901. p. 314.........

Wincl-rush at, Sept. 29, 1896 (IIazen). p. 322................

See also District of Columbia.

Washington, Mount, fluctuations of temperature and pressure at base and summit of (Hazen). 1891. pp. 171, 199, 224, 250.......

Washington State:

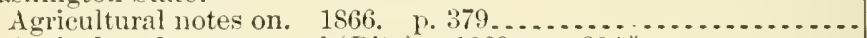

Agricultural resources of (Ritz). 1869 . p. $384^{*} \ldots \ldots \ldots \ldots \ldots$

Agriculture in, statisties of (Simmons). 1869 . p. 370 ..........

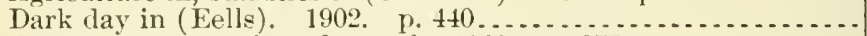

Farm resources and products of. 1868 . p. 277 ...............

Farmers' institute work accomp,ished in (Spillman). 1902. p. 43.

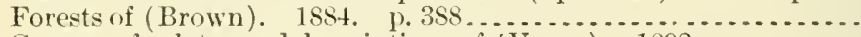

Grasses of, plates and descriptions of (Vasey). $1892 \ldots \ldots \ldots \ldots$

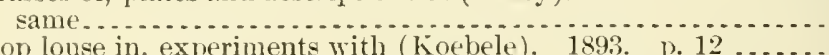

Hop louse in, experiments with (Koebele). $1893 . \quad$ P. $12 \ldots \ldots .$.
Irrigation in, use of water in, 1901 (Waller). $1902 . \quad$ p. 191 ....

Irrigation in eastern part, in 1890 (Nimmo). p. 149 ............

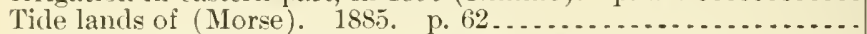

Weather forecasts for, notes on, $1895-99$ ( $\mathrm{A}$ bbe) p. 313 - Yakima
See also Pacific North west-Rainier, Mount - Spokane - Yakima Valley.

Washington University testing laboratory, St. Louis, Mo., mechanical tests of woods made at (Jolnnson). 1843. p. 3 .........

Washita County, Okla., quarantine order for, A ur. 4 , $1899 . \ldots . . . .$.

Washouts, warnings of, for benefit of transportation companies (Snith). 1899. p. 37

Same (Outram). 1899.

Wasp. Se Digger-wasp - Paper-making wasp.

Waster of London, method of disposing of (1lanning). 1572. p. 379.

See also Sewage.

Water:

Arlministration in Ctah (Gemmell). 1902. p. 159

Alkali, salt content of, instructions for determining in fieli (Whitney) .

Amity Canal, Colorado, duty under (Berry) 1900 p. 159

Atmospheric refractions at surface of (Abje), 1896, p. 371 ....

Big Cottonwood Creek, [tah, duty of, 1899 (Gemmell). p. 197 . same, 1900 (fiemmell). p. 165

Boise Valley, Irlaho, duty of, as relater to irrigation problems of

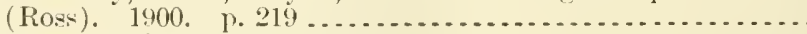

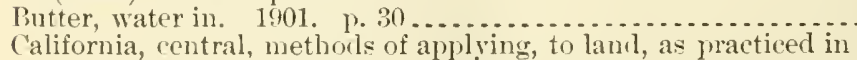

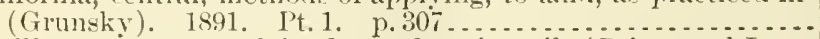

Capillary movement of, in dry and moist soils (Briggs and Lapham). 1902.

* By a misprint, this page number appears twice.

A9.7:4

A29.6:26

A29.6:23

129.6:20

127.9:7

A29.6:28

A13.2:T71

A29.6:29

A $29.6: 24$

A29.6:19

A27.9:4

A27.9:7

A27.9:7

A 29.6:30

A27.9:6

A 10.3:120

A $13.5: 4$

A6.2: ${\mathrm{N} 82^{2}}^{2}$

A 6.3:13

A 9.7:6

A 10.3:119

A 15.2:P94 ${ }^{1}$

A 1.7:7

A $29.6: 27$

A13.3:8

$1+.5: 42$

129.3:2t

A29.3:24

A27.9:10

A10.3:104

A26.4:6

A $10.3: 86$

A $29.6: 24$

110.3:86

A 10.3:104

A 10.3:86

A1.9:133

A 15.2: $\operatorname{Ir}^{2}{ }^{2}$

A26.3:19 
Destitute region (Curtiss). p. 230

Distillerl, for (lrinking purposes (Beal). 1901. J.

Drinking, protection of, on farm (Smith). 1896............. $11.9: 4$ ?

Duty of, general instruetions to observers (1lead). 1899 ........ A10.8:2

Evaporation of, from soils, salts ats influeneing rate of (Briggs). $1900 . \quad$ p. 184

Factor in the growth of plant: (Galloway and Woods). $18 \% 4$.

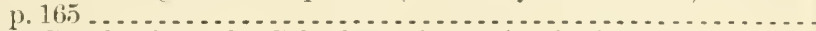
Gage Canal, Riverside, Cal., duty of, 1900 (lrving). 1902. p. 137.

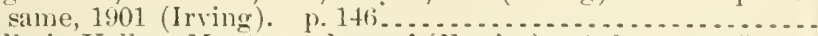

Gallatin Valley, Montana, duty of (Fortier). 1900. P. $175 \ldots$. Higheffect of gales in causing (Alule) 1894 . I. 297 . . . . . . . .

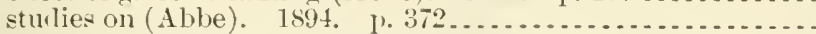

Hot, frost protection by, note on (Ab) e). 1900. p. $110 \ldots \ldots$.

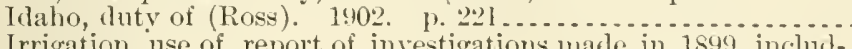
Irrigation, use of, report of investigations made in 1899 , inclurl-
ing reports of special agents and observers. $1900 \ldots . . . .$. Kings River, Cal., appropriation ((irunsky). 1901. p. 259 .... Lake, temperature of (Abbe). 1898. p. $167 \ldots . . . . . . . . .$. Laramie Plains, Wyo., (luty of, $18: 9$ (Fairfield). 1902 . p. $215 .$. Level of-

fluctuation of-

Great Lakes (Guthrie). 1896. p. 420 .............. Lake Erie (Henry). 1902........................... in Great Salt Lake (Gilbert). 1901. p. $23 \ldots \ldots \ldots \ldots$

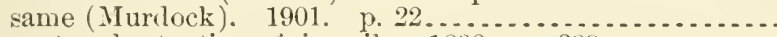
Movement and retention of, in soils. 1898. p. $399 . . . . . . . .$. Nebraska, duty of (Stout). 1900 . p. 149 .................. Physiologieal rôle of, in plants (Gain). 1897. p. 3...........

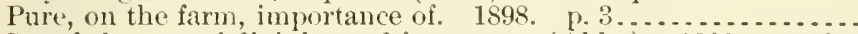
Search for, use of divining rod in, note on (Abbe). 1900, p. 109 Silpply of-

and irrigation in Mexieo. 1885. p. 223 notes on experience of other countries in administration of

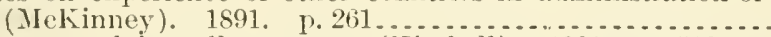
Temperature of, in wells, notes on (Kimball). 1901. 1, $510 \ldots$ Temperatures of Great Lakes (Conger). 1899 . p. $352 \ldots . . . . .$. Tule River Basin, Cal., duty of (Chandler). 1902. 1. $159 \ldots \ldots$. Use of, for irrigation at Wheatland, Wyo. (Johnston). 1402.

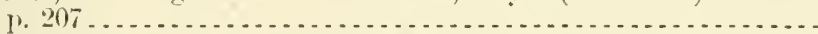

Vapor pressure for, notes on (Abie). 1899 p. 476 ...........

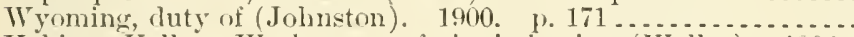
Yakima Valley, Wash., use of, in irrigation (Waller). 1902.

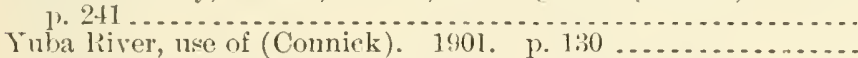

See also Drainage water - Irrigation - Phreatic waters - anil headings beginning Water.

Water-bearing gravels and formations tributary to undergromml water supply of Salinas Valley, Monterey Countr, ('al.

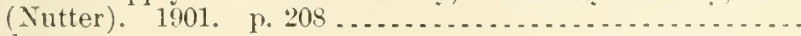

\section{Water bug:}

Found by J. I). Zabriskie, note on (lererroth), 18\%2, p. 321 ...

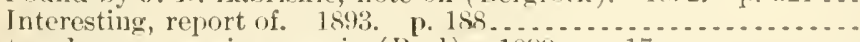

Water gliss, preserving eggrs in (Beal). 1894. 1, 17 ... . . . . . . .

Water hyaeinth ancl its relation to navigation in loricla (ivelober). 1897

Water laws:

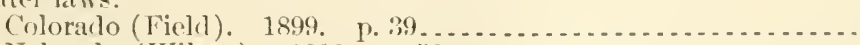

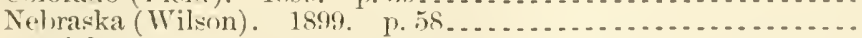

Water rights:

('inadian northwest irrigation aet (Dennis). 1901. P. 11..... interstate, in bear liver (Brekons). 1899. p.2ti.......... Irrigation and, alsstract of laws of States and Territories on (Critchett). 189? - . . . . . . . . . . . . . . . . . . . . . .

Los Angeles River, Cal., study of (Bogress). 1901. p. 327..... $110.3: 100$

A 29.6:23

A.29.5:J

A 29.6:29

A29.6:29

A1.10:898

A $10.3: 86$

A10.6:8

A1.9:73

A29.6:28

A15. $2: \operatorname{Ir}^{-1}$

A $15.2: \mathrm{P}^{4}{ }^{\mathrm{I}}$

A29.6:29

A 29.6:27

A10.3:119

A 10.3:104

1 $29.6: 27$

110.3:86

A10.3:104 A $10.8: 100$

A10.3:100

19.7:4

19.7:5

11.9:103

16.3:18

110.3:58

110.3:58

A10.3:96

$110.3: 70$

115.3:1 


\section{Inolex}

Water rights-Continued

Missouri River and tribntaries (Mearl). 1899.

Classifleation no.

l'rolılems of Bear River. 1899 . . . . . . . . . . . . . .

Yuba River, Cal., features and (Manson), 1901. p. 115....... See also Mead, Elwood.

Water-rotting hemp. Sice Hemp.

Trater storage, problems of, on torrential streams of Southern California as typified by sweetwater and san Jacinto rivers

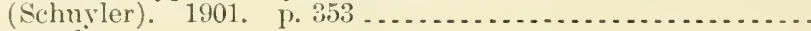

Water supply:

Bear liver and its diversion (Johnston). 1899. p. $9 \ldots \ldots . . . .$. Conservative lumbering, and (fiscussion of (Newell). 1901. p. :3.

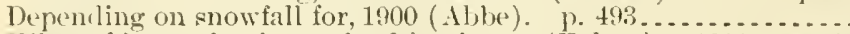
Effect of forest clearing and cultivation on (Fulton). 1899. 1. 89.

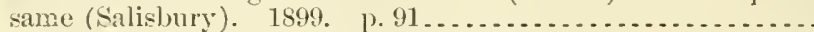

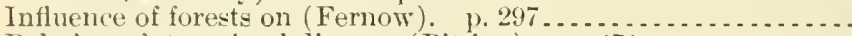

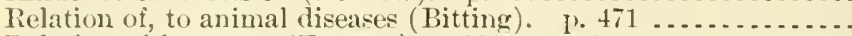
Relation of forests to (Fernow). 1893. p. $123 \ldots . . . . . . .$.

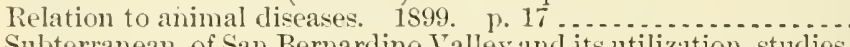
Subterranean, of San Bernardino Talley and its utilization, studies
of (Hilgard). 1902. p. $103 \ldots \ldots \ldots \ldots \ldots \ldots \ldots \ldots \ldots \ldots \ldots \ldots$

See also Water.

Waterhouse, Sylyester:

Abutilon avicennre in New Jersey, cultivation of, letter relative to. p. 606

Jute culture-

importance of the industry. 1883

national importance, ete. p. 289

TTatermelon, wilt disease of (Smith)

Waters, H. J.:

Agricultural colleges, what should be taught at? 1896 . p. 73 .

Irrigation experiments at Missouri Experiment Station, 1901.

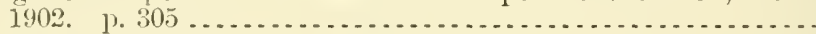

Waterspouts:

Cape May, N. J. 1902. p. 487.

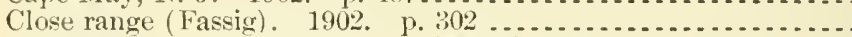
Cloudburst, or tornado, note on (Abbe). 1897. p. $207 \ldots \ldots$.

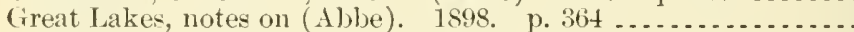

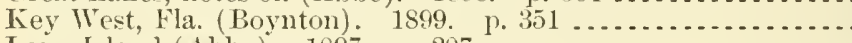
Long Island (Abbe). 1897. p. 207....................

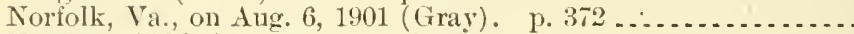

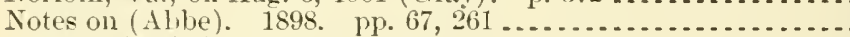

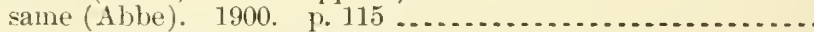

San Diego, report on (Carpenter). 1898. p. $545 \ldots . . . . . . . . .$.

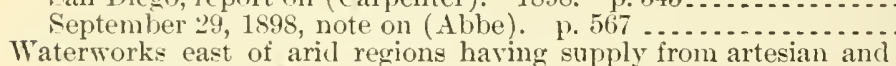
unclerflow sources. 1591. pt. 1., p. 433.

110.3:5̄S

A10.3:70

A $10.3: 100$

110.3:100

A 10.3: 70

A13.3:30

A29.6:28

129.3:24

A29.3:24

A13.1:889

A $4.1: 899$

A13.3:7

A1.9:97

110.3:119

A1.1:878

A1.8:30

11.1: $5 \% 6$

A27.9:8

A:8.3:17

110.3:41

A10.3:119

A29.6:30

A29.6:30

+29.6:25

A29.6:26

A29.6:27

129.6:25

A29.6:29

A29.6:26

A29.6:28

A29.6:26

A 29.6:26

Watkins, James L.:

Cotton-

American, future demand for. 1901. p. 193 ...............

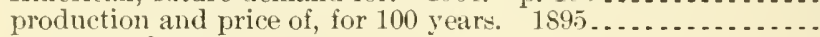

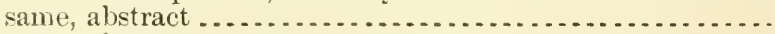

Cotton ('rop of-

189.5

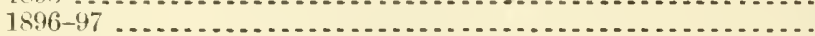

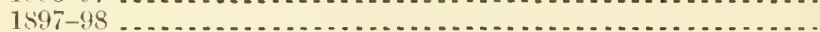

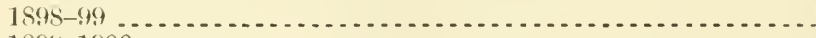

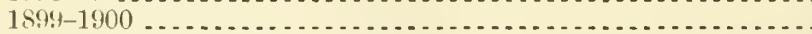

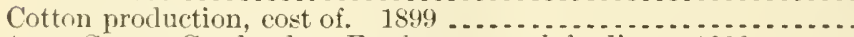

Watson, George Catchpole. Fowls, care and feeding. 1896.......

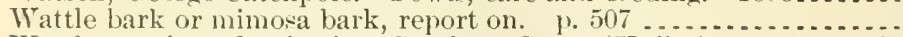

Wrattle tree, introduction into Southem States (Keffer). 1895. p. 19.

A15.2: $\operatorname{Ir}^{2}$

A1.10:901

A27.8:9

A $27.8^{\mathrm{a}}: \mathrm{C} 82$

A.27.4:4

A.7.9:35

A $27.4: 9$

A $27.8: 17$

127.8:19

A27.8:16

A 1.9:41

11.1:878

\13.3:11

Watts, Frederick:

Address at -

Minnesota State Fair, St. Paul, 1572. p. 347.

Philadelphia, Pa., July 4,1875 , at loreaking ground for erec-

A $27.9: 10$

tion of Agricultural Hall for the Centennial. p. 440.

127.9:13 
Wratts, Frederick-Contimned

Agricultural implements. $1872 . \quad$ p. 352................... A27.9:10

- Appointment of, as Commissioner of Agriculture. 16ī. 3. 25ั5. A27.9:9

Blackleg among cattle, letter on. 1874. p. $157 \ldots \ldots \ldots \ldots \ldots$ A27.9:12

Cotton-

American, deterioration of. 1873. p. 253.

$127.9: 11$

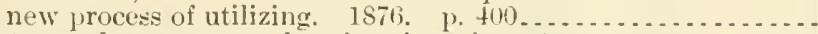

Cotton and sugar cane, deterioration of. 187:. y. 211 .......

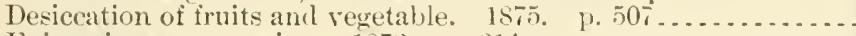

Epizootics among swine. 187". p. 214 ...................

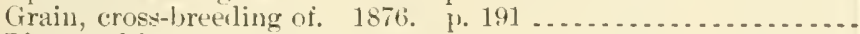

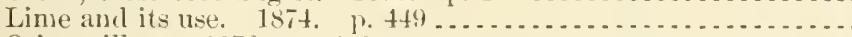

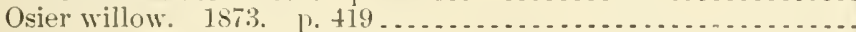

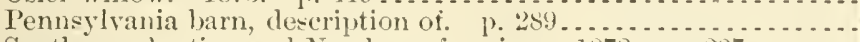

Southern planting and Northern farming. 1872. p. $207 \ldots \ldots .$.

Wheat, cultivation and hybridizing of. I872. p. 432........

See also, for reports as Commissioner of 1 grieulture, $1871-187 t ; .$.

Watts, Harvey Maitland:

Gulf Streain myth, report on. 1900. p. 393

Public and weather forecaster; read before convention of $\mathrm{T}^{2}$ ather

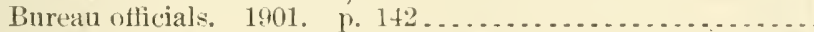

Remarks of, at second convention of Weather Bureau oflicials,

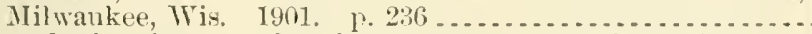

Tornado, hurricane, and cyclone, report on. 1899. p. $307 . . .$.

Teather forecaster and newspaper; read before convention of

Weathor Bureau ofticials. 1901

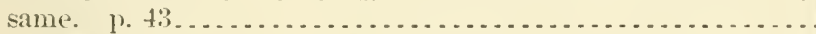

Watts, J. Wash. Sheep husbandry in South Carolina, teorria, and

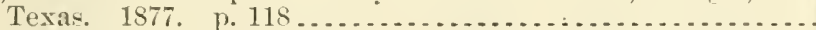

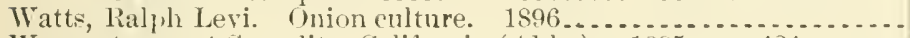

Wave, storm, at Sausalito, California (Abbe). 1595. 1. 424 ..... Wares:

Lake level pressure, sudılen oscillations in (Henry). 189?. p.305

Storm, on Great Lakes and ocean (Abbe). 1595. p. 3t1 . . . . . see rilso Cold waves.

Wax. See Bees.

Weasels of North America, synopsis of (Merriam). 1896

IV eather:

August, on Pacific coast, notes on (Abbe). 1899. p. 421

Bulletins of laily, publication of (foott). $18.44,6 \ldots$

Cablegrams from Azores relative to, note on (Ahbe). 1900. p. 253

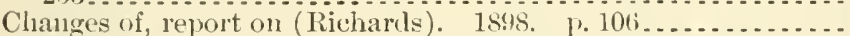

Characteristics of the, monthly notes on, July, 1891-May, $1895 .$.

Climate v's., note on (Abbe). 1899. p. 62 ..................

Coldblessing of (Abbe). 1899 p. $63 \ldots \ldots \ldots \ldots \ldots \ldots \ldots \ldots$
in March in Maryland, records of, $1823-94$ (Aeworth). p. 126.

Conduct and, report on (Dexter). 1899. p. $353 \ldots . . . . . . .$.

Correlation of, in distant localities, notes on (Abbe). 1900. p. 5ist.

Dairy and, note on (Abbe). 1899. p. 475 ................

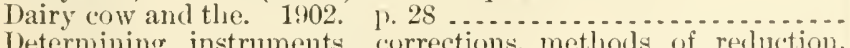

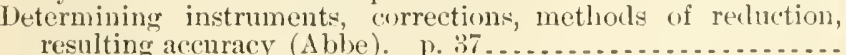

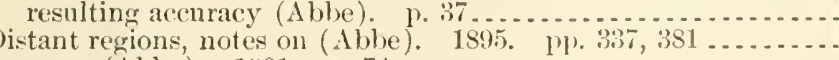

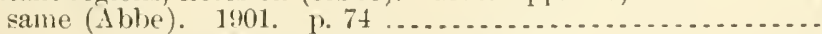

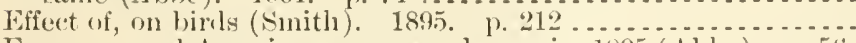
European and American correspondences in, 1895 (Abbe). P. 56 . Hot, of August, 1900 (Henry). p. 333. . . . . . . . . . . . . . . Insects and, luring season of 1899 (Chittenden). p. 51 .......

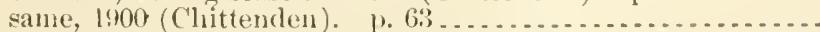

Live stock industry and, report on (Brandenbura), 1900. p.588.

Malta during Oetober, 1898 (Grout). 1.54t . . . . . . . . . . . .

Mauritius sugar (rop :und, 18s0-96 (1bhe). 1. 412...........

Monthly notes on, June, 1868 , to Jan., 1872 ... . . . . . . . . . .

Montly ly statement of average conditions ofAugust, 1898 (Abbe). p. 342.

A $27.9: 14$

A $27.9: 10$

A $27.9: 13$

A27.9:10

A $27.9: 14$

A $27.9: 12$

A $27.9: 11$

A1.1:86t

A $27.9: 10$

A $27.9: 10$

A 1.1:

129.6:28

A $29.3: 31$

A 29.3::1

129.6:27

A29.2:156

1.29.3:31

A1.2:Shy

A1.9:39

A $29.6: 23$

A $29.6: 27$

A29.6:28

A5.5:11

A $29.6: 27$

129.3:11 1

A 29.6:28

A $29.6: 26$

129.6:

129.6:27

A29.6:27

1 $29.6: 22$

A29.6:27

129.6:28

A29.6:27

11.9:149

129.1:891 3

A29.6:28

A29.6:20

A29.6:2:3

1:9.6:23

A29.6.28

19.6:2:3

19.6:30

1:9.6:27

129.6:26

1.9.6:26

127.9:

1:29.6:28 
Weather-Continued

Ionthly statement of arerage conditions of-Continued

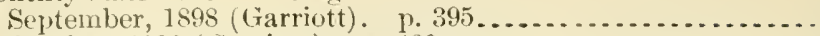

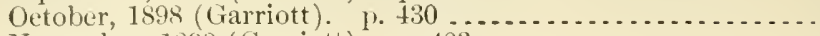

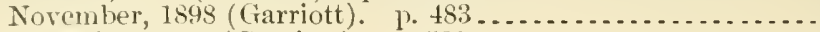

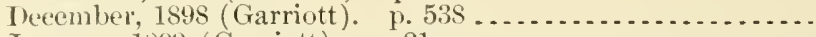

Jannary, 1899 (Garriott). 10. 21.

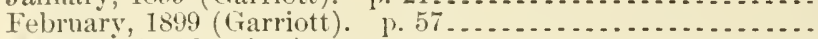

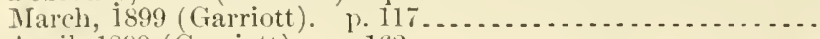

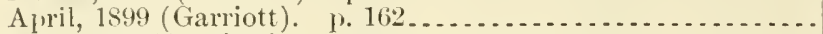

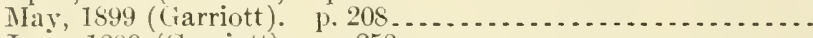

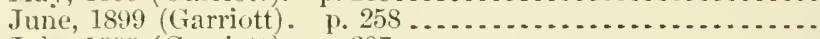

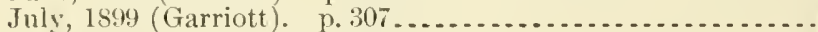

See also Weather of the month.

ILon and, note on, relation of-

1891 (Meech). p. 372

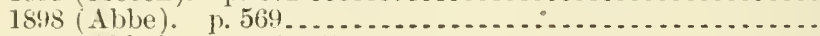

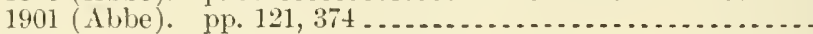

Notes on-

1895. p. 554

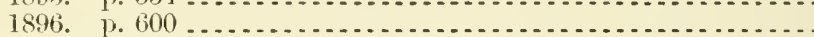

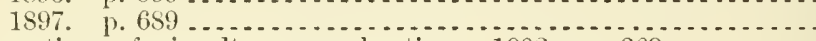

Operations of, simultaneous, charting. 1902. p. $369 \ldots \ldots \ldots . .$.

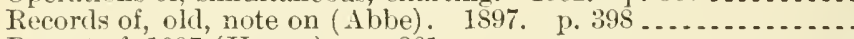

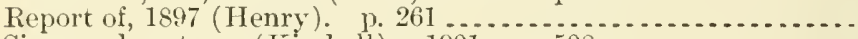

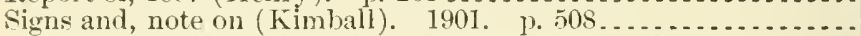

Study of sky polarization with reference to (Schultz). 1902. p. 28. Sun spots and-

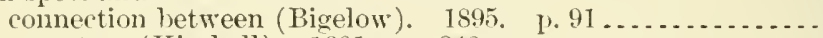

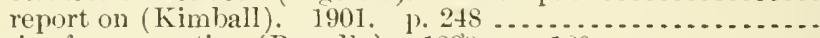

Topic of conversation (Brendle). 1899. p. $160 \ldots \ldots \ldots \ldots \ldots \ldots$

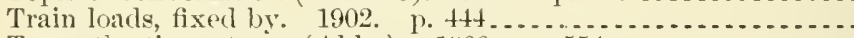

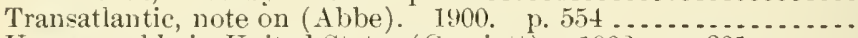

Unseasonable in United States (Garriott). 1902. p. $301 . . . . .$.

see also Barometer - Meteorology - summer - Warm wave Winter.

Weather and crop conditions:

1891. (Dunwoorly). 1. 586.

same, p. $586 \ldots . .6 .6$.

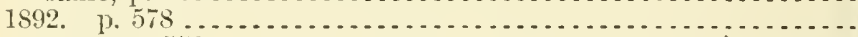
same, 1). 5 זे

1893. p. 113

same, p. 113

1894. (Dnmwoody). p. $529 . \ldots \ldots \ldots$

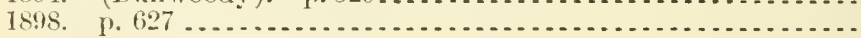

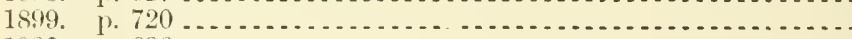

1900. p. $696 \ldots \ldots \ldots \ldots$

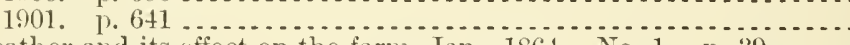

Weather and its effect on the farm, Jan., 1864 . No. 1. p. $39 . .$.

Weather Bureau:

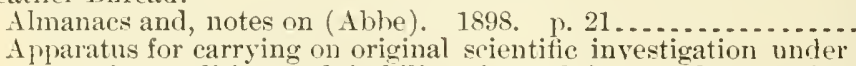
certain conditions, adrisability of supplying employees with

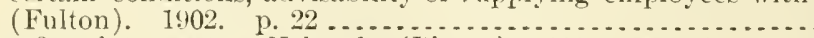

Benefits of, to western Tebraska (Piercy). 1899. p. 144......

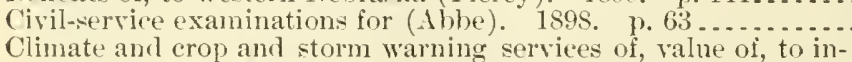
dustries of Cuba and other islands of West Inrlies (Hayes).

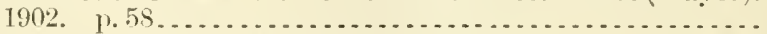

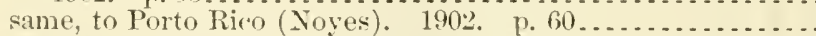

Climate and crop service of, how many climate and crop correspondents are required to meet fully the needs of? (Allen).

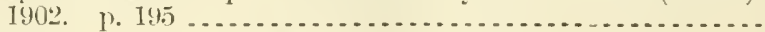

Commerce on Great Lakes and, note on ( 1 bbe $)$ 1900. p. $17 \ldots .$. Cooperation of, with agricultural experiment stations, report of committee on (IIaris). 1893.10 .106$.

Expenditures of Signal service ant, statements of .

A29.6:28

A 29.6:28

129.6:28

A $29.6: 28$

A29.6:29

129.6:29

A:9.6:29

A:9.6:29

129.6:29

+29.6:29

129.6:29

A29.6:29

129.6:26

+29.6:29

A1.10:895

A1.10:896

A1.10:897

A29.6:30

129.6:25

129.1:898

A29.6:29

A29.3:31

129.6:23

129.6:29

129.3:24

129.6:30

$+29.6: 28$
+

A $9.6: 30$

A 1.1:891

A29.1:8912

A1.1:892

+29.1:892

1 1.1:893

A29.1:893 1

A1.10:894

A1.10:898

\1.10:899

A $1.10: 900$

A 1. 10:901

A $27.9: 2$

A29.6:26

129.3:31

129.3:24

1:29.6:26

A29.3:31

+29.3:31

129.3:31

A29.6:28

A 10.3:16

129.2:Si2 


\section{Index}

Weather Bureau-Continued

Higher meteorology in (Bigelow). 1902, p. 19

Classiffeation no.

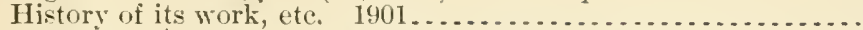

How it disseminates foreeasts and warnings (Calvert). 1896. p). xxii.

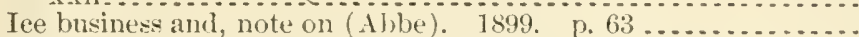

International cloud work of (Bigelow). 1599. p. $404 \ldots \ldots . .$.

International courtesy of ( Ibbe). 1899. p. 160.............

Libraries and, notes on (1bbe), 1898, p. 551 ..............

Library of-

monthly addition: to-

Apr.-Nov., 1897 (Smith) .

Dec., 189--1lareh, 1895 (Phillips)

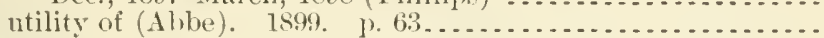

Night forecasts, is it alvisable to distribute by rural free deliverv?

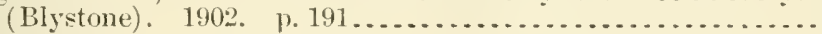

Observers-

stations of instruction for newly appointed, should not cortain important weather burean stations be designated? (Smith).

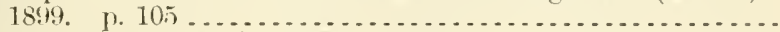

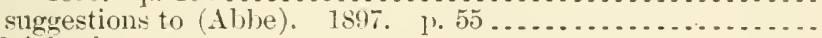

Officials of-

as instructors, notes on-

1900 (Abbe). p. 336.

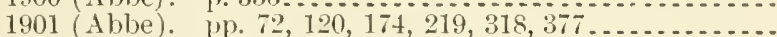

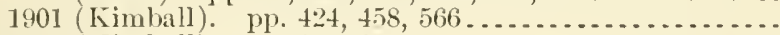

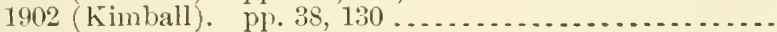

as instruetors in meteorologr, note on (Abbe)-

1900. p. 446

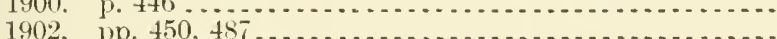

as university lecturers, notes on (Abbe)-

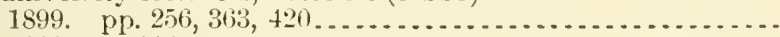

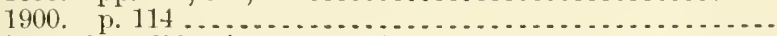
duties and qualifications (Pague). 1899. p. $170 \ldots . . . . . .$. lectures and instruction by, notes on (Ablue). 196)1. p. 25... Pan-American Exposition, exhibit of (Maring). -901. 1.259..

Paris Exposition, exhibit of, notes on (Able). 1400. p. 445...

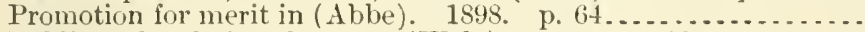

Public and, relations between ( $\mathrm{Walz}$ ). 1899. p. $12 \ldots \ldots . . . .$.

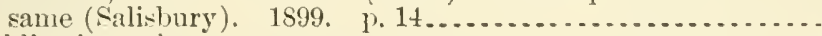

Publications of-

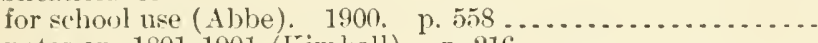

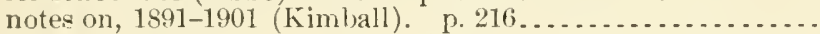

Records of, legal value of, note on (Abbe). 1900. p. 115......

Relation of, to Department of Agricnlture (Calvert). 1899. p. 54.

Relation of meteorological work of agricultural experiment stations and agricultural colleges to (Harrington). 1892. 1\% 42.

Report of (Moore). 1901. p. 595 .......................

Service in, career offered to young men (Nuinn). 1902. 1). $78 \ldots$

Signals of -

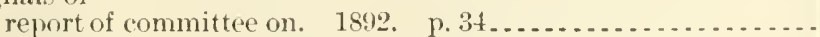

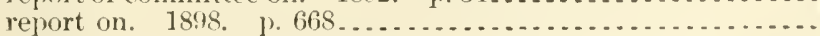
suggestions for inprovement of-

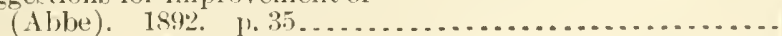

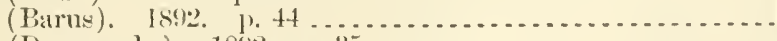

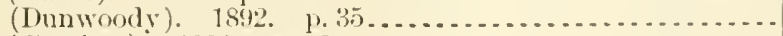

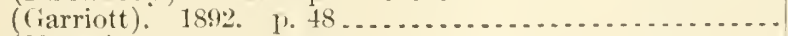

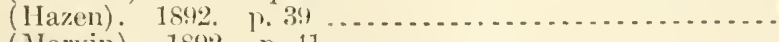

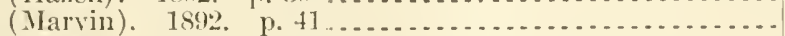

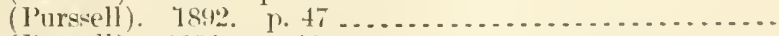

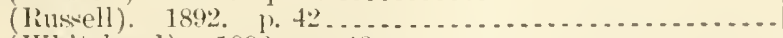

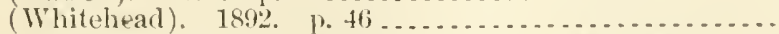

State sections of, notes from reports $(\Lambda])$ e). 1895. pl). 20,65 ,

Universities and colleges and, notes on ( $1 \mathrm{~b} b \mathrm{~b})$

189. 1. $56 \mathrm{~s}$

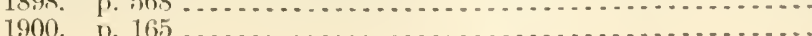

A 29.3:31

A:9.2:1137 1

A29.1:\$96

A 29.6:27

A29.6:27

A29.6:27

A:9.6:26

A $29.6: 25$

A29.6:

A $29.6: 27$

A29.3:31

A 29.3:24

A29.6:25

A29.6:28

A 29.6:29

A 29.6:29

A $29.6: 30$

A29.6:28

A29.6:30

A $29.6: 27$

A 29.6:28

A 29.3:24

A 29.6:29

A29.6:29

A $29.6: 28$

A29.6:26

129.3:24

129.3:24

A29.6:28

129.6:29

129.6:28

129.3:24

110.3:7

129.6:29

A29.3:31

129.3:7

1 1. 10:898

129.3:7

129.3:7

129.3:7

A $29.3: 7$

129.3:7

А $29.3: 7$

A29.3:7

129.3:7

1:99.3:7

A $29.6: 26$

A 99.6:26 1:9.6:28 
Weather Bureau-Continued

Voluntary observers-

examination of monthly meteorological reports of (Bauer).

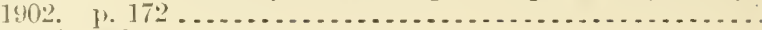

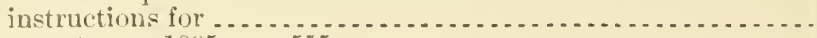

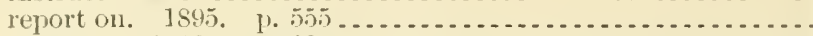

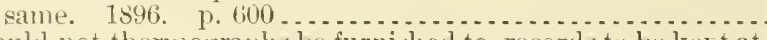

should not themographs be furnished to, records to be kept at

section centers? (ITollaber). 1902. p. 219.............

West Intia service, monthly reports of (Stockman). 1899. p. 194.

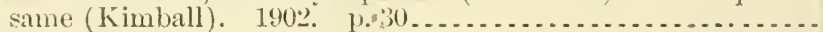

Work of -

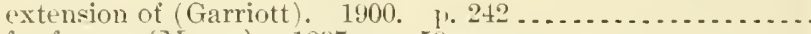

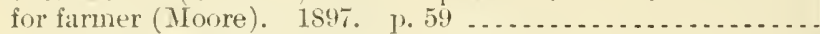

importance of static electricity in (Beals). 1896. p. 39 .....

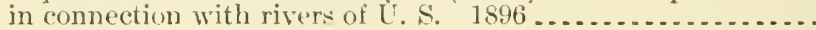

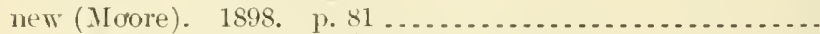

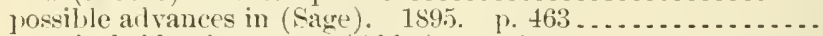
practical side of, note on (Abbe). 1898. 1. $551 \ldots . . . . . .$. present condition of, propositions for its improvement (Bel)-

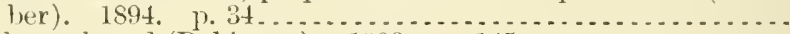
telegraph and (Robinson). 1902. p. 145................ . .

See also Alaska-Atlantic City-Climate and erop service-Inominica - Haiti - Jamaica - Japan - Klondike - New York City - Philippine Islands - State weather services - Weather Burean stations.

Weather Bureau instruments:

Care and use of (Marvin).

Description of (Marvin) -

1891. ए. 19

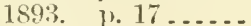

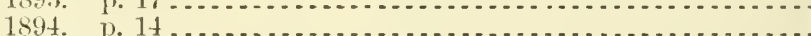

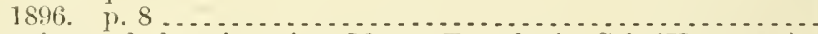

Iocation and elevation of, at Mount Tamalpais, Cal. (Hamnom).

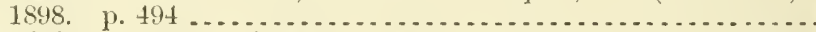

Obtaining and transeribin recorls from, instructions for. 1892 . Sholter for-

(Hazen). 1893. p. 29

(Pague). 1893. p.

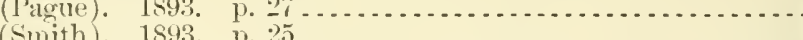

See rlso Anemometer - Barometer - Brontometer - Magnetic instruments-Marvin's weighing rain and snow gauge-Nephoscope - Pyrheliometer - Thermographs - Thermometers Wind barometer table- Wind vanes.

Weatluer Bureau kite:

Observations in 1898, preliminary results of (Abbe). p. 413....

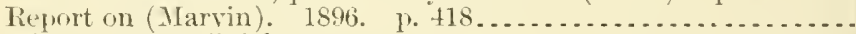

Weather Bureau officials:

First convention of, Omaha, Nebr., Oct. 13, 14, 1898, notes on

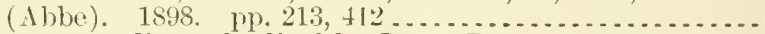

same, proceedings of, edited by James Berry $1899 \ldots . . . . .$. Second convention of, Milwankee, Wis., Aug. 27-29, 1901, notes on (Ahbe). 1901. pp. 25, $317 \ldots \ldots \ldots \ldots \ldots \ldots$

same, proceedings of, edlited by James Berry and W. F. R. Phillips. 1902

Weather Bureau signals. See Storm signals - Weather signals.

Weather Bureau stations:

Is exposure at, satisfactory for all instruments? (Outram). 1902.

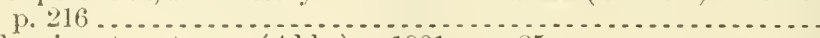

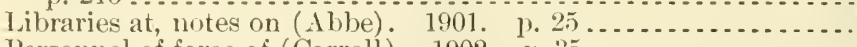

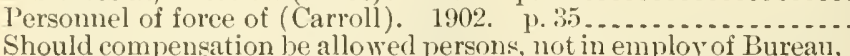

Should compensation be allowed persons, not in employ of Burean,
while learning station duties to enable them to properly perform snch duties in cases of emergency? (Cuthbertson).

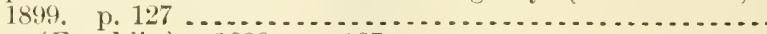

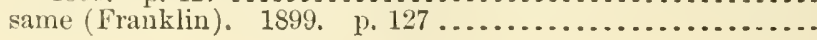

A29.3:31

129.12:1 188

A1.10:895

A $1.10: 896$

A29.3:31

A 29.6:27

A29.6:30

A 29.6:28

A 1.10:897

A 29.3:18

A 29.3:17

A 1. 10:898

A $29.6: 23$

+29.6:26

A29.3:11

129.3:31

$+29.11: \mathrm{F}$

A $29.1: 891^{3}$

A29.1:893 ${ }^{2}$

129.1:894

A29.1:896

A $29.6: 25$

129.11:1

A29.3:7

$+29.3: 7$

$129.3: 7$

129.6:27

A $29.6: 23$

A $29.6: 26$

A $29.3: 24$

A29.6:29

A 29.3:31

A29.3:31

A29.6:29

A29.3:31

A $29.3: 24$

A $29.3: 24$ 
Weather Bureau stations-Continuel

Work of, under existing conditions of is it practicalsle to require assistants to pursue a systematic course of meteorological study"?

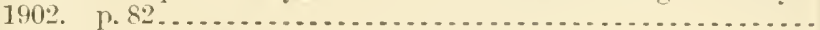

See also Tamalpais, Mount-Turks Island.

Veather chats, explanation of. 189:.

Weather corles. . . . . . . . . . . . . . . . . . . . . . . . . . . . . . . . . . .

Weather erop bulletin of southern (aliformia, listory of (Franklin).

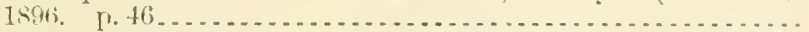

Weather forecast carls by rural delivery, note on (Able). 1900.

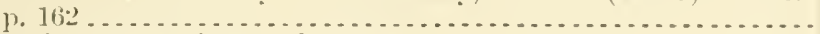

Weather iorecast stations, voluntar:

Object and collateral functions (Mitchell), 18.9. p. $140 \ldots \ldots$.

River and cotton belt, establishment and inspection of (Marbury). 1894. T. 150 .

Weather forecasterand new spaper; readbeforeconvention of 17 eather

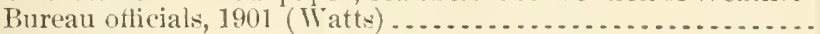

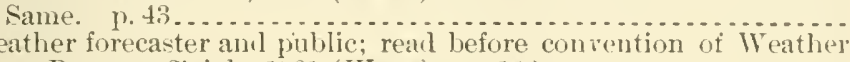

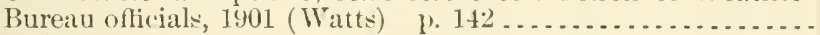

Weather forecasts:

Amplificition of (Henry). 1900. p. $107 \ldots \ldots \ldots \ldots \ldots . . . . .$.

Best calculated to aid maritime interests of Great I akes; methor of reaching those interested (Conger). 1899. . p. 20 .....

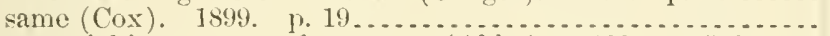

Commercial importance of, notes on (Abbe). 1900. p. $550 \ldots .$.

Distribution of -

by mail (Lyons). 1899. p. $161 \ldots \ldots \ldots \ldots \ldots \ldots \ldots \ldots \ldots$ methods of saving time in (Bły the). 1902. p. $203 \ldots . . . .$. should wording of forecasts be confined to vocabulary of present logotype outfit? is it advisable to extend vocabulary of present logotype outfit? (Chaffee). 1899. p. 48.

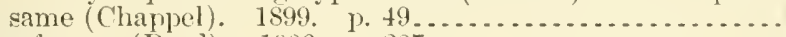

For the farmer (Reer). 1900. 1. $287 \ldots \ldots \ldots \ldots$ General and local, relation between (IValz), 1902. 1). $117 \ldots . .$.

Historical, practical, and theoretical facts. $1894 \ldots . . . . . . . . .$.

Hongkong (Doberck). 1899 p. 98 . . . . . . . . . . . . . .

Improving, double observation as a means of (Denson). 1902. p. 153.

Long-range-

can they he made with any degree of accuracy or profit?

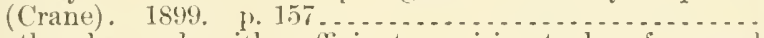
can they be made with sufficient precision to be of general utility?-

(Connor). 1899. p. 44.

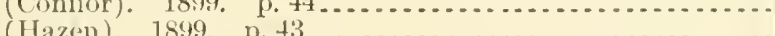

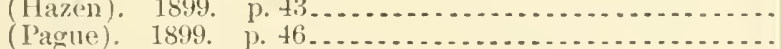

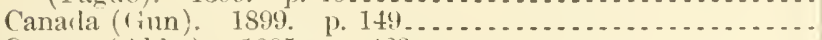

Oregon (Abhe). 1895. 1) $423 \ldots \ldots \ldots \ldots$

physical basis of (Abbe). 1901. p. $551 \ldots \ldots . . .2 . . .2$.

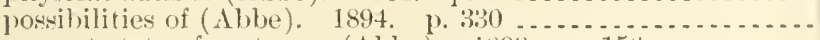
present state of, notes on (Abbe). I899. p. 156 ..........

Methods employed in distribution of (Berry). 1901. p. 14....

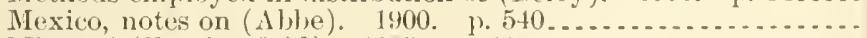

Missouri (Frankenfield). 1895. 1). 292.................

Monthly, notes on-

Oct., 1897-A pr., 189s (Dunwoody) . . . . . . . . . . . . . . . . .

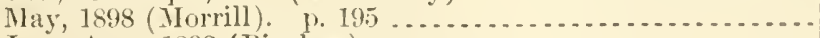

Jure-Aug., 1898 (Bigelow) . . . . . . . . . . . . . . . . . . . .

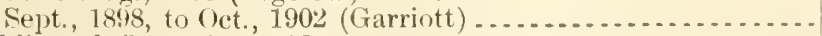

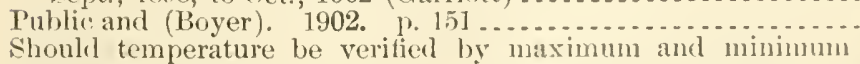

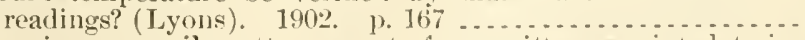

Stamping, on mail matter, report of commitlec appointerl to in-

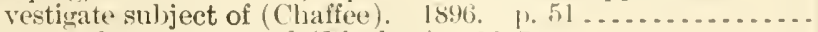

Storm tracks, storms, and (Bigelow). 1s! ............... classifleation no.

$129.3: 31$

A.2!1.2: $: 1133^{-2}$

129.2: $11^{3} 37^{-3}$

$1: 4 \cdot 3: 18$

1:39.6:28

A:3.3:24

A $24.3: 24$

A29.2:176

A $24.3: 31$

A:9.3:31

11.10:900

A 29.3:24

$129.3: 24$

1:9.6:28

129.3:24

A 29.3:31

$129.3: 24$

1.29.3:24

$129.6: 28$

A 29.3:31

A29.3:25

1.29.6:27

A:9.3:31

129.3:24

1 2().3:24

1:29:3:24

1:9.3:24

129.6:27

A29.6:2:3

1:29.6:2:3

$129.6: 222$

1.99.6:27

1.29.6::29

1:9.6:2:-8

A29.6:2:3

129.6:

124.6:26

$129.6: 20$

1:? ti:

1:9.3:31

129.3:31

$129.3: 18$

$129.3: 20$ 
Weather forecasts-Continued

Storm warnings and, how Weather Bureau disseminates (Calvert).

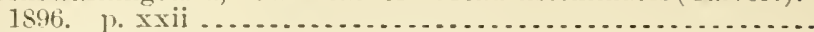

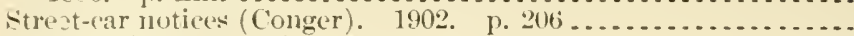
Talue of (Dunwoody). 1594. p. 121

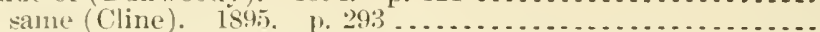
Talue of dew point in, under certain comditions (ivood). 1902.

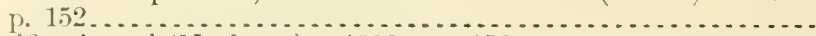

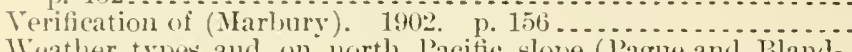
Weather types and, on north l'acific slope (l'ague and Bland-

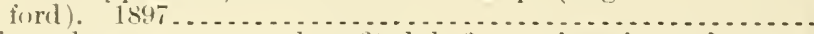

What classes are most benefited by? are they just what are needed? are thev properly disseminated and utilized? (Sage). 1899. p. 40..

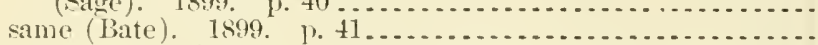

Would not postal card prove satisfactory substitute for map?

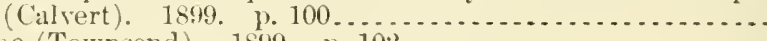
same (Townsend). 1899. p. 102. Sce ulso Semaquir.

Weather guide, Australian, notes on (Abbe). 1898. 1) $365 \ldots \ldots . .$. Weather map:

Daily-

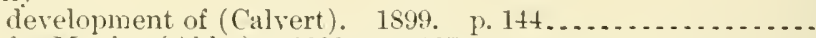

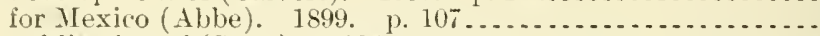

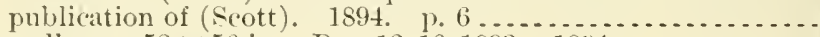
wall map, $52 \times 56$ in. Dec. 13-16, 1893. $1894 \ldots \ldots \ldots \ldots \ldots$.

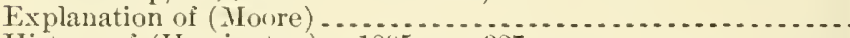
History of (Harrington) 1895 . p. 327

Is it appreciater and understood by the masses? would not postal card weather forecast prove satisfactory substitute

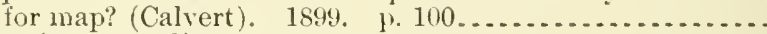

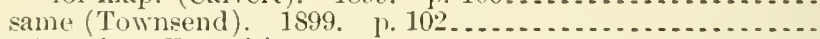

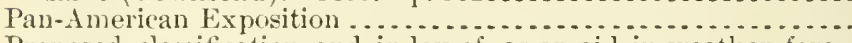

Proposed classification and index of, as an aid in weather fore-

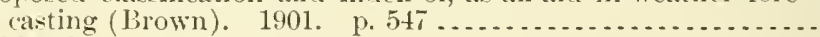

Table of ......................

Utility of isg9 107.6.

Weather observers:

Civil-service examinations for, in Cnited States Weather Burean

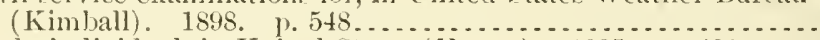
Early individual, in United States (Henry). 1895. p. 291..... Instructions for. 1895 .

Voluntary-

how best to secure and retain services of (Greenewald). 1896.

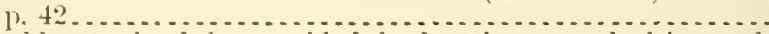

shonld not a book be provided for keeping record of issue of instruments and flags to? (Allen). 1899. p. $125 \ldots .$. same (Bronson). 1899. p. 126 ................... What a weather observer should know (Taylor). 189s, p. 543. Weather of the month:

Jan., 1898-June, 1900 (Henry).

July, 1900 (Day) . . . . . . . . . . . . . . . . . . . . . . . . . . .

Aug., 1900-June, 1901 (Ienry) ..........................

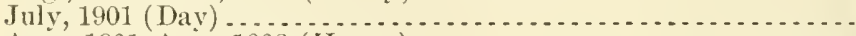

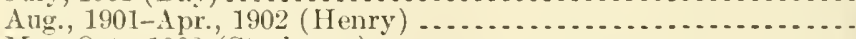

Mav-Oct., 1902 (Stockman) .................................

Classifleation no.

Chastion no.

A 29.1:896

A $29.3: 31$

A1.10:894

A29.6:23

A29.3:31

A29.3:31

129.2:I'11

A29.3:24

A29.3:24

A 29.3:2t

A29.3:24

A29.6:26

A29.3:24

A:9.6:27

129.3:11

A29.2: $1 \mathrm{~V}^{\mathrm{T}}{ }^{\mathrm{T}}$

A29.2:1137

A29.3:112

A29.3:31

A29.3:24

A $29.3: 24$

A29.2:P19

A29.6:29

A29.18:

A29.6:27

A29.6:26)

A29.3:112

A29.12:Ob7

429.3:18

A29.3:24

A $29.3: 24$

A29.6:26

A29.6:

A $29.6: 28$

A29.6:

A $29.6: 29$

A:9.6:

Sie also, Weather, monthly notes and statements.

Weather predictions:

Best method of testing (Köppen). 1894. p. 29 ............

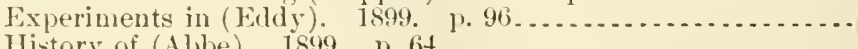

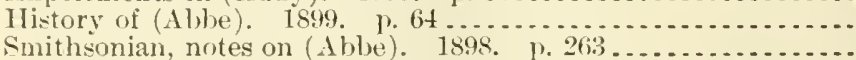

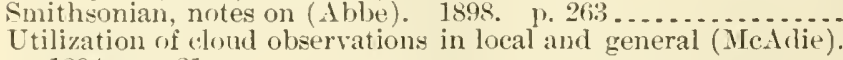

1894 . p. 21 ......................... 
Weather proverbs, mureliable popular, notes on (Able). 1s.66. p. 37t. Weather-recording instrunents, instructions for transcribine recorls from. 189:2

Weather revitw, monthly

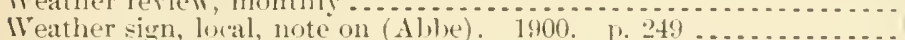

Weather signals:

International symbols recommended for use by meterorological

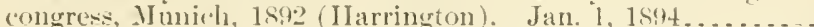

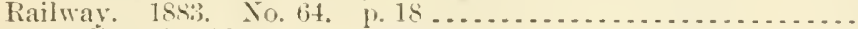

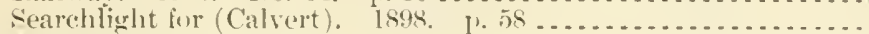

sie also storm signals.

Weather symbols on rual free-relivery wagrons (I'indell). 1902.

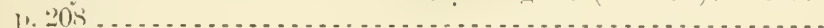

Weather telegraplyy:

Early history of (.1blye). 1895. p. 215.

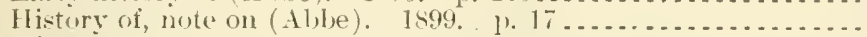

Weatlier types:

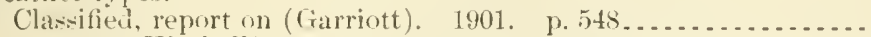

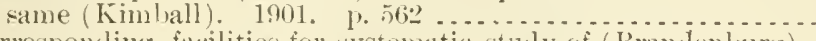

Corresponding, facilities for systematic study of (Brandenlurge).

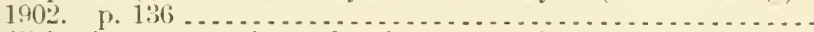

Facilities for systematic study of corresponding (Brandenlumrg).

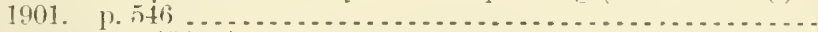

Ilavre, Mont. (Ling). 1898. 1. 410..................

North I'aeific slope (Pague). 1895. 1) 417 ..............

Weaver, Willis. Coffee, culture and habits of, p. $31 \ldots \ldots \ldots \ldots . .$.

Web-worm. See Corn-root web-worm - Juniper web-worm - l'arni[ web-worm - Privet web-worm - Sugar-beet web-worm.

IVebb, Wesley:

Delaware, farmers' institute work aceomplished in. 1902. p. 17 .

Sheep liusbandry in Delaware. 1883. 1. 172 ...............

Ilebber, B. ('. Gales, January, from Great Lakes to maritime

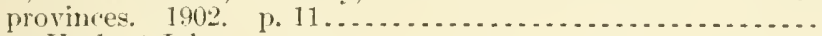

IVelober, Herlyert John:

Fertilization of soil as affecting orange in health and disease. 1894. 1) 1983

Freezes, two, of $1814-95$ in Floricia, and what they teach. p. 159.

Fungons parasite on Aleyrodes eitri R. \& II., preliminary notice

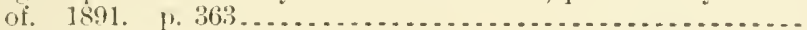

Orange and other citrus fruits, methods of propagating. 1896.

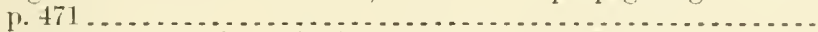

Pineapple inclustry in United States. 1895. p. $269 . \ldots . . . .$.

Plant varieties, influence of enviromment in origination of. 1896. p. 89

Plants, improvement of, liy selection. 1s9s. p. $355 \ldots \ldots \ldots$

Sooty mold of orangeaidl its treatment. 1897 treatuent of. 18 : 5

Water loweintl and its relation to mavionam in Florida 1897

Jenia, or immerliate effect of pollen in maize. $1900 \ldots . . . . . .$.

Kamia, spermatogenesis and fecumelation of. 1901 ...........

See (wso, as joint author, swingle, Walter Tenuyson.

Webber, Herbert Jolin, and Bessey, Jinst $A$. Plant breeding, pro-

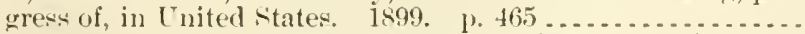

Webber, Ilerbert Joln, and Orton, II. A. Cowpess resistant to

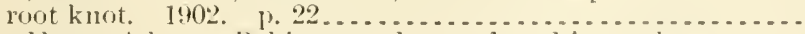

Weber, llenry Aclan. Baking powders as found in market, eompo-

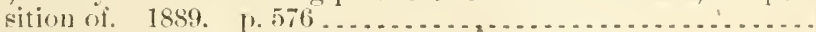

See also, as collahorator, Wiley, Harvey Washington.

Weber, Ilenry Adan, and Mcllierson, Willian. (ilucose, enmmerciat, cane sugar in presence of, report on determination of. 18:4. p. 120

Weber County, Itah, soil survey in (Garlner and Jusen). p. 207..

Webster, C. l:. Silkworm, Japanese oak-feerling, notes on cultiyation of. 1889. 1. 273 flasulfeation no.

$1: 9.6: 24$

1:9.11:1

1:21.63

$129.6: 28$

129.2:Ins

1:27.9:21

A29.6:26

1291.3:31

1:29.6:2:3

1.29.6:27

129.6:29)

129.6:29

A 29.3:31

A2!) $6: 29$

129.6:26

A:9.6:28

A 1.1:879

110.3:120

A1.7:2

A29.6:30

A 1. 10:894

A 1. 10:895

12:5.5:7

11. 10:896

11.10:895

A $1.10: 896$

A $1.10: 895$

A28.3:13

128.4:15

16.3:18

A28.3:22

A 19.3:2

A1.10:899

A 19.3:17

$17.3: 13^{5}$

17.3:4:

126.5:900 1

19.7:1 
Welster, Francis M.:

Arkansas and Texas, injurious and other inrects of, olservations

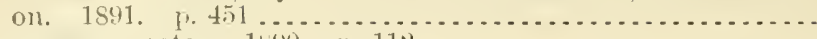

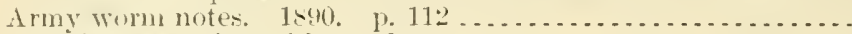

Arsenites, spraying with, rs. bees-

189:2. $\quad \mathrm{v} .5, \mathrm{j}, \mathrm{j}, 1: 1$

lsgt

Anstralia and Tasmania, injurions and bentelicial insectsof, notes

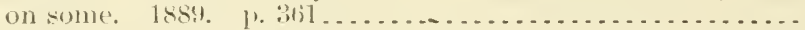

Bryolia, spereses, infesting dwellings, notes on. 18s9. ]. 27.

Buffalo gnats, or simmlinm-

infesting comutry adjacent to Mississipyi River. p. tiff......

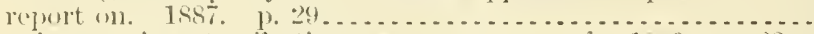

Cercal crops, insects affecting, report on some of. 1840. 1\%.63..

Chinch bue-

interesting outbreak of, in northern Ohio. 1s!9. p. 55 ... in Oliso, outbreak of, three years' study of. 1896. \%. 18.... its probable origin and diffision, its habits and tevelopment, natural cherks and remedial and preventive measures, with mention of hathits of allied Enrojean suecies. 1898 ......

Cimbex, American, arlults of, injuring willow and cottonwood in

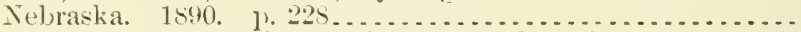

Clover hay-worm, Asopia costalis, somestudies of. 1891. 1. 121. Coccinellidae in conservatory, experiment with. 1890. 1). 363.. Corn, insects affecting, notes 11 on. 18!0. p. 159........... Corn bill-bugs, life history of one of 1889 , p. $132 \ldots \ldots \ldots \ldots$

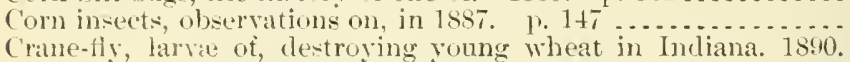
1. $12^{\circ}$..

Curculionirlat, hreeding ani other habits of some species of, especially of cenus Tylukerma, notes on. 1ss9. 1) 109 .........

Ehuria ynahimaculata, longevity of early stages of, notes upon.

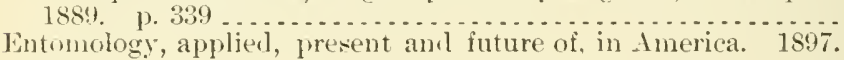

G. 5 . . . . . . . . . .

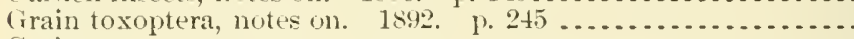
Grains-

American cereal, insect foes of, with measures for their pre-

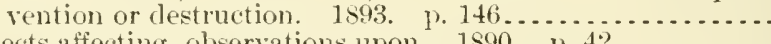
insects affecting, observations upon. 1890 . p. $42 \ldots \ldots \ldots .$.

Grains and grasses, small, inseets affecting. 1. 573 . . . . . . . . . Grasses, instets, which affect upper portion of stems of, notes on some. $1889 . \quad$ p. $372 \ldots$ of puncture of some, upon shrubs, fruits, aud grains, 1886.

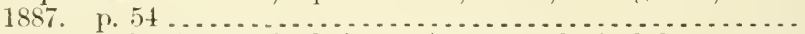

Insectary and office methods in use in entomological department of Ohio Agricultural Experiment Station, rejort on. 1899.

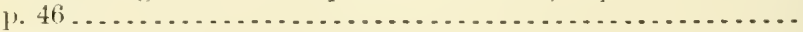

Insects-

destructive, inportation and repression of. 1895. p. $79 \ldots .$. injurions, early fublished reierences to snme of our. 1892. ("). 262,323 . . . . . . . . . . . . . . . . . . . . . . . .

Joint-worm attack, apparent, some features of. 1892. p. $89 . \ldots$ Limax campestris, fool of, further notes on. 1592. p. 128 .... Necrophacous diptera, notes on species of. 1890 . p. 356 ...... Ohio-

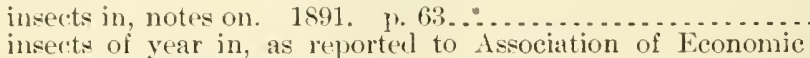
Entomologists-

189:3. ए. $186^{\circ}$

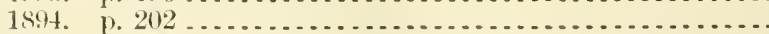

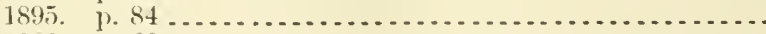

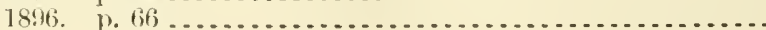

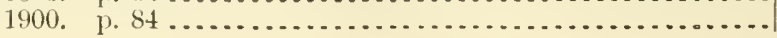

1!1. $7: 3$

$19.7: 3$

$19.7: 5$

A9.7:7

+9.7:1

A.9.7:1

14.1:8si -8

19.3:14

A9.3:29

19.6:20

19.6:6

$19.6: 15$

A9.7:2

A9.7:4

19.7:2

A9.7:3

A $9.7: 2$

A1.1:\$87

A. $7: 3$

19.7:2

19.7:1

A9.6:9

A $9.7: 3$

A9.7:4

A9.7:6

A9.3:22

A1.1:856

A9.7:1

A9.3:13

A.9. $6: 20$

A9.6:2

A9.7:4

A9.7:5

A9.7:5

A9.7:2

A $9.3: 26$

A9.7:6

A9.7:7

A9.6:2

A9.6:6

A9.6:26 
Webster, Francis M.-Continued

Plum curculio, experiments in rearing, from plums ami otlep fruits1585. 1. 19 18.10 I. 305

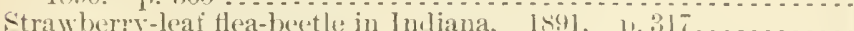

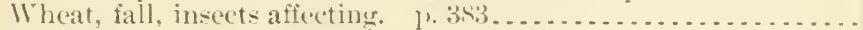

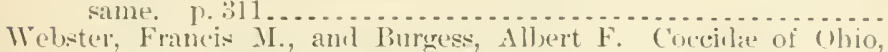

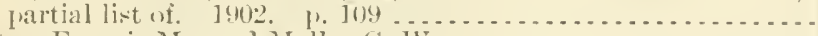

Webster, Francis .I., and Ially, ( $1 \mathrm{I}$.:

Ohin, insets of year in, as reported to Ascociation of Eeonomi Entomolovists-

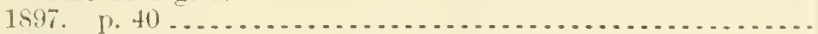

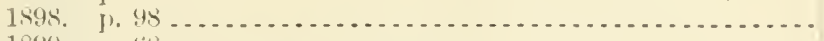

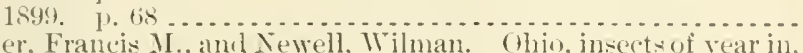

Webster, Francis M., and Dewell, Wilman. Ohio, insects of year in,
as reported to Association of Economic Entomologists. 1901 .

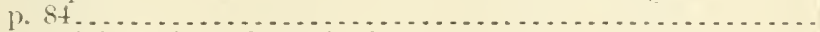

Verllerburn, Alexander John:

Fuorl arlulteration-

jopular treatise on extent and character of. 1890.

special report on extent and character of, including state and

other laws relating to foods and beverages. 1892 .......

Foor and drug adulteration, extent aul character of. $1594 \ldots .$.

Plarmacy and drug laws of States and Territories, compilation of. 1894

Weed, clarence Moores:

Aplididae, certain little known, fifth contribution to a knowledge of. 1891. 1. 285

Cacrecia cerasivorana, oviposition of 1900.

Egrg parasite of Tanessa antiopa, oviposition of. 1900 . p. $32 \ldots$

Kerosene knapsack sprayer, modification of. 1895. 1.28......

Pimpla inquisitor, life history of. 1891. p. $275 \ldots \ldots \ldots \ldots . . . . .$.

Potato rot, injuries of, experiment in preventing. 18s9. ए. 158.

Tent caterpillars, notes on. 1898. 1. 76.................

Weed, Clarence Moores, and Fiske, Willian F.:

Pimpla conquisitor, relations of, to Clisiocampa americana.

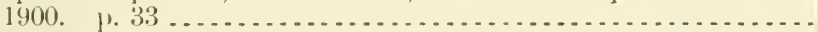

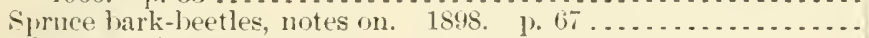

Weed, Howard Evarts:

Carlon bisulphide for crayfish. 1895. 1, $98 \ldots \ldots \ldots \ldots \ldots \ldots$.

Insects injurious to cotton, renedies for. 189:, 1. 167 ........

Knapack kerosene attachment, some experiments with. 1895.

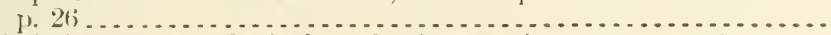

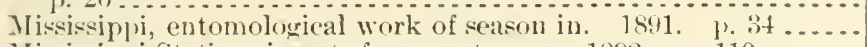

Mississipjei Station, insects from, notes on. 1892. 1. 110 ......

Iosquitoes, some experience with. 1894. 1, 212........... ITeerls:

Abstracts of reports of agricultural experiment stations 011, 18541902

American agriculture (Darjington). p. $509 \ldots \ldots \ldots \ldots \ldots \ldots \ldots \ldots$

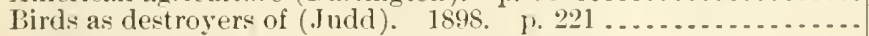

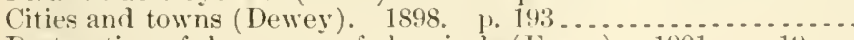

Destruction of, by means of chemicals (Evans). 1901. 1. 19...

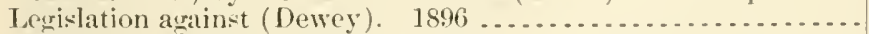

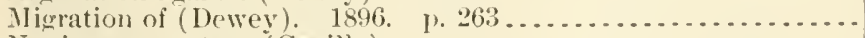

Noxions, report on (Coville)1889. 1. $382^{\circ}$.

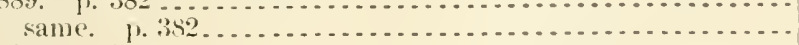

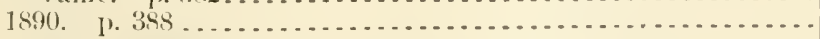

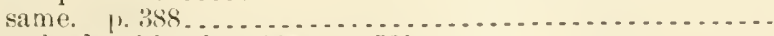

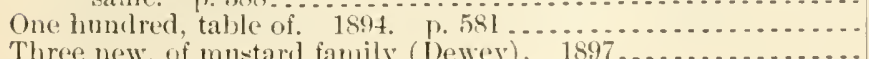

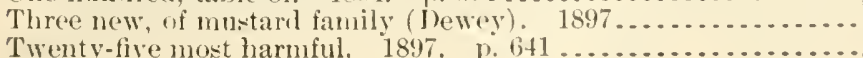

11.1: 1908

1!1 1 : isis

14. $7: 2$

$19.7: 3$

1]. ] $: 484$

11.1:56

A11.13:36

$\$ 9.6: 9$

A9.6:17

A. $9.6: 20$

19.1i:21

127.9:5

A $7 .: 3: 25$

$17.3: 32$

17.:2:41

$17.3: 42$

19.7:3

19.6:26

19.6:26

19.6:2

A!1.7:3

A28.5:5

A.9.6:17

19.6:26

$+9.6: 17$

A19.6:2

A.9.7:6

19.6:2

A9.7:4

A.9.7:5

A $9.7: 7$

170.6:

A $1.1: 865$

1 1.10:898

1 1. $10: 598$

1 1.9:124

16.3:17

1 1. 10:846

1 1. 1:8.

16. ] : 859

11.1:5:10

16. $1: 5.10$

A 1. 10:894

Ai. $4: 10$

1 1.10:897 
Teeds-Continued

Two, new to Lnited States (Rose). p. 35.

$11.1: \$ 91$

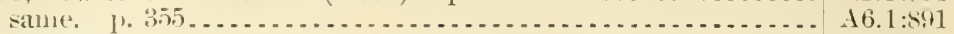

Two hmudred, how to know them and how to kill them. 18,4 .

See also Almtilon avicennce (Indian mallow) - Chess-Cocklebur-Florida heggar weed - ciarlic-lirasses and weedsMustard - Noxious weeds - Russian thistle - Seaweed,

Teen and how to kill them (Dewey). 1845.

Weerils. See Aple tree - Bean - Fly-Mexican cotton-boll-Palm amil palmetto - Pea - Potato-bud - Potato stalk - Strawberry - Tolaceo stalk.

Yeights and measires:

Decimal sistem of (Johnson). 1864. To. 6. p. 20

Explanation of systems of various states. p. 219

Notes on-

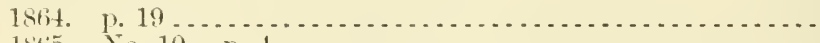
156.5. No. 10 . p. $4 \ldots \ldots \ldots$ 1stib. p. 27 .

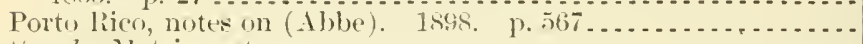
lee also Metrie srstem.

Weight of an animal, what is the live? (Patterson), 1893. p. $150 \ldots$

Weiske, II. Milch cows, food of, do volatile acids in, occur in milk?

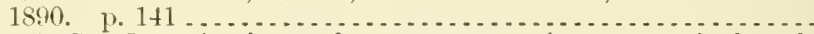

Welch, A. S. Organization and management of seven agricultural schools in Germany, Belgium, and England. 1885.........

Well waters and irainage, lecture on (Warington). 1892. P. 95...

Wellman, Walter. Horse trade, American, of Great Britain. 1897. p. 45... . . . . . . . . . . . . . . . . . . . . . . . . .

Wellman's first polar expedition, 1894 , notes on (Abbe). 1. $312 \ldots$

Wellman's second polar expedition:

Hade in neighborhood of Franz Joseph Land, 1898-99, auroral

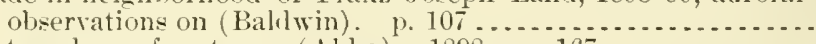

Meteorology of, notes on (Abbe). 1898. p. 167...........

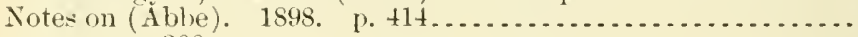

Tiells:

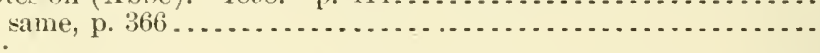

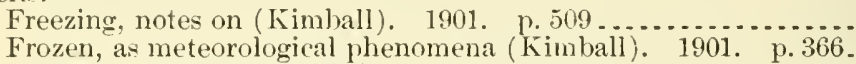

Storns and, note on (Abbe). 1900. p. 293 ...............

Water in, temperature of, notes on (Kimball). 1901. p. $510 \ldots$

Wentworth, C. C. Bridges, country road. 1895 . P. $48 \ldots . . . . .$.
Werner-Smith method of determination of fat in milk (Stokes).

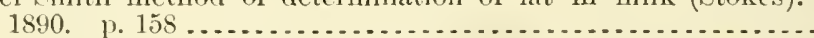

West, Charles F. Atmospheric electricity, early experiments in. 1896. p. 333.

Viest, Max:

Employment agencies for use of farmers, list of. $1900 \ldots \ldots$. . . .

Public domain of United States. 189s. p. 325 ................

West, Robert A. Aquaria, fresh and salt water. $p .446 . . . . . .$.

West:

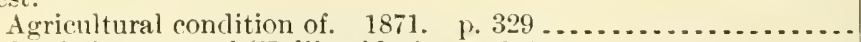

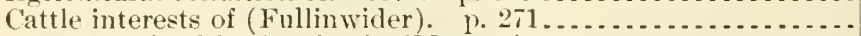

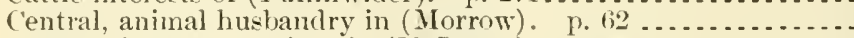

Cooperative grass stations in (McLaren). p. $344 \ldots \ldots \ldots \ldots . . .$.

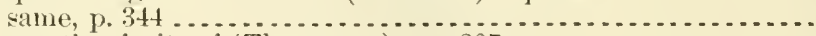

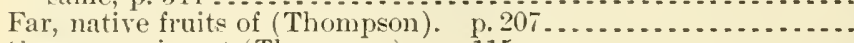

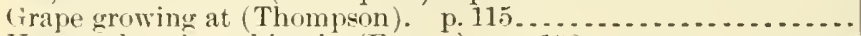

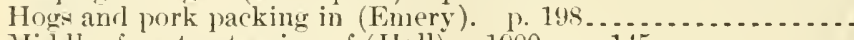

Midlle, forest extension of (Hall). 1900. p. 145............

Semiarid, forage plants for (Georgeson). 18:13. p. 145 . . . . . .

Sheep, husbandry in (Boardman). 1). $286 \ldots . . . . . . . . . . . .$. See rlso Western States and Territories.

Wrest Perkeley, Cal., local squall at, Dec. 11, 1894 (Abbe). P. 509. ..

II est Inclian rufous scale, report of (Cockerell). 1892. p. $390 . . .$.

Thest Inclies:

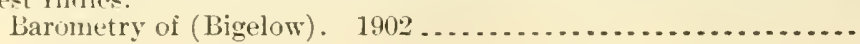

\1.10:\$95

$11.9: 28$

A $27.9: 2$

A1.1:571

A27.9:2

A27.9:3

A27.9:4

A $29.6: 26$

A10.3:16

A7.3:24

A1. $8: 36$

A10.3:8

A 1.2:H78

A29.6:26

A 29.6:29

A $29.6: 26$

A.29.6:26

A 29.6:27

A 29.6:29

A29.6:29

A 29.6:28

A 29.6:29

A22.3:11

A7.3.24

A 29.6:24

A 27.4:13

A1.10:898

A1.1:864

A $27.9: 9$

A 4.1:884

A 1.8:22

A 1.1:891

A 6.1:891

A 1.1:865

A 1.1:866

A 1.1:863

A1.10:900

A 10.3:16

A1.1:862

A 29.6:22

A9.7:4

A 29.1:901 ${ }^{2}$ 
Indey

West Indies-Continued

Clatsiffiatlou no.

('limate of (Hall). 18:0.

Cottun crop and its enemies in, consular reportson. 1585. App.,

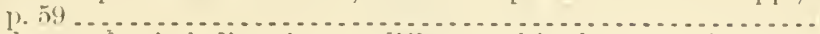

Cyclones of, wind direction at iliferent altiturles aromul, smme

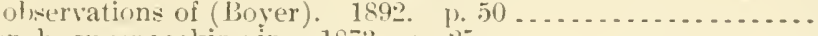

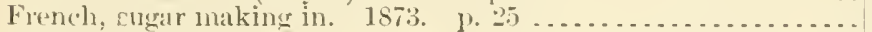

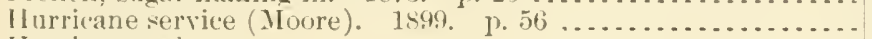

IIurricanes of-

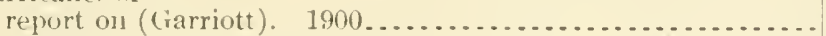

September, 1s96, notes concerning (I Henry). p. $368 \ldots . . .$.

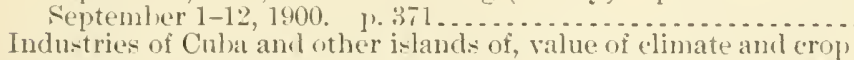
and storm-warning services of Weather Bureat to (Ilays).

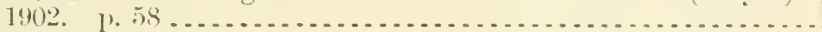

IIonthly weather charts for, notes on (11)be), 1899. p. 111 . .

Relation of forests and rainfall (Hublord). 1873. p. 117 .....

Storms of, relative intensity of (Hazen). 1894. 1.333.........

Telegraph service with (Robinson). 1898. p. $410 \ldots . . . . . .$.

Theather Bureau selvice inmonthly reports of (Stockman). 1599. p. 194 ............

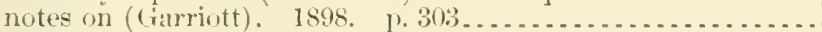

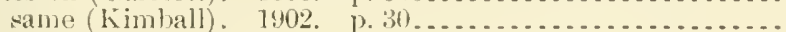

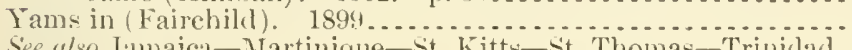

Sep also Jamaica-Nartinique-sit. Kitts-St. Thomas-Trinidad.

We.t Newbury, Mass., farmers elub. 1s70. 1. 2.8 ........... West Virginia:

(Coal-oil in (Shattuck). p. 525

Entomological discoveries ancl olservations of year in (Hopkins).

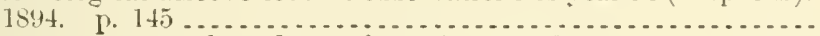

Farm resources and products of. 1868. p. 192...........

Farmers' institute work accomplisher in (Thompson). 190:.

Forest condition and lumber and wood trate of (Hough). 1s8t. p. 348 . . . . . . . . . . . . .

Insects in, some notes on (Hopkins). 1898. p. $44 \ldots \ldots . . . .$.

())servations in, on farm, garlen, and fruit insects, some notes on

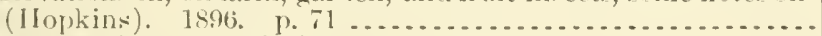

Resturces of, etc, brief history of (I)ocge). 1. $42 \ldots . . . . . . .$.

Roal improvement in, extract from governor's message (Atkin-

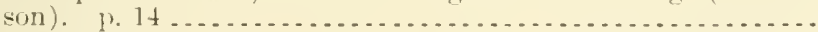

West Tircinia loranirla, some bred (ijopkins). 18\%2. p. 256...

Western cricket, ontbreaks of, in Idaho (Milliken). 1593. 1, 17... Ser rlsu Cricket.

Western fumpi, new (Ellis and Galloway). 1\$89. p.65..........

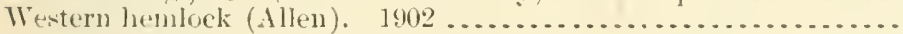
llestern plains:

Sheepl, tape-worm disease of (Curtice), p. 167..

Tree culture on (Thomson) $1891.0 . . .6$.

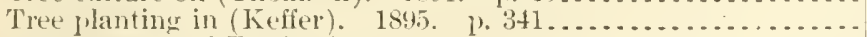

Western states and Territories:

Conclition of forests, timber eulture, ete., in (Baker). 188t. 1). 105.

Farmer of, best breeds of eattle for general use of (Baker). 188.

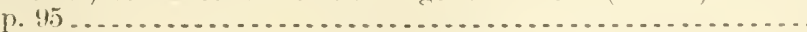

Forest comlition amb lumber and wood trarle of, reports on (Fur11:5). 1884. pr. 246,255 .

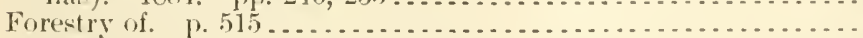

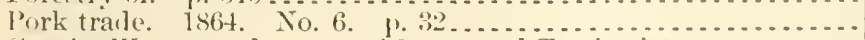

See relso West - and names of States and Territories.

Western wheat enlture, ruinous. 1867. p.321 ............. Westfield area, New York, soil survey (Burke and Mareaui). J. 7. .. Westwaml movenent of daily barometric wase (Fosig). 1:102. p. 1:2. Wetherell, Leander. Iee trade, history of. p. 439............. Wetherill, Cluarles M., chemical analysis of grapes, $180.2 \ldots . . .$.

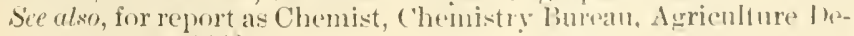
partment, 1862 
Wheat:

Agerian durmm, classified list, with descriptions (Scofield). 1902. A19.3:-

American-

bavis for improvement of (Carleton). 1900

Composition of, investigation of (Richarlison) -

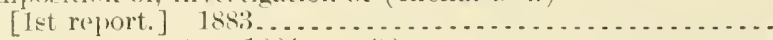

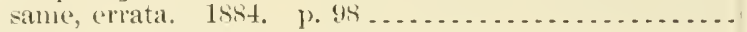

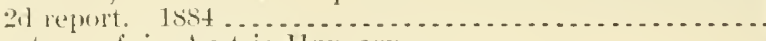

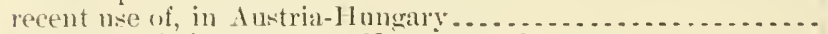

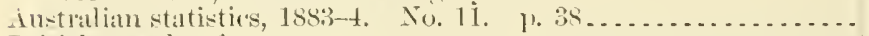
British supply of-

1868. p. 459

1869. PI. $147,2+0$

$1870-71$. p. 324

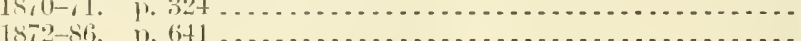

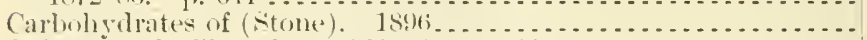

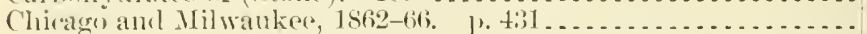

Consmmption of, per calita in Uniter States. 1895. 1. $74 \ldots \ldots$. .

Conse of production and exportation in United States, Canada,

Argentina, Lruguay, Ruswia, and British Inulia, 1880-96 .....

Crop, condition, monthly notes un ........................

Crop statistics, annual. . . . . . . . . . .

Cultivation and hyloridizing of (Watts). 1872. p. 432........

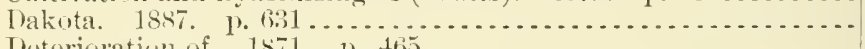

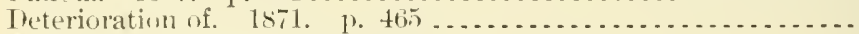

Distribution and consmmption of-

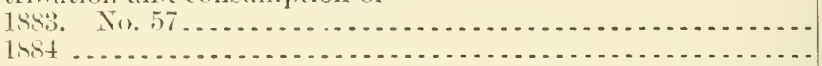

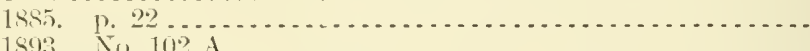

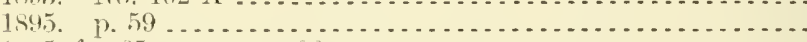

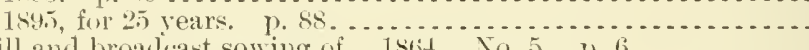

Drill and broad ant sowing of. 1stit. No. 5 . J.6.........

Early plowing for (May). 1900, p. 7 . . . . . . . . . . . . . .

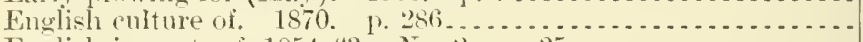

English imports of, $1854-63$. No. 2. p. $25 \ldots \ldots \ldots \ldots$

Engliwh prices of. $1595.193 \ldots \ldots$

European, prospects. Apr., 1883. (Moffat.) No.58. p.31...

Experiments of J. B. Lawes, 1863-73. 1. 596................

Exportation of -

comprative statistics of. 1891. p. $80 \ldots \ldots . . . . . . . . .$.

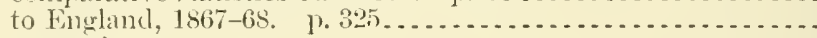

Exports of-

$1830-76 . \quad$ ?. 30

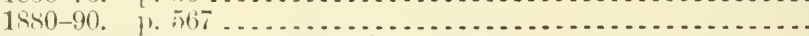

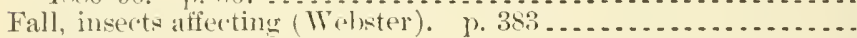

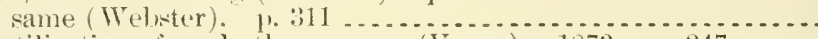

Fertilization of, and uther grasses (Vasey). 1873. p. $247 \ldots \ldots$

Food for growing and fattening animals (salmon). n. 1 ........

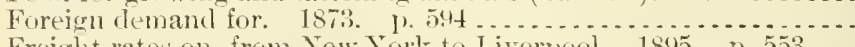

Freight rates on, from New Tork to Liverpool. 1895. p. $553 . .$.

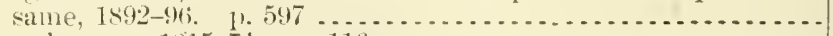

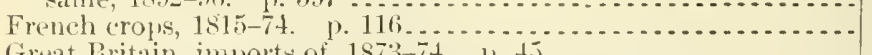

Great Pritain, imports of, $1873-74$. l'. 4.5
Great Pritain and Ireland, consumption and production of. 1865.

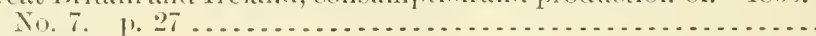

Growing-

cost of, in England. 1885. No. 23. 1. 34 ...............

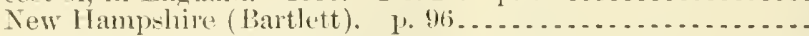

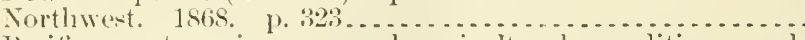

Iacific coast region, general anricultural comblitions and

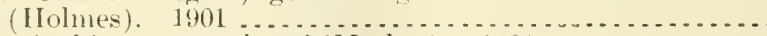

principal insect enenies of (Marlatt). 1901 . . . . . . . . . .

sureseful, in semiariel districts (Carleton). 1900 , p. $529 \ldots$

Horse hoeing, experiment in. 1868. p. 90 ................

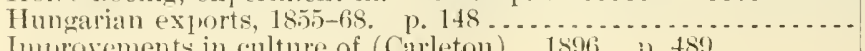
A28.3:24

A $7.3: 1$

A7.3:4

A 7.:3:t

A $12.4: 19$

A $27.9: 222$

A $27.9: 6$

A27.9:7

A $27.9: 9$

127.9:25

A $10.3: 34$

A.27.9:4

127.9:33

A12. $4: 10$

A27.9:

A 27.1 :

A27.9:10

A $27.9: 25$

\27.9:9

127.9:21

A $27.9: 223$

A27.9:23

A27.9:31

127.9:32

A27.9:32

1 $27.9: 2$

A $1.9: 122$

A27.9:8

A27.9:2

A 27.9:33

127.9:21

A27.9:11

A $27.9: 29$

A27.9:6

A 27.9:15

A $27.9: 28$

11.1:884

A $1.1: 885$

127.9:11

At.t:2

A27.9:11

A 1.10:895

A $1.10: 896$

A27.9:14

A.27.9:13

A27.9:3

A27.9:23

A 1.1:862

A 27.9:6

A.2. $8: 20$

A 1.9:132

A 1.10:900

A. $7.9: 6$

A $27.9: 7$

Improvements in culture of (Curleton). 1896. 1). 489 ......... A1.10:896 
Wheat-Continuel

Industry in, new, for semiarid West (Carleton), 1901 . . . . . . .

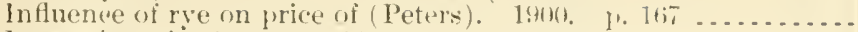

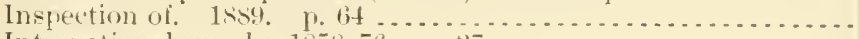

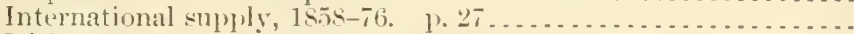

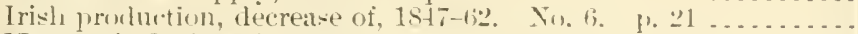

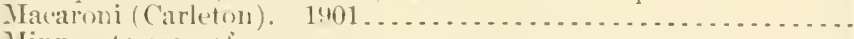

Iinnesota crop oi-

1stiō. P. 1:

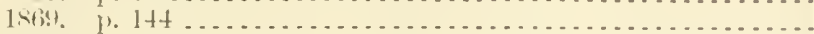

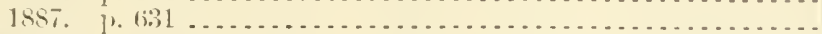

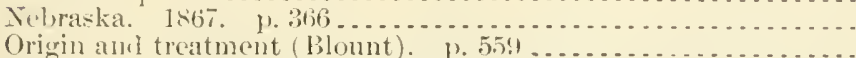

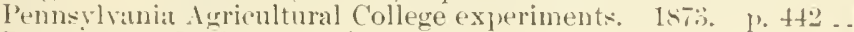

Ports for, on Pacitic coast (Hohmes). 1901. 1) 567 ...........

Preminms for growers of-

1stis. 1) itit.

$1870.1 \% .8$

Prire's of-

1590. 1). 524

$1865-1895$.

Production and exportation in Inited states, Canada, Irentina, [rugnay, Russia, and British India, course of, $1880-96 \ldots . .$.

Production of, in rensus years since $1869.1894 . \quad$, $189 \ldots \ldots .$.

Promets and prices of-

18:T. 1. 361

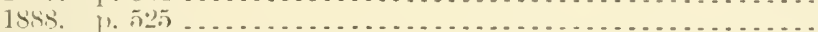

Raising, expense of. 1sit. 1) 106 ......

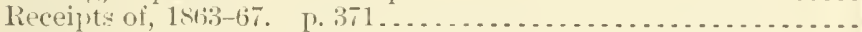

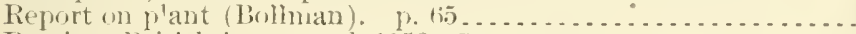

Russian, British imports of, 1852-67. p. 34. . . . . . . . . . .

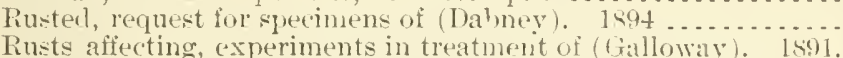

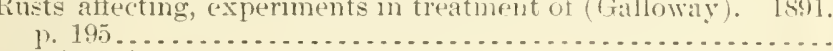

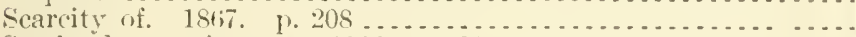

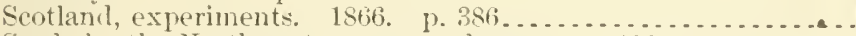

Seerl, for the Northwest, correspondence on. 1868. p. 23is....

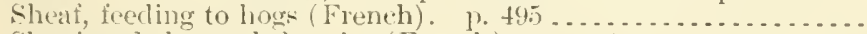

Sheat and chopperl, for pigs (French). 1. 44. ... . . . . . . .

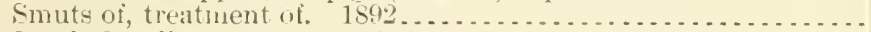

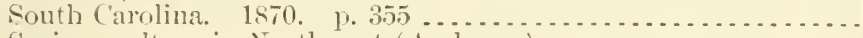

Spring, culture in Sorthwest (Andrews) ...................

Straw and stublele of, specimens requested (kusk). n. d......

Surplus of corn and foreign distribution of. 1890. 1. 212......

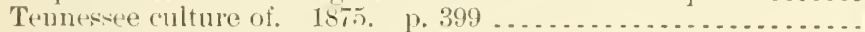

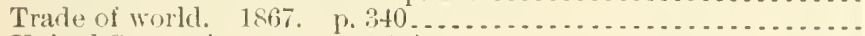

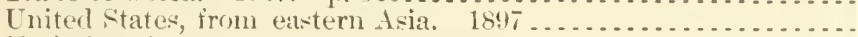

Varieties of-

extension of tests applierl to. 1890. p. 1:81 .............. grown in l nited States. 18ss. p. 229 . . . . . . . . . . . . .

Vietoria, dustralia, crogs. 1894. p. 26..................

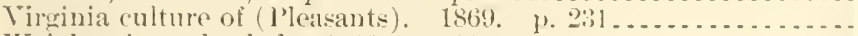

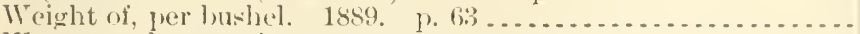

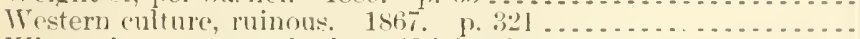

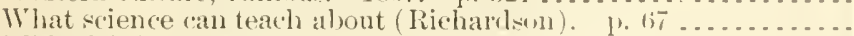

IVide drilling and tilling of. 1870, p. 485. . . . . . . . . . . . .

IVinter, condition of -

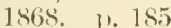

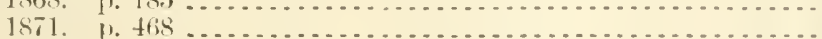

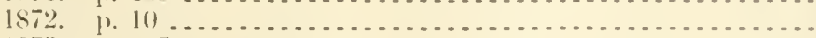

1878.

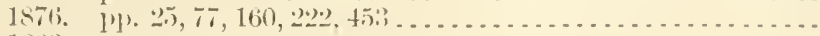

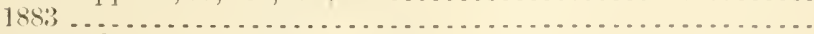

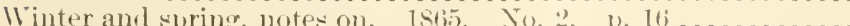

orlit's ("lol)"-

18si, 1). 94

$127.91: 25$

15ss. 
Wheat-Continued

Worlal's ('r)p-Continued

1889. 1. 100

$127.9: 28$

18:1. 1\% TS

A $27.9: 30$

189:3 19 8i

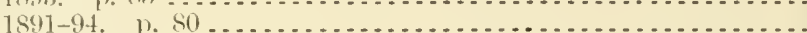

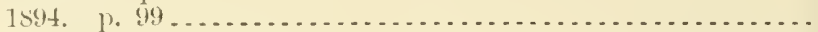

1509

A27.9:31

A $27.9 ; 33.3$

A:7.9:32

Yomnd, in Inıliana, larve of crame-fly destroving (Vebter).

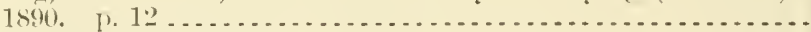

Sce also Cereals, American - Crops, prineipal - Fultz wheat Inclia - Sheaf wheat.

Wheat bran for fattening pigs (Duggar). p. 496.............

Wheat grain and wheat straw, grown at Rothamsteri in different seasoms and by different manures, composition of ash of (Lawes

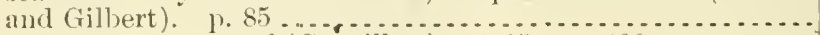

Wheat west, new, report of (Coyuillett). 1895. 1) $406 \ldots \ldots \ldots .$.

Wheat region:

Minnesota and North and South Dakota, Russian thistle and

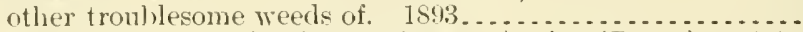

IV eather Burean, service, instructions governing (Berry). 1897.. Wheat saw-flies, notes on (Riley and Marlatt). 1891. p. 168.....

Wheat shorts as food for pigs (Plumb and Anderson). p. 463..... Wheatland, Wyo., irrigation at, nse of water for (Johnston). 1902. p. $20 \bar{T}$.

"Trheel bugs", destroying hive bees, note on. $18 s 6$. p. $44 \ldots . .$. Wheeler, Homer Jay:

Liming of soils . . . . . . . . . . . . . . . . . . . . . . . . . . . . . .

Thosphoric acid determination, increased accuracy in. 1901. p. 44... . . . . . . . . . . . . . . . . . . . . . . . . . .

Plant-sibil tests-

langer of drawing erroneous conclusions from. 1s98. p. 60 . posilibility of drawing eroneous conclusions from. 1899.

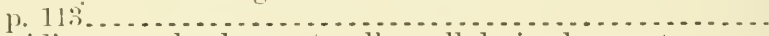

Soils, acidity on npland or naturally well-drained, report on ne-

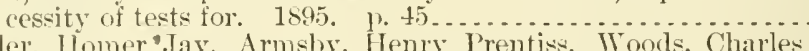

Wheeler, Homer Jay, Armsby, Henry Prentiss, Woods, Charles
Dayton, and Wiley, Harvey Washington. Fertilizer inspec-

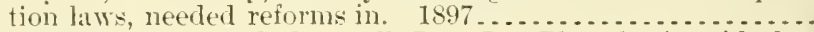

Trheeler, Homer Jay, and Hartwell, Burt L. Phosphoric acid, determination of, use of ammonium nitrate in. 1892 . ए. $53 . .$.

Wheeler, William M. Xiphidium ensiferm, oviposition and embryonic development of, motes on. 1690. p. 22.2. . . . . . . . .

Wheelmen, American, Leagne of, remarks at gooul roals baiquet of, at Albany, X. Y., February 11, 1897. p. 15 ............

Whipplei. Nee Yueca whipplei.

Whirlwinds, local, in New Brumswick, notes on (Kain). 1900. p. 488.

Whitaker, (ieorge M. Milk supply of Boston and other New Eng-

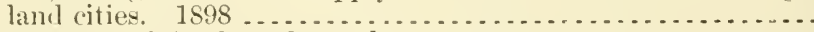

White, C. 1., and Anghey, Samuel:

Artesian well near Fort Lyon, Colo. I. 26.

Artesian wells upon great plains, report of Geological Commis-

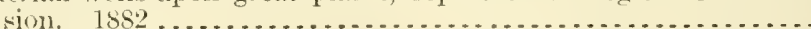

White, H. C.:

Arliress of, as president of Association of American Agricultural Colleges and Experinent Stations, at twelfth anmul con-

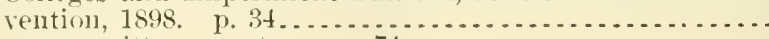

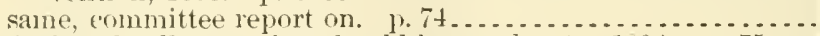
Agriumltural colleges, what should he taught at. 1896. p. $75 \ldots$.

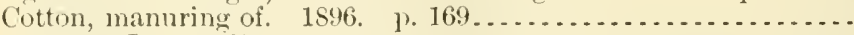

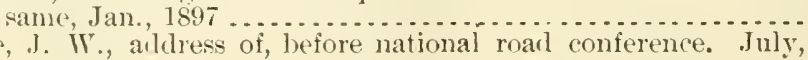

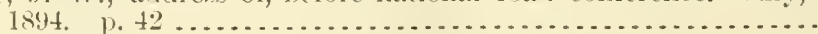

Thite ant:

Circular on (Marlatt). 1902.

Species injurious to wall paper, books, timbers, ete. (Marlatt.) 1896. p. 70

19.7:3

A4. 1:898

A 7.3:4

A9.7:7

A1.9:10

A 29.12:C 1

A.4. $7: 4$

A $4.1: 899$

A10.3:10t

A9.3:12

11.9:7

17.3:62

17. $3: 56$

110.8:65

A7.3:4

A7.4:3

A7.3:35

A.7: $7: 2$

A22.4:28

A29.6:28

A $4.3: 20$

A1.1:881-2

d1.8:19

110.3:65

A 10.3:65

A 10.3:4 I

A 10.3:33

A 1.9: $\pm \mathrm{S}$

A2:. $3: 10$

A9.5:50

A9.6:4 
White Chester breed of swine (Mrorris). 1\% 4\%

White fir, divease of (Ilartig). 1st?. p. 164

White fly investigation, review of, with incilental problems (i ims-

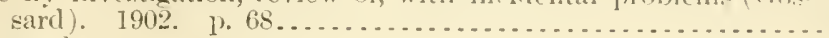

White gruls:

Allorhina, note on (Townsend). 1891. 1\%.25.............

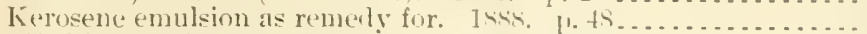

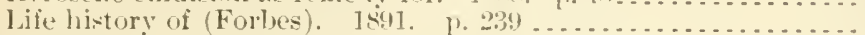

White katir corn. See hafir corn.

White-marked tussock moth. See Tussock muth.

I'hite jine:

Insect enemies of (Chittenden). 1899. p. 5.)

Report on (Spalding), revised and (m) lared by $\mathrm{B}$. 1899

IVood of (lioth). $1899 . \quad$ 19.

IThite scale, se Icerva.

Whiteheat, Mortimer. Signals, Weather Burean. 1892. p. $46 . .$. Whitewater, Wis., ground-water at, fluctuations in level and rate of movement of ( $\mathrm{King}) . \quad 18.12$

Whitney, Milton:

Anmouncement of fumctions of Soils Jivision, Agriculture Depart-

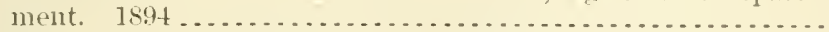

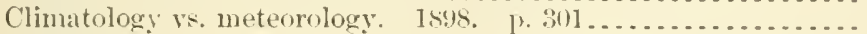

Climatology and soils in theil relation to cotton cultivation. isin.

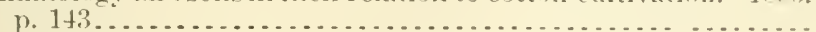

Field operations of Soils Division, Anrioultme Department, in 1899. p. 13

Rainfall and charts of rainfall. 1000. 1. 233

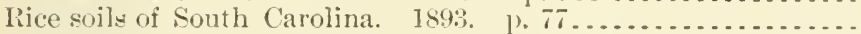

Salt content of alkali waters and soils, justructions for fleternining

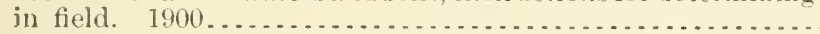

Soil collection of Division of Soils, Acrieulture Departurent,

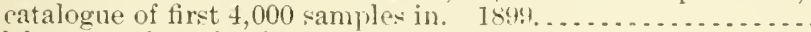

soil features that should be recognizer in all plat work. 1s91.

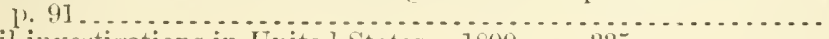

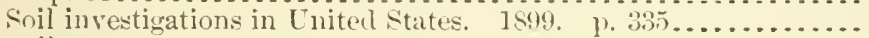
suil-

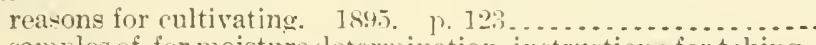
samples of, for moisture letermination, instructions for taking. T.89t

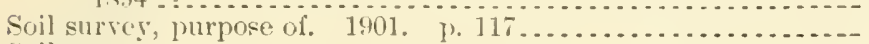
Soils-

Fxhaustion and abardonment of, testimony before Industrial Commision. 1901

in their relation to crop production. 1894. p. $129 . \ldots . .$.

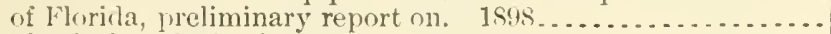

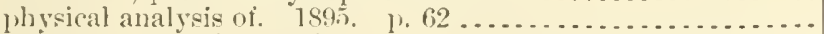
problems, some interesting. 1897. p. $429 . . . . . . . . .$. sonc physical properties of, in their relation to moisture and ('rop) distrilution. 1892.

Soils I ivision, Agriculture Departmentfield operations of-

$$
1899
$$

1900

1901

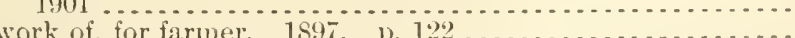

Sumatra tobacco, growing, nmer shade in Connecticut $V_{a l l}$ ? 1902.

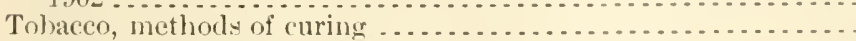

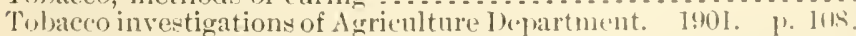

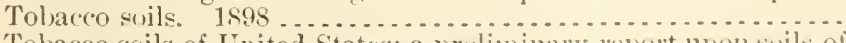

Tobacco soils of United States; a prolininary report upon suils of

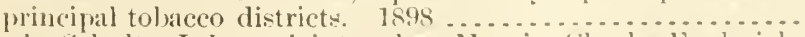

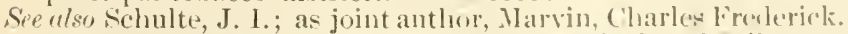

See clso, for reports as Chief of Division of Aericultural soils, ] $\$: 1.1$ to 1896; Soils Division, $] 897$ to 1 !no(); Soils Bureatu, ]!n)] aut $190^{\circ}$
A1. 1:Sij5

$129.5: 5$

11. $6: 31$

$111.7: 4$

19.7:1

11. $7: 3$

113.3:2:)

11:3.3::2.2

1 1 $3,3: 3: 2 \cdot 2$

$129.3: 7$

1:24.:3:5

121;.4:1

1.29.6:26

A 10.3:3:3

A 1.8:154

1.29.6:80

1.27.5:6

$126.4: 6$

A26.3:16

A10.8:

1 1.10:8!19

A $1.10: 595$

126.t:2

A $1.10: 101$

A1.8:70

A1. $10: 5.14$

A26.3:1:3

A $7.3: 47$

A]. $10: 5 ! \%$

A:?1.3:4

11.sitit

1:6.5:1100

1:4t, 5: :101

1 1.10:5.7

$1: 2(i, 8: 2)$

1 1.9:60

110.:3:0!

A1.:1: $: ?$

A:ti.3:1i

A:6. 1: 


\section{Index}

Whitney, Milton, and Briggs, Lx"man James. Flectrical method of deternining temprature of soils. $18 \%$. . . . . . . . . . . . . .

Whitney, Milton, anel Floyd, Marcus L. Tobaceo industry, growth

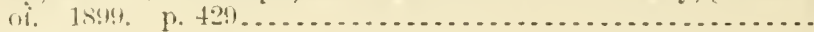

Whitmer, Milton, and Hosmer, Ralph shehlon. Soil moisture; reccril of anount of water contained in soils during crop season

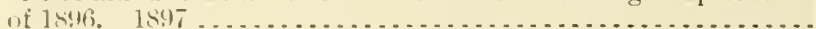

Whitney, Milton, and Means, Thonas Ilerbert:

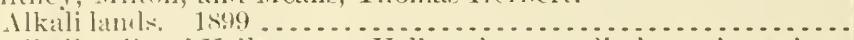

Atkali soils of Yellowstone Valley, from preliminary investigatim of soils near Billings, Mont. 1s9S . . . . . . . . . . . . . . .

(igar leaf tobaco, temperature changes in fermenting piles of.

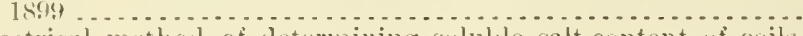

Electrical methorl of determining soluble salt content of soils,

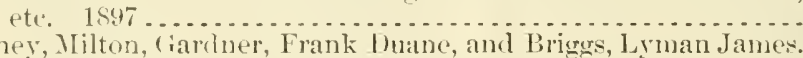

Whitney, Milton, ( iartuer, Frank Duane, and Brigrs, Lyman James.
Electrinal metlum of determining moisture content of arable

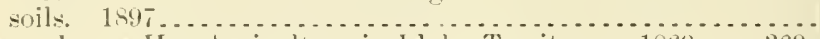

ivhitson, James H. Agriculture in Idabo Territory. 1869 p. 369 .

Whittle, C. L. Roads, forces which operate to destroy, with notes on roal stones and problems therewith connected. $1897 \ldots . .$.

Wiechmann, F. G. See, as collaborator, Wiley, IIarvey Washington.

Wickeon, J.. J.:

Climatrlogy and horticulture. 1900. p. $45 \ldots . . . . . . . . .$.

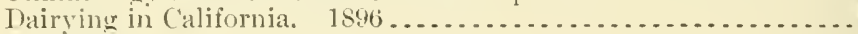

Irrigation-

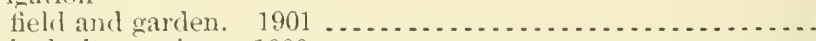

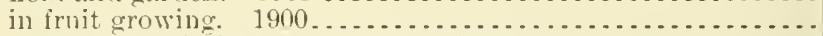

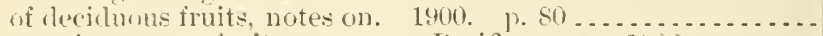
fractice among fruit gromers on P'acific coast. $1900^{2} \ldots \ldots \ldots$.

IVide tires, Jaw of certain States relating to their use (Stone). 1895 .

Widmann, ()tto. House sparrow, passer lomesticus, and Enropean tree sparrow, passer montanus, at st. Lomis, lio., history of.

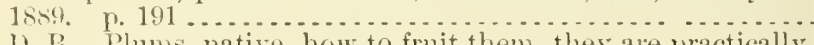

Wier, 1). B. Plums, native, how to fruit them, they are practically

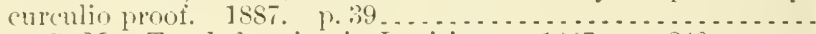

Wiggins, s. II. Truck farming in Louisiana. 1ss:. $\mathrm{I}, 240 \ldots \ldots$. Wight, R. Allan:

Fcerya purchasi and Tedalia cartinalis in New Zealank. 1893.

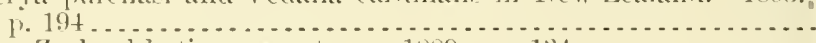

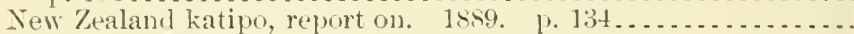

Potato-tulier moth, report on. 1893. p. 163 ............... Root fungus of New Zealand. 1889. p. 199 ................

Wilbour, Joshua. Animals, deacl, disposition of, in Dublin. p. 347.

Wilcox, Earley Vernon:

Calves, feerling, with milk of tuberculons cows. 1899. p. 2:3.... Cattle, northern, protecting arainst Texas ferer. 1900. 1.27 ...

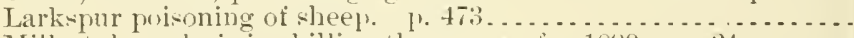
Nilk, tulerculosis in, killing the germs of. 1899. p. $24 . . . .$. Paris green, low grale, nse of, to fruit growers. 1900. [1.14 ... Petroleum, crucle, as an insertivile. 1900. P. $15 \ldots . . . . . .$.

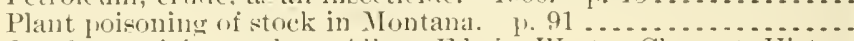
See als", as joint author, Allen, Elwin West - Chesnut, Victor King.

Wilı, Ileinrich, short biography of. 1902. Ir. 451 ............

IVild animals. ,ee Animals.

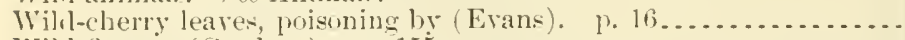

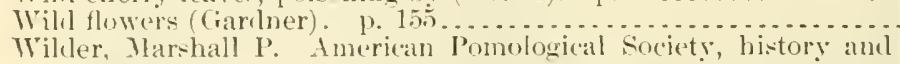

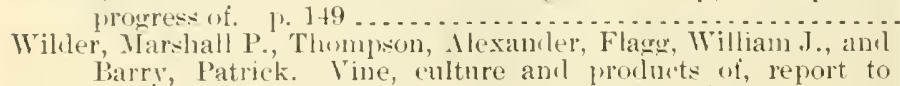
Eniterl states Commesion at Paris Exposition of 1s67. p. 16i:3. A1.1:867

Wiley, Harvey Washinenton:

Adelrese of a president of Association of Official Agricultural Clomists, at third annual convention. 1856. p. 6......... A7.3:12 
Wiley, Harvey Washington-Continued

lericultural chemical analysis, apparatus usel in, sone new

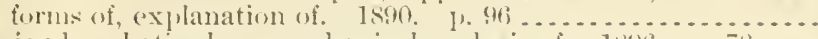

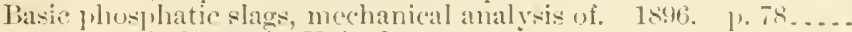

beet-sugar imlustry in [ nited - itates-

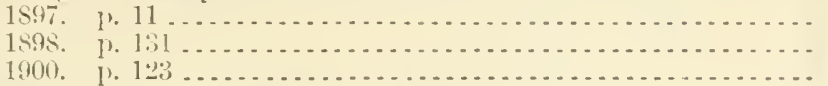

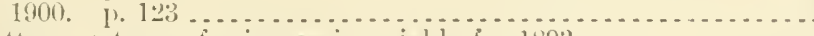

Butter, nostrums for increasing yield of. 189:3............

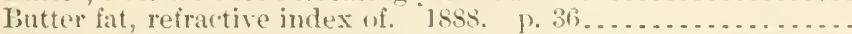

Cannel meats, chenical examination of, circular on. $1899 . . .$.
Cereals and cereal prolucts, arlulteration of, investigations male under lirection of, with collaboration of Karl I'. Mcelilruy, William Jenry Krug, T. C. Trescot, Willard Dell Bigelow,

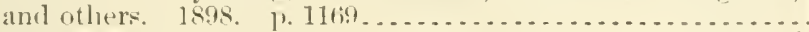

Cereals collected at IVorld's (')lumbian kxposition, analyes of and romuarisons with other data. 1895.

Chemistry I bivision, Agrieulture Department, work of, for larmer.

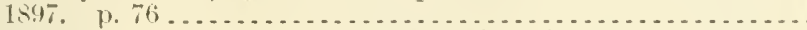

Chemistry, relation of, to progress of agrienlture. $1894 . \mathrm{p}$.

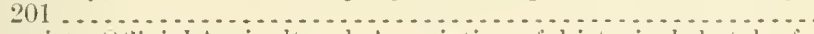

Chemists, ollicial Igricultural, Issoeiation of, lifstorical sketeh of.

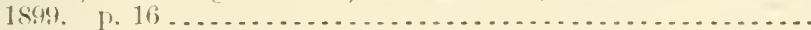

Diffusion-

its application to sngar cane, and record of experiments with

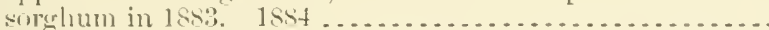
methorls and machinery for application of, to extraction of sugar irom sugar eane and sorghum, and for use of lime and (arlonic and sulphumous acids in purifying the diffusion juices. $18 \$ 6 \%$.

Diffusion and carbonatation, experiments with, at Gttawa, hans. 1885

Industries aut arts true rolations of suence to

Intant and invalid foods, analysis of, provisional methods for.

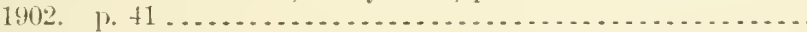

Lavi and lard admiterants. $1889 . \quad 1,405 \ldots . . . . . . . . .$.

Ilaize (Indian corn) -

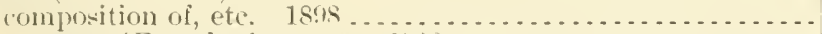

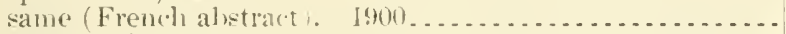

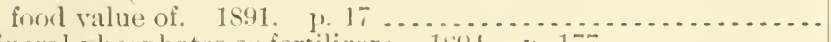

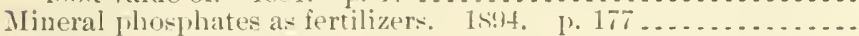

Northern sugar industry, a record of its progress during season of $188:)$

Pigs, (arcasses of, chemical composition of, rewort nn, with collaboration of Errin Elgar Ewell, Willian Henry Frug, T. C. Tresont, and others. 1898.

Plants, chemical composition of, influence of environments on. 1901. ए. 2999.

Potash and its function in acriculture 1896.

Proteinl hodies, separation of, from flesh hases hy nurans of chlorin

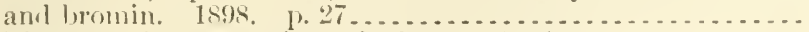
Soil ferments impontant in agrioulture. 18\%5. p. (i) . . . . . . .

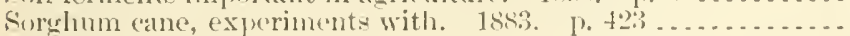

Sorghum, experiments in mannfacture of sumar from-

1886, at Fort S. cott, Kans . . . . . . . . . . . . . . . . . . . . 18ss, at Rio Grantle, X. J., Kenner, La., Comwaly Frnugs,

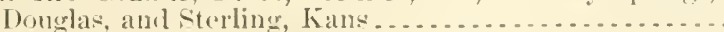

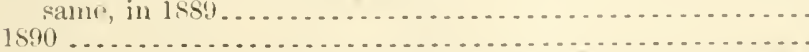
1891, report on, with collaboration of finiliorel latwson

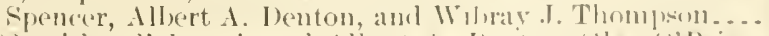
1892, with collahoration of Allert 1 . Ientwn, dilun (1) Prien, C. 1. IInman, Wibray J. Thompen, John I. Fuelling,

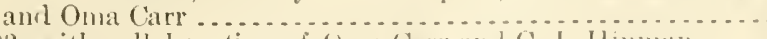
189.3, with collaboration of ()mal (arr and C. I. Ilimman . . . .

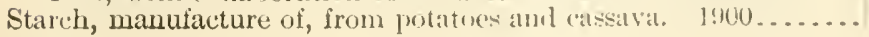

$17.3: 28$ 17.3:49

A 1.2:P3:39

11.2:13:3!14

11.8:6:3

$11.9: 12$

$17.3 ; 19$

17.4.5

A7.3:1: ${ }^{9}$

17.3:45

11.10:897

A1.10:\$:19

A...5:57

$17.3: 2$

A7.3:S

17.3:6

1 1.7:2

$17.3: 65$

$17.3: 13^{4}$

17.8:50

1. $7.4: 6$

11.8:49

$11.10: 5: 9 t$

17.8: :

$17.3: 3$

$11.10: 901$

1 1. 10:5:96

17.3:5.

1 $1.10 .89 \%$

11.1:58:"

17..3:1 1

$17.8: 20$

1 $7 .: 2: 213$

$17 .: 3: 24$

17.2::34

$17.3: 37$

17.28:417

1...3:5 
Wiley, Harvey Washington-Continuel

Sugar, molasses, and sinup, contections, honey, and beeswax, adulteration of, investigations made under direction of, with collaboration of llenry Augustus Huston, II. H. Nieholion, IT. B. Rising, Melville Amasa Seovell, S. T. Slarples, William Carter Stubls, Shippen Wallace, F. G. Wiechmann, Henry Ailm Weber, and Karl P. MeFlroy................... Sugar analysis-

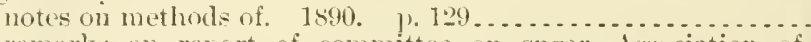
remarks on report of committee on sugar, Association of

(Ofhicial Agricultural Chemists. 1sss. 1. 54........... Siluar beet - -

composition of, influence of enviromment upon. 1901.......

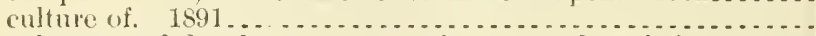
culture, seed development, manufacture, and statistics....... experiments with-

1890 - . . . . . . . . . . .

1891, with collaboration of Walter Maxwell, WY. A. Henry,

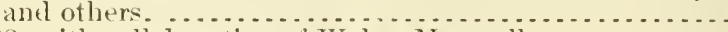

1892, with collaboration of Wralter Maxwell ............

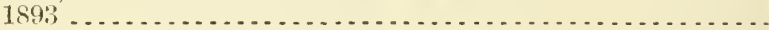

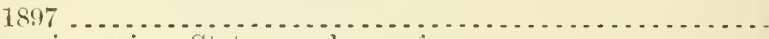

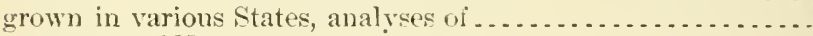

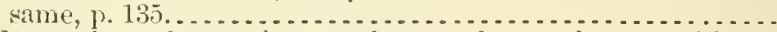
industry in, culture of sugar beet ancl manufacture of beet sucar. 1890.

Sugar industry of United States, cane sugar, beet sugar, sorghum

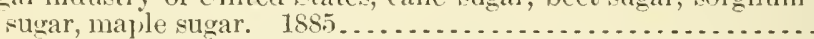
Sunflower plant, its cultivation, composition, and uses. $1901 . .$. Sweet cassava, its culture, properties, and uses. $1894 \ldots . . . . . .$. Table sirups, manufacture of, from sugar cane. $1902 \ldots . . .2 . .$. Tamning materials, official methods for analys of. $1901 \ldots \ldots . .$.

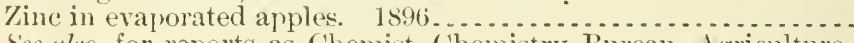
See also, for reports as Chemist, Chemistry Burean, Agriculture Department, $188 \pm-1902 \ldots$

See also, as editor, Chemical analysis, methors of, 1895 and 1898 ; Chemists, Official Agricultural, Association of, proceedings of, 1889-1901-as joint anthor, Wheeler, Ilomer Jay.

Wiley, llarvey Washington, and Krng. Willian Vienry. Filter-tube method, international and official hide-powder methor, com-

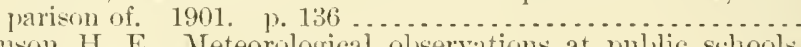

Wilkinson, H. E. Meteorolngical olservations at public schools. 1899. p. 5.50 .

Wilkinson, Levi Washinton. Phosphates, native, containing iron and aluminum, analysis of, proposed methot for. 1891 . p.107.

Willard, X. A.:

American dairying, rise, progress, and national importance. p. 431.

Dairying of America and England, their points of difference and

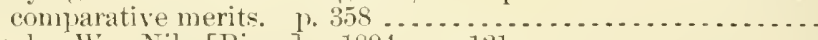

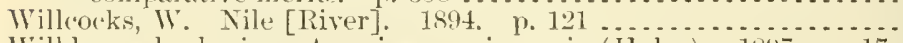

Willdenow lerbarium, American panioms in (Holm). 1897. p. 17.

Willet, J. 1. Cotton worm in Georgia in 1878 . p. 358 .........

Willets, J. H.:

Seeds, purchase and distribution of-

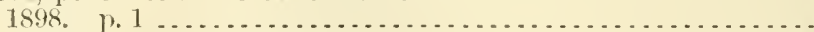

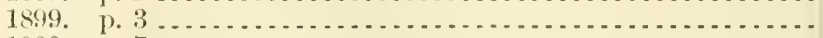

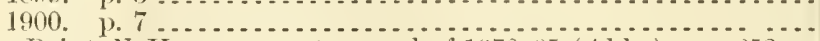

Willets Point, X. Y., auroras at, record of $1870-85$ (Ab)

Williams, C. B.:

Ammonia results in mixed fertilizers, variable. 1901. p. 28 ...

Kilgore's modification of volumetric metlod of estimating phos:

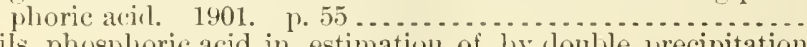

Soils, phosplioric acid in, estimation of, by loulle precipitation with molybdic solution and titration of ammonimm phospho-

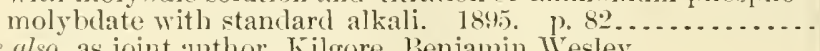
Sep also, as joint anthor. Kilgore, Benjamin Wesley.

Williams, Fanklin, jr. Clearing new land. 1902 . . . . . . . . . \$1.9:150 
Williams, H. E.:

Food products, protecion of, irnm injurious temperatures, 1901 $\quad$ A1.9:125

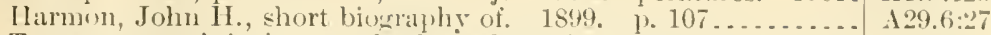

Temperatures injurions to fomd pirolncts in storage and dluring transportation and methoils of protection from same........

Wappenhans, C. F. R., shurt biography of. 1902. 1. $87 \ldots \ldots$. Williams, Thomas Albert:

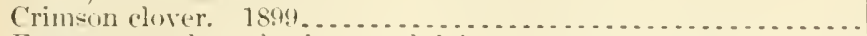

Forage, snceulent, for farm and lairy. p. $613 \ldots . . . . . . . .$.

Grass and forage investigations, copjerative work of Department of Agriculture with state experiment stations. $1900 . . . .$.

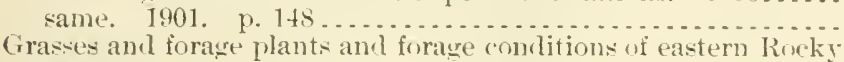
Mountain region. 1 sis . . . . . . . . . . . . . . . . . . .

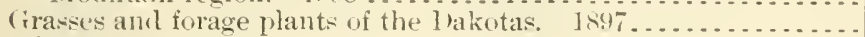

Millets, report on18: 9.267. 1899 ................

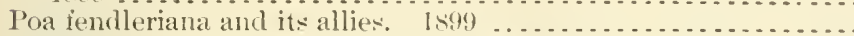

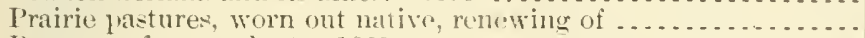

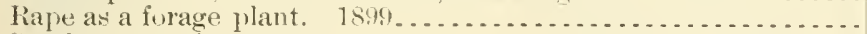

Sorghum as a forage crop - . . . . . . . . . . . . . . . . . . . . .

Soy hean as a forge crop . . . . . . .

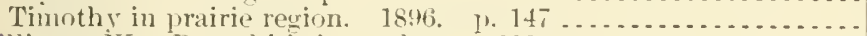

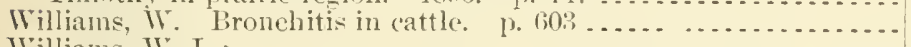
Williams, IV. L.:

Cerebro-spinal meningitis, enzootic, among horses, and hog

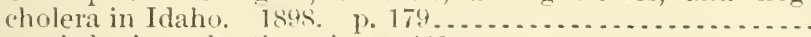

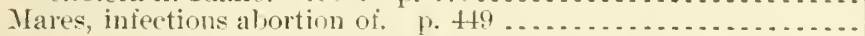

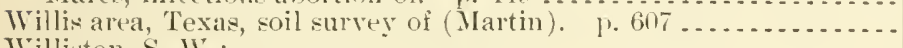
Williston, s. WT:

Australian parasite of Ieerya purchasi. 18s8. p. 21 ...........

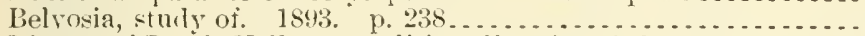

Diptera of Death Valley expedition, list of. 1893. $\quad$ 1. 253.....

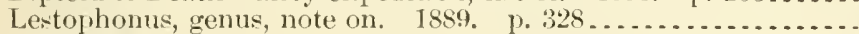
Willits, Edwin:

Adilress of -

before convention of Xational League for Good Roarls. Wash-

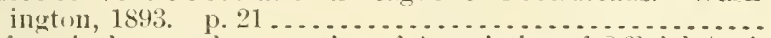
before sixth annual convention of Association of Official Agri-

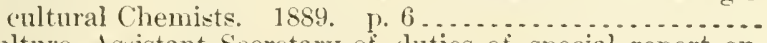

Agriculture, Assistant Secretary of, duties of, special report on.

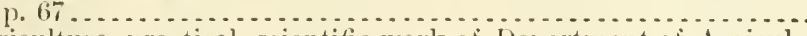

Agriculture, practical, scientific work of Department of Agricul-

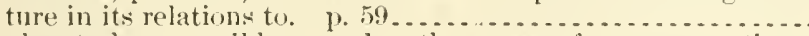

Black-rot, downy mildew, and anthracuose of grape, questions

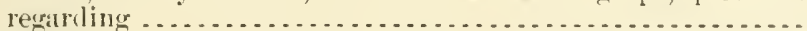

Chicagu World's C'olumbian Exposition, special report on. 1) 5?. sme . . . . . . . . . . . . . . . . . . . . . . . . . . . .

Edneational forces in United States relating to agrienłture, (col)-

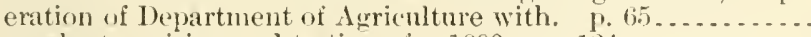

Fiber plants, raising and texting of. 1890 . 1. 124 ..........

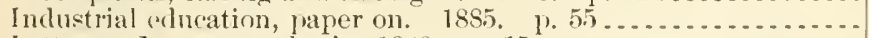

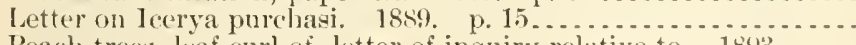

Peach trees, leaf curl of, letter of inquiry relative to. $1893 \ldots . . .$. IIIllow:

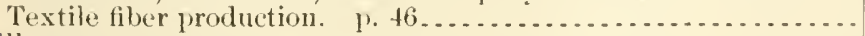

129.:3:1:3

A $29.6: 30$

1:3. $4: 17$

1 1.10:\$ $: 99$

11. $4: 8$

A 10.3:94)

A3.3:1:

A3.8:6

A $1.10: 898$

A 1.9:10I

1:3. $4: 10$

A3.4:4

13.4:12

A 1.9:50

11.9:58

1 1. 10:5:16

A 1.1:S50

14.1:897

A $4.1: 889-90$

126.5:901

A9.7:1

A9.7:5

A5.5:7

A9.7:1

A10.3:14

A 7.3:24

A1.1:89:2

A1.1:890

A 28.4:11

A $1.1: 89.3$

A5. $1: 893$

A1.1:891

110.5::2

A1.7:9

1!. $7: 2$

1.2. $4: 13$

A1.1:889

Cimbex injuring, in Nebraska (Webster). 1890. p. 2:s....... A9.7:2

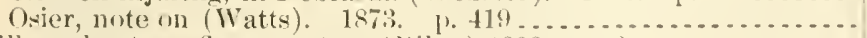
Willow-shoot sawfly, report on (liiley) lsss, p. Willow slug, yellow-spotted, report on (Howard). 18.8, 1.33... A:7.:9:11

19. $7: 1$

19.7:1

Willson, George H.:

San Francisco weather-forecast distriet, report of, Feb., Marels,

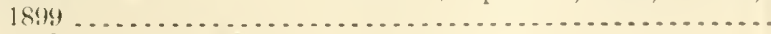
same, Sept, Ocot jouo

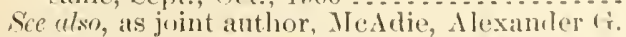

Wilson, C. 'T. K. Atmospheric air, ioni-ation of. 1901. I. 159... A:9.(i:29) 
Wilson, G. W. Gleomargarine, ingrerlients of. p.513.

Tilson, James:

Adrless of-

before American Association of Famers' Institute Workers, at serenth annual meeting. $1902 . \quad 1.45 \ldots . . . . . . .$. before Association of American Anricultural Colleges and Fixperiment Stations, at twelfth amnual convention. 1898.

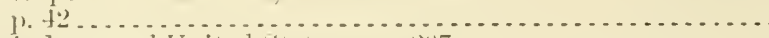

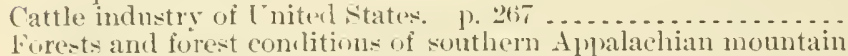
region. 1. 13 . . . . . . . . . . . . . . . . . . . . .

speech delivered July 7,1902 , at school of agriculture, Colmm-

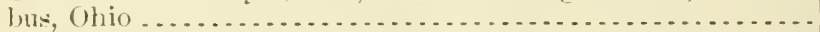

Se ulso, for reports as Secretary of Igriculture, $1897-1901 \ldots . .$.

Wilsun, James, and Curtiss, Charles Franklin. Lambs, feeding of. p. 463.

Wilson, James Maxwell:

Irrigation investigations('ache Creek, Cal. 1901.

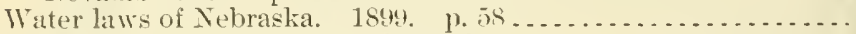

See u/so, as joint anthor, Bond, Freal.

Wilson, dames $\mathrm{W}$. See, as joint author, Curtiss, Charles Franklin.

Wilson, James W., and Hill, George ${ } i$. Chicago, 1ll., international live-stork exposition of 1900 , notes on. p. $63 . . . . . . . . .$.

Wilsm, Lawrence. live-stock industry, comlition of, west of $M$ ississippi River. p. 429.

TVilson, Thomas. Lace, tescription and history of. 1897. p. 359. Wilion, Wilford M.:

Clinate and man: with special regard to climate and climatic elements as curative or causative arelucies of disease. 1902.

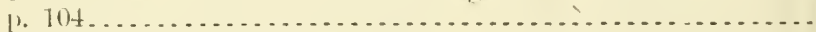

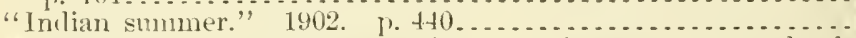

Meteornlocrical statistics, how to improve them to meet needs of medical profession, ete. 1899. p. s2 .................

IVilt disease:

Cotton and its control (Orton). $1900 \ldots \ldots . . . . . . . . . . . .$.

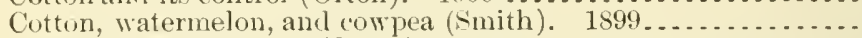

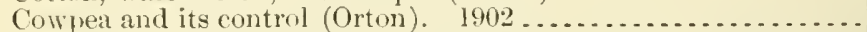

Wincl-barometer table, report on (Garriott). 1597. p. 204.......

Wind-roses for Oklahoma, notes on $1891-99$ (Abbe) . p. $21 \ldots . . . .$.

Wind seale, Beaufort, as used at sea (Abbe). 1894. P. 175.......

Wind signal orlers, cipher code of, amending instructions to special

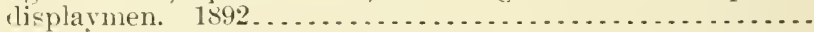

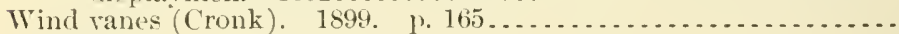

Winclnills:

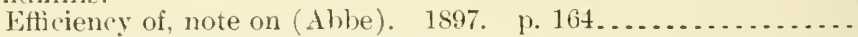

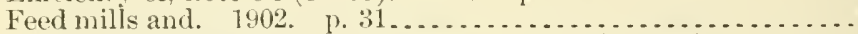

Wind-rush at Washington, D. C., Sept. 29,1896 (Hazen). p. 322 ..

Windstorm, local electricity in, in Wyoming (Abbe). 1894. p. 509.

Winds:

Clomls and, report on (Brillonin) 1897. p. 437.............

Currents and, Broun's law of, notes on (Abbe). 1898. p. 264 ..

Direction and velocity, hourly results from self-registers for

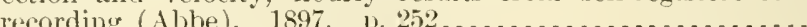

Direction of-

some observations of, at different altiturles around West India

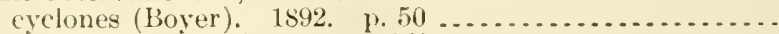

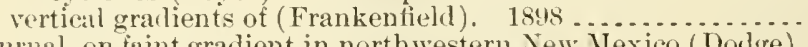

Diumal, on faint gradient in northwestern New IIexico (Dodge).

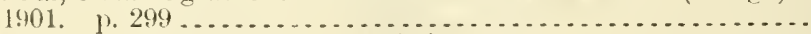

Effert of, on catch of rainfali (ibbe). 1899. p. $308 \ldots \ldots \ldots \ldots$.

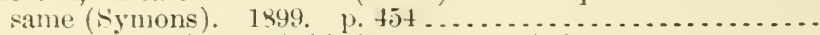

Effect of mountains on (Ablue). 1894. p. $510 \ldots . . . . . . . . .$.

Force of-

first attempt to measure (Abhe). 1896. P. $335 . . . . . . . .$. in tornadoes, notes on (Kimball). 1901. p. $419 \ldots . . . . . .$. ('lassifleation no.

$14.1: 900$

$110.3: 1 \geq 0$

$110.3: 6.5$

$14.1: 9(1)$

11.2: $1 \mathrm{H}^{2} \mathrm{2}^{2}$

11.2:1169

11.1:

$14.1: 898$

1 10.3:100

A 10.3:104

A $10.3: 55$

A $4.1: 900$

A $4.1: 855$

111.5:9

A29.3:31

A29.6:30

A 29.3:24

A $28.3: 27$

A $28.3: 17$

A $19.3: 17$

A29.6:25

A29.6:2S

+29.6:22

A 29.2:C+9

A29.3:24

A29.6:25

A $1.9: 149$

A $29.6: 24$

A29.6:2.2

129.6:25

A $29.6: 26$

A29.6:25

A29.6:20

A29.5:F

A29.6:29

129.6:27

A29.6:27

129.6:22

A 29.6:24

A 29.6:29 


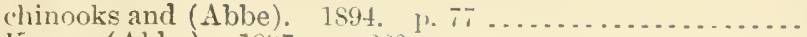

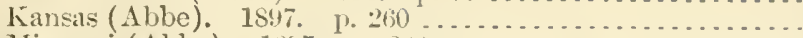
Missonri (Abbe). 1897. p. 260)

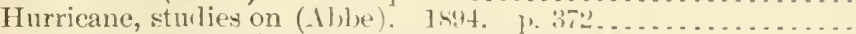
Injurious to vegetation and crops (curtis). 1,45. 11. 43. . . . .

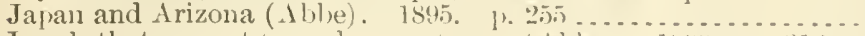

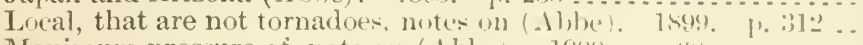
Maximum pressure of, note on (Abbe). 1900). p. lix ........ Measurement of, notes on (Abbe). 1n9s. p. 3rs............ . . Minnesota, movements of (1hbe). 1897. p. 252.

Monthly notes on, July, 1891-0(0t. 1902

Iorement of thunderstoms again-t (Abibe) isys. lil. is.;. $42: 3,465$

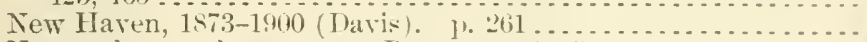

Nomenclature of, report on (Proctor). isi\% 1) $5 t . . . . . . .$.

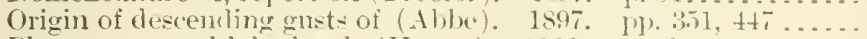

Phenomena and lake levels (Henry). $1900 . \quad$ p.20:3 . . . . . . . . .

Popular queries alont, with answers (Kimball). 1901. 1. 42.3.

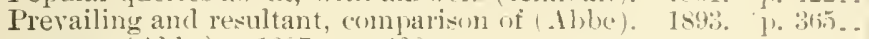

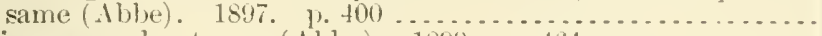

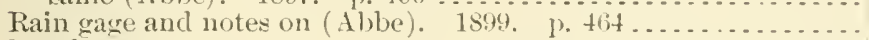

Resultant-calculation of, notes on (Abbe). 1s94. p. t:21 .......... mechanical determination of, note on (Abbe). 1897. P. 540.

Sand dumes and, notes on (Abbe). 1901. 1. 176...........

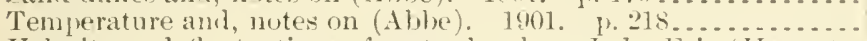

Velocity and fluctuations of water level on Lake Erie (Henry). 1902

Telocity of, early measurements of (Abbe). 15i6. 1. $459 \ldots .$.

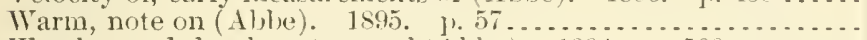

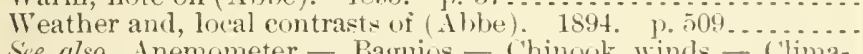

Sce also, Anemometer - Bagnios - Chinouk winds - ('limatology - Cyclone - Dancing dervishes - Derecho - Hurriranes - Pamperos - Tornadnes-Typhom.

Windward Islands, raintall of (Jefferson). 1901, p. 56... . . . . . Wine land, is Texas a? (Bauer). 18t59. p. tõ $1 \ldots . . . . . . . . .$. Wines:

Adulteration of (Crampton). 188\%. 1'.26.;.

American-

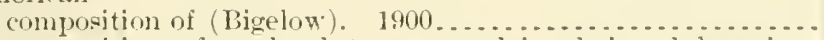
composition of, and snbstances nsed in their allulteration

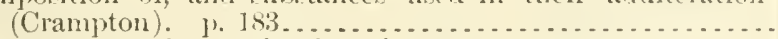
wine grapes and, examination of. 1stit. p. 3it .........

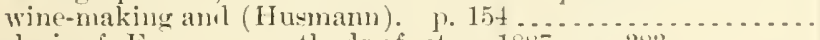

Analysis of, European metlods of, ete 18si. p. 3... ........

Beers, etc., analysis of, nethods projosed for adoption for use in

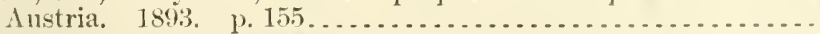

Chemical analysis of (Me.Murtrie). 1873. p. $240 \ldots \ldots . . . .$.

Consumption of, in [nited States, per capita of popmlation-

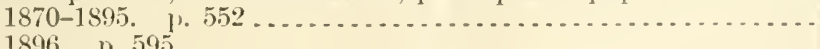

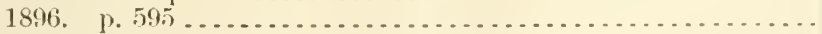

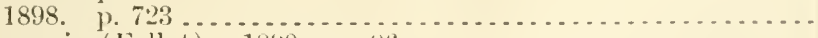

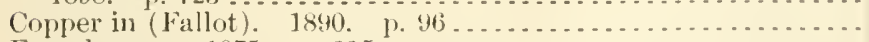

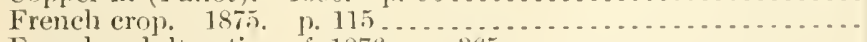

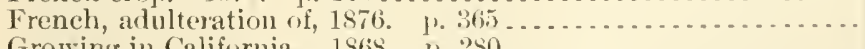

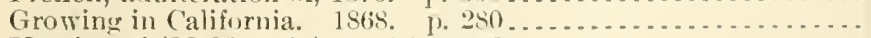

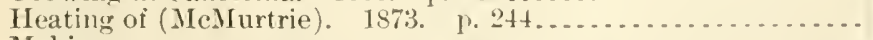

Makinggrape-culture in El Paso del Jorte and (P'ierson). 1s73. 1.24. 1:27,9:11 vine culture in Midnle sutes and ( Iorgere) p. $118 . . .5 . .$.

Janufacture of grape, blacklerry, and other fruit wiues, on (iall's

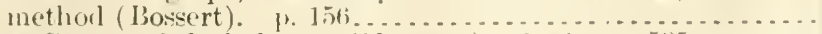

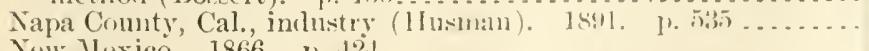

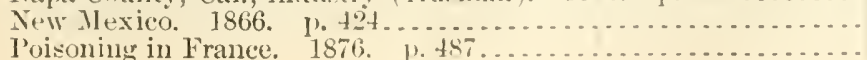

$1:(2),(i::) \cdot 2$

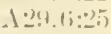

1:96.6: $1: 25$

1.219.1:2:2:2

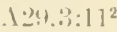

1:2!) $19: 2: 3$

1:24.17:28

$12911: 23$

$12(1,1:: 2)$

.1:49.1::25

1:29.15:

$129,4: 2: 3: 3$

$12 ! 10: 30$

1:2!).1:2:5

$12(1,6: 25$

$1: 29,(i: 2)$

$1296: 6: 24$

$129,0:: 2]$

$124.6(2: 25$

$129.6: 27$

$129.6: 27$

$129.6: 2.5$

129.6:209)

1:94.6:29

1 29. 万.

129.6:24

A29.6:2:?3

A:99.6:2:2

1.94.6:20

1.27.9:15

A. $7.3: 13^{3}$

17.3:59

A].1:

1.27.9:3

11.1:Sti $17.3: 13^{3}$

17.3:38

127.9:11

11.10:5i15

1 $1.10: 5.100$

11.10:5:5

16.3:11

1:2):1:14

127.9:14

1:7.9:6

$1: 7.9: 11$

.11.1:ktiti

. $11.1: N(0 ;)$

127.9):1)

1:7.!1:4

1:7.91:14 
Wines-Continuel

l'rouketion of-

in lirance in 1ss. 1sst. No. 8. p. 45 ................ mineral nutrition of vine for (McMurtrie). 1882. p.. $180 \ldots .$. Scuppernong, analysis of1868. p. 362.

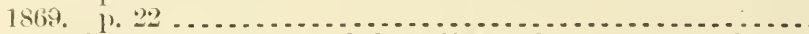

See also California wines and brandies - Grape nust - Grape vine- Grapes - Vine.

Wing, H. H. :

Dairy industry of Tnited States, report accompanying exhibit of Animal Industry Burean, at Paris Exposition of $1859 . \quad$ p. 387.

Feeding experiments, special puints bearing on. 1891, 1.93...

Wimnemnca, Nev., forage conditions between Ontario, Oreg., and

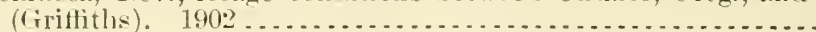

IVinslow, Alfred A. Horse breeding in Belgimm. p. 503 . . . . . . .

Winslow, Edward D. Animals, dead, disposition of, in Stockholu.

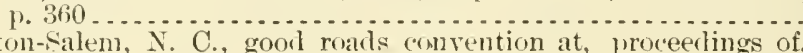

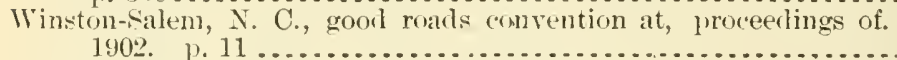

Winter:

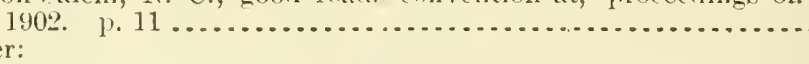

Bee-keeping in (Tupper). p. 209.

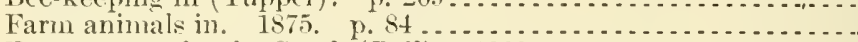

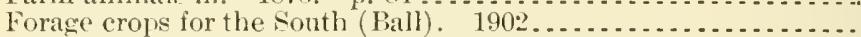

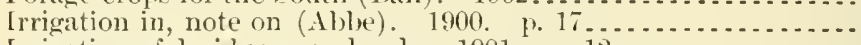
Irrigation of decirtuons orehards. 1901. p. 12............ Severe, lienefits of (Ablue). 1899. p. 62................. . . .

Winter washes, experiments with, against San Jose seake, season of Vinters:

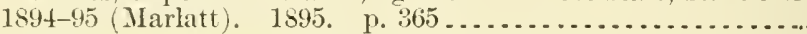

Are our winters changing? (Henry). 1898. p. 540.

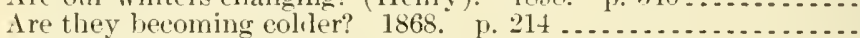

Winton, Andrew Lincoln:

Address of, as president of Association of Official Agricultural Chemists at fifteenth annual convention. 1898. p.9.......

Baking powder and baking-powd $\cdots$ chemicals, analysis of, provisional method for. 1902. p. 49 .

Milk, solids and fat in, Babeock gravimetrie method for reter-

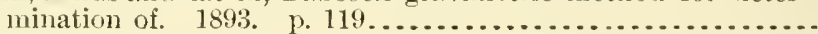

Potash-

bichromate of, does cream lose fat on keeping for long time

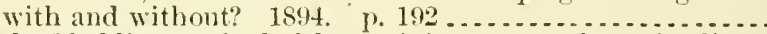

Livdo-Gladding method of determining, report of use of sodium

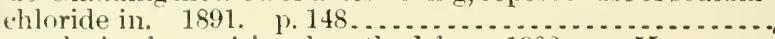

Spices, analysis of, provisional method for. 1902 . p. 55 . . . . . Sep also, as joint author, Jenkins, Edward Hopkins.

iVire:

Early use of, in kite flying (Fergusson). 1897. p. 135........ Irrigation by use of, notes on (Betts). 1899. p. 301 ...........

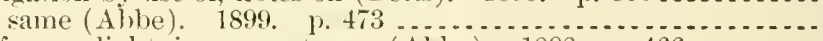

Wire fences, lightning on, notes on (Abbe). 1s9s. p. $466 \ldots . . . .$.

Wireless telegraphy, note on (Abbe). 1900. pp. 12, 113, 294.....

\section{Wireworms:}

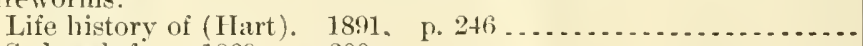

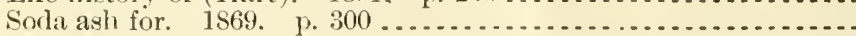

Wisconsin:

Cattle trate and allied industries of (Perry). p. 125...........

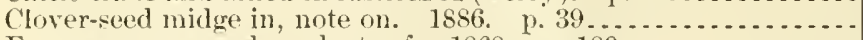
Farm resonrces and products of 1868 . p. $189 \ldots \ldots \ldots$ Farmers' institute work accomplished in (McKerrow). 1902. p.31.

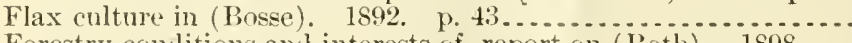
Forestry conditions and interests of, report on (Roth), $1898 \ldots$. same, introduction to report (Fernow). 1898. p. $6 \ldots . . . .$.

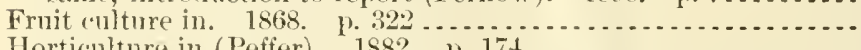

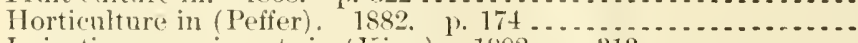
Irrigation experiments in ( $\mathrm{ing}$ ). 1902. 1.313.............

A $27.9: 2: 2$

A1.8:2:2

A $27.9: 6$

A:7.9:7

A $4.1: 857-8$ A10.5:3

119.3:15

A $4.1: 900$

A 4. 1:899

A 22.3:23

A1.1:867

A $27.9: 13$

A1.9:147

A29.6:28

A $1.9: 14 t$

A $29.6: 27$

A.9.7:7

A29.6:26

A $27.9: 6$

A7. $3: 56$

A7.3:65

A 7. $3: 38$

A7.3: 43

A 7.3:31

A7.3:65

A29.6:25

A 29.6:27

A29.6:27

A29.6:26

A $29.6: 28$

A.9. $7: 3$

A27.9:7

A 4. 1:886

A9.3:12

A 27.9:6

A $10.3: 120$

A 11.5:4

A 13.3:16

A 13.3:16

A27.9:6

A1.8:22

A10.3:119 
Live-stock industry nf, enndition of (Campbell), p. 321........

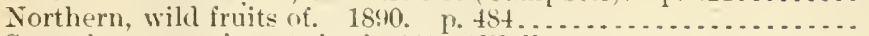

Sugar-beet experiments in, in 18.1 (Woll). 1.90..................

See also La Crosse - Nilwauke - New Richmoni - Whitewater.

Wisconsin Agrieultural lixperiment Station farm, gromel-water on, fluctuations in level and rate of movement of ( $\mathrm{King}$ ). 189:.

Witch-hazel, two species of plant-lice inlabiting, life listory of

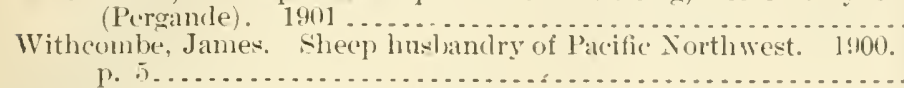

14.1: $: 59-90$

A $27.9: 28$

A7.3:33

A.29.3:5

A.8.:

A1.9:117

Withers, W. A. Nitrification as an element of soil productiveness. 1902. 1). 87

Withers, W. A., and Fraps, G. S.:

Ammonium sulphate and cotton-seed meal in different soils,

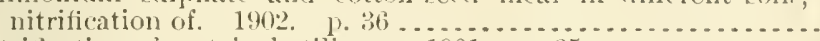

Nitrification of certain fertilizer. $1901.01,25 \ldots \ldots \ldots \ldots \ldots .$.

Woeikoff, A. Ramfall and cliarts of rainfall. 1902. p. 282.......

Wohl, A. Carbohychlatew, character of, alsstract of paper on. 1890.

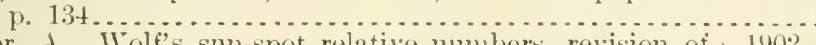

Wolfer, A. Wolf's snn-spot relative numbers, revision of. 1902.

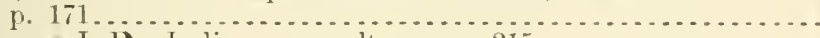

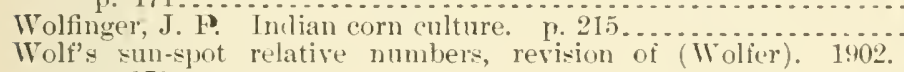
Fritz 171 ilhelm:

Woll, Fritz Wilhelm:

Agricultural education and research in Scandinavian countries

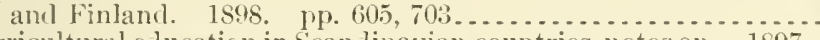
Agricultural eflucation in Seandinavian countries, notes on. 1897.

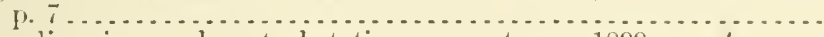
Scandinavian seel-control stations, report on. $1899.1 \mathrm{p} .4 \ldots$. Sugar-beet experiments in Wisconsin in 1891. 1.90 ............ Wollatser, A. B. Thermographs, furnishing of, to voluntary olservers, records to be kept at section centers. 1902.

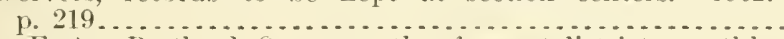

Wollaber, E. A. Portland, Oreg., weather foreast district, monthly

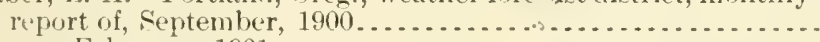

Wolliny, Ewalu:

Physial properties of soil, nature of. 1896 . pp. $761,853,948 \ldots$ Soil, relation of physical properties of, to cultivation of plants. soils1893. pp. 528, 627 .

artificial changes of pliysical properties of. 1900, p. $604 \ldots$. physical properties of, adaptation of methods of cultivation

and manuring to. 1900.4 p. 805
Wollny methorl, application of, to mixed butters (Besana). 1890.

Wolves. See Cattle.

Women's farm institutes (Narllock). 1902. p. 46

Wood, Mrs. A. F. See, as translator, Charpentier de Cossigny, i. J.

Wood, Peter. Dew-point, value of, in forecasting weather mmler Wood: certain conditions. 1902. 1. 152.

A 10.3:115

A7.3:67

17.3:62

A $29.6: 30$

A7.3:28

Az9.6:30

A1.1:\$6

入:9.6:3!)

A 10.6:9

A 10.4:32

A 10.6:10

A $7.3: 33$

A29.3:31

A29.6:29

A29.6:30

A 10.6:6

A10.6:4

A 10.6:11

A10.6:11

A 7.3:24

A10.3:110

A:9.3:31

American, thirty-two species of, summary of mechanical tests (m). Characteristics and properties of, elementaly discussion of ( Roth). 1895 same, introduction to (Fernow). 1895. Consumers of, information to, relative to increasing durability of

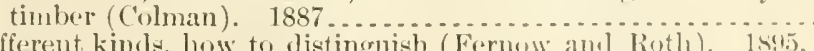

Different kinds, how to distinguish (Fermow and Roth). 1 sis.

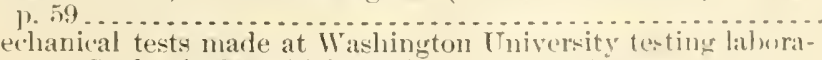

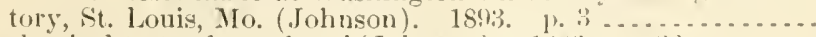

Mechanieal tests of, results of (Jubnson). 1s93. 1. 2..........

A13.4:15

$\Lambda 13.3: 10$

$113.3: 10$

A13.4:3

113.3:10

A $13.3: 8$

113.3.8

More important, of North Ameria, key to. 1895. J.64....... $113.3: 10$ 
Wool-Continued

Native, rlescriptive catalogue of manufactures of, as shown in exhibit of Agriculture Department at World's Industrial and Cotton lixposition at New Urleans, La. (Dodge). 1886 ..... Preservation of -

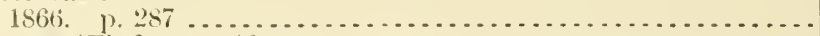

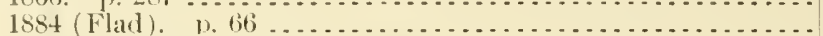

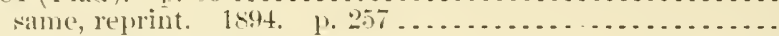

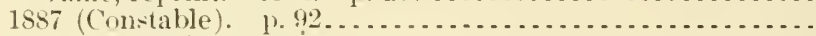

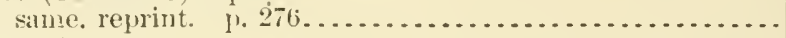

Quality, etc.1895. ए. 590

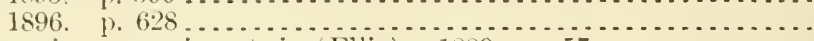

Seatoniug, experiments in (Elliw). 18s9. p. $57 \ldots \ldots \ldots \ldots \ldots \ldots$

structure of, of five southern pines (Roth). p. 133........... same, rev. ed. 1897 . p. 143.

Test material, fieln records of $(M \mathrm{ohr}) .1893$. p. $50 \ldots \ldots$

Trale in certain states (Baker). 1sst. p. 198 . . . . . . . . . . . Trale in lumber and, letter from agent of Forestry Division re-

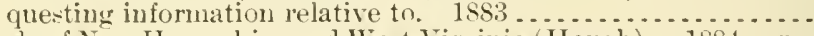

Trarle of New Hampshire and West Virginia (Hongh). 1884. p.

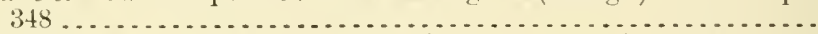

Trarle of Western States and Territories (Furnas). 1894. 1).

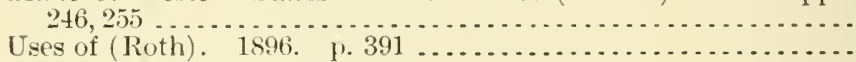

See also Lumber - Timber.

Wood char. See Brown coal and wood char.

Wrood-creosote oil, report on (Bixby). 1887. p. 99.

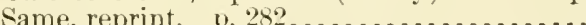

Wood dnck and woolcock, two ranishing game birds (Fisher).

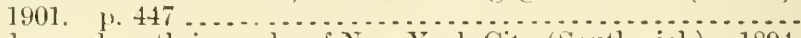

Wood-leopard moth in parks of New York City (Southwiek). 1894.

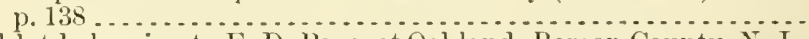

Wood lot belonging to E. D. Page, at Oakland, Bergen County, N.J., working plan for (Graves). 1898. p. $301 \ldots . . . . . . . . . .$.

Wroodeock and wood duck, two vanishing game birds (Fisher).

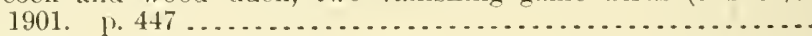

Wooden ties. See Railroad ties.

Woodford, E. S. Fish culture, letter on. 1869. p. $376^{*} \ldots \ldots$...

Woodhaven, Long Island, N. Y., tomado at (Emery). 1895. p. 252 .

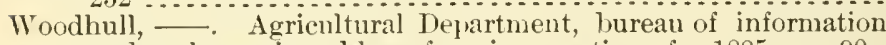
and exchange in, adlress favoring creation of. 1885 , p. 90 .

Woodpeckers:

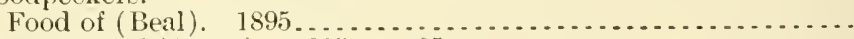

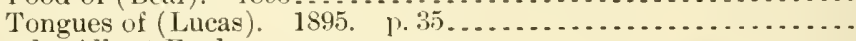

Woods, Albert Fred:

Bermuda lily disease, preliminary report of investigations. 1897

Mosaic discase of tobacco. $1902^{\circ}$......................... Plant physiology in relation to horticulture and agriculure. 1901.

p. 127
Plants, health of, relation of nutrition to $1901 . \quad$ p. $155 \ldots \ldots$

Stigmonose, a rlisease of carnations and other pinks. $1900 \ldots . .$. .

Vegetable physiology and pathology, work in. 1898. p. 261 ...

Woody plants, wounds in, principles of pruning and care of.

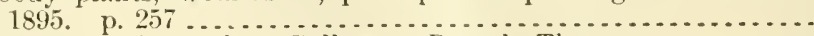

See also, as joint author, Galloway, Beverly Thomas.

See also, for report as acting Chief, Division of Vegetable Physiol-

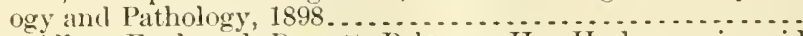

Woods, Albert Frel, and Dorsett, Palemon H. Hydrocyanic acid gas, use of, for fumigating greenhouses and cold frames. 1899 .

Woorls, Cluarles Dayton:

Beef, Anerican and European, comparative composition of, report accompanying exhibit of Animal Industry Bureau, at Paris Exposition of 1889 . p. 426 .

* By a misprint, this page number appears twice.

A13.5:4

A13.2:L97

A $13.5: 4$

A 13:5:4 A1.10:896

A 13.3:1

A13.3:9

A1.10:901

19.7:7

A 1.10:898

A 1. 10:901

A27.9:7

A29.6:23

A $1.7: 9$

A $5.3: 7$

A5.3:7

A28.3:14

A19.3:18

A 10.3:99

A1.10:901

A28.3:19

A1. 10:898

A1.10:895

A 28.1

A9.5:37

A9.5:37

A4. 1:887-8 
Woods, Charles Dayton-Continued

Meats, composition and rooking.

See clso, as joint author, Atwater, Wilbur Olin - Vhecer, IIonjer Jay.

Woods, Clias. Diyton, and Merrill, L. H. Pread, investigations on

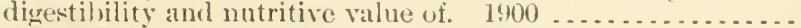

Woodsman's Hamblhook, pt. 1 (Graves), 1902 ... . . . . . . . . . . .

Woodwarl, J. J. Pleuro-pmenmonia anong cattle, pathological anatomy and histology of respiratory oryans in. 1571. j. 64.

Woodworth, C. M:

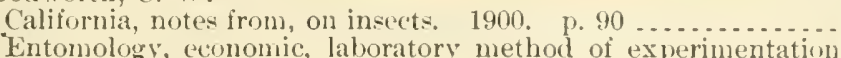

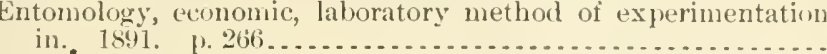

Woody plants, wombls in, pruning and care, principles of (Wonds).

f'lawifleatlon no.

A1.9:3t

1 10.3:\$5

$11: 3: 3: 30$

11.2:C:2:2:

19.6:26;

A!. $7: 3$

A 1.10:S95

IVool:

$$
\text { 1. } 257 \text { ilso Trees. }
$$

\section{American-}

future of (Newton). 1864. No. 1. p. 12...............

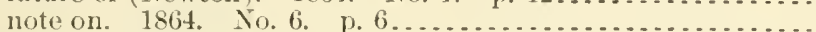

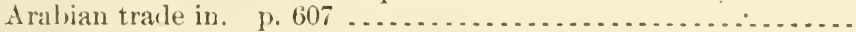

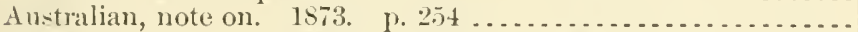

British imports, Jan.-March, 1sts-iit, p. 240.............. Buyers of, protection against. 186s. p. $247 \ldots \ldots \ldots \ldots \ldots$

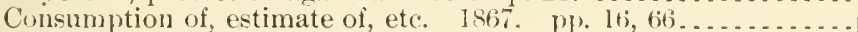

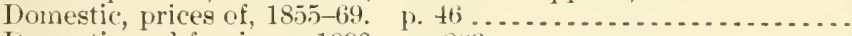

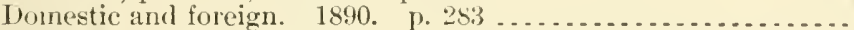
Electoral, culture of, in South, facts relative to. 1878 . p. $124 \ldots$ Export of, from Montevideo in 1901. ए. 607 ............... German production and manufacture, 1876 . p. $494 \ldots \ldots \ldots \ldots$ Germany's import (Stern). p. 520. Growing-

Australia (Kenworthy).

California, 1854-74. p. 248

decreasc of. 1869 . p. 143

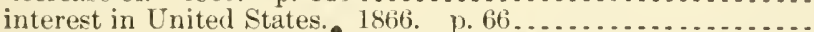
profits of, and future wool market. 1864. No. 1. p. 20.....

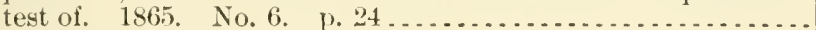

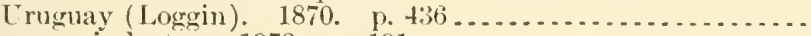

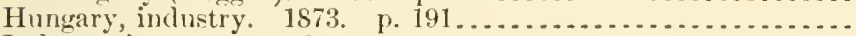

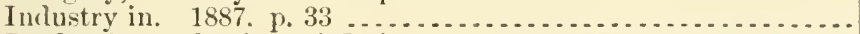

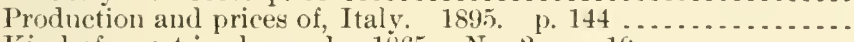

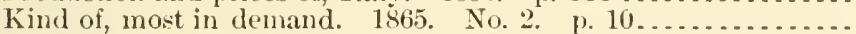

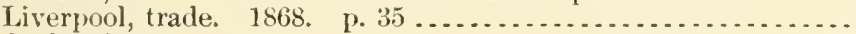
On hand-

Apr. 1867.

Apr. 1868.

A pr. 1869.

p. 149

p. 185

Popular fallacies concerning. $1867 . \quad$, $367 \ldots \ldots \ldots$

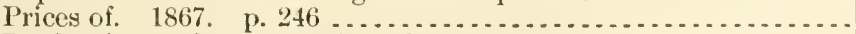

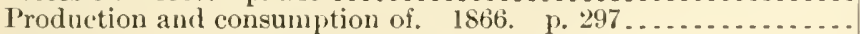

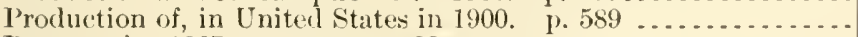

Prospect in, 1867, note on. p. 334 . . . . . . . . . . . . . . . .

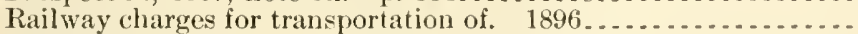

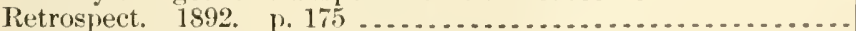

Sheep's, substitutes for. See Alpaca.

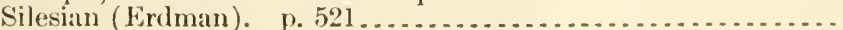

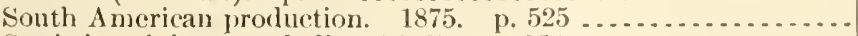

Statistics of, in a nutshell, 1870-87. p. $354 \ldots . . . . . . . . . .$.

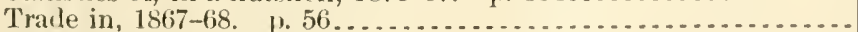

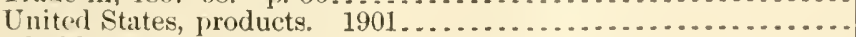

World's clip of-

1875. p. 94.

1894. p. 121

1899. p. 671

1900. p. 591

127.9:2

1.27.4:2

A.1:901

A $27.9: 11$

A $27.9: 7$

A:-7.9:6

A27.9:5

A 27.9:8

A27.9:28

A 1.2:Sh3

A 4. 1:901

A 27.9:14

A $4.1: 899$

A 1.1:864

A $27.9: 13$

A.27.4:7

A27.9:4

A:7.9:3

A27.9:3

A27.9:8

A27.9:11

A $27.9: 25$

A $27.9: 33$

1.27.9:3

A $27.9: 6$

A $27.9: 5$

A:7.4:6

A $27.9: 7$

A27.9:5

127.9:5

127.9:4

A4.1:900

127.9:5

1:7.8:10

A:7.9:30

A4.1:899

127.9:13

1:7.9:2:

A27.9:7

A4.1:901

A27.9:14

A $27.9: 32$

14.1:8:19

A4.1:900

See also Sheep and wool 


\section{Index}

Wrol and woolen mills, statistical report upon [statisties collecter

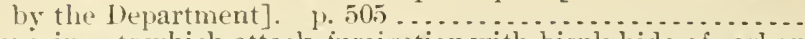

Woolens, insects which attack, fumigation with bisulphide of carbon for complete and rapid destruction of (Du Pysson). 1893. p. 159

Troolly aphis:

California remedies for, note on. 1886, p. $43 \ldots . . . . . . .$.

Of apple-

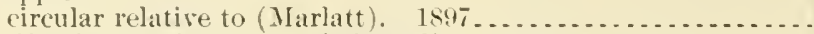

life history of, notes on (Alwood). 1898. p. $70 \ldots \ldots . . . .$. see also Iphis.

Wools and other animal fibers, examination of (Me Murtrie). 1886.

Wools of United States. $\quad$. 1si . . . . . . . . . . . . . . . . . . . .

World's Agricultual Congless, 189:. See Chic'ago, Ill., World's Agricultural Congress.

World's Columbian Exposition, 1893. See ('hicago, Ill., World's Columbian Exposition.

Worl's Industrial and C'otton Centennial Fxposition. Se Tew Crleans, La., World's Industrial and Cotton Exposition.

World's markets for American proluets . . . . . . . . . . . . . . . . . .

Worms. Sép Angleworms - Armyworm-Bollworm-Cankerworms-Cottonworms-Cutworm-Stalkworm - Webworm.

Worth, s. G. Cloud-burst at Erwin, Tenn. 1898, p. 244.........

Worthington, Charles. See, for reports as Statistician, Agriculture

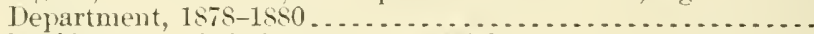

Wounds of horses and their treatment (Michener). p. $477 \ldots \ldots . .$.

Wray, William 11 .

Gireat Britain, Ameriean animals and animal productions in.

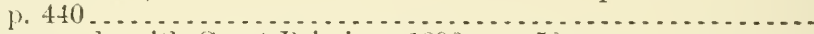

Horse trade with Great Britain. 1898. p. 50 . . . . . . . . . . .

IIorses, American thoroughbred, in England. p. $503 . . . . . . .$.

Live-stock tracle from Argentina and Australia to England. P. S1.

Wrecks. Sep Great Lakes.

Wren, H. B. Climate and corn, report on, relation of. 1902. p. \&..

Wright. Frank Bennett. Weather Burean of Japan. 1900. p. 381.

Wright, John A. C.:

Address of, before convention of National League for Good Roads, Washington. 1893. p. $34 \ldots . . . . . . . . . . . . .$. Highway legislation in New York, history of. 1901. p. 29 ....

Wright, .1. Galveston, Tex., tornarlo, Nor. 6, 1892. p. $309 \ldots . .$. Wurtemburg:

Agricultural productions of. 1869-70. p. 206 ..............

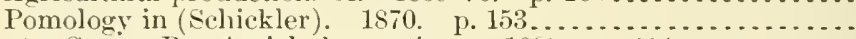

Wurtz, George B, Aerial observations. 1899 p. p. $114 \ldots \ldots \ldots . . . .$.

IVyandotte, American breeds of fowls, 2 (MeGrew). 1901 .......

Wyoming:

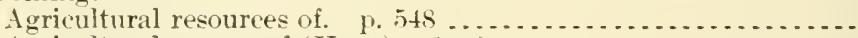

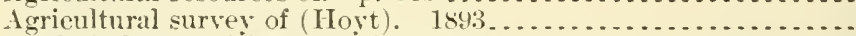

(attle industry of (McNeely). p. 37\% . . .

Duty of water in (Johnston). 1900 , j, $171 \ldots \ldots \ldots \ldots \ldots \ldots$

Forest conditions of Rocky Mountains in (Ensign) p. $41 \ldots \ldots$.
Geology of, east of foothilis of Rocky Mountains (Bailey). 1890. p. 65 . . . . . . . . . . . . . . . . . . . . . . . . . .

Irrigation in, use of water in, and its relation to ownership and distribution of natural supply (Buffum). 1900............

Irrigation system of (Bond and Wilson) 1901. p. $47 \ldots . . . .$.

Iive-stock industry of, condition of (IrNeely). p. $425 \ldots . . . . .$.

l'rairic dog, from, deseription of new (Merriam) 1890, p. 33...

Water supply of, for season of 1900 , as depending on snowfall

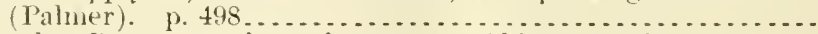

Treather lincan, stations of, notes on (Alive) 1900 . p. $17 \ldots$

Windstorm in, local electricity in (Hunton). 1894. p. $509 \ldots .$.

See also Lawmie Plains - Red Desert of Wyoming - Wheatland.

Wyoming Experiment Station, recent investigations by, in alkali and irrigation (Buffum). 1900. p. 69 ....................

Xanthium strumarium. See ('ocklebur.

Xanthium trypeta, report in (Marlatt). 1s91. p. $312 . . . . . . . .$.

A12.3:

A:9.6:28

A2T.1:

A4.2:H 78

A4.1:598

A1.2:H7s

1 $1.1: 899$

A4. 1:\$4.5-6

129.6:20

A29.6:28

110.3:14

A 22.3:21

A29.6:20

A $27.9: 10$

A27.9:8

A29.3:24

A4.3:31

11.1:870

A27.8:7

A4.1:898

A 10.3:86

A 13.3:2

A15.2:Ar7

A 10.3:81

A 10.3:96

A $4.1: 889-90$

A5.5:4

A29.6:28

A 29.6:28

A29.6:2:)

A10.3:76

A9. $7: 3$ 
Inciex

( laง alfiation nu).

Xenia, or mmediate effect of pollen in maize (Weblwer). $1900 \ldots \ldots .128 .3: 20$.

Xiphirlimm ensiferum, oviposition and emiryonic alevelopment wi,

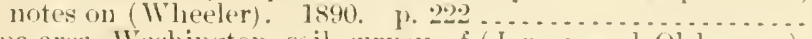

Yakima areal, Washington, soil survey of (Jensen and Olshatisen).

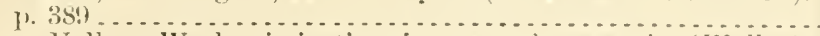

Yakina Valley, Wash., irrigation in, use of water in (Waller).

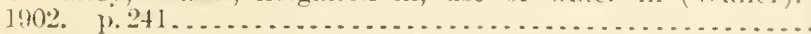

Yakutat bay, Alaska, botany of (Coville and Funston). 1sis.).

Yale. See Harvard and Yale.

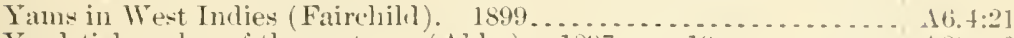

Yardictick, value of the, note on (Ablue). 1897. p. 19 . . . . . . . $129.6: 25$

Yards, disinfection of, ly fire (Stiles). 1902. 1. $15 \ldots \ldots \ldots \ldots \ldots . .14 .3: 35$

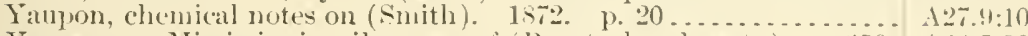

Yazon area, Mississippi, soil survey of (Bonsteel and party). 1, 359. $1: 36 . \overline{1}: 901$

Yearbooks of Agriculture Department:

Index to, 1894-1900 (creathonse). 1902

Tellow-suotted willow slug, report ou (How. . . . . . . . . . . . . . 121.8:7

Yelowstone National Park:

(rovermment roal system of (Chittemen). 1901. p. 72...... 122.3:21

Letter relative to forest needs of (Ilague). 1sss. p. 206 . . . . . . 113.3:2

Yellowstone Valley, alkali soils of, from preliminary investigation of soils near billings, Mont. (Whitney and Means) .......... 126.3:14

Yerhy, M. H., short hiography of (Chaffee). 1900. 1. 539 ..... 129.6:28

Yemioloff, Alexis. Phosphates, Russian mineral. 1873. 1. 2.2... A27.4:11

Yocum, J. H. Tamnin, detemining, by hide power, notes on points

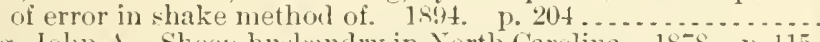

Young, Jolm 1. Sheep, huslundry in Nortl Carolina. 1858. p. 115

Foung people attenrling farmers' institutes, how to interest and

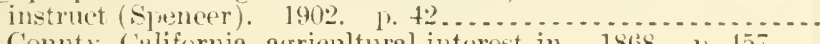

Yuba Comnty, California, auricultural interest in. 1868. 1\%. $457 \ldots$

Yula River, California:

Featmes and water rights of (Mansom). 1901. ]. $115 \ldots . . .$.

L'se of water of (comnick). 1901. p. 100 . . . . . . . . . . . . . .

Yncas, generaphio and rertical distribution of, in deserts and desert langes of southern California, southern Nevala, northwest-

Yuration: (rn Irizona, and southwestern (tah (Merian). 1893. 1.345.

A. $.3: 43$

11.2:Sh:3

A 10.3:110

A27.9:(3)

$+10.3: 100$

1 $10.3: 100$

1.5.5:

A $1.1: 8 t i s$

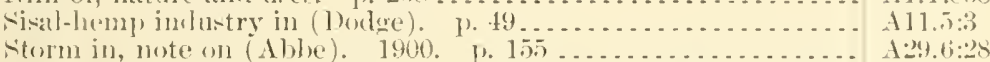

Yucä inscets and yuceat pollination, further noteson (1iley). 1 sis.

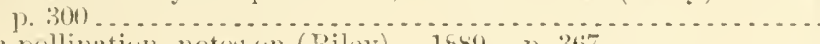

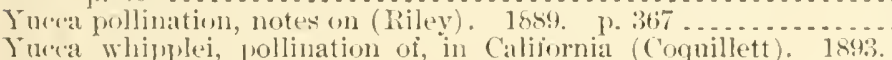

$19.7: 5$

19. $7: 1$

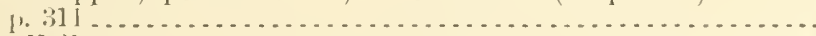

Yukon Valley:

Agricultural and horticultural combitions in, preliminary report

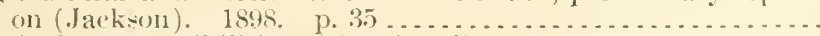
Acricultural possibilitics of (Brainerel). p. 27 . . . . . . . . . .

Yukon region:

Birks of, with notes on other species (Bishop). 1900. 11. 47...

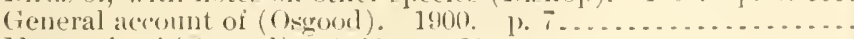

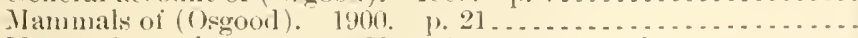
Meteorology of, report on (Myers). 1899. p. 100...........

Yokm Yalley, weather of, report on (Mycrs). 1901. 1.803..... Valloriskic, liev. J. I. Water hug found lis, note on (Bergroth).

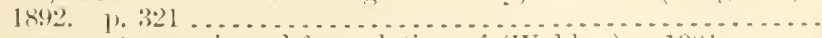

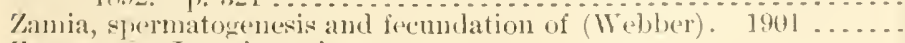
'/apus. Sire Jumping micr.

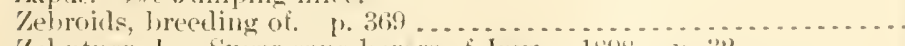

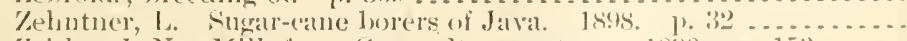
Zeitler, J. N. Milk from (amstart, mport on, 18!n. [1. 153.....

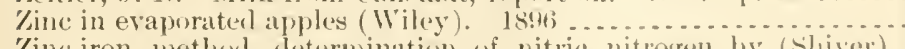
Zinc-iron netlod, determination of nitric nitrogerl by (shiver). 1594. [. 14 '?

\section{A!1.7:5}

A $10.3: 4 \mathrm{~s}$ 1 $10.1^{2}: 101$

1.5. $\div: 19$

15.

15.5:1!)

1:4.ti:27

1:9.6:?:?

1!1.7:4

119.3:23

14.1:598

1!).6:10

17.3:24

17.3:48

17.:3:1:3 


\section{Index}

Znaim cueumbers, cultivation of (Fairchild). 1901

Classifisttion no.

Zones:

Life and crop, of United States (Merriam). 1898 A:3.4:2

Verdant, notes on (Alibe). 1893. p. 365

A.5. $3: 10$

$129.6: 21$

Zoülogy:

Abstracts of reports of agricultural experiment stations on, $1897-190 \%$

A10.6:

Nedical and veterinary, index catalogue of. Ht. 1. Authors: A to Azeredo (Stiles and Hassall). 1902

A $4.3: 39^{1}$ vee ulso Mammalogy.

Zuntz, N. Metabolisin of nutrients in animal body and source of muscular energy. 1897. p. 538 .

Zuyder-Zee, reclamation of. 1875.

$\$ 10.6: 7$

Zyemstros. See Russian zyemstvos.

127.9:13 


\section{APPENDIX}

REPORTS WHICH ORIFINATED IN THE AGRICULTURE DEPARTUENT, BUT WHICII WERE PRINTED ONLY AS CONGRESSIONAL HOCUNENTS 


\section{Appendix}

(1) 37th Cong., 3d sess., H. doc. 14; serial number 1159.

Letter from Commissioner of Department of Agriculture, in answer to resolutions in regard to expenditure of agricultural fund. Dec. 18, 1862. $8 \mathrm{pp}$.

(Contains statement of money paid for agricultural statistics, ete., July 1 to Dec. 5, 186:, and cpinion of Attorney-General on transfer of unexpended appropriation and dehts of (Commiswioner of Patents for agricultural purposes.)

(2) 3sth Cong., 1st sess., S. mis. doc. 13; serial number 117 .

Letter of Commis:ioner of Agriculture to Chairman Committee on Agriculture upon subject of taxation of tohace as recommented by Commissioner of Internal Revenue. January 21, 18tit. 6 pp.

(Shuws reasons for dissent from proposition of Commissioner of Internal Revenue to tax leaf tobacco twenty cents per pouml.)

(3) 38th Cong., 2d sess., S. doe. 35; serial number 1209.

Letter of Commissioner of $A$ griculture, transmitting report of commission appointed to test practirability of cultivating and preparing flax or hemp as substitute for cotton. March 1, 1865. $\$ 16 \mathrm{pp}$.

(4) 39th Cong., 1st sess., H. doc. 49; serial number 1255.

Reply of Commissioner of Auriculture to resolution relative to receipts and disbursements of that Department. February 21, 1866. $4.3 \mathrm{pp}$.

(An itemizerl account of all receipts and dishursements of the Department from its imeption, May 15, 1862, to Jan. 30, 1866.)

(5) 39th Cong., 1st sess., S. mis. doc. 98; serial number 1239.

Letter of Commissioner of Agriculture, communicating information in relation to rinderpest or cattle plagne. April 18, $1866.21 \mathrm{pp}$.

(History of rlisease, remedies and courses of treatment arlvisalule, and measures necessary to prevent its sprearl.)

(6) 39th Cong., 1st sess., S. mis. foc. 103; serial number 1239 .

Communication from Commissioner of Agriculture relative to subject of curing seed and cultivating china grass. May 3, 1866. $5.1 \mathrm{p}$.

(7) 39th Cong., 1st sess., S. mis. doc. 124; serial number 12:39.

Letter of Commissoner of Agrieulture to Chairman Committee on Agrienlture, transmitting communisation from Argentine Republic in reference to purchase by our Government of flock of aljacas. July $5,1866.3 \mathrm{pp}$.

(\$) 40th Cong., 21 sess., 11. (he. 5n; serial number 1330 .

Letter from Commissoner of Agriculture in answer to resolution relative to allowance of twenty per cent for last fiseal year. December 16, 1867. $1 \mathrm{I}$.

(9) 40th Cong., 2d sess., H. rec. 91; strial number 1332.

Report of Commissioner of Agriculture in response to Honse resolution. January 13,18 tis. $11 \mathrm{pp}$.

(Report on conlition of Department, and legislation necessary for rerorganization in keeping with its vast interests.)

(10) 40 th Cong., $2 d$ sess., H. dor. 121; serial number 1337 .

Letter from Commissioner of Agriculture relative to duty on imprortations of foreign stock. Januiry 27,1868 . 2 pp.

(11) 40th Cong., 21 sess., H. doe. 18s; serial number 1337 .

Letter from Commissioner of Agriculture, transmitting memorial of Temessee Horticultural Society for removal of import duties on agricultural sereds, ete, and approving same. February 2.5, 1868. 2 pp.

(12) 40th Cong., 3d wess., H. 1loc. 93; serial number 1381.

hetter from Commisuinner of Agriculture relative to proposed international horticultural exhibition to be hell at Hamburg sept.. 1869. February 24, 1869. $3 \mathrm{PI}$.

(1:3) 41st Cong., 21 sess., H. ex. dor. 107; serial number 1417.

Letter from Commisioner of Igrieulture in answer to resolution in relation to extent and value of foreign commodities susceptible of proluction within limits of country, as plants useful for dye-stuffs, méclicines, and for otlien economic purpeses. Feloruary $3,1870.5 \mathrm{pp}$.

(Ietter includes table showing amount anl value of articles imported at New York City, 1869, and their proilucts.) 
(1.1) 421 Cong., 3ri sess., H. ex, doc. 34: serial number 1565.

Lettor from Commissioner of terrienlture, transmitting list of articles burchased and disposed of hy his department since inventury mate leeventer 1 , isi1. December $10,187:$. 2 ply.

(15) 421 Cong., 20l sess., H. ex. doe. 17; serial number 150s.

Letter from Commissioner of Agriculture rolative to inventory and aceonnts

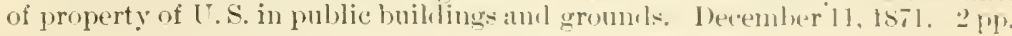

(16) 421 Cong., 2d sess. S. mis. loc. 14t; serial number 1482 .

Jetter from Commissiomer of Agriemltme, ('ommmnicating, in compliance with resolution, statement of statisties of mools and wowlens, showing inumrtation and ilomestic production thereot. April "2t, 18\%2. 6 pr.

(17) 4 th Cong., 1 st sess., S. mis. Ioe. 75 ; serial number 1665 .

Letter from Commissioner of Agricultur, transmitting, in answer to resulution, information in relation to soil and elinate anlapter to growth of seat-island cotton. March 10, $1876.3 \mathrm{pP}$.

(18) 4 th Cong., 1st sess., S. mis. (1oc. 75, pt. 2; serial number 1665.

Letter from Commissioner of Agriculture, (ommuni(ating, in answer to resclution, additional information in relation to eultivation of seat-island eotton. Jareh 20, 1876. 2 $\mathrm{pp}$.

(19) t5th Cong., 21 sess., H. ex. 1or. 24; serial number 1s0:2.

Message from President of United States, transmitting sperial report upon subject of forestry by Commissioner of A griculture. Herember 14, 187. 3 \%).

(A short review of "Report on Forestry, hy Franklin 13. Hough.")

(20) t5th Comg. 21 sess., s. ex. floc. 35: serial ummber 1780 .

Message trom President of the United ctates, onmmmirating, in answer to resolution, information in relation to disease proviling anome swine and uther domestic animals. February $26,1875.149$ (1).

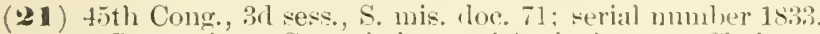

Letter from Commissioner of Agrimulture to Chaiman (ommittes on Igriculture, communieating information on sulpjoct of ylomro-pmenmonia amoner (attle. lebruary 15, 157!. 2:2 p'.

(Consints of many letters irom mon interesterl, listory af alicease and preventive measures ailopterl here and abroarl.)

(22) 4ith Cong., 1st ses.., 11. mis. doc. :30; serial mumber 2utt.

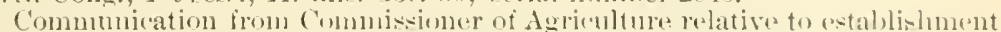

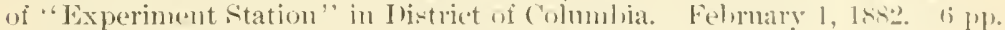

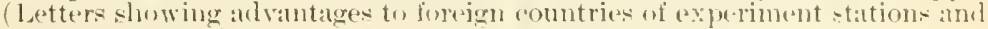
our need for themi.)

(2:3) tith Coner., 1-t sess., II. mis. (1m, 3!); serial number 2046 .

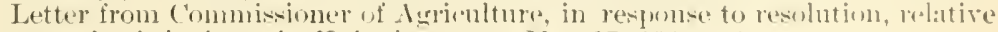
to growth of einchona in United states. May 17, 18s:. 3 [1].

(2.1) t7th Cong., 21 sess. S. mis. doe. 5]; serial nmmbel 20183.

Investigation of scientifie: and exomomic relations of somplnum-sterar industry, ly Committee of National Arademy of Sriences. Noxomber, 1.45:- Washing-

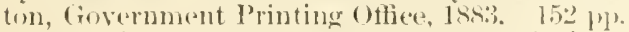

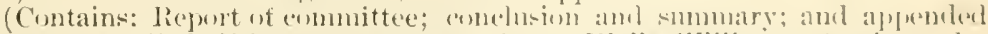

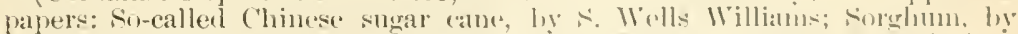

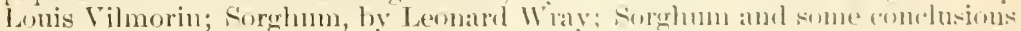

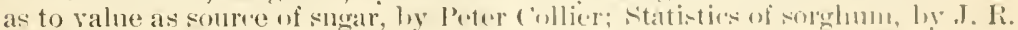

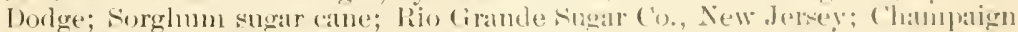

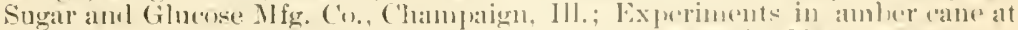

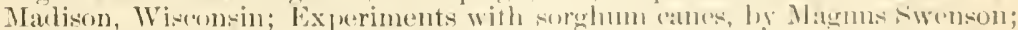

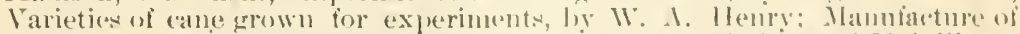

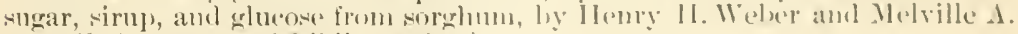
Scovell; letters; anıl bihliograulıy.)

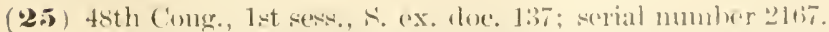

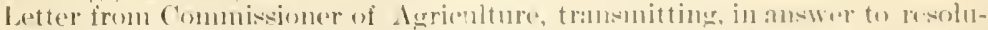

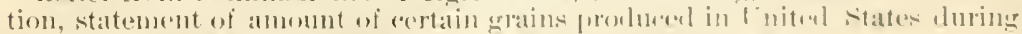

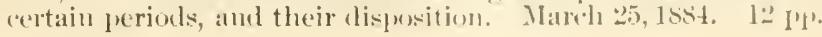


(26) 48th Cong., 2 d sess., H. ex. doc. 46; serial number 2296.

Letter from Commissioner of Agriculture, transmitting list of persons employed and statement of expenditures and of means adopted for suppression of contagious and infectious diseases among domestic animals. December 18, 18st. $8 \mathrm{pp}$.

(27) 49th Cong., 1st sess., H. mis. doc. 154; serial number 2415 .

Letter from Commissioner of Agriculture, transmitting statement of expenditures for fiscal year ended June 30, 1885. March 17, $1886.43 \mathrm{pp}$.

(28) 49th Cong., 1st sess., H. mis. doc. 240; serial number 2418.

Letter from Commissioner of Agriculture, transmitting, in response to resolution, statement showing amount expended for chemical division in laboratory from appropriation for present fiscal year and balance unexpended. A pril 27, 1886. + pp.

(29) 49th Cong., 1st sess., H. mis. doc. 284; serial number 2418.

Letter from Commissioner of Agriculture, transmitting certain papers, in response to resolution calling for copy of Department circular of June 6, 1882; copy of award of committee appointed to carry provisions of circular into effect; copies of all correspondence with Delaware Beet-Sugar Co. on subject, and statement of awards paid and to whom. May 14, 1886. $6 \mathrm{pp}$.

(Circular offers awards to manufacturers of sorghum and beet sugar for best reports on methods used.)

(30) 49th Cong., 1st sess., H. mis. doc. 303; serial number 2488 .

Letter from Acting Commissioner of Agriculture, transmitting, in response to resolution, report by statistician of Department respecting supply and domestic requirement of wheat and corn, and acreage of wheat, for present year, as compared with past five years; also prolable requirements of importing countries and acreage of crop and probable surplus or shortage in exporting countries for ensuing year. June 1, 1886. $11 \mathrm{pp}$.

(31) 49th Cong., 2d sess., H. mis. doc. 20; serial number 2488 .

Letter from Commissioner of Agriculture, transmitting report of expenditures for fiscal year ended June 30, 1886. December 14, 1886. $42 \mathrm{pp}$.

(32) 50th Cong., 1st sess., S. ex. doc. 24; serial number 2504.

Letter from Commissioner of Agriculture in response to resolution relative to employés obtaining patents for process of sugar making. December 13, 1887. 5 pp.

(Letter in restraint of allowing patents to Magnus Swenson, and opinion of Attorney-General.)

(33) 50 th Cong., 1st sess., H. mis. doc. 122; serial number 2565 .

Letter from Commissioner of Agriculture, transmitting statement of expenditures for fiscal year ended June 30, 1887. January 18, 1888. $81 \mathrm{pp}$.

(3.1) 50th Cong., 1st sess., S. ex. doc. 68; serial number 2510 .

Letter from Commissioner of Agriculture, transmitting, in response to resolution, report of Professor Sivenson on sorghum sugar. February 6, 1888. $11 \mathrm{pp}$.

(35) 50th Cong., 1st sess., S. ex. doc. 69; serial number 2510.

Letter from Commissioner of Agriculture, transmitting report for 1887 of Bureau of Animal Industry. February 6, 1888. $75 \mathrm{pp}$.

(36) 50th Cong., 2 d sess., S. mis. doc. 29; serial number 2614.

Letter of Commissioner of Agriculture, transmitting report of Joseph Neumann of result of his study and experiments of wild native silkworm of California. January $5,1889.5 \mathrm{pp}$.

(37) 50th Cong., 2 d sess., H. mis. doe. 62 ; serial number 2654.

Letter from Commissioner of Agriculture, transmitting report for 1888 of Bureau of Animal Industry. January 9, 1889. $116 \mathrm{pp}$.

(38) 50 th Cong., 2 d sess., H. mis. doc. 135; serial number 2654.

Letter from Commissioner of Agriculture, transmitting report of Women's Silk Culture Association of Uniter States for fiscal year 1588. March 2, 1889. 4 pp.

(39) 51st Cong., 1st sess., S. ex. doc. 24; serial number 2682.

Letter of Secretary of Agriculture, transmitting report of operations of Bureau of Animal Industry for year 1889 . January $8,1890$. it pp. 
(10) 51st Cong., 1st sess., H. ex. doc. 104; serial number $2 \pi 41$.

Letter from Secretary of Agriculture, transmitting statement of expenuitures for fiscal year ended June 30, 1889. January 13, 1.90. (ts p p.

(1) 51st Cong., 1st sess., H. ex. loc. 110; serial number 2743.

Letter from Secretary of Agriculture, transmitting reports upon operations of Women's Silk Culture Asoociation of Uniterl states and of Ladies' silk Culture Society of California, and upon experiments marle in District of Columbia with silk-reeling machinery. January $16,1890.30$ юे.

(Includes also report of Joseph Neumann.)

(42) 51st Cong., 1st sess., I1. ex. doe. 423; serial number 2752.

Communieation from Acting Secretary of Agriculture, in referenee to rleficiency in appropriation for Nurth Dakota Agricultural Experiment Station, and stating that said appropriation should he made. June 21, 1890.1 p.

(43) 51st Cong., 1st sess., S. mis. doc. 179; serial number 2700.

Letter of Secretary of Agriculture, transmitting synopsis of report which the Department of Agriculture will make upon subject of irrigation by artesian wells July 1,1890 . 7 pp.

(This is a short synopsis of $(\$ 15.2: \mathrm{Ar} 7)$.

(4) 51 st Cong., $2 \mathrm{~d}$ sess., H. ex. doc. 35; serial number 2855.

Letter from Secretary of Agriculture, transmitting statement of expenditures of all appropriations for fiscal year ended June $30,1890$. December $3,1890$. $95 \mathrm{pp}$.

(45) 51st Cong., 2d sess., S. ex. doe. 8; serial number 2818.

Letter from Secretary of Agriculture, transmitting report of Burean of Animal Industry [for year 1890]. December 11, 1890. 104 $\mathrm{p}$.

(46) 51st Cong., 2 d sess., S. ex. doc. 53. pt. 2; serial number 2818.

Letter from Secretary of Agriculture, transmitting, in additional response to resolution, report of progress of irrigation in montlss of November and December. January 20, 1891. 14 pp. 12 foldel pl.

(47) 51st Cong., 21 sess., H. ex. Anc. 203; serial number 2863 .

Letter from Secretary of Agriculture, transmitting statement of all purchases of cocoons and all sales of silk and silk waste cluring fiseal year ending June 30, 1890; also reports of Ladjes' Silk Culture Snciety of California and Women's Silk Culture Association of United States. January 24, 1891. 25๊ pp.

(4) $52 d$ Cong., 1st sess., S. ex. doc. 11; serial number 2892.

Letter from Secretary of Agriculture, transmitting report of Bureau of Animal Industry for year 1891. December 22, 1891. $129 \mathrm{pp}$.

(49) 52 d Cong., 1st sess., H. ex. doc. 55; serial number 2953.

Letter from Secretary of Agrieulture, transmitting detailen statement of all expenditures of appropriations for year ending June 30, 1891. January 7 , 1892. $134 \mathrm{pp}$.

(50) 52 d Cong., 1st sess., S. ex. doc. 45; serial number 2900.

Letter from Secretary of Agriculture, in response to resolution, transmitting report of agent, of Department of Agrieulture for making experiments in production of rainfall. February 25, $1892.59 \mathrm{pp} .9 \mathrm{pl}$.

(51) 52d Cong., 1st sess., S. ex. doc. 75 ; scrial number 2900.

Letter from Secretary of Agriculture, in response to resolution, ralative to certain employés in Dejartment. April 12, 1892. 5 p'.

(52) 52d Cong., 2d sess., S. ex. doc. 20; serial mumber 3056 .

Letter from Secretary of Agriculture, transmitting anumal report of Bureau of Animal Industry for 1892. Jamuary 5, 189:3. 229 Py.

(5:3) 521 Cong., 2rl sess., H. ex. doc. 251; serial mumber 3107.

Letter from Secretary of Agriculture, tramsmitting statement showing expenditure of appropriation for experiments in manufacture of sugar. Mareh 2, 1893. $3 \mathrm{pl}$.

(51) 53d Cong., 21l sess., H. ex. doc. 14; serial number 320:3.

Letter from secretary of Agrionlture, transmitting dotailuel statement of

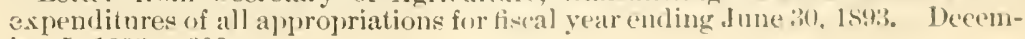
ber 5, 1893. $208 \mathrm{pp}$. 
(\$.j) 53d Cong.. 2d sess., \$. ex. doc. 72; serial number 3160 .

Letter from secretary of Agriculture, in response to resolution, relative to wheat crop of United sitates. April 4, 1894. $2 \mathrm{pp}$.

(56) $53 \mathrm{~d}$ Cong., $2 \mathrm{~d}$ sess., S. ex. doc. 125; serial number 3163

Lettel from secretary of Agriculture, in response to resolution, calling for statement of visible and invisilule supuly of wheat likely to be in Tnited States ou July 1, 1894, and other information concerning crops for 1894. June 29, 1894. 2 pp.

(57) $53 \mathrm{~d}$ Cong., 2d sess., S. ex. doc. 172; serial number 3163.

Letter from secretary of Agriculture, in response to resolution, transmitting information in relation to investigations and experiments in planting native pine seed for growth of native pine in sand hills of the Northwest, and other information called for in resolution. Angust 2, 1894. $14 \mathrm{pp}$.

(Contains extract from rejort of Forestry Division, 1892, on forest-planting experiments in Nebraska.

(58) 53d Cong., 31 sess., H. ex. doc. 8; serial number 3319

Letter from Secretary of Arriculture, transmitting detailed statement of expenditures for fiscal year ending June 30, 1894. December 3, 1894. 180 I'p.

(59) $53 d$ Cong., $3 d$ sess., S. ex. doc. 69; serial number 3280.

Letter from Secretary of Agriculture, in response to resolution, transmitting information in relation to machinery and other materials furnished by General Govermment and used for experimenting in manufacture of sugar. February 12, 1895. $6 \mathrm{PI}$.

(60) 54 th Cong., 1st sess., H. doc. 25; serial number 3390.

Letter from secretary of Agrieulture, transuitting fletailed statement of expenditures of all appropriations for fiscal rear ended . Ine 30, 1545, including supplemental account to date. December 6, 1895. $189 \mathrm{Pl}$.

(61) 54 th Cong., 1st sess., II. doc. 20s; serial number $3+20$.

Letter from Secretary of Agriculture, replying to resolution relating lo efficiency of employees in certain Exerutive lepartments. February 6, 1s:4. 1 1.

(62) 5th Cong., 1st sess., .. doc. 248 ; serial number 3354.

Letter from Secretary of Agriculture in response to resolution directing Secretary of Acriculture to immerlately communicate to senate reasons for delay in supplying seets for distribution. May s, 1s96. 2 $\mathrm{pP}$.

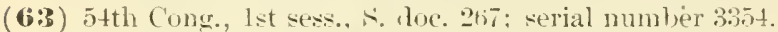

Letter from Artine Seretary of Acriculture relating to bill for surther prerention of 'ruelty to animals in District of Columbia. May 20, 1896. 6 M]'

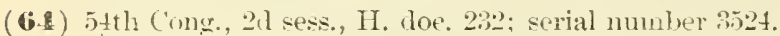

Letter from Secretary of Iericulture, rellying to resolution, rennesting information relating to production and export of ("astor beans. January 30, 1847. 1 .

(65) 54 th Cong., 21 sess. II. doc. 275 ; serial number 35.34 .

Letter from Secretary of Agriculture, transmitins, in resinnse to resolntion, statement as to employees in Department. February 9, 1897. 16: 1).

(\$6) 5tth Cong., 2 d sess., S. doc. 155 ; serial number $3+71$.

Letter from fecretary of Agriculture, communicating, in response to resolution, information relative to removal of certain emplovets in Isupean of Ainimal Industry at Soutl Omaha. February 25, 1597. 13 jil.

(67) 55 th Cong., 1st sess., S. doc. 112; serial number 356\%.

lettel from secretary of Agriculture, in reural to bill entitled "A bill for further prevention of revelty to animals in District of Columbia." Nay 26, 1897. 8 'P.

(6-) 55 th Cong., 21 sess., H. doc. 26; serial number 3651 .

Letter from Secretary of Agriulture, transmitting detailed statement of expenditures of all appropriations for fical year culing June 30, 1897 . December $6,189 \%$. $218 \mathrm{pl}$.

(69) 5isth Cong., 21 sess., S. doc. 63 ; serial number 3592.

Letter from Secretary of Agriculture, in response to resolution, relative to sugar importation, production, and consumption in United States. Jauuary $17,1898 .+1 \%$. 
(70) 55th Cong., 2d sess., H. doe. 309; serial number 360 .9.

[Letter from Secretary of Awriculture, tran mitting report on] arlulteration of wheat flour. February 16, 1898. 4:2 (1).

(71)

inth Cong., 3d sess, II. doe. 23; serial number 3i6s.

Letter from Secretary of Agriculture, transmitting detailed statement of expenditures of all apmopriations for fiscal rear ending June 80 , 1s:18, includ-

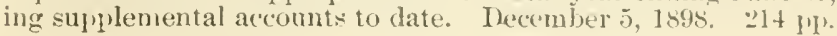

(72) 55th Cong., 3 d sess., H. doc. 181; serial number 3813.

Report upon forestry investigations of lhepartment of $\mathrm{A}$ griculture, 187--189s; by B. E. Fernow. Washington, (iovermment Printing ()ffice. 1sa?. $401 \mathrm{pJ}$. 32 pl. $4^{\circ}$.

(Contains: Memorial of committee, Imerican Association for Adrancenent of Science, in behalf of forest prevervaltion, learling to estalblishment of l)ivision of Forestry; List of publications relating to forestry issuen from Department of Agrieulture sine 18:7; Forests and forestry in United states; Forest poliejes of Europen nations; Forest conditions and methords of foreign management in Germany, with brief account of forest management in British India; Principles of silvieulture; Principles of forest economy; Forest influenes; Work in tintree physies in I ivision of Forestry, loy Filibert Roth; Metal tiey for railways and economies in use of wook +12 tice, by E. E. Russell Tratman.)

(73) 55th Cong., 31 sess., S. doc. 124; serial number :3735.

Message from l'resident of United states, transmitting, in response to resolution, report of fectretary of Agriculture, regarling usefulness of rescropoirs to agriculture in irrigated regions of the Enited States. Feloruary 18, 1899. $1+\mathrm{pp}$.

(7.1) 56th Cong., 1st sess., 11. doe. 173; serial number 3929 .

Letter from Acting Serretary of Agriculture, presenting detailed statement of expenditures of all appropriations for fiscal year ending June 30, 1899. December 13, 1899 . ㄹ:? pp.

(75) 56th Cong., 1st sess., S. doe. 81 ; serial number 3850 .

Letter from secretary of Asriculture, in respgnes to resolution, relative to expenditure of $\$ 50,000,000$ appropriated l,y Congress [to supply urgent ileficienries in appropriations for fiscal year ending June 30, 1898, anil for prior years, and for other purposes]. Jamuary $16,1900.1 \mathrm{p}$.

(76) 56 th Cong., 1st sess., 11. doc. 500; serial number 3929.

Ilessage from President of United States, transmitting report of Secretary of Agriculture on work and expenditures of agricultural experiment stations for fiscal year ended Jume 30, 1899. March 8, 1900. 111 11.

(77) 5 tith Cong., 1st sess., S. doc. 277; serial number 3868 .

L.etter from sereretary of Agriculture, transulitting, in response to resolntion, statement showing number of persins (m) loved in Department of Agrionlture, between certain ages. April 10, 1900. 21p.

(7\$) 56th Cong., 2d sess., II. doc: 29); serial number 4116.

Letter from secretary of Agriculture, presenting defailed statement of expenditures for year colling June 30, 1900. I)ecember:3, 1900. 247 1'p.

(79) 56th Cong., 2d sess., 11. doe. 192; serial number 4145 .

Letter from Seccetary of Agriculture, redaring to printing meprt on investi-

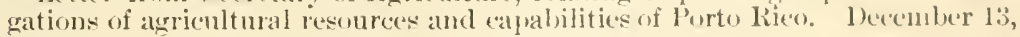
$1900.1 \mathrm{l}$.

(\$0) 56th Cong., 21 sess., S. doc. 108; serial number 4033.

Irrigation investigations in ('alifornia, umler clinetion of Elwond Mlad, assisted by Witliam E. Sinythe, Marselen Mansen, 3. M. Wilsun, ('harlese 1).

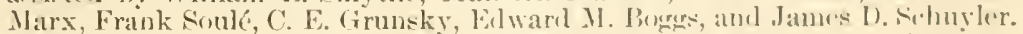
January 24, 1901. Washington, Government l'rinting (1ther, 1!101. Fis Iil.

(\$) 57th (ong., 1st sess., S. doe. 181; serial number tont.

Tabulated statement prepared by Aericultural Department, for Sconate Committe on Manufactures, showing adulteration of most eommon articles of food consumed in Tnited States. February 11, 19002. Washington, Govermment Printing Otlice, 1902. 19 pl\%. 


\section{Appendix}

(\$2) 57th Cong., 1st sess., S. doc. 377; serial number 4245 .

Letter from Secretary of Agriculture, transmitting detailed statement showing location, annual rental, etc., of uguarters occupied by Department of Agriculture. Hay 29, 1902. + pp.

(\$3) 57th Cong., 1st sess., H. doc. 29; serial number 4301 .

Letter from Secretary of Agriculture, tramsnitting detailed statement of expenditures of all appropriations for fiscal year ending June 30,1901 , including supplemental accounts to October 14 , inclusive. December 2,1901 , $27 \pm \mathrm{pp}$.

(\$) 5 th Cong., 1:t sess., S. doc. 24; serial number 4220 .

Report of Secretary of Agriculture in response to resolution, giving data regarding number of employees, ages, and salaries of each in his Department. December $t, 1901$. $33 \mathrm{pp}$. 


\section{INDEX TO APPENDA}

Entry no.

Adulteration, food .................. sl

Ages of employce...................... 75,84

Agriculture Department

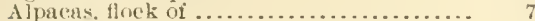

Amber eane...

American Association for Advancement of

Animal Industry Burean ... $35,37,39,45,48,52,66^{\circ}$ Animals.................... 20,26,63, 67 Argentine Repubil:

.....

Artesian wells........................

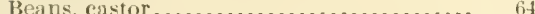

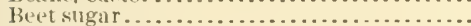

Bibliograjliy of sorghim.

Bogge Eduard II

Britisly India, forests.

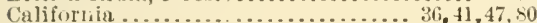

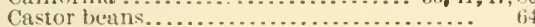

Cattle

Cattle plague.

Champaign Sugar ani Glucose Manufae.

turing Company, Champaign, Ill .......

Chemical loivision.

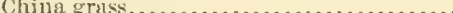

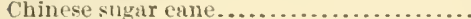

Cincluonats

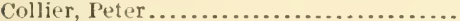

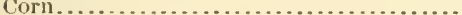

Cotton.

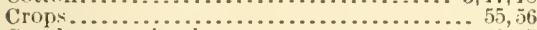

Cruelty to unimals ..................... 63,67

Deficieneie. . . ................... 42,75

Delaware Beet sugar Comjany ...............

Disbursements. See Expenditures.

29

20,26

District of Colmubia.........................

Dodge, J. R.......................

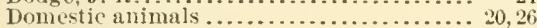

Duty on imjorts............................ 10

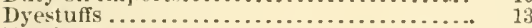

Employees ................. $51,61,65,75,84$

Europe, forest policies.................. 72

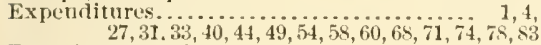

Experiment statiolls............... 22, 42,76

Fernow, B. E...................... 72

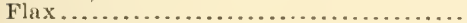

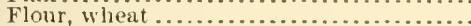

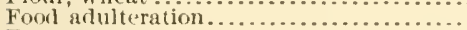

Forestry ........................ 19,57,

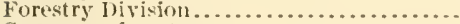

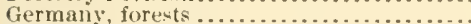

G] 11 cosese.

Grain

Grass, Chine

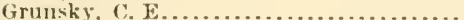

11 amlonrg

Hemp.

Henry, iV.

Horticulture.

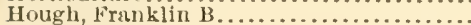

\section{linp}

lnternal-revenue tax

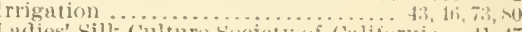

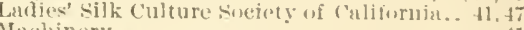

Machinery....................... t1

Madicon, $W i=\ldots \ldots \ldots \ldots \ldots \ldots \ldots \ldots \ldots \ldots \ldots \ldots . .21$

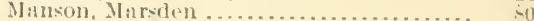

Marx, Claturled D. .................... s.

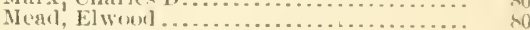

Nedicines ................................

Sutional deademy of coiences ......... 21

Noloraski ...............................

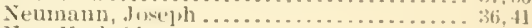

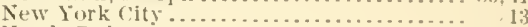

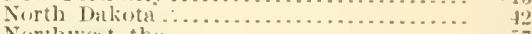

Northwest, the ...................... it

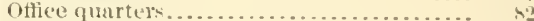

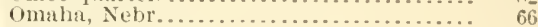

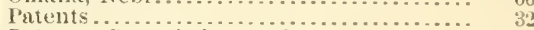

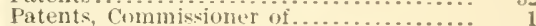

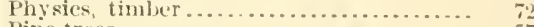

Pine trees ............................ 57

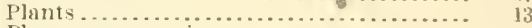

Pleuro-pneumonia ................. 21

Porto liven........................... 79

Property in public buildings.

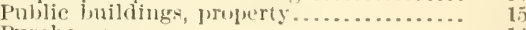

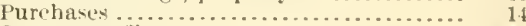

Quarters, nflice.....................

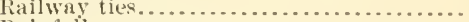

Rainfall .............................. 50

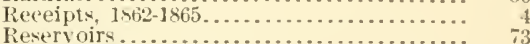

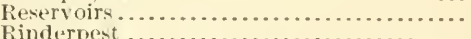

Rio Grande Sugar Company, New Jersey.. is

Schuyler, James I................... 80

Seovell, Melville A...................... 21

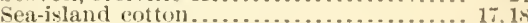

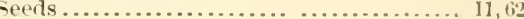

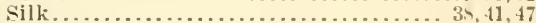

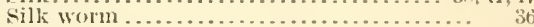

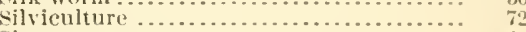

Sirup ............................ 21

Smythe, William E......

Sorghnm sugar. . . . . . . . . . . . . $1,29,34$

Soule, Frank....................... \$

Slatisties, agrieu]tural.....................

Sugar...................21, 32, 58, 59,69

Swenson, Magilus ..................21,32,34

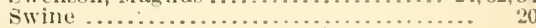

Temnesse fïrticultura] Siscicty.......... 11

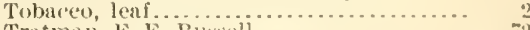

Tratman, E. E. Russell ............... 72

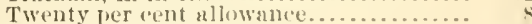

Vilmorin, Louis......................... 24

Weber, llenry $11 \ldots . . \ldots \ldots \ldots \ldots \ldots \ldots \ldots \ldots .21$

IVells, artesian ....................... 4

IVheat 1 .

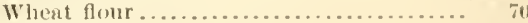

Williams, s. Wells....................

Wilson, J. II .........................

Women's silk Culturo Assm of 1 . . . . . 34, 11,47

Wools and woolens................... 10. 





UC SOUTHERN REGIONAL LIBRARY FACILITY

|||||||||||||||||||||||||||||||||||||||||||||||||

AA 0010717833 


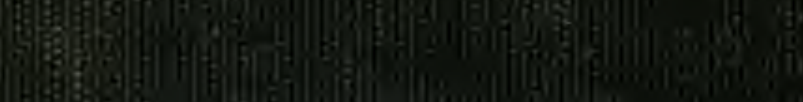

H. Hotion 